Historic, Archive Document

Do not assume content reflects current scientific knowledge, policies, or practices. 

This is a reassembled copy of the four volume DE FRUCTIBUS ET SEMINIBUS PLANTARUM by Joseph Gaertner, 1788-1805. The U.S. National Agriculture Library (NAL), Beltsville MD, has an intact and entire set in its rare book collection under call number 463.4 G119D.

The U.S. National Seed Herbarium (BARC) has an intact and entire xeroxed copy and a reassembled copy in notebooks with the seed identification book collection. A set of reassembled pages has been filed in the family files in (BARC). Other reassembled copies, without an introduction, are housed at the Federal Seed Laboratory (AMS), Beltsville MD; Maryland Department of Agriculture, Turf and Seed Section, Annapolis MD; Botany Department Library, Smithsonian Institution, Washington DC; and with C.R. Gunn, 120 White Squirrel Lane, Brevard, North Carolina. The "original" reassembled copy is with Joseph H. Kirkbride, Jr. (BARC), who plans to make it available through NAL.

For a brief summary of J. Gaertner's career and his book, consult this entry "Gaertner, Joseph", pages 902-903 in TAXONOMIC LITERATURE volume I: A-G, second edition by F.A. Stafleu and R.S. Cowan (1976).

Dr. Alan Fusonie, Head, Special Collections (NAL) kindly allowed me to borrow the NAL volumes for 24 hours January 20 to $21,1987$. During this window, I carefully xeroxed the entire set, and over the intervening years I reassembled the plates and text into this form: Families, genera, and species in alphabetical order. The family and generic concepts follow those in USDA/ARS Technical Bulletin 1796 in 1992: FAMILIES AND GENERA OF SPERMATOPHYTES RECOGNIZED BY THE AGRICULTURAL RESEARCH SERVICE.

With appreciation to J.H. Kirkbride, Jr., Director (BARC); J.H. Wiersema, Nomenclaturalist (BARC); C.A. Ritchie, Contract Botanist; and the Maryland Department of Agriculture, Turf and Seed Section: Malcolm L. Sarna, Chief; Lois Labs, Laboratory Manager; Lois Capshaw, Supervising Analyst; and, the staff,

Charles R. Gunn

965 Running Brook Way

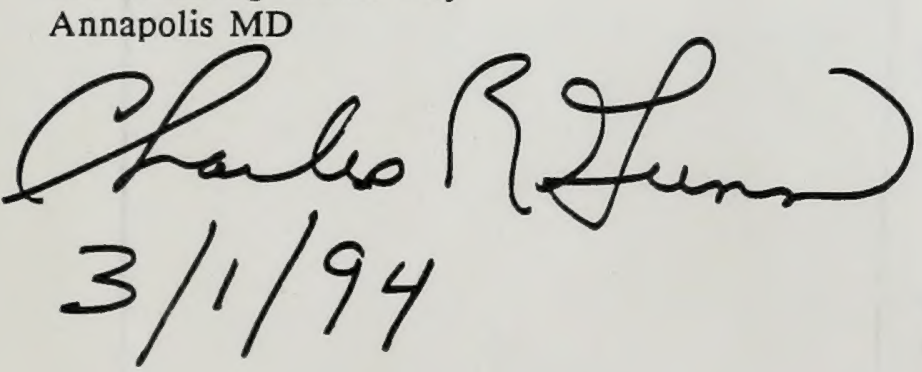




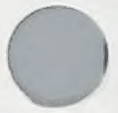

0

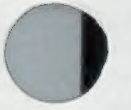


-

- 


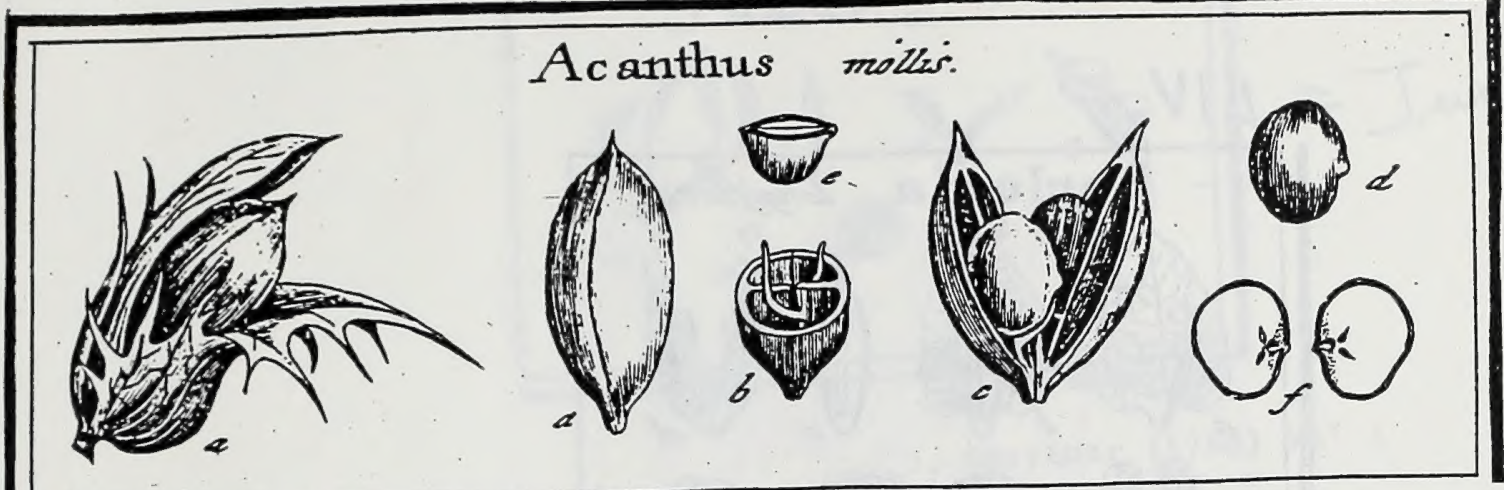

J. Gaertner (1788) Vol. I

\section{ACANTHIS. TourN. t. go. L IN g. ger. 793.}

Calyx bifolius. C.rr. unilabiata, deflexa, trifida. Stam. quatuor inæqualia. Stigmata duo. Caprula bilocularis. Diffepimentum contrarium, retinaculis feminum uncinatis. Semina folitaria.

Aс Алтни mollis. Tab. 54. fig. I.

Acanthus. R i r. monop. t. 87 . В г А K $\square$. herb. t. 89 .

Acantlius foliis finuatis inermilus. LIN N. Jyjl. veg. 580 .

PER. Caplula ovato nblonga, mucronata, glabra, e ferrugineo lutefcens, bilocularis, bivalvis. Diflipimentum ralvis contrarium, bilidum, rctinaculis uncinatis, pro fulctendis feminibus dotatum.

REC. nullum; femma diflepimento ad axillas uncoram affixa.

$S \varepsilon$ м. in fu:gulo loculainento unicum, grandiusculum, ovatum, lenticulari-compreffum, vel \& plano.convexum, glaberrimum, nitidum, latco rufefcens.

In $\mathrm{T}$. duplex: exterius coriaceum, durum; interius fpongiolo membranaceum, tenue. A r. R. nullum.

Ex в. feinini conformis, lutefcens. Cotyl. carnofx, plano convexiufculx, circa radirulx fcitem arcte inter fe connatx. Plum. diphylla: folinlis acuminatis divergentibus. Rad. brevis, conica, intra cotyledones latens, centripeta.

a. 2.) Capfula calyce munita, \& denudata. b.) Eadem diffeta, cum fitu retinaculoram. c.) Eadem delificens. d.) Semrn (rpamtum. e.) Idem transverie (ętum. f.) Idem bipartitum, cum figura cotyledonum, plumula \& radiculs. 


\section{LIV}

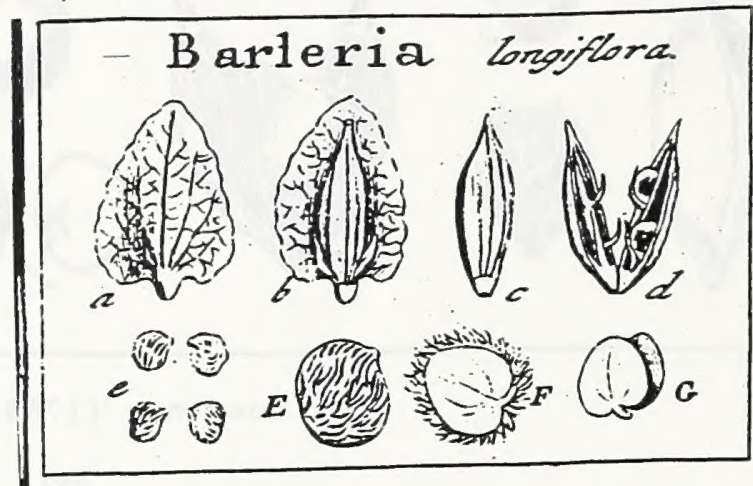

J. Gaertner (1788) Vol.l

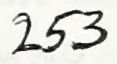

CCCXIV. BARLERIA. Plu ir. gen. t. 31. Linn. gen. 785 .

Calyx quadripartitus: foliolis duobus mainribus. Cor. ringens. Stam. quatuor inzqaalia. Stigma bifiduın. Capfula angulata biincularis. Diilepimentum valvis contrarium, retinaculis feminum uncinatis. Senima geriuina.

BARLERIA longiflora. Tab. 54. fig. 2.

Barleria incrmis, foliis ouatis fericeis, brafteis cordatis fcariojis, corollis longiffumis. L I N N. Sufl. veg. 577 ?

Milla a Koenigio cum somine barlesix cordifolia.

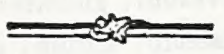

PER. Capfula oblonga, utrinque attenuata, tetragona: Jateribus inaqualibus, bi:ccula. ris, bivalvis, claftice delifeens, e caftaneo atra. Diffepimentum valvis contrarium. bifidum, retinaculis feminum uncinatis, alternis flipatum.

$R E C$. nullum; femina in axillis retinaculorum fefflia.

SE.. 11 fingulo loculamento gemina, rhombeo-rotundata, compreffa, ut fere bractea. $\mathrm{ta}$, fufco fpadicea, villorum appreftorum, fafciculis undulatis, in aqua facile fe fe in comam lloccolam explicantibus undique tecla.

In T. fimplex, membranaceun, tenuifimum.

A t. 8. nullum.

Ear B. fernini conformis, niger! an in recenti femine viridis? Cotyl. oblique cordatz; planx, fubfuliacex. Rad. incurva, brevis, centripeia.

s.) Calycis foliola majora, reticulato venofa, capfulam obtegentis. b.) Capfila ab altero latere dena. data, reliais ntringue calycis foliolis minoribus, lanccolato acuminatis, paleacco menbranaceis, ars niis. c) Capfula integra. d.) Eadem delilcens, cum ferinibus in tieu. e. E.) Semina feparatio

F.) Embryo denudatus, G.) Idem, didutis cotyledonibus. 


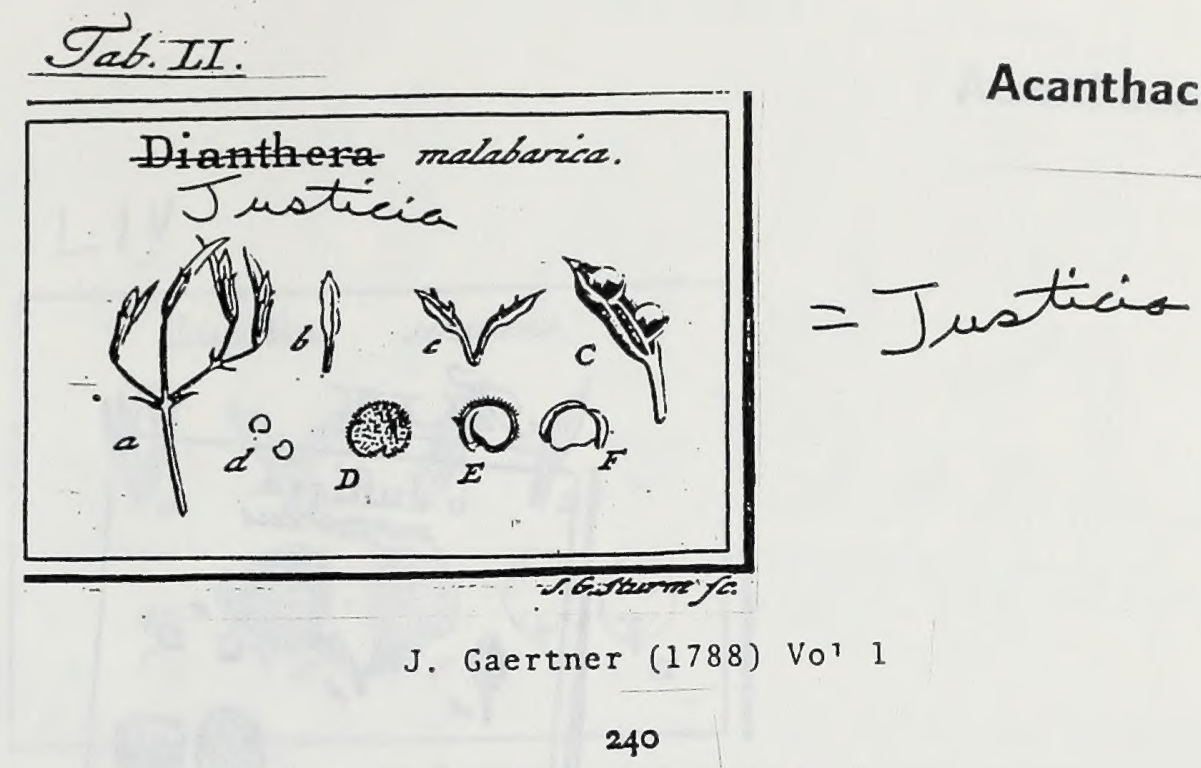

CCXCV. DIANTHERA. LIN g. gen. 28.

Calyx tubulofus, quinquedentatus. Cor. ringens. Stam. duo: antheris geminatis. Styli unicus. Capfula bivalvis elantica. Seminis embryo curvatus.

Di A т теR a malabarica. Tab. 5т. fig. 8.

Dianthera bicaliculata. RE T z. att. holm. 7775 . $t$. 9 .

Dianthera floribus paniculatis, pedicellis bi-l. trifidis, floribus bicalyculatis, tio cinia dorfali majore. L in N. Jiff. veg. 63.

Ex herbario Bankfiano.

PER. Capfula oblonga, compreffiuscula, fupra acuminata, infra in unguem lineiris compreflum elongata, bilocularis, bivalvis: ungue elantico dehifcens. Diflepimend tum valvis contrarium, retinaculis uncinatis pro leminibus infructum.

REc. nulluen; femina in axillis retinaculorum feffilia.

SEM. duo in quolibet loculamento, orbiculata, ad unbilicum emarginato-rofellata utrinque planiuscula, nigro fulca, ininutifinis aculeolis fubcapitellatis fcabrata.

IN T. duplex : coriaceum \& membranaceum; utrumque tenue.

A L в. nullum.

Е м в. magnitudine ferninis, curvatus, albus. Cotyl. ovato-reniformes, foliacex, nuilfinx. Rad. fufformis, curvata, inflexa, a centro devia.

a.) Paniculz pars. b.) Capfala integra. c. C.) Eadem delifeens, cum fitu feminum. d.D.) 60 , mina feparata. E) Enibryodenudatus. F.) Idem feparatus.

Nimis artificiale, nec fatis a Jufticia difinctum genus. 


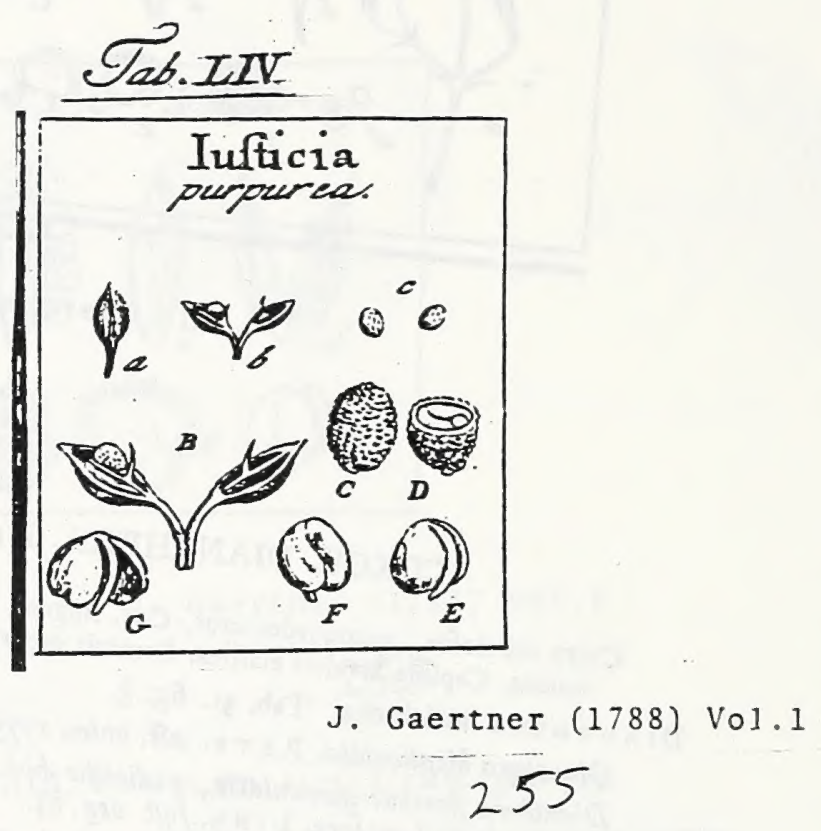

CCCXVI. JVSTICIA. Linn. gen. 27. Adhatoda Tourn. $t .79$.

Calyx quinquepartitus, Cor. ringens. Stam. duo. Stigma finplex. Capfula bilocularis. Difepimentum valvis contrarium : retinaculis femmum uncinulatis. Semina folitaria, aut plura.

Justicia purpurea. Tab. 54 . fig. 4 .

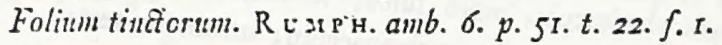

Ginficia foliis ovatis utrinque mucronatis integerrimis glabris, caule geniculato, jpicis jecundis. L I $x \times$. Syft. veg. $\sigma_{3}$.

I:x herliario l:ankliano.

PER. Capfula parva, ovato lanccolata, in pedunculum transicrfe compreftum clongata, bilocularis, biva!vis; pedunculo elaftice dilliliens. Dilepimentum bifidum, valvis contrarium: retinaculo feminum uncinulato ftipatum.

REc. nullum; femina in axillis retinaculorum fefrilia.

SEsr. unicum in fingulo Inculamento, ovatum, ad umbilicum leviter enarginatum, comprefiusculum, undique granulis acutis fcabratum, fordide rufefcens.

IN T. fimpliciflimum, membranaceum, tenue.

A L n. nullum.

Es в. femini conformis, curvatus, extus viridıs aut lividus, intus albus. Cotyl. obovat $x$, fubinaquales, compreftx. Rad. terctiuscula, curvula, e vertice feminis, fecundum alterum cotyledonum marginem, deorfum verfus umbilicum inllexa.

a. b. B. ) Capfula intmgra \& dehifcens. c.C.) Semina (cparata. D.) Semen iransverfe feltam, cum fitu cotyledonum \& radiculx. E.F.) Enbryo desudatus, ab utroque latere fpectatus in fitu naturali G.) Cotyledones diduRta. 


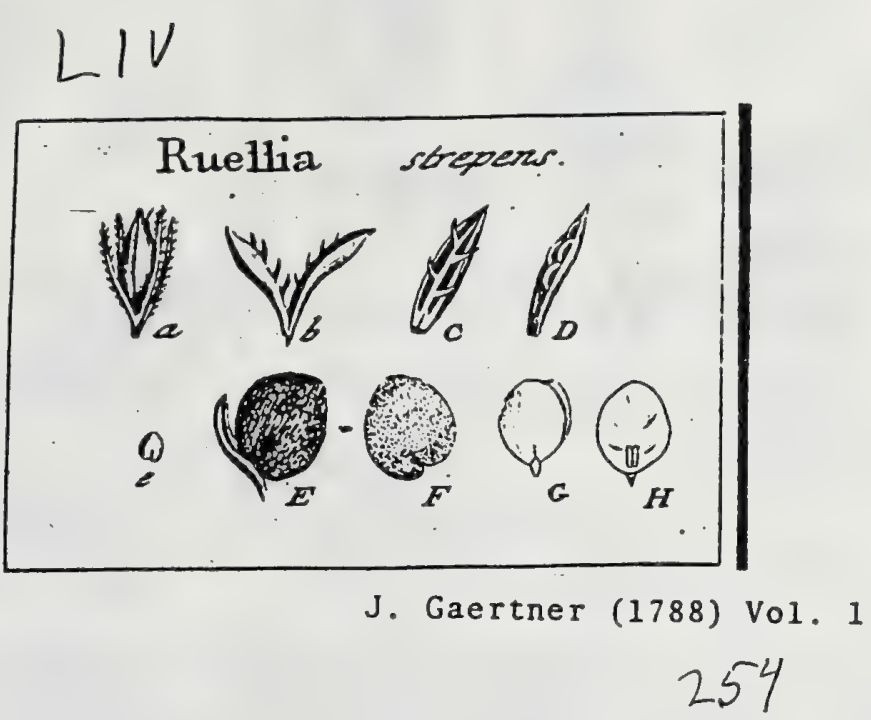

CCCXV. RVELLIA. Plum. gem.t. 2. LINN. gen. 748 .

Calyx quinquepartitus. Cor. ringens. Stam. quatuor inxqualia. Stigin. bif:dum. Caplü la bilocularis. Dillepinentum valvis contrarium : retinaculis feminum uncinulatis: Seınina tcrna I. quaternz.

RUEL I A frepens. Tab. 54. fig. 3 .

Ruellia frepens, capitulis comofis. D I I L. elth. 300. t. 249. $\int \cdot 321$.

Ruellia foliis petiolatis, pedunculis trifloris brevibus. Lxx. $\int y / 6.2 \% g .575$.

PER. Capfula oblonga, fuperne acuminata, in medio ventricola, rotundato tegragona,. ad balin elongata in unguem compreflum elaflicum; bilocularis, bival.is. Diflepincntum bifidum, retinaculis feminum uncinulatis, canaliculatis alternantibus fipatum.

R E C. nullum; femina in axillis retinaculorum feffilia.

SEs. in finculo loculamento tria ad quinque, rotundato cordata, fetis minutifinis aptreslis feabrata, hine leviter convexa, inde planiuscula, cinerco-fufca.

Ist. duplex: utrumque membranaceum; interioris fupcrficies interna fubcarnofa.

A в в. nullum, prater fuperficiem carnofam integumenti interni.

Е м в. femini conformis, ex aibido lividus. Cotyl. nvato rotundatx, foliacer. Plum. diphylla, fulsolis linearibus parallelis. Rad. conica, brevis, centrife.

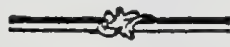

1.) Capfula intrs calyeem integra, b.) Eadem dehifens, C.D.) Valiulx (eparatx, E. E. F.) Se men folutum. G.) Embryo denudatus. H.) Coryledon altera, cum plumula. 


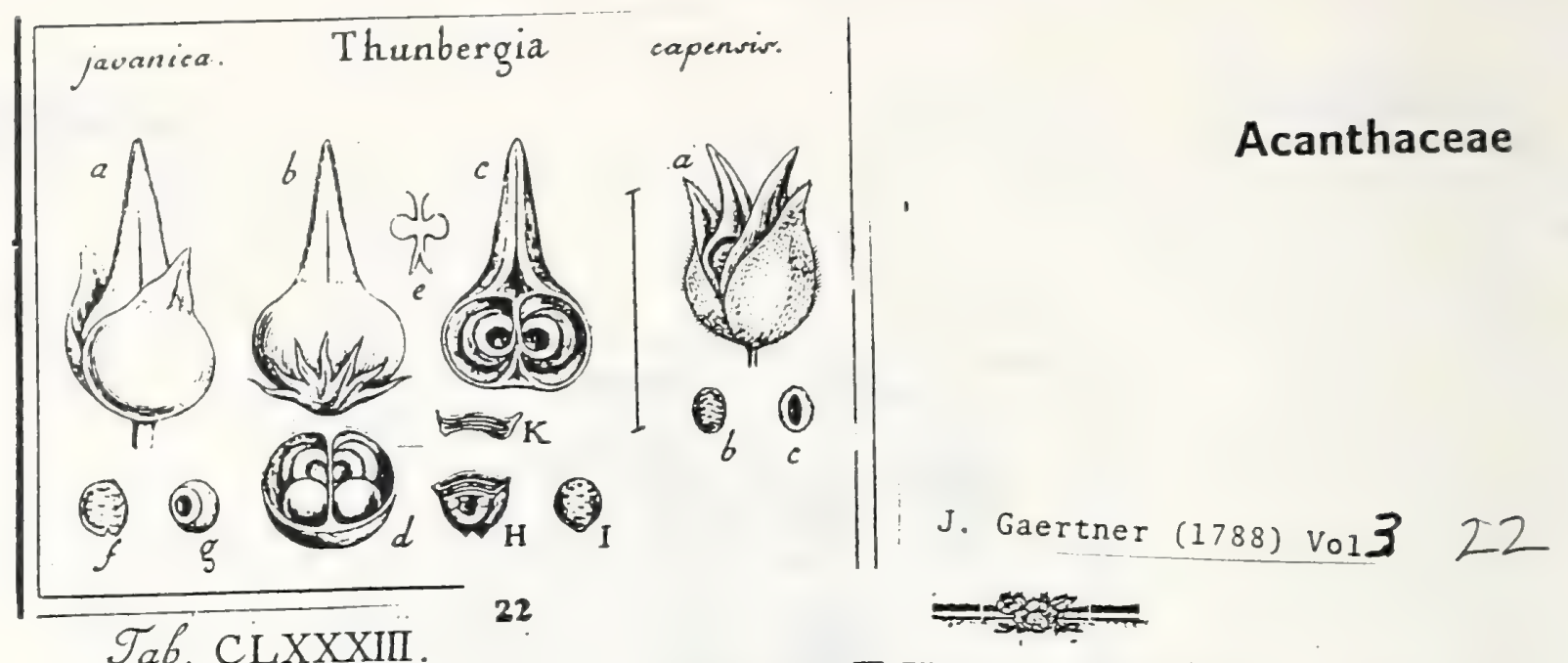

20. TH U N B E R I A.

Lini. Juppl. pl. 46. ThнNв, nou. gen. 22. Sснвев. gen. pl. r058. Juss. gen. p. 103. LAMABCK ill. gen. t. 549 .

Cal. duplex: exterior diphyllus maximus; interior monophyllus, multifidus, exteriore triplo brevior. Cor. monopetala, campanulata, limbo quinquelobo xquili: Stam. quatuor didynama. Ovar. fuperum. Styl. Gimplex cum ftigmate bilobo. Capf. inferne globofa, fuperne comprefle roftrata, bilo. cularis. Sem. in loculis gemina, nenifcoidea.

Thunbergia javanica. Tab. 183. fig. 4.

A Cl. Thunberg. cum fequenti.

PzR. Capfula utroque calyce bafi veftita, ibique globofa, fuperne autem in roftrum pugioniforme, compreffum, rigidum definens; bilocularis, bivalvis. Diffepimenta membranacea, dorlo medio valvularum inferta.

REC. anguftum, ex roftri bafi deorfum productum \& cum difepimento conferruminatum, ac circa medium quatuor lobulis rotundatis carnofis auriculatum: qui feninum cavitatibus immittuntur.

SE Mr. in fingulo loculo gemina, fubrotunda, menifcata, feu in dorfo planiufcula aut leviffime convexa \& obfolete rugata; in ventre autem ampla cavitate rotunda \& paululun excentrica exfculpta, cujus oram annulus craflus, cartilagineus, albus cingit.

IN T. fimpliciflimum, membranaceum.

A L B. nullum.

E a в. viridis, rotundatus, compreffus. Cotyl foliacex, conduplicatx, atque fibi mutuo ita junctx, ut commifura laminarum unius cotyledonis accunibat rimx dehifcenti alterius; \& fic vice verfa. Rad. minutifimx, acuminata, non difcreta, infera.

\section{EXPLICATIO FIGURE.}

2.) Capfula integra, enm calsce exteriore. b.) Eadem cum calyce interiore. c.) Eiusdem de. hifcentis valvula altera, cam feqriubus in fitu naturali. d.) Ejusdem fectio transverfaliso e.) Receptaculum alterius loculamenti, lobulis carnofis auritum. f.) Serninis latus dorfale. 8.) Ejusdem pars ventralis. H.) Ipfius fedio transverialis. a parte veatsali (petaza, 1.) Emo bryo folutus. K.) Cotyledonum fedio transverfalis.

Quibus occafio datz eft recentia videndi femina, fcrupulofe inquirant in Cotyledonum ftructuram incricatifinam; mihi fola duo femina vetufta, hac in parte, non fatisfecerunt.

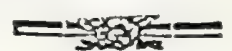

Thunbergil capenfis. ibidem.

Thunbergia. Linn. Suppl. pl. p. 292. Syl. veg. ed. 14. p. 559.

Thunbergia folis ovasis obtufis, cauile diffufo. WILLD. Spec. plo T. 3. P. 1: p. 388.

Icon. Retz. a.7. luard. x. p. 863. LlaMARCK ill. gen. t. 549. f. I.

Calyx exterior maturus (a.) longitudine fere capfulx, totus fetulis rigidis faber. Cal. interior uti \& tota capfulx conformatio pracedenti ex alfe fimiles. Semina elliptica, hinc (b.) convexa \& fcrobiculato-rugofa; inde (c.) cavitate oblongi menifcata, cujus aperturan finplex margo tumidulus fubfungofus fordide rufafcens ambit. Color in his pallide ftranineus, qui in pracedeatibus fufcus. . Enibryonem ob femina omuia caffi fcrutari non licuit. 


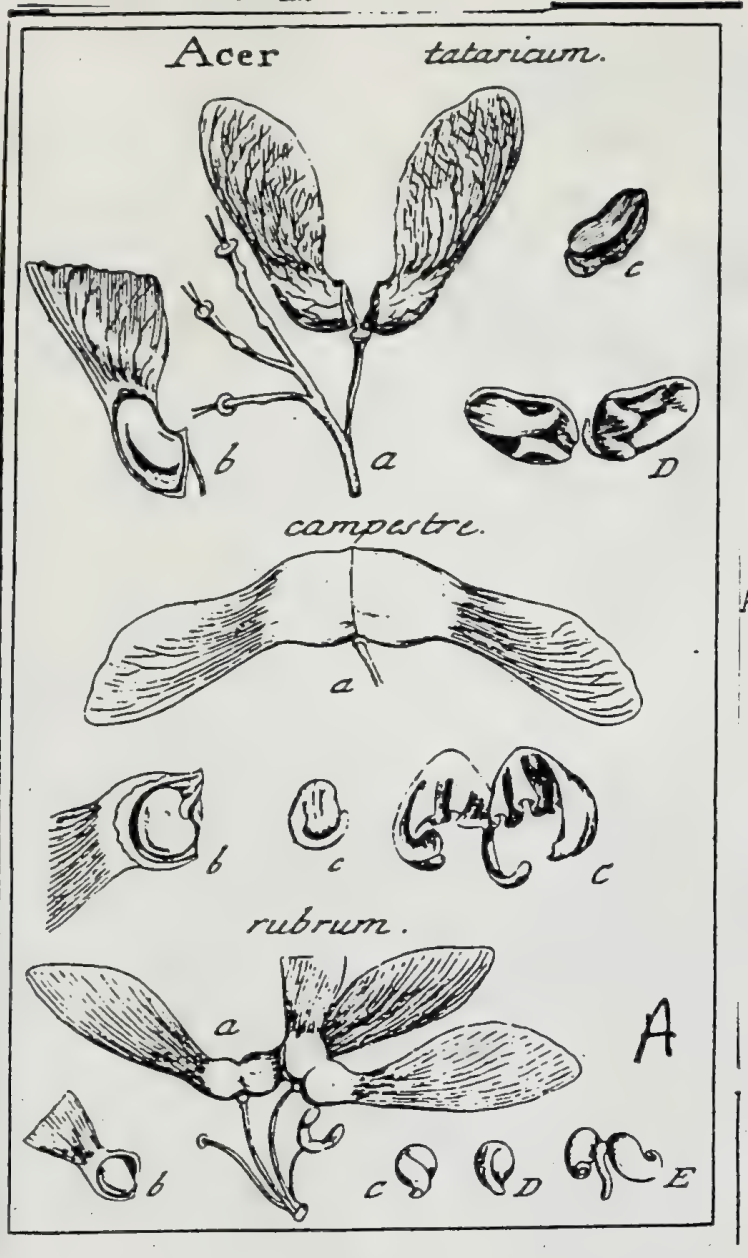

J. Gaertner (1788) Vol. 2

166

DCLXXIX. A CER. TOURn. inft. t. 3S6. LIN. gen. M55.

Calyx quinquefidus. Cor. pentapetala. Sram. ncto l. decen. Ovar. duo, fuperit. Styl. fimplices. Sanarx dux, unialatx. Embryonis cotyledones foliacer.

ACER tataricum. Tab. 116. fig. 1.

Acer foliis oblonge cordatis inequaliter ferratis. KRASHEN. aIf. petrop. 1749. t. 13. Acer foliis cordatis indivifis ferratis: lobis obfoletis, floribus racentofss. LIN. Syyt. veg." 911 .

PER. Sanarx dux, ovatx, comprelfx, divergentes, extrorfum in alam membranaceam ovatan adfcendentem elongatx.

REC. commune fliforme, bifidum, capfulis interjectum; proprism nullum, fed femen bafi loculamenti fui affixum.

SEM. folitaria, oblonga, compreffa, ferruginea.

In r. fimplex, membranaceum, intus fubcirnolum.

A L B. nullum, nifi laminam internam carnofam integunenti velis.

EM B. fenini conformis, curvatus, luteus aut viridis. Cotyl. reniformi-ovatz, foliacex, tenues, irregulariter rugolx. Ktud. teretiufcula, a bafi capfulz verfus ftyli fedem incurvata, f. adfcendens.

a.) Samarx integra. b.) Loculamentum apertum, cum tht \& figura feminis. c.) Embrjo denuchtus. D.) Cotỵledontes feparate \& 2 parte fua interna fpectatz.

ACER campeltre. ibid.

Acer misus. DOD. pempt. 840. OELHAF. t. 98 . bene.

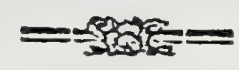

Acer folits femitrilobis obtulis, lobis lateralibus emarginatis. HaLc. hift. 11. 1029. Aier foliis lobatis obtufis emarginatis. Liss. $\int y /$. veg. 912 .

Sanalic dux (a) fubfeniorbiculate, in alam defiexam 1. hnrizontalem definente's, curiaceo-lignofx, compreffx, intus glaberrinix. Sencer (b.) fubreniforme, gibbum, compreffiufculum, albicans. e funiculo umbilicali crafto pendulum. Albumen nullum. Embryo (c.) viridis, convolutus. Cotyl. (C.) foliacex, plicato - contortuplicata. Rad. comprefra, arcuata, adicendens.

ACER rubrum. ibid.

Acer virginianum, folio majore, fubtus argenteo, fupra viridi fplendente. PIUK. plygt. t. 2. f. 3. СатеsB. carol. x. t. 62. SELIGM. av. II. 2. 24. MiLl. ic. t. 8. f. 4 .

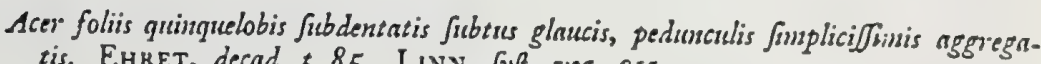

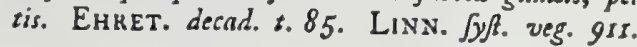

Samarx (a. b.) fubglubofie, membranacex, iu alam lanceolato ovatam, aulfcendentem productie. Senen (b.) fubreniformi-glubofum, fufcum. Albumen nullum. Embryo. (C-E.) viridis, convolutus. Cotyl. oblongx, foliacex, fpiraliter in globum contortx. Rad. curvata, fubadf́cendens. 


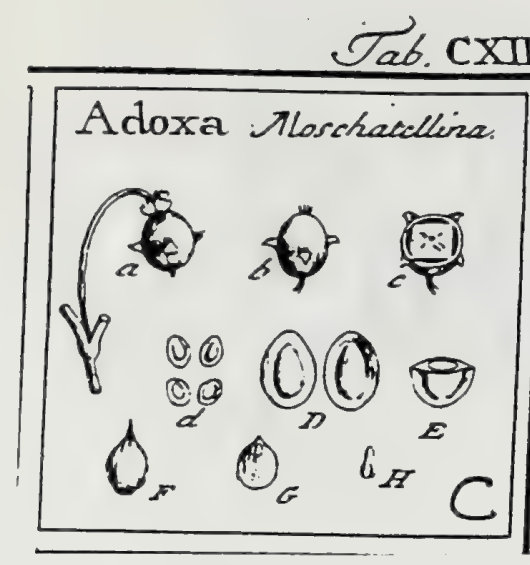

J. Gaertner (1788) Vol. 2

\section{IfI}

\section{A D OXA. LINn. gen. 50r. Mofchatellina.}

TOURN. inf. t. 69 .

Calyx bi-tri-quadridentatus, cum fructus hemifphscrio inferiori intime conmafceiss. Cor. quadri - 1. quinquefida, fupern. Stanz octn l. decen. Ovar. infra corollam pofitum. Styl. quatuor 1. quinque. Bacca calyce femiveftita, pulpofa, unilocularis, tetrafperma.

ADoxa Molchatellina. Tab. I12. fig. 3.

Mofchatella. CORD. biff. 272 , b. c. ic. OED. flor. dan. t. 94.

Funtaria bulbofa $\int$. tuberofa minimas. TABERN. ic. 39.

Mrofchatellina. HaLL. bifl. 11. 1005.

Adoxa. Lisin. $\int y$ f. reg. $3^{8} \mathrm{r}$.

PRR. Bacca ovnto-globola, circa medium adnatis fibi calycinis denticulis fubquaternis ftipata, femipellucida, pulpora, unilocularis, ex viridi pallidat. Pulpa ante maturitaten firmula, feminibus arcte adhæreus, ut tamen hac eximi queant, \& quatuor potius foveas, quam vera loculamenta polt $\sqrt{e}$ relinquant; polt maturitatem autem, ne fovearum quidem veftigium remanet.

REC. nullum; femina pulpx, prope peripheriani immer ${ }_{a}$

SEM. quatuor, elliptica,-comprefra, hinc convexiufcula, inde leviter concava, margiue membranaceo cincta, pallida.

IN T. duplex: exterius chartaceum, -tenue, fubdiaphanum, in marginen feminis amplintun; interius nembranaceum, rufescens, fuperne filiformi attenuatum, \& quafi in funiculum umbilicalem capillarem definens.

A L B. magnitudine lutegumenti interni, lenticulari compreffum, carnofum, album.

EMK. ninutus, in fupremo albumine hxens, inverfus, lacteus. Cotyl. ovatz, compreffr. Rad. teretiufcula, fuperi.

2. b.) Bace integrz. c) Eadem ditrean, cum foreolis, politionem feminnm indicantibus. d. D.) Semina integra, ab ntraque parte fpedata. E.) Semen transierfe diffectum. F.) Albumen propria fua uembrana veflitum. G.) Ejusdem fetio verticalis, cum fitü embryonis. H.) Embryo tolutus \& infigniler audus. 
1

)

D 

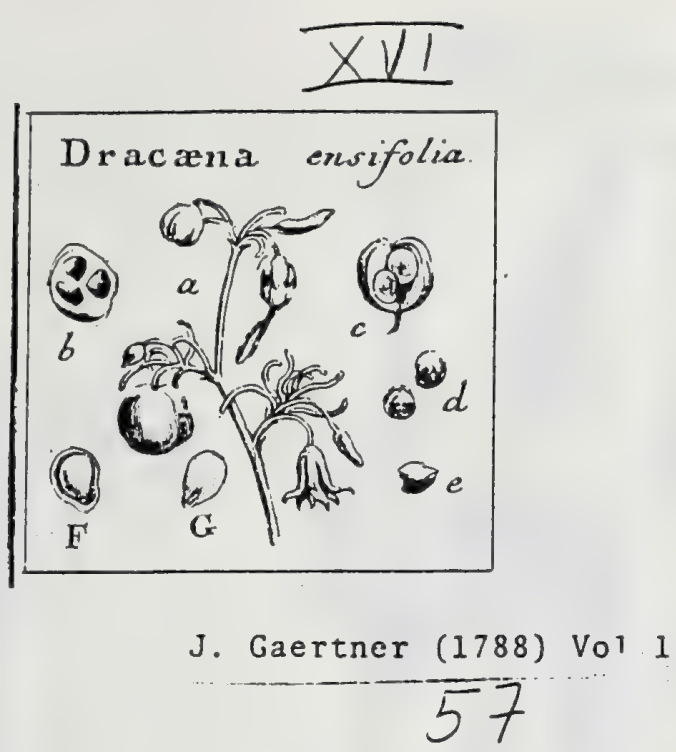

LXV. DRACENA. LINN. gen. 1256.

Corolla fexpartita. Stam. fex. Styl. unicus. Bacca fupera trilocularis. Semina unum aut duo. Embryo prope anbilicum, tertia albuminis parte brevior.

Dracena enfifolia. Tab. 16. fig. 4.

Gladiolus odoratus indicus. Rusr H. amb. 5. p. 285.t. 73.

Dracana herbacea Jubcaulefcens, foliis enfiformibus. LiN N. Syf. veg. 334. Ex horto regio Kewenfi.

PE R. Bacca fupera, fubglobofa, glabra, e violaceo-purpuralcens, caraofa, per maturitaten exarefcens in crufam tenuem, obovatam, trifulcam, ad femica gibbam, trilocularein, evalvem. Diffepinenta unembranacea, a fulcis baccz ad axem ducta.

REc. aullum : Semina angulo loculamentorum interno affixa.

$S E s_{0}$ in fingulo loculamento gemina, rotundato reniformia 1. ad. umbilicum roftellata, lenticulari comprefla $\&$ in medio utrinque umbone conico infructa, glaberrima, Splendentia, atra.

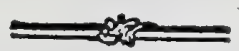
IN T. duplex: exterius cruftaceum, tenuc, fragile; interius membranaceum, pallidum,
chalaza fufca, umbilico oppofita, notatum.

A ᄃ B. figurá Ceminis, carnofun, molle, album.

Es B. monocotyledoneus, teretiusculus, gracilis, lacteo albicans, prope umbilicum pofitus, tertiam albuminis partem vix fua longitudine exxquans.

a.) Racemulus fructiferus, cum bacca integra. b.) Bacca transverfe fect2. c.) Loculamentum apertum, cam feminum fitu. d.) Semiua foluta. e.) Semen trą̧sverfe fectum, F.) Albumen de nudatum. G.) Ejusdem fectio longitudinalis, cum fitu \& figura Embryonis.

Nota. Hxc forfan rectius ad Medeolas transferretur, fructu enim infigniter a D. Dra. cone differt. R U M P H I U S fuo Gladiolo, novem oflicula tribuit, quare. ejus fyno-
nymon dubiun. 
Tab. XVIII.

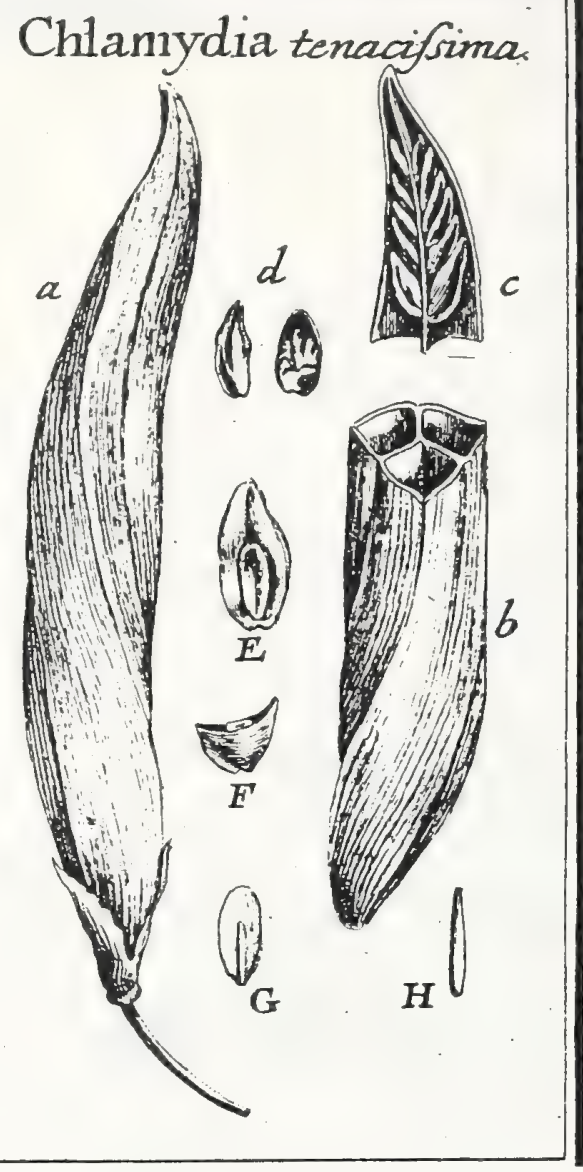

Agavaceae

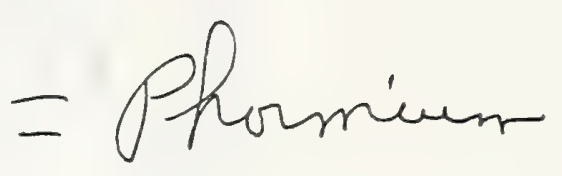

J. Gaertner (1788) Vor.1

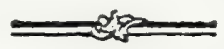

71

LXXXII. CHLAMÝDIA. B AN s. Phormium. Fors r. char. t:24. LIN N. gen. I382.

Calyx nullus. Cor. fexpartita infundibulifornis incurva fubringens: tubi fundo urceolato trigona: limbi lacinis lanccolatis acutis. Stam. fex. Styl. unicus. Capfula fupera trilocularis. Semina plurima bracteata. Embryo dinidio albumiue lougior. (Ex fchedis b. Solandri.)

CHLA MY DIA tenacifluma. 'Tab. 18. fig. 3.

phormium tenax. Fо к T. char. 1. c. Cоок. it. 2. t. g6. Forst. it. germ. I. p. 235 . t. 4. Mir. faff. t. 2.

Phormium foliis phurinis, inflorefcentia ramofa. LIN J fyfl. veg. 336. E collect. Bankfiana.

PER. Capfula fupera, longa, triquetra, torta, extrorfum attenuata, trilocularis trivalvis: valvulis medio leptigeris, extus funofis aut nigricantibus fubtilifime Ariatis; intus lxulgatis, nitidis, pallide Spadiceis.

Ret. margo diITepimentorum internus, cui femina furfun incumbentia, gemino ordisce aflixa.

SE Mr. nuinernfilfuna, oblonga, bracteata, margine inembranaceo cincta, rugola, atra, fplendentia.

IN T. duplex: exterius chartaceum, aridum, tenue, fragile, in marginem feminis ampliatuin; interius fubfpongiofum, arcte nucleo advatum.

A \& в. orato oblongurs, compreflum, carnofun, oleo cito rancefcente fcatens.

Es в. monocotyledoneus, linearis, compreffus, dimidio albunine paulo longior in axi ferninis ad umbilicum locatus, in adultiore fructu, luteo-fuccinei coloris.

a.) Capfula integra, b.) Eadern transverfe ferta. c.) Valvulx pars fuprema, cum fita feminum.

d.) Scilien ab uiroque latcre fpetatuin. E.) Albumca deliudatum. F.) Semev uansverfe fectum.

G.) Albuminis fecto Jongiludina'is, cuin fisu \& figura conbryonis, H.) Enbryo feparatus \& infigniter auctus.

4.2 


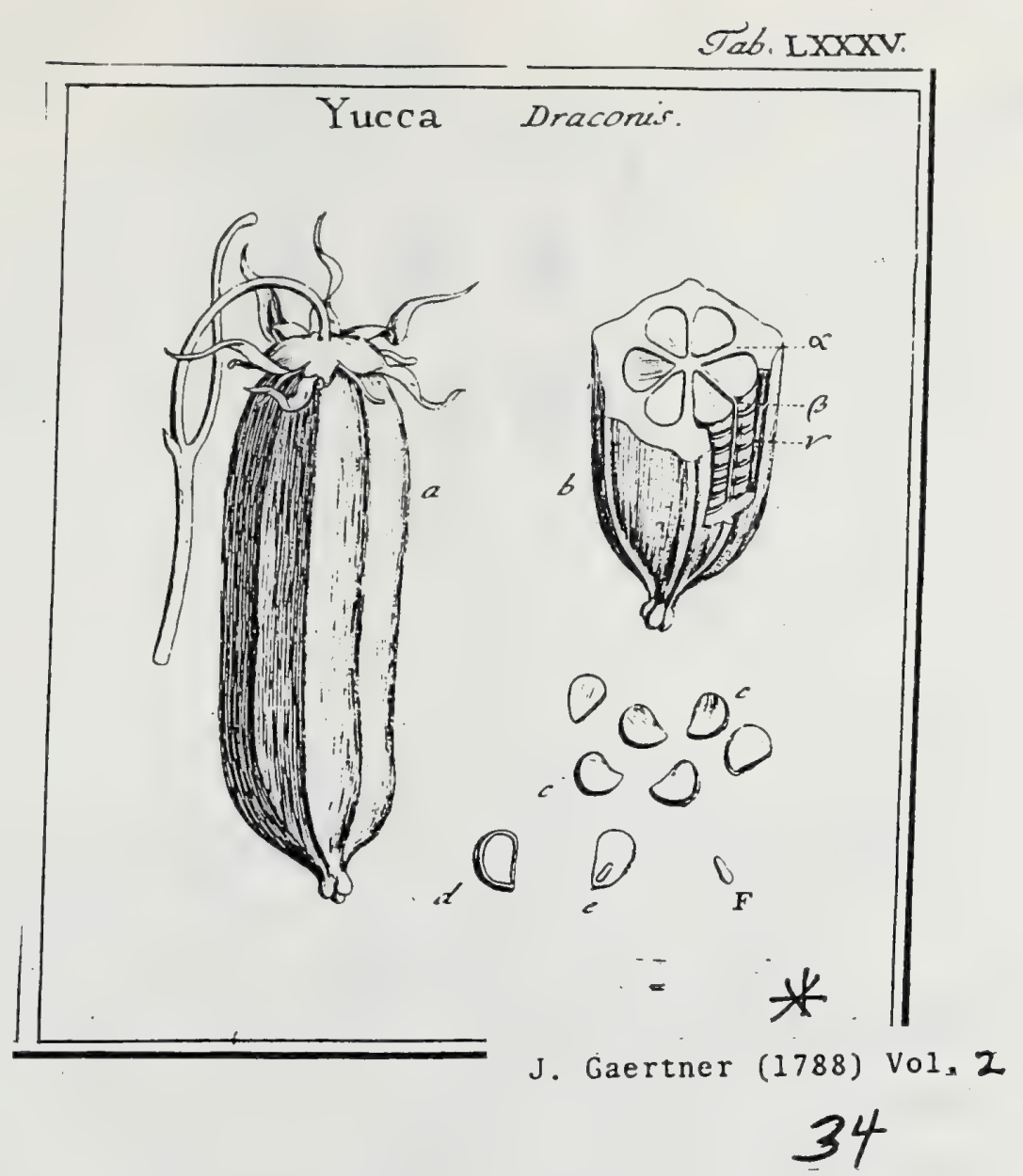

DXXXIX. Y U C C A. LINN. gen. 429 .

Cal. nullus. Cor. hexapetala, tribus interioribus \& tribus exterioribus, baft inter fe connatis omnibus. Stam. fex. Ovarium fuperun, angulatum. Styl. nullus. Stigmata tria, feffilia, introrfum biloba. Bacca carnota, inter ftigmata foramine angufto pertufa, fexlocularis. Semina difcoidea, horizontalia.

Yuccs Draconis. Tab. 85 . fig. 9.

Aloe americana draconis folio ferrato. Coмm. praehud. t. 16.

Treca draconis folio ferrato. DilL. eltb. 437. t. 324.

Tucca folius creviatis untantibus. I

a Cl. Hermana. Prof. Argentor.

PER. Bacca carnofa, oblonga, apice contracta \& inter ftigmata feffilia foramine - angufto pertufa, obfolete hexagona, fexlocularis, nigra. Cuticula tenuifGma, non fecedens. Caro firma, fanguineo - atra \& quafi fufca. Dilfepimenta tria craffiora, \& tria tenuiora, utraque longitudinalia: inter hxc, diaphragmata transverfalia; membranacea, tenuiffima, alba, pro fingulis feminibus cellulas partiales formantia.

REc. nullum, præter angulum centralem loculamentorum, cui femina, finplici ferie longitudinali digefta, \& horizontaliter affuxa funt.

SEN. numerofa, fphxrice triangula, utrinque planiufcula, atra, non fplendentia.

IN T. duplex: exterius coriaceum; interitus membranaceum, utrumque tenue.

A L. B. femini conforme, in recentibus feminibus carnofo-gelatinofum, pallidum, traufparens.

Eм в. monocotyledoneus, teretiufculus, dimidio-albumine paulo brevior, niveus. Ruthl. fubincraffita, contripeta.

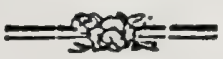

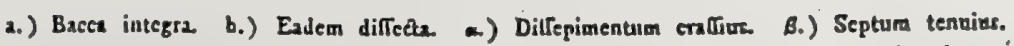
r.) Diaphragma feminibus interpofitum. c. c.) Semina foluta d.) Albumea denudatario c.) Idem longitudinaliter difreetum, cum fitu embryonis. F.) Embryo lepantus atoc. 


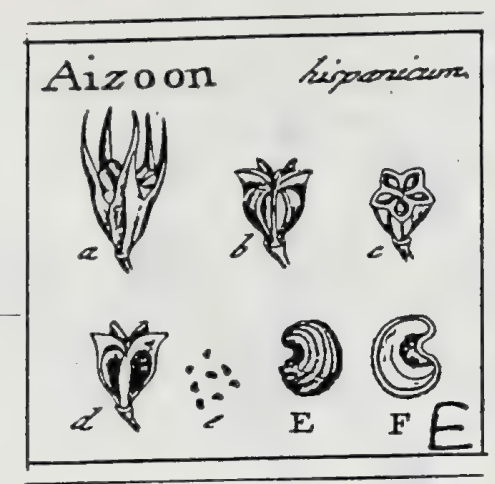

J. Gaertner (1788) Vol.1

CCCCLXXXII. AIZOON. Linn. gen. 6zg.

Calyx ınonophyllus quimquepartitus. Cor. nulla. Stam. plura calycina. Styl: quäh. que. Capprula fupera quinquelocularis, quinquevalvis. Semina renifurmia.

A $1200 \times$ hilpanicum. Tab. 5 . fig. 9.

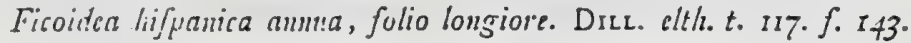

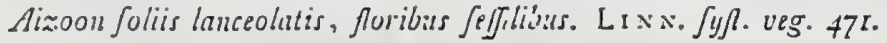

PE R. Caplula Supera, calyce veflita , turbinato ventricofa, apice fella quinqueradiata c valvularun apicibus comprellis corvisaia, membranacea, pentagona, quinquelecularis, quinquevalvis. Difleginnen:a valvis contraria.

REC. columunare, pentagonum, angulis intra loculamenta prominulis, capillares funis: culos cinitcentibus.

SE:s. plurima, circiter $12-19$. in fingulo loculanento, parra, reniformi globofa, fuicis longicudinalibus afperis exarata, atra.

Ix r. duplex: exterius crultaceum, cratiusculum, fragile; interins tenuifimum, rufeliens.

A LD. fubfarinolum, aqueo pallidum, unilatera!e, in feminis concara parte locatum.

Es в. retctiusculus, rraflus, fomicircularis, allicans. Cotyl. plan:o convexx, extror: fum craftiores. Rad. attenuata, centripeta.

a.) Capru!a intra caljecni, b.) liadem denudata - \& c.) (ransverfin feita. d.) Recrptac, cum funiculis unbilicalibus, e. E.) Seniua (eparala. F.) Enbrjo ad latus albuminis incra tekam feminis apertatn. 


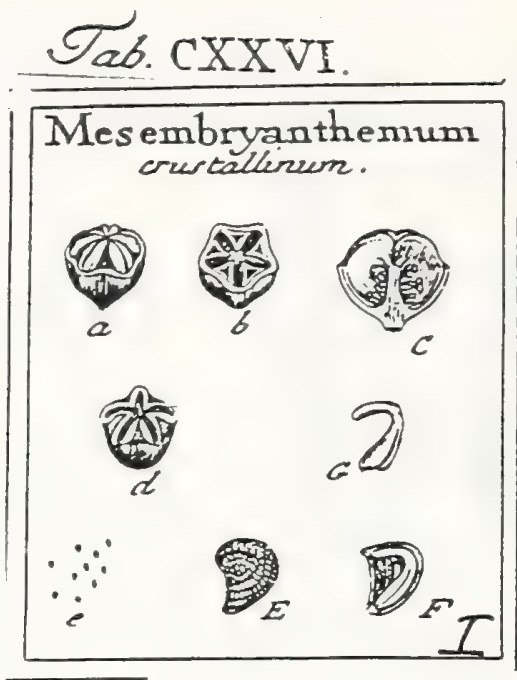

Aizoaceae

J. Gaertner (1788) Vol. 2

201

DCCXIX. MESEMBRYANTHEMUM. LINn. gen. 628.

Calyx femiquinquefidus, cum ovario connatus. Cor. monopetala, multifida, fegmentis imbricatis. Stam: numerofa, calyci adnata. Ovar. itrferum. Styl. quinque. Capfula calyce veftita, quinquelocularis, quinquevalvis. Sem. numerofa.

Mesembryanthemum cryltallinum. Tab. I26. fig. 9.

Mefembryanthemuns ayffallinum, plantaginis folio wudulato. Ditc. eltho 23 r. t. 180. f. $22=1$.

Mefembryauthemum foliis ovatis alternis paprilofis, fioribus Sefilibus, calycibus late ovatis acutis retufis. LINN. Syft. veg. 468.

PER. Capfula infera, f. ultra dimidium cum calycis ventre conferruminata, fub. globofa, apice leviter umbilicata, obfolete pentagona, quinquelocularis, rimis quinque incraffato marginatis in vertice dehifens. Loculamenca angulta, Jamina cartilaginea veftita. Diffepimenca fpongiofa, craffa, verfus axem cuneiformi - attenuata.

REC. centrale, columnare, pentagonum: angulis intra loculamenta porrectis, undique numerofis funiculis umbilicalibus ttipatis.

SEM. plurima, ad viginti quinque in fingulo loculamento, parva, compreffiufcula, renifurmi - triangula, rugofula, nigto - fufca.

202

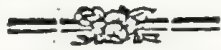

INT. duplex: coriaceum; atque membranaceum.

ALB. faftinofum, pullidum, unilaterale, embryonem in dorfo gerens.

Em B. periphericus, ficcundum dorfi arcum curvatus, Juteolus aut viridefcens. Cotyl. oblongx, planiufculic, extrorfum latefcentes, incumbentes. Rad. teretiufcula, centripeta.

2) Capfula calycis rentri imenerfa. b.) Eadcm transverfim fedu. C.) Receptac. centrale feminum. d.) Capfula apier debifeens. e. E.) Semina feparata. E.) Scmiuis feetiu rerticalis, cun albuminis \& embryonis fita. G.) Embryo folutus. 


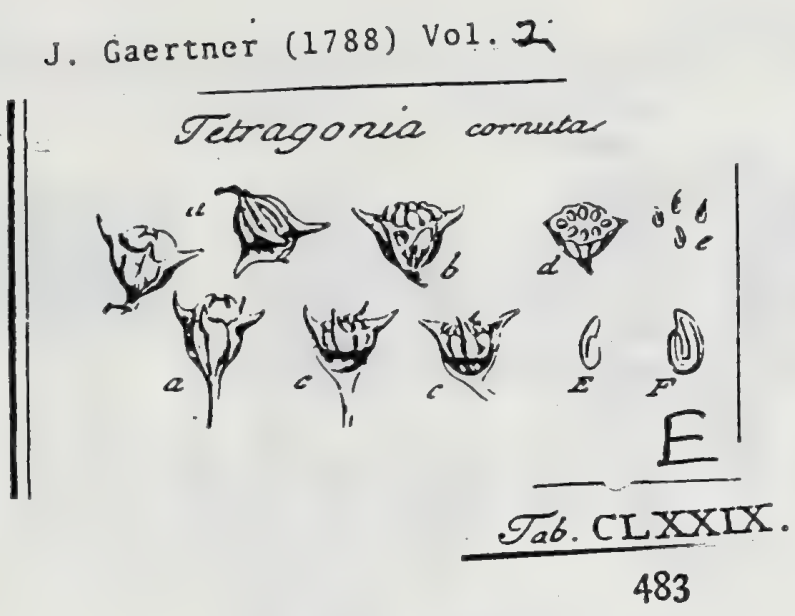

TETR $A$ G O $N$ I A. vid. fupra p. 204 .

TeIragosis cornuta. Tab. 179. fig. 3 .

Tetragonia berbacea, ramis expanjis elongatis, folits probalicis , floribus p'e-

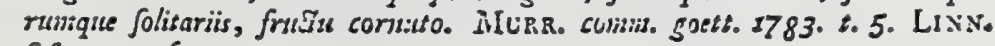
fy, veg. 46 7.

Ex herbario Bankfiano.

Drupa exfuce (2. a), infera, fuhturbinata, rhombeo-comprefis (d.), obfoJete fulenta, calyce connivente quaìidentato coronsta, quadricornis. Cortex herbaceo membranaceus, fuperne in calyeem - \& inferne in pedunculum definens; intus autem inter balin putamitais atque principium pedunculicavitate fubhemisphxrica (c. c.), inani aut fubftantia arancofocellulora replesa, cxfculptus. Putamen (b.c.c.d.) fuboffeum, fructu dimidio fere brevius, vercice fuo nudo, ferrugineo, $6-1.8$ tuberculato (b.) intra calycis cuvintem promiuens, cetera autem a cortice tectum. - quadricorne, odo fulcatum (c. c.), fex - L octoloculare (d.). Seminz (e. E.) folimria, unciutzto - conduplieata, furfum attenuata, rubro-ferru. ginea. Integ. fimplex, membranaceum. Alb. (F.) tenue, farinofura . niveum, embryonem includens. Embryo (F.) inverfus, lucefiens, uncinato-curvatus. Kal. fupcra. 
Tab. CXXVII.

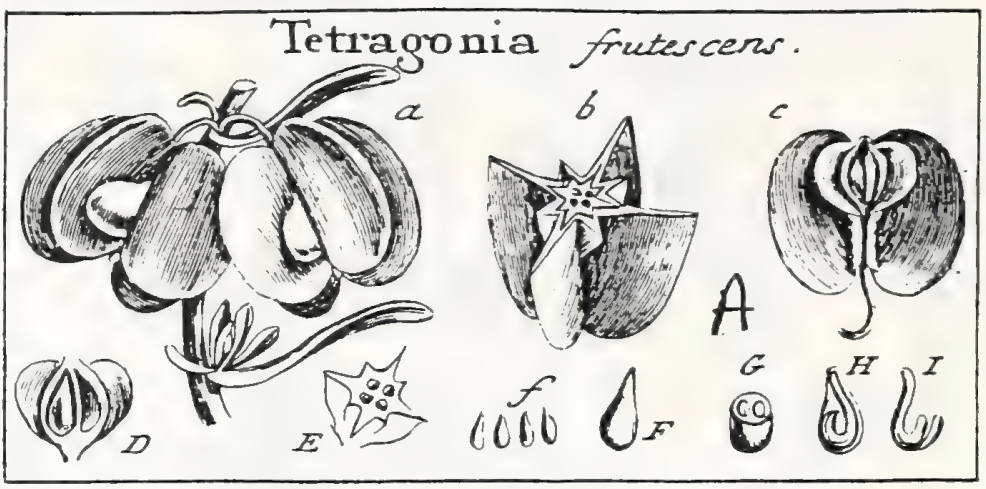

J. Gaertner (1788) Vol. 2

204

DCCXXII. T E T R A G O N I A. LINN. ger. 62\%.

Calyx quadri-1. quinquepartitus, fuperus. Cor. nulla. Stam. denis plura. Ovar. inferum. Styl. quatuor 1. quinque. Drupa ficca, infera, 4. 5. 6. 8locularis. Sem. folitaria. Enbr. inverfus, uncinatus.

Tetragonia fruticofa. Tab. 127. fig. I.

Tetragonocarpos africana, foliis longis Eे angullis. Сомм. hort. 2. p. 205. t. 103.

Tetragunia foliis linearibus. Lis.. fyst. veg. 467 .

Icont. MiLl. ic. t. $263 \cdot f .2$.

Ex horto regio kewenfi.

PER. Drupa exfucca, infera, alis octo, alternis majoribus, omnibus autem rotundatis foliaceo-compreflis atque coriaceis Ptipata. Putamen in fuprema drupx parte pofitum, offeum, ovato-globofum, pariter alis octo rotundatis \& alternatim majoribus exaratum, quadriloculare, evalve. Loculamenta intus glaberrima, e caftaneo fufca.

REC. nullum; femina per funiculum umbilicalem brevem apici loculamento rum affixa.

SEM. Solitaria, ex fubglobofa bafi furfum attenuata \& elongata, glabra, e caltaneo - ferruginea.

INT. duplex: utrumque membranaceum, tenue.

A L B. Fenini conforme, farinofum, album, enibryonem involvens.

Eмв. teretiufculus, uncinato-curvatus, inverfus, lacteus. Cotyl. femiteretes. Rad. longa, fupera.

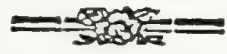

2) Drupz integrze b.) Setio drupz transverfalis. c.) Putaminis denudati fitus. D. E.) Ejus. dem feato longitudinalis atque transverfalis. f. F.) Semina feparan. G. H.) Albumen diftectum, cum litu embryonis. I.) Embryo deaudatus. 
Aizoaceae

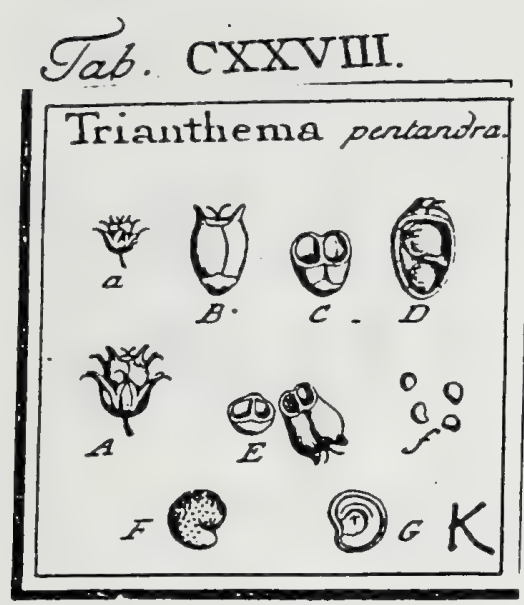

J. GaerEner (1788) Vol. Z

213

DCCXXXIV. T R I A N T H E M A. LINN. ger. 537.

Calyx pentaphyllus, foliolis margine membranaceis, fub apice ariftatis. Cor. nulla. Stitm. quinque aut decem. Ovar. fuperum. S.yl. unus aut duo. Capf. biloculans, circumfciffa. Sem. duo, unum fupra aiterum.

Trianthema pentandra. Tab. 128. fig. 5 .

Portulace affiuis polygonoides, bliti folio E? facie, madrajpatenjss. PLUR pbyte. t. 320. f. 3 .

Trimuthema foribus pentardris digynis. LiNs. Lyf. veg. 410.

PER. Capfula ovata, apice retufa \& duobus coniculis compreffis diftantibus munita, utrinque fulco longitudinali depreffo inferipta, bilocularis, paulo fupra bafin circumfiffa, inæquivalvis: valvula fuperiore multo longiore.

REc. nullum, prater diffepimentum, cui femina utrinque unum fupra alterum in fitu verticali affixa.

SEM. in fingulo loculo gemina, rotundato-reniformia fo roftellata, Ienticularịa aut obfolete angulata, rugora, atra.

IN T. duplex: exterius cruftaceum, fragile; inserius membranaceum, rufefcens.

A L B. farinofum, niveum, centrạle. .

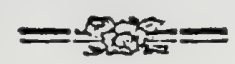

E в. periphericus, annularis, lutefcens. Cosyl. femiteretes, incumbentes. Rad. teretiufcula, infera \& aliquantum centripeta.

2. A.) Caplula eum calyce. B.) Eadem nuda C. D.) Ejusdem fedio transverfalis atque longitudinalis, cun infertione (eminum. E.) Valvuls separatx. E. F.) Seminz folutz G.) Seminis Sectio rertiealis eam fitn \& figura albuminis atque embryonic.

Plura femina, in alia forfan fpccie, numeravit Linnxus, fed in hac ne gemina quidem femper adfunt. Loculamenta quaterna, qux habet Adanfon, aut unicum, quod Linnxus in generibus defcribit, ego vidi nunquam. 
C

-

- 


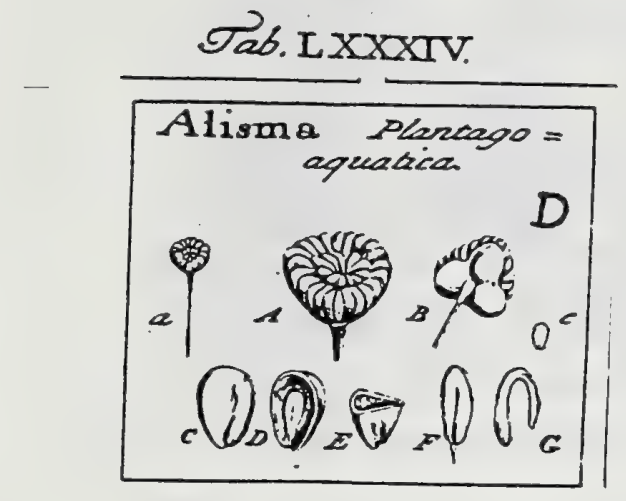

\section{J. Gaertner (1788) Vol. 2}

DXXIV. ALIS M A: LINN. gen. 460.

Cal. monophyllus, trilobus. Cor. tripetala. Stam. fex. Ovar. plura: Atylis fimplicibus. Capfuli pluses, coriacez, uniloculares. Semen conduplicatum.

Alisma Plantago aquatica. Tab. 84 fig. 4.

Plantago aquatica. DOD. pempt.606. CAM. epit. 264. OED. flor. dan. t. 56 r.

Dainafonizum foliis ellipticis lastceolatis, capitulo rotunde triquetro. HALL. biff. 18. 1184 .

Alifina foliis ovatis acutis, frudtibus obtufe trigonis. LINN. fyf. veg. 350 .

PER. Capfulx fuperæ, quindecim ad viginti, intra calicen perfiftentem in capitulum rotunde trigonum atque depreffum collectx, cruftacex, obovatx, cuneiformi-compreffre, uniloculares, non dehifcentes, funolo-ftraminex.

REC. commune: fundus calycis fpongiofus, leviter convexus; proprium, Funiculus umbilicalis brevis, e bafi capfulz ad femen pertinens.

$5 E^{\prime} M$. unicum, oblongum, utrinque linea longitudinali ex umbilico notatum, ut conduplicatum appareat, glabrum, rufelcens.

IN T. fimplex, membranaceum, tenue.

A L в. nullum.

Емв. magnitudine \& figura feminis, tereti-acuminntus, conduplicatus, albus. Rad. incraffata, infera.

a. A.) Capitulum fruetigerum 2 fuperiore $-\&$ B.) idem ab inferiore parte (pedatum. c. C.) Capfula integra. D. E.) Eadem longitudinaliter \& transverfina distedza. F.) Semen cum fuo funiculo umbilicali. G.) Embryo denudatus, cruribus diductis.

Alisma ratans.

Damafonium repens, potantogetonis rotundifolii folio. VAlL. AF. paris. I7Ig. edit. germ. p. 332. t. $17 . f .8$.

Alifina foliis ovatis obtufis, pedrazculis folitariis. LiNN. Jyft. veg. l. c.

Capfulic fex l. octo, teretiufcula, fylo brevi terminatx. Semen figura \& magnitudine catvitatis capfulx, pallidum. Embryo conduplicatus ut in pre. cedenti, fed multo obefior. 


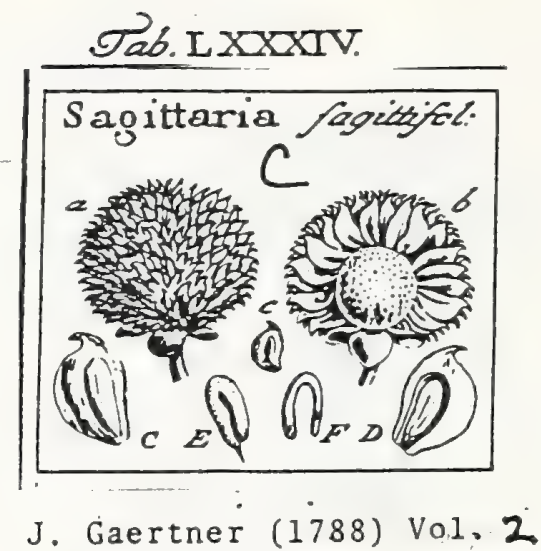

2 I

DXXIII. SA G I T T A R I A. LINN. gen. 106 $\bar{l}$.

Flores fexu diftincti in eodem caule. MAS. Cal. triphyllus. Cor. tripe. tala. Stam. triginti. FEM. Cal. \& Cor. ue in mare. Ovaria plurima conipreira. Capfulix utriculares numeroGifimx, femilunatx, compreffx. Semen teretiufculum, conduplicatum.

Sagittaria fagittifolia. Tab. 84. fig. 3 .

Sagitza. DOD. pempt. 588. CaM. epit. 874. OED. flor. dan. t. 172.

Sagitta foliis acuminatis. HaLl. bift. 13. 2185 .

Sulititaria foliis fugittatis acutis. LiN. Jyyz. veg. 856 .

PER. Capfulx fuperx, numerofifimx, in globum collectx, ante maturitaten lenticulari compreffx; puftea nembranaceo - bracteatx , fubfenilunares, ftylo breviffimo recurvo terminatx, uniloculares, non dehifentes, pullide Itramsiex.

REC. commone globofum, nudum, puncticulatum; proprizm, Funiculus filiformis brevis, intra losulamentum e bafi capfulix porrectus, femen fultiתens.

SEM. unicum, ovato-oblongum, ftria media longitudinali, ex umbilico, utrinque infcriptum, ut conduplicatum videatur, minutilime puncticulatum, rufefcens.

IN T. fimplex, tenuirfimum, tranfparens

A B. nullum.

22

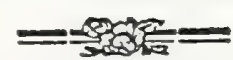

EM B. magnitudine feminis, tereti acuminatus, conduplicatus, albus. Rad. incrallata, infera.

2.) Capfulx maturx in globum collecte b.) Recept. commune denudatum. c. C.) Capfula feparata, integra. D.) Eadem aperta cum fitu \& figur feminis E.) Semen fusiculo unbilicali inftretum. F.) Embryo denudatus, cruribus didußis. 


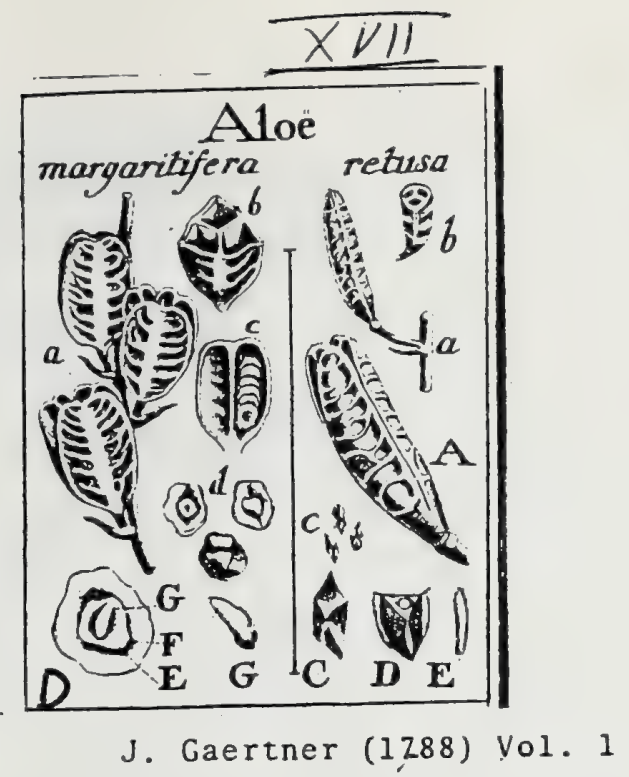

LXXVI. ALOE. TOURN. t. 190. Linn. gen. 430.

Corolla tubúlofa, fexfida. Stain. fex, recep̧taculo, non corollx inferta Styl. unīcus. Capfula fupera, trilocularis. Scinina plura, inargine' inembranaceo. Embryo longitudine albuminis.

ALOE margaritifera. Tab. 17. fig. 5 .

Aloe africana, folio in fummitate trinnguiari, margaritifera, flore fubviridi. Cо si m. hort. Amfl. 2. p. 19. t. 10.

Aloe africana margaritifera, folio undique verrucis mumerofiftmis. Brado. fuçcul. 3. p. T. t. 2 .

Aloe (pumila) floribus fpicatis bilabiatis: labio fuperiore erectiore; inferiore recurvato. LinN. Jyf. veg. 33 ?.

PER. Capfula fupera, elliptica, argure triquetra, nervis elevatis albis transverfalibus, e confimili fulco longitudinali inedio oriundis, affabre rugata, trilocularis, triralvis: valvis medio feptigeris.

REc. nullum : feınina margini difepimentorum centrati, duplici ferie, affixa.

SEM. plura, circiter duodecin in fingulo loculanento, fubrotunda, bracteata, Lato margine membranaceo cincta, nigro fufca.

IN T. duplex: exterius in marginem ampliatum; interius arcte adnatum; utrunque membranaceum.

$\Delta$ L B. Scrnine anguftius, irregulariter rotundum, compreflum, carnofum, album.

Ем в. monocoryledoneus, oblongus, comprefius, lacteo albicans, longitudine fere albuminis, ad umbilicum porttus.

2.) Capfuia integra, b.) Ejus Sectio transverfalis. c.) V'alvula feparata, cum fitu femirum. d.) Semina foluta, ab utraque parte fpectata. E.) Senen longitudinaliter parcitum, cum fuo margiae unembranaceo. F.) Albumen, fcmine multo angunius. G. G.) Eimbryo in fitu, \& (olutus.

Aloe retufa. ibid.

Aloe africana brevifimo crafifinoque.folio, ftore viridi. Сомs. hort. Amß. 2. p. 1I. t. 6. T'si 2. hort. pis. t. 5 .

Aloc fluribus fpicatis triquetris bilabiatis: labio inferiore revoluto. L1x.s. Jy/ veg. 337 .

Cappula steretiuscula (a. A.), obfolete trigona, nervis elevatis albis confuentibus vermiculata, trilocularis (b). Scmisa plura, triquetra (c. C.), zut varie angulata,

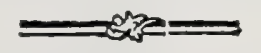

atra : angulis in marginem membranaceum, anguftum (D.) extenuatis. Embryo (D. E.) filiformis, longitudine albuminis. 


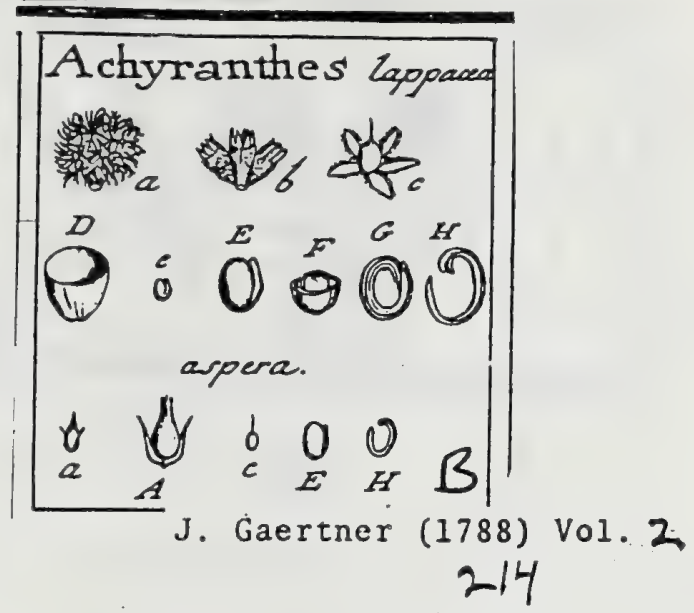

DCCXXXV. A CHYRANTHES. LINN。gen。288.

Calyx pentaphyllus, perGiftens. Cor. nulli. Stam. quinque, cum totidem fquamulis apice ciliatis alternantia, aut bafi inter $f e$ in tubum connata. Ovar. fuperum. Styl. unicus, apice bifidus. Capf. utricularis evalvis. Sem. unicum, inverfum.

Achrranthes lappacez Tab. 128. fig. 6.

Blitun fcandess, fruffu lappaceo. BuRM. 20ylo 47. t. 18. f. . $_{0}$

Achyranthes canle frutico $\int_{0}$ diffulo proftrato, fpicis interruptis, flofectis latesalibus utrinque fafciculo fetarum uncinato. LiNN. fyft. veg. 246 .

PER. Capfula ovata, membranacea, tenuiffma, glabra, unilocularis, evalvis.

REc. funiculus umbilicalis filiformis e fundo capfulx, ad feminis verticem procedens.

SrM. unicum, ovatum, ad alterum latus roftello longitudinali notatum, turgide lenticulare, glaberrimum, lucidum, atrum.

IN T. duplex: extcritu cruftaceum aut chartaceum fragile; interius membranaceum, fubferrugineum.

A LB. farinolum, niveum, centrale.

Eм в. periphericus, annularis, lutefcens. Cotylo lineares, incumbentes: Rad. teretiufcula, adfcendens, fupera.

a.) Calyces maturi glomerati, fetis uncinulatis involuerati. b.) Calyces ab involucto depurati, lanati. c.) (apíla deaudata. D.) Ejus fedio transverfalis. e. E.) Semen feparatam. F. G.) Idem transverfe \& verticaliter diffedum, eum latu \& figura albuminis atque embryoais. H.) Embryo folutus.

АснукАNTHEs afpera. ibid.

Anarmelus ficalse fpicatus. Bocc. fic. 16. to o Pluk. phyt. t. 260. f. 2.

Ailyranthes caule fruticofo ereffo, calycibus reflexis fpice apprefis. LiN N. Jyft. veg. 246 .

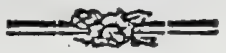

Involucrun (a. A.) diphyllum fubulatum pungens. Calyces folitarii, foliolis paleaceis convergentrbus capfulam obtegentibus. Capfula (c.) tenuiffra, vix a femine difcreta, ut fere nulla Semer (E) ovato-oblongum, fere cylindricum, ad latus roftellatum, melinum. Integ. fimplicillimum membra. naceum. Albumen \& embryo (H.) ut in precedenti. 


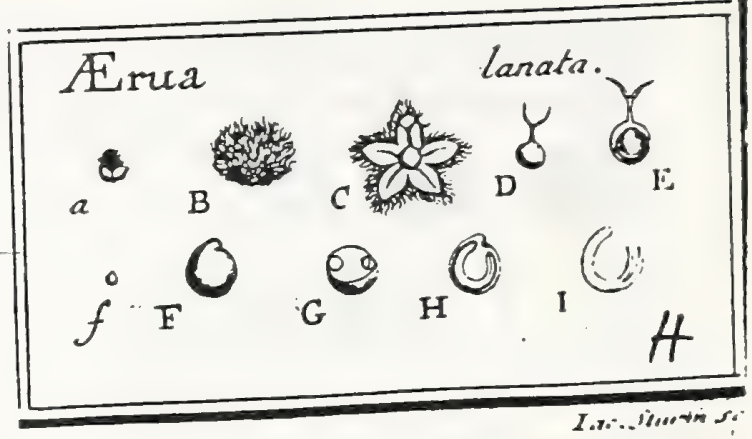

J. Gaertner (1788) Vol 3

\section{A ER Y A. \\ Foвsk. defc. p. r7o. Juss. ger. p. 88.}

Flores bafi bracteis duabus 1 . tribus muniti, nonnunquam dioici:

Cal. monophyllus, profundiffime quinquepartitus, 1. pentaphyllus; foliolis ovatis, patencibus, extus lanuginofis: intus concavis, glabris, nervo intermedio notatis, perfittentibus. Stam. 10., quorum f. Iterilia; filamentis omnibus bafi in tubulum connexis; antheris ovatis, erectis. Ovar. fuperum; ftylo fimplici, bifido, perfiftente; ftigmatibus fubulato-acuminatis. Capf. globola. Rec. funiculus umbilicalis filiformis." Sen. unicum, turgidum, invertum. Alb. centrale, farinofum. Emb, periphericus, annularis.

Merua lanata. Tab. 213 . fig. 8.

Irefine (perfica, ) foliis obovalibus, panicala terminali, fpicls fimplicibus longiffimis. BURM. ind. p. 312. t. 65. $f:$ i.

Celofia (lanata, ) folis lanceolutis tomentofis obtufis, fpicis confertis, Aaminibus lanatis. LINN. Jpec. plo. 298. VAHL fymb. bot. 2. p. 44

Illecebrum (javanicum, ) foliis lanceolutis tomentofis, fpicis cylindraceis nunserofis terminulibus. AIT. bort. kew. i. "p. 28 g. WILLD. Spec. pl. T. x. P. 2. p. 1205.

Achyrantbes perfica. Persoon fyn. t. p. 259,

Ex Aegypto a Cl. Druile, Inlt. Scienc. Gall. Aegypt. Memb.

REC. Capfula globofa, intra calycem perfiftentem recondita, minima, ftylo perfiltente faltigiata, membranacea, tenuis, glabras lutefcens, uniloctlaris, evalvis.

Rec. funiculus umbilicalis filiformis, falcatus, e fundo capfule efurgen \& umbilicum fenmus adeuns.

SEM. unicum, fubglobofum, 1. turgide lenticulare, toltellatum, inverfum, fab vertice umbilicatum, e funiculo penduslum, glaberrimum, airidum, atrum.

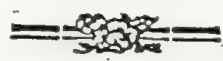

IN T. duplex: exterius cruftaceum, fragile; interius membranaceum, tenuifrmum.

A \& в. centrale, farinofum, candidum.

EMB. periphericus, annularis, lutefcens. Cotyl. lineares, femiteretes, radiculam non attingentes, incumbentes. Bad. teretiufcula, adfcendens, cotyledonibus duplo longior \& paulo altior, obtufa, umbilico externo obverfa, fupera.

\section{EXPLICATIO FIGURE.}

a.) Frutas integer, cura duabus bracteis fioralibus. B.) Calyx eapfalam occoluns. C.) IJem expanfus, cum capfula in fitu. D.) Capfula Separata, iategra. E.) Ejusdem fettio rerticalis, cum femine ex funiealo umbilicali pendulo. f. F.) Semea feparatuo. G. H.) Idem trasverfé \& verricaliter diffetum, cun fitu albuminis atque exbryonis. I.) Embryo folutas.

Amaranthorum ordo apprime naturalis iterata \& accurata revifione generum anthologica quam maxime indiget. 
Amaranthaceae

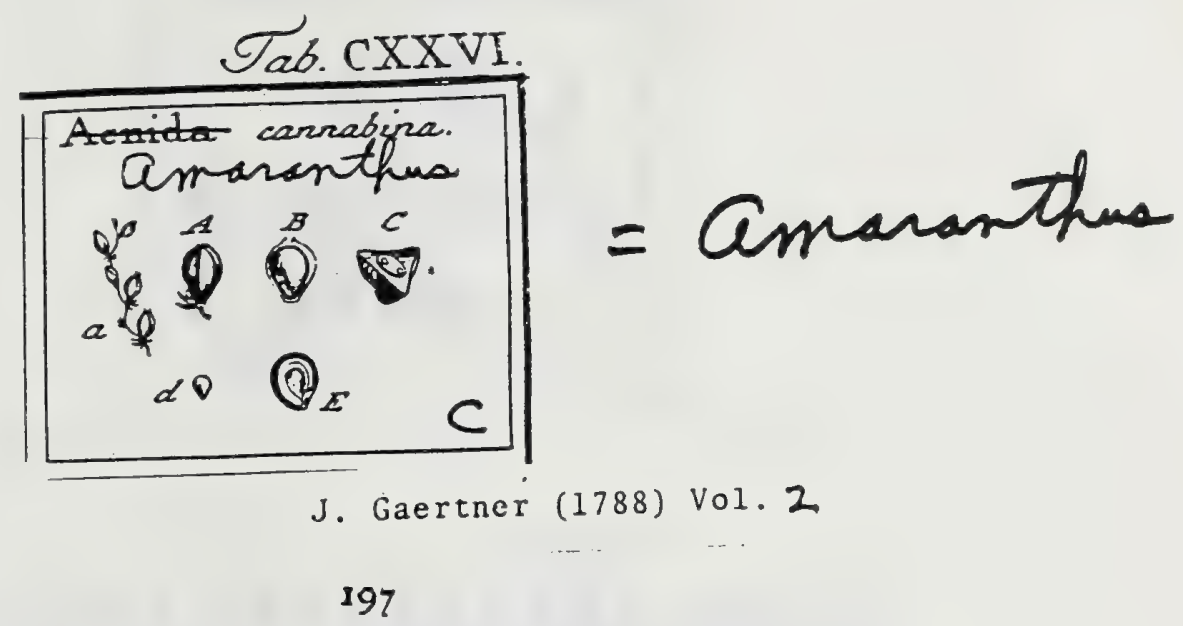

DCCXIII. A C N I D A. Linn. gen. III4

Flores fexu diftinct in feparatis ftirpibus. MAS. Cal, pentaphyllus, foliolis margine membranaceis. Cor. nulla. Sram. quinque. FEM. Cal. tridentatus, bafi munitus fquamula forali parva, lineari - digitata. Cor. uulla. Ovar. fuperum. Styl. quinque, pubercentes. Sem. umicum, calyce fuc culento teckum.

ACXIDA cannabina. Tab. T26. 5g. 3 .

Cannubis folitis fimplicibrs. GroN. virg. 153 .

Acnidr. Linx. fyj. veg. 886.

Ex herbario Bankfiano.

PER. nullum; calyx per maturitarem fucculentus, obovatus, trïbus derricuTis acuminatis terminatus, \& ex tribus fulcis longitudinalibus argute triqueter, ut fere trialatus, femen foret, nec dimirtic.

REc. nullum, procter fundum calycis.

SEM. unicum, ovatum, deorfam acuminatum, compreffrifculum, e caftaneanigricans, glaberrimum, lucidum.

IN T. duplex = extetius cruftaceum, fragile; interins membranaceum.

A L B. centrale, cearnofum, duriufoulum, album.

EM B. terctiufculus, periphericus, arcuatus, lacteus. Cotyl. Semireretes, in cumbentes. Rad. longitudine cotyledonum, infera.

195

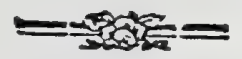

$\bullet$

2. A.) Calyx maturos. B.) Ejusdem fectio longitndinalis, cum fitu femiais. C.) Calycis \& feminis fectio transverfalis. d.) Senen feparatum. E) Idem difectum, cum albumiuis \& cun-
bryonis fitu ac figur.

In ominibus meis exemplis calycem femineum video trifidum \& fructum trifulcum ac triquetrum; nec ut habet Linnxus, calycem diphyllum \& fructum muleangulum. 


\section{Tab. cXXVIII.}

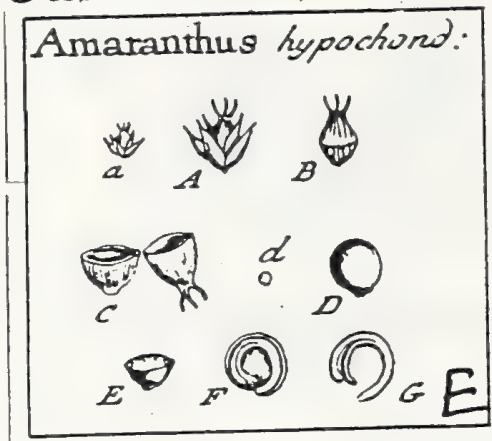

J. Gaertner (1788) Vol:2.

215

\section{A M A A N TH U S. LINN. ger. 1060.}

Flores fexu difincti in eadem ftirpe. MAS. Cal. pentaphyllus. Cor. nulla. Stam. tria aut quinque. FEM. Cal. \& Cor. ut in mare. Ovar. fuperum. Styl. tres. Capfula membranacea circumfcifra. Sem. unicum erectum.

Amaranthus hypochondriacus.' Tab. 128 . fig. 7 .

Anzarmbibus racemis pentandris compofitis confertis eredis, foliis ovatis mucronatis. LIN S. Jyf. veg. 854 .

PER. Capfula ovan, ftylis tribus perfiftentibus terminata, membranacea, compreffiufcula, longitudinaliter obfolete ftriata, colorata, unilocularis, circumfcifa: valvulis zqualibus.

RE c. nullum, at cicatricula minima alba in fundo capfalx, cui femen in fitu erecto affixum.

SEM. unicum, rotundatum, in bafi roffellatum, lenticulari compreffum, glaberrimum, hucidum, e fanguineo-atrum.

IN T. duplex: cruftaceum, aut chartaceum fragile; \& memiranaceum pallidum. A I. B. farinofum, albicans, centrale.

E s в. periphericus; aınularis, lacteus. Cotyl. femiteretes incumbentes. Rad filiformis infera.

2. A.) Fructus inaturus cum calyce. B.) Capinla deandatz. C.) Valvuls feparate d. D.) Se men integrum. E. F.) Idem difreetum cam figurz \& firu albuminis atque embryonis G.) Eom bryo folutus. 


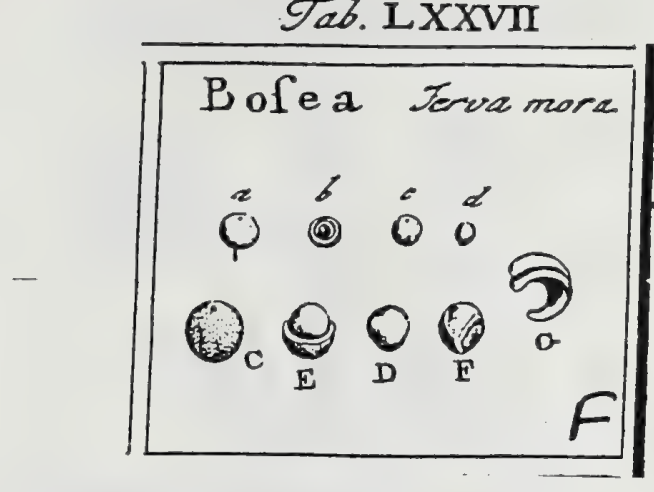

J. Gaertner (1788) Vol.1

CCCCXC. BOSEA. LIN N.: gen. 315 .

Calyx pentaphyllus. Cor. nulla. Stam. quinque. Styl. duo. Drupa baceata unilo. cularis. Semen unicum erectum.

BOSE a Jerva mora. Tab. 77. fig. 6.

Arbuscula baccifera canarienfis ', furinga ccrulece foliis. PLu x. alm. 42.

Frutex peregrimus, yerva mora dizus. Walтн. hort. 42. t. Io.

Bofea. L I N s. Jyft. veg. 265 .

PE P. Drupa lupera, parva, globofa, per maturitatem nigra aut fufco fpadicea. Caro tenuis, intlar febị fragilis, fracturâ ex albo viridefcente. Putamen crufaceum, durum, atrum, puncticulatum, fragile, uniloculare.

REC. nullum; femen bafi affixum.

SEN. unicum, globolun, rufefcens.

I:r. fimplex, men:branaccum, tenue.

A L. B. globofuin, farinofurn, candidifiınum, inaximan partem ab embryone obvo. lutum.

l: sk. priphericus, curvatus, erectus, lacteus. Cotyl. foliacex, ovato oblongx, concava, tenuithimx, albumen involventes. Rad. conica, craliuscula, deorlum curvata, infera.

s. b.) Drupa iutegra \& differta. c. C.) Putamen denudatum. d. D. E.) Semea intra putamea (E.) \& ab co. feparatum. F.) Embryo albumen cingens. G.) Idem Separatus.

Sola aibuninis craflitic \& radicula embryonis infera a Celtide differt.

Curyletonum color lacteus, vel in vetuftiori femine, ab aqua, intra viginti quaruor lioras, in graminco - viridem inutatus fuit: unde femen ex longavis effe viderur.

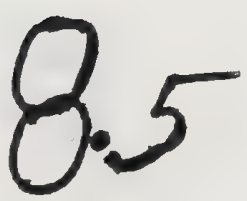




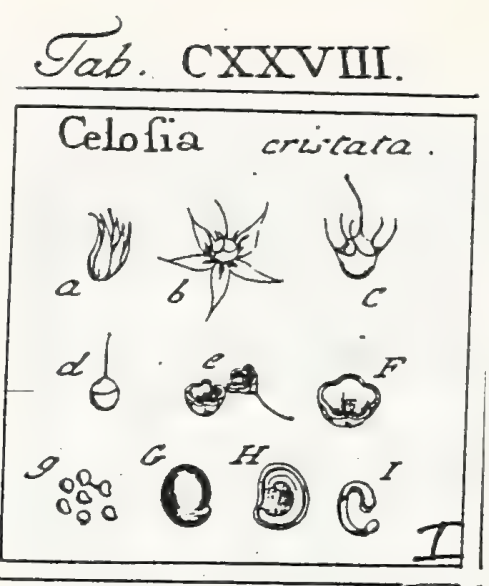

J. Gaertner (1788) Vol. 2

$$
215
$$

\section{DCCXXXVIL C EL O S I A. LIN⿴. gen. 289.}

Calyx pentaphyllus, foliolis duobus vel tribus externe ad bafin accefforiis, omnibus membranaceopaleaceis acuminatis. Cor. mulla. Stam. quinque, bafi in cupulam hemifphxricam ovarium cingentem connata. Ovar. fuperum. Styl. fimplex, apice bifulus. Capfula membranacea circumfcifa. Sem. plura.

Cerosia criftata Tab. 128. fig. 8.

Amaranibus criftatus. CAMi. epit. 792. BESL. Eyff. Aut. II. t. 8. f. 1 .

Amarantbus vulgaris, RUMPH. amb. 5. p.236. t. 84

Celofia criftata \& caftrenifis. Linn. Jyjz. veg. 247.

PER. Capfula fubglobofa, membranacea, tenuis, ftylo longo filiformi termi. nata, unilocularis, circumfcilla: valvulis fubæqualibus, polt dehifcentiam rotunde quinquangularibus.

REc. fubcolumnare, breve, tuberculatum, in fundo capfulx, feminz is fitu erecto fultinens.

SE M. plura, ad decem, irregulariter rotunda, fubreniformia, lenticulari-comprefra, glaberrima, lucida, faturate caltanea.

IN T. duplex : cruitaceum atque membranaceum.

A L B. farinofum, àlbum, centrale.

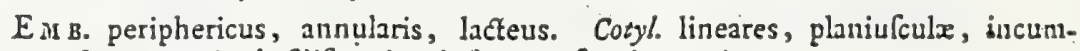
bentes. Rad. filiformis, infera \& Gimul centripeta.

2.) Calyx maturus capfulam obtegens. b. C.) Stamina in cupulam bafin capfule cingenten connata. d.) Capfula denudata integra. E.) Eadeun dehifcens. F.) Receptac in fundu capfuit. g. G.) Semina feparatz. H.) Semea diffecum sum fitu \& figura albumiais ac embryoniso I.) Embryo folutus.

Sxpe in capfulis maturis inter femina perfecta \& rite formata, alia reperiuntur monftrofa aut per prxcocem vegetationem deformata, naturalibus majora, viridula, vacua, crifpo rubroque filo terminata. 


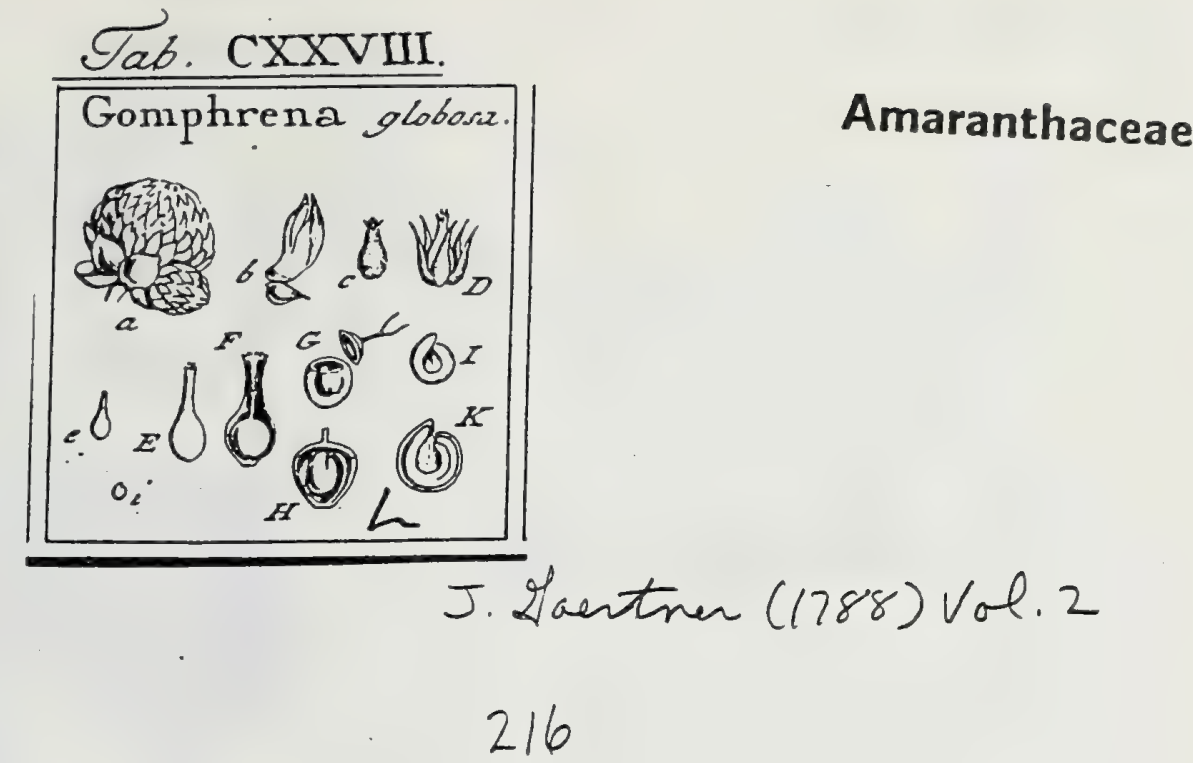

\section{G O M P H R E A. LINN. gen. $3 \mathrm{r}_{4}$.}

Calyx pentaphyllus albo tomentofus, involucratus fquamis tribus, quarum dux maximx, naviculares, comprelifo carinatx, coloratz, conniventes. Cor. nulla, nifi ftaminum tubum velis. Stam. quinque, filamentis in tubum conicum, apice quinquedentatum, inegerrimum connatis. Ovar. fuperum. Styl unicus bifidus. Capfula membranacea circumfcida. Sens. unicum inverfum.

Gomphrena globofa. Tab. 128. fig. 9.

Flos globofiss. Ruмph. amb. 5. p. 289. t. 100. f. 2.

'Amarantho affinis indie orientalis, floribus conglomeratis, ogmafiri folio. BREYN. ceit. 109. t. 51. Coмm. bort. I. p. 85. t. 45 .

Gomplivena caule ereino, foliis ovato - Lanceolutis, capitulis folitariis, pedunculis diphyllis. Liss. Jy/t. veg. 264.

PER. Capfula fubrotunda, compreffiufcula, membranacea, femipellucida, unjlocularis, fupra medium "circumfcilla: valvula fuperiore breviore.

REC. funiculus umblicalis filiformis, e fundo capfulx ad feminis verticen proc:dens.

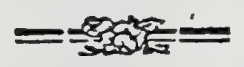

SE S. unicum, fubrotundum, roftellatum, turgide lenticulare aut fubglobofum, glabrum, fulvum.

IN T. duplex : coriaceum \& menbranaceum, utrumgue tenue.

A L B. farinofum, candidum, centrale.

Es B. periphericus, annularis, lutefcens. Cotyl. femiteretes, incumbentes. Rad, teretiufcula, adfcendens, fupera.

2) Capitulum Borus b.) Involueri calțcini fquamx. c. D.) Calgx verus e. E.) Tubus fta. minum integer. F.) Idem apertus cum fitu capfulz. G.) Capfula dehifecns H.) Eajen' longitudinaliter aperta, cum femine e funiculo umbilicali peadeate. I.) Semen integrum. K.) Idem difreatum cum figura \& Itu albumiais atque embryonis. 
6

-

( 

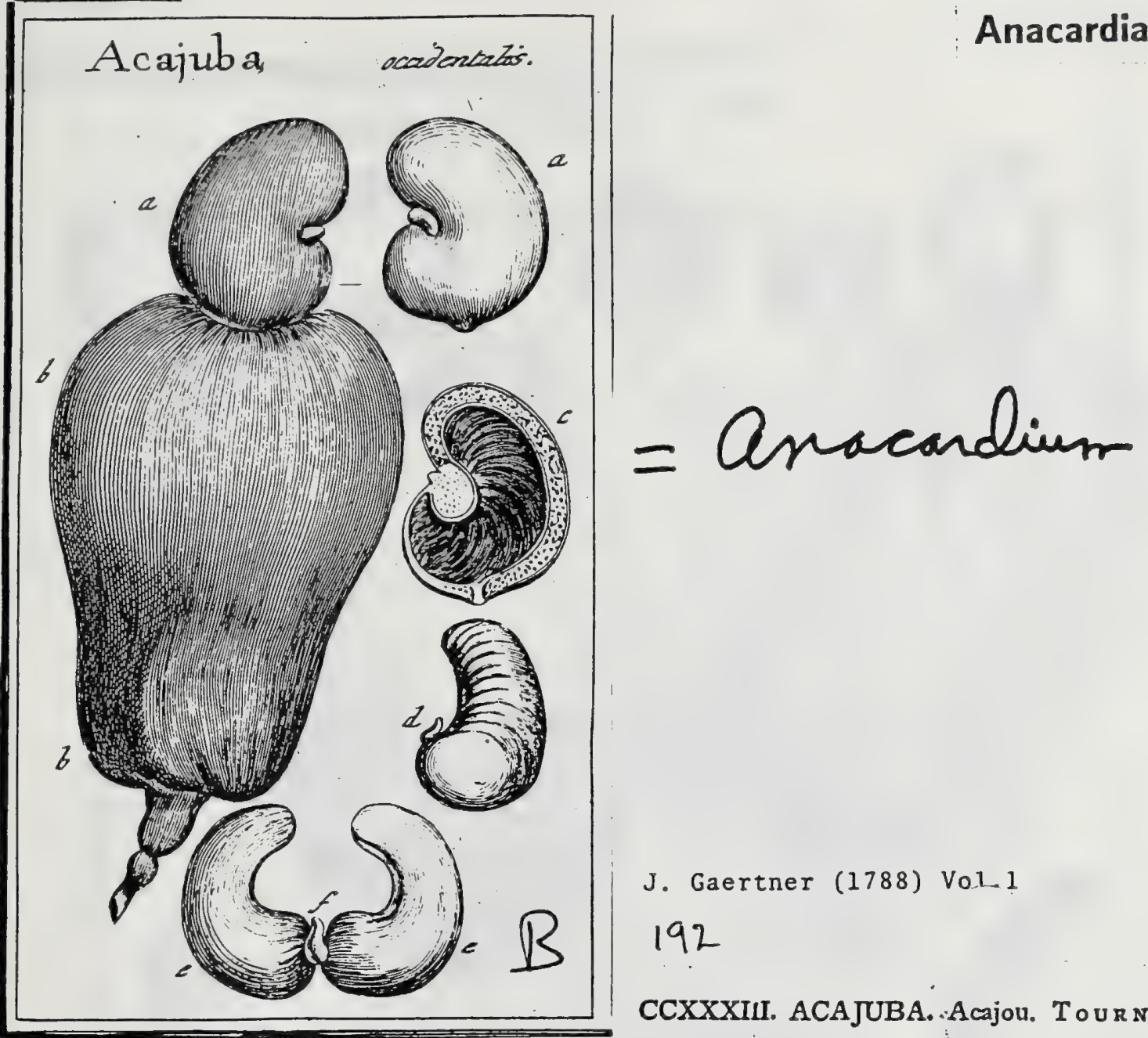

le

Calyx quinquepartitus. Cor. pentapetala. Stam. decem: nno caftrato. Styl. unf cus. Nux fupera reniformis, receptaculo grandi carnolo infifteus. Putauninis di: ploe fungofa, fubfolida.

Acrjuвa occidentalis. Tab. 40. f. 2.

Acajaiba. Marcgr. bras. $p$. 95.

Acajou. Pis. bras. 58 .

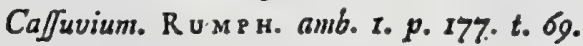

Anacardium. Blakw. herb. t. 36g. Jace. hifl. anser. 124. t. 18т. f. 35. Lrastat S4/. veg. 384 .

PER. Nux fupera, uuda, reniformis, inferne ventricofior, fuperne coinpreffruscola. cartilaginco coriacea, glabra, helvola aut livida, ad reuis pelviun a'bicans, unilow cularis, evalvis. Putamen craftum, contlatum e duabus laminis coriaceis durs:

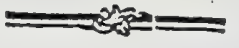
atque fubnantia uredia fuberqfa cellulofa : cellulis minutis, fparfs, irregularibus,
alto fluido fufco acri fcatcntibus.

REC. turbinatum, carnolum, varix inagnitudinis, femper tanien auce ipla multo gran-
dius, c lutto \& purpureo variuın.

SEs. unicum, reniforme, rubro ferrugineum.

IN T. fimplex, coriaceum, tenue, arcte adhxrens.

A L B. nullum.

Exв. Cemini conformis, erectus, lacteo albus. Cotyl. Cemilunatx, obturx, camofx, craffx, plano-convexx. Plam. nulla. Rad. uncinulata, e bafi cotyledounn fur-
fum adfcendens, brevis, exferta.

a.2.) Nux integra. b.b.) Receptaculum earnofum, c.) Nucis feetio longitudinalis, diploes fabrio cam atque pelvis fungofam protuberantian alban, cui ftylus floris infertus erat, oftendens, d.) Semell integrum, ab inprefiionibus putaninis, transverfim obfolete friatum. e. e.) Embryonis densdati cotyledones didultx \& 2 parte fua convexa fpedatz. E.) Radicula figura \& fitus. 


\section{Anacardiaceae}

J. Gaertner (1788) Tab. KL.

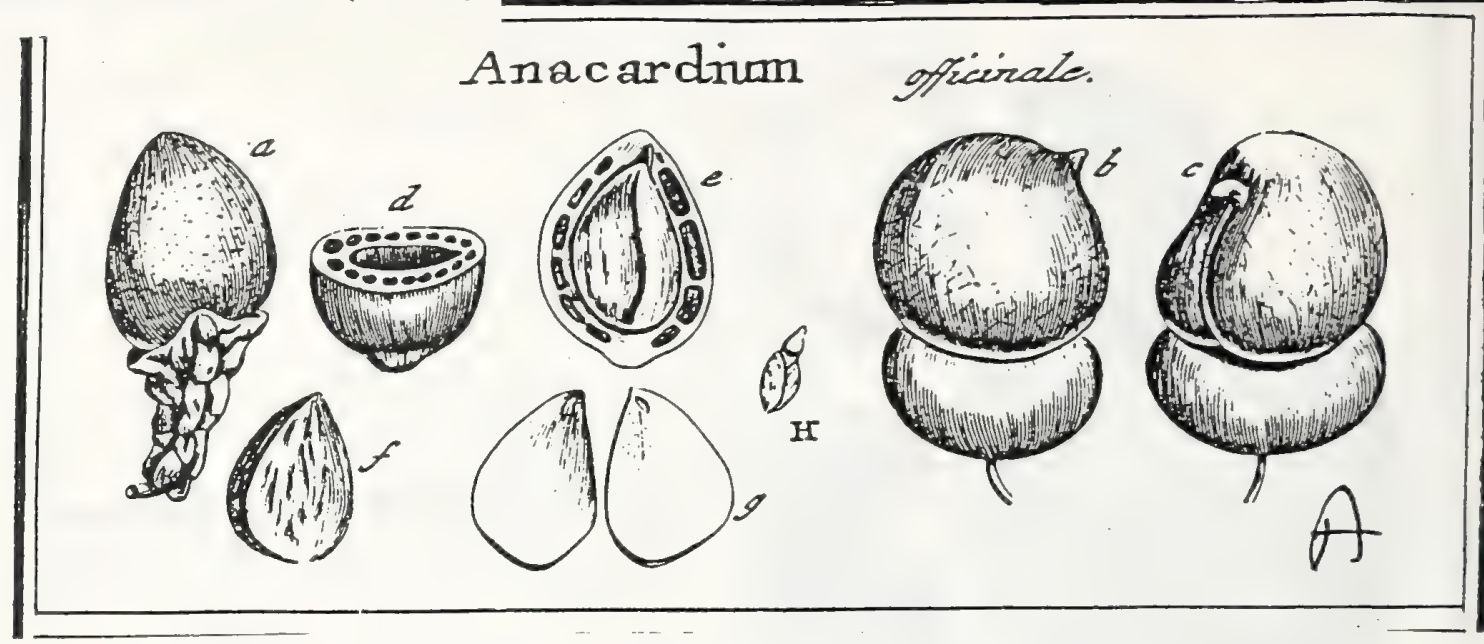

J. Gaertner (1788) Vol.1

CCXXXII. ANACARDIUM. OFFic:

Calyx monophyllus, feniquinquefidus. Cor. pentaperala. Sizm: quinque. Styl. tres. Nux fupera, fubcordara, receptaculo grandi carnofo infinens. Putaninis diploe cellulis terctilus gunnuiferis exfoulpta.

192

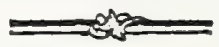

ANACARDIUM officinarum. Tab. 40. fig. T.

Anacardinm. Баин. lifl. x. p. 334. Joнsist. dendir. t. 49. Besz. muf. t. 4.

Semecarpus. LiN. Jilf. veg. 292.

$P \Sigma R$. Nux fupera, nuda, cordato oblonga, compreffiuscula, hinc leviter convexan inde plana, dura, nigricans, unilocularis evalvis. Yutanen crallum, inter dase laniinas coriaceo crulluceas cellulofum: cellulis, terctibus, longitudinalibus, pes diaphragmata fubjivifis \& fulftantiâ refinofo gummofâ atrî̀ fplendente repletis.

REc. fructus, carnofum, grande, nunc fubglobofum, deprefliusculum, glaberrimum, nunc turbinatum, f. oblongum, rugofum; feminis: funsculus umbilicalis breviefi: mus, e vertice nucis, ad femiuis apicem deliendens.

SE s. unicuin, amygdaloides, comprefliusculun, ovato acuminatum, rufefcens, it cinnamoineuin.

IN T. fimplex fubcoriaceum, in fuperficie fua interiore glabrum, fubcarnofura.

А ц в. nullum, nifi tenuiffinain velis laminam carnofan integunenti.

Е м в. Semiui conformis, inverfus, lacteo albus. Cotyl. ainygdalino carnolx obovatzi irregulariter plano convexx. Plumula diphylla: foliolis oxatis, venofis, cone duplicatis, tenerrinis. Radic. minutula, acumnisata, fupera, intra cotyledogume. apicem Latens.

a.) Nux matura vetuka, receptaculo turbinato, ab etate corrugato, infinens. b. c.) Nux in (pirila vini atTervata, receptaculo turgido, glaberrimo inhereus, d. I Sflio putaminis trasuverialis. a) Idem longitudiualiter apertum, cum cellulis refiuiferis \& fitu femisis. f.) Semen foluum. 6.j Cotyledones feparatz, H.) Plumula aula, 
J. Gaertner (1788)
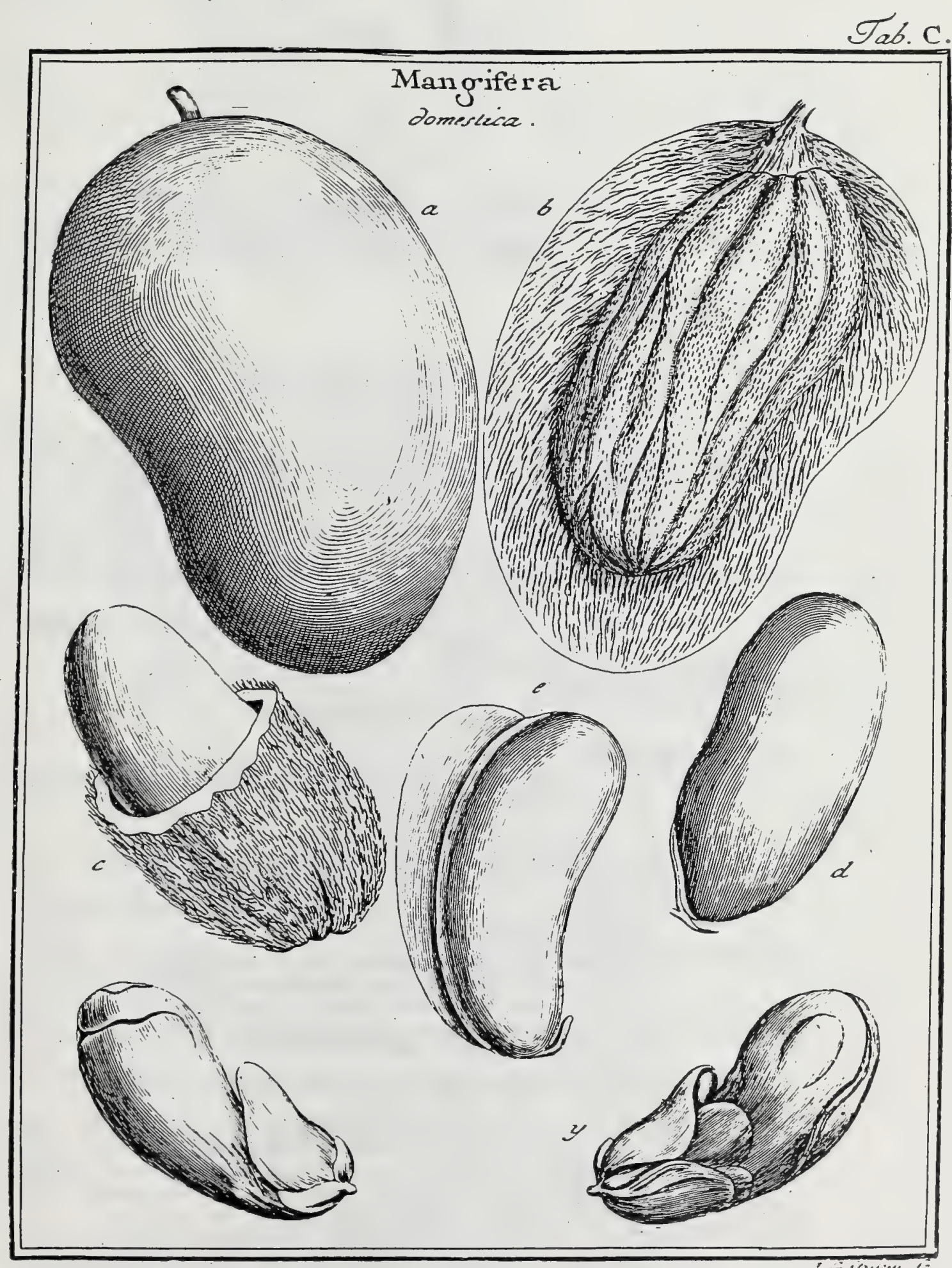

$9.3 A$ 
DCIII. M A N G F ER A. LINN. ger. 278.

Calyx quinquefidus. Cor. pentapetala. Stam. quinque, aut decem. Ovar. fuperum. Styl. Gmples. Drupa baccata monofperma, putamine fibris lignolis crinito.

Mangifera domeltica. Tab. 100.

Matı RHF.eD. mal. 4. p. T. t. 3. 2.

Manga domeflica. RuMPH. amib. I. p. 93. t. 25 .

Mangifera foliis finplicibus, floribus pentandris. LINN. fyft. veg. 242.

E collect. fem. hort. lugdb.

Pr R. Drupa baccata, lenticulari - comprefla, reniformis, glabra, lutea. Caro mollis, pulpora inftar Pruni damafceni. Putamen ovato-oblongum, fubreniforme, coriaceo-crulnceum, durum, uniloculare, evalve; extus ful. cato rugofum atque fibris capillaribus lignofis undique contectun; in:tus vern glabrum atque membrana propria, chartacea, tenacillima, g'aberrima, albicante, \& per maturitatem fponte a putamine fecedente, veltitum.

REc. funiculus unbilicalis breviufculus, e fundo putaminis oriundus, feminisque parti inferiori marginali infertus.

SEM. unicum, grande, ovata-oblongum, plus minus lenticulari comprefium, amygilaloideum, glabrum, rufelcens.

Is r. fimplex, chartaceum, tenue.

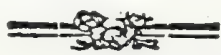

A c 8. nuHum.

E м. femini conformis, erectus, albus. Cotyl. carnofx, plano-convexz. Kud. brevis, furfum incurvata, infera.

a.) Drupa intogrs. b.) Putamen denudatum, integrum. c.) Idem transverfe fetum. d.) Semeu feparatum, curn fuo funiculo unibilianli. e) Embryo denudatus.

Plures hujus Mangx domefticx $\int$ culta dantur varietates, e quibus fequentes potifimum annotari merentur:

Mimga compre $\sqrt{\alpha}$. Putamen grande, fpithanam circiter longum, fuperne quali foliaceo-compreffum, inferne autem parvo loculamento lenticulari dutatum, cetera vero fulcatum atque crinitum uti pracedens.

Marga dodoel. javan. Putamen valde turgidum, de reliquo autem primx fpeciei fimillimum, uifi quod tercia parte brevius fit

Mangra Kayjer. javan. Putamen proxime prxcelenti fimillimum, fed vix fulcatum, \& obiter tantum ftriatum.

Mnnga teloor. javan. Putamen dinidio minus quam procedentium, turgidulum tamen \& profunde fulcatum. Vocatur quoque Mranga - hatty: javan.

Manga Bierie - gandaria. jav. Putamen magnitudine \& forma putaminis Amygdali, coriaceum, tenue, fragile, album, neque fulcasuni neque Atriatum, fed fibris groflioribus hirtum:

In omnibus hifce varietatibus embryo in duas cotyledones regulariter fectus deprehenditur, prxterquam in prima $\mathrm{f}$. domeftica; in qua fcil. fapifime lobi cotyledonei inter fe conferruminati \& in varios partiales lobulos irregulares diviff funt, ficuti figurx fub litt. $x, \& y$. oftendunt. 


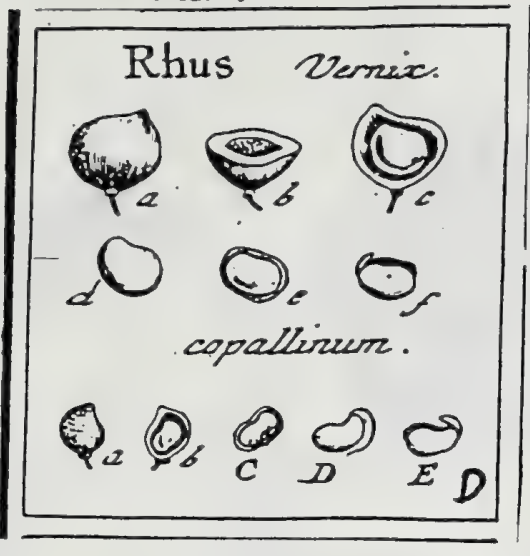

J. Gaertner (1788) Vol.1

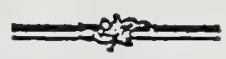

CCXLVIII. RHUS. TOURN. 381 .

Calyx quisquepartitus. Cor. pentapetala. Stam. quinque. Styl. tres. Drupa ficca, acumine ubliquo. Semen inverfum: embryonis radiculâ cotyledonum rimz luperius incumbente.

RHus Vernix. Tab. 44. fig. 2.

Site f. Sitz-difiu. Kessp. amoen. 791. ic. 792.

Rhus foliis pinnatis integris annuis opacis, petiolo integro aquali. IHUNB. $j$ o. pon. I2I. LI IN. Jifl. v8g. 293.

Ex dono $\mathrm{Cl}$. 'Thunbergir.

PER. Drupa exfucca, torgide lenticularis, rotundo-rhomboidea: vertice acuminato, obliquo, excentrico. Cortex craflus, fibrolo fungolus, luperficie lavigatifupa, fplendente, fpadiceo-lutea. Putanen offeum, transverfe ellipticum, obfoletifiline rugofiun, cralliuscultum, teflaceo - pallidum.

REc. funicults umbilicalis capillar is, e fundo putaminis ad ferninis apicem adfcendens.

SE 2r. unicum, obliqưue ellipticun, pallidun.

IN T. fimplex, inembranaceum, iutus fubrarnofum.

$\mathrm{A}$ × в. nullum, proter integumenti parietem fubcarnofum.

Es 8. magnitudine feminis, inverfus, albus. Cotyl. ellipticx, carnofx, plano-convexiusculx, teuves. Rad. fubfuffiformis, intexa, fuperiori cotyledonum rimx incuunbens.

a.) Drupa integra. b.) Cortex transverim fectus, c) Putamen deacdatam d.) Idem Ceparatunn e.) Serninis fitus in patamine. f.) Embryo denudatus.

Rrus copallinum. ibid.

Rhus obfoniorum finilis americana, gunmi candidum fundens. Prux- phyt. t. 55 . f. $I$.

Rhus foliis pinnatis integerrimis, petiolo membranaceo articulato. LINN. fyll. veg. 293.

Drujia parva (a.), rhombeo globola, fanguineo rubra, pubefcens. Cortex te nuis (b.), per xtarem laxis. Putamen (b. c.) duriffunum, teflaceum. Semen (C. D:) retriforme, pallidun; funiculo umbilicali (D.) fetaceo, fufco. Cotyleilones (E.) oblongs lutescentes. Rad. inllexa.

Non apte Bacea dicitur hoc pericarpiun, quia feminis funiculus umbilicalis undique folutus intra oliiculun dacurcit; id quod in propria \& vera fermivis tefta nunquam, Expe vero in putansine accidit. 


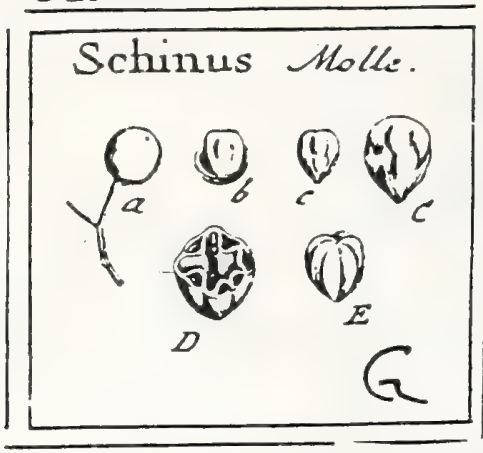

J. Gaertner (1788) Vol. Z

\section{S C H I N U S. LINN. gen. II3O.}

Flores fexu diftincti in feparatis firpibus. MAS. Cal. quinquepartitus. Cor. pentapctala. Stam. decem. FEM. Cal. \& Cor. ut in mare. Ovar. fuperum. Stigmata tria, feffilia. Bacca mono-1. tripjrena: olficulorun loculaments fpuriis o!co aromatico fcatentibus.

Scmuxus Molle. Tab. 140. fig. 7 .

Moile. Clus. car. pof. p. m. 94. c. ic. (foliis edentulis.)

Lewifcus peruana $\int$. molle arbor. Joxist. dentr. t. 84. fig. prior.

Lemifcus africma. SЕв. Mefaur. 2. p. 7. t. 5. f. 5.

Schimes foliis pinumeis: foilolis ferratis impari longilfimo, petiolis equalibus. Lins. Jjok. veg. 891.

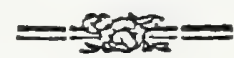

\section{Icon. Koelreut. Diff. de Coleopt.}

A Cl. Hermann: Pr. arg.

PER. Bacca fphxrica, magnitudine pifi, fucculenta, unilocularis, monopyrena (fecundum alios tripyrena). Cuticula charcacea, glaberrina, fplendens, albicans. Pulpa fugax. OfTiculum cartilagineum, durum, fectile tamen ubi emollitum, ovato - turbinatum, obfoletifime angulatum, fubrugofum, pluriloculare: loculamento centrali majore, feminifero; pariecalibus fenis aut paucioribus, fpuriis, anguttis, oleo fragrante aromatico fcatentibus.

REC. nullum; officulum fundo capfulx affixum.

SEM. unicum in fingulo officulo, ejusdemque cavitati centrali conforme, feu obovatum, irregulariter \& profunde angulatum, deorfum acuniuatum, palliduns.

INT. fimplex, membranaceum.

Ацв...... Е вв......

R.) Bacea integra. b.) Eadem diftecta, cum fitu ofliculi folitarii. c. C.) Ofriculum Separatura. D.) Idem transverfe diffedum, cum loculamentorum fitu \& aumero. E.) Scminis adumbratio idealis, a forma pelliculx internz defunata.

Numerus feminum aut pyrenarum varie a variis definitur. Ita Cl. Adasson unicum duntaxat, nobiscum, vidit officulum. FEuvilleus autem, in centro baccx licte rubicundx atque fubftantia gummola farct $x$, duo recentfet femina, piperis fapore, in Prefat. ad operis fui Vol. $3 . p . x=$. Reliqui vero auctores omnes, Schino tria adfcribunt femina. Repetendx igitur obfervationes in fructibus rite facundatis, \& addenda feminis fabrica intcrua 


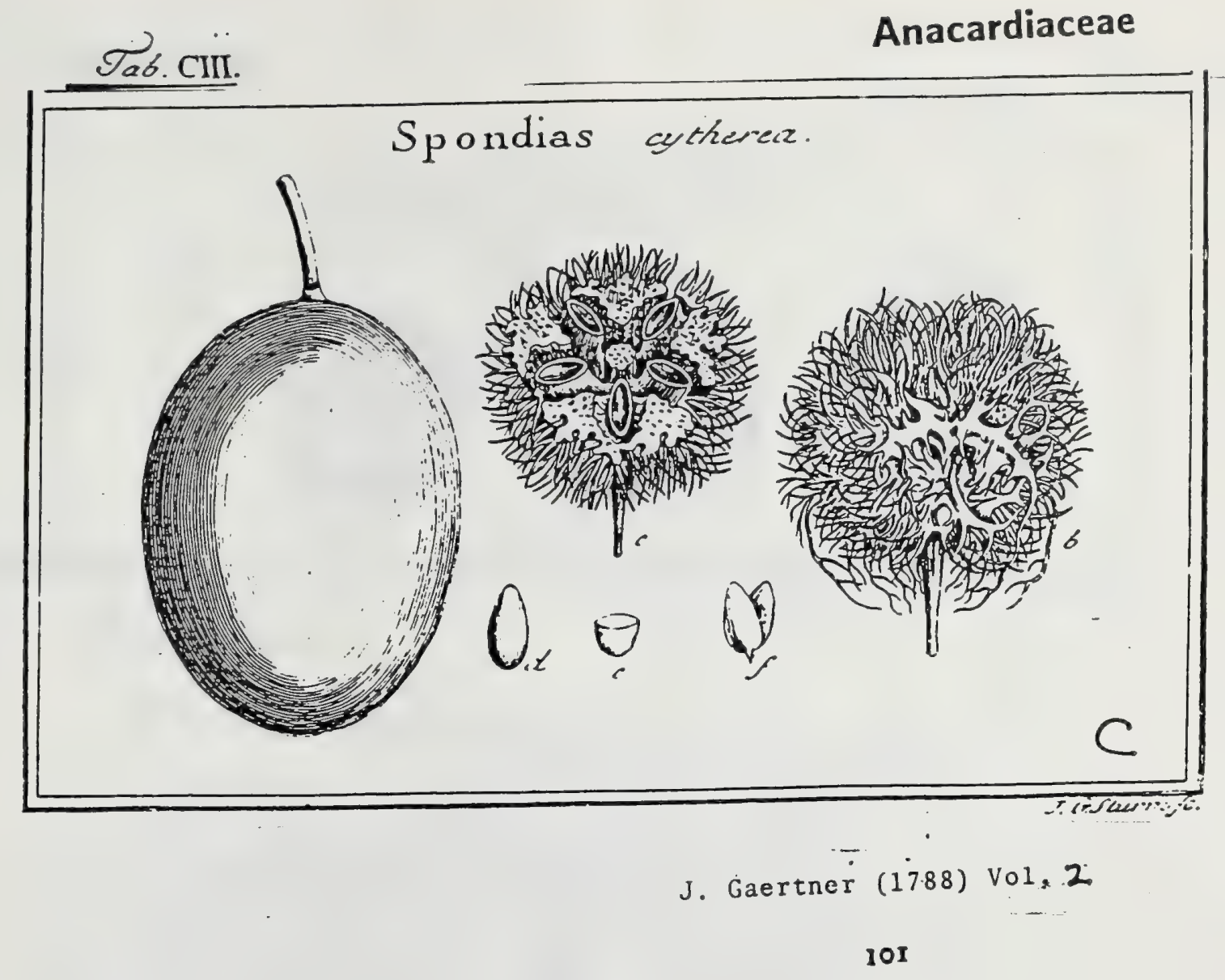

DCVIII. SPONDIAS. LINN. gen. 57\%。

Calyx quinquefidus. Cor. pentapetala. Stam. decem. Ovar. fuperum. Styl. trcs, 1. quinque. Drupa baccata, putamine fibrofo quinqueloculari. Ovula fxpe genina. Semini folitaria.

Spondras cytheres. Tab. 103. fig. 3:

Spondias cythera S. Hevi. SONMRR. it. ind. E chim. 2. p. 222. to. 223.

A Cl. Hegmans. Prof. argentor.

I02

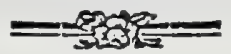

P\&R. Drupa fupera, baccata, ovalis. Cuticula tenax ex fibris capillaribus putaminis contexta, feu cum iisdem cohxrens. Caro firmula, fapida, inftat pomi venetse. Putimen lignofun, fibrofum, lobatum, longe peilunculatum, compofitum ex loculamentis quinque, difcretis, apice \& lateribus liberis, bafi vero inter fe \& cum lubis putamins arcte $\&$ in unum corpus connatis. Lobi plerunique quinque, introrfun angulati \& loculamentis interjecti, extrorfum vero laninis anaftomofantibus, muricibus multiformibus \& fibris lignofis varie echinati atque muricati.

R E C. nullum; femina fundo loculamentorum affixa.

Se s. folitaria, amygdaloidea, feu ovato - attenuata, compreffufcula, rufefo centia.

IN T. fimplex, membranaceum, tenue. .

Á s. nullum.

E s 8. Semini conformis, erectus, albus. Cotyl. carnofx, plano-converiufculx, ovarx. Rad. parva, recta, inferi.

a) Dnipa integra. b.) Putamen folutuus integrum, e.) Idem transverlim diffectuar. d.) Scmen in fitu naturali. e.) Idem horizontaliter diffectume E) Embryo denudatus.

Facile a reliquis fpeciebus difcernitur putamine pedunculato atque locula. mentis, tam a fe invicem, quam ab axi remotis. 


\section{Tab.civ.}

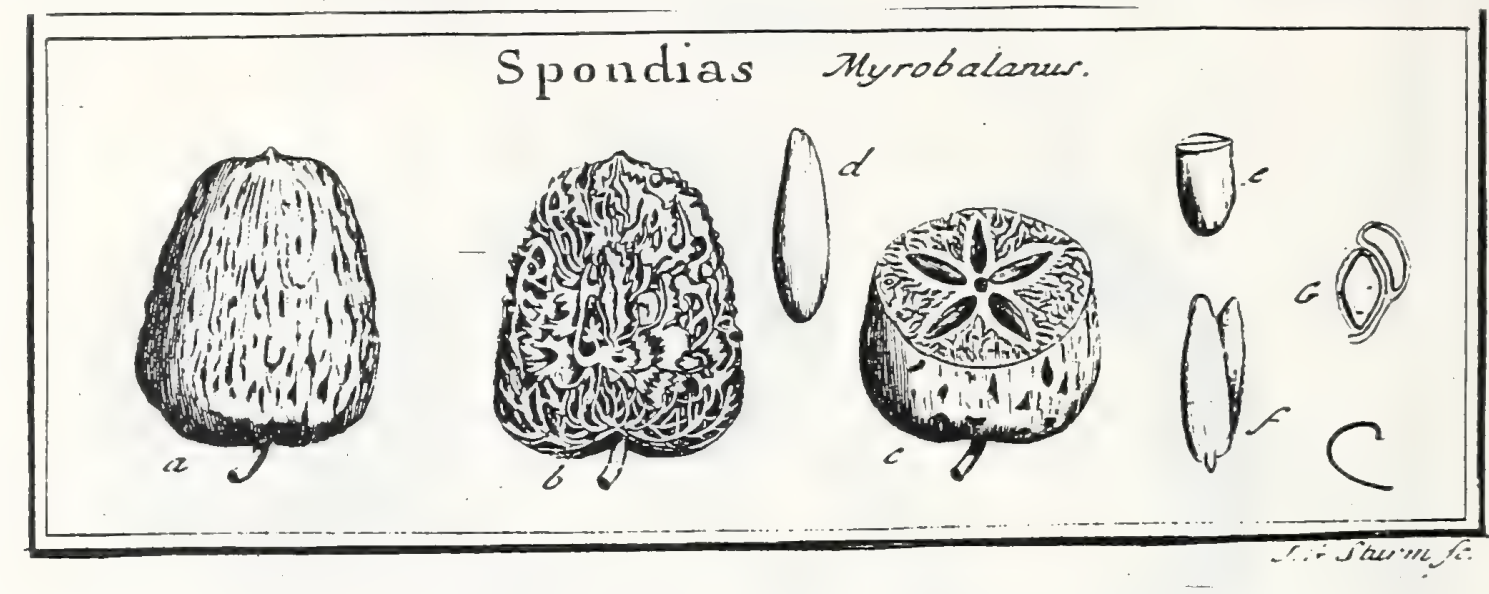

J. Gaertner (17.88) Vo.1.2

Spondias Myrobalanus. Tab. 104. fig. 3. Spondins racemis Sparfis, foliis multo brevioribus. JACQ. biff. aneer. 139. t. 88. Spondias Mombir. Lins. [yje. veg. 428.

Drupa (a.) procedenti triplo minor, ovata, furfum anguftata, apice breviter acuininata. Caro in vetufto fructu fungofa, rufelcens. Putamen (b. c.) lignofum, laminis atque fibris varie reticulatis atque anaftomofantibus muricatum, neque lobatum, neque pedunculatum, fed undique colixrens, etfi hinç inde lacunofum. Loculamenta quinque, inter fe \& cum reliqua putaminis fubftantia (c.) connexa. Ovula immatura (G.) in loculis gemina, funiculo umbilicali communi crafo infiftentia. Semina maturs (d. e.) folitaria, ovato oblonga, lenticulari compreffa, confiftentia \& colore anygdalorum. Integum. membranaceum, intus prope bafin tenuilima lamina c:irnof doplicatum. Albumen nullum. Embryo (f.) Temini conformis, erectus.

Spondias Mombirs. JAce.

Spondias racenis paniculntis terminalibus, longinudine folia aquantibus. JAcQ. bif. amer. 138 .

Spondias Mryrobalinus. Lisv. 1. c.

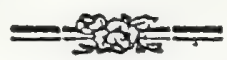

Drupa, in meis fpecininibus, perfecte ovatis, magnitudine proxime procedentis feu pollicem fere cum dimidio longa, obfolevilfime pentagona, angulis ex loculanentorum dorfo formatis. Cuticula fibrofa, tenax, in vetulto fructu dura. Caro pauca fpongiofa. Puiamen ex loculamentis indifcretis atque plurimis fibris lignofis formatum, uti prxcedens. Semina foliaria, longa, angulta ut quafi fubteretia, ferruginea. Reliqua ut in prioribus. Raro loculimenta, unico plura, fœcunda deprehenduntur. 


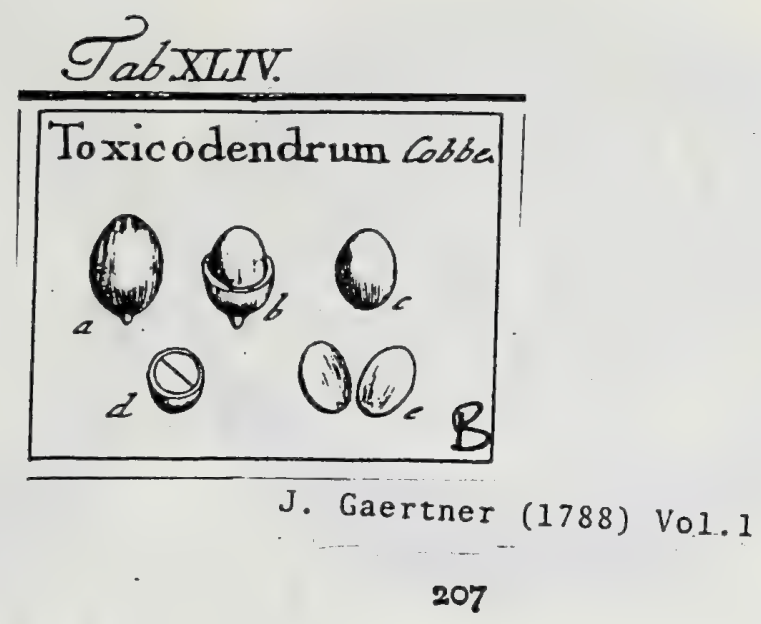

\section{TOXICODENDRUM. TOURN. $t .38$.}

Calyx quinquepartitus. Cor. pentapetala. Stam, quinque. Styl. brevifimas; figma fimplex. Bacca monolperma, feminis embryone recto, erecto.

Toxicodendrum Cobbe. Tab. 44. fig. 5.'

Frutex trifolius spicatus producens baccas nigras. Hекм. mus. 24.

Rhus foliis ternatis: foliolis ovatis acuminatis ferratis, pedunculis tomentofis. LINN. Sy/t. veg. 293.

Kobba. zeylonens. E collect. fem. hort. lugdb.

PER. Bacca fupera, elliptico fphxroidea, in mucronem calyci affixum bafi producta, carnola, glabra nigra unilocularis.

REC. nullum; femen undique carni baccz adhxrens.

SEM. unicum, ovatum, grande.

IN T. duplex: exterius coriaceam, tenue, fubfragile; interius tenaifimum, meas. branaceum.

A เ в. nullum.

Ex в. Femini conformis, erectus, oleofus, Jutefcens. Cotyl. ellipticx, craffifiunx, plano convexz. Rad. globulofa, minima, bafi cotyledonum inmerfa.

2.) Bacca integra. b.) Semen dimidiam a carne denadatum. c.) Idem tatum folatam. d.) Ejusdem fectio transverialis, e) Cotyiedones itparatx.

$\Lambda$ Rhö̈ diffurt femine erecto \& cmbryouis radicula non inflexa. 


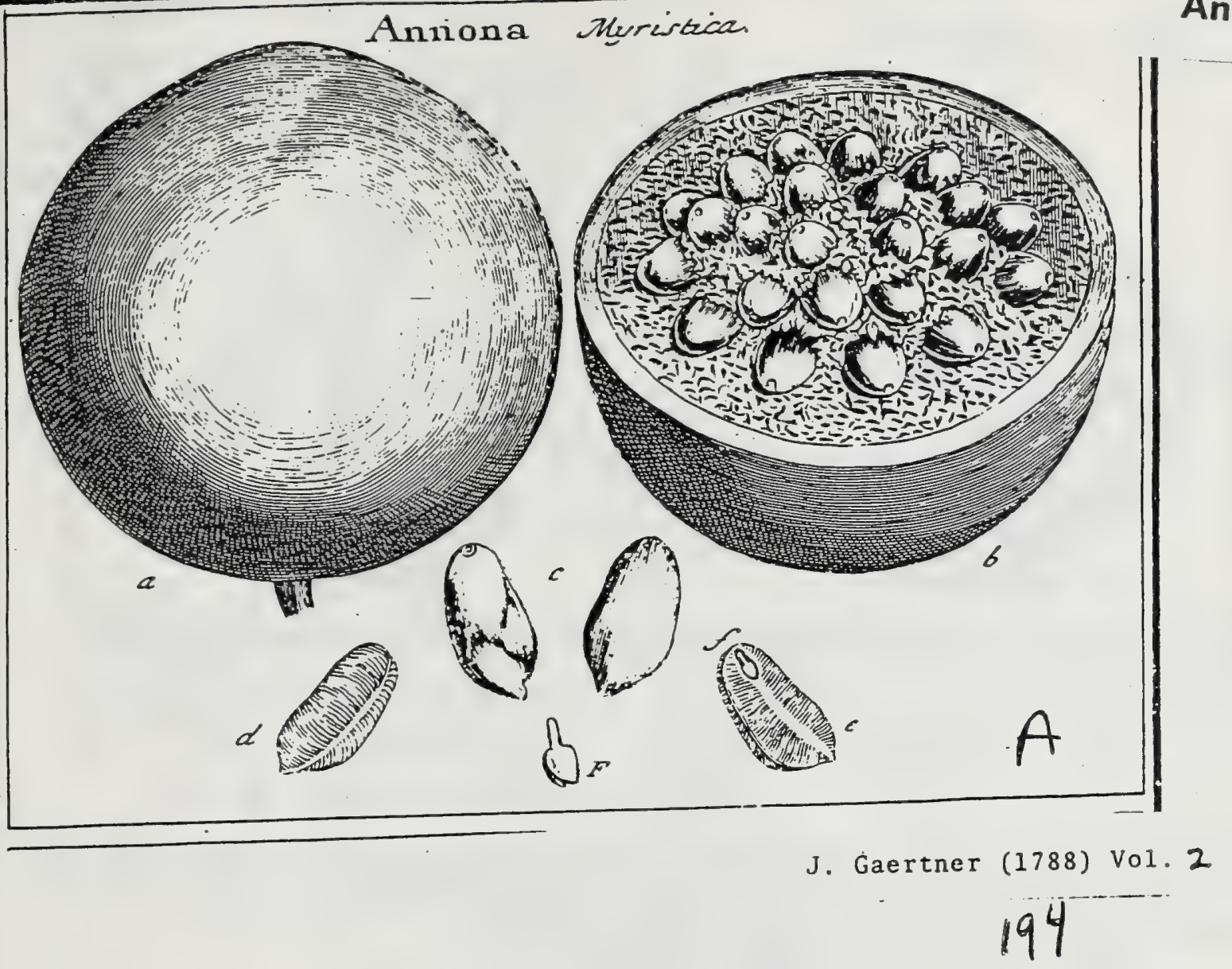

e

AnNoNa Myriftica. Tab. I25. fig. I.

E collectione Bankfinua.

Bacea fimplex (a), fubglobufa, grandis, unilocularis, glabra, corticata. Receptac. nullum, fed femina absque ordine in pulpa (b.) nidulantia. Semina (c.) ovato oblonga, a preflione vicinorum varie angulata, ferruginea, absque fplendore. Integ. \& Albumen (d.) ut in pracedenti. Enbryo (e. f. F.) grandiufculus, lutefcens. Cotyled. foliacex, cordato lanceolatic. Radic. teretiufcula, vaga aut centrifuga.

Annonx fpecies novo \& curnto ferutinio indigent, cum in aliis pericarpium fit fimplex, in aliis compofitum, atque enbryonis radicula in aliis centripeta, in aliis vero centrifuga : dotes enim adeo diverfa uni generi naturali cumpetere nequeunt. 


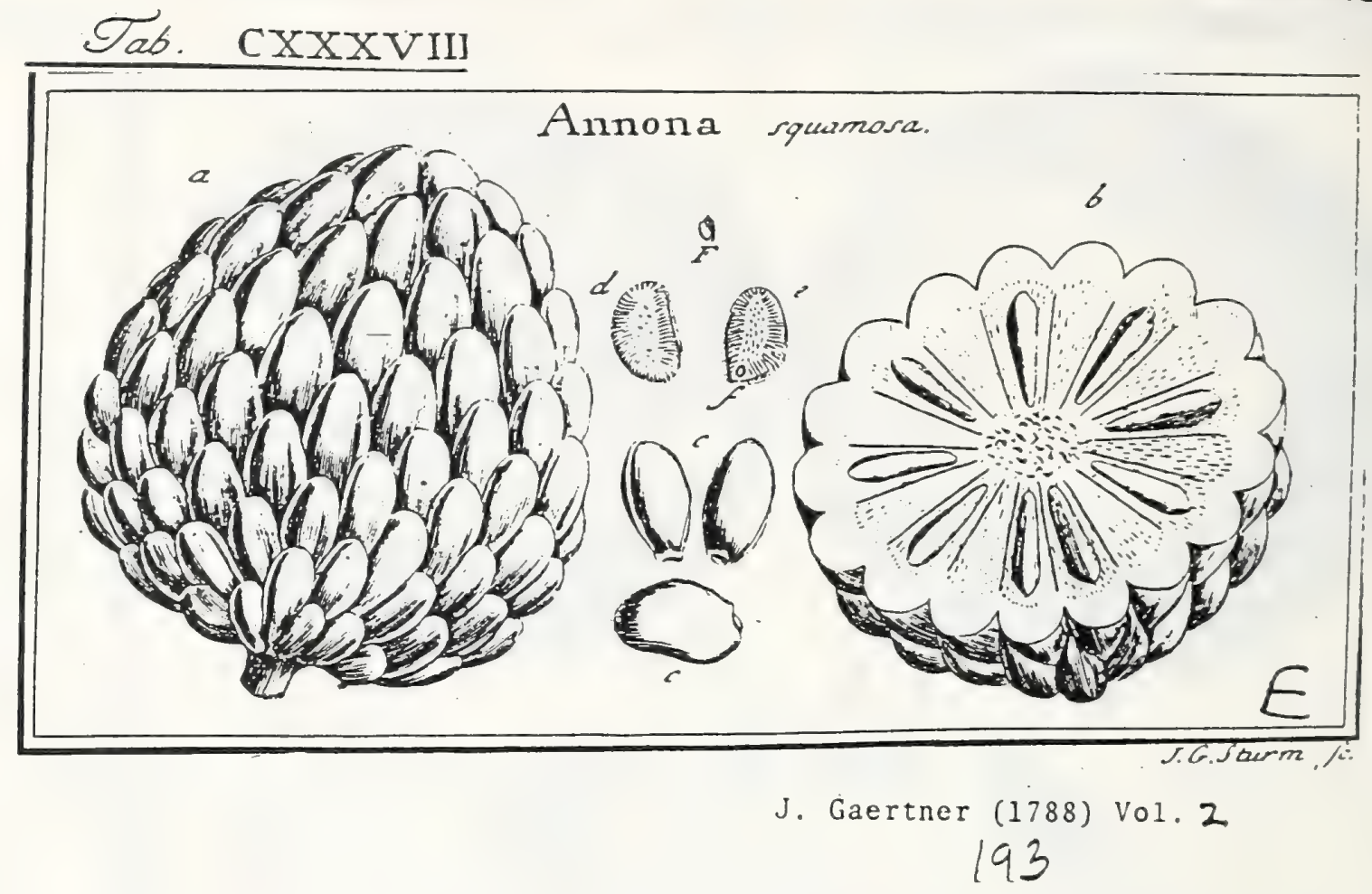

DCCIX. A N.N O N A. Linn. ger. 693.

Calyx triphyllus. Cor. hexapetala, petalorum ferie duplici. Stam. numerofa, Ovar. fimplex aut uno plura, fupera. Stigmata feffilia. Baccs corticat, finplex aut compofita. Sem. numerofa: albumine rimofo.

Annona fquamora. Tab. 139. fig. 5.

Atamaran. RHEED. mat. 3. p. 2t. t. 29.

I94

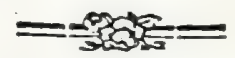

Amona triberofa. Rusph. amb. r. p. ss8. t. 46 .

Amona folits oblongis frutibus obtufe fubfquanutis. LiNs. Jjyto veg. 508 .

A Cl. Thunbergio.

PER. Bacca conoidea, corticata, carnofa, ex baccis partialibus pluribus compofita. Cortex craffus, in verufto fruchu fungofo - fuberofus, tuberculis ovato-oblongis mammillaribus adfcendentibus undique muricatus. Caro pulpofa, in totidem concamerationes partiales divifa, quot funt in cortice tubercula, ut etiam fructus recens in totidem baccas partiales, feu lobulos carnofos, divelli poltit.

REC. commine centrale, columnare, baccas partiales colligens; propritun nullum.

SEM. in baccis partialibus folitaria, in univerfali autem numerofa, prope peripheriam radiatim difpofita, elliptica, extrorfum craftion, conipreffa aut obfolete angulata, glabra, fublucida, caftanea aut nigricantia.

INT. duplex: exterins cruftaceum, fragile; interius membranaçeum, procetis. bus lamellofis alte intrn albuminis rimas demerfis, intus exafperatum.

A L в. femini conforme, carnofum, durum, rimis profundifimis fubparallelis incifum \& ill ambitu, fulco depreffo angufto exaratum.

Eм в. minutifimus, juxta umbilicum politus. Cosyl. obtufx. Rad. axem fructus refpiciens.

2.) Bueca compofita integra. b.) Fjus fedio tmascerfatis etm fitu feminnm. c) Scmina feparatz i.) Albumen Jcuudatum. c.) Ejus fectio lougitudinalis, cum fite cmbryonis. E. F.) Embry̧o folutus. 


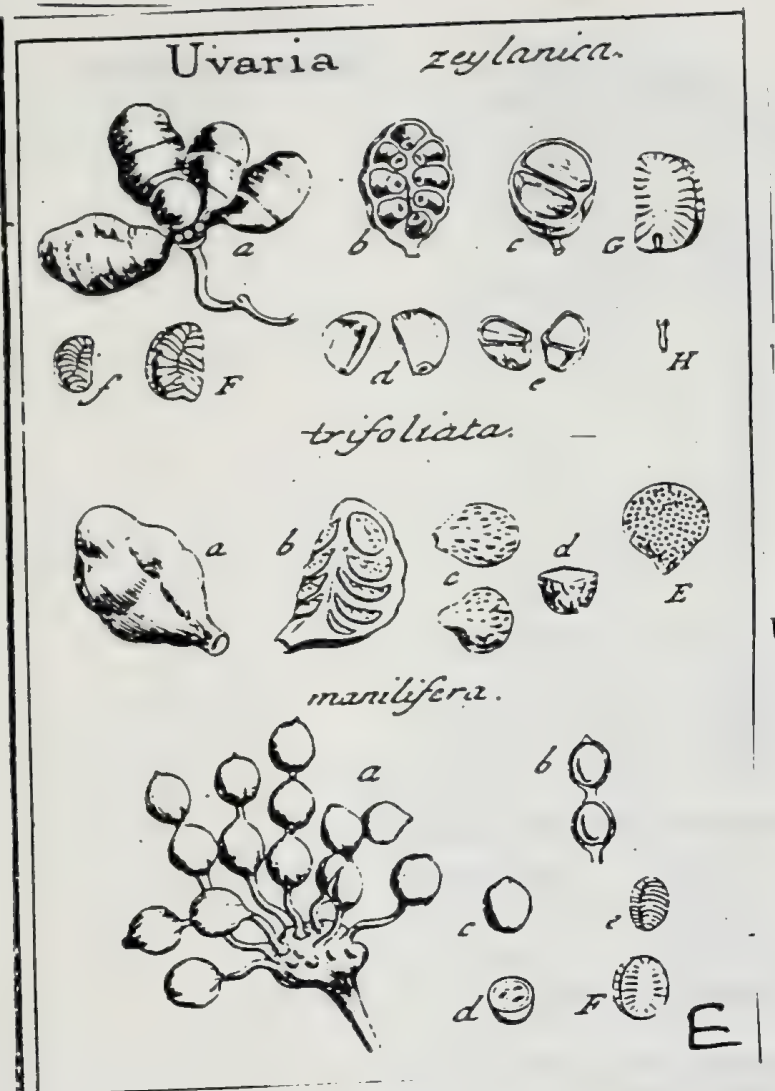

J. Gaertner (1788) Vol. 2

155

\section{U V A R I A. LINN. ger. 692.}

Calyx triphyllus. Cor. hexapetala. Antherre numerofx, feffiles. Ovaria plura, in capitulum collecta. Styli fimplices. Baccx plures, pedicellatx. ubloligx. Semina fibi mutuo impofita, feptis tamen ab invicem difcretz: unbilicis uno verfu difpofitis.

UVARIA Zeylanica. Tab. 114 fig. 2.

Narrun-panel. RHEED. mal. 2. p. Ir. t. 9.

Funis simfarius. RUMPH. amb. 5. p. 78. t. 42.

L'varia foliis integerrinis. Lras. fjy. veg. 508.

Palukena. Zeylon. E collect. fem. hort. lugdb.

Conf. Piper æthiopicum Matth. CAM. epit. 346. Lов. adverf. $47 \pi$.

PER. Baccx plures, communi receptaculo fubglobofo infiftentes, pedunculatx, ovato - cylindricx, ad feminum fedem nodulof \& ex altero latere óbfoleto fulco depreffo infcriptx, cinereo-albidx, incus in totidem loculamenta horizontalia, "gemino ordine pofita, divife, quot funt femina. Difepimenta membranacea, tenuiffima.

REC. nullum; femina parieti interno lateris bacce fulcati longitudinaliter affixa.

SEM. in loculis folitaria, in tota autem bacca duodena circiter aut pauciora, femicircularia, utrinque plana, glaberrima, fplendentia, tom caltanea, preter umbilicum, margine callofo albo notatum.

IN.T. fimplex, coriaceo-membranaceum, intus proceffibus plurinis lamellofis, intra albuninis rimas alte demerfis, fcabratum.

A L в. fenini conforme; carnofum, durum, fulco depreffo marginom totum cingente infcriptum \& profundis infuper rimis transverfalibus undique fncilun.

E«в. minutus, fubulatus, rectus, in regione umbilicali albuminis locatus. Cosyl. lineari acuminatx, brevifimx. Rud. teretiufcula, centrifuga.

2.) Bacearuan integrarum umbella b.) Bacce latus fulcatum refetum, , eum feminam fitu non tnrali. c.) Bacez transverfim feeta. d.) Semina integra, e.) Eadeun differta. f. F.) Albumen Jecorticatum, rimofum, G.) Ejusien fettio longitudinalis, eum fita embryonis H.) Embryo folutus.

156

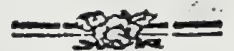

Uvaris trifoliata. ibicl.

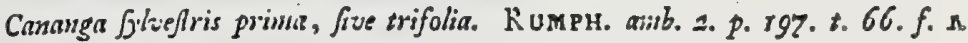

$\mathrm{E}$ collect. fem. hort. lugdb: cun nonine priolis.

Baccx (a.) ovațx, prioribus majores, fenlim in pedunculum attenuatæ, carnofx. Diffepimenta transverfalia (b.), craffa, carnofa. Semina (b. c.) duplici ferie, ut in priori, pofita, octona, ant plura, obovata (c.), leuticulari compretfa (d.), obfoletis foveolis oblongis rugata, e cinereo fpadicen. Integumenti proceffis interni non lamellofi, fed fubulati \& fere aciculares, quare exiam Albumen (E.), loco rimarum, inumeris foraminibus contiguis exfculptum. Embryo minutus, teretiufculus.

Defcriptio Rumphiana Cananga fylveftris, non quadrat penitus in noltros fructus, quare fpeciem hanc, a prxcedenti manifelte diverfam, aliis curatius enodandan relinquo.

Uvaria monilifera. ibid.

an Unona difcreta. LiNN. Juppl. 44. \& 270 ?

Ex herbario Bankfiano.

Baccx (a) in receptaculo communi carnofo \& globofo umbellitx, longe pedunculatx, ifthnis interceptx, feu moniliformes, uni-bi-aut rarius triloculares. Loculamenta fecundum longitudinem digetta (b.), a fe iuvicem remota, monofperma. Senina (b.c.d.) ovaso-globofa, glabra, fplesdentia, e lureo fpadicea, bafi fua futado loculamenti affixa. Integum. chartaceun, intus lamellis exafperatum. Albumen (e. F.) profundis rimis incifum. Embryo in bafi albuminis minutilimus. 


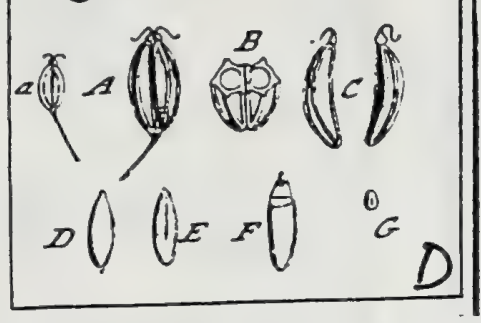

$$
274 \text { J. Gaertner (1788) Val. } 2
$$

DCCCIX. IE G O P O D I U M. IINN. gen. $3^{6 g}$.

Umbella conpolica. Invol. nullum. Petala inxqualia, alba. Fruclus mediocris, ovatus, ftriatus. Folia caulina ternata.

Egopodium Podagragria. Tab. 140 . fig. 4.

Podugraria. Riv. pent. t. 47. HaLl. bif. "1. 759.

Egopodinn foliis coulinis fummis ternatis. LINN. fyfr. veg. 292.

Icoss. OED. flor. dnis. ¿ 670.

PER. nullum. Fructus mediosris magnitudinis, ovatus, transverfam latior quam crallus, lfruatus, bipartibilis.

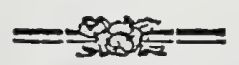

REC. fetaceum, bifidum.

SEM: duo, oblongí, quinqưeftriata. :Strix filiformes, pallidx. Interfitia viridi - fufca, gläbra.

IN $T$. duplex: utrumque membrnnaceum.

A L в. fubcartilagineum, teretiufculum, inodorum, album.

E N B. minutus; fubglobofus. 'Cotyt. breviflimx.' Rad. fupers.

a. A.) Frukeus integer. B.) Idem transycrfe feQue C.) Semina (eparata. D. E.) Albuminis latus utrumqque. F.) Embryonis in albomine fitus. (3.) Embryo Separatus \& auctus. 


\section{Tab.XXII.}

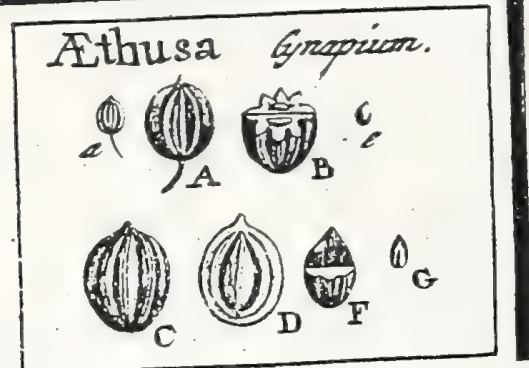

Apiaceae

J. Gaertner (1788) Vol.1

94

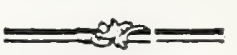

\section{CX. ЖETHUSA. LinN. gen. 355 .}

Unbella compofita. Involuc. univerfalc nullum: partiale triphyllum, deflexum unilaterale. Fructus fubglobolus, profunde fulcatus.

Ẽ т и A Cynapium. Tab. 22. fig. 3.

Cicuta minor fatua. Moris. Umb. t. I. f. T. y. BLARw. herb. t. 517 .

Cinapium. R I v. pent. $t .76$.

AEthufa. HalL. hiff. I. "3. 765. - foliis conformibus. LINx. J4/3. veg. 286.

PER. nullum. Fruftus inferus, parvus, fubglobolus, albus, fulcatus, bipartibilis.

REC. filiforme bifidum.

SE s. duo, fubhemifpharica, profunde fulcata; fulcis dorfalibus- quinis, acutangulis, contiguis, albis : interftitiis anguftis purpurafcentibus. Pars ventralis! plana, vittis duabus purpurafcentibus picta.

IN T. duplex : exterius fungofo coriaceum; interius membranaceum.

A в B. ovatum, fupra acuminalum, plano-convexum, carnofum, inodorum.

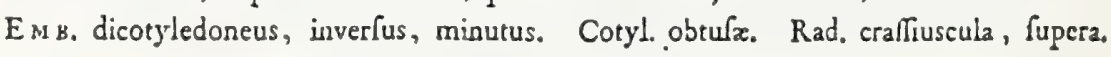

a. A.) Frutus integer. B.) hisem transverfe feâtus. C.) Sominis dorfum. D.) Ejus pars ventralis

C.) Albumen decorticatum, F.) Enbryonis fitus, G.) Embryo feparatus.

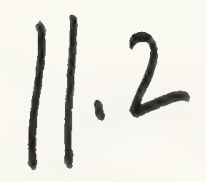



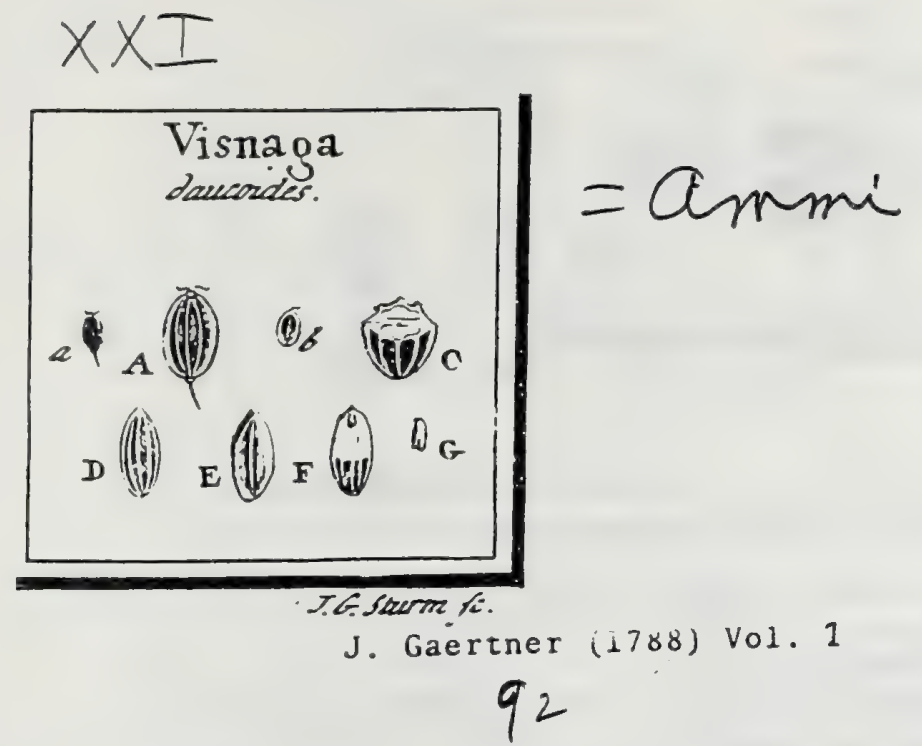

CVII. VISNAGA. RIv.

Unbella \& involucrum Dauci. Fruclus jlenticulari compreflus, attenuato-marginatus, friatus, villolus.

VISNAG A daucoides. Tab. 21. fig. I2.

Gingidiun alterum. D o D. pempt. 792.

Visnaga. RIv. pent. t. 84 .

Daucus feminibus nudis, umbella univerfali bafi coalita. LIN

Icon. J A C C. hort. 3. t. 26.

PER. nullum. Fruf́us inferus, parvus, ellipticus, lenticulari compreflus, villofus; bipartibilis.

REc. filiforme, bifidum.

SEM. duo, parva, albicantia, margine attenuato, non membranaceo circumdata, furiz tres dorfales, filiformes, glabre, interftitiis villofis, planiusculis. Pars ventralis plana.

Ix. T. duplex, utrumque membranaceum, tenue.

A \&B. oblonge ellipticum, in dorfo friis quinque planiusculis glabris, interftitis autem rugofis notatuin, carnofuin, duruın, odoratum.

Емв. dicotyledoneus, inverlus, brevilimus. Cotyl. breves. Rad. teretiuscula'; fupera.

2. A.) Frutus integer. h) Seminis pars plana. C.) Fruftas difretus. D. E) Abumen deceri] vicatum. F.) Embryouis fitus. G.) Idem feparatus. 

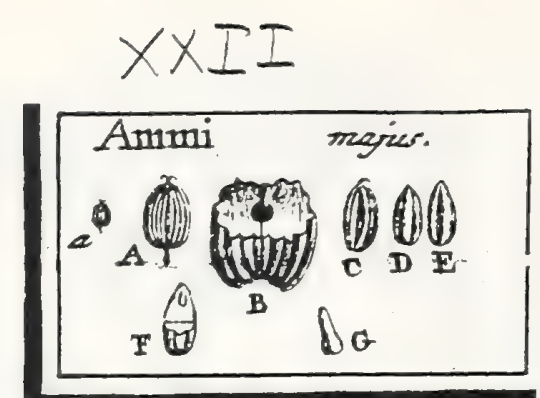

Apiaceae

J. Gaertner (1788) Vol. I

CXV. AMIII. TOURN. t. 159. Li N N. gen. 334 . Umbella compofita. Involucra polyphylla: univerfali pinnatifido; partiali fimplici.
Fructus parvus, ovato globolus, giblus, unutifriatus. A M I majus. Tab. 22. fig. 8.

Ammi vulgare. Do D. pempt. 4T5. B L А K w. herb. t. 447 .

Ammiofelinon. Rrv. pent. t. 85 .

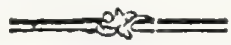

Ammi foliis inferioribus pinnatis lanccolatis ferratis; fuperioribus multifodis lincaribus. Lin s. Jift. veg. 277 .

PER. nullem. Frufius inferus, parvus, ovatus, gibbus, intra calycis perfiftentis

dentictilos tuberculo conico itylifero terminatus, fubciuereus, bipartibilis.

REC. nullum, aut obfoletum.

SEM. duo, femiovata, friis dorfalibus novem, alternis rotundatis, \& alternis acutangulis notata; in ventre fulco fimplici excarata.

INT. duplex, utrunque membranaccum, tenue.

A в . Semini conforme, carnofun, durum, fubodoratum; hine tribus Ariis clevatis, inde fulco deprelTo infcriptum.

Ex в. dicotyledoneus, inverfus, quartam albuminis partem longus. Cotyl. foliacex, oblongx. Rad. cylindrica, lupcra.

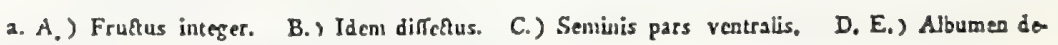
corticatum. F. G.) Eimbryo in fitu, \& feparatus.

In calidis regionibus, femen forfan inagis odoratum. Nam tefte Drosc. L. III. c. 70. Ammio fumen exile, multo minus cumino, origanon refipiens, cui vis excalfactoria, fervens, exficcans. Non ita noltrum, fed potius inodorum, aut quale vult J. BauHinus hiff. 3. 6. 227. misus odoratum.

11.4 

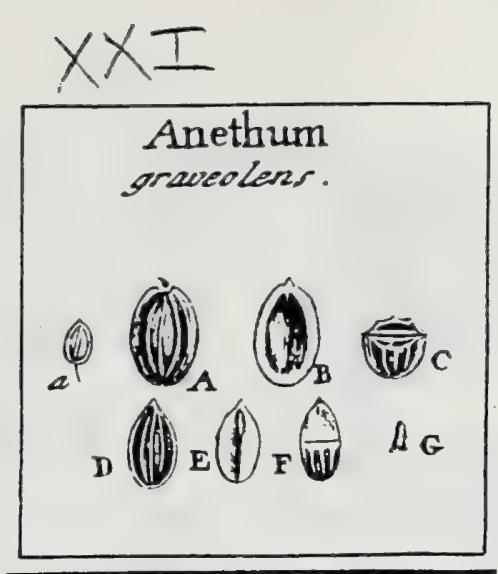

Apiaceae

\section{J. Gaertner (1788) Vol. 1 \\ 91}

CVI. ANETHUM. T OURN. t. 16g. LINN. gen. 364 .

Umbella compofita. Invol. nullum. Petala lutea. Fructus lenticulari - compreflus, parvus, friatus, marginatus

ANETHUM graveolens. Tab. si. fig. it.

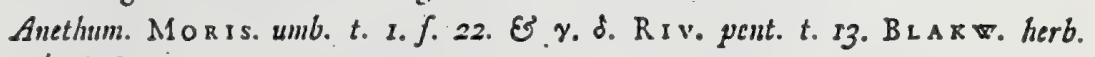
t. 545 .

Ancthum fructibus comprefis. Lis s. Jyf. veg. 290.

PER. nullum, Frulfus inferus, parvus, ellipticus, lenticulari compreflus, bipartibilis.

REC. filiforme bifidum.

Sest. duo, parva, clliptica, in dorfo tribus friis clevatis filiformibus notata, ad oras anguflo margine albicante, fubmembranaceo cincla; in ventre planz, glabra.

IN T. duplex, utrumque membranaceum.

A L's. ovato acuminatum, carnofum, durum, odoratum, hinc obfolete friatum, inde fubconcavum.

Es1 8. dicotyledoneus, inverfus, breviffunus. Cotyl. anguftx. Rad. teretiuscula, fupcra.

92

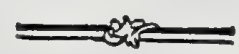

1. A.) Fructus integer. B.) Seminis pars piana. C.) Fruetus diffectus, D. E.) Albanei decos.
tieatum. F.) Situs embryonis, G.) Idem feparatus, 


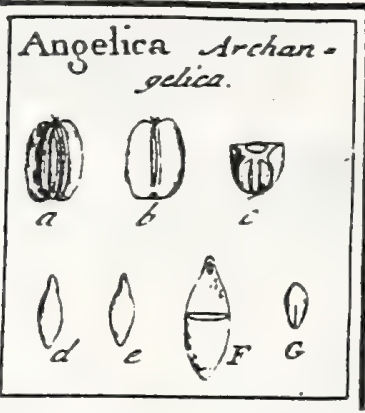

J. Gaertner (1788) Vol, $\mathbf{Z}$

29

DXXXIII. A N GELICA. LINN. gen. 347 .

Umbella compofita globofa. Invol. zoiruerfale fubnullum: partiale decaphyllum. Cor..petala fubviridia, aut ex purpura albicantia. Fructus ovatus, molendinaceus, aut fimpliciter fulcatus \& marginato - alatus.

ANgelica Archangelica. Tab. 85. fig. 3.

Angelica. Riv. penst. t. 15. BLAKw. berb. 6. 496 . OED. flor. dart t. 206. Angelica foliis duplicato-pinuatis, ouatodanceolatis, ferratis. HALL. bift. n. 807 . Angelica folion impari lobato. LINN. Jy?. veg. 284.

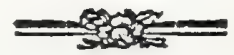

PrR. nullum. Fruêus ellipticus, turgide lenticularis, apice \& bafi leviter emargiuatus, fulcato-alatus, albicans, aut pallide ftramineus, bipartibilis.

REC. fetaceum, bifidum.

SEM. duo, fructui conformia, hinc convexa, ala rigida marginali, tribusque confimilibus dorfalibus ftipata; inde planufcula, fimplici ftria elevata longitudinali infignita.

IN T. duplex: coriaceum \& membranaceum.

A L B. femine multo anguftius, ovatum, utrinque acuminatum, plano-conve xum, album, odoratum.

Es B. minutulus, inverfus, lacteus, in fupremo albuminis apice hrerens, Cotyl. angufte, breviflumx. Rad. ovato-globola, craffior, fupers.

a.) Seminis dorfum b.) Ejus venter. c) Ejusdem fectio trasverfalis. d. e.) Albuminis Latus utrumque. E.) Embryonis in albumine litus. G.) Embryo folutus.

Hæc fabrica in feminibus plante culte $f_{0}$ hortenlis obtinet; fed in fpontaneæ feminibus, alas dorfales nullas, verum tria tantum juga, eaque humillima effe, Hallerus l.c. \& Cranzius Fafc. p. m. $\dot{r}_{7} 8$. affirmant. Hilic Rivini figura feminis, noftre ex affe refpondet, neutiquam vero Cranziana.

\section{6}




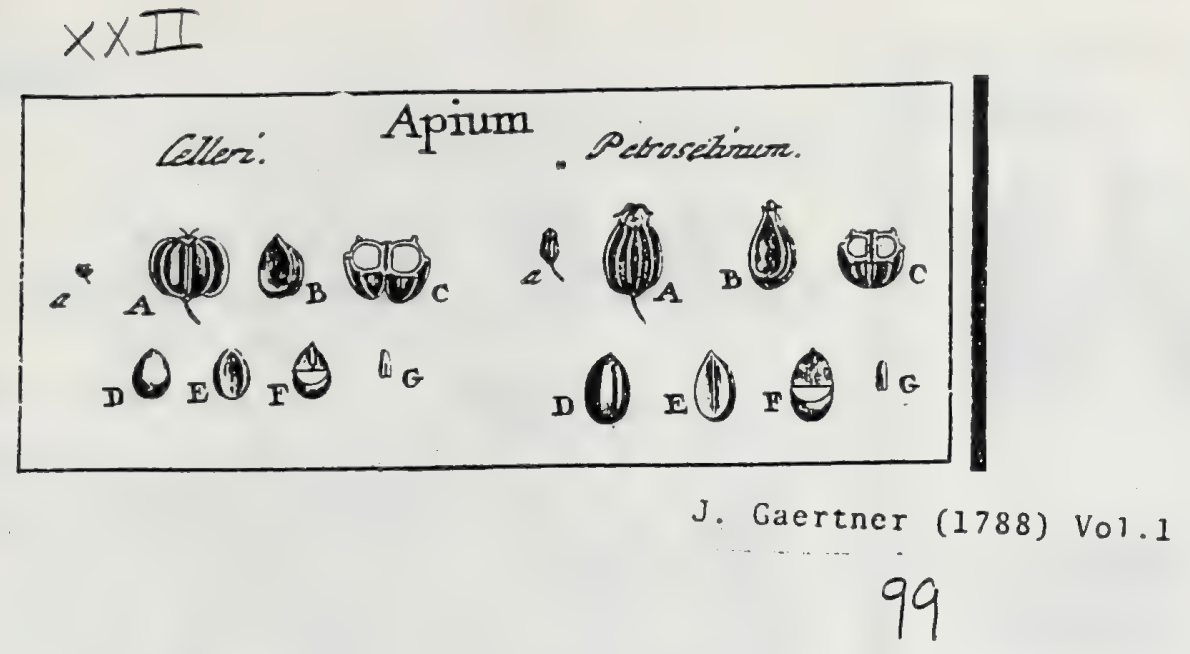

CXVI. APIUM. TOURN. t. 160. LINN. gen. 367 .

Unbella compofita. Involuc. nullum, aut foliola pauca brevia ad umbellas partiales. Fructus parvus, gibbus, coltatus.

A prus Celleri. Tab. =2. fig. 9.

Apizm. Rn. pent. t. 87. BLAKw. herb. 443. OE DER. flor. dan. $t$. 790 .

Apiun foliis pianutis, pimnis trilobatis. Hası. hifl. 1. 1.784 .

Apium foliis caillinis cumeiformibıs. Lix.. Sigl. veg. 292.

Pек. nullun. Fruitus inferus, exiguts, transverie craflus, quafi ex duobas globulis conllatus, filiformi cofatus, bipartibilis.

RE... liiifurme, bifidun.

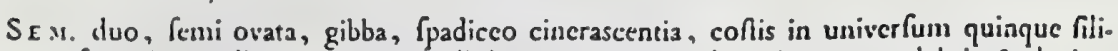
formibus, albicantibus aut pallidis cxarata: interlitiis inter cas glabris \& levirer convedis. Pars ventralis plana.

IsT. duplex, utrumque membranaceum, tenue.

A в. fomini conforme, carnofum, durum, odoratum.

E is $\mathrm{H}_{0}$ dicntyledoncus, inverifus, tertiam fere alburninis partem longus. Cotyl. brctes, iemiteretes. Rarl. cylindrica, fupera.

100

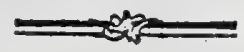

2. A.) Fruetus integer: B,) Seminis pars plana. C.) Frutus dirfetus. D, E.) Albumen decos. eicatum. F. G.J Embryo in fitu, \& Separatus.

Scmina profunde fulcata, \& inter fulcos foraminulenta, qualia Hallerus. I. c deferibit, mihi hacienus videre non contigit.

Selinon Tнворн. hift. I. с. 3. 9. 15. 16. 19. II. c. 5. III. c. 12. VII. c. 1-- 5. \& Drosc. 111. c. 74. hoc noftrum A pium efle, non eft dubium.

A P I U M Petrofelinuin. ibid.

Apiun hortenfe f. Sativum. D o D. pempt. 694 MorIs. Umb. t. I. f. 4. 4. RIV. pent. $t .88$.

Petrofelinum. BL $\mathrm{K}$ W. herb. $t$. I72.

Apium foliis caulinis linearibus, involucellis minimis. LIN N. fyfl. veg. 292.

Fructus duplo majores quam prxcedentis, ovati (a. A.), gibbi, calycis rudimento, $\&$ intra illud tuberculo conico ftylifero terminati. Semina furfun anguftata (B.), quinque contis linearibus (C.) parum elevatis, pallidis aut albicantibus exarata: interfitia inter illas glabra, leviter convexa, fpadiceo cinerea. Albumen (D. E.) odoratum. Embryo (F. G.) brevior quam in precedenti.

Petrofelino fernen Ammii odoratius, fapore acri, aroma olens. Drosc. III. c. 77.

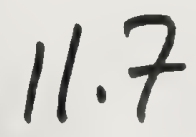



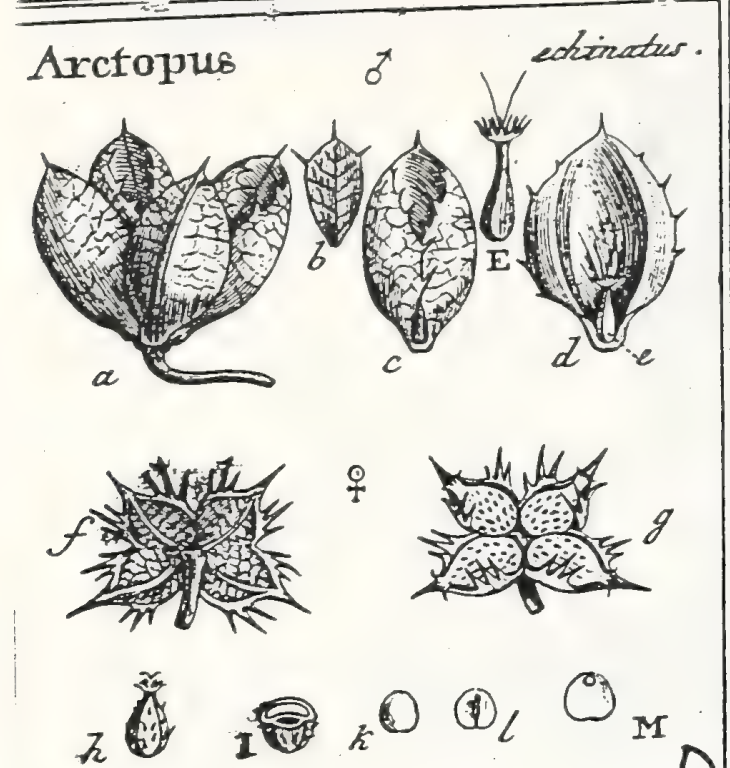

\section{4 J. Gaertner (1788) Vol3}

\section{A R C T O P U .}

LINN. gen. ri65. ed. Schreb. r60r. Juss. gen. p. 225. LAMABCX ill. gen. t. 855 .

Planta diphyta, altera fterilis, quz mas, altera fertilis, quze føcmina vulgo dicinr.

MAS. Umbella univerfalis longa, ex umbellulis partialibus fparfis. Involu crum uriverfale pentaphyllum breve; partiale quadri - l. pentaphyllum. foliolis, fub anthefin, ob-ovatis, fpinulofs, longitudine flofculorum felithum; poft deforefcentiam autem mire grandefcentibus, in folia coriacea, reticulato - nervorz, per ambitum fpinulora, convoluto - bullata, intrd quorum fingulum flos unicus femineus fterilis. Cal. utrique fexui fuperus, quinquedentatus \& Cor. pentapetala. Stam. mafcula quinque. Ovar. feminis fubulatum, \& ftyli duo fetacei, longi recti.

FEM. Umbella fimplex ex umbellulis parcialibus folis involucratis. Involucrum monephyllum, quadrifidum, coriaceum, nervofo - reticulatum, in ambitu \& extremitatibus fuperioribus fpinis rigidis pungentibus armatum. Flofculi omnes fetriles, marium exnete finiles, nifi quod feminei - omnes, i. e. quaterni fertiles, \& ftyli in his breves atque reflexi. Angidion inferum, bifoculare, coriaceum. Sem. unicum, inverfum.

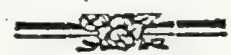

Arctopus echinatus. Tab. 182. fig. 4:

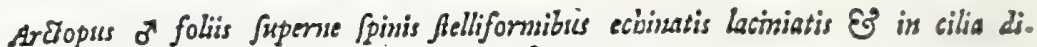
dudis, foribus umbellatis. BURN. afr. p. I. t. I.

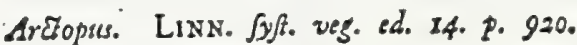
A Cl. Thunberg.

PER. Angidion inferum, ovato-roftratum, flore perfiftente coronatum, in dorfo convexum, glabriufculum, \& ufque ad medium fux longitudinis cum involucro arctifime conferruminatum, in ventre auten deprefiuf culum, craffo fulco elevato medio notatum, atque undique aculeolis parvis confperfum; ceteza coriaceum, biloculare: altero loculamento anteriori, angufto, fpurio, feu confanter inani; altero autem polteriore, Jatifimo, fertili.

R E C. nullum.

Sexs. folitaria, in loculis pofterioribus, rotundata, bafi leviter emarginata, hinc convexa, inde ex fulco depreffo concava, fpadicea.

IN $x$. Gmplex, chartaceum, tenue, facilius a nucleo, quam ab angidio fecedens.

ALB. femini conforme, fubcartilagineum, feu carnofum durum, album.

ENB. minutifimus, fubglobofus, in apice albuminis. Cotyl, breviflima, vix difceruendx. Rad. obtufa, fupera.

\section{EXPLICATIO FIGURE.}

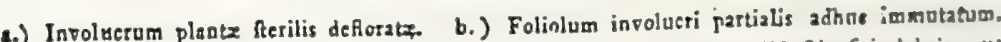
c.) Involueri partialis folium grandefadum bullatum. d.) Idem eum diductis fuis labris, ut interiors pateant. e. E) Flofeulus femineus fterilis, perfiftens. f.) Iavoluerum plante fertilis, parte fuz inferiore fpeftatum. 5.) Idem a parte prona vifum, eum fructibas in fitu Lis, a pacte luz inferiore fpectum integrum. L) Idera transverfe difrcaum cum loculo anteriore

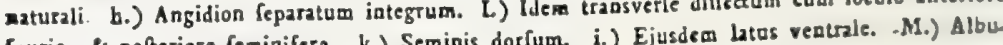
fpurio, \& pofteriore femiaifero. L.) Seminis dorfum. i.

Cum mafcula planta conftantifime fterilis fit, licet quaternos aut quinos in fingulo involucro habeat fofculos femineos, mirandurn, unde fuam trahat originem formamque propriam? Nain vix credibile, quod pollen fofcuJorum mafculorum planta fercilis fuas femellas impragnans, poffit alias producere plantas, quam matribus fuis 'frnillimas. Ergo ftatuendum, alt quod pollen ex planta fterili, quandoque focundet ovaria plantze fercilis, unde proles a matre diverfa; aut quod pollen plante fertilis producere poffit foctus, in totum formis \& deftinatione diverfos: id quod autem miraculo foret proximum, quia hoc in cafu flofculi mafuuli plantex fterilis proter omnem fcopum atque neceflitatem a ratura fuifent produdi. Habentur quiden exempla variarum plantarum feru \& forma diverfarum, \& tamen $a b$ eodem polline productarun; fed exemplum plantz perfectz \& ex aature inftituto fterilis, iftoque modo gignicx, mullum, quod fciam. habetur. 


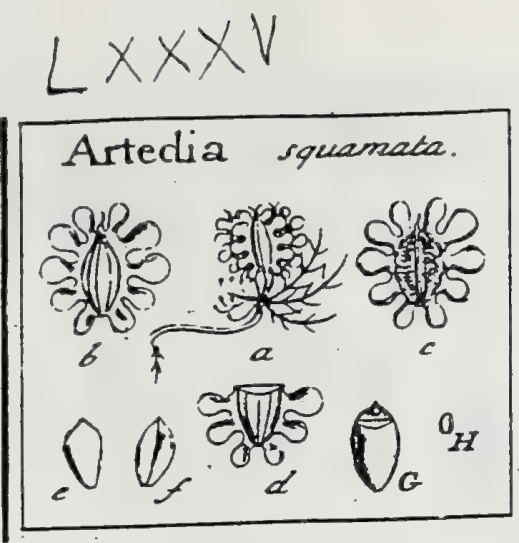

\section{Apiaceae}

\section{J. Gaertner (1788) Vol 2}

\section{2}

\section{A R T E D I A. LINN. gen. 332.}

Umbella compofita. Invol. utrumque pinnatifidum: utiverfale polyphyllum, breve, deflexum; partiale dimidiatum, triphyllum. Flores interiores Pteriles. Fructus compreffus, marginatus: margine memoranaceo, lobato.

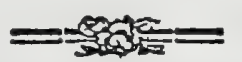

ARTEdia fquamata. Tab. 85 . fig. 7 .

Gingidirtus raunolfix. CA a. bort. 67, t. I6.

Tbupfos folits antbi, fentine fimbriato. MORis. bif. 3. S. 9. t. 18 . f. 11. mala. Artedia feninibus fquamatis. LINN. fyft. veg. 267 .

PE R. uullun. Fructus ovatus, membrauaceo compreffus, ecalyculatus, bipartibilis, fpadiceus, margine membranaceo, pallido, lobato.

REc. Гetaceum, bifidum.

SE Is. duo, hinc levifime convera, Itriis quinque capillaribus longitudinalibus infripta, atque margine membranacen, in lobos decem - l. duodecim, lingui - aut cochleariformes fecto, cincta; inde planiufcula, rugulis fquamolis per totum difcum nuricata, atque linea elevata longitudinali in medio notata. Color partis ventralis fufcus, dorfi autem fpadiceus.

I N T. duplex: exterins chartaceo-coriaceum, tenuifímum; insorins membranaceum, tenuifimum.

A L B. obovatum, ralde compreffum, hinc glabrum, inde linea depreffa exaratum, cartilagineum, album, inodorum.

- Es в. misutulus, fubglobofus, Jutefcens. Coigl. brevifimx, obtufx, Rad. fupera.

a.) R.alius umbelle univerfalis, cum fruelibus tribus immaturis, in fitu naturali. b.) Semiais maturi pars dorialis. c.) Ejusdeus latus ventrale. d.) Idem transverfe (etual, e. f.) Albuminis denudati latus utrunique, G.) Embryonis forma \& fedes in (upremo albumine, H.) Embrgo feparatus. 


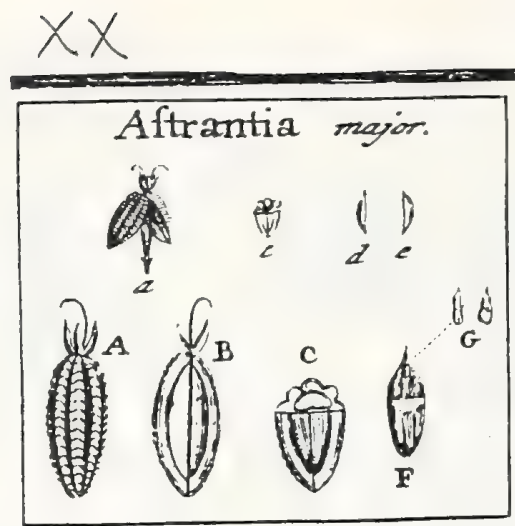

J. Gaertner (1788) Vol.I

\section{8}

XCI. ASTRANTIA. Tourn. t. 166. L In N. gen. 327 .

Unbella fimplex. Involuc, utrumque polyphyllum: folinlis lanceolatis, coloratis; umbella longioribus. Semina cofis quinque rotundatis, transverfe rugolis \& fcabratis.

ASTRANTIA major. Tab. 20. fig. 2.

Afrantia feu iniperatoria nigra. MOR Is. hif. 3. S. g. t. 4. f. I. Unibell. t. I. nro. 85. 86. E R. r.

Afrantia. RIVIN. pent. t. 68. BLA $\mathrm{x} \Psi$. herb. t. 470 .

Afrantia foliis quinquelobis: lobis trifidis. H A LL. hif. I. n. 790. LIN fylt: veg. 272.

PER. nullum. Frutus elliptico-fphaxroideus, bipartibilis, calyce fibi breviore, perfiftente coronatus.

REC. filiforme, bifidum, infra apicem feminibus infertum.

SEM. duo, oblongo elliptica, plano convexa; hine jugis quinque fpongiofis, rorunda. tis, contiguis, transverfe rugofis, aut furfum denticulato feabratis exarata, inde glabra, pallide framinea.

IN T. duplex: exterius cruftaceo fpongioíum, craflum; interius membranaceum, too nuifimum.

AL B. ovato oblongum, hinc convexum, obfolete friatum, inde planiusculum, fima plici fulco deprelTo notatum, carnofum, durum, album, inndorum.

Eмв. dicotyledoneus, inverfus, brevifinus, lacleus. Cotyl. rotundatz, comprefizi. Radic. craltiuscula, fupera.

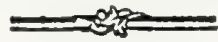

2. A.) Fruetus \& (eminis latus externum, B.) Ejusdem pars plane c. C.) Sectio feminis trans verialis. d.e) Abumea denudatum, ab utraque parte fpectatum. F.) Situs embrjonis in (upremo albumine. G.) Embryo a fronte \& a latere fpectatus.

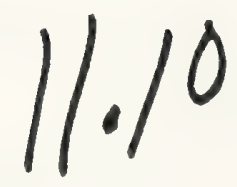




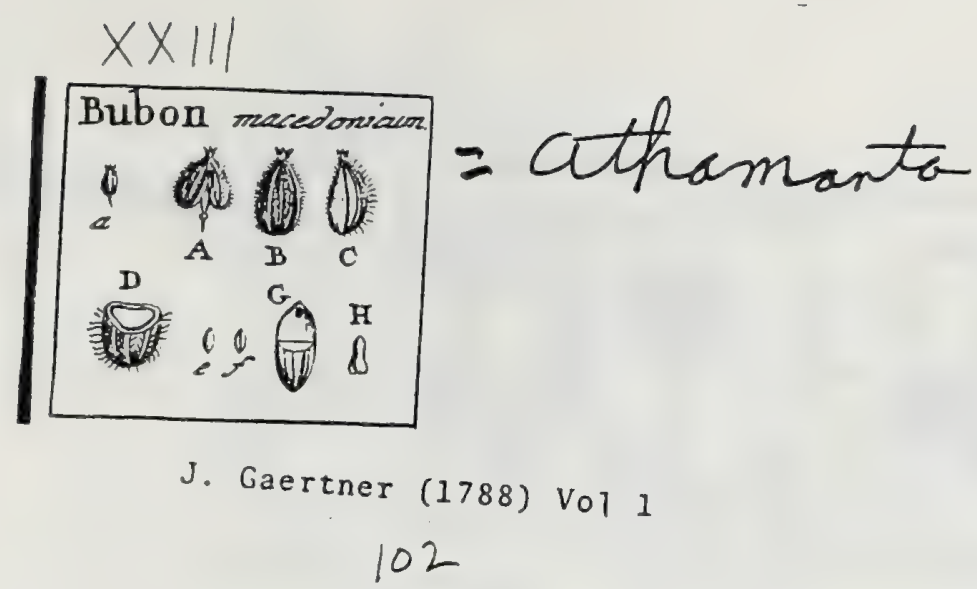

CXX. BUBON. LIN ger. 350 .

Umbella compofita. Involuc. unirerfale pentaphyllum, perfiftens; partiale polyphlyyl. lum. Fructus parvus, ovatus, friatus, villofus.

В и в о m macedonicum. Tab. 23. fig. 2.

Petrofelinum macedonicum. Offic. B $\perp$ А $\mathrm{K} \nabla$. herl. $t .382$.

Daucus macedonicus. R Iv. pent. t. 42.

Bubon foliis rhombeo-ovatis crenatis, umbellis munerofifimis. LINN. Jyfo veg. 285.

$\mathrm{P} \dot{\varepsilon}$ R. nullum. Fruftus inferus, parvulus, ovatus, furfunı anguftartus, calyce perfinente minimo coronatus, villofus, bipartibilis.

REC. fliforme, bifidum.

SEM. duo, ovato acuminata, fpadiceo fufca, hine convexa, lineis in univerfum quinque elevatis pallitis ntriata, villisque canescentibus undigue confperla; inde plana, aut leviliume concava.

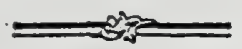

103

IN T. duplex: exterius fufcum; interius ferrugineum, utrumque membranaceum.

A L B. Semini conforme, carnofun, duriufculum, odoratum.

E м в. dicotyledoneus, inverfus, minutus. Cotyl.comprefix. Rad. teretiuscula fupera.

a. A.) Fruftus integer. B.C.) Seminis latus utrumque. D.) Ejus fedio transver(alis, ef.) Atbumen decorticatum. G. H.) Embryo in fitu, \& feparatus. 


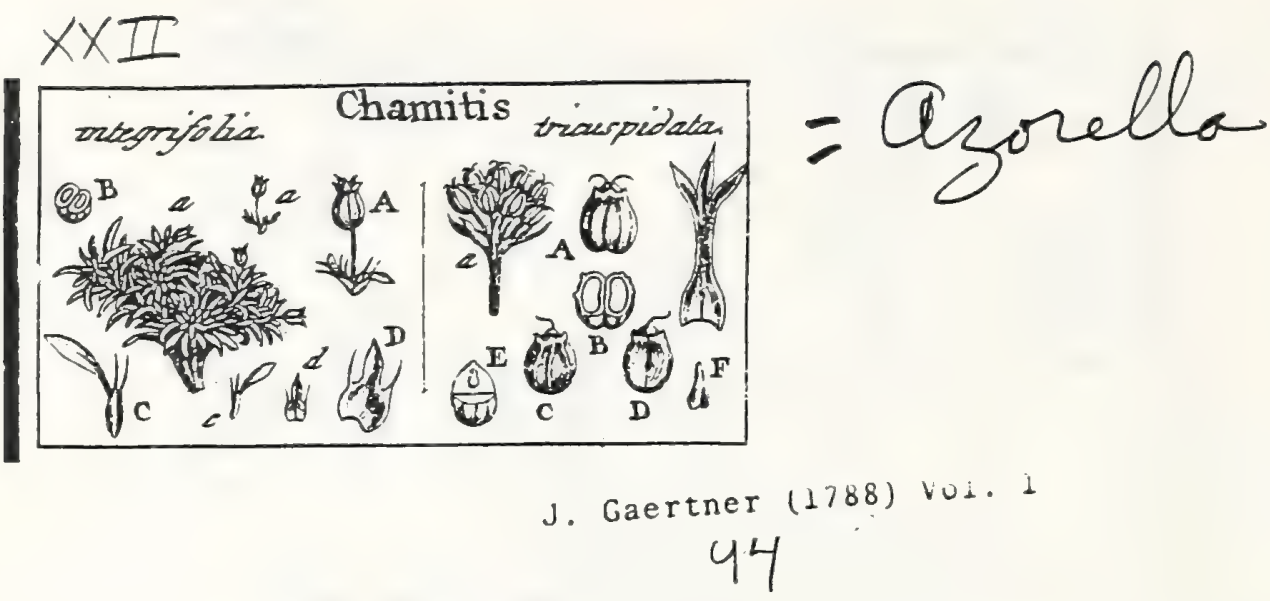

CXI. CHAMITIS. BANKS. = A=*rilz

Umbella nulla, aut fimplex. Involuc, nullum, aut fuboctophyllum. Calyx fuperus, quinquedentatus, perfiftens. Yetala quinque ovato-oblonga, obtufa, integerrima, alba. Stam. quinque. Styl. duo, filiforines: figmatibus craffiufculis. Fructus fub.' globofus, ntriatus, bipartibilis. (Ex fchedis SOLANDRI.)

Cна MI IS integrifolia. Tab. 22. fig. 4.

Ex herbario Bankfiano. Habitat in Terra del Fuego.

PEr. nullum. Fruqus inferus, parvus, leviffune compreflus, calyce perfinenti coro. natus, didỵmus, bipartibilis.

REc. nullum, aut obfoletum inter femina.

$S_{E}$ x. duo, ovata, paulo latiora, quam crafta, hine tribus lineis, elevatis, difancibus notata, inde plana.

Ix т. duplex: exterius fubçoriaceum; interius membranaceum.

A LB. femini conforme, carnofum, durum, album, inodorum.

Ex в. dicotyledoncus, inverfus, minutus. Cotyl. ovatx, planiusculx. Radic. anguftior, terctiuscula, fupera.

95

a) Planta integra", cxipitofs, ramulis apice floriferis. Folia confertifima, vaginantia. Vagina ovata, aperta, utroque margine in fetam capillarem producta, \& ex intentitio earum, Ipfum folioluni lineari lanceolatum (c. $C_{\text {. }}$, aut in fuperioribus folis, ligulam tantummodo ovato acuminatam (d. D.) promens. Fruetus (a. A.) pedunculo capillari infiftens. B.) Idem cosspreffusculus, transverfim (eftus. E.) Albunien cum fitu embryouis. F.) Embryo feparatus.

Non tantum ob flores folitarios, hace genuina Umbellifera, fingularis eft; fed \& id habet peculiare, quod fructus non raro tripartibiles \& trilpermos proferat; quafi Natura umbella defectum, inconfueto in hac gente ferminum numero, compenfare voluiliet.

Cн A M I I Is trifurcata, ibid.

Ex herbario Bankfiano. Habitat cum pracedenti in $T$. del Fuego.

Folia ad radicem conferta, late linearia (g.), fupra trifurcata: lacinüs divaricatis, mucronatis; infra ampliata in vagiuam balin caulis amplexantem. Scapos fimpliciffimus, fubbipollicaris, nudus, aut unico-foliolo feffili, triculpidato ftipatus. Involucrum umbellâ brevius, foliolis fex l. octo, linearibus, acuminatis, perfiflentibus. Umbella (a) fimplex, xqualis, radiis octo ad decem. Flores ut in pracedenti, Fructus (a. A.) eidem quoque fimites, fed quadruplo majores, ovati, fupra anguftati, fubcompreffi B.). Semina hinc leviter convexa (C) tribus lineis elevatis notata; inde (D.) plauiuscula. Albunnen \& embryo, ut fupra.

$$
11.12
$$




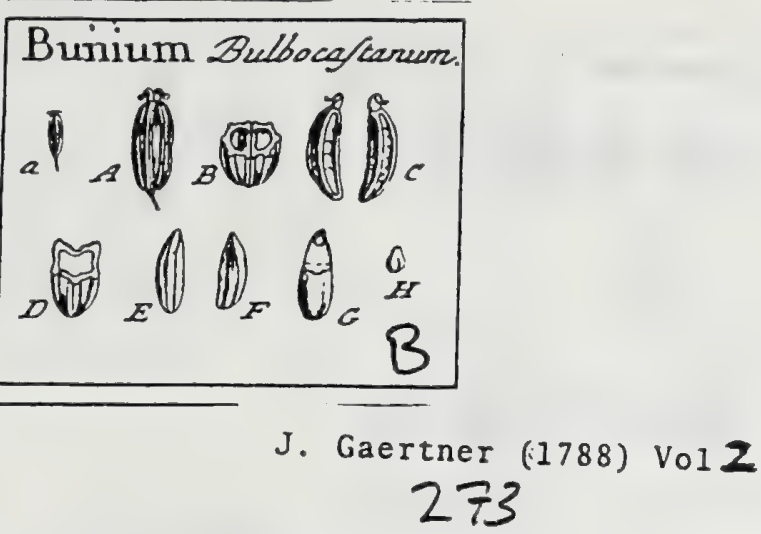

DCCCVII. BUNIUM. Linn.gen. 335. Bulbocaftanum. T o UR N. t. I6r.

Umbella compolita. Invol. utrumque polyphyllum. Petala cyialia, alba. Fructus parvus, ovato - oblongus. Sem. quinqueltriati, interftitiis fubrugolis fufcis.

Bunium Bulbocaftanum. Tab. 140. fig. 2.

Bulbocaftamum. Dod. pempt. 433. BaUн. bift. 3. p. 30. HaLl. bift. M. 783. Bunium. LiN. $\int y f$. veg. $=77$.

Icon. OED. fior. disn. t. 220 .

PER. nullum. Fructus inferus, parvus, oblonge-ellipticus, ftylis perfiftentibus terminatus, bipartibilis.

REc. fetaceum, bifidum.

SE м. duo, oblonga, plano-convexn, ftriata. Strix fingulis quinx, lùtefcentcs, parum convexx; interdun ipfo, dunbus ftriis capillaribus, ue in Fulcaria, diftinctx. Interftitia fubrugofa aut inæequabilia, fufca.

INT. duplex: utrumque membranaceum.

A \& B. cartilagineum, album, fubinodoruw aut odoris debilifime focniculacei. Eм в.' ninutus, fubglobofus. Cotyl. brevifimx. Rad. Supera.

a. ^.) Enuaus integer. B.) IJem transverfe difeaus. C.) Semine (eparata D.) Seminis Iedio transverfalis. E. F.) Albuminis latus utrumque. G.) Embrjonis in albumine Atus. 11.) Embryo fulu:us.

Strix videntur famplices in feminjibus exficcatis, at in aqua emollitis, apparent compolitx. 


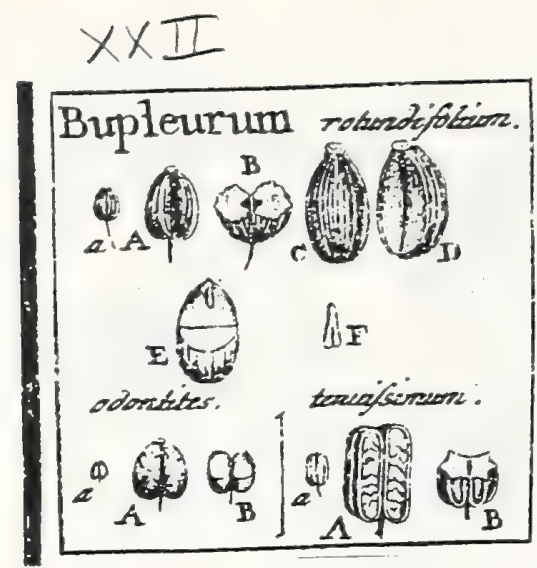

\section{J. Gaertner (1788) V01.1

CXIV. BUPLEURUM. TOUR N. t. 163 . L I N N. gen. 328 .

Folia fumplicia. Involucri partialis foliola lata, patentia. Petala lutea. Fructus ovatus, gibbus, farves, apice non coronatus.

BUPLEURUM rotundifolimm. Tab. 22. fig. 7 .

Ferfoliala. Riv. pent. t. 46. BLAKW. herb. t. 95 .

Bupliurum raule brachiato ramofifrmo, foliis ovato lanceolatis amplexicanlibus. HAL.. hif. I. n. 767 .

- Bupleurum involucris univerfalibus uullis, foliis perfoliatis. Lixx. fyf. veg. 273 .

PER. nullum. Fructus inferus, parvus, ovatus, : Ariatus, gibbus, niger, bipartibilis.

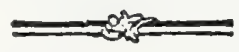

REc. nullum, aut femini adnatunt.

SEM. duo, ovato oblonga, gibba, fupra difco angunifluno plano rufefcente terminata, cetera nigra. Dorfum, ftriis in mise:fun tredecim, elevatis, lintaribus, exaratum: venter planiusculus, fulco fimpicici, deprefío.

IN T. funplex, incmbranaceum, nigrum, arche nuclco adlaxrcus.

A L E. Femini conforme, fubcartilagineum, inojorum.

Emp. dicotyledoneus, inverfus, teretiusculus. Cotyl. angunx. Rad. brevis, fupera.

2. A.) Frutus integer, B.) Idem transverfe feflus. C. D.) Seminis latus utrumque. E.) Ato bumen, cum fitu embryonis. F.) Embryo feparatus.

FUPIEURUM odontites. ibid.

Bupleurum angufifolium montanum. CoLum. ecplir. 84.t. 247 .

Bupleurum caule brachiato, incolicris utrisque pentaphiyllis arifatis petiolos excedentibus. H A L L. hif. 1. $10.77^{2}$.

Bupleurum involucellis pentaphyllis acntis, univer $\int a l i$ triphyllo, flofculo centrali altiore, ramis divaricatis. LINN. Juf. veg. 273.

Icon. J A C Q hort. 3. t. 9I.

Semina quadruplo minora (a. A.), quam pracedentis, nullis omnino firis infignita (B.), fed vel obfolete rugofula, vol glabra, ovato cylindrica, fufca, aut s. gricantia. Pars ventralis planiuscula. Reliqua ut in prxcedenti.

BUPLEURU is tenuiflumum. ibid.

Bupleurum tertiun minimum. Coluss. ccphr. 85.t.247. Mовis. hif. 3. S. g. t. 14. f. 4 .

Bupleurum caule ramnfifrino, umbellis alaribus pauciforis, involucris pentaphyllis lanceulatis, petiolis longioribus. H A L L. hif. I. ts. 774 .

Bupleurtm umbellis fimplicibus aliernis pentaphyllis fubtriforis. LIN. fufo. veg. 274 .

Fruclus parvus (a. A.) ovato oblongus, transveric craftior, utrinque rotundatus, fubemarginatus. Semina pentagono prismatica (F.), in dorfo tribus coflis acutangulis, dinantibus notata, \& àd interflitia obfolcte rugofa, fallida, aut fubcinerea.

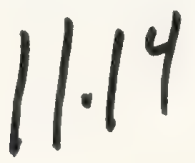




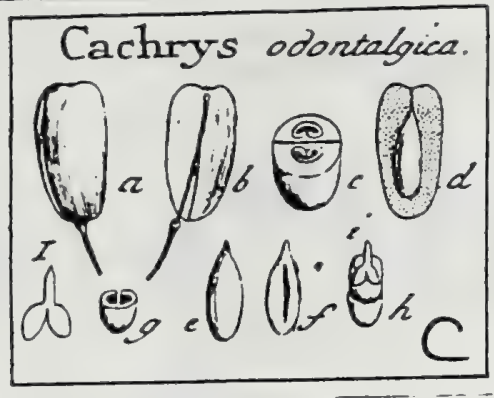

J. Gaertner (1788) Vol. 2

DCCCVIII. C A C H R Y S. TOURN. t. I72. LINN. gen. 342.

Umbella compofita. Invol. utrumque polyphyllum. Petala xqualia, albz. Fructus fuberofus, grandiufculus. Embryonis cotyledones collaterales!

Cachrys odontalgica. Tab. 140. fig. 3.

Cachrys odontalgica. PALL. it. ruth. 3. p. 720, t. G.

Cachrys foliis radicalibus fupra decompofitis tomentofo - canis, caule nudo unzellifero, Seninibus cortice fruberofo levilfimo. LINN. Syjt. veg. 28 o

A Cl. Schrebero.

PER. nullum, nif feminis integumentum externum craffifimum velis. Fructus grandiufculus, ovato-cylindricus, albus, glaber, bipartibilis.

REC. fetaceum, bifidum.

SE M. duo, ovato-oblonga, plano-convexa, glaberrina, albicantia.

INT. duplex: exterizls craffifimum, fungofum, confiftentiá medulx fambuci, fragile, candidum; interius membranaceum, fpadiceum, tenue.

A I B. cartilagineum, femipellucidum, oblongun, irodorum, convexo - concavum: marginibus in ventrem convolutis.

EN B.. grandiufculus, inverfus, lacteus. Cotyl. foliacex, ellipticx, deorfum divaricatc, collaterales, fere ut in Menifpermo, nifi quod anbx in uno fint albuminis loculo. Rad. lineari-acuminata, compreffa, fupera.

3.) Frudus integer. b.) Semen e receptac. fetaceo pendulum. c.) Scetio fructus transverfalis.

d.) Seminis nucleus denudatus. c. f.) Albuminis propria fua mcmbrana veftiti facics utraque.

5.) Ejusdeu fectio trausverfalis. h. L) Embryonis in albunine Gitus \& figurz. 1.) Einbryo folutus \& 2uctus.

Cotyledonum pofitio infolentiffima, fis \& in reliquis fpeciebus locum habue. rit, optimam generis probebit notam characterifticam. 


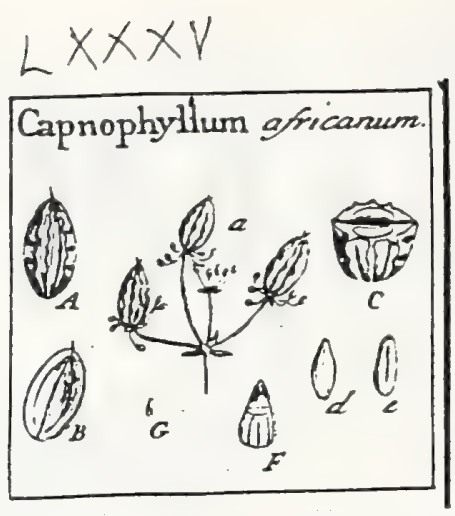

J. Gaertne

\section{C A P N O P H Y L UM.}

Unbella compolita, pauciradiata: Radiis umbellx partialis lateralibus fterilibus, centrali breviffimo fercili. Involuc. utrumoue fubtriphyllum breviffimum. Corollulix irregulares. Fructus fubfeffilis, jugis tuberculato muricatis.

CAPNOPHYLLUM africanum. Tab. 85 . fig. 6.

Cancalis africana, folio minore mutc. BOERH. ligdb. p. $63 . t .63$.

Conium feminibus nutricatis, petiolis pedunculisque levibus. L1NN. $\sqrt{y} f$. veg. 278 . Icort. JACQ. hort. 2. t. 194.

PER. nullum. Fructus ellipticus, lenticulari compreffis, in centro unibellx partialis folitarius, fubfeftilis, bipartibilis.

REC. filiforme, bifidum.

SEM. duo, fructui conformia, hine leviter corivexa, jugis tribus (interdum faltem duobus) dorfalibus, approximatis, tuberculato aut denticulato-muricatis infignita \& in marginem latiufculum, rigidum, tuberculis rarioribus rugatun defanentia; inde plana aut modice concava, linea media longitudimali, duabusque lateralibus, arcuatis, ob oletiufculis notata.

INT. duplex: coriaceum \& membranaceun.

ALB. integumento externo multum anguftius, oblongum, hinc convexum, obfolete ftriatum; inde ex fulco medio leviter concavum; carnofum, inodorum.

Eм в. exilis, teretiufculus, inverfus, lacteus. Cotyl. brevifimx. Rad. cylindrica, fupera.

a) Umbclla matura, cum fitd \& figar (eminum naturali A. B.) Seminis facies dor[alis atque ventralis. C.) Scminz transverlim feta. d. c.) Albuminis deaudati latus utrumque. F.) Em. bryonis in apice albuminis fitas. G.) Embryo folutus.

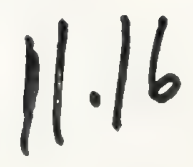




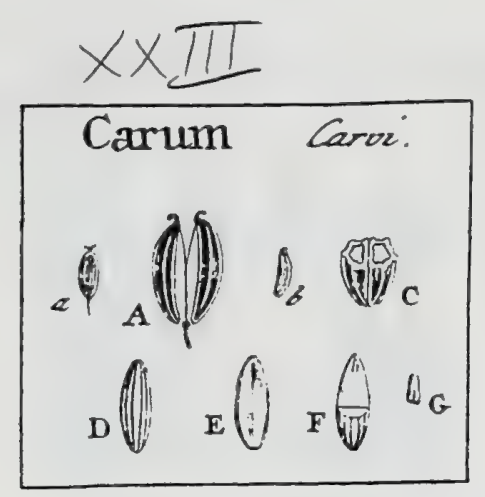

$$
\begin{aligned}
& \text { J. Gaertner (1788) Vol.1 } \\
& 106
\end{aligned}
$$

CXXV. CARVM. LIN N. gen. 365 . Carvi. Tourn. t. 160.

Umbella compofita. Involuc. nullum. Pelata alba. Fructus parvus, ellipticus, gibbus, teretiftriatus.

CAR UM Carvi. Tab. 23. fig. 7.

Carum. D O D. penipt. 299. C A s. epit. 5i6. R I v. pent. $t$. 55. B L A $\mathrm{k}$ w. herb. $t$. 529. J A c C. aufr. 4. t. 393. H A L L. hiff. 1. 13. 789. L in N. Jyfl. veg. 291.

PER. nullum. Fruttus inferus, minor quam foeniculi, filiformi Rriatus, bipartibilis.

REc. fliforme, bifidum.

S E 3. duo, oblonga, gibba, fpadiceo fufca. Strix in univerfum quinqux, modice elevatx, rotundatx, pallide lutex; interfitia planiufcula, fubtilifine ftriata. Pars. ventralis plana, in medio fufca, ad latera fallida.

IN T. duplex, utrumque membranaceum; interius nigro fulcum.

A I. . feinini conforme, carnofum, durum, odoratum.

Eм в. dicotyledoneus, inverfus, minutus. Cotyl. femiteretes. Rad. fupera.

2. A.) Fructus integer. b.) Senivis latus iuteroum. C.) Fructur diffectus D. E, Albamen dem corticatum. F.G.) Embryo in Titu, \& folutus.

Careum, non Carum, latine dici deberet. Conf. P L1s. L. XLX. אect. 49.

$$
11.17
$$




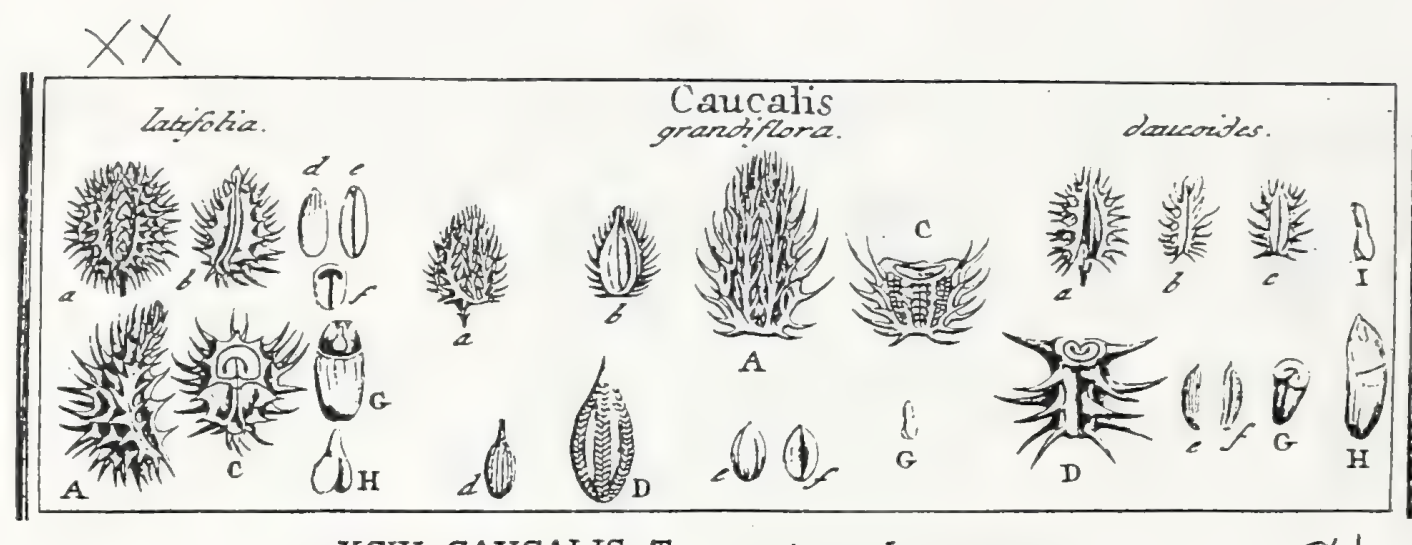

Apiaceae

XCIV. CAVCALIS. TOURN. $t .17$ I. LINN. gen. $33^{1}$.

Involucri univerfalis foliola fimplicia, integra. Corolla univerfalis plerumque manifeftius radiata, quam in Dauco. Semina criftis duplicato fpinofis, aut aculeis fimplicibus per feries longitudinales pofitis.

Cavcalis latifolia. Tab. 20. fig. 5.

J. Gaertnet (1788) Vor.1

Echinopbora major platyphyllos purpurea. CoL v s. ecphr. 1.p.97.98.

Caucalis arven/is echinata latifolia. MORIs. hif. 3. S. 9. t. I4. f. 2. Umbell. t.1. f. 14. 14. EO b. x.

Cancalis fuliis afperis pinnatis, pimis ferratis, involucris ovato lanceolatis. H A L L. hifl. I. n. 738 .

Caucalis umbello univer fali trifida: partialibus pentaspermis, foliis pinnatis ferratis. LIN N. SI/R. veg. 276 .

Icon. JACQ. hort. v. 2. t. 128 .

PER. nullum. Frufus inferus, ovatus, muricatus, bipartibilis.

REC. filiforme, bifidum.

SEM. duo, grandiufcula, ovata, gibba, feptem crifis muricata: harum tres latiores, craftroresque, duplici plerumque aculeorum rigidorum \& pungentium ferie armatx; reliqux autem quatuor, paulo anguftiores \& fimplici tantum fpinarum ordine inftructx. Pars ventralis planiufcula, ftria media elevata \& prope bafin canaticulatâ, inferipta.

In $T$, duplex: exterius coriaceum, craffum; interius membranaceum, tenuifimum.

$\Lambda\llcorner$ B. ovato oblongum, fubcartilagineum, inodorum, hinc convexum, inde marginibus inflexis convoluto-concavum.

Ess. dicotyledoneus, inverfus, brevis. Cotyled. orbiculatx, fubfoliacez. Radic. teretiulcula fupcra.

a.) Fructus \& feminis latus extenum. b.) Ejusdem pars ventralis. C.) Seminis feetio transerfa. 'lis, cum albuminis convolauione. d.e.f.) Aibunien decorticatum \& transverfe fectum, ab utraque parte fpectatum, G.) Situs embryonis in fummo abuminis dorfo, H.) Embrjo Icparatus,

CAOCALIS granditlora. ibid.

Cancalis magno flore albo. Moris. Umbell. t. I. fig. v. $\xi$

Echinophora flore magno. Riv. pent. t. 25 .

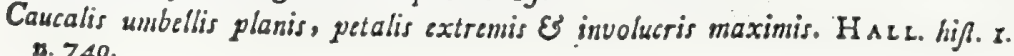

מ. 740.

Caucalis involucris fingulis pentaphylis: foliolo unico duplo majort. LIN $\mathrm{N}$. JUß. veg. 275 .

Icon. J A C Q. auftr. v. 1. t. 24.

Fructus magnitudine fere pracedentis (a.b.), fed non gibbus fo tranfverfe latior, verum potius quodammodo compreftus (C). Coftx dorfales quatuor crafitores (A.C.), fpinis fubalterais aut geminatis, rigidis, adfcendentibus \& pungentibus arınati; inter has, fulci tres elevati (C.D.) aculeolis fetaceis, minutis, brevibus, divaricatis \& furfum incurvatis muniti. Albumen ellipticum (c.f.), plano convexum, folidum (C), inodorum. Embryo (G) minutus, Lacteo albus.

CAUCAlis daucoides. ibid.

Caucalis arven/s echinata, parvo fore. Mor1s. hiß.3. S. g. t. I4. f. 6 .

Echisophora. RIv. pent. $t .24$.

Caucalis foliis triplicato pinnatis, involueris ligulatis, univer fali unifolio. HA L. hifl. I. n. 739 .

Caucalis unbellis trifidis aphyllis, umbellulis trispermis triphyllis. LIN N. Juß. veg. 276 .

Icons. J A C Q. aufr. 2. t. 157 .

Fructus mediocris magnitudinis (a), feminibus oblongis (b.c.D), fubfemicylindricis. Coflx dorales quatuor (D), crafix, aculeis remotiufculis, rigidis, patentibus, pungentibus armatx; inter has, interftitia angufiffima, quafi rima longitudinali divifa, ex qua nonnung̨uan fpinule minutiffima fetacex prodeunt. Albumen (e.f.G. H.) convolutum, urodorum. Embryo (H. L.) cxilis,
Lacteus. 


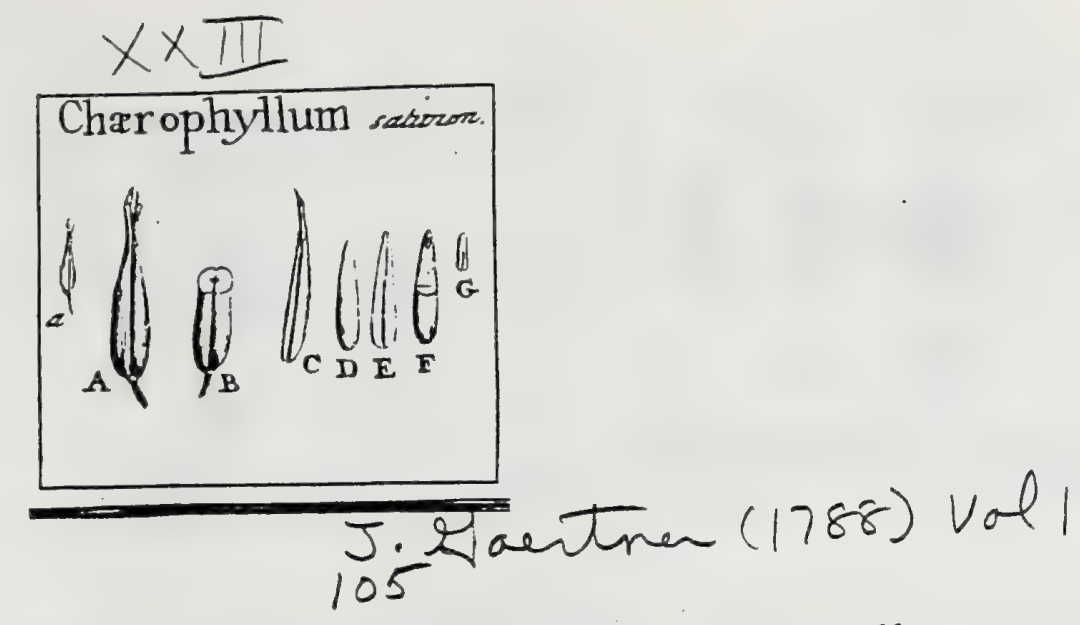

CXXVII. CHEROPHYLLVM. TOURN. $t$. 166.

Umbella fimplex. Involuc. nullum. Fructus tereti roftrates, non ftriatus. Nucleus dimidio femine paulo longior.

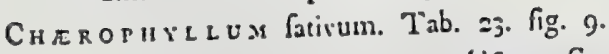

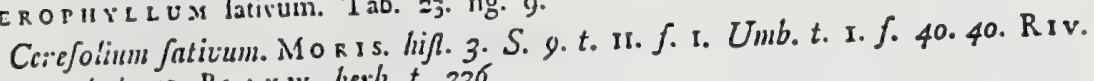
pent. t. 43 . BLA K w. herb. t. 236 .

Charopingllum foliis glabris triplicato pinuatis, lobulis obtufis. HI LL. hif. I. 13. $7+7$.

Scandix feminibus nitidis ovato fubulatis, umbellis fefilibus lateralibus. LIN fyll. veg. 287.

Icon. J A c c. auflr. 4. t. 390.

PER. nullum. Frud̃us inferus, ex ovata \& transverfim crafliori bafi in roftrum fubu. latum, nylisque duobus brevibus unguiculatis terminatum, elongatus, glaber, nigricans, bipartibilis.

REc. fliforme, bifidum. 106

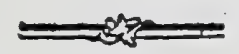

Е мв. dicotyledoneus, inverfus, breviflumus. Cotyl. Reınicylindricx. Rad. teretiuscula fupera.

2. A.) Frudtus integer, b, c.) Seminis latus utrumque. D.) Eadem differta, E.) Embryo in alm mine. F.) Idem feparatus.

MÉu Mutellina. ibid.

Mutellina. С а м. epit. 8 .

Sefeli foliis duplicato pinnatis, pinnulis femipinnatis, lobulis lanceolatis. HaLr. hif. I. n. 763 .

Phellandrium caulo Jubnudo, foliis pinnatis. LIN $\mathrm{I} . \int y /$. veg. 286.

Icon. I c e. auftr. I. t. 56 .

Involucrum partiale fubleptaphyllum, xqualiter difpofitum. Fructus priori fimilis, fed aliquantum inajor, totus rufefcens. (a. A.). Semina (b.c.) fuperne cratfio$\mathrm{ra}$, acuminata tamen \& in fylum Setaceum brevein definentia. Coft $x$ quinque (D), evidentius in membranam anguftiflimam extenuat $x$, pallid $x$; interntitia glabra, nec friata. Albumen (E.) odoratum. Einbryo (F.) teretiusculus.

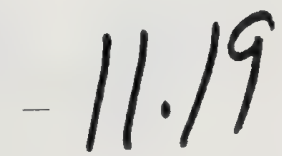




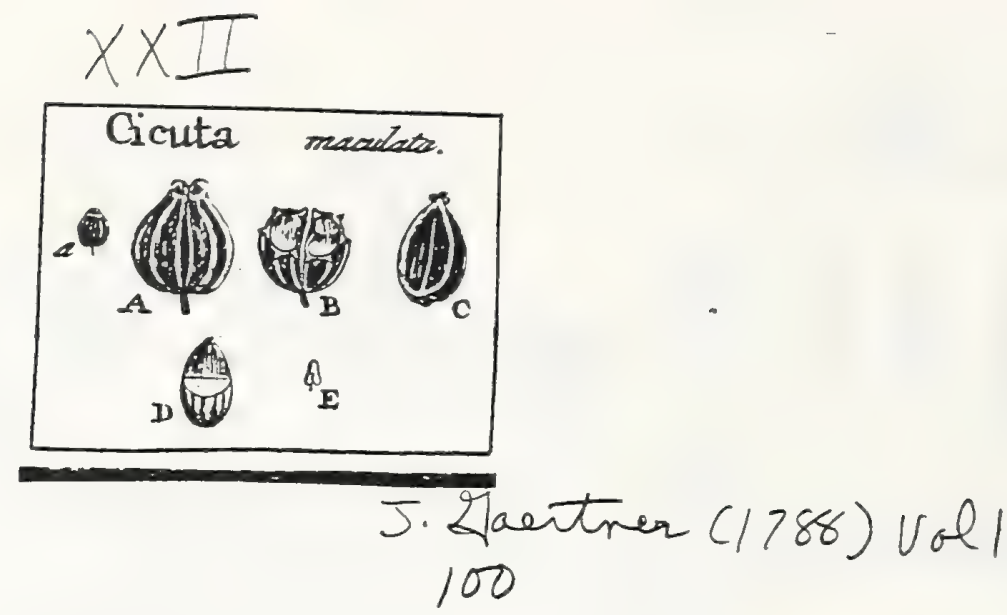

CXVII. CICUTA. Tourn. t. 160. Conium. Linn. gen. 336.

Umbella compofita. Involuc. univerfale tri-f. pentaphyllum, faliolis latiusculis reflexis; partiale triphyllum, unilaterale. Fruchus ovatus, gibbus; coßis compreffis, ante maturitatem undulatis.

Cicut a inaculata. Tab. 22. fig. 10.

Cicuta. RIv. pent. t. 75 . BLAKV. herb. t. 45 I. E 573. a. b. Stoerk. Juppl. t. I. HAL1. hift. 2. n. 766 .

Conium feininibus ftriatis. lins. fult. veg. 278.

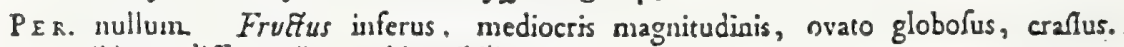
gibbus, diflite collatus, bipartibilis.

REC. filiforme, bifidum.

SEм. duo, ovata, furfun anguntiora, valde gibba, tuberculo contico brevi flyligero atyue calycis rudimento undulato terminata. Cof $x$ quunque, quarum tres dor-: fales of durx laterales, omnes albicantes, diffitz, fubhtexuof $x$, valde eleva: $x$ \& compreilix ut fere inembranacex: interftitia glabra, e fpadiceo rufefcentia Pars ventralis plana.

INT. duplex: exterius coriaceo-membranaceum, tente; iuterius arachnoideum.

А В. femini conforme, carnofum, durum, ingrati \& naufeofi odoris.

Е м в. dicotyledoneus, inverfus, minutus. Cotyl. obtufx. Rad. fubconica, fupera

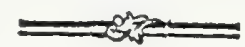

a. A.) Fructus iuteqer, B.) Idem diffectus. embryouis, E.) Embryo Solutus.

Bene monet R IV IN U S. Introduct. $p .22^{\circ}$, feminum frias efle crifpas, dum fennen adhuc viget; nam in probe maturo, iلl $x$ fere rectx fiunt \& vix obiter undulatz funt.

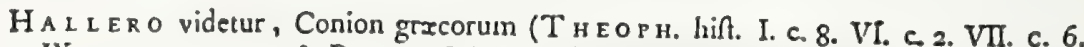
IX. c. 8. 15. 17. 21. \& Diosc. IV. c. 79.) potius aquaticam, quam nofram effe Cicutam maculatam; quandoquidem huic folia ferulx angultiora non competant. Attanen \& altera opinio tueri poteft: nam Dioscorides expreffe Conio fuo femina tribuit Anifi finilia, quod verifumum de Cicuts maculata, non iten de aquatica feminibus.

\subsection{0}




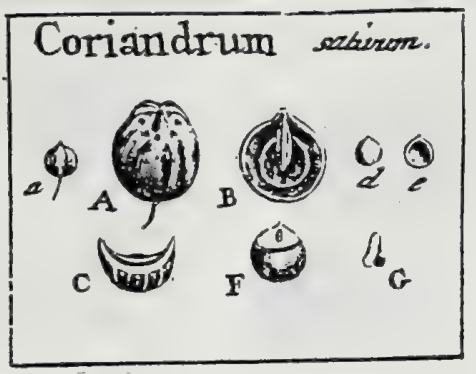

Apiaceae

J. Faentrer $(1788)$ voll

CIX. CORIANDRUM. TOURN. t. 168. LINN. gen. 356 .

Unbella coinpofita. Invol. univerfale fubnullom; partiale tri -1 . pentaphyllum. Fructus Splixricus, glaber.

CORIANDRUM fativum. Tab. 22. fig. 2.

Coriandrunz. CA s. epit. 523. B LA x

Coriandrum majus. R I v. pent. t. 7 I.

Coriandirum fruttibus globojis. HALL. hif. I. n. 764. LINN. Jy/. veg. 287.

PER. nullum. Frufurus inferus, fpharicus, calycis reliquiis \& intra illas tuberculo conico Aylifero terminatus, biparcibilis.

REc. filiforme, bifidum.

SEs. duo, hemifpharica, glabra, Arüs fex capillaribus, vix confpicuis, in dorfo no. tata; parte ventrali concava, medio fulco prominulo infcripta.

IN T. duplex: exterius coriacẹo-cruflaccum; interius arachnoidcum.

AL B. convexo concavun, femine multo angufius, carnofum, odoratum.

Емв. dicotyledoneus, inverfus, breviffinus. Cotyl. fubfoliacex, rotundatx. Rad. teretiuscula fupera.

a. A.) Eru\&us integer, B.) Seminis pars concav2, C., Ejus dorfam, d. e.J Albamen decorticatum. F.) Einleryonis fitus, G.) Eimbrjo feparatus. 


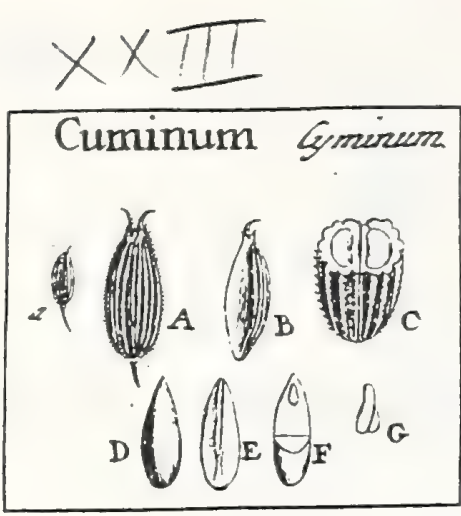

J. Gaertner (1788) Vo1.I

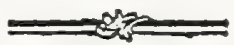

CXXYI. CVIMINVM. L IN gen. 35 .

Umbella compolita. Involuc. utrumque tetraphyllum : foliolis fimplicibus \& trifidis. Fructus parvus, ellipticus, multifriatus, hirfutulus.

Cuminum Cyminum. Tab. 23. fig. 8.

Cuminum fatiunn. CAss. epit. 518 .

Cuminum. RIv. pent. t. 40. IIN 4 . J 8 . veg. 285.

PER. nullum. Eruatus inferus, magnitudine faniculi, calycis denticulis erectis, ftylisque duobus brevibus reflexis terminatus, friatus, hifpidulus, pallidus, bipartibilis.

REc. filiforme, bifidum.

SE M. duo, oblonga, utrinque attenuata, hine convexa, friis in univerfum novem, filiformibus exarata, ac ininutis fetulis undique coniperfa; inde plana.

IN T. duplex, uttumque membranaceum, tenue.

A L B. femini conforme, carnolum, durum, odoratum.

Em B. dicotyledoneus, inverfus, brèvis. Coty̨. ovatx, compreffx. Rad. anguflior, lupera.

a. A.) Fruatus integer. B.) Semiuis latus internum. C.) Fruâus dirfetus. D. E.) Albumex decorticatuu. F. G.) Embryo in fitu, \& feparatus.

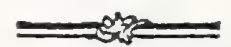

SE s. duo, fubulata, glabra, punctis vix perceptibilibus confperfa, obfolctifune angu. lata, a parte interma fulco longitudinali excavata.

INT. duplex: exterius coriaceum, durum; interius membranaceum, tenue.

A B. femini conforme, fed tertia parte brevius, carnolum, inodorum.

Eм в. coryledoneus, inverfus, parvus. Cotyl. Cemitcretes. Rad. fupera

2. A.) Fruetns integer. B.) Idem transverfe fectus, C.) Seminis pars ventralis. D. E.) Aibumen decorticatuin. F.) Embryonis fitus, G.) Idem feparatus.

In Scandice vera, nucleus vix unam quartam, in Chxroplyyllo tres quartas partes, \& in Myrrhide totam feminis longitudinem attingit.

$$
11.22
$$




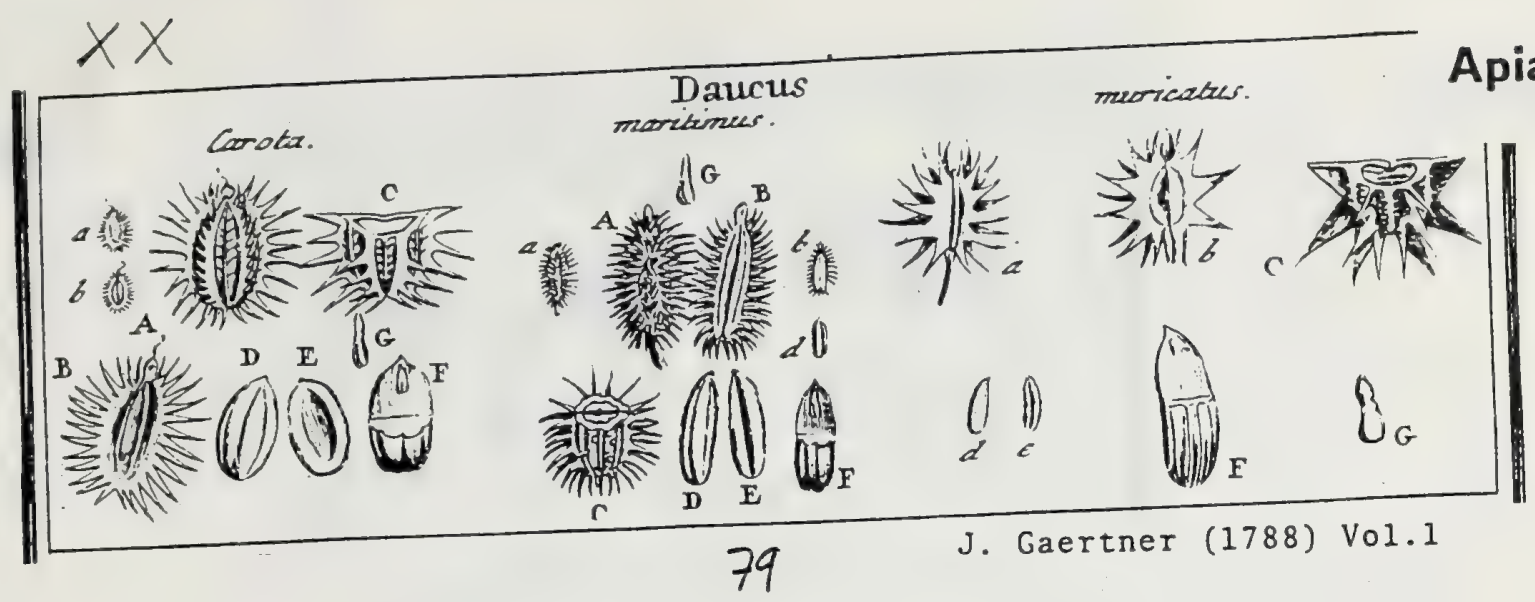

XCIII. DAVCVS. TOURN. t. I6́r. LINN. gen. 333 .

Involucri univerfalis foliola pinnatifida. Semina aculeis in criflas longitudinales con- fluentibus muricatz.

Duveus Carota. Tab. 20. fig. 4.

Pafinaca tenuifolia fativa, radice lutea vel albo. Morıs. hif. 3. S. g. t. I3.f. I.

Unibell t. 1 f. 12.12 \& $\%$. $\$$.

Staphylinus. R Iv. pent. t. 28 .

Daucus fylvefris. B L A K w. herb. t. 546. OED ER. flor. dan. t. 723 .

80

Daucus involucris cavis : communibus pinnatis, peculiaribus lineari lanceolatis: H A L L. hif. $1 . n .746$.

Daucus feminibus hifpidis, petiolis fubtus nervofis. LIN $\mathrm{s}$. fyft. veg. 27\%.

PER. nullum. Fruftus inferus, elliptico-Sphæroideus, bipartibilis.

REC. filiforme, bifidum.

Sesr. duo, plano convexa: dor $f$ criflx quatuor, inembranacex, anguftx, pectinatz dentibus lineari fetaceis, innocuis, fiexilibus; inter illas nervi tres elevati, utrinque aculeolis ninutis, extrorfum arcuatis ftipati. Ventris pars plana, aut modice concava, friis obfoletis longitudinalibus notata.

IN T. duplex: alterum fubcoriaceum, alteruın inembranaccuin; utrumque tenue.

A L B. ellipticum, hinc convexum, friis tribus infcriptum, inde leviter concavum glabıun; fubcartilagineum, album, inodorum.

E м в. dicotyledoneus, inverfus, brevifimus, teretiusculus, lacteus. Cotyl.oblongx, comprefix. Radic. fubcylindrica, fupera.

a. A.) Fructus atque feminis latus convexum. b. B.) Ejusdem pars plana, C.) Seminis fectio trane verialis. D. E.) Albumen decorticatum. F.) Situs enibryonis. G. ) Eabbryo (eparatus.

DA Ucus maritinus. ibid.

Caucalis pumila maritima. MOR Is. hif..3. S. 9. t. If.f. 7.

Caucalis involucro univer fali diphyllo, partialibus pentaphyllis. GERARD. prov, 237. $t$. 10. benc.

Daucus muricatus B. L I N N. Jyff. veg. 277.

Fructus oblongus (a.A.C.). parvus, comprefliusculus. Semina oblonga, interdam fere linearia (B), feptem in univerfum coftis dorfalibus anguftifimis exarata: ba: rum quatuor majores, (C), creffiores, aculeis fetaceis, fcabris, rigidulis, nune? fimplicibus, nune duplici ferie pofitis armatx; tres autem reliqux inerınes, tanquam nervi prominuli (C), ad interftitia priorum pofiti. Albumen (d.D.E.) folidum, inodorum. Embryo (F.G.) minutus, lacteus.

Hxc fpecies omnino a Dauco removenda, \& Caucalidis generi inferenda eft.

DA u cus muricatus. ibid.

Cancalis major daucoides tingitana. Moris. hiff. 3. S. 9. t. I4. f. 4. Unbell!

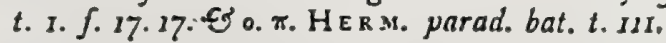

Echinophora tingitana. RIv. pent. t. 27.

Daucus feminibus triglochidi-aculeatis. LI s N. fyfl. veg. 277.

Semina grandiufcula (a), ovara, hine leviter convexa (C.), inde plana (b.). Nz dorfales quatuor, meinbranacex, lat $x$, ferrata-dentatx: dentibus triangulis ini acumen letaceum definentibus. Inter has, coflx tres (C), lineares, utringue. aculeolis brevibus, reckis, ciliatx. Albumen (d.c.F.) oblongum, hine frittum, inde planiusculum, folidum, inodorum. Eubryonis (F.G.) cotyledo:
nes ovatz, fubfoliacex. 


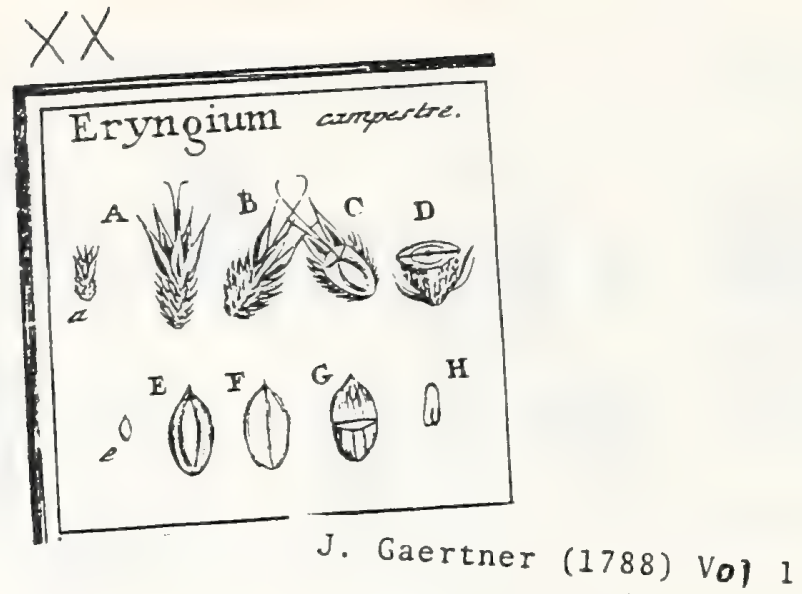

77

XC. ERYNGIVMI. TOURN. t. 173. LINN. gen. 324

Flores ut in Umbelliferis. Involucrum univerfale polyphyllum. Recept. commune pa:eaceum. Stmina fquamulis Hexilibus muricata.

Exymeicm Carnpefic. Tab. 20. fig. 1.

Eryngium. CA M. epit., 447. O E DER. for. dan.t.554. JA CQ. auftr. 2. t. 155.

Eryngium foliis fomipinnatis, pinnis pinnatis, pinnulis labatis fpino/is. HALL. hift + 3 . 75 .

Ėyr:ziam juliis radicalibus amplexicaulibus pinnato laciniatis. LINN. Jyfl. veg. 271.

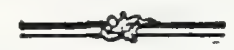

PER. nullum, 1. adnatum. Fruftus obovatus, comprefiusculus, bipartibilis, calyce fibi longiore perfiftente coronatus.

REC. non difcretum, in axi fructus politum.

SEM. duo, ovata, fupra truncata, hine convexiuscula aut obfoletifime angulata, fqua: mis membranaceis, acuminatis, candidis, absque ordine pofitis, contecta; inde plana, glabra.

IN T. duplex: exterius coriaceum; interius tenuiffunum, fufcum.

$\Lambda$ \& в. ellipticum, fupra acuminatum, plano convexum ; hinc triplici, inde fimplici? ftria longitudinali infcriptum, carnofum, album, inodoruin.

E s в. dicotyledoneus, inverfus, teretiusculus, brevifiunus, terminalis, lacteo albus. Cotyl., breves, compreffiusculx. Radic. cylindrica fupera.

a. A.) Fructus integer. B.C.) Semen ab utrogue latere (pectatum. D.) Fructus excuffis fquamis, prater duas, transverfim feetus. e. E.) Albuninis dorfum. F.) Ejusdem pars ventralis. G.) Situs embryonis ad apicem albuminis. H.) Embryo folutus \& auctus.

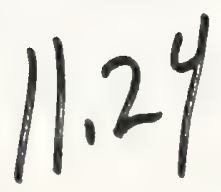




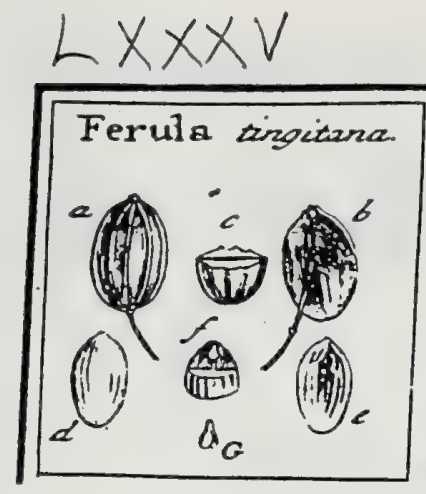

\section{J. Gaertner (1788) Vol $\mathbf{2}$}

28

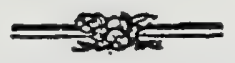

DXXXI. FERULA. TOURN. inft. t. 170. LINN. gers. 343.

Umbella compofita. Involucrum toniverfale caducum: partiale polyphyllum, parvum. Corollx petaln lutea. Fructus ellipticus, ftriatus, fubmarginatus.

Ferula tingitan. Tab. 85. fig. I.

Ferula tingitana folio latifimo bucido. Herns. parad. bat. p. E t. 165. RIV. pent. t. Io.

Ferula foliolis laciniatis: lacimnlis tridentatis inaqualibus oritidis. LINN. fyrs. veg. 281 .

PER. nullum. Fructus inferus, lenticulari - bracteatus, ecaiyculatus, fordide fpadiceus, bipartibilis.

RE c. filiforne, bifidum.

SEM. duo, figura frttus, foliaceo-compreffa, hinc levifime convexa, tribus ftriis elevatis, filiformibus notata; atque angufto margine circumdata, inde plana aut vix fenfibiliter concava, ftriis \& margine confpicuis deftituta.

IN T. duplex: exteritus nucleo latius, fubcoriaceum tenue; interius membranaceum, arcte adnatum.

A LB. ellipticum, femine paulo anguftius, in dorfo obfolete ftriatum, fubcartilagineum, album, inodorum.

E M 8. dicotyledoneus, inverfus, compreffus, quinta parte albuminis brevior, lacteus. Cotyl. fubrotundx, foliacex. Rad. teretiufcula, fupera.

2.) Frnctus \& feminis pars exterior dorfalis, b.) Einsdem facies interior cum infertione receptaculi. c.) Semina tansverfim fecta. d.) Albuminis denadati latus dorfalc. e.) Ejusdem pars ventralis. f.) Embryonis in fupremo albumine fitus. G.) Embryo falutus \& parum autus.

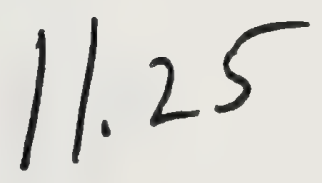




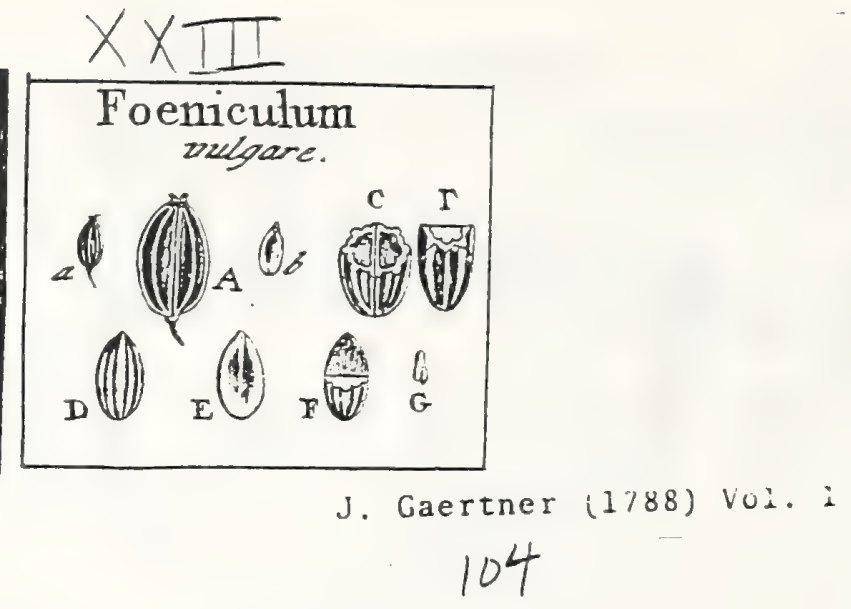

CXXIII. FOENICVLVM. TOUR N. t. 264 .

Umbella compofita. Involuc, nullum. Petala lutea. Fructus parvus, ovato oblongus, friatus, gibbas.

Apiaceae

105

FOENICUIUM vulgare Tab. 23. fig. 5 .

Faniculum. Ca s. epit. 534. Morrs. Unib. t. I. f. $7 \%$. 78. R Iv. pent. t. бr. B L A K w. herb. t. 288. H ALL. hif. I. n. 760 .

Anethum fruttibus ovatis. LIN N. Jy/f. veg. 291.

PER. nullum: Frufius inferus, parvus, elliptico oblongus, paulo latior, quam craffus, friatus, bipartibilis.

$R E$ r. filiforme, bifidum.

SEM. duo, ovato oblonga, hine convexa, lineis in univerfum quinque rotundatis, elevatis, pallidis notatata; inde plana. Interfitia inter coltas glabra, in recentibus, leviter rotundata, viridi fpadicea: in vetuftis depreffa.

IN T. duplex: utrumgque membranaceum.

A Ł. Remini conforme, fulcatum, carnofum, durum, odoratum.

E s1 8. dicotyledoneus, inverfus, minutus. Cotyl. femiterctes. Rad.cylindrica, fupera.

a. A.) Frutus integer. b.) Semiuis latus internum. C.) Frutus recentior transverfe fetus. r.) Semen vetuftum transverfe (ctum. D. E.) Albunten decorticatun F.) Embryonis atus. G.) Idcai feparatus.

$$
11.26
$$




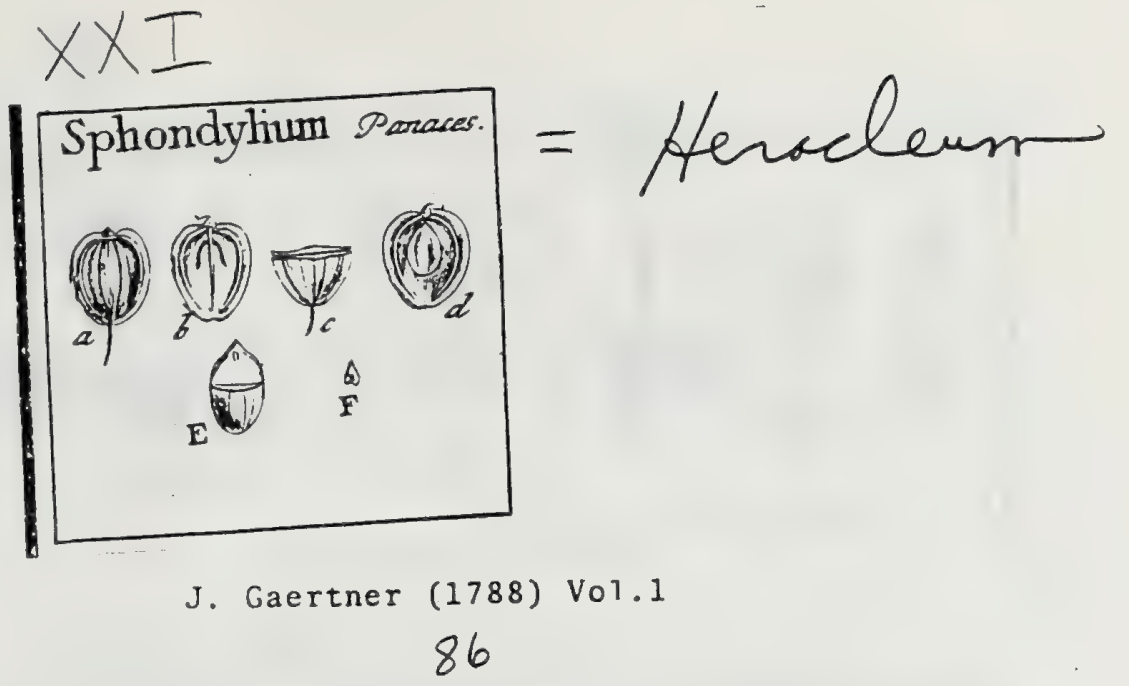

Apiaceae

XCIX. SPHONDYLIVM. ToURN. t. 170. Heracleum. LIN . gen.345.

Umbella compofita. Invol. univerfale nullum, aut paucifolium, caducum; partiale polyphyllum. Petala alba, aut rubicunda. Seinina foliaceo-comprefta, glabra, margine membranaceo, anguftiffuno cincta.

SPRONDYLium Panaces. Tab. ai. fig. 4.

Heracleun foliis pinnatis: foliolis quinis; intermediis feflibus, floribus radiatis: LIN N. Syß. veg. 282.

PER. nullum: Fructus inferus, foliaceo compreffus, bipartibilis.

$R E c$. filiforme bifidum.

S E M. duo, obovata, foliaceo compreffa, glabra, pallide framinea. Dorfum levifime convexum, ftriis tribus capillaribus in medio, atque alia fumili ad marginem nota: tum. Margo anguftus, potius attenuatus, quam membranaceus. Pars ventralis plana, fupra medium macula ferrugineo fúca, deorfum bicruri f. ferrum equinum ximulante picta, ceterum pallide albicans.

Ix r. duplex, utrumque membranaceum.

A L B. ellipticum, fupra acuminatum, femine multo anguftus, compreffum, carnofum, album, odoratum.

Exs: cotyledoneus, inverfus, minutus. Cotyl. breves, obtafx. Rad. teretiufeala, Superz.

87

a.) Frutus \& feminis latus externum, b.) Semiwis pars ventralis. c) Frutus fetio transverfalls. d.) Albunen depudatum. E.) Situs embryouis in albumine F.) 'Embryo feparatus.

Sphondylion folia habet platano quadantenus fimilia, at caulem ferulaceum; femen in cacumine fefeli (i, e. Tordylio) finile, duplex, verum latius, candidius \& magis paleaceum, gravis odoris: Hores albos. Drosc. In. c. 90 . Hxe liquida \& apta: qux autem de Heracleo tradiderunt veteres, ea dubio \& tenebris plena.

$$
11.27
$$


Hermas depauperata.

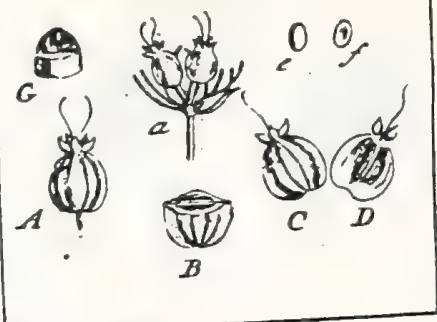

J. Gaertner (1788) Vol.2 2

30

DXXXIV. H E R M S. LINN. ger, I332.

Umbellx compofitx: terminales in medio fertiles, in ambitu fteriles, flofculis caducis; laterales totre fteriles, feriores. Invol. suiverfale polyphyllum, partiale unifolium. Cal. quinquefidus, in fructu perfiftens. Cor. petala, integra, equalia. Fructus fubrotundus, marginatus, lenticularicompreffus.

Heras depauperata. Tab. 85. fig. 4 .

Perfoliata foliis oblongis frnwofis fubtus incanis. BUंRM. afr. 196. t. 7t. f. 2.

Bupleurum frutefcens, foliis amplexicaulibus dentatis fubtus villofis. LINN. IP. pl. 343 .

Hermas. Lins. $\int y f$. veg. 913 .

Ex herbario BankGiano.

PER. nullum. Fructus ovato-rotundatus, lenticulari compreffus, inferne leviter emarginatus, fuperne calyce perfiftente coronatus, bipartibilis.

REC. fetaceum, tenuifrmum; ut vix ullum:

SEM. duo, figur fructus, pallide ftraminea, hinc levifime convexa, in marginem rigidum attenuata, glabra, aut tribus obfoletiflimis jugis infignita, inde plana, cum ftria media longirudinali elevata.

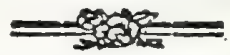

IN T. duplex : coriaceum \& membranaceum.

A L B. femine multo anguftius, ellipticum, plano - aut concavo - convexum, carnofum, pallidum, inodorum.

Eм в. minatus, teretiufculus, inverfus, lacteus. Cotyl. femicylindricx, brevifimx. Rad. fupera.

2) Umbella terminalis partialis, com radiis doobus centralibus frugiferis, brevinsibus, atque - Aonis ftcrilibus longioribus in ambitu. A) Fructus integer, naturali major. B.) Idem transverfe fcetus. C. D.) Scminis latus utrumque. C. f.) Albuminis facies exterior \& interior. G.) Situs \& Ggura Embryonis in apiee albuminis.

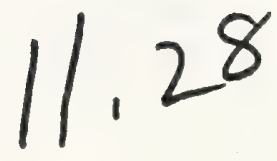




\section{$\times \times \Pi$}

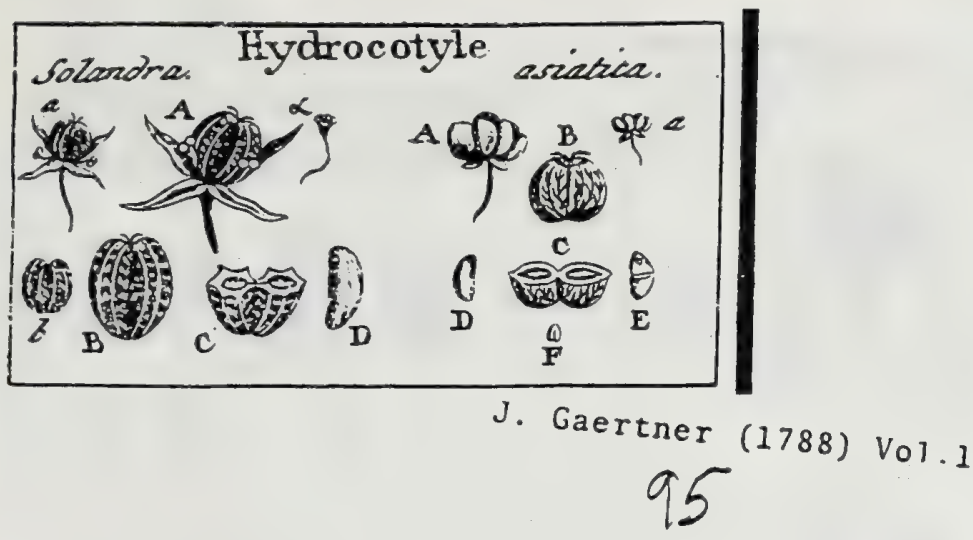

CXII. HYDROCOTYLE. TOURN. t. 773 . L L IN. ger. 325.

Umbella fimplex pedicellata. Involuc. di $-\int$. tetraphyllum. Petala integra. Fructus a latere compreffus, gibbus, bipartibilis.

HYDROCOTYLE afiatica. Tab. 22. fig. 5 .

Pes equinus. R им Р н. amb. 5. p. 455. t. 16́. f. т.

Valerinuella Zeylanica paluftris repens, hedera terrefris folio. Heris. parad. bat. t. 238 .

Hydrucotyle foliis reniformibus, dentato crenatis. L I N. Sy/l. veg. 272.

PER. nullum. Fructus inferus, parvus, rotundatus, a latere compeffus, lentucularis; bipartibilis.

REC. uulluin, aut obfoletum, feminibus adnatum.

SEs. duo, femi - ovata, Jenticulari compreffa, verfus marginem exteriorem magis attchuata, nervis utrinque tribus, arcuatis, ramofis \& inter fe anaftomofantibus reticulata.

IN T. triplex: extimum membranaceum, tenue; medium nucamentaceum, craftum; intimum arachnoideum, nucleo alsatum.

ALE. ovato oblongum, valde comprchum, carnofum, durum, inodorum.

96

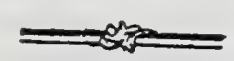
E s в. dicotyledoneus, inverfus, ovatoglobolus, minutus. Cotyl. obtufx. Radic.
fubconica fupcra.

2. A.) Umbella integra, triflora. B.) Fruetus feparatus \& au氏aus.

D.) Alburnen decorticatum. E. F.) Embryo in fitu, \& feparatus.

C.) Idem transverfe fettus,

HYDRocotyle Solandra. ibid.

Hydrocotyle tomentofa, foliis cuneiformibus ovatis retufis Septemdentatis. LinN.
fy/b. veg. 272 .

Ex herbario Bankfiauo.

Umbella pedicellata. Involuc. tetraphyllum, lineare, longitudine fructus, extus to
inentofum. Flofculi guatuor inentofum. Flofculi quatuor, aut fex lleriles, pedunculati $(\alpha$.$) in ambitu, unico$ tere compreffus, didymus, pallidente. Fructus ovatus, (a. A.) gibbus, a la. Ienticularia (C.), contis in univerfum quingue acutis (b. li.) femiovata, turgide rum nervis trausverfalibus fcrobiculato - reticulacutis, exarata \& ad interfitia eadura. Albumen. (D.) \& reliqua, ut in prxcedenti. Crufta feminis nucamentacea, 


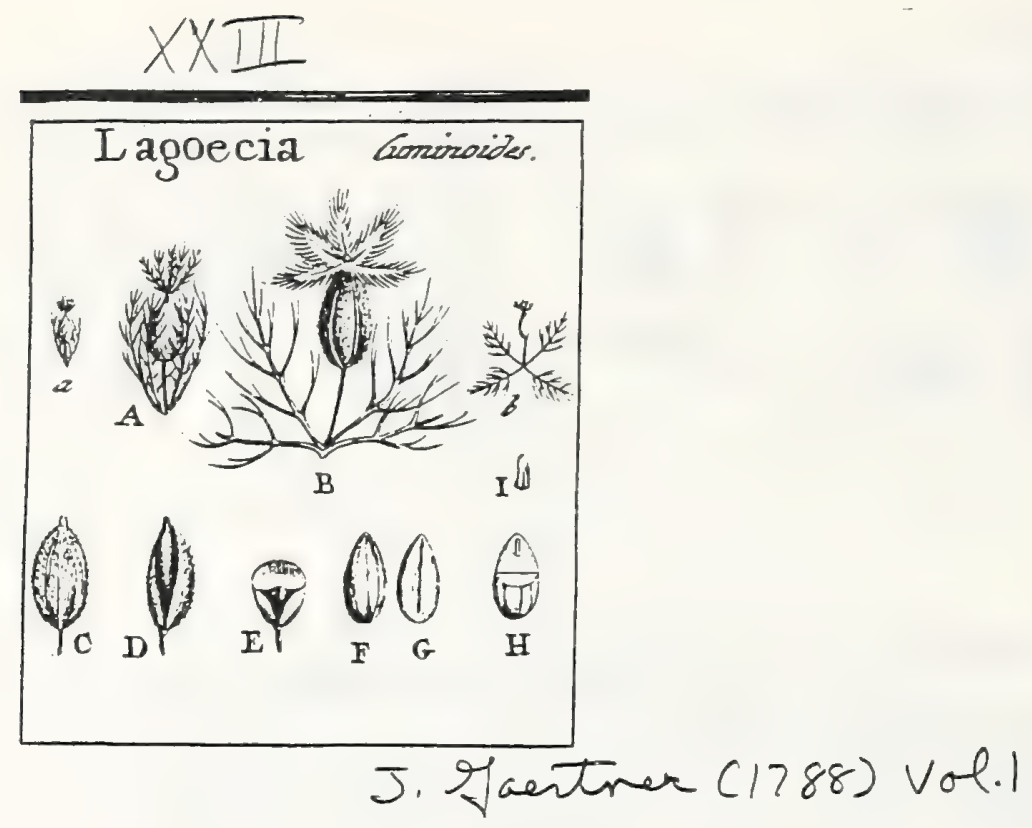

103

CXXI. LAGOECIA. Lin N. gen. 295. Cuminoides. Tour N. $t .155$.

U'mbella compofita: partialibus radio unico. Involuc, univerfale octophyllum pinnato dentatum; partiale tetraphyllum capillaceo pinnatifidum, uniltorum. Calyx perfiftens pentaphyllus, capillacco multifidus. Stylus unicus, figmatibus duobus: altero truncato. Ovaria duo. Finctus maturus monospermos.

LAGOECI A Cuminoides. Tab. 23. fig. 3 .

Cuminum fyluefre. C a s. epit. 518 .

Uinbelliferis affinis, capitulis globofis E' villofis. MorIs. hif. 3. S. g. t.I3.fig. ultim. Umbell. t. I. f. 13. 13.

Lagoecia. Lin N. Syft. veg. 244 .

PER. nullums. Fruftus inferus, parvulus, pedicellatus, ovato acuminatus, calyce ciliato coronatus, villofus, femine unico maturefcente, altero aborivo, prioris apici lateraliter, emarcidx fquamulx formá, affixo.

REc. filiforme, indivifum, femini adolefcenti adnatum.

SEM. unicum, ovato acuminatum, nigro fufcum, undique villis canefcentibus confperfum; hinc convexum, friis quinque capillaribus elevatis, albicantibus notatum, inde planiusculum, fries tribus tenuiffmis, abortivi feminis fedem indicancibus, inferiptum.

IN T. duplex: exterius pallidum; interius ferrugineum: utrumque membranaceum.

A L B. Fenini conforme, carnofum, durum, odoratum.

Es в. dicotyledoneus, inverfus, quartam albuminis partem longus. Cotyl. lemiteretes. Rad. cylindrica fupera.

a. A.b.B.) Fruttus integer. C.) Serninis latus interoum, cum annexo femine abortivo. E, Idem transverfe fellum. F.G.) Albunen denudacum. H. I.) Enbryo in ficu, \& feparatus.

Semen abortivum facilline \& confantifine repcritur, quando fructus in aqua bene esnollitur.

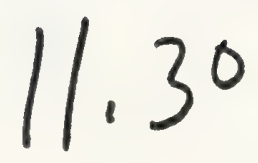




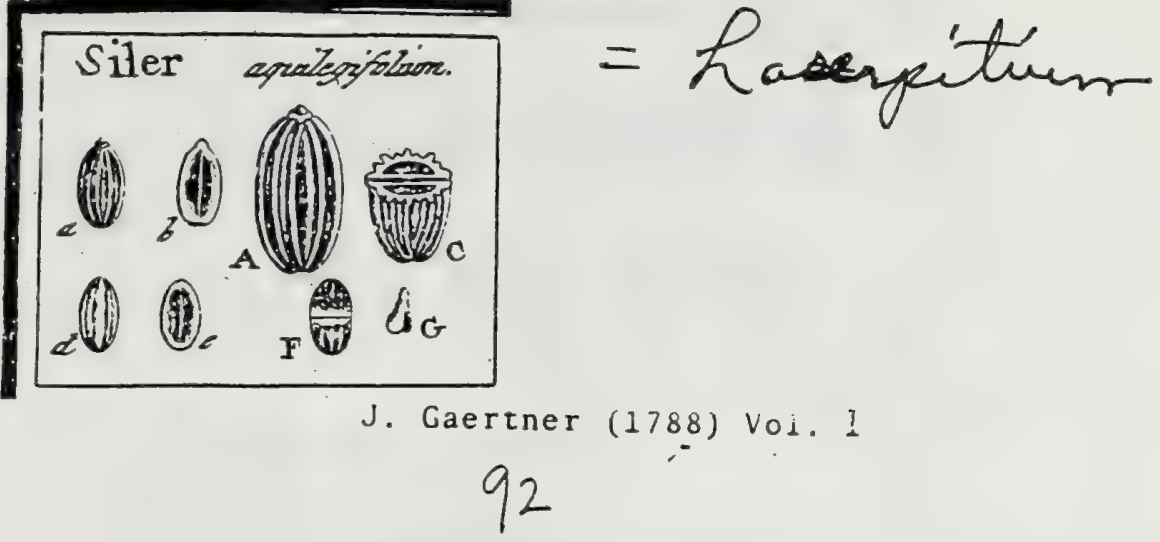

CVIII. SILER. RIV.

Umbella compofita. Invol. univerfale nullum: partiale fubheptaphyllum. Frudưs. oblongo ellipticus, turgide lenticularis, coftatus, apterygius.

SIL ER aquilcgifoliun. Tab. 22. fig. I.

Siler aquilegice folio. MOR Is. umb. t. I. f. 81. 82. ES S. 5. R I v. pent. t. 64

Laferpitium foliis imis rotunde lobatis, vaginalibus linearibus trifidis. HALL hifl. . n. 793 .

Laferpitium foliolis trilobis incifis - $\mathbb{E}$ - foliolis obtufus bafs ovatis lobatis: LiNN. Jiff. veg. 281. n. 2. 3.

Icon. JAC C. auff. 2. t. 147 .

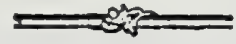

PER. nullum. Fruftus inferus, ellipticus, turgide lenticularis, multifriatus, bipartibilis.

REC. filiforme, bifidum.

SE s. duo, oblonge elliptica, mediocris magnitudinis. Dorfum novemftriatum : ftriis alternis extantioribus: omnibus rotundatis, absque ullo alx vefligio. Pars ventralis plana, vel leviter concava.

IN T. duplex: exterius craffum, coriaceum, lutefcens; interius tenue, fufcum.

$\Lambda\llcorner$ в. femini conforme, carnofum, odoratum, hine fulcis tribus majoribus inferiptum, inde planum.

Eмв. dicotyledoneus, inverfus, brevis. Cotyl. fubovatx, compreffx. Rad. teretiuscula, fupera.

a. A.) Fruntus integer. b.) Seminis pars ventralis. C.) SeAto frutius transvierta. d. e.) Albo. men decorticatum. F.) Ėmbryouis fitus. G.J Idem Sepasatus.

Sulcorum numero, \& alarum defectu plenario, a Laferpitio abunde differt.

$$
-11.31
$$




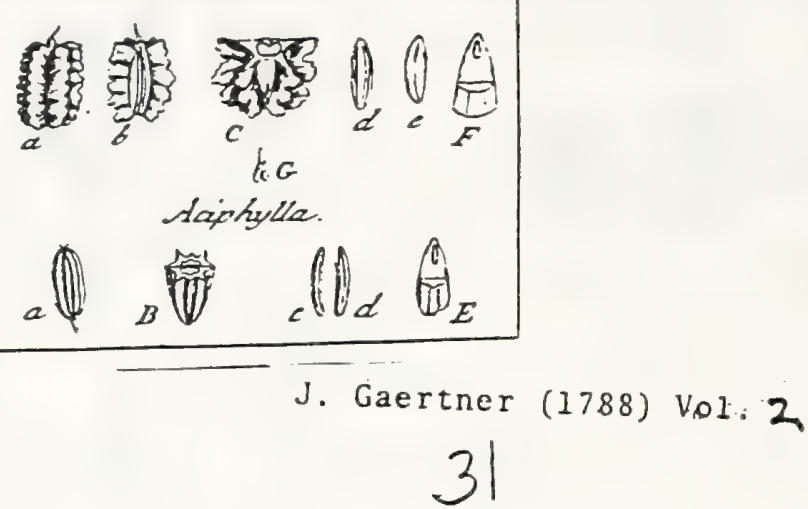

DXXXV. LASERPITIUM. TOURN. inft. t. 172. IINN. gen. 344.

Umbella compofita. Invol. utrumque polyphyllum. Cor. petala inæqualia. Fructus ecalyculatus, molendinaceus. Seminis alx quaternz, membra. nacez, xquales.

LASERPITIUM gallicum. Tab. 85. fig. 5.

Loserpitizom e regione mafilie allatum. BAUH. bif. 3. p. 337. c. ic.

Laferpitimn lobis latioribus, femine crifpo. MoRıs. unb. t. x. f. 10. xo.

Lnferpitizun foliolis coureiformibus frocatis. LINN. byjt. veg. $28 \mathrm{r}$.

PER. nullum. Fructus ovatus, modice gibbus, molendinaceus, albicans aut pallide ftramineus, bipartibilis.

REC. filiforme, bifidum.

SEM. duo, fructui conformia, hinc convera, duabus alis dorfalibus, totidem que marginalibus, omnibus membranaceis, fimbriatis \& ad oram nunc integris, nunc erofis infignata; inde plana, cum linea elevata in medio.

IN T. duplex: coriaceum, \& metnbranaceum.

A LB. oblongum, anguftum, hine convexum, obfolete ftriatum, inde fuloo deprefio exaratum, carnofum, inodorum.

.E м B. minutus, inverfus, lacteus. Cotyl. oblongx, compreffre. Rad. teretiuf cula, fupera.

2.) Seminis pass dorfalis b.) Ejus latus ventrale. C.) Idem transterfe fetum d. e.) Albamen ab utrague parte fpetatum. F.) Enabryonis figura \& Gtus in apice albuminis. G.) Embryo feparatus.

Laserpitium Aciphylla. ibid.

Lnferpitizm caule vaginato, petiolis foliorum dilasatis, folìs digitatis lixearibus elongatis mucronatis. L.1NN. Juppl. 181. Cy3. veg. 282 .

Ex herbario Bankfiano.

32

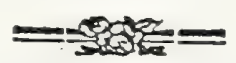

Fructus (a) elliptico-oblongus, demtis alis fubteretiufculus, bipartibilis. Se. mina (B.) alis quatuor nembranaceis ftipan \& in medio dorfo linea elevata, fxpe in alam quintam degenerante, notata. Alre luteo-fpadicex, interftitia autem ferrugineo - fufca. Albumen (c. d. E.) tribus fulcis rotundatis elevatis in dorfo, \& unico deprefo, in ventre, infcriptum. Embryo (E.)
ut in praccedenti.

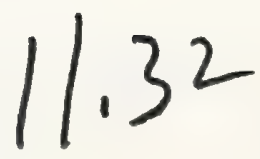




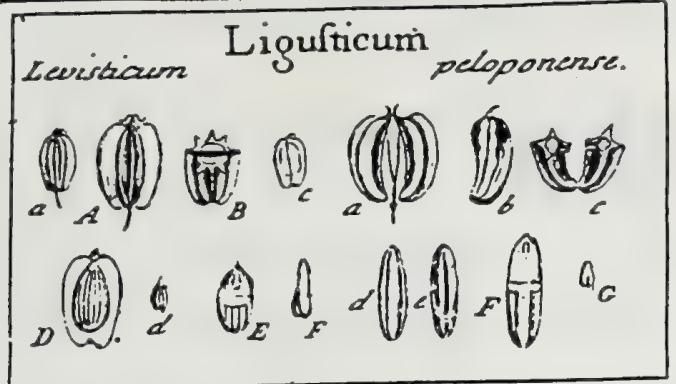

J. Gaertner (17.88) Vol. 2<smiles>[Te]</smiles>

DXXXII. LIGUSTICUM. TOURN. inf., 2. 17 r. LINN. gen. 346.

Umbella compofita. Invol. utrumque penca - 1. pluriphyllum. Cor. petala lutea nut pallida. Fructus oblongus, molendinaceus: alis inxqualibus, nusc marginalibus, nunc dorfalibus latioribus.

Ligusticuas Levifticun. Tab. 85 . fig. 2.

Levificusn vilgare. MOR.1s. zmbell. t. 1. f. M. m. lijf. 3. p. 275. S. g. t. 3. f. x. Riv. pent. t. 6o. BlaKw. berb. t. 275.

Lignficum folis multiplicibus: foliolis fuperne incifis. . LiNx. Jj/f. veg. 283.

PER. nulluin. Fructus ovato-oblongus, obfoleto calycis rudimento corouz tus, apice \& bafi emarginatus, alatus, bipartibilis.

RE c. filiforme, bifilum.

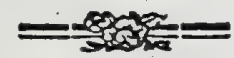

SEM. duo, figura fructus, hinc convexa, tribus alis angultis approximatis inftructa \& ad omm latiori margine rigido nec flexili cincta; inde plana ato que linea longitudinali elevata notata; fpadiceo albicantia.

IN T. duplex: coriaceum \& membranaceum.

A LB. ovatuin, acuminatum, hinc leyiter convexum, obfolete ftriatum, inde planum; album, odoratum.

EMB. inverfus, tertia albuminis parte longior, lacteus. Cotyl. ovatx, foliacex. Rud. teretiufcula, fupera.

2. A.) Frutus a dorfo fpetatus B.) Ejus fodtio transveralis- c.) Seminis latus internum d. D.) Abumen denudatum. E.) Embryonis in albumine fitus. F,) Embryo folutus.

Ligusticus peleponenfe. ibid.

Sefeli peloponerife. Cam. epit. 514 .

Cinutaria latifolia foetidifima. Moris. umb. t. 6. folium. \& t. I. f. X. x. femen.

Ligufficum foliis duplicato pinnzatis, pinnulis acute dentatis longe lanceolatis. HALL. bij. n. $75^{8}$ :

Ligufictum folits multiplicato - piniratis: foliolis pinzation incijis. LINN. Jyyt. veg. 1. c.

Icon. JACQ auffr. 5. app. t. 13.

Semina matura (a. b. c) incurva, e luteo ferruginea, hinc profunde fulcata (a. c.) \& tribus alis rigidis coltata, inde (b) fulco longitudinali exarata at que duabus alis anguftifrmis reflexis notata. Albumen (d. e. F.) oblongum, odoratum, fulcis duobus depreffis (d. F.) in dorfo, \& unico confmili (e.) in ventre exaratum. Embryo (F. G.) brevifimus, ovato-globofus, Jacteus.

Semen abortivum, ut vult LINNEUS l. c. neque conftans, neque corcadiss, i. e. albumen unquam pentagonum eft, nifi ipfa fulci ventralis latera, pro angulis habere velis. 


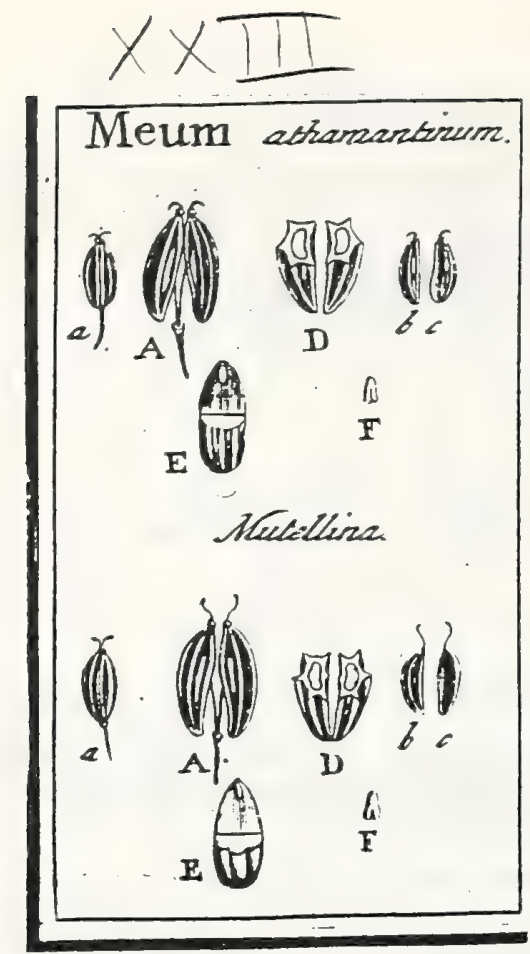

\section{J. Gaertner (1788) Vol.I

$$
105
$$

CXXIV. MEVM. TOURN. $t$. I65.

Umbella compofita. Invol. univerfale fubnullum; partiale, paucifolium: foliolis incifis, fxpe unilateralibus. Fructus mediocris naagnitudinis, ellipcicus, fulcis acutangulis.

MEU M athamanticuin. Tab. 23. fig. 6.

Meum. D O D. pempt. 305. CA M. epit. 7. R I v. pent. t. 63. BL A Kख. herb. t. 525 . HAL L. hifl. 1. n. 76 \%

JEthufa foliis omnibus multipartito Jetaceis. L $1 \mathrm{x}$. Jy/2. veg. 287.

Icon. J A c C. auffr. 4.t. $3^{\circ} 3$.

PER. nullum. Fruttus inferus, forma \& magnitudine foniculi, nifi quod paululusn major \& fulcis acutangulis exfculptus, fpadiccus, bipartibilis.

REc. filiforme bifidum.

SEM. duo, hisc convexa, jugis in univerfum quinque, acutangulis \& fere alatis, pallidis exarata; inde plana. Interflitia quoque inter fulcos planiuseula, fubtilinume friata, angufla, fulca.

IN T. duplex, utrumque membranaceuin, tenue.

$\Lambda_{L B}$. orato oblongum, fupra acuminatum, hine trifulcum, inde planum, carnofum, durum, odoratum.

11.34 


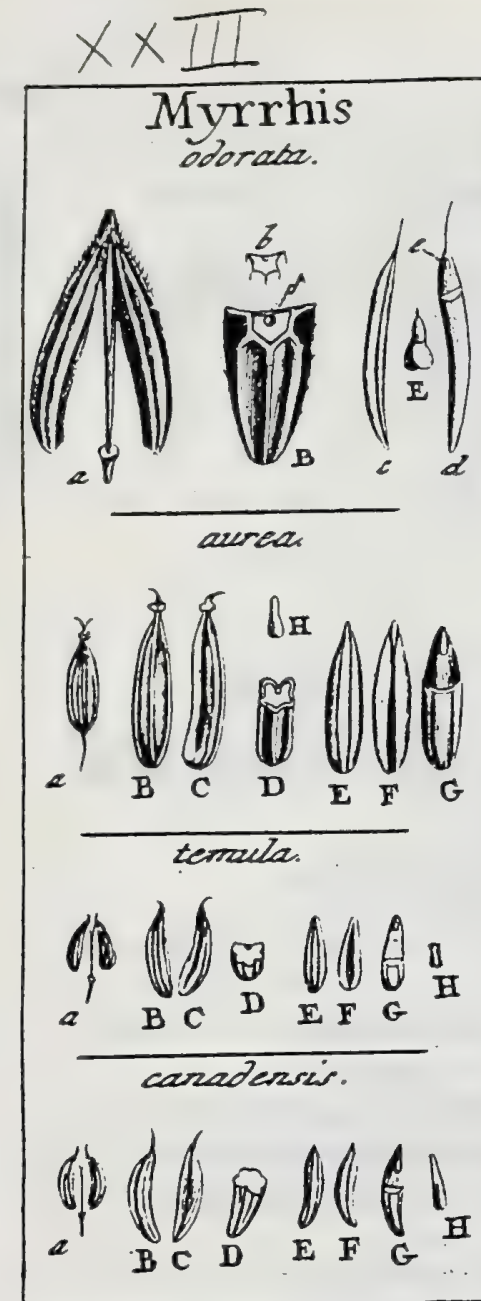

T.6. Sheringe.

\section{J. Ifaetree $(1788)$ vol. 1}

CXXVIII. MYRRHIS. TourN. t. 166. Chrerophyllum. Lin N. gen. 358.

Umbella compofita. Involuc. nullum. Fructus oblongus, fubroftratus. Nucleus longitudine feminis.

MYRRhis odorata. Tab. 23. fig. I0.

Myrrhis perennis alba odorata. MORฯs. hif. 3. S. g. t. 10. f. I. Umb. t. I. f. 34. 34. B t. A K w. herb. t. 243.

Odorata. R I v. pent. t. 57 .

Myrrhis foliis triplicato pinnatis nollibus, fentinibus fulcatis maximis. $\mathrm{H} \wedge \mathrm{L}$ hift. 1. 11. 75 ?.

Scandix fominibus fulcalis angulatis. Lins. Jyf. veg. 287.

Icon. J A c Q. auflr. append. $t .37$.

PER. nullum. Fruttus inferus, ovato oblongus, in rofrum breve attenuatus, fulcato angulatus, glaberrinus, bipartibilis.

REC. filiforme, bifidum.

$S E M$, duo, hinc convexa, fulcis quinque acutangulis, fuperne ciliato fpinulofis, inferne fimpliciter crenulatis exarata; inde plana, fulco longitudinali exfculpta.

IN T. duplex: exterius coriaceum, glabrum, nitidum, luteo fpadiceum, demum nigri: cans; interius membranaceum fufcum.

A \& в. Jongitudine feminis, fed illo inulto angunius, tereti clavatum, a parte interna: fulco excavato inferiptum, carnofun, viridı-fufcum, inodorum.

Eм в. cotyledoneus, inverfus, minutus. Cotyl. fubfoliacex, rotundatx. Rad. conica fupera.

2) Froetus, e maximis. b. B.) Seminis (ectio transverfalis. c. d) Abumen denadatum. e.) Eow

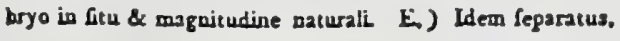

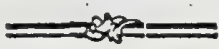

109

MY к R н I s aurea. ibid.

Myrrhis perenuis alba minor foliis hirjutis, femine aureo. Mox1s.' 'hif. 3. p. zor.

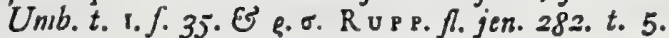

Cerefolium foliis hirfutis, petalis cordatis, feminibus obscure friatis. HALL: hifl. I. n. 249 .

- Charophy!lum caule aquali, foliolis incifis, Jeninibus coloratis fulcatis muticis. LIN S. Jifl. veg. 288.

Icon. J A c C. aufir. I. t. 64 .

Fructus ovato oblongus (a), fubroflellatus. Semina (B.C.D.) pentagona : angulis obtufis, luteo aut fulvo coloratis; interntitiis planiusculis, nigro fufcis. Pars ventralis lato fulco canaliculata, Albunen (E.F.) femini conforme, odoratum. Embryo (G. H.). teretiufculus.

MYrkilas temula. ibid.

MIurrhis annua femine friato levi. MORIs. umb. t. I. f. $37 \cdot 37$.

Myrrhis. R $1 v$. pent.t. 49 .

Myrrhis foliis hirfutis, laciniis obiufis, caule geniculato. Ḣ a L. hiff.r. n. 750.

Charophyflum caulc fcabro, geniculis tumidiusculis. L I N N. fiyf. veg. 289.

Icon. J A c Q. auflr. I. 65 .

Fruchus parvus (a.) ovato oblongus, furfum attenuatus, Semina (B.C.D.) feniteretia, gibba, quinque fulcata: fulcis rotundatis, approximatis rufescentibus ; interftitiis anguftirnumis nigricantibus. Pars ventralis concava, cinereo fufca. Albumen (E.F.) coloris obscuri, inodorum. Embryo (G.H.) teretiusculus,

MYR R I IS canadenfis, ibid.

Myyrrhis canadenfis trilobata. M O R Is. hil. 3. S. g.t. Ir. f. 4. R I v. pent. t. 54 . Sifon foliis ternatis. L inN. Sil. veg. 285.

Fructus magnitudine pracedentis, gibbus (a.), ovatus, flylis perfinentibus acuminatus. Scmina (K.C.D.) deorfuin angulliora, fulcis quinque dorfalibus rotundatis, approximatis, rufescentibus; interftutiis angunifhnis, nigricantibus. Albumen (E.F.) oblcuri coloris, ̈̈nodorum. Embryo (G.H.) longior, quam in congeneribus. Cotyl. lineares. Rad, tereti acuminata. 


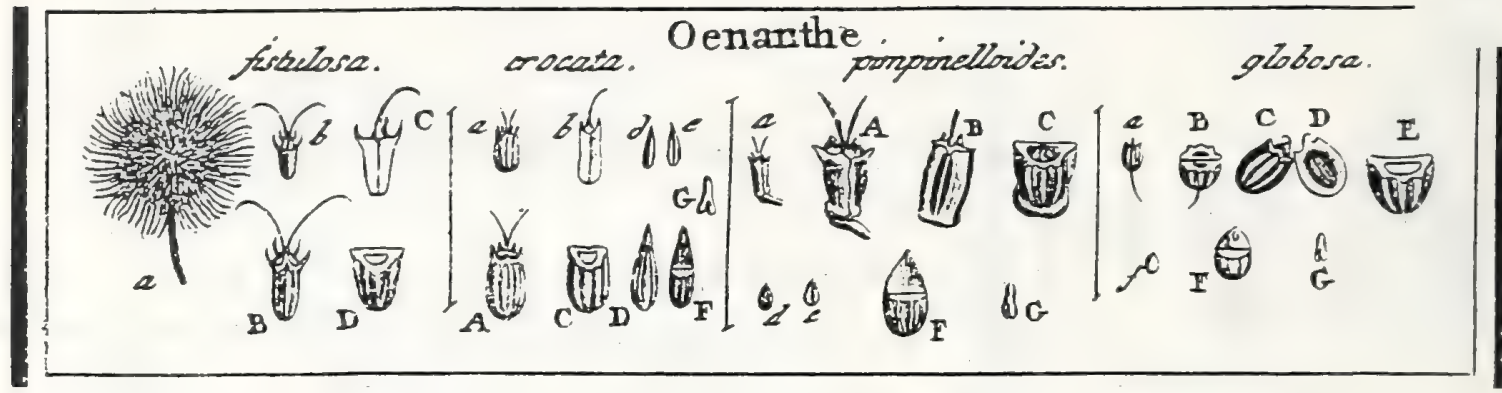

$$
\begin{gathered}
\text { J. Gaertner (1788) Vol. } 1 \\
96
\end{gathered}
$$

CXIII. OENANTHE. TOURN. $t$. 166. LINN. gen. 352 .

Umbella compefita; partiales globofx. Involuc. univerfale fubnullum; partiale po.

lyphyllum. Frúlus fuberofo corticatus, calyce \& fylis perfiftentibus coronatus,

Oenanthe crocata. Tab. 22. fig. 6.

Oenanthc charophylli folio. MORIs. hif. 3.S. g. t. . f. 2.

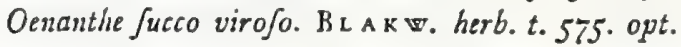

Oenauthe foliis omnibus multifidis obtufis fubaqualibus. L I N Sy. Jeg. 286.

Icon. J A c Q. hort. 3. t. 62.

PER. nullum. Fruf̈us inferus, ovato cylindricus, fulcatus, colonatus, bipartibilis.

REc. nullum, aut obfoletum, femini adnatum,

SEM. duo, femicylundrica, hine fulcis quinque rotundatis infcripta, inde plana.'

IN T. duplex : exterius fungofo coriaceun, craftun; interius inembranareun.

A L B. ollongun, furfum attenuatum, hinc tribus, inde unico fulco excavatum, carnofum, durum, inodorum.

EMB. dicotyledoneus, inverfus, brevifintnus. Cotyl. anguflx. Radic. cylindrica, Supera.

2. A.) Frutus intrger. b.) Seminis latus internum. C.) Semen transverfe (cetum. d. D. e.) Albumen decorticatum. F. G.) Embryo in fitu, \& Icparatus.

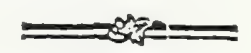

OENANT н E fifulora. ibid.

Oenanthe aquatica triflora, caulibus ffoulofs. Moris. hif.. 3. S. 9. t. ..f. .

Oenanthe. RIv. pent. t. 66. ОЕ D ER. 月. dan. $t .846$.

Oenanthe foliis radicalibus rotunde lobatis planis, caulinis fifulo/is. Hacr. hiff. I. 17. 755 .

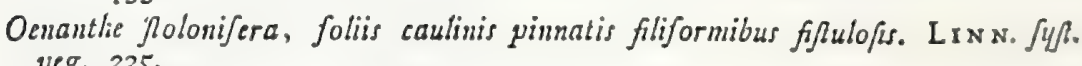
veg. 235.

Umbella partialis frugifera (a.) globofa, undique frylis patentibus hifpida. Fru. ctus (b. B.) inverfe pyramidatus, fubpentagonus, fulcatus (D.): fulcis alternis craflioribus. Pars ventralis (C.) plana. Integum. externum fungofum, craflum. Reliqua ut in procedenti.

OENANTHE pinpinelloides. ibid.

Oenanthe f. Filipendula monspefulana apii folio. R A u н. hifl. $3 \cdot \mu \cdot 190$.

Oenanthe foliis radicalibus cuneatis fiffer canlinis integris linearibus longiffmis fimplicibus. LINN. Jifl. veg. $=96$.

Icon. J A c C. anflr. 4. t. 395 .

Fructus turbinato cylindricus (a. A.), calyce ampliusculo coronatus, bafi annulo callofo a!bo notatus. Dorfum convexum (C.), frriis tribus inlcriptum \& ad latera margine incralTato fipatum. Pars ventralis (B.) plana. Albuneu (d.e.) inodoruss. Embryo (F. C.) minutus, teretiusculus.

Oeranthe fruftibus globofis. Linin. Jyfl. veg. 286.

Fructus parsus (2.) ovato globolus, intra calycis perfifientis coronulam in tuberculum conicun flyliferum productus. Semina fubhemifparica (B.), tribus in durfo fulcis craftiuribus (C.), prater marginem, notata; in ventre (D.) planz. Integuns. extcrnum craflum (E.), fublügofum. Albumen (f.) inoduruin. Embryo (F. G.) minutus, terctiusculus. 


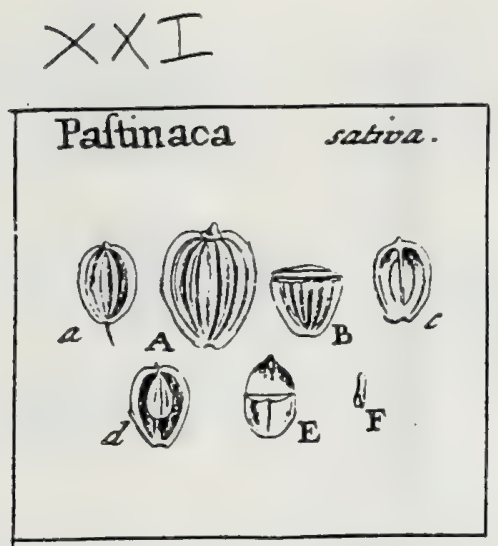

Apiaceae

$$
\begin{gathered}
\text { J. Gaertner (1788) Vol. } 1 \\
87
\end{gathered}
$$

C. PASTIŃACA. Tourn. t. rzo. LinN. gex. $3^{62 .}$

Umbella compofita. Invol. nullum, aut foliola pauca fub umbella univerfali. Petala lutea. Semen ellipticum, foliaceo compreflum, glabrum: margine tenui, angufto.

PAstin a c a fativa. Tab. 2r. fig. 5 .

Pafinaca latifolia fativa. $M$ O R I s. umbel. t. I. f. 26.26.

Pafinaca. RI v. pent. t. 6 .

Pafinaca foliis fimpliciter pinnatis. HA IL. hiff. I' 's. 808. LI N N. fyf. veg. 290.

PER. nullum. Fruttus inferus, foliaceo compreflus, bipartibilis.

REc. filiforme, bifidum.

SExs. duo, mediocris magnitudinis, elliptiç, aut obovata, fuppra leviter emarginata; foliaceo comprefta, pallide framinea, cum internixta, in receusibus, purpura Dorfum levifime convexum, ftriis tribus capillaribus in medio, \& alia prope marginem magis elevata, notatum. Margo anguntus, tenuss. Pars ventralis plana, vittis duabus ferrugineis, arcuatis, longis, non autem ferrum equinum referentibus, ut in Sphondylio, fed bafi introrfun convergentibus \& acuminatis, picta.

IN T. duplex, utrumque membranaccum.

AL B. ellipticum, fupra scuminatu!n, femine multo angufius, compreflum, carnofum, album, odoratum.

Ess. dicotyledoneus, inverfus, breviffunus. Cotyl. anguftx, obiufx. Rad. cylindrica fupera.

a. A.) Frutus \& feminis latus externum. B.) Ejusdem fetlo (nansvaralis c.) Seminis pars veatralis. d.) Albumen deoudatum. E) Sisus embryonis in albumine. F.) Embryo folutue. 


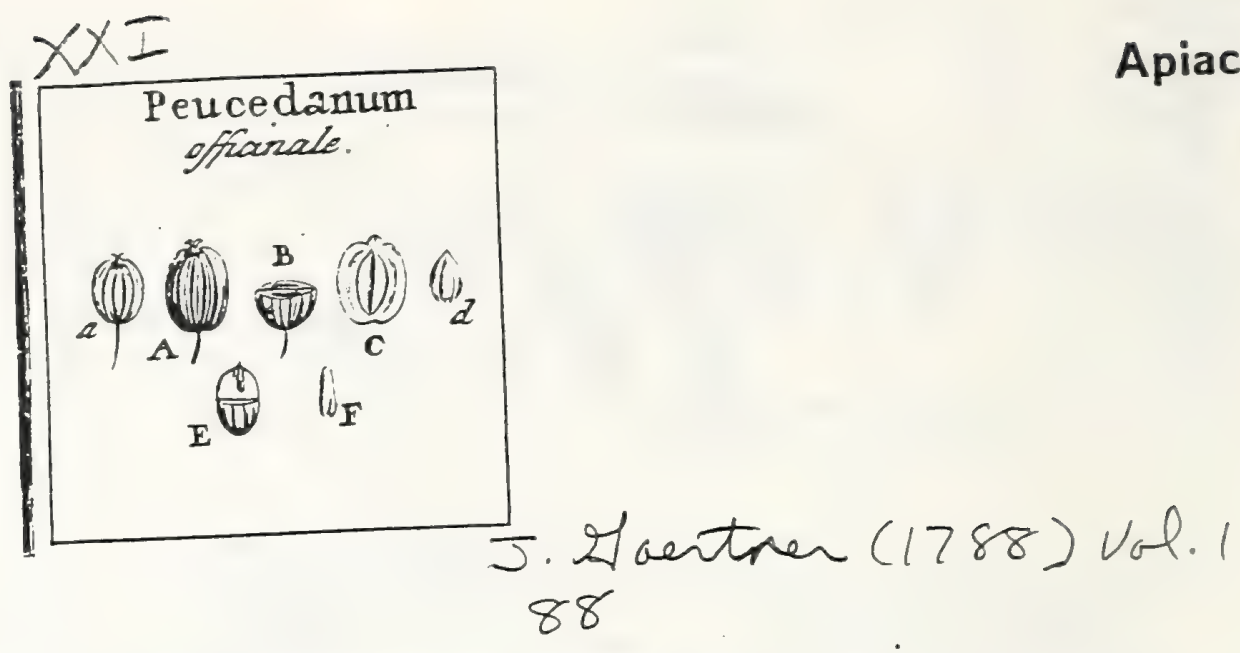

CII. PEUCEDANUM. TOUR N. t. 16g. LIN. gen. 339 .

Umbella compofita. Involuc. utruinque polyphyllum. Petala lutea. Fructus ellipi ticus, lenticulati comoreflus. fubfriatus.

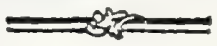

Peucedanum officirale. Tab. 2I. fig. 7.

Peucedanum italicum. Moris. umb. t. I. f. 23. 23.

Peucedanum. Rivin. pent. t. It.

Peucedanum foliis quinquies tripartitis filiformibus linearibus. IINN. J4f: veg. 280.

PER, nullum. Fruftus inferus, medix magnitudinis, rotunde ellipticus, in tenuis lenticulx formain compreffus, bipartibilis.

REc. filiforme, bifidurn.

SEM. duo, fubfoliaceo compreffa, hiuc tamen leniter convexa, tribus ftriis capillaribus elevatis notara atque anguftifimo margine attenuato cincta; inde plana, vitcis duabus ferrugineo nigris, ficut Pafinaca, picta.

IN T. duplex, utrumque membranaceum.

ALB. ellipticurn, fupra acuminatum, femine multo anguftius, compreflum, carnofum, oderatum, album.

Es B. dicotyledoneus, inverius, quarta albuminis parte longior. Cotyl. breves. Radic. teretiuscula, longa, fupera.

2. A.) Fruetus integer. B.) Idem transverfe felus. C.) Seminis Latus internum, d.) Alburea decorticatum. E.) Idean cum fitu \& Gigura embryonis. F.) Embryo feparatus.

11.38 


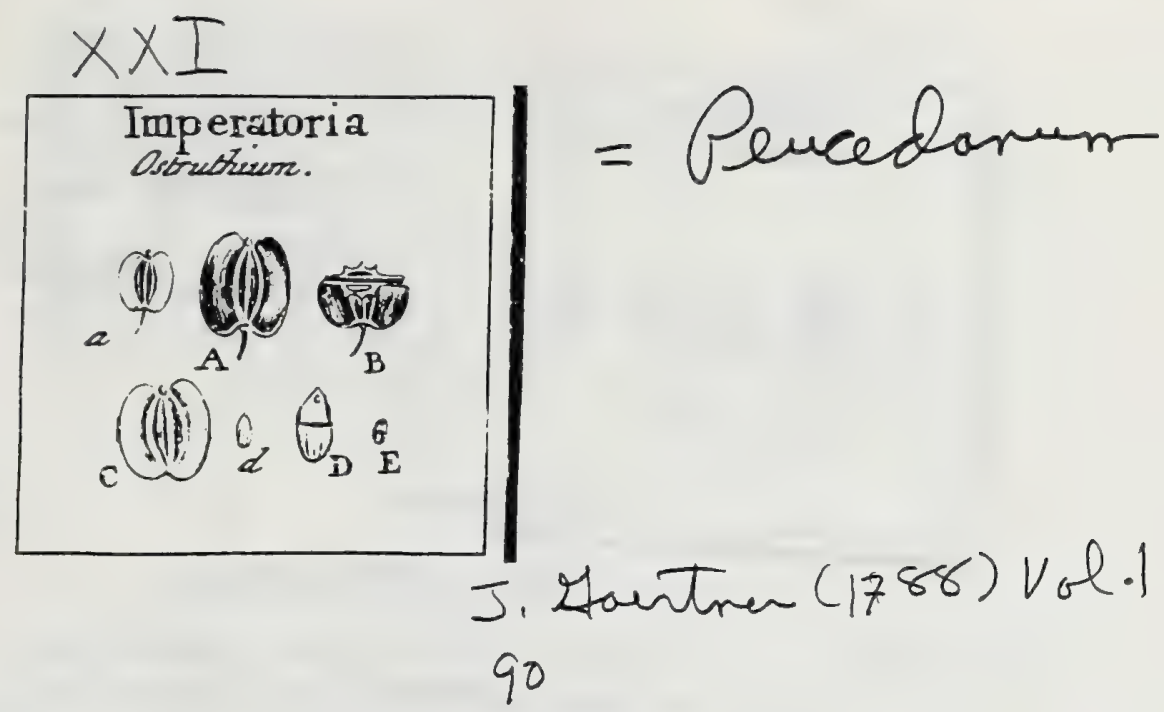

Apiaceae

CIV. IMPERATORIA. TOURN. $t$. I68. LINN. gen. 359 .

Umbella compofita. Invol. univerfale fubnullum: partiale foliolis paucis. Sernen compreftum, margine lato membranaceo \& tribus coftis dorfalibus apterygïis. IMPERATORIA Oftruthium. Tab. 21. fig. 9 .

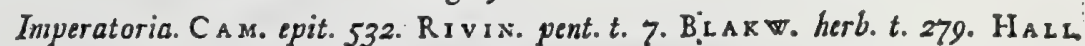
hifl. I. 17. 805. LIN N. $\int y /$. veg. 289 .

PER. nullum. Fruatus inferus, compreftus, eilipticus, utrinque emarginatus, mem. branaceo alatus, bipartibilis.

REC. filiforme, bifidum.

S EM. duo, compreffa, latiflimo margine membranaceo ad latera cincta, in dorfo tri: bus coftis acutangulis, non alatis, albicantibus notata. Pars veutralis plana, vite tis duabus fufcis arcuatis picta.

IN $T$. duplex, utrumque membranaceum.

A L B. ovato oblonguin, angufum, fupra acuminatum, carnofuin, durum, adoratum; hinc obfolete friatum, levifime convexum, inde planiusculum.

Emв. dicotyledoneus, inverfus, fubovatus, minutus. Cotyl. brevillunx, Rad. craft; non dilincta, fupera.

a. A.) Fruttus integer. B.) Idem direftus. C.) Seminis pass ventralis, d.) Albumen decortbcatum. D.) Limbryonis fitus. E.) Idem feparatus.

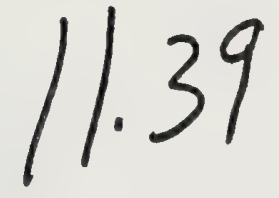




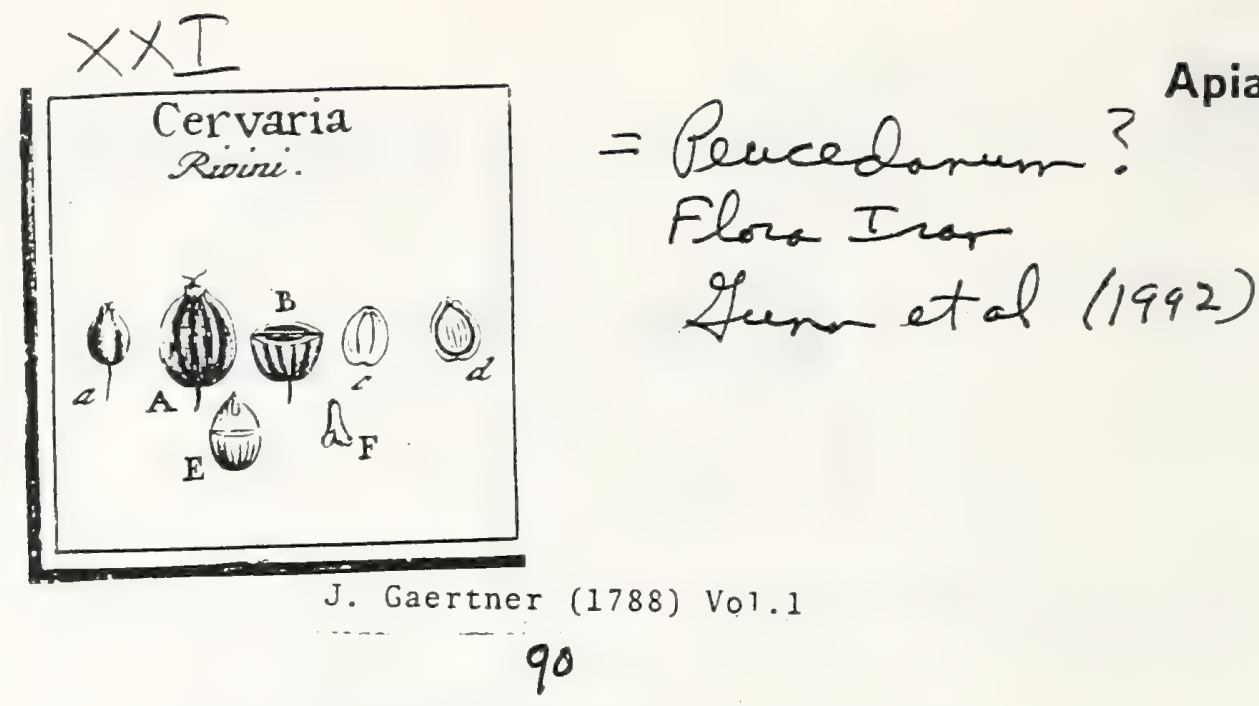

CV. CERVARIA. RIV.

Umbellu compofita. Invol. utrumque polyphyllum. Petala alba Fructus compreffus, obfolcuifime friatus, fubpubelcem, nou unarginatus.

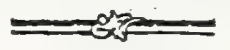

CERYARIA Rivini. Tab. 2r. fig. IO.

Athamaita foliis pinnatis, pinnis pinnatifudis, ranicaliun circa cofiam decuffatis. G M E t.. fib. 1. p. 186. t. 40. f. 2.

Athananta foliolis pimatis iucifo angulatis. LIN v. Syft. veg. 279.

PER. nullum. Fruqüs inferus, ovatus, furfum anguhatus, lenticulari compreflus, fubpubelicens, calycis rudimento coronatus, bipartibilis.

REc. filiforme, bifidum.

SEM. dun, Femilenticularia, valde comprefta, nee tamen ad oras membranacea. Dorfun lincis tribus capillaribus, totidemque fulcis obfoletiflimis depreffis exaratum, fubpubefcens, in margincin glabrum pallidum extenuatum. Pars ventralis plana, vittis duabus fufcis picta.

IṆ T. duplex, urrumque membranaceum.

A L B. ellipticum, fupra acuminatum, femine parum angunius, compreffurn, carno. fum, odoratum.

Esti. dicntyledoncus, inverfus, breviflunus. Cotyl. comprefix, obtufx. Rad. cyLindrica, lupera.

2. A.) Fruêus integer. B.) Idem diffe氏tus. c.) Seminis pars plana. d.) Albumen denudatura. E) Iden cum fiku embryonis, F.) Enbryo (eparatus.

Seminibus latis \& calvis a Libanotide differt.

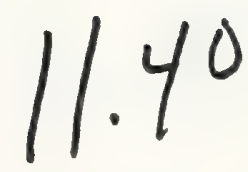



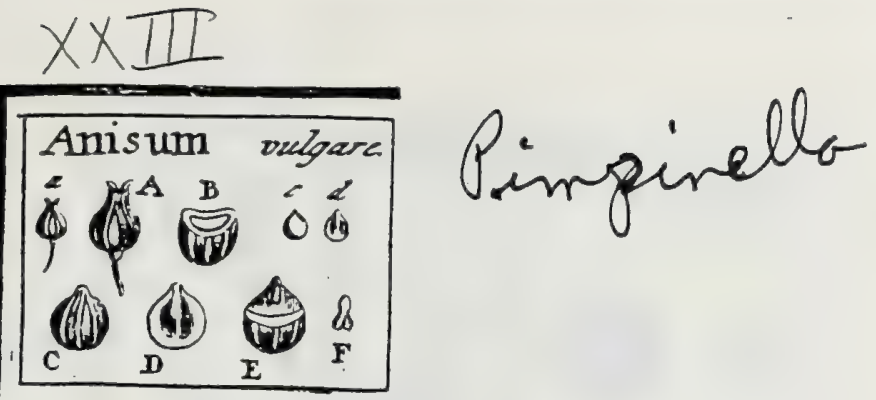

J. Gaertner (1788) Vol. 1

102

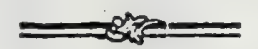

CXIX. A N ISUM. Offic. AdAns. p. 95.

Umbella compofita. Involuc. nullum, aut foliolum unicun. Fructus mediocris, ovato conicus, firiatus, fubpubefcens.

A Nisu M vulgare. Tab. 23. fig. ׳.

Anifun vulgare. CLus. hifl. 2, p. 202.

Anifum. RIv. pent. t. 73. BI A K W. herb.t. 374 .

Pimpinello foliis racidalious trifidis incifis. LI N N. Syft. veg. $29 \mathrm{~g}$.

PER. nullum: Frutus inferus, mediocris magnitudiuis, e ventricofa bafi furfum at-. tenuatus, in tuberculum ftyliferum falligiatus, angulato friatus, fubpubeliens, quafi rore pulverulento confperfus, bipartibilis.

REc. filiforme, bifidun.

SEM. duo, femi ovata, gibba, furfum attenuata, hinc tribus coftis linearibus albicantibus, fimilique alia ad utrumque marginem notata, inde plana. Interlitia inter coflas nunc planiuscula, nunc leviter deprefta, cinerascentia.

Is . duplex: exterius fubcoriaceum, fubpubefcens; interius membranaceun.

A L B. Semini conforme, carnofum, duriufculum, odoratum.

E м в. dicotyledoneus, inverfus, minutus. Cotyl. obtufx. Rad. cylindrica, fupera.

a. A.) Fruktus integer. B.) Semen transierfe fectum. c.C.d.D.) Albumen denudatum, E.) Embryonis fitus in albumine. F.) Embryo feparatus. 


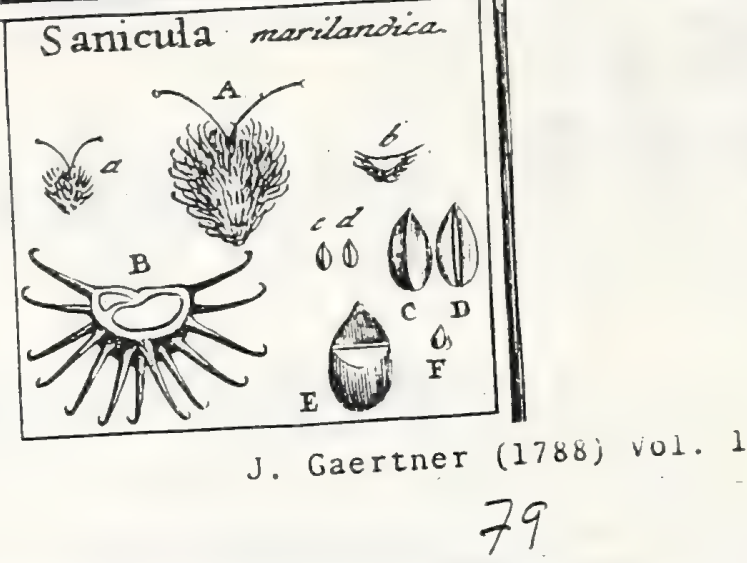

XCII. SANICVLA. Tou RN. t. 173. LINN. gen. 326.

Umbellze confertx, fubcapitate. Fructus aculeis hamatis undique muricatus. SAxicura marilandica. Tab. 20. fig. 3.

Sanicula flosculis masculis pedunculatis: hermaphroditis fefflibus. LINN. fyff. veg. 272.

Ex herbario Bankfiano.

PER. Capfula infera, letis uncinulatis muricata, bilocularis, non bipartibilis, a femine non fecedens.

REC. nulluin.

SE s. duo: altero plerumque abortiente; altero plano-convexo, hinc aculeis fetaceis, apice uncinulatis muricato, inde glabriusculo, aut fgamulis apprefis fcabrato.

IN T. duplex: exterius coriaceum, a pericarpio non difinctum; interius membranaceum, tenuifimum.

A в. ellipticuin, fupra acuminatum; hinc convexum l. angulatam; inde planiusculum aut leviter concavum; fubcartilagineum, album, inodorum.

Ess. dicotyledoneus, lubovatus, minutus, Lacteus. Cotyled. rotundatr. Radic. acuminata, Superz.

a. A.) Caplala integra. b. B.) Eadem transverie sects, cum diffepimento integerrimo, \& locula. mentis inxqualibus. c C.) Albuminis decorticati latus dorfale. d. D.) Ejasdem pars venuralis. E.) Situs embryonis in (upremo albumine. F.) Enbryo feparatus.

Etian in Sanicula europaca. Trewius inxqualitatem loculamentorum in fructu \& frequentem alterius feminis abortum anotavit. Couf. BLAK w. t. 63. f. is.

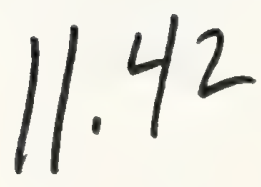




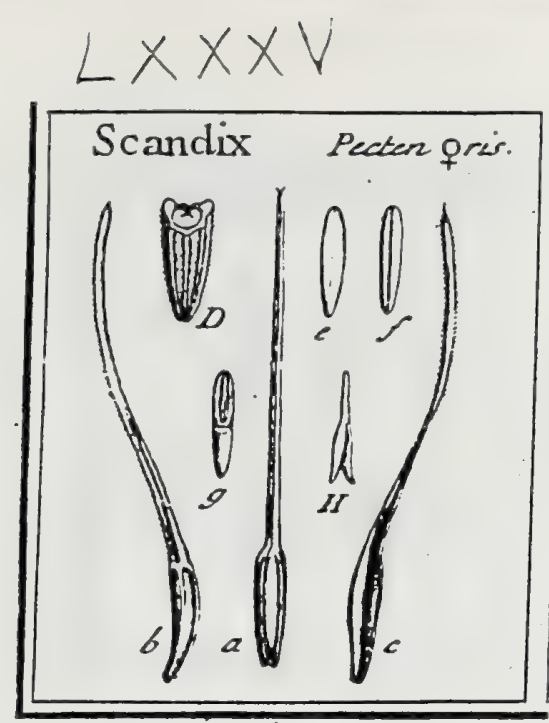

J. Gaertner (1788) Vol2

33

DXXXVIII: SCANDIX. TOURN. inf. t. 173 .

Umbella compofita. Invol. univerfale nullum; partiale pentaphyllum. Fructus longiffime roftratus, nucleo quarta feninis parte breviore.

Scaxdix. Pecten veneris. Tab. 85 . fig. 8 .

Pecten veneris. Cans. epit. 302.

Scardix. Riv. pent. t. 38. OED. for. dan. t. 844. Jace. arfir. 3. t. 263. MORIS. umb. t. I. f. 42.

3fyrrbis feminis cormu longifimo. Halt. biff. 12. 754.

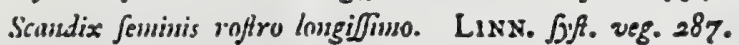

PER. nullum. Fructus ovato-oblongus, obfolete angulatus, roftro longiffmo,

fubulato - conipreffo terminatus, bipartibilis, fumofo-fpadiceus.

REC. fetaceum, bifidum.

SeM. duo, hinc convexa, jugis quinque obfoletis fabris notata, inde fulco profundo longitudinali exarata, in roftrum lineare carinatum \& ad margi$3 \overrightarrow{3}$ nes fabrum definestia.

IN T. duplex: exterins coriaceum tenue; internis membranaceum, ferrugineonigrum, (in aqua fenfim viridefcens) aucleo arctilfime adnatum.

A'rB. oblongum, quarta parte fominis brevius, cartilagineum, album, hinc convexum, glabrum; inde fulco medio, ex marginibus introrfum convo. lutis, profunde exfculptum, inodorum.

EN B. dimidio albumine paulo longior, inverfus, lacteus. Cotyl. lineari - lanceolatx, tenuiffimx. Rad. linearis, compreffufcula, longa, fupera.

2) Fructus integer a marginum comniturs (petatus b.) Seminis pars dorfalis. c.) Ejusdem Lrtus ventralc. D) Idem transverie feanm, eum fulco ventrali albuminis, e marginum cunvolutione oriundo. C. f.) Albuminis denudati latus utrumque. g.) Embryoais magnitudo \& Gitus in albumine. H.) Idem feparatus \& audus. 


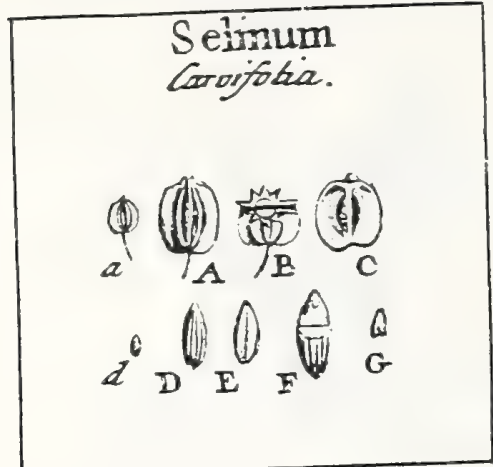

J. Gaertner (1788) Vo1.1

CIII. SELINUM. LINN. gen. 337 .

Umbella compofita. Invol. univerfale nullum; partiale polyphyllum. Scmen parvum, alis membranaceis quinque: lateralibus naximis.

SEl INUM Carvifolia. Tab. 21. fig. 8.

Angelica tenuifolia. R I v. pent. t. I8.

Selinum foliolis pinnatim laciniatis. Gм E L. fibir. 1. p. 204. t. 48 .

Selinum caule fulcato acutangulo, involucro unicerfali evanido, fylis eredis, petalis comiventibus. LIN.S. $\int y$ \&. veg. 278 .

ICo\%. OE DER. flor. dan. t. 667. J A C C. aUfr. t. 16.

PEr. nullum. Fruffus inferus, compreflus, rotundatus, membranacco alatus, bipartibilis.

REc. filiforme, bifidum.

SEM. duo, parva, rotundata, utrinque emargiuata, quinquealata. Alx dux marginales latifinx, patentifium; dorfales tres, prooribus dimidio anguftiores, approximatx, crectiuscula. Pars ventsalis planz, aut leviter concava.

IN T. duplex, utrumque membranaceum.

90

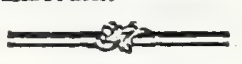

A L B. anguftum; ovato oblongum, acuminatum, carnofum, inodorum; hine convexum, tribus fulcis incriptum, inde planuin, fulco funplici excavatum.

Eмв. dicotyledoneus, inverfus, minutus. Cotyl. anguftx, breves. Radic. tereti: uscula fupera.

s. A.) Frutus integer. B.) Idem diffetus. C.) Seminis pars ventralis, d. D. E.) Albumeg decorticatun. F.) Embryonis fitus. G.) Idem feparatus.

Si fida fit feminum figura in Vaill. bot. paris. t. 5. f. 2. \& Hall. hift. t. 20. differunt omnino a noftris, qua de planta Gmeliniama defumta funt; contra autem bene confpirat forma feminum Rivin. l. c. \& Cranzii fafcic. 3.'t. 3. f. 2. at diffentit jpfus plantx habitus; quod tanen non 'mirum, quia plerxque icones Gmelinianz rudiusculx funt.

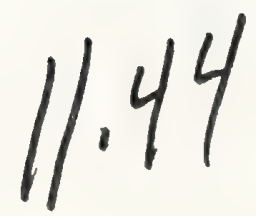




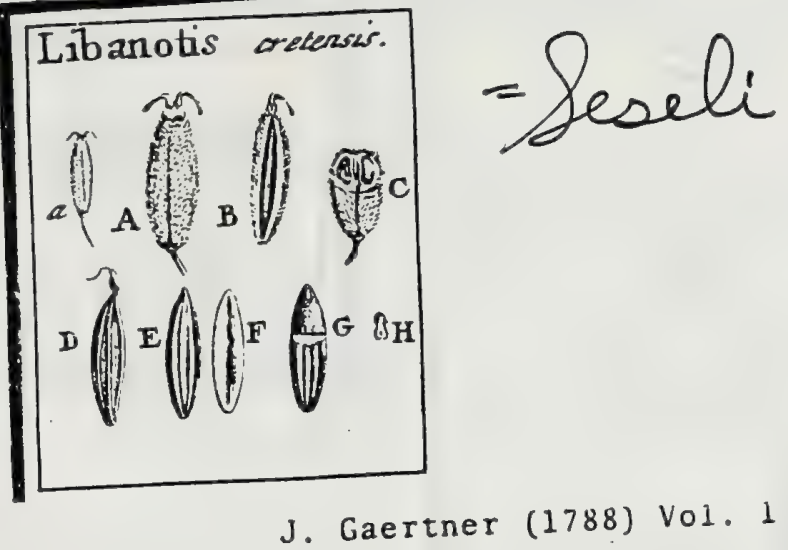

84

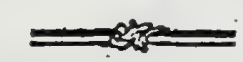

XCVI. LIBANOTIS. HALz. hif. p. 325 .

Umbella compolita. Involucrum utrumque polyphyllum. Fructus oblongus, tomen: tolus.

LIB ANот Is cretenfis. Tab. 21. fig. I.

Daucus creticus. С А м. epit. 536. BцА к

Myrrhis Jenine villoso incaßo. Mo R Is. Umb. t. 1. f. 39. a. $a$.

Libanotis foliis hirfutis triplicato pinnatis, lobulis profundiffme bipartitis. $\mathrm{H} \wedge \mathrm{L} \mathrm{L}$. hifl. I. n. 745 .

Athamanta foliis bipinnatis planis, umbella hemispharica, Seninibus hirfutis. LINN. Sy/f. veg. 279.

Icon. JA C e. aufir. v. 4. t.392. OED ER. flor. dan.t. 754 .

PER. nullum. Fruttus inferus, oblongus, bipartibilis.

REC. obfoletum in axi fructus.

SEM. duo, oblonga, fubfemicylindrica, paulo tamen latiora, quam craffa, hirfuta, albicantia, demto tomento, lineis quinque elevatis dorfalibus notata, fimplici autem fulco in parte ventrali exfculpta.

INT. duplex: coriaceum \& membranaceam; utrumque tenue.

$\Lambda\llcorner$ в. femini conforme, carnofun, album, odoratum; hinc convexum, quinquefriatum, inde leviter concavuin.

E\& B. dicotyledoneus, inverfus, luteus, minutus. Cotyled. obtufz. Radic. cylindrica, Superz.

a. A.) Frutus integer. B.) Seminis latus internam. C.) Fruttas transverim fectus. D.) Semen excufia hirfutie ftriatum. E.F.) Albuneo decorticatum. G.) Embryonis fius. H.J Embryo Separatus.

Occurrunt nomnunquam femina ovato conica, qualia Camerarii figura monfrat; fed ea immatura funt. Vix dubium ef, quin hxe fit Libanotis veterum: Fructum ei candindum, fcabrum, oblonguin \&c. tribuit Т не о Рн. hift. IX. с. 12; \& Semen candidum, refinoli adoris ac in mandendo linguam exurens. Diosc. L. II. c. 87 .

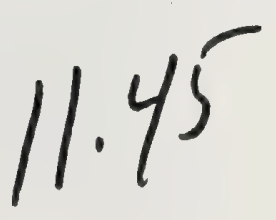




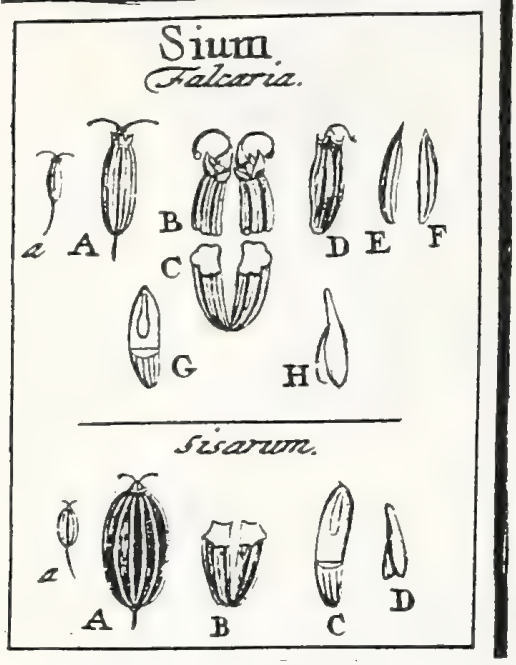

J. Gaertner (1788) Vol. 1

104

CXXII. SIVM. TouRN. $t$. I62. LINN. gen. 348.

Umbella compofita. Involuc. utrumque polyphyllum. Fructus ovato oblongus, trans: verfe craffior, ftriatus. Embryo longitudiue dinnidii albuminis.

SIU M Falcaria. Tab. 23. fig. 4.

Anumi perenne repens. Morss. hift. 3. S. g.t.8.f. I.

Falcaria. R I v. pent. $t .48$.

Sium foliis frmis ferratis pinnatis, nervo foliaceo latefcente. H A L.. hiff. I. n. 782 .

Sium foliolis linearibus decurrentibus connatis. Linn. Jyft. veg. 284.

Icons. J A C Q. auftr. 3. t. 257 .

PER. nullum. Fruquus inferus, parvus, ovato oblongus, thiatus, calyce perfiftente \& intra illum tuberculo nylifero fquamulis parvis circumvallato, coronatus, bipartibilis.

REC. filiforme, bifidum.

$S_{E M}$. duo, femiteretia, hinc in univerfum fulcis quinque rotundatis, fria capillari in medio notatis, 'approximatis, pallidis, exarata, inde platra. Iuterflitia inter fulcos profundiuscula, angufta, cinerascentia.

IN T. duplex, utrumque inembranaceum.

A ц в. femini conforme, carnofum, durum, inodorum.

EM в. dicotyledoneus, inverfus, longitudine fere dinidii albuminis. Cotyl. foliacex, oblongo ellipticx. Rad. gracilis, teretiuscula, fupera.

2. A.) Frutus integer. B.C.) Iden diffatus. D.) Seminis latus internum E. F.) Albumea de. corticatum. G.) Embryo in (fta. H.) Idem Icparatus.

Si us Sifarum. ibid.

Sifarum. Do D. penzpt. 68r. Riv. pent. t. 56.

Sium foliis pinnatis: floralibus ternatis. L I N.' $\int y /$. veg. 284 .

Fruchus ellipticus (a.A.), parvus, tuberculo fiylifero, fed nullo calycis vefligio co. ronatus. Semina pentagona, utrisque acumusata, per maturitatem fxpius incurva. Conx in univerfum quisyue (B.), anguniffunx, lineares, diflitx, fliaminex aut lutefccntes: interflitia inter eas lata, planiuscula, ferruginea aut fufca. Albumen ofnratum. Embryo longitudine dimidii fere albumiuis, lacteus. (C.). Cotyl. foliacex (D), ovato oblongz. Rad. teretiufcula.

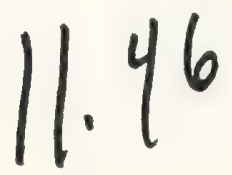




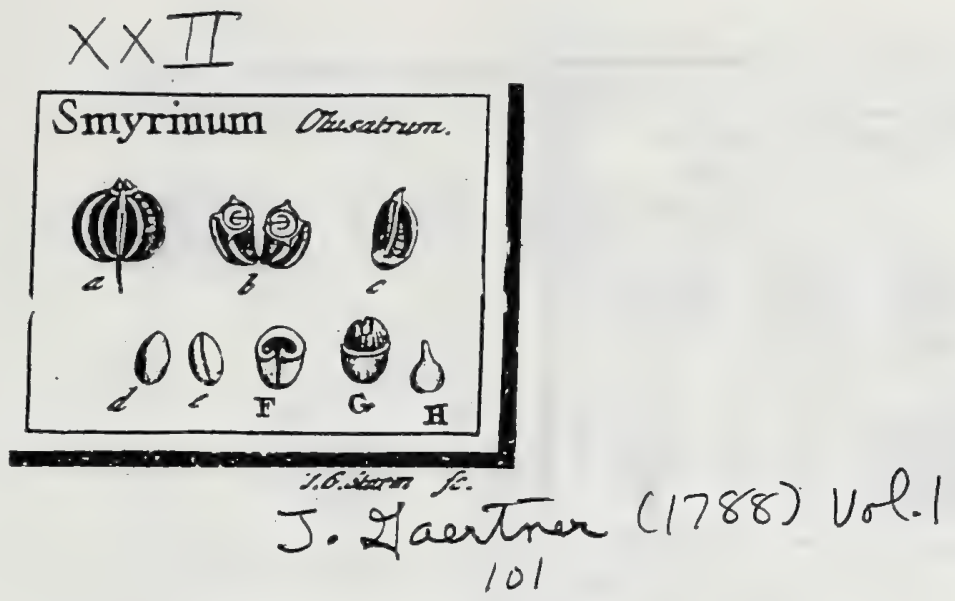

CXVIII. SMYRNIUM. TOURN. t. I6g. LINN. gen. 363.

Umbella compofita. Involuc. nulluın, aut partiale tantuın foliolis paucis, brevibus. Petala lutca. Fructus ovato globofus, gibbus, angulato coftatus. Albumen marginibus involutis.

SMYRNIUM Olufatrum. Tab. 22. fig. I1.

Smiyrnium Jemine magno nigro curvo. MOR Is. hijl. 3. S. g.t. 4. f. r. Umb. t.x. $f . P \cdot p$.

Smyrnium. RIv. pent. t. 69. B I к к w. herb. t. 408 .

Smyrnium foliis caulinis ternatis petiolatis ferratis. L I N . fyft. oeg. 290.

Pe.r. nullum. Fructus inferus, grandiufculus, infigniter gibbus; profunde fulcatus; ater, bipartibilis.

REc. nullum, aut obfoletum.

Sex. duo, fcmilunata, crafta, collis tribus dorfalibus acutangulis \& fere alatis exarata \& inter coflas fubrugola. Pars ventralis in rotundum angulum prommens, ac in medio, fulco longitudinali exfculpta.

IN T. duplex: extcrius crufaceo-coriaceum, atrum; interius membranaceuin, fernugineum.

A в. ovatum, camnfum, tercbinthinam redolens, hinc conrexum, glabrun, inde concavum, marginibus introrfum convolutis.

Es в. dicotyledoneus, inverfus, brevis. CotyL foliacex, fuborbiculatx. Rad. teretiuscula, iupera.

a) Fruftus integer. b.) Idem diffeftus. c.) Seminis pars ventralis. d.e.) Albumen decorticatars

F.) Idena trausverfe (columu. G.) Einbryouis qutus in albuniwer H.) Embrjo leparatus,

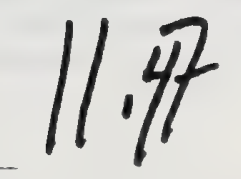




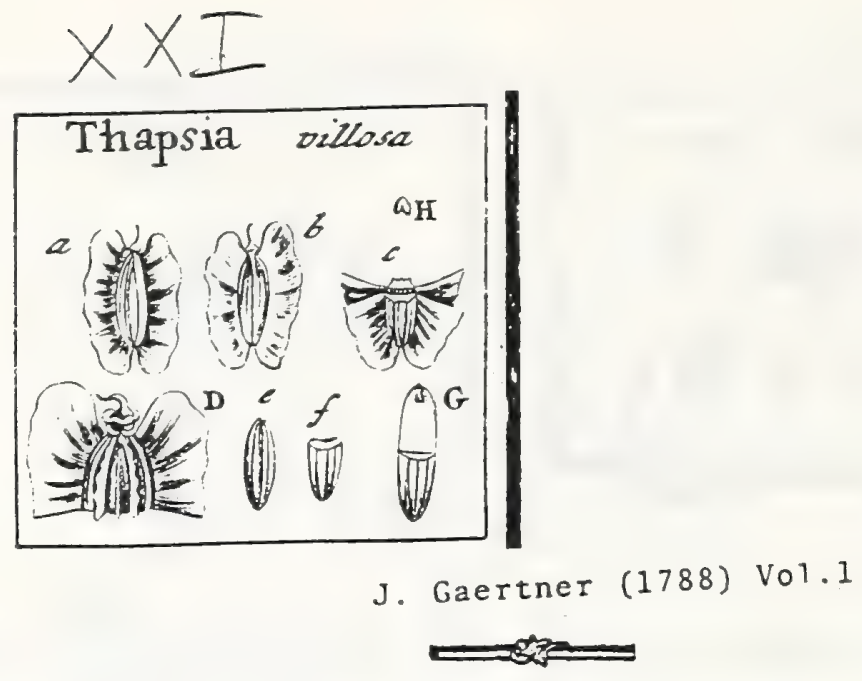

Apiaceae

\section{CENTURIA SECUNDA.}

CI. THAPSIA. ToURN. t. I7T. LINN. gen. 36 r.

Umbella compofita. Involucrum nullum. Petala lutea. Semina oblonga: alis membranaceis quatuor; lateralibus maximis.

Tнарsia villora. Tab. 21. fig. 6.

Thapfia. Cevs. hift. 2. p. 192 .

Thapfia latifolia villofa. MOR I s. hift. 3. f. g. t. 18.f.3. Umb. t. I. f. Ir. Ir.

Thapfia foliolis dentatis villofis baji coadunatis. LIN N. Jufl. veg. 290.

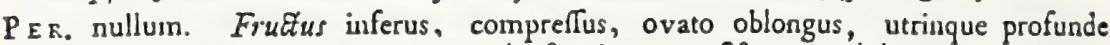
emarginatus, terminatus receptaculo ftaminum perfiftente undulato, pedunculato, \& infra illud, foliolis quinque calycinis, corniculorum infar furfum curvatis; cetera alatus, bipartibilis.

REc. filiforme, bifidurn.

SEM. duo, alis quatuor membranaceis ftipata, quarum dux laterales ampliftume, femine longiores, \& dux alix dorfales, anguftifunx, undularz, longitudine feminis: inter iftas alas, frix tres elevatx, longitudinales, comprefl $x$, nec tamea membranacex. Pars ventralis plana, absque fulco deprefio.

IN T. duplex, utrumque membranaceum.

$\Lambda_{L}$ B. oblongum, angufuin, carnofum, album, grato odore fragrans, hine convexum friatum, inde leviter concavum.

Eas в. dicoryledoneus, inverfus, fubglobofus. Cotyl. brevifinz. Radic. fubconica, fupera.

a. D.) Frutus \& feminis latus exterius. b.) Ejusdem pars ventralis, c.) Idem trensverie rofuse ef.) Albumen decorticatum. G.) Embryanis fitus. H.) Esobryo Separatus.

11.48 


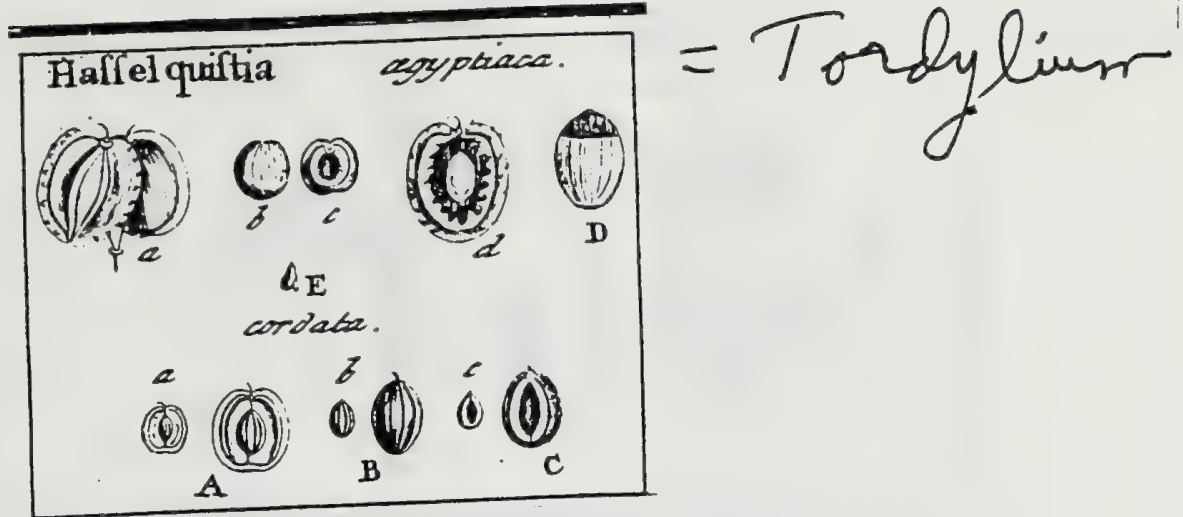

J. Gaertner (1788) Vor.1

84

XCVII. HASSELQVISTIA. LIN $\pi$. gen. 34T.

Umbella compofita. Involac. utrumque polyphyllum. Semina difformia: exteriora orbiculata plana; interiora bullata.

HASSEL QU ISTrA zgyptizca. Tab. 2r. fig. 2.

HaJjelquiflia foliis pinnatis, foliolis pinnatifidis. L IN N. fyf. veg. 275 .

Icon. J A C Q. hort. I. t. 87.

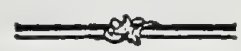

PE R. nullum. Frufus inferus; bracteatus, bipartibilis.

REC. fuliforme, bifidum: in fructibus difci.fumplex, adnatum.

S EM. difformia : Exteriora geminata, orbiculata, comprefla, plana, margine angufo, fubfcabro, parum incraflato cincta, Arainineo albicantia. Interiora, omnino quoque geminata, fed altero confanter abortiente, \& fquamulx emarcidx forma, alterius lateri interno prope verticem adbxrente; altero autem adolefcente, in bullam inembranaceam converfo, quz ad latus internum, amplo foramine rotundo, fungolo \& crenulato margiue circurndato, hiat, \& unico duntaxat embryone fota eft.

IN T. duplex, utrumque membranaceum \& tenue.

A L 3. Semine multo anguftus, ellipticuin, in tenuem lamixam compreffum, carnolum, inodorum, album, in feminibus planis, planum, in bullatis, concavum.

E м в. dicotyledoneus, inverfus, minutus. Cotyl. fubfoliacez, breves. Rad. teretiufcula, fupera.

2.) Semina radid. b. c.) Semina difci, d.) Albamen feminis radii denudatum, D,) Idem folutare a maguitudine auftum, cum fitu embryonis. E.) Embryo feparatus,

HASSEl CUIS T i a cordata. ibid.

Hafelquifia foliis cordatis. IIx N. Jy $\mathrm{I}$. veg. 275.

Icon. JAcQ. hort. 2. t. 193.

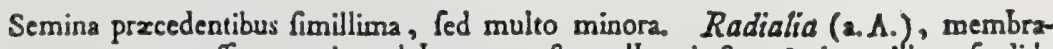
naceo compreff, mergine glabro, angufto, albo cincta, \& intra illum fordide ferruginea. Centralia (b. B.) ovato bullata, in dorfo pariter fpadiceo-ferruginea, \& ad aperturain margine incraftato, glabro, albo circumdata (c. C.). Albumen \& embryo, ut in pracedenti.

$$
11.49
$$




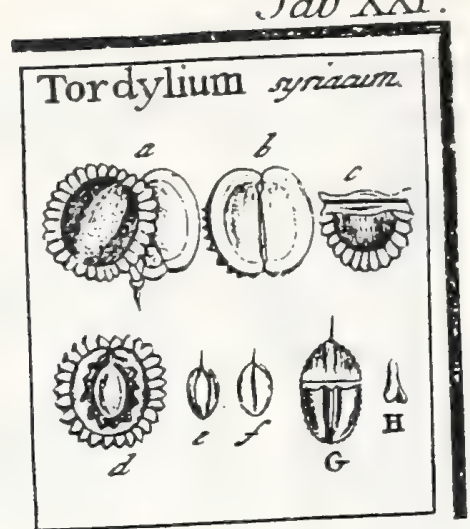

J. Gaertner (1788) Vol.1

\section{5}

XCVIII. TORDYLIUN. TOURN. t. 17o. Linn. gen. $33^{\circ}$.

Umbella compofita. Invol. utrumque polyplyyllum. Semina omnia orbiculata, conr prefla, plana, margine incraflato cincta.

Tordylium creticum. BES L. hort. Eyfl. afiv. XII. t. g. f. x. bene.

Tordylium fyriacum minus, femine granulato majore. Moris. hift. 3. S. g.t. 16. f. . U. Umbell. t. I. f. 28.28 .

Tordyliun fyriacum. R I v. pent. t. 3. IA c Q. hort. 3. t. 54 .

Tordylium involucris umibella longioribus. Lin N. Jy/6. veg. 275. -

PER. nullum: Fructus inferus, orbiculatus, bipartibilis.

REc. filiforme, bifidum.

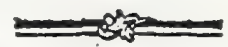

SEx. duo, orbiculata, comprefra, plana, in medio leviffime convexa \& fubpubefcentia, ad peripheriam margine cralfo fubcrofo, albo, tuberculis crenulato circumdata. Pars ventralis plana, glabra.

Ix т. duplex: exterius coriaceum, nucleo amplius; interius membranaceum, tenue.

Aцв. ellipticurn, fensine multo angufius, compreffurn, carnofum, album, fubo. doratum.

Е м в. dicotyledoneus, inverfus, minutus. Cotyl. brevifimx, obtufx. Rad. cylindrica Supera.

2.) Frufus integer. b.) Seminis pars plana, c.) Frutus transverie (etus. d.) Albumen dene. datum. c. (.) Idem decorticatum. G.J Situs embryouis. H.) Embryo feparatus.

Sxpe accidit, ut ex duobus feminibus, alterum abortet, atque tunc alterum in bullan cymbiformem convertatur. Hinc, quoniam Haffelquifia, folis fuis ferninibus, frequentius in bullam converfis; Artedia autem, folo feminum fuorum margine, crenulato-dobato, a Tordylio differat: ambas ad Tordylium rectifime re tulit ADANSON Us.

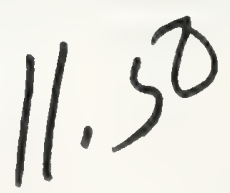




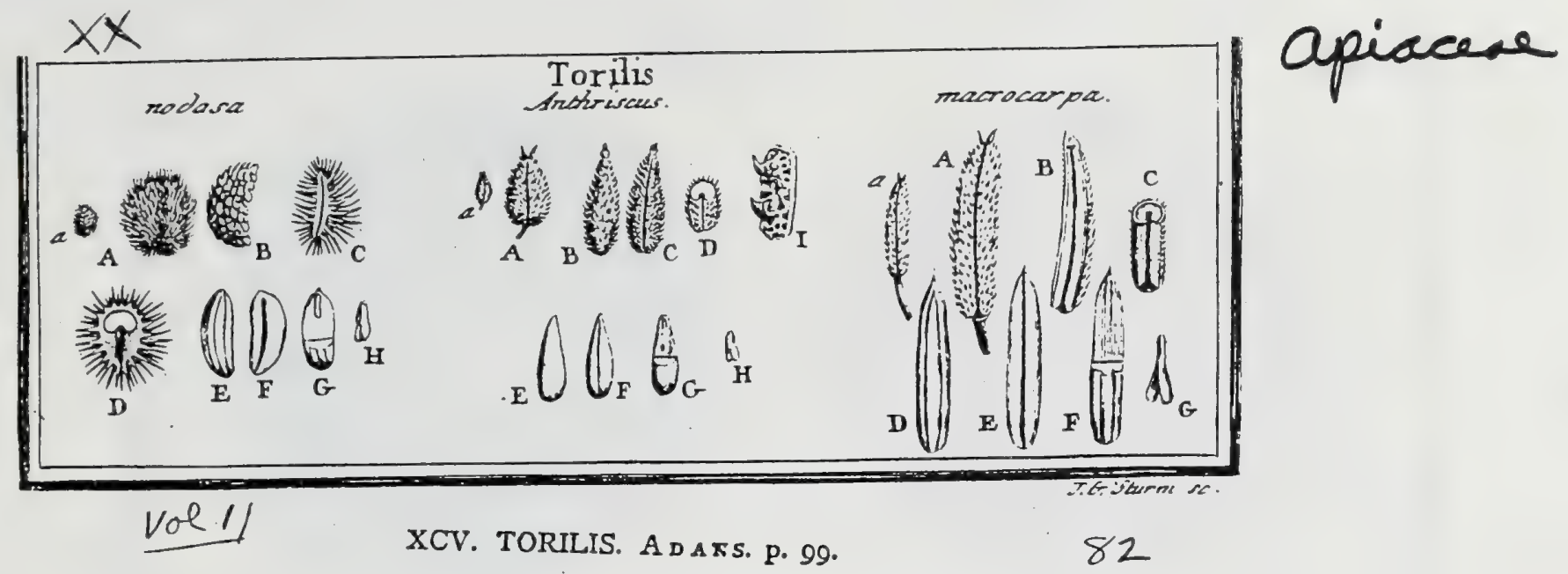

Umbella fimplex. Involucrum nullum, aut foliolis paucis, fimplicibus. Semina

Torizis. nodofa. Tab. 20. fig. 6.

Cancalis nodofa echinato femine. MORIs. hif. 3. S. 9. t. 14.f. 4. Umbel. t. x.
f. 19. so a.

Caucalis ad alas florens. RIv. pent. $l .36$.

Tordylium umbellis fimplicibus fefflibus, feminibus exterioribus hifpidis. Lix $\$$ :
fyf. veg. 275 .

Icon. J A C Q. auftr. v. 5. app. t. 24.

PER, nullum. Frufus inferus, fubglobofus, hifpidus, bipartibilis.

REC. aulium, aut filiforme, bifidum.

SEM. Duo, feniovata, valde gibba: radialia, undique aculeis fetaceis, fcabris, apice leviter aduncis echinata; centralia vero, tuberculis faltem afperis hiac inde in aculeos breves abeuntibus fcabrata. Yars ventralis angufta, fulco excavato inferipta.

INT. duplex : coriaceum, craflum, \& inembranaceum, tenuifinsum.

A в в. ovato oblongum, carnofum, album, inodorum; hine friis tribus, inde fulco deprefto notatum.

Eмв. dicotyledoneus, inverfus, teretiufculus, lacteus. Cotyl. oblongz Radic. cylindrica, fupera.

2. A.) Fructus ex radialibus, B.) Senten ex centralibus. C.) Pars feminis ventralis. D.) Semen transveríe fectum. E. F.) Abumen decortieusum. G.) Situr embryonis in apice albuminis. H.) Embryo feparatus.

Torilis Anthrifcus. ibid.

Myrrhis Jenvine aspero brevi. Mor Is. Unibel. t. I. f. 39.39.

Caucalis folio cerefolii. R I v. pent. $t .35$.

Caucalis vaginis lanuginofis, foliis triplicato pinnatis, feminibus roftratis. Ha L 2 . hif. I. 1. 743 .

Scandix feminibus ovatis hifpidis, corollis uniformibus, caule tavi. LINN. fyfh. veg. $287^{\circ}$

Icon. OE DER flor. dan. t. 863. JA c e. auftr. vi:z.t. 554 .

Fructus ovato acuminatus (2.A.) Aylis perfiftentibus brevibus crafis roftratus, nigro fufcus. Semina oblonga (B.C.) furfum attenuata, fubteretia (D), undique aculeis brevibus (I.), incurvis. Fcabris, pallidis, cartilagineis hifpida, cetera vero excavato punctata, nigro fufca. Albumen (E.F.) femini couforme, durun, inodorusn. Embryo (G.H.) minutus, tereciusculus.

TORILIS macrocarpa. ibid.

Myrrhis nodofa, femize afpero longo. Mor Is. Umb.t. x. f.38.т. v.

Scandix feminibus fubcylindricis hifpidis, canle hifpido: geniculis tumidis. LINN. fiyl. veg. 287.

Icon. J A c Q. hort. 3. t. 25 .

Fructus fubcylindricus, transverfe latior, pallidus, nylis perfintentibus roftellatus (2. A.). Semina fernicylindrica (B.C.), undique fetis rigidis, brevibus, inferne globofis, adfcendentibus, hifpida; a parte ventrali (B.C.) planiufcula, fulco excavata. Albumen (D.E. F.) hine friatum, inde fulco inferiptum, durum, inodorum. Embryo (F.G.) Lungiusculus : cotyledonibus folisceis, linearibus. 
1

-

- 


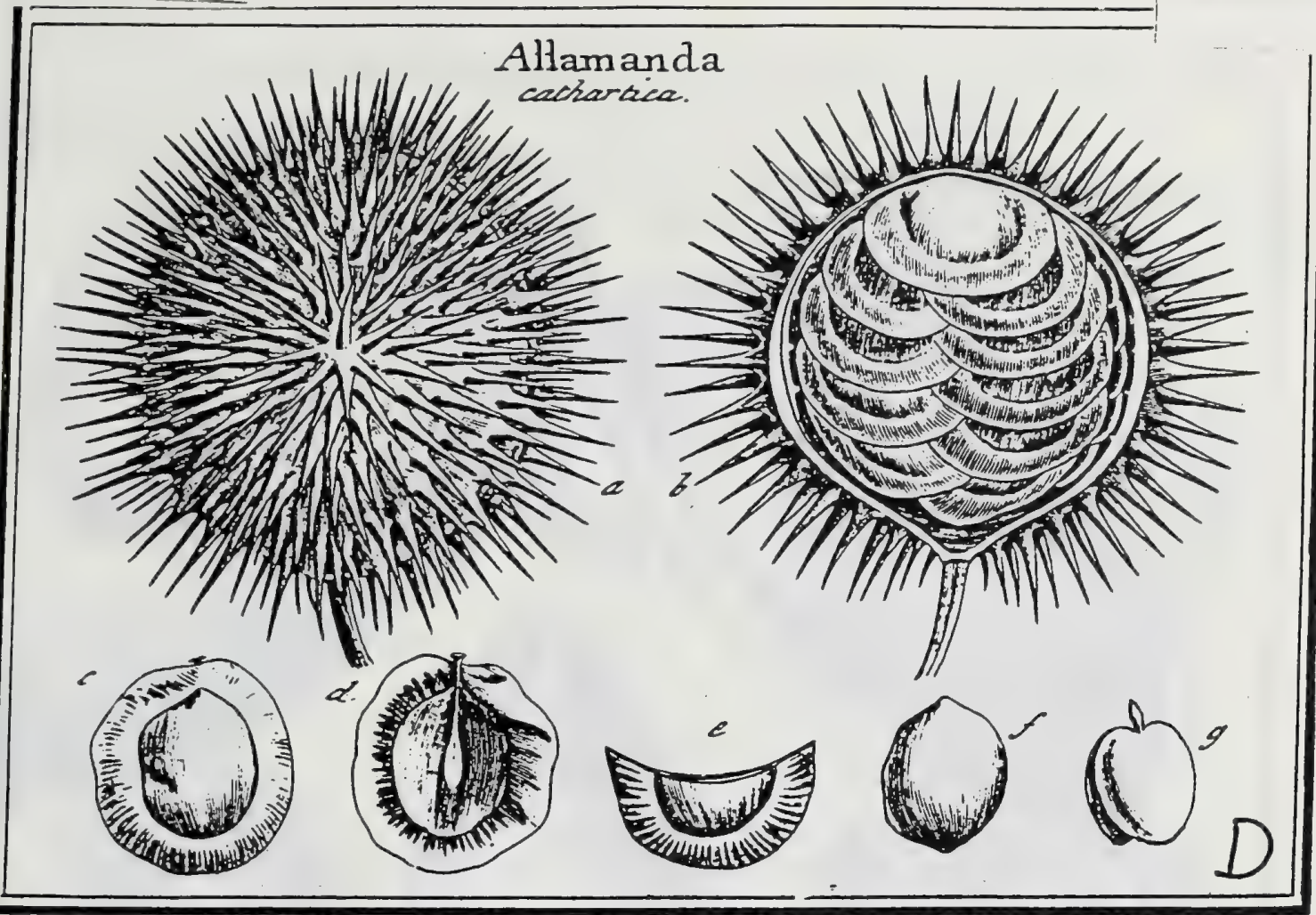

T.G. Soerm fe.

J. Gaertner (1788) Vol. I

\section{ALLAMANDA. LiNN. gen. 1295.}

Calyx pentaplyyllus. Cor. infundibuliformis quinquefida contorta. Stam. quinque.
Styl. unicus. Capfula echiuata unilocularis. ginibus aflixa.

ALLAMANDA cathartica. Tab. 6r. fig. 4.

Orelia grandiflora. AuвL. guian. 27r. t. 106.

Allamanda. LIN N. Jifl. veg. 252.

PER. Capfula fuborbiculata, turgide lenticularis, futurâ deprefrâ in ambitu cincta, undique aculeis rigidis pungentibus echinata, unilocularis, bivalvis.

REC. nullum, proter incraffatum valvularum marginem, unde funiculi fetacei longi, ad centrum usque feminum pertingentes.

SEs..numerofa, quadruplici ferie deorfum imbricata, fuborbiculata, leviter convexo concava, bracteata, faturate rufefcentia aut ferruginea, lato margine membrana-
ceo, pallidiore cincta.

IN T. limplex, membranaceum, arcte adnatum, in inarginem ampliatum.

A 1. B. Inagnitudine difci feminis, compreftun, cartilagineum, altum.

EM B. albumine paulo minor, niveus. Cotyl. ovato cordatx, foliacex, tenuifimx. Rad. Lincari acuminata, comprefta, centrifuga.

2.) Capfula integra. b.) Valvula altera cum duplici ferie anteriori feminum. c.) Seminis latus ventrile cum infertione funiculi umbilisalis. e.) Semen transverie sectum. f.) Albumen deunda-
sum. 5.) Einbiyo feparatus. 
Tab: CXXIII

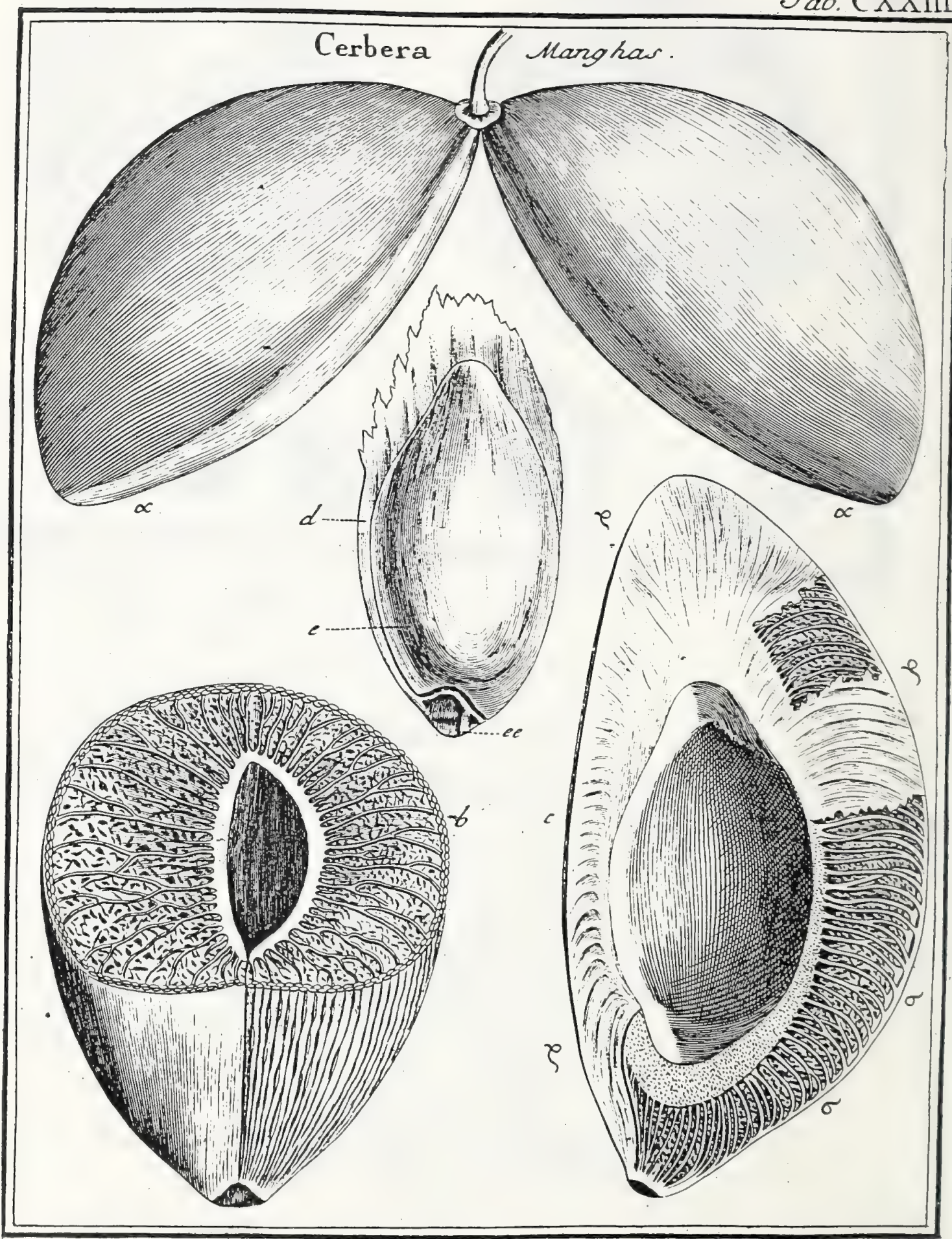

T.G. Skerm/c. 


\section{Apocynaceae}

Tab. CXXIV.

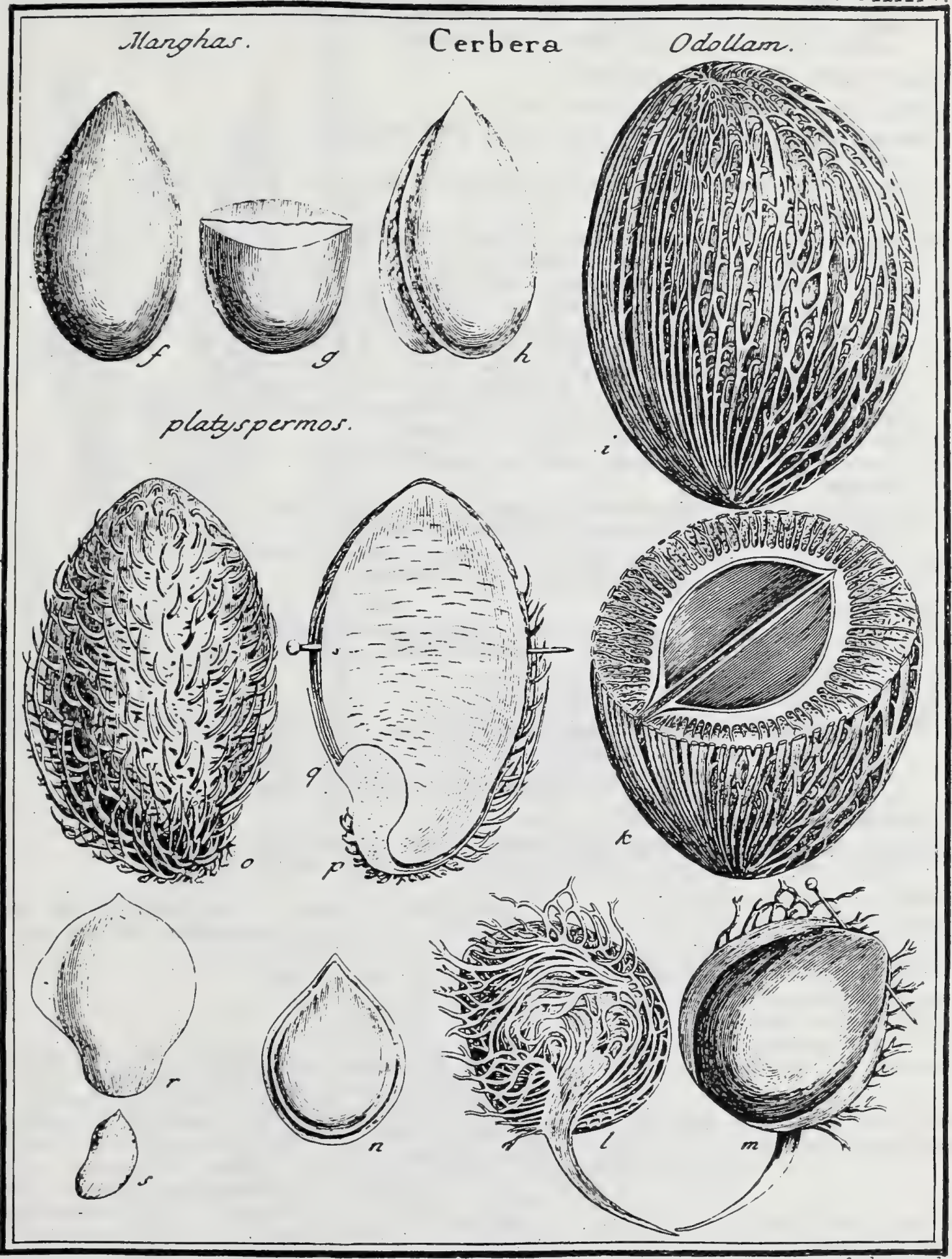

J.G.Juem $j$. 
DCCVIII. C E R B E R A. IINN. gen. 294.

Calyx quinquefidus. Cor. monopetala, infundibulifornis, quinquefida: Stam. quinque. Ovar. duo fupera. Stigmata feffilia. Drupx dux, exfuccx, puizamine fibrofo femibivalvi, uniloculari: loculamento per feptim mobile in duas concamerationes divifo. Sem. fubfolitaria.

Cerbera Manghas. Tab. 123 \& 124. fig. I.

Aibor lactaria. RUMPH. amb. 2. p. 240. t. 81 .

Manghas ladefcens, foliis nevii crabis venofis, jafinini flore, fruffu perfice fonili veneszato. BURM. Zeyl. 150. t. 70. f. I.

Cerbera foliis lanceolatis, nervis transverfalibus. Lins. Jyf. veg. 251.

$E$ collectione Bankliana.

PER. Drupx dux; exfucce, grandes, ovato-oblongx, in dorfo gibbx \& oblo: letiffime ftriatx, in.ventre autem planiufculx cum fulco medio leviter depreffo. Cuticula extima menbranacea, tenuis, nigro fufca. Caro fungofa, inftar exficcate fambuci medullx, inter putaminis fibras hxrens. Putamen lignofum, extus fibris teretibus, verfus periplierian radiatin productis, ibique in novas fibras planiufculas longitudinales \& peculiarem corticem lignofum formantes, converfis undique ftipatum; intus uniloculare atque ex futura, per ventrem in medium ufque dorfum deducta', femibivalve. Loculamentum excentricum, fepto membranaceo mobili atque valvis interjecto, in duas concamerationes divifum.

REC. nullum, proter feptum mobile, cujus alteri fuperficiei remen undique adnatum.

SEM. unicum, (altero conftanter abortante) grande, ovato-oblongum, lenticulari comprefum, fuperne attenuatum, fordide ferrugineum.

INT. duplex: exterius fubcorizceum, difepimento arctifime adnatum; interius membranaceun, tenuifimum, diaphanum, pallide fpadiceum.

A L B. nullun.

E M B. Semini conformis., inverfus, atro-viridis. Cotyl. ovato-oblongx, carnof: extus leviter convexz, intus planiufcula \& valde rugof $x$. Kad. brevillima, acuminata, fupera.

๔. ๔.) Frutus integer. b.) Drupa transverfin fetza, \& enticula lateris dextri fublata. c.) Ejusdem fectio longitudinalis, ubi fo f. fo) fpatium futurz dehifcentis; \& o. $_{0 .}$.) valvularum coalitionem dor[alen indicant. d.) Septum metahranaceum. e.) Semen fepto adnatugn. e.e.) Ovulum calfum. E.) Semen e tefta cxertum atque fola membrana interna tetamo g.) Cotyledones transverfim feetz. b.) Embrgo denudatus.

Loculamentum regulariter deberet effe centrale; Teptum bipartitum f. ex duabus laminis compofitum; \& in fingula concameratione fenen unicum

aut genellum; at in quinque hujus fpeciei exemplis, qux mihi incidere licuit, non aliam, quan fupra defcriptam fabricam deprehendere potui.

Cerbera Odollam. Tab. 124. fig. I.

Odollaw. RHEED. mal. 1. p. 75. t. 39.

E femiuario Amttelod.

Drupa plerumque folitaria, elliptice globofa, hinc valde convexa, inde planiuf cula, e viridi flavefcens. Stratuni fibrarum corticale (i.), ut in pracedenti, lignofum, fed fibrx planiufculx, latiores, magis ramofix, \& in dorfo creberrime reticulatx. Putamen (k.) Semibivalve, uniloculare, in duas tamen concamerationes divifun. Diffepimentum (k. l. m.) liberum, bipartitun, ex pedunculo lignofo curvo oriundum, atque a parte fur interiore fo axem refpiciente, multiplici fibrarum tortuofarum plexu (J.) ftipatum a a parte autem exteriore (m.) femmigerum. Senen, in lingula putaminis camera, fingulum, ovato - acuminatum $(m)$, hinc infigniter convexun, inde planum, asque diffepimento ita adnatum, ut folus apex liber fit. Menbrans feminis interna (dI) tenuiffma, vafculis capillaribus ftipata, citra nucleum in anguftum marginem produda. Albumen nullum. Embryo femini confornis, atro-viridis, inverfus. Reliqua ut in precedenti.

Hanc non meram effe precedentis-varietatem, ut vult Linneus, ex diverfiffima fructus fabrica facile intelligitur.

Cerbera platyfpermos. ibid.

Ex dono amicið. Dr. Berkhey.

Putamen (o. p.) lignofum, ovatum, fibris nultiformibus, furfum incurvatiundique muricatum, fubbivalve, feu ad bafin ufque futurs divifum, \& duas concamerationes valde comprefras ope fepti mobilis partitum. Diffep. inentum - (q.) coriaceum, bilamellatum, ipfi valvularum futurx interjectum. Semina, ill fingula concameratione, gemina (r. s.), foliaceo-comprefia, ferruginea, undique libera, inxqualia: altero majore (r.), ovatu-[patulato, fupcriore; altero minore (s.), fubreniformi, inferiore. Embryo defuit. 


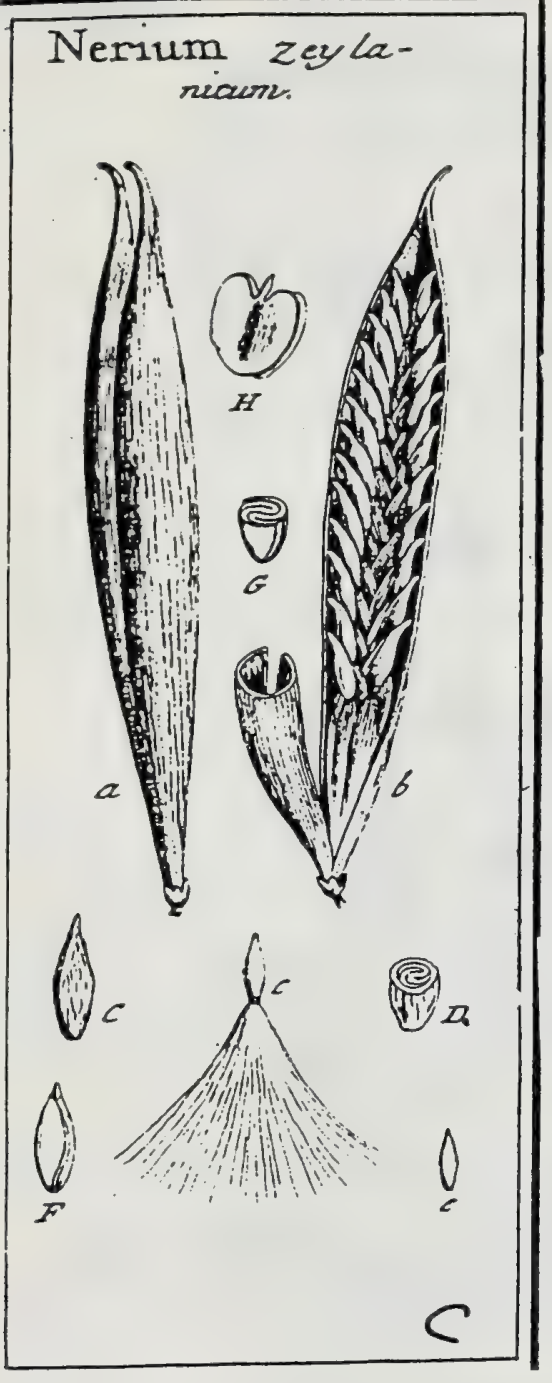

J. Gaertner (1788) Vol. 2;

172

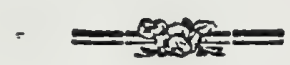

DCLXXXVI. NERIUM. TOUR N. inf. t. 374. LIN. ger. 297.

Calyx quinquefidus. Cor. infundibuliformis : limbo quinquepartito : fauce lacinulis coronata. Stam. quinque. Ovar. duo, fupera, in ftylum fimplicem coadunata. : Folliculi duo. Receptac. nullum. Semiua futurse dehifcenti affixa, crinita.

Nerium zeylanicum. Tab. I17. fig. 4 .

Apocynum arborefcens, nerii flore, minus. BuRM. Zeyl 23. to 12. $f_{0} 2$. Nerizm foliis lanceolatis oppofitis, ranis reçis. LIN. Ljf. veg. 253.

E collect fem. hort. lugdb.

PER. Folliculi duo, coriacei; extus fubtilifime ftriat, fumof, intus glaberrini, albicantes, fufformes, uniloculares, interno latere dehifcentes.

REC. nullum; femina, baff fua, futuris folliculorum utrinque affux, deorfum pendula, ut crinitus vertex fundum pericarpii refpiciat!

Sem. numerofa, fufiformia, rugofula, cinerufcentia, crinita. Crines fimplices, fericeo-albicantes, fenine quadruplo longiores.

IN T. duplex: exterius craffiufculum, herbaceum, molle, ut forfan in recenti fructu baccatum?" interius nembranaceum, tenuiflnsum, diaphanum.

A I B nullum.

E M B. femini conformis, inverfus, rofeo colore tinctus. Cotyl. foliacex, cardatx, figmoideo plicase \& convolutx. Rad. teretiufcula, rubro fanguinea, fupera, $\mathcal{E}$ apicen folliculi refpiciens.

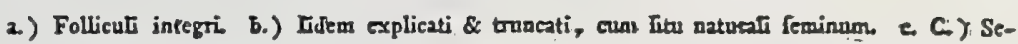
men, parte fuz inferiore crinitum. D.) Ejus Iedio transverfalis. c.) Embryo feminis membranz

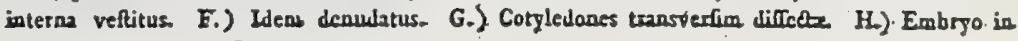
aque explicatus \& auctus. 


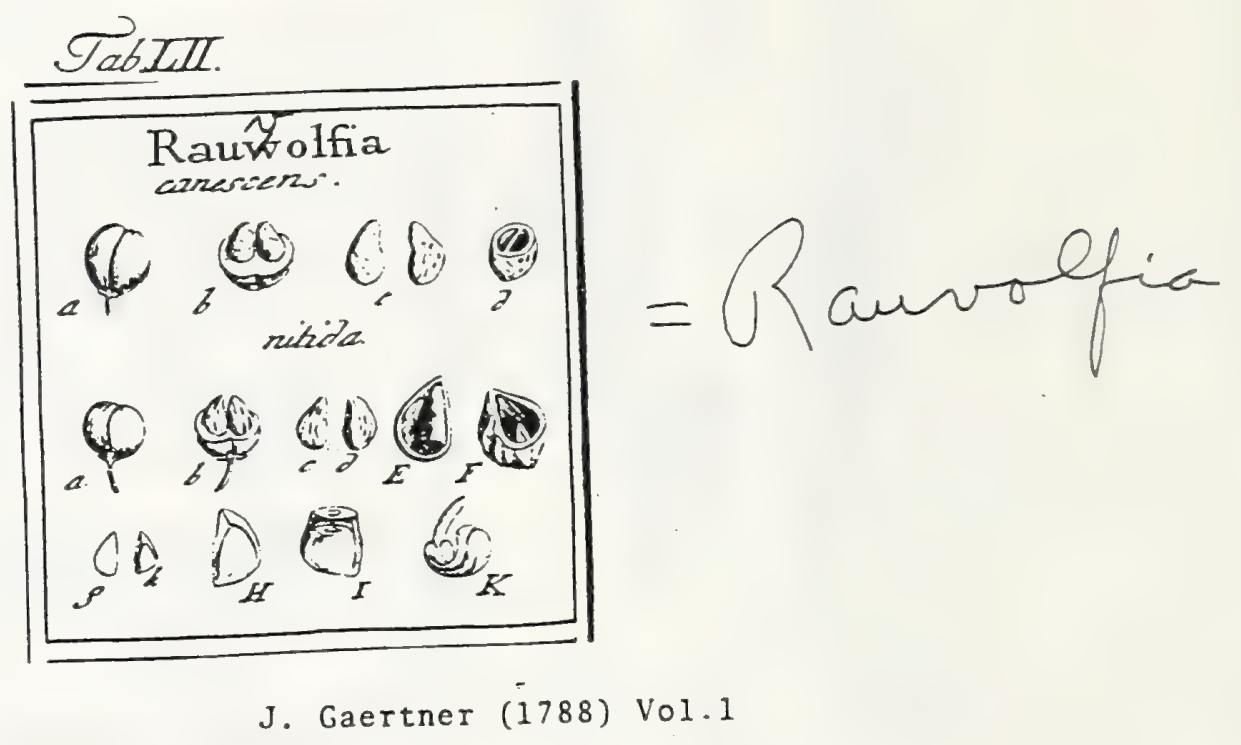

242

CCXCIX. RAUKOLlFIA. Prum. gen. t. 40. LiNn. gen. 293.

Calyx quinquedentatus. Cor. infundibuliformis contorta. Stam. quinque. Stỵ. unicus. Bacca fupera dipyrera: Oficulis bi-1. femibilocularibus. Semina folitaria.

RAU OLFIA nitida. Tab. 52. fig. 4 .

Rnuwolfia tetraphylla angufifolia. $\mathrm{P}_{L}$ U M. ic. t. $236 . f . x_{0}$

Raurolfia glaberrima nitidiffsma. Li N. h. Cliff. t. 9. Jyf. veg. 250.

Ex horto regio Kewenfi.

PEr. Racca globofa, carnofa, didyma, dipyrena. Oficula gigartoidea, oftea, albr. cantia, rugofa, bafi ventricofa, gibba; apice attenuata, compreffla; dorfo carinata;

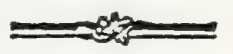

ventre. convexiuscula aut plana; intus fpadicea lavigatiffma; femibilocularia: diffepimento incompleto, parti ventralt affixo.

REC. nullum; femen apice affixum.

$S \dot{E} M$. in fingulo officulo unicum, compreftum, utrinquée attenuatom, conduplicatum: extremitate inferiori rellexa.

IN T. finplicifimum, inembranaceum, palliduen.

A.в. Semini conforme, carnofum, molliusculum, album.

EMB. albunine paulo brevior, inverfus, uncinato curvatus, lacteus. Cotyl. lineari oblongx, foliacex, furfum recurvatx. Rad. fubcomprefia, longa, fupera.

a.) Bacca integrs. b.) Chro ad dimidian refela. c.d.) Oricala denudata, E.F.) Eadem transverfe \& (ongitudinaliter feta. g.) Semen feparatum. h.H.) Ejusdem latus alterum, eum extremitate fua iuferiori reflexa. I.) Albumen conduplicatum, tranfverfe feaum. K.) Embryo deaudatus.

RAU W OLEIA canefcens. ibid.

Ex herbario Bankfiano.

Bacca ovato globofa didyma (a), dipyrena (b). Oficula gigartoidea (c) rugora, biloculariz (d.). Sernen deen. 

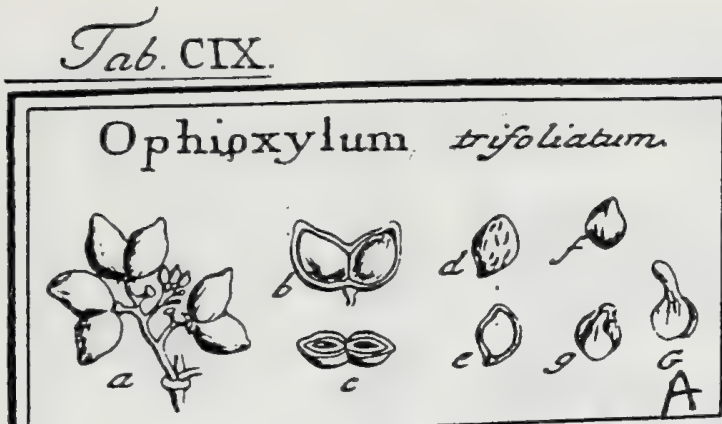

J. Caertner (1788) Vol. 2
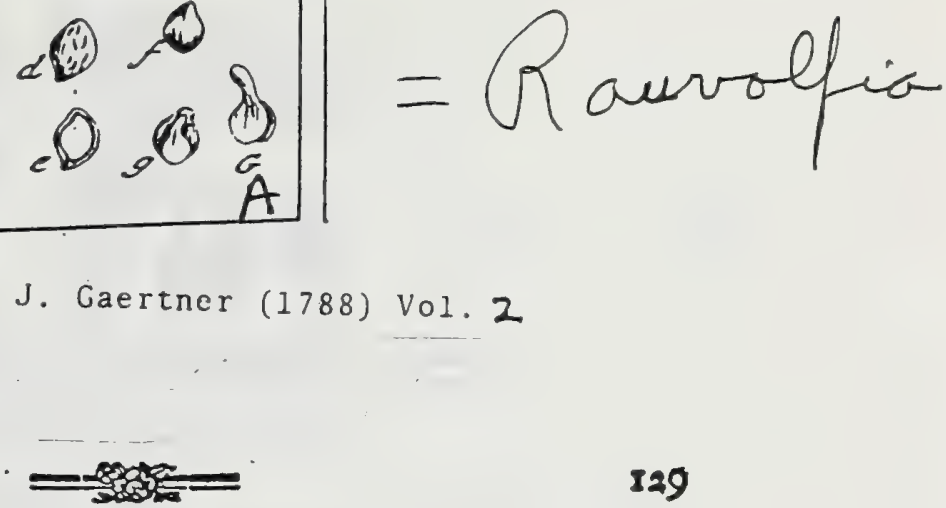

\section{O P H I O X Y L U MD LINN. ger. II42.}

Flores hermaphroditi atgue mafculi fteriles in eadem ftirpe. MAS. Cal. bifidus. Cor. quinquefida, infundibulıformis, ore cylindrico Nectarifero. Smm: duo. HERM 1 PH. Cal. quinquefidus. Cor. quinquefida. Stam. quinque. Ovar. fuperum. Styl. Gmplex. Bacca biloba, dipyrena. Sem. Solitaria.

Ophioxycum trifolintum. Tab. rog. fig. 2.

Tsjovanire RHEED. mal.6.p.87. t.7.

Radix muliele rubra. R'Mprs. amb. 7. p. 30. defcript. non icon:

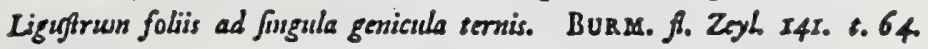

Ophioxyluxx. Lisw. f. Zyl. 398. Lyf. veg. gu.

$E$ collect. fem. hort Jugdb.

PER. Bacca carnofa, liloba, calyce minutulo tri-1. quinquefido exceptz, lenticulari compreffa, dipyrena, lateritio-rubra. Caro tenuis, firmula. Olficula ovats, urrinque, fed magis verfus batin, acuminata, obfolete ruga fula, craffa, lenciculari compreffa, unilocularia.

REc. nullum.

SeM. folitaria, ovata, furfum anguftata; comprefluscula, pallida.

Is $x$. fimplex, membranaceum, albicans.

A L в. carnofum, crafium, molle, album.

E M в. magnitudine fere albuminis, fubcurvatus, inverfus, lacteus. Cotylo orbicularx, foliacex, planx. Rad teretiufcula, curva, fupera.

2.) Racemi frugiferi nenulus b.) Bace integra c) Eadea transverfin (eda. d.) Otieulen integrum. c.) Idem longitudinaliter apertum. f.) Semea (eparatum. g.) Sitas embroais intra albumea. G.) Embryo folutus \& suAuc:

Recentes fructus, fecundum 'Rumphium $L$ a gaident bacca didyma, obtu fifima, ex duobus globis, ut in Caprifolio, compolion, atque pulpa aquofa referta; malui autem baceas delineare atque deferibere, quales coram vidi, \& quales eti.ım reprefentavit Burmannus. Icon Rumphii, non fpecicm noftram irfoliatam, fed aliam, fcil. albam, Gitit, foliis oppolitis, cruciatis, Goribus albicantibus, \& baccis nigris. 


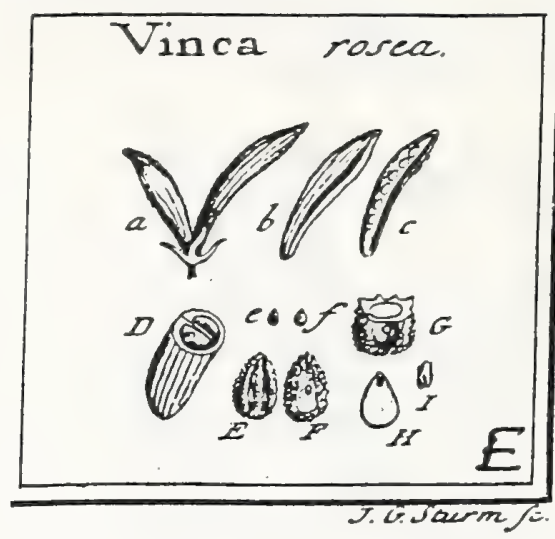

\section{J. Gaertner (1788) Vol. Z<smiles>[Te][Te]</smiles>

\section{VIN C A. LINN. gen. 295. Pervinca TOURN. inst.t. $t$. 45 .}

CaIyx quinquefidus. Cor. infundibuliformis: limbo quinquepartito; fauce nuda. Stam. quinque. Opar. duo fupera, in ftylum fimplicem commu nem definentia. Folliculi dua, femibiloculares. Rec nulluma. Semina diffepimento alfirz, calve

TLNCA rofea. Tab: II7. fig. F.

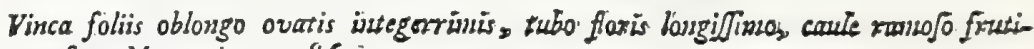
cofo. MLLL. i. L. 286.

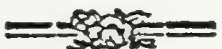

Vincal caule frutefcente ereifo, foliis ovato oblongis, petiolis bafi bidentatis floribus geminis feffilibus. LiNN. Gifo. veg. 252.

PER. Folliculi duo, parvi, teretes, fubclavati, ftriat, pubefcentes, femibiloculares, latere interno dehifcentes. Diffepimentum anguftum, duplicatum, ex futura introrfum plicata euatum.

REC. nullum; femina diffepimento utrinque longitudinaliter affuxa.

SEN. plurs, fedecim ad viginti in Gngulo folliculo, parva, ovata, fupra acuminata, hinc fulcata \& tuberculis acutis feabrata, inde in medio glabra atque papillula umbilicali notata, e caftaneo - fufca aut nigricantia, calva.

IN T. fimplex, membranaceum, aut fubcoriaceum.

A L в. carnofum, craflum, aqueo - pallidum.

Es B. minutulus, fubovatus, lutefcens, in vertice tuninis pofitus. Cosy\%. breviflimx. Rad. Supera.

2. b.) Folliculi integri \& dehifceus c. D.) Diflepimentam cum infertione feniaum. e. $E$. E. F.) Seminz ab utroque latere fpecata. G.) Scainis \& albuninis feAtio transverfalis. H.) At bumen verticaliter diffectum, end fitn \& Eigura embryonis. I) Exbryo folstus. 


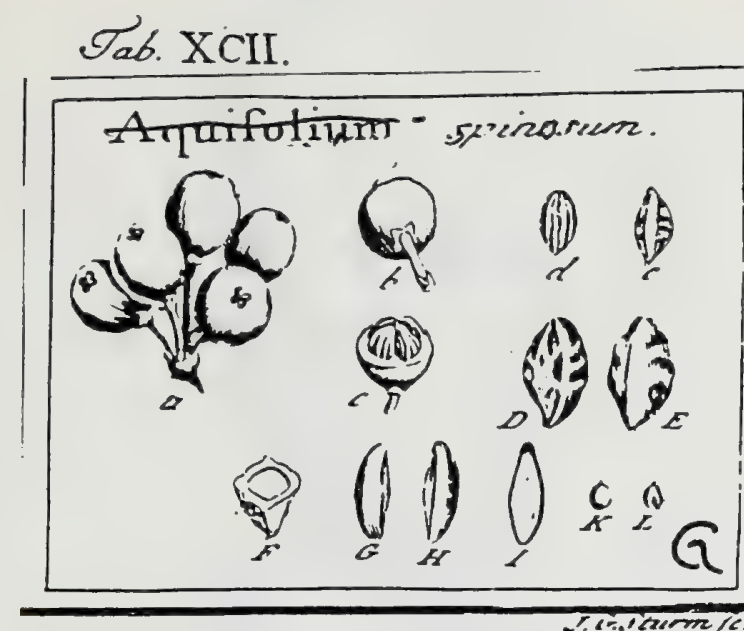

\section{J. Gaertner (1788) Vol 2}

72

DLXXVIII. - TOURN. inf. t. $37 \mathrm{r}$.

\section{- llex. LINN. gen. 172.}

Calyx quadridentatus. Cor. quadrifida rotata. Stam. quatuor. Ovar. fuperum. Stigmata quatuor feffilia. Bacca tetrapyrena.

AQuizolium fpinofum. Tab. 92. fig. 7 .

Aquifolium. Cam. epit. 84. Blakw. berb. t. 205. Ozd. fior. dan. t. 508. HALL. bift. 1.667 .

Ilex foliis ovatis acusis jpinofis. LIN . $\int y$ ft. veg. 168 .

PER. Bacca fupera, carnofa, ovato globofa, nitida, coccines, quatuor ftignatibus aridis atris coronata, tetrapyrena. Caro firna, flavefcens, fubfarinofa. Oflicula ovata, utrinque acuminata, rugofa, hinc convexa, inde angulata, unilocularis, monofperma, ofea.'

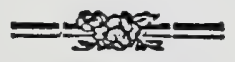

REC. nullum.

SEM. quatuor, oblonga, utrinque acuminata, fubtriquetra, lutefcentia.

IN T. fimplex, tenuifimum, membranaceum, aridum, facile fecedens.

Ai в. femini conforme, carnofum, albicans, intus fifura longindinali fubdivifum.

EMB. minutiffinus, globulofus, niveus, inverfus, in fupremo albumine hxrens. Cotyl. brevifimx, craffx. Rad, obtufa fupera.

a. b.) Bacez integras e.) Oliculorum in baces fitus. d. D.) Otuculi latus dorfale. e. E.) Ejas. dem pars ventralis. F.) Oficulum cum femine difectum. G. H.) Seminis facies anterior \& pofterior. L) Albumen verticaliter feetum, cum fitu Embryonis. K. L.) Embryo feparatus. 


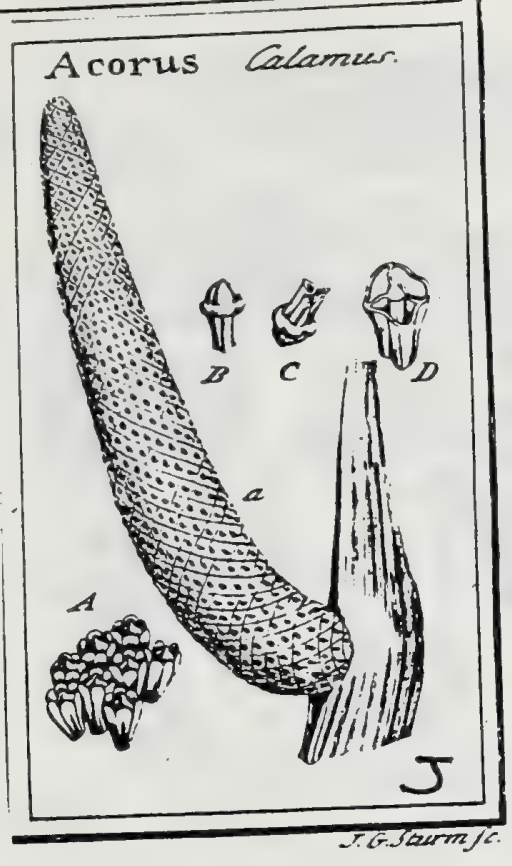

J. Gaertner (1788) Vol 2

27

DXXX. A C O R U S. LINN. zen. 434.

Spadix fubcylindricus, undique Aofculis tectus. Cal. nullus. Cor. herapeala. Stam. fex. Ovar. oblongum, ftigmate fefidi. Capl inverfe pyra. midața trilocularis. Sem. .....

Acorus Calamus. Tab. 84 fig. 10.

Acorum. CAN. epit. 5.

Acorus verus. Best. Eyjt. vern. VIII. t. g. f. x. BLakw. berb. t. 466.

Acoris. Hall. bif. $n .1307$. LiNs. byft. veg. 339.

PEr. Capfula fupera, oblonga, quafi ex duabus pyramidibus compofita: Pars superior, brevior \& craffior, fubcoriacta, parabolice - convexa; ttriis tribus depreffis infcripta, \& ad latera in marginem incraffatum, obtufe crenatum, feu in tubercula divifun, protuberans. Pars inferior longior, inverfe pyramidata, rugofe angulata, membranacea, tenuifima, diaphana. Loculamenta tria, non dehifcentia, farcta gejatina vitreo pellucida, qux etiam in vetufto fructu, in aquam conjecto, reproduci poteft.

REc. nullum, precter columnan centralem ex concurfu diffepimentorum formatam.

SEXS. ....

a.) Spadix magnitudine naturali. A.) Flofeuli infigniter audi, capfulas contineates. B. C.) Capfulx a parte fua fupesiori atque inferiori fpecatze D.) Capfula fettio transveralis, cum dillepimentis axem centralem formantibus.

Incompletan hujus fructus defcriptionem atque iconem tradere cogor, quia, omni licet adhibita diligentis, nullas tamen ejus capfulas fecundas in hunc ufque diem obtinere potui. Neque etiam recentiorem quemquam reperio, qui matura hujus plantz femina certa fide viderit, proter folum MíchzLIUM; ut tamen vel ipfa illa Michelii femina tria folitaria aliquantum fufpecti fint, quum in loculamentis farctis fere femper uno plura reperiri foleaut, nifi infa baccata fint. 


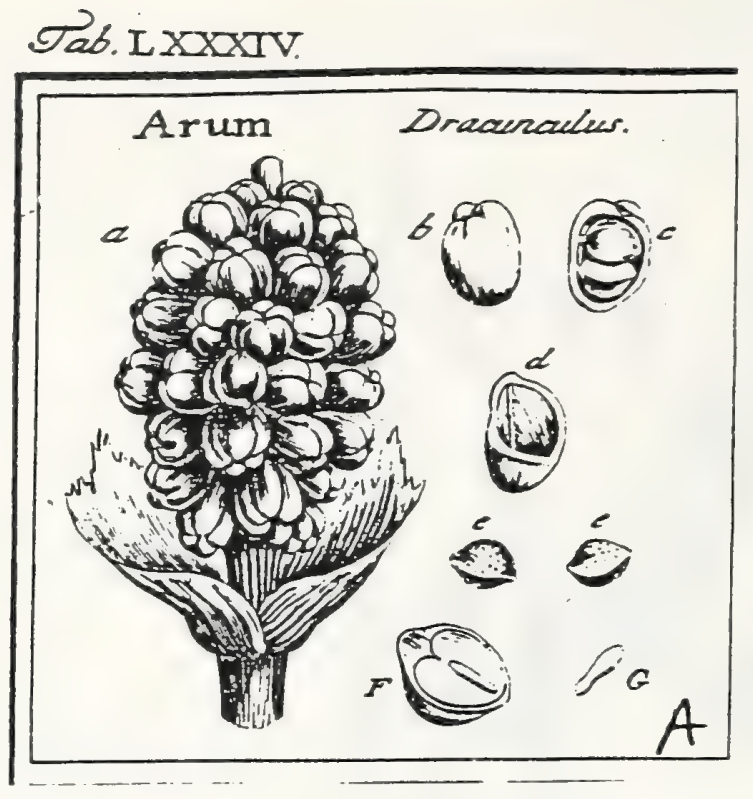

\section{J. Gaertner (1788) Vol, 2}

I9

DXXI. A R UM. TOURN. .inf. t. 69. LINN. gen. IO28.

Spatha furalis monophylla, oblonga, inferne convoluta, fupērne acuminata, interne colorat. Spadix clavatus, inferne ovariis \& in medio antheris ftipatus, cetera vero nudus. Bacca unilocularis. Semina pauca, fubglobofa.

Arum Dracunculus. Tab. 84. fig. I.

Dracontimm. Dud. perieft. 329. BLakw. berb. t. 269. - majus. BEsL. Eyft. sfiv. IV. t. I. f. . .

20

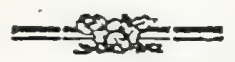

Artum paluftie polypbyltum. Riv. monop. 8. 125.

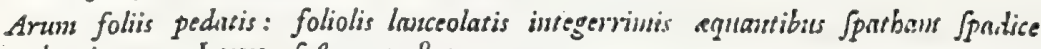
longiorem. LINN. Jys. veg. 8 27 .

PER. Bacca obovati, a vicimarum preffione fubangulata, ad verticis fcrobiculum quadri-1. pentacullis, glaberrina, nitida, coccinea, carnofa, unilocularis. Loculamento propria membrana veftito, a feminibus difcreico.

REC. filiformi - comprefum, parietale feu loculamenti lateri fuperiori appreffun \& cum eo conglutinatum, quatuor circiter funiculis umbilicalibus brẹvifTmis ttipatum.

SEM. duo, reliquis abortientibus, horizontalia, ovato-globofa, a mutuo contactu fubangulata, urrinque in mucronem producta, fubcarnofa, albicantia aut rufefcentia, rugofula.

IN T. duplex: exterius fpongiofo carnofum, ad umbilici fedem infigniter craffum; interitus membranaceum, tenuifimum, albumini adnatum.

A I B. obovatum, prope umbilicum fovea infundibuliformi exfculptum, ut fectio ejus longitudinalis cordata appareat, cetera farinofum, friabile ciundidiof mum.

Eм в. monocotyledoneus, teretiufculus aut fubclavatus, teclus, lutefcens, in parce albuminis umbilico oppofita locatus. Rad. leviter incratata, vercicem feminis \& Iatus baccx receptaculo oppoftum refpiciens.

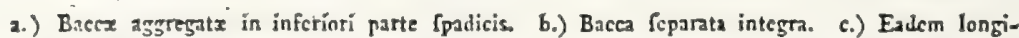
tudisaliter diffeda, cum fitu feminum naturali. 山.) Ejusícen fedto transscrfalis, cum seceptaeulo feminum parictali. c. e.) Scminz foluta. F.) Seminis \& albuminis fedtio longitudiaalis, cum litu cunbrỵonis. G.) Einbryo feparztus.

Etian in Aro maculato femina video parieti baccx affixa, fecus atque ha bet icon Flor. dan. t. sos, in qua \& julto plura, \& verfus centrum vergentia ac rubicunda pinguntur femina. 


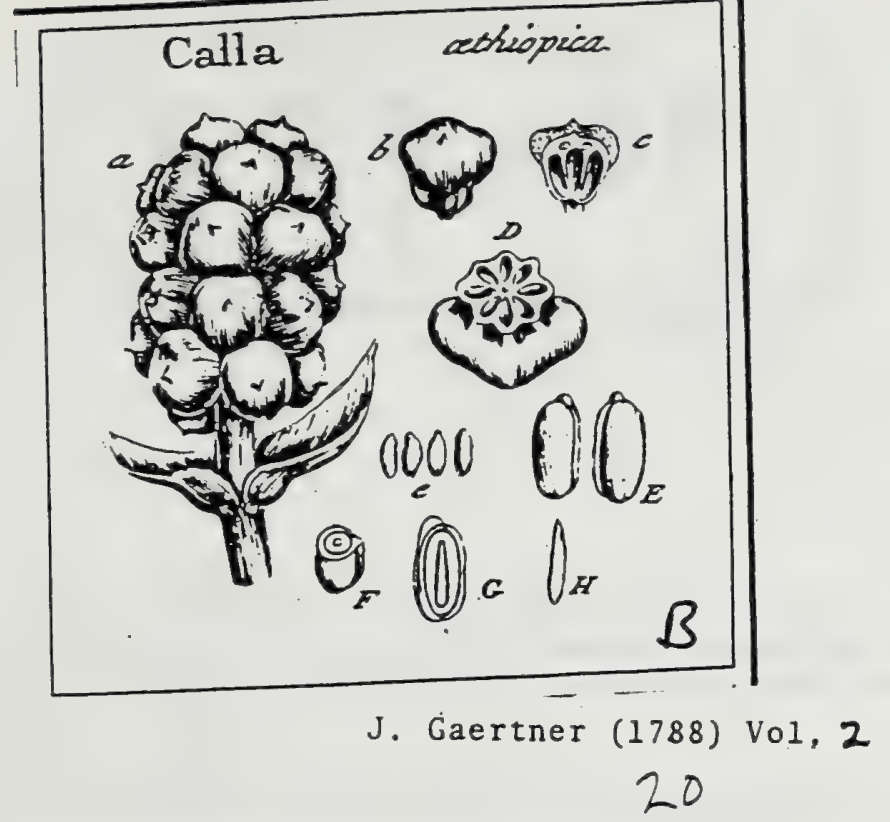

DXXII. C A L L A. .LINN. ger. IOZO.

Spatha monophylla, ovato - cordata, patentiufcula. = Spadix fubulatus fimplex fructificationibus tectus. Stamina nunc fupra ovaria in fpadice pofita, nunc is intermixta. Bacca carnofa plurilocularis. Semina folitaria eteckit.

Calla $x$ thiopica. Tab. 84. fig. 2.

Aruin celliopicum, flore albo odorato mofchuns oleste. Cons. bort. amfl. x. p. 95 . 2.50.

Calla foliis fugittato-cordatis, fpatha cucullata, spadice fuperne mafoulo. Liss. fyjt. vers. $8=9$.

Ex harto regio Kewenf.

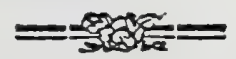

PER. Bacea turbinata, vertice turgido pulvinato carnofo, lateribus angulatis, deorfum attenuatis \& prope bafin fubmembranaceis diaphanis, cetera fex - 1. octolocularis, e minio rubra.

REC. nullum: feniina fundo loculamentorum affixa.

SEM. in fingulo loculamento fingulum, fubteretiufculum, utrinque obtufum, ad latus internum hilo protuberante compreffo ab umbilici foranine ad le. ninis apicem decurrente notatum, nigro fufcum, glabrum.

IN T. duplex: exterius cruftaceum, foraninulo umbilicali in bafi perforatun; interins męmbranaceum, lutefcens, chalaza fufca in vertice notatum.

A L B. Semini conforme, earnofum, album.

Em в. monocotyledoneus, fubulatus, rectus, lutefcens. Rad. incraffata, infera.

2.) Baces ad bafin fpadicis aggregate. b.) Bacca feparata, integra. c) Exdem Iongitudinalitcr diffecta. D.) Ejusdem, inverfz, featio transwcrfalis, cum fitu \& numero loculamentorum. c. E) Seniua in fitu uaturait. F.) Seminis atque albuminis fertio transverfalis. G.) Utriusqut fectio longitudinalis, cum Geu embryonis. H.) Embryo folutus. 
-

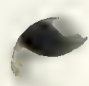

1 


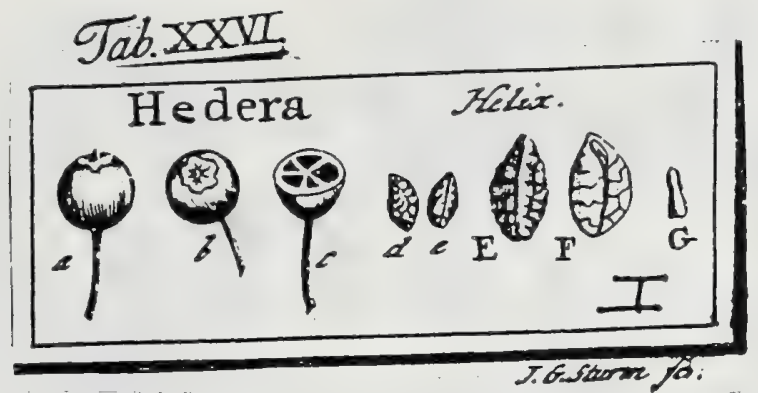

J. Gaertner (1788) Vol. 1

130

CLVI. HEDERA. T o U R N. t. 384. LIN g. gen. 283.

Calyx minimus, quinquedentatus , fuperus. Cor. pentapetala regularis. Stan quinque. Styl. unicus. Bacca exfucca quinquelocularis. Semina folitaria: nucleo rumurato.

HEDER A Melix. Tab.26. fig. s.

Hedera. B $\mathrm{A} \wedge \mathbb{\times}$. herb. $t$. I 88 .

Hedera foliis ferilibus trilobatis; fruEtiferis ovato lanceolatis. H^LL. hif. I. n. 826 .

Hedera foliis ovatis lobatisque. L I N N. Jyfl. veg. 243.

PER. Hacca infra receptaculum floris polita, ejusque rudimento pentagono friato pallidiore coromata, primo fucculenta, tandem coriacea, exfucca, globofa, obfoletiffime pentagona, glabra, atra, quinquelocularis. Loculamenta propria membrana vefita, fericeo albicantia. Diflepimenta tenuiffuna, uno vel pluribus per maturitatem fxpe obliteratis.

RÉc. nullum; femina angulo loculamentorum centrali affixa.

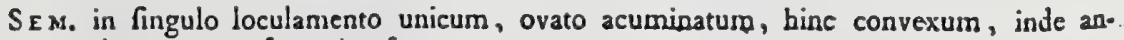
gulatum, rugofun, lutefcens.

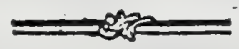

IN T. fimplex, membranaceum, tenuiffumum, albumini arcte adhzrens \& intra ejus rimas alte demiftum.

A L B. femini conforne, carnofun, album, undique profundis rimis obliquis quafi in lobulos inter fe colixrentes divifum, ac praterea fulco longitudinali intus excavatum.

Ess. dicotyledoneus, inverfus, breviffimus, lacteo albus, in fuprema albuminis parte locatus. Cotyl. fubrotundx, compreffiusculx, breves. Rad. teretiuscula, longior, fupera.

2. b.) Baeca integra. c.) (Eadem difcifra. d.) Scminis dorfum. e. E.) Ejusdem pars ventralis.

F.) Albunien longitudinaliter fectum, cum fitu embryouis in ejus apice. G.) Embryo feparatus, 


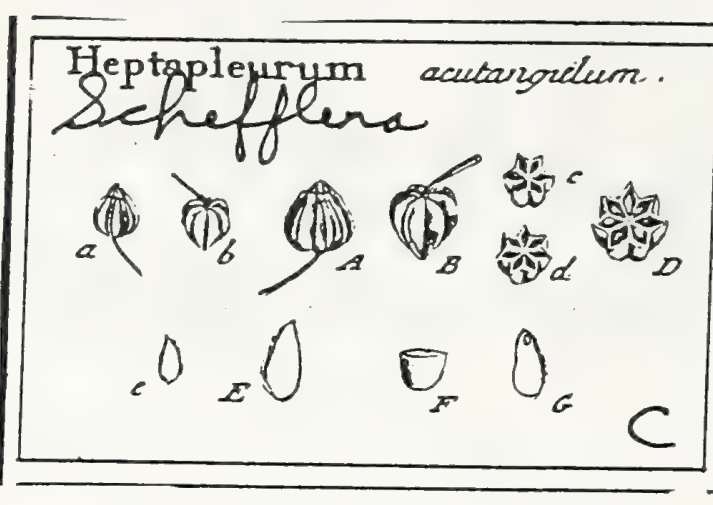

J. Gaertner (1788) Vot Z

472

\section{HE P T A P L E U R U M.}

Flos .... Capfula fubpyramidalis, ftellato - angulata, evalkis., Șem. folitaria.

Heptapleurum ftellatum. Tab. 178. fig. 3.

Bukera. Zeylonens. E collect. fem. hort. lugdb.

PER. Capfula parva, coriacea, ovato - pyramidalis, anulo obfoleto, a foris lapfu? fub apice notata \& fupra eum in mucronem fulcatuin atque rufefcentem producta, Itellato - angulata, fex l. fixpius feptemlocularis, evalvis, pedunculo obliquo gracili, ficuti Umbellifera, infiltens.

REC. nullum; femina vertici loculamentorum affixa.

SEM. Solitaria, ovata, furfun anguftiora, comprefla, pallide rufefceutia.

INr. fimplicifimum, tenuifimun, membranaccum.

A L в. Sernini conforme, carnofum, pallidum.

E $\mathrm{B}$ B. in fuprema parte albuminis, minutilimus ..... an monocotyledoneus?

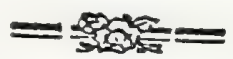

x. A.) Fructus a fuperiore, $-\&$ b. B.) Idem ab iaferiore parte fpcelatus. c.) Capfulx fexdificetun difictum. G.) Albuninis fectio verticalis cum fitu embryonis.

Iuter vigiıti quinque fructuum exempla, tria folummodo erant fexlocularia, reliqua vero omina feptemloculan ia. Recens quoque fructus videcur cortice molli aut carnofo effe indutus, quum vetufti fuperficies valde rugofi fit. 


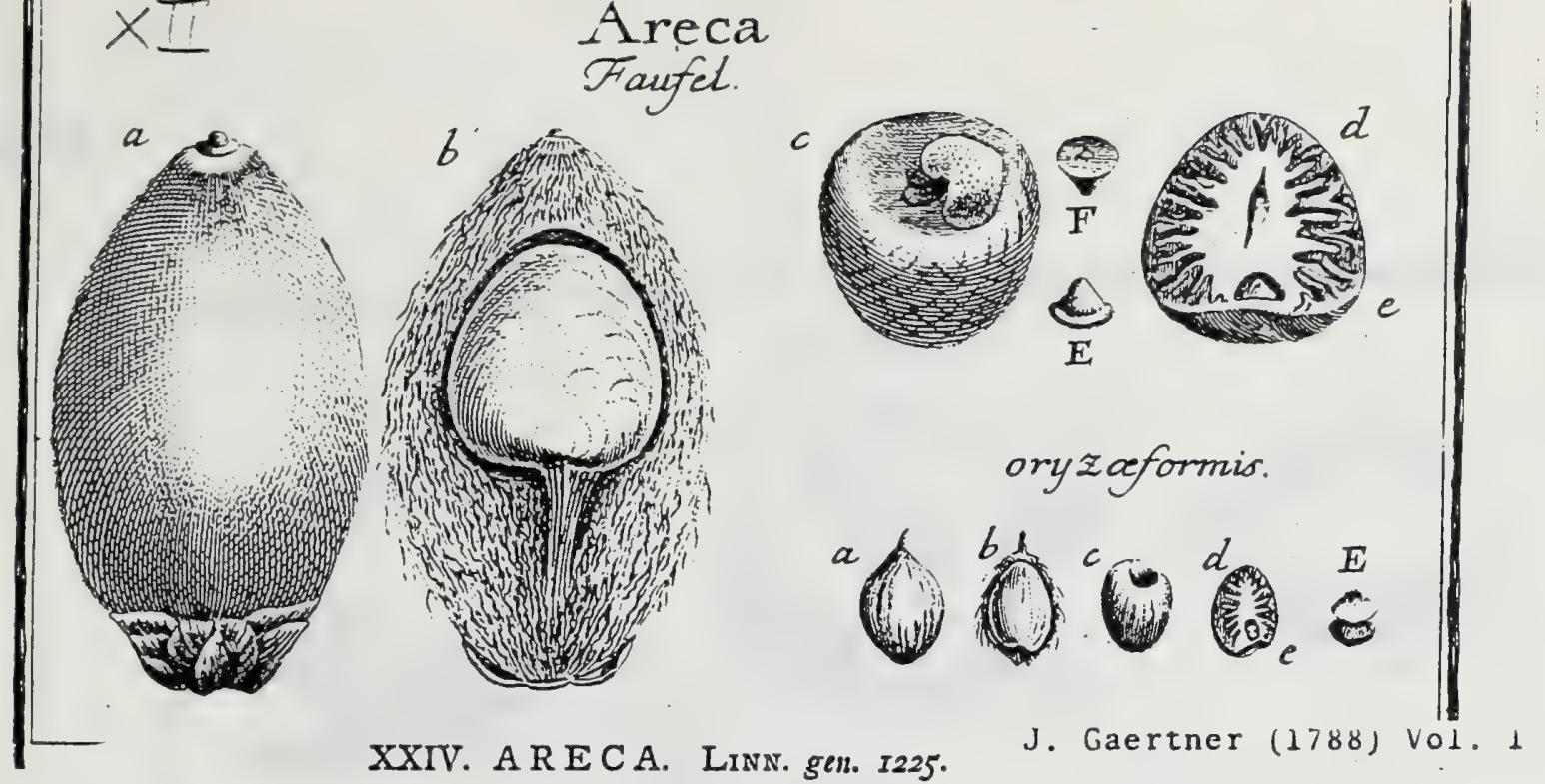

Flores fexu diftincti in eodem fpadice. Spatha univerfalis. MAs. Cal. triphyllus. Stam. novem. FEM. Cal. hexaphyllus. Cor. nulla. Drupa fupera putamine chartacco. Alb. ruminatum. Einb. in bafi feminis.

ARECA. Faufel. Tab. 7. fig. 2.

Areca f. Faufcl. Cesalp. 83. Blakw. herb. t. $387^{\circ}$

Faufel. Bauн. nit?. I. p. 389. Star. theopls. 356. Worss. mus. 199.

Cuanga. Riнed. mal. I. p. g. t. $5-8$.

Pinanga. Rumph. amb. I. $\mu .26 . t$. 4 .

Areca frondibus pinnatis: foliolis replicatis oppofitis pramorfis. Lrsw. fyjl. veg. 986.

E collect. Bankfiana.

PER. Drupa baccata, ovata, bafi cincta calyce hexaplyyllo, coriaceo, glabro, nitido; apice terminata umbone orbiculato, depreflo, fubcartilagineo, nitido, ftyli rudimento apiculato. Cuticula tenuifima, in adulto fructu leucophza, in recenti crocea, 1. rubicunda. Caro crafta, capillari-filamentofa. Putamen chartaccum, tenuilimum, fragile, album, venis rufescentibus arcuatis pietum, undiyue cum carne coharens.

REc. Fafciculus fibrarum rigidifiumarum, furfum craflescentium \& feuninis bafi lateraliter affuxarum.

SEx. unicum, rotundato conicum, cinereo fpadiceum, friis depreflis arcuatis reticnlatum, fubtus area umbilicali cordata, tumidula, alba, excentrica notatum, \& juxta hanc, in medio, foveola fubrotunda cum papillula embryonifera ftipatum.

IN . fimplex, crufaceum, durum, fuscum, in fuperficie fua interiori, variis pro. ceffibus lamellofis, alte intra albuminis fubftantiain demerfis, auctum.

А в . feınini conforme, cartilagineum, in medio, cavitate comprefta exfculptum, verfus peripheriam, valde ruminatum, ex albo \& ferrugineo varium.

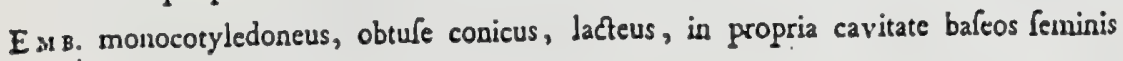
locatus.

2.) Drupa integra. b.) Eadem longitudinaliter diffeta, putaminis formam \& receptaculi feminis (2sciculum fibrofum oftendens. c.) Semen inverfum, cum area fus umbilicali cordata \& foveola centrali embryouifera. d. Albumen longitudinaliter fetum, cum fitu embryouis (e.) naturall, E. F.) Embryo folutus, a fuperiose \& inferiore parte fperatus.

Rectius forlan pericarpium, Bacca diceretur, quia putamen tenuiflunum, \& cum fibrofa carne arctiflune connexum eft, \& quia in alis fpeciebus, ut in fequenti, plane deficit.

$\triangle R E \subset \wedge$ orizxformis. ibid.

Pinanga Jytueftris oryzaformis. Ruмrн. «mb. 1. p. 4o. t. 5. f. c.

Bacca ovata (a), fylo perfiftente terminata, parva, rubra, denum fpadicea. Caro fibrofa (b.) tenuis, undique femini adhereas, ut loculamentum propria tunica, non veftitum fit, ficut in precedenti. Semen ovato conicum (b.c.), 2mpla fovea ad bafin excavatuin, atque intra hane muntifluma papilla fipatum, e cinereo fpadiceum. Albumen runinatum (d.), nulla cavitate in meoro exfculptum. Embryo (c. E.) parvus, albicans, in medio anguftatus, quafi ex duobus globulis compofitus, quorum iuferior rotundatus, fuperior vero obtufiffime conicus ef.

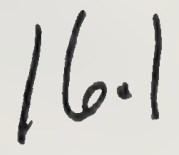


Arecaceae

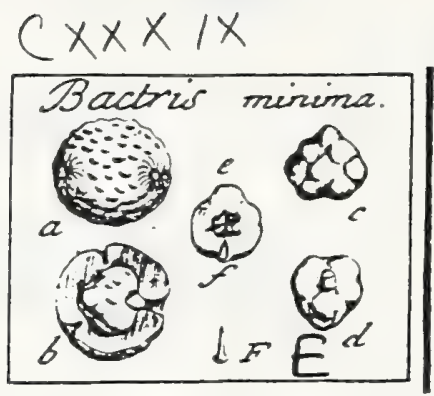

J. Gaertner (1788) Vol. 2

271

B A C T R I S. Conf: Vol. I. p. 22-

BACTRTs minima. Tab. I39. fig. 5 .

Buctris frutibus fubrotzudis. Jace. bif. anter. 279. t. 17 r. f. $x$.

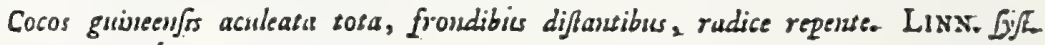
veg. 985 ?

A Cl. Hermann. Pr. arg.

Drupa fubrotunda , depreffufcula, fucculenta, acidula. Cortex coriaceus. Putamen (a.) fubglobofum, Japideum, craltilimum, undique fcrobiculis atque tuberculis obfoletis exafperatum; \& in medio ambitu tribus foraminibus, ad oftia fua radiation ftriatis., pertufum; extus helvolum, intus \& factura ocirraceo - fulcum. Foramina duo minora coca (b), tertium pervium \& ad Luculamentum centrale ducens. Semen conoideum (b. c.), horizontaliter 270

decumbens, tuberculatum, fufcum, papillula embryonifers valde prominula, in bafi coni (d.) ftipatum. Albumen (e) carnofun, friabile, ampla cavitate in medio dotatum. Enbryo ( $f . F$. ) fubulatus, intra papillam locatus, hori. zontalis. Rad. retufa, mediam fructus peripheriam refpiciens.

Anne potius Palmx Grigri fructus Jacq. t. 171. f. 3. ob ftrias radiantes ad for. mina!

16.2 


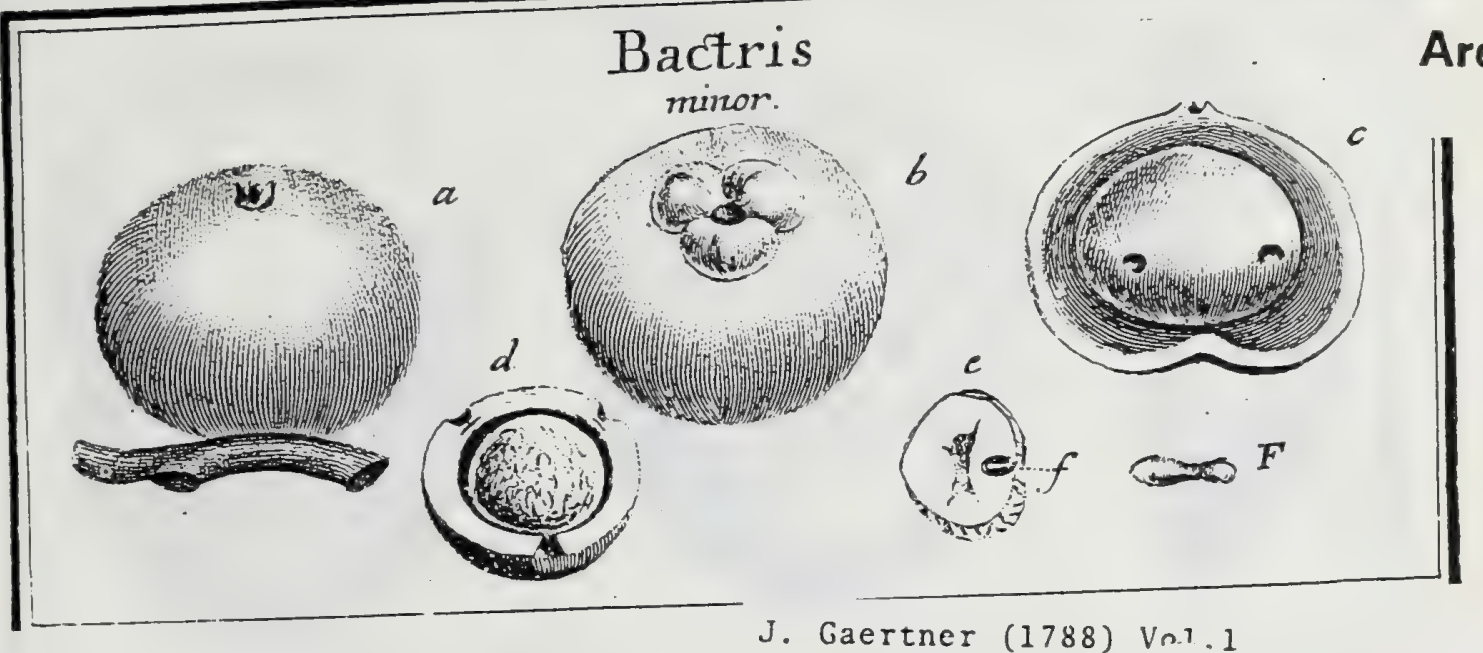

XXVII. BACTRIS. JACE.

Flores fexu diffincti, in eodem fpadice. Spatha univerfalis. Mas. Cal. tripartitus. Cor. inonopetala, trifida. Stann. fex. FEs. Cal. hexaphyllus: foliolis cxterioribus: minutis, caducis; interioribus rotundatis, magnis, perfiftentibus. Ovarium triloculare. Drupa fuptra, matura unilocularis, fupra bafin trifora. Alb. cavurn. Embr. lateralis.

BACTris globola, (minor) Tab. 9. fig. x.

Palmn pinis Es caudice ubique aculeatifmis, frudu mnjusculo. Brows. hifl. jam. $3+4 \cdot$ n. 7 .

Palma frondibus pimatis, ubique aculeatis, aculeis nigricantibus, frutu majore Mils. gard. diส̃. 1 . 3 .

Broad palma-cocco. GREW. mus. $\mu .203$. t. 16.

Mackaw-trie. jamaic. E collectione Bankfiana.

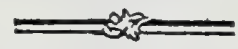

PER. Drupa globola, depreffiuscula, fubpollicaris, ftigmatibus tribus acuminatis feffilibus tcrminata; bafi munita calyce hexaphyllo: foliolis coriaceis, rotundatis: extcrioribus minuris. Cortex cratlius, coriaceus. Caro fibrofa, fucculenta, demum fungofo-coriacea, olliculo adnata. Putamen giobofum, fublenticulare, lapidcum, craîtum, ochraceo-fuscum, uniloculare, tribus ad latera foraminibus exfculptum, quorum duo carca, tertium vero pervium.

REc. nullum, femen foramisi pervio horizantaliter accumbens.

SEM. unicum, fubglobofum, prope foramen putaminis planiusculum aut ' leviter dęretlum, undique friis arcuatis reticulatum, fpadiceo-fuscum.

IN T. fimplex, membranaceum, tenue, nucleo arcliffime adnatum.

ALB. carnofum, oleofum, album, fubfriabile, intus cavitate exfculptum.

EMB. horizontalis, oblongus, lacteo albicans, e teretiuscula bafi, peripheriam refpiciente, in laminaın craftam, oblongan clongatus.

2.) Drupa integra, a parte fuperiorc, b. ) a parte iuferiore (pentata, c.) Putamen in fitu naturall. d.) Idem transverfe feftum, cum loculamento fertili, maximo, in medio, \& duobus aborivis ad foramiua coeca locatis, e.) Albuninis felio verticalis, cuna fitu \& magnitudine uaturali Embryonis. f. F.) Embryo, magnitudine naturali \& autha.

Obf. Embryonis fitu horizontali abunde a Cocco differt. 
C.

c 


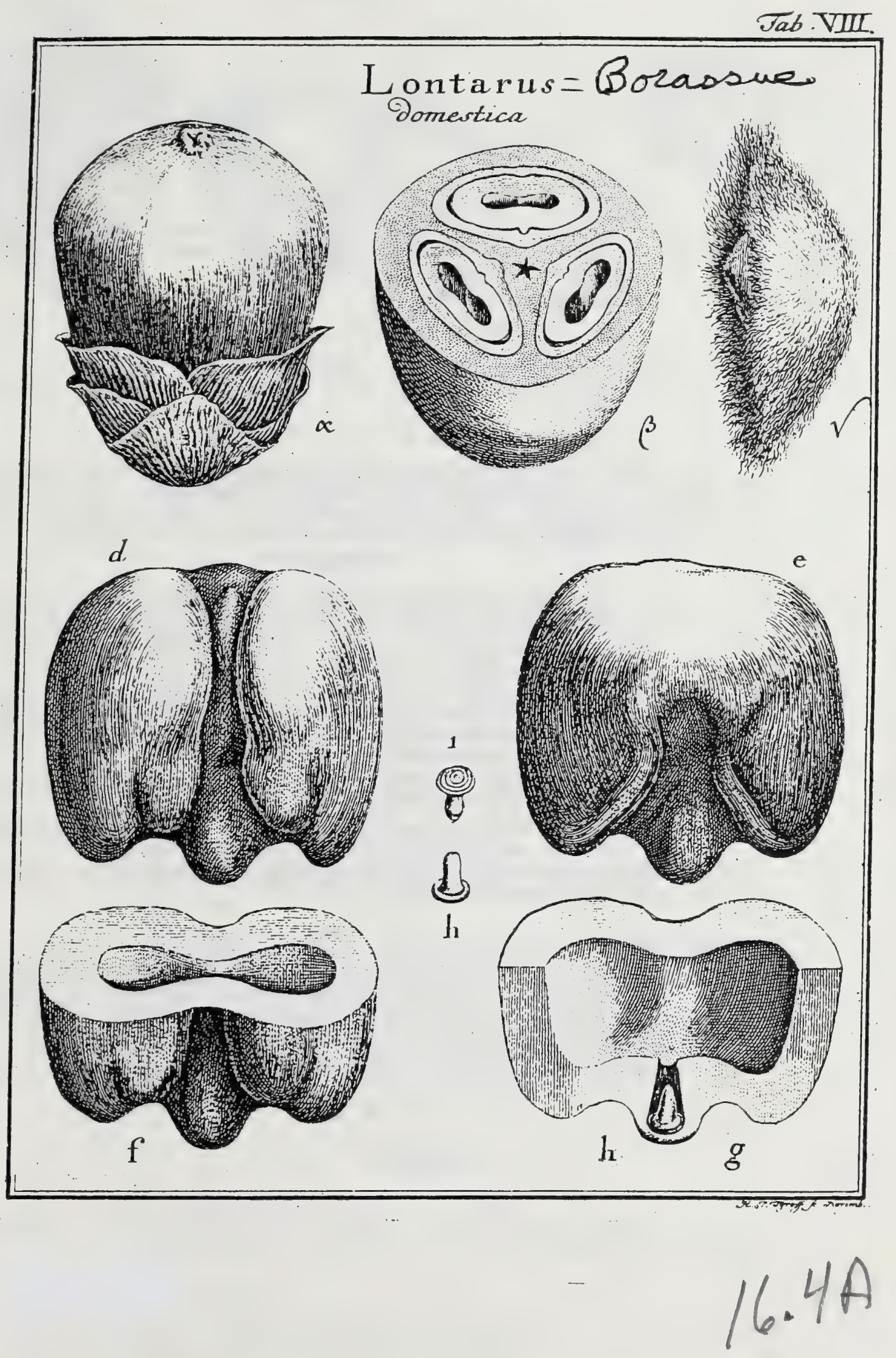




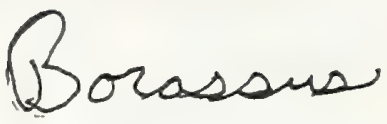

\section{J. Gaertner (1786j vol. 1}

\section{LONTARVS. ₹umpr. Boraflus. Linv. ger. 1220.}

Flores fexu diftincti in feparatis caudicibus. Spatha univerfalis. Mas. Cal, triphylios. Stam.fex. Fem. Cal. hexaphyllus. Cor. nulla. Bacca fuperz, tripyrena Semea lobaturn. Alb. cavum. Eunbr. in bafi ferninis.

LoN tarus domeflica. Tab. 8.

Ampana Ë Carim-para. Rнегd. mal. I. p. 11. 13. t. 9. 10.

Lontarus domeficr. Ruмpн. amb. 1. p. 45. t. 10.

Boraffus frondibus palmatis plicatis cucullatis, fipitibus ferratis. Lrwe. fys. veg. 984 .

E colledtione Bankfiana.

PER. Bacea fibrola, primum turbinata, triangula, deinceps rotunçato trigons, utrinque umbilicata, fupra tribus figmatibus fefflibus terminata, infra calyce grandi liexaphyllo, coriacio excepta, glaberrima, faturate caftanea, tripyrena Oificula Lignofa, dura, crafla, rnaguitudine circiter volx manus, fulrotunda, undique

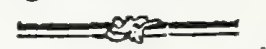

fibris capillaribus denfiltime crinita, line convexa, inde obtufiffime angulata \& in umbonem conicum producta, unilocularia, bafi foramine fimplici rotuudo pertufa,

REc. funiculus umbilicalis craftus, fibrofus, bafin finguli officuli intrans, fuisque fibris, per utrumque feminis latus difperfus.

SEM. in fingulo officulo unicum, grande, fupra craflius, obtufifiınum, indisifum, infra tenuius, trilobatum: lobis duobus lateralibus diftantibus rotundatis; tertio intermedio conico, embryonifero; catera, hine convexiusculum, inde fulco amplo longitudinali excavatum; helvolum, aut cimamomeum.

IN T. duplex: exterius fibrofo-furfuraceum, craflum, friabile; interius coriaceum, tenue, ferrugincum, arctisime a'linatum.

A I B. Semini conforme, cartiagineo-coriaceum, durum, tenacilimum, smpla cavitate in medio, atque alia mimore, in proceftu fuo conico, exfculptum.

E s в. ercctus, ex orbiculata \& concentrice ftriata bafi in conum faftigiatus, lactco albicans, feminis bafi immerfus.

๙.) Bacea immatura cum fuo calyce. $\beta$.) Setio transverfalis baccz maturx, naturall mulcoties minoris. $\gamma_{\text {.) }}$ Officulum Separatum, a latere (petatum. d.) Seminis jufta magnitudinis latus inter. num, fulco medio exfculptum. c.) Ejusdem latus dorlale. f.) Albumen transveric fefium. g.) Ejusdem figmenti featio vericalis, utramque albuminis cavitatem cum fitu embrjonis h. ) offendens, h.) Embryo ereftus, i.) Iden inverfus, cum orbiculo fuo concentrice fristo.

Boraffum, Elaten \& Spathan, fynonyma efle vaginx fpadicis inembranacex, docet DiosC. L. 1. C. 150. 


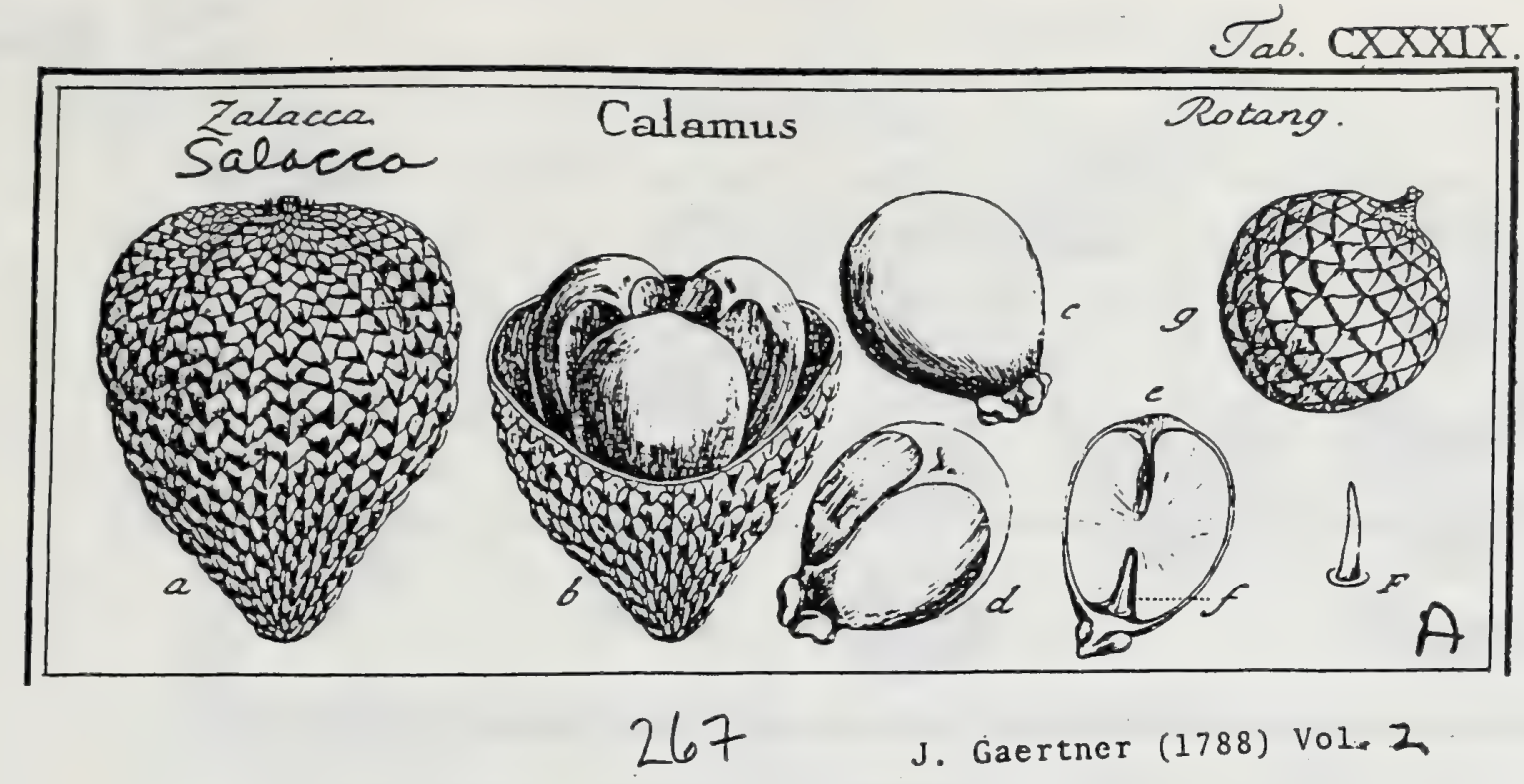

\section{C A L A M U S. LINN. gen. 436.}

Flores omnes hermaphroditi. Spatha communis nulla; partiales vagxe. Spadix ramofus. Cal. hexaphyllus: foliorum ferie duplici; exteriore breviore. Stam. fex. Ovar. unicum. Styl. conicus, apice trifidus. Bacca loricata, unilocularis, trifperma. Embryo in feminis bafi.

Calamus Zalacca. Tab. 139. fig. I.

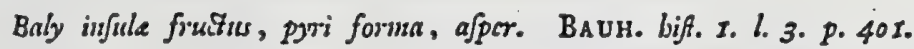

Zulucca f. Rottang zalack. RUMPH. amb. 5. p. 233. t. 57. f. 2.

A Cl. Thunberg.

PER. Bacca grandiufcula, turbinata, a vicinarum preffione varie angulata \& gibberofa, fcutellis retroverfis loricata, e fpadiceo-rufefcens, unilocularis, primum pulpofia, demum exfucca. Cortex tenuis, chartaceus, tectus icutulis lubcartilagineis: fupremis erectis linearibus; reliquis omnibus appreffis, deorfum imbricatis, fubcordatis, linea media elevata notatis, atque apice fubreflexis, ut bacca ad tnctum afpera fit. Caro pulpofa (aurantiorum carni finilis, nec tamen veficulofa Rumplo) per xtatem penitus evanefcens.

REc. nullun; femina fundo bacex affixa.

SEM. tria, duobus plerumque aborticntibus, baccata, fubglobofa, hinc convesa, inde angulata, lobulo umbilicali fungofo craffo fubcordato inferne appendiculata.

IN T. tripłex: extimum pulpofum, (grati uvarun mofchatellarum faporis Rumpls.) denum exarefcens; medirm cruftaceum, tenuiftrmum, proceffum fubula. tum corncum intra albuminis canalem verticalem demittens; iutinsun membranaceum, e luteo - rufefcens, arctilime adnatum.

A I B. Femini conforme, coriaceo-cartilagineum, nivcum, fuperne canali idfundibuliformi a vertice ad medium ulque perforatum, inferne autem cavitate oblonga conica, pro embryone, exfculptum, cetera folidum, nec ruminatum.

EM B. morocotyledoneus, fubulatus, lacteus. Rad. retura, orbiculata, in!era.

$\approx 68$

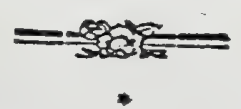

2.) Bacen integra. b.) Eadem difTedr, cum fitu (cminum, c.) Semen z dorlo - \& d.) idem

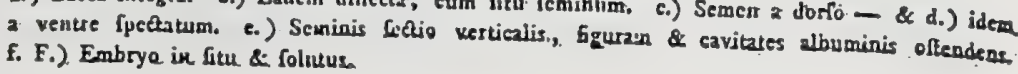

\section{Calansus Rozang. ibict.}

Palmjzonces calupparizs. RUMPH. ant. 5. p.97. t. 5t.

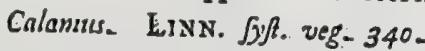

E eolfect. fem. hort. lugdt.

Bacca magnitudine globi fclopetarii najoris, fphxrica, fuperne in mucronem conicum., apice trifidum, praducta, ferrugineo-fpadicea, loricata. Satramis car tilagineis, crafis, quadrangulis, linea media depreff notatis, glabris, nec
tamen fplendentibus. Semina defuerunt. 


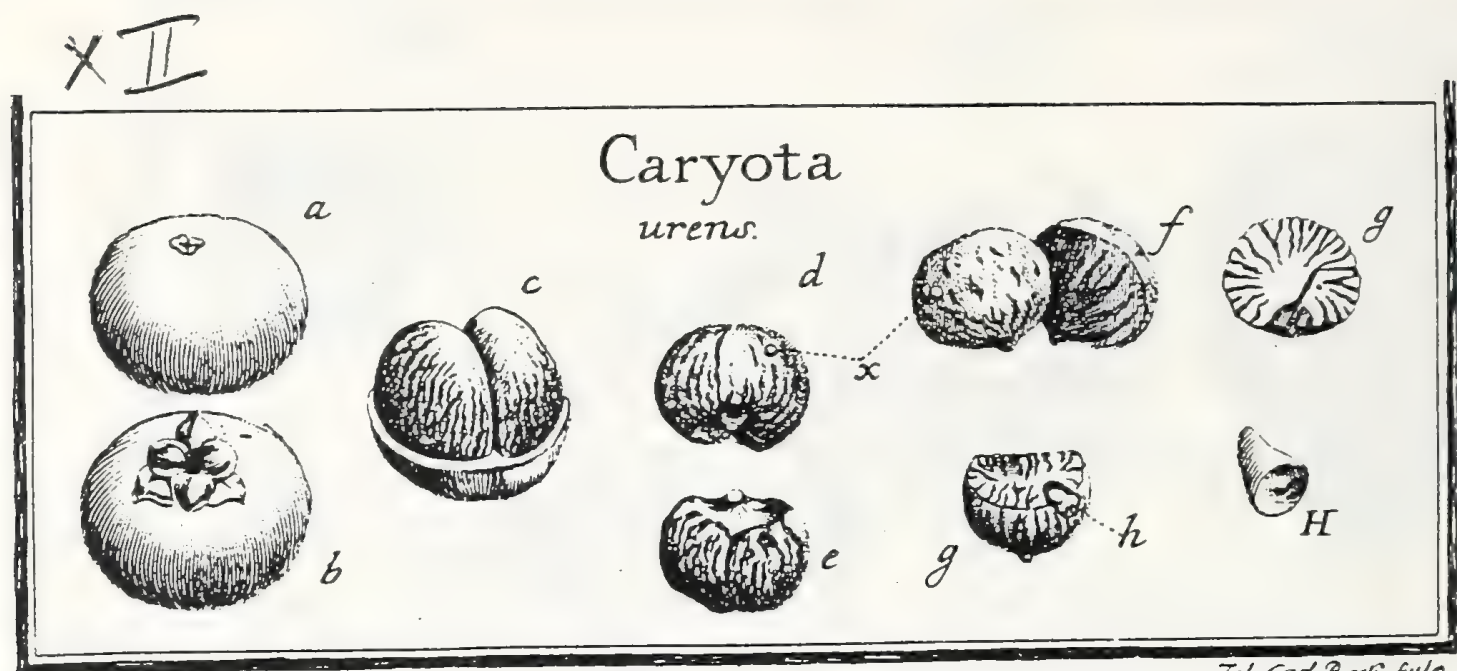

J. Gaertner (1788) Vol.1

\section{0}

XXV. CARYOTA. LINT. Gen. 1228.

Fiores fexu diflineti in feparatis fpadicibus ejusden caudicis. Spatha univerfalis. Mas. Cal. hexaphyllus. Stam. plurima. Fens. Cal. hexaphyllus, Cor. nulla. Bacca fuperz, unilocularis, difperma Alb. ruminatum. Eubb, in dorfo femimis.

САвхОтА uRCR. 'I'ab. 7. fig. 3 .

Scinunia-paua. RHEеd. mal. r. p. I5. t. It.

Seguafer major. Russp. amb. I. p. $\sigma_{4}$. t. I4.

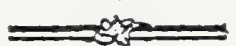

Coryota frondibus bipinnatis: foliolis cunciformibus oblique pramor/is. Lins. Jyff. veg. 986.

E collect. fern. bort. lugdb.

P E r. Bacca fucculenta, globofa, depreffiuscula, ftigmate gemino, triangulari, adnato, terminata, nigricans, unilocularis. Caro tenuis, fucco, in recenti fructu, acerrimo, urente.

REc. nullum: femina bafi, umbilico fuo roftellato affixa.

$S E$ E. rarius unicum, fubglobolum; frequenter duo, fubrotunda, hínc convexa, inde plana, bafi in mucronem brevem umbilicalem producta, rugofa, e cinereo nigricantia, papilla minima pallida, fupra medium dorfi, infignita

IN T. funplex, crufaceum, plicis fuis atque proceflibus lamellofis internis arctifine cum albumine connatum.

$\Lambda$ Lв. cartilagineum, durum, ruminatum, ex albo \& ferrugineo varium, in medio folidum, ad peripherian dorfi parva cavitate pro embryoue exfculptum.

Esв. monocotyledoneus, conicus, parvus, lacteo albicans, dorfalis: Rad. obtufa, peripheriam refpiciens.

a. b.) Baccz facies prona \& fupina, c.) Situs feminum in bacea transverfe fete. a) Semen folitarium, fubglobolum, fuperne, \& e.) Idem inferne fpetatum. f.) Semins doo, plano convexa.

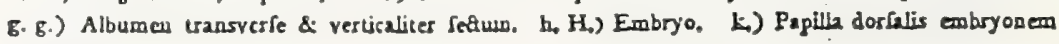
obtcgens. 


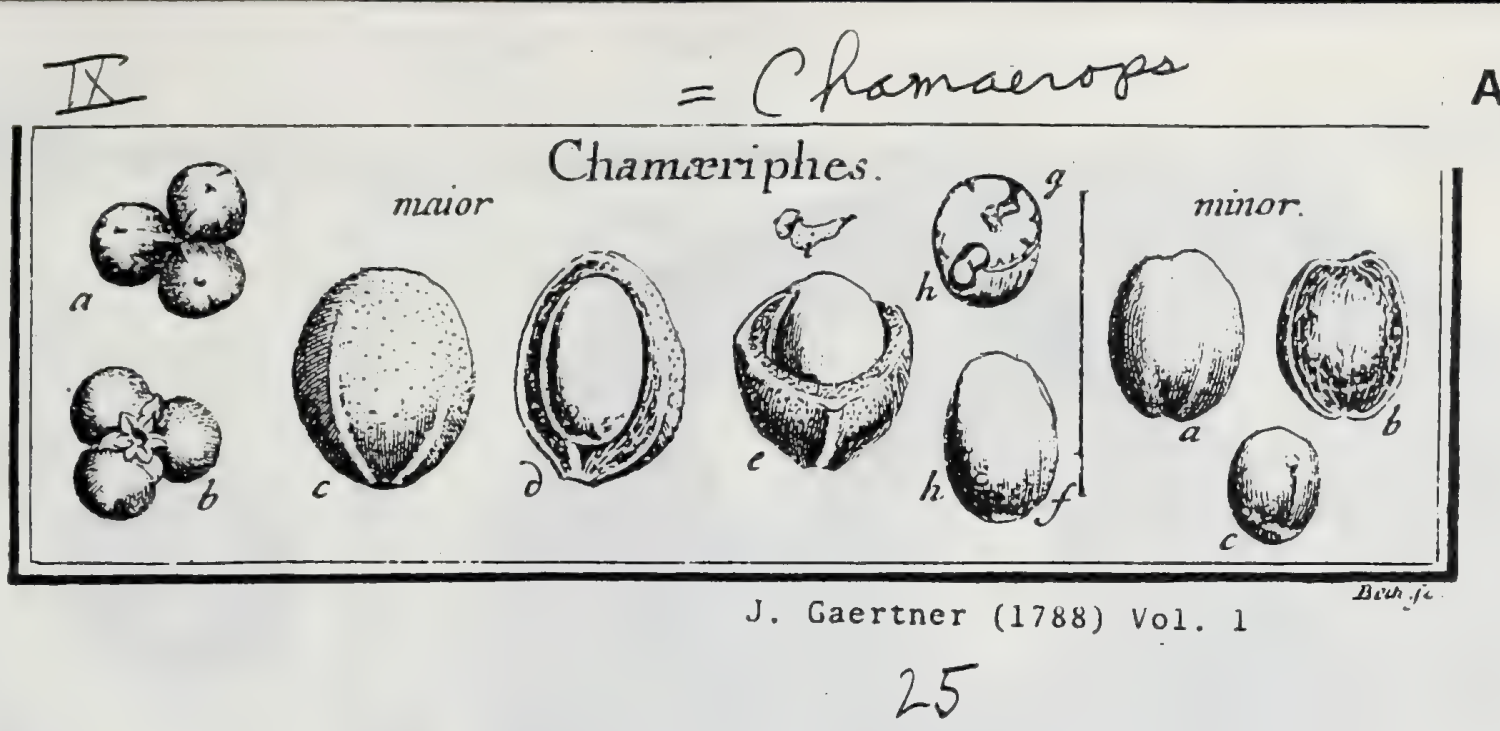

\section{CHAMERTPHES. Ponted. Chamzrops. Linn. gen. zizg.}

Flores androgyui \& mafculi, nunc in uno communi, nune mafculi foli in feparato caudice. Spatina univer'alis, bifida. Calyx utrisque hexaphyllus, Corolla androgynis tripetala, calyce longior. Stam. fex ad novem. Baccz tres, fuperx, uniloculares. Albumen ruminatum. Embryo Lateralis.

\section{6}

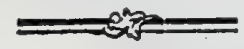

CमAM ERIPнаs major. Tab. 9. fig. 4.

Chamariphes. DO D. pempt. 820.

Palma humilis f. Chamariphes. B А v H. hifl. I. p. 370.

Chamariphes tricarpos fyinofa, folio flabelliformi. PON T E D. anthol. p. 147. t. 8 - 10. bene.

Chamarops frondibus palmatis plicatis, fipitibus fpino/is. Li N N. Jyf. veg. 984.

PER. Baccx tres, uniloculares, ovato globof $x$, inferius rotundato trigonx, c cananeo rufefcentes, punctis elevatis, callofis, pallidis confperfx. Cortex tenuis, fubcoriaceus. Caro craffiuscula, fibrofa, a femine difcreta, in vetuftis fruclibus, fuberofo- coriacea, dura, inodora.

R'EC. nullum. Semen fundo baccx late adnatum, ut ejus bafis quafi derafa.

SÉM. unicum, elliptico-Sphxroideum, glabrum, fpadiceo-rufcicens, aut teflaceum̄; papilla exigua Laterali, infra medium fux Jongitudinis notatum.

IN T. cruftaceum, procelíbus fuis intra fubltantiam nuclei receptum; cidemque ardifilme adnatum.

A L в. cartilagineum, duriflunum, grofto ınodo ruminatum, ex aquco-albicante \& ferrugineo variun, in medio folidum.

Е м в. conicus, fubaduncus, candidifiuzus, lateralis.

2.) Ovariz immatara, a paste fuperiore fpeftata. b.) Eadem inverfa, calyce \& corolia perfiftentibus munita. c.) Bacca matura, intrgra. d.) Eadem verticaliter fefta, e.) Ejusdem feftio transver(alis. f.) Sement desudatum. g-) Albumen transverfe fefum. h. h.) Papilla embryouem obtegens. i) Embryo folutus.

С н A MERIPHES minor. ibid.

Ex horto Carolsruhano.

Baccx cylindrico ovatx, Zizyphi baccis forma \& magnitudine (a) xmulx, carnolx, glaberrimx, crocex aut fulvx. Culticula tenuiffima. Caro mollis, etiam in vetufto fruclu digitorum preffioni facile cedens, \& tunc fuboleofa, rancidum butyrum redolens, intus fibrola (b), femini undique adna:a. Scmen brevius \& rotundius, quam in prxcedenti, duplici papilla (c) notatum: altera fuperiore, prorfus folida, altera inferiore, minore, embryonitega. bafis feminis dcrafa \& umnia reliqua ut in procedenti.

Hic fructus ef ex Chamzriphe, proprio fuo polline focundata, fatis quidem a priori diverfus, nec tamen pro diverla fpeciei fatu habendus.

Quid Chamxinps a Chamxriphe diliet? liquida docent Ptinil verba, quando inquit: Chanaropi funt myrtea circa caulem gemina folia $\mathcal{E}^{\circ}$ cajitula gracula rofa. L. 26. fect. 27. \& irerum - illa etiam alio nomine dicitur Chamadrys É latine Trixago. L. 24 . fect. 80. 


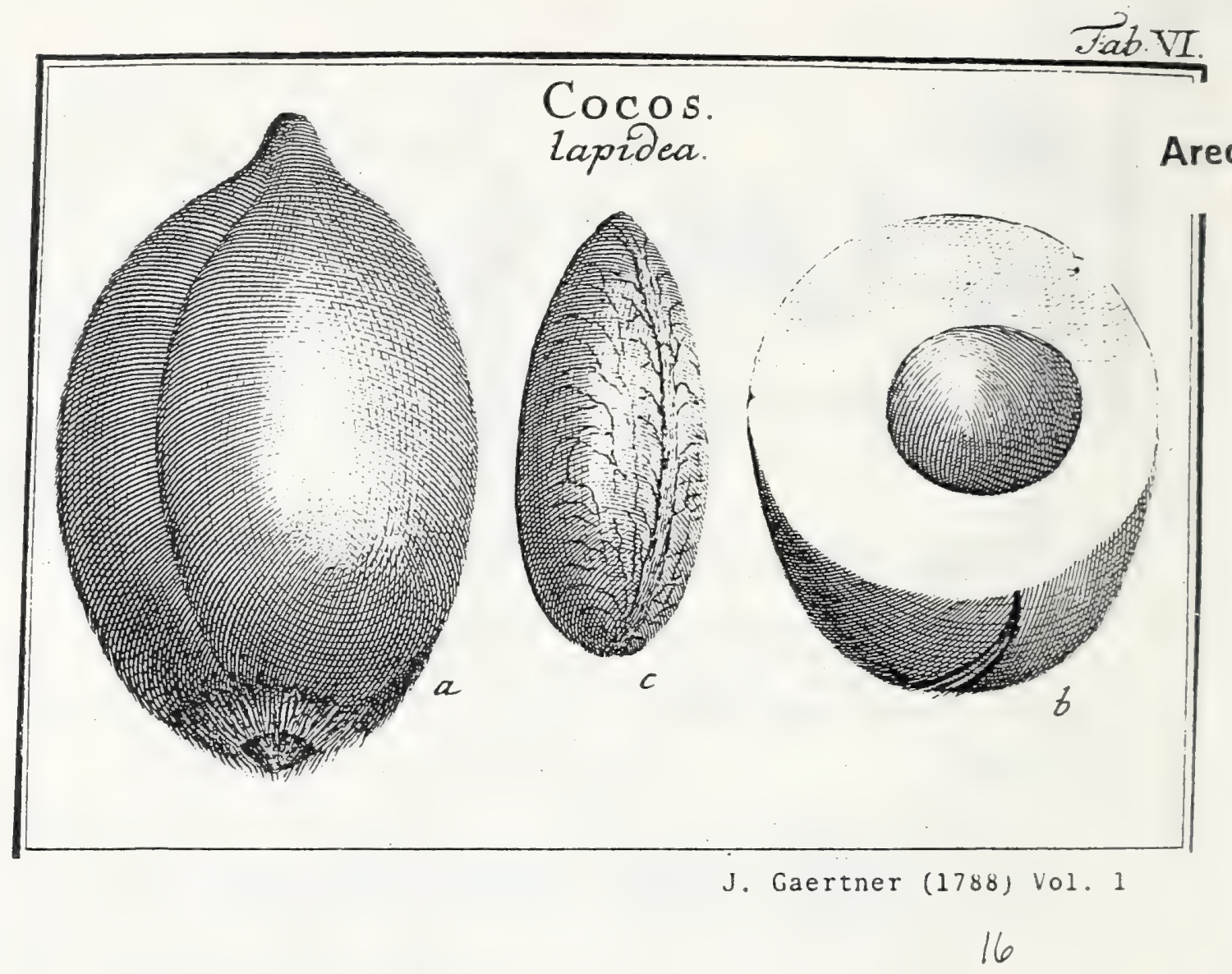

Coccos lapidea. Tab. 6. fig. \&.

Drupa ovata (a), magnitudine ovi anferini, 1. \& duplo major, apice in mucronem brevem, mammillarem producta, bafi in pyramidem trigonam, tribus for2minibus flipatam fafligiata, \& ad latera tribús linturis fifuriis, depreffis infcripta, glabra, nigro fusca. Cortex crultaceus, tenuiltunus, putamini ardilline adnatus.

Caro nüla, prater paucam fubnantiam fungofam inter fibras rigidilimas, in quas cortex circa bafin fructus folvirur. P̈stamen a cortice non difcretum, duriftunum, craftefimum (b.), unico loculamento angufto, exceutrico exfculptum. Semen (c.) unicum, figura \& inagnitudine loculaınenti, fasciâ \& vafis arcuatis, ut in pracedenti fpecie pictum, nigro-fuscum. Albuminis \& embryonis ftructura, prorfus ut in antecedenti.

Ex hac nuce, fibulx, Scipionum capitula \& alia utenfilia fabricantur, ut mirum fit, quod nulla ejus in botanicorum \& peregrimatorum feriptis fiat mentio, \& vel ipfa ejus patria adhuedum ignoretur. 


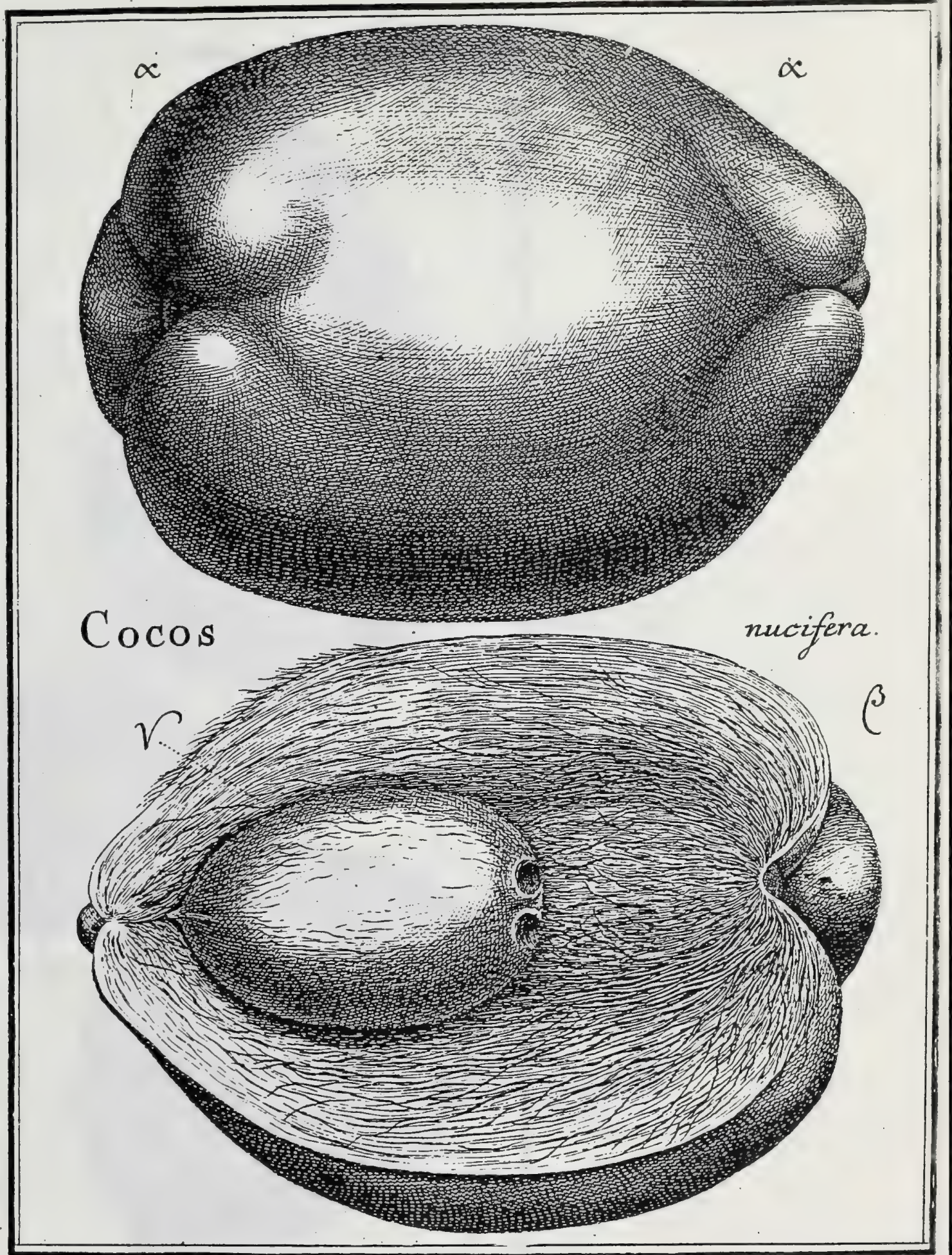

सम्युज्ञgy

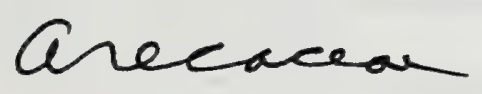

\section{$16.9 A$}


Jab. V

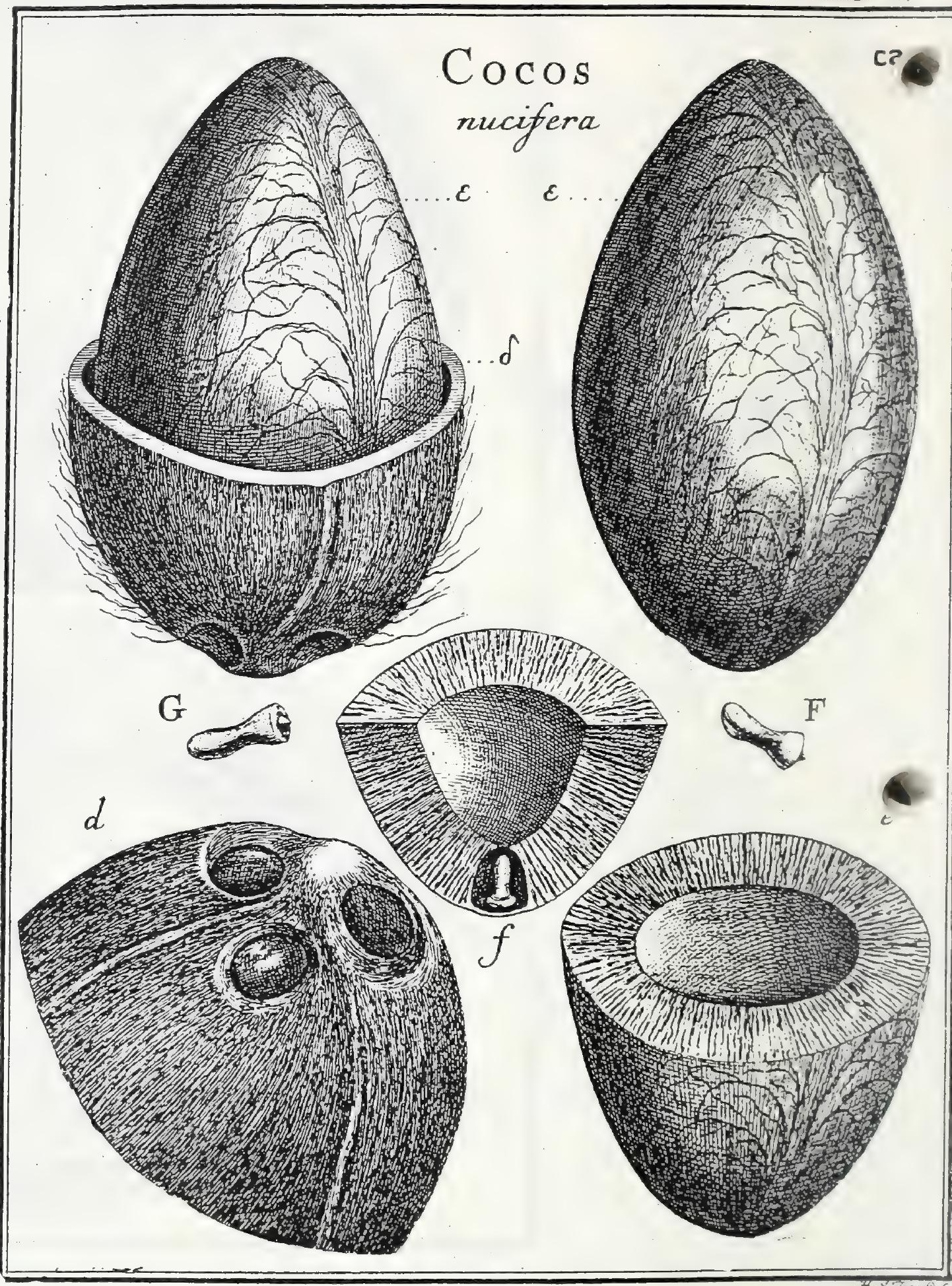

Arecaceare

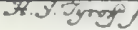

\section{$16.9 B$}




\section{J. Gaertner (1788) Vo1.1}

\section{COCCOS. LiNx. gen. Isะ3.}

Flores fexu difingi in codern fpadice. Spatha univerfalis. Mas. Cal. hexaphyllus. Cor. nulla. Stan. fex. Fras. Cal. hexa;)y.llus. Cor.nulla. Ovarium triloculare. Drupa fupcra, baccata unilocularis. Alb cavum, grumofum. Embryo in bafi fcmisis.

Coccos nucifera. Tab. 4. 5.

Tenga. RHeEd. mal. I. p. I. t. I - 4. opt.

Calappa. 'Rимвн. amb.'T. p. I. t. I. 2.

Coccos $\mathbb{N}$ Nux indica. BesL. mus. p. 19. t. 5. GRew. mus. I5.

Cocos inermis, frondibus pinnatis: foliolis replicatis enfiformibus. LiNs. $\int y$ f. veg. 985. Jace. hij. t. 168 .

PER. Drupa fupera, baccata, maxima, ovata, rotunde trigona, utrinque umbHlicata, fulva, aut rubicunda, demum helvola. Cuticula tenuis, tenaciltuma. Caro fibrofa, in vetufto fructu fungofa, vinum redolens. Putanien ofleum, ovatum, triquetro acuminatum, tribus futuris fpuriis elcvatis notatum \& ad bafin tribus foraminibus, atro tympano claufis inftructum, uniloculare, evalve, nigro fuscum.

REc. nullum: femen bafi affixum.

SEM. unicum, cavitati putaminis conforme, Ipadiceo rufescens, vafis numerofiftumis, arcuatis, e fascia laterali, longitudinali oriundis, pictum.

IN T. finplex, coriaceum, tenue, intus glabrum, \& de recenti femine facile Secedens.

A ८ B. amygdalino - carnofum, album, ex innumeris trabeculis virgatis, \& demum inter fe coalescentibus contignatum, extus rimofum \& fubruminatum, intus duplici cavitate exfculptum, quarum altera, in medio, maxima, \& in recenti feınine, lymplıa dulci plena; altera vero in bafi, embryonem includens, priori multuties minor.

Es B. monocotyledoneus, oblongus, erectus, niveus. Plum. ovato ohlonga, conpreffiuscula, verfus bafin attenuata. Rad. conica, extus apiculata, infera.

a.) Drupz, naturali dimidio minor. $\beta$.) Ejus feltio longitudinalis cum putamine integro (quod autem in medio fruetu pofitum efle deberet). $\gamma_{0}$ ) Putamen, mediantibus fithis capillaribus, carni undique affixum. E.) Idem transverfe fettum. d.) Ejus basis, cuin tribus fuis foraminibus, typano claufis, naguitudine naturali. €. ๕.) Semen, naturali paulo minus. e.) Ejus fcaio tranısverfalis. f.) Embrjo intra cavitaten albuminis minoreni. F. G.) Embrjo (olutus.

Putamen trivalve dicunt Grewrus, Liss.eus \& Jaccusx; fed contrariun docent avtuplia \& pocula e Cocco tornata. 


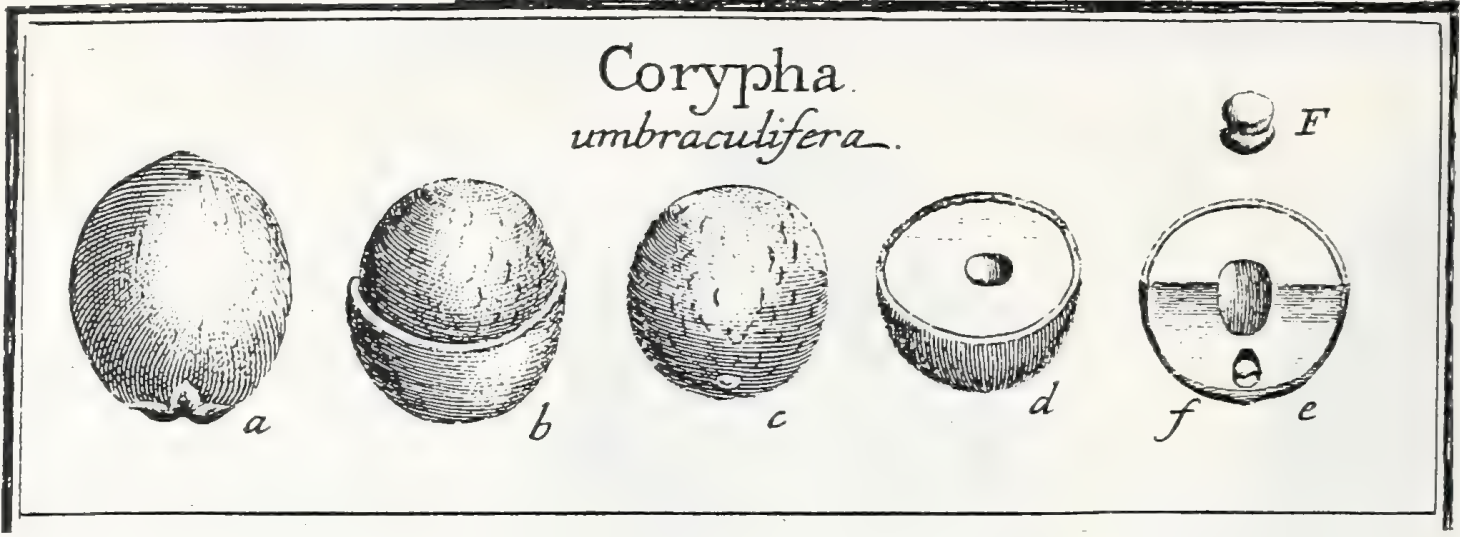

J. Gaertner (1788) Vol.1

18

XXIII. CORYPHA. LINN. gen. 1221.

Flores hermaphroditi, hexandri. Spatha univerfalis nulla. Cal. hexaphyllus. Cor. nulla. Bacca fupera, monosperma. Alb. cavun, cartilagineum. Embryo in bafi feminis.

Cок у вна umbraculifera Tab. 7. fig. I.

Coláa-pana. Rherr. mal. 3. p. 1. t. I- 12 .

Sar:birs. Ruмrн. amb. 1. p. 42. t. 8 .

Corypha frunaibus pinnato-palmatis plicatis frloque interjeftis, fipitibus ciliato finofis. 1.x.x. Jyjl. veg. 984 .

E collect. fcm. hort. lugdbat.

PER. liacca fpharica, aut ovato-globofa, carnola, nigra, unilocularis. Cuticula tenuis, memb:anacca. Caro pauca, mollis, fubpuguis, friabilis, fennini adhareas.

REC. nullum: femen carni sisnatum.

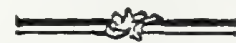

SEM. unicum, grande, globofum, obfolete rugofum nigro-fuscum, bafi, papilla rufescente, parva notatum.

IN T. duplex: exterius cruftaceum, durum, crafiiusculum; interius membranaceum, rufescens: utrumque arctinime adnatum.

AL . Comini conforme, cartilagineum, album, cavitate cylindrica, brevi in medio exfculptum.

E s. monocotyledoneus, fubcylindricus, brevis, in medio coarctatus, utrinque obtufus, lacteus albicans, bafi ferninis intra papillam immerfus.

a.) Bacca integra. b.) Eadem transterfe ferta, cum femine in fitu naturaith c.) Semen denodatum, d.) Ejus feftio transverfalis. e.) Ejusdem fegmeuti fetio verticalis, duplicem albuminis cavitatem cum enbryonis fitu \& figura oftendens. F.) Enibryo feparatus.

Cruflaceum feminis integumentum, non poteft pro Putainine, adeoque nec pericarpium, pro Drupa haberi; quia crufa hxc, ipfan illam papillam format, qua embryo obtegitur. 


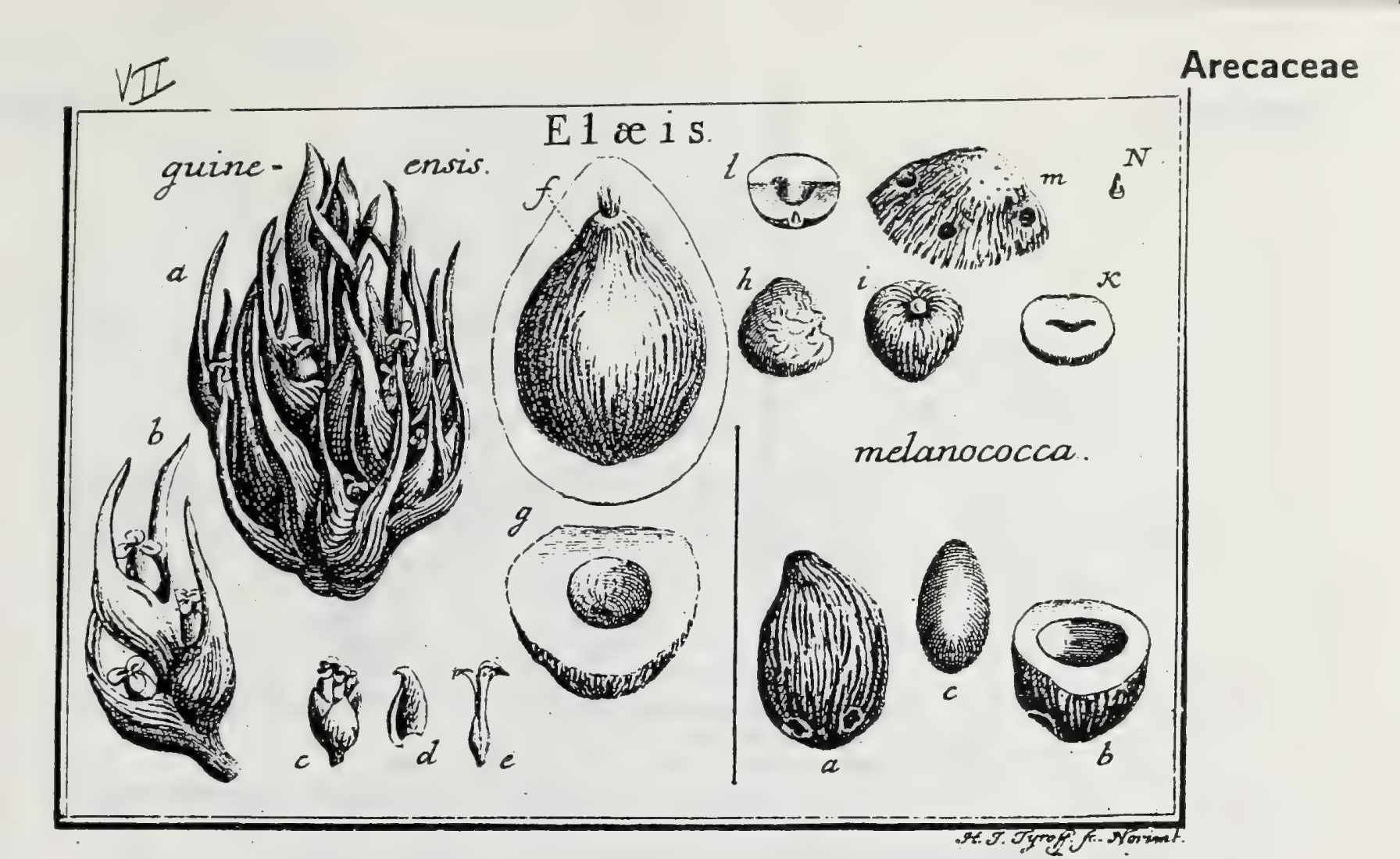

$$
16 \cdot 1 / A
$$


Flores fexu difincti in feparatis truncis. Spatha univerfalis nulla; partiales ventricofx, Itriatz, roftratx. Mas. Cal. hexaphyllus. Cor. Sexfida. Stam. Sex. Fem. Cal. enneaphyllus : foliolis interioribus longioribus. Cor. nulla, nifi caljycis partem velis. Ovarium triloculare; ftylus craflus, triquerer; nigmata tria refexz. Drupa fupera, baccata, unilocularis. Alb. cavum, friabile. Einbryo in bafi feminis.

E. L IS guineenfis. Tab. 6. fig. 2.

Nucula indica fecunda. Crus. cur. p. m. 85. c. ic.

Palina foliorum pediculis jpinofis, fruktu pruniformi luteo oleofo. SLOan, hifl. jam. $113 . t$. 214 .

Elais guineenfis. JACC. hift. 1. \%. 280. t. I7̧2.

Elais frondibus pinnatis, flipitibus dentato fpinofis divergentibus: denticulis fupremis recurvatis. LINN. fy/f. veg. 985 .

E collectione Bankfiana.

Per. Drupa baccata, ovata, glabra, lutescens. Cortex tenuis. Caro crafta, oleola, fibrola: fibris rigidiusculis, putanini aretiflume adnatis. Putamer ovatum, fupra coarctatum, infra tribus foraninibus: uno pervio \& duobus coccis, perforatum, obfolete trigonum, rugofum, Japideum, craffum, luteo-ocliraceum, uniloculare, evalve.

REc. nullum: femen bafi affixum.

SEs. unicum, globofe conicum, fubtus umbilicatum atque media papillula immer $\int_{2}$ nipatum, firiis arcuatis deprefits reticulatum, fpadiceum, aut cinereo-fuscum.

IN T. fimplex, nombranaceum, tenue, arctiflune adnatum.

$\Lambda\llcorner$ в. camofum, fragile, oleofum, angufta cavitate transverfali in medio exfeulptum, non ruminatum.

Ess. monocotyledoneus, parvus, conicus, lacteus, in papilla bafeos ferninis intra propriatn cavitatem locatus.

2.) Pars Spadicis feminel florescentis. b.) Ejusdem portio feparata cum floribus, intra Tpatsie partiales veutricofas, friatas, longe rofratas, fefilibus. c.) Flos femineus feparatus; foliolis tribus exterioribus latioribus, oyatis ( d.) colteavis, brevibus; fex interioribus anguftioribus, longioribus, apice reflexis, cocra vero priorihus confiftentia finillinis. e.) Ovarium iminaturum, cum ftylo \& figmatibus. f.) Jutamen niaturum, linea extra peripheriam circumferiptum, quá drupa integre forma indiginatur. f.) Idem transverfe feltım. in.) Ejusdem bafis, cun tribus fuis foranuinibus. h. i.) Sencu a partc fuperiori \& iufcriori fpeftatum. k.) Albumeu transverfe fctum, cam cavitate fuz nedia compreffa. 1.) Ejusdem leguenti foctio veruicalis, cuin fitu embryonis intra papillam bafcos. N.) Eimbrjo (cparatus.

Figura \& magnitudo drupx in variis, varia eft. Sunt, qux pyri minoris magaitudinem aliecquuntur, ut noftra; aliz funt pruniformes; alix ovato oblongx \& utrinque attenuatx, qualem Jaceurivus habet; funt \& alix, vix Oliva lifpanica inajores, tefte MílLero in gard. lex.

ELEIS melanocacra. ibid.

Nux indica velut larvant ofendens. ВАบн. hifl. 1. p. 38.7. f. т. 2.

Nux indica larvata. Јонмsт. dendr. tab. 48 .

Prxcedentis mera forfan varietas; differt: Putanine (a) multo minore, nec ita ventricofo, fed potius oblongo \& ad apicem fubito in mucronem obliquum contracto. Craflities quoque teflx (b.) huic minor eft \& fuperficies externa, frris teflaceis, irregulariter confluentibus, cum aliis fimillimis, fed anthraciuis, alternantibus, egregie variegata. Fractura fuligineo atra, nec ut in pracedenti, pallide ochracea. Semen (c.) ovato oblongum, fuscuin. 


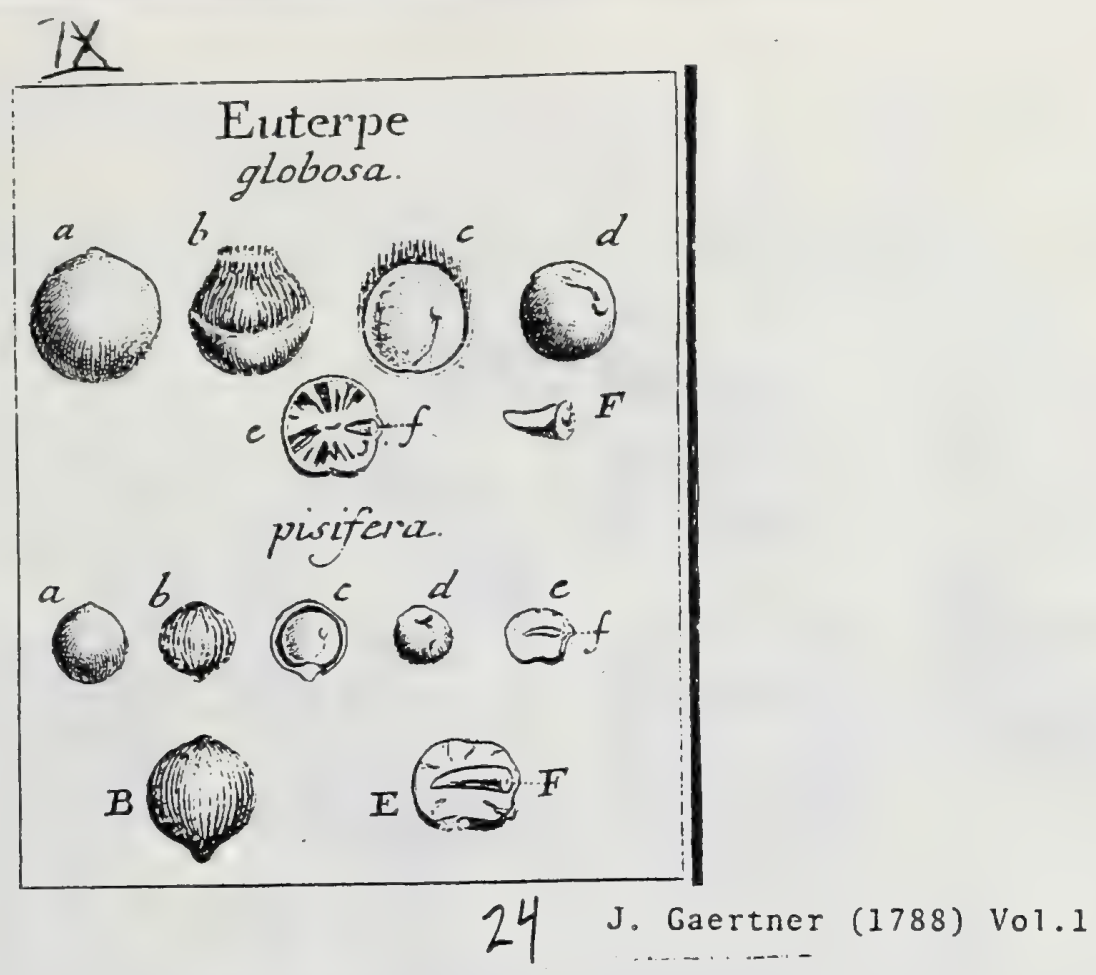

\section{EVTERPE.}

Flores fexu diflincti in eodem fpadice. Spathx partiales, fingulis foribus fubjectx: Bacca fupera unilocularis, monofperma Albumen ruminatum. Embryo Lateralis. E U TERPE globofa. Tab. 9. fig. 3.

Pinanga fylveftris globofa. Rumph. amb. r. p. $38 . t .5 \cdot f \cdot$..$A$.

PER. Bacca fphxrica, cum brevi acumine ad apicem, glabra, unilocularis, femipollicaris, interdum vix magnitudine pifi majoris, fpadiceo fusca. Cuticula tenuis,

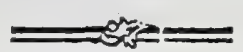

coriacea. Caro pauca, per maturitatem-tota in fibras fecedens: fibris intinis in tunicam loculamenti chartaceam, tenuiffinam, pallidam, connatis.

REc. fusiculus brevis, femini adnatus, e fundo loculamenti ad papillam cjus lateralem adfcendens.

SEM. unicum, bafi adnatum, fphaxicum, ftriis depreffis, arcuatis, reticulatum, cinereo fuicum: bafi notatum area umbilicali oblonga, depreffiuscula, \&. fupra hanc in latere, papilla exigua, embryonem obtegente.

IN T. fimplex, cruftaceum, introrfum proceffibus auctum, a nucleo non folubile.

$\Lambda$ L B. cartilagineum, ruminatum, ex albo \& ferrugineo varium, in medio plerumque cavitate compreffa exfculptum.

Ex B. parvus, conicus, lacteo albicans, horizontalis, in latere feminis medio hxrens.

2) Bacca integra, medix magnitudinis. b.) Endem, per maturitatem fponte in fibras dehifcens. c.) Ejusdem fetio longitudinalis, cum feniue in fitu naturali. d.) Semen inverfum, aream umbilicalem exhibens. c) Ajbumen verticaliter (actum, f.) Embryonis fitus \& magnitudo aaturalis. F.) Idem folutus \& 2uttus.

E U T ERPE piffera, ibid.

E collect. fem. hort. lugdb.

Bacca fphzrica (a), fuperne in apicem brevifinnum producta, magnitudine Pifi communis. Cortex tenuis, crufaceus, fragilis, in vetuftis fructibus plerumgue fponte abfcedens, Caro fibrofa, inferne quari in pedunculum (b. B. c) producta: fibris non dehifcentibus, fed rigidis, craftis, extus in frias longitudinales elevatas, intus vero in tunican loculamenti propriam (c); crufaceam, Ixvigatam, faturate callaneain, conferruminatis. Semen (c. d.) fubglobofum, pallide lutefcens, laxo friarum reticulo inlcriptum, fovea umbilicali, in media baff (d), atque ex ea, fulco ad embryonis fedem adfeendente (c) exaratum. Integumeatum tenue, nembranaccum, folubile. Albumen (e. E) cartilagineum, album, prope peripheriam parce ruminztum. Embryo (t. F.) tereti attenuatus, horizontalis, dimidio fenine transverfo paulo longior.

Obf. Differt Eutrepe ab Areca, ficuti Bactris a Cocco, fitu nempe embryonis laterali. Etram in fpadicis forma, ingens invenies difcrimen, $\mathbb{G} R$ U M P H U M I. $c$. - confulere velis. 


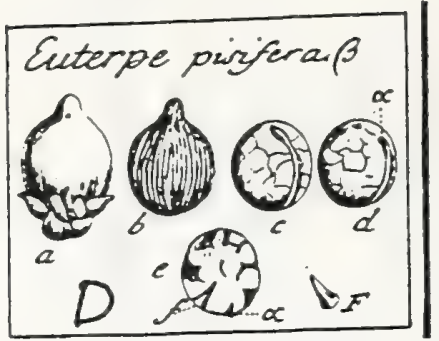

$$
\begin{gathered}
\text { J. Gaertner (1788) vol. 2 } \\
268
\end{gathered}
$$

\section{EUTERPE. Conf. Vol. I. p. 24.}

Euterar pilifera $\beta$. Tab. 139. fig. 4 .

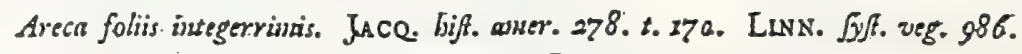
Chon palmifle. gall. A Cl. Hermann. Pr. arg.

Cnlyx hexaplyyllus, foliolis coriaceis, nitidis: interióribus majoribus, apice plicato-tridentutis. Bacca (n) ovato-mucromatn, glaberrima, gitva: Loculamenti membrana (b.) chartscea, ftriis longitudinalibus fulcis exarnta, cetera vero extus atque intus pallide albicans. Semen (c. c.) elliptico-globofum, glaberrimun, ex albo. \& teftaceo eleganter marmoratum, a bafi $(\alpha . d$.$) , ad$ apicen (c) fulco umbilicali elevato, pallido,-infcriptum, \& retro bafin, papillula embryonitega deprefa in infimo dorfo notatum. Albumen (e.) cartilagineum, ex albo \& ferrugineo prope peripheriam pulchre ruminatum. Embryo (f. F.) conicus, dimidio femine brevior, fubbafilaris, nec horizonltalis, ut in varietate $\alpha$.

Figura c.) Semen in fita naturali, f. exectum, altera vero d.) ident inverfum fiftit; atque $\alpha_{-}$) principium fulci umbilicalis denotat.

Propius hxc, quam prior Euterpes piffere varietas ad Arecam accedit; differt tamen manifefte: fulco unbiticali in altero latere feminis; atque embryoue: excentrico.

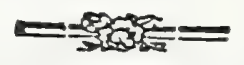

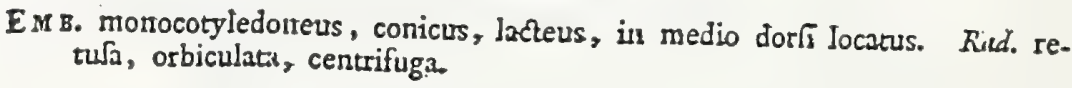

a.) Drupz iutegra. b.) Putamen a parte fuperiore - \& c.) idem penitus denudatum. I.) Ejus(E.) Eedio trasverfalis. e) Seminis latus ventrale. f.) Ejusdeun pars dorfalis, cum papillula. (E.) embryonitega L) Albumen transverfe featum. (I) Embryonis Gitus \& figur. 


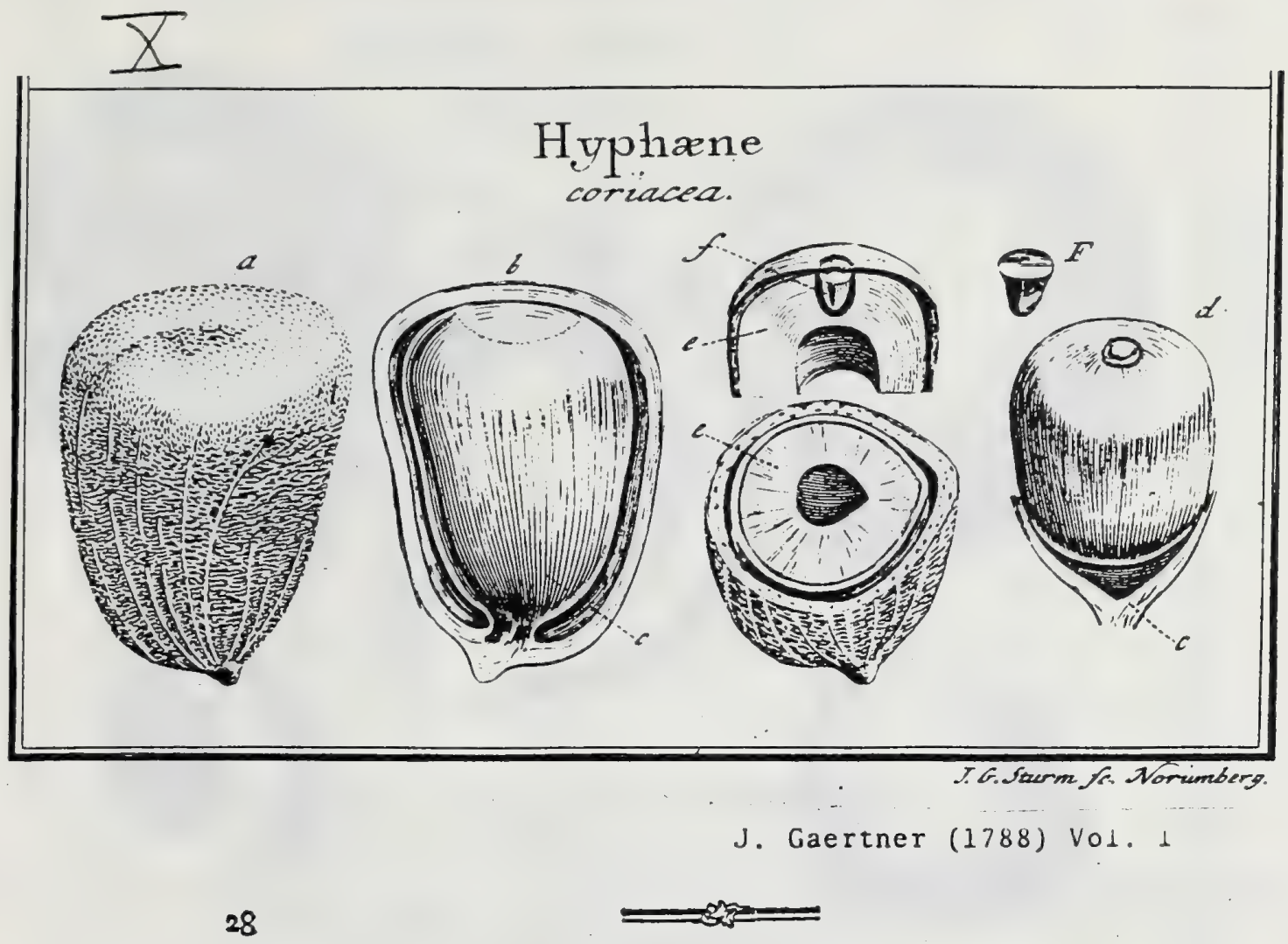

XXXII. HYPHENE.

Flores .... Spatha .... Bacca fupera unilocularis, monofperma. Albumen in me. dio cavun. Embryo in vertice feminis !

HY Р С Е E coriacea. Tab. 10. fig. 2.

Palma-pinus coccifera, nucibus amplis pyriformibus, furculis velut in racenum rariorem appenfis $\mathrm{PL}$ U $\mathrm{x}$. phiytogr.t. $300 . f .5$.

Nuci-daftylus. GrE w. mus. p. 204. t. 16. f. 1.2.3.

PER. Bacca turbinata, ad alterum latus angulo prominulo carinata, unilocularis ferrugineo fufca. Cuticula extima inembranacea, tenuis, glabra. Cortex craflus, coriaceo-fibrofus, totus miro artificio contextus e fibris corneis, tenaciffunis: aliis longitudinalibus, craffioribus, rectiusculis; aliis vero transverfalibus, ad angulos rectos e prioribus oriundis, tenuioribus, implicatis \& tandem in fetas flexiles $f$. tomentum rigidiusculum abeuntibus. Caro fungofa, tenuis, apice \& bafi cum curtice coslita, alibi vero difcreta $\&$ in vetuflo fructu luteola $f$. helvola.

REC. nullum. Semen vertici baccx late adnatum \& ex eo penduluin.

$S$ E.s. unicum, grande, cylindrice globofum, ex altero latere angulo obtufo notatum, in vertice papilla depreffiuscula munitum, glabrum, fufco ferrugineurn.

Ix т. fimplex, offeo cruftaceum, nucleo pertinacifime adharens.

A L B. cartilagineum, durifunum, album, ftriis obfolecis, radiantibus fubruminatum, in inedio cavitate fubcylindrica exiculptum.

E 18 . conicus, lacteo albicans, ad verticem feminis pofitus.

2) Bacca magnitudine maturall, fed detraca ejus cuticula externa ut corticis fibrofus \& tomentofus contextus statim appareat. b.) Endem longitudinaliter aperta, Dexum carnis cum cortico ofteodens. c. c) Caro femen obtegiens. $d_{0}$ ) Semen denudatum. $\left.e_{.}\right)$Bacez \& feminis featio transveŕalis, cum cavisate albuminis media. e. f.) Albuminis portio fuperior verticaliter feta, fitum embryonis exhibens. f. F.) Embryonis fg are \& magnirudo nauralis, ac aude,

EX dono aniciflumi D. BERKH E. 


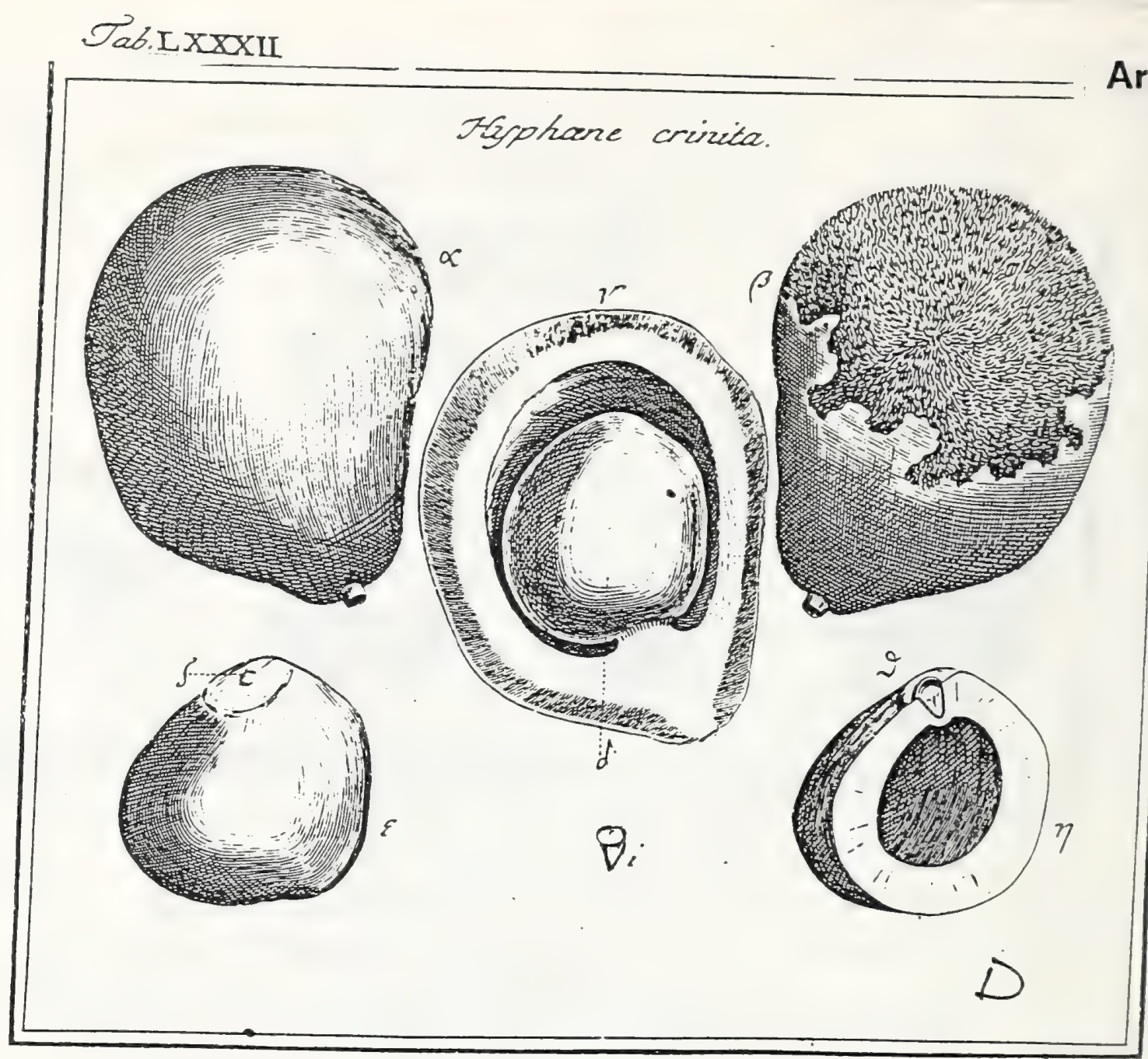

J. Gaertner (1788) Vol. 2

32* HYPHIE $N E$. vid. Vol. I. p.2S.

HyPHENe crinita. Tab. 82. fig. 4.

Ex fensinario hort. Amftelod.

Drupa (๔. $\beta . \gamma$. ) obovata, verfus alterum, f. rectiufculum latus in acicm obtuGfinnam comprefía, fpadiceo fufoa, nagnitudine voliz manus. Cuticula (B.) tenuis, membraniacea. Putamen ( . $_{\text {. }}$ ) uniloculare, corneocoriaceum, tenacifimum, fibris capillaribus rigidiufculis denfifime contectum, xquabiliter craffum, praterquam in fupremo dorfi arcu, ubi craffities ita deliquefcit, ut foli fere crines regionem iftam teneant \& proxime fubjectam embryonis papillulam obtegant. Recepsac. in fundo putaminis ex fibris lignofis, baG feminis infertis. Semen ( $\delta$.) grande, fubglobofum, hinc ì obtufifrmam aciem comprefium, inde infigniter gibbum \& rotundatum, ac ad apicem in brevem umbonem productum. Integ. fimplex, crafum, rufefcens, extus furfuraceum, intus cruftaceum, albumini arctiffime adnatum. Albumen (๕.) femini conforme, cartilagineum, obfoletis ftriis fubruminatum ( $\left.x_{.}\right)$, album, juxts verticem urea fubrotunda ( $\zeta_{.}$) cum papillula embryonitega ( $\curvearrowright$ ) notatum, intus amplifrina cavitate in:mi exfculptum. Embryo ( $\vartheta_{\text {. }}$ ) monocotyledoneus, conicus, inverfus, lacteus, in vertice albuminis locatus. Radic. orbiculata, planiufcula, fupera.

Ergo Hyphxne omnino proprii generis Palma eft, cui hactenus foli embryo contingat in vertice feminis pufitus. 


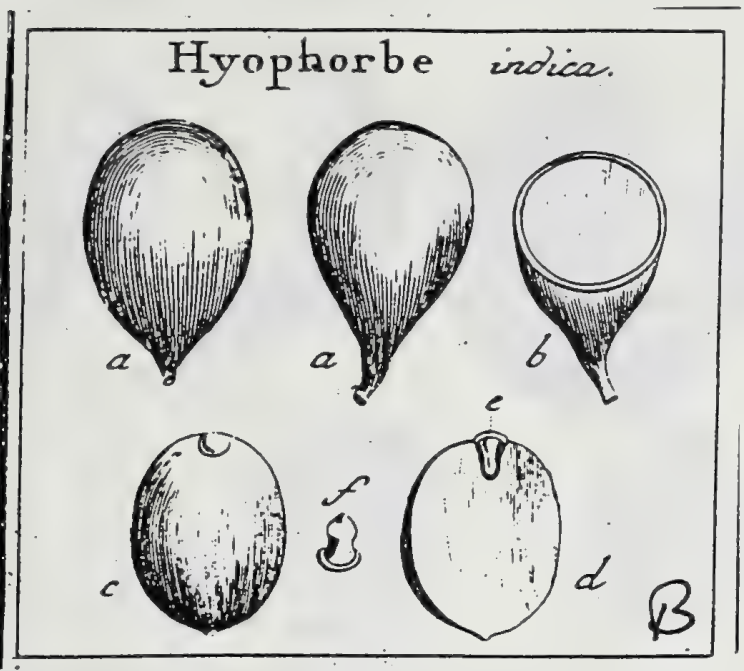

\section{J. Gaertner (-1788) Vol.Z}

196

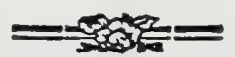

DCCII. H Y O P H R B

Flores .... Spatha .... Bacca monofperna. Albumen cartilagineum folidum. Embryo in vertice feminis.

HYOPHORBE indics. Tab. 120. fig. 2.

Palmier de tisle de Bourbout. A Cl. Hér. Prof. argent.

PER. Bacca ovata, deorfum attenuata \& in pedunculum brevem . elongata, carnofo - fibrofa, unilocularis. - Cuticula membranacea, tenuis, nigricans aut funofa: Caro paucifima, fibris capillaribus creberrime anaftomofantibus intertexta, femini arcte adhærens.

REC: nullum.

SE M. unicum, elliptico - globofum, glabrun, e caltaneo - fufcum, inferne in breviffimum mucronem definens, in vertice autem Papillula embryonitega infignitum.

IN T. fimplex, fubcruftaceum, albunini arctifime adnatum.

A L в. femini conforme, folidum, niveum, cartilagineo-coriaceum \& digitorum preffioni paulifper cedens.

Em 8.: monocotyledoneus, fubpyramidatus, inverfus, lutefcens; in vertice albuminis pofitus.

2. 2.) Bacen integra, longius breviusre pedunculata. b.) Ejusdera atque feminis fectio trans verfalis. c.) Semen denudatum, d.) Idem vercicátiter diffectum. e.) Embrgo in Gitu naturali f.) Idem folutus \& $2 b$. aqua tumefactus. 


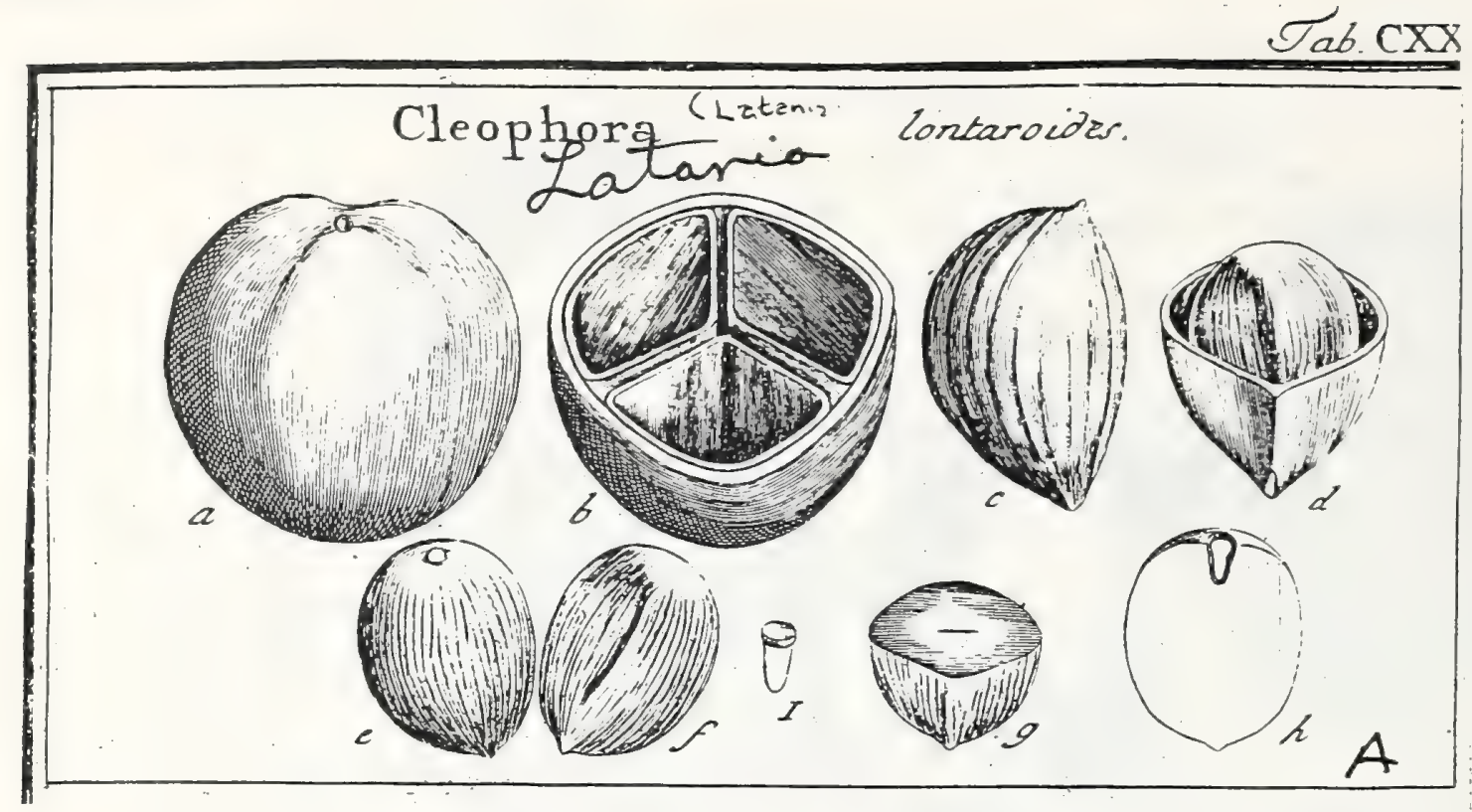

J. Gaertner (-1788) Vol 2

184

DCCI. CLEOPHORA. Lantania. Juss. p. 39.

Flores fexu diftncti in feparatis caudicibus. MAS. Spatha polyphylla, folia. lis imbricatis. Spadix ramofus, ramis apice digitato-partitis fubcylindricis. Cal. -expartitus, -Jaciniis exterioribus minoribus. Stam. fedecim, bali coalita. (ex Jufs.) - FEM. Spatha . . Spad. . . . C.l. hexaphyllus. Bacca globofa, unilocularis, tripyrena, Alb. corneum, folidum. Embr. in vertice feninis.

Cleophora lontaroides. Tab. 120. fig. I.

Imitanier rouge de lisle de France. A Cl. Hermans. Prof. arg.

PER. Bacca globofa; obfolete trigona, glabra, unilocularis. Curtex coriaceus, .tenuis, per atatem fragilis \& fere cruftaceus. Pulpa fucculenta, fugax, in fcorias membranaceas pyrenis adhærentes exarefcens, absque ullo Gbrarum aut difeepimentorum veftigio. Officula tria, cruftacea, tenuia, Inc convexa \& obfoletifime ftriata; inde angulata, glabriufcula, extus fpudiceo-fufca, intus ferrugineo- ochracea, monofperma.

REC. nullum.

SEM. in fingulis oliculis Grigula, fubelliptica, crafa, fubtilifime \& tremula qualf manu ftriata, Juteo - ochracea; pulverulenta, hiic convexiufcula, inde obfoletiflime angulata, inferne in brevem mucronem definentia, fuperne autem Papillula embryonitega paulo retro verticem notata.

IsT. fimplex, fubcruftaceum, tenue, albumini perinacifime adnatum.

A L B. femini conforme, corneum, durifimum, prope peripheriam aqueo-glallcum \& transparens, in medio autem album, opacum atque rima transverfali, vir perceptibili, incifum.

Es B. monocotyledoneus, teretiufculus, e bafi latiufcula conice attenuatus, lacteus, inverfus, in albuminis vertice pofitus.

a. b.) Bacca integra \& transverlim fedz. c.) Ođiculam (eparatam, integram, a dotio fpectatum. d.) Idem diffeA $\mu m$, cum fitu [cminis. c. f.) Semen denudatum $Q$ ab vtrique parte fpedatum, 5.) Albumen transverfe diftedum. h.) Ejusdecu fectio longitudinalis, eum embryone (i) in Etu aaturali. L.) Embryo folutus \& autus. 
Tab. CXXXIX.

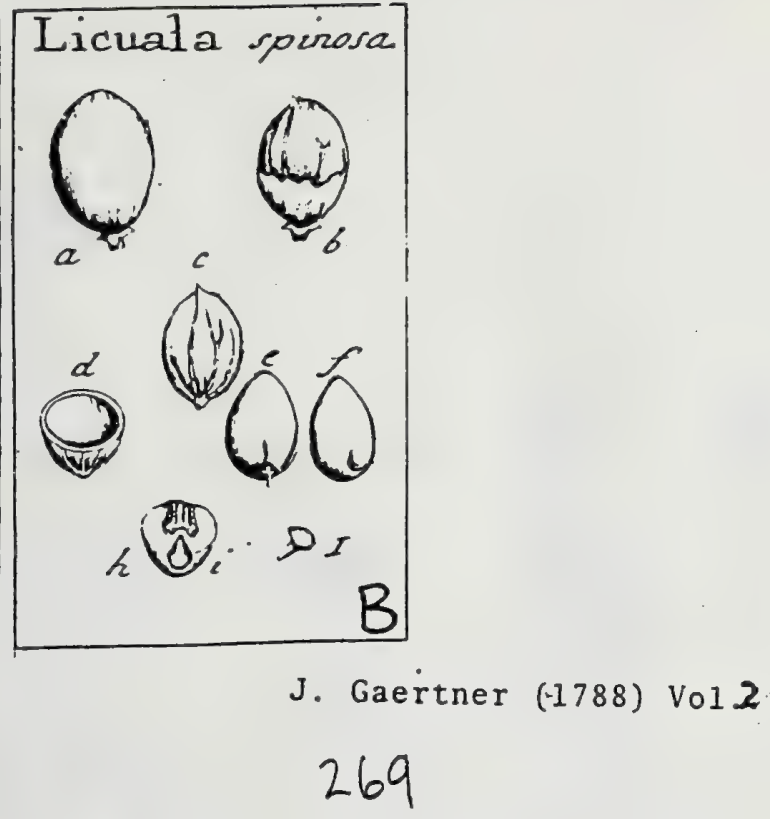

DCCCII. L I C U A L A. THUNB.

Flores omnes hermaphroditi. Spatha communis nulla; partiales. vagx. Spadix ramolus. Cal: tripartitus, perfiftens. Cor. tripartita decidua. Nectar: fetiforne. Stam. fex. Ovar. unicum. Styl. fimplex. Drupa unilocularis, mono fperma. Embra dorfalis:

IIcuala fpinofa. Tab. 132. fig. 2.

Licuala arbor. RUMPH. ambi 1..p. 44: t. a.

Conplia foliis palmatis. BURM. ad Rusurpls.

Licuala. ТнUNв. ait: bolins. 1282. p. 284 .

A. Cl. Hermans. Prof. arg.

PER. Drupa carnofa, parva, ovalis, calyce tripartito remotiufculo bafi nưnitaCortex membranaceus, tenuilfimus, nigro - fufcus. Caro paucilfima, pulpofa, fugax. Putamen offeum, tenue, fragile, albicans, elliptico-globofum, fuperne in acutifimum, breviffimumque mucronem definens; inferne pariter mucronatum \& ex mucrone nervis oflers fubramofas parce itriatun; intus glaberrimum, uniloculare.

Rec. nullum, nifi fit funiculus uabilicalis fetaceus, rigidis, e fundo putaminis ad feminis latus ventrgle adfcendens, ibique definens.

SEN. unicum, ellipticum, cinerafcens, hine modice convexum \& verfus bafin ubtufitrimo angulo, cui funiculus umbilicalis innergirur, carinatum; inck gibbun \& in medio ampla papillula embryonitega infignitum.

Is T: Gmplex, cruftaceum, tenuifimum, arctilfine adnattum.

A I B. femini conforme, cartilagineum album $_{2}$ a purte ventrali late. \& profunde ruminatum. 
(i)

C 
Tab.CIXXVI.

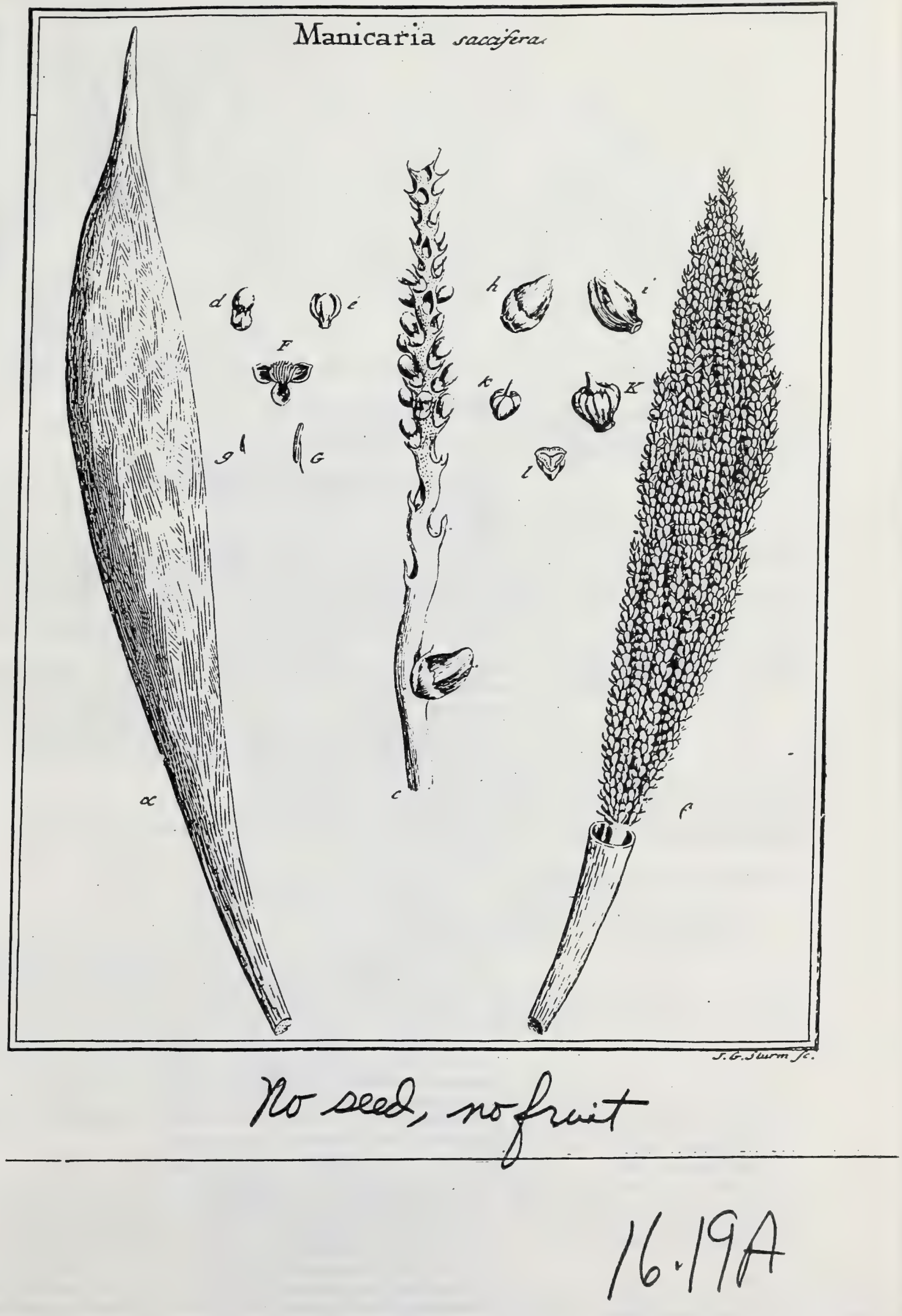




\section{J. Gaertner (1788) Vol 2}

\section{M A I C A R I A.}

SP А т и А нniverfalis maxima, fufformis, fibrofa, non dehifecus, mire dilatabilis. Spatibe portiales nullx, aut anguftifimx, fetaceo acuminatx, ad bafin fin.
guli folculi.

SFADIX utrique fexui communis, virgatus: ranis fimplicifimis, ftrictis, comprefris, ad Alofculorum fedem emarginatis, tomentufis, ferrugineis.

$\lambda I \mathbf{s}$ c. flores numerofifimi (fupra bis mille), fpadicis ramos undique vbtenentes. Cal. monophyllus, brevis, angulatus, Jacerus, fariofus, niveus. Cor. ubovata, trigona, coriacea, tripetala. Stame. viginti quatuor, difcreta: flamentis capillaribus; antheris oblongis, fulcatis, albis.

FEn. paucx, vix fupra viginti, in ima parte ramorum fpadicis feffiles. Cal. monophyllus, membranaceus, tenuis, oblique itriatus, crenulata Jucerus, albicans. Cor. ovato-acuminata, compreffe trigona, coriacea, tripetala, mafculinis quadruplo grandior. Ovar. unicum, fuperun, turbinatum, trigonum, triloculare. St. $\%$ conicus, craflus, brevis. Stign. fimiplex. Per. Nux aut Drupa exfuica. ....

Manicaria faccifera. Tab. I76.

Palmi faccifera. Clus. exot. L. I. c. 2. BАUн. bif. I. L. s. p. 385. Jonst. dendr. P. 152. t. 47.

Palus maxicam bippocraticam referens. BAUH. pin. 507.

A Cl. Wiedemand Prof. Stuttgard.

Fructus defideratur.

ж.) Sratha irminuta integra. B.) Spadix denuilatus, c.) Ramus fpadicis feparatus \& tronotus cum fitu \& magnitudine partiugn naturali. d.) Flos mafculus claufus. e.) Ejus corolla dehireens. F.) Eadem explieata cum fitu faminum. g. G.) Stamen (eparatum. b.) Flos femineus integer. i.) Ejus corolla dehilcens. L. K.) Ovarium integrum. L.) Jdem diffectum.

Spatha quadripedalis \& ultra, e fpadiceo ferruginea, tota ex fibris capillaribus tenaciffrmis, cocculi bombycini adınftar, coritexta, ut capiti honiuis adulti mitrz in modum absque rupturse metu fuperinduci queat, etfi maxima ejus Iatitudo vix quatuor pollices parifinos exxquec. Ovarii loculamenta tria, angulta; parietes aucem crafti, atque toti corpufculis linearibus offeis, arcte adnatis \& verticaliter difpufitis ita referti, us ovarium difficulter transverfim fcindi queat.

Fructum maturum, Cjufius equidem, Juglandis drup $x$ fimilem, atque femina perfecte fphxrica \& duriffima dixit. Sed hxc fabrica vix in noltran Palmam quadrare poteft, fiquidem ejus ovarium curbinato roftratum atque totum fpiculis offeis repletum fit, ut adolefcento non polfit non in Drupam duram, aut Nucem lapideam, unbonatam ac trilocularem converti. Hinc verifinile, quin vix non certilfinum mihi videtur, quod genuinus hujus Palnix fructus, alius non fit, quam ille Cuoci lapidec. Vol. 1. p. 16. defcriptus, quum \& umbonatus iltius vertex, \& rigidifimis offeisque fibris flipata bifis, \& tota lapidea ejus confiltentia, fabrice \& figurx ovarii Manicarix noftrx optime refpondeast. Habitat in Curaçao \& Guians belgica. 


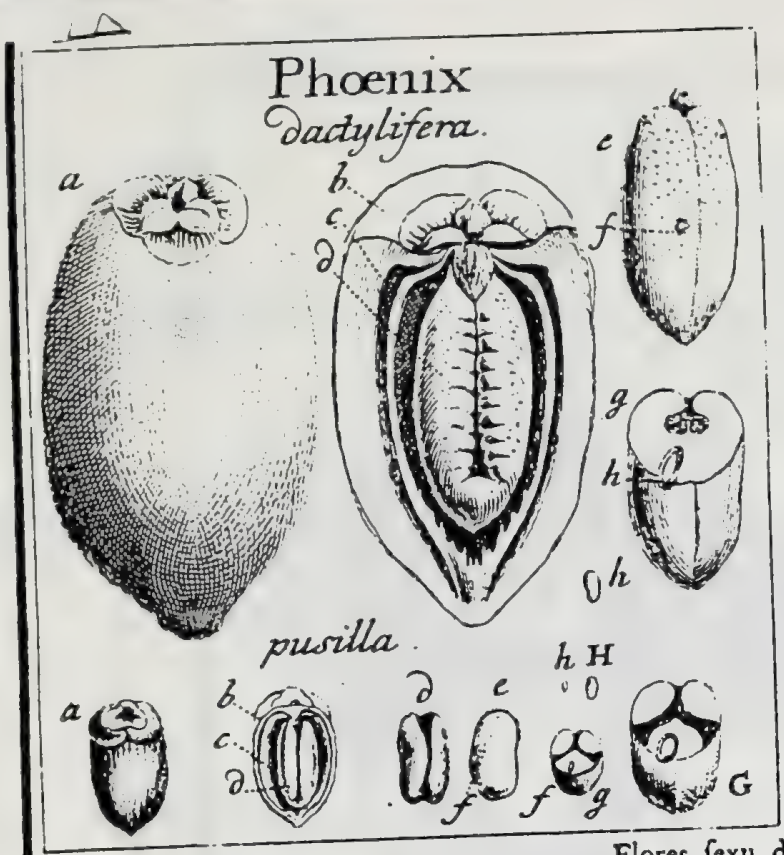

Arecaceae

J. Gaertner (1788) Vol 1

XXVIII. PHOENIX. LINN. gen. 1224

Flores fexu diftincti in feparatis caudicibus. Spatha univerfalis. MAs. Cal. hexa.

- phyllus. Cor. nulla. Stam. tria. Fess. Cal. hexaphyllus. Drupa fupera, mollis, putamine membranaceo. Semen bifulcum. Embryo dorfalis.

Yноеліх dactylifera. Tab. 9. fig. z.

Palma. Don. pempt. 8rg. Cas. eptt. 124. Baun. hifl. 1. p. 35 I.

Palma hortenjis mas \& femina. Kespr. amoen. 673. 697. $t .1 .2$.

Phanix frondibus pinnatis, foliolis cufiformibus complicatis. LIN veg. 985 .

Icon. Seminis. Stapfl. thophr. g9. Malpigh. op. t. 7. 8. g. Grew. anat. t. 75. E. N. C. 1689 . edit. germ. l\%ol. 1s. t. 2. $5.6-9$.

PER. Diupa mollis, carnofa, ovata, lutescens aut fulva, calyce perfiftente bafi cincta. Cortex membranaccus, tenuistimus. Caro craftiuscula, tenera, dulcis. Putamen membranaccum, in fibras folubile, fericco-albicans, bafi \& apice cum carue coloxrens, cerera undique folutum, femen laxe involvens.

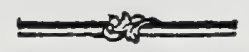

REc. funiculus fibrolus, craffus, brevis, feminis bafi infertus.

SEM. unicum, oblongum, rufescenti- Spadiceum, minutilfunis rugis \& punctulis elevatis fabratum, hine, fiflura profundâ, obfolete crenulata atque intus in cavitatem longitudinalem ampliata, incifum; inde convexum, tcnui Aria longi. tudiuali notatum \& ad alterum hujus latus, papillula albicante, depreffiuscula infignitum.

IN T. fimplex, cruftaceum, filfurx cavitatem materie paleaceo-furfuracea, rubro-ferru. - ginea, aut fpadicea replens; cetera nucleo arctiflune adnatum.

ALB. cartilagineum, duriffimum, album, przter fiflurx cavitatem, folidum.

Ess. oblongus, lacteo-albicans, in medio feminis dorfo horizontaliter locatus.

2.) Drupa integra, inverfa, b.) Eadem longitudinaliter aperta. c.) Putaminis faccolus. d.) Semen e funiculo umbilicali pendens. e) Ejus pars dorfalis, f.) Papilluk embryonem obtegens, g.) Albu. men transverfe fequm, h. b.) Embryo magnitudine naturali,

Pноел 1 X pufilla, ibid.

Palma dafylifera aculeata minima. Plum. gen. 3?

Drupa ovata (a. b.), parva, vix fernipollicaris longitudinis, coriacea, rufescens; bafi cineta calyce grandiusculo: foliolis tribus interioribus majoribus, rotundatis, concavis: unico exteriore dimidio minore, trilobato. Putamen membranaceum (c.), tenuifimum, album, a carne vix discretum, ut pro mera loculamenti tunica haberi queat. Semen (d. d. e.) ovato oblongum, nigro fuscum, lato fulco, fed parum profundo ex altero latere (d. d.) incifum; ex altero autem (e.) glabruin, convexum \& papillula pallida (f.) in medio notatum. Albumen (g. G.) cartilagineum, groffo inodo ruminatum, ex albo \& ferrugineo varium. Embryo (h. H.) dorfalis, teretiusculus, albus.

Habitat in India orientali \& Ceylona, unde fructus in Collect. fem. hort. lugdbat. Species hodie ignota, non item veteribus: exprefle enitn TEOPHR. hil. L. 2. c. 8. de Palinarum agens fructibus, inquit: quidan habent magnitudinem Ciceris; \& Plivius L. 13. Tect. 9: quidam nors Junt najores Faba; ut hic plane noftram intellexifle videatur. 

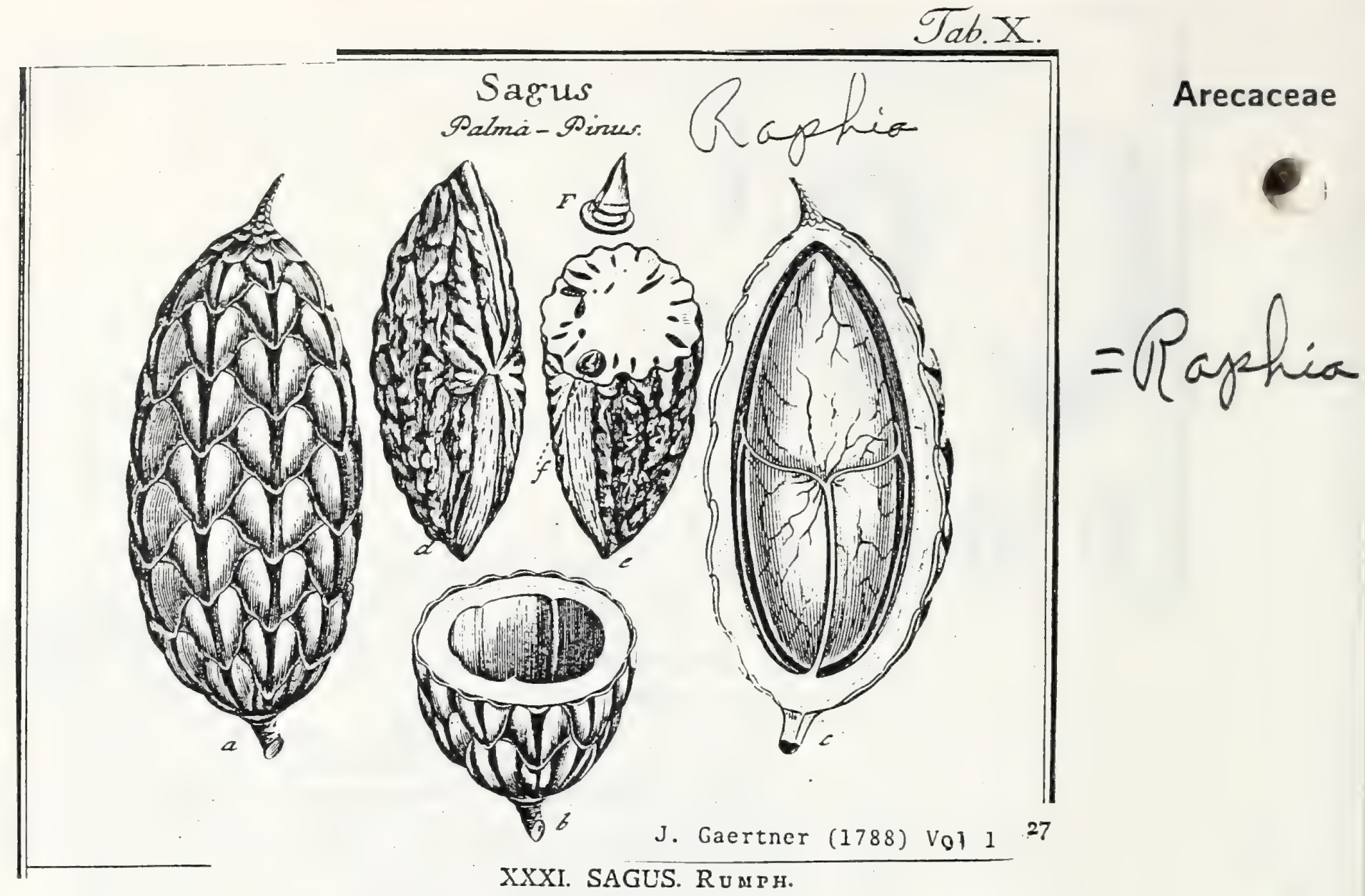

Flores fexu diftincti in eodem caudice. Spatha univerfalis. Bacca fupera, corticata fquamis cartilagineis retrorfum imbricatis. Albumen ruıninatum. Enbryo lateralis.

S a G U S Palma-Pinus. Tab. 10. fig. I.

Palina-pinus. Lо в. adverf.p. 450. D А І Ес н.- -hifl. 1832.

Exotici fruatus aut arboris ramus, cum fruttibus fquanofis. C飞vs. cur. pofer. 82. 84 .

Fruțus peregrinus abiegna nuci perfmilis. Palna-pinus f. Conifera. ВА ин. hifh. 1.p. 398 .

Palma conifera. Іон нот. dendr. t. 48 .

Areca f. Faufel. B Es L. mus. p. 22, t. 5 .

7'ccot!. GREW. Muा p. 200.

PER. Hacca ovato-oblonga, fupra in inucronem fubulatum producta, corticata, unilocularıs, fubtripollicaris. Cortex compofitus ex fquamis cartilagimeis, nitidifimis, luteo-rufefcentibus, medio fulco longitudinali deprefio notatis, fubcordatis, per feries longitudimales a fummo apice, ad imam bafin deductis \& quafi deorfum imbricatis. Caro crafiuscula, fungofo coriacca, nou fibrofa, intus quatuor aut quinque nervis confluentibus notata.

REc. nullum, prater nervos fuperficiei internx baccx inferiptos \& cum femine cohxrentes.

SF.s. unicum, grande, ovato oblongum, utriaque acuminatum, rugis profundis \& tuberculis inaqualibus varie contluentibus veruniculatum; fafcia glabriuscula ftriata a bafi ad embryonis fedem adfcendente nutatum; fpadiceum.

I.v T. duplex : exterius furfuracco-crufaceum, fubrafile; interius ofteum, nigricans, introrfuin proceflibus auctum, a nucleo non folubile.

A 1. B. cartilagincum, durillimum, fublutcolum, ruminatum, folidun.

Eм в. triquetro-pyramidalis, laftco-albicans, medio feminis latcri horizontaliter im merlus.

a.) Baca illegra. b.) Eadem transierfe fefta: c.) Ejusdem felio longitudioalis, cum nervis nuritiis, fominis intogumento exterso annexis. d.) Semen folutum, a latere fuo embrionifero Ipctatum. e.) Albuminis fritio transverblis, cum fur \& magniudine embryonis naturali. (. F.) Einhryo junte \& auts maquitudinis.

Obf. Afinislina Sagus ef Rotangx, fed in hac omnes flores funt hermaphroditi, \&, quantum ex iconibus fufpicor, embryo non batcralis fed in bafi ferninis collocatus. 

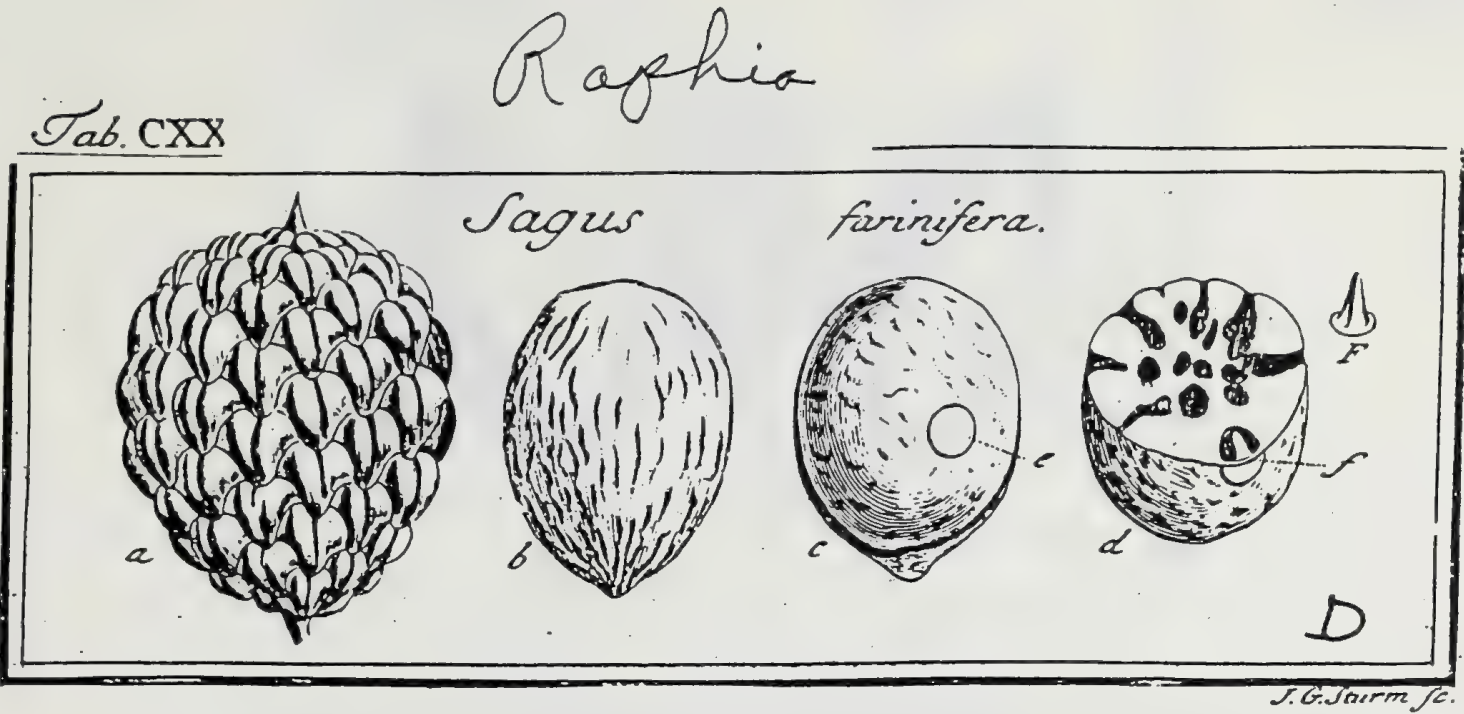

\section{J. Gaertner
$\qquad 1788)$ Vol. 2}

.S A G US. vid. Centor. p. 27 .

SAgus farinifera. Tab. 120. fig. 3 .

Sagus longifpina. Rüpr. amb. x. p. 75. ob magnitudinem fructus.

$$
\text { a Cl. Hermanis. }
$$

Bacca (a) forma \& magnitudine ovi gallinacei minoris, ftylo fubulato cartiJagineo folido terminata atqué fcutis cartilagineis haltato - cordatis bifulcis levigatiffmis deorfum imbricatis ac late xerampelinis loricata, exfucca, tenuis, unilocularis. ,Rec. nullum. Semen unicum (b.c.d.) grande; ovataglobofum, inferne leviter, mucronatum. Integun. exterius (b.) membranaceo-fpongiofum, ad bafm feminis (c.) incraffatum, ochroleucum; interius, (c. d.) fubcruftaceum, tenue, obfulete tuberculatum, e caftaneo-fufcum, albumini arctifime adnatum. Albumen (d.) cartilagineum, ex albo \& ferrugineo eleganter ruminatum. Papilla embryonitega (e) ampla, deprefà, in latere teminis. Embryo (f. F.) horizontalis, pyramidatus, lacteus.

Sagus a Calamo differt: Semine folitario, nec trigemino;-\& embryone laterali, nec bafilari. 


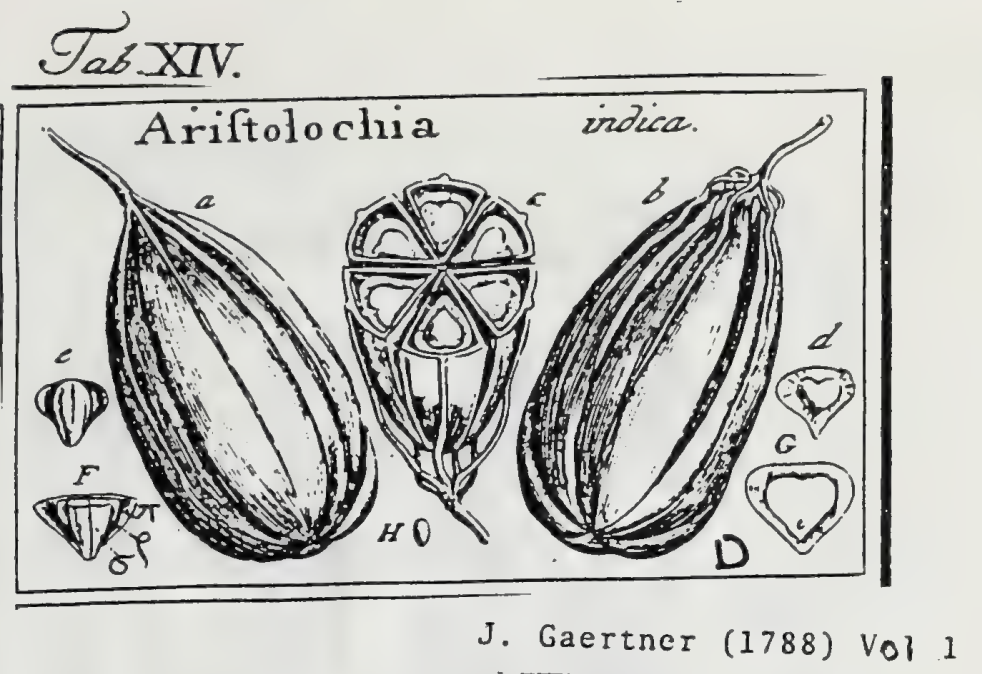

Aristolochiaceae

\section{ARISTOLOCHIA. TOURN. t. 7r. LINN. ger. IO22.}

Calyx nullus. Cor. monopetala, ligulata, integra. Stam. fex: Styl. fex. Capfula infera fexlocularis. Semina comprefia, horizontali incumbeutia, interno loculamentorum angulo affixa.

ARISTOLOCHIA indica. Tab. 14. fig. 4.

Carclu-vagon. R н е Е D. mal. 8. p. 48.t. 25.

Arifolochia foliis cordatis acutiusculis, caule volubili, pedunculis multifloris. LIN N. Jy/l. veg. 824.

E collect. fein. hort. lugdb.

PER. Capfula infera, elliptico-turbinata, bafi in pedunculum defimens \& ex eo, nervis fex, prominulis ac medium valvularum dorlum percurrentibus, ftriata, fexlocu. laris, fexpartibilis: fegmentis triquetris, claufis, unilocudaribus, a bafi dehiscentibus, \& e nervis pedunculi communis pendentibus.

REc. nullum : femina angulo centrali loculamentorum afis:a \& fibi mutuo horizontaliter incumbentia.

SE s. numerofa, rotunde triangula, plano-comprefla, margine membranaceo , albicante, ftriato cincta; hiuc punctis elevatis fcabra \& fufca inacula cordatâ infcripta; inde fungofa epiphyfi alba, oblonga, didyma \& inferiori feminis pagiuz arcte ad. hacrenti, munita. Odor etiam in vetuftis feminibus grate aromaticus.

IN T. duplex: exterius fubcoriaceum, in marginem feminis ampliatum, fpadiceum; interius arachnoideum, arctiffune nucleo aduatuin, rufefcens.

A L B. cordiforme, femine anguftius, compreffum, fubcartilagineun, album.

E s B. minutulus, ovato globolus, lacteus, in extremitate albuminis umbilicali locatus.

a.) Capfula integra b.) Endern 2 bafi delifceus, c.) Ejus fectio transverfalic d.) Seminis latus fuperius. e.) Ejusdem pars inferior. F.) fectio Seminis transverlalis, in qua: $\pi$ ) marginem membrataceum, $\varrho$ ) corpus ipfum feminis, \& $\sigma$ ) fungofan epiphyfin denotant. G.) Semen longitudinaliter diffectum, albuminis figuram \& embryonis fitum exhibens, H.) Embryo folutus \& iufiguiter auctus.

Aristozocin Clematitis.

Arifolochia Clematitis. Bц А $w$. herb. t. 255 .

Ariflolochic foliis cordatis, caule eredo, floribus axillaribus confertis. LINN. Jyj. veg. 825. H A L L. hif. I. 11. 1029 .

Capfula globofa, lincis fex pallidis ad diffepimentorum fedem frepius notata. Diffcpimenta membranacea, tenuifima, son bipartibilia. Seınina flana, triangula,

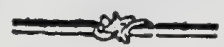

fuperne tuberculato feabra, ferruginea, non marginata; inferne flipata membrana alba, tenui, figura \& magnitudine ipfius feminis, ejusdemque medix colix longi-
tudinaliter affixa. 


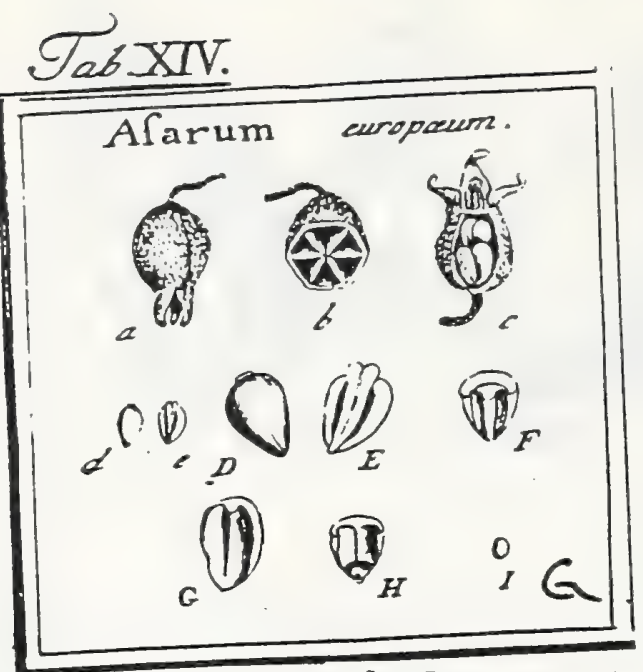

J. Gaertner (1788) Vo. ... I

LIV. ASARUM. TOURN. t. 286. LINN. gen. 589.

Calyx fuperus, femitrifidus: denticulis incurvis. Cor. nulla. Filamenta duodecim, ulura antheras in corniculum producta. Antherx in fingulo filamento geminx, aut

48

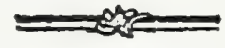

una, biloba. Styl. onicus: Rigmate fexradiato. Capfula infera, coriacea, fexlo. cularis, evalvis. Diffepimenta ad axem foluta. Semina meniscata.

ASARUM europrum. Tab. 14. fig. 7 .

Afarum. С Ам. epit. 19. B ЕS1. hort. Eyf. vern. VI. t. g. f. 2. В Іакш. herb. t. 383. OE D E R. flor. dan. t. 633 .

Afarum foliis reniformibus fublir. futis. HA L L. hift. 2. 5.1547.

A Jarum foliis reniformibus obtufis binis. LIN N. /y/l. veg. $44^{\text {r }}$.

PER. Caplula ovato globofa, calyce perfiltente coronata, hirfuta, obfoletintune hexa. gona, fexlocularis, evalvis, Diflepunenta angulis caplulx adnata, prope axem foluta \& difcreta!

REC. nullum, prater marginem centralem diffepinentorum, cui femina affixa.

$S E M$. pauca, quatuor circiter in fingulo locularnento, ovata, deorfum anguftata, hinc convexa, glabra; inde concava, epiphyfi glandulofa; femine paulo longiori, \& fuperue cralliori, glandulofa, lutefcente, demum vero in fulcuin elevatum fpongiofum exarefcente, notata. Color in dorfo fufcus, in ventre pallidior.

I $\mathrm{x}$. finplex, membranaceum, tenue, fimini adulto pertinacifime adhxreus.

A L в. femini circiter conforme, convexo-concavum, marginibus.introrfun flexis, cartilagineum, album.

Ем в. minutifimus, globofus, albus, in infima albuminis parte locatus.

a.) Capfula integra. b.) Eadem transverfe fefta. c.) Loculamentum apertum, cam fitu feminum uaturali. d. D.) Seminis pars dorfalis, convexa. c. E.) Ejusdem latus ventrale, cum epipliya fuz glandulo $\sqrt{2}$, aut fpongiofa. F.) Seminis fefto transverfulis. G.) Albumen desudatum, a parte ventrali fpefatum H.) Ejusdem fetio tmusverfalis, \& fublata ad befin cjus fubfantia, ut embryo in confpedum veniat. 1.) Einbryo folutus $\mathbb{S}$ infignices autus. 
Tab. CXVII.

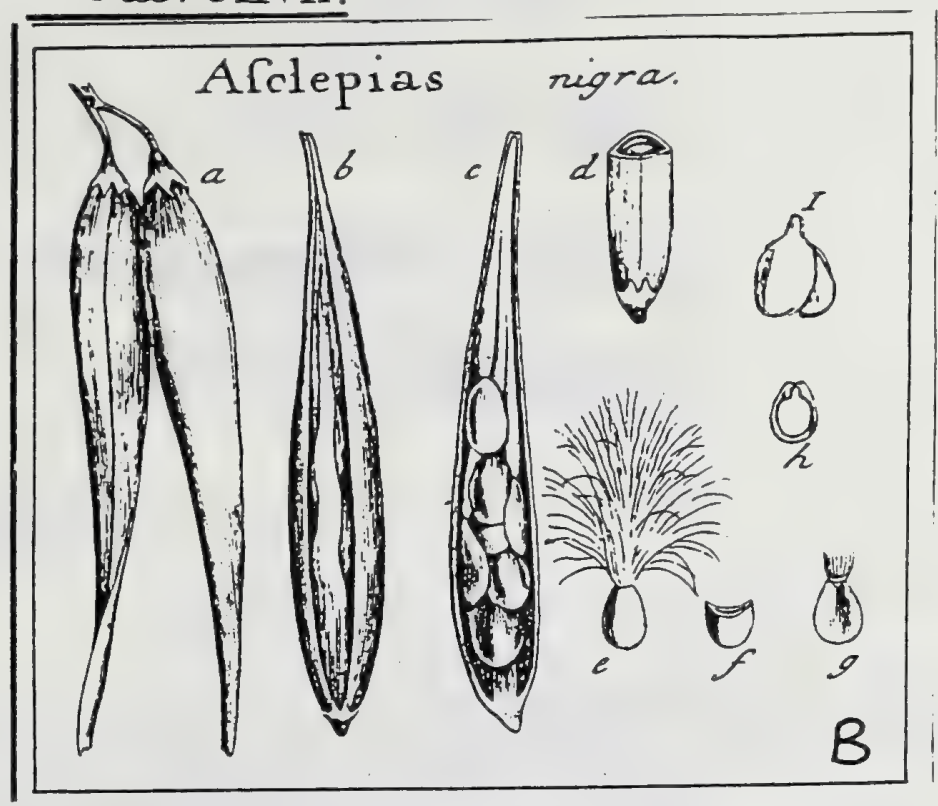

J. Gaertner (1788) Vol. 2

170

DCLXXXIV. ASCIEPIAS. TOURN. inft. to 22. LINN. ger. 306.

Calyx quinquefidus. Cor. quinquefida. Nectar. quinque, callofa, aut corniculata. Stam. decem, per paria fibi juncta, intra rimas involucri, ovarium obtegentis, recondita, deorfun: pen!ula. Ovar. duo, involucro ex quinque fquamis compolito obtecta. Stigmata feffilia. Folliculi duo. Receptac. liberum Semina bracteata, crinita.

Asclepias nigra. Tab. 117. 6g. 2.

Viscetoxiczun fiore nigro. САM. epit. 560.

Afclepias foliis ovatis bafi barbatis, caule fuperne fubvolubili. LINN. $\int y f$. veg. 259 .

PER. Folliculi duo, oblongi, e ventricofa bafi furfum anguftati, hinc convexi, inde planiufculi, ad latera autem fubcomprefr, uniloculares, introrfum dehifcentes.

REC. lineari oblongum, fungofum, compreffum, liberum.

SEM. pauca, octona aut dena, deorfuñ imbricata, ovata, brecteata f. foliaceo compreffa, convexo - concava, rufefcenti cinnamomea, fafciculo capillarum fimplicium, fericeo alborum, longorum in vertice crinita.

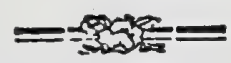

InT. fimplex, membranaceum, tenue.

A L B. Femini conforme, tenue, carnofum, aqueo-pallidum.

E s 8. longicudine albuminis, inverfus, luteus. Cosyl. ovace, fuliacez. Rad. cumpretla, brevis, fupera.

a.) Folliculi integri. b.) Folliculus dehifcens, enm receptac. feminum, (futurz obrerío. c) Idem, cum Seminibus deorfum imbricatis. d) Ejusdem \& receptacili fcatio transverhalis. c. f. g.) Se unina ab utraque parte fpecata, integra \& diffezuma. h) Albumea eum embrgone. I) Embryo fo.utur. 


\section{Oab. CXVII.}

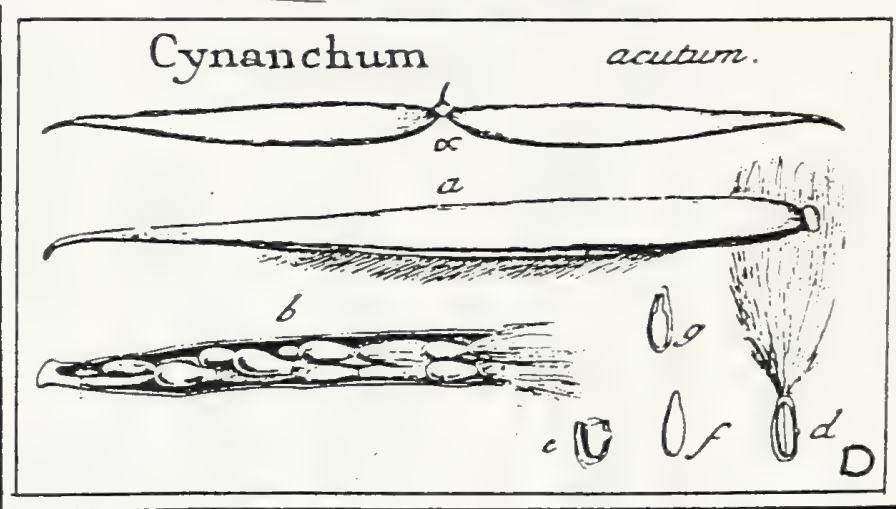

J. Gaertner (1788) Vol. 2

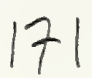

\section{C Y N A N C H U M. Lins. ger. 304.}

Calyx quinquedentatus. Cor. quinquefida. Nectar. nulla. Stam. decem, pendula, intra ovarii involucrum ablcondita. Ovar. duo, fquamis quinque in cylindrum conjunctis involucrata. Folliculi duo. Recepaca liberum. Senina crinim.

Crnanchua acutum. Tab. 117. fig. 3.

Apocinnum III latifolium. CLUS. bift. 1. p. 125.

Scammonea monspelienfis. BesL. Eygt. aftiv. XIIl. t. g. f. 2.

Cynarcbum caule volubili berbaceo, foliis cordato oblongis glabris. LINN. ESt. veg. 257 .

Ex herbario Bankfiano.

PER. Folliculi duo, per maturitatem horizontaliter divergentes, teretes, acuminati, glabri, latere interno longitudinaliter dehifcentes, uniloculares.

REc. lineare, membranaceum, liberum.

SEM. plura, deorfum imbricata, ovato - oblonga, comprefliufcula, angulto margine membranaceo cinda \& in eo quoque umbilico laterali ftipats, rufefcenti - ferruginea, crisita. Crines Gimplices, fericeo-abi, fermine quintuplo longiores.

Ix T. fimplex, membranaceum, tenue.

A ц. femine paulo anguftius, carnofum, album:

EM B. longitudine albuminis, inverfus, lacteus. Cotyl. oblongo-ellipticx, tenues. Rad. teretiufcula, longa, fupera.

*.) Fullieuli horizontalites patentes, naturalibus dimldio minores, 2) Folliculus fingulas magaitudinic naturali b.) Idem longitudinaliter apertus, cuut fitu feminum. c.) Receptece e bas folliculi oriundum. d.) Semen integrum. e.) Idem diffeturn. f.) Albumen desudatuan 5.) Idem difreaum, cum fitu \& Ggüra Embryonis. 


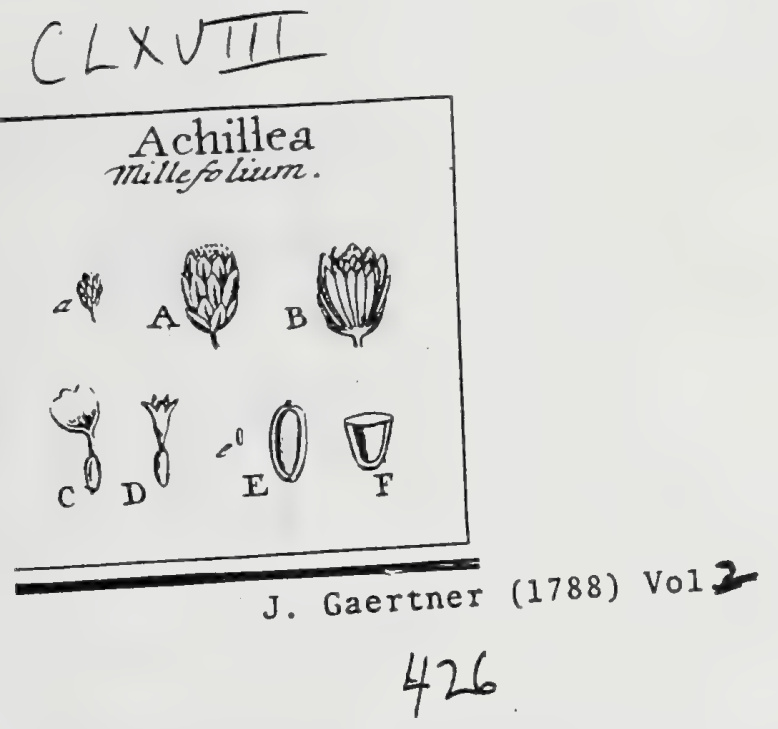

\section{Asteraceae}

DCCCCXCVI. A C H I L L E A. LINN. ger. 971.

Millefolium. T OURN. t. 283.

Calvx ovatus, imbricatus fouanis anguftis appreftis. Thal. planus paleaceus. if indrogyni ; radii feminei, ligulis ovatis transverfim latioribus Flofc. difi androgyni ; radit feminel, calva.

AchIL LEa Millefolium. Tab. 168. fig. 9.

Millefolimu. BLAKw. berb. t. 18 . OED. flor. davi. t. 737.

Achi ea folies bipinnatis nutis: laciniis linemibus dentatis, caudibus fuperne fulca

tis. LiNs. Jyft. veg. 778 .

REC. angultum, planum, paleaceum: paleis lineari oblongis, calyce paulo brevioribus.

SE. parva, oblonge elliptica, compreffiufcula, in medio fpadicea aut cineralcentia, ad peripheriam margine tumidulo pallido aut albo cincta, calva.

IN T. fimplex, membranaceum.

EM B. albus.

2.) Calyx integer. B.) Reeept. paleaceum. C.) Florc. Jalii. D.) Flofe. difci. C. E.) Senren integrume F.) Idem diffedum. 


\section{$C L X V$}

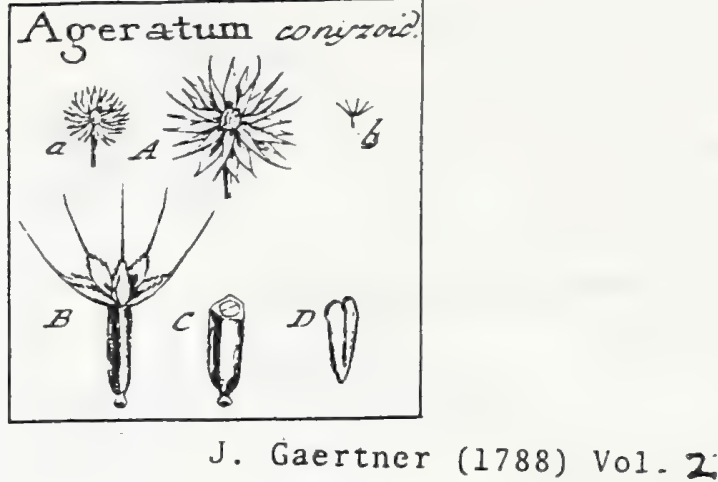

DCCCCLX. A G E R A T U M. Linn. gen. 936.

Calyx ovato-cylindricus, duplici 1. triplici ferie polyphyllus, fubxqualis, per maturitatem patentiffimus. Flofc. uniformes, onmes androgyni, quadrifidi, fertiles. Thal. nudus. Sen. pappo pentaphyllo.

Ageratum conyzoides. Tab. 165 . fig. 8.

Eupatorian bunile africanum, fenecionis facie, foliv lamii. Hers. parad. 161 . t. $I 6 r$.

Ageratum foliis ovatis, canle pilofo. Lins. fyjt. veg. 737.

REc. ovato-globofum, fcrobiculatum, nudum.

SE s. parva, columnaria, angulata, glabra, nigricantia, bafi elongata in umbilicun tunidulum, album.

Pappres longitudine feminis, albus, pentaphyllus: foliolis membramaceis, ciliato-dentatis, in ariftam longam futaceam fcabram defuentibus.

IN T. exterius fubcruftaceum, aut coriaceum durum.

EMB. albus.

2. A.) Calyx maturus cum receptac. b. B. C.) Semen integrum \& difreetum. D.) Embr. denudatus. 


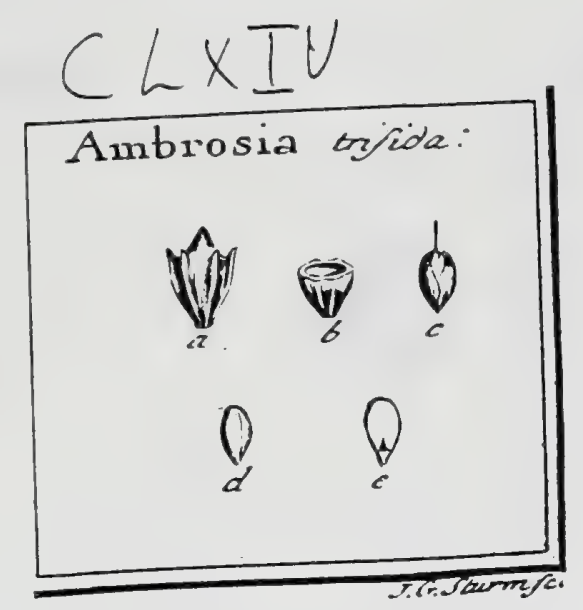

J. Gaertner (1788) Vol?

\section{7}

DCCCCIXXXVI. A M BROSI A. TOURN. t. 252. LINN. gex. IO5\%•

Hlores fexu diftinci, in diverfis calycilus ejusdem caulis. MAS. Cal. monophyllus hemifphxricus multillorus. Elafe. infundibulifornes quinqullus, pentandriantheris difcretis. Recept. nudum. FEM. Cal. monophyllus, uniforus, extus dentibus quinque' in 'medio yentre mulcatus,

semeu involucrans. Cor nulla

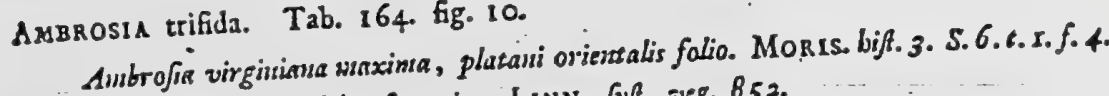

Ambrofia virginiana waxina foliis trilabis ferratis. Lix. Gyf. veg. 852 .

Calyx femineus mutatur in feminis involucrum cariaceo-nuea.

PER. nullum. Calyx femineus mutatur in feninis involucrumis adfcendencibus mentaceum, turbinato- pyramidalibus in medio muricarum, undique rectis \&

.. claufun.

Rec. nullum, preter fundum calycis.

SEM. folitarium, obovatum, calvum.

INT. finplex, membranaceum, venofum, Spadiceo-ruffum, in Atylum fli. formen definens.

A L. B. nullum.

Es в. Femini conformis, e viridi livefcens. Cotyl. plano - converze. Plusy. bicornis. Rad. cunica, infera.

\footnotetext{
418

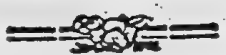

*

2.) Nux integra b.) Eadem dirtecan c.) Semea folutum. d.) Eabs. denudatus .e) CotyLedon cum plumula

Receptaculo tloris mafculi paleas fetaceas tribuit Cl. SCHMIEDeL. Asalys. p. 6x. \& in Epift. ad Burm. differtat. de Geraniis.
} 

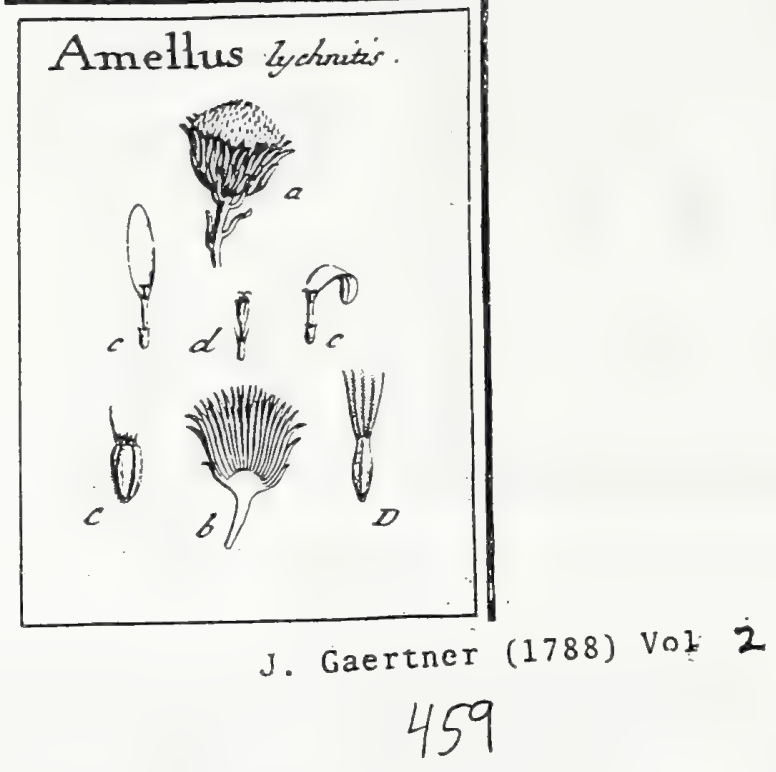

MXL. A M E L L U S. LINN. gen. 978 .

Calyx fubhemifphrricus, imbricatus fquamis linearibus appreflis. Thal. paleaceus. Flufc. difci androgyni; radii feminei, ligulis oblongis cеruleis apice vix fenfibiliter 2.13. dentatis: utrique fertiles. Sem. difformia. Pappus omnis fimplex: radii paleaceus; difci fetaceus.

AMELLUS lychuitis. Tab. 173. fig. 3.

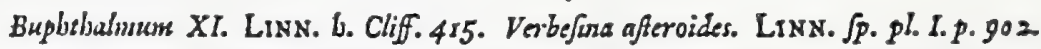
Amellus foliis oppofirtis lanceolatis obtufis tomextofis, pedrarculis surifioris. BERG. cap. 298. LiN. Jÿ. veg. 778 .

REc. levifime convexum, paleaceum: paleis membranaceis, linearibus, fetsceo-acuminatis, calyce longioribus.

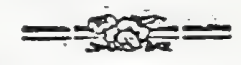

SEN. difformia : sadii breviora, latiora, ovata, conspreflo- plana, ad marginem ciliata; difci longiora, ingultiora, oblonge elliptica, rhombea-comprefia, ad marginem glabra.

Puppus diffurmis: radii palenceus, 4- Gphyllus, foliolis acuminatis, tertia feminis parte brevioribus; difci fetaceus, rigidiufculus, dentatociliatus, radiis quinque, fenime longioribus.

Ix $\mathrm{T}$. fimplex, membrauaceun.

E $\triangle$ B. femini conformis.

2.) Calyx maturus integer. b.) Idem tiftetus eum seccptace paleaceos c. c. C.) Flo[tulus \& femen radii d. D.) Flofculus \& femen difci.

Interdum unicus radius fetaceus longior pappo femirrum sadii paleaceo admifcetur. 


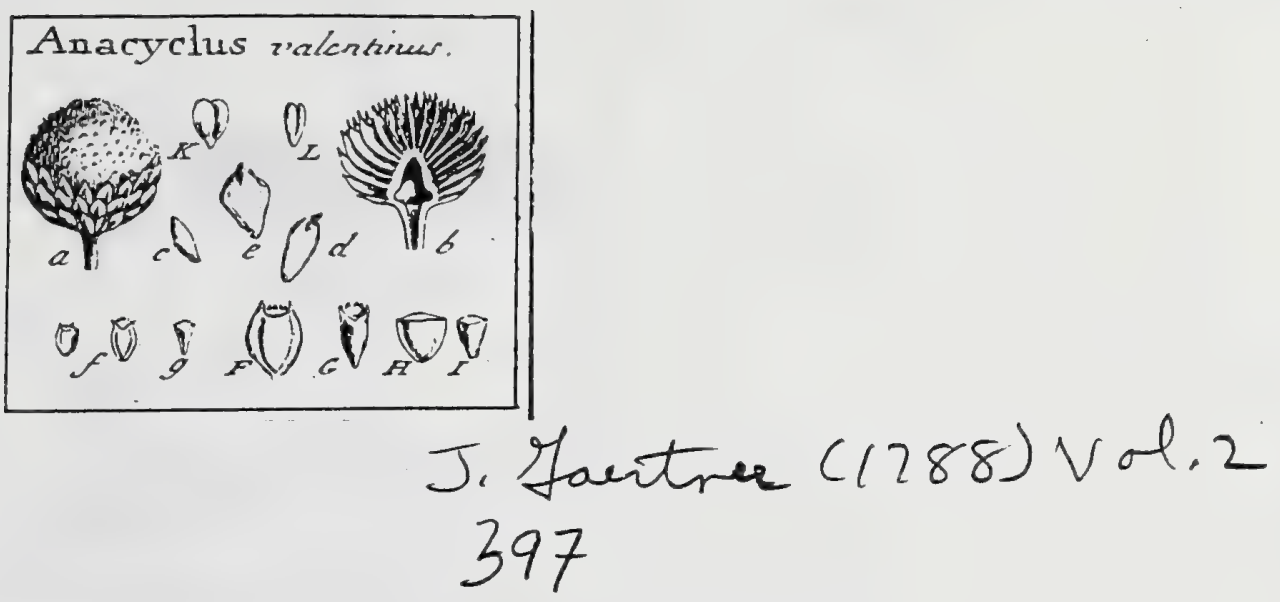

DCCCCLIX. A N A C Y C L U S. LINN. gen. 969.

Calyx hemifphxricus, imbricatus fquamis mucronatis, fenfim longioribus \& in paleas receptaculi degenerantibus. . Frof. uniformes: difci androgyni; radii feminei: utrique fertiles. Thal. conicus paleaceus. Sem. difformis: exteriora majora; interiora anguftiora: utraque coronata margine crenulato.

ANACYCLUS valentinus. Tab. 165 . fig. I1.

Chryfanthemum valentimum. CLUs. bift. т. p. 332.

Buplsebalmo tenuifolio fimile. ВА чн. bift. 3. p. 125.

Anncychus foliis decompofitis linearibus: laciuriis divifis teretiufculis acutis, floribus flofalofiss. LiNs. Lyft. veg. 775 .

REC. conicum, altitudine dimidii toris, intus cavum, extus undique paleis tectum.

SEM. difformis: radii majora, triplici quadruplicive ordine difcum cingentis, obovata, compreffiufcula, utrinque in marginem membranaceum, ceu alan, attenuata, albicantia; difci minora, oblonga, triquetra, fpadicea, marginibus albis.

Pappus marginatus, brevis, crenulatus aut denticulatus, dimidiatus, in latere ventrali deficiens.

IN T. utrumque membranaceum.

EN B. feminibus conformis, albus.

A.) Calyz maturns integer. b.) Hem diffedus, cum receptac. earitate interna. c.) Squara całyciaz extima; d.) media; e.) iatima, a thalami paleis non diverfi. f. F. H.) Semen madis integrum \& diffectum. g. G. I.) Secoen difei, K.) Embryo radii L) Ember. difei

Gcrus bifrons, accedente radio affimilatur Bupbtbaluso aut Autbemidi. 


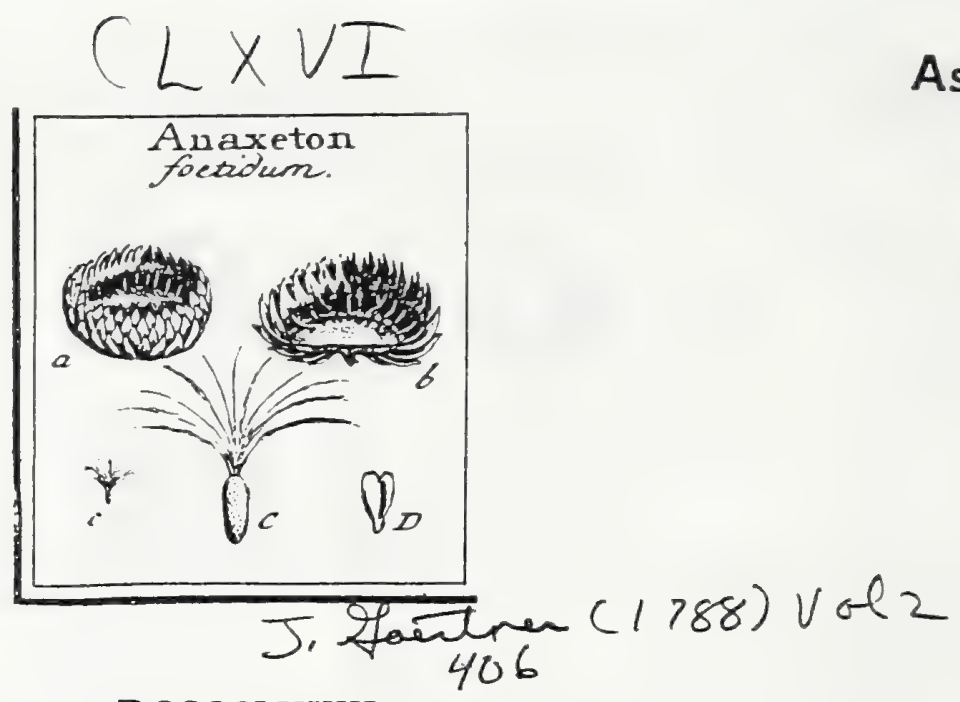

\section{DCCCCLXXIII. A N A XE T O N.}

Calyx imbricatus fcariofus. Flofe. omnes androgyni, aut feminei andro gynis mixti. Thal, villofus, aut verfus peripheriam faltem paleaceus. Pappus capillaris.

Anaxeton foctidum. Tab. 166. fig. 10.

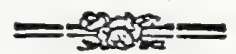

Gnapbalium africanum latifolizan foetidum, capitulo argenteo. Conss. bort. amft. 2. p. 111 . t. 56 .

Guaphalium berbacerm folits antplexicaulibus integetrimis acutis fubtus tomentofis, caule ramofo. LINN. Jyz. veg. 748 .

REC. planum, amplum, excavato punctatum, verfus peripheriam paleis linearibus raris diffitis confperfum.

SEM. parva, teretiufcula, punctis elevatis feabrata, ferruginea

Pappus capillaris, fimpliciffimus, femine triplo longior.

IN T. fimplex, membrauaceun.

Eм в. albicans.

a.) Calyx integer. b.) Idem difrectus cum paleis reteptac. marginalibus. c. C.) Semea integrum D.) Embr, dequdatus.

Hre non eft genuina Anaxeti fpecies, fed e Filagine per culturam enata; propofuimus tamen eam exempli loco, quum fequentes veras fpecies hactenus infpicere non licuerit.

Anaxeton arboreuns.

Gisapbalium arboreuns. BERG. cap. $=59$.

Calyx fubturbinatus, parvulus, quinqueforus. Flofc. omnes androgyni. Receptaculum lanatum. Pappus pilofus rarus. Berg. l. c.

Anaxeton aijpums.

Grapbaliums crifpum. ḄERG. cap. 253.

Flufculi androgyni \& feminei mixti. Thal. intimis calycis fquamis palea ceus, cetera nudus. Pappus pauciflemus, fetaceus, crifpus, longitudine fere corollx. Berg. I. c.

Anaxeton undifolium.

Guphalinm madifolitm. BERG. cap. 247.

Flofculi omnes androgyni. Thal. paleaceus: paleis lanceolatis, fubemarginatis, fcariofis, ovario paulo Jongioribus. Berg. L. c. Sed Linnxus Gnaphalio mudifolio exprefle receprac. nudum tribuic. Vid. fy/t. veg. 747 .

Genus problematicum, ab aliis curatius definiendum, Anaseton eft Guaphalii fynonymon. Diosc. in Nosbis p. m. 459. 


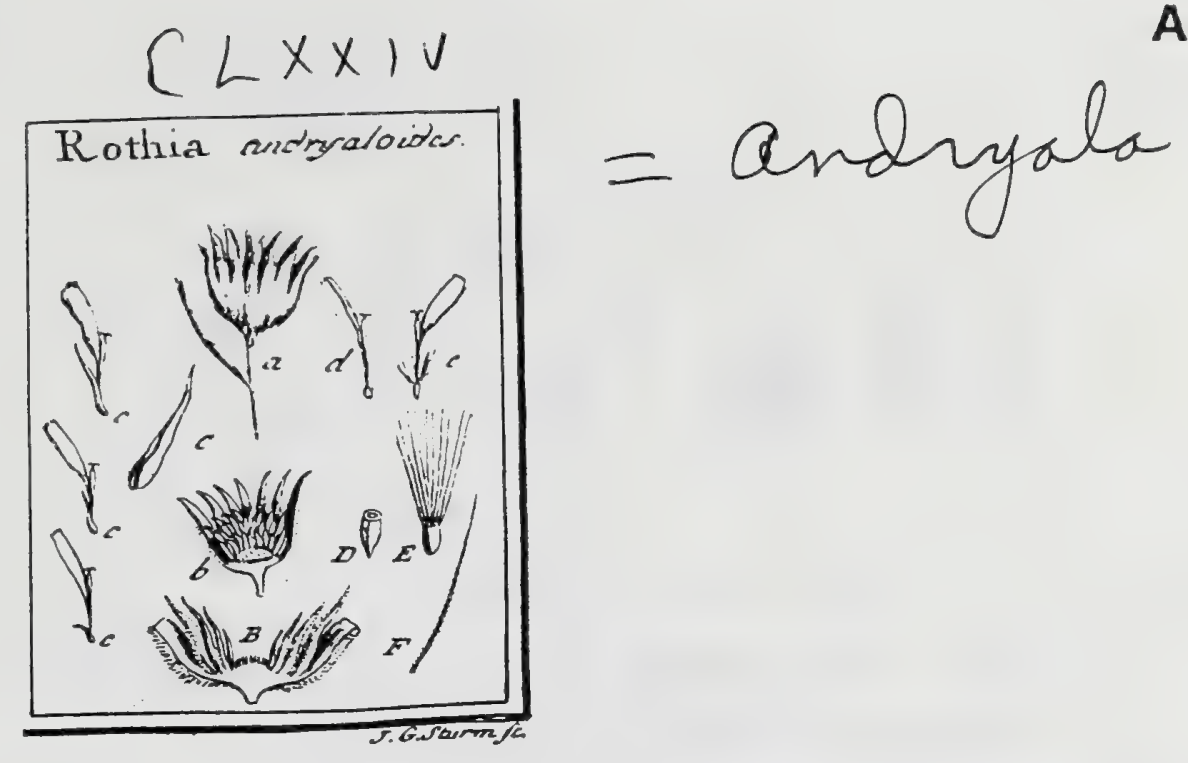

J. Gaertner (1788) Vol. 2

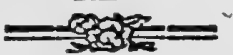

\section{SEMINIBUS DIFFORMIBUS. (*)}

a. Pappo marginalium nullo.

\section{DCCCCXXIII. R O T H I A. SCHREB.}

Calyx fimplici ferie polyphyllus, xqualis, lanatus. Thal. in ambitu palezceus, in medio villofus. Sen. marginalia calva; centralia pappofa.

Ro'THIA andryaloides. Tab. 174, fig. 9.

Voigtia. Roth. Diar. botan. tigur. 1790. in. X. p. 17.

A Cl. Schrebero.

REC. planiufculum, in medio villofum, verfus peripheriam multiplici ferie palearum tectum. Palec lineari-acuminatx, marginibus in vaginam fofculos amplexantem convolutæ, extus lanatæ, verfus peripheriam gradatim longiores, \& demum foliolis calycinis fimiles.

SEN. marginalia (quousque paleis locus eft) calva, minutula, ovata, deorfum infignicer acuminata, ftriata, ferruginea, fingula fingulis thalami paleis involuta.

cestralia perinde minutula, teretiufcula 1 . cylindrica, ftriata, ferruginea, non involuta, pappofa.

Pappus fetaceus, feffliis, albus: radiis numerofis, femine quintuplo longioribus, perf́ftentibus, bafi fubbarbatus, apice vero fimpliciter denticulatis.

INT. utrisque fimplex, nembranaceum.

EM B. femini confurmis, albicans.

a.) Calyx integer. b.) Idem difTeAus cun receptac. B.) Receptac. magnitudiae infugniter audum. c. c. c. C.) Palex diverfor longitudinis, Hofeulos bafi involveates d. D.) Vlofculus \& femen radii ealvum, e. E.) Flofeulus \& femen difei pappofum. $\dot{F}_{\text {.) }}$ Paspi sadius' infigaiter auctus.

(•) Ditluruitas oritur vel ex femiac ipfo, vel ex pagpo folu, vel ex utrisyue limulo 


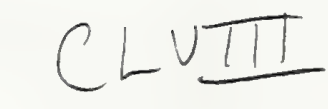

\section{Asteraceae}

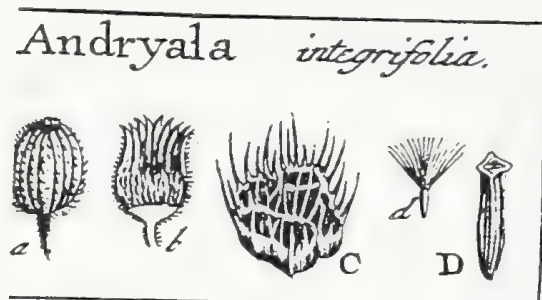

\section{J. Gaertner (1788) Vol 2 \\ 361}

DCCCCXI. ANDRYALA. LINN. ger. 9I5. Eriophorus. VAIIL.

Callyx ovato-cylindricus, duplici ferie polyphyllus, xqualis, tomentofus.

Thal. alveolatus, pilofus. Pappus pilofus, fectilis.

ANDRYala integrifolia. Tab. Is8. fig. 4 .

Soncluss lunatus. DaLech. bift. n116.

Andryalu foliis inferioribus runcinatis, fuperioribus ovato-oblongis tomentofis. LiNN. fyl. veg. 720 .

Rzc. planum, alveulatum, marginibus alveolorum ciliatis, ciliis fetafeis prelongis.

SEM. columnaria, ingulata, ftriata, fetis thalami paulo breviora.

Pappus felfilis, pilofus, obfolete denticulatus, bafi connatus, caducus, albicans.

INT. duplex: coriaceum atque membranaceum.

Ем в. Cemini conformis, albicans. Cotyl. oblongx. Rad. brevis, non difcreta.

a. b.) Calşx integer \& ditteâus. C.) Beceptac. pars infigniter auda. d. D.) Semen feparatuw. 


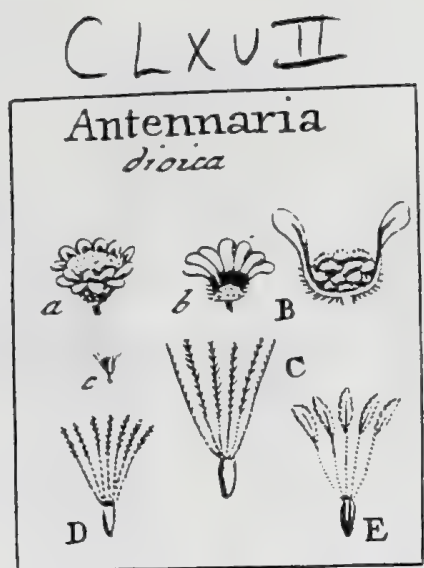

Asteraceae

J. Gaertner (1788) Vol. 2:

DCCCCLXXVII. A N T E N A R I A.

Calyx fubrocundus, imbricatus fquamis fariofis obtufis inxequalibus. Flofic. androgyni atque feminei nixti. Thal. fcrobiculatus, a fcrobiculorump marginibus denticulatis feaber. Pappus capillaris apice penicillatus.

axtennaria dioica. Tab. 167 . fig. 3.

Pilofella minor. Dod. pempt. 68.

Guaplutiun farmentis procumbentibus, caule fimplicifimo, corymbo fouplici, floribus dioicis. LiNs. Jjy. veg. $7+8$.

REC. planiufculum, fcrobiculatum, a fcrobiculorum marginibus ciliatis hirfutum aut fcabratum.

SE\&. parva, teretiufcula, fetis mmimis adfperfa, pallida.

Pappis niveus, radis plurımis, bali letaceis, apice penicillato-plumoles.

INT. fimpliciffimum, tenue.

EN B. albicans.

2.) Calyx integer, b. B.) Receptac udenudatum, ie. .C.) Seunen eum rapro.

Antenuaria Leontopoditum. ibid.

Filugo Leoustopodism. Liss.

Semina (D.) teretiufculn, ferilis adfperfa. Pappus niveus, radiis numerofis, 'penicillato - plumolis.

Anternaria :alpina. ibid.

Gnapbalium : alpiumm. LINN.

Semina (E.) :pracedentibus fimilia. Pappus niveas, radiis bafi fetaceis, apice explanatis in Jaminam clavatam folid:m! pinnatifido - Atratam.

Huc porro Ipedant: Gnaphal. feripbioides, mucronatum, mavicatums \&c. quibus $\mathrm{Cl}$. Bergius pappum :tribuit pilofum, sadiis tamen apice iincrallatis \& penicilliformi-plumolis. 


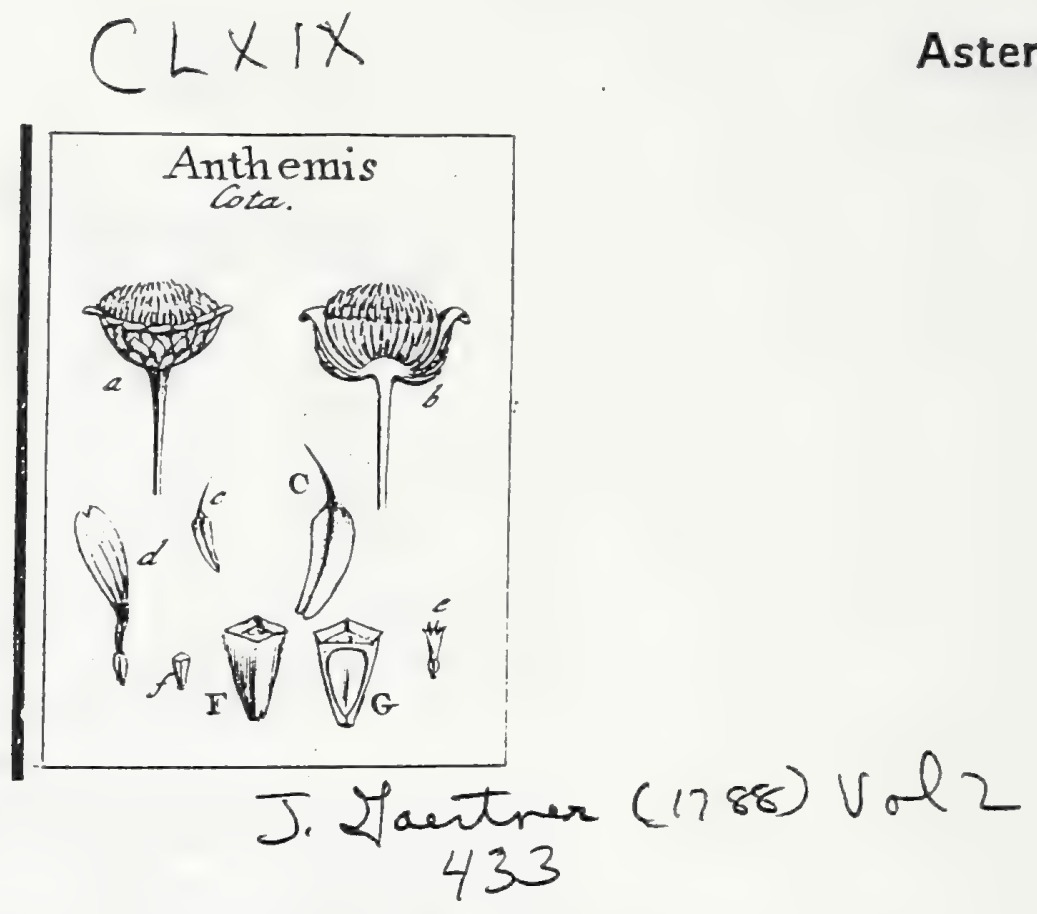

MV̀. A N T HE MIS. LINN. gen. 970.

Calyx hemifphæricus, imbricatus fquamis lineari-oblongis. fubxqualibus, margine fubmembranaceis. Thal. paleaceus. Flofc. difci androgyni; radii feminei, ligulis oblongis, apice interdum emarginato tridentatis: utrique fertiles. Semina uniformia aut fubdifformia, coronata margine edentulo. Folia omnibus diffects.

Axтнемis Cota. Tab. 169. fig. 4

CDamemelsun comnum ramrofun, cotule foetide floribus amplioribus. Moris. bifl. 3. S. 6. t. 8. f. Ir. TILL. pif. t. 19. f. 2. bene.

Autbeutis florum paleis rigidis prongentibus. LiNN. fyft. veg. 776 .

REC. levifime convexum, paleaceum: paleis membranaceis, planis, oblongis, furfum latefcentibus, apice in ariftam longam pungentem dęfinentibus.

SE x. uniformia, inverfe pyramidata, tetragona, glabra, pallida.

Pappis marginatus, membranaceus, erectus, brevis, edentulus.

IN T. exterius fubcoriaceum, tenue.

EMB. albus.

a.) Calyx integer. b.) Recept. palcaceum. c. C.) Palez (eparata. d.) Fiatc. nujit c.) Flofe. difei. f. F.) Semen iategtum. G.) Idem diగteaum.

Anthenis timforia. Lins. BLAkw. berb. t. 439.

Semina difformia: difci inverfe pyramidata, tetragona, obfolete ftriata, coro. nata margine membranaceo integro crenulatu. Sem. radii obovat, incurva, comprelie trigona, ad latera quafi in alas extenuata, coronaca margine integro. Media eft inter Anthemidem \& Buphthalmum, ut tamen ab hoc, feminum coroná non incifa \& foliis diffectis, Eacile diltinguatur.

Anthemis itaque eft Anacyclus sadio larvatus. 


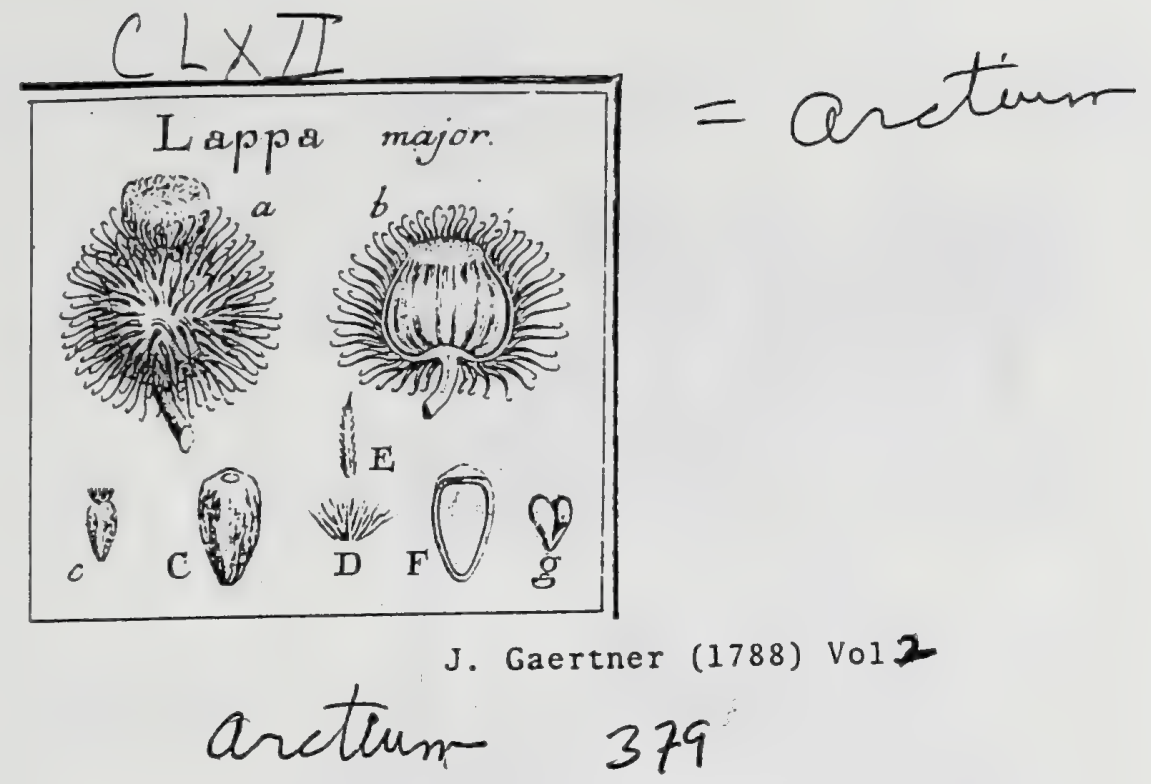

\section{DCCCCXXXIV. IA P P-A. TOURN. t. 256. JUSs. p. 173 .} Aretium. LiNn. gen. 923.

Calyx fphrricus, imbricatus fquamis linearibus, in fpinam apice hamatani definentibus. Flofa omnes androgyni. Thal, paleaceus. Sem. coronata pappo brevi inxquali rigido perfiltente.

LAPPA major. Tab. 162, fig. 3 .

Bardana S. Lappa major. DoD. penzpt. 38. BLAKw. berb. t. 117.

Arđium foliis cordatis inermibus petiolatis. LiN. Jyfl. veg. 723 .

Lcon. OED. for. dnn. t. 642 .

REC. paleaceum, paleis fetaceis, longitudine calycis.

S g M. oblonga. furfum latiora, rhombeo - compreffa, fufca, teftaceo maculata. Pappus dimidio femine brevior, pallide ftramineus, perîitens: radiis numerofis, paleaceis, denticulatis, rigidis, duplici l. triplici ferie vertici feninis aduatis.

IN T. exterius coriaceum, durum, cra Tum.

EMB. femini conformis, albicans.

a.) Calyx integer. b.) Reeept. (ctaceum. c. C. F.) Semea integram \& ditretuim. D. Ė) Puspus (eparatus. 5) Eubbryo denudatus. 


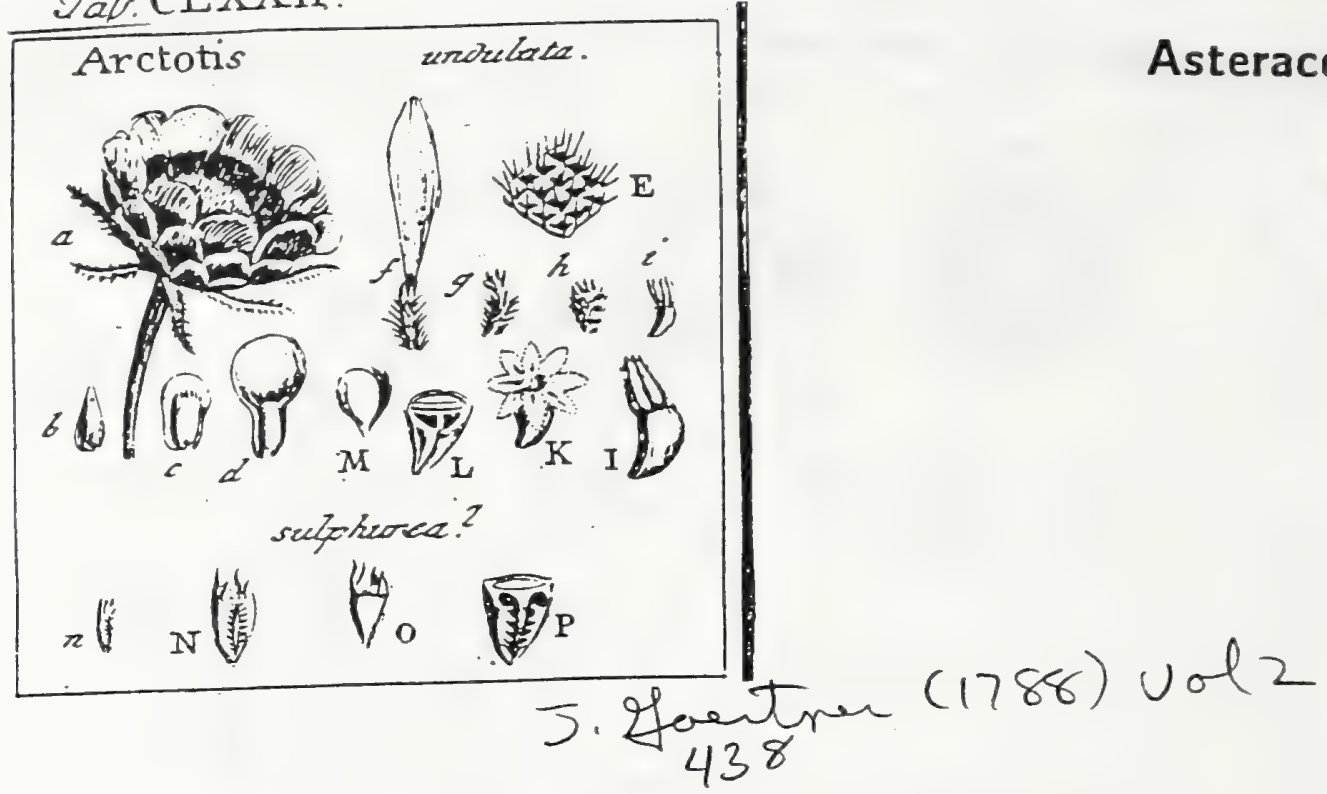

MXII. A R C T O T I S. LINN. gers. $99 \mathrm{r}$.

Calyx hemifpharicus, imbricatus fquanis inxqualibus: interioribus apice fcariofis. Thal. alveolatus, villofus. Flofc. difsi androgyni, Pteriles aut fertiles; radii feminei aur neutri, ligulis lanceolatis tridentatis, perinde fteriles au fertiles. Semina plerisque pfeudo-trilocularia. Pappus palezceus, limplex, tetra - odtophyllus.

Arctots undulata. Tab. 172. fig. S.

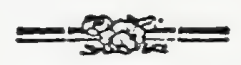

Asemonospermos afra, folio jacobes tenuiter laciniato, fiore eurantio pulchentiuno BozRH. lugdb. I. p. 10.0., t. 100.

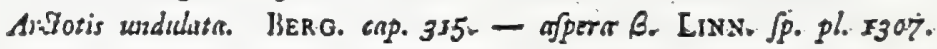

R E c. planum, alveolatum, alveolorum marginibus pilofis, pilis longitudine feninum; unde thalamus oblique infpeetus, quafs totus villofus.

SE M. uniformia, denfa lauugine alba veltita, inverfe conica. gibba, duabus alis in dorfum reflexis atque ita fe mutuo contingentibus ftipata, ut femen transverfe fectum, tria exhibeat loculamenta, guorum duo dorflio vacua, tertium autem ventrale nucleo fuxtum.

Is T. exteritus fubcruftaceun, durum, e caftineo-nigricans, pfeudo-triloculare; interius membranaceum, tenuifimum, embryonem involvens.

Es. B. obovatus, compreffus, albicans.

2.) Calyx integer, b: c. d.) Ejus fquanx extimx, medix \& intima E.) Thal, alveoli portio infiguiter aud2. E.) Flofc. feminets. T.) Flofc, anüro:ynus. h.) Semea lanz obvolatus. i. I.) Idcm exeuta laus deaudatum. K.) Pappus explicatus L.) Scminis cectio tracrverfalis. M.) Embryo denudatus.

ARCTOTIS fulphiurea? ibid:

an ArEtotis bypocliondriaca: LINN. Giff. oeg. $79 x$ ?

Semen lanatum, inverfe pyramidatum (n. N. ().\%), obfolete tetragonum; fufcum. Alx dorfi (P.) coriacex, pallidx, cartilagineo-denticulatx, recurvatx, fed fe mutuo non contingentes:- unde loculamenta fpuria incompleta, $\&$ dorfi fulcus medius denudatus. Pappi palex quatuor majores ovato-aciminatx, erectx; intermedix quatuor caducx.

In omnibus genuinis Arctotidis fpeciebus, quas ex ditifino Herbario Bankfiano examini fubjicere mihi licuit, femins aut ovaris conltanter reperis pfeudotrilocularia, excepta fola $A_{i}$ trifti.

Arctotides thalamo pileaceo \& pappo compolito dutatas, ad' Ur.fritars referimus. 

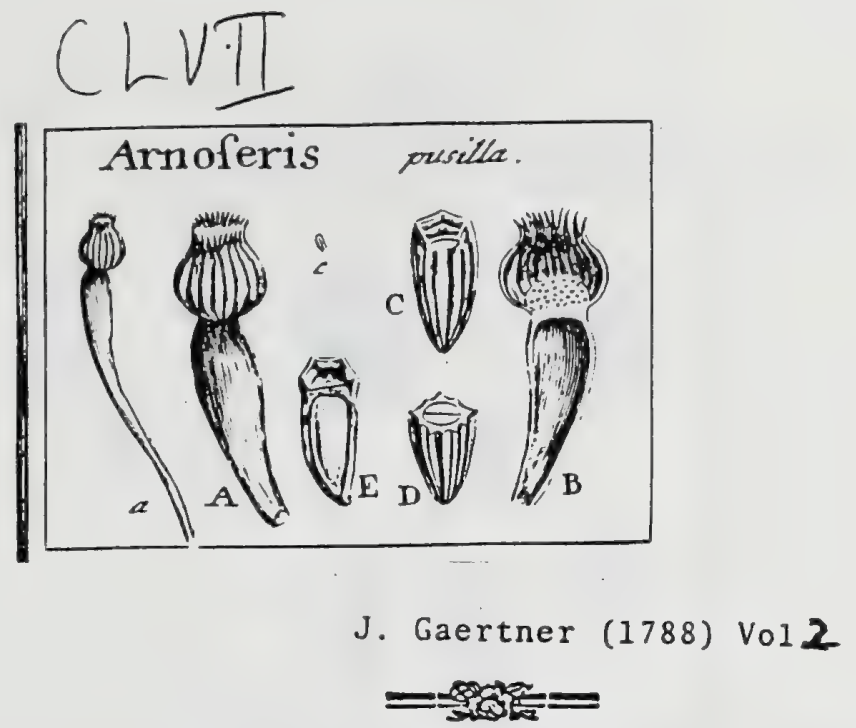

\section{DCCCCIII. A R N O S E R I S.}

Calyx fimpsex, polyphyllus, per maturitatem torulofus \& globofe connivens. Scm. margine coriaceo erecto integerrimo curonata.

AKNOSERIS puGilla. Tab. 157. fig. 3.

Hieraciun minimum. CLUS. Lijf. 2. p. 142.

Lapfana foliis ovatis dentatis, caulibus nudis, fub flore tumentibus. HaLL. bifl. U. 4 . Hyoferis caule divifo mudo, pedurculis inarafasis. LINN. fy/f. veg. Z2r.

Icons. OED. flor, divs, t. 20 .

REC. nudum, plauum, excivato-punctatum, glabrum.

SEM. parva, cinerafcentia, angulata, fulcata : fulcis alternis latioribus compreffs, alternis vero angultioribus rotundatis; utrisque albicantibus, interItitiis autem, in lemine receuti, viridulis.

Pappus marginacus, coriaceus, latiufculus, erectus, pentagonus, integerrimus, edcntulus.

IN T. duplex : coriaceum atque membranaceum.

Em B. femini conformis, albicans. Cotyl. obtufx. Rad. acuninata, non difereta.

2. A.). Calyx maturus integer. B.) Idem ditectus, fuperne receptaculum nudum, \& inferne pedunculum inlatum racuum oftendens. e. C.) Semen iategrum. D. E) Idem transverfiun \& longitudinaliter diffectum, cum fgura embryonis

$\Lambda$ Lapfana perinde atque $a b$ Hyoferide differt: $a b$ ifta nempe calyce \& pappo: ab hac autem pappo nec phyllode nec difformi abunde difcrepat. 


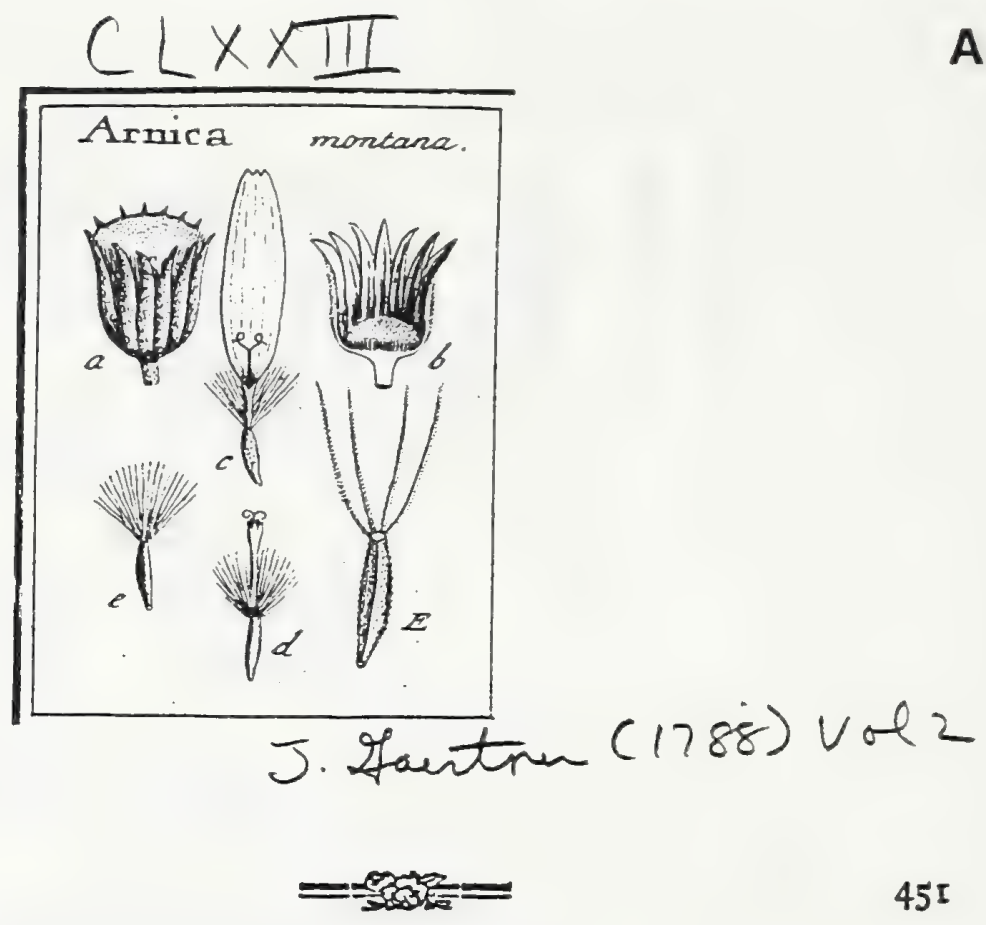

Asteraceae

MXXVIII. A R N I C A. OfFic. Linn. ger. 958.

Calyx fimplici aut fubduplici ferie polyphyllus xqualis. Thal. breviatime villofus. Flofc. difci androgyni; radii feminei, filamentis quinque caltratis, ligulis oblongis tridentatis: utrique fertiles. Semina uniformia. Pappus fetaceus.

AsNiCA montana. Tab. 173. fig: $t$.

Caltha alpina. BesL. Ey/f. aftiv. XIV. t. 8. f. 2. BLAKW. berb. t. 595. bona. OED. flor: das: t. 63 . mal.

Arnica folits ovatis integris: caulinis geminis oppofitis. LINx. fyf. veg. 768 .

R Ec. planum, profunde fcrobiculatum, fcrobiculorum marginibus fenceo ciliatis, ut totus thalamus appareat villofus.

SEM. üniformia, oblonga, compreffufcula, fetulis minimis adfperfa, nigricantia. Pappus difci \& radii unifornis, fetaceus, pallide ftramineus, denticulatus, femini xqualis aut paulo longior.

IN T. exterius coriaceun, tenue.

Es B. albus.

a.) Calyx maturus integer. b.) Idem dilfiectus, eura receptaculo. c.) Flofe. radii. d.) Flofo. difci. c. E.) Semen feparatum.

Corollulx radii utique habent filamenta quinque fterilia, fecus atque vult Cel. Jussiaus. Doronicun Bellidiaftrum LINN. genuina eft Arnicx fpecies, propter femina radii pappofa, nec calva. 

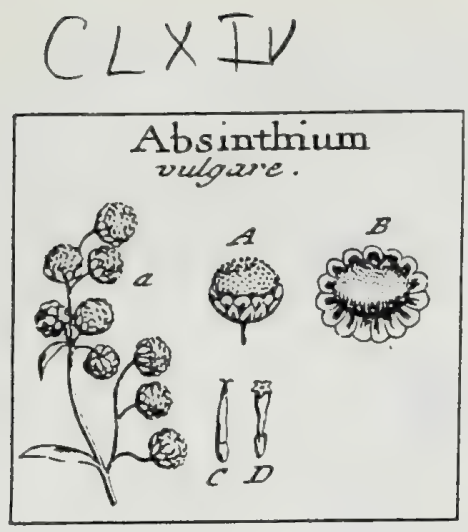

- artemisia

J. Gaertner (1788) Vol. 2

393:

DCCCCLIII. A B S I N T H I U M. TOURN. $t .260$.

Calyx fubglobofus, imbricatus fquamis obtufis appreflis. Flofc. difformes: difci infundibuliformes, quinquefidi androgyni; radii fubulati, edentuli, feminci : utrique fertiles. Thal. villofus. Sem. calva.

ABsinthium vulgare. Tab. 164 . fig. $70^{\circ}$

Abfintbizum. Cans. epit. 452. BLaKW. berb. t. ry.

Artemijsia foliis' compositis ntultifidis, fioribus fubglobofis pendulis: receptaculo villofo. LinN. fyjt. veg. 744.

RRC. planiufculum, tectum villis fericeo albicantibus, calyce dimidio brevioribus.

SEM. uniformia, parva, ovata, oblonga, pallida, calva.

Is T. Iimplex, membranaceum:

EM B. femini confurmis, albicans.

2.) Racemulus fiorum feparatus. A.) Calyx Boridus. B.) Idem, exeufis dofculis, \& deandato receptac. D.) Flofe, difci C.) Flofcursadii : uterque cum fuo femine.

Huc porro fpectant ex Linnxaus Artemifiis : arborefccus, glacialis, rupefris, tausacetifolia, \& alix. 


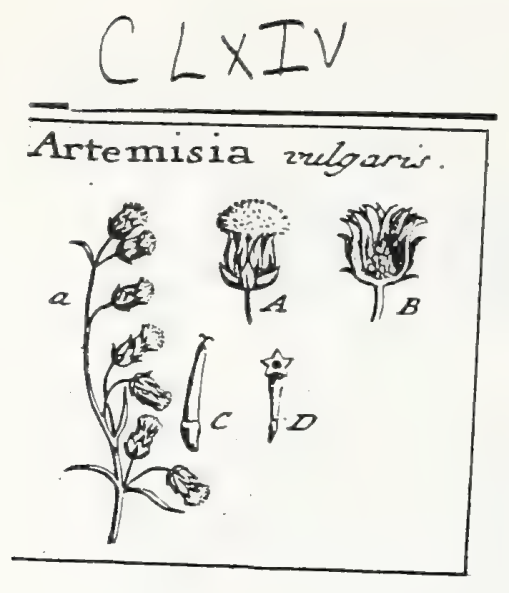

J. Gaertner (1788) Vol.2

387.

DCCCCXLIV. A R T E M I S I A. TOURN. t.260. Linn. ger. 945.

Calyx fubovatus, imbricitus fquamis oblongis apprefis. Flufc. ditormes: difci infundiluliformes quinquedentati androgyni numerofs; radii fubulati edenculi feninei pauciores: utrique fertiles. Thal, nudus. Sem. uniformia calva.

ARtesisin vulgaris. Tab. 164 fig. I.

Artemijia. BLAKw. berb. to 43 r.

Artensifia foliis pinnatifidis planis incijis fubtus tomentofis, racennis fantlicibus recurvatis, floribus radio quisqueforo. LINN. Jyjt. vez. 744 .

REC. conicum, alcitudine dimidii calycis, anfractuofe tuberculatum, nudum.

S в M. uniformia, parva, ovata, deorfum. anguftiora, fpadiceła cạlvạ.

IN T. fimplicifimum, membranaceum.

E M. B. Semini conformis, albicans.

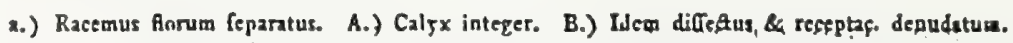

C) Flofe. radii femincus. D.) Flofc. difci andrugyaus: uterque cum fuo femiac calvo. 


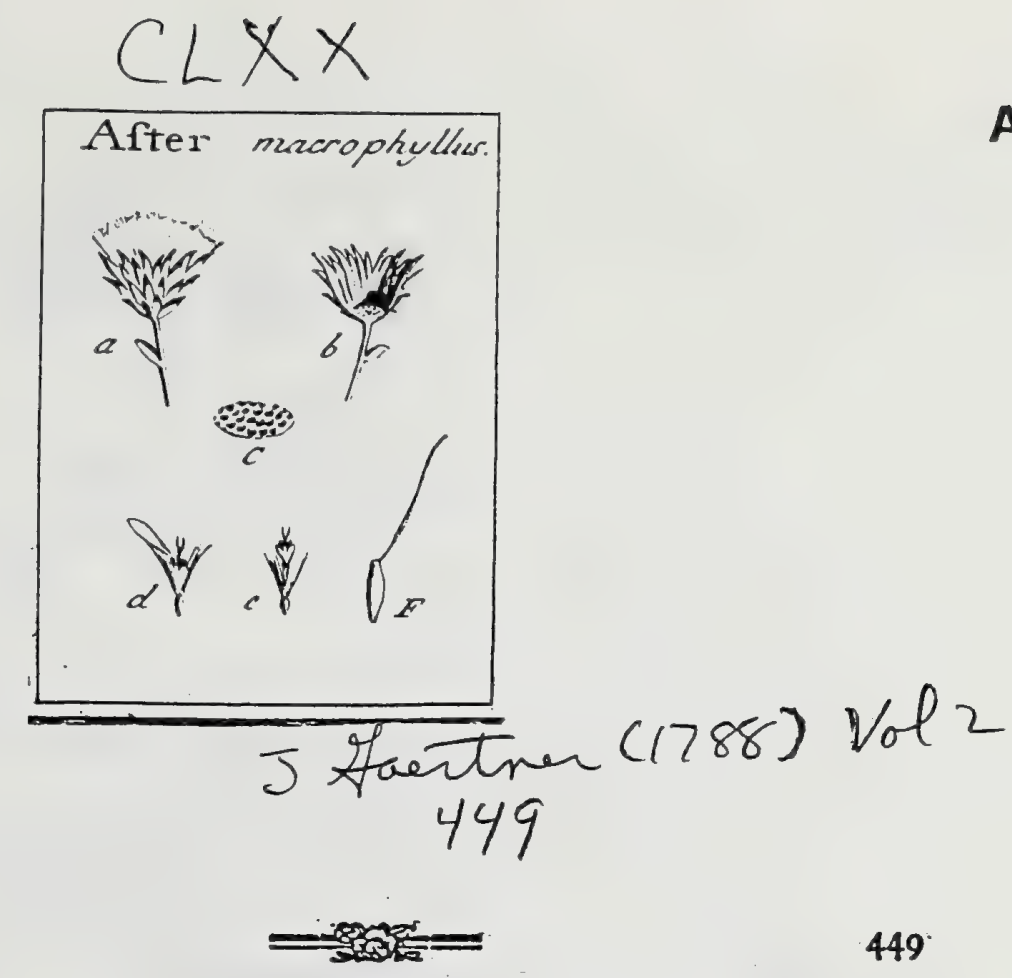

Asteraceae

MXXV. A S T E R. TOURN. t. 274. LINN. ger. 954.

Calyx imbricatus, fublquarrofus, fquamulis, prefertim inferioribus, patulis. Recept, nudum, puncticulatum glabrum, aut fcrobiculatum feabrum. Flofe. difci androgyni ; radii feminei, ligulis lanceolatis, purpurafcentibus aut albis: utrique fertiles. Pappus capillaris.

AsTer macrophyllus. Tab. 170. fig. 7.

Afer foliis ferratis: radicalibus mzximus cordatis trinervatis: carlixis ovatis Segilibus. Lins. [yft. veg. $76_{3}$.

R E c. planiufculum, fcrobiculatum, glabrum, nudun.

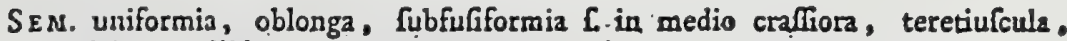
glabra, pallida.

Pappis pilofus, minutirime denticulatus, femine duplo longior, rufefcens.

INT. fimplex, membranaceum.

Eм в. femini conformis.

2.) Calyz maturus. 'b.) Idem diffeQns, eum receptzeulo (b. C.) Icrobiculato, d.) Flole. sadil

c.) Flo[e. dilci. F.) Stanen magnitudine autum.

In nonnullis fpeciebus receptaculum profundius ferobiculatum \& a fcrobicu. Jorum marginibus denticulatis aut ciliatis. fcabratuni elt, ut in $A$. nove anglia \& novi belgii.

Adde Corryze radium, \& habebis Afterem aut Inulam. 

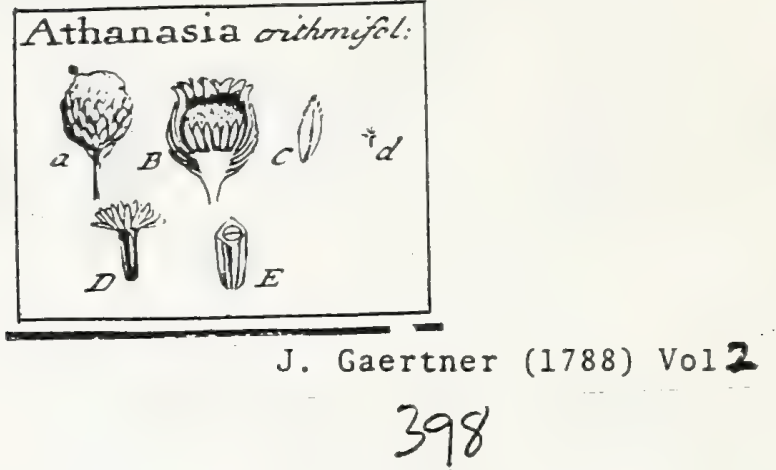

DCCCCLXI. A T H A N A S I A. Linn. gerr. 943.

Calyx ovatus imbricatus rquatnis appreffis duris. Flofc. uniformes, omnes androgyni, fertiles. Thal. paleaceus. Sem. uniformia, pappo tri - 1 . polyphyllo, brevi.

Athaxasia crithnifolia. Tab. 165. fig. 9.

Coma aurea africana fruticans, folis crithmi marini. CoмM. bort.2. 2. 50. bene.

Simtolina. MILL. ic. t. $327 \cdot f .2$.

Atbunafia corymbis fmplicibus, fuliis femitrijidis linearibus. LINN. fyft. veg. 741 .

REc. planum, paleaceum, paleis calyce brevioribus.

SEN. parva, columuaria, angulata, ftriata, ferruginea.

Pappus fenine brevior pólyphyllus, foliolis linearibus, membranaceopaleaceis, albis.

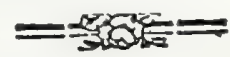

IN T. fimplex, membranaceum.

Eas B. Remini conformis, albus.

a.) Calyx integer, B.) Idem diffectus cum receptae, paleacen, C.) Palez leparatz d. D.) Se men inteģrum. E) Idsm diftetum.

Genus bifrons, accedente radio nutatur in Eilopem. 


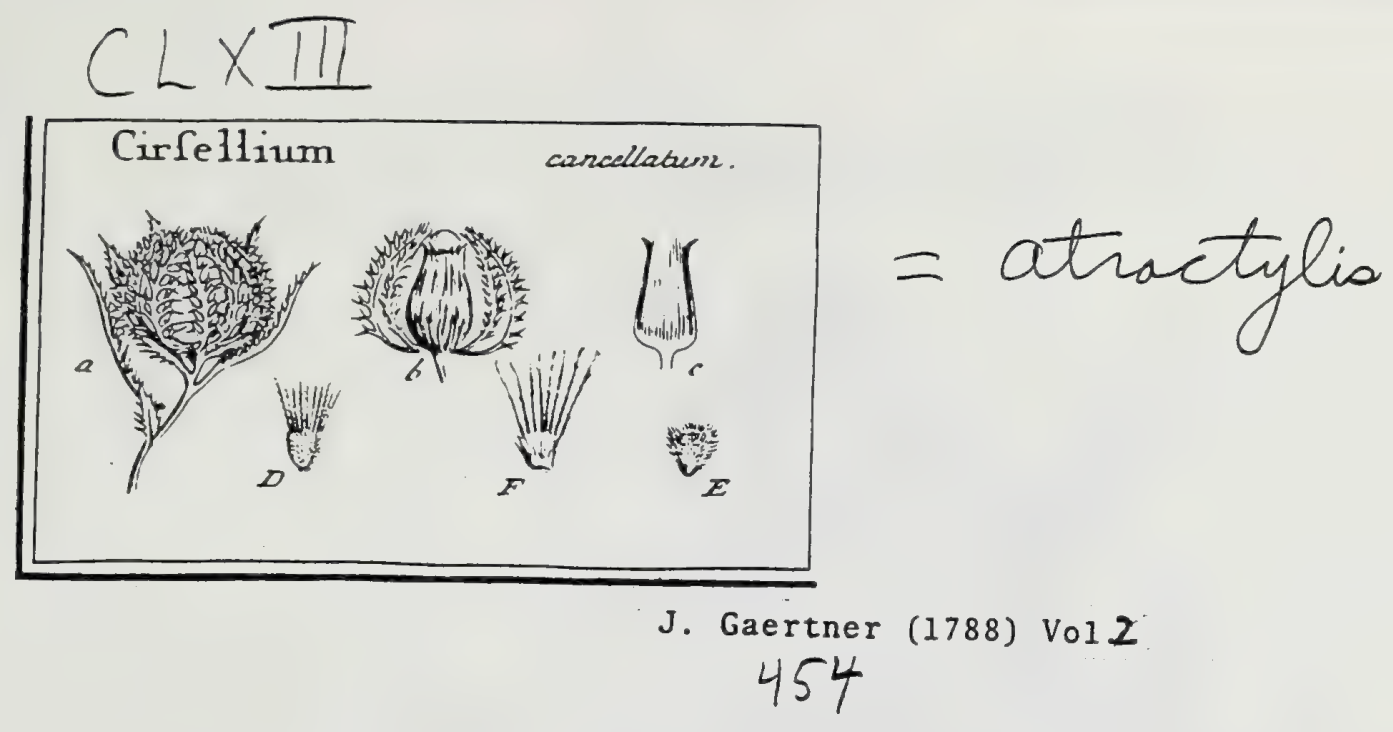

\section{C I R S E L L I U M.}

Calyx imbricatus fquamis inermibus aut fpinofis. Thal. fetaceo-paleaceus. Flofc. difci androgyni; radii ferminei ligular: utrique fertiles. Sem. uni-
formis. Pappus plumofus.

Cirselliva cancellatum. Tab. 16;. fig. 2

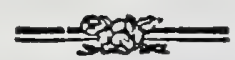

Carduus parous. BavH. bije. s. p. 93.

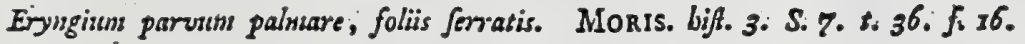
Atraifylis involucris cancellatis ventricofzs lineavibus dentatis, calycibus ovatis, floribus fooculofs. Liss. bylt. veg. $7=9$.

RRC. planum, paleaceum, paleis longitudine calycis, lineari-acuminatis, tenuibus, Gexilibus, albis, bafi inter fe connatis.

SEM. inverfe pyramidata 1. obovata, lana rufefcente, ipfis paulo langiore, veftita.

Pappus plumofus, femine duplo longior, pet maturitatem deciduus, radiis numerofis, bafs in annulum connatis, atque feminis lana obvallatis.

IN T. fimplex, membranaceum.

Em 8 . albicans.

a.) Calyx involuero eancellato ftipatus. b.) Idem denudatus c.) Ejusdem fetio rerticalis, enm receptac. paleaceo. D.) Semen integrum. E) Idemi pappo fuo orbatum Fu Pappus feparatus, ball lanz acceltoriz ftipatus.

Hxc fpecies fxpius radio caret, \& memorix faltem cavfa prolata eft.

Cirfellium bounile.

Carlina minima caulodes bifpanica. BARR. ic. 592.

Atracylis brimilis. Lins. l. c.

Thalanus planiufculus paleaceus, paleis fubconnatis laciniatis: laciniis fetaceis, lungitudine calycis, apice cxruleis. Semina oblonga, fubcompreffa, tomento fericeo, ipfis longiore, obvoluta. Pappus plumofus longus: pinnarum crinibus bafi \& apice copiofioribus. LOEFL it. edit. germ. p. 218.

Anne \& huc fpectant Atrat. gummifera, lancea, ovata; nec non Carthamus falicifolius?

Cirfellium itaque eft Cirfinm radio larvatum. 


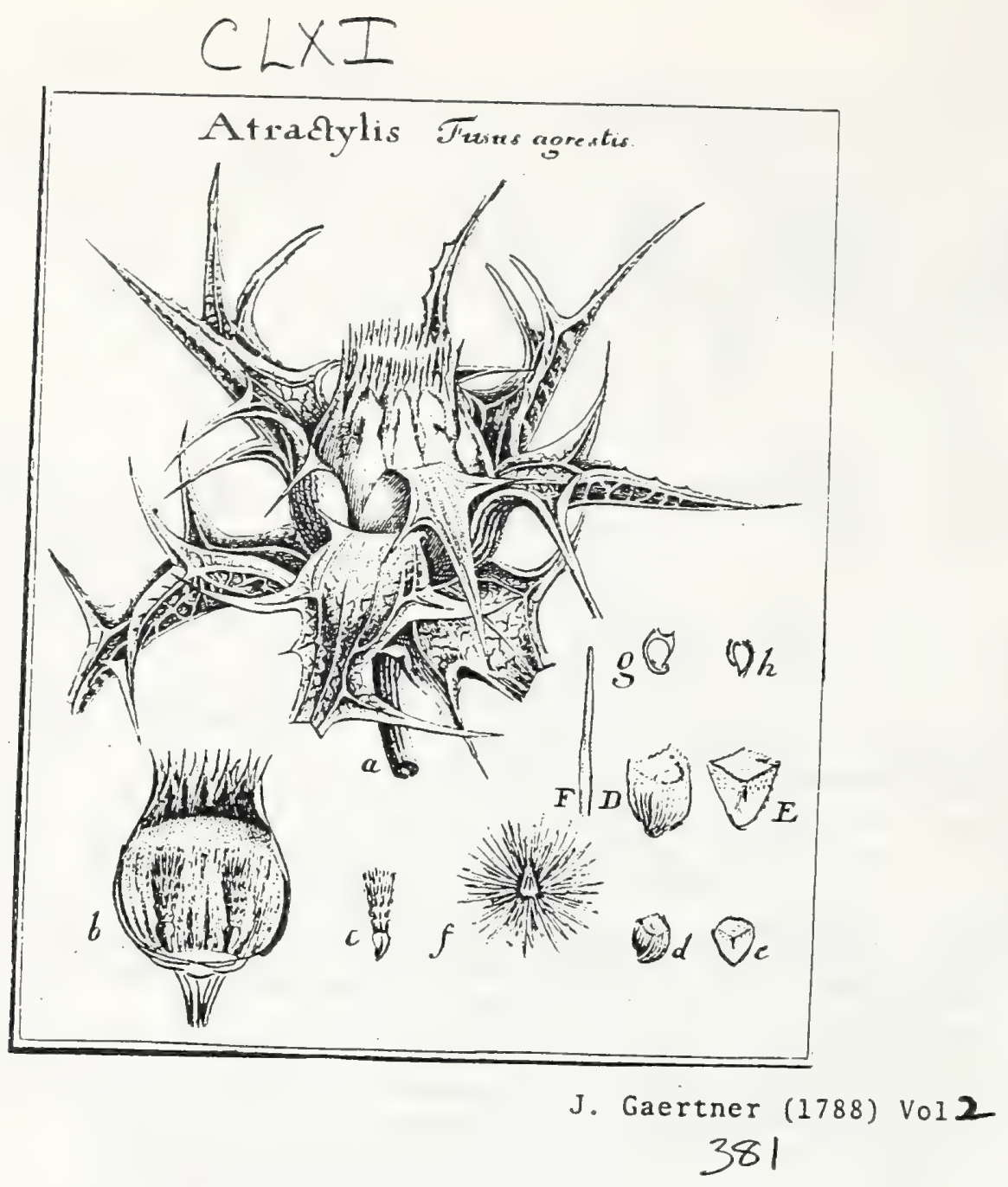

\section{DCCCCXXXVII. A T R A C T Y I.S. VAILL.}

Calyx ventricofus, imbricatus fquamis exterioribus foliaceis, reticulato-nervofis, pinnatifido-fpinofis; interioribus carcilagincis, fuperne dilatato-appendiculatis, ciliatis, in fpinam pungentem delinentibus. Flofc difei androgyni; radii neutri aut feminei. Sem. fubdifformia. Pappus inxqualis paleaceus, rigidus.

ATRACTYLIS Fufus agreftis. Tab. 161, fig. 2.

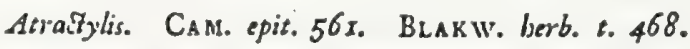

Curthamus coule piloto, fuperue lumato, folits inferioribus pinnatifudis: fummis amplexicaulibus dematis. LINN. $\int y / 6$, veg. 730 .

REc. paleaceum, paleis fetaceis, dimidio calyce longioribus.

SEM. inverfe pyramidata, fubdiftormia: marginalia obefiorn, hinc convera, gibba, inde angulan; centralia tenuiora, rhombeo - tetragona: utraque apice truncata atque nargine prominulo crcnulato terminata, obfolete fulcata, inferne glabra, fuperne furfuraceo-fcabra, fordide fpadicea.

Pappus feminum radii nullus! difci plurimus, pallide ftramineus, per xtaten caducus : radiis lineari-paleaceis, ciliatis, rigidis, incqualibus: intimis brevilfmis, fubulatis, conice convergentibus.

IN T. exterius crufticeum, durum, cralium, f. nucamentaceum.

EM B. obovatus, albicans.

a.) Calsx integer. b.) Recept. palcaecum. c.) Orarium immaturim. d. D.) Seraina marginaliz. c. E.) Sem. eentralia. f. F.) Pappus feparatus E.) Semen dilfeftum. h.) Embr. folutus.

In A. leucophen, f. Carch. cretico LiN. Semina margiualia pappo carere alfirmat HaLl. b. goett. 363. \& idem quoque de nultra fpecie allinit Trew. l. c. Mihi nondun contigit femina matura in fitu fuo natursli vidille; quantum vero ex amplitudine \& fcabritic arcic verticalis in feminibus marginalibus Fusf agrefis coujicere licet: utique nec lixc pappo füo carere videntur.

Atrafylis Linnacana eft genus chauticum, fponte in plantas genere diverfiumas dilabens. 


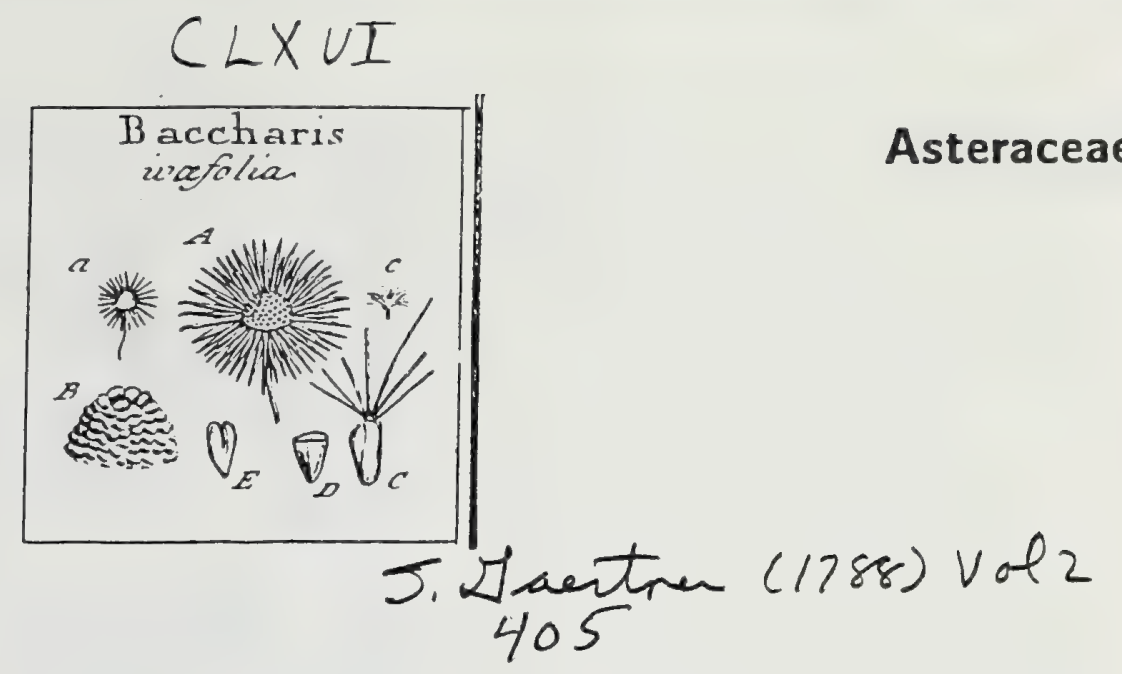

\section{DCCCCLXX. B A C C H A R I S. LINN. gen. 949.}

Calyx cylindricus, imbricatus, per maturitatem patentmimus. Flofe. difformes: difci infundibuliformes, androgyni, quinquefidi, pauciores, fteriles; radii fubulati, fubedentuli, feninei, numerof, ferciles. Thal fcrobiculatus. Pappus capillaris.

Baccharis ivæfolia. Tab. 166. fig. 9.

Eupatorium africanum, agerato affinis peruviano, foribus albis. PLux. plyyt. t. $328 . f .=$.

Conyza frutefcens, foliis anguftioribus nervofis. Feuv. pernz. 750. t. 37.

Baccharis foliis lausculatis. longitudinaliter dentato fenratis. LiNs. fyft. veg. 75r.'

REC. obtufe conicum, in vertice alveolatum, alveolis margine denticulatis; ad latera autem fimpliciter \& obfolete fcrubiculatum.

S E M. feninis parva, ovato-oblonga, compreffiufcula, obfolete marginata, pallida. Pappus capillaris, parcus, femine duplo longior, fubedentulus.

IN T. fimplex, membranaceum.

EMB. albicans.

a. A.) Calyx maturas patentifimus. B.) Receptac. infigniter auQum s. C. D.) Semen inter grum \& diffeaum. E.) Emhryo denudatus.

Genus vix ac ne vix quidem a Conyza diftincuum. 


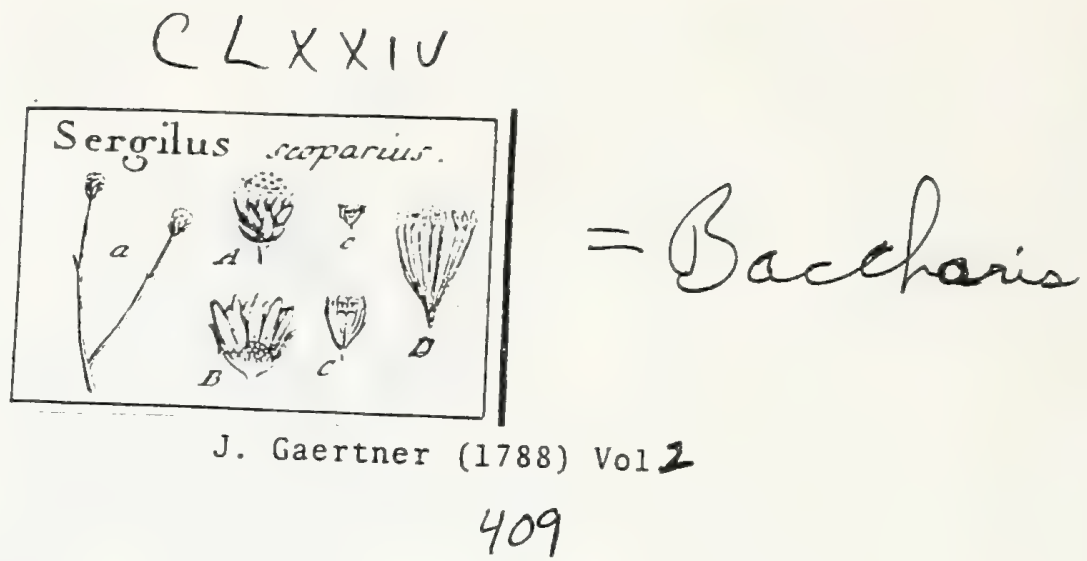

Asteraceae

DCCCCLXXVI. S ER G I L U S.

Calyx fubturbinatus, imbricatus fquanis appreffis, inxqualibus, fubfcariofis. Flofe omnes androgyni, quinquefidi, ferriles. Thal. nudus. Pappus capillaris, apice penicillatus.

Sergilus fcoparius. Tab. I74. fig. 6.

Chryfocoma arborea ramofifma, ramis teretibus quadrato-fubmaginatis, foliolis pancioribus minimis linearibus. BROWN. bifl. jam. 376. t. 34. f. 4 .

Calea canle fuffruticofo, ramis fuboppofitis angulatis. LiNs. fyft. veg. 740.

A Cl. Thunbergio.

REC: angultum, tuberculatum, nudum.

Ses. uniformia, minutula, ovata, glabra, pallida.

Pappus calyce longior, multiradiatus: radiis capillaribus albis, apice penicillato-plumofis.

I $\mathrm{T}$. Gniplicifimum, membranaceum.

EM B. femini conformis, albicans.

2. A.) Calyx integer. B.) Receptze. denudztum. c. C.) Flofeulas integer cam fuo feraime. D.) Semen feparatum \& infigniter autuun.

A Calea, receptaculo atque pappo, a Chryfocome autem folo pappo differ: hinc utique pofteriori magis affunis eft. Folia quandoque oppolica etfe videntur; funt autem generatim ninutifina atque remiotifima. 


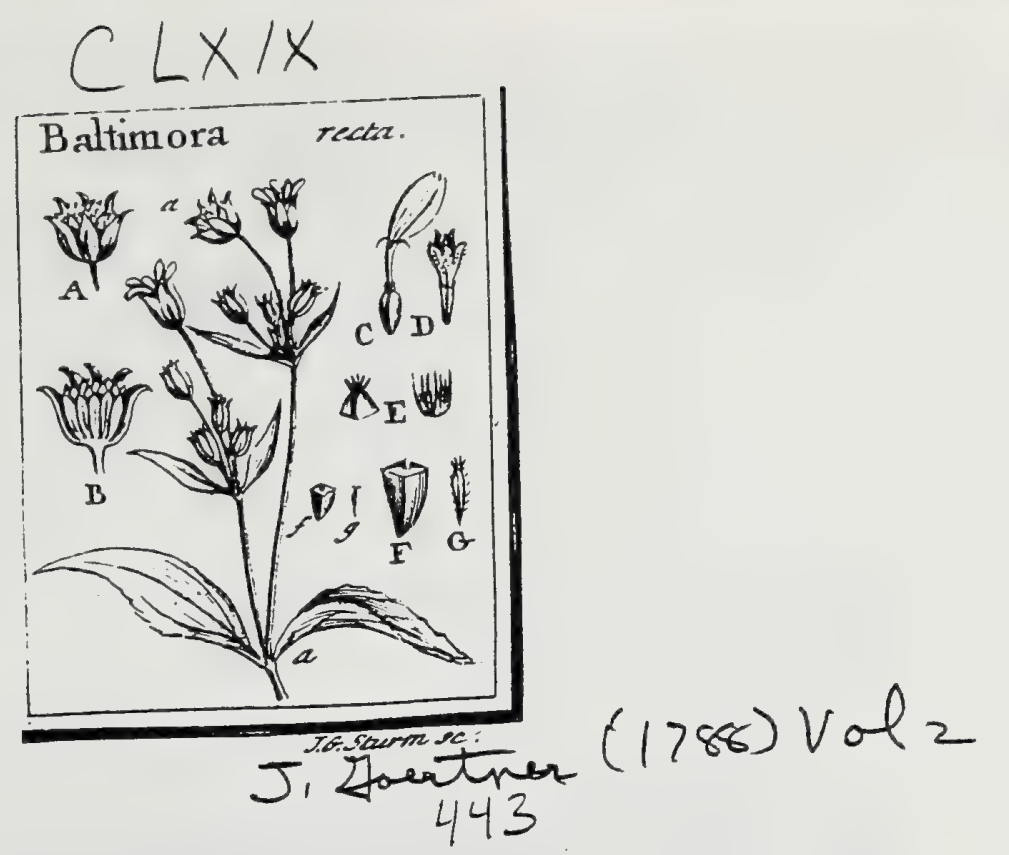

\section{B A L T I M O B A. - LINA. gen. I3ะ3.}

Calyx fubcylindricus, duplici ferie polyphyllus: foliolis interioribus paulo brevioribus. Thal. paleaceus. Flofc. difci androgyni, fubdeni, quinquefidi : dentibus externe hirfutis: antheris atris; tteriles; radii feminei, quini, ligulis ovatis tridentacis, fertiles. Pappus polyphyllus, breviflimus, marcefcens.

\section{4}

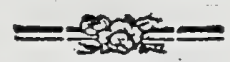

Baztimora recta. Tab. 169. fig. 9

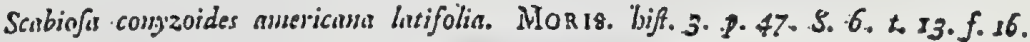

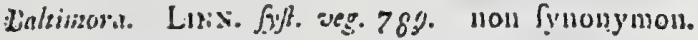
$\Lambda$ Cl. Dar. च. KOYEX

REC. angultum, paleaceum, paleis membranaceis, lineari-oblongis, calyce brevioribus.

SEM. fentinis inverfe pyramidata, triquetra, glibra, fufca.

Pappres breviffinus, po!yphyllus: foliolis inembranaceis, lineari - actnninatis, narcefcentious, inxqqualibus: :tribus aut quatuor reliqquis longioribus.

IXT. exterius coriaceum, durum.

E M.B. femini conformis.

2. a.) Pars extima rami horidi. A.) Calyx integer. B.) Reecptac. paleacenm. C.) Tlufe. rä̈ii. D.) Flofc. difci. E.) Pappus infiguiter auctus. f. F.) Senen integruin. g. G.) Ovarium at:costirum fhusculi andrugyni.

'Caulis quadrangulus, angulis rotundatis fcabris, lateribus profunde \& angufto fulco exaratis. Folin petiolata, fcalbra, trinervia, non decurrentia. Flores aggregati, terminales atque axillares, pedunculis glabris fimpliciffmis, inxqualibus: ferioribus brevioribus. Corollula omnes fulphurex, $f$. pallicie lutex. Figura Morifoni l. c. inforefcendi modum bene reprafentat, reliqua autem non perinde congruunt. At Pluknetiana icon, a Linuso excitata, penitus diverfa \& certiffime Phaëthufre eft. 
Wo Arawirgs

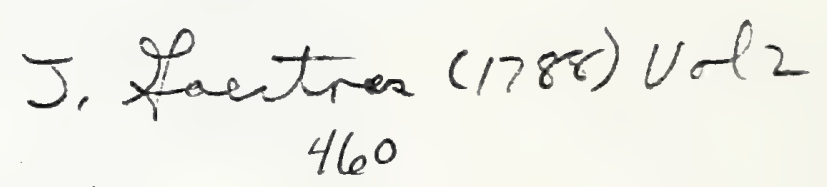

B A R N A D S I A. LINN. ger. I4Ig.

Calyx fubventricofus imbricatus pungens. Thal. planiufculus villofus. Flofe. difci androgyni, terni l. quaterni; ratii feminei (androgyni Juff.), ligulis

- lanceolatis, apice fiffis, extus hirfutifinis: utrique ferciles. Semz uniformia. Pappus difci fetaceus, retrofractus. (Fpiralis JuIf.), denticulato. ciliatus ; radii plumofus.

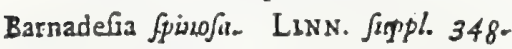

Semina ovata, pilofa, pilis reverfis. Pappus difei fetaseus, radiis rigidis, retrofractis, denticulato-ciliatis. Pappus radii lingus, erectus., patulus, nultiradiatus, plumofus, mollis. LINN. l. c. 56 . 


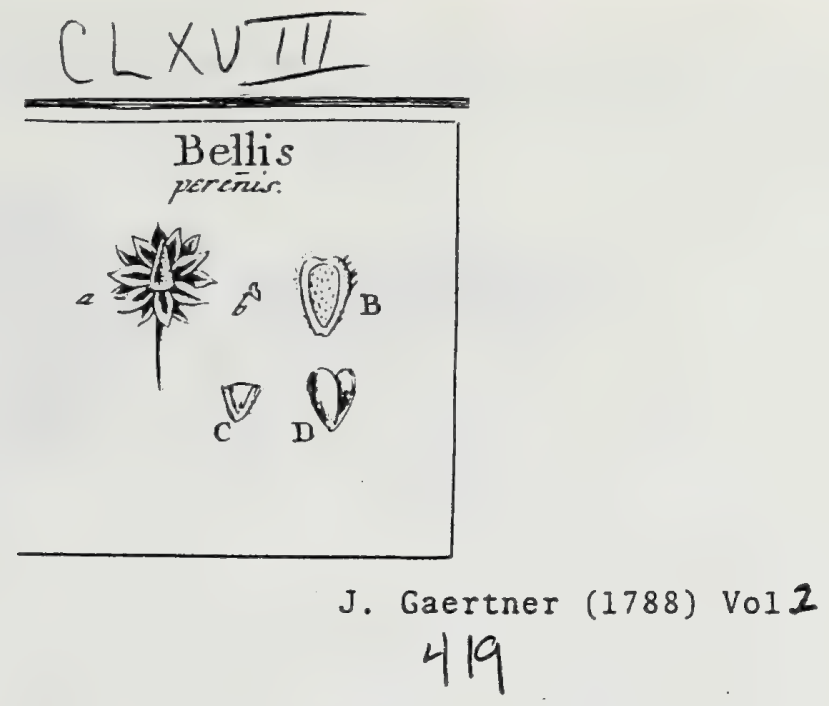

DCCCCLXXXVIII. B E L L I S. TOURn. t. 280. Linn. ger. 962.

Calyx hemifphrcericus, duplici ferie polyphyllus, xqualis. Thal. nudus, conicus. Flofc. difci androgyni, infundibuliformes, quinquefidi; radis feminei, numerofi, ligulis anguftis nnceolatis: utrique fertiles. Sem. cumpreffa, calva.

BELL1S perennis. Tab. 168. fig. 1 .

Bellis. Dod. penpt. 265. BLAKIv. berb. t. 200. \& 530. OED. fior. dars. 4. 503 . Bellis Scapo mido. LiN. Jyfo veg. 770 .

REC. argute conicum, tuberculatum $f$. puncticulato feabratum, nudum, lougitudine foliorum ealycis.

SEM. cordato.oblonga f. apice emarginata, compreffa, albicante margine cincta, in medio autem fpadiceo-cinerafcentia, rarisque villis albicantibus cunfperfa, alva.

Ix T. fimplex, membranaceum.

Е ал в. Semini conformis, albicans.

3.) Calyx a parte ineerna fpetatus, cun reseptacula, b. B.) Sewes integram. C.) Idem diffezuma. D.) Eabryo deaudatus. 
Asteraceae

ho dravingo

$$
\begin{gathered}
\text { J. Haentree (1788) Vol.2 } \\
461
\end{gathered}
$$

B E L L I U M. LINN. ger. I322.

Calyx fimplex polyphyllus xqualis patens. Thal. conicus nudus. Florc. difci androgyni quadrifidi; radail feninei, deni aut duodeni, ligulis elliptifoliolis octonis pajeaceis exteriozibus, totidemque radiis fetaceis aut aritta tis interioribus.

Belliunt bellidioiles. Linn. fyft. veg. 770 :

19.26 


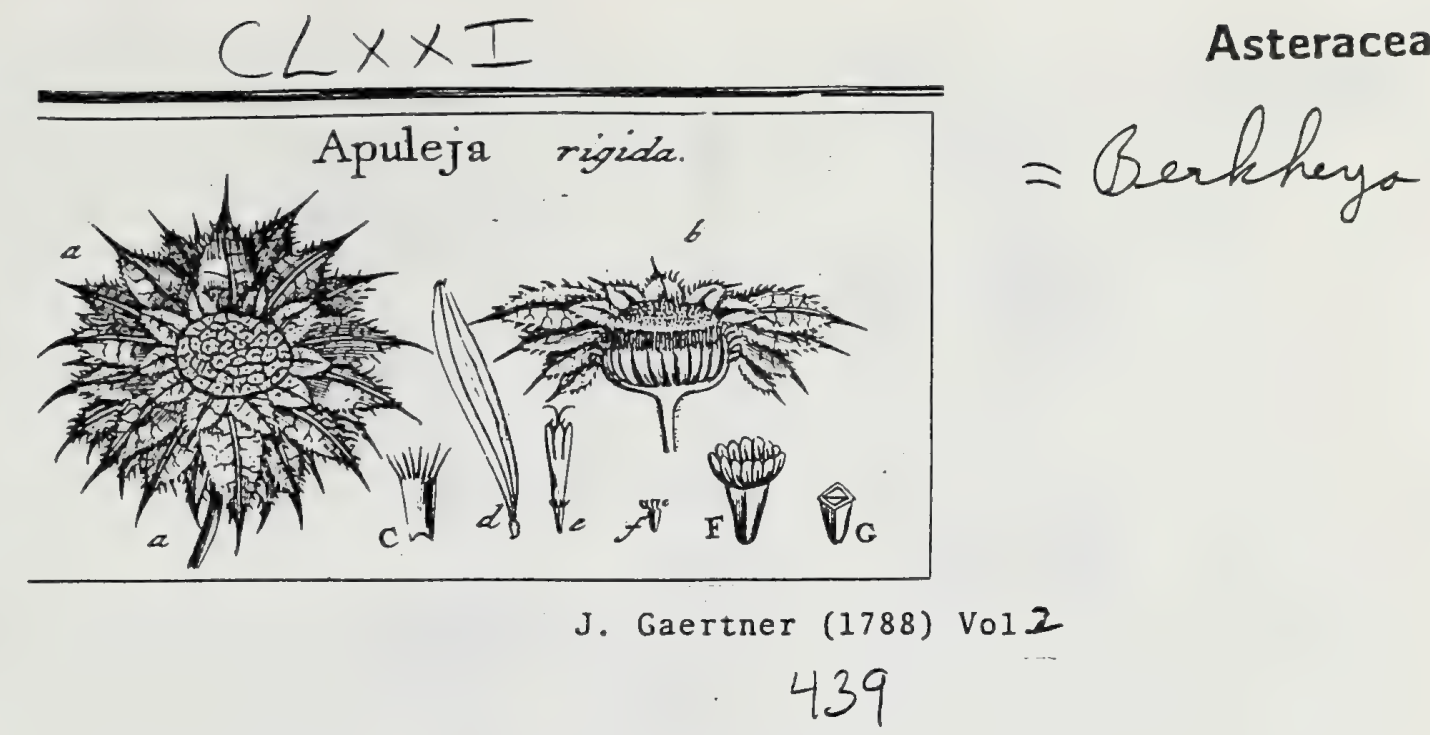

\section{A: P U I E J A. Agriphyllum. Juss. p. I90.}

Calyx fquarrofus, imbricatus fquamis foliaceiș trium lo pluriums ordinum, inferne coaltis, fuperne patentibus, dentato. Spinofis. Thal. profunde alvenlatus, fetaceus. Flufc. difci andrugyni, fertiles; radit. neutrib, ligulis longilfimis tridentatis. Pappus palesceus, poly phyllus.

ApULEJe rigida. Tab. 171 . fig. 1 .

Gorteria rigidi: Banks. bort. fice:

REC. planum, alveolatum:: alveolorum inarginibus fetaceo: laceris, femine lungioribus.

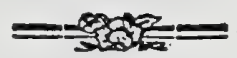

SE M. audrogynis inverfe pyrnmidata, tetragona, glabra, fpadicea.

Pappus paleaceus, polyphylius: radiis duplici ferie politis, xqualibus, hinearibus, obturs, pallidis, femine brevioribus.

INT. coriaceum, tenue.

Eм в. femini conformis, albicanss.

2.) Calyx matorus integer. b.) Idem diffictus cum receptacuto. C.) Alreolus lonyitudinaliter diffedus. d.) Flo[s. ligulatus zcuter. a) Flofe. androgynus. f. F.) Seinen [eparatnu. G.) Item transverfo dirfectum.

Apuleja fruticofa.

Cartbamus africamus frutefcens, fotio ilicis spinofo, fore ausco. WALtн. bort. 13. t. 7 .

Gorteria fruticoja. Berg. cap. $3 b^{j} 2$. LINN. Sp. plo 1284 .

Attraliylis oppofitifolia. LiNn. fylt. veg. 730.

Calyx multo laxior, nec fquamis adeo mumerofis imbricatus, ut in proccedenti; practerea quoque folia \& fquamx fubtus albo tomentofa, nec nuda ut illius. Thalamus \& fofculi omnino prioris. Ovaria oblonga, furfum latiora, undique rufefcentibus fetis hifpida. Pappus paleaceus, sadiis plusibus, linearibus, acaminatis, brevibus.

Apuleja?" afleroides.

Gorteria aferoides. LIN Suppl. 38 r.

Palex laciniis linearibus. Semina villora, coronata corona ftellari : foliolis multis. LIN. l. c. 


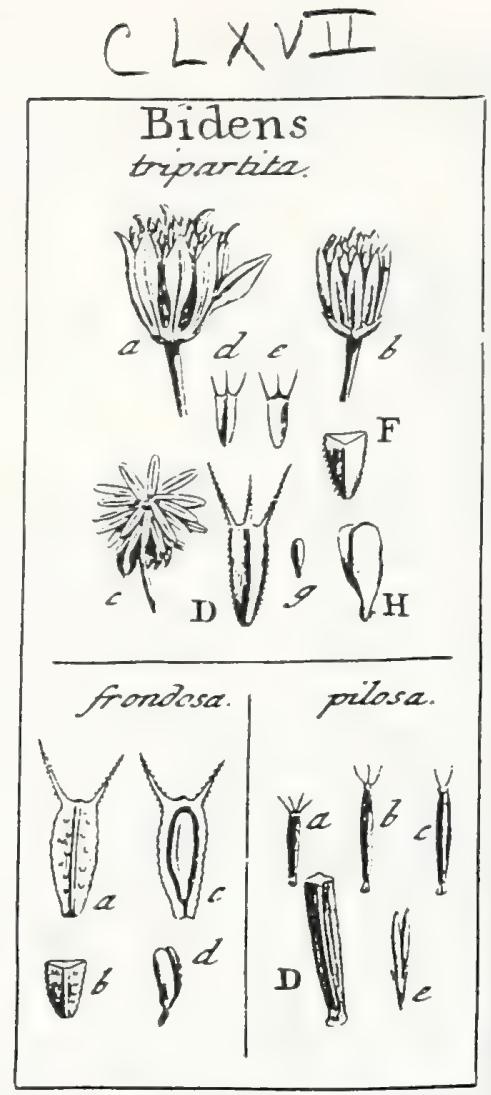

T. G. Sitornse.

J. Gaertner (1788) Vol. Z,

412

DCCCCLXXX. B I D E N S. TOURN. t. 262. LINN. gen. 932.

Calyx duplici ferie polyphyllus inxqualis. Flofe. omnes androgyni. Thal. calyce brevior paleaceus. Pappus ariltis duabus 1. tribus, fcabris.

Bidess tripartita. Tab. 167. fig. 7 .

Acmella germuica. BLAKw. berb. t. 519 .

Bidens foliis trifudis, calycibus fubfoliofis, feminibus erefis. LINN. Sff. veg. 732.

REC. convexum, calyce multo brevius, undique tectum paleis oblongis, obtufis, concavis, calycinis foliolis fimilibus \& zqualibus.

SEณ. cuneiformi - oblonga, triquetra, comprefliufula, glabra, lipida, ad utrumque marginem aculeato.ciliata.

Pappus ariltatus, bi - 1. triradiatus: radiis erectis, dimidio femine brevioribus, retrorfum aculeolatis.

IN T. duplex: exterius coriaceum, tenue.

EM B. lividus.

2. b.) Calyx fubfoliofus \& nudus. c.) Palex per maturitatem divergentes, d. D. c.) Sescea intcgrnm. F.) Idcm diffetum. g. H.) Eunbryo denudatus.

BIDENS frondofa. ibid.

Icon. Semt. BERKH. 2iff. t. 5. f. 5 .

Semina grandiufcula (a. b.), ovato-oblonga, compreffa, punctis callofis difitis confperfa, ad margines crenulata, cinnamomea. Pappus ex ariftis duabus validis, retrorfum aculeolatis. Embryo (c. i.) Sublividus.

Bidens pilora. ibid.

Bidens lasifolia birfusior, feming angufiore radiato. DiLl, elsh. $8.43 \cdot f .5$ s.

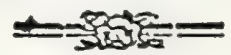

Semina linearia (a. b. c.), comprefis (D.), frinta, glabra, fublucida, nigra. Pappus ex ariftis 2 - 5 fetaceis, fabris, femine qnadruplo brevioribus. Embryo (c.) linearis, lividus.

Gcuus bifrons, accedente radio mutatur in Coreopfrdem. 


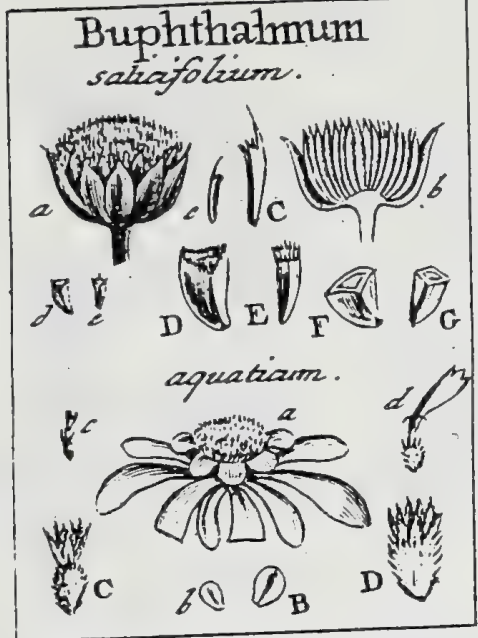

J. Gaertner (1788) Vol. Z

434

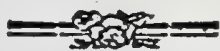

\section{B U P H T H A L'M U M. LINN. ger. 977.}

Calyx imbricatus fquamis herbaceis, nunc xqualibus \& floris radio brevio. ribus: nunc. vero exterioribus. longioribus. atque radium fuperantibus. Thal. paleaceus. Flofc. difci indrogyni; radii teminei, ligulati: utrique fertiles. Sen. difformia, aut fubuniformia, curonata margine incifo, aut fubphyllode: Folia indivifa.

Buphthazmum falicifolium. Tab. 1.69- fig: 5.

Conyzas majos: altera: THAL. burc. 27. t. 2.

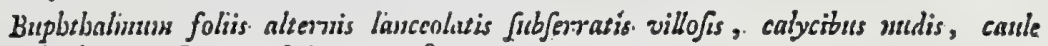
berbaceo. LiN. Jjyt. veg. 780.

Iton. JACQ. auftr. t. 370 .

REC. leviffime convexum, paleaceum: paleis longitudine calycis, carinatis, furfum latefcentibus, truncatis, denticulatis \& ex carina in ariftam breven flexilem definentibus.

S. B. diffurmia : difi minora;, oblonga, angufta, tri- l'. tetragon', compreffrufcula, recta; radii maiora, incurva, rriquetra, ad latera fere in alana extenuata: utraque apice uruncata atque margine dentato coronata.

IN T. exterius coriaceum, durum, pallide ftramineum.

EмH. fenini conformis, livefcens.

2.) Calyx intcger. bi) Recept. palenceum. o: C. ) Palea feparata. d. D. F.) Scmen radii integrum \& diffectum. e. E. G.) Semen difci. integrum \& diffectum.

Margo fominum difci intendum adeo profunde incifus eft, ut ex pluribus foliolis paleaceo-fetaceis compofitus effe videatur.

BUPHTHALMUM aquaticum: ibid:

Afler odoratss amutus creticus. Z\&NON. biff. t: 244

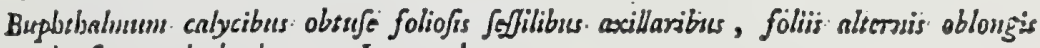
obzulis,, casile berbaceo, LiNN. l. c:

Calyx (ai) bafi fuliofus. Palex (b. Bi) obovate, membranacex, pellucidic: Semina compreffa, fpadicea, fetis albicantibus hifpida, fubuniformia : difci. (c. C. ) minura, ovata, deorfum acuminatas radii. (d. D.) paulo majorn, cuneiformi - triangula, ad latera valde compreffa \& quafi in alam extenuati:: utraque coronata Pappo polyphyllo:. foliolis memibranaceis, acuninatis, ciliato dentatis, dimidio femine brevioribus. Integ. Gmplex, membranaceum. Embryo gramineo - viridis.

$S i$ in omnibus. Aflevifis T. feninum pappus non fit marginatus, fed phyllodes, poterunt omsino, quin debejunt, a- Buphtzalmis fegregario.

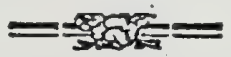

In Buphthalmo belianthoide L. Feminum corouam omnem negat HaLI. b. goett. 38 . 


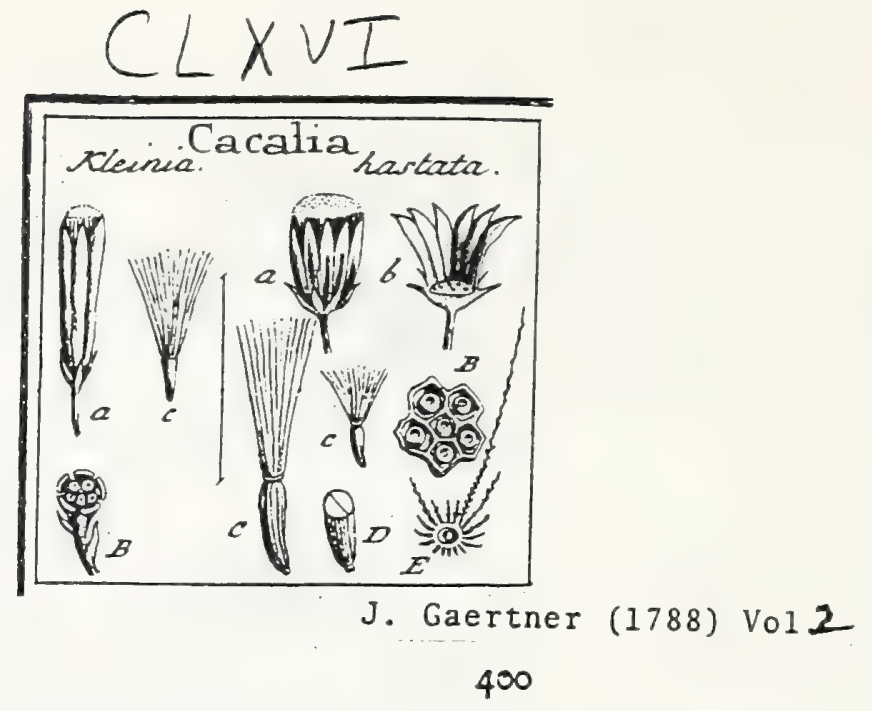

Asteraceae

DCCCCLXIII. C A C A I I A. TOURn. t. 258. Linn. gen. 933.

Calyx fimplex cylindraceus bafi fquamis paucic brevifinis calyculatus. Flofe. omnes androgyni, quinquefidi. Thal. papillofus, mudus. Sen. coronata pappo capillari.

Cacalia Kleinis. Tab. 166. fig. I.

Cacaliautbemene folio merii glanco. Dilc. elth. t. 54. f. 2.

Cacalia caule fruticofo compofizo, foliis lunceolutis phanis, petiolornin cicatricibus obfoletis. LiNN. Jjye. veg. 733 .

REC. anguftun, papillis obfoletis confperfum, nudum, glabrum.

SEM. oblonga, teretiufcula, glabra, rufefcentia.

Pappus calyce longior, fericeo-albus, radiis capillaribus, minutifime denticulatis.

IN T. fimplex, membranaceum.

Eni B. albicans.

a.) Calyx maturus integer. B.) Receptac. denudatum: c.) Semen integrum

Cacalia haftata. ibid.

Senecio folis ex dentato trilobis acuminatis ferratis. Gmet. fib. 2.. t. 66 .

Cacalia craule berbaceo, foliis trilobis actuminutis ferratis, foribus untmutibus. LiN. l. c.

Calyx cylindraceus (a.), fimplici aut fubduplici ferie polyphyllus, barf fquamulis acuminatis calyculatus. Thal. phaniufculus (b: 13:) uudus, areolatus: areolis pentagonis, papillulan depreflam includentibus. Semina (c. C. D.) teretiufcula, itriata, pallide fpadicea. Pappus (E.) capillaris, mollis, albus, minutifime denticulatus, femine paulo longior.

Genus bifrons, accedente sadio nutatur in Cinerminin. 

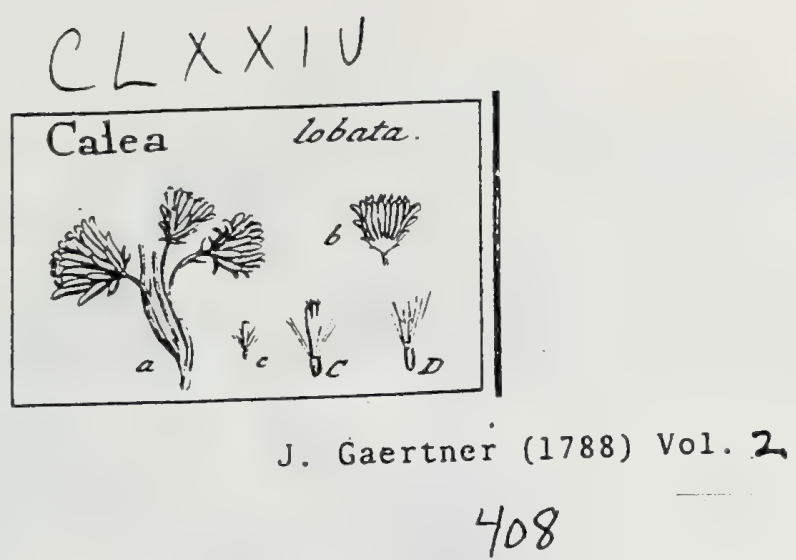

DCCCCLXXV. C A L E A. LiNN. gern. 94 I.

Calyx imbricatus foliolis oblongis, fenfim in paleas receptaculi degenerantibus. Florc. omnes androgyni, quinquefidi, fertiles. Thal. paleaceus. Pappus pilofus.

Lis.en lubata. Tab. 174. fig. 5 .

A Cl. THUNBERGIO.

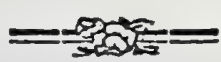

REC. fubconvexum, paleaceum: paleis forma \& confiftentia foliolis calycinis finilibus, interioribus gradatim longioribus.

SE Mr. parva, oblonga, glabra, fpadices.

Pappis pilofus, fubedentulus, albus, paleis receptaculi brevior flofculo sutem xqualis, caducus.

IN T. fimplex, membranaceun.

Es B. albicans.

a.) Flores longe peduneulatio b.) Calyx diffelus cum reseptaeulo. c. C.) Flofeulus infandibulifurmis, corullula profuade qaiuquefida. D.) Semen ialiguiter auctum.

Hxc atq̨ue C. jumuncenfrs characteri generico Linmacano folx refpondent; reliqux fpecies ad diverfa trahendic funt genera, nifi notas ex ipfis fructificationis partibus namantes, foliis \& externx plantarum faciei, poltponere nalueris. 

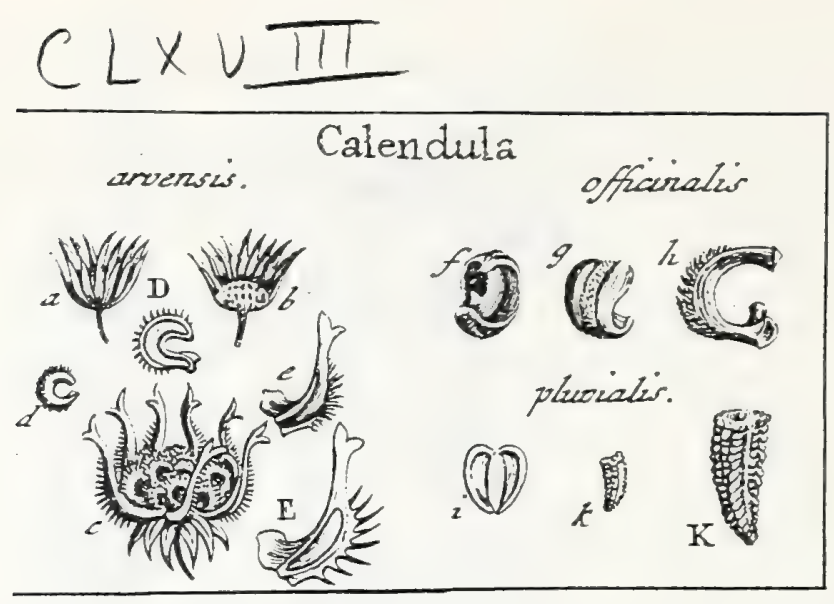

Asteraceae

J. Gaertner (1788) Volz

$$
421
$$

DCCCCXCI. C A L E N D U L A. LINN. ger. 990.

Caltha. TOURN. t. 284 .

Calyz fimplex, polyphyllus, xquslis. Recept planum, nadum. Florc. centrales fteriles, malculi; difci androgyni, infundibuliformes; radio feninei, ligulati: horum utrique fertiles. Semina difformia, calva.

Calendula arvenfis. Tab. 168. fig. 4

Calliba minima. BAuH. bijt. 3. p. 103 .

Calendula fenwinibus cymbiformibus nunticatis iscurvatis: extimis ereatig proten/as Lis.s. 53y. veg. $79 \pi$.

R E C. planum, elevato-punckatum, mudum.

SEM. difformia: diffi fenicireulari - incurva, nequaquam cymbiformia aut marginata, fed teretiufcuta, \& a purte ventrali in aciera compre $\mathbb{F}_{1}$, in dorfo autem convexa atque brcvibus aculeolis innocuis murian.

Radii longiosa, furrecta, figmoideo curvara, furfum attenwata \& in roftrum apice Lamellofum bilobum elongata, extus ạculeolata, intus glabra. \& prope bafin procefiu Jamclloro aucta.

IN T. exterius coriaceum, e Atramineo pallidum.

Eмy. teretiufculus, ad norman ferainum curvatus, faturate Juteus

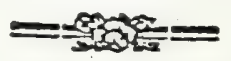

2.) Calyx integer. b.) Thal. denudatus. c.) Semiuz in atu naturali. d. D.) Semen dirci. c. E.) Sencn radii. D. E.) Eubryo utriusque femiuis.

Calendula officinalis. ibid.

Calenduia. DOD. coron. p. m. 60. BLAkw. berb. t. 506.

Calendula feninibus cymbiformibus muricatis incurvatis omaibus. LiNN. l. e.

Semina difci (f. g.) cymbiformia, parte concava fepto longitudinali difcreta, parte convexa fulco medio elevato muricato notata. Semina radii $(h$.$) tere-$ tiufcula, femicirculari .--arcuata, extus muricata, intus glabra \& prope bafin fxpe proceffu erecto lamellofo inftructa.

Calendula pluvialis. ibid.

- Calendula bunilis africana, fore intus albo, extus violaceo. Hers. lugdb. 105. BREYN. ic. t. 14. f. 1. Mill. ic. t. 25. f. x.

Semina difci (i.) rotundato cordata, comprefro-plana, margine tumido cincta, e ftramineo albicantia. Sem. radii ( $k . K$. ) oblonga, inverfe pyramidata, 3. 1. 4 gona, lateribus atque angulis tuberculato - muricatis.

Calendula bybrida. LinN.

Cullbu "fficana, flore intus albo, foris violaceo, femine majoie oblongo. BREYN. ic. t. 14. f. 2. MILL. ic. t. 75. f. 2 .

Semina difci, proxime precedentis fimillima, fed paulo majora, elliptico. cordats, ad marginen nequaquam tumida. Sem. radii inverfe pyramidata, triquetra, lateribus convexiufculis glabris, angulis autem compreffis atque 


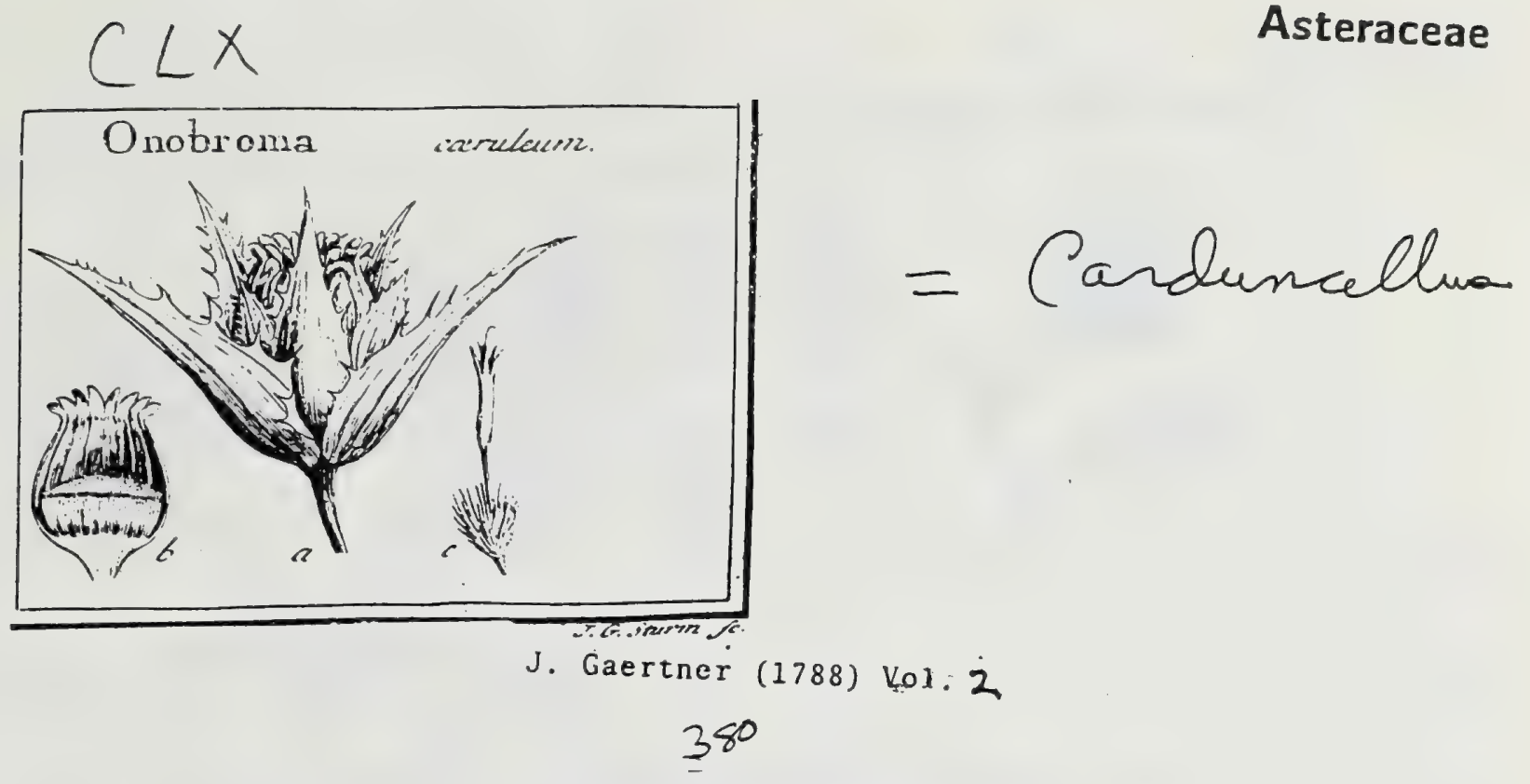

DCCCCXXXVI. O N O B R O M A. Carthamoides. VAILL. Carduncellus. ADANS. p. II6.

Calyx ventricofus, imbricatus fquamis exterioribus majoribus herbaceis acu. minatis denticulato-fpinolis; interioribus coriaceis inermibus, apice appendiculato - fcariofis. Flofc. omnes androgyni. Thal. paleaceus. Sem. coronata pappo fetaceo rigido inæquali.

Onobrona cxruleum. Tab. 160. fig. 7.

Cricus alter, ceruleo flore. Clus. hif. 2. p. 252.

Cordusus cnici facie, foliis difestioribus. Mors. bif. 3. S. 7. t. 33. f. 18.

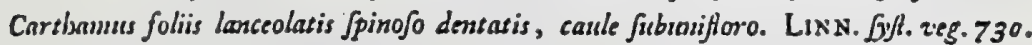

REC. paleaceum, paleis capillaribus, flexilibus, dimidio calyce brevioribus.

SEM. Ovato-turbinata, Jubrufa.,

Pappus pallide ftramineus : radiis numerofffimis, lineari - acuminatis, paleaceis $\perp$ fetaceis, rigidis, inxqualibus.

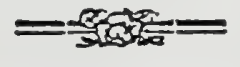

Iะ T. exterius cruftaceum f. nucamentaceum.

E $\times$ B. femiur conformis.

2.) Calyx integer. b.) Recept. palezeeum. c.) Ovarium immaturum oum foleulo atgque pappo adhuedum imperfera.

Semen maturum hactenus obtinere non potui. Clufius illud dicit femine Carch. timforii minus \& fubrufum: hinc figura Horifoni 1. c. videcur elle erronea. Pappo manifelto \& copiofo, a Carthamo abunde differt. 


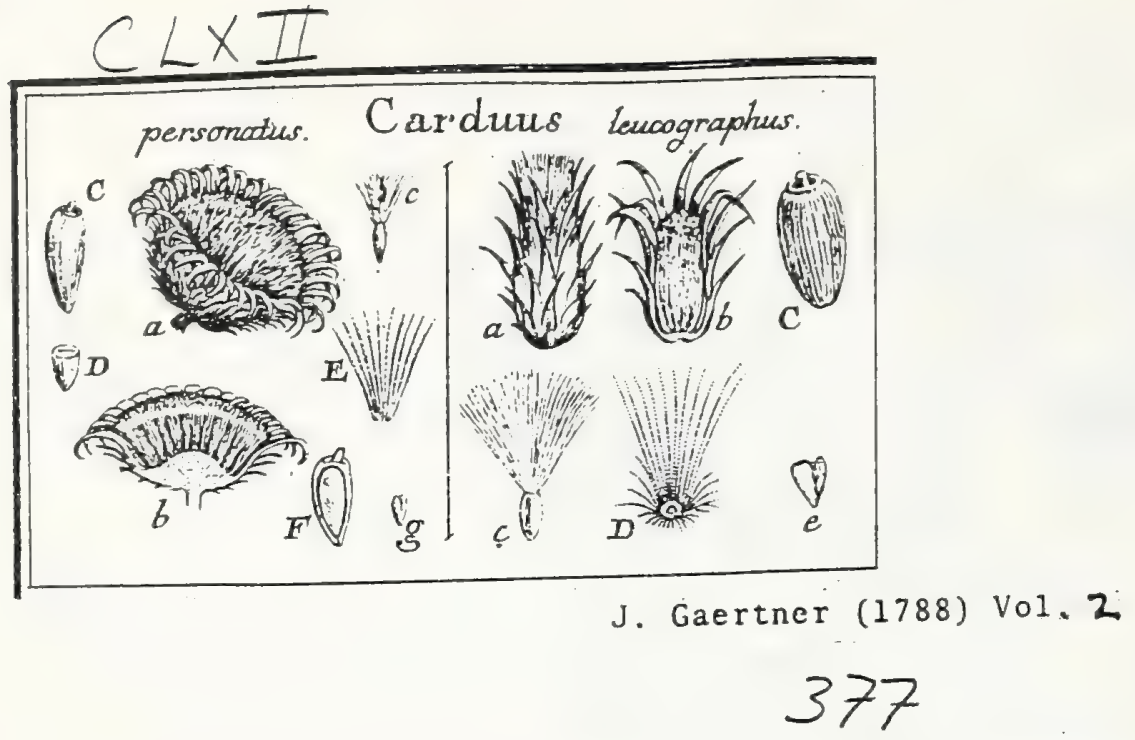

DCCCCXXXII. C A R D U U S. TOURN. t. 253. LINN. ger. 925.

Calyx imbricatus fquamis fimplicibus, non appendiculatis, scuminatis, fpiua terminatis. Elolic. omnes androgyni. Thal. fetaceo - paleaceus. Ser. coronata pappo.capillari, bafi in annulum connato, deciduo.

Cardues leucographus. Tab. 162. fig. I.

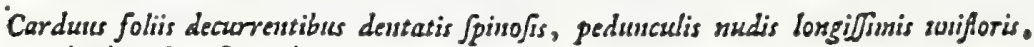
calyeibus fpinofis inclisatis. LIN . Sylt. veg. 724

Icont. Jace bort. 5. t. $=3$.

Rec. fetaceo paleaceum, paleis linearibus, fericeo albicantibus, longitudine tubi calycis.

SEM. ovata, lenticulari comprefra, ftriata, glabra, nitida, pallida, glutinofa dum recentia, margine carrilagineo integerrimo \& intra illum brevi tuberculo cylindrico terminats.

Pappos femine triplo longior, caducus: radiis capillaribus denticulatis, xqualibus, bafi in annulum conferruminatis.

INT. exterius coriaceun, t:nue.

EMB. obovatus, $e$ viridi lutefcens.

a.) Calyx integer. b.) Idem dilreAas can receptac o. C.) Semen integram D.) Pappus bar in annulum cunatus c.) Einbryo denudatuc

Clrouus perfonatus. ibid.

Cardans inernis, foliis imis pimntis, fuperioribus ovato-lanceolat is ferratis, fquamis calycis reflexis. HaLc. bifl. n. 162. 8. 3. Enum. t. 29.

Argium perfonata. LiN. Gof. veg. 723.

Icon. JACQ. allfir. t. 348 .

Calyx maturus (a) hemifphacricus, imbricatus fquamis linearibus recurvis pun. gentibus. Receprac. (b.) leviter convexum, paleis rigidis tectum. Semina (c. C. D.) oblonge elliptica, lenticulari compreffa (D.), fpadicen, margine annulari (C. F.) \& intra illum papilla cylindrica terninara. Pispus (E.) femine paulo longior, capillaris, bafi annularis, caducus. Embr. (F. g.) luteus. 

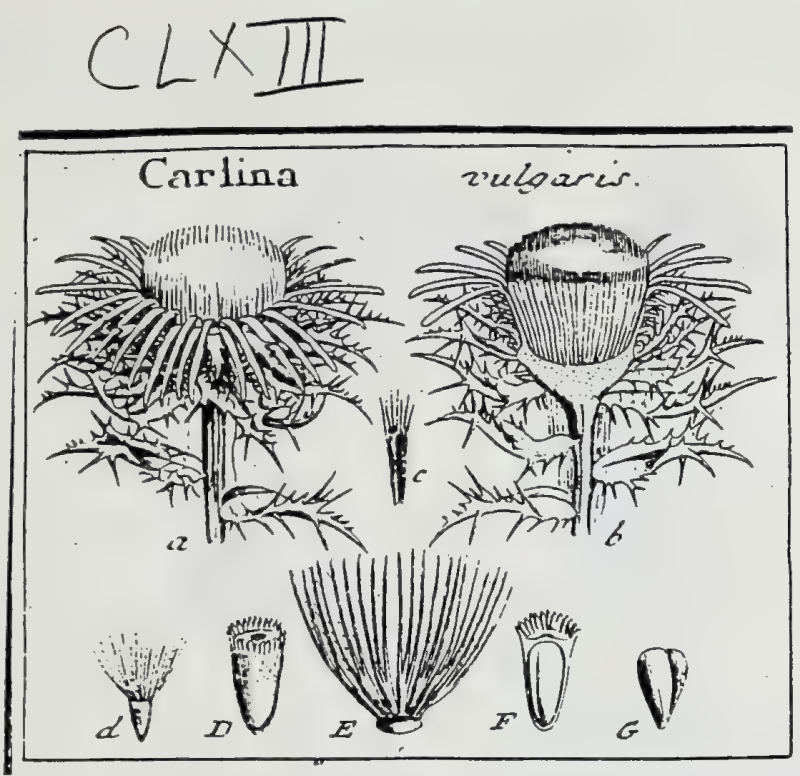

\section{J. Gaertner (1788) Vol 2 384}

DCCCCXI. CARLINA. TOURN. t. 285. LINN. gem. 929.

Calyx ventricofus, imbricatus fquamis exterioribus laxis, pinnato-fpinofis; intinis inermibus cartilagineis ritidis coloratis radiantibus. Flofc umnes androgyni. Thal. palezceus, paleis apice multifidis. Sem, corouata pappo plumofo: radiis ramofis bafi in annulum commatis.

Carlina vulgaris. Tab. 163. fig. I.

Atrafylis nitior. Fuchs. bift. lat. 121. gerns. ic. 66 .

Heracantha. BESL. Ej,f. aft. XI. t. 8. f. 3 .

Carliua caule multifinro corymbofo, furibus terminalibus, calycis radio albo. LiNN. Jyft. veg. 729 .

REC. concavur, paleaceum: paleis inferne membranaceis carinatis integris in alveolos cum vicinis conferruminatis, fuperne fctaceo nulcifidis, longitudine calycis.

SEM. parva, oblonga, deorfum anguftiora, fubcumpreffa aut obfolete angulata, cinerafcentia, villis fericeo a!bis confperli, iisdemyue fupra verticem productis, quafi annulo paleaceo albo cononar.

Puppus femine duplo longior, plumofus: ridiis filifernibus, binis vel ternis fxpe longius inter fe colsxrentibus \& quafi ramofis, onnibus bafi in annulum connatum.

IN T. utrumque membranaceum, teriue.

Ë в. femini conformis, albicans.

a.) Caljx integer. b.) Reecptac. paleaceum, c.) Palca feparata.

E) Pappus feparatus, F.) Semen diffetum. G.) Emus, denudatus,

d. D.) Scmen unecgrum. 


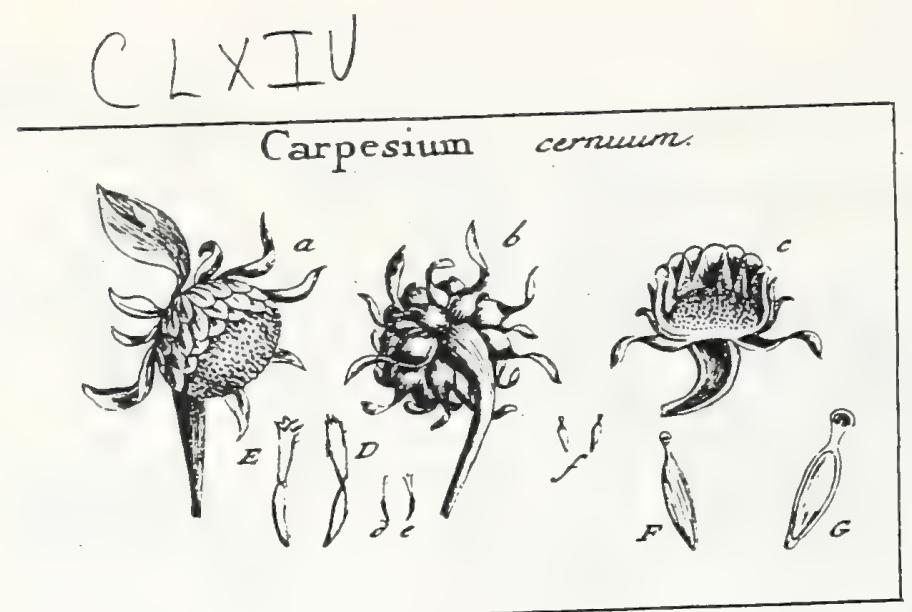

\section{J. Gaertner (1788) Vol 2 \\ 387}

\section{DCCCCXLV. C A R P ES I U M. LINN. gen. 948.}

Calyx fubglobolus, imbricatus fquamis extimis foliaceis appendiculatis; medio acuninatis apice rellexis; insimis membranaceis albis obeufis crenulatis. Flofc. fubuniformes: difci infundibuliformes quinquefidi androgyni; radii fubcylindrici quinquedentati angultiores feminei: utrique fertiles. Thal. nudus. Sem. uniforniza, calva, in ftipitem. absqque pappo definentia!

Carpesium cernum. Tab. 164 fig. 4.

Ajle cermus. Cor. eqplr. r. po $=5$ r. 2. $25=$. BARR. ic. rt42:

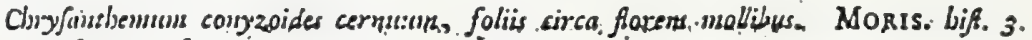
S. 6. t. 5. $f .=3$.

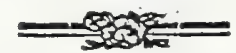

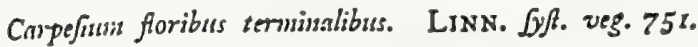

Icon. JACe nuffr. to 204.

REC. planum, amplum, excavato - punctatum, nudum.

SEN. uniformia, oblonga, teretiufcula aut ob́foletiflime angulata, multifriata, pallide fpadicea, in ftipitem breven apice leviter dilatatum edentulum \& omni veftigio pappi deftitutum definentia.

INT. duplex, utrumque membranacaum.

E21 8. pallide albicans. Cotyl. oblongo-ellipticx, plano-convexiufcula. Rad. irevis, cratiufcula.

a. b.) Calyx integer, a prona \& fupina parte fpectatus. c.) Idern diffectus, cum receptac. plano nudo. d. D.) Flofc. radii femincus. c. E.) Flofc. difci androgstnus. f. F.) Semina feparata intcgra. G.) Semen longitudinaliter diffectum, ftipritis \& embryonis formam oftendens.

Figura feminis Morifoniana 1. c. penitus falfa eft. 


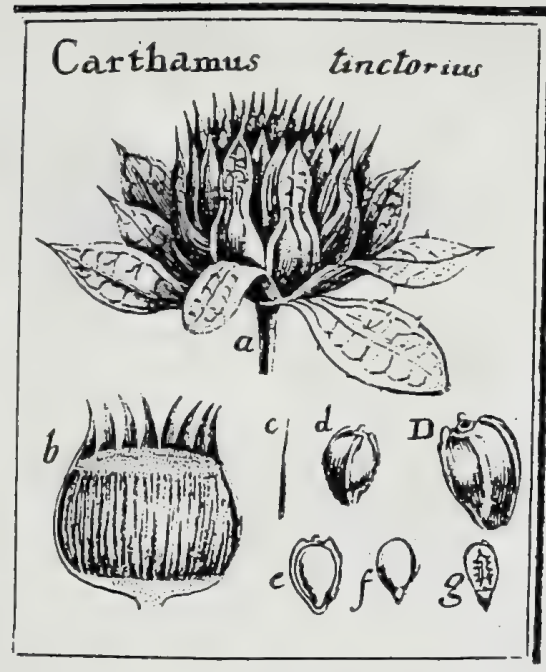

J. Gaertner (1788) Vol 2
375

DCCCCXXIX. CARTHAMUS. TOURn. t. 258. LINN. gen. 93T.

Calyx fubglubufus, imbricatus fquamis exterioribus herbacejs laxis; interio ribus coriace's arcke incumbentibus, fupra medium cuarctutis: onnibus apice in lpunulam brevem delinentibus. Flolculi omnes androgyni. Thal. paleuceus. Sem. nucamentacea, calva.

Carthamus tinctorius. Tab. 161 . fig. 2.

Cuicus fativus, f. Carthanus. BEsL. Eyjf. eft. XI. t. 3. f. s. bene. Carthamms foliis ountis integris ferrato aculeatis. LiNs. fy.t. veg. 730.

REc. planificulum, fetaceo-puleaccum: paleis lineari acuminacis, longitudine fere calycis, tenuillimis.

SEM. uniformia, turbinata, coftis 4.6 , inferne obfolefcentibus notata, glaberrima, nitida, nivea, calva. Umbilicus fupra bafin feminis.

I s T. exterius craffum, offeum, $f$. nucamentaceum.

Es B. obovatus, luteus. Cotyl. crafix, intus rugofie. Rad. conica, brevis.

376

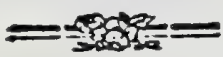

1) Calyx integer. b.) Idem diffearus, eum recept. palezcea. e.) Palez (eparata. d. D.) Seraer integrum. e.) IJem difteaum. F.) Embryo denudatus. 5.) Cotyledonic fuperficies interna rugola. 


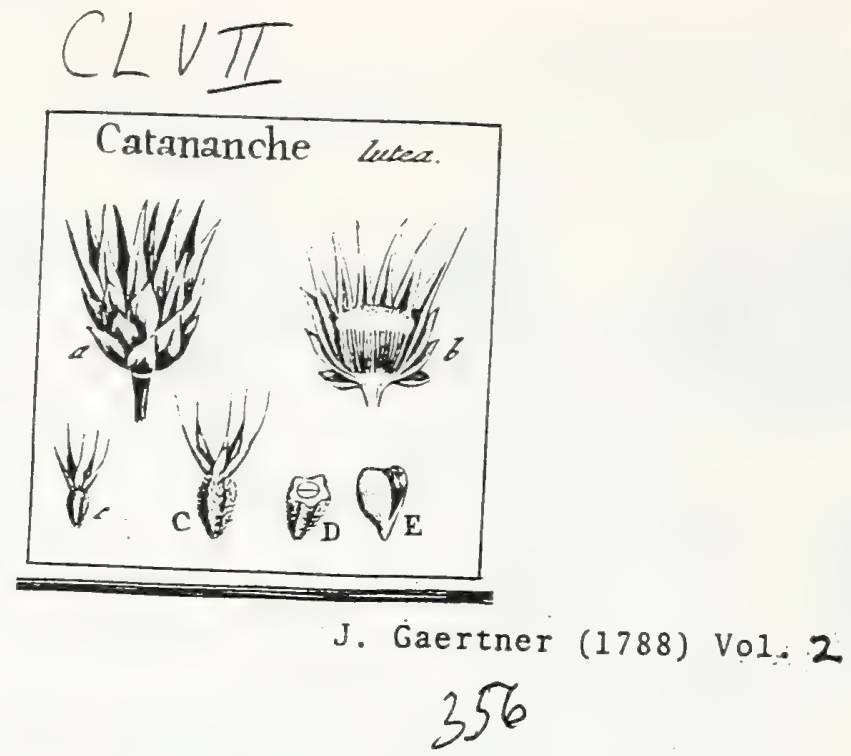

\section{B. Pappo phyllode 1. paleaceo.}

DCCCCV. CATANANCHE. TOURN. to 27r. Linn. gen. 290.

Calyx laxe imbricatus fquamis fariofis nitidis fubpellucidis gradatim longioribus. Thal. paleaceus. Pappus pentaphyllus, foliolis acuminato-ariftatis.

Catananche lutea. Tab. 357 . fig. 5.

Cbondrilla cyanoides lusea, coronopi folio non divifo. Bocc. mus. 2. p. 2r. t.7. BARR. it. 1335 .

Catananclise fquamis calycinis inferioribus lanceolatis. LINN. Jyf. veg. 722.

Rrc. planiufculum, paleaceum: paleis fetaceis, longitudine dimidii calycis.

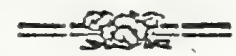

SEM. turbinata, fulcato-pcntagona, fetis albis appreffis confperfa, cinerafcentia. Pappis pentaphyllus: foliolis baf membrunaceis, furfum attenuatis in ariftam capillarem, femine triplo longiorem.

INT. duplex: coriaceum atque nembranaceun.

EN B. fenini conformis, viridis aut fufcus. Cotyl. obtufie. Rad. acuminata.

a.) Calyx maturus integer. b.) Jjem diffe̊us, cum receptac. paleaceo. c. C.) Semen iutegrum. D.) Iicm diffectum. E.) Embryo denudatus.

Catamnchen grecam pracedentis varietatem ftatuit Millerus; fed id non folum folia incifa, verum etiam pappus feminum dodecaphyllus aperte segaut. Conf. Tours. it. p. m. 86. t. 86. 


\section{Tab. CIXIII}
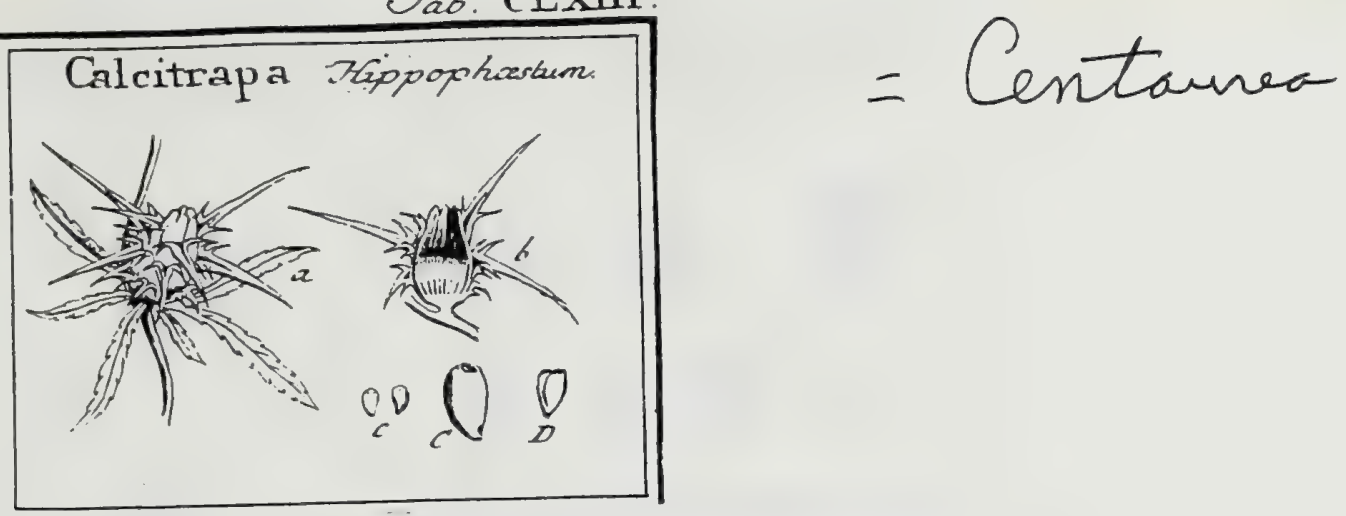

\section{J. Gaertner (1788) Vol.. 2 \\ 376}

DCCCCXXX. C A L C I T R A P A. VAILL. Juss. p. I73.

Calyx ovato conicus, imbricatus fquamis cartilagineis, apice in fpinam valldam, ad latera fpinulis dentam, defincntibus. Flofc. difci androgyni; radii feminei. Thal. paleaceus. Semina calva.

Calcitrapa Hippophxitum. Tab. 16;. fig. 2.

Hippopbefum. Cor. phytob. 2. 24.

Cardsues fellatus. DOD. purg. 448. pempt. 733.

Centarrea calycibus fubduplicato - Jpinofis fellilibus, foliis pinnatifidis linearibus dentnsis, caule pilojo. LiNs. Jyyt. veg. 787.

REC. Fetaceo-paleaceum, paleis dimidio calyce maturo brevioribus.

SEM. parva, obovata, deorfum acuninata, glabra, non lucida, pallide livida, calva, ammulo carrilagineo minutulo in verrice notats. Umbilicus fupra balin feminis.

IN T. exterius coriaceum, tenue.

En \&. femini conformis, luteus.

8.) Calyx integer. b.) Idem diffectus, eum receptac. paleacto, c. C.) Serren fepämtum, D.) Enibrjo deoudatus.

His fubnecti poffe videntur: Acofr. ADANs. p. 117. \& Centans: folfitialis, cui fecundum Allion. hijt. ped. $16_{3}$. femina radii calva, difci auteın letis coromati. 


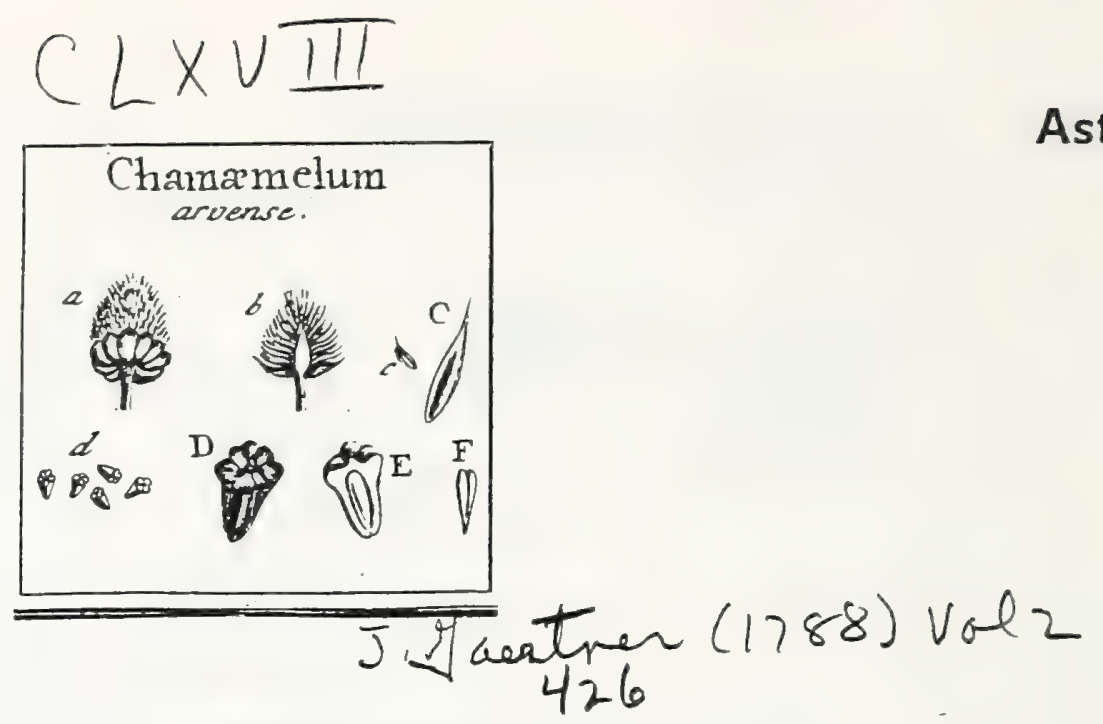

DCCCCXCVII. CHAM बMELUM. TOURN, t.28r. HALL. I.p. 43.

Calyx hemifphxricus, imbricatus fquamis duplici l. triplici feric, fcariofis. Thal. conicus, paleaccus. Flofc. difci androgyni radii feninei, ligulis triplo longioribus quam latis: utrique fertiles. Sem. calva.

Снамдmelicis arvenfe. Tab. 168. fig. 10.

Chansemelum foliis glabris duplicato pinnatis, servo foliaceo, pinmselis Lmceolatis, feiminibus lavibus. HaLl. bijt. 3. 103.

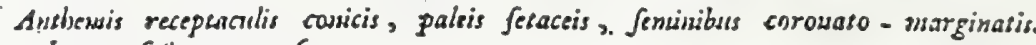
Lins. Gyt. veg. 726 .

REC. fubulawm, calyce duplo altius, tedum paleis Lareolatis, fetaceo-acu- mixatis.

Szar. inverfe pyramidatn, tetragona, fulcata, pallide ftramines, vertice, in recentibus, torulofo, calvo ; in vetultis Gimpliciter truncato, absque ullo marginis veftigio.

IN T. exterius coriaceum, craftufeulum,

EM B. teretiufculus, albus.

2.) Calyz integer. b.) Recept denudatum. c. C.) Palez feparata, d. D.) Semea iategram, vertice torulofo. E.) Idem difictum. F.) Embr. denudatus.

Chamxmelum plenario diadenatis feminum defectu $a b$ Anthemide differt: hine \& fecundum Halz. l. c. Anth. nobilis \& Cota. Lins. huc Spectant. 


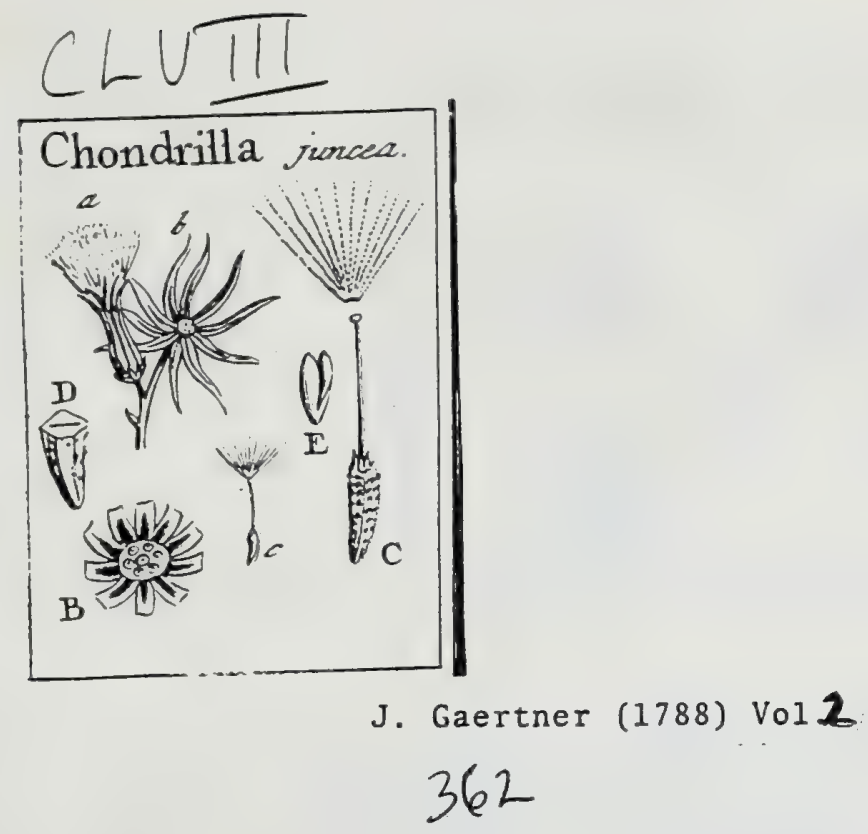

DCCCCXIII. CHONDRILLA. T OURN. t. 268. LINN. gers. g10.

Calyx fimplex, cylindraceus, fubdecaphyllus, fquamis paucis brevibus calyculatus Thal. excavato-punctatus, glaber. Pappus capillaris, Itipitatus, Guxilis.

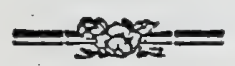

Chondrilla juncea. Tab. 158. fig. 6.

Clondrilla foliis radicalibus roncinatis, caulinis linsearibus integris. Lixx. Gjs. veg. 7 '3.

Jcon. JACQ. anffr. t. 4:7.

REC. anguftum, excavato-punctatum, glabrum.

SEM. oblonga, furfum craffiora, obfolete angulata, ftriis tuberculato-fcabratis exafperata, rufefcentia.

Pappus capillaris, fericeo-albus, fugax, ttipitatus. Stipes fetaceus, femine fesquilongior.

IN I. duplex: exterius fubcruftaceum, durum.

Ens. femini conformis, albus. Cotyl. oblongx, Rad. conica.

2) Calyx claufus. b. B.) Idem dehileens, cum reeeptac. denudato. c. C.) Semen integrum.

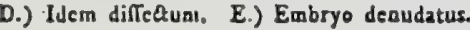

Chondricla (Lafinca in Icon.) turalis. ibid.

Soncbus levior vulgaris. Clus. bif. 2. p. 146. OEd. flor, dant t. 509.

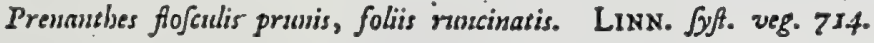

Semina (a. A. B.) obovata, compreffa, ftriis feptem crenulatis fcabrata, atra. Pappus niveus, mullitrimus, fugax. Stipes capillaris, vix dimidio femine longior. Senina quidem Lactucx, fed calyx \& reliqua funt Chondrillx. 


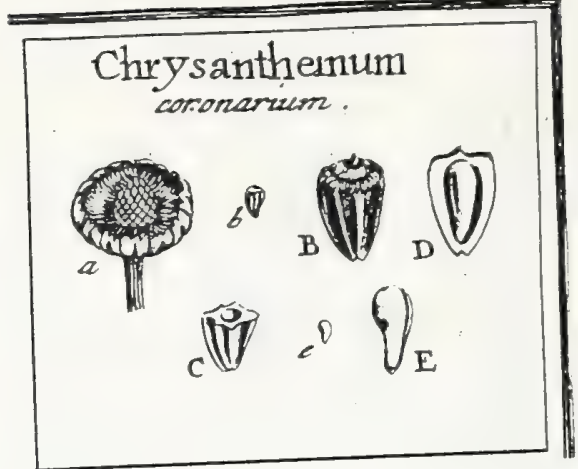

J. Gaertner

$$
420
$$

DCCCCXC. CHRYSANTHEMUM. TOUR N. t.280. IINN. gen. 960.

Calyx hemifpharicus, imbricitus fquamis plurium ordinum coriaceis margine fcariofis. Recepe conxexum, nudum. Flolc. omnes fertiles: feminarum ligulis ovato oblongis, patentibus, frepius apice truncatis. Sem. calva.

Chrtsanthemum coronarium. Tab. 168. fig. 3.

Chryjanthemsm creticums. CLus. bif. 1. p. 335. BESL. Eyf. Af. V. .. 6. f.2.3. ZANON. biff. t. 5 I.

Coryfansbenmon foliis pinnatis incifis extrorfum latioribus. LINN. fyft. veg. 773.

R E c. fubparabolicum, alycis limbo altuus, ftriis decuffatis teffulatum, nudum, glabrum.

SEM. inverfe pyramidata, compreftiufcula, falcato-angulata, glabra, e Rramineo albicantia, calva.

Ix T. exterius cruftaceum, durum, craffum.

E \&. clavatus, albus.

a.) Calsx cum receptac. Ueandate. b. B.) Scmen integrum. C.) Idem transver fom, \& D.) lokgitudiazlice dificaum. c. E) Embryo denudatur.

In plantis culis hujus fpeciei, radium femper fterilem deprehendo.

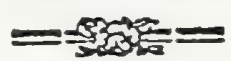

\section{Chryfanthemum Zexcautbemum. . Liss.}

Seinina ex ovatis inverfe pyramidata $\mathcal{f}$. turbinata, donec recentia, ferruginea atque fulcis decen elevaris lactcis pulchre variegata; poltea vero nigricantia, cum iisdem fulcis pallide fpadiceis. Vertex calvus.

Onues Chryfanthcmi fpecies, quarum femina manifefto margine coronata funt, ad Pyretbrian amandamus. 


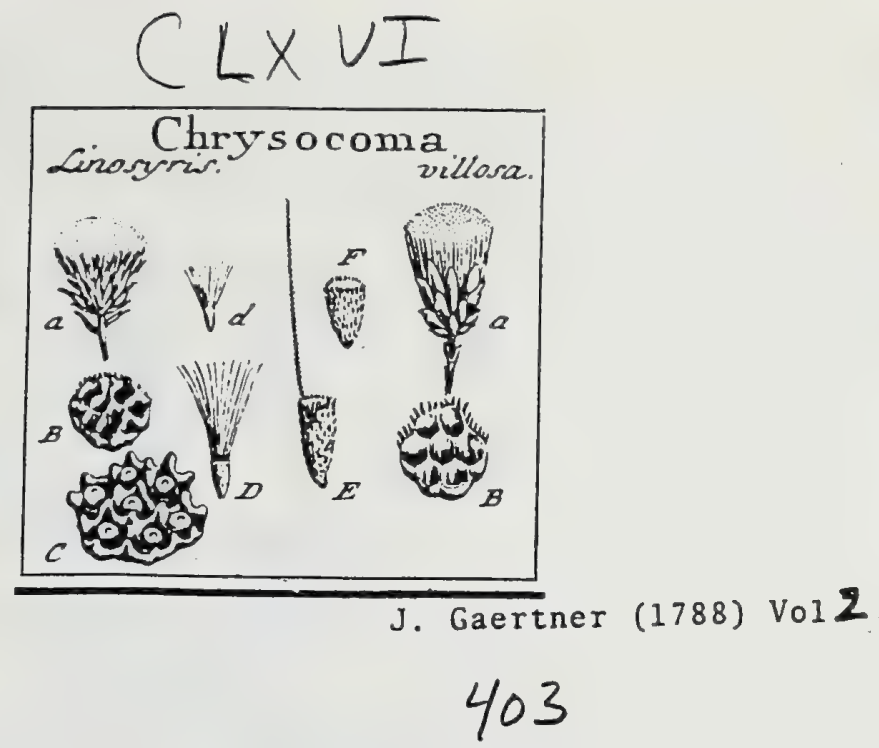

\section{DCCCCLXVII. C H R Y S O C O M A. Linn. ger. 939.}

Calyx hemifphxricus aut ovatus, mediocris magnitudinis, imbricatus fquamis oblongis, extus convexis. Flofc. omnes androgyni. Thal. fcrobiculatus, a 'fcrobiculorum marginibus denticulatis fcaber. Pappus pilofus, creberrime denticulatus, afper.

Chrssocoma Linofyris. Tab. 166. fig. It.

Ofyris auffriaca. Clus. bift. 1. p. 325.

Chryfocome diofcoridis Eo ptintii. CoL ecplor. 1. p. 81. t. 82 .

Chryfocoma berbacea, foliis linearibus glabris, calycibus laxis. Lins. Syfi. veg. 740.

REC. Scrobiculatum aut alveolatum, alveolorum marginibus ante plenam maturitatem dentato - ciliatis; poftea obfolete quinquedentatis, papillulam minutulam includentibus.

SEM. oblonga, furfum latefcentia, comprefliufcula, villofa, pallida.

Pappres fetaceus, femine duplo longior, fordide albicans aut ruffus, creberrime denticulatus, ajper.

IN T. fimplex membranaceum.

E s E. albicans.

2.) Calyx integer. B.) Alveoli thalasni immaturi. C.) Thalumus matarus. d. D. E. F.) Semen integrum \& diffectum, cum ftruturn pappi.

Chrysocoma villo⿰a. ibid.

Afer incanus, calycibus laxis oblongis Eंc. GMEL. fib. 2. p. 192. t.82. f. 2.3. Cloryfocomsa berbaceu, foliis lanceolatis villofis, calycibus ardis. LiNN. l. c.

Calyx inverfe conicus (a.), fquamis oblongis ubtufis incanis. Thal. angu.ftifimus, convexus, alveolatus (B.), alveolorum marginibus ciliatis. Semina parva, inverfe pyramidata, vlllo[a, fericeo-alba. Pappus pilofus. ruffus, minutifime denticulatus.

Genus bifrons; accedente radio mutatur in sficrsws. 


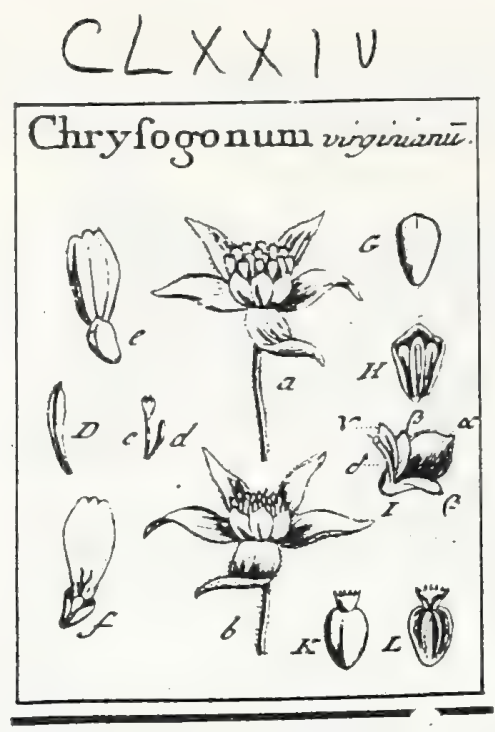

J. Gaertner (1788) Vol. 2

436

MIX. C H R Y S O G O N U M. LINN. ger. 98S.

Calyx fimplex pentaphyllus, foliolis oblongis, acuminatis, radio fubxquaJibus, extus fcabris intus nudis, patentibus. Thal. paleaceus: paleis difformibus; radialibus quinis majoribus. Flofc. difci androgyni, plurimi, fteriles; radii feminei, quini, ligulis ovatis tridentatis, fertiles. Sem. obovata, coronata fquamula turbinata, intus dehifcente, extus integerrima denticulata.

Chrysogonum virginianum. Tab. 174 fig. 8.

Coryfanthemum virginicum villofum, difco luteo, quinis petalis crentate. PLUK. plyyt. 8. 83. f. 4. t. 242. $f .3$. utraque nala.

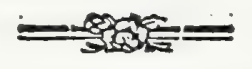

Clrryfogonim petiolis folio tongioribus. LiNe. Jyft. veg. 790.

\section{A Cl. Schrebero.}

REC. planun, paleaceum, paleis diffurnibus: difci Gmplicibus, lineari-oblongis, obrufis, concavis, extus pubefcentibus, ad fingulos flofculos fingulis; rudii compofitis, ad fingulum fofculum quaternis, in theam femini proprian coadunatis: exteriore maxima, obovat, hine convexa; inde concava, dorfo feninis accumbente; tribus interioribus anguftis, lineari oblongis, aperturam exterioris ita claudentibus, ut dux, latera feninis obtegant, tertia autem medio ventri incunbat, atque ante $f_{e}$, fterilis flofculi ovarium, fibi affixum, gerat.

SENL femiuis obovata, extus convera, intus concava, atque fulcis duobus longrtudinalibus obfoletis notata, pallide fpadicea.

Pappus membranaceus, monophyllus, turbiluatus, dimidio femine brevior, intronfum dehifcens $f$. deliquefcens, dentibus fex 1 paucioribus in fupremo margine incifuș.

IN T. fimplicifinum, nembranaceum.

EN B. albicans.

2) Calyx cum flofenlis difci \& tribus radii paleis in fitu naturali. b.) Idem eum receptac folis paleis tecto. c. d. D.) Flofc. difci cum fua paler e. E) Flofc. radii, cam fua palea, ab utroque latere fpectatus. G.) Theca feminis paleacex latus exterius. H. L.) Ejusdem pars intesiar; \& quidem a.) Palea major dot(alis; $B B$. ) dux interiores laterales; $y_{2}$ ) palea ventralis medir cum ovario ftecili (j), bafi ejus alasta $K$ ) Seneen a dasfo - \& L) Idem a yentre Spertatume. 


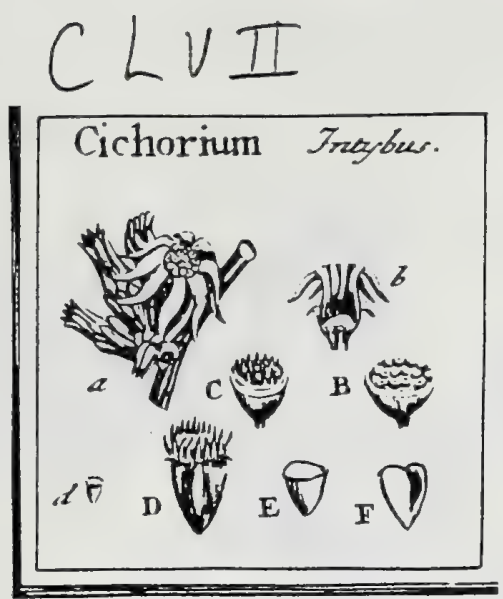

\section{J. Gaertner (1788) Vol 2 357}

DCCCCVI. C I C H OR I U M. TOURN. t. 272. LINN. gen. 921.

Calycis foliola oblonga, duorun ordinum: exteriora brevia, appreffa; interiora pei maturitatem longiffima reflexa. Thal. nudus, aut fetis diffitis confperfus. Pappus paleaceus, penta - aut polyphyllus, femine multoties brevior.

Cichorium Intybus. Tab. 157. fig. 6.

Cicborium fyluefre. BLakw. berb. t. x83.

Cichorium foribus geminis feffilibus, foliis runcinatis. LiNs. fyft. veg. 722.

REc. planiufculum, nunc papillis minutis depreffis, nunc vero fetulis parvis difitis \& inter has ferobiculis obfoletis confperfum.

SEM. obovata, compreftiufcula, obfolete ftriata, glabra, ftramineo-lutea.

Puppus polyphyllus, foliolis paleaceis, acuminatis, breviffnis, albis.

INT. duplex: coriaceum atque membranaceum.

E s B. albus. Cotyl. obtufx. Rad. acuminata, non difcreta.

2) Calyces maturi, duo vel plures aggregati, feffiles. b.) Calyx longitudinaliter diffeetus. B.) Receptac. papillofum, \& aliud C.) fetulis confperfum. d. D.) Semen integrum. E) Idem difTcaum. F.) Embryo denudatus.

Pappum ex margine obfoleto fubquinquedentato, ut vult Linnxus, ego hac tenus non vidi, fed conftanter polyphyllum, \& quafi ex duplici fqdiorum ferie compolitum. 


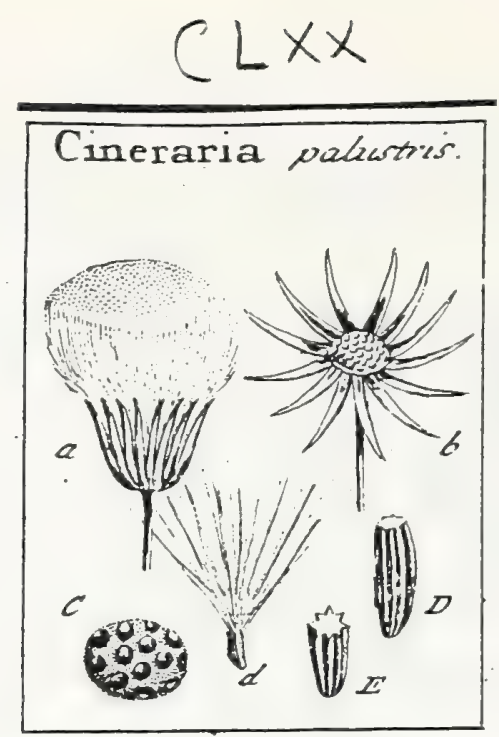

J. Gaertner (1788) Volz
446

\section{C I N E R A R I A. LINN. gen. $957^{\circ}$}

Calyx fimplici aut fubduplici ferie polyphyllus xqualis, bafi nudus aut fquanis paucis brevifitmis calyculatus: foliolis fphacelatis nullis. Thal. fcrobiculatus nudus. Flofc. difci androgyni; radii feminei ligulati: utrique fertiles. Pappus capillaris. Folia indivifa.

Cineraria paluftris. Tab. i70. fig. 2.

Solidago foliis inferioribus lanceolutis, funuato-farutis. GMEL. fibir. 2. t. 72.

Cineraria foribus corymbofis, foliis lyrato-lanceolutis dentato-frmuatis, cande villofo. LINN. Jjift. veg. 765 .

Icon. OED. flor. dan. t. 573 .

REc. Jeviter convexum, diffite fcrobiculatum, interfticis fungofis puncticulatis nudis.

SEM. columnaria, profunde fulcata: fulcis acutis, alternis profundioribus.

Puppus capillaris, albus, mollis, vir denticulntus, femine quadruplo longior.

INT. extcrius coriaceum, tenue, pallide ftramineum.

EMB. albus.

2.) Calsx matarus integer. b. C.) Receptac. denudatum. d. D.) Semen integrum. E.) Idem diffectum.

Cineraria Ainelloides. Linn. Berg. cap. 290.

Icon. MILL. ic. 8. 76. f. 2.

Calyx hemifphxricus polyphyllus fimplex: foliolis xqualibus, linearibus, per maturitatem horizontaliter patentibus. Thal. modice convexus, alveo-

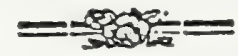

Jatus, fcabriufculus. Semina elliptica, compreffa, pallida, margine tumidulo albicante cincta. Pappus capillaris, minutifime denticulatus, albus, femine duplo longior.

Difrimen inter Jacobxam atque Cinemriam, genera utique fibi vicinifima, non tam in fphacelatis calycum fquamulis, quam in foliis integris aut pinuatifidis, ponimus: hinc C. maritimutas, canadenfen \& capillacean. LiNN. ad Jacubxam referimus. Generatin vero Cineraria eft Cacalia radio larvata.

Cineraria glauca \& purptroata. L. ob pappum plumofum, proprii generis planta funt. 


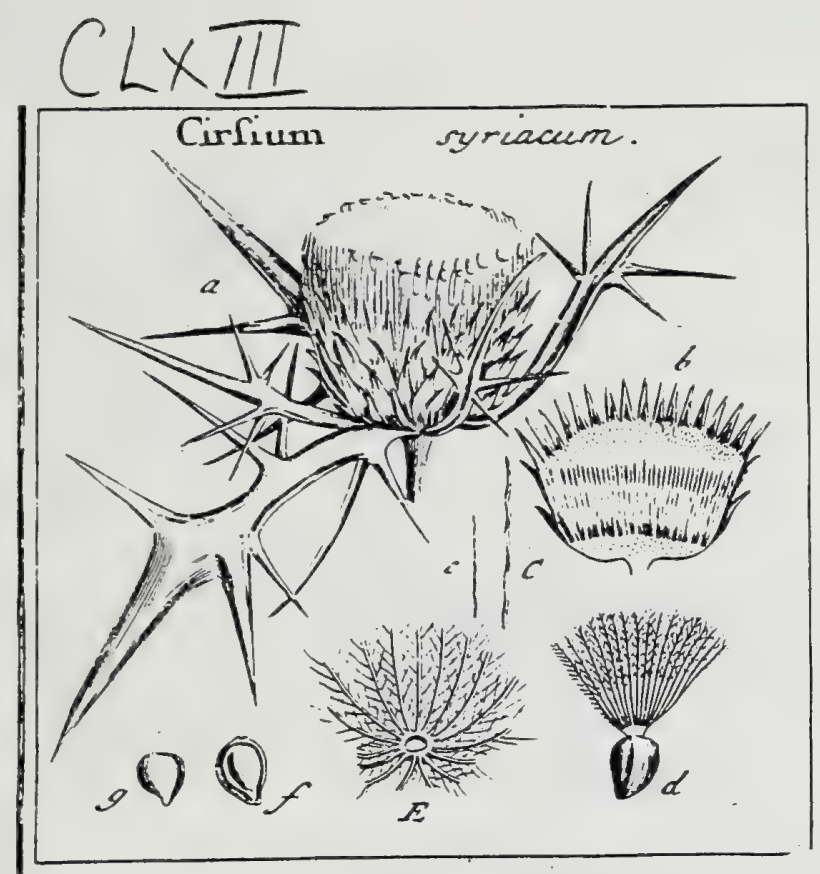

C. Pappo plumofo.

DCCCCXXXIX. C I R S I U M. TOURN. t. $255^{\circ}$

Calyx ventricofus aut cylindricus, imbricatus fquamis acuminatis, innocuis aut pungentibus, nunquam appendiculatis. Flolc. onures androgyni. Thal. paleaceus. Sem. coronata pappo plumolo: radiis filiformibus, fubxquali. bus, bafi in annulum conferruminatis.

Cirsium fyriacum. Tab. 163. fig. 2.

Carduus la Jeus fyriacus. CAM. bort. 35. 8. 10.

Cardues foliis amplexicaulibus anguluto- Spinofis, floribus folisaries fubfeldibus obvallatis foliolis fubquisisis. LiN. bifl. veg. 726 .

REc. paleaceum, paleis capillaribus, tlexuofis, longitudine fere calycis.

SEx. obovata, lenticulari compreffa, pallide teltacea, linea media longitudinali pallidiore.

Pappus plumofus, fenine duplo longior, caducus: radiis filiformibus zequalibus, bafi in annulum connatis.

IxT. exterius nucamentaceum ac fere lapideum, crafum.

E $\mathrm{M}$ 8. femini conformis, lutefcens.

a.) Calyx integer. b.) Receptac paleaceum. c. C.) Palex feparaiz d.) Semen integtum:

E.) Pappus (eqnaratus. f.) Semen diffectum. 5.) Embryo folutus

Vaftum genus, a calycis varia forma in plures phalanges ordiunndun. Quando rarius Cirfio additur, tunc mutatur in Cirfellium, quod vide infra. 
Asteraceae

ho drawirg

$$
\begin{gathered}
\text { J. Haetren (1788) } \mathrm{Voll}_{394} \\
394
\end{gathered}
$$

C I I B A D I U M. IINN. gen: 1329. Calyx imbricarus fquamis ovatis acutis. Flofc. infundibuliformes quinque-
fidi: difii plures, androgyni, ovario effucto pedicellati, Pteriles; Antheris difcretis; radii tres 1. quatuor, feminei, feffiles, fertiles. Thal..... Semina feminis cordata, comprefra, baccata, calva.

395

Clibadium ftrina:uenfe. LINs. fyff. veg. 85 s.

Hujus luci efle videtur, etfi receptaculi fabrica hactenus fit ignota.

19.48 


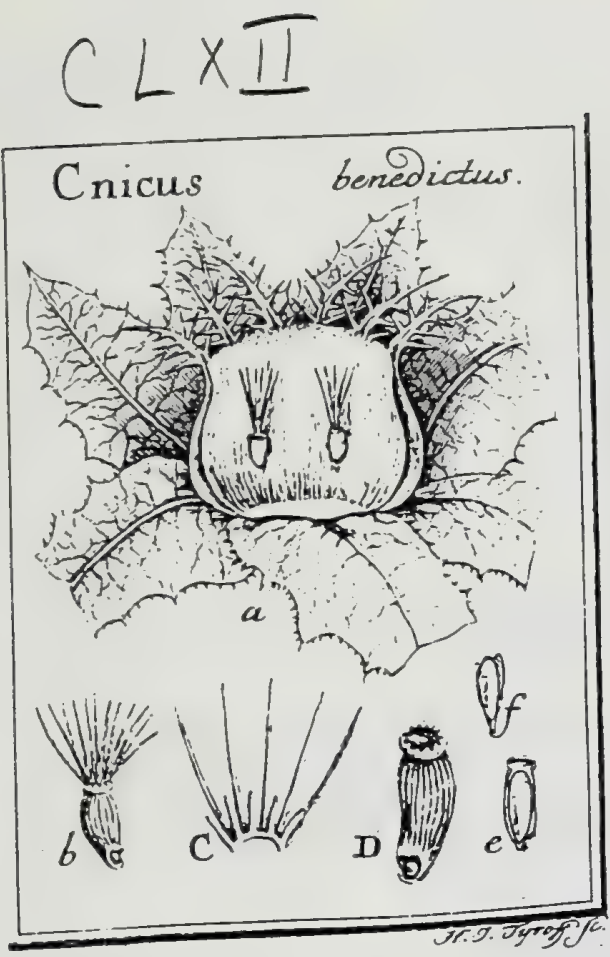

J. Gaertner (1788) Volz

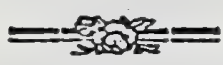

D. Pappo fpino\{́o.

\section{DCCCCXLI. C N I C U S. T OURN. t. 257. M. M. VAILI.}

Calyx ventricofus, imbricatus fquamis apice duplicato-Spinofis, circumvallatus foliis ovato oblongis, dentato fpinofis. . Flofc. omnes androgyni (fidaus.). Thal. paleaceus. Sem. coronata pappo duplici: exteriore calyculato, interiore fpinofo.

Cricus benedietus. Tab. 162. fig. 5.

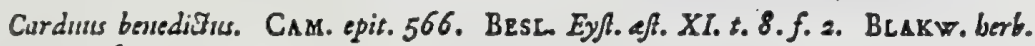
t. $47^{6}$.

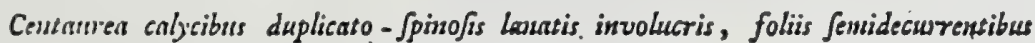
densicmato - spinofis. Lisis. Dift. veg. 787.

REC. paleaceum, paleis fecaceis, longirudiue fere calycis.

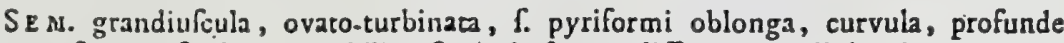
ftriata, fpadicea; umbilico fupra bafin anplifimo, papillula obturato.

Pappis duplex: exserior, cupula hemifpharica, fcariofa, monophylla, brevis, per oram denticulnta, denticulis fubduodenis, inflexis; insevior fpinolus, radiis acicularibus, pungentibus, alternis brevioribus, omuibus bafi inter fe connatis.

Iн T. exterius cruftaceum, durum, crallim, ad umbilicum late perforatum.

E m B. femini conformis, luteus.

2.) Calyx diffectus, cam invuluero foliofo, atque recertae. pralsacco. b. D.) Semen integrum. c.) Pappi interioris radii Spinofi, longitudiac alteruautes e.) Semen difiętum. E.) Embrye Solutus. 


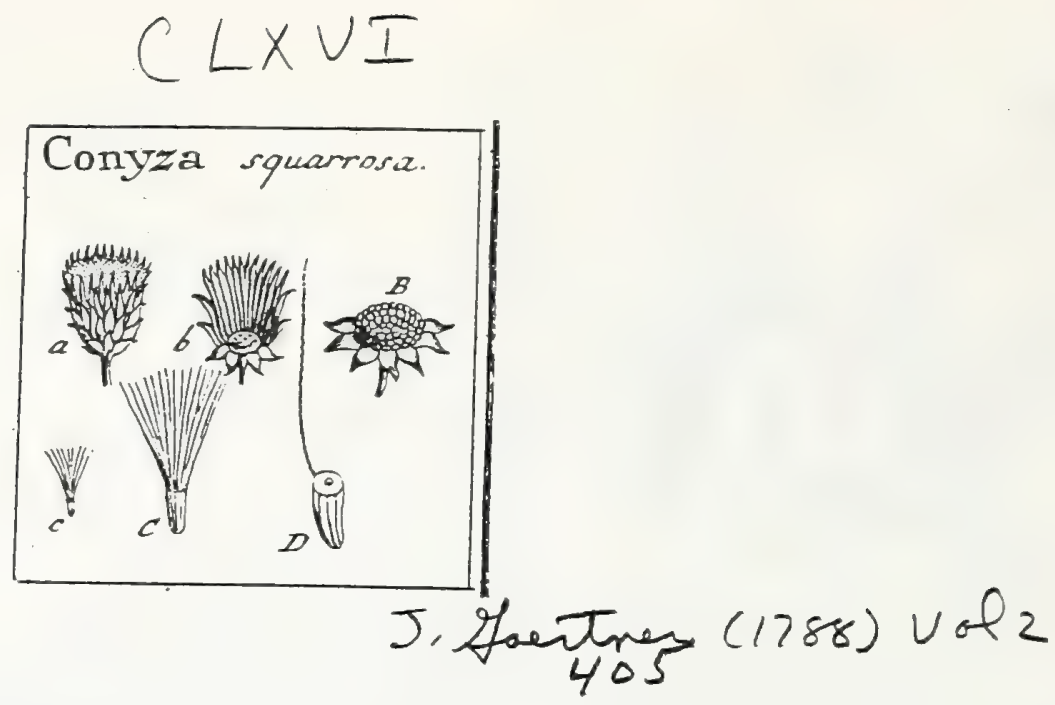

DCCCCLXXI. C O N Y Z A. TOURN. t. 259. LINN. gen. 950.

Calyx ovato-cylindricus, imbricatus fquamis acuminatis. Flofc. difformes : difci infundibuliformes, quinquefili, androgyni; radii filiformes, tridentati, feminei: utrique fertiles? Thal tuberculatus. Pappus capillaris.

Conyza fquarrofa. Tab. 166. fig. 6.

Conyza major. CAM. epit.612. OED. for. dm. t. 622

Bacebaris nouspelienfucm. BLaKw. berb. t. 102.

Conyza foliis lanceolatis acusis, caule berbuceo corymbofo, calycibis fquanrofis. LIN. Syft. veg. 752.

406

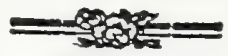
REC. planum, aut modice convexum, tuberculis contiguis, \& punctis elevatis:
grandioribus fcabratum.

SE «. oblonga, angulata, fulcata, glabra, fpadicea.

Pappus capillaris, femine triplo longior, minutifime denticulatus.

IN T. fimplex, nenbranaceum.

E.M B. albicans.

a) Caljx integer. b. B.) Receptac. denudatum. c. C.) Semen (cparatum. D.) Idem, cux radio pappi, infizunter auaura. 


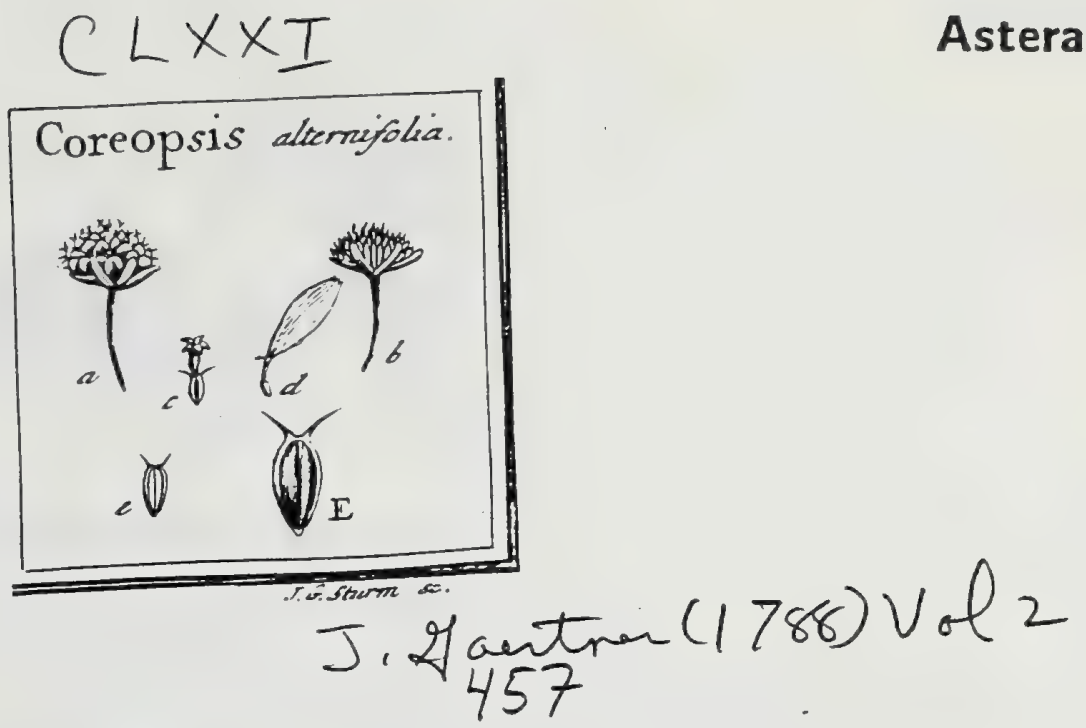

MXXXVII. C O R E O P S I S. LINN. gen. $98 \mathrm{I}$.

Ca!yx polyphyllus, foliolis a recepeaculi paleis vix aut parum diftinctis. Thal planiufculus aut leviter convexus, paleaceus. Flofc. Lifci androgyni, fertiles ralii feminei aut neutri, ligulis difco transverfo xqualibus aut lon. giaribus. Iteriles. Pappus bi - 1. triariftatus: ariltis glabris aut retrurfum feabris.

Corgorsis alternifolia. Tab. 171. fig. 9.

Cloryfuntbemam virginianum, caule alato, ramzofus, fore minore. PLox. plyts t. 159. f. 3.

Coreogfis foliis lanceo!:tris ferratis alternis petiolatis decurrentibus. LiNx. 6ff. veg.783.

Jcon. Jace. bort. t. 210.

438

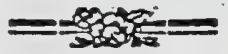

REe. plarriufculum, paleaceum: paleis linenti lanceolatis, anguftioribus quam calycina foliola, cetera vero eis fimilibus.

Sens. nudrogyuis obovata, compreffa, ftria media elevata longitudinali notata; margine angufto membranacco integerrimo cincta, elilute caltanca:

Pappus biariftatus: ariftis fubulatis, xqualibus, divergentibus., glabris, dinidio fenine brevioribus.

IN T. fubcoriaceum, temue.

EM 8. albicans.

2.) Calyx maturus. b.) Receptzc. paleis tectum. c.) Flofc. difci fertilis. d.) Flufc. radii fterdis. e. E.) Seenen fiparatum.

Coreopfis. itaque eft Bidens radio harvata. 


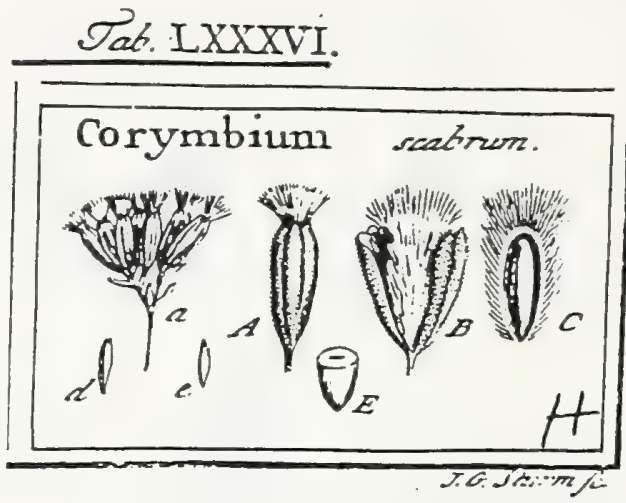

\section{J. Gaertner (1788) Vo12}

42

\section{DXIVII. C O R Y M B I U M. LINN. gerr. I004.}

Calyx bivalvis, inferus, perfftens. Cor. fupera, monopetala, quinquefida, regularis. Stam. quinque: antheris in cylindrum coalitis. Ovar. infra corollam. Styl. finplex, apice bipartitus. Utriculus pilofus, calycis valvulis complexus, monofpermus.

Corymbium fabrum. Tab. 86. fig. 8 .

Buplenrifolia femine pappofo, valerianoides umbellata, cauliculo fcabro. PLUF phyt. t. $272 . f .5$.

Corymbium foliis ad radicem longifinis lyratis. BURM. afr. to 70. f. x.

Corymbium foliis lanceolatis canaliculatis nervofis recurvatis glabris caule brevioribus. Lix. Jys. veg. 799.

$\wedge$ Cl. v. Royen \& Thunbergio.

$P E R$. Utriculus inferus, intra calycis perfiftentis valvulas cruftaceas, fulcatoangulatas, fcabras, apice pervias \& obtufe quinquedentatas collocatus, membranaceus, tenuiffimus, albus, \& albis pilis fericeis, calyce longioribus, undique contectus, femen arcte claudens.

$R$ E c. nullum.

SEM. unicum, oblongum, teretiufculum, aeorfum leviter attenuatum, glabrum, e caltaneo-ferrugineum.

IN T. duplex, procter Utriculum : exterius fubcruftaceum; interius membranaceum.

A І в. femini conforme, carnofum, crafiǘfculum, pallidum.

EA B. gracilis.......

2. A.) Calyx maturus claufur B.). Ejusdem valvula diduax, cum medio Utriculo pilofo. c.) Utriculus per longiturirnem fetus, cum femine. d) Semen feparatum, magnitudine natusali. e.) Albumen denudatum. E.) Idem transverfe fectum, cum cavitate media pro embryone.

Embryonem in meis exemplis immaturis cernere non licuit, fed ex albuminis fabrica fufpicor, eum efle linearem atque inverfum. 

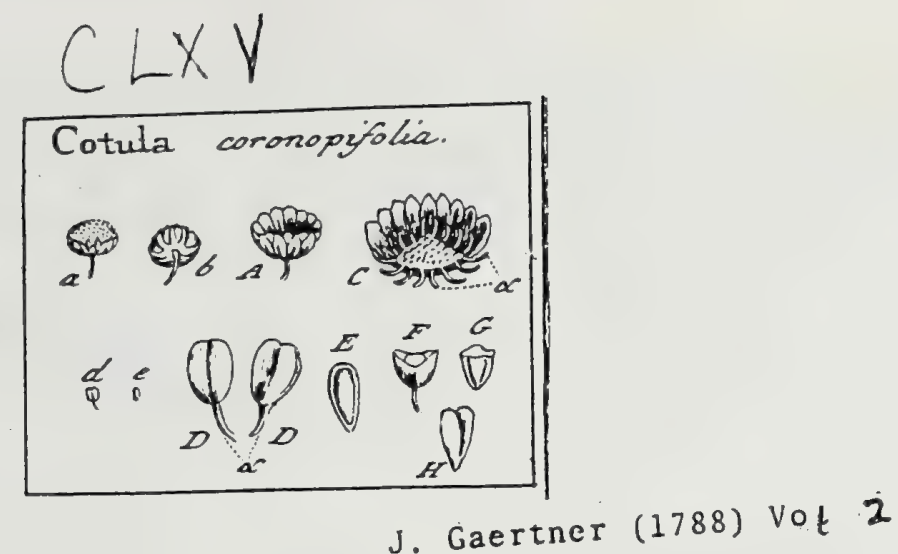

\section{8}

DCCCCXLVI. C O T U L A. LiNn. gen. 968.

Calyx hemifphxricus, bafi externn monophyllus, fupm duplici ferie poly. phyllus, xqualis. Flofc. difformes: difci infundibuliformes, quadrifici, androgyni; radii edentuli, breviflimi, feminei: utrique fertiles. Thal. fubconicus nudus. Sem. difformia: feminis grandiora pedicellata, androgynis minora felfilia.

Cotula coronopifolia. Tab. 165. fig. 10.

Clny/anthemum exoticum mimus, capite aphyllo, chamemeli midi fucie. BR E Y N. cent: t.76. Corula foliis lanceolato - linearibus amplexicaulibus dentatis, floribus fofculo/is. LINN. Jjeft. veg. 774 .

Icon. OED. flor, dan. t. 34 I.

REC. conicum, depreffum, tuberculatum, nudum, in ambitu pedicellis fiofculorum femineorum radiatum.

SEM. difformia: ridii majora, obovata, apice emarginata ut quafi cordata, bafi pedicello filiformi ftipata, hinc plasiufcula aut fulco depreffo exarata, inde obtulo angulo carimata, glabra, compreffe triquetra, albicantia, calva; difci minora, oblonge elliptica, comprefliufcula, margine leviter incraflato albicante cincta, in medio autem rufefcentia, feffilia, glabra, calva.

INT. exterius coriaceum, tenue.

EM B. femine anguftior, albicans.

2. A. b.) Calycis facies prona atque fupina. C.) Reeptac. cum pedicellis ( $\left.\alpha_{0} \alpha_{0}\right)$ feminan radii. d. D. D. F.) Sentina ridii integrn \& difreaz c. E. G.) Semed dilci integrum \& diffcQun. II.) Embryo denudatuc.

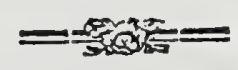

Marginem in. vertice feminum, quen C!. JUSsntu eis tribuit, ego reperire non potui in hac fpecie. Genus cetera bifrons: $\cdot$ accedente enim radio, mutatur in Lancifiam. Adans. 1. Cenian. Juss. 
Asteraceae

No dening

= Cotula

J. Aautren (1788) Vol 2 422

LANCISIA. PONTED. diJ. 204. AdANs. 126. Cenia. JUSS. p. I83. Omnia Cotulx, procter forculos radii femineos, ligulatos: ligulis integerrimis. Calyx quandoque turbinatus, fub receptaculo vacuus.

Hue potiffimum fpectant: C. turbinata, capenfis, fricia \& vifcofa. Linx. Videndum tamen, anne in his omnibus femina fint diffornia, ficuti id de
Lancifia stabinata conttat, cujus quoque feminibus radialibus, pedicellos Pontedera b. c. adfcribit. Eft igitur Lancifia nihil aliud, quam Cotulia radio larvata.

19.54 


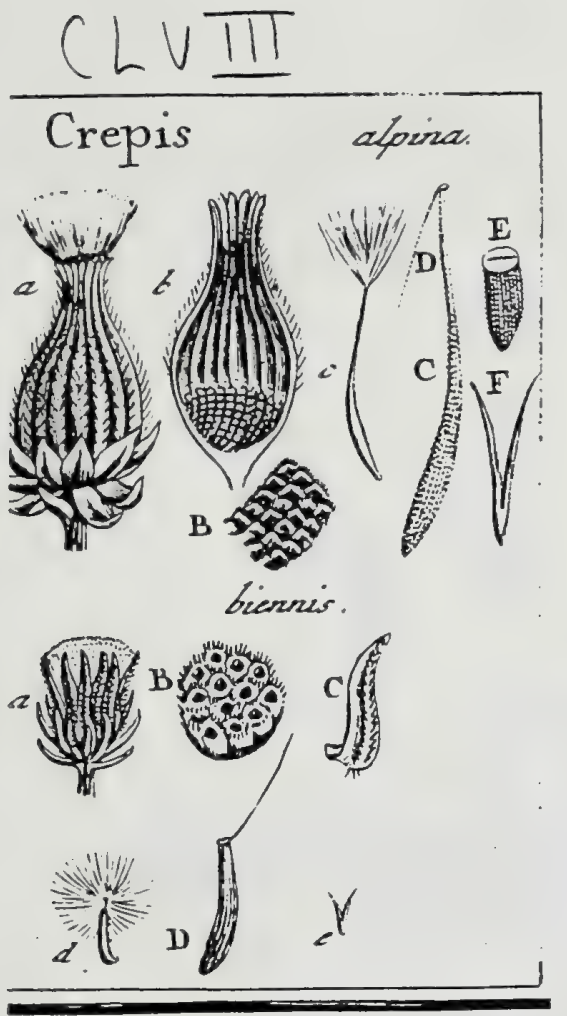

Asteraceae

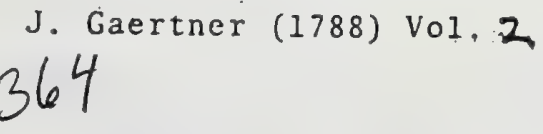

DCCCCXV. C R E P I S. LINn. gen. gr4. Hieracioides. VAIIL

Calyx fimplex, polyphyllus, per maturitatem torulofus, ventricofus; bafi auctus fquamis pluribus patulis. Thal. alveolatus aut fcrobiculatus. Sen. oblonga, fuffformia, aut tarius columnaria. Pappus pilofus, in plerisque ftipitarus, in paucioribus felfilis. Difcrimen pracipuum, ab Hieracio, confiftit in calycis maturi forma ventricola atque torulofa; a Picride autem pappo non plumofo diftat.

CREPIS alpina. Tab. I58. fig: 8.

Leontodon calyce toto ereflo; infcriore fquanis ficcis, foliis amplexicandibus. GNEL. Sibir. 2. 8. 5 .

Crepis involucris fcariofis longitudine calycis, floribus folitariis. LINN. fyyt. veg. 719 .

REC. concsvum, profunde alveolatum, àlveolorum marginibus ciliatis.

SEs. prolunga, ftriis numerufis feabris exafperata, paliide fpadicea, e clavata bafi fenfim in ftipitem attenuata:

Pappus capillaris, albus, femine multo brevior, ftipitatus. Stipes fubuJato - feraceus, fcaber, Jongitudine feminis.

IN T. duplex: exterius cruftaceum, durum.

Ess B. fubulatus, albus. Cotyl. acuminatx. Rad. conica, non difcreta.

1. b.) Calyx maturas integet \& diftezus B.) Receptac. pars infigniter autar. c. C.) Scmen integrum. D.) Pappi radins capillaris denticalatus. E.) Semen diffectum. F.) Embryo aicnudatus.

Eadem fabrica gaudent quoque femina Cr. veficarie, rubre, foetida, \&c.

Crepis biennis. ibid.

Hieracism eruce folio birfutsum. ВАUн. bifs. 2. p. 1025. bene.

Crepis foliis rumcinaso pimnatifidis faabris: bafi Juperue dentatis, calycibus musi catis. LiNs. byt. veg. 719.

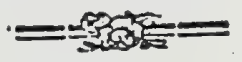

Calyx (a) calyculatus, fquamis inferioribus glabris, patulis; fuperioribus erectis, dorlo rotundatis (C.) atque hifpidis. Thal. alveolatus (B.), alveo. Jorum marginibus ciliaris. Semina (d. D.) oblonga, teretiufcula, ftriata, glabra, lutea aut ferruginea, furfum graciliora, nec tamen in verum ltipitem attenuata. Pappus feffilis, capillaris, aiveus, deciduus. Enbryo (e) fubulatus, albus.

Crepis virens. LINN.

Calyx maturus, Arnoferidis fimillinus, ventricofus, torulofus, vix calycu latus. Thal. obfolete fcrobiculatus. Semina aquabiliter columnaria, profunde fulcata, ruféfcentia. Pappus capillarıs, ferlitis, fenine fefyuilongior, deciduus. Haxc folo calyce ab Hicracio differto

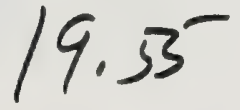




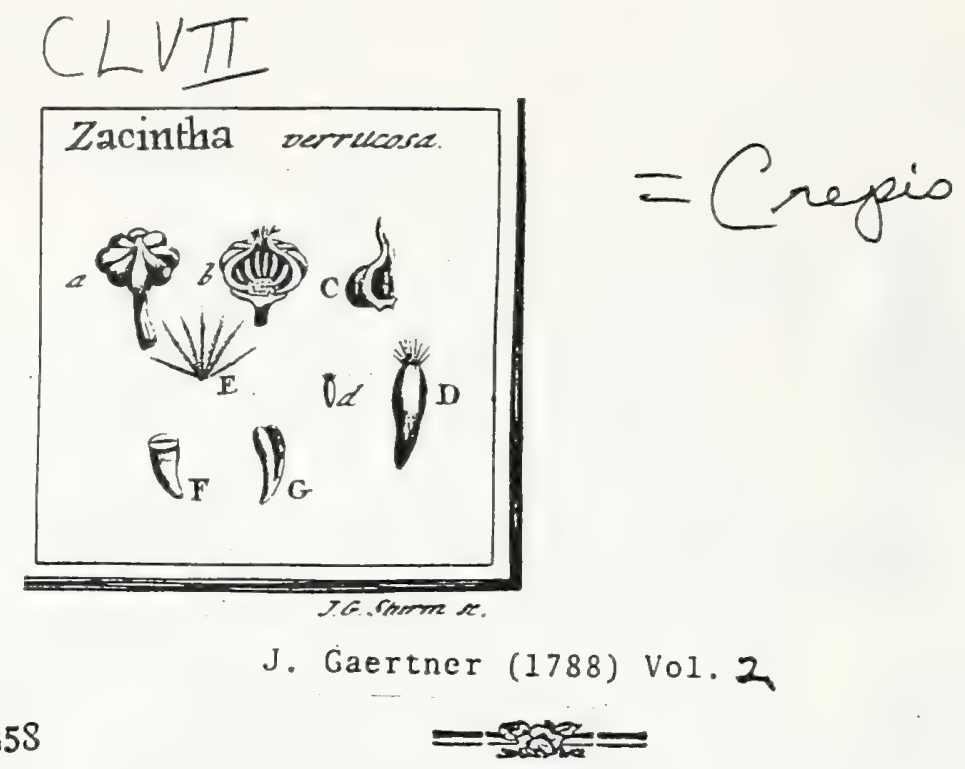

DCCCCVII. Z A C I N T H A. TOURN. t. 269.

Calyx fimplex, octophyllus, bafi fquanulis minimis calyculatus, per matu. ritatem coriaceus, torofus, deprefle globofus, cum umbone conico brevi in vertice. Thal. glaber. Sein. uniformia. Pappus fetaceurs, denticulatus, brevifimus.

Zacintha verrucora. Tab. 157. fig. 7 .

Cichorium verrucaritms, f. Zacintba. CLUS. bift. 2. p. 144.

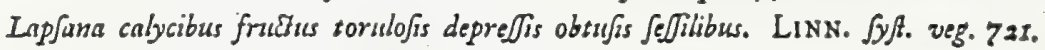
REC. planum, excavato-punctatum, glabrum.

SEM. oblonga, deorfum attenuata, glabra, rufefcentia, marginalia curvula, a calycinis foliolis femiamplexa; centralia libera, recta.

Pappus Setaceus, creberrime denticulatus, fubfragilis, candidifrmus, radiis inæqualibus, dimidio fenine brevioribus.

INT. duplex : utrumque membranaceum.

EMB. albicans. Cotyl, obtufie. Rado attenuata, non difcreta.

a.) Calyx maturas integer. b.) Idem apertus cum receptacula C.) Calycis foliulum fepantam. d. D.) Semen integrum. E.) Pappi radii, magnitudine aueti. F.) Seminis fectio transver[alis G.) Embryo denudatus.

Heclypnoës utique ex pappo \& calyce affinis; fed differt, feminibus ipfis non manifefte difformibus. 


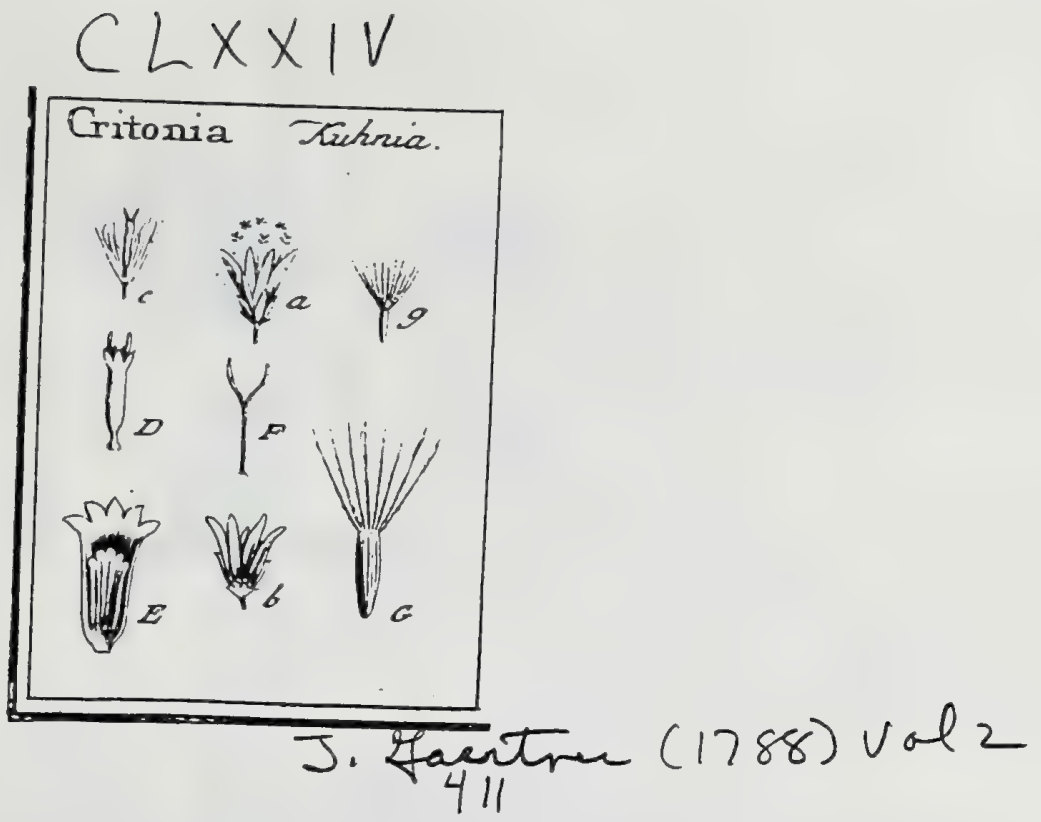

\section{DCCCCLXXIX. C R I T O N I A. BROWN.}

Calyx oblongus, imbricatus fquamis inxqualibus. Flofc: omnes androgyni, quinqueñdi; tubo antherali integerrimo;- ltylo profunde bifido. Thal. mudus. Pappus plumolus.

Critonia Kuhnia.- Tab. 174 fig. 7.

Eupatorium foliis alternis, calycibus multifloris, pappo plsuno $\int$. ARDuss. Spec. 2. p. 40. t. 20 .

Kubnia eupatorioides. LIN. dec. 2r, t. II. Lyft. veg. 277 .

\section{A Cl. Thunbergio.}

REc. nudum, fcrobiculatum, fcabriufculum.

S\&m. oblonga, teretia, ftriata, glabra, e Itramineo-rufefcentia.

Pappus femine paulo longior, eleganter plumofus, a albus. aut per zetatem ruffus.

Is T. duplex : utrumque membrannceum, tenue.

EM B. fenini conformis, albicans.

a) Calyx maturus integer. b.) Recept. denudatum. C) Flofeulus feparatur. D.) Cotollofa integra. E.) Eadeun diffeca, eum tubo antherail longitudinaliter aperto. E.) Stylus profude bigdus. E. G.) Semen eurn pappo.

Antherx nequaquam difcretx funt, uti voluit Linnxus, fed in tubum integerrimum adeo pertinaciter connatz, ut nec polt macerationem per 24 horas fponte a fe invicem difcefferint. Hinc Krelnis character linnzeanus plane fictitus, atque genus, quod ob pappum manifelte plumofum cum Eupusurio fuciari nequit, ad Critoniam BRows. jam. 490. amandandum eit. 


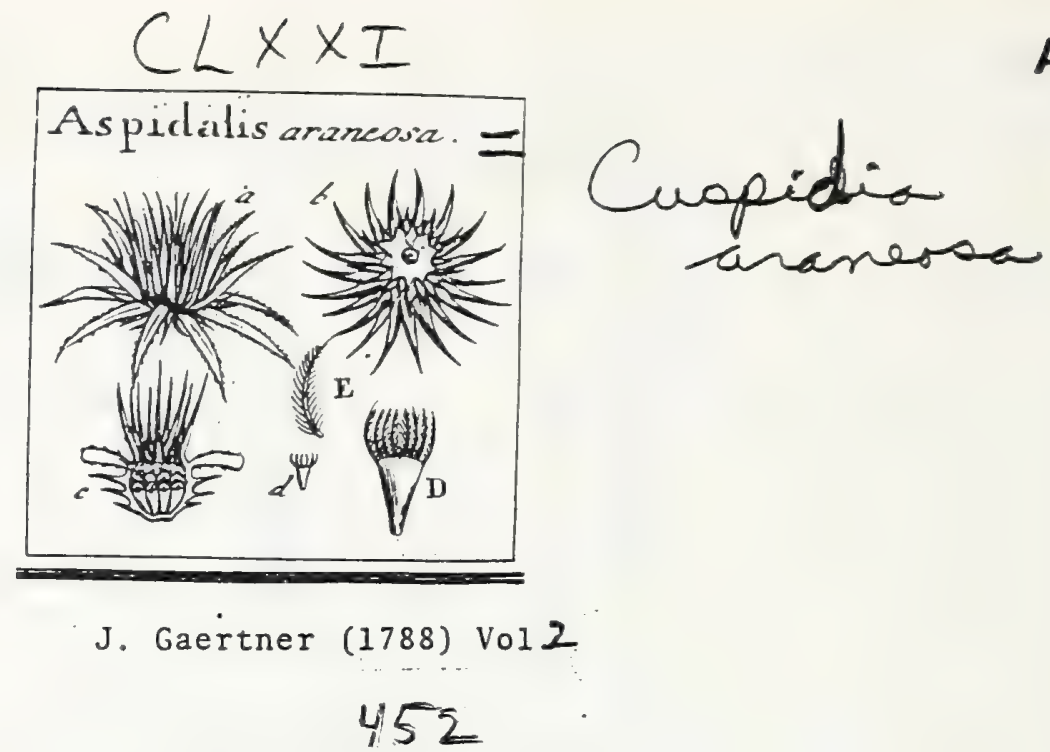

\section{C U S P I D I A.}

Calyx monophyllus, ventricofus, muricatus fquamis aculeatis pungentibus: inferioribus brevioribus patulis; fuperioribus acicularibus erectis. Thal. alveolato - paleaceus. Flofc. difci androgyni; radii feminei ligulati: utrique fertiles? Sem. uniformis. Pappus plumofus.

Cuspidia araneofa. (Afpidalis in Icons) Tab. I71. fig. 5.

Gorteria cernun, foliis oblongis amplexicaulibus dentato fpinofis patentibus glabis, calycibus ciliato ferratis, floribus cernuis. LisN. fyjt. veg. 784.

KEC. planum, profunde alveolatum, alveolis paleaceis tenuiffmis, albicantibus, apice ciliatis aut laceris, ventri calycis longitudine xqualibus.

SeM. . . . Ovaria inverfe pyramidata, angulata, glabra.

Pappus multiradiatus, eleganter plumofus, femine paulo brevior.

IN T. .... E E B. ....

a.) Calsx integer a prona \& fupina parte fpetatus. c.) Idem difrectus cum receptac alveolato. . d. D.) Semen immaturum Ieparatum. E.) Pappi plumof radius infigniter audus.

Calyx maturus fponte deciduus, bali integerrimus \& aculeis brevibus conicis, inftar fructus Medicaginis; pulchre echinatus. Hujus loci forfan quoque G. Jpinosn. 


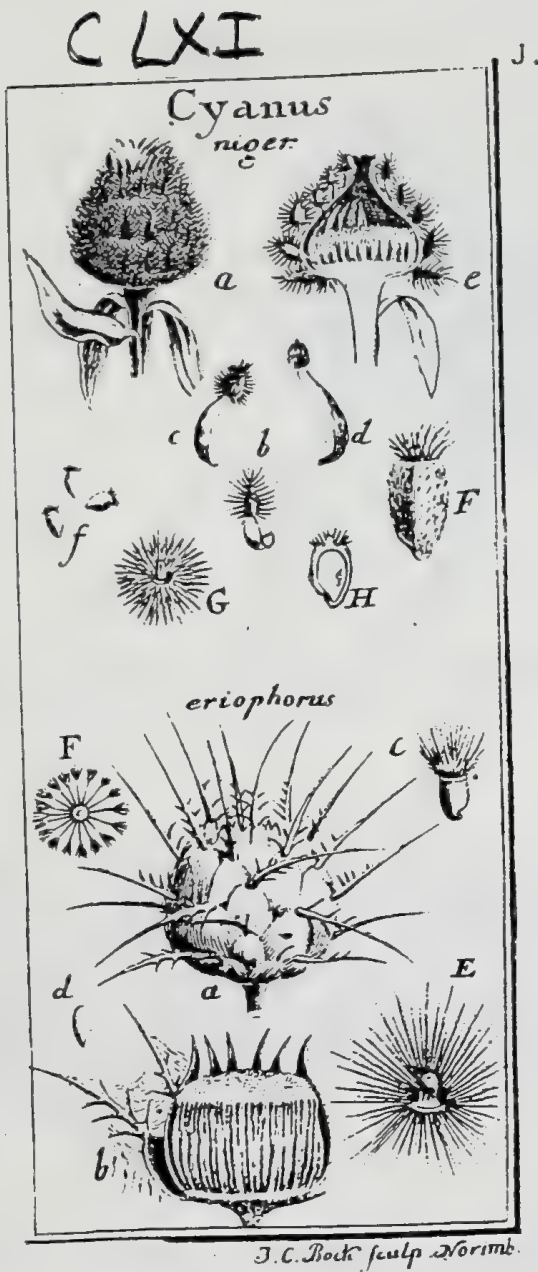

382

\section{DCCCCXXXVIII. CY A N US. TOURN. t. 254. JUSs. p. I74.} Centaurea. Linn. gen. 984.

Calyx inibricatus fquamis apice laceris, ciliatis, aut fpinofis. Flofc difci androgyni; radil neutri plerumque grandiores \& a reliquis forna difcrepantes. Thal. paleaceus. Sem. uniformid. Pappus fetaceus aut paleaceus, inxqualis, perfiftens: centro umbonato, vario.

Cranus niger. Tab. 161. fig. 4

Jacen foliis radicalibns femipinnatis, candinis ovato-lanceolatis, caulibus angulatis. HaLl. bif. n. 284 .

Centaurea calycibus ciliatis: fquanula ovata: ciliis capillmibus erefisis, foliis lyraso angulatis, fiuribus flofcrlofis. LIN. fyft. veg. 785 .

R Ec. palezceum, paleis fecaceis, longitudine dimidii calycis.

SE 3. ovata, lenticulari compreffa, minutis fetulis ad $\int_{p e r}{ }_{2}$, nitida, pallida. Pappus dimidio femine brevior, albus, perfiltens : radiis acuminatis, paleaceis, denticulatis, inxequalibus; umbone centrali cylindrico, fo. lido, brevi.

IN T. exterius coriaceum, tenue.

EM в. femini conformis, albus.

2.) Calyx integer. b.) Squama extima; c.) media; d.) intims. e.) Recepto paleaceum. f. F.) Semen integruu. G.) Pappus feparatus cum fun umbone. H.) Embryo in femiac ditfedo denudatus.

Differt a reliquis, fofculis omnibus androgynis \& unifornibus.

Cyanus eriophorus. ibid.

Centan'ea calycibus duplicato - Spinofis lanatis, foliis femidectorentibus integris funutisque, caule prolifero. LiNn. $l$. $c$.

Calyx fubglobofus (a), fquamis intimis (b.) fimpliciter acuminatis; reliquis fpina femunciali tava, patula, utrinque aculeata armatis, atque lana arachnoidea obvolutis. Palex receptac. (b.) fetace:c, longitudine fere calycis. Semina (c.) grandiufcula, ovata, lenticularia, glaberrima, lucida, pallide ciltanea, ad umbilicum profunde emarginata. Pappus $(E)$ Fetaceus, rigidus, denticulatus, fufcus, longitudine feminis, inxqualis. Umbo compufitus ex radiolis brevibus penicilliformibus (F.), ereetis \& parnbolice (E) conniventibus. Embryo (u.) albicans.

Cyanus mofchatus.

Semina oblonga, duarum circiter linearum, turgide leviticularia, nigricantia, albis villis adfperfa; unbilicus quoque albo margine cinctus. Pappus

lineari-paleaceus, denticulatus, albus, dinidio femine brevior. Umbo centralis cylindricus, folidus, breviflimus.

Cyanus fibiricus.

Semina oblanga, rhombeo-compreff, glabra, pallida aut rufefcentia. Pappus dimidio femine brevior, fetaceo-paleaceus, fufcus. Umbo centralis cylindricus, tubulofus, brevis, bafi margine cartilagineo cinctus.

Cyanus uapifolins.

Semina fesquilinearia, ovata, turgidula, e viridi livida, lineolis interruptis albicantibus variegata, glaberrima, nitida. Pappus albus aut rufefcens, dimidii feminis longitudine. Umbo centralis tubulofus.

Cyanus pullutus.

Semina parva, albicantia, lenticularibus turgidiora. Pappus dimidio femine paulo longior, lineari-paleaceus, denticulatus. Umbo ex radiolis fubulatis, brevillimis, conice convergentibus.

Cyanus ragufumus.

Semina ovato-oblonga, lenticularia, glabra, albicantia. Pappus longitudine feminis, pallide Gavefcens, lintari-paleaceus. Umbo ex radiolis fubulatis brevifimis, conice convergentibus.

Cyanus meliterfis.

Semina vix lineam longa, ovata, turgidula, glabra, pallide virefcentia, lineolis albis longitudimalibus variegata, ad umbilicum profunde emarginata \& quisf in roftellum aduncum bafi definentia. Pappus albus, Jongitudine fere feminis. Umbo ex radiolis brevifimis, parabulice convergencibus.

Umbo centralis pappi in pluribus fpeciebus fcrumandus, antequam genus - in plures cohortes carpologice diftribui polfit. Etiam umbilicus feminis aliquam meretur attentionem.

19.59 


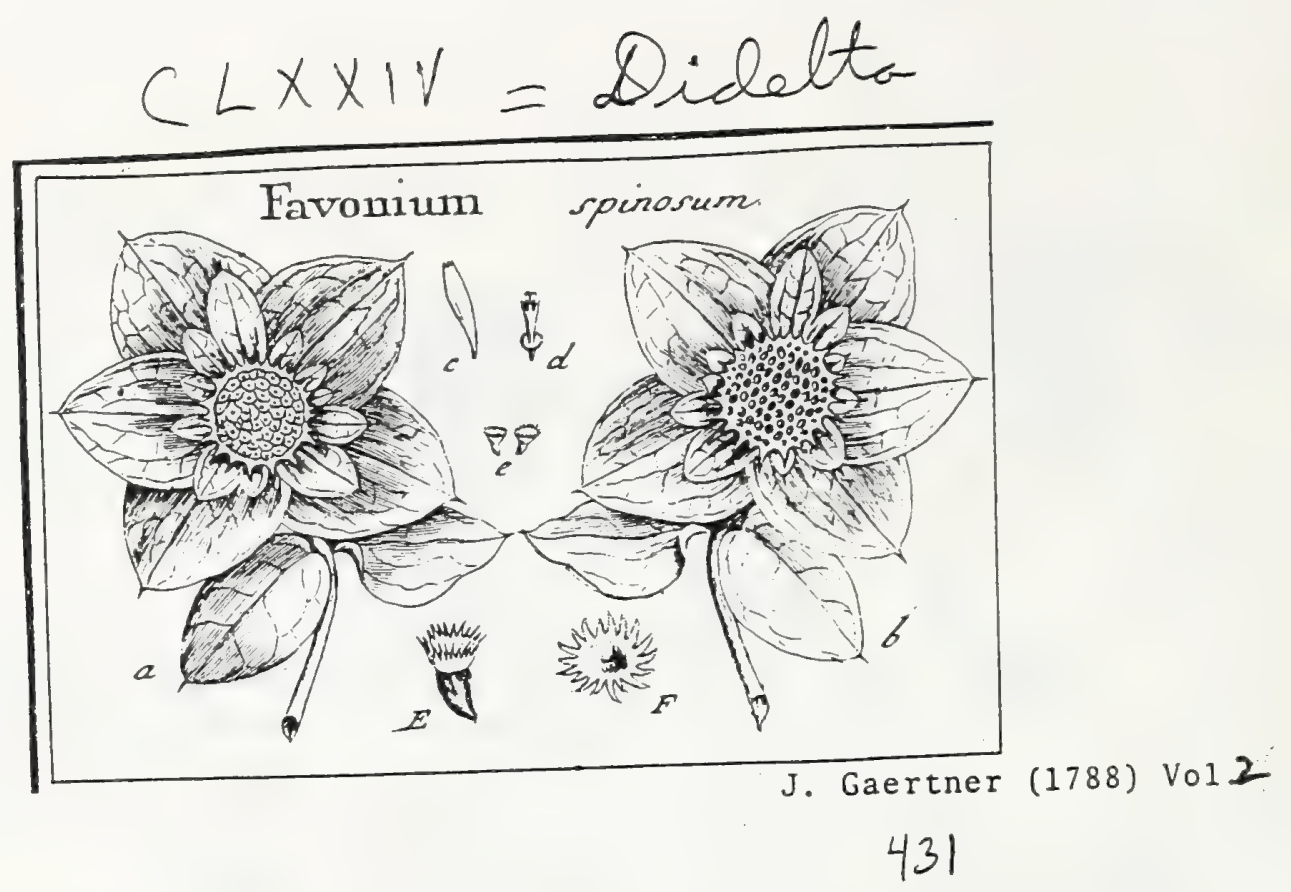

\section{F A V O N I U M}

Involucrum floris duplex: exterius tetra -1 pentaphyllum maximum; interizs polyphyllutn brevius: utrumque herbaceo - foliofum, foliis ovatis aut ellipticis, venofis, glabris, apice in fpinulam brevem defmentibus. Calyx communis monophyllus, cum receptaculo penitus connatus, per ambitum multidentatus: dentibus fubulatis, inxqualibus, horizontali patentibus.

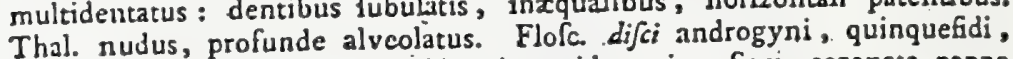
ferriles; radii neutri, ligulis oblongis, tridencatis. Sem. coronata pappo monophyllo multidentaro.

Fayonivas fpinofum. Tab. 174. fig. 1.

Chorijes glabra. Socaxd. injs.

Polymuia Spinofa, folits oppofitis ovato - cordatis feJilibus, aculeis fupra axillaribus, caule fruticofo evejo. LINN. Jyft. veg. 790.

$\Lambda$ Cl. ThUNBERgio.

REC. a calyce non difcretum, convexiufculum, amplum, nudum, profunde alveolatum: alveulorum marginibus nequaquam fariogs Sed besbacea sollibus, integerrimis, glabris, nigro-fufcis.

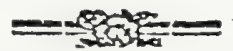

SEM. inverfe pyramidata, rhombeo-compreffa, glabra, livida aut plumbea:

Pappus monophyllus, membranaceus, albicans, fubcampanulatus, nargine duodecin - 1. multifito, dentibus fetaceis, inxqualibus, denticulato - fcabris.

INT. duplex : coriaceum \& membranaceun; utrumque tenue.

EM B. albicans.

8.) Involuctum utrumque, fum calyce \& receptaculo folis feminibus tecto. b.) Receptac. exeuflis feminibus, denudaturs. c.) Flofc. radii nenter. d.) Flofe. difei androgyaus. c. E.) Seanina (eparata F.) Pappus explatıatus \& infigraiter auchus.

Cum Wedelia convenit pappo, fed differt calyce, receptaculo \& fterilinte radii; cum Polymnia autem ne umbran quidem affinitatis habet: biuc omnino proprii generis planta eft. 


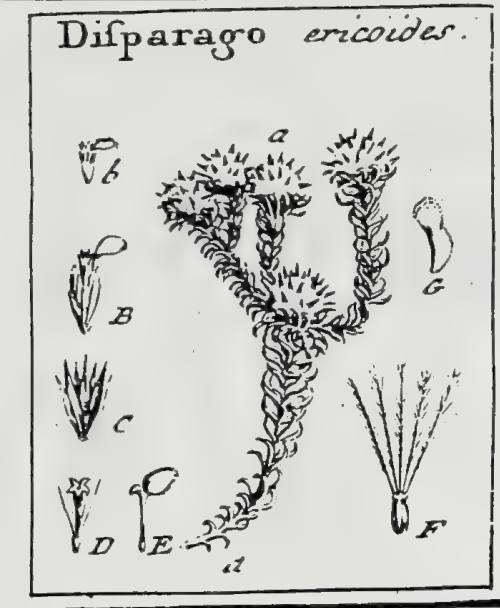

J. Gaertner (1788) Vo12

$$
463
$$

\section{D I S P A A G O.}

Calyx communis nullus, proter extimas thalami paleas. Recept. communune palesceum; partiale nudum: Calyces partiales plures, interjacentibus paleis fegregati, fubulat, imbricati fquamis fariofis inxqualibus, bitori. Flofc. alter androgynus tubulofus fertilis; alter femineus aut neuter, ligulatus, fterilis. Sem. oblongum. Pappus pluniofus.

Disparago ericoides. Tab. 173. fig. 8.

Eupatorium ericoides, capitis bous fpei. BreYN. cent: I40. t. 9: Morrs. bift. 3. S. 7. t. 28. f. 10.

Stoebe ericoides, foliis recurvatis incanis, corollis bifloxis difformibus. BRRG. cap. 339. LINN. Jyl. veg. 298 .

A Cl. Thunberglo.

REC. commusue fubglobofum, paleaceum, paleis fpatulatis, externe tomentofis, ad fingulos calyces partiales pluribus, eisque brevioribus. R. propriunk anguftifimum, nudum.

SEs, minutulum, oblongum, obfolete ftriatum; fpadioeuni:

Pappus longitudine flofculorum, quinqueradiatus: radiis bafi nudis fetaceis, cetera plumofis, perfiftentibus.

Is T. Gimplicifimum, membranaceum.

EN B. femini conformis.

2 2.) Ramuli foriferi parz exterior. b. B.) Cilyx partialis eum fio(culo gentello. C.) Caljyx difretus cum receptace partiali. D.) Flofe. androgynus. E.) Flof́, neutes. F.) Semen oum: Gio. pappo. G.) Palca receptaculi corrmi:nis Separats.

Floiculus neuter, qnem Cl. BERGius femineum ticit, femper gritet twho filiformi, longitudine calycis, in ligulam defineute; fed ligula in aliis fimplex eft, in aliis vero tubi limbus eft bilabiatus (qualen fig. E. reprx. fentat): labio interiore minore, lineari, recurvo; exteriore autem majore, ovato, apice tridentato. Si planta hxc non fit proprii generis, certe non ad Stoeben, fed potius ad Scriplintis, ex ftructura calycis partialis, debebit referri. 

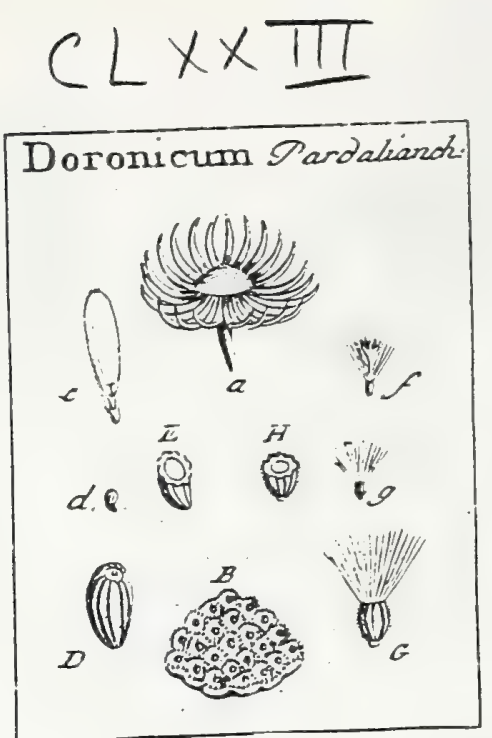

J. Gaertner (1788) Vol. 2 .

$$
459
$$

MXXXVIII. DORONICUM. TOURN. t. 277. LINN. gen. 959.

Calyx fimplici aut duplici ferie polyphyllus xqualis. Thal. convexus, brevilfine villofus. Flofi. difci androgyni; radii feminei, ligulis ovato oblongis tridentatis: utrique fertiles. Sem. radii calva; difci pappofa.

Doronicun pardalianches. Tab. 173. fig. 5.

Doroniczura latifolium: Clus. biff. 2. p. 36. BLAKw. herb. t. 239: Mill. ic. t, 128 .

Doronicum foliis cordatis obtufis denticulatis: radicalibus petiolutis; couldinis am-

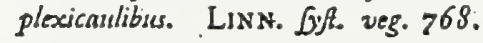

Icor. JACQ. anifir. v. 4. t. 350 \& \& v. 2. t. $x_{3} 0$.

R E C. depreffe conicum, alveolatum, ab alveolorum marginibus denticulatis aut ciliatis breviffune villofum.

S.EM. difformis: radii majora, fubturbinata, decemfulcata, glabra, atra, calva: difci ninora, obovata, octofulcata, hirfutula, fufar, bali annulo umbilicali cartilagineo albo terminata, apice pappigera.

Puppos difformis: radii nullus; difci fetaceus, minutifime denticulatus, rigidiufculus, albicans, femine fesquilongior.

IN T. exterius cruftaceum aut coriaceum, durum.

EM B. Semini conformis, albicaus.

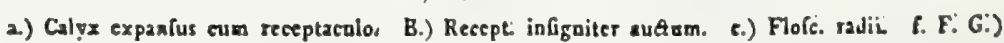

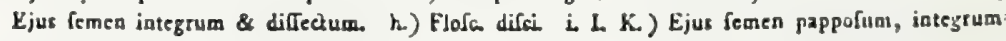
\& direaum. 


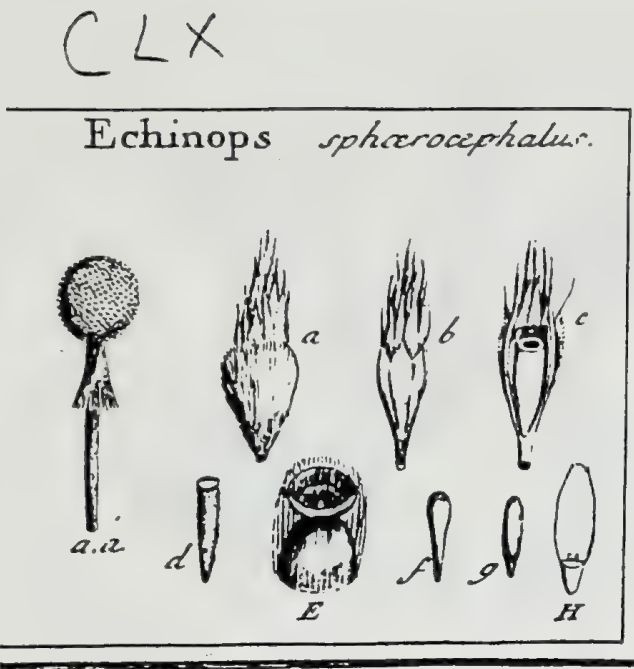

J. Gaertner (-1788) Vol2

\section{5}

DCCCCXIII. E C H IN O P S. TOURN. t. 262. LINN. ger. 999.

Calyx communis nullus, preter fquamas fetaceas in pedunculum foris reflexas; proprizs oblongus, uniflorus, inbricatus fquamis fcariofis, ariftato-acuminatis, bafi in pedunculum teretem, fetis numerofiffimis ftipatum, conferruminatis. Rec. commune fplixricum, nudum; proprium angultifimum perinde nudum. Fioic. ummes androgyni. Semen pappo nullo, aut calyculato.

Ecuinops Tphxrocephalus. Tab. 160 . fig. 6.

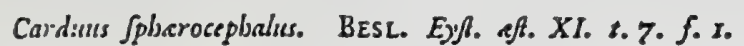

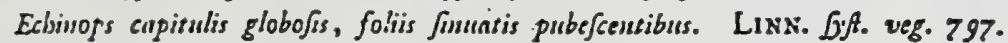

REC. comnsuse fph:cricum, pدpii.olum, nudum; proprinus nullum, procer fundum calycis.

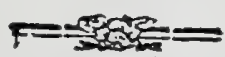
SEAs. oblongum, deorfum acuminatum, fetulis albicantibus appreflis confper-
fum, cetera fpadiceo-fufcum.

Pappos nullus, prater cupulam membranacean, crenulatam, forfan a lapfu corollula refiduam, \& a feminis villoGitate obtectam.

IN T. utrumque membranaceum, tenuifrnum.

EM ๖. fenini conformis, lividus.

1. 2.) Recept. commune. 2.) Calyx proprius, bafi mnltifetofus b.) Idem absque fetis c.) (Jem longitudinaliter ditredus d.) Semen (eparatum. E.) Seminis cupula denudata, f.) Nucleus propria membrana veftitus. g.) Eunbryo denudatus. H.) Cutyledonis facies interas, cum Plu. 


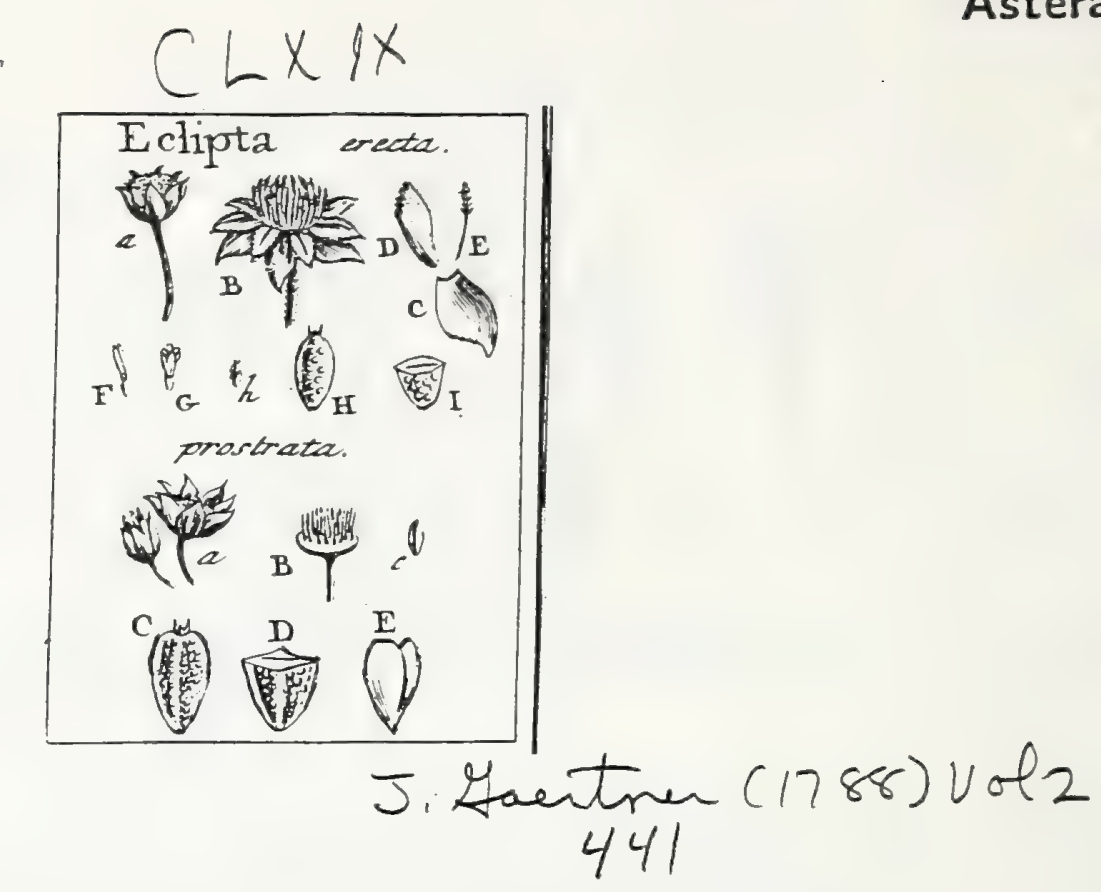

\section{E C L I P T A. IINN. gen. I32I.}

Cislyx polyphyllus, foliolis ovatis, acuninatis, duplici ferie pofitis: inte rioribus paulo minuribus. Thal. paleaceus. Flofc. difci androgyni, quadrifidi; :udii feminei, numerofi, ligulis lineari angultis: utrique fertiles. Pappus pauciphyllus, brevis, marcefcens.

EcLiptA erects. Tab. 169. fig. 6.

Euputorioplalacume bulfumine fenine folio, flore albo difcoide. Dill. elth. t. 113. f. 137 .

Terbçina albar. Linn. $\int p \cdot p l . s=72$. Cotula alba. Livs. $\int y f . X I I I \cdot p \cdot 564$ Eclipts ereifa. Lins. Jyft. vez. XIV.p.778.

KEC. planiufculum, paleaceum: paleis inferne fenceis, fuperne clavato - incraffatis denticulatis, Jongitudine fofculorum.

SE Mr. uniformia, elliptica, lenticulari-aut trigono-comprefra, punctis elevatis fcabrati, e luteo-rufefcentia.

Pappis brevilfimus, 2. 3.1. 4phyllus: foliolis nembranaceis, lineariacuminatis, marcefcentibus \& per maturitatem fxpe obfolefcentibus.

IN T. exterius coriaceum, aut fubcruftaceum, durum.

EM B. albicans.

a.) Calyx maturus intiger. b.) Idem explicatus, cum receptac. palcaceo. C.) Calycis foliolum exterius - \& D.) interius E.) Palea (cparata. F.) Flufe. feniueus G.) Flofc. andregyaus, h. H.) Semen integrum, I.) $\mathbf{l d e m}$ difteQuan.

Eclipta proftrata. ibid.

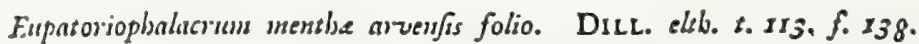

Eclipta caule proftrato, foliis fubundulatis fubpetiolatis. LINN. l. c. 442

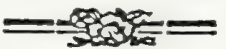

Calyx (a.) priori finilis, foliolis tamen omnibus xqualibus. Paler (B.) Gimpliciter fetacex, diffitx, a receptnculo non folubiles. Corollulix omnes lu$t: x$, nec ligulx albx, ut in priori. Semina (c. C. D.) uniformia, obovata, tri- l. tetragono - compreffi, rugofa aut tuberculata, fufca. Pappus quadriphyllus, brevillimus, marcefcens. Embryo (F.) albicans. 


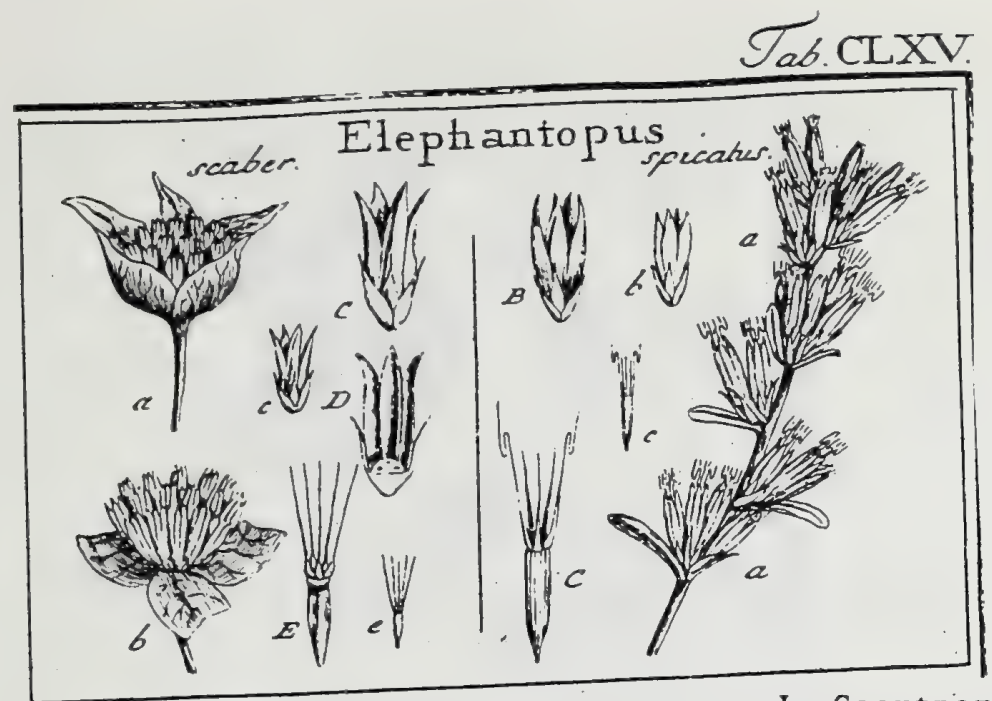

J. Gaertner (1788) Vol 2

414

DCCCCLXXXIII, ELEPHANTOPUS. VAILL LINN. gen. 997•

Calyx univerfalis nullus, aut triphyllus, multillorus, foliolis concavis latis acutis, purtiales fubcylindrici, pauciflori, imbricati fquarsis exterioribus fubulatis inzqualibus, interioribus quaternis lineari - oblongis aqualibus. Flofc. umnes androgyni, profunde quinquefidi, laciniis oblongis aqualibus.

Recept. utrumque nudum. Pappus paleaceo-ariftatus.

Elephantopus f́aber.

Anafchoundi. RHEED. mal. 10. t.7.

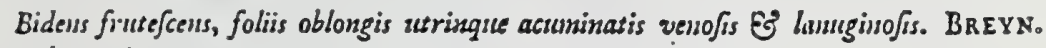
ic. 32. t. 24.

Elephantopus congze folio. Ditl. elth. t. 106. f. 126 .

Elephantopus foliis oblongis fcabris. Lins. Jyjs. veg. 796.

REC. commune nudum; partiale planum, nudum, excavato - punctatum.

SE s. oblonga, deorfum acuminata, comprefa, fetulis minimis adfper $f_{a}$, ferruginco - fufca.

Pulppus femine paulo longior, quinqueradiatus: radiis bafi paleaceis, apice in ariltam fetaceam longam feabram definentibus.

IKT. fimplex membranaceum.

E.M R. albicslls.

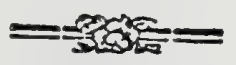

a.) Calyx exterior integer. b.) Idem truncatus \& calyces partiales denudati. c..C.) Calyx

partialis ieparatus integet. D.) Dlem dougitudinalitcr apertus cum receptac. partiali nuJo.
c. E.) Semen integrum.

Elephantopus fpicatus. ibid.

Elepbantopus jpicatus. AUBL. guian. 809.

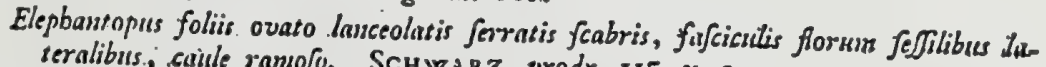
seralibus, cuille ramofo. SCHWaRz. prodr. 115.32 .3$.

Elephantopus foliis Janceolatis frubfcabris, capituis axillaribu feIflibus. Spicatis, feminum arifis apice replicatis. LANARK. Fugycl 2. p. 379.

Conjza minor inodora belenii folio. Sloan. bijf. juino 1. p. 256 . 4. 150. f. 3. 4.

A Cl. SСнневеRo.

Flores fafciculati (a.a.), involucro deftituti, in fuliorum axillis ferfiles, \& in fupremis ramis fpicatim digefti. Calyces (b. B.) fubcylindrici, tetraphylli, bafi fquamis totidem fubulatis imbricati, quadritori. Semina (c. C. ) oblonga, deorfum nttenuata., campreffa, striata, futulis.appreflis minutifromis fulvis

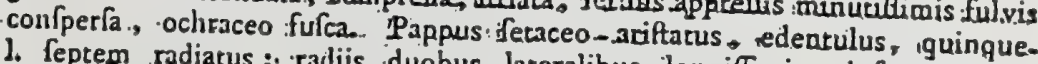
1. feptem radiatus : radiis duobus Jateralibus longifimis. infra apicem, duplici curvatura, primo deorfum, tunc iterum furfum inflexis; reliquis. omnibus rectis., brevioribus, quin nonaunquam breviffmis; cetern omnin bus e ftramineo albicantibus, bafi leviter ampliatis., edentulis, glabris.

Corollulas infigni errote ligulatas dixit Linnxus, cum manifeftifine fint itubulof $x$ \& $x$ qualiter ac profunde quinquefidx. Erroci forfan anfam dedit, quod extinx dux lacinix guandogue inter fe quafi conglutinate reperiantur. 


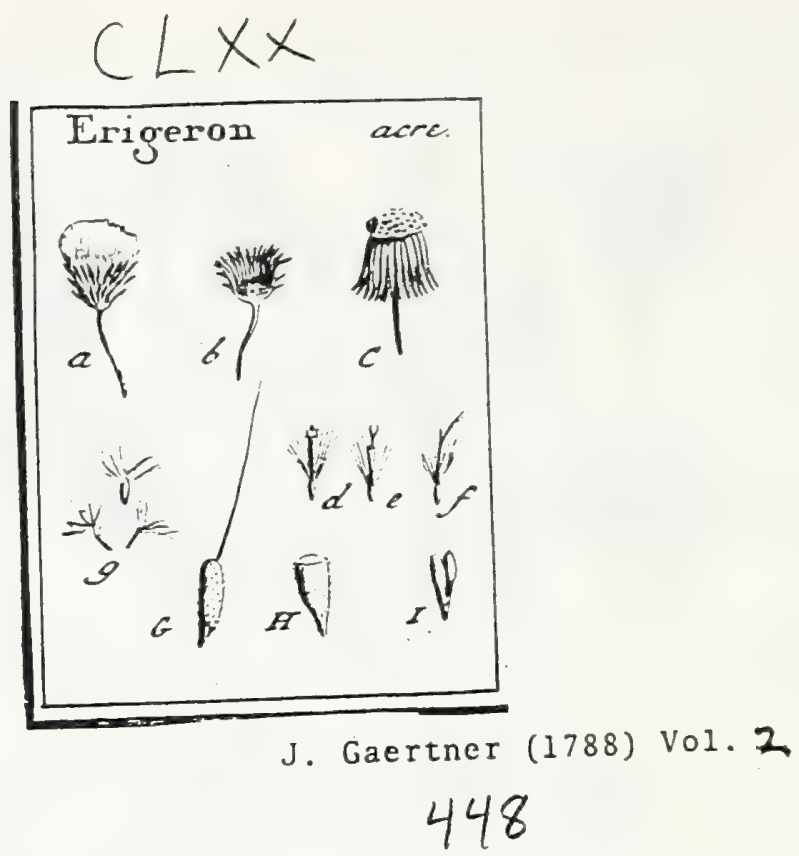

Asteraceae

\section{E R I G E R O N. LINN. gen. 951.}

Calyx fubcylindricus aut hemifphxricus, imbricatus fquamulis anguftis apice patulic. Thal. Ferobiculatus nudus. Flofc. difci androgyni infundibuliformes; radii feminei, partim tubulofi filiformes, \& partim ligulati angufti lineares: omnes fertiles. Pappus capillaris fimplex.

Erigeron acre. Tab. 170. fig. ;-

Amellis montanus aquicolorum. CoL. ecpir. 2. t. 26 .

Evigeron pedunculis alternis tuifloris. LiNN. $33 \%$. veg. 754 .

REC. ante plenan maturitatem planum, glabrum, excavato-punctatum; pofte2 vero pulvinatum, ferobiculatum, nudum.

SEM. oblonga, prope bafin elongato-attenuata, lenticulari compreffa, fetulis minutifimis confperfa, pallide fpadicea.

Pappos cnpillaris, fubedentulus, femine duplo longior, per xtatem ruffus.

IN T. fimplex, membranaceum.

Em B. fermini confurmis.

a.) Calyx fensine pragnans. h.) Idem diffectus, cum receptac. plano. C.) Idem per maturitatim totus rifisxus, cum thalamo pulvinatu. d) Fiofc. difsi infundibulifurmes. c.) Flofe. radii filifurmis, \& - f.) alius ligulatus. 5. G. H.) Senen integrum \& difiectur. 1.) Embryo deintdatus.

Affunitatem quandam habet cum Chryfocome, ut Erigeron fit Chrofucoma radio difformi larvata. 


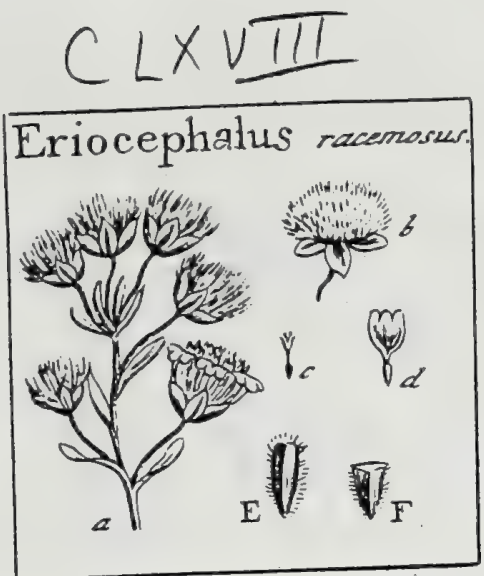

J. Gaertner (1788) Vol 2

\section{8}

DCCCCXCIX. ER I O C E P H A L U S. LINN. ger. 994.

Calyx pentaphyllus fimplex, aut decaphyllus, foliolis xqualibus, duplici ferie pofitis. Thal. lunatus. Flofc. difci plures, androgyni, fteriles; radii feninei, circiter quimi, ligulis obovatis trifdis; fertiles. Sem. villofi, pappo deftitutz.

Erjocephalus racemolus. Tab. 168 . fig. 7 .

Eriocepbalus foliis linearibus indivifis, fioribss racemofis. LinN. fyje. veg. 795. Ex herbario Bankfiano.

REc. planum, lanatum: Jana copiofa, fericea, eftramineo albicantc, fufculis longiore.

SEM. fenimis oblonga, deorfum anguftata, comprefle triquetra, pilofa aut parce Janati, cetera vero omni pappo deftituta.

1N T. Fimplex, membrasaceum.

EM B. femini conformis.

3.) Pars racemi florid. b.) Recept. lanatum c.) Flofe. difci. d.) Flole ndii: utergat porspareas. E. F.) Seinen integrum \& diffectum.

Calycis exterioris nullum in hac fpecie adeft reftigium. 


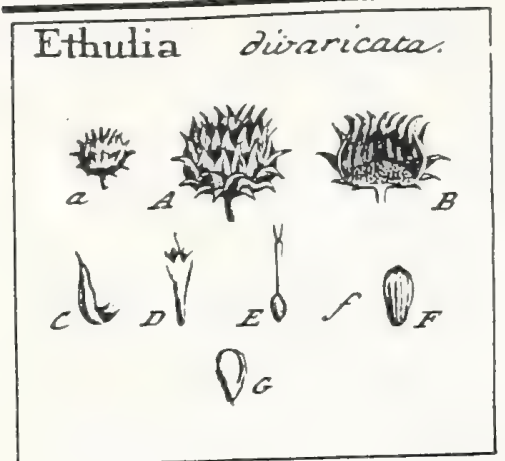

J. Gaertner (1788) Vol.2

389

DCCCCXLVIII. E T H U L I A. LINN. ger. 934.

Calyx fubglobofus, fubfquarrofus, imbricitus fquamis oblongis acuminatis apice patulis aut recurvis. Flofc. difformes: difci infundibulifornes, quinquefidi, androgyni, fteriles, pauciores; rodii fubulati, edentuli, feminei, fertiles, numerofifimi. Thal. nudus. Sem. feminis alva.

Eтuula divaricata. Tab. 164 fig. 2.

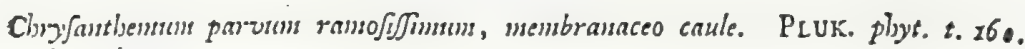
f. 5. bene.

Ethulia foliis linearibus dentatis decurrentibrs, oppofsti foliis aniforis, caule divaricato. Buras. flor, ind. 176, t. 51. f. I. Lisn. Jy/t. veg. 734.

REc. planum, amplum, excavato-punctatum, nudum.

SE R. feminis fubturbinata, ftriata, minutula, pallida.

IN T. finplicifinum, menbranaceun.

EMB. femini conformis, albicans.

a. A.) Calyx integer. B.) Idem diffeetus, cum receptac. C.) (alycris (quanıa feparata. D.) Finfc. difci androgtrnus. E.) Flofc, radii femineus. f. F.) Semen fiparatumb. f..) Enbr, denudatus.

Ethulias feminum margine cotyloide dotatas ad Sparganophorum referinus, quum \& infuper folculis omnibus fertilibus \& uniformibus gaudeant. 


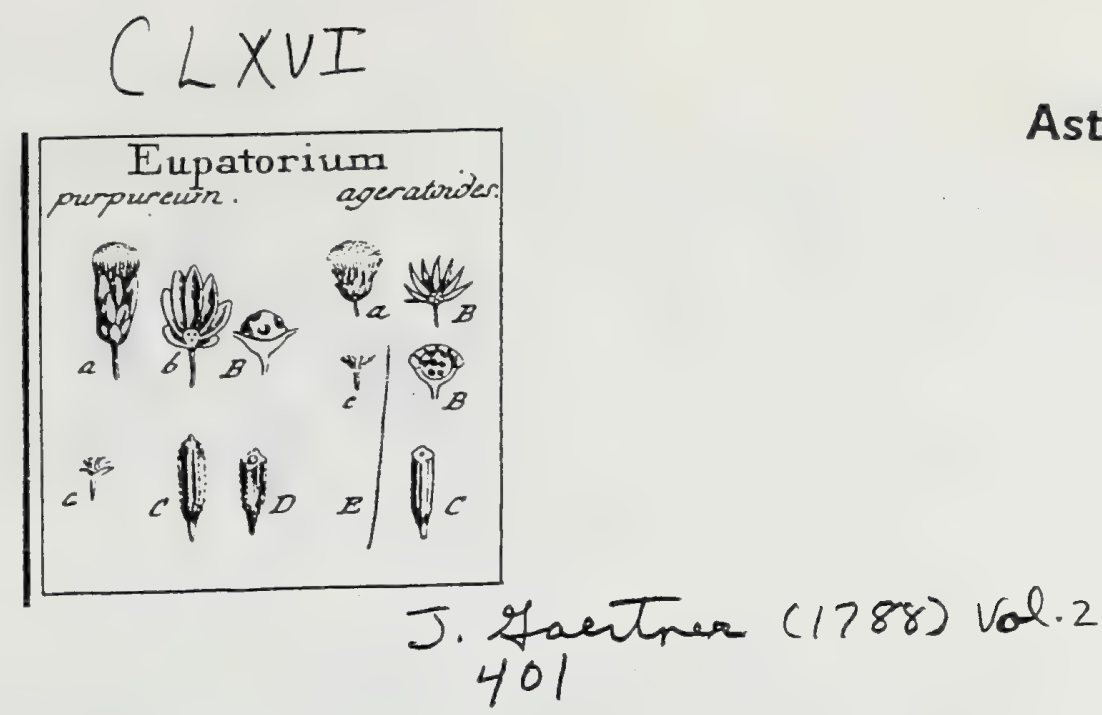

DCCCCLXV. EUPATORIUM. TOURN. t. 259. LINN. ger. 935.

Calyx oblongus, imbricatus fquamis inxqualibus, plerumque pauciforus. Flofc. onmes androgyni: ftylis profunde bifidis, frepe corollula longioribus. Thal. nudus, fcrobiculatus. Pappus capillaris. Folia in plerisque oppofin.

Eupatorium purpureun. Tab. 166. fig. 4

Eupatoriun canadenfe elatins, longioribus folits rugofis, integris \& casclibus ferrmgineis. Moris. bifl. 3. S. 7. t. 13. f. 4 .

Eupatoriun foliis quaternis fcabris lanzeolato-ovatis inaqualiter ferratis petiolatis rugofis: Lins. Jyyt. veg. 736.

REC. anguftum, convexum, fcrobiculatum, nudum, glabrum.

SEM. parva, tetragono-columnaria, bafi valde acuminata, ftriata: ftriis atque angulis pundiculato - fabris, albicantibus; interftitiis glabris, lividis.

Pappus capillaris, minutifime denticulatus.

IsT. exterius coriaceum, tenue.

Eм в. teretiufculus, albus.

2.) $\mathrm{C}_{2} \mid \bar{r}$ integer. b. B.) Reeeptac denudatum. c. C. D.) Semen iategrum \& difeQtum

E.) Radius pappi feparatus \& infigniter auQus.

EUPATORIUM Ageratoides. ibid.

Eupatorium fcroplularic foliis glabris, fiore albo. Moris. bijt. 3. S. 7. t. 28.

f. It. SELIGM. av. V. t. $g$.

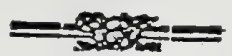

Eupatorium foliis ovatis ferratis petiolatis, cande glah'o. Lins. i. c.

Calyx (a) imbricatus fquamis lineari-acuminatis. Thalamus (B. B.) convexus, fcrobiculatus, glaber. Semina (c. C.) oblonga, tetragona, ftriata, glabra, pallida, bafi infigniter attenuata. Pappus \& reliqua ut in præcedenti.

Eupatorio pappum plumofum perperum tribuit Lims.eus 6.c. in numerofis enim, guas examinavi fpeciebus, non alium vidi nifi capillarem, eumque fimpliciter faltem denticulatum, aut breviffme ciliatum, ut in E. cannabino. 


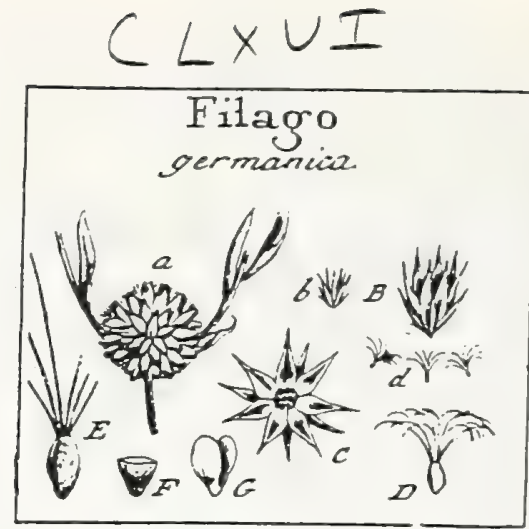

Asteraceae

J. Gaertner (1788) Vol 2

$$
404
$$

DCCCCLXIX. F I L A G O. VAILL. Linn. gen. 995.

Omnia Elichryfi preter folos fiofculos, quorum, in Filagine, interiores androgyni, exteriores autem feminei \& plerumque foli fertiles funt.

FILAGo germanica. Tab. 166. fig. 8.

Guapbulism. FuChs. bift. lat. 222 . germ. ic. 125. - vulgare. CAM. epit. 606. Filago panicula dichotouna, foribus rotundatis axillaribus birfutis, foliis acustis. LIN N. Jyf. veg. 795 .

Rec. anguftum, planum, excavato punctatum, nudum, glabrum.

SEM. feminis parva, obovata, compreffiufcula, fetulis adfperfa, pallida.

Pappus capillaris: radiis octodecim, femine triplo lungioribus, fubedentulis.

IN T. Gmplicifimum, membranaceum.

EMB. albus.

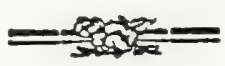

*

2. Flores glomerati, axillates \& terminales b. B.) Calyx (eparatus integer. C.) Receptac. denudatum. d. D. E. F.) Semen integrum \& ditreaum. G.) Embryo denudatus.

Valtum genus, a corollularuni uniformitate \& difforminate, a florculorum fertilitate aut fterilitate; a calycibus ftrictis aut radiantibus, \& denique a foribus folitariis aut conglomeratis, in plures phalanges diftribuendum. 


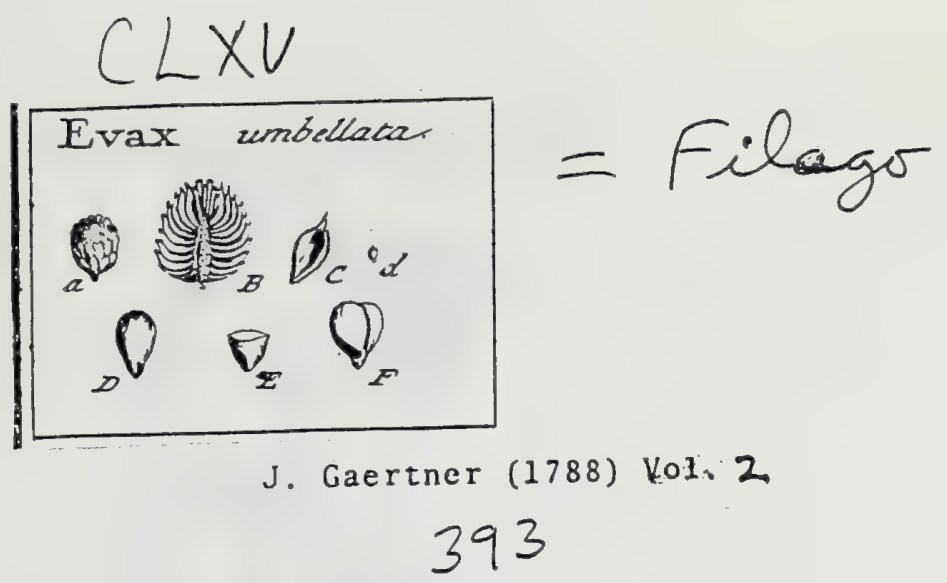

DCCCCIV. E V A X. Filago. Linn.

Calyx fubglobofus, imbricatus fquamis oblongis appreflis acuminatis fenfim in thalami paleas degenterantibus. Flufc. difformes: difci fepteni aut deni, infundibuliformes, quadridentati, androgyni, fteriles; radii nunierof, filiformes, brevillimi, edentuli, ferciles. Thal. fubulatus, paleaceus. Sem. feminis calva.

Evax umbellata. Tab. 165 . fig. 3.

Guaphalium uimbellatum minimum. ВА Uน. bijl. 3. p. $26:$

Filngo floribus accalibus felfilibus, foliis flor alibus majoribus. LINs. Jyf. veg. 795.

REC. Subulatum aut crlindricum, calyce altius, apice nudum, paucisque flofculis androgynis itipitum, cetera undique paleis ovato acuminatis, tomen. tofis, calycinis fquamis fimilibus, contectum.

Sess. feminis parva, obovata, compreffa, glabra, pallida, calva.

J $\dot{\mathrm{x}}$ T. fimpliciffimuri, membranaceum.

ENB. femiui confornis, albicans.

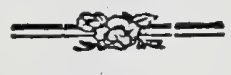

2) Calrx maturus integer. B.) Rcceptac. palcis \& finfculis androgynis ftipatum. C.) Palez fepzratz. d. D. E.) Semen iutegrum \& diffectum. F.) Embr. denudatus.

A-Filagine abunde differt: receptaculo fubulato; flofculis androgynis pauciffimis; \& feminibus omnibus pappo deltitutis. 


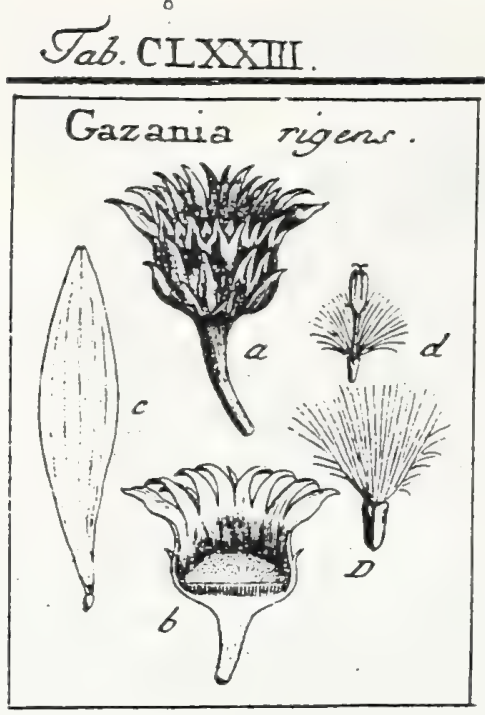

\section{J. Gaertner (1788) Vol 2 451}

\section{G A Z A N I A.}

Calyr monophyllus, bafi ventricofus, extus imbricatus fquamis, herbaceis acuminatis erectis. Thal. alveolato-villofus. Flofa. difci androgyni feriles: radii feminei aut neutri, ligulis lanceolatis longiftamis bidentatis, Iteriles. Sem. androgynis tetragona. Pappus capillaris, caducus,

GazaNia rigens. Tab. 173. fig. 2

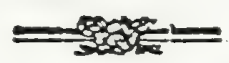

Arifotis ramis decumbentibus, foliis lineari-Lanceolatis rigidis, fubtus argenteis, flore nugno asceo, peduraulo longiffimo. MiLl. ic. 4.49.

Gorteria rigens. BERG. cap. 304. LINN. byf. veg. 783 .

REC. planum, alveolatum, alveolorim marginibus brevifime piloGs, wt thalamus oblique infpectus totus villofus appareac.

SEж. . . . Ovaria androgynis inverfe pyramidata, tetragona, glabra, pappo eoronata, foccunda; feminis obovata, minutula, compreffa, calva, fterilia.

Pappus capillaris, fericeo 1. aureo-fulvus, crinibus onnium tenuiffimis; numerofifimis, edentulis, bafi in annulum conferruminatis, ut co. rona pappi integra de femine fecedat.

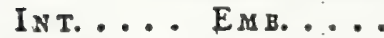

2.) Calyx integer. b.) Idem difreaus, cum receptac villofo. c.) Flofe. radii Acrilis d.) Flofe. difei fercilis. D.) Ovarium infignites auạupe.

Cum Gorterix, calyce monophyllo, \& cum Arctotide, thalamo alveolato quodammodo congruit; differt autem ab utraque Pappo definito capillari \& caduco. 


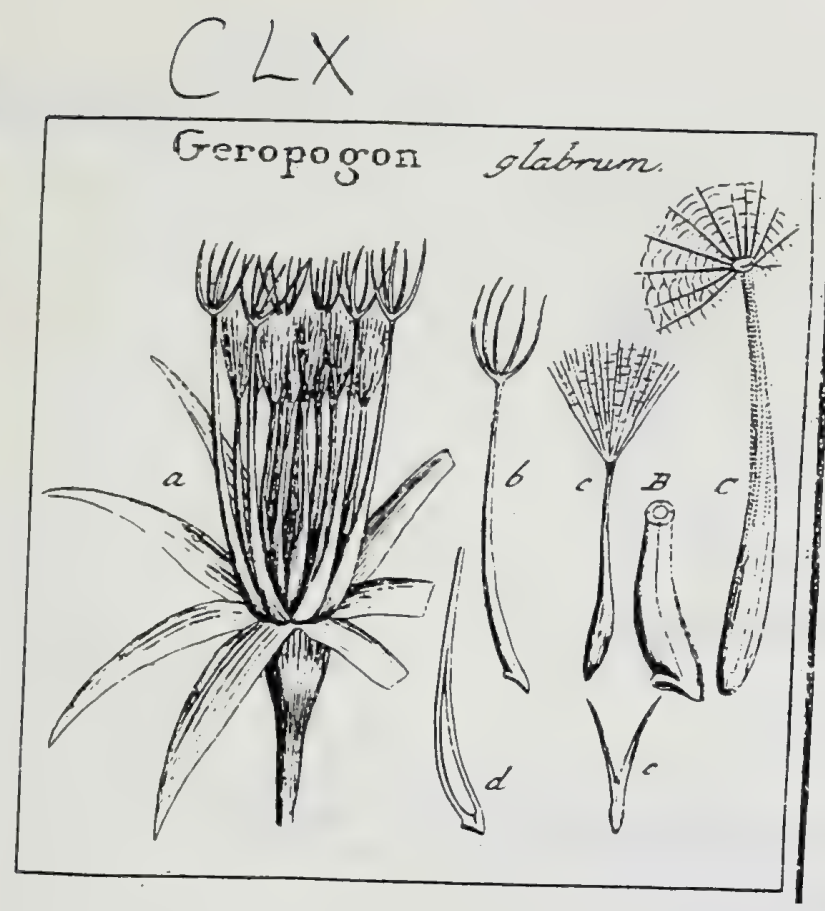

\section{J. Gaertner (-1788) Vol 2 \\ 374}

DCCCCXXVIII. G E R O P O G O N. LIN. gen. 904.

Ca!yx finplex pyramidatus polyphyllus xqualis. Thal. nudus. Sem. difformia prolonga in ftipitem definentia. Pappus radii fubulatus: difi plumolus.

Geropogon glabrum. Tab. 160. fig. 5.

Gerop:san foliis glibris. Lis.s. fjof. veg. 709.

livir. Jice. bort. t. $3 \hat{3}$.

REC. planum, excavato- punctatum, nudum.

S E M. difformia: radii longiora, fubulata, inferius glabra, ftriis quanor deprellis notata, fuperius in Itipitem fcabriufculum definentia, a recepracisto non fpunte lecedentia; difci breviora, fiffiformia, ft:iis dicen e!evatis fcultis exalperats, in ttipiten fetaceum delinentia, fponte dectua:

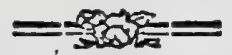

Pappus radii ex ariftis quinque, filiformi - fubulatis, glabris, dimidio Itipite brevioribus; difci plumofus multiradiatus, ftspitis longitudine.

INT. exterius coriaceum; interius membranaceum, fericeo album.

EMB. fubulatus, viridis.

2.) Calyx maturus, cum fitu ferinum. b. B.) Semen rzdii. c. C.) Semen difei d.) Seminis sadii fcatio longitudinalis. e.) Embryo fcparatus.

Receptaculum nonnulli dicunt fetnceo - paleaceum, fed tale ego neque in forente neque in fructefcente calyce deprehendere potui. 

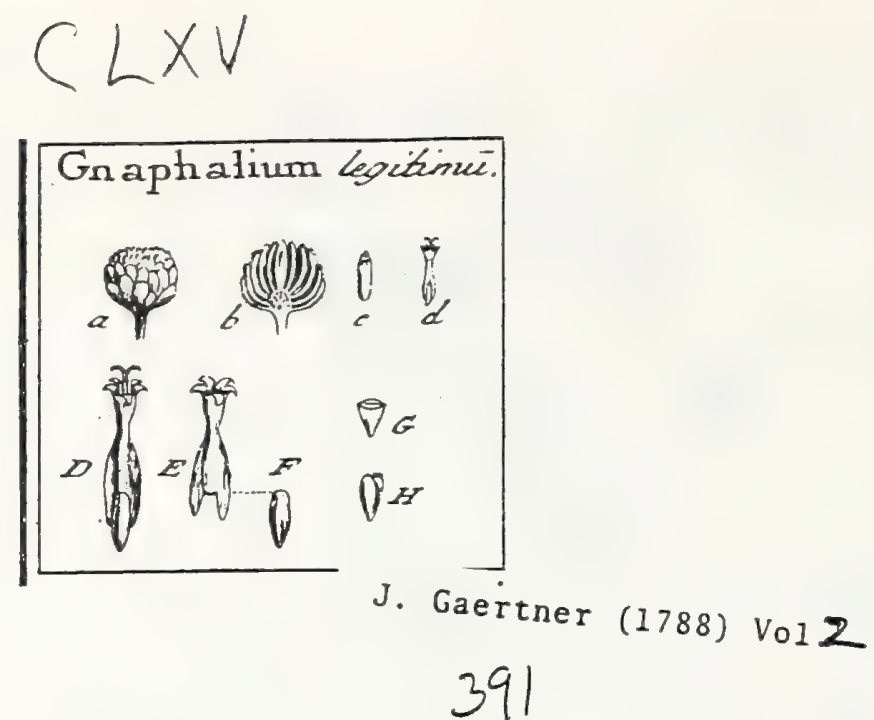

DCCCCLI. G N A PH A I I U M. TOURN. t. $26 \mathrm{r}$.

hemilphacricus, inbricatus fyuanis oblongis appreffis tomentofis. Flofe. omnes uniformes androgyni: corollulis quinquefidis, inferne comprellis

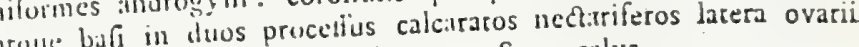
dilatatis atque definembus! 'Thal, paleaceus. Sem. calva.

Geaphalium legitimum. Tab. 165 . fig.. 2.

Gmophalium. CAм. epit. 605.

Clnylantsenum peremue graphaloides maritimum. MORıs. bift. 3. S.6.t. 4. f. 47 .

Filago miritima. Mile. ic. t. 135.

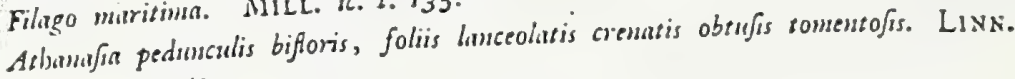
by/t. veg. 741 .

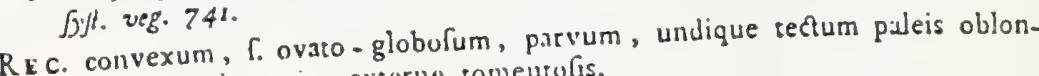
gis, concavis, apict externe tomentulis.

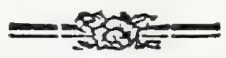

Sem. parva, oblonga, deorfum acuminata, cumprefa, calva.

IN T. Cimplex, membranaceum, tenue.

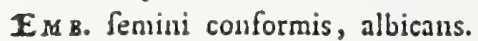

a.) Calsx maturus integer. b.) 1 icm diffectus, eum receptac. palesceo. c.) Palez leparata. d. D.) Flofculus ovario infiftens. E.) Corollula feparatz. Fo) Semen magnitudiae zuêtum G.) Idem diftedum. H.) Ekibs. denudatus.

Genus a fummo TOURNEFORTIO rite conftitutum, quicquid etiam oggarriat Vaillaut in ACt. paris 17 19. p. m. s73. non tantum ab Athanalia \& Filagine, fed \& ab omuibus reliquis Difcoideis, infolentifima corollularum fuarum forma, abunde differt, ut fervari mereatur. 


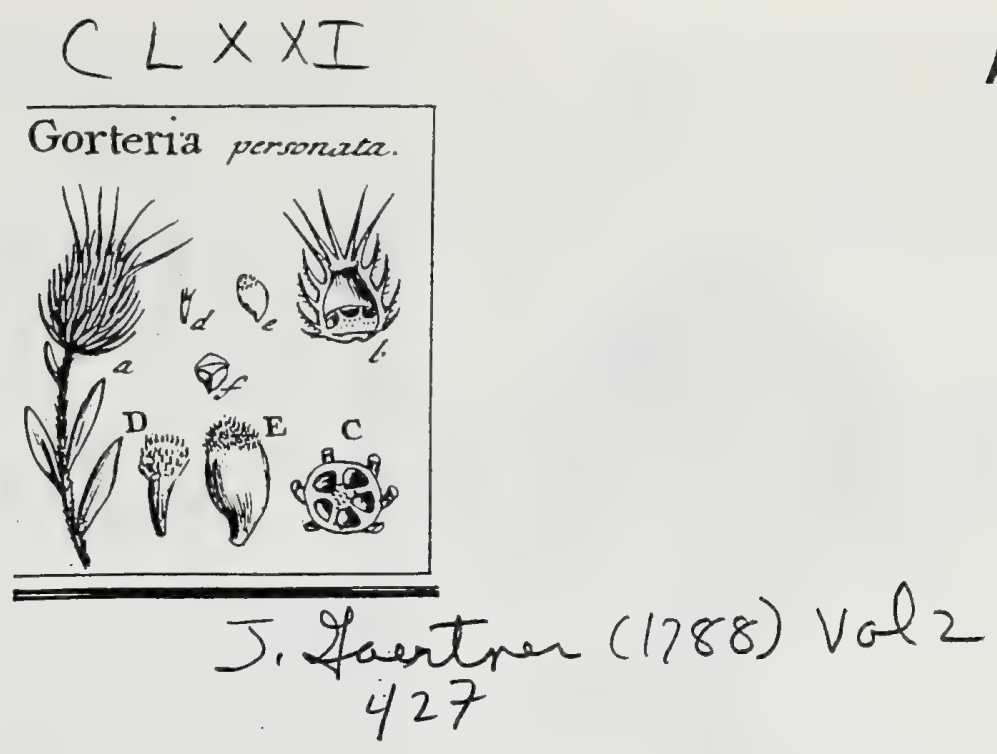

\section{DCCCCXCVIII. G O R T E R I A. LINN. ger. 982.}

Calyx monophyllus, e ventricofa bafi furfum conicus, extus imbricatus fquanis fpinolis: fuperioribus gradatin longiorßbus, \& demum acicularibus. Thal. in medio fetaceo - feabratus, in anbitu fcrobiculatus. Flofe centri mafculi; difci androgyni, \& ex his quinque 1. pauciores foli fertiles; radii feminei aut neutri, ligulati, lteriles. Semina lanata, pappo vero deltituta.

Gorteria perfonata. Tab. I7 I. fig. 4

Corduus atbiopicus perprefilus, pilofelle folius incanis bifpidis, perfonate capitulis. PLuk. phyt. t. 273 . f. 6.

Gorteria foliis houceolatis integris finuatisque, cuule erefo, floribus pedusculatis. Linn. $\left\{y f\right.$. veg. $7^{8} 3$.

REC. planum, in medio fetulis rigidis brevibus fabratum, in ambitu autem foveulis quinque 1. paucioribus pro feminibus exfculptum.

S E s. obovata, bafi roftellata, obfolete trigona, pallida, lanà crifpà fericeo-albà in :fuperiore profertim fua parte late obtecta, pappo autem vero penitus defticuta.

IN T. fimplicifimun, memuranaceum.

EN в. femini conformis, lutefcens.

a.) Calyx maturus integer. b.) Idem longitudinaliter ditretus, enm (pinarum origine. C.) Reecpt feparatum. d. D.) Ovaria abortiva, aut ab unico plerumqque maturefcente feaine fuffocata. c. E) Semen maturum integrem. f) Idem trassverfe diffequm, cum rima cotyledonum.

Calyx maturus, ob aperturx fux anguftiam, fenina non dimittit, fed unacum is decidit. Hinc fit, ut, dum unicum faltem eorum perficitur, illud fua radicula non modo calycis fundun perforet, fed \& ita cum eo conferruminetur, ut novella pianta, inconfueto prorfus nec nifi in Neurada recurrente exemplo, matcrnum calycem fupra fuam radicion gerat perennem.

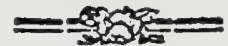

Linnacus in hoc genere calycem monophyllum unice refpexiffe videtur; hine plures ei inmifcuit plantas, ad alia genera manifettilime pertinentes. 


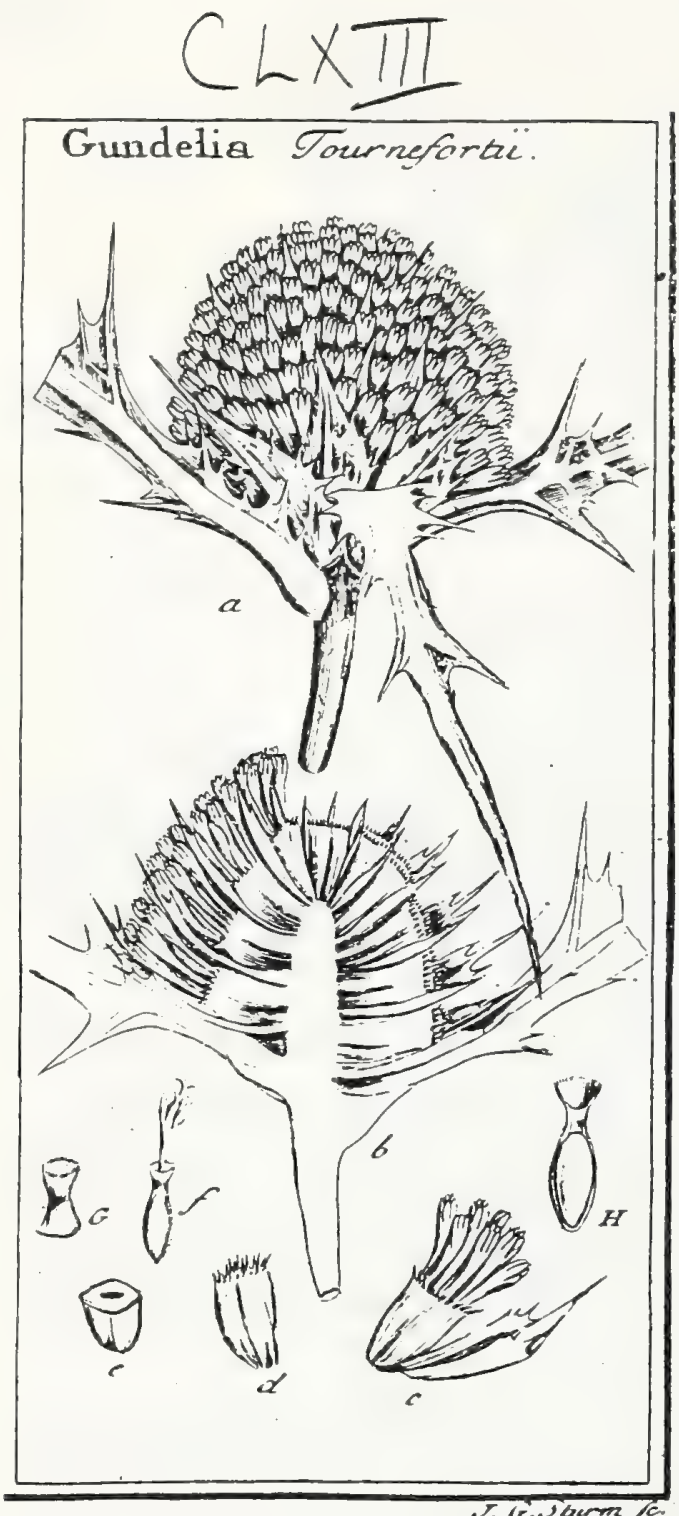

J. Gaertner (1788) Vo: : 2 386

DCCCCXLIII. G U N D E L I A. TOURN. t. 486. Lins. gen. I000.

Calyx nullus. Recepc suiverfale cylindricun, lobatum, jnter Jobus paleaceum; partialia inverfe pyramidata, fubfeptemtora, vertice aculeolaw. Flofc. marginales in fingulo lobuln malculi, Iteriles; centralis, unus aut geminus, androgynus, fertilis. Semina lobulis immerfa, coronata pappo fubltipitato, cotyluide, cilato.

Gundelia Tournefortii. Tab. 163. fig. 3.

Silibum diofcoridis, f. Hacub-alkardeg ferapionis. RAuw. it. 74. t: 74.

Gundeliu orientalis, acantbi aculeati foibo, capite glabru. TOURN. it.p. M.108. t.109.

Gencielia. MiLl. ic. t. 287 . LinN. [y/f. veg. 797 .

REC. miverfale cylindricum, undique in lobulos carnofos divifum, \& ad horum intcrltitia paleis membranaceis extrorfum latefcentibus ac in fpinas pungen. tes definentibus, Ripatum. Rec. partialia carnofa inverfe pyramidata, rhombeo-comprel $\Gamma_{3}$, apice fcrobiculata atque aculeata, tri- Septemitora.

SEs. intra fingulum lobulum fingulum (raro geminum), totum intra carnem abfcondicum, oblonge ellipticum, lenticulari-compreffum, glabrun, pallidum, in ftipitem breviliınuns finfim attenuatum.

Puppus cupularis, membranaceus, monophyllus, per orarn fetaceo-ciliatus.

IN T. fimplex, membranaceum, tenuc.

Eм. femini conformis, albus.

a.) Flos capitatus integer: b.) Idem Jongitudinaliter diffectus, etm paleis lobulos receptaculi difcriminarabibs. c.) Receptac. partiale, cum fuis fofculis atque palea propriz d.) Jdeul, excutlis fiufculis, fupeme aculeatum. c.) Jilem trausverie fectum; cum cavitatc, in gna feinea berce. f.) Sineu integrura. G.) Pappus cupularis. H.) Scrmen longitudinaliter diffeaum, cum ombryonc. 


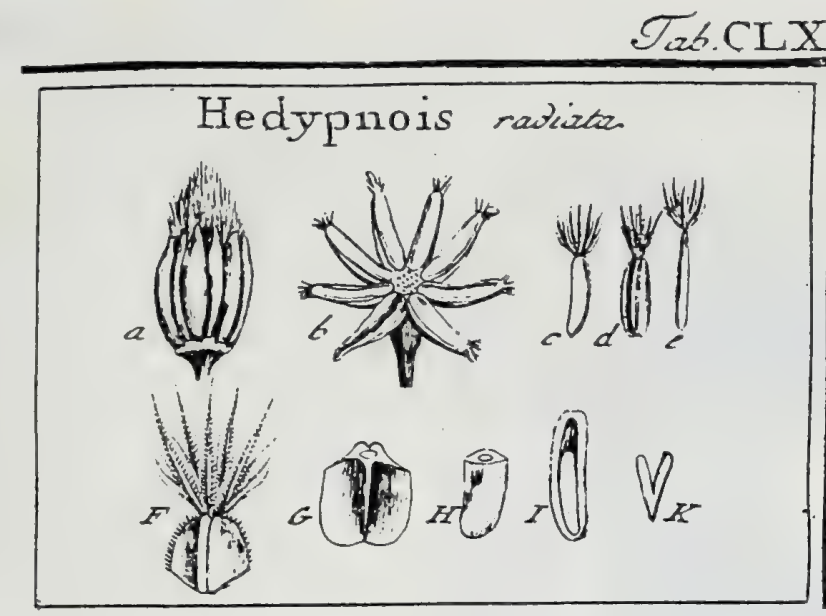

\section{J. Gaertner (1788) Vol $\Sigma$

DCCCCXXVI. HE D Y P NOIS. TOURN. t. 27 r. JUSs. p. I6g.

Cillyx fimplici ferie polyphyllus, bafi fquamis brevibus calycukatus, per maturitatem torofus, foliolis extus gibbis, intus concavis, femina marginalia amplexantibus. Thal. excavato-punctatus. Semina ipfa difformia. Pappus. uniformis inxqualis feftilis.

Hedvenols radinta. Tab. 160. fig. 3.

Dens leonis minor, foliis radiatis. PLuk. pbyt. t. 37. f. 2.

Hyoferis Jcapis unifloris, foliis glabris mucinatis angulis dentatis: apice laciniasis. LIN N. Jy $\%$. veg. 720.

REc. planum, glabrum, excavato-punctatum.

SEM. triplicis furnix: extisna oblonga, angufta, compreftiufcula, fuberofa, cillycis folıolis comprehenfa; media oblonge - elliptica, ad latera membranaceo coniprelfa \& quafi alata, in medio craffiulcula atque fulco longitudinali utrinque infcripta; intiana teretsulicula, glabra, reliquis longiora: omnia lutefcentia aut cinnamomea.

Pappis felfilis, uniformis, multiradiatus: ndiis paleaceis atque fetaceis mixtis, denticulatis, pallide ftrammeis, inxqualibus: quinis nempe reliquis paulo Jongioribus.

IN. duplex: cxterius fuberofum aut coriaceum.

Ex в. femine brevior, oblongus, comprelfufculus, albicans.

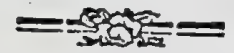

2) Calyx claufius. b.) Idem per maturitatem patentifimus, cum receptac, c. H. I.) Semine exteriora. - d. F. G.) media. - e.) centralia. K.) Embryo denudatus. 


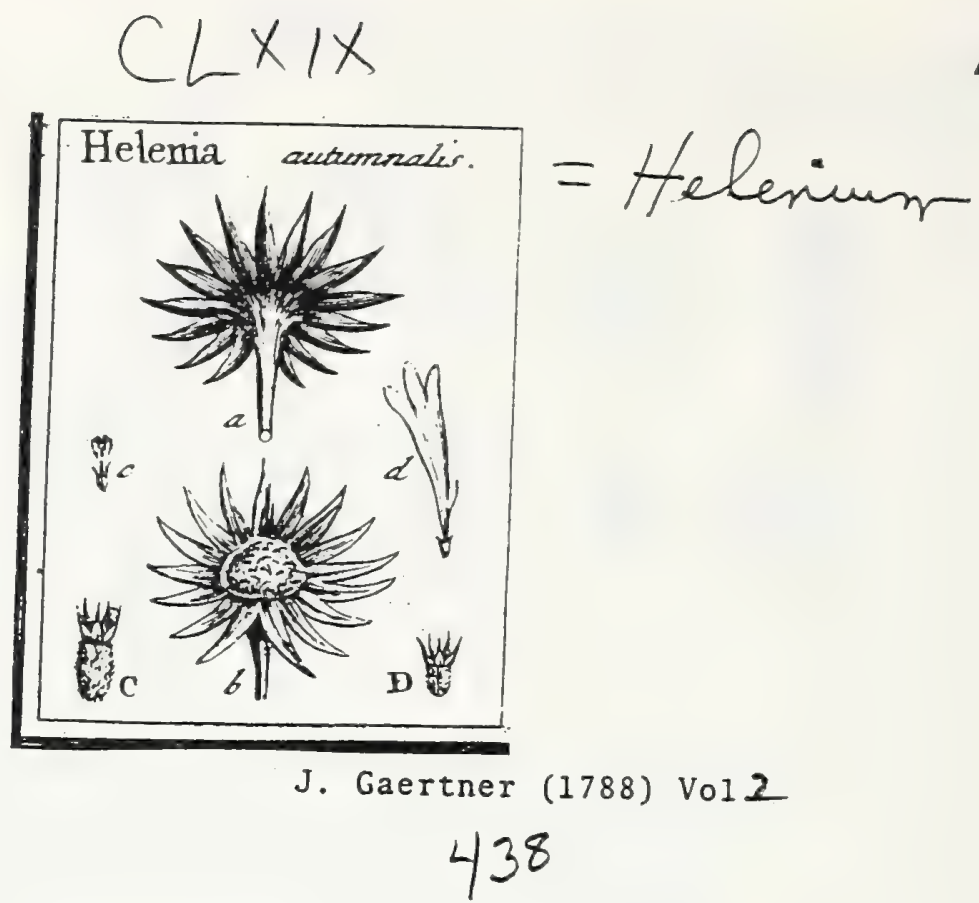

MXI. HE L E N I A. LINN. b. Cliff. 4 Is.

Calyx fimplex, multipartitus, laciniis oblongis acutis xqualibus. Thal. convexus nudus. Flofc. difci androgyni; radii feminei, ligulis oblongis extrorfum latefcentibus \& apice trilobis: utrique fertiles. Sen. villofa, pappo pelitaphyllo paleaco.

Helenis autunualis. Tab. 169. fig. 7 .

Afer foridanus maress, casle alato." Pluk. phyt. t. 372. f. 4 .

Helenilux foliis ferratis. LINN. fyjo veg. 769 .

REc. convexum aut depreffe conicum, tuberculis obfoletis fcabratum, nune penitus nudun, nunc vero in ambitu foliolis calycinorum amulis luxurians.

SEM. ovata, obefa, fulcata; hirfuta. (Hall. b. goett. 407.)

Puppus penraplyyllus, foliolis membranaceo - paleaceis, denticulatis, detaceo-acuminatis, dimidio femine paulo longioribus.

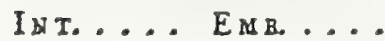

a.) Calsx ab inferiore parte (petatus. b.) Receptac. deaudatnm, absque paleis margiaalibus, quz in meo fpeeiunine plane defunt. c.) Flofc. difci. c.) Flofc. radii. C.) Ovarium andeogsnowa." D.) Ovariua feminewan: hac priori paulo minus, cctera vero fimillimum. 
Tal. CIXXTI.

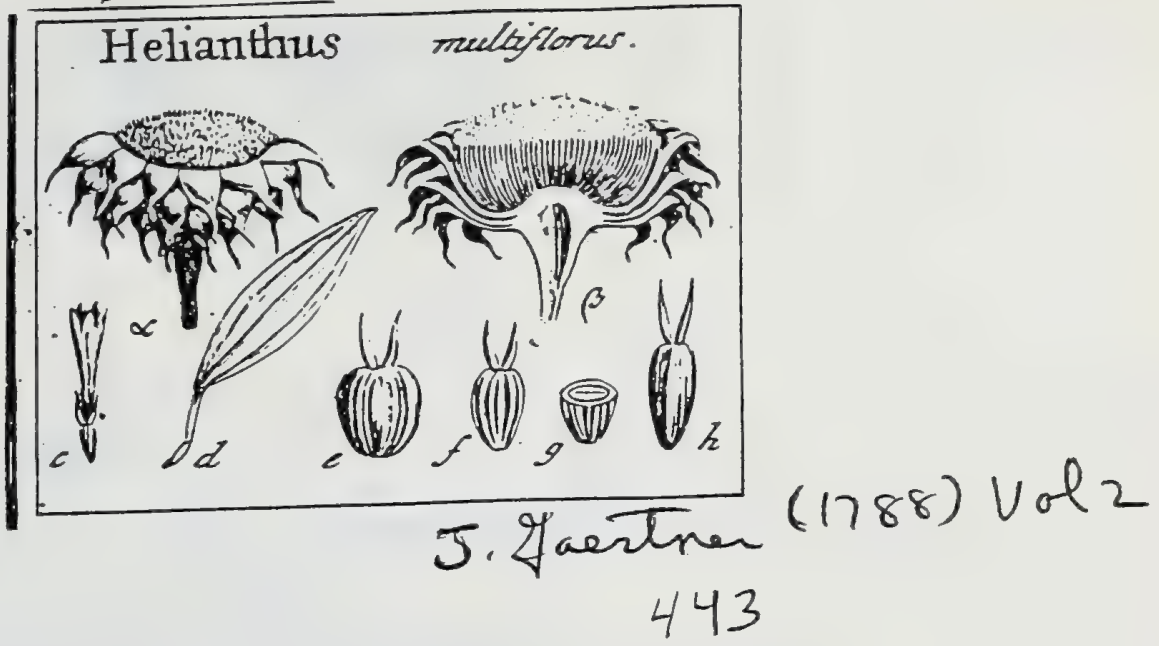

MXVII. H E L I A N T H U S. LINN. gen. 979.

Calyx hemifphxrico patentior, fquarrofus, imbricatus fquamis herbaceis apice retexo-patulis. Thal. paleaceus. Flofc. difci androgyni, fertiles; radii neutri, ligulis ovato-ublongis maximis. Pappus diphyllus, caducus.

Helianthus multitlorus. Tab. 172. fig. 2.

Corona folis minor fenima. TABERN. ic. 764 .

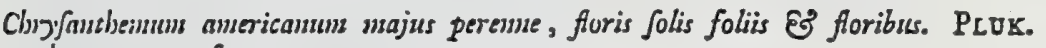
plyyt. 2. 159. $f .=$.

Heliautbus folits inferioribus cordatis trinervatis: fuperioribus ovatis. LINN. Syft. veg. 781 .

REC. planum aut modice convexum, amplum, paleaceum: paleis linearibus, acuminatis, flore brevioribus.

SEM. androgynis fubnucamentacea, longius aut rotundius ovata, lenticularicomprella, ftriata, glabra, alba, nigra, fufca, aut variegata.

Pappus diphyllus, foliolis lincari-acuminatis, membranaceis, dimidio femine paulo longioribus, deciduis.

I $\mathbf{T}$. exterius cruftaceum $f$. nucamentaceum, crafum.

Е м. fenini conformis, albus.

«.) Calyx integer, naturali plus quam dimidio minor. B.) Recept. paleaceum. C) Florc. aadro. gynus. d.) Flule. neuter. c. f. h.) Semina varix formz. g.) Semen diffectum. 


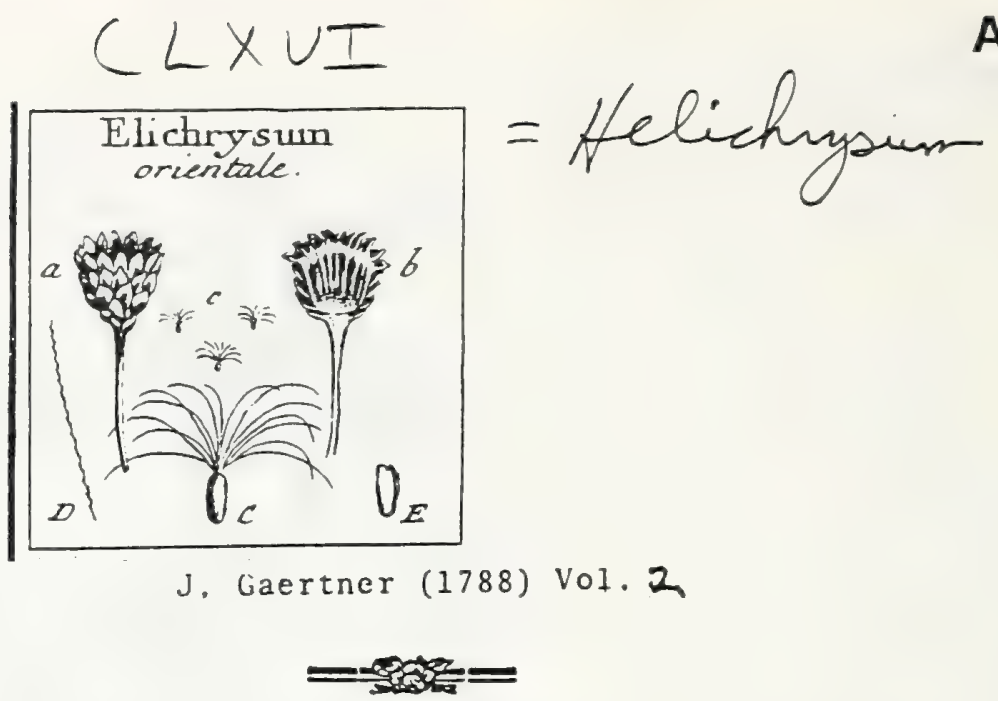

404

DCCCCLXVIII. E L I C H R Y S U M. TOURN. t. 259. Gnaphalium. LIN gen. 946.

Calyx imbricatus fquamis inxqualibus obtufis feariofis fepiffime colontis. Flofc. uniformes, onmes androgyni quinquefidi fertiles. Thal. nudus puncticulatus glaber. Pappus capillaris fubedentulus parcus.

ELICHRysum orientale. Tab. 166. fig. 7 .

Elicboryutun africanum frutefcens, angufis \&o longis foliis incanis. Cons. bort. ainf?. 2. 2. 55 .

Guaphalium fubberbaceum, foliis lineari-lanceolatis Seflibus, corymbo compofito, pedunculis elongatis. LIN $\int_{y j}$. veg. 747 .

REC. planum, nudum, excavato-punctatum, glabrum.

SEM. parva, ovato-oblonga, teretiufcula, glabra, pallide fpadicea.

Pappus capillaris, albus, femine triplo longior, remotifime denticulatus, parcus.

I $\mathrm{T}$. finplicifimum, membranaceum.

EM B. albicans.

a) Calyx maturos. b.) Receptac, denudatum. c. C.) Semen integrum. D.) Radius prapi reparatus \& infigniter auctus. E) Embr. denudatus.

Huc non tantum Gnaphalii, fed \& Xeranthemi atque Filaginis fpecies Linneanas referimus umnes, quibus non funt fofculi fexu diftincti, nec pappus plumofus aut penicillatus, nec denique thalamus villofus aut paleaceus. 


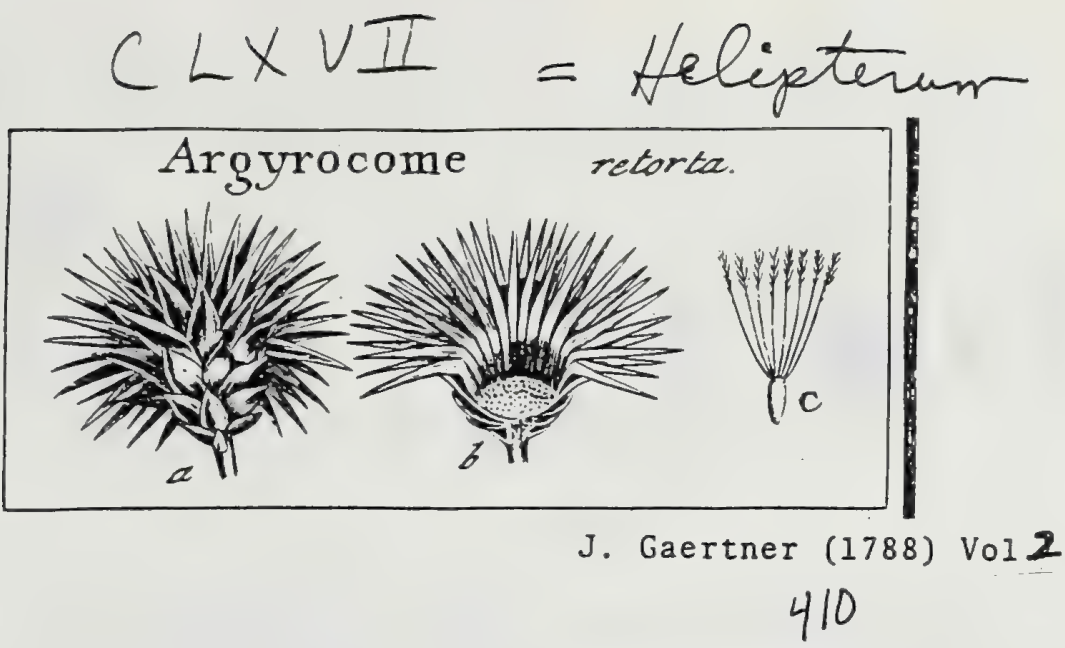

\section{DCCCCLXXVIII. A R G Y R C O ME.}

Calyx imbrictus Tquamis fariofis nitidis: intimis longioribus radiantibus coloratis. Flúf. androgyni \& feminei mixti. Thal. nudus glaber. Pappus penicillatus : aut totus iplumofus.

Argyrocome :retora. 'Tab. i 67. 'fig. 3.

Xeranibemoides procumibens, polii folio. DiLl. elth. 8. $32=f .415$.

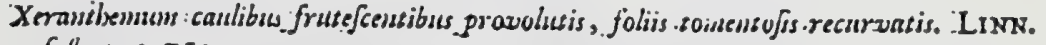
fyst. veg. 750.

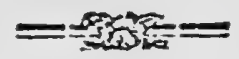

REc. planum, amplum, excavato-puncatum, glabrum.

SEa. oblonga, teretiulcula, glabra, pallida.

Puppis hiveus, femine triplo longior: radiis, numerolis, bafi fetaceis denticulatis, apice penicillato - plumolis.

İ T. fimplicifimum, nembranaceum.

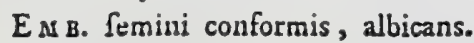

2.) Calyx integer, a parte fupian (pectatus b.) Thalaaus denudatac C.) Semea magnitadine zuetum, cum fuo pappo penicillato.

Hujus prateren loci funt omnia Linnxi Xerarithema, quibus ipfe pappum plunofum tribuit; nec nou ejus Grapbulia, fimili calyce, receptaculo atque pappo dotata. 

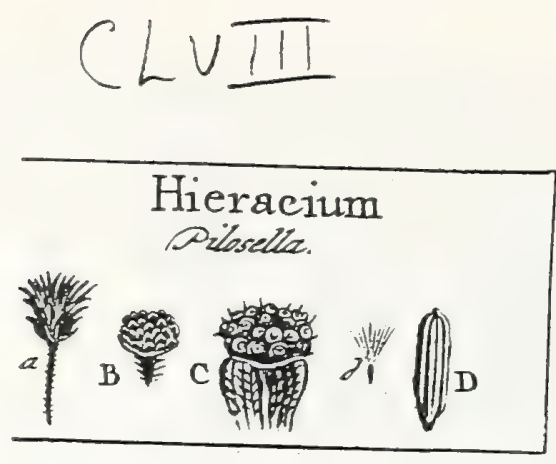

J. Gaertner (1788) Vol. 2

360

DCCCCX. HIER A CIUM. TOURN. t. 267. LINn. gen. 9r3.

Calyx polyphyllus, imbricatus fquamis lineari-oblongis inxqualibus. Thal. fcrobiculatus, fabriufculus. Pappus felflis, fetaceus, denticulatus, rigidiufculus.

Hieracium Pilofella. Tab. 158. fig. 3.

Pilojella major. BLAKw. berb. t. 365 .

Hieracium fuliis integerrimis ovatis fubtus tonsentofis, frolonibus repentibus, fcape' amiforo. LINs. โyf. veg. 716 .

REc. ante plenam maturitatem planiufculum, fcrobiculatum, \& ex fcrobiculurum marginibus denticulatis afperum; poltea vero fubglobofum, pulvinatum, papillofum, \& inter papillas fewlis minimis confperfum.

SEM. columnaria, apice obtufa, angulata, fulcata, atra, fublucida.

Pappus feftilis, fetaceus, denticulatus, fubfragilis, fordide albicans, perliltens.

INT. duplex: coriaceum atque membranaceum.

EM B. albicans. Cotyl. oblongre. Rad. conica, non difcrets.

2.) Calgx maturus. B.) Receptac. immaturum, C.) IJem maturum d. D.) Semen istegrum.

Ex aliis generibus Linnxanis huc omnino fpectant: Lcontodon aureson, \& Hypochxris pontana. Contra autem eliminanda funt: Hier. Taraxaci, quod fecundum Allions obfervationes, ad Viream pertinet; \& Hier. Sprengerianum, quod ob pappum ftipitatum plumofum, Helmintic fpecies eft. 


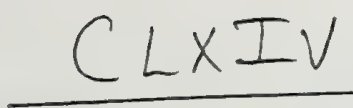

Hippia frucercens.

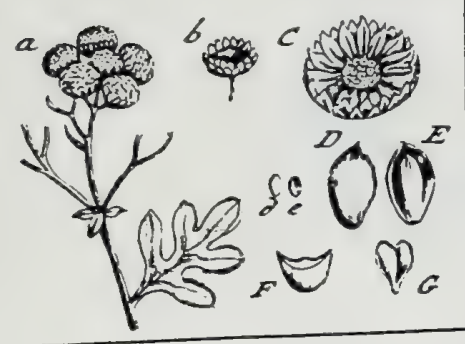

J. Gaertner

(1788) Vol. 2

\section{0}

DCCCCXLIX. H I P P I A. LINN. gen. I324.

Calyx hemifpharicus, imbricatus fquamis oblongis apprelfis margine menabranaceis. Flofc. difformes: difci infunadibulitormes, quinquefidi, androgyni, fteriles; radii tubulof, comprelfi, brevilimi, 2-3. dentati, feminei, ferriles. Thal. nudus. Sem. feminis calva.

Hippia frutefcens. Tab. 164, fig. 6.

Tanacetsm africanum arborefcens, foliis lavendule multifide. Coms. bont. aimfl. 2. p. 201 . t. 201.

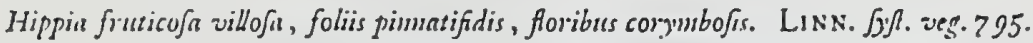

Rec. planiufculum, nudum, papillulis depreffis, pundto medio excavatis, confperfum.

SE \. feinimis elliptica, apice in mucronem, ab exarcfecute corollula feminea formatum, producta, verfus bafin angultata, cunvexo-cuncava, ad laterit quafi in alam extenuata, pallida, calva.

IN T. extcrius fubcoriaceum, tenue, utrinque in narginem membranaceum productum.

Emr. Semine multo anguftior, ovato-oblongus, albus.

a.) Pars corymbi florum, b.) Calyx feparatus. C.) Receptic. dentulatum. d. D.) Seminis Iatus externum convexum. e. E.) Ejusdem Latus internum concavum. F.) Ejusdem fectio tratsrit. Falis. G.) Eimbrro denudatus.

Corollula feninca cum feminis f. ovuli integumento externo contisua nec ab co dificets elt, plane ut in Tarchonantho. 

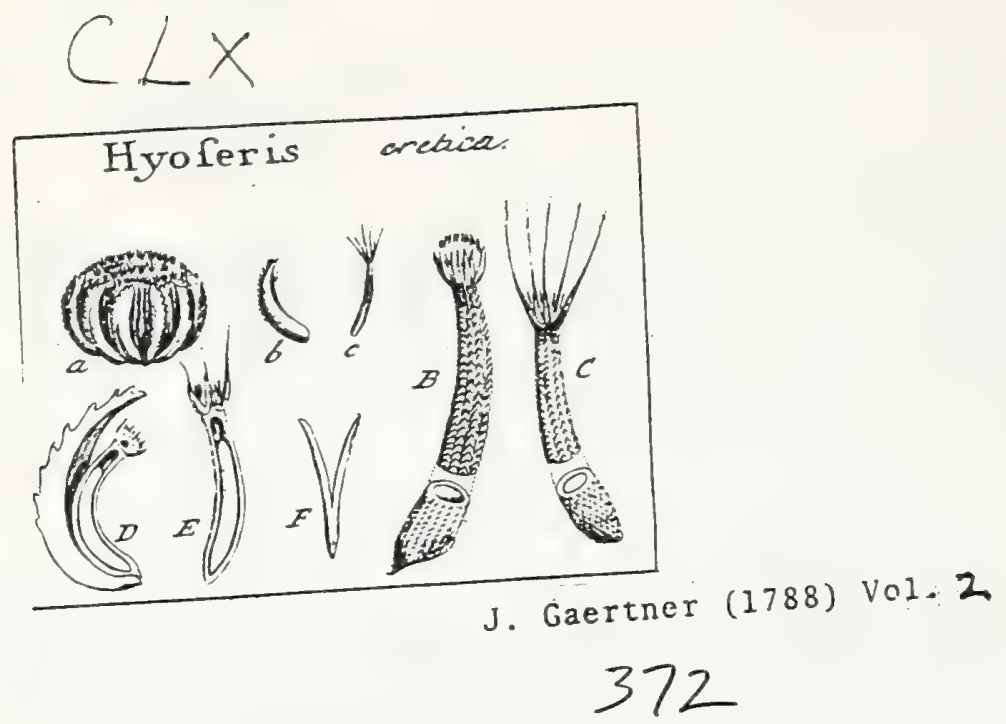

DCCCCXXV. H V O S ER I S. LINN. gen. gi6.

Calyx fimplici ferie polyphyllus, fquanis breviflimis calyculatus. Thal. excavato punctatus. Pappus diffornis: difci compolitus ef radiis inxqualibus; radii polyphyllus xqualis.

Hyoseris cretica. Tab. 160. fig. 2. ex fide Mortini Stuttgard.

Hyoferis frultibus ovatis fcabris, caule ramofo. LINN. fyf. veg. 721.

REC. planum, glabrum, excavato - punctatum.

SEN. teretiufcula, fcabra, ferruginea; interiora longiora rectiufcula; marginalia breviora, incurva, foliolis calycinis femi involuta: utraque pappofia.

Pappis difformis: radii polyphyllus, brevis, foliolis paleaceis, denticulatis, bafi connatis, fubrqualıbus, aut tribus faltem breviter atiftatis; difi compolitus ex foliolis pluribus fubulatis brevibus, \& quinis paleaceis, in ariftam longıtrmam denticulacam definentibus.

INT. duplex : exterius cruftaceum, fragile.

EMB. femine brevior, fubulatus, albicans.

מ) Calyz maturas fubglobofus, torolus: foliolis carint dentatis gibbis, intus canaliculatis, Senina marsinalia (D.) amplexantibus b. B. D.) Semina radii. c. C. E) Scmina difri. E.) Enjbrgo deaudatus

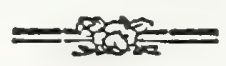

Hyoferis virginica. LINs.

Semina tetragona, coronata margine membranaceo integro \& infuper fetis tribus 1. quatuor longis. LINN. Sp. pl. 1138 .

Hyoferis feabra. LiN .

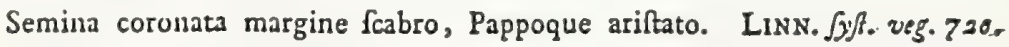

Hyoferis lucidus. LINN.

Senuina marginalia vix pappofa. Live. mant. 108.

Hyoferis Hedgpnois. Lins.

Semiua difci coronata calyculo fetaceo; radii vero margine. LINN. b. $u \int p \cdot p \cdot 246$.

Hyoferis birta. nub.

'Leoustodon birtsuns. Lins.

Senina radis incraffata albida vix fcabra calyculo brevi multidentato coronata. Sen. difci tenuia, fufca fabra, pappo feffili: in centralibus fubftipiento; radiis tredecim, bafi lunceulatis, extrorfutn plumofis, \& aliis tredecim brevioribus funplicibus cum prioribus alternantibus. LEERS. flor, berborn. 372. $\Lambda$ ut hujus loci, aut proprii generis planta eft. 


\section{CLIX}
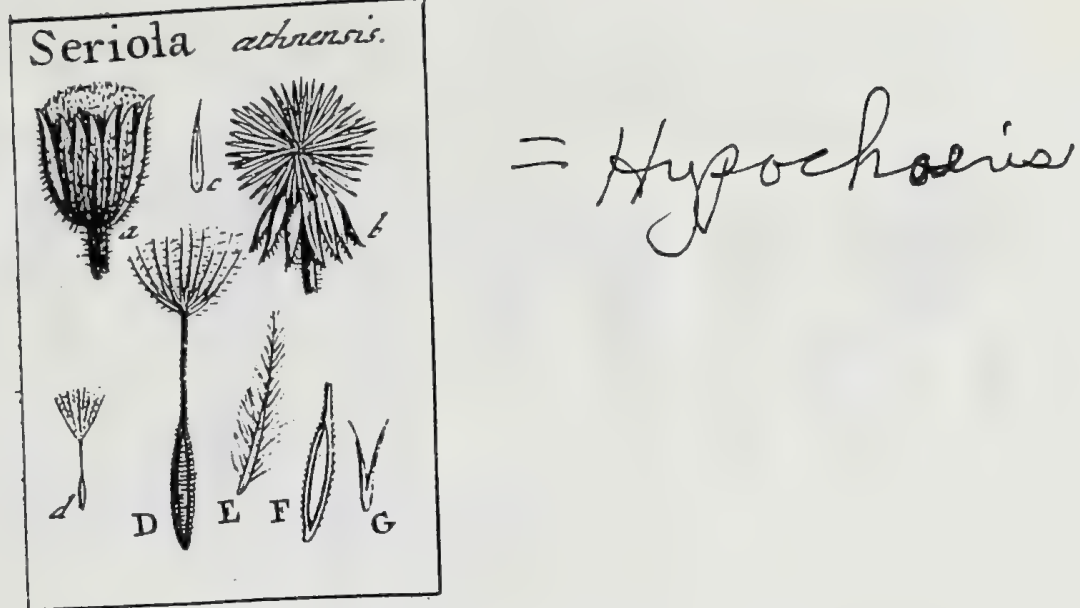

\section{J. Gaertner (1788) Vol.2}

b. Thalamo paleaceo. .

DCCCCXXI. S E R I O L A. LINN. gen. 91\%.

Calyx fimplex, polyphyllus, fubxqualis. Thal. paleaceus. Sem. uniformir. Pappus ftipitatus plumofus : radiis bafi paleaceis.

SERIOLA xthnenfis. Tab. 159. fig. 5.

Aclyyrophorrus birfutus, bellidis obtufo folio. VAILL. all. gall. $172 x$.

Seriola bifpida, foliis obovatis Jubdentatis. LiNN. fyf. veg. 721.

Icon. JAce. obf. IV. t. 79 .

REC. convexum, undique tectum paleis membranaceis, lineari - lanceolatis, calyci fubxqualibus, deciduis.

SEM. parva, fuffiformia, ftriata, punctis acutis fcabrata, rubro-ferruginea.

Pappus plumofus, perfiftens, ftipitatus: radiis. fubdenis, paleaceo-fetaceis, albis. Stipes capillaris, longitudine feminis.

IN T. duplex: exterius cruftaceum, fragile.

E M B. fubulatus, albus.

a.) Calyx maturus. b.) Receptac. paleis teQtum. c.) Palex feparats. d. D.) Semen integrum

E.) Pappi radios feparatus. F.) Senen longitudinaliter apertum. G.) Embryo denudatus. 


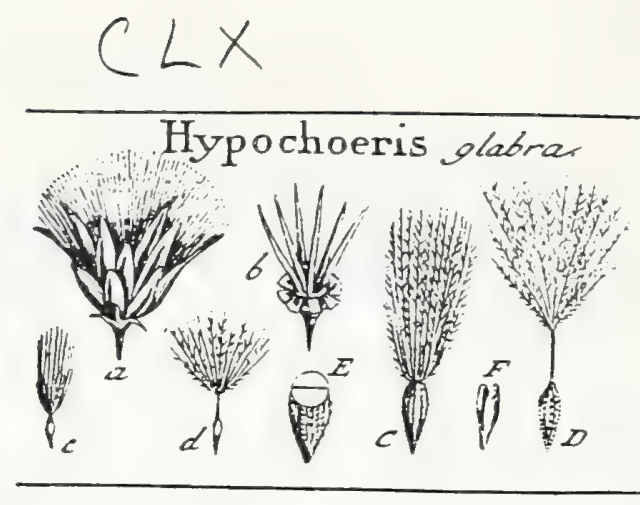

\section{J. Gaertner (1788) Vol. 2}

\section{3}

DCCCCXXVII.. H Y P O C H $Æ$ R I S. LINN. gen. gr8.

Calyx imbricatus. Thal. paleaceus. Sem. difformia. Pappus radii fefralis, difci ftipitatus.

Hy POCHeris glabra. Tab. 160. fig. 4 .

Hypocberis glabra, calycibus oblongis imbricatis, cande ransojo mudo, foliis demtato fumlatis. LiNN. Jyjt. veg. 721.

Icon. OED. flor. das. t. 424 .

R Ec. planum, tectum paleis membranaceis, lineari-acuminatis, calyci xqualibus deciduis.

SR N. fubdifformia: radii teretiufcula, furfum inctaflata, apice obtufa; difci fufformia, in ftipitem fecaceum longum defmentia: utraque ftriata fiabra, faturate ferruginea.

Pappus plumofus longitudine feminis, in feminibus radii feffilis, copiafior, longior; in feminibus difci ftipitatus, parcior, brevior.

IN T. exterius cruttaceum, fragile.

E 1 B. ubovatus, albicans.

2.) Calyx maturus. b.) Receptac. denudatum. e. C.) Seaina radii. d. D.) Semina difei. E) Scminis fedio trassver[alis. F.) Embr. denudatus. 


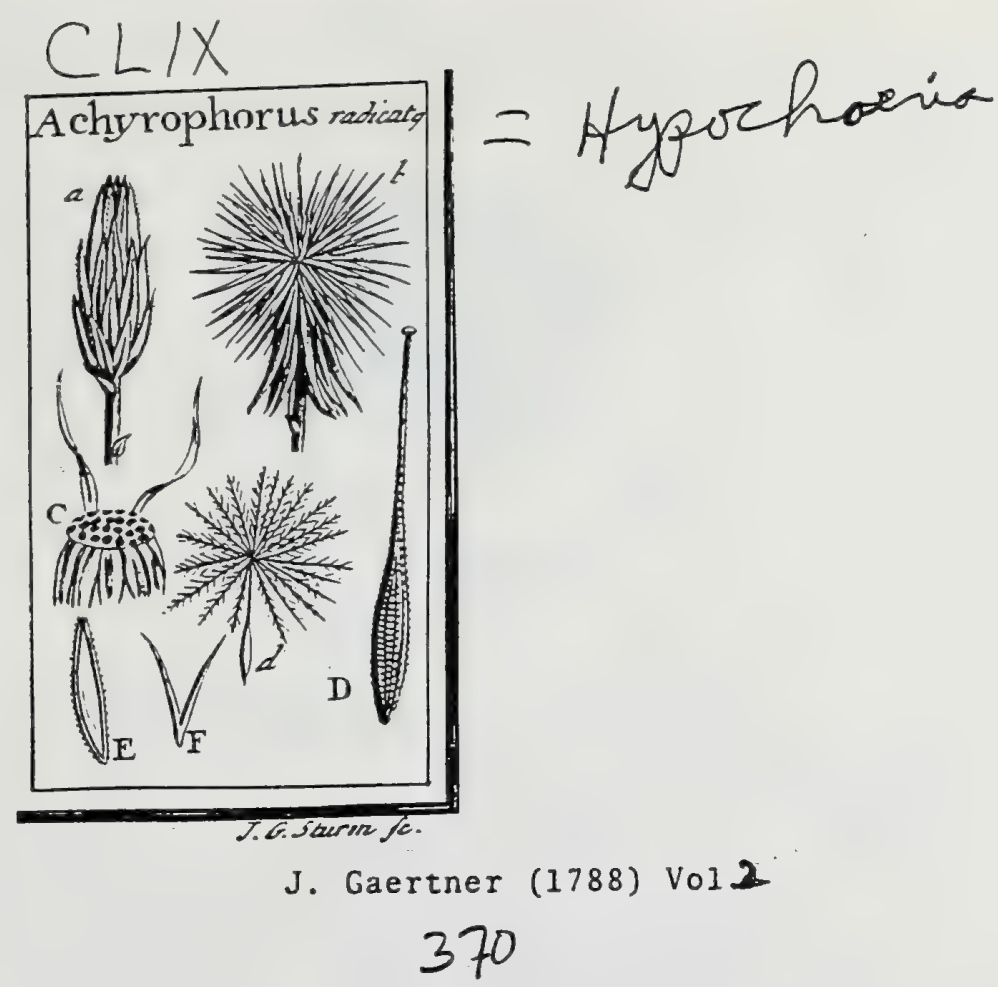

DCCCCXXII. A C H Y R O P H O R U S.

Calyx oblongus, polyphyllus, imbricatus. Thal. paleaceus. Sem. uniformia. Pappus ftipitatus plumofus, radiis fliformibus.

ACHYROPHURUS radicatus. Tab. 159. fig. 6.

Hieracium III. DoD. pempt. 639. O\&D. for. dan. t. 150.

Hypocharis foliis runcinatis obtufis feabris, caule ramofo nudo lavi, pedunculis Squamofiss. LIN . Lyft. veg. 722 .

REC. modice convexum, tectum paleis membranaceis, lineari - acuminatis, calyci fubxqualibus, deciduis.

SEM. fufifurmia, ftriata, feabra, faturate ferruginea.

Pappus ftipitatus, plumofus: radiis numerofis filiformibus ftipite longioribus. Stipes fetaceus, femine longior.

INT. duplex: exterius fubcruftaceum.

$E_{M B}$. fubulatus, albicans.

2.) Calsx claufus. b.) Idem per maturitatem refiexus, eum receptac. paleacco. C.) Receptac. denudatuu. d. D.) Semen integrum. E.) Idem lóggitudinaliter apertum. F.) Eimbryo dcnudatus. 


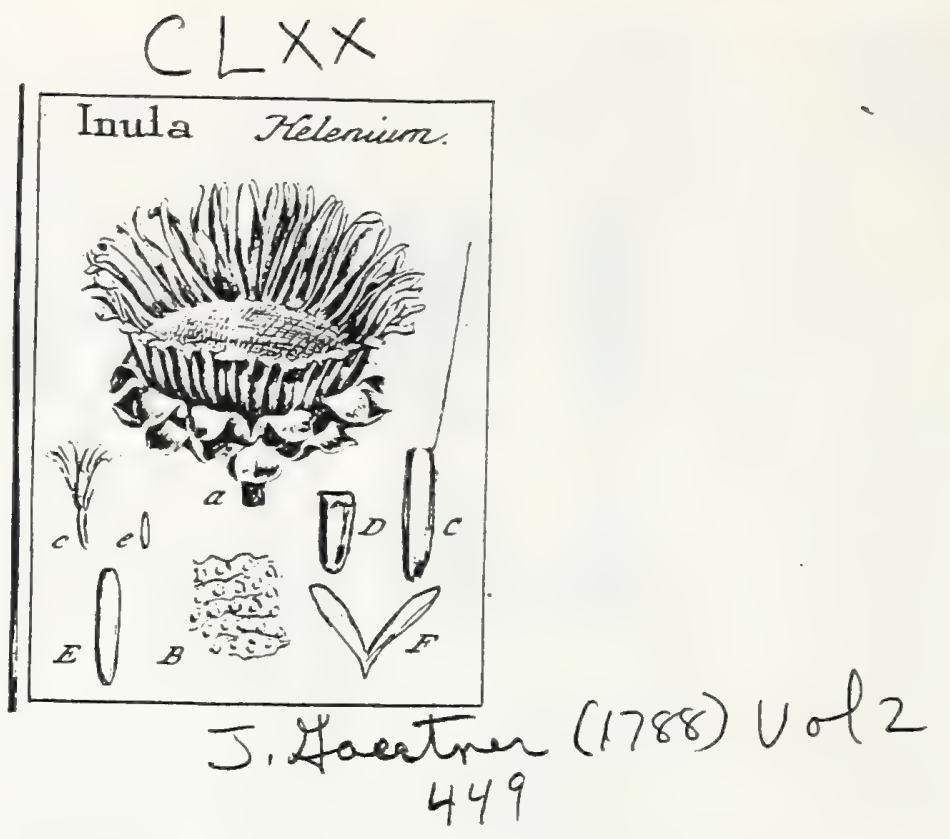

MXXVI. I N U L A. LINN. gen. 956.

Omnia Afteris, nifi quod in Inula radii ligule numeroliores \& confanter lutex fint. In nonnullis fpeciebus antherx bafi bifetr, nequaquara vero in omnibus, immo ne quidem in potiori earum numero.

Invia Helenium. Tab. 170. fig. 2.

Helenrium. Fuchs: bif: lat. 242 germ. ic. 134. BLakw. herb. t. 473. Ozd. flar. drs. t. 728 .

Inula folits amplexicunlibus ovatis rugofis frubtus tomentofos, calyczan fquänis ouatis. LiNn. Jy/. veg. 766 .

REc. planum, amplum, glabrum, excavato-puncatum aut minutiffime fcrobiculatum: fcrobiculis angulatis ad margines vix fenfibiliter dentellatis.

SEM. columnaria, tetragona, oblolete ftriata, glabra, e cinnamomeo fpadicea: umbilici margine cartilaginto, albo.

Pappus capillaris, fubedentulus, albus, femine duplo longior.

$45^{\circ}$

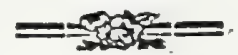

IN T. exterius coriaceum, tenue.

EM B. teretiufculus, albus.

r.) Calyx integer, fquamis intiuis per maturitated infigniter elongatis rigidis \& quafi cartila gineis. B.) Receptac. pars infigniter auda: c. C. D.) Semen integrum \& difredum. e. E. $F_{f}$ Embryo membrana interiore teckus, \& denudatus.

Aut Inula, ad mentem Tournefortii \& Halleri, cum Aftere conjungenda, aut difcrimen, cum Vaillantio, in folo radii colore ponendum: linnxana enim nota characteriftica nimis crebro fallax eft. 


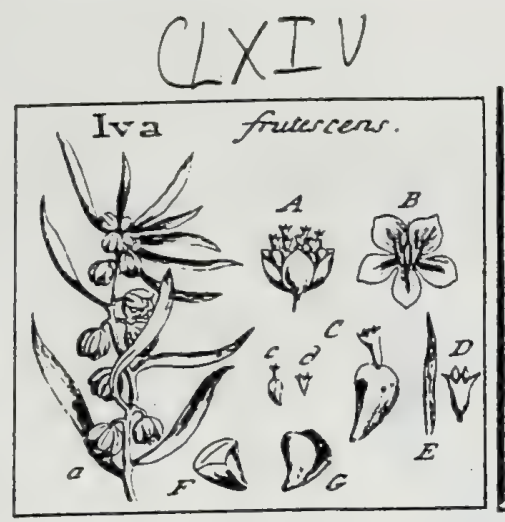

\section{J. Gaertner (1788) Vol 2 \\ 393}

\section{DCCCCLV. I V A. LINN. ger. I059.}

Calyx tri-1. pentaphyllus, foliolis ovatis, globofe conniventibus. Florc. difformes: difci campanulato - infundibuliformes, quinquefidi, androgyni, fteriles: Autheris quinis difcretis; radii prioribus finiles fed anguftiores, aut tubulofi edentuli, feminei, quini aut pauciores, fertiles. Thal. paleaceus. Sem. feminis calva.

Iv frutefcens. Tab. 164. fig. 8.

Agerato affuis peruviana frutefcens. Pruk. plyyt. t. 27. f. 1.

Ion foliis lanceolatis, caule fruticofo. LiNN. Sy/t. veg. 853.

Ex herbario Bankfiano.

REC. planiufculum, paleis linearibus, diffitis, calyci fere xqualibus, ftipatum.

SEN. feminis oborata, deorfun acuminata, hinc convexiufcula, inde angulata, 1. fubtriquerra, ftrammeo-pallida, zlabra, calva.

IN T. exterius coriaceun, tenue.

EM B. femini conformis, albus.

2.) Racemi pars fuperior cum florihus. A.) Calyx fofculis ftipatus B.) Idem explicatus cum receptac. paleaceo. E.) Palea feparata c. C.) Flofe. radii cum fuo (corinc. d. D.) Flofe. difei fterilic. F.) Semen transverfe fectam. G.) Embr. deaudatus.

Iva amuk. Lisw.

Icon. SснміDEL Analys. t. 16. exinia.

Calyx glubufus, pentaphyllus, rarius 3.1. 4 phyllus. Thalami palex lineares, Holculis androgynis longiores. Corollulic feminex crenulati, non diltincte \& regulariter in dentes fecr. Semina feminis obcordata, angudata. Sclumid to c. p. 59 . 


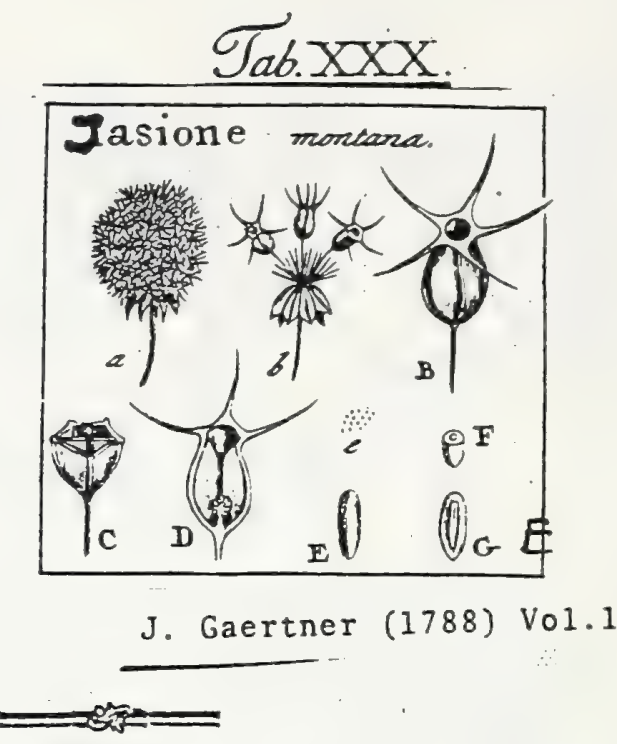

\section{JASIONE. LINN. gen. 1005.}

Calyx fuperns, dentibus quinque fubulatis. Cor. monopetala, profundo quinquefida. Stam. quinque. Styl. unicus. Capfula infera, bilocularis, apice pervia. Receptaculum liberum.

JAsio e montana. Tab. 30. fig. 5 .

Rapunculus foliis linearibus fubafperis, fpica planiuscula, petalis liberis. HALI. hif. 1. n.678.

Jafione. LIN N. fi/f. veg. T99.

ICOn. OEDER. flor. dan. t. 319 .

PER. Capfula infera, membranacea, tenuifina, pyramidato nvata, pentagona, dentibus calycis radiantibus coronata, bilocularis, apice amplo foramnine rotundo de. hiscens. Diffepimentum ad axem divifum, folis capfulx parietibus adnatum.

REC. fubglobofum, parvum, pedunculatum, tuberculatum, liberum, in bafi capfulz inter diffepimęnti valvas pofitum.

SEM. numerofa, exilia, ovato oblonga glaberrima, nitida, pallide caftanea.

IN T. fimplex, fubmembranaceum, tenue.

A вв. femini conforme, carnofum, album.

Eм в. dicotyledoneus, filiformis, niveus. Cotyl. ferniteretes. Rad. longa, centripeta

a.) Umbella integra. b. B.) Capfala cam foramine verticali. C.) Eadem transvef(e, \& D.) longitodisaliter feta, cum forma \& fitu diftepimenti atque receptacull. e. E.) Semina feparata. F. G.) Albumen transverfe \& longitudinaliter fêtum; cum embryone.

Diffepimento ad axem fiffo, non tantum a Phytevinate, fed \& ab omnibus reliquis Campanulaceis abunde differt. 
Asteraceae

No drainirg

$$
\begin{gathered}
\text { J. Afaetren }(1788) \text { vol } 2 \\
\text { 415 } \\
=\text { Jurgia }
\end{gathered}
$$

TRI A-A C T-E. Jungia. IIN N. gen, 1422.

Calyx miverfalis triflorus, polyphydlus; partiales polyphylli, xguiles, multiflori. Flofc. omnes androgyni., uniformes, tubulofi, bilabiati: labio exteriore longiore :revoluto apice dentato; interiore biparcito erecto acuto. Réc..... paleaceum. Senina coronata pappo plumafo.

Trinacte ferrugineu.

Jungin fenruginea. :Liss. Jupplo. 390.

Capitula florum parva congelta. Scmina anguilata. Pappus longus femis plumofus. Lisso.l.c.

19.91 
Asteraceae
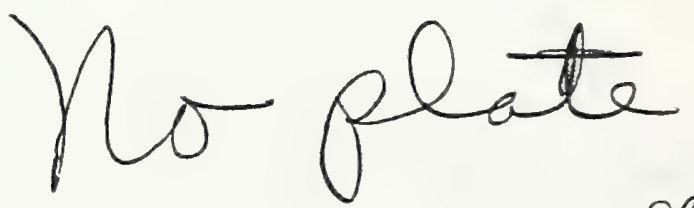

J. foentrex (1788)

$360 \quad \mathrm{Voll}_{2}$

= Krigia Schel

Calyx oblongus, conicus, fimplex, aut imbricatus fquamis inxqualibus. Thal. nudus, puncticulatus, glaber. Pappus fellitis, pilofus.

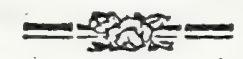

$$
36 r
$$

Hujus loci funt Tragop. dandelion, virginicum \& luiatus. LINN. plante a Tragopogonis charactere generico multum difcrepantes \& ab avtoptis curatius fcrutandx.

19.92 


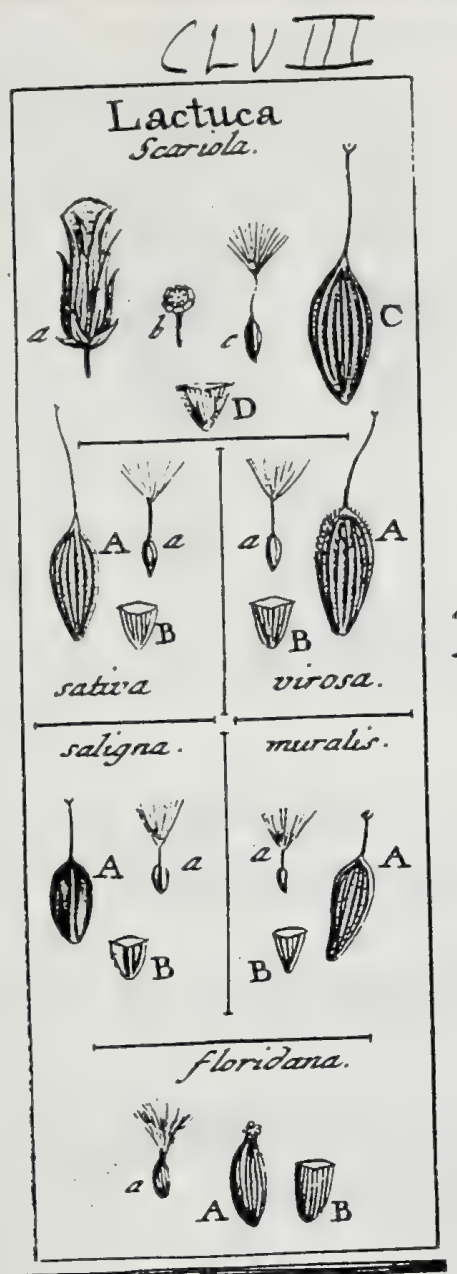

J. Gaertner (1788) Vol 2

361

DCCCCXII. L A C T U C A. TOURN. 2. 267. LinN. ger. 909.

Calyx ublongus, polyphyllus, imbricatus fquamis inxqualibus acuminatis margine feariofis. Thal. excavato- punctatus, glaber. Pappus ftipitatus, capilluris, mollifimus, fugax.

Lactuca Scariola. Tab. 158. fig. 5.

Lnifuca agrefis. CORD. bif. 157. b.

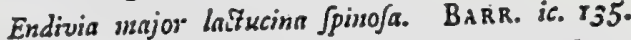

Laduca foliis verticalibus currina aculeatis. LINN. 6yf, veg. 723 .

REC. planiufculum, excavato-punctatum, glabrum.

SEM. ovata, utrinque attenuata, compre何, ftriis feptem crenulatis longitudinalibus exarata, e ferrugineo nigricantia.

Pefpess Itipitatus, capillaris, mu!lilinumus, fericeo-albus, femini xqualis, fugrax. Stipes fetaceus, lungitudine feminis.

Is T. duplex: exterius fubcrultaceum, durum. 362

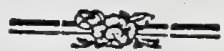

E̊ B. femini conformis, albus. Cotyl. ellipticx. Rad. acuminata.

2) Calyx integer. b.) Reeeptac. denudatua. c. C.) Semea feparatum. D.) Idem transterfe fuetum.

Lactuca fativa ibid.

Lăfuca. BLAKW. berb. t. 88 .

Laifuca foliis rotundatis caulinis cordatis, caule corynbofo. LINN. l.c.

Semina (a. A. B.) paulo minor quam in procedenti, fed turgidiora, deorfum valde anguftata, Atriis feptem crenulatis exarata, cinereo-fpadicea aut albi. cantia. Pappus mollifimus, fugax. Stipes longitudine feminis.

LACTUCA virofa. ibid.

Lafuca fylvefris lato folio, nervo virofo. BauH. bifl. 2. p. 1002.

Lafiuca folins borizontalibus carina aculeatis dentatis. LINN. Io $c_{1}$

Semina (2. A. B.) per fingula puncta L. fative finillima, nifi quod margines atque ftrix, prope verticem feminis, minutillimis aculeolis exafperatx Gint.

LActuca faligna, ibid.

Lachuca foliis imis femipinnatis, fuperioribus amplexicaulibus banatis, nervis fpinofis. HALL. bijf. n. 13. fior. jent. t. 4 .

Lafluca foliis baftato linearibus feffilibus carina aculeatis. LiNs. l. c.

Icon. JACQ. anfir, t. $=50$.

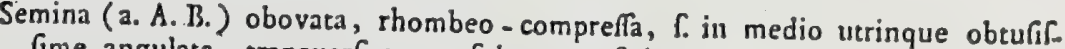
frme angulata, transverfim rugofula, non ftriata, cinnamomea aut c luteo fpadicea. Pappus mullifimus, longus. Stipes femine brevior.

LACTUCA foridana, ibid.

Soncbus fioridanss, pedurculis fquamo/is, foliis lyrato-lsafatis. LINN. fyff. veg. 712.

Semina (a. A. B.) ovato-oblonga, comprelli, ftriata, glabra, fumofa aut fufa, in collum $\int$. breviffimum ltipitem definentia. Stipes craffus, terminatus calyculo minutifimo, quinquedentato, fubreflexo; intra quem Pappus mollifimus, niveus, fugax. Hacc, a Lacluca perinde atque a Soncho, quin ab oninibus Ligulatis, pappo compofito differt, \& in vivo Specimine curatius examinari meretur. 


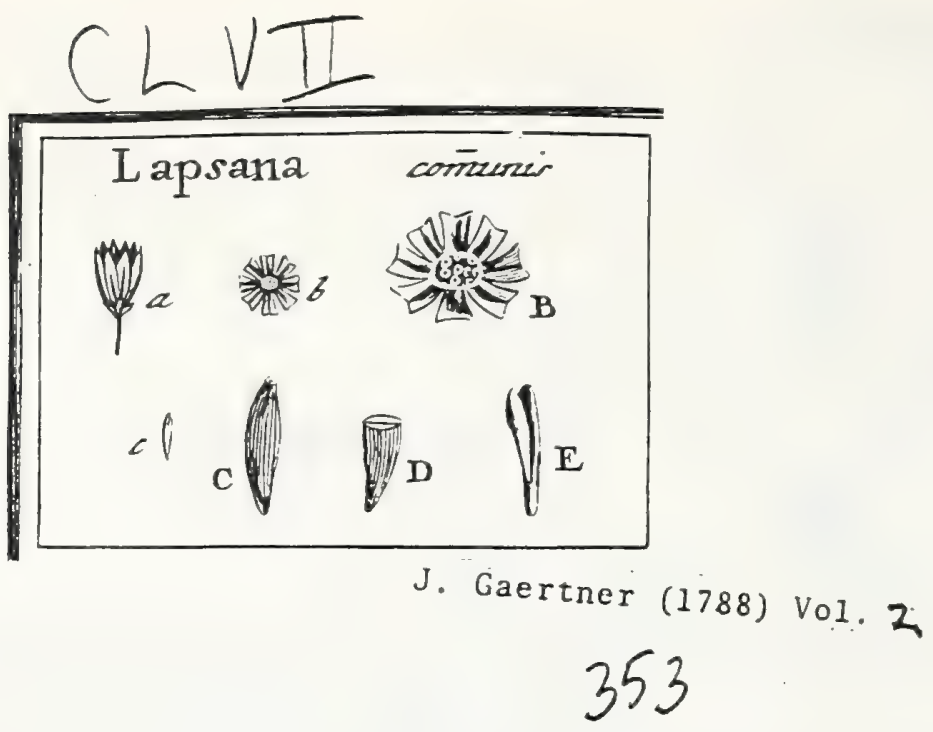

DCCCCI. L A P S A N A. TOURn. t. 272. Linn. gen. 9 ig.

Calyx finplex, octophyllus, erectus, comivens, bafi calyculatus fquamulis paucis breviffinis. Sem. calva, non involuta, decidua.

Lapsana communis. Tab. 157. fig. 1.

Lapfanu calycibus fruifus angulatis, pedunculis renuibis ramofistimis. LINx. Gyf. veg. 721 .

Icon. OED. flor. dart. t. 500 .

R E C. pl:ınum, papillulis depreflis confperfum, ceters glabrum, nudum.

SEM. ublonga, dcorfum acuminata, obfolete angulata, ftriata, calva, lutefcontis, fponte a receptaculo fecedentia.

\section{4}

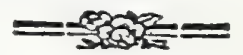

IN T. duplex: coriaceum atque membranaceum; utrumque tenue.

E м. Semini conformis, albus. Cotyl. oblongre. Rad: teretiufcula, non difcreta. *

a.) Calyx maturus, foliolis angulo obtufo carinatis. b. B.) Recept. denülatum. -e. C.) Semea" integrum. D.) Ejus fetio transver(alis. E.) Embryo denudatus.

Hyoferis foetida. LINs. onınino genuina eft Lapfanx fpecies, uti jam HAL. LERUS cenfuit. Cillyx ei oftophyllus, fquamulis fex, lineari-acuminatis. calyculatus. Thal. iludus. Sen. uniformia, columnaria, fulca, fponte decidua, calva, absque ullo marginis l. pappi veftigio. 


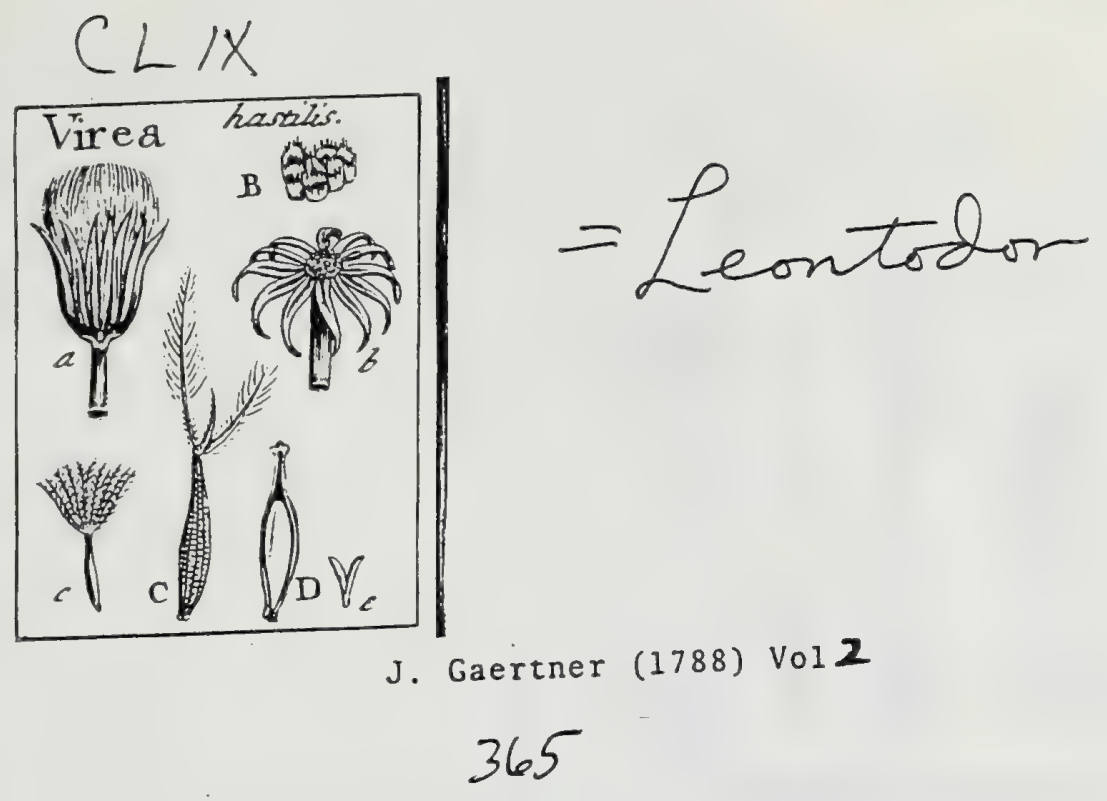

DCCCCXVI. VIREA. ADANs. p. II2. Taraxaconoides. VAILI. Leoncodon. Juss. p. 170 .

Calyx polyphyllus, nunc fubimbricatus, nunc vero fimplex, xqualis \& bafi fquamis paucis brevibus calyculatus Thal. fcrobicularus, villofiufc:alus. Sem. teretia, obtufa aut furlum graciliora. Pappus plumofus, fefrlis, aut fubltipitatus: radiis paleaceis \& fetaceis mixtis.

VIREA haltilis. Tab. 159. fig. 3.

Leoneodou fcapo calyceque Levi, foliis lanceolatis deutatis integerrimis glabris. Linn. fy/t. veg. 715.

Icon. JACQ. auflr. 8. 164.

REC. modice convexum, fcrobiculatum, a fcrobiculorum marginibus ciliatis villofiufculum.

SE M. fuliformia, friis longitudinalibus afperis fcabrata, rufefcentia, in ftipiten obfolerum definentia.

Pappus plumofus, fubltipitatus, inxqualis : radiis longioribus inferne planis, barbatis; brevioribus autem fetaceis, imberbibus \& fimpliciter denticulatis.

IN T. duplex: caterius fubcruftaceum, durum.

Es B. feminis tefta quarta parte brevior, fubulatus, albus.

a.) Caly maturus. b.) Idem per maturitatem rubreflexus. B.) Receptac. pars infigniter aofas. c. C.) Scmis inłegrum. D.) IJcm longitudinaliter apertum. e.) Embrgo magnitutinc naturati.

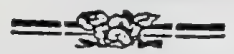

Semina Vir. bifpide, precedentibus fimillima, fed paulo minora \& minus afpern funt. Huc etiam fpectat Hitrac. taraxici. fecundum Allo minus big pedens. p. 211. Sed Leontod. aroreios, quod etiam Cel. Jussieu huc refer, zanto confidentius ad Hieracia depellimus, quod ejus pappum, ipfis hie aciis fimpliciorem, in exemplis helveticis coran. videamus, \& talem quo. que pronunciet J^ce. in fior: virudob. p. 269 . 


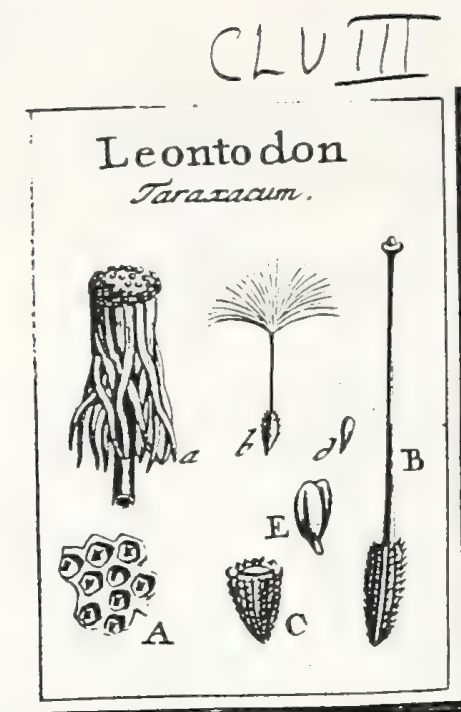

TG.Sturm F. SFumb

J. Gaertner (1788) Vol. 2

\section{3}

DCCCCXIV. L E O N T O D O N. LINN. gen. 912

Dens leonis. Tour N. t. 266. Taraxacum. Juss. p.16g.

Calyx oblongus, polyphyllus, foliolis interioribus exectis xqualibus; exterioribus reflexis aut patulis inxqualibus: utrisque per maturitatem deflexis.

Thal. excavato - punctatus. Pappus capillaris, ftipitatus.

LEONTODON Taraxacum. Tab. 158. 6ig. 7.

Dess leonis. Cans. epit. 286. Blarw. berb. 2. 508. Oed. for. dass. t. 574.

Leontodon calyce fguamis inferne refiexis, foliis roncinatis denticulatis levibus. Lis.. Jj\%?. veg. 7J5.

R E C. excavato- punctatum, glabrum, primo planum, demum pulvinatum.

SEM. oblonga, deorfum anguftiora, comprefrufeula, ftriis in fungulo latere 5. 1. 6. Jongitudinalibus, inferne fimpliciter tuberculatis, fuperne autem muricatis \& quaf imbricato fquamofis exafperata: cinereo - fufca.

Puppus capillaris, deciduus, thipitatus. Stipes fetaccus, rigidiufculus, bufi angulaius, femine triplo longior.

IN T. duplex: exterius fubcruftaceum, durum.

Eas. albicans. Cosyl. ellipticx. Rad. attenuata, non difcreta.

2.) Calyx maturus deflexus, cum receptac. pulvinato. A.) Recept parg infigniter. nucta b. B. C.) Semen integrum \& diTedum. L E.) Embryo denudatus.

Senina in aliis lime rudioris adinftar afpera, in aliis vero leniter tubercu. lata, \& jterum in aliis penitus glabra ac fimpliciter tantum ftriata deprehenduntur. Conf. GMEL. fibir. 2. p. 35. 


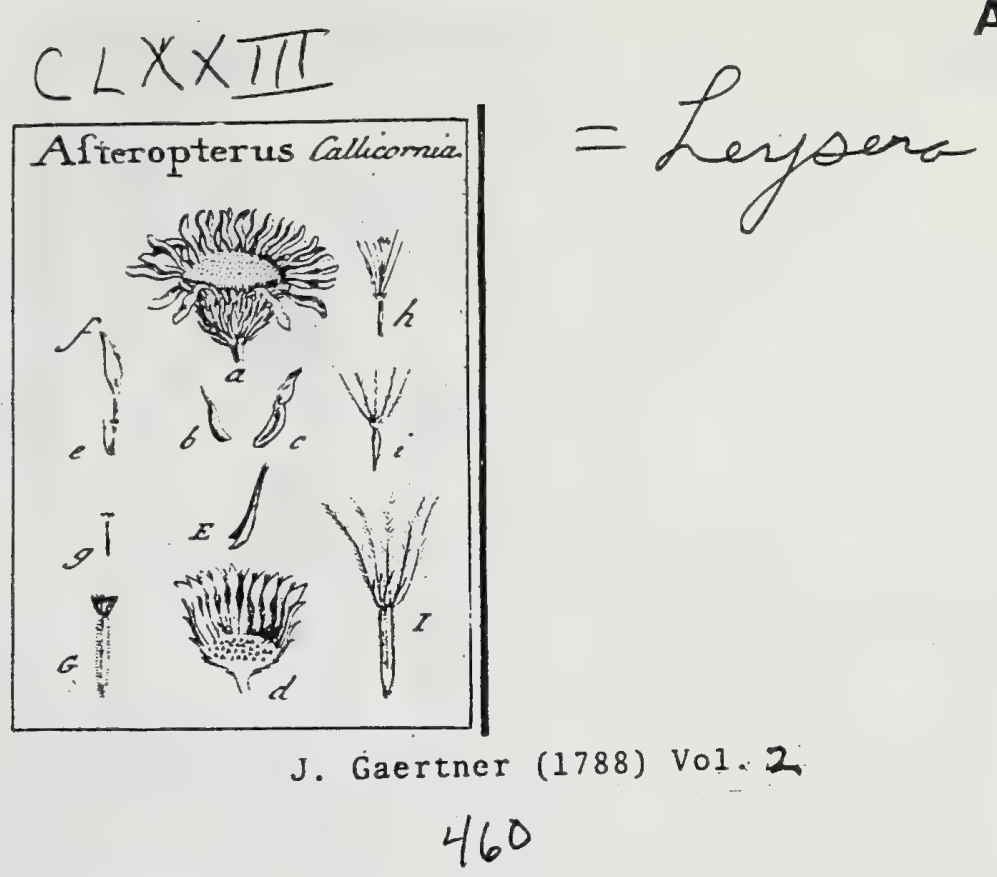

\section{MXII: A S T ER O P T E R U S. VAIIL. af. gall. 1720.}

Calyx fubrotundus, imbricatus fquamis oblongis fariolis inxqualibus: interioribus apice lameeolato appendiculatis. Thal. elevato - punćtatos, ad peripheriam paleaceus. Flofc. difci andrngyni; radii feminei, ligulis lanceolatis integerrimis: utrique fertiles. Scm. uniformia: Pappus difformis= radii fimplex; difci compolftus.

Asteropterus Callicornia. Tab. 173. fig. 6.

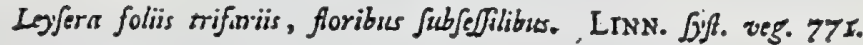

Ex herbario Bankfiano.

Rec. planum, in medio clevato-punctatum, nudum, fcabrum; ad peripheriam fimplici ferie paleareum : raleis feariolis, abis, feninarum ovaria exterue obtegentibus, jiş̧ue vij aut purum !onerioribus.

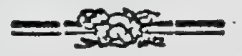

SE Mr. uniformia, lineurí-oblonga, compreffa; ad margines feabriufcula, fubferruginea.

Puppus difformis: radit fimplex, paleaceus, decaphyllus: foliolis lineariacuminatis, niveis, femine quadruplo brevioribus; difci compolitus. ex ratiis quinis, paleaceis, lineari acumilatis, brevifinnis, \& ex quinis aliis plumolis, femine longiuribus ac cum prioribus alternan. tibus.

IN T. fimplex, membranaceum.

EMr. Serniui conformis.

a.) Calsx maturas integer. b.) Squama ealycina exterior - \& c.) alia ex interioribus, d) $\mathrm{Ca}_{2}$ lyx diffetus cum receptaculo. e. E) Palez ovarii feminei. E. g. G.) Flofe radii com fuo fenine $h_{0}$ i. I.) Flore difei cum fuo femine.

Nomnunquam unicus radius plumofus pappo feminarum additur; \& in androgynorum fenrinibus fixpe paleacei radioti uno L altero folialo augentur, ut ex pertapliyllo. evaclat 6 - 1. Sphyllus. 


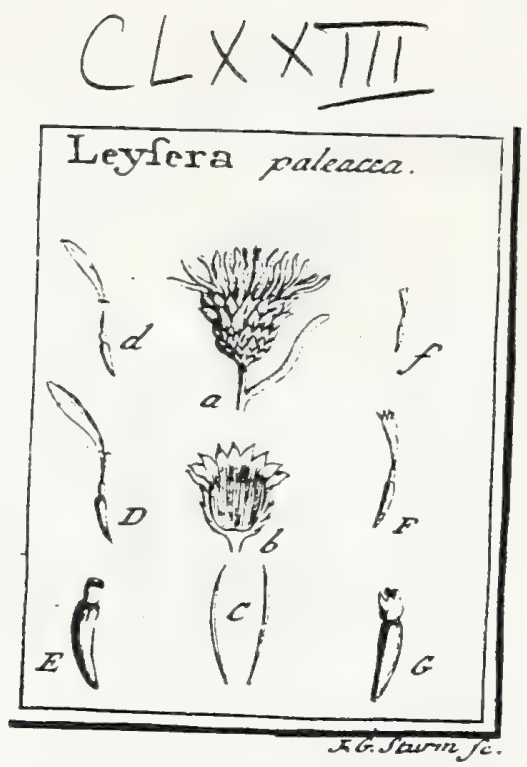

J. Gaertner (1788) Vol. 2

$$
432
$$

\section{L E Y S E R A. LINN. gen. 965.}

Calyx imbricatus fquamis numerofifimis, cartilagineis, nitidis: inferioribus fimplicibus acuminatis, appreffis; fuprenis in appendiculam lanceolatam, fcariofam, patulam, apice dilatatis. Thal. palcaceus. Flofc. difci androgyni; radii feminei, ligulis lanceolatis tridentatis: utriq̨ue fertiles. Sem. coronata tubulo fariofo, fubedentulo.

Leysera paleacea. Tab. 173. fig. 9.

Loyfera ericoides, foliis stiquetris obtufus, floribus fefilibus. BEKG. cap. 294. Leyfera foliis triquetris apice callofis recurvatis. LiNw. fif. veg: 77 r.

A Cl. Thunazrgio.

REC. planiufculum, anguftum, paleaceum : paleis longitudine flofculorus, linearibus, anguftillinis, deciduis.

SEM. unifornia, oblonga, deorfum attenuata, obfolete angulata, aut teretiufcula, glabra, fpadicea.

Pappus monophyllus, tubulofus, fariofus, niveus, tertia feminis parte paulo brevior: apertura tubi, in feminibus radii, integerriosa; in reliquis obfolete \& obtufe quadridentata.

IN T. fimplex, m:mbrauaceum.

E 1 B, albicans.

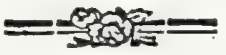

a.) Flos integer. b.) Calyx difetus, cum receptac. palezceo. C.) Palex feparatz. d. D) Flofe. sadii ligulatus. E.) Ejus femen eum tubo pappi edeatula E. F.) Flofe difa tubulofus. G.) Ejus femen, cum pappi tubulo quadridentata.

Leyfers, receptaculo nuda \& pappo compofito dotatas, ad antiquum Aferopteri genus Vaillantiauum referimus. 


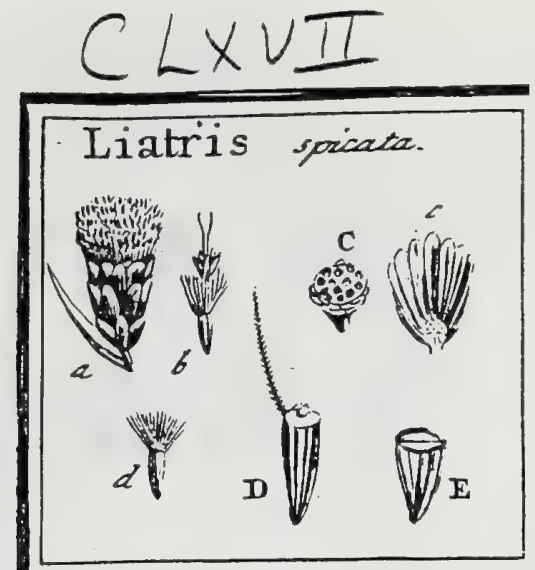

J. Gaertner (1788) Vol. 2

402

SUPRAGO (Liatris in Icon.) fpicata. Tab. 167. fig. 1.

Jacea angufifolia, tuberofa radice. PLuK. phyt. 2. 424. f.6.

Cirfran tuberofun, lalluce capitulis Jpicatis. DiLL. elth. t. 72. f. 83.

Serratula foliis linearibus bafs ciliatis, floribus fefilibus lateralibus fpicutis, caule fouplici. LiNs. fyje. veg. 723 .

Calyx (a) fubcylindricus, imbricatus fquanis oblongis, obtufis, sppreffis, ficuti tota planta glutinofis. Thal. anguftus (c. C.), fcrobiculatus, glaber. Flofculi (b.) rubri, Itylis profunde bifidis, ftigmatibus filiformibus longitrimis. Semina (d. D. E) oblonga, deorfum acuminata, trigono - aut rhombea compreffa, Itriata, glabra, e plumbeo- fpadicea. Pappus longitudine feminis, albicaus: radiis numerofis, xqualibus, fetaceis, dentato-ciliatis.

Huc proteren fpectare videntur: Serr. prealea, fquarrofa \& novaboracentis. LINN. qux tota fua facie externa. fungite receptaculo calvo, longiflime ab Acanattigmata filifornis propter folla fuperiora oppofita (in S. praalsa,), \& propter ftigmata filiformia (in S. Jpicata), proxime ab Eupatorio diftant. 


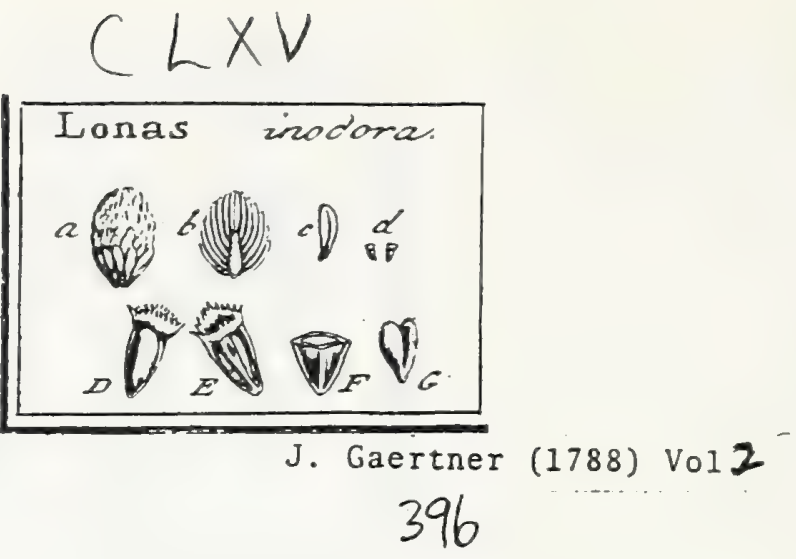

Asteraceae

DCCCCLVIII. L O N A S. ADANS. p.II8.

Calyr fubglobofus, imbricatus fquamis appretis, fenfim in paleas receptaculi degenerantibus. Florc. onmes androgyni, fertiles. Thal. fubulatus paleaceus. Sem. uniformia, coronata margine dimidiato aut oblique truncatu.

Lowas inodora. Tab. 165. fig. 5.

- Elichyfum inodorum glabrum, corouopi folio, anumum. HERM. lugdb. 228. ic. 227. Acbillea inodora. LINN. $\int p$. pl. 1265 . SELIGM. av. V. t. 15.

Atbanafia anrwa, corymbis fmplicibus coardatis, foliis pinnatifidis dentutis. Lis. $\int y / t$. veg. 741 .

REC. fubulatum, longitudine dimidii floris, undique tectum paleis oblungis, obtulis, apice luteo-coloratis.

SEM. parva, unifornia, ex acuminata bafi_furfum latefcentia, compreffa, cinerafcentia, a!bo marginita, hinc planiufcula, inde colta media alba cum ocello fufco, obtufe angulata:

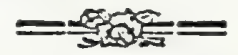

Pappus marginatus, nembranaceus, oblique truncatus, f. fubdimidiatus, dentato- lacerus.

IN T. exterius fubcoriaceum, tenue.

EMB. albicans.

a.) Caligx maturus integer. b.) Idem longitudinaliter dificetus cuin receptac. paleaceo. c.) Ptlea feparata. d. D.) Seminis pars Jorfalis. E.) Ejusdeun latus ventrale cum fua cola macula ocellari oblonga inferipta. F.) Seminis fectio trausver[alis. G.) Enbro denudatus.

Seninis macula ocellari congruit cum quibusdam Achillex fpeciebus; fed $a b$ his, perinde atque ab Athanafiis, pappo \& receptaculi forma, abunde difcrepat. 


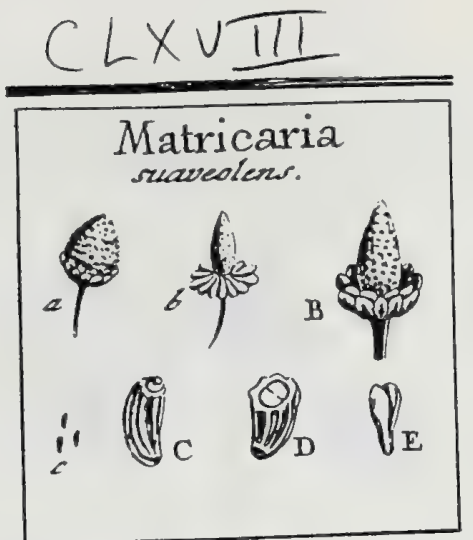

Asteraceae

J. Gaertner (1788) Vol 2

420

DCCCCLXXXIX. MA TR I CARIA. TOURN. t. 23 r. IIN . ger. $96 \%$.

Calyx hemifphxrieus, imbricatus fquamis herbaceis acutis paucorum ordi. num. Thal. conicus, undus. Flofe. omnes fertiles: feminarum ligulx oblongx, fxpe deflexx. Sem. calva.

Matricaria fuaveolens. Tab. 168. fig. 2.

Matricariu leucantbensos aumua funveolens, chansemeli folio, ovarïs albicantibus. VAILL. alt. gall. 1720. p. m. 556 .

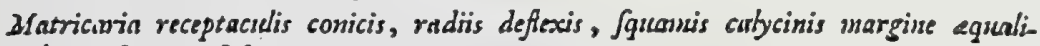
bus. LinN. Jyst. veg. 774 .

REC. ovato-conicum, acuminatum, altum, elevato punctatum, nudun.

SE M. parva, inverfe pýramidata, fulcata, glabra, albicantia, calva.

IN T. exterius coriaceum, cra Tiufculum. $^{2}$

EN B. teretiufculus, albicans.

2.) Calyx cum receptucalo feminibus tectn. b. B.) Receptas. dervidatame e. C.) Semen istegrum D.) Ejus fectio transverlatis. E.) Enbr. denudatus.

Recepeac. in aliis multo brevius \& fimpliciter convexum eft. Si diadema fominibus Mfatricarix accedit, mutatur in Pyreelozim. 


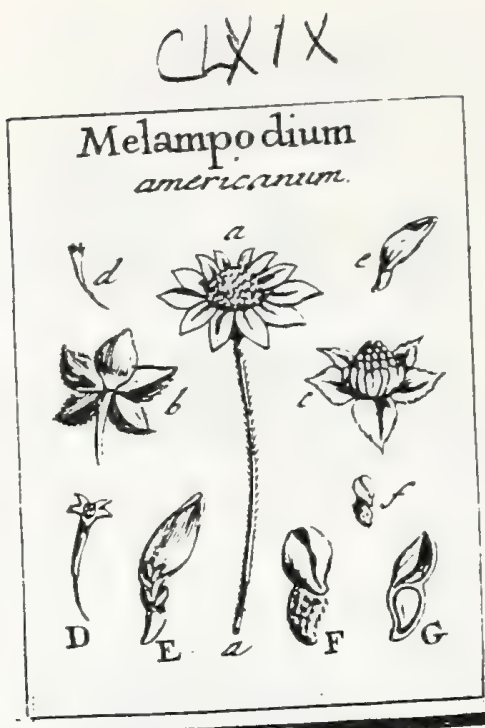

J. Gaertner (1788) Vol 2

436

MVIII. M E L A M P O D I U M. LINN. ger. 989.

Calyx finplex, pentaphyllus, foliolis ovato-acuminatis patentibus. Thal. paleaceus. Flofc. difci androgyni, plurimi, fteriles; radii feminei, fub. deni, ligulis ovato-lanceulatis integerrimis, fertiles. Sem. obovata, co. ronata fquama carrilaginea, obcordata, marginibus introrfum conyolutis bifulca.

Melampodium americanum. Tab. 169; fig. 8.

Melampodiun caule ereito, foliis fublinearibus utrinque unidentatis. LiNN. fyfo. veg. 790.

Ex herbario Bankfiano.

REC. planun, paleaceum: paleis oblongis, obtufis, mensbranaceis; interio. ribus gradatin longioribus, ut foris difcus appareat conicus.

SEM. feminis obovata, ab utroque latere comprelfa, fufca : dorfo arcuato ftriato; ventre ad lineam figmoideam curvato \& in aciem attenuato; late. ribus planis, tuberculato fcabris.

Pappis cotyloides, feminis vertici oblique infiftens, pallide ftramineus, formatus ex lamina per maturitatem fubcartilaginea, monophylla, obcordata, ab inflexis marginibus intus bifulca, $f$. mediâ rimà longi. tudinali in duo labra turgidula divifa, l. hyfteromorpha.

IN T. exterius corjaceum, durum.

Em B. obovatus, albicans.

2.) Flos integer, cum fuo pedunculo filiformi fcabro. b) Calyx a parte inferiore fpectatus 2.) Idem cum receptac palcis tedo. d. D.) Flofe. difci fteriles. c. E.) Flofc. femineus. f. F.) Semen maturum integrum. G.) Idem longitudinaliter diffectum, cuar pappi margine ventrali inflexo, atque embrgone in Gitu naturali. 


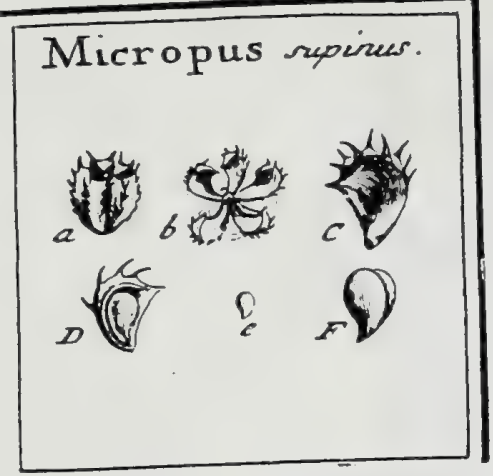

J. Gaertner (1788) Vol. 2

DCCCCXLVII. M I C R O P U S. Linn. gen. 996.

Calyx fimplex pentaphyllus, foliolis galeatis dorfo innocue fpinofis lanatis, marginibus comprel(Ts conniventibus, femina involventibus. Flofc. difci infundibuliformes, quinquefidi, androgyni, fteriles; radii apecali, feminei, fertiles. Thal. nudus. Sem. feminis compreifa, calva.

Micropus fupinus. Tab. 164 . fig. 3 .

Guaphalium fupinum eclyinato femine. PLUk. phyt. t. 187. f. 6.

Micropis caule procumbente, folits gemsinis. LisN. fyft. veg. 796.

REC. anguftifimum, puncticulatum, nudum.

SE M. feminis ubovata; compreffa, glabra; nigricantia, calva, intra calycis foliola abfcondita.

IN T. fimplicifinum, tenuifimum, membranaceum.

EM B. femmi conformis, viridis aut per xtatem fufcus.

a.) Calyx connivens. b.) Idera explicatus cum receptac. C.) Calycis foliolum feparatum, exculfa lana, integrum. D.) Idea apertum eum fitu feminis e.) Semen feparatum. F.) Embr. cenudatus.

Paleas receptac. marginales, quas habet Linnxus, ego fruftra quælivi; \& fufpicor illas uihil aliud effe, quam folivia minutula, quibus calyx ad bafin. obfolete calyculatus eft.

Micropus erextus. Lins.

Calycis foliola 7 - 9. compreffa, lanata, inermia. Thal. fubulatus, in tubercula teretiufcula difcretus, nudus. Semina obovata, calva, calycinis foliolis inclufa. Loeff. it. edit. gerdiz. 225. t. I. f. 3 . 


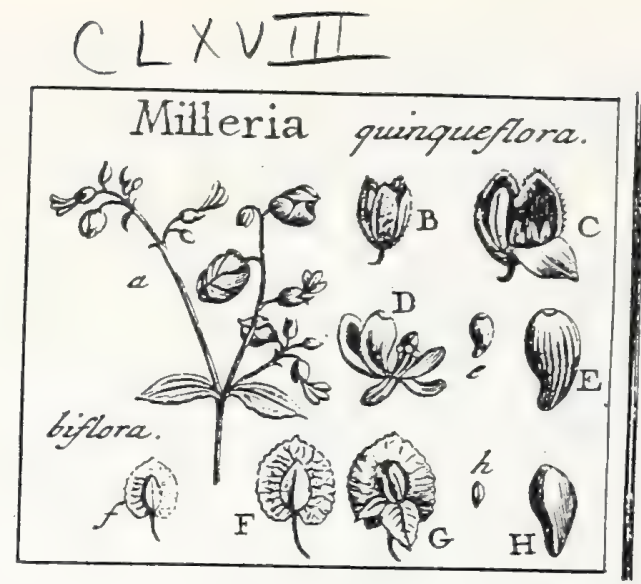

J. Gaertner (1788) Vol. 2:

423

DCCCCXCII. M I L L E R I A. LINN. gers. 985.

Calyx finplex, aut duplicatus : ifte monophyllus, inxqualiter trifidus; hic infuper auctus foliolis quinque inzqualibus, prioris interno parieti accunibentibus: uterque perfltens, femen involucrans. Rec. nudum. Flofa. difci duo vel tres, infundibuliformes, androgyni, fteriles; radii uuicus, ligulatus, femineus, fertilis. Semen calvum.

Míleria quinquetora. Tab. 168. fig. 5.

Milleria amua ereja, floribus fpicusis luteis. MART. cent. t. 47. f. 2 .

Milleria foliis cordatis, pedeanculis dichosomis. Lixs. fyff. veg. 789 .

Milleria calycibus duplicatis. Nob.

PER. nullum, afed calycis exterioris fegmenta, per maturintem arete Gbi mutuo juncta, formant conceptaculum ovato turbinatum, gibbum, coriaceum, nigrum, quod femen claudit, \& fimul interior calycis foliols, quina, membranacea, tenuifrima, oblonga, inæqualia, paleas mentientia, occulanc

REc. anguftitimum, nudum, feu effoctis androgynorum flofculorum ovaris lineari oblongis tectum.

SeM. unicum, fubclavatum, ftriatum, incurvum, fufcum, calvum.

IN T. exterius cruftaceum, craflum, durun, \& fere offeum.

EM B. clavacus, albicans.

2.) Pars cymz florentis \& frugifers. B.) Caly̧x exterior tritidns. C.) Ejusdem lacinix didutux, ut iutcrioris calycis foliola in confpetum veniant. D.) Calyx interior feparatus \& explieatus, sum utu ferinis \& ovarioruin ferilium. c. E.) Seunen maturum feparatum.

Poffent quoque ifta calycis foliola interiora pro paleis haberi, quum \& numero \& diverfic magnitudini ovariorum refpondeant: quoniam vero extra receptaculum pofita funt, atque in altera fpecie peuitus deficiunt, malui ea ad calycem referre.

MILleria bitora. ibid.

Milleria crefta annua minor, foliis parietorie, foribus ex folionrus alis. MIART. cent. t. 47. f. 2 .

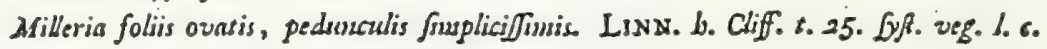
Millevia calycibus funplicibus. Nob.

Calyx (f. F. G.) fimplex, herbaceus, trivalvis: Valvula unica maxima, fubcordaca, crenulata,..cavicate ovali (G.) in medio exfculpta; valuulx duie seliquac multo nirores, lanceolato ovasx: fubxquales, cavisatem valvula

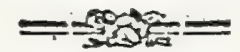

majoris antice claudentes. Rec. nudum, nec ullum palearum veltigium. Semen (h. H.) unicum, oblongum, denrfum acuminatum, fubtriquetrum, e caltimeo rufelcens, glabrum, calvum. Integum. coriaceum. 
Asteraceae

ho erawiog

$$
\begin{gathered}
\text { J. Ofaertren (1788) Volz } \\
453
\end{gathered}
$$

- MU T I S I A. LINN. ger. I42I.

Calyx cylindricus imbricatus. Thal. nudus. Flofc. difci androgyni trifidi radii feminei, ligulis ovati - oblungis: utrique fertiles. Sem. uniformia. Pappus plumofus.

Mutifa Clematis. - LINN. Juppl. 373.

Flos magnitudine \& figura majoris Dianthi caryophylli. Linn. I. c.

19.105 


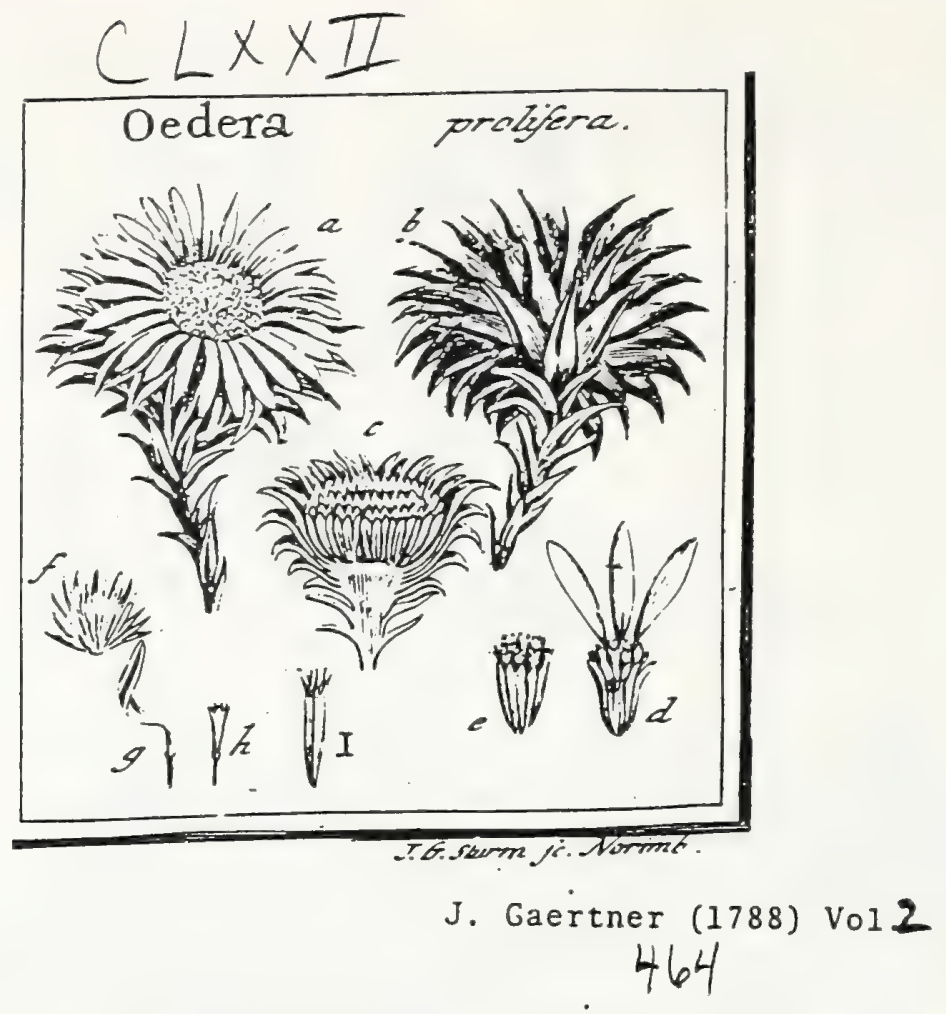

MXLV. OED ER A. LINN. gen. I325.

Calyx comnunis inverfe conicus, fquarrofus, inibricatus Tquanis lanceolatis recurvato - patentibus, lanugine alba ciliatis. - Receptac. utrumgue palezceum. Calyces partiales fubquindecinflor, fubcylindrici, fimplici ferie polyphylli : foliolis fcariofis, oblongis, furfum latefcentibus, apice acu. minatis, nitidis. Mofc. difci androgyni, numerofi; radii feninei, gemini aut terni in calycibus partialibus exterioribus, ligulati: ligulis oblongis integerrimis: utrique ferriles. Sem. uniformia. Pappus paleuceus brevis.

Oedera prolifera. Tab. 172. fig. 6 .

Buplathalinum capenfe. LINN. Sp. pl. 1274. Ber G. cap. 297 .

Oedera folitis lanceolatis oppofitis ciliatis utrinque glabris. LiNN. fj\%. zeg. 796. Ex herbario Bankfiano.

REc. commure planum, amplum, pałeaceum, palcis linearibus fparfis; partiake anguftum, paleaceum, paleis linearibus, deciduis, caly'ce fuo aliquantum brevioribus.

SE 3. uniformia, oblonga, compreffa, obfolete friata, glahra, fpadicea.

Pappus paleaceus polyphyllus, foliolis lineari-acuninatis, tertia feminis parte brevioribus.

IN T. Simplex, meobranaceum

Es в. fenini conformis.

2.) Flos integer. b.) Calyx parte pofteriori (pectatis. c.) Ejusdem fectio rerticatis cua aturnli calyculorum partialium fitu. e.) Calyculus partialis e difco fleris, folis finfeulis antirn zynis ftipatus. d.) Alius calyconlus partialis, e floris radio, tribus fufculis ligulatis femi radiatus. f.) Calyculus partialis ditfectus, cum fuo receptac. palcaceo. g.) Flofe. femineus, cum linula fuz lutex, in Jorfo linca atropurpurea notata. h.) Flofe, androgyaus. 1.) Semen uatusali majus. 


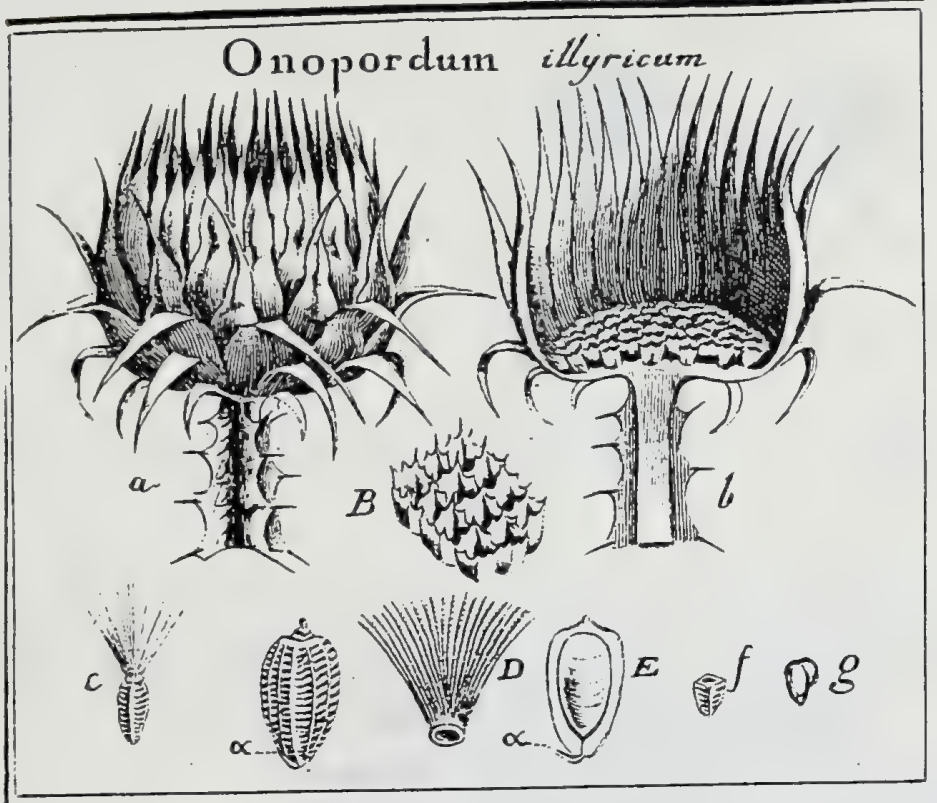

J. Gaertner (-1788) Vol 2

DCCCCXXXI. O N O P OR D U M. VAIll. LIN. gen. 92?:

Calyx ventricofus, imbricatus fquamis oblongis in fpinam fimplicem definen. tibus. Flofe. omnes androgyni. Thal. alveolatus. Sem. coronata pappo pilofo, bafi in anmulum connato, deciduo.

Osopordum illyricum. Tab. 161. fig. I.

Aimthim! illynicums. ВАКR. ic. 50т.

Onopordun calycibus fqueurofus: Jquamis inferioribus uncinutis, foliis lanceolatis pimatitidis. Liss. $\int 3 y$. veg. $7=8$.

ICom. JACe. bort. $t .78$.

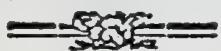

R eC. planun, alveolatum, \& intra fingulum alveolum infuper Palea ftipatum minutula, bafi feninis adharenti \& cum eo decidua.

Sex. obovata, rhombeo compreffa, lineis aliquot longitudinalibus elevatis Itriata \& inter eas rugis obfoletis transverfalibus exarata, cinerafcentia.

Pappus femine duplo longior, caducus, radiis filiformibus, creberrime denticulatis, fubrequalibus, bafi inter $f e$ in annulum conferruminatis.

INT. exterius crafrum, durum, cruftaceum, quafi nucamentaceum.

E M B. femini conformis, albicans.

a.) Calyx integer, b.) Idem diffcaus, eum receptac. B.) Alreali infigniter serti. c. C.) Scmen integrum, exon fua palez (*.) ad bafin. D.) Pappus (eparatus. E.) Sencn apertuin, cum

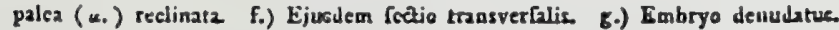

Senina O. Acastbii per fingula puncta prioribus fimillina, faltem paululum minora atque rufefcentia. Palea cum Senine decidua, in hoc genere fingularis eft. 


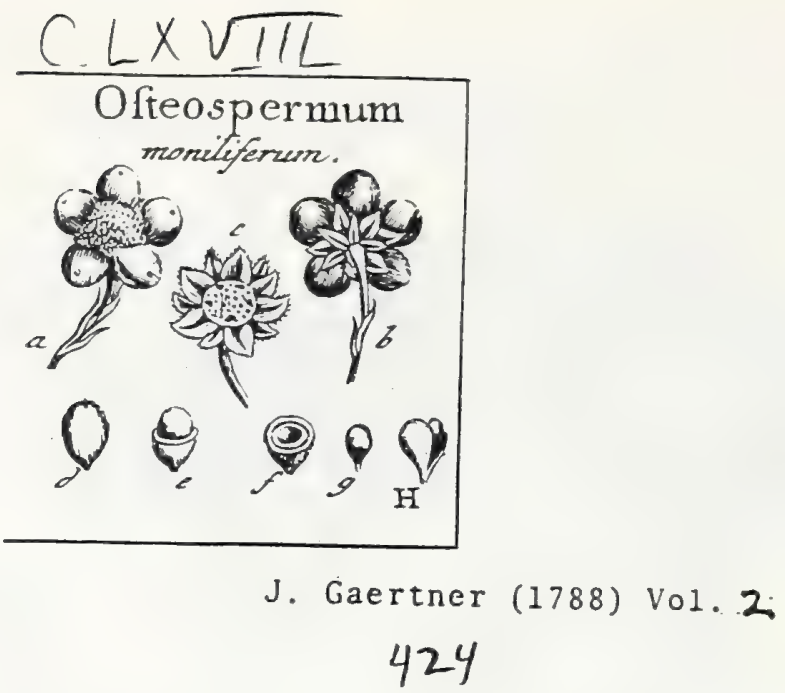

DCCCCXCIII. O S T E O S P E R M U M. LINN. ger. 992.

Calyx finplex aut duplici ferie polyphyllus, fubxqualis. Thal. nudus. Flofc. dijfi androgyni, fteriles; radii feminei, ligulis longis anguftis, fertiles. Sem. baccata zut nucamentacea, calva.

Osteosperinum moniliferum. Tab. 168. fig. 6.

Cbryfantieswoides africansm, populi a!be folits. DiLr. eltib. t. 68. f. 79.

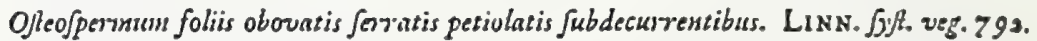

REc. planum, in medio elevato punctatum, in ambitu fcrobiculis parvis pro feninibus feminarum exfculptum, nudum, glabrum.

SEN. feiainis ovatu-globofa, baccata, atro-purpurea, glabra, calva.

In'r. triplex: extimus carnofum, tenue; mediuns cruftaceum, cralfus, durum; intimsum membrausceum, pallide rufefcens.

$E_{M B}$. obovato roftellatus, albus.

a. b.) Calşx maturus ab utragte paste fpectatus. e.) Rieept denudatum. d.) Semen bacea-

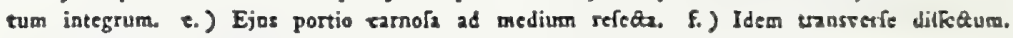
5. H.) Embryo denudatus.

Integumentum carnofum in plerisque fpecicbus deficit, atque femen finpliciter mucament:ceum eft. 


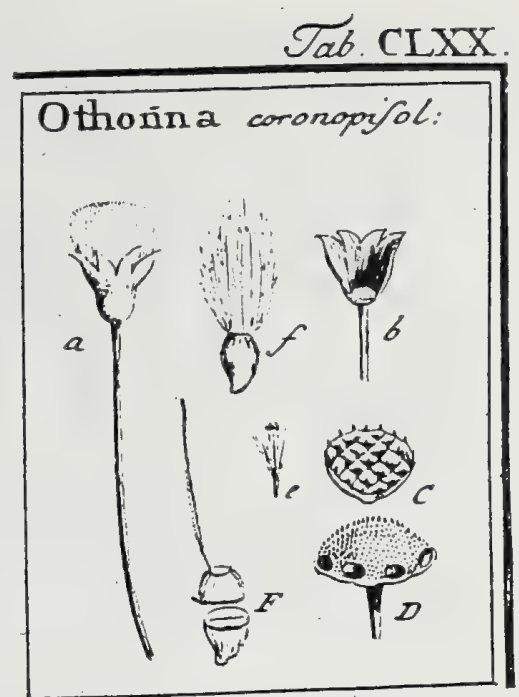

J. Gaertner (1788) Vo1. 2; 452

MXXX. O T H O N A. LINN. ger. 993.

Calyx fimplex monophyllus, nunc apice tantum, \& nunc ad bafin ufque in octo aut plura fegmenta divifus. Recept. in medio villofufculum, ad marginem vero foveis exfculprum. Flofc. difci androgyni fteriles; radii feminei, fubdeni, ligulati, ferriles. Pappus capillaris.

Отнохма coronopifolia Tab. 170. fig. 7 .

Jacobea africana frusefcens, corosopi folio. Coмm: bort. 2. t. 70.

Othoma foliis infimis lanceolatis integerrimis: fuperioribies finuato.- dentatis. LIN. Jyfs. veg. 794 .

REC: anguftum, convexiufculum, in medio alveolatum: alveolorum marginibus breviffime feenceo ciliatis, unde thalsmus villofus apparet; ad marginem vero fex $\perp$ ofto foveolis amplis, feminarum ovaris recipientibus, exfculptum.

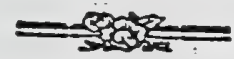

SEM. Seminis grandiufcula, obovata, bafi fubroftellata, ftriata, fericeo:incana. Pappus copiofifimus, capillaris, fericeo-albicans, femine triplo longior. IN T. fimplex, membranaceum, tenue.

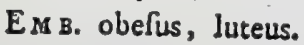

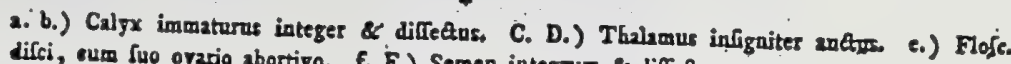
difci, eum fuo ovario abortivo. f. F.) Semen integrum \& diffestum. 


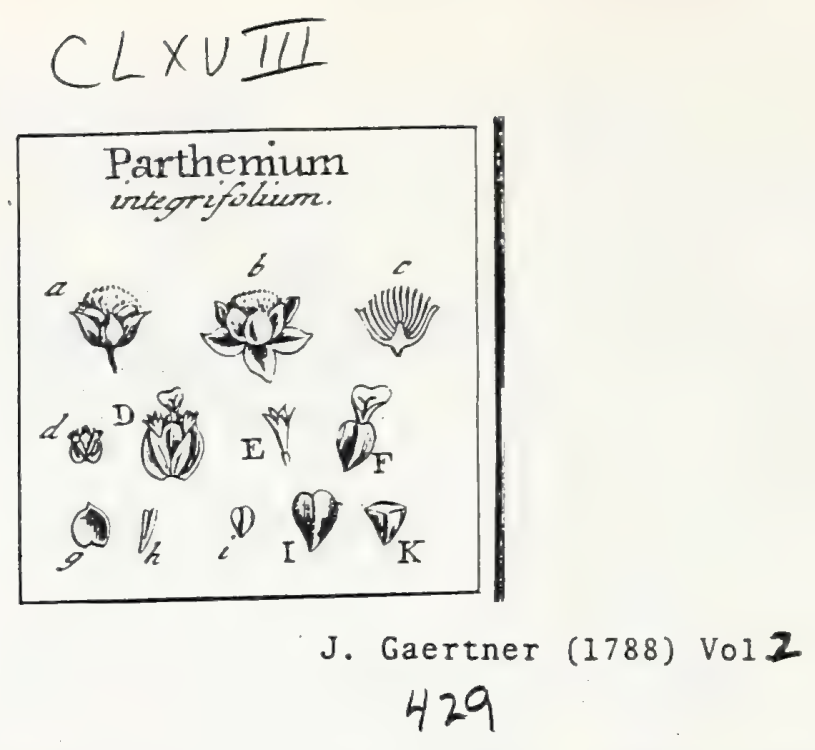

\section{PAR THENI U M. LIN. gen. I05S.}

Calyx hemifphxricus, fimplex, pentaphyllus, xqualis. Tlal paleaceus: paleis difformibus. Flofc. difci plurimi, androgyni, antheris diferetis, fteriles. Radii feminei, quini, ligulis obcordatis, ferüles. Sem. obovata, calva

Parthenium integrifolium. Tab. 168 . fig. \&

Partheniafrum belenii folio. DisL. elsb. to. $2=5 . f .292$

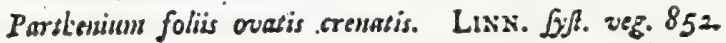

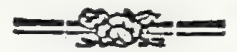

REc. conicum, breve, anguftiffmum, ut fere fubulatum, tectum paleis difformibus. Palex radii quinque, foliolis calycinis fimillimz \& cum iis alternantes, fubrotundx, concava, intus ftipatre fofculo unico feniueo, \& duobus androgynis, ad latera feminx pofitis atque paleả, fingulus fuà, lineari-acuninata, antice tectis. P. difci plurimx, oblongx, furfum la. tefcentes, carinatx, apice emarginatx atque extus furfuraceo - villofx.

SEM. feminis obovata, deorfum infigniter acuminata, compreffe triquetra, gla. bra, nigra, calva.

IN T. exterius coriaceum.

EM B. albicans.

2.) Calyx maturus integer. b.) Ejus foliola reelinata atque palez radii denudats. e.) Tbalami fectio verticalis. d. D.) Palea radii cum tribus fuis fofculis in fitu naturali. B.) Eadem, excurtis flofeulis. E.) Flofe. androgynus. Fo.) Flofe. fearineus, h.) Palea difei, i. I.) Senica integrum $K$ ) Idem diffectum.

Palex iftx grandes, ob formam confiftentiam atque fitum fuum, ad calycem pertinere mihi vifæ funt; quoniam vero Vaillantius, Linnæus atque Juffireus eas pro palens habent, a majorum fententia recedere nolui.

Hanc Sectionem ingrediuntur etiam Silphii quxdam fpecies, feminis corona deftitutex. 

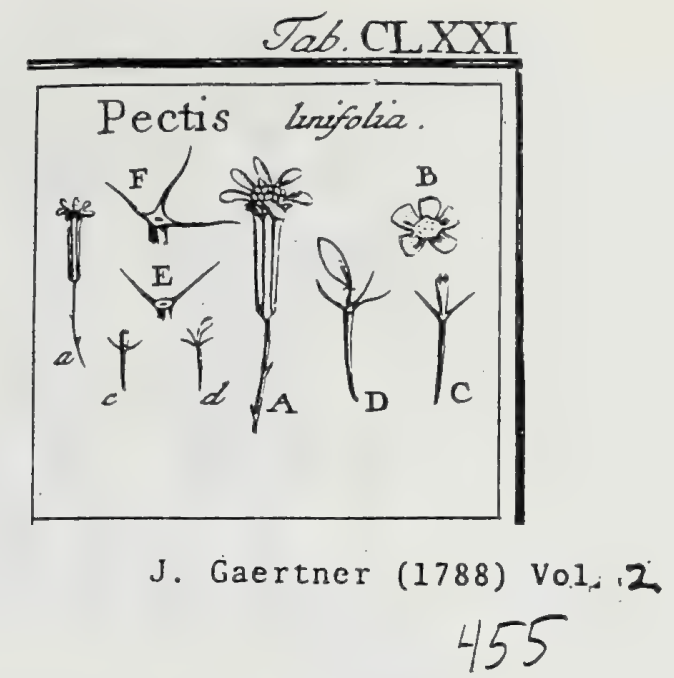

MXXXIV. P E C T I S. LINN. gen. 965.

Calyx fimpliciffimus cylindricus pentaphyllus. Thal nudus. Flofc. difci androgyni, fubquaterni; radii feminei, fubfeni, ligulis integerrimis: utrique ferriles. Semina uniformia. Pappus ariftis duabus aut tribus.

Pectis linifolia. Tab. 171. fig. 6.

456

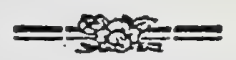

Hieracirm fruticofrum, angufidinis granineis folis, capitulis parvis. SLOAx: bift. jamt. 1. t. 149 . f. 3 .

Pellis foliis linenribus integerrimis utringue levibus. Lixx. 6yft. veg. $77 x$.

Ex herbario Bankfiano.

REC. anguftum, nudum, excavato-punctatum.

S E M. uniformia, linearia, furfum paulo crafiora, compreffa; glabra, nigricantir. Pappus ariltatus: radiis fetaceis, glabris, in feninibus difci geminis; in S. radii ternis, patulis, fubrufefcentibus, tertia feminis parte brevio: ribus.

IN T. exterius fubcoriaceum, tenue.

EM B. albicans.

2. A.) Flos integet. B.) Receptac. pundatum. c. C.) Flofc. difcio d. D.) Flo[c. radit, E.) Pappus biarifatus dirci. F.) Idem triasiltatus radii. 


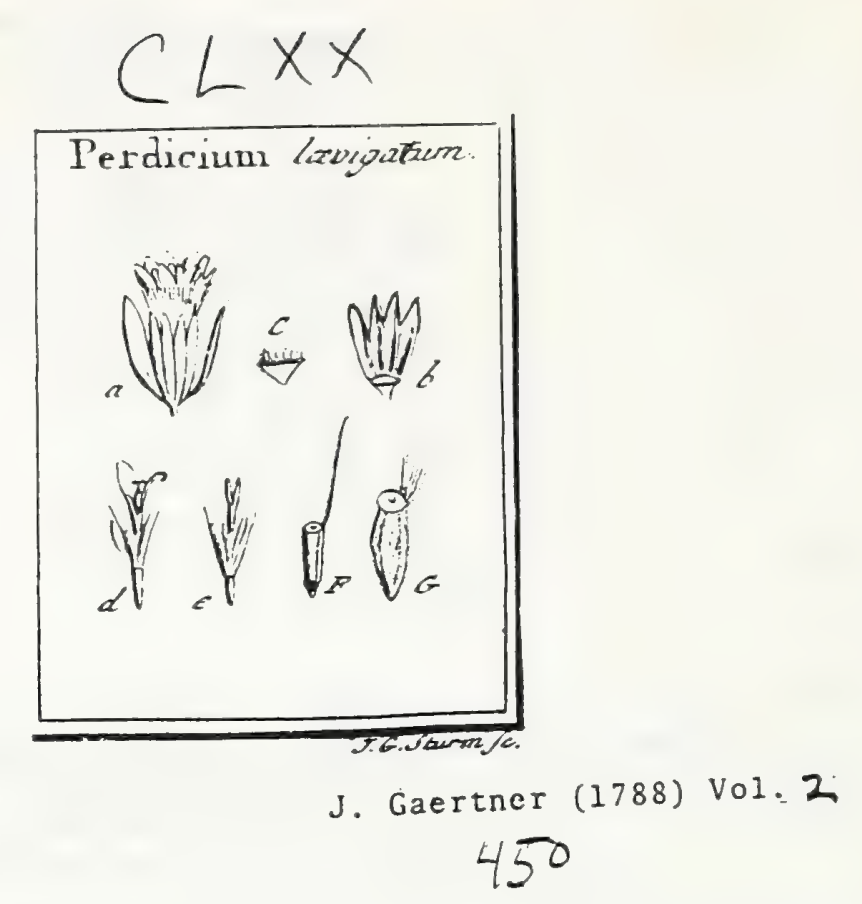

\section{P E R D I C I U M. IIN. gen. 960.}

Calyx cylindraceus, fimplici ferie octophyllus, xqualis; bafi. ficpe foliolis duobus aut quatuor confimilibus fed paulo longioribus ftiparus. Thal brevilime villofus. Flofc. omnes androgyni, bilabiati, fertiles: centrales quaterni aut quini, tubulofi, apice bifidi, latais xqualibus, concavis, integerrinis, extus villofis; radiales octoni, inxqualiter bilabiati: labio exteriore ovato-oblongo, 2.1. 3. dentato, radiante; labio interiore lineari, integerrimo, apice revoluto. Sen. uniformia. Pappus fetaceus, denticulatus.

PERDICIUM lavigatum. Tab. 170. fig. 9.

Perdicium fioribus fubradiatis, caule fuffruticofo, foliis lossceolatis acutis integerrimis. BERG. ad. bolm. 7772. p. m. 228. t. 7.

Ex herbario BankGano.

Rzc. anguftum, planum, denfe \& brevifime villofum.

Szж. uniformia, oblonga, obfolete angulata, fetulis minutiffimis confperfa, fpadicea.

Pappiss. fetaceus, creberrime denticulatus, femine duplo longior.

Is T. fimplex, membrnaceum.

Ear femini conformis.

2) Flos integer. b.) Calyx dimidiatus, cum receptactla. C.) Reeept. fcparatum \& magnitudine audam. d.) Flose. radii. c.) Florc. difci. F. G.) Semen azturali multo majus.

Forma flofculorum, in aliis, alia eft Conf. Linn. l. c. \& Juss. p. $18 x$. 


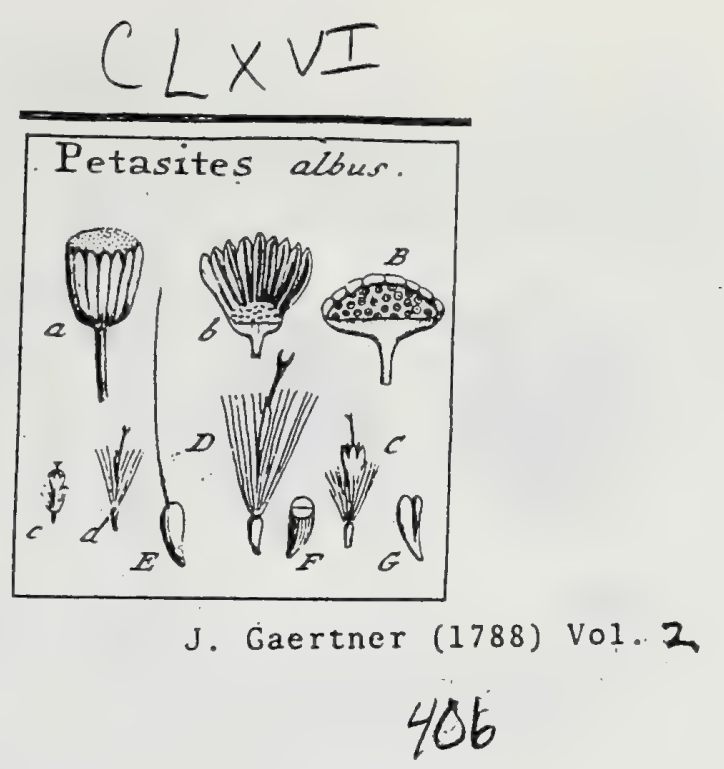

Asteraceae

DCCCCLXXI1. P E T A S I T E S. TOURN. t. 258.

Calyx fimplex, polyphyllus, zqualis. Flofc. nunc omnes uniformes andro gyni, nunc difformes: difci infundibuliformes quinquefidi androgyni; radii filiformes edentuli feminei: utrique fertiles. Thal. nudus, elevato-punctatus. Pappus capillaris.

Petasites albus. Tab. 166. fig. 2.

Petafites flore albo. CAM. epit. 593 OED. flor. dan. t. 524.

Tuffilago thyrfo fafigiato, flofculis femineis mudis pancis. LiNN. fyft. veg. 755.

REC. planum, punctis grandioribus difitis elevatis confperfum, nudum.

SEM. uniformia, teretiufçula, deorfum acuminata, ftriata, glabra, rufefcentifpadicea.

Pappes capillaris, minutiffine denticulatus, femine triplo — \& in feminis quïtuplo Jongior.

IN T. fimplex, membranaceum.

ED1 B. albicans.

a.) Calyx integer. b. B.) Thal. denudatus, c C) Flofc. difci. d. D.) Folc. radii. E. F.) Se. men integrum \& diftectum. G.) Eubryo denudatus.

Genus bifrons, accedente radio mutatur in Tufilaginesx.

9.113 


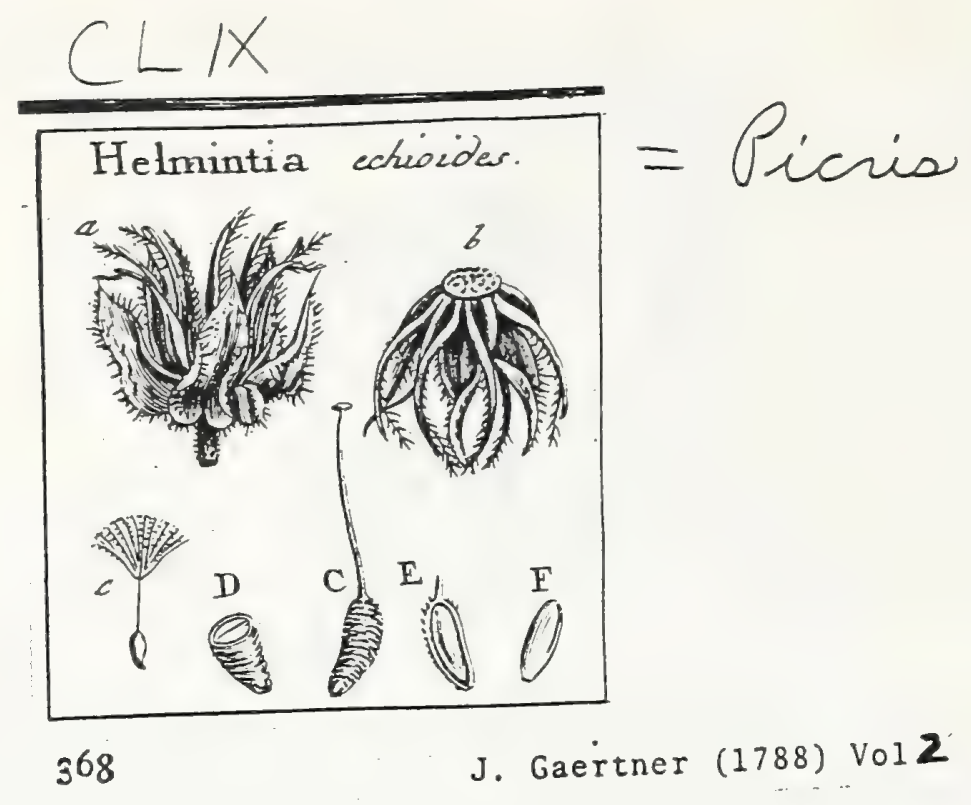

\section{DCCCCXIX. H E L M I N T I A. Juss. p. rךo. Helminthotheca. VAILL.}

Calyx fimplici ferie volyphyllus, nunc latioribus foliis involucratus, nunc vero brevioribus fquamis bafi calyculatus. Thal. mudus; tuberculatus; aut fcrobiculatus. Semina transverfim Itriata. Pappus plumorus ftipitatus, ftipite \& radiis filiformibus.

Helmintia echioides. Tab. I59. fig. 2.

Hieracium capitulis casdus benediafi. Вачн. bif. 2. p. 10=9.

Picris periantbiis exterioribus pentaplbyllis, interiore arifato majoribus. LINN. fyft. veg. 7 Ir.

REC. planun, tuberculis $\int$. papillis minimis confperfum, nudum.

SEN. obovata, brevia, rugis obfuletis fubundulatis transverfalibus exarata, ex aurantio -rufefcentia.

Pafpres plumofus, fericeo albicans, radiis filiformibus xqualibus longitudine ltipitis. Stipes feraceus, femine duplo longior.

IN T. duplex: utrunique membranaceum.

EM B. ovato oblongus, pallide viridis.

2.) Calyx eum involucro. b.) IJem reficxus \& thalamus denudatus. c. C.) Senien integrum.

D. E.) Ejustera fedio transycralis atgue longitudinalis. F.) Einbryo devilatus

Helnintia Sprengeriana.

Hieracinn fprengerinnuth Liss.

Thaldanus ante plenam maturitutem alveolatus. Semina transverfim fulcata of Jimie adinftar dencate $\int$ f fabrati. Pappus ftipitatus plumofus. Alciox. liif. ped. 221. 


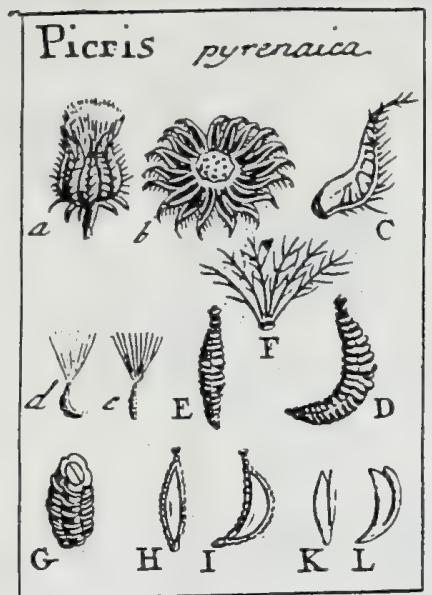

\section{J. Gaertner (1788) Vol, 2 ; 366}

DCCCCXVII. P I C R I S. JUss. p. I70. LinN. gen. go7.

Calyx fimplex, polyphyllus, xqualis, bafi fquamis brevibus calyculatus. Thal. excavato punctatus. Pappus plumofus, fubfeflilis: radiis omnibus filiformibus.

PICRIS pyrenaica. Tab. 159. fig. 2.

Helminthotheca bijpidofa pyreraica, blattarie folio. VAILL. aif. gall. 1721. p. 118. 732.

Hieracium pyrenaicuns. Lisw. fy/t. veg. 718.

REc. planum, ubfolete fcrobiculatum, glabrum.

SEM. teretiufculn, utrinque attenuata, ftriis quatuor longitudinalibus depreffis in totidem quafi valvulas divifa, infuperque rugis transverfalibus crafles muricata, rubro-ferruginea: narginalia curvata; centralia recta.

Pappus plumofus, fubfeffilis, femine longior, caducus : radiis omnibus filiformibus, xquabiliter barbatis.

IN T. duplex: exterius crafum, fuberofo-coriaceum; interius nembranaceum, tenuifTinum.

Eмв. Semini conformis, albicans aut fublividus.

a.) Calsx maturus, torofus. b.) Idem demum patentifiınus, eum seceptac. Serobieulato. C.) Foliolum calycinum fcparztum. d. D.) Semiura marginaliz. e. E.) Semina centralia.

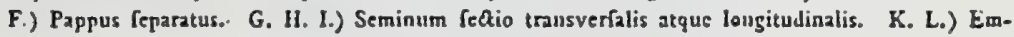
bryo Teparatus.

Picris bieracioides. LINN.

Receptac. planum, foveolis fubpentagonis neutiquam profundis exfculptum \& intra eas papillula minuta infignitum. Semina unifornia, oblonga, teretiufcula, utrinque attenuata, ftriis longitudinalibus atque transverlalibus minutim cancellata atque fcabrata, nullis futuris lateralibus inferipta, helvola aut cinnamomea. Pappus feffilis, plumofus, femine duplo longior: radiis filiformibus, xquabiliter bar'attis.

A Virea, radiis pappi unifornibus, \& ab Helmintia, pappo non manifefte Itipitato differt. 


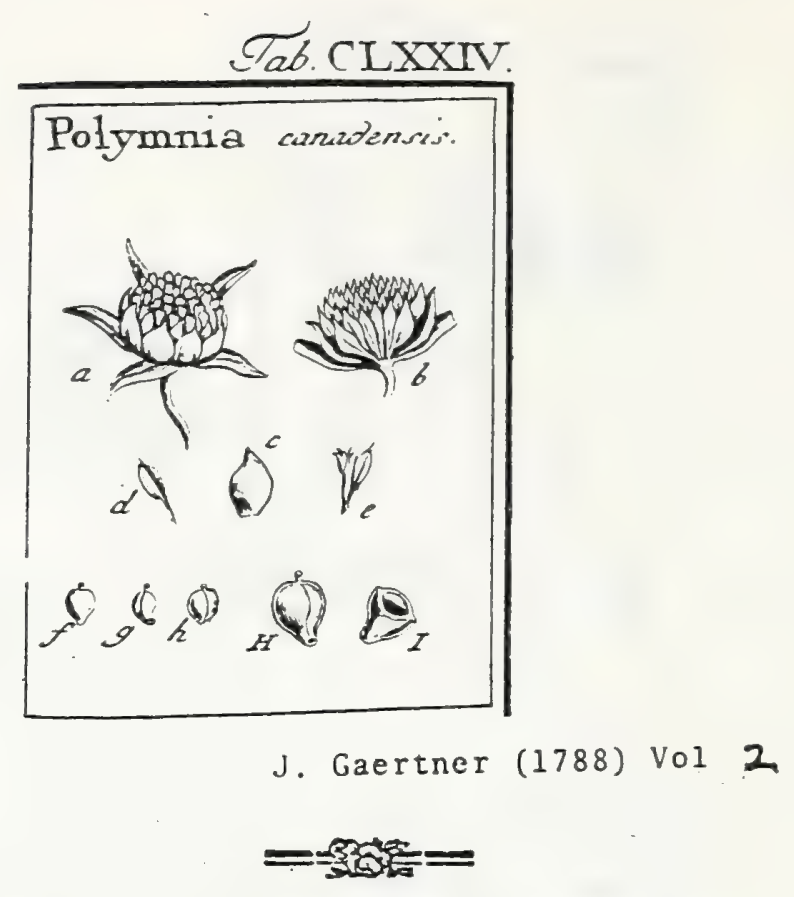

\section{P O L Y M I A. LINN. ger. 987.}

Calyx fimplex pentaphyllus patens: foliolis oblongis, acuminatis, fore prulo longioribus, extus fcabris, intus a bafi ad medium lavigatis albicantious. Thal. palexceus : palcis difformibus. Flofc. difci androgyni, plurimi, Iteriles; radii feminei, quini aut deni, ligulis ovatis tridentatis, ferciles. Sens. obovata, gibba, calva.

Polyinia canadenfis. Tab. 174. fig. 2.

Poly:lnnial foliis alternis bafuta - frnuatis. LINN. amoen, acad. 3. p. J5. B. I. f. 5. Jyll. veg. 790 .

\section{A Cl. Thundergio.}

REC. planum aut modice concavum, palenceum : paleis membranaceis, tenuiffinis, difformibus: extimis (qux calyx interior Linn.) denis, ovatis, acuminatis, concavis, feffilibus, dorfo feminarum accumbentibus; interiori: bus minoribus, lanceolatis, fubcarinatis, in pedunculum attenuatis, bzfi ovariorum fterilium adnatis.

SEM. feminis obovata, turgidilfme lenticularia, ad latern in anguftifimum marginem attenuata, \& in ventre linea longitudinali elevata notata, dura, e teflaceo - fufca, apiculo capitellato in vertice terminata, cetera autem perfecte calva.

IN T. exterius nucamentaceum, durum, fragile.

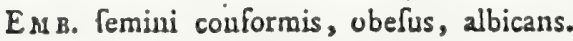

balyx matrius, eum foleulis difci perfiftentibus. b.) Recept paleaceras c.) Palea mJi. d.) Palea difci. c.) Flore andrugjnus cum fua palez. f. g. h. H.) Semen maturam integrum, $x$ dorlo, latere \& ventre fpectatum. I.) Tefta feminis tmarrerlims Sedx

Cum extimx receptaculi palex, nihil quidquam a reliquis, proter fulam majorem fuam Jatitudinem differant, eas tanto minus calyci annumerandas cenfemus, cùm vel ipfe Linnzeus, fimillimas Chryfogoni \& Parthenii. fquamas, non calycis, fed receptaculi partibus annumeraverit. 

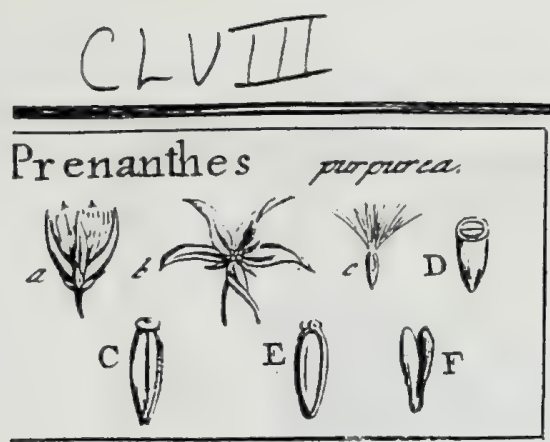

\section{J. Gaertner (1788) Vol 2 \\ 358}

DCCCCVIII. P R EN A N THE S. VAILL. LINN. ger. gri.

Callyx fimplex, cylindraceus, fubpentaphyllus, fubquinquetorus, bafi fquamis aliquot brevilfinic calyculatus. Thal. glaber. Pappus capillaris, fef-
filis, mollis, femine longior.

Prenanthes purpurea. Tab. Iss. fig. I.

Sonchus levior pamonicus IV. propureo flore. CLus. biff. 2.' p. 147.

Sousbus montanus purpureus tetrapetalos. COL. ecpir. r. p. 244 t. 246.

Prenauthes fiofculis quinis, foliis lanceolatis denticulatis. LiN. Syft. veg. 716.

Icoss. Jace. auffr. t. 307 :

R E C. anguftifimum, papillofum, glabrum.

SEM. oblonga, inferne attenuata, obfolete angulata, ftriata, pallide ftrminea.

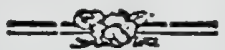

Pappris feflilis, caducus: radiis capillaribus, numerolis, fericeo-albis, parce denticulatis, femine fesquilongioribus.

IN T. duplex: utrumque membranaceum.

EM в. albicans. Cotyl. oblongx. Rad.teretiufcula.

2) Calyx maturue b.) Idem explicatus cum receptac. papillis. c c.) Semen integrama

D. E.) Idem diffectum. F.) Embryo deaudatus,

A Chondrilla differt potifimum pappo non ftipitato. 


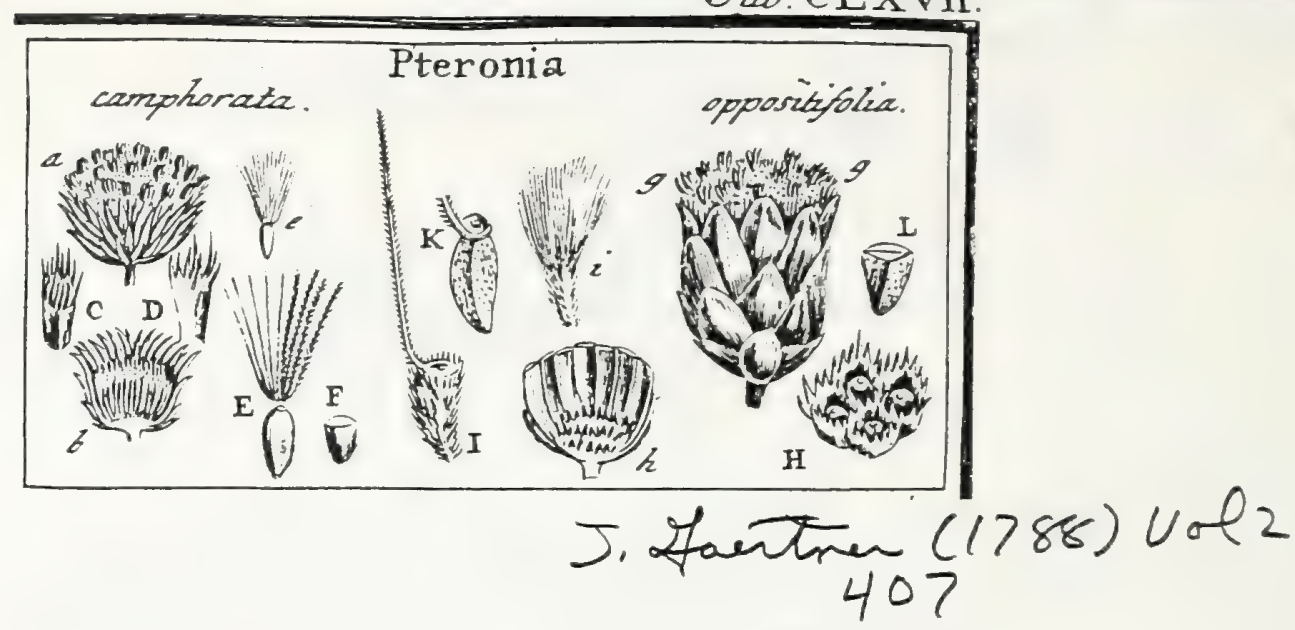

\section{DCCCCLXXIV. P T E R O N I A. LINN. ger. 937.}

Calyx oblongus, imbricatus fquamis inzqualibus. Florc. uniformes, omnes androgyni. Thal. alveolatus, alveolorum narginibus palcaceis multifidis. Sem. uniformia. Pappus feraccus, Late ciliatus, f. fubplumofus.

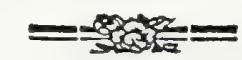

Pieronia camphorata. Tab. 167. fig. 2.

Conyza aromatica frutefcens mauritanica, camplorata foliis ad margines pilofu, flore magno aureo. PLUK. phyt. t. 345. f. $56 . n$. 2.

Pteronia foliis $\int \mathrm{f} a \sqrt{\mathrm{s}} \mathrm{b}$ bafl ciliatis. LINN. $\int y / t . v e g \cdot 737$.

REC. planum, alveolatum, alveolis paleaceis, profundis, apice lacero-fetaceis, rigidiulculis.

SEM. ovato-oblonga, lenticulari-compreffa, glabra, fubcaftanea aut ferruginea. Pappus femine duplo longior, cirrinus, caducus: radiis fliformi - feta ceis, utrinque longiufcule ciliatis, $f$. fubplumols, bafi in anuulum conuratis.

IN T. exterius coriaceun, tenue.

EM B. albicans.

a.) Calsx integer. b.) Thalamus paleaceus. C. D.) Aveolus inteģer \& lang:tadinaliter apertus. e. E. F.) Semen integrum \& dilfeetum.

Pteronia oppofitifolia. ibid.

Cyanus centanoides frutefens, lavendule folio. BREYN. prodr. t. 17. f. 3 .

Pteronia foliis oppofatis, ramis dichotonis divaricatiso LiNN. J3y. veg. 737 .

Ex herbario Bankfiano.

Flos (g.) e grandioribus hujus ordinis atque generis. Calyx cylindricus, inıbricatus fquamis cartilagineis, lrvibus, apice fubpubefcentibus, margine memuranaceo-attenuatis. Thal. (h. H.) alveolatus: alveulorum marginibus breviffmis, lacero - fetaceis, mamnillam depreffam includentibus. Semina oblonga (i. I. K.), rhombeo-compreffa (L.), hirfuta, fericeo alba. Pappus (1.) fetaceus, rigidus, fublutefcens: radiis numerofifimis, fubplumofis, femine duplo longioribus, ejusque vertici (K.) arcte adnatis, nec in anuulum coeuntibus.

Mluitum utique affinitatis habet Pteronia cum Capisatis, ut eis quoque annumerata fuerit a Cel. Jussieu; fed propter folia oppofita aut fere accrofa, \& recepiac. non in umnibus manifefte paleaceum, fuum quoque inter Difcoideas locum tueri polfe videtur. 


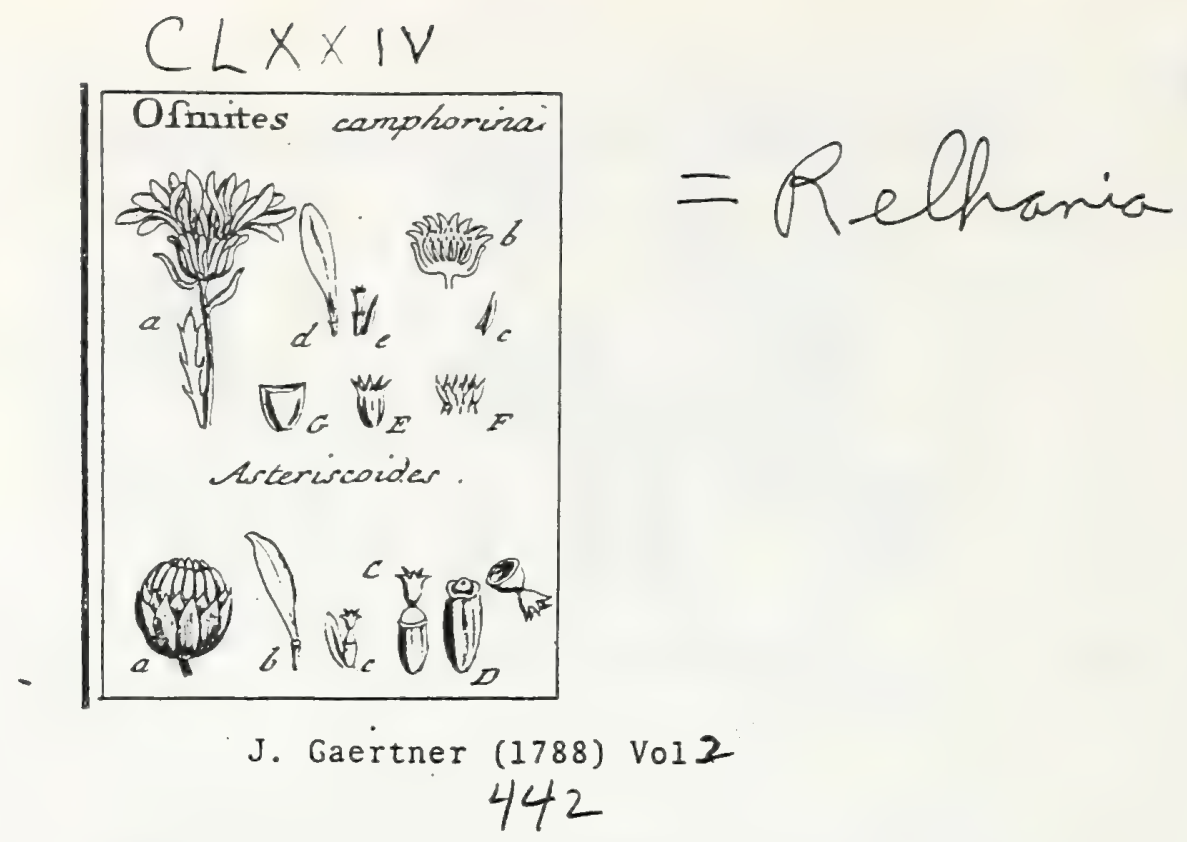

Asteraceae

\section{O S M I T E S. LINN. gcn. 993.}

Calyx imbricatus, foliolis fariofis aut herbaceis. Thal. palcaceus. Flofc. difci antrogyni, fertiles; radii neutri aut feninei, ligulis lanceolatis integerrimis, Iteriles. Pappus paleaceus polyphyllus brevis, aut margo edentulus.

Os.utres camphorina. Tab. 174. fig. 3 .

bellis camphorifera africana aquatica, flore albo. SEB. thefaur. 1. p. 343.t. g0: f. 2. Osurites foliis lanceolatis fubferratis bafi dentatis. L1NN. fjyl. ieg. 783 .

A Cl. Thunibrgio.

REC. fubconvexum, paleaceum : paleis lineari-oblongis, concavis, calyce paulo brevioribus, $f$. longitudine flofculorum difci.

SEM. androgynis parva, ovata, utrinque in marginem obfoletum attchuata; hinc convexiufcula, obiter fulcata aut ftriata, inde plana; pallichis.

Pappus padeaceus, polyphyllus: foliolis dinidio femine brevioribus, acunimatis, integerrimis aut denticulatis.

I $\mathrm{T}$. fimplex, membranaceum.

E M B. albicans.

2) Flos daturus integer. b.) Calyx diffeans, eum receptaculo, c.) Palea feparata. d.) Flofc. radii neuter. e.) Flofe. difci fertilis. E.). Scmen unagnitudine auetum. F.) Pappus grandefatur G.) Semo diftêtum.

Osmites Afterifcoides. ibid.

Lencaulienum fruticofum camploratum, foliis crafsis angufis actitis. BuRx. afr. 161. 6. 58. f. x.

Osmites foliis lumceolatis pumfatis, caulibus foliofis. LINN. l. c. BERG. car. 305 .

A Cl. Thushergio.

Calyx (a.) hemifphacricus, duplici ferie polyphyllus, foliolis herbaceis, acuminatis, fubequasibus, extus pubefcentibus. Thal. planiufculus, paldeiceus: paleis (c.) longitudine fiofculorum difci. Flofc. salii (b.) ncutri, Jisuis ovato lancioluts, integerrimis, Juteis. Flolc. dilci (c. C. D.) androgymi,

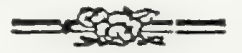

tubulofi, fertiles, cotollulis per maturitatem bafi fornicatis in calyptran hemifphxricam (D.), incraffato fpongiofam, verticem feminis obtegenten. Senina androgynis oblonga (C. D.), hinc convexiufcula, fulcata, inde plitua, e caltaneo fufca. Pappus nullus, fed ejus Joco margo fubundulatus, integerrimus, a calyptra corollule tectus, cingens papillulam albicantem brevem in ipfo feminis vertice poltam.

Multis numeris hxc polterior Osmitis fpecies a priori differt, ut proprium ex ea confici poffet gemus. 


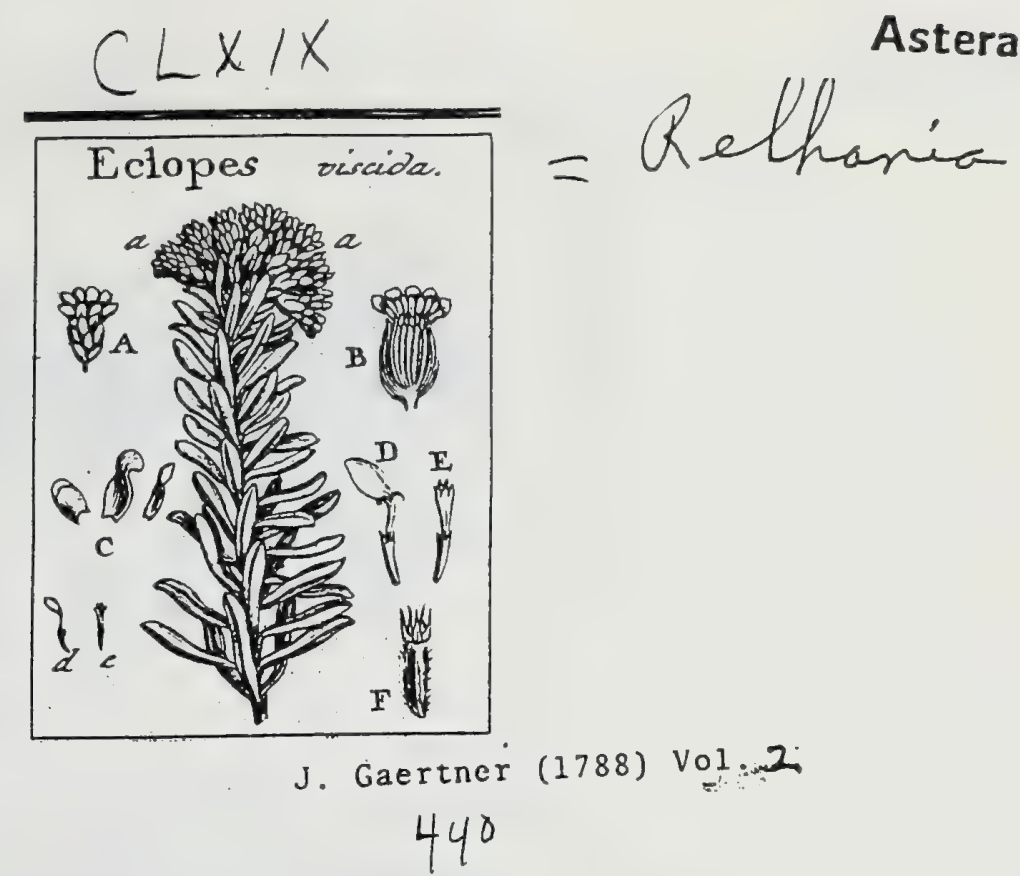

\section{E C L O P E S. BANKS.}

Calyx ovato - oblongus, imbricatus fquanis cartilagineis appreffis, apice appendiculatis fcariofis. Thal. paleaceus. Flofc. difci androgyni; rudii fenninei, ligulis ovato - lanceolatis integerrimis: utrique fertiles. Pappus foliulis quinis aut paucioribus, brevibus.

ECLOPES vifcida. Tab. 169. fig. 2.

Ex herbario Bankfiano.

REc. anguftum, paleaceum: paleis lineari oblongis, acutis, calyce paulo brevioribus.

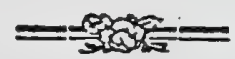

S E M. uniformia, oblonga, angufta, compreffa, fubillofa, ferruginea.

Pappus pentaphyllus, foliolis paleaceis, acuminatis, fenine dimidia brevioribus.

IN T. fimplex, nembranaceum.

EM B. fenini conformis, albicans.

2. 2.) Ramulus cum corymbo deflorato. A.) Carbx integer. B.) Idem diffectus cum pakeis receptac. C.) Calycis (quamulx, naturalibus majores, feparatx. d. D.) Flofc. femineus. ( E.) Flofe. androgynus. F.) Semeu.

Eclopes buxifolia. Ex eodem herbario, habet pappum tri - 1. tetraphyllum, brevifiunum.

Genus Athauafix affine, ut nihil Git aliud quam Athanafia radio larvata. 


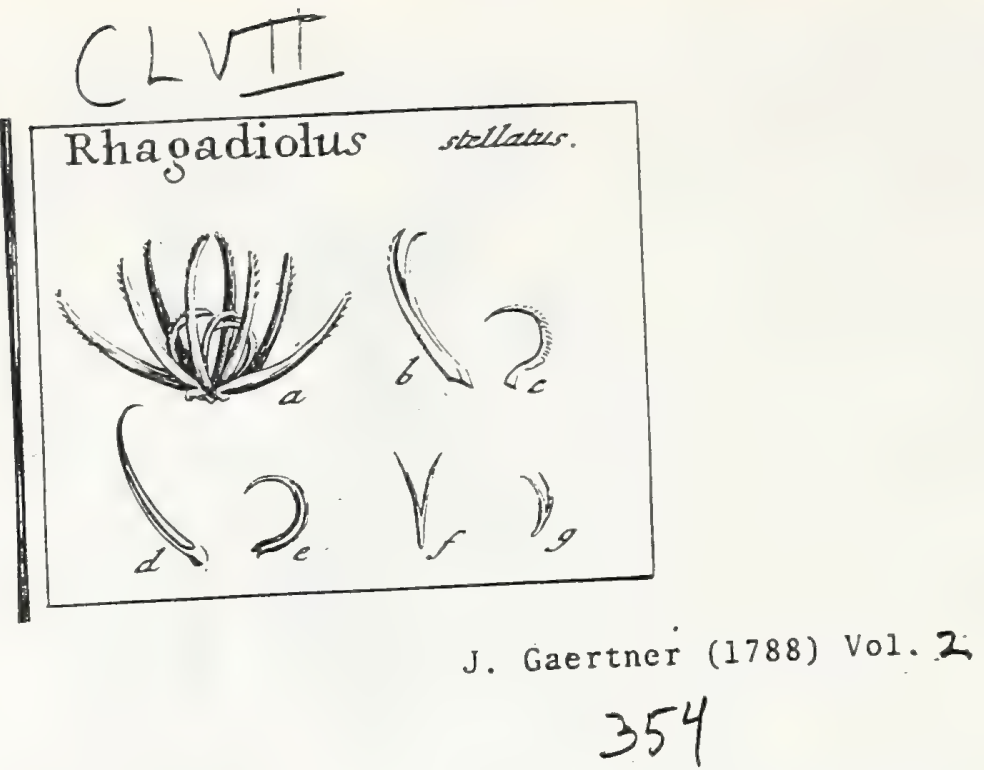

Asteraceae

DCCCCII. R H A G A D I O L U S. TOURN. t. 272.

Calyx fubdecaphyllus, foliolis duplicis feriei, perfiftentibus \& per maturitatem femina involventibus. Sen. calva, fubduffurmia, involuta, a recepta. culo non fponte fecedentia.

Rhagadrolus ftellatus: Tab. 157. fig. 2.

Hieracium frellatım. Baun. bijl. 2. p. 19 is.

Lapfuna calycibus frufurs undiyue putentibus: radiis fubulatis, foliis caulinis lanceolatis indizifis. LiNN. Jy jt. veg. 722 .

REC. nudum, anguftifimum, ut vix ullum.

SEM. fubulata, calva, involuta, fubdifformia : riddii octona, longiora, patentillima, leviter arcuata, extus fub apice denticulato-aculeata; difci gemina aut terna, falcata, minora, per totum dorfum fetulis rigidis retroverfis exafperata.

IN T. duplex: exterins a calyce acceflorium, fuberolum aut coriaceum, craffum; intesius proprium, membranaceum, tenuilfimum.

E as B. fubulatus, pallide viridis. Cotyl. acuminatx. Kad. conica, craffa, non difcreta.

2.) Calyx naturas integer. b. c.) Semiaa feparata. d. e.) Crufa feminum longitudinaliter aperta. f. 5.) Embrgo denudatus.

Rhagadiolus edulis.

Ribagadiohs edulis, bieraciis affinis. BAUK. bif. J. c.

Lapfana Rhagadiolus. LiNs. I. c.

Semina mdii fere recta, tota glabra, apice Tpinula incurva termunta. Sem. difci falcata, raris villis pubefcentia aut lavia.

Non poffunt Rhagadioli femia jure inter difformia reponi, quoniam eorut difformicas mere accidencalis elt atque ab involucro calycino proficifcitur. 


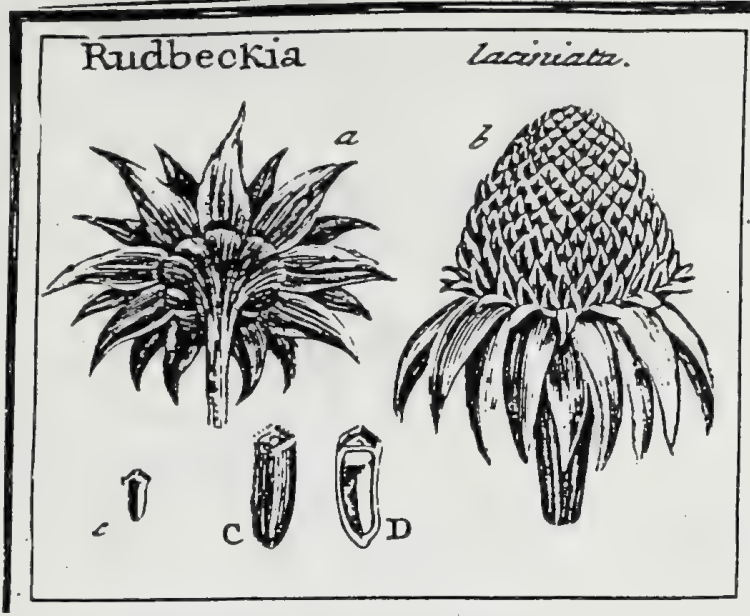

\section{J. Gaertner (1788) Vol 2 435}

MVII. R U D B E C K I A. LINN. gen. 980.

Calyx planiufculus, duplici 1. triplici ferie polyphyllus, per maturitatem rettexus. Rec. conicum, paleaceum. Flofc difci androgyni, fertiles: radii feminei, ligulis oblongis peadulis, Rteriles. Sem. oblonga, margiue brevi coronaza.

RUBвECKin laciniata. Tab. 172 fig. I:

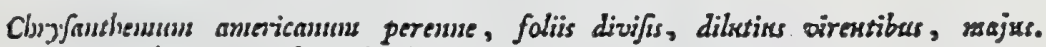
Moris. hiff. 3. S. 6. t. 6. f. 53.54 .

Rudbeckia foliis compofitis laciniatis. LINN. JSf. veg. 782 .

REC. conicum, paleaceum: paleis oblongis, carinatis, interdum coloratis, de: ciduis.

SEN. andronynis columstaria aut inverfe pyramidata, tetragona, tenuiftime Itriata, e luteo-fpadicea, coronata margine brevi, integerrimo, crenulato.

INT. exterius coriaceum, durum.

Es B. albicaus.

2) Calsx a parte inferiore fpetatus, b.) IJem maturus deflexus, cum recept paleis seda. c. C.) Serasen integrum. D.) Idem diftetum, cum eunbryonc.

Dantur fpecies, ut R. bijta, in quarum feminibus maturis wasgo obfolefeit vel \& plane deficic. 


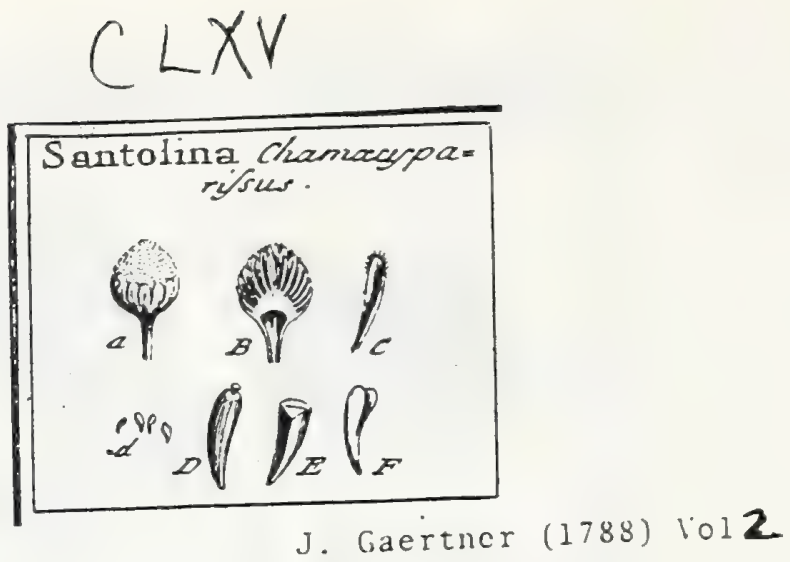

DCCCCL. S A N T O L IN A. TOURN. ז. 260. LINN. gers. 942.

Calyx hemifphxricus, imbricatus fqumis oblongis apprellis inxqualibus. Flolic. ommes infundibuliformes, quinquesti, androgyni, fertiles. Tha! paleaceus. Sem. oblonga, calvia.

Santolina Chamacyparilfus. Tab. 165 . fig. 1.

Abrotmmil femina. BESL. Eyjl. aj?. XIV. t. 7. f. 5. BLAKw. bert. t. 376.

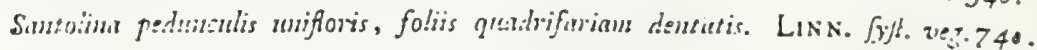
REC. convexum, undique tectum paltis ublongis obtu.is carinatis apice externe pubelccntibus.

SEM. oblonga, deorfum acuminata, fupra obtura, angulata, obfolete ftriata, pallida, calva, apiculo obtufo terminata.

Is T. utrumque membranaceum.

EM B. Femini conformis, albicans.

a.) Calyx integer. B.) Idem diTectus, cum receptac. C.) Palca recept. (eparata. 4. D. E.) Semen intcytum \& diffeaum. F.) Embryo dentudatus.

Calcan oppofitifolian \& Amellum LiNe. rectiffime ad Santolinam priden retulit

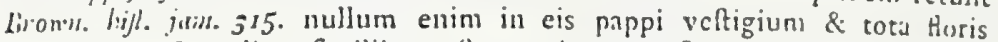
conformatio Santolinc fmillima eft: quod autem foliis abludant, id chioriskteri generico officere nequit. 

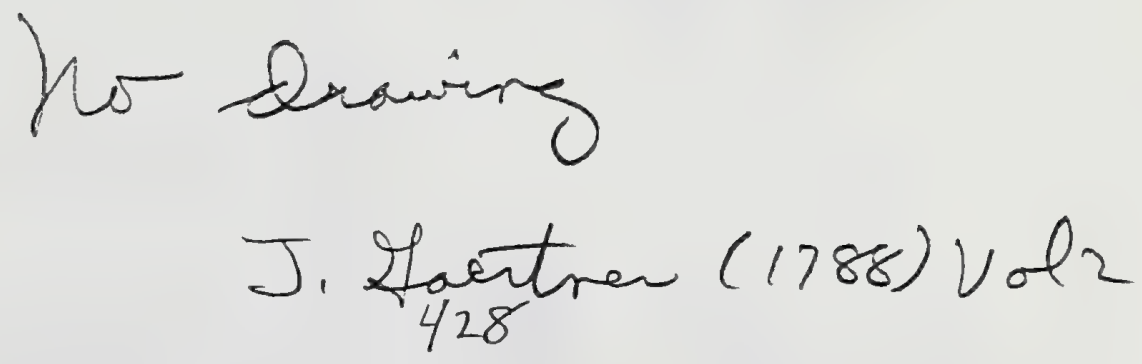

\section{S C L ER O C A R P U S. JACQ. JUSS. p.i86.}

Calyx fubhexaphyllus, foliolis duobus l. tribus exterioribus majoribus, caulinis finilibus ; interioribus tribus parvis, fquamiformibus, flofcutis ligulatis appofitis. Thitl. paleaceus: paleis perfilfentibus, indurefcentibus, acuminatis, hinc rotundatis ventricofis, inde conduplicato - cansliculatis, femin involventibus. Flofc. difci fuboctoni, androgyni, ferciles; ratdii pauciffnni, unus l. quatuor, neutri, ligulis fubtutegris, brevilfinis. . Semina calva. (Ex Juss.)

Sclerocarpus africanus. JACQ. nov. al. betv. x. p. 34. t. 2. LiNs. Jyf. veg. 783.

Senina dimidiato obovata, deorfum infigniter anguftata, nigra, ntida, calva. Jincq. l. c.

Huic Sectioni fe fe intrudunt nownullix Rudbeckis \& Helisulbi fpecies, femiuum diademate deftituric. 


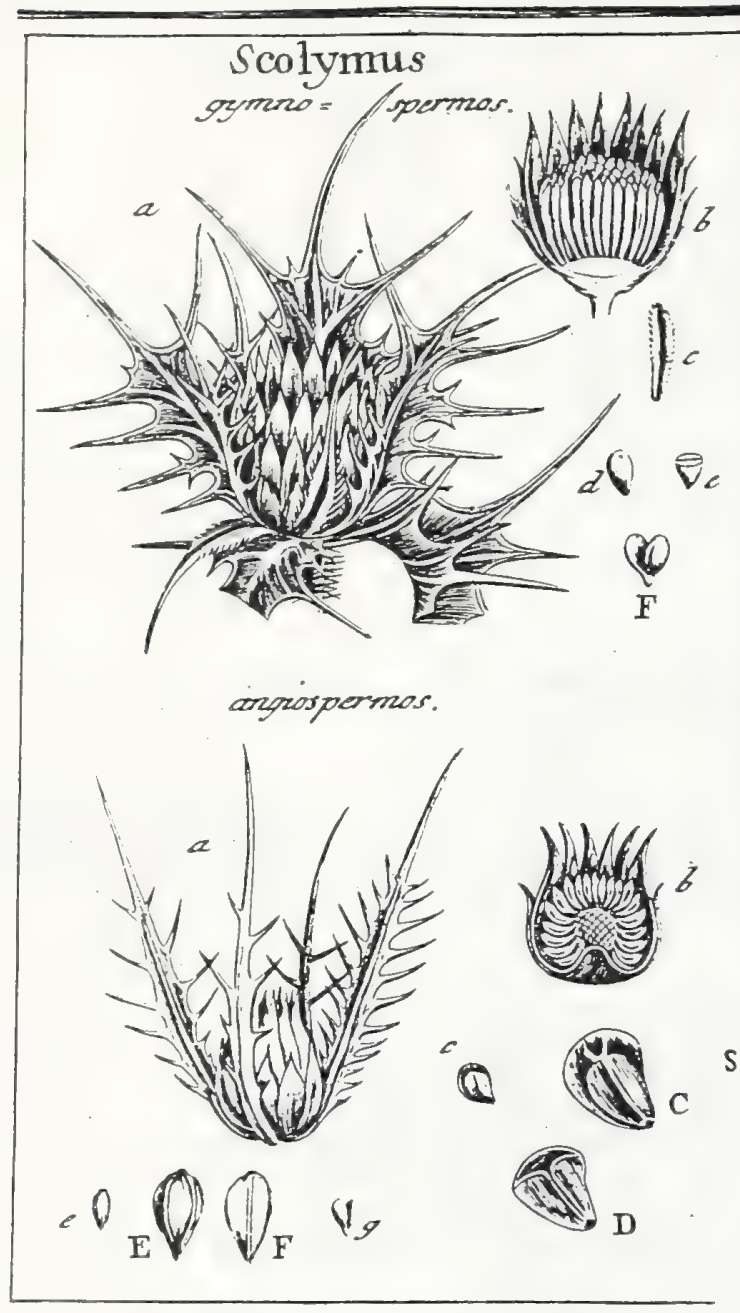

Asteraceae

J. Gaertner (1788) Vol. 2

355

DCCCCIV. S COL Y MU S. TOURN. t. 273. LINN. gers. 922.

Calyx polyphyllus, imbricatus fquamis rigidis acuminatis pungentibus. Thal. convexus palenceus. Semina calva.

Scurymus gymnolpermos. Tab. 157. fig. 4 .

Scolyanes theoplirafit marbonenfis. CLus. bifs. 2. p. 153.

Scolyunes bifpanicus folits margine incrafasis. LINN. Jp. plo 1143. MILL. is. 2. $2=9$.

Scolymus maculatus floribus folitariis. LiN . [vft. veg. 722 .

Rec. leviter convexum, ut fere planum, tectum Paleis oblongis, carinatis ciliatis, femine anguftioribus.

SEs. calva, ovats, glabra, lucida, pallide ftraminea aut rufelcencia.

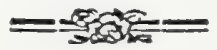

In T. duplex: exteriss coriaceum, craffufculum, durum; interius membraina. ceum, tenue, pallidurn.

EsB. femini conformis, albus. Cotyl. ellypticx. Kad. acumisats, non difcreta

2.) Calyz maturus integer, b.) Idem diftedus, cum receptac. paleaceo. c.) Palea feparata, a parte fua concava fpectata. J.) Semen integrum. c.) Ideon dilfectum. F.) Embryo deaudatus.

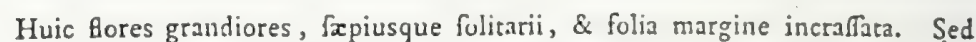
ha notse nequaquan certx aut conftantes funt; quarc vera differentia fpecifica a paleis receptaculi, femina non involventibus, petenda eft.

Scolyuus angiofpermos. ibid.

Scolynus theophreafi bispanicus. Crus. l. c.

Scolynus cloryfautbensos ammuss. DODAR. mem. edit. geris, t. 29.

Scolynus maculatus foliis margine attenuatis. LINN. Sp. pl. $1 \times 43$.

Scolymus bifpanicus, floribus congefis. LINN. fy/l. veg. 722 .

Calyx maturus (a) procedenti minor \& anguftioribus quoque foliis circumvallatus. Receptac. (b.) valde convexun \& fere globofun, Palex (c. C. D.) membranacex, obovatx, marginibus introrfun flexis (D.) conduplicatx, femina fingula, tanquan in theca propria, claudentes ac pcnitus occulcantes. Semina (e. E. F.) obovata, deorfum infigniter acuminata, hinc convexiufcula (E), duplicique linea longitudinali notata, inde (F.) planiufcula, cum linea media folitaria. Integum. fimplex, membranaceum, nivcum; non fplendens. Embryo (g.) albus aut lividus.

Pappum huic fpecici ex ariftis duabus aut tribus facile deciduis adferibit ALLıos. hifl. pedens. p. 207. quem nutem ego in plantis cultis nunquam vidi. Etiam Ehrhartus. Beytrag. ข. 4. p. 373 . Femen Scolyni dicit biariftatum, fed fpe 


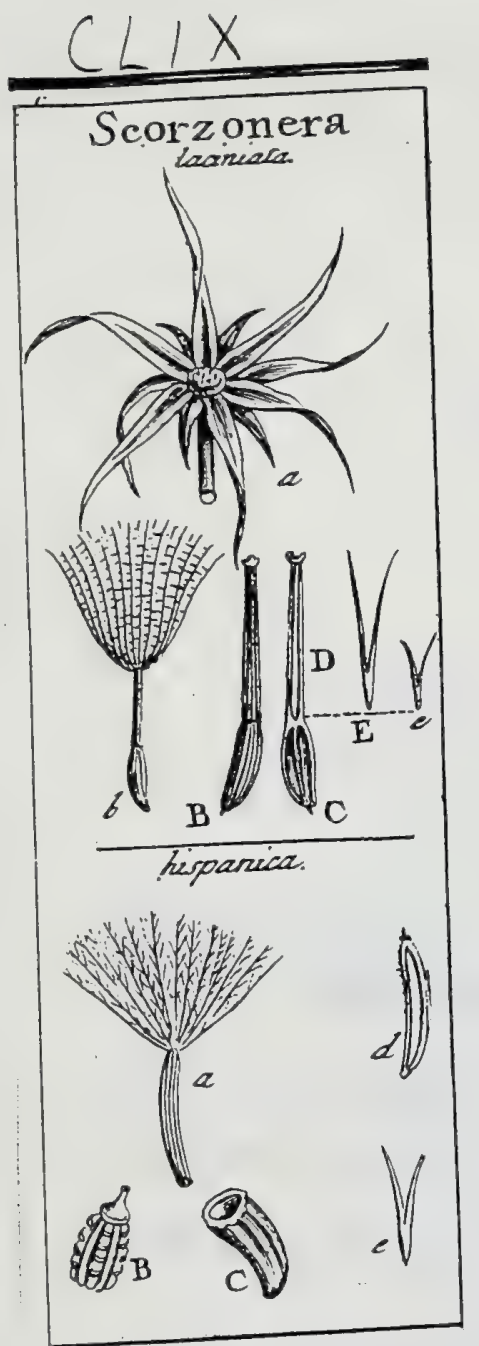

J. Gaertner (1788) Vol 2

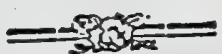

DCCCCXVIII. SCORZONERA. TOURN. t.269. LINN. gen. 906.

Calyx oblongus, polyphyllus, imbricatus fquamis acuminatis, inxqualibus, margine membranaceis. Thal. nudus, papillofus. Sem. longa, furfum attenuatr. Pappus plunofus fellilis: radiis paleaceis \& fetaceis mixtis.

SCOrzonein laciniata. Tab. 159. fig. I.

Tragopogon laciniatis foliis. CoL. plyytob. t. 32.

Scorzonera foliis linearibus dentatis acutis, caule ereifo, calycis fqumuts patulo mucronatis. LINN. Jy't. veg. 711.

Icont. JACQ atyl?. t. $35^{6}$.

REC. leviter convexum, tuberculis minutis papillofum.

SEN. longa, e pedunculo ovato ttriato intus cavo atque funiculum umbilicalem filiformem contincute, elongata in columnam rectam, tetragono-compreifam, Itriatam, pedunculo fuo anguftiorem fed duplo longiorem, atque ipfo nucleo foetain.

Puppus plumofus, feflilis: radiis paleaceis inxequalibus; crinibus longis, fericeo albis.

IN T. duplex : exterius coriaceum, femine longius \& bafi in ampullam inflatum; interits nembranaceum, tenuilfimum, embryonem inveftiens.

Eмв. fubulatus, longitudine columnx feminis, lutefcens.

me b. Semen integram. C.) Ejusilen diffeti 2.) Calyx maturus patens, cum funiculo umhilicali in ejus medio. D.) Columa feminis aperta, embryonem fovens. c. E.) Embr. denudatus.

Uti in Scorzonera, feminis pedunculus, ita in Tragopogone, pappi ftipes, cavus deprehenditur: utrum vero hxc fingularis fabrica novis generibus conftituendis fufficiat, penes alios judicium efto.

Scorzonera hifpanica. ibid.

Scorzonera E' Viperaria. BLAKw. berb. t. 406.

Scorzonera caule ramojo, foliis amplexicaulibus integris fermulatis. Lixw. $L c$.

Semina (a. B. C.) longa, teretiufcula, fuperne palo anguftiora: exteriora leviter incurva \& in dorfo planiufcula (C.); interiorn autem recta \& obfolete and utrnque longitudinaliter ftriata, inferne (C.) glabra, fuperne vero (B.) tuberculis lunatis transverfalibus exafperata, albicantia aut pallide ftraminea. Pappus plumolus, fuffilis: radiis paleaceis iıxqualibus. Embryo (d. e.) longitudine feminis, fubulatus, e viridi livefcens. 


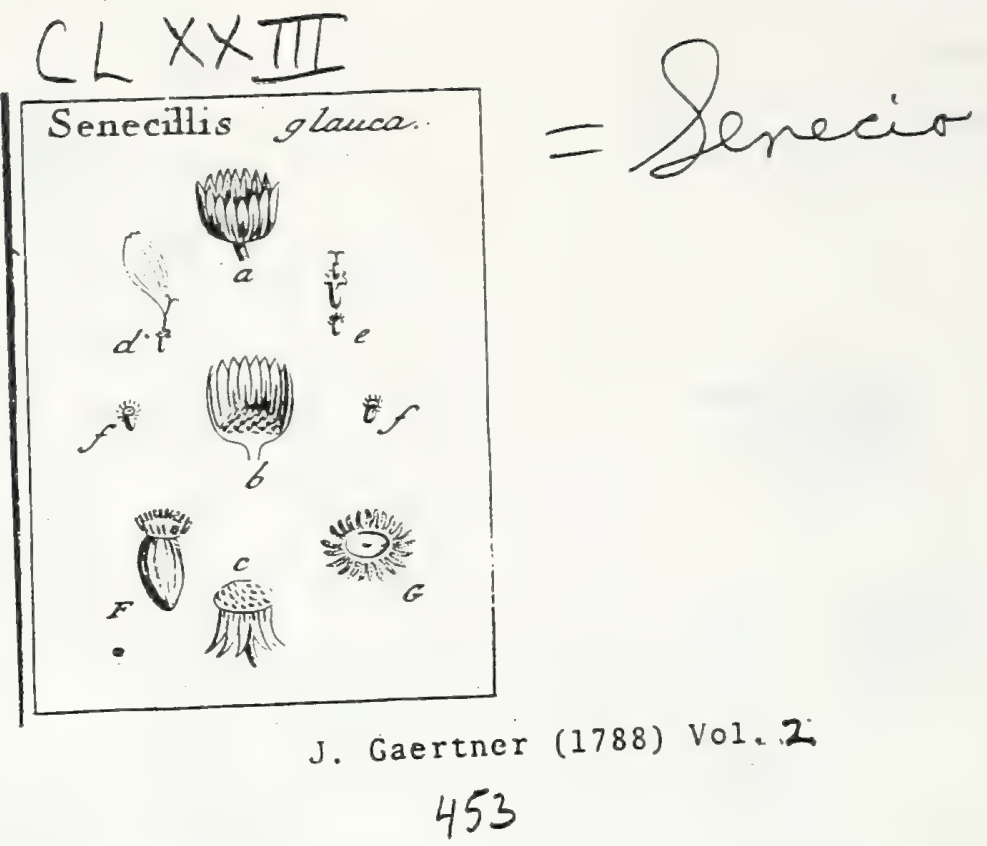

\section{S E N E C I L L I S.}

Calyx cylindraceus, fimplici ferie polyphyllus zqualis. Thal. nudus. Flofe. dijci androgyni; radii feminei, fubduodeni. ligulis ovato-oblongis tridentaris: utrique fertiles. Sem: uniformia. Pappus plumofus.

Senecillis glauca. Tab. 173. fig. 4.

Solidago floribus fpicatis, foliis fubcordatis glaberrinuis glancis oblonge ellipticis amplexicaulibus. GreL. Sibir. 2. p. 166. t. 74 rudis.

Cinseraria racemo fimplici, foliis spatulato - cordatis integerrimis, caule funplicifomo. LiNs. Lyft. veg. 764 .

R Rc. ante plenam maturitatem planum, fcrobiculatum, \& a fcrobiculorum marginibus dentatis fabrum; poltea vero convexum \& papillis minimis confperfum.

Sг M. uniformia , parva, ovato-turbinata, Itriata, glabra, fpadiceo-fufea.

Pappus dinidio femine brevior rigidiufculus fragilis albicans: radiis numerofis hifpidis, quafi aculeolato-plumofis, baG in orbiculum, feminis vercici impofitum, connatis.

IN T. fimplex, membranaceum.

EMB. albicans.

2.) Calgx fiotidus integer. b.) Iders diffectus eum receptac. feabro. c.) Ider maturus tefiexur eum receptac pulvinato. d) Flofe. salii. c.) Flofic difci. f. f. F.) Semed feparatum. G.) Pappus in figniter auceuc

Senecillis puopurasa.

Ciseraria caule fubbifioro, folits obovasis tomensofus. Lisw. fyf. veg. 765 .

Calyx polyphyllus, foliolis lanceolatis fubxqualibus, paucis brevioribus pubefcentibus. Thalamus nudus. Pappus plumofus. Linn. mant. 285.

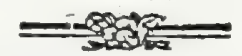

Hxc revidenda, cum pappi plunof appellatio apud Linnxum fit admodum vaga \& fxpilime errorres. 


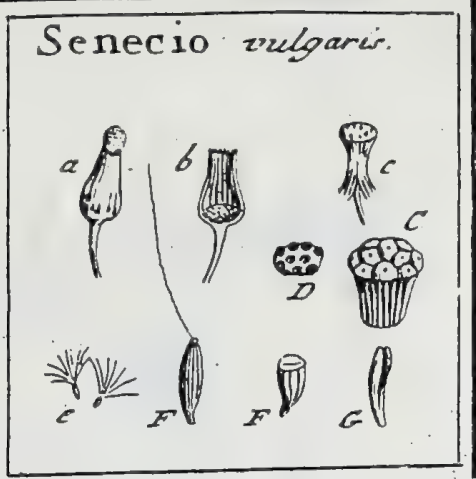

J. Gaertner (1788) Vol. 2

$$
400
$$

DCCCCLXIV. S E N E C I O. TOURN. t. 260. Lins. gerr. 953.

Calyx cylindraceus aut conicus, fimplici aut duplici fuliorum xqualium ferie polyphyllus, bafi calyculatus fquamulis fubimbricatis, apice p!srumque exarido-fufcis $f$. fphacelatis.' Flofc. onnes androgyni. Thal. fcrobiculatus, mamnillatus. Sem. pappo capillari.

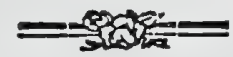

SENECIO vulgaris. Tab. 166. fig. 3.

Erigeron nimus. Dod. penpt. 64t. Bua Kw. berb. t: 132. OED. fior. dans. t. 5 r3. Senecio corollis nudis, fuliis pinnato finuatis amplexicaulibus, floribus fparfis. LiN. Syll. reg. 756 .

REC. nudum, ante maturitatem concavum ferobiculatum, poftez pulvinatum mammillatum.

SEM. parva, oblonga, utrinque attenuata, ftriata, fetulis appreflis confperfa, fpadiceo - furca.

Pappus capillaris, albus, fimpliciflimus, femine duplo longior.

IN T. utrumque membranaceum.

EMB. albus.

a.) Calvx integer. b. D.) Receptae. immaturuq. C. C.) Idem maturamo. C. E.) Semen integrum. F.) Idem diffeaum G.) Embryo deaudatus.

Genus bifrons, accedente radio mutatur in Jacobeam. 


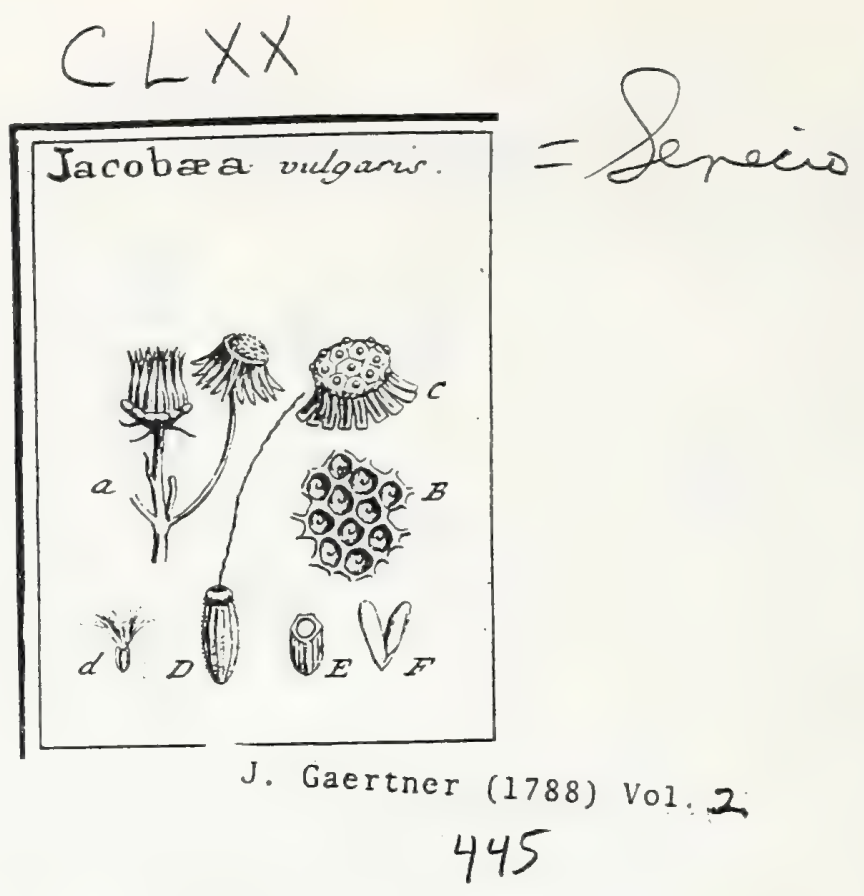

MXXX. JA C OB E A. TOURN. 7.276.

Calyx fumplici ferie polyphyllus xqualis, bafi fquamulis parvis appreftis auctus, per maturitaten refiexus, foliolorun apicibus fphacelatis. Thal. - excrvato - punctatus : glaber. Flofc. difci androgyni; radii feminei ligulati: utrique fertiles. Pappus capillaris. Foliz dillects.

Jасовея vulgaris. Tab. 170. fig..1.

Hería St. Jacobi. Fuchs. bif. lat. 742 . germ. ic. 425.

Senccio corollis radiumribus, foliis pinnoto byratis: laciunis locimilatis, caude ereju. Lis. Syft. veg. $75 \mathrm{~s}$.

446

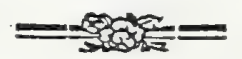

REc. floridum planum, fcrobiculatum, nudum, glabrun: frugiferum pulvina: tum, mamnillatum \& inter mammillas lineis elevatis areolatum.

SEN. uniformia, parva, teretiufcula aut obfolete pentagona, ftriata; villis raris adfperfa, fpadicea.

Puppus capillaris, fericeo albicaus, remote denticulatus, femine duplo longior.

IN T. fimplex, membranaceurn.

EMB. albicans.

a.) Calyx ereâtus \& demum rcfexus. B.) Receptaculi foridi portio anßaz. C.) Recept. frugiferum pulvinatum. d. D.) Semen integrum. E) Idem diffectum. F.) Embryo feprasatus.

Jacobxa itaque eft Senecio radio larvatus. 


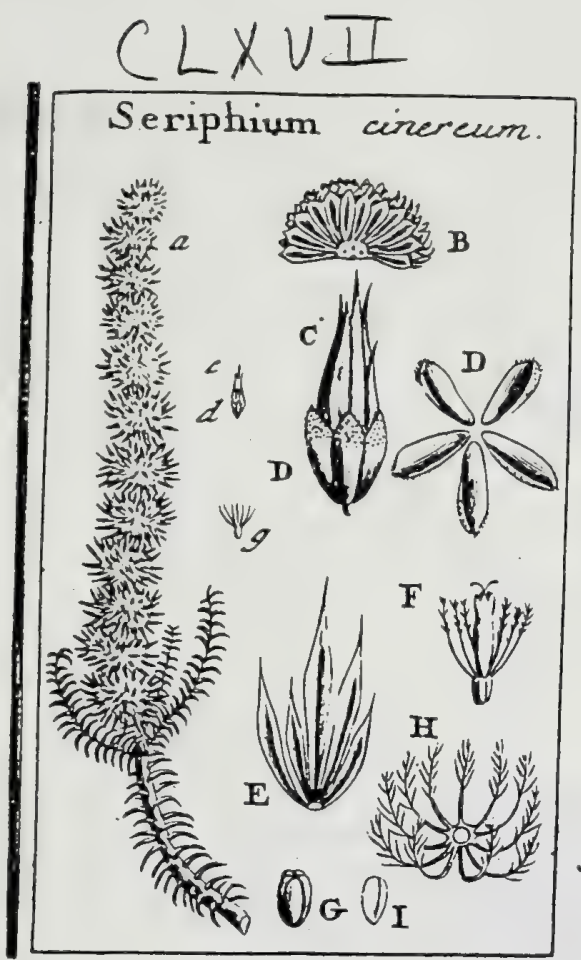

J. Gaertner (1788) Vol. Z; 416

\section{DCCCCLXXXV. S E R I P H I U M. LinN. gen. rooz.}

Calyx univerfalis nullus, aut ab extimis receptaculi paleis non diftinctus; partislis unifiorus, duplicatus, uterque pentaphyllus: foliolis exterioribius brevioribus, tomentofis, obtufis, receptac. paleis fitnilibus, xqualibus; interioribus longioribus, fariofis, glabris, fetaceo acuninatis, inxqualibus, fupra receptac. paleas longe prominulis, ut capitulum evadat echinatum. Elofc. cylindrico - infundibuliformes, androgyni, quinquefidi. Recept. commune convexum, palenceum; proprium in fundo calycis. Pappus peur cillato-plumofus, caducus.

Sẹriphiua cinereum. Tab. 167. fig. 2.

Frusex cineracens mufcofus, berbe impice capitulis, in fpicam fefrlibus. PLux. phyt. t. 297 . f: 1 . nuala.

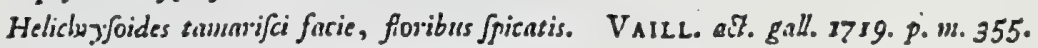
Seriphimm cinerentm, foribus verticillnto-spicatis unifloris, foliis putsusibus. LiNx. Gyl. veg. 798.

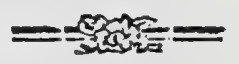

REC. commme fubglobofum, undique tectum paleis ovato-oblongis, concavis, extus tomentolis; proprium ullum, proter fundun calycis.

SEs. folitaria, ovatu-globofa, quinquefulcata, glabra, parva, pallide albicantia. Pappus longitudine corollulx, enducus, radiis fubduodenis, apice penicillifurmi-plumofis, bafi nudis, feraceis, in annulum connatis.

IN T. exterius fubcoriaceum, tenue.

EN B. fenini conformis, lutefcens.

a) Ramus floridos, e fpecimine arborefeente. B.) Recept commune palezecum. c. C. d. D.) Caljx proprius cum Suis fquanis exteriotibus. E.) Idem apertus, folas fquamas interiores feariofas ofteasus. F.) Flofeulus feparatus, \& infixaiter suQuc g. G.) Semen iMfegrum. H.) Pappus Scypratus. 1.) Embryo denudatuc.

Seriphium aut Stocbe, cujus tofculis radius additur, mutatur in Difparaginers. 


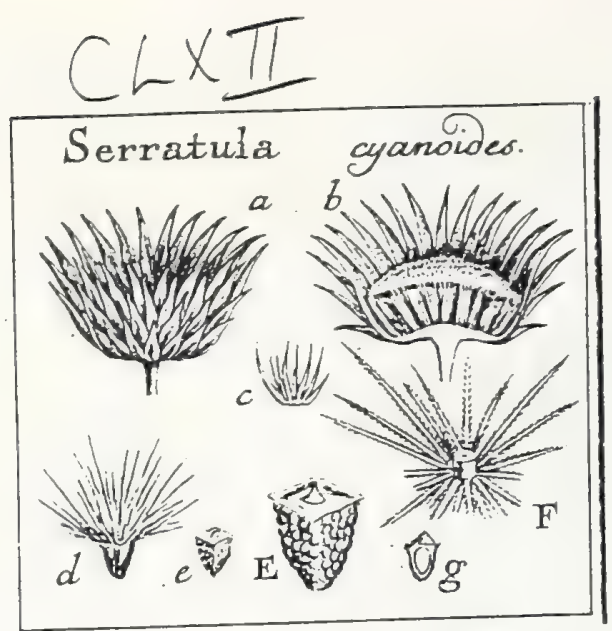

J. Gaertner (1788) Vol. 2

379

DCCCCXXXV. S E R R A T U L A. LINN. ger. 924.

Calyx ventricolus aut cylindricus, imbricatus fquamis inermibus, acuminatis aut appendice fcariufa auctis. Flofc. omnes androgyni. Thal. paleaceus. Sem. coronata pappo inxquali rigido denticulato aut ciliato, perfiltente.

Serratula cyanoides. Tab. 162. fig. 4.

Cardius canle fimplici, foliis pimatifidis, rarius dentatis infra candidis, fquimis calycums lanceolutis adfcendentibus. GMRL. fib. 2. p. 42. t. 15. 16.

Carduus folits decumentibus pimasifidis lissemibus integerrinis inermibus petioletis, Jubsis tomensofis. Lis.s. JyHt. vez. 725.

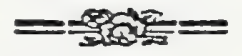

REc. paleaceum, paleis brevibus, rigidis, bafi inter fe cohxrentibus.

SEN. inverfe pyramidata, tetragona, tuberculato - rugofa, e ferrugineo fufer. Pappis fericeo albus, perfiftens aut fero caducus: radiis inæequalibus, planis, rigidis, dentato ciliatis, multiplici ferie circa papillam cylio. dricam policis.

IN T. extcrius coriaceum, durum, craflum.

EN B. femini conformis, lutefcens.

a.) Calyx maturus. b.) Recept paleaceunt. c.) Palez feparatz. d. e. E.) Semen integrum

F.) Pappus cum fuo nabone centrali. 5.) Semen diftedum cum embryone.

Serratula tinforia. LINN.

Pappus copiofus, ex aureo \& fufco fplendens, radiis fetaceis rigidiufculis vix aut minutifime denticulatis.

Serratula multiflora. LINN.

Pappus fericeo albicans, radiis multorum ordinum lineari-paleaceis ciliatis inxqualibus.

Serratula centamroides. LINN.

Pappus ftranineo-albicaus fplendens, radiis numerofrfimis inxqualibus lineari-paleaceis, creberrime denticulato - ciliatis.

Huc quoque porro fpectant ob pappum \& tofculos omnes androgynos: Cnicus centaurnides, Centaurea Rhaponticum, \& varix alix inter Carduos, Cricos \& Centaureas Lins. fparfx. 


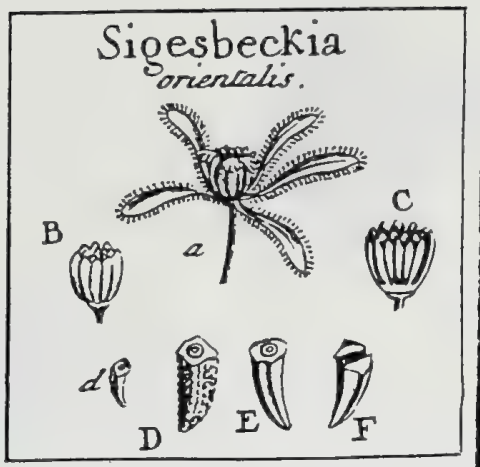

\section{T. G. Shem se \\ J. Gaertner (1788) Vol 7 \\ 424}

DCCCCXCIV. S I G E S B E C K I A. LINN. gers. 973.

Calyx limplici ferie polyphyllus, xqualis, circumvallatus, foliolis quinque libi duplu longioribus, parentibus, extrorfum latefcentibus, villofis: villis capitellatis glutinofis. Thal. paleaceus. Flofc. difci androgyni, plures; rodsi tres 1. quirque, feminei, ligulati, in uno enmeum calycis latere politi: utrique fertiles. Sem. oblonga, calva.

Sıgesteckis orientalis. Tab. 168. fig. 11.

Cichorio afrisi lapfoun fivica, mesutbaftri foliis, cabyce funbriato biffido. Plux. plizs. t. 380. $f .2$.

Sigisbeckin petiolis fellitibus, calycibus exterioribus majoribus linearibus patentibus. Lisx. is. Cliff. r. 2 s. Lffi. veg. $77 y$.

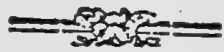

REC: anguftum, planum, palenceum : paleis longitudine \& Gailitudine foliorun calycis.

Ses. inverfe pyramidata, tetragona, tuberculato-feabra, glutinofa, fufca,

IN T. exterius coriaceum, tenue.

E M в. femini conformis, albicins.

1.) Calsx floriduinteger. B.) Idem ahsque iavolucro, C.) Idem difredus, eum paleis seceptsculi. d. D. E) Semina trberculata \& glabra. F.) Embsyo deaudatus.

Semina, qux e Chima habui, omnia exant glabra atque plumbea-livida: quile fub litt. E. reprofentatur. 


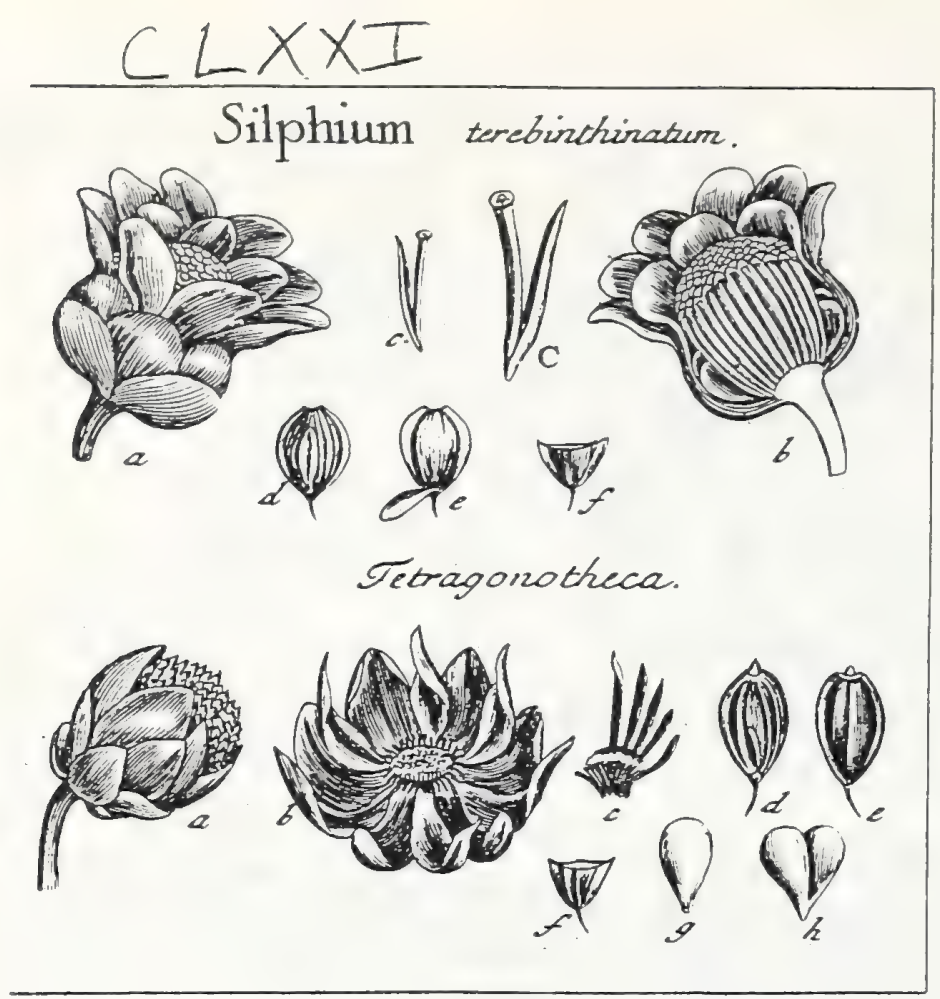

\section{J. Gaertner (1788) Vo12 \\ 444}

MXIX. S I L P H I U M. IINA. ger, 986.

Calyx imbricatus, Tguarrofus, Yquamis latis herbaceis. Thal. palenceus: paleis feminarum minoribus, in dorfo feminis perfiftentibus. Flofe. difci androgy'ni, fteriles; radii feminei, ligulati, ferriles. Sen. ovata, convexo-concava, fetaceo-pedicellata. Peppus dịphillus, brevirimus, aut nullus.

SILPhiun Tetragonotheca. Tab. 177. fig..2.

Tetragonutbeca doronici maximi folio. DiLL. elth. 378 . t. 365 .

Polymnia foliis oppofrtis jpatrilatis fribdentatis. ZINN. Jyy. veg. 790.

:Ex hort. botan. Stuttgard.

R.E.C. planiufculum, paleaceum: palcis difci lineari-oblongis, concavis, calyci equalibus, deciduis; radii linearibus, obtufis, planis, feraceo pedicellatic, Semine brevioribus \& in ejus dorfo perfiltentibus.

SE r. duplici feric in radio pofita, pedicollis pale:rum letuceis infiftentia, ovata, hinc convexa, tribus ftris elevatis longiduduaibus notata, inde pland aut

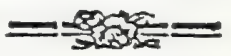

concava, glabra; ad latera in anguftum margincu membranaceum extenuata, \& in apice levillime ćmarginata, fpadicea, terruginca, aut nigricantia.

Puppus diphyllus, brevifimus, foliolis fubulatis, perGfteutibus.

IsT. exterius coriaceun, tenue.

En B. obovatus, albicans.

2.) Calyx maturus claufus. b.) Ideur expilicatus \& seccptac. denudutum. c.) Receptaculi fopzsati fectio verticalis, cum fitu palcarum difci. d.) Seminis pars turfalis, cuu palca fua nerrífetatc. \&.) Ejusdem latus ventralc. f.) Sectio femiuis traesver(alis. g. L.) Embrgo denudarus.

Forma calycis per culturan mutati, in characterem Tetragonothec: Linn. gen. 976. haud quidem rite quadrat; fed reliquarum partiun \& inprimis foliorun ftructura atque figura, hanc omuino Polymn. Tetragonosbecaia Linn. effe docuerunt.

Sıрничм terebinthinaceum. ibid.

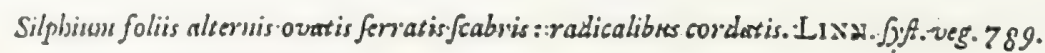
Icon. JAce. bort. t. 43 .

Calyx (a.) bafi veutricafus, fuperne fquatrofus. Reccptac. (b.) paleaceum: Palex difci (-c.c.) longitudine fere folculorum fterilium; palex radii (d.e.) ovato-oblunge, planx, femine panlo breviores, ejusdemque bafi athxx. Semins (d. e.f.) ovato-rotundata, plano-convexa, valde coniprefra, bafi fetaceo pedicellata, apice fimpliciter emarginata, absque pappo confpicuo.

Genera Pappo paleaceo difformi aut compolito dotata, guxre infra. 


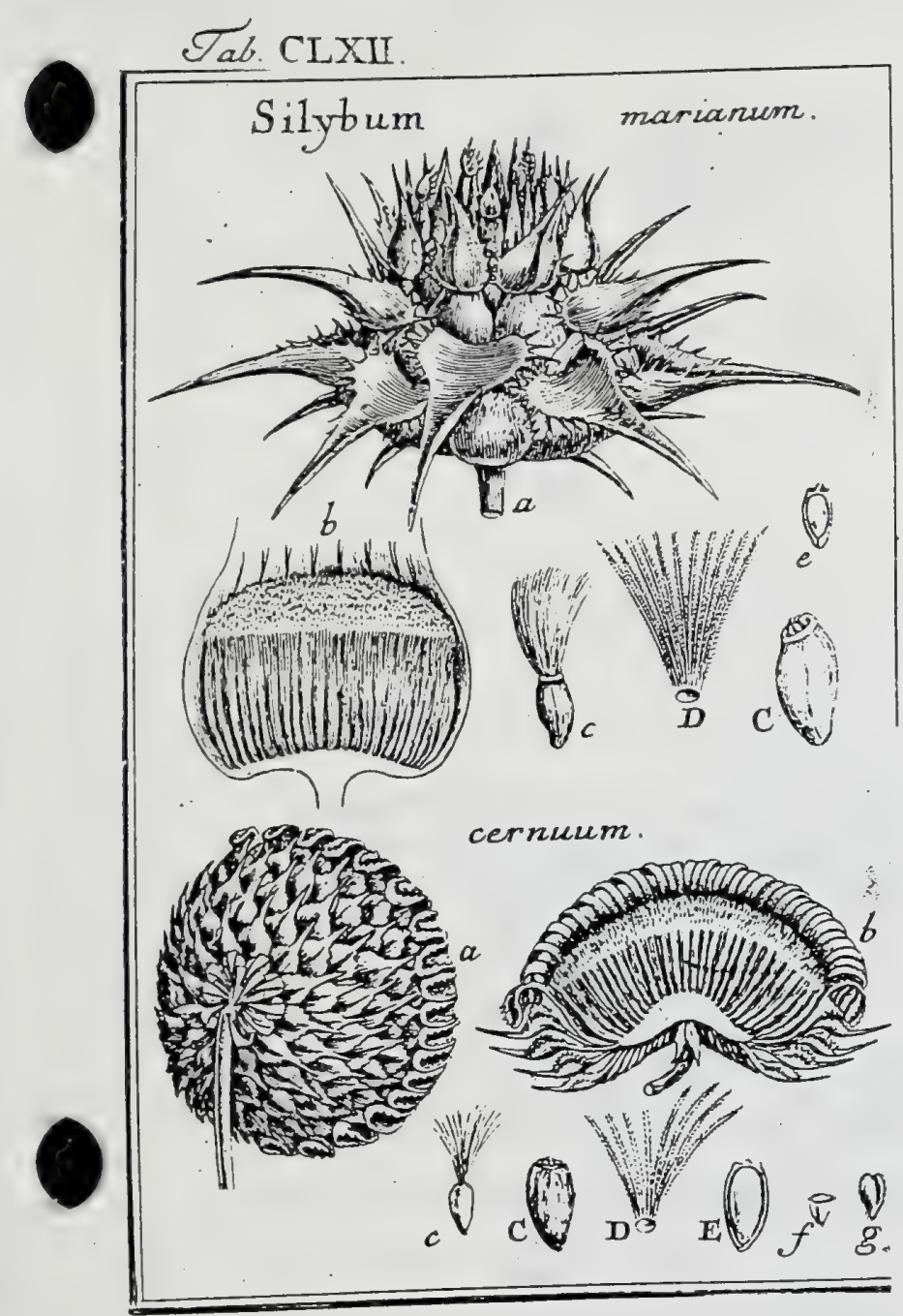

J. Gaertner (1788) Vol. 2

378

\section{DCCCCXXXIII. S I L Y B U M. VAiLL.}

Calyx ventricolus, imbricatus fquamis arcte appreflis, apice appendiculatis: appendicibus refracto - patulis dentatis roftratis: intimis cuchleariformibus. Flofc. omnes androgyni. Thal. paleaceus. Sem. coronata pappo lineari. paleaceo, bafi in annulum connato, deciduo.

Silybum marianum. Tab. 162. fig. 2.

Carduse maria. BLAKw. berb. t. 79.

Carduns foliis amplexicuulibus haftato-pinnatifidis fpinofis, calycibus aplyylis: fpinis canaliculatis duplicuto jpinofis. Lis. Jjyt. veg. 726 .

REC. paleaceum, paleis fetaceis, dinitio calyce longioribus.

SEM. oblique ovata, glabra, pallide ftraminea \& fufco culore fuffúa, annulo terminali cartilagineo albo, ac intra illum, tuberculo pentacolli notata.

Pappus femine duplo longior, cuducus: rndiis lineari paleaceis, planis, rigidis, creberrime denticulatis, f. ciliatis \& quafi fubplumofis, bo $\sqrt{3}$ in annulum conferruminatis.

IN T. exterius coriaceum, aut fubcruftaceum, durum.

EMB. ovatus, albicans.

a.) Calyx integer. b.) Receptac. paleaceum. c. C.) Semen inteyram. D.) Pappus Ecparatus, e.) Semca apertum, cum embryone.

Silrbug cernuum. ibid.

Carduus foliis ex cordato - lanceolatis margine ferrasis $\&$ fpinofss, fquamis calycum laceris fpinofis, capitulis mutautibus. GMER fib. 2. p. 47. t. 19.

Ciricies foliis cordatis, petiolis crifpis spinofis amplexicaulibus, floribus cermus, calycibus fariofis. LixN. fyjl. veg. 727 .

Calyx maturus (a.) hemifphxricus, imbricatus fquamis fcariofis : exterioribus ex angulta bafi in appendicem fubcordatam dentatara atque Spina innocua

$$
=30
$$

terminatam definentibus; int:mis vero linearibus longifimis, appendice retexa cochleariforıni terminatis. Recept. (b.) fctaceo-paleaceum. Semina (c. C. E. f.) obovata, lenticulari - compreffa. ftriata, fpadicea, annulo cartilagineo \& papilla pentacolli terminata. Pappus (D.) femine longior deciduus: radiis fetaceis, rigidis, ciliatis, bafl in annulum connatis. Embryo (g.) lividus aut albicans. 


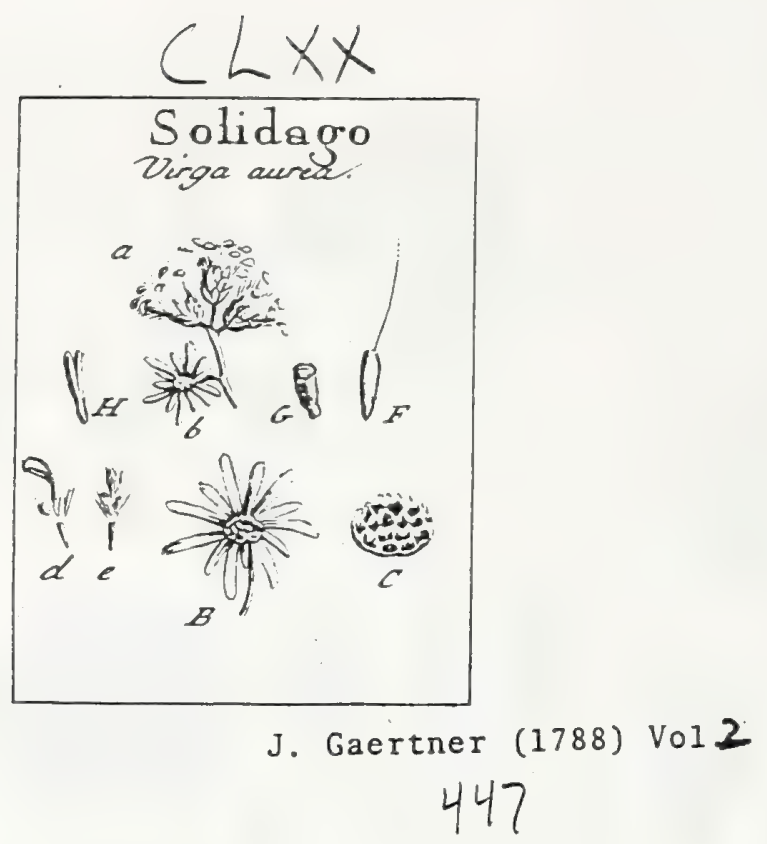

Asteraceae

MXXIII. S O L I D A G O. Linn. getr. 955. Virga aurea. TOURN. t. 275 .

Calyx imbricatus fquamulis oblongis inxqualibus appreftis. Thal. fcrobicuculacus, nudus. Flufc. difci androgyni; radii femmei, quini aut paulo plures, ligu:atı: utrique ferriles. Pappras capillaris. Flores in plerisque mediocris maguitudinis, quin parvu!i, racematim crefcentes.

448

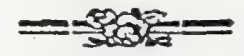

Solidago Virga aurea. Tab. 170 . fig. 5.

Vinga aurea. CAMr epit. 748. BLAkw. berb. t. 169. OEd. flor, daus, t.663.

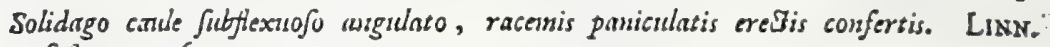
Syjl. veg. 764 .

REC. angultum, planum, nudum, fcrobiculatum, a fcrobiculorum marginibus denticulatis fabram.

SEM. parva, oblonga, deorfun attenuata, teretia aut obfulete angulata, fetulis minutillimis confperfa, fpadicea.

Pappus capillaris, remote denticulatus, femine fesquilongior.

IN T. fimples, membranaceum.

EM B. albicans.

2.) Calyx femine prxguans. b. B.) Ilem per maturitatem patentilimus, cum receptaculo (B. C.) farobiculato. d.) Flofe. radii. e.) Flofe. difcio F. G.) Semen integrum \& dillistum. II.) Kinbryo folutas.

19.136 


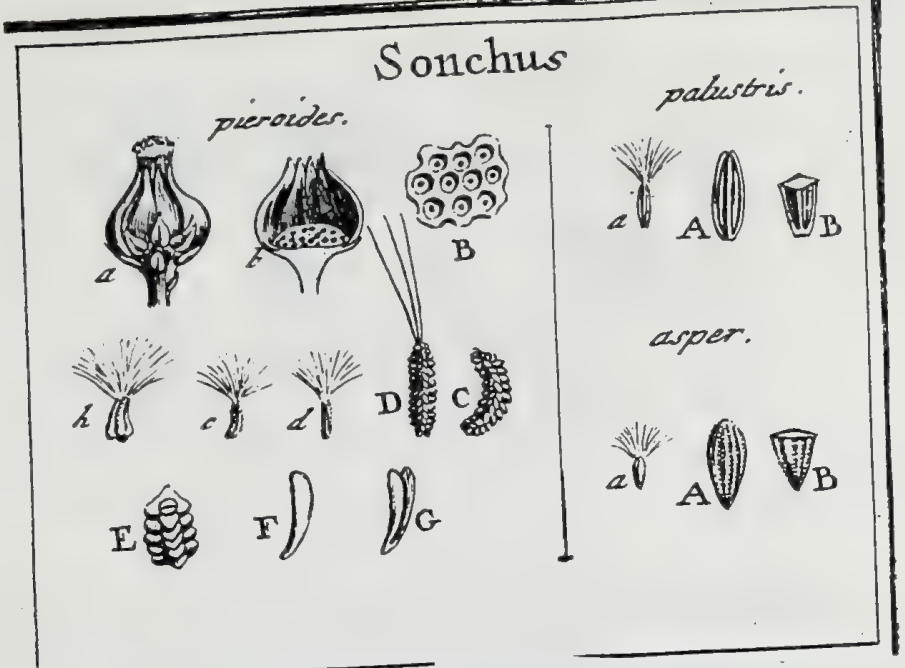

DCCCCIX. S O N C H U S. TOURN. t. 268. LINN. gen. 908.

Calyx polyphyllus, imbricatus, bafi ventricofus, per maturitatem conice. conuivens. Thal. excavato-punctatus. Pappus capilluris, mollifinus, fugax.

Sonchus picroides. Tab. 158. fig. 2.

Sonclises fubrotundo folio noftras. PLuk. plyyt. t. 6r. f. 5 .

Scorzonera foliis fuperioribus amplexicaulibus insegerrimis, inferioribus runcinatis, pedrinculis fquamofis. LINN. fy/f. veg. 711.

REC. planun, excavato - punctatum, glaberrimum.

SEM. brevia, obefa, tetragona, ferruginea: exteriora curvata; interiora recta: utraque tuberculis transverfalibus muricata \& in fingulo latere linea longitudiuali depreffa infcripta.

Pappus mollifimus, candidus, fefflis, fugar: radiis capillaribus, remotifine denticulatis, femine longioribus.

IN T. duplex : exterius coriaceo - fungofum, craffum, fxpe fponte quadrifariam: fecundum lineas laterales dehifcens; interius membranaceum, tenuifimum.

Eм в. teretiufculus, albicans aut lividus. Cotyl. obtufe. Rad. non difcretr.

2) Calyx maturus integer. b.) Idem diffeaus. B.) Receptac. pars infigaiter anta c. C.) Semina marginaliz. d. D.) Sem. centraliz E.) Iategum, exterius trasserfe fedum. F. G.) Emliryo denudatus.

Eadem fabrica, per fingulas frudificationis partes, gaudet quoque Sonchus (Scorzon.) tingitanus; \& in utraque fpecie fixpius deprehenduntur femina albicantia, non muricata, fed ad angulos filtem crenulata: marginalia autem liujus fortis femina, funt infigniter cralfa (h.), \& ex latiori bafi. faftigiantur in pyramidem curvulam, obfolete teuragouam.

360

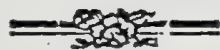

Sonchus afper. ibid.

Soucbus afper. DOD. peutpt. 64j. BLAKw. berb. t. 30. DED. fior: das. t. 843. Soncbus oleraceis $\gamma$. Lins. Jyfl. veg. 712.

Receptuc. ante plenam maturitatem concarum, papillis depreffis minutifimis confperfum. Semina (a. A. B.) obovata, compreffa, ftriis 3.1.5. longitudi. nalibus exaratn, aliisque transverfalibus obfoletioribus atque tenuifimis can cellata, e Juteo-ferruginea, aut. cinnamomea. Pappus capillarts, fefilis niveus, femine triplo longior. Cum his ad amuftum congruunt femina S. Levis.

S. paluffis fenius, ibidem reprefentata, omittimus, utpote dubia. 


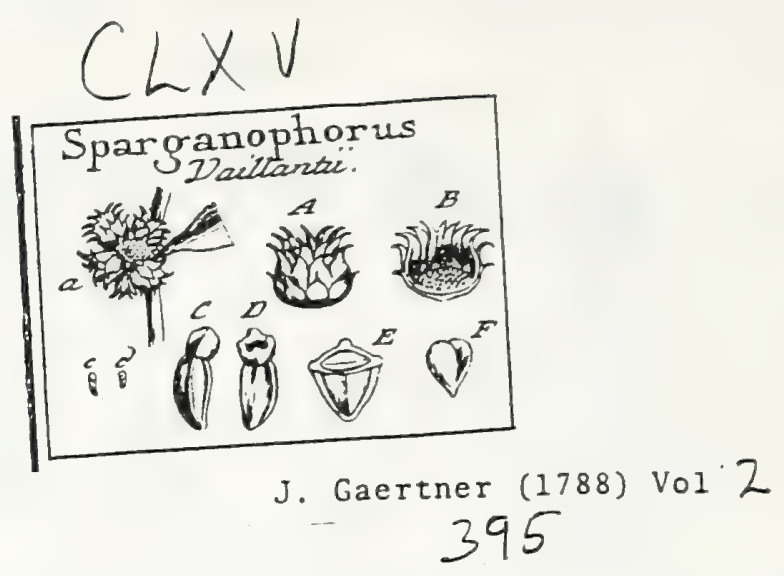

\section{DCCCCLVI. S PAR G A O P H O R U S. VAILI.}

Calyx fubglobofus, imbricatus fquamis inxqualibus, apice recurvato-patulis. Flufc. omnes androgyni, uniförmes, fertiles. Thal, uudus. Sem. coronata cupula fubcartilaginea, integerrima, nitida.

Srarganophor us Vaillantii. Tab. 165. fig. 4

Sparganophoros virge aures folio, floribus e foliorsen alis absque pedurculis. VAIL. ait. gall. 1719. p. in. $3^{6} 8$.

Ethulia foribus felfilibus luteralibus. LinN. fyjt. veg. 734.

R ec. planum, elevato - punchatum, nudum.

SEM. parva, uniformia, orạta, deorfum anguftiora, rhombeo - comprefla, angulis lateralibus atque dorfali, colta alba notatis, interfitiis autem atque plano velutrali pallide teftaceis.

Pappis cotyloides, dimidio fenine paulo longior, fubcartilagineus, niveus, nitidus, tetragonus, integerrimus aut obfolete quadridentatus.

IN T. exterius corinceum.

EM B. obovatus, fublividus.

a.) Flores $3-s$ in axillis foliorum (ctriles A.) Calyx feparatus integer. B.) Receptze. dentdatum. c C.) Seminis pars dor[alis. 4. D.) Ejusdem latus veatrale. E.) Semen trasver(e SeQum. F.) Ėmbr. denudatus.

Cum Ethulia fupra defcripea nihil commune habet proter folam calycis formam externam. 


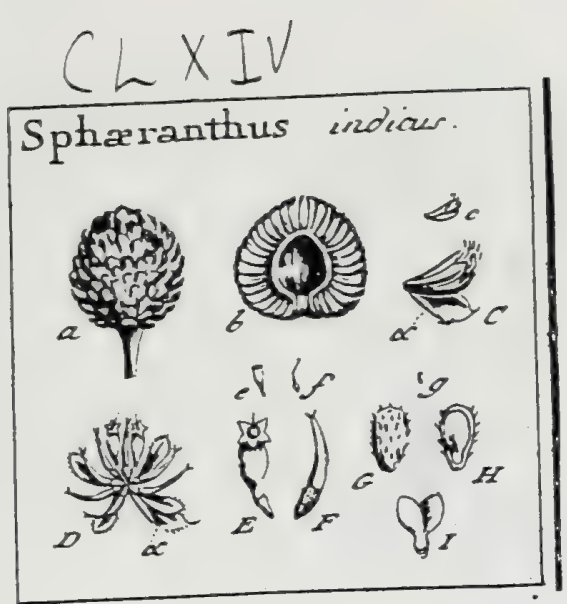

\section{J. Gaertner (1788) Vol 2 \\ 413}

DCCCCLXXXII. SPHERANTHUS. VAILI. LINN. ger. 998.

Calyx univerfalis nullus, niG extimas receptaculi fquamas velis; partialis tetra1. pentaphyllus, xqualis, fubdecemforus. Flofe. androgyni, infundibuliformes, monoftyli, gemini aut terni, in centro; feminei fubulati, edentuli, ftigmate bifido, quini aut plures, in ambitu finguli calycis partialis. Recept commone globolum, paleaceum, intus cavum; partiale anguftiflmum, nudum. Semina feminis calvz.

Spheranthus indicus. Tab. 164 fig. 5.

Adaca-manjem. RHEED. mal. 20. 8. 43.

$4 \times 4$

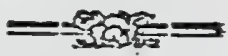

Spheratbus purpurea alata ferrata. BuRM. 2egl. t. 94. f. 3.

Spberantbus foliis decurrenstibus lanceolatis ferratis, pedunculis crippatis. LINN. by $f$. veg. 797 .

REC. commone globofun, intus cavum, extus paleaceum : paleis ad fingulos calyces partiales lingulis, ovatis, acuminatis, villofis; partinle angultiti. mun punctatum, glubrun, nudum.

S e r. foninis parvula, ovata, fetulis albicantibus adfperfa, e fufco fpadicea, pappo deftituta.

Is T. fimplicifimum, menbranaceum.

EM B. albicans.

2.) Capitulum globufum integrum. b.) Idem difretum, ecull receptac, communi intus cavo. c. C. ) Calyx partialis feparatus claufus, eum palea.( $\left.\alpha_{*}\right)$ ad balin calycis externam acecfloriz,

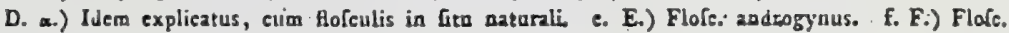
femineus. 5. G.) Semen feparatum. H. L) Eunbryo deaudatus,

Paleas ad fingulos flofculos partiales quindecim, \& corollulas femineas quinquedentatas, quas Sphxrantho tribuit Adans. p. 114. non in noltro iuvenies; ut forfan ille de S. africano loquatur, de quo Cel. Jussieu dubitat, num hujus generis Git. 


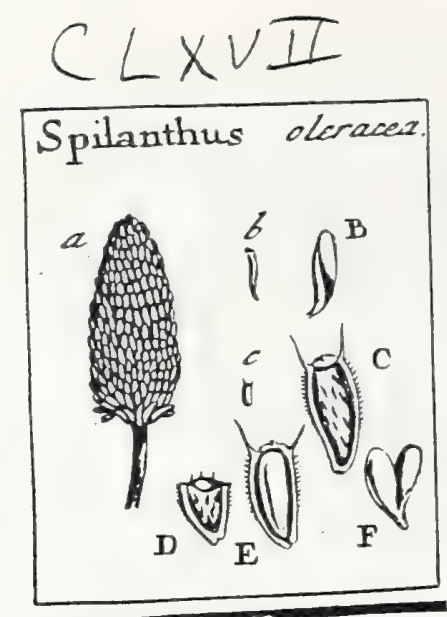

J. Gaertner (1788) Vol 2

\section{3}

\section{DCCCCLXXXI. S P I L A N T H U S. LINN. ger. 1287.}

Calyx duplici ferie polyphyllus xqualis. Flofe. omnes androgyni, quinquefiti. Thal. paleaceus, teretiufculus, calyce multoties longior. Pappus ariftis duabus fecaceis glabris.

Spilanthus oleracea. Tab. 167 . fig. 6.

Bidens foliis oppofitis ovatis fertatis, canle procrunbente, foribus folituriis. BRRG. a.7. bolin. 2768 . p. 118. 259. t. 7 .

Spilautibus foliis fubcordatis ferrulatis petiolatis. LiNs. fyfe. veg. 731 .

Icon. JACQ. bort. t. $x_{35}$.

REc. cylindricum, longifimum, undique teetum paleis herbaceo-membranaceis, apice-coloratis, femina fubamplexantibus.

SEM. parva, ovato-oblonga, comprefla, fetulis albis adfperfa, fufea, marginibus albicantibus ciliatis.

Pappus fetaceo-ariftatus: radiis duobus, dimidio femine brevioribus, fubinzqualious, flexilibus, glabris.

IN T. fimplicitimum, membranaceum.

EM в. albicans.

a.) Calsx eun reeeptactulo. b. B.) Palea feparita c. C. D.) Semen integram \& ditedum. E. F.) Embrgo denudatus.

Genus bifrons, accedente sadio mutatur in Verbefuram. 
Asteraceae

No drawing

J. Lfaertren (1788) Volz

412

S T E H. E. L I N A. LINN. gerr. 938.

Calyr oblongus, imbricatus. Flofc. onmes androgyni, antheris bafi caudatis. Thal. breviffime paleaceus. Pappus rimofus.

Si genus hoc fervandum, nec potius cum Serratula fit mifcendum, quod polterius equidem omnia fuadent, \& vel ipfa Serrat. mboren. SCHREs. dec. x. p. 1. t. I. Angitare videtur: non hujus erit loci, fed ad Capitatis debebit trausferri. Cetern, pappi ramofi appellatio valde xquivoca eft: verfus enim pappus ramofus in tota hac vaftiffma familia non reperitur; \& ipfe pappus Carlinx revera non eft ramofus, fed ex radiis fimplicillinis atque bati faltem inxqualiter conglutinatis, compofitus.

19.141 


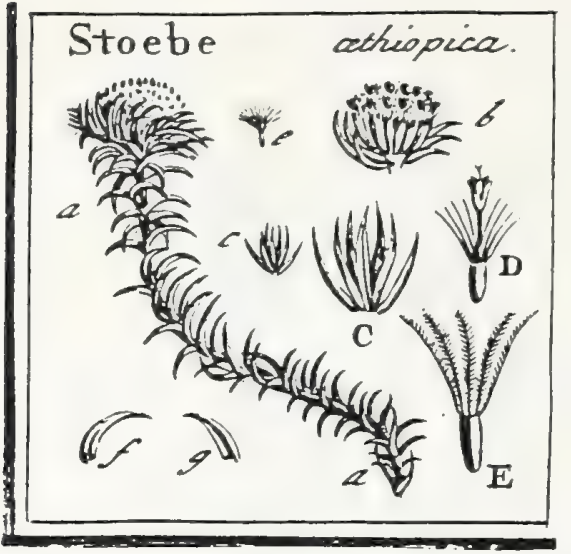

J. Gaertner (1788) Vo1.2

415

DCCCCLXXXIV. S T O E B E. LINN gen. s001.

Calyx zuiverfalis nullus, vel faltem a fupremis plante fullis aut ab extimtis recepeaculi paleis :non diftinclus; purtialis pentapliyllus, :uniforus: foliu-

lis paleis receptaculi formà confiftentia \& longitudine fimilibus. Flors.' infundibuliformes androgyni quinquefidi. Rec. conmsone paleaceum; pro prinum in fundo calycis. Pappus plunofus, perfiftens.

Stoese xthiopica. Tab. 167. fig. 3 .

Helichyroides jmiperi creberrimis aduncis foliis, floribus in ranulornus cymin VAIL. ar. gall. $x 79$. p. m. 355 .

Stoebe athiopica folis recurvato. uncinutis medis. LINN. Jyfo. veg. 798 .

REC. conmune in cymis ranorum, folis plantx foliis crebrioribus \& fubimbricatis linutum, undique tectum paleis fubulatis f. lineari acuminntris, confiftentiâ \& longitudine folioruna calycis proprii; partiale nullum, proter fundum calycis proprii.

SEM. in fingulo calyculo fingulum, parvulum, oblongum, glabrum, pallidum. Puppus plunofus, multiradiatus, fenine duplo longior, perfiftens.

IN T. fimplicifinum, membranaceum.

EMB. albicans.

a. a.) Ranulus floridus, b.) Cupitulnm a foliis lateralibus repurzantum. c. C.) Calyx propros, cum duabus receptaculi paleis, ad bafin fuam. D. Fiofeulus feparatus, idignitcr auâus. E.) Semen cum fuo papro. f. g.) Foliola eaulina, fubtus concava ineana, fupra viriliz glabra, pungentia.

Calyx partialis, ftricte loquendo, nullus eft, fed palex forculis proximx, ejus vice funguntur. 


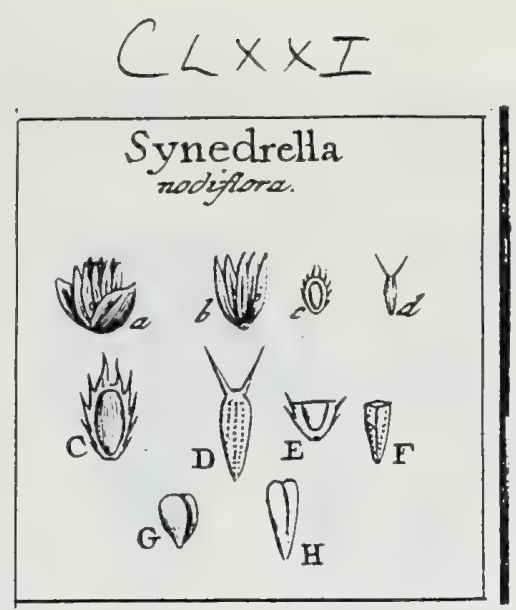

J. Gaertner (1788) Vol 2

456

\section{S Y N E D R E L L A.}

Calyx duplex: exterior diphyllus, foliolis ovatis acutis oppofitis xqualibus, in finu fuo utrinque Gingulum flofculum femineum ligulatum foventibus: interior fimplici ferie octophyllus xqualis. Thal. in calyce interiori nudus. Flofc. difci androgyni; radii, f. potius exteri, feminei, ligulis integris aut leviter emarginatis: utrique fertiles. Sem. difformia. Pappus biariftatus.

Symedrella nodifior. Tab. 171. Gig. 7.

Bidens nodifiora, folio tetrabit. DiLl. elth. t. $45 \cdot f \cdot 53$.

Verbefina foliis oppofitis ovatis ferratis, calycibus oblongis fefilibus; caulinis late: ralibus. LiNN. 6y/l. veg. 779.

R E c. anguftum, planum, intra calycem interiorem.

SEdr. diturmia: exteriora duo, majora, ovata, compreffo-plana, glabra, e fpadiceo-livida, margine membranaceo dentato albo cincta; interiora plura, cuneiformi-oblonga, compretra, punctis aut tuberculis obfoletis fcabrata, margine deftituta.

Puppus utrisque biariftatus: ariftis, in feminibus externis, fubmembraunceis, flexilibus, innocuis; in feninibus interioribus autem fubulatis, pungentibus, divergentibus, feminis longitudini fubrequalibus.

IN T. exterius coriaccum, tenue.

ENB. Semini conformis, oblongus aut uvatus, albicans.

a.) Calyx uterque. b.) Calycis interioris pars dimidia, cuin receptac pundato. c. C. E.) Seminz exteriora. d. D. E.) Semina intra calycem interiureso conclufa. G. H.) Eubryones atriusque femiuum fpeciei.

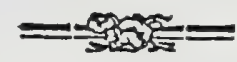

Proptcr receptaculam manifefe nudum; radium biforum exterum, atque Semina liquide difformia, cum Verbelina apte Saciari nequit. 


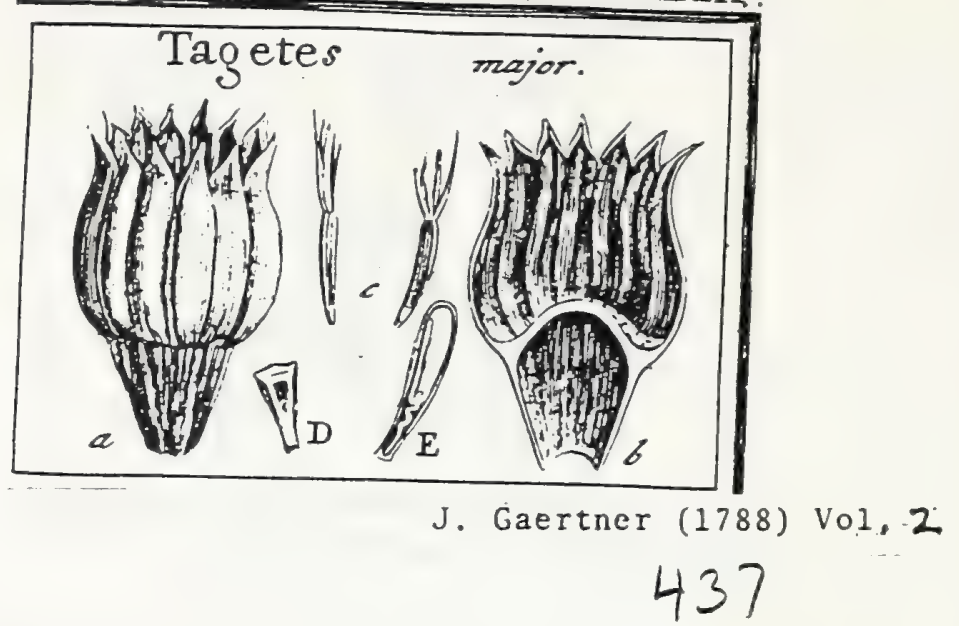

\section{T A GET.ES. TOURN. L 278. IINN. ger. 964}

Calyx-monophyllus, tubulorus, angulartus aut torofus, dentatus: dentibus numeru angulorum refpondentibus. Thal. nudus glaber. Flofe. difci androgyni plures; radii feminei, pauci, ligulis late ovatis: utrique ferriles. Sem. oblunga. Pappus pencaphyllus rigidus inxqualis.

TAGETES major. Tab. 172. Fig. 4

Caryophyllus indicus. CAx. epit. 40C. BESL. Eyjt. eft. XIT. t. 2. א.3.

Tagetes cunce fimplici ereito, pedunculis mudis asriforis. L1xN. Lyf. veg. 770 .

REC. planum aut fubconvexum, excavato punctatum, nudum, glabrum.

SEM. lineari-oblonga, deurfum anguftiora, fubcompreffa, angulata, friaa. glabra, atra, bafeos mucrone albicaute.

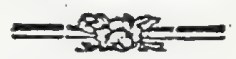

Papros dimidio fenrine 1ongior, pallide framineus, pentaplyyllus: raliis paleaceo-rigitis, inxqualibus, linearibus, glabris, nitidis, acumi antis aut obtufis.

IN T. exterius cariaceuro, istra bafu fura condens funiculum umbilicalem cupiliaren, tortuofum.

Es B. Semine brevior, compreffus, albus.

2.) Craiyx integer. b.) Idem diffectus cum receptzeulo. c.) Semen integrum. D. E.) Idem srausperfaliter \& longitudiualiter difiedum. 


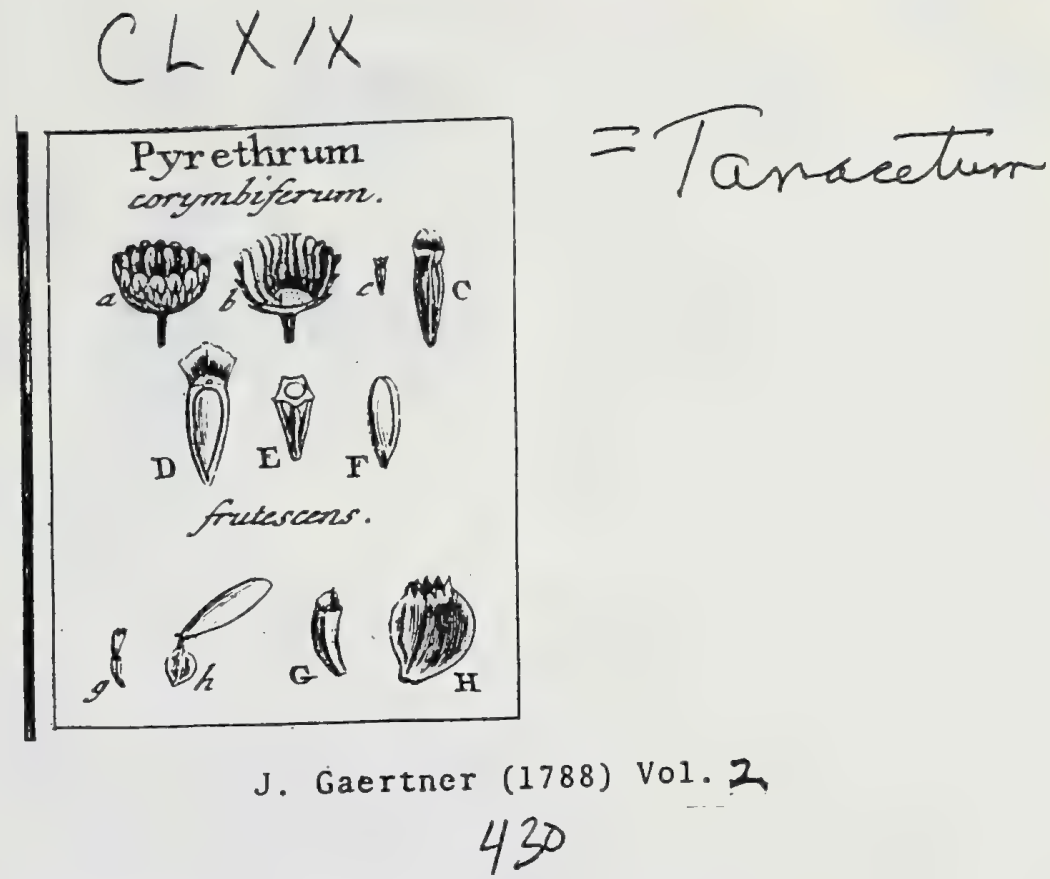

\section{P Y R E T H R U M. HALL. bif. x. p. 40.}

Calyx hemifphæricus, imbricatus fquamis duris appreffis margine fenriofis. Thal. nudus. Flofe. difci androgyni; radii feminei, ligulis oblongis tridenearis: utrique fertiles. Sem. margine prominulo coronata, uniformia, aut rarius difformia.

Pyrethrum corymbiferum. Tab. 169. fig. 1.

Tanacetums. inodorum. I. II. Clus. biff. I. p. 338 .

Chryfansbenum foliis pinsatis incifo Serratis, caule multifforo. LiNs. Syft. veg. 772.

Icors. JACe. aufri. $t .379$.

REC. convexiufculum, minute tuberculatum $\mathrm{f}$. elevato - punctatum, sudum.

SEM. uniformia, oblonga, deorfuri anguftiona, 4- sgona, glabra, sufefcentia, angulis pallidioribus fubcoftatis.

Puppus marginatus, tertia feminis parte brevior, ora repanda aut obfolecilfime quinquedentata.

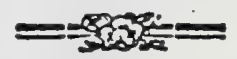

IN T. exterius coriaceum.

E,M B. teretiufculus, albus:

2.) Calyx integer. b.) Reept. denudatum. c. C.) Semen Integrom. D. E.) Idem longirudL naliter \& (ransverfim difteaum. F.) Embryo denudatus.

PYrethrum frutefcens. ibid.

Lencautbenum canarienfe, Sapore pyretbri. WALTH. bort. t. 24. bene. Chryfunsbemun fruticofum, foliis carnofis linearibus pinnatis dentatis apice trifo dis. LINN. l. c.

Receptaculum depreffe conicum, tuberculatum, nudum. Semina difformia: difci (g. G.) minora, inverfe pyramidata, tetragona, glabra, pallida, coronata, margine membranaceo lato crenulato. Sem. radii (h. H.) majora, cordita, compreffe triangula, ad latera fere in alam .extenuata, pallide ftraminea, curonata matgine brevifrimo denticulato. Solo palearum defectu a Buphthalmo recedic.

Huc porro quoque fpectant: Chry. inodorsm, alpinzus, atratum B, ferotinum, arificum, Myconis, bipimatums; nec non Matric. afteroides; \& Achill. pubefcens. LINN.

Eft itaque Pyrethrum nihil aliud, quam Tanacetum radio larvatum. 


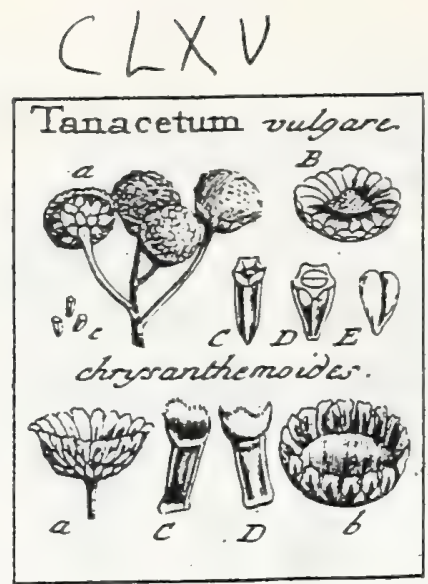

J. Gaertner (1788) Vo: 2

\section{5}

DCCCCLVII. TANACET UM. TOURN. t. $26 \mathrm{r}$. LINN. gen. 944.

Calyx henifpharicus, imbricatus fquamis appreftis. Flofe nunc omnes androgyni \& uniformes, nunc androgyni quinquefidi in difco, \& feminei trifidi in radio: utrique tamen fertiles. Thal. nudus. Sem. uniformia, coronata margine integro aut dimidiato.

TANACETUM vulgare. Tab. 165 . fig. 7 .

Tanacetum. Dod. pentpt. 36. BLیkw. berb. t. 464. Oed. fior. dar. t. 872

Tanacetum foliis bipinnutis incifis ferratis. LINN. Gff. veg. 742.

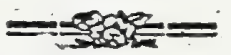

REC. convexun 1. fubconicum, nudum, elevato - punctutum.

SEN. :parva, uniformia, inverfe pyramidata, pentagona, fubcinerea, angulis colta pallida notatis.

Pappis marginatus, anguftus, membranaceus, pentagonus, obfolete quinquedentatus, pallide albicans.

IN T. exterius coriaceum, duriufculum.

Eм B. albicans.

1.) Pars corymbi. B.) Receptac, denudatun, c. C.) Semen integzam. D.) Idem diftetum.

E.) Embryo denudatus.

TANACETUM chryfanthemoides. ibid.

Bellis major Jpinofa, petalis carens. Moris. biff. 3. S. 6. t. g. f. 16.

Cotula grandis. Lins. $\int p$. pl. 1257. Jace. obf. IV. t. 8 s.

Cloryfunthemum fofculofum, fiufculis omnibus usiformibus bermapbroditis. LinN. fyjt. veg. 773 .

Calyx hemifpharicus (ar), imbricatus fquamis margine fcariofis. Flofc. onues androgyni, quinquefidi. Thal. (b.) planus, nudus, excavato-punctatus. Ovaria (C. D.) oblonga, comprelia, coronata margine membranaceo, dimidiato, f. latere interiore (C.) exfecto l. deficiente, exteriore autem (D.) erecto, concavo, denticulato, pallide albicante. Semina matura non vidi.

Genus bifrons, accederite radio mutatur in Pyrethorum aut Chryjantbemunn. 


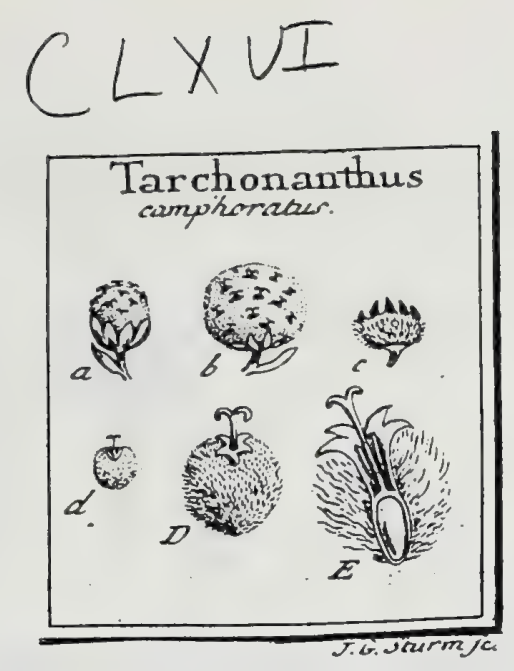

\section{J. Gaertner (1788) Vol. 2 392}

DCCCCLII. T A R C H O A A T H U S. Linn. ger. 940.

Calyx manophyllus, fubfeptemfidus, extus tomentofus, intus glaber nigro coloratus. Flofc. omnes androgyni, fertiles; corollulis lanatis, cum feminis integumento externo continuis. Thal. villofus. Sem. lanata, absque pappo vero.

Tarchonanthus camphoratus. Tab. 166 . fig. 12.

Elichryso affuis africann arborefcens, floribus purpureo violaceis, foliis falvie, odoris roris marini. PLuk. phyt. t. 174 . f. $x$.

Tarcbonanchus foliis oblongis plavis, calyce monophyllo quinzuefudo. LINs. Sy.t. veg. 740 .

R E c. planiufculum, villofum, villis calyce brevioribus.

SeM. parva, ovata, lanata, coronata corollula perfiftente, extus lamata \& cum integunento feminis externo continua. Pappus, practer lanam copiofam, fernini \& corollulx comnunem, nullus.

Is T. duplex: utrumque membranaceum, tenuifinumi.

Es в. infra fundum corollula proprix, ovatus, albicans.

a.) Calyx Aoridus. b.) Idem maturus, patentiufculus. c.) Receptac. villofium. d. D.) Semen corollila coronatum \& copiofa lana obvolutuas. En) Corollula longitudïualiter apcrta, cum ge- nitalibus, \& embrjone infra corollz fundum polito.

Non audiendus eft Bergins, quando flor. cap. p. 256 . ovariun dicit fuperum; nec Limens l. c. quando feminibus pappun tribuit plumofum. 


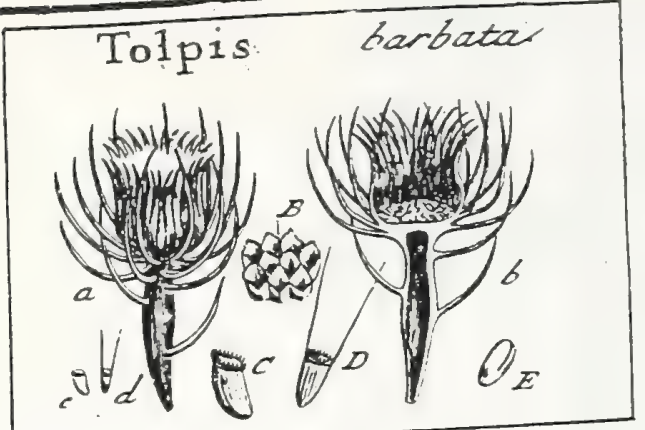

\section{J. Gaertner (1788) Vol 2

DCCCCXXIV. TOLPIS. ADANs. p. II . Drepania. Juss. p. I6g.

Calyx duplici ferie polyphyllus, rubaqualis, bafi circumvallatus fauamis fetzcuis fparfis per maturicatem falcato-incurvis. Thal: alveolatus. Pápgu's diffurnis: difci nargiuatus, cum fecis duabus 1. quatuor longiflimis; ridai polyphyllus axquadis.

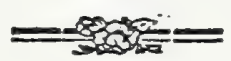

TOLPIS barbata. Tab. 160 . fig. 1.

Hieracium calyce barbato. CoL. ecplsr. 2. p. 28. t. 27. f. 1 .

Hieracirm, medio nigro, boeticum mujus. HERM. parad. t. 185.

Crepis involucris calyce longioribus: fquamis fetaceis fparfis. LINN. fyft. veg. 719 .

REC. planum, alveolatum, alveolorum marginibus denticulatis.

SEx. unifurmia, parva, ovata, ftriata, ferruginea, pappo feffili coronata.

Pappus difformis: rudii, fubpaleaceus, breviffinus, perfiftens, foliolis numerofis acuminatis albis, bafi in anuulum, femen coronantem, conuatis; difci, margo crenulatus breviffimus, e quo fetx dux l. qua. tuor, oppofitx, capiliares, vix denticulatx \& femine duplo longiores.

Is T. duplex: utrumque membranaceum, tenue.

EM B. femini conformis, albus.

2) Calyx integer. b.) Idem difeetus cum pedunculo fuo caro, atque receptac. alveolato.

B.) Alveoli infigniter auti. c. C.) Scmina radii d. D.) Semina difei. E.) Embryo deaudatue

Proprii generis effe plantam, jam pridem monuit Hall. bort. goett. 421. 


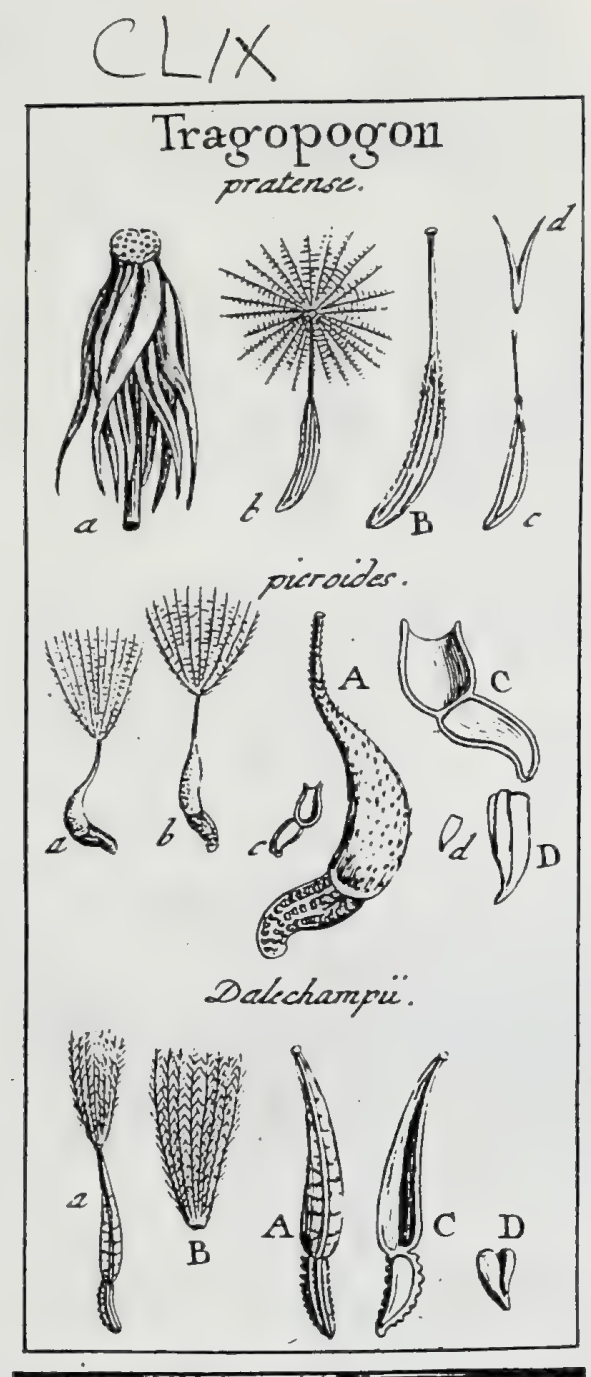

J. Gaertner (1788) Vol. 2

368

DCCCCXX. TRAGOPOGON. TOURN. t. =7\%. LINN. gin. 905. Urofpermum. JUSs. $p$. I 7 I.

Calyx longe pyramidatus, fimplex, fubdecemfidus, xqualis. Thal. nudus, excivitu punctatus. Senina prolonga. Pappus ftipitarus plumofus.

Tragopogon pratenfe. Tab. 1 59. fig. 4

Tragopogon. Fuchs. bift. lat. 827. germ. ic. 47 I. Cans. epit. 352.

Tragopogon calycibus corolle radiun aquntibus, foliis integris frictis. Less. by: veg. 709 .

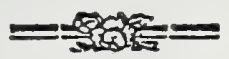

REC. nudum, primo planun, demum convexiufculum, punchatum.

SEN. prolonga, fufiformi-clavita, ftriata, glabra aut punctis acutis feabrata, albicantia, in ftipicen delinentia.

Pappus plumulus, albus, caduous: racnis prieaceis inxqualibus, longi-

tudine Atiprtis. Stipes fubulato-fetaceus, folidus, femini fubrequalis.

INT. duplex: exterins fubcrultaceuns; interius membranaceun, fericeo albuns.

EM в. fubulatus, albicans.

a.) Calyx maturus refiexus eum receptaculo. -b. B.) Semea integrum, c.) Ejas (ettio longitudinalis. d.) Embryo denudatus.

TRAGOPOGON picroides. ibid.

Cbondrille cretice nomine nifja, femine crifpo. BA Ur. biff. 2. p. 1022.

Tragopogon calycibus monophylis corolla brevioribus aculeatis, foliis runcinatis denticulatis. LiNn. fÿt. veg. 7 10.

Semina fubdifformia: radii (a. A.) incurva; difci (b.) rectiufcula: utraque bafi compreffa, embryouifern (C.), plana, nunc triplici ferie fyuamularum horizontaliter patentium (A) utrinque muricata, nunc folummodo ad marginem fuperiorem crenulata. Stipes femine multo craffior, curvatus, inferne inflatus, cavus (c. C.), fuperne filiformi attenuatus, undique punctis acutis fcabratus, unacum femine rubro-ferrugineus. Pappus fericeo - albus, plumofus, caducus. Ėmbryo (c. C. d. D.) oblongus, plano-compretius, apico truncatus, lividus.

TrAGOPOGON Dalechanipii. .ibicl.

Hedypnois monfpefsulana. Вай. biff. 2. p. 1036 .

Hieraciums fulplureun, incifis folits, montanum. BARR. rar. 1045. ic. 20 g.

Trazoposoul calycibus monsopbyllis corolla brevioribus inernibus, fuliis rroccinatis. Lis.. l. c.

Senina (a. A.) in ratione ad ftipitem fuum brevia, oblonga, compreffa, triplici aut quadruplici ferie tuberculorum acuminatorum muricata, albicantia. Stipes (A. C.) femine craffior \& triplo longior, fubulatus, obfolete ftriatus atque rugofus, compreifus, intus cavus (C.), Gexilis, nec cruftaceus ut in precedenti. Pappus (B.) plumofus, caducus, ruffus aut e rubro purpurafcens. Embryo (D.) obovacus, cumpreilus, albus.

Polteriores duas frecies, proprio Urofpermi nomine generico a Tragopogone fe. paravit Scopoli. 
Asteraceae

No draving

$$
\text { J. Foentren }(1788) \text { volz }
$$

T: R I D A X. LIN ger. 972. Calyx cylindraceus, imbricatus fquamis ovato-oblongis erectis. Thal. palea-
ceus. Flufc. difci androgyni ; radit feminei, ligulis tripartitis: utrique fertiles. Sem. uniformia oblonga. Pappus pilofus, calyce paulo longior. Tridax procumbens. LiN. fyf. veg. 778 .

19.150 


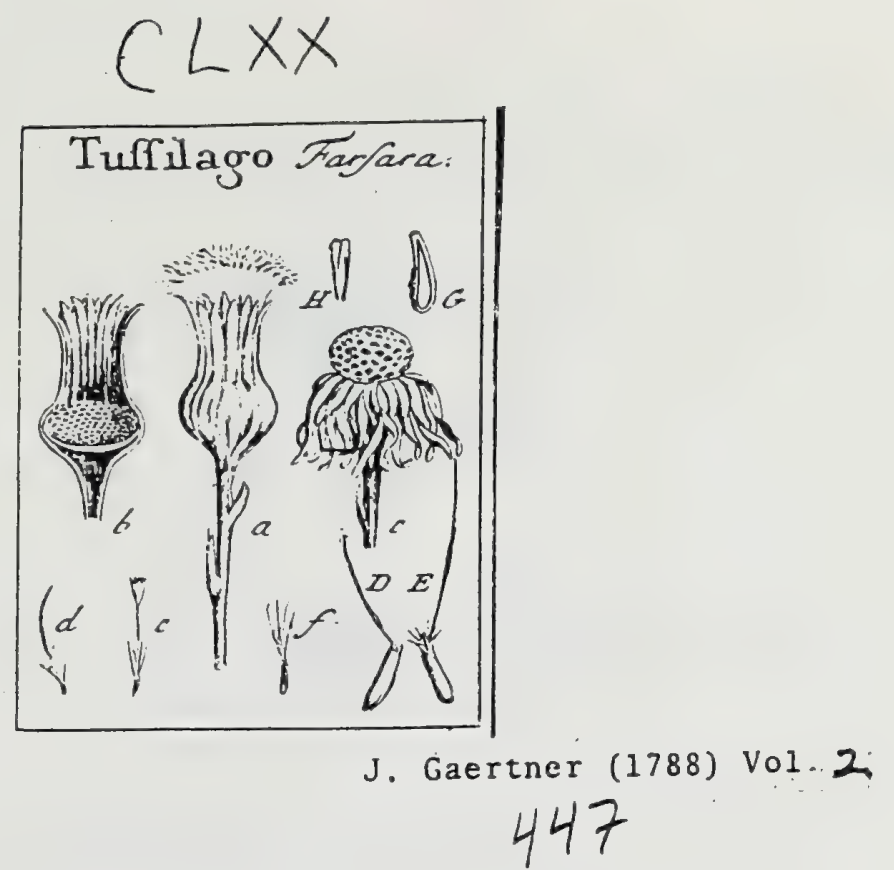

447

MXXII. T U S S I L A G O. TOURN. t. 276. LINN. gen. 952.

Calyx fiuplici ferie polyphyllus xqualis, per maturitatem bafi ventricofe tumidus \& demum totus refexus. Recept. ferobiculatum glabrun. Flofc. difsi androgyni; radii feninei, ligulis linearibus: urrique fertiles. Pappus felfilis capillaris.

Tussilago Furfara. Tab. 170. fig. 6.

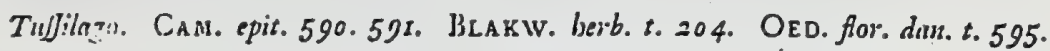

TuJilugo foupo uniforo imbricuto, foliis Jubcordutis angulutis denticulatis. LINN. J.j.t. veg. 755.

REC. ante maturitatem planum aut leviter concavun, poftea pulvinato globofum, fcrobiculatum, nuduin, glabrum.

SE M. uniformin, oblonga, furfum leviter attenuata, teretiufcula aut obfolete angulara, fpadicea.

Pappens capillaris, feffilis, fubedentulus, femine duplo longior.

IN T. exterius fubcoriaceum, tenue.

EM B. fubulatus aut cylindricus, albus.

2) Calyx maturus, rentricole conicus. b.) Ejus featio verticalis, ct:m receptac, adhucidum plano. c.) Jdem rehixus, cum reecptac. demum pulvinato. d. D.) Finfe. sadii ligulatus. c. E.) Flofe. dilci tubulofus. f.) Semen feparatum. G. Hi.) Emürso denudatus.

Tutrilago itaque eft Petufites radio larvatus. At fub neutra plantx forma, ç̀o pappum unquam vidi ftipitatum, ficuti voluit Limuxus. 
Asteraceae

ho drowing

J. Foutres (1788) volz

$$
42 \%
$$

U N X I A. LINN. ger. I420.

Calyx fubrotundus pentaphyllus. Flofc. difci androgyni quinque, infundibuliformes; radii feminei, quinque, ligulati : utrique fertiles. Recept. nudum. Sem. calva.

Unzia camplorata. LiNn. frppl. 368 .

Flores folitarii, e dichotomia, fubpedunculati, magnitudine pif. Semina ovata, dura, calva. Lims. l. 6 .

Si fofculi androgyni fteriles funt, uti ex Jugf. fufpicari licet, genus hoc proxime a Milleria collocandum erit.

19.152 

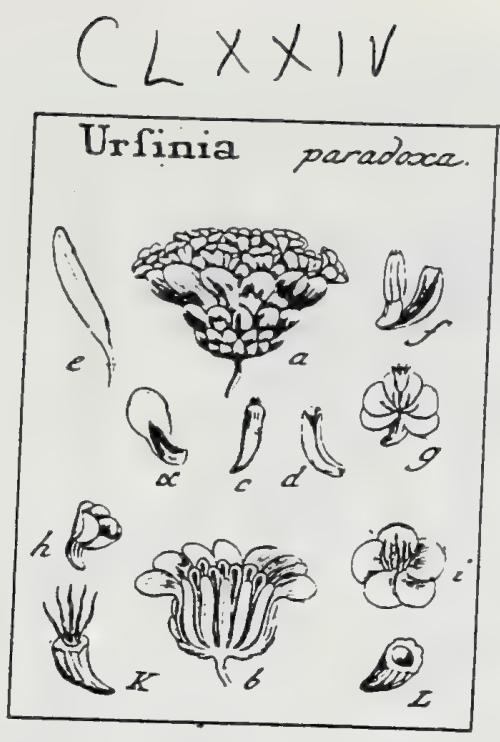

J. Gaertner

(1788) $\operatorname{vol} Z$

\section{2}

\section{MXIIII, U R S I N I A.}

Calyz hemifphxricus, imbricatus fquamis coriaceis opacis, margine \&*apice fcariofis pellucidis. That. planus paleaceus. Flufc. difci androgyni tubulofi fertiles; radii feminei aut neutri, ligulis oblongis integerrimis, fteriles. Sem. cononata pappo compofito: exteriore fcariofo peutaphyllo; interiore 'quinqueradiato fetaceo.

URsinis paradoxa. Tab. 174 fig. 4

Ecabiofa punila cotule folio, flore albo innurrefcente africma, f. Xer anstemaides atbiopicunz fofcalis albis fiftulofis. PLUK. alik.'334. phyt, t. 312. f. 5. mala.

Arifotis fofanlis radiantibus ferilibus, paleis colaratis difco longioribus, folis bipinnatis lineasibus. LINs. fyft. veg. 792.

A Cl. Thumbergio.

R g c. planiufculum, paleaceum. Palex fcariofse, ochroleucx, in fiftulas tiofculus difci amplexantes iisdemque longitudine fere xquales convolutex, hinc integerrimx, inde fiffura longitudinali apertx, apice crenulatx aut denticulatx.

SEM. inverfe conica, curvula, ftriata, glabra, pallide albicantia, unilocularia.

Pappus compofitus : exiterior pentaphyllus, foliolis fubrotundis fcariofis niveis femine fesquilongioribus, ante explicationem circa flofculum convolutis, eumque occultantibus; interior fetaceus, radiis quinque, bafi comaris, pappi exterioris fuliolis dimidio fere brevioribus.

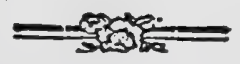

Ix T. exterius fubnucamentaceum, focruftaceum, craflum, durum, uriloculare: EB B. femini conformis, albicans.

a.) Calyx matorus isteger. (n) Squama calycina feparatr. b.) Calyx diffedus cum paleis in: fitu naturali. c.) Palex feparatr latus dorsale; d.) Ejusilen pars ventralis. c) Flofe. radii Aterilis. f.) Flufc. direi, pappo fao obvolutus. s.) Ejusdem corollula deandata h.) Scmes: cum pappo exteriore. i) Pappus exterior explicatus, cum pappo interiore in fitro nafurali. K.) Semer cum folo pappo isteriore. Lu) Scrainis tefta transverfim. fedz.

Hujus prixterea generis funt: A. pilifera \& antbemoides. BekG. \& forfan quoque reliqux Arctotides paleacex Liss. Sed videndum prius, anue omnes. perinde duplici pappo gaudearit. 


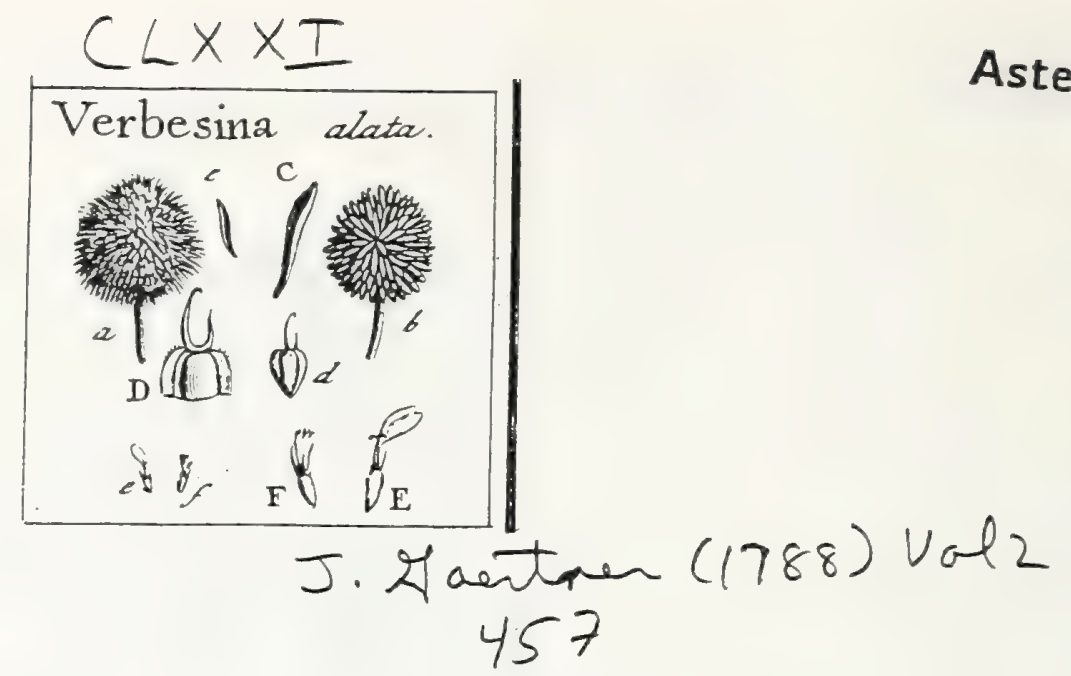

MXXXVI. V E R B E S.I N A. LINN. gen. $975^{\circ}$

Calyx polyphyllus, foliolis a receptaculi paleis vix aut parum diftinctis. Thal. convexus alut conicus, paleaceus. Flofc. difci androgyni; redit feminei, ligulis latitudine difci brevioribus: utrique fertiles. Sem. uniformia.' Pappus bi - 1. triariftatus.

Tierbesisa alata. Tab. izi. fig. 8.

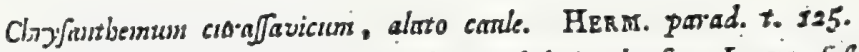

Tierbefira folits alsenis decurrentibus undulazis obtufse LiNN. [yft. veg. 779 .

REc. oblongum, fere fubulatum, undigue re\&um paleis oblongis concavis extus pubefcentibus.

SE r. uniformia, obovata, comprefo-plana, fufca, margiae pallido membraz1aceo cinća.

Pappus biariftatus: ariftis fetaceis, altera paulo longiore incurvats; altera breviore recta.

Is T. nembranaceum, tenue.

EM. albicans.

a.) Calys maturus. b.) Receptae. palcis tezum, c. C.) Pulez Ieparate: a. E.) Flofe, radie f. E.) Flofe. difī. d. D.) Semen feparatam.

Verbefina igitur eft Spilantlus radio Jarvatus. 


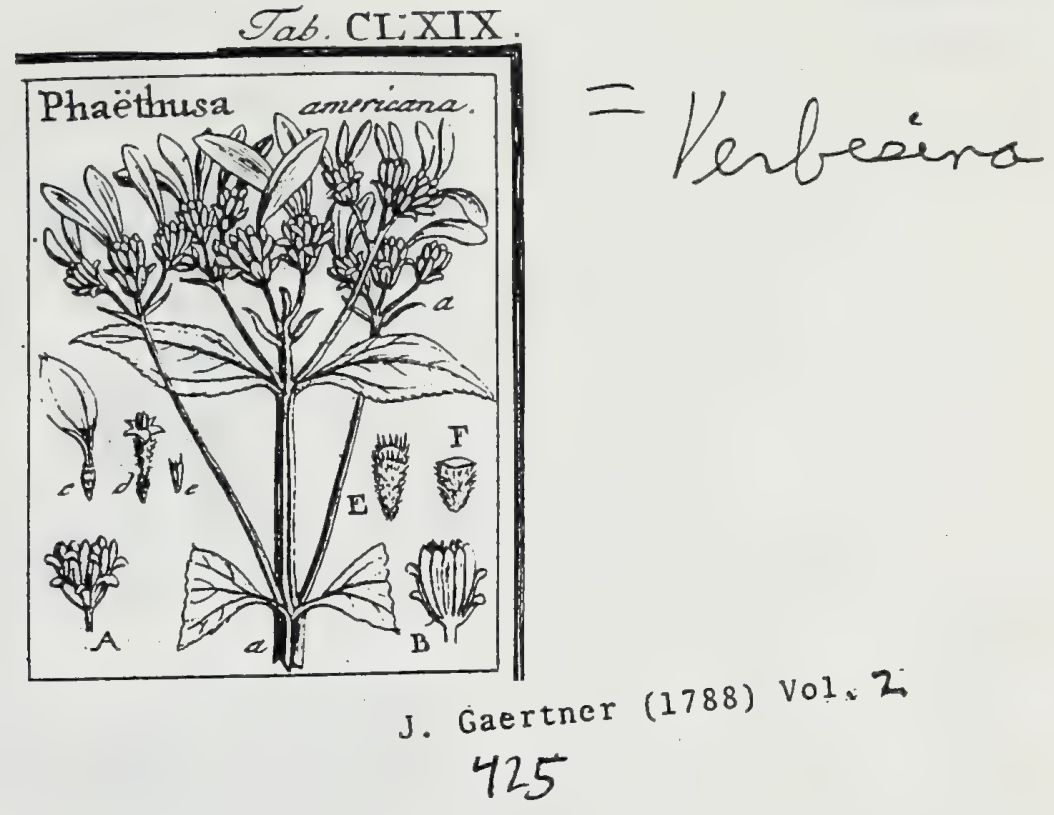

\section{DCCCCXCV. P H A E T H U S A.}

Calyx fubcylindricus, polyphyllus, imbricatus fquamis inxequalibus, apice recurvis. Thal. paleaceus. Flofc. androgoni plures in difco: femineus unus aut alter, liguli ovato-oblonga bidentata, in radio: utrique fertiles. Semius hifpida absque pappo.

Рнавтнusa americaua. Tab. 169. fig. 3.

Cluyfunthemum anericanum caule alnto, foliis amplioribus binatis, floribus paltide lusefcentibus parois. Plux. plbyt. t. 342. f. 46 . 4.3 .

Vierbsfina foliis ovatis petiokntis decurrentibus oppofitis, fofculis radiorwn folitariis, Gros. virg. 1. p. 179.

Sigesbeckia petiolis decanrentibus, calycibits undis. LINs. 6yft. veg. 779 .

REc. anguftun, paleaceum : paleis lineari-oblongis, obtufis, concavis, apice viridibus, a fquanis calycinis vix vel parum diftinctis.

SEM. parva, oblonga, dẹorfum anguftinra, compreffa, undique fetulis rigidis, fupra verticem fenuinis prominentibus, hifpidata; ip fo autem vertice calvo.

Ix T. fimplex, membranaccum.

EM B. albicass.

a. a.) Pars corgmbi florum. 1.) Calyx feparates integer. B.) Idem ditcetus, cum paleis re. ecptzeuli. c.) Flof. sadii. d.) Flofc. difri. e. E.) Semen integruan. F.) Idem ditietuino

Caulis giganteus, 18 pedalis, a decurrentibus foliorum petiolis angufte quadrialatus. Folia grandia, oppofica, ovaţo-acuminata, triplinervia, obfolete ferrata, fubpubefcentia. Corymbus terninalis, brachiatus, amplifinus. Corollulx androgynx extus hirfutx: antheris prominulis atris. Fenivix plerumque folitarix, vix unquam terna: ligula fulphurea, ovata, utrinque attenuata, apice breviline bidentata. Pappus uullus . léd-hirfu-

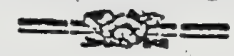

ties fominis, paulo fapm ejus verticem producta, mentitur marginem
palenceo-lacerum.

A Sigesbeckia perinde ac a Milleria, toto fuo habitu externo, fofculis utrius.
que generis atque funinibus, abunde differt, ut cun neuta earum que generis atque fininibus, abunde differt, ut cuni neutra earum fociari
pollit. 


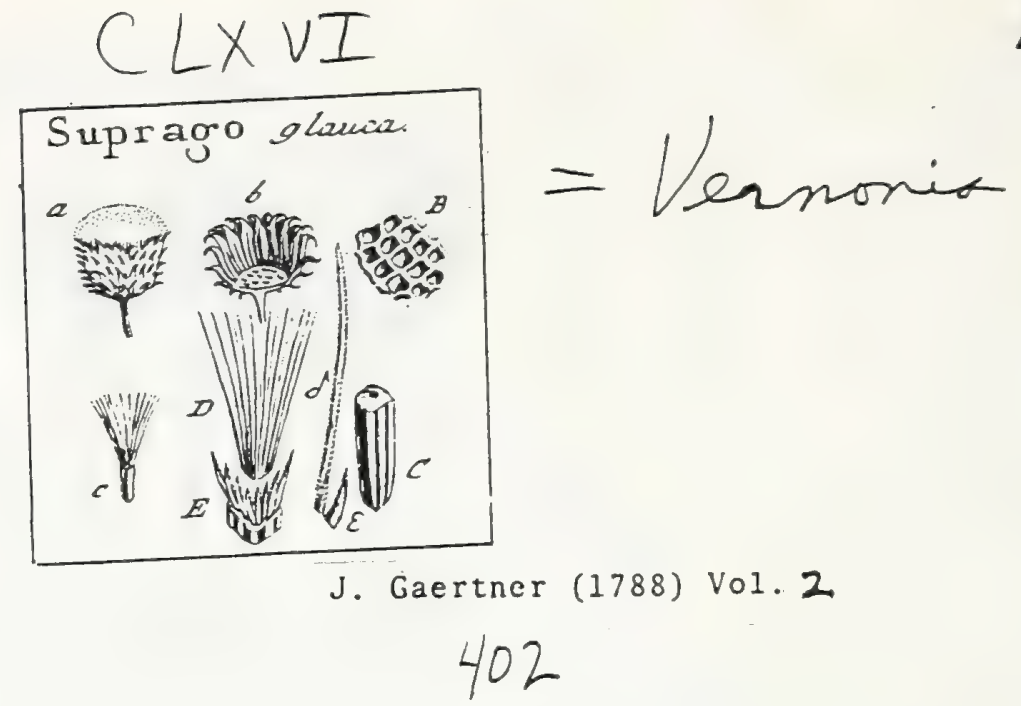

DCCCCLXVI. S U P R A G O. Serratula. Linn.

Calyx polyphyllus, imbricatus, xquabilis aut fquarrofus. Flofe. onnes androgyni. Thal. planus, nudus, excavato punctatus. Pappus Setaceus, rigidus, dentato- ciliatus.

Suprago glauca. Tab. 166. fig. 5.

Serratula marilundica, folits glaucis, cirfii ingtar denticulutis. Dicl. elth. t.262. f. $34 t$.

Serratula foliis ovato oblongis acuminatis ferratis, fioribus corymbofs, calycibus fubrotusidis. LiNN. $\int y /$. veg. 732.

REC. planum, nudum, obfolete fcrobiculatum, glabrum.

SEN. oblonga, tetragono-columnaria, ftriata, glabra, rufefcenti-fpadicea.

Pappis fetaceus, rigidiufculus, fubfragilis, fordide albicans, dentato ciliatus : radiis extimis brevillimis, reliquis femine longioribus.

IN T. exterius coriaceum, tenue.

EM B. femini conformis.

2.) Calyx maturus integer. b. B.) Receptac. (erubiculatum. c. C.) Semen integrum. D. \&) Pappi radii interiores. E. s.) Ejusder radii extimi

SUPRAGO (Liatris in Icon.) fpicata. Tab. 167. fig. 1.

Jacea angufifolia, tuberofa radice. PLuk. phyt. t. 424. f. 6.

Cirfrom suberofsun, laduce capitulis fpicatis. D1LL. clib. t. $72 . f .83$.

Serratula foliis linearibus bafi ciliatis; fioribus fedilibus laterulibus fpicutis, cante frusplici. LINN. Ejs. veg. 723 .

Calyx (a) fubcylindricus, imbricatus fquamis oblongis, obtufis, appreffis, ficuti tota planta glutinofis. Thal. anguftus (c. C.), fcrobiculatus, glaber. Flofculi (b.) rubri, ftylis profunde bifidis, ftigmatibus filiformibus longi( $T_{1}$ mis. Semina (d. D. E) oblonga, deorfum acumiusta, trigono-aut rhombeoconpreffa, itriata, glabra, e plumbeo-fpadicea. Pappus longitudine feminis, albicans: radiis numerofis, xqualibus, fenceis, dentato-ciliatis.

Huc prxterea [pectare videntur: Serr. prealsa, fquarrofa \& novaboracenfis. LiNN. qux tota fua facie externid. fung:te receptaculo calvo, longillime ab Acanaceis recedunt, ac propter tolsa fuperiora oppofita (in S. praalsa,), \& propter ftigmata filiformia (in S. fpicata), proxime ab Eupatorio diftant. 
Asteraceae

No chauirg

$$
\text { J. If aertree (1788) Uol2 }
$$

W E D E L I A. JACQ. bif. p. 217. JUss. p. r8g.

Calyx tetraphyllus magnus laxus. Thal. paleaceus. Flofc. difci androgtrii ralii feminei, ligulis obcordatis fenibilobis: utrique fertiles. Sem. coronata pappo monophylto campanulato decendeutato.

Wedelia frutefcens. Jace. bif. amer. $227 . t .130$.

Polyimia folits lasceolatis, conde fruticofo. LINN fyf. veg. 790.

Receptaculum planiufculum, palesceum: paleis numero \& longitudine flofcuJurum, concavis, obtufis: interioribus apice coloratis. Semina uniformia,
abovata, coronata calyculo campanulato, circiter decemdentato. Jacg. Lc.

19.157 


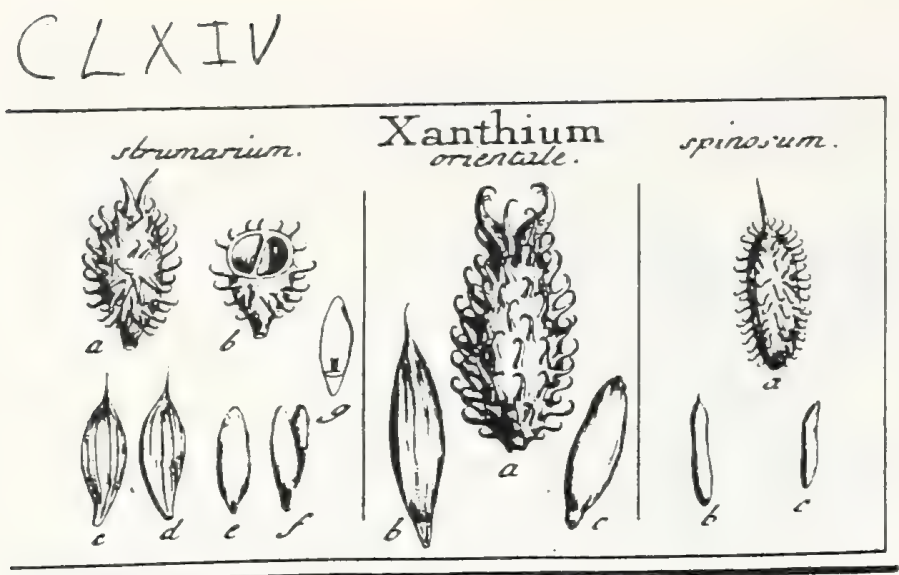

\section{J. Gaertner (1788) Vol, 2 \\ 418}

DCCCCLXXXVII. XANTHIUM. T OURN. 2. 252. LINN.gen. 1056.

Flores fexu diftincti, in diverfis calycibus ejusdem caulis. MAS. Cal. polyphyllus, imbricatus, mulitiorus. Flofe infundibuliformes, quinqueEsi, pentandri: antheris difcrecis. Recept anguftifrmun palcaceun. FEM. Cal. monophyllus, oblongus, biforus, biroftris, bilocularis, fpinis uncinatis undique muricatus, perfiftens, femina involucrans. Cor, nulla. Sem. folitaria, calva.

Хaxthum ftrunarium. Tab. 164 fig. 9.

Xantbium. Fuchs. bif. lat. 579. gemm. ia 529. Can. epit. 926. Blakiv. berb. t. 444 .

Xustbium caule inermi, foliis cordatis trinervatis. LINN. fyjt. veg. 852.

PER. nullum. Calyx femineus nutatur in feminis involucrum coriaceo-nucamentaceum, oblongum, intus fepto longitudinali divifum, extus fpinis fubulatis hamatis muricatum, apice in duo cornua; primum rectil, deinceps incurvato - uncinata atque latere fuo interno rima longitudinali hiantia definens, non dehifcens.

REC. nallum, prater fundurn loculamentorum.

SEM. in fingulo loculo fingula, ovato - oblonga, utrinque attenuata, ftriata, hinc convexa, inde plana, nigro - fufca.

IN T. duplex, utrumque membranaceum: exterius in ftylum definens.

A L B. nullun.

EM B. fermini conformis, erectus, albicans.

2.) Involucrum nocameataceum integrnm, immaturnm, eum dnobus roftris rectis, b.) Ejus rectio transverialis. c. d.) Semen a parte dorfali atyue ventrali fpectatum. e. f. t. ) Earkyo ener fuis cotyledonibus atgue plumula bicorai.

Xanthuщ orientale. ibid.

Xomtlizun casle inermi, foliis cuoreifonmi ovatis fubtrilobis. LiNe. dec. 33. 8. 17. bit. veg. I. c.

Fructus (a.) priori fimillimus, fed duplo fere majur, ferrugineus nec pallide ftramineus atque circa bafin roftrorum \& fpinarum fubtumentofus, nec undique glaber. Semen (b.) longe ellipticum, ftriatum, fufcum. Embryo (c.) alhus.

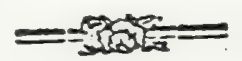

Xantuluar Spinofum. ibid.

Xantbium lufitanicume fpinsofum. PLUK. pbyt. t. 239. f. 1. НЕкм. parad. t. 246. MAGNOL bort. =08. c. ic. VOLK. norimb. t. 149.

Xmutbinu Jpiris tematis, foliis trilobis. LIXN. fyft. veg. l. c.

Fructus (a.) ovato-cylindricus, terminatus roftro fimplici fubulato recto cartilanineo glabro. Aculei diftri, horizontales, fetacei, rigidi, apice unciurlaci. Semina (b.) oblonga, feniterctia, nigricantia. Embr. (c.) albus, gracilis. 


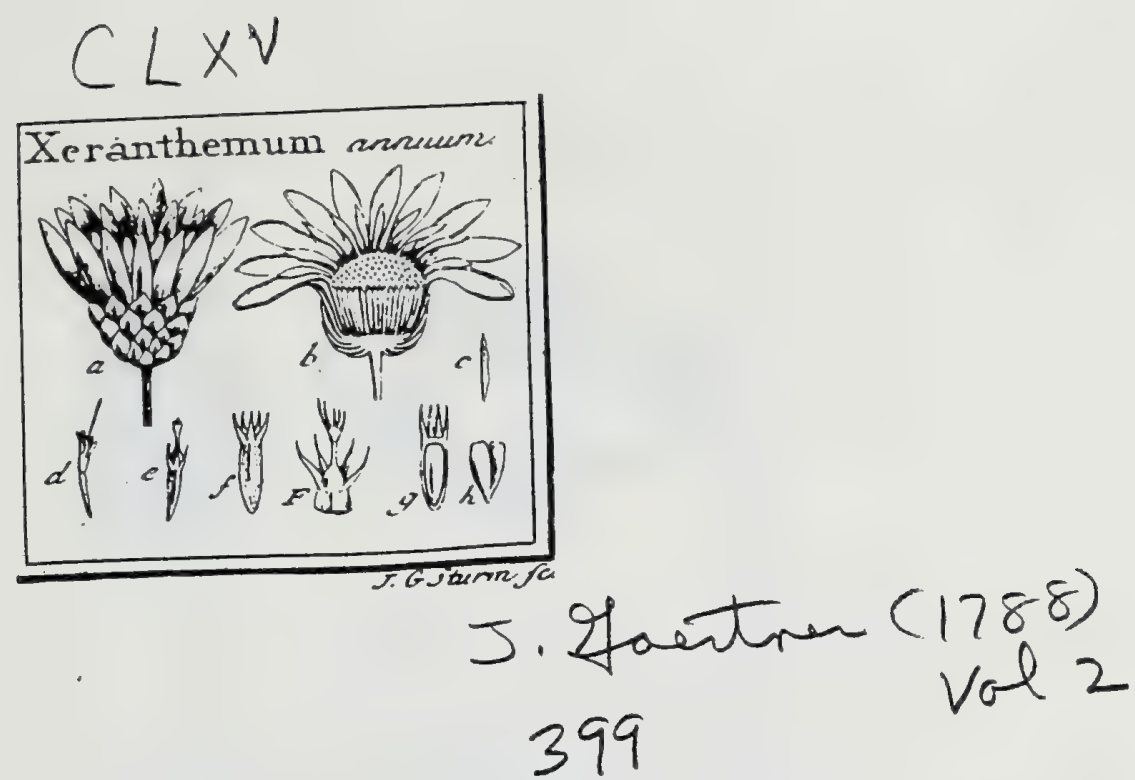

DCCCCLXII. XERANTHEMUM. TOURN. t. 284. Linn. gen. 947.

Calyx imbricatus fquamis fariolis inacualibus: intimis elongatis coloratis nitidis radiantibus. Flofe. infundibuliformes, quinquefidi: difici androgyni numerofi fertiles; rudii feminei pauciores teriles. Thal. paleaceus. Sem. androgynis pappo pentaphyllo; femizisis calva effora.

Xeranthenum annum. Tab. 165 . fig. 6.

Xerautbemum berbaceum, foliis lanceolatis patentibus. LiNN. fyft. veg. 749.

Icom. MILL. ic. t. 297. Jace. aufir. t. 388 .

REC. planum, paleaceum, paleis lineari-acuminatis, rigidis, calycis ventre paulo longioribus.

SEns. feminis nulla, f. effors, ex ovario lineari - oblongo, ftrinto, glabro, compreito calvo, perfiltente \& perfiltente quoque corollula coronato.

androgynis oblonga, deorfum acuniinata, rhombeo-aut lenticulari-compreffa, villis albicantibus apprellis confperfa, e cinereo fufca, pappofz.

Pappus fcariofus, albus, pentaphyllus: foliolis lanceolatis aut triangu lis, fetaceo acuminatis, vix dimidio femine longioribus.

Is T. utrumque membranaceum, tenuiffinum.

E $\mathrm{A}$ B. Semini conformis, lutcus.

2.) Calyx integer, b.) Idem diffelus cum receptaculo. c.) Pales recopt (eparatz. A.) Ovarium femineum, corallula fua perfiftente corunatum c.) Semeu Elofe. androgyai, pappo pentephyllo atque corollula, emarcida, demum caducz, coronafum. f.) Idem absque corollula. F.) Ejusdem pars fuperior refecta, cum curollulx, quandoque perfifeutis, sudinente g.) Ldim longitudinaliter apertum. h.) Embryo denudarue

Figurx f. g. J. ad femina plantx hortenlas conciunate funt; in fpontaneis omsia duplo vel triplo minora deprehenduutur Videant alii, num feninarum ovaria quandoque fuccundentur, cum iplas femina calga tribuat Limuars l. c.; in meis certe Specininibus omaia emnt calla.

Character generss Linnxanus in hanc folam quadrat fpeciem, a reliquis vero omnibus recedit longitime; quare iftas partim Argyrocomx \& partim Elichry fo inferendus cenlemus. 


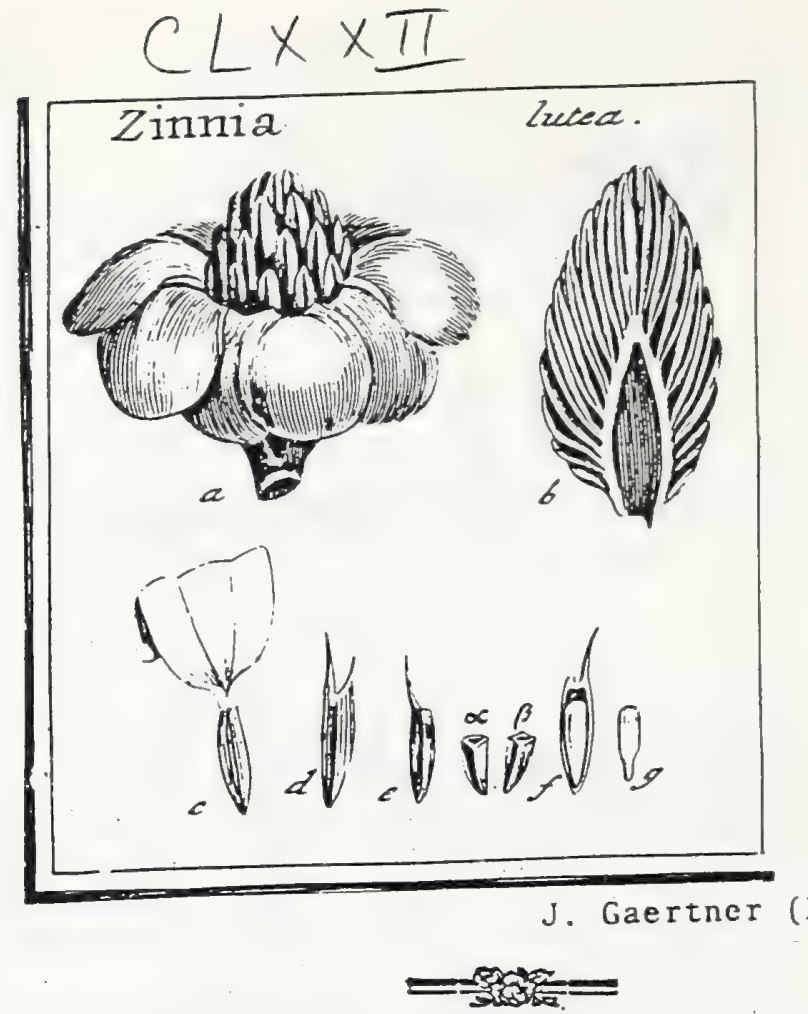

(1788) Vol. 2

\section{Z I N N I A. LINN. ger. 974}

Calyx turbinatus, inıbricatus fquamis inxqualibus rotundatis rigidis appreflis. Thal. conicus, paleaceus. Flofc. difci androgyni; radii feminei, ligulis obovatis perfiftentibus: utrique fertiles. Sera. uaifarmin Pappus zadif nullus; difci ariftatus.

Zisnin lutea. Tab. 172. fig. 3.

Rudbeckia foliis oppofitis. Zins. h. goett. t. c.

Bidens calyce oblongo, Seminibus radii corolla nons decidua cororatis. Mren. ic. t.64.

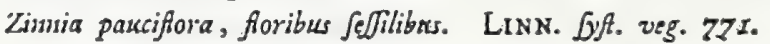

$R E c$. ovato-conicum, inferne fquamis calycinis, fuperne autem paleis techum, intus cavun. Palez oblongx, carinatx, femine longiores.

SE M. uniformia, oblonga, trigono - aut rhombeo-compreffa, Itrista, pallida: Pappus difformis: radii nullus, fed ejus loco emarcida corolla feminea perfiftens; difci ariftatus: ariftis fubulatis, fpinofis, rectis, inzquzlibus, folitariis geminis aut rariffme ternis.

Is T. exterius coriaceun, tenue.

Eмs. oblongus, faturate viridis aut e caftaneo fufcus. Cotyl ovato.oblougd, extus tenuifime ftriatz. Rad. teretiufcula, brevis.

a.) Fics maturus integer. b.) Receptac langitudinaliter diffeAum. c.) Semer natiii, enrolls

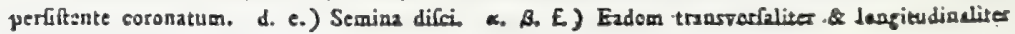
ditet.2. 8.) Eiubryo feperatus. 
Asteraceae

J. Foutren (1788) Volz

Z O E E A. LINN. gers. I27r.

Calyx Cyanii ovatus imbricatus. Thal. fetaceo - paleaceus. Flofc. difci androgyni, tubulof, fertiles; radii feminei, ligulis planis, fụbquinquedentatis, iteriles. Sem. ovata. Pappus fetaceus.

Zoegea Loptuarere. Lins. fyf. veg. 784

19.161 


\section{Tab. CXIII.}

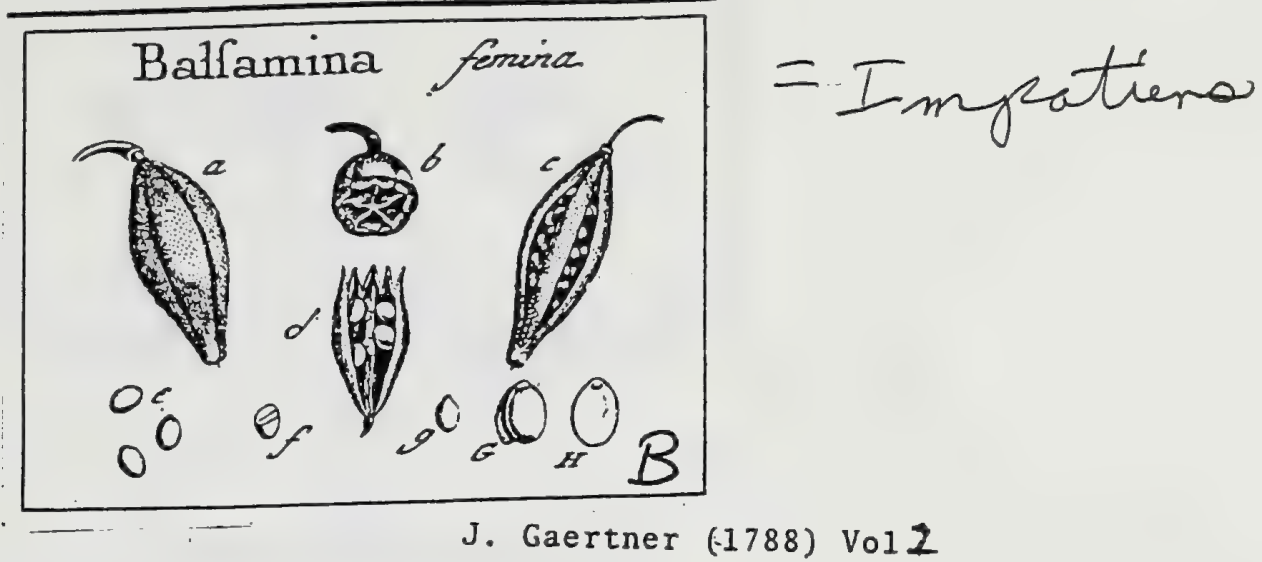

$15 \mathrm{r}$

DCLXI. BALSAMINA. TOURN. inf. t. 235. Impatiens. LINN. gent. IOOS.

Calyz diphyllus, caducus. Cor. pentapetala, irregularis, calcarata. Stam. quinque, antheris in tubum coalitis. Ovar fuperum. Stigina felfile. Capfula quinquelocularis, quinquevalvis. Semina plur.

Balsamina femina. Tab. 113. fig. 4 .

Baljamina. Dod. pempt. 67x. BESL. Eyft. autum, t. 4. f. t. RIv. teirap. t.x20. BLAKW. berb. $t .5^{8} 3$.

Impatiens pedusculis uniforis aggregatis, foliis lanceolatis: fuperioribus alternis, ueitaris flore brevioribus. LINN. fyy. veg. 804 .

PER. Capfula ovata, furfum attenuata, villofa, quinqueftriata, ante plenam maturitatem herbaceo carnofa, quinquelocularis: difepimentis membranaceis, tenuilfinis, medio valvularum \& axi fimul affixis; poft naturitatem coriacea, tenuis, unilocularis, quinquevalvis.

REC. axis filiformi angulatus, perfiftens, ex concurfu diffepimentorum formatus, cui fęmina longitudinaliter affixin.

SEM. decem circiter in quovis loculo, parte tamen plus quam dimidia plerumque abortante, ovato-globofa, compreffiufcula, ferruginea, minutifimis atonis fulvis confperfa.

IN T. duplex: utrumque menibranaceum, tenue; interius album.

$A$ \&. nullum.

EMB. femini conformis, inverfus, primum viridis, deinde albicans, aut lividus. Cotyl. ovatz, craffx, plano-convexz. Rad. breviflima, mucrosis tantum fpecie, fupera \& fimul centripeta.

2) Capfula integra. U.) Eadem ante plenam maturitatem transverfim feda. c.) Eadem in ratvulas dehifcens. d.) Receptaculum ceatrale cum feminibus. e.) Scmina integra. f.) Semca transverie feetam g. G.) Embryo denudatns. H.) Cotyled. facies interas, cum veftigio plumulx bicornis.

Balfumina Noli zangere. Linn.

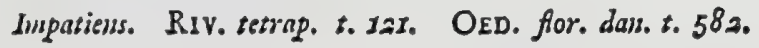

Capfula fubbipollicaris, cylindrica, ftriata, quinquelocularis, quinquevalvis: valvulis a bafi elattice dehifcentibus, revolutis. Receptac. centrale, per maturitatem liberum \& a diffepimentis fecedens. Semina elliptica, fupra roltellata, tetragono comprefla, primum viridia, demum fpadicea. Albumen nullum. Embryo inverfus. Cotyledones fragiles \& fere friabiles. Radic. exferta, brevis, fupera. 
Tab. 213.

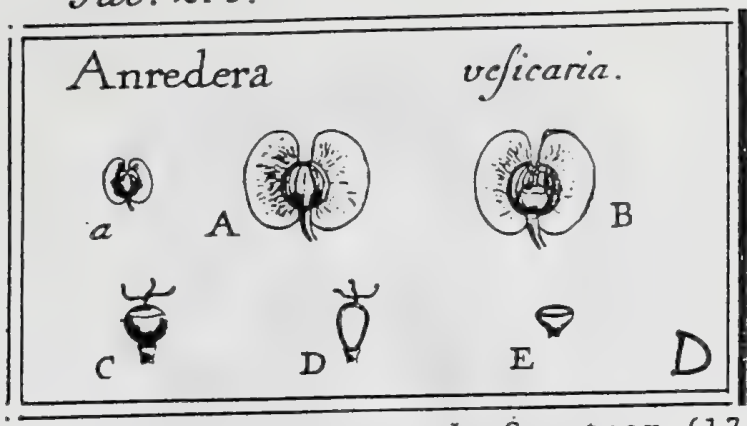

J. Gaertner (17.88) Vol. 3

176

\section{A N R E D E R A.}

Juss. gen. pl. p. 84 .

Cal. monophyllus, quadridentatus: laciniis duabus majoribus, cum duabus minimis alternantibus. Cor. O. Stam. 5. Ovar. fuperum; ftylo unico, trifido; ftigmatibus tribus, fimplicibus. Per. nullum, Semen intra calycem perGftentem occultum. Rec. nullum. Alb. ... Emb. ...

ANRedera velicaria. Tab. 213 . fig. 4.

Bafella (veficaria, ) folis fubcordatis, pedunculis fimplicibus, fructibus orbiculato. comprefis veficariis. LANARCE diä. I/ p. 38 .

Auredera, PERSOON Jy, I. po 297.

Ab amicifimo $D^{\text {no }}$ DECANDOLLE,

PER. nullùm: preter extimam ovarii cuticulam, per maturitatem feminis rumpentem \& cum ftylo caducam. Calyx quadripartitus, membranaceus, medio globofe inflatus. femen occultat; lacinix calycis majores oppoftex, globofo - naviculares, dorfo in marginem latum membranaceum femiorbi. cularen ampliatx; alterx cum prioribus alteruantes minimx, ovatx, adpreifx.

REc. nullum; femen fundo calycis adnatun,

SE M. unicum, obovatum, lenticulari - compreffufculum, ereêum, fub pellicula exteriore fufcum, nitidum.

Is T. duplex: exterius craffiufculum, coriaceum duriufculum; 1. cruftaseivm; interius nembranaceum.

A L B. . . .

ENB. . .
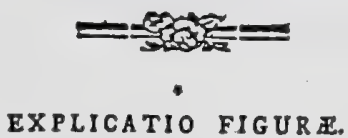

a. A.) Frueus integer. B.) Calycis lacinin ovata \& parr globoin laciniarum majornm abletx; cun ovario in fitu. C.) Ovarium leparatua. D. R.) Bjusdem feaio loagitudinalis, \& trase vercalis. 


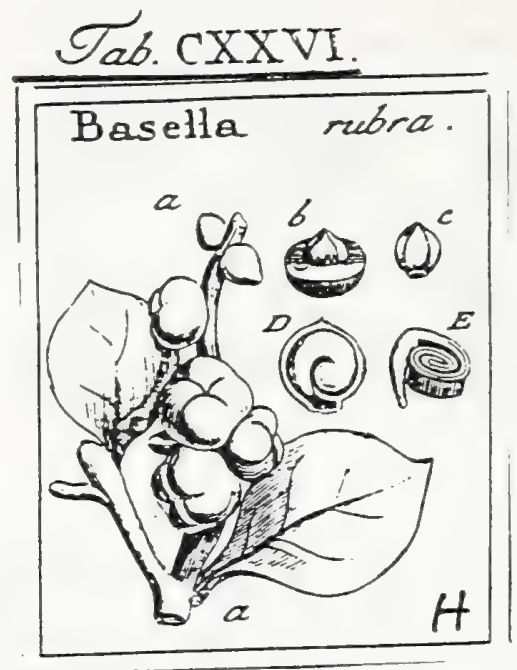

J. Gaertner $(-1788)$ Vol 2

200

DCCXVIII. B A SEL L A. LINN. gen. 3S2.

Calyx quinque - feptemfidus, fegmentis inxqualibus. Cor. nulla, nifi ca. lycem velis. Stam. quinque. Ovar. fuperum. Styl. tres. Semen wicum, nucamentaceum, calycis fegmentis sarnofs involueratum.

Basella rubri. Tab. I26. fig. 8.

Bafella. RHEED. mal. 7. p. 45. t. 24.

Gundula rubra. RuMPH. amb. 5. t. 154 .

Bafella foliis planis, pedunculis fmplicibus. Liss. fy.t. veg. 298.

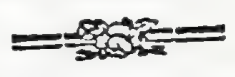

PER. nullum; calyx in baccam fpuriam, carnofam, stro rubentem, depreffiufciatim fulcatam, converfus, femen fovet, nec dimittic.

REc. nullum, procter fundum calycis.

SEณ. vиicum, nucamentaceum, fubglobofum, obfoletiflime quinqueftriatum. bafi foramine umbilicali amplo perforatum.

In T. duplex: exterito offeum, pallide teftaceum, tenue; interius membransceun, rufefcens.

A L B. vix ullum, proter paucam fubfantiam fpongiofam aut fubfarinofam alban in centro utriusque lateris integumenti interni.

minadine femirris, fpiralis, albus. Cotyl. lineari oblongx, planiufmagnitudine femirns, fpiralis, albus.
culx, fubfoliacex, centrum fpirx formantes. Rad. tereti - acuminata, extimum fpirz gyrum ab a. a.) Calyces baceati clauli. b.) Caro refecta \& (eminis pars fuperior denudata. e.) Nneula folutus.

Nuculam naturaliter effe trilocularem atque trifpermam afferit $\mathrm{CL}$. Medicus Malv. famil. p. 85 . 


\section{Begoniaceae}

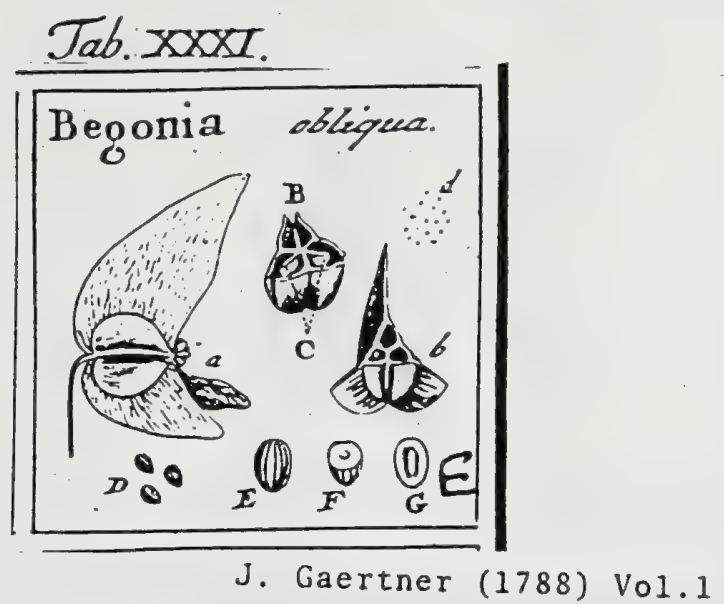

156

\section{BEGONIA. TOURN. t. 442. LINN. gen. IIS6.}

- Flores fexu diftincti in eadem planta. Mas. Cal. nullus.- Cor. fupera tetrapetala: petalis duobus oppofitis obcordatis. Stam. plura. Fex. Cal. \& Cor. ut in mare. Styli tres bifidi. Capfula infera, trilocularis, trialata: alis inxqualibus.

Begonia obliqua. Tab. 31. fig. 5.

Aceris fructu herba anomala, flore tetrapetalo albo. Sloan. hifl. jam. 1. t. 127. f. 1. 2.

Begonia acaulis, foliis incegualiter denticulatis. LINN. Sy . veg. 857.

Ex herbario Bankfiano.

PER. Caplula infera, corolla perfiftente coronata, triangularis, trilocularis. Anguli compreff, in alas membranaceas ampliati: quarum una reliquis duplo major; omnes vero bipartibiles, per maturitatem cuin valvulis dehifcentes. Diflepimenta membranacea, tenuifima, anguftifima, valvis contraria.

REC. lamina fpongiofo coriacea, tenuis, finguli loculamenti angulo interno affixa, utrinque feminfera.

S E м. numerofifrma, minutifima, ovato globora, pallida, lineis rufefcentibus longitudinalibus friata, bafi in tuberculum fufcum definentia.

IN T. fimplicifimum, membranaceum, tenuifimum.

A L B. femini conforme, carnofum, pallidum.

Ем в. teretiusculus, albus, longitudine fere albuminis. Cotyl. ... Rad. receptaculo obver $\int_{3}$.

a.) Capluix integra. b.) Eadem transverle feta. B.) Esdem absque alis in valvolas divifa. C.) Receptacula tria, axi fruftus inferta. d. D. E.) Semina teparata, F. G.) Sexiuis \& albuminis rediones, cum fgura \& ficu embryonis.

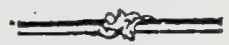

Embryonis formam diftincte vidi, at cotyledones difcernere non valui, five quod nimis fint minutx, five quod femina nou fueriut rite inatura. 


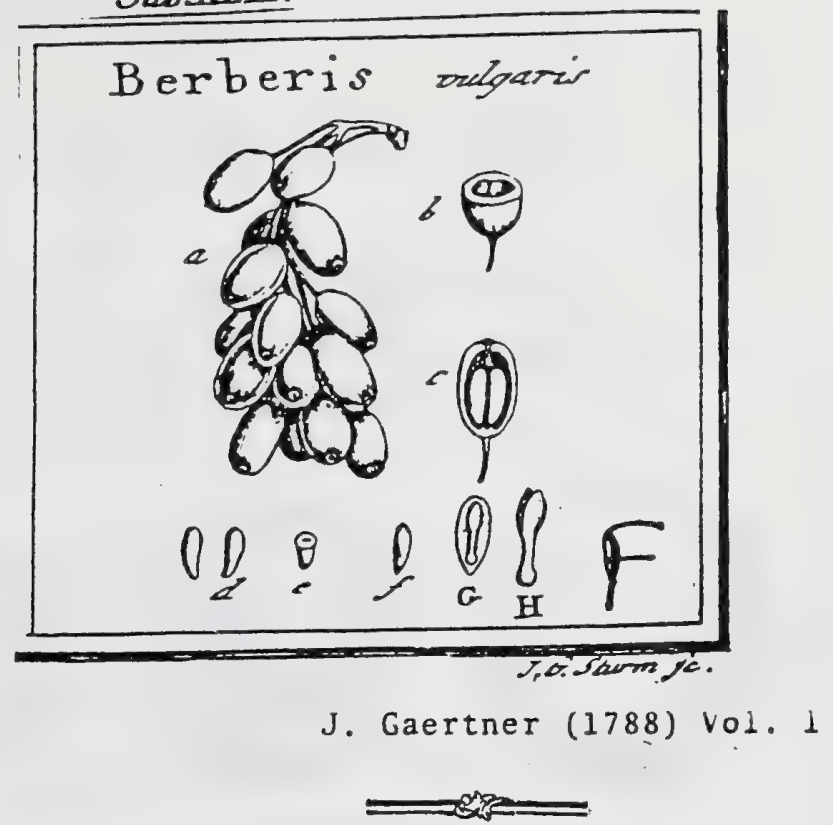

CCXLT. BERBERIS. TOUR N. t. 385. LIN. gen. 442.

Calyx hexaphyllus. Cor. hexapetala. Stan. fex. Styl. nullus. Bacca fupera, unilocius ris, apice perforata! Semiua duo !, tria.

BER B ERIS vulgaris. Tab. 42. fig. 6 .

Berberis. B L А к w. herb. $t$. 165 .

Berberis racemifera, foliis ciliatis. H A L, 1. iiff. 1. n. 828 .

Berberis pedunculis racenofis. LIN N. J4f. veg. 343 .

PER. Bacca fupera, parva, carnola, ovato-cylindrica, apice papillâ fufcâ foraníne perviâ notata, unilocularis, rubra. Loculanentum feminibus amplius, in altero Jatere, ftria elevata e foramine deorfum tendente, infcriptum.

REc. tubercula duo !. tria minutiffusa in fundo baccx, quibus femina affixa.

SEs. duo, rarius tria, undique libera, oblonga, furfum crafliora, obtufa, glabra, pallide teftacea, dura.

IN T. duplex : exterius coriaceo cruftaceum, durum, tenue; interius membranaceum, pallidum, chalaza verticis fufca.

A L 8. Cemini conforme, craflum, carnofum, durun, pallidum.

EM B. longttudine fere albuminis, erectus, niveus. Cotyl. ellipticz, foliacex. Rad. longa, gracilis, inferne capitellata, infcra.

a.) Baccarum racemus b.c.) Bacca transverfim \& longitudinaliter reta. d.) Semina fepanta e.) Semen transverfe fettum. f.) Albumen denudatum. G.) Ejus fetio longirudinalis cum fitu ena bryouis. H.) Embryo (eparatus. 


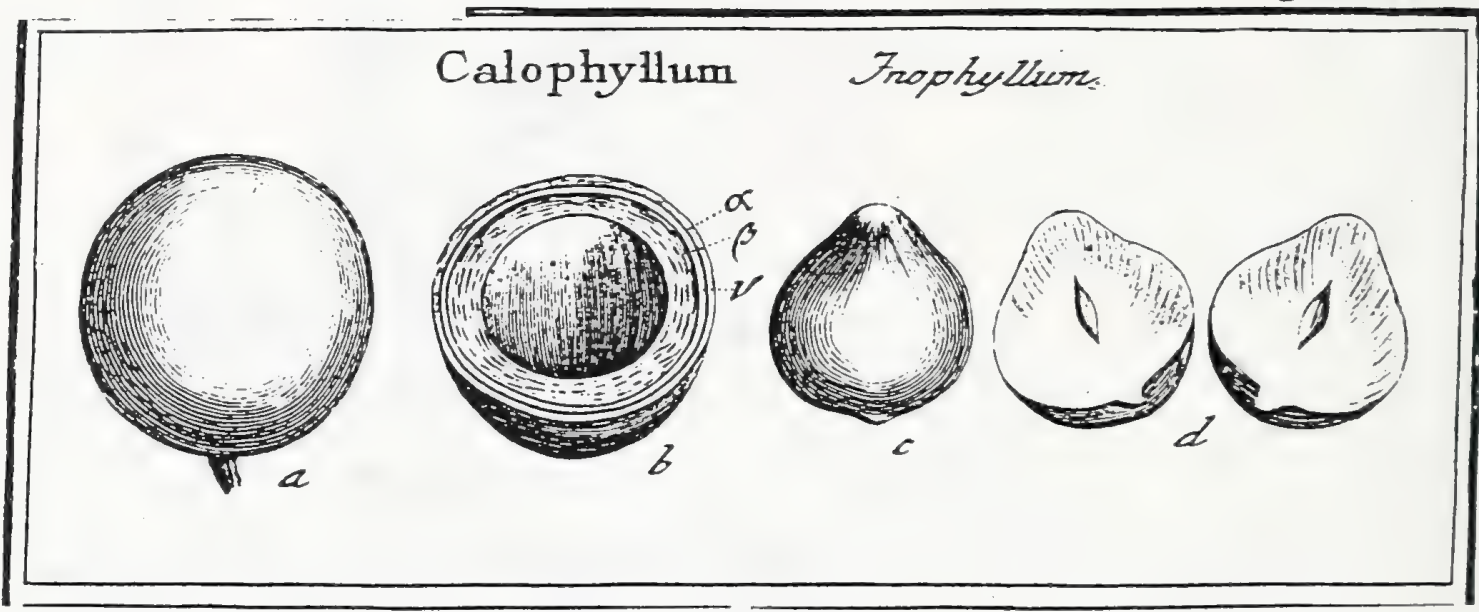

J. Gaertner (1788) Vo1 1

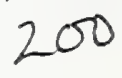

CCXLח. CALOPHYLLVM. LinN. ger. 658 .

Calyx tetraphyllus coloratus, Cor. tetrapetala. Stan, numerufa. Styl. unicus. Drupa baccata monofperma: putamine intus fungolo.

Calophylum Inophyllum. Tab: 43. fig. I.

Arbor indica, nali medica amplioribus folits. P I U K. phyt.t. I47. $f \cdot 3 \cdot$

Calophyllum foliis ovalibus. Lin N. fy/f. veg. 492.

E colleckione Bankfiana.

PEr. Drupa fupera, grandiuscula, fpherica, glabra, nitida. Cortex baccatus, carno. fus, modice craffus. Putamen coriaceo cruftaceum, tenue, albicans, uniloculare, intus auctuin \& incraftatum fubfantia fungofa, fublamellofa, craltia, (iu adulto
fructu) ochracei coloris.

Rec. nullum; femen fundo drupz affixum.

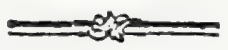

201

SEм. unicum, grande, e globola bafi in conicum umbonem faligatum, feu inverfe pyriforme, ipadiceo fufcum.

IN T. fimplex, membranaceum, tenuifinum.

ALB. nullum.

Es в: feinini conformis, erectus, albus. Cotyl. maximx, carnof $x$, oleof $x$, plano convexx, intus fxpe parva cavitate in medio exfculptx, crafiflumx. Rad. parva, exigui tuberculi couci Specie, c bafi cotyledonum prominens.

2.) Drupa integra, b.) Eadem dirrefra: $\alpha_{\text {. }}$ ) Cortex carnofus. $\beta_{\text {. }}$ ) Putaminis pars cruflacea. $\gamma$ ) Ejusdem pars lamellofo fungora. c) Semen desudatum. d.) Cotyledones feparatze.

Non poten femen haberi pro baccato, quia fungofa fubitantia, non cun ipfo, at pertinacifume cum putanine colixiet. 
Tab. XCII.

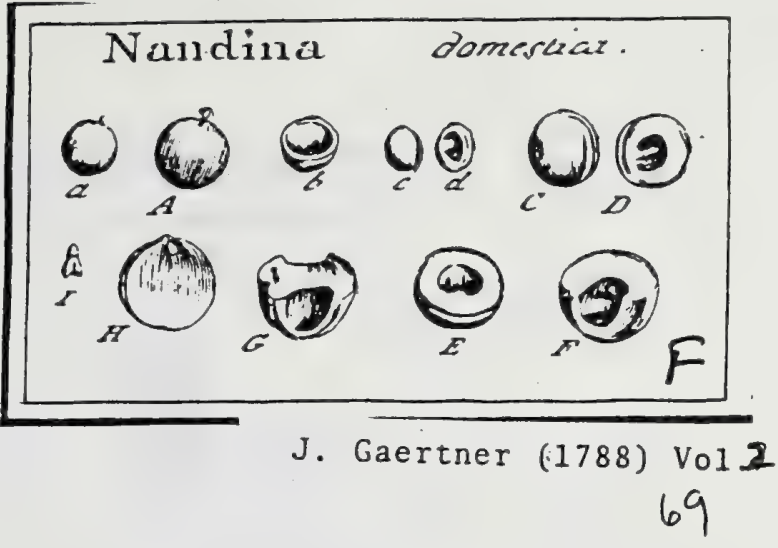

DLXXIV. NA N D INA. THUNB.

Calyz polyphyllus imbricatus. Cor. hexapetala. Stam. fex. Ovar. fuperum. Styl. unicus. Stigma capitatum. Bacca exfucca unilocularis, difperma.

NANDINA domeftica. Tab. 92. fig. 3.

Nandina. Thunb. jap. p. 9. \& 247. Lins. Jjif. veg. 344 .

A C. Ночтихм.

70

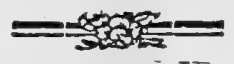

PER. Bacca fupera, magnitudine pifi, fplscrica, exfucca, coriacea, ftylo brevi atque ftignate capinato trilobo terminata, extus rubra aut per xtatem fpadiceo rufefcens, intus membrana alba veftita, unilocularis.

REC. fpongiofum \& quafi adipe fcatens, feminibus interjectum, eorumque cavitatem intermam farciens: hinc in recenti fructu globofum, album.

SEM. duo, menifcoidea, f. convexo concava, rotunda; ad alterum fuun marginem ftria deprefla, a bafi ad apicem decurrente notata, cinerafcentia, aut rufefcentia.

IN T. fimplex, tenuiffimum, arcte adnatum.

A Lв. femini conforme, cartilagineum, durum, aqueo-pallidum.

Eм 8. minutus, niveus, inverfus, in apice albuminis locatus. Cotyl. rotundatz, fubfoliacex. Rad. incraffata, brevis fupera.

2. A.) Baces integra. b.) Eadem ditreaze c. C.) Seminis pars convexa, d. D.) Ejusdem pars concava. E.) Suleus in margine feminis. F.) Albumen transverfe fectum. H.) Idem verticalitcr fetum, cum fitu Embrgonis. I.) Embryo feparatus.

Numerus feminum naturalis, binarius eft, fed interdum nonnifi unicum adolefcit, \& tunc alterum, bafi ejus, fub forma fquamulx cmarcidx adhrete. Etiam figura confueta, menifara f. oculorum Cancri xmula eft; at nonnunqua!n femina, utrinque fovea excavata deprehenduntur, quale reprofentatur in fig. G. 


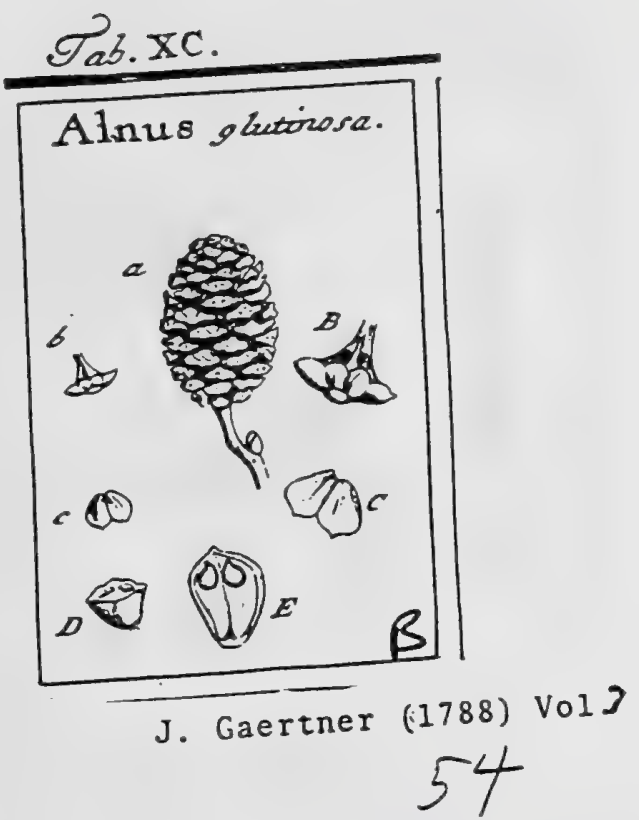

DLIX. A LNUS. TOURN. inft. t. 359 .

Flores fexu diftincti in eodem caule. MAS. Amentum juliforme, imbricsum fquamis primoribus majoribus cordatis, quibus annexa fecundaric ternix, minores, corolliferx. Cor. rotata, quadripartita. Stam. quatuor: Antheris bilocularibus. FEM. Amentum ftrobilaceum, ovato - globofufm, imbricatum fquamis fuberofis, ex angulto principiodrilobum ampliatis", bitransverfe oblongum \& margine fuo fuperiom comprefum, biloculare. Styl. foris. Cal. nullus. Cor. nulla.

duo. Nux compreffa, bilocularis.

Alvus glutinofa. Tab. 9o. 6g. 2.

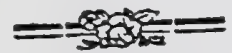

Alums. CaM. epit. 68.

Alum foliis glabris rotundis rotunde crenatis : fpongiolis ad nervornun angulos.

HaLL. bjet. n. $163^{0}$.

Berula peduaculis ramofis. LiNs. Jyft. veg. 849.

PER. Nux obovata, lenticulari compreffa, feu ex medio angulo obfoleto verfus laters declivis. Epidermis tenuis, luteo-fpadicea, glabra. Putamen offeum, durum, prope verticem duobus loculamentis exfculptum, evalve.

REC. nullum.

SEN. in fingulo loculo fingulum, lenticulare, rotundatum, fuperne oblique extrorfun ncuminatum, glabrum, pallidum.

IN T. fimplicifimum, membranaceum.

A L B. nullum.

Eм в. Semini conformis, inverfus, albus. Cotyl. rotundate, tenues. Rad. tereciufcula, fupers.

a.) Strobilus maturus. b. B.) Squama Ieparata. c. C.) Nuculx dux in fitu naturali fibi jundzz v.) Nucis rectio trinsveralis. E.) Eadem longitudinaliter fetas, cum fitu \& figura feaninum.

Ergo abunde Alnus a Betula differt, ut non carpologice tantum, fed \& anthologice $a b$ invicem feparari debeant. 


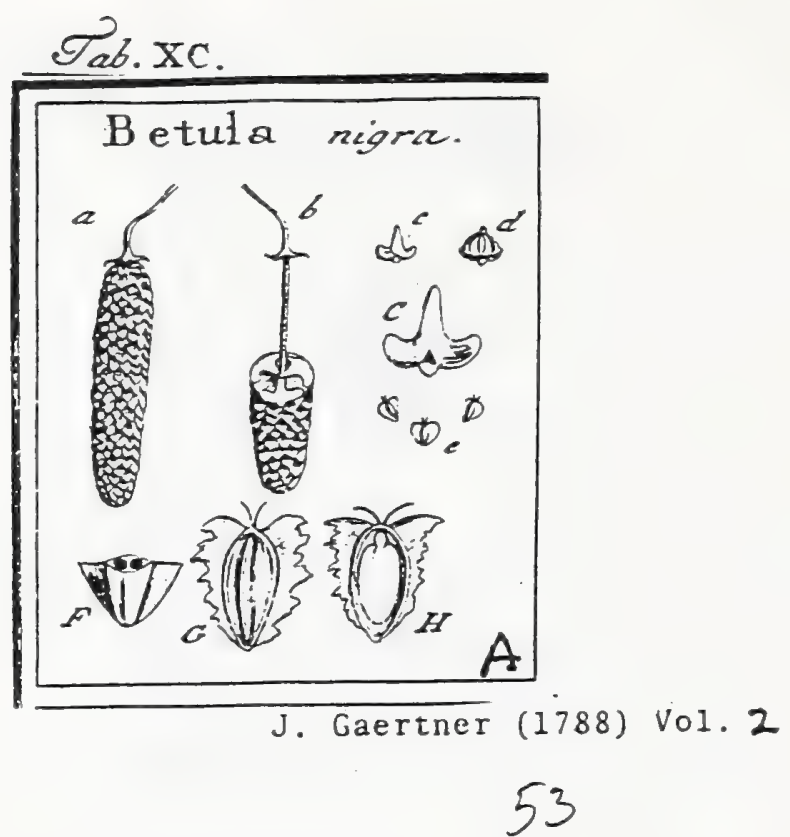

DIVIII. BETULA. TOURN. ix/. t. 360. LINN. ger. I052.

Flores fexu diftincti in eodem caule. MAS. Amentum juliforme, imbricatum fquamis ternatis: media majore ovata, duabus lateralibus anguftiorihus lanceolatis, omnibus concavis. Cor. nulla. Stam. duodecin, fquanax medix inferta. FEM. Amentun juliforme, imbricanm fquamis hori-

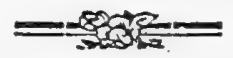

zontalibus, ex angufto principio extrorfum latefcentibus, apiceque trilobis, ad bafin vero bi-1. trifloris. Cal. nullus. Cor. nulla. Ovar. compreffum, ala membranacea cinctum, biloculare: Ovulis in fungulo loculo fingulis. Styl. duo. Samara cordata, unilocularis.

Betula nigra. Tab. 9o. fig. I.

Betula foliis rhombeo ovatis actuninatis duplicato ferratis. LINN. Jyjeveg. 849. A Pbil. Milllero.

PER. Samara parva, obcordata, in medio rufefcens aut ferruginea, ad utrumque latus ala membranacea, tenuilitima, pallida cincta, per maturieatem unilocularis: altero fcil. loculamento fere femper abortante.

REc. nullum. Semen ex ipfo vertice luculamenti pendulum.

SEM. unicum, ovato oblongum, comprefiiufculum, pallidum.

IN T. Gimplex, tenuifimum, ad radicule fedem intus fubcarnofum.

A L B. nullum.

EMB. magnitudine feminis, inverfus, albus. Cotyl. ovato oblongx, planiufculæ, oblongæ. Rad. teretiufcula, brevis, fupera.

a.) Julus femiscus integcr. b.) Ejusdem rachis denudata, cum fitu fquamarum c. C.) Squama feparata. d.) Eadem cum tribus fuis Samaris in fitu naturali. e.) Samarz feparatx. F. G.) Samira immatura transverfaliter \& longitudinaliter difiecta, cum fuis duobus loculamentis. H.) Ensbryo denudatus in eavitate Samarz matura.

Betu!a alba. LiNin.

Juli pracedentibus fimiles, fed quarta parte breviores. Squamarum bafis non ita angufta, \& tota earum furma, magis ad cordis, quam anchorx figuram accedens, ut perinde tanien trilobatx fint. Samarze ad fingulam fquamam tantun dux, rarius tres, $x$ quilaterx, totx fpadicex; prioribus dinidio fere minores, cetera eis ex affe fimiles. 


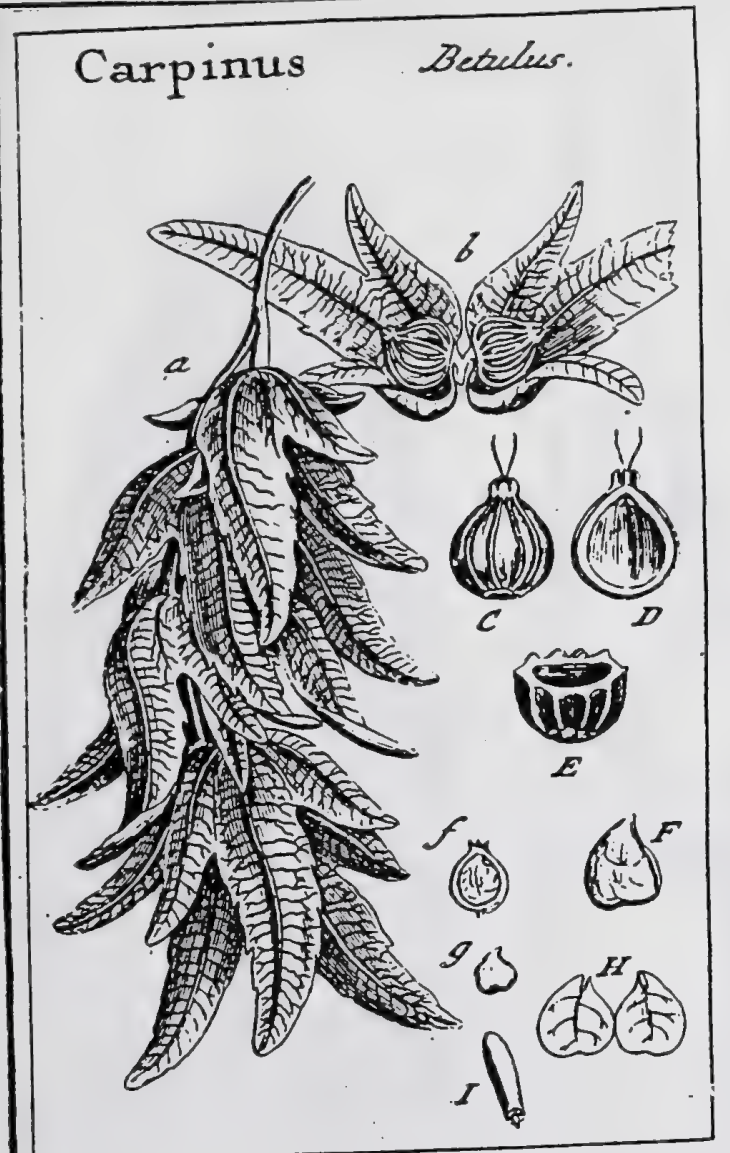

\section{J. Gaertner (1788) Vol2}

\section{CARPINUS. TOURN. inf. t. 348. LINN. gers. roz3.}

Flores fexu diftincti in eoden caule. MAS. Anentum juliforme, compofitum e fquamis ovatis, acuninatis, concavis, ciliatis, lixe imbricatis. Stan. octo ad quatuordecim : antheris spice viliolis. FEM. Amentum fquarrofum, laxum, pendulum: fquamis unifloris, petiolatis, trilobis, reticulato venofis maximis. Cal. fuperus, fexdentatus, inxqualis. Cor. nulla. Ovar. inferum, biloculare, compreffiufculum, difpermun. Styl. duo, filiformes. Nux unilocularis, evalvis.

Carpinus Betulus. Tab. 89. fig. 2.

Compinus. Cans epit. 7I. Dod. pempe. 84r. Hall. bifon. 13. $16=7$. Carpinus fquamis frobilorum planis. LiNs. Jyft. veg. 859 .

PER. Nux infera, parva, calyce membranaceo corticata atque coronata, offen, ovata, lenticulari compreffa, coftis longitudinalibus filiformibus ftriata, unilocularis, evalvis.

REC. funiculus umbilicalis breviffimus, ab apice loculamenti ad alterum feminis marginem defcendens.

SEM. unicum, altero fcil. ovulo fere conftanter abortiente, compreffiufculum, rotundacum, fuperne oblique acuminatum, glabrum, pallidun, venis arcuatis ex funiculo umbilicali infignitum.

Is T. finplex, membranaceum.

A I B. nullum.

EM B. femini conformis, inverfus, albus. Cotyl. obovatx, carnofx, planiufculx. Phum. acuminata, minutiffima. Rad. cylindrica, immerfa, fupera.

2.) Amcrutur feminenm maturum. b.) Nucularum fitus in fquamis amenti. C.) Nux feparata, intcgra. D) Eadem Longitudinaliter feda, cura fitu ovulorum geminorum. E.) Ejusdem fetio transverfalis. f. F.) Scrisn propria fua membrana veftitum. G.) Embrgo denudatus, H.) Cotyledones fiparatx. I.) Radicula a Plomala infigniter autax. 


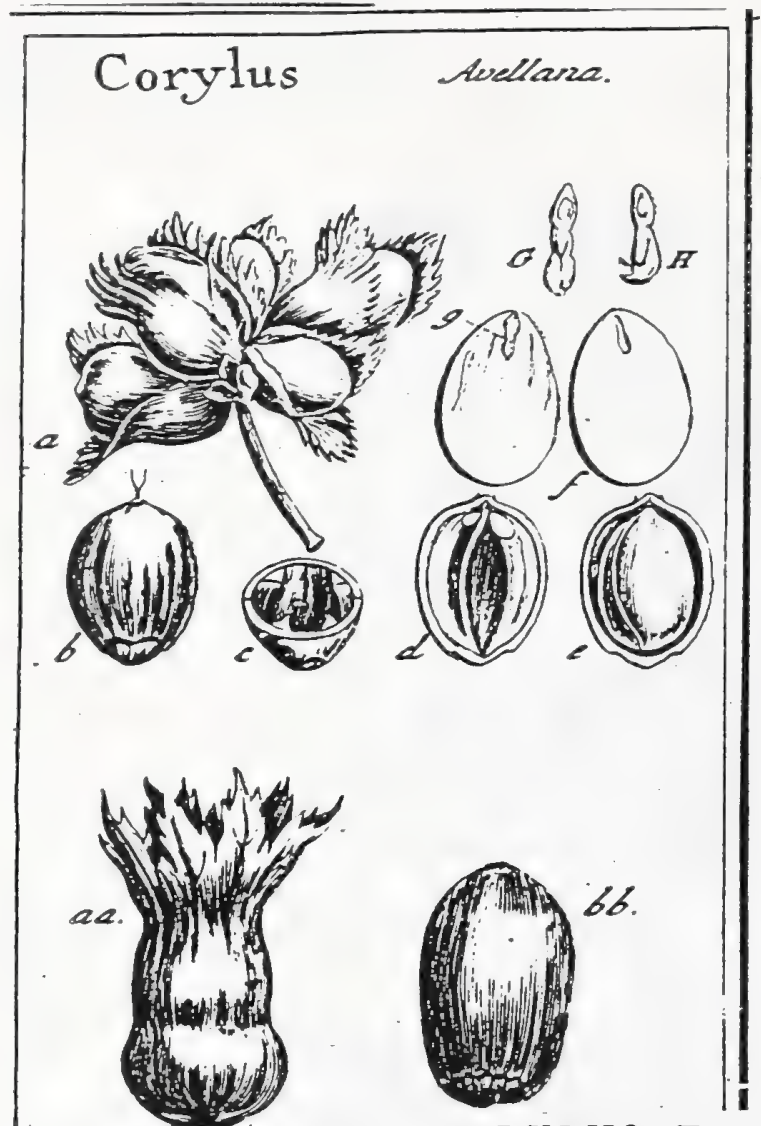

Betulaceae

J. Gaertner (1788) Vo1. 2

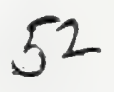

DLVII. CORYLUS. TOURN. inf. t. 347. LINN. ger. 1074.

Flores fexu diftincti in eodem caule. MAS. Amentum juliforme, ex fquamis imbricatis, hirfutis, tripartitis: lacinia media majore, obtegente laterales, dimidio anguftiores. Stam. fex l. ofto, brevifima. FEM. Amentum fubglobolum minimum, e fquamis gemmaceis \& involucris florum propriis

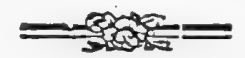

compofitum, per maturicatem pedicellatum. Involucra monophylla, inferne carnofa, turgida, fuperne bilabiata, lacera, uniflora. Cal. obfoletus, factus ex margine epidermidis nucis brevifimo, aream transverfe oblongam ad bafin ftylorum cingente. Cor. nulla. Ovar. biloculare? Styli \& ovula duo. Nux unilocularis, evalvis, bafi derafi.

Corveus Avellana. Tab. 89. fig. 3.

Corylhus fatiou. BLAKw. berb. t. 299 .

Corylhus Sepitum. HALL. biff. 13. $26=5$.

Corylus fipulis ovatis obtufis. Lins. fy/. veg. 859 .

PER. Nux ovato globofa, nuda, offea, glabra, aut obfoletifime ftriaca, bafi derafi, vertice leviter compreffa, unilocularis, ante maturitatem fubltantia fpongiofo-furfuracea farcta, evalvis, cultro tamen in duas valvulas féctilis.

REC. filiforme, e bafi nucis oriundum \& ad ejus apicem pertingens, ubi duo fultinet ovula pendula.

SEM. unicum, aut rarius duo: hacc varie angulata; illud cavitati unucis conforme, glabrum, albicans, rufefcens, aut fanguineum.

IN T. duplex: utrumque membranaceun, tenue.

A I B. nullum.

E M R. magnitudine \& figura feninis, inverfus, albus. Cosyl. ovatx, carnofx, plano - cunvexx. Pismo diphyllia, foliolis ovato acuninatis, conduplicatis. Rud. uvata, immerfa, fupera.

1.) Amentum fcuineum naturam peduncilatum: b. ) Nux iotegra. e) Ejus fcetio transrerialis, cum furfuracea materic parictibus intarnis adhxrente. d.) Receptac. filiforme cum ovulis. c.) Seracn intra nucem cum funiculo umbilicali. \&.) Cotgledunes feparatx. 5. G. H.) Radicula in Plumulam defincns.

Varietates Avellanx fativx dantur plures, \& una ex pracipuis earum eft:

Corylus fativa frotion oblongo rubeuse. C. B. Duнan. arb. ed. germ. p. 1;6. ic. p. 1;5. fig. 1 .

Involucrum (a. a.) tubulofum, inferne carnofun, turgidum, craftum, fuperne

liscrum. Nux ovato oblong: (bb), grandiufcula. Nuclei cuticula externa 


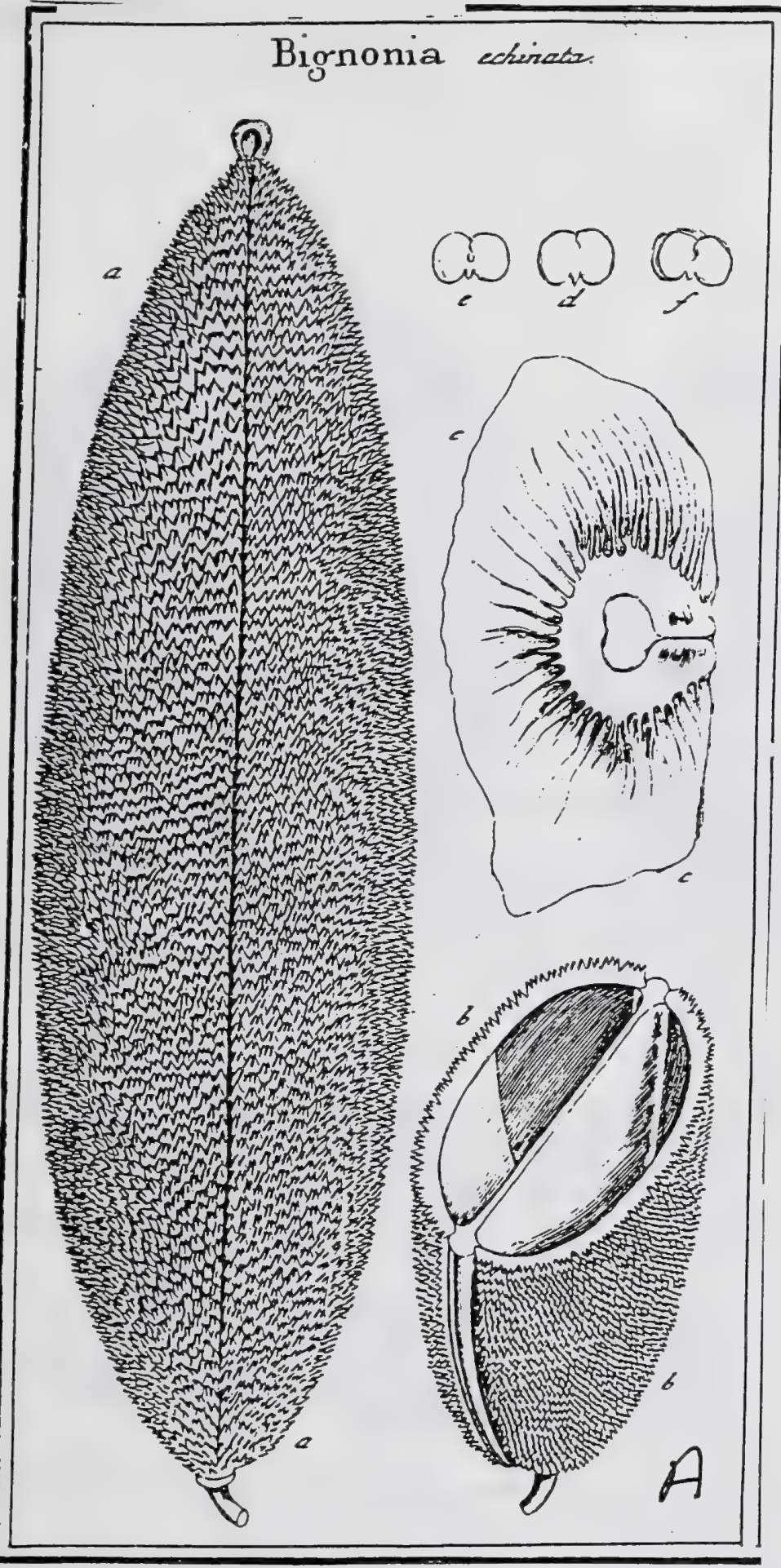




\section{J. Gaertner (1788) Vol 1}

\section{0}

\section{BIGNONIA. TOURN. t. 72. LIN . gen. 759 .}

Calex quinquefidus. Cor. limbus irregularis. Stam. quatuor inxqualia, Capfula filiguorfa bilucularis. Semina membranaceo alata.

BIGNUXIA eclinata. 'Tab. 52. fig. 1.

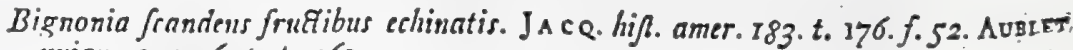
guian. 2. $y \cdot 6+8 \cdot t .263$.

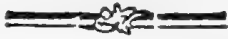

PER. Capfula filiquofa, elliptico oblonga, levifime compreffa, in mediis lateribus fulco longitudinali obfoleto inferipta, \& ad utrungue marginem protuberante diffepimenti rotundatî orâ infignita, undique aculeis fubulatis, brevibus, \& bafi conflucntibus muricata, bilocularis, bivalvis. Diflepimentum planum, coriaceum, valvis interjectum, ad inargines incraflatum.

REC. nullum, prater incraffatum diffepinenti marginem, cicatriculis oblongis intus infigniturn, quibus femina affixa.

SEM. numerofifitina, plano coinpreffa, latifinna ala membranacea diaphana \& venofa cincta, duplici ferie in fingulo loculamento profita.

INT. duplex: exterius membranaceo fpongiolum, ad embryonis fedem albicans \& in inedio macula cordata fufca pictum, cetera diaphanum, in alam ampliatum; in. terius tenuifimum, embryoni adlixrens.

A \& B. nullum.

EM B. compreflus, rectus, lacteus. Cotyl. bilobx, lobis rotundato reniformibus, foliaceis, tenuillinis. Rad. brevillima, recta, centrifuga.

a.) Capfula integra, b.) Eadem diffela c.c.) Semen (eparatum, d) Nucleus propria fua membrana tettus. e.) Embryo denudatus. (.) Cotyledoues divaricacz. 


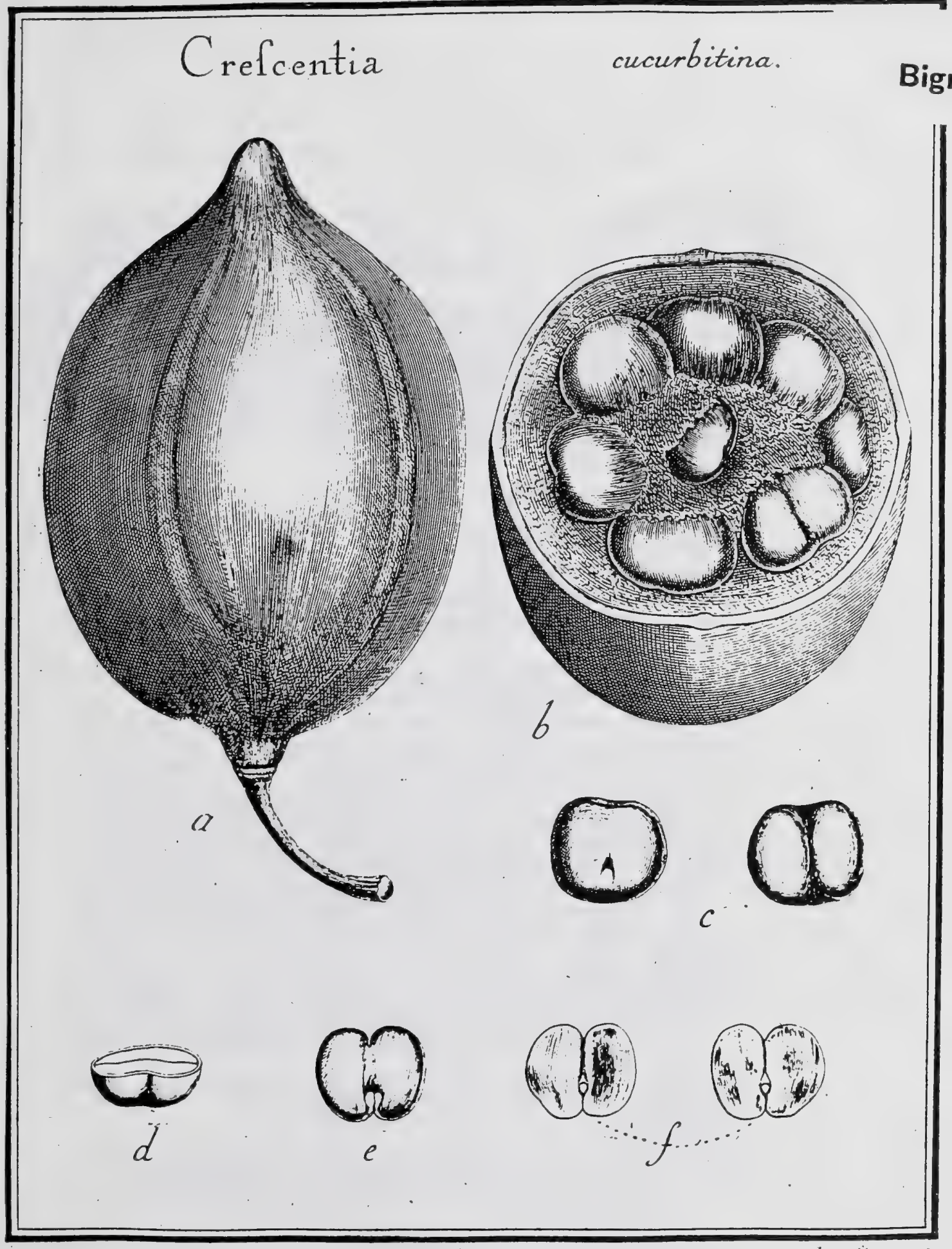

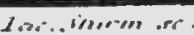




\section{J. Gaertner (1788) VoI 3}

\section{C R E S C E N I I A.}

LINN. gen. 762. ed. Schreb. 1021. Juss. gen. p. 127.

Lasrabck ill. gen. t. 547. Cujette. Pluar. gen.

t. 16.

Cal monophyllis, inferus, xqualis, bjpartitus, deciduus. Cor. monopetala,

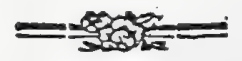

irtegularis; tubo infundibuliformi, incurvo, fupra bafin coarctato, ad me. dium vero rurfus ampliato; limbo inxquali, bilabiato: labio fuperiore breviore, crenato: inferiore longiore, trifido. Stam. quatuor, didynama, corolla inferta; filamenta ad corollam curvata, teretia; anther bafi cohxo. rentes, bivalves. Ovar. fuperum, pedicellatum; ftylo fimplici, corolla longiore; ftigmate bilamellato. Bacca corticata, intus pulpofa, Rec. nullum. Sem. plura, compreffiufcula, vaga. Alb. nullum. Emb. magnus; radicula recondita, immerfa.

Crescentia cucurbitina Tab. 223.

Arbor americana cucurbitifera, folio longo mucronaso, frudiu oblongo. Coмss. bort. 1. p. 137. t. 7 I.

Cujette latifolia fruatu putamine fragili. Plum. ic. t. 109.

Crefcentia foliis lanceolatis utrinque attenuatis. Liss. bort. cliff. p. 327 .

Crefentia arborefcers, foliis fingularibus ovatis nitidis, fructu minore. BROWN jum. p. 266.

Crefcentia (latifolia,) foliis ovatis petiolatis alternis, fruliu ovato acuminato, feninibus orbiculatis comprefliso. LAM. did. x. p. 558 .

Crefcentia foliis lanceolato- ovatis. LiNs. mant. p. 250. Syls. veg. ed. 14. p.565.'

Crescentia foliis ovatis fubcoriaceis difsing is, frublibus ovatis acuminatis. SWARZ obf. p. 234. W1LLD. Jpec. pl. T. 3. P. T. p.31T. Persoos fyn. 2. p. 268.

PER. Bacca grandis, interdum pedalis, fupera, ovata, utrinque obrufe mucronata, fulcis quatuor levibus elevatis longitudinalibus deorfum delique. feentibus infignita, pedunculo tenui infidens, glabra, corticats, intus pulpofa, ficcitate fpadicea, unilocularis, polyfperma. Cortex non admodum craffus, fublignofus, fragilis, extus cuticula tenui veftitus, intus va. forum fafciculis quatuor fulcis externis obverfis \& in sete vafculofum divifis inftructus. Pulpa a membrana propria inclufa, mollis, femina ob. volvens, albida.

REC. nullum; femina in pulpa inordinate horizontaliter tamen nidulantia.

SEM. numerofa, $30-c, 0$ \& ultra pro magnitudine bacce, fuborbiculata; paulo latiora quam longa, compreffiufcula l. lenti:ulari convexa, fulco medio levi longitudinaliser inferipta, \& caruncula umbilicali fupra bafía notata, fufcr.

IN T. fimplex, fubcoriaceum, ad bafin ferninis paulo crafius, facile detra: hendum.

A I B. nullum.

$E_{M B}$. femini fere conformis, magnus, utrinque leviter emarginatus, comprefGufculus, (vetuftate) fufcus. Cotyl, fuborbiculatz, utrinque profunde \& acute emarginatix, plano - convexx, comprelfuffulix, fulco intermedio

levi longitudinaliter bipartitx, glabella bifida ad emarginationem bafilasem infignitx, cralfufcula, amygdalino-carnofx, leviter undulato-plicatre, incumbentes. Rad minima, brevifima, conico-acuminats, intra cotyledonum emarginationem alte recondita, umbilico externo obverfa, vaga.

\section{EXPLICATIO FIGURE.}

2.) Bacez interra. b.) Eadem medio erasveríe dificena, cum fitu feminum intra pulpam. c.) Semiaz (eparata. d.) Idem medio transverfe diffeaum. e.) Embrgo folutus. f.) Cotyleda aes feparatx, a parte interiore vifx, cum infertione \& figura rabliculz.

Nili error quidam fubfiftat, C. Cujette L. ob Semina bilocularia vix hujus generis effe poteft. 


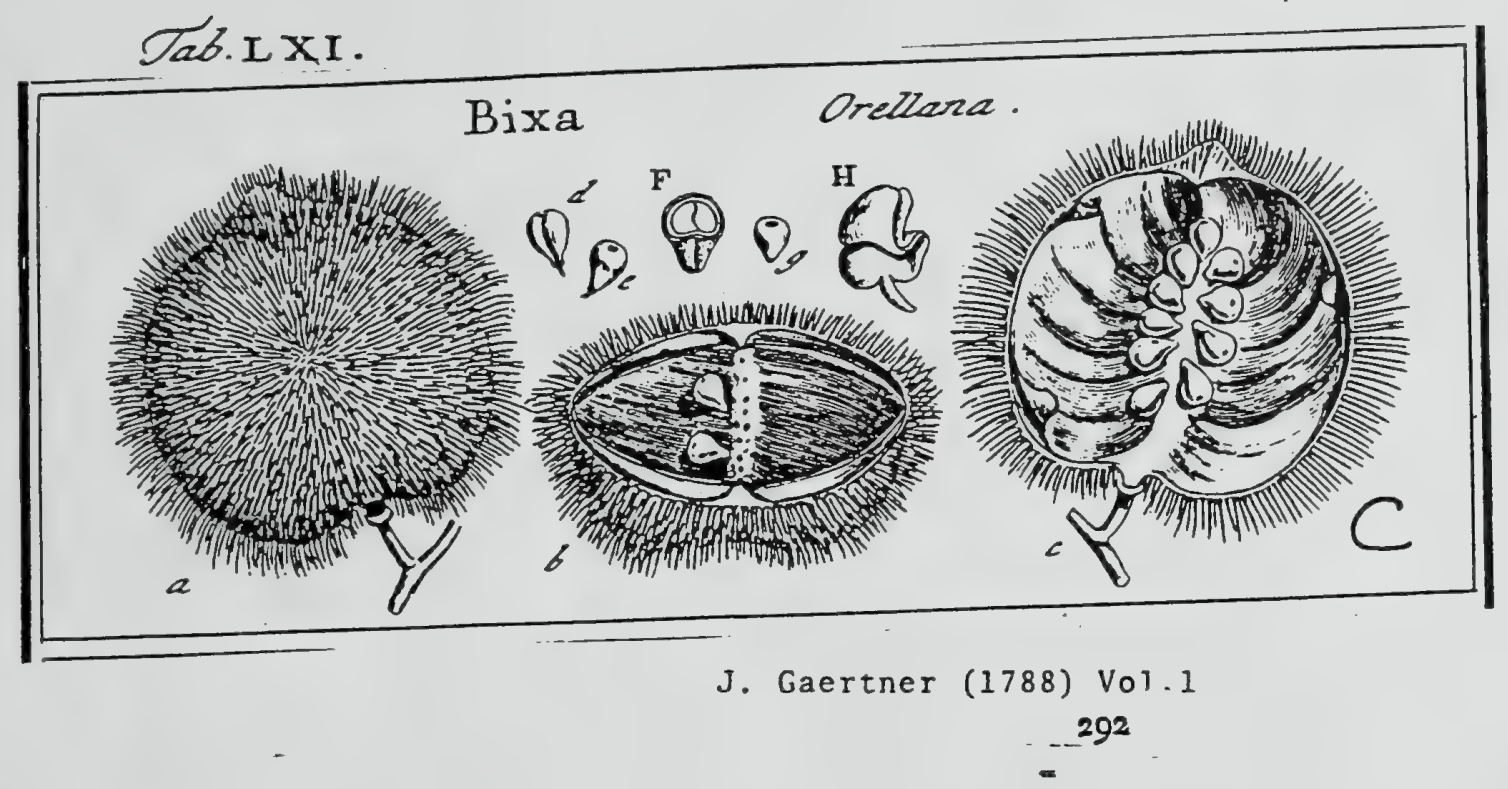

CCCLXIX. BIXA. LinN. gen. 654.

Calyx quinquedentatus. Cor. decapetala. Stann. numerofa. Stỵl. unicus. Capfula hifpida unilocularis. Sem. baccata, medio valvularum longitudinaliter affixa.

Brxa Orellana. Tab. 6I. fig. 3.

Pigmentaria. R им н. amb. 2. p. 80. t. 19.

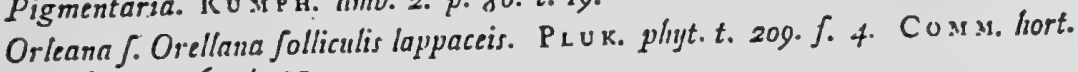
amfl. 1. p. 65. t. 33.

Bixa. Lix: Siff. veg. 49t.

PER. Capfula ovato cordara, turgide lenticularis, undique aculeis fetaccis hifpida, unilocularis, bivalvis. Valuula intus propria membrana veftita \& in medio, fulco longirudinali prominulo hipatx.

REc. nullum; femina fulco interno valvularum affixa.

SEM. plura, ad fingulain valvulain circiter duodena, turbinata, ex altero laterc ftria deprella inferipta, in vertice tuberculo fufco notata, cocenica, fubbaccata.

IN T. triplex : extinum pulpofum, in focculam rubram, per sy:tationem in aqua, fe. cedens; medium contueun, craflum, fufcum; intimum umcmbranaccum, rufer. cens, clialaza nigra notatum.

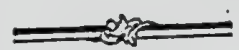

A L B. fenini conforme, amygdalino carnofum, album, facile rancefcens.

Es 8. magnitudine fére albuminis, fallide luteus. Cotyl. ovato cordatx, foliacex, varie llexuofx. Rad. fufformis, centrifuga.

- Senarata, cum membrana sua interna atque feminum

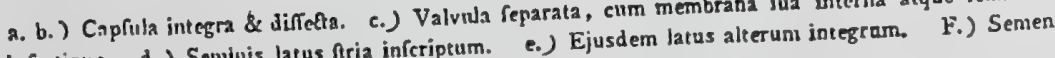
infertione. d.) Semilus latus ftria inf́criptum. H.) Embryo feparatus.

transverfe feftum. g.) Albumen denudatum. H.) Embsyo repara hif. I. L. XII. p. 440. bene. mera eft

Buxa occidentalis, qux Bixa Ovicdi. Bauh. hin. ovato acuminatx, minores, nec prixcedentis varietas. . Capfula tamen ci conftanter ovato acurofundo lulco, ut quafi

ita denfe fpinolx. Semina lubtrigona, gigartoidea, elative minor.
biloba. Cotyl. minus flexuof $x$; \& totus embryo relat 


\section{Jab. $\operatorname{cxxxV}$}

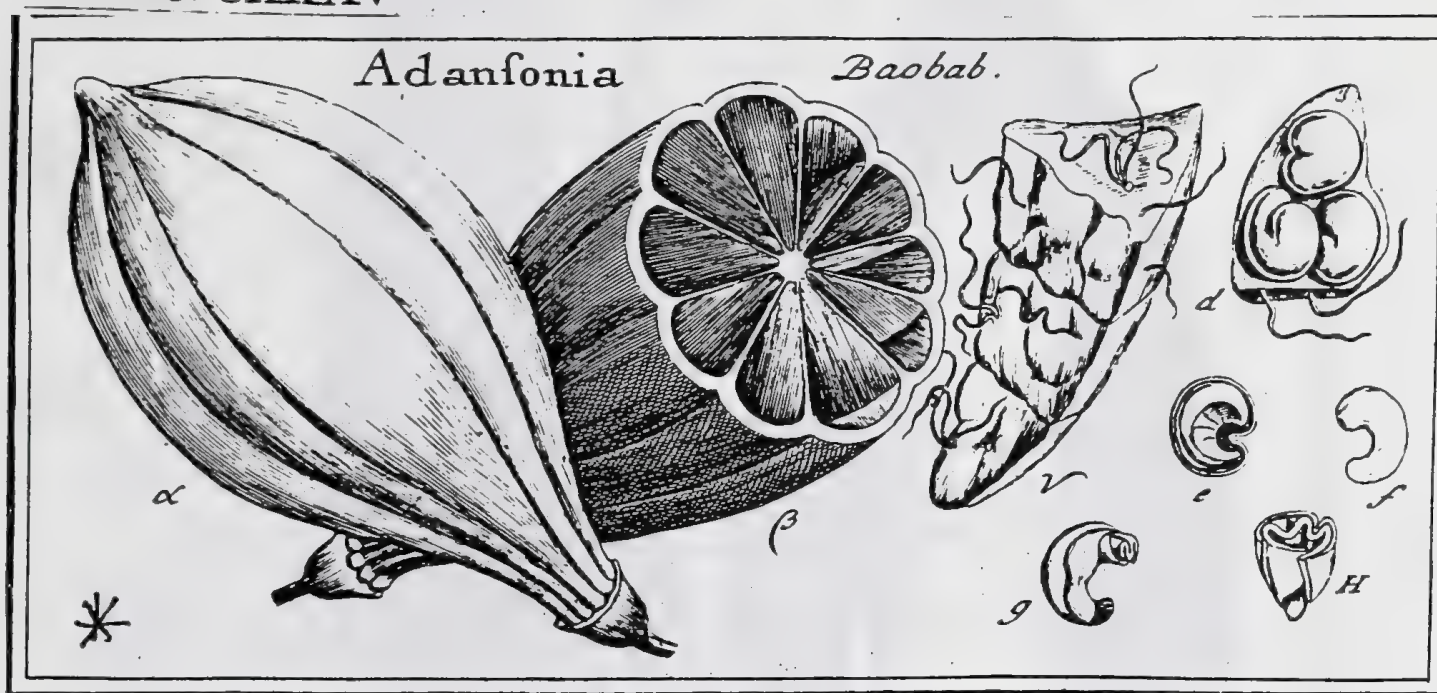

T. G. $5 / 24 \mathrm{~mm} / \mathrm{c}$

\section{J. Gaertner (1788) Vol. Z}

\section{A D A N SONIA. LINN. ger. 836 .}

Calyx fimplex, monophyllus, quinquefidus. Cor. quinquepartita. Stam. numerofilima, bafi in urceolum connata. Ovar. unicum. Styl. Gimplex longifimus, tubulofus, ftignatibus decem radiunibus. Capf. lignofa Furcta plurilocularis. Sens. plurima nidulantia.

ADANSONA Babab. Tab. 135. fig. 5.

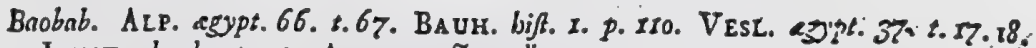
JoNST. dendr. t. 29. ADANS. a.7. gall. I759. t. I. 2.

Adrufouia digatata. Liss. $\{y$. veg. 620 .

PER. Caplula grandis, lignofa, ovata, apice in mucronem producta, bafi vario in variis attenuata, longitudinaliter fulcata, multilocularis, pulpa exfucca furcta, non dehifcens. Diffepimenta membranacea, tenuia. Loculameuta decem ad quatuordecim, farcta Pulpa fungofo - farinofa, rubicunda, acidula, in varias portiones irregulares transverfim fecedens atque fibris plurimis filiformibus pertexta.

REC. nullum, proter pulpam, in qua femina, in omnem fenfum difpofita, nidulantur.

SEM. numerofa, grandiufcula, globofe reniformia, glabra, fubfplendentia, e caltaneo nigra aut prorfus atra.

IN T. triplex: extimum corneum, duriffimum, ut fere offeum; medium fubco. riaceum, durum, ferrugineum, prope umbilicum valde incralfatum; in timum membranaceum, pallide ftramineum.

A L B. tenue, carnofo membranaceum, intra cotyledonum plicas demerfum.

EAs B. femilunatus, niveus, lubricus. Cotyl. foliacex, chryfiloideo - contortu. plicatco. Rad. craffa, curva, vaga.

a. B.) Capiula integra \& diftect. Y.) Pulpz, e loculamento fuo extratx, fruftum. d.) Ejofdem frufti apex magnitudine naturali \& dificaus cum fitu \& figura feminum. e.) Scruinis integumentum intimum deaudatum. f.) Albumen decortientum. 5.) Embrgo folutus. H.) Co tylciones tansverlim fectx. 
Tab. CXXXIII.

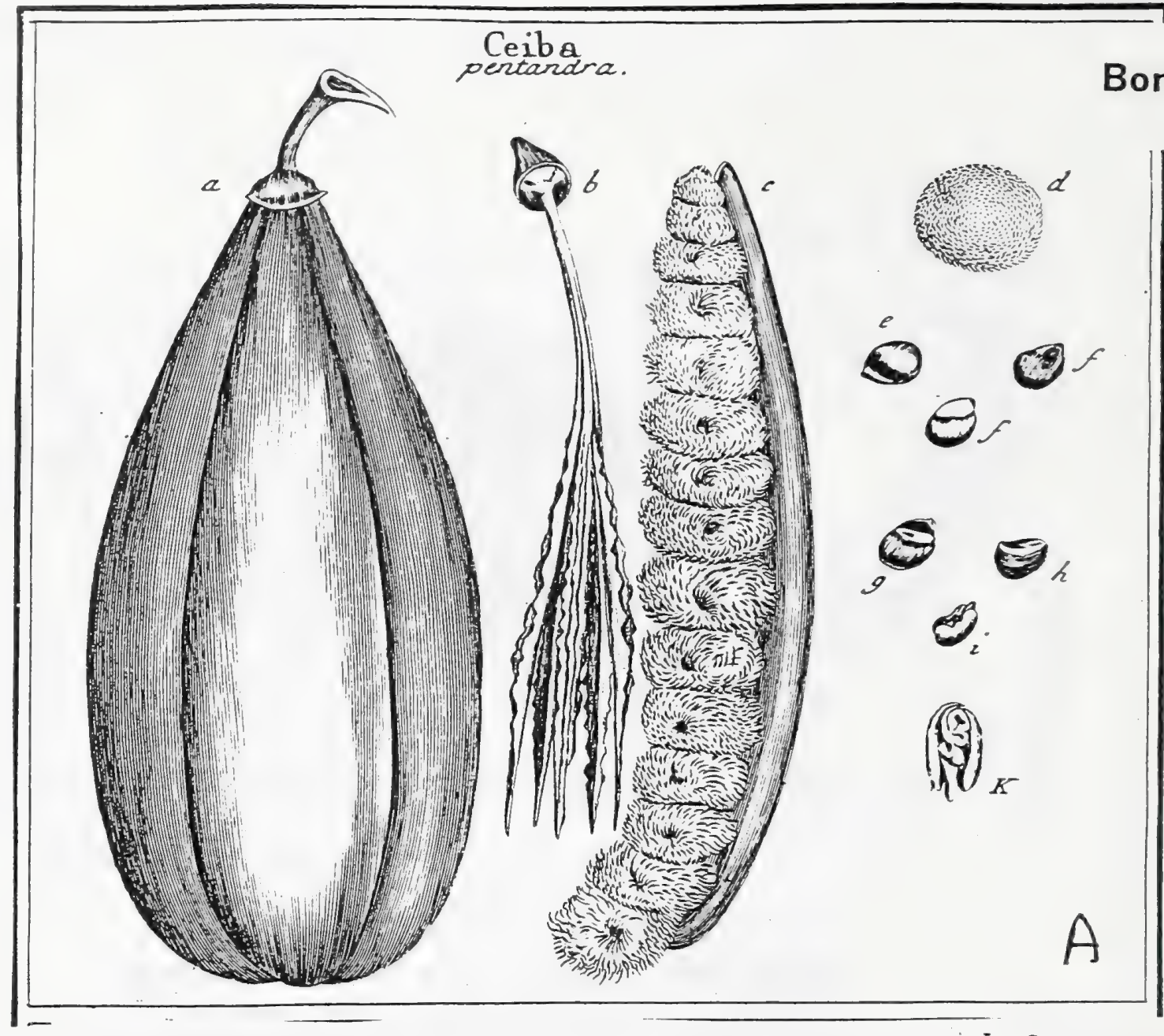

DCCLXXVII. C E I B A. PIUM. t. 32. Bombax. LINn. gen. 835.

Calyx fimplex, campanulatus, quinquefidus, bafi perfiftens. Cor. quin. quepartita, cum ftaminum urceolo connnata: Stam. quinque aut plura, bafi monadelpha. Ovar. unicum, fuperum. Siyl. fimplex, ftigmate capitato aut quinquefido. Capf. lignola, quinquelocularis, quinquevalvis Sem. numerofa, lanara.

Ceiba pentandra. Tab. 133. fig. I.

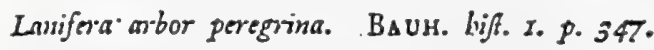

Eriopboros javmas. RUMPH. amb. T. p. 194. to. 80.

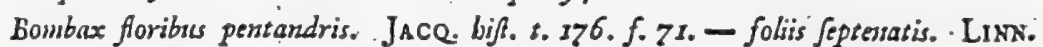
[Sy.t. veg. 620.

PER. Capfula grandis, elongato - turbinata, rotunde pentagona, quinqueloct laris, quinqucvalvis. Difepimenta membranacea, futuris obverfa, per: maturitatem evanefcentia. Valvulx lignofx, extus curtice coriaceo fuf́co tectx, intus fpadicex \& a feminum imprelfionibus areolatx.

REC. centrale, fufiformi-- columnare, quinqueparibile: fegmentis introrfum angulatis, extrorfum fcabrofis, fulcatis \& quafi alatis.

SEN. numerofa, duplici 1. triplici ferie Jongitudinali digefta, ovato-globofa, ad unbilicum leviter acuminata \& comprel[a, undique lana tenuifima, fericea \& cinerafcente obvoluta.

INT. triplex: extimums tenue, fubfpongiofun, lanatum; meditum cartilagineum, glabrusn. fpadiceum aut fertugineo - fufcum; insimsum membranaceum, laminz farinofa intus duplicatum.

ALB. nullun, prxter integumenti interni laminam farinofam, qux intra cotyledonum plicas fe fe demittit, \& ab aqua in gelatinofum embryonis invo.

J. Gaertner (-1788)

244 lucrum convertitur.

EM 8. magnítudine feminis, curvatus, lacteus. Cotyl. folincex, chryfaloideacontortuplicatse. Rad. conim, infera \& fimul centripeta.

2.) Capfula integra. b.) Receptac feparaturn, c.) Semina in valvulz eavitate barentize d) Lana cirez-femen glubofe convoluta. c. $f . E$ ) Semina denudata 5 .) Tela feminis aperta. b.) Nualeis propriz fua pellucils tedus, i. K.) Embryo denudatus. 

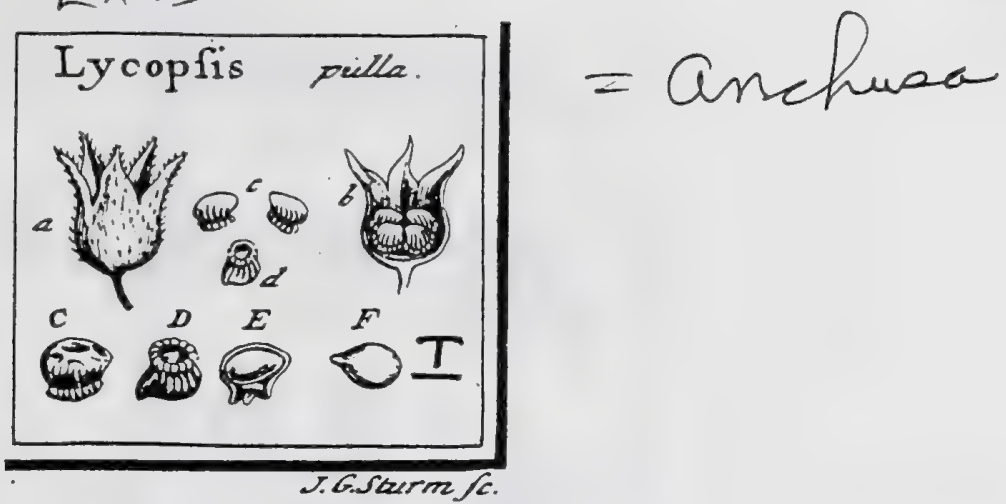

J. Gaertner (1788) Vol. 1

\section{7}

CCCCXXI. LYCOPSIS. Lin

Calyx quinquefidus. Cor. infundibulifornis, tubo ineurvato, fauce fquamulis clau-

fa. Stam. quinque. Styl. unicus. Nuces quatuor perforatz umbilico fublaterali. L ycopsis pulla. Tab. 67. fig. 9.

Echism pullo flore. Clus. hifl. 2. p. I6 \%. Jace. for. aufir. 2. t. 188 .

328

Lycopfis foliis integerrimis, caule ereto, colycibus fructefcentibus inflatis pendislis. LIN N. Jiff. veg. 188 .

PER. Nuces quatuor, medincres, cruftacex, ovato-acuminatx, umbilico fuo quati oblique incumbentes, fupra obfolete reticulato rugofx, ad laterà vero friis paral lelis fulcatx, \& in marginem umbilici crenulatun coarctatx; framineo lutefcen tes, uniioculares, evalves. Apertura umbilici amplifina, fupra bafin nucula. ad. latus internum pofita.

REc. funiculus craftus fungofus, lateri feminis infertus.

SEM. folitaria, ovato acuminata, turgide lenticularia, nigro fufca.

IN T. fimplicifimum, membramaceun, tenue.

A\&B. nullum.

E в в. femini conformis, horizontali inclinatus, albus. Cotyl. ellipticx, plano-convcxx, carnofx, fubpellucidx, fragiles. Rad. conica, brevis, fupera.

a. b.) Nuces Intra calycem, c. C.) Nucis dorfum. d. D.) Ejusdem pars ventralis. E.) Ejais fello, veruicalis cum umbiliel infertione. F.) Einbryo denudatus. 

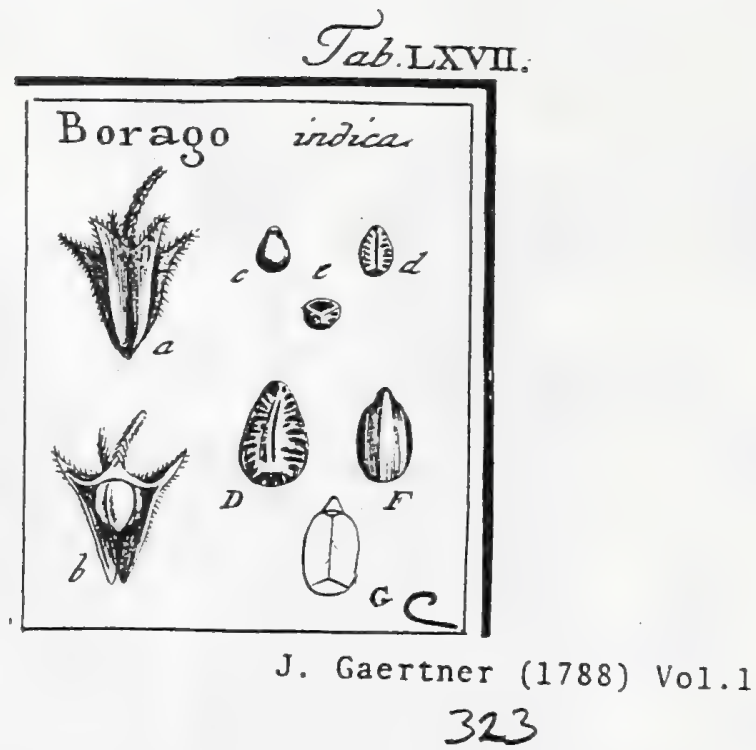

CCCCXV. BORAGO. TOUR N. t. 53. LIN gen. 188 .

Calyx quinquefidus. Cor. rotata, fauce radiis claufa. Stam. quinque. Styl. unicus. Nuces quatuor uniloculares, imperforatz.

BORAGO indica. Tab. 67. fig. 3.

Cynoglo Joides folio caulem anplexante. Iss А R D. AZ̈. gall. 1718.t.g.f.I-N.

Borngo foliis ramificationum oppofitis amplexicaulibus, pedunculis uniforis. LIN N. fyfl. veg. 188 .

PER. Nuces quatuor, oflex, ovatz, compreffusculx, hinc leviter converx, glabrz, nitidx, dilute caftanex, inde obfolete angulatz, fulco inedio longitudinali \& rugis transverfalibus parallelis exfculptx, bafi fubtruncatz, imperforatx, uniloculares, evalves.

REC. funiculus capillaris intra nuculam.

SEM. folitaria, ovato acuminata, lenticulari comprefta, nigra \& fere atra.

IN T. fimplex, tenuifimum, aridum.

A L B...nullum.

Eм в. femini conformis, inverfus, albicans. Cotyl. ovatz, carnofx, comprefrx. Rad. conica, compreffa, fupcra.

a.) Calyx maturus claufus. b.) Semina in fitu natura!i. c.) Nucis dorfum. d. D.) Ejus pars veriratis. e.) Liadem dilfetz. F.) Semen decorticatum. G.) Cotyledon altera, a parte plana fpeftata.

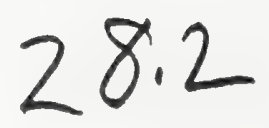


Tab. 212.

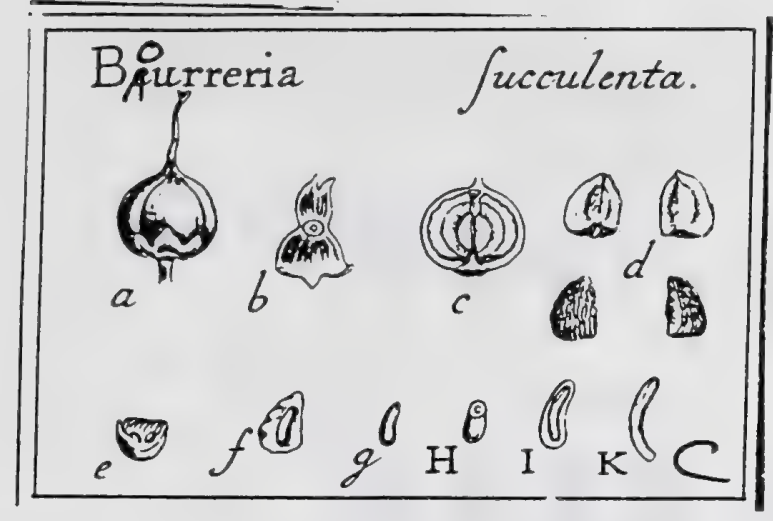

370

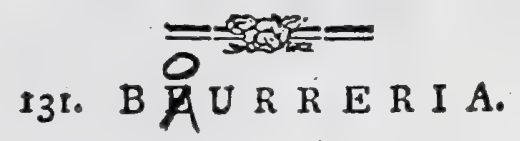

J. Gaertner (1788) Vol.3

Brown jam. t. !5. f. 2. Ehretia، Linn. gen. 257. el. Schreb. 352 . Joss. gen. p. 128. Lamarcxill. gen. t. 95.

Cal. monophyllus, inferus, bilobus: lobo altero majore tridentato, altero anguftiore bidentatos perfftens. Cor. monopetala, calyce multo major, tubulora ; tubo cylindraceo; limbo quinquepartito: laciniis xqualibus, planis, obtufis. Stam. 5.3 filamentis fubulatis, ad medium tubum infertis; antheris erectis, haftatis. Ovar. fuperum; ftylo fimplici, perfiftente, longitudine ftaminuin 3 ftigmate bilobo. Bacca fubglobofa, bafi retufa, tetrapyrena, octo-locularis. Rec. nullum. Sem. oblonga, folitaria. Alb. carnofum, vaginale. Emb. erectus, curvulus.

BEURRERIA fucculenta. Tab. 212. fig. 4.

Mespilus americana latrifolia glabra, fructu subro mucilagisofo. CомеL. burt: amft. 1. p. 153. t. 76 .

Jafminum periclymeni facie, fiore albo, frullu flavo rotundo tetrapyreno. SLOAN jam. 169 . biffo 2. p. 96. to 204. f. I,

Elretia foliis ovatis integerrimis laevibus, floribus fubcorymbofis, calycibus glabris. LiNn. Spec. pl. p. 275 . Syf. veg. ed. 14. p. 230. W1LLD. Spec. plo T. x. P. 2. p. 1078 . Persoon fyn 1. p. 167 .

Beurreria arborea foliis ovatis alterris, racenis rarioribus terminalibus. BROWN jam. p. 168. t. 15. f. 2.

Beurreria (Succulenta), fructibus fucculentis, integris. JAc0. amer. p. 44.

Ex Infula Hifpaniola, a $D^{\text {no }}$ Porteau.

PER. Bacca fubglobofa, ftylo perfiftente faftigiata, bafi retufa \& calyci perfiftenti infiftens, obfoletiffime rotundato-tetragona, 1. fulcis levibus quaruor longitudinalibus exarata, pulpofa, : nurantia, tetrapyrena. Caro pulpofa, mollis; cuticulà lavigata inclufa, tenuis, dulcis, pyrenis adnata, lutefcens. Pyrenz quatior, offex, hinc convexx, ex lamellis tenuibus longitudinalibus, per rimas profundas difcriminats \& pulpa repletis conflate; inde cuneate lateribus planiufculis, bafi retufx, biloculares, difpermx. Loculanienta parva, ovato-oblong, altero fxpiffrme abortivo.

REC. nullum: pyrenx arcte Gbi approximatx, pulpa tenui \& valis nutrientibus tenuibus interpofitis juncte s femina fundo \& parti ventrali locula mentorum leviter adhærent.

SEM. folitaria, ovato - oblonga, erecta, leviter incurva, utrinque obtufa, candida.

IN T. Gimplex', membranaceum, tenuifimum.

A L B. Semini conforme, non admodum craffun, vaginale, carnofum, album.

EM B. albumine paulo brevior, erectus, filiformis, falcatus, compreffufculus, Jacteus. Cotyl. tertiam albuninis partem longitudine mentientes, obtufx, leviter undulato - plicatx, incumbentes, Rad. filiformis, longa, curvula, infera.

\section{EXPLICATIO FIGURE.}

a.) Baeca integra. b.) Calyx feparatus, a parte interiore (petatus. c.) Bacea verticali modo difiedu, cum fitu pyrenarum. d.) Pyrenz folutz. e.) Ejusdem fetio transverlalis, \& f.) Ezdem longitudinaliter difreca, eum fitu \& forma loculamentorum, 5.) Semen feparatup. H.) Al. bumen tracsverfe feaum. I.) Embrgonis fitus intra albumed. K.) Idem folutus. 


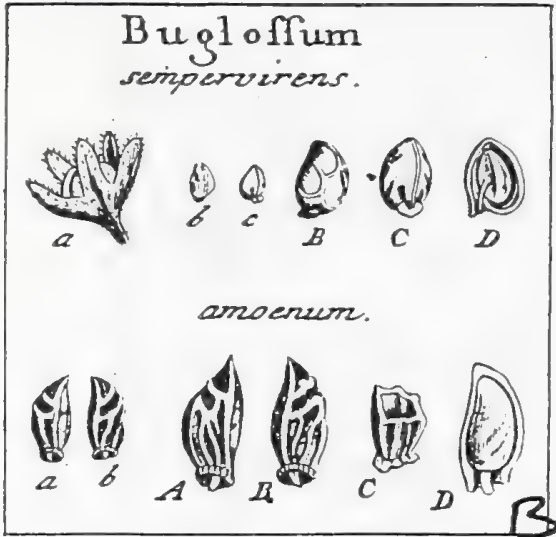

J. Gaertner (1788) Vol. 1<smiles>[10BH][12BH]</smiles>

\section{CCCCXIV. BUGLOSSUM. T OUR N. t. 53 .}

Calyx quinquepartitus. Cor. infundibuliformis: fauce fquamulis fornicatis claufa. Stam. quinque. Styl. unicus. Nuces quatuor uniloculares, bafi perforatz.

Bugicossum fempervirens. Tab.67. fig. 2.

Bugloffum latifolium fempervirens. MOKIs, hif. 3. S. II. t. 26.f. 2

Anchufa pedunculis diphyllis capitatis. LIN N. Jy/l. veg. 186.

Ex fide MARTINI, qui Cemina mifit.

$P E R$. Nuces quatuor parvx, ovatx, reticulato- rugof $x$, hine gibbx, inde obfolete angulatz, fupra attenuatx, infra foramine, mcmbranacea appendice cincto, perforatz, cruflacex, fpadiceo fulcr, tenucs, uniloculares, evalves.

REc. funiculus filiformis, per canalem foraminis ad internum ferninis latus adfcendens.

SEM. folitaria, ovato acuminata, line convexa, inde obfoletifime angulata, lutefeno fpadicea.

IN T. fimplicifiroum, membranaceum, tenuc.

$\Lambda$ L. nullum.

Ex в. magnitudine feminis, inverfus, lutescens. Cotyl. ovatx, carnofz, plano-convexx. Rad. conica, brevis, fupera.

a.) Nuces Intra calycem. b. B.) Nucalx dorfum. c. C.) Ejusdem pars ventralis, cum apper. dice umbiliali. D.) Nucula apert2, cum femine \& funiculi jufertione.

Sxpe lamina qux umbilici foramen cingit multo trajor, \& in rofrum craftum, concum producta deprehenditur.

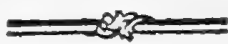

BUGLOSSU amoenum. ibid.

Buglofum orientale ereftum, foliis undulatis, flore aneone caruleo. Tou R. cor. 6.

Conf. Buglo Jum fyriacum, bullatis foliis, floribus albicantibus. Moris. hil. 3. S. II. t. $28 . f$. 2. quoad figuram feminum.

Nuces prioribus duplo majores (a. b.), ovato-oblongx, triquetro angulatx (C.), reticulato rugofx (A. B.), fupra acuminatx, infra amplo foramine pertulx, quod crenulatus \& turgidulus margo cingit. Putamen coriaceo cruftaceum, durum, non fragile uti procedentis, frainineo pallidum. Funiculus umbilicalis (D.) craftus, brevis, bafi feminis infertus. Semen ovato oblongum; reliqua procedentis.

A Buglofio undulato fructuum formâ longifime recedit.

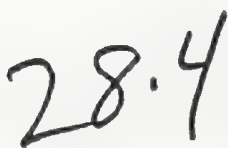




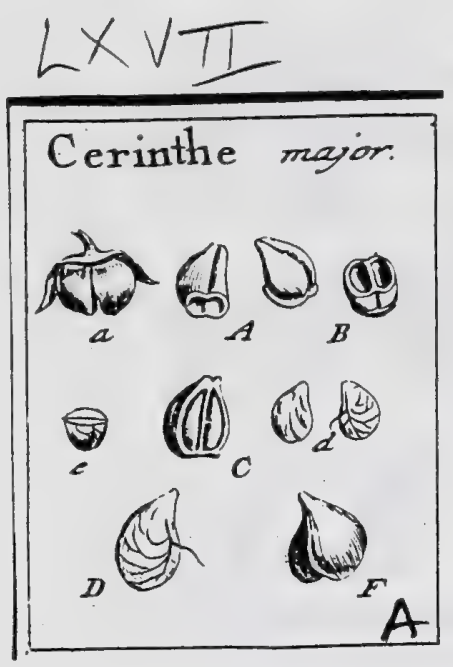

Boraginaceae

J. Gaertner (1788) Vol. 1

321

CCCCXIII. CERINTHE. TOUR N. t. 56. L I N s. gen. 186.

Calyx quinquepartitus. Cor. cylindrico campanulata, quinquedentata: fauce pervia nuda. Stam. quinque. Styl. unicus. Nuces dux, biloculares, bafi claufx.

CERINTне major. Tab. 6-. fig. 1.

Cerinthe major, finvo flore. C1.u s. hif. 2. p. 167. MIL L. diqf. ic. t. gr.

Cerinthe foliis amplexicaulibus ovatis, floris denticulis revolutis brevifinis. Hacl. hif. 1. n. 602 .

Cerinthe foliis amplexicaulibus, corollis obtufiusculis patulis. IINN. fyfl. veg. 187 .

322

PER. Nuces dux, offex, mitraformes, hinc gibbx, inde rectiasculx, fulco depréli. usculo inferipta, bafi truncatz, planx, marginatx, imperforatx, glabre, fpadiceo.
fufex, biloculares; evalves.

REc. funiculus capillaris, medio ferninis lateri interno infertus.

SEs, in fingulo loculamento unicum, ovato acuminatum, compreffiusculum.

Is $\mathrm{r}$. finplex, membranaceum, pallide lutescens, vafis ex umbilico arcuatis pictum.

A L B. aullum.

Eм в. femini conformis, inverfus, luteus. Cotyl. obovatx, carnofx, planiuscultz. Plum. exilifima, comprefta. Rad. conica, acuminata, obliqua, fupera.

2.) Noces in fitu natarall. A...) Nucula a parte ventrali atque dorfali (pectata. B.) Ejus featio transverfalis. C.) Loculamenta longitudinaliter aperta, cum infertione funiculorum nmbilicalium d. D) Semina foluta ab utroque latere fpetata, e) Semen transverfe feftum, F.) Embjo. do: sudatus, 


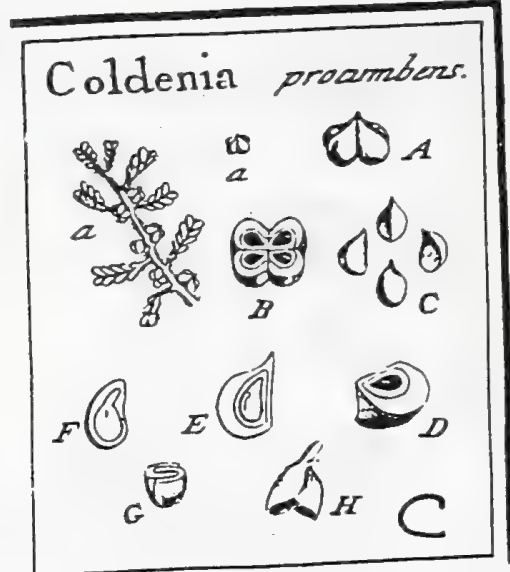

J. Gaertner (1788) Vol. 1

\section{CCCCXXIV. COLDENIA. LiN $x$. ger. r73.}

Calyx quadripartitus. Cor. infundibuliformis, fatice pervia. Stann. quatuor. StyL. unicus, nigmate bifido. Nuces quatuor, curtice fungolo.

COLDENIA procumbens. Tab. 68. fig. 3 .

Teucrii facie bisnagarica tetracoccos ro/rata. P\&u x. phyt. t. 64. f. 6 .

Coldenia. Linn. fyn. veg. I69.

Ex herbario hankfiano.

PE ₹. Nuces quatuor, parvulx, corticatz, in fructum rotundato-tetragonun, mucrosatum coadunatx. Cortex fungofus, in dorfo nucularum craflifinns, ad latera

fenfim attenuatus \& fere membranaceus. Putamina oflea, dura, hine con: vexa, rotundata, inde in acutum angulum comprefla, unilocularia.

REc. nullum, prxter fundum calycis.

SEM. folitaria, ovato acuminata, rufefcentia.

IN T. fimplex, membranaccum, tenuc.

A ᄂ. B. femini conforme, carnofum, tenue, album.

I Mв. albumine paulo minor, inverfus, lacteus. Cotyl. foliacex, tenuifimx, con. duplicatx, laminis internis, vicillum intra duplicaturz rimam receptis. Rad. teretiuscula fupera.

2.) Fruttrs in ramnlis fefriles, a. A.) Fruatus feparatus integer. B.) Idem transverfe fettus. C.) Nincula feparatx. D.) Sctio nucis transvesfa. E.) Albumen in inedia nuce denudatam. F.) Einbryo intra albumed. G.) Cotjledones junax, transverfim (c九tx. H.) Embryo, didulis proIulun coryladonibus.

Froxima affinitate, ut recte fatuit ADsnsonus, cum Afperifoliis cohxret. Differt auten feminibus albuminofis \& cotyledonibus conduplicatis; prxter minorem par. tum numerun in flore.

\section{6}


Tab. 21,2

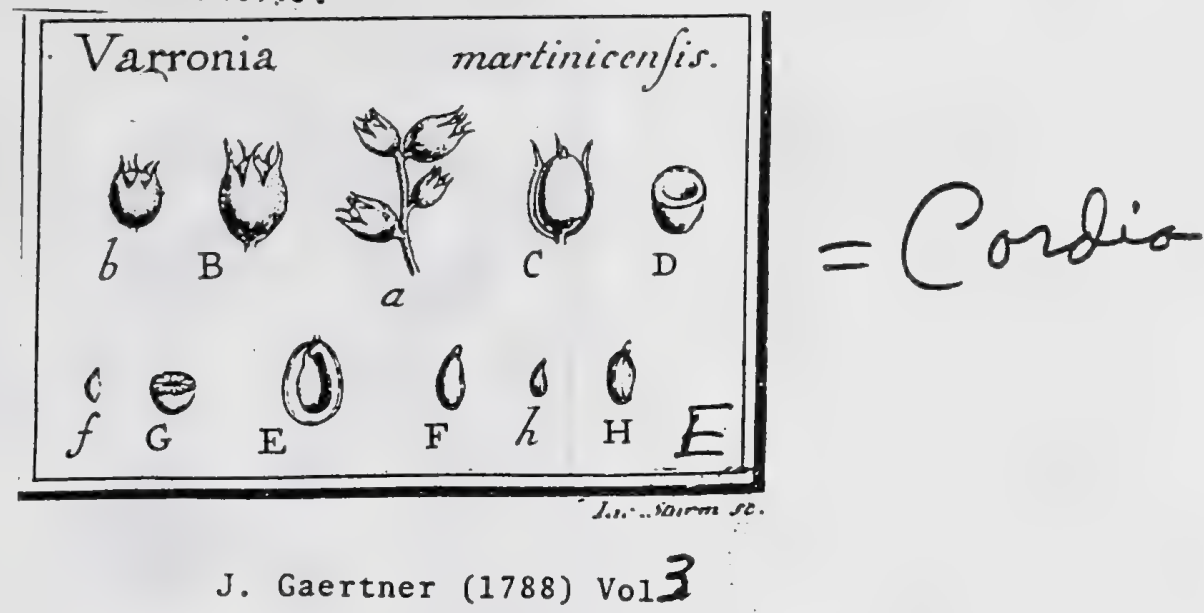

171

\section{2. $V A R R O N I A$.}

BвоWN jam. t. 13. f. 2. LINN, gen. 258. 2d, Schreb. $353^{\circ}$

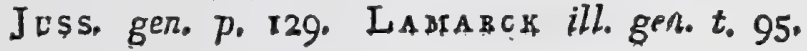

Cal. monophyllus, inferus, tubulofus, quinquedentatus, perfftens. Cor, monopecala, subulofa : tubo cylindraceo; limbo quinquepartito, patente. Stam. 5.; filamentis fubulatis, tubo corollx fub fauce infertis; antheris in. cumbentibus, exfertis. Ovar. fuperum; ftylo fimplici, filiformi; ftigmatibus quatuor, fetaceis. Drupa ovata, a calyce involucrata, unilocularis. Rec, nullun. Ser. unicum, inverfum. Alb, nullum, Emb. inyerfus,

VARRONIA martinicenfis, Tab, 212 . fig, 's.

Varronia foliis ovatis acuminatis, Jpicis oblongis. JACe. amer. p. 4r. LINN.

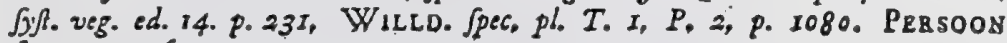
fyn. 1. p. 267 .

Icon. JACQ. 1. c. t. 32 ,

A Cl. Thunberg,

PzR. Drupa parva, ovata, a calyce perfiftente hirto obvolucrata \& vertice tantum ex ipfo prominula, apice mucronulata, glabra. Caro valde tenuis, putamini adnata. Putamen ovatum, offeum, crafrufculum, ad latus in vertice canali obliquo pro istroitu vaforum umbilicalium perforatum, uniloculare, monofpermum.

REC. funiculus unbilicalis candidus, per canalem ad verticem putaminis intrans, \& in integumentum feminis dilatatus,

SEM. folitarium, ovatum, in vertice mucronulatum, levifime friatum, in. ver $\int u m$, albicans.

IN T. fimplex, membranaceum, pallide fpadiçeum.

172

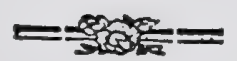

A L B. nullum.

EM B. fenini conformis, inverfus, albus. Cotyl. craffx, amygdalino-carno: fre, longitudinaliter plicztz \& corrugatie. Rad. difcreta, ovato - acuminata, umbilico externo obverfa, fupera.

\section{EXPLICATIO FIGURE.}

a.) Pars fpicz fruglferx. b. B.) Drupa integra, calyes obvolucrata. C.) Eadem, dimidia calycis parte ablata. D.) Ejusdem fectio transver[alis, \& E.) Eadem lougitudinaliter diffean, eura fitu \& forma loculamenti. f. F.) Semea feparatum. G.) Idem transverfe feftum. h. H.) Em. bryo denudatus. An putamen per abortum uniloculare? an reliqux fpecies pluriloculares
genere diverfo? 
Boraginaceae

Tab.L Xxvi

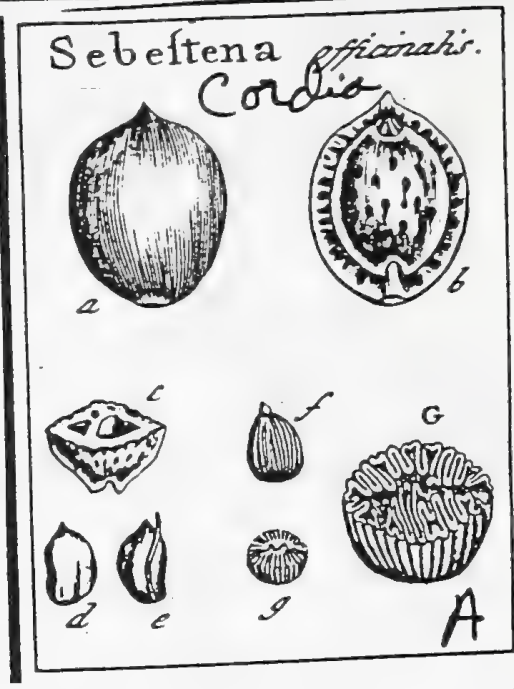

J. Gaertner (1788) Vol.I

364

CCCCLXXIV. SEBESTENA.

Calyx monoplyyllus quinquedentatus. Cor. monopetala infundibuliformis. Stam. quin. que. Styl. unicus dichotomus. Diupa baccata, bi-l. quadrilocularis. Semina folitaria juverfa.

SE BESTENA officinalis. Tab 76. fig. $x$.

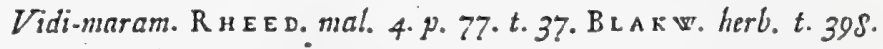

Sebefena domefica f. IIysa. Co s. hort. amf. I. p. r39.t. 72

Cordia foliis ovatis fupra glabris, corymbis lateralibus, calycibus decem friatis. LiNN. Jyjl. veg. 230.

PER. Drupa haccata, ovato globofa, apice mucronata, nigra. Caro fucculenta, modice cralta. Putamen offeuin, ovatum, bafi \& apice emarginatuin, perforatum, turgide lenticulare, obfolete fcrobiculaturn, fubquadriloculare. Loctilamenta duo fertilia, intus membrana nivea friabili veftita; reliqua plerumque nerilia, aut penitus obliterata.

REC. fibre lignolx, axem putaminis perforantes, dimittentes fuperne funiculos umbilicales filitormes, ad bafm feminum defcendentes.

SEM. folitaria, ovata, fupra acuminata, hine convexa, inde obfolete angulata, albicantia.

IN T. fimplex, inembranaceum, pallide fpadiceum, intus fubcarnofum.

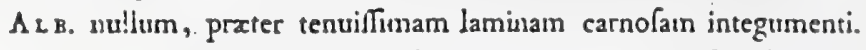

Е м в. Semini conformis, inverfus, albus. Coty l. craflx, formatx ex lamina amygdalino carnola, fecundum longitudinem fuam in plicas ferpentinas contiguas, fimbrix manualis adinftar, corrugata. Rad. globulofa, fupcra.

365

a.) Drupa integra. b.) Putamen denudatum. c,) Idem transverfe (cetam. d.e.) Seminis lasus utrunque, cuin funiculo umbilicali, ad partem veitralem. fo) Embryo deuudatus. g.G.) Cotyledones transverfim fecta. 


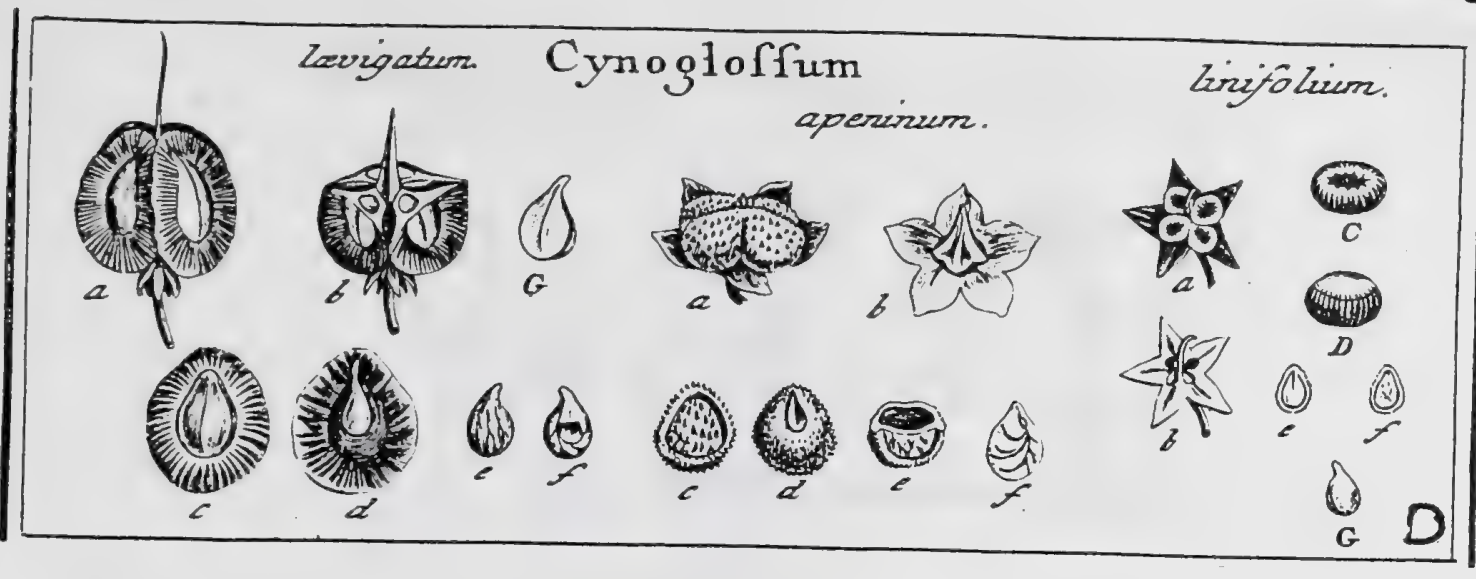

J. Gaertner (1788) Vol.1

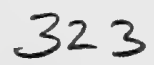

CCCCXVI. CYNOGLOSSUM. Tour N. t. 57.58. L IN N. gen. 183 .

Calyx quinquefidus. Cor. infundibuliformıs: fauce fquamulis fornicatis claufa. Stam. quinque. Styi. unicus. Nuces quatuor deprefl $x$, imperforatx. Recept. fubulatum.

CrNogrossum lrvigatum. Tab. 67. fig. 4 .

Rindera tetrafpis. Pallas. it. 1. app. 486.t. F. fig. 1. 2.

Cynoglofrum folitis lanceolato oratis glabriusculis, calycibus tomentofis, femini. bus lavibus. LIN N. fyf. veg. 186 .

PER. Nuccs quatuor, coriaceo membranacex, extus fcutifcrmes. Scutum ovatun, amplum, membranaceo marginatum, lineolis ferrugineis radiatum. Nux ipfa, in concara parte fcuti locata, ovato globofa, fupra acuminata, area oblonga unbili. cali in medio notata, unilocularis, evalvis.

REc. commune tetragono - fubulatum, in nylum definens; proprium, funiculus capitlaris infra rofruin feminis infertus.

SE s. folitaria, ovato roflellata, fubcomp̧reffa, fpadiceo- nigra.

IN T. fimpliciflimum, nembranaceum, arcuato-venofum.

A 5 B. nullum.

Ex п. fcmini confurmis, inverfus, albus. Cotyl. ovato rotundatx, carnofx. Rad. tcreti acuminata, obliqua, incurva, fupera.

2.) Fruftus integer. b.) Nuces truncatre in receptaculo harentes, c.) Nucis dorfum fentiforme:

d.) Ejus pars ventralis. e.) Seainis decorticati latus externum. f.) Ejusden tatus iuternam:

G.) Embryo denudatus.

CYxOG zossum appenninum. ibid.

Cynoglofa montana maxima frigidarum regionum: Cor. ecphir. I. p. 168.t. 17\%:

Cynoglufrum faminibus corollam aquantibus. LIN x. Jy/. veg. 186.

Nuces quatuor (a), cruftacco- coriacex, receptaculo pyrsmisato (b.) affise, ovato acuminatx (c. d.), fupra planiuscula (difco in vetultis depreflo), acaleolis ertelis (c. e.) muricatx, infra autem \& ad latera gilibx, punctis acuris (d.) fabratx, pallide framinex, unilocularcs (e.). Semen grande (f.). obovato rollellatum, fub rofiello umbilicatum, fufcum. Reliqua ut in pro: etdenti.

CrNogrossum linifolium. ibid.

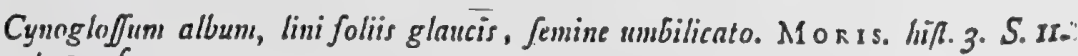
t. 3o. f. II.

Cinnoglofum foliis lineari lanceolatis glabris. LiN. Jyjg. ves. 186.

Liuces quatuor parvx (a), receptaculo fubulato (b.), per maturitatem incurvo, accumbentes, fubmembranacex, comprclix, nvato acuminatx (c. $\left.f_{0}\right)$, ad oram (D) extcriuatx in neinbranam diaphatram, albicantem, profunde friatam (C). amplo foramine deinticulato in vertice pertufam, ovato buellataus. Scmen nigro. fufcum. Embryo $(G)$ graminco viridis. 


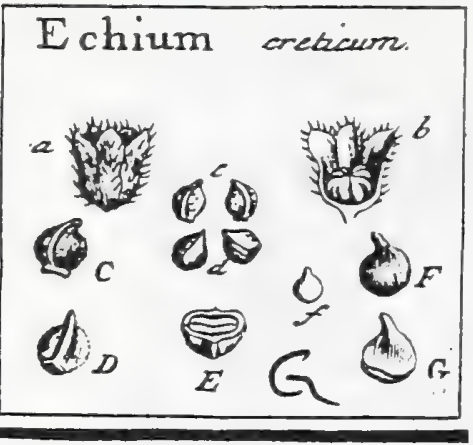

J. Gaertner (1788) Vol. I

$$
326
$$

CCCCXIX. ECHIUM. TOURN. t. 54. LinN. geir. igr.

Calyx quinquefidus. Cor. monopetala irregulatis. Stann. quinque. Styl. unicus. Nuces quatuor, gigartoidex, fcabrx, imperforatx.

Ескич сreticum. Tab. 67. fig. 7.

Echium caule procumbente, calycibus fructefcentibus diftantibus. IINN. fy/t. veg. 190.

Ex fide MARTINI, qui femina mifit.

PER. Nuces quatuor, cruftacex, fragiles, gigartoidex; hinc convexx, fulco medio elevato, inter duo tubera lateralia, notatz; inde angulatx; undique punctis ofreis albis, fufco apiculatis, fcabrata; ad bafin area triangulari imperforata appendiculatx; extus ferrugineo fumolx; intus atrx, glaberrinix; uniloculares, evalves.

REC. funiculus capillaris, ad apicem feminis in proprio canals decurrens.

Sем. folitaria, ovata, longe roftellata, fubcomprefTa, fpadices.

IN т. fimplicifinum, membranaceum, tenue.

A LB. nullum.

Es в. femini conformis, leviter curvatus, inverfus, luteus. Cotyl. obovatx, retulx, carnofx. Rad. tercti acuminata, longiuscula, fupera.

2. h) Naces intra calycem, c. C.) Nucis dorfum. d. D.) Ejas pars ventralis. E.) Eaden transverfe feth. 8. F.) Semen decorticatum. G.) Embryo denudatus. 


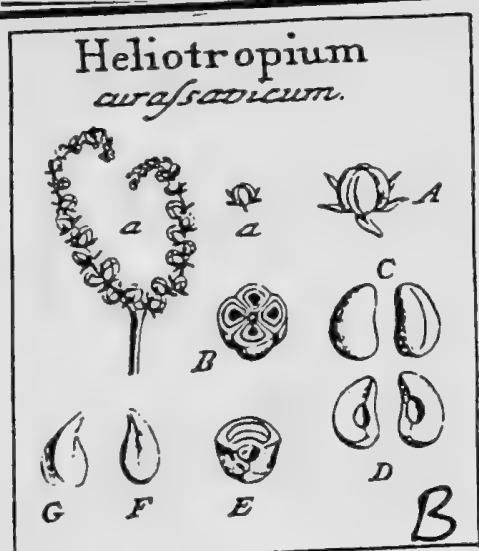

J. Gaertner (1788) Vol.l

CCCCXXIII. HELIOTROPIUM. T OURN. t. 57. Li N N. gen. I79. Calyx quinquefidus. Cor. Inypocratcriformis, fauce fornicibus claufa. Stan. quinque.
Styl. unicus. Nuces quatuor, nudx aut corticatz, imperforatx.

HELIOTROPIUM curaftavicum. Tab. 68. fig. 2.

Heliotropium americanum procumbens, facie lini umbilicati. HE R M. parad. 183.

t. 183 .

Heliotropium foliis lanceolato linearibus glabris aveniis, fpicis conjugatis. Lrse. fyft. veg. is 4. Burm. flor. ind. t. 16. $f .2$.

PER. Hacca oiato globofa, tetrapyrena, per maturitatem exarefcens, quadripartibilis.

Caro tenuis, in corticem nucularun inembranaceum abcuns. Nuculz cruftacex,

durx, modice craftae, hinc convexx, inde angulatx, \& in medio angulo, pro-

funda foveola exfculptz, imperforatx, uniloculares.

REC. nullum manifeftum, prater carneın fungolam, nuculas connectentem.

S EM. folitaria, ovato oblonga, fubroftcllata, hinc convexa, inde leviter concava, pallida.

I T. fimplicifimum, membranaceum, tenue.

$A<B$. nullum.

Eм в. femini conformis, inverfus, albus. Cotyl. ovatx, carnofx, leviter concarz. Rad. tereti acuminata, fupera.

2. 2. A.) Fruthus integer. B.) Idem transverfe diffetus. C.) Nuculx a dorfo fpectatæ. (avelei fento Semen decorticatnum, G.) Embryo denudatus. 


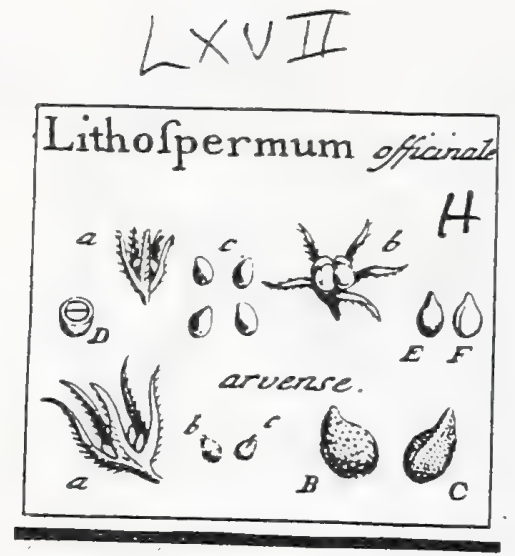

J. Gaertner (1788) Vol.1

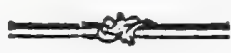

CCCCXX. LITHOSPERMUM. TouRN. $t$. 55. LI N N. gen. 181.

Calyx quinquefidus. Cor. infundibulitormis: tubo longo gracili: fauce pervia. Stan. quinque. Styl. unicus. Nuces quatuor lapidex, imperforatz.

LITHOSPERMUM officinale. Tab. 67. fig. 8.

Lithofpermum minus. CAM. evit. $6_{5}$ g.

Litho/permum caule erefto ramo/3/smo, floribus calycem vix fuperantibus. HazI. hift. 1. 21. 595 .

Lithofpermum feninibus lavibus, corollis vix calycem fuperantibus, foliis lanceolatis. LIN A. fy/t. veg. 185 .

PER. Nuces quatuor, parvx, lapidex; oviformes, a latere interiori, ftriâ cum duabus lincolis obfoletis notatx, imperforatz glabcriunx, nitidx, eburnex aut livefcentes, uniloculares evalves.

REc. funiculus capillaris, ad Icminis apiccm pertingens.

SEM. folitaria, ovato roflllata, nigro fufca.

Is T. fimplicifimum, membranaceum, tenue.

Аะв. nullum.

Eмв. femini conformis, inverfus, luteus. Cotyl. ovatz, crafiz, plano-convexx. Rad. tereti acuminata, fupera.

2. b.) Nuces intra calycem. c.) Nacula (eparata, D.) Setio nucis transrerfa, E) Semen naturali majus, F.) Embryo denudatus.

LIT HOSPFR MU M arvenfe. ibid.

Echoides flore albo. RIv. mon. t. 9. BIAKw, herb. $t$. 436. OEDER. fl. dan. t. 456 .

Heliotropium folits lingulatis, floribus tubulofis. HaLr. hift. I. n. 594 .

Lithofpermun feminibus rugofis, corollis vix calycem fuperantibus. LINN. Jyft. veg. 185.

Nuculx parvx (a. b. c.), lapidex, ovatx, acuminato roftratx, hinc (b. B.) convex $x$, inde carina media (c. C.) angulat $x$, undique tuberculis afperis feabratz fordide albicantes. Religua ut in pracedenti.

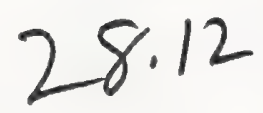




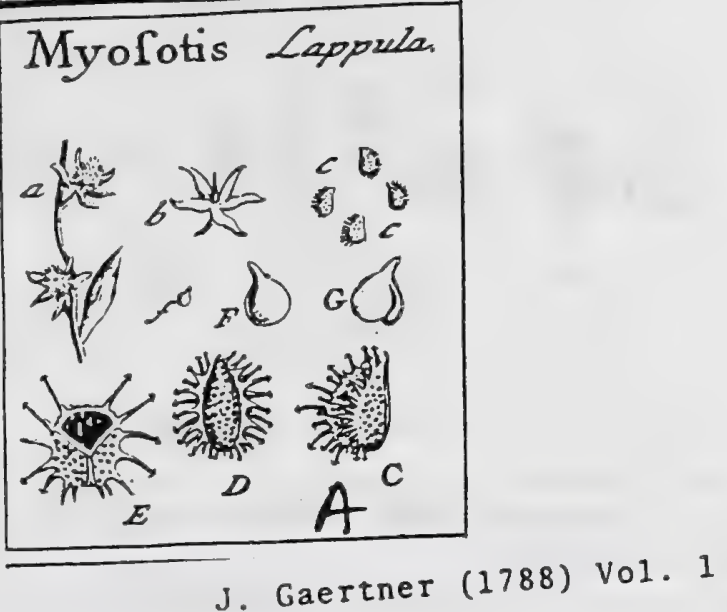

\section{8}

CCCCXXII. MYOSOTIS. Lin N. gen. igo.

Calyx quinquefidus. Cor. infundibuliformis, fauce fquamulis fornicatis claufa. Stam. quinque. Styl. unicus. Nuces quatuor, inperforatx.

M × о 0 т is Lappula. Tab. 68. fig. I.

Cynoglo $/$ a ninor nontana Jerotina altera. Co L. ecphr. 1. p. 179. $t$. 180. Oedes: flor. dan. t. 692 .

Cynoglo/um glandulis in faucibus florum glabris. H a L L. hif.. 1. 11. 589.

Mynotis feminibus aculeis glochidibus, foliis lanceolatis pilofis. LIN Jy/t: veg. 185 .

PER. Nuces quatuor parvx, coriacex, ovato acuminatx, undique punctis offeis apiculatis fcabratx; hinc convexx \& ad latcra gemina ferie glochidatorum aculeorum mnricat $x$; inde angulat $x$; inperforat $x$, uniloculares.

RE c. funiculus fetaceus intra crufain nucis.

S Eм. folitaria, ovato rofellata, fpadicea.

IN T. fimplicillimum, membranaceum, tenue.

A LB. nuilım.

Exв. inverfus, albus. Cotyl. fuborbiculatx, plano convexx, tenues. Rad. tereti:acuininata, fupera.

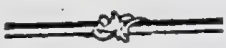

a.) Nuces intra ealycem. b.) Receptac. fubulatum. c. C.) Nincule a latere (pertatix. D.) Nucis dorfuni, E.) Ejus fetio transverialis. f. F.) Semen decorcicatum. G.) Embryo denudatus.

Nimis artificiale genus, a Cynoglofo, in effentialibus, nihil diverfum. 


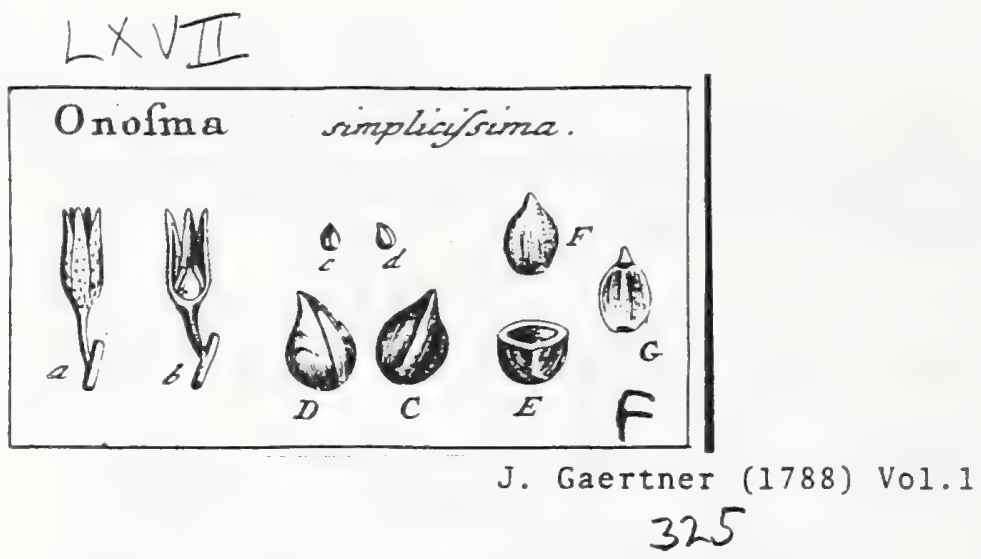

CCCCXVIII. ONOSMA. LINN. gen. 187.

Calyx profuride quinquefidus. Cor. fymphyti. fod absque radiis. Stam. quinque.

Styl. unicus. Nuces quatuor, lapidex, nitidifinnx, inperforatz.

O Nosm a finplex. Tab. 67. fig. 6 .

Onofma foliis lanceolatis hispidis, fruftibus pendulis. Gmes. fib. 4. p. 76. t. 40. utcunque.

Onofma foliis confertis lanceolato linearibus pilofis. L I N N. fiff. veg. 188.

PER. Nuces quatuor, parvx, lapidex, ovatx, fubroflellatx, hinc leviter convexx, inde angulatx, ad bafun arcola triangulari terninatx, imperforatx; cetera lxviçatiflunx, nitidx, cincrco-albicantes, punclis \& lineolis teftaceis exilifinis variegatx, uniloculares, evalves.

REc. funiculus capillaris ad Serninis apicem pertingens.

SEM. folitaria, ovato acuminata, compreffiuscula, fpadiceo-fufca.

IN T. fimplicifinum, membranaceum, tenue. 326

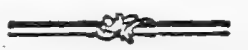

A L B. nullum.

Емв. femini conformis, inverfus, albus. Cotyl. ovatx, carnolx. Rad. conica, brevis, fupera.

a. b.) Nucule intra calyeem. c. C.) Nucis pars ventralis. d. D.) Ejus dorfum. E, Eadem diffeta. F.) Semen decorticatum. G.J Cotyledonis pars interna.

Corolla conftanter alba. Planta fpontanea, uno pede nunquam altior, tactu mollis. Habitat copiofe in rupibus cretaceis ad Wolgam, fed in Ucraniam usque non de. fcendit, ubi contra féquens non rara eft.

ONOSM A echioides.

Anchufa tertia. CА s. epit. 736. J A c Q. for. aufl. $3 \cdot t .295$.

Symphytum foliis lingulatis hifpidis. HaLl. hif. I. n. 601 .

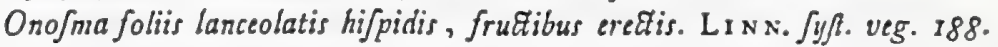

Nucula dinidio grandiores, quam in prxcedenti, tot $x$ ex cincrco fpadicex \& haud raro duobus ocellis albicantibus, fulco annulo cinctis, ad latera dorfi nota. tx, nitidilimx, glaberrinx, argute roftellatx. Reliqua pracedentis.

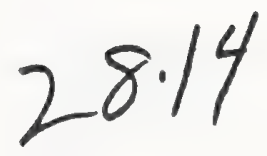




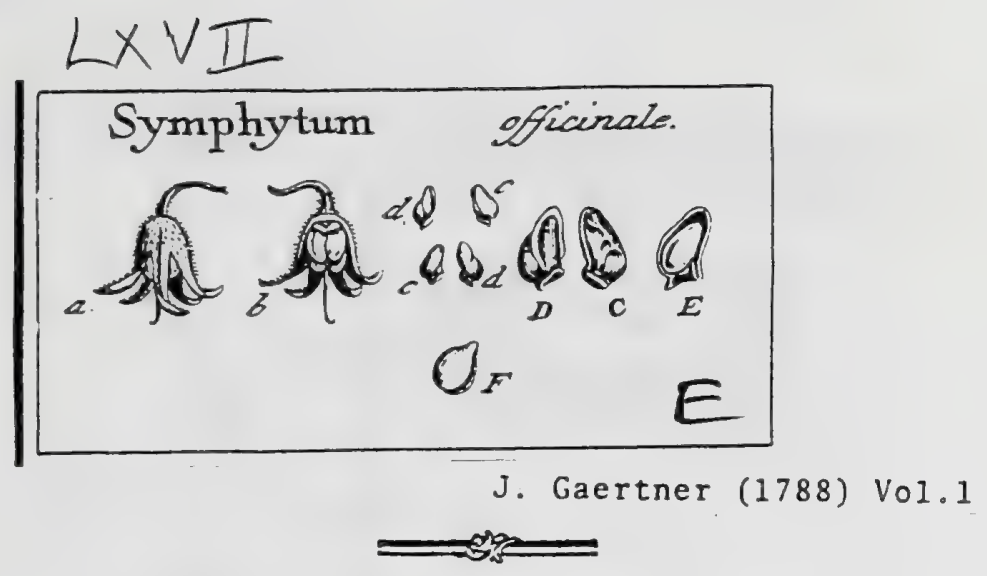

CCCCXVII. SYMPHYTUM. TOU RN. $t$. 56. Linn. gen. 185.

Calyx quinquefidus. Cor, infundibuliformis, fuperne ventricofa: fauce claufa radiis fillulufis extus foramine, fub limbo coroll $x$, hiantibus. Stam. quinque. Styl. unicus. Nuculz quatuor, perforatx.

SY M Р Y Т Т М oflicinale. Tab. $6 \%$. fig. 5 :

Symplintum majus. CAs, epit. 700. BLAк世. herb. t. 252. OеDER. for. dan. t. 664 .

Symphytum foliis ovato lanceolatis decurrentibus. HAгr. hif. I. \%. 600. LIN N. III. veE. 187.

PE R. Nuces quatuor, parvx, cruftacex, fragiles; hine gibbx \& obfolete reticulatorugnfx; inde angulatx, lateribus planis; fupra compreffx; infra coarctatz, marginatx, perforatx; cetera fufcx aut fumof $x$, uniloculares, evalves.

R r.c. Enniculus filiformis, medio feminis lateri interno infertus.

SEM. folitaria, ovata, fupra acuminata, pallida, aut rufefcentia

IN T. fimpliciflunum, membranaceum, teaue.

$\Lambda$ L R. nullum.

E M B. maguitudine feminis, inverfus, albus. Cotyl. ellipticx, carnofx. Rad. conica, brevis, fupera.

a. b.) Nuces intra calycem. c. C.) Nucis dorfum. d. D.) Ejusdera pars ventralis, E.) Semen cum funiculo inura nuceor. F.J Embryo denudatus.
Boraginaceae

325 


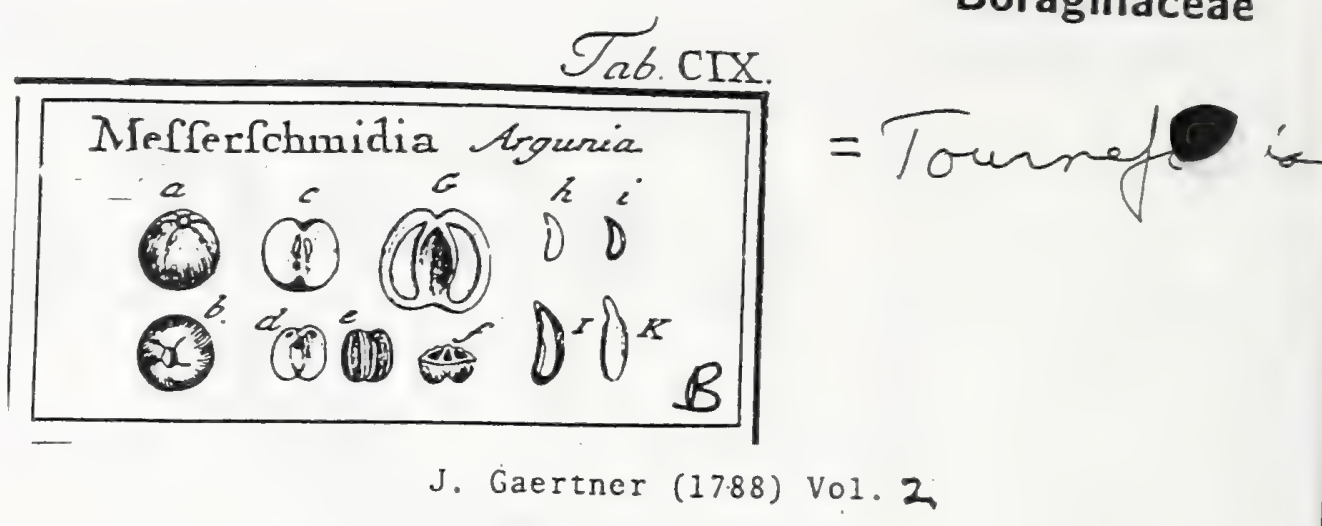

\section{9}

\section{MESSERSCHMIDIA: LINN. ger. 1245.}

Calyx quinquefidus. Cor. infundibuliformis, fauce nuda. Sam. quinque. Uvar. fuperum. Styl. firplez. Bace exfucca, dipyrena, bipartibilis: olficulis difpermis, trilocularibus.

\section{0}

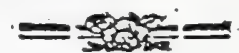

Messerschmidra Argunia. Tab. 109. fig. 3.

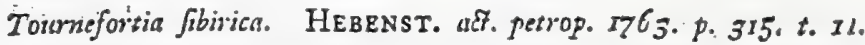

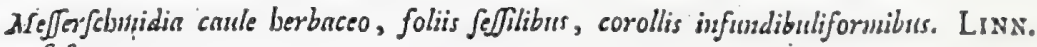
[Dff. veg. 190.

PER. Bacca exfucca, globofa, utrinque umbilicata, obfolete ftriata, cinereofufca, dipyrena, bipartibilis. Cortex craflus, fungofo - coriaceus. $O \mathbb{f r}_{\mathrm{I}}$. cula fubrotunda, hinc convexa, longitudinaliter ftriata, inde planiufcula, trifora, trilocularia: loculamentis duobus lateralibus feminiferis; tertio intermedio, fterili, fuperne femi aperto.

REc. funiculi umbilicales breviflimi, per foramina pyrenarum fuperiora lateralia ad femina pertingentes.

SEM. folitaria, adeoque in tota bacca quaterna, oblonga, furfum leviter attenuata, obfoletifime angulata, ut fere teretia.

IN T. Gimplex, membranaceum, tenue, friabile, candidifimum, $\Gamma_{p}$ lendens.

AL B. femini conforme, carnofum, tenue, album.

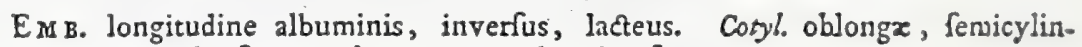
dricx, obtufe. Rad. attenuata, brevis, fupera.

2. b.) Bacea integra, 2 prona \& fupina parte fpeetats. c) Ejusden pars dinidia, per matoritatem fronte ab altera folutz \& a parte fua interiore plana fredata. d. c.) Oliculz decorticara integra. f.) Loculamenta pyrenarum transverlim, \& G.) Eadem longitudinaditer apcrta, eum fitu fcminum. h.) Semen feparatuas. i l.) Albumen lougitudinaliter diffe.tum, cum Gtus embryonis K.) Eabryo folutus \& autus. 


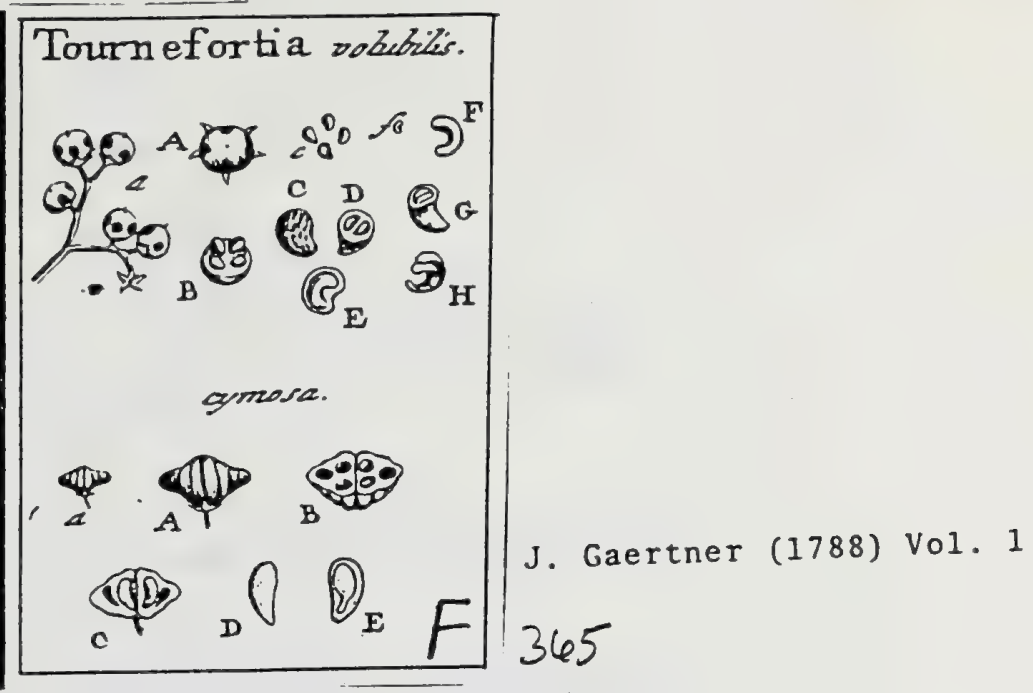

CCCCLXXV. TOVRNEFORTIA. LIN Gen. 192.

Calyx quinquepartitus. Cor. monopetala infundibuliformis. Stam. quinque. Styl. unicus. Bacca pulpofa, bi-l. tetrapyrena: officulis difperınis. Semina erecta.

Tournefonta volubilis. Tab. 7 6. fig. 2.

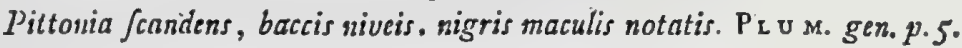

lirga aurea americana frutescens glabra, foliis fubtus cafis. Pzux. phyt. t. $235 \cdot f .6$.

Tonrnefortia foliis ovatis acuninatis glabris, petiolis reflexis, caule volubili. L 1 N N. Syjl. veg. Iyt.

Ex horto regio Kexenfi.

PER. Pacca fupera, pulpola, globole-depreffituscula, fubdiaphana, mnilocularis tetrapyrena a!ba, maculis rotundis atris pyrenarum numero \& fitu relponjentibus notsta. Oflicula difantia, fubglobofa, deorfum anguhata, tuberculato rugofa, bilocularia.

REC. nultum; ollicula in fundo baccx convergentia, ibidemque affixa.

SEM. in fingulo loculamento unicum, incurvum, fragile, pallidum.

IN T. fimplex, membranaccum, tenuiffinum.

A L в. femini conforme, tenue, carnofurn, album.

Е мв. femicirculari arcuatus, erectus, lutefcens. Cotyl. oblongae, fubfoliaceae. Rad. rerctiuscula, infera.

a. A.) Bacca integra. B.) Eadem diffecta. c. C.) Officula feparata. D.) Officulum transverfim-\& E.) Idem longitudinaliter fectum, f, F,) Nucleus membrana fus veltitus. G.) Idem transverfe fettus. IH.) Embryo denudatus.

TOURNEFORTIA cymofa. ibid.

Heliotropii flore frutex, folio maximo oblongo acuminato. SLOA.N. hift. jam. 2. p. 109. t. $2: 2$. $f .2$.

Tournefortia foliis ovatis in'egerrimis nudis, fpicis cynofis. LInN. fift. veg. 19:.

Bacca (vetufla \& exficci:a) transier!e oblonga (a. A.) utrinque acuminata, quafi ex duobus conis conlata. fulcafa, rufufceriti fumofa, dipyrena. Oflicula irregulariter conica, fulcara, Uilocula:ia (bi). Loculamenta duo interiora (B. C.) fertilia; tertium, exterius, conftantcr inane. Semina oblonga (C. D.), deorfum anguftiora, leviter curvata, nivea. Integumentum aridum, triabile. Aibumen

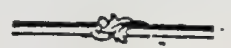

ut in praecedenti. Embryo (E.) erectus, modice curvatus, lutefcens: Cotrity ellipticae, foliaceae. Rad. attenuata, infera. Ob fitum radiculae inferum, Tournefortia, Verbenis Adanfoni quam Alperifolite
propior ef.

Baccam gemino poro in apice perforatam, ut vult Linnaeus, minu nunguam $\mathbf{M}$. dere contigit: quare haec nota generica vel plane erronea, velacerce nop pubiper 
-

- 


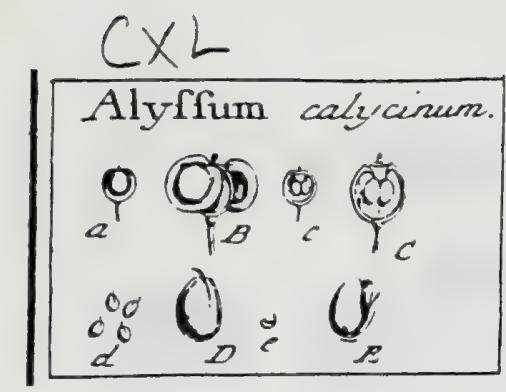

J. Gaertner (1788) Vol 2

\section{2}

DCCCXVIII. A L Y S S U M. TOURn. t. 104. LINN. gen. 805.

Silicula rotuniata aut ovata, vix vel parum emarginata, turgidula, bilocularis, bivalvis. Septum valvis parallelum. Sem. uno plura. Filanienta duo, in quibusdum, denticulo introrfum notata.

Alyssum calycinum. Tab. 141. fig. 4 .

Alygor: Car. epit. 558. f. x. - nimimum. Clus. bif. 2. p. 133.

Aly Jusu caulibus berbaceis, famiuibus oumibus denturis, calycibus ferfiftentibus. Lisin. J3\%. veg. 590.

kon. Jace aufr. t. 358 .

PER. Silicula orbiculata, Jeviffme emarginata, in medio lenticulari-convexa, ad Jatera autem in marginem planum comprefà, bilocularis, bivalvis. Valvulic patelliformes. Diffepimentum tenuilhmun, valis parallelum.

REC. intervalvulare, filiforme, e fuperiori \& laterali parte duos funiculos umbilicales utrinque promens.

SEx. in fingulo loculo gemina, uno tamen fxpius aborticnte, ovata, hine convexa, inde plana, rufercentia, anguftilimo niargine albicante circumdata, mucilaginofa.

Ix T. finplex, membranaceum, fuperficie exteriore ab aqua in mucilaginem pellucidillinam, crifluimam, refolubili.

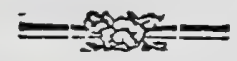

Ex B. curvatus, luteus. Cotyl. ovatz, plano-convexiufcula. Rad. teretiufcula, furfum intexa, rimx cotyledonun accumbens, centrifuga.

a.) Silicula integra. B.) Eadem dehilcens. c. C.) Diftepinentum cum (eminibus in fitu nathrali. d. D.) Semina foluta. E) Embryo denudatus.

Alyfium finuatum. LiNe.

Evica peregrina. Clus. bift. 2. p. 134.

Silicula magnitudine pifi, fubglubufa, inflata, glabra, albicans. Semina rotunda, comprefla, ut fere folizcea aut bracteata, fordide rufefcentia aut ferruginea, margine membranaceo albicante cincta, mucilaginofa.

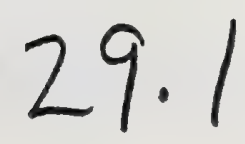




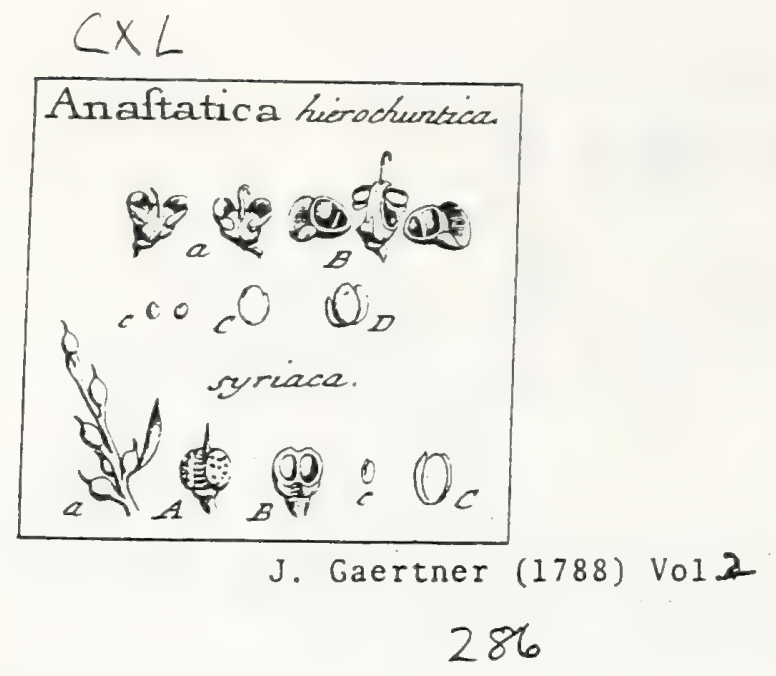

DCCCXXIV. A N A S T A T I C A. LINn. ger. 798.

Silicu!a fubglobofa, bivalvis: valvula fingula fuperne proceflu transverfali unguiformi aurita.

ANastatica hierochuntica. Tab. 14r. fig. Ir.

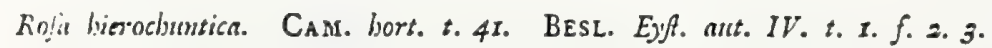

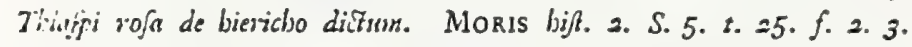

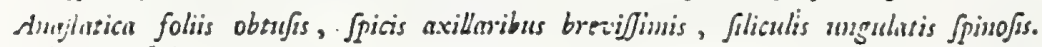
LIN S. Jy\%. veg. 584 .

PER. Silicula turbinato-globofa, ftylo perfiftente rigido, obliquo aut uncinulato terminata, bilocularis, bivalvis. Valvula extus proceftu unguiformi prope fuperiorem fuam extremitatem auritx; intus vero levigatifinix, atcue ope diaphragmatis incompleti in duas concamerationes if cavitates drvila: quaruin fuperior fola feminifera; inferior autem fterilis \& inanis. Dillepinentuna valvis parallelum.

REc. matervalvulare, Jatiufculum, rigidun, ftapediforne, fensina vertici fuo atlixiı gerens.

Sex. duo in hinguli loculamenti cavitate fuperiori, elliptica, fubroftellata, rufelcentia aut ferrugine:

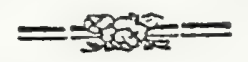

287

IN T. fimplex, membranaceun.

ENB. curvatus, lutefcens. Cotyl. ellipticx, foliacex, planx. Rad. teretiufcula, rime cotyledonum accumbens, fupera.

3.) Silicula integra. B.) Eadem aperta, cum Valvulis a parte fua interna fpecatis, atque Re. ceptaculo ftapediformi fupra fentinigero. c. C.) Semina feparata D.) Embryo denudatus.

Anaftatican fyriucain vide infra fub Buniude. 


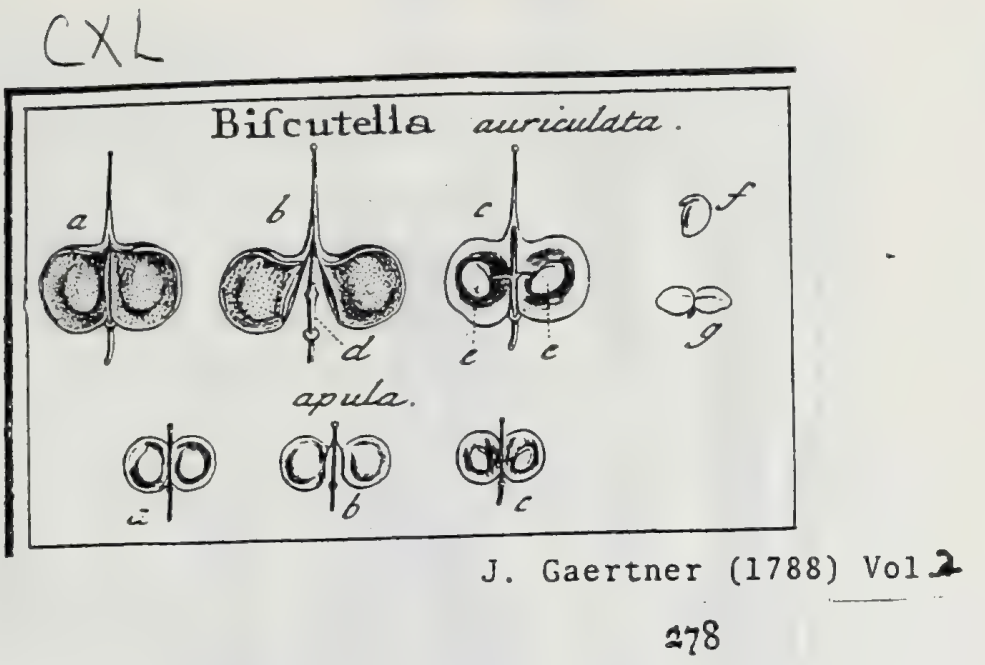

\section{B I S C U T E L L A. LINN. ger. 808 . Thlafpidium. T OURN. t. IOr.}

Silicula biloba, compreffo-plana: lobis fuborbiculatis, monolpermis, cvalvibus, ab axi fecedentibus.

Biscutella auriculata. Tab. 141. fig. I.

Leucojum montanum, flore pedato. Cozum. ecplyr. 2. p. 59. t. 6s.

Bifcutella calycibus metario utringue gibbis, filiculis in fylum cocusuibus. LinN. fys. veg. 592 .

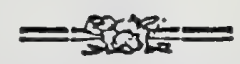

PER. Silicula transverfe ovata, comprefra, plana, punctis elevatis fcabrata, biloba: Jobis rotundatis, inferne difcretis, fuperne in ftylum, fibi multo longiorem confluentibus, unilocularibus, claufis, non dehifcentibus, fed ab axi fecedentibus. Diffepimentum proprie sullum, fed ftylus comprelfus, filiculis geminatis interjectus.

Rec. axis fructus compreffus, e quo utrinque funiculus umbilicalis filiformis ad femina procedic.

SEN. folitaria, lenticulari - compreffa, ovata, roltello inflexo notata, glabra, ferruginea.

IN T. fimplex, membranaceum.

En B. curvatus, Juteus. Cotyl. ovatx, plano - convexx, tenues. Rad. teretiufcula, fecundum fuperiorem \& interiorem cotyledonum marginem inflexa, relative centripeta.

2.) Silicula intcgra, b.) Ejusdem lobuli ab axi fecedentes. c.) Eadem verticaliter aperta. d.) Dirrepiacntum lobis interpofitum. c. e., Seminum infertio \& figura. f.) Eubryo denuda. tus. 8.) Cotyledones didutix.

Biscutella apula. ibid.

Tbluspi clypeattum. Clus. bif. 2. p. 333.

Joudraba alyfoides aprila fpicata. Colum. ecplor. 1. p. 283. t. 284. f. 1 .

Bifcutella frlicula levi, foliis afperis dentatis. HaLL. bift. "2. 50 r.

Bifcutella filiculis farbris, foliis lanceolatis feffilibus ferratis. LiNw. Dyfl. veg. 592.

Silicula (a.) precedenti dimidio ninor, nunc tota glabra, nunc punctis elevatis feabrata. Lobi fuborbiculati (b.), cum Itylo fuperne non confluentes, ab axi fecedcntes, evalves. Semina (c.) \& reliqua, ut in proccedenti, faltem ninura omuia.

Cum lilicula lobi in Bifcutella undique claufi \& foramine tantum in margine fuo interiori, pro transmittendo funiculo umbilicali, fint pertufi: fructus bifsliquofius, f. ex duabus filiculis partialibus contatus, dici poteft. 


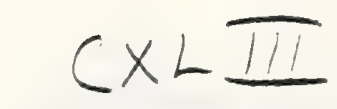

Brassicaceae

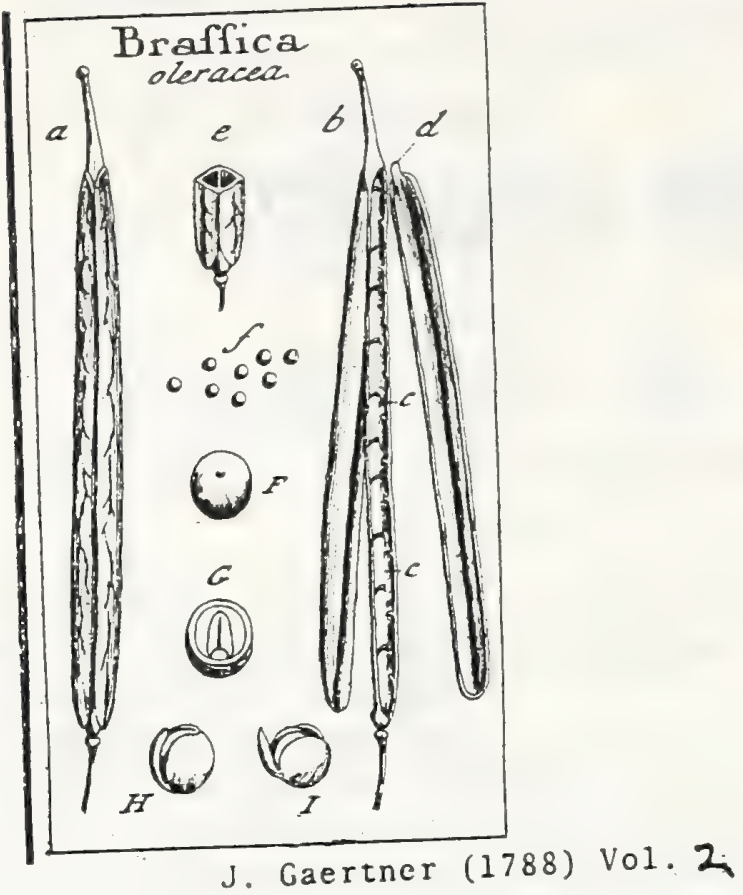

\section{5}

DCCCXXXIV. B R A S S I C A. TOURN. t. IO6. LINn. gen. $\$ 20$.

Siliqua longa, rhombeo-compreffa. Diffepimentum valvis contrarium, eisque longius $\&$ in raftrum fubulatum definens. Stigma retufum. Cotyledones conduplicatx. Glandula juxta ovarium quatuor.

Brassica oleracea. Tab. 143. fig. 2.

bragica radice caudefcente tereti carmofa. Lins. 6yf. ves. 601.

Brafica fealilis. noftratibus.

PER. Siliqua longa, rhombeacompreffa, bilocul:tris, bivalvis. Diffepimentum pellucidum, valvis contrarium, fuperne in roltrum fungofuns, fubulatum, latitudine filiqux duplo longius atque ftigmate obtufo terminatum definens. Valvula carinatx, in extremitate fua fuperiore retinaculo uncinulato atque roltri bafi immifo, ftipata.

REC. intervalvulare, fliforme.

SEa. plurima, viginti circiter in fingulo loculo, parva, globora, atra.

IN I. fimples, coriaccum, durum, fubfingile.

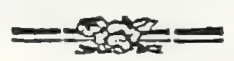

E M B. curvatus, luteus. Cotyl. cordatx, fubfoliacex: exteriore convexo-con. cava, involvente interiorens conduplicaram. Rad. teretiufcula, duplica. turx fulco accumbens, centrifuga.

a.) Siliqua integra. b.) Eaciem dehifcens. c. c.) Septum in roftrum delinens. d.) Valvula a parc fua interna (pectata, cum resinaculo unguiculato. f. F.) St:mina (cparata. G.) Semiais a embryonis fettio unasverfalis. H.) Embryo denudatus. I.) Cotgled. leviter diductz.

In Br. Eruca roftrum compreffum enfiforme: hinc Brafficx per Erucam affuitas cum Sinapi.

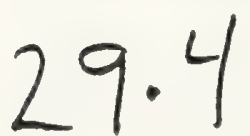


CXLII

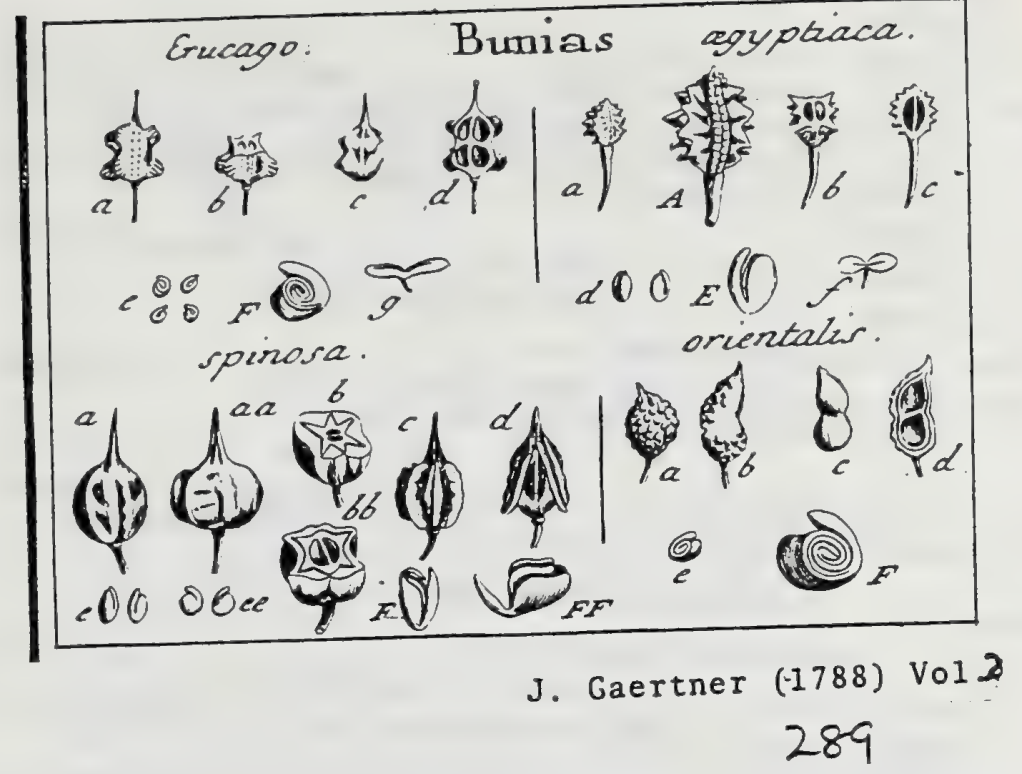

Brassicaceae

DCCCXXVIII. BUNI A S. LIN . gen. 8z3. Erucago. Tourn. t. 103.

Șilicula drupacer: putamine offeo, bi-l. quadriloculari; loculis omnibus fertilibus, indiferctis. Senina folitaria.

* Loculis geminis collateralibus.

Busins xgyptiaca. Tab. 142. fig. 2.

$29.5 \mathrm{~A}$ 
Bunins falicnlis tetragonis zudique vexrucofo muricatis, foliis runcinutis. LINN. fre?. veg. 603 .

Icon. JACQ. bort. 2. t. 145.

PER. Silicula drupacea, parva, ovata, tetragona: lateribus duobus angtiftioribus verrucofo-muricatis; duobus vero latioribus duplici ftria elevata, crenulata aut fubtuberculata, longitudinali, exaratis. Cortex tenuifimus, membranaceus. Putamen offeum, muricatum, biloculare: loculis- juxta fe politis.

REC. funiculus umbilicalis tenuiffimus, e loculamenti apice ad femen defcendens. SE M. folitaria, ovata, hinc convexa, inde plana, rufefcentia.

In T. fimplex, membranaceum.

E в в. curvatus, albus. Cotyl. ovatæ, plano-convexx. Rad. teretiufcula, furfum inflesa, rimx cotyledonum accumbens, fupera.

2. X.) Silieula integra. b.) Eadem transverfe fea. c.) Putamen denudatum \& longitudinaliter apertum. d.) Semina (eparata. E.) Embryo Jcaudatus. f.) Cutyledones explicatz.

Bunias fyriaca. (Anaftatica fyriaca) Tab. 141. fig. II.

Roja biericbrantica alia. CA . bort. t. 42.

Myagrum rigidum. PALL. it. ruth. 3. p. 741. t. Ll. f. x.

Anaftatica foliis acutis, fpicis folio lóngioribus, filiculis ovatis roftratis. LINN. Syft. veg. 584 .

Silicula drupacea parva, fubglobofa (a. A.), ftylo fubulato terminata, \& ex hoc, fulco depreffo longitudinali \& transverfim ftriato didyma, ad latera fphxrice gibba \& tuberculato fcabra aut feris hifpida. Cortex tenuiffimus, ut fere nullus. Putamen offeum, biloculare (B.). . Semina folitaria, ovata, planoconvexa, pallida. Enbryo (c. C.) femini conformis. Reliqua ut in pracedenti.

Siliculx, quas ego olim in Ucrania legi \& quas ex hortis botanicis habui, onnes erant calvæ: ideo autem vix crediderim, quod M. rigidrm $\mathrm{P}_{\wedge L L}$. 1. c. a noltra planta fpecie differat, etfi ejus filiculx fint hifpidx. Alterum autem ipfius Myagrum tab. $M$ m. f. 2. plane diverá generis planta effe videtur.

Bunzas fpinola. Tab. 142. fig. 2.

Braffica fpinofa. Alp. exot: 201. ic. 200.

Bunias racemis fpinefcentibus. LIN . $\int y / 2$. veg. 603 .

Silicula drupacea, ex ventre turgido, tetragono, glabro, in mucronem pyramidatum faltigiata (a. aa.), pallide ftraminea. Cortex craflus (b. bb.), fuberofus. Putamen (c. d.) offeum, biloculare, fexangulare: angulis conpreflis: duobus mediis oppofitis anguftioribus. Semina folitaria, uvata (e),

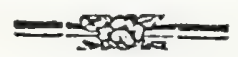

aut fubrotunda (ee.) plano-convexa. Embryonis çotyledones (F. FF.) conduplicatx folizecx. Rad. intlexa, duplicaturz fulco accumbens, fupera.

** Loculis geminis fibi nuutuo impofitis.

Buniss orientalis. ibid.

Crambe orientalis, dentis leonis folio, encaginis facis. Toury. cor. 41. Bunias filiculis ovatis gibbis verrucofis. LINN. fyft. veg. 603.

Silicula drupacea fubglubora (a) aut ovato-oblonga (b.), gibba, verncola, in ftylum brevem definens. Corter fungofus, framineo albicans. Putamen (c. d.) offeum, filiculx conforme, extus glabrum, intus duobus loculamentis, fibi fuperimpofitis, exfculptum: quorum fuperius in fructibus fubglobofis plerumque obliteratur. Senina fubglobofa, rufefcentia. Embryonis cotyledones (e. F.) oblongx, fpiraliter convolutie.

$$
\text { ** Loculis quaternis, per paria fibi Juperimpofitis. }
$$

Bunias Erucago. ibid.

Evuca monspeliaca, faligna quadrangula echirata. Bauk. prodr. 4r. c. ic. Burias faliculis tetragonis: angulis bicrifasis. LINN. fy/t. veg. b. c.

Icost. JACQ. auffr. t. 340 .

Silicula drupacea quadrangula (a), in medio anguftata (b.), ttylo longo terminata, \& ad angulos crilta interrupta infignita. Cortex fpongiofo-membramaceus, telluis, albicans. Putamen (c. d.) olfeum, quadriloculare: loculis duobus inferioribus totidemque fuperioribus, ommibus fertilibus. Semila (e.) fubglobofa, coclileas, rufefcentis. Embryonis cotyledones fpiraliter convoJutx (F.), lineari oblongx (g.).

Buniadis characterem unice in drupaceo fructu ponimus; qui autem generum multitudine delectantur, poterunt hoc genus, ab interna drupx, feminumaue fabrica, in Buniadem, Lxliam \& Erucaginem difpefcere. 


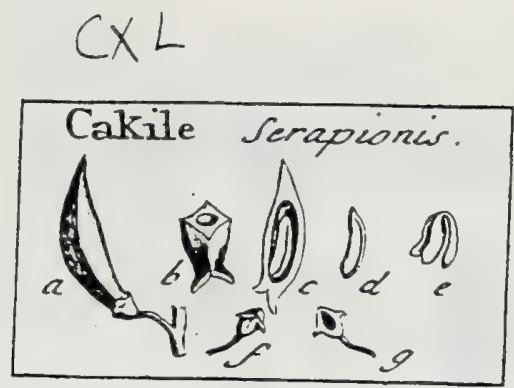

\section{J. Gaertner (1788) Vol. Z}

\section{7}

DCCCXXV. C A K I L E. TOURN. t. 483.

Silicula rhombeo - tetragona, biarticulata, ad articulos fecedens : articulo utroyue monofpermo; inferiore tamen ficpe terili.

Cakile Serapionis. Tab. 141. fig. 12.

Culiale ferupionis. Lов. ic. $2 \approx 3$.

Cakile f. Evuca murina. Вачн. bift: 2. p. 868.

Bruias filiculis ovatis levibus ancipitibus. LINN. 5yf. veg. 603.

PER. Silicula oblonga, acuminata, inique tetragona ut quasidoque anceps, fuberofa, biarticulata, ad articulos fecedens. Articulus fuperior major, ad bafin profunde enarginatus, fpongiofo - fuberofus, conftanter fertilis, unilocularis, evalvis, ut tanen fecundun angulos extanciores facile in duas valvulas findi poffit. Art. inferior minor, fubturbinatus, numc perfecte folidus; unuc unico loculo inani dotatus; regulariter autem mono. fpernos.

REC. nullum aut obfoletun. Semen articuli fuperioris, absque notabili funiculo unbilicali, inferiori parti loculanenti lateraliter affixum.

SE s. in articulo fruperiori unicum, oblongum, fubfalcatum, utrinque linea Jongitulinali infcriptum, ferrugineum: in art. inferiori nullum, aut perinde unicuin.

Is T. fimplex, nembranaceum.

Е.мв. Sminis fuperioris oblongus, curvatus, lutefcens. Cotyl. oblongx, fubfalcatx, piano - convesiufculx. Rad. fufilormis, deurfum inâexa, rimx cotyledonum sccumbens, infera. Sem. inferioris curvatus. .....

8.) Silicula intęrz. b.) Aricalus fuperior transwerfim feetus. c.) Iden lougitudinaliter apersus, cum fitu \& infertione feminis, d.) Senen feparatum. e.) Einbrye denudatus. E.) Arti-

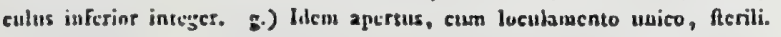

Senuma inferion nihi hatenus videre non contigit: addant itaque alii eorundem fabrican intersam, $\&$ doceant num cotyledoues fint plano-cunvexix, num convoluta, anue vero fpirales? 

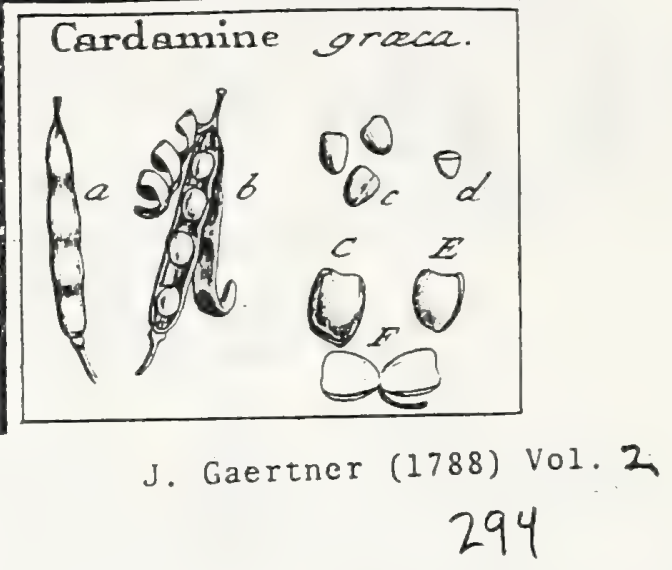

DCCCXXXIII. CARDAMINE. TOURN. t. IOg. LINN. gen. 8 ra.

Siliqua ublonga, anceps, ftylo mediocri terminata. Valvulx elaftice dehifcentes, a bafi furfum revolutx, aut contortx. Diffepimentuin membranaceum, valvis parallelum. Cotyledones planx.

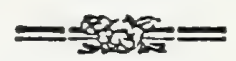

CardaniNe grxca. Tab. 143. fig. I:

Sio minimo Alpini affinis, filiculis hutis. Bocc. fice. 84. t. 44. f. 2.

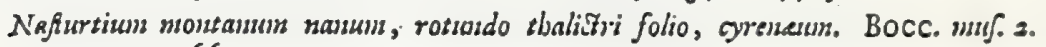
p. 17 ז. $t .166$.

Cordamine foliis pinnatis, foliolis palmatis aqualibus petiolatis. LıN̦N. Cyßß. veg. 594.

PER. Siliqua oblonga, lenticulari-comprefa, in ftylum latitudini filiqua xqua. lem definens, bilocularis, bivalvis, elaftica. Valvulze chartacex, dehifcento fpiraliter contorta aut verfus apicem revolutx. Difepimentum tenue, fericeo-album, valvis parallelun.

REc. intervalvulare, filiformc, funiculis umbilicalibus alternantibus utrinque ftipatum.

SEM. pauca, quatuor circiter in fingulo loculo, ovata, ad umbilicum quafi truncata, lenticulari compreffa. anguftifimoque margine membranaceo, in regione umbilico oppofita, ftipata, pallide ferruginea.

IN T. fimplex, membranaceum.

EM B. curvatus, albidus. Cotyl. obovatx, utrinque planiufculx. Rad. gracilis, rinax cotyledonum accumbens, centrifuga.

a.) Siliquz integra. b.) Eadem dehilecns. c. C.) Semina folutz, integra. d.) Semen diffectum.

E.) Embry. dcandatus. F.) Cotyledones explicatx. 


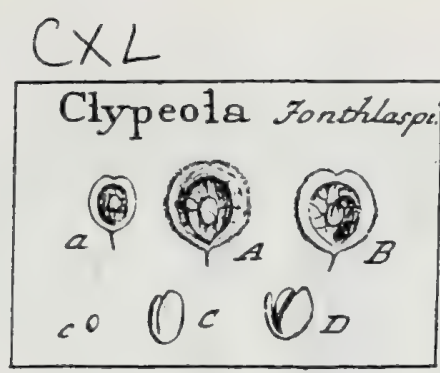

J. Gaertner (1788) Vol. Zi

283

DCCCXIX. C L Y P E O L A. LINN. ger. SO\%.

Jonthlafpi. TOURN. t. 99.

Silicula orbiculata, plano-comprefla, vix vel leviflme enarginata, unilosularis, monofperma.

Clypeora Junthlappi. Tab. 141. fig. 6.

Jontblufpi minimum fpicatsm lonatum. Colum. ecpiss. s. p. 28 s. t. 284.

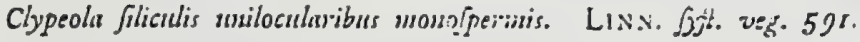

PER. Silicula fuborbiculata, apice leviflime ensarginaid, follacco-comprefta, pubefcens, margine pallidiore aut albicante atque tenuifime ciliato circu:ndata, unilocularis, non fponte dehifcens, facile tamen in duas valvulas membranaceas atque tenuilfmas divifibilis.

REC. nullum, proter funiculum umbilicalem capillarem, e margine alterius valvulx oriundum \& ad centrum loculamenti porrectun.

SEs. unicum, ellipticum, comprelfum, glabrum, fulvum.

INT. finplex, membranaceum.

EM B. curvatus, lutefcens. Cofyl. ovatx, furfum anguftiores, fubfoliscex. Rad. tcretiufcula, furfum infexa, rimic cotyledununs accumbens, fupera.

a. A.) Silieula integra. B.) Valvula altera eum fitu \& infertione feminis. c. C.) Semen (eparstum. D.) Embryo denulatus.

Reliqux Clyp̧colx fpecies Linnxanx utique ad Alyfum pertinent. 
CXLII

Brassicaceae

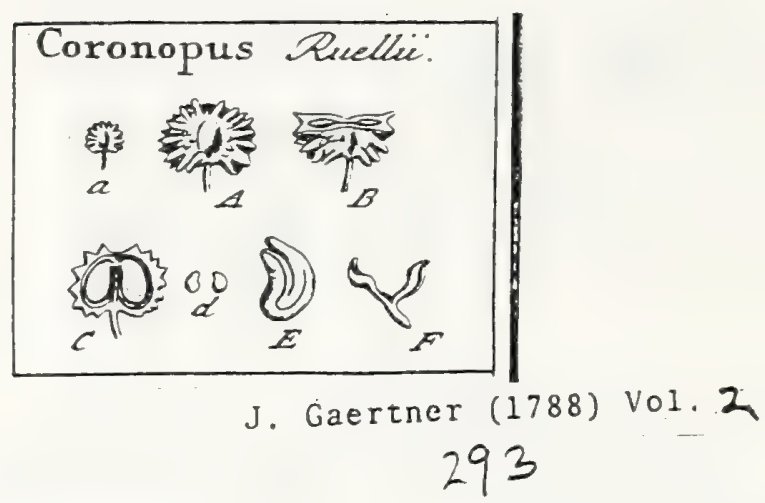

DCCCXXXI. C OR O N O P U S. Hall. bi/f. p. 217 .

Silicula rotunidato-reniformis, muricana, bilocularis: loculis collateralibus, monofpermis, cvalvibus.

Coroxopus Ruellii. Tab. 142. fig. S.

Pfeudo-ambrofia. CAM. epit. 596. OED. flor. dan. 6. 202.

Coronupus. BLAKIv. berb. t. 120. . HaLL. hif. 11. 502.

Cocblearia foliis pinuarifidis, caule deprejJo. LINs. Jiß. ieg. 588 .

PER. Silicula rotundato-reniformis, tuberculis atque lamellis radiantibus verfus peripheriam muricata \& in ambitu quafi criftata, in medio autem glabriufcula; cetera compreffa, bilocularis, evalvis. Loculamenta undique claufa \& ad axem inter fe connata, ut pericarpium ex duabus filiculis partialibus compoficum effe videatur.

REc. nullum; fenina apici Juculamentorum affixa.

SE.r. folitaria, ovata, Ienticulari-compredia, e luteo-rufefientia.

IN T. fimplex, nembranaceum.

297

Е м в. curvatus, lutefcens. Cotyl. oblongx, figmoideo-curvatx, fubplicata. Rad. conica, brevis, dorfo. non rimx cotyledonum accumbens, fupore.

a. A.) Silicula integra. B.) Eadem transverfe - \&. C.) longitudinaliter diffectz, euan iafertione: feminum. d.) Scmina feparata. E.) Embryo denudatus. F.) Cotyledones explicate.

29.9 


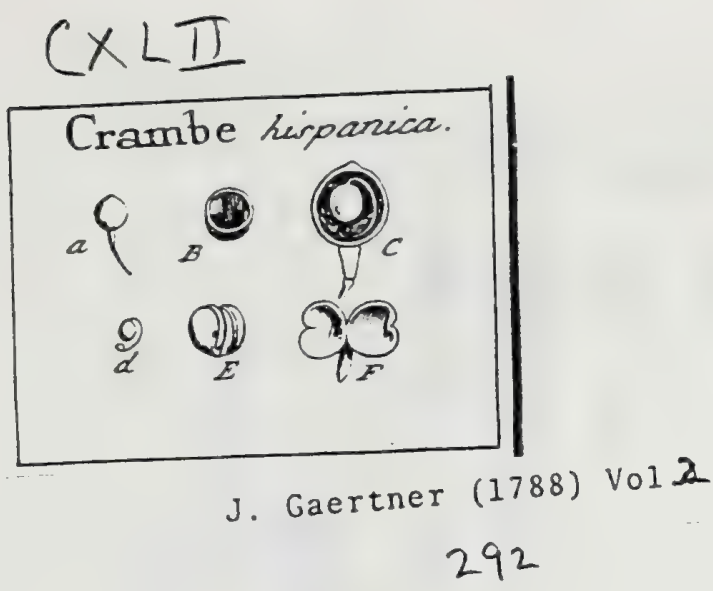

DCCCXXX. C R A M B E. TOURN. t. I00. Linn. gert. 825.

Staminum filamenta longiora apice bifurca: crure altero antherifero. Silicula coriacez, evalvis, biarticulata: articulo fertili globofo; altero ficpius abortivo, gracili.

Cиambe hifpanica. Tab. 142. fig. 4 .

Kapifrum maximum rotrudifolizm monofpermum. Con. cmad. t. 148. MORIS. livil. 3. S. 3. t. J3. f. I.

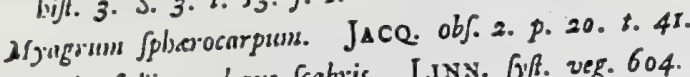

Crmube foliis canlegre fcabris. LINs. fj\%. veg. 604 .

PER. Silicula parva, biarticulata. Articulus inferior oblongus, folidus aut un locularis, ftcrilis, per naturitatem major, fphxricus, coriaceus, glaber, unicens. Art. fuperior niultoties major,

Jocularis, evalvis, ab inleriori sonte

REC. funiculus umbilicalis filiformis; longiffimus, tortuofo tuxu e fundo , dehinc fupra feminis verticem adfcendens, \& reloculanenti oriundus, altera illud in fitu pendulo fultinens.

SEM. unicum, fubglobofum, cavicate loculamenti fui mulco anguftius, pallide rufeicens.

IN T. fimplex, membranaceum.

EMB. curvatus, lutefcens. Cotyl. cordatx, fubfoliacex, exteriore convexoconcava, amplectente interiorem conduplicanam. Rad. teretiufcula, furfum inflexa, conduplicaturx fulco accumbens, fupera.

3.) Silicula integra. B.) Articulus fuperior transverfim feetus. C.) Ejusdem, nec non articuli

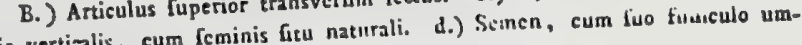

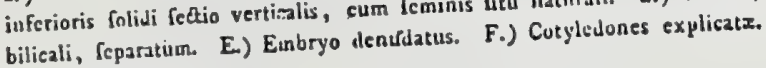

Crambe maritima. Liss.

Icon. OED. for. dan. t. $3^{16}$.

Silicula biarticulata. Articulus inferior minor, unilocularis, monofpermus. Art. freperior maximus, globofus, bilocularis, difpermus. Recepracula in loculamentis fuperioribus filiformia, libers; in inferiori nullum manifeAum, fed femen ex apice loculamenti pendere videcur. P'er maturitatem plerumque omnia femina, prater unicun in articulo funeriori, furfocautur.

Inter Crambem, Cakilen \& Mlyagrum prosima intercedit affinitas.

$$
29.10
$$




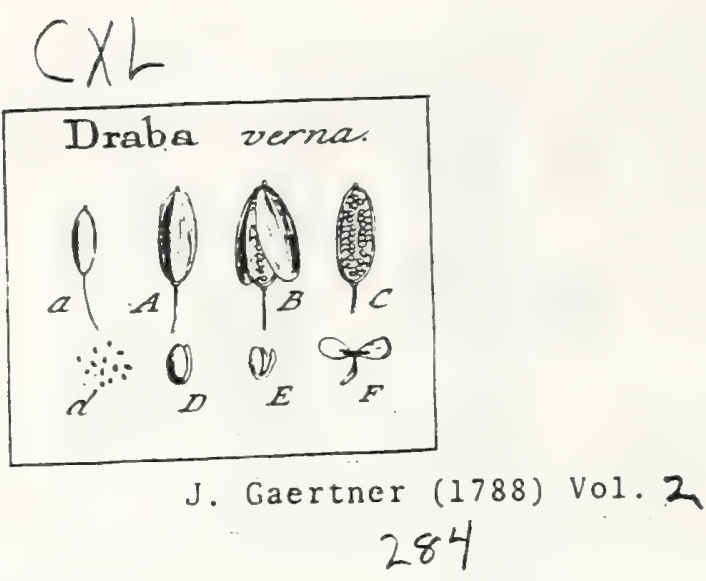

DCCCXXI. D R A B A. IInN. gen. sco.

Silicula cliptico-oblonga, compreffiufcula, non emargimata, bilocularis, polyfperma. Diffepimentum valvis parallelum.

DRABA verua. Tab. 141. fig.' 8 .

pilofella mistor. THAL. harc. t. 7.f. E.

Aly fou vulgare polygoni folin; caule nudo. SEGU1. veron. 1. p.575 t. 4. f.3. Draba cauliculis mudis, foliis fubbirfusis fubdentatis. HaLL. bift. "1. 496.

Draba fcapis mudis, foliis fubjerratis. LIN. Jj/f. veg. 585 .

PER. Silicula parva, ovato - oblonga, plus quam lenticulari compreifa, non emarginata, ftigmate fubfeffili terminata, bilocularis, bivalvis. Difepimentun tenuiffimum, valvis parallelun.

REc. intervalsulare, filiforme, plurimis funiculis umbilicalibus introrfum verfis utrinque itipatum.

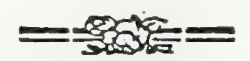

SEM. plurima, ad viginti quatuor in fingulo loculo, ovata, compreffiufcula, ruffit aut ferruginea.

I N. fimplex, membranaceum.

E n v. curvatus, Jutefcens. Cotyl. ovatx, fubfoliacex, planx. Rad. teretiufcula, furfum intexa, rimæ cotyledonum accumbens, centrifuga.

2. A.) Silicula integrz. B.) Eadem dehifens. C.) Diflepimentum cum infertione fcminum d. D.) Scmira feparata. E.) Eınbryo desudiatus. F.) Cotyledones diduax.

\subsection{1}




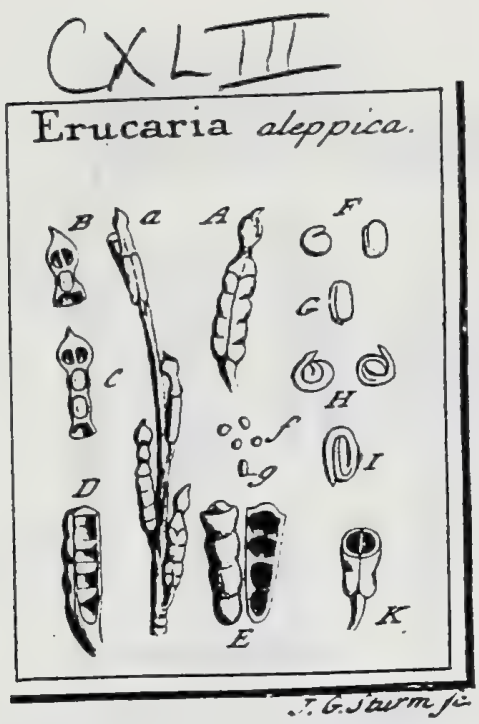

J. Gaertner (1788) Vol, 2

\section{8}

\section{E R U C A R I A.}

Siliqua teres, biarticulata! articulo inferiore bivalvi polyfpermo; fuperior evalvi oligofpermo aut fterii.

ERuCar14 aleppica. Tab. 143. fig. 9.

Rapbanifrum aleppicum, fiore dilute violaceo. TOURs. corolo I7.

Ex horto leydenfi.

PER. Siliqua teretiufcula, fubfemipollicaris, biarticulata. Articulus fuperior brevior, ex anguftiori collo in globum apice membranaceo-mucronatum intumefcens, fponte $a b$ inferiore fecedens, nec tamen dehifcens: Collum longius aut brevius, uno intus aut duobus loculamentis fibi mutuo impo. fitis \& feminifetis exfculptum; Capitulum autem globofum conftanter fterile, \& duobus loculamentis collateralibus fpuriis dotatum. Art. inferior longior, teretiufculus, torofulus, bilocularis, bivalvis. Difepimentum membranaceum, valvis parallelum, ab impreffionibus feminum alternatim. finuofum.

REC. in articulo fuperiore nullum, fed femina baf loculorum affixa; in articulo autem inferiori, funiculi umbilicales capillares, e lateribus difepimenti oriundi.

Sz M. articuli fuperioris folitaria, ovata, lenticularia; artic. inferioris quaterna in Gingulo loculo, fubglobofa angulara, uno latere conftanter plano: utraque ferruginea.

IN T. fimplex, membranaceum.

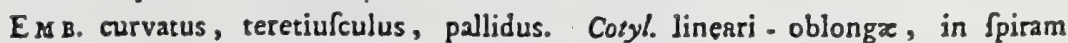
convolutx. Rad. teretiufcula, in feminibus fuperioribus, infera, in inferioribus, centrifuga.

1. A.) Siliquz integra. B. C.) Articulon fuperior apertus. D.) Artic. inferioris diffepimentum (inuofum. E) Ejusdem valvule (cparatz. K.) Ejusdem (eAtio transverGlis. E. F.) Semina articuli inferioris. g. G.) Eadern articuli fuperioris, H.) Embryo deaudatus feminis inferi. 1) Idem Seminis Iupesi.

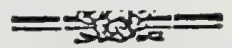

Plantam floribus \& fructibus ftipanm vidi olim in herbario Rsuwolfiano, quod Leydx afervatur, fed nomen, ni fallor, nullum ei adfcriptum. Tournefortii fynonimon aliquantum etiam dubium eft, quum ille Erscaix cbalegertemt filiquis articulatis. Moris. 2. S. 3. t. 25. $f$. 23 . excitet, qux a nottr, fliquarum forma, manifefte differt, nifi id pictoris fit culpa.

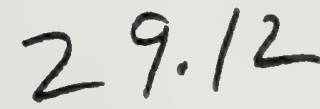


Tab. CXIIII.

Brassicaceae

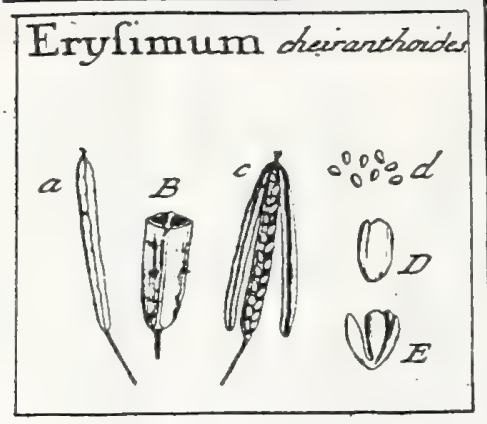

J. Gaertner (1788) Vol, 2

297

DCCCXXXVI. ER Y SIMUM. TOURN. t. III. LINN. gen. 8r4. Siliqua tetrngoцa, mediocris longitudinis, ftigmate capitato. Septum valvis contrariun. Sem. numerofa. Cotyl. planxe. Glasdulx dux intra Itamina breviora.

ERYsimum cheiranthoides. Tab. 143. fig. 7.

Cannclina, Myagrom alterum tblajpi effigie. LOB. ic. 225.

Enyfunmm foliis lanceolatis integerrinis, faliquis patulis. LIN

lion. OED. for. dan. t. 735. JACe. aufir. to 23.

$P \varepsilon$ k. Siliqua pollicaris, rhombeo-tetragona, ad femina obfolete nodulofa, bilocularis, bivalvis. Diffepimentum membranaceum, valvulis contrarium, vel certe latitudine filiquxe anguftius. Valvule angulo acuto extrorfum carinatc.

REC. intervalvulare, filiforme, in brevifimum ttylum cum ftigmate obtufo definens.

Ses. numerofa, octodecim circiter in fingulo loculo, ovata, trargidula, roftellata, ruffa aut luteo-ferruginea.

IN T. fimplex, membranaceum.

EM B. curvatus, luteus. Cotylo oblongx, plano-convexz. Rud teretiufcula, dorí, non rimx cotyledonum accumbęns, centrifuga.

a.) Siliqua integta. B.) Ejus fectio trasver[alis. c.) Eadem dehirens. d. D.) Semina (eparata. E.) Embryo denudatus.

29.13 

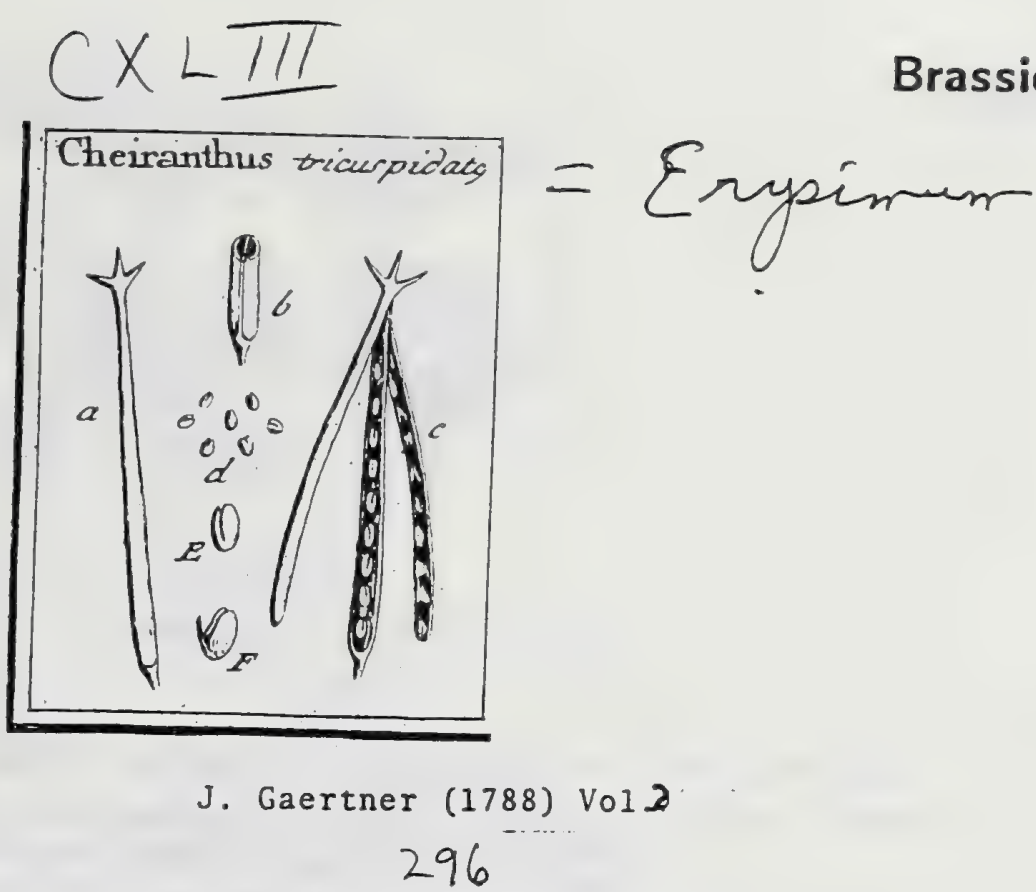

\section{C H E I R A N T H U S. LINN. gen. Si5.} Leucojum. TOUR N. t. IO7.

Flos caryophyllaxus. Siliqua longa, teres aut compreffa, apice bidentata. Diffepinentum parallelum, non fungofum ut in Hefperide. Sem. com. prena, lapius membranaceo-marginaza. Cotyl. planx. Glandulx dux. justa bafin ovarii.

Cheiranthus triculpidatus. Tab. 143. fig. 3.

Lescojum marimum. Сам. bort. 87. t. 24. MORIs. bif. 2. S. 3. t. 8. f. x3. Clseiramtlus foliis lyratis, filiguis apice tridentatis. LINN. Jyyt." veg. 598 .

PER. Siliqua bipollicaris, teretiufcula, ad feminum fedem obfolete nodulofa, apice in tres cufpides fubulatos defmens, bilocularis, bivalvis. Dilfepimentum telluiliniun, valvis parallelum.

$R$ EC. intervalvulare, filiforme.

SEM. plura, decem aut duodecim in fingulo loculo, ovata, compreffa, roltelo lata, rubro - ferruginez, non marginata.

IN T. fimplex, membranaceum.

Eм в. curvatus, luteus. Cotyl. ellipticx, plano-converiufculx. Rad. teretiufcula, rimx cotyledonum accumbens, centrifuga.

2.) Siliqua integra. b.) Ejus fedio transver[alis, c.) Eadem dehifeens eum valvulis in ipfos cufpides elnngatis. do) Seminz (eparate. E.) Embryo denudatus. F.) Cotyled. leviter diductio.

Secundum III. LAMARK, glandulx difci in Cheirantho nullx, \& omncs fpecies glandulis dotatx, Hefperidi affociandx funt. In Hefperide proterea, feptum fungofum, cui femina imprelfa: quod non ita in Cheirantho. Conf. HaLL. hijt. x. p. 192. 195. 


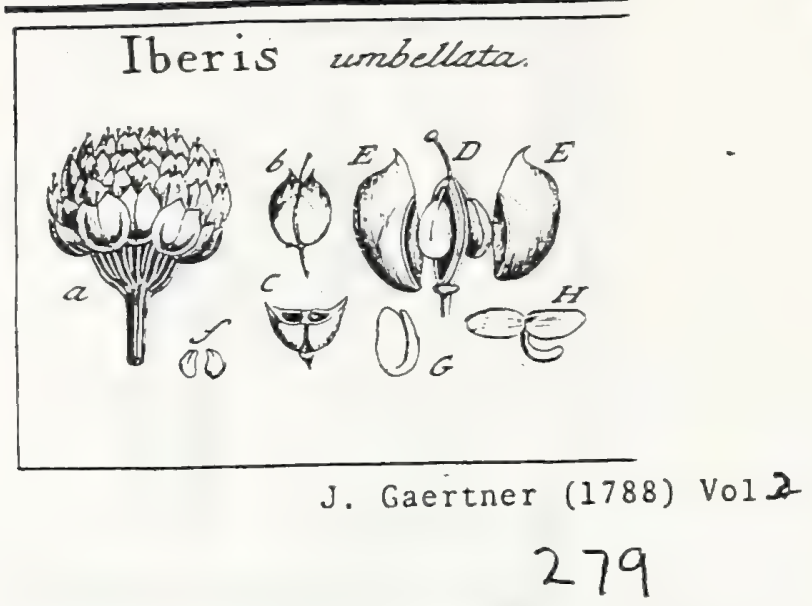

\section{I B E R I S. LINN. gen. 804}

Corolls irregularis, petalis duobus exterioribus majoribus. Silicula fubro tunta, apice cmarginata, bilocularis, bivalvis: diffepinento valvis contrario.

IBERIS unibellata.

Draba f. Arabis f. Thlaspi candic. DoD. pempt. 73 3.

Thlanjpi cappudocicum fore albo \& incarnato. BeSL. Eyjt. afiv. VII. t. II. f. 2. 3.

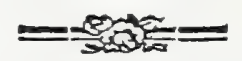

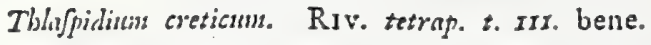

Iberis berbacea, foliis lanceolatis acuninatis: inferioribus ferratis; fuperioribus integerrimis. LINN. Jy.\%. veg. 589 .

PER. Silicula ovato-rotundata, ad apicem triangulari-emarginata ut quafí biaurita, compreffiufcula, hinc convexa, inde plana aut leviter concava, bila. cularis, bivalvis. Valvulæ naviculares: carinì latá folinceo-comprefra \& quafí in alam extenuatà. Diffepimentum angultum, valvis contrarium, fecundum longitudinem fuam in duas laminas membranaceas partibile.

REc. intervalvulare, filiforme, longitudinaliter, unacum diffepimento, bipastibile, ex apice fuo utrinque funiculum umbilicalem promens.

SEas. folitaria, ovara, compreffiufcula, juxta umbilicum roftellata, e ferrugineo rufefcentia.

IN T. fimplex, membranaceum, craffum, intus fubcarnofum.

EM B. curvatus, luteus. Cotyl. ellipticx, plano- convexx. Rad. teretiufcula, rimx cotyledonum extern $x$. carinum valvularum refpicienti accumbens; furfum intexa, fupera.

2.) Fruetus in corgmbo hemilphxrico. b.) Silieula (cparata, integra. C.) Eadem transverín fea. D. Receptac. vaivis interpofitum, cum fominihus in fitu uaturali, E. E.) Valvula feparatz. f.) Semina foluta. G.) Embryo denudatus. H.) Cotylodones diductx.

lberis amara LiNe.

Tblaspidisun folio iberidis. Riv. tetrap. t. II .

Fructus in racemis elongatis. Siliculx rotundiores \& prilo minores quam in procedenti, cetera vero eis fimiles. Senina magis elliptica, lenticularicomprefia, pallidiora f. lutefcentia, anguftifinmoque margine membranaceo fiturate colorato circundata. Embryonis radicula pariter extera, fo a centro frućtus semota \& dorfo valvularum vicina.

Si diffepimentum in omnibus lberidis fpeciebus bipartibile, in generis characterem debet recipi, \& fructus, pariter atque Bilcutellix, ad bililiquofos poterit referri. 


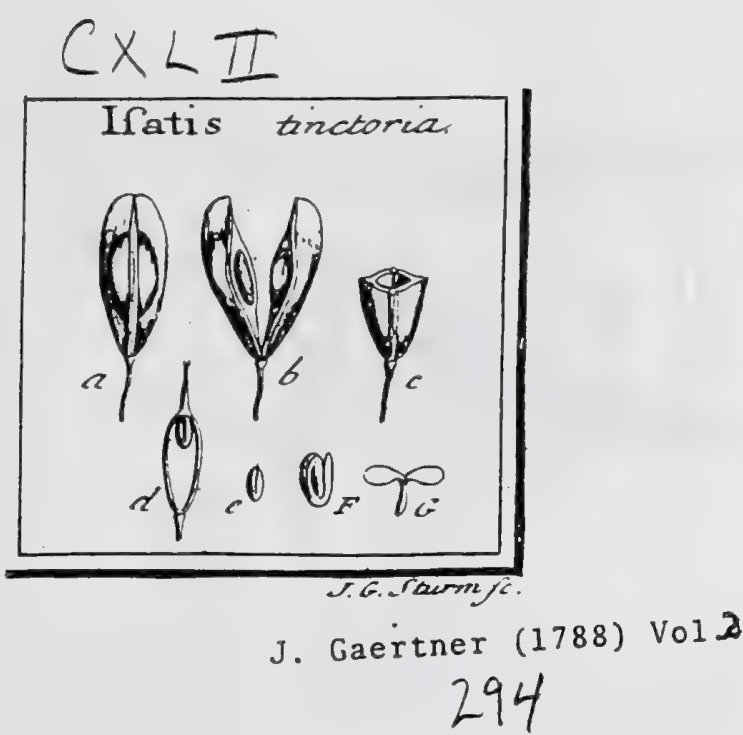

DCCCXXXII. I S A T I S. TOURN. t. 100. LINn. gen. 824.

Silicula elliptica, comprefra, unilocularis, bivalvis, monofperma: valvulis fuberofis navicularibus, vix fponte dehifcentibus.

Is itrs tinctoria. Tab. 142. fig. 6.

Jfutis Jyluefris. Fuchs. bifl. lat. 330. germe. ic. 186. 187. CaM. epit. 410. BLAKIV. berb. t. 246 .

Ifat is foliis radicalibus petivlatis ovatis; caulinis amplexicaulibus. HALL. hiff. 11.523 . Ifatis foliis radicalibus crenatis; caulinis Sagittatis, faliculis oblongis. LINN. Jyf. veg. 604 .

PER. Silicula oblonge elliptica, fuperne \& ad margines in aciem comprefra, in medio lenticulari turgefcens atque futura longitudinali recta utrinque notata, unilocularis, bivalvis, vix tamen fponte dehifcens. Valvulx fpongiofo fuberofx, naviculares.

REc. intervalvulare, filiforme, feneftratum, fuperne in ftylum, intra filiculam occultatum definens, atque femen ex fumino arcu pendulum fuftinens.

SEN. unicum, ovatum, e luteo - rufefcens.

IN T. fimplex, menibralaceum.

E s в. curvatus, lutefcens. Cotyl. ovatx, carnofx, plano. convexi. Rad. teretiufcula, furfum intexa, dorfo, non rimx, cotyledonum accumbens, fupers.

a.) Silicula integra b.) Ejus valvule feparatx, cum feminis fitu. c.) Ejusilem fectio transo verfalis. d.) Receptac, a valvulis folutum. e.) Semen feparatum. F.) Enıbryu denulatus. G.) Cotyled. explicatz.

Radiculx itaque fitus, in Siliculofis, varius eft. Nempe in omnibus polyfpermis, radicula eft centrifuga; in monofpermis autem, plerunique fupera; rarius centripeta; \& in fola Cakile, infera. 


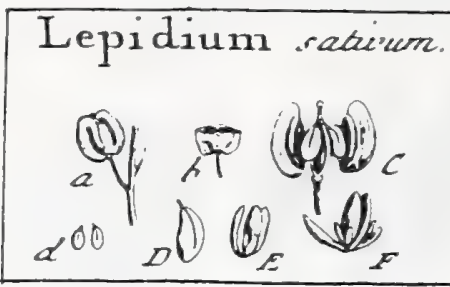

$$
\text { J. Gaertner (1788) Vol. } 2
$$

\section{1}

\section{L E P I D I U M. LIN ger. sor.}

Silicula thlafpeos, fed ninus profunde emarginata. Semina folitaria. Embryonis anbic cotyledones ad balin ufque tripartitx: lobulo medio majori.

Lepidiun facivum. Tab. 1+1. fig. 5 .

Niffurtium lourerse. DOD. pempt. 77 r. BLAKw. berb. \$. 23.

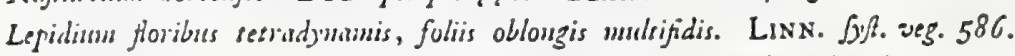

PER. Silicula ovata, utrinque modice emarginata, comprefra, bilocularis, bival. $2 S^{2}$

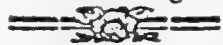

vis. Vislvulx naviculares: carina in marginem membranaçeum definente. Diffepimentum lanceolatum, valvis colurrarium.

REC. intervalvulare, filiforme, ex apice utrinque funiculum umbilicalem brevem emittens.

SEMr. folitaria, ovati, compreffiufcula, lineola depreffa media utrinque notata, glabra, ferruginea aut fulva, mucilaginofa.

INT. fimplex, membranaceum : fuperficie exteriori in mucilaginem pellucidiffrmam ab aoua convertibili.

ENB. curvatus, lutefeens. Cotyl. tripartite: lobulo medio majore oblongo, fubfoliaceo; laternlibus dinidio brevioribus, linearibus. Rad. fufformis, furfum intiexa, dorfo non rimx cotyledonum accumbens; extera $\{$ valvularum cirine propior.

a.) Silicula integra. b.) Ejusilem fectio transverfalis, C.) Eadem dehifens, cum infertione femisum. d. D.) Semina feparata. E.) Embryu denudatus. F.) Cutyledioncs diducta.

Lepidii fpecies, qux fimplicibus gaudent cotyledonibus \& fimul polyfpermx funt, ad Thl:irpi poffunt referri: qux vero in fingulo loculo unum tantum continent femen, Naftursii intrabunt genus. 


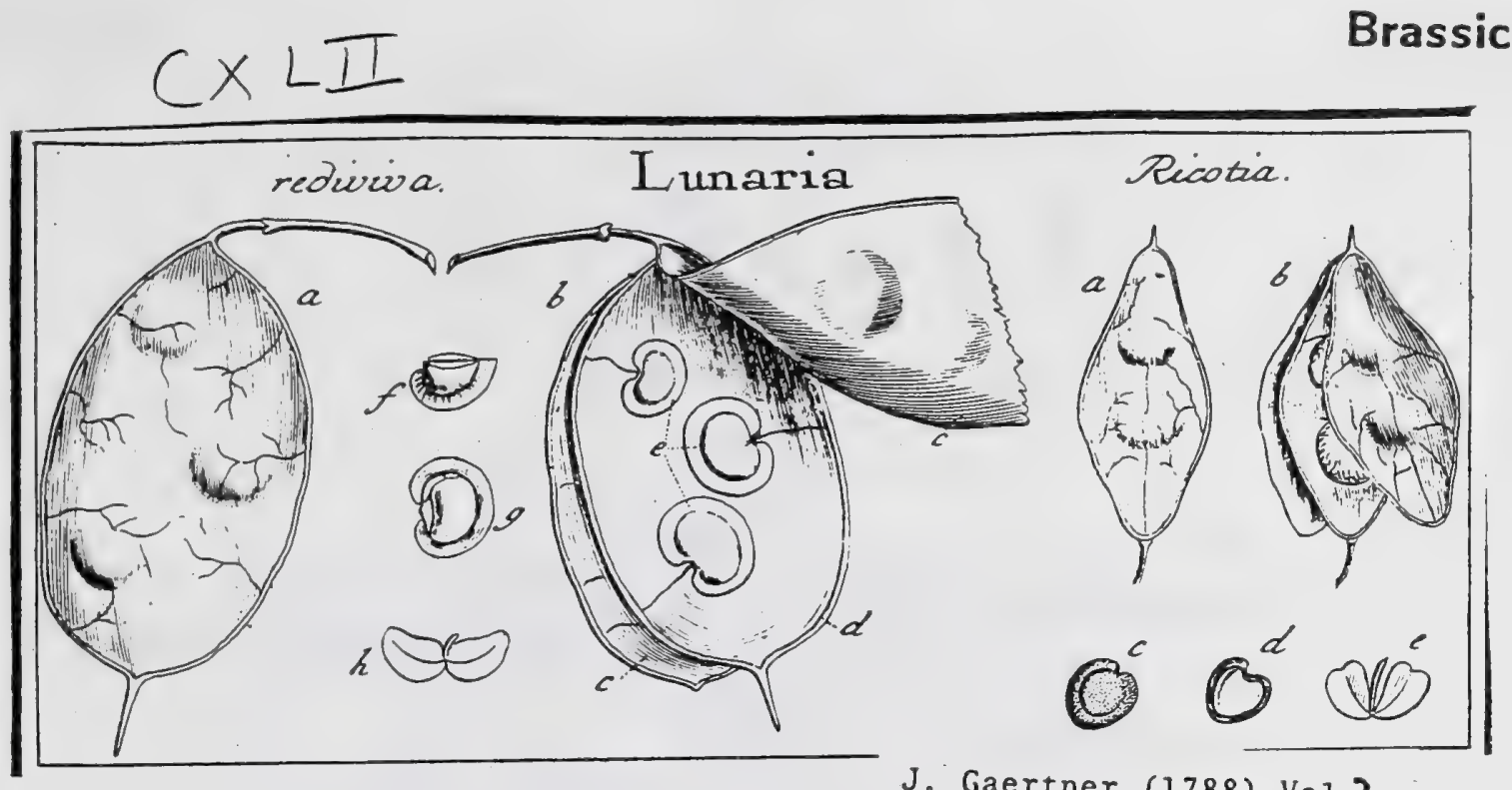

DCCCXXVII. L U N A R I A. TOURn. t. ro5. Lins. gen. 809. 288
Ricotia. Lins. gen. 8 10.

Silicula grandis, rotundius 1. oblongius ovata, foliacco compreffa, bilocularis, bivalvis. Sem. pauca, fubreniformia.

LUnaras rediviva. Tab. I +2 . fig. 1 .

liola latifolis, Limmia odorata. Cevs. hiff. x. p. $=97$.

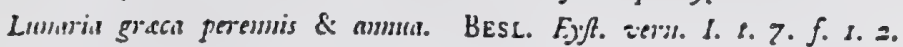

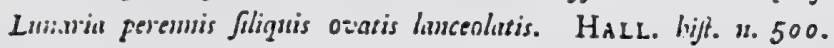

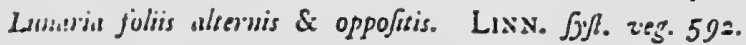

PER. Silicula inter affines maxima, elliptica, fupra in ftylum, infra in pedunculun attunata, compretio-plana, bilocularis, bivalvis. Dillepinzentum prypraceum album, valvis parallelum.

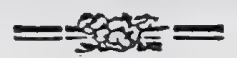

R E C. intervalvulare, filiforne, utrinque funiculos umbilicales; fepto adnatos, verfus ocntrum emittells.

SEM. pauca, duo l. tria, vix quatuor in fingulo loculo, grandia, ovato-reníformia, lenticulari comprefia, lato margine membranaceo cincta, primo zufefcentia, tandem fufca, ninutifime puncticulata.

INT. duplex; utrumque membranaceum.

EN B. curvatus, luteus. Cotyl. ovatx, plano-convexiufculx. Rad. cotyledonibus dimidio brevior, earumque rimx accumbens, teretiufcula, centrifuga.

a.) Silicula integra b.) E2dem debifeeus. c. c.) Valvule. d.) Diflepimentum. e) Semins ia fitu. f.) Semen transverie diffetum. g.) Idem longitudinaliter apertum, cum fitu \& figura embryonis. h.) Cotjlcdones explicatz.

Difcrimen verum inter L. redivivam \& ammum proter durationem, non datur; nec colorem calycis ac corollx, aut odorem, ut vult HaLLERUS, heic quicquam valere cenfeo: differentia autem Specifica Linuxaun, a fitu foliorum, mere fictitia eft.

Lunaria Ricotia, ibid.

Lumariu folits fupradecompofritis: foliolis trifidis, filiquis ablongis pendulis. MiLl. ic. $t .169$.

Ricotia agyptiaca. LiN. Jjy. veg. 593.

Silicula (a) ovato - Qblunga aut shombeo - elliptica, foliaceo-compreffa, bilocularis, bivalvis. Diffepimentum (b.) valvis parallelum, tenuifimum \& fere arachnoideuns, per mazuritateni fructus valvis plerunqque agglutinatum, ut incautis abeife videatur. Sęminz (b. c ) in fingulo loculo unum vel duo, fubcordata, f. ad unbilicum profunde emarginata; compreffa, ad tactum fcabriufcula, obfolcte narginata, fufca. Enibryo (d.) curvatus, luteus. Cotyledones (e.) ovato - cordatx.

Quum diffepimentum ccrtilime adfit, noll poteft Ricotia, in tanta partium fruetificationis conformitate, a Lunaria divelli, etri ei proprius \& ab hac diverfilinus fit habitus externus. 


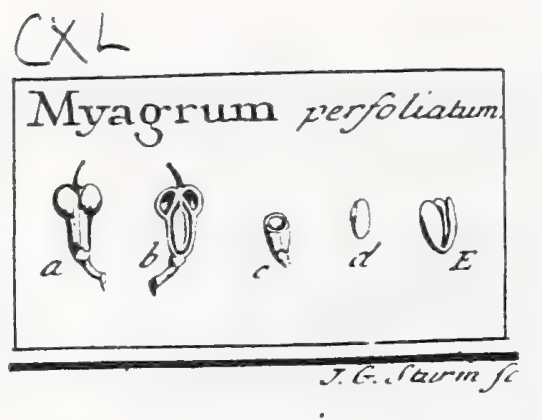

\section{J. Gaertner (1788) Vol.2}

DCCCXXVI. M Y A G R U M. TOURN. t. 99. Linn. ger. 796.

Silicula fuberofa evalvis: loculis fertilibus atque fpuriis, fibi mutuo fuper. impofitis. Enbryonis cotyledones planx.

Myagrum perfoliatum: Tab. 141. fig. 13.

Mj"rgrum monofpermunn latifolium. BaUн. prodr. $5=$ ic. 5 r.

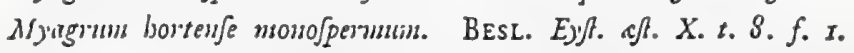

Alyugrum loculo foecuudo conico, ferili biloculuri. HaLL. bijf. in. 524.

Mgugrum frliculis obcordatis Jubfedilibus, foliis amplexicaulibus. Liss. Jy/t. veg. 584.

PER. Silicula fpongiofo-fuberofa, oblonga, ftylo fubulato ternimata; fupra didymo.globofa, infra cylindrica aut obconica: parte inferiore uniloculari, fertili; fuperiore biloculari, fterili: utraque evalvi, nec unquam dehifente.

REC. funiculus umbilicalis brevis, e vercice loculamenti inferioris ad femen delcendens.

SEM. unicum, ovato-oblongum, ftria-media utrinque notatum, ferrugineum.

1x T. finplex, nembranaceum.

En B. curvatus, luteus. Coty\% ovato-oblongax, plano-convexx. Rad. tere. tiulcula, furfum infexa, rimx cotyledonum accunbens, fupera.

a.) Silicula integra. b.) Eldem rerticalites diffecta, cum fitu \& nuncro loculamentorum, atque incrtione fuminis. c.) Ejusdem pars inferior transverlion feeta. d.) Seascn feparatum. E.) Enbruo denudatus.

1)itfert a Crambe, cotyledonibus planis, nec concavo-conduplicatis. 


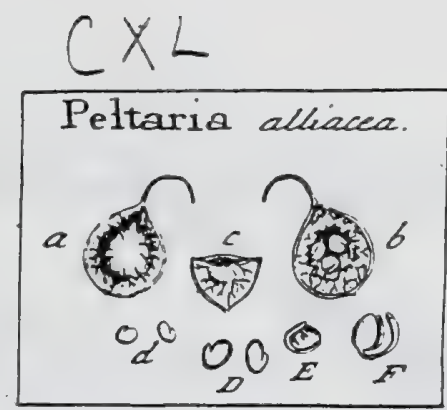

\section{J. Gaertner (1788) Vol 2 \\ 283}

DCCCXX. P E L T A R I A. LINN. ger. 806.

Silicula obovata, fuliaccu-comprelía, unilocularis, evalvis. Semen unum ad tria, reniformia.

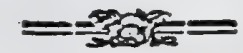

Peltaria alliacea. Tab. 14r. fig. 7 .

Thlaspi moutanum. Clus. bifl. $=$. p. 130 .

Clypeola peremis, foliis inferioribus petiolutis corduto-mugulatis: fuperioribus ane plexicaulibus lanceolatis, filiculis miniloculuribus. ARD UIN. Spec. t. 16 .

Peltaria foliis amplexicaulibus oblongis indivijis. LINN. Jyjto reg. 591 .

Icons. JACQ auftr. t. 223.

PER. Silicula obovata 1. orbiculato - pedunculata, non emarginata, foliaceocompreffa, corincen, rigidula, reticulato-venofa, glibra, unilocularis, evalvis, nec culcro in regulares valvulas fillilis.

REC. nullum aut obfoletum. Funiculi umbilicales capillares, ex utroque fili. cula margine procedentes \& verfus centrum vergentes, femina fultinent.

SEM. unum ad tria, raro plura, ovato-reniformia, compreffiufcula, ferruginea IN T. fimplex, membranaceum.

E м в. curvatus, lutefcens. Cotyl. ovato-lanceolatx, foliacex. Rud. filiformis, cotyledonibus dimidio longior \& circa earundem marginem circumitexa, centrifuga.

2.) Silieula integra. b.) Ejus cavitas centralis aperta, cum infertionc femiuum. c.) Ejusicm fuctiv transverfalis. d. D.) Simira fiparata. E.) Emtryo denudatus, cum flexura radicula in ambitu cotylcdonum. F.) Ralicula \& cotyledoncs leviter diductit.

Non multum quidem Peltaria, proter habitum fuum externum valde diverfum, a Clypeola diftat: attanen \& in filicula \& in feminibus ejus funt notx fufficientes, qux feparationcm horum duorum generum fuadent.

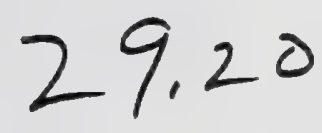




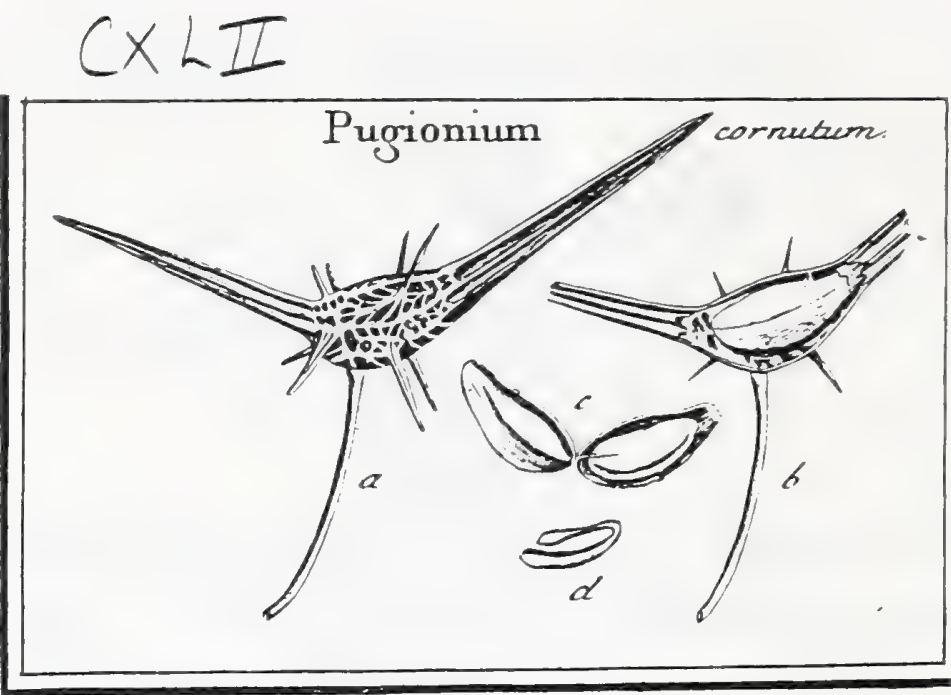

\section{J. Gaertner (1788) Vol 2}

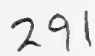

\section{P U G I O N I U M.}

Silicula transverfe ovalis, utrinque in proceffum pugioniformem produca, unilocularis, evalvis, monofperma. Semen arillatum!

Pugronium cornutum. Tab. 142. fig. 3 .

Burias filiculis divaricato bicornibus bafs fpinofis? LINN. Gof. veg. 603.

A b. Martins Stutgard. I. G. Gimelini per Sibiriam itineris focio.

PER. Silicula nembranacea, lenticulari - comprefta, consverfe ovalis; extrenitate utraque in proceffum longum, comprefium, ftriatum, enfiformem producta; Juteribus autem reticulato stervofis, ad gervorum interfitia linb-

transparentibus, \& ex nervis ipfis, quatuor fpinis innocuis, divergenti. bus, utrinque in medio armatis; cetera unilocularis, evalvis, pallide fpa. dicea. Loculamenta naturaliter quiden duo, juxta fe pofita atgue fepto dicea. Loc a fe invicem difcreta, fed in maturo fructu, alcerum conltanter obliteratur, remanente altero folo, oblongo \& undique claufo.

REC. nullum; femen ope arilli fui, bafi proceftus majoris affixum.

SEN. unicum, ovato-oblongum, compreffum, arillo inclufum.

Avillus chartaceus, tenuis, linea longitudinali depreffa utrinque infcriptus, laxus, albicans, femen totum involvens.

IN T. fimplex, menbranaceum, intus quafi pulpofum, ut in recenti femine albuminis initamentum quoddam adefie videatur. Ens. femine nulto angultior, curvatus, graminco - viridis. Cotyl. linearicotyledonum rinix accumbens, relative centripeta.

1.) Silicula integra. b.) Eadcm apertz, cum femine intra arillum conclufo. c.) Arillus feparz rus \& longitudinaliter apertus, cum feminis figura \& magnitudine naturali. d.) Embryo denudatur.

Non fructu folo, Pugionium, fed \& fore abunde a Buniade differt. Flos ei parvulus, Drabx vernalis haud major. Petala angufta, integerrima, aclminata, alba, calyce aliquantulum longiona. Stan. tetradynama. Ovar. hifpidulun, biloculare. Styl. brevis. Folia linguiformia, integerrima, glauca, avenia, femiamplexicaulia. Racemi terminales, per maturitatem Jaxillimi, pedunculis divaricatiffimis. Mirum, quQd tam parvulum flofculum, tam grandis fequatur fructus. 


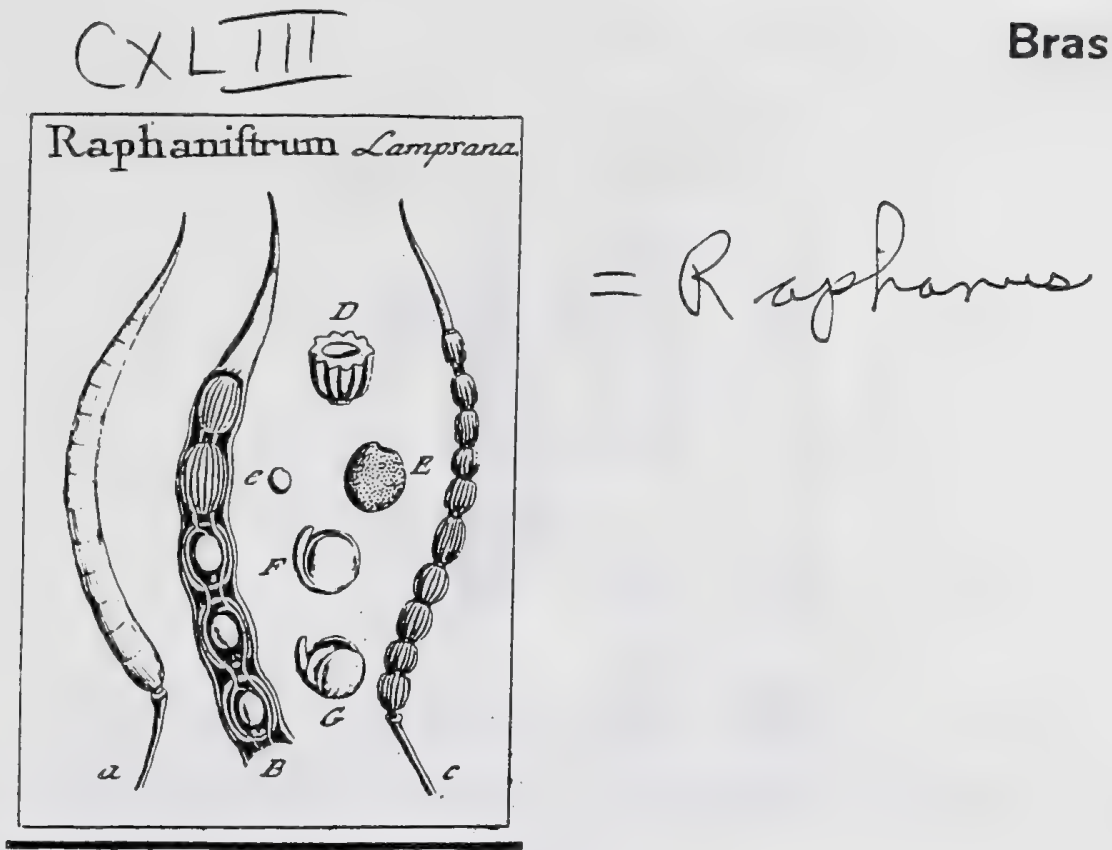

J. Gaertner (1788) Vol 2

$$
300
$$

DCCCXLI. R A P H A N I T R U M. TOURN. t. II5.

Siliqua teres, acuminata, per maturitatem moniliformis, evalvis, plurilocu. laris: loculamentis ofleis, fimplici ferie longitudinali digeftis.

Raphanistrum Lampfana. Tab. 143. fig. 6.

Fapifrum flore albo: enuce foliis. LOB. ic. $x 99$.

Rapiftrum purpureum. Lampjana flore melino. TABERN. p. 407. 408.

Raphanus filiquis teretibus articulatis levibus unilocularibus. 'LiNN. $\int y / t . v e g .603$. Icon. OED. flor. dans. $t .678$.

PER. Siliqua longa, acuminata, ante plenam maturitatem glabra, teres, obfoleriftime articulata, poftea autem moniliformis: araculis lenticulari-compreffis, fulcatis, ifthmis interceptis, unilocularibus. Loculamenta oflea, ftriata, fegregata, apice \& bafi, pro transmittendis receptaculis, perforata, cetern integerrima, evalvia.

REc. bilaterale, filiforme, loculamenta ipfa intrans atque alternos funiculos umbilicales promens.

SEM. in articulis folitaria, in univerfum dena aut duodena, turgide lenticularia, excavato punctata, crocea.

IN T. fimplex, membranaceum.

$$
=-3 x=
$$

Eм B. curvatus, Jutefcens. Cotyl. rotundato-cordatx, fubfoliacex: exteriore convexo-concava involvente interiorens conduplicatam. Rad. conduplicarurx fulco accumbens, centrifuga.

$$
\text { * }
$$

2.) Siliqua vegeta C. fuceo adbue diftenta. B.) Eadem longitudinaliter aperta, cum loculamentis olTeis integris \& difteatis, aec ann receptzculorum decurfu \& in femina infertione. e.) Silịqua alulta \& exfucea D.) Loculamentum ofteum transverfe (eatum c. E.) Semen feparatam. F.) Embryo denudatus. G.) Cotyled. diduetz.

Non tantum fimplici loculamentorum, eorundemque offeorum ferie, fed vel maxime quoque receptaculis loculamenta ipfa intrantibus, a Raphano differt. Siliquan in origine fus bilocularem, uti HaLLER US bif. $x$. p. 204. habet, ego vidi nunquam. 


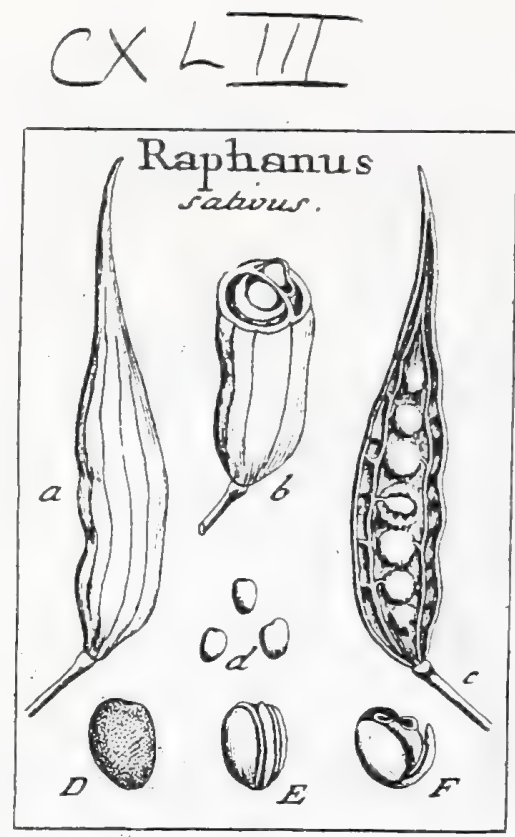

Brassicaceae

\section{J. Gaertnet (1788) Vol. Z 211}

DCCCXI. R A P H A N UIS. TOURN. t. II4. LINN. ger. 822

- Siliqua tereti - acuminata, fungora, evalvis, plurilocularis : loculanentis membranaceis, duplici lerie longitudinali digeltis.

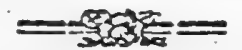

Raphanus fativus. Tab. 143. fig. 5 .

Rapbanus bortenfis. BLAKw. berb. t. 8x.

Rapjuinus filiquis teretibus torofis bilocularibus. LiNN. J32. veg. 603 .

Icon fent. GREW. alsat. t. 70. f. t. t. 75. f. x. 2. 3.

$\mathrm{PER}$. Siliqua longa, teres, acuminato - roftrata, torofa, fungofa, alba, difite ftriata, evalvis, plurilocularis. Loculamenta membranacea, claufa, duplici ferie longitudinali, juxta feptum medium, digettr.

R \& c. bilaterale, filiforme, extra loculamenta pofitum, funiculis umbilicalibus alternis, loculorum cavitatem intrantibus, ftipatum.

SEM. fingula in fingulo loculo, in fingula autem ferie, terna ad duodena, fubglobofa, ferruginea, minutifime elevato - puncticulata.

IN T. Gimplex, membranaceum.

E M B. curvatus, luteus. Cotyl. rotundato-cordatx, fubfoliacex: exteriore convero-concava, involvente interiorem conduplicatam. Rach. conduplicature fulco accumbens, centrifuga.

a.) Siliqua integra. b.) Eadem transverfina aperta, dupliecm loculorum feriem oftendens. c) Ejusdem featio longitudinalis, cum receptaculis \& ferie loculorum longitudinali. d. D.) Seminz (cparaiza. E.) Embryo denudatus. F.) Cotyled. leviter diductx. 


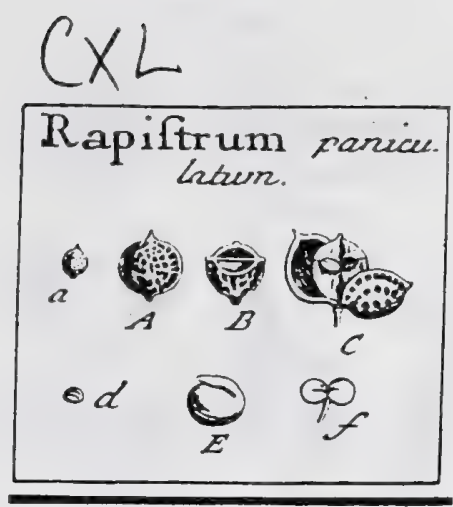

J. Gaertnet (-1788) Vol 2

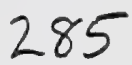

DCCCXXII. R A P I S T R U M. TOURN. t. 99.

Silicula fubglobofa, nucamentacea, non emarginata, bilocularis, non fponte dehifcens. Diffep. membranaceum, valvis parallelum. Sem. folitaria.

Rapistrum paniculatum. Tab. 141. fig. 9.

Afyagro funilis, fliqua rotunda. Ba Uн. prodr. 52. c. ic. OED. flor. dan. t. 204. Ayrggrum monofpermum birfutum, filiquis rotundis. Loes. praff. I74. t. 56.

Rapiftrum foliis amplexicaulibus auriculatis acutis. HaLL. bift. 12. 52*.

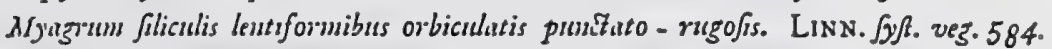

PER. Silicula parva, rotundato-acuminata, turgide lenticularis, ad margines in acien cxtcnuata, nucamcutacea, corticata. Cortex tensis, corisceus, fcrobiculato - rugolus. Putamen cruftaceum, durum, biloculare, non fponte dehifcens, facile tamen fecundum marginem in duas valvulas partibile. Diffepinentum membranaceum, tenuilfinum, valvis parallelum, per naturitaten fixpe deficiens.

Rec. nullum aut obfoletun. Funiculi umbilicales capillares e margine diffepimesti.

SEs. unicum in fingulo loculo, altcro tamen conftanter abortiente, remanente unico, fubylubufo, fubroftellato, glabro, rufefcente.

IN T. fimplex, membranaccum.

Es B. curvatus, Jutefcens. Cotyl. ovatx, carnofix, craffic, plano-convexx. Fid. fubulata, inflexa, non rimx, fed convexac cotyledonum parti accumbens, centrifuga.

a. A.) Silicula integra. B.) Ejus fectin transverfalis. C.) Diffepimentum cum infertione femiแมm. d. E.) Eimbryo denuilatus. E.) Cotyledones didudx. 

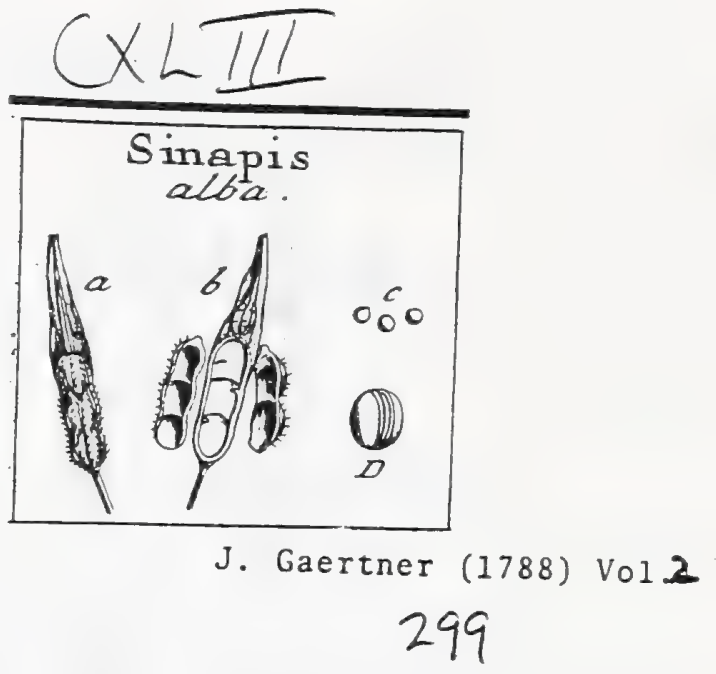

DCCCXXXIX. S I N A.P I S. TOURN. t. II2. LINN. ger. 82 I.

Siliqua teretiufcula, mediocris longitudinis. Difepimentum fupra valvulas in roftrum longum productum. Stigma obfoletum emarginatum compreffun. Cotyl. glubole conduplicatx. Glandulx ad bafin ovarii quaterux.

Sinaris alba. Tab. 143. fig. 4

Sinapi futivun alcerunt. DoD. pempt. $70 \%$.

Sinapi allerun. Bцакพ. berb. t. 29.

Sinapis filiquis bifpidis: roftro oblique longifimo enfiformi. LINN. Lyf. ueg.602.

PER. Siliqua pollicaris, teretiufcula, torofa, hifpida, roltrata, bilocularis, bivalvis. Difepimentum membranaceum, fupra valvulas in roftrum coriaceum, opacum, enfforme productum. Valvulx tribus ftriis longitudinilibus notate, fetulis rigidis hifpidx.

REC. intervalvulare, filiforme.

Sem. paucs, duo 1. tria in Gingulo loculo, globora, nigro-ferruginea, mucilaginols.

INT. duplex: exterius coriaceun, fuperficie exteriori in mucilaginem pellucidiffrmam ab aqua refolubili; interius membranaceum; absque albuminis veftigio.

EM R. curvatus, luteus. Cotyl. rotundate, fubfoliacex : exteriore converoconcava, involvente interiorem conduplicatam. Rad. fulco conduplicaturx sccumbens, centrifuga.

a.) Siliqua integra. b.) Eadeur dehirenas. c.) Semina feparata. D.) Embrgo denudatux.

Sxpe intra roftrum filiquxe loculamentum deprehenditur, idque vel Tpurium ac inane, vel unico fensine, reliquis fimili, at multo minore, foctum : Hinc affinitas cum Erucaria, licet ill illa rofrum fit folubile, quod non ita in Sinapi. 


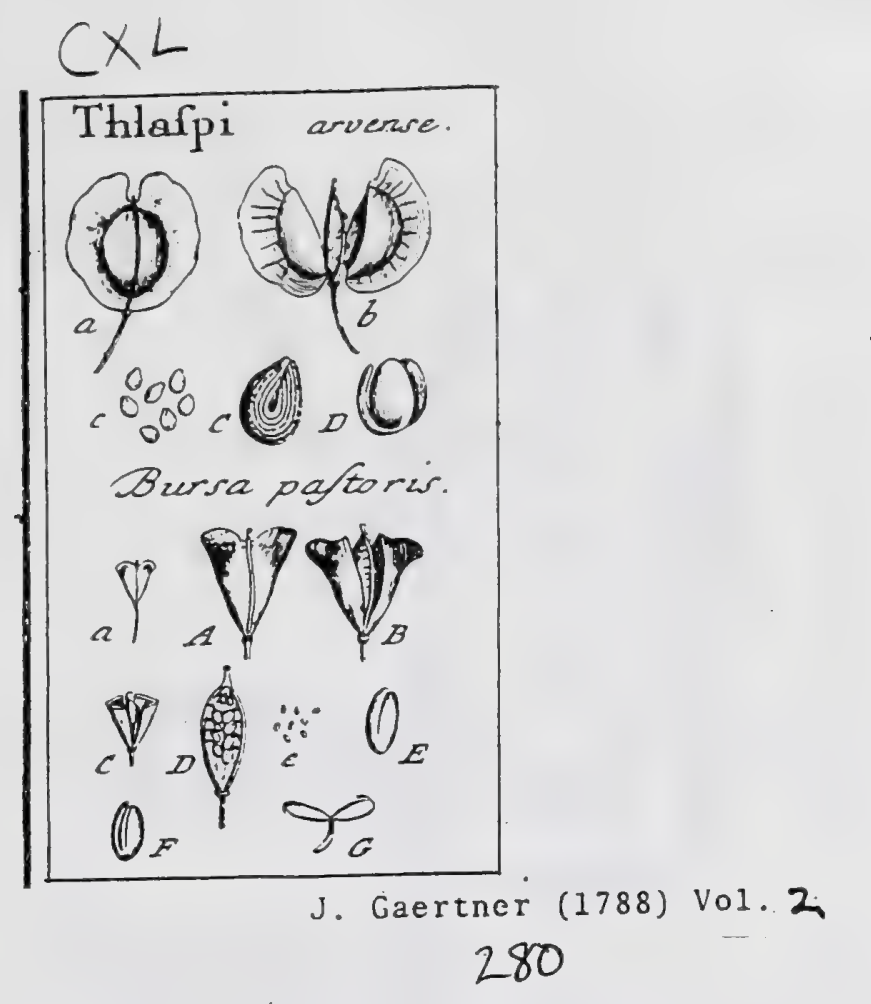

\section{T H L A S P I. TOURN. t. IOI. LINN. gen. 802. Burfa Paftoris. TOURN. t. 103.}

Silicu!a emarginata, obcordata aut fubrotunda, bilocularis, bivalvis, polyfperma: valvis carina aut apice membranaceo-marginatis.

Thlasti arvenfe. Tab. 1 41 . fig. 3.

Thlaji latius. DoD. fempe. 712. BL.Mi.r. berb. t. 68.

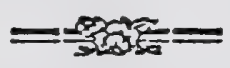

Thluspi filiculis orbiculatis, foliis oblongis dentatis glubris. LINN. $\int y f$. veg. 587 . 1cons. OED. flor. dan. t. 793.

PER. Silicula ovato - rotundata, fupra profunde emarginata, lenticulari-comprefla, bilocularis, bivalvis. Valvula maviculares: carina in latum narginem definente. - Diffepimentum anguftum, valvis contrarium, fimplex.

REC. intervalvulare, filiforme, utrinque plures funiculos umbilicales breves emittens.

SEM. plura, quinque ad feptem in fingulo loculo, ovas, verfus umbilicum anguftata \& roftellata, fulcis cum nargine parallelis minutilfmeque crenulatis cxarata, fubfplendentia, nigro-caftanea.

INT. duplex: exterius cruftaceum, durum, fragile; interius membranaceum, pallidum, inprellionibus fulcurum intcgumenti externi pulchre vernicu. latum.

En B. curvatus, luteus, allium redulens. Cotyl. cllipticx, plano - convexx. Rad. tereciufcula, rima cotyledonum accumbens, centrifuga.

a.) Silicula integra. b.) Eadem detrifeens, cum diffepimento atq̨ue feminum in[crtione ia fitu naturali. c. C.) Scmina [nluta. D.) Eusbryo denudatus.

Rarum \& forfan unicum feminis ftriati exemplum in hac familia.

Thlaspi Burfal paltoris. ibid.

Burfat paloris. Cast. epit. 340. BLAkw. herb. 2. 5. OEd, for. daru. t. 729 .

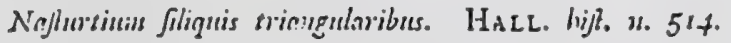

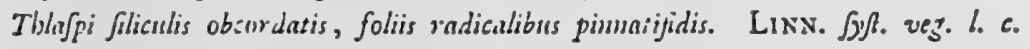

Silicula (a. A.) obcordato-triangula, comprefiufcula: valvulis carinatis (B. C.), fuperne tantum in marginen attenuatis. Difiepimentum valvis contrarium (C.), membranaceum, ficpe formmine in medio pervium. Semina in lingulo luculo (D.) circiter duodena, ovata, roftellita (c. E.), glabra, croce:a. Embryo (F.) curvatus, luteus. Cotyledones (G.) oblonga, plano-convexx. 


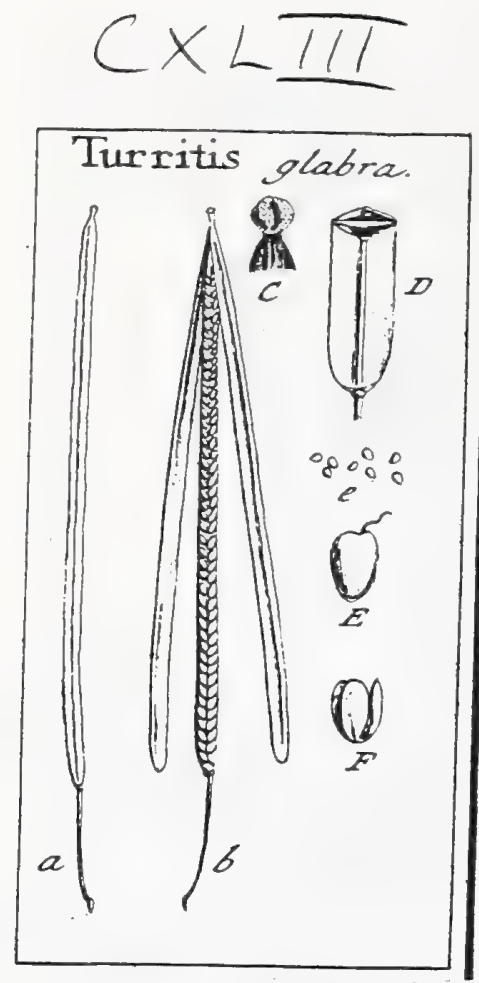

Brassicaceae

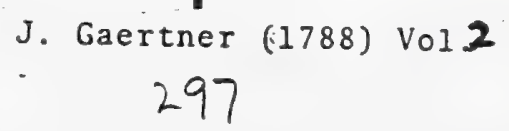

DCCCXXXVII. T U R R I T I S. LiNn. ger. 8Ig.

Siliqua longiffima, ftricts, rbombeo comprefra, ftigmate bicolli feffili terminata. Septuin valvis parallelum. Sem. numerofiltima. Cotyl planz. Glandulix ad balin ovarii nullx aut dux ad quatuor.

Turritis glabra. Tab. 143. fig. 8 .

Tumisis foliis radicalibus dentatis bifpidis; caulinis integerrimis anaplexicandibus glatsis. LIN. Jjer. veg. 600.

Icoss. OED. fior. dan. 4. 809 .

PER. Siliqua tripollicaris \& ultra, linearis, rhombeo-comprefla, glabra, bilocularis, bivalvis. Diffepimentum membranaceum, valvis parallelum, f. niaimx filiqux latitudini xquale, ftigmate ferfli breviter bicolli termi. natum. Valvulx in medio obtufifrime angulatz.

$R E C$. intervalvulare, filiforme, ftigmate terminatum.

SEM. Iumerofifima, fexaginta circiter in fingulo loculo, ovata, compreffiufcula, 298 margine membramaceo anguftilfinio \& fere obluleto terminata, fulva.

IN T. Gimplex, membranaceum. EM B. curvatus, luteus. Cotyl. ovatx, plano-convexiufculx. Rad. cotyleda.
num rims accumbens, centrifuga. a.) Siliqua integra b.) Eadem dehifeens. C.) Stigma bicolle. D.) Diflepimentum valvis paral.
Iclum. e. E.) Semains feparata. F.) Embryo deaudatus.

Longitudo filiqux optima generis nota eft. 


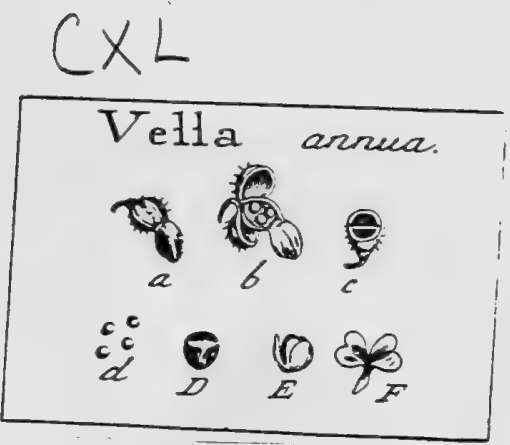

\section{J. Gaertner (1788) Vol 2 \\ 285}

DCCCXXIII. V E L L A. Linn. gen. 797.

Silicula glubola, bilucularis, bivalvis: difepimento extra valvulas in laminam curiaceam cochleariturmem produćto.

Vella anuua. Tab. 141. fig. 10.

Nafturtizm fylvefire valentimum. CLUS. bift. 2. p. ז30. TREW. ic. t. 8.

Vella foliis pinuatifidis, filiculis pendudis. LinN. Jyft. veg. 584 .

PER. Silicula fubglobofa, dura, fetis mollibus hifpida, bilocularis, bivalvis. Valvulex crultacex, extus tribus ftriis elevatis, e quibus ferx nafcuntur, notatx, intus lexvigatx, nitidx. Difepimentum valvis paralle!um, intra filiculam tenuifinum, diaphanum; extra illan in laminam ovatan opacam coriacean cochleariformem \& leviter fimam productum.

REc. intervalvulare, filiforme, funiculis unbilicalibus utrinque ftipatum.

SE M. pauca, tria 1. quatuor in fingulo loculo, fubglobofa, angulata, nigroicrruginea, mucilaginofa.

I:T. fimplex, membranaceum, fuperficie externa in mucilaginen pellucidiffimam craffam ab aqua refolubili.

Ex 8. curvatus, e viridi lutefcens. Cotyl. cordatx, convolutx: exteriore convexo - concava obtegente interiorem conduplicatam. Rad. teretiufcula, infexa, conduplicature fulco accunbens, centrifuga.

a.) Silicula intrgita. b.) Eadem aperta c.) Ejusdem (cctio transverfalis. A. D.) Semima foluta. E.) Embryo denudatus. F.) Cotyleilones explicatr. 
$\checkmark$

$-$

- 


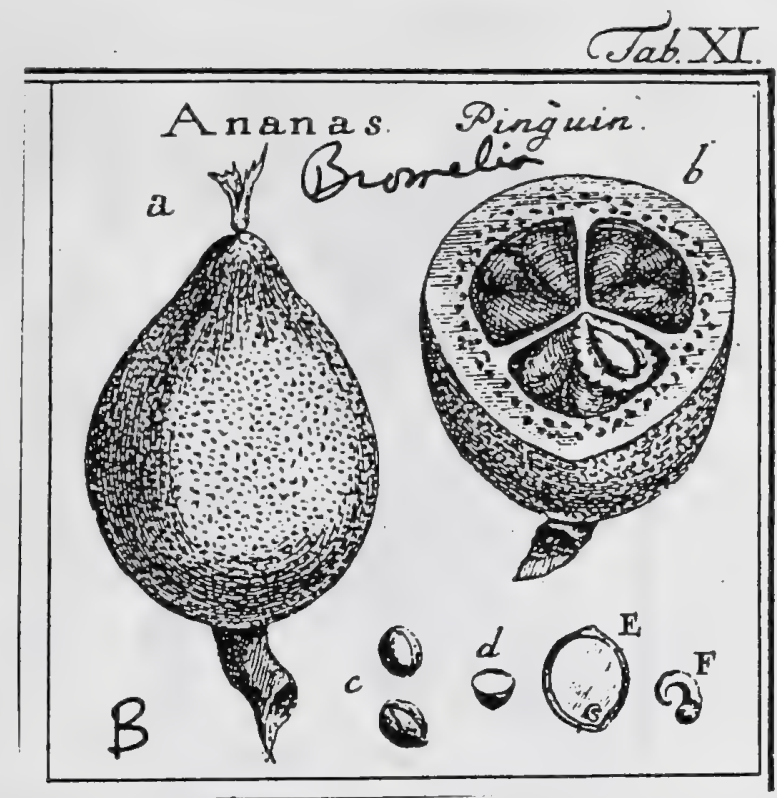

J. Gaertner (1788) Vol. 1

XXXIV. ANANAS. To uR N. t. 426- 428. Bromelia. LIN N. gen. 395 .

Calyx tripartitus. Corolla tripetala. Stam. fex. Stylus fimplex. Bacca infera, trilocularis. Semina nidulantia. Embryo curvatus.

Ananas Pinguin. Tab. 11. fig. 2.

Ananas americana Jyluefris altera minor. PLik. phyt. t. 258. . 4.

Pinguin. D I L. hort. elth. $320 . t$. $240 . f .3 I I$.

Bromelia foliis aculeatis, caule racemofo laxo terminatrici. L IN. h. Cliff. 129 . Е н R $\mathrm{T}$. decad. $t$. 51. non icon frultus.

Bromelia folits ciliato-Jpinofis mucronatis, racemo terninali. IINs. Jy/ß. veg. 3 iz.

PER. Bacra infera, corticata, orato-pyramidata, obfolete trigona, punctis elevatis conflucutibus fcabrata, trilocularis. Cortex craffus, fuberofo carnolus, istrorfum dilepimenta tria, membranacea, ad axem comilucutia producens. Caro pulpofo pombranacea, in plures cellulas partiales divifa, anuco-pallida.

REc.rnullum; Semina intra proprias cellulas nidulantia, umbilicis verfus axem baccx directis.

SEs. plurima, ovato globola, turgide lenticularia, ad umbilicum angufiora, in vertice tuberculo minimo fufco notata, glabra, nitida, e caftanco-ferruginea.

I x т. duplex : exterius coriaceum, craflum; interius membranaccum, tenuifunum, nucleo arcte adnatum.

$\Lambda$ Lв. Semini conforme, fubfarinofum, duriusculum, candidifimum.

Es R. parvus . fublutefcens, in bafi albuminis locatus, teretiusculus, uncinatus. Cotyl. tercti acuminata. Rad. incraftata, fubbulbofa.

2.) Bacea integra, b.) Eadem transverfe ferta, cum loculamentis pulpà celluiofă farkis. c) Semina foluta. d.) Albumen rransverfe feftum. E.) Ejuscem (otio longitudinalis, cum fitu embryonis. F.) Enibryo ieparatus \& ivigniter auttus. 


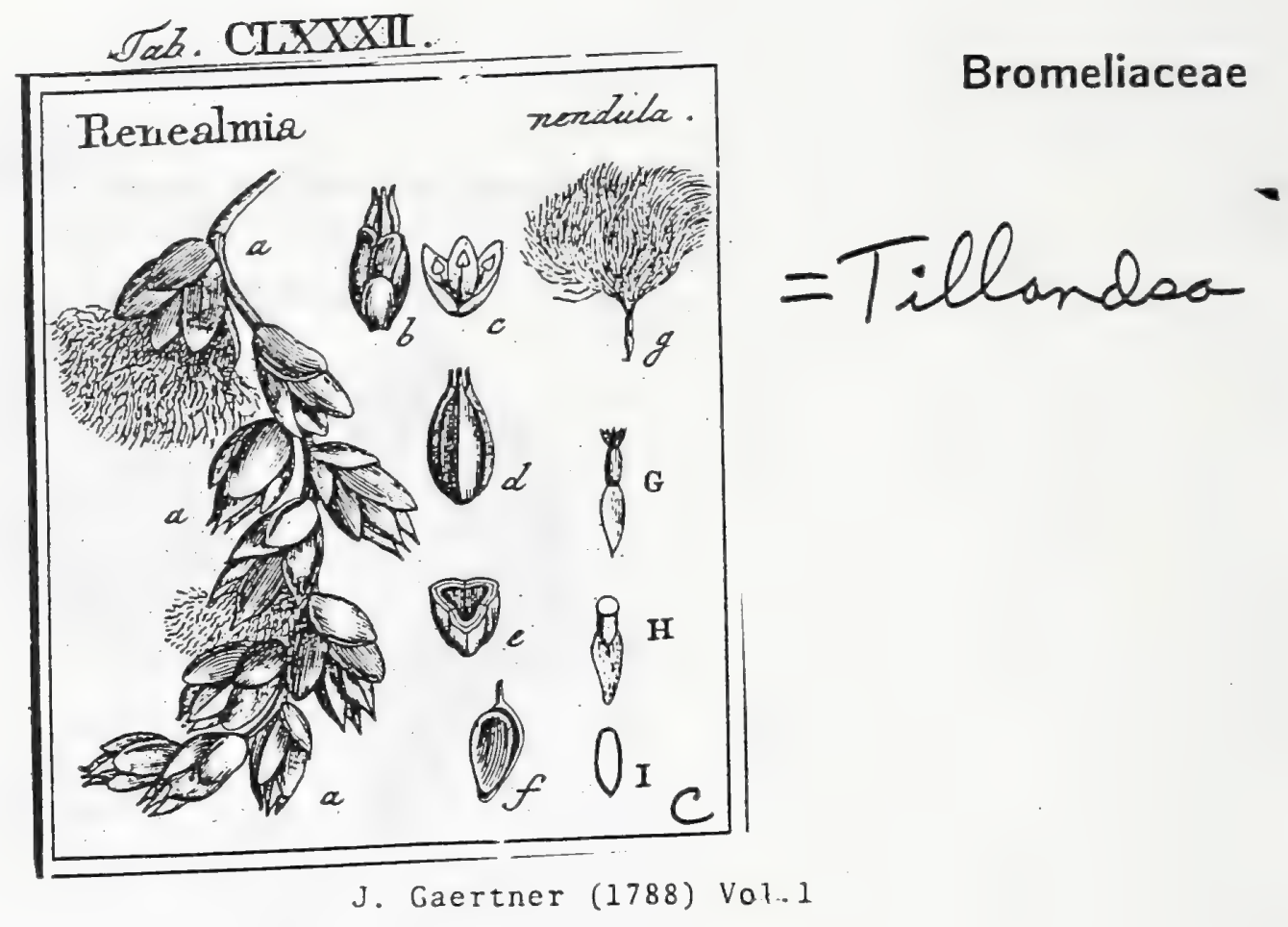

12. REN E A L I A.

P I UM. gen. t. 38. Tillandfia. Lrn g. gen. 396. ed. Sclireb. 54r. Juss. gert. p. 50 .

Cal. triphyllus, foliolis latis ovatis concavis Itriatis fubinxqualibus; antice munitus fquama forali confunili, fed paulo breviore. Cor, tripetala, nembranacea, tenuifima, alba, petalis ovato-oblongis, calyce paulo brevioribus. Stam. fex, quorum tria in petalis perfiftentia. Ovgr. fuperum. Styl. unicus. Capr. unilocularis, trivalvis, duplicata. Sem. plurima, apice crinita, bafi appendiculata.

Rexearmia pendula. Tab. 182. fig. 3.

Tillandjia pendula. THuNBERG in litt.

PER. Capfula fupera, oblonga, furfum angultata, obtufe trigona, unilocularis, trivalvis, duplicata. Valvularum lamina exterior herbaceo-coriacea, excolor, in dorfo fulco prominulo carinata, apice in mucronem brevem filifornien definens, ut capfula paululum hians appareat triroftris Limina interior papytacea, ab exteriore peritus foluta, ovato-ublonga, obtura, extus fordide cinerez, intus nigro-caltanea, glabra, fub-fplendens.

RRC. nullum: femina in medio capfula in tres glomerulos collecta atque caudis fuis bag valvularum alfiam

1

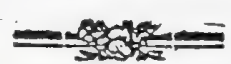

SE M. numerofietima; parva, teretiufcula, fordide nigricantia, bafi cauda fub. lanceolata, \& deorfum infigniter acuminata, albicante terminata, apice vero crinibus fericeis tenuiffimis fimplicillimis longiffimisque coronata.

IN T. duplex : exterius-fubmembranacesu, formatum ex ipfss coronx crinibus, qui in feminis toti fuperficie in membranam conftipantur, atque infra ejus bafin in lanceolatam caudam iterum ampliantur; interius membranaceum, craffiufculum, ferrugineum, aretifime adnatum.

A L B. Semini conforme, teretiufculum, bafi acuminatum, carnofum, durum, album.

E凡 B. monocotyledoneus, minutiflimus. . : :

EXPLICATIO FIGURE:

2. 2. 2.) Raoenus florum \& fruauua. b.) Flos maturas feparatur, calycern ptrfertion cum fua fquama torali ofteadens, t.) Cornila feparata. d.) Capfula matura integra. c.) Ejus fedtio transverfalis. 5.) Valvularuon lamina utraque a parte fua interna (peatata. g. G.) Semea integrum. H.) Ejus \& albuminis fectio transverfalis. I.) Albumen longitudinaliter diffecum.

Anne cufpides in valvularum laminis externis, totidern funt ftylorum reliquix? Ut caudarum origo \& fabrica rite liquelcat, in aqua emolliendz funt, ubi brevi tota in crines refolvunur, cum coron feminis continuos. 


\section{Tab.XXX.}

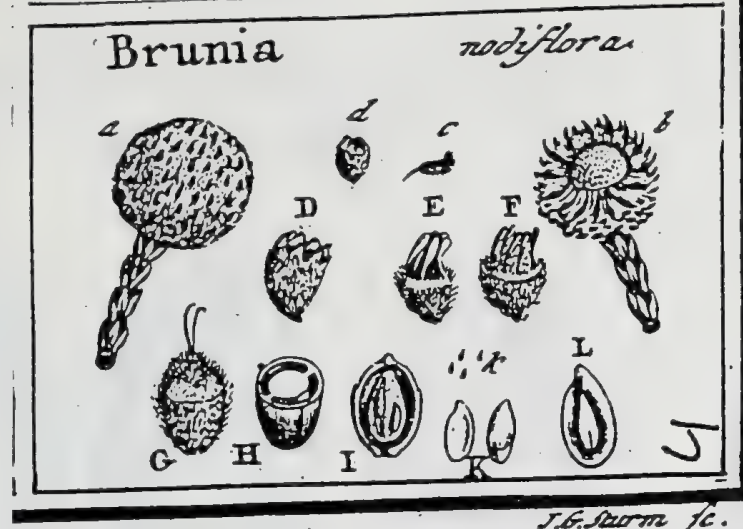

J. Gaertner (1788) Vol. 1

152

\section{BRVNIA, LINN. gen. 274 .}

Flores aggregati. Calyx pericarpio adnatus, quinquedentatus. Cor. pentapetala. Stam. quinque. Styl. duo. Drupa ficca infera bilocularis. Seiniña pauca, comprefta.

BRUNI A nodiflora. Tab. jo. fig. 10.

Cuprefo-pinulus capitis bonce Jpei. B R E Y N. cent. I2. t. I2.

Erica capitata f. nodiflora cupreffformis africana. PLux. phyt. t.346. f. 4 .

Brunia folitis imbricatis triguctris acutis. Lix.. Jyfl. veg. $2+0$.

PE R. Drupa exfucca, calyce fibi atchiffune adnato corticata, femi infera, parva, ovata, lanata. Cortex menibranaceus, tenuis. Putamen durum, fuboleum, biloculare, evaluce.

REc. duplex: fruf̆us, globofum, paleaceum, villofum ; feminis, ovato globofum, fungofum, maximum, utrinque recipiens difiepimentum tenuilumum, fibi adnatums.

$\mathrm{S}$ s.. quinque J. fex in fingulo loculamento, parva, ovato oblonga, fuperius anguftiora, comprefia, pallide rufefcentia, pendula: umbilico tcrinisali, fublaterali.

INT. limplex: nembranaccum, tenue.

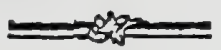

A c. B. nulluin, aut tenuifimum.

Е мв. dicotyledoneus, inverfus, feminis tefta multo anguftior, albus. Cotyl. breves. Rad. oblonga, fupera.

2.) Fruetus integer. b.) Receptac. commune denadatum, palels pedicellatis (c.) ripatum. d.D.) Drupa calyce tecia. E.) Petala unguiculata. F.) Staniira siavata, G.) Drupa, alycis corona orbata. H.) Ejus fectio transverfalis. I.) Eadem longitudisaliter aperta, cum feminum fitu in receptaculo. K. K.) Senina feparata, L.J Seminis fectio Jongitudiualis, cum fitu enbryonis.

Totum genus Brunix curatiori indiget examine, nec in unum conftipand $x$ funt fpecies, quibus inferus, \& quibus fuperus eft fruclus, prxfertim quum \& ipf $x$ floris partes multuin differant.

Pericarpium reclius $N u x$, quain Drupa diceretur.

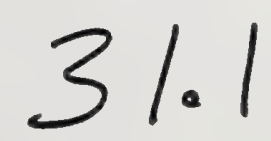





\section{Burseraceae}

Tab. CII.

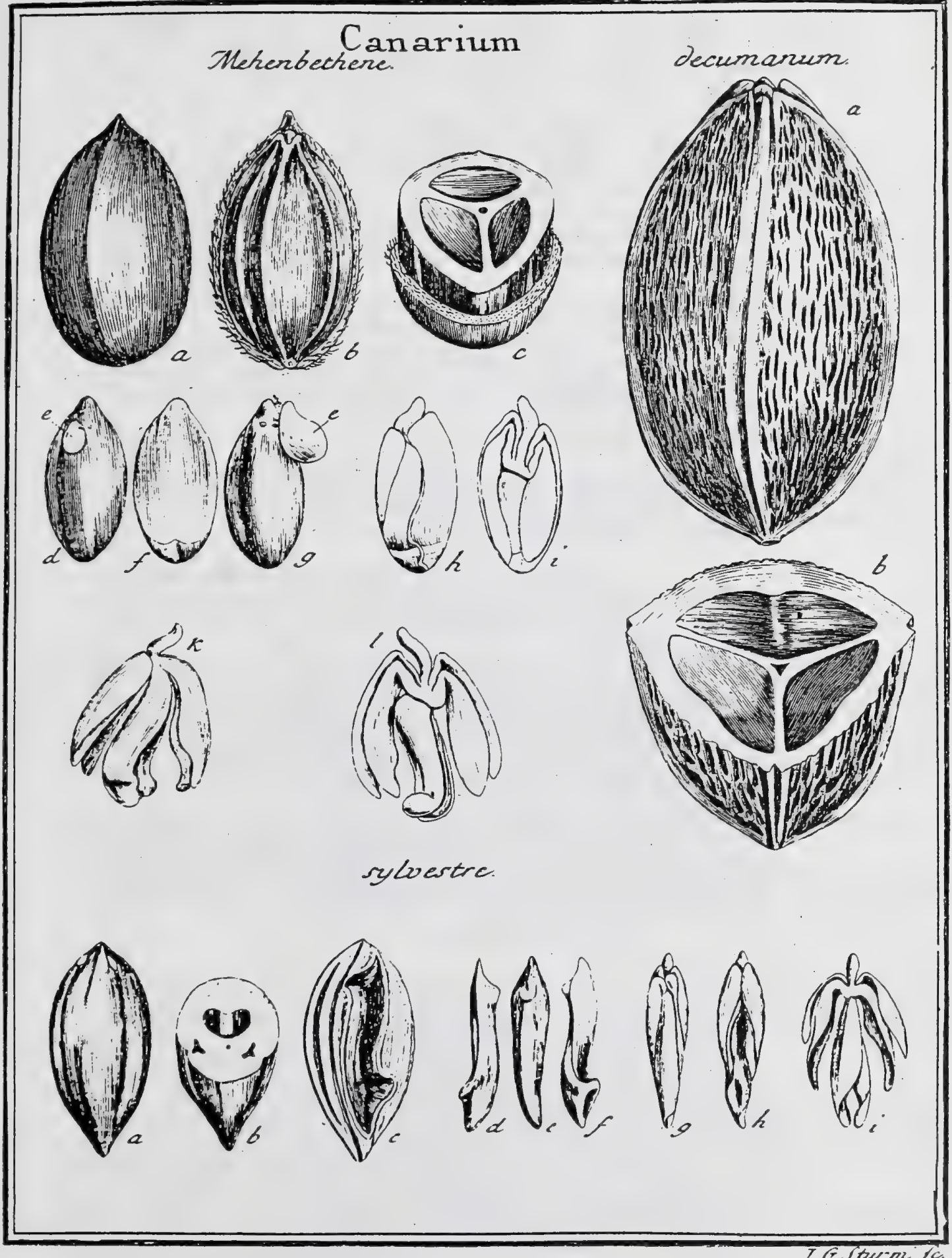

32. $1 \mathrm{~A}$ 
Flores feru diftincti in fepsratis ftirpibus. MAS. Cal. diphyllus. Cor. tripetala. Stam. quinque. FEM. Cal. \& Cor. ut in mare. Ovar. fuperum. Styl. nullus. Stigma feffle. Drupa baccata, putamine trilocuhri.

CANarium Mehenbethene. Tab. 102.

Avellania mehembethente Cortufr. BaUH. bift. I. l. 3. p. 308.

Areherabethene capillata EO fine capillis. Bes工. mus. p. 22. t. 5 .

Cantrinms vulgare. RUMPH. canb. 2. p. 145 . t. 47.

Caniriusin commsne. Lins. Jy. veg. 885.

PER. Drupa fupers, baccata, ovato - acuminata. Cuticula tenuis, olivacea: Caro pauca, fibris capillaribus pertexta. Putamen olfeum, ovatum, obfoletifime fcrobiculatum aut glabrum, trigonum, triloculare, tribus ad apiccm dentibus obtufis incifum, tribusque lineis elevatis obfoletis in lateribus notatum, \& fecundum totam axis longitudinem canali filiformi perterebratum.

REC. filiforme, lignofun, in axis canali pofitum, fuperne in funiculos umbilicales breviffmos divifum, $e$ quibus femina pendent.

SEM. in fingulo loculo gemina, e quibus unicum tantummodo adolefcit, ovato - oblongum, hinc planiufculum cum gibbere transverfali paulo fupra bafin, inde modice converum, cum rudimento ovuli cafi infra apicem.

IN T. finplex, membranaceum, tenue, rubro ferrugineum.

A L B. nullum.

EMB. nagnitudine feminis, inverfus, lacteus. Cotyl. fex, aut dux profundifime trifidx, lobulis oblongis, fubfoliaceis, varie contortis. Rad. comprefliufcula, longa, fupers.

2.) Drupa integra. b.) Potamen denudatam. e.) Pataminis \& corticis fibrofo carnof feäio kransverfalis. f.) Scrrinis latus dorfale. d. 5.) Ejusdem latus ventrale, cum annex* ovali abortivi (c. c.) rudimento. h.) Embryozis latus dor(ale. i.) Ejusdcm pars ventralier k. L) Ca tyledones explieatz \& diduezz.

Canarium commuse. LINN. mers elt pracedentis varietas. Drupa ei paulo major eft \& caro absque fibris. Putmen argutius triquetrum, angulis prope verticem albo colore infignitis \& quafi fungofis; lateribus autem glaberrimis, planiufculis, absque ftria media elevata. Loculamenta tria, duobus fere obliteratis, tertio folo fertili \& majore quan in Mehenbethene. Semeu quoque paulo grandius, cetera vero præcedenti, colore \& tota fua ftructura fimillinium.

In vetuftifimis etian feminibus, utriusque hujus varietatis, nucleum nunquam deprehendi ranciduin, fed dulcem femper \& recentium anygdalorum faporis: quod tanto magis mirandun, cum coryledones, polt detractum feminis integumentum, oleo quafi videantur illite, ut lubricilinix fust \& omnem aqux collectum ayerfentur.

Casarium fylvelte. ibid. Canariums fylvefive alterzm, fre Nanarium. RUмPH. anb. 2. p. 155. t. 49.

Drupa carnofa, ubovata, f. fuperne craflior, rotundata, nec fphxrice trigona, ut in præcedentibus. Putamen (a. b. c.) ovatum, lapideun, crafrifimum, obfoletiflime trigonum, tribusque lineis deprefls longitudinalibus notatuni, quibus totidem tubercula parva callofa fub apice putaminis pofita junguntur. Loculamenta tria, quorum duo fepe obliterata, tertio folo fertili, nujore (b.c.), valde irregulari, atque propria crufta cartilaginea lxvigatilima, intus veltito. Semen (d.e.f.) oblungun, trigonum, figmoideo curvatum, prope utramque fuam extremitatem contrarie gibbofum. Integum. fimpler, membranaceum, e caltaueo-fpadiceum. Albumen nullum. Embryo (g. h. i.) femini conformis, albus, .fragilifimus. Cotyled. (i.) fex, inxquales, fub. foliacex, varie inflexe (g. h.). Radic. oblonga, fupera.'

Ob fingularem fusm formam atque fragilitatem, femen nunquam e fuo putamine folvi potelt integrum, nifi hoc caute.\& fecundun longitudinem fuam apcriatur; quod.etian Rumphius 1. c. annotavit.

CaNiarium decumanum. ibid.

Canariuns decunsanums. RuirpH. ausb. 2. p. 166.t.55.

E feminakio hort Amftelod.

Drupa, inter omnes hujus generis, maxima. Putamen (a. b.) ovato-oblongum, triquetrum, Lipideum, crafum, apice fexdentatum. Anguli prominentes, glabri, fulco longitudinali medio exarati. Latera foveolis oblongis confertifinis fcrobiculatat, ut quafi vermibus arrofa. Axis triguetro canali perforatus. Loculamenta tria, ampla. Semina defuerum 


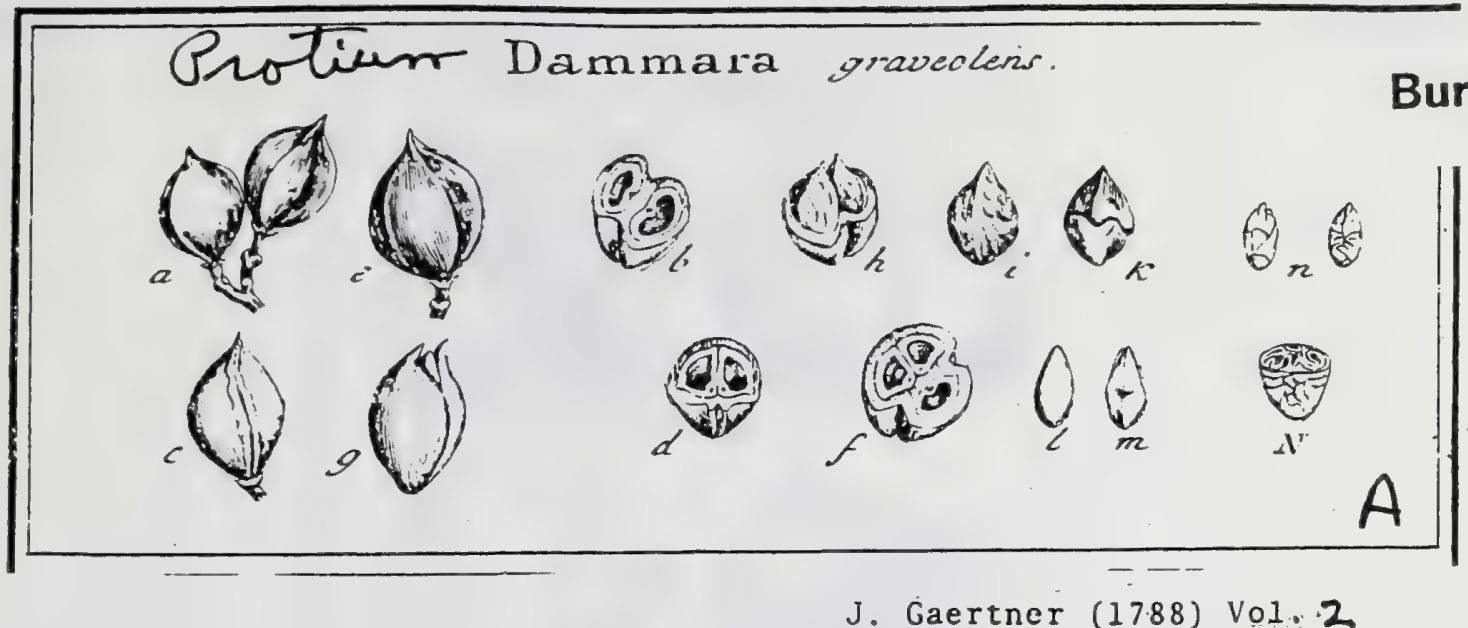

J. Gaertner (17.88) Vol. 2

Calyz: quinquepartitus, foliolis brevifrunis, acuminatis, perfiftentibus. Cor. .... Stam. ..... Ovarium fuperum. Styl. nullus aut brevithimus. Stigma fubcapitatum", quinquetuberculatum. Bacca bilocularis, loculamentis mono - 1 . dipyrenis.

Danmara graveolens. Tab. 103. fig. I.

Dammara Itam f. nigra. RUnPH. amb. 2. p. 160. t. 52?

Ex infula Mauritii. A Cl. Hermanno Prof. argentor.

PER. Bacea fupera, acuminata, regulariter biloba, feu lato fulco utrinque exfculpta., bilocularis : loculamentis mono - L dipyrenis. Caro modice crafra, per maturitatem dura, fragilis, rufefcens, oleo multo terebinthinaceo - aromatico fcatens. Officula unum aut duo hapidea, pallide ftraminea, utrinque acuminata, hinc convexa, rugofula, inde pro vario fuo nuniero, vel obtufe vel acute angulata, rugis gibbofis infcripta atque in medio rima umbilicali perforata, unilocularia, monofperma.

REC. cicatrix fungofa, craffa, alba, loculamentorum diffepimento medio inferta, \& pyrenarum rimz ventrali immiffa.

SÉN. in Gngulo officulo unicum, oblongum, furfum attenuatum, hinc convexiufculum, inde angulatum \& fcrobiculo umbilicali profundiufculo exaratum.

INT. fimplex, membranaceum, rufefcens.

A L B. nullum.

EMB. femini conformis, inverfus, gramineo viridis. Cotyl. foliacex, tenuiffimx, vario \& inextricubili modo rugatx atque contortuplicatx. Rad. tereti-compreffa, fupera.

2 b.) Bacea biloba, bilocularis, dipyrenz. e. d.) Alia, cajus alter lobus ubliteratas, alter vero nxilocularis, dipyrenus. e. f.) Alia grandior \& inique biloba, lubulo minore mono - altero dipyreno. g.) Aliz apice triroltris. h.) Officula in Giv. i) O(ticuli dorfum. E) Ejnsdem pars ventralis. L. m.) Seminis latus utrumque. n.) Embryo denudatus N.) Cotyledonam contortuplicatarum fetio transverfalis.

Odor balramicus hujus fructus adeo penetrans eft, ut per $* 4$ horas digitis, etiamfi lotis:" pertinacifime inlixferit. Amyridi vicina \& forfan genuina ejus fpecies eft. 


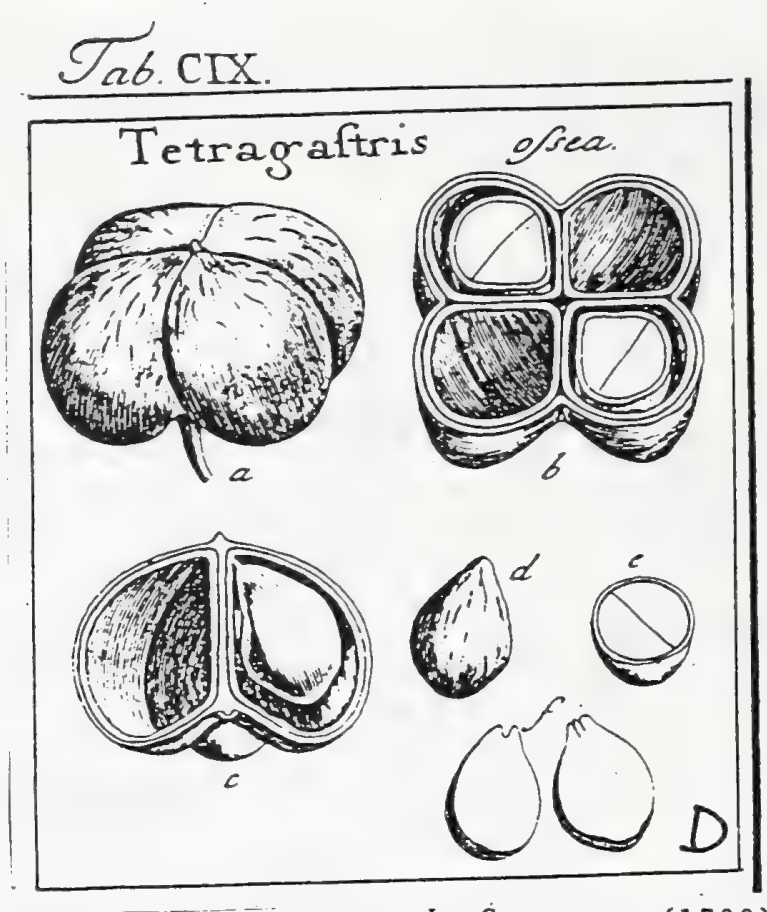

Burseraceae

J. Gaertner (1788) Vol. 2 ;

\section{I30}

DCXXXV. T E T R A A S T R IS. Heertrew

Flos... Bacca depreffa, quadriventris, tetrapyrena Semina folitaria,

Tetragastris offea. Tab. 10g. fig. S.

Ex feminario thort amftelod.

PER. Bacca fubglobofa, deprefiufcula, grandis, fupra convera \& ex acuminato vertice, quatuor fulcis depreffis infcripta, inferne autem in quatuor lobos pulvinatos diftantes, quali totidem ventres, divifa, tetrapyrena. Caro, in vetufto frütu, tenuis, fubcoriacea. Officula grandia, dura, unilocularia, hinc gibba, inde angulitta, modice craffa, vel potius tenuia, albicantia, nulla carne intermedia a fe invicem difcreta.

RE c. centrale, in apicem bacex definens, fuperne breves ad femina funiculos umbilicales promens.

SE M. folitaria, grandia, ovato.acuminata, rufefcencia,

INT. fimplex, coriaceum, tenue.

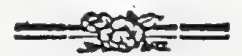

A L B. nullum:

EMB. femini conformis, inverfus, pallide albicans. Cotyl. craffe, carnofx, plano-coiscxie, ad radicule fedem emargiratz. Rad. exigua, intra cotyledones, retraca, fupera.

1.) Bacer integra b. c.) Eadem transrerfaliter \& longitudinaliter difeean, eum Gitu \& infertione feninum. 1) Semen (eparatum. e.) Ejusdem atque cotgledonnm fetio transveralis. f.) Cotyledones feparatz. 


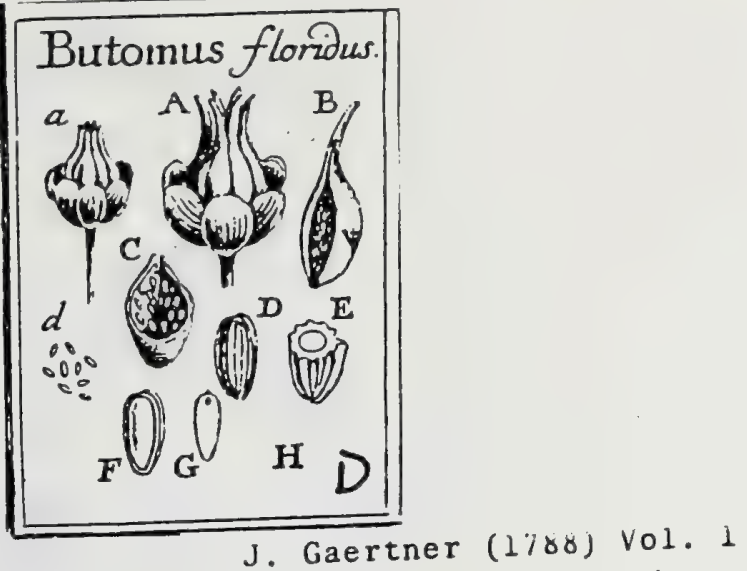

LXXXVI. BUTOMUS. TOURN. t. 243 . LINN. gen. 50\%

Corolla hexapetala. Stam. novern. Capfulx fex. Semina parietalia. Embr, in re.: gione umbilico oppofita.

Boтоsus Aloridus. Tab. 19. fig. 3.

Funcus floridus. С А $\mathrm{x}$. epit. 78 .

Funcus cyperoides paludofus. Besz. hort. Eyf. vern. IX.t. $4 . f .4$

Butomus. H А b. hifl. 2. n. II86. L IN J. fy/l. veg. 395 .

Icon OEDER. flor. dan. t. 604 .

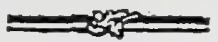

Per: Capfula fex, intra corollam perfiftentem, ovato roftratx, infra ad dimidium fere longitudinis fux inter fe connatx, membranacex, uniloculares, introrfun deluis. contes.

REC. nullum: fenina undique parietibus capfularum affixa.

SEM. utumerofifiuna, parva, fubcylindrica, fulcata, ex altero latere cofa membranacea anguhilima $f$. hilo infignita, rufefceutia.

IN T. duplex: exterius crufaceum, durum, fragile; interius membranaceum, tenuifimum, nucleo arcte adnatum, viride.

A с в. terctiusculum, verfus umbilicum attenuatum, carnofum, album.

Es в. monocotyledoneus, ovato globolus, miuutus, in craffiore \& umbilico oppofita albuminis parte locatus, viridefcens.

2. A.) Capfuiz integrz. B.) Capfula feparata introrfum dehifcens. C.) Ejus fetio transverfalis, cum (cunisum fitu. d. D.) Scmima separata. E.) Semen transverfe (eetum. F.) Idern longitadinaliter apertum, G.) Nibumen longitudinaliter feftum, cum fitu enbryonis. H.) Ecobryo foparatus. 
f

-

- 


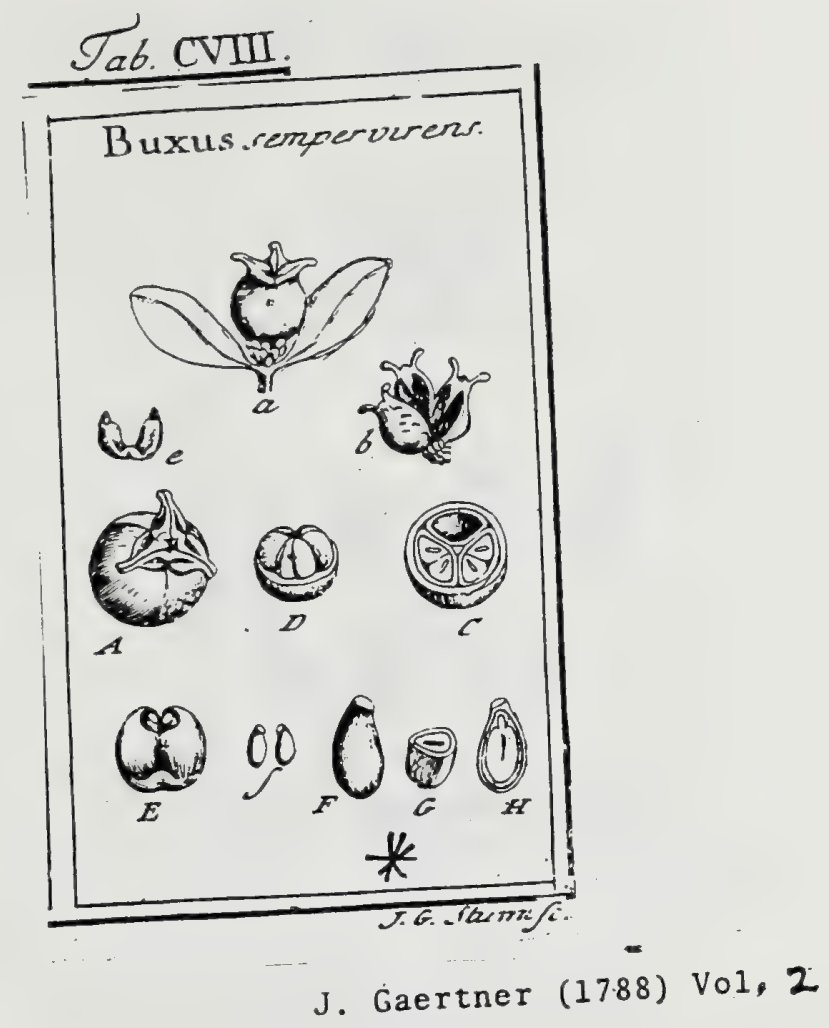

125

DCXXX. B UXUS. TOURN. inft. t. 345. LINN. gen. 1053.

Flores fexu diftincti in eadem ftirpe. MAS. Cal. triphyllus. Cor. dipetala. Stam. quatuor. FEM. Cal. tetraphyllus. Cor. tripetals. Ovar. fuperuin. Styl. tres. Capfula coriacea, tricocca, triroftris. Semina gemina.

Buxus fempervirens. Tab. 108. fig. 6.

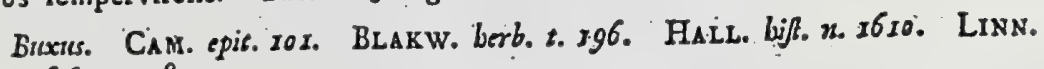
fyjt. veg. 849 .

PER. Capfula globofa, glaberrima, nitida, coriacea, tricocca, ante dehifcentian triroftris. Cortex trivalvis: valvulis bicornibus. Cocculi chartacei, bivalves, elaftice dehifcentes.

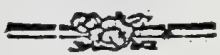

REC. centrale, triquetrum, breve.

SEM. in fingulo loculo gemiua, ovata, furfum attenuata, triangulari - compreffa, apice in umbilicumoblique truncatum, fubfpongiofun album definentia, cetera nigro-fufca, aut atra, glabra.

IN T. duplex: exterius coriaceum, durum; interizs membranaceun, pallidum.

А г в. femini conforme, carnofum, craffum, album.

EM B. magnitudine fere albuminis, inverfus, lacteus. Cotyl. ovatx, foliacex, planx. Rad. teretiufcula, brevis, fupern.

a. A.) Capfula integra. b.) Cortex in valsulas dechifeens. C.) Capfula diffecta. D.) Coeculi clauG, in Gtu. c. E.) Cocculns folutus, bivalvis. f. I.) Stuniaz (pparata. G. H.) Albumea transverfaliter \& longitudinaliter diffectum, cum fitu \& fogra Emltyuais.

Semen, Carthegon grace dictum, a nullo animalium tangi, affirmat PLiN. hilt. 1nat. L. 16. p. m.14.

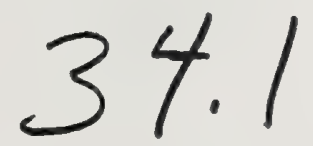




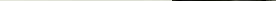




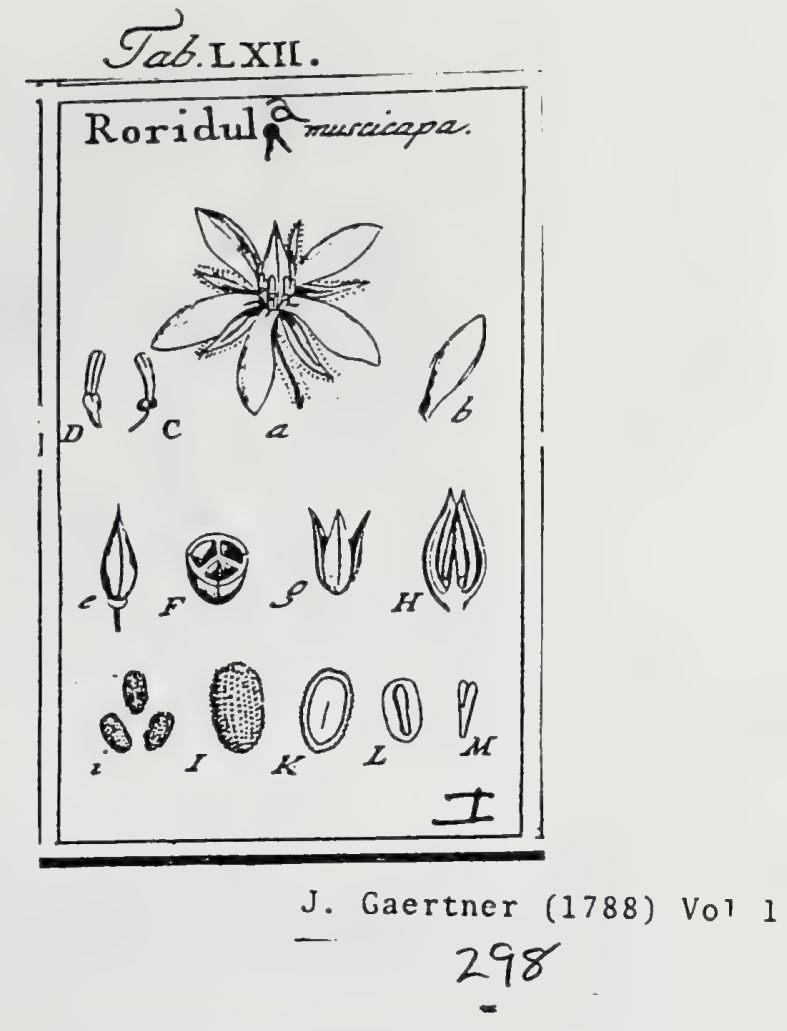

Byblidaceae

CCCLXXVIII. RORIDULA. LIN N. gen. 1234 .

Calyx pentaphyllus. Cor. pentapetala. Stam. quinque: antheris bafi glandula didyma. Styl. unicus. Capiula trilocularis. Semina folitaria.

RORIDULA muscicapa. Tab. 62. fig. 8.

an Roridula dentata. LIN N. Jyß. veg. 244 ?

Ex herbario Bankfiano.

PER. Capfula pyramidata, acuminata, rotunde trigona, trilocularis, trivalvis. Diflepimenta axi adnata, valvis coutraria, \& ab iis per inaturitatem ita fecedentiz, ut columna pyramidata triquetra in medio perfifat.

REc. axis capfulx, cui femina paulo fupra bafin affixa.

SEs. in fingulo loculanento unicum, grandiusculum, ovatum, fubcompreffum, in dorfo planiusculum, in ventre obfolete angulatum, fcrobiculis minutifimis, per feries longitudinales digeftis profunde alveolatum, ruffo - ferrugineun.

Iพ ร. duplex: exterius fuberofo cruflaceum, craflum, tragile; interius membranaceuIn, palliduin.

A \& в. fornini conforme, linea longitudinali in ventre iufcripturn, crafturn, carnofam, nolle, albuin.

E M B. longitudine fere albuminis, erectus. Cotyl. foliacex, lineari oblongx. Rad. comprefla, linearis, recta, infera.

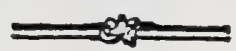

a.) Flos integer. b.) Petalum. C.) Stamen pirte-exterlore, \& D.) Idem a parte interiore (peta. tum. e.) Capfula lategra. F.) Esdem diffeta. g.) Valvulix dehilcentes. H ) Columan diffepimentorum triquetra centralis. I. I.) Semina folutn. K.) Atbuuse deuudsuno, L.) Idem longitudinaliter feetum cum embryone. M.) Embrjo feparatus,

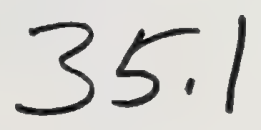


-

-

- 


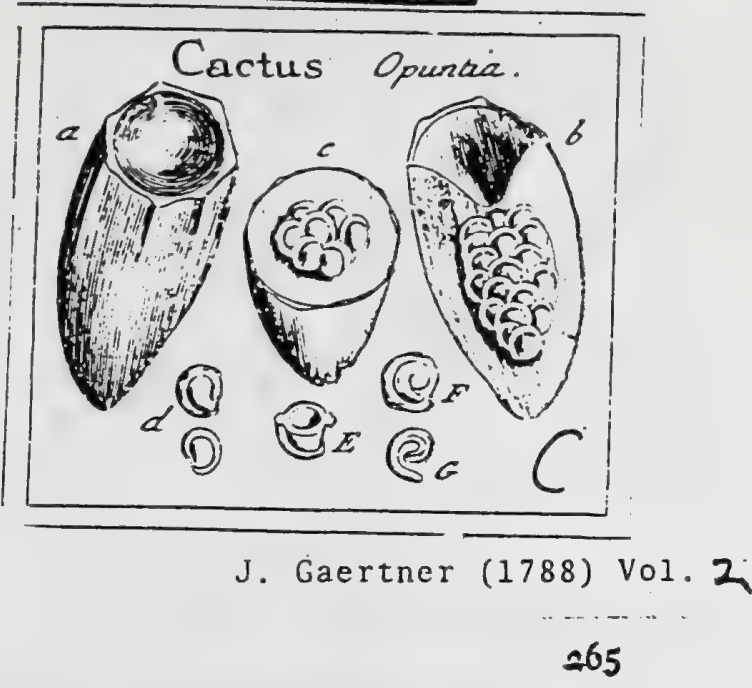

DCCXCIX. CA C T US. Linn. ger. 6I3. Opuntia. Tourn. t. I23.

Calys lipcrus, imbricatus, deciduus. Cur. polypctala. Stam. numerofa. Styl. fimp!cx; apice multifidus. Bacca infera, carnofa, unilocularis. Sem. plurina, amulo calluío cincta.

Cectus Opuntia Tab. 138. fig. 3.

Of:timia unlgo berbariorun. BauK. bjfl. 1. p. 154. MILL. ic. rg1.

Ogrumtin foliis ovatis comprelfis, fpinis fesaceis. Mall. bife. "u. rogg.

Cucsus articuluto-prolifer laxius, articulis ovutis, fpisis fetaceis. LINN. fy/8.veg. 460.

PER. Facca infera, carnofi, ovato ciblonga, inferne attenuata, fuperne truncata \& profunde umbilicats, glabra, rubra, unilocularis, fareta. Car• mollis, fpongiofa, fanguinea.

REc. nullum; femina in carne nidulantia.

SEM. plura, quindecim aut viginti, offex, reniformia, turgide lenticularia, pallide teftacea, ammulo craffo callofo circumdata.

IxT. dup!ex: offeum crafum, durum; \& membranaceum rufefcens.

A L R. dulluns.

F.м в. teretiufculus, fubfpiralis, lacteus. Cotyl, femiteretes, incumbentes. fisid. longa, curva, vag'd.

266

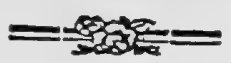

a.) Bace integra. b. c.) Ealem difteas, cum fita feminum. d.) Semina foluta E.) Semini refta transverfim, \& F.) eadem longitudinaliter aperta, cum eubryone propria fua pelieala
teftc. G.) Embryo denudatus.

Melocacti femina dicuntur monocotyledonea.

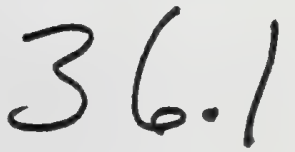




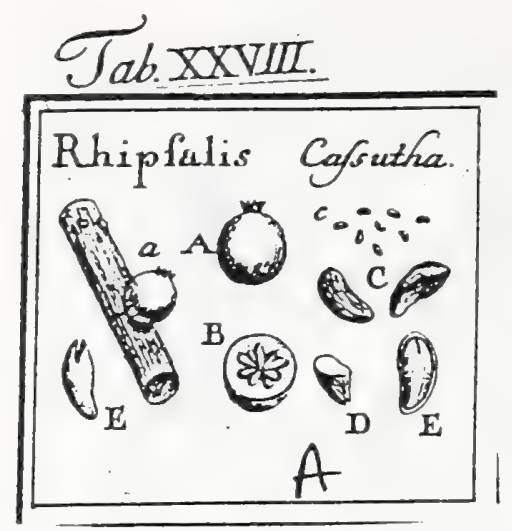

137

\section{J. Gaertner (1788) Vol 1}

\section{CLXTV. RHIPSALIS. L aertirer}

Calyx fuperus, tri-l. quadripartitus, brevifunus: dentibus acuminatis, membranaceis, tenuiffimis. Cor... Stam. .... Styl. . . . Bacca inferz, unilocularis. pellucida. Semina duodena, centralia.

Rhipsalis Caftutha. Tab. 28. fig. i.

Cafyta polyfperma. Artos. cat. hort. Kew.

PER. Bacca infera, floris rudimento coronata, fpharica, nivea, pellucida, unilocularis. Pulpa aquofa, Ceminibus undique circumfufa.

REc. nullum, przter vara autritia, capillaria, femina ad axem fructus alligantia.

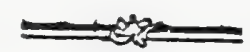

SE 3. odto 1. duodecin, in centro fructus conglomerata, parra, oblonga, fubanguiata aut cuneiformi comprefta \& extrorfun crafiora, tenuifime punctato firiata, fer-
ruginea.

INT. duplex: exterius crufaceum, durum, fragile; interius membranaceum, te.

A L \&. ruilum.

EMs. dicotyledoncus, magnitudine cavitatis feminis, e viridi albicans. Cotyl. in parte
embryonis cralfiore, Greviflumx embryonis craltiore, Grevifimx, fubacuminatx. Rad. maxima, umbitico ob
verfa, ccutripeta.

2. A.) Bacca integra. B.) Eadem diffecta c. C.) Semina foluts. D.) Semen transverfe fcctum donibus.

E, Embryo Separatus, didustis leviter cotyle Ad Cacti genus referri pofte cenfet Ill. Banks. in litt. fed Cacti fernivis alburnen farino
fum, \& embryo fubfpiralis eft.

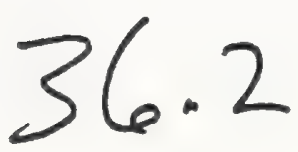




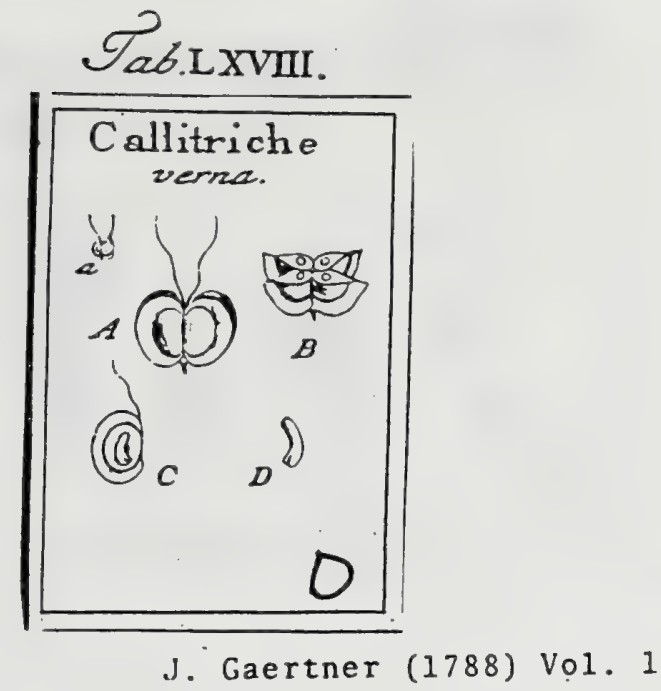

Gaertner (1788) Vol.

330

CCCCXXV. CALLITRICHE. LIN N. gen. 13.

Flores in ailis hermaphroditi, \& in aliis fexu difincti. Cal. nullus. Cor. dipetala. Stam. unicum. Styl. duo. Semina quatuor nuda, hine meinbranaceo marginatio.

CAILIT RI C e verna. Tab. 68. fig. 4.

Callitriche Plinii. Col. ecphır. 1. p. 315. t. 316. OEDER. flur. dan. t. 129.

Stcllaric foliis petiolntis fubrotundis. HaL. . hif. 1. n. 553.

Callitrichc foliis fuperioribus ovnlibus, floribus androgynis. L I N . Jifl. veg. 53.

PER. nullum, nifi ipfam ferninum tunican velis.

REC. fetaccum, in axi fructus pofitum, aut nullum.

S E x. quatuor, feni elliprica, lenticulari comprefia, ad oram exteriorem latiusculo mar gine membranaceo cincta, in crucem comprefiam ita difpofita, ut per paria fik: juncla videantur, pallide fpadicea.

Ix r. fimplex, membranaceum, tenue, nucleo arcte adnatum, \& citra cum in mar ginem inembranaceum productum.

$\Lambda$ с в. rotunde cllipticum, compreffuin, feınine multo anguftius, carnofum, pallidum.

Exв. longitudinc albuminis, reretiusculus, leviter curvatus, inverfus, lacteus. Cotyl. breviflunx, obtufx. Rad. longa, cralla, fupcra.

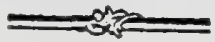

*

2. A.) Frufns integer. B.) Idem difeetus. C. ) Semen feparatum veruicaliter fetum, cum embryose intra albumen. D.) Embryo feparatus, 
-

-

- 


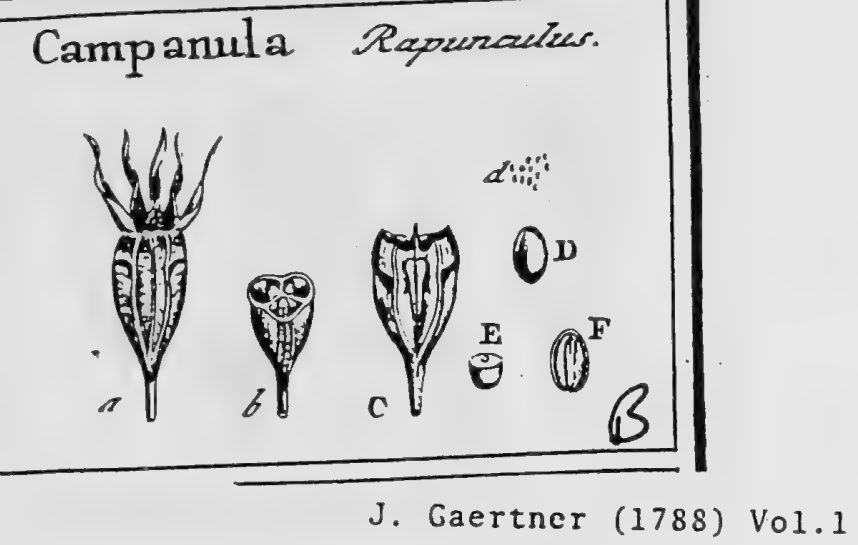

CLXXXVI. CAMPANULA. TOURN. t. 37. LinN. gen. 218.

Caly $\times$ quinquepartitus fuperus. Cor. campanulata. Stam. quinque : filamentis bafi di-

latatis, fornicatis. Styl. unicus: Rigmate triplioi. Capfula infera, trilocularis, fo ramiuibus lateralibus dehiscens.

CA zS A N ULA Rapunculus. Tab. 31. fig. 2.

Campanula foliis ellipticis Jerratis Jublirfutis, caule afpero, floribus paniculatis. HALL. hiff.̧. I. n. 6g9.

Campasula foliis ividulatis: radicalibus lanceolato ovalibus, panicula coarËata. LIN N. fiyf. veg. 206.

Icon. O E D E R. for. dan. t. 855 .

$P \Sigma \approx$ Capfula infera, calycis foliolis lanceolato linearibus coronata, retufa, inverfe pyramidato ovata, trigona, ad angulos rotundatos triplinervia, trilocularis, tribus foraminibus lateralibus, paulo fupra medium longitudinis fux dehiscens.

REC. oblonguin, deorfuin acuminatum, fungofum, ferobiculatuin, angulo interno finguli loculaınenti longitudinaliter adnatum.

SEm. plurima, parva, elliptica, lenticulari compreffa, glaberriına, nitida, pallide ferruginea.

IN T. finplex, membranaceum, tenue.

AL B. Semini conforme, carnofurn, aqueo-pallidum.

E as в. dicotyledoneus, teretiusculus, filiformis, niveus. Cotyl. femitcretes. Rad. longa, centripeta.

2.) Capfula integra. b.) Eadem transverfe (ecta. C.) Ejusden localamentam anterius spertum can fitu \& fęura receptaculi. d.D.) Sewins feparata. E. F.) Ejusdem fectiones, cum fitu \& fgara embryonis intra slbamen.

Campanula rapunculoides.

Caplula ftructurâ \& figurâ praceedentis, fed dimidio fere minor, Calycis foliola, linearia, dimidia capfula longiora, reflexa, appreffa. Foramina ampla, in ip $\int_{2}$ capfula bafi locata. Semina elliptica, valde compreffa, ut fere bracteata, hine glabra, inde linea elevata longitudinali notata, fpadiceo lutescentia, parum lucida.

Campanula rhomboidalis.

Capfula parva, vix tres lineas longa, inverfe pyramidata, non ovata, trigona; angulis rotundatis craffis triplinerviis; interllitiis anguftis depreffis. Calycis dentes erecti, fubulati, capfula longiores. Foranima, mox infra bafin calycis. Semina ıninuta, ferruginea, lucida. 


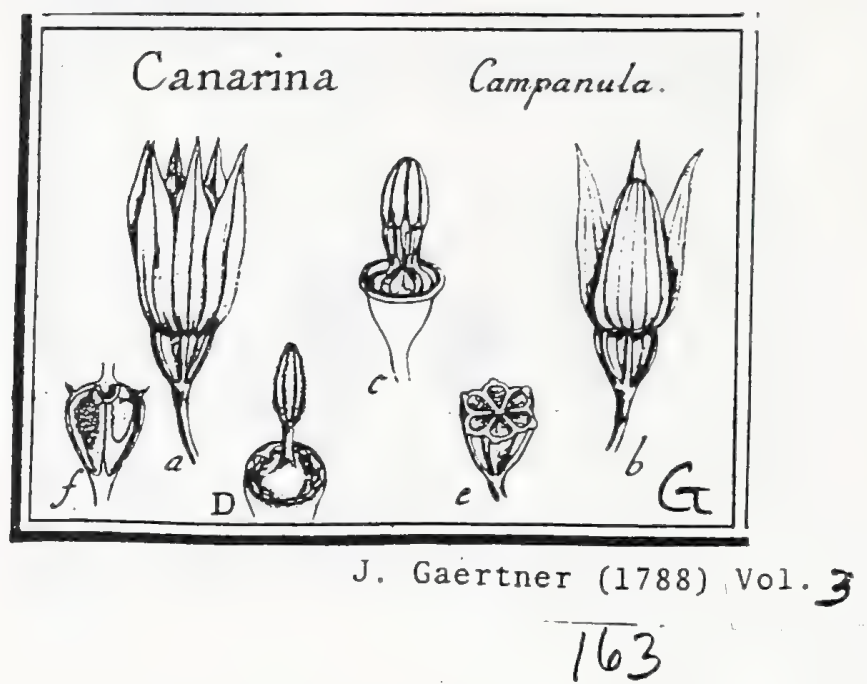

\section{C A N A R I N A.}

LIN. mant. p. r48. gen. ed. Sclireb. 603. Juss. gen. p. r64. LAMABCK ill. gen. t. 159 .

Cal. fuperus, fexfidus: laciniis lanceolatis, intus albido-pruinstis, trinerviis, perfiftentibus. Cor. campanulata ; tubo longo, furfum ampliato, ftriato, ovario prope calycem inferto; limbo fexpartito: laciniis ovato-acuminatis, patentibus. Stam. 6.; filamentat prope corolla tubum ovario inferta, e lata bafi mox angultata, inflexa, linearia; antherx erectre, ovato-oblongx, medio fulcatx, in tubum itigma occultantem connatx, biloculares. Ovar. inferum; ftylo fimplici columnari, cylindraceo, ftigmate craffo, clavato, obtufo, fex-coltato, pubefcente. Capf. inverfe pyramióata, hexagona, fexlocularis. Rec, 12., in fingulo loculo gemina, parva, membranacea, ad ukumque latus diffepimertorum. Sem. numerofa, jarva. Alb. ... Emb. ...

Canarina campanula. Tab. 211. fig. 7 .

Campanula canarienfis regiu fo Medium radice tuberofa, foliis fomuatis caefis atriplicis aemulis ternis circum caulem anbientibus, fore ansplo pendulo colore flamuseo rutiluste. PLUkn. alm. 76. to 276 . $f$. x.

Campanula fuliis baftatis dentatis, caule determinate foliofo. LINN. bort. cliff. p. 65. t. 8 .

Campanula (canarienfis,) capfulis fexlocularibus, foliis oppofitis baftatis dentatis petiolatis. LIN Spec. pl. p. 238.

Cansarina. Lins. Juppl. p. 225. Syyf. veg. ed. 14. p. 344. WILLD. Jpec. plo T. 2. P. 1. p. 24 . PeRsoon fys. I. p. 392.

Ex horto regio Kewent.

PER. Capfula infera, laciniis calycinis lanceolatis coronata, ad verticem retufa, obovata, 1 . inverfe pyramiditis, hexagona, ad angulos rotundatocoftata, inter angulos fulcata, coriacea, fexlocularis; loculanentis ad verticem capfulx dehifcentibus. Diffepinenta membranacea, fulcis externis inferta, fubintegra 1 . ad verticem capfulx in ipfius axi emarginata \& apice deftituta, ut loculamenta omnia inter fe communicent.

REC. in quovis loculamento genina, ad utrumque latus diffepimentorum fub emarginatione radice angufta inferta, lobata l. obovata, membranacea, fcrobiculato - punctata, intra loculamenta libere pendentia, quibus femina undique adherent.

SEM. numerofa, parva, angulata.

INT. .... ALB. .... ENB....

a.) Flos integer, nondum explicatus. b.) Idem, ablatis tribus calycis laciniis, ut infertio corollz appareat. c.) Staminum infertio atque fitus. D.) Stylus, cum ftigmate. e.) Capfula medio transverfe di[reta. F.) Ejusdem featio longitudioalis, cum fir \& forma seceptaculorum. 


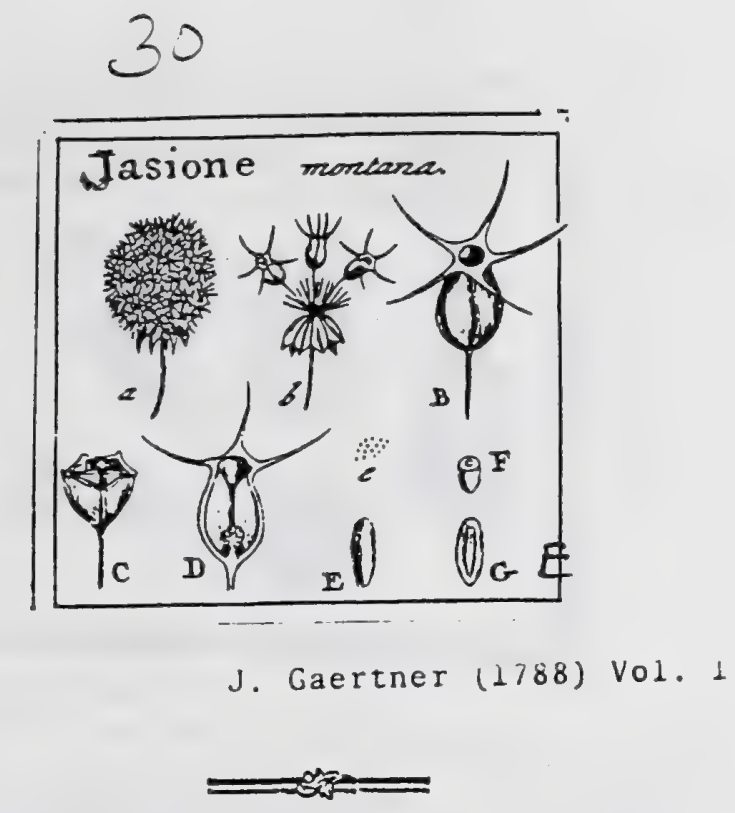

CLXXIX. JASIONE. LINN. gen. roo5.

Calyx fuperus, dentibus quinque fubulatis. Cor. monopetala, profundo quinquefida. Stam. quinque. Styl. unicus. Capfula infera, bilocularis, apice perviz. Receptaculum liberum.

JAsIox E montana. Tab. 30. fig. 5 .

Rapunculus folits linearibus jubajperis, fpica planiuscula, petalis liberis. HA LL. hifl. $x$. n.678.

Fafione. Lin x. fifl. veg. 799.

ICon. OEDER. flor. dan.t. 319 .

PER. Capfula infera, ineinbranacea, tenuiftina, pyramidato ovata, pentagona, dentibus calycis radiantibus coronata, bilocularis, apice amplo foramine rotundo dehiscens. Diffepimentum ad axem divifum, folis capfulx parietibus adnatum.

REc. fubglobofum, parvum, pedunculatum, tuberculatum, liberum, in bafi caplulx inter diffepimenti valvas pofitum.

SE «. numerofa, exilia, ovato oblonga,glaberrima, nitida, pallide caflanea.

IN T. fimplex, fubmembranaceum, tenue.

A Lв. Cemini conforme, carnolum, albuin.

Es s. dicotyledoneus, filiformis, niveus. Cotyl. femiteretes. Rad. longa, centripeta

2.) Umbella integra b. B.) Capfala cam foramine verticali. C.) Eadem transverfe, \& D.) longitodinaliter feta, cum forma \& fitu diffepimenti atque receptaculi. e. E.) Semina feparata. F.G.) Albumen transverfe \& longitadinaliter feftun; cum embryone.

Diffepimento ad axem fiffo, non rantum a Phytevmate, fed \& ab omnibus reliquis Campanulaceis abunde differt. 
Campanulaceae

Tab.XXX.

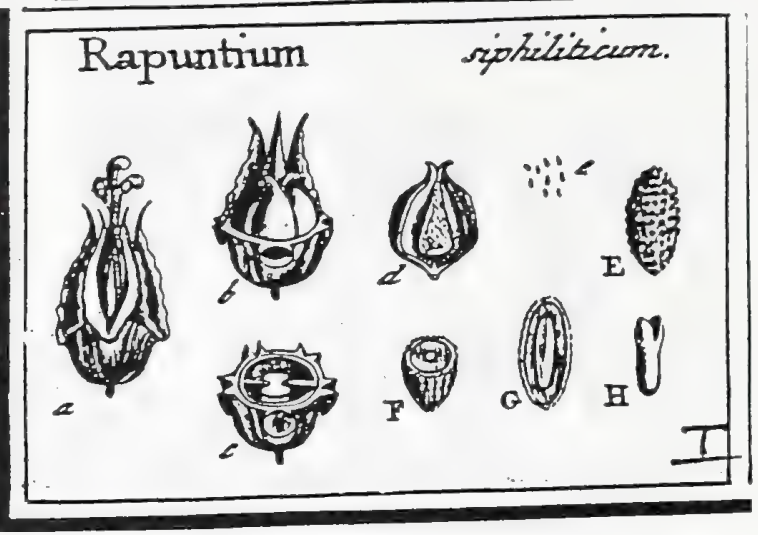

= Lobelia

J. Gaertner (17.88) Vol. 1

151

CLXXXIII. IRAPVNTIVM. T OU R. t. 5t. Lobelia. LiNk. geib. 1oo6.

Caljx ultra dimidium cum pericarpio connatus, quinquefidus. Cor. monopetala irre-

I52

gularis. Stam. quinque, antheris fxpe conglutinatis.: Capfula infera, bi-1. trilocula. ris. Dilfepinsesta valvis contraria.

RAPUN TIU M fiphiliticum. Tah. jo. fig. 9.

Rapuntium americanum, flore dilute caruleo. DOD A T. men. 297. edit. germ: 32I: $t .26$.

Lobelia canle ereeto, foliis ovato lanceolatis fubferratis, calycum finubus refiexis. LINN. 44 t. veg. $80 t$.

PER. Capfula ad medium usque cum calyce coalita, fubglobola, mucronata, utriaque fulco levi infcripta, bilocularis, bivalvis. DifTepimentum valvis contrarium.

REc. fpongiofum, fcrobiculatum, conicum, hine convexum, inde medio diffepimen. ti utrinque adnatum.

SEM. numerofa, exigua, ovato oblonga, fcrobiculato-rugola, e lutco rufefcentia.

IN T. duplex: exterius fubcoriaceum; interius inembranaceum.

A Lв. Femini conforme, carnofum, pallide albicans.

EM в. dicotyledoneus, teretiusculus, albus. Cotyl. brevifiunz. Rad. crafla, longa, centripeta.

a.) Fructus calyce \& corolla vefitus. b.) Capfula denudata. c.) Eadem transverfe fecta. d.) Receptaculi in diffepimento fitus. e. E.) Servina (cparata, F.G.) Seninis \& albuminis fectiones, cum fitu erabryouis. H.) Enbryo feparatus.

38.4 


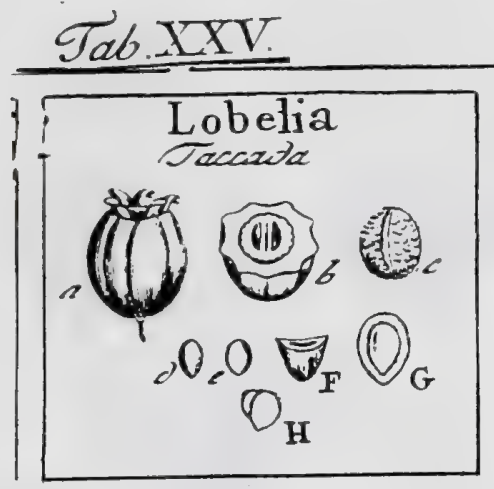

\section{J. Gaertner (1788) Vol. I

CXLI. LOBElia. Plus. gen. t. 31. Scaevola. Lin n. ger. 1294.

Calyx quinquepartitus, fuperus. Corol!a monopetala, unilabiata : filfura longitudinali in latere tubi labio oppofito. Stam, quinque. Styl. unicus. Drupa baccata, infera, bilocularis. Semina folitaria.

Lobeura Taccada. Tab. 25. fig. 5.

Bela. Modagam. R н е $\mathrm{D}$. mal. 4. t. 59.

Buglofum littoreum. Ruмpн. amb. 4.p. 116. t. 54 .

Arbor exilioja marima lakfefcens indica, Taccada vocata, fruquu cerafi magnitudine incarnato friato. HE R M. mus., zeyl. 45. B U R.M. Zeyl. 29.

Screvola. LIN s. Sy/l. veg. 213.

Taccada. Leylon. E collect. fem. hort. lugdb.

PER. Diuppa baccata, infera, calyce perfifiente coronata, fubglobola, transverfiun paulo craftior, fúleis feptem ad decem clevatis grofto modo friata, incaruata, demum fumo?a. Caro fungola, crafta. Putanen offeum, fpharicuin, tuberculato ruzofum, latura fpuria elevata infcriptum, biloculare.

REC. nullum; femina fundo loculamentorum aftixa.

SEM. in fiugulo loculannento unicum, rotundatum aut obovatum, prope bafiu lcviter acuusinatum, plano convexum, albicans.

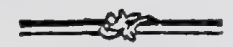

IN T. fimplex, meinbranaceum, non arcte adnatum.

A с B. Semini conforme, tenue, carnolum, molliusculum, aqueo-pallidum.

E s в. dicotyledoneus, erectus, magnitudine fere albuminis, lacten albus. Cotyl. obo. vatx, hinc levifime convexx, inde planx. Radic. acuminata, brevillima, infera,

2.) Fructus integer. b.) Idem diffectus. urraque. F.) Albumen trausverfe feetum. bryonis. H.) Embryo (eparatus. c.) Putamen decorticatum. d. e.) Seminis facies

G. ) Iden longitudinafiter apertum, cum fitu em-

Deferiptio Ruspнri optime in noftum fructum quadrat, nec multum quoque $a b^{2}$ co abludit figura Hort. malab. 1. c. nifi quod calyx in tubum nimis angunum contractus fit. Contra, in Lobelia occidentali, omnia alia funt: nam livic $1^{\circ}$. corolla aliter divifa; $2^{\circ}$. calyx in fructu nullus, led margo faltem brevillimus in-: xqualiter quinque dentatus; $3^{\circ}$. Drupa ovalis, glabra, nigra; \& $4^{\circ}$. P’utamen ovato acuminatum, tuberculis grandioribus undique muricatum. Conf. $P_{L} \cup M$. ic. t. 165. f. 1. JA C Q.'aner. defcript. \& t. 179. f. 88. Hinc Lobelia Taccada, fi non pro diverfa fpecie, faltem pro infigni varietate habenda erit. 


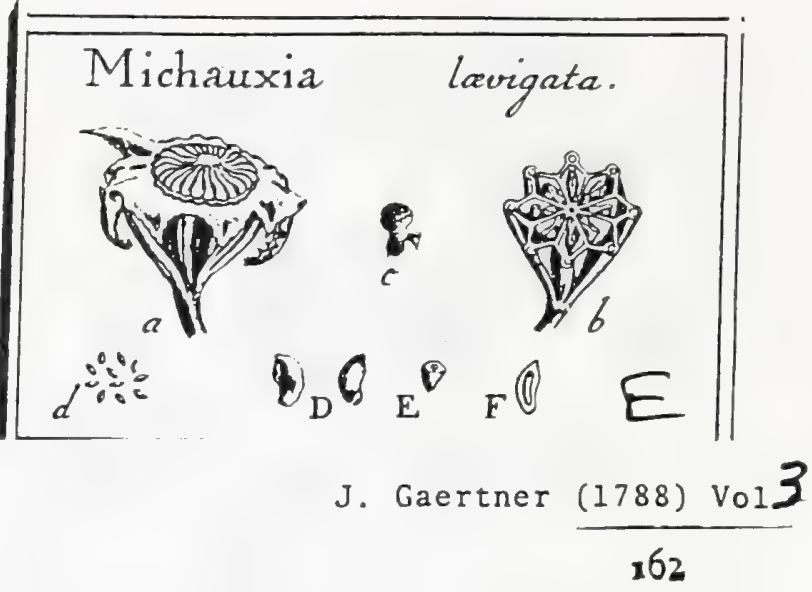

r25. M I C H A UX I A.

L'Herit. monogr. Ait. hort. helv. 2. p. 8. Schreв. gen. 1769. Lamaвск ill. gen. t. 295. Mindium. Adans, fam. p. r 34 .

$$
\text { Juss. gen. } 7.164 .
$$

Cal. fuperus, 8. 1. 16. fidus, perfiftens. Cor. monopetala, rotata; tubus breviflimus; limbus octofidus, calyce major: laciniis patentiffimis, apice revolutis. Stam. 8.; filamenta brevia, fubulata, ovario adnata, bafi in membranam con!iventem cordatam dilatata; antherx longiffmx, lineares, erectx, ftylo adpreffx. Ovar. inferum; ftylus ftaminibus longior, cylindraceus, furfum pubefcens; Atigma ofto-partitum : laciniis fubulatis, revolutis. Capf. inverfe conica coriacea, octo-coltata, octo-locularis. Rec. fungofa, ex angulo loculamentorum prodeuntia. Semina numerofa. Alb. carnofum. Emb. oblongus, rad. centripeta.

Michauxia lxvigata. Tab. 211. fig. 6.

Michurnia foliis radicalibus ovatis ferratis, canlinis oblongatis femiamplexicaulibus; caule laevi gluberrimio. VENT.: bort. celf. p. 8I. PERSUON fyn. I. p. 418 .

Ex horto Celfeano.

PER. Capfula cor:acea, inver fe pyramidata, truncata, in vertice filamentorum reliquiis radiatim comniventibus crifpata, calycis laciniis perfiftentibus revolutis fpinulisyue cincta, octoguna 1. potius ucto-coltata, '\& fulcis profundis cum cultis altermantibus exarata: cultis incrallatis, rotundatis, intus fubltantia nivea repiecis; cacterum glabra, fpadiced, l. ferruginea, otholoculatis. Diffepimenta membranacea, fulcis externis inferta. Loculamenta angulata, cuneiformia, ad verticen dehufcentia?

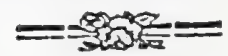

R ec. ad medium aren in ipfo loculamentorum angulo pedunculo brevi radicat3, ovata, deorfum procefu ninore rotundato aucta, intra loculamenta libere prominula, comprefliufcula, fcrobiculato-pundata, fungofa.

SEM. numerofa, parva, oblonga, l. ovata, utrinque acuminata, angulata, ab adjacentibus curvata \& compreffiufcula, fpadicea, l. dilute ferruginea, ad unbilicum colore obfcuriore tincts.

I s T. fimplex, crultaceum, difficulter feparandum.

A L в. Cemini conforme, carnofum, album.

E B. tereti-oblongus, albunine brevior, rectus, centralis, erectus, molliufculus, \& fere madullaris. Coty $\%$ brevilfamx, obtufx. Rad. longa, teretioblonga, ubtufa, umbilico externo obverfa, centripeta.

\section{EXPLICATIO FIGURE.}

-) Capfula integra. b.) Eaden transwerfe لjiftecta, cum forms ac Gita loculamentoram \& receptaculorum, c.) Receptaculusn fingulum feparatum. d. D.) Semina foluta. E.) Albumea transverfe fealum. F.) Ejusdem fectio longitudinalis, cum fim \& forma Embryonis.

In capfulis bene maturis nullibi dehifentix locum detegere valui.

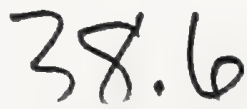




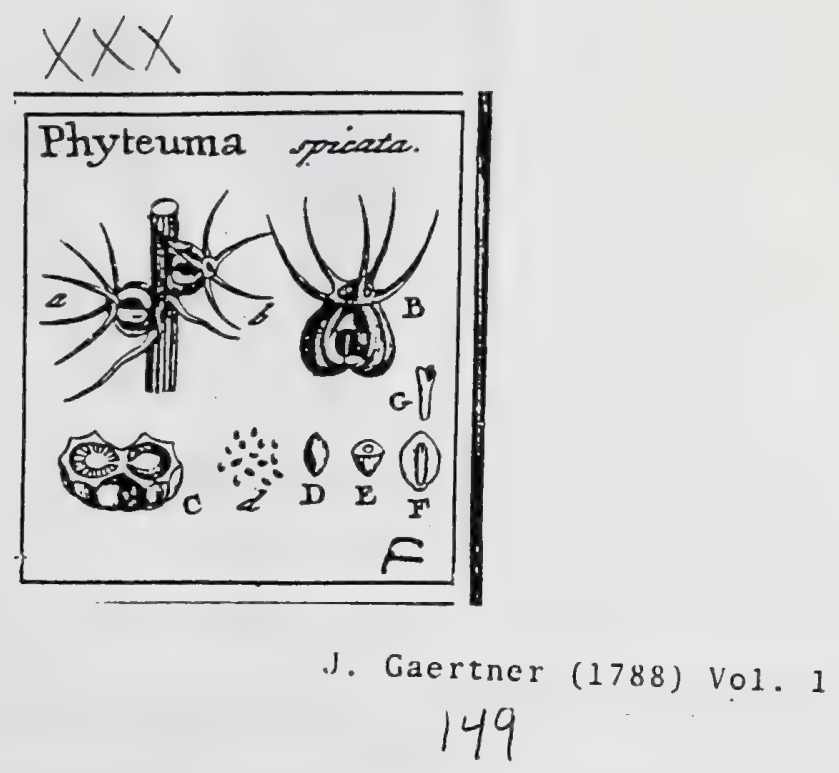

CLXXX. PHYTEXMA. LinN. gen. 220. Rapanculus. T o uR N. t. 38 .

Calyx fuperus, dentibus quinque fubulatis. Cor. monopetala, profunde quinguefida. Stam. quinque. Styl. unicus. Capfula infera, bi-l. trilocularis : foramine laterali dehiscens. Recept. mediante lamina cum diffepimento colıxrentia.

РнхтеймА fpicata. Tab. 30. fig. 6.

Rapunculus corniculatus, fpica longiore. $\mathrm{R} I \mathrm{v}$. monop. t. Iog. $f .2$.

Rafunculus foliis radicalibus cordatis, tubis bicornibus revolutis. HALL. hif. I. n. 684 .

Phyteuma spica oblonga, cap fulis bilocularibus, foliis radicalibus cordatis. L1 NN. fill. veg. 212.

ICON. O E DER. flor. dan. t. 362 .

150

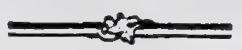

PE в. Capfula infera, membranacea, tenuițuna, dentibus calycis radiantibns coronata; pyramidaro globofa, profunde bifulca, contis in fingulo lubo tribus, 1. quinque acutangulis exarata, bilocularis, foramine rotundo datcrali intcr lobos dehiscens.

REC. oblongum, carnolum, tuberculatum, diflepimento utrinque ope tenuis laminz intergerinx longitudiualiter affixum.

SEx. numerofiffuma, parva, ovata, fubangulata, glabra, nitila, fubferruginea, apice \& bafi faturatius colorata.

IN T. fimplex, fubineinbranaceum, terive.

$\Lambda$ L. femini conforme, carnofun, pallidum.

E 3 в. dicotyledoneus, teretiusculus, longitudinc albuminis, niveus. Cotyl. Icmiteretes, breves. Rad. longa, centripeta.

2.) Caprula integra. b. Б.) Eadem foramine in utroque Iatere deliscens C.) Ejus ferio transver(alis, cum receptaculi infercione, d.D.) Seruina feparata. E. F.) Alouminis feliones, cum atu Ėmbryonis.

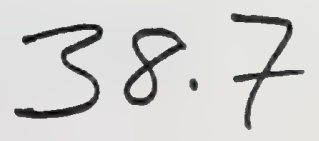




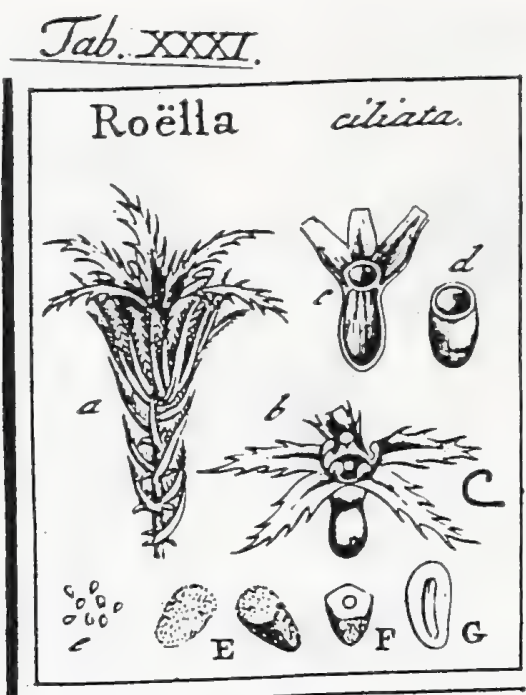

J. Gaertner (1788) Vol.1

154

CLXXXVII. ROELLA. LINN. gen. 219.

Calyx quinquepartitus, fuperus, laciniis magnis pinnato dendatis perfiftentibus. Cor. monopetala iufundibiliformis. Stan. quinque: filamentis bafi dilatatis in fquamulas

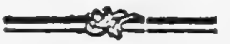

quinque, concavas, perfiftentes. Styl. unicus. Gapfula infera, unilocularis, apice amplo foramine pervia.

ROE l l a ciliata. Tab. 31. fig. 3 .

Campanula africana frutefcens aculeofa, flore violaceo. Соммвц. h. amfl. 2. p. 77 . t. 30 .

Roëlla foliis ciliatis : nucrone req̃o. LIN N. h. Cliff. tab. 35. fy/f. veg. 2 rr.

PER. Caplula infera, calycis foliolis pisnato dentatis rigidis, \& intra hrc, Starninum fquamulis quinque in cupulam hemispharicam bafi coalitis, coronata, ovato-cylindrica, unilocularis, apice foramine amplo rotundo dehifcens.

REc. funiculi aliquot tenuifimi, e vertice capfula deörfun penduli, quoruä ramulis femina affixa.

SEM. plura, fubovata, angulata, punctis elevatis fcabrata, ferruginea.

IN T. duplex: exterius coriaceum, craftusculum; interius tenuilinum.

A \& B. fenini conforme, carnofum, pallidum.

E M B. dicotyledoneus, fliformis, niveus. Cotyl. femiteretes. Rad. longa, receptaculo obverfa.

a.) Caprüla (erminalis, foliolls circumvallaca. b.) Eaden denudata. c.) Ejus fetio lorigitudinalis, \& d.) transverfalis. e.E.) Semina folut2. F.) Semen transverfe ferlum G.) Ejusderi \& albu. minis fectio longitudinatis cum fitu embryonis.

In maturis capfulis, quas folas videre mihi hactenus contigit, uullür diffepimenti adef veftigium, neque etram receptaculun feminum fatis diftincte apparuit. EIN. Neus caplulan dicit bilocularem; \& Bergius pl. cap. 42. fubbilocularem; fed uterque de receptaculo filet. 

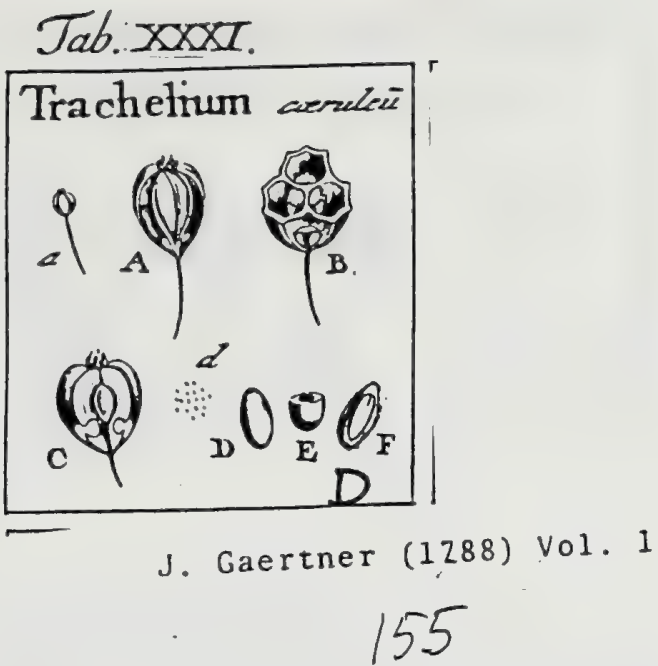

CLXXXVIII. TRACHELIYMM. T OuR N, t. 50. LinN. gen. 221.

Calyx brevillinus quinquedentatus fuperus. Cor. infundibuliformis, tubo gracili. Stam. quinquc. Styl. unicus, fine globolo. Capfula infere, trilocularis, bafi foraminibus dehifcens.

Trachelius cxruleum. Tab. 3t. fig. 4.

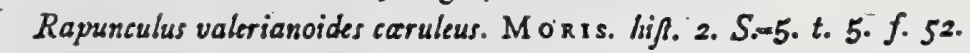

Trachelium ramofun ereaium, foliis ovatis ferratis planis. LiN N. Jyfl. veg. 212.

PER. Caplula infera, calyce brevi coronata, parva, fubglobola, rotundato trigona, \& ob latera deprefta, quafi triloba, ad lobos triplinervia, trilocularis, tribus prope bafin foraminibus dehifcens.

REc. ovato globofum, parvum, Frobiculatum, finguli loculamenti angulo interno circa unedium adnatum.

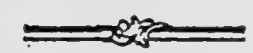

SE 31. humerola, minutula, oblonge elliptica, lenticulari compreffa, glabra, lucida, pallide ferruginea.

IN T. duplex : exterius chartaceum, fragile; interius araohnoideum.

A г в. femini conforme, carnofum, albuin.

Eм в. dicotyledoneus, rectus, niveus. Cotyl. femiteretes, breves. Rad. craffius. cula, longa, centripeta.

a. A.) Capfula integra. B.) Eadem difrett2. C.) Ejus loculamentum anterius apertam, cum fita receptaculi \& foraminum. d. D.) Semina feparata. E. F.) Seminis feftiones, cum fitu \& figura embryouis intra albumen.

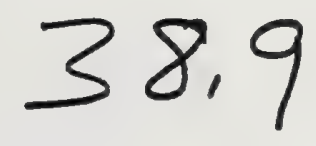


-

-

- 


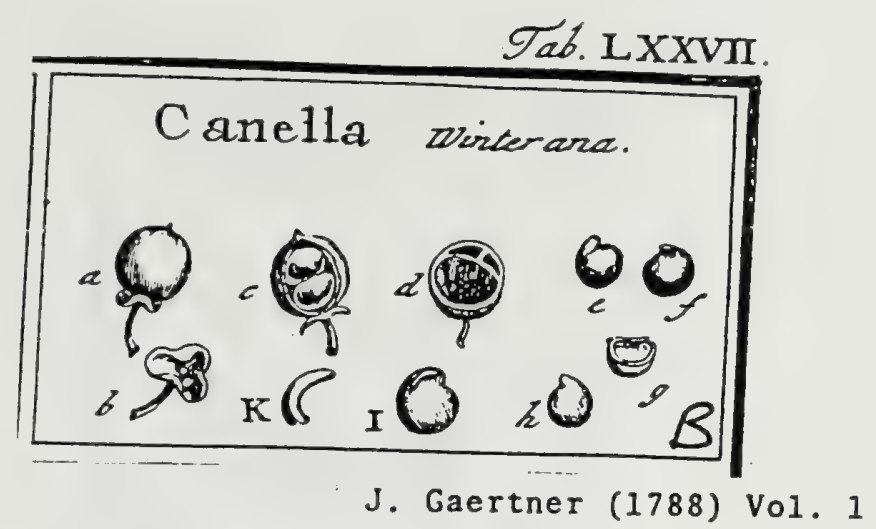

\section{CCCCLXXXVI. CANELLA. Brown.}

Calyx monophyllus, patens, rotunde trilobatus. Cor. pentapetala. Nectar.. urceolatuin, antherigerum. Antherz duodecim. ad viginti.. Styl. unicus. Bacca trilocularis. Semina geminata, nitida.

CANElLa Winterana. Tab. 77. fig. 2.

Canella foliis oblongis obtu/is nitidis, fructu viridi calyculato racemofo. B R 0 W. hif. jam. $275 \cdot t \cdot 27 \cdot f \cdot 3$.

- Winterania. L I N N. Jilf. veg. ed. 13.p. 36g. Juppl. 247.

Canella albr. MUR R A $1 . \sqrt{ } y$ f.. veg. 443.

Ex herbario Rankfiano.

PE R. Bacca globofa, carnofa, glabra, nigra, trilocularis: loculamentis uno aut duobus fxpe abortientibus.

$R$ Ec. angulus loculamentorum centralis, cui femina affixa.

SEM. in fingulo loculamento regulariter duo, pro abortientium ovulorum \& Joculamentorum numero varie formata, plerumque globola, rofellata; lemper glaberrima, nitida, atra.

IN T. duplex: exterius cruflaceum, tenue, fragile; interius rufefcenti fpadiceum.

AL B. femini conforme, carnofum, duriusculum, aqqueo pallidum.

E.s B. exiguus, curvatus, teretiusculus, in feminis roftello locatus; luteus. Cotyl.3tiat?

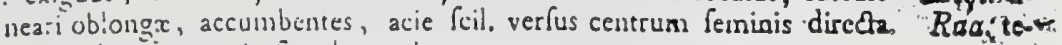
retiuscula, lupera \& limu' centripcta.

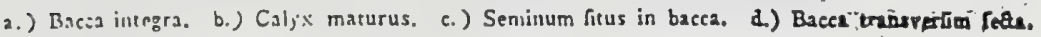
c.f.) Scmina feparata. g.) Semell transicerfe fettum. h.) Albumen desudatum Ly Eubryonds fitus in aljumine. 1.) ISe:il feparatus.

Winterana vera Offic. \& Solandri, qux Drgmis Forferi, diverfifuni generis planta colt. 
$-$

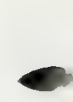

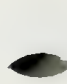




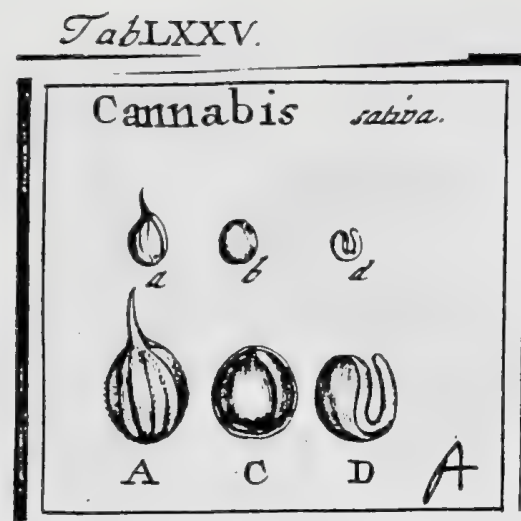

J. Gaertner (1788) Vol.1

\section{7}

CCCCLXIII. CANNABIS. TOURN. t. 308. Linn. gen. mis.

Flores fexu dinineti in feparatis plantis. Mas. Cal. pentaphyllus. Cor. nulla. Stam. quinque. Fras. Cal. monophyllus, oblongus, latere hians. Cor. nulla. Styl. duo. Nucula bivalvis. Embryo curvatus, inverfus.

CAXNAnis fativa. Tab. 75. fig. 1 .

Cannabis. BLA K w. herb. t. 322. a. b. HALL. hifl. 2. n. 1616. LINN. Jyft. veg. 886.

PEк. Nux parva, calyce perfifenti vefita, lenticulari globofa, tenuis, unilocularis, bivalvis.

REC. nullum,

SEM. Unicum, nucis cavitati conforme, fpadiceun, vel fi recens, viride.

I $\mathrm{T}$. fimpliciffmum, membranaceum, tenue.

A .. B. nullum.

Ex 8. magnitudine feminis, curvatus, inverfus, albus. Cotyl. ovatz, craflx; altera plano convexa, altera utrinque planiuscula. Rad. longitudine cotyledonum, tere. tiuscula, furfum incurvata, apiceın nucis refpiciens.

A. A.) Nucuia calyce velita, b.) Eaden denudata, C.) Semen intra nacis valvalam. 4. D.) Em bryo denudatus in fitu naturall.

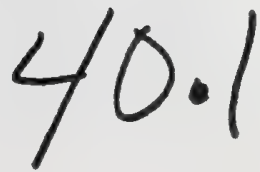


Cannabaceae

$\mathscr{T}_{a b} \mathrm{LXXV}$

Lupulus coñumsis.

= Humulus

J. Gaertner (1788) Vol. 1

358

CCCCLXIV. LVPVLVS. Tours. t. 309 .

Flores fexu diftincti in feparatis plantis. Mas. Cal. pentaphyllus. Cor, nulla, Stam. quinque. FEM. Arobilus ex fquamis membranaceis, ovatis, bafi involuto tubulofis, billoris. Cal. Squamula mocophylla, parva, obovata, ovarium externe amplectens. Cor. nulla. Sty $L$ dun. Semen unicum. Embryo fpiralis inverfus.,

LOPULUS communis. Tab. 75. fig. 2.

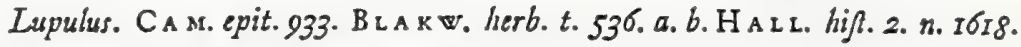

Humbulus. LIN N. $\left.\int \mathrm{g}\right]$. veg. 886 .

PER. nullum, nifi feminis tunicam rugolulam velis.

REc. nullum: femen fundo fquainx loralis affixum.

SEM. unicum, lenticulari globofum, margine acuto cinctum, apice compreffiusculum, fpadiceo-fufcum.

IN T. triplex: extimum membranaceum, rugofulum; medium crufaceum, tenue; in timum membranaceuın, extus viride \& areola chalaziua fufca in vertice notatum; intus fubcarnofum, album.

A I B. nullum, prater integumenti fuperficiem internam, fubcarnofam.

E s в. filiformis, fpiralis, albus. Cotyl. longifimx, lineares, utrinque planiusculx. Rad. brevis, teretiuscula, fupera.

a.) Strobilus fenineus, b.) Squama trobili folata femen involvens. c. c.) Semen foparatam. d. D.) Nucicus denudatus. e. E) Embryo nudus.

40.2 


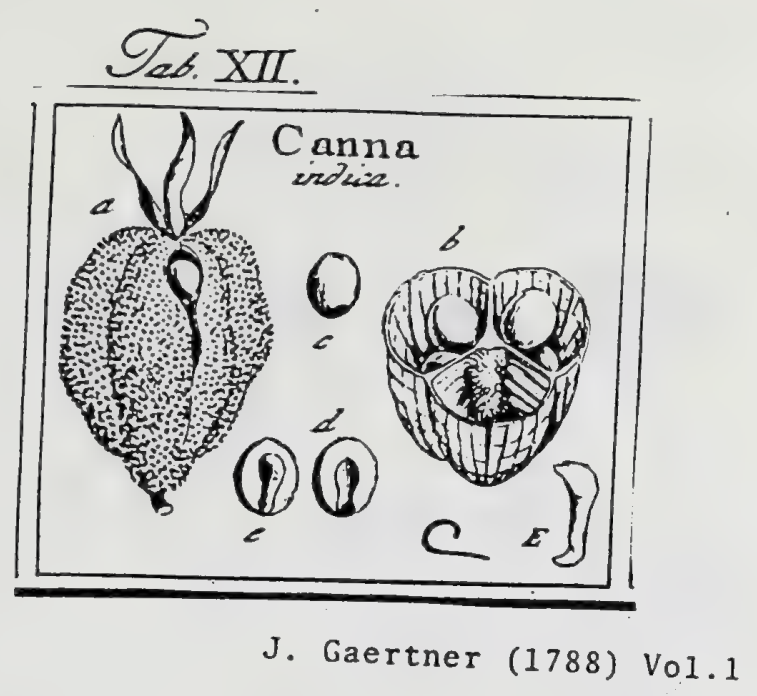

XLI. CANNA. LIN g. gen. I. Cannacorus. To $\mathrm{kN}$. $t$ Ig2.

Calyx triphyllus, perfiftens. Corolla monopetala, irregularis: limbo duplici Stam. unicum. Styl. fimplex. Capfula infera, trilocularis. Semina receptaculo centrali affixa. Albumen cartilagineum.

CANNA indica. Tab. 12. fig. j.

Gladiolus indicus. CA м. epit. $73^{\text {I. }}$

Canna indica. BesL. hort. Ey/l. Aut. IJ. t. I. 2. Rivin. monop. t. 'ITr. II2.

Canna foliis ovatis utrinque acuninatis nervojis. $\mathrm{L}$ in N. Syftveg. 50 .

PER. Capfula infera, membranacea, ovata, interdum fubturbinata, 'gibba, trifulca, extus fpinis mollibus feabrata, intus ftriis elevatis areolata, fubdiaphana, trilocularis, trivalvis Diffepinenta tenuifima, medio valvularum \& axi inferta.

R Ec. axis capfula fpongiofus \& villofus, cui femina horizontaliter affixa:

SEM. pauca, vix quina in fingulo loculamento, grandiufcula; globofa, glabra, nigricantia, aut teflaceo-fulca.

IN T. fimplex, coriaceum, nucleo arctiffune adnatom, umbilici canalem vagina invefiens.

A L B. femini conforme, cartilagineum, durifinum, album.

EsB. oblongus, cavitati albuminis refpondens, lacteo albicans. Cotyledon fublancea lata, craffa, carnola, fubinflexa. Radic. teretiuscula, bafi incurva, centripeta.

a.) Capfula matura, fcabra, b.) Eadem transverfe sefta, \& delapfis fponte acaleolis, in areolas quadratas difparita. c.) Semen (eparatum. d.) Idem verticaliter diffedum; ex altera parte albuminis cavitatem \& ex altera embryonem paturali magrisudine inura inam.locatum oftendens. E) Em. bryo feparatus \& infigniter aulus.

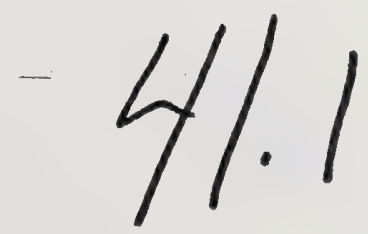


8

$\checkmark$

$\checkmark$

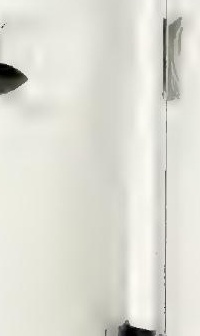




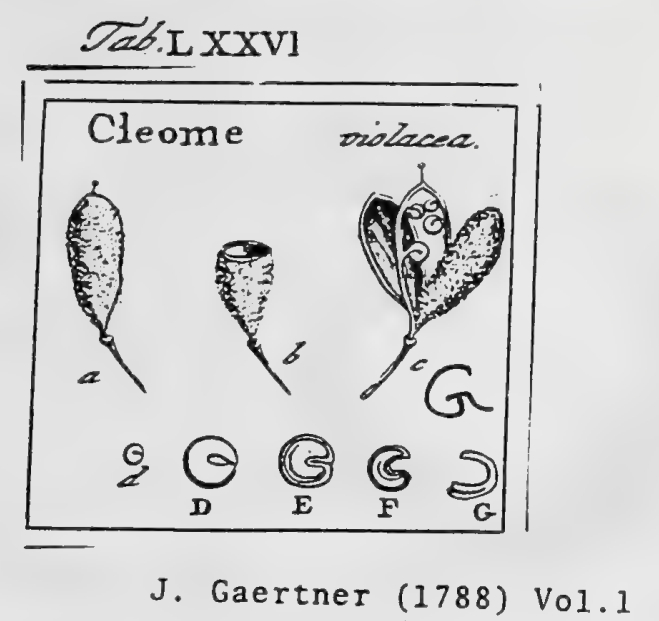

CCCCLXXIX. CLEOME. LIN ger. 826 .

Calyx tetraphyllus. Cor. tetrapetala. Stam. fex ad viginti quatuor. Styl. unicus: Capfula filiquefa unilocularis. Semina reniformi globofa.

Cᄂ fo me violacea. Tab. 76 . fig. 6.

Sinapin rum trifoliatum. Riv. tetrap. t. 75. f. 2.

Cleome floribus hexandris, foliis ternatis folitariisque: foliolis lanceolato-linearibus integerrimis. LI N

PER. Capfula filiquofa, fubpedicellata, oblonga, obtula, lenticulari comprefta, villofa, unilocularis, bivalvis.

REc. filiforme, valvulis interpofitum, funiculos umbilicales introrfum emittens.

Ses. duodecim, aut plura, fubglobofa, utrinque foveola depreffa \& verfus umbilicum acuminata notata, glabra, rubro ferruginea.

IN T. triplex : extinum tenuiftunum, vix nif fcalpendo perceptibile (in aliis autem pilolum ); medium crufaceun, tenue, fragile; intimum membranaceun.

$\Lambda$ L B. ferninis cavitati conforme f. femilunatum, carnofum, tenue, pallide lutefcens.

E M B. teretiusculus, femicirculari arcuatus, luteus. Cotyl. oblongx, plano- convexx. Rad. tereti attenuata, fuperiorem feniuis partem tenens, centrifuga.

2.) Capfula e minoribos, alias duplo I. triplo longior. b.) Eadem difreta. c) Eadem dehircens, cum feminibus receptaculo affixis. d. D.) Semen feparatum. E.) Albumen denudatum, F.) Embryo intra albumen, G.) Idem feparatus.

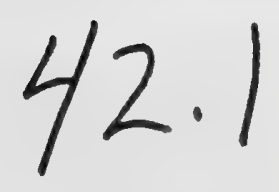




\section{Morifonia}

anericana.
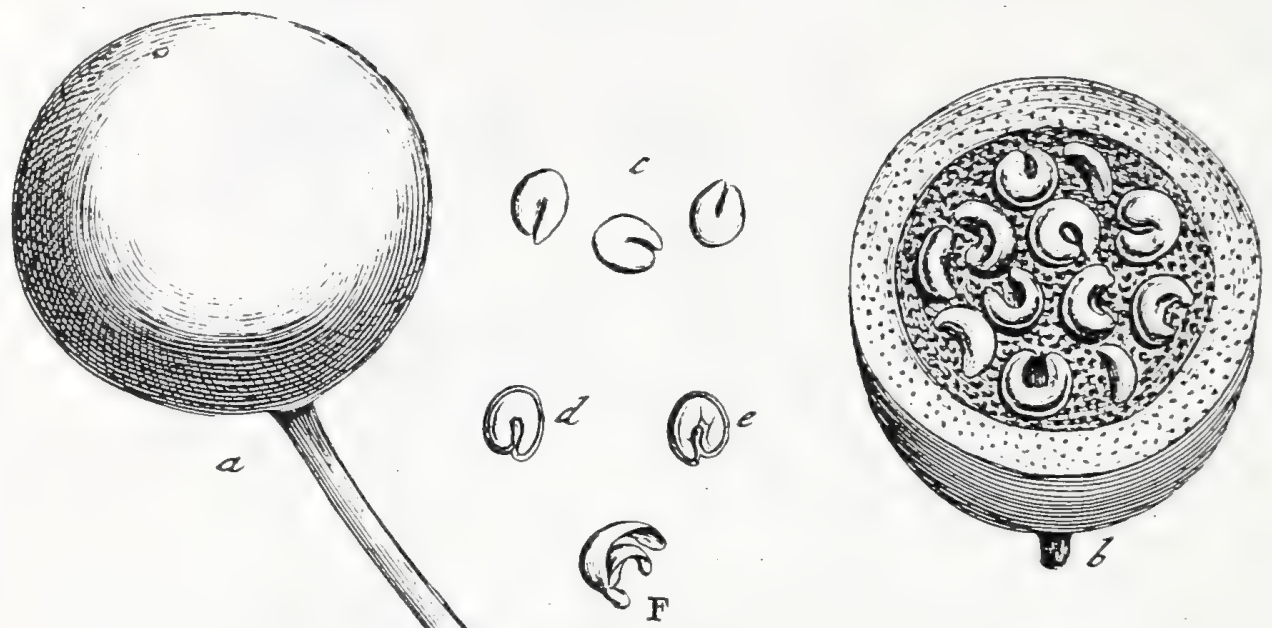

J. Gaertner (1788) Vol.1

$$
738
$$

CCCCXCIV. MORISONIA. P I UM. gen. t. 23. LrN gen. 6q.

Calyx monophyllus bifidus. Cor. tetrapetala, Stam. plura, bafi inter fe connata. Styl. unicus. Bacca corticata, pedicellata, unilocularis. Semina plurima, uiduJantia.

MORISONIA americana. Tab. 78. fig. I.

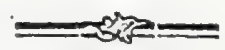

Morifona arbor, nucis juglandis folio. Prux. ic. t. 203.

Morifonia americasa. JAce. hifl. ancr. 156. t. 97. LIx s. fyfl. veg. 632. E cullectione Bankfiana.

P ER. Racta fupera, fplixrica, unilocularis, longifinue pedicellata. Cortex coriaceus, durus, craftus, extus punctis fcabratus. Caro fungola, alba. Pedunculus bacca duplo longior, punctis callofis confperius \& ad bafin, geniculo tumido, Rriato, \& tuberculorum minutilfimorum ferie coronato, inftrudtus.

REc. nullum; femina in omnem directionem carni baccx inmerfa.

SEM. numerofa, grandiuscula, fubreniformia, glabra; albida aut rufefeentia.

INT. duplex: exterius crufaceum, tenue, fragile; interius tenuiftimum, pallidum. $A \perp B$. nulluin.

EM B. Inagnitudine feminis, curvatus, lacteus. Cotyl. amsgdalino-carnofx, fubfoliacex, extus convexx, intus concavx, rugatx, varie convolutx. Rad. brevis, fubfufiformis: raga.

a.) Bacea integra, b.) Eadem transverfe fetta, cum feminum fitu naturali. c.) Semina feparata. d.) Nucleus drnudatus, rclitta ejus membrana propria. e.) Embryonis fitus intra femen. F.) Embryo feparatus. 


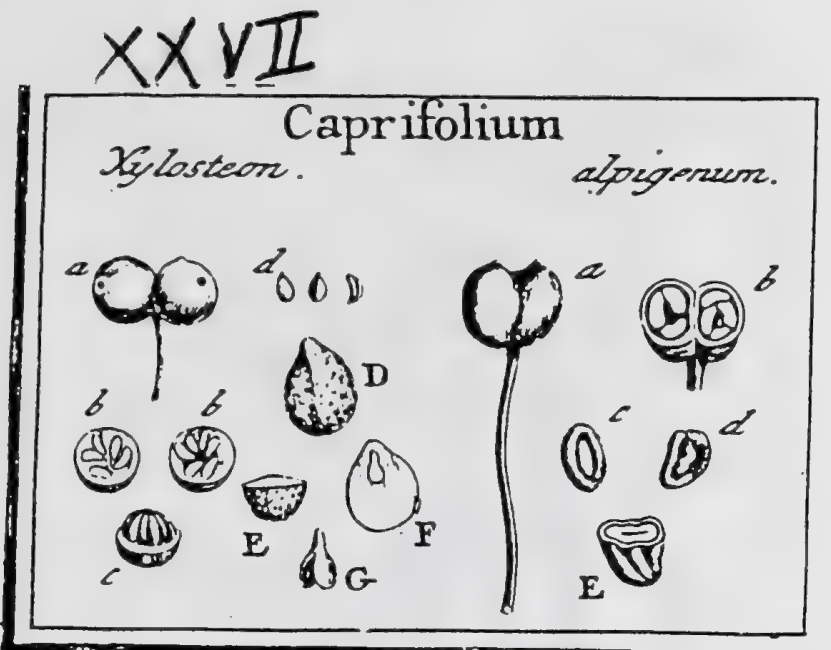

Caprifoliaceae

J. Gaertner (1788) Vol 1

\section{CAPRIFOLIUM. Tour N. t. 378. Lonicera. LIN $\mathrm{I}$.}

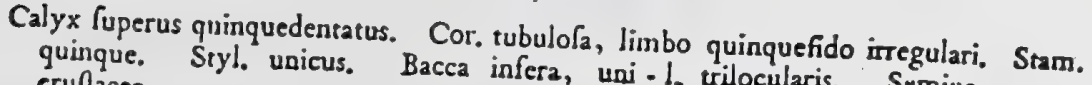
crufacea. Styl. unicus. Bacca infera, uni-1. trilocularis. Semina pauca,

Cafrifolium Xyloneum. Tab. 27. fig. 6.

XIlofleum. RIVIN. monop. t. I20. OEDER. flor. dan. t. 808 .

136

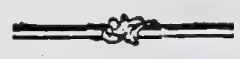

Caprifolium foliis ovatis acuminatis Jubhirfutis, baccis gemellis. HALL. hif.t. n. 677 .

Lonicera pedunculis bifloris, baccis diftinctis, foliis integerrinis pubescentibus. LIN N. fyf. veg. 216 .

PER. Bacca infera, fphxrica, calycis rudinnento coronata, rubra, aqueo-pulpofa, fub. transparens, unilocularis.

REC. nullum; femina undique carni adnata,

$\mathrm{S}$ Ess. fex, ad duodecim, nunc absque ordine, nunc in orbem pofita, fubcartilaginea, dura, compreffiuscula aut angulata, rubicunda.

IN T. duplex: exterius crufaceum, craffum, punctis minutifimis fcabratum; interius inembranaceun, tenuifinum.

$\Lambda$ \& s. Sernini conforme, carnofum, duriusculum, pallidum.

E м в. dicotyledoneus, inverfus, dimidio slbumine brevior, lacteo albus. Cotyl. folia:cex ellipticx. Rad. teretiuscula, fupera.

a.) Frugus integer. b. b.) Bacen immatura transverfim refla, parium feminum fitum oftendens, c.) Aliz bacca, eum (eninibus in orbem pofitis. d. D.) Sennina feparata, varix figurz. E.) Se men transverle fettum. F.) Ejus \& albumiois fettio verticalis, cum titu embrjouis, "G.) Embryo Separatus.

Baccan trilocularem, quam AdANsosus $X y l o j t e 0$, aut bilocularem, quan univerfo Lonicerx fux generi LiNNeus perperam tribuit, mihi videre nunquam contigit.

Caprifoltum alpigenum. ibid.

Xylofeun folio cerafi. R I v. monop. t. $12 \mathrm{~T}$.

Caprifoliun foliis ovato lanceolatis, bacca fingulari, bicolli, biflora. HALL. hifl. I. n. 675 .

Lonicera pedunculis bifloris, baccis coadunatis didynis, foliis ovali lanceolatis. L 1 N N. Syft. veg. 216 .

Icon. J A c C. aufir. 3.t. 274 .

Baccs longe pedurrculata (a.), ovata, bicollis, rubra, ex dualus haccis confata, quarum "ringula manifettillime trilocularis." Loculanicr.ta proprít membranâ vollita, \& a feminibus undiy̧ue difcreta; per inaturitateın vero nomuunquam obliterata (b.). Sensisa in quolibet loculamento regulariter duo adeoque is usiverfo fructu duodecim; ex his auten sonnifi tria, aut duo faltem maturestunt, atque hac grandiuscula (c.d.), Subovata, craffa (E.), glaberrima, pallide fraıninea, hine convexa, aut irregulariter gibba, inde plana aut fubconcava, nitida. Albumen carnofum. Einbryo minutulus, inverfus. Cotyl. brevifinnx. Rad. Subglobofa.

Propter baccas manifene triloculares \& femina libera, nitida, poffet laxe praeunte Auansono, a reliquis Caprifoliis, nomiue Ifica, dintingui. 


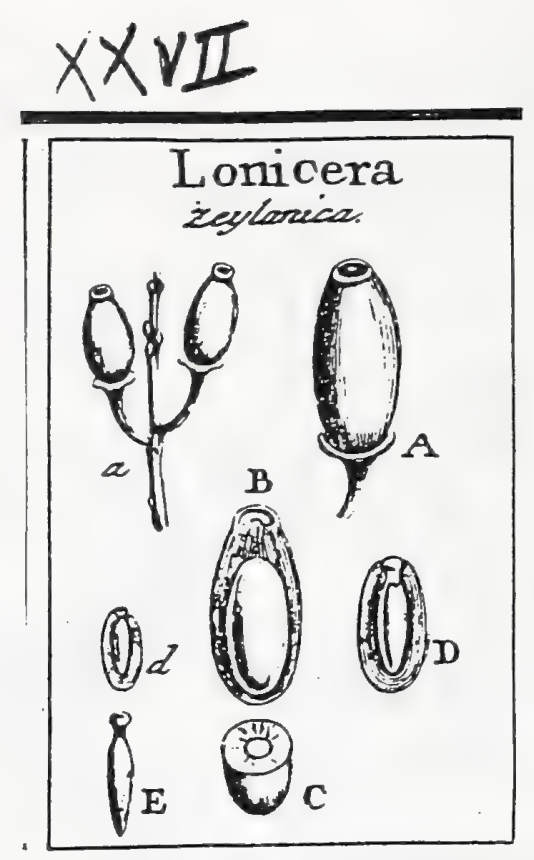

Caprifoliaceae

J. Gaertner (1788) Vor. I

132

CLVIII. LONICERA. P L U M. t. 37. Loranthus. LIN

Calyx fructus inferus; floris nullus. Cor. fexfida. Stam. fex. Styl. unicus. Bacca infera, unilocularis, monofperma. Embryo monocotylcdoneus imverfus.

Loxicra Leylanica. Tab. 27. fig. 2.

Vifcus fruftibus oblongis rubicundis, floribus oblongis tubulofis. Н в в ss. nuus. zeyl. 20. BUR N. zeyl. 229.

Pilila. Zeylonẹs. E collect. fem. hort. lugdb.

PER. Bacca infera, ovato cylindrica, carnola, unilocularis, primum rubicunda, tandem nigra; apice coronata annulo membranacco a lapfu corollx refiduo; bafiautem cincta difco orbiculato, edentulo, fubcoriaceo. Caro craffiuscula fernini undique adhzrens.

REc. nulluin.

SEs. unicum, elliptico fphxroideum, carnofum.

IN T. funplicifinum, arachuoideum, vel nullum.

A ₹ в. femini conforme, granulofo carnofum, durum, apice, pro transmittenda emsbryonis radicula, perforatum.

Eu в. monocotyledoneus, inverfus, viridis. Cotyledon longitudine fere albuminis, fubfufformis, folida, absque ullo divifionis veltigio. Rad. capitata, verticem al. buminis perforans.

2. A.) Barca integra. B.) Ejusdem fefto longitudinalis, eam femine in fitu aaturali. C., Semen feu albuaien transverie retum. a D.) Ejusdem fetio longitudinalis, cum futu embryosis. E.) Embryo Separatus.

Non ef Loranthus loniceroides LINN. cui flores fint in umbella pedunculata feffiles; neque etian cuin Loranthe americano confpirat, cui quippe baccz fint fphxricz \& su cyman dilpofitz, dun contra in noftra baccx habeantur ovales in racemo valde elongato. De genere autem Lonicerx Plunieri, noftram efle, dubium plane nulluin en: nam in P LU M. gen. 1. c. \& ic. t. 166. f. x. capitulum embryonis manifelte extra nucleum fuum perinde prominct.

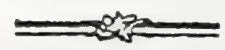

In cavitate albuminis vetufiorum baccarun fxpe refina cryftallifata, alba, pell ucida, Camplorx fumillima, fed ob ztatem odoris expers, reperitur.

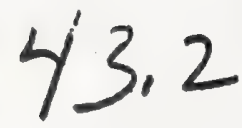




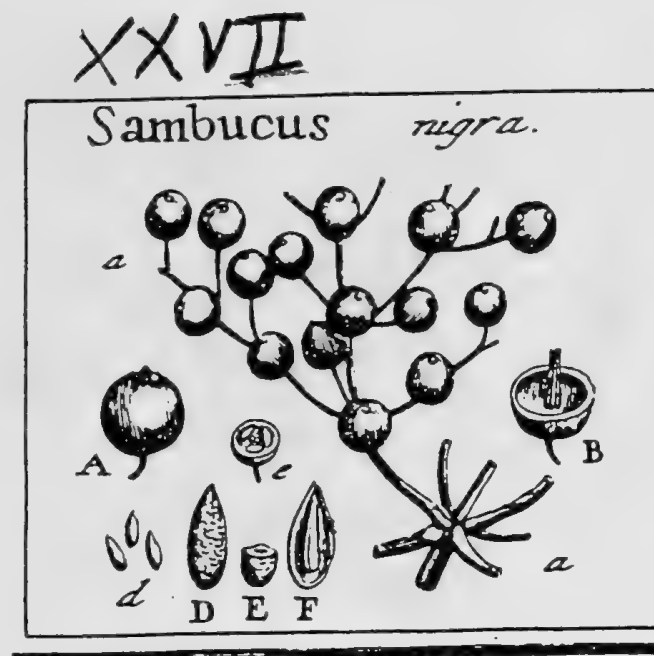

T. G.5emp/

J. Gaertner (1788) Vor 1

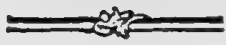

CLXIII. SAMBUCUS. TOURN. $t .376$. LIN ger. gen. $37^{2}$.

Calyx fuperus quinquedentatus. Cor. monopetala, femiquinquefida, regularis. Stam. quinque. Stigmata tria. Bacca unilocularis. Semina tria.

Sasbucus nigra. Tab. 27. fig. 7 .

Sambucus. R L А кw. herb. t. 151. OEDER. flor. dan. t. 545 .

Sambucus arborea, floribus unbellatis. H a L. hill. I. n. 670 .

Sambucus clymis quinqucpartitis, foliis pinnatis, foliolis fubovatis ferratis, caule arboreo. LIN N. f4ß. veg. 295 .

PER. Bacca infera, globola, calycis rudimento coronata, atra, pulpola, unilocularis. Pulpa fubaquola, rubra.

REC. funiculi tres, fliforınes, in axi baccx conflituti, apici feminum inferti.

SEM. tria, oblonga, furfum angufiora, cartilaginea, rugis minutilimis fcabrata, com. prefiuscula, hine leviter convexa, inde fubangulata.

IN T. duplex, exterius crultaceum, durum, crafrusculum; interius meinbranaceum, tenue, albuin.

A L B. Cemini conforıne, carnofum, album.

E ss 8. dicotyledoneus, inverfus, longitudine fere albuminis, lacteo albus. Cotyl. Lineares, planiuscula. Rad. longitudine cotyledonum, teretiuscula, fupera.

1. A.) Bacea integra. B.) Receptaculum feminurr. c) Baces transverfim feets, d. D.) Seminz feparata. E.) Semiuis (edio transverfalis. F.) Idem longitudinaliter diffetum, eum fitu embryonis intra albumen.

Sainbucus racemofa.

Baccx magnitudine grani piperis, fphxricx, rubrx, intra calycis rudimentum umbone nigro notatx. Pulpa fubaquofa, lenta, pallida. Semina tria, pripribus dimidio breviora, cetera vero eis per fingula puncta conformia. 


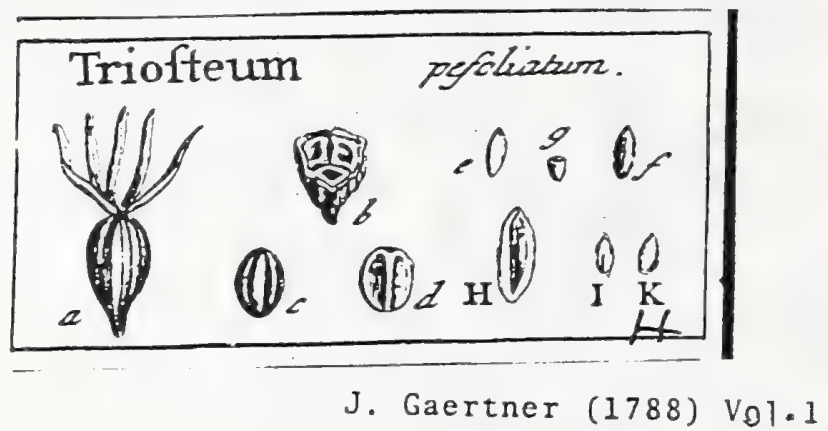

CLV. TRIOSTEUM. LIN . gen. 234.

Calyx fuperus, quinquefidus, longitudine corollx. Cor. monopetala, fubrqualis. Stam. quinque Styl. unicus. Bacca infera unilocularis. Seinima tria ollea, fulcata.

130

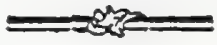

TRIOSTEU u perfoliatun. Tab. 26. fig. 8.

Trioficospernum latiore folio, fore rutilo. Diz L. h. elth. 394.t.293.f.378.

Iriofteum floribus verticilletis feffibus. LIN N. fyf. veg. 217.

P Eк. Bacca ovato globofa, calyce longo coronata, pulpola, lutea, unilocularis. Pulpa ante plenam maturitaten fpongiofa, feminibus arcte adnata.

REC. nullum; femina apice fuo axi fructus affixa.

SE M. tria, grandiuscula, oflea, elliptica, hinc convexa, tribus fulcis elevatis craffis exarata; inde obfolete angulata, aut planiuscula, unico fulco mectio elevato infcripta.

IN T. duplex: exterius ofleum, crafum; interius mambranaceum, aridum, fubfriabi. le, pallide ftrainineum.

A I B. oblongum, anguftum, hinc convexum, inde angulatum, carnofurn, durum, album, intus rima longitudinali incifum.

EM B. dicotyledoneus, inverfus, brevifinnus, in luprema albuminis parte hxrens, lacteo albus. Cotyl. ovatx, fubfoliacex. Rad. brevis, obtufe conica, fupera.

2.) Bacca integra, exarida. b.) Ejus atque feminum fectio transverialis. c. d.) Sernina ab utroque latere (pectata. e.f.) Albumen decorticatum. 8.) Ejus rectio transverfalis. H.) Idem longisudi. naliter apertum, cum fitu embryonis. I. K.) Embryo feparatus.

Neque hujus fructes femina plene matura ine obtinuiffe fufpicor.

$$
43.4
$$




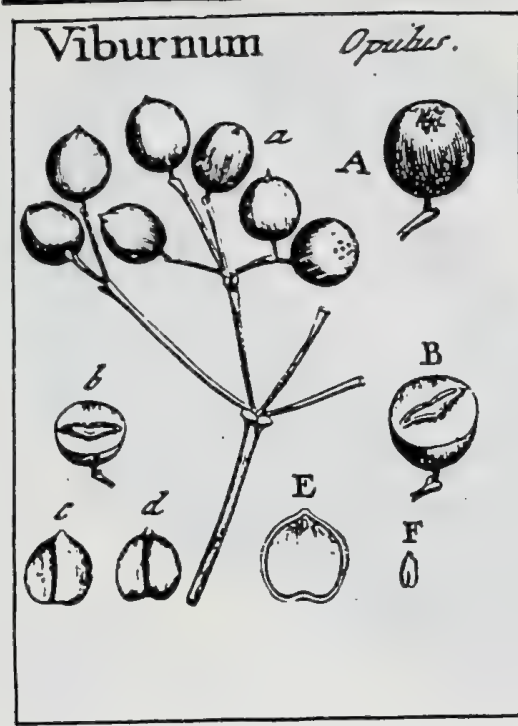

J. Gaertner (1788) Vol. I

133

\section{VIBURNUM. TOURN. t. 377. LIN ger. 370 .}

Calyx fuperus quinquedentatus. Cor. monopetala ferniquinquefida, Stam. quinque. Stigmata tria. Bacca infera monofyerna. Semen compreflum.

Viburnum Opulus. Tab. 27. fig.3.

Sqmbucus arbor rofea. Best. h. Eyfl. vern. Frut. t. Io. f. I.

Opulus. H А L. hif. I. "2. 668 .

Viburnum foliis lobatis, petiolis glandulofis. L IN Syf. veg. 294.

Icon OE DE R. flor. dan. t. 6бr.

PER. Jacca infera, globofa, fquamulis quinque minutiffunis calycinis coronata, carnofa, unilocularis.

REC. nullum; caro baccx femini undique adnata.

SEM. unicum, latitudine baccx, rotundato cordatum, compreflum, hine angulo obtufifimo prominulo, inde confinili fulco deprefto notatum, teftaceum.

IN T. duplex: exterius cruftaceo coriaceum, durum; interius membranaceum.

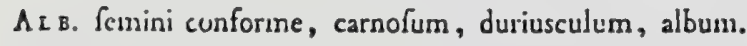

Ess в. dicotyledonets, inverfus, fubovatus, parvus, lacteus. Cotyl. brevifluma, obtufx. Rad. conica, craifa, fupera.

1. A.) Bacca integra. b. B.) Eadera cum femine transverfim feta. c.) Seminis pars ventralis. a.) Ejus dorfum. E) Ejus \& albuminis fealo vericalis, cum fitn embryonis. F.) Embryo feparatus

Paccx nunc fphoricx, nunc ovatx, ac utrxque vel lutefentes, vel c luteo \& rabro varix, vel \& totx rubrx funt.

Viburnum acerifolium.

Fruclus priori fimillimus, fed bacex paululum majores, atre, lucidx. Sernen rotundum, fupra leviter acuminatum, comprelfum, angulo interno obfoletifime. Albumen fubcartilaginemu; reliqua ut in priori.

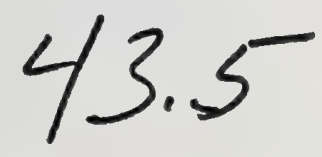


-

-

? 


\section{Caricaceae}

\section{Tar. CXXII}

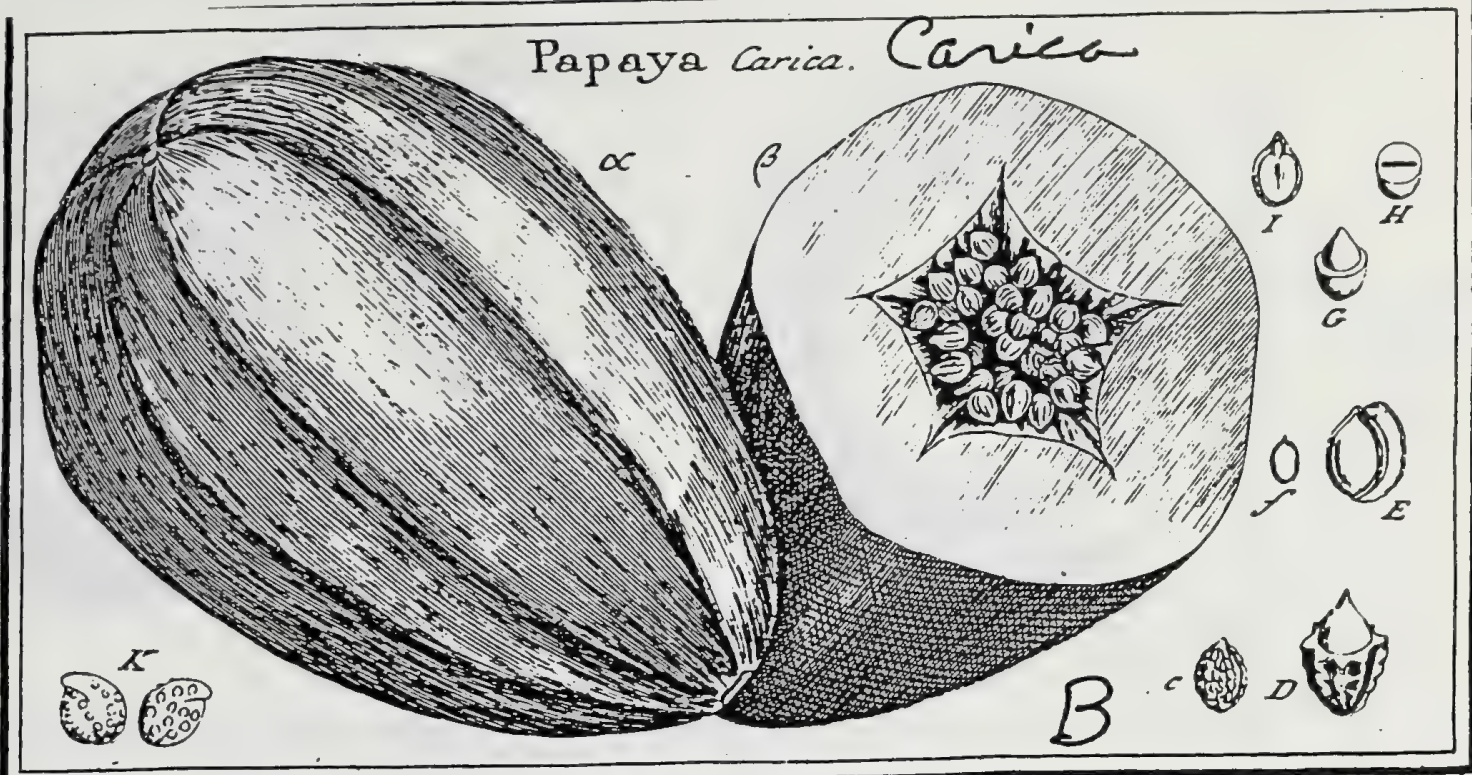

T.5.50ernis:

J. Gaertner (1788) Vol, 2

DCCVII. PAPAYA. TOURN. t. 44r. Carica. LINN. gern, II27.

Flores fexu diftincti in feparatis ftirpibus. MAS. Cal. quinquedentarus. Cor. monopetala, infundibuliformis , quinquefida. Stam. decem, altérnis brevioribus. FEM. Cal, quinquedentatus. Cor. pentapetala. Ovar. fuperum. Styl. quinque, ftrigmatibus dìlatatis ćtiftatis. Bacca carnofa unilocularis. Sem. numerofa, baccata, parietalia.

Papaya Carica. Tab..122. fig. 2.

Papaya - maram \& Ambapaya. RHEED. mal. T. to 15. f. 1. 2.

Papaya fructu oblongo melonis effigie. EHRET. decad. 1. t.7.

Carica foliorum lobis fintuatis. LiNN. fyff. veg. 891.

PER. Bacea grandis, ovata-, obfoletifrme pentagona, carnofa, unilocularis. Caro craffa, firma, fucco dulci fcatens. Loculamentum pentagonum, lateribus introrfum convexis, tuberculato - anfractuofis.

REC. nullum, preter internos bacce parietes, quibus femina affixa.

SEM. numerofa, ovato globofa, baccata, per exficcationem vero fulcato-tuberculata, ad alterum latus raphe umbilicali, valde prominente notata, fubfufca aut fumofa.

Ix T. quadruplex: $1^{\circ}$ ) Pellicula tenuis, diaphana. $2^{\circ}$ ) Subltantia craffa, olim mollis, fed in exficcato femine fungofa aut fuberofa, profunde \& itregulariter fulcata, ad alterum latus in raphem lamellofam planam extenuata. $3^{\circ}$ ) Tefta cruftacea, tenuis, fragilis, pallide lutefcens. $4^{\circ}$ ) Membran arachnoidea, ad bafin chalazxoparva albicante notata.

ALB. tefte cavitati conforme, fubdiaphanum, friabile, oleofo-carnofum. pallide albicans.

EM 8. magnitudine fere albuminis, lacteus. Cotyl. cordato-elliptica, foliacerc. tenuifímze, planx. Rad. teretiufcula, céntrifuga.

*.) Becer integra. B.) Eadem difrecta cum femirum fitu. c.) Semen feparatum D.) Ejasdem rabfantia funrofa ufque ad medium refect \& teftz pars fuperior denudata. E.) Eadem longitudinaliter difretz, eum nphe lamellario f.) Tefta feninis integrz. G.) Albumen luperae denudatum. H. Ii) Ejusdem fedio trasver(alis \& longitudinalis cum fitu \& figun Embryonic k.) Ovuli recentis figura magnitadine aueas.

Figuras a. f. k. ex Hort. mal. \& Ehretii decadibus mutuatus fum; fructum enim recentem ipfe.non, vidi. 


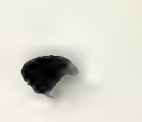

$-$ 


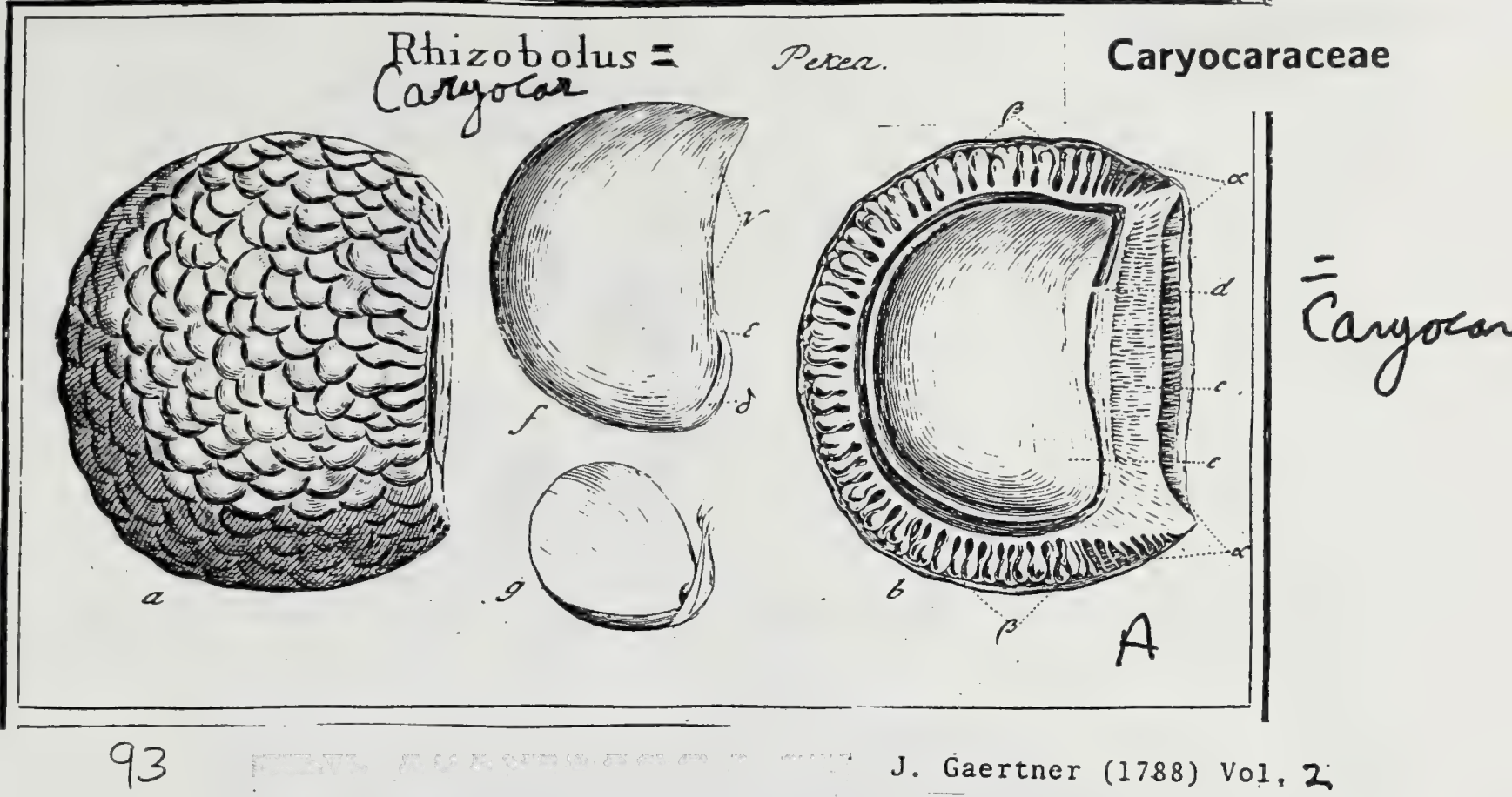

\section{R H I Z O B O L U S.}

$\mathrm{C}_{2 l y x}$ femiquinquefidus. Cor. pentipetala. Stam. numerofa. Ovar. quadrilobum fuperum. Styl. quatuor. Nuces quatuor uniloculares evalves mcnofperma.

Rнгzовогus Pokez. Tab. 98. fig. I.

Amygdala guianensis. BauH. bift. I. l. 3. p. 329. PLUK. plyzt. t. 323. f. 40

Amiygdalus grastatenfis. 'JONST. dendr. t. 42.

Pekea tuberculofa foliis digitatis, Jubtus tomentofiss. AUBL. griass. 597. t. 239.

Oronocco - moten. Belg. curaffav.

PER. Nuces quatuor, aut pauciores, grandiufcula, tuberculate, fubfemilu11atx, hinc infigniter gibbx \& globofe turgidx, inde compreffrufculx \& in marginem rectilineum, rimaque incifum conniventes. Putamear crafifirmum, ex duplici fubftantia conflatum : altera ligneo corticofa, fufcoochracea, fragili, exteriore; altera interiore, cartilagineo membranacea, tenaciffima, rufefcente, extus numerofifimis procelfibus clavatis, tuberculatis, fubulatis, aut aliis, intra corticalem fubftantiam alte demerfis atque ruffo ferrugineis muricata; intus autem glaberrima atque ipfum nucis loculamentum formante.

REc. commune, columna centralis quadrialata, alis fuberofis, rimam nucum intrantibus atque circa feminis latus internum ampliato \& fpongiofo fine fe diffundentibus: propriwn; funiculus umbilicalis fetaceus, brevifimus, ex modo dictis alis oriundus, atque feminis integumento interno infertus.

SEM. unicum, grande, fubreniforme, fuperne compreffo-mucronatum, ferrugineum.

IN T. duplex: exterius fungolum, tenue, rafile; interius nembranaceum, rufefcens.

A L B. nullum.

ENB. Renini conformis; lacteo albus. Cotyl. parvulx, ovato-lanceolatx, foliacex, nervo longitudinali extus notatx. Plums. nulla. Scaprs inter cotyledones atque radiculam medius, longiufculus; fubulatus, anceps.

94 Rad. omulum maxima, totam nuclei fubftantiam amygdaloideam efficiens, furfum adfcendens \& ad apicem feminis brevi mucrone terminata.

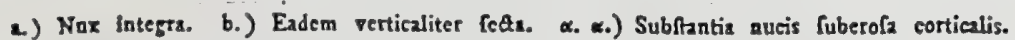
B. B.) Ejusdeun membrama cartilaginea cum procetrbus fuis multiformibut ofteis. - c.) Fragmentum receptaculi communis in riusa nucis hxrens. d.) Ejusdem expantio fuagofa curn funiculo umbiliesli. e.) Seunen in titu naturali. f.) Embryo denudatus, cum Radicula $\gamma_{0}$ ), Scapo $\left.\delta\right)$ Q cotyledonibus s.) in fitu \& magnitudine naturalio F.) Bafis radicula refecta, infertionena feapi oftendens.

In Rhizobolo butyraceo, cortex nucis mollis \& fere butyraccus eft-

Perfecte folidum effe nucleum $f$. radiculam illam prorfus fingularem, nec bipartibilern aut ulla rima incifum, uti ex Clufio, Bauhinus l. c. refert, iteratis experimentis abunde confirmatum habeo. Cetera, Nuces magnitudine \& tuberculis plurimum variant. Habeo monnullas pugnum fere xquantes, habeo \& alias dimidio minores; utrasque nutem vel tuberculaas vel absque tuberculis, prefertim e minoribus, qux fxpius totx glabre \& argutius femilunate func.

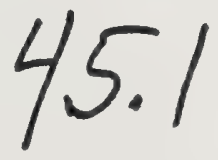




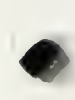

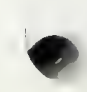

- 1 


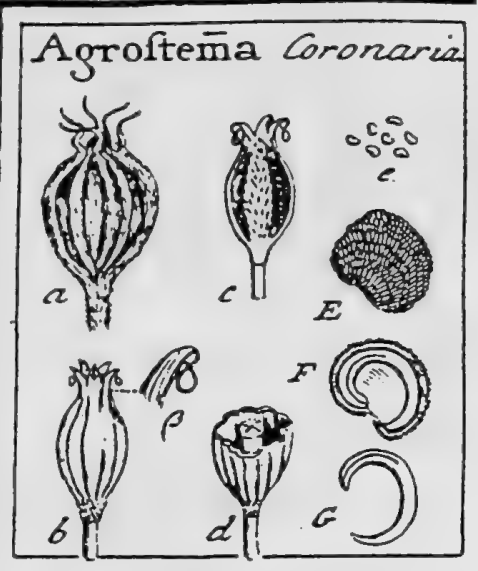

J. Gaertner $(-1788)$ Vol 2

\section{8}

DCCLVI. A GR OSTEM M A. LINN. gen: 583.

Calyx monophyllus, cubulofus, quinquedentatus, perfiftens. Cor. pentapetala, unguiculata : laminis: obtufis, indivifis; nudis aut barbatis. Stam: decem, fitu alternantia. Óvar. fuperum. Styl. quinque. Capfo unilocularis, apice quinquevalvis. Recept. columnare, liberun.. Sem. plurima.

Agrostemna: Coronaria: Tab. 130. fig. 1:

Iycbnis. CaM: epit. 569 - coronaria. DOD. Lempt. I70. BEsL. Ejyf. Afiv. IX. ti $s: f_{0}: 2=3$ :

Iychis tomentofa, calycibus coftatis, floribus: longifime: pedunculatis. HaIL. bift. n. 925 :

Agrofenmm tomento $\sqrt{a}$, foliis ovato-linceolatis, petalis enarginatis coronatis ferratis. LIN.N. Jyft. veg. 435 .

RER: Capfula calyce tomentofo decem coltato veftita; ovata, decem fulcata; unilocularis, apice: quinquefariam: dehifeens:- laciniis. fingulis ftylo indu. rato \& recurvato: terminatis.

R.E. columnare, cylindricum;, Iberum, diiffitum; longitudine fere capfula: SEM: numerofa, globofe - aut angulato - reniformia, tuberculis transverfis oblongis per feries parallelas digeltis: denfifime confperfa, e cinereo-nigricantia.

Iw.T. duplex: coriaceum atque niembranaceum.

A.LB.. farinofum, , niveum, centrale:

Eм в. periphericus, hemicyclicus, lutefcens. Cotyl. femiteretes. Rad: centri. peta.

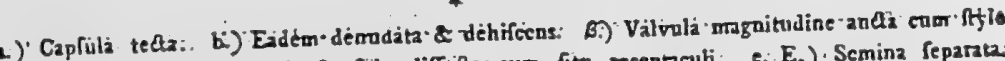

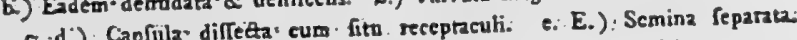

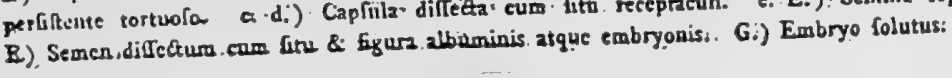

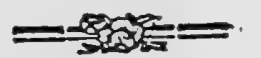

Ne unica quidem fatis idonea nota diftinctiva a Eychnide differt, mif haso 2 loculamentorum numero, fatis infido, in plura genera diferpere velis. 


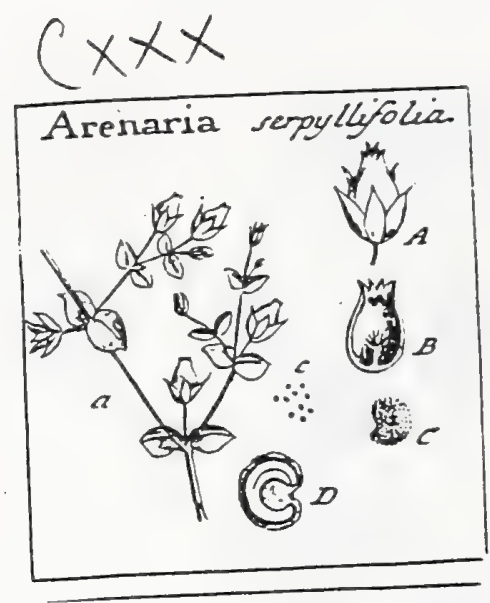

Caryophyllaceae

J. Gaertner (-1788) Vol 2

232

DCCLXII. A R E N A R I A. LINN. gen. 569.

Calyx pentaphyllus. Cor. peatapetala, laminis integerrimis. Stam. decem. Ovar. fuperum. Styl tres. Capf. unilucularis, apice dehifcens. Recept. mullum aut breviffmuns. Sen. plurima.

Arenaria ferpyllifulis. Tab. I;0 fig. 7 .

Alfine minor. Fuchs bif. lat. $=3$. germ. ic. 12.

Alfine foliis ovato - lanceolatis fubbirfutis, petalis calyce brevioribus. HaIL. bift. ง. 875 .

Arenuria foliis fubovatis acutis felflibus, corollis calyce bierioribus. LINN. Jyfo. ieg. 403.

PER. Capfula ovato - conica, calyec perfiftenti paulo longior, unilocularis, apice denticulis brevibus quinis aut fenis dehifens.

R gc. nullum aut breviffmum ex funiculis umbilicalibus fliformibus fafciculatis fundo capfulz infertis.

SEM. numerola, parva, reniformia, punctis elevatis feriatis minutiffuis confperfa, rufefcentia aut fpadices.

INT. duplex; utrumque membranaceum.

A L B. firinofum, album, centrale.

Ė в. periphericus, henicyclicus, lacteus. Cotyl. Feniteretes. Rad. inferocentripets.

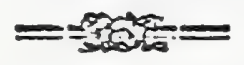

233

2. A.) Capfula fexfariam apice Jchifecas, B.) Receptace in fuado oapfula. c. C.) Semina (eparata. D.) Albuminis \& embryonis fitus atque Goura.

Ad Stellariam proxime accedit, ut folis petalis integris ab ea differat.

$46 \cdot 2$ 
Caryophyllaceae
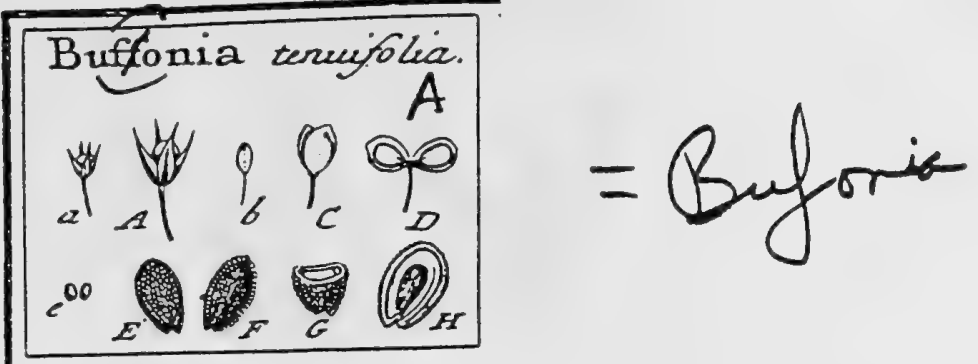

J. Gaertner (-1788) Vol 2'

220

DCCXLIII. B U F O N I A. LINN. gen. I68.

Calyx tetraphyllus. Cor. tetrapetala. Stam. duo aut quatuor. Ovar. fuperum. Styl. duo: Capf. unilocularis, bivalvis, difperna.

Bufronis tenuifolia. Tab. 129. fig. 1.

Polygonum angufifiniso gramineo folio erectum. MAGN. bort. monsp. 97. ic. 97. Alsme polygonoides tenuifolia, flofalis, ad longitudinem caulis velut in spicam difpofzitis. Plux. plyyt. s: 75, f. 3 .

Bufonia. LiNN. fy/f. veg. 167 .

PER. Capfula parva, ovata, compreffiufcula, unilocularis, bivalvis.

REc. nullum; femen Gngulum ope funiculi capillaris breviflimi fundo-capfula affixum.

SEN. duo, ovata, plano-convera, ad bafin emarginato-roftellata, punctis elevatis contiguis feabrata; fufca.

IN T. duplex: coriacéum atque membranaceum.

A L B. carnofum, aqueo-pallidum, centrale.

En в. periphericus, annularis, albus. Cotyl. lineares, incumbentes. Rad. filiformis infera.

2. A.) Frütus maturus cum calyce. b. C.) Capfula claufa \& dehifcens. D.) Infertip feninum in bafin eipfuix. e. E.F.) Semina ab utroque latere (peeata G. H.) Semen difrectum cum Citu \& figura albuminis atque embryonis.

46.3 


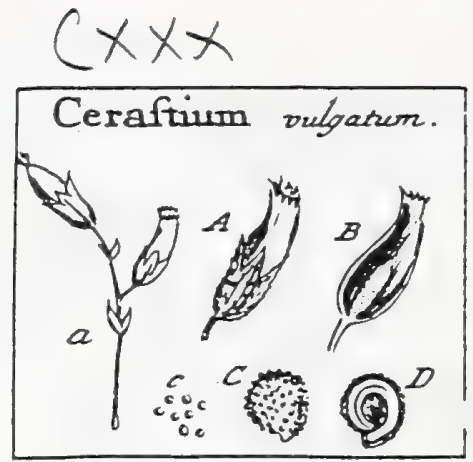

J. Gaertner (1788) Vol. Z

$$
231
$$

DCCLXI. C E R. A S T I U: M. IINN. gen 585*

Myolotis, TOURN: inft. to 126 .

Calyx pentaphyllus. Cor. pentapetala, laminis bifidis. Stan. quinque 1:. decem: Ovar. fuperum: Styl. quinque. Capf. unilocularis,, apice de: hifcens. Recept colunnare liberum. Sem. plurima.

Cerastjum vulgatum. Tab: 130. fig. 6 .

Myofotis arvenjis birrjita, parvo flore albo. Viall. garis. ti. 3202 f. It.

3\%

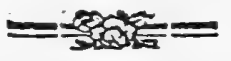

Rryofotis fuliis ounto lanceolatis, petalis calycis lungitudiue. HaLL. bijt. n. 893 .

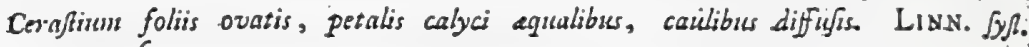
veg. 436 .

PER. Capfula oblonga, fubcylindrica, glabra, diaphana, tenuis, umilocularis, apice dentibus decem brevibus dehifens.

REc. columnare, liberum, teretiufculum, nudum, fcrobiculatum, longitudiue dimidiz circiter capfulx.

SE M. plurima, fupra quinquaginta, fubglobofa, roftellata, tuberculis difitis \& quafi fquamofis confperla, luteo-ferruginea.

INT. duplex: coriuceum atque membranaceum.

A L B. farinofum, album, centrale.

Eм в. periphericus, anuularis, lactens. Coty\% femiteretes. Rad. centripeta.

2. A.) Capfula claufa atque dehifocns B.) Capfula diffecta cum receptacula c. C.) Semina fsparnta. D.) Albuminis \& embrgonis fitus atque figura.

Alix fpecies capfulas oblongas, alix vero globofas habent. 
Tab. LXXVII.

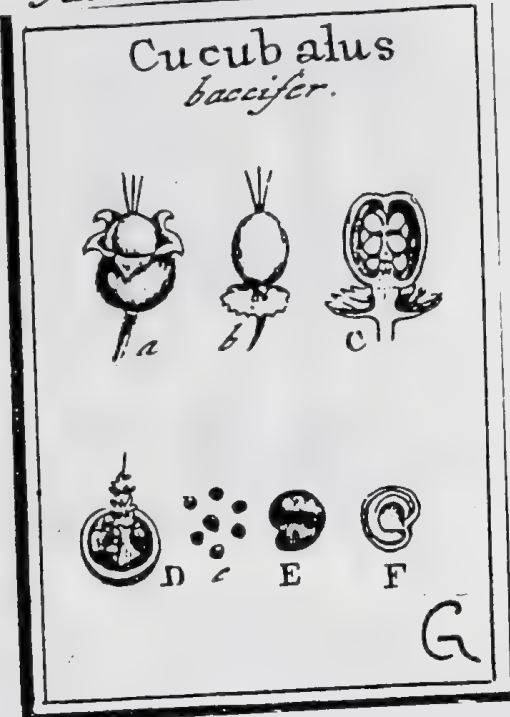

J. Gaertner (1788) Vol.1

\section{CCCCXCI. CUCUBALUS.}

Calirx monophyllus inflatus quinquedentatus. Cor. pentapetala: petalis unguiculatis abique barbs ad faucem. Stam. decem. filamentis thalameis \& corallinis alternenSiy thacca exfucca unilocularis. Receptac. liberate. nifurmia.

Cucuritus baccifer. Tab. 77. fig. 7.

Aijue repens. Dod. pennt. 403. Mirl. diđ. ic. t. 112.

Vifcago baccifera, petalis ferratis. HА L. hifl. I. n. 912.

Cuculialus calucibus campanulatis, petalis diflantibus, pericarpiis coloratis, ra. mis divaricatis. Lisw. Jyf. veg. 419.

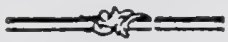

PER. Bacca intra calycem perfiftentem fubpedunculata, elliptico-fphreroidea, exfucca, coriacea, glabra, nitida, extus atra, intus fericeo-alba, unilocularis, non dehiifcens.

REc. columnare, liberum, prope bafin nudum triquetrun, in medio plurinis funiculis unbilicalibus fcabrum, apice definens in procellum filiformen bacex vertici infertum.

SE M. plura, circiter triginta, reniformia, glabra, nitida, atra.

INT. duplex: exterius chartaceum, tenue, fragile; interius membranaceum, palliduin.

A LB. centrale, farinofum, candidifrmum.

EMB. teretiuscultus, periphericus, femicircularis, pallide albicans, Cotyl. fernicylisdricx. Rad. craffitie cotyledonum, centripeta.

a. h.) Bacea intra calyecm, atque nuta. C.) Seninun fitus in baca. D.) Bacex pars iuferior cum recptaculo. c. L.) Senina foparata. F.) Embryonis di siuminis fitus intra fenen.

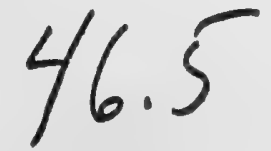




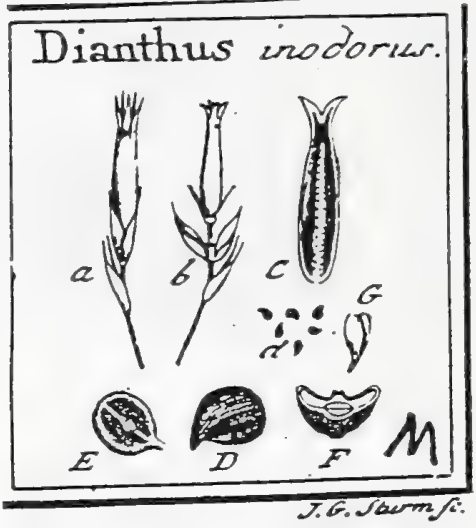

J. Gaertner (1788) Vol. 2

\section{7}

DCCLV. D I A N-T H U S. IIN gen. 656. Caryophyllus.

TOURN. inft. t. 174 .

- Calyx monophyllus, tubulofus, quinquedentatus, bafi fquamis accefforiis appreffis calyculatus. Cor. pentapetala, unguiculata, denciculata. Stam. decem, petalis \& receptaculo alternatim affixa. Ovar. fuperum. Styl. duo 1. tres. Capf unilocularis, apice 4 svalvis. Recepe liberum. Sem. plurima, comprefla.

Dianthus inodorus. Tab. 129. fig. 13.

Caryopbyllhus fyluefris, fiore rubro inodoro, calyce oblongo cuns brevibus surguibus. SEgUI. veron. 435. t. 7 . f. .3.

Tunica ramis soniforis Eं biffuris; petalis levibus, fipulis calycinis brevifinis. HALL. bif. 23. 896 .

Dianthus foribus folitariis, fquannis calycinis fubovatis brevifintis, corollis cressatis. LINN. $5 y /$. veg. 418 :

PER. Capfula fubcylindrica 1. ovato-oblunga, calyce perfiftente veftita, glabra, unilocularis, apice quadrifariam dehifcens.

REc. columnare, gracile, fcrobiculatum, liberum, capfuja quarta parte brevius, undique feminibus vario fitu pofitis tectum.

SEM. numerofa, circiter quinquaginta, obovata, roftellata, comprefa, hinc tamen leviter convexa, inde fubconcava, ftriis longitudinalibus atque transverfalibus tenuiflimis cancellata, atra. Umbilicus in medio feminis ventre.

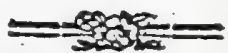

Is T. fimplex, coriaceum, tenue.

A LB. farinofum, niveum, unilaterale.

Es. dorfalis, vix aut parum curvatus, albus. Cotyl: ellipticx, fubfoliacex. Rad. tereti-acuminata, cotyledonibus brevior, vagar plerunque tamen infera.

a.) Capfula intra ealycem. b.). Eadem denudata. \& debificens. c:) Receptac. columnare. d. D.) Seminum latus doriale. E.) Eorum pars ventralis. F.). Sectio lérinis transverfalis cuma fitu albumiais, atque cmbryonis. G.). Embryo, folutus.

Semina D. cljinemfis \& cartlusfianoszm. procedentibus fimillima, fed.nagis plaua \&. triplo fere majora.

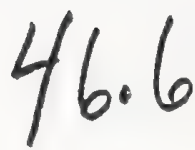




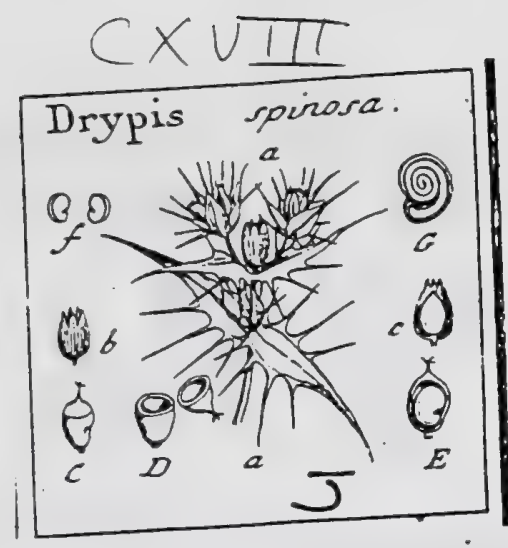

\section{J. Gaertner (1788) Vol: Z}

\section{8}

DCCXLI:- D R:Y P: I. S. LINN: gen:: $38 \mathrm{r}$

Calyx: monophyllus, , ovarus; , multiftriatus;, femiquirquefidus , , perfiftens:Cor. pentapetala :: petalis bifidis, , unguiculatis, ad i faucem: gemino denti-
Styl: unicus, breviliculo barbatis. Stam. quinque:. Ovar: fuperum.. Sty. unicus, brevilimus, trifidus.. Capfi. unilocularis,, circunafifia, mo Spiralis.:

Dxyprss fpinofa.. Tab. 128 . fig: 122.

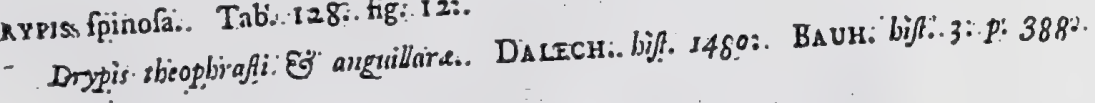

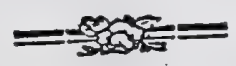

Drypis italicn acteleatn, floribus albis ümbellatis compactis. Mich. gex. t. 23.

Diypis spinofa. JAce. bort. t. 49. LINx. Jyft. veg. 298.
A Cl. Schrebero.

PER. Capfula a calyce tecta, ovata, fuperne mucronata, inferne leviter anguftata, membranacea, tenuifima, diaphara; unilocilaris, fupra: medium circumfcifla.

Re c. funiculus umbilicalis filiformis, e fundo capfulx; ad feminis latus emarginatum adfcendens.

SEM. unicum, magnitudine capfulx, reniformi-roftellatum, in dorfo linea prominula carinatum, cetera lenticulari compreffum, glabrum, fublucidum, fulvum aut e fpadiceo-luteum.

IN T. duplex: cruftaceum atque niembranaceum.

A L B. farinofum, candidiflimum, folis integumenti interni. lateribus adnatum, in ejus autem peripheria deficiens.

Eм в. fpiralis, filiformis, longiffimus, lutefcens., Cotyl lineares; in fpiram trium gyrorum convolute.' 'Rád. peripherica', curvata, infẹrz.

- b.) Calyx feparatus, integer. c) Idem ditectus. 2. 2.) Sureulus eum elycibus maturis. b.) Calyx fepartus, itu feminis. f.) Semen a dorfo C. D.) Capfula integra \& dehifecns. E.) Eadem aperta curis. fpectatum. G.) Idero difiedum, cum tigura \& 


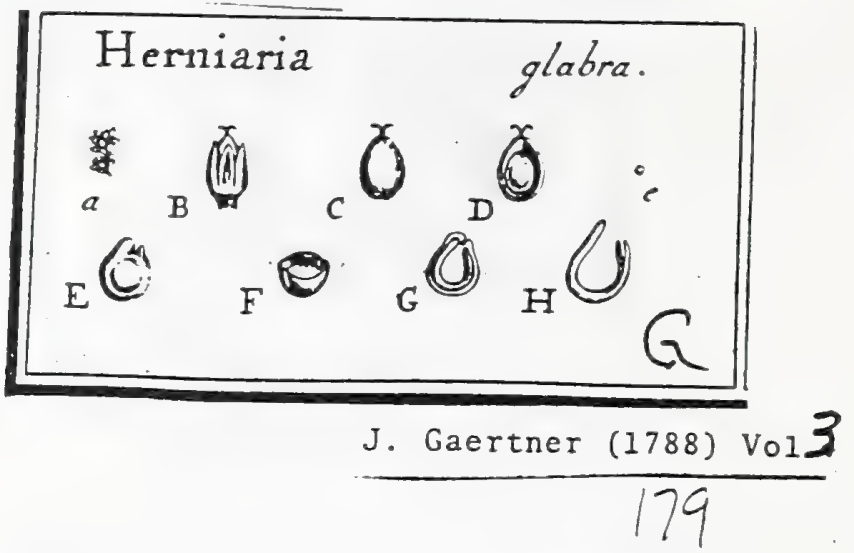

\section{I39. H E R I A R I A.}

TuUвN. inf. t. 288. LIN gen. 308. ed. Schreb. 434. Juss, gen. p. 89. LAзавск ill. ger. to 180.

$C_{3}$ l. monophyllus, inferus, quinquepartitus, intus coloratus, perfiftens. Cor. nulla, nifi calycem fumas. Stam. 10., quorum quinque alterna longiora caftrata; filanencis fubulatis, imo calyce infertis; antheris ovatis, erectis. Ovar. fuperum; ftylo brevifimo, bipartito; ftigmatibus acuminatis, Capf, minima, ovata, evalvis. Rec, funiculus umbilicalis, flifurmis. Se.d, unio cum, inverfum, Alb. farinofun. Emb. periphericus, annularis,

Herniaria glabra, Tab. 213. fig. 7.

Herniaria glibra. BauH. bif. 3. p. 378. Hald. bifr. belv. r. 4552 .

Herniaria glabra, glonerulis multifforis. LiNs. Jpec. pl. po 317. Syft. veg. ed. 14. p. $261_{0}$ WILLI. Spec. pl. T. 1. P. 2. p. 1296 .

Herniaria 'berbacea glabra, glomerulis multifloris Jpicae-formibus. LANARCK dir. 3. p. 124. PERSOON fyr. 1. p. 292 .

Icols. OED. for. dar. t. $5=9$.

Per. Capfula minina, a calyce connivente amplexata, ovata, ftylo perfiftente faftigiata, membranacea; tenuifima, glabra, pallida, unilocularis, evalvis.

REC. Funiculus umbilicalis filiformis, e fundo caplule lateraliter affirgens, ad feminis verticem procedens \& umbilico infertus.

SEM, unicum, ninimum, ovatum, ad verticem emargiuato- umbilicatum, Jenticulare, marginatum, medio vero turgidum, loculamento ipfo anguftius, inverfum, l. e funiculo utnbilicali pendulum, glaberrimum, nitidum, atro- fulcum.

In T. duplex: exserius crultaceum, fragile; inserius membranaceum, tenujarmum, dilute ferrugineum.

A L B. centrale, farinofum, niveum.

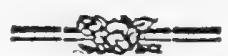

$E_{M}$ 8. periphericus; fubangulato- annularis, lutefcens. Cotyl. Sineares, dimidio embryone breviores, obtufx, incumbentes. Rad. filiformis, teretiufcula, ex angulo rotundato rectiufcula, adfcendens, obtufa, umbilico externo obverfa proxima, fupera.

\section{EXPLICATIO FIGURE.}

a.) Glometulus frugifet. B.) Capfula a calyce emplexata. C.) Eadem deradatu integra D.) Ejusdem fectio verticalis, com femiae in fitu. c. E.) Semen feparatum. F.) Albuaex transverfe difiecuum. G.) Embryonis litus Intra albamen. 


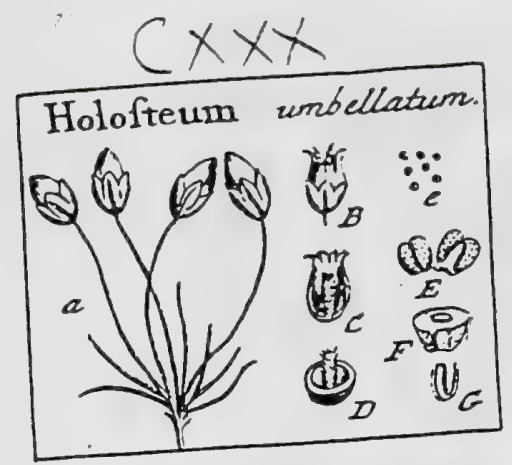

\section{J. Gaertner (1788) Vol..Z}

\section{1}

\section{H O L OS.T E. U.M. LINN. gers. ro4.}

Calyx pentaphyllus. Cor: pentapetala. Stam. tria aut quinque. Ovar. fuperum: Styl. tres. Capfo unilocularis, fexvalvis. Recept. columnare, liberum. Sem. numierofa.

Hozosteum umbellatum. Tab. 130. fig. So

Lycbnis graminea birfita umbellifera. Moras. bifs. 2: S. 5. t. 22. f. 46 o

Aljune fioribius umbellatis, petalis ferratis. HALL. biff. 13: 879 .

Holofieum fioribus umbellatis. LiNs. Jyft. veg. 12g.

PER. Capfula ovata, glabra, fplendens, unilocularis, fexvalvis; vix ultra medium dehifcens:

R.ec. columnare, liberum, funiculis umbilicalibus hifpidum, dimidia capfula: paulo longius:

SE M. numerofa, airciter feptuagina, fubovata, compreffè trigona, punctis: elevatis fparfis feabrata, fulco in dorfo deprefliufculo: in ventre autem prominulo \& quafi appreffe roftellato notata, rufefcentia.

IN T. fimplex, membranaceo-fpongiofum, tenue.

A L в. femiri: conforme, carnofum, album, embryonem involvensi

E N.B. uncinato-curvatus, tectus, albus. Cotyl: ovato-oblonga, fubfoliacex dorfales. Rud. tereciufcula, in ventrem feminis. refexa, centripeta..

2) Fruetins unbellati. B.) Caprula dehifcens. C. D.) Eadem difteta; - cora figura receptaculi:. e. E.) Semina feparata. F.) Semen transverfe fedam; , cum fitu.cotyledonum \& redicula intre albuminis-\{ubfantiam G.). Embryo folutus: 


\section{Tab. CLXXXIV.}

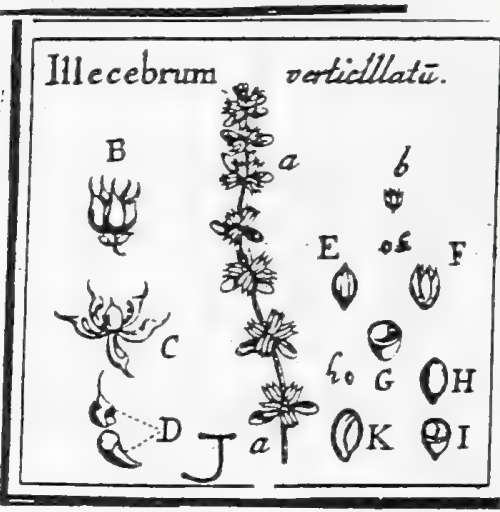

J. Gaertner (1788) Vol 3

\section{I L L E C E B R U M.}

Linn. gen. 290. ed. Schreb. 407. Juss. gen. p. 89 .

Cal. pentaphyllus, Rellato-pentagonus, infra pedunculum fuum tribus brackeolis Boralibus ftipatus, foliolis fubclavatis fungofis folidis niveis, extus convexis, intus plano curvo excifis, apice prinum incraffatis, mox vero in ariftam fetaceam extenuatis. Cor. nulla. Stam. quinque, bafi in tubum urceolatum connata. Ovar. fuperum. Styl. Gimplej, ftigmate obrufo. Capf. unilocularis, yuinquevalvis, monofperma.

ILLECEB⿱口龰 $M$ verticillatum. Tab. 184. fig. 10.

Paronychia fergyllejolia palujiris. VAILL. paris. t. I5. f: I.

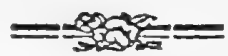

Illecebrum floribus verticillatis nudis, caulibus procumbentibus. IIN . fyf. veg. ed. i4. p. 248 . Spec. pl. ed. Willd. T. 1. P. 2. p. 1205.

Icon. OEv. for. dar. :. 335.

PrR. Capfula parva, ovata, utrinque acuminata, membranacea, ftriata, tenuis, unilocularis, quinquevalvis.

REc. nullum; femen fundo cnpfulx roftello fuo infertum.

SE N. unicum, minutulum, ovatum, utrinque acuminatuns \& ad bafin roftello brcvi inftructum, nitidum, fitturate caltaneum.

INT. duplex: exterius cruftaceum, fragile, tenue; interins arachnoideum.

A L B. unilateralc, farinofum, candidifimun.

Eмв. periphericus, fubrectus, feu leviter tantum ad normam dorfi feminis curvatus, erectus, teretiufculus, albus. Coryl. breves, feniteretes. Radic. longa, infera.

\section{EXPLICATIO FIGURE.}

a. a.) Cauliculi frugiferi pars fuperins. b. B.) Calyx integer. C.) Iden diduetus \& eapfula denudata. D.) Ejusdem foliulum diffectum. e. E.; Capfula leparata integra. F.) Eaden deo hiferns. G.) Ejus feetio transverfalis. h. H.) Semen inte;rum. I. K.) Ejusdem fettio transverfalis \& verticalis, curm fieu \& Ggura albuminis atque Embryonis.

Hac forfan fola \& unica eft genuina Illecebri fpecies, in quan fcilicet genericus Limsei character quadrat; reliquae emm, quas vid, omnes ad aliz genera fpectant. Ab affinibus Queria, Paronyclia \& Herniaria non tantum calycinis foliolis incraftatis folidis, fed imprimis quoque capfula manifefte quinquevalvi, \& embryone non annulari ditier. Bracteolas tres florales non poffum pro calycis parte habere, cuin infra ejus pedunculum locatz Gunt.

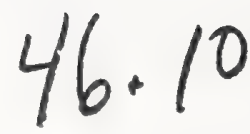



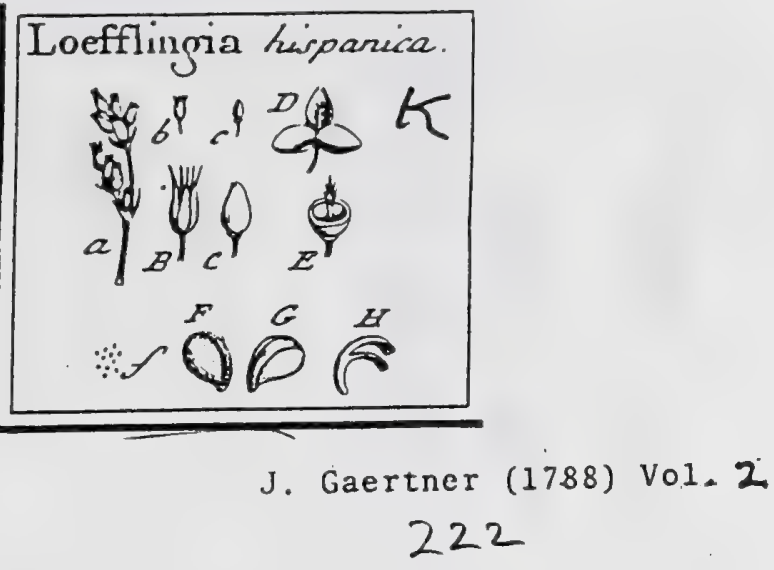

DCCXLVII. I O E F L I N G I A. LINN. gen. 52 .

Calyx pentaphyllus. Cor. pentapetala, minima. Stam. tria. Ovar. fuperum. Styl. unicus, fimplex. Capfo unilocularis, trivalvis, polyfperma.

Loeflingis hifpanica. Tab..I29. fig. 5 .

Loefingia. LINN. act. bolin. 2758 . t. I. f. I. Jjf. veg. 83.

PER. Capfula parva, ovata, fuperne anguftior, unilocularis, trivalvis.

REc. columnare, liberun, fuperne penicilliformi-ramofum, longitudine fere capfulz.

SE M. plura, fedecim ad viginti, parvula, ovata, in roftellum producta, fulco dorfali leviflime depreffo notata, excavato-puncticulata, ftraminea aut rufefcentia.

I.N T. fimplex, membranacenm, tenue, fubdiaphanum.

A L B. farinofum, niveum, unilaterale.

$E_{M}$ B. dorfalis, arcuatus, lutefcens. Cotyl. lineares, planiufculx, incumbentes. Rad. teretiufcula, brevis, infera \& fimul centripeta.

2.) Fruetus in corymbis terminalibas. b. B.) Calyx perfiftens. C. C.) Capfula claufa D.) Endem dehifens. E) Recaptac centrale. f. F.) Semina (éparata. G.) Embryo albuminis dorfo incumbens. H.) Idem folutus. 


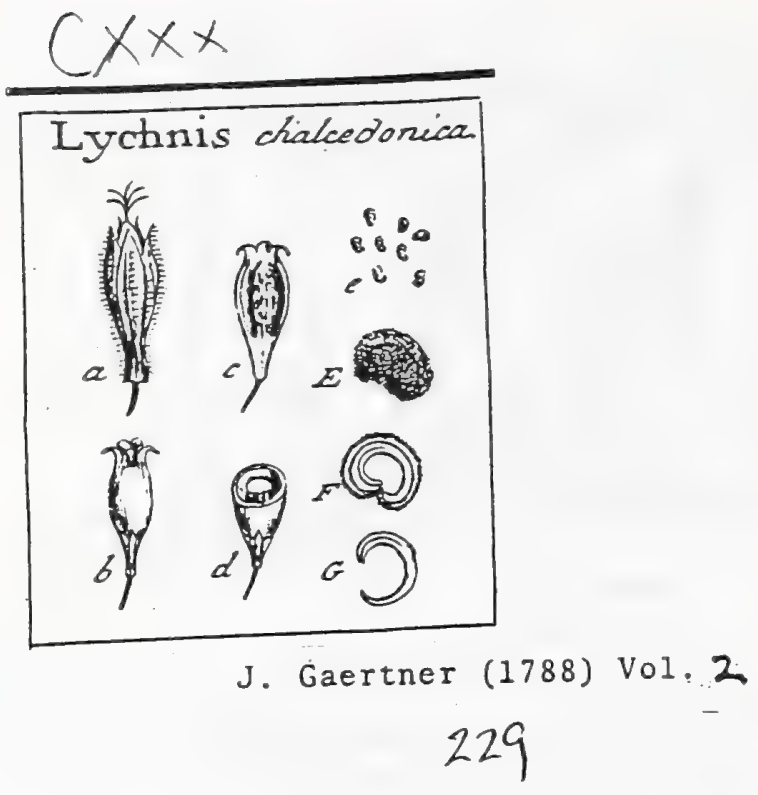

Caryophyllaceae

DCCLVII. I Y C H N I S. EINN. gen. 584.

Calyx monophyjllus, tubulofus, quinquedentatus, perfilteus. Cor. pentapetala, unguiculata: laninis fubbifidis. Stam. decem, fitu alternantia. Ovar: fuperum. Styl. quinque. Capf. uni - tri - 1. quinqueloculans. apice quinquefariam dehifcens. Receph liberum aut feptigerum. Sem. plurinia.

LYснкis chalcedonica. Tab. I30. fig. I.

Flos confantinopolitanus. Dod. pempt. 178. BesL. Eyft. afiv. $X$. t: $5 \cdot$. f. x: Lyclonis floribus fafciculatis faftigiatis. LIN . Gyf. veg. 435.

P.в. Capfula calyce membranaceo nervis decem villofis. ftriato veftita, ovata, deorfum attenuata, glabra, unilocularis, apice quinquefariam dehifcens.

RE c. columnare, cylindricum, liberum, fulcatum atque forobiculatum, nudum.

SEN. numerofa, angulato - reniformia, tuberculis acuminatis feriatis fabrata; ferrugitrea.

IN. I. duplex: coriaceum atque membranaceum.

A. L B. farinofum, niveum, centrale.

En B. periphericus, fubmnularis; lutefcens. Cotyl. femiteretes. Risd. centripeca.

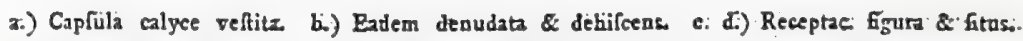
c. E.) Semina (eparata. F.) Albutrinis \& emlryouis fitus ac figura. G.) Embryo- folutus.

Lychnidi generatim tria loculamenta, Juss. \& quinque, LIN. tribuunt; fed potior fpecierum numerus capfulas promit uniloculares.

46.12 

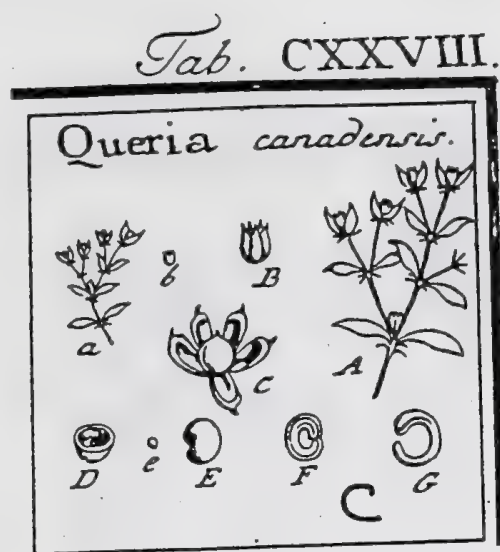

J. Gaertner (1788) Vol.2

217

DCCXXXIX. QU E R I A. LINN. ger. IOS. -...

Calyx pentaphyllus, foliolis oblongis, margine membranaceis, apice intus fornicatis, extus mucronatis. Cor. nulla. Stam. tria Ovar. fuperum. Styl. unicus trifidus. Capfula utricularis evalvis. Sem. unicum erectum.

Queria canadenfis. Tab. 128. fig. 10.

Mollu:0 follis oppofitis, fipulis quaternis, caule dicbotonso. Gron. virg. I4. Quteria foribus folitariis, caule dicbotomo. LiNs. Jyf. veg. 130 .

Ex herbario Bankfiano.

PER. Capfula parva, globofa, apice mucronata, membranacea, tenuifima, unilocularis, non dehifcens.

REC. nullum, preter nervun elevatum in latere interno capfulx, cui umbilicus refpondet.

SEN. unicum, reniformi-globofum, glaberrimum, lucidum, atrum.

IN T. duplex: cruftaceum atque membranaceum.

A L B. farinofum, candidum, centrile.

E $M$ B. periphericus, annularis, 'lacteus. Cotyl. femiteretes, incumbentes. Rad. filiformis, infera, fubadfcendens.

2. A.) Plantz frudiferz ramulus. b. B.) Calyx eppiulam obtegens. C.) Capfula denadata. D.) Eadem transverim feQta. C. E) Semen integrum. F.) Idem difrectum, cum fitu \& figura albuminis atque embryonis G.) Embryo colutus.

Hxc, a Q. bifpanica, non tantum habitu fuo externo fed \& calycis atque capfulx fabrica multum recedit, atque plurimum affinitatis cum Arenaria \& fequenti Paronychia habet, ut ab his nonnif Itaminum numero differre videatur. 


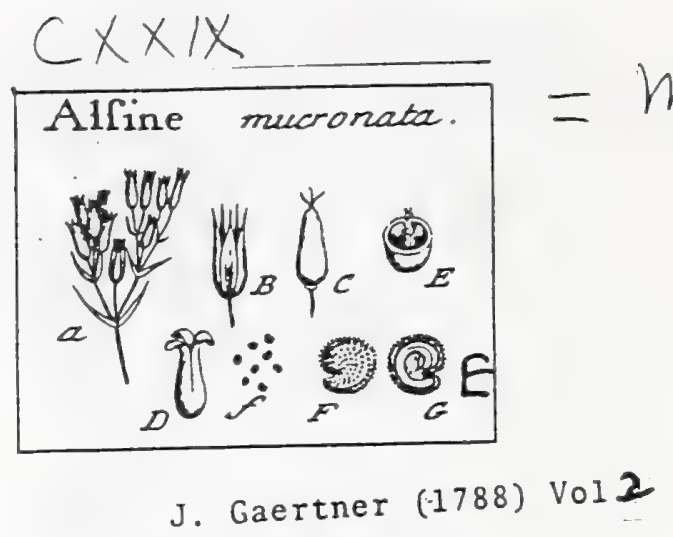

223

DCCXLIX: A L.S I N E. LINN. gen: 380 .

Calyx pentaphyllus. Cor: pentapetala: Stam. quinque. Ovar. füperum.

Styl.. tres.. Capfula unilocularis, trivalvis, polyfperma..

ALsine mucronata: Tab. 129 : fig. 7\%:

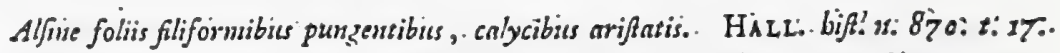

Alsme petalis integris brevibus, foliis fetaceis, calycibus arifatis. LiNsi-fyjt: veg: 298 .-

P.ER:. Capfula ovata -oblongạ: 1. fulcylindrica, , tenuis , unilócalaris, trival vis..

224

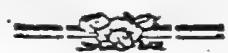

REc. colunmare, liberum, longum, funiculis ambilienlibus capillaribus crinitum.

SEN. plura, reniformia, punctis acuminatis per feries digeftis fcabrata, rufelcentia.

IN T. duplex: coriaceum atque membranaceum.

ALB. farinofum, niveun, centrale.

Eмв. periphericus, annularis, albus. Coryl. femiteretes. Rad. filiformis, infera \& fimul centripeta.

2.) Plantz frugiferz ranulns. B.) Calyx maturus. C.) Capiula claufa, D.) Eadem dehifeens. E.) Ejusdem featio transverfalis, cum receptaculo. f. E.) Semina (eparatz. G.) Albuasinis \&e embryonis figurs atque fitus in femine verticaliter diffecto.

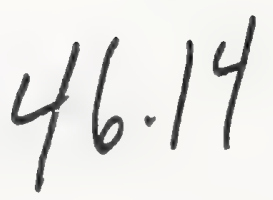




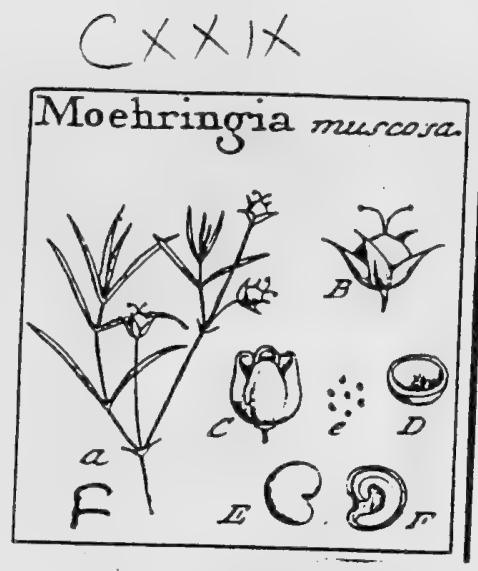

J. Gaertner (1788) Vol.2;

226

DCCLIII. M O E H I N G I A. LINN. gert. 394.

Calyx tetraphyllus. Cor. tetrapetala. Stam. octo.. Ovar. fuperum. Styl. duo, ftigmatibus globulolis. Cap̣ unilocularis quadrivalvis. Recept. nullum. Sem. pauca.

ḾOEhringia mufófi. Tabi I2g- fig. IT-

Alfine montana, capillaceo folios. Piux. pliyt: t: 75 . f. $x$.

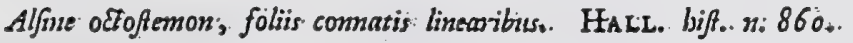

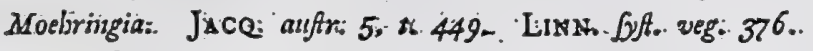

PER. Capfula calyce perfiltente cincta, fubglobofa, unilocularis, quadrivalvis.

REC. nullum, prater funiculos umbilicales brevifrmos in fundo capfulke.

SE M. pauca, circiter decem; renifurmia, glabra, rufefcentia.

IN T. fimplex, coriaceum, tenue.

A IR farinofum, niveum, centrale.:

EM B.. periphericus, annuliris, albus.. Cotyl. femiteretes. Rad. infera:

22): Plantz frugiferfe rimulis: B.) Capfula clanfra. C.) Eadem dehifens: D.) Ejur fedio transverralis, , cum funiculis, umbilimalibus. c. E.); Semina foluta. F.). Semea difeetum, cum atbumine: \& exbryone.

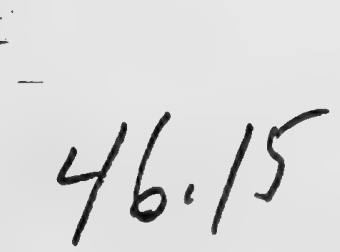



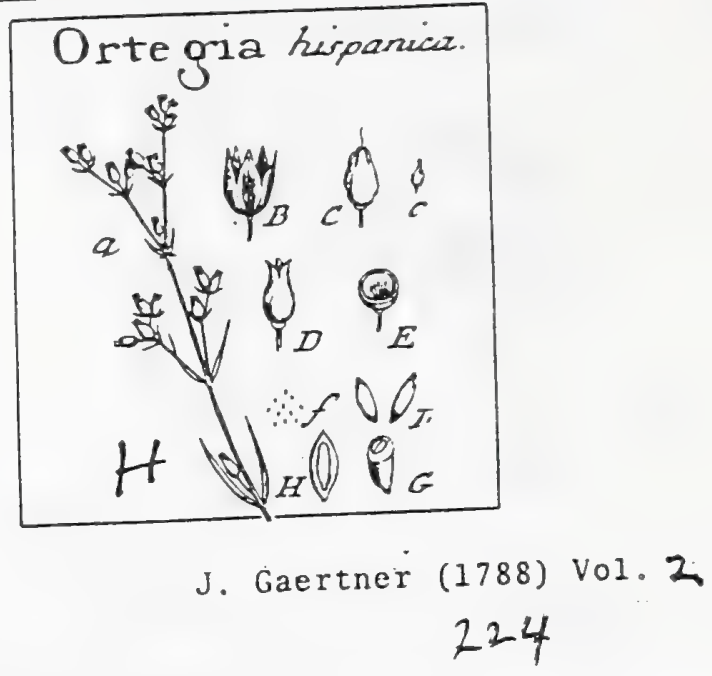

DCCL. OR T E G I A. LINN. gen. 5r.

Calyx pentaphyllus. Cor. nulla. Stam. tria. Ovar. fuperum. Styl. unicus, ftigmate capitato aut trifido. Capf. unilocularis, apice trifariam dehifcens. Sem. plura, ublonga.

Ortegla hifpanica. Tab. 129. fig. \&.

Juncaria falmantica. CLus. bift. 1. p. 174 .

Ortegia floribus fubverticillatis, caule fmplici. Liss. jyft. veg. 82.

PER. Capfula parva, ovata, fuperne attenuata \& obfolete trigona, undocularis, apice trifariam dehifcens.

REC. nullum; femina funiculis unbilicalibus filiformibus fundo capfute affixa.

SEN. plura, circiter duodecin, parvula, oblonga, fubterecia, utriuque attenuata, glabra; ferruginea.

IN T. fimplex, membranaceun, tellue.

$\Lambda_{L}$ B. farinofum, candidifrmum, unilaterale.

EM B. dorfalis, rectus, albus. Cotyl. ablongx, planiufculx, incumbentes. Rad. teretiufcula, brevis, infera.

2.) Plantz frugiferz ramulus. B.) Calyx maturus, margine membranaceur. c. C.) Capfula chaufa. D.) Eadcm dehifecns. E.) Ejus feetio transverfalis cun fáficulo funiculorum unhilitio calium. f. F.) Sermina feparata. G. IL) Semen diffeetum, eum Gitu \& figura albuminis atque embryonis.

Embryone gaudet penitus recto, minus ufitato in hac familia cxemplo. 


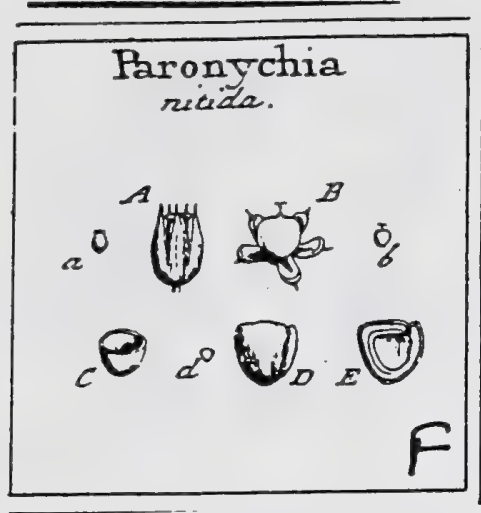

\section{J. Gaertner (1788) Vol. Z}

218 ,

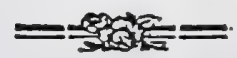

DCCXL. PAR O N Y HIA. TOURN. t. 288 . JUss. p. 89. lllecebrum. LINN. gen:: 290 .

Calyx pentaphyllius, foliolis: oblongis, , margine: membranaceis, apice intus fubfornicatis, extus mucronatis.. Cor. nulla.. Stam. quinque, , cum toti'dem fquamulis. linearibus: alternantia.. Ovar.-fuperum.. Styl. unicus. bifidus. Capf. utricularis. Sem.. unicum, inverfun.

Paronychis nitida. Tab. 128. fig. II.

Paronychia bijpanica: Clus: biff: $=$ : p: 182 .

Illecebruin floribies braffeis nitidis, obvallatis;, caulibis procumbentibus; foliis levibus. LiNN. Jyfl. veg: 248 :

Pi ER. Capfula fubrotunda, , bafi anguftior, apice ftylo bifurco terminata, membranacea, tenuifina, , unilocularis, non dehifcens.

KE C. funiculus, umbilicalis filiformis, e funda capfulx. ad feminis verticem pertingens.

SEN: unicum, fübturbinatum, aut ex anguftiori bafi furfum globofè latefcens, ab altera latere. roftello, nigricante infignitum, cetera glaberrinum, luci-. dum, , ruffo - ferrugineum.

IN T. duplex : cruftaceum atque: membranaceum:

A ¿.B: farinofum, candidum, centrale.

E M B. periphericus, . annularis, albus.. Cotyl:' lineares, pläniufculix, . incum:bentes.. Rad. fliformis, adfcendens ufque. ad verticem, fupera.

2. A:) Capfula calýce cincà: b: B.) Eadem denudata: C:) Ejus fectio transverfalic;. d. D.) Se-men intrgrum. E.) Idem diffeAum cum albuminis \& embryonis fitu.

Inter omnes: lllecebri fpecies, quas videre mihi hactenus contigit, folum verticillatzm; . Linnzana characteri, refpondet; reliqux, ad alia genera, ut Parunychiam, Achyranthem \& Celofiam, tun propter ftanina bafi conмзtа; tum: propter; capfulis evalves: aut circumfciffis debent: referrio.

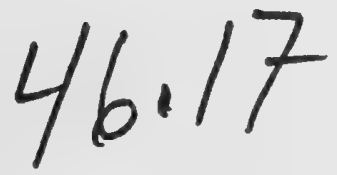


Tab. 213.

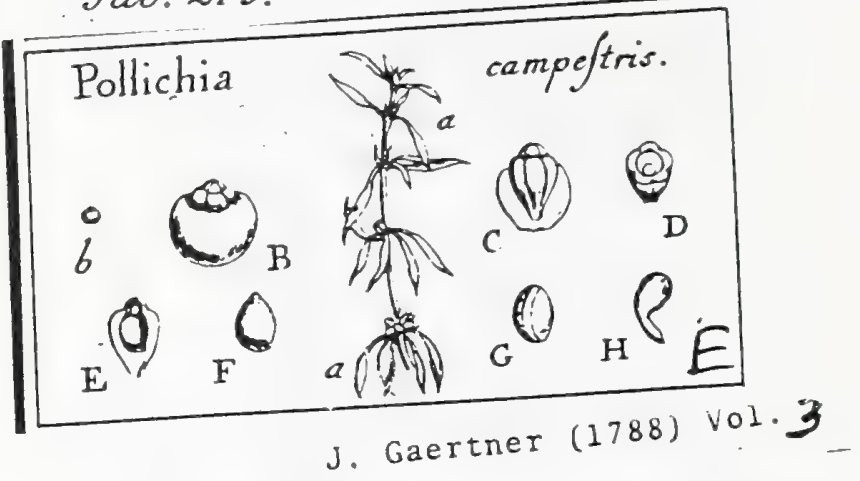

II7

\section{P O L I C H A:}

AIs. hort. Kew. 3. 7) 505. Sснвев. gen. 1705 .

Cal. monophyllus, inferus, fubcampanulatus, quinquedentatus, perfiftens. Cor. 0 : nifi calycem fumas. Stam. unicum; filamento filiformi; anthera fubrotunda. Ovar. fuperum; Itylo fumplici; ftigmate bifido. Sem. unicun intra calycem abfconditum, \& ab ipfo arcte inclufum. Alb. carnofum. Emb. fubperiphericus.

Pollichia campetris. Tab.2I3. fig. S.

Neckeria. GazL. fyft. veg. p. 16.

Pollichia. AIt. 1. c. 1. p. 5. W.ILLD. Spec. pl. T. 1. P. 1. p. 23. PRR. s0ON Jyis. 1. p. 4.

Ex horto Regio Kewenfi. PER. nullum: calyx fubcarnofus, in corpus globofum pulpofum cupuliforme dato-pentagonus, 1 quinquefulcatus, quinquedentatus femen fovet, nec alces calycis breviffimi, fulco circulari a tubo difcriminati, conniventes, arcteque claufi.

REC. nullum: femen fundo calycis lateraliter adhxrct.

SEM. Unicum, ninutum, ovatuin, paululum obliquum, bafi obtufum, apice mucronulatum, a calyce liberum, album.

Ix T. fimplex, tenue, firmum.

A L B. ovatum, carnofum, ab embryone ad dorfum fulcatum, candidum.

EM B. fubperiphericus, per dorfum albuminis locatus, \& ipfum rima verticali fecans, erectus, falcatus, albus Cotyl. ovatx, pano-convexiufcula, ac cumbentes. Rad. cotyledonibus paulo brevior, teretiufcula, ad angulum obtufum cum cotyledonibus commifa, acuminata, infera.

aris foralibus bacentibus cozlitis immera. A.) Ramulus frugifer. b. B.) Calyx baceatus, bratcis toralibus baecantibus collis innerfus. C.) Idean a parte denudatus, ut ejus infertio vifui palcat Dato fenine. F.) Semen feparz falis una cum femine. E.) Calyx longitudinaliter difte embrgone. H.) Embryo folueus. tum. G.) Albumen a dorfo vifum, cun

178

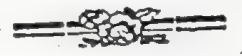

Embryonis fitus \& forma in Perficaria fimiles, fed in hac inverfus.

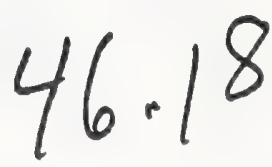


Tab. $\operatorname{~XXXIX.~}$

Polycarpon celvaphytum.

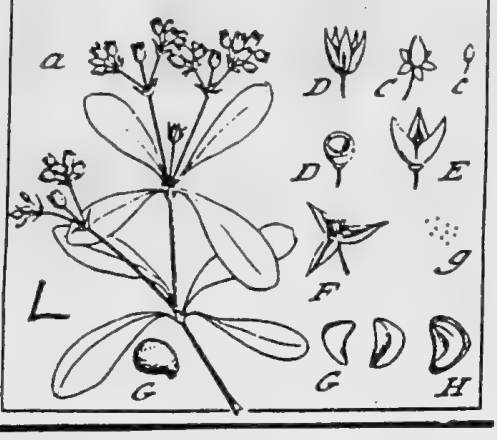

J. Gaertner $(-1788)$ Vol 2

224
Caryophyllaceae

225

POLYCARPON tetraphyllum. Tab. 129. fig. 9.

Prrongebia altera. Dalech. bif. 12x3. c. ic

Anthyllis alfinefolia polygonoides major. BARR. rar. 103. 53.54.

Polycarpon caule ramofo proftrato, foliis quatenuis. LiNN. fyft. veg. 129.

PER. Capfula parva, ovata, unilocularis, trivalvis: valvulis membranaceis; polt dehifcentiam introrfum convolutis.

REC. nullum, preter fafciculum funiculorum umbilicalium in fundo capfure.

SEM. plura, ad quindecim, parvula, ovato roftellata, punctis elevatis fabra, aut ante plenam maturitatem angulata glabriufcula, pallida.

IN T. fimplex, membranaceum, tenue.

A L E. unilatérale, carnofum, album.

Eм́ в. dorfalis, arcuatus, albus. Cotyl femiteretes, incumbentes. Rad filiformis, infera.

2) Phente frugiferz ramulos, B.) Calyx onaturus. c. C.) Capfule clapla, com corolle períftente. D.) Eadem transverfe feda. E. F.) Valvulz dehilcentes, cum penleillo funiculntum umbiliealium, g. G.) Seminz matura \& immatura. H.) Sempinis fedio verticalis, cum fita \& figura albuminis atque embryonis,

46.19 


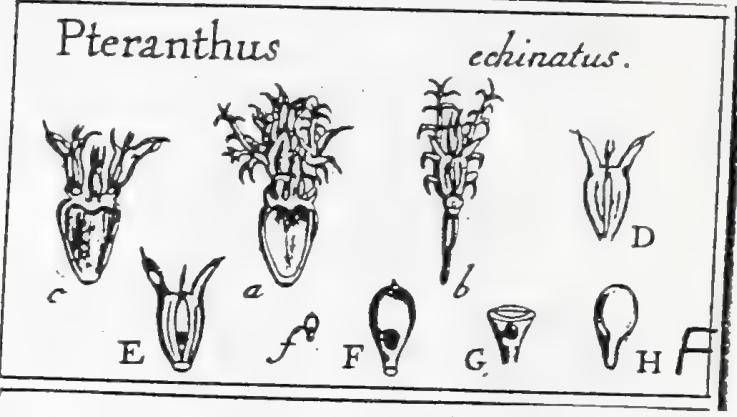

J. Gaertner (1788) Vol.3

\section{P TER A N T H US.}

Fовьк. defc. p. 36. Louichea. L'Hевгт. Sert. r. $t .65$. Schreb. gen. I 7 68.

Flores terni in pedunculum coriaceo-membranaceum congefti, uno intermedio transverfim inferto, duo alteri vero ad utrumque latus, cum pedunculo paralleli, inter duos proceffus, foliis fpuriis muricatos, occulti.

Cal. monophyllus, quadripartitus: laciniis concavis, criftatis, perfiftentibus: Cor. O. Stam. 4; filamentis bafi leviter connatis; antheris fubrotundis. Ovar. fuperum; Ptylo filiformi, bifido. Sem. unicum, obovatum, chalazà lata no. tatum, erectum. Alb. unilaterale, farinofum. Emb. fuperficialis, erectus.

Pteranthos echinatus. Tab. 213. fig. 6.

Camphorofina ramofifima, pedunculis enfformibus dilatatis, bradseis criftatis. LiNs. mant. po 41 . Syyt. veg. ed. 14. p. 166. VAHL fymb. bot. 3. p. 21. WILLD. Spec. pl. x. p. 697.

Louichea cervina. L'HeRIT. 1. c. p. 135.

Pterantbus echinatus. Desfont. f. alt. I. p. 144. Persoon fyr. x. p. 149: Ex collectione $\mathrm{Cl}$. Desfontaings.

P E R. nullum, prxter cuticulam tenuem: femina in quóvis pedunculo terna: intermedium majus, pedunculo contrarium: duo oppofita paria, minora. Ca. lyx obovatus; compreffiufculus, lenticulari-convexus, quadripartitus femen occultat; nec dimittit; lacinix calycis duxe majores; marginales, naviculares, ad verticem in procellum membranaceum apice mucronalatum!defnentes: laterales vero angultiores, ab illis fere obrecta, in ariftas breves attenuatre.

REC. nullum: femen bafi calycis adnatum.

SEM. unicum, ex collo tenui obovatum, comprefiufculum, lenticulari-convexum, in vertice mucronulatum, erectum, pallidumi.

IN T. fimplex, membranaceum, adnatum, ferrugineum, ad collum lateris albuminofi chulazi orbiculari fulca notatum.

$\Lambda \subset \mathrm{B}$. ad unuin latus feminis locatum, non admodum craffum, ad alterum vero in membranatn teluen extenuatum, cxterum femini conforme, carnofo. farinofum, candidum.

EM B. longitudine fere albuminis, \& ipfi quafi fuperimpofitus, 1. fuperficialis, erectus, viridiufculus. Cosyl. dimidio embryone majores, ovato-orbiculares, plano - convexiufculx, accumbentes. Rad. cotyledonibus paulo brevior, recta, teretiufcula, conica, infera.

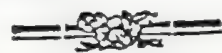

\section{EXPLICATIO FIGURE}

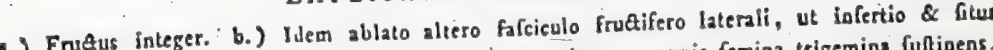
1.) FruAus integer. b.) Nem ablato alteso Pectenculus communis femina trigemina furtinens, feminis intermedii in confpequm veniat. c.) Pedunculus communis Semén intermedium, calyce inclufum. E.) Seminis fitus, intra calycem, demta altera lacinis H.) Embryonis forma \& fitus tum. G.) Album 


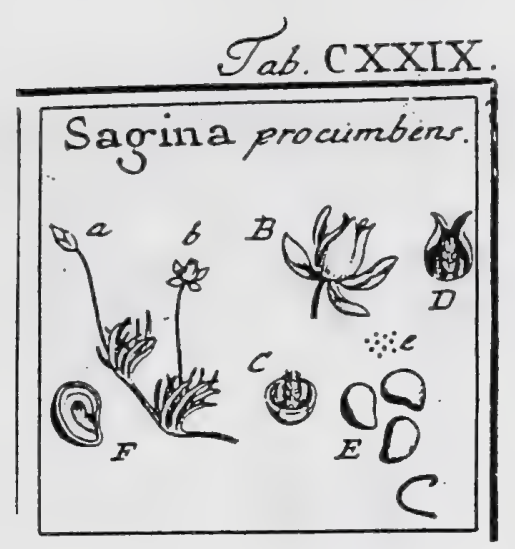

J. Gaertner (1788) Vol 2

\section{5}

DCCLII. S A G I N A. IINN. ger. I 76.

Calyx tetraphyllus. Cor. tetrapetala. Sam. quatuor. Ovar. fuperum. Styl. quatuor. Capf unilocularis quadrivilvis. Recept. columnare. Sem. numerofa.

Sagina procumbens. Tab. I29. fig. I0.

Alfine pufilla graminea, fiore tetrapetalo. SEgur. verox. 42t. t. 5. f. 3 .

Alfine tetrafiemon, foliis comatis lanceolatis. Hacl. biff. n. 86r.

Sigina ramis procumbentibus. ARD. Jpec. 2. t. $8^{\circ} . f .2$. Liss. Gyf. veg. 169.

PER. Capfula calyce perfiftente cincta, ovata, tenuis, unilocularis, quadrivalvis, ulura medium dehifcens.

R E c. columuare, liberum, hifpidum, dimidia capfula paulo longius.

SEM. numerofa, fupra quinquaginta, minutula, fubreniformia, glabra, ferru. gines.

I s T. finplex, coriaceum, tenue.

A L B. farinofum, album, centrale.

Eмв. periphericus, hemicyclicus, Iutefcens. Cotyl. femiteretes. Rad. centripeta.

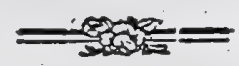

2.) Plantz frugiferre ramulus: b. B.) Calyx cum capfula debiffente: C. D.) Capfula trantwerfim \& longitudinaliter: diffeta, cum: receptac. colunınario. e.. E) Semina. Scparata. F.) Albumiuis \& embryonis. Gitus in femine verticaliter difletto. 


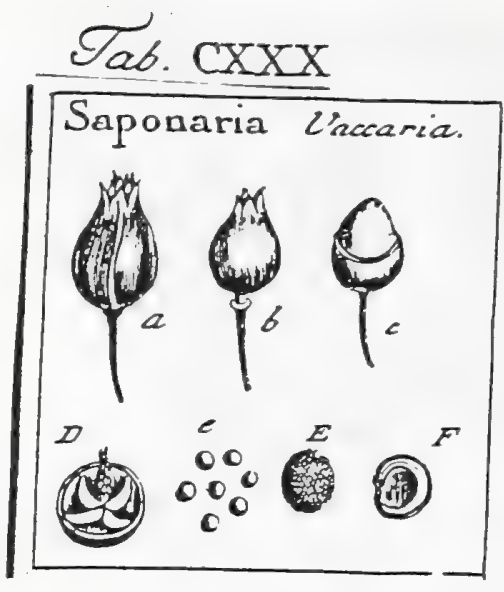

\section{J. Gaertner (1788) Vol.2i}

DCCLXIV. S A P O N A R I A. IINN. gen. 564.

Calyx monophyllus quinquedentatus. Cor. pencapetala, laminis integris aut bifidis, nudis aut barbatis. Stam. decem, fitu sleternantia. Ovar.

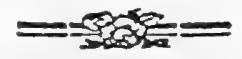

fuperum. Styl. duo. Capf. incomplete bi - tri - 1. quadrilocularis, apice dehrifens. Rec. colummare. Sem. plurx.

SaPONARIA Vaccaria Tab. 130. fig.9.

Vaccmia. Dod. pempt. 104.

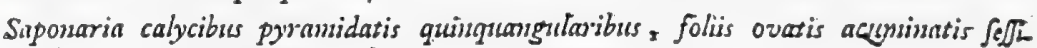
libus. LINN. fyft. oeg. $5^{85}$.

$\mathrm{PER}$. Capfula calyce glabro baf̧ pentagono veftita, ovato-conica, fuperne unilocularis, inferne tri-1. quadrilocularis, ex duplici lamina conflata: exteriore fcil. chartacea f. cartilaginea, glabra, apice dentibus quatuos dehifente; interiore autem fpongiofo-membranacea, alba, tenuiffims: fuperne irregulariter rumpente, inferue autem diffepimenta incompleta, formante. Diffepimenta anguftiffma, in bafi faltem capfulx obvia.

R R c. columrare, fupra liberum, gracile, funiculis umbilicalibus hirtum, dimidia capfula paulo longius.

SEN. plura, circiter viginti, fubglobora, punctis elevatis obfoletis denfiflame confperfa, atra.

INT. duplex: coriaceum atque membranaceum

ALB. farinofum, niveum, centrale:

EM B. periphericus, andularis, lutefcens. Cotylo lineares planiufcula. Rad. centripeta.

a.) Capfula calyce tcata. b.) Eadem denudata, apice dchifens. c.) Ejusdem lamina exterior ad' mclium ufque refecta, ut interior appareat integra. D.) Bafis capfulx cum diffepimentis incotrpletis arquc receptaculo.. c. E) Semiua fepratatz. F.) Senten diffctum, com fitu albuminir atque cmbryonis.

Saponaria officinalis. LiNN.

Capfuda anilocularis, feu ope diffepimenti anguftifrumi \& in bafi faltem capfüz confpicui in duo loculamenta incompleta divifa.. Forma ctian capfule in hac magis oblonga \& ex fufformi - ovata eft. 


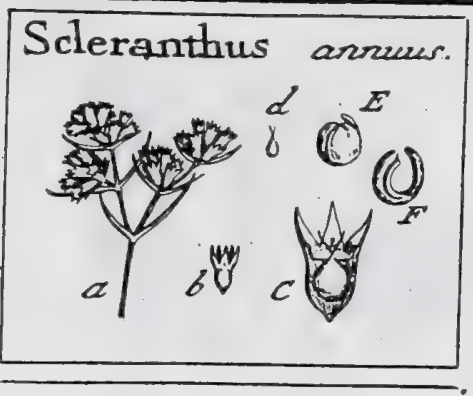

J. Gaertner (1788) Val. 2

I96

DCCXII. S C I ER A N T H U S. LINN. gen. 562

Calyx Yupcrus, quinquedehtatus, perfifters. Cor. nulla. Stam. a quinis ad dena. Ovar. inferum. Styl. duo. Sem. unicum, calyce cariaceo
corticatum.

SClERANTHUS annuus. Tab. I26. fig. 2 .

Scleraxtlos frotibus patulis. Haic. bifr. $n . x 55$.

Sclerantibus calycibus frusus patulis. LINN. Syft. veg. 725.

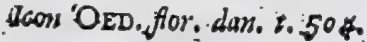

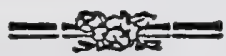

$P_{E}$. nullum; calyx maturus coriaceo - fuberofus \& fere aucamentaceus femen involvit, nec dimittit.

REc. nullum, pretet fundum calycis.

SEN. unicum, ovato acuminatum, glabrum, pallide ftramineum.

IN r. triplex: catimum a calyce durum, apice foramine pertufum; medium membranaceum, laxum, ftyligerum; intimutm arachnoideum.

$\triangle$ Lв. farinofum, candidum, centrale.

EN B. peripbericus, annularis, lutefcens. Cotyl. lineares, utrinque planx, incumbentes. Rad cotyledonibus paulo brevior, adfcendens, fupera.

2) Corgmbur fruteifer. b.) Cahyx maturns integer. C.) Ideun longitudinaliter aperiex d.) Semen feparatum. E.) Abumen ab embrgone cinęum. E.) Embryo folutus.

Integumentum medium poffet omnino pro Capfula utriculari cum Linnxo haberi; femina autem folitaria, nee gemina, Atatuunt quoque; pretcr me, Dillenius, Haller \& Adanfor. 


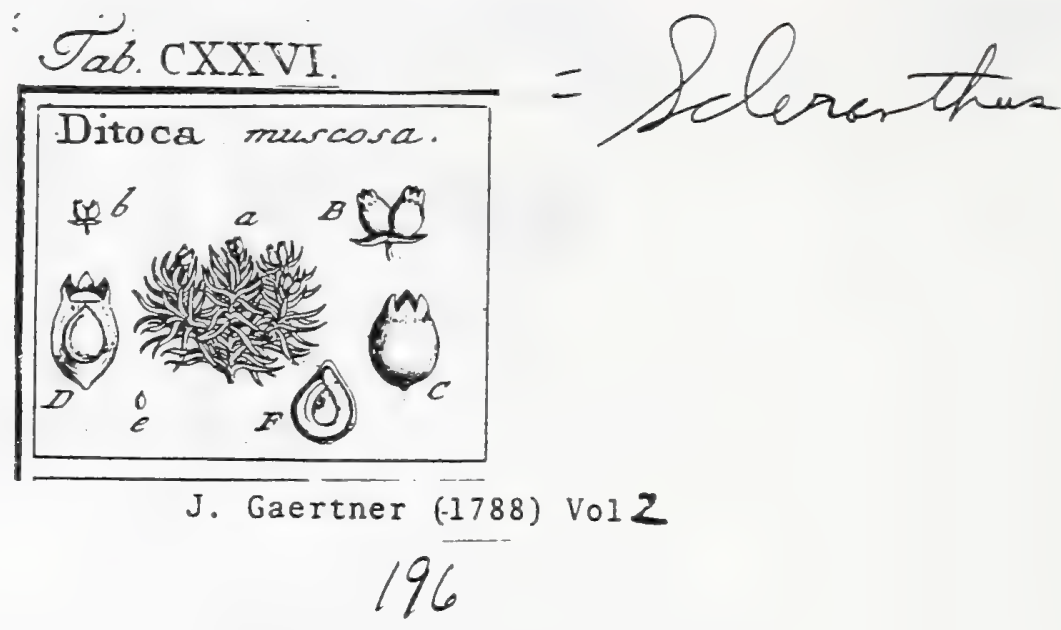

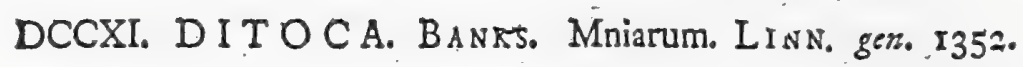

Flores duo terminales in pedunculo communi elongato, fquamis quatuor foralibus bafi muniti. Cal. quadridentatus, fuperus, perfiftens. Cor. nulla, nif calycem velis. Stam. duo, aut rarius unum. Ovar. inferum. Styl. duo. Sem. unicum, enlyce iucraffato corticatum.

Drтoca mufcora. Tab. I26. fig. I.

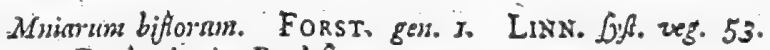
Ex herbario Bankliano.

PER. nullum, hifi calycem velis fuberofo-coriaceum, qui femen involvit, nec dimittit.

REc. nullum, preter fundum calycis.

SEM. unicun, ovato-acuminatum, glabrum, gilvum aut pallide ftramineam.

1NT. duplex: exterius a calyce craffum, corizceum, apice foramine pervium; intcrius membranaceum, tenue.

A I в. farinofum, candidifinum, centrale.

EMr. teretiufculus, periphericus, annularis, lacteus. Cotyl. femineretes, radicula paulo breviores. Rad. longa, adfcendens, If fupcra

a.) Phant frugifers ramulus. b. B.) Flores gemini pedanculati c.) Calgx saxturus integer.

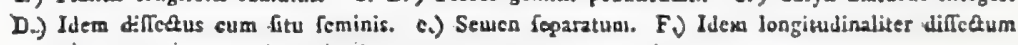
cum alburaints atgue exibryonis fut

Debet inter diandras reponi, quum ex oblerqatione Solandra ftamina ge mella mulco fint frequentiora, quam folitarium. 
Tab. CXXX

O
Silene nockfflora.

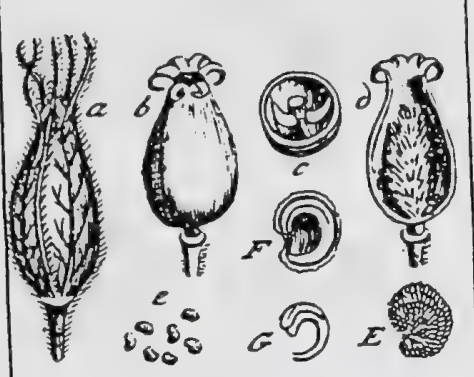

J. Gaertner (-1788) Vol 2

233

DCCLXIII. S I L E N E. LINN. ger. $56 \%$.

Calyx monophyllus, quinquedentatus. Cor. pentapetala, laminis integris aut bifidis, nudis aut barbatis. Stam. decem, fitu alternantia. Ovar. fuperum. Styl. tres. Capf. incomplete trilocularis, apice quinque - 1 . fexfariam dehifcens. Recept. columnare. Sem. numerolilima.

SILENe noctifora. Tab. I 30 . fig. 8 .

Ocyunoides noclifforum. CAMs. bort. ic. 34. BESL. Eyff. affivo. DII. to 12. f. 3. Vifcago foliis ovato-lansceolatis birfrutis, cuule brucbiuto, culycibus verofis. HaLL. bijl. "1. gir.

Silene calycabus decangularibus: dentibus tubum aquantibus, caule dicbotomo, petalis bifidis. LINN. Jyjt. veg. $42 \pi$.

PER. Capfula calyce venis alternis ramolis notato veftita, ovato-conica, fupra unilocularis, infra trilocularis, apice fexfariam dehifcens. Diffepimenta membranacea, tenuiffina, brevifima, ad paricten cupfulx fuperiorem in meras ftrias elevatas deliquefcentia.

REc. columnare, fupra liberum, hifpidum, craffum, dimidia capfula longius.

SEN. numerofiarma, centum circiter \& quinquaginta, reniformi-globofa, in dorfo planiufcula, tuberculis acuminatis feriatis fabrata, e ferrugineolutefcentia.

IN T. duplex : coriaceum atque membranaceum.

A L B. farinofum, album, centrale.

Eмв. periphericus, anmularis, lutefcens. Cotyl. compreffx, fubfulizcex. Rael. terctiufcula centripet..

2.) Capfula claufa, calyce veftita. b.) Eadem dehifcens. c.) Ejusdem bafis triloculatis. d.) Rccept. hifpidum. c. E.) Scmina feparata. F.) Albuminis \& embryonis fitus. G.) Embryo folutus.

Ad Silenem illas quoque Cucubali fpecies referimus, qux pericarpio valvatro gaudent.

46.25 


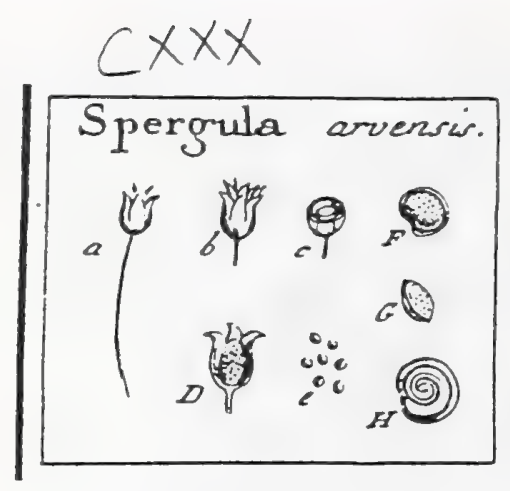

J. Gaertner $(-1788)$ Vol 2

230

DCCLIX. S P E R G L A. IINN. 'gen. 586.

Calyx pentapliyllus. Cor. pentapetala, lamivis indivifis. Stam. quinque 1. decem. Ovar. fuperum. Capl. unilocularis, quinquevalvis. Recept globofum liberum. Sem. plura, margiue cincts

Spergula arvenlis. Tab. I 30 . fig. 4

Spergula. DOD. peinpt. 527 .

Alfune foliis verticillatis, feninibus rotundis. HaLL. bif. 17.873 .

Spergula foliis verticillatis, floribus decandris. . Lins. Jy/2. veg. 437.

- Icon. Sen. GREW. nnat. t. 73.

PER. Capfula ovata, calyce cincta, unilocularis, quinquevalvis, vix ultra medium dehifcens.

REC. globofun, grande, liberum, fungofum, frobiculatum.

SEM. plura, circiter viginti, turgide lenticularia aut fubglobofa, margine acuto, ante plenam maturitatem membranaceo, cincta, plurimisque gramulis globofis albis, primum pedicellatis demum vero feffilibus, confperfi, ad umbilicum leviter emarginata, nigro-fulca.

I $v$ T. duplex: coriaceum atque membranaceum.

A L B. vix ullum, aut parciffmum in utroque feminis latere inter integumeats atque embryonem.

E м в. magnitudine feminis, fpiralis, lacteus. Cotyl femiteretes, unum cum dimidio fipirc gyrum abfolventes. Rad. peripherica, centripeta.

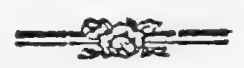

$23 \pi$

$*$.

2. b.) Capfula intra calycem, claufa \& dehifcens. e. D.) Eadem ditectia cum figun receptaculi. e. F. G.) Semlas a latere \& 2 dorfo lpetzatz. Fi) Semen apertum, cum embryone fpirali.

Spergula pentandra gaudet feminibus. foliaceo - compreffis, nigris, margine membranaceo albo cinctis.

46.26 
Tab. $\operatorname{cxxx}$

Caryophyllaceae

Stellaria Folostea.

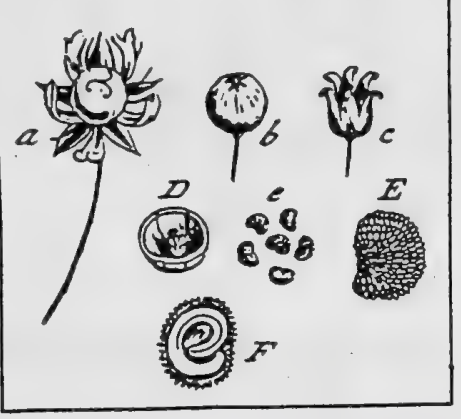

J. Gaertner (1788) Vol. 2

229

DCCLVIU. ST E L L A.R I. A. EINN. gen. 568 .

Calyx pentaphyllus. Cor. pentapetala, laminis bipartitis. Sram. decem; fitu altemantia.. Ovar. fuperum. Styl. tres. Capro. unilacularis, fexvalvis. Recept. brevifimum. Sem. plum.

Stellaria holoftea. Tab. I'30. fig. 3.

Gramen: Fuchs. bifl. Lat. 136. germ. ic. 74: - alieruan: Cins. epit. 745 . Alfine foliis gramineis ciliatis. HAEL. bift. $n_{i} 884$

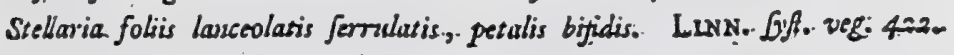

Icon. OEd. flor, dan, i. 628 .

2.30

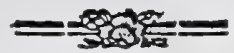

P.ER. CapTula globofa, tenuis, fubdiaplana, unilocularis, fexvalvis, ad bafin ufque dehifcens.

REc. breve, liberum, in fundo capfula, ex tuberculis parvis fungolis compofitum, inter qux funiculi umbilicales filiformes ad femina ruperiora procedunt

SEM. plura, circiter duodecim, grandiufcula, globofe reniformia, tuberculis acuminatis per feries remotiufculas parallelas digeltis pulcbre muricata, e luteo - rufefcentia.

INT. duplex: coriaceum atque membranaceum.

A цв. farinofum, candidum, centrale.

E s B. periphericus, fubfpiralis, albus. Cotyl. femiteretes, Rad. infero-centripeta.

.2) Caplula chaufa. b. c) Eadern dehifcens D.) Receptac, in fundo capfule. e. E) Sentina feparata. F.) Semen difecturn cum albumine \& embryose.

46.27 


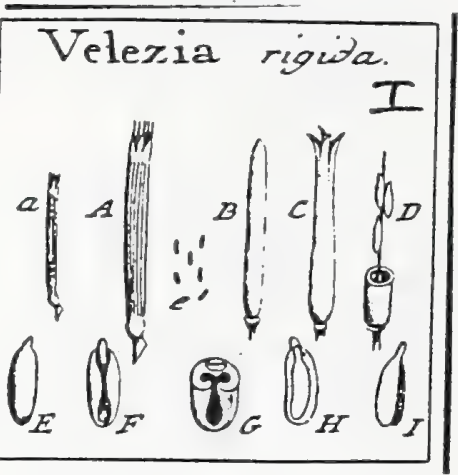

\section{J. Gaertner (-1788) Vol 2

\section{DCCIIV: VELEZ I A IINN. gert: 447.}

Calyx monophyllus, tubulofus, longiflimus, quinquedentatus. Cor: pen: tapetala, parva. . Stam: quinque: 1. fex. Ovar. fuperum. Styl. duo. Capr: unilocularis, apice quadtivalvis. Recept. fetaceum.liberum. Sem. inverfa.

Viezzla rigidá Tab:129.. fig:12:.

Lycljuis conticuláta minar. BARR:. ic. 1017. 1018: Bocc: muf. 2: p: 50: t: 430

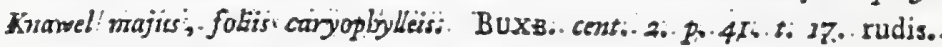

Helezia: Lins: fygt: urg:266.

Ex herbario : BankGiano:

Per. Capfula cylindrica, longiffims, calyce : perfiltente veftita, uniloculáris, apice quadrifariam: dehifcens.

REc: feraceum, centule, liberum; longitudine fere: capfulx, feminilus fub. alternis, , deorfun incumbentibus. tectum.

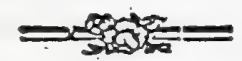

SEM. plura, ad duodecim, parva, oblonga, apice in brevem -mucronem producta, hinc convexa, inde ex marginibus in ventrem refexis concava, atque rima ampla longitudinali hiantia, ceterum glabra, nigricantia, in verfa. Unibilicus in nedio feminis ventre.

IN.T. duplex: coriaceum atque membranaceum, utrumque tenue.

A L B. farinofum, album, unilaterale.

Емв. dorfalis, rectus, inverfus, lacteus. Cotyl. oblongx, comprefrx, nee tamen foliacex. Rad. teretiufcula, brevifima, fupera.

a. A.) Capfula matara, calyce tecan. B.) Eadem deaudata, claula C.) Eadem apiee debifecens D.) Ejusdem fectio transveralis enm receptaculo atque feminum infertione. e. E) Seraioz fen parata, a parte do:[ali fyetazta. F.) Seminis latus ventrale. G.) Ejusdem feetio transverfalis H.) Embryonis fitus in dorfo albuminis. I.) Idem Colatus

A Diantho precipue differt: definito feminum fitu \& minori ftaminum numero, nec non fquamarum ad calycis bafin defecu. 


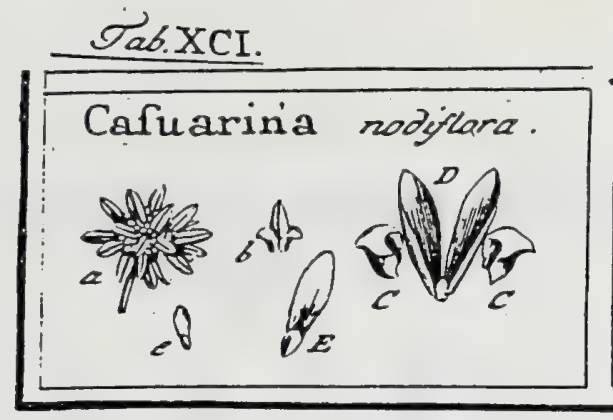

J. Gaertner (1788) Vol 2

\section{3}

DLXVIII. C A SUARIN A. LINN. ger. I428.

Flores fexu diftincti in eadem ftirpe. MAS. Amentum undique imbricatum Squamis fubmembranaceis, verticillatis, Janceolato-fubulatis, bafi connatis, uniforis. Cal. bivalvis: valvulis acutis, xqualibus, navicularibus, fquamis amenti brevioribus. Cor. nulla. Stam. unicum, capillare, fquama longius. FEM. Amentum ut in mare, fed multo brevius. Squamx etiam breves, fed geminatz. Cal. bivalvis ut in mare, fed fquamis longior. Ovar. compreflum, ovatum. Styl. fimplex, apice bifidus. Semen unicum, alatum. Ex fchedis SOLandrI.

- Casuarina nodillora. Tab. 91. fig. 4.

Cafuariza terreftris. RUMPH. anb. 3. p. 87. t. 58 . rudis.

Cafuariua verticillis faminum remotis. ТнuNB. gen. nov. p. 54. LINN. fuf. veg. 840 .

Ex herbario Bankfinno.

FRU CT. Strobilus fubglobofus, echinatus, pedicellatus. Squama amenti matur $x$, valdo incrafiat $x$, fuberof $x$, retufx, nivex, geminat $x$, ita juxta vicinas pofitx, ut ftrobili corpus egregie quadrangulo-teffulatum apparat. Calycum valvulx admodum elongata, coriacex, concavx, femen tanquan in theca claudentes \& demum dimittentes.

PER. nullum; calycis valvulx hoc officio funguntur.

R E C. nullum; femen bafi affixum.

Sem. unicum, ovatum, compreffum, glabrum, fuperne ala ovato-oblonga, fubpellucida, longitudine calycis, auctum.

IN T. duplex: exterius in alam definens; interizs arachnoideum.

A Lв. femini conformé, carnolum, pallidum.

Em.......

64

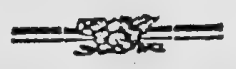

$*$

2) Strobilus integer. b.) Flolculus femineus matanus feparatus. C. C.) Squamx fuberolz apienti. D.) Valvule calycis maturi 2 parte interas fpedatz. C. E.) Semen fepuratum.

Amenti feminei fquamre breviores, forfan rectius pro calyce, \& longiores, pro corolla haberi polfent; fed quare ir charactere generico Syjt. veg. l. $c$. alterutro earum defint, cum mitraformes iftos echinati Strobili radios vel ipfe Rumphius recte annotaverit, non liquet.

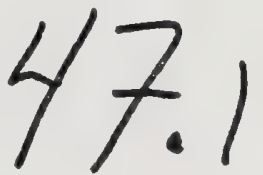


6

-

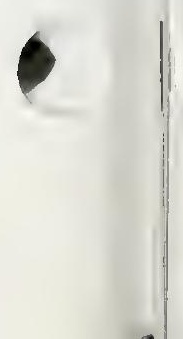


Tab. XCII.

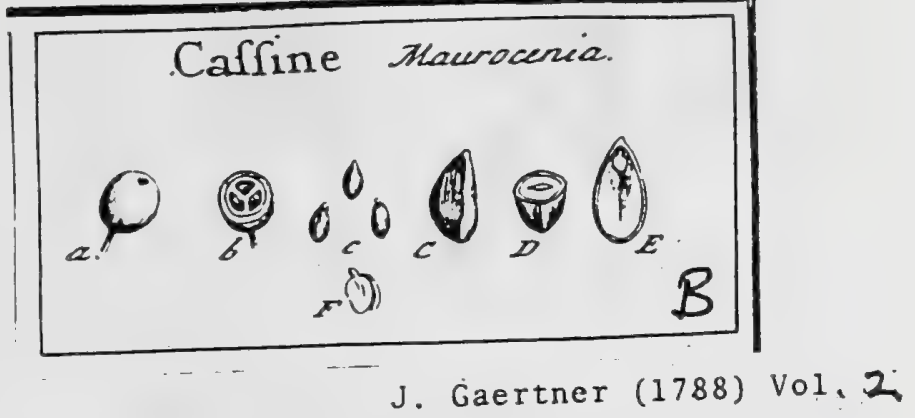

70

DIXXV. CASSINE. LINN. gen. $37^{1}$.

Calyx quinquepartitus. Cor. peniapetala. Stem. quinque. Ovar. fuperum. Stigmata tria feffilia, reflexa. Drupa baccata, trilocularis.

Cassine Maurocenia. Tab. 92. fig. 4.

Cerafus africana, foliis plemumque in fummo finuatis, fruflu rubro. PLUK. phyya t. 158 . f. 2 .

Frargula fentpervirens, folio rigido fubrotundo. DiLc. elth. 146. ¿. I21.

Calime foliis fefilibus integerrimis obovatis coriaceis. LiN. Jyjz. veg. 295.

Ex herbario Bankfiano.

PER. Drupz fupera, baccata, globofa, tribus in vertice ftigmatibus elevatopuncticularibus notata. Cortex carnofus, tenuis, cuticula externa e minio rubra. Puttamen cruftaceum, tenue, triloculare.

REc. nullum; femina apice loculamentis affixa.

SEM. folitaria, opata, fupra acuminata, cum-umbilico terminali minuto albicalte, cetera atra, hinc convexa, inde angulata.

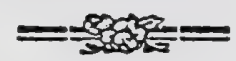

IN T. duplex: exterius coriaceum, craffufculum; interins membranaceum, rufefcens.

A L B. femini conforme, carnofum, album, cavitate compreffa in medio divifunr.

$E_{M B}$. dimidio albumine brevior, inverfus, luteus. Cotyl. ovatæ, foliaceo. compreffx. Rad. brevifima, fupera.

2.) Drupa iategra. b.) Eadem dFea c. C.) Scmina (eparata. D.) Seminis \& albuminis fertio transvetalis. E.) Embrgonis in fupremo albumine fitus. F.) Embryo folutus.

Embryonem aduliorem totam albuminis cavitatem replere, verifimile eft.

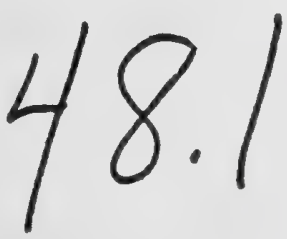




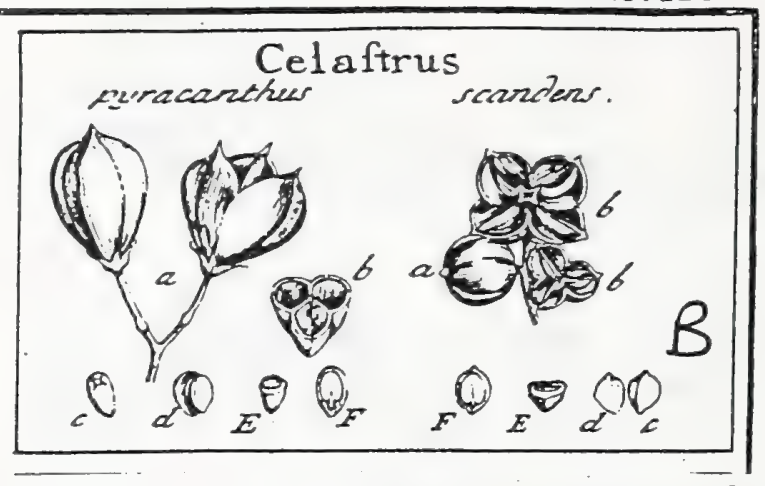

J. Gaertner (1788) Vol, 2

\section{C E L A S T R U S. LIN gen. 270}

Calyx quinquefidus. Cor. pentapetals Stam. quinque. Ovar. fuperum. Stylus fimplex: Atigmate trifido. Capfula trilocularis. Semina arillo colorato tecta.

Cerastrus pyracanthus. Tab. 95. fig. 4.

Lyciom etbiopicun, pjacantbe folio. Comm. bort. anf/s. I. p. 163. t. 84.

Alaternus fempervirens africaus, foliss lucidis, fpinofa. PLuk. phyt. t. 126. f.2.3.

Celufirns fpinis mulis, ramis teretibus, foliis acutis. LINN. Gyft. veg. 237.

PER. Capfula fupera, obovats, apice acuninata, triquetra, trifulca; extus rufefcenti ferruginea, intus pallide ftraminea, trilocularis, apice trifariam dehifcens, bafi integra. Difepinenta valvularum fulcis mediis deprellis refpondentia.

REc. nullum; femina margini centrali diffepimentorum brevibus funiculis umbilicalibus affixa.

SEN. pauca, quatuor circiter in fingulo loculamento, e quibus vix duo adolefcunt, ovata, verfus umbilicum attenuats, fufca, arillaca.

Arillus membranaceus, mollis, coccineus, a parte umbilico oppolita pervius: ore quadrifido inxquali.

IN T. fimplex, membranaceum, tenue.

I I в. femini conforme, carnofum, album, fragile.

EN B. longitudine fere albuminis, lacteus. Cotyl. cordato-ellipticx, foliacex, obfoletifime in medio concavx. Rad. brevis, teretiufcula, centripeta.

2) Capfula integra $\&$ dehifens. b.) Ejus fetiso transterfatis, co) Semen arilio veftitum. 4) Idem desudatum. E.) Albumes trastofic fetum F.) Ejusdem fetio longitudiaslis cum Embryone.

Celastrus fanderis. ibid.

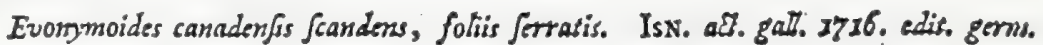
p. 652. t. 30.

Celafirus inernis, caule volubili. LisN. Jyzo veg. 237 .

Capfula fphxrica (a), tri-1. quadrilocularis, totidensque valvis: valvis (bb) per maturitatem horizontaliter patentibus, extus e viridi lutefcentibus, intus unacum diffepimentis membranaceis, albis. Arilli membranacei, molles, miniati. Semina (c. d.) ovata, utrinque_attenuata, compreffiufcula, plano-conveia (E.), ferruginea. Albumen \& Embryo (E.F.), ut in precedenti.

Arilli in omnibus meis fpeciminibus vermibus adrofi erant, ut eorum aperturam certo definire non aufim. Cetera genus totum expungendum \& cum Evvonymo fociandum videtur, quia nulla idonea nota characteriftica ab hoc differt, atque loculamentorum aut valvularum numerus, extra Carpologix ambitum, vix ullius momenti lit.

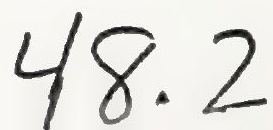


Celastraceae

Tab.IVIL

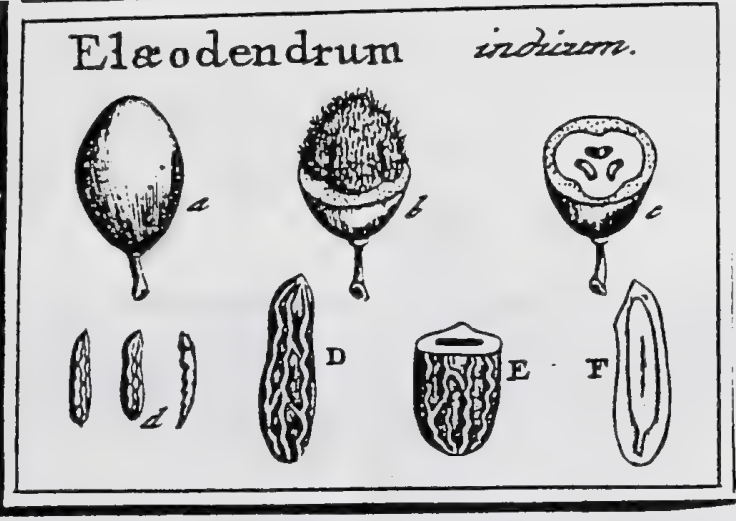

J. Gaertner (1788) Vol. 1

274

CCCXLIV. ELAEODENDRVM.

Flos.... Drupa fupera baccata. Putamen triloculare hirtum. Semina bafi aflixa, ge minata.

ELEODENDRUM indicum. Tab. 57 . fig. 5.

Bois d'olive: cum hoc nomine miffum a Serenif́. b. m. CAR OLINA March. Bad.

an Elaodendrum orientale. J A c Q. rar. $t$. 32. L INN. Jyfl. veg. 241 ?

PER. Drupa baccata, obovata, aut elliptica, rubicunda, fupera. Caro tenuis, fibris. capillaribus a puramine oriundis intertexta. Putamen offeum, craflefimum, extus (plerumque) fibris capillaribus rigidiusculis hirtum, tribusque fulcis profundis inferne exfculptum, rotundato trigonum, triloculare: loculamentis compreffiusenlis, glaberrimis; uno ant duobus fxpe obliteratis.

REc. cicatricula parva, albicans, paulo fupra bafin anguli interni loculamentorum.

SEM. in fingulo loculamento gemina, altero conflanter abortante \& fquamulx emarcid $x$ forma, bafi alterius affixo; altero oblongo, compreffiusculo, rufefcente, valis un. dulatis \& reticulatis infignito. Unbilicus in imo latere interno feminis.

IN T. fimplex, membranaceum, aridum, albumini arctiflune adharens.

A L B. Semini conforme, carnofum, duriufculum, 1. fubcartilagıneum, candidum.

En 8. longitudine albuminis, compreflus, erectus, albus. Cotyl. oblongx, foliacez, omnium tenuifisnz. Rad. linearis, comprefla, recta, infera.

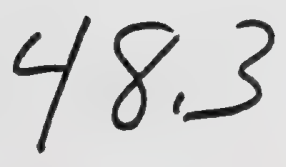




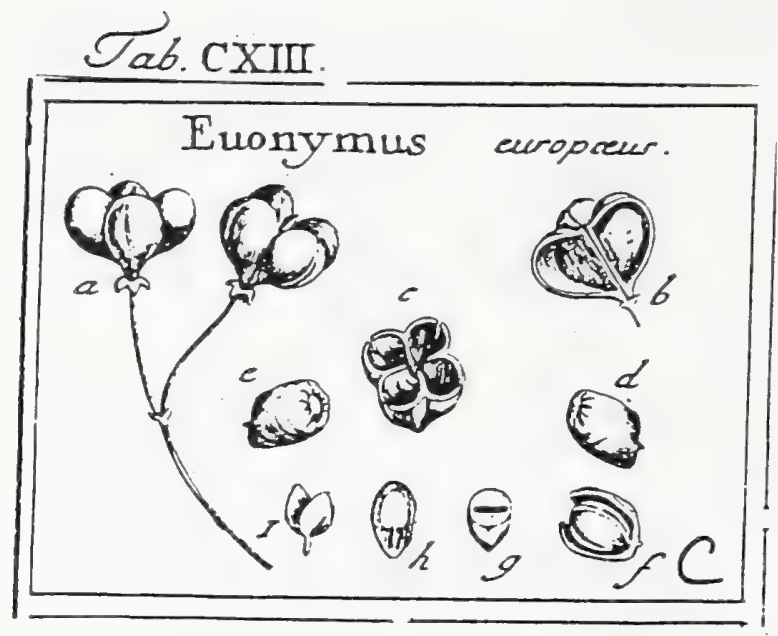

149

\section{J. Gaertner (17.88) Vol. 2}

DCLIX. EXONYMUS. TOURN. inf. t. 388. LINN. gen. 27.

Calyx monophyllus, quadri-l. quinquefidus. Cor. tetra-1. pencapetala. Stam. quatror aut quinque. Ovar. fuperum. Styl. fimplex. Capfula quadri-1. quinquelocularis, colorata. Sem. folitaria, arillata.

Evonymus europxus. Tab. I13. fig. 2.

Evorymuls. Cam. epit. 102. Dod. pempt. 783 . Halt. bjf. n. 829 .

Evorymus latifolius. Clus. bift. 2. p. 56. JACQ. aufr. 3. t. 28 g. HaLL. bifr. n. 830 .

Evonynnus floribus plerisque quadrijidis. LIN . Jp. pl. 286 .

Evonymus latifolitus \& europarts. LiN. [y/t. veg. 238 .

PER. Capfula turbinata, pulvinato - quadrifulca, membrana molli rubra corticata, ceterum coriaces, quadrilocularis, quadrivalvis. Diffepimenta medio valvularum fulco adıara.

REC. nullum; femina angulo centrali loculamentorum affixa.

SEN. folitaria, aut rarifime gemina, ovato globofa, arillats, fafcia dorfali Jongitudinali intra arillum notata, glabra, pallide incurnata l. rofea.

Arilliss carnofo-fpongiofus, in parte unibilico oppofita perforatus, femen totum obtegens, ejusque fafcix dorfali alfixus, croceus.

IN T. fimplex, chartaceum, craffiufculum, fplendens, albumini arce adnatum.

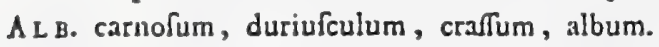

Ess. longituline albuminis, fuberectus, in recenti femine viridis. Cotyl. ellipsicic, fuliacca. Rad. teretiufcula, inferd \& Gmul centripeta.

a.) Capfula integra. b.) Seminis in marginem difrepimentorum infertio. c.) Capfula diftecta. L. e.) Semins arillo veftiti. f.) Mrillus dongitudimaliter apertus, eum femine denudato, ejus-

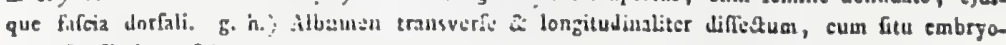
nis. I.) Enboryo folutus.

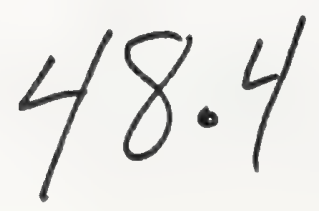




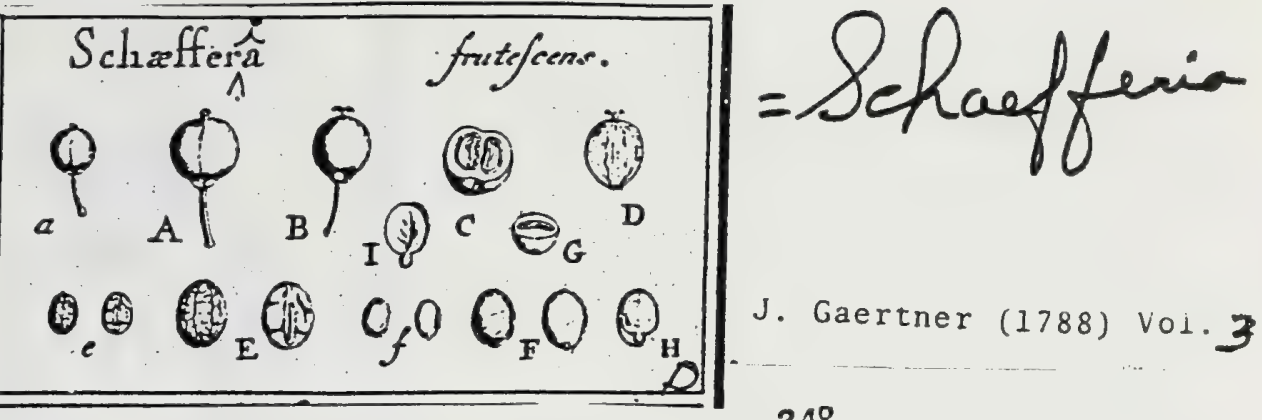

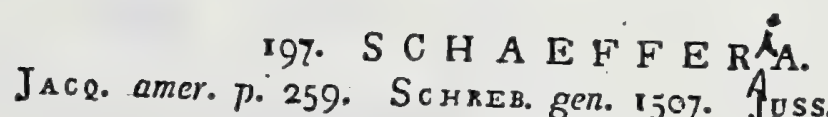

4 . 507. Joss. gen. p. 426.

LaMARCK ill. gen. $t .809$. SWARz flo ind. occid. $t$. 7 .
Flores fexu diftineti in feparatis plantis.

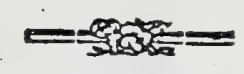

Mas. Cal. profundiffime quadripartituss, minimus, inferus, perfiftens; laciniis alternatim majoribus. Cor. petala quatuor, ovata, concava, fub ovario cum ftaminibus inferta, calyce multo majora, Stam. quatuor cum petalis alcerna; filamentis fubulatis; antheris fubrotundis." Ovarii rudimentum ovatum.

Fo ex:- Cal. ut in mare, fed laciniis minus profundis. Cor. petala quatuor; fpathulata, fub oyario inferta. Stam. nulla. Ovar. fuperum; ftylo bifido, breviffimo, rellexo; ftigmatibus fubfimplicibus, 1. leviter bifidis. Bacca parva, bifulcata, dipyrena; pyrenz movofpermx. Rec. nulluna. Sem. erecta, plano-convexa, Alb. çarnofun?. Emb. erectus.

Schaeffera frutelcens. Tab. 225.: fig. 7 :

bruxi folio majove acuminato ajbor baccifera, frudu minore croceo dipyreno. STIOAN bijt. 2. p. 102. t. 20g. f. 1.

Schaefferia (completa, ) floribus tetrapetalis axillaribus. SWarz prod. p. 38. fi. ind. occid. 1. p. 327. WiLLu. Jpec. pl. T. 4. P. =. p. 74 .

Schaefferia frusejceluss. JAcQ. I. c.

Ex lrilula Hípanioja, a $D^{\infty}$ Porteaư.

PER. Bacca parva, granum piperis paulo excedens, obovato-globofa, transverfim paulo lacior, fubdidyma, 1. fulco longicudinali obfoleto bipartita, calyci ninimo indiftens, vertice vero. Itylo bifido fulco bacce contratio faftigiạta, glabra, lutea 1 coccinea, bilocularis, dipyrena. Caro cuticula tenui teda, mollis, diffepimentum tenuifimum valis umbilicalibus mixsum formans, pyrenis undique adnati. Pyrenæ ovatx, plano - convexæ, hinc fulco elevato \& rima umbilicali intermedio infcripte, inde eminethr tiis minimis a vaforum impreffionibus fạbrate, fubofex, tenues, uniloculares, monofpermx.

REc. nullum : proter funiculum umbilicalem breviffimum, cujus ope femina pyrenarum bafi interna affixa.

SE N. folitaria, erecta, ovata, lenticularia, latere exteriore magis convera, interiore planiufcula, ferrugineạ.

IN T. Implex, membranaceum, tenue, facile detrahendum.

$\Lambda$ ᄃ B. fermini conforme, ad marginem tenue, lateribus vero \& bafi crafum, carnofum, ad peripheriam fordide lutefcens, verfus centrum vero pallidum.

E M B. magnitudine fere albuminis, erectus lutefcens. Cotgl magnx, ovatx, folinceo-carnofx, cochleariformes, 1 . intus concave extus convexx, nervofie, incumbentes. Rad. brevis, teretiufcuta, ad umbilicum externum incurva \& ipfi obverfa, infera.

\section{EXPLICATIO FIGUKE.}

a. A. B.) Bacca.dntegra. C.) Eadem una cum pyrenis atque feminibus transvinte ditreda. D.) Ljusdew fectio langitudinalis, fecundum fulcụm. e. E.) Pșrena foluta, ab utraque parte "

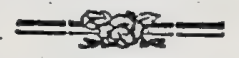

Spetats. f. F.) Semen fiparatum, cum funiculo urebilicali ad ejus baful. G.) Ejusdem fetio transverfalis. H.) Albumeu longitudinaliter diffetum, eum easl ryone in fitu. I.) Embryo
solutus. 


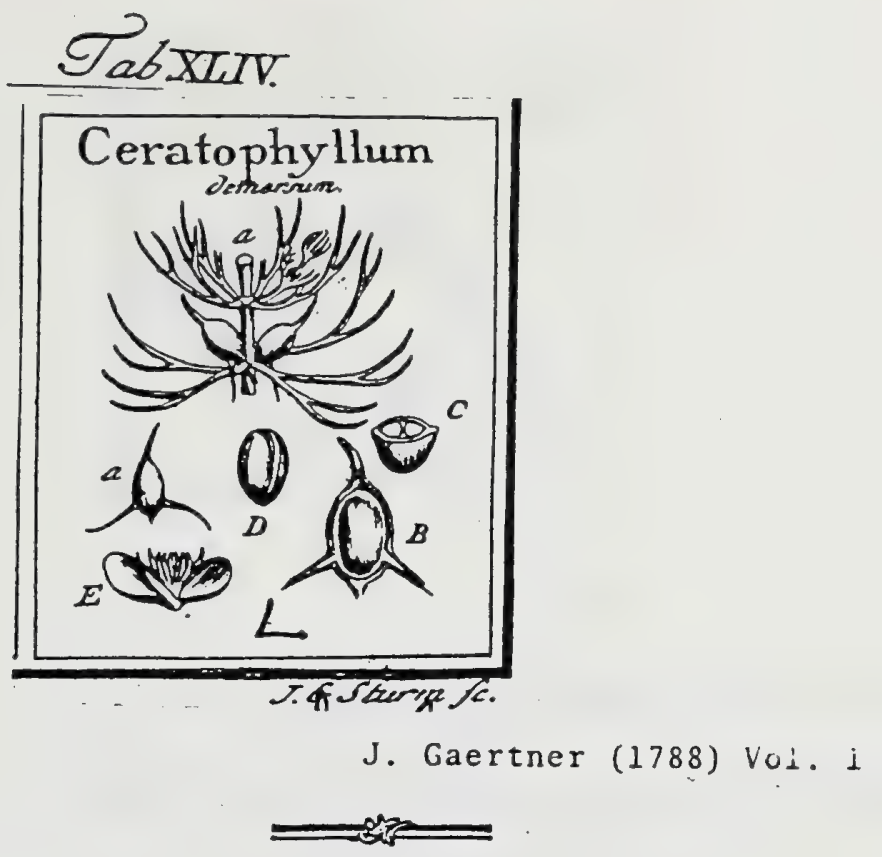

Flores fexu difincti in eodem caule. M \& s. Cal. multipartitus. Cor. nulla. Stam. plara: ad viginti. F ₹ s. Cal. \& Cor. ut in mare. Stigma fefisle. Nucula corticata evalvisis? Scminis embryo multipartitus.

Секлторнуц.um demerfum. Tab. 44. fig. 22.

Hydroceratophyllim folio afpero, quatuor cornubus armato. V A I x. cut. gall! 1719. t. 2. f. 1 .

Ceratophyllum foliis fubspinofis, capfula tricorni. H a L L. hifl. 2. n. 1599.

Ceratophyllum foliis dichotomo bigeminis, fructibus trifpino/is. LINN. fyfb: veg. 856.

P E R. Nux fupera, parva, elliptica, lenticulari comprefla, tribus (pinis mollibus armata, corticata. Cortex tenuis, fubcoriaceus, tandem fere in membranam exarefcens. Putamen ofleum, uniloculare, evalve, tres fpinas fetaceas, ex acuto fuo margine. proinens.

REC. nullum; femen fundo putaminis affixum.

IN T. fumplicifinum, membranaceum.

A L s. nullum.

VIT. bilobus, cotyledoniformis, carnofus, albus: lobis oblongis, intus concavis, exan tus angulo cariuatis, bafi conuatis, radiculam occultantibus.

Ex B. longitudine loborum vitelli, ereclus, albicans. Cotyl. plures, teretiufcula, breves, inxquales. Rad. intra vitellum abscondita, infera.

2. 2.) Nueula integr3. B.) Ejus putamen denudatum. C.) Necis \& nuclei fctio transverfalis; at lateralis fitus loborum vitelli con'piciatur. D.) Vitellus conbryonern ampleftens. E) Lobi jus dira: ricati, cum fitu \& figura cotyledonum embryonis. 
Tab. L XXVII.

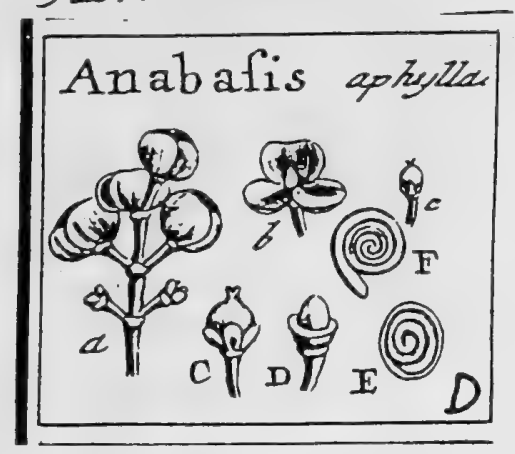

a bertucr (17ss) Vol.1

374

CCCCLxXXVIII. ANABASIS. Linn. ger. $3^{12 .}$

Calyx triphlıy!lus, coriaceus, nitidus, maximus. Cor. pentapetala, minima. Stam. quinque. Sigi. duo. liacca a:juola monolpermu. Semen erectum.

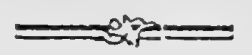

Anatis is aphylla. Tab. 77. fig. 4 .

Káli lincrifcrum, falicornice facie. BuxB. cent. I. $\mu$. It. t. IS.

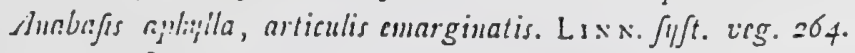

PER. Jacta fupera, Marra, calyce maturo coriaceo grandifimo tccta, fubglobola, fuipofa, rubra, unilocularis. Pulpa ąuo!a, luteo tingens.

R r.c. nullum; femen bafi affixum.

SEM. Unicum, oratum, lenticulari compreftum, virids.

Ix r. fmplicillimum, membranaccum, diaflunum.

A.B. nullum.

Eм m. magnitudine feminis, filifomis, fpiraliter convolutus, crectus, gramiseoviridis. Cotyl. Semiteretes, longillima. Rad. filiformis, infc:a.

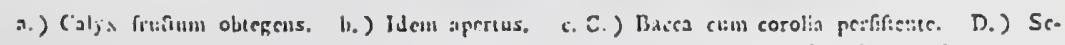

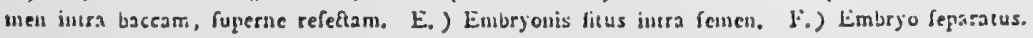

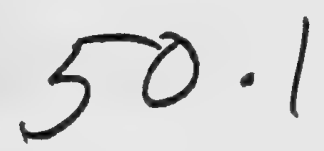


Chenopodiaceae

Tab. CXXVI.

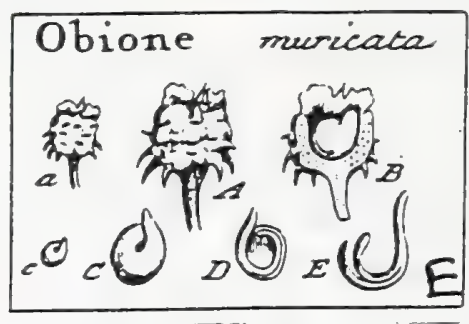

= atriflex

J. Gaertner (-1788) Vol 2

I9S

DCCXV. O B I O N E.

Flores fexu diftincti in eadem aut diverfa ftirpe. MAS. Cal. quadripartitus. Cor. nulla. Stan. quatuor. FEM. Cal. monophyllus, bijabiatus, inuricatus. Cor. nulla. Ovar. fuperum. Styl. bipartitus. Sem. uuicum, calyce indurato tectum.

Oblone muticata. Tab. 126. fig. S.

Spinacbial foliis angulofis, caule ramofisimo. HaLL. goets. 22.

Spinacio foliis triangularibus ex finuato dentatis. GMEL. fib. 3. p. 85. t. 15. f. . . mala.

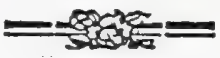

I99

Atriplex canle berbaceo, foliis deltoidibus angulatis, calycibus frulfus extus muricatis. LINN. Jylt. veg. $90 \mathrm{~g}$.

PER. nullum; calyx induratus, fuberofus, bafi integerrimus fpinis refexis muricatus, apice vero bilabiatus dentatus connivens, femen fover, nec dinittit.

REC. nullum; femen fundo calycis affixum.

SEM. unicum, ovato-roftellatum, lenticulari compreflum, pallide cinereum.

IN T. triplex: extinum, pellicula tenuilfima, facile de femine fecedens, ut pro capfula utriculari haberi poffet; medizm chartaceum, e rubro-ferrugineum; intimuin membranaceum rufefcens.

A ц в. farinofum, album, centrale.

E м в. periphericus, annularis, lutefcens. Cotyl. femiteretes, incunbentes. Rad. cotyledonibus paulo brevior, fupera.

2. A.) Calyx matures, integer. B.) Iden diffeatus; cum femine in fitu naturali. c. C.) Semen (eparatum. D.) Embryo circa albumen convolutus. E) Idem feparatus.

Staminibus, calyce, \&, . quod caput eft, feminis ac embryonis fitu inkerfo abunde a Spinacia \& Arriplici differt, ut cum his fociari nequeat.

50.2 


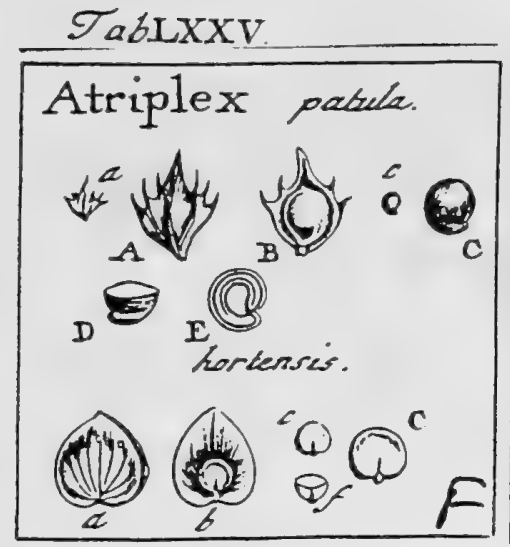

J. Gaertner (1788) Vol.1

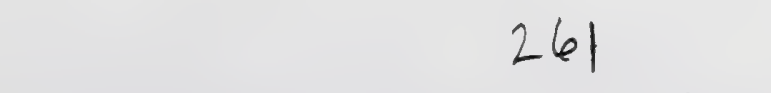

CCCCLXX. ATRIPLEX. T OU R N. t. 286. LIN N. gen. II53.

Flores hermaphroditi \& feminci in eadem planta. HER $x$. Cal. pentapliyllus. Cor. nulla. Stam. quinque. Styl. duo. F E M. Cal. diphyllus. Cor. nulla. Semen utrisque unicum, crectum.

A TRIPLEX patula. Tab. 75. fig. 8.

Atriplex fylveftris anguflo oblongo folio. Mor is hift. 2. S. 5.t. $32 . f \cdot 15$.

Atriplex foliis imis hamatis, reliquis lingulatis, vafculis feminalibus dentatis. Н а ц 1.. hifl. 2. n. 1616 .

Atriplex caule herbaceo patulo, foliis fubdeltoideo-lanceolatis, calycibus fenimum difco dertatis. L I N $\mathrm{N}$. fy $\int$. veg. yog.

PER. nullum, proter extimam feminis curiculam. Calyx rhomboideus, acuminatus, per oram atque dorfum dentibus acutis, quafi fpinulis armatus, femen occultat.

RE. nnilum.

SEM. unicum, leaticulare, rofellatum , erectum, fub pellicula extcriore atrum, nitidum.

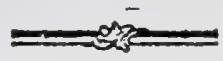

Is r. triplex: extimum tenuifimum, cinerascens, friabile; medium chartaceum, fubfragile; intimum incmbranacem, rufescens.

A цв. centrale, farinofun, candidifinum.

E жв. teretiusculus, periphericus, anuularis, lacleus. Cotyt. femicylindrica. Rad.tereti acuninata, infera.

2. A. B.) Semen intra calycens. c.C.) Idem folutum. D.j Ejus fectio transverfalis. E.) Ideen verticaliter feetum, cum fitu albumivis \& embryonis.

A TRIPIEX hortenfis. ibid.

Atriplex caule erefto herbacco, foliis triangularibus. LIN N. fyft. veg. 909.

Calycis valvula (a.b.) ovatz, cordatx, ftriatx, integerrimx. Scnuina orbiculatz (c.C.), utrinque planiuscula, tubro ferrucinea, ad marcinem fa:urate \& quafi anrulo nigro colorata. Scmitia fnris hermaphroditi lentiḉlaria (f.), fub fellicula cencrascente, atri, glabcrima, nitida. 


\section{Tab. CXXVIII.}

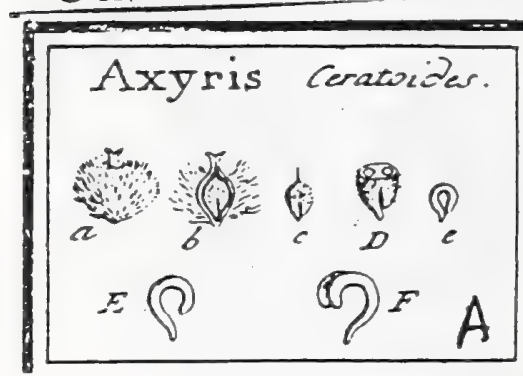

\section{J. Gaertner (1788) Vol. 2 \\ 210}

DCCXXX. A X Y R I S. LinN. gers. Iof7.

Flores fexu diftincti in eadem ftirpe. MfAS. CiIt. tripmtitus. Cor. mulla. Stan. tria. FEM. Cal. di - pentaphyllus. Cor. nulla. Ovar. fuperume Styl. bifidus. Capfula monofperma, calyce tecta.

AXYRIs Ceratoides. Tab. I28. fig. I.

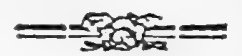

Axyyis frutcicofn, foribus fentineis lanatis. GMeL. fibir. 3. p. T7. t. 2. f. r.

Axyntis foliis lanceolatis tomentofss, foribus fentineis Lanatis. LiN. fyff. veg. 846 .

PER. Capfula utricularis parva, obovata, tenuiftma, hifpidula, ftylo perfiftente terminata, involucrita calyce claufo bicorni lanato.

Rec. rullum; femen bafi affixum.

SEMr. unicum, vix a capfula diftinctum, obovatum, deorfum infigriter acuminatum, comprefiufculum, pallidum.

INT. fimplicifimum, niembranaceum, diaphanum.

A L B. farinofum, candidifimum, centrale.

E s B. periphericus, uncinaro-curvatus, albus. Cotyl. femiteretes, accumbentes. Rad. fliformis, infera.

a.) Calyx maturus integcr. b.) Iilem longitsdimalitcr aperturs, capfulam incladens. c.) Capfula fcparata. D.) Capfule \& feminis :-Etio transverfalis. e.) Semen feparatum, in giro, ob transparentiam intcgumenti, albumen \& enbryo faciic conf́iciuntur. E. F.) Embrțo folutus.

Poffet capfula hxc utricularis pro feminis integumento externo haberi, niti ftylo eifet terninata; femen ipfun laxe ambiret, atque fuperficien izaboret villis brevibus rigidiufculis fübraram. 


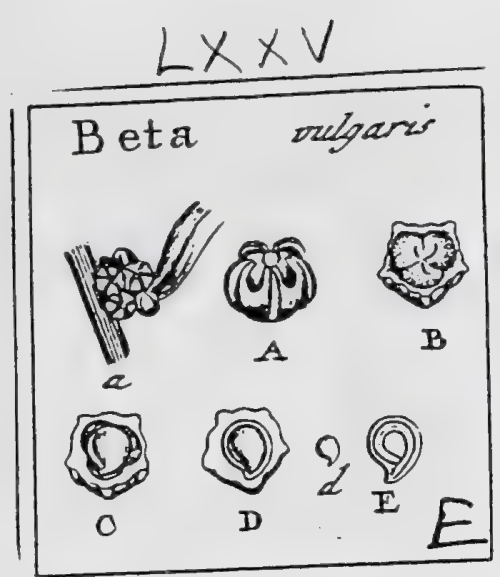

\section{J. Gaertner (1788) Vol.1

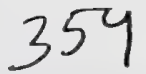

CCCCLXVII. BETA. T Ou R. t. 286. LIN N. gen. 310.

Calyx quinquefidus, per maturitatem connivens, quinqne colatus. Cor. nulla. Stam, quinque. Styl. duo l. tres. Sernen calyci immerfum, iuferum, horizontale.

B E T A vulgaris. Tab. 75. fig. 5 .

Beta rubra aut nigra. BLA $\times$ ש. herb. $t .235$.

Beta floribus congefis. LIN N. Jyf. veg. 262.

PE . nullum; femen intra receptaculi floris fubftantian carnolam, tribus eminentîs: convexis notatam, latens.

REc. nullum.

SEM. unicum, horizontale, reniformi globofum, argute roftellatum, leve, ferrogineurn.

IN T. duplex: exterius coriaceum; interius membranaceum; utrumque tenue.

$\Lambda$ цв. centrale, globofum, farinofum, candidıfimum.

EM B. teretiusculus, periphericus, albus. Cotyl. Senuicylindricx. Rad. tereti-acuminata, horizontalis, cenerifuga.

1.) Frutus glomerati. A.) Calyx maturus inteqer. B.) Ejus dentes refetl, \& receptactum carnolum trilobum convexum denudatum. C.) Semen intra receptaculi fubftantiam locatum. d. D.) Nocleus desudatus \& Separatus, E, Embryo in peripheria feminis pofitus, albumen centrale atma. pleftens.

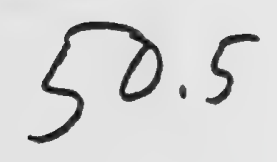




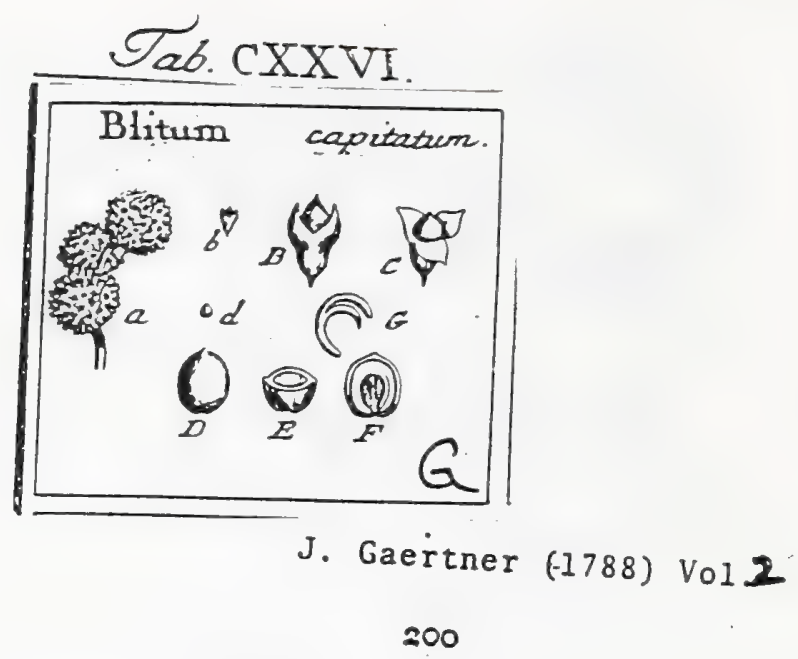

DCCXVII. B I I T U M. Lins. gen. I4.

Calyx trifidus, coloratus. Cor. nulla. Sam. unicum. Ovar. fuperum. Styl. duo. Sem. unicum, calyci carnoro immerfum.

BLITUM capiatum. Tab. 126. fig. 7 .

Atriplex mori fructul major. Moris. bift. 2. S. 5. t. 32. f. $g$.

Blitum foliis feniitrilubis -raritet dentatis. HALL. biff. 11.157 1.

Blitun capitellis Jpicatis terminatibus. LiNN. Jyjt. veg. 53 .

PER. nullum; calyx per maturitatem carnofus semen fuftinet, nec obtegit.

REC. nullum; feminis bafis calyci immerfa.

SEM. unicum, parvum, fubglobofum aut lenticulare, nunc ad alterum, nunc ad utrumque !atus in marginem anguftifimum f. aciem extenuatum, atrum.

IN T. duplex: exterius cruftaceun autcoriaceum durum; interins membranaccum.

A L B. carnofun, aqueo-pallidum, centrale.

EM B. periphericus, annularis, albus. Cotyl. femiteretes, incumbentes. Rad. infers.

.2.) Fruetus capitati. b. B.) Calyx unaturus. C.) Idem sum (eminis infertione. d. D.) Sement feparatup. . E) Ejus,fectio transverfalis. F.) IJcm verticaliter diffectun, eum albuminis a embryonis fitu. G.) Embryo folutus. 


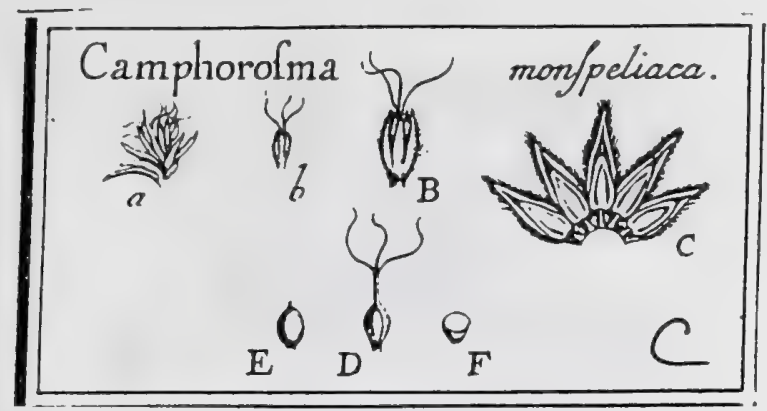

\section{J. Gaertner (1788) Vol3}

175

135. C A M P H O O.S M A.

LINN. gen. 164. ed. Schreb. 22r. Juss. gen. p. 84.

LAM A в C K ill. gen. t. 86. Camphorata.

TочвN. act. gall. 1705.

Flores minimi, axillares, terni l. rarius quaterni intra foliorum cxípitem.

Cal. urceolatus, quinque - (in floribus inferioribus quadri-) partitus 3 lacinîs lanceolatis, conniventibus, verfus apicem margine involutis 1 . concavis, ciliatis s duabus minoribus. Cor. 0 . nifi calycem velis. Stam. s. (1. 4) erecta, calycis laciniis breviora, \& in illarum concavitate fita 3 filamentabrevia, imo calyci inferta, fubulata; antherz ovato - cordatx, craffa, acutx, erectx. Ovar. fuperum, triquetrum; ftylus fimplex, filiformis, tri - ( $L$ bi-) fidus; ttigmatibus fetaceis, flexuofis, acutis. Per. nullum. Semen unicum, intra calycem abfconditum. Alb. ... Emb. ...

Canphorosma monípeliacs, Tab. 213 . fig. 3.

Camplorata birfuta. BАUн. pir. p. 486. BणXв. cent. т. p. 18. t. 28. f. x. Camplorata monspetiensum. B⿺UK. bif. 3. p. 379. LOB. adv. 774 .

Camphorofna foliis birfutis linearibus. LINN. amoen. I. p. 392. Spec. pl. I78. Syf. veg. ed. 24 p. 166. WILLD. Spec. plo. T. I. P. 1. p. 6g6. PER-

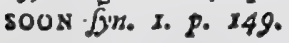

r76

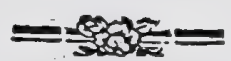

PER. nullum : calyx pubefcens dentibus conniventibus femen occultat.

REC. nullum : femen bafi calycis adaatum.

SEa. unicum, obfolete rotundato-triquetrum, mucronulatum,

IN T. fimplex ...

A L B. carnofum ... Е Мв....

EXPLICATIO FIGURE.

a.) Florum glomerulus. b. B.) Flos feparatus. C.) Calyx expanfus, cum Gitu \& forma famiaum. D.) Ovarium fepatatum. E.) Semen folutum. F.) Ejusdem fetio transverfalis, Paucos nonnif inveni tores, in quibus calycis laçinia quinta \& Itamen quin.
tum defuit, his quaque erat ftylus bifidus. 


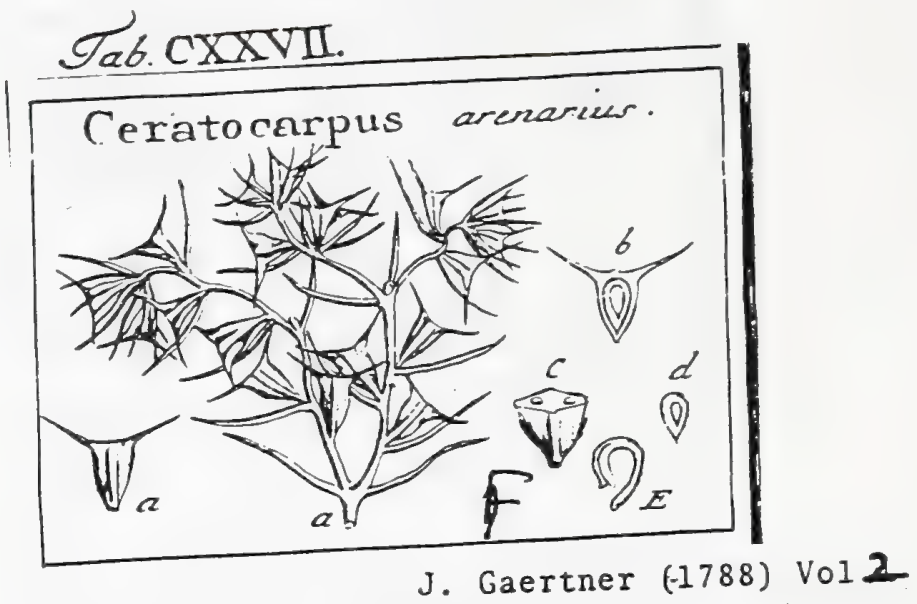

\section{C ER A T O C A R P U S. LINN. gen. IO35.}

Flores fexu diftincti in eadem ftirpe. MAS. Cal diphyllus, xqualis, obtufus. Cor. nulla. Stam. unicum. FEM. Cal. diphyllus, foliolis oblongis, carinatis, apice in fpinam extrorfum patulam definentibus. Cor. nuliz. Ovar. fuperum. Styl. duo. Semen calyce perGiltente corticatum.

CERA tocarpus arenarius. Tab. 127. fig. 7 .

Ceratocarpus. BuXB. af. petrop. I. p. 244. t. 9. GMEL. fi6. 3. p. 14. LIN. fy.l. veg. 838 .

PER. vullum; calyx maturus confertuminatus in thecam oblonge triangulam, compreffam, fulco elevato medio utrinque notatam atque apice fuo in duas fpinas innocuas \& horizontaliter divergentes delinenten, 'femen fovet, nec dimitrit.

REc. nullum, proter fundum calycis, cui femen affuxum.

SEN. unicum, obovatum, deorfum infigniter acuminatum, compreffum, fub. fufcum.

IN T. Gimpliciffinum, membranaceum, tenue.

A I B. furinofum, niveum, centrale, arcte cum integumento connatum.

EMB. periphcricus, uncinato-curvatus, gramineo-viridis: Cotj\%. femiteretes, accumbentes. Kad. filiformis, infera.

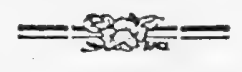

a. 2.) Ramulus cum enifcibus fruetus integris. b.) Calyx longitulinaliter apertus, cum iafertione feninis. C.) Ejusilem foctio transverfalis. L) Semen feparatum. E.) Enibryo denudatus.

In recenti firpe fedulo inquirendum, utrum ftyli, feminis integumento externo, utrumve interno, inferti fut? In priori enim cafu, fructus dicendus effet capfularis, inferus, \& folx $\int_{\text {pin }}$, calycis feminei fupplerent munus.

\section{8}




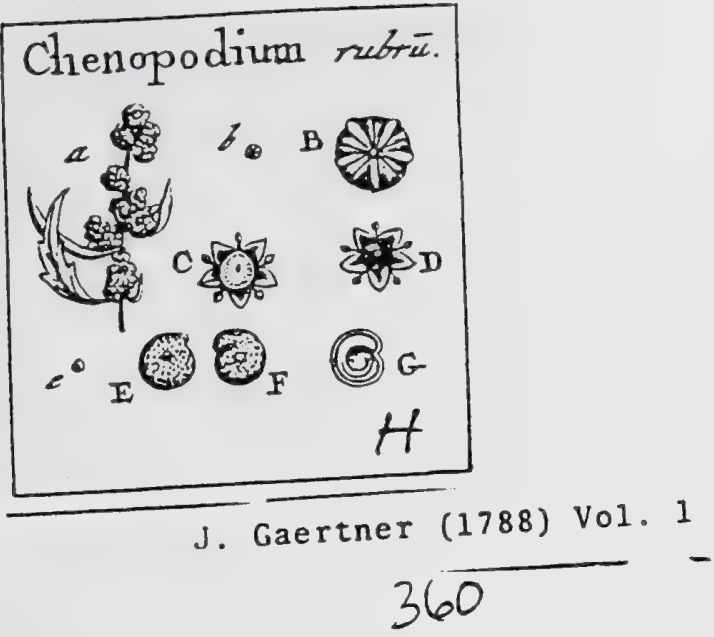

CCCCLXVIII. CHENOPODIVM. TOURN. t. 288. LIN ger. 309:

Calyx quinquefidus, per maturitatem connivens, femen totum obtegens, quinquecónatus. Cor. nulla. Stam. quinque. Styl. unicus, bi-l. trifidus. Semen fuperum, horizontale.

Chenopodus rubrum. Tab. 75. fig. 6.

Pes anferinus. F ч с н s hif. lat. 633 . germ. ic. 372 . D० D. pempt. 616.

Chenopodium foliis glabris nitentibus acute circumdentatis. H A L L. hifl. 2. 2.1583 .

Chenopodiun foliis cordato triangularibus obtufusculis dentatis, racenis erettis conspolitis fubfoliofis caule brevioribus. L I N . Sijl. veg. 261.

PER. nullum, nifi tenuifinam velis pelliculan feminis extmmam. Calyx maturus obtegit totum femen.

REC. nullum, proter cicatriculam minimam in fundo calycis, cui fernen affixum.

SEM. unicum, horizontale, Ienticulare, roftellatum, fub cuticula extima atrum, glabru!n.

IN T. triplex : extimum membranaceum, pallidum, tenue friabile, utrinque in medio apicillo prominulo notatum; nediu

A L. . centrale, farinofum, album.
E м в. reretiuscuius, periphericus, annularis, albus. Cotyl. femicylindricx. Rad. horizontalis, centrifuga.

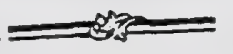

(a) Calyx claufus. C.) Idem explicatus cum femine in fitu. D.) CaCalyx claufus. C.) fidem explicatus cum. F.) Ejusdem pars infelycis fundus cicatricula notatus. e. E.) Serainis latus transverfe feêtum, cum embryone peripherico. rior cum cicatricula umbilicali in centro. 


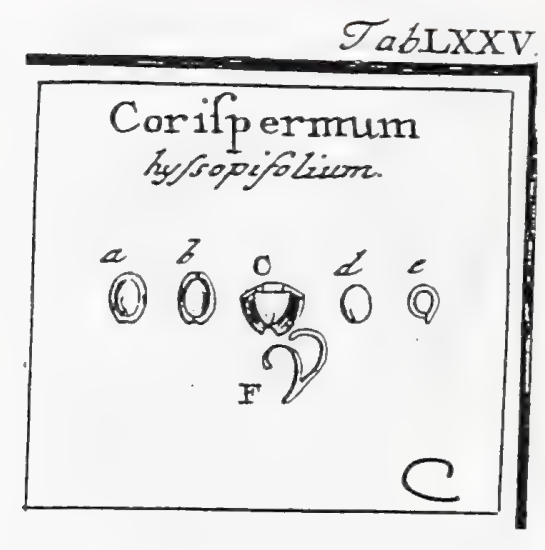

\section{J. Gaertner (1788) Vo].I \\ 362}

CCCCLXIX. CORISPERMVM. LIN N. gen. 12.

Calyx diphyllus. Cor. nulla. Stam. unum ad tria. Styl. unicus. Semen ellipticum, plano convexum, erecłum.

CORispermum hyflopifolium. Tab. 75. fig. 7.

Corifpermum floribus lateralibus. Li N N. Jyf. veg. 53 .

PER, siullum.

REc. nullum, prxter calycem.

SEs. unicum ellipticum, hine leviter convexum, inde planiusculum, aut fubconca. vum, acuto margine cinctum, glabrum, fpadiceo-pallidum.

IN T. duplex : exterius fubcoriaceum, in marginem anpliatum; interius tenuifimum.

A \& в. ceutrale, ellipticum, compreffusculur, farinofum, candidur.

Eмв. filiformis, periphericus, albus. Cotyl. lineares, planiuscula, incumbentes. Rad. teretiuscula, infera.

a.) Seminis latus convexum. b.) Ejus pars concava. C.) Idem trassverfe fectum. d.) Nucleus deo nudảitus. e.) Embryo albumen cingeis. F.) Idem folutus. 


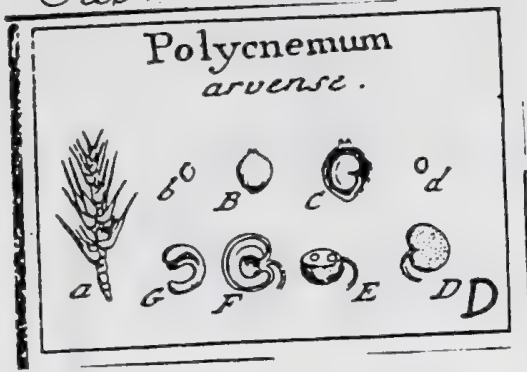

J. Gaertner (1788) Vol. 2

$$
211
$$

DCCXXXI. P O L Y C E M U M. LINN. gen. 53 .

Calyx bi-1. triphyllus, foliolis glumaceis. Cor. 2. 3. spetala, petalis calyci conformibus. Stam. unum ad quinque. Ovar. fuperuin. Styl. duo. aut unus bifidus. Capfula utricularis. Semen erectum.

Polycnemum arvenfe. Tab. 129. fig. 2.

Chenopodiun foliis fubulatis prifmaticis, floribus foliturüs feJilibus axillaribus. GUETT. Ramp. 14

Polycuenum arvense. JAc(2. auftr. 4. t. 365 .

Polycuenums. Liss. fyfo. veg. 83 .

P\&R. Capfula utricularis, fubrotunda, turgide lenticularis, tenuifima, pallida, genino ftylorum rudimento apice terminata.

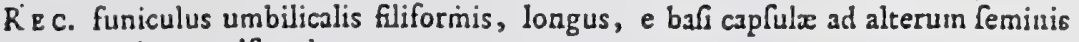
marginem adfcendens.

SEN. Unicum, rotundato-reniforme, lenticulare, punctis elevatis minutiffmis confperfum, rufefcens, erectum.

INT. duplex: coriaceum atque membranaceum, utrumque tenue.

A LB. carnofum, album, cenirale.

212

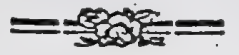

Eм в. periphericus, annularis, albus. Cotyl. femiteretes, incumbentes. Rad. tereciufcula, infera.

2.) Fruetus in foliorum axillis, bafi dilatatis, membranaceis, albis, b. B.) Capfula integra. C.) Eadem Ingitudinaliter aperk, cum funiculo umbilicali \& femine in fitu. d. D.) Semen feparatum. E. F.) Idem diffeetum cum fitu \& figurk albuuinis atque embryonis. G.) Embryo folutus.

Cum tanta fit numeri partium floris varietas, obfervationibus PALLAssı abunde confirmata, recte omnino fecife videtur ADANson, qui Polycnemon cum Camphorofna mifcuit. 
Chenopodiaceae

Tab. CXXVII.

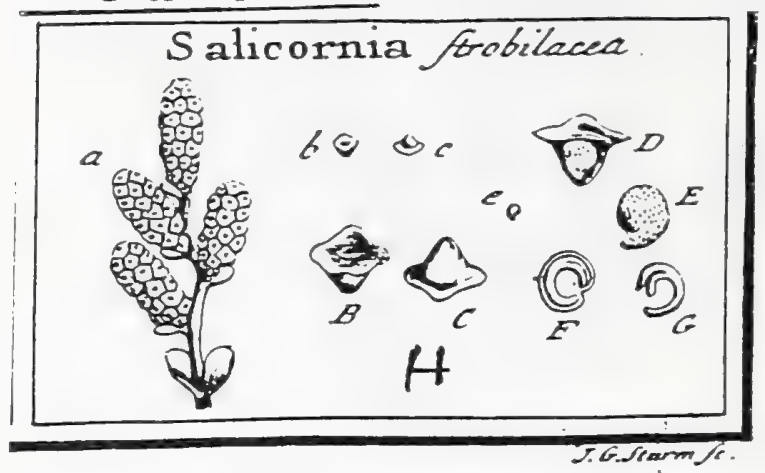

$$
\begin{gathered}
\text { J. Gaertner (1788) Vol. Z } \\
210
\end{gathered}
$$

DCCXXIX. SAIICORNIA. TOURN. t. 485. LINN. gert. IO.

Calyx inverfe pyranidatas, aitgulatus, edertulus, femen involucrans. Cor. nulla. Stam. unum aut duo. Ovar. inferum. Styl. bifurcatus Sem. unicun, in calycis ventre abfonditum, erectum.

SAlicorsis ftrobilacea. Tab. 127. fig. 8.

Salicorria frobilacea. PALL. it. ruth. x. p. 48r. t. B. f. r. z.

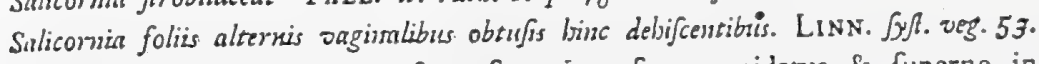

PER. nullum; calyx maturus fungofus, inverfe pyramidatus \& fuperne in narginem repandum ampliatus, femen in ventre fuo fovet, nec dinitrit. REC. nullum; femen fundo calycis in fitu erecto affrum.

SEM. unicum, turgide Jenticulare, roltellatum, ninucifimis punctis clevatis denle confperfum, rufefcens, erecturn.

INT. duplcx: coriaceum arque membranaceum, utrumque telluc.

ALB. Eurinofum, niveum, centrale.

EN B. periphericus, annularis, fubviridis. Cotyl. ferniteretes: incumbentes. Rad. filiformis, infera.

a.) Ramulus cum f́picis maturi's, magnitudine naturall. Б. B.) C3Igx naturns a parte fuperiose, \& c. C.) iden a parte inferiore fpectatus: D.) Calyoris feetio verticalis, euin fitu feminis. e. E.) Semen folutum. F.) Ekisdera fectio verticalis cun figura \& fieu albumisis atquic embeyonis. G) Embrร̧o Solotus.

Silicornix Species difficillime extricantur, cım eadent planta, pro varia fua xtate, loco, tempore, varia atque varia fit. Sxpius uni floficulo fermineo adfant duo mafculi minores.

50.12 


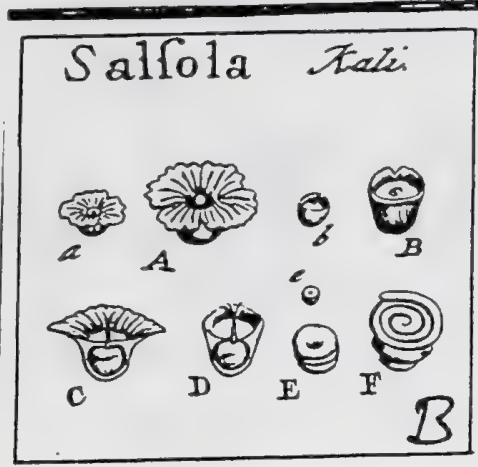

J. Gaertner (1788) Vol. 1 :

CCCCLXVI. SALSOLA. LINN. gen. $3^{11}$.

Calyx monophyllus, quinquefidus, in fructum abiens. Cor. nulla. Stam. quinque. Sty!. bifidus. Semen unicum inferum, calyce corticatum.

SA L SOL A Kali. Tab. 75. fig. 4.

Tragum. С А м. epit. 779 .

Kali spinofo affinis. MOR I s. hift. 2. .5. 5.t.33. f. 1 r.

Salfola herbacen decumbens, foliis fubulatis fpino/is fcabris, calycibus marginatis axillaribus. LIN N. Jufl. veg. 217 .

PER. nullum. Calyx, in marginem, nunc ampliffumum patentem, nune breviorem. ereftum, extenuatus, femini adnafcitur.

REC. nullum.

SEM. unicum, inferum, fubglobofum, fylo perfiftente terminatum, lutefcens.

IN T. finplex, membranaceum, tenuifimum.

$\Lambda$ L B. nullum.

Eм. filiformis, in cochleam globofam convolutus, viridefcens. Cotyl. longiffimz. lincares. Rad. terctiuscula, in fuprema feminis parte horizontaliter locata.

A. A.C.) Calyx margine patentifimo, \& b.B.D.) Jdem, margine crefo, Semeo incrufars, c. E. Semen feparatum. F.) Embrjo denudatus. 


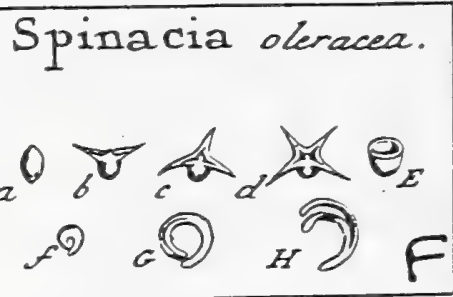

\section{J. Gaertner (1788) Vol. 2}

198

DCCXIV. SPINACIA. TOURN. t. 308. LINN. gen. IIIz.

Flores fexu diftincti in feparatis ftirpibus. MAS. Cal. quinquepartitus. Cor. nulla. Stam. quinque. FEM. Cal. monophyllus, 2.3.4fidus, perfiftens. Cor. mulla. Ovar. fuperum. Styl. quatuor. Sem. unicun, calyce ill. diurato claufo tectum.

Spinacia oleracea. Tab. 126. fig. 4.

Spinabijia. Dod. pempt. 6rg. BLAKw. berb. t. 49.

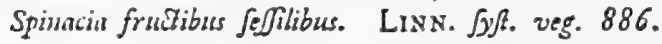

PER. nullum; calyx induratus, claufus, \& nunc inermis, nunc 2. 3.1.4. Tpinis cannliculatis horizontaliter patentibus terminatus, femen fovet nec dimittit.

REC. nullum; femen fundo calycis affixum.

SEM. unicum, fubglobofum, baf acuminatum, rufefcens.

IN T. fimplex, membranaceum, albumini adnatum.

A L B. farinofum, candidifimum, centrale.

EM B. periphericus, annularis, albus. Cotyl. lineares, planiufculx, incumbentes. Rad. teretiufcula, infera.

a. b. c. d.) Calygcis maturi forma varia. E.) Ejusdem fetio transver(alis. f.) Semen separatum. G.) Embryo albumen cingens H.) Idem folutus. 


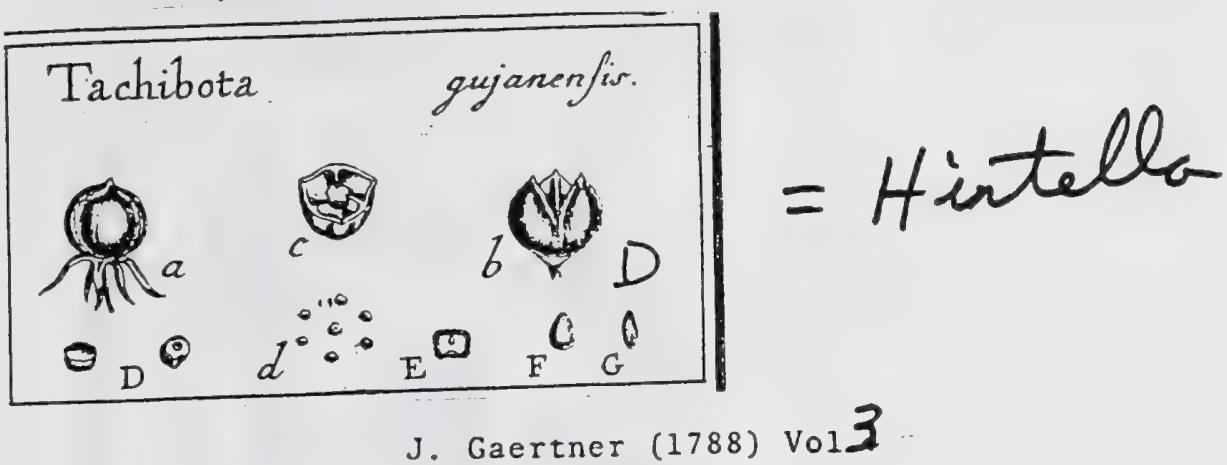

187. T A C H I B O T A. 237

A UвL. guian, t. r12. Juss. gen. p. 295. LasraвcK ill. gen. t. 208. Salmafía. Sс нвев. gen. 5 rз.

Cal. monophyllus, inferus, quinquepartitus, perfiftens; laciniis ovato-acuminatis. Cor. petala quinque, lanceolata, patentia, cum faminibus fub ovario inferta, cum laciniis calycinis alterna. Stam. quinque; filamenta fubulata; antherz oblongx, bali emarginatx, didynix. Ovar. fuperum; fylo fubnullo;'ftignate tripartico. Caplula membranacea, rotundato - triquetra, trilocularis, trivalvis; difepimento valvis contrario. Rec. centrale, fungofum. Sen. numerofa, angulati. Alb. carnofum. Emb. minutilfmus, inverfus.

Tаснивота gujanenlis. Tab. 224 fig. 6.

Salinafia racemoja. WILLD. Spec. pl. T. 1. P. 2. p. 1502. PERSOON fyn. 1. p. 329 .

Tucbibotu gujanenfis. AUBL. guian. t. p. 287 .

Ex cullectione Bankfiana.

PRR. Capfula fubglobofa, rotundato-triquetra; apice mucronulata, calyci perfittenci inliltens, coriaceo-membranacea, ad angulos ab apice ad ine. dium usyue trivariam dehifcens; trilocularis, pi:ylperma. Diliepinenta telluia, curiaceo.- membranacea, medio valvularum dorio inferca, \& cum iplis ill ari dehufentia.

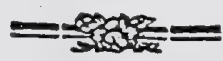

R \& c. fungofa, fubovata, exigua, ad augulum loculamentorum internum diffepimentis adnata.

Sear. numerofa, arcte fibi approximata, angulata, deprefa retufaque, ad verticem convexiuícula, ad bafin foveola parva umbilicali inftructa, ad latera planiufcula, puncticulato - fcabriufcula, atro - fufca, centrigeta,

IN T. fimplex, cratifiufculum, crultaceum, adnacum.

$\Lambda$ L B. femini conforme, craffum, carnofum, candidum,

EM B. minutifimus, in fumma albuminis parte locatus, ellipticus, compref. Gufculus, lenticulari - convexus, inverfus, albus. Cotyl. brevifima, obtura. Rad. cotyledonibus paulo longior, attenuata, umbilico externo e diametro contraria, centrifuga.

\section{EXPLICATIO FIGURR.}

a.) Capfula integra, claula, b.) Eadem dehifcens. c.) Ejusdem featio transverfalis, d. D.) So. reina feparatz. E.) Seminis fedio verticalis, cum fitu embryonis intra albumen. F. G.) Emo
bryo Lolutus.

In ipfo hujus ftirpis fpecimine Aubletiano, in collectione Baukfana afferva to, antheras oblervavi oblongas atque erectas. 


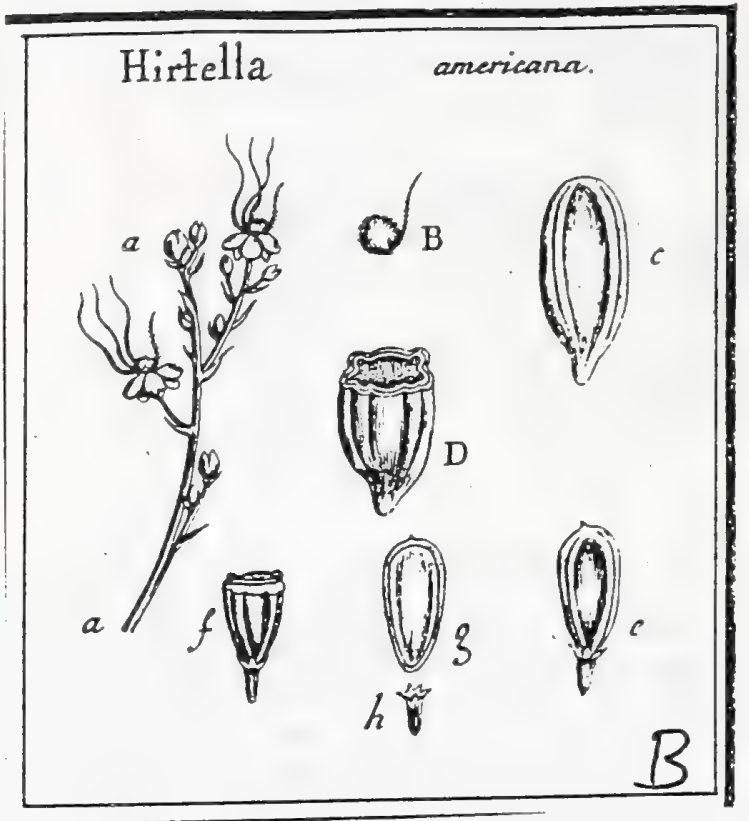

J. Gaertner (1788) Vol3

\section{H I R T E L A.}

Liñ. gen. 280. ed. Schreb. 388. Juss. gen. p. 340.

Cal. quinquepartitus, laciniis reflexis. Cor. pentapetala. Stam. tria, quinque aut fex, eidem calycis lateri omnia inferta; filamentis longiffimis tortuofis. Ovar. fuperum hifpidum. Styl. e bafs \& latere ovarii ftaminibus oppofito, fimplex, fetaceus, fubplumofus. Drupa ovali-oblonga, fulcata, compreffiufula, unilocularis, monofperma. Semen drupx conforme, pedicellaturn.

Hirtella triandra.

Hirtella americana in Icone. Tab. 185. fig. 2.

Hirtella americana. JAce. hif., 8. t. 8. LiNN. fyjf. veg. ed. 34. p. 242.

Hirtella (triandra) foliis oblongis acuminatis, racemis compofitis laxis forribus triandris SWARTZ prodr. p. 51. Fl. ind. occid. 1. p. 508.

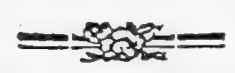

Histella racemis compofitis tesuninalibus folitasiis, pedunculo commnni pubefcente. foribus triandris, foliis oblongis acuminatis. WILLD. Spec. pl. T. I. Y. 2. p. $255 x$.
A Cl. Thunberg.

PER. Drupa coriaceo-carnofa, longe elliptica, fupra paulo latior, compreffiufcula, duobus fulcis elevatis longitudinalibus utrinque intra marginem notata, villo holofericeo brevilimo pubelcens, unilocularis. Caro firnas, fubcuriacen, cralfiufculg. Putamen terue, chartaceum, durum, extus uti drupa fulcatum intus totum breviter villofum! uniloculare, evalve.

REC. funiculus umbilicalis aut pedunculus feninis crafus, fuberofus, inferne angultior, apice quinque-dentatus, e fundo putaninis oriundus, fensuque in Gru erecto fuftizens.

SEM. unicum, drupa penitus conforme, fufcum.

IN T. fimplex, membranaceum, tenue.

A L B. femini conforme, carnofum, pallidum.

EMB. magnitudine fere albuminis, erectus, Jutefcens. Cotyl foliacez, ommium tenuifimx, ovato-oblongz. had. atteruatz, non difcrets, iufera.

\section{EXPLICATIO FIGURE.}

8. a.) Racemus flotidus absque corollis. B.) Ovarium [eparatum \& auctam, eum fuo ftylo late. rali fubplumolo. c.) Drupz integra. D) Ejus fostio transverfalis, putaminis loculamentum intus villofum ofteodeas. e.) Semen integrum. f.) Ejusdem nec non albuninis \& cotyledunum fectio transverfalis. E.) Embryo ab una parte ab albuarise dequdatus h.) Semiais peAnsevilie renapatus. 


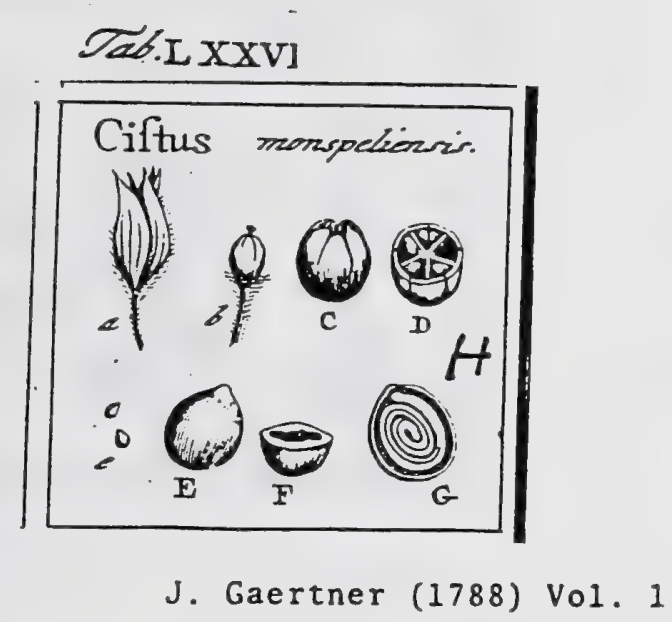

370

CCCCLXXXIII. CISTUS. T OURN. $t$. $33^{6}$. L InN. gen. 673 .

Calyx pentaphyllus, fuliulis inxqualibus. Cor. pentapetala. Stam. plurima. Stýl.

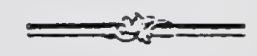

unicus. Capfula fupera quinque-1. decemlocilaris, totidcinque - valvis. Semina axi fructus allixa. Embryo fpiralis.

Cistus innirpelienfis. Tab. 76. fig. Io.

Ledum l. C. cus. hifl. r. p. 79 .

Cifus arborefcens exflipulatus, foliis lineari lanceolntis feffilibus utrinque villofis trincritis. LI N N. Silf. veg. 49T.

PER. Cap̧rula ovato globofa, glabra, quirnquelocularis, quirı̣neralvis. Septa valvis contratia.

REc. tuberculum papillofum in angulo loculamentorum interno, cui fernina affixa.

SEs. pauca, quatuor circiter in fingulo loculamento, orata, comprefiuscuia aut angulata, glabra nigricantia.

Ix T. duplex: exterius membranaceum, pallidum; interius chartaceum, ferrugineum, albunini arche adnatum.

A \& B. feunini conforme, fubfarinofum, candidum.

: Es 8. filiformis, fpiralis, lacteus, totus istra albumen locatus. Cotyl. Feniteretes, longillimz. Rad. brevis, centripeta.

a. b.) Capfula teîa \& denudata. C.) Eadem de'iifeens. D.) Ejus fert:o trarsterfalis cum re. ccptac. fitu. e. E.) Semida feparata. F.) Albumis seato transverfalis. G.) Eribryo iutra a:bunses. 


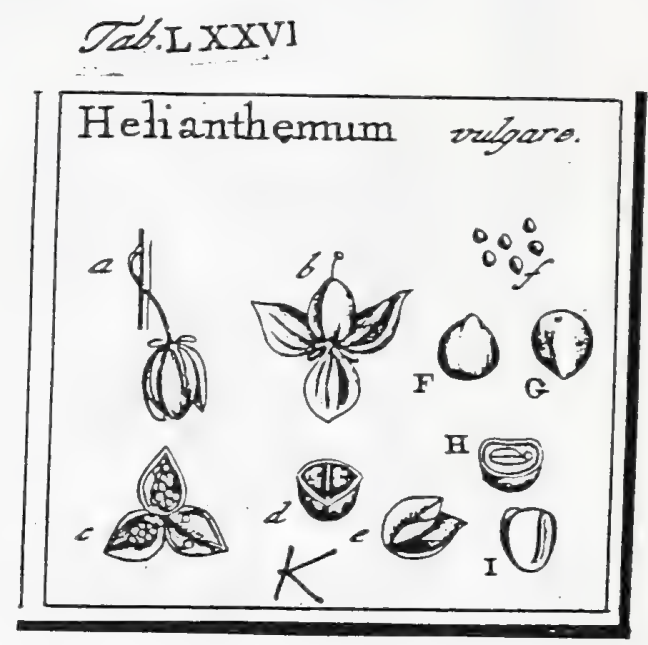

J. Gaertner (1788) Vol.1

371

\section{CCCCLXXXIV. HELIANTHEMUII. TOU RN. t. I2s.}

Calyx pentaphyllus, foliolis duohus minimis. Cor. pentapetala. Stam. plurima. Styl. unicus. Caplula fupera unilucularis trivalvis. Semina vatus airixa. Embryo uncinato inflexus.

IIEL I ANTHEMU vulgare. Tab. 76. fig. II.

Flos folis f. Panaces chironium. CA ss, epit. 50r. OE D. flor. dan. t. Ior.

Ci,lus foliis conjugatis ellipticis hirfutis intcgcrrimis, petiolis uniforis fublirfubis. H. 1.1. hifl. 2. 13. 1033 .

Ciflus fuffruticofus procumbens, fipulis lanceolatis, foliis oblongis, revolutis

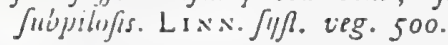

PER. Caplu!a ovata, trigona, glabra uniloculatis, trivalvis: Valvulis intus tonui membrana diaphisua ventiti.

RE c. nervus tufcus, membranz valvularum internx adnatus, plurimos funiculos umbilicales emittens.

SEM. plura, ad fingulan valvulam circiter decem, angulata, glabra, e tefacco rufof. centia, mucilaginola.

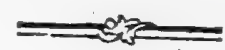

IN T. triplex : extimum tenue, ab aqua in mucilagineum albicantem refolubile; um coriaceum, duriusculun; ; intimum mombianaceun, chalaza fufca in: gnitum

A L B. femini conforme, tenue, farinofum, album.

Eм в. conduplicartrs, albumine paulo minor, Jureus. Cutyl. ohovatx, carnofx, pla. niusculx. Rad. tereti acuminata, ad latus cotyletonum uncinato inilexa, cen-
trifuga.

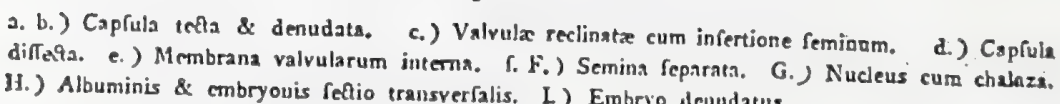
HEL. I A T HEM UM ledifolium.

Capfula priori funilis, fed rigidior \& dimidio fere major. Semina prioribus multo minora, rubro-ferruginea, angulata, non mucilaginnfa. Albumen valde tenuc. Limbryo ut in priori conduplicatus: cotyledoubus plerumque albis, interdum vero
rubicundis.

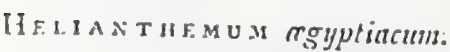

Capfulat ut in pracedcntibus. Semina magnitudine H. vulgaris, cvato acuminata, annulata, obfcure ferruginca, valde. mucilaginofa. Embryo conduplicatus, lu.
teficus. 
Tab. 210.

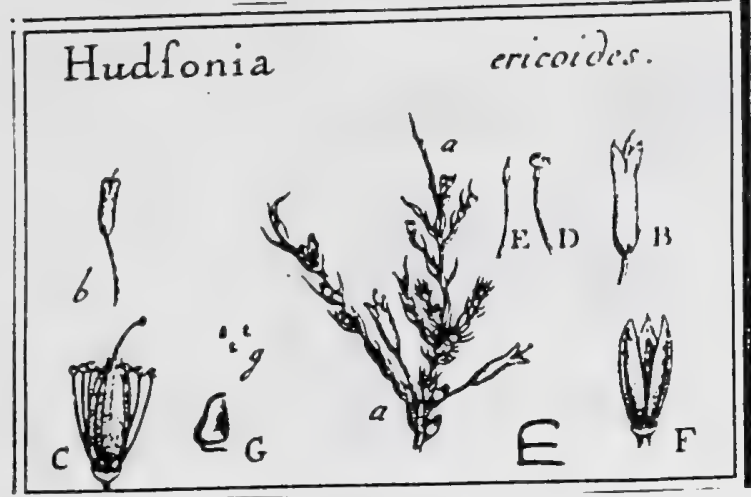

J. Gaertner (1788) Vol. Z

152

\section{II7. HU D S O N I.}

LIN mant. p. Ix. gen, ed, Schreb. 822. Juss. gen. p. 162.

Cal-monophydius, cylindraceq-infundibuliformis hirtus, tripartitus : laciniis concayis, fubinflexis, nohunquam una' l. altera iterum partita. Cor. nulla, nifi calycen velis. Stam. 12 - 18., Iongitudine fere calycis; filamentis fctaceis, apice fufformi-fubulatis; infta ovarium infertis; antheris fubrotundis, compreffis, erectis. : Ovar. fuperum; ttylo fimplici, longitudine ftaninum; Itigmate obtufo, Capfula ovato - oblonga, unilocularis, trivalvis, Rec. funiculus umbilicalis brevis. Sem, tria, angulata. Alb. cannofum. Enub. ...

Hudsonia ericoides. Tab. 210. fig. S.

Ericaeformis fuffrutex virginianus, floribus exignis, vafenlo feminali oblongo trivarrann divifo, rLUK.N. mant. p. 88.

Hudfonia. LiNw. mant. p. 74. Syft. veg. ed. 14. p. 445. WILLD. Spec. pl. T. 2. P. 2. p. 858 . PERSOON Jyn. 2. p. 6.

Icon. BERG. af. bolm. I778. p. 18. t. 2. ed. gerim. Vol. 40. p. 18. t. 1. LAMARCK ill. gen. t. 407 . (figurx pellimx.)

Ex collectione Bankfiana.

PER. Capfula minima, ovato-oblonga, intra calycem perfiftentem abfondita, extus fetulis albidis hirta, intus glabra, unilocularis, trivalvis. Valvx menbrauacex, ténues, nervo medio notatx.

REc. funiculi umbilicales breves, quorum ope femina bafibus fundo capfulz adhrerent.

SEM. tria minima, angulata, hinc rotundata, inde ad latera plana cuneats, bafi truncata \& ad partem cralliurem umbilico parvo exferto in funiculum umbilicalen abeunte inltrucha, glabra, ferruginea.

IN T. duplex: exterins crultaceum, fragile, tenue; iuterius membranaceun, tenuilimum, adnatum.

A L B. fenini conforme, carnofum, album.

EMB. . .

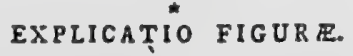

a. a.) Ramulus frugifer. b. B.) Calỵx integer. C.) Ovarium, cum ftaminibus in fita. D.) Stamen feparatum, integrum. E.) Filamentum absque anthera. F.) Capfula integra dehifcens. g. G.) Seminz fepatatz, funiculo umbilicali ftipata.

Ne mininum pelatorum veftigium nec ullum ipforum rudimentum in meis exemplis detegere valui; hinc fufpicor, corollam aut quam maxime elfe fugacen, aut nullan plane adeffe; uti jam pridem Itatuit Linnæus. 


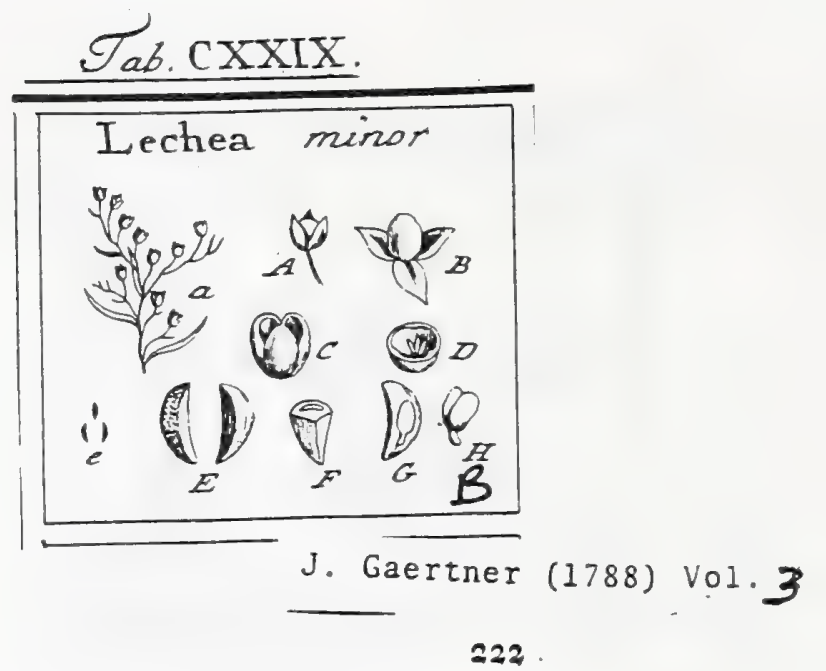

DCCXLVIII. L E C H.E A. Linn. gen. Iog.

Calyx triphyllus. Cor. tripetala. Stam. tria. Ovar. fuperum. Styl. tres. Capf. unilocularis, femitrivalvis. Recept. linearia, centralia. Sem. tria.

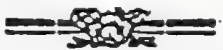

LECHEA minor. Tab. 129. fig. 6.

Scoparia foliis zenuifomis, in plures \& tenuifinos ramulos divifa \& fubdruifa. RAJ. fuppl. 132.

Lechea folis lineari lanceolatis, floribus paniculatis. LINN: fyft. veg. 130 . Ex herbario Bankliano.

PER. Capfula magnitudine capitis acicula minoris, ovato - globofa, vix aut obfoletiffme trigona, unilocularis, femitrivalvis: valvulis intus ftria longitudinali elevata atque faturatius colorata notatis.

R\&C. fquamula tres, breves, lineares; $\in$ centro fundi capfulix oriundx \& ventri feminum accumbentes.

SEN: tria, oblonga, utrinque acuminata, triquetra, hinc convexa, inde angulata, obfolete pundiculara, fufca.

IN T. Gimplex, coriaceum, tenue.

A L B. unilaterale, femini conforme; carnofum;, aqueo-pallidum:

ENs B. dorfalis, fubarcuatus aut rectiufculus, lutefcens. Cotyl. ovato-oblongx, fubfoliacex, incumbentes. Rad teretiufcula, brevis, infera.

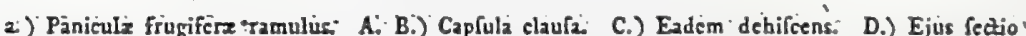
transpetílis, eum tribùs (quamulis receptaculi. e. E.) Semina feparatz. F.). Semen transiverfe: fcetum: G.) Embryo albuminis dorfo incumbens. H.) Idem folutus.

Capfulam maturam, in hac fpecie; conftanter unilocularem; nec aliud diffepimentorum veftigium deprehendo; . præter ftriam modice elevąam in medio pariete interno valvularum:- Interiores autem tres valvulx, quas Liunæus: fabet, certe non adfunt; nifi ipfas illas velit receptaculi fquamulas anguftillinas, brevifimas atque lineares, qux nequaguam pro valvulis, ao ne: pro diffepimentis quidem haberi poffunt, quum nec. fupra femina nec ad: parietes ufque capfula extendantur.

Embryo non pro more gentis cyclicus; fed rectiufculus: eft, ut: in Ortegia;, Velezia. \&. Diumblo:

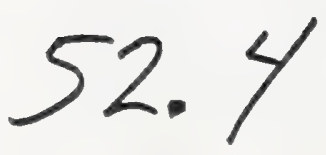




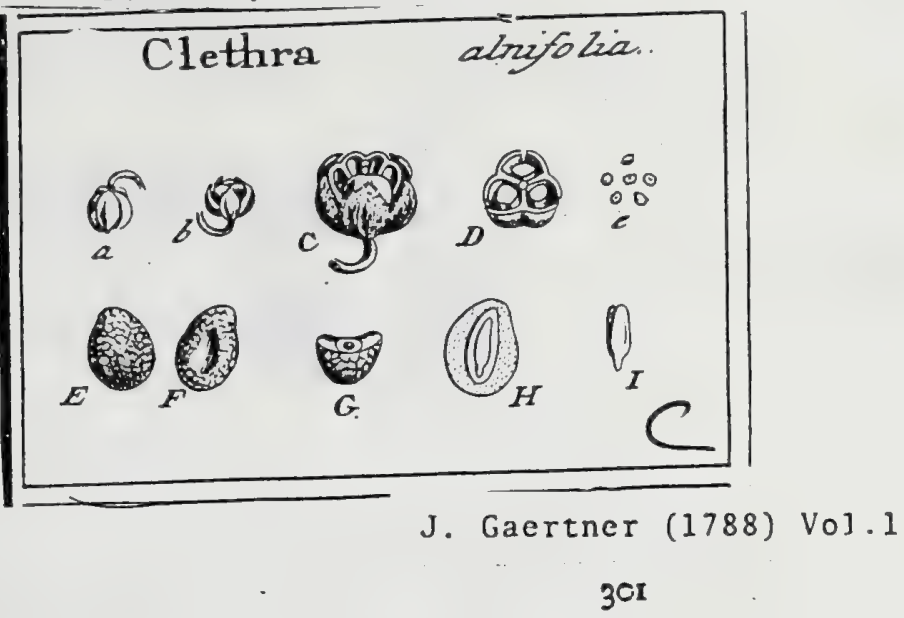

CCCLXXXIII. CLETHRA. LINN. gen. 553 -

Calyx pentaphyllus. Cor. pentapetala. Stan. decem Styl. unicus, fingmate trifido. Capfula trilocularis. Dillcpinenta fimplicia, valvis contraria Recept. fingula, caduca. Sern. pauca.

302

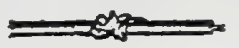

Cletra a alnifoliz, Tab. 63. fig. 2.

Alnifolia americana ferrata, foribus pentapetalis albis fricatis. $\mathrm{P}_{\mathrm{L}} \mathrm{v} \mathrm{x}$, phyt. $\mathrm{t}$. ri5. f. I. C A т Es B. carol. I. t. 66. S ELtG M. av. 11. t. 32.

Clethre. MILr. dift. ic. t. 28I. LIN N, fy/l. veg. 409.

PER. Capfula parva, fubglobofa, crufacea, trifulca, trilocularis, trivalvis. Dirfepimenta fimplicia, valuis contraria.

REC. in fingulo loculamento fingulum, ovatum, angulatum, bafi adnatuin, per ma: turitatem deciduum.

SEM. pauca, fexL ofto in fingulo loculamento, parva, fubnvata, varie angulata, fub. coinpreita, rugofula, rufescentia, Unbilicus in media parte ventrali, concavus, e regione embryonis politus.

IN T. duplex: exterius fungofum, crafum, nucleo multo latius; interius tenuif. finiun.

A I 8. ovato oblongum, fernine inulto anguftius, carnofum, aqueo-pallidum.

Eм в. longitudine fere albuminis, rectus, niveus. Cotyl. lineari oblongx, extus leviter convexz. Rad. tereti-acuminata, brevis, infera.

a.b.C.) Capfula integra \& dehifens. D.) Ejus feltio transverfalis cum receptaculorum fitu. e. E.) Seninis dorfum. F.) Ëjus pars ventralis. G.) Idem transverfe difietum. H.) Ejusdem \& albumi. nis feftio lougitudinalis cum fitu embryouis. I.) Eimbryo Separatus. 


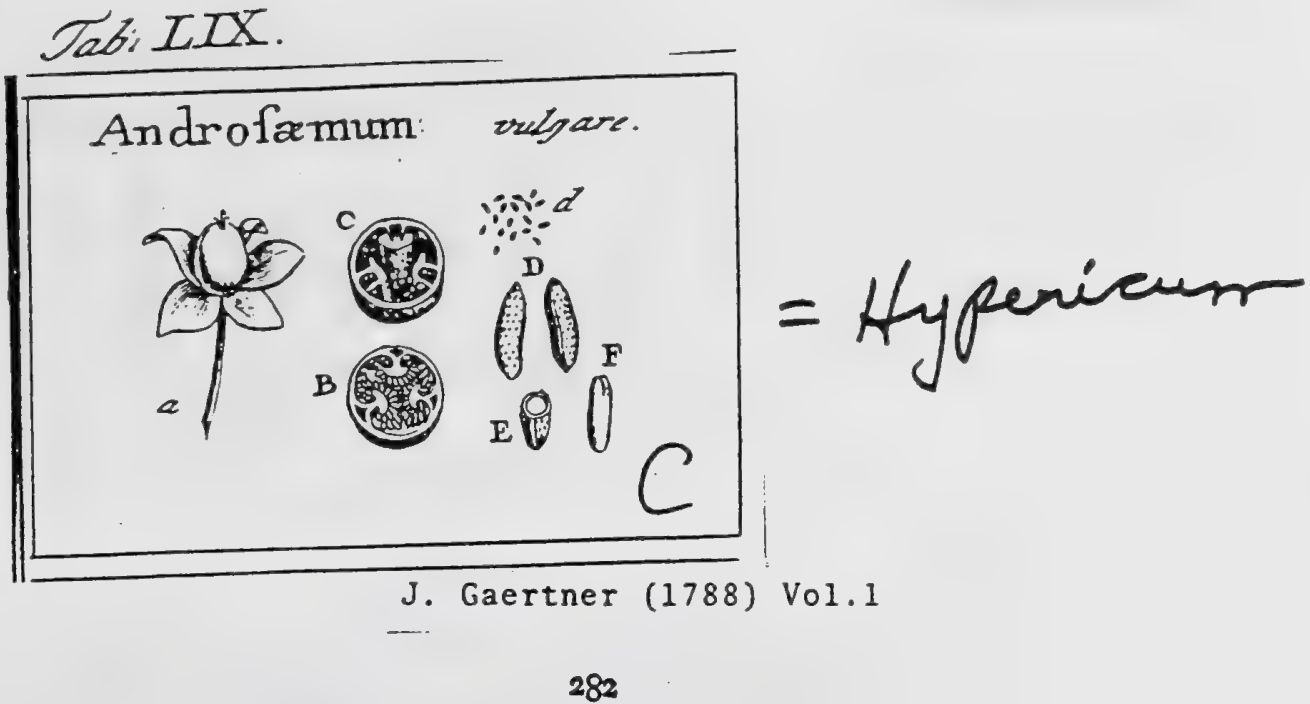

CCCLV. ANDROSAEMVM. TOURN. $t .128$.

Calyx quinquepartitus. Cor. pentapetala. Stam. plurima, bafi in fafciculos connata. Segl-tres. Bacca unilocularis. Receptacula parietalia. Sctn. plurima.

$\triangle N D R O S \pi M U$ M vulgare. Tab. 59. fig. 2.

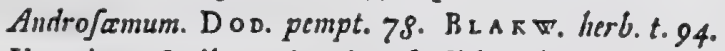

Hypericum floribus trigynis, frulfibus baccatis, caule fruticofo ancipiti. $L 1 \times N$. Sy, . veg. 200.

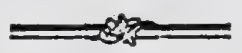

PER. Bacca coriacea, ovata, glabra, nitida, atra, uni-l. incomplete trilocularis.

REc. tria, fungofa, oblonga, mediante lamina intergerina, primum folida, poftea bifida atque fpatium vacuum fuis cruribus includente, parietibus baccz aftixa.

S Es. numerofiffuna, teretiuscula, hinc filiformi hilo longitudinali notata, undique excavato punctata, ipadiceo fufca.

IN T. duplex: exterius cruftaceum, tenue, fragile; interius inembranaceum, tenuiffimum.

A LB. nullum.

Е м в. Remini conformis, lacteo-albus. Cotyl. femiteretes, brevifimz. Rad. crafla, cylindrica, centrifuga.

2.) Bacea integra. B.) Eadem diffeqa, cum fitu feminum. C.) Receptacuia adulta, in bacen trans. verfim fefta. d. D.) Semina feparata, E.) Senen transverfe fettum. F.) Embryo denudatus.

Propter pericarpium baccatum, maxime vero ub femina centrifuga cuma Hyperico fociari nequit. 


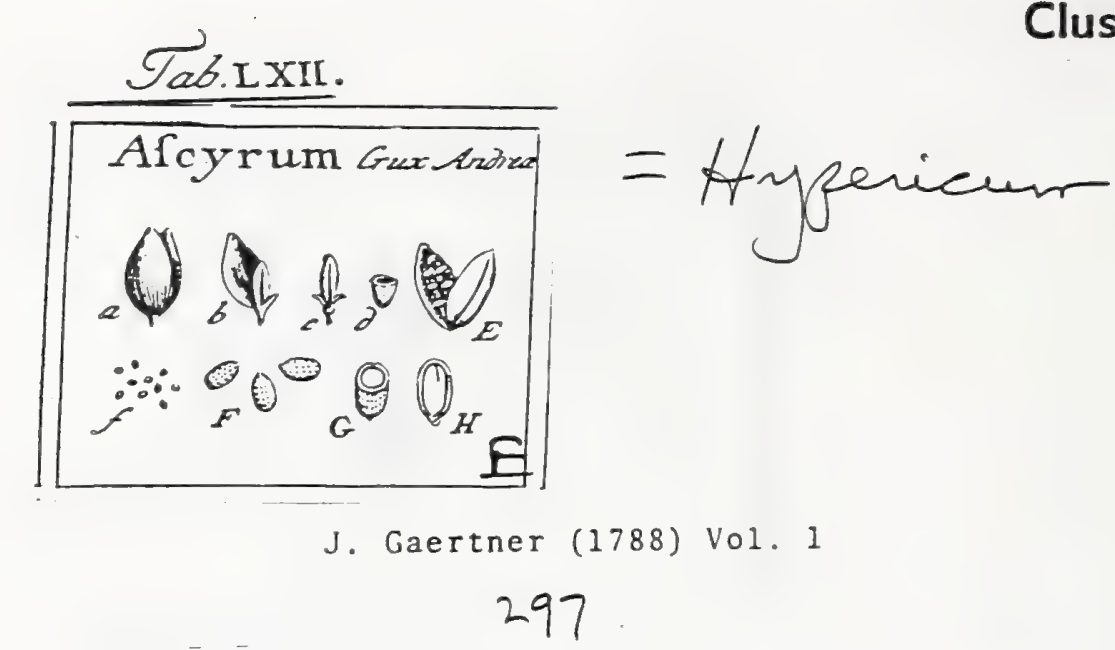

CCCLXXVII. ASCYRUM. L I N N. gen. go3.

Calyx tetraphyllus : foliolis duobus maximis, fructum occultantibus. Cor, tetrapetala. Stam. plurima, bafi in quatuor fafeiculos connata. Styl. unicus. Capfula unilocularis. Sernina valvularum inargini affixa.

298.

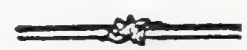

Ascreua Crux Arärez. Tab. 6a. fig. 7.

Afcyrum foliis ovatis, canle tereti, panicula dichotoma. LIN $\pi$. /4/ veg. 702. Ex dono Dn. A I 5 os.

PE R. Carfula parra, calyce obteda, oblongza, utrinque acumınata, lenticulari-compretla, obfolete bifulca, unilocularis, bivalvis.

REc. margo uterque valvularum, fpongiofo incraftatus, funiculis umbilicalibus brevifimis flipatus.

SEM. numerofa, circiter viginti, parva, ovato cylindrica, feriatim excavato punctata, nigro fufca.

IN T. duplex: exterius cruftaceum, durum, fragile; interius membranaceum.

A L B. sullum.

Е м в. Cemini conformis, lacteus. Cotyl. femicylindricx. Rad. crafra, centrifuga.

a. b.) Calycis foliola majora orata, capfulam occultantia, b. c.) Foliola ejusdem minora 21 bafia capfula pofita. d.) Capfula transverfim ireta. E.) Ëadem delificeas, cam fitu feminum. C. F.) Semina feparata. G. H.) Semen transverfe \& longitudiualiter fetum, cum figura embryouls.

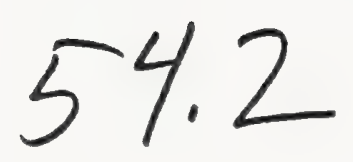




\section{Clusiaceae}
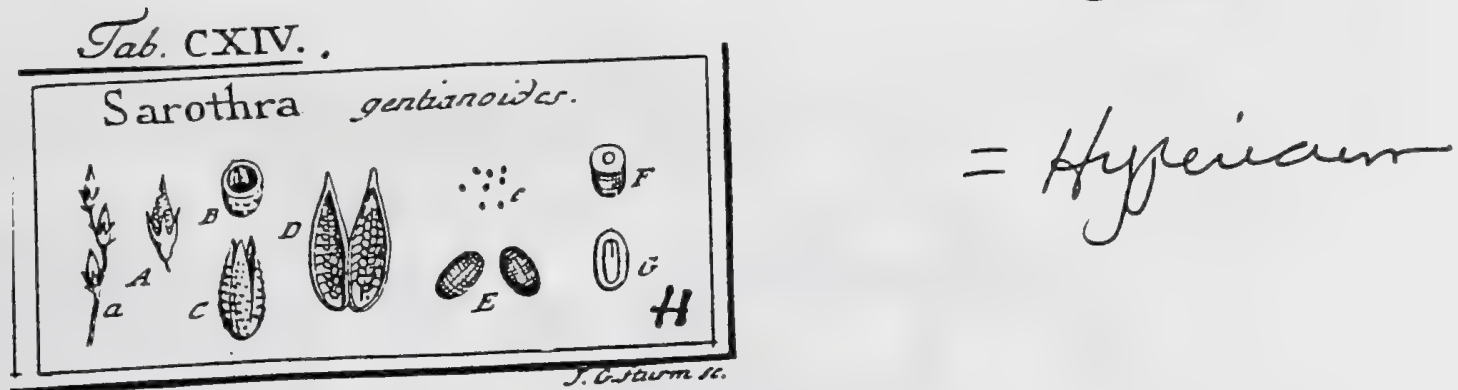

J. Gaertner (1788) Vol. 2

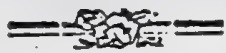

$x 6 \mathrm{x}$

\section{S A R O T H R A. IINN. gen.. 383.}

Calyz quinquefidus, perfiftens. Cor. pentapetala. Stam. quinque. Ovar. fuperum. Styl. tres. Capfula membranaces, unilocularis. Sen. plurima, valvularum futuris affixa.

Sarothra gentianoides. Tab. 114 . fig. 8 .

Cenitaurium mimus fpicatum angufifinro folio S. fcoparium marilardicum novrus. PluK. plyyt. t. 324. f. 4 .

Sarotisra. LinN. Jyfl. veg. 299.

Ex herbario Bankfiano.

PER. Capfula parva, membranacea, ferrugineo-rubra, teretiufcula, veríus apicem infigniter attenuata atque acuminata, 2 feminum impreffionibus undique tuberculora, unilocularis, trivalvis.

REC. nullun, proxter funiculos umbilicales fetaceos, ex internis valvularum marginibus oriundus, e quibus femina pendent.

SEMr. numerofu, parva, fubcylindrica, longitudinaliter \& transverfaliter fubtilifime ftriata, pallide fulphurea.

IN T. duplex: cruftaceum \& membranaceum, utrumque tenue.

AL B. modice craflum, carnofum, aqueo-pallidum.

Eм в. teretiufculus, rectus, lutefcens. Cotyl. obrufx, breves. Ead. cylindrica, centrifuga.

a. A.) Capfula integra. B.) Ejas fectio transterfalis. C.) Eadem in tres valvulas dehiftens.

D.) Valvulx duz, feparatz, cum feuinum infertione. e. E.) Semiaz integra. F. G.) Semiuis

4. albumiois fectio transrerfalis atque longitudinalis, cum litu \& figura Enbryonis. 


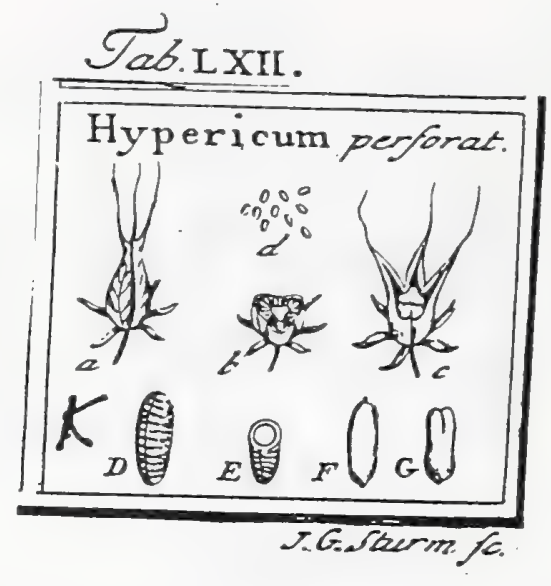

Clusiaceae

\section{J. Gaertnet (1788) Vol 1 \\ 300}

CCCLXXXI. HYPERICVM. T OUR N. t. T3I. LIN N. gen. 902.

Calyx quinquepartitus. Cor. pentapetala. Stann. plurima bafi in fafciculos connata. Styl. tres 1. quinque. Caplula tri-l. quinquelocularis. DifTepimenta duplicata ex inflexis valuularun inarginibus. Semina numeroli.

HYPERICUM perforatum. Tab. 62. fig. $\mathrm{n}$.

Hypericum. Du d. pempt. 7б. B Esน. hort. Ey/l. afliv. VIII. t. 10. f. 3. BLAх berb. t. 15.

Hypericum caule terete alato ranofiffmo, foliis ovatis perforatis. HALL. hifl. 2 n. 1037.

Hypericum floribus trigynis, caule ancipiti, foliis obtufis pellucido punatatis. LIN N. fy $\Omega$. veg. 70I.

PER. Capfula pyramidata, filiformi-tricornis, trigona, trilocularis, trivalvis. Diffepimenta duplicata, ex intlexis valvularum marginibus formata.

REc. columnare, fubulatum, triquetrum, cui \& valvulaum margines \& fernima affixa.

SEM. numerofa, circiter triginta in fingulo loculo, cylindrica, liilo lineari ab altero latere notata, undique tuberculis obfoletis feriatis fcabrata, paliide rufefentia.

INT. duplex: exterius coriaceum, durum, interius membranaceuin, utringue punda. acuminato fufco terminatum.

A L B. nullum.

E м в. fcmin conformis, lactcus. Cutyl. femicylindricr. Rad. crafl, centripeta.

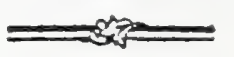

a.) Capfula integra. b.) Esdem difeqla. c.) Ejus valvalz dehiicentes. d D.) Semina (eparala c.) Sennen dirfetums. F.) Nucleus decorticatus. G) Eubryo deradatus.

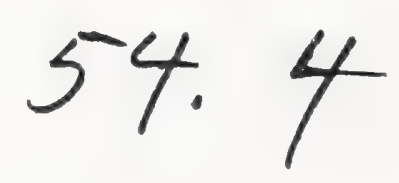


Clusiaceae

Tat. CV.

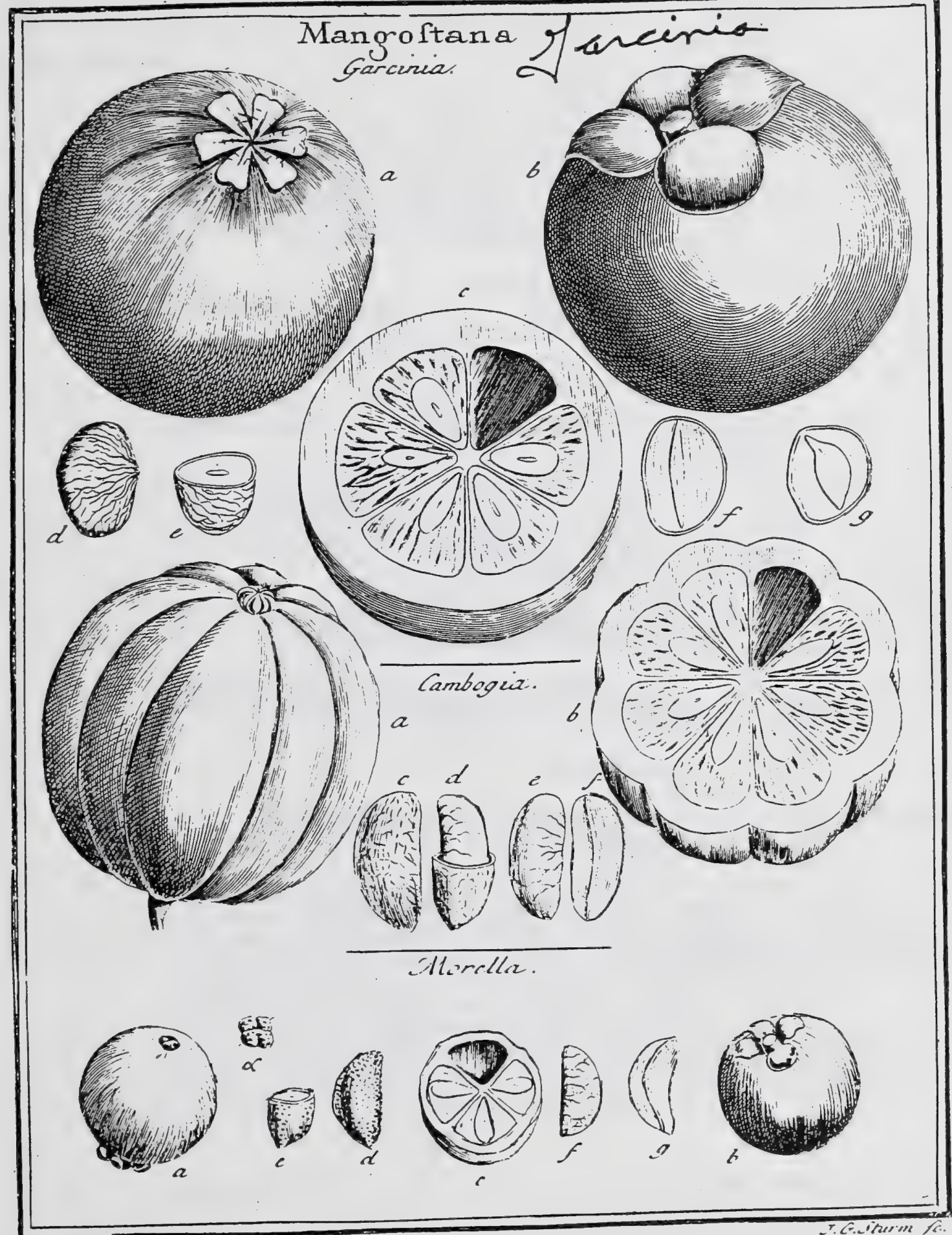

$54.5 \mathrm{~A}$ 


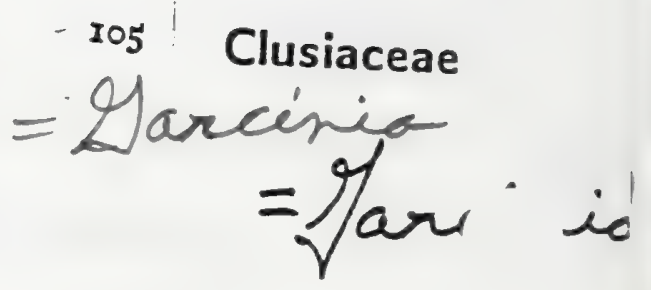

Calyx tetraphyllus. Cor. tetrapetala. Stam. duodena aut plura. Ovar. fuperum. Styl. nullus. Stigma feffile, lobatum: lobis numero loculamentorum xqualibus. Bacca corticata, loculamentis farctis, quaternis aut duplo pluribus. Semixis cmbryo pleudo-monocutyledoneus, cum abumine conferrumitzatus.

Mangostana Garciniz. Tab. 105. fig. I.

Arugofana. Ruмrн. antb. x. p. ग32. 4. 43.

Garcinia folits ovatis, peduncrlis wuifioris. Lins. Syf. ves. 443.

PER. Bacea grandis, fpherica, glabriufcula, ftigmate plano, penitus adnato $\&$ in fex 1. octo lobulos triangulares fecto coronata. Cortex craffus, in vetultis fructibus, coriaceo fungofus, coloris cinnamomi. Loculamenta numero radiorum ftigmatis refpondentia, fareta carne pulpora, fapida, per xtaten evanefcente: diffepimentis interjaceutibus nembranaceis, tenuifrimis.

REC. nullum; remen pulpa copiora involutum.

SEM. folitaria, ovata, compreffiufcula, vafis atque rugis transverfalibus, ex umbilico marginis interni oriundis, varie reticulata, fufca.

IN T. duplex: exterius coriaceum, tenue, folubile; iuterius membritiaceum, rufefceus, albumini arcte adnatum.

A В B. femini conforme, coriaceum, tenuiffinum, in vetuftis feninibus helvo. lum, impreffionibus vaforum integumenti infcriptum, cum embryone percinaciter conferruminatum.

E м B. longitudine albuminis fed anguftior, nunc fere linearis aut lineari lanceolatus, nunc ovato - lanceolatus, femper vero compreffus, pfeudomonocotyledoneus, inverfus. Cotyl. folincex, planx, in unum corpus indifcretum coalitx. Rad. e cotyledonibus fenfim attenuatis enata, infera. (non fupera, qualem fig. 9. exhibet.)

2. b.) Bacez integra, magnitndine naturali. .c.) Eadeu transverfe fecta. d.) Semen feparatum, integrum. e.) Ejus fectio transverfalis. f. g.) Abumen longitudinaliter difteetum, cum furma Embrgonis in variis varia.

Semina facillime abortant, ut frepius in tota bacca vix unicum adolefcat. Figura quoque eorum varia, attamen ufitatilima illa, qux fupra defcripta eft.

\section{Mangostana Cambogia. ibid.}

Coddan - pulli. RHEED. mal. r. p. 47. 2. 24. BLAKW. herb. t. 392.

Combogia Gutta. LinN. Jjer. veg. 490.

Semina e collect fem. hort. lugdb.

Bacca (a.b.) globofa, fulcata, ftigmate feffili fubhemifphxrico fulcato terminata, octo 1 . decem locularis (b). Semina (c.) fubreniformi-oblonga, Jerticulari - compreffi, obfolete rugofa, fufca. Integumentum exterins (d.) coriaceum cralliufculum; interius menbranaceum, venofum, ferrugineum. Albumen (e.) coriaceum, durum, estus vaforum impreffionibus infcriptum, intus folidum, embryoni aretillime adnatum. Embryo (f.) longitudine albu niuis, fliformi - compreffus, pfeudo-monocotyledoneus, neque in cotyledones, neque in radiculam, ullo perceptibili modo, dilcretus.

Ex fide $\mathrm{Cl}$. v. Royes hxc remina ad Cambogiam, \& quidem eo confidentius retuli, quod \& Hort. malab. figura, cum noftris exemplis, ad amulim con fpirec.

Mangostana Morella. ibid.

Arbor indica grmuni guttan fundens, firntu dulci roundo, ceras magnitudine, Cariupuli A coll.c. Hern. mus. Zeyl. 76. Burn. Zeyl, $=7$.

Io) Kannanakoraka, aut Kuma-koraka. Zeylonenf. quod polterius nomen ipfa Hermanui mane fchedula fructibus adjectr infcriptum eft in Collea. ferm. hort. lugdb.

Bacci Spharica (a. b.), glabra aut per exficcationem fubtilifime ftriam, inferne calyce tetraphyllo (b.) excepta, fuperne Rigrate feffili, fabro, tetracolli (a.) umbonata, quadrilocularis (c.). Cortex \& diffepimenta coriacea, craffiufcula. Caro pulpofa, fugax. Semen (d. e.) ovato reniforme, compreffum, fcabriufculun, fordide fufcum. Iiteg. exterins cruftaceum, craffum (e.); interins membranaceum, ferrugineum. Albumen (f.) coriaceum, durum. enteriss membranaceum, pertinacifame adnatum. Embryo (g.) preudo-monocotyledoneus, filiformis, curvatus.

Semina in aquam conjecta, eam brevi citrino colore inficiunt.

Inter Garciniam inque \& Cambogiam non aliud datur difcrimen, nifi quod ex 


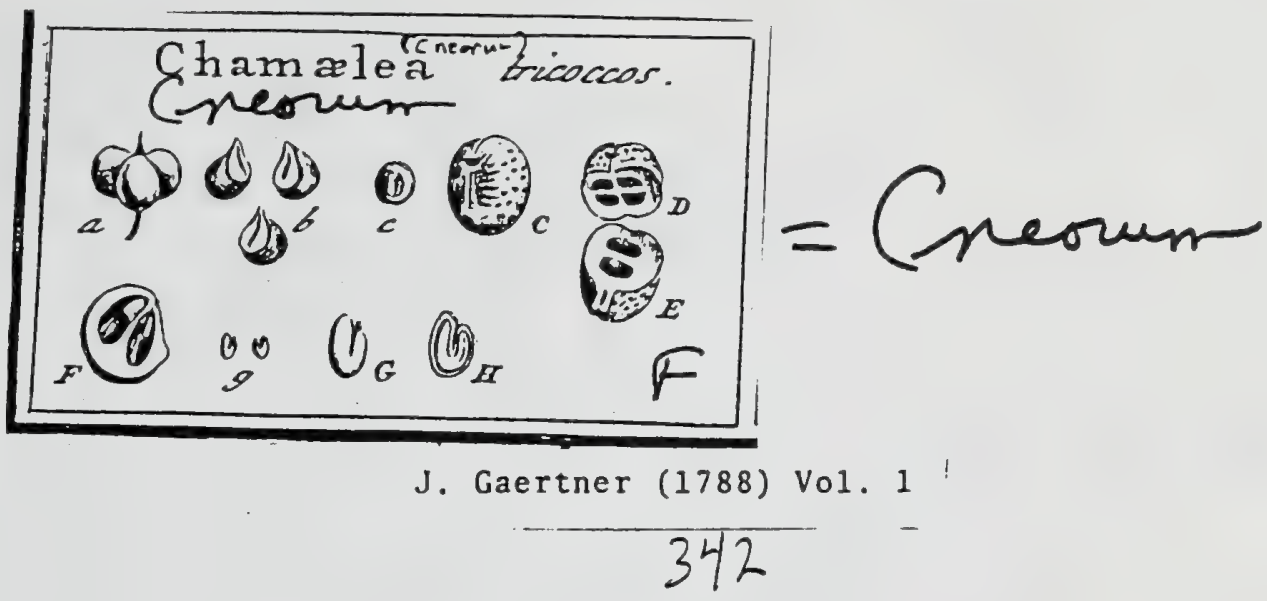

CCCCXLI. CHAMELEA TOUR N. $t .42$.

Calyx tridentatus. Cor. tripetala. Stam. tria. Styl. unicus. Drupx tres baccatz. Puta: men biloculare. Semina folitaria conduplicata.

Chameles tricoccos. Tab. 70 . fig. 4.

Chamalea. CA M. epit. 973.

Cneorum. LiN N. Si/fr. veg. 8r.

PER. Drupx, tres, baccatx, parvx, linic gibbx, inde angulatix, ad cominunem axem junctx, per maturitatem fufex. Caro tenuis, herbacea. Putamen offeum, craffum, fubglobofum, rugofum, a parte ventrali fulco atque foramine umbilicali exfculptum, hiloculare, evalve. Loculamentorum alterum, retro alterum pofitum, utrumque ad radicula fedem, tenui feptulo fubdivifun, ut fuprema pars pitaninis quadrilucularis appareat.

REC. commune filiforme, in fylum abeuns; proprium, funiculi umbilicales breviffimi, ab axi fructus, ad fernina pertingentes.

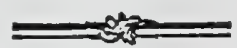

SEM. in fingulo loculamento unicum, parvulum, ovatum, vermiculi inftar conduplicatum, albicans, ad umbilici infertionem caruncula fufca notatum.

IN T. fimplex, membranaceum, tenuifimuin.

A r. B. Semini conforme, carnofum, album.

E $M$ B. teretiusculus, inverfus, lacteus, uncinato-curvatus. Cotyl. femicylindricx, in breviori feminis crure locatz. Rad. longa, furfum recurvata, ultra coryledones elongata.

\section{-}

a.) Fruftus integer. b.) Drupz feparatze. c.C.) Putamen a parte ventrali (petatam. D. E.) Ejus. dem fetio transverfalis. F.) Idem longitudinaliter apertum. g. G.) Semioa (eparata. H.) Enbbryo intra albumen.

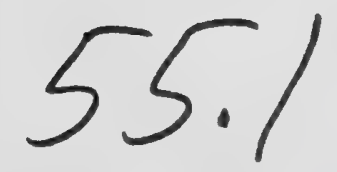




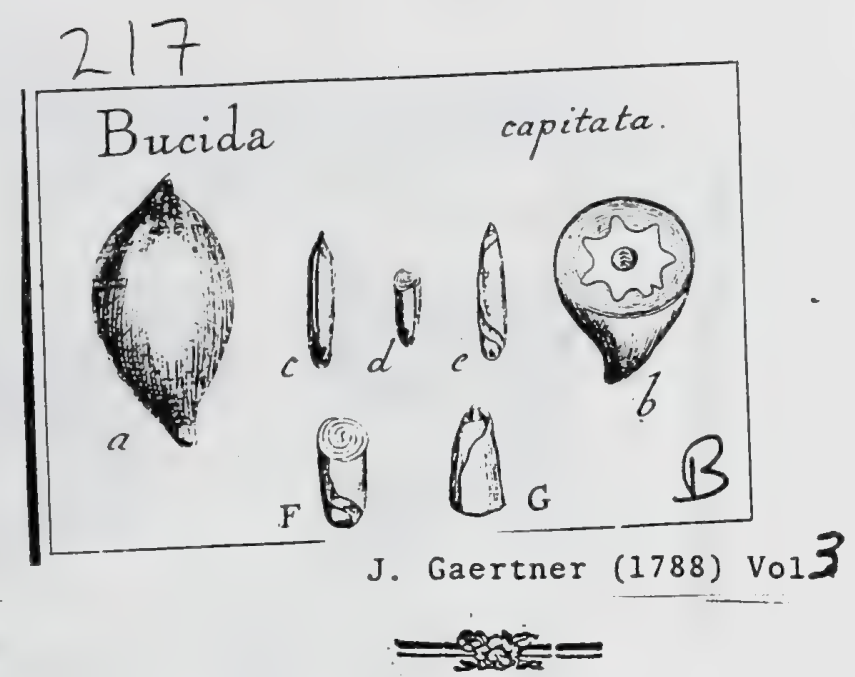

\section{B U C I D A.}

LINN. gen. 54t. ed. Schreb. 758. Juss. gen. p. 75. Ladraвcx ill. gen. t. 356. Buceras. BвоWN jam. t. 23. $f$. 1 .

Cal. monophyllus, campanulatus 1 . urceolatus, fuperus, quinquedentatus, deciduus. Cor, nulla, Stam. decem; flamenta litzearia, duplici ferie difpoljta; quinque inferiora bafi calycis inferta, cum fuperioribus longioribus ad incifuras calycis alternantià ; ancheræ erectx, didymx, Ovar. inferum, Ityla fimplici fubulato, calycem fuperante; tigmate fimplici, acuto. Drupa baccata. Putamen angulatum, uniloculare. Rec. nullum. Sem. unicum, cy。 lindraceo-oblongum. Alb. nullum. Emb. inverfus; cotyledonibus con. volutis.

Bucida capitata. Tab. 217. fig. 2.

Bucida floribus capitato - Spicatis, foliis cuneiformibus margine villofo- ciliatis.

VAHL ecl. amer. 1. p. 50. PERsOON Jyu. 1. p. 485.

Icon. VAHL 1. c. $t .8$.

Tavernon. Gall.

Ex Infula Hifpaniola a $D^{\text {no }}$ Porteav.

PER. Drupa pollicaris, infera, baccata, ovata, purpires, utrinque attenuata hinc in mucronem breviffimum acuminatum, inre in pedunculum brevem obtufufculum. Cuticula tenuis, glabra. Carof criffa mollis, flavefcens, dulcis. Putamen ovatum, utrinque acuminatum, octangulum, totitemque fulcis rotundatis exaratum, crafum, offeum; lutefcens, uniloculare. Loculamentum tereti-oblongum, bafi obtufum, apice acuminatura, ad Jatera oppofins ftria longitudinali l. futura fpuria infignitum, evalve, wonofpermum.

R c. nullum : femen bafi lóculamenti adhxrens.

SEM. unicum, ereatum, tereti - oblongum, I obfoletifime rotundato-tetragonum, bafs obtufum, apice conico-acuminatum, pallidum.

IN T. fimplex, membranaceum, validum, facile detrahendum, bafi chalaza lata ferruginea l. fufca infignitum.

A L в. nullum.

EM B. tereti-oblongus, verfus a picem conice attenuatus, inverfus, althes. Co. tyl. Longitudinaliter convolutx, foliaceo-carnofx, magnz, ovatx, obtufx. Rad. brevis, intra cotyledones conyolutas abfcondita \& vir apice ex ipfis promiwula, conica, umbilico e'diametro contraris, fupera.

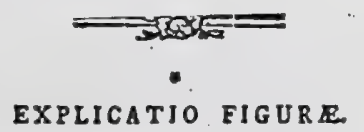

209

EXPLICATIO FIGURE

a.) Drupi Integra b.) Eadern cum putamine medio transverfe difecta. e.) Semen feparatura; integrum. d.) Ejusdum fectio transver(alis, e.) Embryo Colutus F. G.) Idea medio crese verse dirtedus, 


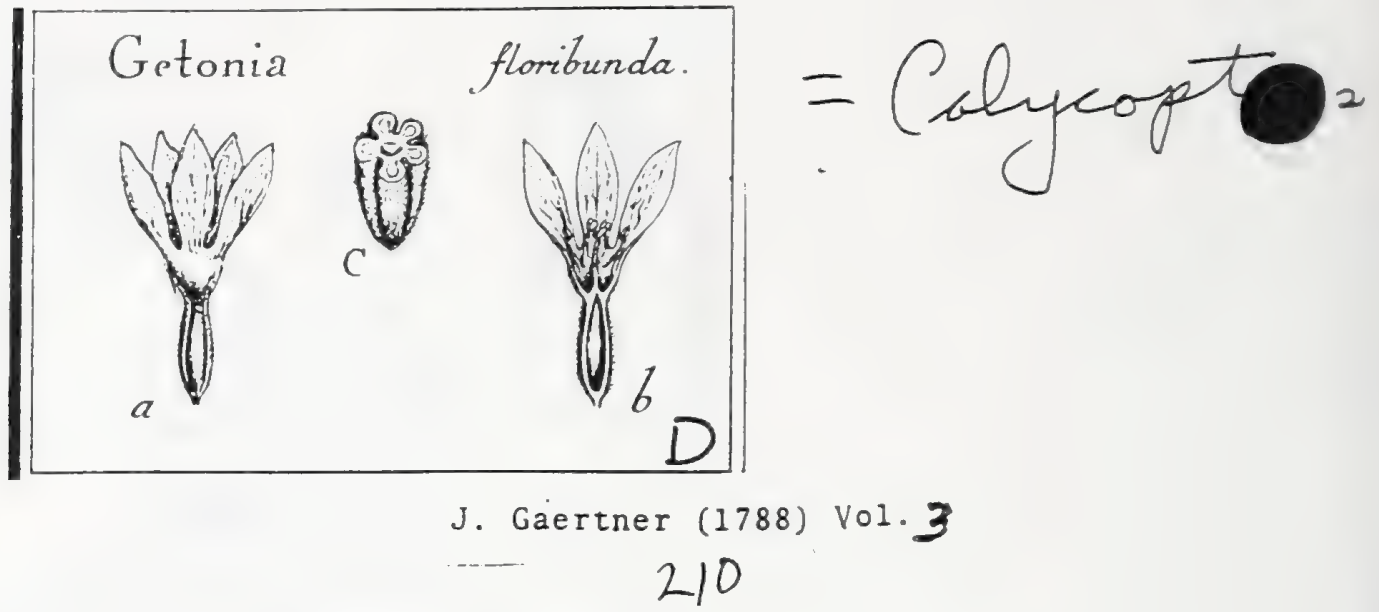

\section{G E T O I A.}

Roxi. pl. corom. t. 87. Calycopteris. LAмAвCx $i l l$. gen. t. 357 .

Cal. monophyllus, fuperus, perfftens; tubo brevi, ventricofo; limbo quin. quepartito : laciniis lanceolatis, acutis trinerviis, patentiufculis. Cor. nulla. Stam. decem, exferta, laciniis calycis breviora; flamenta fubulata, duplici ordine difpofita: exteriora ad incifuras, interiora cum prioribus alternantia prope fundum calycis inferta; antherz incumbentes, orbiculares, didymx. Ovar. inferuni, ftylo fimplici, fliformi, longitudine ftaminum, fubincurvo, pubefcente; ftigmate finiplici, obtufo. Nux ovato-oblonga, calyce coronsta, corticata, rotundato-pentagona, unllocularis, evalvis. Sem. unicum, ovato-acuminatum. Alb. ... Emb....

Getonı foribunda. Tab. $21 \%$. fig. 4.

Getonia, Roxв. 1. c. x. p.,64. Persoon fyn, I. p. $47 \%$

A Cl. Lambert.

PER. Nux infera, cum calyce perfiftente coronante connata, ovato-oblonga, quinqueloba: lobis rotundatis incratsatis; inridenqque fulcis profundis exarata, pubefcens, corticata, unilocularis, evalvis. Cortex coriaceus, cralfiufculus, putamini adnarus. Putamen tnuct conforme, craliulculum, quinyuelobum, dutun, fuboifeum, album, umluculare; loculamentum ovato - acuminatum.

REC. nullum; femen bafi loculamenti adnatum?

SEN. Uncun, ovato-oblongun, furfum acuminatum, erectum.

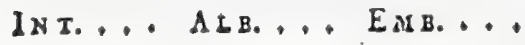

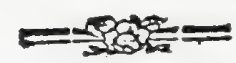

\section{EXPLICATIO FIGURE:}

a.) Ovarium immaturum. b.) Idem longitudinaliter dimidiatum, equ faminibas \& flylo in citu, \& figura loculamenti, C.) Ejusdem fectio transverfalis

Defcriptio feminis \& 


\section{Tab.XXXYI.}

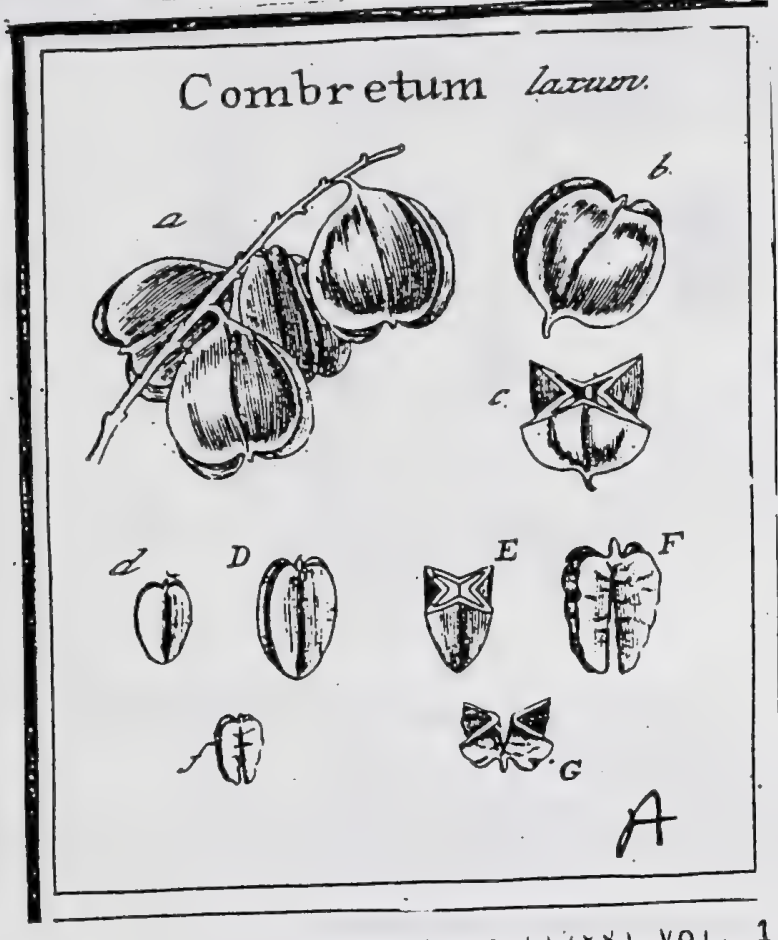

J. Gaertner (1/8b) vol. 1

176

CCXII. COMBRETVM. LIN gen. 475 .

Calyx fuperus campanulatus quadri-l. quinquedentatus. Cor. tetra-l. pentapetala. Stam.

СомвR в.тUM laxum. Tab. 36. fig. I.

Combretum laxum. A U BLET. guian. p. 351. t. 137.

Combretuin Spicis laxis. LIN N. Jyft. veg. 359.

Ex lierbario Bankfiano.

$P E$ R. nullum, nifi tunican feminis externam velis.

REC. nullum.

SEM. unicun grande, obovato rotundatum, luteo-fpadiceum, glabrum, quadrialatum: alis compreitis, rotundatis, coriaceis.

IN $\mathrm{T}$. duplex: exterius chartaceo coriaceum, tenue; interius fpongiolo-mcmbranaceum, fubfufcum.

A L B. sulluin. $\quad$ a oboratus, inverfus, femine multo angufior, quadrialatus, graE s s. dicoryledoneus, oboratus, inverus, foliacex, tenues, rugofulx, folioiis plicá mineo-viridis. Cotyl: ovato cordats, Rad. teretiuscula, brevis, fupera. medía rellexis, cruciato-divaricatis. Ror

Semina ramo pendula. b.) Semen (eparatum integram. c.) Idctn difefum, absque nuciea. Semina e ramo pendula. b.) Sem lua menibrana fufca teflus. E.) Idem transverfe fectus. F. . d. D.) Nucleus decorticatus, propria fua menibram fecta \& paululum ab invisen diductze. Embryo denudatus.

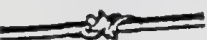
Combretum decandrum, quod eft Crifaria coccinea So sner a r. voy. aux ind. 2.
p. $247^{\circ}$ t. 140 . Senire gaudet quinque alato, flaminibus decen, petalis \& calycis demtibus quinis. 
Tab. CLXXVII.

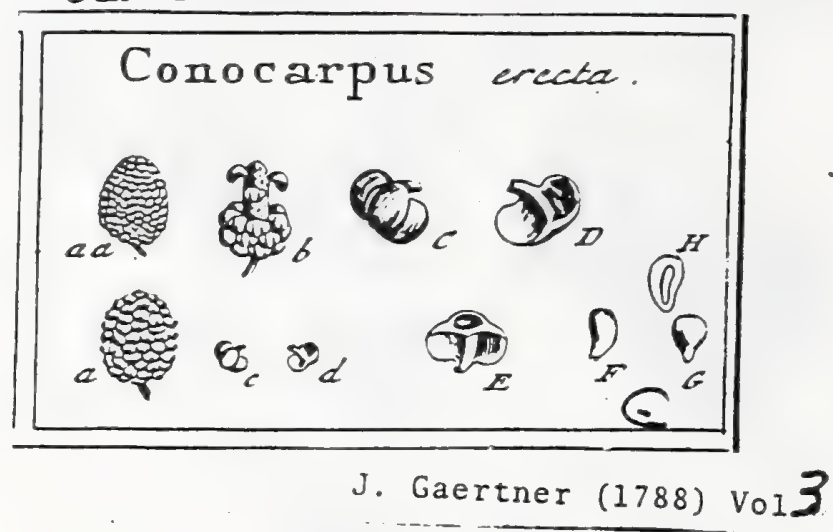

205

CONOCARPUS. Conf. Carpol. Vol. II. p. $47^{\circ}$.

Conocarpus procumbens. Tab. 216. fig. 4.

Conocmpus procumbens, folits obovatis. Jace. amer. p. 79. LiNx. fyf. veg. ed. 14. p.,217. WILLD. Spec. pl. T. 1. P. 2. p. 995. Persoon Jyn. 1. p. 211.

Icoin. JAce. aner, to.52. f. 2. ed. pid. \&. 260. f. 22. (folium.)

Ex Infula Hifpaniola a $D^{\text {mo }}$ Porreau.

Frudus (a.) Atrobilaceus, cunflatus ex ramaris (b.) parvis, coriaceis, axi communi fpiraliter affixis, cochleariformibus, 1. ovatis: fuperne converis turgidulis, in duas alas rotundatas ampliatis: inferne autem concavis, fulco intermedio infiguitis. fubltamia alba fpongiofa farctis, e rufo fufcis, uni locularibus, munofpermis. Rec. nullum; femen fundo loculamenti atf. sum. Semen (C. d. D.) unicum, centripetum, ovatum, dorfo gibbum, ad

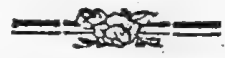

ventren planiufculum 1. leviter convexum, \& valis umbilicalibus ferrugineis undique cum integumento deliquefcentibus infignitun,' album.' Int. fimplex, membranaceun, crafiufculum, cbalazn parva ferruginea ad fummun ventrem infrgnitùm. Albumen (E.) femini-conforme, carnofum, album. Embryo prope bafin albuminis locatus. . . . Cotyl. ovatre. . . R.ad. brevis, tereciufcula, obtufa, mucronulata, umbilico externo contraria, centrifuga.

Intęr has famaras nondum plane maturas \& inveni alias (F. G.), quarum lo culamenta fubltantia fpongiofa alba, Atriis rufefcentibus intermixta, repleta erant; in apice hujus fubltantia (G.) in proprio lectulo duo corpufcula (H.) $)^{\}}$ oblonga, compreffa, angufto margine cincta \& funiculo tenuifimo adhærentia, locata funt. $A n$ itaque in ovariis virgineis ovula bina adlunt, quorum vero uni. cum conftanter abortat; an embryo eft geminus aut deformatus. Ii, quibus occafio data eft, fructum recentem \& bene maturum videndi, dubium folvant,

Radiculam quidem, primam polt fœcundationem parten conformatam, uti punctum faliens in ovis incubatis, dictinctiffme vidi, quamvis de embryonis figura non fatis fim certus, Hoc genus raro fructus maturos proferre videtur. 


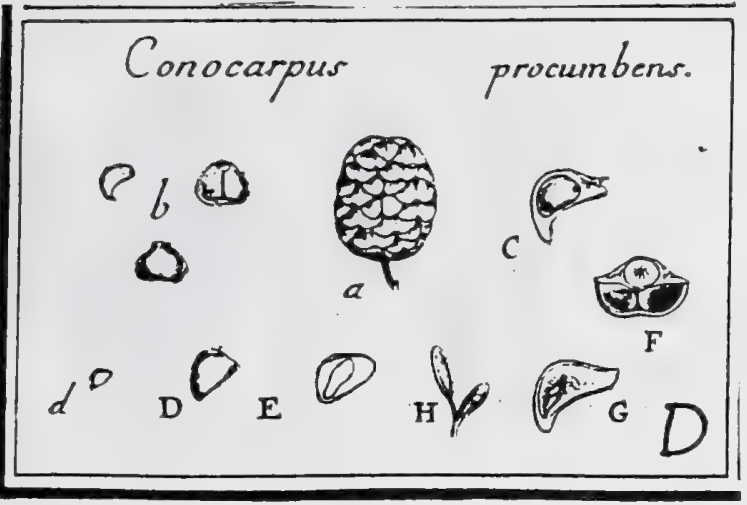

J. Gaertner (1788) Vol. Z

470

\section{C O N O C A R P U S. LINN. gen. 236 .}

Calyx fuperus, minimus, quinquepartitus. Cor. nulla, aut pentapebla. Stani. quinque, aut decem. Ovar. inferum. Styl. unicus, fimplex. Sanuara cochlearifornis, munoiperma.

Conocarpus erecta. Tab. 177. fig. 3.

Ahus maritiusa myrtifolia coriariormus. Pluk. phyt. t. 240. f. 3 .

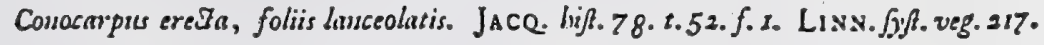

Ex herbario Bankfiano, \& a Cl. Thunbergio.

FR U CT. ovato-globofus, retrorfum inbrientus Samuris plurimis axi communi atfixis.

PER. Samara infera, coriacea, rotundato-cochleariformis, C. fuperne gibba, inferne concava \& ad latera in duas alas rotundatas ampliara, e fpadicen rufefcens, unilucularis, fubltautia fpongiofa alba fareta.

KE C. commene cylindricum, craflum; proprium nullum, aut funiculus capilla. ris telte feminis adnatus, \& ad ejus bifin defcendens.

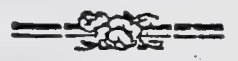

SEs. unicum, fubgigartoideum, f. obovatum, deorfum scuminatum, hine gibbuin, inde obfolete angulatum, album.

Is T. exterius craffum, prope embryonis feden cruftaceum, verfus peripheriam autem fuberofo - fungofum, friabile; interius arachnoideum.

AL B. nuhum.

EM B. teretiufculus. ....

2. 2.) Frudus integer junior. a.) Alius maturitati prosimus. b.) Receptac. commune cum Sao maris in fitu naturali. c. C.) Samarx pars dorfalis. d. D.) Ejusdem tatus ventrale. E.) Eajem transverlim fetaz. F.) Semen a latere fpectatam. G.) Ejusdcur latus doriale. H.) Tefta feminis crafra, pet medium dorfum verticaliter diffecta, cum loculamento tereti pro embryone.

Semen fæcundum \& rite maturum non vidi. In C. racemo $\sqrt{2}$, albumen nullum; embryo fub integumento membranaceo viridis; \& cotyledones folincex circa mediam radiculam convolute, fecundum Jacq. l. c. Sed recte quarrit Cl. Jufien, utrum hac fit genujina Conocarpi fpecies? 

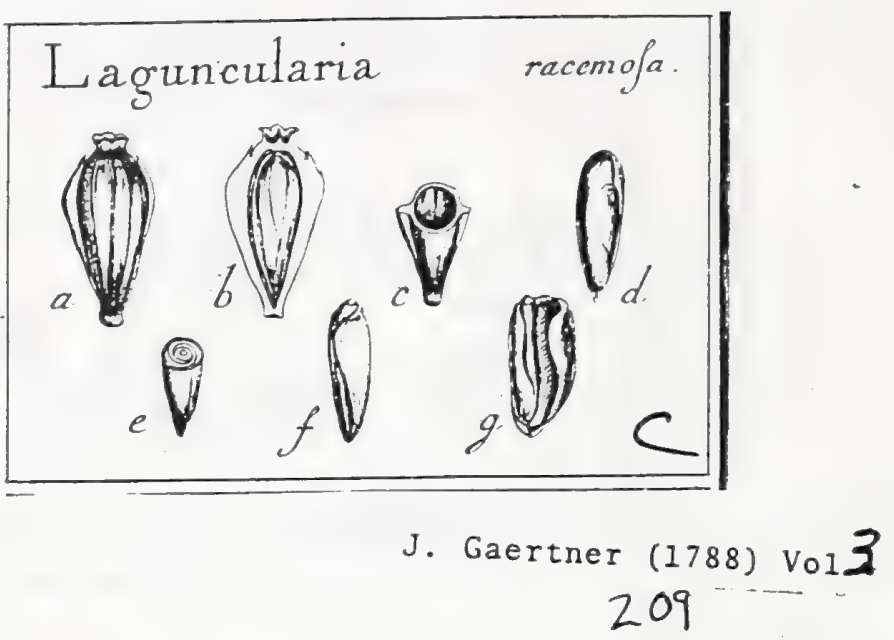

164. I A G U N C U L A R I A. Haentreaf.

Cal. monophyllus, fúperus, breviter tubulofus, L. fubcampanulatus, quinquepartitus, perfiftens; laciniis obtulis, rotundatis. Cor, perala quinque, minima, ad incifuras calycis inTerta, obtufa, pacula, caduca, Stan, decem; filamenta duplici ferie calycis tubo inferta, fubulata, alterna Jungiora, ca. lyce vix breviora; antherz fubrotundz. Ovar. inferum; ftylo fimplici, fubulato, ftaminibus breviore; Itigmate capitato. Nux marginata, coriacta calyce coronata, evalvis, Rec. nullum. Sem. unicum, inverfum. Alb. nullum. Emb. inverfus; cotyledonibus convolutis; radicula longitima.

LAGUNCUIARIA racemora, Tab, 217, fig. 3.

Mangle julifera foliis ellipticis ex adverfo nafcentibur. SLOAN bif. jam. 2. p. 68. Conocarpus foliis elliptico - ovatis, petiolis biglandulatis; raceinis laxis, frutribus Sejunfiss. . Brown jum. p. 159 .

Conocarpus floribus conspletis remotis. JACQ. amer, p. 80.

Conocarpus foliis lanceoluto - ovatis obtufiufculis, fruIibus fegregatis. LiNN. [yft. veg. ed. 14. p. 217. WILld. Jpec. pl. T, I, P, 2, p. 995, SWARz obS, bot. p. 79. Peksook fyn. 1. p. 21T.

Icon. JACQ. 1. c. t. 53. ed. pid.' t. 79.

Montachiba. Peruv. Collect. Sem. Muf. Paris

Ex Infula Hifpaniola, a Dao Poireau.

PRR. Nux vix pollicaris \& minor, ex ubovato-oblonga, calyce perfiftente ca ronata, \& intra illum Itylo brevi inftructa, ad latera duo oppofita alis incompletis 1 anfis furfum in dentem brevifimum acutum folutis deorfum vero deliquefcentibus aucta, fulcis exiguis elevatis longitudinalibus ftriata, coriacea, ferruginea, albido-pubefcens, evalvis, unilocularis, monofperma.

REC. nullum: femen ope funiculi umbilicalis brevifimi apici loculamenti af. fixum.

SE M. unicum, inverfum, fufiforme, $\perp$ obovato-oblongum, deorfum acuminatum, apice obtufum, rufurm.

IN T. fimplex, membranaceum, craffufculum, funiculo umbilicali cum ipfo undique cumatato \& ad bafin feminis decurrente infignitum.

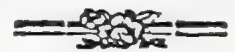

A L B. nullum.

E M. forma \& magnirudine feminis, inverfus, viridiufcuius. Cotyl. foliaceocarnofx, magnx, fupra radiculam convolutx atque recurva. Rad. longa, in axi embryonis libere sd apicem fere coryledonum defcendens, fere tota intra ipfas recondita \& apice tantum prominula, teretiufcula, adfcendens, fupera.

\section{EXPLICATIO FIGURE.}

2.) Nux integra. b.) Eadem longitudinaliter diffecta, cum ferine in fito. c.) Ejusdem feaio uransverfalis. d.) Semen (Ieparatum, integruor. e.) Ejusdem (eatio transverkalis. f.) Embryo folutus. 8.) Idem cotyledonibus evolutis, ut figura \& infertio sadicule in confpettum veniato

An flos vere, corolla inftructus? 


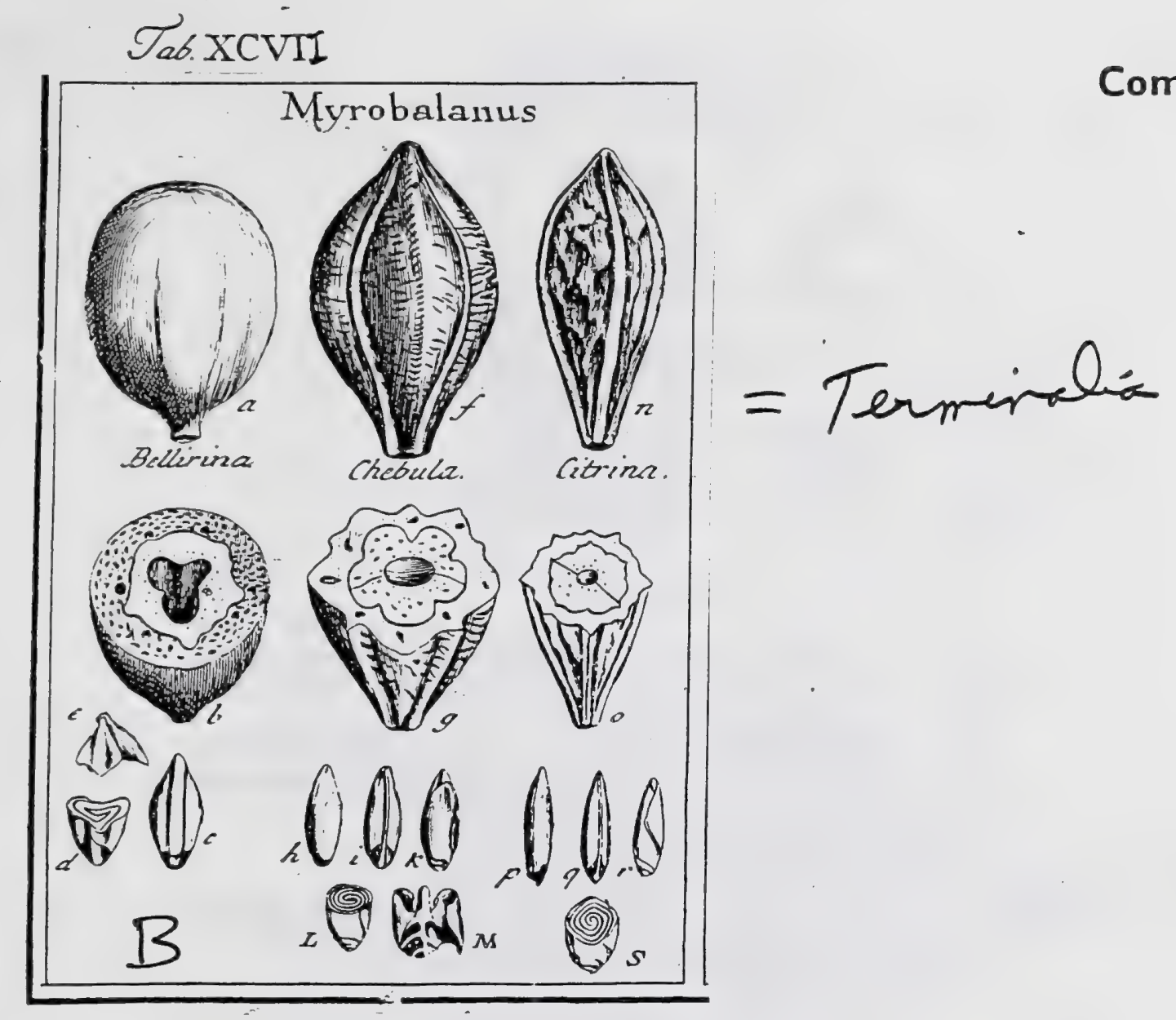

$56.7 \mathrm{~A}$ 
DXCIX. MYROBALANUS. OFFIC.

Flos ..... Drupa baccata, putamine rotunde angulato fulento uniloculari. Semen amygdaloideum inverfum, coryledunibus foliaceis fpiraliter convolutis.

Myrobalanus bellirica. Tab. 97. fig. 2.

Tam. RнеED. mal. 4. p.23. t. 10.

Mirobalanus Bellirica. Бвечs. ic. 18. t. 4. BLazw. besb. t. 404 f. x. mate.

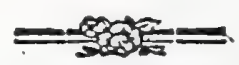

Per. Drupa ovato globora, obfoletifime angulata, fumora aut fufca. Caro craffa, in vetufto fructu dura, fufca, hinc inde porofa. Putamen offeum, durilfimum, crafium, ovatum, irregulariter pentagoaum, evalve, uniloculare : loculamento rotundato - triangulo.

REC. nullum, prater fubltantiam rungofam in apice loculamenti, cri femen affuxum.

SeM. unicum, triquetrum, fupra acuminatum, infra obtufum latifimaque chalaza nigro caftanea notatum, cetera pallide favefcens.

IN T. fimplicillimum, membranaceum, tenue.

A C B. nullum.

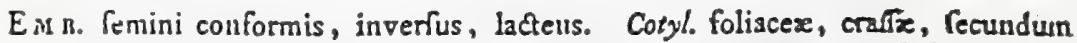
longitudinem ferminis in fpiram triangularem convoluter. Rad, brevis, tereti acuminata, a cotyledombus obtecta, fupera.

2) Drupa integra b.) Ejas atg̨ue putaminis fetio transrerkalis. c.) Semen feparatum. d) Ca tyledonum convolutio triangularis. c.) Radieula a cotyledoaibus obvoluta.

Myrobaranus chebula ibid.

Myrobalanus cbebula. Blakw. t. 40I. f. 2. mediscr.

Terminalia foliis ovatis nudis, petiolis fupra biglondulofis, racenis fimplicibus. RETZ fafc. 5. p. 31 .

Drupa (f.) procedenti major, ovata, per xtatem utrinque attenuata, nigrofufca, decagona, angulis alternis majoribus. Caro durifima, fragilis, e fufco fplendens inftar refinz. Putanien ( $\mathrm{g}$.) offeum, pentrgonum, angulis craftis rotundatis; cetera evalve, fpuria tamen futura infcriptum, \& uniloculare, loculamento tereti. Semen (h. i.) ovato oblongum, fupra acuminatum, infra lata chalaza atra (i.) notatum, \& ex ea funiculo umbilicali filiformi inltructum, tereti compreffum, ferrugineum. Embryo (K. L. M.) fenini conformis; Cotyledonibus (L.) Spiraliter convolutis; Radicula (M.) tereciufcula, fupera.

Mrrobalanus citrina. ibid.

Drupa ovato - oblonga (n.), denrfum valde attcruata, e fpadiceo lutefcens, varic angulata \& inter angulus fimper rugofo. Caro \& Pueamen $(0)$ ut in proxime procedenti; fed putaminis anguli in dorfo carinati, \& futura Ipuria paulo magis confpicua. Senien (p. q.) ut in pracedenti, chalaza etian \& funiculo umbilicali ( $q$ ) inftructum, fed gracilius \& quafi ex tereci anceps. Embryo (r. S.) carnofo foliaceus, fpiraliter convolutus.

Myrobalanum belliricam a reliquis diftinctam elfe fpeciem, ex ejus fructu fatis liquet, fed chebula atque citrika funt forfan merx varictates unius ftirpis, 2tque indica, qux Otficins dicitur, mhil aliud elfe videtur, quam M. citrine

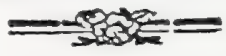

fructus immaturus, anam proxime ad hanc, forma fua accedit, fed conftanter fenine orba eft.

is Terminalix characterem effentialem, in fpirali cotyledonum convolutione, cum b. Koenigio pofueris: utique Badan \& omnes Myrobalani fpecies ad genus iftud migrare debebunt.

\section{$56.7 B$}




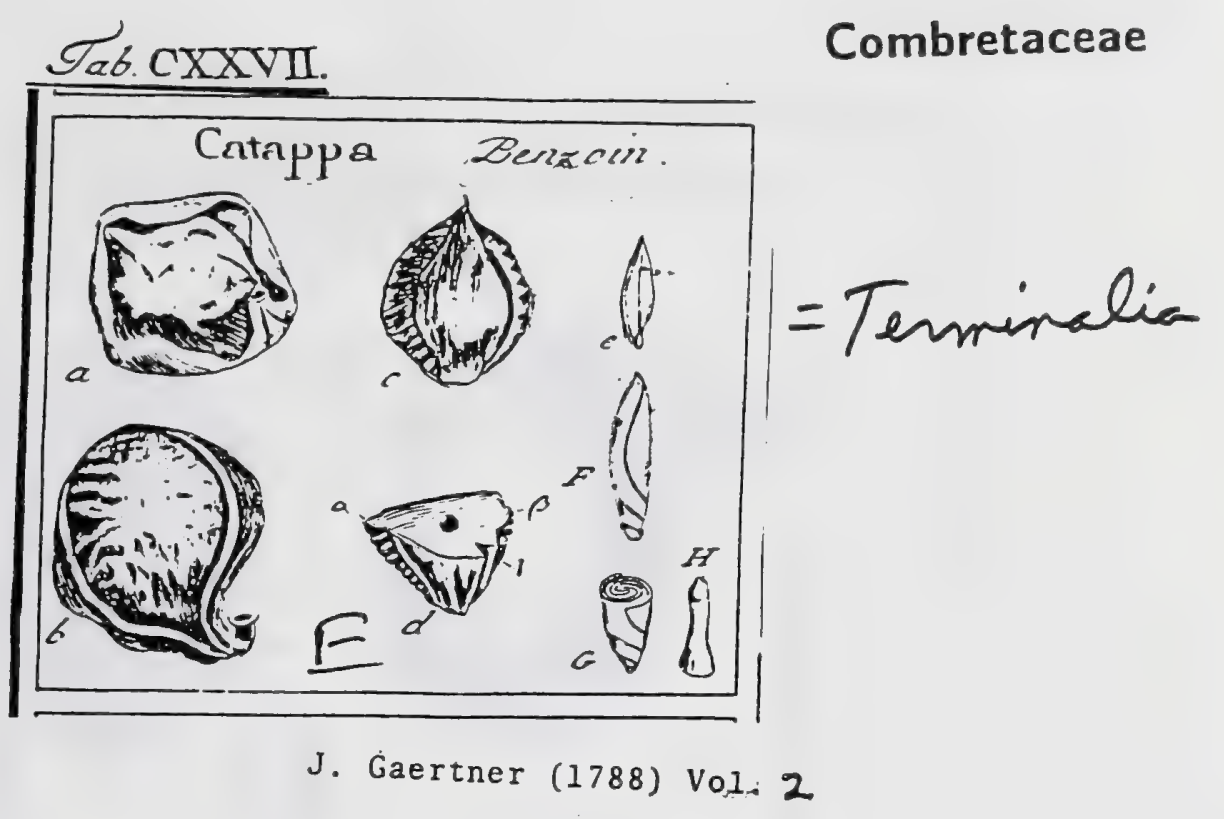

206

Calyx fuperus, quinquefidus, inferum. Styl. fimplex. Drupa ficca, inferal nulla, Stam. decem. Ovar. unilocularis, monofpernia. Cotyled. foliacex, non coronata, compreffa,

CatAppa Benzoin. Tab. 127. fig. 3.

Terminalia anguftifolia. JAcQ. bort. 3. p. 51. 8. 100.

Terninaliat foliis lanciolatis. LIN fyjt. veg. 910 .

A Serenif. Princ. CAROLINA March. Bad. PER. Drupit ficca, infera, obovato - cochleariformis, hinc fcil. convexiufeula,
obfoletifime (per exficcationem) rugofa atque prominulo nervo cum
margine parallelo notata, inde, autem conction rante putanine, gibba. inde. autem concava ac in medio, a protubeceus, glaberrimus, fublucidus, coriaceus, tenacilfimus, rufefcenti-fpadiultrat putansen in latum marginem coriatus fubltantia fpongiofa ltipatus, ovatum, acuminatum, inique \& gibbofe tigo productus. Putamen fub. autem fragile, cariofum, lacerum, uno inrus an, lapideun, ad angulos exfculptum.

REc. nullum; funiculus umbilicalis filiformis, femini arcte adnatus, illud apici
loculamenti affigit.

SEM. unicum, oblongum, teretiufculum, fuperne acuminatuni, palib cens, inferne attenuatum, bofl of fuperne acuminatum, pallide luter-

IN. fimplex, membranaceum, tenue funiculo umbilicali rufefcentibus.

A I B. nullum.

EM B. femini conformis, inverfus, lacteus. Cotyl. foliacex, fecundum axem
fructus fpiraliter circa radiculam fupera.

c.) Drupe mars coneatra

transverfe fectum, angulis ( $\alpha_{0}$ B. $\gamma_{0}$ ) attenuatis,

F.) Embryo denudatus. G.) Cotyledones transver, Atriatis, laceris. c.) Semen (eparatum.

Confer Badamiam \& Myrobalanum, fupra pag. H.) Risicula fcparata. GUU ad Catappam refert.

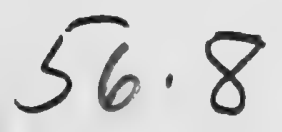




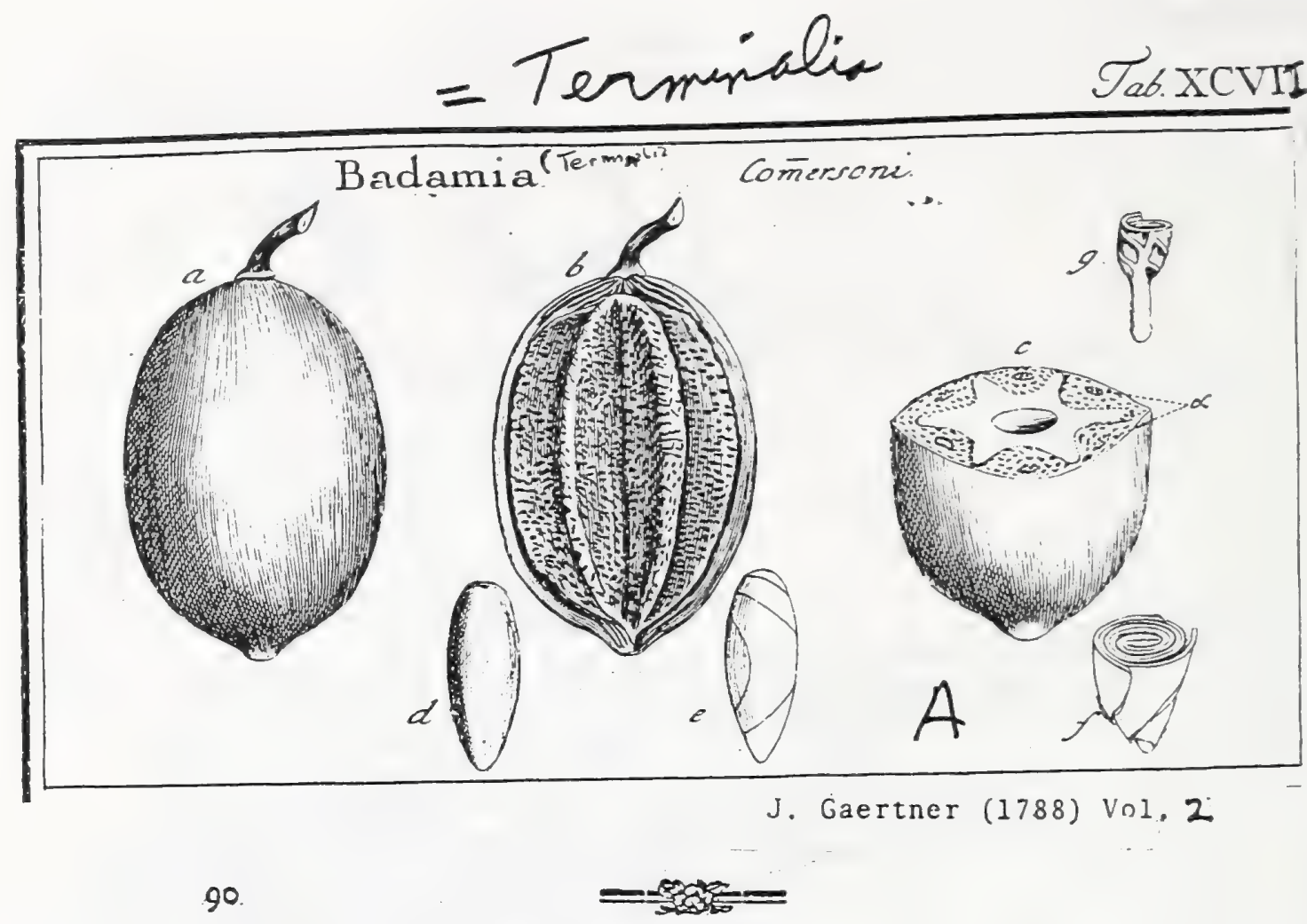

DXCVIII. B A D A M I A.

Flos .... Drupa exfucca, putamine uniloculari, molendinnceo f. alato-hexa. gono. Semen amygdaloideun inverfum, cotyledonibus foliaceis fpiraliter convolutis.

Badama Commerfoni. Tab. 97. fig. I,

Badanie de madagafcar. A ferenifr. Prina CAROLINA March. Bad.

Conf. Sonnerat voy. 2. p. 63.

PER. Drupa exfucca; elliptica cum brevi mucrone ad apicem, turgide lenticularis, glaberrima, paliide fpadicea. Cuticula tenuifima, fed tenax, ut difficulter rumpatur. Caro fungnfa, putamini arctiffime adnata \& quafi mera ejus propago: intra eam funiculi fex crafit, ex fibris lignolis compoliti \& a bafi drupz, ad ejus apicem, inter putnminis alas, decurrentes. Putamen offeum, craffum, extus fibrofum, cellulofumque, alis `ex craffis longitudinalibus diftinctum; intus levigntum uniloculare.

REc. nullum; femen fundo loculamenti late adnatum.

SEM. unicum, oblongum, amygdaloides, glabrum, e luteo rufefcens.

IN T. Gimplcx; membranaceum.

A L E. nullum.

E 1 в. femini conformis, inverfus, lacteus. Cotyl. foliacex, crafinufulx, fecundum longitudirem feminis fpiraliter convolutx, \& prope radiculi ortum nervis elevatis eleganter reticularc. Plum. nulla. Rad. longiufcula, fubanceps 1. cylindrico - comprefla, obtufa; fupera.

a.) Drupz integrz. b.) Putamen denudatum. c.) Drapx fetio transverfalis, fafciculos fibranm ligatarum (a) sotra earacm difpolitos, atque putaminis alas oftendens. d.) Semen fua membrana veftitum. e.) Embryo denudatus integer. f.) Ejusdem pars fnperior transverfim fecta, cum . Ipiris cotyledonnm \&.) Radicula denudata, cum principio cotjledonum.

Affinis eft Catappx \& pro.Terminalix quoque fpecie habetur ab Aubletio Vol. 2. Append. F. 140 ; fed fabrica fructus eum defcripcione Rumphii non congruic 


\section{Combretaceae}

= Tenmiralí

Tab. 217.

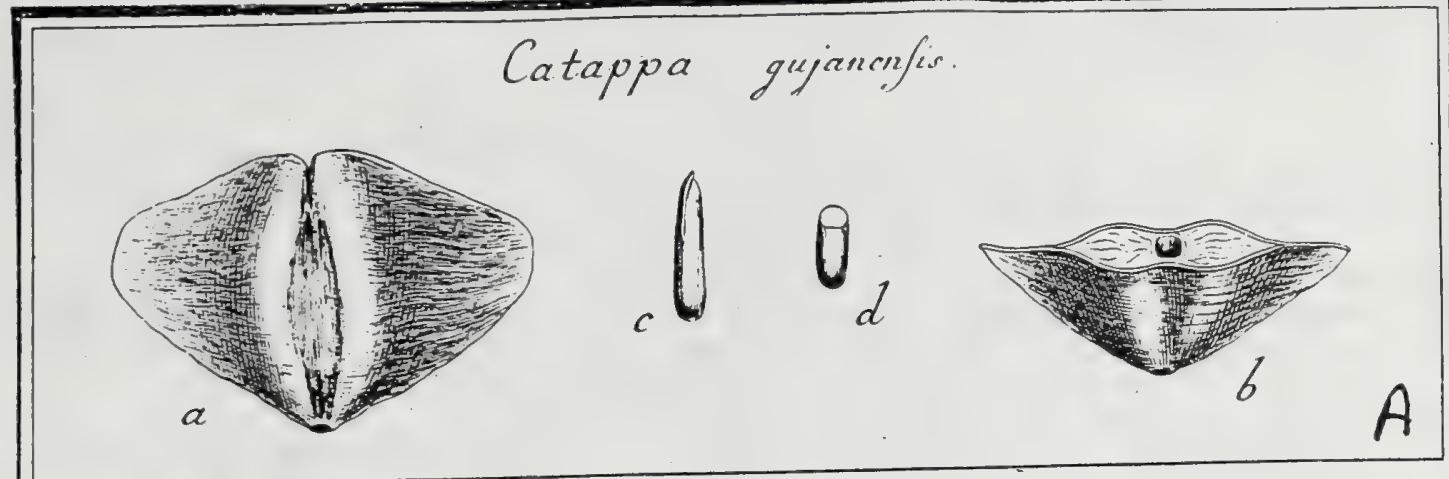

J. Gaertner (1788) Vol. 3

207

C A T A P P A. Conf. Carpol. Vol. II. p. 206.

Catappa gujanenfis. Tab. 217. fig. I.

Icon. Lamarck ill. gen. t. 848. f. 3 .

Habitat in Infula Cilyenne. Ex collectione Cl. Desfontaings.

Drupa (a.) duos pollices lata \& fefquipollicem longa, rotundato - rhomboidea, apice emarginata, compreffa, medio a protuberante putamine utrinque convexa \& fulco abfoleto rotundato longitudinaliter fulcata, transverfe rugofoftriat:l, ficca, viridis. Cortex (b.) coriaceus, tenuis, glaber, fubftantia albida intus ltipatus, in duas alas corisceas rigidas rotundatas ultra putamen productus. Putamen ovatum, ofeum, ad inarginem cariofum \& intime cum fubftantia fpongiofa connatum, comprefisufculum, longitudinaliter fulcatum, uniloculare. Loculamentum oblongum, obfolete tetragonum, monófpermum. Semen (c. d.) unicum, ovato-oblongum, ad verticem mucronula tum, ad balin obtufum \& cbalaza nigro-fufca nocatum, ferrugineum.

Catappa mauritiana.

Termisaliat mastritiana. LaM. ditr. I. p. 349.

Drupa Catappo Benznin fimilima fed paulo major obcordata \& in emarginatione mucronata. Cxtera ut in hac. 
-

$\rightarrow$

0 
LVI. COMMELINA. PI U M. gen. t. 38. LIN ger. 62.
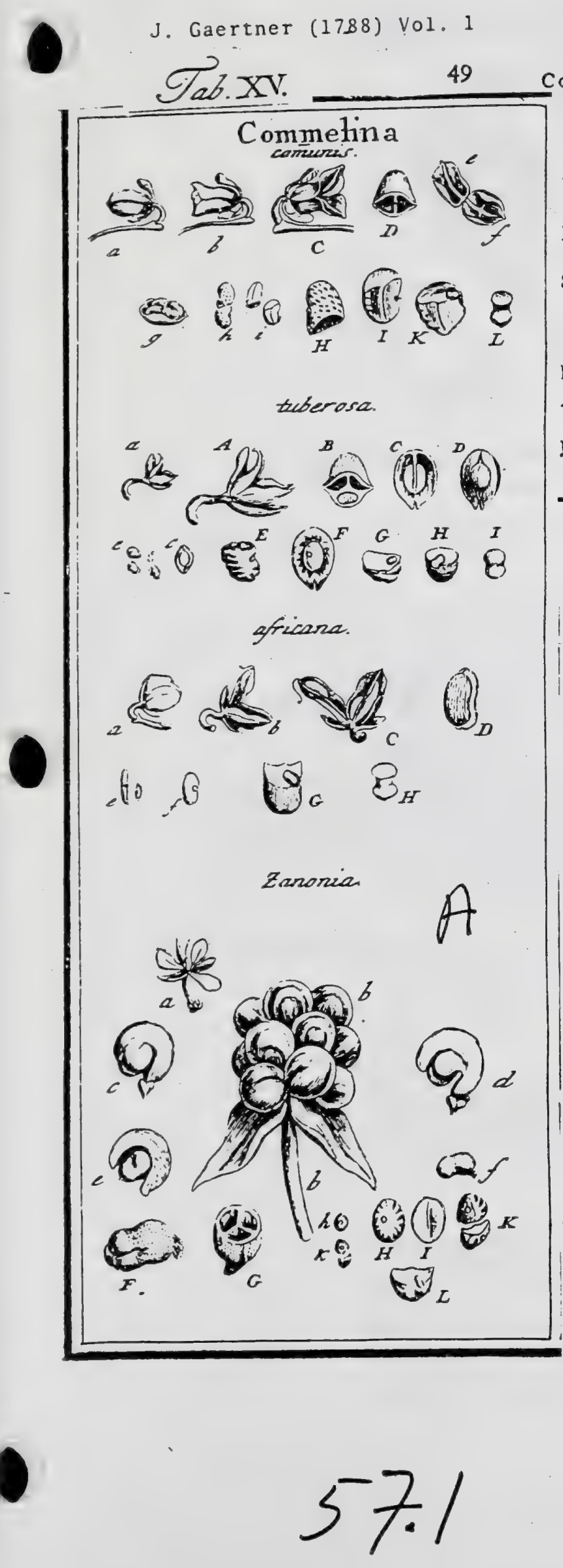

Corolla hexapetala. Nectaria tria cruciata, pedicellata: Stain. tria, StyL fimplex. Capfula fupera, bi- 1. trilocularis. Semisa pauca Embryo in latere, aut in dorfo feminis.

COM MELINA communis. Tab. 15. fig. t.

Commeliua procumbens annua, faponàtía folio. DILL. h. elth. 93. t. 78. f.89.

Commelina corollis inrequalibus, foliis ovato lanceolatis acutis, caule repente glabro. Lis N. Syf. veg. 94.

PER. Capfula fupera, orata, utrinque levitcr comprefta, fubanceps, bilocularis, bivalvis. Valvulx tenues, membraracex, fepto intus longitudinali fipatx.

REc.nullum: femiua valuulis, prope infertionem difTepinenti, affixa: ita, ut duo oppolita alteri, \& itctum duo alteri valvulx adhxreant.

SE M. in fingulo loculamento geinina, ea parte, qua fe mutuo contingunt, truncata, cetera vero ovata, hine gibla, inde plana, Ccrobiculis in parte convexa, in plana autem linca longitudinali cxarata, \& ad altcrum latus fovea umbilicali exfculpra, Subcincres.

IN T. fimplex, mcmbranaceum, albumini arCtifirie aduatum.

A L B. Femini conforne, cartilagineurn, aqueo-pallidum, ad alterum latus forea pro rccipicisdo embryone, ut in Yalmis, cxiculprum.

Es B. moncotyledoneus, trochleari-cylindricus, $f$ in incdio attenuatus, lactco-allus. Radis. centuifuga.

- Capiula integra. D. C.) Eadein apice dehifcens. D.) Ejus fertio transvierfalis. e. f.) Valve ix didutize, cum diffepinento longitudiuall. 5.) Semina in fitu naturali: umbiliris feil. duobus furfum, \& duobus deorfum verfis. h. H.) Seminis latus dorlale. i. 1.) Ejusdem pars ventralis, K.) Albunien transverfe fetun, cain embrjonc in propria fua cavitate. L.) Embryo feparatus \& infigniter autus.

Simillima luic fabrica gaudet quoque fructus Commelinx virginicx; fed ei capfula paulo major, albicans, \& femina magis rugofa ac fpadiceo-cinerea.

Cом

Commelina radice anacampferotidis. DiL'L. h. elth. 94. $t .79 . f .90$.

Commelina corollis aqualibus, foliis fefrlibus ovato lanceolatis fubciliatis. LINN. Syfl. veg. 94 .

Capfula ovato acuminata, depreffuscula, bivalvis (a A.), trilocularis (B.). Valvula fuperior, per feptum longitudinale in duo loculamenta divifa; inferior autem unilocularis, fupra leviter concava (C.), infera convexa (D.), fernini arcle ad. nata. Semina, in fingulo loculamentorum fuperiorum, gemina (e. E.) tuberculato rugofa, ferruginea. In inferiori loculamento femen unicum, capfulx vajvula (c. C. D. F.) vellitum, ellipticum, glabrum, lenticulari-compreffum, โpadiccum. Albumen (G. H.) figurâ feminum, cartilagineum, Embryon (G. H. I.) trochleari cyiindricus, in feminibus fupcrioribus, lateralis (E. G.); in femine folitario autem dorfalis (F. H.)

COMMELINA africana. ibid.

Commelina corollis inaqualibus, foliis lanceolatis glabris, caule decumbente. LIN N. fyft. veg. 97.

Capfula ovata (a), bivalvis (h. c.) trilocularis, Aruclurá omuino precedentis, fed duplo major. Semina in fuperioribus loculamentis (C.) bina, tcina l. quaterna, teretiuscula, glabra (e), umbilico quidem ad latus notata, fed femper ferilia \& embryone orba. Semen loculamenti inferioris (D.) folum fertile, \& totum valvula fibi adnata veftitum, ellipticum (f), fupra planum \& margine, ex valvula, membranaceo (C.) cinctim; infra convexum, umbilico ad latus (f) notatum, ferrugineum, aut fpadiceum. Albumen (G.) femini conforme, carcilagincum. Embryo (H.) ut in pracedentibus.

Сом MEINA Zanonia. itid.

Periclymemm reftum herbaceum, gentiana folio, folii pediculo caulem ambiente. Sı.0... hif. jail. 1. p.243. t. 147. f. 1 .

Commclina corollis aqualibus, pedunculis incrafjatis, foliis lanceolatis: vagi-

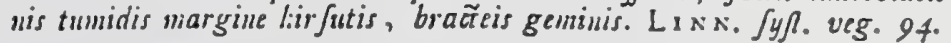

Ex l:oren regin Kewenfi.

Fruchns inaccati, feltiles in racemo terninali (b. b.) ovato, bracteis duabus floralibus, reflcxis, bali flipato. Baccx fpurix, purpuralcenti-atrx, formarn ... ....11

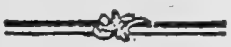

(a), transmutata in galeam carnofain (c.d.e.) fucculentam, trilobam. (d), capfulx fuperinductain (e), camque totain occultantern (c.) Capfula ( $f_{0} F_{0}$ ) cylindrico-ovata, cruftacea, feriatim puncticulata, teflacea, trilocularis (G.), apice trifariam delusceus. Scmina duo $(k)$, vel \& unicum $\left(h_{0}\right)$, in quolibet locula. sonto: illa angulata ( $k$ K. ), rugolula, cinerafcentia, papiliula. embryonitega in latere notata ; hoc, ellipticum (h.H.I.), plano convexum, in ambitu_rugofulum. \& in inedio dorfo embiyoniferum (H.) Albumen (L.) femunibus conforme, cartilagineum. Embryo cylindricus, centrifugus. 


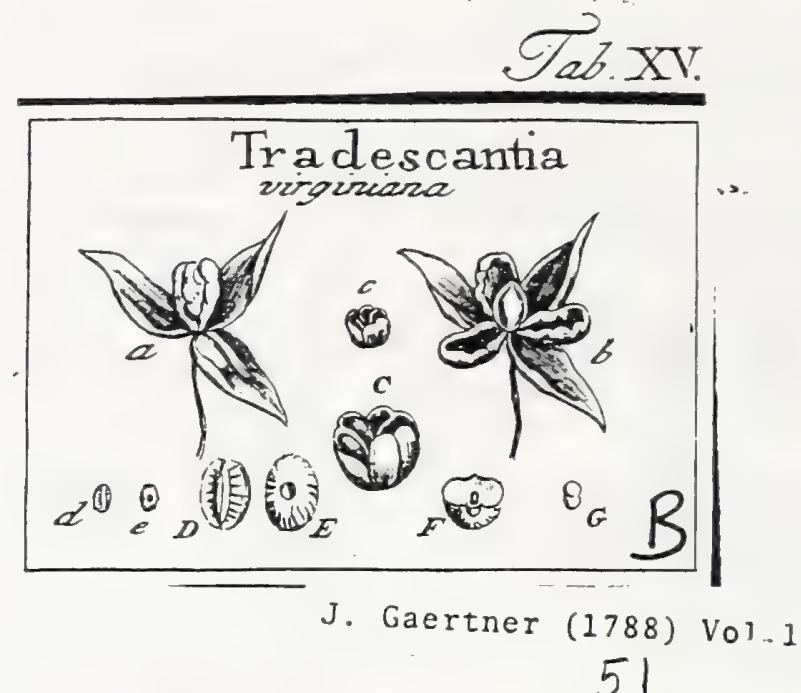

\section{TRADESCANTIA. Linn. gen. 398. Ephemerum.} TOURN. t. 193.

Calyx triphy'llus. Cor, tripetala. Stan. Sex. filamentorum pilis articulatis. Stylus
fumplex: Rignate tubuloro fumplex: nignate tubulofo. Capfula fupera, trilocularis. Semina pauca, dorfo
vel lateribus embryonifera. TRADESCANT1A virginiana. Tab. 15. fig. 2.

Ephenerum phalangoides tripetalum non repens virginianum gramineum. Moris hifl. 3. p.600. S. 15.t. 2.f. 4 .

Tradefcantia ereta lavis, floribus congefis. I IN s. Jyfl. veg. $3^{14}$.

PE R. Capfula fupera, corolla perfiftente obvoluta, parva, ovata, obfolete trigona, trifulca, trilocularis, trivalvis: valvulis medio feptigeris.

REC. nullum: femisa umbilicis fuis valvularum parieti interno affixa.

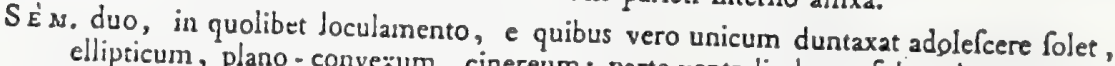
ellipticum, plano-convezum, cinereum: parte ventrali plana, fulco elevato tenui, \& juxta hunc rugis transverfalibus ad utrumque latus inferipta; parte dorfali autem infignita.

INT. funplex, fubcrufaceum, nucleo pertinacifime adnatum.

A L B. Semini conforme, cartilagineum, pallidum. E s в. fubcylindricus, in medio angullatus \& quafi ex duobus globulis nedullaribns com-
pofitus, Jacteo albicans. Rad. centrifuga.

a.) Corrolla corrußata, capfulam obvolvens. b.) Capfula derudace. c. C.) Eadem delifcens. d. D.) Seminis pars ventralis. p. Fo, Ejusdeni Intus externun. F.) Albumen transverfe fetium, cum cavisace fua enibryonilcra. G.) Enbryo Scparatus \& infigniter autius.

Ob. Chare ex his omnibus patet, quod Trade-Scantia \& Conmelina, nonnifi unicum
genus maturale efrciant.

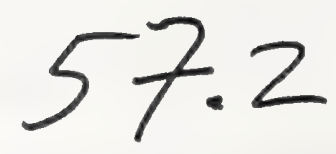




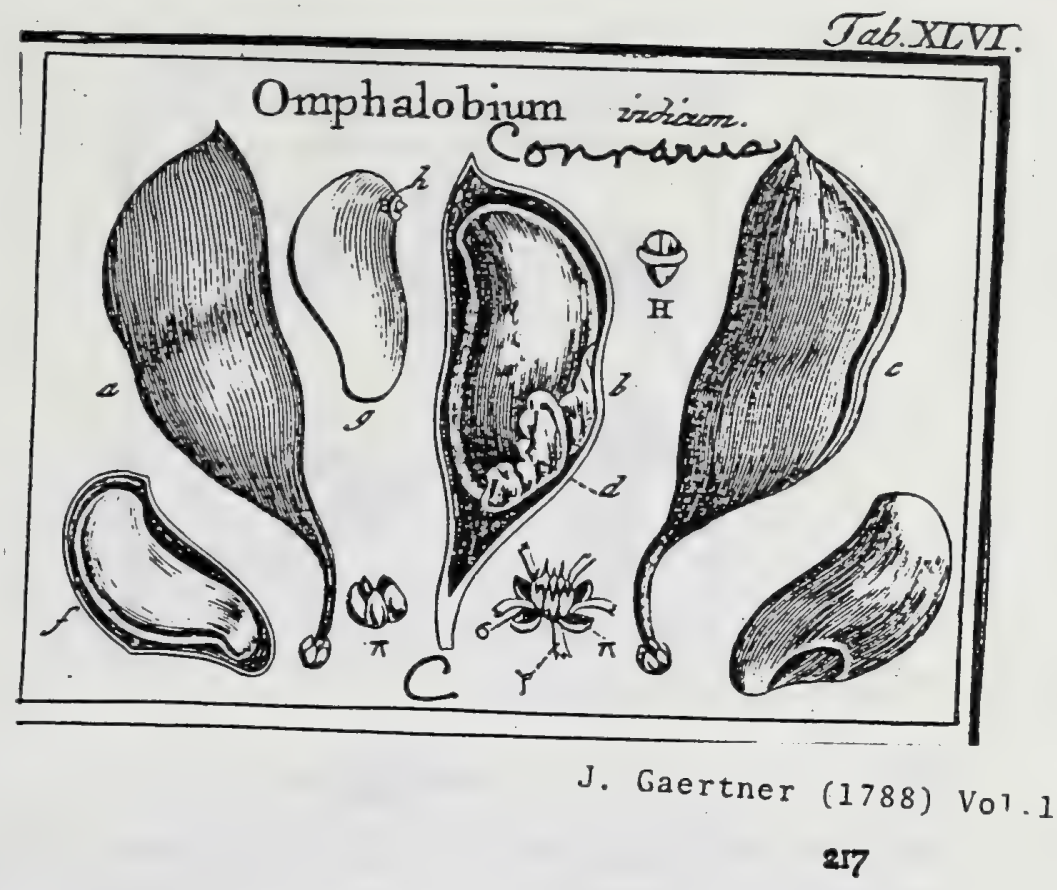

CCLV. OMPHALOBIVM.

Calyx pentaphyllus perfinens: foliolis parvis ovatis concavis. Corolla pentapetala; uuguibus linearibus. Stam. deccm, longitudine calycis; filamentis fubpolyadelphis. Capfula leguminofa pedicellata. Semen unicum: Arillo incompleto glandulofo.

ОМРнАІОВхчм indicuns. Tab. 46. fig. 3.

Raddi.lyi. zeylonens. E colled. fem. hort. lugdb.

PER. Capfula leguminola, coriacea, pedunculata, fubtilifime friata, unilocularis, evalvis, aut latere exteriore gibbo dehifecns.

REc. uullusn; femen futurz lateris gibbi inferne afixum.

SEм. unicum, grande. fubreniforme, glabrum, fplendeus, farurate caftaneum aut nigrum, ad umbilici regionem utrinque foves oblonga impreflum, ibique cum arillo umbilicali couferruminatum.

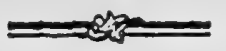

Arillus incompletus, carnolo glandulofus, varie lobatus \& quafi crifpatus, exterion \& inferiori feminis parti fecundum totam fuam longitudinem arcte adhxrens.

INT. duplex : exterius crufaceum, tenuilfmum, fragile; interius arachnoideum, palliduın.

A 1 в. nullum.

Es в. magnitudine feminis, oblongus, compreffusculus, figmoideo-curvatus, inverfus? lutefcens. Cotyl. carnofx, craffx, plano-convexx. Phim. diphylla : foliolis fubra tundis, conduplicatis, hirfutulis. Kad. exigua, conica, in fuperiori atque umbios lico directe oppofita feminis regione locata.

a.c) Legumen integrum \& dehifcens, b.) F.jusdem valvula altera eum fitu ferainis, d.) Arillo barin feminis cingens. e) Semen alusque arillo. f.) Idem longitudinaliter apertum, cum embryoni. v.) Cotyledon altera feparata cum plumula \& radicula h.H.) $\pi \pi$. ) Calyx magnitudiue aucti e.) Petalorum ungues. $\sigma$.$) Filamesica connata.$

Videtur affinitatem quandam cum Copaifera habere, cui nempe LrNweus fyj 409. Legumen ovatum \& femen, arillo baccato, tribuit; licet Jaxc cum Marc. GRAvil \& Pisonis Copaiba nequaquam confeutiant; \& preterea in noltris fpeci: miuibus calyx manifefius adfit. 
-

0

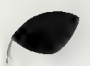




\section{Tab. CXXXIV.}

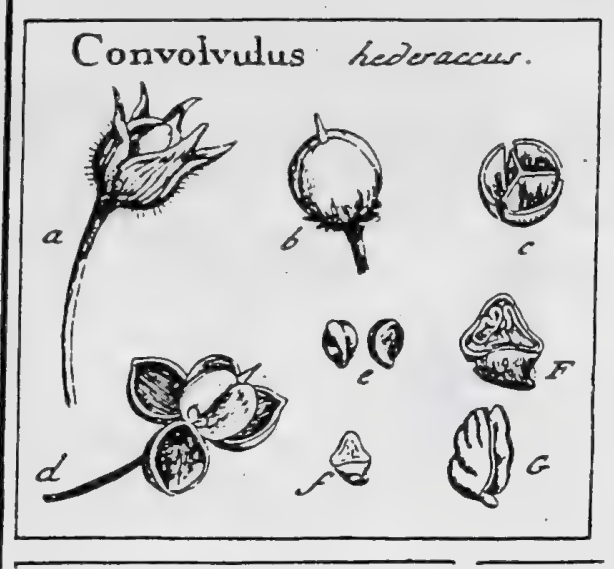

J. Gaertner (1788) Vol. 2

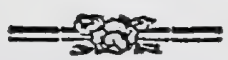

DCCIXXX: CONVOL.V.ULUS. TOURN. t. 57. LINN. gerk.2I5.

Calyr-monophyllus, femiquinquefidus: Cor: monopetala, campanulata aut infundibuliformis! Stam. quinque. Ovar. fuperom. Styl. fimplex, ftigmate bifido. Capf. tri - 1 . .quadrilocularis. Sem: pauca, - embryone contortuplicato.

Contolvulus hederaceus. Tab. 134, fig. 2.

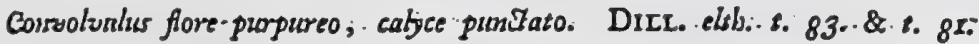

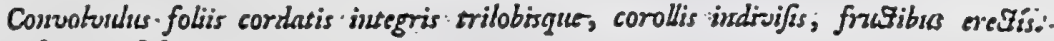
LINN: Jift: veg: 200 .

-P.er. Capfula fpharica, glabra, tenuis, trilocularis, trivalvis: Diffepimenta: futuris valvularum obverfa.

$R E c$. cicatrices dux parvxe ad bafin anguli centralis lóculamentoram.

SEN. dúo in fingulo loculumento, hinc convexa, inde anguhata; verfus bagin: attenuata, atra; ghabra.

Is T. triplex: extinum -tenuiffmam, nigra- füliginis adinftà femini adhærens; mediun cartilagineum; tenue; fpadiceo-fufcum; intimum membrantaceum, lamina furinofa duplicatum.

AI.B. tenue, farinofum,-candidifimam; intra'cotylèdonum plicas defcendens; ab aqua in gelatinam pellucidam convertibile.

E M B. magnitudine feminis, curvatus, .lutefcens. Cotyl. foliacex, chryffloideos. contortuplicasca. Raclo. teretiufcula, infera.

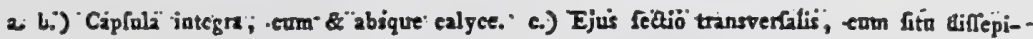

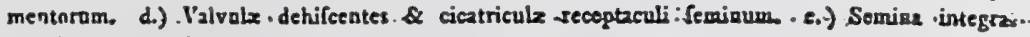
f. F.) Semen difrcaum. . G:) Embrga denudatus. .

Ex föla feminis Coirvolisloirmn fabrica Juculentrum "eft"; quod in ordine 'natarali neque ad Pessonatas, uti Adasson, neque ad Campanacess, -uti LINNäUS \&. ERXIEBEN voluerunt, referri queant; fed quod vel in peculiarem funiliam, ad mentem Ill.' JUSS1Rl, ncongregari, -vel cum Aratiaceis fociari debeant, .cum guibus etiam . foliatura froillime congrumnt. 


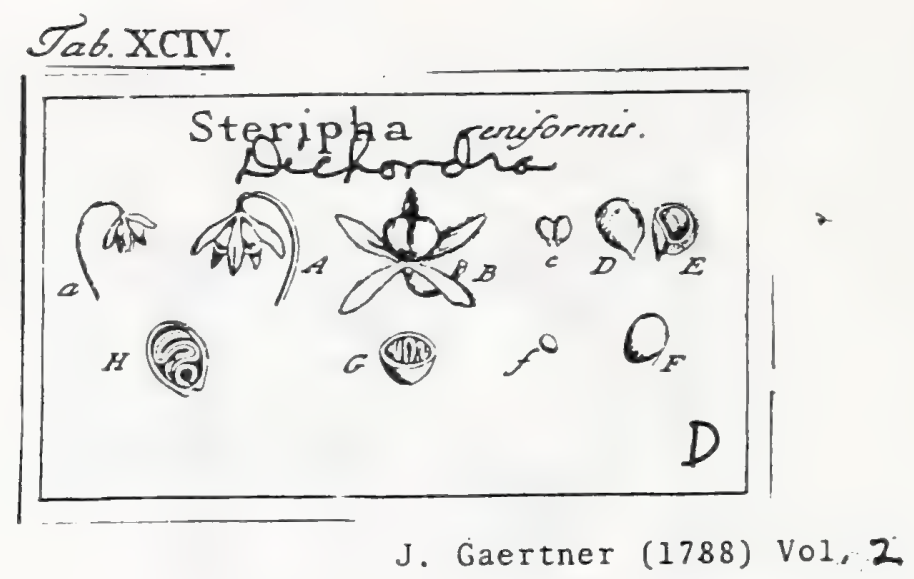

\section{STERIPHA. BANKS.}

Calyx quiiaquepartitus perfiftens. Cor. monopetala infundibuliformis. Tubus cylindraceus calyce brevior. Limbus quinquepartitus, laciniis oblongolanceolatis obtufiufculis. Stam. quinque, tubo cotolle intra finus inferta. Oraria duo fupera, plano - convexi. Styl. duo filiformes, ftigmaibus magnis capitato - peltatis concavis. Capfulx duxe. Ex fchedis Solakdri.

STERIPHA reniformis. Tab. 94. fig. 6.

Steriples reniformis. SULAND. $n i s$. Ex herbario Bankfiano.

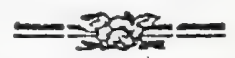

PER. Utriculi duo fuperi, membranacei, plano - convexi, villof, brevifime pedicelati, femen laxe cingentes, nec dimittentes.

REc. nullum; femen bafi affixum.

SEM. folitaria, fubglobofa, ad umbilicum puncto excavato notata, nigricantia.

IN T. duplex: exterins cruftaceum, durum, cralfum, fragile; internus membranaceum, palliduns.

$\Lambda$ L B. teauifimum, ut In ficco femine vix ullum appareat, fed ab aqua mutatur in gelatinam vitreo pellucidam, fubviridulan, embryonem involventem \& ejus plicis interjectam.

ENB. magnitudine fere feminis, dicotyledoneus, contortuplicatus, erectus, albus. Cotyl. foliacex, tenuiffimx, diverimode \& anfractuofe contortuplicatz. Rad. teretiufcula, fubfpiralis, infera.

2. A. B.) Calyx fruaifer. B. c.) Utriculi coadunati. D.) Utrieulus feparatus integer a latere \{no plano fpedatus. E) Idem diffeetus. E. F.) Semen integrum. G. H.) Idem transverfaliter \& longitudinaliter difeetum, eum plicis \& convolutionibus embryonis obiter exprefles, quia penicillo ad naturam delineari neynennt.

Poft Operculariam, hxc una ex fingulariftmis orbis antarctici plantis elt. Habitu fuo externo refert Sibthorpiam exroparm; at partium fructificationis numero, proxime ad Schreberani accidit! 


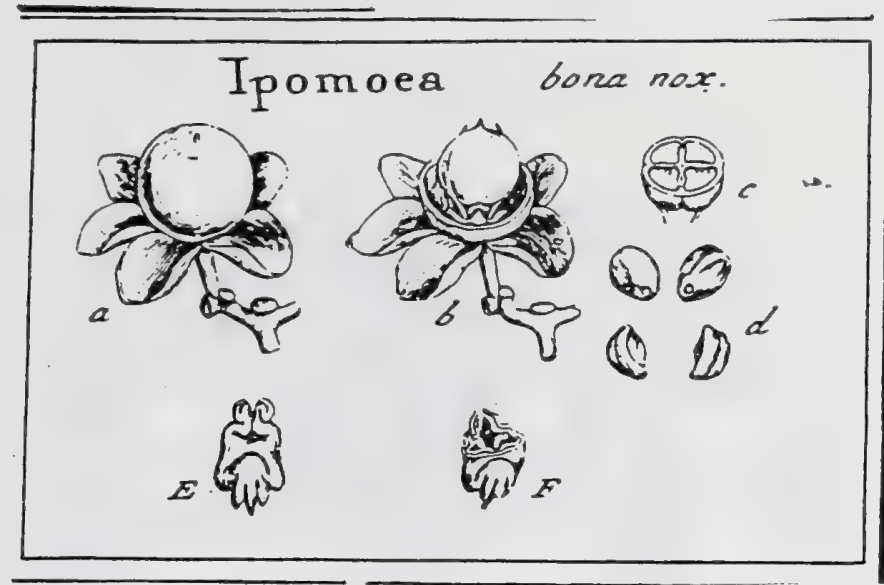

J. Gaertner (1788) Vol. 2 ;

DCCLXXXI.: I P O MO E A. LINN. gen. 216:

Oslyx, corolla, Stamina atque femina Convolvali. Baces exfucen aur fucclu. lenta, unilocularis, tetrafperma aut 'per abortum' difperma".

Iromoes bona nox: Tàb.' 134. fig. 3 .

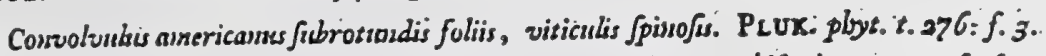

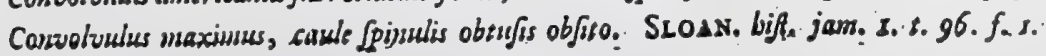

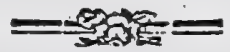

Iponsoea foliis cordatis acutis integerrimis, caule aculeato, foribus teirnis, corollit, indivifiss. LiNs. $\int y / t$. veg. 204.

E collect. Bankfiana.

PER. Bacca exfucca, globofa, unilocularis, rufefcens aut nigra, glabra. Cor. tex coriaceus, a carne per maturitatem fponte fecedens, intus membran alba tenuifima veftitus atque ftriis fex longitudinalibus infcriptus. C Caro. fungofa, nivea, tenuis, vafis nutritiis filiformibus perforata, feminibus. arcte adhærens, ut unacum iis in quatuor partes divelli poffit.

Rqc. nullum, prater eminentiam conicam in fundo bacex, cui femina \& vafa, carnis nutritia affixa.

SE N. quatuor, ovata, hinc convexa atque fulco depreffo notata, inde angulata, juxm bafin anplo foramine umbilicali pertufa, glabra, pallide teftacea.

IN T. duplex l. potius triplex: extimum, a carne, fungofum; medinm coriacea: crultaceum, durum; intinutu membranaceum, cum albumine cohxrens.

A \& B. tenuifimum, membranaceo-farinofum, niveum, intra cotyledonun plicas defcendens, ab aqua in gelatinam convertibile.

Eм в. magnitudine feminis, curvatus, albus. Cotyl. foliacex, chryfaloideo. contortuplicarc. Rad. tereciufcula, infera.

2) Frutus integer, b.) Bacez cortex difreatus, eum cemis fungolis globo a vafis nutritiis fuftentato. c.) Idem globus, unacum femiribus, transverlim fectus d.) Secnisa folute E.) Embryo denudatus, a dorlo (pectatus. F.) Cotyledones diffeax \& Ieviter explicatz.

Confer I. Loylanicain in Append. tab. 177. Reliquas Ipomocx fpecies, quaruin capfule in valvulas folvustur, ad Convolvulum referimus.

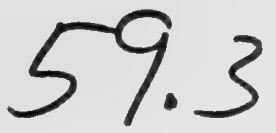




\section{Tab. CLXXVIII.}

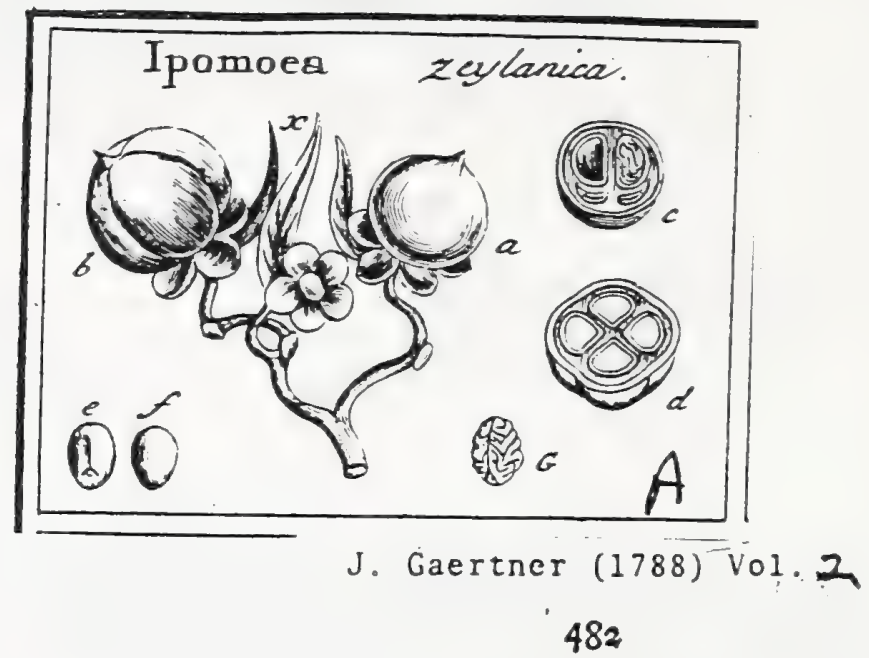

\section{POMOEA. vid. fupra p. 247.}

IPOMOEA zeylanica. Tab. 178. fig. I.

Eiri- tiella. Zeylonens. E collect. fem. hort. lugdb.

Bacca (a. b.) globofa, carnofa, in acutum mucronem spice definens, nune penitus rotunda (a.c.), nunc vero obfolete rutundato - tetragona, pallide viridis, glabra, corticara. Cortex modice craffus (c.d.) carnofus, a pulpa facile feparabilis. Pulpa fpongiofa, quadri - aut per abortum, bilucularis (c. d.); loculis membrana propria veftitis, nec cum femine coharentibus. Semina folitaria, in baccis biloculuribus gemina.(c.), plano-convesa; in quadrilocularibus quaterna (d.), hinc convexa (f.), inde angulata (e.), e cinereo fufca. Integ. exterius coriaceum, craffum, glabrum. Album. pulporo - membranaceum, intra cotyledonum plicas demerfum. Embr. (G.) albicans, chryfaloideo- contortuplicatus. Rad. infera.

$\Lambda$ reliquis hujus generis fpeciebus, proter modo dictam pericarpii fabricam, effentialiter quoque differt: foliolis flomlibus $(x$.) fub fingulu calyce fingulis, lanceulatis, fefrilibus, perfiftentibus \& calyce fuo triplo longioribus.

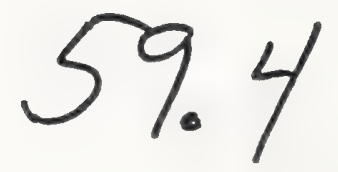




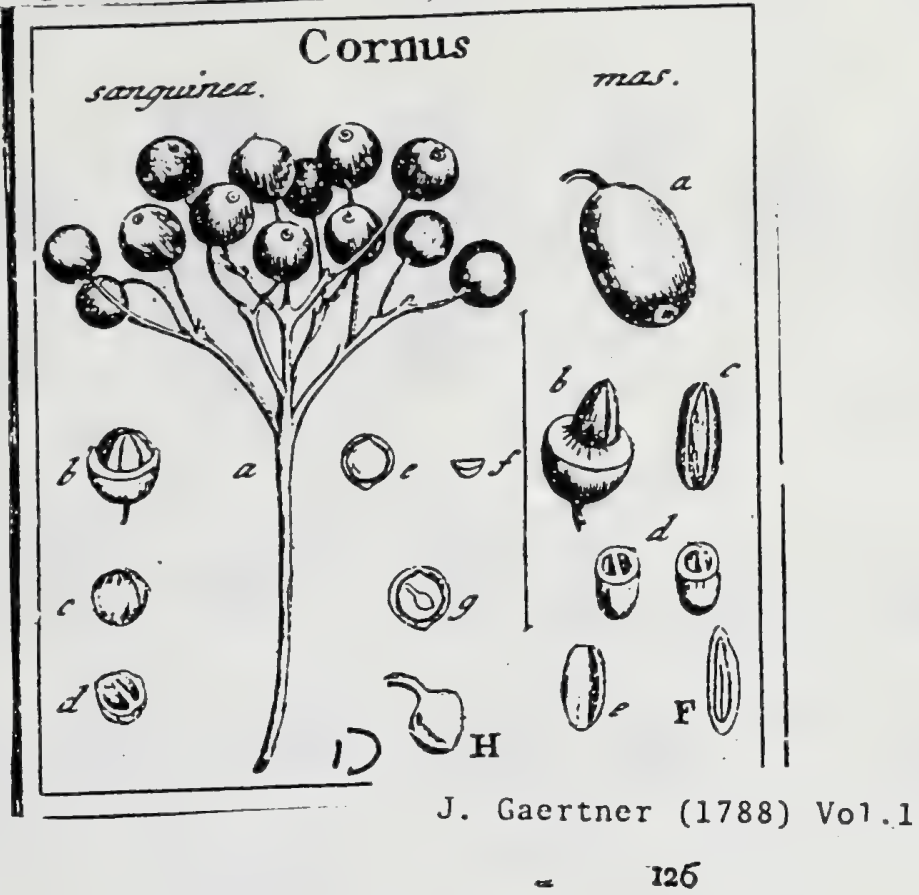

CLI. CORNVS. TOURN. t. 4TO. LINN. ger. I49.

Calyx fuperus minimus quadridentatus. Cor. tetrapetala, Stam. quatuor. Styl. unicus. Drupa baccata infera bilocularis. Semina folitaria.

C ORN U S fanguisea. Tab. 26. fig. 4.

Virga Janguinea. D O D. pempt. 782. O E D E R. flor. dan. t. 48 r.

Cormus arborea umbellis mudis. H A LL. hifl. I. "2. 816 .

Cormus arborea, elymis nudis, ramis rettis. LIN N. filf. veg. 159 .

PER. Drupa infera, glnbofa; obfolete umbilicata, cxruleo atra. Pulpa mollis viridiuscula. Putamen globofurn, offeum, obfolete octo fulcatum, biloculare.

REC. nullum; femina difepimenti parti fupremx affixa:

$S E M$. in Tingulo loculamento unicum, rotundatum, plano-convexum, niveum.

IN T. fimplex, membranaceum, ariduin, tenue, friabile.

А в. femini conforme, carnofum, albun.

E м в. dicotyledoneus, inverfus, graınineo-viridis. Cotyl. ovato acuminatz, foliacez: Rad. teretiuscula, leviter incurva, oblique furfum adfcendens.

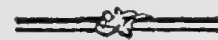

a.) Cyma fragifera. b.) Putsmen fuperne denudatum c.) Idem prorfus decorticaturn, a) Ejusdem fettio transverfalis. e.) Semen in fitu. f.) Sencn transverfe fedam. g.) Albumea longitudi. naliter apertum, cum fitu \& maquitudiae enbryonis naturali. H.) Embryo feparatus.

Core us inafcula. ibid.

Cornus mas. BL A Xw. herb.t. I2r.

Cornus arborca, umbellis involucrum aquartibus. HA LL. hifl. I. n. 815. IINx. Jyft. veg. 159 .

Drupa elliptico fplıxroidea (a) carnofa, mollis, rubra. Putamen (b.c.) teretiusculum, quatuor ftriis elevatis notatum, offeum,-biloculare (d.) loculanento altero fxpc obliterato. Semina (e) oblonga, feniteretia. Integum. candidiffmum, friabile. Embryo (F) lacteo albus, longitudine albuminis. Cotyl. lineares, plauiusculx. Rad. recta, cotyledonibus brevior, fupera. 


\section{Tab. $2,6$.}

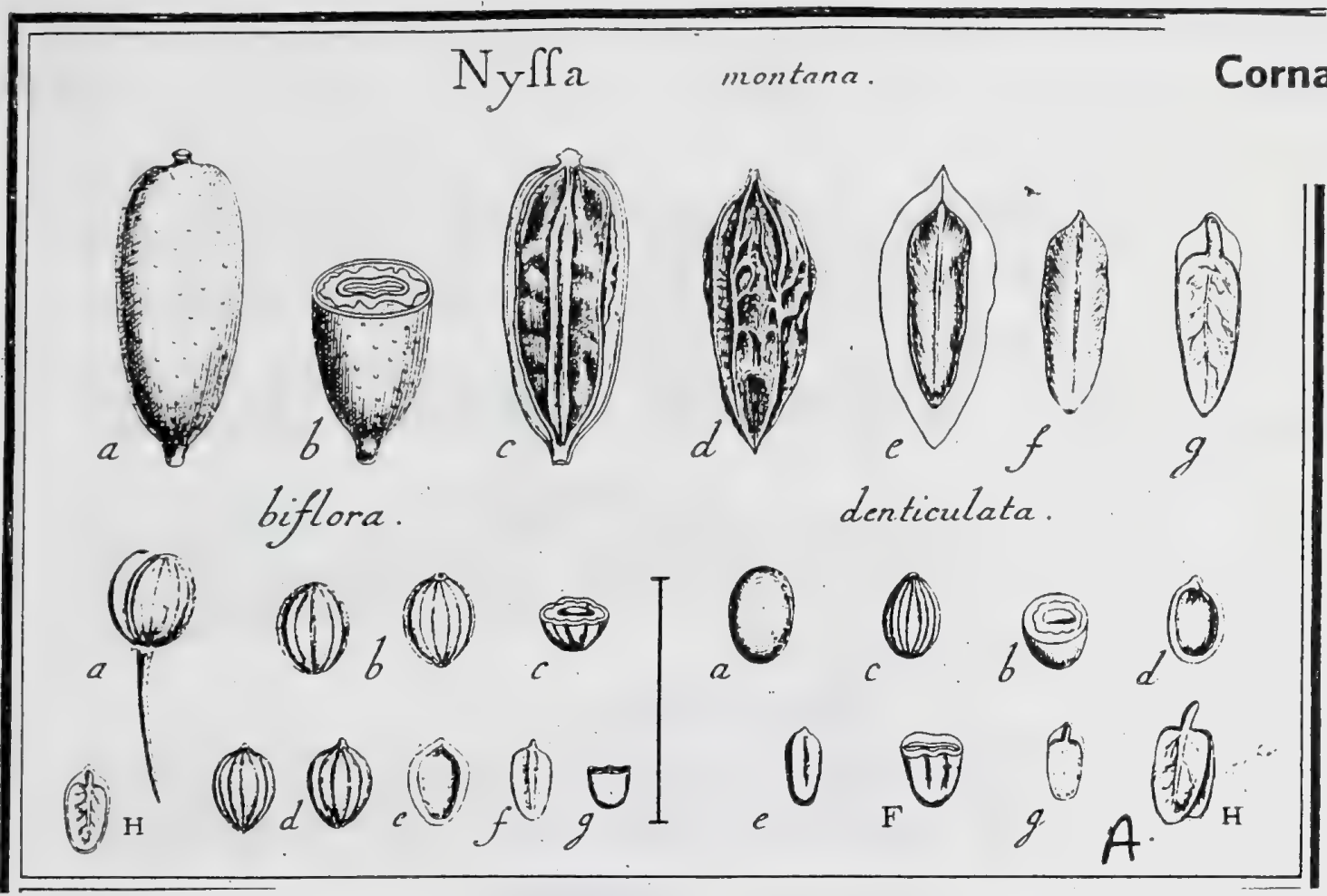

J. Gaertner (1788) Vol3

159. N Y S S A.

LINN. gen. Ir63. ed. Schreb. 1599. Juss. gen. p. 75.

LAMAвCK ill. gen. $t .85 \mathrm{x}$.

Flores hermaphroditi \& mares in diverlis plantis.

M A s. Cal. quadripartitus, patens. Cor. nulla. Stam. decem; filamentis fu. bulatis, calyci infertis \& ipfo brevioribus; antheris didymis; longitudine filamentorum. Ovar. nullum.

H в м а P н. Cal. quadrifidus, fuperus, deciduus. Cor. nulla. Stam. quinque; filamentis fubulatis, erectis; antheris fimplicibus: Ovar. inferum; ftylo fimplici, fubulasto, incurvo; ftignate fimplici. Drupa baccata; putamine inxquabili, uniloculari. Rec nullurn. Sem. unicum, comprelfiufcus: lum. Alb. tenue, carnofum. Emb. inverfus; rad, brevi, curvula

Nyssa montane Tab. 216. fg. 1.

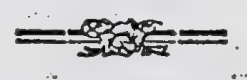

an Nyfa foliis longe petiolatis, inferioribus Jubcordatis, plerisgue ovalibus, acuminatis, rariter anguluto-dentatis: pedunculis foemineis unjforis. $\mathrm{MicH}_{\mathrm{i}}$ for. bor. amer. 2. p. 259 ?
A Cl. Ventenat.

P \& R. Drupa fesquipollicaris, infera, obovato oblonga, utrinque mucronata, pedunculo longo infidens, compretfiufcula, J. hinc planiufcula inde convexa, baccata, dilute fufca J. Spadicea. Cuticula valida, lavigata, verrucis parvis raris albidisque confperfa. Caro tenuis, ficcitate evanefcens, vafis validis rugis putaminis adhærentibus percurfa. Putamen ex obuvato ellip, ticum, utrinque acuminatnm, angulatum, rugis elevatis ramofis acutis inxquabile, fabrum, in dorfo magis convexum, cratriufculum, ex fibris offeo- chartaceis intime intertextis compaginatum, durum, pallidum, uniloculare, evalve. Loculamentum angultum, obovato-oblongun, apice mucronato-acuminatum, \& in canalem tenuilfmum abeuns, compreffufculum, membrana propria putamini aduata veftitum.

REC. nullum.

SEN. unicum, cavitatem putaninis exacle replens, obovato-oblongum, ad verticem mucronulato-acuminatum, plano-convexum, fulco hinc elevato inde profundo longitudinali infignitum, ex fulco parallele fubtilifime lineatum, leviter undulatum, lutefcens $\mathrm{J}$. ferrugineum.

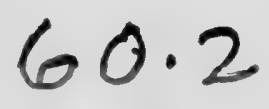


INT. Fimplex, membranaceum, tenue, adnatum, ad bafin cbalazd parva ob: fcuriore inftructum. A $i$ B. femini conforme, tenue, ad marginem in membranam extenuatum, apice
vero craflum, carnofum, album.

EM B. Jongitudine fere albuminis, inverfus, compreffus, albus. Cotyl. Jancea: late, obtufx, bafi obliqux, foliacex; nervofz, undulatec, accumbentes. Rad, brevis, teretiufcula, curvula, obtufa, umbilico coutratia, fupera.

\section{EXPLICATIO FIGURE.}

1.) Drupa integra, pedunealo deftituta. b.) Eadem cum putamise transverife dilitela. c.) Pu tamen parte planiore a carne denudatum, \& ejus fitus intra carpem. d.) Ideen irparatem, 8. ab altera parte convexiore v.fum. e.) Ejusdem fetto longitudinalis, cum fur feminis; f.) Semen folutum, ab alterz parte convexiore fpetatum. 8.) Enibryonis fitus iotra albumea.

Nyssa bifora. ibid.

\section{Ex colleciune $\mathrm{Cl}$. Desfontaines.}

Drupx (a.) binx pedunculo communi inGidentes, ovato - orbiculatx (b.), extus lenticulari-convexix, inde planiufculx, per ambitum rotundato-obtufa, ad verticem areola parva a calycis lapfu notatz, fulcis obfoletis ftriatz; baccata. Caro (c.) tenuis a putamine lubénter fecedens. , Putamen (d.) figura

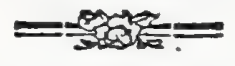

fere drupx, obovatum, apice muctonulatum, turgide lenticulare, extus vero magis convexum, fulcis elevatis rotundatis longitudinalibus protuberantibus infcriptum, craftiufculum, durum, fubofeum, pallidum, uniloculare, evalve. Loculamentum (e.) compreffufculum, plano-convexiufculum, obovatomucronulatum, nembrasa propria veftitum. Semea (f.) unicum, obovatoellipticum, in vertice mucronulatuin, compreffiufculum, hine convexum, inde fubconcavun \& Sulco intermedio elevato infignitum, pallide ferrugineum. Albumen (g.) tenue, eirnofum. Embryo (H.) albumine paulo brevior, inverfus, albus. Corglo foliacex, obcufe. Rad, brevis.

Nyssa denticulata, ibid.

A Cl. Ventenat, ex dono Cl. Heranan, defunct. Prof. Argentor.

Drupa (a.) obovata, turgide lenticularis, 1. vix comprefiufcula, baccata, glabra. Caro (b.) eraftiufcula, firma. Putanen (c. d.) ellipticum, vix comprefiufculum, fulcis rotundatis infignitum, durum, fuboffeum, lutefcens. Semeu (e.) longe obellipticum, comprelfiufculum, Secundum longitudinem leviter plicatum, 1. hinc convexum \& fulco intermedio exaratum, inde fub concavum \& fulco elevato infignitum. Albumen ( $\mathcal{E}_{0} g$. ) craffus, cxtera ut in prioribus. Embryo (H.) ut in priore.

Embryo Nydx oleo unguinofo fçatet. 


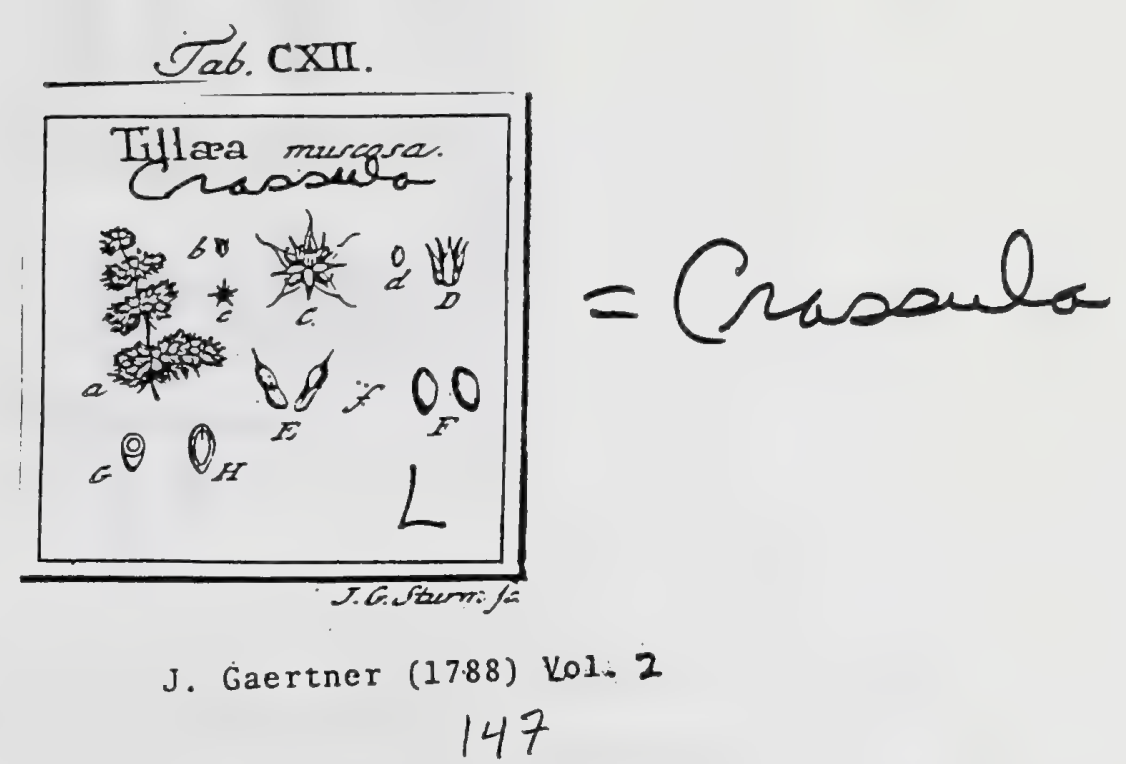

DCLVII. T I L L E A. LINN. gen. I77.

Calyx quadri -1 . quinquepartitus. Cor. quadri -1 . peutapetala. Stam. quatuor 1. quinque. Ovaria fupera, in Itylos fimplices definentia. Capfula quatuor 1. quinque uniloculares, introrfum dehifcentes. Scmina gemina.

Tirlea mufcofa. Tab. II2. fig. 12.

Polygomust mufcofunt minimutus. Bocc. fic. 56. t. 29 .

Tillea mufcofa ammu perfoliata. Mich. gen. 22. t. 20.

Tillda froctmbens, floribus trifidis. Lisx. Jylf. veg. 170 .

PER. Capful:x tres, sut quinque, in planta culta, oblongx, acuminatr, ereftx, ad leminum feden nodulofe, uniloculares, longitudiualiter introrfun dehifcentes.

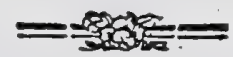

REc. nullum; femina futuric dehifcenti affixa.

SEM. duo, minutula, ovata, glabra, ferruginea.

IN T. Gimplex, membranaceun, tenue.

A L B. femini conforme; carnofum, aqueo-pallidum.

EN B. magnitudine fere albuminis, lutefcens. Cotyl. brevifimm, obtufx. Rad. crafia, attenuata, relutive centripeta.

2) Ramulus plantx fruetifers. b.) Flofeulus feparatus. C. C.) Idem explicatus. d. D.) Capfulz clauix. E.) Exdem dèhifentes. E. F.) Scmina integra. G. H.) Eaden transverfim do longitudiualiter diffela cum fitu \& figura albaminis \& Embryouis.

Solo Nectariorum defectu a Craffula differt; nam partium numerus diverfus, parum in Succulentis valet.

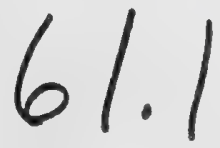




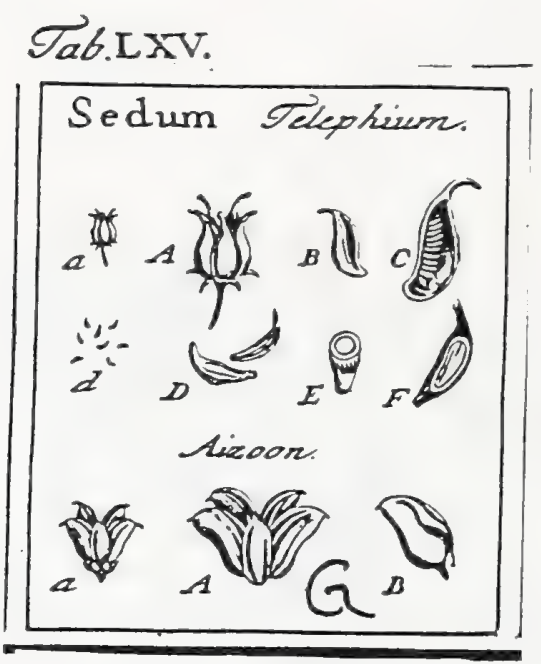

J. Gaertner (1788) Vol. I

CCCXCIX. SEDUM. TOURN. t. 140. LIN N. gen. $59 \%$.

Calyx quinquefidus. Cor. mono-1. pentapetala. Squamulx quinque nectariferz circs ovaria. Stam. decem. Styl. quinque. Capfulx quinque, dilcretz, leguminofx. Scmina ad futuram dehifcentem.

SEDUM Telephium, Tab. 65. fig. 7.

Telepíilim. F U С н. hifl. lat. 800. germ. ic. 460 . OЕDER. flor. dan. t. 686 .

Sedun androgynum Soliis confertis Jerratis, floribus denfe umbellatis. Hall. hift. I. 13. 954 .

Sedum foliis planiusculis ferratis, cortymbo foliofo, caule ereato. Lins. Ju/to. veg. 422.

PER. Capfulx quinque, leguminofx, oblongx, acuminatx, filiformi - roftratx, membranaccx, uniloculares, introrfum dehifeentes.

REc. margo futurx Jehifcentis, cui femina multiplici feric affixa.

SEM. numerofitima, exigua, fubfcobiformia, longitudinaliter tenuifime friata, pallida.

I. T. duplex: cxtcrius membranaceum, utrinque citra nucleum productun; interius tcnuifimum, fuperficie interna carnofa.

$\Lambda$ св. nullum, aut tentrilimum.

Es в. cylindricus, femine multo brevior, albus. Cotyl. plano-convexz, breves. Rad. cralfa recla, relative centripeta.

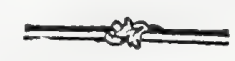

a. A.) Fractis interer. B.) Capfita dehifeens, C.) Infertio reninum. d. D.) Semina folata. E.) Senen transverfe fectum. F.) Ejusdem fectio longitudiualis, embryonis fitum \& fogram
oftendens. SEDUM Aizoon. ibid.

Anacamperos flore fiavo. Амм. ruth. 96. t. n. GMEL. fibir. 4.t. 67. f. r.

Sedum foliis lanceolatis ferratis planis, caule erefto, cyma feffli terminati. Lins:
Syл. veg. 430 . Carfulx (a.

purpurafcentes, futura dellificente compreffx, bafi connatx, crecto-patentes, titrscula, extrorfum craftiora, obtufa, alta, reflexa, Semina oblonga, tere. magnitudine feminis.

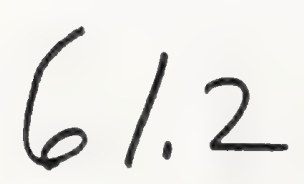




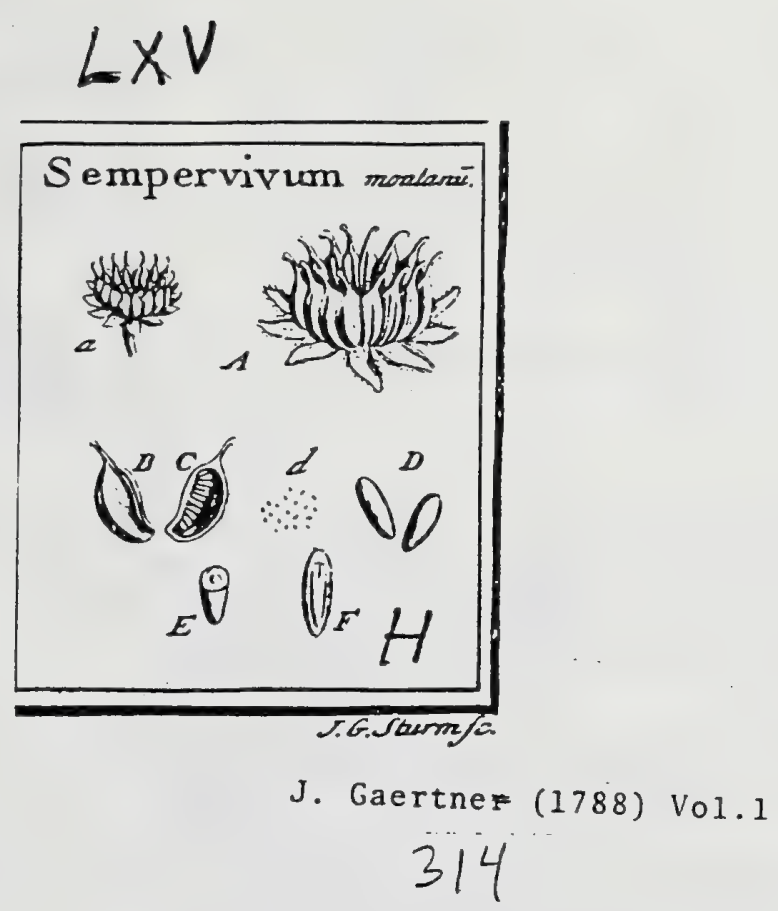

\section{CCCC. SEMPERVTUUM. L IN N. gen. 612.}

Calyx duodecimfidus. Cior. mono-1. polypetala. Stan. duodecin. Capfulx dtodecim 1. plures leguninofx. Sem, unilateralia.

SEMPER VIVUA montanum. Tab. 65. fig. 8.

Sedum minus flore rubente. Bes L. h. Ey/f. vern. VI. t. 8.f. 2.

Sedum rofulis femipatulis hirfutis, petalis novenis fublirfutis. Haxц. hift. \&. n. 951.

Sempervivum foliis integerrimis, propaginibus patulis. Linn. Juf. veg. 456.

Icon JAce. flor. aufir. 5. app. t. 41.

PER. Capfulx leguminof $x$ duodecin ad fedecin, membranacex, in amplum orbern difpofitx, oblongx, figmoideo curvatz, roftratx; uniloculares, introrfum dehif, centes.

REc. margo futurx dehifcentis, cui femina multiplici feric affixa.

SEM. numerofiffima, minutiflima, oblonga, teretiuscula, glabra, ruf:fecntia.

IN T. fimplex, membranaceum, intus fubcarnofun.

$\Lambda$ L в. nullum, aut tenuifrunum.

Eм в. teretiusculus, rectus, albus. Colyl. breviflinn. Rat. cylindrica, relative centripcta.

2. A.) Fruetus integer. B.) Capfula dehifeens. C.) Infertio feminums. d. D.) Semina feparate E.) Semen transverfe, \& F.) Idem longitudinaliter fectum, cun fitu \& figura enbryouis.

Corolla huic monopetala ef, ficuti in fedis variis.

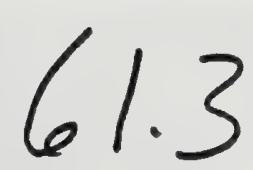




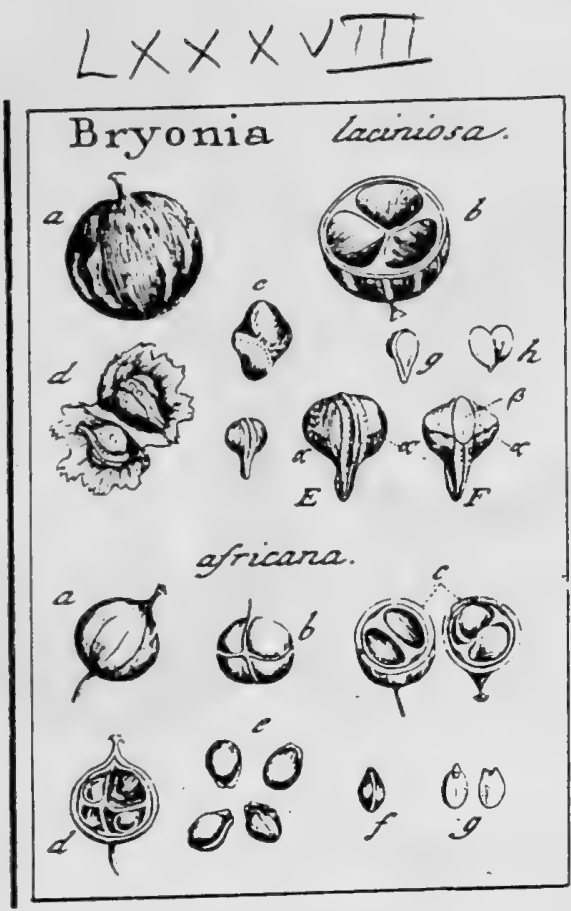

\section{Cucurbitaceae}

J. Gaertner (1788) Vol:2

46

DLI. BRYONIA. TOURN. inft. t. 28. LINN. gen. rog3.

Flores fexu diftincti, in eadem aut in diverfa planta. MAS. Cal. quinque. dentatus. Cor. quinquepartita. Stam. filamenta tria. FEM. Cal. \& Cor. ut in mare. Ovariun inferum. Styl. trifidus. Bacen fphaxrica,'- parva. Semina pauen, non plura fenis, cellulis propriis conclufa.

ERYONIA laciniofa. Tab. 88. fig. 2.

Bryonia zeylanica, flore huteo, frutu rubro. HeRM. parad. t. 307.

Bryoura foliis palmatis: Inciniis lanceolatis ferratis, petiolis muricatis. LINX. J3y. veg. 870 .

PER. Bacca infera, fphrcrica, rubra, vittis albis integris aut interruptis varicgata, carnofa, trilocularis. Loculamentorum pulpa gelatinofo-membranacea, bilocularis, viridis, ab ipfis loculamentis facile feparabilis.

REC. nullum procter pulpam, in qua femina, contrario fitu pofita, umbilicis fuis externos loculamentorum angulos refpiciunt.

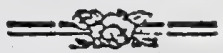

SEM. fex, in fingulis cellulis fingula, gigartoidea, feu inferne roftrato acuminıta, in lateribus rotundato gibba, \& in medio fafcia elevata annulari cincta; ceterum albicantia, rufefcentia aut fubferruginea.

IN T. triplex: extimun arachnoideum, in recenti femine digitis facile detergendum; meditus cruftaceum, ad Jatera infigniter incraffatum \& gibbofum; intimusu membranaceum, pallidum; tenue.

A L B. nullum.

EM B. ovato - acuminatus, compreffiufculus, latitudini feminis contrarius! lacteus. Cotyl. ellipticx, tenues. Plum. immerfa. Rad. acuminata, brevillima, centrifuga, aut Laterifcopa.

2.) Bacea integra, in Ittn inverfo. b.) Ejus fetio transverfalis. c.) Loculamenti pulpa feparata, integra d) Eadem aperta, cum fitu feminum in cellulis fuis propriis. e. E.) Scmen feparatum. F.) Iden transverfe fetum, ut tefte gibbolitas $\left(\alpha . \alpha \alpha_{\alpha}\right)$, \& embryonis litus, hatitudin: tefte contrarius (B. B.), rite appareant. B.) Semen longitudinaliter fiffum, cum ouclen 2 latere f. oblique fpectato. h.) Eabryo denudatus, cum cotyleduuibus leviter didudis.

BryoNia afticana. ibid.

Bryonia africana laciniata, tuberofa radice, foribus berbaceis. HERM. parad. 6. 208 .

Bryonia foliis palnatis quinguepartitis utringue levibus: Lacinis pinuatifdis. LINN. 万y. veg. 870.

Bacca (a. c. d.) globofa, roftellata, corticuta. Cortex carnofus, craffiufculus, externe aurantiacus, interne (c. d.) a pulpa difcretus. Pulpa (b. c. d.) membranaceo fpongiofa, regulariter in fex, fed in noftro exemplo, in quatuor tantummodo cellulas partiales divifa, quarum duze fuperiores (c.), totidemque inferiores (d.). Semina numero cellularum refpondentia, ovato-globofa (e), ad latera \& prefertim verfus umbilicum, in marginem acutum compreffa, pallide fufcal, fetulis aut fquamulis minutifrnis, albicintibus, apprelfis confperfa. Integ. triplex: pellicula intima nigricante, ipfum embryonem ( $f_{0}$ ) involvente. Albumen nullum. Cotyledones ovate (g.), carniofx, plano-convexx. Radicula brevis, parietibus baccx obverfa. 
Cucurbitaceae

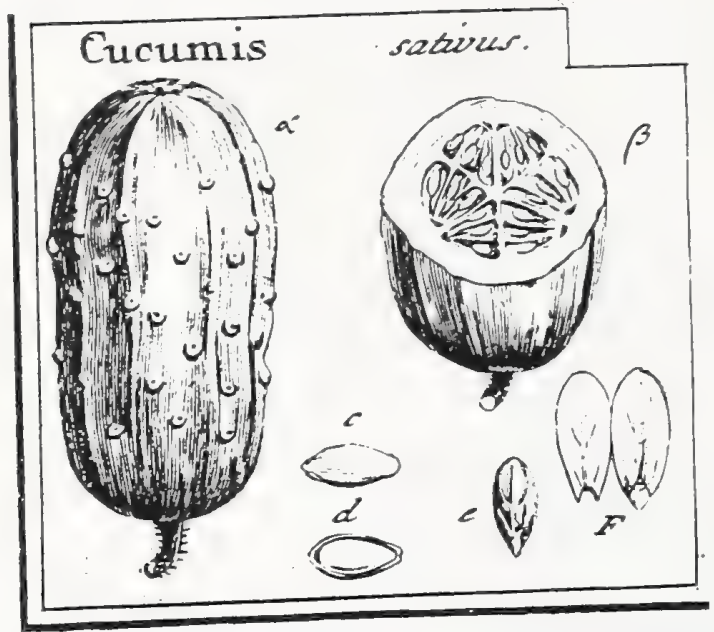

$$
\begin{gathered}
\text { J. Gaertner (1788) Vol2 } \\
47
\end{gathered}
$$

DLII. CUCUMIS. TOURN. inft. t. 31. 32. LINN. gen. IOg2.

Flores fexu diftincti, in eodem caule. MAS. Cal. quinquedentarus. Cor. quinquepartita. Stam. filamenta tria. FEM. Cal. \& Cor. ut in mare. Ovarium inferum. Styl. trifidus. Bacca trilocularis : loculamentis fubdivifis, gelatina farclis. Seminis margo indifcretus, argutus.

Cucumis fativus. Tab. 88. fig. 3:

Cuckunis vulgaris. DOD. pempi. C6. - fativus. BLAKW. berb. t. 4 .

48

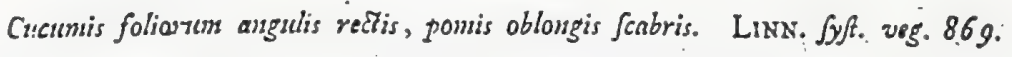

PER. Bacca infera, ovato-oblonga, obfoletifime angulata, verrucis fcabris confperfa, carnofa, multilocularis, corticata. Cortex tenuis, coriaceus, per naturitatem flavefcens. Caro fpongiofa, in difepimenta membranacea introrfum producta. Loculamenta primaria tria aut quatuor, per totam longitudinem bacex regnantia: horum fingulum, in duo fecandaria divifum, \& denique hxc ipfa, nova divifione, in concamerationes feminum proprias, pellucida gelatina farctas, partita.

REC. funiculi umbilicales filiformes, ex angulis loculamentorum primorum externis oriundi \& ad femina producti.

Sen. numerofifima, horizontalia, elliptico-acuminata, compreffufcula, verfus marginem attenuata, albicantia.

IN T. triplex: extimsun, cuticula tenuis, diaphana; medizm coriaceum; intiusun membrassaceum, palliduns.

A L B. nullum.

E s B. Semini conformis, lacteo-albicans. Cotyl. ellipticx, carnofic, tenues, venis albis infignite. Plum. ninima, acuminata. Rad. brevis, comprefa, centrifuga.

a.) Bacen naturali multotics minor. B.) Exdem trarsveric fecta, cum loculamentorum partitioлe \& fenisum (itu. c.) Semen feparatum. d.) Nuclcus imra telani, propria fuz pelliculn adbucdum veftitus. e.) Embryo plane denulatus. F.) Cotyicdoncs a parte interna fpedatx.

$$
62 \cdot 2
$$


$L x \times x \cup 111$

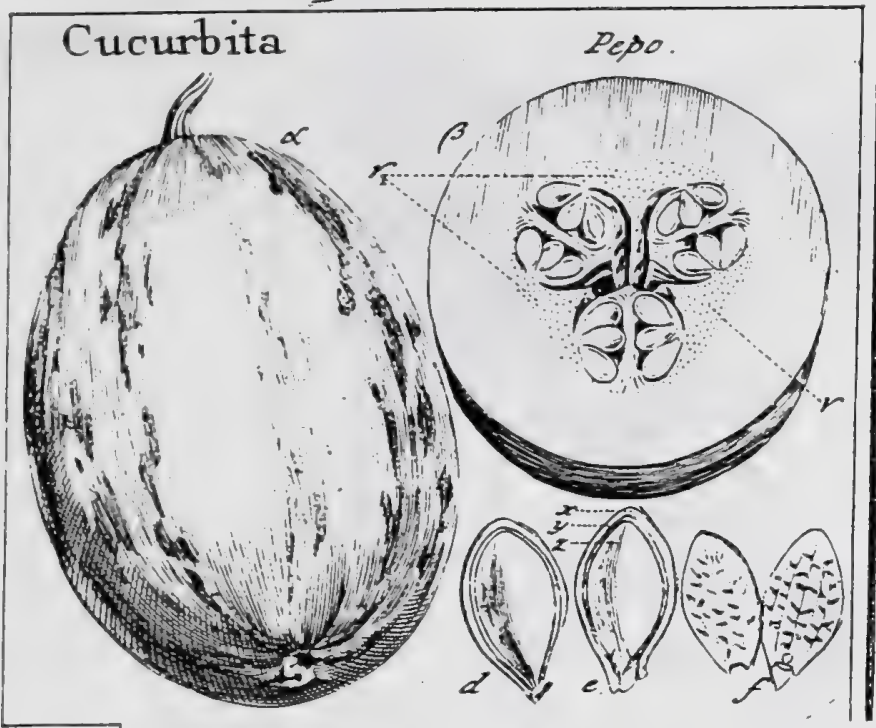

Cucurbitaceae

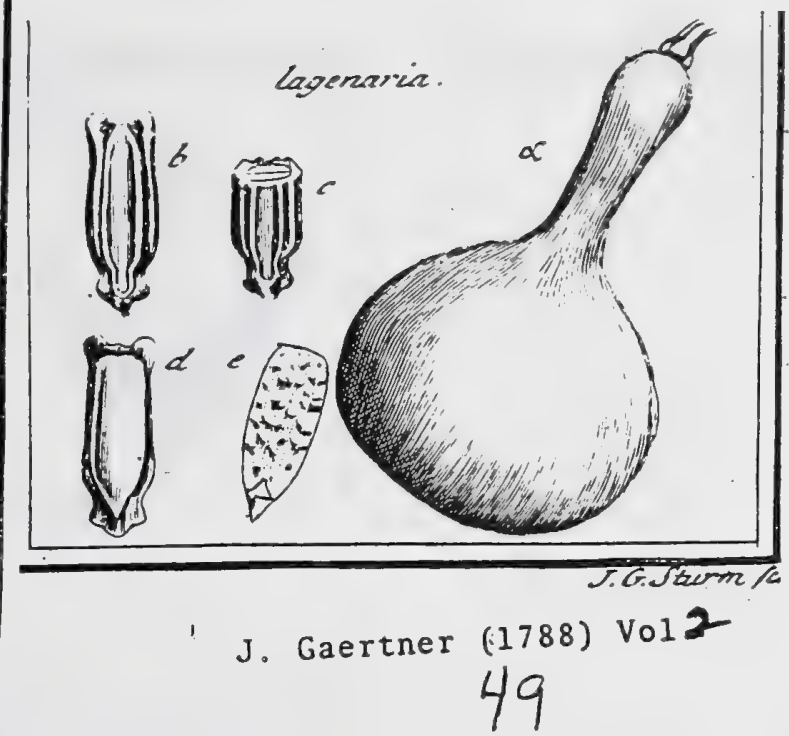

DLIV. CUCURBITA. Linn. gen. rogr. Pepo \& Melopepo. TOURN. inft. t. 33.34 .

Flores fexu diftincti in eodem caule. MAS. Cal. quinquedentatus. Cor. quinquepartita. Stam. filamenta tria. FEM. Cal. \& Cor. ut in mare. Ovarium inferun. Styl. quinquefidus. Bacca trilocularis: loculamentis bipartitis. Semina margine tumido cineta.

Cucurbita Pepo. Tab. 88. fig. 5.

Pepo oblongus. Dod. pempt. 665 .

Cucurbita folizs lobacis, pomis levibus. LiNN. byf. veg. 868 .

PER. Bacea infera, rotundato - 1. ovato-globofa, carnofo- fpongiofa : parte fpongiofa per maturitatem trifariam introrfum dehifcente; ceterum glabra, lutefcens, vittis viridibus interruptis picta, plurilocularis. Loculamenta primora terna ; fecundaria geninata, trifpermia ; \& hace iterum in concame rutiones feninum proprius, exfuecas, fubdivifa.

REc. nullum : femina angulis loculamentorum fecundariorum externis, iplas fuis umbilicis affixa.

Sem. numcrofifima, horizontalia, elliptica, lenticulari-compreffa, glabra, albicantia, margine rotundato tumido, \& intra eum, linea elevata, cincta.

IN T. quadruplex: extimn , tenuifimum, diaphanum; alternon coriaceum, fragile, album; tertiun, fubcarnofum, viride; intinum membranaceum, arachnoideum.

50

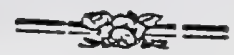

A \& 8. nullum.

EM B. ellipticus, albus. Cotyl. carnofie, extus leviter convexx, intus planx,
venofo-rugate. Pluns. minima, capitell venofo-rugate. Plums. minima, capitellata, compreffa. Rad. acuninata,
centrifuga.

*.) Baces natur

in[ertione. $\gamma$.) Subfantia baces. B.) Eadem transverfe fecas, cum loculamentis \& feminum magnitudiue naturali. e.) Idem longiofa, per maturitatem introrfum dehifcens. d.) Semen

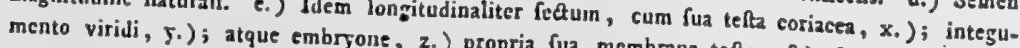
ratz, a parte interna fpectatz.

Cucurbita lagenaria. ibid.

Cucurbita lagenaria fert officinarum. BLAKw. Terb. t. 522. a. b.

Cucwibita foliis fubangulatis tomento 0 is bafi fubtus biglandulofis, ponsis liguofis.
Lins. Io c.

Bacca (๔.) elongato-turbinata, cortice glaberrimo, per maturitatem cruftaceo, fulvo, veftita. Semina (b. c.) quadrangulo-oblonga, compreffa (c), fupra emarginato - truncata, infra trigono - roftrata, linea gemina elevata, intra (d.) cruftacea, craffa, durs , glabriufcula, pallide fpadicea. Telta feminis fus, in acutificsam radiculam definens rugofx. 


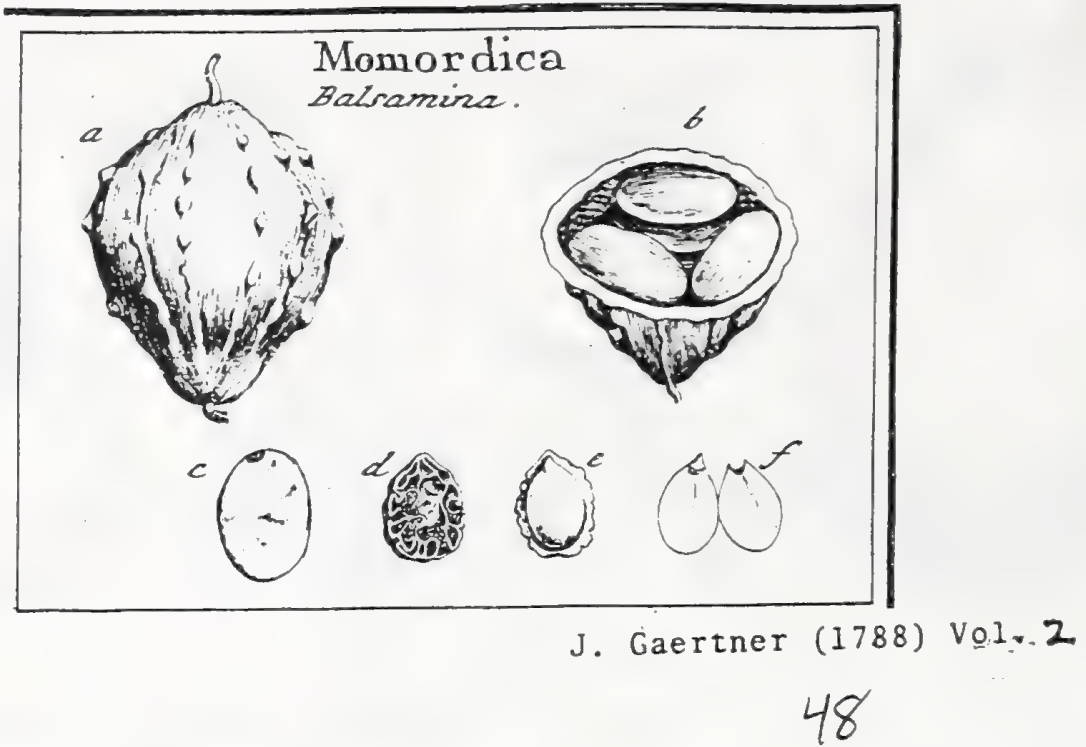

DLIII. MOMORDICA. TOURN. inf. t. 29. 30. LINN. gen. IOgO.

Flores fexu diftincti, in eodem caule. MAS. Cal. quingquefidus. Cor. quinquepartita. Stan. filamenta tria. FEM. Cal. \& Cor. ut in mare. Ovarium inferum triloculare. Bacca matura unilocularis, infata, elaftice dehifcens.

Momordica Balfamina. Tab. 88. fig. 4.

Baljuinina mas, fruful puniceo - \& huteo subefcente. BESL. Eyf. autturs. I. t. 4. f. 2. 3.

Alomordica Balfamina mas. BLAKW. berb. t. 539. a. b.

Momurdica pomis angulatis tuberculatis, foliis glabris patenti-palnzatis. LINN. 63. veg. 868.

PER. 3acca infera, carnofa, ovata, utrinque attenuata, obfolete angulata, per feries longitudinales remote tuberculata, ceteruin glabra, coccinea, unilocularis, inflata, per. maturitaten irregulariter difrumpens atque femina elaftice fpargens.

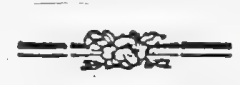

REC. Latera baccx interna, quibus femina, triplici ferie longitudinali ita aff$x a$, ut umbilici alterni dextras, \& alterni laxvas, ejusdem feriei partes refpiciant.

SEM. plura, ovata, compreffiufcula, horizontalia, ad marginem obrufe crenata atyue lineis elevatis ferpentinis cripta, in difoo autem punctis elevatis fcabrata, pallide fufca, arillata.

- Arillus membranaceus, femen laxe ambiens, tenuis, ruber.

IN T. duplex: exteriss coriaceum, craffum; inserins membranaceum, album, fericeo - fplendens.

$\Lambda$ L B. nullum.

EM B. ellipticus, verfus radiculam mucronatus, lacteo - :lbus. Cotyl. craffiz, carnofix, utrinque fere planx. Pluns. minima, bicornis. Rad. conica, brevis, centrifuga f.' Jateriliepas.

a.) Bacea integra. b.) Eadem transverfe fecta, eum triplici ferie feminum. co) Semen intra Arillum fuum harens. d.) Idem denudatum. c.) Ejusdem fectio longitudivalis, cum Embrgone. f.) Cotgledonum facies interua. 


\section{$L X X X \sqrt{11}$}

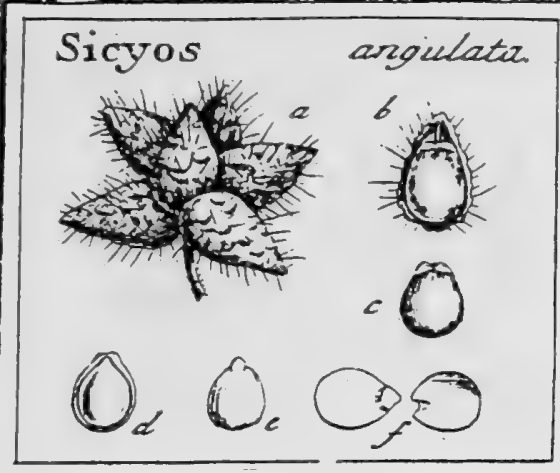

\section{Cucurbitaceae}

J. Gaertner (1788) Vol 2

DL. SICYOS. LINN. gen. 1094 Sicyoides. TOURN. inft.t. 28.

Flores fexu diftincti in eodem caule. MAS. Cal. quinquedentatus. Cor. quinquepartita. Stam. filamenta tria. FEM. Cal. \& Cor. ut in mare. Ova-

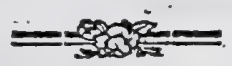

rium inferum. Styl. trifidus. Bacca matura exfucca, unilocularis monofperma.

Sicyos angulata. Tab. 8s. fig. I.

Cuctunis bryonioides bifnagarica, frutu parvo. PLuk. pbyt. t. 26. f. 4. Bryonioides fore \& frulfu minore. DiLl. elth. 58. 5. 5x.

Sicyos foliis angulatis. Lins. Jyjt. veg. 870 .

PER, Bacca infera, carnofa, demum exfucca, coriaceo membranacea, ovatoacuminata, compreffiufcula, undique tomento rigido crifpo, fpinisque tenuibus lutefcentibus \& pungentibus obfita, unilucularis.

REc. funiculus umbilicalis filitormis, brevis, $a b$ apice baccx ad feminis verticem defcendens.

SEM. unicum, ovatum, compreffufculum, glabrum, ferrugineo-fufcum, ad umbilicum callis quatuor albis infignitum.

IN T. duplex: exterins cruftaceum, craffum, fragile; interius membranaceum, pallidum aut viridefcens.

A L B. nullum.

Ем в. feminis cavitati conformis, inverfus, albus. Cotyl. carnofx, oyatorotund $15 x$, plano-convexx. Pluns. bicornis, minima. Rad. brevis, comprefliufcula, fupera.

2.) Bacer integra, in pedunculo communi aggregata. U.) Bacea longitudinaliter aperta, cum femine e funiculo unbilicali pendente. c.) Semen feparatum. d.) Tcfta feminis longitudinaliter tiliza. c.) Embryo denulatus. f.) Cotyledones feparatx \& a parte fua interna fpectata.

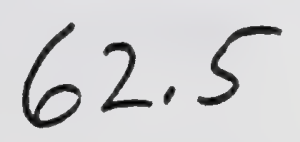




\section{Cucurbitaceae}

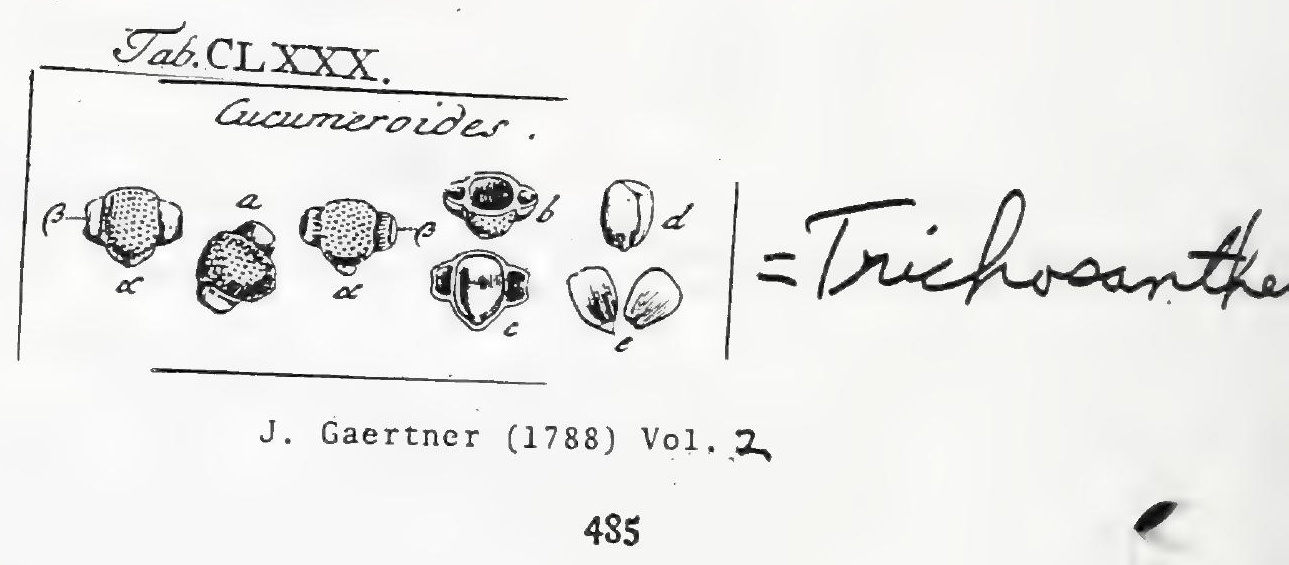

CUCUMEROIDES. Tab. 180. fig. 4

Ex Japonia. A Cl. Houturn.

Semina (a. b. c.) fubtriangula, leviter comprefía, in medio cincta fafcia (a. a.) protuberante, latiufcula, elevato punctata \& in mucronem compreffum definente; ad latera autem porrecta in duas apophyfes ( $\beta_{\text {. }} \beta_{\text {. }}$ ) horizontales, breves, apice truncatas atque perforatas. Color totius feminis e fpadiceo ferrugineus. Integum. triplex: extimum (b.) cruftaceum, craffum, triloculare: loculo medio (c.) Seminifero; Jateralibus autem fterilibus vacuis; medium membranaceum, tenuifimum, argenteo fplendens, omnibus loculamentis commune; intimum arachnoideum, pallidum, foli embryoni proprium. Albumen nullum. Embr. (c. d. e.) loculamento medio conformis. Cotyl. carnofx, plano-converz (d. e.). Plam. mink tiflima, acicularis. Rad. acuninata, brevis.

Cum feminibus Bryonix laciniofe proximam affinitatem habent hac Gingulariflima femina. Genus fibi ignotum teftatur $\mathrm{Cl}$. THuNBerg. in lits.

\section{6}




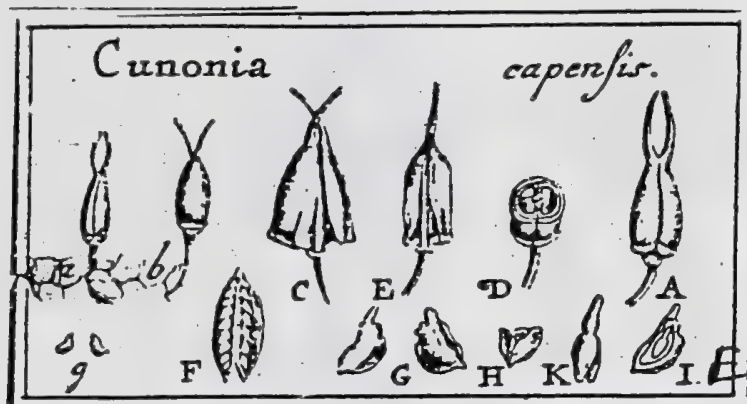

J. Gaertner (1788) Vol.3

\section{4}

\section{C U N O N I A.}

LIN gen. 556. ed. Schreb, 76r. Jogs. gen. p. 310.

LAM A B K K ill. gen. t. 37 r. Ofterdykia.

BuxM. afr. t. 96 .

Cal. pentaphyllus 1. profundiffime quinquepartitus, parvus, decidurs 3 foliolis ovatis. Cor. petala quinque, obovata, cum calycis laciniis alterna, imo caJyci cum ftaminibus inferta. Stam. decem; filamenta petalis Jongiora, fubulato - linearia, bafi latiora; antherz fubrotundx, erecta, didymx. Ovar. fuperum; ftylo gemino, fubulato, Jongitudine ftaminum; ftigmatibus fimplicibus. Capfula ex duobus folliculis corticatis a bafi dehifcentibus compofita. Rec. nullum. Sem. imbricata, comprefluufcula. Alb. carnolum, Emb. ininverfus.

Cononia capenfis. Tab. 225 . fig. 3.

Arbufculu; arbuti alatis folits, africana. PLuk. alm. p. 45. t. $141 ., f .4$.

Ofrerdykin floribus fpicatis pentapetalis, folits oblongis fubincanis ferratis.:-BURM.' afr. p. 259.

Cumonia. LinN. Spec. pl. p. 56g. Syjt. veg. ed. 14. p. 410. Тнunв. prod. p. 81. WILLD. Speo. pl. T. 2. P. 1. p.634. PERSOON Jym. d. p. 486.

\section{A Cl, LAMBERT.}

Pв R. Capfula parva, longe elliptica, fupera, fulcis duobus longitudinalibus: exarata, ex duobus folliculis corticatis co:adumatis contata, a bafi fecundum fulcos apicem usque dehlfcens, fpadicea. Folliculi gemini, longe elliptici, bå truncati \& callo femicirculari inftructi, inde in ftylum perfiftentem nucrumato-fubulatum attenuati, hinc convexi atyue corticati, inde planiufculi nuri, \& rima intermedia longitudinali a bali ad apicem usque elaltice dehifcentes, chartacei, polyfpermi. Cortex curiaceus, tenuis.

REc. nullum: folliculi ope vaforum umbilicalium, ex pedunculo affurgentium \& cum folliculis longitudinaliter dehifcentium, ad apicem arctius cohærent; fenina margini folliculorum introlleso affixa, \& ab utraque parte 1. gemina ferie fimpliciter imbricata.

SEM. ovula multa, 10-I 12 in unoquoque latere, adeoque in folliculo 20-24, quorum vero rarius plura quam fex l. octo maturefcunt, inverfa, dequentia, ovato-triangularia, triquetra : angulis margine membranaceo angufto cinctis; uucleo protuberante infgnita, ad marginem interiorem fub apice umbilico minimo fufco inftructa, fpadicea l. ferruginea.

IN T. fimplex, membranaceum, in alas feminis ampliatum, albumini adnatum.

A L B. nucleo conforme, ovato-oblongum, l. longe ellipticum, triquetrum, carnofum, album.

Em B. albumine paulo breyior, \& in ejus parte fuperiore-locatus, inverfus, viridiufculus. Cotyl. elliptice, obtufr, incumbentes. Rad. Jongitudine cotyledonum, difcreca, cratiufcula, tereti-oblonga, curvula, umbilico externo obverfa, centripeta.

\section{EXPLICATIO FIGUR}

a. A. b.) Capfula integra, non dehifcens. C.) Eaŕem dehifcens. D.) Fjusdem featio transver6alis. E.) Folliculus alter feparatus, dehifcens, a parte-interna (pectatus, cum infertione vafo num ambilicalium ad apicem folliculi. F.) Idem non dehifcens, parte convexa ablats, ut femi num fitus naturalis appareat. g. G.) Seninz (eparata. H.) Ejusdem Sectio transvertalis. I.) Embryonis fitus intra albumen. K.) Embryo tolntos. 
Jab. 225.

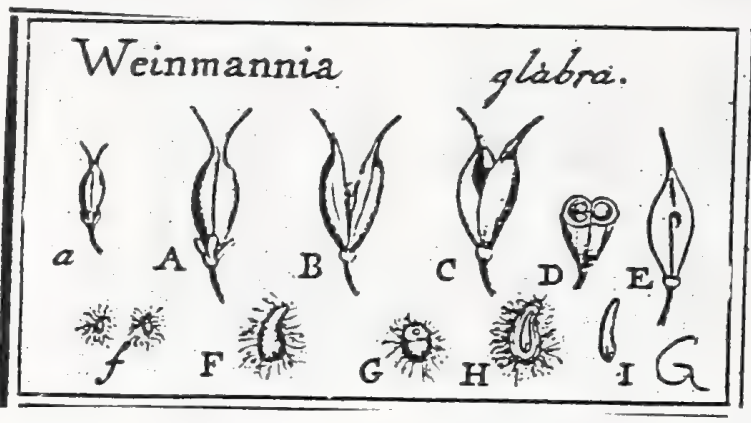

J. Gaertner (1788) Vol3.

245

194. W EI N M A N I A.

LINN. gen. 493. ed. Schreb. 674. Juss. gert. p. 309.

LA

Brown jam. p. 212.

Cal. quadriphyllus 1. profundifime quadripartitus, periffens; Iaciniis ovatis. Cor. petala quatuor, imo calyci inferta, ipfi majora, ad divifuras inferta, ovata. Stam. octo; filamentis brevibus; ancheris erectis, fubrotundis. Ovar. fuperum; ftyli duo; ftignata acuminata. Folliculi duo, ill capfulam curticatam coadunati. Rec. exiguum, centrale. Sem, crinita. Alb. carnolum. Emb, inverfus; rad. centripeta,

246

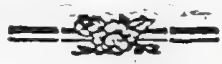

Weinmannia glabra. Tab. 225. fig. 4.

Weinmasnia pimata. LIN Spec. pl. p. 515 .

Weinmannia foliis pinnatis, foliolis ubovatis erenatis lacvibus, LIsN. Juppl. p. 228. Syf. veg. ed. 14. p. 374. Swarz obf. p. 75 t. WILlu. Jpec. plo. T. 2. P. 1. p. 436, PERsoON fyn. 1. p. $43^{8}$.

Ab amiciffimo $D^{* 0}$ Dupuis.

PER. Capfula parva, ovato - oblonga, 1, obovata, fulco levi bipartita, \& fe. cundum fulcos in duos folliculos antea coadunatos ab apice balin usque dehifcens. Folliculi chartacei, cortiçe tenui extus tecti, hinc convexi, inde plani, ad verticem in ftylum mucronulato - lubulatum perfiltentern producti, intus rima intermedia longitudinali cocculurum more elaltice ab apice balin usque dehifcentes, polyfipermi. Cortex coriaceus,

REC. fafcifculus columnaris vaforum umbilicalium e pedunculo in axi capfuliz affurgentium folliculos ad medium usque conjungens, \& ad ambo latera receptaculo exiguo in folliculus prominulo abiens.

S E M. pauca, quatuor 1 . Sex in quovis folliculo, reniformia 1. longe elliptica, curvaca, capillis longis raris albidisque confperfa, ad apicem umbilico fufco notata, inverfa, cinnamomea.

IN T. duplex : exterius coriaceo-membranaceum, crafiufculum, cum funicula umbilicali ab spice fernmis per ventrem decurrente undique conferruminatum, facile detrahendum; interius tenuiffimum arachnoideum, albumini adnatum, ad bafin chulaza minima fufca notatum,

A \&. B. Semini conforme, bafi mucronulatum, carnofum, lutefcens.

$E_{M}$ B. oblongus, curvulus, inverfus, albus. ' Cotyl, craffx, brevifimx $x_{2}$ incum. bentes. Kad. longa, teretiufcula, furfum attenuata, curvula obtutiufeula, umbilico externo obverfa, centripeta.

ExPLICATI0

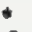

EXPLICATIO FIGURE

A. A.) Capfula integra, non debilcens. B.) Eaded dehifcens, cum fafeiculo columpari rafo= sum umbilicalium. C.) Eader a latere vifa, ut folliculorum dehifcendi modus appareat, D.) Ejusdem fictio transveralis. E.) Folliculus feparatus, a facie interäa fpetactus, cum de hifientix rima. f. F.) Semioz feparatz. G.) Ejusdena featio transiverfalis. H.) Embrgonis fitur intra albument. I.) Iuter folutus.

Magna Cununiz Weinmannixque eft affinitas cun Itea p, 142. defcripte. prafercim in fructu, ut jure meritoque in eaden familiz militarent.

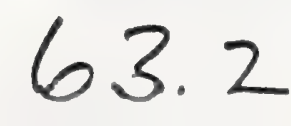




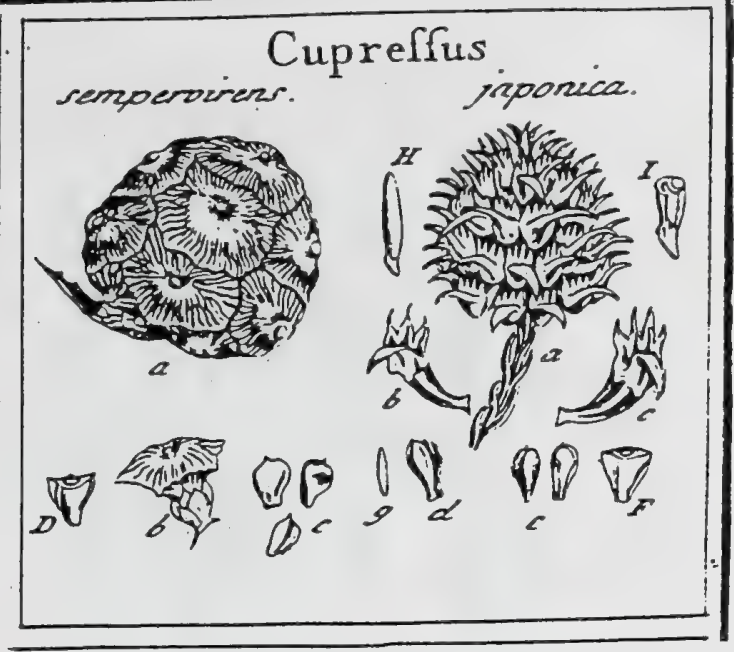

J. Gaertner

\section{4}

\section{CUPRESSUS. TOURN. inft. t. 358. LINN. ger. IO79.}

Flores fexu diftincti in eadem ftirpe. MAS. Anentun ovatum, ex Squamis fubrotundis, pelatis, oppofitis. Cal. nullus. Cor. nulla. Anthere quatuor in fuperficie fquamarum interua feffiles. FEM. Amentum fubglobofun ex Squamis angularis, peltatis, multitoris. Cal nullus. Cor. nulla. Ovaria quatuor ad octo, pedunculo pelce affixa. Stigma limplex feffile. Nux angulata, unilocularis, evalvis.

Curressus fempervirens. Tab. 91. fig. 5.

Cuprefsus. CaM. epit. 52. Besc. Eyft. aftiv. frut. to s. f. x. BLAKw. berb. 6. 127. Cuprefus foliis imbricatis, frondibus quadrangulis. LiNs. fyyt. veg. 861.

FR UCT. Galbulus ovato-globofus, compofitus ex fquamis grandibus, angulatis, peltatis, fuberofis, parte fua exteriore convexiufculis, radintim ftriatis \& in centro mucronatis, parte autem interiore in pedunculum craffum \& angulatun definentibus, cujus extremitati nuculx quatuor aut plures adhorent.

PER. Nux parva, offea, obovata, compreffa aut irregulariter angulata, veftita epidermide membranacea gilva \& in angultifimum marginem nuculam cingentem producta, unilocularis, evalvis, cultro tamen facile fifflis.

$R E$ c. nullum, prater peduneulum fquam $x$, cujus fini interiori nuces affiguntur.

SEM. lineari oblongum, fubteretiufculum, fpadiccum.

IN T. fimplicifGmum, nembranaceum.

A L B. nullum.

E M 8. femini conformis......

2) Galbulus integer. b.) Pelta feparata, ad balin fuam nucifera. c.) Nuces fefaratz, ab utroque latire fpetatz. D.) Nucis atgue Seminis fectio transveralis.

Curressus japonica. ibid.

Cuprefiss foliis quadrifariis falcatis comprefis fulcatis decurrentibus. Tнимв. jap. p. 265. LiN. Jyf. veg. $86 x$.

A Cl. Thungergio \& Houtuys.

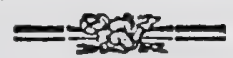

Strobilus (a) ovato globofus, fquarrofus, muricatus. Squamarum (b. c.) pedunculus crafus, ftriatus, arcuatus, prrepilatus Pelta coriaceo membranacea; inferne varie angulata; fuperne tri - 1 quadrifida: laciniis membnnaceis, lanceolato - acuminatis erectis; \& denique anterius producta in roftrum longum, acuminatum, carinatum, recurvum. Nucula (d. e.) ad fingulam fquaman quaternx aut fenx, per paria (d.) coadunate, obovate, lenticulari compreffie (F.), aut angulata, anguftiflimo margine membranaceo cinctx, fpadicex. Semen (g.) teretiufculum, atrum. Albumen prorfus nullum. Embryo (H. I.) magnitudine feminis, erechus, viridis, terebinthinam redolens, nonocotyledoneus, aut ex cotyledonibus quatuor, inter fe conferruminatis (I.) compofitus. Radicula obliqua, infera

Transverfe fectus embryo, ex aliquot, circiter quatuor, diftinctis bacillis 'carnofis compofitus elfe videtur; fed externe nullum divifionis apparet veftigium, nec poffunt ifti bacilli ulla ratione a fe invicem feparari, quare hic embryo monocotyledonibus poterit accenferi, etfi forfan fub germinatione in plures lobulos fponte folvatur: dicotyledoneus certifime non eft. 


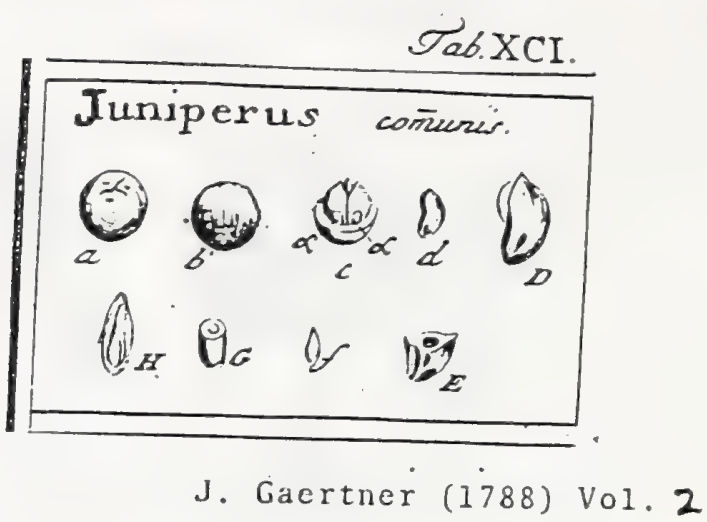

DLXVII. JUNIPERUS. TOURN. inft. t. $36 \mathrm{r}$. LIN gen. II 34 .

Flores fexu diftincti, in feparatis ftirpibus. MAS. Amentum ovatum, ferfile, ex fquamis trigonis, peltatis. Cal. nullus. Cor. nulla. Antherx quatuor ad octo, fimplici l. duplici ferie, fquamis interne affixx. - FEM. Amenţum ex Squamis tribus, concavis, connicentibus, denum carnofis \& in Galbulum fpæricum coalefcentibus. Ovaria tria, folitaria. Styl. fimplex. Nux olfea, unilocularis, glandulis balfaniferis ad bafin externam ftipata.

Juniperus communis. Tab. 91. fig. 3 .

Juniperus. Cam. epit. 53. BLakw. berb. t. 187 .

Juniperus foliis convexo concurvis ariffatis, buccis alaribus fefrlibus. HaLl. biff. n. $366 x$.

Juniperus foliis ternis patentibus mucronatis, bacca longioribus. LINN. $\int_{3} \%$. veg. 894 .

F ₹ U CT. Galbulus fphrericus, baccatus, nigro-caruleus, rorulentus; fuperne tribus punctis elevatis, fulcoque trifurcato notatus, inferne involucello minimo ftellato exceptus; cetera exfuccus, fpongiofo-carnofus, tripyrenus.

PER. Nucula offea, milocularis, evalvis, gibba; hine ex lato \& convexo dorfo verfus balin anguftata atque carinata; inde obtufifine angulata five fulco medio elevato longitudinali infcripta; preteres autem ad bafin externam fcrobiculis quatuor oblongis exarata, quibus totidem Gluidule balfamifere inferte funt.

$R$ R C. nullum; caro nuculis inferne adnata.

SEM. unicum, ovato acuminatun, gilvum, bafi areola fufca notatum.

IN T. fimpliciffimum, membranaceum.

AL B. Femini conforme, craffifculum, carnofum, pallidum.

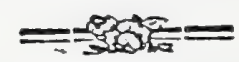

EMB. longitudine albuminis, tereti-clavatus, inverfus, lacteus. Cosyl. ellipticic, plano convexic. Rad. longa, gracilis, fupera.

a. b.) Galbulus iuteger a parte fuz fuperiore atque inferiore fpectatus. c.) Ejjus featio transverfalis, cum nucibus, verfus bafin Glandulis balfamiferis ( $\alpha_{\text {. }}$ ) Atipatis. d. D.) Nux feparata. E.) Eadem sransverfe fecta. F.) Semen denudarum. G.) Albumen transverfe, \& H.) Idem longitudinaliter ditTedum, cum Embryone in fitu naturali.

Glandulas balfaniferas primus mnotavit GEOFFroY in ACt. gall. 1721. edit. germ. p. 689. earum autem nonnifi octo numeravit, cum naturaliter duodenx fint.

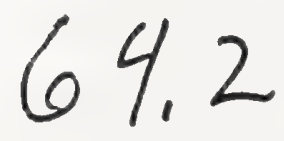


Tab.XCI.

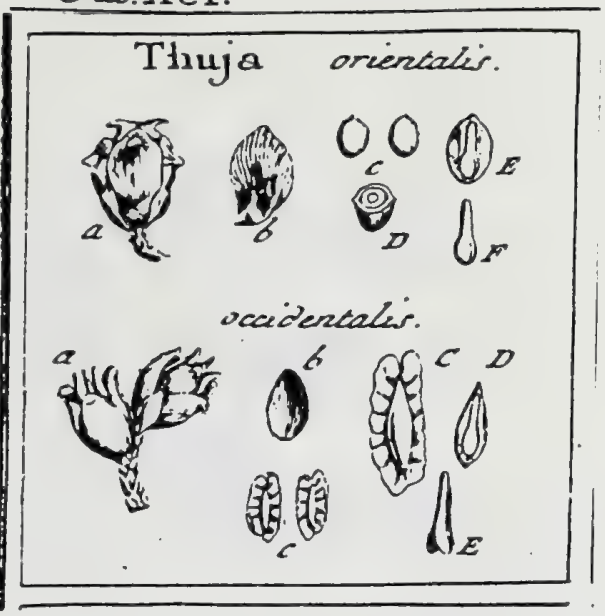

J. Gaertner (1788) Vol. 2 .

$6 I$

DLXVI. THU J A. TOURN. inft. t. 358. LINN. ger. IOZ3.

Flores fexu diftincti in eadem ftirpe. MAS. Amentum ovatum ex fquamis concavis, obtufis, fubovatis. Cal. nullus. Cor. nulla. Anthere qua. tuor, fubfeffiles. FEM. Amentum ftrobilaceun, insbricatum fquamis coriaceis, oppofitis, extus fub apice tuberculo ll. unguiculo notatis, bitoris. Cal. nullus. Cor. nulla. Ovar. ad fingulam fquamam geniina. Styl. fimplex. Nux unilocularis, evalvis, utrinque in marginem membraniceum, magis vel minus amplun, definens.

THujA orientalis. Tab. 91. fig. 2.

Tibrja frobilis Jquarrofis: Jquainis acutis. LiNN. Jyf. veg. 86x.

Fruct. Strobilus parvus, ovatus, obfolete tetragonus, compofitus e fquamis oblongis, craflis, fuberolis, per paria oppofris, fub apice uncinulo securvo extu's armatis, intus glaberrimis \& prope bafin duplici foveola exfculptis.

PER. NucuJa offea, globofa, unilocularis, evalvis, veftita epidermide tenui, fpadiceo-rufefcente, ad utrumque latus in marginem anguftiffimum \& vix perceptibilem producta.

REC. nullum, proter fquamarum foveolas, in quibus nuculx jacent.

SEM. unicum, elliptico-globofum, pallidum.

IN T. fimplicifrnum, membranaceum.

A L B. femini conforme, carnofum, crafum, album.

EM.B. longitudine fere albuminis, tereti - clavatus, inverfus, Jacteus. Cosyli plano-convexx, breves. Rad. cylindrica, longa, fupera

2) Strobilus integet. b.) Squama a parte interna (pelata c.) Nicula feparate D.) Nux

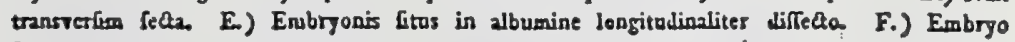
Soluture.

62

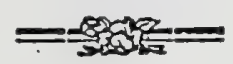

THUJA occidentalis. ibid.

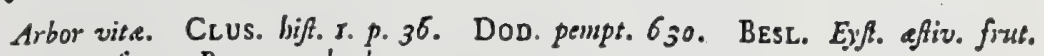
t. I. f. T. BLAKIV. berb. t. 220.

Thuja frobilis lavibus: Squamis obtufis. LINN. Syfs. veg. 86r.

Strobilus (a) elliptico globolus, prxcedenti paulo minor. Squamx coriacex, extus fub apice tuberculo parvo obfoleto notatx, intus (b.) fimpliciter concavx. Nuculx (c. C.) oblongx, (padicex, utrinque Ala membranacea, apice \& bafi emarginata, latiufcula cinctre. Albumen (D.) oblongum, furfum attenuatum. Embryo (D. E.) inverfus, coryledonibus compreffis $f$. fubfoliaceis, radicula nultoties brevioribus.

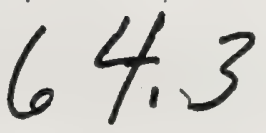




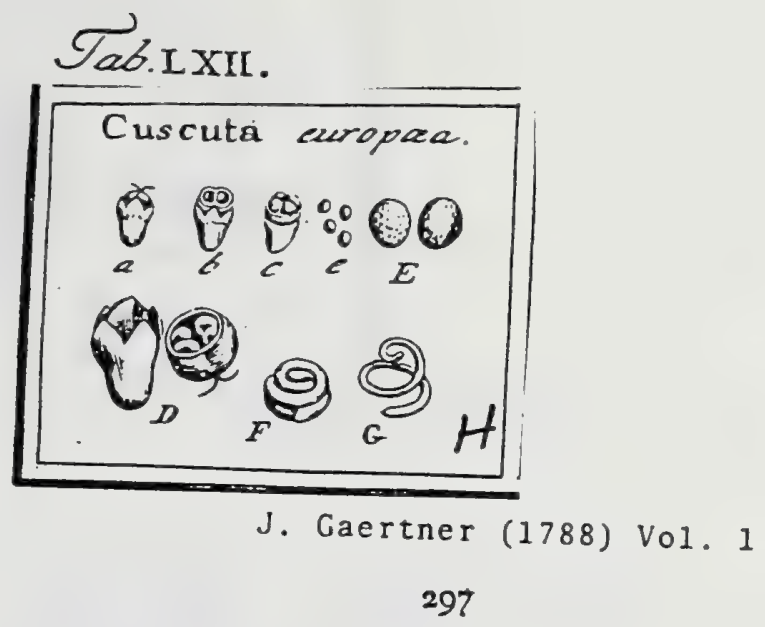

CCCLXXVI. CUSCUTA. TOURN. t. 422. LINN. gen. i7o.

Calyx quadri-l. quinquefidus.

tuor 1. quinque. Styl. duo. Caplula bilocenala quadri-1. quinquefida. Stam. quaEmbryo fpiralis monocotyledoneus. Cuscut a europxa. Tab. 62. fig. 6 .

Cufcuta. B LА Kख. herb. $t$.

Cufcuta floribus Sefflibus. 554. O ED ER. flor. dan. t. 199.

PER. Capfula parva, calyci carnofo ad dif. n. 654 . Linn. 44 f. veg. 167.

cea, diaphana, bilocularis, infra medium fere immerfa, globofa, membrana.

REc. nullum; fernina diftepimento prope bafin circunscifra.

$S$ E.M. duo in quoliber loculanento, prope affixa

fpadicea.

IN T. fimplex, coriaccum, albumini arche adnatum.

A L s. centrale, fubglobofum, carnofum, aqueo-pallidum.

EM в. filiformis, monocntyledoneus, luteus, tribus circiter gyris circa albumen con-
volutus, Rad. modice incraffata, infera.

1.) Caprula integra

Semima folutx, F.) Embryo cira albumen convolutus. G.) Ejusdema (appula dehiscens. e. E.)

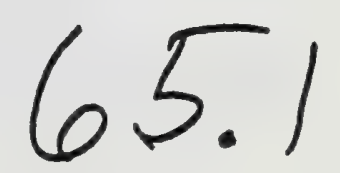


2 


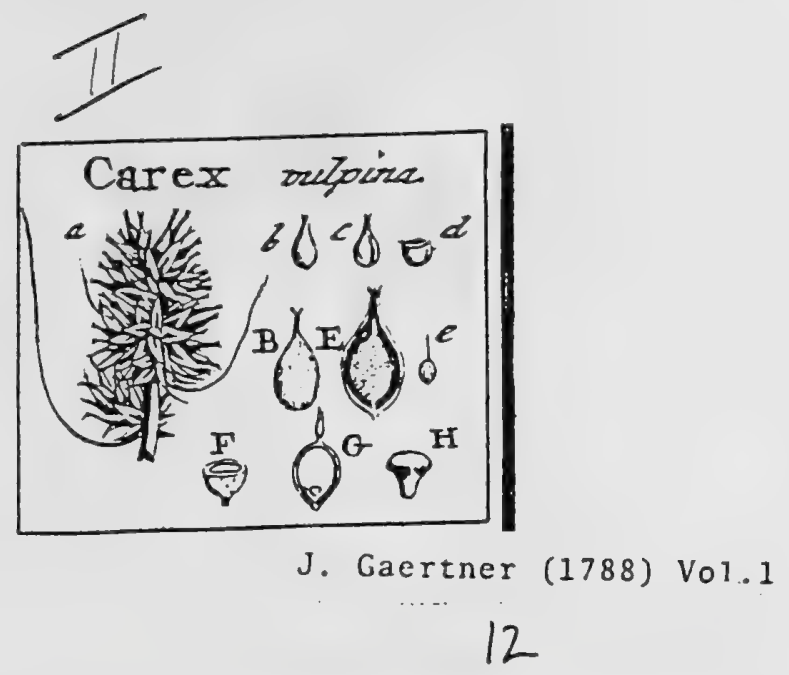

XVII. CAREX. LiNs. gen. 1046 .

Glumre fimplices, undique imbricatx in fpiculas fexu diffinctas, in eadem, aut diverfa planta. Nux coriacea, femine pedicellato.

CAREX vulpina. Tab. 2. fig. 6.

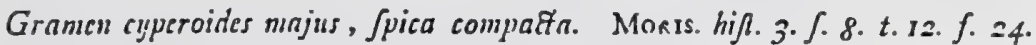

Carex fpiris fribrotundis echinatis, fupremis conflucutibus, capfulis rofratis. H. A.L. lifft. 2. n. 1364 .

Carex frica fuproviecompofita inferne laxiore, fpiculis ovatis androgynis glomeratis: fuperue mafculis. LiNe. $4 y /$. veg. $8+3$.

Icon OEDE. Jur. dan.t. gos.

PER. Nux coriacea, nato roftrata, hine convexa, inde planiuscula, friata, fpadicea, unilocularis, evalvis. Roftum agice bidentatnm, tubulofum, vaginans flylum fetacenu, perfiftentcm.

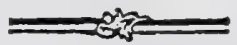

REc. Pedunculus brevis fetaceus, e fungola bafi nuculx oriundus atque feminis extremitati inferiuri infertus.

SEM. unic:un, ovatum, compreffiusculum, hine leviter convexum, inde planum, minutiflime puncticulatum, Spadiceum, nylo perfifente terminatum.

IN T. duplex: exterius coriaceum, craflusculum, durum; interius membranaceum, pallidurn.

А $ь$ в. femini conforme, farinolum, candidiffunum.

E s s. monocotyledoneus, fungiformi -turbinatus, minutifimus, lacteus, in bafi albuminis locatus.

2.) Spica conglomerata. b. B.) Nucis pars convexa. c.) Ejusdem latus planam. d.) Seflio ejus transicrifalis. e. E) Seminis figura \& fitus intra nucem. F.) Semen transverfe fetum. G. Ejurdem \& aibuminis feftio longitudinalis, cum fitu embryonis. H.) Einbryo feparatus.

Nux, fricte loqucndo, non verum pericarpium, fed merum feminis involucrum eft, cx corcolla indurara, aut nectario, ut vult Limnxus, oriundum, quia ftylum libere transmittit, quod contra naturam pericarpii en. 


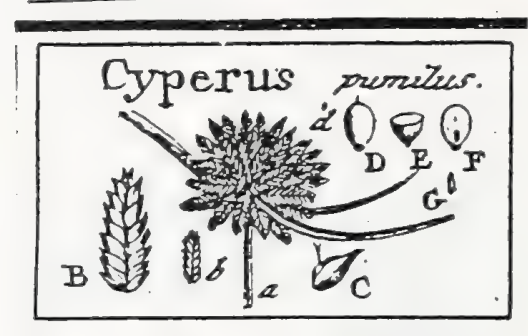

J. Gaertner (1788) Vol.1

9

XIII. CYPERVS. LINN. gem.66.

Glumx funplices, carinatx, distiche imbricatx in fpiculas oblongas, compreftas, ancipites. Semen nudum, aut cruftaceum: pappo ad bafin nullo.

CYPERUS pumilus. Tab. 2. fig. 2.

Gransen cyperiodes pumilum elegans e madraspatan. Рцак. phyt. $t$. Ig1. $f$. 8 . bene.

Cyperus culmo triquetro nudo, umbella Jubdiphylla compofita, fpiculis alterno digitatis lanceolatis glunis, mucronatis. Lis.s. fy/l. veg. 97.

PER, nullum.

REC, nullum: prater fundum glumx, cui foncn affixum.

$S_{E}$ M. unicum, parvum, ellipticum, lenticulari comprelTum, bafi tuberculo rotundo umbiicali munitum, apice Ayto bifito terminatum, fubrufescens.

Ixt. dujlex: exterius fubcoriaccum, tenuc; interius membranaceum, tenuifimum, aduatum.

ALB. fomini conforme, carnofum, duriusculum, pallidum.

EM R. monocoryledoneus, fubiylindricus, utrinque obtufus, albumine dimidio brevior $\&$ ad bafin ejus lucatus, candidillimus.

a.) Capituluan terminale. b. B.) Spicula (cparata. C.) Giuma Semice pragrians. d. D.) Semen

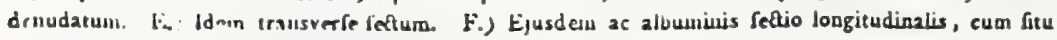
cubrjosis. G.) Einibryo icparatus.

IO

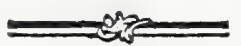

Culmus triqueter, fubtripollicaris inferne aliquot foliis veftitus, fuperne longe nudus. Involucrum tryphyllum, inxquale. Capitulum ex fpicis feffilibus, quarum ina. jores fxpe ad bafin una, aut duabus minoribus auctix \& quafi digitatx. Spiculx oblongx, compreffx, fpradicex, e glumis $16-20$, ovatis, carinatis: carinâ viridi, is mucronem producta, atque ope linex elevatx, a lateribus difincta.

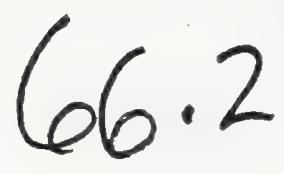




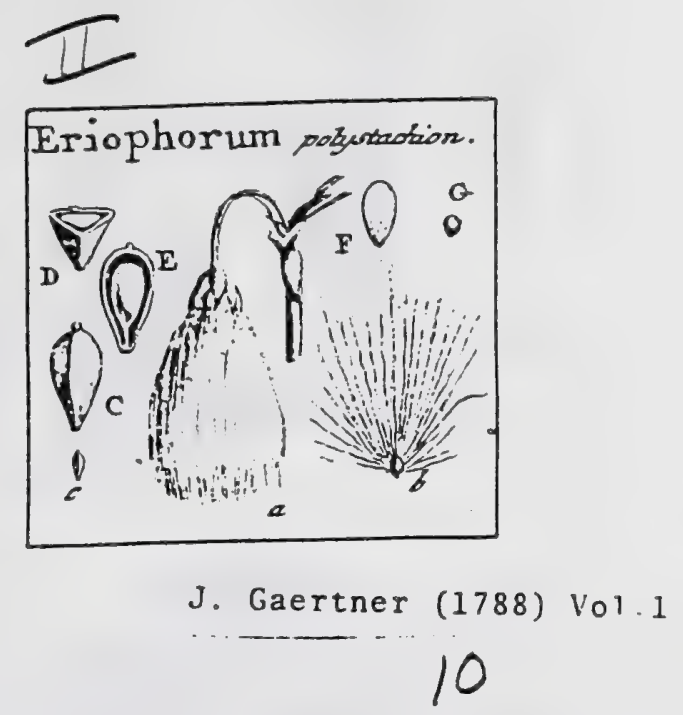

XV. ERIOPHORVM. LIN ger. 68.

Glumx fimplices, convexx, undique in f picam ovatam imbricatz. Semen nucamentaccum: $\Gamma^{2}$ ppo ad bafun longifino, capillari.

ERIOPHORUM polyfachion. Tab. 2. fig. 4 .

Linagrofis panicula ampliore T. VAILL. paris t. 16. $f .1$.

Eriophorum foliis planis, fpicis pendulis. HazL. hif. 2. n. I331.

Eriophorum culmis teretibus, foliis pedunculatis. Lixs. Jyjl. veg. 102.

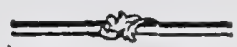

PER. Nux parva, coriaceo-cruftacea, obovata, trigona, glabra, aut obfolete friata, e cafaneo rufescens, unilocularis, cvalvis, bafi veftita laná fericco-alba, fimplicillima, nucula duodecuplo longiore.

REc. filiforme, e fundo nucis ad bafin feminis adfendens \& fecundum alterum ejus latus ad fuscam usque verticis chalazan decurrens.

SEM. unicum, fubellipticum, obfolete trigonum, pallidum.

IN T. fimplex, membranaceum, fubdiaphanum.

A L B. femini conforme, carnofum, pallidum.

Eмr. monocoryledoneus, fubglobofus, mninutifimus, lacteus, in ima albuminis regione politus.

a.) Spica matura pendula. b.) ovariun maturitati proximum, lana e bafi oriunda teftum. c. C.) Nucula marura. D.) Ejus lettio transverfalis. F.) Eadem longitudinaliter aperta, cum fernine ejusque fuliculo unbilicali. F.) Albumes verticaliter fetum. G.) Einbryo folutus.

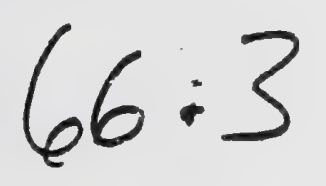



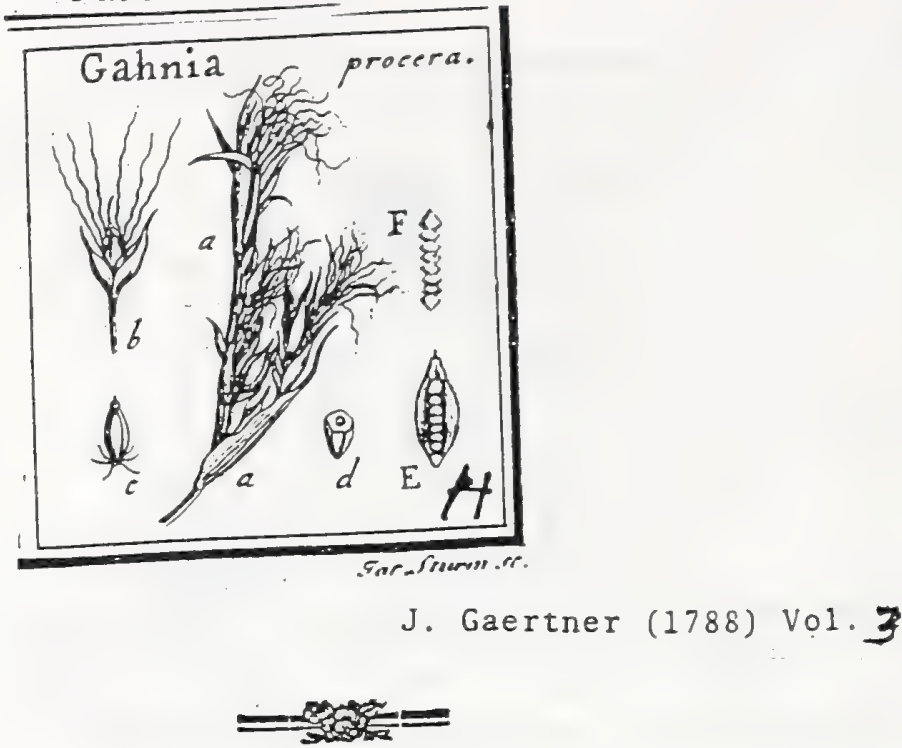

\section{GAHNIA.}

Foss's. gen. p. 51. t. 26. LINN. gram. gen.p. 34. Suppl. p. 3r. gen. ed. Schreb. 606 . Juss. gen. p. 27 .

LA $А$ А С ill. ger. t. 263 .

Flores omnes hermaphroditi. Cal. bi - 1. trivalvis: valvis ovatis, argute

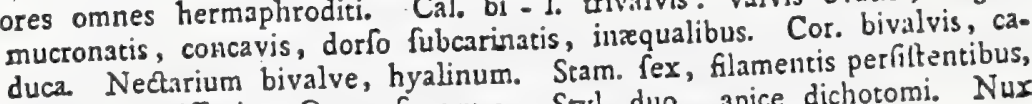
demum longiffmis. Ovar. fuperum. Styl. duo, apice dichotomi. Nur utrinque acuminata, angulata, unilocularis, evalvis, monofperma.

Gahnis procera. Tab. I8I. fig. 8.

Galmia procera. Forst. gen. n. 26. Ad. nov. upf. 3. p. 278 .

Gabnia paniculis pluribus elongatis, frocculis bexandris. FORST. prodr. n. 158:

Galmia procera. Lisw. Supplo 21r. Syjo. veg. ed. 14. p. 345. Spec. plo ed. Willd. T. 2. P. X. p. 244.

\section{A Cl. Thunberg.}

PER. Nux oflea, ovata, utrinque acuminata, angulata, rufefcenti- - padicea; glabra, unilocularis, evalvis. Loculamentum farchum perinde fubftantia offea, 1. faltem valde dura, fed nigra, atque impreffionibus annularibus profunde exarata : hre fubftantia in nucibus immaturis fuliginofo-pulverulenta eft.

R \& c. nullum.

SEN. unicum, campomorphum ! f. teretiufculum, in annulos fex, vel feptem, valde prominulos, quafi totidem articulos, diftinctum, atque capitulo conico, plerumque annulis paulo craffore terminatum, pallide fpadiceum.

IN T. Gmplicifimum, membranaceum.

A L B. ....

\section{EXPLICATIO FIGURE.}

a.) Ramulus paxicula frugiferx feparatus. b.) Calyx maturus eor femine \& flamentu pere Nucula feparata, integra. d.) Eadem transverfe diffe.

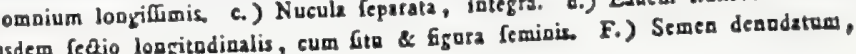
As E.) Ejusdem fectio longitodialis, cum fota \& figora femiois. f.) Semea deandstom integrum.

Quantacunque etiam Git Gahnix cum Schœnis nonnullis, ex habitu externo affinitas, tamen in unum genus compingi nequeunt, ob folum ftaminum numerum, perfiftentiam \& miram elongationem, quorum fimile nihil in

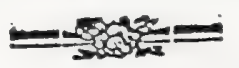

tota Cyperoidearum gente habetur, ut de fingulari feminis forma fileam. focce femen primum habui pro larva infecti cujusdam, qux nucleum deftruxerit: poltquam auten annulares impreffiones in durifima nucis fubiftantia interna vidi, \& poltquam eandem fabricam in octo alis nucibus deprebendi; plane convictus fui, quod veriflumum femen, ueciulects larva Git.

$$
66.4
$$




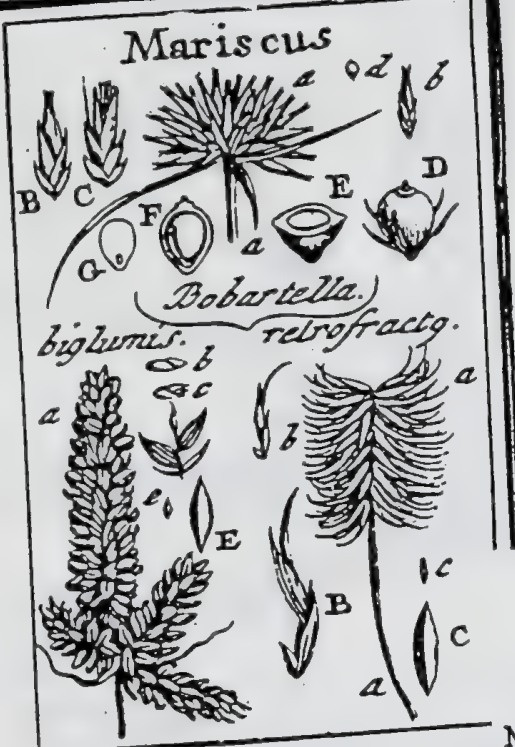

J. Gaertner (1/80) vol. 1

XVI. MIARISCVS. Hall. Schœnus. LINN. geir. 65. Glumx fimplicen, varie imbricatx: inferiores fieriles, fuperiores fertiles, femen
nucamentactum: pappo ad bafin nullo, aut brevilfuno.

Mariscus mucronatus (Bobartella) Tab. 2. fig. 5 .

Schoenus culmo tereti nudo, fpiculis ovatis fasciculatis, involucro fubliexaphyllo, foliis canaliculatis. LixN. Syf. veg. 95 .

R. Nux parsa, fuboftea, fragilis, obovata, Jenticulari comprefta, ad oras acuta, fupra terminata orbiculo depretlo, in cujus medio papiilula prominens; infra coarctata in bafin acuminatam, pilis aliquot paupolis, fumplicibus, femine paulo longioribus ftipatan; unilocularis, evalvis, albicans.

REc. nullum: fonen bafi aflixum.

SEs. unicum, obsiatum, lenticulare, rufescens.

INT. fimplex, mombranaceum, tenue.

A ᄂ.н. Semini conforme, carnofum, pallidum.

Es B. monocotyledoneus. cylindricus, lactcus, brevilimus.

a.) Capitulum (erminale. b. B. C.) Spicula leparata. d. D.) Nux, cum pappo ad bafur. E.) Ejus Cefin transimbialis. F.) Senru iu:ra nucen. G.) Albumen longitudinaliter diffétum, cum fitu \& fiqura cubryunis.

Culmus fublesquipedalis, triqueter, ad medium usque veflitus foliis dilfitis, carinatis, culno vix longioribus. Capitulum ex fpiculis Seltilibus, divergentibus, natis,

12

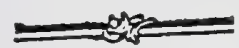

angulatis, fubulato rofratis, e luteo-ferrugineis. Glumx inferiores ovato-acumiatx, fteriles. Differt culmo ac foliis a Sch. mucronato, cetera vero fatis cum eo congruit, ut pro diftincta fpecie vix laberi queat.

MARIscus biglumis. ibid.

Kyllinga culmo Setaceo triquetro; Spicis cylindricis imbricatis; floribus triquetris fubulatis erefto patentibus. RuTтB. pl. nov. p. 15.t. 4. f. 1. quoad figur.

Kyllinga panices. LINN. fyf. veg. 101.

Culmus triqueter. Involucrum univerfale polyphyllum, longifimum; partiale nullum, aut foliolis anguttis, brevibus. Umbella terminalis, funplex, aut radiata. Spiculx cylindricx (a), imbricatx llosculis (b. c.) ovato oblongis, angulatis, brevibus. Glumx dux inferiores (D.) minores, inxquales, neriles; dux fuperiores majores, ovatx, friatx, concavx, ferriles: his fixpe accedit quinta, terminalis, jterum Rerilis. Nucula parva (e. E.), oblonga, utrinque acuminata, triquetra, coriaceo-crufacea, minutiTtune puncticulaıa, ferrugisea. Semen figurá nucis, pallidum. Albumen \& Embryo ut in pracedenti.

MAR Is C US retrofractus. ibid.

Scirpus culmo triquetro, umbella fimplici, fpicarum flosculis retrofraftis. LINN. \y . veg. 100 ?

Culinus triqueter. Involucrum univeríale polyphyllum, partiale nullum. Limbella funplex, radiis fape longiftunis. Spicx cylindricx, ftrigofx (a), retrorfum imbricocurvis, roftratis. Gluma infima, ovata, brevifina, Rerilis; dux aut tres proximx, oblongx, friatx, mucronatx, feminex, fertiles; extima fubulata, recurva, mafcula, llerilis. N'ucula coriacea, oblonga, utrinque acuminata, triquetra, rufesccus. Reliqua ut in pracedentibus. 


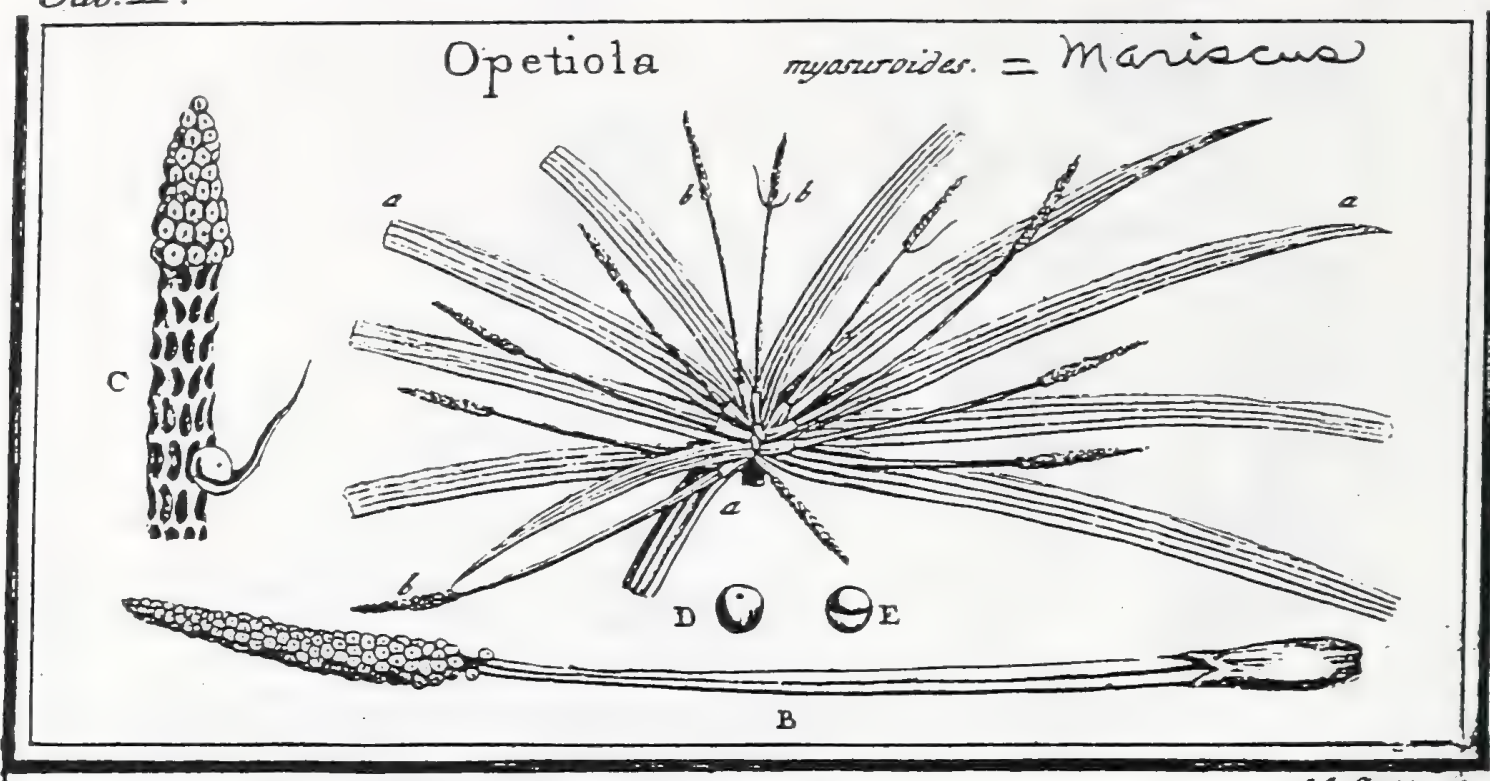

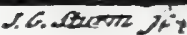

J. Gaertner (1788) Vol 1

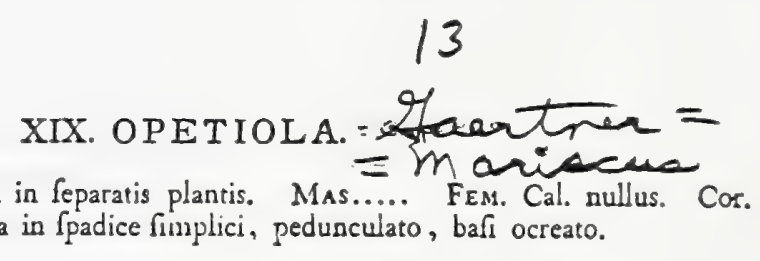

mulla. Semina plurima in fpadice fimplici, pedunculato, bafi ocreato.

OPETIOLA myoluroides. Tab. 2. fig. 8.

Gramen cyperoides perpufillum india orientalis, fpica longa gracili, caudam nuris camulante. PuU. alm. p. 178.

PER. nullum.

REC. Spadix fumpliciffimus, pedunculatus, tereti-acuminatus, undique exaratus foveolis atque frobiculis oblongis, quorum marginibus elevatis feminza infident. Peduncul:. Epadice duplo vel triplo longior, triqueter, friatus, ad bafin ocrea brevi, oblique truncata, vellitus.

SEM. globofum, minimum, pallide albicans, cicatricula obfolcta in vertice notatum. lit . fimplex, coriaceun, fubfpongiofum, tenue.

ALB..... EsiB.....

2.) Planta integra, truncatis faltem foliis nonnullis, longioribus. b. b.) Spadices cum feminibus magnitudine naturali. B.) Spadix feparatus, infignister auttus. C.) Spadicis fuperficics alveolata. D. E.) Senien Separatuin.

Culınus nullus, aut brevifimus. Folia conferta, rigidiuscula, trinervia, glabra, guadripollicaria, ad bafin tres lineas lata: interioribus paulo minoibus. Spicic $e$ foliorum axillis: centrali fere feftili ac brevioruna: reliquis pedunculatis, longitudine dimidii fere folii. Pedunculi triquetri, fupra plani; fria longitudiuali Jeprefia exarati, ocreati. Spadices pedunculo fuo paululum crilliores, ad bafin fape uno 1 . altero foliolo lineari ntipati \& quafi involucrati.

\section{6}


II

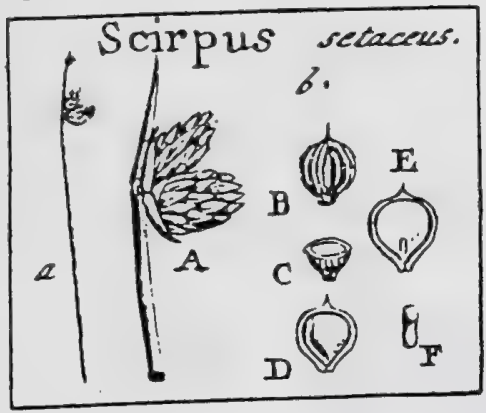

Cyperaceae

$$
\begin{gathered}
\text { J. Gaertner (1788) Vol.1 } \\
10
\end{gathered}
$$

XIV. SCIRPVS. TOURN. t. 300. Lins. gen. 67 .

Glumx fimplices, convexx, undique in fpicas ovatas, non compreftas, inbricat $x$. Semen nucamentaceum: pappo ad bafin nullo.

Scirpus fetaceus. Tab. 2. fig. 3 .

Juncellus omnium minimus. MOR1s. hifl. 3. f. 8. t. 10. f. 23.

Mariscus fetaceus, capitulis lateralibus pauciffmis. HaLl. hif. 2. 12. 1345 .

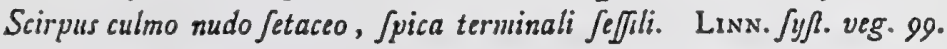

Icon Oeder flor. dan. t. 311. Rotes. nov. plant. t. 15. f. 4. 5. 6. opt.

PER. Nux minima, fubrotunda, aut obovata, cruftacea, fragilis, hinc convexa, inde planiuscula, fupra fylo perfiftente acuminata, infra in tuberculum umbilicale coarctata, longitudinaliter fulcata, e caftameo-rufescens, unilocularis, evalvis.

REc. nullum: fanen fundo nucis affixum.

SEs. unicum, obovatum, lenticulare, rufefcens.

INT. fimplex, membranaceum, tenuifimum.

A L B. Semini conforme, fubfarinolum, album.

Es в. monocotyledoneus, fubcyliudticuș, in medio coarctatus, utrinque obtufus, dunidio albumine brevior \& in ejus bafi locatus, niveus.

2. A.) Spicz geminx laterales b. B.) Nucula (eparata. C.) Ejus fedio transverialis. D.) Eadem . longitudinaliter aperta, cum fitu \& figura feminis, E) Albumen longitudiualiter difrettum, cum embryone ad ejus bafiu. F.) Limbryo feparatus.

66.7 


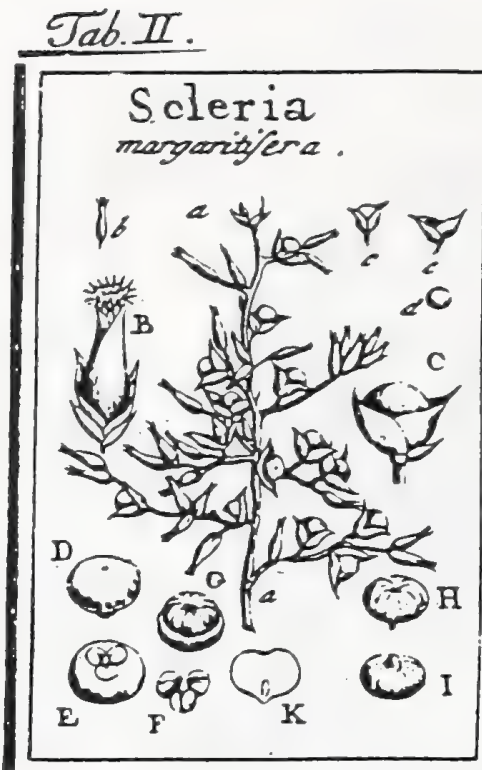

J. Gaertner (1788) Vol.1

\section{SCLERIA. BERG.}

Glumx fimplices, undique imbricat $x$ in fpiculas fexu diftinctas, in eadem planta. Spicx malculx inultiforx, apetalx. Spicx feminex uniflorx: corolla tripartita, petalis rotundatis. Nux globola, nitida.

SCLERIA margaritifera, Tab. 2, fig. 7.

Cyperus naximus americonus, lithospermi femine. Moris. hif. 3. . 8.t. Ir. f. I6.

Gramen cyperoides Jylvaticum maximum geniculatum asperius, femine milii folis. SLOAN. hif. jam.1. $\%$.118.t. 77.f. I.

Scirpus - Schamus - Carex lithospermos. Lins. $\int p$. pl. ed. I. p. sI. ed 2. p. $65 \cdot \int y / \cdot 2 \mathrm{es} \cdot 946$.

Sclerin (Flagellum nigrorums) culmo articulato fcabro, pedunculis axillaribus

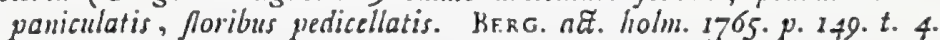

PER. Nux coriacco-cruftacea, globofa, deprefituscula, iiferne in tuberculum umbilicale producta, glabra, nitida, alba aut viulacco fuffufa, unilocularis, evalvis.

REc. nullum: femen bafi aflixum.

SEM. unicum, figurâ nucis, fpadiceun, valıs ramolis pictum.

IN T. fimplex, membranaccum, tenue, rufescens.

A \& в. Semini conforme, fubfarinofum, duriusculum, candidam, fuperne foveola, inforne mucrone notatum.

Es 8. monocotyledoneus, tcretiusculus, breviffunus, Jacteus, bafi albuminis immerfus.

14

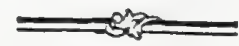

a. a.) Panicula pars. b. B.) Spica mascula, c. c. C.) Calyx femineus imbricatus, D.) Nucis pars fuperior. E.: Nux iuverfa, cum corolta ad ejus bafu. F.) Corolla feparata. G.) Semcn intra nuceor transverfe feftam. H. I.) Semiuis decoricaci facies fuperior atque inferior. K.) Abumen vercicalites retum, cum figura \& fitu embryouis,

Spiculz mafculx oblongx, pyramidatx, imbricatx fquanis ovato acuminatis: inferio. ribus minoribus, vacuis; fuperioribus gradatim longioribus, namisibus intra fingulam tribus. Flores feminei feflies, imbricati fquamis rigidis, glabris, quatuor 1 . fex: inferioribus minoribus; duabus fupremis inaxinis, ovato acumuatis, per maturitatem hemisphrrico - concavis. Corolla in fundo calycis tripetala: petalis retundacis, concavis, membranaceis, tenuiftunis, albis, minunis. 


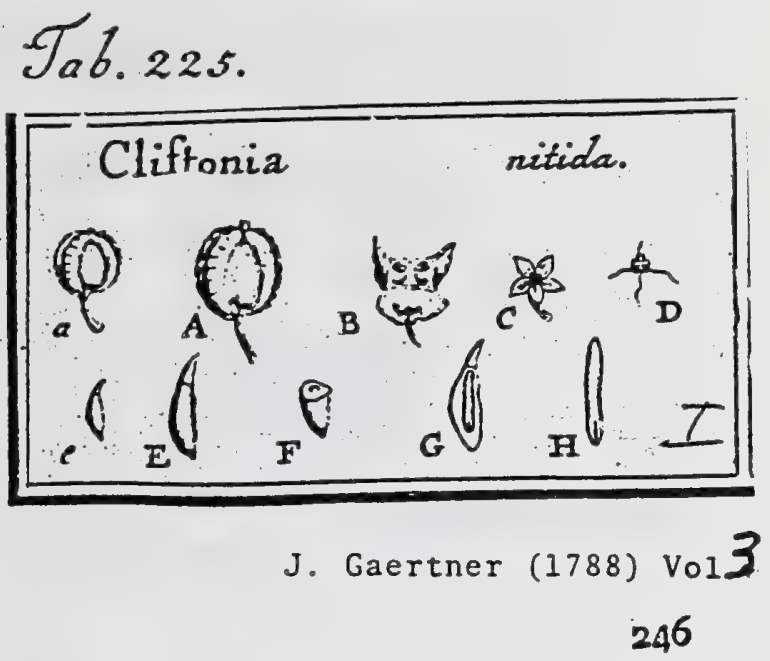

195. C L I F T O N I A. Banks.

Cal. pentaphyllus, minimus, perfiftens; folioia ovata, acuta, ereat. Cor, petala quinque, ovata. Stam. decem; filamentas bidentatis, infra medium

dilatatis. Ovar. fuperum; Aylo nullos ftigmate obturo, tri-1. quadrifulcato. Drupa quadrialata, putamine quadriloculari, tetrafpermo. Rec, nullum. Sem. inverfa. Alb. carnofum. Emb. inverfus.

Cliztonia nitida. Tab. 225 . fig. $50^{\circ}$

Habitat iñ Florida occidentali. Ex collectione Barkfiana.

PER. Drupa ovata, parva, corticata, tetragona: anguli in alas membranaceas transverfe undulatas produci; calyci perfiltenti infiftens, fpadicea, nitida. Cortex coriaceo-fpongiofus, cuticula valida tectus, putamini arcte adnitus. Putamen ovato-ellipticum, levirer ex cortice protuberans, chartzceum, fecundum loculamenta in quatuor partes partibile, quadriloculare. Loculamenta in angulis drupæe locata, comprelfiufcula.l. verfus centrum putaminis cuneata, elliptico - acuminata, monofperma.

REc. nullum : femina ope funiculi umbilicalis craffufculi fubulato-acuminati ad apicem loculamentorum affixa.

SE M. folitaria, ovata, dorfo magis gibba, ventre vero rectiufcula, lateribus planiufcula \& ventrem verfus cuneata, inverfa, ferruginea.

IN T. Gmplex, membranaceum, tenne, albumini adnatum.

$\Lambda$ L B. femini conforme, carnofum, album.

E м в. longitudine fere albuminis, filiformi - teretiufculus, inverfus, viridiufculus. Cotyl. breves, attenuate, incumbentes. Rad. longilfima, furfum paululum dilatata, ad apicem compreffufcula, umbilico externo obver反a, fupera.

$$
\text { EXPLICATIO FIGURE. }
$$

8. A.) Drupz integra. B.) Ejusdem fedto transverfalis, etım fitu loculamentorum. C.) Calyx feparatus. D.) Stigma folutum. e. E.) Semina feparatu, cum funiculo umbilicali. E.) Ejusdem fectio transverfalis. G.) Albumen verticali modo diffectum, cum embryone io fitu. H.) Embryo folutus.

Ob fructus fabricam confimilem Cyrillx affinem effe fufpicor.

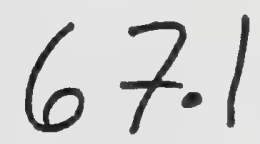


Tab. 209.

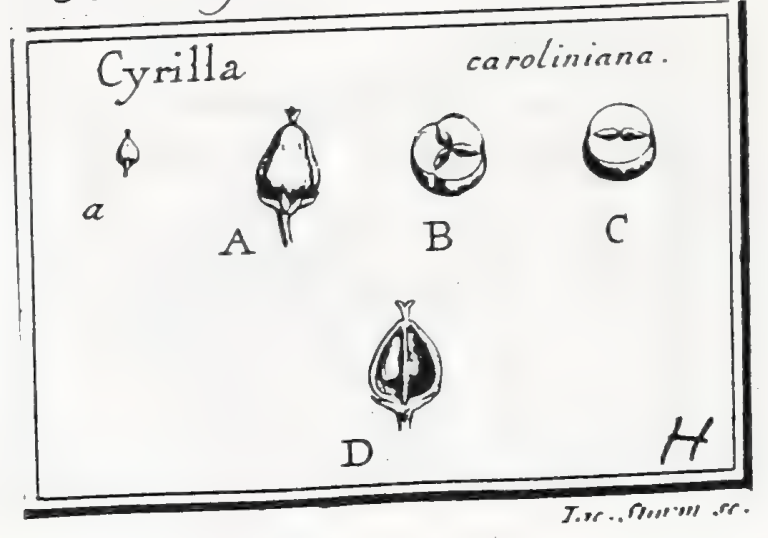

J. Gaertner (1788) Vol3

$147^{\circ}$

\section{II3. C Y R I L L A.}

Linn. gen. ed. Schreb. 380. Juss. gen. p. 160.

Cal. minutus, quinquepartitus, perfiftens. Cor. pentapetala; petalis bafi valde approxinatis, imo calyci infertis. Stam. S. filamenta cum pecalis alterna, fetacea; antherx fubcordatz, incumbentes. Ovar. fuperum; ftylus Gmplex, brevis, perliltens; ftigmata duo, 1. rarius tria, obtufa: Capfula pufilla, ovato - pyramidata, bi-1. rarius tri-locularis, evalvis. Rec. nullfum. Sem. folitaria, ovato-oblunga, axipendula. Alb. . . Emb. ...

Cyrilla caroliniana. Tab. 209. fig. 8 .

Itca foliis integenimis. L'HERIT. Airp. nov. x. p. 137. t. 66. SWARz obf. p. 94. t. 4. (male fi noltra.)

Cyrillis. Lis. mant. p. 50. Syj. veg. ed. I4. p. 241 . JAce. coll. I. p.162. Jcon. rar. 1. t. 47.

Cyrilla foliis cuneato - lanceolutis, acutis, membrasaceis nervillofis; fpicis gracilibus; petalis pedicello longioribus. Mich. flor. bor: ames. 1. p. 158. - Persoon fou. I. p. 175 .

Ex collectione Cl. Desrontaines \& ex dono Cl. Ventenat.

PER. Capfula pufilla, fungofa 1. fubbaccata, fubglobofa, ovata, l. ovatopyramidara, hinc calyci infiltens, inde ftylo taltigiata, leviter bi-1. trifilcata, Ixvigata, ftraninea 1. pallide fufca, bi-1. rarius trilocularis, evalvis. Loculamenta menabranacea, furfum ovato-acuminata, comprefliufcula, levigata.

REc. nullum ; fenina funiculis umbilicalibus brevifamis in fummo loculamentorum apice ad ayem caplula affixa.

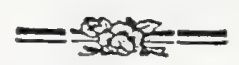

SEM. folitaris, I. in quovis loculamento fungulun, axipendulum, ovato - ob. longum, comprefliufculum.

INT. .. . :

A ᄃ B. . .

EMB. - .

EXPLICATIO FIGURE.

a. A.) Capfula integra. B.) Eadem frilocularis, melio transrerfe dirteaz. C.) Ejusüear biloeti haris feetio transverfalis. D.) Eadem fecumilum futuram verticali modo bipartia, cum loculameutis \& fernine in fitiz

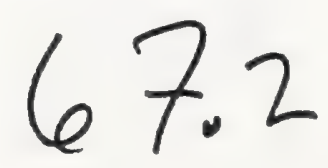


Datiscaceae

Tab.XXX.

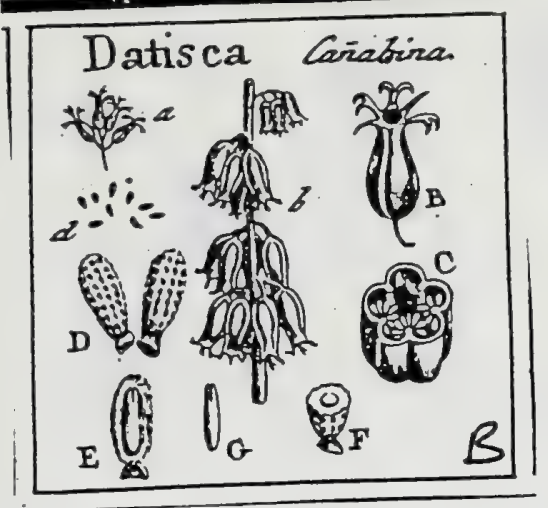

J. Gaertner (1788) Vol.1

47

CLXXVI. DATISCA. LINN. gen. I132.

Flores fexu diftincti in feparatis plantis. M A s. Cal. pentaphyllus. Stam. quindecim. FEm. Cal. bidentatus luperus. Styli tres bifidi. Capfula thfera unilocularis. Receptacula feninum parietalia.

DA r Isc a cannabina. Tab. 30. fig. 2.

Cannabis hutea fertilis. A Le exot. $30^{\circ}$. t. 298. Moris. hift. 3. S. II.t. 25. f.4.

Datifca caule lavi. LinN. fyft. veg. 892.

PER. Caplula infera, uvato oblonga, calycis dentibus duobus fubulatis \& Aylis tribus bifidis coronata, membramacea, tenuis, rotundato-tri-l. pentagona, unilocularis, evalvis, apice amplo foramine rotundo hians.

REC. anguli capfula introrfum prominentes, tres ad quinque, femina ferentes.

S Es. numerofitina, parva, teretiuscula, fcrubiculis exilifinis per feries longitudinales digeftis exarata, fulva aut crocea, bafi cupula membranacea pallida pro umbilico terminata.

IN T. fimplex, membranaceum, modice craffum.

$\Lambda$ L B. Semini conforme, caruofum, pallidum.

Е зв. dicotyledoneus, rectus, teretiusculus, lacteus. Cotyl. brevifimx. Rad. longa, crấla, centrifuga.

2. b. B.) Caprula integra. C.) Esdem transverfe feta, cum infertione feminum. d.D.2 Scmina (eparata. E. F.) Semen transverfalixer \& longitudinaliter diffelum, cum fitu embrjouis. G.) Embryo separatus.

68.1 
e 


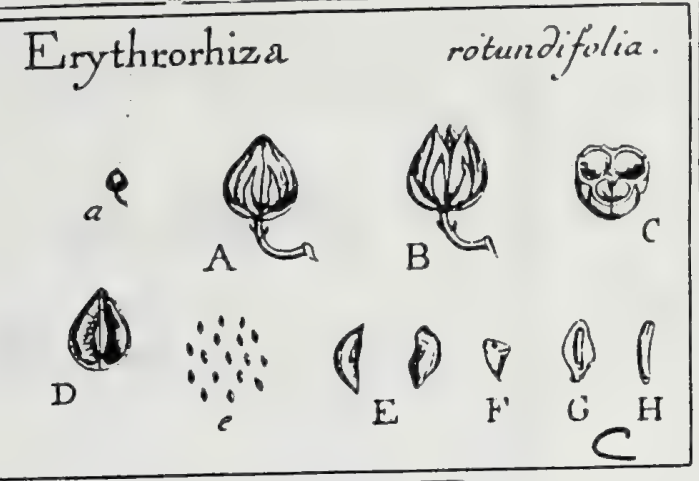

J. Gaertner (1788) vol 3

\section{ER Y THROR H I Z A. \\ MíhaUX flor, bor, amer. 2. p. 34.}

Cal. monophyllus, parvus, quinquepartitus, perfiftens. Cor. pentapetala ; petalis bafi connexis \& ad bafin ovarii cum itammibus calyci infertis, fuperne patentiufculis. Stam. 10., monadelpha, quorum quinque alterna longiora antheris deftituta, quinque breviora antherifera; filamenta petalis breviora, fterilia fetacea, fertilia autem paulo obefiora; Ovar. fuperum; fylo vix illo; ftignate fubfelfili, capitato, fulcis tripartito. Caplula minima, ovato - pyramidata, trilocularis, trivalvis. Rec. nullum. Sem. plura, imbricata. Alb. carnofum. Emb. teretiufculus, curvulus, rad: centripeta.

ERYTHRORHIZa rotundifolia. Tab. 210. fig. 3.

Anonymos f. Beluedere. Clayt. n. 4. Gron. virg. p. 25.

Solasandra cordifolia. VeNt. hort. walm. p. 6g. PERsuoN fyn. 2. p. 215.

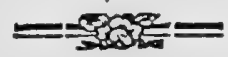

51

Erytbrorbiza glaberrima; fulits orbiculato-reniformibus, dentatis; Spica longiffima. MicH. f. bor. amer. 2. p. 36. t. 36 .

Ex colleđtione BankGana.

PEr. Capfula minima, a calyce perfiltente fupra medium prehenfa, ovatopyramidata, rotundato - triquetra, trifulca, coriacea, lutefcens, trilocularis, tricalvis. Valvule $a b$ apice ad medium ufyue elaftice dehifcentes, medio feptigere; difepimenta fulcis externis obverfa, coriacco - membranacea, in axi fructus coadunata.

REC. nullum; femina crift anguftifrmx ad angulum diffepinentorum internum fitx unbilicis affixa, arcte fibi incumbentia.

SEM. plura, 15-20. in quovis loculanento, angulata, hinc rotundata, inde cuneiformia, 1. ab incumbentibus hinc inde verfus umbilicum cuneifornicompreffa, ferruginea.

If $T$. finplex, membranaceum, vafculofo - reticulatum.

$\Lambda$ С в. Semini conforme, carnofum, album.

E $\mathrm{M}$ в. rectus, teretiufculus, curvulus, àlbus. Cotgl. obtufx, minimx. Rad. longa, conica, curvula, umbilico externo obverfa, centripeta.

\section{EXPLICATIO FIGURE -}

2. A.) Capfula integra B.) Eadearapice dehifcens. C.) Ejusdem fedio transveralis, eum fitu diTepimentorum. D.) Valvula feparata, cum feminibus in fitu. e. E.) Senina feparata. F.) Al. buminis fectio transrerfalis. G.). Idem longitudinaliter fecum; cum fiu embryonis. H.) Embrjo feparatus.

Si characteri Galacis aphyllae, a Linnæo prolato, fides habenda eft; duo hxe genera quam maxime $a b$ invicem diverfa func. Michsuxii, qui prior plantx nonsen impofuit, denominationem retinui, donec de vero Galacis charactere certiora iunotefcant. 


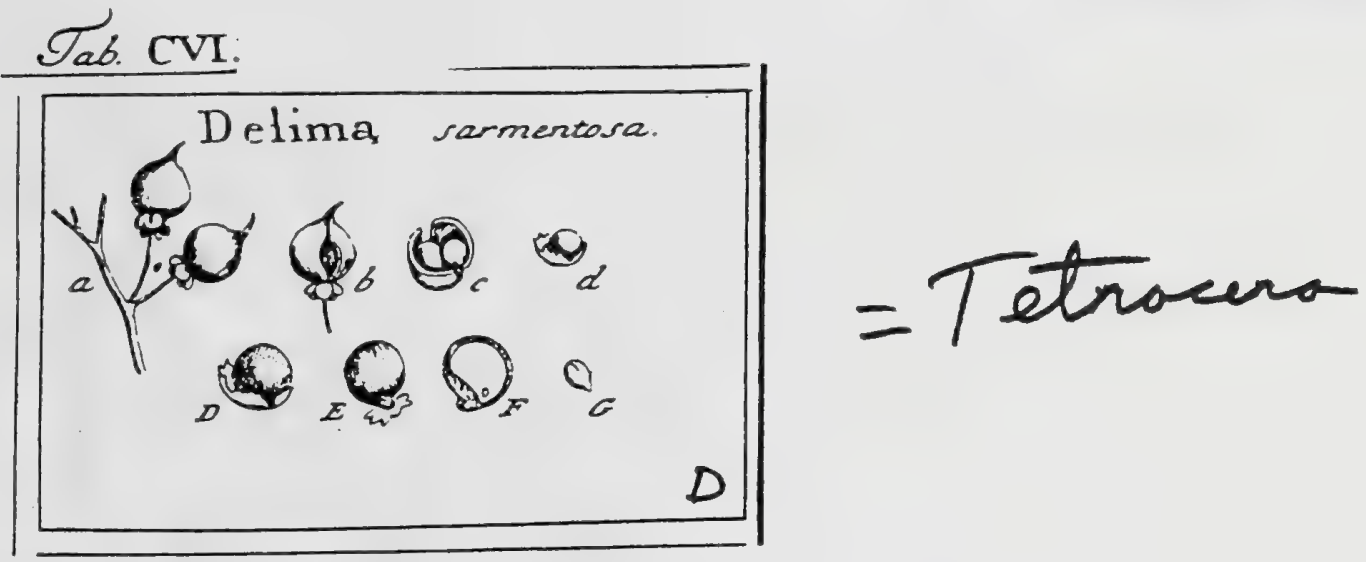

J. Gaertner (17.88) Vol, 2

12

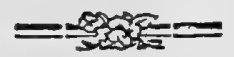

DCXVII. D E L I M A. LIN gen. 67\%.

Calyx pentaphyllus, perfiftens. Cor. nulla. Stam. numerofa. Ovar. Cuperum. Styl. limples. Capfula coriacea, unilocularis, difperma. Seniua arillata.

Delisis farmejtofa. Tab. 106. fig. 6.

Peripu. Rheed. mal. 7. t. 34 .

Delina. Burs. for. ind. t. 37. f. r. bene. Lins. Jyf. veg. 494.

$E$ collect. fem. hort. lugdb.

PER. Capfula corjacea, ventricofa, in roftrum incurvum definens, glabcrima, juteo-fpadicea, unilocularis, altero tantum latere rima longitudinali dehifcens.

REC. nullum; femina fundo capfulx affixa.

SEM. duo, globofa, juxta baGu adunca, baccata, arillata, rabra aut per xtatciu atra.

Arillus incompletus, fpongiofo-membramaceus, niveus, ad oram lace: rus, vix dimidiam feminis partem inferiorem obtegens.

IN T. duplex: exterius carnofum, tenue, etiam in vetuftifimis feminibus aquam rubro colore tingens; interins membranaceum, ferrugineum, prope balin in roftellum feminis aduncum, fuberofum atque folidum incraffatum.

A LB. fomiglobofum, bafi fcil. quafi truncatum, cartilagineum, durum, album.

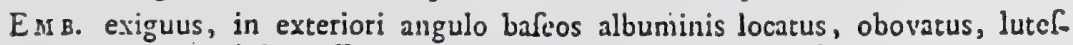
cens. Cotyl. brevifinse, craflx. Rad. acuminata, iufera.

a. b.) Capfula integra \& dehifecns, c.) Eadem transverfe feeta, cum fitu feminum. d. D.) Sce men arillo fuo femiveftitum. E.) ldem ad bafin ufque denudatum. F.) Scminis \& albuminis feato verticalis, cum fitu embryonis. G.) Eunbryo feparatus \& intiguiter auctus.

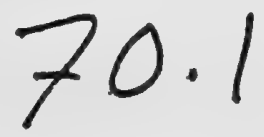




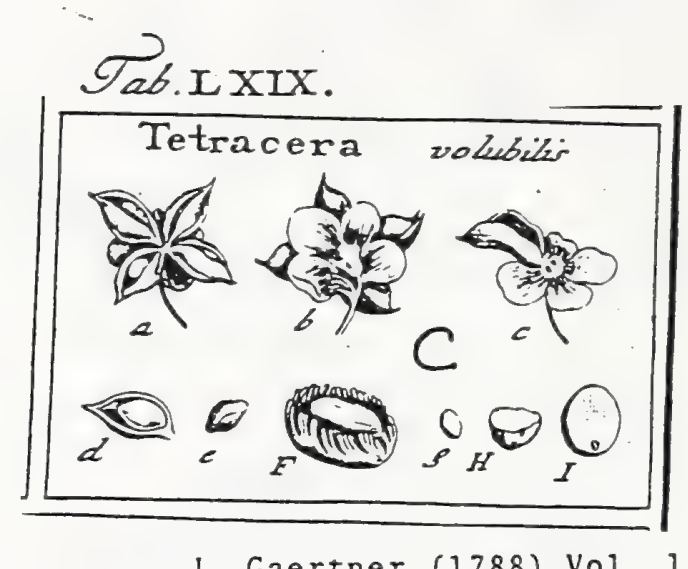

J. Gaertner (1788) Vol. 1

\section{.336}

CCCCXXXIII. TETRACERA. Lin N. gen.683.

Calyx monophyllus, quadrifidus, lobis rotundatis, fubinxqualibus. Cor. nulla. Stam. plurima perfiftentia. Caprulx quatuor: uniloculares, monofpermx. Semina arillata.

Tetracera volubilis. Tab. 69. fig. 3.

Arbor americana convoluulacea platyphyllos, foliis ferratis. P L U $\mathrm{k}$. phyt. I46. $f$. $I$.

Tetracera. LIN N. fifl. veg. 504 .

Ex herbario Bankfiano.

PER. Capfulx quatuor, ovatx, utrinque acuminatx, horizontali patentes, coriacez, glabrx, nigro caftanex, uniloculares, margine fuperiori dehilcentes.

REC. nullum; femen fundo capfula affixum.

SEM. unicum, ovatum, fubrugofum, fubangulatum, atrum, lucidum, minutifime puncticulatum, arillatum

Arillus carnofo membranaceus, albus, inferne integcrimus, umbilico adnatus, fu. perne longitudinaliter rima divifus, \& ex ea, verfus utrumque latus, in laciniar. lincares parallelas profunde fillus.

IxT. duplex: exterius chartaceum, aridum, ardiffime interioni adharens; interius membranaceum, rufefcens, albumini adnatum.

ALD. femini conforme, fabulofo carnofum, durum, aqueo-pallidum.

EM в. minutifinus, fuhovatus, lacteus, in bafi albuminis pofitns. Cotyl. brcvifimz. Rad. rotundata, infera.

a.b.) Fruflus interer, ab utraque parte fpeitatus. c.) Capfula dehifcens. d.e.) Semen arilloteftam. F.) Arillus in aqua tepida explicatus. g.J Semen denudatum. H.) Nlbumen transverfe fearm. 1.) Embryonis figura \& fitus in bafi albuminis.

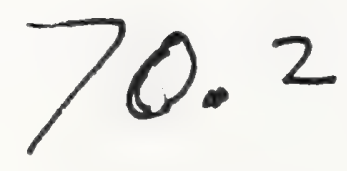




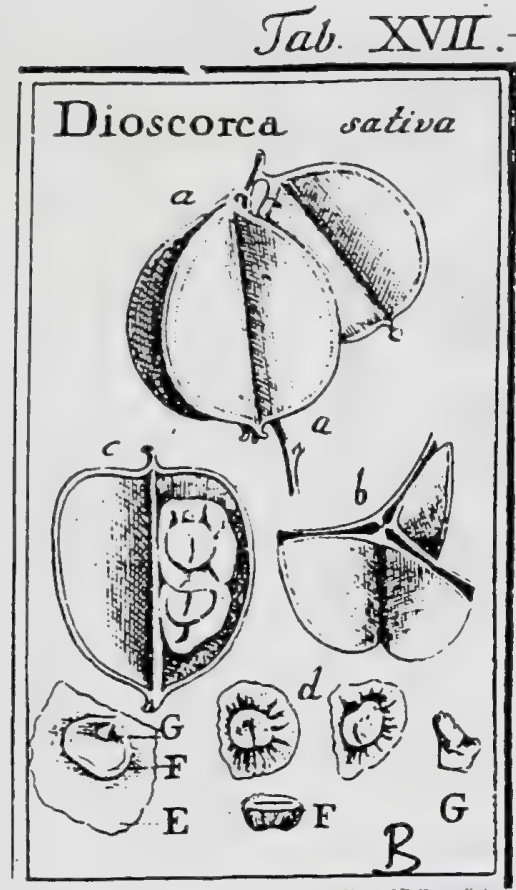

J. Gaertner (1788) Vo1.1

66

LXXVI. DIOSCOREA. PLum. gen. t. 26. LIN N. gen. 1122.

Flores fexu dinincti in feparatis caulibus. Cai. campanulatus, fexfidus. Cor. nulla Mas. Stam, fex. F es. Styli tres. Capfula fupera, trilocularis. Semina bracteata. A bumen cavitate maxima, comprefla.

Dioscorea fativa. Tab. 17. fig. 4.

Mu-kelengu. R H Е Е. mal. 8. $\mu \cdot 97 \cdot t \cdot 5$ I.

Olus fanguinis. R ч $\mathrm{P}$ н. amb. 5. $\mu .482 . t$. 180 .

Diofcorea.fcandens, foliis tamm, fruftu racemofo. P Lum. ic. t. 117. f. . .

Diofcorea foliis cordatis alternis; caule lavi tereti. Lix $i$. fyf. veg. 888 .

PER. Caplula fupera, obovato rotundata, coriacea, trilatera, in tres alas compreffa, trilocularis, trivalvis. Valvula fecundum alarum marginem dehifentes, in medio angultiffimo difTepinento ftipatz.

REC. nullum : fenina diffepimentorum margini interno affixa.

SEM. in fingulo loculamento gemina, bracteata, irregulariter triangula aut fubrotunda, lato margine meinbranaceo cincta, rufefecuria.

IN . duplex: exterius in marginem feminis ampliatum; interius nucleo ardiffime ad: natum: utrumque membranaceum, tciuc.

A L в. fubrotundum, aut transterfe ovatum, valde compreftum, cartilagineum, album; fubpellucidum, factum ex duabus laminis prope peripheriam folummodo inter fe conferruminatis, in medio auten folutis atque latam cavitatem comprefiam inclodentibus.

Eзв. monocoryledoneus, minutus, lacteo-albus. Cotyledon foliaceo-comprefta, plana, cuneiformis, tencrima. Radic. brevis, tcretiufcula, adfcendenti-centripeta.

2.2.) Capiula integra, b.) Ejus fertio transverfalis. c.) Valvula feparata, com fita femisues d.) Semina foluiz E.) Semen longitudinaliter partitun. F.F.) Albununis figura, ejusque cavitas interm. G. G.) -Situs embronis ad umbilicum, idenque folutus \& iofignier antuus.

Diofcorea tripinylla.

Capfula duos pollices longa, ex emarginata \& quafi cordata bafi, in ellipricam figuram elungata, \& ad apicem in brevem nucronen contracta; cctcrum fabrice \& confiltentia pracedenti fimilis, nifi quod multo rigidior. Semina geminata, femi elliptica, pollicem circiter longa, coloris cinnamomei. Nbumea: \& Embryo ut in procedenti.

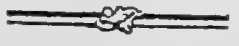

Obf. Ampla ifta cavitas albuninis comprefta, folis, quod hactenus fcian, Rajanix \& Diofcorex feminibus propria eft. 


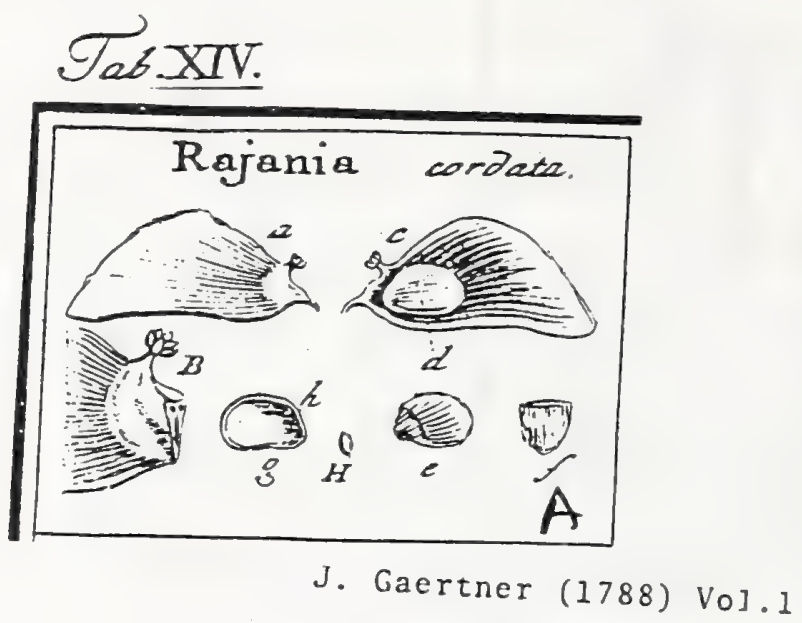

XLVIII. RAJANIA. LINN. gen, II2T.

Flores fexu diftincti, in feparatis truncis. Mas. cal. fexpartitus. Cor. nulla. Stam. fex. FEм. ut in mare. Ovarium inferum tiloculare. Semen maturum unicun, ovarii tunica corticatum, unialatum.

RA JANIA cordata. Tab. 14. fig. I.

Fanraja fcandens, folio tamni. $\mathrm{PLU}_{\mathrm{M}}$. ic. $155 . f$. 1 .

Rajania foliis cordatis feptemnervïs. LIN N. Syft. veg. 888. Ex herbario Mankfiano.

PER. Capfula infera, pergamea, trilocularis, evalvis : Loculamentis duobus ferilibus, fubobliteratis, apterygiis; tertio fertili, comprefto, in alam membranaccam, fphx-

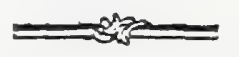

rice trigonam, inaximam producto. Color fericeo fulvus. Superficies alz, ex fede feuninis, radiatim flriata.

REC. sullum: Semen angulo antcriori loculamenti, infra floris exortum, affixum.

SE s. unicum, fubellipticum, compreflum, glabrum, filendens, faturatecaflaneunn.

INT. membranaceum, fimplex, tenuifinum.

A с в. femini conforme, fubcartilagineum, flexile, albicans, quafi ex duabus laminis ad peripheriam inter le conferruminatis conflatum, intus anpla cavitate comprefta donatuin.

EMB. ininutulus, fubovatus, compreflus, ad angulum ferninis umbilicalem locatus, fublutefcens.

a.) Capfula integra, maqnitudine naturali. B.) Eadem truncata \& magnitudine ancta, cum tribus fuis loculamentis. c.) Eadem lonqitudinaliter fi $\pi_{2}$. d. ) Semen in fitu naturali. a) Idem folutum \& ab altero laterc fpectatum. f.) Ejus fectio trausverfalis, ut crafities appareat. g.) Albumen loacitudinaliter fectum, cum embryone in fitu naturali. h.H.) Eimbryo maguitudine naturali \& aucta.

Ab xflu folis, plana capfulx forma xxpe in concavam mutatur, hinc bullatz illix fructus figurx in iconibus PlUmierI, \& ex his quoque obfeura ejus deferiptio in LI N $\mathbb{E}$ I generibus.

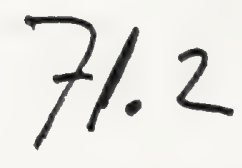




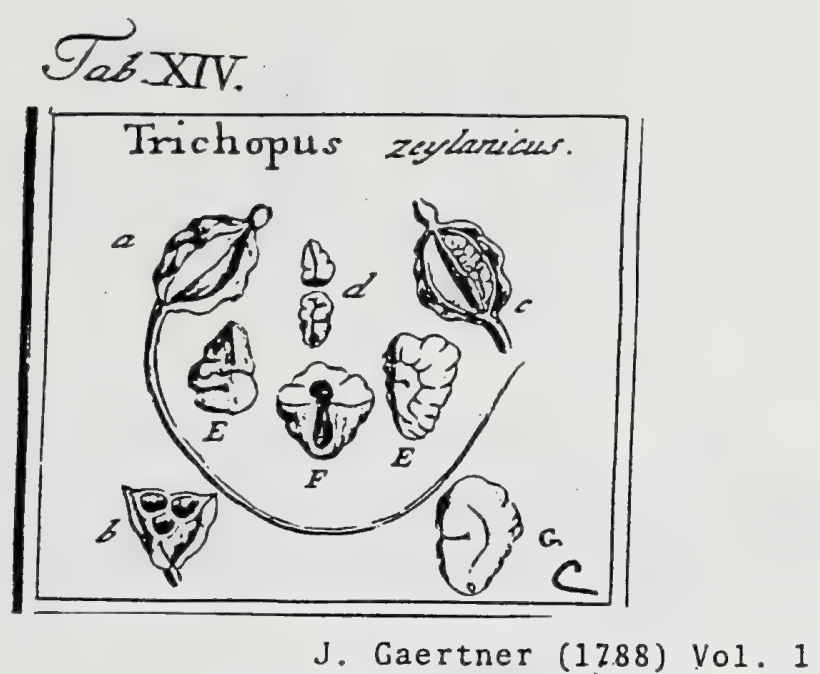

44

L. T R IC H.O P V S.

Flos fuperus..... Capfula membranacea, trialata, longifiune pedunculata. Semina rinis profundis cxta.

Tr Iс н о о' zeylanicus. Tab. 14. fig. 3.

Bempul. zeylonens. E collect. fem. hort. lugdbat.

PER. Capfula infera, menbranacea tenuifinua, ovata, trilocularis, evalvis, triquetra ; angulis margine membranaceo undulato auctis, lateribus vero planiusculis, lineá mediâ deprelâ inferiptis; bafi definens in pedunculum longifimuın, ex triquetro principio, in fetaceum finem attenuatum. Diffepimenta tenuillima, e inediis capfulx lateribus oriunda

REC. nullum: femina ope fubftantix pulpofx diffepinentis affixa.

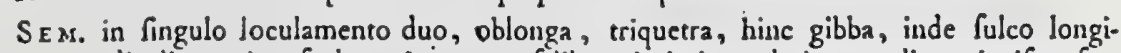
tudinali tereti exfculpta \& transverfalibus rimis irregulariter undique incifa, ferrugisea.

I N T. fimplex, membranaceum, arctifime nucleo adiatum.

$A \_$в. femini conforme, \& intus quoque rima longitudinali incifun, cartilagineum, durum, pallidum.

Eмв. monocotyledoneus, minutiffmus, in infına albuminis parte, formá puncti me: dullaris lactei lazrens.

2.) Caprula integra, floris reliquiis coronata. b.) Ejus fectio transverfalis. c.) Loculamenta duo aperta, aitero vacuo, aitero femina in fitu naturali exhibente. d.) Semina (eparata. E. E) Eadem accta, rimis varie incifa. F.) Semen transveric fectum, \& a latere, quod fulco longitudivali inferiptum, Spectatum. G.) Albuminis fectio verticalis, cum fitu embryonis.

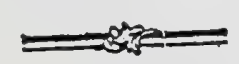

Nonnullam cum Commelinis fimilitudinem habere videtur; fed capfulx firus, diverfiffinuun declarat plantx genus, cujus in feriptoribus veftigium nullum reperio.

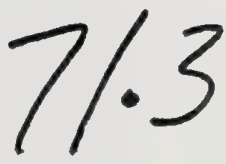


Tab. IXXXXVI.

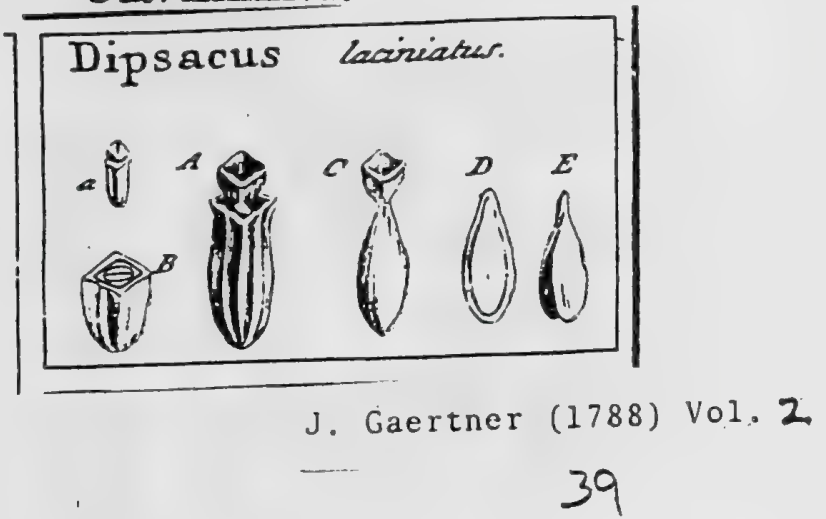

DXLIV. DIPSACUS. TOURN. inft. t. 265 . LINN. ger. II

Involuc. conmouse polyphyllum; propritum monophyllum, angulatum. Rec. comsunuse clongatum, paleaceum. Cal. Cuperus, per maturitatem in pappum cupularem abeuns. Cor. monopetala, quadrifida. Stam. quatuor. Ovar. inferum. Styl. Gmplex. Semen unicum, pappo monophyllo indivifo.

\section{0}

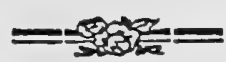

Dipsacus laciniatus. Tab. 86. fig. 5.

Dipfactus folio laciniato. Moris. bif. 3. S. 7. t. 36. f. 4. JACQ anfit. 5. t. 403. Dipfacus foliis coninusis fintatis. LINN. fyft. veg. 143.

PER. nullum, preter involucrum floris proprium, corjaceum, tetragonum, oblongum, fulcatun, apice perviun \& margine xquabili obfolete crenulato terniuratum.

REC. commane conicum, paleaceum : paleis flore longioribus.

SEM. unicum, inferum, ovato oblongum, rhombeo compreffum, pallidum in brevem ftipitem atteinuatum. Pappris cupularis, tetragonus, fericeo villofus, integerrimus, aut obfolete divifus.

IN T. finsplicillimum, membranaceum.

$\Lambda$ \& в. femini conforme, carnofum, album.

Ea B. inverfus, albus. Cotyl. oblongæ, comprefix. Rad. teres, fupera.

2. A.) Involucram crm (cmine integrum. B.) Idem transveric (cetum. C.) Semen denudatnm, cum Pappo cupulari, D.) Embryonis in albumine Gutus, E.) Embryo folutus.

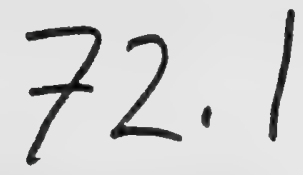




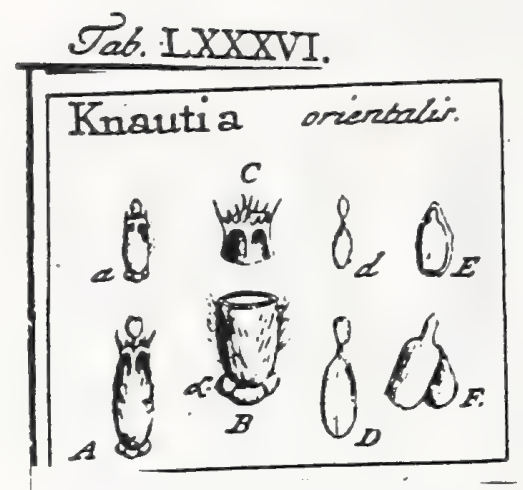

J. Gaertner (1788) Vo, 2

\section{KNA UTIA. LIN gen. II6.}

Involuc. commun fimplex, fubcylindraceum, foliolis quinis aut pluribus: proprintm ovario adıatum, integerrimum, coriaceum, apice pervium. Recept. commone anguftum, nudum, pauciforum. Calyx fuperus, brevilifimus, fubpappofus. Cor. monopetala: limbo inxqualicer quadrifido. Stam. quatuor. Ovarium inferum. Styl. findplex. Semen involucro, toris proprio corticatum.

36

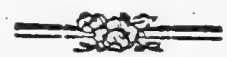

KNAUTIA orientalis. Tab. 86 . fig. 2 .

Enautia foliis incijss, corollulis quinis calyce longioribus. LINN. $\sqrt{y} f$. veg. 147.

PER. nullum, preter involucrum Aloris proprium, coriaceum, ovato oblongum, lenticulari-comprefinn, fpadiceo-luteum, pilis raris coufperfum, luperne rima transverfali pervium, atque duodecim dentibus fetaceis, quorum quatuo reliouis longiores, terninatum; inferne autem, baf callofa, alba, trifulca, inftructum.

REC. conmonze angultum, nudum; proprizm nullum.

SEM. unicum, inferum, involucro fuo multo brevius, oblongum, lenticulari-compreffum, in ftipitem brevem pappigerum definens. Pappus cupularis, fericeo-albus, villofus, brevifrimus.

IN T. fimplex, membranaceum, pallidum.

ALB. femini conforme, carnofum, album, tenue.

EM B. albumine paulo minor, inverfus, luteus. Cotyl. ovatx, carnofx, planiufculz. Rad. teretiufcula, fupera.

a. A.) Semen insoluero fuso corticatur. B.) Ejus pars inferior, eum bafi $\left(\alpha_{0}\right)$ callo[a albz. C. Ejusdem pars fuperior denticulis coronsta. d. D.) Semen denudatum, cum fuo Pappo fubftipitato. E.) Albuncu longitudinalites difTeaum, cum Esura \& fitu embryouis. F.) Embrio Scparatus.

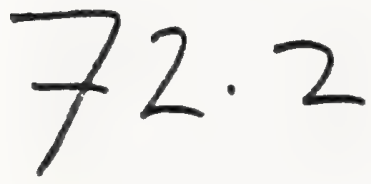




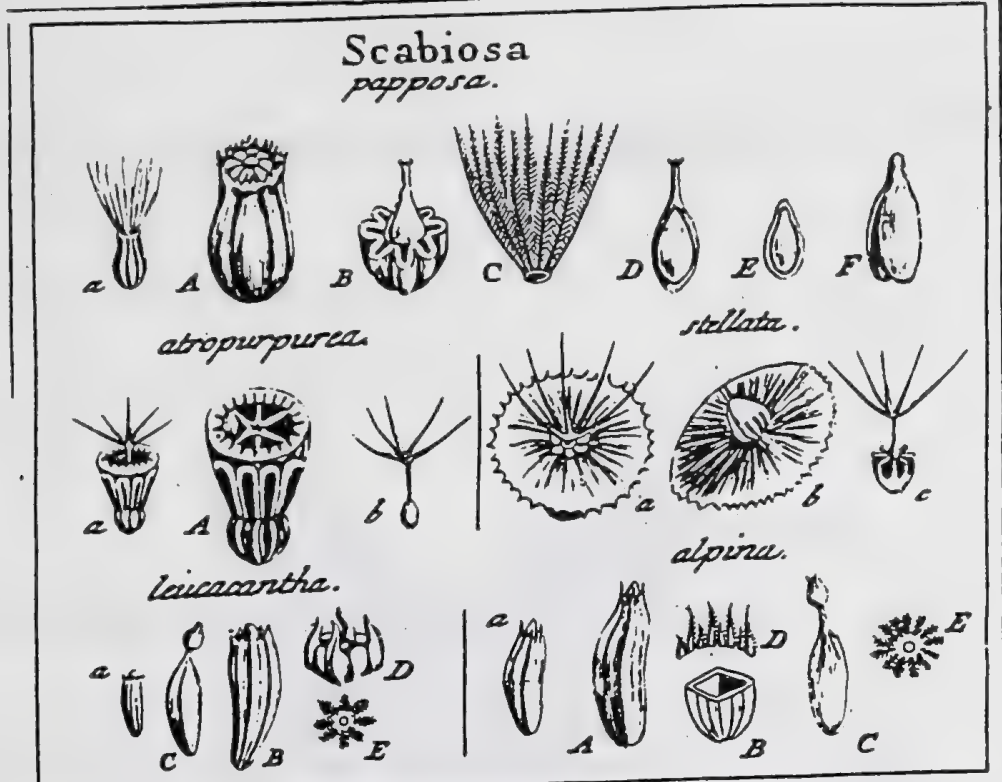

J. Gaertner (1788) Vol. 2

\section{SCABIOSA. TOURN. inft.t. 263:264. LINN. gers. II5.}

Involuc. commine patens, polyphyllum: proprism mongphyllum, apice pervium, multiforme. Rec. commane convexum, paleaceum, multilorum, Cal. fuperus, per maturitatem in p:sppun varium abiens. Cor. monopetala, quadri-1. quinquefida, regularis 1. irregularis. Stam. quatuor. Ovarium inferum, Styl. fimplex: Semun unicum, involucratum.

Scabiosa pappola. Tab. 86. fig. 4 .

Srabinfa corollulis quinuquefdis inequalibus, caule berbaceo ereato, folits pinnatifn dis, fenumibus arifiatis plumofoque - pappofis. LINN. fyrf. veg. I 46.

PER. nullum, prxter involucrum flòris proprium cylindrico-urceolatum, fungofum, octo plicatum, apice truncatun \& denticulis duodecim-1. pluribus breviffimis fetaceis terminatum.

REC. commnure convexiufculun, paleaceum; proprisms nullun.

SEग. unicun, iuferun, ovato acuminatun, in ftipitem brevem pappigerum attentuatun. Pappus plumofus, albus, fenine longior.

IN T. fimplex, membranaceum, pallidum.

$A$ \&B. carnofun, album, tenne.

Es в. inverfus, luteus. Cotyl. ellipticx, plano-convexx, tenues. Rad. brevis, teretiufcula, fupera.

2. A.) inroluerum feminis integrum. B.) Idem transverfe fectum, cum fuis plicis. C.) Pappus feparatus. D.) Semen longitudinaliter diffeatum, cum albumise integro. E.) Embrgonis in albumine diffeêto fítus. F.) Embryo folutus.

SCABIOSA atropurpurea, ibid.

Sarbiofa indica. Clus. bift.2. p. 3.-flore faturate rubro. BesL. Eyft. efiviv. IX. t. 10. f. 1. 2.

Scabiofa corollulis quinquefidis radisutibus, foliis differtis, receptaculis. florum fubulasis. LisN. bytr. veg. 145.

Iivolucrum feminis (a. A.) e bafi globofa, ofto fulcata, definens in cupulam granden, inverfe conicam, membranaceam, margine inflexo crenulato terninatam \& ad latera arcubus octo elevatis, opacis, areolas oblongas fubdiaphasas includentibus, infcriptani. Semen (b.) fubglobofun, parvum,

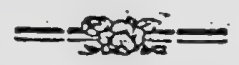

definens in ftipitem filiformem, Pappo fetaceo, quingueradiato terminatum. Albunien tenue. Embryo inverfus, albus. 


\section{J. Gaertner $\frac{(1788) \text { Vol2 }}{39}$}

Scablosa ftellatio ibid.

Scabiofa major bijpanica. Clus. biff. 2. p. I. Best. Eyjf. aftiv. IX. t. 9. f. r. Scabiofa corolludis quinquefidis radiantibus, folits dijerfis, receptaculis florzem fubrotindis. LINN. l. c.

Involucrum feminis (a. b. c.) turbinatum, fungofun, lanatum, album, prope verticem (b.c.) profundifime octoplicatum, terminatum difco amplo, rotundato, memibranaceo, radiatim ftriato \& ad oram denticulato. Semen, Pappus \& reliqua, ut in proxime præcedenti.

Scabiosa leucanths. ibid. ex fide Martyni Stuttgardiens.

Scabiofu corollutis quadrifidis fubaqualibus, fquunis calycinis ovatis imbricatis, fuliis pimnatifidis. LiNN. Syf. vog. 344. *

Involucrum (a.B.D.) tetragonum, oblongum, membranaceo-coriaceum, ftriatum (B), termiratun denticulis quatuor (D.) acuminatis majoribus totidemque brevioribus obtufis. Semen involucro fuo brevius, ovato-oblongum (C.), rhombeo - compreffum, in breviffimum ftipitern pappigcrum attenuarum. Pappus brevifimus (E.), radiis conniventibus, fubdems, plumofis aut villolis. Albumen tenue. Embryo inverfus.

Scabiosa alpina. ibid. ex fide Martyni.

Scabiofa alpina maxima. LOB. adv. p. 232. ic. 233.

Scabiofa alpina centantroides. BEst. E) je. aftiv. IX. t. 8. f. т.

Dipfacus foliis pinzatis, pinnis ferratis, capirulis globofis. HaLL. bif. $13 .=00$.

Scabiofa corolludis quadrifidis equalibus, calycibus imbricatis, fieribus conzuis, foliis pinnatis: foliolis lanceolatis fenratis. LINN. Jyfr. veg. 143.

Involucrum (a. A. B.D.) oblongum, tetragonum (B); membranaceo-paleaceum, Itriatum (A.), fubvillofum, definens in dentes octo fetaceos, fcibiulculos (D.), inrequales. Semen (C.) ovatum, ftriatum, pallidum, in ftipitem brevem attenuitum. Pappus (E) fericeo cinerafcens, brevifinus, bafi monophyllus, apice divifus in radios plures villofos, aut plunofos. Albumen carnofum. Embryo e luteo viridis.

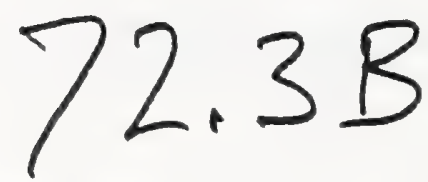




$$
\begin{array}{lll}
\hline & 0 & 0 \\
0 & 0 \\
0 & 0 \\
0 & 0 \\
\hline
\end{array}
$$




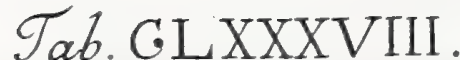

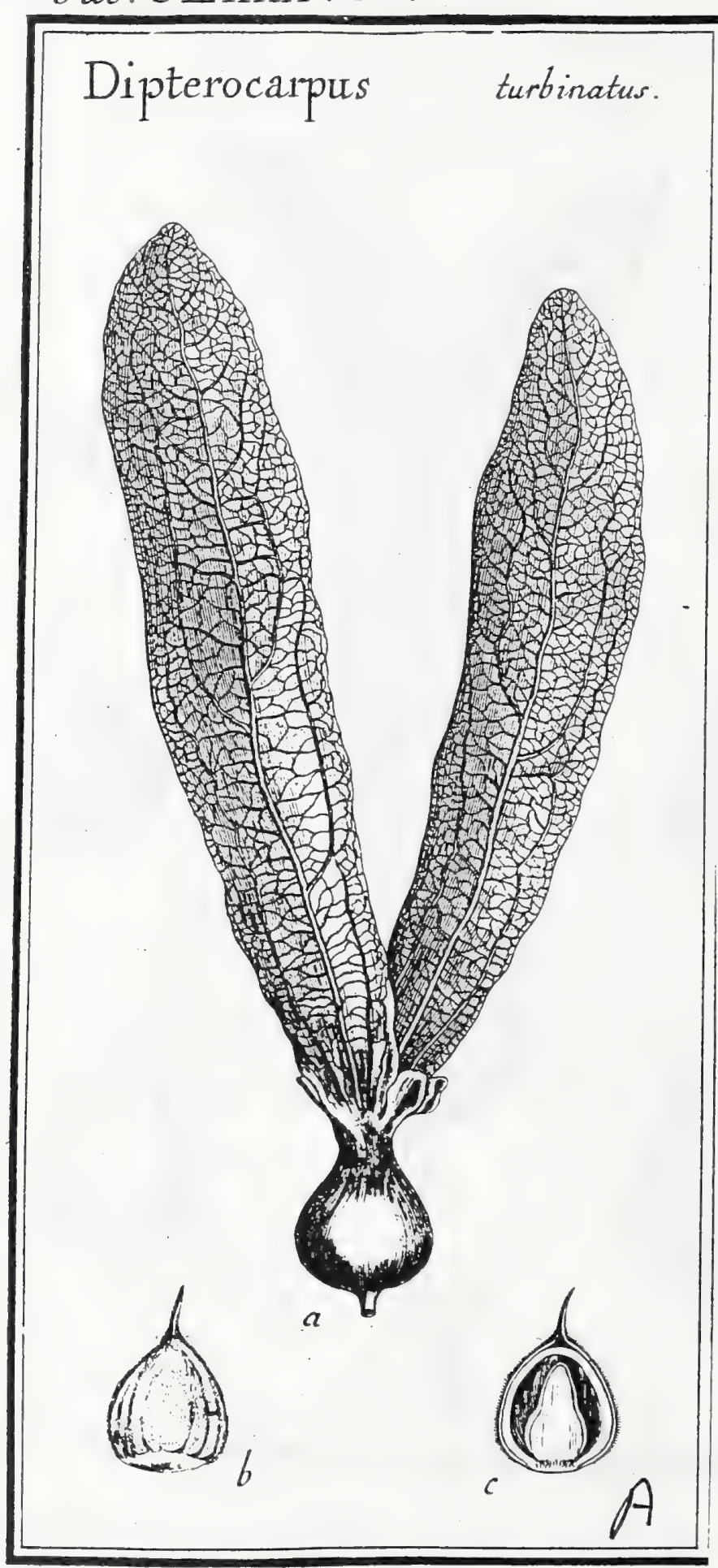

$73.1 B$ 
Cal. monophyllus, inferus, cupulatus; limbo quinquefido inxquali : laciniis rigidis reticulato - venofis, duabus oppofinis"longiflimis ligulatis obtufis, tribus reliquis, quarum una oppofita, multo minoribus ovatis auriculatis. Cor.... Stam.... Ovar. fuperum; ftylo implici perfiftente. Nux a calyce, cum fructu increfcente, involucrata, coriacea, unilocularis, evalvis. Recept nullum. Sem. unicum. Alb. nullum. Cotyl chryfaloidea: contortuplicata. Rad. fupera.

Dipterocarpus coltatus. Tab. 187.

E collectione BankGiana cum fequente:

P z R. Nux fupera, coriacea, a calyce globofo incraflato lignolo levigato quinquecoltato, coltis acutis cum incifuris calycis correfpondentibus, involucrata, ovata l. elliptica, turbinata, furfum attenuata \& in mucronein fubulatum producta, bafi derafa extus albido - favefeens, intus rufefcens, unilocularis, evalvis.

Rec. nullum; nif funiculum umbilicalem, incraftatum, comprefum, e fundo nucis oriundum, ad latus ventrale feminis verticem usque adfcendenrem, \& cum integumento externo undique colliquefcentem fumas, quibus mediantibus femen fundo riucis arceiflume adnatum.

SEN. unicum, grande, cavitate nucis paulo anguftius, obfoletifime tetra. tum, ferrugineun.

IN I. fimplex membranaceum, validum, extus xquabile, e bafi nucis oriundum \& intus fungofo-carnofum, intra cotyledonum plicas \& rugas adfcendens ita, ut intricatifime cum cotyledonibus oommixtum \& folo colore ferrugineo fit-difcernendum.

ALB. nullum; nifi integumenti proceffus fpongiofo-carnofos \& Eum cotyledonibus marmoreo-commixtos velis.

EM в. Semini conformis, bafi umbilicatus, craffus, inverfus, albus. CotyL maximx, carnolx, foliace:e, intricatifine chryfaloideo-contortuplicatx, ad radiculic infertionem filfre, xquales. Plum. fimplex, minim., conica, diphylla. Rad. brevis, cratia, tereti-oblonga, e cotyledonum vertice oriunda $\hat{\alpha}$ iutra ipfas recondita ita, ut vix apice obtufo pronineat, fapera.

\section{EXPLICATIO FIGURE.} 1.) Frudus integer. h.) Calyx iavoluerans medin transverfe sbseitius, eam muce in litu. . Ejo integumento detradto. F.) Ejusdern transverle dityledonis alterz pars fuperior cerm rugit atgue guxenti jotermixtionem repreientans. G.) Cotyledonis altera pars fupula.

Dipterocarpus turbinatus. Tab. 188. fig. 1.

Shorea trinervea. Collect. Banks. Shorea trinervea. Collect. Banks
Calyz ellipticus 1. pyramidatus, furfum attenuatus, turbinatus, ad limbum
rurfum ampliatus; limbo quinquefido, laciniis duabus longilinis, alatis, reticulato - nervolis, tribus reliquis, quarum una oppofita, minimis ov:tis (a.). Nux a calyce involucrata, ovata, coriacea, long: mucronata, tomentofa, fongitudinaliter octo fulcata: fulcis ad bafin protundior:bus exa(b) Semen unicum, tetragonum (") bafi nucis affixum (c.).

Shorea, Dryobalanops \& Dipterocarpus, ob fimilem habitum utut fibi proxine affinia, diltinctilina tamen a fe invicem fiftunt genera. Caryolobis Carpo!. Vol. 1. p. 215. t. 45. quoad labricam ferninis internan ad hace proxime accedit, quamvis calyce nucea involucrante alato orbata fit; fed fructus ibi mihi videtur effe mancus. Dipterocarpus defectu columnx centralis incraffatx aliquantum a reliquis generibus recedit, $\int^{2}$ ipf competic analoga integumenti fabrica, hoc cnim bafi craffifimum, hinc fundo mucis adnatum, inde cabryouis unbilico torulofo inmerfum eft, \& ibi in laminas, iutra cotyledoun plicas î convolutiones adlcendentes, divifum; columna igitur centralis inter characteres hujus tribus familiares referri debet. His nornifi hucusque cognitis ftirpibus fingulare hoc integumenti adilitamentum proprium eft, ab omnibus fructuum partibus effentialibus diverium; materie quidem \& confiftentia receptaculorum fpeciem præ fe fert, inter germinationem autem, fruetibus adhuc in arbore hxrentibus jam inchoantem, albuminis vices gerere videtur.

Habitum, quod attinet, fructuum externum, cotyledonum convolutiones \& radiculam fuperum generum modo recenfitorum, ad Acera accedunt, in reliquis vero partibus ab illis aliena videntur; alii itaque, quibus occafio eft, omnes fructificationis partes videndi, locum fuum in ordinibus plantarum adjudicent. 


\section{Dryobalanops aromatica.}
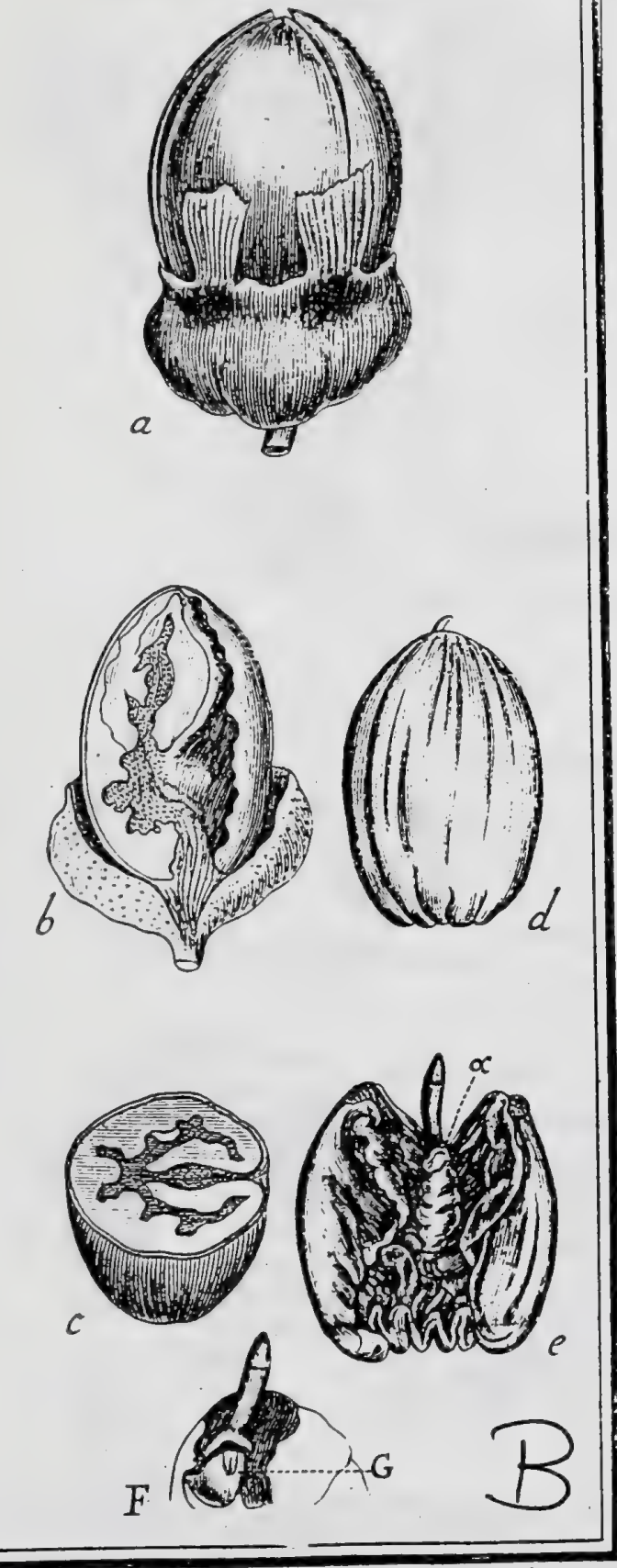

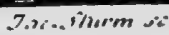

\section{D R Y B A L A NOPS.}

Cal. monophyllus, inferus, cupulatus, rotundato-gibbus; limbo in alas quinque folinceas ligulatas remotas erectas rigidas nervofas ad apicem dilatatas obcufitimas divifo. Cor. . . Stam. . . O Ovar. fuperum. Capl. ovata, cupulx calycina incrallatz immerfa, unilocularis, trivalvis. Sem. unicum. Cotyl. chryfaloideo - contortuplicatz, impares. Rad. fupera.

DRYOBAlanoys aromatica. Tab. 186: fig. 2.

Habitat in Zeylona. E collectione Bankfiana.

PER. Capfula fupera, ovata, lignofo-fibrofa, a calyce incraffato cupulato rotundato-gibbo excepta, unilocularis, trivalvis. Valva sequales, craffiufculx, extus glabrx, intus nervofo - Itriatx, hinc acuninatx, inde truncatx \& ungue acuto calyci paulo fupra medium infercx.

Rec. nullum; femen mediante integumento \& columna centrali fundo cupula calycinx aduatum.

SRM. unicum, grande, cavitati capfulx figura fua exacte refpondens, ovata oblongum, ftriatum, vertice acuminatum, bafi truncatum \& torofo-umbilicatum, ventre fulcatum, rufefceus.

IN T. fimplex, membranaceum, tenue, extus xquabile, ad fulcum ventralem ferninis intro flexum, \& cum columna centrali colliquefcens. Columna centralis e fundo cupula calycina oriunda, \& per totum feminis axem verticem usque adfcendens, mollis, fungofo xarnofa, comprelta, hinc cum integumento externo connata $\&$ femeu verticaliter in duos lobos dorfo connatos dividens, inde aucta lobis longitudinalibus mollibus columnà brevioribus, intra cotyledonum plicas fefe demergentibus: duobus majoribus lateralibus ad ventrem recurvis: duobus minoribus dorlalibus cirra axem productis divergentibus.

$A$ L B. nullum.

EM B. dicutyledoneus, femini conformis, inverfus, lacteus. Coty $L$ amygdalinocarnolx, cralfiufculx, chry ${ }^{2}$ loideo-contortuplicatx, impares; Altera externs maxima, totsn feminis luperficiem externam conftituens, extus oblolete fulcato - friata \& rinis aliquot longitudinalibus incifa, intus plicis prom fundis rotundatis \& rina ampla longitudinali excavata, ad verticem acu.

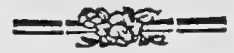

minata \& dorfum verfus usque ad radiculx infertionem profunde fiffa, bafi torofo - umbilicata \& marginibus ventralibus introrfum Bexa; Altera interna minor, auriculæformis, fulcis obliquis fubcochleata. Plnis. fimplex, conica, diphylla. Rad. longa, e fupremo embryonis dorfo, ubi cotyledones iuter fe conferruminatz funt, \& ex angulo fiffurx cotyledonis majoris oriunda, furfum directa, in fulco cotyledonis externx abscondita, ad fcapum angulata, cxterum teretiufcula, apice conico obtufulf culo terminata, adfcendens, fupera.

\section{EXPIICATIO FIGUR F}

a.) Frultus integer, eum amputatis laeiniis calycinis, b.) Semen, cum cupula calycinz \& ca lumna centrali fuperae bifida vertiealiter feđum, excuGis capfula valvis, relieto circulo infertionis intra cupulam. c) Idem transverfe diffectum, cum columna centrali ejusque lobis lateralibus \& dorfalibus d.) Embryo a latere (petatus cum radiculs spice prominula. c.) Idem a parte veatrali vifus limbo introflexo divaricato, ut \& $\alpha$.) Cotyledon interna vifui pateat F.) Radieula e dorfo embryonis orta \& a valis nutriciis nerterebrata, \& G.) Plumula.

In hac arbore genuinum eunque pretiofffimum corticem Cinnamomi innafci perhibent.

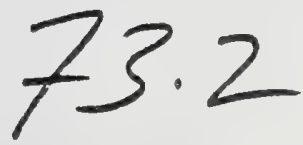


Dipterocarpaceae

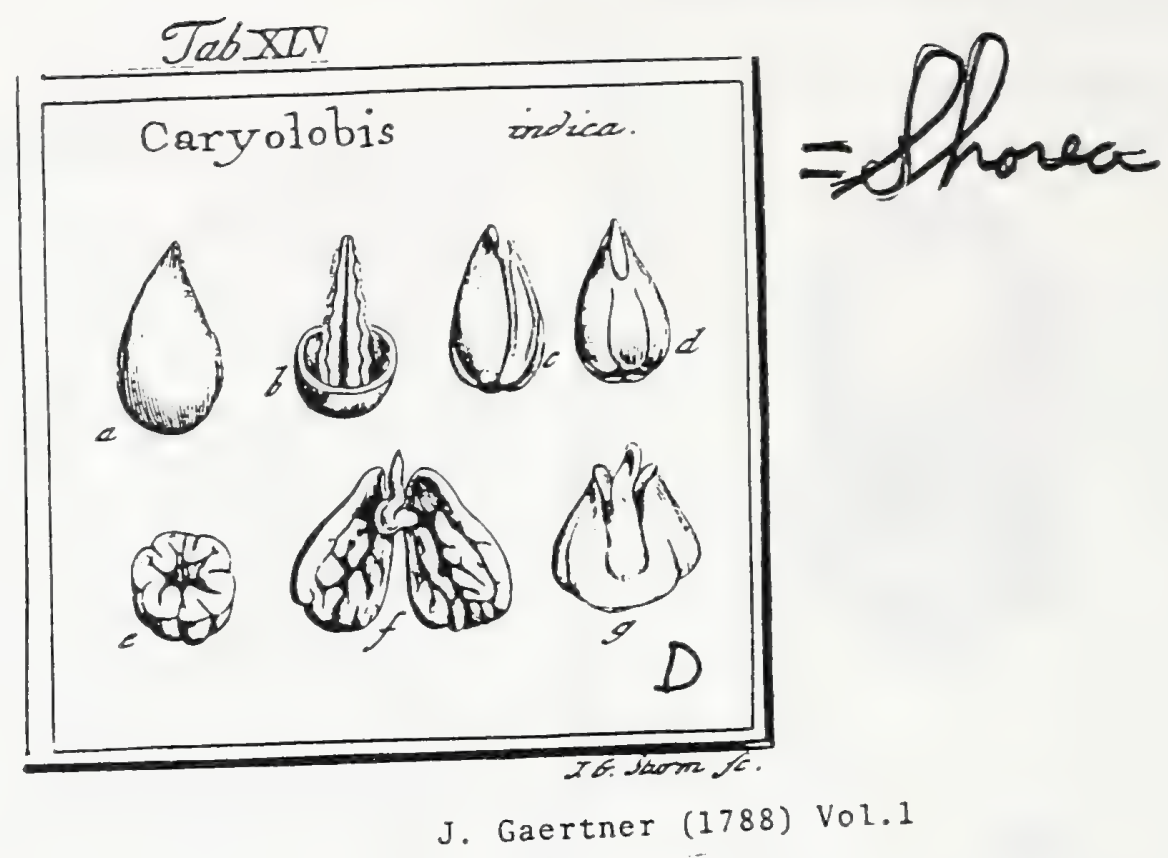

$2 i 5$

CCLXII. CARYOLOBIS.

Flos. . Bacea monofperma? Semen unicum, intus columna centrali, axem embryonis perforante, inftructum!

CARYOLOB IS indica. Tab. 45. fig. 4.

Berelie. zeylonens. E collect. fein. hort. lugdb.

PER. Bacca ovato globofa, unilucularis? (ita ex ramentis, tcfx feminis adbarentibus, conjicere licet.)

REC. nullum.

SEM. unicum, ovato acominatum, acumine paolulam obliquo, pallide fpadiceum.

INT. fumplex, tenue, membranaceum, extus xquabile, intus variis proceffibus intra cotyledonum rimas alte demerfis auctum, \& e bafi fua columnam promens centralem, fuberofo carnofan, totum embryonis axem perforantem, fuisque proceffibus lateralibus mollibus, intra iffius plicas fele demerzentem.

$\Lambda_{L}$ B. nullum, nifi columne centralis proceffus velis gelatinofo carnofos.

E s в. magnitudine feniuis, inverlus, albus. Cotyl. dux, amygdalino-carnofz, crafix, extus rimis longitudinalibus incif $x$, intus plicatn-rugolx \& ampla cavirate longitudinaii excavatio. Fad. llexuofia, e fupremo cmbryosys dorfo, ubs coryledones inter fe coulerruminatz luut, oriunds, furfuma directa.

Ejus integamentum transverfe feAum, con columba centrali, embryom 2.) Semen integrom. nem perforante. c.) Eubr)

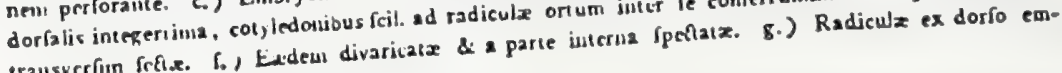
bryonis ortus.

Stupenda feninis fabrica, \& hachenus finc pari. Si cum ulla cognitarum plantarum, reurota ti cum Nianisperino alfiuitas cule videtur.

73.3 
CLXXXVI

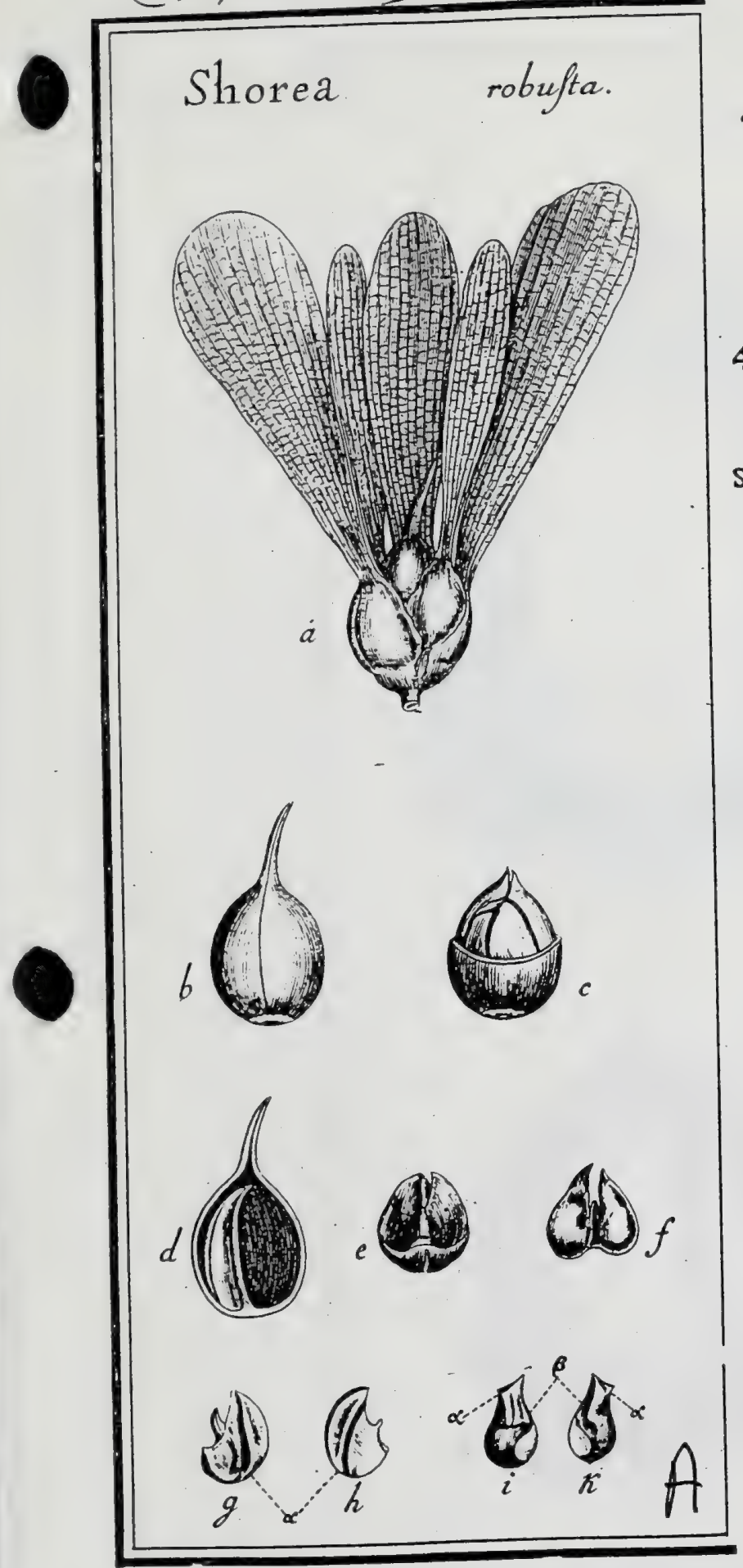

J. Gaertner (1788) vui. 3

47

\section{SHORE A. ROXB.}

Cal. inferus, pentiphyllus, imbricatus: foliolis fquamiformibus, per maturitatem ovario arcte adpreftis, bafi gibbis, dorfo incraffatis, margine fcario fis, ad ovarii apicen anguftatis, \& inde in ligulas fenfim la:iores lougas foliaceas lineari - nervolas apice rotundatas productis. Cor. . . . Stam. . .

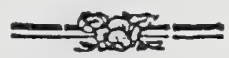

Ovar. fuperum; ftylo unico, perfiftente. Nux coriacea, roltrata, bivalvis.

Sem. unicum. Alb. nullum. Emb. inverfus, cotyledonibus bilobis.

SHOREA robufta. Tab. 186. fig. I.

E collectione Cel. Lambert, Vice-Presid. Soc. Linn. Lond.

PER. Nur fupers, a calycis fquamis imbricatis ad apicem conniventibus arcle inclufa, ut apice tantum roftellato vifui fit aperta, ovaro-globofa, albidopubefcens, coriacea, bali derafa, vertice in muctonem roltellatum dimidiam nucis partem æquantem curvulum producta, intus rufefcens, unilocularis, bivalvis.

REc. nullum, femen cum integumento per columnam centralem baí nucis adratum.

SE ג. unicun, totam qucis cavitatem replens, ovato-3cuminatum, rufefcens.

IN T. fimplex, membranaceum, tenue, extus xquabile; intus membranà a dyplicatura integumenti ortà falcatà auctum, e bafí fua craffiore columnulam promens centralen rotundatam in adverfo latere paulo fub vertice ad radiculan terminatam, ficcitate fibrofan, totam enbryonis axem perforantem.

A L B. nullum.

E M B. magnitudine feminis, dicotyledoneus, inverfus, albus. Cotyl. crafix, amygdalino-carnof $x$, pedunculat $x$, oblique fibi incumbentes, profundiffime bilobx, impares. Cotyledon altera major inferior, hinc convexa, bafi ab introitu radicis colunux centralis umbilicata; inde oblique truncata, impreifionibus concavis pro recipiendis protuberantiis cotyledonis fuperioris notata, usque ad radiculx fcapum xqualiter fiffa: lobis latere. interno inpreffione, ex foveola bafilari orta, canaliculata rectiufcula longitadinali notatis. Cotyledon altera fuperior minor, inferiori oblique infidens, hinc cum embryonis fuperficie externa contigua, acuminata; inde protuberantiis rotundatis margine externo acuto circumfcriptis convexiufcula, xqualiter per axem bifida, inter lobos fulco incurvo pro recipienda radicula exfculpta. Rad. craffiufcula, longa, conica, angulata, fere e centro embryonis, fed dorfo cotyledonis, fuperioris paulo propior oriunda, \& inter thujus lobos recordita, curvula, afcendeus, fupera.

\section{EXPLICATIO FIGURE.}

a.) Fruetus integer. b.) Niux a calyce Teparata. c.) Eadem medio transverle feda, cum femine in fitu naturali, d.) Eadem longitudinalites fifia, com columna centrali embryoncm perforame \& integumenti parte cum columna conata $\&$ coryledones verticaliter bipartiente. c.) Cotyledon major infera, a dorfo fpetata cum parte majore radicula. f.) Cotyledon (uperior a parte interna ventrali fpecata, cum postioue minore radicula. g. \& h.) Lobi cotyledonis inferioris all fcapum radiculz dilacerate. i. \& k.) Lobi cotgledonis fuperioris a fe invicem

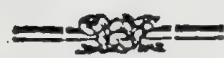

feparati \& ab icterna parte fpectati. $\alpha_{*} \varkappa_{*} \varkappa_{.}$) Decurfuc fulci verticalis pro recipieada columna centrali. B.) Fuveola \& fulcus pro radicula.

Ii, quibus occasio data eft, recentem videndi fructun, in cotyledonum cum radicula nexum denuo inquirant; in noftro enim fpecimine radicula videtur effe nanca \& pars ejus fuprema ablata.

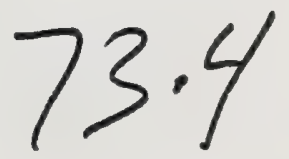


Dipterocarpaceae

$\tau_{a b}$. CLXXXIX.

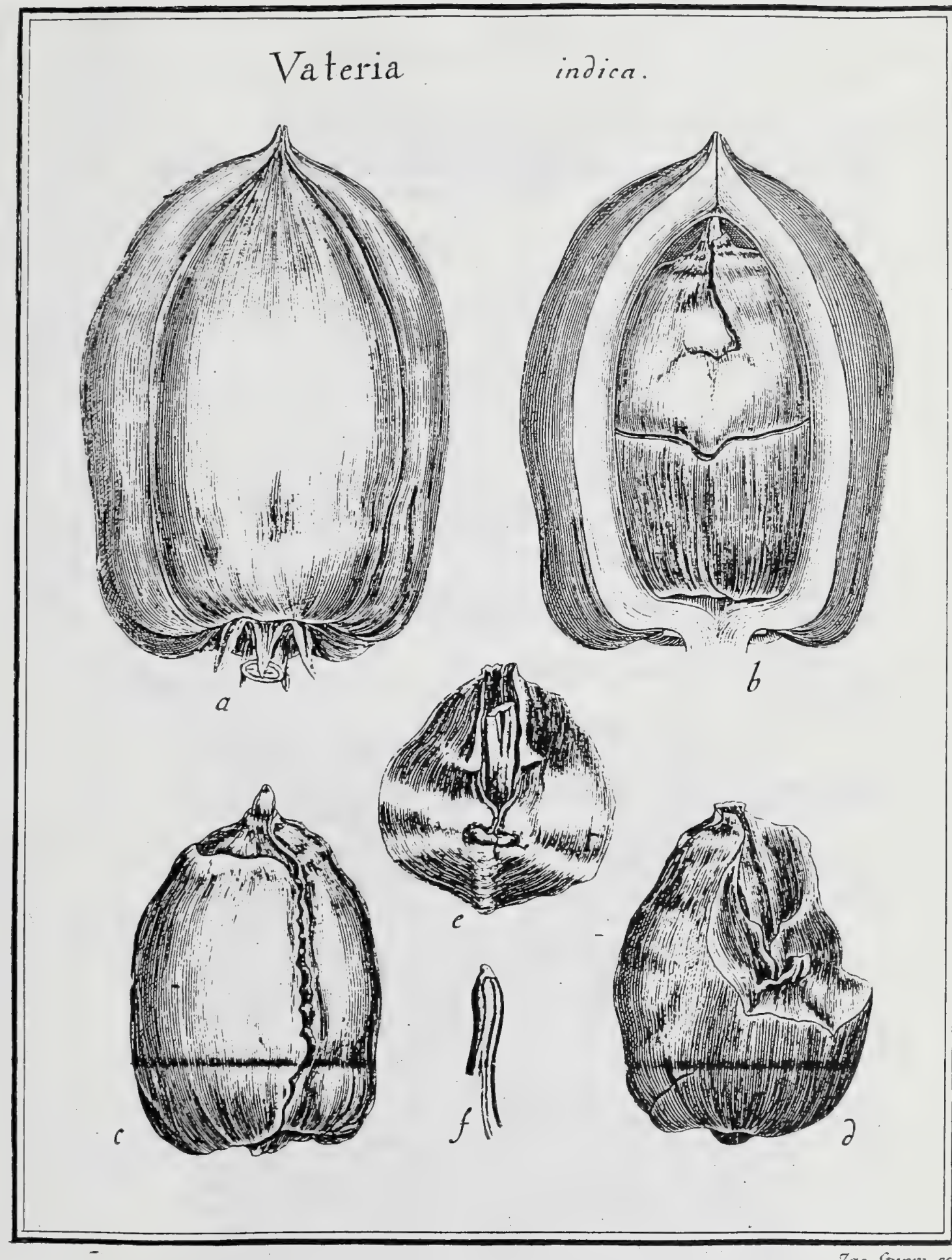

$73.5 A$ 


\section{J. Gaertner (1788) Vol3}

53.

48. VA T ERIA.

LIN gen. 666. ed. Schreb. 906. Juss. gen. p. 258.

Cal. quinquefidus, inferus; laciniis lanceolatis acutis perfiftentibus. Cor. pentapetala: petalis ovatis, obtufiufculis, calycem fuperantibus, patentibus. pump fefilibus, fubulatis. Ovar. fuperum, ftylo fimplici \& ftignate capitato infructum. Capl. fubpyramidata, coriacea, rotundato-trigona, unioculatis, ribus, petiolatis; radicula fupera.

VATERIA indica. Tab. 189.

Paenu. RHeED. bort. mal. 4. 2. 33. t. 15.

Eleocarpris (copalliferus, ) foliis integris. RETZ. obf. 4. p. 27.

Elaocarpus foliis integervimis, panicula terminali. VAHL. fymb. bot. 3. p. 67.

WiLld. Spec. pl. T. 2. p. 1170 .

Vateria (indica.) Luns. jpec. pl. p. 734. Syf. vete. ed. 14 p. 494.

E collectione Cel. Brugnanns, Profess. hift, nat. Lugd. Bat.

PRR. Capfula grandiufcula, fpongiofo-coriaces, fub-pyramidata, furfum allguftata, mucronata, rotundato - trigona, fulcis profundis ad valvularum futuras infculpta, ad partem inferiorem torofa, bafi truncata, umbilicata, pedunculo infiftens valido calyce profundifime quinquefdo refilis, veftito, pulvinata, atropurpurea, unilocularis, trivalvis. Valva crallic, protuberanuis ortis infignita, rufelcentes.

REC. nullum.

SEM. unicun, grande, cavitati capfulx figura fua exade refpondens, ovato, protuberantiis convexiufculis nozatun, in. vertice obrufe mucronatum, rufun

INT. Gimplex, membranaceum, validum.

ALB. nullum.

\section{4}

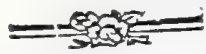

EN B. dicotyledoneus, maximus, femini conformis, in vertice area lata oblcura

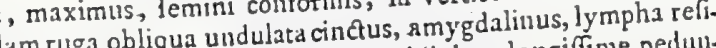

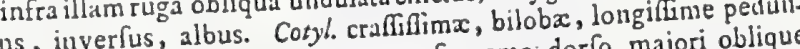
nofa ratens, mverfus, cularx, impares. Cotyledon altera minor e fupren terminata, fcuiformis, infiftens \& in nedio embryonis dorfo transver terbicum acutum undulata; quadrante totius embryonis vix minor, per ambitum acutuminente roexterne convexa \& in media ejus convexitate tuberculo prominertice ad exudato noluunquam in nafi formam protracto notata, fifura a inxuliter cuberculum usque defcendente in duos lobos divila; interne fulco profundo convexa, fulcis transverfis elevatis infcripts, a vertice fia convexitate longitudinali in medio fundum petente exarata, \& in media colicula cotyforamine oblongo cum fulco contuente pro exitu pedax priorem magnituditie ledonis majoris inftrueta. . Cotyledon altera major, quax pris totum ejus latus fere plus triplo fuperat, \& a fummo vertice embryonis to bafin obtufifiventrale bafin \& dimidiun latus dorfale complet, inli notata eft, ad apimam rorofo-umbilicatam tuberculo prominente mxquali notacera cotyledone cem vero in roftrum brevifimum fenicirculare actur ;inc inxqualiter conorifciun pro radicula exitu integrans producitur; hinc is fulco rotundato vertice ad bafin usque lateris ventralis futco rotundato vexa, a \& rina profundifina ufque ad bafin lateris oppofit perting fub ju duos lobos aquales fif́a, (lobis nonunquam fifura ilam majorem fusque angulo recto fcindente iterum bifidis); inde autem a vecuflati, inxqualiter dorfum vel oblique vel fub angulo obtufo undulatim decusan plica transverconcava, impreffionibus atque eminentis rotundatis infcripta \& alteram cofali ab utroque latere in centro embryonis contuente inforis minoris canalem tyledonem excipiens, fulco longitudinali cunn ilo cotylo ipfo prope embryonis pro radicula exitu efficiente exarata, \& in angulo ipfo prope en incurvum centrum radiculix pedunculum canaliculatum undulate radicarum in duos gerens. Plum. fimplex, conica, scuminata, canaliculatos \& ad infertionem pedunculos cotyledoneos compreflos externe canaliculedonum canalen indivaricatos filta, longa, compreffiulcula, intra cotyla, in axi embryonis clufs, \& vix apice

adfendens, fupera.

\section{Dipterocarpaceae}

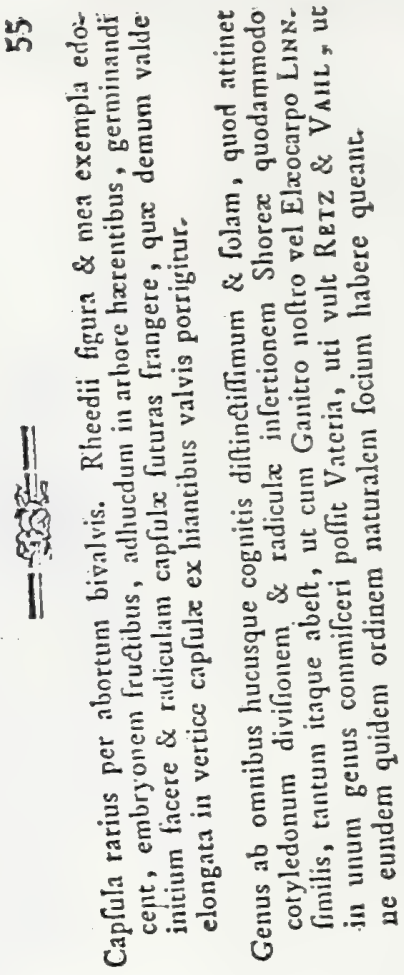

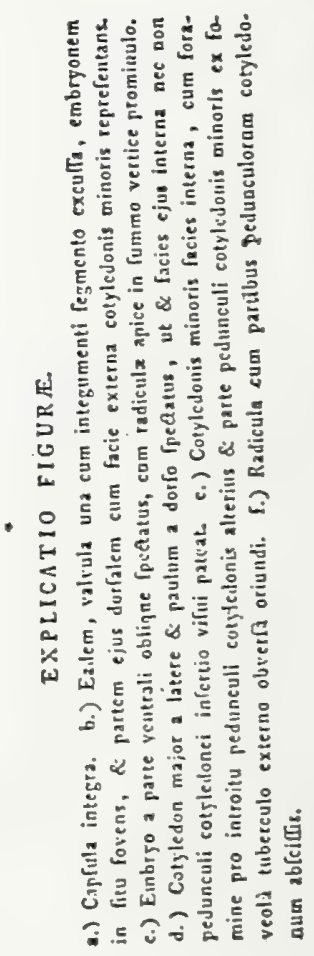

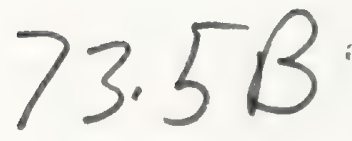




\section{Droseraceae}

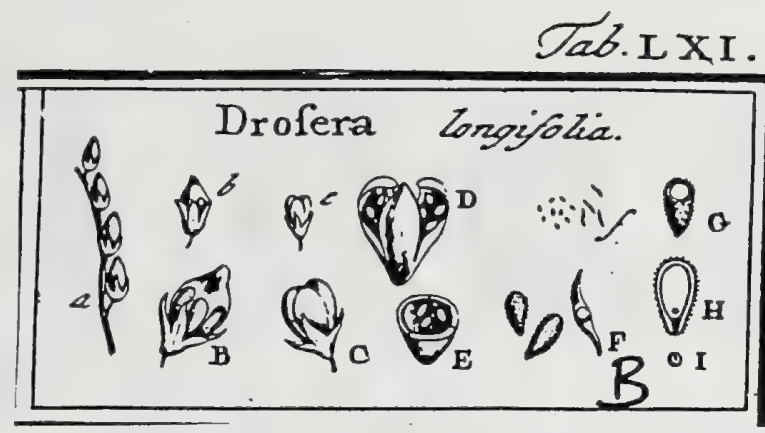

J. Gaertner (1788) Vol. 1

\section{1}

CCCLXVIII. DROSERA. I. IN Ren. 3gt.

Calyæa quinquepartitus. Cor. pentapetala. Stam. quinque. Sty. quinque. Capfula uiilocularis. Somitia parietalia.

Drost: a A longifolia. Tab. 61. fig. 2.

hos fulis. Dod. pempt. 474 .

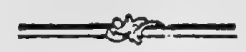

Rorella foliis ellipticis, caule nudo paucifloro. H a I L. hif. r. n. 833 .

Drofern fcapis radicatis, foliis ovali oblongis. LIN N. Jyfl. veg. 304 .

PE R. Capfula ovata aut turbinata, corollit in calyptram exarefcente veflita, unilocula. ris, ab apice ad medium usque in valvulas tres, quatuor, 1. quinque delifeens, inferius integerrima.

REC. nulluin; femina omni valvularum parieti interno aftixa.

SEM. numerofifima, parva. aute maturitatem feobiformia, deinceps ovato oblonga, verlus umbilicum attenuata, undique nuinutiflimis apicibus fcabrata, fufca, aut fordide cinerea.

IN T. duplex: extcrius membranaceum, tenue; interius coriaceum, fufcum.

$A<$ в. fenini conforme, fed brevius, carnofum, album.

Eм в. minutiffimus, globofus, niveus, in ima parte albuminis locatus. Cotyl. breviflunx. Rad. obtufa, centrifuga,

a.) Capfula integra, b. B.) Eadem corolize caljptra tcak. " c. C.) Fadem denudata, D.) Eadem in tres valvulas dehifcens. E.) Endem transverfin feita. (. F.) Senina foluta, imsnatura atque maturs. G.) Semen maturun transverfe, \& H.) Ideun longitudinaliter fętum, cum embryone intra albumen. 1.) Embryo Separatus.

Droferx rotundifolix fructus, nihil quicquam a modo dictis differunt.

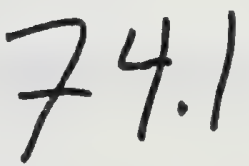


Tab. 208.

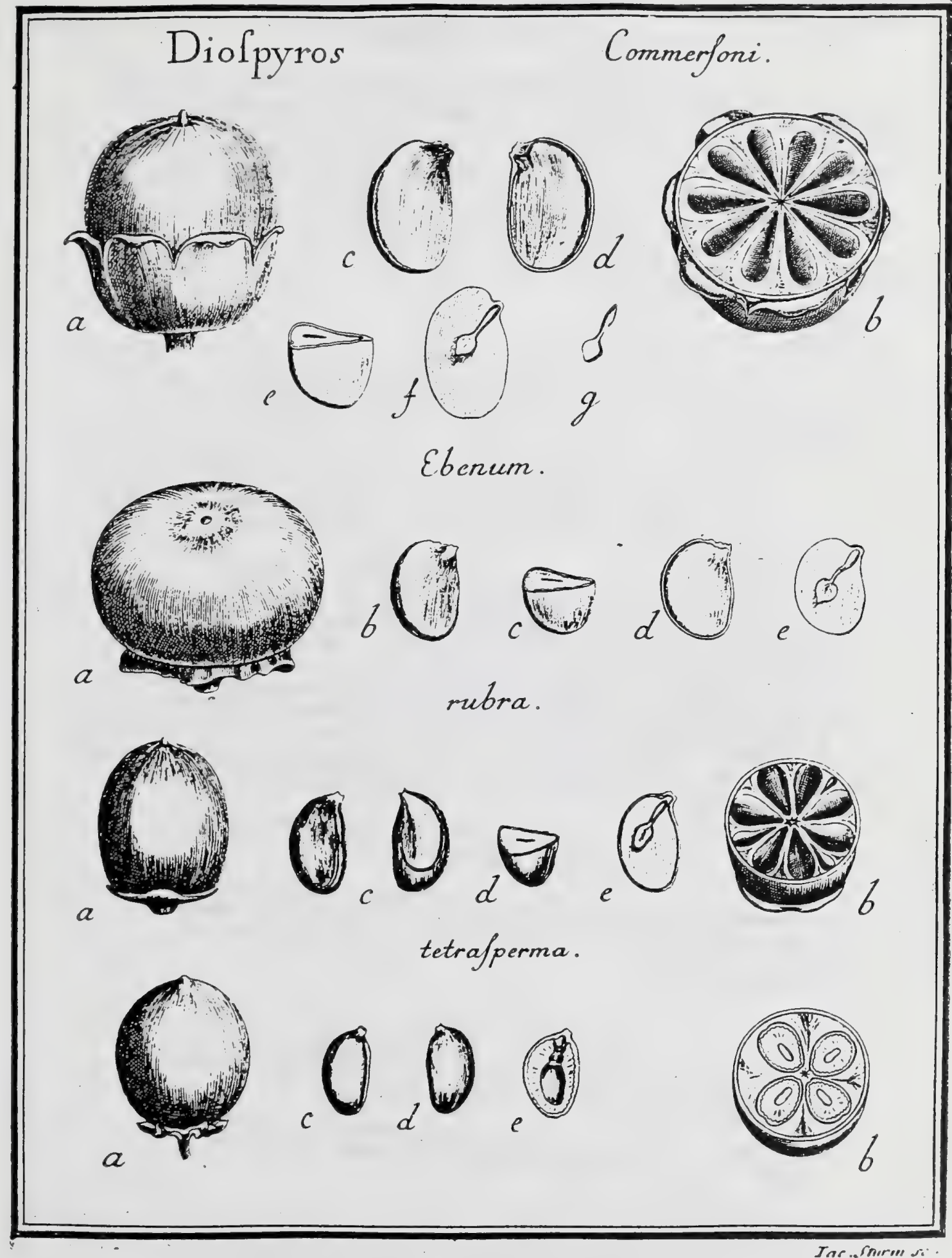

$75.1 \mathrm{~A}$ 
J. Gaertner (1788) Vol3

137

LInN. gen. II6r. ed. Schreb. 1598. Juss. gen. p. 156.

Laмавск ill. gen. 858. Guajacana. Tоив , inft.

t. $37 \mathrm{r}$.

Cal. 4- L $5-1.6$ - partitus, inferus, perfiftens. Cor. monopetala; tubus bre. vis, fundo calycis infertus; limbus $4-1.5$ - partitus, patens. Stam. 8 . 1. I6.; filamenta brevia, imo corollz tubo inferta; anthera effoetr. Ovar. uperum; Itylus 3-1. 4-fidus, ftigmata 3. L. 4., nonunquam bifida. Bacca corticata ( 4 \% 1.) $\{-1.8-1.10$ - locularis; loculamentis monofpermis, uno vel altero abortiente. Rec. O. Sem. (4. ? 1.) 5.1. 8. 1. 10. inverfa, lines depreffa per ambitum cincta, Alb. cartilagineum. Emb. inverfus, excentri,
cus, declinis.

Diosprros Commersoni. Tab. 208,

Ebenus. Commers. Ic. ined.

Bois d'olive. Collec. Sem. Muf. Parif.

Ex collectione Delefertiana. Habitat in Madagafcar.

PER. Bacca grandiufcula, ovata L. fubglobofa, paululum depreffa, muerone parvo faftigiata, ufque da medium a calyce $s-16-$ partito arce amplexata, corcicata, e lutefcenci caftanea, decemlocularis. Corter

glaber, coriaceus, fragilis. Pulpa mollis, rufefcens, a valis nutrientibus ex pedunculo derivatis percurfa. Loculamenta monofperma, membrana tenui vafculofa veftita.

REC. nullum; nifi vala, ex pedunculo in axi bacce ad verticem affurgentiz $\mathcal{E}$ in funiculos unbilicales congefts, fumas; qui funiculi dein verticem feninum adeunt, per dorfum defcendunt, \& lic per totum eorum ambitum circumferuncur, donec per ventris marginem ad verticeor reduces unbilicum intrant.

SEM. folitaria, femiovata, cuneiformi-compreffa, altero latere convexiufcula, altero plana, in fummitate anguli interni fub vertice umbilicata, inverfa, fcabriufcula, ferruginca.

Is T. duplex; exterins coriaceum, compastum, fere teftaceum, linea deprefra per totum anbitum infcriptums inserius telluiffimum, albumini pertina. ciftime adnatum.

ALB. Cemini fere conforme, ad umbilicum tefta paulo angultius mucronatum. cartilagineum, durum, lectulo enbryonem excedente exfculptum, fordide pallidum.

EM в. grandiufculus, excentricus, $a b a x i$ baccx declinis, inverfus, niveus. Corgl. ovato-cordatx, foliacex, planx, nervis levibus infcriptx, accunibentes. Kad. longa, recta, clavata, acuminata, umbilico exteruo prosima, fupera.

\section{EXPLICATIO FIGURE.}

a.) Bacea integra, a calyce fexpartito excepta. b.) Ejusdem featio tracterfalic. c.) Semea integrum, fepatatum. d.) Idem, detrada altera teftx parte. e.) Ejusdem fedio transrerf́lis. f.) Alhumin horizontali modo difectum, cum Embrgone in fisu.

Conf. Carpol. Vol. II. p. 478. t. 179. an endem fpecies? fed forma \& colore Senima aliquantum diverfa; fynonina d. c. certifime non bujus loci.

'Diospyros Ebenum. ibid.

Diofpyros Ebesusm. KоENig AE. Lsurd. V. x. P. 3. p. 176.

Dinfpyros foliis oblongis suringue glaberrimis coriaceis verofo - reticulatis, floribus axillaribus folitariis feJilibus. LINN. fuppl. p. 440. Sy.l. veg. ed. 14. T. $988^{\circ}$.

a Cl. Desfontaines.

Bacca (a.) fubglobofa, deprefla, fimulque retußa, calyci reflexo quinquedentato intiftens, glibra, corticata, dilute ferruginea, decemlocularis. Corter coria. ceus, tenuis, ficcitate fragilis. Pulpa mollis. Semina (b. c) ut in priore,

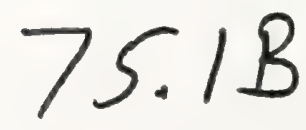


cinerafcentia. AJbumen (d. e.) cartilngineum, album. Enbryo ut in antecedente, cotyledonibus cordato-acuminatis.

Dlospyros rubra, ibid.

Bois d' Ebente rouge. Collect. Deleffert.

Bacca (a. b.) ovata, 1. ovato-oblonga, in vertice mucronulata, calyci plano cratiufculo quinquedentato infidens, corticata, glabra, lutefcens, decemlocularis. Senina (c. d.) ut in prioribus, fed magis elongata, fufca. Albumen (d. e.) cartilagineum; album. Embryo ut in prioribus, cotyledonibus ellypticis obtulis.

Diospyros tetrafperma. Tab. 20 S.

Diofpyros foliis menbranaceis cumeiformibus nitidis, baccis Seminibus quatuor. Swallz prod. p. 62. Fl. ind. occid. 2. p. 678.

Percontonoborly. Collect. Deleffert.

Bacca (a. b.) globofa, 1. ovato-globofa, apice mucronulata, calyci quinquepartito laciniis margine dentatis undulatis retexis inftructo infidens, corcicata, glabra, quadrilocularis Cutex coriaceus. Pulpa valis nutrientibus

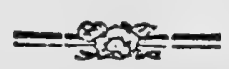

intermixta. Loculamentorum unum val duo abortire folent, relictis rimis inanibus. Sernina (c.) ovato - oblonga, rotundato - cuneiformia, ad verticem mucrolnatum umbilicata, linea depreffa circuncincts, glabra, fufca. Integ. duplex: exterius teftaceum, fragile, intus emineutiis papillaribus exasperatum; interius membranaceum, tenuifimum. Albumen (d.) ad apicen truncatum, hinc fenine paulo anguftius, lectulo embryonis maximo excavatum, radiato-ftriatun quafi fibrofum, carnofum, album. Emb. ...

Enibryopteridi fortaffe congener eft hxc fpecies; alii, quibus femina matura inlpiciendi occafio eft, dubium folvant. 


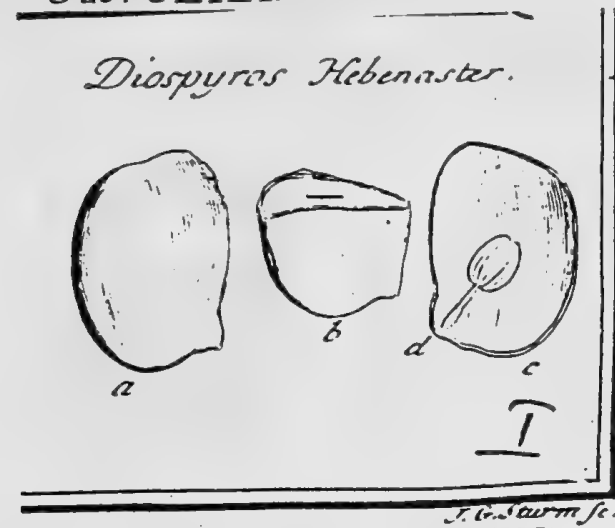

J. Gaertner (1788) Vol

478

\section{O S Y R O S. LINN. ger. II6I.}

Drospyros Hebenafter. Tab. 179. fig. 9.

Hebenafier. Rumph. amb. 4. p. s3. t.6.

Diospyros foliis oblongis rutrinque glaberrinis coriaceis venofo xeticulutis, foribu axillmibus folitariis feftilibus. LinN. Jylt. veg. 9r8"

Ebeinier du bord de da mer. A Serenif. Princ. CAROLINA Marcl. Bad.

PER. Bacea globofa, depreffiufcula, octo-1. duodecimlucularis. ( $J u(f)$ )

REC. . . . .

SEM. folitaria? in univerfum octona aut duodena, femi ovata, cuneiformiconpreffa, hinc taneu leviter convexa, inde plana, per onunem ambitum linea deprelis infcripta, ruffo - ferruginea.

IN T. fumplex, a depreffa niarginis linea quafi bivalve, pertinaciffme albumint; adnatun.

A L B. cartilagineum, durifimum, ut fere offeum, album.

Е мв. grandiufculus, niveus, inverfus? Cotyl. ellipticx, foliacex, planx; nervis longitudinalibus infcripte. Rad. fufiforni-fubulata, longa, recta, fupara?

a.) Semen integrum. b.) Idem tranverfe diffectum. c.) F.jt:sdem fcaio serticalis, eum figurt \& nugguitudine naturali Embryonis (d).

$=-3 \sec =$

Enbryonem non erectum, qualem fig. c. reprefentat, fed inverfum efle fulpicor.

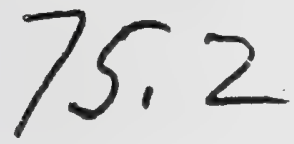




\section{Ebenaceae}
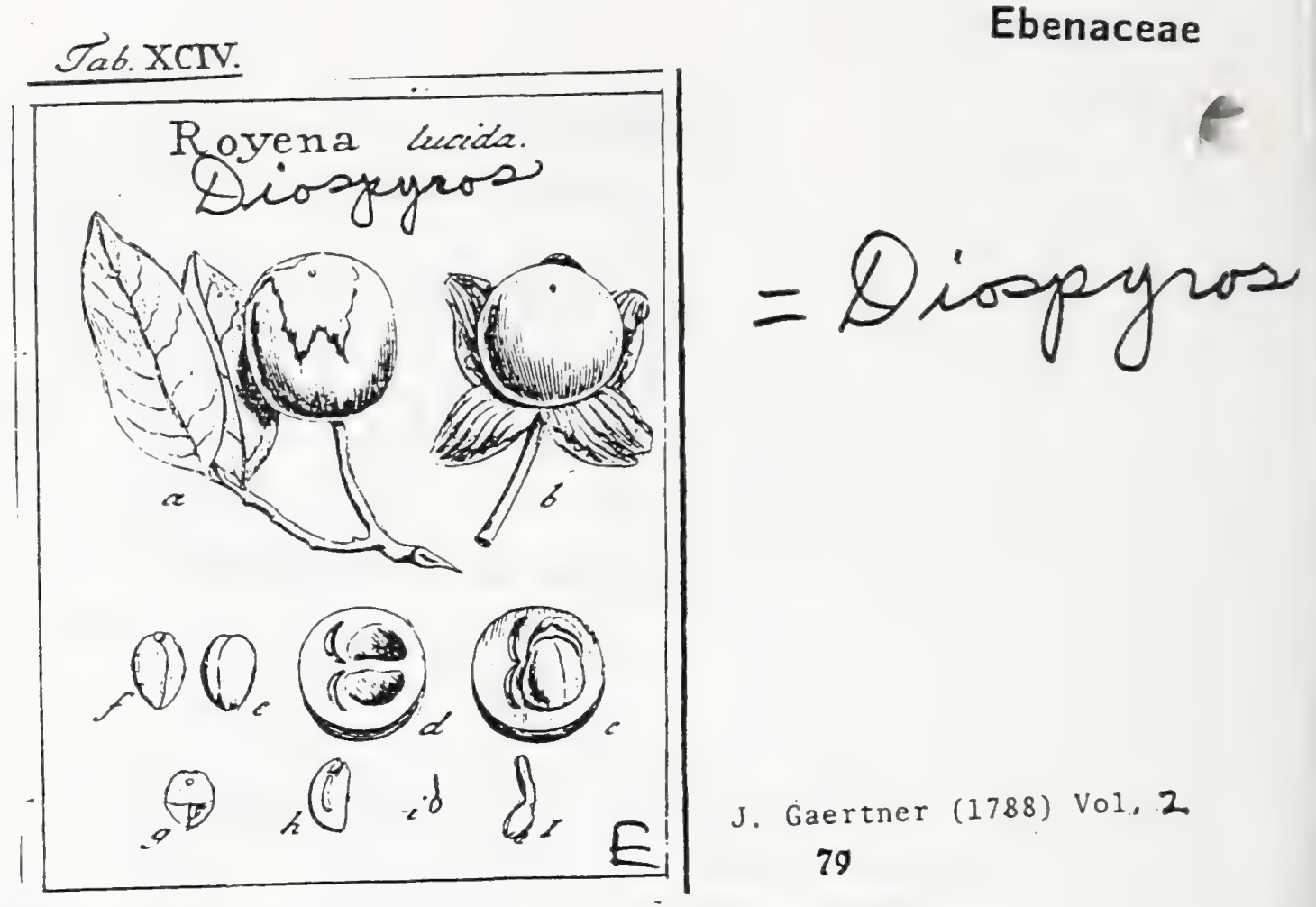

\section{ROYENA. LINN. gen, 555.}

Calyx urceolatus, quinquedentatus, perfiftens. Cor. monopetala, limbo quinquefido revoluto. Stam. decem. Ovarium fuperum globofum. Styl. duo fimplices. Liscea calyce veftitz, quadrilocularis. Sem folizaria, cartilaginez.

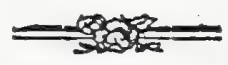

Royena lucida. Tab. 94. fig. 4 .

Staphylodendruns africanum fempervirens, foliis fplendentibus. Coms. bort. amf.x. p. 187 . 6. 96.

Stuplyylodendrum africanum folio frigulari lucido. HeRM. parad. t. 292.

Royena foliis ovatis fcabriufculis. LINN. fyjt. veg. $4 \mathrm{IO}$.

a Cl. Hermanno Prof. Argentor.

PER. Bacca calyce perfiftente coriaceo lacero \& intus ftriato veftita, carnofa, globofa, glabra, fuperne rubra, inferne pallida, quadrilocularis. Caro firma, albicans, fere ut in malis. - Loculanenta, pulpa vitreo pellucida repleta, nec ulla membrana propria veftita: duobus frepe abortientibus, compreflis, lunatis.

REC. nullum: femina gelatina involuts atque apici diffepimentoruni affixa.

SEM. folitaria, \& in univerfum quatuor, aut duo: illa oblonga, fubtriquetra; hrec, elliptica, plano-convexa, glabra, fublucida, gilva, umbilico in vertice notata, atque ex hoc ipfo ducta per dorfum atque ventrem linea depreffa infignita.

IN T. Gimplex, tenue, membranaceum, albumini pertinacifime adnatum.

AL B. femini conforme, cartilaginofum, durifimum, albun, fuperne umbilico feminis tubulofo profundiufcule perforatum.

$E_{M}$ B. longitudine dimidii albuminis, incurvus, inverfus, niveus. Cosyl. ellipticz, tenuiffmx, incumbentes, cum dorfo femiris parallele. Rad. teretiufcula, longa, fupera.

b.) Baccz integra, tedz \& denudata. c.) Eadem transverfe feAs, cun duobuc feminibus in utu naturali. d) Ejusdem loculamenta quatuor, quorum duo lunata, fterilia. e. E.) Seminis Latus dorfale atque ventrale, utrumque ftria longitudinali infcriptum. g.) Abumen transverfe fectum. h.) Ejusdem fectio longitudinalis, cum umbilici fiftula atque embryonis atu, i. I.) Embryo feparatus.

Commelini figura fructus id inprimis peccat, quod baccam reprafentet nimis parvam atque apice inftructam; fed femina quaterna recte fe habent. Pellicula propria, quam feminibus tribuit, nihil aliud effe poteft, quana exficcata loculamentorum gelatina. Linnxi defcriptio fructus, ad iftam figuram concinnata, tota erronea eft. 
Tab. 207

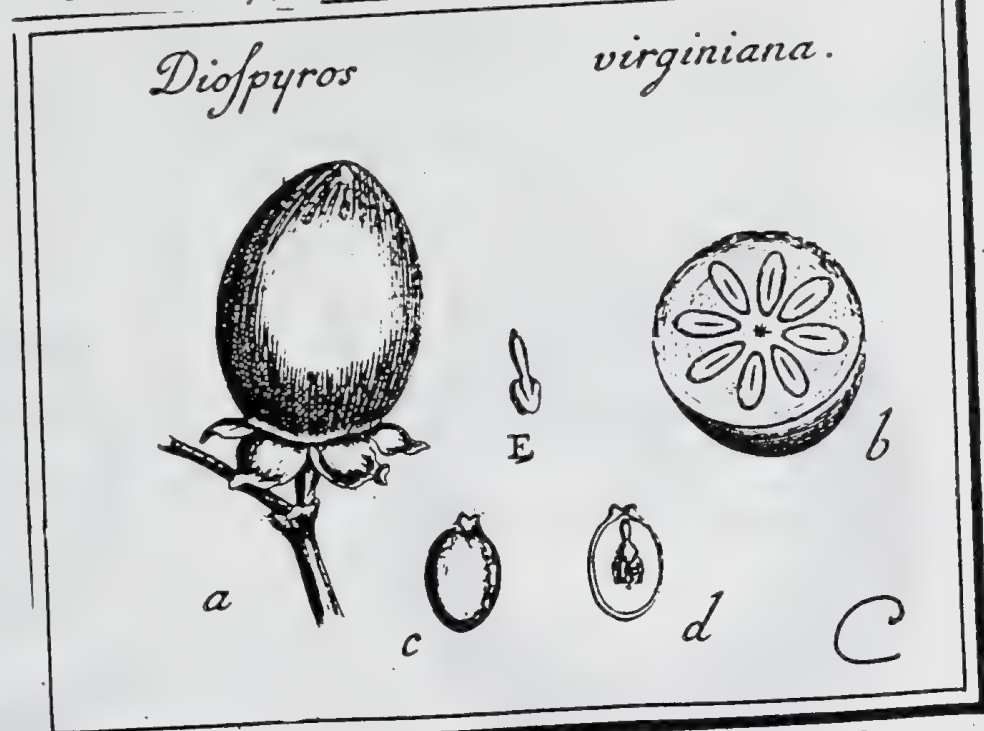

Tar.fromen $x$

J. Gaertner (1788) +01. 3

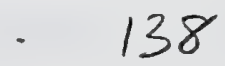

Drospyros virginiana. Tab. 207 . fig. 3.

Guajacana loto arbori afunis virginiana Piflamia diffa. PLUKN, alm. 280. t. 244. f. 5 .

Gujacana. Catess. car. =. p. $76 . t .76$.

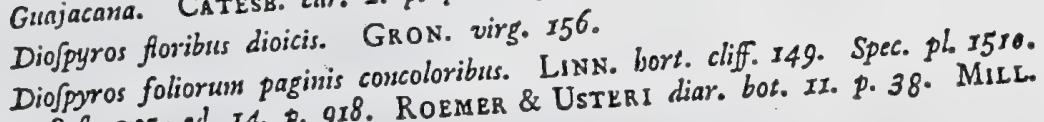
Syj. veg. ed. 14. p. 918. Roemer \& Usteri diar. bot. II. p. 38. MiLl. ic. t. 126 .

Diofpyros foliis longe petiolatis, oblongo-ovalibus, acuminatis, Jubtus pubentio biss. Mich. flor. bor. amer. 2. p. 258 .

Ex dono amiciffimi $D^{\text {ai }}$ Dupuis.

Bacca (a. b.) orata, in vertice mucrone parvo inftructa, bafi calyce quadrifido veftita, carnofa, glabra, ockolocularis. Caro firma, epidermide tenui veftita. Semina (c.) ovata, lenticulari - compreffa, livida. Albumen (d.) ad verticem femine paulo anguftius, lectulo lato pro emb. Embryo (E.) inverfus, fum, durum, 1. fubcartilagineum, fordide palidatx, obcufx, nervo valido

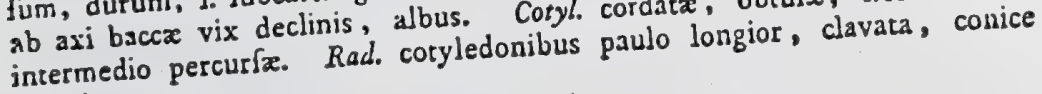
acuminata.

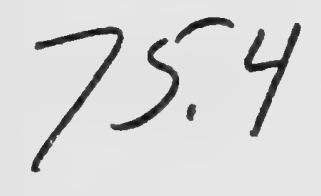




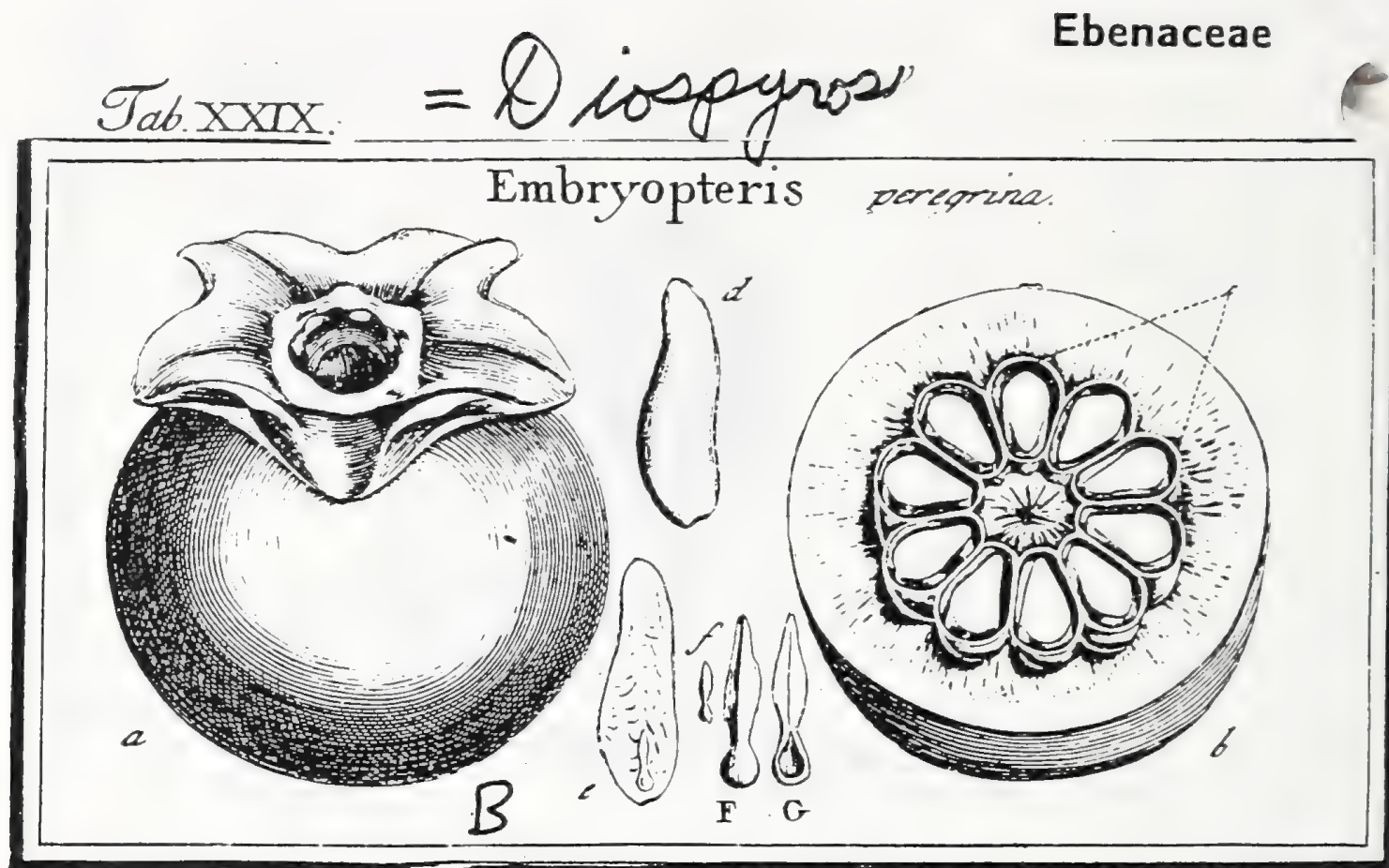

T. G. Stum fo

J. Gaertner (1788) Vol.1

\section{EMBRŸOPTERIS.}

Calyx fupcrus, monophyllus, fuberofo coriaceus, plicato fentagonus, maximus. Cor.... Stam.... Styl.... Bacca infera, fphsrics, umbilicata, corticata, tuilo-
cularis, decafperina.

EMBRYOPTERIS percgrima. Tab. 29. fig. 2.

Ex dono amiciffuni. D. BER K HF.

PER. Pacca grandiuscula, fphzrica, calyce amplo, craftifimo, integerrimo: ex plicis quinque retufis pentagono, coronata, Jata \& profunda fovea in vertice umbilicata, carnofa, corticata, unilocularis. Cortex fuberofus, craffus, durus. Caro in vetullo
frudelu fungola, rufefcens.

146

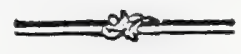

REc. nullum; femina circa axem fructus in orbem pofita, undique cum carne breat \& frpius quoque inter fe connata.

SE m. decern, oblonga, figmoideo curvata, furfun anguftiora, cuneiformi comprefta'

IN r. duplex: exterius chartaceum, ariduin, feinen in vetufto fruetu laxe ambicar, luperficie interna rubro ferruginea; interius membranaceo fpongiofum, nucieo pertinaciffune adnatum.

A Ł в. Senini conforme, e viridi palidum, carnofum, quafi ex minutifiunis fquamalin pulpofis conllatum \& fubgrumofum, verfus peripheriam folidum \& duriusculum in snedio autem molle \& $\mathrm{ab}$ aqua fere in gelatinam convertibile.

Ess. monocotyledoneus, erectus, in bafi albuminis locatus. Cotyl. lanceolata, com; prefia, folida, non fifilis. Rad. fubglobofa, lenticulari comprefla, intus capar infera.

2.) Fruftus integer. b.) Idein difuifus. c.) Integumeota feminum exteriora, chartacea, fape is. ter fe conierruminata, facile tamen folubilia. d.) Nucleus exemtus. e.) Albumen longitudimalite: retum. f.F.) Embryo integer. G.) Idem lougitudiualiter difeftus.

Sedulo inquirant, quibus datum erit fructum hunc videre recentem, nonne feminuu integumentum externum fit Arillus; \& nonne intra radicula globulum cavum verus lateat Embryo? Si poherius fucrit, uti quidem fufpicor, embryo quem dixi, Vitellus erit dicendus. 


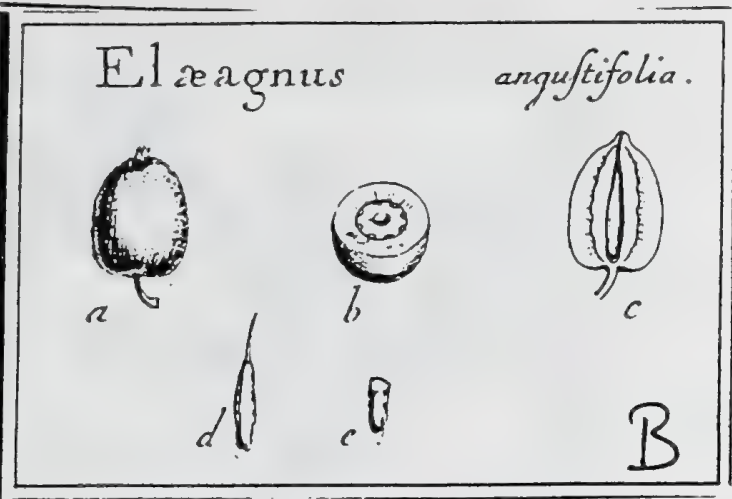

J. Gaertner (1788) Vol3

203

\section{E L A E A G U U.}

I'O UвN. inft. t. 489. LIN gen. 159. ed. Schreb. 2 I3. Juss. gen. 7). 75. LAMARCB ill. gen. t. 73 .

Cal. monophyllus, fuperus, campanulatus, quadrifidus, extus faber, intus coloratus, deciduus. Cor. nulla. Stam. quatuö; filamentis breviffimis, ad incifuram calycis infertis; antheris incumbentibus. Ovar. inferum; ttylo \& ftigmate fimplici. Drupa baccata, carne'exfucca. Putamen oblongum, uniloculare, monofpermum. Sem. oblonguri, acuminatum. Alb. caruofum. Emb. ...

Elaeagnus anguftifolia. Tab. 2 r6. fig. I.

Olea fylveftris, folio molli incano. BaUн. pin. p. 472.

Elaeagus. Cas. epit, p. 206.

Elaeggnus inermis fuliis lanceohtis. LiNw. Spec. pl. p. 776. Syft. veg. ed. 14 p. 163 . Willd. Spec. pl. T. 1. P. 1. p. 685. Persoon Jin. 1. p. 148. 160n. Du HAMEL arb. 1. t. 8g. PAllas flor. rolf. 8. to 4.

a Cl. Hermanis, def, Prof. Argent.

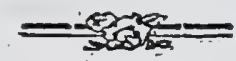

PER. Drupa femipollicaris, baccata, ovata, bafi umbilicata, pedunculo brevi infidens, in vert ce calycis reliquiis obtufe mucronata, turbinata. Cuticula tenuis, rufefcens l. ferruginea, tomento albido levi confperfa. Caro fungofa, exfucca, ficcitate fpongiofa, friabilis, putamini arcae adnata. Putamen oblungum, offeum, durum, atrofufcum, fafciis longitudinalibus remotiufculis infignitum, crafliufculum, uniloculare, evalve. Loculanientum fubulatum, Jongifimum \& ad fummum putaninis apicem pertingeus, intus membrana propria albida veftitum.

R Ec. nullum; femen bafi loculamenti affixum.

SEM. cavitatem loculamenti replens, oblongum, in nucronem longum fubu. laturn pruductum, erectum, ferrugineun.

Ixт. fimplex, membranaceum, tenue ...

A L B. femini conforme, carnofum ...

Ex B....

\section{EXPLICATIO FIGURE.}

1.) Drupz integra. b.) Eadem transverfe diteda. c.) Ejusdem fedio longitudinalis, cnm fita \& forma putamiais atque loculamenti. d.) Semen feparatum. e.) Idem transverfe feénom.

In pluribus drupis ne unicum femen maturum inveni.

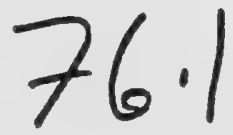




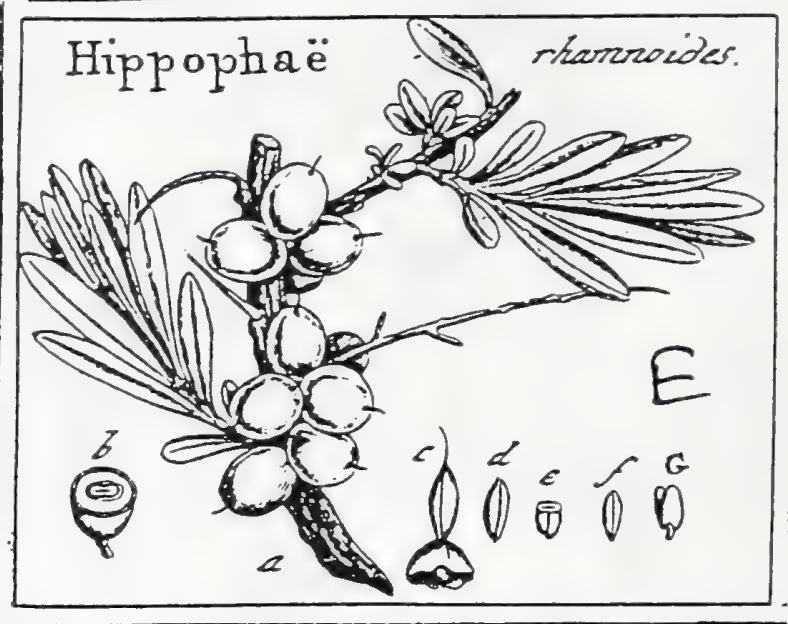

J. Gaertner (1788) Vol.1

199

CCXL. HIPPOPHAE. LiN ger. II06. Rhamnoides. TourN. t. 48 I.

Flores fexu diftincti in feparatis truncis. M A s. Cal monopbyllus, bilobus. Cor, nulla Stam. guatuor. F ĖM. Cal. monophyllus, jubulofus. Cor. nulla. Styl. unicus. Bacca fupera unilocularis. Semen durum, nitidum.

HI Р ОРна Е Rhamnoides. Tab. 42. fig. 5.

Rhamnus t. Oleafer germanicus. В А ч H. hif. I. 6. VI. p.33.

Hippophä Soliis dinearibus fubtus rubiginofis. H А L 1. hif. 2. n. 1603.

Hippophä foliis lanceolatis. LIN N. $\int y / 2 . v e g .884$

Icon OE DE R. flor. dan. t. 265. cum nylo duplici.

PER. Bacca fupera, ovato globofa, fucculeata, glabra, hinc inde punctis callolis confperfa, rubra l. crocea, unilocularis Loculamentum, inembrana propria, tenuifima, cum ftylo cobzerenti, veftitum.

REc. nullum; fenen bafi loculamenti affixum.

SEM. unicum, oblongum, deorfum attenuatum, fubcompreffum, atrinque linea longitudinali deprefla notatum, glaberrimum, atrum, lucidum.

IN T. duplex : exterius crufaceum, durum, fragile; interius mensbranaceum, fufeo ferrugineum, intus prope radiculam fubeariofum.

A в в. nullum, nifi tenuiffinam velis lanellam camóam integunenti interni.

EM B. magnitudine fere feminis, erectus, luteus. Cotyl. ovato oblongz. carnof $x$, pla no convexiusculx. Plum. minutituma, acumiusta. Rad. tereciuscula, paulun obliqua, brevis, infers.

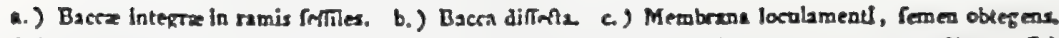
d.) Semen dmudatum, e) Ideor usasverfe fedun () Nucleusinterna membrans velirus G.) Embryo desudatus.

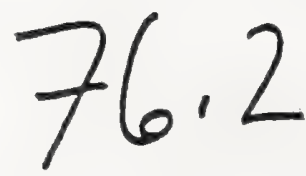




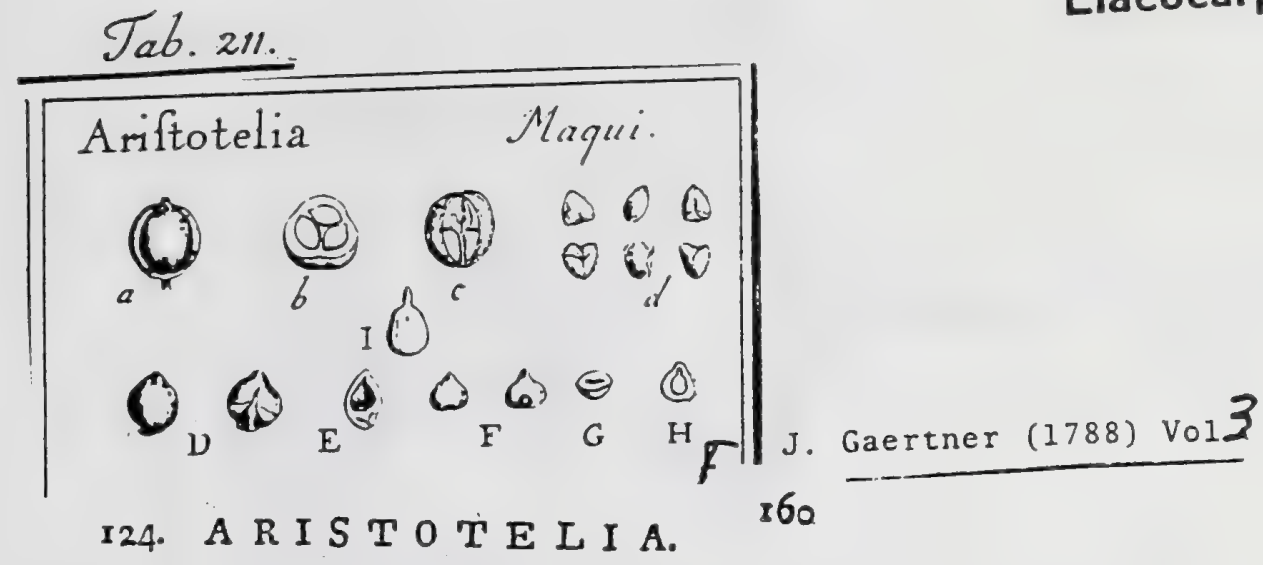

\section{L'HF.RIT. Airp. t. I6. RUIZ \& PAVon prod. t. 12. Joss. gen.} 7. 433. Sснвев. gcn. 8і6. Ladraвck ill. gen. t. -399.

Cal. monophyllus, turbinatus, $\{-16-$ fidus, inferus; lacinix lanceolate, acutz, decidux, relicto infertionis difcó. Cor. petala 5.L.6., obcordata,

cum calvcis laciniis alterna, \& eodem difco extus inferta, erecta, l. conniventin. Stani. 15. 1. 18., ad quodvis petalum tria, hinc medium ipfi oppofitum; filamenta brevia, eodem loco, quo petala, inferta; antherz eredax, oblongx, biloculares, apice poris binis dehifcentes. Ovar. fuperum; ityli $3 .$. filiformes; Atigmata fimplicia. (Stylus unicus, ftigmate tripartito L'HEkIT.) Bacca rotundato - triquetra, pulpora, trilocularis; loculamentis difuermis. Rec. centrale. Sem. fex, (uno aut pluribus plerumque abortientibus,) offea, angulata, unsbilico appendiculato inftructa. Alb. carnofum. Emb. inverfus, rai. brevi, centrifuga.

Akistotelsa Maqui. Tab. 2ri. fig. 5.

B:aumaria As:qui. Collect. Deleflert.

Arifotelin foliis ovatis ferratis, furibus racemofis. L'HER IT. flipp. 2. p. 2T. AIT. bort. kea. 2. p. 176. WWLLD. Spec. plo T. 2. P. 2. p. 85 I. PERSDON f3\%, 2. p. 10 .

Ex dono, Cl. Ventexat, \& ez Collect. Deleffert.

PER. Bacca parva, ovata, $\backslash$ l. globofa, rotundato - triquetra, fulcis tribus ob ${ }^{\circ}$ letis longitudinalibus exarata, in vertice a ftyli lapfu mucronulata, baff difco calycino xquali infidens, pulpofa, cocrulea, trilocularis. Pulpa mollis, dulcis, cuticula tenui glabra inclufa. Diffepimenta membranacea, tenuilfims, fuccis baccx obverfa \& cum membrana loculamentorum continua.

REC. in axi baccx afcendens, trigonum, cum difepimentis confertuminatum, prope centrun bacca in tres ramos brevifimos divifum, quorum papillulis fenima umbilicis adlaxrent.

SEN. in quovis loculo gemina, adeoque in tota bacca fex, quorum vero plerumque unum l. plurs abortant, incumbentia, angulata, in dorfo convexa, ad angulum internum umbilico appendiculato pallidiore infignita, ofea, centripeta, fufca.

Is T. duplex: exterius offeum, craffufculum, ad angulum internum. pro introitu vaforum umbilicalium poro inftructum, intus gdaberrimum; interius membranaceum, tenue, fpadiceum, ad bafin cbaleza orbiculari fufes infgnitum, detrahendum.

A L B. cavitatem teftx replens, obcordatum, compreffiufculum, lenticulari-convexum, carnolum, ad peripheriam dilute ferrugineum, in centro vero album.

EM B. ellipticus, albumine paulo brevior, inverfus, lacheus. Cotyl. ellipticx, foliacex, longitudinaliter undulato-plicatx; I. fulco intermedio infcripte. Rad. brevis, teretiufcula, conice acuminata, umbilico externo e diametro contraria, centrifuga.

\section{EXPLICATIO FIGURE.}

162 s.) Bacca integra. b.) Ejusdem Sectio transverfaliso c.) Eajem longitndinaliter aperta, cuon litu feminum \& receptaculi. d. D.) Semina foluta. E.) Tefta lonģituliulaliter diffeda. F.) Nucleus feparacus, ab utraque parte vifus, cum chalaza ad bafin. G.) Alhumen eransverfe Leaum. H.) Ejusilem feacio dongitudinalis, cum embryone in fitu. I.) Embryo folutus.

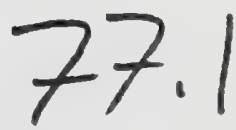

Cum Grewia affinitaţem habere, arq̧ue hita Tiliis adnumeranda effe videtur. Senina offea Ariftotelix rectius forfan pyrenx nuncupanda funt, non-obftante unbilico exlerto. 


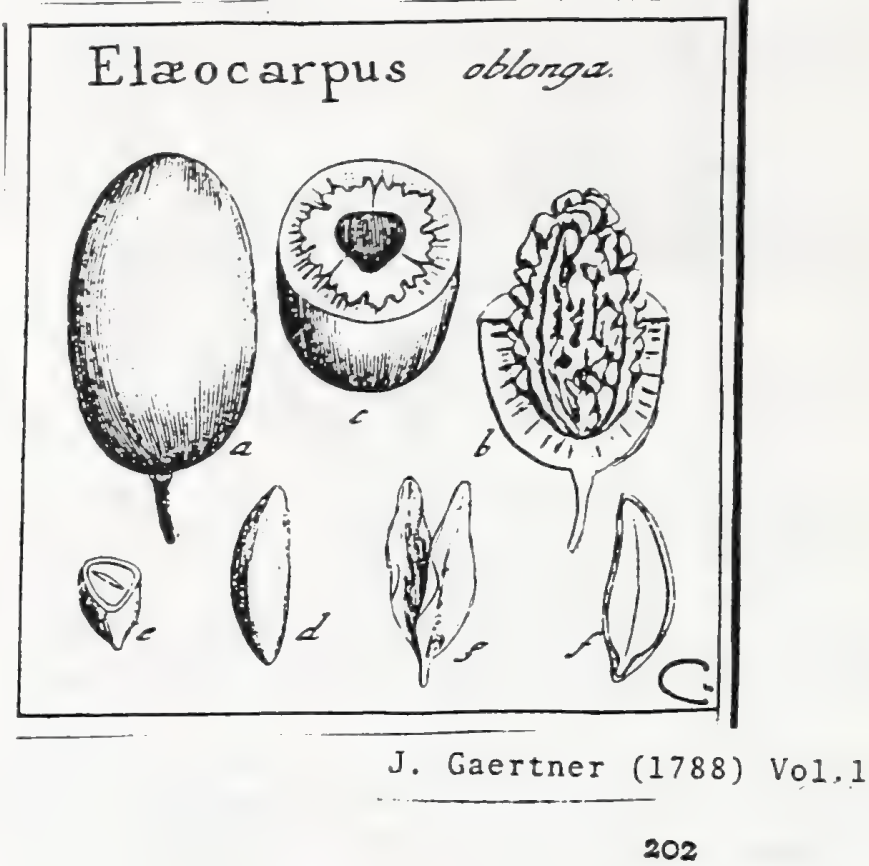

\section{ELIEOCARPUS: LINN. gen. $66_{3}$.}

Calyx pentaphyllus. Cor. pentapetala lacera. Stan, numerofa, antherarum apice bivalvi. Styl. unicus. Drupa unilocularis: putamine muricato, fubvalvato. Se. men erectum.

Eleocarpus oblonga. Tab. 43. fig. 3.

Ganitrum oblongum. Catulampa. Ruмpн. amb. 3. p. 161. t. 102. E collect. fem. hort. lugdb.

PER. Drupa baccata fupera, orato oblonga 1. fubcylindrica, glabra. Cortex carnofus: mollis. Putamen lapideum, oblongum, tuberculis irregularibus muricatum \& crifpatum, tribus futuris fpuriis, uunquan dehifcentibus, infcriptum, uniloculare, teflaceum.

REC. funiculus umbilicalis filiformis, femini adnatus, e bafi putaninis oriundus.

SEs. unicun, oblongum, utrinque attenuatum, obfolete trigonum, ferrugineuın.

INT. duplex: exterius cruftaceum, fragile, fuperficie iuxquabili \& fubfurfuracea; interius meinbranaceum, coloratum, ferrugineam.

A IB. Semini conforme, durum, fubcartilagineum, pallidum.

E s в. longitudine albuninis, erectus, niveus. Cotyl. lanceolatx, foliacex, tenuíl. mx, Jublexuofx. Rad. teretiuscula, brevifima, infera.

a.) Drupa integra. b.) Patamen denadatum. c.) Corticis \& pursminis fellio transverfalis. d) Semen feparatum, e.) Idem \& albumen transverfe fetium, f.) Aluumisis fertio longitudinalis cam Gick \& Egara embryonis, E.) Embryo folutus

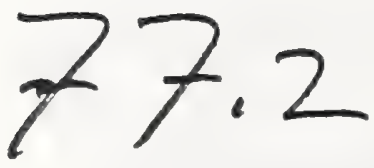


Elaeocarpaceae

Tab. CXXXIX.

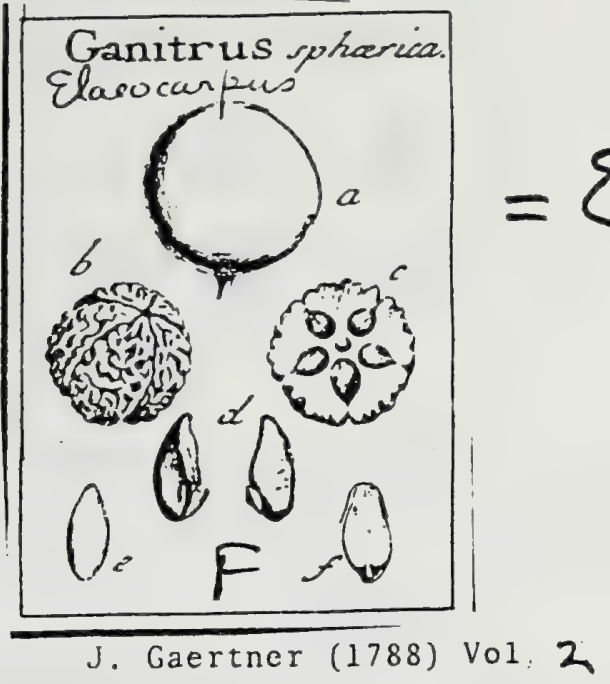

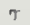

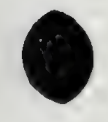

DCCCIV. G A N T R U S. RUMPH.

271

Calyx quinquepartitus. Cor. pentapetala, multifido-laciniata. Nect. glandulofum, orbiculatum. Stam. nunierofa. Ovar. fuperum, Styl. fimplex. Drupa carnofa, putanine ferupofo, quinquefulcato, quinqueloculari, evalvi. Sen., folitaria.

Ganitrus fplixica. Tab. 139. fig. 6.

Ganitrus. RUMPH. anto. 3. p. 260. t. 101.

Elcosarpus foliis luuri fervatis, floribus Jpicatis. Burns. Zeyl. 39. t. 40.

Elcocurpus folits alternis oblongis ferratis, racemis axillaribus. Lins. Jjyt. veg. 494. A Cl. Hermans. Prof. argentor.

PER. Drupa carnofa, fphxrica, fupera. Caro pauca, viridis, arenulofa (Rumph.) Putanen lipideum, crafum, fubglobofum, foveis profundis atque tuberculis irregularibus eleganter fcrupofum, fulcis quinque longitudinalibus, quafi totidem futuris, diltinctum, ad axem penitus perforatum, quinqueloculare, in quinque valvas fpurias $f$. non dehifcentes difcretum.

REC. fubftantia fpongiofa, in canali axeos pofita, per foramen proprium in bafi anguli loculamentorum centradis ad fenina pertingens, eademque fundo loculorum affigens.

SEM. folitaria, oblonga, furfum paulo attenuata, glabra, atra, juxca bafin umbilico laterali fungofo ftipata.

IN T. duplex: exterius chartaceum, tenue; interins membranaceum, lusefcens. A L в. femini conforme, amygdalino-carnofum, album.

Ем в. longicudine fere albuminis, erectus, lacteus. Cotyl. foliacez, cordatolanceolatx, tenuifimx. Rad. brevis, fubobliqua, infera.

2.) Drupa integra (ex Rumphio mutuata). b.) Putamen integrum. c.) lilem transverfe feftum. d.) Senina (eparata. e.) Albumen deaudatum f.) Illeun verticaliter diffcaum, cum fitu \& Egura embrgonis.

Hxc equidem genuina eft Eleocarpus BurM. \& LIss. quoniam vero id nominis fructui diverliflimo jam fupra Vol. I. p. 202. inditum fit, huic antiquum Ganitri nomen eo Jubentius relinyqumus, quod ipfi cum Olex fructu nulla prorfus fit fimilitudo. Perin-kara. Hort. mal. 4. t. 24. non ad Ganitrum, fed ad Elxucarpum noltram fpectare videtur, ob drupas ovales \& ofticula oblonga.

773 
:

$-$ 


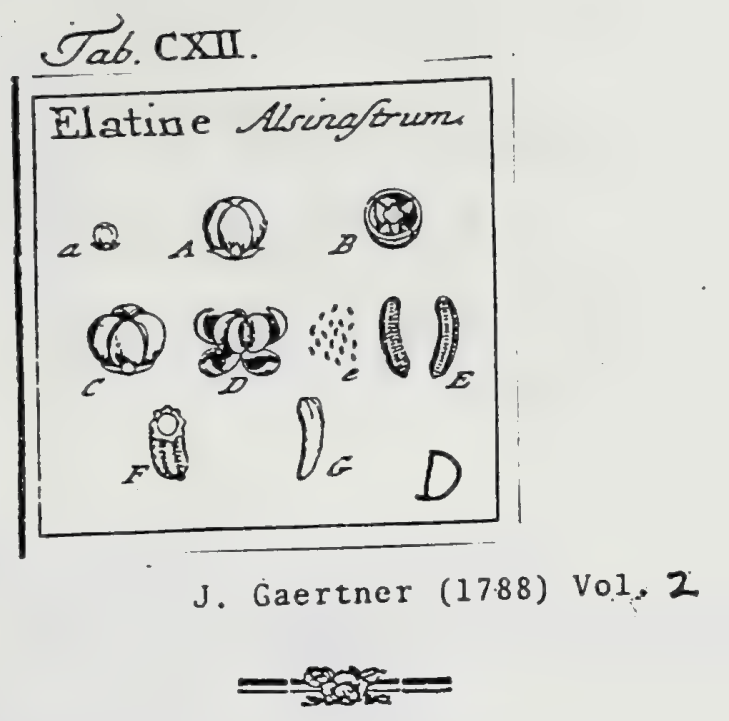

DCXIIX. E L A T I N E. LINN. gen. 502.

Calyx tetraphyllus. Cor. tetrapetala. Stam. octo. Ovar. fuperum. Styl. quatuor. Capfila quadrilocularis, quadrivalvis. Diflepimenta futuris obverfi.

Elatine Alfinuftrum. Tab. 112. fig. 4

Almafform galii folio. VaILL. paris. t. 2. f. 6 .

Elatine foliis verticillatis. LINN. Jyf. veg. $38 x$. HaLL. biff. $n .857$.

PER. Capfula globofa, parva, depreffufcula, membranacea, quadrilocularis, quadrivalvis. Dilfepimenta axi adnata \& futuris valvularum obverfi.

RE.c. axis fructus fpongiofus, angulis quntuor rotundatis intra loculamenta prominens, atque femina fibi affixa gerens.

SEM. numerofa, exigua, teretiufcula, ftriis Iongitudinalibus craffiopibus, aliisque transverfalibus multo tenuioribus egregie cancellata, curvula, cinerafcentia.

IN T. fimplex, fubcoriaceum, intus fubçarnofun.

A L B. nullum, proter fuperficiem internam integumenti.

EM B. femini conformis, incurvus, teres, lacteus. Cotyl. femicylindricx, breviffinix. Rad. longa, craffa, centripeta.

2. A.) Capfula integra. B.) Ejus (cetio transverfalis. (.) Eadem dehifecns. D.) Ejusitem valvula diduez, ut receptaculum cum diffepimentis ríte appareat. c. E.) Semina feparata. F.) Scmen transverfe feetuur. G.) Embryo derudatus.

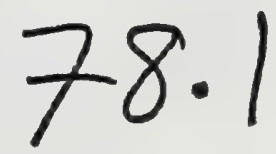




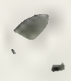




\section{Tab. CVI:}

\section{Empetraceae}

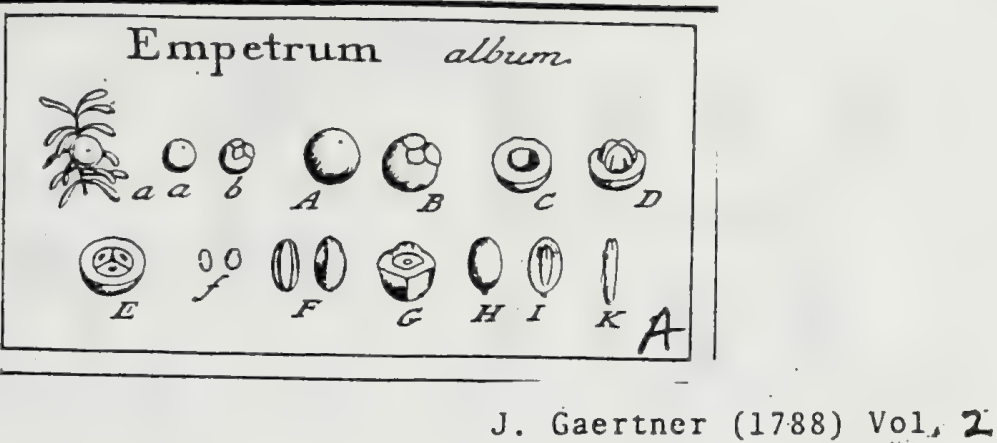

I0Y

DCXII. EMPETRUM. T OURN. injf. t. 42r. LINN. ger. IIOO.

Flores fexu diftincti in feparatis ftirpibus. MAS. Cal. tripartitus. Cor. tripetala. Srain. tria. FEM. Cal. \& Cor. ut in mare. Ovar. fuperum. Styl. tres ad novem. Bacca unilocularis, tri-1. ennea perma.

Entetrum album. Tab. 106. fig. I.

Erica coris folio decima. Clus. bij. 1. p. 45.

Empetrum erechum. Liss. Jyf. veg. 880.

Ex herbario Bankfiano.

P E R. Bacca globofa, calyce triphylto bafinunita, carnofa, alba, nitida unilocularis.

Rec. nullum, femina bafi affixa.

SEM. duo, tria, raro plum, offea, hinc convexa, obfolete fulcata, inde angulata, aut planiufcula.

IN T. duplex: exterius offeum, craffum; stterius membranaceum, chalaza tuberculatia fufca, quafi funiculo brevi umbilicali, ad bafin notatum.

A с B. feminis cavitati conforme, carnofun, album.

$\mathrm{E}$ ns в. longitudine albuninis, teretiufculus, erectus. Cotyl. breves, femicylindricx, fubacuminatex. Rad.. longa, recta, infera.

2. A. b. B.) Bacea integra. C. D. E.) Eadem transverfe fecta, cum fitu feminum. f. F.) Semina fepasata G.) Simsn transwerfe fectum. H.) Albuunen propria fuz tunica, ad balin chalazigera, sectum. I.) Iden verticaliter diffetum. . K.) Embryo folutus.

I08

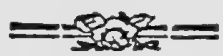

Empetrum rigrutît. Liss.

Bacca magnitudine \& colore bacca. Juniperi aut Myrtilli minoris, glubor:t, apice fcrobiculo rotundo notati, bali calyce triphyllo albicante \& corvila tripetala rubicunda munita, carnoli, unilocularis. Caro folidiufcula, pallide viridis, fed verfus peripherian purpurafcens. Receptac. centrale, colunnare, gracile, circa quod femina in orbem pofita, eidemque paulo fupra bafin affixa funt. Semina fex ad novem, oblongiufcula, hinc convexa, inde angulata, offea, pallida. Integ. \& reliqua ut in procedenti.

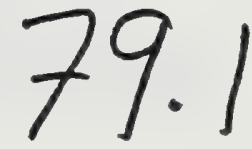


I 


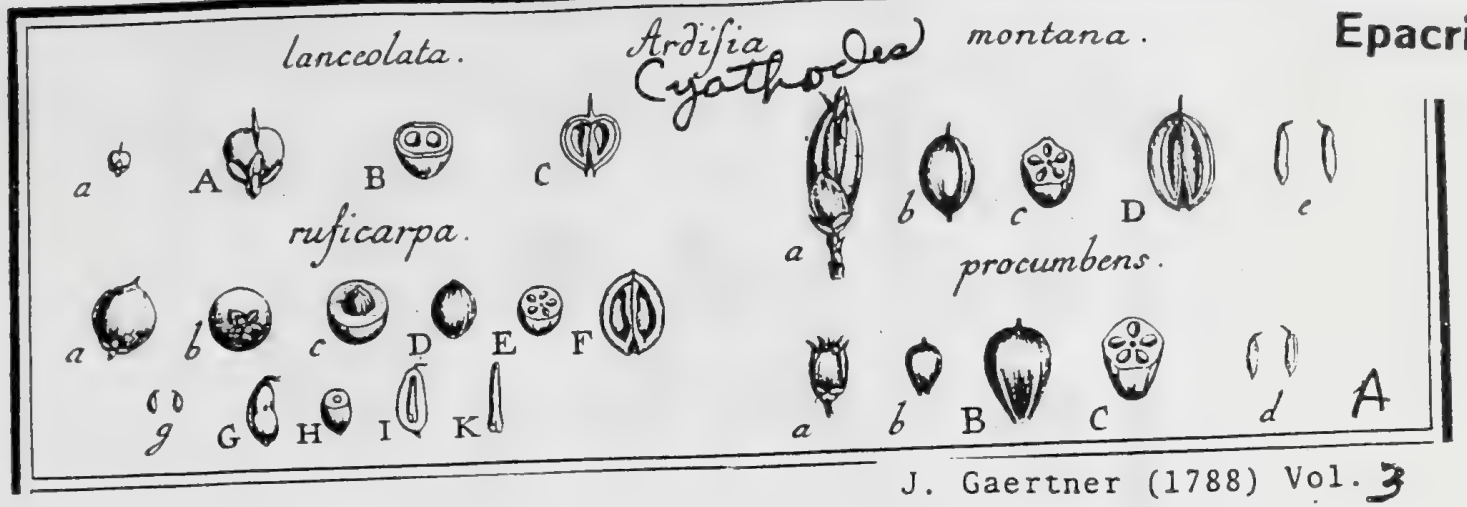

148

ARD ISI A. Conf. Carpol. Vol. II. p. 78.

ARdisia lanceolata. Tab. 2Io. fig. \&.

Ex collectione Bankfiana.

Drupa (a. A.) minima, cordata, fulco intermedio bipartita, ftylo perfiftente faftigiata, calyci bracteis parvis munito infiftens, purpurea. Caro tenuis. Putamen (B.) offeum, biloculare. Loculamenta (C.) obovata, apice a vafis umbilicalibus in axi fructus adfcendentibus perterebrata. Sem.... Int. ... Alb.... Emb. ...

ARDisia ruficarpa. ibid.

Ex collectione. Cl. LaMbert, cum fequente. Habitant in Nova Hollandia.

Drupa (a. b. c.) Supera, haccata, parva, Spherica, apice ftylo breviffimo nucronata, rufefcens. Caro craffa, firmin, vafis fibrofis intermixta. Yuta. men (D. E.) olfeum, globufum, utrinque mucronalatum, fcabriufculum, Jimeis quinque longitudinalibus ftriatun, quinqueloculare. Loculamenta (F.) ovato-oblonga, apice a funiculo umbilicali perforata. Rec. sullum; nifi funiculum umbilicalem brevem apici feminis infertum fumas; qui per dorfum feminis cum integumento conferruminatus ad bafin feminis defcendie \& ibi in unbilicum niucrunulatun abit. Semina (g. G.) in fungulo loculamento fingulum, ovato-oblongum, ad dorfum magis curvatum, ventre rectiufculum, inverfun, pallidum. Integumentum fimplex, membranaceum, zenue, ad bafin feminis chuluza tuberculari inftrnctum. Albumen (H. I.) femini conforme, craffiufculum, carnofum, albun. Embryo (K.) teretiufçuJus, inverfus, niveus. Cotyl. brevillima, obtufx. Rad. longa, conico-teretuufcula, fupera.

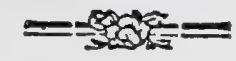

ARdisin montana. ibid.

Drupa (a: b.) ficca, a calyce pentaphyllo fcariolo involucrata, parva, ovata, pentagona. Caro tenuis, adnata. Putanen (c. D.) drupx conforme, fuboffeum, quiinqueluculare. Loculanenta oblonga, lxvigata, angulis exterio ribus obverfa. Sem. (c.) folitaria oblonga, iuverfa. Alb. ... Emb. . . .

Calyx maxinus, bafi ftipulis pluribus ovatis obtufufculis adpreffis munitus, pentaphyllus, cum fructu increfcens; foliolis lanceolatis, acuis, fearioGs, comniventibus.

Ardisia procumbens. ibid.

Ventenatia caude fruticoso procumbente, foliis lineari - Lanceolatis imbricatis cilidtis, foribus axilluribus folitariis. CAv. ic. 4. p. 28.' t. 349. f. I:

Styplsclia procumbens. Persoos fyn. ic. p. 174.

Ex collecaione Cl. Desfontalies.

Drupa (a. b. B. C.) parva, ficca, vertice tantum e calyce obvolucrante prominula, obovata, bafin verfus anguftata, pentigoira, vertice obtufifina. Caro valde tenuis, membranacea. Putsmen offeum, quinqueloculare Semina

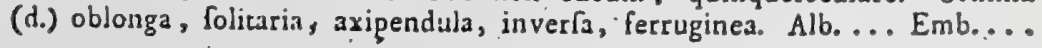

In pluribus drupis, quæ diffecare mihi licuit, femina femper inveni folitaria, nec unquam ovuli ibortivi veftigium detexi, loculanentorum quidens unun vel alterum nonunouam neniruc nhliterate. 

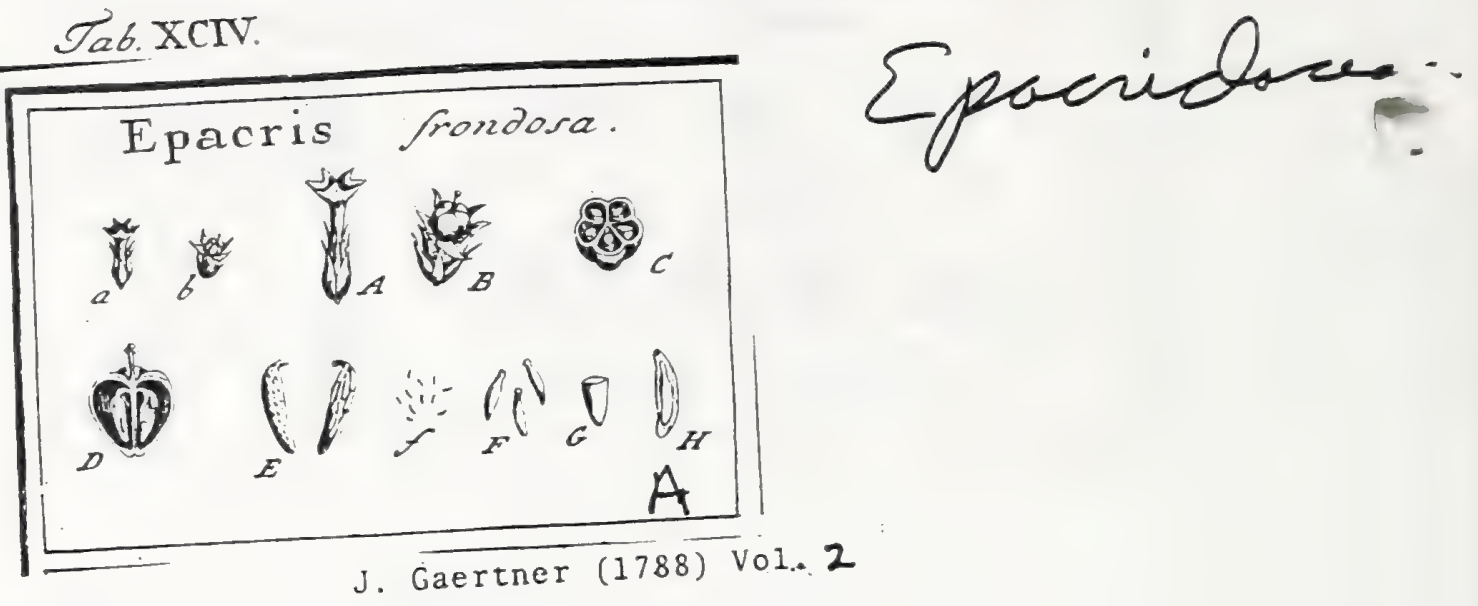

DIXXXIV. E P A CR I S. LIN N. ger. I36g.

Calyx pentaphyllus perfiftens, foliolis Janceolatis acuminatis erectis : duobus interioribus anguftioribus. Cor. hypocrateriformis tubo laxo longitudine calycis: Limbus patens, quinquepartitus, xquilis, tubo duplo brevior. Nectar. Squamx quinque, bafin ovarii cingentes, oblongx, truncatoemarginatx, ovario breviores. Stan. quinque, brevia, fauci corollx inferta. Ovar. fuperum. Styl. filiformis: Itigrnate capitato angulato. Capfula quinquelocularis: loculamendis polyfpermis. Ex fchedis SOLANDRI.

EpsCRIs frondofa: Tab. 94. fig. I.

Ardifia frondofa. Soland. m/s.

Epacris arborea, foliis fubulusis vaginantibus, racenis relis, floribus oppofitis? LiNN. fyy. veg. 198 .

Ex herbario BankGano.

PER. Capfula fupera, fubturbinata, rotundato-pentagona, quinquelocularis, quinquevalvis. Diffepimenta medio valvularum inferta atque fulcis capfu. J externis depreffis refpondentia.

REc. in fingulo loculamento fingulum, liberum, oblongum, ex tereti-co:n. preffiufculum, pedunculo curvo ex axi fructus oriuntum, atque altcra fuit extremitate deorfum pendulum, feminibus undique contectum.

SEM. plura, minutula, lineari oblonga, utrinque attenuata, rufefcentia.

IN T. finplex, membranaceum, tenue.

A L B. Semini conforme, carnofum, aqueo pallidum, tenue.

$\mathrm{E}_{\mathrm{MB}}$. oblongus, inverfus, albus. Cotyl. lineares, foliacex. Rad. teretiufcula, fupera, f. relative centripeta.

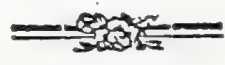

*

a. A.) Flos natarali \& auct magnitudine. b. B.) Capfulz integra, calỵci maturo impolita. C.) Ejus fectio transvcr(alis. D. E.) Receptacula in Gtu naturali \& foluta, cum feininum infercione. F.) Senioa feparate \& auA.s. G.) Semen tansverie, \& I.) Idem longitudinaliter difietum, cun Gtu \& fgura cmbryonis.

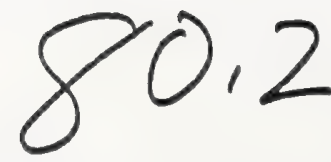




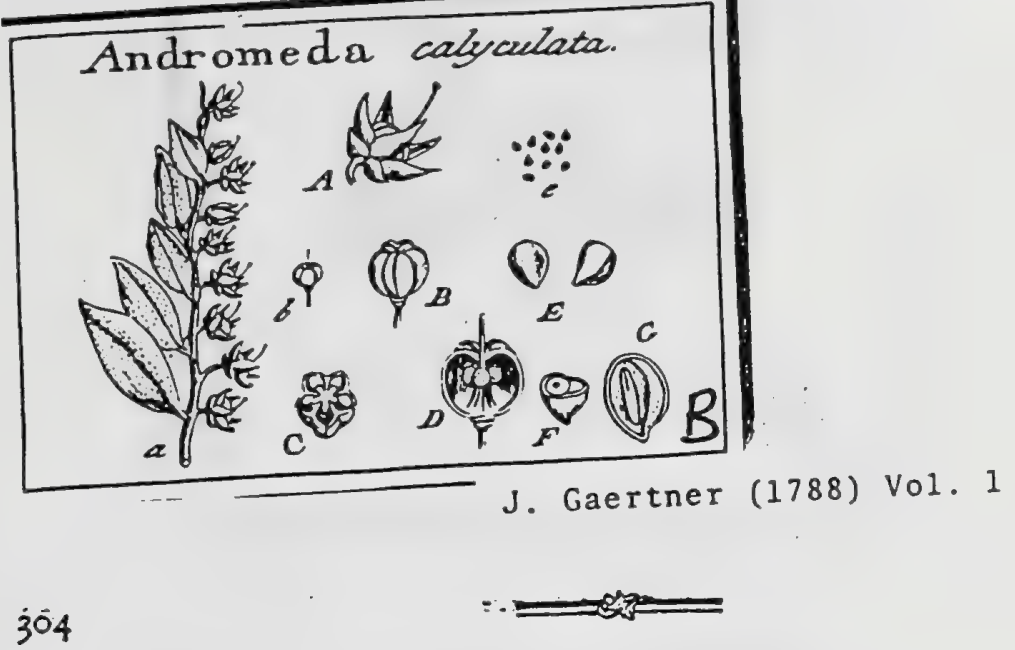

CCCLXXXVI. ANDROMEDA. LINN. gen. 549.

Calyx quinquepartitus. Cor. ovata, ore quinquefido. Stam. decem. Styl. unicus, lligmate fimplici. Capfula quinquelocularis. Septa valvis contraria, Semina pauca.

ANDROMEDA calyculata. Tab. 63. fig. 5.

Chamedaphne. B u.x 8. Comm. Petrop. I. p.*24t.t. 8. f. r.

Andromeda racemis fecundis foliaceis, corollis fubcylindricis, foliis alternis lan-: ceolatis obtufis punéatis. LIN N. Jif 8 . veg. 407 .

PER. Capfula parva, cruflacea, fubglobofa, rotundato pentagona, luperne profunde umbilicata, quinquelocularis, quinquevalvis. Septa valvis contraria.

REc. quinquelobuin, axi affixum: lobulis fungofis, fubglobofis, intra loculamenta propendentibus.

SEM. pauca, quindecim circiter in fingulo loculo, obovata, verfus umbilicuin acuminara, angulato-compreffa, glabra, fublucida, ferruginea.

IN T. duplex: exterius coriaceum, renue; interius membranaceurn, ad compreflum feminis latus, craffun, fpongiofun, album.

A ¿. Semine anguftius, ovato oblonguin, carnofum, aqueo.pallidum.

E мв. filiformis, rectus, niveus. Cotyl. Semiteretes, longiusculx. Rad. longior, recta, centripeta.

a.) Pars raceml, eum capfulis maturis. A.) Capfula dnplici calyce munita. b. B.) Eadem denudata. C.) Ejus fettio transverfalis. D.) Receptac. fitus \& figura. e. E.) Semina (eparata. F.G.) Embryo intra slbumen. 


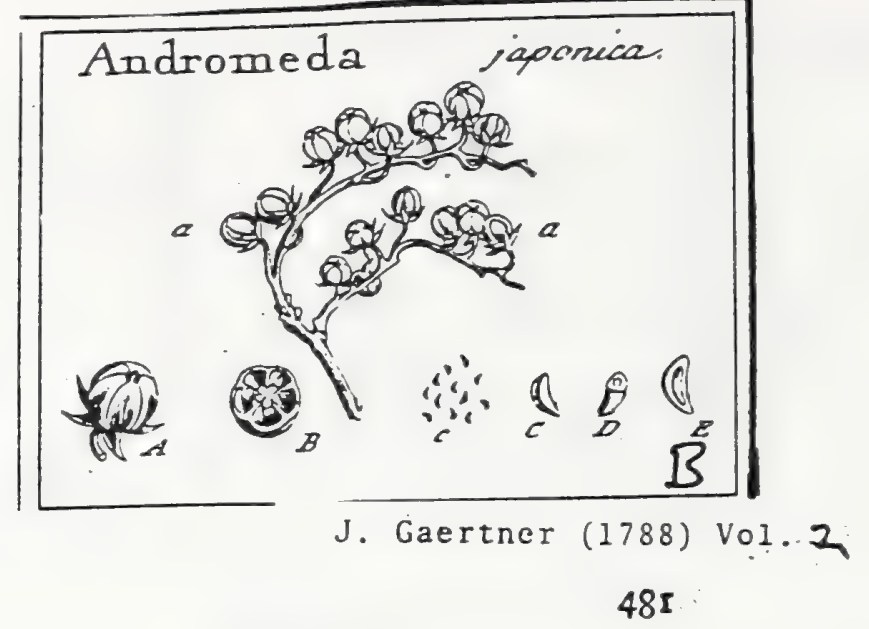

ANDROMEDA japonicas Tab. 178. fig. 2.

Andromeda racenis paniculatis cylindricis brafieatis, folits ellipticis refiexis apice ferratis. THUNB. jap. 183. 3. 22. LINN. Gyf. veg. 407.

A Cl Houturn.

Racemi frugiferi (a) filiformes, flexuof, bracteati. Capiula (2 A.) globota, obfoletifime pencagona, bafi calyce periftence \& patente munica, apice 482

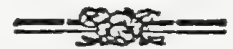

leviter umbilicata, quinquelocularis (B.), quinquevalvis. Valvulx chartacex, tenues, fplendentes quafi vernice obductie, rufefcenti-Jutex, inferne Jata macula fufca notatx. Receptac. fungofum, centrale, quinquelobum. Senina (c. C.) oblonga, angulata, utrinque attenuata, ferruginea. Alb. (D. E.) femini conforme. Embr. (E.) teretiufculus, lacteus.

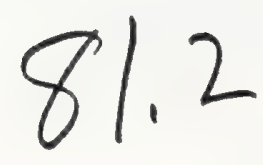



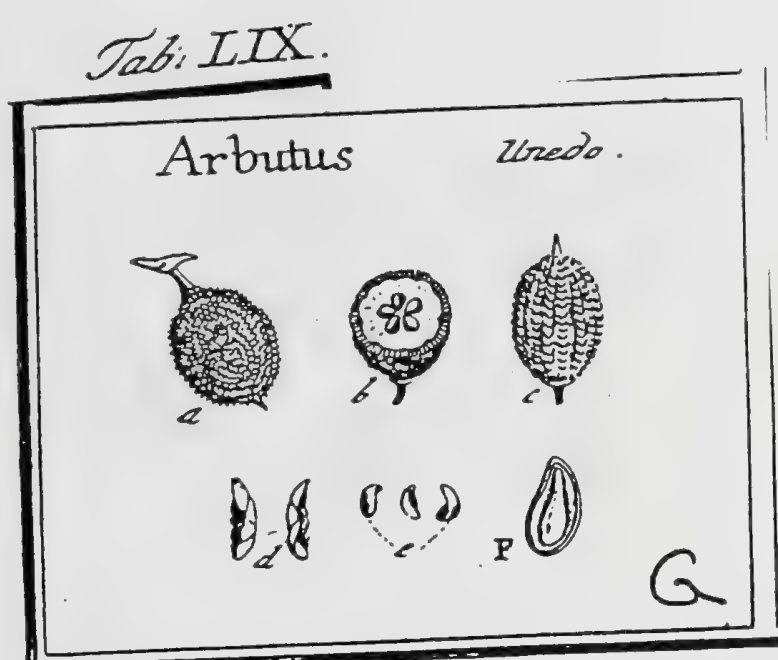

J. Gaertnet (1788) Vol. 1

284

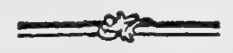

CCCLVII. ARBUTUS. TOURN. t. 368. LinN. gen. 552.

Calyx quinquepartitus. Cor. monopetala, ore quinquefido. Stam. decern. Styl. unicus. Bacca fupera, quinquelocularis. Receptacula pendula: polyfperma.

$\Lambda R$ B I U S Unedo. Tab. 59. fig. 4 .

Arbutus. Сам epit. 168. Mirx. dï. ic. t. 48. f. 1. 2. Serigu. av. V. t. 1.

Arbutus caule arboreo, foliis glabris obtufe Jerratis, panicula tcrminati, baccis polyspermis. L IN N. fy/f. veg. 407 .

PE R. Bacca ovato globofa, carnofa, granulis duris angulatis acuninatis corticata, fylo brevi terminata, quinquelocularis. Caro firmula, extus tuberculis parvis, quibus corticis granula adhxrent, per feries longitudiuales fcabrata.

REc. lamina membranaceo carnofa, ex apice funguli loculamenti deorfun pendula, cui femina undique affixa.

SE s. quatuor 1. fex in fingulo loculamento, ovato açuninata, compre $\int_{2}$, varic curvata, glabra, ferruginea.

I $\mathrm{N}$. fimplex, fubcoriaccum, tenue.

A Lв. femini conforme, carnolum, album.

Exв. longitudine fere albuminis, inverfus, lacteus. Cotyl. ellipticx, fubfoliacez. Rad. linearis, comprefla, longa, fupera.

2.) Bacea integra, b.) Eadem diffeta. c.) Eadem, excufis granulis corticalibus, tubercalato friata. a.) Receptacula Soluta, cum fitu (emiuum. e.) Semina (eparata. H.) Embryonis figura \& 6tus intra albumen. 


\section{Tab: 209 .}
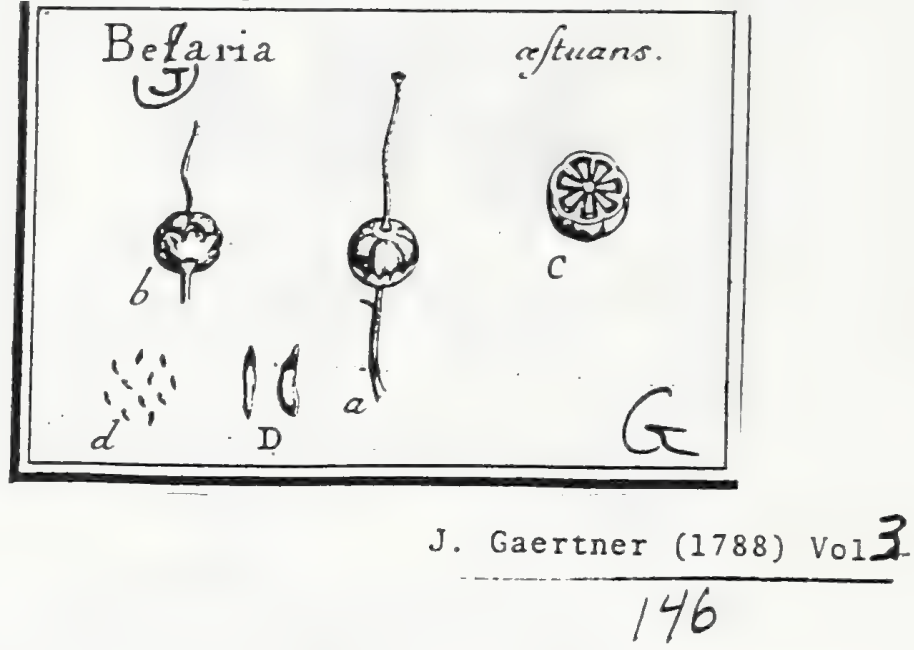

I12. B E $\mathrm{F}$ A R I A. Mutis.

LIN m. mant. p. 152. gen. ed. Schreb. 8 r. Juss. gen. p. I59.

Cal. monophyllus, fubcampanulatus, feptemdentatus, inferus, perfiltens. Cor. petala feptem, in ipfo angulo calycis \& ovarii inferta, calycem multo fuperantia. Stam. 14 filamenta eodem loco cum petalis inferta, feptem alterna breviora, omnia infra pubefcentia; antheræ oblongæ, incumbentes, verfatiles. Ovar. fuperum; ftylo tereti, perfiftente, longitudine ftaminum; ftigmate capitato, feptempartito. Capf. fubglobofs, rotundato - heptagona, feptemlocularis, feptemvalvis. Rec. fungofum, fubglobofum, - feptemlobatum. Sem. numerofa. Alb. carnofum. Emb. . .

Befaria xituans. Tab. 209. fig. 7-

Befaria. Lisw. mant. p. 242.

Befaria folits Tancelatis, fisbtus tomentofis, foribus racentofis. LisN. fuppl. p. 247.; Syf. veg. p. 443. WILLD. Spec. pl. T. 2. P. 2. p. 847. " PkRsooN for. 2. p. 3 .

Icon. Murss amer. I. t. 7 :

Ex collectione $\mathrm{Cl}$. Desfontaines \& ex dono Cl. Ventenat.

PER. Capfula fubglobofa, granum piperis magnitudine paulum excedens, in vercice parum deprefa, \& circulo callofo notata, ftylo perfiftente faftigiata, ad bafin vero a calyce feptemdentato excepta, rotundato - heptagona, ex duabus laminis conferruminata: exteriore tenuiore, coriacea; interiore craftiore, chartacea 1. fuboffea ; feptemlocularis, feptemvalvis.Diffepimenta duplicata a valvularum marginibus infexis \& ad axem usque productis formata.

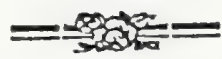

REc. colunnare, globofum, ftylo perfiftente faltigiatum, fungofum, reptem. lobatum; lobi cuneiformes, intra loculamenta alte prominentes, quibus fenina furfum inbricata umbilicis adhxrent.

SEN. numerofa, oblonga, ad extrenitatem fuperiorem unbilico inftructa, pallida.

INT. duplex: exterius membranaceun, laxum; interius tenuiffinum, albumini adnatum.

A L B. Semine paulo anguftius, oblongun, carnofun, album.

Es B. . .

EXPLICATIO FIGURE.

a.) Capfula integra. b.) Eadem medio transverfe feda. c. C.) Sconira folutz.

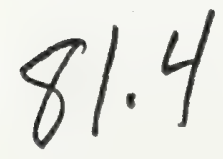




\section{Tab. CIXXIX.}

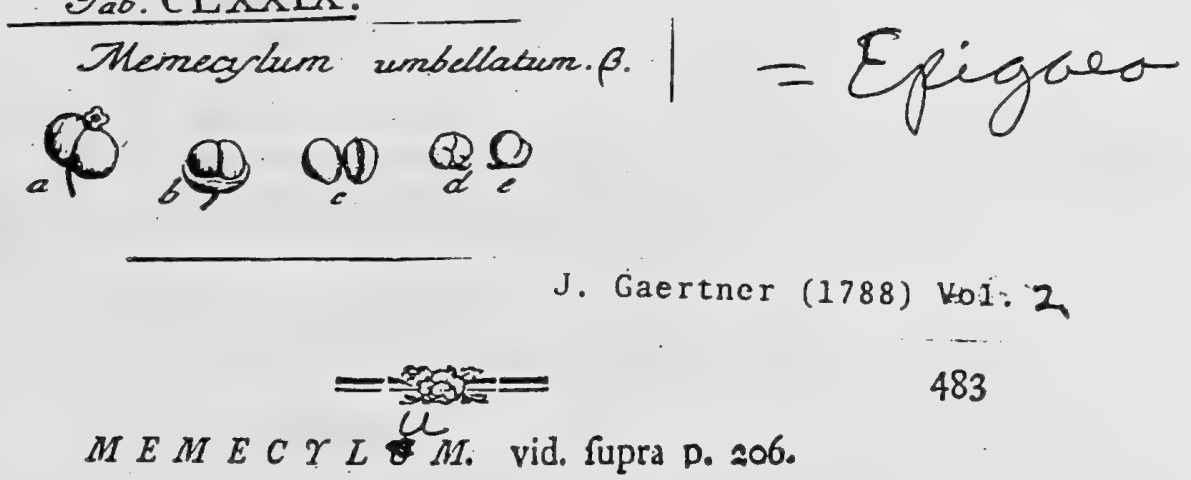

Meмecylum umbellatum $B$. Tab.-179. Gg. 2:

Bacca fubglobofa (a.), didyma, calyce obtufe quadride rato coronata, unilocularis (b.), difperma, glabra, pallide ftraminea. Cortex per vetuftatem tenuiffmus \& quafi chartaceus. Calycis tubus intus lievis, absque ullo ftriarum veftigio. Semina duo (c.), hemifpharica, levigatiffima. fplendentia, gilva. Album. prorfus nullum. Embr. (d.e.) curvatus, albus. Cotyl. in globum convolute. Rat. fubulata, curva, infern.

Differt a Memecylo fupra defcripto: 1.) Baccis multo minoribus. 2.) Cor. tice tenuiore \&-glabro. 3.) Calyce intus nequaquam ftriato. 4) Seminibus fapius geminis. Et 5.) Pedunculis baccarum longiufculis ac manifette corymbolis.

Hre absque ullo dubio elt Samara lata L. fed genericus characher limnzanus, quoad fitum Soris is frulus, certifime eft erroneus. 


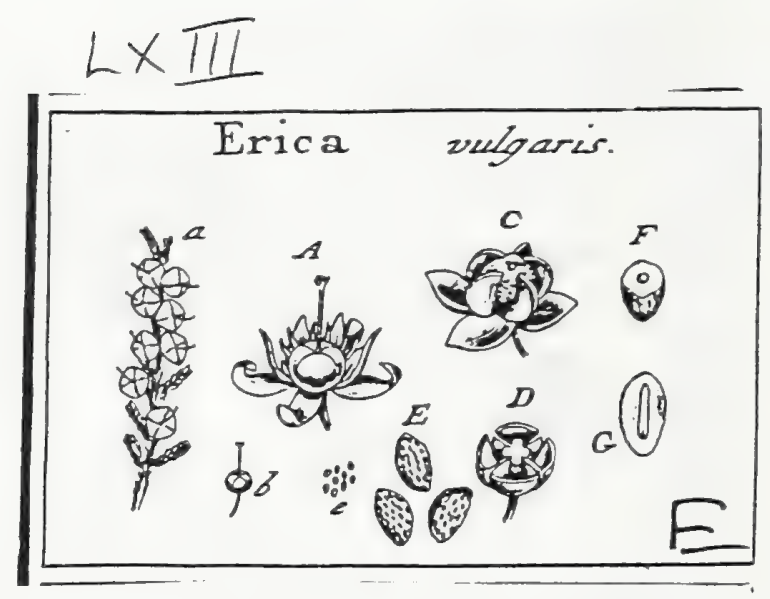

J. Gaertner (1788) Vol. 1

302

\section{ERICA. TOURN. t. 373. LIN ger. ge. 484.}

Calyz tetraphyllus. Cor. monopetala quadrifida. Stan. ofto, thalamo inferta Styl. unicus, ftigmate quadrifido. Capfula quadrilocularis. Diffepimenta fimplicia, axi adnata. Sem. pauca.

ER ic A vulgaris. Tab. G3. fig. 3 .

Erica prima. C А м. epit. 75. O в о е R. flor. dan. $t .677$.

Erica foliis imis appreffis finplicibus, foralibus calcaratis. HAI'. hif. I. ri: 1012.

Erice antheris ariflatis, corollis campanulatis fubincqualibus, calycibus duplicatis, foliis oppofitis fagittatis. L IN N. fygl. i'tg. $3^{6} 3$.

PER. Capfula parva, flore perfinente obvoluta, globsfa, depreffiuscula, quadrilocularis, quadrivalvis. Diffepincuta finplicia, axi capfulz aduata, \& ipfis. valvularum futuris oppofita!

REc. globolum, carnofum, quadrilobum, in fuprema parte caplule pofitum.

SEM. fex, ad novern in fingulo loçularnento, exigua, fubovats, ferobiculato rugofa, pallide lutefcentia.

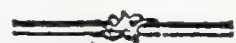

Iх т. fimplex, cellulofo fpongiofum, tenue.

A B. Cemini conforme, carnofun, alhum.

E s в. filiformis, inverfus, niveus. Cotyl. brevifimx. Rad. longa, fupera.

2. A. b.) Capfula terla \& denudata integra. C.) Ejus raivale didaktx, cam fita receptacall. D.) Capiula difrefia, e.E.) Semina folua. F.G.) Embryo lotra albumer.

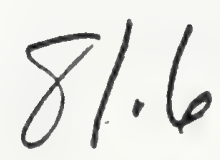




\section{Gaultheria procumber.}

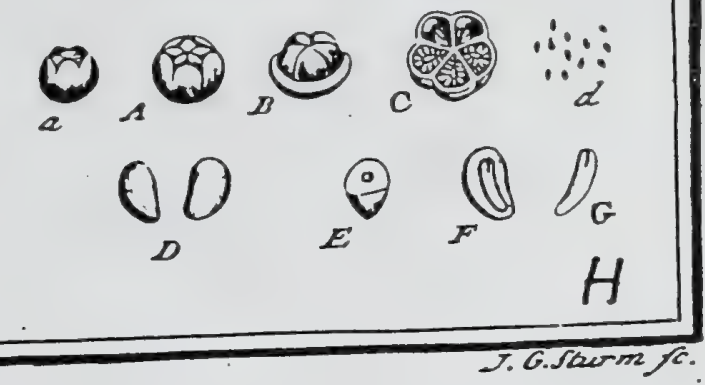

J. Gaertner (1788) Vo1.1

$$
306
$$

CCCLXXXIX. GAVLTHERIA. LiN N. gin. 55

Calyx monophyllus, ventricolus, quinquedentatus, demun baccatus, coloratus. Cor. monopetala, ovata. Nectar. glandulx decem, mucronatx, ovarium cingentes. Stam. decem. Styl. unicus. Capfula quinquelocularis. Receptac, libera, bafi affixa, Sern. plurima.

Gaultheria procumbens. Tab. 63. fig. 8.

Ganltheria. D и н А м. arb. I. p. 286. t. II3. L INN. fyf. veg. 407 .

. Ex herbatio Bankfiano.

PER. Capfula calyce carnofo rubro obtufe quinquedentato veftita, globofa, deprefliuscula, rotundato pentagona, nembranacea, tenuifima, a protuberantibus feminibus tuberculofa, quinquelocularis, apice quinquefariam dehícens. Diffepimenta tenuiflima, axi \& fulcis deprefis adnata.

REc. quinque, carnofa, compreffa, arcuata, bafi affixa, cetera libera, aut ope tenuiffunx nembranx cum axi fructis conncxa.

SEM. numerofa, exigua, ovata, fubangulata, glabra, lucida, ferruginea.

IN T. duplex: exterius cruftaceum, duriusculum, fragile; interius tenvifimum.

$\Lambda$ L. . femini conforine, carnofum, album.

Ess. fubfiliformis, leviffme incurvus, Lacteus, Cotyl. brevifimx. Rad. longa, centripet2.

2. A.) Capfula verita. B.) Calyx baceatus refeftus \& capfula faperne denudata. C.) Receptac. 2 feninum fitus. d.D.) Semina foluta. E. F.) Embryo intra albumer. G.) Idem Separatus. 


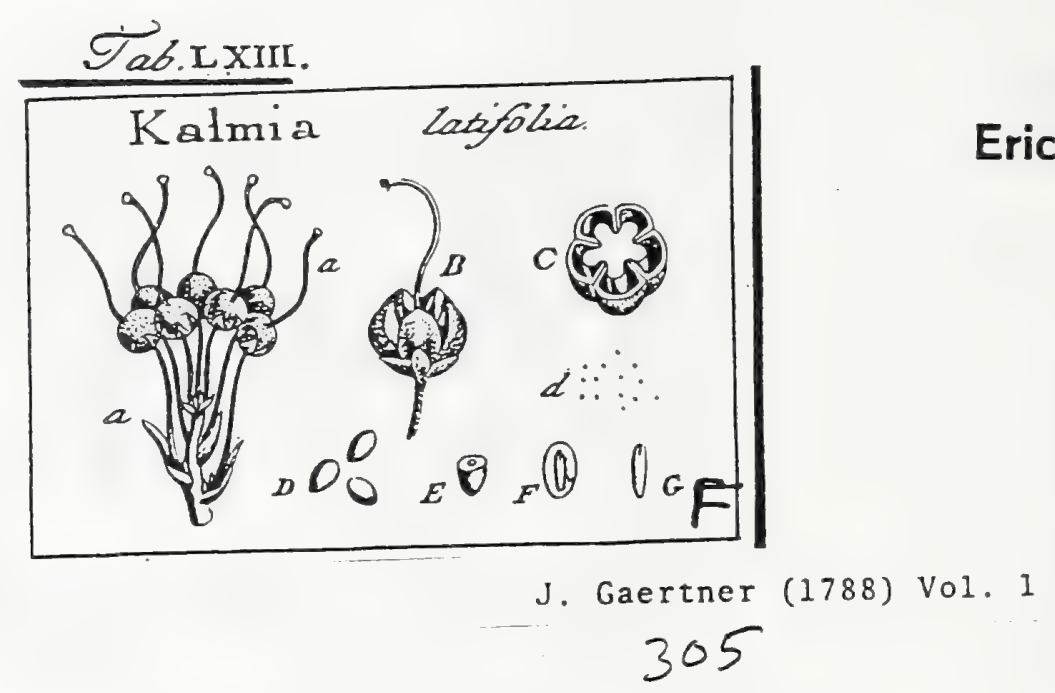

CCCLXXXVIIL. KALMIA. LINN. gen. 545 .

Calyx quinquepartitus. Cor. hypocrateriformis, limbo quinquefido, fubtus quinqueplicato. Stam. decem. Styl. unicus, figmate ampliato. Capfula quinquelocularis. Diflepimenta duplicata. Semina plurima.

KA L i a latifolia. Tab. 63. fig. 7.

Chamadaphe foliis tini, floribus bullatis. Ca tess. carol. 2. p. $98 . t$. 98.

Ledum floribus bullatis confertis in fummis caulibus. E н R E T. decad. t. 38.f.x.

Kalmia foliis ovatis, corimbis terninalibus. LIN N. Jyft. veg. 404 .

Ex horto regio Kewenf.

PER. Capfula globofa, magnitudine pifi majoris, vix, aut obfoletiffme pentagona, tomentola, glutinofa, quinquelocularis, quinquevalvis. Diflepimenta duplicata, ex inllexis valvularum marginibus formata.

$\mathrm{REC}_{\mathrm{C}}$. centrale, fungofum, craffum, quinquelobum: lobis rotundatis, intra loculos prominentibus.

SEM. plurima, parva, ovata, glabra, fufca.

IN T. fimplex, fubcoriaceum, tenue.

A L B. femini conforme, carnofum, album.

Емв. fuliformis, rectus, niveus. Cotyl. brevifimx. Rad. longa centripeta.

306

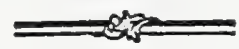

a.) Capfula claufa, B.) Eadem introrfum dehifcens. C.) Ejus fefio transverfalis. d. D.) Semina Separaica. E. F.) Embryo intra albumen. G.) Idem feparatus.

Nimis artificiale genus, ab ADAssono rectifime ad Rhododendrum refertur.

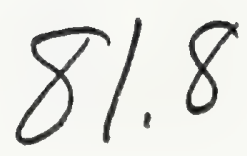


Sab. CXII.

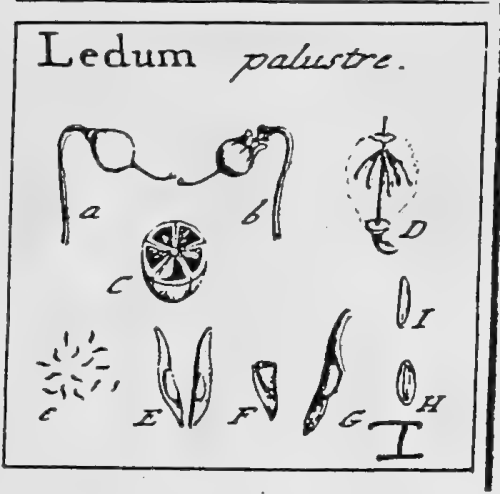

J. Gaertner (17.88)

KoI 2

\section{5}

DCLIV. L E D U M. LINN. gen. 546.

Calyx quinquefidus. Cor. quinquepartita. Stam. decem. Ovar. fuperum. Styl. fimplex. Capfula quinquepartibilis. Receptac. libera, pendula. Sem. fcobifornia.

LEDU N paluftre. Tab. 112. fig. 9.

Rofinarinum fylueftre. CAM. etit. 546 .

Ledzan. LiNN. Jyff. veg. 404.

PER. Capfula parva, obovata; Atylo perfiftente longo terminata, ex loculamentis quinque difcretis compofita, quinquefariam a bafi dehifcens. Valvulx coriacex: diffepimenta vero membranacea, ex valvularum marginibus oriundo, duplicata, angulo fuo interno rima longitudinali dehifcentia.

REC. quinque, filifornia, curvula, e fuprema parte axis fruchus oriunda atque libera intra loculamentorum cavitatem deorfuni pendentia.

SE M. numerofiftura, minutillima, lineari - fcobiformia, plana, utrinque acuminata, e ftramineo rufefcentia.

IN T. fimplex, paleaceo - nembranaceum, albumine multoties longius.

ALB. minutulum, ovatum, lenticulari compreflum, carnofum, album.

E M B. longitudine fere albuminis, filiformis, inverfus, niveus. Cotyl. brevillinix. Rad. longa, recta, fupera, \& fimul centripeta.

140

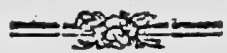

a.) Capfula interisis L.) Eadem dchifecus. C.) Ejus reetio transverfalis. D.) Keceptac axi fruAtus affica. c. E.) Seminz integra. F.) Seuinis \& albuminis fectia tmusvorfalis. G.) Albunen denudaturn. H.) Ideu lougitudiualiter dilfectum, cum fiku cmbryonis. 1.) Eabrỵo folutus. 
Tab. 209

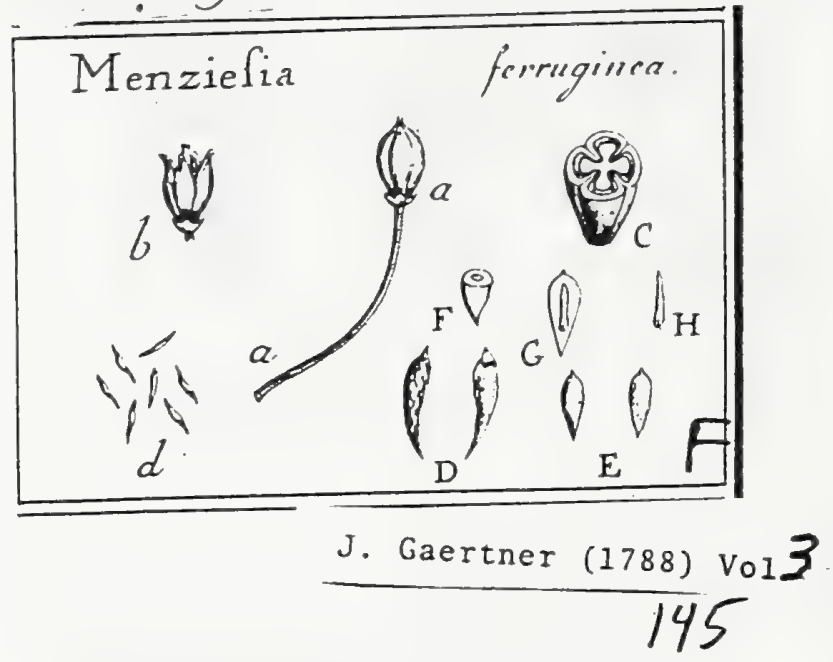

Ir. M E N ZIES I A.

SМIтн ic. ined. t. 56. LAMARCK ill. gen. $t .285$.

Cal. parvus, monophyllus, planiufeulus, quadridentatus, inferus, perfiftens. Cor. monopetala, ovata, fubcampanulata; tubo ad aedium ventricofo; Jimbo quadridentato. Stam. octo, curolla paulo breviora; filamenta fubulata, in ipfo angulo infertionis corollz affixa, conniventia; antherx rectx, oblongx, didynix. Ovar. fuperum; Itylus fimplex. faninibus paulo longior, rectus, tetragonus; ftigma capitatum. quadrilotum. Capf, obovata, fupera, quadrilocularis, quadrivalvis. Rec. columnure, quadrilobum. Alb. carnofum. Emb. linearis, cumpreffiufculus, rad. centripeta.

Menziesia ferruginea. Tab. 209. fig. 6.

afenziefia. Smith 1. c. p. 56. Lanarck diz. 4. p. 115. Walld. fpec. pl. T. 2. P. 2: p. 355 .

Alesziefia floribus folisque terminalibus, fafciculatis, luaceolutis, planis, fubtus luevibus. Juss. ae. bift. nat. mus. parif. x. p. 55. PERSOON jim, x. p. 419 .

Ex collectione Bankfiana.

PER. Capfula parva, obovata, apice nuucronata \& Atylo perfiftente faftigiata, verfus bafin paulum attenuata, calyci perfiftenti parvo pubefcenti inûltens, rotuindato - tetraguna, coriacea, rufefcens, quadrilocularis, quadrivalvis. Diflepimenta duplicata, a valvularum marginibus inderis \& ad angulos receptaculi pertingentibus formati.

IE c. columinare, oblongum, quadrilobuin, cum ftylo tetragono perfiftente continuum, fungofum, cui femina furfun imbricata umbilicis adhxrent.

SE M. numerofa, frobiformia, binc convexa, inde planiufcula, unbilico pervio notata, ferruginea.

IN T. duplex: exterius membranaceum, laxiufculun, reticulato-vafculofum; interits tenuillimun, adnatum.

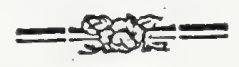

ALB. Semine paulo anguftius, ovatum, deorfum acuminatum, apice mucro. nulatum, hinc lenticulari-convexum, inde planiufculum, carnolum, album.

Eм в. rectus, linesris, curvulus, compreffiufculus, albus. Cotyl. brevifimx, incumbentes. Rad. longa, linearis, obtufa, umbilico obverfa, centripeta.

\section{EXPLICATIO FIGURE.}

a. a.) Capfula integra, ftylo perfiftente orbata, non dehifcens. b.) Eadem dehifeens. C.) Ejus. den fecto trensverfalis. d. D.) Semica foluta. E.) Nucleus feparatus. F.) Albumen transverfe fectum. G.) Embryonis fitus intra albumen. H.) Eubryo folutus.

Semina Menziefize uti plurimarum Rhodoraccarum oleo unguinofo fcatent.

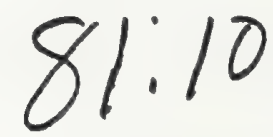




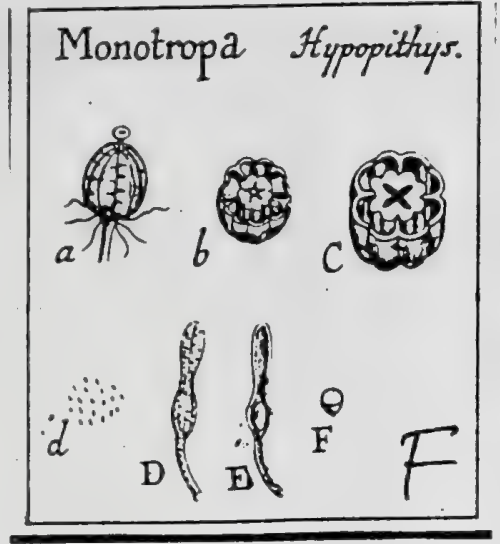

\section{J. Gaertner (1788) Vol3}

Linn. gen. 536. ed. Schreb. 737. Juss. gen. p. 430. Lamarcx ill. ger. t. 362 . Orobanchoides Tourn. A. G. 1706. p. 85 . Hypopitys. DILI, gen. $z$.

Cal. 4 l. 5 phyllus; foliolis coloratis, lanceolatis, petalis brevioribus, \& cum his in cylindrum conniventibus. Cor. $4 \mathrm{l}$. 5 petala; petalis cum calycis foliolis alternantibus, fub ovario infertis, cum calyce deciduis, cavis, extus gibbis; bafí unguiculatà appendicibus duabus auctà. Stam. 8 1. 30. filamentis duobus fubulatis, fub ovario infertis perfiftentibus; antheris fimplicibus, parvis. Ovar. Superum; ftylo fimplici, cylindraceo; ftigmate difcoideo, umbilicato. Capf ovata \& 1 . 10 fulcata, 41 . 5 locularis, 4 . 5 valvis. Recept. rotundato -41 . 5. gonum, carnofum, cavum. Sem. numerofifina, fcobiformi involucro veftita; albunine carnofo.

Mowotroza Hypopitys. Tab. 185. fig. 6.

Orobmebe, que Hypopitys dici potef. C. Baur. prod. p. js.

Orobaucbe lypopitys lutea. MENTZ. pug. rar. pl. t. 3. f. 5 .

Orobancbe verbafci odore. PLuK. alin. $=73$. t. 209. f. 5.

Hypopitys fpica forida nutante. HaLl. belJ. n. I002.

Nonotropa foribus lateralibus ofundris, terminali decandro. LiNx. Syfo. vag. ed. 34. p. 402 . Spec. pl. ed. Willd. T. 2. P. T. p. 573 .

Icors. OED. for. dan. $t .=32$.

Per. Capfula elliptica, apice umbilicata, ftylo pervia, 8 1. so alternatim profundius fulcata, impreltionibus tiansver isibus ad fulcos profundiores gibba, ad bafin Itaminibus perfiftentibus ftipata, 4 i. 5 locularis, 41 . 5 valvis. Dillepinenta membranacea, fulcis profundioribus valvu'arum \& receptaculi fulcis emarginatis inferta.

REc. in axi capfulx afcendens, \& cum ftylo \& Itygmate perfiftentibus continuum, quadri-l. quinquelobum; lobis cordatis medio cum diffepimentis connatis, \& inter fe ad latera connexis, fulcis longitudinalibus acutis ad commiffuras remanentibus; carnofum, intus ftellato - cavun.

SEM. numerofifima, minutiffima, involucro fcobiformi tunicata, tereti-oblonga.

lnvolucrum (arillus) tenuifinum, reticulato vafculofum, membranaceum, clavato-faccatum, $2 d$ medium femen fovens turgidum, fpadiceum.

INT. fimplicifimum, membranaceum, albumini areifirne adnatum, vis difcernendun.

A L в. femini conforme, carnofum, albicans.

ENL...

\section{EXPLICATIO FIGURE.}

3.) Capfula integra quinquelocularis, filamentis perfifentibas bafi ftipats. b.) Eadem medio transverfe diffcta, cum diffepimentorum \& receptaculi fita. C.) Eadem quadrilocularis \&ic d. D.) Senina foluta. E.) Involuerum longitudinaliter difretum, cum (emire in Etu. E.) Albumen transverfe feaum.

Nunerus partium quaternarius ufitatior quinario, folammodo in floribus terminalibus obvio. Magna eft Mionotropx cum Pyrola quoad capfulx. feminumque fabricam Gimilitudo, ut \& embryonis rationes in ambabus fimiles cenfendx. Monotropa vel rarifime profert femina forta, vel Embryo omnium minutifimus, etiamvis omni ufus fim affiduitate \& intenderim oculorum lentiumque aciem, in plurimis ferninibus, ne embryonis quidem umbram detegere valui.

Semina per aliquod tempus in aqua detenta eam viridi, \& fpiritum vini rubicundo tingunt colore. 


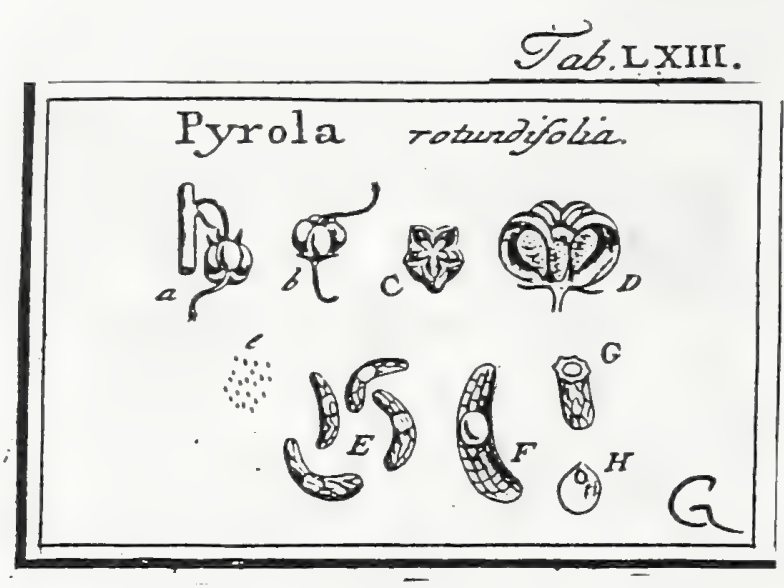

J. Gaertner (1788) Vol. 1

\section{PYROLA. TovRN. t. I34. LinN. gen. 554}

Calyx quinquepartitus. Cor. pentapetala. Stam. decem. Styl. unicus, ftigmate bicuspidato. Capfula quinquelocularis. Segta valvis contraria. Semina fcobiformi arillata. -

PYROL A rotundifolia. Tab. 63. fig. 4 .

Pyrola. R Iv.pent.t. 136. f. 2.t. 137. t. 138.f. 1. BLAK区. t. 594. OEDER. fior. dan. $t$. 110.

Pyrola foliis fubrotundis, tubis recurvis. HaIc. hifl. i. n. 1010.

Pyrola fantinibus adfeendentibus, pifillo declinato. LINN. J4f. veg. 408.

PER. Capfula globola, utrinque umbilicata, rotundato pentagona, quinquelocularis, quinquevalvis. Diflepimenta valvis contraria.

REc. quinquelobum, fungolum, axi affixum : lobis convexis, deorfum attenaatis intra loculamenta propendentibus.

SEM. numerofiffima, minutitima, nucleo globofo intra arillum fcobiformem.

Arillus tubulofus, vafculoro reticulatus, aracbnoideo membranaceus, compreflus, fpadicco rafefcens.

IN T. fimplicifimum, vix a nucleo difcernibile.

ALв. Temini conforme, fphxricum, in media arilli cavitate hxrens, carnolum, pallide albicans.

E м в. punctum medullare niveum in albuminis extremitzte umbilicali barens. Cotyl.... Rad. rotundata receptaculo obverfa

a.b.) Capfula integra. C.) Fadem difreta. D.) Receptre. figura \& fitus. e. E) Semina folata F.) Arillus longitudinaliter \& G.) Idem transyeríaliter diffeflus, cum feminis fitu \& figura propria. H.) Albumen diffetum, cum embryone.

Cotyledones in embryone difcennere non valui, five quod re ipra monocotyledoneus lit, five quod partes nimis minutx \& fere intractabiles, five denique, quod hactenus femina perfecte matura nou obtinucrim?

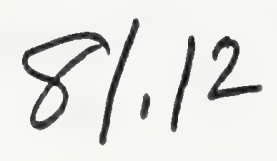




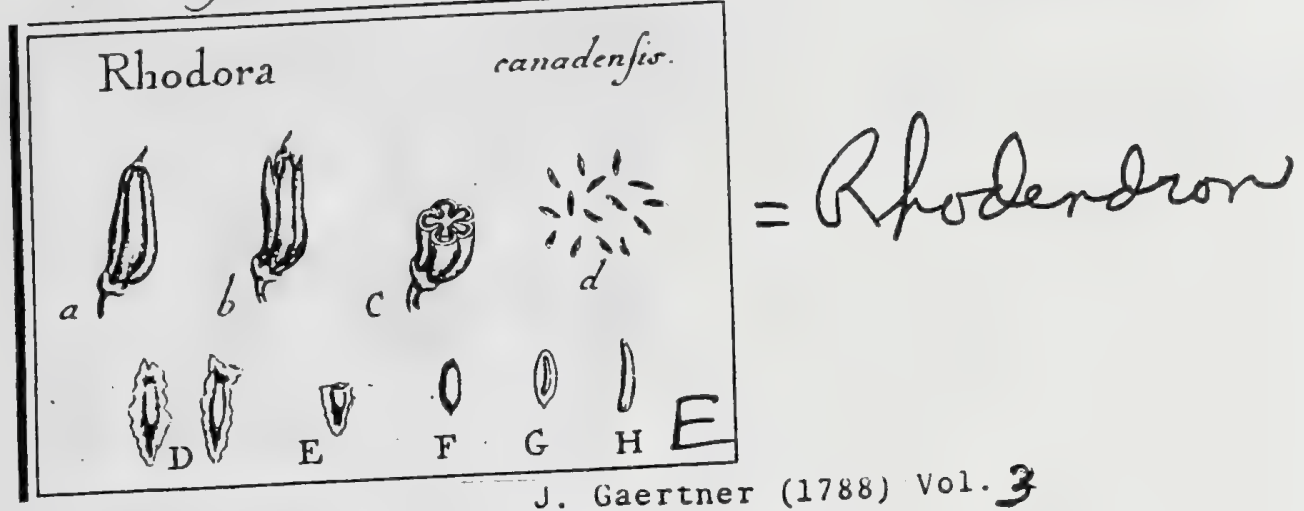

$\mathbf{r} 44$

\author{
二综落二 \\ rio. $\mathrm{RHODO} \mathrm{O}$ A. \\ LAMARCK ill. gen. $t$. 364 .
}

LINN. gen. 547. ed. Schreb. 745. Jóss. gen. p. 159 .

Cal. parvus, quinquedentatus, inferus. Cor. difco calycis adnata, irregularis, fubbipetala, 1. profundiffime bifida : labio fuperiore anguttiore, profunde 2 - 1. 3 - partito; inferiore latiore, obtufifime bidentato. Stam. 10.; filamentis filiformibus, inxqualibus, declinatis, difco calycino infertis; antheris didymis, poro genuino fupra dehifcentibus. Ovar. fuperum; Itylo filiformi, declinato; ftigmate capitato, quinquefido. Caprula oblique pyramidata, duplicata, quinquelocularis, quinquevalvis. Roc. columuare, quinquelobum. Sem. plurima, difco membranaceo cilscła, Alb. çarnofum. Enb. curvulus, centripetus.

Rhodora canadenlis. Tab. 20y. fig. S.

Cbamaerbodendros. Duнan. Fein. app. p. 10. t. 27. f. 2:

Rbodora. Lins. Spec. plo p. 56 r. ed. Willd. T. 2. P. I. p. 603. Persoox fyn. 1. p. 477 .

Icon. L'HeRIT. firp. nov. 1. t. 68 , Ex collectione Bankfiaua,

PRR. Capfula oblongo-pyranidata, oblique 1 ad bafin lateris externi ventri. cofa, rotundato- pentagona, ex duabus laminis conferruminata : exteriore coriacea, tenui; interiore chartacea; quinquelocularis, quinquevalvis. Diffepimenta ex valvularum marginibus inflexis \& in receptaculi fulcis productis formata

R RC. columuare, pyramidatum, in ftylum perfiftentem excurrens; fungofum; quinquelobum; lobi hinc rotundati, inde axim verfus cuneati, \& ibi coaliti, intra loculanenta alte prominentes, quibus fernina furfum imbricata \& quafi verticaliter defuentia umbilicis adhærent.

Szм. numerofa, parya, oblonga, compreff, inverfa, margine membranaceo inxquali cincta, nucleo in medio protuberante \& ad extremitatem fupe. riorem umbilico ferrugineo minimo immerfo notata, pallide fulca.

Is T. duplex : exterius membranaceum, reticulato-vafculofum, in marginem meabranaceum ampliatum; interius tenuffimum, arachnoideuin, albu. miai arcte adnatum.

A L B. femine multo anguftius, ovato roblongum, utrinque in apiculam coloratiorem minimamque productum, lențiculari-convexum, 1. hinc conyexum inde planiufculum, carnofum, album.

EN B. filiformis, minimus, curvulus, niveus. Cotyl breviflimx: Rad. longa, coniça, umbilico obverfa, centripeta.

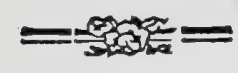

$\mathbf{r} 45$

\title{
EXPLICATIO FIGURE.
}

a) Capfula integrs, claufa, b.) Eadem dehifeens. C.) Setio eapfule transverfalls. d.) Semiss foluta. D.) Eadem magnitudine auda, nucleum in medio \& nabilicum fub vertice

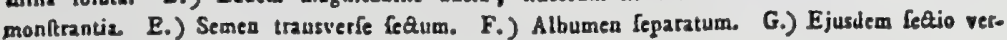
ticalis, eum fitu embryonis. H.) Embryo folutus.

Rhodorim a Rhododendro genere vix effe diverfam, tam ex anthologicis quam carpologicis patet. 


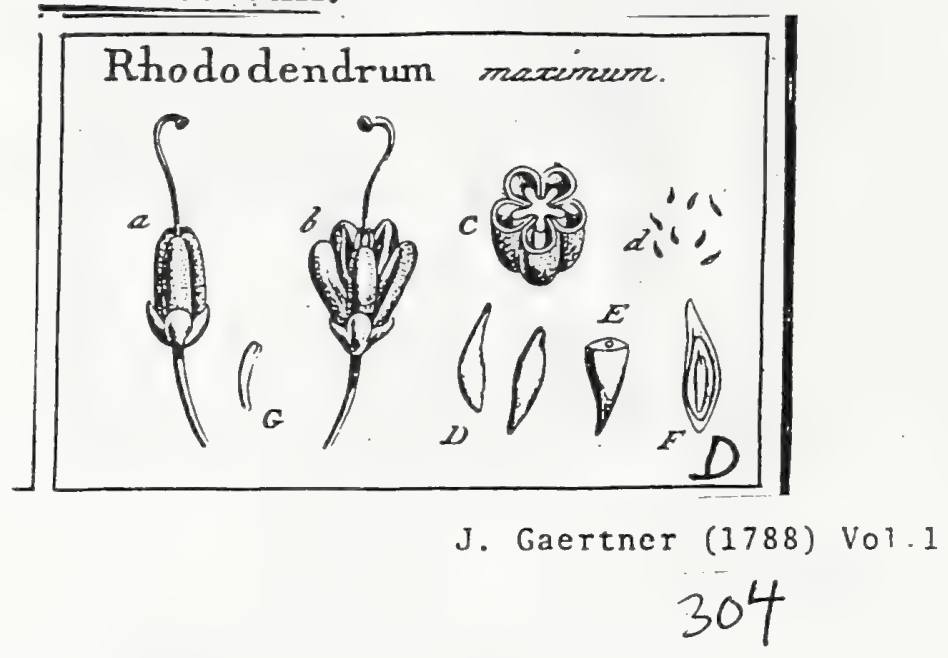

CCCLXXXVII. RHODODENDRVM. LIN . gen. 548 .

Calyx quinquepartitus. Cor. infundibuliformis. Stam. decem, declinata. Styl. unicus, figmate ampliato concavo. Capfula quinquelocularis. Diffepimenta ex inflexis valvularusn marginibus duplicata. Senina plurima.

Rhododendrum maximum. Tab.63. fig. 6.

Chamarhododendros lauri fulio fempcruirens, floribus bullntis corymbo/is. Catess. carol. 3. t. $17 \cdot f .2$.

Kalmia foliis lanceolato ovatis nitidis fubtus ferrugineis. M I L. diq. ic. t. 220.

Rhododendrum foliis nitidis ovalibus obtufis venofis margine acuto refiexo, pe-

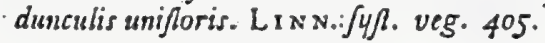

Ex horto regio Kewenfi.

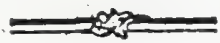

PER. Capfula oblonga, rotundato pentagona, pubefcens, vifcola, ferruginea, quinquelocularis, quinquevalvis. Diltepimenta duplicata, ex inflexis valvularum marginibus tormata.

REc. columnare, fungofum, quinquelobum : lobis compreffiusculis, intra loculamenta prominentibus.

SEM. numerofa, lineari oblonga, fubpaleacea, utrinque acuminata, glabra, fulva aut Saturate rufelcentia.

IN T. duplex: exterius fubcoriaceum, utrinque citra nucleum in ligulam membranaccain productum; interius tenuifimuin, adnatuin.

A z B. ovato oblongum, femine brevius, lenticulari compreffum, carnofum, albun.

Е м в. filiformis, rectus, niveus. Cotyl. breviflunx. Rad. longa, .centripeta.

1.) Capfula integra. b.) Eadem totis loculamentis dehifcens. C.) Ejus feilo transverfalis. d.D.) Semina lepanta. "E.) Semen trausverfe fetum. F.) Idem longitudinaliter diffeltum, cum embryo. ae intra albumeo, G.) Embryo Separatus.

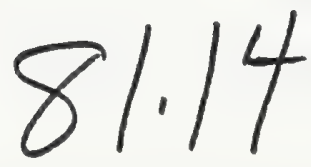




\section{Sab.LXIIr.}

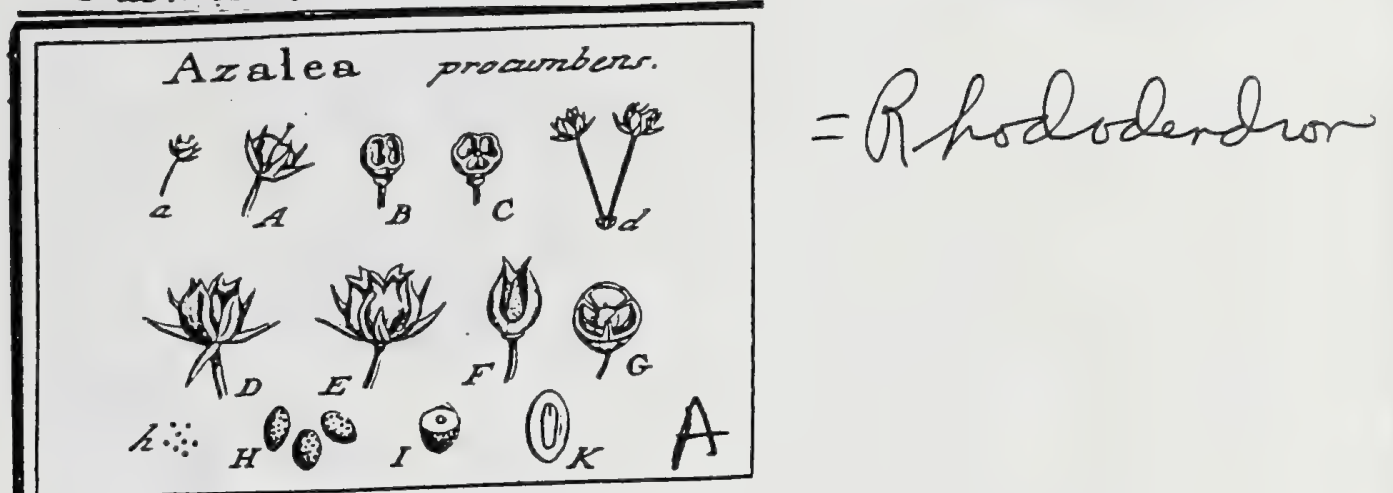

\section{Ericaceae}

J. Gaertner (1788) Vol.1

CCCLXXXII. AZALEA. LINN. gen. 222.

Calyx pentaphlyyllus. Cor. campanulata, aut infundibuliformis. Stam, quinque. Styl. unicus. Capfula bi-eri-quinquelocularis. Diffepinenta duplicata. Receptac. columnare. Semina plura.

A 2 A LEA procumbens. Tab. 63. fig. I.

Chamarhododendros fuvina ferruginea, thymi folio, alpina. Bocc. mas. 2. p.64 t. 53. OE D E R. flor. dan. t. 9 .

Azalea caule procumbente, foliis ovatis, margine introverfo. H А ع . hift. I. 21. 666 .

Azalca ramis diffufo procumbentibus. Lin s. fl. lafp.t. 6.f.2. $\int y /$. veg. 198.

PEk. Capfula parva, fubglobola, cruftacea, dura, bi-l.' trifulca, bil-1. trilocularis, totidemque valvis: valvulis maturis apice fxpe bifidis. Difiepimenta duplicata, ex inflexis valuularum margiuibus orta.

REc. centrale, columnare, tereti acuminatum, deciduum

SEM. plurima, minutula, ovata, excavato panctata, robro ferruginea.

IN T. fimplex, coriaceun, tenue.

$\Lambda$ \&. Semini conforme, carnofum, duriusculum, pallidum.

E м B. filiformis, rectus, niveus. Cotyl. brevilfunx. Rad. longa, centripeta

a. A.) Capfula integra, B.C.) Eadem differa, d.D. F.j Valvula dehicentes. F.) Valvala (eparata, cun receptactilo. G.) Diffepimenta duplicata. b. H.) Senina foluta, 1.K.) Embryo intrz, 2'buniert.

In hac fpecic, capfula trilocularis frequentiffina eft; quinquelocalaris bactenus mibi non obvenit.

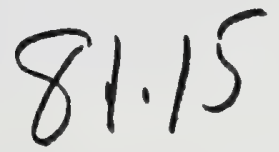




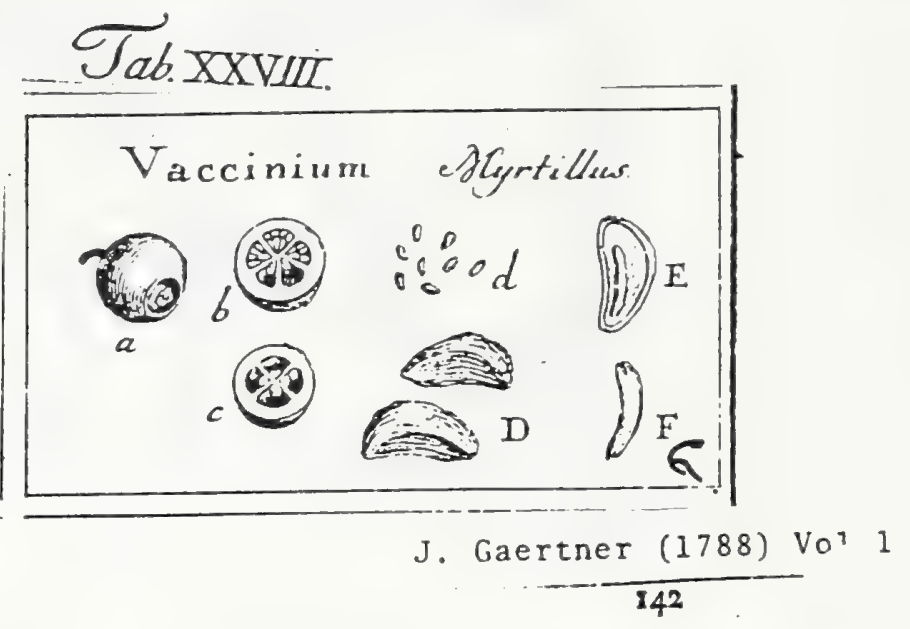

CLXX. VACCINIUM. Linn. gen. 483 .

Calyx brevifrmus, fubedentulus, fuperus. Cor. monopetala, campanulata. Stam. ofto. Styl. unicus, Bacca infera, umbilicata, quadri-1. quinquelocularis. Se misa plura.

Vaccinium. Myrtillus. Tab. 28. fig. 7.

Vaccinia. B L а к $\Psi$. herb. t. 463.

Vaccinium foliis rugofis ovato lanceolatis ferratis, caule angulofo. HA L. hifl. 1. n. 1020.

Vaccinium pedunculis unifloris, foliis ovatis ferratis deciduis, caule angulato. LIN N. fy l. veg. 362 .

$\mathrm{PER}$. Pacca inferz, Cphxrica, intra calycis marginem integerrimum arế depref̂a, obfolcte crenulatá, umbilicata, nigro-cxrulea, quadri-1. quinquelocularis. Pulpa mollis; purpureo-fanguinea.

R c c. camolum, globulofum, fcrobiculatum, angulo interno finguli loculamenti ad. natun.

SEM. plura, ad triginta, in quolibet loculamento, oblonga, angulata, tcnuiftme \& quafi tremula naanu firiata, lutefcentia, aut rubro ferruginea.

IN T. Simplex, membranaccum, tenue.

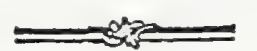

A L B. femini conforme, carnofum, durum, album.

EMB. dicotyledoneus, filiformis, longitudine fere albuminis, Jevifime curvatus, niveus. Cotyl. minutilfunx, brevilimx. Rad. longiffuna, centripecs.

a.) Bacea illtegra. b. c.) Eadem quadri \& quinguelocularis difrezta. d. D.) Semina fulula. L.) Seminis \& albuninis fectio longitudiualis, cum fitu embryonis. F.) Embryo feparatus

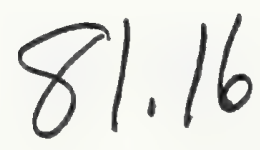




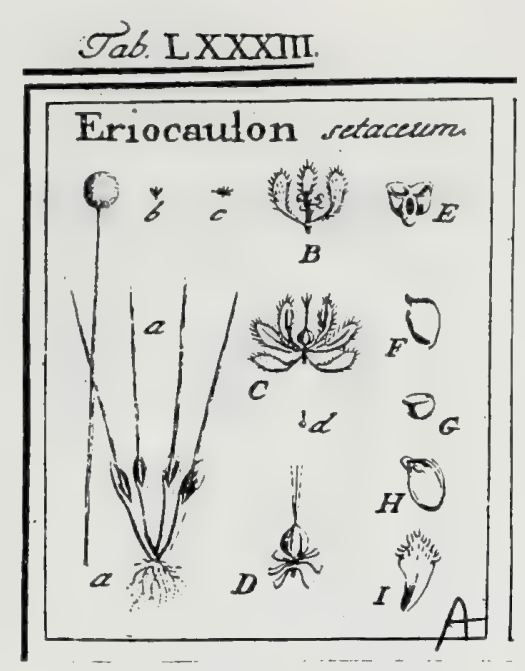

\section{J. Gaertner (1788) Vol. 2}

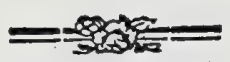

\section{ERIOCAULON. LINN. ger. IOO.}

Elores aggregati, mafculi atque feminei in eodem receptaculo communi globolo palesceo. MAS. Cal. nullus. Cor. tripetala, extus hirfutula. Stam. fex. FEM. Cal. nullus. Cor. hexapetala, mafculse fimilis. Ovar. fub. rotundum, trigonum. Styl. tres. Capf. pedicellata trilocularis. Sem. Solitaria.

Eriocauzon fetaceum. Tab. 83. fig. I.

Tsjern -kotsjiletti - pullu. RHeEd. mal. 12. p. 12g: t. 63.

Randalia malabarica, capillaceo folio. PeTIV. gaz. t.53. f. xo.

Gramen junceum, cbamemeli capitulis albis aphyllis, minuls. BURM. zeyl. 10.9.

Eriocaulon culmo fexangulari, foliis fetaceis. LINN. fy/t. veg. $22 \%$.

PER. Capfula fubrotunda, argute trigona, membranacea, diaphana, pedicella. ta, trilocularis, vix dehifcens.

REc. nullum, prater angulum internum loculamentorum, cui femina fuperne affixa.

SE s. in fingulo loculo fingulum, minutulum, compreffum, ovatum, fupra roftellatum, glabrum, rufefcens.

IN T. fimpliciffimum, tenue.

A L B. femini conforme, carnolum, pallidum.

EM B. monocotyledoneus? minutilimus, in fuprema albuminis parte locatus.

2.) Planta magnitudine naturali, cum vaginis foliorum, ipfis autem foliis delapfis b. B.) Co rollula mafcula. c. C.) Corolla ferninea. d. D.) Capfula integra. E.) Eadem transverfe feda. F.) Semen in fitu naturali. G.) Idem transverfe $-\&$ H.) longitudinaliter fcetum, cum rudimento Embryonis. 1.) Palez receptzculi communis, fuperne villofa \& iffigniter aucza.

Embryonis formam atque fabricam in minutifimis nec rite maturis feminibus non diftincte vidi, quare alii determinent, num monocotyledoneus, anne vero dicotyledoneus fit? prius interim fuadent, ternarius loculamentorum \& fenarius ftaminum numerus, nec non plants habitus, ad Juncos accedens. 


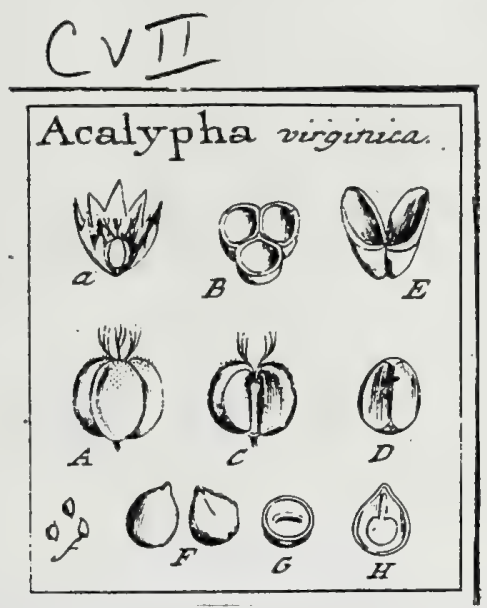

J. Gaertner (17.88) Vo1, 2

DCXXI. A C ALY P H A. LINN. gen. IOS2.

Flores rexu diftincti in eadem planta. MAS. Cal. tetraphyllus. Cor. nulla. Stain. octo aut fodecim, bafi. connata. FEM. Involuerum varium. Cal.

I16

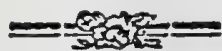

triphyllus. Cor. nulla. Ovarium fuperum. Styl. tres, tripartiti. Capfula pedicellata, tricocca, claftica. Semina folitaria.

Acalypha virginica. Tab. I07. fig. 3.

Mercevialis tricaccos bermaphroditica. Plum. phyt. t. 99. $f .4$.

Acalyplar virgulto $\int_{a}$, foliis ovato acunsinatis atque crenatis, fpicis suriformibus alaribus. Brown. bifl. jam. $346 . t .36 . f .2$.

Acalypha involucris femineis cordatis incifis, foliis ovato lenceolatis petiolo longioribus. LiNs. Jyjt. veg. $86_{2}$.

PER. Capfula fubrotunda, glabra, trifulca, tricocea. Cocculi ovati, hitnc convexi, inde obtufe angulati, characei, bivalves, elaftice dehifcentes.

RÉc. centrale, filiforme, apice tribus papillis lateralibus.

SE M. folitazia, fubglobofa, fuperne acuminata, glabra, cinerea aut ferruginea, umbilico Gmplici minutiflimo fusb apice notata.

IN T. triplex: extimutn tenuiffimum, cinerafcens; medizm cruftaceum, minutiffime puncticulatum, ferrugineum; intimum membranaceum, pallidum.

A $\llcorner$ в. femini conforme, carnofum, pallide albicans.

EAs B. longitudine fere a!buminis, "inverfus, lutefcens. Cotyl. fuborbiculatx, foliacex, leviter concavie. Rrid. cylindrica, longa, fupera.

2. A. B.) Capiula integra intra involucrum, \& difecta. C.) Receptac. cocculis interjectum. D. E.) Cocculus integer \& dehifcens. f. F.) Semina feparata. G.) Scminis \& albuminis feato trausverfatis. H.) Eorundem fectio verticalis, cum fitu \& figura Embryonis.

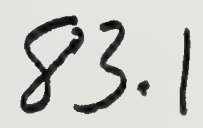


Euphorbiaceae

= Alewrites

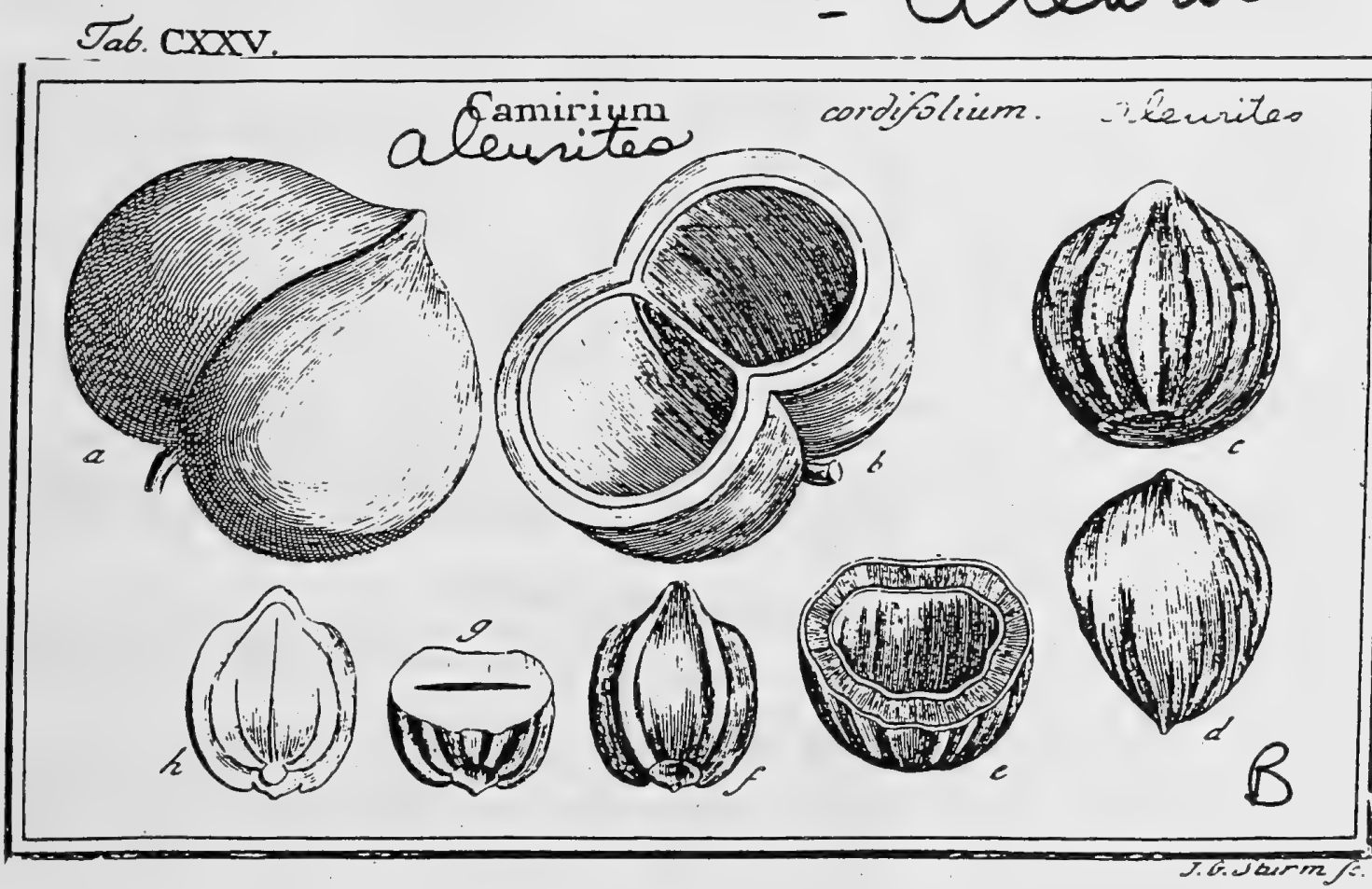

$83.2 \mathrm{~A}$ 


\section{J. Gaertner (1788) Vol. 2}

\section{C A M I R I U M. RUMPH.}

Flores fexu diltindi in eadem ftirpe. MAS. Cal. monophyllus, inxqualiter 2. 3. 4 fidus, lacinies concavis, una reliquis majore. Cor. petalit quin-

que, oblonga, bafi angultata, receptnculo inferta, calyce longiom. Stam. plura, ad octodecim. FEM. Cal. \& Cor. ut in mare. Nechar. glasdule quinque ovatx intra balin petalorum. Ovar. fuperum. Styl. duo, bipartici. Drupa ficca bilocularis. Sem. folitaria, nucamencacea. (Ex fchedis Solandri.)

Camirium cordifolium. Tab. 125 . fig. 2.

Camirium. RUмPH. amb. 2. p. 180. t. 58 .

Telopea. SOLAND: $m / s$.

Aleurites. Forst. gern. 11т. t. 57 .

E collectione Bankfiana \& ex feminar. Amftelod.

PER. Drupa exfucca, transverfe ovata, apice nucronaca, didyma, bilocularis. Cortex herbaceo coriaceus, tres circiter lineas craffus, extus pruinofus feu farina quafi \& fabulo confperlus. Putamen crultaceun, tenue, biloculare.

REc. nullum; femina difepimento affixa.

SEN. folitaria, nucamentacea, tunicata, irregulariter globofa: fuperne fcil. obtufa \& in aciem transverfalem acutam comprefia, in medio autem infigniter gibba, \& verfus bafin in mucronem crafum conicun definentia, cererum varie rugofa \& quafi fulcata.

IN T. triplex: extinum, tunica coriaceo-fungofa, albicans, feminibus vetuftis undique \& arctifime adhxrens; medutu lapideum, crallum, extus nigrum, vel in aliis, livido quafi encaufto obductum; fractura autem in omnibus hepatica, fplendente, \& gypfi adinftar, fibris tenuilimis horizontalibus eleganter friata; intimun membranaceum, niveum, aridum, fubfriabile, difficulter a telta fecedens.

A L B. femini conforme, gibbofum atque rugofum \& in vertice appendicula fubcordiformi conprefirufcula auctum, cetera vero curnofum, oleofum, craflum, album, fragile.

EMB. nagnitudine fere albuminis, inverfus, lacteus. Cotyl. grandes, ovatocurdatx, foliacex, thinervix. Rad. fobglobofa, craffa, fupera.

a.) Drupa integra. b.) Eadem difeQa. c.) Scmen a dorfo fpeatum, in fitu inverio. d.) Iderw a Latere vifum. c.) Integum transverfím feta. f.) Albumen deaudatum, in fitu inverfo. g. h.) Idem transverfe \& longitudinalitet diffectum, cum Embryone in fitu inverfo.

Seminum fitus naturalis in pericarpio integro ulterius explorandus eft, mihi enim nonnifi femina foluta videre contigit; fufpicor tamen embryoneá atque femina effe inverfa, non auten erecta, Gicuti in icone delineata funt. Tunicam feminis extimam, amplo foramine perviam dicit Rumphius 1. c. fed in meis feminibus omnibus eft integerrima; eamque nihil

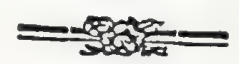

bliud effe cenfeo, quam amplifimam expanfionem fubfantix illius fungofe, juxta umbllicos feminum in Tithymaloideis adeo frequentis \&
ufitata. 
Euphorbiaceae

Tab. CVIII.

Andrachne telephioides.

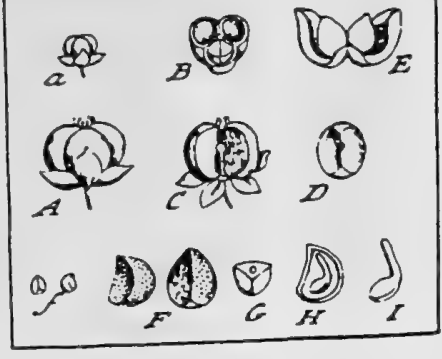

J. Gaertner (17.88) Vol. 2

124

DCXXVIII. A N D A CHNE. LINN. gen. I095.

Telephioides. TOURN. inft. t. 485 .

Flores fexu diftincti in eadem ftirpe. MAS. Cal. pentaphyllus. Cor. pentapetala. Stam. quinque. FEM. Cal. pentaphyllus. Cor. nulla. Ovar. fuperum. Styl tres, bifidi. Capfula tricocca,.elaftica. Semina gemina. Andrache Telephioides. Tab. 108. fig. 4.

Glaux procumbens, myrti tarentime folio. Bocc. mu. 2. p. I68. t. 19 .

Telepbioides gracum bumifufum, flore albo. DicL. elth. 377. t. 282 . BuXB. ceni. 2. p. 20 . t. 12. f. 2.

Andracbue procumbens berbacea. Lixis. 6yf. veg. 871 .

PER. Capfula parva, globofa, trifulca, tricocca, glabra. Cocculi papyracei, tenues, bivalves, elaftice dehifcentes.

Rzc. centrale, filiforme; breve.

SEM. in fingulo loculo gemina, triquetra, punctis planis, quafi Squamulis, undique confperfa, cinerafcentia. Umbilicus fimplex in media carina ventrali.

IN I. triplex: exrimum tenuiffimun, quafi furfuraceum, abbum; mediuns cruftaceum, pallide luteum, glabrum, fragile; intimun nembranaceum, pallidum.

A L B. fenini conforme, friabile, album.

ENB. longitudine fere albuminis, fubgnomonice arcuatus, inverfus, luteus, aut albus. Cotyl. ovatx, foliacex, radicula breviores. Rad. filiformis, curvata, longa, fupera.

125

2. A. B.) Capfula integra \& difletza C.) Receptac. cocculis interpolitum D. E.) Coceulus integer \& elaftice dehifcens. F. F.) Senina feparata. G. H.) Albumen transverfaliter \& longitudinaliter diffectum, cum fitu \& figura embrjonis: G.) Embryo folutus,

83.3 


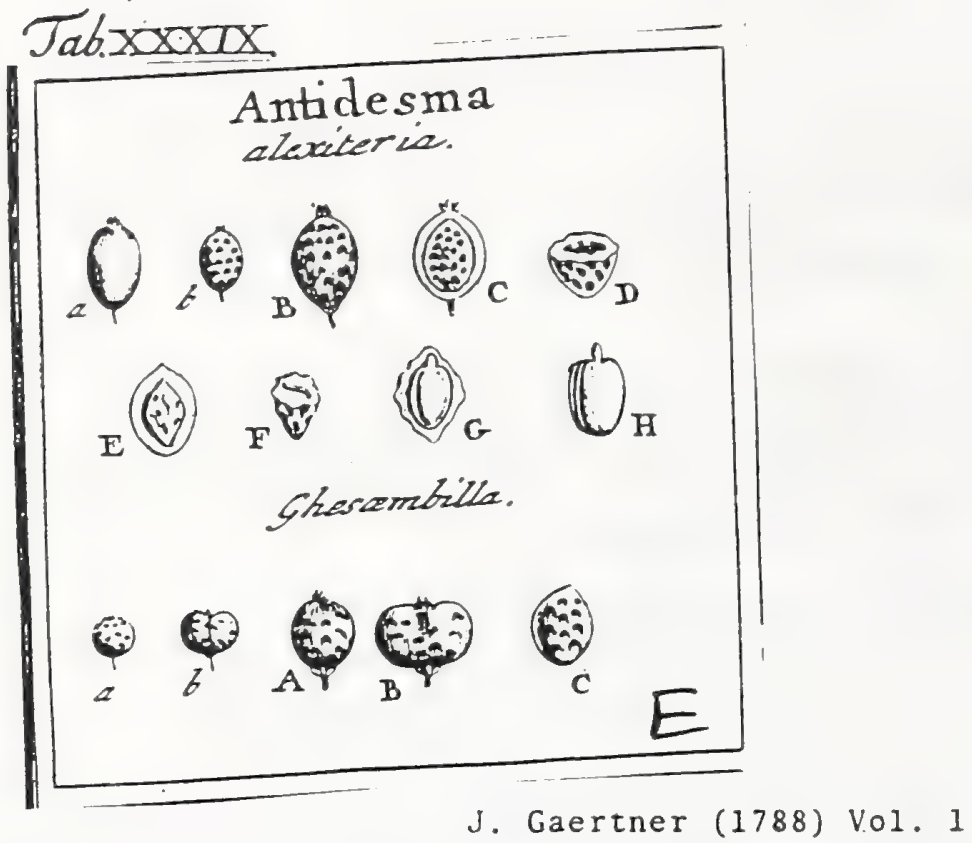

\section{ANTIDESMA. LINN. gen. IIIO.}

Flores fexu diftincti in feparatis truncis. MAs. Cal. pentaphyllus. Gor. nulla. Stam. quinque, antheris bifidis. F E M. Cal. \& Cor. ut in mare. Styl. nulli. Stigunata quin. que feffilia. Drupa baccata, unilocularis, putamine extus fcrobiculato.

Antidesma alexiteria. Tab. 39. fig. 5.

Nocli-tali. RheEd. mal. 4. p. 115. t. 56 .

Arbor indica, ovali folio, flofculis plurimis in spicis funmo ranulo difpojitis, acinifera. Plux. phyt. t. 339. f. I.

Antidefma. LIN N. fyfl. veg. 885 .

Katta-kotje. javan. E collect. fem. hort. lugdb.

PER. Drupa baccata, fupera, elliptico fphzroidea, per vetuftatem lenticu!ari comprefla, rugofa, fuperne quinis flignatibus, inferne calyce pentaphyllo terminats, rubre. Caro renuis. Putamen offeum, craflum, ovatum, leuticulari compreftum, profun: funde frobiculatum, uniloculare.

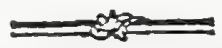

REc. nulluin.

SE ss. Unicum, ovatum, utrinque acuminatum, 2 putaminis impreflionibus varie rugatuin \& fcrobiculatum, rufeicens.

IN T. fimplex, tenue, membranaceum.

A L B. Cemini conforme, cralfiusculum, carnofum, album.

Es в. magnitudine fere albuminis, inverfus, lutefcens. Cotyl. ellipticx, foliacex, tenuilimx, transverGur figmoideo flexuolx. Rad. tereciuscula, brevilfuas, fupera

2) Drupa in aqua emollita. b. B.) Eadem exficcata, rugora. C.) Putamen a parte anterior denudatum. D.) Idem transverfe fectum. E, Ejusdem fectio longitudinalis cam femiais figura \& fitu. F.) Albuinen transverfe Sectum. G.) Idem longitudiualiter apertum, curm fitu embryonis. H.) Eirabryo feparatus.

ANTIDESMa Ghelxmbilla. ibid.

Grofularia zeylanica major Ghafembilla zeylonenjibus diafa. Burs. zeyl. 112.

Ribefioides. LIN N. fl. zeyl. n. 403 .

Ghafembilla. zeylon. E collect. fem. hort. lugib.

Fructus per fingula puncta priori fimilis, fed dimidio fere minor (a. A.) \& ma. gis rotundus, nec raro didymus ( b. B. ) ac duobus officulis (c.), fcrobiculatis dotatus." Calyx, fligmata \& ipfe color, ut in pracedenti.

Wxlembilla quoque zeylonenfium ad hoc genus, minime vero ad Elxagnum fpectat; fiquidem fructus ejus, pracedentibus fimillimi funt, nifi quod caro pauciffina \& color e fpadiceo fufcus; quod autem vel mere accidentale, vel \& inde procedere poten, quia fructus ante juflain maturitatem lecti fuerunt. 


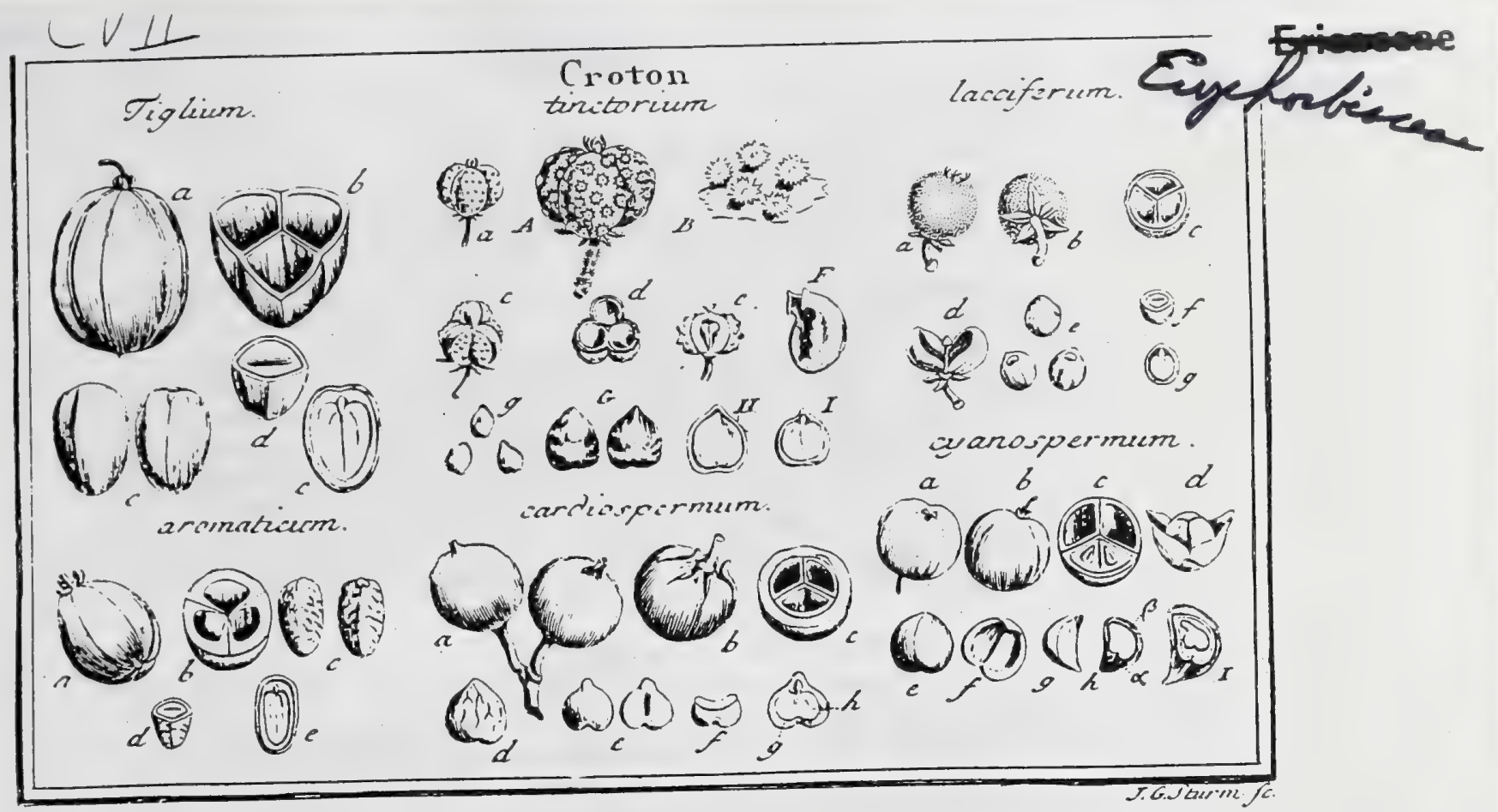

\section{J. Gaertner (17.88) Va.1.2 2}

DCXXIV. C R O TON. IINN. gen. IOS3.

Ricinoides. TOUR N. inzt. t. 423 .

Flores fexu diftincti in eadem planta. MAS. Cill. pentaphyllus. Cor. pentapetala aut nulla. Nectar. quinque glandujufạ. Stam. quindecim, bafi connats. HEM. Cal. \& Cor. ut in mare. Nectar. nulla. Ovar. fuperum. Styl. tres, bifidi. Capfula tricocca, elaftica. Sem. folitaria.

Croton tinctorium. Tab. 107. fig. 6.

Ricinoides ex qua paratur Totrnefol gallorum. Nissol. af. gall. 1712. edit. germ. p. 138 . t. II.

Croton tinctoriuns. BurM. for. ind. t. 62. f. s.

Croton foliis rbombeis repandis, capfulis perdulis, caide berbaceo. Lins. Gys. vig. 863 .

PER. Capfula fubglobofa, trifulca, tricocca, corticata. Cortex tenuis, herbaceus, feparatim dehifcens, tuberculatus: tubercula parva diffita, fquamulis ftellato - Jaceris argenteis nitidifausis prapilata. Cocculi chartacei, ovati, bivalves, elaftice dehifcentes.

REC. centrale, triquetrum, furfum incraffatum.

SEM. folitaria, ovata, fuperne leviter acuminata, inferne quifi truncata, $f$. emarginato - obtufa; oblolete rugofa, albicantia aut teftaceo fufca. . Um. bilicus non diftisctus, fed ejus loco cuticula tenuis alba verticem \& totam fuperiorem feminis partem obtegens.

IN T. triplex: extimum tenuiffimum ab umbilici cuticula formatum; inedizm cruftaceum, fufcum, fragile; intimun membranaceum, aridum albun \& fxpe argenteo nitore intus fplendens.

A в. femini conforme, craffum, friabile, album.

E si B. magnitudine fere albuminis, inverfus, lacteus Cotyl. rotundatx, foliacex, trinervix, tenuifimx. Rad. teretiufcula, brevis, fuperd.

2. A.) Capfula integra B.) Corticis tubercula (quamatz infigniter aucta. c. c.) Cortex feorfim dehifcens. d.) Capfula diffedan e.) Receptaculum: F.) Cocculus nudus dchifuens. g. G.) Scmina integra. H.) Albumen denudatum integrum. I.) Ejusdegi fectio verticalis cum fitu \& Ggura Embryonis. 


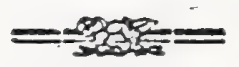

Croton Tigliun. ibid.

Cadel-aunsacu. RHero. mal. 2. p. 6r. t. 75.

Granus molnccum. RUnPH. antb. 4. p. 98. t. 42.

Ricinoides indica folio lucido, fruIu glabro Grana tiglia officinis diso. BUrm. f. Zeyl. 200 . t. go.

Croton folis ovatis glabris acuminatis ferratis, caule arborec. LiNw. Gyf. veg. $86_{3}$.

$E$ colled. fem. hork lugdb.

Calyx pentaphyllus brevifimus fub capfula retexus. Capfula (a) ovata, grandiufcula, coriacea, tenuis, glabra, trigona, trifula, tricocca (b.). Dilípimenta tenuilima, fere imembranaces. Color ftramineo pallidus. Semina (c) ovata, folitaria, hinc convexa, inde obtufiflime angulata, ad margines in aciem acutam extenuan, ftraminea, fufca, aut nigricantia. Umbilici cicatricula fimplex, parva, in extremitate feminis obtufiore atque fuperiore. Integ. exterius crultaceum; interius membranaceum, fericeo-album. Albumen carnofum (d.) cralfum. Enbryo (e. ) inverlus, lacteus. Cotyl. ovatucordata, foliacex, tenuiflinx. Radic. breviltima, fupera.

Croton aromaticum. ibid.

Arbor Zeylanica aromatica acris Laccam fundens media. HERM. mul. Zej\% p. गु. Eீ 46 .

Ricinoides arbor aromatica, circee foliis, media BURM. fl. Zyl. 202.

Croton foliis cordutis fcabris fubferrat is petiolatis, cande arboreo. LiNN. Lyf. veg. 864. Wallappetbya, Zeylon. E collect. fem. hort. lugdb.

Calyx pentaphyllus, brevis, fub capfula reflexus. Capfula (a.) ovata aut glo bofa, glabra, coriacea, craffl, ligneo fulca, ftriis fex pallidioribus longitudinalibus notata. Cortex fuberofus, craffus. Cocculi, feu loculamentoruin (b) membrana interna, chartacea, elaftica, albz Semina (c) folitaria ovato oblonga, hinc convexa, inde angulata, tuberculis obfoletis undique rugata, faturate fpadicez Umbilicus bilobus, fungofus, albus, in vertice feminis. Albumen (d.) \& Embryo (e) ut in procedentibus.

Halecus litorea Rumph. 3. t. 126. perperam a Linnxo ad hanc fpeciem refertur.

Croton lacciferum. ibid.

Ricinoides aromatica arbor, circee foliis birfutis, foribus fpicatis major. BURM. f.' 2eyl. 201. t. 9 I.

Halecus terreftris alba?" RUмPH. amb: 3. p. 198. t. 197. altera.

Croton folits ovatis tomentofis ferrulutis pesiolatis, calycibus tomentofis. LINx. fojlt. veg. 864 .

E cullect. fem. hort. lug db.

Capfula globofa, exfulca, corticata, tricocea, calyce perfiftente pentaphyllo patulo (a. b.) bari munita. Cortex coriaceus, integerrimus (c.), extus ilbo tomentofus. Cocculi tres (c. d.) chartacei, albi, elaftice dehifcentes. Semina (e.) folitaria, fubrotunda, turgide lenticularia (f.), obfoletiffime rugofula, fufco fpadicea. Umbilicus fub apice feminis, bilubus, albus. Alburnen \& Enbryo (g.) ut in prioribus.

Croton? cyanofpermum. ibid.

Lyan-gheddie. Zeylon. E collect. fem. hort. Jugdb.

Cillyx pentaphyllus, parvus, fub capfula (b) reficxus. Capfula (a. b.c.) globofa, glabra, obfoletifine trifulca, trilocularis (c.), tricocca. Cucculi chartacei, bivalves (d.), elaftici. Semina in fingulo loculo gemina (c. g.), inter fe conglutiuata (d.e.f.), hinc convexa (e), inde (d. f.) obtufifime angulata, poft feparationen vero acute trigona (g.), apice \& bafi acuminata, arido-baccata, violacea, aut e purpura crerulea, devigatifina, fplendentia. Integun. triplex: extimum nembranaceun, intus fpongiofum, ipfa tefta feminis multo amplius (h. $\alpha_{.}$); medium offeum, parvum, oblique cordatum, compreffum, in fuperiore parte integumenti extini (h., .) hxrens; intimum, denique membranaceum, pallidum, albumini adnatum. Albumen (1.) teft $x$ feminis conforme, carnofun, album, tenue. Enibryo (I.) inverfus, jactcus. Cotyled. foliacex planx, oblique cordatx, feu inferius profunde emarginatx Ridic. teretiufcula, brevis, fupera.

Ad Adrachuen fofian, ob fenina geminata \& embrionem fubcurvatum, lixc debuifer referri; fed \& ab Adrachne \& ab omnibus mihi notis Tricoccis, mira feminis fabrica, xque diftat, quare heic ei locum feci, donec de ftirpe
ipfa, certion innotefcant.

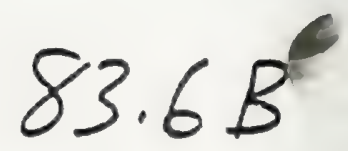


CROTON cardiofpermum. ibid.

Kebella \& Kebbele. Zeylonenf. E collect. fem. hort. lugdb.

Capfula globofa (a. b. c.), acumine triquetro, trituberculato terminata, glabra, cxfulca, tricocca, corticata. Cortex fuberofus craffus (c.), a bafi fexfariam (b.) dehifcens. Cocculi chartacei, elaftici, albi, ovati. Semina (d.e.f.) folimaria, cordiformia, compreffiulcula $(\mathrm{g})$, hinc convexa, inde plama aut leviter concava, in ipfa cordis ensarginatura albicante, foramine umbilicali pertufa. Integ. triplex: extimum membranaceum, rugolum (d), ut reccis carnofum fuiffe videtur; medium (e. f.) cruftaceum, fragile, pallide framineum; iutinum menibranaceum, tenuifimum, fufcum. Albumen (g.h.) teltx feminis conforme, carnofum, album. Enbryo $(h)$ inverfus, gramineo-viridis. Cotyl. foliacex, rotundato-curdata, feu trunsvarfim latiores. Rad. brevis, recta, fuperis.

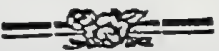

Non eft dubium, quin hic fruetus ad Crotonis genus nequaquam fpectet; attamen nialui nomen, fub quo datus fuit, retinere, quam absque ulteriori ftirpis cognitione, novum ei facere.

Kebella a Kebbele id faltem differt, quod extimum feminis integumentum in polteriori fufcum, in priori vero fulvum aut rubrum fit. 


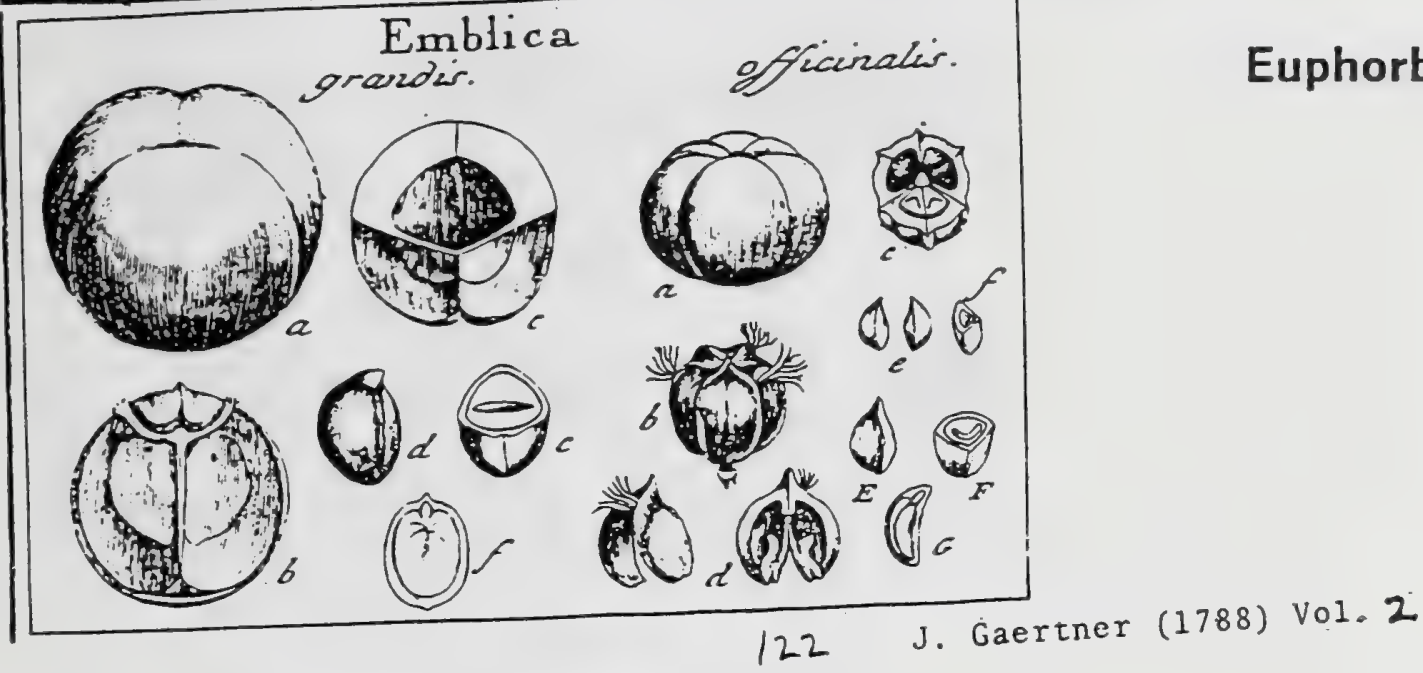

\section{E M B I I C A.}

Flores fexu diftincti in eadem ftirpe. MAS. Cal. fexpartitus. Cor. nulla. Stam. tria. FEM. Cal. \& Cor. ut in mare. Ovar. fuperum. Styl. tres, bifidi. Capfula drupacea, tricocca: Semina folitaria, aut geminata.

IMBLICA officinalis. Tab. 108. fig. 2.

Nili camaram. RHEED. mal. 1. p. 69. t. 38. BLAKw. berb. t. 400.

Mirobalanrs Ensblice. RUMPH. amb. 7. p. I. t. x. bene.

Pbyllanthus foliis pimatis floriferis, caule arboreo, fruafu baccato. LINs. Jyfto veg. 847 .

PER. Capfula drupacea, globofa, depreffa, fexfulcata, tricocca. Cortex coriaceo carnofus, craflus, glabriufculus. Putamen lapideum, obovatum, hexangulare, apice mucronatum, compolitum ex cocculis tribus offeis, hinc fulco elevato dorfali, fibris lignofis fafciculatts criftato, infiguitis, inde angulatis, femibivalvibus, a baci elaftice demicentibus.

REC. centrale, columnare, triquetrum,

SEM. in fngulo loculo gemina, triquetra, hinc arcuata, inde lateribus planis in angulum acurum convergentia, glabra, fpadicea, dura. Umbilicus fimplex, exiguus, in medio feminis ventre.

INT. triplex: extimum membranaceum; medium cruftaceum, durum, fragile; intinuon membranaceum, ferrugineum.

$\Lambda \perp$ B. carnofum, friabile, pallidum.

Е м в. longitudine fere albuminis, inverfus, Jacteus. Cotyl. foliacex, cordatolanceolatx, marginibus fuis verfus dorfum feminis gutturnii in fpecielu retlexx, atque leviter arcuata. Rad. teretiufcula, fupera.

2.) Drupa integra, b.) Putamen folutum, integrum, a) Ejus fectio transverfalis d) Coceulus dehifcens, ab utraque parte (peezatus. .e. E.) Semiaz Separata f. E.) Seminis \& aucici fedio transverfalis. G.) Embryonis in albumine fitus \& figura.

Crines dorfales cocculorum quandoque deficiunt.

Emslici grandis. ibid.

an Phyllanthus baccatsus? Lisw. l. $c$.

Ex feminar. hort. Amftelocl. Drupa globofa, grandiufcula (a), obfolctiffime trifulea, glabra, per xtatem
fumofa sut fufca, tricocca. Cortex tenuis (b.), coriaceus. Cocculi offei, in dorfo crnfitioni (c.) convexi, ad latera vero tenues $\&$ in angulum convergentes, bivalves. Receptac. inferne obfoletum (b.), fuperne sutem trifurcatim : brachiis teretiufculis, furfum curvatis, \& in propriis fujcis inter cocculorum latera ad corticis cruftan decurrentibus, in qua ultimis fuis fibrie difperguntur. Semina (d.) folitaria, grandiufcula, obefa, hinc gibba \& in dorfo quafi carinara, inde leviter convexa (e.), ftriaque media ventrali nocnea ; ceters glabra, fpadicea, atque parvo forsmine umbilicali fub apice perforata. Integ. exterius cruftaceum: interius membranaceum, lata chalaza ferruginea in bafi notatum. Albumen (e.) crafium, olcofum, albicans. Embryo (f.) inverfus, niveus. Cotyl. cordato - ellipticx, foliacex, planx. Rad. parva, fupera.

Nont tantum fructu drupaceo, fed \& embryone non Tpirali, Emblica a Phyllantho diftat, ut. carpologice nequaquam fociari.queant. 


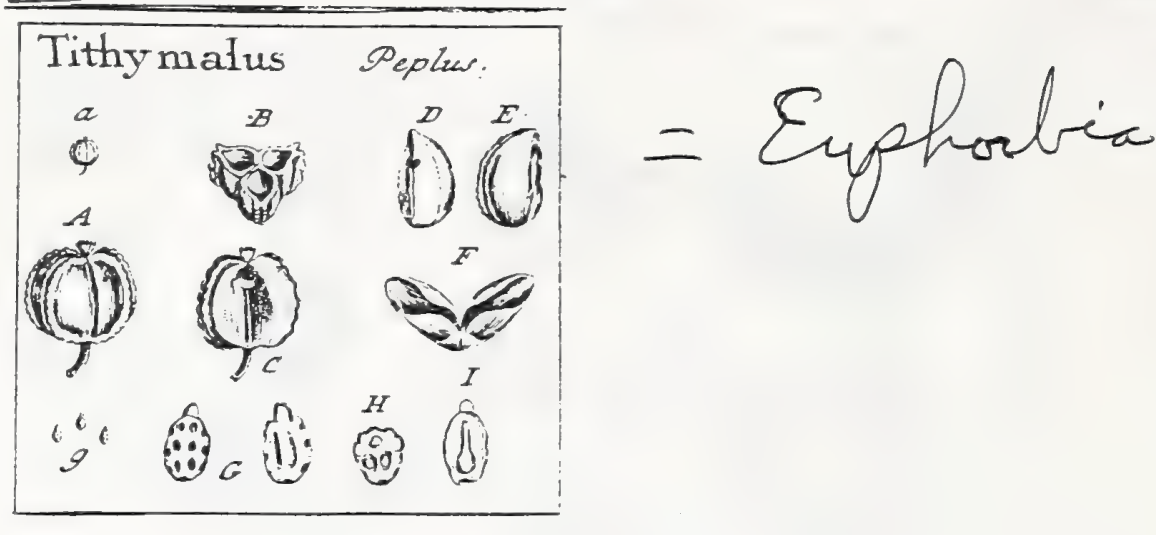

J. Gaertner (1788) Vol. 2

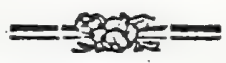

DCXX. T I T H Y.M A L U S. TOURN. inf. t. Is. Euphorbia. LINN. gen 609 .

Calyx crnpanulatus, quadri-1. quinquefidus. Petala quatuor 1. quinque, fegmentis calycis interjecta, fucculenta, ovata, aut lunata. Stam. duodecim aut quindecim. Ovar. fuperum. Styl. tres, bifidi. Capfula pedicellats, tricocca, elaftica. Sem. folitaria.

Tithyalus Peplus. Tab. 107. fig. 2.

Peplos. Dud. purg. 26 . pempt. 375 .

Ejultu folio rotundo. Riv. tetrap. t. 118 .

Ticlyymahus foliis rotundis, fripulis foralibus cordatis obtufis, petalis argute corri culatis. HaLL. bifr. " 1049 .

Euphorbia unbella trifida: dichotoma, inrolucellis ovatis, foliit integerrinsis obovatis petiolatis. Lis. Jijl. veg. 45 r.

PER. Capliula parva, fubrotunda, glabra, trigona, tricocca. Cocculi ovati, criltis duatus nembranaceis undulutis anguitziffmis in dorfo notat, ex adverfa patie angulati \& fub vertice foramine perforati, chartacei, bivalves, elaltice dehifcentes.

REc. columnare, centrale, gracile, capitulo depreffo fpongiofo terminatum.

SEM. folitaria, ovata, hinc convexa atque feriatim fcrobiculata, inde fulco medio elevato angulata, ex. albo cinerafecntia, umbilico conico fungofo folido albo in vertice notata.

IN T. fimplex, coriaceum, craftiufculum.

A L B. Semini conforme, etiam fcrobiculatum, carnofum, friabile, aqueopallidum.

EM B. longitudine albuminis, inverfus, gramineo-viridis. Cotyl. fubrotundx, comprefix, parvix. Rad. cylindrica, longa, fupera.

2. A. B.) Capfula integra \& difeda. C.) Receptac, reculis interjectuna. D. E. F.) Cocculus integer \& dehifcens. g. G.) Semina feparata. I.) Seminis \& abuminis fetio transverfalis k.) Eorundem fedio verticalis cuss fitu \& figura Eabryonis.

Nunerofic Tithymalali fpecies conmode a fructu bifariam difpefcuntus: in lsies fcil. atque suberculatos, quarum pofteriores minus frequentes funt.

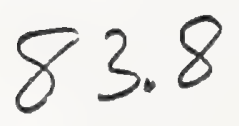


Tab. CVIII.

\section{Excoecaria \\ lyallocha. \\ (1) (2) \\ $O_{D} \bigcup_{E} \underset{G}{0}$}

J. Gaertner (1788) Vo.1. 2

126

DCXXXI. EX COE C A R I A. LIN N. gen. Iro2.

Flores fexu diftincti, in feparatis ftirpibus. MAS. Cal. nullus. Cor. nulla. Stan. ternata, in receptaculo communi cylindricu anientacco. FEM. Cal. niullus. Cor. nulla. Ovaria nuda in fpicis fubramofis. Styl. tres, fimplices. Capfula fubglobofa', trifulca. Sem. folizaria.

Excoecaria Agallocha. Tab. 108. fig. 7.

Arbor excoecans. .RUMPH. amb. 2. p. 257 . t. 79.80.

Excoectria- Lins. Jyft. veg. 882.

Ex herbario Bankfiano.

PER. Capfula parva, magnitudine baccx juniperi, fubglobofa, trifulca, -glabra, nigra, trilocularis, chartacea, nullis intus cocculis diftinctis dotata, fed fimpliciter in tres valvulas (preffione) dehifcens.

REC. nullum; femina apice fuo loculamentorum angulis internis affixa.

SEM. folitaria, fubglobofa, fuperne acuminata, hinc convexa, inde obtufiffime angulata, glabra, rufefcentia.

IN T. duplex: coriaceum \&.membranaceum, utrumque tenuẹ.

A L B. carnofun, pallide albicans.

E M 8. magnitudine fere albuminis, inverfus, lacteus. Cotyl. fuborbiculatx, foliacex. Rai. brevis, fupera.

2.) Capfula integra. b.) Eadem, preftione in valvulas foluta. c.) Ejusdem fectio transver(alis. d. D. E.) Sernina feparata. F.) Albumen transverfe f(ctum. G.) Ejusdem fectio longitudinalis cum litu \& figura Embryonis.

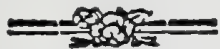

Secundum Rumphium, capfulx funt magnitudine capparidum, per maturitatem rufelcentes \& elaftice dehifcentes; atque Semina dura \& Ricini inftar variegata: qure onuia in noftris fpeciminibus, forfan haud rite maturis, non ita fe habent. 
Euphorbiaceae

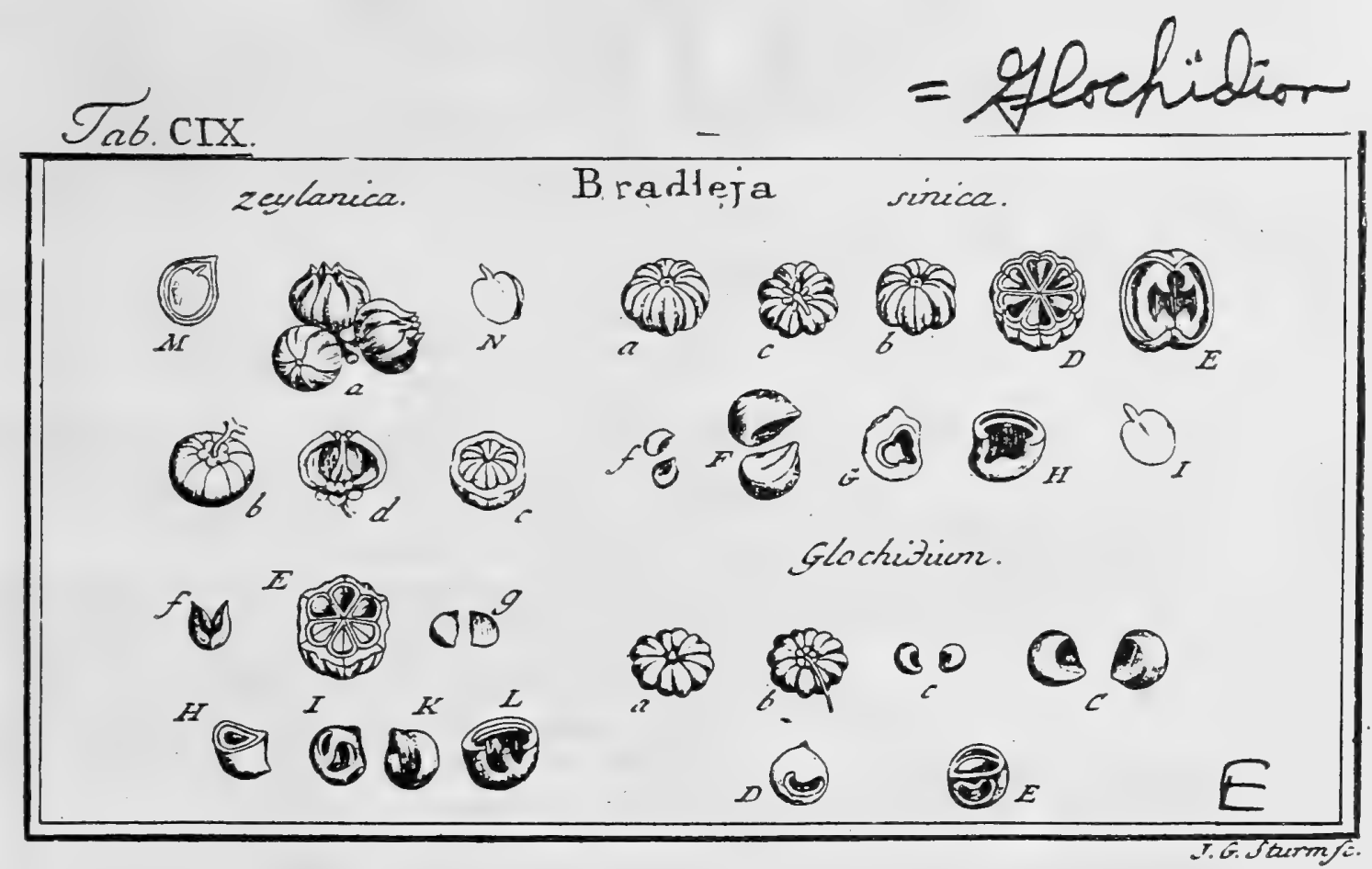

$83.10 \mathrm{~A}$ 


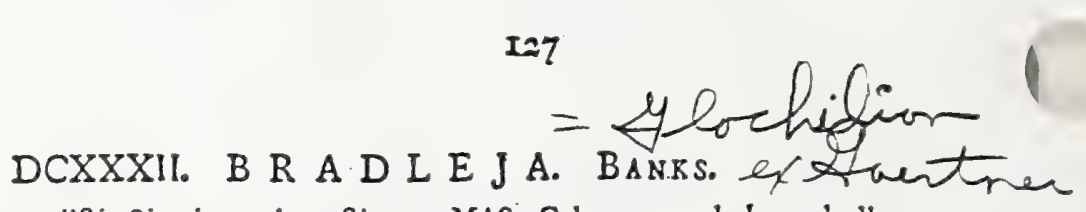

Flores fexu diftineti, in eadem ftirpe. MAS. Cal. penta - 1. hexaphyllus, perfiftens. Cor. nulla. Stam. Sex. FEM. Cal. \& Cor. ut in mare. Ovar. fuperum. Styl. craffus, fuperne fexfidus: ftigmata fimplicia, obtura. (Ex fchedis SolandRI.) Capfula corricara, hexacocca. Semina gemiun, menifcoideo fenteltrata.

BradLeja finica. Tab. I09: fig. 1.

Arbufcula finica, anone dulcis folio non fplendente, frubtu ex foliorum alis com-

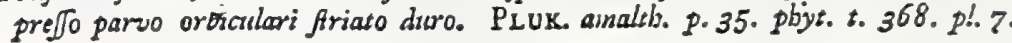

Eे cullectione Bankfiana.

PrR. Capfula fubglobofa, deprefliufcula, utrinque umbilicata, fex l. octo torulis medio fulco dorfali notatis pulvinata, corticata. Cortex fpongiolo membranaceus, per maturitatem fexvalvis. Cocculi fex 1. octo, chartaced, bivalves, elaftice dehifcentes, pallide albicantes.

R E c. centrale, filiforme, breve.

SEM. in fingulo loculo gemina, non juxta $f e$, ut in reliquis fpeciebus, fed fibi mutuo impofita, angulato - globofa, coccinea, arido baccata.

INT. triplex: extimun membranaceo fpongiofum, coccineum; medium cruftaceuin, durum albicaus, dup!ici cavitate dotatum : altera inflata, inani, amplo foramine irregulari feneftrita; altera autem comprefla, claufa, embryonifera; intimum denique, membranaceum, fufcum, intus fubcarnofum.

128 .

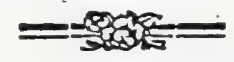

A L в. nullum, nifi fuperficiem carnofam integum. intimi velis.

EM B. magnitudine cavitatis compreffx feminis, iıverfus, lacteus. Cołyl. ova. to- cordarx, concavx, folincex, tenuifimx. Rad. linearis, compreffa, fupers.

a. b. c.) Caplula integra, utringue (pedizt. D.) Eadem Jiffeda, hexacocer. E.) Cocculus cum cortice fuo, a parte (ua iateriore fpetatus, slaftice dehifeens. f. F.) Semina extima fus membrana adhuedum reflita. G.) Tefta feminis deuudata, amplo foramine pertufa. H.) Eadema transverim feca, cum daabus fais cavitatibus. I.) Embro folutus.

BRADLEJA Glochidion. ibid.

Glocbidion. Fonst. charaf.

Dodda - mare \& Puan-kere. javan. E collect fem. hort. lugdb. \& ex herbario Bankfiano.

Capfula orbiculata (a. b.), valde depreffa, torulis fex 1. octo, didymis, pulvinata, totidemque continens cocculos chartaceos, elafticos, ab epidermide f. cortice non fponte fecedentes. Semina geminata (c. C.) pracedentibus fimillima, etiam vivide coccinea. Tefta feminis.(D.E.) pariter bilocularis, fed feneftra loculamenti vacui non ita ampla, verum potius oblonga \& rim transverfali frmilis.

Bradreja Zeylanica. ibid.

Guru-Kierille. Zeylon. E collect. fem. hort. Iugdb.

Calyx, in hac, monophyllus (b.) quinquefidus. Capfula (a. b. c. d. E.) glos bofa, depreffiufcula, ftriata, minime vero torofa, glabra aut per xtatem obfolete hexagona (c. E. ), heracocca, corticata. Cortex craffus, fuberofo coriaceus, apice fexfariam (a) dehifcens. Cocculi (c.f.) characei, elatici, bivalves. Semina geminata ( $\mathrm{E}$ g.), rotundata, hinc convexa (H.), inde plana. Integum. extinum membransceum, tenue, rufefcens, feu propter vecuftatem excolor; medrian (I: K. L.) offetrm, biloculare (L.): loculamento inarii tribus foraminibus (I.) feneltrato; intimuni nigro ferrugineun, Jamina carnof, loco albumunis (M.) duplicatum. 'Embryo (M. N.) e luteo - viriAefcens, taverfus. Cotyled. \& Radic fupera: foliaceo - compreffx.

Mültum affinitatis Bradleja cum Phyllantho habet, prafertim cum \& tria tantum ftamina Glochidio fuo Cl. Forfter tribuat; fed feminum tabrica in hoc genere adeo fingularis eft; ut ab omnibus cognitis Tithymaloideis !ongiflime recedat atque proprio nomine utique difingui mereatur. 


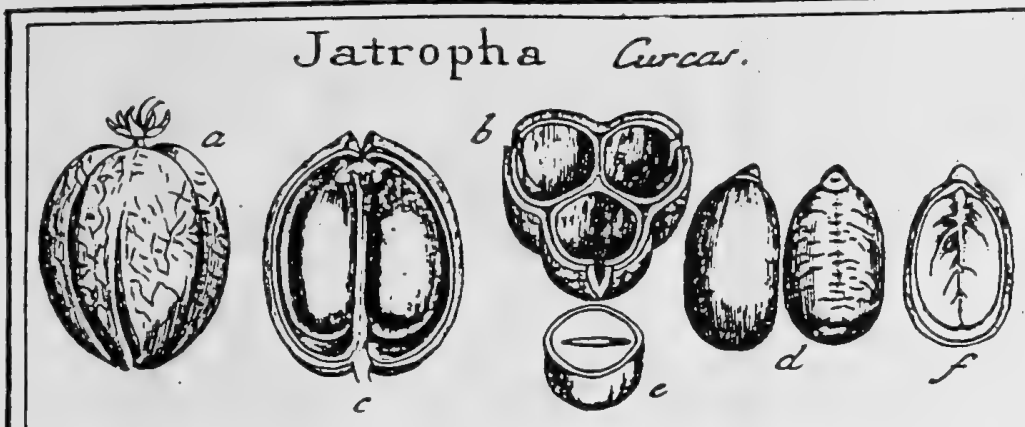

J. Gaertner (17.88) Vol. 2

$$
|2|
$$

\section{J A T R O P H A. IINN. gen. ro84.} Manihot. TOURN. inft. t. 438.

Flores fexu diftincti in eadem ftirpe: MAS. Cal. nullus, aut quinquefidus. Cor. monopetala, infundibuliformis. Stam. decem : alterna breviora. FEM. Cal, nullus. Cor. pentapetala, patens: Ovar. fuperum. Styl. tres, bifidi. Capfula tricocca, corticata. Sem. folitaria aut gemina.

Jatropha Curcas. Tab. 108. fig. I.

Jutropha folits cordutis angulatis. LINN. Syf. veg. 865 .

Icors. JACQ. bort. ข. 3. t. 63 .

PER. Capfula grandiufcula; ovata, trigona, .per maturitatem extus rugatofcabrata, fumofa, corticata. Cortex craflus, curinceus. Cocculi tres, chartacei, albicantes, bivalves.

REc. centrale, columnare, glacile, fuperne in capitulum depreffum fungofum incrafratum.

SEM. Folitaria, grandia, ovato oblonga, hinc convexa, inde obfoletifime angulata, ut fere cylindrica fint, cxtera apice in mucronem cavum producks, in quo umbilicus fungofus albus jacet, nigra, rimis minutis cera $\&$ ad tactum afpera.

INT. duplex: exterins cruftaceum, fragile; insterius membranaceum, fericeoalbumi.

A L B. crạfum, carnofum, fragile, album.

EMB. magnitudine fere albuminis, inverfus, niveus. Cotyl. ovato oblongz, foliacex, planx, venofx. Rad. teretiufcula, brevis, fupera.

a.) Capfula pendula, integra, preter corticem ad apicem dehilceatem. b.) Eadem transverium fecta. c) Receptac. cum litu \& infitione feminum. d.) Scmina ab utroque ntere fpectin. e. f.) Seminis fcctio trausverfalis atque longitudinalis cum craffitie, fitu \& figura albuminis (e) \& Embryonis (f.).

Nucleo feminum vefci poffe absque noxa, quando embryo demtus eft, Boyleus, ni fallor, primus obfervavit. 


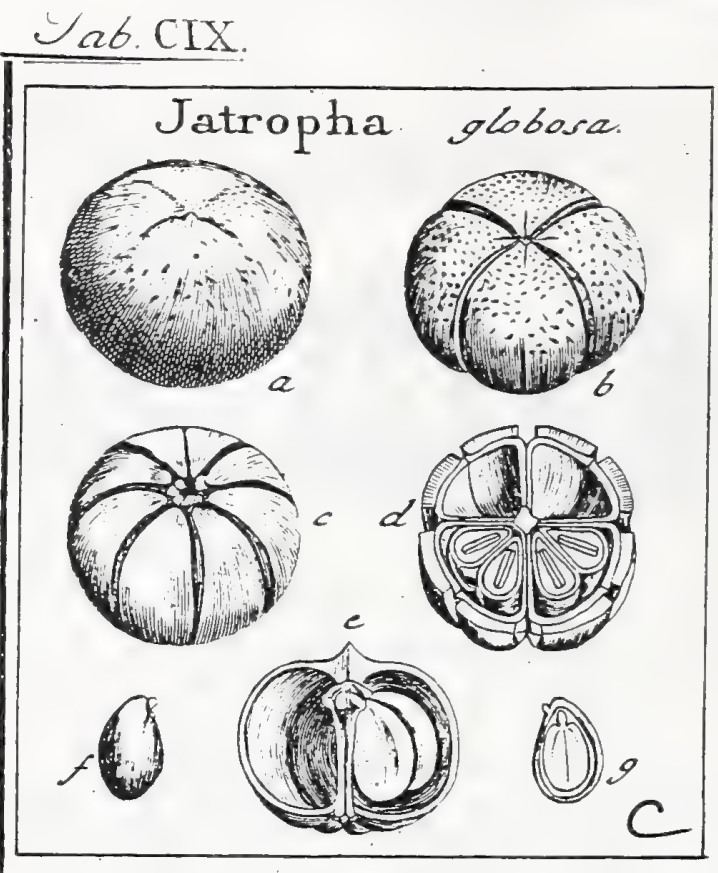

\section{Euphorbiaceae}

J. Gaertner (17.88) Vol. 2

122

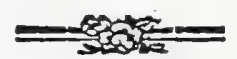

JATROPHA globofa. Tab. 109. fig. 3.

Ex Curaffao, ab amicif. D. Berkhey.

Capfula globofa (a. b. c. d.e.), depreffa, tetracocea (d.), drupacea. Cortex craffus, coriaceus, fcabriufculus, a bafi verfus apicem (c. b.) in octo fegmenta dehifcens. Cocculi quatuor (d.) offei, craffiufculi, elaltici, pallide albicantes zut teftacei, bivalves. Receptac. columnare (e.) capitatum. Semina (f.e.d.) in fingulo loculo gemina, ovata, furfum anguftata, trigono - conpreffa, glabra, fplendentia, caftaneo - nigricantia. Umbilicus fungofus, albus. Integ. exterins cruftaceum, fubftantia quadam friabili \& ferrugineo - rub intus veftitum; interius membranaceum, fericeo - album. Albumer femini conforme, fragile, fubpellucidum. Embryo ( $\mathrm{g}$ ) inverfus, gramineo - viridis. Cotyl. ellipticx, foliacex'. Rad. brems, fupera.

Quaternaribin loculamentorum numerum non conftantem effe puto; fed bina. rius feminum numerus, \& embryonis, etiam in vetufto fructu, color viridis, hanc.affatim diftinctam faciunt a reliquis fpeciem. 


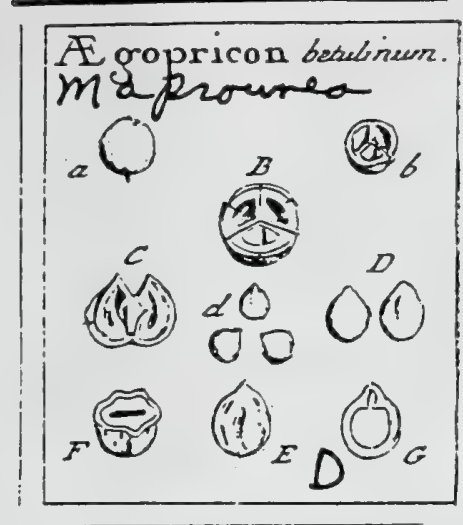

J. Gaertner (1788) Vo1, 2

\section{DCCC. Æ G O P R I C O N. LINN. gen. 14zG.}

Flures fexu diftincti in endem ftirpe. MAS. Amentum ovato-globofum, parvum. Cal. trifidus. Cor. nulla. Stam. unicum. FEM. Flores folitarii. Cal. \& Cor. ut in mare. Ovar. fuperum. Sryl. tres, ftigmatibus fimplicibus. Capf. tricocca, elaftica. Sem. folitaria, arido baccatu.

EgOpricon betulinum. Tab. 138. fig. 4.

Egopricon. Linn. Juppl. 4ז3. Jyf?. veg. 840.

kion. SмIтн. fafe. $=$. $t .42$.

A Cl. Thunbergio.

PER. Capfula globofa, magnitudine pifi ninoris, glabra, gilva, tricocca, trilocularis, trivalvis: valvulis bifidis. Cortex tenuiffimus, membranaceus, arcte adhxrens. Cocculi fuhoffei, craffi, elaftice dehifcentes.

REC. obfoletun; femina angulo loculamentorum centrali fupra nedium affixa.

SEM. folitaria, fubglobofa, fuperne in mucronem attenuata, hinc convexa, inde angulata, pallide fpadicea, tunica fpongiofa $f$. arido baccata.

IN T. triplex: extimum fpongiofo-membranaceum, tenue, in recenti femine forfan carnofum; medinim cruftaceum, fragile, fcrobiculis fparfis parum profundis exaratum, fufcum; intimum membranaceum, pallidum.

ALB. teftx feninis conforme \& in fuperficie quoque obfolete ferobiculatum, carnofum, oleofum, friabile, album.

Es 8. magnitudine fere albuminis, inverlus, niveus. Coty\% foliaceic, orbiculatx. Rad. tereciufcula, fupera.

1.) Capfula integra. b. B.) Eadem trankverfim fecta. C.) Valvula a parte interiore fpectata. d. D.) Semina fepatatz. E.) Tefta feminis denudata \& a latere durfini (peclata. 'F.) Ejusdem, vt \& albumivis fectio transver[alis. G.) Albumen longitudinaliter diffetun, cum fitu \& figura embryouis.

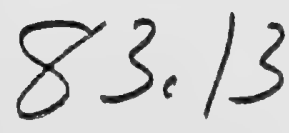




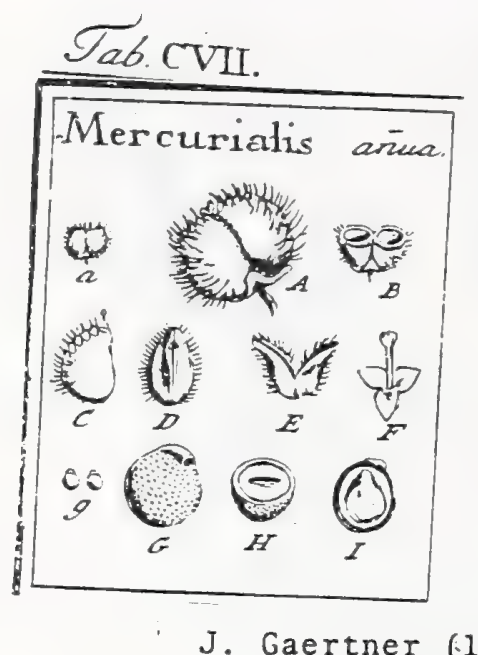

\section{Euphorbiaceae}

\section{4}

DCXIX. MER C U RIAIIS. TOURN. inft. t. 308 .

\section{LIN N. gcr. IIIS.}

Elóres fexu diftincti, in eadem, vel \& in diverfa ftirpe. MAS. Cal. tripartitus. Cor. nulla. Stam. novem 1. paulo plura. FEM. Cal. \& Cor. ut in mare. Ovar. fuperum. Styl. duo. Capfula dicocca, bilocularis. Semina folitaria.

Mercurialis annua. Tab. 107. fig. I.

Mercucialis mas EO femina. Can. epit. 996. 997. Brakw. berb. t. IE2.

Mercurialis caule ammo brachiato, foliis conjugutis ovato - lanceolatis glabris. HALL. bift. n. 1600 .

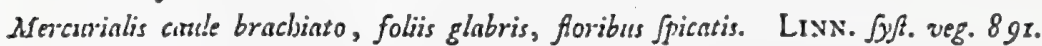

PER. Capfula fubrotunda, didyma, dicocca, parsa. Cocculi ovati, turoidi, in dorfo fetis albis, \&, prope futuram ejus, in duas criltas anguftilinas confuentibus hifpidati, verfus axen vero glabri, fubcomprefi, clartacei, bivalves, elaftice dehifcentes.

REC. lineare, compreffum, cocculis interpofitum, fuperne duobus tuberculis incraffatum, e quibus funiculi brevilfini oriuntur, qui cocculorum foramen vertici proximum intraut atque femina pendula fuftinent.

SEM. folitaria, globofa, tuberculato - afpera, rufefcentia aut cinerafcentia, fuperne umbilico fungofo, fiftulofo, albicante terminata.

IN T. duplex: exterins cruftaceum, tenue, fragile; interius membranaceum, tenuifimum, chalaza exigua rufefcente ad bafin notatum.

A в в. femini conforme, carnofum, friabile, album.

$E_{M B}$. magnitudine fere albuminis, inverfus, lacteus. Cotyl. fuborbiculatx, foliacter. Rad. attenuata, brevis, fupera.

2. A. B) Capfula integta \& dificta. C. D. E) Coctulus integer, a dorfo \& vertre tpcetatus, idemqne dchifcens. F) Receptac. centrale. g. G.) Semina feparata. H.) Scminis \& albuminis featio transverfalis I.) Eorunden fedio verticalis, cum fitu \& higura Enbbryunis.

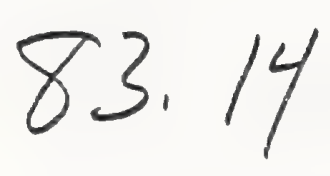


Tab. CVIII.

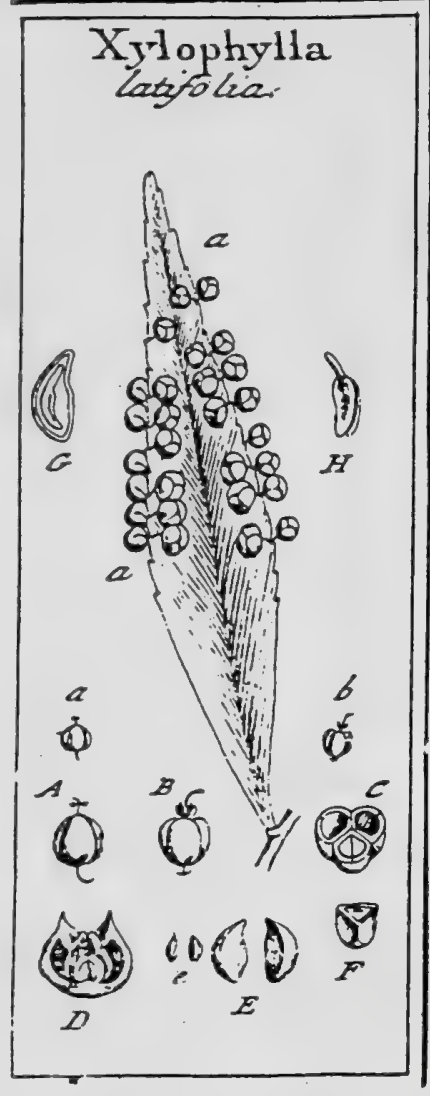

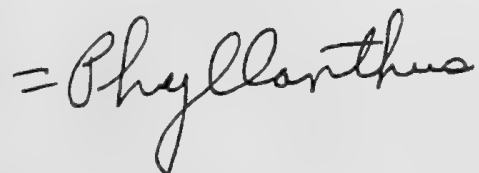

J. GaertneI (1788) Vol: 2

123

DCXXVII: XYLOPHYLLA. LINN. ger. 1299. =

Flores omnes hermaphroditi. Cal. quinquepartitus, culoratus. Coir. nulla. Stam. quinque. Ovar. fuperum. Styl. finplex, ftigmatibus tribus bifidis. Capfula pedicellata, cricocca, elaftica. Semina gemina.

Xxlophylla latilolia. Tab. 108. fig. 3.

Phyllanubis anericans planta, flores e fingulis folionom crenis proferens. Coims. bort. amet. 1. p. 199. t. 102. CAтESB. carol. 2. p. 26. t. 26.

Filicifolia bemionitidi affunis americana epiphyllanthos Ëc. PLUK. plyyt. t. 247. f. 4. \& $8.3^{6 . f} \cdot 7$.

Xyloplyylla foliis lanceolatis, ramis teretibies. LINN. Gyf. vet. 296.

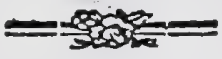

PER. Capfula parva, globofa, pedicellata, fuperne attenuata, glabra, rufercens, trifulca, tricocca. Cocculi papyracei tenues, bivalves, elaltici, albi, ab cpidermide non fecedentes.

REC. centrale, filiforme, breve.

SEM. in fingulo loculo gemina, oblonga, triquetra, fuperne magis acuminata, glabra, fpadicea.

INT. duplex: cruftaceum atque membranaceum, utrumque tenuilimum.

A L B. carnofum, album, tenue.

EMB. longitudine albuminis, lineari compreffus, inverfus, fecundum dorfi feminis curvaturam leviter arcuatus, pallide viridis. Cotyl. foliacex, lanceolatx, planx. Rad. teretiufcula, longa, fupera.

2. A. b. B.) Capfula integta. C.) Eadem transverfim diffecta. D.) Cocculus dehifcens. e. E.) Se。 mina feparata. F. G.) Scminis fettio transverfalis atque longittidinalis cum albuminis \& Eisbryonis jutu \& figura. H.) Embryo Solutus: 
Tab. CVIII.

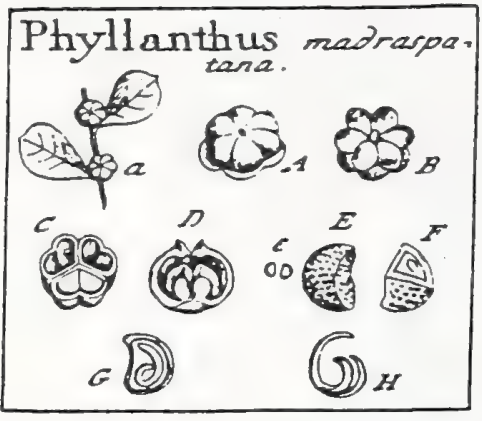

Euphorbiaceae

125

DCXXIX. PHYLLANTHUS. LINN. geis. 1050.

Flores fexu diftineti in eadem ftirpe. MAS. Cal. :expartitus. Cor. nulla, Stam. tria. FEM. Cal. \& Cor. ut in nare. Ovar. fuperum. Styl. tres, bifidi. Capfula tenuis, orbiculata, fexfulca, tricocca, elaftica Semina gemina.

Puyllanthus madrafpatana Tab. 108. fig. S.

Phyllantbus foliis alternis cuneiformibus mucronatis. LINN. fylt. veg. 847 .

Ex herbario BankGano.

PER. Capfula orbiculata, depreffa, baG calyce hexaphyllo, fibi paulum latiore excepta, toris fex obfoletiufculis diftincta, tricocca. Cocculi papyracei, ab epidernide non fecedentes, bivalves, elattice dehifcentes.

REC. centrale, filiforme, breve.

SEM. in fingulo loculo gemina, triquetra, punctata, ferruginea.

IN T. duplex: cruftaceum \& membranaceum, utrumque tenuiffimum.

A L B. tenue, carnofum, album.

Eагв. linearis, compreffus, inıverfus, fubfpiralis, gramineo viridis. Cotyl. in gyrum laxum fimplicem tortæ; cetera planx; lineares. Rad. filiformis, cotyledonibus longior, arcuata, fupera.

2. A. B.) Capfula integra, prona \& fupina. C.) Eadem ditfeta D.) Cocculns elaftice dehireens. e. E) Seminz (eparata F. G.) Seminis \& albuminis fectio transverbalis atgue longitudinalis, cum firu \& figura cmbrgonit. H.) Embrgo folutus.

$83 \cdot 16$ 


\section{Tab. CVII.}

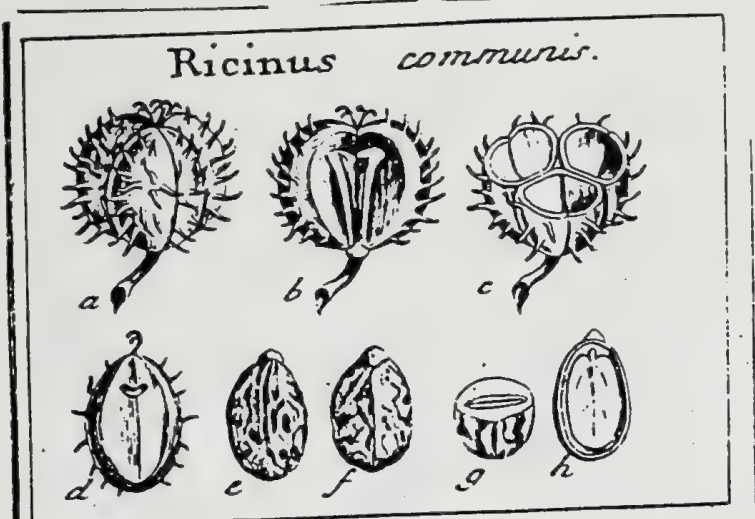

J. Gaertner (1788) Vo12

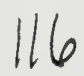

\section{RICINUS. TOURN. inf. t. 307. LINN. gen. I085.}

Flores fexu diftincti in eadem ftirpe. MAS. Cal. quinquepartitus. Cor. nulla. Stam. numerofa, bafi in fafciculum connata. FEM. Cal. tripartitus. Cor. nulla. Ovar. fuperum. Styl. tres, bifidi. Capfula corticata, trifulca, tricocca, fubevalvis. vem. folitaria.

Ricinus comnunis. Tab. 107. fig. 4 .

Ricinus minor Є̂ major. BesL. Eyff. aftiv. VIII. t. Ir. छิ 12. f. x.

Cataputia major E' Ricinus. BLAKW. berb. t. 148. bene.

Ricinus foliis peltatis frubfalmatis ferratis. LIN $\int_{y j}$. veg. 865 .

PER. Capfula fubglobofa, corticata, undique fpinfs mollibus echinata, trifulce, tricocca. Correx herbaceus, tenuis. Cocculi ovati, chartacei, hinc convexi, ftria dorfili notiti, inde angulati \& foramine cordato fub apice perforati, bivalves, vix camen aus raro, apud nos, dehifcentes.

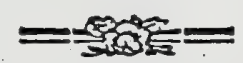

REc. columuare, trigonum, fupra latefcens, triplicique fine obture foramine cncculorum ventralia intrans.

SEM. Solitaria, grandiufcula, owsta, hinc convexa, inde obtufiffime angulata, glabra, fubnicida, nunc lividil \& nebulofis maculis infignita, nunc lineolis punctis atque lituris albis fuper fundo teftaceo aut fufco varie \& ventris aranearum adinttar egregie picta. Umbilicus fungofus craffus albus vertici impolitus.

IN T. duplex: exterius cruftaceum, fragile; interius membranaceum, fericeo albicans, bafi puncto fufco chalazino notatum.

A ¿ в. femini conforme, crafum, carnofum, friabile, album.

EM B. magnitudine fere albuminis, inverfus, lncteus. Cotyl. ovatse, foliacex, vafculofx, tenuiflimx. Rad. teretiufcula, brevis, fupera.

2. c) Capfula integra \& difeeta. b.) Receptac. cocculis interju\&um. d.) Cocculi feparati latus veatralc. e. f.) Senina ab utraque parte (pedata. 5.) Seninis fedio transverfalis \&- h) Ejusdem fectio longitudinalis eum fitu \& figura albuminis atgue Embryonis 


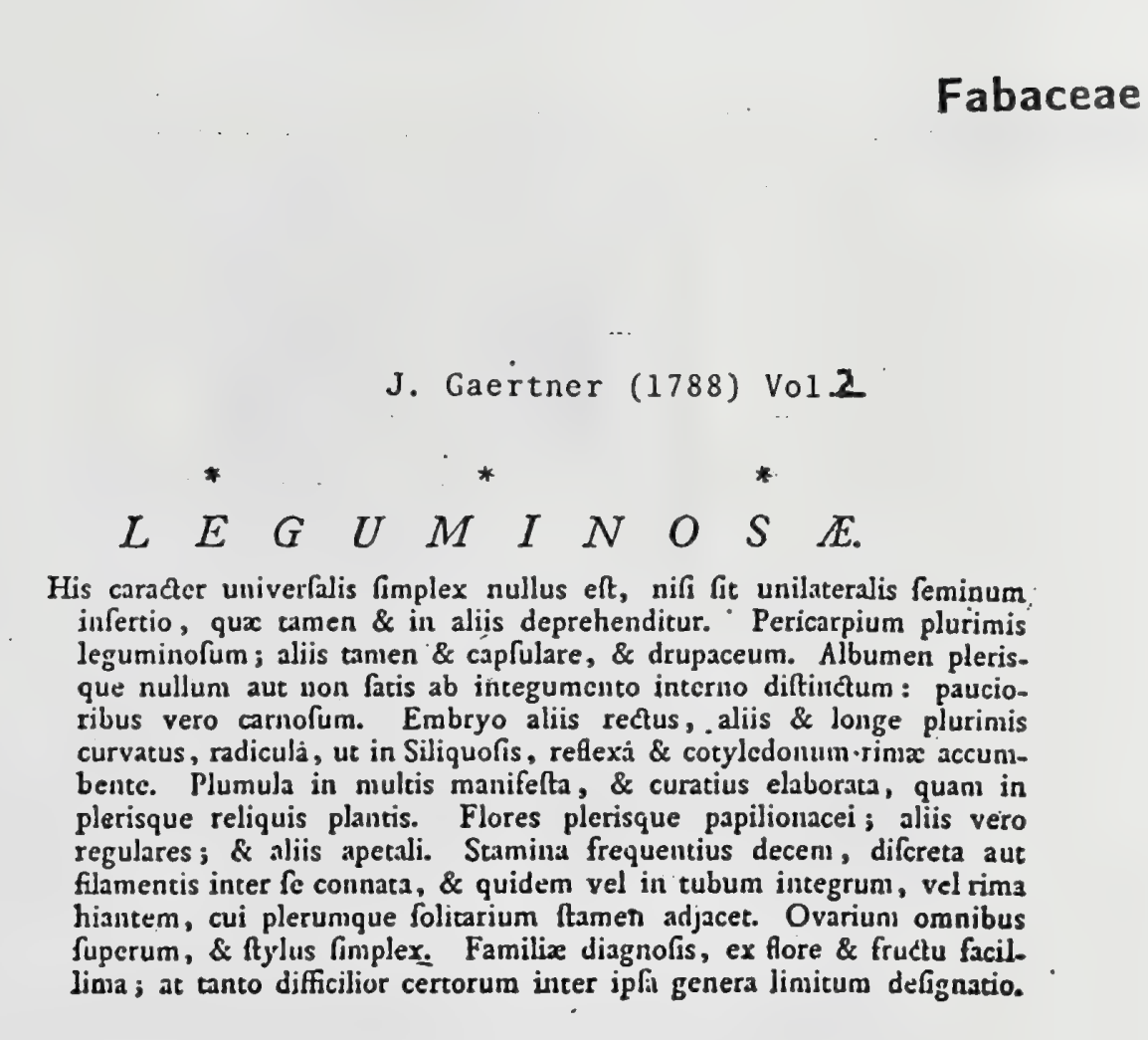

84.0 


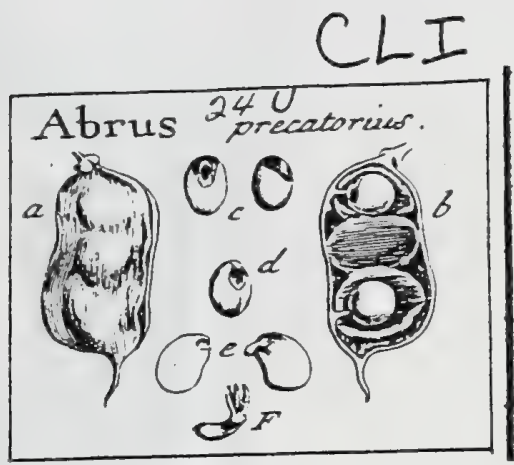

J. Gaertner (1788) Vol 2

DCCCLXXV. A B R U S. LINN. gen. I $=96.328$

Calyx obfolete quadrilobus, lobo fuperiore latiore. Cor. papilionacea. Stam. noven, ima bafi connata, fuperne difcreta. Legum. oblongum, conprefum, arachnoideo-loculamentofun. Sem. exalbuminofa. Emb. curvacus.

ABRUS precatorius. Tab. I 5 I. fig. 5 .

Ko:mi. RheEd. mal. 8. p. 7\%."

Abrus. RUMPH. amb. 5. p. 57. $t, 32$.

Pluscolus arborefcens alatus, fructu coccineo, hilo nigro notuto. PLUk. phy't. t. $214 . f .5$.

Abrus. LINN. Jyft. veg. 64 I.

$E$ collect. Bankfiana \& hort. lugdb.

PER. Legumen ovato - rhomboideum, aut oblongum, lenticulari-compreffum, ad femina torulofum, glabrum aut fubpubefcens, fubpluriloculare, bivalve. Diflepimenta ex'membrana alba, tenuiffina, per maturitatem focpe evanefcuncis.

REc. funiculi breves, e futura rectiore.

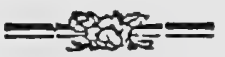

SEM. tria ad fex, ovato - globofa, lxvigatifima, nitidifina, fxpius coccinea cum lata macula atra in extremitate feminis umbilicali.

IN T. duplex : exteriits cartilagineum, durum; interius membranaceo - fpongio fum, ad umbilici fedem valde incraffatum.

A L B. nullum.

Es B. curvatus, albus, prope radiculam areola plana depreffa ab integumento interno notatus. Cotyl. ovata, plano convexx. Plım. tri-1. tetmphylla, folio!is pinuatis, fex-1. feptemjugis cum impari. Rad. brevis, inflexa, centrifuga.

a.) L.eguman integrum. b.) Valvula altera, cum difrepimentis anchnnideis. c.) Seauina feparata. d.) Enthrgo denudatus, cum arcola plana umbilicali. c.) Cotyled. feparatre F.) Plumula inligniter auka.

Legumen in aliis oblongum, hexafpermon, vix manifefte in loculos difcretum. Seniura etian nunc tota atra, nunc parva tantum macúla coccinęa infignita, nunc vero, \& frequentifime, ad extremitatem umbilicalem folummodo atra. Dantur quoque fenina penitus alba aut ruffa; fed noune hacc diverfa fint fpecjei, nondun conftat. 


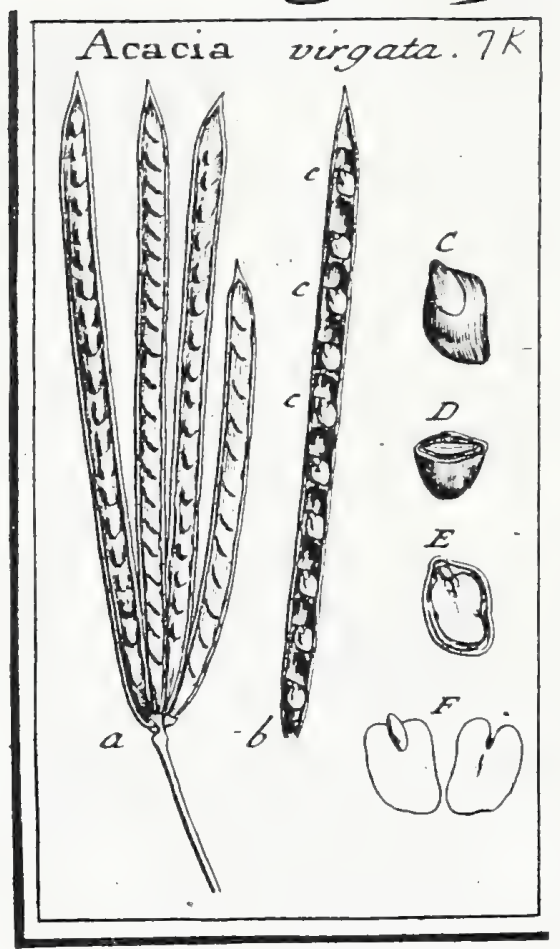

J. Gaertner (1788) Vol 2

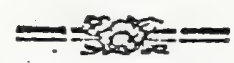

DCCCLX. A C A C I A. TOURN. t. 375 .

Calyx tubulofus, tri-1. quinquedentatus. Cor. mono-aut pentapetala nulla. Stam. quatuor ad decem aut plurima, difcreta aut inter fe nata. Legum. continuum $[$ non articulatum, bivalve. Sem. plura, minofa. Embr. rectus.

ACACIA virgata. Tab. 148. fig. 3.

Nitu-todda-vaddi. RHEED. mal. g. p. 35. t. 20.

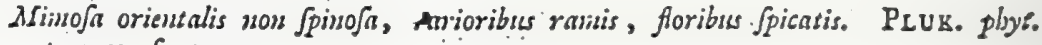
t. $307 . f .4$.

Minofa inermis erefia angulata, foliis bipinnatis, fpicis decandris: inferioribus caftratis mafculis, caule ereazo angulato. LiN.s. $\int y^{\prime} /$. veg. 915.

Icont. Jace. bort. t. 80 .

PER. Legumen lineari - oblongum, planiufculum, ad femina obfolete torulofum, futura filiformi incrafata utrinque marginatum, uniloculare, bivalve.

REC. funiculi capillares, e futura interiore f. rectiore.

SE M. plura, duodecim ad viginti, thomboidea, gibbofe lenticularia, fria ocellari elliptica ex umbilico utringue notata, glabra, lucida, faturate caftanea.

IN T. fimples, cartilagineo- coriaceum.

A LB. aqueo - pallidum, in medio crafrum, durum, ab aqua in gelatinam convercibile.

EMB. rectus, lutefcens. Cotyl. foliacex, cordato-rhomboidex. Flum. nulla. Rad. tcretiufcula, exferta, recta, centrifuga.

a.) Legumina integra in peduncalo eommuni. b.) Valvula fcparata. c. c. c. C.) Semina iategn. D.) Seminis fectio transvertalis, cum Gitu cotylejonum intra albumen. E.) Ejusdem Sectio verticalis, cum embryone denudato. F.) Cotyledones feparatz.

Genus, refpectu florum perinde atque leguminum, polymorphum, judiciofe autem a fummo TOURXEForTio in duo divifun: quorum alterum Acacias, legunine continuo, \& alterum Minofas, legunine articulato, compledtitur. 


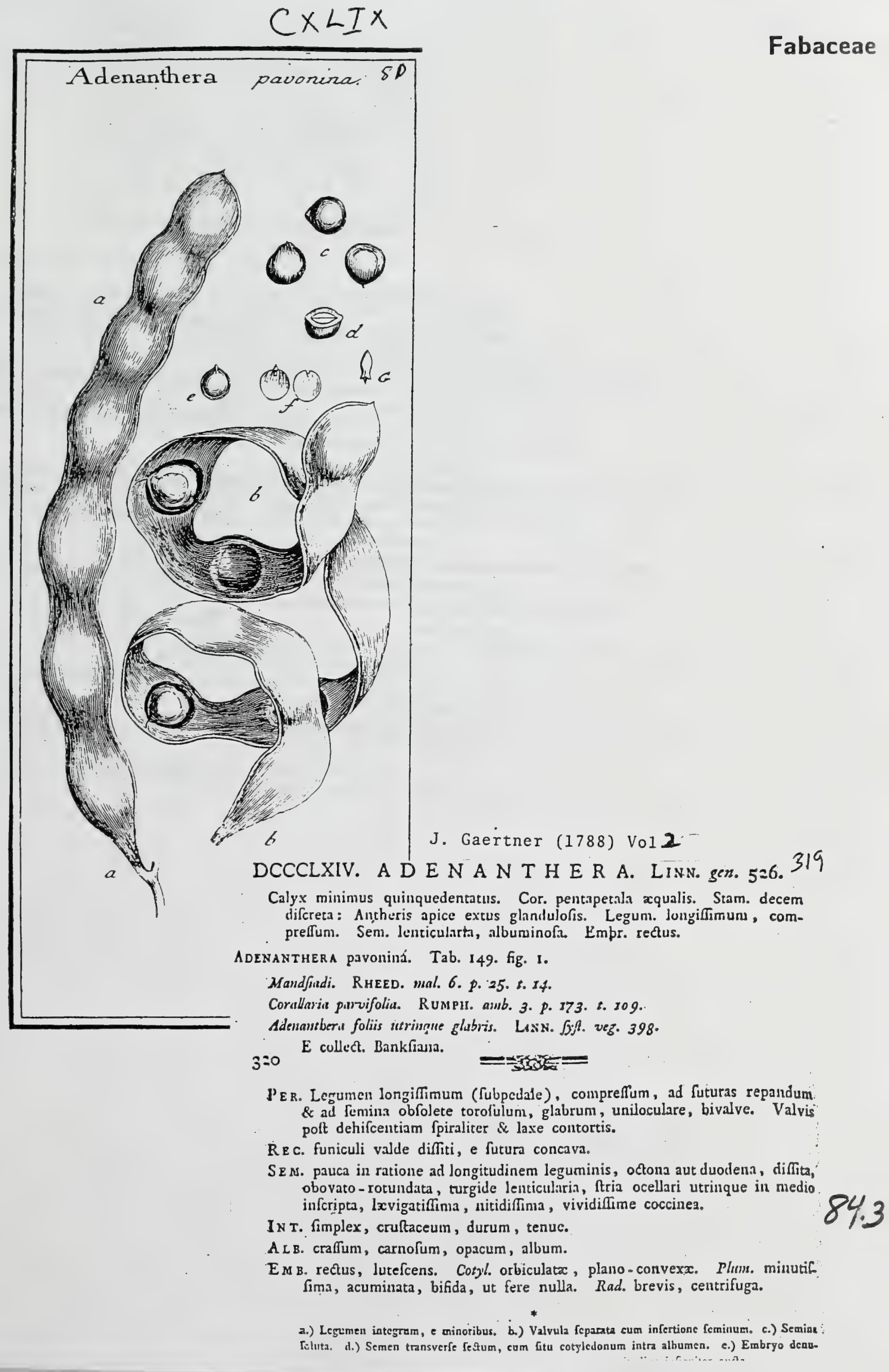




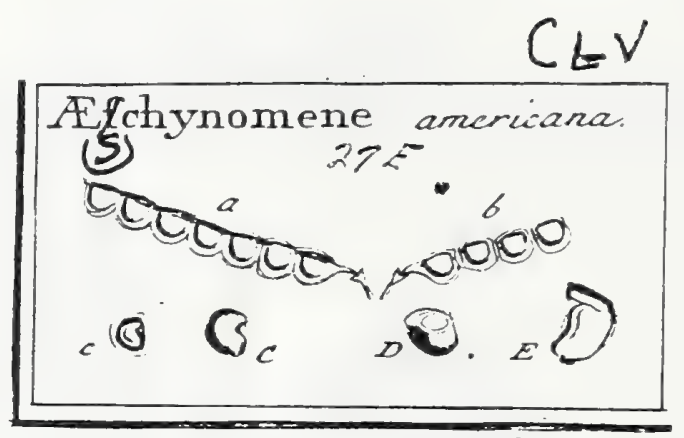

J. Gaertner (1788) Vol2

DCCCXCVI. ÆS C H Y N O M EN E. LINN. ger. 888.

Calyx bilabiatus. Legum. oblongum, compreffum, articulatum: futura altera recta, altera lobato crenata. Sem. exalbuminofa. Emb. curvatus.

ESCHYNOMENE americama. Tab. iss. fig. 6.

Hedyfarum caule bivfuto, mimsofe foliis alatis: pinsis acutis minime gramincis. SLons. bif. jam. 1. p. 186 . t. 118. f. 3 .

Efclyynomene caulo berbaceo bifpido, leguminum articulis femicordutis, foliotis acunimatis, braffeis ciliatis. LINN. byft. veg. 67t.

Ex herbario Bankfiano.

PER. Legumen lineari-oblongum, compreflum, ad futuram feminiferam rectum, ad oppofitam lobato-crenatum, articulatum. Articuli fepteni 1. pauciores. femiorbiculati, in medio gibboli, ad marginem comprel[i, evalves; fponte 2 fe invicem fecedentes.

R E C. funiculi breves e futura recta:

- Se m. folitaria, lunato-reniformia, turgide lenticularia, glabra, lucidab atra.

INT. fimplex, corisceo-chartaceurr.

A I в. nullum.

348

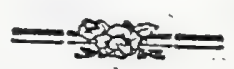

EM E. curvatus, luteus. - Cotyl. reniformes, plano - cunvexx. Plim. nuwa
Rad. intexa, centrifuga. a.) Legumen integrum. b.) Idem articulatio difeedens c. C.) Semiais figura \& infertio. D.) Ejes
feetio transverfalis. E.) Embryo denuclatus.

Totum genus apte polfet expungi, atque fpecies ejus partim ad Hedyrarum,
\& partim ad Galegam transferri. 

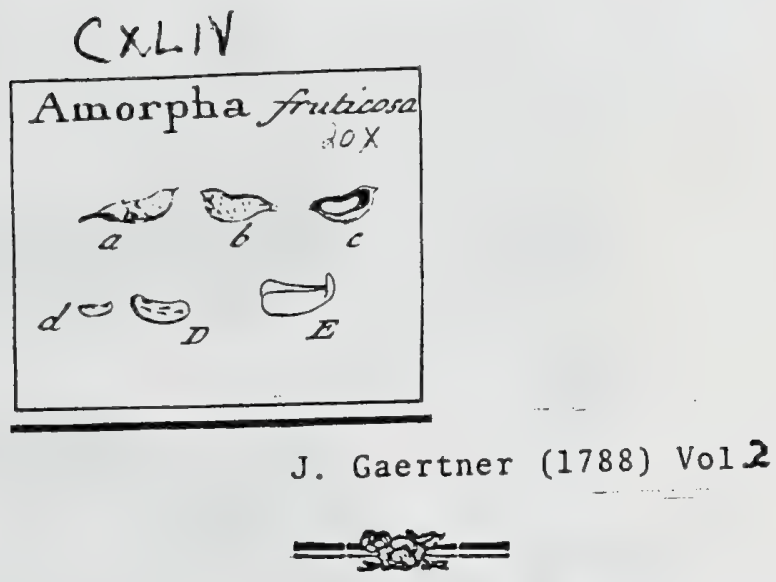

DCCCXLVI. A M O R P H A. LINN. ger. 86r.

Calyx quinquedentatus. Cor. monopetala, ex folo vexillo absque alis \& carina. Sam. fubdifcreta, f. bafi tantum inter fe connata monadelpha. Legum. parvum, tuberculatum. Sem. exalbuminofa. Embr. curvatur.

Aмоrрна fruticofa. Tab. 144. fig. 5 .

Amorpha. Linn. b. Cliff. t. 2g. Jyft. veg. 649. Mirc. ic. t. 27 .

Ex herbario Bankfiano.

PER. Legumen parvum, vix trientem pollicis longum, fubfalcatum aut lutntum, lenticulari compreffum, plurimis granulis glandulofis terebinthinsceun liquorem fudautibus fcabratum, uniloculare, bivalve.

REc. funiculus brevis, e futura fuperiore.

SEM. unum aut duo, oblonge reniformia, difite fcrobiculata, glaberrima. fublucida, faturate caftanea.

IN T. duplex: coriaceum atque membranaceum; utrumque tenuifimum.

A \& B. nullum.

EM B. curvatus, gramineo-viridis. Cotyl. oblongx, planiufculx, Pluns. nulls. Rad. breviflima, incurva, centrifuga.

a) Legumen cum calyce perfiftente. b.) Idea deaudatum. c.) Valvila Ieparata cum iafertioze feminis. d. D.) Scunea feparatuat. E.) Embryo denudatus, 


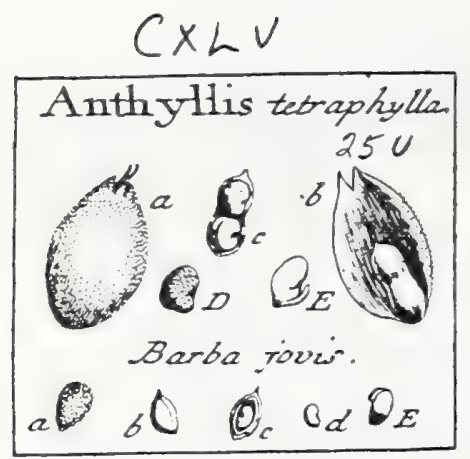

J. Gaeıtner (1788) Vol 2

DCCCXLIX. A N T H Y L L I S. LINN. gen. 864 .

Vulneraria. TOURN. t. $2 I I$.

Calyx ventricofus, quinquedentatus. Cor. papilionacea. Stam. decem, ba $\&$ monadelpha. Legum. calyce tectum, uniloculare. Sem. exalbuiminofz. Embr. curvatus.

ANTHYLLis tetraphylli. Tab. 145. fig. 3.

Trifolinun balicacabuns. САM. bort. t. 47.

Autbyllis bispanica. Riv. tetrap. t. 18. f. 2.

Autlyyllis berbacea, foliis quatemo-pinnatis, foribus lateralibus. Lixx. fyft. veg. 654 .

$P E R$. Legumen intra calycem infatum pubefcentem quadridentatum latens, oblongum, fubfenipolicare, membranaceum, tenuifinum, uniloculare. bivalie.

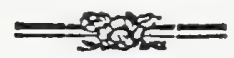

REC. funiculi brevifimi, e futura rectiore.

SEM. duo, reniformi globofa, gibba, rufefcenti - ferruginea, punctis elevatis confertiffimis confperfa, ut fuperficies primo adfpectu holoferices appareat. IN T. duplex : coriaceum \& membranaceum, quorum polterius ab ayua in.
albuminis gelatinofi fpeciem convertitur.

A เв. nullum, aut tenuiffimum.

Eм в. curvatus, luteus. Cotyl. elliptico-reniformes, comprefra. Plzun. nulla. Rud. fuffiformis, centrifuga.

a.) Calyx matarus integer. b.) Idem apertus, cum legumine iutegro. c.) Legumen apertum cum Seminibus. D.) Semen audum. E.) Embryo denudatus.

ANThyLlis Barba jovis. ibid.

Barba jovis. Riv. tetrap. t. 4. f. x. bene.

Anthyllis fruticofa, folits pinnatis aqualibus tomentofis, foribus capitatis. LiNs. fyjt. veg. l.: c.

Calyx maturus (a.) claufus, tomentofus, fericeo-albus. Legumen (b.) parvulum, ovatum, utrinque attenuatum, turgide lenticulare, ex duplici lamina conflatum: exteriore fct. membranaces, \& interiore cartilagineo chartacea; cetera uniloculare, evalve $f$. non fponte dehifcens. Semen unicum (d.), reniforme, glabrum, rufefcenti ftramineum. Embryo (E.) curvatus, luteus:

Legumen in hac, Nuculam, confiftentia fua xmulatur.

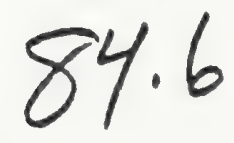




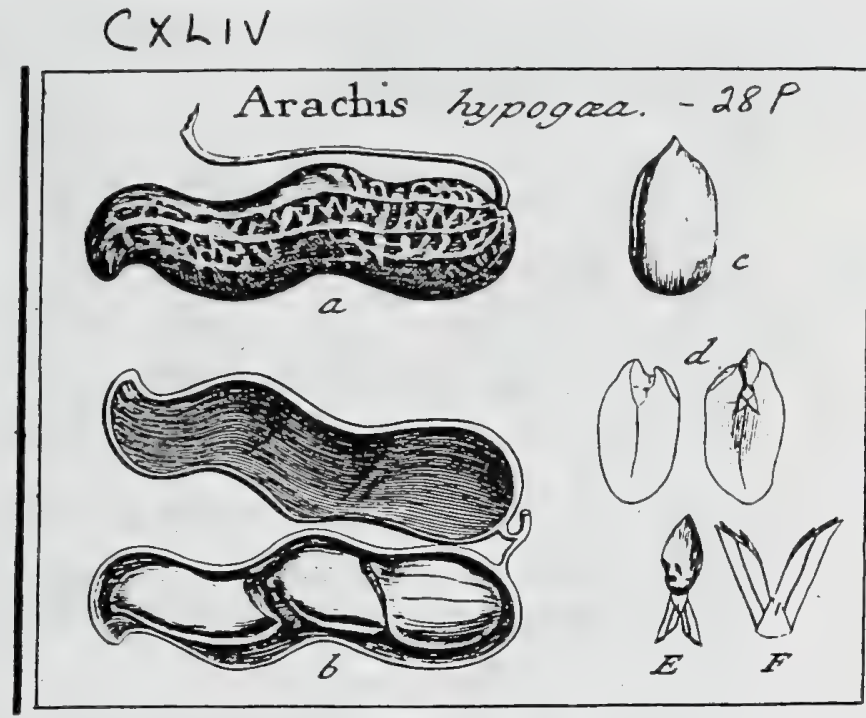

J. Gaertner (1788) Vol, 2

\section{A R A C H I S. Lins. gen. 876. Arachidna.}

PLUM. t. 37 .

Calyx bilabiatus, fupra quadrifidus. Cor. papilionsce̊a, refupinata. Stan. omnid commata, uno fterili. Legum. coriaceum, nervis reticulatum, evalve. Sem. exalbuminofa. Embr. rectus.

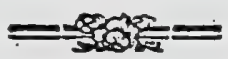

ARACHis hypogza. Tab. 144. fig. 2.

Mundubi. Marcgr. bras. 37. c. ic. Wokm. mis. p. 208 .

Clamsbalanus japousica. RUMPH. amb. 4. p. 387. t. 256.

Arachidna quadrifolia villo $5 a$, fore luseo. EHRET. pid. t. 5. f. 3.

Arachis. LiNs. Jyft. veg. 655 .

PER. Legumen oblongun, coriaceum, teretiufculum, torofum, nervis prominentibus reticulato - fcrobiculatum, uniloculare, non dehifcens, nec futura confpicua dotatum.

REC. funiculi breves, obfoleti, e fuperiore latere loculamenti.

SEM. pauca, unum ad tria, vix plura, ovata, ad mutuum contactum quafi oblique truncata, , rubro - fernuginea, vafis longitudinalıbus inggnita.

Is r. fimplex, membranaceum, tenue.

A I B. nullum, nec ejus veltigium.

Eм 8. magnitudine feminis, rectus, albus. Cotyl. carnofx, crafx, planoconvexx. Plunt. grandiufcula, diphylla: foliolis bijugis, conduplicatis, linearibus: conjugatione inferiore longiore. Rad. ovato-acuminata, obefa, centrifuga.

2.) Legumen integram, e maximis. b.) Idem longitudinaliter spertum, cum litu \& Ggara feminum. c) Embryo denudatus, ab aqua tumefactus. d.) Cotyled. Latus iaternum. E.) P(umula feparata, cum annexa radicula. F.) Eadem incigniter ault.

Magnitudo \& figura lcguminis numero feminum refpondet: hinc fpecimina monofperna, fere ovato-globofa, \& difperma, ovato-cylindrica, ac proportionate longa deprehenduntur. Conftanter autem unilocularia funt, nec feptum in illis ego vidi unquam, quale icon Marcgravii repræfentare videtur. 


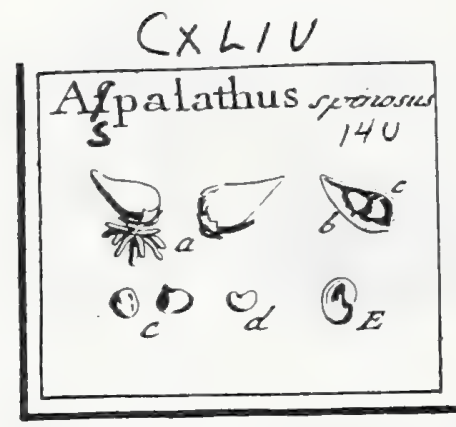

\section{J. Gaertner (1788) Vol. 2}

DCCCXLV. A S P A I A T H U S. LINn. gen. 860.

Calyx quinquefidus, lacinia fuperiore majore. Cor. papilionacea. Stam. omnia connata in vaginam fiffam. Legum. uniloculare, breve. Sem. albuminofa. Embr. curvatus. Folia fafciculata.

Aspalathus f́pinofus. Tab. 144. fig. 4.

Geniflella Spinofa africana, laricis folio. BREYN. cent. t. 26.

Genifta minima atbiopica, foliolis thymi confertis. PIUK. plyyt. t. 297 . f. 6.

Afpalathus foliis fufciculatis linearibus undis fpinam gemmacean circumftantibus.

LINN. fyjt. veg. 646.

Ex herbario Bankfiano.

PER. Legumen parvulum, ex ovata bafi furfum triangulari attenuatum; lenticulari-compreflum, uniloculare, bivalve.

REc. funiculi breves, e futura fuperiore.

SE s. unum aut duo: illud reniforme, compreffufculum; hxc fubglobofa, latere quo fe mutuo contingunt planiufcula vel angulata: utraque albicantia.

ls T. fimplex, tenue, chartaceun.

A L B. tenue, ab aqua in gelatinam convertibile.

En в. curvatus, luteus. Cotylo obovatx aut reniformes, carnofx, plaso-conve:x. Plums. nulla Rad. incurvata, cralfiufcula, centrifuga.

a.) Legumen integrum. b.) Valvula alters, cum infertione feminum. c. C.) Segina gemella. d.) Seinen folitarium reniforme. E.) Embryo denudatus.

A foliis fufciculatis \& habitu fruticulo nota generis certior \& facillima. 
Tab. CLIV.

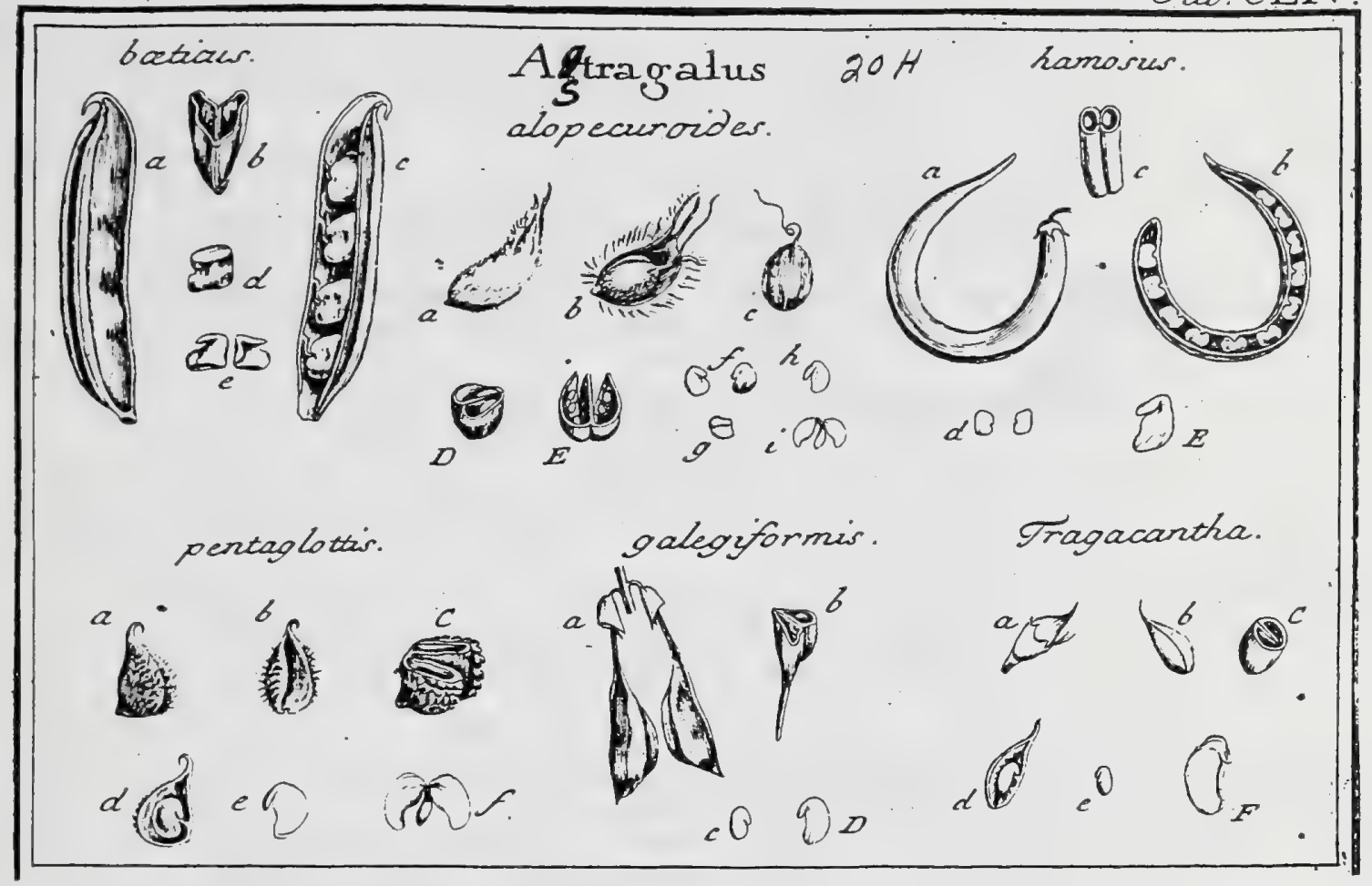


DCCCLXXXV. ASTRAGALUS. TOURN. t. 233. LIN. gen. 892.

Legumen biloculare f. geminatum : fepto longitudinali bifido; valvis parallelo. Sem. fubalbuminofa. Embr. curvatus.

Astragalus alupecuroides. Tab. Is4 fig. I.

Afragalus alpinus procerior alopecsaroides T. MiLL. ic. t. 58 .

Afragalus caulefcens, fpicis glindricis fubfeJilibus, calycibus leguniuibusque laussis. LIN Jif. veg. $68 \mathrm{x}$.

PER. Legumen calyce latrato teetum, ovato-globofun, fubtrigonum, membramnceum, villofuns, biloculare, nargine inferiore f: compreffo dehifcens.

REC. Suniculi breves e futura dehifcente.

SEM. in fingulo loculo quatuor, e quibus unum aut duo faltem maturefcunt, fubreniformia, compreffiufcuia, glabra, lutef́centia.

IN T. fimplex, chartaceum, intus fubcarnofum.

A L R. nullum, aut tenuifimum a lamina cariofa integumenti.

EMB. curvatus, luteus. Cotyl. reniformes, compreffic. Plun. nulla. Rah. intexa, centrifuga.

2. b.) Calsx maturus intcger \& diffectus. c.) Legumen integrim. D) H.jus fcctio transverlaiis. E) Idem dehifeens. f.) Semina fiparzta, s.) Semen trausverife fceuus. h) Eubryo denudatus, i.) Cotyl. Separatx.

Astragalus bxticus. ibid.

Afragalus besicus. Riv. eetr. t. 105.

Afrazalus caulefcens procumbens, fpicis pedunculutis, legunnibus prifmaticis refitis triquetris apice unsimatis. LiN. l. c.

Legumen ( $a, b . c$. ) fubbipollicare, rectum, trigono - prifnaticum, fulco lato ac profusdo (b.) in dorfo exaratum, apice reflexo uncinulatum, coriaceuın, biloculare. Serm in fingulo loculo (c. d.) quatuor, angulata, gibba, glabra, palinda. Albunien cratliun. Ensbr. Luteus, cotyledonibus (e.) crallis, Gexuofis, gibbis.

Astragalus hamofus. ibil.

Aflragalus filiqua curva. Riv. tetr. 8. 107.

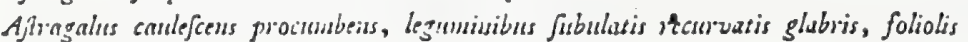
obcordasis fiubtus villofis. LixN. l. G.

Leguncu (a.b. c.) uncinatn - curvatum, teretiufculum, glabrum, ad utramque luturan (c.) fulco longitsiinuli deprefto infriptum, bipartibile. Seminz (b. d.) dena aut duodena in fingulo loculo, irregulariter quadrangula, compretra, fordide viridula aut luteofufca. Albumen crafrum. Embryo (E.) luteus.

ASTRAGALUS pentagiottis. ibid.

Afragalus bifpanicus, filiqua epiglottidi fmili, fore purpureo majore. HERM. ligdb. 74.7 .75 .

Glaux hijpanica. Riv. tetr. t. rog. $f_{0} 2$.

ABrgagalus caulefiens proctumbens, legurninibus capitatis replicatis compreflis cons. nitentibus criftatis acumine reflexo. LINN. l. c.

Legumen (a. b. C. d.) coriaceum, cordato-acuminatum, conduplicatum, refezis fcil. cordis ventriculis (C.) ac fibi mutuo accumbentibus, cetera nigro fufcum, fquamulis atque fetis rigidis extus fcabratum, apice uncinulatun. Semen (d.) unicum, grandiufculum, compreffum, reniforme, lutefcens aut ferrugineum. Albumen crafiufculum. Embryo (e. f.) luteus.

ASTRAGaLUs galegiformis, ibid.

Afragalus caulefcens frichus glaber, floribus racenofis pendulis, leguminibus trigretris utringue mucroutis. LINN. l. c.

Legumen (a. b.) e longo gracilique pedunculo in ventrem triquetro-prifmaticum intumefcens, apice nucronatum, bipartibile (b), glabrum. Semina in fingulo loculo quinque, unico duncaxat marurefcente, reniformi (c.), glabro, e viridi luteo. Album. vix ulum. Embr. (D.) luteus.

Astragalus Tragacautha. ibid.

Tragacautha. CAM. epit, 446. BLAKW. herb. t. 264 .

Afragalus caudice arborefcente, petiolis fpinefcentibus. Liss. b. c.

Legumen parvun ( $a-d_{.}$), coriaceun, ovatum, roltrato-acuminatum, glabrum, futuris elevatis notatum, fubfemibiloculare. Septum bilamellatum, non penitus ad opporitum latus pertingens. Senina in fingulo loculo (d.) tria, uno faltem adolefcente, reniformi (e.), glabro, e viridi luteo. Albumen tenue. Embryo ( $F$. ) Juteus.

Poftet Tragacantha, fecundum rigorem, ad Pbacam referri, quia difepimentum non penitus ad oppofistum latus pertingic 


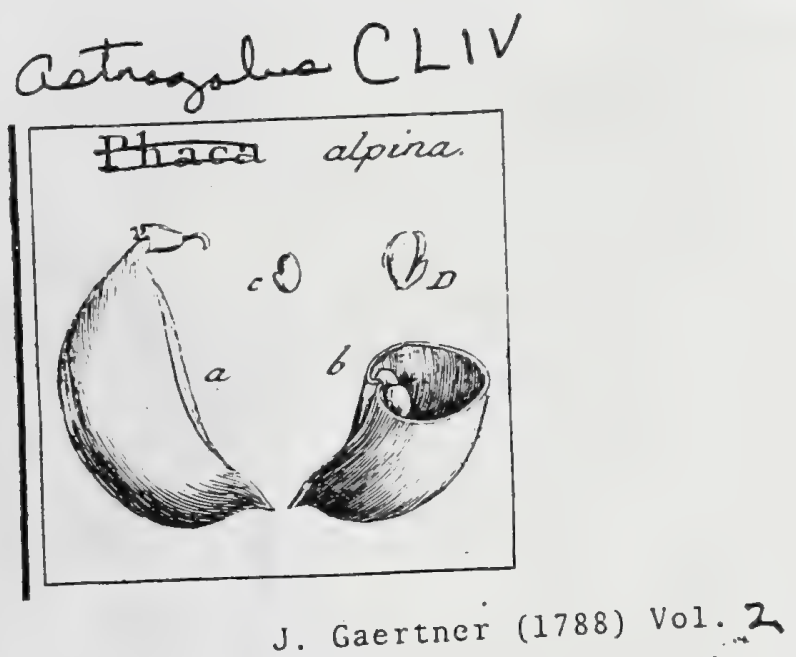

DCCCLXXXVII. P H A C A. LIN gen. 89r. 341

Flores \& habitus Aftragali. Legun. Senibiloculare, aut rarius uniloculare. Sem. exalbuninefa. Embr. curvatus.

Pнaca alpina. Tab. 154. fig. 2.

Pbacal leguminibus pendulis Jemiovatis. GMEL. fib. 4. p. 35 . t. 14 .

Altrugalus caule ereifo ramofilfmo, fuliis ellipticis birfutis, foliquis verficariis pendiclis. HALL. biff. M. $40 \pi$.

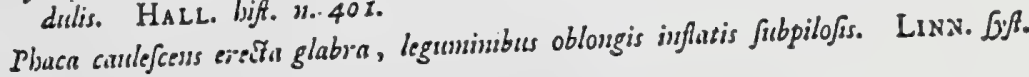
veg. 680.

ICOH. OED. for. dan. t. 856 .

PER. Legument ${ }^{\circ}$ fumiovato - oblongum, intatum, utrinque attenuatum, membrankceun, fubpubefcens, uniloculare, bivalve. Diffepimenti veftigium prorfus nullum.

REC. funiculi breves e futura concava.

SEM. octo, reniformia, compreffiufcula, fordide viridula aut fufca.

IN T. fimplex, cartilagineo-coriaceum.

A LB. nullum.

E мв. curvatus, luteus. Cotyl. ovata, plano-convexiufculx. Plans. nulla. Rad. intexa, centrifuga.

a. b.) Legumen integrum \& dilfedum cum infertione (eminum. c.) Semen (eparatum. D.) Em bryo denudatus.

$3+2$

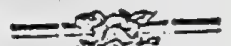

Refertur hxc fpecies ad Colutean ab III. LaMrank; fed Soris forma obftare viderur. Ouod in Placa, futura liuperior, \& in ditragalo, inferior, intro. flexa fit; id contantis legis non elt, uti ex A. alopecurvide \&. Tragacautba clare patec. 


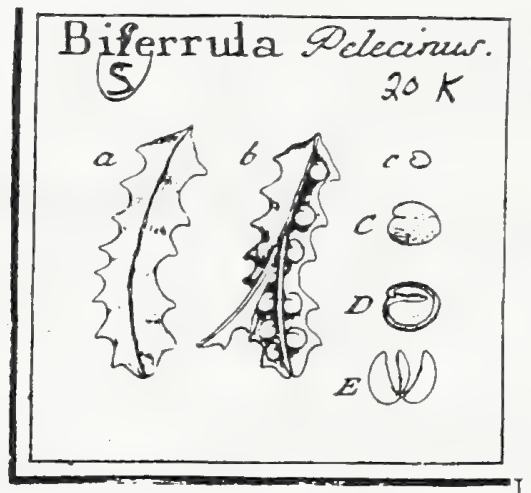

Gaertner (1788) Vol 2

\section{B I S E R R U L A. LINN. gen. 893.340
Pelecinus. TOUR N. t. $234 . ;$}

Legumen compreffo - planum, biloculare: fepto longitudinali folido valvis contrario. Sem. fubalbuminofa. Embr. curvatus.

Biserkula Pelecinus. Tab. 154. fig. 3.

Securiduca peregrina. Clus. bifr. 2. p. 238.

Utringue ferrata. K1v, zetr. $t .20$.

Biferrula. LiNs. Jjt. veg. 685.

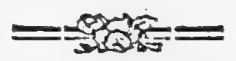

PER. Legumen oblongum, planum, ad utrumque marginem ferntum, in medio futura longitudinali notatum, biloculare, quadrivalve. Difrepimentum anguftifimum, fimplex, valvis contrarium.

REC. funiculi breves e futura media.

SEM. infingulo loculo octons, rotunde reniformia, comprelfa, glabra, lutefcentia.

IN T. fimplex, coriaceo - charcaceuni.

A L B. tenue, aqueo-pallidum, ab emollitione gelatinofum.

Eм B. curvatus, lutefcens. Cotyl. femilunares, folincex. Pluns. nulia. Rad. fufformis, inflexa, relative centripeta.

2.) Legumcu integrum. b.) Locnlamenta aperta cum infertione futninum. c. C.) Semen (cpasztun. D.) Embryonis in albumine fitus \& figura. E.) Cutyles. explicatx.

Legumen non fimplex, fed geminatum, ex duobus partialibus, altero fuo margine justa fe pofitis atque coalitis, conflatum.

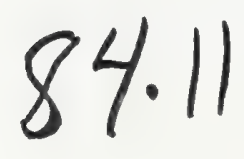




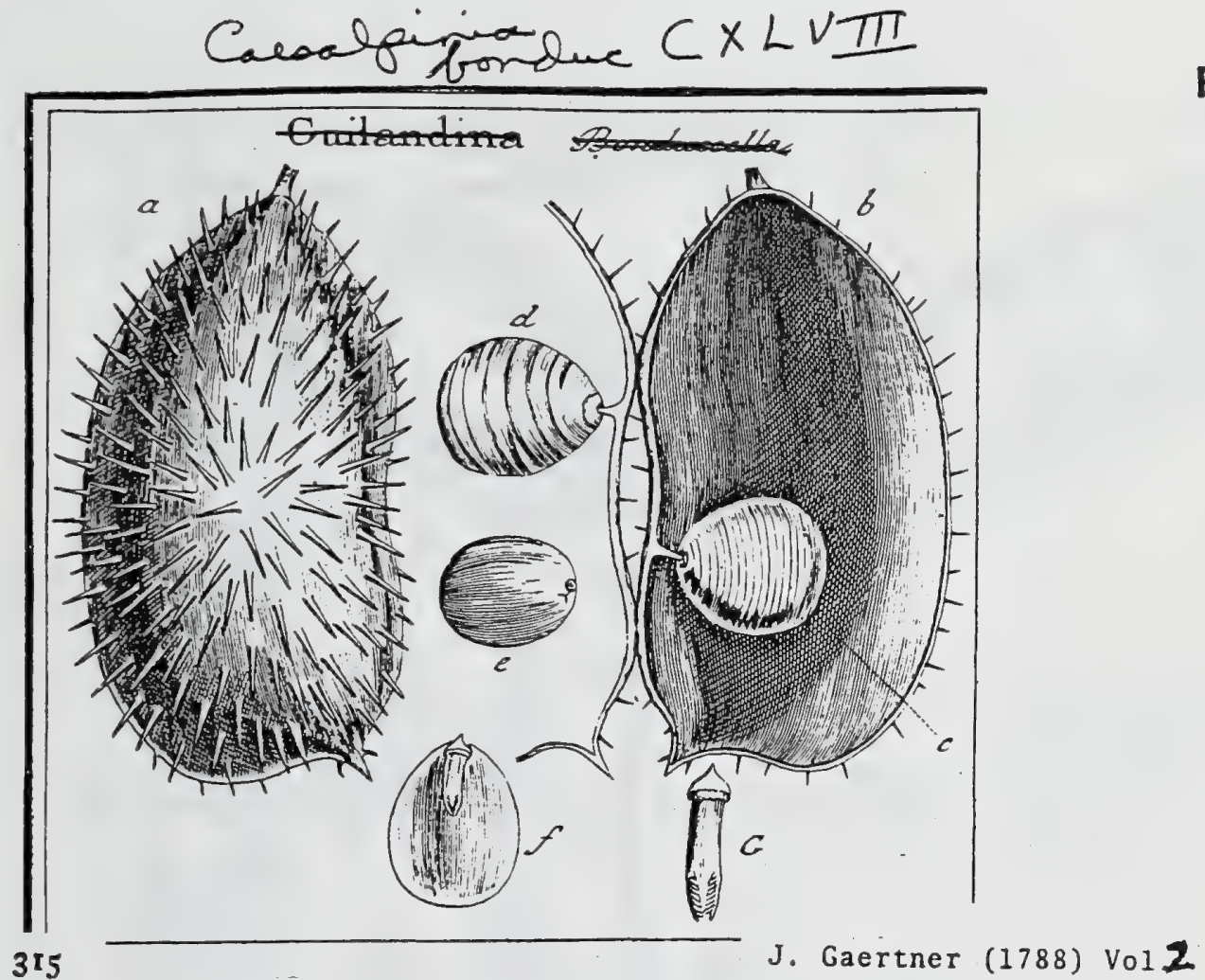

DCCCLVIII. G U I L A N I N A. LINN. gen. 5ry.

Bondur. Plum. t. 39 .

Calyx urccolatus profunde quinquefidus. Cor. pentapetala, fubxqunlis, petalis non unguiculatis. Stam. decem, difcrera, bafi villofa. - Legum. ventricofo - compreffun, uniloculare, bivalve. Sem. pauca, lapidea, exalbuminora. Enutr. rectus.

Guilandixa Bonduccella. Táb. 148. fig. r.

Caretti. RHEED. mal. 2. p. 35. t. 22.

Globuli majores. Ruspur. amb. 5. p. 92. t. 49. f. $x$.

Crifa pavousis glycyrrbize folits minor repens fpinofifima; flore luteo Spicato minimo, filiqua latifina ecbinsta, fenine rotundo cinereo lineis circularibus cinfto มrajore. BКЕYN. ic. p. 33.t. 28.

Guilandina aculeata, pinsis oblongo ovatis, foliolis aculeis geminis. LINe. fyfl. veg. 396. A Pbil. Millero chels.

PER. Legumen grandiufculum; ovato - rhomboideum, in medio ventricofum ad latern vero compreffum $\int$. turgide lenticulare, undique . pinis rigidis, vix tamen pungentibus, ehinntun, extuś fpadiceo-ferrugineum, intus pallidun, uniloculare, bivalve. Valvulx intus.glaberrimx, absque ullo dilfepimenti veltigio.

REc. funiculi brevcs, comprefi, e futura rectiore aut concara.

SEM. pauca, duo aut tria, ovato globofa, glaberrima, fplendentia, quafi tenuiftmis fisuris parallelis atque anmularibus rimofa, atumen integerrima. e plumbeo-livida aut cxfia, areola fufea ad umbilicum notata.

IN T. lapideum, craffum, ex triplici lamina compagiustum: extines feil. vitcea, lecvigatifina; tenui; media craftiore, Japidea, ochraceo-fufar ; intima offea, albicante: omnibus tamen it inter fe cohxreutibus, ut nullo mode ab invicem folvi queant.

A L B. nullum, nec ejus veltigium.

Es в. globofus, albus. Cotyl. craftifimx, plano-convexx. Pliems. grandiufcula; fapo tereti longo; foliolis oppolicis, pinnatis, octijugis cum impari. Rad. deprele conica, retractil, centrifuga.

1.) Iegumen integrum, b.) Valvula a parte interna fpedata. c.) Seminis figura \& infertio. c.) Erabryo deaudatus. f.) Cutyledon in aqua emollita \& a parte fua interas fpedatn, crom Plumulx magnitudine naturail G.) Plumula infigniter auba.

Guilandina Bonduc. Liss. quoad legumen procedenti fimillima eft. Semina autem ejus funt flavicantia, zonis parallelis (fig. d.) croceis, annularibus aut interruptis, egregie variegata. Integum. pariter lapideum; fed lamina media coloris faturate rofei aut incarnati. Reliqua omnia ut in priori.

Major eft inter Cxfalpiniam atque Guilandinam, quam inter hanc atque Moringam affinitas. 


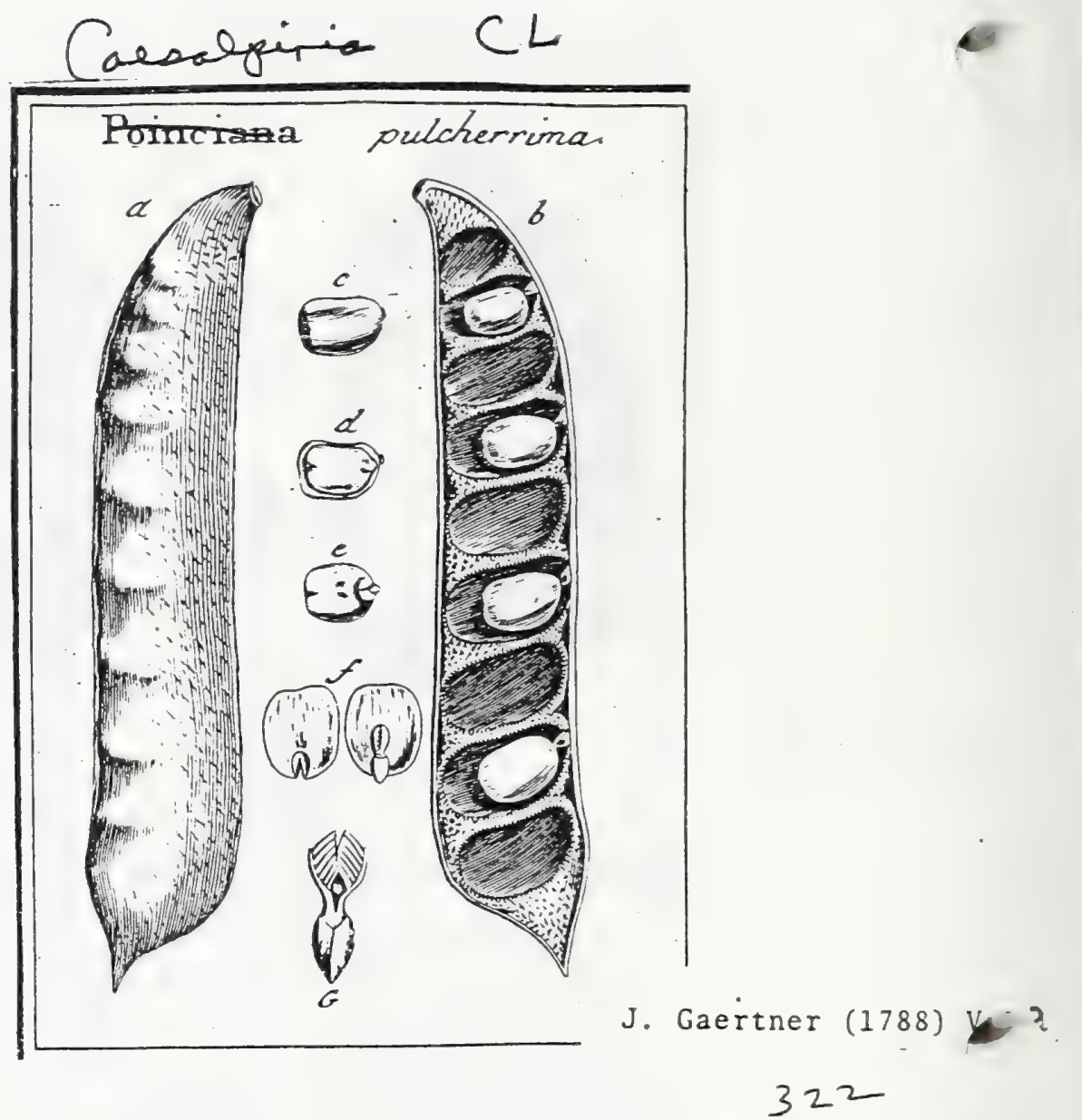

\section{P O IN C I A N A. TQURN. t. 39 I. LINN. gen. $5^{15}$.}

Calyx turbinatus, limbo quinquepartito iıxquali deciduo. Cor. pentapetala, petalis unguiculatis, quatuor æqualibus, quinto najore aut minore. Stam. decem difcreta bafi hirfuta. Legum. oblongum pluriloculare. Sen. albu. minofa. Embr. rectus.

Poinciana pulcherrima. Tab. I 50 . fig. I.

Tsjetti - mandaru. RHERD. mal. 6. p. T. t. T.

Frutex pavoutinus, crifta pavonis. BREYN. cent, 61. t. 22.

Poinciana aculeis geminis. LINN. Jyf. veg. 395 .

A Pbil, Millero chels.

"PER. Legumen oblongum, compreffiufcalun, coriaceum, pluriloculare, bivalve. Diffepimenta craffufcula, e fetis rigidis denfe conftipatis formata.

REc. funiculi breves, crafis, e futura rectiore.

SEM. folitaria, in univerfum octona aut paulo plura, ovato-quadrangula, craffa, utrinque plana, lavia, fubfplendentia, e caltaneo rufefcentia.

IN T. fimplex, cartilagineo-coriaceum, tenue, intus fpongiofum.

A L B. carnofum, aqueo-albicans, tenue.

E м в. rectus, lutefcens. Cotyl. ovatx, carnofx, utrinque planix. Plum. gran. diufcula, diphylla: foliolis pinnatis fejugis absque impari. Kad. ovatoacuminata, retraeta, centrifuga.

a) Legumen integrum. b.) Idem apertum. c.) Semen feparatum. d.) Embryonis Gtus intra

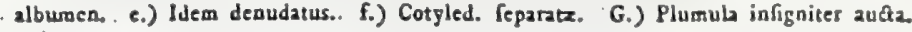




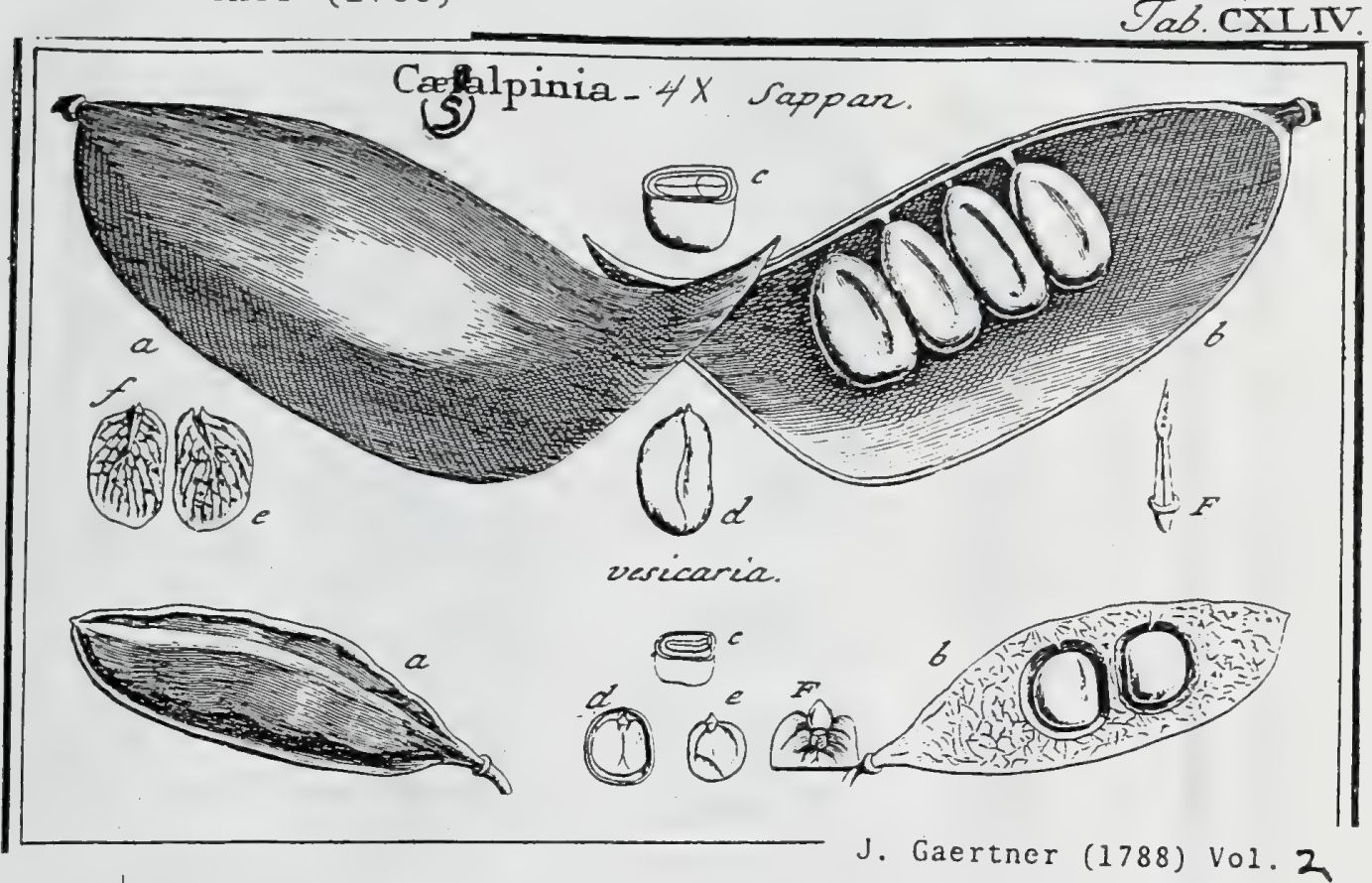

Calyx quinquefidus, Lncinia infima majore. Cor. pentapetala, petalo infimo pulchriore. Stam. decen, difereta. Legum. Suberofuin, fubevalve, coinprefium. Sem. albuminofa, utriıque planiufcula. Embryo rectus.

Cessalpinia Sappan. Tab. 144. fig. 1.

Tsiams - pungans. RHEED. imal. 6. p. 3. t. 2.

Liguress Snppas. RUMPH. amb. 4. p. 56. t. $2 x$.

Cafalpinia coule actleato, foliolis oblonges insequilateralibus eimarginatis. Lins.

PBR. Legumen fublignofum, ovato-rhomboidale, roltratum, lenticulari-cora. prefium, uniloculare, bivalve.

R \& c. funiculi brẹes, e futura leguminis fuperiore f. rectiore.

SEN. quatuor, grandiufcula, ovato-oblonga, utrinque depreflo-plana, glabra, teftacea.

IN r. duplex: exterius cruftaceum, durum, craflum; interius tenuifimum.

A CB. tenüifimum, candidiffimum, ab aqua in gelatinam convertibile.

E м B. rectus, viridis. Cotylo ovatx, crnffx, carnofx, extus fulco longitudinali quafi biparritz, glabre; intus rugofx afperx. Plum. longa, feapo fubu lato; foliolis duobus aut quatuor pinnatis: pinnulis multijugis cum im. pari. Rad. retracta, brevifima, centrifuga.

2) Legumen integrum, mediocris magnitadinis. b.) Valvula feparta cum infertione \& fign feminum. c.) Semen transverfe diffeaum, albuminis \& cotyledonum formam oftendeac. d.) Embryo denudatus, e.) Cotyledonua fupcricies interaz. f. F.) Plumula cum Radicula.

Cessalpinia veficariz. ibid.

Semza-jpuria arborea Jpino $\int a$, foliis alatis decompofitis, fore luteo, filiquis brevibus fudcatis migris, fabina odore. SLOAN. bifl. jam. 2. p. 50. t. 181. f.2. 3 . Cefalpinia carde aculeato, foliolis obcordatis fubrotundis. LINN. lo c.

Ex herbario Bankfiano.

Legumen (a.b.) fuberofum, farckum, ovato-oblongum, fulco obfoleto tumido cum utraqué futura parallelo juxta peripheriam notatum, dehinc verfus marginem declive \& in aciem compreffum, in medio autem turgidum, planiufculum, fubtorofum, biloculare (b.), cvalve. Loculamenta lamina propria cartiłaginea veftita. Semina irregulariter rotunda (b.), lenticulari - aut plano - comprefla, craffa tamen (c.), \& fordide ferruginea. Integum. exterius coriaceum; interius Fublpongiofum. Albumen (c. d.) carnofum, in medio craffum, ad laters extenuatum, ab aqua in gelatinam vitreo pellucidam convertibile. Embryo (c.d.e.) rectus, albus. Cotyl. utrinyue planx: crafix, fubtexuofx (c), extus ftria obfoleta (d. c.) nutatx; intus glabre, nervis ftriatc. Plumula minuta, diphylla (F.), foliolis pinustis cum impari. Radic. conica, brevis, exferra. 


\section{J. Gaertner (1788) Vol. 2;}

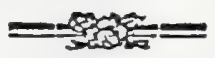

DCCCLVI. C A S S I A. TOURN. t. 392. LINN. gess. 5 I4

Flos Sennx. Legun. longum, teres, lignofum, evalve, pluriloculare. Loculamenta pulpa farca. Sem, albuminofa: albunine rima utrunque incifo. Embr. rectus.

ssis Filtula. Tab. 147. fig. I.

Conna, RHEED. mal. I. p. 37. t. 2 .

Caffia fificla. Сомм. bort. amft. x. p. 215. t. 1ro. Ruмpr. ans. 2. p. 83. t.22, VALENT. mus. x. p. j41. c. ic. BLAKw. berb. t. 381 .

Cadia folits quinanejugis ozatis acuninatis glabris, petiolss eglusdulatis. Linn. Sy.t. veg. 393 .

'ER. Legumen lignofum, cylindricum, longifinum (fubbipedale), pollicem circiter craflum, in dorfo fulcis duobus elevatis obfoletis, future indicibus notatum, corticatum, multiloculare, evalve. Cortex tenuis, membranaceus, nigto - fufcus. Diffepimenta lignofa tenuia. Loculamenta fupra feptunginut, pulpa molli, femen involvente, fards.

ig C. funiculi capiltares, e futura fpuria bifulca oriundi.

E M. folitaria, elliptics, crała, utrinque planiufcula, in latere inferiori linea longitudinali depretra notata, ceterum glaberrima, fplendentia, lutefcentia.

s T. fimplex, fubcartilagineum, durum.

LB. carnofum, cralum, opacum, album, juxta marginem rimá longitudina in' utroque latcre incifum.

M B. rectus, Jutefcens. Cotyl. ovatz, carnofx, utrinque planx, fed transverfim figmoideo-Hexuofx. Plim. diphylla, foliolis pinnatis conduplicatis quinquejugis uno verfu difpolitis. Rad. fubglobofa, centrifuga.

a. a.) Legumen integrum, B. b.) Idem apertum. C. d.) Seminis latus fuperius atqque inferiut c.) Ejusdem foctin transverfalis. f.) Albumen deaudatum, com rima fuz longitudinali, pre transmittendo cotyledonum margine. h. H.) Embrgo folutus. I.) Cotgled. tzasterfia fed. K. L) Plumula cum radicula.

In fructibus vetuftis loculamentorum pulpa valde extenuatur atque diaplargo matibus fub fpecie tenuis orbiculi (b.) carnofi utrinque adthxret.

Jafia Bacillus. Nob.

Cadia fifula indica, flore carneo, Jageri. Brexw. prodr. 2. p. 5 1.

Ab amicir. meo Hudsono.

Legumen pracedenti fimillimum, faltem paululum gracilius \& in fuperficie fua externa anuulis obfoletis, ad diaphragmatum fedem, infcriptum. Loculamenta atque disphragmata perinde lignofa ut in procedeati, fed

$$
=-\mathrm{J}_{\mathrm{i}}=
$$

chartacex propemodun tenuiatis. Pulpa coriaceo-fungofa, exfucci, fubru bicunda, totum loculamentum replens, atque intus \& in meditullio fuo propria'cavitate exculpta, qux etiam peculiari membrana veftica, \& in ampliufculam concamerationem lenticularem pro femine laxata eft. Semen per fingula puncti procedenti funillimum. Albumen etiam ut in priori, fed rimz magis a margine remotze \& fere in medio pofitx. Embryo feminis latitudini conararius : cotyledonibus angultis, argutius fexuolis. Plumula omnino ut in pracedenti, fed fejuga 


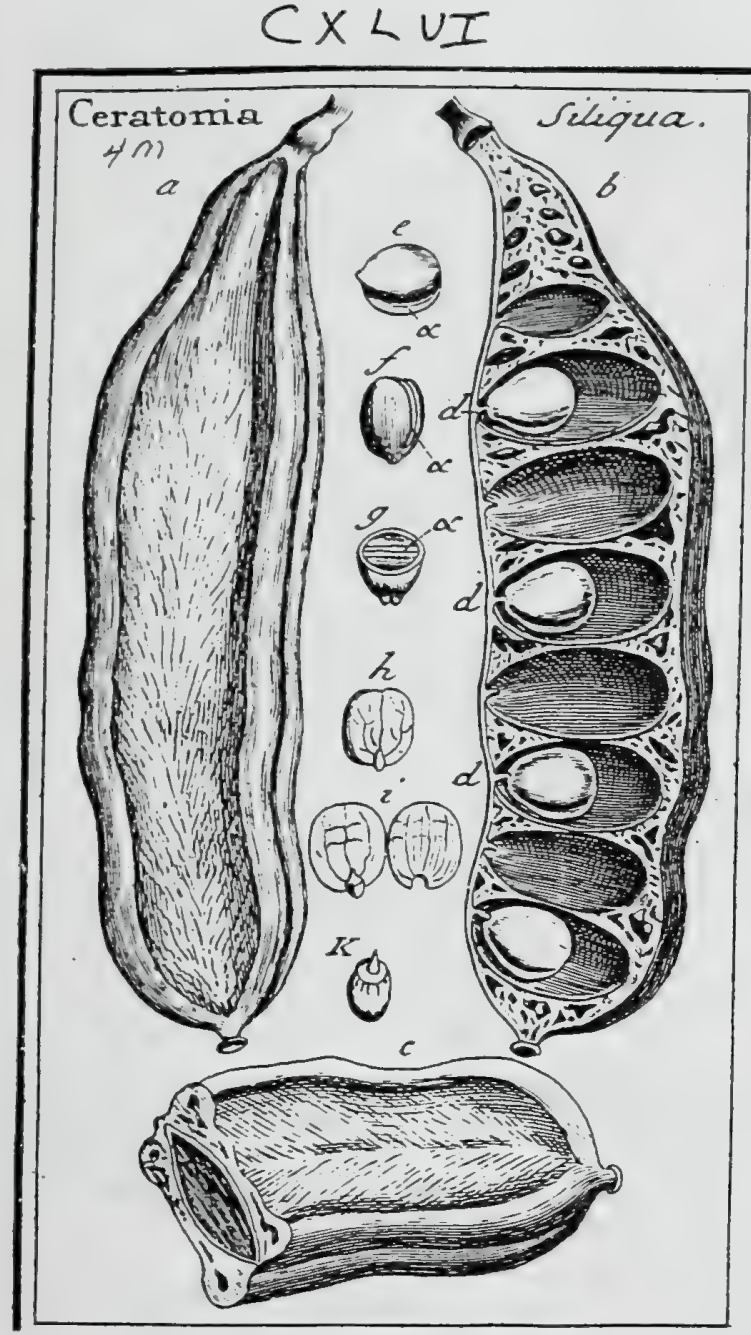

310

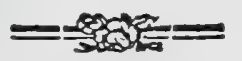

DCCCLII. C E R A T O N I A. LIN gen. II6\%. Siliqua. TOURN. $t .344$

Flores nune hermaphroditi, nunc fexu diftincti in feparatis ftirpibus. Cal. minimus, quinquefidus. Cor. nulla. Stam. quinque, difareta. Legum. longum, pulpofum. Sem. albuminofa. Embr. reaus.

Ceratonia Siliqua. Tab. 146. fig. I.

Siliqua. Can. epit. 139. BLakw. berb. to 209.

Ceratonia. LiN Syft. veg. $92 \pi$.

PER. Legumen longum, quadripollicare \& ultra, compreffum, per exficcatin. nem tetragonum, ferrugineo-fufcum, glabrum, carnofum, multiluculare, evalve. Caro pulpofa, per exficcationen dura, cevernulofa. Loculamenta octo aut plura, propria lamina chartacea veftita.

REC. funiculi breves, e futura rectiore.

SEM. folitaria, obovata, turgide lenticularia, glabra, e ferrugineo caftanea, fublucida.

IN T. duplex : exterints cartilagineum, durum; interins membranaceum, tufefcens.

A LB. carnofum, album, in medio crafum, opacum, ad marginem vero exthnuatum \& pellucidum: ut embryo lutei anuuli fpecie transpareat.

$E_{M B}$. rectus, luteus. Cotyl fuborbiculatx, craffx, utrinque planxe, vais deprelfis infcriptx. Phom. minutiflina, acuminata. Rad. hrevifima, ovato-globufa, centrifuga.

a.) Legumen exficcatuin, integrum. b.) Idem longitudinaliter diffectum. c.) Ejusdem feaie transverfalis. d. d. d.) Seminum fitus \& figure. c. f.) Albumen decorticatum, cum margine

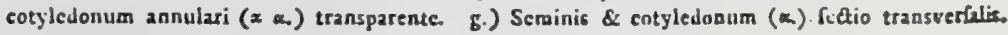
h.) Embryo denulasus. i) Cotgled. feparatz K.) Rzdic. \& plumula fepazacz \& audz. 


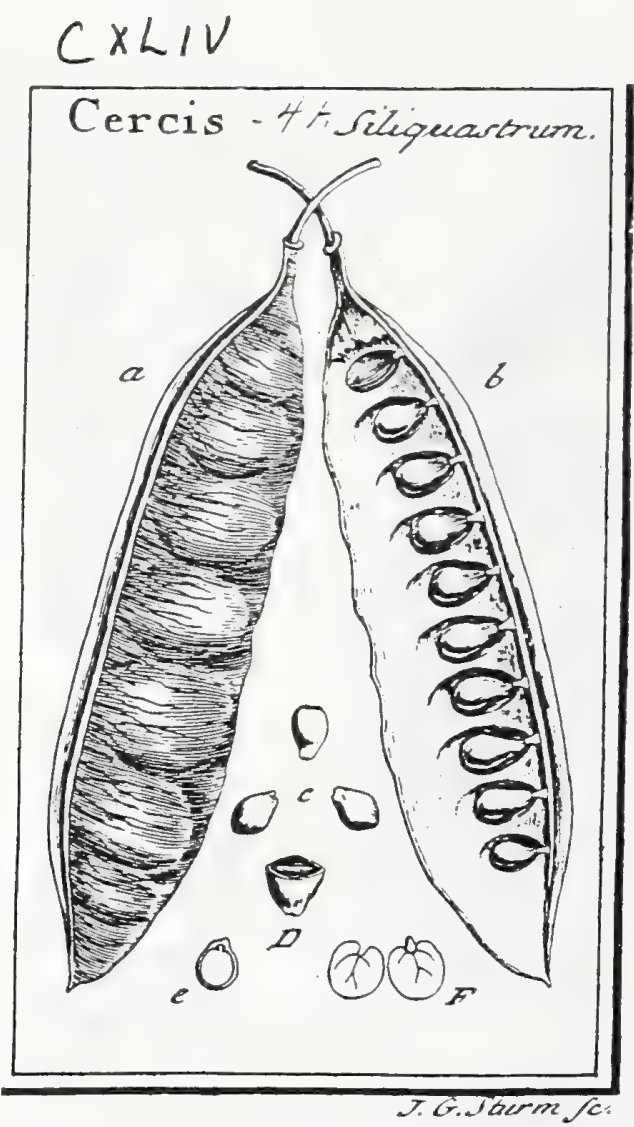

\section{C E R C I S. LINN. gen. 5 Io. Siliquaftrum.}

\section{TOURN. 2. 4I4.}

Calyx quinquedentatus. Cor. pentapetala, unguiculata, papilionacea. Stam. decem difcreta. Leguns. compreffo-planum, uniloculare, evalve. Sem. albuminofa. Embr. rectus.

CERcis Siliquaftrum. Tab. 144. fig. 3 .

Arbor juda. DoD. pempe. 786 . BEsL. Eyf. veru. frut. t. 3. f. т.

Siliguafruns. Riv. pent. 8.816 .

Cercis foliis cordato - orbiculatis glabris. LINN. Jy/. veg. 392.

PER. Legumen oblongum, tenue, foliaceo-compreffum, ad infertionem feninum nervo crafio prominulo notitum \& extra illum in futuram membrana.

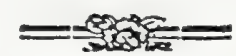

ceam anguftam extenuatum, uniloculare, margine futurx feminiferc oppofito dehifcens.

REC. funiculi breves, comprefli, e nervo future marginatx oriundi.

S E M. plura, feptem ad deccm, obovata, lenticulari-comprefia, atra, non fplendentia. IN T. duples : exterius coriaceum, tenue; interius fubfpongiofun, fufco-ferruginteum.

A LB. carnofum, album, in medio craffufculum opacuin, ad latera extenus. tun \& fubtransparens.

Eм B. rectus, lutefcens. Cotyl. orbiculate, foliacex, planx. Phum. immerfa, f. non confpicus. Rad. brevis, reda, centrifuga.

a.) Legumen integrual. b.) Idem longitudinaliter apertum, eum infertione [eminum. c.) Seminz feparata. D.) Semen cum nucleo transverie feAtum. e.) Embryo in albumine hareas, F.) Cotyled. feparatx.

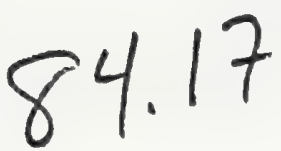




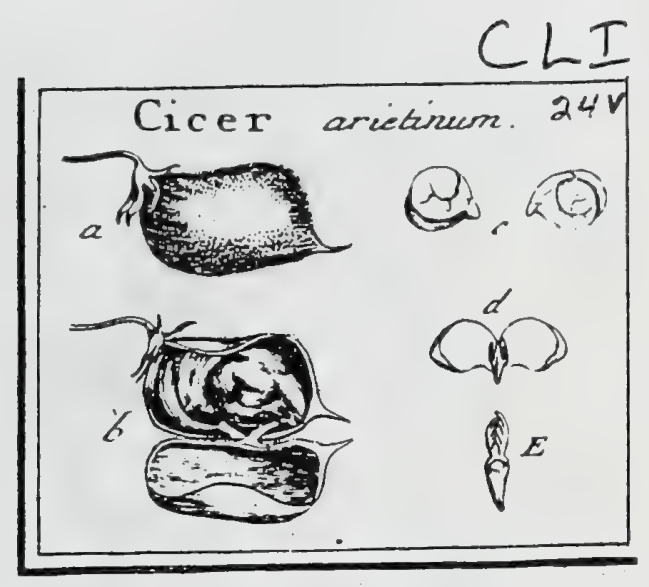

Fabaceae

J. Gaertner (1788) Vol 2

DCCCLXXII. C I C E R. TOURN. t. 210. LINN. gen, 875.

Calyx quinquefidus, longitudine corolls papilionacex. Legum. rhomboidcum, influmn, uniloculare. Sem. duo, arictis calput referentia, cxalbuminofilo.
Embr. curvatus

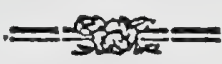

-CICER arietinum. Tab. I s. fig. 2.

Cicer. Riv. tetr. t. Ig. BLaki. berb. t. 557.

Cicer foliis ferratis. Lisn. Jy/f. veg. 665 .

PER. Legumen ovato-rhomboideum, infatum, villofum, uniloculare, bivalve.

REC. funiculi longi, compreffi, e futura rectiore.

SEM. duo, nunc. exacte globofa cuni roftello brevi ad umbilicum, nunc angulato-globofi atque capitis arietis formam xmulantia, pallide älbicantia aut rufefcentia.

IN T. duplex: coriaceum àtque membranaceum; utrumque tenue.

A LB. nullum.

Em B. curvatus, luteus. Cotyl. craffic, carnofie, plano-convexx. Plum. diphyllla, foliolis pinnatis, quadrijugis cum impari. Rad. brevis, conica, centrifuga.

2.) Legrmen integrum. b.) Idens dehilcens cum fitu \& figurz feminum. brauz interna valculosz veftitus. d.) Cotyied. Scparatz. E.) Plumula auéz.

c.) Nucleus mem- 


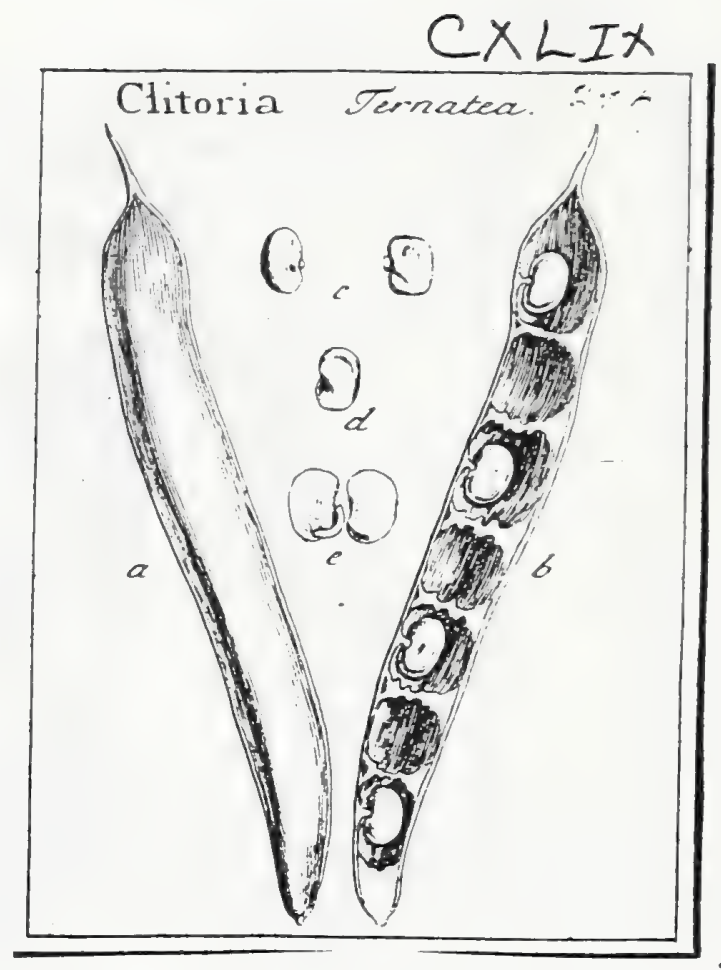

DCCCLXVI. C I I T O R I A. LINN. gen. 869. Ternateá.21 TOURN. act. gall. I.706. t. I.

Calyx tubulofus quinquedentatus. Cor. papilionacea fupinata, vexillo magno alas breves \& carinam breviorem obumbrantc. Legum. lincarielongatum, compreftiufculum. 'Sen. exalbuminoli. Embr. curvatus.

Clitoria Ternatea. Tab. 149. fig. 3.

Flos cerrilens. Ruarest. amb. 5. p. 56 . t. 3 t.

Flos clitorius Breynii. Cons. bort. amf.. 1. t. 24. femina uptiane.

Plsafeolus foliis pinuatis. R1v. tetr. t. 34.

Clitoria folits pinnatis. LINX. fy/t. veg. 660.

PER. Legunen angultum, elongatum, digitale \& ultra, lenticulari-compreffun, enode, fubpubefcens, pallidum, ftylo fubulato longiufeulo terminatum, pluriloculate, bivalve. Dilfepimenta tenuia, e valvulurum mers. brana interna cellulufa \& candidifima formata.

Rec. funiculi comprelii, e futura concava.

SEM. fulitaria, in univerfum feptena ad duodena, ovato - reniformia, ad alteram extremicatear quafi truncata, cornpreffufcula, utrinque abibofula. cetera vero glabra, e caltaneo fulca.

INT. duplex: coriaceum atque menbrastaceum; ytrumque tenue.

A LB. nullum.

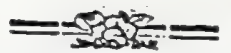

Eм в. curvatus, e luteo viridefcens. Cotyl. reniformes, extus gibbofule intus planx. 'Plumi, nulla. Ris. unciulalat, centrifuga. 2.) Legumen integrum. b.) Valvula cum infertione feminum. c.) Semina (eparata. di) Eo.
bryo denudatus. c.) Cotyled. fiparatx. Plunulx defectu a Phafeolis \& Viciis facile difcernitur. Scljonga-cufpi. RheED!
mal. 8. p. 69. L 3 S. propter foliola obovata, noftra effe nequit. 


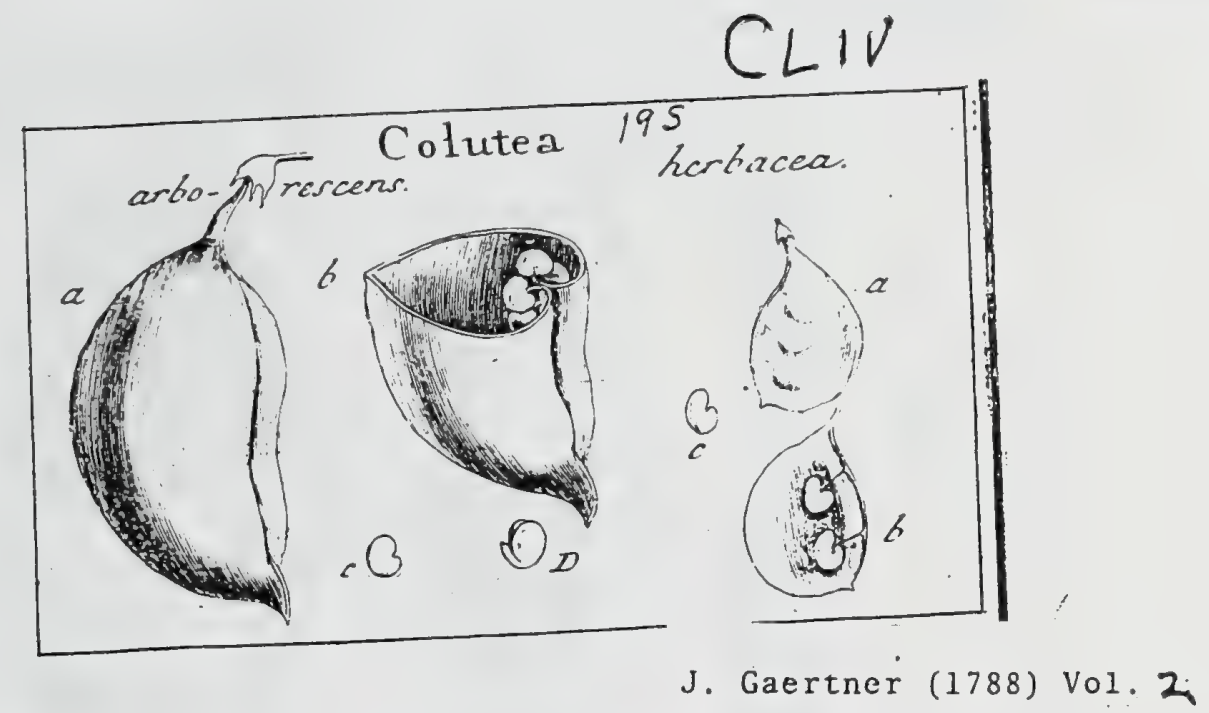

DCCCLXXXVIII. COLUTEA. TOURN. t. 4I8. Linn. gen. 890.

Calyx campanulatus quinquefidus perfiftens. Stigma hinc villofum. Legum. pedicellatum, membranaceum, inflatum aut compreffum, uniloculare. Sem. exalbuminofa. Embr. curvatus.

Colutea arborefcens. Tab. 154. fig. 4.

Coluter. Dod. penipt. 784. Cam. epit. 540. RIv, tetr. t. 20.

Coluten arborea, foliolis obcordatis. LiNs. Syft. veg. 668.

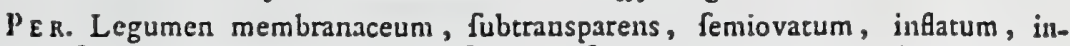
ferne in pedunculum longiufculum, fuperne in mucronem brevem definens, uniloculare, rima faltem in bafs futuræ feminiferx dehifcens.

REc. funiculi longiufculi; ex media folummodo parte futurx concavx.

- SEN. plura, ad viginti \& ultra, reniformia, compreliiufcula, rufefcentia.

IN T. finplex, cartilagineo - coriaceum, tenue.

A L B. nullum.

EMB. curvatus, luteus. Cotyl. ovatx, plano-convexx. Plums. nulla. Rad. intexa, centrifuga.

a. b.) Legumen integrnm \& difectum, cum infertione fenuinum. c.) Semen f:paratum.

D.) Einhrgo denudatus.

Collten herbacea. ibid.

Colutea africana ammu, foliolis parvis mucronatis, veficalis comprefis. Coms. byrt. amf. 2. p. 87. t. 44 .

Colutera berbacea, anma \& peremmis. Lisn. fyt. veg. l. c. n. 3. 4.

Legumen (a. b.) parvum, membranaceum, tenuifimuin, foliacco-compreftun, uvatum, pedicellatum, oblique mucronatum, uniloculare, bivalve. Semina (3. c.) duo aut quatuor, grandiufcula, reniformia,' compreffa, fordide caftsแe: Al. Alburaen nullum. Embryo luteus. 


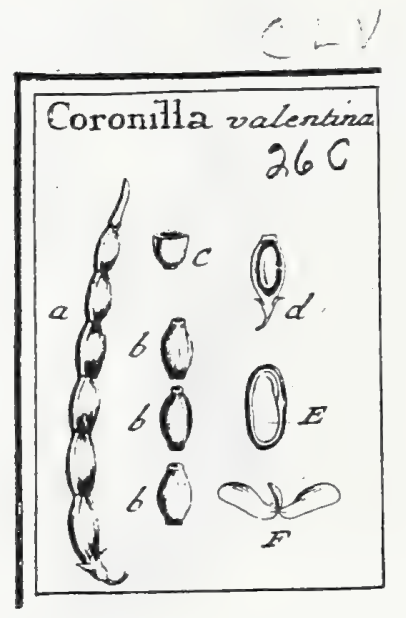

Fabaceae

J. Gaertner (1788) Vol. 2 344

DCCCXCI. CORON I L A A. TOURN. t. 419. Linn. ger. 883."

Calyx bilabiatus. Vexillum vix alis longius. Legum. articulatum, articulis ad juncturas fecedentibus. Sem. fubalbuminofa. Enubr. curvatus.

Coronilia valentina. Tab. Iss. fig. I.

Coroisilla. Riv. tetr. t. 92.

Coronilla fruticosa, foliolis fubbrovernis, fipulis fruborbiculatis. LINN. Jy/s. veg.66g.

P\&R: Legumen longum, rectum, teretiufculum, articulatum, ad articulorum juncturas fecedens. Articuli tres ad feptem, elliptici, turgide lenticulares, evalves.

REC. funiculus brevifimus e margine finguli articuli.

SEM. folitaria, ovato-oblonga, leviter compreffa, rubro-ferroginez.

IN T. finplex, coriaceu-chartaccum, intus carnofum.

A LB. vix ullum, prater laminam integumenti carnofan, alban, tenuiffimam:

EM B. curvatus, luteus. Cotyl. oblongx, planiufculx. Pluin. nulla. Rad. inAlexa, centrifuga

2.) Legumen integrum, e longiurihus. b. b. b.) Articuli (iparati. C. d.) Articulus diffectus, cum figura \& infertione (cminis. E.) Embryouis in albamine Gatus.

F.) Cutyled. explicatz.

84.21 


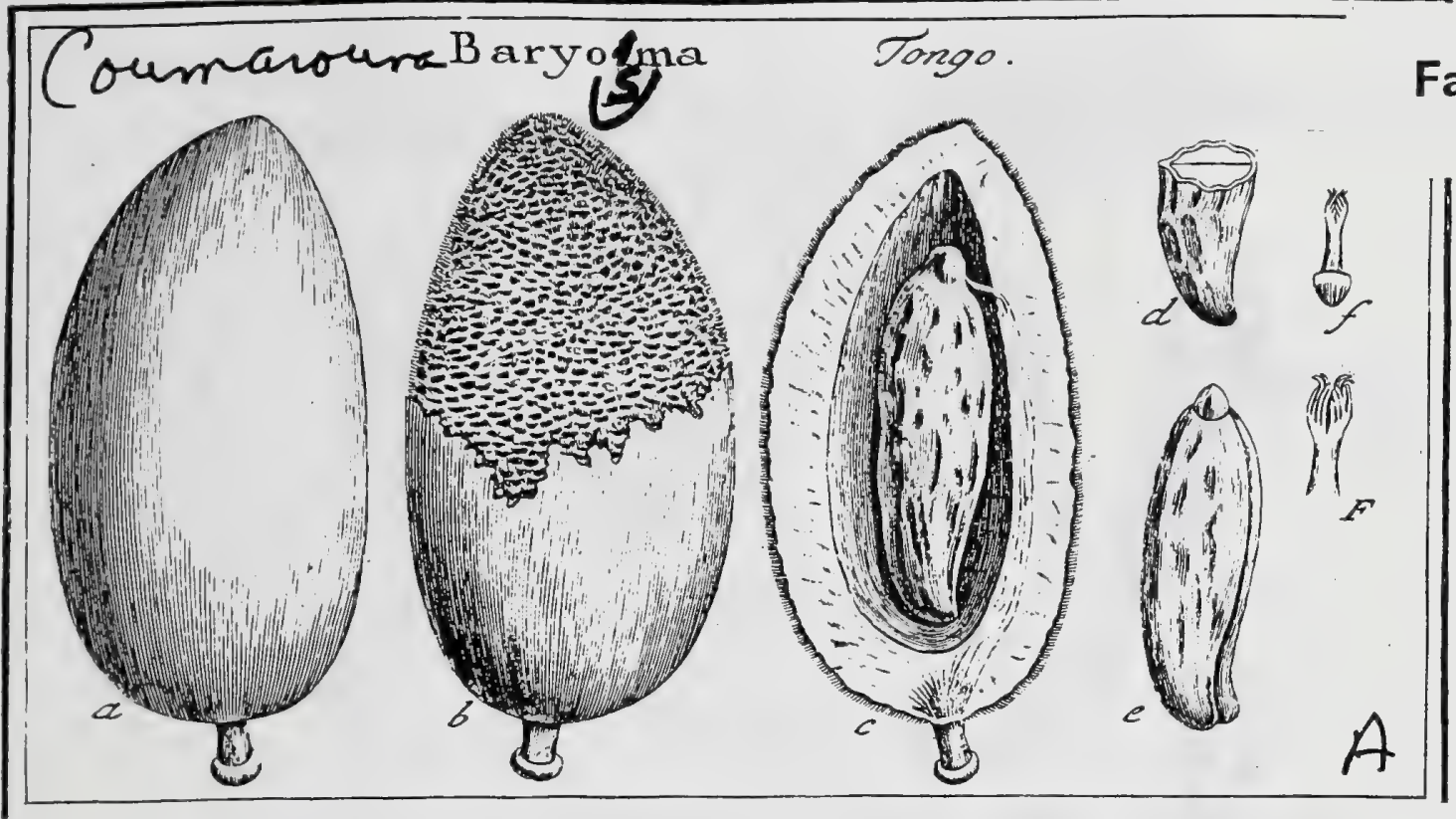

73

\section{B A R y OS M. Yanten}

Flos .... Drupa fupera baccita, putanine hifpido uniloculari monofpermo.

Baryosma Tongo. Tab. 9;. fig. 1.

Ex Ceminario hort. Amftelod.

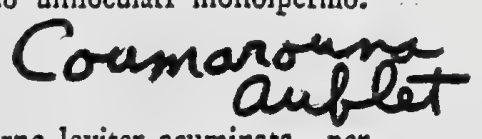

PER. Drupa fupera, buccata, ovato oblonga, fuperne leviter acuminata, per xtatem pallide ftraminea. Cuticula tenuis, glabra, nitida. Caro fucculenta, pauca, per xtatem evanefcens. Putamen figura \& magnitudine drupx, Japideum, crafum, undique fetis brevibus rigidis fubfafciculatis hirpidum, uniloculare, evalve.

REC. funiculus umbilicalis brevis e putaminis valis nutritiis oriundus atque feminu fub apice fuo infertus.

SzM. unicum, cavitate putaminis multo brevius \& angultius, oblongum, letrticulari compreffum, obfoletis rugis infcriptum, atrum, fplendens, graveolens.

Is T. fimplex, aridum, chartaceo-coriaceum, tenue, extus quafi pinguedinofun \& aqux cóntactum refpuens, intus fubferrugineum.

A \& B. nullum.

Eмв. fenaini conformis, inverfus, per xtatem, aut ab olei, quo fcatet, copia melinus. Cotyl. ovato oblongx, plano convexiufculx, extus obfolewe rugofx. Phun. grandiufcula, ex fcapo longø, ancipit, \& foliis geminis pinnatis, tri-1. quadrijugis, cum impari. Rad. ovato acuminata, compreffa, fupera.

2.) Drupa integra, e majoribus, nam dantur dimidio minores. b.) Eadem, detrica cuticula, ut putaminis fuperficies hifpida in confpectum veniat. c.) Putamen longitudinaliter apertum, cum (emine in fitu natusali. d.) Semen transverfe feanm. e.) Embryo denudatus. f.) Radicula \& plumula, magnitudiae naturali. F.) Plumula feparata \& aucta.

Semen valde oleofum eft, ut fxpus materies alba butyracea inter cotyledo. nes reperiatur; forti etiam \& vellicante odore praditum eft, quare Nicotimx pulveri Iternutatorio femina hxc addi folent. 


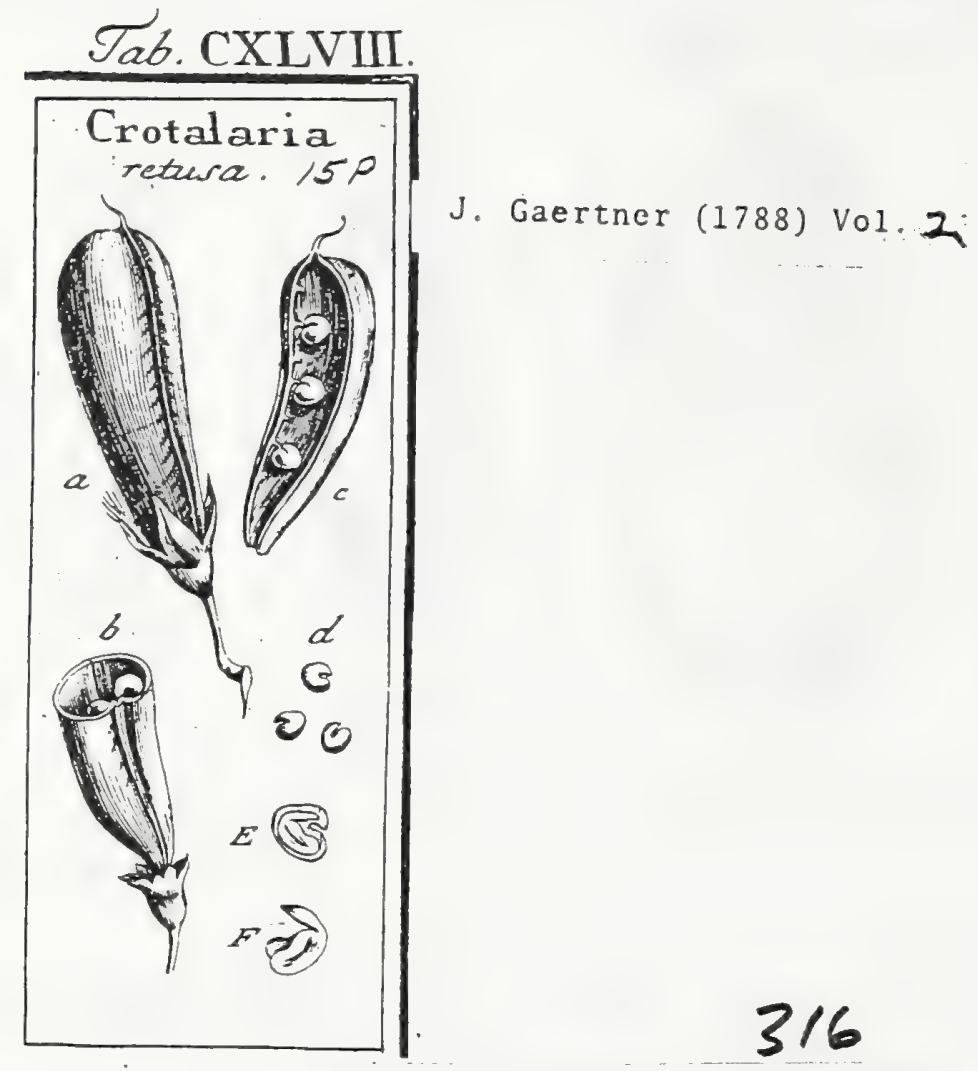

\section{C R O T A L A R I A. LINN. ger. 862.}

Calyx urceolatus trifidus. Cor. papilionacea. Stam. omnia connats cum fifura dorfali. Legum. infacum, pedicellatum, uniloculare. Sem. uncinulato - roltellata, albuminofa. Embr. curvatus.

Crotalaria retufa. Tab. 148. fig. 2.'

Tendale - cotti. RHEED. mal. g. p. 45. t. 25.

Crotalitia major. Rumph. ainb. 5. p. 278 . t. 96. f. x.

Crotalaria afiatica, floribus huteis, folio fingulari cordiformi. Herm. lugdb. p. 200. t. 201.

Crotalaria foliis finplicibus oblongis cuneiformibus retufis. LINN. fylt. veg. 649 .

PER. Legumen oblongum, furfum ampliatum, infatum, ad latera turgidum, fecundum futuram feminiferam depreffum \& verfus bafin fenfim in pedunculum attenuatum, charcaceum, uniloculare, bivalve.

- RËc. funiculi breves, e futura deprefra.

Sem. plura, quindecim ad viginti, obefula, trigono-reniformia, in roftellum a femine diftans \& uncinulatum definentia, glabra, lucida, nigro-crifta. nez aut helvola

IN T. duplex: cartilagineum, durum; \& membranaceum, ferrugineo-fufcum.

$\Delta$ L B. vitreo-pellucidum, ab aqua in gelatinam convertibile.

E\& в. curvatus, luteus. Cotyl. ovato - reniformes, planiufculx. Plum. nulla. Rad. fufformis, infexa, centrifuga.

a.) Legumen integram b.) Idem transverie feetum. c.) Valvula Separatz eum infertions feminum. d.) Semina foluta. E,) Embrjo intra albumen. F.) Ilem folutus \& levitcr explicatus 


\section{Cynometra IW cauliflora.}

$\propto$
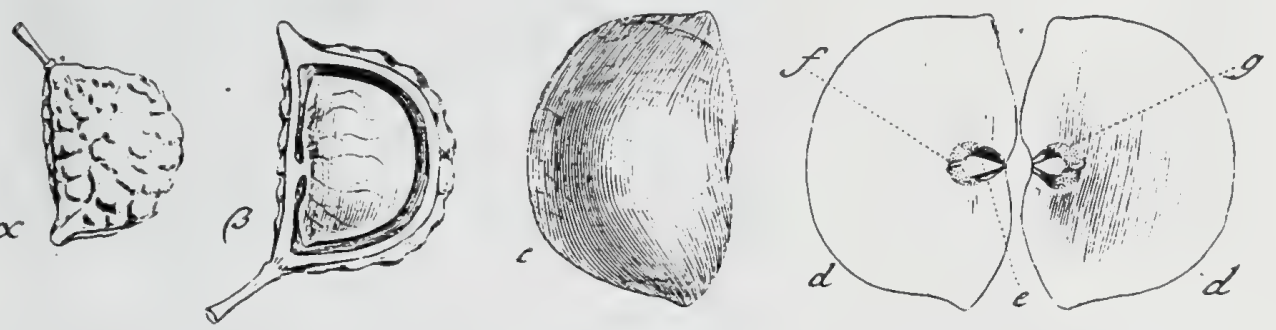

J. Gaertner (1788) Vo1.2

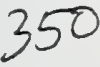

DCCCXCVIII. C Y N O M E T R A. LINN. gen. 519:

Cajyx quadripartitus refiexus. Cor. pentapetala regularis. Stan. decen difcreta, antheris apice bifidis. Legum. carnofum, tuberculanum, monofpermum. Sem. exalbuminofum. Emb. rectus : radiculà tomern fulvo a cotyledonibus difcretá !

Cymometra cauliflota. Tab. 156. fig. I.

Cynomoritm. RuMPH. amb, r. p. 163. t.62.

Cynometra trunco florifero. Liss. Jyjt. veg. 396 .

$E$ collect. fem. hort. lugdb.

PER. Legumen carnofum, grande, magnitudine dimidix volx manus \& ultra, femilunatum, lenticulari comprelfum, per omnem fuum ambitum fulco depreffo, tanquam futura, cinctum, in lateribus tuberculatum \& ad tactuin panni lanei adinftar afperum, uniloculare, non dehifcens.

REC. funiculus crafus brevis e media futura recta.

SEM. unicum, leguminis cavitati conforme, glabrum, vafis capillaribus arcuatis ex umbilico infignitum, rubro-ferrugineun.

IN T. fimplex, coriaceum, tenue, in vetuftioribus feminibus vix aqua fer̨vida 2 nucleo folubile.

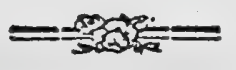

A LB. nullum, nec ejus veftigium.

EMB. femini conformis, albus. Cotyl. plano - convexx, ad radiculx fedem cavernula intus exfculptx. Plum. exilis, bicornis, circa bafin fuam villis brevifrmis mollibus fulvis aut rubro - ferrugineis ttipata, quibus radicula ad dimidix linex diftantiam a cotyledonibus fecernitur. Rad. conica, immerfa, centrifuga.

-) Legumen integrum, valde diminutum. B.) Idem apertum eum infertione feminis. c.) Semen magnitudine naturali, fed minoris moduli. d. d.) Cotyledones a parte interna fpeftatz. c.) Radicula in propria cavitate hxrens. f.) Plumula bicornis. 8.) Tomentuor fulvum radicuIIm 2 cutyledonibus difcernens. 

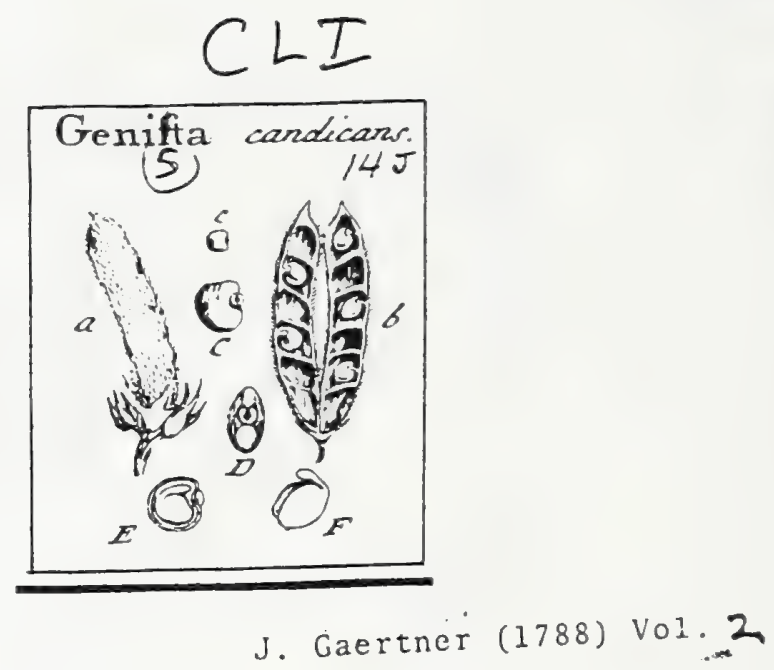

DCCCLXXVI: G E N I S T A. LINN. gen. 859. 329

Calyx bilabiatus, dentibus duobus fuperioribus \& tribus inferioribus. Cor. papilionacea, laxa, vexillo a genitalibus deorfum refexo. Legum, oblongum, uniloculare. Sem. fubalbuminofa, umbilico marginato. Emb. curvatus.

Genista candicans. Tab..151. fig. 6.

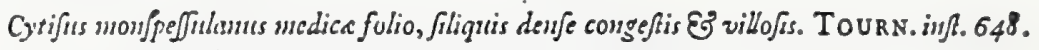

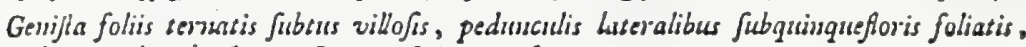
leguniduibus birfustis. LiNs. Gy/t. veg. 645.

Ex horto regio Kewenti.

PER. Legumen oblongum, angufum, comprefium, obfolcte torulofum, fur. cun, albo villofum, uniluculare, bivalve. Valvula intus profunde fcrobiculatx, vix tamen loculamentofie.

REC. funiculi breves, e futura convexiore.

SEM. quatuor 1. Sex, fubreniformin, nigra, glabra, fublucida. Umbilicus margine glandulofo, proniuulo, lumato, albo aut luteo, perfiftente, cinclus.

INT. duplex: utrumque membranaccum, tenuc.

A L D. e virill-albicans, tcuue, fubcarnolum, ab aqua in fpifam gclatinam convertibile.

EM в. curvatus, luteus. Cotyl. ovatx, utrinque planiufculx, Plum. nulla. $R \boldsymbol{\alpha}$ intexa, centrifuga.

2.) Legumen integrum. b.) Idem dehifeens, c. C.) Scmen Separatum. D.) Umbilicus vifui obverfus. E.) Embryo intra albumen. F.) Idem folutus.

Caruncula umbilicum cingens \& ab integumentorum fubftantia diverfa, in Genifta, Ulice \& Spartio fingularis eft. 


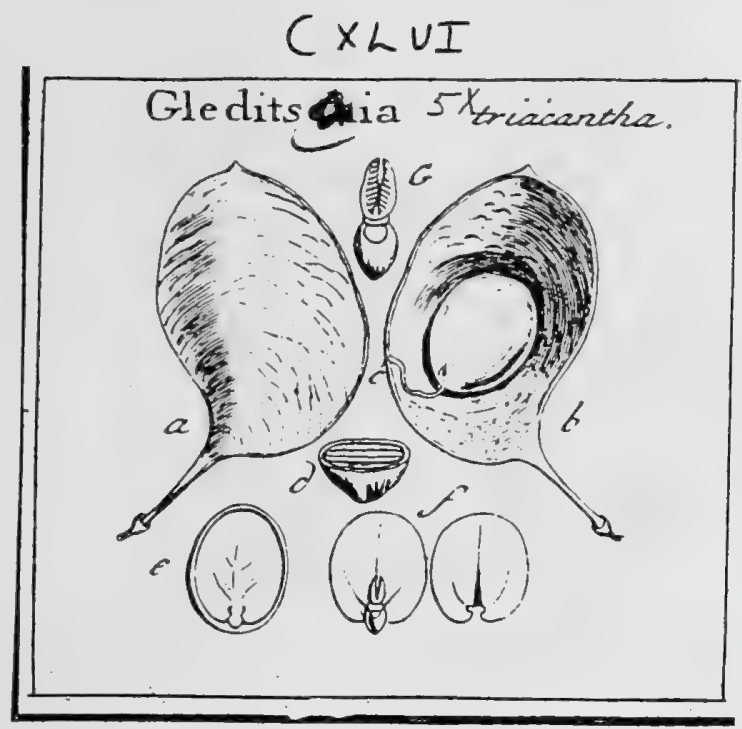

J. Gaertner (1788) Vol.Z Z DCCCLIV. G LED I T S I A. Linn. gen. II59.

Flores hermaphroditi aur fexu diftincti is feparatis ftirpibus. MAS. Cal. trifidus. Cor. tripetala. Stam. fex. HERM. Cal. quadrifidus. Cor. tetrom petala. Stam. fex. Legun. ut in feminis. FEM. Cial. quinquefulus. Cor. pentapetala. Legum. latum, foliaceo - compreflum. Sem. albuminofl Ensbr. rectus.

Gleditschia triacantha. Tab. 146. fig. 3.

Acacia abruce folio triacmutbos, capfula ovali unicum fenten clastente. Catrsp carol. 1. p. 43. t. 43. Seligm. av. t. 86.

Geditfur cande fpinis triplicibus axillaribus. LINs. Jyft. veg. grg.

A PU. Millero chels.

PER. Legumen coriaceum, renue, valde compreflum, pedicellatum, inique ellipticum, uniloculare, bivalve, vix tanen fponte dehifcens, quia Vat vulxe extra loculamenti cavitatem tenui fubltantia cellulofa inter fe connexze.

REc. funiculus unbilicalis longus, tortuofus e gibbofiore leguminis margine oriundus.

SÉ. unicum, ellipticum, utrinque planiufculum, durum, glaberrimum, lueidum, luteo - fpadiceum.

IN T. Gimplex, cartilagineum, in aqua mollefcens.

A s. carnofun, album, in medio crafum \& opacum, ad latera valde extenus. tum \& tranfparens.

Es в. rectus, luteus. Cotyl. ovatx, juxta radiculam profunde emarginatex. craffufculx, utrinque planx. Plum. diphylla, foliolis pinuatis decem. jugis. Rac. ovato-globora, centrifuga.

a.) Legumen integram. h.) Idem apertum, cum feminis figura atque fitu naturali, c.) Frai culus umbilicalis d.) Seminis fedtio transver\{alis. e.) Embrgo ab uno latere denudatus, albus mini adharens. f.) Cotyledones fepantz. 8. G.) Plumula cum radicula.

Alteram varietatem, cui Legumen maximum, latun, compreffifimum, dif. fepimentis plurimis transverfis, iftmisque pulpa repletis ftipatum, Linn. 1 c. tribuit, nondum vidi. 

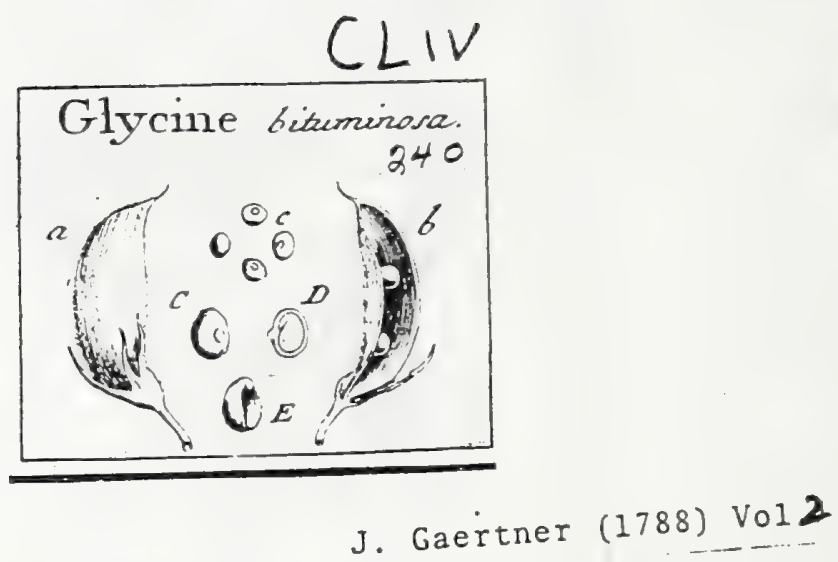

DCCCLXXXIX. G L Y C I N E. LiNN. gen. 808.342

Cillyx bilabiatus, fupra emarginatus, infra trifutus inxqualis. Cisrinx aps: ilcatus refectens vexillum. Legum. oblongum uniloculare. Sin. exalbumisof.. Enb. curvatus.

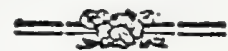

Glycine bituminofa. Tab. is4. fig. 5.

Pbafeolus africanus birfusus bituminofus, filiquis bullatis, fore furvo. HERis. lugdb. 492. t. 493 .

Glycine foliis ternatis, floribus racemofos, leguninibus tzumidis villofis. LINN. Syfo veg. 660 .

Ex horto regio Kewenfi.

PER. Legumen ovato-oblongum, utrinque acuminatum, turgidum \& qu; inflatum, villofum, uniloculare, bivalve.

REC. funiculi brevifini e futura concava.

SEM. quatuor, parva, glubofa, depreffiufcula, atra. Umbilicus tumidus, callorus, niveus.

IN T. duplex: exterius coriaceo-chartaceum; interius fpongiofo membranaceum, ad umbilici regionem valde incrafatum, ut area latiufcula plana infra embryonis radiculam oriatur.

A L B. nullum, nec ejus veftigium.

E мв. curvatus, viridis aut albicans. Cotyl. crafix, plano-convexx. Plum. nulla. Rad. brevis, inflexa, centrifuga. .

a.) Legumen integrum. b.) Valvula altcra cum infertiene feminum c. C.) Semina feparata D.) Tefta feminis aperta cum Gtu embryonis. E.) Eubryo denudatus \& a parte arcolx umbilicalis deprefix spectatus.

Genus difficile \& hactenus e fpeciebus manifefte heterogeneis conflatum, ulteriori indiget fcrutinio.

84.27 


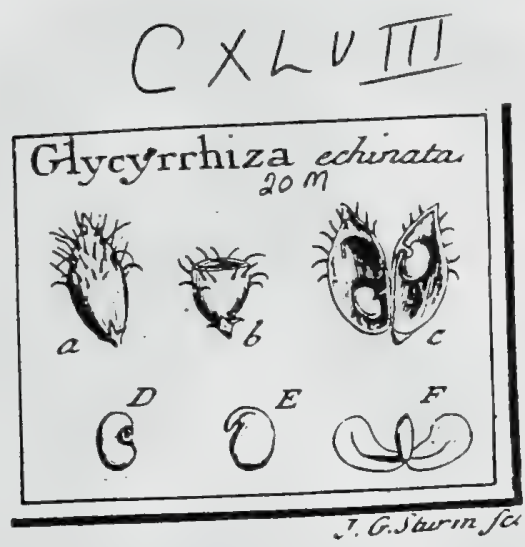

\section{Faentren $(1788) 2$}

DCCCLXIII. GLYCYRRHIZA. TOURN. t. 2ro. LINN. gen. 882.

Calyx bilabiatus: labio fuperiore trifido; inferiore finplici. Cor. papilionacea. Stan. diadelpha. Legum. breve, comprefiufculum; undoculare. Sem. exalbuminofa. Embr. curvatus.

Grycyrrhiza echinata. Tab. 148. fig. 6.

Dulcis rudix. CAM. epit. 423.

Pjeudo-glycyrrbiza. Riv. tetr. t. 3. bene.

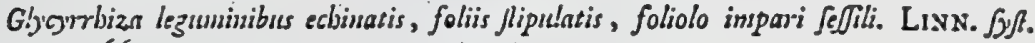
veg. 669 .

Icons. Jace. bort. t. 95.

P E R. Legumen ovato-lanceolatum, fubfemipollicare, lenticulari-comprefum, dimidia fua parte fuperiore fpinis pungentibus armatum, uniloculare, bivalve.

REC. funiculi breves, e futura interiore f. rectiore.

SEM. duo, reniformia, glabra, ad umbilici foramen annulo tumido cartilagineo notata, rufefcentia.

Is T. fimplax, cartilagineo coriaceun, intus-fubcarnofum.

EM B. curvatus, luteus. Cotyl. ovato - reniformes, plano-convexx. Plum. null. Rad. clavata, inflexa, centrifuga.

a.) Legnimen integrum. b.) Ejus fectio transverfalis. c.) Iulem dehifoens, cum feminum Gtu \& Gigura, D.) Scmen auduin. E) Eubrgo denudatus F.) Cotyled. explicatz. 


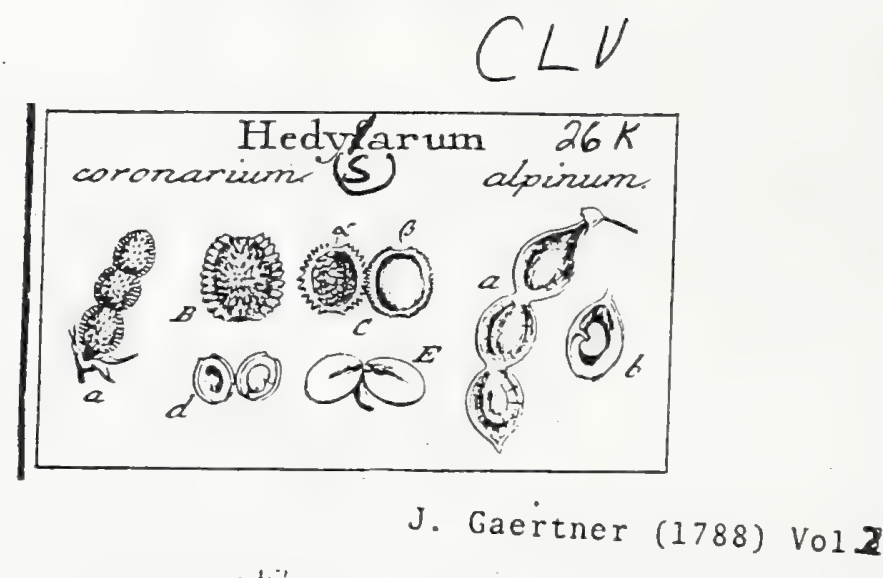

DCCCXCV. HEDYSARUM. TOURN. t. 225. LINN. gen. 887 .

Carina ad angulum rectum incurvata, ad curvaturam ipfam transverfe obtufa, fupra eam roftrata. Legum. comprefium, articulatum: articulis monofpermis a fe invicem fecedentibus. Sem. exalbuminofa. Einbr. curvatus.

HEDYSARUM coronarium. Tab. Iss. fig. 5.

Hedyynum clypeatuns, fore funviter rubente. BESL. Eyft. eß. XIIt. \&. 2. f. I.

Hedyforrum. Riv..tetr. t. 98 .

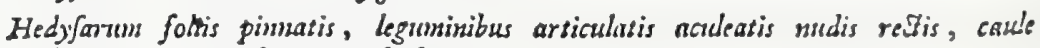
diffuro. Lins. fygl: veg. 676 .

PER. Legumen oblongum, rectum, compreffiufculum, articulatum. Articuli terni aut pauciores, fubrotundi, crenulato - marginati, corticati. Cortes tenuis fungofus, extus aculeolis brevibus nuuricatus. L:Iminx proprix characex, glabre, vix fponte dehifcentes, fed articulatin fiecedentes.

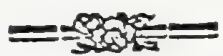

$R$ E. funiculus tenuis e margine laminx articulorim proprix.

SEM. folitaris, renifornia, lenticulari - compceffa, glabra, lucida, lutefcentir.

IN T. fimplex, coriaceo - chartaceum.

A L 8. nullum.

Eas B. curvatus, luteus aut albus. Cotyl. ovatx, platio-convexiufculx. Plusx. exigua, fubrotunda, comprefra. Rad. intexa, centrifuga.

1.) Legumea integrum. R.) Articulus (eparatus. C.) Articuli cortex \&.), \& B) ejusdem lanina prepriz. d.) Valvulz articuli feparate cum infertione \& fgura feminis. E.) Enbryo deaudatus \& explicatus.

Corticatis articulis porro quoque gaudent H. fextrofum \& grandiffornun; in reliquis, mili notis, ommibus fimplices funt.

Hedysarum alpinum. ibid.

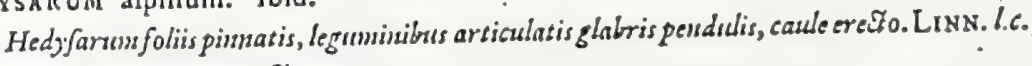
Icus. GreL. flor. fib. 4. to 10 .

Legumen (a) membranaceum, foliaceo-compreffum, bi - l. quadriarticulatum. Articuli (b.) ovati, glabri, nervis reticulati, Sponte a fe invicem fecedentes, non dehifcentes. Semen (b.) oblongo - reniforme, glabrum, ferrugineuin. Alhagi \& Glycyrbiza afpera Palc. propter legumina moniliformia, Hedyfaro commode affociari poffe videntur. 


\section{Tab. CXIV}

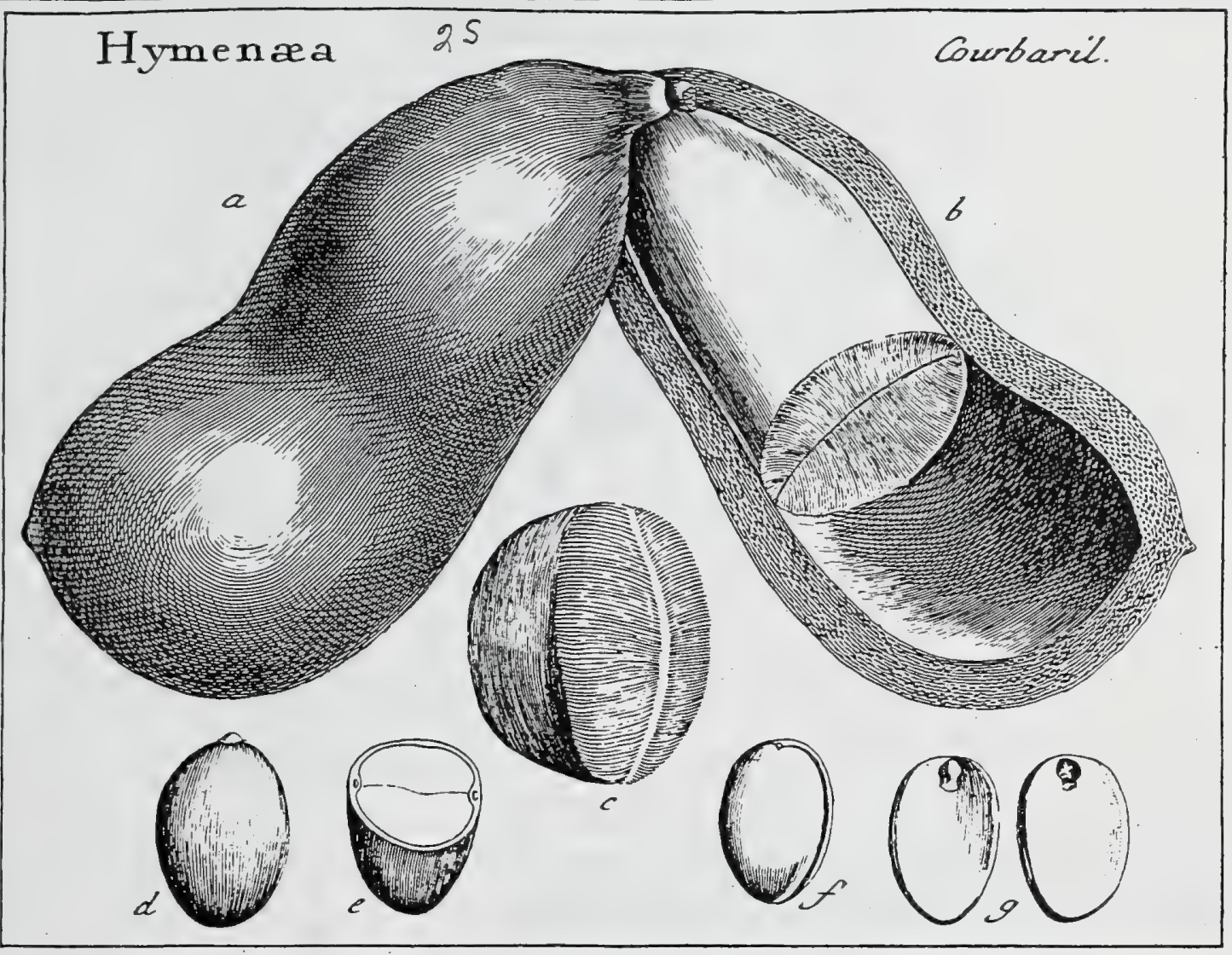

DCCCXILII. H Y M E N \& A. LINN. gen. 512. Courbaril. PLUM. i. 36 .

J. Gaertner (1788) Vol. Z

Calyx turbinatus, limbo quinquepartitu. Cor. pentapetala, fubxqualis. Stam. decem, difcrets. Legum. lignofum, pulpa exfucca farctum. Sem. involuta, exalbuminofa. Embr. rectus: coty่ledonibus fulco depreffo in ambitu difcretis !

Hymenea Courbaril. Tab. 145. fig. I.

Jetaiba. MarcGr. bras. ror. c. ic. PIs. bras. 60.

Ceratia diply'llos antiguna, ricini majoris frutu nigro, filigua grandi inclufo. Plux. plyyt. t. B=. f. 2.

Hymeencar. Lins. Jys. veg. 392.

E mufxo Storriano.

P \& . Legumen grande, lignofum, crafum, oblongo-reniforme, extrorfum craffefcens ac obtufum, uniloculare, evalve, pulpa ficca farctum. Pulpa

306 cavitatem leguminis exacte replens, extus pulvere lateritio-rubro conifperfa; intus alba, fungofz, in innumeras philyras lineares arctifrme fibi incum-

bentes folubilis arque infuper in tot portiones difcretas feparabilis, quot, funt femina, quibus arctiffine adharet, eaque tota obvolvit.

REC. nullum, proxter pulpam, in qua femina latent.

SEM. quatuor ad octo, grandia, elliptico-globofa, obfoletifine compreffa, atra, Umbilico folido fungofo albo, fuperiorem $\mathcal{L}$ concavam leguminis futuram refpiciente, terminata.

IN T. fimplex, fublapideum, durifimum, anthracinum, intus fulco prominulo, cotyledonum rimx imnerfo, notatum, \& intra ipfam fulci fubftantiam nervo calcareo niveo ex umbilico oriundo infignitum.

$\Lambda$ LB. nullun, nec ejus veftigium.

E. B. femini conformis, rectus, lutefcens. Cotyl. craffx, plano-convexx, ad totum commiffure fux ambitum fulco depreffo ab invicem difcretæ \& quafi hiantes. Plum, nulla. Rad. globulofa, retracta, centrifuga.

a.) Legumen integrum, e minoribus. b.) Jdem apertum, cum dimitia pulpx parte relica. c.) Portio pulpz leparath \& 2 parte inteciore fpectata, ut philyrz lizeares, e raphe media utriaque oriundx, melius in confredum veniant. (h) Semen denudatum. c.) Idem transverfe fectum E.) Embryo denudatus, g.) Cotyl feparatx, cum fitu \& figurz Radicals. 
Tab. CXXXIX.

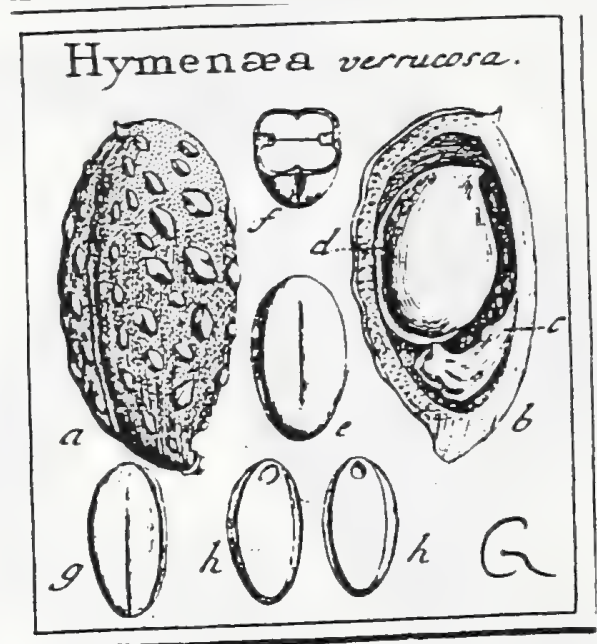

Hrmenea vertucora. Tab. 139. fig. 7 .

Tanjourout madagafcarienfrum. Juss. gen. 35x?

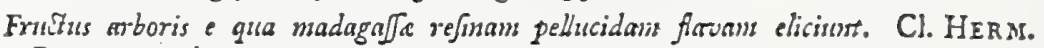
Pro. arg. in litt.

Legumen, refpectu pracedentis, parvulum, perinde tamen durum atque coria. ceo-fuberofum; obovatum (a), turgidum, verfus apicen craffius; extus confertiffmis ac minutifimis punctis cinerafcentibus, quafi mufcarum ftercore, confperfum, infuperque verrucis diffitis, depreffiufculis, fubpolyxdris, lxvigatiffimis, fplendentibus \& faturate caltaneis egregie variegatum; intus autem unico loculamento (b.) exfculptum atque pujpa ficca incomplete farctum: Receptac. (c.) unilaterale, craffum, fungofum, arcuatum (nifi id feminis abortivi pulpa fit). Pulpa femen obvolvens (d.) alba, fungura, folida, nec in philyras fecedens. Semen (e) unicum (altero forfan fuffocito), ellipticum, utrinque planiufculum (f.), feu obfoletifime tetragonum, fubfplendens, e ferrugineo rubrum. lnteg. exterius fublupideum; interius croceum, quatuor fulcis (f.) introrfum prominulis diftinctuns. Embryo (g.) albus, in utroque latere fulco obfoleto infcriptus, in margine auten fulco profundo totam peripheriam ambiente exfculptus. Cotyled. (h.h.) carnofa, ad ambitum a fulco extenuatx, in medio crifix. Rad. globulufa, immerfa, fupera.

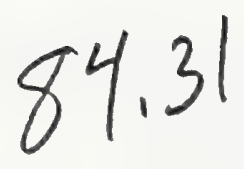




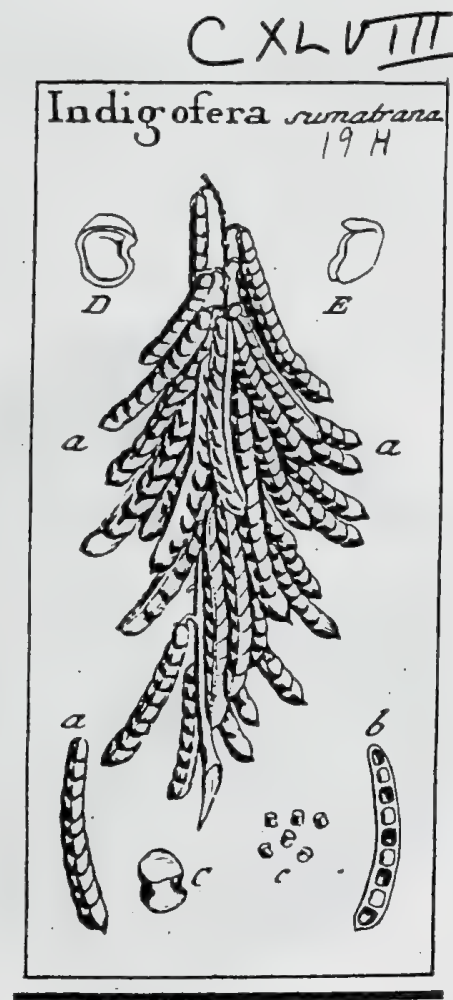

Fabaceae

\section{J. Gaertner (1788) Vol 2 Zi}

DCCCLXI. I N D I G O.F E R A. LINN. gen. $889.3 / 7$

Calyx patens, quinquedentatus. Cor. papilionacea : carina utrinque colcare fubulato patulo. Stam. diadelpha. Legum. lineari - oblongum, fxpius tetragonum. Sem. cuboidea, exalbuminofa. Embr. curvatus.

INDigoferis fumatrana. Tab. 148. fig. 4.

$\Lambda b$ amicif. Dn. Hudson.

PER. Legumen lineari oblongum, fubfalcatum, rhombeo-tetragnnum ad fe-

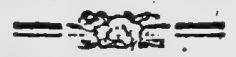

mina torulofum, multiloculare, bivalve. Diffepimenta fpongiofo menbranacea, a valvulis facile feparabilia.

K ₹ C. funiculi breves, e futura concava.

SE M. folitaria, in univerfum auten fubduodena, reniformi - cubica, glabra; pallide viridula, punctis duobus callofis nigris infra umbilicum notata.

IN T. fimplex, cartilagineo - coriaceum.

A L B. nullum.

Es 8. curvatus, luteus. Cotyl. ovato - reniformes, hirc gibbx 1. angulatx; inde planz. Pltm. nulla. Rad. fuftornis, intexu, centrifuga.

2. 2. 2) Fruatus racemofus. integer, leguminibus recurvatis pendulis. b) Valvula cum feminibus. c. C.) Semina feparain. D.) Semen verticaliter apertum, cum embryone in fitu naturali. E.) Eunbryo folutus.

Cubica f. reniformi - retufa Teminum forna, plurimis, fi non omnibus Iridigoferx [peciebus" communis eile videtur. 
Inocarpus cdulir.

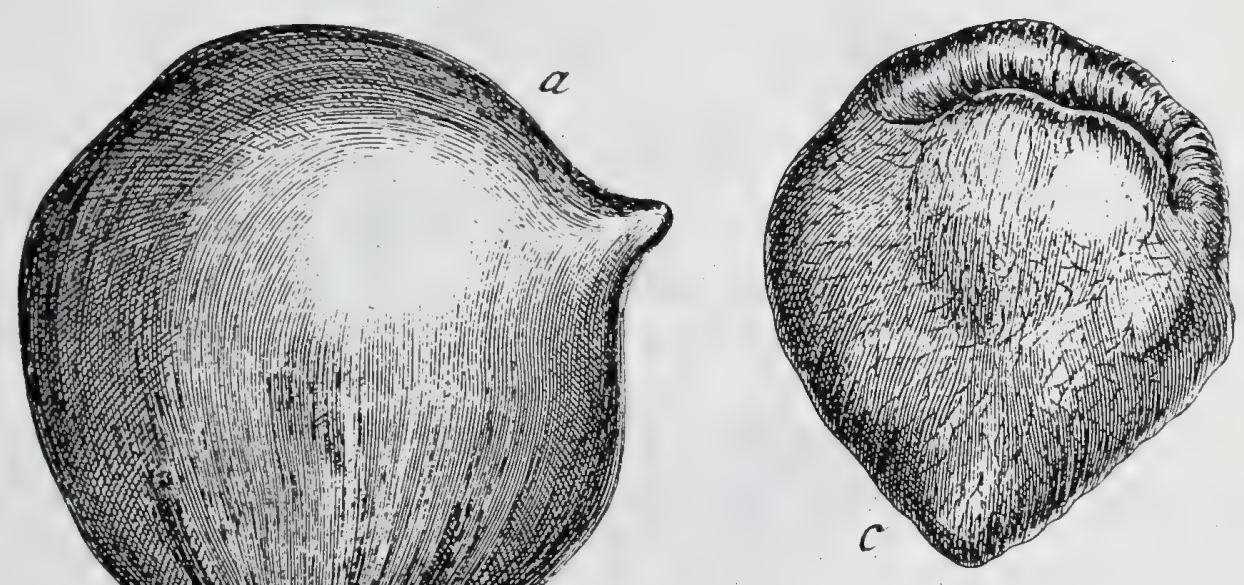

a
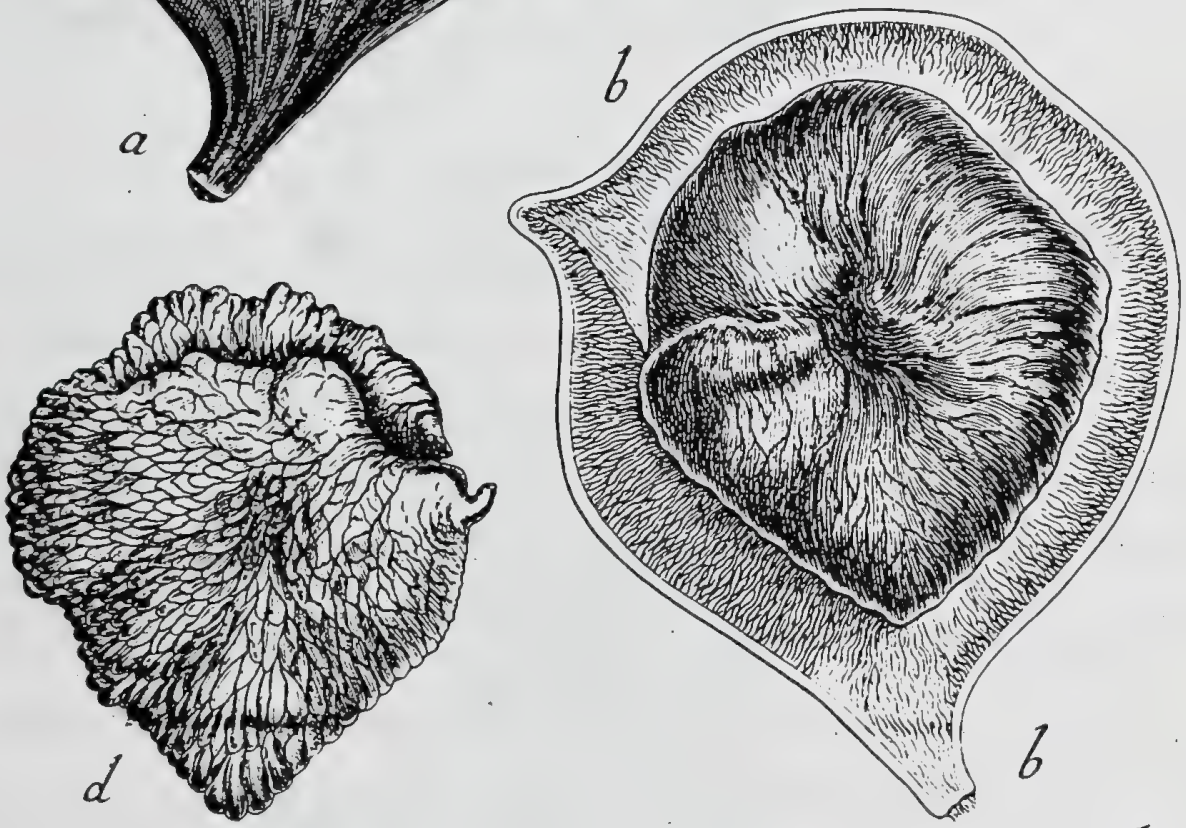

Tab. C C.

$$
\text { Inocarpus edulio. }
$$
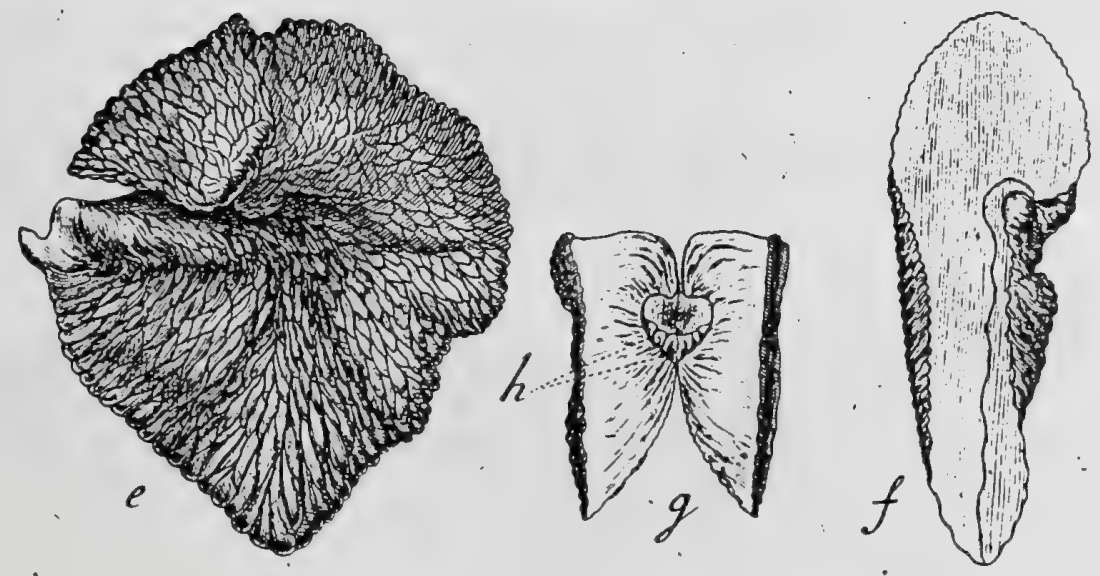

$84.33 \mathrm{~A}$ 


\section{J. Gaertner (172ミ) Vol.3}

\section{4}

\section{I N $O$ C A R P U S.}

E овsт. chat. t. 33. LinN. Juppl. 35. Thunb. nov. gen. 45. Sсквев. gen. 754. Juss. gen. 152. Labaвcx ill. gen.

$$
\text { t. } 362 \text {. }
$$

Cal. monophyllus, bifidus: laciniis fubxqualibus, pubefcentibus, deciduis. Cor. monopetala, tubulora; tubo cylindrico, longitudine caly'cis; limbo 5.1 .6$. partito: 1aciniis longis, linearibus, undulatis. Stam. 10.1.12., filanentis brevifimis, duplici ferie, altera in fauce ipfa, altera paulo inferius corollx alternatim infertis; antheris erectis, didymis. Ovar. fuperum, villofum; ftylo nullu; ftigmate excavato. Drupa grandis, compreffa, lignofo-fibrofa, monofperma. Rec. nullum. Sern. comprefinn, ovato.cordatum. Alb. nullum. Enb. magnus, inverfus; rad. lac.rali, parva, adfcendente.

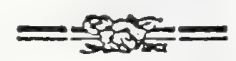

INocarpus edulis. Tab. 199. \& 200. fig. I.

Inocarpus. Forst. clar. ger. p. 66. Prod. 13. 197. Pl. efcul. p. 50. Lisn. fuppl. p. 239. Syf. veg. ed. 14. p. 408 . WiLLD. Jpec. pl. T. 2. P. x. p. 624 .

A Cel. Labillardiere, \& ex Collectione Deleffertiana.

PBR. Drupa magna, corticata, ovata, comprelfa vel Jenticulari - convexa, margine obrufifimo rotundata, paulum fub vertice ventrem verfus in mucronem trevem obtufum producta, ad bafin vero nervis quatuor 1 . quin. que in pedunculum craffufculum collectis Rtipata, glabra, viridis. Cortex carnofus, tenuis, cum putanine arde commixtus, \& inter putaminis fibras hxreus, ficcitate evanefcens. Putamen crafum, ex fibris lignofis verfus peripheriam radiatim productis \& varie intertextis, ad umbonem vero rectis compaginatum, ad ventren inde a mucrone ad pedunculum usque fecundum futuram fiffile, L fubbivalve, intus grabrum \& impreftionibus nervolis notatum.

R B c. nulluri; femen prope radiculam, externo mucroni drupx obverfam, putamini affixum.

SEM. unicum, grande, totam putaminis cavitatem replens, ovato-cordatum, compreffum, fuperne craftius, inferne attenuatum, ad ventrem ruga circulat mucroni drupz externo obver $\sqrt{ }$ notatum, nervis fuperficialibus analtomofintibus infcriptum, ferrugineum, (in recenti album. Forst.)

IN T. duplex; exterius nembranaceum, cralfum, firmum, reticulato-venofum, facile derrahendum : inserius tenuilimum, arachnoideum, embryoni arcte adnatum.

A L B. dulluni.

E M. maximus, femini conformis, utrinque concavus, inverfus, lacteus. Coty). maximx, latifimx, crafix, carnofic, extus a vaforum integumenti externi imprelfionibus reticulato - tuberculatx, intus leviter undulato inxquabiles, fubplicatx, fupra radiculam rima transver $\sqrt{a}$ filix, accumbentes. Plum. fimplex, compreffa, fubcriftata, acuminata. Rad parva, curvula, compiefla, ad marginem cmiryonis fub filfura cotyledomum fita \& mucroni drupx obverfa, fubadicendens, fupera.

a. a.) Drapa integra mediocris watnitudinis b. b.) Eadem verticaliter ditedes eum femine in fitu. c.) Secren fulutum, ab altera parte f́pedztum. d. \& c.) Embryo integumento externo orbatus, ab utraque parte vifus. f.) Cotyledonum fidio verticalis. s.) Earnudeor partes tadieales atfeifr, \& a fe invicem diduax, ut infertio radieule \& b.) Plumula in confpectura renisnt. 


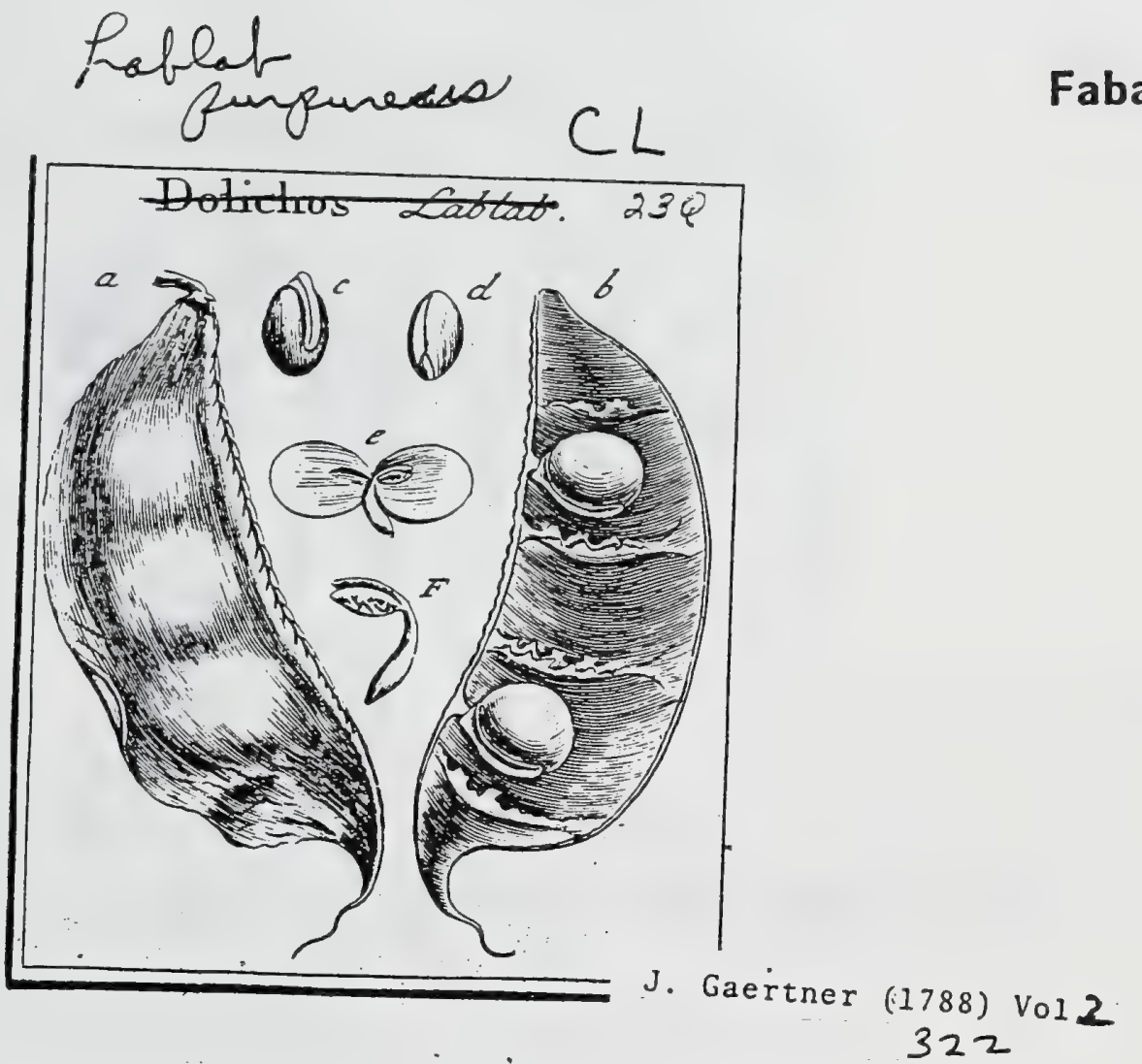

DCCCLXVIII: D O L I C H O S. LINN. gen. $\$ 67$.

Calyx brevis quadridentatus. Cor. papilionacea: vexillo bafi callis duobus parallelis alas fubtus comprimentibus. Stam. diadelpha. Legum. varium. Sem. exalbuminofa, callo ad umbilicum crafio, ublongo aut annulari. Embr. curvatus.

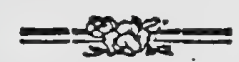

DoLichos Lablab. Tab.'1 50. fig. 2.

Plbafeolus peregrinus XIIII. Leblab. Clus. bij. 2. p. 227.

Pbafeolus. Riv. ketr. t. 29. f. 4 .

Dulichos volubilis, leguminibus ovato-acinaciformibris, feminibus ovatis bilo arcuats verfus alterani extremitatem. LINN: fyjt. veg. 657 .

PER. Legumen' ovato-acinaciforme, compreflo-planum, ad utramque futuram crenulatum, pluriloculare, bivalve. Diffepimenta tenuifima,, e mem-

- brana cellulofá, nivea.

REC. funiculi breves, craffi, e futura rectiore.

SEN. Folitaria, in univerfun tria aut quinque, ovalia, compreffiufcula, glabra, non fplendentia, ntra aut ferruginea, ab altero latere callo fungofo, niveo, ex unbilico proficifcente 'marginata.

IN T. duplex : cartilagineo-coriaceum, atque membranaceum.

A цв. nullum, nec ejus veftigium.

E M в. curvatus, albus. Cotyl. ellipticx, plano - convexx. Plems. diphylla; foliolis cordato-acuminatis, venofis, conduplicatis. Rad. intexa, centrifuga.

1.) Legumen integrum, b.) Idem apertum cum feminum infertione. c.) Semen feparatura. d.) Enbryo denudatus, cum radicula, ex oppofita umbilico ferminis extrcaritate, oriunda c) Cotyled. explicatz F.) Plumula infigniter audi.

Species curatius determinent 'ex hilo unilaterali, annulari, aut nullo, quibus plantas frugiferas ipfas videndi data eft occafio. 


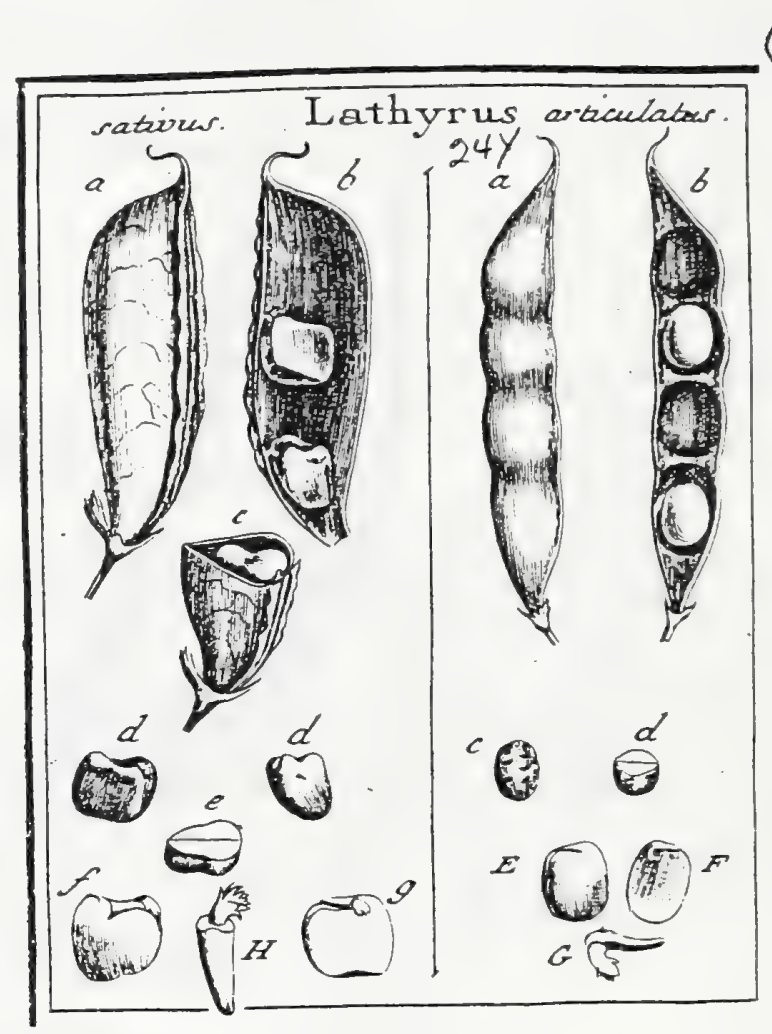

\section{J. Gaertner (1788) Vol. 2}

DCCCLXXVIII. I A T H Y R U S. TOURN. t. 216.217 .330 LINN. ger. 872 .

Calyx quinquefidus, lacinüs duabus fuperioribus brevioribus. Vexillum amplum, nlis \& carina majus. Styl. planus, fuperne latior; ftigmate anterius villofo. Legum, oblongum. Sem. exalbuminofa, Enıbr. curvatus.

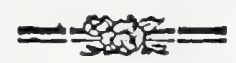

LATHYRUS fativus. Tab. I52. fig. I.

Latbyries foligua latiore. RIv. tetr. t. 47. bene:

Latbyrus peduculis unifioris, cirbis dipbyllis tetraphyllisque, leguninibus ovatis compreffis dorfo bimarginatis. Lis. $\int y / f$. veg. 662.

PER. Legunen ovato-oblongum, fubinflatum, ad futuram feminiferam craffius, ad oppofitam vero in carinam acueam definens, uniloculare, bivalve. Valvulx fecundum futuran feminiferam lamina lineari undulata refexa marginatac.

REC. fusiculi breves, apice bifurcati, e futura marginata.

SE s. tria aut quatuor, triquetra, gibbofa, Livida, albis lituris maculata. Umbilicus minimus, oblongus.

IN T. fimplex, chartaceum, intus fubcarnofum.

$A$ LB. nullum, aut tenuifinum.

En в. curvatus, luteus. Cotyl. fubquadrangulx, hinc gibbs, inde planx. Plum. polyphylla, foliolis linearibus fubimbricatis. Rad. conica, centrifuga.

2) Legumen integrum. b. c.) Idem longitudinaliter \& transverfaliter diffecum. d. d.) Semiax feparata. e.) Seutinis fcaio transveŕalis. f.) Embryo dcaudatus, g.) (otyledoa cum plumula. H.) Plumula audz.

LATHYRUS articulatus. ibid.

Lathyyrus foliis pimatis. Rrv. tetr. 't. 48 .

Lethyrus pedrucculis fubivifforis, cirtbis polyphyllis foliolis alternis. LiNN. l. c.

Legumen oblongum (a.b.), anguftum, utrinque atteriuatum, compreffum, ad femius torofum. Funiculf bifurcati. Semina (c. d.) quatuor, elliptica, lentricularia, glabra, e cinereo \& fufco nebulata. Embryo (E. F.) curvatus. luteus. Plumula (F. G.) fubtetraphylla. 


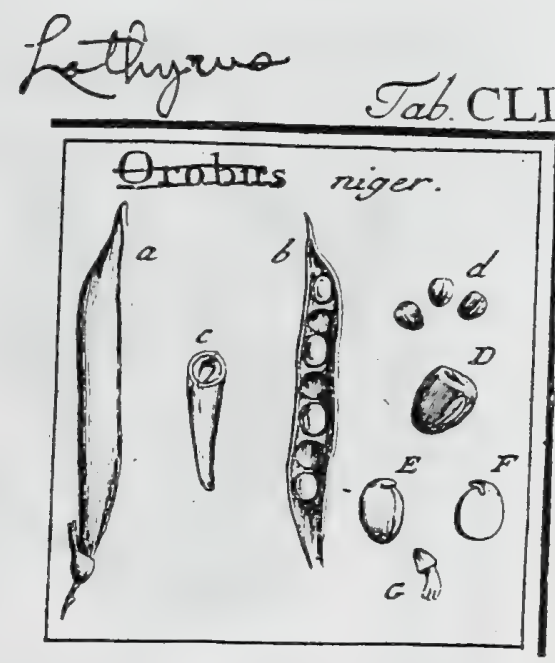

Fabaceae

J. Gaertner (1788) Vol 2

DCCCLXXIII. O R O B UY S. T OURN. t. 214. LINN. ger. 87 r.

Calyx tubulofus, quinquedentatus: dentibus fuperioribus brevioribus. Cor. papilionacea, vexillo obcordato. Legum. teretiufculum, uniloculare. Sem. exalbuminofis. Emb. curvatus.

Oroвus niger. Tab. I 5 I. fig. 3 .

Orobis parmossicas, II. Clus. bif. 2. p. 230 ,

Orobus foliis vicice RIv. tetr. t. 60.

Orobus caule ramofo, foliis fexjugis ovato-oblongis. LiNs. $\int y f$. vtg. $66_{2}$.

PER. Legumen oblongum, teretiufculum, glabrum, nigrum, uniloculare, bivalve. .

REc. funiculi brevifimi, apice bifidi, e futura rectiore.

SEM. Sex 1. octo, cylindrico-J. conoideo-ovata, e cinereo-fpadicea, punctis fufcis fparfis notata. Umbilicus linearis, Jongitudine fere feminis.

IN T. fimplex, cartilagineo-coriaceum, intus fubcarnolum.

$\Lambda$ LB. nullum.

En в. levifime curvatus, Juteus. Cotyl. ovatx, plana-convexx. Plum. tetraphylla, foliolis oppolitis. Rad. conica, brevillma, centrifuga.

- a.) Legumen integrum. b.) Valvula cum feminum infettione. c.) Sectio leganiais transtería. d. D.) Semina (eparata. E.) Embryo deaudatur. F.) Cotjledon cum pluuulz G.) Plumula

- inGgaitcr audz. 

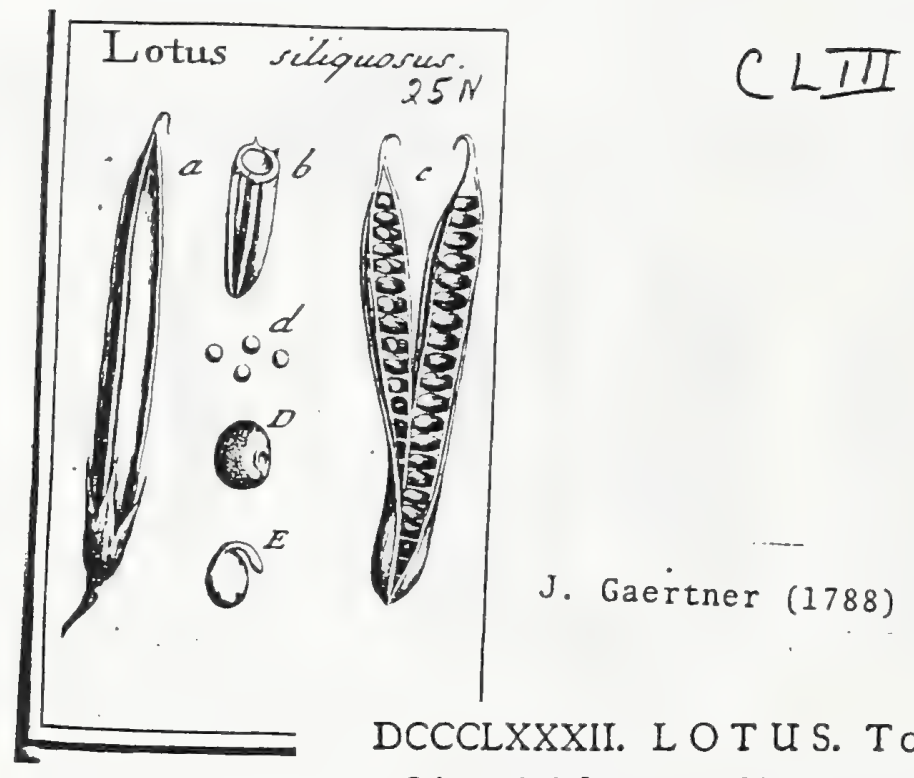

Fabaceae

\section{J. Gaertner (1788) Vol 2}

DCCCLXXXII. L O T U S. TOURN. t. 227. LINN. gen. 897 .

Calyx tubulofus quinquefidus aqualis. Alx vexillo longiores furfum conniventes. Legum. oblongum uni - 1. multiloculare. Sem. exalbuminofia Embr. curvatus. Stipulx foliis fmiles, ut folia fint apparenter quinata.

Lot's filiquofus. Tab. I53. fig. 2.

Lntus tetragonolobus. Riv. tetr. t. 79 .

Lotus leguninibus folitariis membranaceo-quadrasgulis, caulibus procrmbentibus, joliis jubtus pubefcentibus. LINN. Jjy. veg. 691.

sion. JACQ. flor. auffr. t. 36 r.

Рєк. Legumen coriaceum, teres, glabrum; juxta utramque futuram. gemina al: nembranacea angufta nec undulata ftipatum, muliloculăre, bivalve. Diffepimenta fpongiofo: membranacea, nive:a, periiltentia.

REC. funiculi brevilfini, e futura interiore.

SEM. plura, circiter viginti quatuor, fubglobofa, leviter compreffia, glabra. lituris of punctis atris confertis fuper fundo pallide luteolo confperfa.

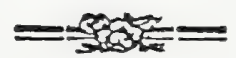

IN T. fimplex, cartilagineum, tenue, intus fubcarnofum.

- A L s. nullum, aut tenuifimun.

Eas в. curvatus, luteus. Cotyl. ovatx, crafx; planiufculx. Pltus, nulla. Rad. inflexa, centrifuga.

2.) Legumen integrum. b.) Ejus featio trasverfalis, c.) Idem debifers. L. D.) Semina feparata. E.) Embryo denudatus.

Lotus tetrugonolobus. LiNx.

Lotus. Can. bort. t. 26. Best. Eyfo afo. XIII. t. 4. f. 3. Riv. tetr. t. 80.

Legumen rectun, .cylindricum, crafum, alis quatuor latioribus \& unda'atis ftipatum. Seniua fubglobora, magnitudiue pifi nilnoris, glabra, pallida aut e livido purpurafcentia, immaculata.

Lotus angufifinuss. LINN, ex fide Martini.

Lotus corniculata, filiquis Jingularibus fo binis. BAUH. biff. 2. p. 356 .

Legumen teres, gracile, fubbipollicare, ad femina obfolete torulofum. Seinima circiter 23, fphxrica, pallide fulphurea, glaberrima, margaritarura adinftar fplendentia, magnitudine capitis aciculx.

Lotus onvitlopodioides. Lins.

Losus peculiaris filiquofa. CAM. bort. t. 25 .

Lotus filigua arcuata. Riv. tetr. t. 76. $f .3$.

Legumen lineari oblongun, falcatum, compreflum, ad femins torofuns. Semina circiter is, lentiformia, fplendentia, lutelcentia aut caftanea. magnitudine feminum ' L. filignoofis.

Lotus reî́n̈s. Lins.

Losus libica. Riv. setr. t. 78 .

Legumen rectum, teretiufculum, ad femina obfolete torulofum, nigrum, longitudine unguis humani. Senina 6.1.8. parva, globofa, atra, non fplendentia. 


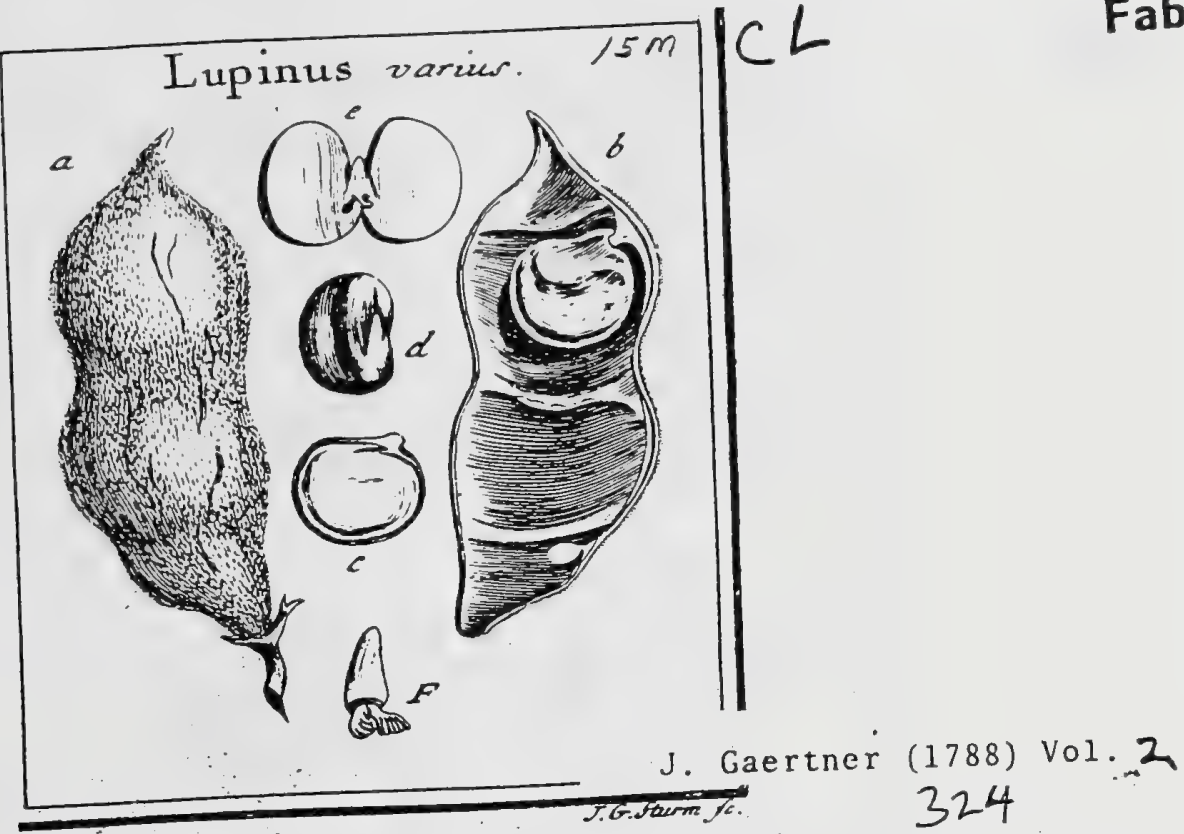

DCCCLXX. L U. P I N U S. TOURN. t. 213. LINN. gen. 865.

Calyx bilabiatus. Cor. papilionacea. Stam. decem bafi monadelpha: antheris quinque oblongis \& quinque fubrotundis. Legum. coriaceum. Sem. exalbuminofa. Enbr. curvatus.

Lupinus varius. Tab. I so. fig. 4.

Lupinus fativus major. BEsL. Eyft. affiv. XIII. t. 3. $f .1$. bene.

Lupinus flove caruleo vel rubro. Riv. tetr. t. 27.

Lupinus enlycibus feniverticillatis appendiculatis: labio fuperiore bifido; inferiore frubtridentato. LINN. $f y f$. veg. 655 .

PER. Legumen ovatum, obefum, compreffiufculum, villofum, ad femina to rofum, fubquadriloculare, bivalve. Diffepimenta cellulufo membranacea, per maturitatem obfolefcentia aut deficientis.

'REC funiculi craff, breves, e futura convexiore f. dorfali.

SE M. folitaria, in univerfum bina, raro plura, grandia, irregulariter rotunda, fupra umbilicum umbone brevi roftrata, utrinque planiufcula, \& in medio lata macula ferruginea notata.

IN T. fimplex, cartilagineo-coriaceùn, craffum, durum, fuperficie exteriori quafi ex niculis glacialibus compofita, attamen aquabili, glabra \& fubfplendente.

A L B. nullum.

Em B. curvatus, luteus. Cotyl. ovatx, craffx, utrinque planiufculx. Plum. diphylla, foliolis digitatis, feptenis, linearibus. Rad. inflexa, centrifuga.

$$
\text { * }
$$

2) Legumen integrum. b.) Valvula feparata, cum fotu \& Ggara feminis c.) Seminis tefta vervicaliter aperta, cum cmbryonis radicula in propria ragiaz harente. d.) Embryo denudatus. e.) Cotgl explicatz. F.) Plumula infíniter atcas.

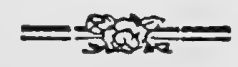

Lupinus albus. LiNs:

Lupinus flore albo. Riv. tetr. t. 25.

Legumen oblongum, villofum, fubhexafpermum. Sem. fubrotunda, lenticulari compreffa, levigatiffima, candidifima, immaculata, prioribus dinidio fere minora. Unibilicus annulo prominulo notatus.

Lupinus hiceus. LINN.

Lupinus flore luteo. Riv. t. 26.

Legunen ovatum, villofum, fubtetrafpermum. Sem. fubrotunda, lenticularia, albicantia aut Iutefcentia, punctis nigris nut fufcis, diferetis atut confluentibus maculata, triplo sninora quam L. varii. Umbilicus obfoletus.

Lupinus angurfifolins. LiNN.

Lupinus flore correleo minore. Riv. t. 28.

Semina ovato-globofa, undique xquabiliter turgida, obfcure cinerea, maculis fufcis ramofis variegata, infuperque guttis albicalntibus rarioribus collfperfa, glabra, procedentibus omnibus ninor. Unbilicus obfoletus. 


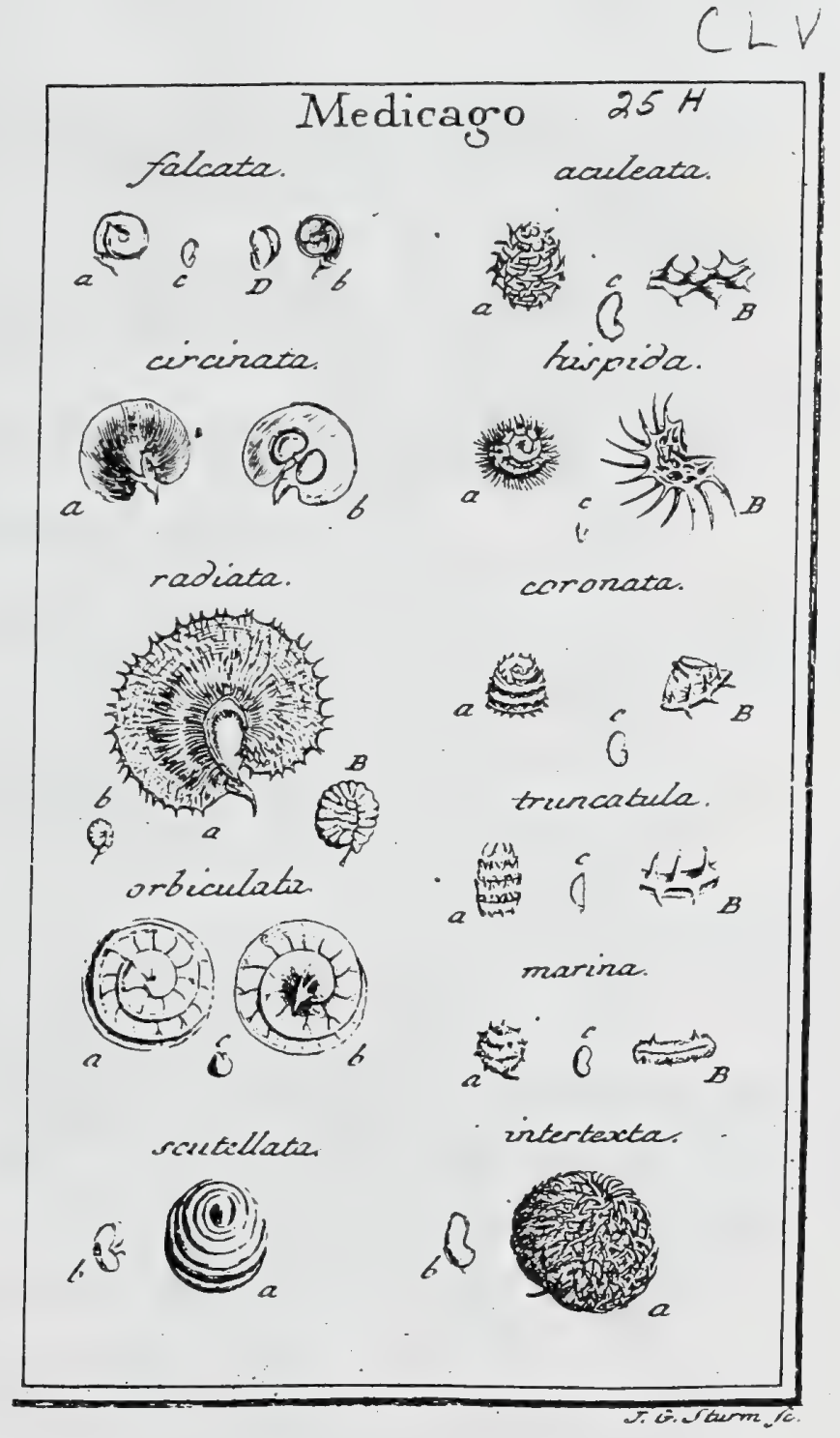

Fabaceae 
DCCCXCVII. MEDICA GO. TOURN. t.:23 t. LINN. ger. 899:

Calyx quinquedentatus. Carina a vexillo deflectens. Legum. falcatum aut cochleatum. Sem. exalbuminofa. Emb. 'curvatus.

Medicago falcata. Tab. 155. fig. 7.

Falcata. Riv. tetr. t. 84 OED. flor. dan. t. 233 .

J. Gaertner

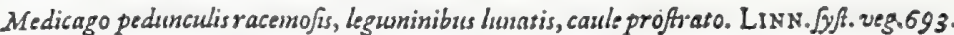

$P E$ R. Legumen parvum; iunato-falcatum aut fubfpirale, glabrum, leviter comprefium, uniloculare, bivalve.

Rec. funiculi e futura coneava.

S E M. duo 1. tria, reniformi-oblonga, luteola, glabra, non fplendentia.

IN T. fimplex, coriaceo-chartaceum.

$\Lambda$ L B. nullum.

EM B. curvatus, luteus. Cotyl. oblongx, plano-converx. Plum. nulla. Rad. intexa, centrifuga.

2. b.) Legunien istegrum \& apertum. c.) Scmen Fenasatum D.) Embryo deaudates.

Medicago circinnata. ibid.

Falcata folits antbyllidis. RIv. tetr. 2. 87 .

Medicago leguxinibus reniformibus margine dentatis, foliis pimatis: LIN. l. c.

Legumen (a. b.) reniforme, in medio leviter convexum, verfus peripheriam autem attenuato membranaceum, glabrum, non reticulatum, ad anbitum denticulatum aut edentulum, biluculare, evalve. Semina duo (b.) reniformia, rufefcentia

Medicago radiata ibid.

Medicago annua, filiqua fatcata Atiata. Moris. bifs. 2. S. 2. t. 26. f. 3.

Afedicago leguninibus reniformibus margine dentatis, foliis temutis. LiN. l. c.

Legumen (a.) reniforme, membranaceum, fubdiaphanum, pallidun, vafis capillaribus radiantibus reticulatum, foliaceo-cumprefum, ad femina obfo. lete corulolum, \& ad utramque futuram fetaceo-denticulatum, pluriloculare,

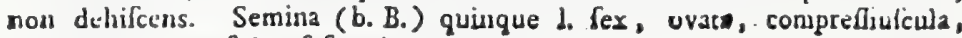
ruberculato - rugula! rufefcentia,

Medicago orbiculata. ibid.

Cocbleata fruturu orbiculato: Ruv, tetr. t. 88. f. s.

Mredicago legruninibus folitorius cocbleatis depreffis planis, fipulis ciliatis, caule diffiefo. LIN. l. c.

Legumen (a. b.) orbiculatum, depreffum, cochleatum: fpiris fubquateruis, foliaceo - compreflis, horizontalibus, ftriis radiantibus diffitis notatis, eder tulis, plurilocularabus, non dehifcentibus. Semina (c.) quinque ad novem, fubrotunda, turgide lenticularia, rufefcentia.

Medicago fcutellata. ibid.

Cocbleata frufu fautellato. Riv. t.88. f. 2. \& t. 8g. f. 1.

Medicago cocbleata najor, dicarpos, capfula roturda globofa fautellatid. Lisv. l.c.

Legumen' (a.) fubglobofum, cochleatum: fpiris feptenis foliaceo compretfis, oblique ftriatis, furfum concavis, edentulis, plurilocularibus, non dehifcentibus. Semina (b.) quinque 1. fex, grandiufcula, reniformia, juxta. umbilicum profunde emarginata, ex aurantiaco-rufefcentia.

Medicago aculeata. ibid.

Cocbleata frukfu turbinato Eे ecbinato. RIv. t. 88. f. 7.

Legumen (a) ovato-globofum, cochleatura: fpiris quinis arctilime fibi incumbentibus, coriaceis, compreffis, fpadiceo-fufcis; futura exteriore (B) linea deprefa inferipta atque aculeolis conicis rigidis curvis utrinque armata. Loculamenca feptem 1. novem. Semina (c.) reniformi - oblonga, . Iutefcentia.

Medicago hipida. ibid.

Cofileata frolihu longius ecbinato. RIv. t. 88, f. 12. Moris. t. 15. f. 13.

Medicago pedunculis paucifioris, leguminibus cocbleatis, bannulis longisudine legur mumun, LIs. l. $c$.

Legumen (a.) orbiculatum, depreffum, cochleatum: fpicis quaternis difcretis, compreffis, reticulato - vennfis (B.); futura exteriore acuta, duplici ferie fpinarum fetacearum ipfoque legumine longiorum armats. Semina (c.) fex ad novem, parvula, reniformi-oblonga, fordide rufef́entia

Medicago coronata (ibid.- M. ñuspidie apieulata)

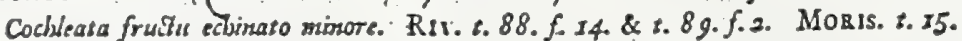
f. 12.13 .1420 .21$.

- Medicago fristi minino, coronulam uerinque dentatans referense. Liss. $b$ c. Legumen (a.) fubconicum, ochleatum: Spiris quarernis difcretis, comprefls; futura extcriore (B.) linea elevan notata \& ex illa fpinulis brevibus fubalternis oblique furfum \& deorfum vergentibus armata. Semina (c.) quatuor 1. quinque, reuiformis, lute[centia. 


\section{J. Gaertner (1788) Vol 2}

$35^{\circ}$

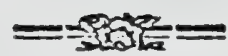

ilrdicago truncatula. ibid.

Conf. MORIs. bijf. 2. S. 2. t. 35. f. 36.57 .

Legumen (a) cylindricum, utringue obtufum \& quafi truncatum, cochleatum: fpiris quaternis arcte fibi incumbcntibus, comprelîs; futura exteriore (B.) fpinis verticalibus juxta mediam lineam elevatam utrinque armata. Semina (c.) quinque !. Sex, parvula, reniformia, lutea.

dedicago marina. ibid.

Cocbleata fruthu ecbinato incano. Riv. t. 88. f. 15 .

Medicago pedunculis racemoo/s, leguninibus cochleatis $\int p i n o f i s$, canle procumbente tomentitofo. Lins. l. c.

Legumen (a.) cylindrico-globofum, cochleatum: fpiris fubquaternis, contiguis, cinereo tomentofis; futura exteriore (B.) convexa, fpinulis difficis brevitrimis pungentibus utrinque munita. Semina (c.) quatuor 1. quinque, reniformia, lutea.

Medicago intertexta. ibid.

Cocbleata frutu ecbrisato maximo. RIv. t. 88. f. g. Moris. l. c. f.7.8. g.

Legumen (a.) ovato-globofum, maximum, cochleatum: \{piris quinis compreffis, vccultatis ab aculeis fubulatis pungentibus recurvis utrinque e futura exteriore filiformi \& a legumine folubili, oriundis. Sernius (b.) quinque aut plura, grandiufcula, renifurmia, e caftaneo uigricantia, fublucida. 


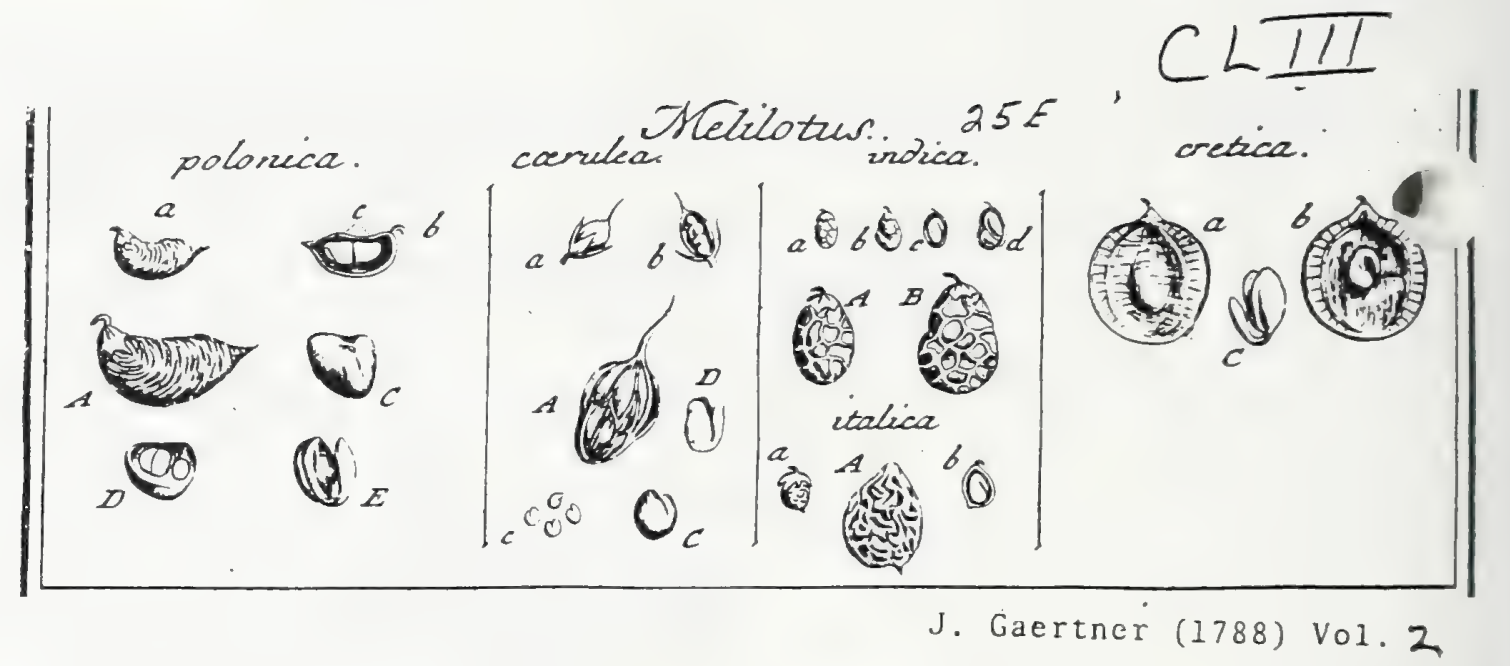

Trifolium Mrelilotus polonica. ibid.

Trifolitun leguminibuis racemofis nudis difpermis danceolutis, caule creifo. LiNN. Jy/8. veg. 687 .

Legumen (a. A.) coriaceum, falcato-lanceolatum, turgidum, fulcis elevatis arcuatis anatomofantibus egregie verniculatum, uniloculire, bivalve, fed vix fponte dehifcens. Semina duo (c. C. ), future concava (b.) inferta, trigono-glubofa, glabra, rufefcentia. Albumen (D.) craffum, cnrnofun, ab emollitione in aqua gelatinofum. Embryo (D. E.) curvatus, luteus.

TrIfolium M. carulea: ibid.

Mfeillotus carulca. Riv. teti. t. g.

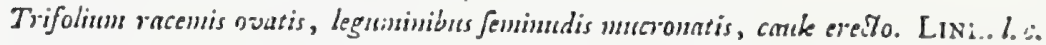

Legumen (a. A.) calycis dentibus fubulatis haud multo longius, obovatum, ftylo fubulato terminatum, membranaceum, nervis longitudinalibus anaftomofantibus laxe reticulatum, uniloculare, evalve. Semina (b.c. C.) duo vel quatuor, rotundato - reniformia, glabra, luteola. Albumen tenue. Embryo YD.) luteus.

T.RIFOLIUM M. indica. jbid.

Arelilotus minima. Rur. tetr. t. 8.

Trifolium leguminibus racemofis midis monofpermis, caule ereifo. LinN. l. c.

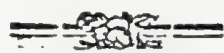

Legumen (a. A. b. B.) membrairaceum, tenuifimum, denfe reticulatum, ob. tufum, calyce brevilsimo bafs. munitun. Semina (c. d.) unum, aut duo, ovato - J. angulato-renifornail, ferruginea. Reliqua ut in praccedenti.

Trifolius $M$. italica. ibid.

Melilotus italica. RIv, tet). t. 7. CAM. bort. t. 29. nielius.

Trifulitum leguminibus racerirofis mudis difpermis rugofis obtufis, caule eveita, foliolis integris. LINN. l. c.

Leguinen (a. A.) coriaceum, fubglobofum, hreviffime mucronatum, ad latera tortuofe rugofim, ad margines auten futura glabra prominula notatum, non dehifcens. Semen (b.) Tnicum aut duo, reniformia, rufeloentia. Reliqua ut in prioribus.

Trifolium M. cretica. ibid.

Trifolium pelsatums creticum. BAUH. prodr. 142. C. ic.

Trifolinu leguminibus racemofis undis difpermis membrunaceis, canle erefinfculo. LiN . l. c.

Legumen (a. b.) orbiculatum, membranaceum, foliaceo-compreffum, vafis capillaribus transverfis parallelis friato-reticulatum, pallide ftramincum, fub. marginatum, non dehifiens. Semen (b.) reniforme, minutiline élevato. puncticulatum, comprefiufculum, ferrugineum. Albumen vix ullum. Enmbryo (C.) curvatus, croceus 1. aurantiacus. Si duo adfunt fermima; tuac funt transverfm pofita. 


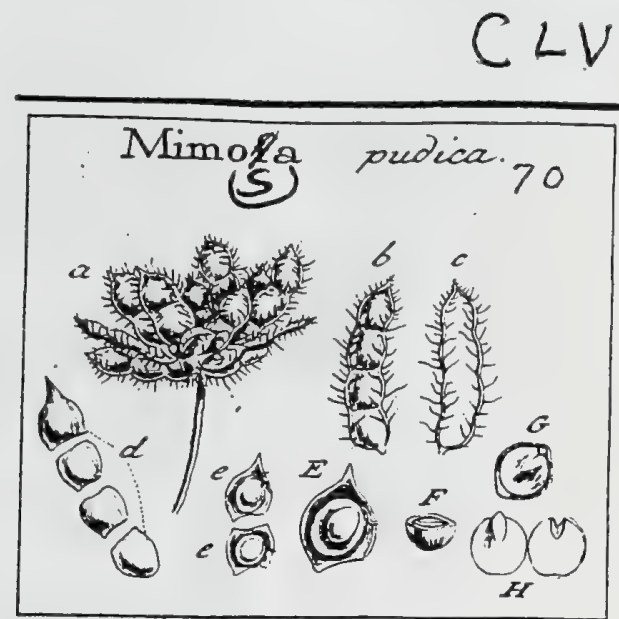

Fabaceae

\section{J. Gaertner (1788) Vol. 2}

DCCCXCII. MIM OSA. TOURN. t. 375. LINN. gen. II58.

- Flores \& habitus Acacix. Legum. articulatum, ad articulos difcedens. Sem. albuminofa. Embr. rectus.

Mimosa pudica. Tab. iss. fig. 2.

Affclynomene fpinofu, floie globofo albido, filiculis articulatis echinatis. Cuxss. bort. aimft. I. p. 57 . t. 29 .

MFimofa bumilis frutefcens EO Jpinofa, filignis conglobatis. PLUM. ic. t. 202.

Mimnfu aculeata, foliis fubdigitatis pimatis, cumle hijpido. LIN J Jy?. veg. 984.

PER. Legumen oblongum, compreffum, articulatum, futura filiformi innocue . Spinulofa cinetum. Articuli duo l. quatuor, chartacei, uniloculares, a fé invicen \& a futura fecedentes, atque infuper in duas valvulas dehifcentes.

$R$ Ec. funiculus capillaris e valvalarum margine interiore.

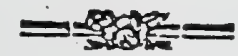

SE N. folitaria, rotundata, Jenticularia, glabra, lucida, meilina aut rufefcentia, ftria ocellari in medio utrinque notata.

IN T. Gimples, chartaceum, tenue.

ALB. aqueo-pallidum, tenue, integumento arcte adhxerens. Em в. rectus, lutcus. Cotyl. orbiculatz, foliacex. Plums. nulla. Rad. gran-
diufcula, retracta, recta, ceutrifuga.

a.) Legumina in capitulum congefa. b.) Legumen feparatum. c. $\lambda$ Sutura filiformis foluth. d.) Articuli feparati. c. e. E.) Stuninis in valvulas infertio \& figurs. F.) Semen transrerfo feaum. G.) Eubryonis in albumine fitus. H.) Cotyled. (eparatz, cam radieula figara. 


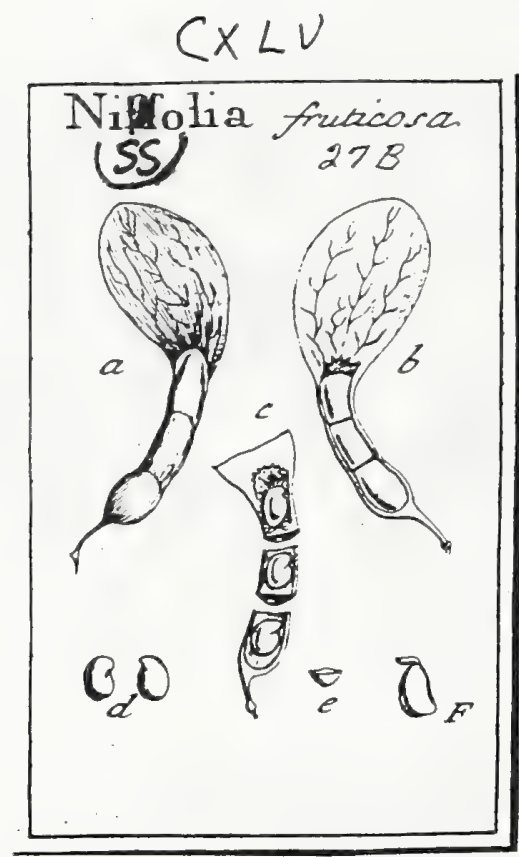

Fabaceae

\section{J. Gaertner (1788) Vo.1: 2}

DCCCLI. N I S S Ó L I A. LINN. gen. 853 .

Calyx quinquedentatus, inxqualis. Cor. papilionacea. Stam. decem, omnia inter fe connata. Legum. articulatum, ala coriacea elliptica terminatum. Sem. fubalbuminofa. Embr. curvatus.

Nissolia fruticora. Tab. 145. fig. s.

Niffolin caule fruticofo volubili. JAce. bift. anner. 198. 8. 179. f. 44. bort. . . t. 367 . LiNs. [yft. veg. 641 .

Ex herbario Bankfiano.

PER. Legumen femidigitale aut brevius, articulatum: articulis duobus aut tribus, vix pluribus, transverfim fecedentibus, fubfantia fungofa farctis: infimo fubglobofo, in pedunculum gracilem deorfum elongato; medio fubcylindrico, aut nonnunquam plane deficiente: fupremo in alam coriaceam, magnam, obovatam aut ellipticam, venofam definente.

REc. nullum aut obfuletum; femina fubltantix fungofx articulorum immeŗa SE M. folitaria, ovato-reniformia, lenticulari-compreffi, ferruginea.

IN T. duplex: utrumque membranaceum; interius ab aqua in carnem alban emolliendum.

A L B. tenuifimum, album, ut fere nullum.

EM B. curvatus, lutefcens. Cotyl. ovatx, fubfoliacex. Phus. nulla. Rat. incurva, centrifuga.

a.) Legamen intcgrum. b.) Idem apcrtum, cum fubftantiz fua fungofa in tres partes divifa. c.) Ejusdem articuli feparati \& verticalizer difteAi, cum fitu (eminum. d.) Serina feparata. c.) Sedio feminis transverlas. F.) Embryo denudatus. 


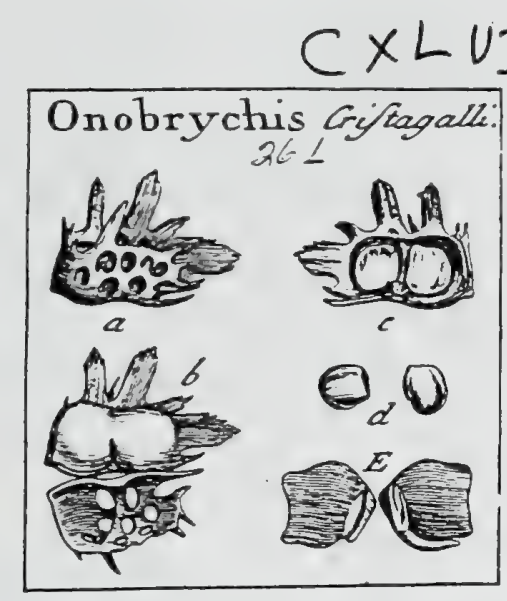

J. Gaerțer (1788):2

DCCCLXII. ONOBRY CHIS. TOURN. t. 2 Ir. $3 / 8$ :

Corolla papilionacea: carinà rectangula; alis omniun brevifincs. Legum. uniloculare, fucura altera criftatura, cribrofe corticatum. Sem. exalbuminufa. Embr. curvatus.

ONoвrychis Crifta galli. Tab. 14s. fig. 5.

Onobrychis f. Caput galli minns, frutiu maximo ingrgniter ecbinato. TRIUMr. obf. 65 .

Hedyfarum foliis pimnatis, legunimibius monofpermis aculeatis : crifta lacinits lun ceolatis denticulatis. LINN. fy,t. veg. 676 .

PER. Legumen fubfemipollicare, ovato-oblongum, criftatum, corticatum, uniloculare, bivalve. Cortex coriaceus, cribrofus, aculeatus. Valvulx carciliginex, glaberrimx, margine futurx feminiferx oppofito interrupte criftati: criftis oblongis, denticulatis.

REC. funiculi breves, e futura criftx oppolita.

SE s. unum 1. duo, fubreniformia, turgide lenticularia, glabra, non lucida, c luteo rufefcentia.

IN T. fimplex, coriaceum, intus fubfpongiofum.

A I B. nullum.

EM в. curvatus, luteus. Cotyl. carnofx, plano-convexx. Plum. diphylla, foliulis ternatis linearibus. Rad. fubulata, inflexa, centrifụga.

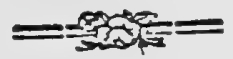

1.) Fruâs integes, b.) Legumea propriom denudatum, eum reclinata corticis crihrof valvula. Loculamentum apertum, cum (eurinibus in lixu naturali. d.) Scmina (oluta. E) Cotyledones feparats. 


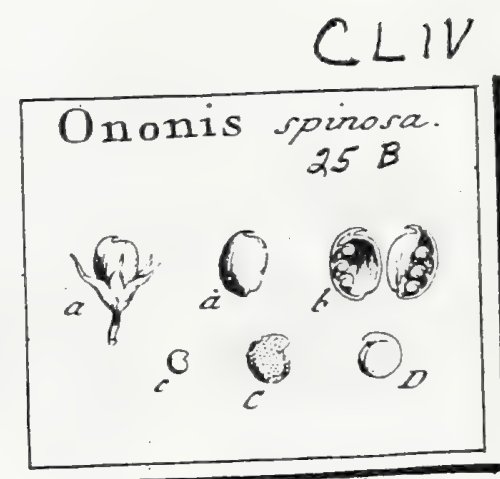

J. Gaertner (1788) Vol 2

DC̈CCXC. O N ON I S. LINN. gers. 863. TOURN. t. 408.343

Calyx quinquefilus, dentibus linearibus. Vexillum ftriatum. Stam. bafi monadelpha, absque filfura dorfali. Legum. turgidum, felfile, uniloculare. Sem. exalburuinofa. Embr. curvatus.

Oinonis fpinofa. Tab. 154 fig. 6.

Anonis. Fuchs. bif. Lut. 60. germs. ic.34. Riv. tetr.t.68. BLAKw. berb.t. sor.f.r. OED. flor: dirr. t. 783 .

Ononis foribus racemofis folitariis, folits ternatis folitariisque, ramis fpinofis. LinNefyyf. veg. 651 .

$\mathrm{PzR}$. Legunen vix calyce longius, oblique ovatum, fylo perfiftente uncinu-latum, lenticulari compreffum, uniloculare, bivalve.

REC. funiculi e futura breviore $\int$. minus gibba.

SEN. quatuor l. Rex, reniformi-globofi, ninucilimis punctis elevatis Labrata, teftaces aut fufca.

$3+4$

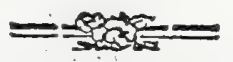

IN T. fimplex, cartilagineo-coriaceum, durum.

A L B. sullun.

Es 8. curvatus, luteus. Cotyl. hemifphxricx. Plum. nulla. Rad. inflexa, centrifuga.

$*$

a. 2) Legumen integrum. b.) Idem dehifoens. c. C.) Semina foluta, D.) Embryo deaudatae 


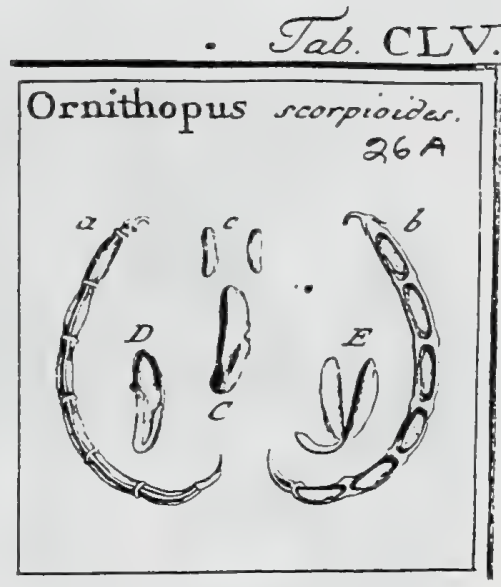

Fabaceae

J. Gaertner (-1788) Vol 2

DCCCXCIII. OR NITHOPUS. LINN. gen. 884. TOURN. t. 224.

Legumen fubulatum, arcuatum, articulatum, gracile, inerme. Sem. exalbuminofa. Embr. curvatus.

Ornithopus Scorpioides. Tab. 155. fig. 3.

345

Scorpioides. DoD. peimpt. 71. . Riv. tetr. t. 96.

Ornithopus folits sernatis fubfeflilibus: inspari waximso. LINN. byft. veg. 670:

PER. Legumen fubbipollicare; gracile, fubulatum, fulcato-angulatum, arcuatum, articulatum, vix tamen fponte ad articulos fecedens. Articuli fex L octo oblongi, uniloculares, evalves: ultimo minimo, Pterili, unguiculato.

REc. fubnullum; umbilicus feminis marginiloculamenti ad futuram exteruam äfixus.

SE r. folitaria, oblonga, fubcompreffa, leviter incurva, glabra, nigricantia.

Umbilicus in medio feminis margine convexo.

IN T. fimplex, cartilagineo-coriaceun, intus fubcarnofum.

A L 8. nullum, aut tenuifimum.

EM 8. curvatus, luteus. Cotyl. oblongx, planiufcuix. Plums, nulla. Rad. inflexa, centrifuga.

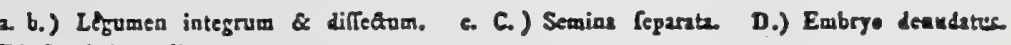
E) Cotyled. explieztr. 


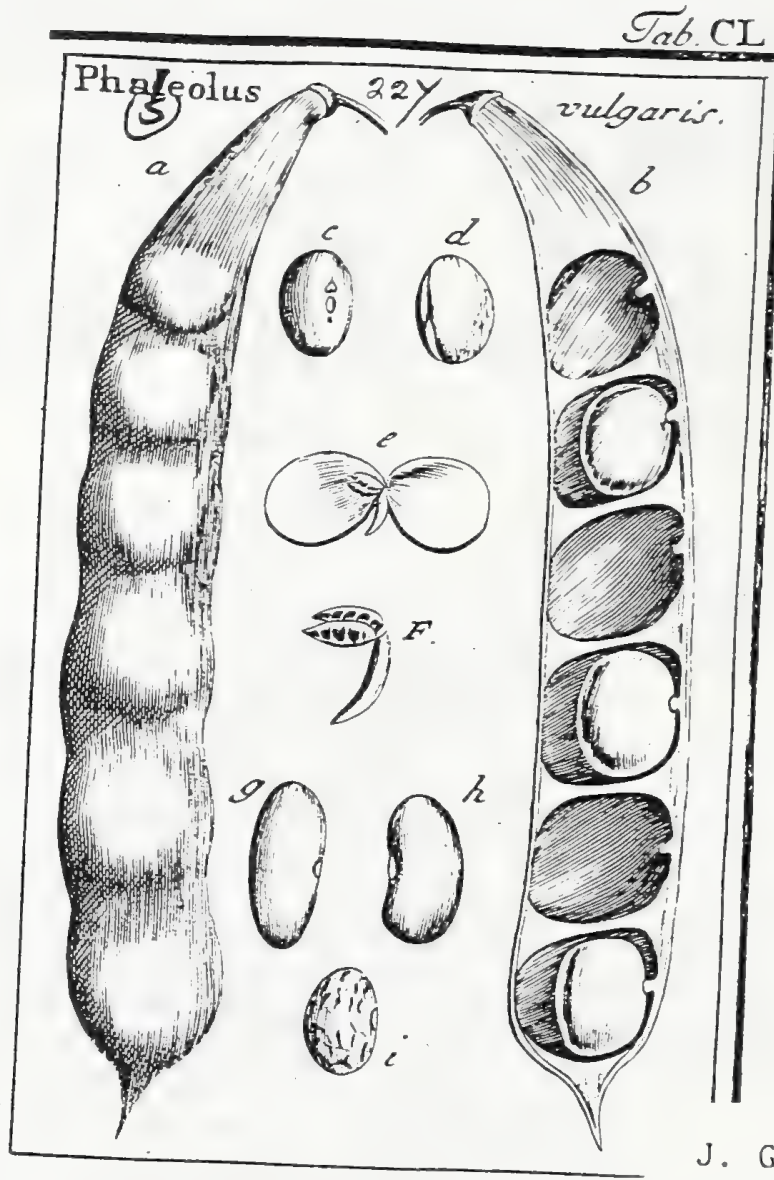

\section{J. Gaertner (1788) Vol 2

DCCCLXIX. PHASEO L U S. TOURN. t. 232. LINN. gern. 866.

Calyx bilabiatus. Carima cum genitalibus in fpiram contorta. Legum. ob. longum, per maturitatem uniloculare. Sem. exalbuminofa. Embr. curvatus.

Phaseolus vulgaris. Tab. 150. fig. 3.

phareolus vulgaris. LOB: ic. 59.

Phafeolus. Riv. tetr. t. 30. \& t. 29. f. s, 2. 3.

Pbaseolus caule volubili, floribus racemofis geminis, bra Iseis calyce nisisoribus, legre minibus pendulis. Lisis. Jyjl. veg. 656 .

PER. Legunien oblongum, ad femina torulofum, per maturitatem uniloculare, bivalve. Diffepinentorum veftigia arachnoidez.

REc. funiculi brevifimi, e futurs rectiore.

SEN. plura, ovato - aut oblungo - sentiformia, glabrs, fplendentia. Unbilici feneftra cartilaginca, fuperne fcrobiculo, inferse autem geroino pundto callofo ftipati.

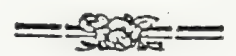

INT, duplex : chartaceo-coriaceum; atque membranaceo-Spongiofum.

A L B. nullum.

Em n. curvatus, albus, Cotyl ovatx, plano-convexx. Plum. diphylla, folio: lis cordato-acuminatis, venolis, conduplicatis. Rad. inflexa, centrifuga.

a.) Legumen integrum. b.) Idem apertum ante plenam maturitatem, cum diffejimentis trans. verfis fpengiofo carnofis. c.) Seuen feparatum. d.) Enbryo denudatus. e.) Cotylo cxplicatz. F.) Plumula aucta.

Semina hujus fpeciei, magnitudine, figura atque colore, fupra omnem modum variant. Figura tamen reniformis omuium ufitatidima, eaque vel ovato oblonga (g.h.), vel elliptica (i.). Color autem adeo multiples, ut proter viridem, omnes reliqui deprehendantur, etiam ipfe cxruleus, alias adeo' infrequens. 


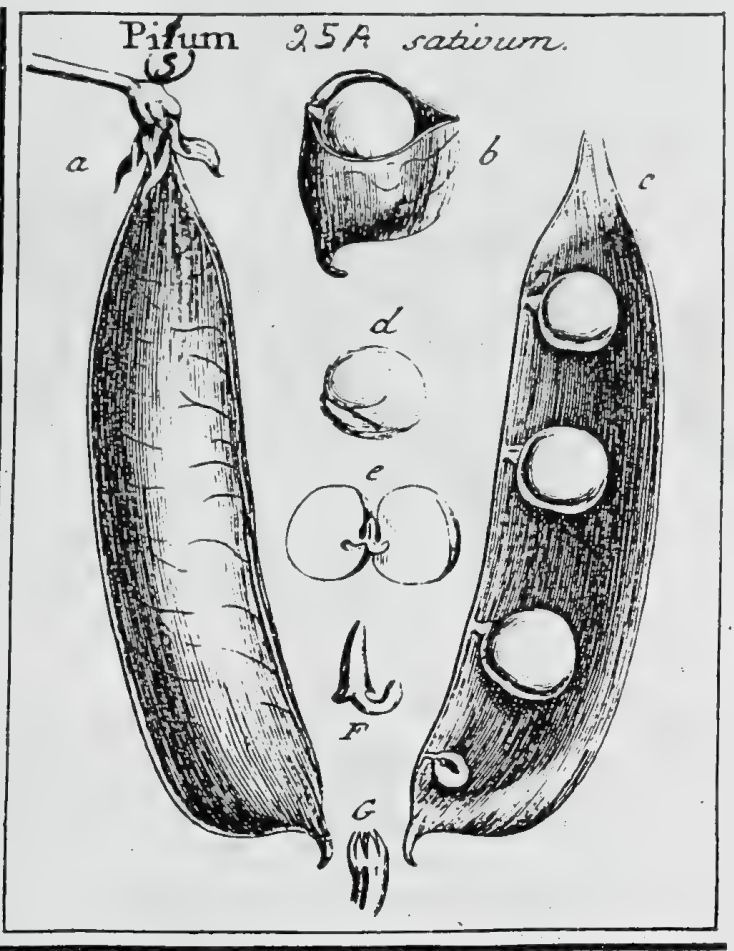

\section{J. Gaertner (1788) Vol. 2,}

DCCCLXXIX. P I S U M. TOURN. t. 215. LIN ger. 870.331

Calyx \& Corolla Latbyri. Stylus triangulus, fupra carimatus, pubefcens. Legun. oblongum uniloculare. Sem. globofa, exalbuminofa. Embr. curvatus.

Pisum fativun. Tab. I 2 2. fig. 2.

pifun. Cam. epit. 21j. Riv. tetr. t. 36-38. BLakw. herb. to 83.

Pifun petiolis teretibus, fripulis inferne rostusdatis crenatis, pedwuculis multiflaris. LINN. Jjy. veg. 660.

PER. Legumen oblongum, d fituram Teminiferam turgidum, ad oppofitam comprefum, fubintatum, glabrum, uniloculare, bivalve.

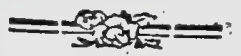

REC. funiculi breves, craffi, fimplices, e futura rectiose.

SE M. feptem l. octo globofa, glabra, albicautia, umbilico parvo oblongo:

A L B. nullum.

EM 8. curvatus, luteus. Cotyl. hemifphxricx. Plum. polyphylla, foliolis: lanceolato - linearibus, oppofitis. Rad. infexa, comprelfi, centrifuga.

a.) Legumen integrum. b. c.) Idem apertum, cum fitu \& figura feminum. d.) Embryo denti datus. e.) Cotyl. explicatx. F.) Radicula cum plumula curvata. G.) Plumula infigniter aucha 


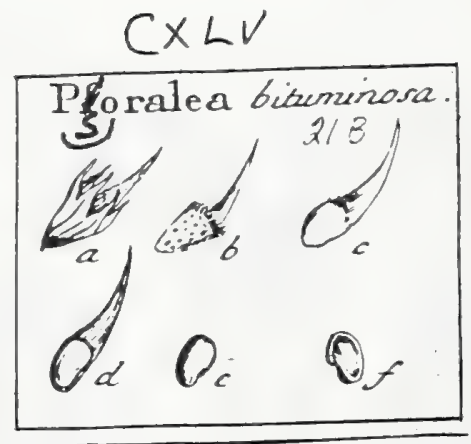

Fabaceae

J. Gaertner (1788) Vol. 2

DCCCL. P S O R A L E A. LINN. ger. $894^{\circ}$

Calyx turbinatus, femiquinquefidus, punctis callofis adfperfus. Cor. papilionacea. Stam. decem, diadelpha. Legum, uniloculare, femini (an in omnibus?) arctifrme adnatum. Sem. unicum, exalbuminofum. Embs. curvatus.

Psoralea bituminofa. Tab. 145. fig. 4

Tryolitum bituminofsm. DoD. pempt. 566. Best. Eyjl. afiv. X. t. 1J. f. 1. . Riv. tetrap. t. 14 .

Pforalea foliis omnibus tematis, foliolis Lmecolatis, petiolis lavibus, foribus ca pitatis. LiN. [yf. veg. 686.

$P E R$. Legumen parvum, ex ventre ovato in roftrum acuminatum Jongum definens. Pars inferior longitudine tubi calycis, Ienticulari compreffa, fuperne fetis rigidis divergentibus. hifpida; inferne autem punctis e cultaneo fufcis fuper fundo pallide ochraceo confperfa, tenuiffina, unilocularis, femini arcisfime adnata, ut non niff fealpendo detrahi poffit. Rofinum.

ventre fefquilongius, membranaceum, foliaceo - compreffum, acinaciforme, ftramineum, fubcaducum.

REC. obfoletum in leguminis margine inferiori, paulo fupra bafin.

SEM. unicum, obovato-reniforme, lenticulare, glabrum, atrum, lucidum.

IN T. duplex: exterins durum, fragile; interins membranaceum.

A L B. nullum.

Eм в. curvatus, inverfus, luteus. Cotyl. ovatx, plano-convexiufcula. Plsas. nulla. Rad. deorfum intlexa, centrifuga.

2.) Lepumen cum calyce. b.) Iden denudatum. c.) Illem 2 fetis atque villis sepurçatum, at roftri continuitas cum parte ventrali melius in confpcetum veuizt. A.) Ejusilen fectiv longitu. diwalis, cum infertione feminis. e.) Scmen fępratum. E.) Embryo Jenudatos.

\subsection{8}




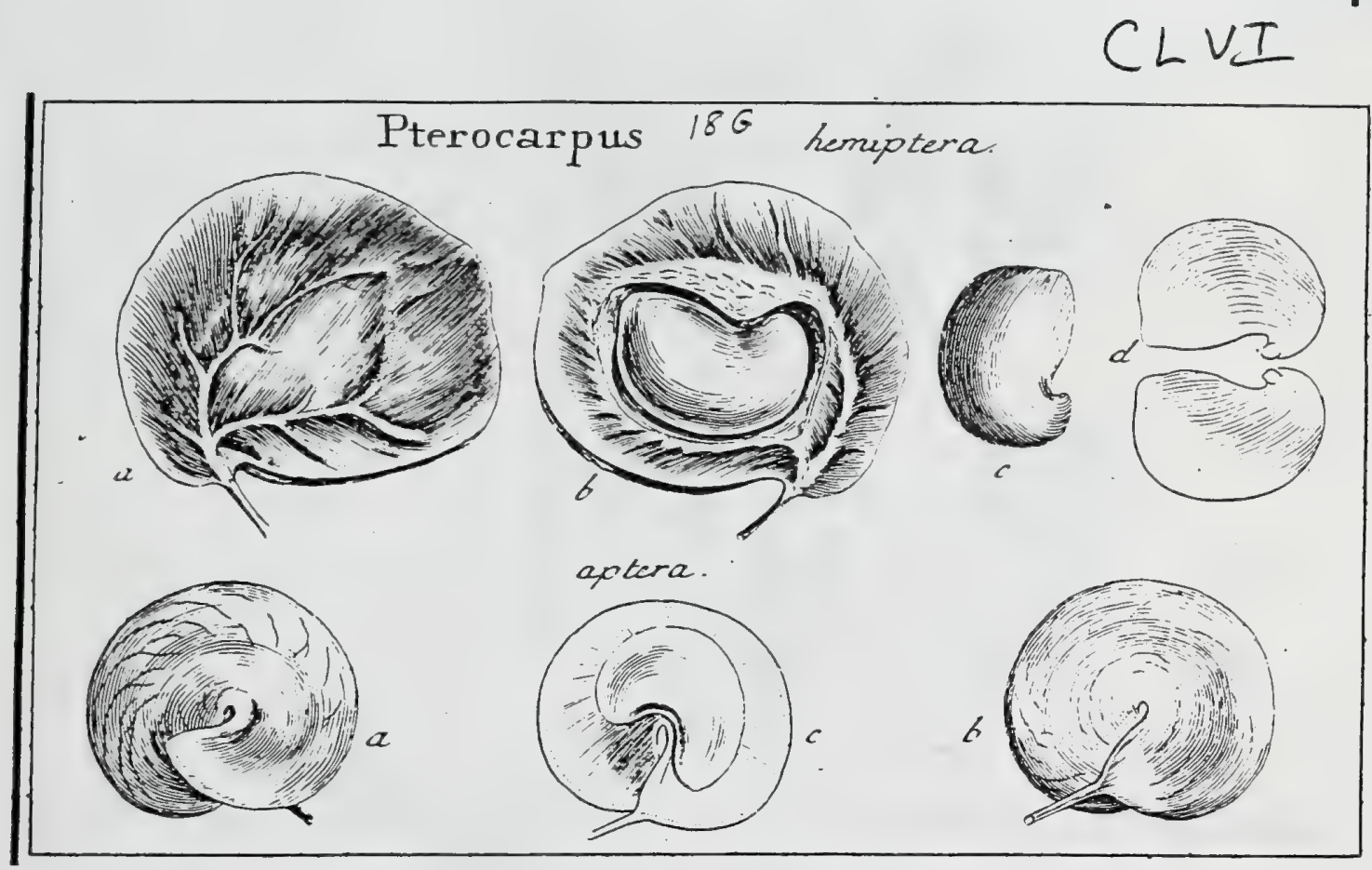

\section{J. Gaertner (1788) Vol 2}

DCCCXCIX. P T ER O C A R P U S. LINN. gen. 854. $35 T$

Cúlyx campanulatus quinquedentatus. Cor. papilionacea.' Stam. omnia conנ1ata. Legun. falcatum. Sem. exalbuninofi. Emb. lunatus.

Pterocarpus hemiptera. Tab. 156. fig. 2.

E Seminar. hort. Amftelod.

PER. Legumen obovato- falcatum, lenticulari-compreffum, nervis crafis protuberantibus varicofum; hinc futura tumida fulco depreffo infcripta notatum, inde in alam membranaceam, majoren leguminis arcum efficientem, extelluatum; extus fordide fpidiceum, intus fibrofo-fuberofum \& quafí drupaceum, uniloculare, evalve.

REc. nullum; femen bafi fua lateri früctus alato affixum.

SEN. unicum, grande, reniforme, fuperius tamen craffius, inferius autem

'thnguftius \& in roftrum aduncum definens; cetera turgide lenticulare, gla-

berrimum, lucidum, atrum.

INT. fimplex, chartaceun, aridum, tenue.

$\Lambda$ Lв. nullum, nec ejus vcftigium.

E а B. femini conformis, albus. Cotyl. carnofx, plano-convexx. Phuns. nulla. Rud. globulofa, parva, in apice roftelli cotyledunum pofita, lateri fruetus alato obverfa.

a.) Fruetus integer. b.) Loculamentum apertum cum iufertione \& Gitu femisis. c.) Semen fo paratum. d.) Oargled. facies interna

In Pr. Dracome legumen eft membranaceum, magisque falcatum; \& femina duo 1. tria, phafeolorum xmula, parva, ac rubicunda. Conf. Comms. bors. anlfy. I. P. 233.

Pterocarpus aptera. ibid.

Orucoria, frufus filiquofis. Bauk. bif. x. L 22. p: 435. n. 3?

E collect. fem. hort. lugdb.

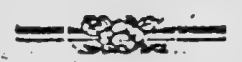

Legumen (a. b.) fungoto-roriaceum, craflum, planum, orbiculatum, fubcochleatum, venis e peripheria obfoletis arcuatis inferiptum, uniloculare, evalve. Senien (c.) unicum, grande, fenilunatun, ad arcum interiorem tumiduns f. lenticulari turgidum, ad exteriorem vero admodum compreffum \& in acu$\mathrm{tm}$ aciem definens, cetera glabrum, luteo - ferrugineuin, non fplendens. Umbilicus tuberculatus in medio arcu concavo f. interno. Integ. finplex, membranaceum. Albumen uullum. Enbryo femini conformis.

Ob diverfam feminis infertionem, forfan quoque diverfi generis fructus eft. 


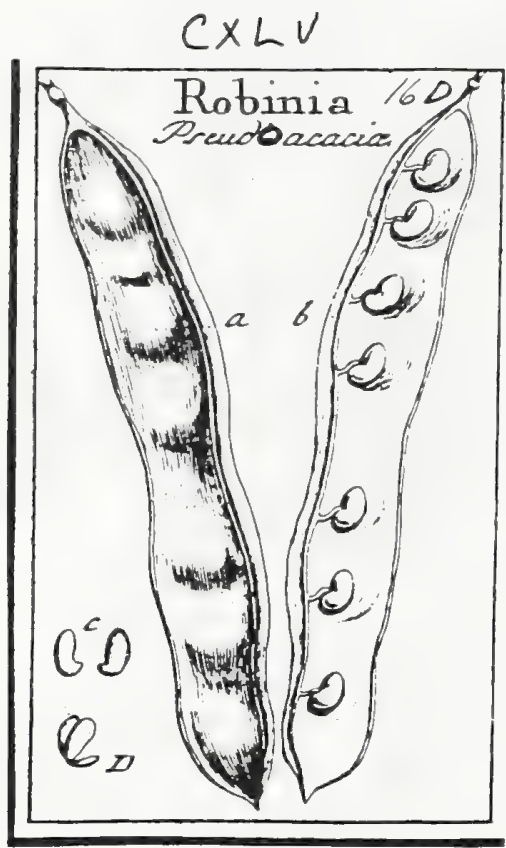

J. Gaertner (1788) Vol 2

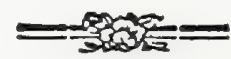

DCCCXLVIII. R O B I N I A. LINN. ger. 879. Pfeudacacia. TOURN. t. 4 I $\%$.

Calyx campanulatus, obfolete quadrifidus. Cor. papilionacez. Stam. disdelpha. Legum. longum, compreffum; uniloculare. Sem. exalbuminofs. Embr. curvacus.

Roвinia Pf́peudacacia. Tab. 145. fig. 2.

Pesudo-acacia. Riv. tetrap. t. 63.

Acacia antericana faliquis glabris. SEB. thefatr. r. t. $15 . f$. $x$.

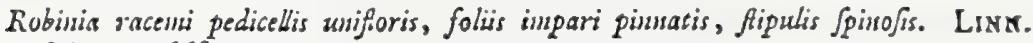
fyst. veg. 668.

PER. Legumen oblongum, comprefro - planum, juxta futuram feminiferara nervo longitudinali inforiptum, \& extra illum, in marginem membrans. ceum extenuatum, uniloculare, bivalve.

REC. funiculi umbilicales e futura narginata.

SEM. plura, ad fedecim, reniformia, is roftellum aduncum definentis, leuticulari-compreffa, rufefcentia.

IN T. duplex: exterins coriaceum, tenue; intorius membramaceum, ab zquz in albuminis fpeciem emolliendum.

A L B. nullum, aut tenuifimum.

Ess. curvatus, lutefiens. Cotyl. oblongx, plano-convexiufculx. Plim, nulla. Rad. teretiufcula, intexa, centrifuga.

8.) Legumen integtum. b.) Item spertum, cura infertione (eminure. c) Semian feparats. D.) Enbryo deaudatus, \& Ieviter explicatus.

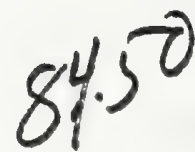




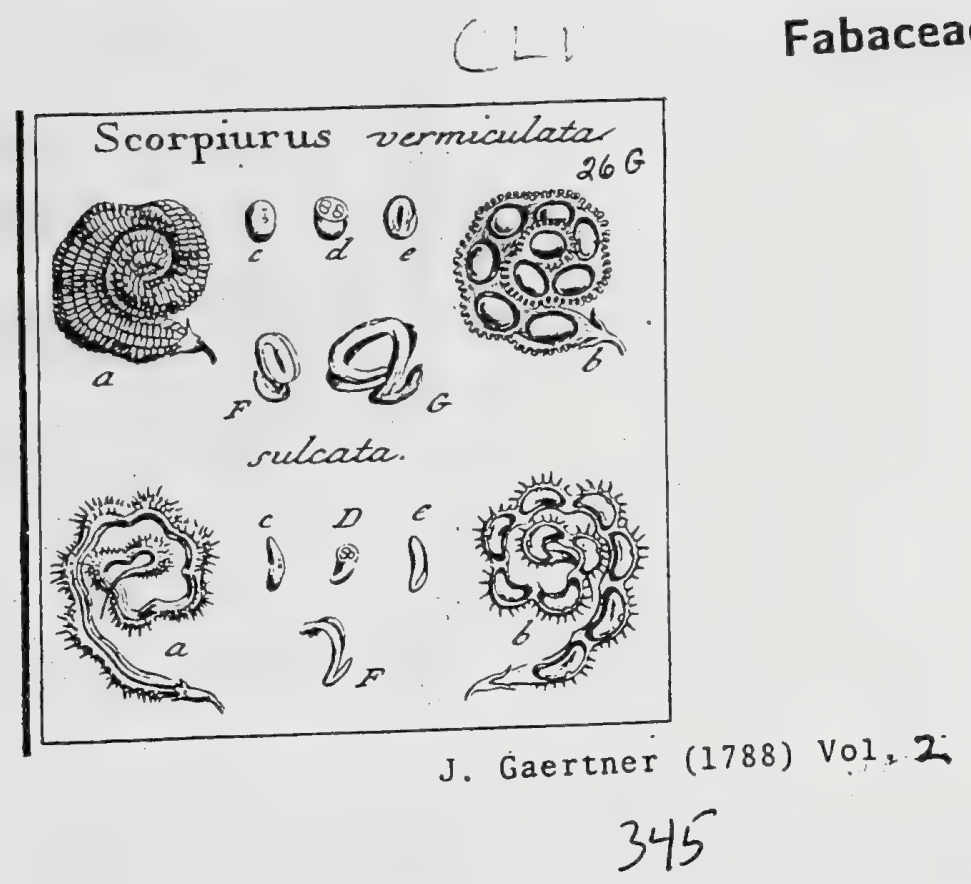

\section{SEO R P I U R U S. LINN. gen. 886. Scorpioides. TOURN. t. 226 .}

Legumen teretiufculum, fpirali-convolutum, ad femina nodofum \& quafe articulatum, muricatum. Sem. albuminofa. Emb. teretiufculus; curvatus.

Scorpiurus vermiculata. Tab. 155 . fig. 4

Campoides. Riv. tetr. t. 96 . bene.

Scorpionus pedumculis wsifloris, legruminibus tedfis uxdique fquamis obtufis. LIxx. byf. veg. $67 x$.

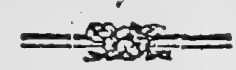

PER. Legumen teres, obefum, coriaceum, in fpiram arctam convolutumi ad, femina torulofum; extus fquamis capitellatis \& per feries longitudinales digeftis undique tectum; intus in fex l. novem loculamenta divifum, evalve; nec ad articulos fecedens.

REC. fubnullum; femina loculamentorum lateri exteriori affixa.

SE M. folitaria, ovato-globofa, glabra, ftaminea aut rufefcentia. Umbilicus in medio feminis durfo:

IN T. Iimplex, cartilagineo-coriaceum, tenue.

A LB. aqueo-pallidum, durum, diaphanum, ab emollitione gelatinofun.

EMs. teretiufculus, retortus, luteus. Cotyl. femiteretes, figinoideo-curvatx. Plum, nulla. Rad. recurva, centrifuga.

2. b.) Legumen integrum \& apertum cum litu faninum naturali. e.) Semen feparators. d.) Ejusdem \& embryonis feat:- transverfalis. e.) Idem longitudinaliter diffeetum, cum fita naturali ralieula, verfus umlidicum recurvatx. F.) Embryo denudatus. G.) Cotyl. diduetz.

Scorpiurus fulcata. ibid.

Campoides bifpida. Ruv. tetr. t. 96.

Scorpinrus pedurculis fubbifioris, leguminibus extrorfum fpinis difinftis. LIN . l.c.

Legumen (a. b.) teretiufculum, gracile, in fpiram laxain undulatam convolutun, articulatum, fulcatum: fulcis dorfalibus quatuor fpinofss, reliquis ut \& ventralibus inermibus. Articuli feptem ad decem, curvati, evalves, nec a Se incicem fecedentes. Semina (b. c.) teretiufcula, curvula, ferruginea. Albumen (D. e.) ut in proccedenti. Embryo (e. F.) luteus; cotyledonibus femiteretibus, fubfalcatis.

In tota hac familia non datur Embig'o teres, practerquam in Hippocrepide \& Scorpiuro. 


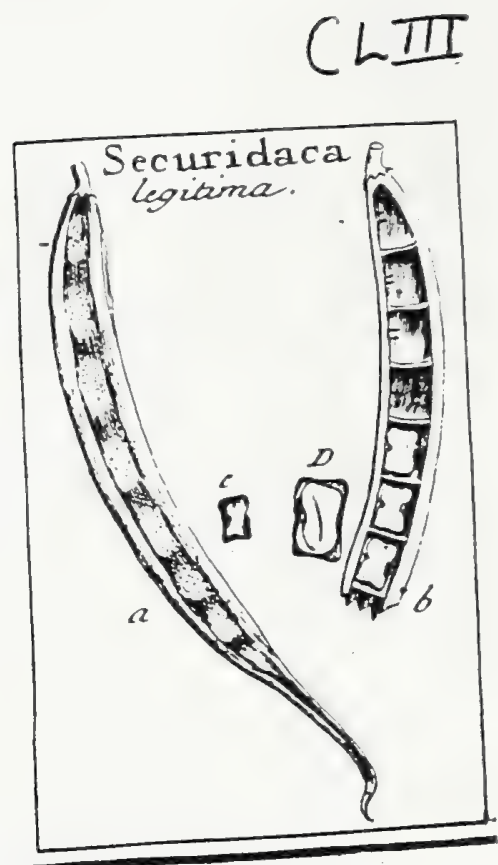

J. Gaertner (1788) Vol. 2

DCCCLXXXIII. S E C U R I D A C A. TOURnoit. $=24$.

Calyx femiquinquefulus. Vexillum rotundatum refexum. Legum. falcatum. marginatum, compreifum. Sem. quadrangula albumisofa. Embr. curvatus.

Securddaca legitima. Tab. 153. fig. 3:

Securidaca vera. Clus. bif.. 2. p. 236 . Ruv. tetr. t. 83.

Hedyfarsun prinusus. DoD. pesupt. 546 .

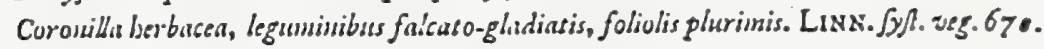

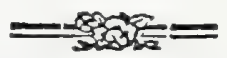

PER. Legumen longum, compreffum, falcato-gladiatuni, ftigmate brevi unguiculato inarticulato ternimatum, in medio pubefceus \& ad femina obrolete torulofum, ad Jatera autem glabrum \& late marginatum, pluriloculare, bivalve. Sutura feminifera fulco profundo divifa. Diffepimenta membra. nacea, tenuifima, perfiltentia.

Rec. funiculi brevifimi e futura concava.

Sкм. fubduodena, oblonge quadrangula, comprefa, glabra, rubro-ferruginea. I $\%$. finplex, coriaceum, tenue.

A L B. carnofum, durum, aqueo - pallidun.

Eм в. curvatus, luteus. .. Cotyl. obovato - truncatr, utrinque planx. Plum. nulla. Racl. inflexa, centrifuga.

a.) Legumen integrum. b.) Idem loagitudiatiter apertum. c.) Semeul feparatum. D.) Emm bryonis in albumine litus \& fignrz.

84.52 


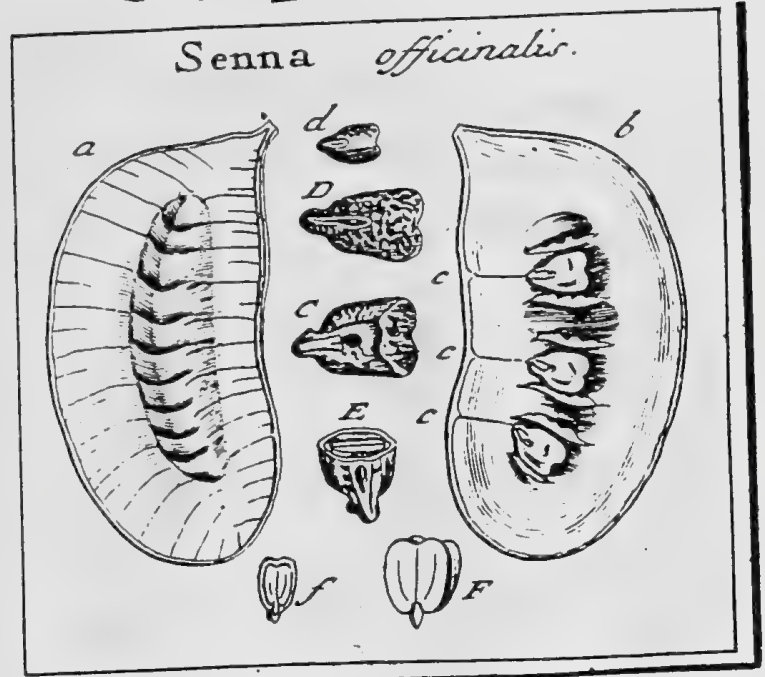

\section{S'E N N A. TOURN. t. 390.}

Calyx quinquepartitus, deciduus. Cor. pentapetala, petalis inferioribus majoribus. Stam. decem, difcreta, antheris tribus fupremis fterilibus, reliquis foccundis \& -harum tribus infimis arcuatis. Legum. membrana. ceum, pluriloculare. Sem. albuminofa. Embr. rectus.

\section{SENNA officinalis. Tab. 146. fig. 4 .}

Sema. DOD. pempt. 361 .

Senna alexandrina \& italica. MORIS. bif.. 2. S. 2. t. 24. f. 1. 2.

Cafia foliis fejugis fubountis, petiolis eglandulatis. LINN. Jyft. veg. 393.

PER. Legumen ovato - reniforme, membranaceum, foliaceo-compreffum, ad feninum fedem torofum, ftriis capillaribus transverfis parallelis notatun, fex-1. novem loculare, bivalve. Diffepimenta transverfalia, tenuifima.

Re.c. funiculi capillares recti e futura interna $\mathrm{f}$. concava.

S.EM. folitaria, obcordato-oblonga, roftellata, utrinque planiufcula, verfus peripheriam in marginem acurum declivia, fcrobiculato-rugofa, liguli lineari pallida ex roftello \& fupra eam in medio macula parva caltinea atque fplendente in utroque latere notata; cxterum pallide cinerea.

Ix . fimplex, cruftaceura, durum.

A L B. craffum, vitreo pellucidum, integerrimum, embryanem totum involvens.

EмB. rectus, luteus Cotyl. obcordatx, trinervix, utrinque planx. Plum. nulla. Rad. Lubulata, brevis, centrifuga.

2.) Legamen istegrum. b.) Idem apertum. c. C. d. D.) Scmina in fitu, atque foluta. É.) Semen difretum, eum litu cotyledonum intra albumen. f. F.) Embryo denudatue.

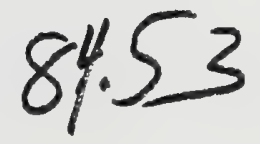




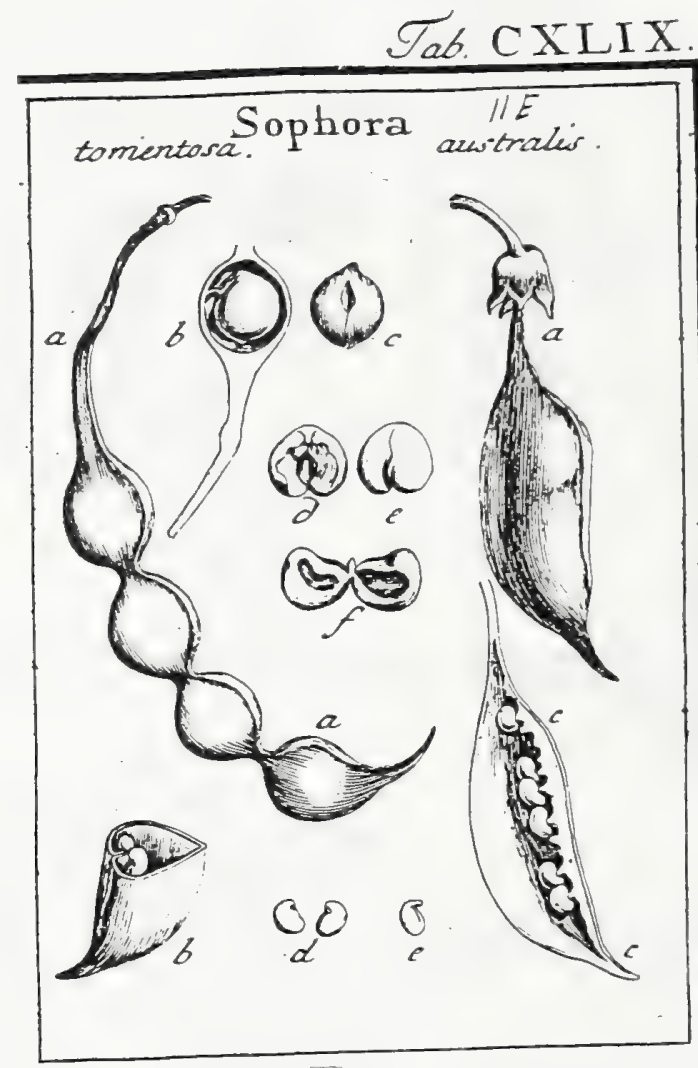

J. Gaertner (1788) Vol.2

DCCCLXV. S O PHORA. LINN. gir. 508. 320

Calyx urceolatus quinquedentatus. Cor. papilionacea pentapetala Stam. decem difcreta. Legum. pedicellatum, elongatun, moniliforme (aut in variis varium Limb.). Sen.. exalbuminofa. Embr. curvatus.

SOphora tomentora. Tab. 149. fig. 2.

Colutea zeylanica mgestitea tota Herar. lugdb. 169 . t. I7 r.

Sophora foliis pinnatis: foliolis numer ofis fubrotrudis tomentofis. LINx. Jyp. veg. 391.

E collect. Bankfiana.

PER. Legumen pedicellatum, moniliforme, fericeo tomentofum, album, pluriloculare, bivalve. Loculamenta ifthmis fpongiofis intercepta. Valvulx vix dehifcentes.

REC. funiculi breves, e futura interiore $\int$. coneava.

SEM. folitaria, in univerfum quaterna aut paulo plura, fubglobofa, utringue in brevem mucronem attenuata, ad umbilicum foveola oblongal excavata, glabra, e fpadiceo-caftanea, aut helvola.

IN T. duplex: exterins chartaceum, duriufculum; interins membranaceo - Spongiofum, juxta umbllici regionem infigsiter incraffatum.

A I B. inullum.

Es B. globofús, curvatus, luteus, in regione umbilicali lata area deprefia ats que irregulari, ab integumenti interni protuberantia, exfculptus. Cotyl. craffix, carnofx, intus concavx aut planx, extus convexte. Phon. nulla. Rad. brevillima, incurva, centrifuga:

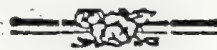

321

2) Legumen integrum. b.) Loculamentum iufimum apertum, cua ferine in fitu naturali. c.) Seinea a parte fovex umbiliealis fpectatum. d) Embropais deaudati latus vombilicale.

c.) Ejusdem pars doralis, f.) Cotyled, explicatx.

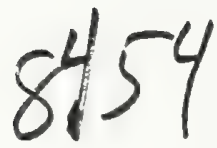

SOPHORA auftralis, ibid.

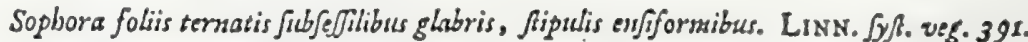

Ex horto regio Kewenl.

Legumen (it) pedicellatura, inflatum, juxta futurana feminiferan (b.) turgidum, in oppofito auteni latere, compreffo-carinatum, chartaceun, nigrofufcum, rorulentum, uniloculare, bivalve. Receptac. (c.) fungofum, albun, in varius procefitis conoideos, loco funiculorum umbilicalium definens, quibus femina multiplici ferie affixa. Semina (d.) numerofa, reniformia, glabra, gilva. Integumenti lamina interna fubcarnofa, alba. Embryo (e.) Juteus, curvatus.

Hæc, a calyce \& fruetu, omnino majorem cum Crotalaria, quan cum Sophora 


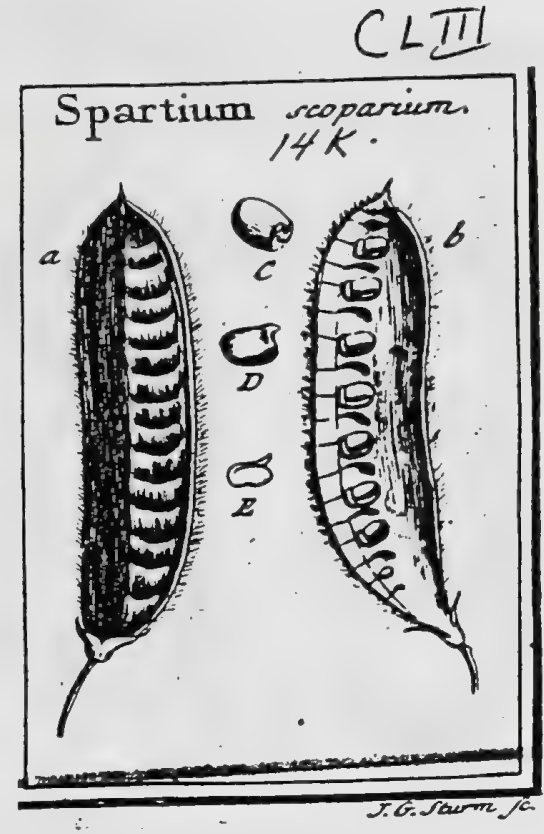

J. Gaertner (1788) Vol2

DCCCLXXXIV. S P.A R T I U M. LINN. gen. 858.338

Calyx bilabiatus. Corolle papilionacex vexillum ampliffin:un. Legum. uniloculare, mono - l. polýpermum. Sem. fubalbuninofa, carunculà umbilicali deciduá aut nullâ. Embr. curvatus.

Spartium fcoparium. Tab. 153. fig. 4.

Genifta. Dod. pempt. 76x. Ruv. tetr. t.65. f. x. BLAKw. berb. t. 244. OED. fior. dan. t. 3тз.

Spartizum foliis ternatis folitariisque, ramis inernibus angulatis. LiNN. f.37. veg. 644 .

PER. Legumen oblongum, compreffun, villarum, nigricans, uuilotelare, bivalve. Valvularum futura feminifera intus lato margine diftincta.

REC. funiculi fetncei, e futura convexiore.

SEM. plura, ad octodecim, oblonge elliptica; comprefía, glabra, e fpadiceolutefcentia, fupra umbilicum mucrone brevi roftellata. Unbilicus ghandula alba, biloba aut cordata, poft plenam naturitatem decidus, munitus.

INT. Ginplex, coriaceum, tenue.

A L B. aqueo-pallidum, tenue.

E AB. curvatus, luteus. Cotyl: ablongx, compreffx. Phum. nulla. Rad. inBexa, centrifuga.

2.) Legumen integrum. b.) Iden apertum. C.) Semen eum earuneula umbilicali. D.) Idem absque caruneula. E.) Eonbryo denudatus.

In feminibus Sp. juncei caruncula umbilicalis deficit, vel certe in meis exemplis deeft. 


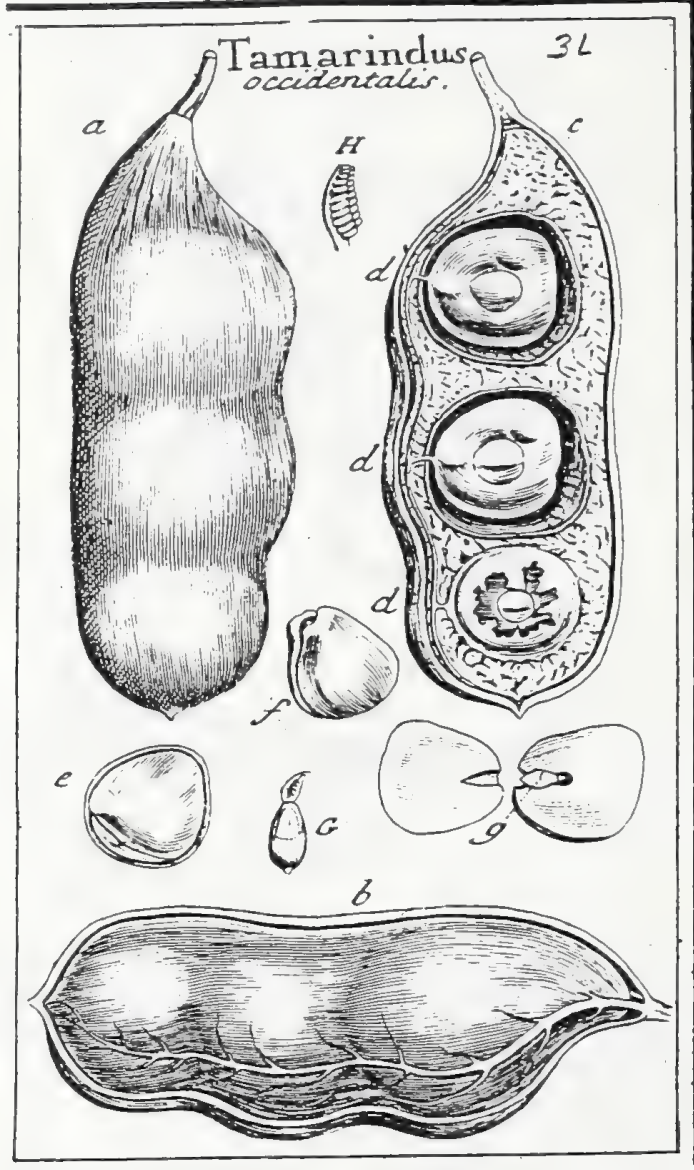

Fabaceae

DCCCLIII. T A MAR IN D US. TOURN. t. 445. LIN. ger. 46.

Calyx bafi turbinatus, limbo quadripartito deciduo. Stam. feptem aut novem, bafi coalita: tribus longioribus antheriferis, reliquis Iterilibus. Legum. corticatum, pulpofum. Sent. exalbuminof. Embr. recaus.

TAMARINDUS occidentalis. Tab. I46. fig. 2.

Tamarindus. BLAKw. berb. t. 20r. JACe. bij. amer. 10. t. 10. \& 179. f. 98. LiNs. Gy?. veg. 81.

PER. Legumen oblongum, obtufum, leviter compreffum, ad feminum fedem fubtorofun, corticatum, pulpa farcium, plutiloculare, cvalve. Cortex per xtatem fuberofo-cruftaceus, fragilis. Pulpa mollis, acidula, fub cortice tribus validis nervis longitudinalibus in margine obtufiore ftipata; intus

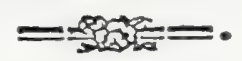

in tria vel quatuor loculanenta divifa. Loculaments membram propria tenuifrsma veftita.

REC. funiculi filifornes ex nervo pulpx medio.

SEM. folitaria, grandia, obovato-rotundata, comprefla, in utroque latere obfolete gibbofula atque in medio ftria circulari, quasis occllo, inferipta, ceterum glaberrina, lucida, caftanea.

IN T. fimplex, cruftaceum, durum.

A L в. nullum, sес ejus veftigium.

EM B. rectus, albus. Cotyl. crafix, camofx, plano-converx. Plum, diphylla, foliolis pimatis, fubduodecimjugis. Rad. ovato-globolit, retracta, centrifuga.

s.) Legumen integrum. b.) Pulpx denudata integrz, eum fuis nervis sutricis in margine. c.) Legumen longitudinaliter apertum. d. d. d.) Seminum fgura \& fitus naturile. c) Scminis tefta apesta atque embryo denulatus f.) Eubryo folutus. E.) Cotyledoses fepasatz cum ple mula. G. H.) Plumula \& radicula infigniter auda.

Tamarindus orientalis differt legumine longiore \& majori feminum numera Conf. Rheed. mal. 1. t. 23. Rumph. amb. 2. t. 23. Blakw. to 221. 


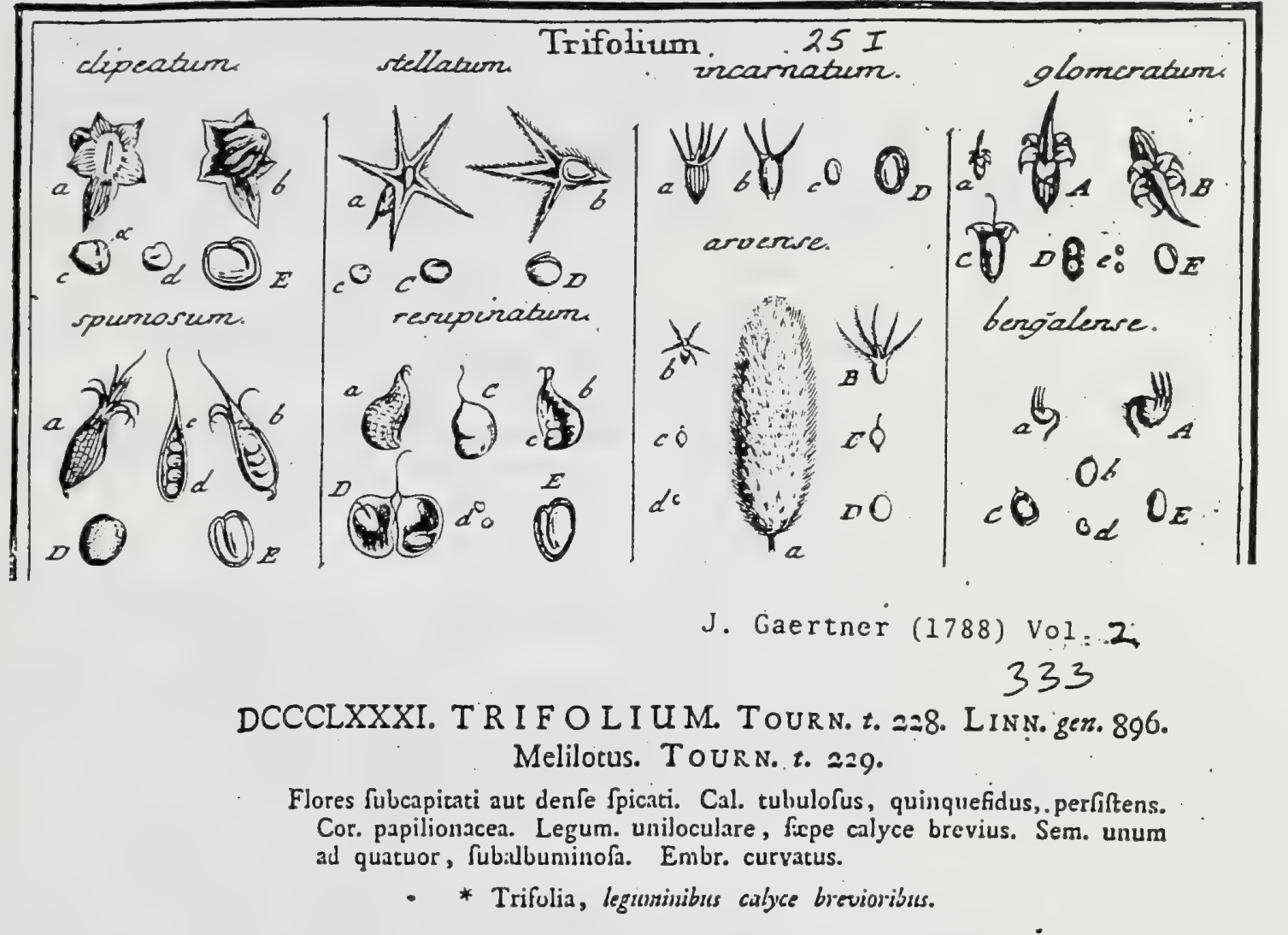


TrIFOLIU⿴囗十 clypeatum. Tab. 153. fig. I.

Trifolium clypeatun argenteun. ALP. exot. 307. t. $306 . \quad 333$

Trifoliun spicis ovatis, calycibus patulis: lacinia infima maxima lanceolata, foliolis ouatis. Linn. fyft. veg. $68 \mathrm{~g}$.

$P E R$. Legumen in calycis quinqueradiato-peltati obturati ventre fulcato hatens, ovatum, cumpreffum, apice truncatum ibidemque callo fpongiofo albicante prapilatum, nembranaceum, tenuiffnum, uniloculare, non dehifcens.

REC. funiculus brevilimus, in medio marginis fuperioris.

SEN. unicum, ovatum, cumprefrum, gibbofulum, glabrum, ferrugineum.

IN T. fimplex, cartilagineo- coriaceun.

A L B. cirnofum, craffiufculum, opacum, album.

Eмв. curvatus, luteus. Cotyl. obovatix, utrinque planiufculz. Plum. nulla. Fud. fufiformis intexa, centrifuga.

a.) $C_{215 x}$ maturus 2 parte fuperiore $-\&$ b.) Idem 2 parte inferiore (peetatus a) Legumen dentidatun, cum callo $(\alpha)$ fungofo in vertice. d.) Semen Ifparztum. E.) Embryonis figura \& Gitus intra albumen.

TRIFOLTUM ftellatum. ibid.

Lagopus latifolius. Riv. tetr..t 17 .

Trifolium jpicis pilofis ovatis, calycibus patentibus, caule diffufo, fuliolis obcerdnis. LiNe. l. c.

Calyx maturus (a.) pilofus, obturatus, ftellatus dentibus quinque inxqualibus planis patentifinis. Legumen incki ventrem calycis (b.), ovatum, membranaceum, tenuilimum. Semen (c. C.) unicum, elliptico - reniforme, rufefcens. Albumen tenue. Einbryo (D.) luteus.

334

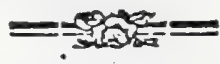

Trifolium incarlantum. ibid.

Trifolinen fpicis villafis oblongis obtufis aplyyllis, foliolis fubroturdis cresultis. LiNs. l. C.

Caly'x maturus (a.) villofus, non obturatus, terminatus dentibus quinque fubulatis erecto-patentibus fubaqualibus; inferne turgens in ventrem ovatum decemfriatum. Legumen in calycis ventre (b.) ovatum, menbranaceum, tenuifrmum, apice compreffun. Semcn unicum (c), elliptico-reniformae; lutefcens. Albumen \& Embryo (D.) ut in procedenti:

TRIFOLIUM glomeratuns. ibid.

Trifolium cum glomerulis ad caulizun nodos fubrotusdis. PLUK. pibyt. to 113. f.5. Trifolium capitulis Sefribus bemifphericis rigidis, calycibues frïatis. pasulis equalibus. LiN. l. c.

Calyx maturus (a.A.B.) ovatus, compreffus, decenftriatus, lavis, dentibus quinque ovato-acuminatis, rigidis, recurvatis. Corolla emarcida, roftrata (B.)., periftens, legumen obvolvens. Legumen (C. D.) oblongum, compreiliufculum, membranaceum, diaphanum. Semina duo (e. E.) ovatoglobofa, pallide fulphurea. Reliqua ut in pracedentibus.

Trlfolium fpumolum. ibid.

Tiifolinin coule nudo, glonierutis glabris. BAUH. L:A. =. p. 379 .

Toifolizm fpicis ovatis, calycibus imfatis glabris quinauedentatis, invohucris un: veroralibus pentaphyllis. . LinN. l. c.

Calyx maturus (a.) ovato-oblengus, ventricofus, menbranaceus, reticulatur, terminatus dentibus quinque fetaceis recurvato-parulis. Corolla enarcida lacera perfiftens legumen involvcus. Legumen (b.c.) oblongum, menbranaceum, tenuifimum, in ftylum fetaceum definens. Semina (d. D.) quatuor, (aut duo grandiora), fubglobofa, minutilfme clevato-puncticulata, fulphurea, lutea, aut ferruginea. Embryo (E.) \& reliqua ut in prioribus.

TrifCLIU⿴⿱冂一⿰丨丨八

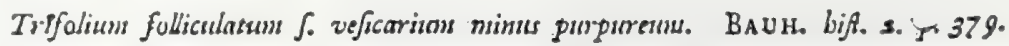
Trifotinn Jpicis fubountis, corollis Jupinatis, calycibus inflatis dorro gibbis, calllibes projlyatis. LuNN. l. s.

Calyx maturus (a. b.) ovato-roftratus, inflatus, gibbus, membranaceus, rcticulatus, denticulis duobus fetaceis uncinulatis terminatus, in dorfa integerrimus, in ventre rima longitudinali fiffus. Legumen (c. C.) parvulum, obovatum, membranaceum, tenuifmum. Senina (d. D.) duo (rarius unicum), ovata, glabra, e luteo fpadicea. Albumen gelatinofum. Embryo (E.) lutefcens. 
IRIFOLIUM arvenfe, ibid.

Lngopts. Riv. tetr. t. 15.

Trifolisun fpicis villofis viulibus, dentibus calycinis fetaceis villofss. aqunlibus. L1Nv. L.c.

Spica matura (a) cylindrica potius, quam ovaca. Calyx (b. B.) villofus, fria-

- tus, dentibus fenceis, villofis, xqualibus, ventre duplo longioribus. Legumen (c. C.) membranaceum, ovatum, calycis ventri xquale. Semen unicum (d. D.), elliptico-globofum, e viridi lutefcens. Reliqua ut in prrecedenti.

TRIFOLIUM benghalenfe. ibid.

A Sclsalio, hortulano Altdorffenfi.

Calyx maturus (a. A.) fubglobofus, villofus, cernuus, dentibus tribus fetaceis longilfnis furfum incurvatis. Legumen (b. C.) calycis ventre tedum, ellipticum, glaberrimum, lividum, fplendens: Semen (C. d.) unicum, reniforme, ruffum. Albumen nullum. Embryo (E.) luteus.

Anne hxc potius Hedyfari fpecies, ob calycem pedunculatum, legumen non membranaceum \& femen exalbuninofum?

** Meliloti, leguminibus calyce longioribus.

Trifolium Melilotus polonica. ibid.

Trifolinn leguminibuis racemofis undis difpermis danceolutis, caule creito. LINs. fiys. veg. 687 .

Legumen (a. A.) coriaceum, falcato-lanceolatum, turgidum, fulcis elevatis arcuatis ana?tomofantibus egregie verniculatum, uniloculate, bivalve, fed vix fponte dehifcens. Semina duo (c. C.), futurse concava (b.) inferta, trigono-glubora, glabra, rufefcentia. Albumen (D.) crafum, carnofum, ab emollitione in agua gelatinofum. Embryo (D. E.) curvatus, luteus.

TrIfolium M. cxrulea: ibid.

Meillotus carulsa. Rrv. ietr. t. 9.

Trifolinm racenis nvatis, leguminibus feminudis mucronatis, cance eref7o. LINN. l.c.

Legumen ( a. A.) calycis deutibus fubulatis haud multo longius, obovatum, ftylo fubulato terminatum, membranaceum, nervis Jongitudinalibus anaftomofantibus Jaxe reticulatum, uniloculare, evalve. Semina (b. c. C.) duo vel quatuor, rotundato - reniformia, glabra, luteola. Albumen tenue. Embryo (D.) Juteus.

Trafrolium M. indica. ibid.

Melilosus minima. Ris. tetr. t. 8.

Trifoliun leguminibus racemofis nudis moisofpermis, caule ereifo. LiNN. l. c.

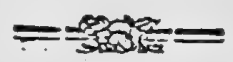

Legumen (a. A. b. B.) membrairaceum, tenuifimum, denfe reticulatum, ob. tufum, calyce brevilfimo bafi munitum. Scmina (c. d.) unum, aut duo ovato - 1. angulato-reniformia, ferruginea. Reliqua ut in pracedenti.

Triforıum M. inalica. ibid.

Melilotres isalica. RIv. tetr. t. 7. . CAM. bort. t. 29. melius. Trifulium leguminibus racemofis undis difpermis rugofis obtufis, caube ereato,
foliolis integris. LINN. l.c.

Leguinen (a. A.) coriaceum, fubglobofum, brevifime mucromtum, ad latera tortuofe rugofum, ad margines autem futura glabra prominula notatum, non dehifens. Semeu (b.) unicum aut duo, reniformia, rufeloentia. Reliqua ut in prioribus.

TRIFOLIUM MI. cretica. ibid.

Trifolium peltatum creticum. BAUH. prodr. 142. c. ic.

Trifolinm leguminibus racemofis mudis difpermis.membranaceis, cande ereftiufculo.

LiNN. l. c.

Legumen (a.b.) orbiculatum, membranaceun, foliaceo-compreffum, vafis capillaribus transverfis parallelis Atriato-reticulatum, pallide framineum, fub. marginntum, non dehifiens. Semen (b.) reniforme, ninutilfime elevato puncticulatum, compreffiufculum, ferrugineum. Albumen vix ullum. Enbryo (C.) curvatus, croceus 1 . aurantiacus. Si duo adfunt femina, tunc funt transverfin polita. 


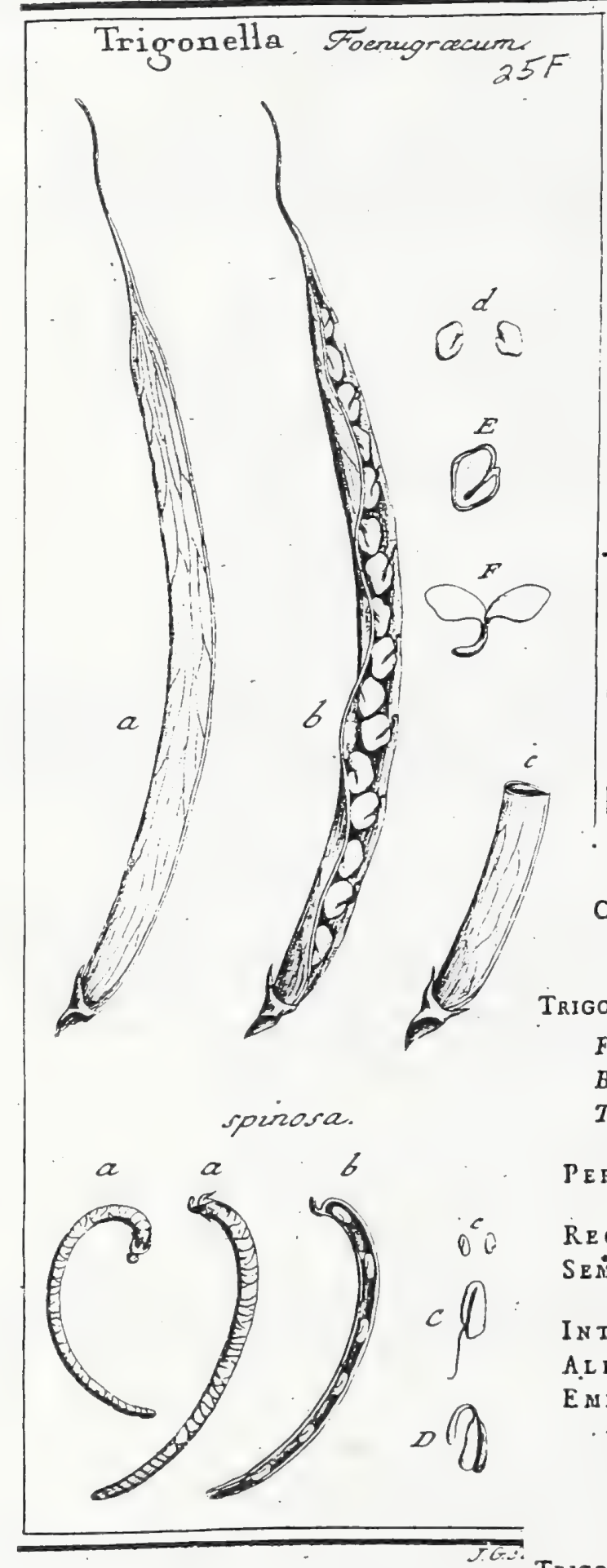

\section{J. Gaertner (1788) Vol 2}

\section{1}

DCCCLXXX. T R I G O NEL L A. LINN. ger. 898.

Fœnum græcum. TOURN. $t .230$.

Calyx femiquinquefidus. Cor. papilionacea, alis cum vexillo patentibus \& corollam tripetalam xqualem nientientibus: Legum. lineari-obln--im, uniloculare. Sem. fubalbuminofa. Embr. curvatus.

Trigonella Fœnugræcum. Tab. I 52 . fig. 3.

Foenum gracum. CAM. epit. 199. RIv. tetr. to 81. BLAKW. berb. t. 384. Buceras frliquis feflibus aruatis undique divergentibus. HaLL. biff. "3. 379 .

Trigonella leguminibus feljilibus frifitis erefinfcudis fubfalcatis acuminatis, caule: redto. Lisn. Jyjt. veg. 692.

PER. Legumen longifimun, filiformi acuminatum, anguftum, fubcomprefium, fubfalcatum, uniloculare, margine convexo dehilcens.

SEM. plura, ad octodecim, rhomboidea, gibba, linea depređa roltellata, Eavicantia aut crocea.

IN T. Cimplex, coriaceum, tenue.

A.L B. aqueo-pallidum, tenue, ab aqua in gelatinam convertibile.

E м в. curvatus, Juteus. Cotyl. ovatx, utrinque planiufculx. Plom. null. .. Rad. fufformis, inflexa, centrifuga.

a.) Legumen integrum. b.) Ilem dehifcens. c.) Ejus Settio trasterfalis, d.) Semina (eparata: E.) Embryo ab albuarine cinđtus. F.) Cotyledones explisatz.

Trigonella fpinofa. ibid.

Foenugracron fyluefire polyceration creticum majus. BнEvN. cent. t. 33. f. r. Trigonella leguminibus fubpedunculatis congefis declinusis falcatis comprefis, pedusculis fpinofis brevijJinis. LIN. $l$. $c_{\text {. }}$

$$
=-\sin =
$$

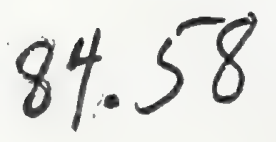

Legumen (a. a. b.) lineari ob!ongum, falcatum, teretiufculum aut levifinte. compreffum, nervis elevatis transverfalibus exaratum, uniloculare, bivalve. Semina (b. c. C.) ucto ad duodecim, ovato-oblonga, roltello motata. Jutea. Embr. (D.) curvatus, luteus. . 

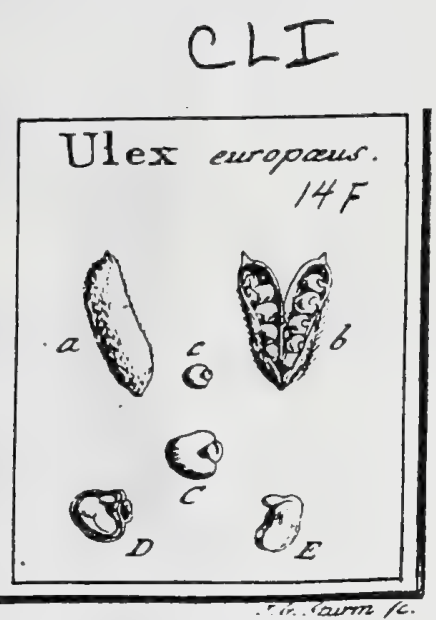

J. Gaertner (1788) Vol. Zi

DCCCLXXVII. U L E X. Linn. gen. 88i. Genifta-fpartium.

\author{
TOURN. t. II2.

Calyx profunde bipartitus, fupra bidentatus, infra tridentatus. Cor. papilionacea laxa. Stam. omuia connata. Legum. oblongum uniloculare. Sem. fubalbuminofa; umbilico bilabiato. . Embr. curvatus.

UlEX europxus. Tab. if I. fig. 7.

Genifar fpirofa. Dod. pempe. 659. Riv. tetr. t. 65. f. =. OED. flor. dar. t.608. Ulex foliis villofis acutis, Jpinis jparfis. LuNN. fylf. veg. 648 .

PER. Legumen oblongum, fubfemipullicare, turgidulum, villofum, uniloculare, bivalve. Valvulx intus glaberrimæ; absque fcrobiculis aut difepimentis.

REc. funiculi craffiufculi, breves, e futura rectiore.

SEM. octo. 1. decem, reniformi-triangula, turgide lenticularia, glabra, fublucida, rufefcentia aut fubviridula. Umbilicus valde prominens bilitbiatus, ex lamellis duabus glandulofis albis aut lutefcentibus, feneftrx ovali utrisque appofitis.

IN T. duplex: utrumque nembranaceum, tenue.

AL B. carnofum, album, tenuifimum, ut vix ullum.

EN B. curvatus, luteus. Cotyl. crafiufculx, plano-convexx. Plsm. nulla. Rad. intexa, centrifuga.

a.) Lequmea integrum. b.) Idén debifcens, cum feminum infertione. c. C.) Semen feparatum. D.) Ejus fettio verticalis, cam umbilici labio altero atque embryonis fitu. E.) Embryo folutus. 


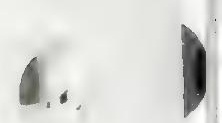

1 
CLI

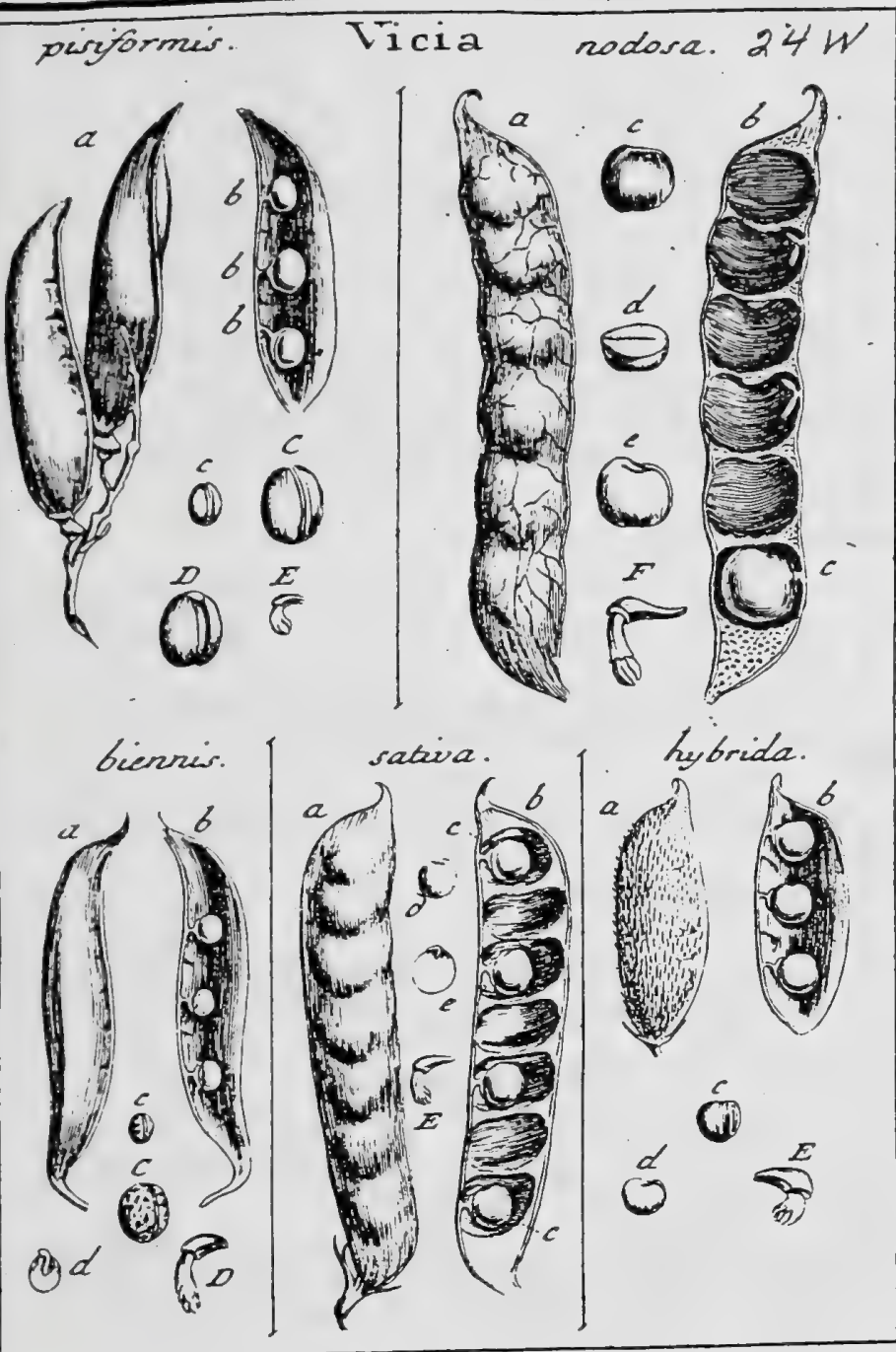

Fabaceae

\section{$8460 A$}


DCCCLXXI. VI C I A. TOURN. t. $22 \mathrm{I}$. LINN. gen. 873.325

Calyx femiquinquefidus. Cor. papilionacea : vexillo femicrecto. Stam. mono. aut diadelpha. Stylus fub ftigmate thansverfe barbatus. Legum. oblongum, uni-aut membranaceo-pluriloculare. Sem. exalbuminofa. Embr.
curvatus.

Vicia fativa. - Tab. Is s. fig. I.

Vicia. Riv: tetr. t. 54. BLAKW. berb. 2. 429. OED. for. dail. t. 522.

Vicia legtuminibus Sellilibus fubbinatis eveifis, foliis retufis, fripulis notatis. LinN. Jij. vieg. 664 .

PER. Legument ohlongun, bipollicare, compreffum, ad fernina torofum, feptemloculare, bivalve. Dillepinentat tenuilina, perfiftentia.

REc. funiculi e futura rectiore, apice bifurcati.

SEM. fex l. fepten, irregulariter rotunda, turgide lenticularia, e fufco \& ferrugineo varia.

IN T. fimplex, cartilagineo- coriaceum.

$A$ L B. nullun.

Es B. curvatus, luteus. Cotyl. fubrotundi, "plano - convexac. Plumo ad radiculani normalis, polyphylla, foliolis incumbentibus. Rad. compreffi, centrifuga.

$3 \geq 6$

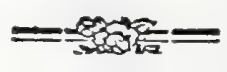

a.) Leguraen integrum. b.) Valvuli (eparata. e. e.) Seminum figura \& infertia d.\} Eun. bryo denudatus. c.) Cotyicd. altera. E.) Plumula auda.

Hujus mera variecas eft Vicia nodofa. ibid. Legumen (a. b.) paulo grandius, diffepimentis membranaceis pariter perfiftentibus. Semina (c.c. d.) duplo majora, rotunde quadrangula, lenticularia, cinerafcentia. Embryo (e.) \& plumula (F.) ut in pracedenti.

Vıçia pifformis. ibid.

Piftum Syluefire. Clus. hifs. 2. p. 129 .

Cracca fore oclurolenco. Riv. tetr. t. $5=$.

Vicia pedunculis multifforis, petiolis polyphyllis, folinlis ovatis: imis feJtibus. LiNs. Jjik. veg. 663 .

Icon. JACQ. for. antis. t. $3^{6} 4$.

Icgunen (a) oblongum, acuminatum, in medio convexum ad fututas compreffum, uniloculare, absque ullo diffepinentorum veltigio. Funiculi umbi. licales (b.) apice bifidi. Semina (c. C.) ovato-globofa, e ferrugineo nigricantia, unbilico lineari, longitudine feminis. Enbryo (D.) luteus. Plumula (E.) tetraphylla, foliolis oppolitis, ovato-acumilsatis.

Vicia biemnis. ibid. ex fide Martini.

ricia pedunculis multiforis, petiolis fulcatis fubdodecaphyllis: foliolis lanscolutis glabiris. LINN. fjy. veg. l. c. GNeL. fib. 4. p. 10. t. 2.

Legumen (a. b.) pracedenti fimile, fed anguftius \& inferne quafi in pedunculum attenuatum. Dillepimenta nulla. Funiculi (b.) bifidi. Senina (c. C.) globora, . fordide lutea, nigro maculata. Umbilicus linearis, longitudine ieminis. Plumula (d. D.) dimidiis cotyledonibus paulo longitr, polyphylla.

Vicis hybrida. ibid.

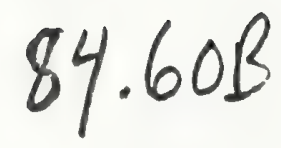

Vicin legunimibus fesilibus refexis pilofis pentafpermis, corolla vexillis villofis. LiN . l. c. liois. Jace. for, anfir. t. 34 .

L.çumen (a. b.) ovato - oblongum, compreffum, villofum: villis bafi bulbofis rigidulis, albicintibus. Diffepimenta nulla. Funiculi bifidi. Senina $\left(c_{0}\right)$ quinque, globofa, ferrugineo-nigricantia. Umbilicus linearis, brevis. Embryo ( $\mathrm{d}_{0}$ ) \& plumula ( $E_{\text {. }}$ ) ut in procedentibus. 


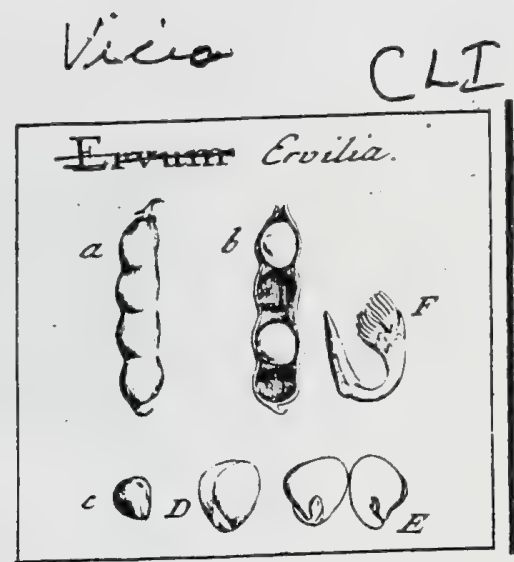

Fabaceae

J. Gaertner (1788) Vol. 2

328

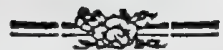

DCCCIXXIV. E R V U M. TOuRin. t. 22r. Linn. gen. 874.

Calyx quinquefidus, longitudine corollse papilionacex. Stylus apice non barbatus. Legum. oblongum, torofulum, uniloculare. Sen, exalbuminofa. Embr. curvatus. Plum. grandiufcula, polyphylla.

'Ervum Ervilia. Tab. Isı. fig. 4.

E)vuns. Cans. epit. 215. Riv. tetr. t. 6r.

Erven germinibus rusdato-plicutis, foliis intpari pinuatis. LINN. Jyft. veg. 665.

PEK. Legumen oblongum, teretiufcuium, ad futuram feminiferam valde torofum \& quari moniliforme, uniloculare, bivalve.

REC. funiculi brevifimi, fimplices, e futura gibbofiore.

SEM. tria l. quatuor, trigono.globofa, glabra, pallide albicautia.

IN T. fimplex, chartaceun, tenue.

A L B. nullum.

EM B. curvatus, luteus. Cotyl. crafre, plano convexx. Plum. grandiufcula : fcapo tereti incurvo; foliolis pinnatis linearibus, cum fquamulis plurinis ad bafin accelloriis. Rnd. infera, centrifuga.

1.) Legumen integrum. b.) Valvula altera, cum infertione femilsum. c.) Semen feparatum. D.) Embryo denudatus. E.) Cotyled. feparatz. F.) Pluknula inligniter auda. 
ae

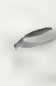


CCXVIII. CASTANEA. TOURN. $t .352$.

Flores mafculi atque hermaphroditi in eodem trunco. M A s. Amentum pralongum, foribus fellilibus glomeratis. Cal. fubhexaphyllus. Cor. nulla. Stan. quinque, ad vinginti. HE R M. Involuer. commune bi-l. trillorum, quadrifidum, fpinis ramofis pungentibus armatum. Cal. fuperus; roftro ovarii infintens, quinque-l. hexaphyllus. Cor. nulla, fed ejus loco tomentum rigidum. Stam. fubduodena, coccinea, effoeta, in somento latitantia: Styli fex cartilaginei. Ovarium inferum, fexloculare : ovulis rofellatis pendulis, in fingulo loculamento genuivis. Nux matura unilocularis; mucronata, evalvis. Sem. unun ad tria, rugola.

Castanea véca. Tab. 37. fig. I.

Cafanea. СА м. epit. I78. В гА х herb. t. 330 .

Cnfanea foliis ovato lanceolatis, acuminato ferratis, dentibus nduncis. HALL. hifl. 2. 11. 1623.

Fagus foliis lanceolatis acuminato ferratis fultus nudis. L I N s. fyf. veg. 850.

F R U т Us compolitus e Nucibus duabus vel tribus, bafi aftixis Involucro globolo; quadrivalvi, fpmis ramofis echinato.

PER. Nux infera, coriacea, rotundato-mucronata, hinc convexa, inde planiuscula vel in angulos prella, glaberrinz, nirida, rufefcenti ochracea, bafi derafa, unilocularis, evalvis.

REc. funiculus umbilicalis filiformis hirfutus, ex obliterato ovarï axi formatus, hine bafi nucis, inde feminis apici infertus.

SE M. unum, ad tria, rariffune plura, nucis cavitati, fuâ formâ, adaptata, rugofa, Sfadiceo-rufefcentiz.

Ix T. fimplex, membranaceum, fubaridum, intus variis plicis lamellofis iutra nuclei fubflantiain demerfun.

A \& в. nullum.

E ss в. magnitudine \& figura feminis, inverfus, lutcicenti-albus. Cotyl. carnofx, craftx, rimofx \& rugof $x$, plano-convexx, per maturitatem lixpe pertiwaciter inter fe coalitx. Rad. uvoidea, acuminata, parva, fupera.

a.) FruAtus integer. b.) Involuerum transverfe fefum. c.) Idem longitudinsliter apertum, tribus nucibus praguans. d.) Ovarii inımaturi fenio transverfalis, cum loculamentis tomento rigido rmple-

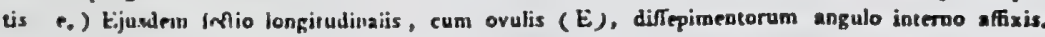
f. p.) Nuris niature lacies uiraque, h.) Sernen decorticatum. i.) Embrjo denudatus, $k$.) rijusdeni frtio iransverfalis, I.) Cotyledon altera a pare interna fpectata, cum radicula. M.) Radicula feparata \& aust2.
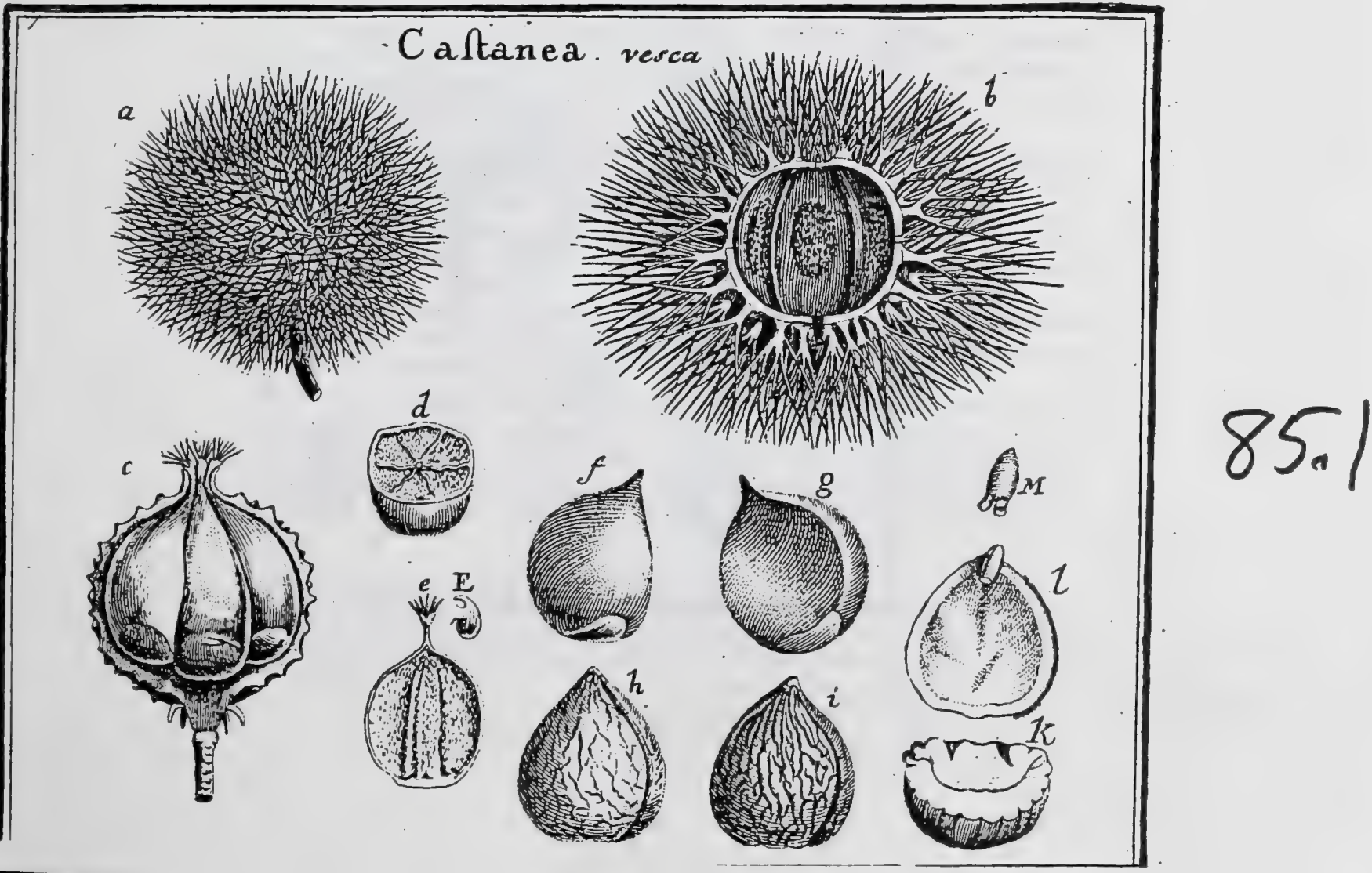
CCXIX. FAGYS. TOURN. t. 35T. LIN g. gen. 172.

Flores masculi \& feminei in eodem trunco. MAs. Amentum globofum e longo pe. dunculo pendulum. Cal. campanulatus fublexfidus. Cor. nulia. Stan. octo. F e a: Involuc, commune bitlorum, quadrifidum, !pinjis mollibus hifpidum. Cal. fupe ros hexaphyllus, tomentofus. Cor. nulla. Styl. unicus trifidus. Ovarium immatu. rum triloculare: ovulis fubulato caudatis, in fingulo loculamento geninis. Nux; matura unilocularis, triquetra. Semen unicum $L$ duo, angulata.

F A G us fylveftris. Tab. 37. fig. 2.

Frgus. Greтсн. d. Neufl. tab. r7.

Fagus foliis ovato lanceolatis, oris undulatis. H^ IL. hifl. 2. n. 2622.

Fagus foliis ovatis obfolete ferratis. Ins. Jyft. veg. 859.

Fruct us coropolitus e Nucibus duabus, bafi adnatis Involucro ovato-globolo, qua. drivalvi, extus fpinis mollibus hispido, intus glaberrimo, fericeo.

PEx. Nux infera, coriacea, ovato-L fabcordato-pyramidata, argute triquetra ac fere trialata, glaberrima, nicida rufefcenti-lutea, unilocularis, evalvis.

REc. funiculus umbilicalis pilofus, ex ovarii columna centrali formatus, feminis apici infertus.

SEm. unicum, ex rotundata bafi pyramidatum, triquetrum, pallide fpadiceum, aut rufefcens, glabrum.

IN T. fumpliciffanum, membranaceum, tenue.

A ᄂ в. nulluin.

Eм в. Semini conformis, inverfus, albus. Cotyl. carnolx, craffiusculx, extus laves \& xquabiles, intus plicis irregularibus, hinc prominentibus, inde depreflis exaratz \& fibi mutuo coaptatx. Rad. ovato acuminata, brevis, fupera. -

a.) Fructus Integer. b.) Involucrum dehiscens, cum Nucibus in fitu naturall. c.) Ovarium immsturum masverfin fectum. d.) Ejusdem fertio Josgitudinalis, cum axi fructus piloro \& orulis (D) rofuracis. e.) Semen maturum, cum funiculo umbilicali. f.) Cotyledones transverfim (ectz. F.) Farunden facies interna.

Involucrum fruetus, duplici fepto divifum, ac nuces tres vel quatuor, ut Halleros 1. c. refert, mihi sunquas obvenerunt.

J. Gaertner (1788) Vol.1
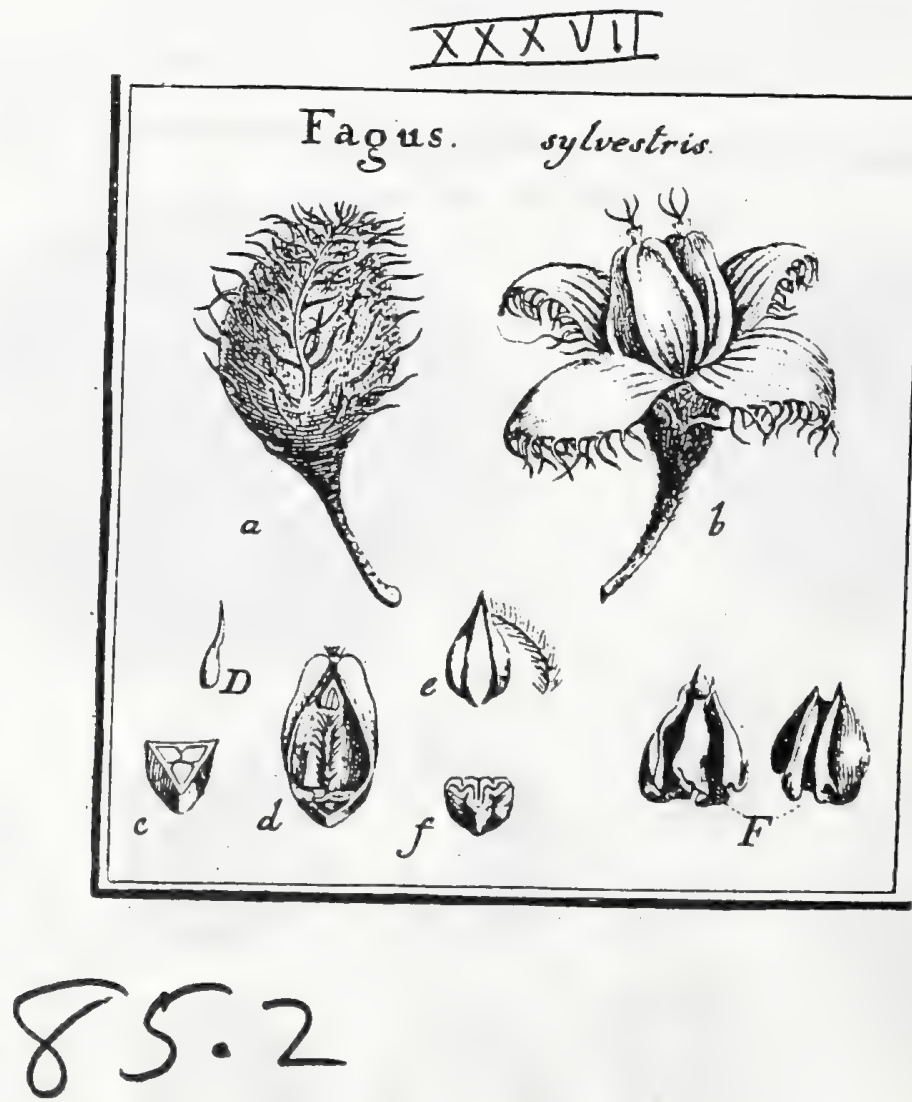
Tab. 2.2 .4$.

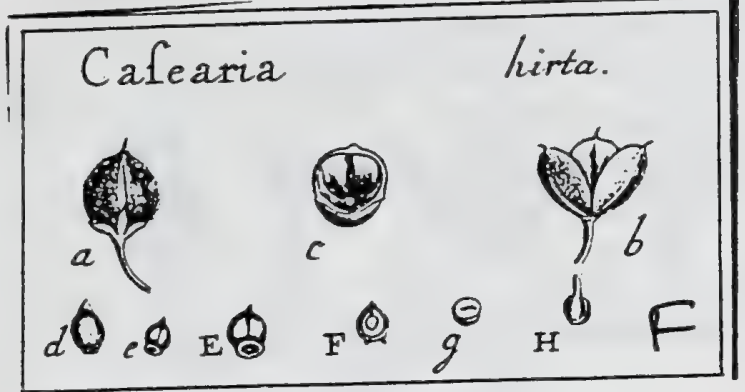

J. Gaertner (1788) vol3

188. C A S E A R I A.:

JAcl. amer. p.132. Sснвев, gen. 756. Samyda, Linn. gen. 543 . Anavinga. Joss. gen. p. 438. LamaBcK ill. gen. t. 355.

Cal monophyllus, quadripartitus, perfittens; laciniis ovatis, erectis. Cor. nulla. Stam. ofto 1 decem, fub ovario inferta \& cum glandulis totidem brevitumis glabris alternantia. Ovar. fuperum; ftylo fimplici, filiformi, triquetro, longitudine ftaminum; Atigmate trilobo, pbtufo, Capl, rutundato. triquetra, unilocularis, trivalvis, poly fperma. Rec. nullum. Sem. baccata, ophiocephaloidea. Alb. carnorum. Emb. inverfus; cotyledonibus plicatis,

Casearia hirta. Tab. 224. fig. 7 .

Samyda comentofa. SWARz prod. p. 68.

Cafearia (birta, ) foribus offandris, foliis ovatis ferratis fubtus birtis. SWARZ f. ind. occid. 2. p. 756 . WILLD. Spec. pl. T. 2. P. 1. p. 627. Pzrsous fyn. 1. p. 484 .

Ex Infula Hifpaniola, a D Portext:

PER. Capfula majufcula, ovata i. fubglobofa, rotundato-triquetra, fulcis tribus elevatis infignta, hinc calyci perfiftenti infiltens, inde ityli reliquiis

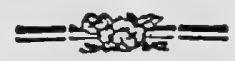

239

mucronato-acuminata, fetulis raris hirta, coriacea, rufefcens, unilocula ris, ad latera $a b$ apice balin usque tribus valvis dehifcens, polyfperma.

REc. nullum: prater papillulas ad valvularum nervum intermedium, quibus femina umbilicis adhrerent.

SEN. ovula 20 l. 24., quorum vero rariffime plura quam fex 1. octo maturefcunt, baccata l. intra facculum carnolo-pulpolum per lineam ventralem teltze aduatum inclula, opiocephaloidea $\mathrm{l}$. lubglubofa, in vertice mucronulats, ad balin vero truntaram circulo elevato cincta, \& intra hunc area umbilicali pallida paululum immerfa infignica, glabra, pallide fuadicea $L$ lutelcentsa, centrituga.

IN T. triplex: extimum carnofum, cuticula tenui faccata teftr longitudinaliter adnatum; medium taltaceum, cradiufculum, fragile; interius membranaceum, tenuillinum, adnatum.

A L B. ovato - acuminatum, telta ipfa paulo brevius, carnolum, craffum, album

E \& B. albumine paulo brevior, \& ad ejus apicem locatus, inverfus, lacteus. Coryl. orbiculares, foliacex, longitudiualiter figmoideo-plicatx, accumbentrs. Rad. longitudine fere cutyledunum, lineari-teretiulcula, curvula, adfcendens, umbilico externo e diametro contrarsa, centripeta.

\section{EXPLICATIO FIGUR止.}

2.) Capfula integra, b.) Eadem dehifeens, feminibus excufrs. e.) Ejusdem fectio transverfalit. d.) Semen intra facculum inclufum. e. B.) Idem ex ipfo folutum. F.) Ejusdem feaio longi wJinalis, cum ltu embryoais Iotrz albunen. g.) Albumiais fectio transerialis. H.) Embryo forutus: 


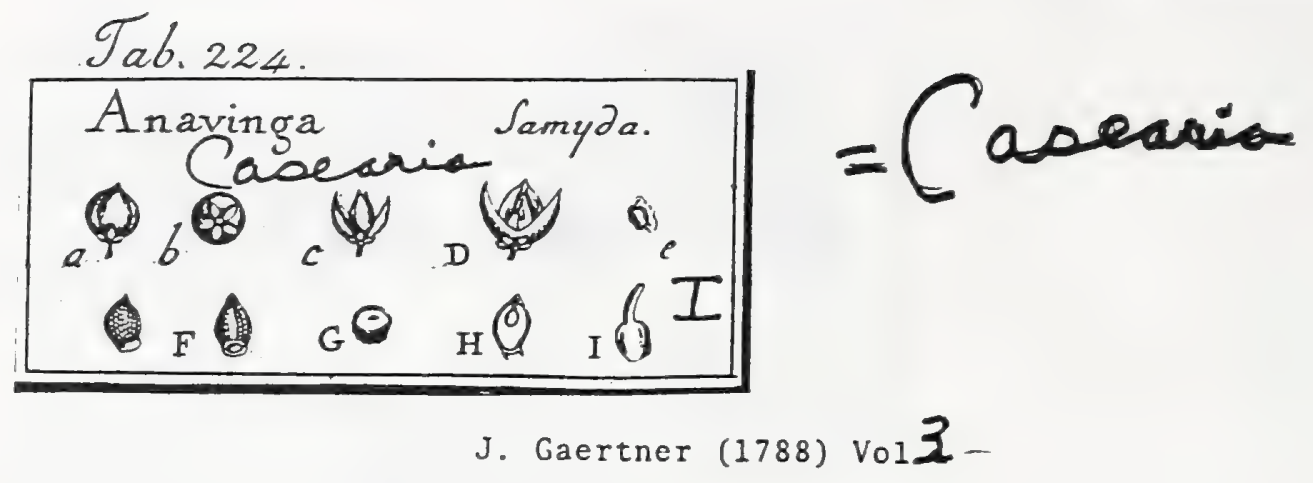

rgo. A N A V I N G A.

LAMARCK ill. gen. t. 355. Juss. gen. p. 438 . Samyda. LINN.

Cal. pentaphyllus, inferus, 'perGitens; foliola parva, ovata. Cor. nulla. Stam;

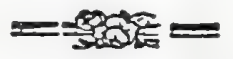

decem, diftincta, fub ovario inferta, cum glandulis totidem brevibus ovatis Itipitatis ciliatisque alternantia ; filanenta flifornia, longitudine calycis; antherx erectx, ovata. Ovar. fuperum; Itylo Gmplici, brevifimo; ttigmate capitato, Capf. fubglobola, coriacea, trifulca, unilocularis, polyfperma. Rec. nullunn. Sem. bạccata, ophiocephaloidea, Alb. carnofum. Emb. in. verfus; rad. curvula.

Anavinga Samyda. Tab. 224. fig. 9p

Habitat in Porto-Rico. Ex collectione Cl. Despontaikes.

PER. Capfula parva, pifformis, fubglobofa, obfolete rocundaro-triquetra l. tetragona, tri- - . quadrifularta, pundis minimis callolis confperfa, tri-l. quadrifariam ab apice dehilçens, undocularis, oligolperma, Valvula co. riacez, bafi cohxrentes.

REc. nullum: prater nervuın intermediun yalyularum incraflatum, \& cum valvis ipfis bạ lata colliquefcentem papillulis $\rfloor$. funiculis umbilicalibus breviffinis inftructum, quibus femina adhxrent.

SE M. pauca, 4-8., baccats, 1, intra fucculum carnofo. pulpofum linea veatrali teftz adpatum inclufa, ophiocepbaloidea, apice mucronulaca, bafi area umbilicali imnserfa pallida orbicularị initruẹta, puncticulato- fcrobiculata, ferruginea:

IN T. triplex : extimum carnofo - pulpofum; mediuns crafruff̧ulum, teftaceum, fragile; intimum tenue, adnatum.

A L D. Semini fere conforme, oyato-acuminatum, crafuni, carnofum, album.

$E_{M}$ B. nininuus, inverfus, ad apicem albuminis locatus, albus. Cotyl. ovatx, foliacex, leviter fecundum longitudinem plicute. Rud. cotyledonibus paulo longior, curvula, teretiufcula, leviter atcenuata, obtufa, umbilico externo contraria, centripeta.

\section{EXPLICATIO FIGURE.}

a. b.) Captula integra, non dehifeens c.) Eadem quadrifariam dehi(cens. D.) Eaden trifa: sım debifcens, cum dervo valvularum intermedie. e.) Semen integrum, facculo pulpofo in clufum. F.) Idem folutum. G.) Ejusdem fectio trasverfalis. H.) Embryonis fitus intra albumen. I.) Embryo Colutur.

Nec in Cafẹria, nec în Samida, nec denique in Anavinga receptaculura columnare inveni; quale Plumierius \& Browneus in iconibus tradiderunt; fundus enim capfularum in omnibus eft nudus. Semina baccantia fortaffe in recenti fructu fibi invicem in corpus columnare globolum conglutinata \& a valyularum nervo fecedentia fic receptaculi fpeciem xmulantur.

Albumen Samydurum oleo unguinofo icrtet.

Genera modo dicta una cum Iroucana Aubr. \& Meliftauro Forst., fruaus feminuasque fabrica conforaia, calyce vero ftaminum \& filamentorum in-

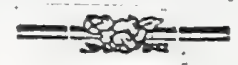

fertione atqque nexu ; xque ac glandularum forma \& cxt. diverfi, diffinctam conftituere videntur familiam, qux quidem iterata forum inveltigatione in vivis indiget: 


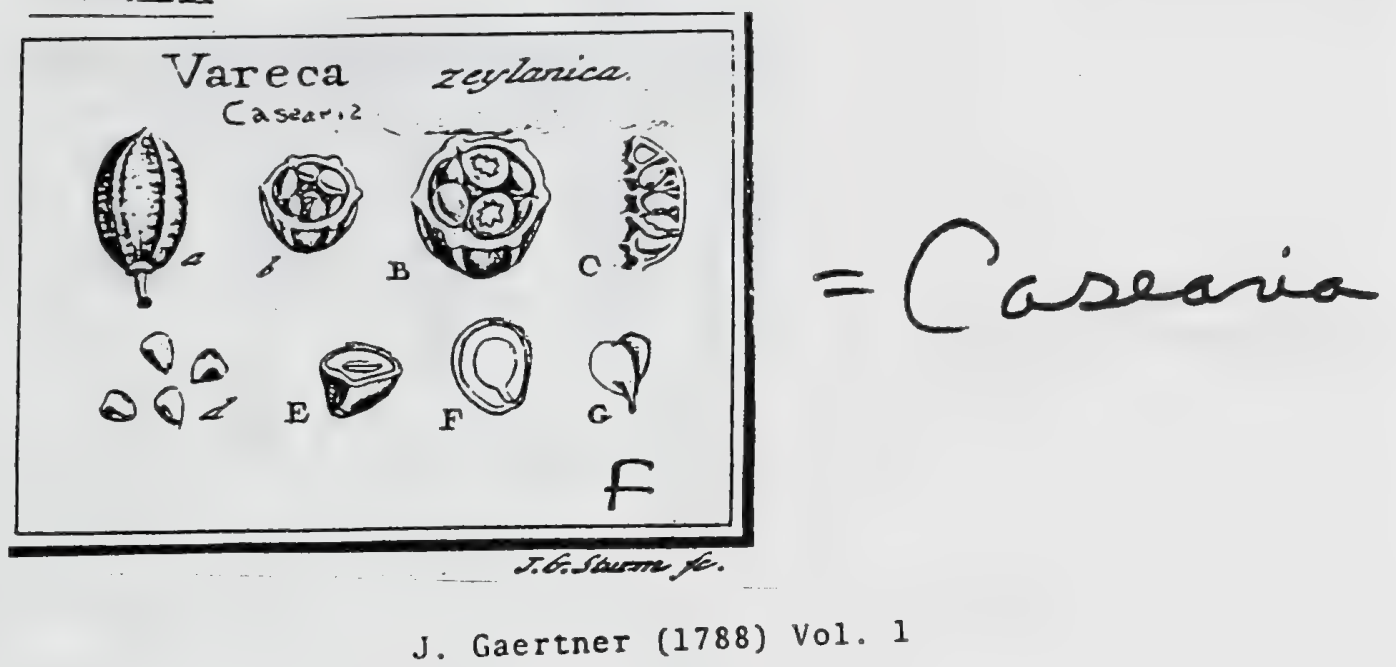

\section{VARECA. .}

Flos.... Bacca fupera, unilocularis, pulpî in plurimas cellulas partaies pro feminibus divifi. Senina parictibus baccx affixa.

VARECA zeylanica. Tab. 60. fig. 6.

Waluareka. z.cylon. E collect. fem. hort. lugdb.

PER. Bacca femipollicaris fupcra, ovata, hexagona, bafi orbiculo rotundo obfolete fexerenato flipata, apice brevi mucrone teinumata, unilocularis. Cortex coriaceus tenuis. Caro per xtatcm frongiofo membranacea, in cellulas partiales pro feminibus difereta.

REc. nervi tres prominentes, parieti interno baccx adnati, quibus femina cxteriora antixa.

SEM. plura, cellulis propriis inclufa: exteriora parictibus affixa; interiora nidulantia, grandiuscula, fuboviata, a mutuo contaçu varie angulata, fum.jó- - padicea.

IN T. duplex: exterius craflum, corjaccun; interius membranaceum, tenuifinum.

A \&. femuini conforme, craffum, amygdalino carnolum, album.

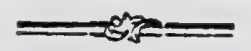

Eмв. magnitudine fere albuminis, compreflus, pallide luteus. Cotyl. ovatx, aut rotundatx, foliacex, planx, tenuillinx. Rad. longa, teretiuscula, centrifuga, aut vaga.

a.) Bacea integra. b. B.) Eadem transwerfim feita. C.) Seminum exteriorum in parietem baccre infertio. d.) Semina (eparata, E. F.) Embryonis figura \& fitus intsa albusnen, G.) Embryo de-
sudatus.

De Cucunerum fabrica multum quidem hic fructus tenet; fed ab omnibus hactenus cognitis Cucumeraceis differt, fitu fupero \& feminibus notabiliter albuıninofis, qux in ifis exalburninola effe folent. 
Tab. 224

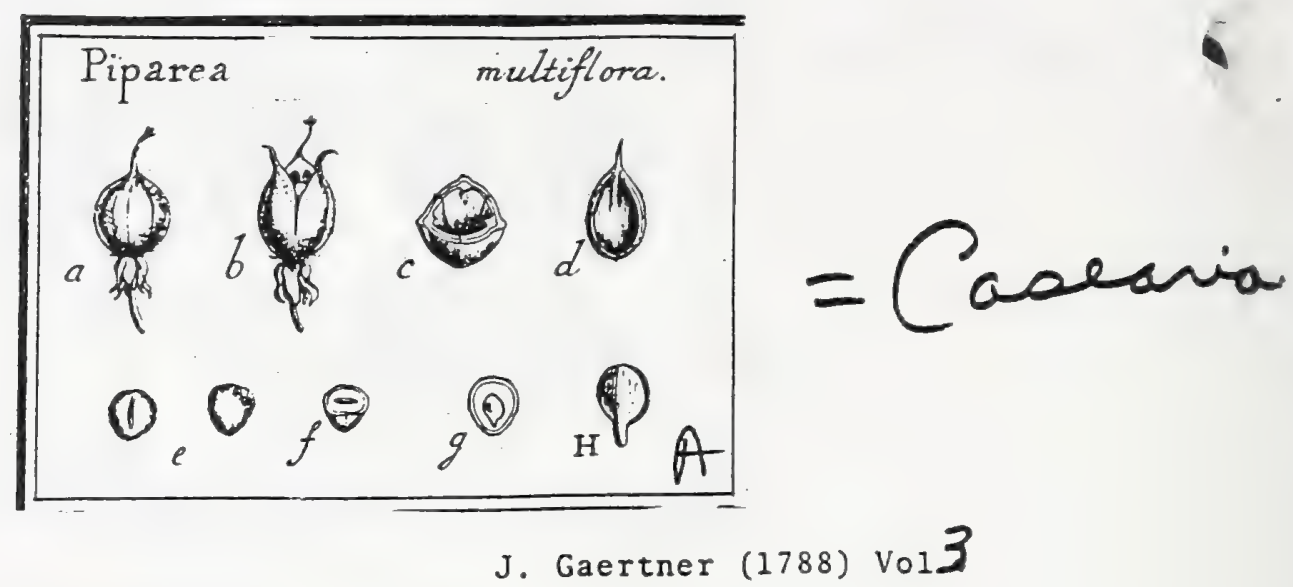

231

\section{P I P A R E A.}

A бвI. guian. t. 386 . Juss. gen. P. 295.

Cal: monophyllus, quinquefidus, inferus, perfffens; laciniis ovatis, acutis, demum releris. Cor. fub ovario cum ftaminibus inferta. . . Stam. ... Ovar. fuperum; ftylo fimplici, filiformi; ftigmate tripartito, obtufo: Capfula duplicata, rotundato - trigona, unilocularis, trivalvis. Rec. nullum. Sem. tria (duobus fxpe abortientibus,) hirfuta Alb. carnofum. Emb. erectus; cotyledonibus foliaceis.

Piparea multilora. - Tab. 224. fig. I.

an Piparea dentata. AuBL. '1. co app. p. 31 ?

Ab amicilfmo DaO DEcandolle:

PER. Capfula vix femipollicaris, ovato-globofa, rotundato-triquetra 1. fulcis tribus elevatis obloletis infignita, hinc ftylo filiformi terminata, inde calyci perfiftenti retexo infltens, pubefcens, duplicaca; lamina exieriore tenui, coriacea, per atatem fufea: interiore paulo craffiore, charcaceolignofa, albida, intus pubefcente; cxterum unilocularis, ab apice per latera dehifcens, trivalvis.

REC. nullum; preter fulcos elevatos villofiufculos coltis externis obverfos deorfum deliquefcentes, quibus femina umbilicis adhxrent.

SEM. ovula tria, rariffime vero vix uno plura ad maturitatem pervenientia; hinc fxpiffime folitarium . cordato-fubglobofum, hirfutum, ad ventrem cicatricula lineari deorfum deliquefcente umbilicali alba notatum, fubinverlum, fufcum.

IN T. duplex: exterius craffufculum, chartaceum, interius membranaceum; tenue, aduatum.

\section{2}

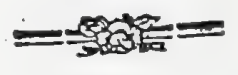

A L B. fernini conforme, carnofum, craffum, lutefcens.

E a B. albumine ipfo dimidio fere brevior, \& ad ejus bafin locatus, erectus, albus. Cotyl. oblique ovarx, foliacez, incumbentes. Ras. brevis, obtufa, ab umbilico extermo averf́, infera,

\section{EXPLICATIO FIGURE.}

a.) Cupfula integta, non dehifcens. b.) Eadem dehifcens. c.) Elusdem fedio transverfalis. adharct. e.) Semen folitarium, integrum, a veatro -) Ejusdem fecio longitudinalis, cum fitu ęmbryanis. H.) Embryo folutus.

Ob femina immatura in noftris fpeciminibus catyledonum forma non fatis certa,

Folia magna, alterna, ovato-oblonga, apice muçronulata, integerrima, per ambitum vix undulata, breviter pedunculata, nervora, glabertiom noltram dicelli unituri, aggregati ex foliorum axillis fpecie ab illa Aubleții diverfam ệe, fufpicor, 


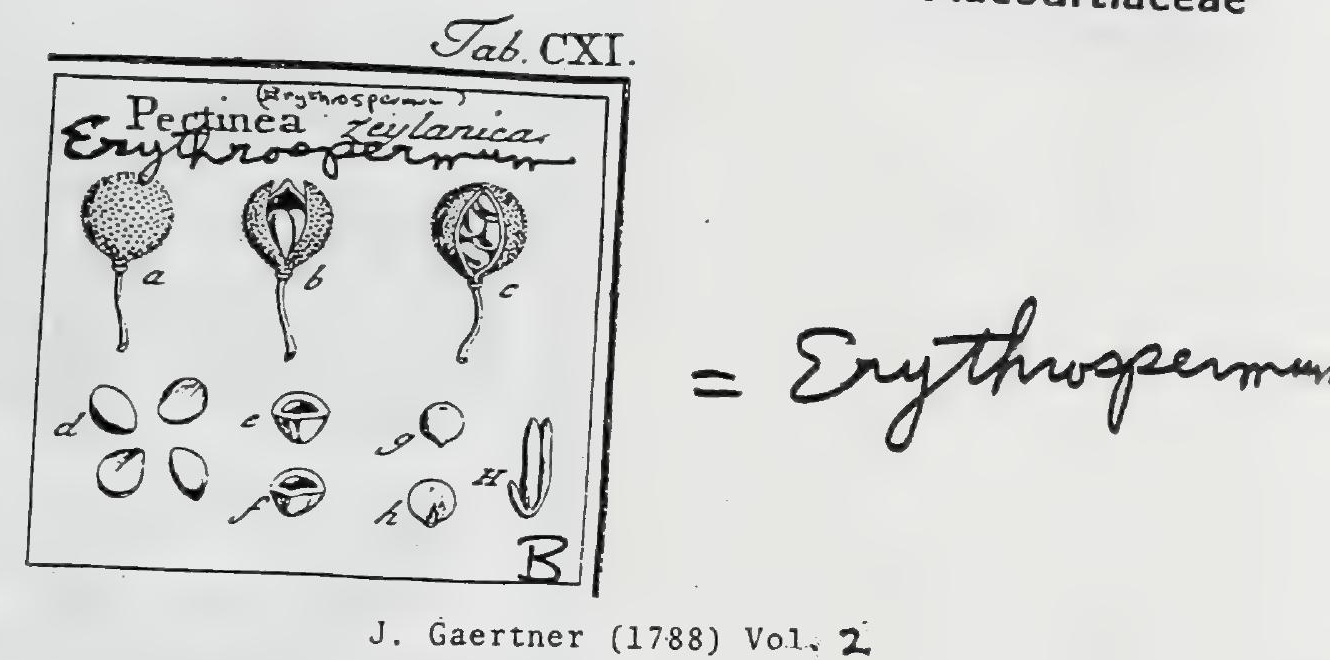

I36

\section{P E C T I N E A.}

Flos ..... Capfula baccam unilocularis. Semina offea colorata. Embryonis radicula verfus centrum feminis uncinato reflexi.

Pectinea zeylanica. Tab. II f. fig. 3.

Dodbam-para. Zeylan. HerM. muf. Zeyl. 67. BURM. Zeyl. 89.

E collect. fem. hort. lugdb.

PER. Capfula baccata, fubglubofa, unilocularis, trifariam ad bafin fere ufque dehifcens. Cortex coriaceus, craffus, extus punctis elevatis confertifimis fcabratus, fumofus aut fufcus; intus lxvis, fplendens, luteo fpadiceus. Pulpa in immaturo fractu feminibus circumfufa, aquofa, per maturitatem penitus evanefceris.

REC. nullum; fenina fundo capfulx affxa, aut in pulpa nidulantia.

SEM. duo, tria, \& plerumque quatuor, grandiulcula, hinc convexa, inde varie angulata, offea, rubra.

IN T. triplex: extimum, pellicula fubcarnofa, lateritio 1. miniato rubra; meditum offeum, craffum, teftaceum; intimum membranaceum, tenuifimum, pallide albicans.

A L в. cavitati femin. couforme, carnofum, crafum, ālbum.

EM B. dimidio albumine brevior, uncinulatus, linearis, lutefcens. Cotyl. lineari oblongx, comprefre, planx. Rad. brevis, teretiufcula, in uncun, a bafi feminis, verfus ejus centrum retexa! vaga, aut, in feminibus geminatis, infera.

2.) Capfula integra. b.) Eadem dehileens, difperma. c) Alia tetrafyerma d.) Semina Lepa-

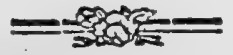

rats, integra. e. f.) Tetar feminis transverfim feda. g) Albumen integrum. h.) Idem longltudinaliter difekum, çum Gtu \& figura 'Embryonis' H.) Embryo Solutus \& auchus. 


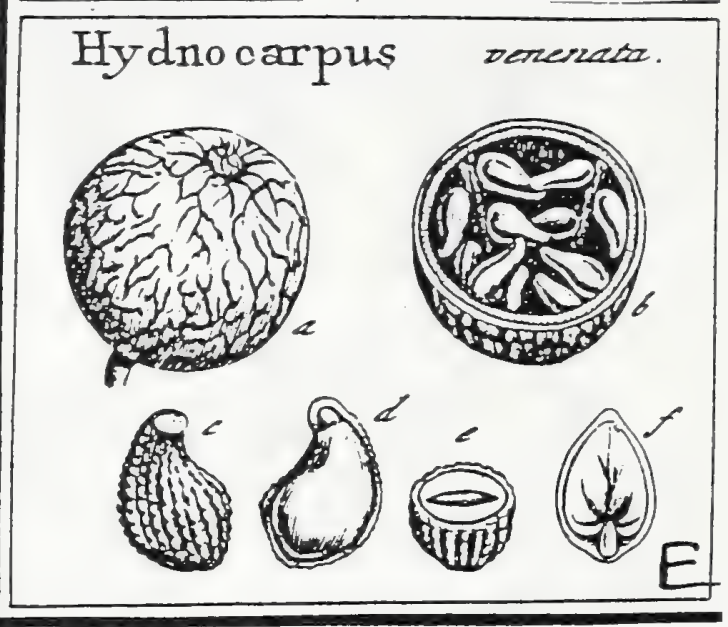

J. Gaertner (1788) Vol. I

\section{HYDNOCARPUS.}

Flos ..... Bacea fupera, tuberculo \& quatuor figmatibus feffilibus refiexis umbo. nata unilocularis. Recept, parietalia. Sem. tuberculato fülcata.

Hydnocarpus venenata. Tab.60. fig. 3.

Makulu, E Makulu-ghaha arbor. Herм. zey!. 5o. BurM. zeyl. $3^{\circ}$.

E collect. fem. hort. lugdb.

PER. Racca fphxrica, apice tuberculo fubrotundo deprefiusculo \& quatuor figmatibus rethexis terminata, fubtomentofa, rimofa, inflar tuberis efculenti rugofa, c cinero fordide liclvola, unilocularis. Cortex exterior tenuis, fungofus, pubclcens; interior albicans, granulofus, friabilis. Pulpa, per xtatem exarefcens, \& in grumofam fubfantian converfa parietibus bacex atque leminibus adharens.

REc. frix quatuor parum elevatx, fuberolx, Jateribus baccx inferiptx, quibus fémina affixa,

SEM. numerola, e quibus vero plerumque duo aut tria tantum adulefennt, grandia, gibba, ovata, verfus umbilicum in roftrum curvatum anguftata, ihique callo gla. bro, albicante, prominulo dotata, ceterum friis tuberculato licabratis exarata, canefcentia, aut cinera.

INT. duplex; exterius cruftaceum, durum, craftum, fragile; interius menbranaceum, ferrugineum.

$\Lambda\llcorner B$. fumini conforme, amygdalino carnofum, craftum, album.

EM в. magnitudine fere albuminis, compreffus, niveus. Cotyl. ovato cordatx, folia. cex, tenuifimx, quinquenervix. Rad. brevis, extrorlum craftior, centrifuga

a. b. ? Bacea integra \& difneta, cum infertione ovulorum. c.) Semen maturum feparatum. d.) Nucleus deoudatus, e.j Seminis \& albuminis retio transverfalis. f.) Embryo intra albumeti.

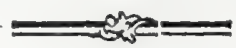

Fructus comeni ebrietatem inducunt \& avide devorantur a pifcibus Lellu \& Pethijo, alias fatis delicatis; eo vero tempore, quo fructus Makulu maturefcunt, tales pilces nequaquam comeduntur ob vomitus aliaque fymptomata, qua $a b$ efu horum pifcium caufantur. Bu R M. L. c.

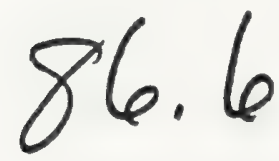




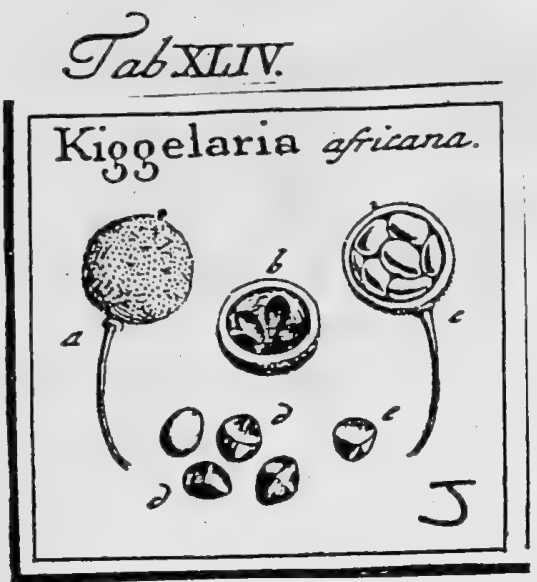

J. Gaertner (1788) Vol.1

206

CCL. IIIGGELARIA. LIN N. gen. 1128 .

Flores fexu diftincti in feparatis truncis. Mas. Cal. quinquepartitus. Cor. pentape. tala. Nechar. glandulx quinque trilobx. Stam. decem, anthosis apice perforatis. FEM. Cal \& Cor, ut in mare. Nectar. nulla. Styl. unicus; figmata quinque filiformia. Capfula baccata unilocularis. Scmina sidulantia.

KigGelaria africana. Tab. 44 fig. 4.

Evonymo affinis athiopica fempervirens, fruttu globofo Jcabro. P L U x. plingt. to. 176. $f .3$.

Kiggelaria. Lis N. h. Cliff. t. 29. Syf. veg. 89r.

PER. Capfula baccata globofa fabra unilocularis. Cortex coriaccus craflus, extus pubefcens atque atomis granulofis fcabratus, intus ab exarefcente pulpa, in foveolas feminibus adaptatas exfculptus, per tmaturitatem quinquevalviso. Pulpa teunis cellulofo meinbranacea, rufelcens.

REc. aulluin; femina vario fitu pulpx inmerfa.

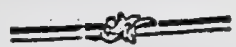
SEN. pauca, circiter octo, grandiuscula, hinc convexa, inde varie angulata, rofes-
ccutia. Centia.
IN T. triplex: extimum, pellicula tenais a pulpa exficcata; nedium coriaceum, te-
nue; intinum inembranaceum, chalaza fulea notatum.

AI . . . . . .

Езв.......

a.) Caprala intrgra. b.) Eadem difrecta. c.) Situs Seminum, d.) Semina (eparata, e) Tefta Seminis transverle fecta. Setninis transverle fecta.
prxcedenti, cuin tanta in reliquis fructificationis partibus inter las plantas inter-
presium, quin nucleus feminis, quem hactenus non vidi, formatus fit ut cedat conformitas.

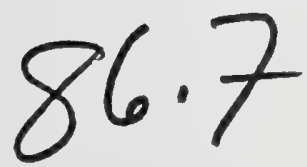




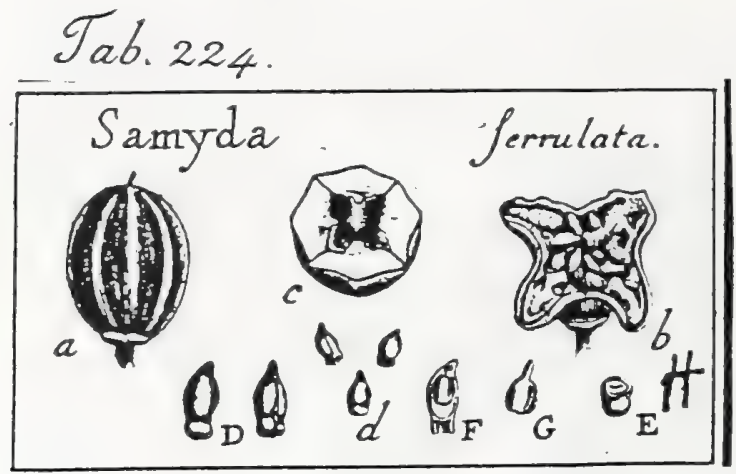

J. Gaertner (1788) Vol3

239

\author{
189. S A M Y D A. \\ LrnN. gen. 543. ed. Schreb. 755. Juss. gen. p. 439. \\ LAMABCE ill. gen. t. 3j5. Guidonia. Pruar. gen. \\ t. 24 .
}

Cal. monophyllus, quinquepartitus, coluratus, perfiftens; laciniz ovato-lanceulatx, patentes. Cor. nulla. Stam. 10-18.; filamenta in tubum conicum, medio calyci infertum, 10-18 ftriatum, totidemque dentibus antherileris intructum, connara; antherz erectx, fubrotunda. "Uvar. luperum; ftylo limplici, tiliformi; Itigmate globolo. Capfulä ovato-oblonga, coriaceo-carnula, unilocularis; quadri-1. quinquetariam dehifcens, polylperma Rec nullum. Sem. numerola, baccata, gigartoidea, umbilicara. Alb. casnolun. Emb. inverlus.

SAMYDA lerrulaca. Tab. 224. fig. 8:

240

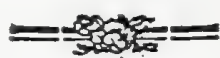

Guidonia ulmifolio, fore rofeo niveo. PLUM. ic. t. J46. f. 2.

Samyda floribus dodecundris. Jace. amer. p. 132. Collex. 2. p. 328. t. $x 7$. f. $\mathbf{I}$.

Sanyydi foribus dodecandris, foliis ovato - oblungis ferrulutis. LINN. Spec. pl. p. 558. $S$ f. veg. ed 14. p. 40 g. W1LLD. Spec. plo T. 2. P. s. p. 626. YERSUON Jjo. io p. 4840

Ex Infula Hirpaniola, a Doo Porteau.

PER. Capfula pollicaris \& ulera, ovalis 1 . globofa, calyci perfiftenti infiftens, ftyli reliquiis faltigiata, rotundato - octo - 1 decagona, extus fetulis minimis hirca, coriaceo-carnofi, unilocularis, ab apice ad medium usque quadrı. 1. quinquefariam dehifcens. Valva crafix, intus fulco elevato incralfatx, transverfim rugofæe, incomplet $x$, ad medium usque dehifentes, $\&$ apice revoluto patentes.

REC. nullu!n : femina umbilicis valvularum rugofitatibus horizontaliter adhai rent, ut apice axim bacce refpiciant.

Se s. plurima, baccata, 1. intra facculum carnofum teltxe ventri adnatum in: clufa, gigartuidea l. ovato-oblonga, apice mucronata; bafi truncara \& foramine umbilicali profundo inftructs, glabra, ferruginea.

IN T. triplex: extimum carnofu-pulpofum, linea ventrali teftx adhrerens; modium teftaceum, crafiufculum, fragile, fovea profunda umbilicatum; intio mum membranaceum, tenue, albumini adnatuin, pallidum.

A L B. femine multo brevius, ovato_oblongum, apice acuminatum, bafi ob. tufun, carnofum, Jutefcens,

E M B. albumine paulo brevior, \& ad ejus apicem locatus, inverfus, albus. Com tyl. ovato-oblungx emarginatx, foliacex, longicudinaliter figmoideo-plicatz, accumbentes. Rad. Lineari - teretiufcula, cotyledonibus paulo bro: vior, obtura, umbilico externo e diametro contraria, centripeta.

\title{
EXPLICATIO FIGURE
}

a.) Capfula integra, non debifcens. b.) Eadem quadrifariam dehifcens, eum feminibus in fitui c.) Ejusdem fectio transverfalis, feminitus cxcutts. d. D.) Semina feparata. E.) Idem prass verfe diffectum. $F_{0}$ ) Ejusieun fectio longitulinalis, cum litu embryonis inisa albamea, G.) Embryo Solutus. 


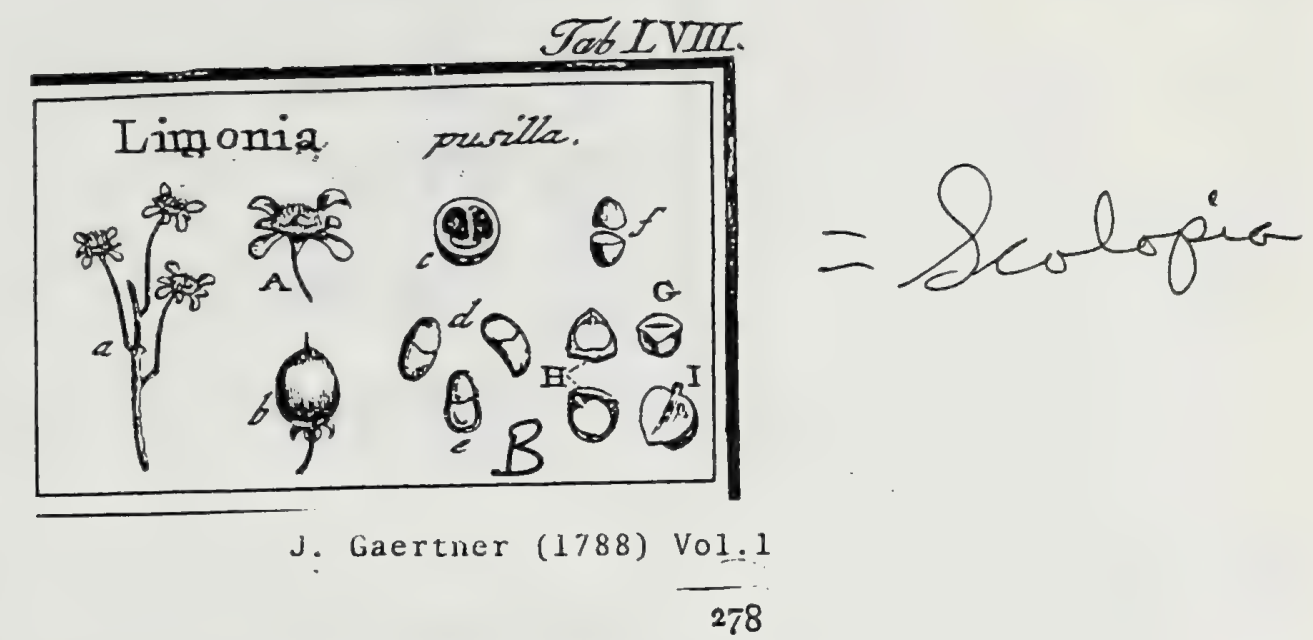

CCCL. LIMONIA. LINN. gen. 534 .

Calyx-quadi-1. quinquefidus. Cor. tetra-1. pentapetala, calyce duplo Iongior. Stam. decem-1. numerofifima, petalis breviora. Styl. unicus. Bacca trilocularis. Pulpá a loculamentis difcreta, fernina aridli adinftar involvens.

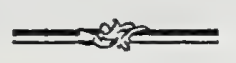

LiMONis pufilla. Tab. 58. fig. 4 .

Malus limonia lentici folio zeylanica, fruftu minino; warum magnitudine. PLuK. al!n. 239?

Khatu-Kurundu. zeylonens. E collect. fem. hort. lugdb.

PER. Bacca elliptico Splaxroidea, nylo brevi terminata, carnofo-coriacea, intus tribus fulcis prominulis in tres loculos incompletos divifa. Pulpa, undique a loculamentis per membranam propriain tenuifimam fegregata, \& in tres folliculos molles oblongos formata, in quibus femisa locantur.

REC. nullum; femina in pulpa folliculorum hxrentia.

SEM. in fingulo folliculo gemina, rarius terna, fibi mutuo impofita, ad mutuum contaftum oblique \& irregulariter truncata, cetera fubovata, hinc convexa, inde an gulata, nigra, fubsplendentia.

IN T. duplex: exterius cruflaceum, tenue, fragile; interius membranaceum, rufefcens.

Aцв. Semini conforıne, craftum, carnofun, album.

Ex B. longitudine albuminis, compreffus, inverfus, gramineo viridis. Cotyl. fuborbiculatx, foliacex, tenuifimx. Ràd. brevis, fupera.

a. A.) Flores in racemo longo, longiffime pedunculati: pedunculis bafi erticulatis, tetrapetall, polyfiemones, b.) Bacca integra. c.) Eadem diffela. d.) Folliculi pulpofi clauli. e.) Unas eorum Jongitudinaliter apertus, cum fitu feminum. f.) Semini feparata. G.) Albumen tansverfe fettum. H.) Embryonis fitus intra albumen. 1.) Embryo feparatus.

Non en Limon pufillus fylveflris zeylanicus Bu R m. zeyl. r43.t. 65.f. r. cui quippe alius floris partium numerus \& diverfiftumus intlorefcendi modus. Monophyllam tamen \& hanc effe, ex zeylanico nomine conjictre licet: nam Khatu-kurundu, fignificat Cinnamomum fpinofum, atque hinc fufpicioni locus ef, quod nirps noftra, foliis \& externo habitu, Cinnamomo fimilis, fed fpinis fuis, diverfa fit.

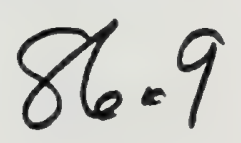




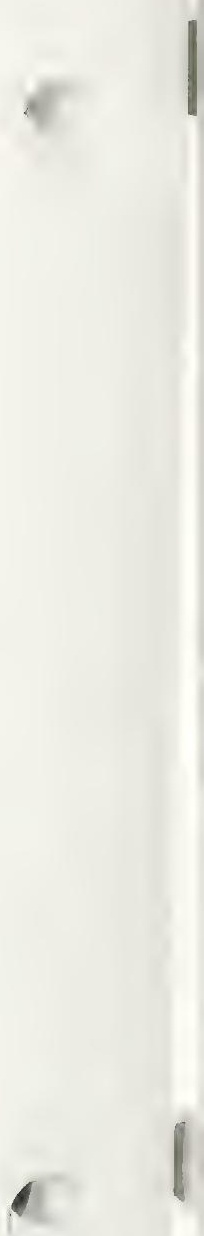

1 


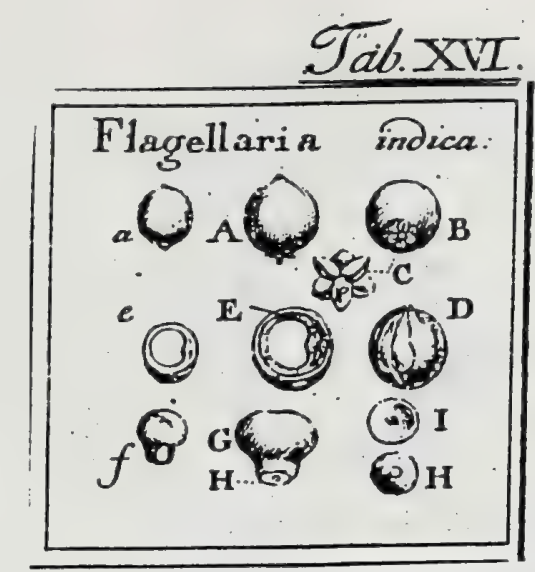

J. Gaertner (1788) Vol.1

\section{FLAGELLARIA.}

Calyx hexaphyllus coriaccus: foliolis tribus exterioribus ovato lanceolatis; interioribus rotundatis; omnibus concavis. Drupa baccata, fupera, trilocularis. Embryo patellixformis, extra albumen pofitus!

F 1 A GELLARIA indica. Tab. 16 . fig. 9 .

Palmijuncus lavis. R омг в. amb. 5. p. 120. t. 59.f. 1 .

Arundo farmentofa indica baccifera, foliis in extremo-capreolatis. BORM. $\mathfrak{l}$. zeyl. 35 .

Ghoigiwal. zeylonens. E collect. fem. hort. Jugdb.

P E . Drupa baccata, fupera, rubra, magnitudine baccx juniperi, bafi munitz calyce perfifente, apice auten terminata rudimento ftyli, absque ullo floris fuperi veftigio. Caro tenuis, in vetufto fructu coriacea. Putamen durum, corneum nigro fufcum, globofum, ex altero latere protuberantia deprefliuscula, Lanceolato-cordata \& tenuiffuna linea longitudinali infcripta, notatuin; intus uno loculamento grandi, fertili, \& duobus terilibus, fere obliteratis, fub ifta protuberantia locatis, excavatum.

REc. nullum : femen obtufo fuo vertice, loculanenti fornici agglutinatum.

SEM. unicum, fubturbinatum, feu fuperne globofum, inferne coarctatum \& juxta loculamenta obliterata, areâ planiulecula impreftum, cetera pallide rufefcens ac in vertice linca transverfali, cafaseo-fufca notatum.

IN T. finplex, membranaceum, tenuifunum, nucleo undique arftifime adnatum, nifi prope embryonis fidem, ubi facile folvitur.

A L8. femini conforme, farinofum, friabile, candidilimum.

Eм в. monocotyledoneus, frblutefccns patellxformis, in bafi feminis extra albumen locatus \& a folo intcgumento feminis proprio obtectus, Patella orbiculata, tenuif-

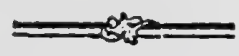

fima, magnitudine bafeos albuminis, cui exactifime refpondet \& leviter falteın agglutinata eft: intus modice concava, extus vero convexa \& in medio minutifima papillula radiculari notata.

a. A.) Drupa in fitu erecto, B. C.) Eadem inclinatx, ut calyx C.) in confpectum veniat. D.) Putamen integrum 2 parte protuberantize fux lauceolato-cordace fpectatum, c. E.) Putaininis fectio uransverfalis, cum tribus fuis loculanientis. f.) Semen maguitudine naturali. G.) Iden, naturali majus \& detracto ad bafin integumento, ut fitus embryonis $H_{\text {. ) }}$ in conf (pectum veniat. $H_{\text {. }}$ ) Embryo nis patella a parte coavexa, I.) Eadem a parte concava spectata. .

Hanc nou effe Flagellariam Linn. ex folo floris fitu abunde liquet; inalui tamen retinere nomen, fub quo hic fructus a $\mathrm{Cl}$. R $\mathrm{R}$ Y $E$ No mihi datus fuit, quam novum ei facere; prafertin quum \& defcriptio Palinjunci lavis Ru $\mathrm{M}$ Pr. quem ad fuam Flagellariam excitat LINN.EUS, fatis bene in nofram quadret. 


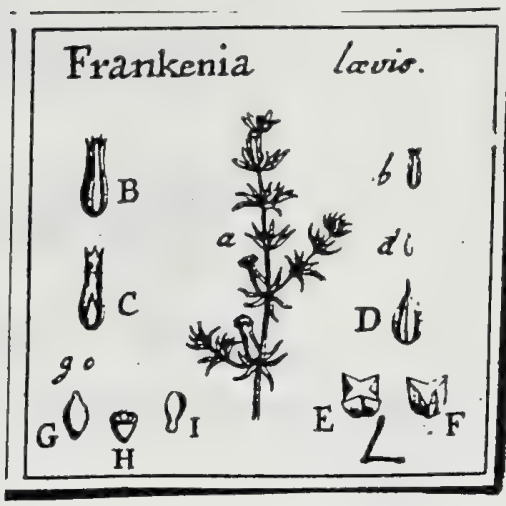

J. Gaertner (1788) Vol 3

36. F R A K E I A.

LinN. gen. 445. ed. Schreb. 604. Juss. gen. p. 303 .

L A \IA вс K ill. gen. $t .262$.

Cal. monophyllus, fubcylindricus, angulatus, quinquedentatus. Cor. pentapetala : petalorun ungue longitudine calycis, intus canaliculato. Stam. fex. Ovar. fuperum. Styl. unicus, @tigmatibus tribus. Capf. tri-1. quadrivalvis. Sem, plura. .

Frankenia levis. Tab. 184 fig. 12.

Franka maritima Jupisa faxatilis glauca evicoides fempervirens, fore purpureo. Mick. gers. t. 22. f. 1. male fi noftra.

Frankenia folits linearibus confertis bafi ciliatis. LINN. $\sqrt{3} 3$. veg. ed. 14. p. 344.

Frankenia foribus folitariis, petalis fubrepandis obtulis, foliis linearibus baficiliatis. WILLD. Spec. pl. T. 2. P. x. p. 241.

A Cl. Hekarann defund. Prof. Argentor., \& ex Collectione Bankfiana.

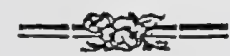

PER. Capfula ovato - acuminata, parva, angulata, tri - 1. quadrivalvis, polyfperma. Valvula lanceolate, acuminatx, planiufculx, fulco medio bipartitx, menbranacex, rigidiufculre, rufefcentes.

Rec. nullum; feminz arcola derafa in bafi capfulx funiculis umbilicalibus adhxrentia.

SEM. plura, octo ad duodecim; fed unum tantummodo ad plenam maturitatem pertingens, reliquis omnibus abortientibus; ovatum utrinque acuminatum, glabrum, exiguum, caltameum.

IN T. fimplex, tenue, membranaceum.

A LB. vaginale, in duas laminas xquales embryonem contegentes divifum, farinofum, album.

$E_{N}$ в. rectus, piriformis, viridulus. Cotyl. rectx, oblongx, craffiufculx, obtufx. Rnd. brevis, coryledonibus gracilior, obtufinlima, infera.

\section{EXPLICATIO FIGURE.}

a.) Ramulus frugifer, cum fuliolis Eliformibus confertis glaberrimis, b. B.) Calyx fepatates integer. C.) Idem longitudinaliter apercus, cum capfule fitu. d. D.) Capfola Separaz. E.) Eaden quadrivalvis, \& F.) trivalvis transverfe dilecta. g. G.) Semen (eparatam. H.) Albumen transverle dift Eum cum litu eunbryonis. 1.) Embryo folutus.

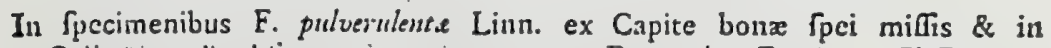
Cullectione Bankliana atiervatis, nec non F. vevoluta Forst., a Cl. DeLiLe ex Aesypto allatis, maxinum capfularum numerum deprehendi quadrivalvem, in F. levi $L$. ex parte putiore caplulx erant trivalves. Semina in duabis prioribus fpeciebus rarius calli \& inde ab adjacelltrbus compreffa \& angulata, reliqua autem cum $F$. levi omnia paria lunt. 


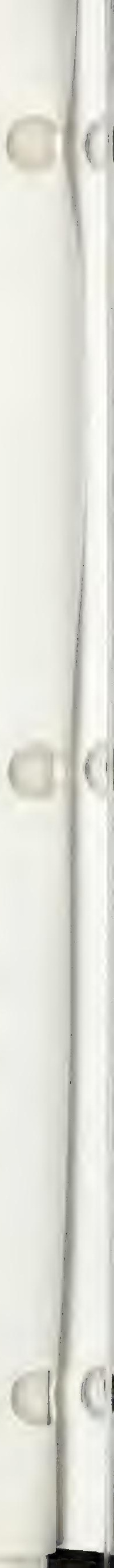




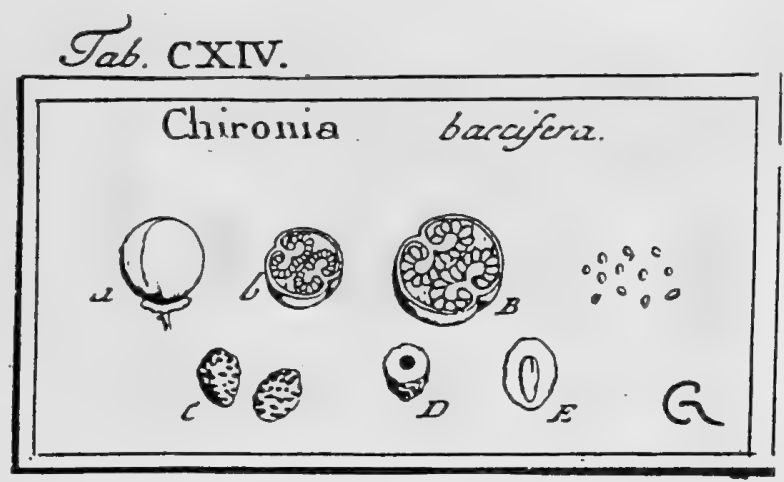

\section{J. Gaertner (17.88) Vol, 2 \\ 156}

DCLXVII. CHIRONIA. LINN. ger. 255.

Calyx quinquefidus. Cor. quinquefi.ta, rotata. Stam. quinque : antheris demum contortis. Ovar. fuperum. Styl. fimplex. Capfula aut Bacca uujlocularis. Receptac. lateralia, oppofita. Sem. plurima.

Chironia baccifera. Tab. 114. fig. 3.

Centaurium mimus arborefcens pulpiferun. CoN. rar. g. t. 9.

Clivonia frutefcens buccifera. Livs. Jj\%. veg. 2=9.

Ex herbario BankGano.

PER. Bacca fucculenta, fubdiaphana, globofa, didyma, rubicunda aut crocea, unilocularis. Cuticula tenuiftma, tranfparens. Pulpa aquofa, fed receptacula fpongiofa.

REc. duo, utrinque parietibus baccex longitudinaliter \& fecundum ejus fulcum externum affixa, introrfum biloba: lobis ad latera recurvatis.

SE s. Munerofa, parva, ovato. globofa, fcrobiculata, e caftaneo- nigricantia.

Is T. duplex: coriaceum tenue, \& membranaceum rufefcens.

A L в. carnofum, craflum, aqueo-pallidum.

Ess 8. dimidio albumine longior, teretiufculus, lacteuș. Cotyl- femicylindricx, breves. Rad. attenuata, ceutrifuga.

a.) Bacez integra. b. B.) Eadem ditreta, cum receptaculorum, feminumqque figura \& infertione. c. C.) Semina feparate intcgra. D.) Albumen trasverfim, \& E.) Ideal longitudinaliter diffeQum, cum figurz \& fitu Embryonis.

Etiam in Ch. frutefcente. Linn pericarpium baccatum eft, fed, precedenti multo minus, totum intra calycem latens, ovatum, acuminatum, rubrum, \& per ztatem in duas valvulas, juxta fulcum, fecedens. Semina \& reliqua omnia pracedenti fimillima funt. 
Gentianaceae

Tab. CXCVIII.
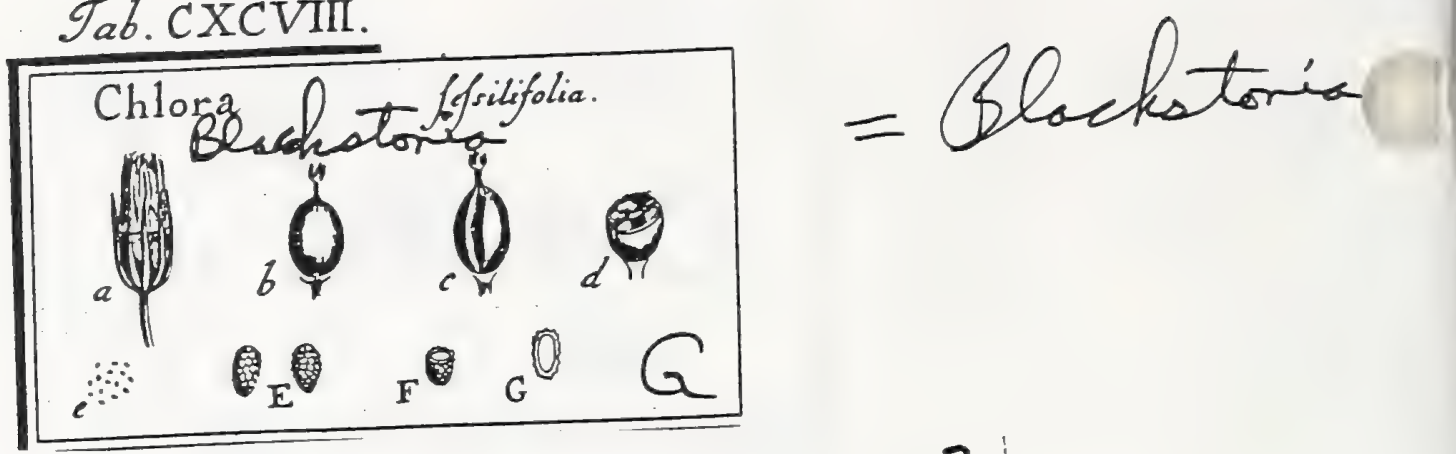

J. Gaertner (1788) Vo13

110

Blackstoric fuds.

Sснвев. gen. 653. Juss. gen. p. I42. Lamarce ill. gell. t. 296. Blakftonia. Huds. ang!. 146.

Cal. monophyllus, inferus, 8. J.10. L 12 . partitus, perfiftens. Cor. monopetala, hypoctateriformis; tubo brevi, linbo 8. 1. 10.1. 12. partito. Stam. 8. 1.10. 1. 12.; filamentis brevilfinis, ad faucem tubi infertis; antheris linearibus, erectis, exfertis. Ovar. fuperum; ftylo finplici; ftigmate quadrifido. Capfo oblonga, at latera dehifcens, fubunilocularis, bivalvis. Rec. nullum. Sem. plurina. Alb. carnofum. Emb. ...

Chrora fefrilifolía. Tab: 198. fig. 7 . E collectione Cel. Deșrontaines.

Pzr. Capfula ovato-oblonga, fupera, a calyce odo partito perfiftente laxe amplexata, coriaceo-menibranicea, compretiulcula, l. transverfe paulo latior quam cratfa, ftylo perfiltente faltigrata, ad latera debifcens, fubbilocularis, bivalvis. Valve naviculares, margine introlexie. Diffepimentum incomplesum, a margine valvularum intexo ortun, duplicitum, longitudinaliter dimidiatum, membranaceun, valvis parallelum.

Rrc. nullum; proter margines dilfepimenti pubefcentes, quitus femina duplici ferie athixa.

Sen. plurima, minuta, oblonga, reticulato-fcabriufcula, atrofufca

IN T. fimplex, membranaceum, reticulato - vafculofum.

A L B. Senini coufurne, carnofum, album.

EM B....

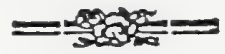

II

EXPLICATIO FIGURZ्Z

a.) Capfula ints calycem fefilis, \& corolla emarcida in vertice inftrudta. b. Eadera clanta, \& a calyce denuidata. c.) Eadem a lateribns dehifens. d.) Ejusdem featio transterGlis. e. E.) Semins foluta. F.) Albumen transverfe - \& G.) Jiem verticaliter fectum

89.2 


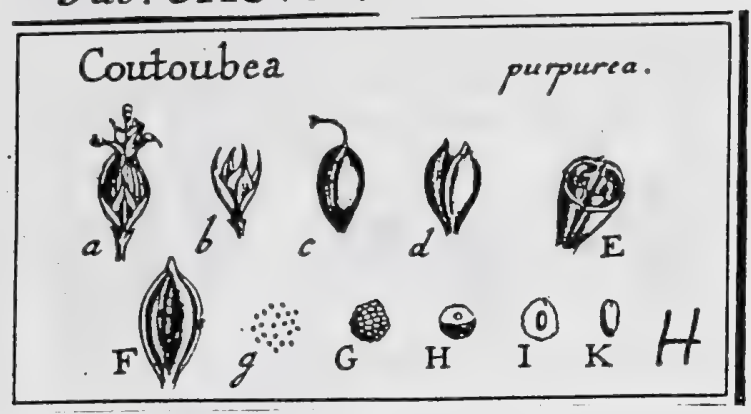

J. Gaertner (1788) Vol. 3<smiles>C=CC</smiles>

\section{9r. COU T O U B E A.}

AUвL. giry. t. 27. Juss. gen. p. I4I. Lamarci ill. gen. t. 79. Picrium. Sc hreb. ger. 1726.

Cal. bafi bracteis minimis inftructus, inferus, quadrifidus, perfftens: Iaciniis oblongis, acuminatis, margine fcariofis. Cor. monopetala, infundibuliformis; tubo calycem vix fuperante; limbo quadrifido. Stan. quatuor; filamentis medio tubo infertis, ad bafin dilatatis, fuperne margine fubconniventibus, corollam fuperantibus; antheris erectis, fagittatis, exfertis. Ovar. fuperum; ftylo fimplici; ftigmate bilamellato. Capf. ovata, fubbilocularis, bivalvis: diffepimentis incompletis, duplicatis. Sem. numerofa. Alb. carnofum. Emb. centralis, rad. vaga.

Covtoubea -purpurez. Tab. 198. fig. 8.

Coutoubea (ransofa,) foliis angufis, acuminntis; flore purprorafcente. AUBL. guy. I. p. 74 .

Exacum floribus fubfpicatis oppofitis, foliis lanceolatis, caule ramofo. VАHL.

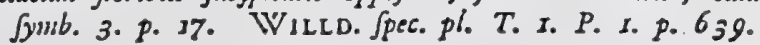

Coutoubea (purpurea,) caule ramofo, fioribus pedicellutis oppofitis axilluribus. LAM. ill. gers. 23. 3556. PERSOON fyr pl. x. p. J37.

E collectione Cel. Desfontaines.

P IR. Capfula fupera, a calycc perfiftente excepta, ovato-oblonga, ad bafin paululum attenuata, turgidula, ad dehifcentic futuram fulco elevato cincta, feninibus undique referta, unilocularis, bivalvis. Valvula naviculares, coriaceo - membranacex, teutues, marginatx. Diffepinenta incompleta, duplicata, ex pariete valvularum interno paulum intra marginem orta, angufta, membranacea, intra cuvitatem capfulac intorta.

REC. nullum; nifi nargines diffepimentorum pubefcentes fumas, quibus femina adhxreut.

SE M. numerofa, ninima, vaga, fubglobofa, hinc inde a vicinis comprefra, reticulata, pallide fpadicea.

IN T. Ginplex, membranaceum, tenue, reticulato - vafculofum

A 1 в. Semini conforme, craflum, carnofum, album.

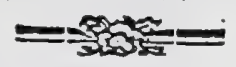

EMr. minimus, centralis, oblongus, albus. Cotyl. brevifimx, obtufre. Rad. coryledonibus multo longior, oblonga, obtura, umbilico externo obverfa, vaga.

\section{EXPLICATIO FIGURE.}

a.) Capfula cum corolla emarcida h.) Caljx feparatus. c.) Caplula denudata, ftรlo inltruda, noul dehifeens. d.) Eadem dehifeens, \& feminibus fareta. E.) Ejusdem fectio transverfalis cum fitu diffepimentorum. F.) Valvula altera feparata cum forma \& fitu diffepimenti incrumpleti. 5. G.) Semina filuta. H.) Albumen ttansverfe - \& 1.) Idem verticaliter fetum cum fitu
embryonis. K.) Embryo feparatus.

Ex his liquet, Coutoubeam cum Exaco in unum genus compingi non poffe. 
Gentianaceae

Tab. cXrv.

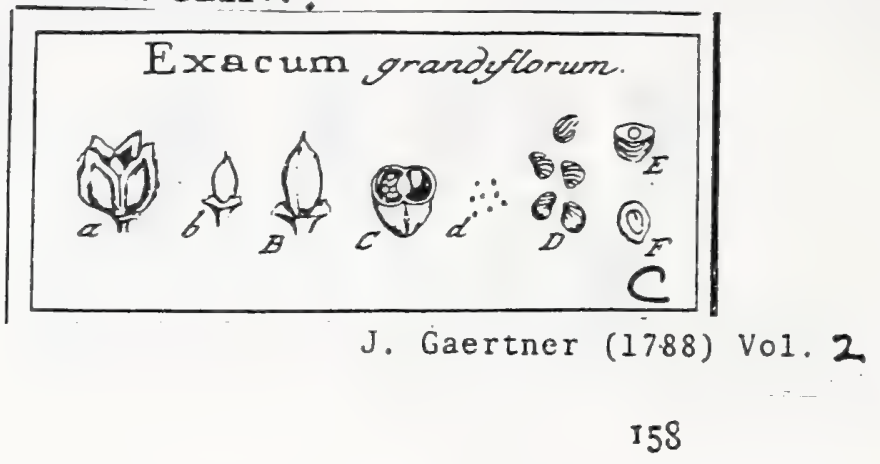

DCLXIX. E X A C U M. LINN. gen. I4T.

Calyx quadriphyllus. Cor. quadrifida: tubo globofo. Stam. quatuor. Ovar: fuperum. Styl. fimplex. Capfula bilocularis. Receptac. centsale adustun. Sem. numerofa, Atriata:

Exacum grandiflorum. Tab. 114 fig. 5.

an Exacum cordatum. LiNe. fuppl. 124?

Ex herbario Bankfiano.

PER. Capfula, intra calycem profunde quadrifidum atque in lacinias oratas, margine membranaceas \& in apice mucrone linguiformi ftipatas fectum, latenş, ovatu - obionga, membranacea, tenuis, fubdiaphaua, fulco profundo utrinque infcripta, bilocularis, apice dehifcens.

REC. fungofum, difepimento utrinque longitudinaliter \& in medio adnatum.

SEM. plurima, irregulariter angulata, fubovata, ftriis profundis parallelis, obliquis, transverfis, aut longitudinalibus inferipta, albicantia.

IN T. duplex: cruftaceum atque membranaceum, utrumque tenue.

A L R. carnolum, craffum, aqueo - pallidum.

F. а в. dinidio albumine longior, teretiufculus, lackeus. Cotyl. femicylindricx, breves. Rild. reda, centripota.

a) Calyx capfulam cingens, magaitadine naturali. b. B.) Capfula denudar, integra. C.) Eait 'in diffeetz, cuin fitu receptaculi. d. D.) Semiuz (cparata. E.) Albumen transverfe \& F.) Idem longitudinaliter diffectum, cum litu \& figura Embryonis.

89.4 


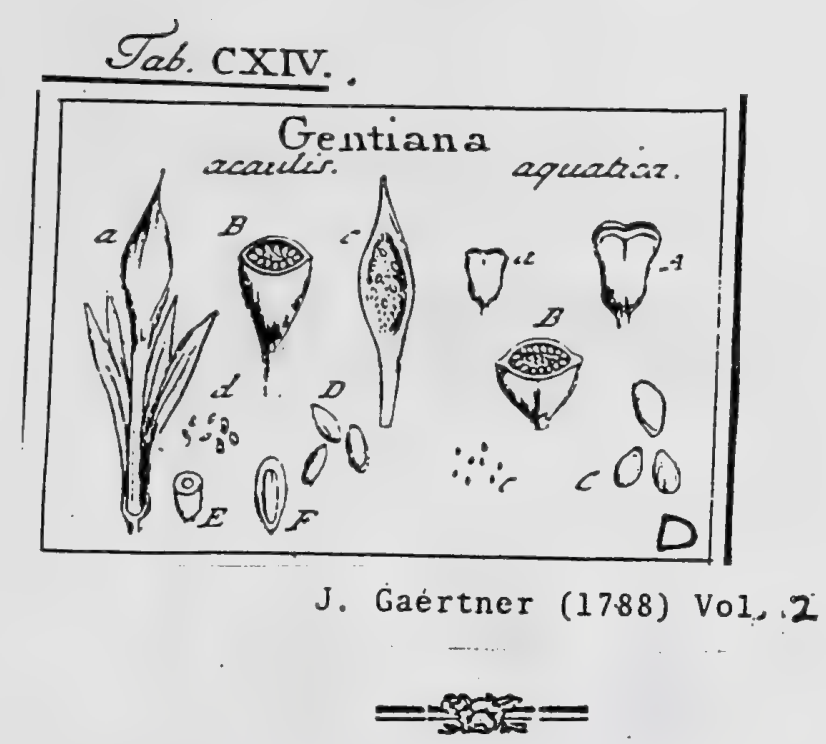

\section{DCLXX, GENTIANA. TOURN. inft. t. 40. LINN. gen. 322.}

Callyx varius, fxpius tamen quinquepartitus. Cor. varia, frequentius quinquefida. Stan. fxpius quinque. Ovar. fuperum. Styl. fimplex aur Itrgmata duo fefiliz. Capfula unilocularis, bivalvis, compreffurfcula. Semina parietibus capfulze undique aftixis.

Gestians acaulis. Tab. 114. fig. 6.

Gentianella verza major. Crus. biff. 3 r 5 .

Gentiana foliis lanceulasis, caule zoniforo, fore musims campaniformi. HaLl. biff. 31. 642 .

Gentiana corolla qquinguefida campanulata caulent excedente. L1NN. [y/f. veg. $\$ 67$.

Icors. JAce. flor. auftr. 2. t. 135 .

Ex Sibiria, a Cl. Laxmanu.

PER. Capfula fufiformi-clavata, parte ventrali turgide lenticulari, uniloculari, bivalvi : pedunculo \& apice folidis.

REC. nullum; femina parietibus internis capfula undique affixa.

SE M. numerofa, elliptica, utrinque attenuata, fpadicea; glitbra.

IN T. fimplex, membranaceum, tenue.

A L B. carnofum, modice craflum, album.

EN B. longitudine albuminis, teretiufculus, lacteus, Cotyl. femicylindricx, breves. Rad. longa, centrifuga.

2.) Capfula istegra. B.) Eadem transverfim fetza. c) Valvola altern, eam infertione feminum. d. D.) Semina feparata. E. F.) Embryonis in albumine fitus \& Egura.

Semina in fibiricis plantis glabra, nec ut in helveticis undique fulcatr: dummodo fructus, quos ex fide LAXMANNI recenfui, de hac, nac de alia quadam fpecie lint defumit.

Gentiana aquatica. ibid.

Gentiana humilis aquatica verna. ANN. rutb. 4. t, r. f. T.

Gentiana corolks quingurefidis infundibuliformibus terunzalibur fefribus, folis margine membranaceis. LINN. fyft. veg. $=68$.

Capfula (a. A.) obovato-oblonga, f. burfiformis, lenticulari-compreffa (B.), apice transverfim dehifeens, unilocularis. Senina parietibus undique affixa, parva, ovato-acuminata, pallide fpadicea. Reliqua ut in pracedenti.

Etiann hujus fpeciei Gentianx fructum ex fide Laxmanni trado. Contraria quidem videntur, qux Linnxus de feminum forma in Anoeti. acad. Il. p. 316. profert, quando illa fubrotunda, comprellis \& leviter emarginaus dicic. Sed

hxc ipfa femina, non aquaticx, fed montans funt Meferfchmidii Gentianx, quam Linnxus, proceunte Ansmanno, 1. c. peffime cum aquatica confundit; fiquilum illa ne ad Gentianas quidem fpectet, quoniam ei Mefferfchmidius expreffe receptaculum fenimum centrale tribuit, quod ab omni vera Gentian conftanter abeft. 
Tab. CLXXXIII.

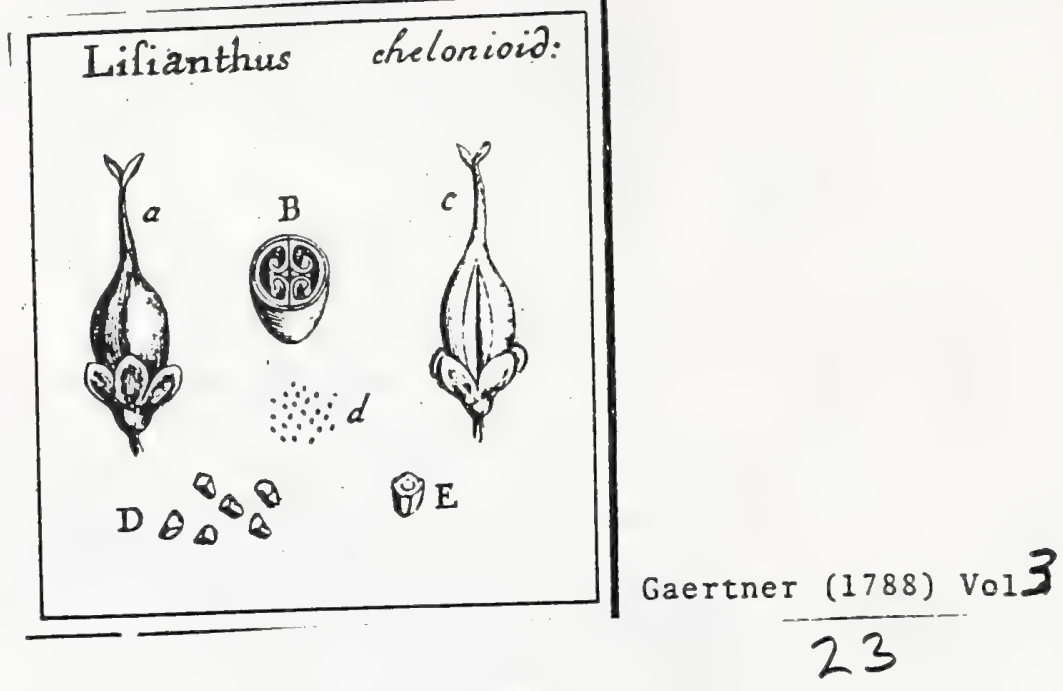

2r. I I I A N T H U S.

BвоWn. jam. t. 9. Linn. mant. pl. r. p. 6. gen. pl. ed.-Schréb. 274. Juss. gen. p. 142. L АМ А В

Cal. quinquepartitus, laciniis carinatis margine membranaceis. Cor. monopetala, bafi anguftata, tubo fuperne ampliato, limbo quinquefido. Stam. quinque. Ovar. fuperum. Styl. unicus, ftigmate bilobo. Capl. ovata, bilocularis, bivalvis, valvularum marginibus intortis. Sem. numerofa, parietalia.

Lisianthus chelonioides. Tab. 183. fig. 5.

Lifrantibus gluber, foliis oppofitis fubconnatis, panicula terminali diclotoma ra-

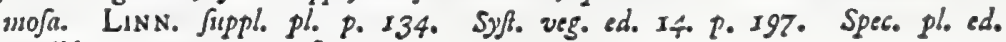
Willd. T. т., , 2, p. 827 .

A Cl. Thunderg.

PER. Capfula ovata, ftylo perfiftente roftrata, bilocularis, bivalvis, duplicata : Lamina exterior herbacea, tenuis per maturitatem fponte fecedens; interior charcacea, duriufcula, marginibus fuis infexis loculamenta formans. Duffepimenta duplicata, ex laminx interioris capfulx margiuibus inflexis, \& deincéps finibus fuis intra loculorum cavitates fere fpirali modo intortis.

REC. nullum: femina parietibus internis capfulx \& diffepimentorum undique affixa.

SE M. numerofifima, minutifima, angulata, rufefeentia.

INT. Gimplex, meiubranuceun.

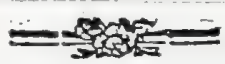

A I E. Femini conforme, carnorum, 2queo-pallidum:

EN B. teretiufculus, niveus. Cotyl. . . Rad. centrifuga.

\section{EXPLICATIO FIGUR居}

D.) Capfula integra. B.) Ejus fectio trasverfalis. c.) Eadem dehifeere lacipiens. d. D.) Se: mloa Toluta. E.) Albumen transverfe fetum.

Et] Semina perquam fint nilutula, embryonis tamen fubftantiam nivean diftinctiffme vidi; at cotyledones ob fummam partium minutiem difcernere non potuis

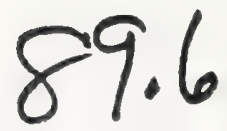




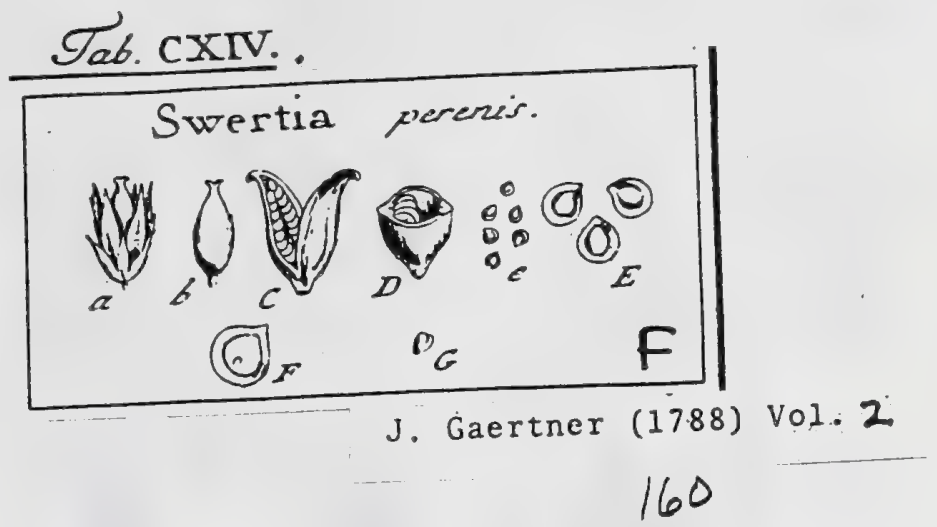

\section{SWERT IA. LINN. ger. 32r.}

Calyx quadri - 1. quiliquepartitus. Cor. quadri - 1. quinquefida. Stam. quinque, 1. pauciora. Qvar. fuperum. Stigmata fe(filia. Capfula unilocularis, bivalvis. Semina valvularum futuræ affixa, \& tamen Embryonis radicula centrip̧en !

Sivertia perennis. Tab. II 4 . fig. 7 .

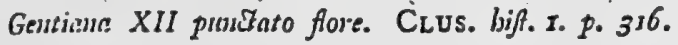

Gentiuna foliis radicalibus petiolutis owatis, floribus paniculatis rotatis fricatis. Hall. bijt. u. $6_{3} 6$.

Sirentin corollis quinguefidis, foliis radicalibus ovalibus. LINN. fy/t. veg. 266.

Icon. JACQ. flor. auftr. 3. t. 243.

PER. Capfula calyce \& corolla perfiftentibus cincta, ovato-oblonga, utrinque asunimata, fuperne tamen a divaricatis ltignatibus brevilfime biroltris, lenticulari-compresín, unilocularis, bivalvis.

KEC. nullum ; femina incrallatis valvularum marginibus duplici ferie longitudimali affu:a.

SE N. uumerofa, fuborbiculata, foliaceo-compreffa, lato margine membrana. ceo cincta, fcrruginea.

Ix т. duplex: utrumque membranaceum; cxterius folum in marginem anpliatum.

A L B. femine multo anguftus, orbicalatum, carnofum, e viridi lutefcens.

EMB. minutus vato globofus, lacteus, in extremitate albuminis unbilico directe oppofita locatus. Cotyl. breviffimx. Rad. obtufa, axem fructus reficiens, f. centripeta.

1: b.) Caprula integra C.) Eadem dehif(ens. D.) Ejus fedto transwerfalis. c. E) Semina (epranta integra. F.) Seminis \& albuminis fcêtio longitudinalis, cum fitu \& figura cmbryouis. G.) Embryo folutus.

Quantacunque etiam fit Swertiæ cum Gentiana affinitas, tanell in unum genus, propter diverfilfimum feminum \& embryonis fitum, non fociari polle videutur. 


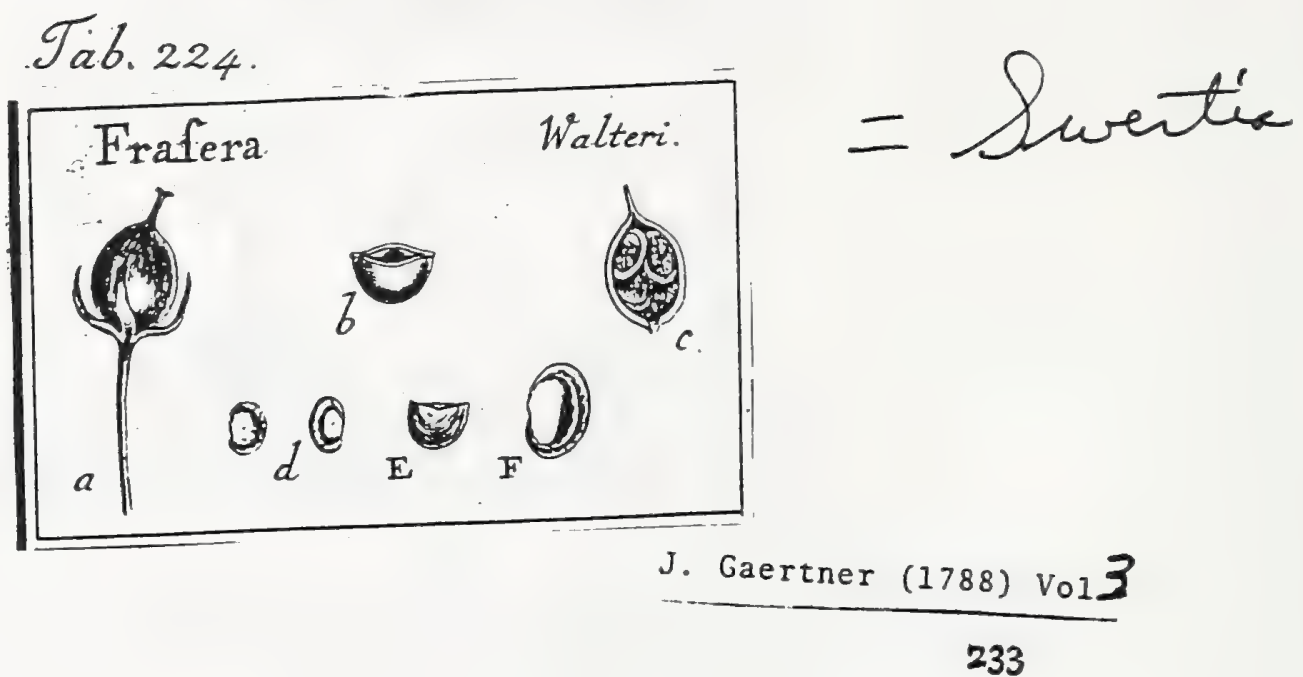

\section{F R A S E R A. Walt. \\ Miehaux flor. bor. amer. I. p. 96.}

Cal. monophyllus, quadrifidus, perfiftens; laciniis lanceolatis, patentibus. Cor. monopecala, calyce multo major, quadritida; laciniis ovatis, pacentibus. Glandula magna ad medium fingula laciniz, orbicularis, fublenticularis, barbata. Stam. quatuor, cum corollx laciniis alterna, \& an ejus ba. fin inferta; filamenta fubulata, bafi dilatata, margine membranacea; antherx ublungz, bali emarginatx, denum retexic. Ovar. fuperum; ftylo funplici, Itigmate bipartito, obtufo. Caṕfula coriacea, lenticuları-comprelfa, unilocularis, bivalvis. Recr.nullum. Sem. plura, parietalia, compret5a, Alb. carnofum, Emb. ....

Erasera Walteri. Tab. 224. fig. 3.

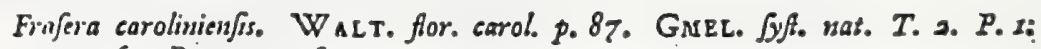
p. $=56$. Persoon fyn. 1. p. 137 .

Frafera (Walteri, ) eresta alsilfima, foliis oblongo - ovalibins verticillatis oppofit: sisque. Michaux l. c. p. 97.

Ab amiciflimo $D^{\text {ao }}$ Drcandolle.

PER. Capfula femipollicaris, ovata, ftylo perfiftente mucronata, calyci infiftens, primum carnofa, denique cartilagineo-coriaces, lenticulari-com. preffa, per ambitum vix incralfata, bafi paulo cralfior obcufa, unilocularis, margine dehifcens, bivalvis.

RRC. nullum : fenina margini valvularum interno utrinque duplici ferie adharent.

S B M. multa, 12-18, bracteata, ovato-orbicularia, foliaceo-compreffa, integerrima, nucleo protuberante excentrico \& medio puncto oblcuriure inGignita, fpadicea.

IN T. duplex: exterius membranaceum, in marginem feminis ampliatum; intevirs tenue, albumini adnatum.

A $\llcorner$ B. femine anguftius, \& extra ejus centrum prope marginem externum locatum, ovatum 1. ellipticum, compreffum, carnofum, album.

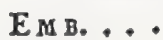

\section{EXPLICATIO FIGURE.}

a.) Capfula tategra b.) Ejusdem fedtio transverfalic c.) Valvola altera feparata, enm feminam fitu atgue infertione. d.) Semina feparata. E.) Idem tranarerfe diffequm. F.) Integumenuman feminis externum, nucleo deftitutum. 
marchatem

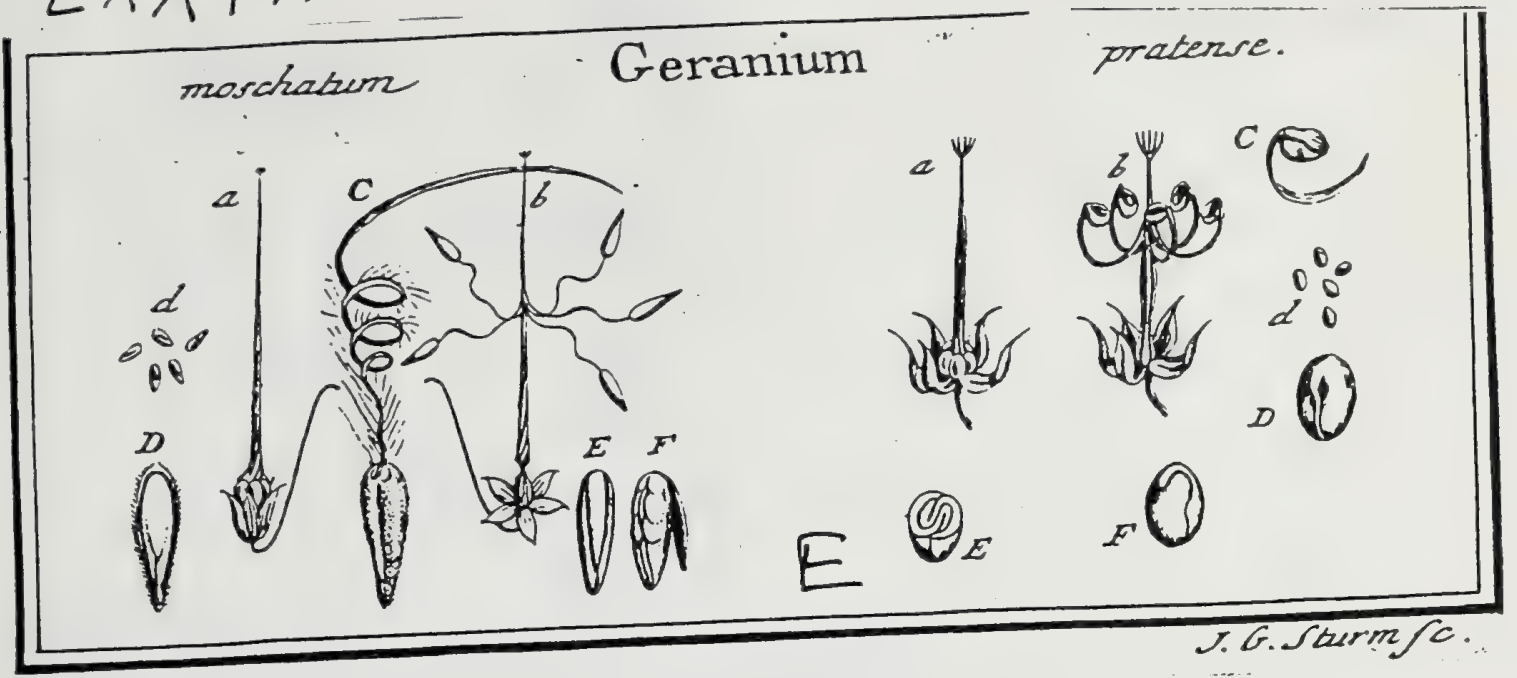

J. Gaertner (1788) Vol.1

D. GERANIUM. T TouRN. t. 142. Lin N. ' gen. 837.

Calyx quinquepartítus. Cor. pentapetala. Stam. quinque ad decem. Stigm. quinque. Receptac. commune roltratum. Cocculi quinque, cauda longiffuna tortili.

GFRANIUM mofchatum. Tab. 79. fig. 5 .

Geranium rubertianum. R Iv. pent. t. 124 . $\mathcal{E} G$. foetens. t. us.

Geranium petiolis multifloris, caule procumbente, foliis duplicato pinnatis, pinmulis acute incifis. H A L L. hift. 1. n. 944.

Geranium pedunculis multifloris, floribus pentandris, folis pinnatis incifis, cotyledonibus pinnatifidis. LINN. fij/. veg. 615.

PE R. Cocculi quinque oblongi, deorfum acuminati, utrinque linea longitudinali infeript, villofi, melini, unilocalares, non dehifentes; fupra terminati cauda longifima, pilofa, lincari, tortili.

R E c. commune fubulatum, quinquefulcatum longilfimum; proprium funiculus ambilicalis filiformis e bafi cocculi ad leminis ur.bilicum adfeendens.

S E 11. fulitaria, cocculi cavitati conformia, deorfum acumiuata, glabra, ferruginea.

\section{4}

IN T. duplex: exterius coriaceum; interius membranacenm, tenüfimum.

A L B. nullum.

Ex 8. magnitudine feminis, inverfus, albus aut lntefcens. Cotyl foliacex, confoluto: plicatx, pinnatifido - lobatz. Rad. lineari acuminata, compreffiuscula, enbryo paululum brevior, a vertice, verlus balin deflexa, recta, infer:

3) Fruttus mataras, integer. b.) Cocculi a receptaculo fecedentes, C.) Cocculns Séparatus, curm cauda fus tortili. D.) Semiais fitus intra cocculum, cam foniculo umbilicall- a) Semina magnl.: tudine naturall. E) Embryo a parte ventrali fpeltatus. F.) Ejosdem latus dorfale eum radicala paululum reclinsta.

GER A I U M pratenfe. ibid.

Geranium batrachioides caruleum. Best. h. Eyfs. vern. I. t. 8. f. 2. 3.

Gernnium caule ereato, foliis rugofis hirfutis multilobis, lobis trifidis, lobulis Semipinnatis, floribus umbellatis. H A 2 L. hift. 1. n. 93 t.

Geranium pedunculis bifloris, folits fubpeltatis multipartitis rugo is acutis, pe: talis integris. LIN N. Jy/. veg. GI7.

Cocculi ovato globofi (a) glabri, cauda lineari elaftica, vix tortili terminati (b. $)_{2}$ uniloculares, membranacei, melini aut lividi, latere interiori (b. c.) dehifcéntes femina cum impetu excutientes. Semina (d.-D.) elliptico globola, ad alterund latus linea elevata umbilicali notata, minutiffme puncticulata, cinerascentia. Ems bryo (F.) gramineo viridis, aut in vetuftis feminibus lutescens. Cotyledonet (E) figmoideo flexuofx, convolutz. Radic. (F.) brevis, deflexz; pice Juo fundum cocculi refpiciens. 


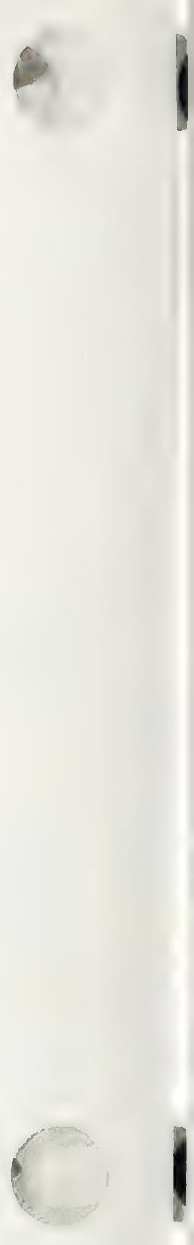




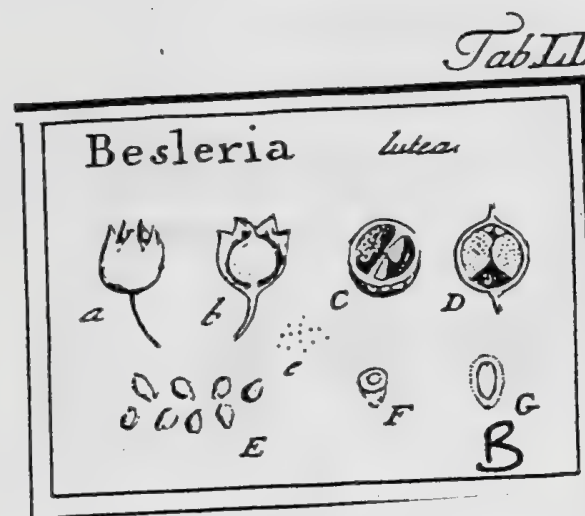

J. Gaertner (1788) Vol.1

$24^{x}$

CCXCVII. BESLERIA. PLUM. gen. t. 5. LIN ger. 755 .

Calyx quinquepartitus. Cor ringens. Stam. quatuor inzqualia. Styl. unicus. Baceafupera bilocularis. Diffepimentum in medio divilum. Sem. parietalia.

BESL ER I A lutea. Tab. 52. fig. 2.

Besleria virge aurea foliis, flore luteo, minor. $\mathrm{P}_{\perp}$ ч м. ic. $t .49$.

Besleria pedunculis fimplicibus confertis, foliis lanccolatis. L IN N. fi/f. veg. 559 .

Ex herbario Rankfiano.

PER. Racca globofa, pulpola, Aylo crafto brevi terminata, fublilocularic. Diffepimentun ex laminis duabus membranaceis, hinc baccx parieri affixis, inde liberis, quafi fluctuantibus, ora interna rotundatis.

Rec. funiculi umbilicales innumeri, brevistmi, capillares, ex omni intema bacex lupeficie oriundi, ut illa quafi villofa apparcat, quando pulpa elota $e$ f.

SEM. numerofifima, minutillima, ovata, obovata pvriformia, aut angulata, punchis clevatis vix difcernibilibus fcabrata, laturate rufeicentia, \&, fi plura in acernuluin congerantur, pulverem eleganter rubro ferrugineun referentix.

Iv $\mathrm{T}$. fimplex, tenuifinum.

A z. fernini conforme, carnofum, album.

Exs ธ. teretiusculus, niveus. Cotyl. brevifiunx. Rad. craftiuscula, centrifuga.

242

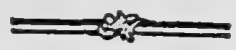

2.) Bacea ealyce veftita, b.) Eadem denudata. C.) Ejus fetio transverfalts D.) Difepimeat k melle in fitu. e. E.) Semina feparata. F. G.) Albuminis fetiones, cum fitu \& figura enibryonis.' 


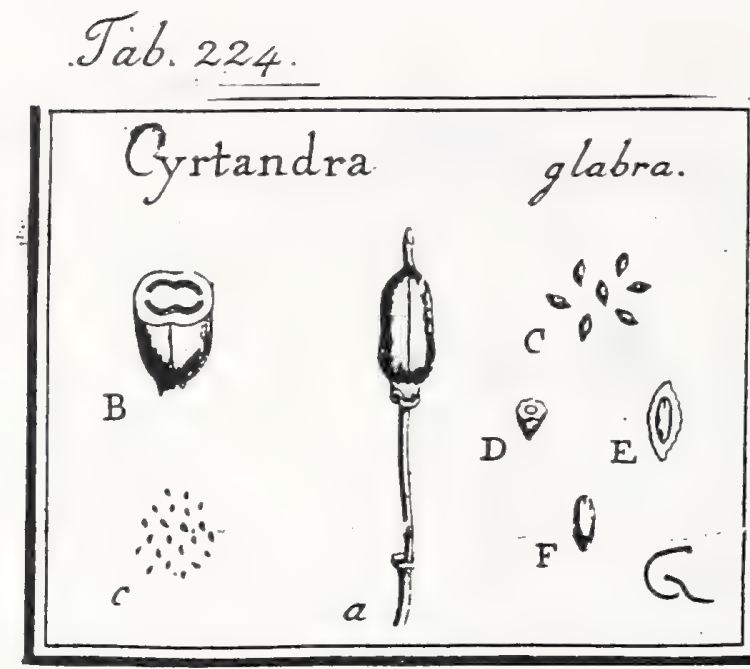

Gesneriaceae

J. Gaertner (1788) Vo13

\section{4}

\section{C Y R T A D R A.}

Fовот. char. t. 3. Juss, gen. p. I2I.

LAMA ICK illo gen. $t$. xt.

Cal. monophyllus, inferus, zqualis, fubbilabiatus, quinquepartitus : incifuris 'duabus inferioribus profundioribus, deciduus. Cor. monoperala, magna, irregularis; tubo incurvo, ad faucem ampliatu; limbo quinquelubo: Jaciniis inzyualibus, duabus fuperioribus płanis, tríbus inferioribus paientifimis, concavis. Stam. quatuor, didynama; flamenta duo fuperiora fertilia, tlexuola; duo inferiora caltraca, recta, filiformis. Ovar. fuperum; Itylo fim. plici, Ihigmate incrallato, bitido. Bacca ovata, corticata, bilocularis. Kec. nullum. Sem. plurima. Alb. carnolum. Ėab._oblongus; radicula centri peta.

Cyrtandra glabra. Tab. 224. fig. 4.

Cyrcandra glabra. Collect. Banks.

Habitat in Otahiti.

P IR. Hacca ovatu - oblonga, calycis reliquiis in callum incraffatis \& pedunculo longulimo inlittens, itylo cralliufculo faltigiata, lulcis duobus obfolecifi-

mis exarata, corticats, intus pulpofa, glabra, purpurafcens, bilncularis. Cortex craffiufculus, carnofus, lutefeens. Pulpa mucilaginofo-glutinofa, hyalina, femins obvolvens: Dillepinentum craftum, carnufo-pulpulum, fulcis exteruis contrarium. Loculamenta angufta, curvata, medio longitudimaliter fulcatr.

REc. nullum; femina funiculis umbilicalibus brevibus in pulpam refolutis diffepimento uadique adharent

SEM. numerofa, minuta, ovata, yerfus umbilicum aciminata, punctis eleva. tis fcabrata, centripeta, e rufo ferruginea.

IN T. Gimplex, membranaceum, tenue,

A L в. femini cunforme, carnofum, album.

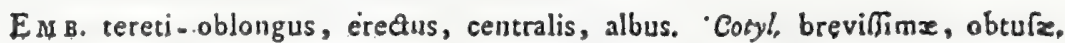
Rud, cratrufcula, atteouata, obtula, umbilico externo ubverfa, centripeta.

\section{EXPLICATIO FIGURAR.}

a.) Bacca integra. B.) Ejusdem fectio transverlalis, cum forms receptaoulorum \& fitu femin oum. c. C.) Semina (eparats. D.) Albumen transverle dilieaum, E.) Ejusdem fedio loagio tudinalis cum Gitu embryoais, F.) Embrỵo Colutus.

An fpecie diserfa a C. biffora Forst. 1 c. p. 6 .

Cyrtandra cymora. ibid.

Befleria $(c y m o j a$, pedunculis cymojis, pedicellis bradseolatis, foliis ovatis are. nasis, FORST, prod. "2, 237,

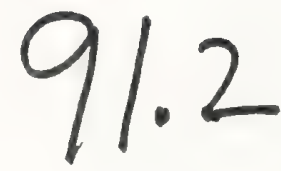

Cyrtandra pedunculis mudis, Fonst. clorr. p. 6.

Cyrtuntra pedunculis fubcymofis, foliis ovatis crenatis bafi obliquis frubers pubefcentibus. VAнL. Jymb. bоt. 2. p. 2. Enum. pl. 1. p. 104 WILLD. Spec, fl, T. I. P. I. p. 79, PERSOON fyk. 2. p. 165.

Ex collectione Bankfjana,

Bacea ovata, compreffiulcula, ftylo brevi obtufo faftigiata, calycis difoo callofo infidens. Reliqua omuia ut in priore.

Biccex inveftigatio in exemplis yetuftis yalde difficilis. 


\section{Tab. CIXXVII.}

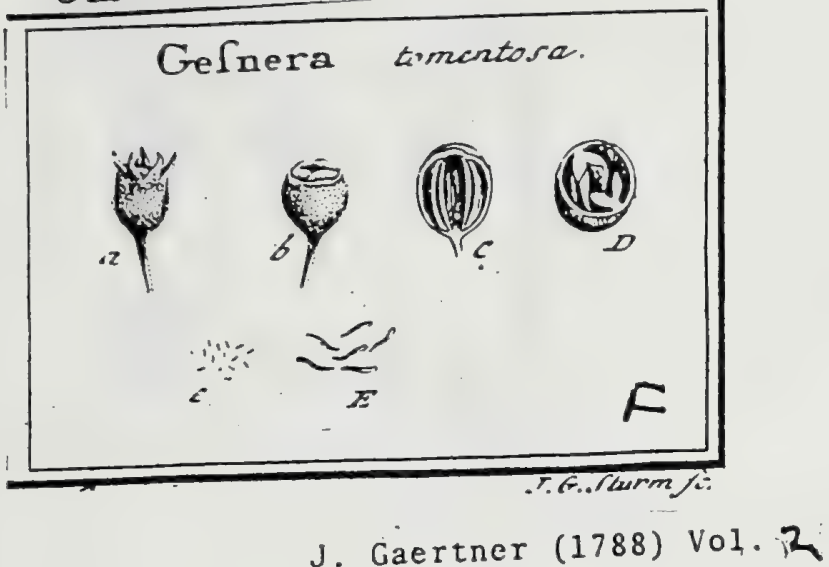

\section{1}

\section{G E S N E I A. PIUM. t. 9. IINN: ger. 749.}

Calyx quinquefidus ovario adnatus. Cor. fupera, monopetala, incurva, limbo quinquefido irregulari. Stam. quatuor didynama. Ovar. unicum inferum. Styl. fimplex. Capf. unilocularis. Receptac. parietalia. Sem. Icobiformia.

Gesneria tomentofa. Tab. 177. fig. 6.

Gesneria amplo digitalis folio tomentofo. PLUM. ic. t. 134.

Gesuera foliis ovato - lanceolatis crenatis birfutis, pedunculis lateralibus longifumis. corymbiferis. Jace. bift. 179. t. 175. f. 64. LiN. Jyj. veg. 554.

Ex herbario Bankfiano.

PzR. Capfula ovato-globofa, calyce fibi arcte adnato tomentofo corticata, ejus. que dentibus perfiftentibus coronata, unilocularis, apice foramine ovali dehifceus.

Rzc. duo, fungofa, oppofita, parietibus capfulx aduata, juxta axem a $\int_{e}$ in. vicem difcreta \& ex profundo fulco introrfum biloba, capfulam in duas concamerationes incer fe communicantes difpertientia.

SEM. numerofifima, minutifina, lineari - Scobitormia.

IN T. membranaceunt. . . .

AІв. . . . . E ER. . . . .

2.) Capfula calyce corticata. b.) Ejusilcm apex denudatus \& foramine dehifcens. C.) Eadem transverfim, \& D.) verticaliter dillecta, eum fitu \& figura reccptaculorum. c. E.) Semina Ieparata.

A receptaculorum fitu \& caplulx dehifcentia, affinitatem quandam cum Saxifragis habet.

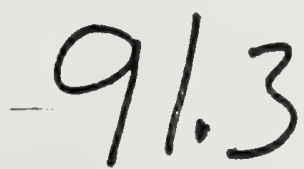


Globulariaceae

TabxtN.

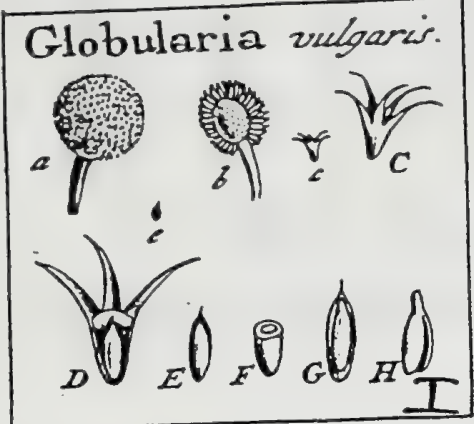

J. Gaertner (1788) Vol.1

2iI

CCLVII. GLOBULARIA. T о и R. t. 265. LIN g. gen. $I I 2$.

Flores aggregati in capituluin globofum. Cal. communis nullus, aut inbricatus; proprius monophyllus, quadri-L quinquedentatus: dentibus fetacico acuminatis. Cor. monopetala, irregularis. Stam. quatuor aqualia. Styl unicus. Semen uni-cuin, fuperuin, nudum.

Globularia vulgaris. Tab. 44 . fig. II.

Aphyllantes Anguillara. Camer. hort. 18. t. 7.

Globularia foliis radicalibus enarginatis ex nervo ariflatis, caulinis lanceolatis. H A L L. hift. "1. 218 .

Globularia caule herbaceo, foliis radicalibus tridentatis; caulinis lanceolatis. LiNN. figl. veg. 142 .

PER. nullum prxter calycem floris, aperturâ fuâ villis claufưn, feınen obtegentem.

REC. commune, ovato globofun, paleaceum; proprium uullum, preter fundum calycis, cui femen aftixum.

SEM. unicum, teretiufculum, parvum, fupra in flylum brevem elongatum, infra attenuatum, glabrum, nigro-fufcum.

IN T. fimplex, inembranaceum, albumini adnatum.

A в. Semini conforme, carnofum, aqueo-pallidun

Es B. longitudine fere albuminis; inverfus, viridis, aut obfrure ruf:feens. Cotyl. lineari oblongx, fubfoliacez, planiusculx. Rad. brevis, fupera.

a.) Capitulum maturum intexrum. b.) Receptac. commune denudatum. c.C.) Caljx proprius femen fovens. D.) Idem apertus. e.E.) Semen folutum, F. G.) Albumen diffectum, cum filu embryouis. H.) Embryo Separatus.

92.1 


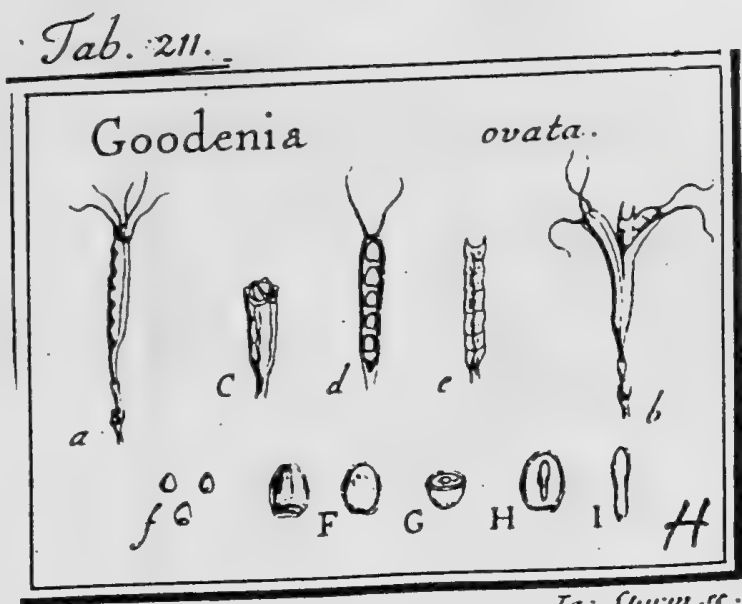

\section{GOODE.N I A.}

\section{Sмгітн ACF. Soc. Linn. Lond. 2. p. 346.}

Cal. monophyllus, fuperus; angulatus, quinquepartitus: laciniis linearibus, patentibus, perfiltentıbus. Cor. monopetala, irregularis, bilabiata; tubo brevi; labio fuperiore bipartito, reflexo: inferiore tripartito: Jaciniis omnibus margine undulatis. Stam. 5., filamentis fetaceis, arcuatis, inter lacinias labii fuperioris prominulis; antheris adnatis, linearibus, apice pubefcentibus. Ovar. inferum; ftylo fimplici, arcuato, longitudine ftaminum; ftigmate urceolato, ciliato. Capf. filiqux formis, calyce coronata, bilocula-ris, bivalvis: diffepimentum valvis parallelum. Rec. o. Sem. erecta, ovata, compreffiufcula. Alb. carnolum. Emb. oblongus, erectus.

Goodexia ovata. Tab. 211 . fig. 8:

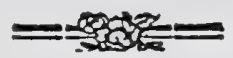

Goodenia foliis ovatis denticulato - ferratis glabris, peduneulis trifloris, fruifu linenri. Sмiтн 1. c. p. 347. W1LLd. -Spec. pl. T. 1. P. 2. p. 954. PeRsoov fyn. s. p. 195.

Icon. ANDREW. repos, t. 68. VENT. bort. celf. to 3 .

Ex colledione Cl. Desrontaines, \& a Cl. Ventenat.

PER. Capfula oblouga, elongata, fliquxformis, coriacea, calyce perfiftente coronata, 2 feminum protuberantiis nodulo $\Upsilon_{2}$, fulcis quinque elevatis, a calycis laciniis fubulatis prodeuntibus \& ad pedunculum ufque decurrentibus'longitudinaliter ftriata, pedunculata, pallide ferruginea, longitudinaliter dehifcens, bilocularis, bivalvis. Diffepimentum membranaceum, a feminum impreffionibus undulatum, ad apicem lunulato - emarginatum 1. bicufpidatum, nervo intermedio $a$ bafi ad apicem ufque adfcendente infignitum, valvis parallelum.

REc. nullum : femina umbilicis fuis papillulis minimis, a nervo intermedio diffepimenti derivatis, adhrent.

SEM. pauca, 5 1. 7. in quovis loculamento, parva, ereAa, bafi truncata 1. emarginata; hinc convera, medio fulcata; inde planiufcula, margine membranaceo anguftiffimo cincta, ad bafin umbilico minimo inftructa, Itraminea, 1. pallida.

Is T. duplex: exterius cruftaceum, fragile, quafi in duas valvulas fecundum marginem facile partibile; interitus fimplicilfimum, adnatum.

$\Lambda$ L в. femini conforme, plano-convexum, carnofum, album.

EM B. erectus, oblongus, comprefrufculus, rectus, niveus." Cotyl dimidio embryone paulo breviores, ovato-oblongx, plano convexiufcula, rectr, incumbentes. Rad. coryledonibus paulo anguftior, comprelfurcula, tere. tiufcula, ubilico obyerfa, infera.

\section{EXPLICATIO FIGURE.}

2.) Capfula integra, non dehifcens. b.) Eadem ab apice dehifcens, cum fita ditrepinenti. c.) Ejusdem fetio trancverfalis. d) Valvula altera feparata, eum feminibus in fim. e.) Dif fepimeatum folutum. - f. F.) Semina (eparata. G.) Albumen uansverfe diffectum H.) Ejus dem fettio longitadinalis, cum embrione in fitn. 1.) Enbryo folutur

Nova hujus generis fpecies, intermedia, in vaftifrma collectione BankGana proltat, eadem fructus fabrica gaudens, fed omnibus partibus minor; hinc valcle dubito, num G. bellidifolia, cui capfulam quadrivalvem tribuic Cel. Sastr, vere hujus congener fit. 


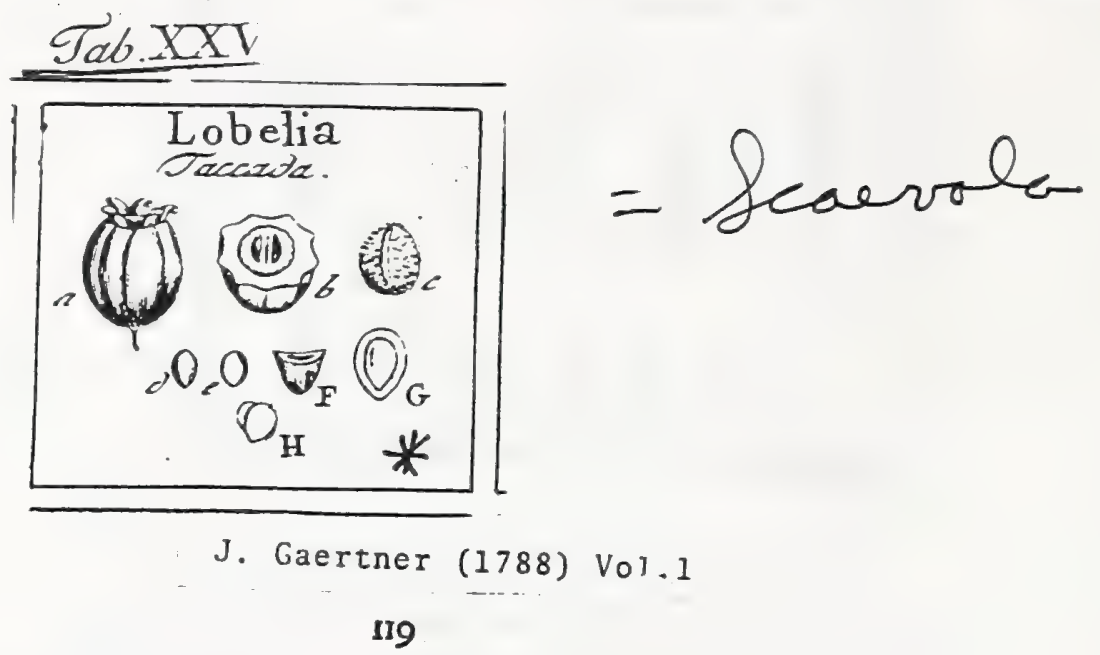

\section{LOBELIA. Plus. gen. t. 31. Scaevola. LIN gen. I294}

Calyx quinquepartitus, fuperus. Corolla'monopetala, unilabiata: fiffurs longitudi: nali in latere tubi labio oppofito. Stan. quinque. Styl. unicus. Drupa batcata, infera, bilocularis. Semina folitaria.

Loselia Taccada. Tab. 25. fig. 5.

Bela-Modngam. R не Е. mal. 4. t. 59 .

Buglođum littoreum. Ruмрк. amb. 4. p. 1I6. t. 54 .

Arbor exitio/a marina laftefcens indica, Taccada vocata, fruqu cerafi magritudine incarnato friato. HER M. nus:: zeyl. 45. B U R.M. Zeyl. 29.

Scavola. LIN N. Jyft. veg. 213.

Taccadis. Zeylon. E collect. fern. hort. lugdb.

PER. Druppa baccata, infera, calyce perfintente coronata, fubglobola, transverfin paulo craflior, fulcis feptem ad decem clevatis grufto modo friata, incaruata, demum fumo!a. Caro fungola, crafta. Putamen ofteum, fpharicum, tuberculato rugofusn , fatura fpuria elevata infcriptum, biloculare.

REC, nullum; femina fundo loculamentorum aftixa.

SEM. in fingulo loculamento unicum, rotundatum aut obovarum, prope bafin lo viter acuminatum, plaun convexum, albicans.

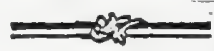

IN T. fimplex, meinbranaceum, non atcte adnatun.

A ц B. Semini contorme', tenue, carnolum, molliusculum, aqueo-pallidum.

Eм в. dicotyledoneus, erectus, magnitudine fere albuminis, lacteo albus. Cotyl. obovat $x$, hinc levifime convexx, inde planx. Radic, acuminata, brevinima, infera,

a.) Fructus integer. b.) Idem diffectus. c.) Putamen decorticatum. d. e.) Semivis facies utraque, F.) Albumen transverle fectum. G.) Idem longitudiualiter apertum, cum fitu em. bryonis. H.) Embryo (eparatus.

Deferiptio RuмpнII optime in nofrum fructum quadrat, nec multum quoque $a b^{*}$. eo abludit figura Hort. malab. 1. c. nifi quod calyx in tubum nimis anguflum con. tractus fit. Contra, in Lobelia occidentali, omnia alia funt: nam huic $1^{\circ}, c_{-}$ rolla aliter divifa; $2^{\circ}$. calyx in fructu nullus, ied margo faltem brevifinus in.: xqualiter quinque dentatus; $3^{\circ}$. Drupa ovalis, glabra, nigra; \& $4^{\circ}$. Putamen ovato acuminatum, tuberculis grandioribus undique muricatum. Conf. $P_{L} \cup$ ss. ic. t. 165. f. 1. JA c e.'ainer. defcript. \& t. 179. f. 88. Hinc Lobelia Taccada, fi non pro diverfa fpecie, faltem pro infigini varietate habenda erit.

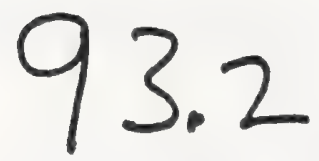




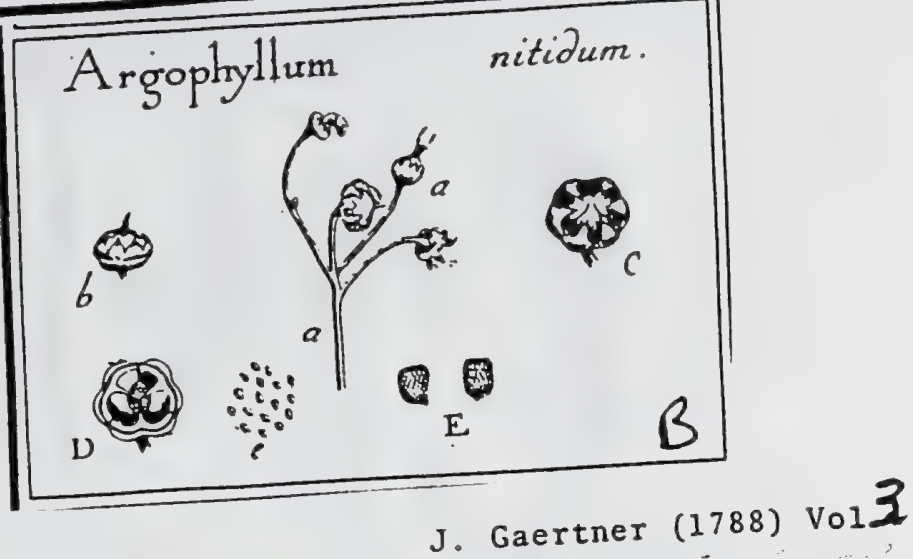

149

\section{ri4. A R G O P Y L L U M.}

ForS T, char. gen. t. I5. LIn N. Juppl. p. 22. gen. pl. ed. Schreb. 393 . Juss. gen. p. r6s. Lamarcx ill. gen. t. Ixt.

Cal. monophyllus, turbinatus, (quinque - For $\Omega$.) fex - dentatus, inferus. Cor. duplicata, parte exteriore (5.1.) fex-fida: laciniis angultis, calyce multo longioribus, patenti-relexis; parte interiore tubulo ${ }_{2}$, pyramidato - truncata, (s.l.) hexagona, ad bafin integerrims, limbo auten fere ad medium ufque fimbriata, Stam. (5.1.) 6.; filamentis. fubulatis, in ipfo angulo tubi infertís; antheris erectis, ovatis, bilocularibus, Ovar. feminferum; tylo fimplici; figmate capicato. Capfula femiinfera, deprefluffula, trilocularis, trivalvis: diliepinenta valvis coistraria. Rec. diffepinientis adnata. Sem. numerofa, rotundato - angulata, Alb. carnofum. Emb. ...

ArcopHYLLUS nitidum. Tab. $21 a$ fig. 20

150

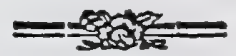

Argoplyllum. FORST. char. gen. p. 30. IINN. Suppi. po 156. Syft. veg. ed. 24. p. 242. Willd. Jpec. plo. T. x. P. 2. p. Ir.8. Peksoon fyn. I. p. 275 .

ab Cl. La Billardirre.

Per. Capfula parva, femifupera, a calyce fexdertato adnato amplexata; depreflo - pyramidata, obfoletifime rotundato - trigona, apice tribus fulcis infculpta \& ftylc perfiftente faftigiata, coriacea , fufca, trilocularis, trivalvis, ab apice per fulcos dehifcens. Difepimenta coriaceo-membranacea, valvis contraria, mediis valvis adnata.

REC. nargo difepimentorum internus, rotundato - incraffatus, pubefcens a funiculis umbilicalibus brevillimis, quibus femina umbilicis adhrentent.

SE M. numerofa, rotundato-angulata, cuneiformi - pyramidata, 1. oblonga, ab adjacentibus hinc inde planiufcula, umbilico nimimo protuberante notata, centripeta, ferruginea 1 . fufca,

IN T. duplex : exterius membranaceum, reticulato - vafculofum; interius tenuif: fimun, adnatum.

Aцв. femini conforme, carnolum, album.

EMB.

\section{EXPLICATIO FIGURE.}

a. 2.) Ramulas frugifer. b. C.) Capfula iategra. D.) Eadem medio transverie feata, cum fits difrepimentorum. c. E.) Semina foluta. 
Fab. CXVII.

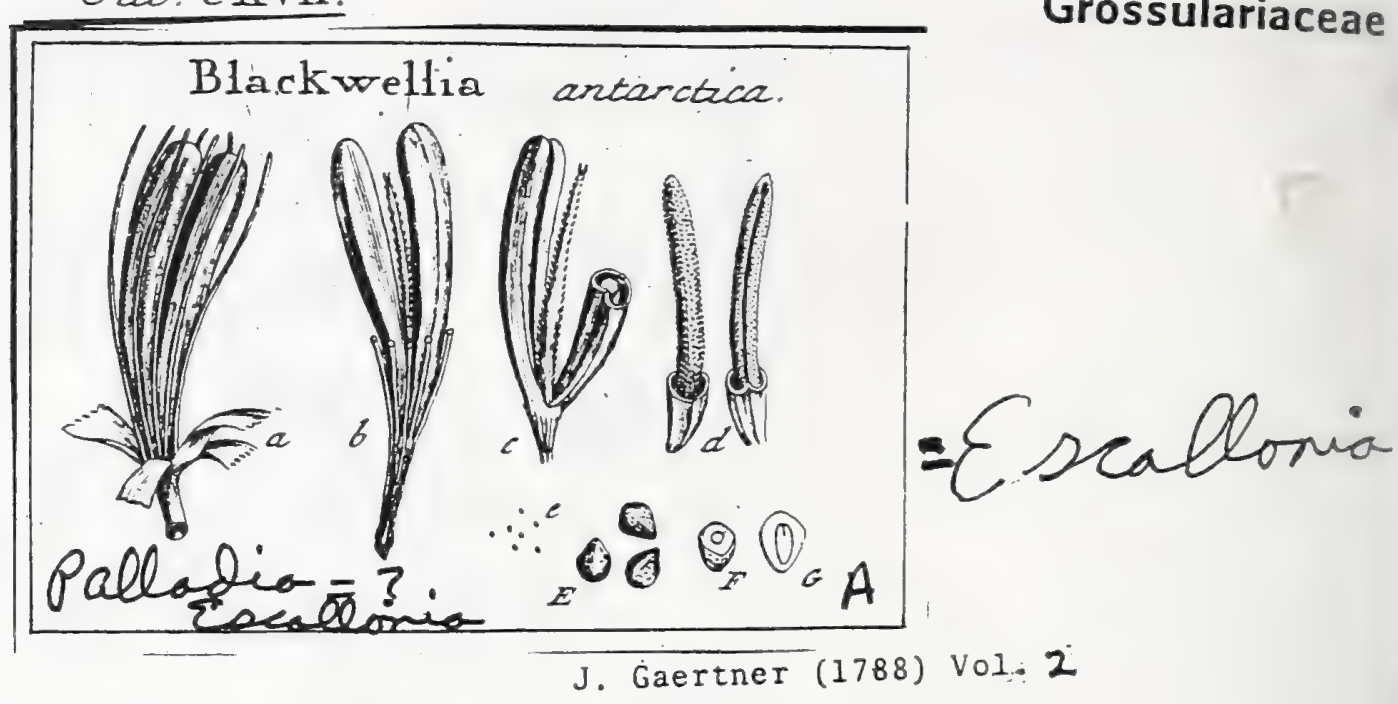

Iing

DCLXXXIII. B LA K W ELLI A.

Calyx monophyllus, infundibuliformis, colontus: nuov brevi; Trimbo qualtifido: laciniis pbuvatis. Cor. monupetala, infundibuliformis, tubo longo, 170

octoplicato; limbo oftifido: laciniis oblongis. Stam. odto, fllamentis rigidis, perfiftentibus, corollx tubo ultra medium longitudinis fux adnatis. Ovar. duo fupera. Styl. fimplex compreffus, inter ovaria politus, ad margines denticulatus, ftigmatibus duobus pitulis terminatus. Capfulx dux, oblongx, uniloculares, bivalves. Sem. numerofa, parva.

BLAKWELL1A-antarctica. Tab. 117. fig. I.

Data mihi pro Skimera, ni fallor, a Cl. Reinh. Forster.

Pre. Capfulx dux oblongx, prifmatico-chvatx, charcacex, rigidx, hinc obfolete angulatx, inde profundo fulco exaratx, uniloculares, bivalves: valvulis poft dehifcentian funis adinftar fe contorquentibus.

REC. fungofum, longitudine cap「ulx, ejusque futurx ventrali longitudinaliter adnatum; hinc convexum, inde fulco excavatum, undique minutifimis papillis fabratum.

SEM. numerofifima, parva, angulata, rufefcentia.

I N T. Gimplex, coriaceun, tenue.

A L B. carnofum, album, modice craffum.

EMB. cylindricus, lacteus. Cotyl. brevifimx. Rad. centripeta.

x.) Capfulx in fitu naturali fibi mutvo junAx. b.) Exdem paululum diductx, ut intermedius ftylus appareat. c) Latus ventrale capfularim, cun ftylo plane dentidato, atque fite receptaculi feminum. d.) Receptaculi facies asterior atque pofterior. c. E.) Semina integra F.) Albumen transverfe, \& G.) Idem longitudiualiter diffeanm, onw Gtu \& Ggura Embryonis.

94.2 


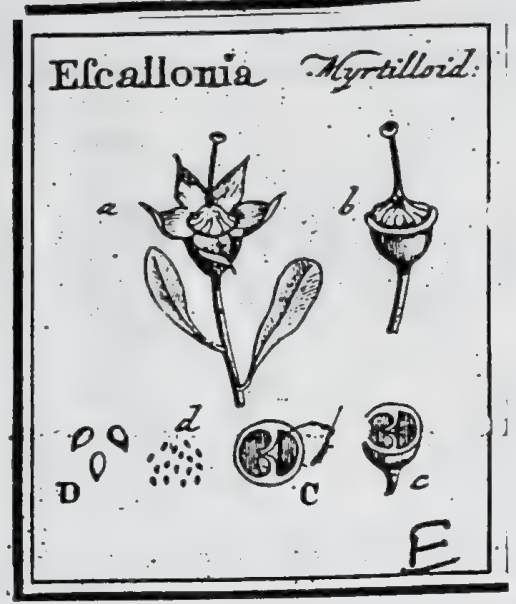

J. Gaertner (1788) Vol3

16

14. ES C A L L O I A.

LIN . fuppl. pl. p. 2r. gen. pl. ed. Schreb. 386.

Juss. ger. $p .32 r$.

Cal. fuperus, quinquefidus, fegmentis perfiftentibus, demum ovato-mucronatis. Cor pentapetala, petalis ligulatis diftantibus. Scam. quinque. Ovar. inferum. Styl. unicus ex thalamo depreffe conico elongatus atque ftigmate orbiculari prxpilatus. Bacca infera, coronata, bilocularis. Sem. numeroGfirma, nidulantia

Escallonia Myrtilloides. Tab. 182. fig. 5.

Efcallonia. Lins. fuppl. pl. p. 156. Syft. veg. ed. 14. p. 242. Spec. pl. ed. Willd. T. I. P. 2. p. 1149 .

Efcallonia foliis ferratis mucronulatis fubsus venofise. SuITH icor, iked. va!. 1: Eafc. 2. p. 30. t. 30.

A Cl. Thunberg.

P д . Bacca infera, coronata dentibus calycis perfiftentibus \& grandefactis, ac intra eos faftigiata in umbonem depreffe conicum, ftriato-rugofum, in Stylum definentem; inferne fubglobofa, glabra, fubcoriacea, bilocularis, Difepimentum in medio bipartitum, laminis dimidia bacec latitudine la-

tioribus atque hixc marginibus fuis internis in alterutrum loculamentorum recurvatis. Loculamenta pulpa molli farcta.

REC. nullum: femina nidulantur in pulpa.

SeM. numerofifims, exilifima, '́padicea aut rufefcentia.

Is T. fimplicifinum, mémbranaceum.

Һ L B. ...

ENB....

\section{EXPLICATIO FIGURJE}

2.) Eacez coronrta integra. b.) Eadem exeufis calycis fegmentis a denuilato verticis umbone, \& C.) Bacez fectio transverfalis, sum diffepinenti laminis setexis. d. DJ Semiaa foluta.

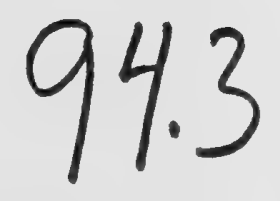


Tab. 209.

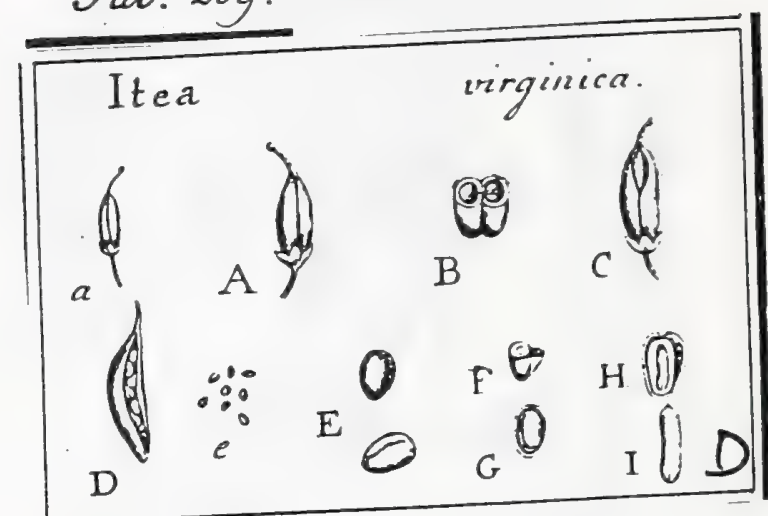

\section{I T E A.}

Linn. gen. 275. ed. Schreb. 38r. Juss. gen. p. 159.

LAMARCE ill. gen. t. 147. Diconangia. MIтон.

gen. 5 .

Cal. quinquefidus, parvus, perfiftens. Cor. pentapetala ; petalis fummo calyci infertis, patentibus, deciduis. Stam. s.; filamenta petalis breviora, fubu1a:a, cum peralis atrerna, erecta; anthers oblongx, incumbentes. Ovar. fuperum; ftylo cylindraceo, longitudine ftaminum; ftigmate capicato, rotun. do, convexo, fulco obfoletiffimo transverfali notato. Capfula parva, ovato oblonga, in ftylum perfiltentem attenuata, bilocularis, bivalvis. Rec. 0 , Sen. plura, fubcordata Alb. femine anguftius, carnofum. Emb. sreaus, curvulus, teres.

Ires virginica, Tab, 209. fig. 4

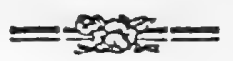

Itea foliis ferratis. L'HERIT. Sert. angl. I. p. 138 .

Itea foliis ovatis acutis ferratis. SWARZ prod. p. J51. Obf. bot. p. 94. WILLD. Spec. pl. T. 1. P. 2. p. 2146.

Irea foliis oblongis, fenratis: Jpicis pubentibus. Мıcн. fior. bor, anser, s. p. 157. Persoos Jjn. J. p. 775 .

Icon. Trew Ehret t. 98.

Ex collectione $\mathrm{Cl}$. Desfontaines.

PER. Folliculi duo coaliti in capfulam ovato-oblongam, in ftylum perfiftentem bipartibilem attenuatam, fulco longitudinali utrinque infculptam, caJyci parvo infiftentem, coriaceam, bilocularem, bivalvem. Valvulæ per fulcos vertice prius dehifentes, in fructu inmaturo marginibus inflexz \& duplicatic difepimentum formantes.

REC. nullurn: femina margine interno valvularum ab utroque latere alternatim unbilicis borizontaliter affixa.

SEN. plura, 8. ad 12 . in quovis loculamento, parva, fubcordata, obtufa, compreffiufcula, inxquabilia, dorfo craftiora ab albumine longitudinaliter protuberante, umbilico minimo inftrucka, nitida, fufca.

IN T. duplex: exterins teftaceum, craffufculum, fragile, reticulatum, nucleum ad dorfum fovens, laxiufculum; interits membranaceum, tenuiffinum, albumini adherens, pallidum.

A I 8. femine multo anguftius, in dorfo feminis locatum, tereti-oblongum, mucronulatum, carnofum, album.

Eм в. centralis, erectus, tereti-oblongus, curvulus, albus. Cotyl, brevifimx; obtufre. Rad. longa, teretiufcula, recta, mucronulata, umbilico axterno obverfa, centripeta.

\section{EXPLICATIO FIGUR串.}

A. A.) Capfula integra, non dehifens. B.) Ejusdem fedio transerGlis, catn fita feminum. C.) Esden dehifcens. D.) Valvula eltera, $\mathrm{cnm}$ feminibus in fitu. e. E.) Semina foluta. F.) Semen medio transverfe feAtum. G.) Ejusdem featio horizontalis com Gro nuelei. H.) TeAt cam alhumine verticalizer ditces, cum fito embryonis. I.) Embryo Solutus, valde audus.

Stylus unicus fed facile bipartibilis, \& cum folliculis continuus. 


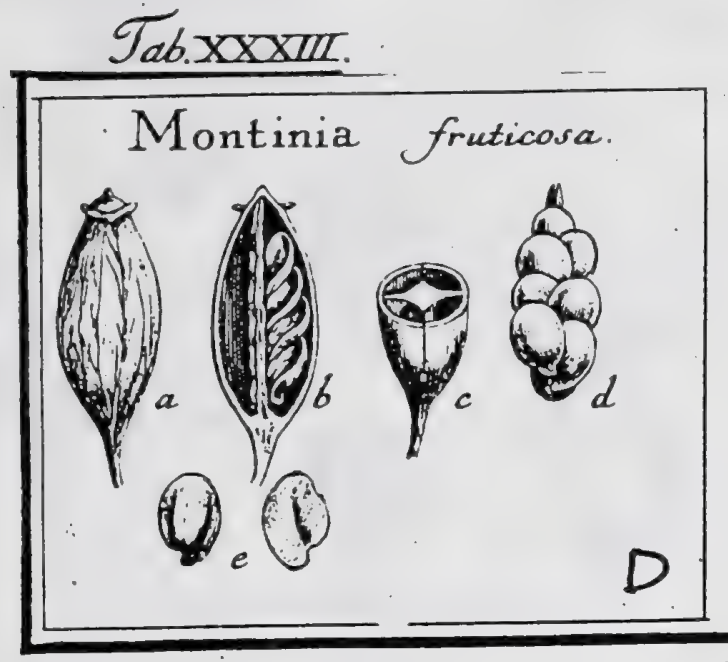

\section{J. Gaertner (1788) Vol.I}

170

CCV. MONTINIA. SOIAN D. LinN. gen. 1432.

Flores fexu diflincti in feparatis plantis, feu potius in aliis fleriles, \& in aliis fertiles, Cal. quadridentatus, breviffimus, fuperus. Cor. tetrapetala (mihi vifa monope: tala). Stam. quatuor. Styl. unicus, bifidus. Capfula infera, bilocularis. Semina bracteata, furfum inbricata.

Montrinia fruticola. Tab. 33. fig. 5.

Montinia acris. LIN . $\int y / t . v e g .883$.

E collect. Bankfiana.

PER. Capfula infera, calycis denticulis quatuor patentiffimis coronata, ovato oblonga, bilocularis, bivalvis. Diffepimentum tenuiliunum, valvis contrarium, ex receptaculo oriundurn.

REC. Spongiofum, rhombeo tetragonum, angulis acutioribus in diffepinentum elongatis; obturioribus autem femina duplici ferie furfum incumbentia fuflineutibus.

SEM. in fingulo loculamento fex ad ofto, grandiuscula, fubovata, foliaceo comprefta, concava, ad umbilicum leviter emarginata, lato \& integerrimo margine unembranaceo cincta, fpadicea.

IN T. fimplex, membranaceum, in marginem ampliatum.

A L в. ovatum, compreffum, tenue, carnolum, fubdiaphanum, pallidum.

Ex в........

a.) Capfola integra. B.) Esdem longitudinaliter aperta c.) Ejus fettio transverfalis, d.) Re ceptaculum folutum, com fita.feniuum aaturais. e.) Semina feparata, ab utroque latere fpectate 


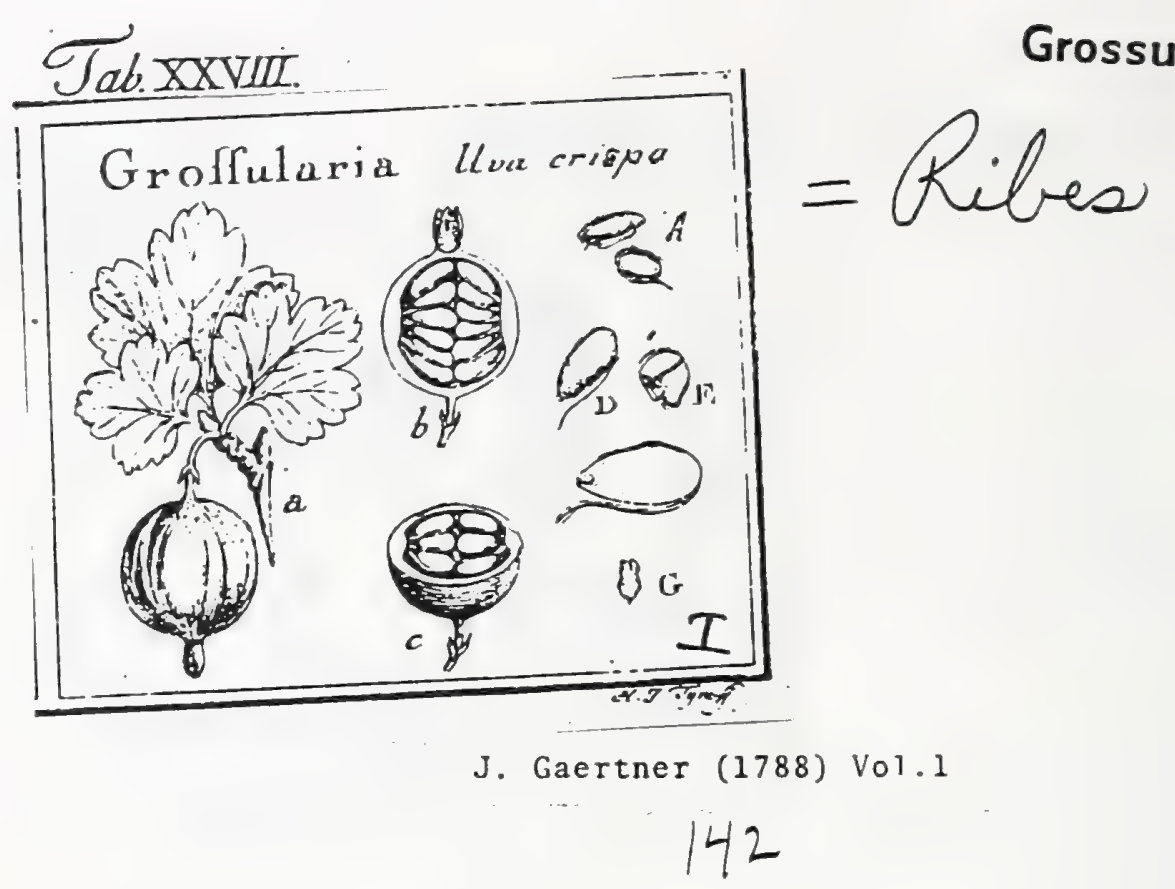

CLXXI. GROSSULARIA. TOURN. $t$. 409. Ribes. LINN. gen. 25\%

Calyx monophyllus femiquinquefidus fuperus. Cor. pentapetala. Stain. quinlyus. Styl. unicus. Bacea infera unilucularis. Scmina parietibus utrinque affixa.

Grossula ri A U'a crifpa. Tab. 28. fig. 9.

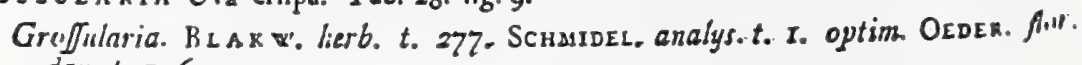
dan. $t .5+6$.

144

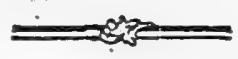

Ribes ramis aculeatis, foliis rotunde lobatis. H A I L. hifl. I. n. 820.

Ribes ramis aculeatis, baccis glabris, pedicellis braftea monopbylla. LIN veg. 243 .

Icon fruquus. GREw. anat. t. 6g. f.3. 4.5.

PER. Bacca infera, fphxrica, calyce perfiltente coronata, pedunculata, pulpola, fuh. diaphana, pallida, melina aut purpurascens, pubefeens aut glabra, unilocularis; Pulpa fubaquofa, dulcis.

REc. duo, oppofita, ex parietibus baccx incraftatis formata, oblonga, angufta: funiculis umbilicalibus filiformibus, longitudine feminum, \& eorundem extremitati in: teriori obtufiori inferti.

SEM. plura, ad triginta, ovato üblonga, gclatiná pellucidâ baccata, rufefcentia.

IN T. duplex : exterius gelatinofum, diaphanum, fxpe rubro colose in vertice tindum; interius membranaceum, tenue, ferrugineo luteum.

A ᄃ 8. Semini conforme, duriusculum, carnolum, candidum.

Е м в. dicotyledoneus, minutus, lutescens, in extremitate feminis anguftiore locatus: Cotyl. breviftunx, obtufx. Rad. fubglobola, centrifuga.

a.) Bacca integra. b.c.) Exdem longitudinaliter \& transver(aliter fecta. d.) Semina gehtini pellucida baccata: D.) Eadern absque gelation, folo relicto funiculo umbilicali. E) Albumes trans. verfe, \& F.) Idem longitudinaliter fecturs, cum fitu embryonis, G.) Embryo feparatus,

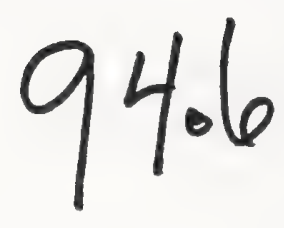




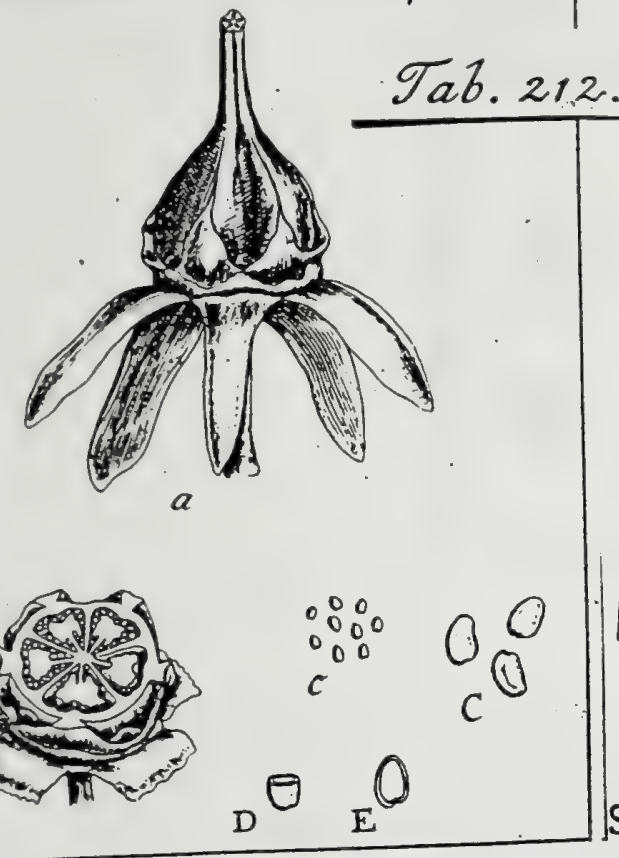

\section{R O U S S E A.}

Calyx (quadri - SaIt l.) quinquefidus, coriaceus, perfiftens; laciniis lanceolatis, patentibus. Cor. fubcampanulata; tubo brevi, fubglobofo, intlito, furfum vero paululum coarctato; Jimbo (4.-1.) quinque-partito : laciniis acu. tis, reftexis. Stam (t.l.) s., filamenta corollam multo fuperantia, erecta, conniventia, comprella, verfus apicem angultata; (ovario inferta?) anthe. rx recte, fagitratx. Ovar. fuperum, attenuatum in ftylum fimplicem longitudine ftaminum (tetra - 1.) pentagonum perfiftentem; ftigmate fimplici. truncato, concavo, ftellato. Bacci ovito-pyramidata, in ftylum perfiftentem attenuata, (tetra - 1.) pentagona, (quaḑri - 1.) quinquelocularis. Rec. carnofa. Sem. numerofa. Alb. carnofum. Emb. ....

Roussea finplex. Tab. 212. fig. I.

Rouffea. WILLd. fpec. pl. T. I. P. I. p. 607. PERSOON fjn. I. p. 130.

Icous. SMITH. 1. c.

PER. Bacca fupera, grandiufcula, bafi cum calyce perfiftente arcte conferru. minata, ovato - pyramidata, in ftylum craffufculum,- uti bacca ipra, (tetra-1.) pentagonum attenuata, carnofa, intus pulpofa; latera leviter concava, ad bafin bacce immerfa \& macula triangulari (a filamentorum lapfu?) infignita ; anguli vero acuti, cum laciniis calycinis a1terni, deotfum in caruisculas craffis triangulares bafi colserentes dilatati; cæterum glabra, (quadri - 1.) quinquelocularis. Caro craffufcula, firma. Diffepimenta carnofo - membranacea, hinc in axem fructus contuentia, inde lateribus baccæ inferta. Pulpa mollis, femina obvolveus.

REc. ovato - oblonga, angulata, dorfo craffifima \& medio longitudinaliter carinata, inde anguftiura \& fulco profundo latoque exarata, cui lamina intermedia longitudipalis inferta, cujus ope receptacula angulo loculamentorum interno affixa fünt, fungofa, punctato - fcrobiculata.

SE s. numerofa, parva, cordato - ovata, umbilico minimo inftruata, lenticulari-compreffufcula, margine paulum incrafrata, centripeta, ftraminea, 1. pallide ferruginea.

INT. duplex: exterius coriaceum, crafiufculum; interius membranaceum, tenue.

A L B. fenini conforme, carnofum, album.

EM B. . .

\section{EXPLICATIO FIGURE.}

2) Bacea integra. h.) Eadem medio transwcrie diffeta. c. C.) Semina Leparata D.) Albu.

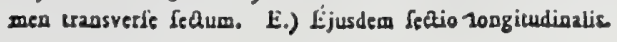

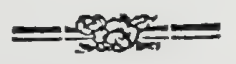

Cl. Sмгтн 1. с. numerum partium obfervavit quaternarium, egomet illum inveni quinarium; quinam vero ufitatior fit, nondum conftat.

Cuamvis in plurimis feminibus, qux diffecui, ne minimum embryonis veftigium invenerim, ob fructum tamen baccatum \& totam ejus fabricam nou ad Campanularum ordinem (uti vult Cl. Jussiev Dinr. bif. nat. mus. parif. $V .5 . p .426$.) fed ad Solanaceas plantas fpectare videtur hac ftirps. 


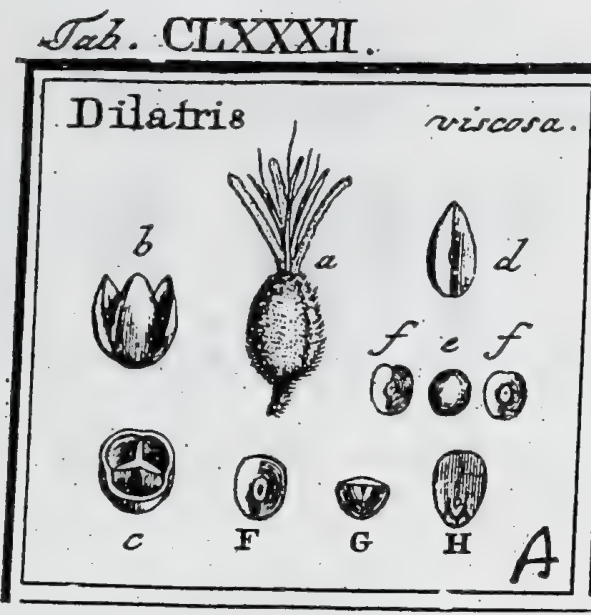

J. Gaertner (1788) Vol 3

II

\section{D I L A T I S.}

BEв G. cap. 9. LrNn. Juppl. p. ro. gen. pl. ed. Schreb. 82. Juss. gen. p. 59. Lasr A в С ill. gen. $t .34$.

Cal. nullus nifi corollam velis. Cor. fupera, hexapetala, in variis varia. Stam. tria, aut fex tribus accefforiis brevifimis, ferilibus. Orarium inferum Styl unicus. Capf. trilocularis, trivalvis : diffepimento triquetro libero. Sem. folitaria, bracteata, in medio ventre umbilicata.

Dilatras vifcofa. Tab. I82. fig. I.

Dilatris petalis linearibus, corynubo faftigiato villofo vifcofo. LINN. Suppl. p. IoL. Syyt. veg. ed. 14 p. 93.

Dilatris petalis linearibus, panicule villofo-vifcida. THUNB. prods. 20. AD. Joc. Berol 4. p. 48. LiNd. Spec. pl. ed. Willd T. I. P. x. p. 247.

A Cl. Thunberg.

P\&R. Capfula infera, ovata, rotunde trigona, villofo - vifcofa, trilocularis, trivalvis. Difepimentum ovato - oblongum, triquetrum, liberum, cura valvulis intus glaberrimis nullo modo connexum.

REc. cicatricula minima, in medio finguli lateris plani diffepimenti.

SE 2r. folitaria, rotundata, bracteata, feu hinc levilfine convexa, inde autem, f. in ventre fubconcava aut planiufcula \& in ipfo centro minutifimo fcrobiculo umbilicali notata; cxterum glabra, ferrugisea, \& par ambitum vix fenfibiliter crenulata.

INT. Gimplex, membranaceum, arctifime sdnatum.

A L B. cartilagineum aut carnofum, durum, pallidum, femini conforme, fed in bafi tribus dentibus profunde incifum: quorum medius reliquis ninor.

Ex B. monocotyledoncus, ovato-globofus, minutiltumus, in medio albuninis dente hrens.

\section{EXPLICATIO FIGURE.}

C.) Fruatus maturss integer, con fore perliftente. b.) Capfula villis denudata, trivalvia c) Ejusdem ftetio transverfalis. d) Dillepimentum liberum (cparatum. e.) Seminis dorfum. E. f. F.) Ejus part ventzalis. G.) Idem transvetfe ditredum. Ul.) Albuminis fetio verticalis, croc fitu \& figura Embryonis.

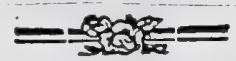

In meo fpecinine petala tria exteriora latiora, villola, escolora; tria veró interiora angufte linearia, glabrs, colorata; atque his ftamina tria adjaceut. 
Tab.XV.

Haemodoraceae

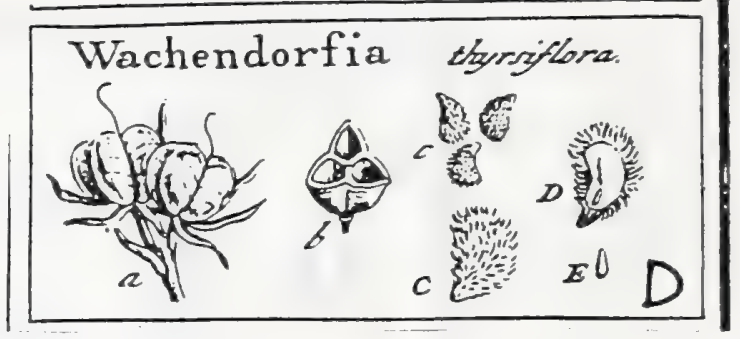

J. Gaertner (1788) Vol 1

52

LIX. WVACHENDORFIA. LIN $\mathrm{N} . g e n \sigma_{1}$.

Corolla hexapetala, inxqualis. Stam. tria. Styl. unicus. Capfula fupcra, triquetrar trilocularis. Stmina folitaria, ad baful loculamcontorum atlua. Eusbryo dunidio albumine brevior.

WACHENDORFIA thyrfilora. Tab. 15. fig. 4.

Wachendorfin foliis lanceolatis quinumencrüis canaliculato plicatis, foribus in thyrfum colleftis. B U R B. monogr. 2. f. 2.

Wachendorfia fcapo fimplici. Lis... Syl. veg. 94.

53

PER. Caplula fupera, fubrotunda, argute triquetra, trilocularis, trivalvis. Valvulz in medio feptigerx, \& extus nervis raris transverfalibus friatz.

REC. nullum: femina loculamentorum bafi, prope axem affixa.

$S E$ As. in fingulo loculamento unicum, comprefrusculum, obovatum $\mathcal{\complement}$ deorfum angufatum \& in roftratan bafin definens, undique fetis paleaceis mollibus hirfurum, nigro fufcum.

IN T. fimplex, arcte adnatum, nigricans.

A Lв. Cemini conforme, fubfarinofum, candidiflimum, duriusculum, sntus rima media incifum.

EMB. cxilis, in bafi feminis locatus, tcretiusculus, furfum gracilefcens, tacteo-albus.

a.) Capfulx dux integrxe. b.) Capfula per medium frta. c.) Semina naturali magnitudine. C.) Senen auctum, in fitu naturali. D.) Ejusdem fectio longitudinalis, cum figura albuminis \& fitu embryouis. Lં.) Eubrjo Sçaratus, infigniter auctus. 


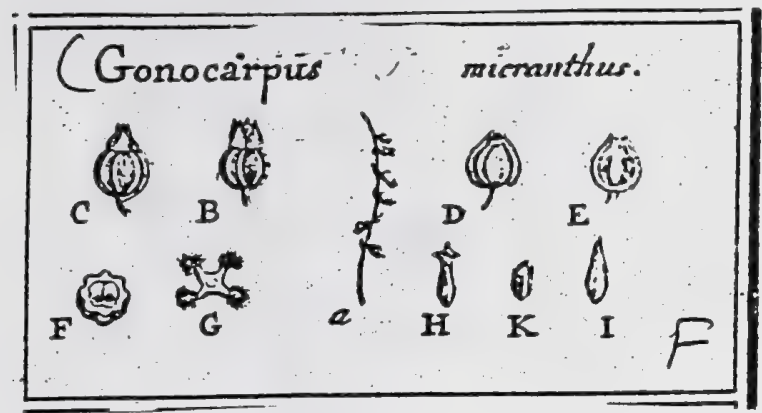

J. Gaertner (1788) Vol. 3

\section{G O N O C A R P U S.}

Iнопв. jap; p. 5. nov. gen. 55. Juss. gen. p. 442. Lasrácx ill. gen. -t. 73. Gonatocarpus. S С н вев. gen. 214.

Cal. tetraphyllus, fuperus, perfiftens; foliola cordato-haftata, margine incraffata l. introflexa, erecta, demum conniventia. Cor. monopetala, ino calyci inferta, quadripartita; lacinix lineares, cum calyce alterne, apice villofo - fimbriatz. Stam. quatuor. . . . Ovar. inferum; ftylo nullo; ftigmate feffili, concavo. Nucula calyce coronata, monofperma. Rec. nullum. Sem. tetragonum, inverfum. Alb. carnofum. Enb. ...

Gonocarpus micranthus. Tab. 225 . fig. 8.

Gonatocarpus. WILLD. Spec. pl. T. x. P. x. p. 690.

Gonocarpus. THUNB. f. jap. p. 69. t. 15. LINN. [j/. vieg. ed. 14. p. 164.

Ex collectione Bankfiana, \& a Cl. Desfontalnes.

PE R. Nucula minima, globofo - elliptica, 1 . in mucronem truncatum brevem protracta, calyce perfiftente coronata, octogona, totidemque fulcis profundis exfculpta, coriaceo-fuberofa, fordide fufca, intus albida, unilocularis, evalvis. Loculamentum globofo-ellipticum, fulcis quatuor elevatis feminis angulis obverfis inferiptum, monofpermum.

Rrc. nullum: ferren apici loculamenti adharet.

SEN. unicum, inverfum, loculamento ipfo multo anguftius, ovato-oblongum, furfum acuminatum, tetragonum, lutefcens $\mathcal{L}$ dilute ferrugineum.

INT. duplex, utrumque membranaceum; exterius magis frmum, fecundum angulos quafi in quatuor valvulas lanceolatas facile partibile; interius te. nuiffimum, adnatum.

A l в. femiai conforme, carnofun, album.

EMB. ...

\section{EXPLICATIO FIGURE}

8.) Parz f́piez frogilerz. B.) Nucula feparata, calyce.\& corolla inftuta. C.) Eadem corolls orbata. D.) Eadeut calyce deftituta. E.) Ejusdem fetio longitudinalis, eum Gtu feminis intra loculamentum. F.) Eadem transverie diffeda. G.) Corolla feparata, a parte inferiore fpeAata. H.) Semen, eum adhxtente ftigmate \& ftaminum ndimeatic. I.) Idem liberum. K.) Ejusdem Sectio transverfalis.

Specimina mea deflorata nec tamen matura \& floris \& fructus mancam tantum permiferunt defcriptionem; alii itaque de ftamiaibus \& embryone

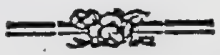

certiora addant; cxterum inveltigatio in tanta partium minutie precipue in exemplis vetuftis inericatifima.

De loco in ordinibus naturalibus ob defectum embryonis dubium reltat 3 certo Thefiorum familiz ob forem corollinum annumerari nequic. 
Jab.xxxII.

Haloragaceae
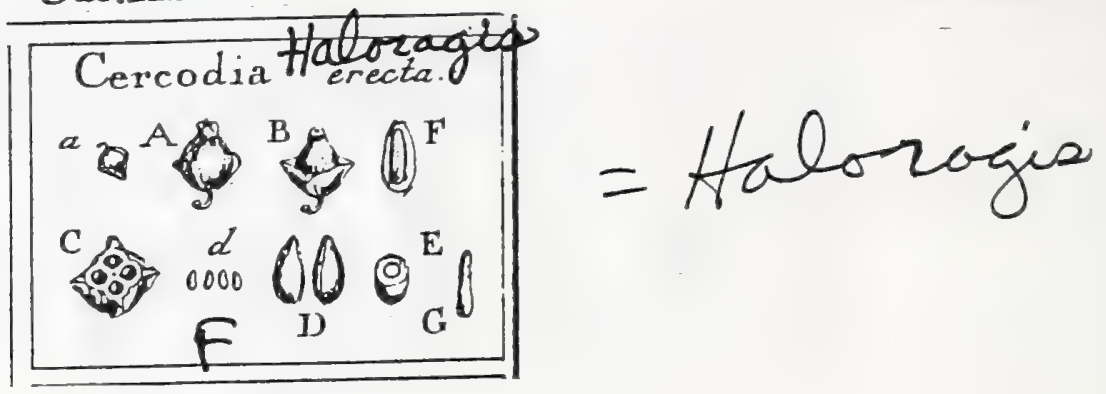

J. Gaertner (1788) Vol.1

164

CXCIX. CERCODIA. BA N s.

Calyx quadripartitus fuperus. Cor. tetrapetala: petalis oblongis, concavis, calyce duplo longioribus. Stam. octo. Styl. quatuor, conici. Drupa infera, tetragona, tetrafperina. Embryo inverfus, rectus.

Cercodia erceta. Tab. 32. fig. 6.

Cercodia erefta. Mu R R. Comment. gatt. 1780.p. $3 \cdot t$. 1 .

Tetragonia erefta glabra, foliis petiolatis ovato lanceolatis ferratis, petnlis deciduis. Lis s. Jyft. veg. 467 .

PER. Drupa exfucca, infera, parva, ovato-pyramidata, tetragona: angulis in alaun membranaceam anguflifimam extenuatis. Cortex coriaceus, tenuis. Putamen. ovato conicum, crufaceum, durum, quadriloculare.

REc. nullum; femina apici loculamentorum affixa.

SEм. in fingulo luculamento unicum, oblongum, fupra attenuatun, album, a latere interno linea longitudinali \& in bafi areola chalazina, utrisque rufef́centibus nota. tum, fubdiaphanum.

Ixt. fimplex, tenuistumum, pellucidum.

A L8. Émini conforme, carnofum, friabile, album.

E.м. dicotylejoneus, inverfus, teretiusculus, longitudine fere albuminis, niveus. Cotyl. Semicylindricz, brevifima. Rad. longa, crafta, fupera.

a. A.S Drupa integra. B.) Putamen usque ad medium denudatam. C.) Drupa transverie feta. d. D.) Seniua (eparata. E. F.) Albumixis feltiones, cum Gtu \& figura embrjouis. G.) Embrjo leparatus.

6,2 


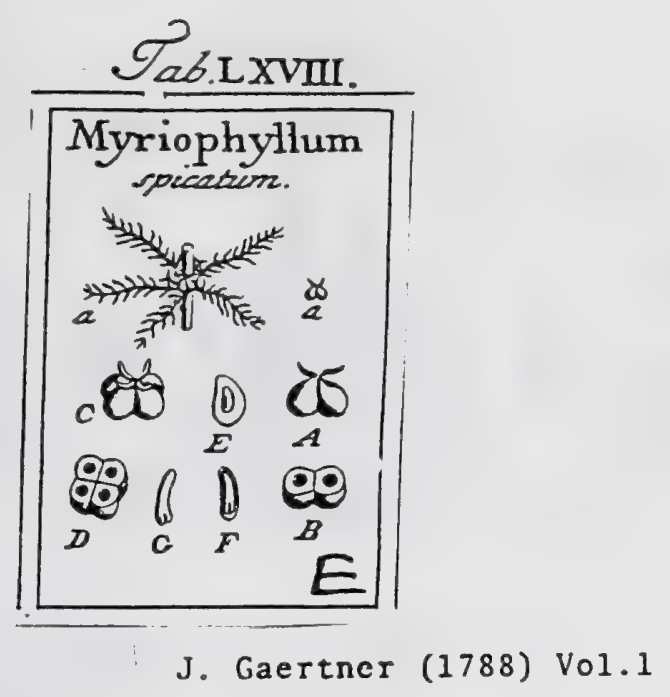

CCCCXXVI. MYRIOPHYLLUM. LIN N. gen. 1066.

Flores fexu diftincti in eodem caule. Cal. quadriphyllus. Cor. nulla, aut dipetala. Stam. octo. Stign. duo aut quatuor fellilia. Nuces dux, aut quatuor corticatx. MYR IOР н Y L UM f́picatum. Tab. 68. fig. 5.

Millefolium aquaticum, pennatum, fpicatum. BAUH. prod. 73. c. ic. OEDER. Flor. dan. t. 681.

Pentapteris fpica nuda. Hall. hift. I. n. 993.

Myriophyllum floribus mafculis interrupte fpicatis. Liss. fyf. veg. 856.

PER. Nuces dux, aut frequentius quatuor, parvx, fuhglobol $x$, ante maturitatem, corticis ope, inter fe conferruminatx, poftea feparabiles. Cortex teituis, membra. naceus. Putamina dura, fuboflea, crafta, albicantia, unilocularia.

REc. nullum, preter fundun calycis.

S E M. folitaria, fubcylindrica, pallida.

IN т. fimplex, membranaceum, tenuiffinum, fuperficie interna carnola.'

$\Lambda$ L B. vix ullum, preter crafliusculam fuperficiem carnofam integumenti.

Eм B. magnitudine fere feminis, levifime incurvus, teretiusculus, inverfus, lacteus. Cotyl. brevifimx, obtufx. Rad. Longa, crafta, fupera.

2.) Fruttus in axillis foliorum ferfiles. a. A. B.) Frutus nueulis geminis. C. D.) Alius, naculis quatenis. E.) Puramen longitudinaliter aptrtum \& nucleus denudatus. F.) Enbryo intra feminis integumentum fubcarnolum. G.) Embryo feparatus.

Omnino ad dicotyledones fpectat, quin in Myriophyllo geminx cotyledones multo facilius, quam in ipfa Callitriche, difcernuntur \& ab invicem feparantur.

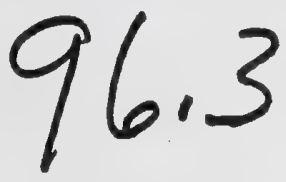




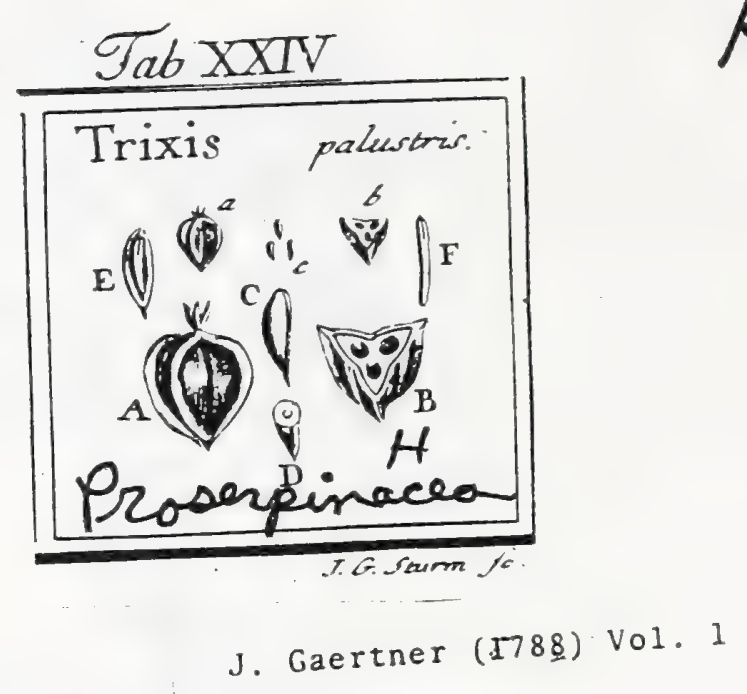

CXXXVI. TRIXIS. Mrter. Proferpinaca. Linn. gen. 102. Calyx tripartitus fuperus. Cor. nulla. Stam. tria. Styl. tres. Drupa exfucea in.
ferz, trilocularis, trifperma.

Trixis paluntris. Tab. 24. fig. 8 .

Trixis. Mitchel. E. N. C. 1748. n. 23.

Proferpinaca. Lins. Jift. veg. 128 .

PER. Drupa exfucca, parva, infera, calyce perfifiente coronata, obovata, triquetra:

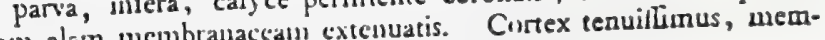
angulis in angufiam alam mon fuboficum, albicans, triloculare.

branaceo fpongiofus. Putamen fubilicin filiformen, a bafi ad verticem feminis

REC. nullum, prater funiculam interno adnatum.

SE s. in fingulo loculamento uncum, oblongum, deorfum acuminatum, fubteretius. culum, pallide rufefcens.

IN T. fimplex membranaccun.

AL B. fenini conforme, carnofum, craffiusculum, album.

n6

Ess. dicotyledoneus, erectus, teretiusculus, longitudine fere albuminis, lacteo albus: Cotyl. leuniteretes, breviffumx. Rad. longa, recta, infera.

c. C.) Semisum forma, D.) Semen transverfe, antegra. b. B. J Eadein difcira embryouis intra albumen. F.) Erabrjo feparatus.

E. Idem to:igitudinaliter fectum, cum fitu embryonis intra albument

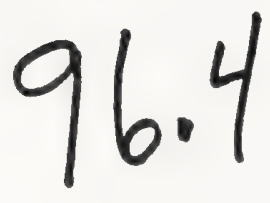




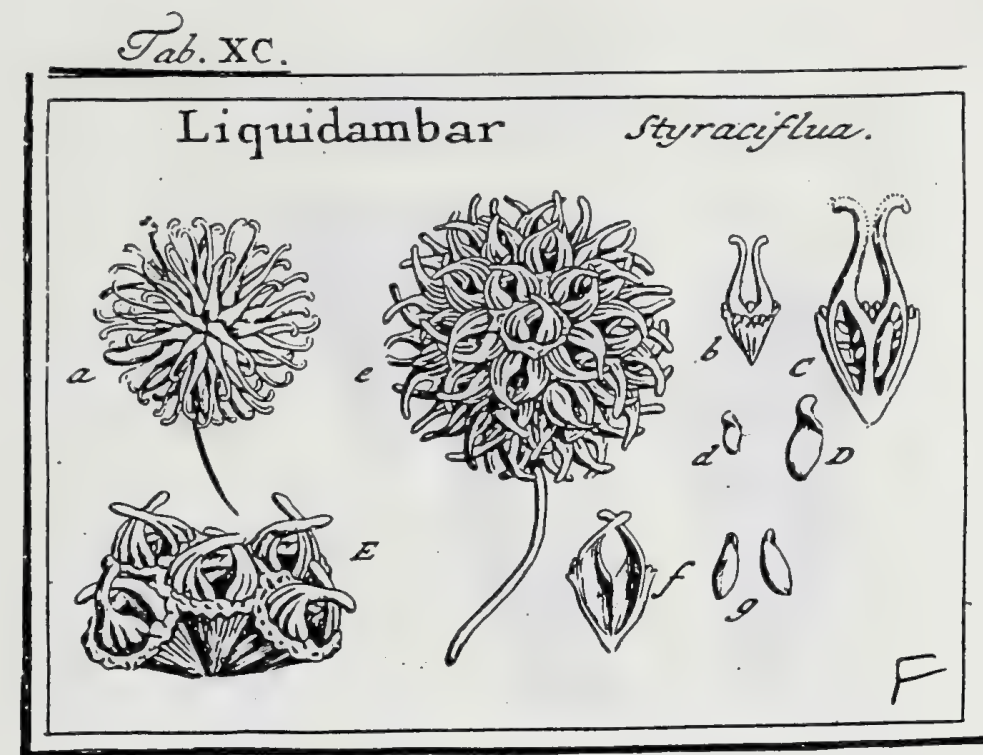

J. Gaertner (1788) Vo1. 2

DLXIII. I I QU I D A M B A R. LIN gert. ro76.

Flores fexu difineti, in eadem firpe. MAS. Amentum conicum, longum, laxum, munitum Involuc commusi tetraphyllo, caduco. Cal nullus. Cor. aulla. Stam. numerofir FEM Amentum globofum, bafi munitum Invol communi tetraphyllo, ut in mare, compofitum ex Calycibus inverfe pyramidatis, angulatis, linabo exteriore verrucolis, \& inter fe, in pilam profunde alveolatam, coalitis. Cor. nulla. Ovaria duo, unilocularia, inter fe \& cum calycibus fuis conferruminata, ftylo, quodque fuo, longo fubulato \& apice recurvato terminata. Capfulx dux, roftratx, introrfum dehifcentes. Semina parietalia.

Liquidambar Styracilua. Tab. 90. fig: 6:

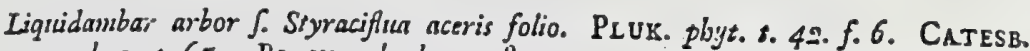
carol. 2. t. 65 . BLAKW. berb. 2. 485.

Liquidambar foliis palnato-angulatis: lobis indivifis acutis. LINN. $\sqrt{y} f$. veg. 860. A Pbil. Miliero \& Laur. Gronovio.

PER. Capfulx, in fingulo amenti alveolo, geminx, roftratz, coriacex, fulcatx, nitidx, fpadiceo-ferruginex, uniloculares, margine interiore lolt. gitudinaliter dehifeentes.

REC. commure globofum, favofum, ex calycibus femineis campanulatis, inter fe connatis; proprium, nullum, preter internos.capfularum parietes, quibus ovula undique affixa.

SeM. plura, ad fedecim in fingula capfula, oblonge elliptica, lenticulari comprefia, fuperne in membramulam definentia, nitida.

IN T. duplex: coriaceum \& membranaceum, utrumque tenue.

$\Lambda \perp$ B. .......

EMB. . . . . .

2) Amentam femineam immaturum, b.) Calsx cum enpiulis fuis geminis feparatus c.) Ejus dem \& Capfularum fectio longitudinalis, cum infertione ovulorum. d. D.) Ovula feparata. e. E.) Amentum eum eapfulis maturis dehifentibus. f.) Calycis \& capfularum dehifentium fetio longitudinalis. \&) Scmima magnitudine naturali, fed immatura.

Corpufcula acerofa, quibus membranaceam feminis extremitatem immifceri tradit Linneus gers. l. c. nihil aliud funt, quam ovula immatura. 
$-$ 


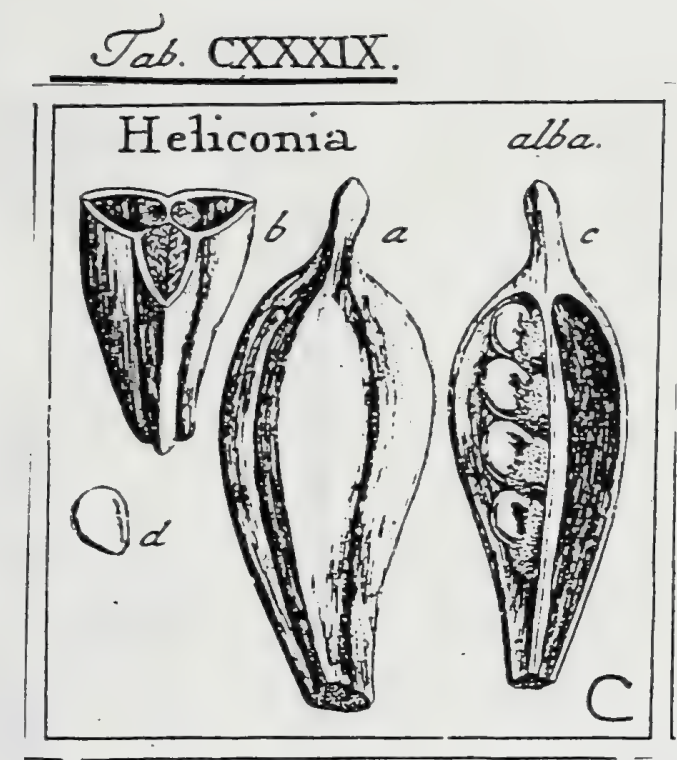

J. Gaertner (1788) Vol, 2

\section{H E L I C O N I A. LINN. gers. 1297.}

Calyx fuperus, corolliformis, bilabiatus : labio inferiore fimplici, fuperiore tripartito, laciniis lateralibus anguftioribus. Cor. nulla, nifi calycen velis. Stam. fex, quorum unum fterile. Ovar. inferum. Styl. fimplex. Capf. coriacea, trilocularis. Sem. pauca, membranà villofa aut glandula criftatá ad infertionem ltipata.

IIEliconia alba. Tab. 139. fig. 3.

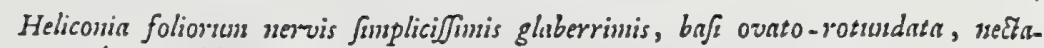
rio bafato libero. Liss. $\int y$. veg. 245 .

A Cl. Thunberg.

PER. Cappfula infera, coriacea, ovato - oblonga, furfum latior, apice in mucronem longiufculum prifnnaticum elongata, triquetra, trilocularis, trivalvis. Difíepimenta medio valvularum inferta.

REC. laminx dux membranacex, extus lantex aut villofix, angulo loculamentorum centrali longitudinaliter adnatx, inferiorem partem feminum ab utroque latere amplectentes, eademque dillepinentorun margini interno, fimplici ferie longitudinali affigentes.

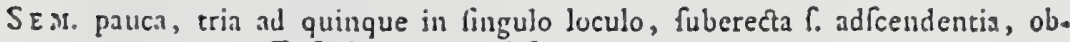
ovata, compreffrufcula, nigro - fúfa.

$1 \times$ T. duples: exterius coriaceum, craffum; interius nembranaceum.

ALв...... E E⿺辶.....

a) Capfula integra. b.) Eadem transterfe fecta. c.) Valrula feparata, cum feminibus in litu naturnli, ad hafin fuam meinbrana villofa ftipatis. d.) Semen fulutum.

Membranam villofam aut lanatam ad bafin feminum, nihil aliud effe, quam fericm Arillorum incompletorum \& inter fe conferruminatorum, fuadet fabrica $H$. birfutce \& protacorum, quarum feminibus glandulam criftatam \& crenatam ad infertionem tribuit Liss. Suppl. P. 358.159. 
- 


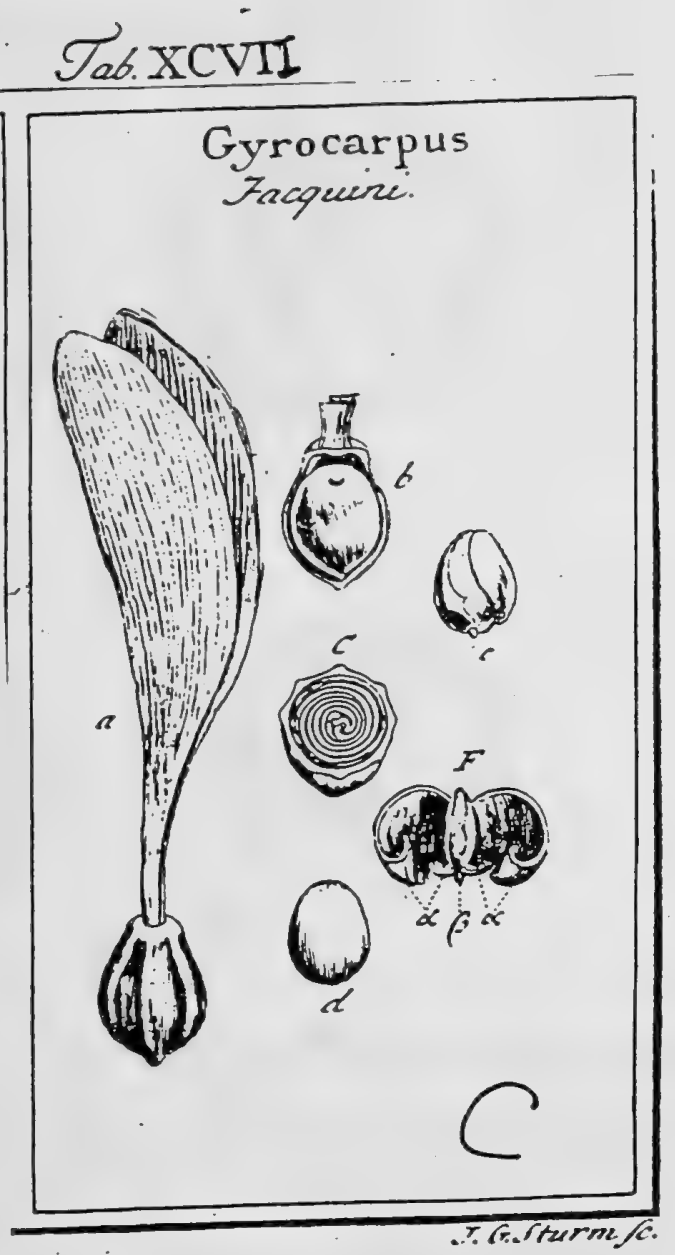

J. Gaertner (1788) Vol, 2 ;

\section{GYR O CAR P U S. JACQ.}

Flos .... Nux coriacea unilocularis alis duabus maximis pedicellatis conti-. guis ftipata. Seminis embryo fpiraliter convolutus.

Gýocarpus Jacquini. Tab. 97. fig. 3.

Grocarpus americanis. JACQ bifs. amer. 282 t. $578 . f .80$.

E collectione fem. Bankfiana.

PER. Nux ovata, furfum anguftata, obfolete octangula, nugofa, corticata, terminata alis duabus maximis, femiovatis, coriaceis, contiguis, petiolatis, ima bafi inter fe connatis. Cortex tenuis membranaceus, intus cellulofus, putamini adnatus. Putamen coriaceum, tenuiffimum, glabrum, e cuftaneo nigricans; uuiloculare, evalve, apice foveola parva nocatum.

REC. nullum.

Sess. unicum, figura \& magnitudine cavitati putaminis refpondens, albicans, circa bafin fufcum.

INT. Gmplex, membranaceum, craffiufculum.

A L E. nullum.

EMB. ovato - globofus, erectus, lacteus. Cotyl. foliacex, lobate, petiolatz ! fpiraliter circa plumulam in globum convalute \& fubeontortuplicate. Plurr. grandiufcula, ovato oblonga, diphylla, contortuplicata. - Rad. parva, pa pillaris, inferm.

2.) Nux integra. b.) Ejus cortex apertus \& Putamen deaudatam C.) Nucis atque Semiois fectio transverfalis, con gyris cotyledorum. d.) Senen feparatam. ee.) Embryo denndatat. F.) Cotyledones petiolatz $\left(\alpha \alpha_{0}\right)$ refeetz, cum Plumula centrali, atqque Radicula (B.) infer.

De Aceris familia, etiam propter cotyledonum convolutiones, effe videtur, fed ab omnibus cognitis pluntis, cotyledonibus intra femen petiolatis differt, quippe quod hactenus absque exemplo eft. 


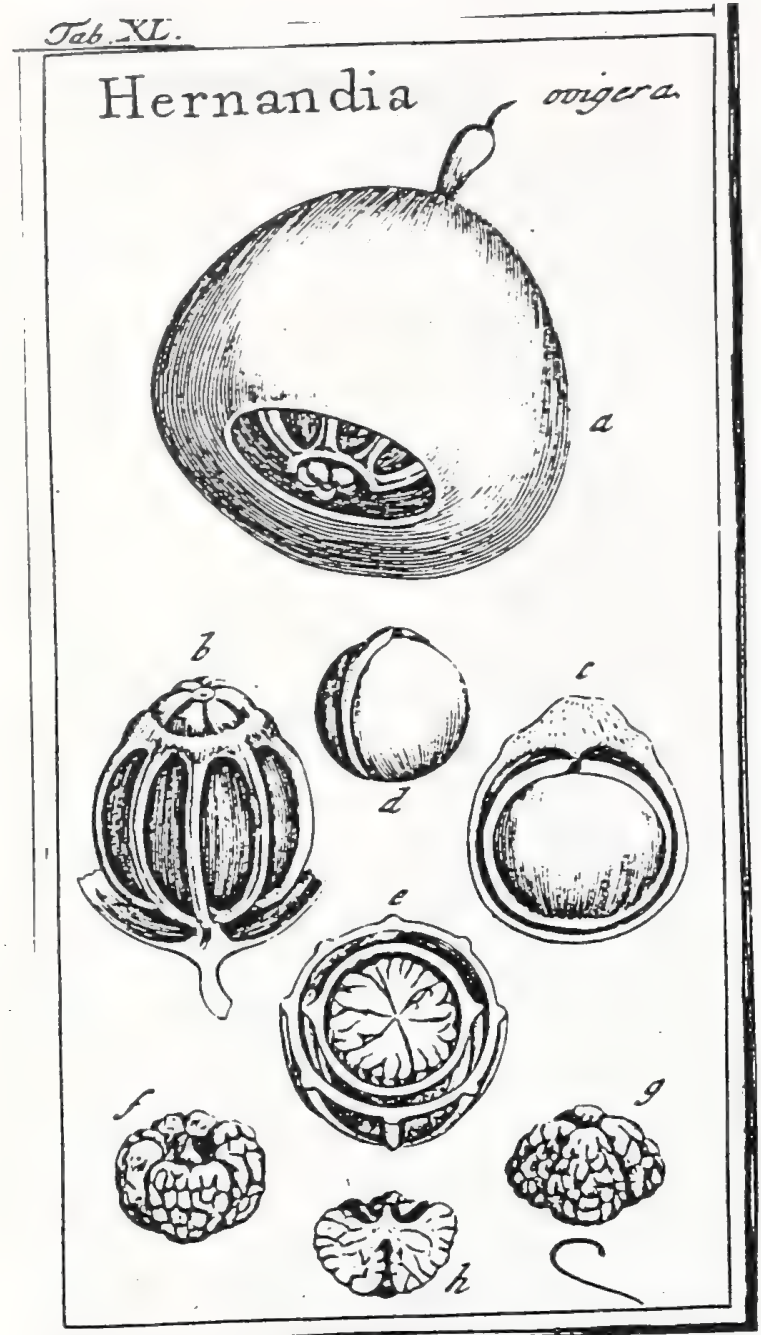

J. Gaertner (1788) Vo1..1

\section{Hernandiaceae}

193

CCXXXIV. HERNANDIA. P I u m. gen. t. 40. LIN gen. I049.

Flores fexu difincti in eodem trunco. MAs. Cal. tripartitus. Cor. tripetala Stam. tria. F e s. Cal. mowophyllus, integerrimus, perfiftens, inflatus. Cor. hexapetala. Nux fupera, calyce intato veflita. Semen globofum ofleum.

Hernandia ovigera. Tab. 40. fig. 3.

Arbor ovigcra. R ч м 8 н. umb. 3. p. 193. t. 123.

Hernandia foliis ovatis bafi petiolatis. LIN N. $\int f^{2}$. veg. $847^{\circ}$ E collectione Bankfianz.

PER. Nux intra calyccm grandcfactum membranaceuro, inflatum lixrens, coriacez. dura, e ventricofa bafi furfum in urcei formann anguftata, octo colis elevatis in. feripra atque umbone conicxo, octo torulis radiato teruninata, nigra, glabra, unilocularis evalvis. Putamen fomine amplius, ad umbonem craflitimum \& intus fungolo jpongiolium, cetera tenue, undique a femise difcretusn \& fubfantia tenui cellulula repletum.

REc. nullum; f(men apice fuo cum umbone fungofo putaninis colixrens, cetera ab cjusdem collulufitate undique cum parietibus revinclum.

SEM. unicum, grande, globofum, nfteum, fuperne nargine compreffo crifatum, vel \& totumab illo markine, tariquam amulo, cusctum, glabriusculum; pallide tefa. ceum, aut rufelicenti ipadictum.

IN т. duplex, exterius crufactum, durun, e caftanen nigricans; interius, monbranacto frongiofum, intra nudci rimas alte demerfuns.

194

ALB. aullum.

Ess. magnitudine feminis, obovato globolus, utrinque unbilicatus, lobatus, tomen tofus, inverfus. Cotyl. per maturitatem pertinaciffime inter fe coalitz, in lobosi varios (quatuor l. quinque) majores \& deinde in multus alios minores irregulariter divifx, carnolx, oleofx, friabiles, albicantes. Rad. acuminatz, ininima; in depreflo vertice embryonis locata, furfum poriccta.

2) Calyx maturus, nucem occultans. b.) Nux intra calycetn breviter pedunculate a) Nudi fectic verticalis, cum femine, ex umbonis fubrantia incraftata, pendulo. e.) Nucis \& feminis fecilo trank verfalis. d.) Semen folutum. f.) Embryo a parte fuperiore (pectatus. g.) Idem inverfus, b. 2 Con
ryledones \& radicula verticaliter fects.

Hernandiz fonora fructus per fingula puncta cum pracedenti convenit, nifi quod fo minis crifta l. annullus confanter deficiat atque femen perfecte globofum \& aliquantum depreflum fit. 
Hippocaftanum vulgare.

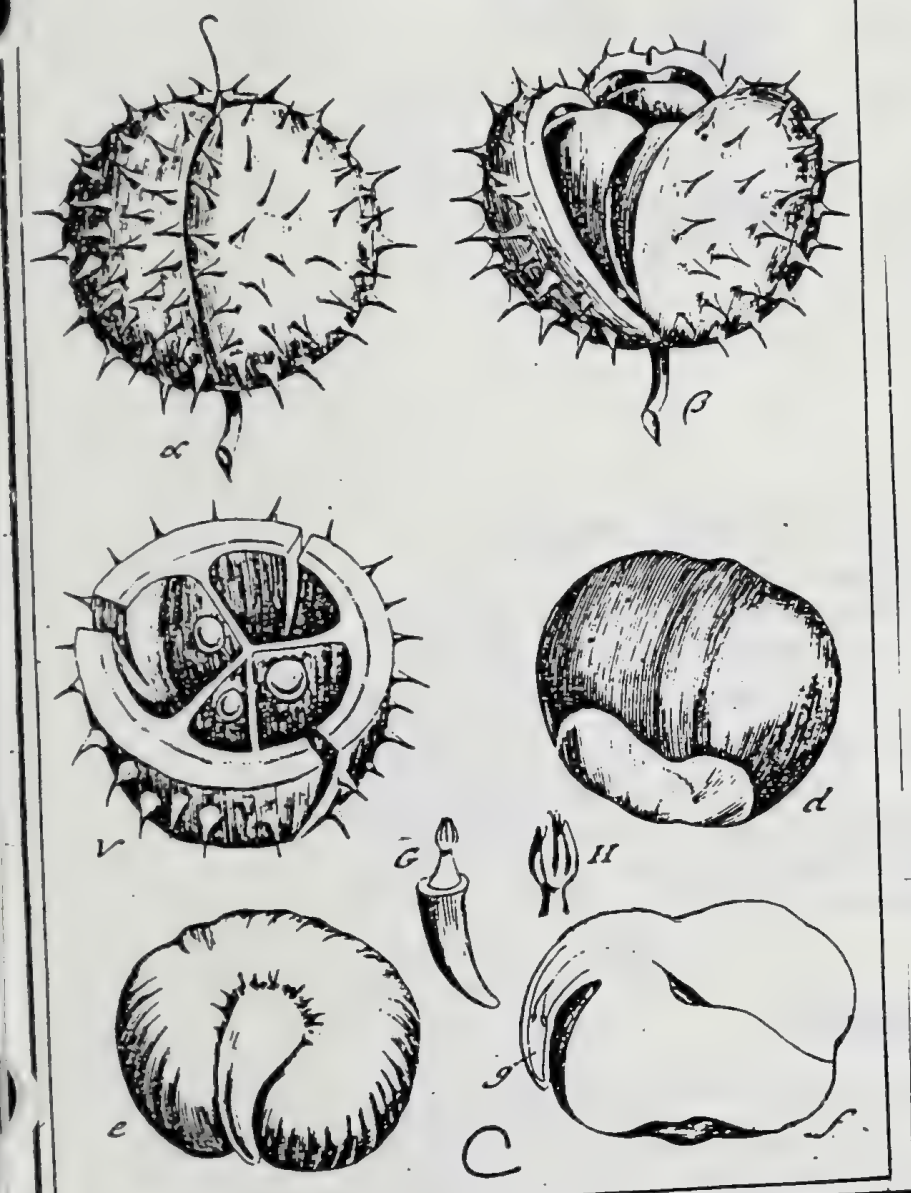

Hippocastanaceae
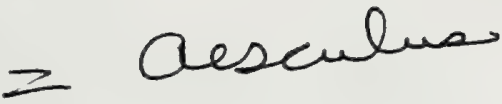

J. Gaertner (17.88) Vol. 2

I35

DCXII. HIPPOCASTANUM. TOURN: inft. $t .382$. IEfculus. LINN. gen. $46 \mathrm{r}$.

Calyx campanulatus, quinquedentatus. Cor. pentapetala, calyci inferca. Stam. feptem. Ovar. fuperum. Styl. Gimplex. Capfula trilocularis, trivilvis. Semina geminata, caftuniformia.

Hippocastanum vulgare. Tab. III. fig. 2.

Caftanea folio multifido. Clus. bift. т. p. 7.

Hippocaftanum. Riv. pent. t. 123. OELHAr.t. 37-39. bene. HALL. bif. n. 1029.*** Ifculus floribus beptandris. Livs. Dift. veg. 352 .

PER. Capfula fulglobofa, undique fpinis pungentibus armata, trilocularis, trivalvis, fubcorticata: fubftantia fcil. exteriore, crafliore, herbzces, cingente aliam tenuiorem, fungofo nembranaceam, candidam. Diflepimentá medio valvularum adnata.

REC. nullum; femina diffepimentis prope axem affixa.

SEN. in fingulo loculamento regulariter gemina, plerumque autem in tota capfula vix tria, caftumeas ex affe æmulantia, fubglobofa fcil varie a vicinis compreffa \& angulata, fuperne öbtufa, inferne derafa, glabra, fplendentia, fpadiceo l. fufco ferruginen.

-IxT. duplex: exterius coriaceum, denfum, firmum; interius membranaceo. fpongiofum, rufefcens, nucleo arcte adnatum.

A L B. nullum.

E $\triangle$ B. Semini conformis, curvatus, inverfus, albus. Cotyl. carnofx, craffifluma, gibb:c, per maturitatem plerumque inter fe conferruminatx. Pliwnula

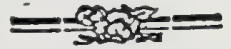

mandiufcula, radicula immerfa, diphylla: foliolis digitatis, conduplicatis. Rad. craffa, conica, curvata, a vertice feminis, verfus bafin ejus defexa, \&. axi fructus obverfa, feu obliqge centripeti.

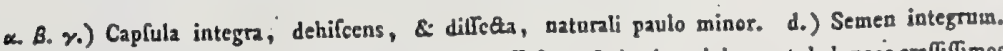
e) Embryo denudatus. f.) Idem verticaliter diffectus, \& in duos lobos cotyledoneos craflifimos divirus. G. G.) Plumula ex Radicula enalcens, \& intra hujus fubfantiam profunde imnicrla. H.) Plumule foliola conduplicatz, infigniter au\&a.

Radicula embryonis conftantem fitum in maturo fructu non habet, quia femina fitum fuum per maturitatem mutant; attamen conltanter radiculx apex derafam feminis bafin refpicit; \& quum hxc, ante maturitaten, femper axi fructus obverfa Gr, ipfam quoque radiculam regulariter centripetam effe, fponte liquet. 



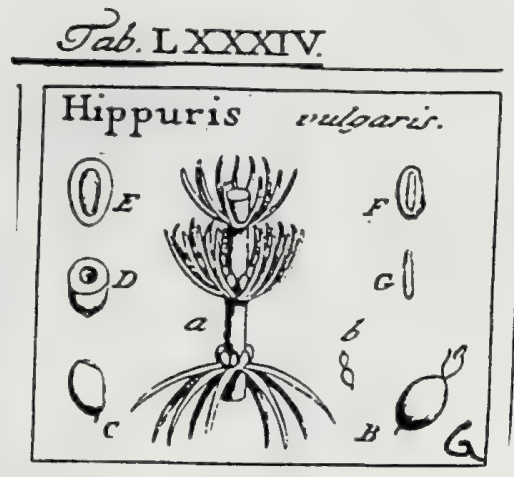

\section{J. Gaertner (1788) Vol. 2}

\section{H I P P U R I S. LINN. gen. ir.}

Cal. nullus. Cor. nulla. Stam. unicum, vertici ovarii innatum. Ovarium fubglobofuns: Stylo fimplici, capillari, longitudine ftaminis. Nux ovatoglobufa, unilocularis, monofperma.

HippURis vulgaris. Tab. 84 fig. 7 .

Polygonsun fenina. CAM. epit. 68g. OzD. for. dan. t. 87.

Limnopence. Hall. biff. "3. 5572 .

- Hippuris foliis oftonis fubulatis. Lins. Eyft: veg. 53 .

PE R. Nux infera, elliptico-globofa, breviffimo peduncuTo nixa, glabra, fpadicea. Curtex tenuiffimus, membranaceus. Putamen craffum, durum, album, uniloculare, evalve.

REC. nullum.

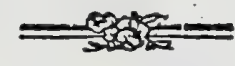

SEM. unicum, magnitudine \& figura cavitatis putaminis, molle, albicans.

IN r. fimplicifinum, membranaceum.

A L B. femini conforme, amygdalino - carnofum, craffiufculum, album.

E M B. teretiufculus, furfum attenuatus, rectus, longitudine fere albuminis, lacteus. Rad. leviter incraffita, infera.

a.) Nueulz in verticillis folioram fe(tiles. b. B.) Nueula feparata, cum fuo famine atque frylo. C.) Putamen denudatum. D.) Idem transverfe fectum. E.) Semen in cavitate putaminis, lopgitudinaliter apcrti. F.) Abumen longitudinaliter diffęum cum embryone. G.) Embryo rolutus.

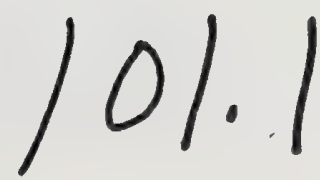


. 


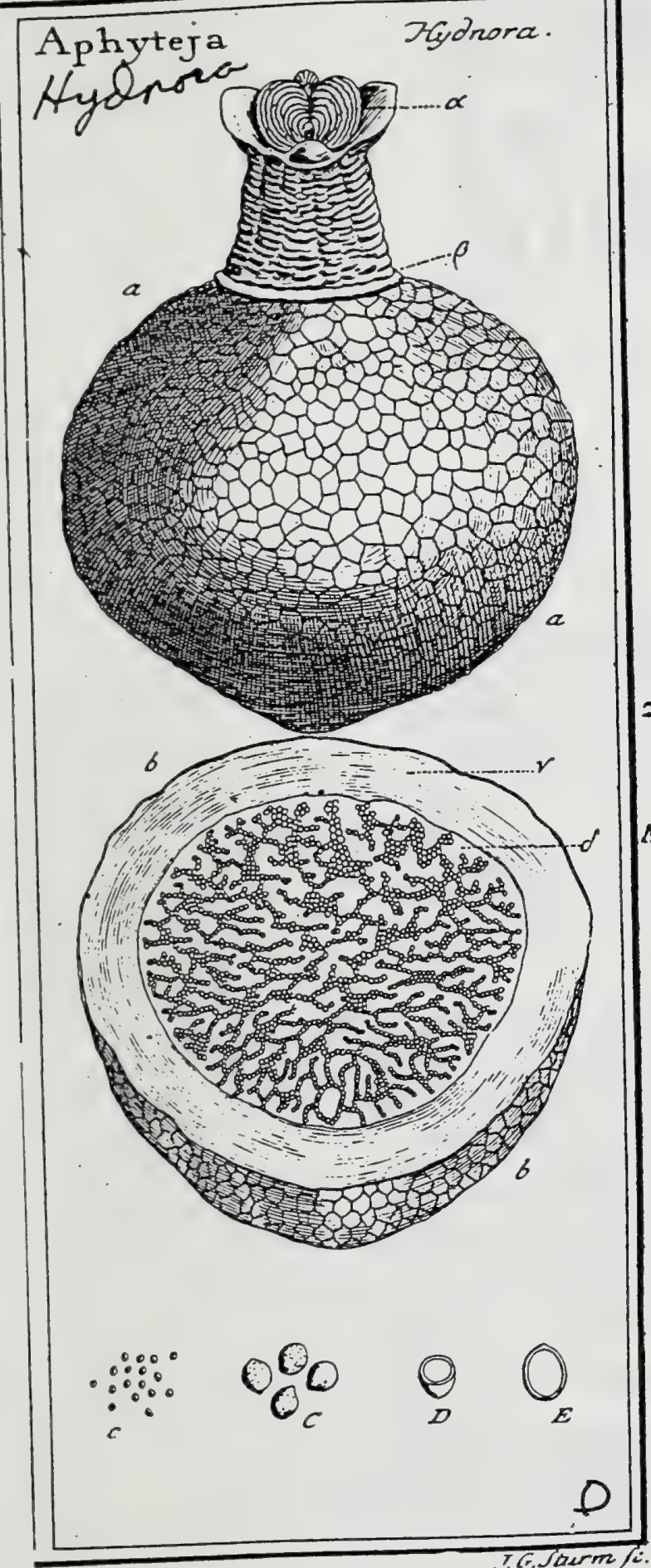

TESaerm :

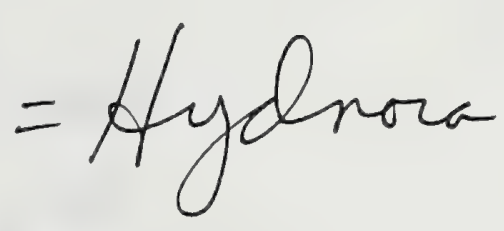

J. Gaertner (1788) Vol.2

261

\section{A P H T E J A. LINN. gen. r4IO.}

Calyx fuperus, femitrifidus, coriaceus. Cor. tripetala? Stam. filamenta corpus trilobum : lobis erectis connive perfiftentes, bali connatex in fubundulatis longitudinalibus in fuperficie exteriori fubreniformibus, ftriis

262

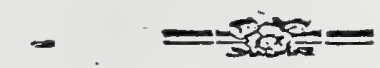

iuferum. Styl. crafus, brevis. Stigm. trigonum. Baccz infera, fareta unilocularis. Sem. numerofifima.

APHYTEJA Hydnora. Tab. 137. fig. 3.

It)dnora africaus THUNB. act. Lolm. 7775 . t. 2. \& 1777. t. 4.

Aployzeja. Lins. fil. diff. p. 7. c. ic. by.t. veg. 60 g.

A Cl. Thunbergio.

PER. Bacca infera, fubglobora, obfolete trigona atque gibbofa, unilocularis, corticata; fuperie elongata in collun cylindricum rugofum, flore terninatum; inferne auten definens in mucronem breven obtufifmme conicum radiciferum. Cortex craffus, fuberofus, externe fubrimofus, lineolisque deprefis reticulatis teffulatus. Caro fpongiofa', mollis, alba.

$\mathrm{R}$ E c. nullum; fenina nidujantur in pulpa, in qua ftrias formaut irregulares ex acervulis feminum laxioribus aut denfioribus.

SEM. numerofifima, exiliffima, fubglobofa aut a vicinorum preftione varie angulata, nigro-fufea.

Ix T. finiplex, craffufculum, fpongiofo - membranaceum.

A L в. fenini conforme, fubgrumofum $\int$. granulofe carnofum, aqueo-pallidum.

ENB. ......

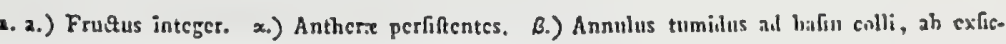
catione baccx forfan elaztus. b. b.) Bacen transverfim feíta. r.) Corticis crufitities. f) Pulpa cum feminibus. c) Semina ab aqua cmollita \& tumefaeta, aridis \& exficeatis duplo majorz. C.) Eadem aueta. D. E.) Albuminis feétio transverfalis atque lousitudiualis.

Magnitudo fructus varia, a gallinacei ovi, ad pugni amplitudinen quando. que laxata. Collum ante floris explicationem nullum, fed calyx in vertice pyrifornis \& tunc manifeftius trigonx bacca feftilis. Intra hunc, curollx rudinenta (in meis abrupta); \& demum fornix valde depretlus, ex tribus fegmentis triangularibus, fubtiliatime \& elegantidine lungitudinaliter Itriatis ac fibi mutuo ita coaptatis, ut ne rima quidem patcat; $c$ quibus autem, demum folutis, ipfx fornantur antherx, omni flamentorum veftigio nenitus deftitutx. Enbryonem detegere potui nullun; Cilten in unico obefiori paulifper femine vidi minumm cavitatem fubrotund:ı, in ipfo albuminis centro, fed inanem illam atque vacuan. Anut his feminibus faltem embryo posentialis concefus; aune vero mea fenina nondum rite matura?

Nullo jure hac planta ad Alonudelphus relata fuit; debuiffet potius Symgencfiis inferri, ad exemplum Cucurbitacearum, cum quibus etiam, refpectu fabricx antherarum, aliquantulum affuitatis habet. 
. 


\section{Tab. cLXXXIV.}

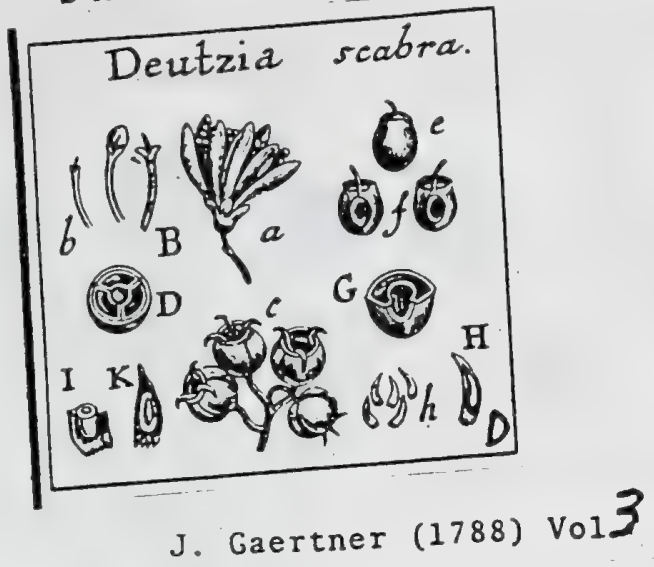

28. D E U T Z I A.

28. D E U TZI A.
THUNB. nov. gen. 19. jap. io. LINN. gen. ed. Schreb. $77^{6 .}$
Joss. gen. p. $43^{\text {I. }}$

Cal. inferus, turbinatus, monophyllus, quinquefidus, tomentofus, parvus. Cor. penta - heptapetala; petalis ovato - oblongis, albis, calyce duplo longioribus. Stam. decem : filamentis corolla paulo intermedix cufpidi affixis. apice triculpidatis; antheris obefls didy ${ }^{2}$, truncata, umbilicata, tricocca, Ovar. fuperum. Styl. tres. Caplo globof, tra, membranaceo - compreffi, Atylis tribus

Deutzia fcabra. Tab. 184. fig. 4.

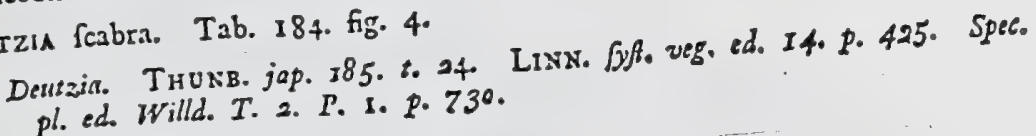

a Cl. Thunberg.

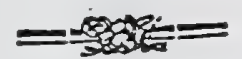

PE r. Capfula urceolsto - globofa, fo apice truncata, \& ampliffime umbilicata, obfolete trigona, tribus ftylis perfiftentibus ariftata, corticata, tricucca, trivariam a bafi dehifcens. Cortex tenuis, cinereus, pundis minutitimis callofis fcaber. Cocculi tres aut quatrolfi, \& in medio ventre, in dorfo convexi, ad latera cuneiform dehilcenti membrana facta, exarati ampla cavitate ex propria \& demumiti.

atque ftylo perfiltente rigefacto muniti.

REC. mullum; fenina corlum pendula atque imbricata.

SEM. plura, ad duodecim in fingulo cocculo, oblonga, verfus apicem acuminatiffina, ad bafin latiora \& denticulata, cetera foliaceo-compreffia, fcobitornia, furca.

IN T. fimplex, membranaceum, fupra \& infra nucleum in tenuem laminam elongatum.

$\Lambda \perp$ B. femine dimidio brevius \& in ejus medio.hærens, ovatum, lenticularicompreflum, carnofum, pallidum.

E M B. Iongitudine fere albuminis, gracilis, compreffus, inverfus. Cotyl. minurifimx, obculix. Rad. longa, recta, fupera.

\section{EXPLICATIO FIGURE.}

2.) Flos integer eum corolla beptapetala. b. B.) Filementa feparatz, apiee tricufpidata. c.) Ra cemulus, cum capfulis maturis integris D.) Capfula eransverfim difteda. C. f.) Cocculi fepaa ventre (pedati. G.) Cocculus transverfe diffectus. h. H.) Senina feparata. 1. K.) Seminis Iectio transverfalis \& longitudinalis cum fitu \& Ggura Embryonis intra albumetu.

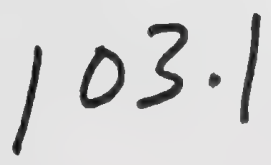


. 


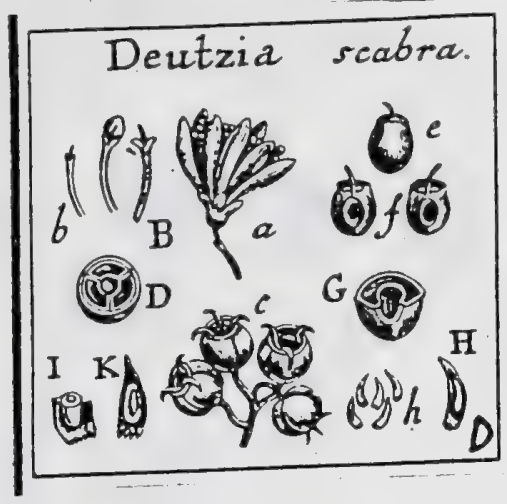

J. Gaertner (1788) Vol3

Thuлв. nov. gen. 19. jap. io. LINN. gen. ed. Schreb. $77^{6}$.

Joss. gen. p. 43x.

Cal. inferus, turbinatus, monophyllus, quinquefidus, tomentolus, parvus. Cor. penta - heptapetala; petalis ovato - oblongis, albis, calyce duplo longioribus. Stam. decem : filsmentis corolla paulo brevioribus, linearibus, apice tricufpidatis; antheris obefis didymis, intermedix cufpidi affixis. Ovar. fuperum. Styl. tres. CapL. globofa, truncata, umbilicata, tricocca, ftylis tribus perfiftentibus ariftata. Sem. plurs, membranaceo - compreffi, fcobiformia.

Deutzia feabra. Tab. I84. fig. 4.

Dentzia. Тнихв. jap. 185. t. 24. Lisx. fyfo veg. ed. If. p. 425. Spec. pl. ed. Willd. T. 2. P. 1. p. 730.

A Cl. Thunberg.

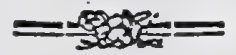

PE R. Capfula urceolsto-globora, f. apice truncata, \& ampliffime umbilicata, obfolete trigona, tribus Bylis perfiftentibus ariftata, corticata, tricieca, triviriam a bafi dehifcens. Cortex tenuis, cinereus, pundtis minuriltimis callofis faber. Cocculi tres aut quatuor charcacei, uniloculares, in dorfo convexi, ad laters cuneiformi comprelli, \& in medio ventre, ampla cavitate ex propria \& demum dehilcenti menbrana facta, exarati atque ftylo perfiltente rigefacto muniti.

RIC. nullum; Tenina convexx parti membranx cocculorum ventralis prope verticem affixa, deorlum pendula atque imbricata.

SE K. plura, ad duodecim in fingulo cocculo, oblonga, verfus apicem acuminatifima, ad bafin latiora \& denticulata, cetera foliaceo-comprefa, fcobitormia, fufca.

IN T. fimplex, membranaceum, fupra \& infra nucleum in tenuem laminam elongatum.

A L B. femine dimidio brevius \& in ejus medio.hærens, ovatum, lenticularicompreffum, carnolum, pallidum.

E M B. Iongitudine fere albuminis, gracilis, compreflus, inverius. Cos y. minutifimx, obcuiz, Rad. longa, recta, fupera.

\section{EXPLICATIO FIGURE.}

a.) Flos integer cum corolla heptapetala, b. B.) Filamenta (eparata, apice triculpidatz. c.) Rs. cemulus, cum capfulis maturis integris D.) Capfula transverfion diffecta. C. f.) Cocculi feparati a vorfo \& a ventre fpedati. G.) Cucculus transverfe diffedus. h. H.) Semina feparata.

1. K.) Seminis fectio transterfalis \& longitudinalis cum fitu \& figura Embryonis intra albumeu.

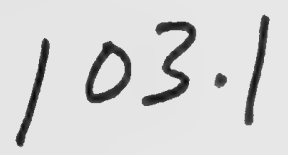




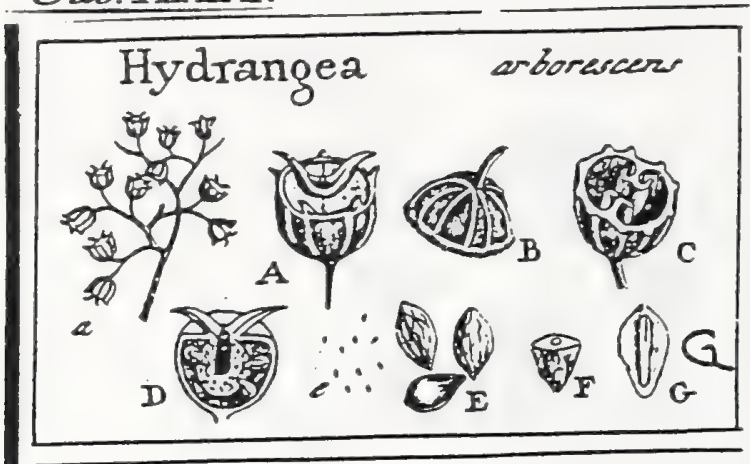

\section{J. Gaertner (1788) VoJ.I \\ 150}

\section{HYDRANGEA. LINN. gem.'557.}

Caly'x pericarpio adnatus, quinquedentatus. Cor. pentapetala. Statn. decen. Styl. duo. Caplula infera, bilocularis, foramine inter ftylos dehifcens.

HYDRA NGEA arborea. Tab. 30. fig. 7 .

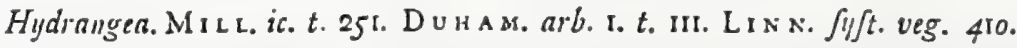

PER. Caplula infera, parva, calycis undique areीulime adıati denticulis quinque diflan. tibus, parvis, coronsta, lubhemisplıxrica, decem friata, fupra planiuscula, fyylis duobus fubulatis divergentibus terminata, bilocularis, evalis, loramine centrali inter Aytos dehiscens. Dillepimentum membranaceum, per maturitatem fuperne pervium.

REc. fpongiofum, diflepimenti parti fuperiori utrinque adnatum, per maturitatem foramine medio dehiscens: marginibus utrinque reltexıs.

S F.s. plura, circiter viginti in fingrilo loculancuto, parsa, ovato acumisata, fubangu. lata, lenticulari comprefia, venis reciculata, fufca.

Ix r. finplex, membranaceum, tenue.

A L в. femini confo:me, pallihlum, carnofum.

E.sn. dicrsyletoncus, teretiusculus, longitudine albuninis, lutescens. Colyl. Femite. retes. Red. longa, craita, centripeta.

2.) C) Sprötus. C. ) F.jus fielin transwerfalis. D.) Faden longitudinalier ferta. cum forma receptaculi maturi. c. ) Scinina (eparata, F.G.) Albuniuis feltioues eum enibryol:e.

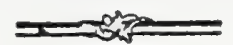

Capfulam circtmfcifam dicit $\operatorname{LIN}$ E $\mathrm{U} S$ in recentioribus fuis fcriptis ; olim vero eam foramine inter cornua dehifcere, rectius forfan dixerat: nam hac fola pofterior fabrica in noftris fpeciminibus occurit; ut tamen \& altera, ficcit in Heuchera videbimus, locum habere queat: 
Tab.XXXV

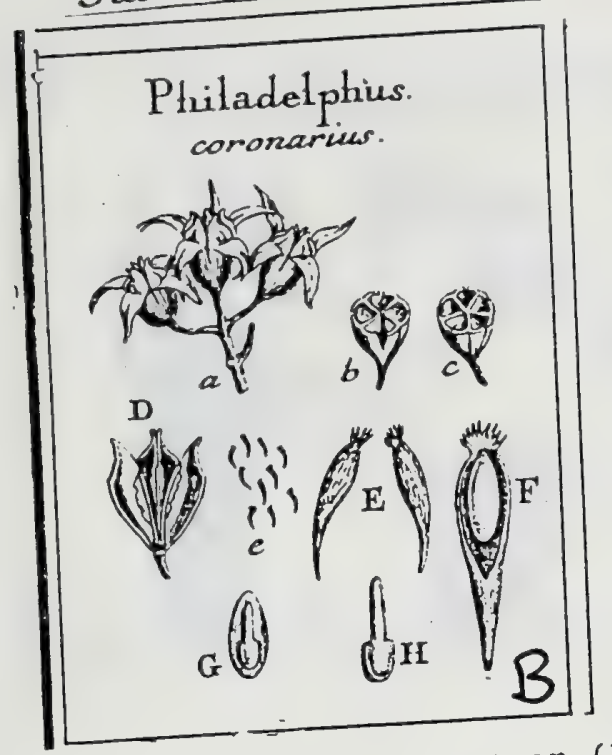

J. Gaertner (1788) Vol.1

173

Hydrangeaceae

(

CCVIII. PHLLADELPHUS. LIN gen. 614. Syringa.

T OUR N. t. 389 .

Calyx ovario adnatus, quadri - L quinquepartitus. Cor. quadri-L. pentapetala. Stam. plura, difcreta, calyci adnata. Sryl. unicus. Caplula femi intera, quadri-1. quinquelocularis. Semina arillata.

PHILADELPHUS coronarius. Tab. 35. fig. 2.

Syringa flore albo fimplici. B E.s t. hort. Eyf. vern. frut. t. 2. f. 3 .

philadelplus foliis fubdentatis. H A L L. hifl. 2. n. 2100 . LINN. Jygl. veg. 460 .

$P E$ K. Capfula feni-infera, ovata, utrinque acuminata, quadri-l. quinquelocularis, in cotidein valuulas dehiscens. Diffepimenta valvis contraria.

REc. margo diffepinentorum centralis incraffatus \& reflexus, cui fenina deorfum incumbentia affisa.

SEs. numerofiffuma, exiliffuna, fubfcobiformia, fpadiceo rufescentia, arillara.

Arillus membranaceo fpongiufus, oblongus, ad umbilicum fimbria lacera terminarus, in parte oppofita in caudam acuminatam dcfinens.

INT. inembranaccum; tenuifinum, nucleo adnatum.

A \& B. ovato globofuus, arillo fere triplo brevius, carnofum, album.

EM B. dicotyledoneus, inverfus, Jongitudine fere albuminis, lecteo albus. Cotyl. ovatx, planiuccula. Rad. teretiuscula, coryledouibus fesqui longior, recta, fupera l. cenwipets.

174

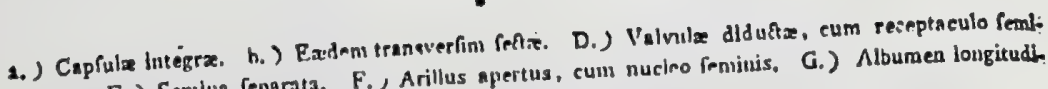
num. e. E.) Semlua (rparats. F., A rillus apertus, cum nuciro frnituis. G.) Mbumen longitudi saliter difaliam cum fitu \& figura enibrionis. H. ) Embrjo feparatus.

103.3 
.

4

8 


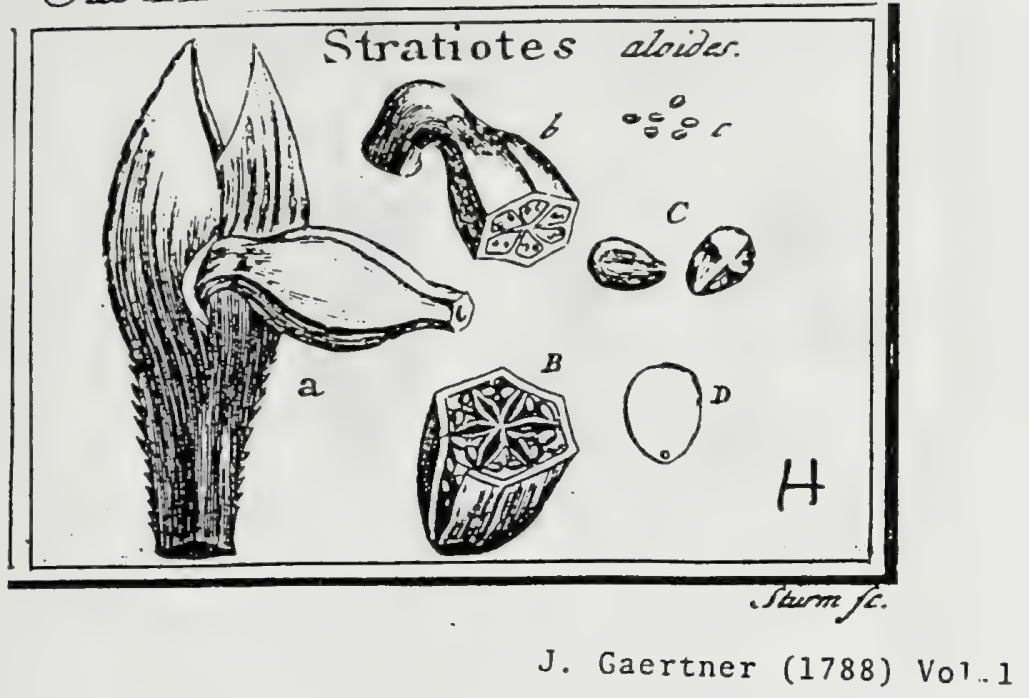

LV. STRATIOTES. LINN. gen. 687.

Planta in regionibus tempcratis diphyta, in frigidis monopliyta. Spatha dipliylla. Cal. trifidus, aut triphyllus. Cor. tripetala. Stam. in hermaphroditis viginti : in mafculis, novem ad duodecin antheris inftructa, reliquis caftratis, in ambitu pofitis. Bacca infera, hexagona, fexlocularis. Semina parittalia.-

STR A TIOTES aloides. Tab. 14. fig. 8.

Stratiotes. Z1 N N. Comment. gatt. 1753 . Vol. 3. p. 425. t. 9. 10. OE DER." flor. dan. t. 337.

Stratiotes foliis enfiforni triangulis ciliato aculeatis. LIN N. fyf.veg. 506.

PER. Pacca infera, ovata, utrinque attenuata \& quafi roftrata, cernua, carnola, hexagona, fexlocularis. Loculanenta, ope duplicis membranx, tenuillimx, fecunduin longitudiucin fuaw, ab ívicem difcreta, pulpa cryflallina repleta,

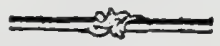

R E c. nullum; femina intra pulpain nidulantia \& parietibus baccx, prope externos loculamentorum angulos aftixa. Sess. plura, decem ad duodecim in fingulo loculamento, ovata, fubangulata, pallide
rufefcentia.

IN T. finplex, membranaceum, arctifime nucleo adnatum.

A L B. Semini conforme, carnofum, duriusculum, album.

Eм в. minutilfunus, in extremitate feminis umbilicali locatus. ...

2.) Bacca integra, b. B.) Eadem transverfe feta. c. C.) Semina feparata. D.) Albumen longitridinaliter fetum, cum fitu enbryonis.

Pulpa, in Aatu naturali, pelluciditatem habet vitrei oculorum humoris fimilem, in Spiritum vini autem demerfa, opaca \& alba fit, prorfus ficut coctum ovi albumea, aut ficut fimilis illa pulpa pellucida in baccis Callx xthiopicx; cum vero ambx hx bacca aqua redjuntur, pulpa redit pelluciditas.

Embryonem, in feminibus non rite forfan maturis, non difincte vidi, fed in ejus fede, punctuin faltem gelatiofum. 


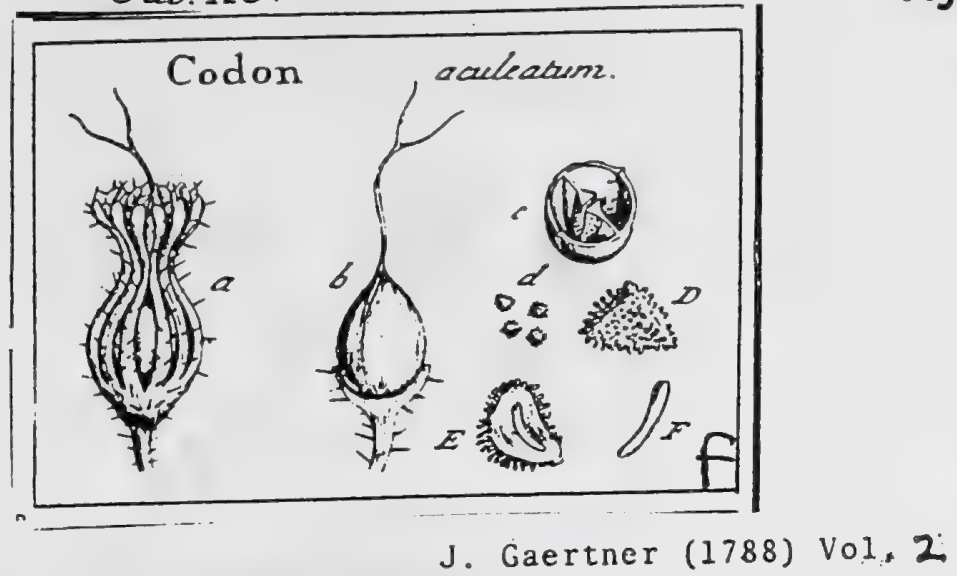

87

\section{C O D O N. LINN. gers. 12S5.}

Calyx decempartitus perfiftens. Cor. campanulata, limbo decempartito. Neet. fquamulix decem consiventes, rcceptaculum tegentes. Stam. decem. Ovar.

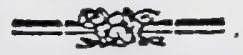

fuperum. Styl fimplex, compreffus, apice bifurcatus. Capfula bilocularis. Semina papillis mollibus echinata.

Codos aculeatum. Tab. 95. fig. 7.

Codou. Lins. Syf. veg. 397.

Ex herbario Bankfiano.

PER. Capfula cilycis perfifentis laciniis linearibus, carinatis, aculeolatis conniventibus comprehenfa, ovato-acuminata, Itylo compreffo bifurento terriinata, \& ex eo futura acuta utrinque infripta, cetera glabra; bilocularis, bivalvis. Difepimento valvis contrario, ad axem bifido \& fposto giofe incraflato.

REC. nullum, præter difepimenti fubftantian verfus axem infigniter incrifatan \& qual rhombeo-quadrangulam.

SEM. numerofa, parva, varie angulata, rutilo-fanguinea atque pspillulis mollibus ejusdem coloris undique contectir.

Isi. fimplex carnofum, tenue, papilliferum, albunini arcte adnatum.

A L B. femini conforme, fabulufo-carnufum, durum, in medio glaucum, verfus peripheriam colore fanguineo fuffufum.

Es в. longitudine fere albuminis, filiformis, incurvus, niveus. Cotyl. brevifGmx. Rad. longiffima, centripets.

a.) Capfulz ealyee teda. b.) Eadem denudatz c.) Ejusiem fettio transverfalis d. D.) Semina feparata. E.) Albumen longitudinaliter difeetum, cum fitu embryonis. E.) Embryo Solutus \&. infigniter audus, 


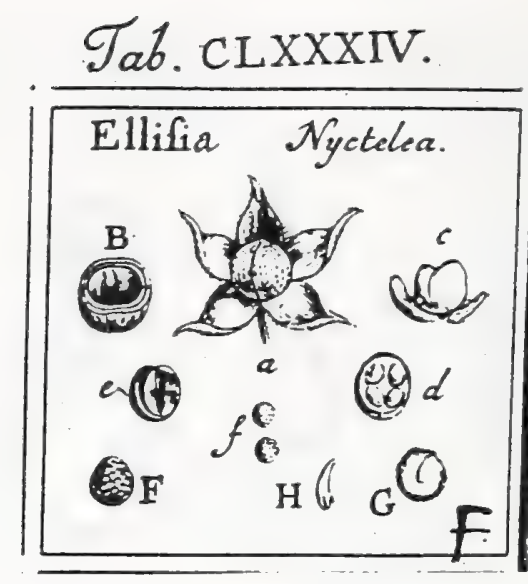

Hydrophyllaceae

J. Gaertner (1788) Vol3

30. E L I I S I A.

LINN. gen. 2440 ed. Schreb. 268. Juss. gen. p. 129.

LAM А в в ill. gen. t. 97 .

Cal. profunde quinquefidus. Cor.minar infundibuliformis, quinquefida. Stam: quinque, non exferta, antheris fubrotundis. Ovar. fuperum. Styl. fimplex, ftigmate bifido. Capfula receptaculo feminum baccata f. farcta, unilocularis, bivalvis. Receptac. per maturitatem exarefeens ill conceptaculum feminum proprium, biloculare, bivalve. Sem. in loculis gernisa, uno fupra alterum.

ELIisya Nyctelea. Tab. 184. fig. 6.

Ellifra. Lins. Nov. a.7. upf. V. r. f. 97. t. 5. f. 5. Mramt. 336. SyA. veg. ed. 14. p. 295 . Spec. ph ed. Willd. T. I. P. 2. p. 815 .

A. Cl. Heratank.

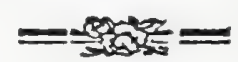

PER. Capfula fubglobofa, coriacea, fetulis minimis hifpida, unilocularis, bivalvis; ante plenam maturitatem feminum receptaculo carnofo farcta.

REc. magnitudine \& figura cavitati capfulx refpondens, ejusque parietes internos undique contingens, ante maturitatem carnoium \& feminibus quaternis intra fe nidulantibus fcatens, poftea vero exarefcens in thecam feminum propriam, membranaceam, fpadiceo - fufcara atque in eundem modum \& fenfun, uti capfula ipfa bifariam dehifcentem. Valvula intus, a parte dorfali, fulco elevato obfoleto notatx, ut feminum theca fiat incompletiffime \& vix fenfibiliter bilocularis.

San. quatuor, in fingulo latere gemina, fibi mutuo fuperimpofita, ellipriceglobofa, excavato-punctata, nigra.

IN T. fimplex, menbranaceum, albumini pertinacifime adnatum.

A L B. femini conforme, cartilagineum; in peripheria late glaucum aut fufcum, in centro niveum undique opacum.

E M B. tereti - acuninatus, longitudine dimidii albuminis, niveus. Cotyl. brevifimx. Rad. longa, attenuata, prope albuninis feripheriam excentrice locata, vaga.

\section{EXPLICATIO FIGURE.}

a.) Fruaus integer magnitudine natarali. B.) Caplulx \& thecz femianm propriz fetio traas verfalis. c.) Capfula dehifeens, cum theca feninum integra. d.) Ejosdem immatura \& adhuem dum carnofx featio verticalis, cum fitu ovulorum. e.) Capfulx \& thecx valvala alterz a parte iuterna fpeatatz. f. F.) Semina (eparatz. G.) Albuminis fectio verticalis, cum fitu \& figure embryonis. H.) Enibryo folutus.

Tanta eft inter fruelum Ellifix \& Hydrophylli Carpol. noftre V. 2. p. 133. 8. II0. affinitas, ut, nifi probe ad figuram, numerum \& colorem feminum, nec non ad longitudinem embryonis attendatur, yix alia dentur fogna, quibus a fe invicem diftingui queant. 


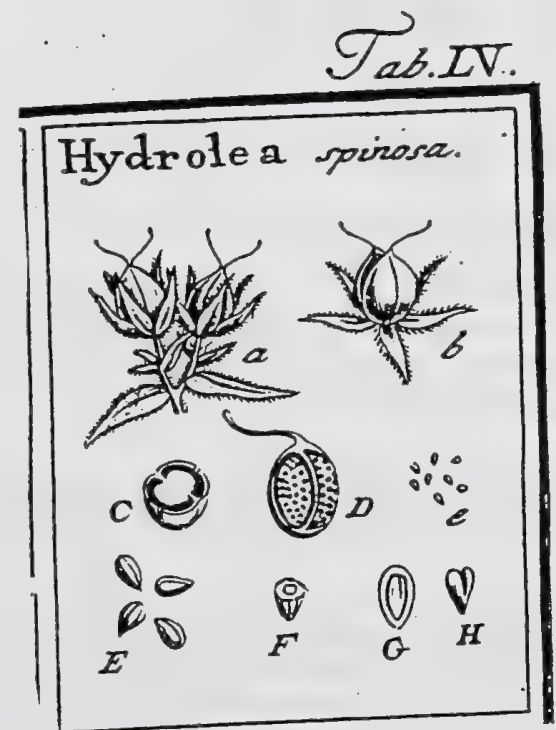

J. Gaertner (1788) Vol. 1

CCCXXIX. HYDROLEA. LINN. gen. 318 .

Calyx pentaphyllus. Cor. rotato - campanulata. Stam. quinque: filamentis bafi cordatis. Styl. duo. Capfula bilocularis. Diffepimentum contrarium. Recept. maximum. Seinina parva.

HYDRolea fpinofa. Tab. 55. fig. 9.

Hydrolea. LIN N. Jilf. veg. $26 \mathrm{~g}$.

Ex herbario Bankfiano.

PER. Capfula ovata, acuminata, utrinque fulco"infcripta, membranacea, tenuifuna, fubdiaphana, Diffepimentum fimplex, angufiffimum, valvis contrarium.

REc: maximum, fungofum, ferobiculatum, fulco, cui feptum inferitur, qua $\sqrt{1}$ in duo hemifphxria partitum.

SEM. numerofifima, parva, ovata, verfus umbilicurn attenuata, obfoletiffime fulcata, fallide ruffecentia.

INT. duplex: exterius coriacenm; interius membranaceum, fuperficie interna carnofuin.

$\Lambda$ L B. nulluin, prater fuperficiem carnofan integumenti interni.

E м в. fubclavatus, reclus, luteus. Cotyl. plano-convexx, extrorfum paulo crafrio res. Rad. corica, brevis, centripeta.

a.) Ramuli frugiferi spex, cam capfalis claufis, b.) Capfula dehifens. C.) Ejas fello trans verfalis, D.) Recepiac, denudatum. e. E.) Semina feparala. F. G.) Embryonis fitus \& figura Lutra feminis integumenta. H.) Embryo feparatus. 

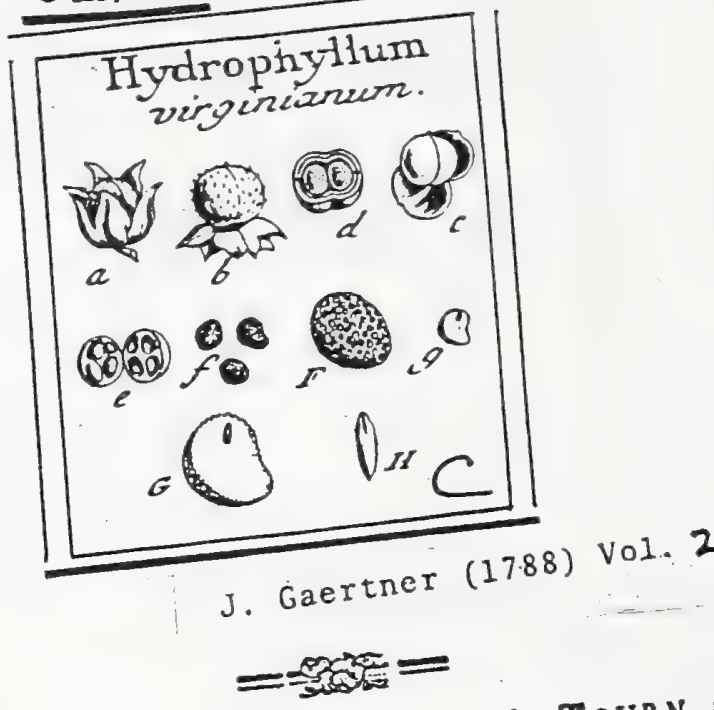

\section{H Y D R O P H I LUM. TOURN. inft. t. I6.}

Calyx quinquepartitus. Cor. moriopetala, campanulata, internę ftris quinque melliforis longitudinalibus. Stam. quillque. intra recepraculum bacesfimplex. C:ıpula

HYDROPHXLLUM virginiatum. Tab. 110. fig. 3.

Dentaria affinis, eclii
germ. p. 295 . t. 12 .

Hydrophylltom foliis pomatifidis. LINN. Jyft. veg. $195^{\circ}$. inferipta, fetulis albis

PER. Capfula globofa, utrinque fulco palvis.

undique confperfa, unlloculais, capfulx cavitatem replens, primo herbaceo-

REC. globofum, liberum, totam capum numero xquales partirum, deincens. carnofum, in cellulas or rufefecns, una cum capeceptaculum nidulantia, membranaceo fponger, fxpe vero patiora, intra receptis eleganter reticulata,

SEM. regularicer quatuor \& angulata, minutiflimis ferobitata ex alho lutefcentia.

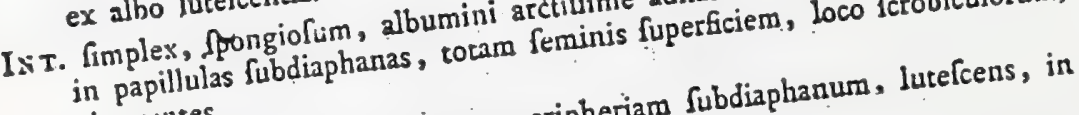

in papillulas.
obtegentes.
A IB. cartiligineum, durum, prope peripheriam fubdiaphanum, lutelcens, in
medio autem opacum, album. medio autem opacurioimis, lacteus, prope peripheriam craffa, longa, vaga,

E I B. minutulus, Cotyl. brevifime, acuminata.

f. determinatum Gitum in fruetu nor

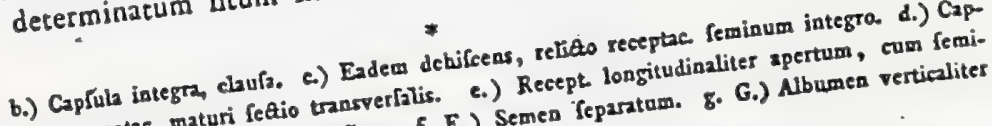

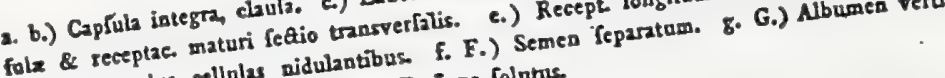
sibus intrz ejus cellalas sidula H.) Embrgo folutus. ditretum, cum litu embryonis. .H.

\section{4}




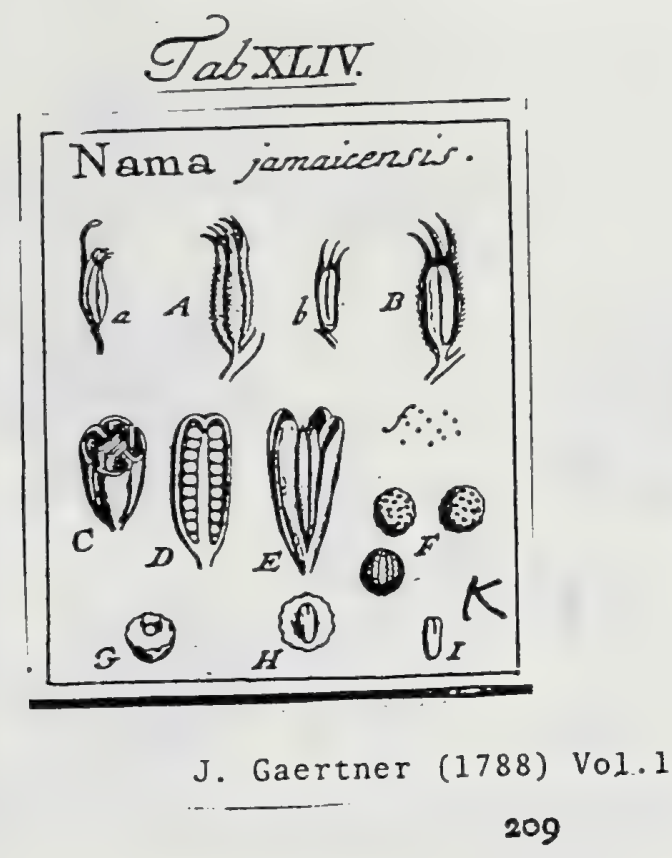

CCLIV. NAMA. LIN

Calyx pentaphyllus. Cor. quinquepartita Stam. quinque. Styl. duo. Capfula fupera bilocularis. Receptaculum bilamellatum diffepinentis interpolitun. Semina numerofa.

Nas a jamaicenfis. Tab. 45. fig. $\varepsilon$.

Nama reclinata villofa, foliis ovatis petiolatis marginatis recurrentibus, floribus fulitariis. likOw . hift. jam. 185.t. 18.f. 2.

Nama caule decumbente, foliis ovatis, floribus folitariis. LiNN. fyfl. veg. 265.

Ex herbario Bankfiano.

PER. Capíula oblonga, teretiuscula, utrinque fulco inferipta, obtufa, bilocularis, bivalvis; valvis per maturitatem bifidis. Diffepimentum valvis contrarium, ex in. flexis earundem marginibus formatum.

R E c. laminx dux membranacex, lineares, acuminatx, in axi capfule \& ad concurfum diffepimentorum pofitx, liberx, femina in quolibet loculamento duplici ferie pofita fuftinentes.

SEs. numerofa, fubglobofa, parva, fcrobiculata aut cancellatim friata, fufca.

INT. duplex : coriaceum \& membranaceum; utrumque tcnue.

A B. femini conforme, carnofun, aqueo-pallidum.

Ess. teretiusculus, pallide albicans. Cotyl. breviffmx. Rad. crafra, centripeta.

A. A.) Capfula calyce fabro vertita. b. B.) Eadem denudata. C.) Ejus \& receptaculoram fetio ra A.) Situs (emioum in receptaculo. E.) Capfula delisicens. C. F.) Semina foluta. in aqua emollitum, cancellato friatum. G. H.) Embryo intra albames differtum. 1.) Enibrjo Scparatus.

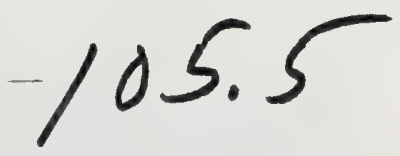




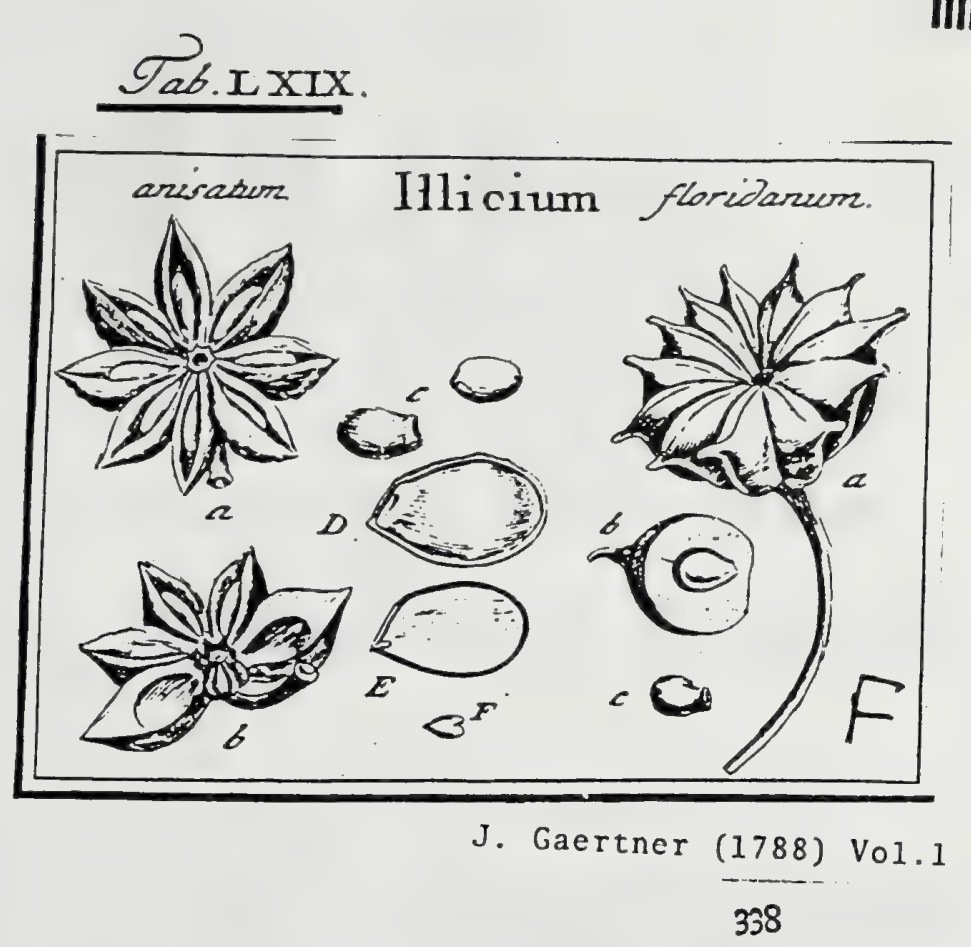

CCCCXXXVI. ILLICIVM. LTNN. gen. Gir.

Calyx hexaphyllus. Cor. polypetala. Stam. plura, thalamea. Styl. plures. Capiulzer plures, in orbem pofitx, margine fuperiori dehifcentes. Semina folitaria, nitida.

ILlieivm anifatum. Tab. 69. fig. 6.

Zingi fruftus fellatus S. Anifum indicum. В А ч н. hifl. т. p. 485.

Somo vulgo Skimmi. K e M P F. aman. 880 . ic. $\$ 81$.

Illiciun foribus flavefcentibus. L I N. $\int y / f$. veg. 507.

PER. Capfulx fex l. octo in orbem pofitx, ovato lancesolatx, compreffusculx, horizortales, fuberofo lignofx, extus fabrx, intus lavigatx, uniloculares, margine. fuperiore dclifcentes, fortem anifi odorem triturâ fpirantes.

REc. conımune, axis fructus brevifimus, multangulus; propritsm, nullum prater extremitatem centralem loculatnenti.

SEM. folitaria, elliptica, antice fubtruncata, lenticularia, lavigatifima, nitida, e ciŕnamomeo-rufelcentia.

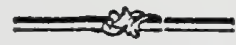

In r. duplex: exterius cruflaceum, tenue, fragile; interius Spongiofo membranaccum, ferrugineum.

A .8. femini confurme, carnofum, odoratum, melinum.

Е м в. minutiffunus, fubglobolus, in bafi albuminis locatus, albus. Cotyl. brevifinim. Rad. craffa, infera f. relative centripeta.

a.) Fruthus maturns dehilcens, b.) Recept. commune, cum figura loculamentorum. c.) Semina foluta. D.) Nucleus denudatus. e) Embryo intra albumen. F, Idem feparatas.

IL I ICIU M floridanum, ibid.

Illicium floribus rubris, fruttibus odoratiffmis. ELI Is, att. angl. 1770. t. I2.

Illicium floribus rubris. LinN. fu/. veg. 507.

Ex dono Dn. A I T o n.

Fructus longe pedunculatus (a); fupra depreffusculus, umbilicatus; infra hemi[plixrice convexus; fubviginticapfularis. Capfulx (b) rotundatx, verfus axem cuntiformi compref $x_{x}$, in dorfo autem convexx, craff $x$, teretiroftellatx; ante plenam maturitaten carnof $x$, lamina cartilaginea intus veflitx; demum coriaceo-fuberof $x$, margine fuperiore dehifentes, grate aromaticx. Semen obovatum (b.c.), lenticulare, glaberrinum, nitidum, e fpadiceo lutefeens, antice umbilico turgidulo, cartilagineo, albicante terninatum. Reliqua ut in pracedenti. 


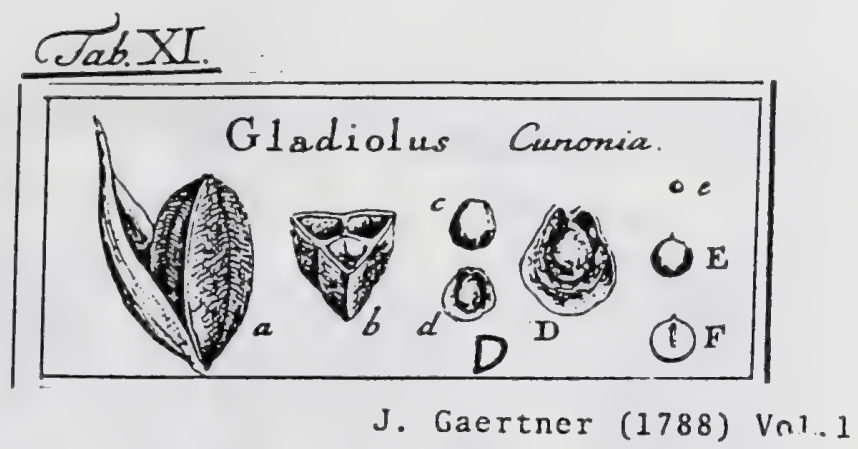

XXXVI. GLADIOLUS. Tourn. t. rgo. Lins. gen. 57. Antholyza.

LiNN. ger. 58 .

Spathx bivalves. Corolla fex fida, irregularis, incurva. Stam. tria Styl. finsplex. Capfula infera, trilocularis, trivalvis. Semina plura. Embryo dinidio albunine longior.

G I.A D I L L U S Cunonia. Tab. ns. fig. 4.

Cunonia foribus fajlibus, fpathis maximis. B х т т N. hort. cun. 2Ir. t. I.

Antholyza corollis Julpapilionaceis: labii lobis duobus externis latioribus adfcendentibus. Lis $x$. Syfl. veg. 87.

PER. Capfula infera, inembranacea, ovata, trigona, pallide albicans, trilocularis trivalvis. DilTepinenta medio va'vularum longitudinaliter adnata, infertioni extus reSpondente lineadepreffa, e qua utrinque frix tenuifimx, parallele, oblique defcendentes, fuperficiein valvularuin exornant.

RE c. margo diffepimentorum centralis, cui femina utrinque affixa.

32

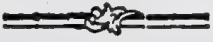

SE M. plurima, duplici ferie longitudinali deorfum imbricata, obovata, bracteata f. lato margine membranaceo cincta, concava, fpadicea.

is т. duplex: exterius tenue, in marginem feninis ampliatum; interius tenuifunum, rubro ferrugineum, nucleo archifime aduatum.

A B. globofum, parvun, fubcartilagineum, aqueo-pallidum.

E M s. teretiusculus, rectus, lacteo-albicans, dinnidio albumine paulo longior, in ejus. den axi prope umbilicum locatus.

2.) Capfula iotegra. b.) Esdem transverfe feta. c.) Seminis latus externum. d. D.) Ejasdem (acies interna concava, e. E.) Albumen denudatum. F.) Ejusdem felto longitudinalis, cum fitu \& figura Embryonis.

Antholyza LIN . commode Gladioli genus intrare poteft. 


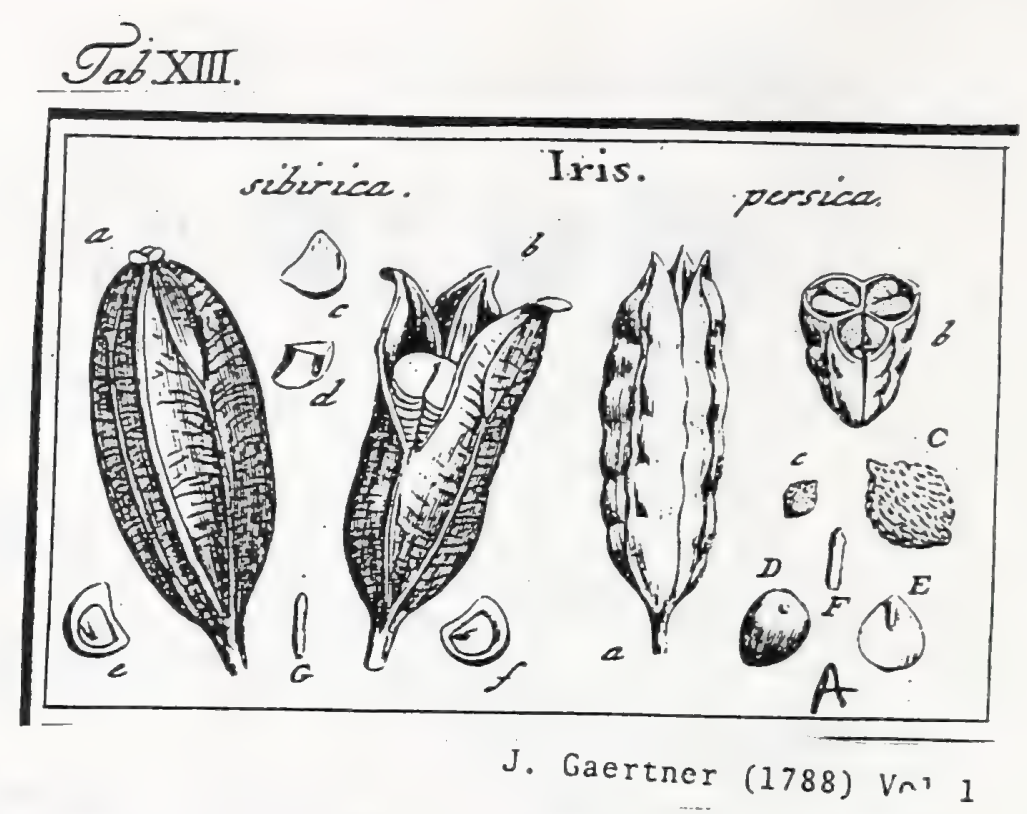

XLIII. IRIS. TOURN. t. 186-187. LINN. gen. 99.

Corolla fexpartita : petalis alternis reflexis, alternis conniventibus erectis. Stam. tria. Stigmata petaliformia. Capfula infera, trilocularis. Semnina numnerofa, hornzon. talia. Embryo dimidio albumise brevior.

IR is fibirica. Tab. 13. fig. 1.

Iris anguflifolia II. CLus. hift. I. p. 227.

Iris foliis linearibus, caule fuburdo, petalis reflexis imberbibus venofis, tubarum arcu acuminato. HA L L. hifl. 2. n. 1259.

Iris imbcrbis, foliis linearibus, fcapo fubtriforo tereti, germinibus trigonis. 'Г H U B. diff. n. 33. LINN. Jy $/$. veg. gI.

Icon. JAC@, auftr. $t$. 3 .

PER. Capfula infera, ovato oblonga, trigona, in fingulo latere nervo medio prominulo fupernc bitido inferipra, coriacea, trilocularis, trivalvis.

REc. margo interior dit'tepimentorum, cui femina utrinque duplici ferie longitudinali affixa.

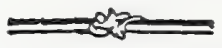

SEM. numerofa, horizontalia, depreffa, utrinque plana, femilunata $f$. altero margine recto, altero Semicirculari circumfcripta, rulfo-ferruginea.

IN T. duplex: exterius fpongiofun, nucleo latius; interius arachnoideum, arcte adnatum.

$\Lambda$ \& . femicirculare, comprefum, femine anguftius, carnofum, durum, fubdiaphanum, aqueo-pallidum.

EM D. monocotyledoneus, teretiusculus, rectus, ad umbilicum locatus, dimidio al. bumine paulo brevior, lacteo albus.

2.) Capfula integra. b.) Eadein apice dehifcens, fitum feniuum oftendens. c.) Semen feparatum. d.) Ejusdem foflio transverlalis. e.) Albumen deaudatum. f. ) fettio feminis horizontalis, cum fita \& inagnitudise ombryonis natorali. G.) Embryo Separatus \& sultus.

Ir is perfica. ibid.

Iris perfica bulbofa varicgata pracox. D О D A к т. mem. edit. germ. 305. t. 18.

Iris imberbis, foliis linearibus planis, fcapo uniforo, petalis alternis brevioribus. TuUNB. diff. n. 27. LIN N. fy/. veg. $9 t$.

Capfula oblonga (a), trifulca, rotundato trigona (b), a protuberantibus feminibus nodulofa, charracea, alba. Sernina (c. C.) fubglobola, utrinque in brevern mucronem producta, rugofe tuberculata, ferrugineo lutefentia. Integ, exterius membranaceo fpongiofum. Albumen obovato globofum, in vertice (D) ruberculo chalazino 'nigro notatum, fubcartilagineum, album. Embryo (E.F.) teretiusculus, rectus, vix dimidii albuninis longitudine (E.), lacteo albus. 


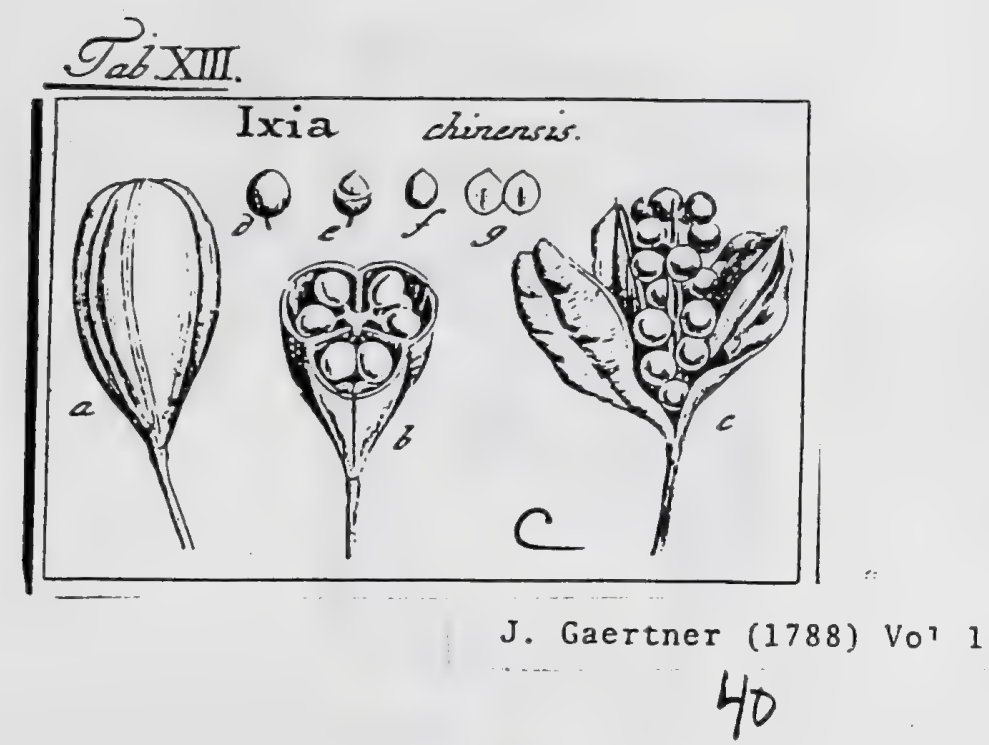

XIV. IXIA. LINN. gen. $\varsigma 6$.

Corolla hexapetala patens. Stam, tria. Stigmatz tria fimplicia. Capfula infera. Semina baccata. Embryo dimidio albumine longior.

IX I A. clinenfis. Tab. 13. fig. 3.

Bermudiana radice carnofa, floribus maculatis, feninibus pulpa obductis. Asss. Comment. petrop. XI. p. 308. t. 7 .

Ixia foliis enfiformibus, floribus remotis. Е н в ет. decad. t. 52 .

Ixia foliis enfiformibus, foribus remotis, pedunculatis, panicula dichotoma. LIN N. Sp. pl. 52 .

Moraa caule compreffo, foliis enfiformibus, panicula dichotoma, floribus pedunculatis. LINN. Syft. veg. 93 .

PER. Capfula infera, ovata, verfus bafin coarchata, rotundato trigona, coriacea, trilucularis, trivalvis.

REc. fubulatuin, triquetrum, per maturitatem liberum, cujus angulis femina duplici, in fingulo loculanento, ferie affixa.

SEM. plura, fex ad decern in quolibet loculamento, fplszrica, glabra, atra, nitida. baccata.

IN T. triplex : extimun membranaceum; medium pulpofun, molle; intiwum arachnoideun, fufcum, arcliflune nucleo adnaturn.

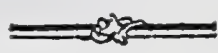

A L 8. Phaxricum, in vertice tuberculo minimo chalazino notatum, carnofum, durum, album.

Eмв. monocotyledoneus, teretiusculus, rectus, dimidio albumine paulo longior, in axi feminis prope umbilicum locatus, lactco-albus.

a.) Capfula integra. b.) Eadem per medium fella. c.) Eadem dehiscens, cam fitu \& Gigura roceptaculi, d.) Semen folutum. e.) Idem, ad medium usque carne fua exatum. f.) Albumen desudatum. g.) Iden longitudinaliter diffeţunı cunı fitu \& figura embryonis. 


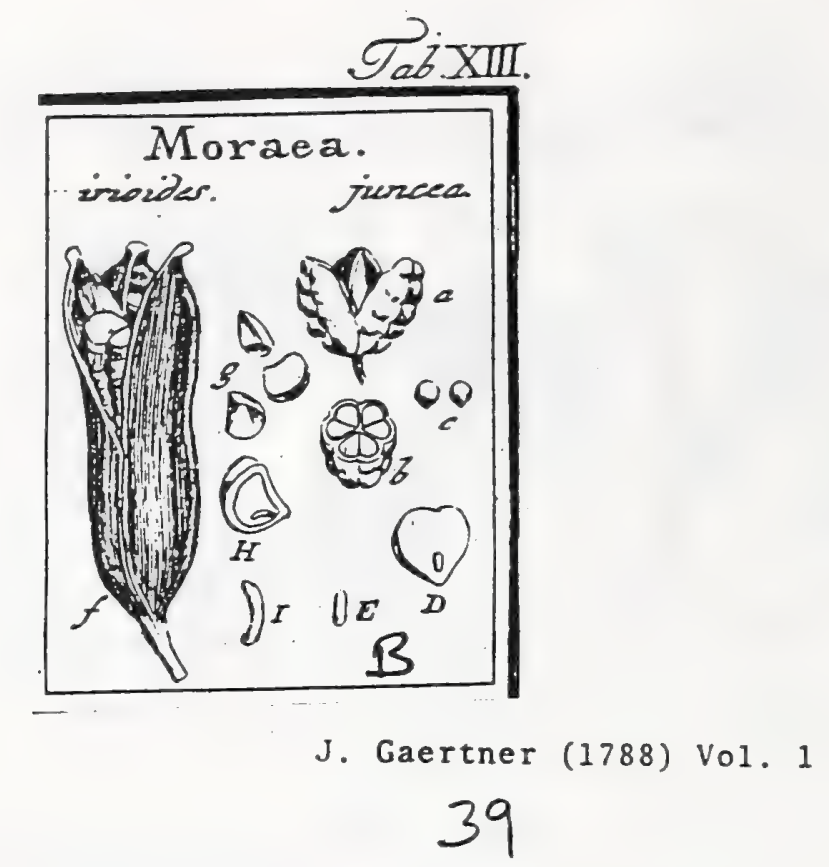

XLTV. MORXA, LIN g. gen. 60.

Omnia Iridis, prater petala tria interiora patentia.

MOR EA juncea. Tab. 13. fig. 2.

Morcea Spatha bifora, foliis fubulatis. Miri. dit.

Moraa foliis fubulatis. Lin N. $\int y$. pl. 59 .

Iris (phtmaria) barbatn, follis linearibus, fcapo multiforo, Rigmatibus feta-

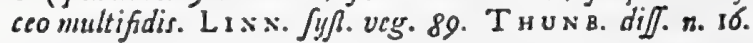

PE R. Capfula infera, ovata, femipollicaris, rotundato trigona, trifulca, ad femina nodulofa, chartacta, alba, trilocularis, trivalvis.

REC. anargo centralis diltepinentorum, cui femina duplici ferie affixa.

SEM. plura, octo ad duodecim in fingulo Inculannento, fubglobofa, verfus umbilicum acuminata, glabra, rufescenti ferruginca.

IN T. duplex, utrumque membranaccurn, arcle adnatum.

A L B. Semini conforme, cartilagineuin, aqueo-pallidum.

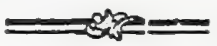

Ess. monocotyledoneus, cylindricus, rectus, dimidio albumine brevior, Lacteoalbus.

2.) Capfula deliscens. b.) Ejus fetio transverfalis, c.) Semina feparata, D.) Abbumea longitydinaliter diffetum, cum fitu embryouis. E) Embryo falutus.

Morea irioides. ibid.

Morcea foliis enfiformibus. LIN N. fyff. edit. 13. p. 79 .

Morac foliis gladiatis. LinN. fy/. veg. edit. 14. p. 93 .

Capfula oblonga. $\left(f_{.}\right)$, obfolete trigona, coriacea, nigro fufca, tenuiffune friatz. Semina numerofa, varie angulata $(\mathrm{g}$.$) , in univerfum tamen deprefia, !ateribus$ duobus planis, reliquis fecundum loculamentorum parietes curvatis; ceterum crafta, nigro fufca, punctis confluentibus confperfa. Integum. exterius papyraceutn, aridum, tenuiffimum; interius fungofun crafiusculum $\left(H_{0}\right)$, ut lemina arido baccata fint, ficut Ireos $\int p u r i a$ \& graminex. Albumen fernine anguntius $\left(H_{.}\right)$, carnofum, durum, aqueo-pallidum. Einbryo (H. L.) teretiusculus, leviter incurvatus, lacteus.

Obf. Genus nimis artificiale, rectius partim cum Iride, \& partim cum Lxiz mifceretur.

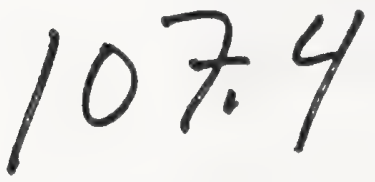


Tab.XI.

Iridaceae

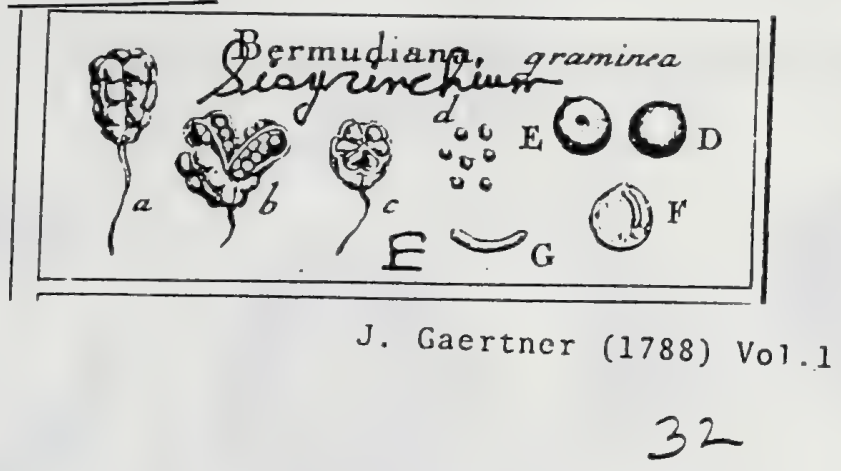

XXXVII. BERMUDIANA. Tourn, $t$. 208. Sifyrinchium.

LINN. gen. IoI\%.

Spatia diphylla. Corolla hexapetala, aqualis. Stam. tria. Styl. finplex. Capfula infera, trilocularis, trivalvis. Sem. plura. Embryo excentricus, curvatus.

BERMUDXAXA graminea. Tab. it. fig. 5 .

Bernudiana graminea, flore minore caruleo.' DiLL. h. elth. $49 . t$. 4 I. f. 49 .

Sifyrinchium caule foliisque ancipitibus. L i N N. Jp. pl. 1353. Sс н в в в. E. N.C. $2767 \cdot p \cdot 341 . t .6 .6$.

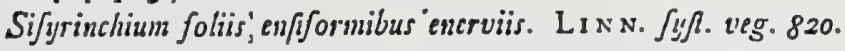

PER Capfula infera, fubturbinata, rotundato trigona, a protuberantibus feninibus no. dulofa, tribus fulcis depreffis exarata, nigro fufca, trilötularis, trival vis. Diffepimenta medio valvularum inferta.

REC. margo internus $f$. centralis diffepimentorum, cui utrinque funiculi umbilicales, brevifimi, inferti.

S.E ss. plura. duodecim 1. fedecim in fingulo loculamento, duplici ferie pofita, globola, latere, quo fe inutuo contingunt, foveola obfoleta notata, atra, minutiffime punchiculata, aut rugofula.

Is т. duplex: exterius tenuifumum, diaphanum, pallidum; interius coriaceum, atrum, a nucleo vix fcparabile.

A I в. fcmini conforme, granulofo-cartilagineun, aqueo-pallidum.

Ess B. monocotyledoneus, teretiusculus, leviter curvatus, lacteo albicans, dimidio al.

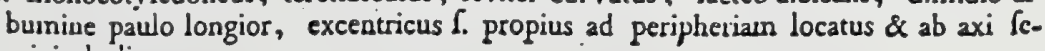
minis declimans.

33

a.) Capiula claufa, b.) Eadem dehícens c.) Ejusdem fetrio transverfalis d.) Semina foluta. D.) Seminis latus externum. E.) Ejusdem latus internum foveola notatum. F.) Albumen vercicaliter fettum, cum fitu embryonis. G.) Embryo folutus \& autus,

Si Moluccellx, cur non \& Bermudianx nomen ferenduin? idque co magis, quod inonente TheорнRAsto: peculiare fifyrinchio datum, ut una radix primo augeatur hyeme, tum ineunte vere, quod in ino excrevit contrahatur, Supernum. que crefcat, quod naanditur. hilt. L. 7. c. 13. P L I N. L. 19. Sect. 30. Hzc veteris fifyrinchii monumenta, non deberent prxpoftere ufurpato ejus nomine, deleri.

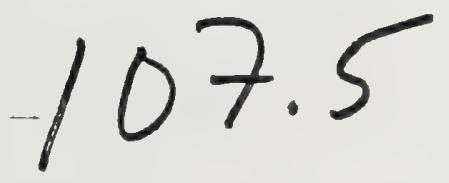




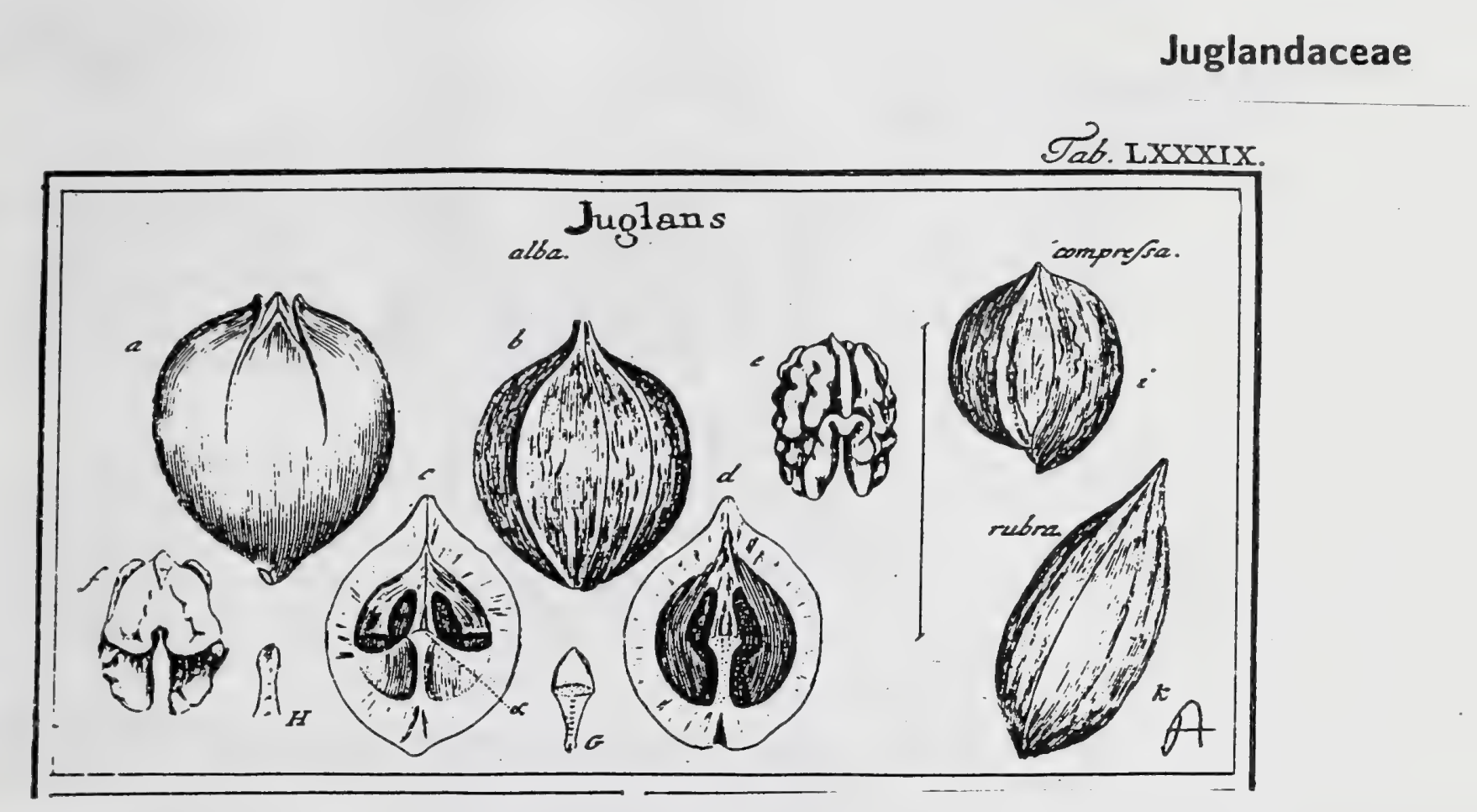

$$
108.1 A
$$


DIV. JUGLANS. LinN. gen. IO7 I. Nux. T.OURn. inft. t. 346 .

Flores fexu diftineti in eodem caule. MAS. Amentum juliforme, compofitum ex fquanis duplicibus: exserioribus triangulis, dorfo interiorun alfixis; interioribus transverfe - oblongis" pinnato-fexfidis. Stam. 12 ad 24 , flamentis craftis, in nuucronem productis; antheris geminis, lateralibus. FEM. Genrmx dux contigux, uniforx, tetraphyllx, caducx. CaL fuperus, quadripartitus, in corticem fructus adolefcens. Cor. nulla. Ovar. inferum. Siyl duo, ftigmatibus clavatis apice laceris. Nuy corticata, bivalvis.

Juglans alba. Tab. 89. fig. 1.

Nux juglans alba virginienfis. CatesB. carol. x. t. 38. SeLigm. av. x. t. 76. Juglanu foliolis Seprenis lanceolatis Serratis: impari feflili. LINN. S: At. veg. 859.

PER. Nux infera, corticata. Cortex crafus, coriaceus, per maturitatem apice quadrifariam dehifcens. Putamen ovato-globofum, tetragonum, mucrone valido guadrangulo terminatum, lineis obfoletis, non rugis, infcriptum, glabrum, albicans, bivalve, femiquadriculare. Valvulx ulítex, -cralifif

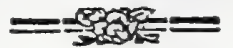

fimx, nulla extus futura confpicua infignitx. Diffepimenta etiam offez, craffa, rufefcentix: duobus lateralibus longitudinalibus, \& uno transverfali in bafi putaminis; omnibus vero incompletis atque cavitatem femi quadrilocularem efficientibus.

Rec. nullum, practer cicatricem in confluxu diffepimentorum inferiori obviam, cui femen atfixum.

SE N. unicum, grande, femiquadrilobum: Jobis varie \& irregulariter rugolis. tuberculatisque.

IN $\mathrm{T}$. duplex, utrumque membranaceum: exterius pallide ftramineum, venis reticulatum; interius arachnoideum, tenuifimum, intra cotyledonum fifuras defcendens.

A L B. nullum.

EM B. femini conformis, inverfus, lacteus. Cotyl. carnofx, bilobx, extus varie tubercularx, intus fifura tortuofa exarata. Plum. conica, diphylla, pinnata: petiolis craffis ad latera remote denticulatis; pinnulis heptaphyllis, conduplicatis. Rad. craffa, ovato-acuminata, fupera.

2) Cortex apice dehifcens. b.) Potimen integram. c. d.) Ejus valvulx feparatz. a) Cieatrieula cui femeu a.fixum, e.) Semen integrum. f.) Cotyledon altera, a parte interna fpectata. G.) Radicula in plumulan defineas. H.) Plumula feparata \& infigniter anda.

JUGLans comprefra. ibid.

Juglans foliolis lanceolatis ferratis glabris Jubaqualibus. MiLL. gardo did.

A Phil. Millero, Chelfeano.

Putamen (i.) ovato - rocundatum, ad bafin oblique truncatum, lenticulari-comprelfum, ut tamen rhombeo - tetragonum fit, cetera album, glabrum, craffifinum atque duritimum. Sutura linearis, vix perceptibilis. Valvulx naviculares, carina compreffa acuti. Difepimenta ut in priori. Nucleus, in rationc ad putamen, parvus, femiquadrilobus, integumento é luteorufercente.

Juglans rubra. ibid.

Noix Pacanes de Afadugafcar. A ferenif. b. m. CAROLINA March. Bad.

Putainen $(k$ ) ovato oblongum, utrinque ncuminatum, prafertim fuperne, ubi in longum mucronem tetragonum producitur; cetera glabrum, futura vix difcernibili notitum, modice crafum, durum, pallide teftaceum. Diffépimerta coriaceo - cruftacea, fragilia, fufca. Nucleus oblongus, quadrilobus, totaque fua ftructura prioribus fimilis. Cuticula externa tota ruvilo fanguinea.

Solius, quod hactenus fciam, Juglandis regie putamen gaudet futura rite diftincta \& tumido margine circumdata. Notatu quoque dignum eft-., quod

Millerus in gard. dif. affirmat: libenter fcil. Juglandes e femine enams a natrun fuarum forma deflectere, nec dari certas earum differentias fpecificis, anteguan fructum tulerint. 


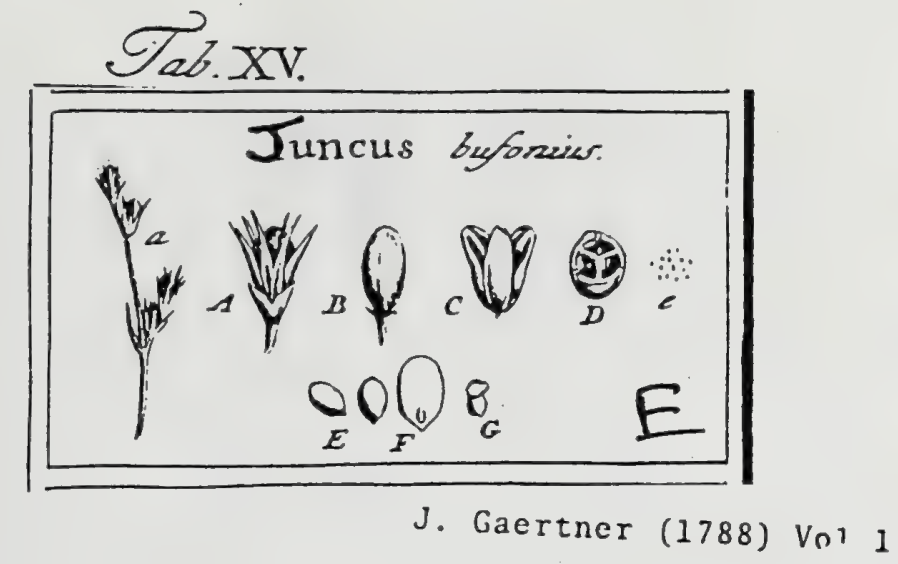

\section{JUNCUS. TourN. t. 127. LIN}

Gluma floralis diphylla. Calyx corollxformis hexaphyllus. Stam. fex. Styl. unicus, apice trifidus. Caplula fupera, trilocularis, polyfperma; aut unilocularis, trifperma. Eınbryo dimidio albumine imulto brevior.

Ju N c us bufonius. Tab. 15. fig. 5 .

Gramen bufoniun ereftum latifolium E' angufifolium majus $\mathcal{E}^{3}$ minus. B A R R. ic. 263. $2 \sigma_{4}$.

Iuncus caule brachiato, foliis fetaceis, floribus folitariis ad ramos feflibus. $H_{A}$ L 1. hiff. 2. n. 1319 .

Funcus culmo dichotomo, fuliis angulatis, floribus folitariis fefflibus. L INN. Jigf. veg. $3 t^{I}$.

PEк. Capfula fupera, parva, ovata, rotunde trigona, glabra, nitida, ferrugíneo-nigra, trilocularis, trivalvis: diflipumentis valuularum medio adnatis.

REc. nullum, prxter margincm centralem diffipimentorum, cui femina affixa.

SEM. plurima, suinutula, ovato globola, ad utramque extremitatem, prxfertim vero as umbilicum, arcola nigra, cum levi acumine, infignita, cererum pallide rufefceutia, glabra.

IN T. fimplex, inembranaccim, arcte ajhxrens.

AL B. Semini conforme, carnofum, duriusculum, album.

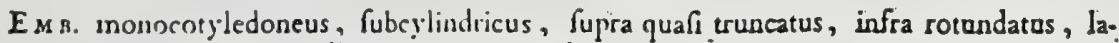
cteo-albus, tertia albuminis parte vix longior.

54

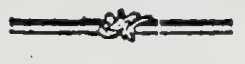

2. A.) Caprula calyce perfiftente munita. B.) Eadem dewudats, hitegra, C.) Eadem deliifens, D.) Ejus fentio trausverfalis. e. E.) Semiua (eparata. F.) Albumen longitudinaliter fectum, cam fitu embryonis, G.) Embryo (eparatus \& infiguiter auctus,

Juncus pilofus.

Gramen hirfutum, perenne, lini utriculis. Barr. ic. 748. n. I.

IIuncus foliis planis hirfutis, floribus umbellatis folitariis petiolatis arifatis. Ha Li. hif. 2. "1. 1325 .

Juncus foliis glanis pilofis, corymbo ramofo. LINN. fyfl. veg. 34 r.

Icon. OE.der. flor. dan. t. 44 I.

Capfi!la turbinata - rotunde triçona, unilocularis, trivalvis, absque ullo ditepinentorum veftigio. Recept. nullum: femina fundo capfulx, umbilicis fus, ante plenam maturitatcm fpongiofis, albis, affixa. Semisa tria, ovata, glabra, nitida. F.mbryo in bafi feminis minutiffunus, tercti-acuminatus, lacteus. Radic. craflior, infers.

Duas in Junci fernine cotyledones fe vidiffe perhibet ADANsONus. fam. 2. $p .45$. In curopxis fpeciebus ego nihil finile vidi unquam. 
c.

a.

I 


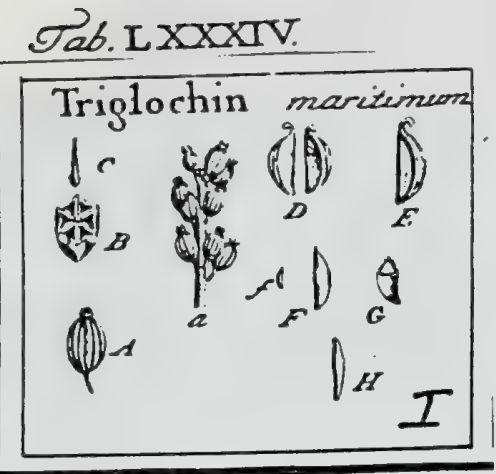

Vol.2 J. Gaertner

26

DXXIX. TRIGLOCHIN. LINN. gen. 453.

Juncago. TOURN. inft. t. 142.

Cal. triphyllus. Cor. tripetala, calyci fimilis, nifi quod paulo minor ac te. nerior. Stam. fex. Ovar. fubrotundum aut oblongum: ftigmaribus tribus aut fex. Capf. tres aut fex, uniloculares, evalves. Sem. folitaria.

Triglochin maritimum. Tab. 84. fig. 9.

Triglochin capfulis fexlocaribus ovatis. LiNv. af. bolm. 3742. p. 347. t. 6 . f. 4. 5. Jy t. veg. 348 .

Icon. OED. flor. dar. t. 306 .

PER. Capfulx fex, fupere, in fructum ovato-globofum ftriatum coadunatx, triquetrx, hinc gibbx, fulco depreffo infcripta, inde acutangulx; rectx; cetera coriacex, uniloculares, evalves.

REc. comnusue filiforme, triquetrum, in axi fructus pofitum; proprium, Funiculus umbilicalis brevifimus, ab apice loculamenti ad feminis apicem ductus.

SEM. in fingula capfula unicum, longum, utrinque acuminatum, triquetrum. pallide viridefcens.

IN T. membranaceum, tenue, facile fecedens.

A L B. nullum.

Eм в. magnitudine \& figura feminis, monocotyledoneus, lutefcens, Rad. acuminata, infera.

2. A.) Fricus integer. B.) Ejus fettio transverfalis C.) Recept commune. D.) Capfula far lutz integrz. E.) Capfula longindinaliter aperta, cum fitu feminis. f. F.) Semen feparatum. G.) Ejus fectio transverfalis H.) Embryo denudatue.

Triglochin paluftre. Oed. for. daj. t. 490. Hall. biff. n. 3308 . Linn. l. c.

Fructus angufti, elliptici, tripartibiles, tricapfulares. Capfulz deorfum acuminatx, triquetro, evalves. Recept. commune, ut in pracedenti triquetrom, fed infuper tribus alis, quafi totidem diffepimentis intercalaribus auctum, qux forfan totidem fuerint caplula abortivx \& a vicunis fuffocata:" Reliqua ut in priori.

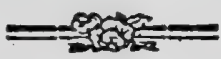

Per germinationem ulterius exploraridum eft, num feminum Triglochines, Sagittarix, Alifmx \& Potamogetonis nuclei, fint embryones ipf, anne vero alius intra eos hareat embryo minutifimus? Poftérius tomen non videtur verifinile; atque fecundum nuperiores meas obfervationes, vel ipfum Butomi embryonem, Vol 1. p.75. defcriptum, expungendum effe cenfeo, quoniam ejus nuclei, tefta fua orbati \& penitus denudati, ubi per aliquot horas aqux innatarunt, ut fimul aēris acceffu fruerentur, ex pallidis, qui antea fuerunt, toti faturate virides facti funt: id quod folis veris embryonibus, neutiquam autem albumini aut vitello contingere folet. 

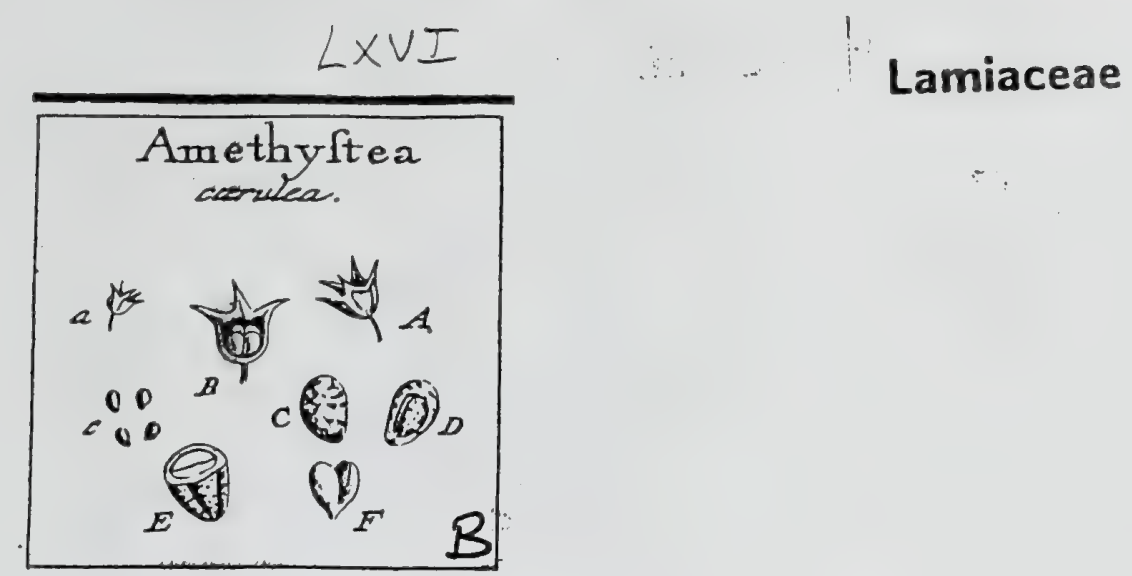

J. Gaertner (1788) Vol. 1

315

CCCCII. AMETHYSTEA. L I N N. gen. 34 .

Calyx fubcampanulatus, quinquedentatus. Cor. ringens, quinquefida: lacinia infma patentiore. Stam. duo. Sem. quatuor gibba, parte veintrali a dorfali fulco difcreta.

A 2 E T и YSTEA cxrulca. Tab. 66. fig. 2.

Ancthyfina. Ha r. Comm. gatt. 1751. p. 209. t. 10.

Amethylea. Lax s. $\int y \rho$. veg. 67 .

अ6

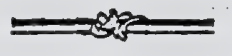

PER. nullum; femina intra calycem inmutatum.

REc. nullum.

SEs. obovata, gibba, hinc convexa, rugofa, inde angulata, fufca.

IN $x$. duplex: exterius cruftaceum, in dorfo crafius, rugofum, durum, in ventre tenuius, pallidum, fuberolum; parte ventrali a dorfali; ficut in Verbenis, per li. neam depreftan difcreta; interius membranaccum, tenue.

A $\mathrm{L}$. nullum.

Ess в. femini conformis, erectus, albus. Cotyl, ovatx, carnof $x$. Rad. conica, infera.

\footnotetext{
a. A.) Calyx integer. B.) Semina intra calycem. c. C.) Seminis dorfum, D. E.) Ejus pars ventratia, $E_{4}$ ) Idem transverfe fetum. F.) Embryo denudatus,
} 


$$
L X V I
$$

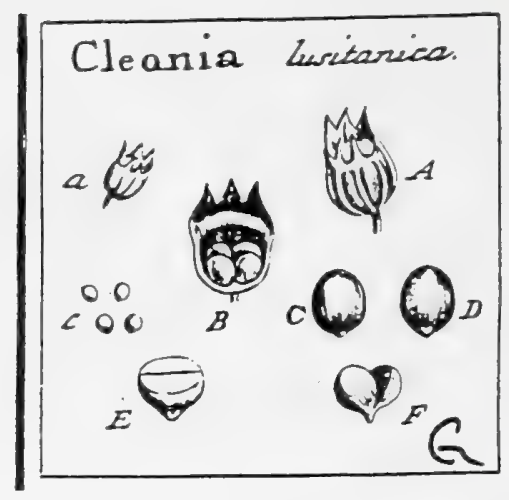

J. Gaertner (1788) Vol.1 318

CCCCVII. CLEONIA. LIN gen. $73^{\text {6. }}$

Lamiaceae

Calyx bilabiatus. Cor. ringens. Stam. quatuor , filannentis apice bifurcatis: crure altero antherifero. Stigma quadrifidum. Semina quatuor.

Cieonia lufitanica. Tab. 66. fig. 7 .

Prunella brafieis pimato dentatis ciliatis. MrLc. ditf. ic. $40 . t$. 70 .

Cleonia. Lin N. Silf. veg. 548 .

PER. nullum; fenina intra calycem ventricofum, friatum, tomento albo ore claufum. REC. nullum.

SEs. quatuor, fubrotunda, turgide lenticularia, bafi nucronata, rufefcentia. Limbilicus ypriloides, niveus.

IN T. duplex: coriaccuin, \& crufaceum, utrumque tenuc. A LB. nullum.
EMr. femini conformis, ereclus, albus. Cotyl. obovatx, carnofx. Radi. acuininata, infera.

319

a. A.) Calyx integcr. B.) Semina intra calycem tomento elanfum. c. C. D.) Semina ab utrngue parte (petata. E.) Semen diffetum, cum caruncula umbiticali. F.) Embrjo denudatus.

111.2 


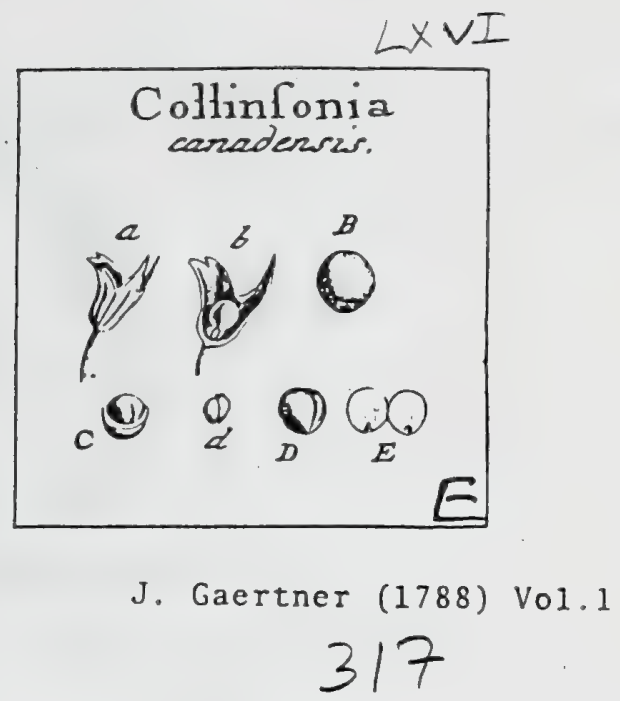

CCCCV. COLLINSONIA. LINN. gen. $4^{0}$.

Calyx bilabiatus. Cor. ringens: labio inferiore multifido capillari, Stam. duo, Ovula quatuor. Semen maturum fxpius unicum.

Cozlixsioxia canadenfis. Táb, 66. fig. 5 .

Collinfonia. LIxx. h. Cliff. tab. 5. fiff.,veg. 72

PER. nullum; femina intra calyecm immutatum.

REC. nullum.

SEM. unicum, tribus fcil. reliquis fere femper abortientibus, globolum, cinereum, venis fufcis oblolete reticulatuns.

IN T. duplex: coriaceum atque membranaceum; hoc, fria tufca ad alterum latus, quafi funiculo umbilicali notatum.

A 2 n. nullum.

E sв. Femini conformis, crectus, albus. Cotyl. hounifphxricx. Plum. exilifima, acuminata, Rad. minima, infera.

a.) Calyx integer, b.) Semen cum tribus ovulis abortivis intra calycem. B.) Semen magnitudiDe autium. C.) Ejuspem membrana interna denudata, cum aria laterali furca. d. D.) Embryo desudatus. E) Cotyledones Separats. 


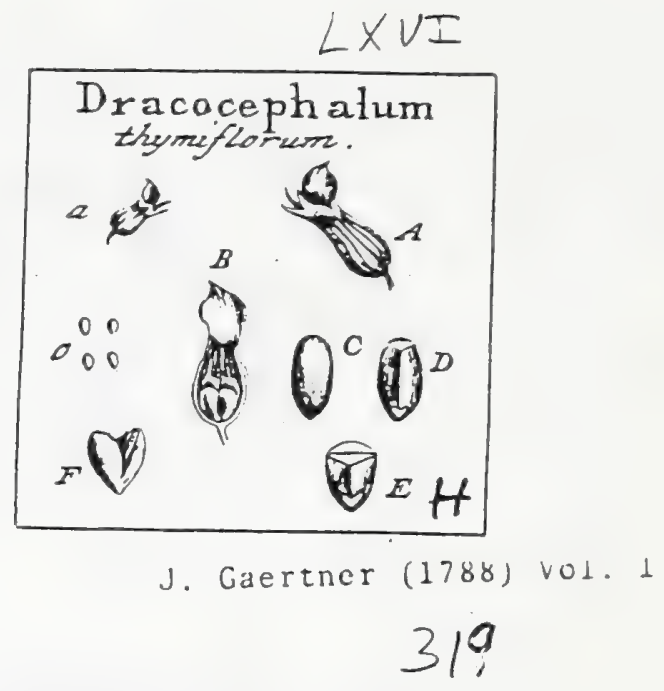

CCCCVIII. DRACOCEPHALUM. T o U R N. t. 83. Lixin. getr. 729.

Calyx bilabiatus. Cor. ringens, fauce inflata, labio fuperiore concavo. Stam, quatuor. Scmina quatuor.

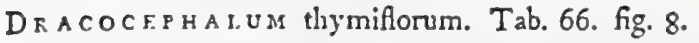

Dracocephalum floribus verticillatis, bradteis oblongis integerrinis, corollis vix calyce majoribus. GMEL. fibir. 3. p. 233. t. 50. Lix s. Jilf. veg. 544.

PER. nullum; femina intra calycem imnutatum.

REC. vullum.

SEM. quatune, farra, ovato ohlonca, line convexiuscula, inde angulata, e cananco nitgricantia. Umbilicus spfiloides, albus.

IN T. duplcx, coriaccum \& membranaceum; utrumque tenue.

A. p. nullum.

Eм в. femini conformis, erectus, albus. Cotyl. ovatz, carnofx. Rad. conica, infera.

2. A.) Calyx integer. B.) Semina intra calycem. c. C.) Serninis dorfum. D. E.) Ejusdom pars veneralis cum umbilico. E.) Semen dıfefum. F.) Embryo denudatus. 

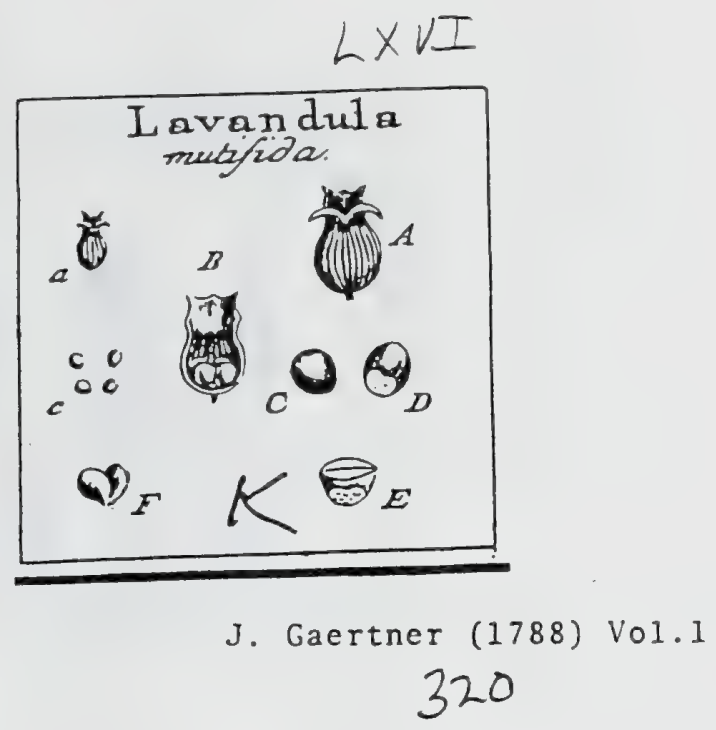

CCCCXI. LAVANDULA. TouRn. $t$. 93.95. L IN N. gen. 711.

Calyx bilabiatus, Ariatus, ventricolus. Cor. ringens refupinata. Stam. quatuor. Sem. quatuor, bafi late derafa.

LA Y A DUL A multifida. Tab. 66. fig. 11.

Lavcndula multifido folio. CLus. hifl. x. $\mu$. 375 . R Iv. mon.t. $5+f \cdot \hat{3}$.

Lavandula foliis petiolatis pinnatis: foliolis decurfive pinnatifidis, fyicu quadrangulari: angulis fpiralibus. LiNs. f1/ $\beta$. veg. $53^{T}$.

PER. nullum; femina intra calycem immutatum.

REC. nullum.

SEM. quatuor, fubrotunda, parva, fpadicea, hime convexa, inde obfolcte angulata, bafi oblique truncata atique latifina area umbilicali alba uotata.

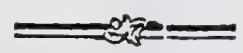

IN T. duplex : exterius cruftaceum ; interius membranaceum, pallidum.

A I. nulluin.

Eм в. Cernini conformis albus. Cotyl. fuborbiculatx, tenues. Rad. minima, infera.

2. A.) Calyx integer. B.) Semina intra calycem. c. C.) Eadem foluta. D.) Area umbilicalis. E.J Semen transverfe featum. F.) Embryo denudatus. 


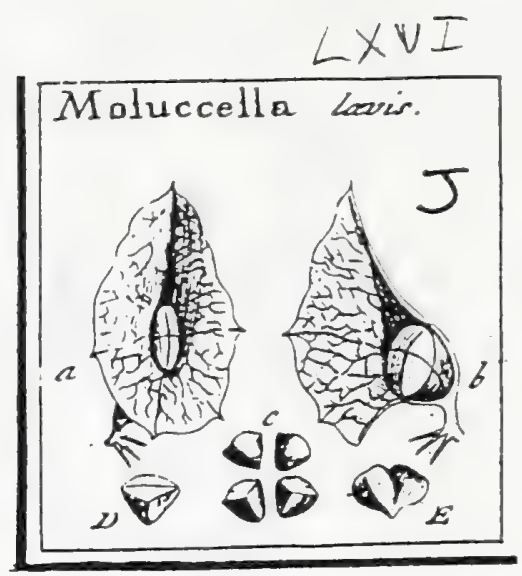

\section{Lamiaceae}

J. Gaertner (1788) Vol. 1

$$
320
$$

CCCCX. MOLUCCELLA. Tourn. $t$. 88. LinN. gen. 724 .

Calyx campanulatus, ampliatus, reticulatus, fpinofus. Cor. ringens, calyce multoties anguftior. Stam. quatuor. Semina quatuor triquetra.

Moruccella lavis. Tab. 66. fig. 10.

Molucca lavis. Do D. pempt. 22, R I v. mon. t. 64.

Mioluccella calycibus campanulatis fubquinquedentatis: denticulis crqualibus. Lins. Sigh.trg. $57^{\circ}$.

PER. nullum; femina intra calycem innutatum.

REC. nullum.

SEM. quatuor, obefa, brevia, triquetra, glabra, fpadicea.

IN. duplex: exterius cruflaceum, duriusculum; interius membraraceum.

A L B. nullum.

Exв. femini conformis, erectus, albus. Cotyl. obovatx: altera plano convexa, altera coinpretito trigona. Rad. acuminata, brevilfuza, infera.

2.) Calyx integer. bi) Seminam fitus intra calycem. c.) Semina Separata. D.) Sernen diffet̂um. E.) Embryo denudatus. 


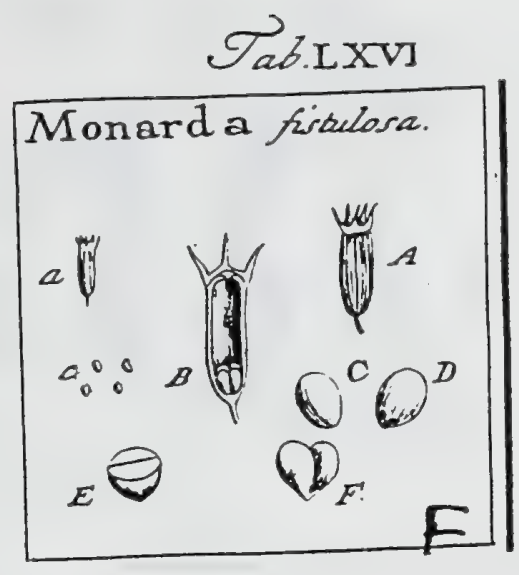

J. Gaertner (1788) Vol. 1

CCCCVI. MONARDA. LIN N. gen. 37 .

Calyx tubulofus, quinquedentatus. Cor. ringens: labio fuperiore integro linean. Stam. duo. Semina quatuor: umbilici fcrobiculo gemino.

MONARDA fifulola. Tab. 66. fig. 6.

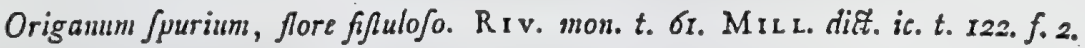
Monarda capitulis terminalibus, caule obtusangulo. LIN N. $\int 4$ f. veg. 68 .

PER. nullun; femina intra calycem, ore villis, in fquamulas quinque convergentibus; claufum.

REC. nullum.

SEM. quatuor, parva, fubovata, turgide lenticularia, rufefeentia: fcrobiculis unbilica. libus duobus, minimis.

Ix r. duplex: coriaceum \& incinbranaccum; utrumquc tenuc.

A L B. nullum.

Eм в: Semini conformis, erectus, albus. Cotyl. obovatx, carnolx. Rad. conica, infera.

a. A.) Calyx integer. B.) Semina intra ealycem, (quamulis lanuginolis ore claufum. c. C.) Se minis dorfum. D. E.) Ejusden pars ventralis cum ferobiculis unbilici. E.) Scuncu diffęum, F.) Eimbryo denudatus. 

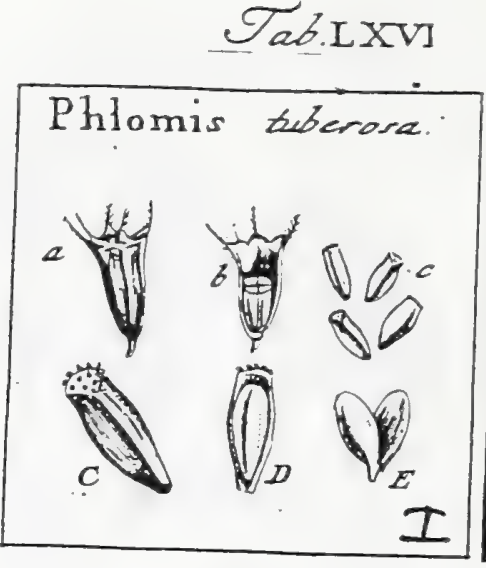

Lamiaceae

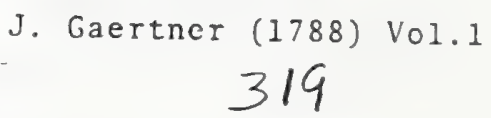

CCCCIX. PHLOMIS. TOURN. t. 82. LinN. gen. 723 .

Calyx angulatus quinquedentatus. Cor. ringens: labio fuperiore villofo. Stam. qua. ruor: filanentıs bafi uncinato appendiculatis. Senina quatuor.

Phlo mis tuberofa. Tab. 66. fig. y.

Phlomis foliis cordiformibus, galca lacera. HALL. Comment. gett.' T75T. t. Ir. opt.

Phlomis involucris hifpiris fubulatis, foliis cordatis fcabris, caule herbaceo. Lisis. Jifl. veg. 5.39 .

PER. nullum; femina intra calycem immutatum.

REC. nulluin.

SEM. quatuor, ovato oblonga, hine convexiuscula, inde angulata, fupra truncata, $\int_{e}$ tisque nellatis albis hifpida, infra acuminata, glabra, ferruginea, aut faturate ca. Aanca. Umbilicus in baft fominis, fimplex.

IN T. duplex: exterius coriaccum, nucleo paulo longius; interius menbranaccum, intus circa umbilicum fubcarnofum.

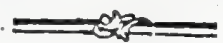

$A\llcorner$ в. nullum, aut tenuifinum circa radiculam. Em B. oblongus, erectus, albus. Cotyl. ellipticx, carnolx. Rad. tereti acuminata,
infera.

a.) Calja integer. b.) Semina intra colycem, c.C.) Esdem reparata. D.) Nucleas intra teftam.
E.) Embryo denudatus. 


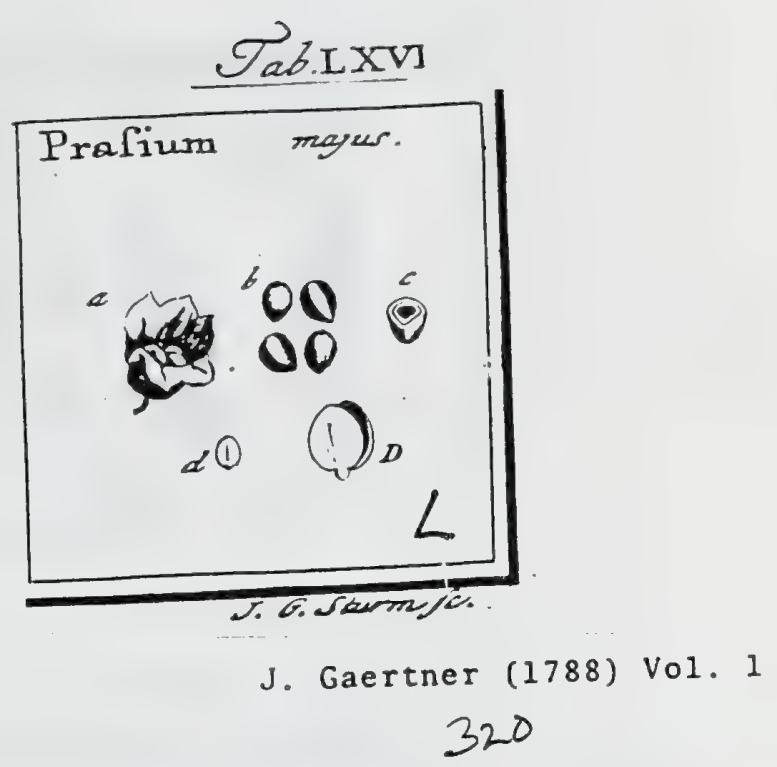

CCCCXII. PRASIUM. LIN gen. $73 \%$.

Calyx bilabiatus. Cor. ringens. Stam. quatuor. Semina quatuor, epidermide molli baccata.

PRASIUM majus. Tah. 66. fig. 22.

Mrelifir fruticafin cretica fempervirens, teucrii facie, flore albo. Mor Is. hift. 3. S. 11. t. $21 . f .3$.

Prafium foliis ovato oblongis ferratis. Linn. Syfl. veg. 548.

PER. nullum, nifi ferninis epidermidem carnofam velis.

REC. nullum.

SEM. quatuor, baccata, fubglobofa, hinc convexa, inde angulata, atra.

IN T. triplex : cxtinnum carnofum, tenue, molle; medium cruftaceum, fragile; intimum membranaceuin, aridum.

A с в. nullum.

Em в. femini conformis, crectus, albus, Cotyl. ovatx, carnofx. Rad. globulofa; parva, infera.

2.) Calyx cum feminibus, b.) Semina (oluta. c.) Seminis integumenta transverfim fefta. d. D.) Embryo denudatus. 


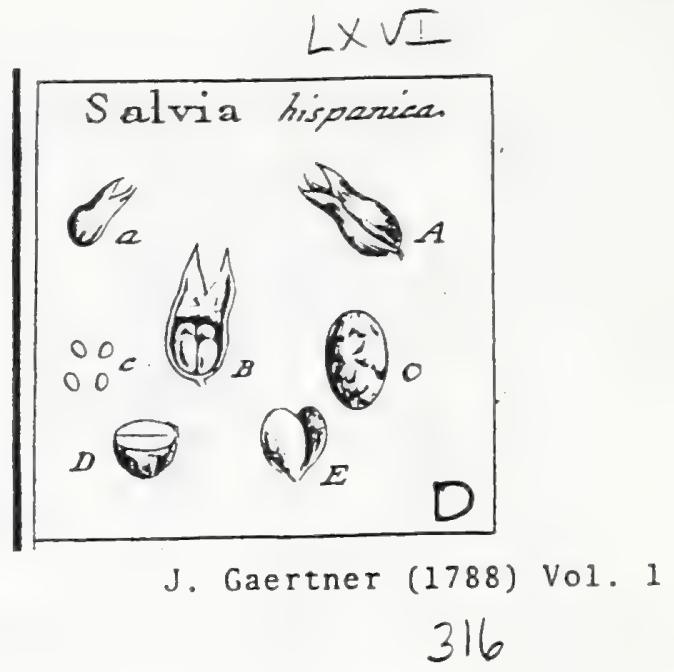

CCCCIV. SALVIA. TOURN. t. 83. LIN N. gen. 3y.

Calyx monophyllus. Cor. ringens. Filamenta faminum fertilium transverfalia, pedicello proprio affixa. Sem. quatuor, fxpe mucilaginora.

S A I va hifpanica. Tab. 66. fig. 4 .

Sclarea hifpanica. Т А в в R. hif. 764 . ic. 374 .

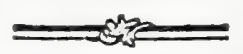

Saluia foliis ovatis petiolatis utrinque mucronatis, fpicis imbricatis, calycibus

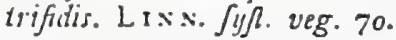

PER. nullum; femina intra calycem immutatum.

REC. nullum.

SE s. quatuor, elliptica, lenticulari compreffa, glabra, nitida, cinerafcentia fufco masmorata.

Is т. duplex: coriaceum \& membranaceum; utrumque tenue.

$\Lambda$ L B. nullum.

Eus. Comini conformis, erectus, albus, Cotyl. ellipticx, carnofx, Rad. brevifima, infera.

a. A.) Calyx integer. B.) Senina intra calycem. c. C.) Eadem feparata. D.) Semen transverfe fêum. li., Finhryo denudatus.

Varix fpucies Salvix, ut Verbenaca, difermas, argentea, ccratophylla, Ethiogis, urticifolin, canarienfis Eैc. feminibus mucilaginofis gaudent; absque mucilagine autem funt: hispanica, rutans, slutino $\sqrt{a} E^{\prime} c$.

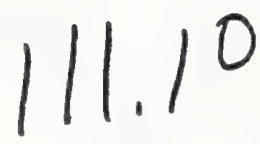




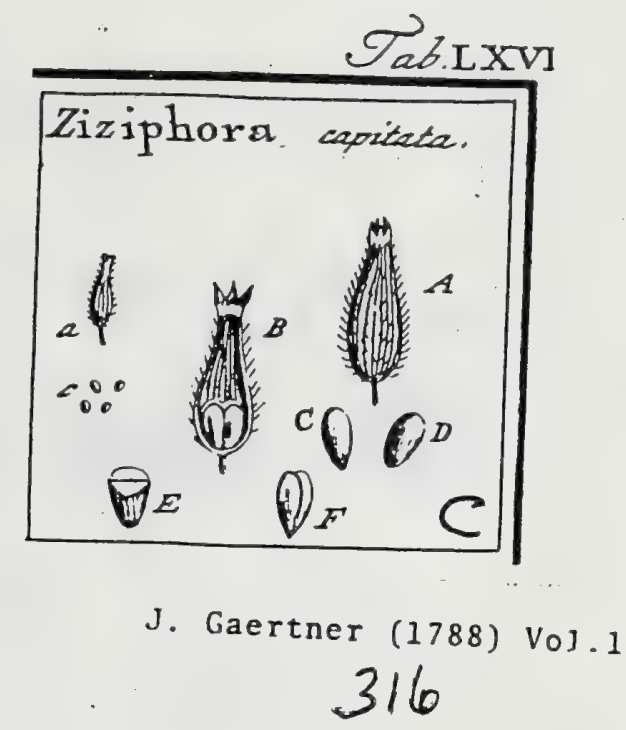

CCCCIII. ZIZIPHORA. L in N. gen. 36 .

Calyx teretiusculus, friatus, quimquedentatus: ore per maturitatem villis claafo. Cor. ringens, labio fuperiore retlexo integro; inferiore trifido. Stam. duo. Se. mina quatuor, ovata, mucilaginola.

ZIZі н о в а capitata. Tab. 66. fig. 3.

Clinopodium fifulofum pumilum, fummo caule floridum. $\mathrm{P}_{\mathrm{L}} \mathrm{u}$. p. phyt. $t .164 . f \cdot 4$. Ziziphora fafciculis terminalibus, foliis ouatis. L IN N. fy $\int$. veg. 67.

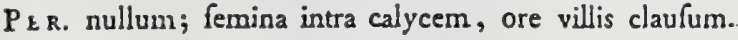

REC. nullum.

SEM. quatuor, ovata, verfus bafin angufiora, hinc convexa, inde obfolete angulata, glabra, e f padiceo rufefcentia.

IN T. duplex: exterius coriaceum, fuperficie, per aquam, in mucilaginem pellucidirimam refolubili; interius membranaceum, tenue.

A L B. nullum.

Ем в. femini conformis, erectus, albus. Cotyl. ellipticx, carnofa. Rad. conics, infera.

a A.) Calyx claufus, $\quad$ B.) Semina intra calycem. c. C.).Scmon, a parte dor(ali, \& D. E) Idem a ventrali fpetatum. E.) Semen difretum. F.) Limbryo denudatus. 



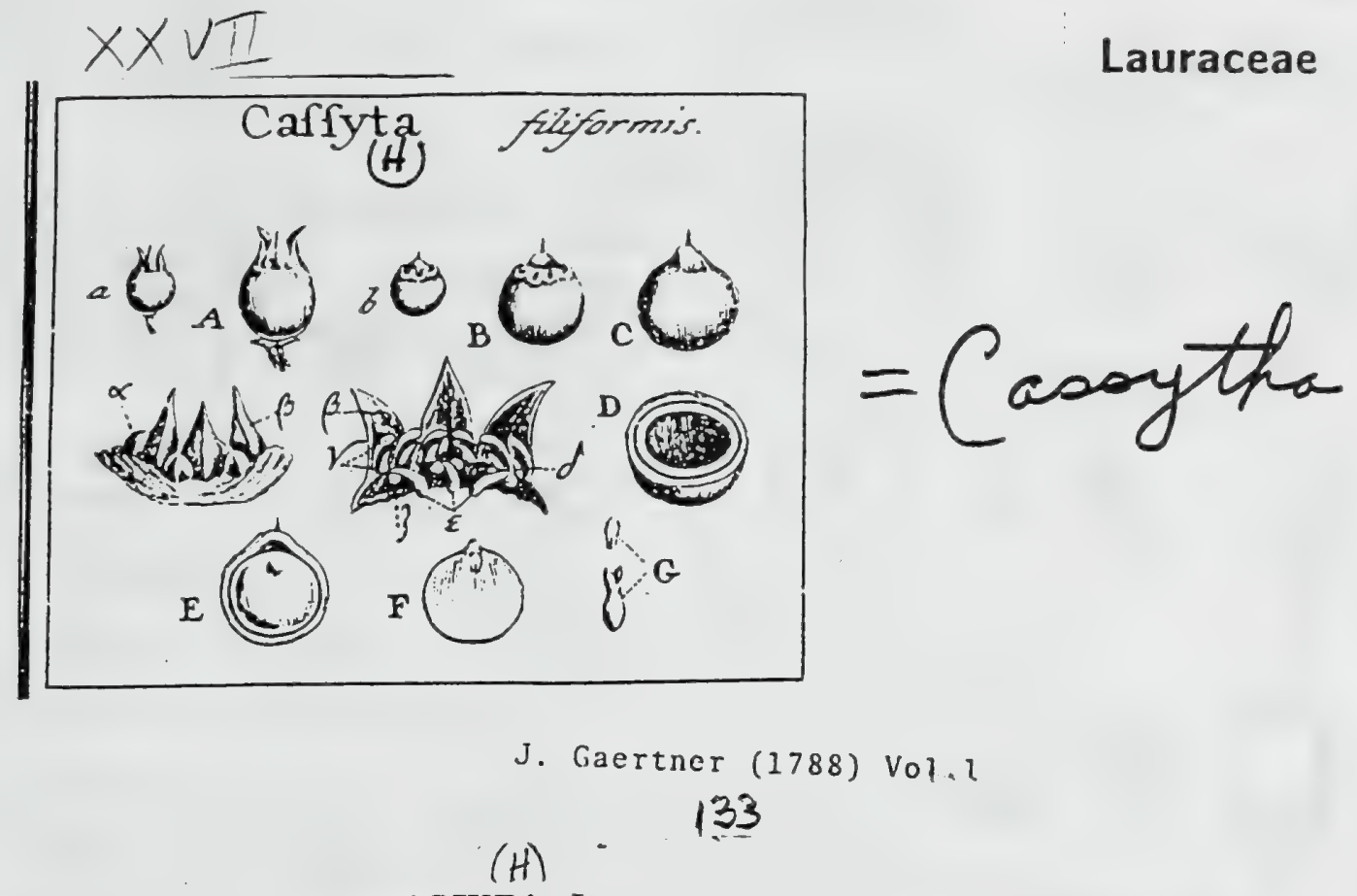

CLX. CASSYTA. Linn. gen. 505.

Calycis venter per maturiarem globofus, baccatus, femen vefiens. Filamenta lex aut novin; interioribus bafi biglandulofis. Nux fupera, nzonofpernsa, evalvis, calyce baccato veftita.

Casssta fliformis. Tab. 27. fig. 4.

134

Cafyta filiformis. JA C Q. hifl. amer. Ir5. $t$. 79.

Cadyta filiformis laxa. LiN N. Jy/. veg. 384 .

Ex herbario Rankfiano.

$P E . R$. Nux fupera, orato globofa, coriacea, unilocularis, evalvis, veflita calycis vei:tre baccato, ovato, molli, fupra pervio ac perfinentibus foris partibus corouiato.

$R E C$. nullum przter fundum calycis, cui fernen arcte adnatum.

SE ss. unicum, glabrum, nigrum, nucannentaceum.

IN T. duplex: exterius coriaceo cartilagineun, craffrusculum; interius meinbranaceum, lutef́cens.

A L B. Semini conforme..... Embr...... ut in fequenti?

2. A.) Fruftus integer, calycis ventre teftus, cui fuperne fequentes partes adnatz: $\varkappa_{.}$) Squa. mule tres calycinz, rotundatx, concava, caducx. $\beta \beta$.) Petzla tria, trisngulari acuminata, ca.

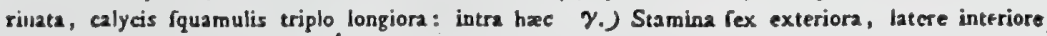
$(\gamma)$ antherifera. Antherx $(d$ ) oblongx, (ex incuria heic, tanquam lacinula a filamentis fepa-

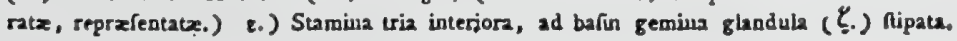

Cassyta zeylanica. ibid. litt. $b-G$.

Cufcuta rumbut - putri. $\mathrm{R} \cup \mathrm{MP}$. $a m b .5 \cdot p \cdot 491 . t$. 184. f. 4 .

Cufcuta indica, floribus albis fellatis. Hers. muf. Zeyl. 67. B u RM. Zeyl. 84.

Cufcuta zeylanica flofculis incarnatis. Н Е R M. mufs-Zeyl. 42. B U R M. l. c.

Aganulinetti $\mathcal{E}$ Miele. Zeylonens. E collect. fen. hort. lugdb.

Calycis venter globofus, baccatus, ut in priori, fed non totam nucem obtegens; ad oram flipatus fquamulis fex, pallidis, obtufis, concavis, diffitis (b. B. ), totidem denticulos mentientibus: harum tres breviores \& paululum exteriores; reliqux tres aliquantum majores: oinnes introrfum conniventes. Stamina fex, fim. plici ordine intra fquamulas pofita; horuen tria breviora, fquanis majoribus refpondentia, fubulata; tria autem reliqua, intra fquamulas minores pofita, longiora \& prope bafin fuara utrisque glandula globofa, ut in pracedenti, nipata.

Nux globofa (b: B. C.), fupra in umbonem producta, brevique nylo, tribus fig. inatibus infignito, terminata, e cafaneo nigra, glabra, unilocularis (D.), evalvis. Intcguin. penitus ut in precedenti, etian interius lutefcens, hinc friz umbilicali fufca, \& in bafi, clalaza nigricante notatum. Albumen (E. F.) Semini conforme, carnofun, molle, in aqua facile in pultem deliquefecens. Embryo (F. G.) dicotyledoneus, inverfus, parvus, lacteo albus, in apice albuminss locatus. Cotyl. brevifinz, fubfoliacez. Radic. globofe cosica, fupera.

$1 / 2 \cdot$ 


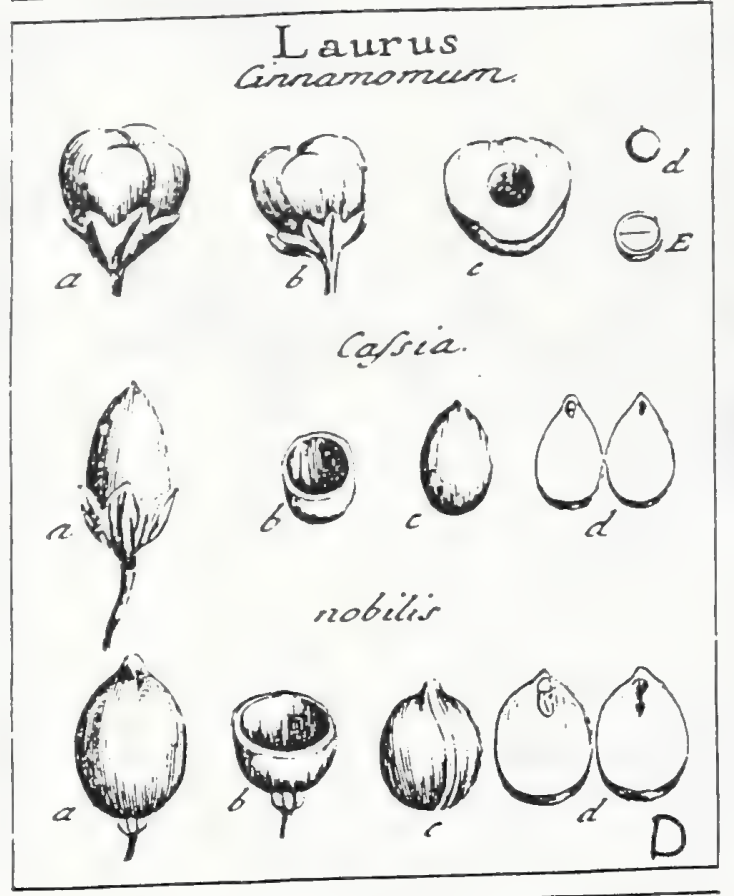

Flores hermaphroditi, vel \& fexu deftincti in feparatis ftirpibus. Calyx ma nophyllus, quadri - I feptemfidus. Cor. nulla, aut quadrifida. Stam. fex ad decem: filamentis interioribus bafi glanduliferis. Ovar. fuperum. Styl. fimplex. Bacca, unilocularis, monofperma.

LAURps nobilis. Tab. 92. fig. 2.

Lazorus. Cам. epit. 60. BLAKw. beerb. t. I75.

Lanous foliis ovato - lanceolatis, rajnis florigeris folio brevioribus. HALL, bif. n. 2602 .

Inurus foliis laniceolatis venofis perennantibus, floribus quadrifidis. LINN. Syso. veg. $3^{8} 3$.

PER. Bacca fupera, ovata, carnofa, tenuis, unilócularis, violaceo-atra.

REC. nullum, practer tuberculum parvum in fundo bacce, unde fafcia vafcu lofa utrinque fecundum longitudinem feminis afcendit, \& in ejus apice finitur.

SEX̃. unicum, grande; ovatum, fupra leviter mucronatum.

IN T. fimplex, charcaceum, aridum, tenue, facillime a nucleo fecedens atque - carni baccac adherens, ut fenen in vetuftiori fructu acoccon videatur.

A \& B. nullum.

Es в. femini conformis, inverfis, albus. Cotyl. ellipticx, carnofx, craf $x$, plano-canvexx. Plkm. diphylla, grandiufcula, foliolis linearibus. Rad. parvula, fubglobofa, fupera, immerfa f. intra cotyledones latens.

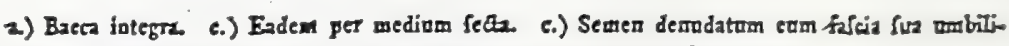
ali. d.) Cotyledenes feparate, cum Plumula atgue Radicula in fitu maturali.

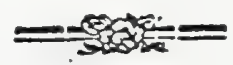

Laurus Caftia. ibid.

Carrar. Rheed. mal. x. p. 107.t. 57. Cafia ligizea. Brakw. berb. 8. 398. Latous foliis triplinerveis lanceolatis. LiNs. Cyf. veg. $3^{8} 3$.

E collectione fem. hort lugdb.

Baces oviato-oblonga (a) apice mucronata, bafi calyce campanulato, coriaceo, angulato, inæqualiter $5-6$ dentato excepta, cxruleo - fufca, glabra, unilocularis (b), demum in cruftam coriaceam tenuen \& prorfus infipidum inodoramoue exarefcens. Semen (c) integumento chartaceo, ab ipfo femine foluto atque carni arcte adhrerenti tectum, ovato-acuminatum, in duas cotyledones craflas (d.) partibile. Radicula atque Plumula minima, intra cotyledones, ut in precedenti latent.

Laurus Cinnamomum. ibid.

Cafia cimamonizea. Herds. lugdb. 129. t. 655.

Conzamonum foliis lat is ovasis frugiferzun. BURM. 2el. 62. t. 27 .

Cinzamomsum. BLAKW. berb. t. 354 . f. r. non fig. 2. c. d. qux precedentis eft.

Laurus folits trinterviis ovato-oblongis: nervis verfus apicem evausefcestibus. LINN. byjt. veg. $3^{8} 3$.

Baru - Kravindu. Zeylonens.

E collect. fem. hort. lugdb.

Baca fubglobofa (a. b.), apice deprefliufcula atque torulofa, bafi calyce craffo, coriaceo, angulato, fublobato \& inxqualiter fex - novem denato excepta, carnofa: Carne craffifima (c.), per xtatem fungofa, cinnamum fortiter redolente. Semen (i.) fphxricum, aut globofum, integumento cruftaceo, fragili, fed tenui (E.) teaum. Embryo femini conformis.

Non poffum abs me impetrare ut Cafliam ligneam, cum Cl. Thunbergio, meram Cinnamomi varietatem credam. Eft enim in fructu difcrimen infigne, non tantun quod ejus fabricam \& figuram, fed \& quod odorem ejus fpeç qui fcil. in Cafrix baccis nullus, in Cinnamomi vero etiamf veruftifimi hos centum ante anios ab ipfo P. Hermanso in Ceylona lectis, Jong tifrsmus \& fortifimus deprehenditur. 
Tab. 222.

Tetranthera

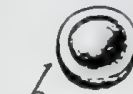

b

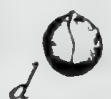

apetala.
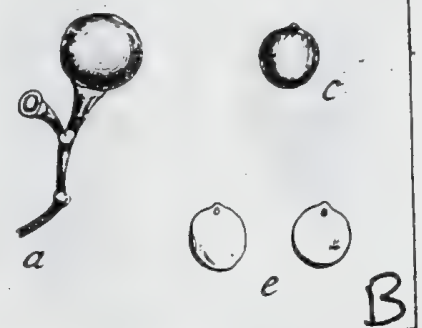

J. Gaertner (1788) Vo13

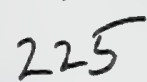

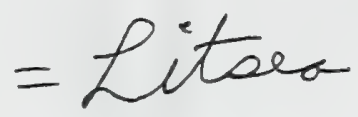

177. TETRA N T E B A,

Jace. hort. Schoenb. x. $t$, гъ. Litlea. Juss, Diar. hift. nat. muf. paris. 5. 7. 197.

Flores fexu diftincti in feparatis ftirpibus, quorum fex in utraque involucro commutu pentaphyllo collecti.

Toll. 111 .

226

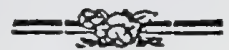

M \& \&. Cal. monophyllus, bafi tubulofus, quinquepartitus. Cor. nulla; pra: ter calycem. Stam. 16 l. 20.; duplici ferie difpofita; filamenta corollx inferta, octo 1. decem exteriora breviora, glandulxeformia 1 . caftrata, cum interioribus longioribus antheriferis alternantia; anthera quadriloculares. Ovar. nullum.

Foem. Cal \& Cor. ut in mire. Stam. nulla Glandulze oblongx. Ovar. fuperum; ftylo \& ftigmate fimplici. Bacca calyci truncato infidens, unilocularis. Rec. nullum. Sem. unicum, inverfum. Alb. nullum. Emb. inverfus.

Tetranthera apetala. Tab. 222. fig. 2.

Tetrautiera apetala. RoXв. corom. pl. to 147 .

Ex collectione BankGiana.

PER. Bacca parva, globofa, pedunculo incraffato in calycem truncatum am: pliato infidens; purpurea, unilocularis, monofperma. Loculamentum membrana tenui firma veltitum.

REC. nullum.

SENS. unicum, inverfum, ovato-globofum, apice mucronulatum, album.

Is $x$. fimplex, membranaceum, tenue, facile detrahendum.

A L B. nullum.

EN 5. femini conformis, inverfus, mucronulatus, lacteus. Cotyl. craffx, carnofx, hinc convexx, inde leviter undulato - planiufculx, accumbentes. Rad. minima, globofa, cotyledonibus immerfa, fupera.

\section{EXPLICATIO FIGURE}

2) Pars cyaz fragiferz. b.) Bacos-veparata. c.) Semea (feparatom. d.) Embrye Solutue c.) Cotyledones fepartitx, a parte interna (pettatz. 


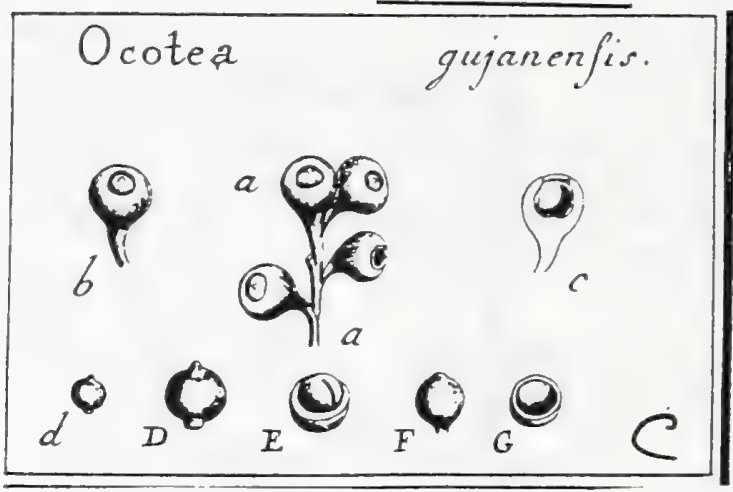

J. Gaertner (1788) Vol3

\author{
178. O C O TE A. . \\ A UBI. guian. t. 3ro. Juss. gen. p. 80. Poroltema. \\ Sснавв. gen. 1226. N'ectandra. Rоттв. jl. Jurin. \\ p. 10.
}

Cal. monophyllus, fubgloborus, perfiftens; limbo fexpartito: laciniis deciduis, tribus exterioribus majoribus. Cor. nulla, prater calycem. Stam. novem, duplici ordine difpofita, fex exteriora \& tria interiora; filamenta membranacea, tria interiora paulo craftiora; antheræ quadriloculares. Glandula fex, fubrotund $x$, cum ftaminibus exterioribus alternz. Ovar. fuperum, ftylo fimplici crafio; ftigmate concavo. Drupa parva, a calyce coriaceo truncato

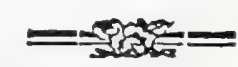

globofo obvolucrata; putamine monofpermo, Rec, nullum. Sem unicum. Ảb. nullum. Emb. inverfus.

Ocotea gujanenfis. Tab, 222. fig. 3.

- Nesandra (bijuga,) foliis ovato - lanceolatis acuminatis, racemis fuliformibus. foribus polygamis, antberis bijugis. ROTTB. plo furin. p. I0.

Laurus (Jurinamenfis, ) folitis ovato - lanceolatis acunsiuatis, ramis patentiGimis, racenis filiformibus lateralibus axillaribusve. SwaRz f. ind. occid. 2. p. 708 . Willu. Spec. pl. T. 2. P. I. p. 48 2. Persoon Jom. 1. p. 449.

Ocotea. Aubl. guiam 1. c. p. 780.

Ex collectione Cl. Desfontaings, \& ab amicifimo Do Decandoliz.

PER. Bacca parva, vix granum piperis magnitudine mentiens, vertice tantum ex calyce obvolucrante coriaceo fubglobofo 1 . obovato \& apice foramine orbiculari pervio prominula, globofa, utrinque mucronulata, fundo caly. cis adnata, glabra, lutea, unilocularis. Caro tenuis, ficcitate farinofa, lutefcens, cuticula tenui Jevigata tecta.

REC. nullum; proxter funiculuni umbilicalem filiformem, a bafi bacce ad apicem reminis adicendentem.

SEM. unicum, globofum; apice nucronulatum, vertice umbilico parvo, quo funiculus umbilicalis infertus, inftructum, inverfum, fufcum.

IN T. duplex: exterius cruftaceum, fragile; interius membranaceum, tenue em: bryoni adhærens.

A ᄃ в. nullum.

EN в. femini conformis, inverfus, ...

EXPLICATIO FIGURE.

2. a.) Pars eyma frugifera, b.) FruQus integer, Ieparatus. C.) Calyz longitadinaliter dimidia. tus. d. D.) Bacez Separata. E.) Semen, ab apice ad medium ufque a carne denudatud, cura decurfu funiculi umbiliezlis. F.) Semen leparatum. G.) Tefla medio transverfe difecta. 


\section{Borbonia}

$$
\text { cupularis. }
$$

Lauraceae
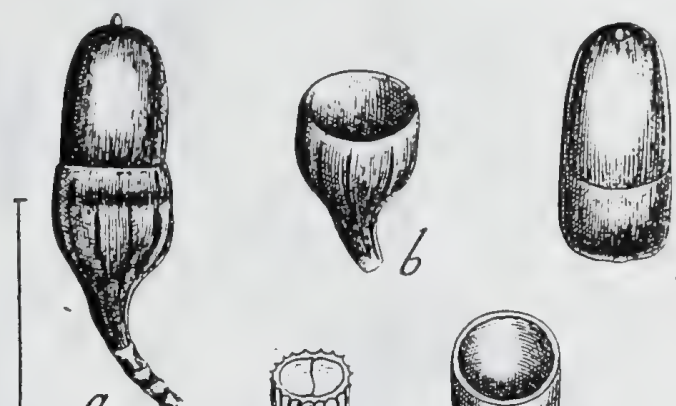

c

a
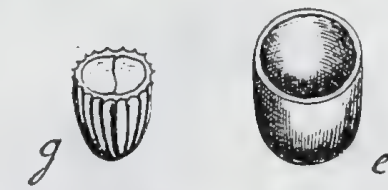

226

J. Gaertner (1788) Vol3
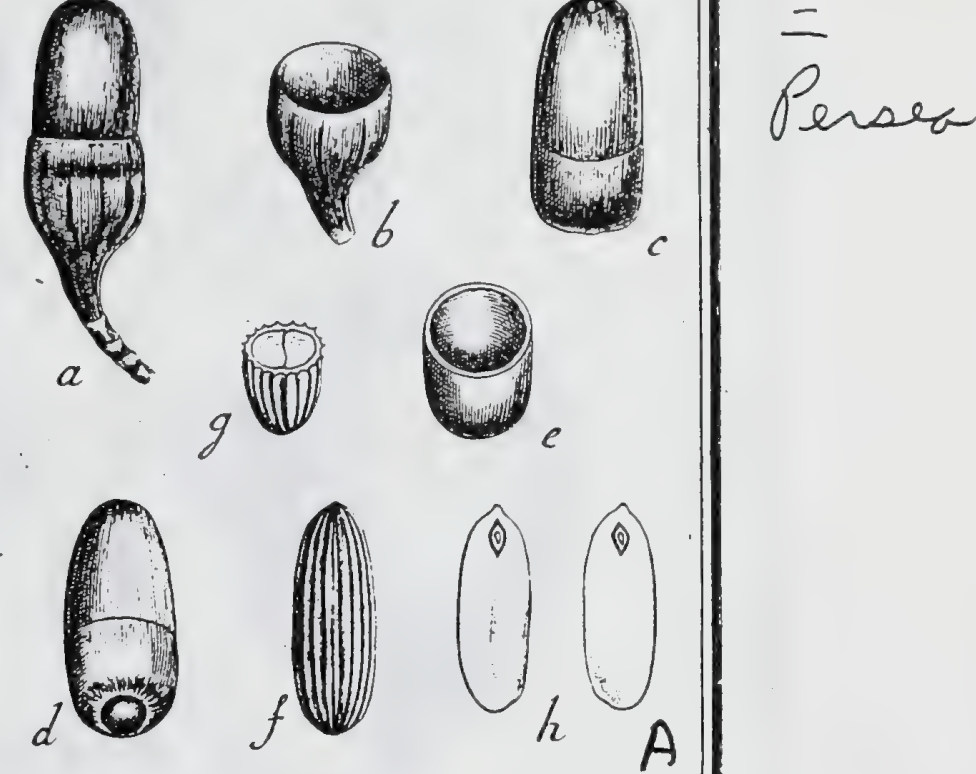

BORBONia cupularis. ibid.

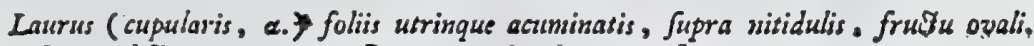

LAM. dit., 3. p. 447. PERSOOQN fyn. 'x. p. 448.

Ex collectione Deleffertiana.

Fruetus (a.) glandiformis conftans ex calyce (b.) coriaceo, profunde cupulato, margine truncato atque acuto, cylindraceo-torulofo, in pedunculum attenuato, cui bacca (c. d.) immerfa eft ovato-cylindrica, apice mucronulata, bafi area lata calycis fundo affixa, glabra, viridiufcula, unilocularis. Caro (c.) tenuis, in cruftam curiaceam fragilem exarefcens. Semen (f. g.) ovato-oblongum, apice mucronulatum, ficcitate loculamento multo anguftius \& longitudinaliter rugofum, e cinereo virideicens. Integ. duplex, femen arche includens: exterius ad apicem paulo cratius \& cum valis umbilicalibus intime conferruminatum, chartaceum; interins fufcum, intus glaberrimum, Emb. femini conformis, inverfus, albus. Coog \%. (h.) carnofx, crafar, plano sonvexz, intus fecundum longitudinen leviter plicatx. Plsm. diphylla, acuminata. Trad. conico-acuminata, ab apice cotyledonum remoța, imnier= fa, fupera. 


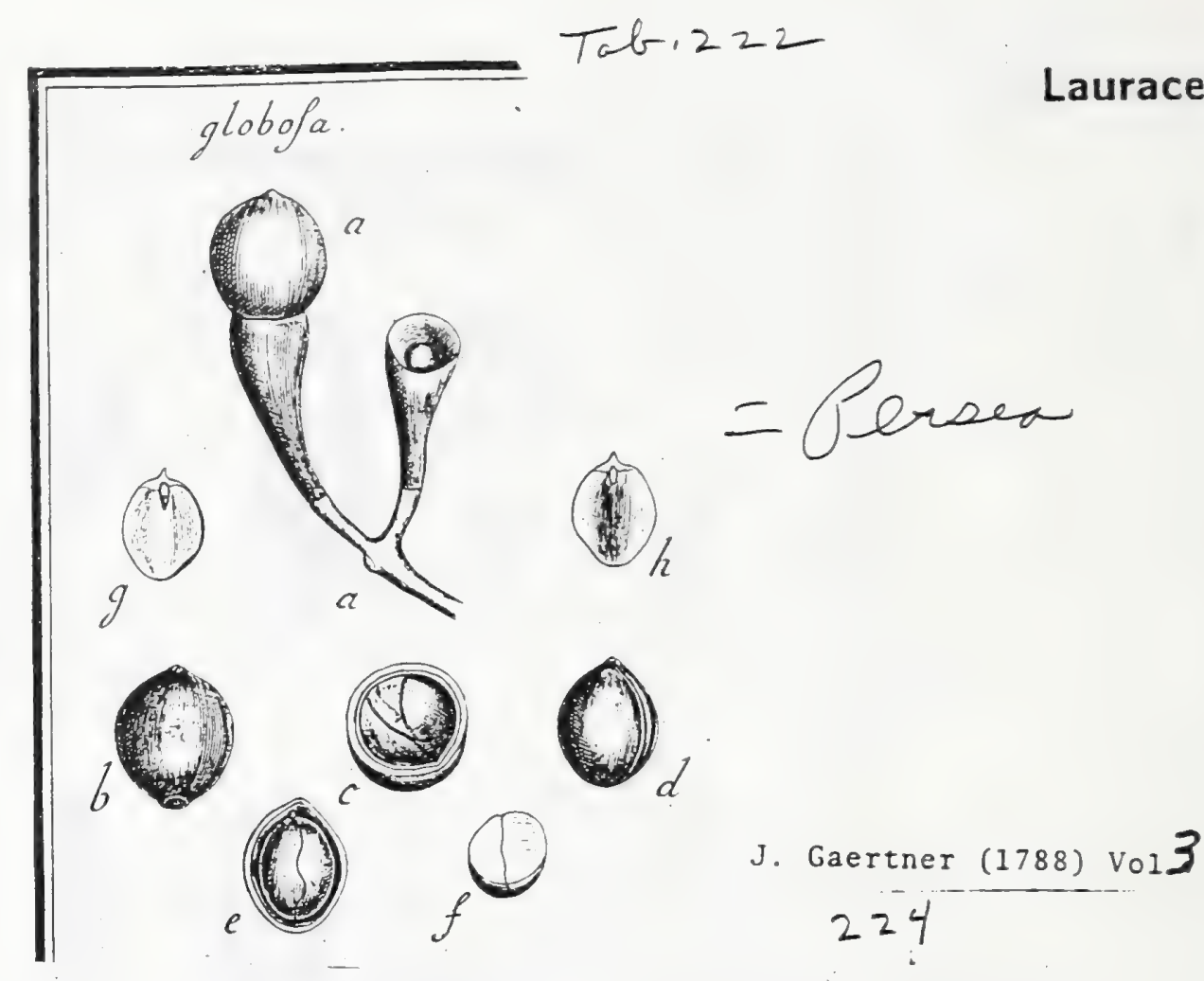

r776. B O R B O N I A.

Prum. gert. t. 2. Laurus. LinN. \& Juss.

Flores hermaphroditi \& mafculi, nonnunquam \& fexu diftincti in diverfis ftir pibus.

Cal. monophyllus, fexpartitus, perfiftens; laciniis ovatis, acutis, deciduis. Cor, nulla: prater calycem. Stam. octo l. novem, duplici ordine difpofita; fex externa; duo l. tria interna, ad bafin filamentorum glandulis binis pedicellatis globofis inltructa; filamenta brevitfima; antherx tetragonx; apice quadriloculares. Ovar. fuperum; ftylo fimplici, fubulato, longitudine ftaminum; ftigmate obtufo. Drupa baccata, calyci truncato cupulato immerfa, unilocularis, monofperma. Rec, nullum. Sem, unicum. Alb. nullum. Eub. inverrus,

BORBONIA globora. Tab, 222. fig. I.

an Laurus (globofa, ) foliis ovatis glabris, cymis peduneulatis axillaribus, drupa globoja. LAM. dia. 3. p. 451. Persoos L'm, 1. p. 449?

A Cl. A. Lo de Jussieu.

PER. Drupa baccata, femipollicaris, ovato-globola, apice mucronulata, calyci in pedunculum longum clavatum cupuleformem truncatum rubrum immerfa, glabra, viridis, unilocularis. Caro mollis, non admodum craffa, a loculamento per. ataten feparabilis, cuticula tentuifima inclu⿰a, Putanen ovatum, cruftaceuin, fragile, fulco elevato longitudinali inforiptunı, apice a vafis umbilicalibus perterebratum, glabrum, evalve, unilor culare, monofpermum.

REC. nullun; proter cicatricem ftellatam, in .vertice loculamenti a valis umbilicalibus per putamen transeuntibus exasperatau, cui femen affixum eft,

SEM. unicum, ovatum, apice mucronulatum, grande, per xtatem vero loculamento ipfo paulo angultius, inverfum, lurefcens.

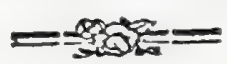

IN T. Gmplex, membranaceum, tenue, cum varis unbilicalibus a vertice divergentibus undique conferruminatum, \& per exficcationem feminis ab ipfo fecedens \& loculamento adhrereus.

A ᄃ B. nullum,

Ens femini conformis, fubobliquus, inverfus, albus. Cotyl. ovatre, apice acuminato-nucronulate, carnofx, crafx, leviter undulato-plicate, plano-convexz. Plum. parva, diphylla: foliolis conico-acuminacis. Rudo parva, ovata, obtufa, a peripheria cotyledununa remota \& iplis imnerfa, unbiliço extẹrno obyerfa, fupera,

\section{EXPLICATIO FIGURE,}


Tab. 221.

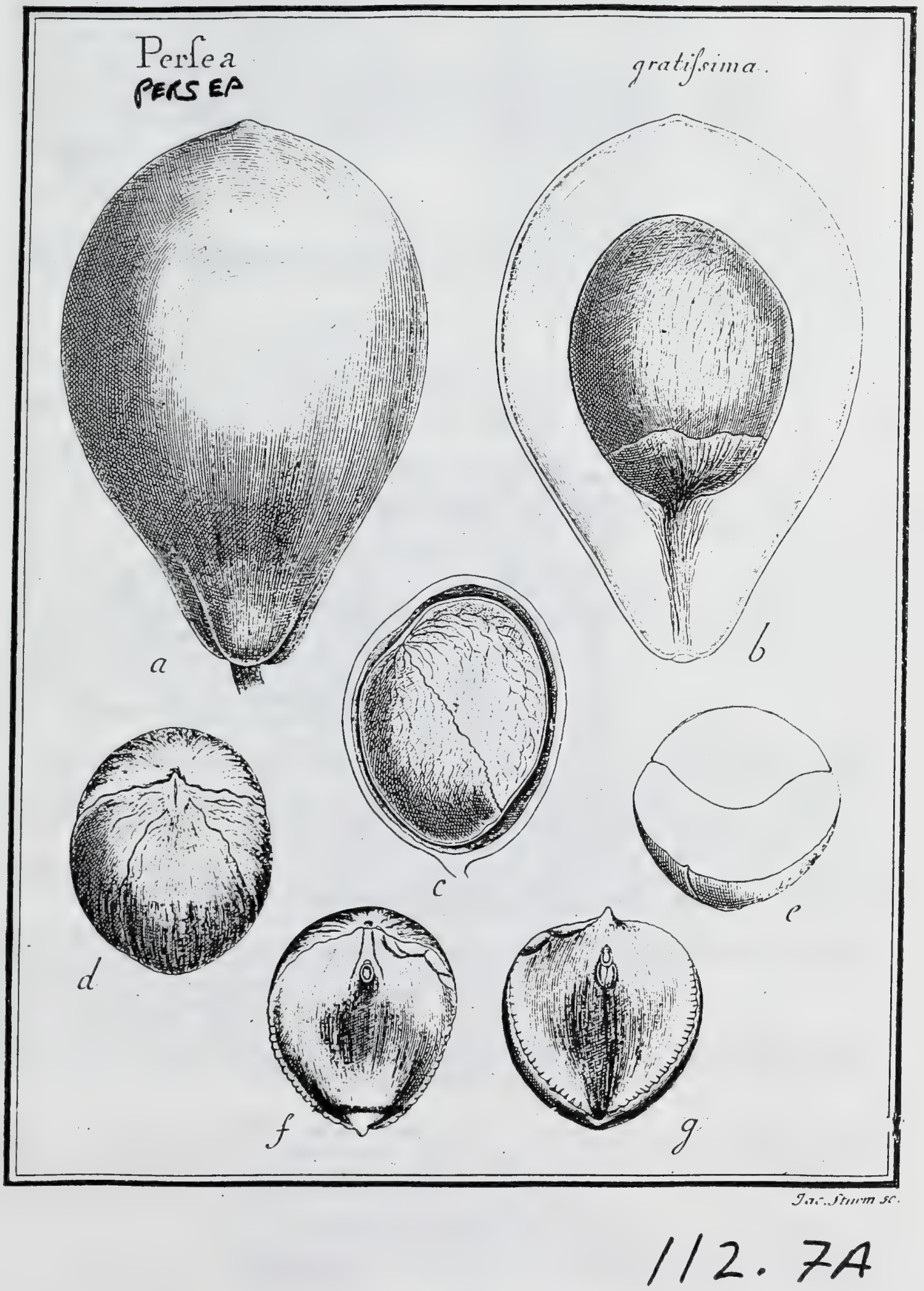


175. PER S E A.

PIUM. gen. t. 20. Laurus. LINN. \& Juss.

222

Cal. monophyllus, inferus; hirfutus, coloratus, deciduus; tubo brevi; limbo fexpartito. Cor. nulla; niG calycem velis. Stam. (fex, MrLf) novem, duplici ordine difpofita, quorum tria interiora; filamenta calyci inferta \& ipfi longitudıne equalia; anthera quadriloculares; loculis apice operculo erecto perfiftente dehiccentibus. Głandula novem, pedicellate, glubofx, inter filamenta prope bafin infortz. Ovar, fuperum; ftylo fimplici, longitudine ftaminum; ftigmate obtufo. Bacca pomacea, nuda; loculamento chartaceo. Rec nullum. Sem. unicum, inverfuns. Alb, nullum, Emb. inverfus.

Persea gratifima, Tab. 221 .

Pyro frmilis frulfus in nova bispania, nucleo magro. BaUн. pirr. 439.

Perfer. Clus. bijl. I. p. 2.

Prunifera arbor fructu maximo pyriformi viridi, pericarpio ef culento busyraces nucleum unicum muximums nullo efficulo seiturn cingente. SLOAN jam. 132. bifi. 2. p. 13.

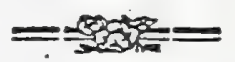

Arbor americana, amplifimis perganenis foliis fuperficie nitidifima, frü̃u pyriforni cruftaceo cortice coriato. PLUKN. alm. 39. t. 267.f. I.

Laurus foliis oblongo-ovatis, frufu obverfeovato, pericarpio butyraceo. BROWN jam. p. 28.4 .

Lairus foliis ovatis coriaceis transverfe venofis perenmantibus, floribus corymbo. fis. Lisn. Jpec. pl. p. 529 . Syfl. veg. ed. 14. p. 383. JACE. Obf. 1. p. 37. Sivarz obf. p. 152. W'IlLD. Spec. pl. T. 2. P. 2. p. 480 . Persoon fyn. I. p. 449 .

1 Ex collectione Deleffertiana.

PER. Bacca grandiufcula, tres pollices crafa \& quinque circiter longa, varize formx, ovata, plerumque vero obovata 1. pyriformis, bafi torofa \& calyce urbata, apice obtufe mucronulata, pedunculo valido infidens, pomacea, corticata, viridiufcula, 1. e fufco faturate purpurafcens, unilocularis. Cortex coriaceus, non admodum craffus, a carne facile detrahendus. Caro crafa, mollis, 1 butyracea, ad peripheriam viridefcens, centrum verfus albida. Loculamentum centrale, ovatum, laca bafi carni arctius adıatum $\hat{\alpha}$ deorfum in pedunculi váfa abiens, chartaceo-coriaceum, craffiufculum, monofpermum.

R R C. nullum: femen ante maturitatem bacce prope verticem loculamento ope vaforum umbilicalium adhæret.

SEN. unicum, magnum, ovatum, oblique comprefrufculum, turgidum, locuJamento paulo anguftius \& adepta maturitate ab ipfo liberum, inverfum, album.

IN T. finplex, meunbranaceum, validum, cum vafis umbilicalibus ex umbilico emanantibus \& per totam feminis fuperficiem divifis intime conferruminatum.

$\Lambda$ L B. nullum.

E\& в. femini conformis, maxinus, obligue inverfus, albus. Cotyl. maxima, craffifima, amygdalino - carnofie, margine transverfim rimofa, incumbentes, fubaquales: altera fuperiore, paulo minore, ovata, ad bafin mucronulata, intus inxquabili : 'altera inferiore paulo majore, fubconcava, fuperiorem excipiente. Phrms. magna, diphylla, comprefía: foliolis tenuibus, acuminatis, margine ciliatis. Rad. minima, longe a cotyledonum margine diftans, incra cotyledonum foveolam abfcondita, umbilico externo obverfa, fupera.

\section{EXPLICATIO FIGURE.}

4.) Baces integra. b.) Ejusdem fetio longitudinalis, eum fitu \& forma exteras locolamenti. c.) Loculamentum feparatum \& loogitudinaliter cum integumento apertum, ut embryonis bors naturalis appareat. d.) Embryo Eeperatus, paulum a vertice vifus. C.) Ejusdem featio trank verfalis. r.) Coryledon fuperior Separata, a parte interaz Spetata. z.) Cotyledor allesa infosior, cum latu \& forma plumula atgue sadicols

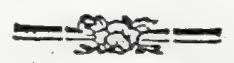

Nucleus odoris plane expers.

Hujus quoque congener videtur Laurus pendula. SWARz f. ind. occid. 2. p. 719. ob baccam mollein \& baG nudam.

Laurorum familiam in plura geinera dispefcere fatius effe duxi, utut dıficilis fit certoruminter ipfa gẹnera limicum delignatio; fed ejusmodi exeinpla in ordinibus plantarum non rara, ut uno genere tota familia complecti poffet: genera vero iterato examine florum in vivis quam maxime indigent. Conferantur quoque anmotationes fuper hunc ordinem, qux Cl. Jussigu

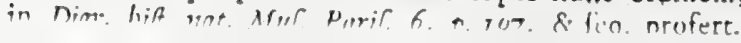




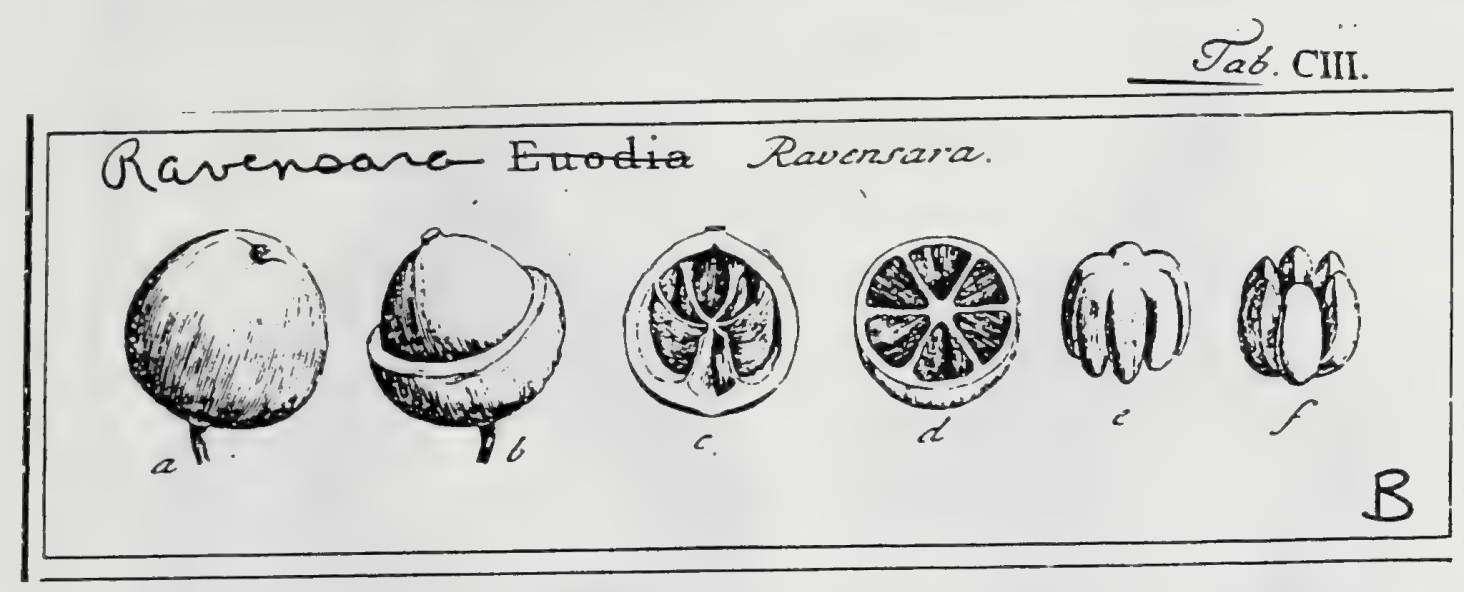

J. Gaertner (1788) Vol..2

INO

\section{E V O D I A.}

Calyx fuperus, breviffimus, edentulus. Cor. hexapetala, villofiufcula. Stam. duodecim, calyci \& peralis alternatim inferta- Ovarium inferum. StyL

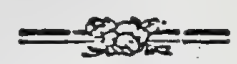

fimplex, figmate pubefcenti. Drupa exfucca aromatica, putamine femi. fexluculari, monofpermo.

Evodia Ravenґara. Tab. 103. fig. 2.

Ravenfara aromatica. SONNER. it. ind. $\mathcal{E}$ cbin. p. 226. t. Is7.

A Cl. Heraranno. Prof, argentor.

PER. Drupa infera, pyriformis aut ovato-globola, in vertice cicatrice orbiculata a lapfu calycis \& tribus furiis breviffmis obfoletis notnta, rufefcenti fumofa. Cortex fuberofo - fungofus, modice cralfus, putamini arctifrme adnatus. Putamen coriaceo-lignofum, fubglobofum, mucrone plano tcrninatum, femifejloculare, evalve. Diffepimenta coriacea, dura, a bali ad medium putaminis integerrima; fuperne vero arcu deorfum concavo excifa, ut fex loculamenta bafeos, in unicam verticis cavitatem contuant.

REc. nullum, practer columnum craffam, ex concurfu diffepimentorum in axi putaminis formatam, cui femen infidet.

SE A. unicum, grande, fuperne convexiufculum, integerrimum, inferne in fex lobos difantes, ficuti juglandis nucleus, divifum.

I* T. Gimplex, membranaceum, fufcum.

A L B. nullum.

EM B. femini conformis, inverfus, albus, aromaticus. Cotyl. ex lobis embryonis, fecundum longitudinem fuan irregulariter bipartitis furmata, carnofix, duodenx. Rad. obfoleta, fupera.

2.) Drupa integra. b.) Putaminis pars fuperior denudata c) Ejus fectio verticalis, diffepimentorum verlus apicem deliquium oftendenc d.) Ejusdem featio transverfalis, cum loculamentis \& colurana bafeos. c.) Semen in fitu saturali. f.) Idean inverfum \& a parte inferiore Spcetatum.

Odor quidem omnium partium, prxfertim corticis atque feminis, gratiflime aromaticus eft, fed non fatis mihi videtur fortis atque durabilis, ut hi fructus locum inter merces invenire queant, queadmodun $\mathrm{CL}$. Somweras \& Circ libi perfuafum habent. 
r

a

- 
Tab.CI.

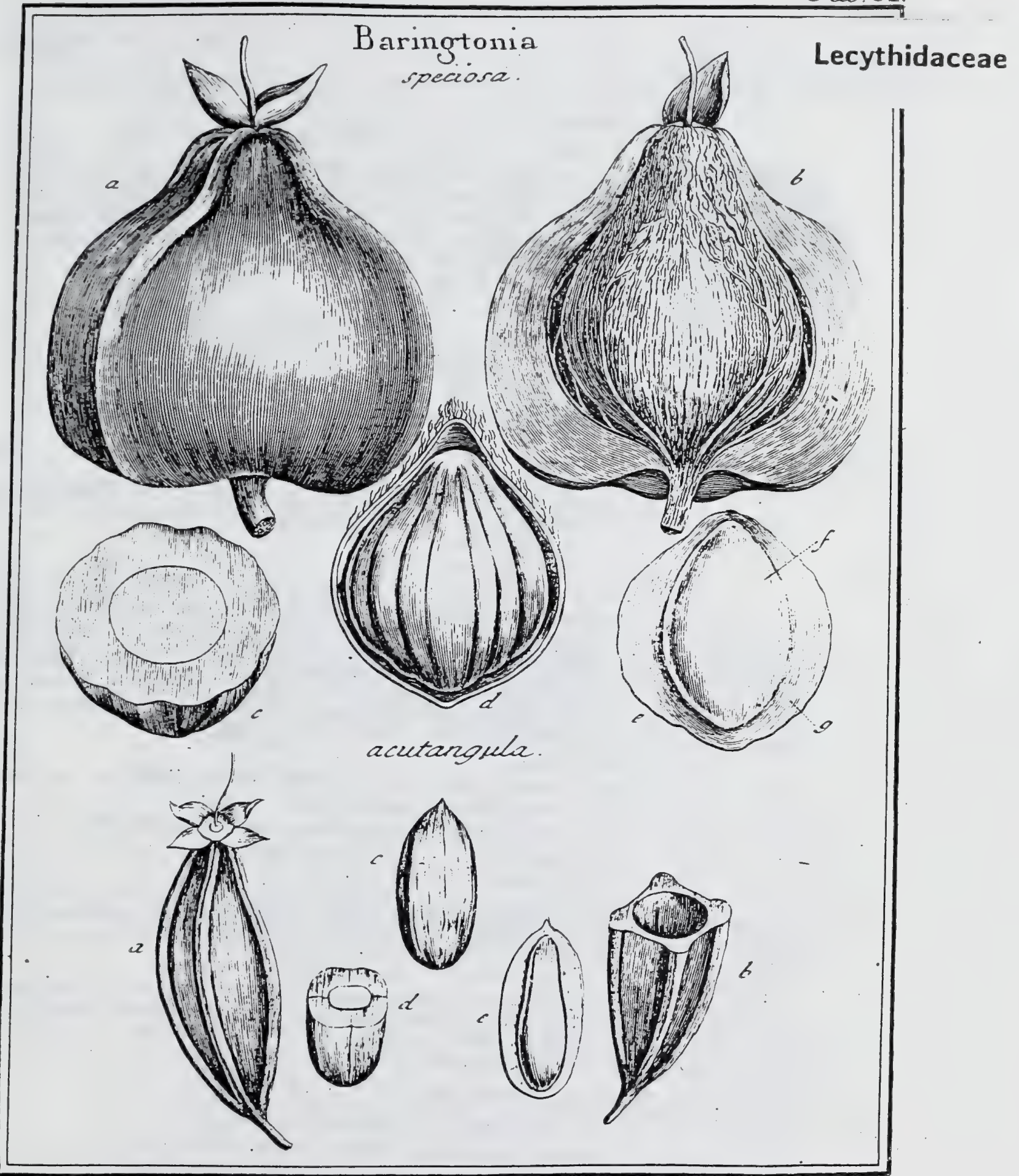

$1 / 3.1 \mathrm{~A}$ 


\section{BARINGTONIA. LINN. gen. I4I3.}

Calyz monophyllus, ventricofus, dehifcens in foliola duo, ovalia, concava, patentia, perfiftentia. Cor. tetrapetala. Stam. numerofa, bafi connata in cylindrum brevem. Ovarium inferum, quadriloculare, ovulis in fingulo loculo geminis. Stylus fimplex, filiformis, longitudine ftaminum. (Ex fchedis SolandrI) Bacca tetragona, unilocularis, monofperma, embryone pleudo-monocorgledoneo.

Baringtonia fpeciola. Tab. ior.

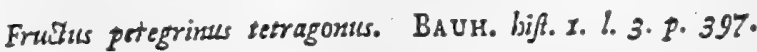

Samiftrauadio. Rheed. mal. 4. p. II. t. 6.

Butonica Jyluefris alba. RUMPн. amb. 3. p. $38 x$. t. 116.

Commerfond. S. Bouket guarré. SONNERAT. it. guils. p. 14. t. 8. 9.

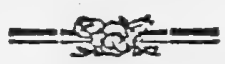

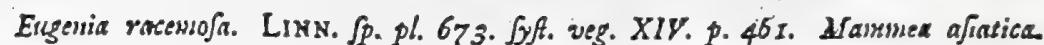

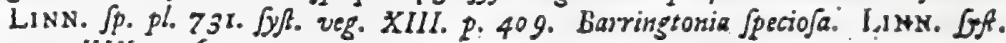
veg. XIV. p. Gee.

E collect. fem. hort. lugdb.

PEA. Bacca infera, grandis, tetragona, e ventricofa \& umbilicata bafí furfunt pyramidata, atque calyce perfiftente, di-i triphyllo coronats, per maturicatem conftanter unilocularis. Cuticula tenuilfima, glaberrima, fplendens, gilva aut e luteo rufefcens. Caro craffa, firma, prope peripherians fungofa, prope loculamentum autem fibrofa : fibris octo aut decem ctaffiuribus lignofis, reliquis vero capillaribus. Loculanenti membrana propria coriacez aut chartacea, tenuis, inverfe pyriformis \& fibrarum ope a carne dilcreta, ut pro putamine haberi poffet

REC. nullum.

SEN. unicum, grande, ovato-globofum, furfum attenuatum, per xtatem longitudinaliter fulcatum, rufefcens.

Is T. finplex, cruftaceun aut coriaceum, arcte nucleo adnatum.

A ८в. Femini conforme; fubfarinofun, firmum, album, cum embryone aretif fime conferruminatum.

EM B. elliptico-globofus, fuperne attenuatus, carnofus, albus, pfeudo--monocotyledoneus. Cotyl. inter fe coalitx, ut ne rims quidem aut ftria at invicen difcretx fant. Rad. cum cotyledunibus confufa, atcenuata, fupera.

2.) Bacez integra, b.) Eadem verticaliter diffeca, relito putamine, f. loculamenti membrau propria, integto. c.) Semen, intra loculamenti fui membranama diftectam, integrum. d.) Ejus dem fectio transverfalis e.) Idem vertiealiter difcilum, cum Embryons (f.) ab uno Letere deaudato, ab altero autem cum albumine (5.) counexo.

Beringtonia acutangula. ibid.

Tsjieria - famfircuadi. RHEED. mal. 4. p. 15. t. . .

Eutonica terreftris rubra. RUNPH. amb. 3. p.181. t. 115.

Engenia foliis crenatis, pedarculis terminalibus, pomis oblongis acutangutis. Lins. Jint. veg. 465 .

Aredella. Zeylon. E collect. fern. hort. lugdb.

Bacca (a.) calyce terraphyllo coronata, oblonga, utrinque aitenuata, tetrago17a: angulis incraffatis, prominemtibus. Caro tenuis, per xtatem coriaccofungofa, loculamento oblongo, nulla confpicua membrana propria veftito, exfculpta (b.). Semen (c.) oblongum, rotundato tetragonum, fuperne mucronatum, in lateribus ftria longitudinali notatum, cxters fubrugofum, fufcum. Albumen (d.e.) Temini conforme, granulufe - carnofum, durum, albidum, quadripartitum! Embryo (e.) oblopgus, furfum attenuatus, car-

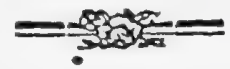

nofus; preudu - monocotyledoneus. Cotyledones conferruninatre, fitria tamen transverfali obfoletifima abinvicen diftindx. Radicula non difcreta, fupera.

Calyce tetraphyllo, defectu putaninis, \& prefertinı albumine quadripartito, abuinde a priori ditrert, ut proprium ex hac fpecie confici poffet genus. Satius tamen videtur, in unum jungere utrasque, quum reliqua floris \& fructus fabrica inter fe confpirent. 


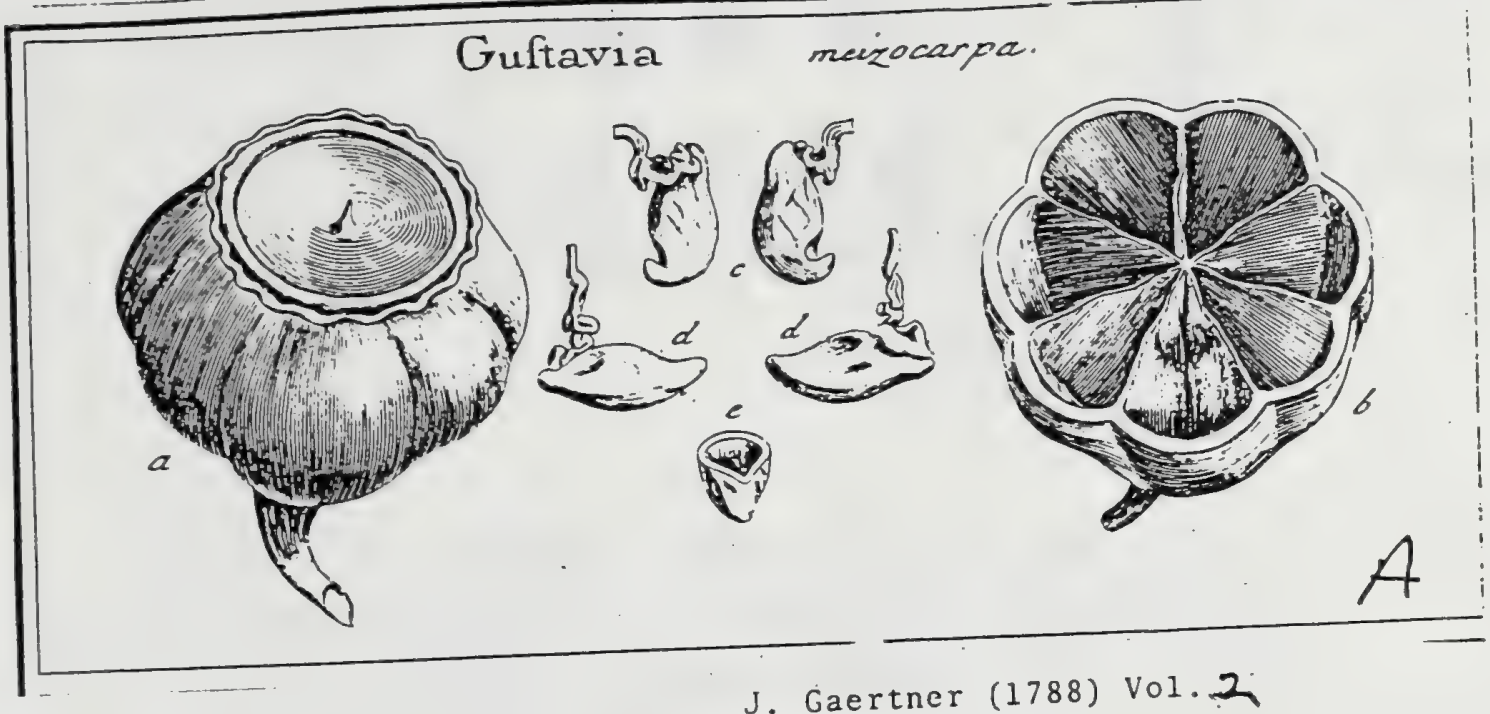

\section{G U S T A V I A. LINK. gen. I4I4.}

Calys nullus, aut margo breviffimus edentulus fubundulatus ovarium coro. naus. Cor. fupera, fex 1. octopetala. Stam. numerofa, bafi in annulum louge a ftylo diftautem connata. Ovar. inferun.. Styl. fimplex, brevis: ftigma lobatum Bacca infera, exfucca, apice truncata, quadri-1. plurilocularis. Sem. plura, anygdaloidea, funiculis umbilicalibus perGltentibus caudata.

Gustavia meizocatpa. Tab. I38. fig. I.

Jupurmdibr. MARCGR. bras. p. rog. c. ic.

Piriguna tetrapetala. AUBL. guinu. 487. 2. 192

Gujhovia. Lins. fyft. veg. 620 .

\section{A Cl. ThuNBerg.}

PER. Bncea infera, exfucca, turbinato - globofa, torofa, fuperne truncata \& levicer concava, inferne in pedunculuni conicum fulcatum producta, quadriad fepremlocularis. Cortex coriaceus, externe cinereo-albidus, venofus, interne flavus, glaberrimus. Diffepimenta tenuia, chartacen, flexunfa.

REc. nullum, fed ejus loco funiculi umbilicales, prinum carnofi, demum fub. cornei, tortuofi, anfractuofi, ftriati, Aavi, perliftentes, quibus femina, angulis loculamentorum internis, a vertice ad medium ufque, infertil, ut luperiora fut pendula, inferiora autem oblique l. horizontaliter decumbentia.

SEM. tria ad quinque in fingulo loculo, ovata, a vicinorum preftione varie ingulata, e cinnamomeo-lutefcentia, funiculis umbilicalibus pefiftentibus appendiculata f. caudata.

Ix T. duplex: exteritus coriaceum, craflum, durum, ut ferc cruftaceun; interists membranaceum.

A L ४. ..... (nullum ?)

F.M D. ..... (amygdaloides, bilobus. Marcgr:.)

a.) Bacca integra. b.) Eadem transverfim feQz. c.) Semina fuperiora, pendula, ab utroque latere fpectala. d. d.) Semina inferiora, decumbentiz. c.) Teft= rectio transreríalis.

Funiculi umbilicales haud bene in Aubletio exprefi; in meo autem exemplo, in Ppiritu viri ex Anerica translato, eus obtinui incorruptos.

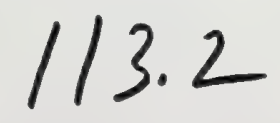


5

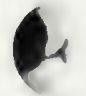

- 


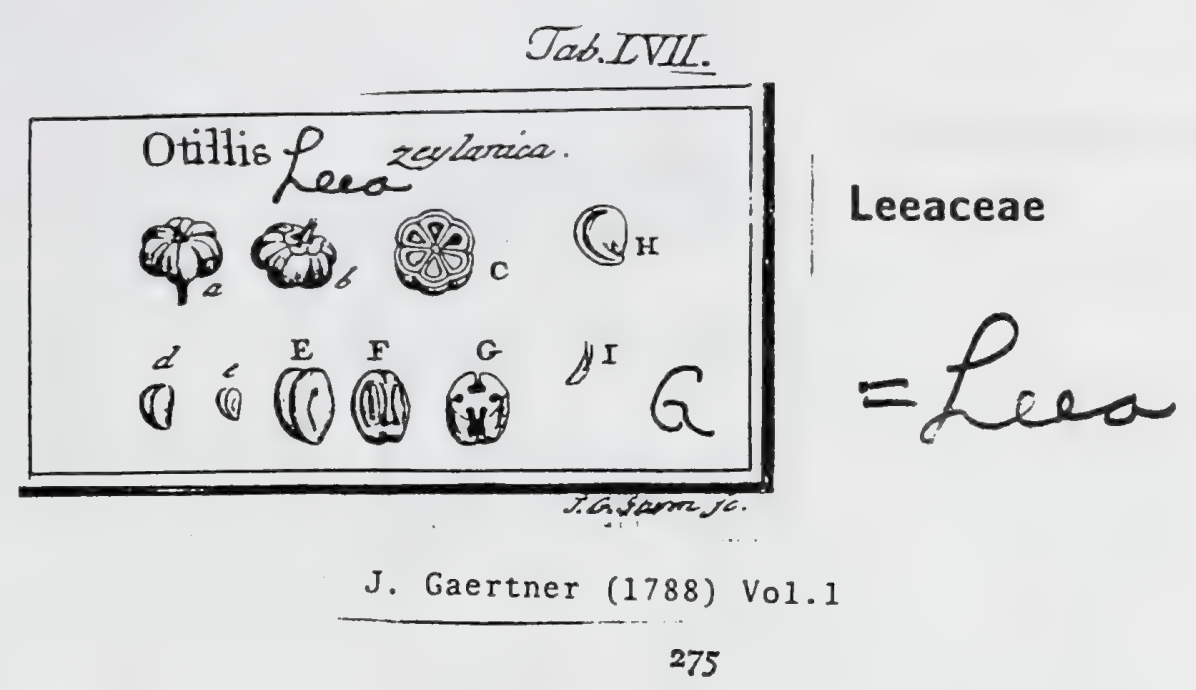

\section{AQVILICIA. LIN N. gen. $=296$.}

Flores hermaphroditi, vel \& fexu dinincti in codem caule. Cal. quinquefidus. Cur. pentapctala. Nectar. urceolatum. Stain. quinque. Styl. unicus. Bacca deprefla torulofa penta - 1. hexapyrena. Albumen cartilagineum, lobatum!

ACUILICIA Otillis. Tab. 57. fig. 7.

Otillis zeylanica. in Icon.

Burule. zeylonens. E collect. fem. hort. lugdb.

an Leca aquata. Lins. $\int y /$. veg. 885 ?

PER. Bacca fupera, rotundata, deprefta, utrinque leviter umbilicata, quatuor ad fex torulis, linca media inforiptis pulvinata, carnofa, pallida aut rabicunda, unilocularis, inodora.

REc. nu!lum; fermina bafi affixa, \& carni baccx undique adharentia.

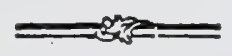

SEM. fex, oflea; in orbem pofita, hinc convexa arcuata, inde cuneiformi compreflr ferruginea. Ix т. duplex : exterius offeum, durum, craffusculum; interius fpongiofum, ferrutg.
neo rubrum, intra rimas albuminis demerfum.

A \& в: obfolete trigonum, cartilagineum, profunde quinquelobum: lobis duobus dortaj libus maxinis, auris humana helicen amulantibus; duobus lateralibus minoribus: extus planiusculis; denique quinto ventrali onuium minimo in aciem comprefto:-

Ex в. minutulus, tereti acuminatus, in ima parte albuminis intra ejus lobulum ven-t tralem pofitus, leviter arcuatns, niveus. Cotyl. lineari-acuminatx. Rad. conicait infera.

2.b.) Bacea integra. C.) Eadem difieta. d.) Semen offenm feparatum. e. E.) Albumen dennda.: tum 2 parte dorfali fpeqatum. F.) Idem a Intere ventrali vifum. G.) Ejusden fectio transverfalis, cum fitu \& forma interna lobulorum. H.) Ejusdem (ectio verticalis, cum fitu embryonis. I.) Eines brjo feparatos.

Ex fructibus Aquilicix fambucine, a cl. Thunbergro mifts, didici, Otillidem meam ad hoc genus certifime pertinere, quum in alio nullo fimilis detur albuminis $\mathrm{fa}_{\mathrm{a}}$. brica. Differt autem hxe ab A. fambricina: numero feminum; colore bacce pallido: nec atro; \& fapore fatuo, nec grate aromatico: lime vix dubium, quin nofra ad: Leeam fpectet, quam ipfam quoque cum Aquiliçia conjungendam elle, idem $\mathrm{Cl}_{\text {: }}$ - Vir flatuit.

\section{J. Gaertner (1788) Vol. 2}

* A U U.ILI I I A. vid. Vol. I. p. 275.

AQuilicia fambucina. Tab. 108. fig. 8.

Staplisylea indica. BURM. flor. ind. 5. 24. $f .2$.

114.1

Aquilicin. LIN E. Eff. veg. 243.

Ex dono Cl. Thunberg.

Baca (a. b.) orbioulata, depre $\sqrt{a}$, torulis tribus ad fer diftincta, atra, aromatica, unilocularis (c.), tri - hexapyrena. Ofricula (d.) hinc gibba, inde angulata, rufefcentia, unilocularia (E.). Albumen (F.G.H.I.) eundem in modun lobatum, ficut in Otilide, fed minus durum. Embryo (K) fubulatus, incurvus, prorfus ut in prima fpecie. 


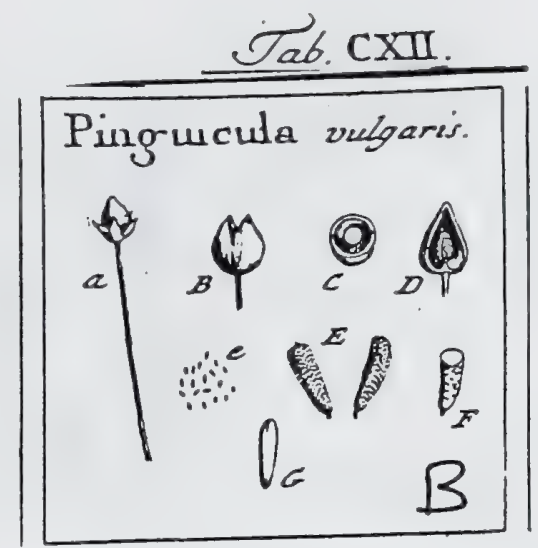

Lentibulariaceae

J. Gaertner (17.88) Vo.1. 2

I 40

DCXLVII. PING UI I U LA. TOURN. inf. t. 74.

LINN. gen. 30.

Calyx campanulatus, quinquefidus. Cor. ringens, bilabiata, calcarata. Stam. duo, bifida. Ovar. fuperum. Styl. fimplex. Caplula unilocularis, femibivalvis. Receptac. centrale. Sem. numerofifima.

Pinguicula vulgaris. Tab. 111. fig. 2.

Pinguicula. Ceus. bift. 1. p. 310. mal. OED. flor. dait. t.93.

Pingucula calcare foris longitudine. HALL. bif. $\pi, 29 \Omega$.

Pinguicula metiario cylindraceo longitudine pezali. LINN. Jy/f. veg. $C_{5}$.

PER. Capfula parva, coriacea, ovæso-acuminata, unilocularis, femibivalvis, f. $a b$ apice ad medium ufque bifariam dehifcens.

REC. centrale, liberum, ovato - oblongum, fcrobiculatum, fubpedunculațum.

SEN. numerofiffima, exiliffima, apparenter linearia, fed vitrea lente fpectata terctia, obfoletilifime angulata, elevato puncticulata, verfus bafin leviter attenuata, \& in breviffimum funiculum umbilicalen definentia, cinerafcentia aut Ppajicea.

IN T. fimplex, membranaceuni, tenue.

A L B. nullun, aut tenuifinum.

Eмв. fenini conformis, albus. Cotyl. femicylindricx, breves. Rad. teretiufcula, longa, centripeta.

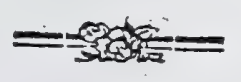

$$
*
$$

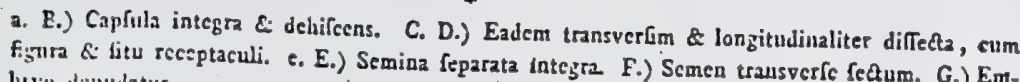
bigo diandatus. 


\section{Tab. CXCVIII.}

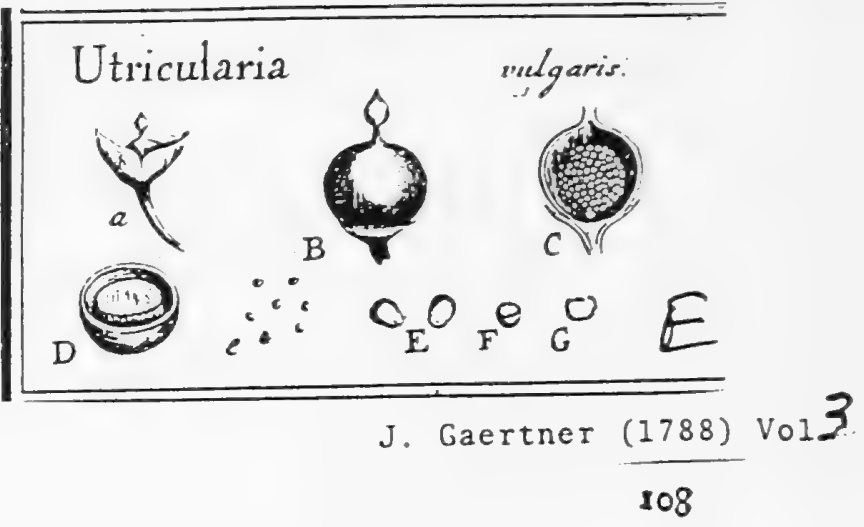

88. U $\mathrm{T} R I C U L A R I A$.

Linn. gen. 3r. ed. Schreb. 4r. Juss. gen. p. 98. Lamarex ill. ger. t. 14. Lentibularia. V A IL. act. gall. ryrg.

DIIL. gen. t. 6.

Cal. bifidus: laciniis concavis, poft corollx lapfum adhuc perfiftentibus. Cor. ringens, calcarata, bilabiata; Jabio fuperiore erecto, obtufo; inferiore majore integro, palato cordato inter labia prominulo. Stam. duo; fuamentis bre. viffimis, incurvis, Jabio fuperiori infertis; antheris commatis. Ovat. fuperum; ftylo fimplici: ftignate cipitato, conico. Cisprula globula, unilocularis, evalvis?' Rec. fungofum, globofum, liberum. Sen plurima, ad umbilicum areolata. Alb. nullum. Emb femini conformis.

UTRICllaria vulgaris. Tab. 198. fig. 5.

Lentibularia major. VAIL. aI. gall. J. c.

Lentibuluria. Riv. monop. t. 79.

Utricularia calcare conico, fcapo panciforo. CRANTz auffr. p. 290.

Utricularia neJario conico, fcapo punciforo. LINs. fy/t. veg. ed. 14.9 .65$. Spec. pl. ed. Willd. T. 1. P. 1. p. 112. PERsoON fyit. pl. 1. p. 18: VAHL eisum. pl. 1. p. rgo".

Icon. OED. flor. dan. t. 138 .

Pz R. Capfula globofa, 1. elliptied, calyci infiftens, in vertice otylo perfiftente brevi munica, coriaceo-membranacea, unilocularis, evalvis?

REC. fungofum, globofum, in verrice brevillime apiculatum, pedunculo brevi fundo capfula adnatum, liberum, levifime alveolatum.

S I m. plurima, receptaculo ftrato fimplici infidentia \& arcte fibi approximata, ovata, circum umbilicum minimum ad feminis bafin locatum areola parva notata, e rufefcenti ftraminea.

IN T. fimplex, membranaceum, crafiufculum.

A L B. nullum.

E a в. femini conformis, albus. Cotyl. ... Rad, obtufifims.

EXPLICATIO FIRUR.E.

2.) Capfula integra, calyee adhucilum veftita. B.) Eadem a calyce denudata. C.) Ejusiem fetaio rerticalis eum forma \& fitu receptaculi atque fcminum. D.) Ejusdem fietio transicrlalis. e. E.) Semina folutz. F.) Semen uansverfe - \& G.) Idem verticaliter difrecalum.

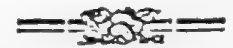

Capfula cum feminibus in noftro fpecimine erant immatura; hinc nec de dehifentia capfulx, nec de embryonis vera conditione aliquid certi addere poltumus.

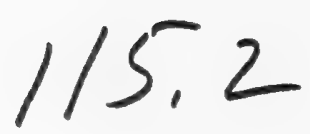




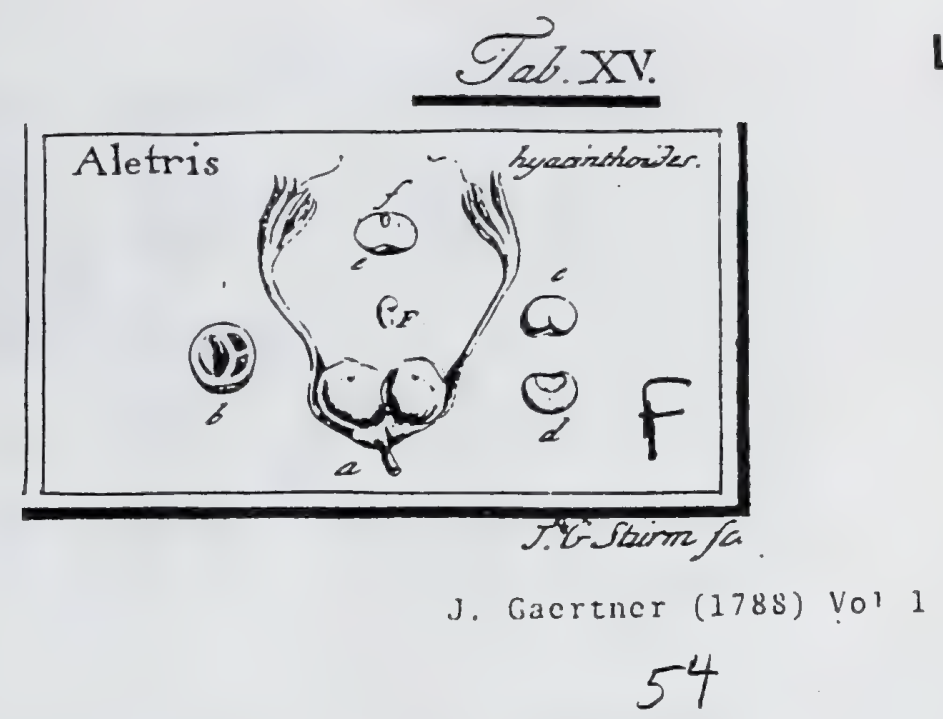

LXI. ALETRIS. LINN. ger. 428 .

Calyx nullus. Cor. infundibuiiformis. Stam. Sex. bafi laciniarum corollix inferta. Sirlus unicus. Bacca fupera, trilocularis. Scmina folitaria. Embryo dinidio albumine brevior, umbilico ofpofitus.

ALETR is hyacintho:jes. Tab. 15. fig. 6.

Alctris ncaulis, foliis lauccolatis carnofis, floribus geminatis. LINs. Jy/l. irg. 336 .

Ex horto regio Kewenfi.

PE r. liacca fupera, mollis, carnofa, globofa, obfoletifime tiifulca, coccinca, trilocularis: Juculamentis uno, aut duobus fapius obliteratis.

REC. nuilum: femen dillepingento prope axcm late adnatum.

SEM. unicum in fingulo loculanento, fubglobofum, deprelliusculum, grande, inelitum: unbilici regione lubconcava, late derafa.

IN T. fimplicillimum, tenuifimum, ut vix ullum.

A в. . femini confurme, cartilagineum, femidiaphanum, pallidun.

EMB. in parte feminis uubiiico oppofita, proxime ad periphcriam lccatus, oblongus, curvatus, laćccus, albumine tertia parte brevior. Radic. Jcritcr incrafiata, cciltrifuga.

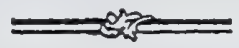

2.) Baccx gemiux, integrax. b.) Selio baccx transverfalis. c.) Semen, a parte fuperiore (pela. tun. d.) Ider inverfun, cum latillina umbilici area. e.) Albumen vertialiter (eीum 6.) Ėmbryo in fitu \& maguitudine naturali. F.) Idem feparatus ae infigniter autus. 


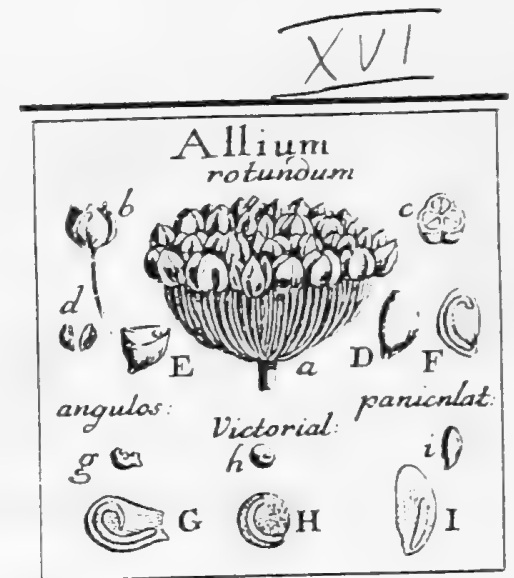

Liliaceae

J. Gaertnet (1788) Vol.1

\section{6}

\section{ALLIUM. TOURN. t. 204. 205. 206. LINN. gen. 209.}

Spatha Horalis arida. Corolla hexapetala. Stam. fex. Styl. funplex: Niginate acuto. Capfula fupera, trilocularis. Scmina pauca, atta. Embryo periplsericus, dimidio albumine longior, curvatus, aut fpiralis.

ALIIU r rotundum. Tab. 16. fig. 2.

Allium radice multiplici, foliis gramineis, fpica Spharica, paminibus alternis trifidis. HALL. hiß. 2. 11. 1219 .

Alliwm caule planifolio umbellifero, faminibus tricufpidatis, umbella fubglobosa, floribus lateralibus mu!antibus. L iN N. Syll. $2 \mathrm{Eg} .321$.

PER. Capfula fupera, fubglobola, rotundato trigona, trilocularis, trivalvis: valvulis medio feptigeris.

REC. nulium, proter tuberculum parvum in margine centrali diffepimentorum cui fe. mina allixa.

SEM. in fingulo loculamenten gemina, ovato-oblonga, bafi fubroflellata, hine levi. ter convexa, inde plana, atra.

IN T. fimplex, membranaceum, nucleo arćte adnatum.

A L в. Cemini conforme, carnofum, aqueo-pallidum.

Eмв. monocoryledoneus, filiformis, lacteus, prope feminis marginem exteriorem locatus, cjusque curvaturam legens, ipic uncinato - curvatus.

a.) Unibella frugifera. b.) Capiula feparata. c.) Fadem transverfe fefia. d.) Semida feparata. D. Seminis latus convexum. E.) Ejusden fectio trausverfauis, F.) Albumen longitudinaliter rectuin, cum figura \& fitu embryonis.

Allium paniculatum. ibd.

Scmina duo, procedentis fimillima (i). fed pauln majora. Embryo (I) fubredus, lateralis, non uncinatus, feminis tertia parte brevior

Allium Vifforialis. ibid.

Semina duo fubglobora (h.), rugofa, atra. Embryo (H.) filiformis, fccundum dorf feminis curraturam in arcum fere femicircularem tiexus.

Allium angulofum. ibid.

Semina obovata, aj bafu nblique truncata (g.); hinc plana, inde gibba, rugo/a, 2tra. Iimbryon (G.) fiiiformis, fubperiphericus, extremitate fua, ab umbilico remoiori, in fpiran convolutus.

116.2 


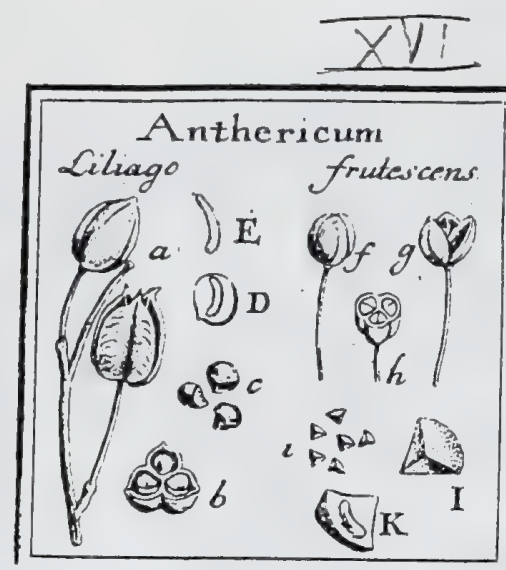

\section{J. Gaertner (1788) Vor.1 55}

\section{LXU. ANTHERICUM. LIN gen. 422. Phalangium TOURN. t. 293.}

Corolla hexapteala, absque nectario. Stam. fex. Styl. fimplex: ftigmate trigono. Capfula fupera trilocularis. Embryo longitudinc fere albuminis, fubincurvus. ANTHER ICU M Liliago. Tab. 16. fig. I.

Phalangium non ramofum. Don. pempt. 106.

Phalangium radicibus teretibus, foliis radicalibus carinatis cufiformibus, petiolis anifluris. H A L L. hif. 2. 12. T207.

Anthericum foliis planis, frapo fimpliciffmo, corollis planis, pifillo declinato. LINN. Jil $\beta$. veg. $33^{\circ}$.

Icon. Oeder. fior. dan. t. GI6. JACe. hort. t. 83.

PER. Capfula fupera, ovata, trigona, profunde trifulca, fubrugofa, trilocularis, trivalyis: valvulis medio feptigeris.

REc. nullum, prater marginem difiepimentorum centralem, cui femina duplici ferie afhxa.

SEM. fCx vel octo in fingulo loculanento, hinc convexa, inde angulata, atta, nitida, punctis minutifinis, excavatis confperfa.

IN T. duplex exterius crufaccum, tenue, fragile; intcrius membranaceum, rufefcens.

A 2 в. figurâ feminis, carnofum, durum, aquen-pallidum.

Eм в. monocotyledonens, fubincurvus, terctiusculus, lacicus, longitudine fore albuminis, ad unbilicum of in axi feminis politus.

a.) Caprula intrgra, $\delta$ deliifcens, b.) F.jus fectio transverfalis. c.) Semina foluez. D.) Albuineı lougitudinalies feftum, cum fitu embrjonis. E.) Einbryo fo paratus \& auीus.

ANTHERICUM frutefcons. ibid.

Phalanginm capenfe cauleferns, foliis cepitiis fuccofis. Dict. h. elth. 310. t. 231.

Anthericum foliis carmofis teretibus, caule fruticofo. Lis N. Jyft. veg. $33^{\circ}$.

Capfula ovaro globofa, magnitudine pifi medincris (f. g.), glabra, trifuica, trilocularis (h.), irivalvis. Sémina (i. I.) in fungulo loculamento fex, triquetro pyramida:d, nigro fufca, excavato pundlata. linteg. fimplex, arcle adnatum. $\Lambda$ bumen (Ki) "fomisi confurme, carnofurn, grallidum. Embryo teretiusculus, Ic-

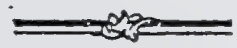

viter curvatus, in feminis exteriori ac umbilico directe oppofito latere, transverfa. liter pofitus.

Si funilis fit pofitio embryonis in reliquis Phalangiis capenfibus, uti quiden fufpicari licet, cum Antherico ablolute son porerunt manere.

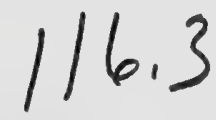




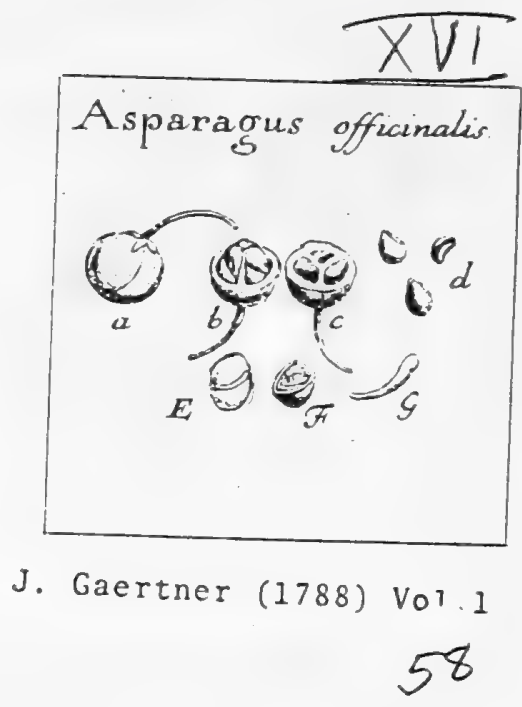

LXVI. ASPARAGUS. Tourn. t. I54. LIN ger. 424.

Corolla fexpartita. Stam. fex. Styl. fimplex, brevifimus. Bacca fupera, trilocularis. Semina geminata. Embryo in regione umbilico oppofita, transverfalis.

Asparagus officinalis. Tab. 16. fig. 5.

Afparagus. CAM. epit. 259. Bes s. hort. Eyf. vern. IX.t.g. B L A x w. herb.t. 332.

Afparagus foliis filiformibus fipulatis. H A I L. hifl. 2. 13. 1239.

Afparagus caule herbaceo tereti ereato, foliis Jetaccis, fitpulis paribus. LINN. $\int y /$. veg. 332.

Icon. OEDER. for. dan.t. 805 .

PER. Bacca fupera, Sphzrica, glaberrima, nitida, fubpellucida, coccinea, pulpola, trilocularis.

RE C. nullum: femina angulo loculamentorum interno, unum fupra alterum, affixa

$S E M$. in fingulo loculamento gemina, hiric convexa, inde angulata, glabra, atra.

IN r. fimplex, coriaceum, nucleo arcte adnatuin.

A I B. Semini conforme, cartilagineum, durum, album.

Esв. monocotyledoncus, fubclavatus, incurvus, lacheo albicans, in dorfo fersinis transvefe, I, oblique locatus, ab unbilico remotiflmus.

2.) Bacea integra. c.) Eadera sperta, cum feminum fitu. c.) Ejusdem fectio transverfalis. d) Semina feparalz. En) Seminis dorium decorticatun, cum fitu embryonis. F.) Albumen transresfe fecturs, cum embryone peripherico. G.) Embryo feparatus, infigaiter auctus, 


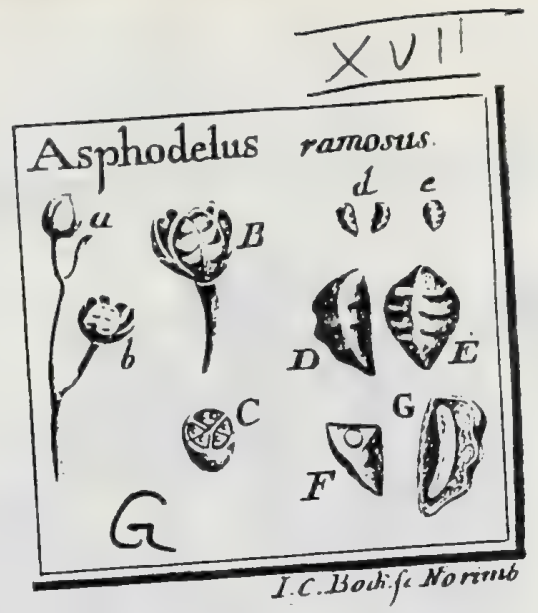

Liliaceae

J. Gaertner (1788) Vol.I

68

LXXVIII. ASPHODELUS TOUR N. t. 178. LiNs. gen. 421 .

Corolla fexpartita. Stam. fex. filameutis bafi dilatatis. Styl. unicus, nigmate fun. plici. Capfula fupera, trilocularis. Semina geminata, erecta., Embrjo long: tudine albuminis.

ASP H ODELUS filtulolus. (dele ramofus in icon) Tab. 17. fig. 6.

Afphodelus minor. Czus. hift. 1. p. 197.

Afphodelus caule nudo, foliis frititis fubulatis frriatis fubfifulofis. L1N veg. 330.

PER. Caplula fupera, globofa; magnitudine Pifi mmoris, transverfe rugofa, trilocu. laris, trivalvis: valvulis medio Eeptigeris.

REC. uullum: femina diftepimentis prope bafin aftixa, crecta.

$S E$ M. in fingulo loculariento geıniua, altero fxpe abortiente, oblonga, triquetra, deors fum acuminata, fcrobiculis profundis \& rugis transverfalibus exarata, fpadiceo fulca.

IN т. fimplex, membranaceum, nucleo arctiflune adnatum.

A L B. femini conforme, carnofum, duriusculum, aqueo pallidum.

E A B. inanocotyledoneus, teretiusculus, fuperne paulo craffior, leviftune incurvus, lacteo albus, longitudine albumini fore xqualis.

a.) Capfula integra. b. B.) Eadem dehifcers. C.) Ejusdem, ut \& feminum fentio transverfalis. d. D.) Seminis geminat, \& e. E.) Ejusdem folitarii figura. F.) Albumen transverfe, \& G.) Iden longitudiualiter Cettum, cum Gitu \& figura embryonis. 


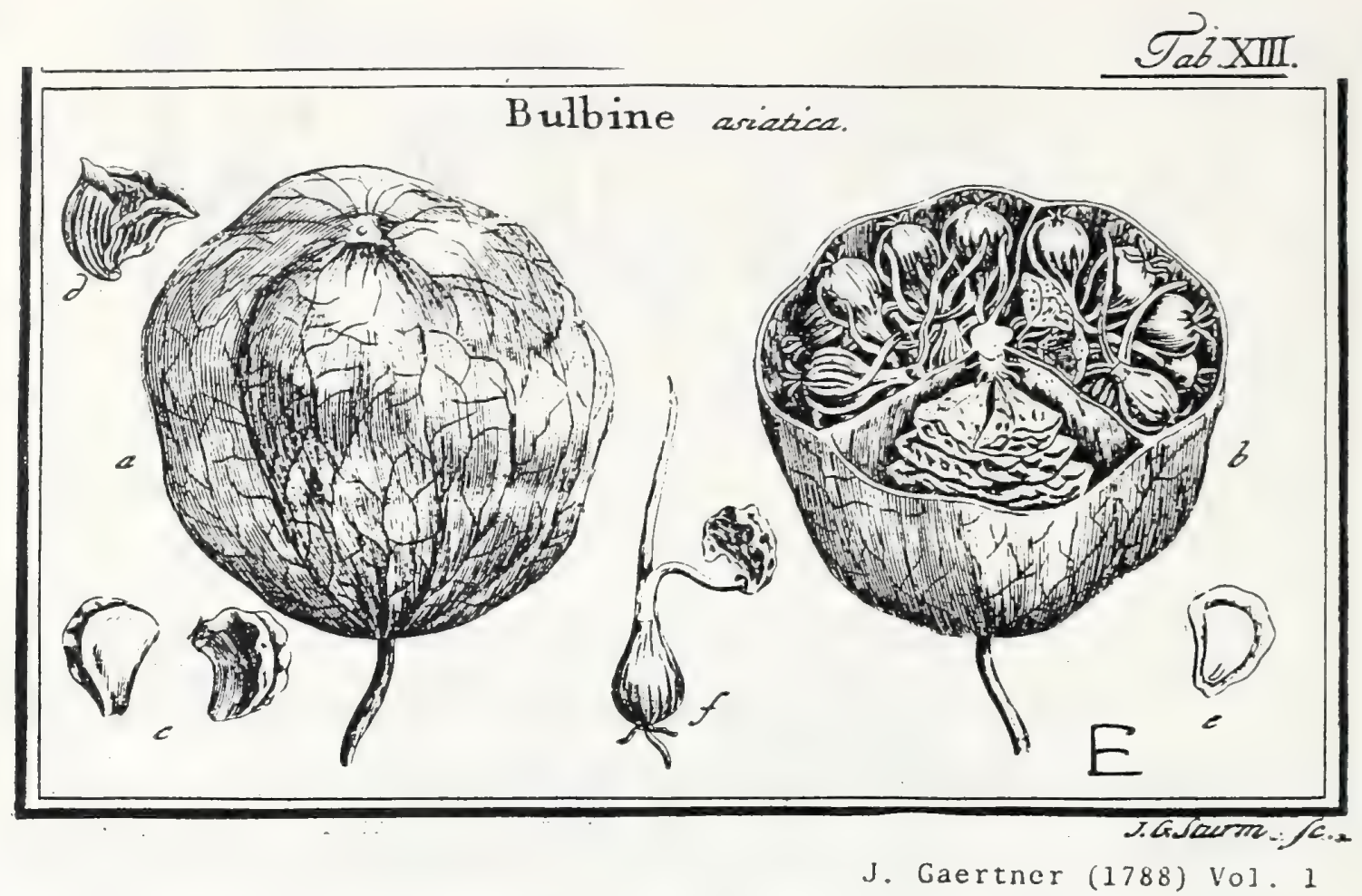

Liliaceae

J. Gaertner (1788) Vol. I

\section{BULBINE.}

Corolla infundibuliformis, fexpartita: laciniis apice non uncinatis. Stam. fex. Styl. fimplex. Capfula infera, membranacea, inflata, evalvis. Semina triquetra: angulis membranaceis. Embryo dinidio albumine brevior.

42

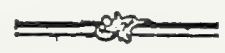

BUL BINE afiatica. Tab. 13. fig. 5 .

Belutta.pola-taly. R H E E. mal. II. p. 75. t. 38 .

Lilium zeylanicum bulbiferum EO unbelliferun. HE R s. hort. lugadb. 683.

Crinum foliis carinatis. LIN N. fy 9 . veg. $3^{18}$.

PEк. Capfula infera, grandis, fubglobofa, gibba, obfoletiflune trigona, membranacea, inflata, tenuiflina, transparens, trilocularis, evalvis, a germinancibus feminibus demum irregulariter rumpenda.

REc. axis fructus triqueter, cui femina duplici ferie, funiculis propriis umbilicalibus affixa.

S EM. plurima, ante plenam maturitatem triangula, fubcompreffa, deinde ventricofe triquetra, Ariata, rufefcenti fpadicea; angulis membrana pallida, undulata marginatis.

IN T. duplex: exterius coriaceo-fpongiofum, craflum, nucleo latius; interius membranaceum, tenue, arcte adnatum.

Ax.в. fernini conforme, fed anguflius, carnofum, durum, aqueo.pallidum.

EM B. monocotyledoneus, teretiufculus, lacteo albus, prope umbılicum locatus, citifune in traducen teretem bulbiferum excrefcens, ut fxpiffine capfula matura bulbillis germinantibus, loco feminum, replcta fit.

a.) Capfala integra magnitudine naturali. b.) Eadem transverfe feeta, c.) Semina immatura fea aboriva. d.) Semen foecunduns. e.) Albumen longitudiustiter fectum, cum fitu \& figura embryosis. f.) Bulius intra pericarpium gerninans, cum adharente fibi per traducis funiculun, vacuá feminis têtá.

Magis adhuc hxc a Crino differt, quam Alfroemeria ab Hemerocallide: nam Crino capfula ef fupera, prismatica, trivalvis; \& femina parvula, furfum inbricata, zla membranacea, ficut is Pino, terminata. 


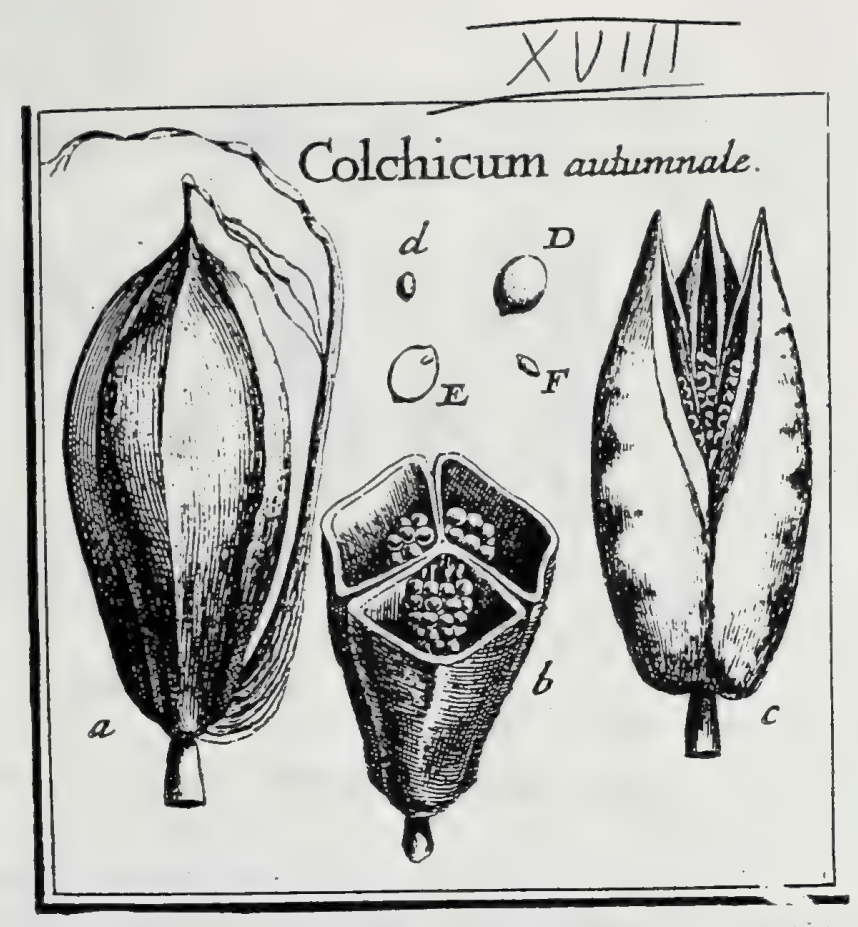

\section{J. Gaertner (1788) Vol.1}

\section{0}

LXXXI. COLCHICUM. TOURN. t. 181. 182. LiNN. gem. 457.

Corolla monopetala : tubo radicato longifino: limbo fexpartito. Stam. fex. Styli tres. Caplulx tres, coadunatx in unicam trilobam, fuperam. Semina numerofa. Embryo in regione feminis umbilico oppofita.

Cогсн гси аutumnale. Tab. 18. fig. 2.

Colchicum. F чснs. hifl. germ. ic. 201. 202. B L A K w. herb. t. 566 .

Colchicum flore folium longe pracedente, petalis ovatis. H A L L. liff. 2. 13.1255.

Colchicum foliis planis lanceolatis erettis. L IN $x$. fyfl. veg. 379 .

PER. Capfula fupera, obovata, trigona aut ab adjaccntibus in varios angulos prefla, triloba, compofita ex capfulis tribus partialibus, unilocularibus, inl:acis, trip̧uctris, membranaceis, ad axem inter fe comatis, futura interna ad medium usyue dehifecntibus.

$\dot{R}$ Ec. margines futurx internx, quibus fernina, absque ordine, funiculis fuis umbilicalibus filiformibus, circa medium folummodo aftixa, ut fuperius atque inferius fpa: tium late vacuum fuperfit.

IN T. fumplex, meinbranaceo fpongiofum, tenue, nucleo arcte adnatum.

A L в. figurâ feminis, fubcartilagineum, durum, aqueo pallidum.

Eмв. monocotyledoneus, minutifimus, ovato globofus, lacteo albicans, in parte albuminis umbilico oppofita \& fimul extra axem feminis pofitus, extrenitate fuz obtufiore peripheriam; tenuiore vero centrum feminis refpiciens.

2.) Capfula integra, b.) Eadem transverfe (ecta. c.) Eadem dehifeens. d. D.) Semen feparatum. E) Albumen longitudinalite fectum, cum embrjone in fitu naturali. F.) Embrjo feparatus. 


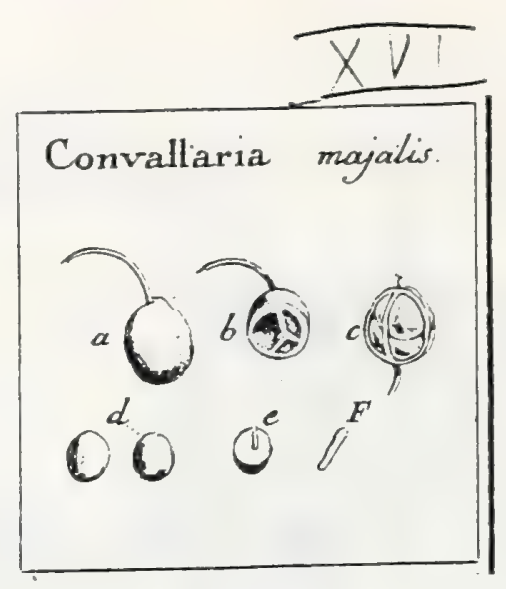

J. Gaertner (1788) Vo1 1

59

LXVII. CONVALLARIA. L IN N. ger. 425. Lilium convallium. TOURN. t. I4.

Corolla monopetala, fexfida. Stam. fex. Styl. unicus. Bacea fupera, trilocularis. Semina gemina. Embryo rectus, in oppofitz ab umbilico feuninis plaga pofitus.

CONVALLARIA majalis. Tab. 16. fig. 6.

Lilium convallium. C A M. epit. GI8. B. ES L. h. fyft. vern. IX, t. 6.f. 2. 3. В С А Хष. herb.t. 70. OED E R. flor. dan. t. 854 .

Polygonatum fanpo diphyllo, floribus Jpicatis nutontibus samipaniformibus. HA iz. hif. 2. n. $124 \mathrm{I}$.

Convallaria fcapo nudo. Linn. Jy/f. veg. 334.

PER. Bacca fupera, elliptico fphrroidea, carnofa, glabra, rubra, trilocularis: loculainento uso aut duobus fxpe obliteratis.

REc. nullum: femina angulo interno loculanentorum, unum fupra alterum, affixa.

SEM. in fingulo loculamento gemina, altero plerumque abortiente, fubglobofa, obfolete angulata, glabra.

IN T. fimpliciflumum, tenuifimum, nucleo arche adnatum.

A вв. Semini conforme, cartilagineum, durum, album.

EM B. monocotyledoneus, teretiusculus, altera extremitate paulum incraflatus, rectus, lacteo-albus, longitudine dimidix craftitiei feninis, atque in hujus exteriori latere ita collocatus, ut craffiore fua extrensitate peripheriasn, altera vero teauiore, centrum albuminis refpiciat.

a.) Bacea integra, b.) Eadem transverie fela. c) Loculamenta duo longitudiaditer aperta, can Gitu feminum. d) Semina feparata. e.) Albumeu transycrfe fetum, cuin fitu exbryonis. F.) Eonbrjo Separatus \& infiguiter au氏us.

$$
116.8
$$




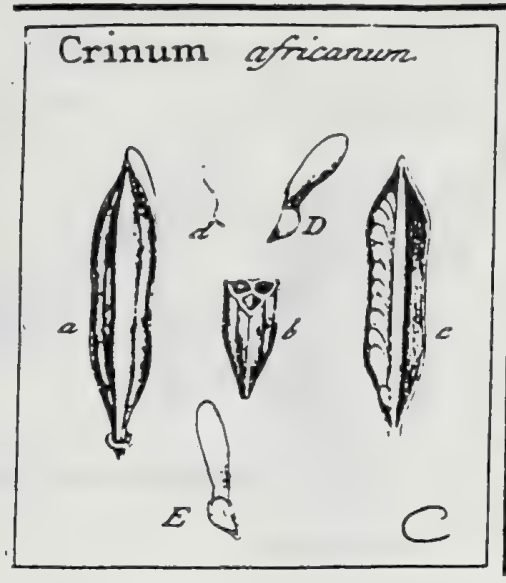

J. Gaertner (1788) Vol. 2

\section{CRINUM. LINN. gen. 405 .}

Involuerum fpathaceum umbelliferum. Cal, nullus. Cor. infundibuliformis, monopetala fexfida : laciniis alternis apice incraflato uncinatis. Stam. fex. Ovar. oblongum fuperum. Styl. fimplex. Stigm. trifidum minimum. Capf. oblonga trilocularis. Sem. numerofa imbricata alata.

CRINUN africanum. Tab. 83. fig. 3 .

Hyacintsus africamus tuberofis, fore caruleo umbellato. Cомm. bort. amp. a. p. 133. 4. 67. BREYN. ic. 23. 2. 10. MILL ic. t. 210.

Crinum foliis fublanceolatis p!mis, corollis obtufiss. LiNN. fyfto veg. $37 g$.

Ex horto regio Kewenfi.

Pz R. Capfula fupera, triangulari-prifmatica, utrinque acuminata, trilocularis, trivalvis. Valvulx planiufculx, extus linea longitudinali depreffa, intus fepto medio ftipatix.

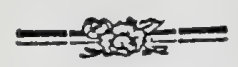

REC. nullum, preter angulum centralem loculansentorum, .cui femina, duplici ferie atque furfum inbricata, alfixa.

Sess. numerofa, circiter 24 in fingulo loculamento, parva, compreffa, ovato acuminata, fpadicea, Ala membranacea oblonga alba fuperne inftructa.

Is T. duplex, utrumqque nembranaceum, tenue.

A \& B. femini conforme, carnofum, aqueo-pallidum.

EM B. monocotyledoneus, ..... in bafi albuminis.

2) Capfula integra b.) Ejus fedio transverfalis. c.) Valvula a parte fuz interna fpectata, eum fitu \& infertione feminum. d. D.) Sermen feparatum. B.) Albumen denudatum.

$\mathrm{Ob}$ immaturitatem feminum, in omnibus meis fpeciminibus, embryonis forman confpicere non licuit.

Errat certe BREYNIUS 1 c. quando fructum tricaplularem \& femina rotunda dicit.

$$
116.9
$$




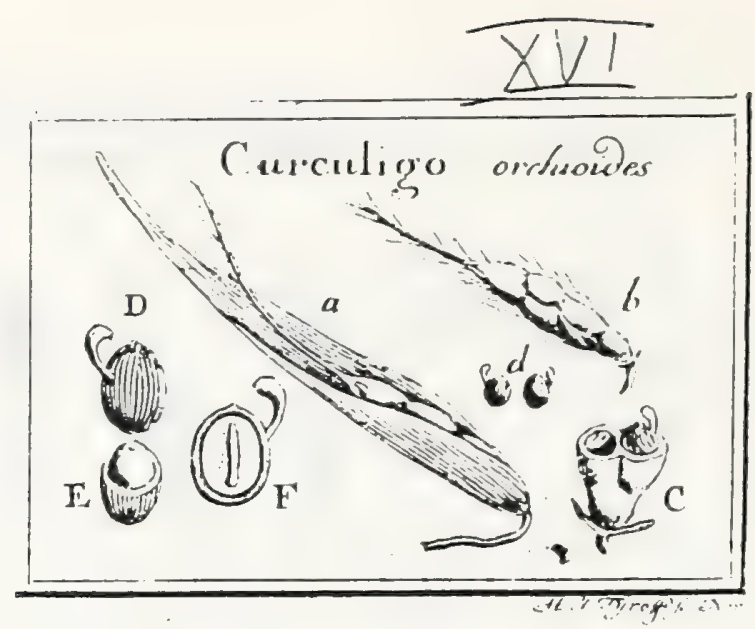

Liliaceae

J. Gaertner (1788) Vol.1

,

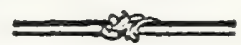

\section{CVRCVLIGO.}

Spatha monophylla, Janceolata, ftriata, fructu duplo longior, eumque amplectens: Flos..... Capfula fupera, lanceolata, plurilocularis: loculamentis fecundum lon. gitudinem digenis. Semina proceflu corneo laterali roftrata.

CuRCULIGo orchivides. 'Tab. 16. fig. 11.

Orchis amboinica najor, radice raphanoide. RU M P . amb. 5.p.II7.t.54. f. I: fecundum Kanigium.

E collcclione Baukfiana.

PER. Capfula fupera, lanceolata, membranacca, compreffiuscula, a protuberantibus feiniuibus nodulofa, raris villis confperfa, in nylum longum filiformem pilofum definens, plurilocularis, evalvis. Loculamenta fex ad novem, fubalterna, duplici furic longitudinali pofita.

REC. nullum: femina loculamontis fuis a parte fuperiore \& exteriore affixa.

S Ex. in.fingulo loculamento $f$. cellula propria unicum, ovato globofum, longitudina. liter fulcatum, atrum, fplendens: fupremis, fumpliciter fubglobofis; medis autem atque inferioribus, a.parte fuz exteriore \& fupcriore, proceffu corneo, teretiusculo, furfum incraftato, leviter incurvato \& rufrum Curculionis xumulante, ftipatis.

IN T. duplex: exterius cruftaceum, craflum, fragile; interius membranaceum, tenuif fumum, pallide framineum, chalaza fufca, in regione roftro oppofita, notatum.

A г в. Ceminis cavitati conforme, carnolum, molle, fubfriabile, aqueo-pallidum.

EMB. monocotyledoneus, tereciusculus, rectus, lateo albicans, longitudine fere albuminis.

a.) Spatha frufum ampleftens, peduneulo filiformi donata. b.) Capfula denudats. C.) Capfula Sctio transverfalis. d. D.) Semina (eparats. E.) Núclei pars inferior deuudata \& inverfa, cann chalaza. F.) Seninis fectio longitudinalis, albumiuis \& embryonis formam \& fitum ofendeus.

Non effe hunc, Orchidis amboinicx, fupra citat $x$ fructum, quilibet facile intelliget,

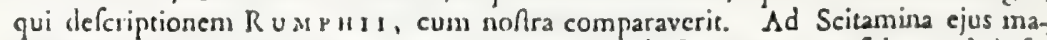

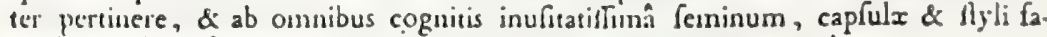
bricí abunde differre palam en, ut proprio nonine mercatur tradi.

$$
116.10
$$



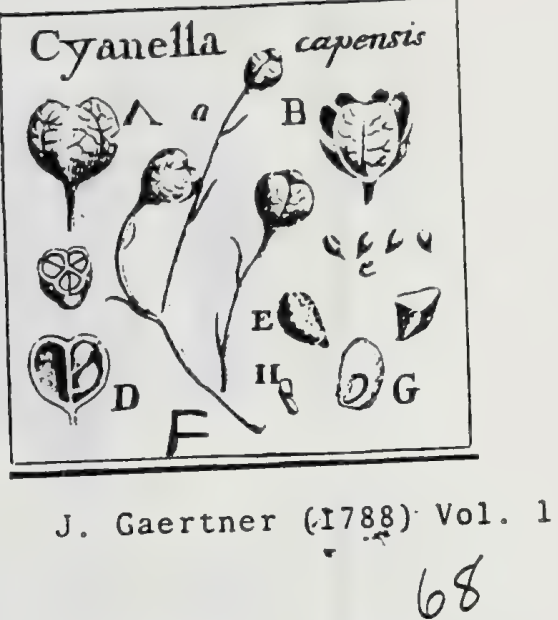

LXXIX. CYANELLA. LIN g. gen. 420.

Corolla hexapetala: petalis tribus inferioribus propendentibus. Stam. fex, infuno longiore declinato. Styl. unicus. Cap?ula fupera, trilocularis. Semina pauca, erecta. Embryo prope umbilicum, longitudine dimidii albuminis.

CYANELLA capenfis. Tab. 37. fig. 7.

Cyanella foliis undulatis, ramis patentifmis. L IN N. $\int y / 2 . v e g .329$.

Icur. Jace. hort. v. 3. t. 35 .

P E r. Caplula fupera, globofa, rotundato trigona, nervis obfoletis reticulata, triloetlaris, trival vis: valvis medio Septigeris.

REc. nullum: Semiua erecta, duplici ferie margini diffepinentorum centrali affixa.

SEX. in fingulo loculamedto quatuor, fubovata, deorfunn angufata, varie angulata, nigro fufca.

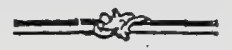

IN T. duprex: exterins fpongiofum, craflusculum, varie rugofum, ut forfan in recentioribus licminibus carnofum; interius membranaceum, tenuifimun, arcte ad. natum.

$\Lambda$ ᄃ. figur:i feminis, carnofum, durum, aqueo pallidum.

Esт в. monocotyledoneus, teretiusculus, leviter incurvatus, Lacteo albicans, dimidio al. bumine gaulo brevior, ad unbilicum pofitus.

a. A. B.) Capfula integra, \& dehilceus. c.) Ejus fextio transverfalis. D.) Valvuia feparake, cum fitu fconinum. e. E.) Sesnina foluta. F.) Albumen transverfe feltum G.) Ejus fectio longitudinalis, cum embryonis fitu. H.) Limbrjo (eparatus.

$$
116.11
$$




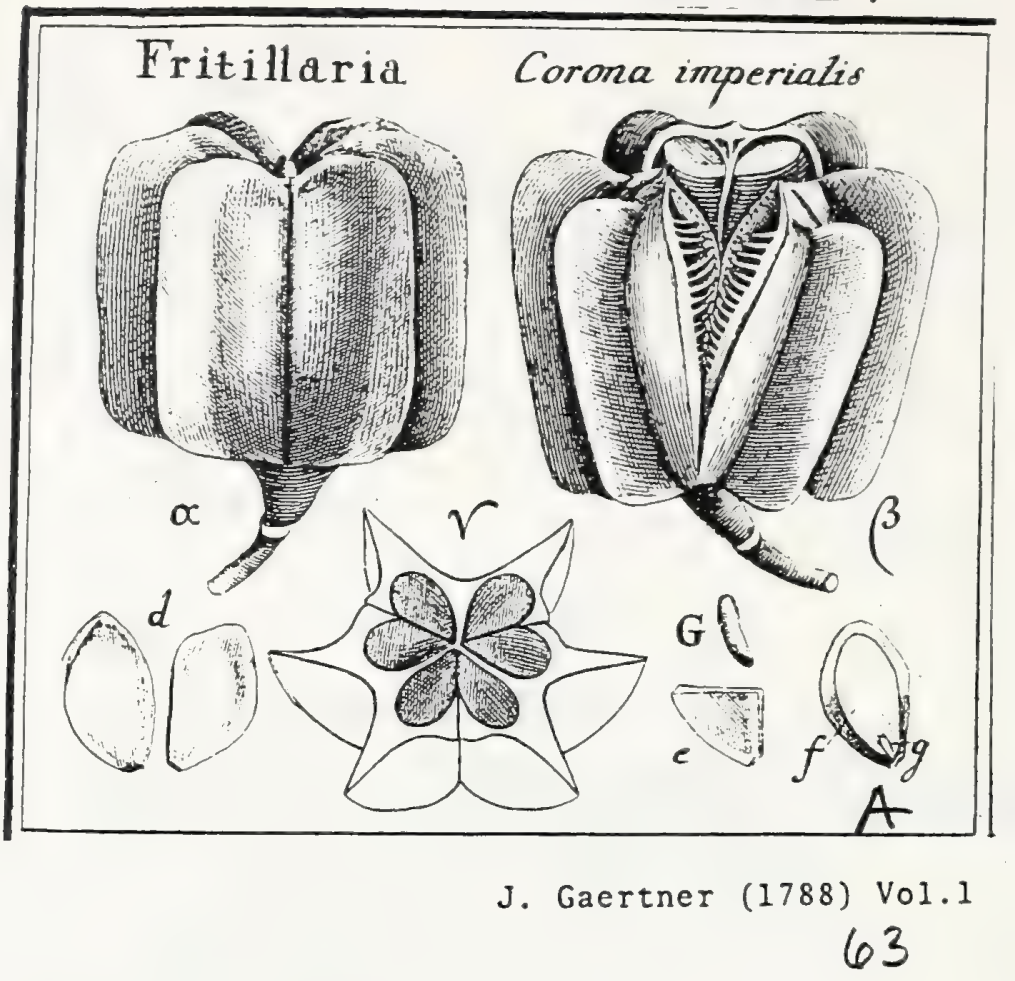

\section{FRITILLARIA. TOUR N. t. 201. \& 197. 198. LIN N. gen. 4 II.}

Corolla hexapetala: petalis fupra unguem forea necharifera inferiptis. Stam. fex. Styl. fimplex: lligmate trifido. Capfula fupera, tritocularis. Semina planz. Einbryo ad umbilicuin, albuminis quarta jarte brevior.

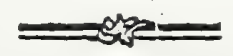

FRITILLARIA Corona imperialis. Tab, 17. fig. x.

Tufai. Cr.us. hifl. I. p. $12 \%$. 128.

Corona imperialis. Bess. hort. Eyf. vern. V.t. 1.2.3.

Fritillaria racemo comofo inferne nudo, foliis integerrimis. LI N N. Jyfl.veg.324.

PER. Capfula fupera, prifmatico hexagona: angulis in alas extenuatis, trilocularis, trivalvis. Valvula fingula extus profundo \& lato fulco inferipta atque duplici ala crafta infructa; intus dillepimento inedio flipata \& ad utrumque futurx marginem vibriffis candidis introrfun directis, ciliata.

REC. nullum: prater marginem centralen diffepimentorum, cui fernina duplici ferie horizontaliter affixa.

$S_{E}$ s. numerofa, obovata, verfus umbilicum anguftata, utrinque plana, obfolete mar. ginata, fulva aut cinnamomea.

In T. duplex: exterius fungofo cruftaceum, crafiusculum, nucleo latius; interius meinbranaceuin, arctiffine adnatum.

A L B. obovato acuminatum, compreffum, femine angufius, fubcartilagineum, album; transparens.

Емв. inonocotyledoneus, rectus, compreffus, linearis, quarta albuminis parte brevior, ad umbilicum locatus.

a.) Capfula naturali minor, integra. $\beta_{\text {.) }}$ Eadem dehifcens. $\gamma_{\text {.) }}$ Ejusdem fertio transverfalis. d.) Semina jußa magnitudiue. e.) Sernen transverfe fettum, f.) Albumen denudatum g.G.) Embrjo juftx, \& anfx magnitudinis.

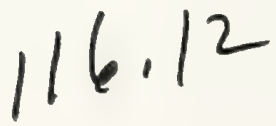




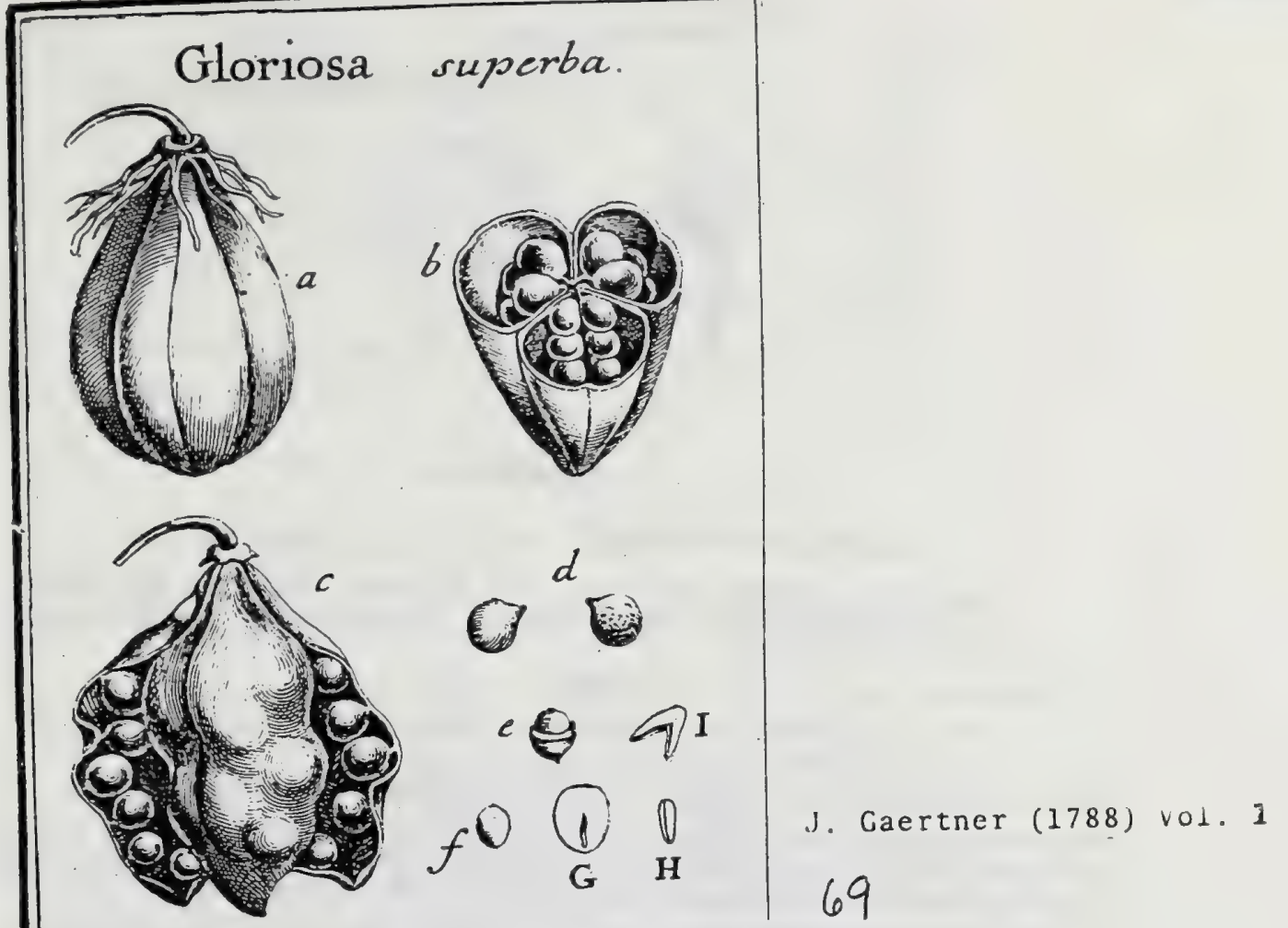

LXXX. GLORIOSA. LINN. gen. 413 .

Co:n!la hexaffetala: peralis reflexis undulatis. Stam. fex. Stylus longus, ad axem orarii obliyuus. Caplitula fupera, compofita, triloba. Scmina baccata. Embryo conduplicatus.

GLORIOS^ Superba. Tab. 18. fig. 1.

Mendoni. R не Е. mal. 7. p. 107. t. 57 .

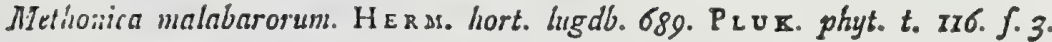

Lilium zeylanicum fuperbum. Сомм. h. Amfl. 1: p. 6g.t. 35 .

Gloriofa foliis cirrhiferis. LIN N. Jyf. veg. 325 .

$E$ collect. fem. hort. lugdb.

PER. Capfula fupera, turbinata aut elliptico fphzroidea, coriacea; opaca, triloba, trilocularis, trivalvis. Valvulx dorfo rotundatx, linea deprefta longitudinali inferiptz, glabrx; intus lineis transverfalibus parallelis friatx, holofericeo fplendentes, Ipadicco lutefcentes, futura fua interna dehifcentes. Diffepimenta ex inflexis valvularum marginibus formata, duplicata, ad axcm fructus coadunata.

REC. nullum: Cemisa futurx valvularum internx duplici ferie affixa.

SEs. plurd in fingulo loculamento, ad duodeciu, globofa, verfus umbilicum acumisata, baccata, coccinca.

IN т. duplex: exterius fub pellicula rubra \& tenui, carnofo spongiofum, craffum; intcrius membranaceum, tenue, rufefcens, chalaza rotunda nigra notatum, uucleo arctifime adnatum.

A LB. orato globolum, carnolum, duriusculum, aqueo pallidum.

E м в. inonocorylcdoneus, parvus, lacteo a!bicans, ad umbilicum locatus, conduplicatus: crure altcro riretiusculo, inferne aceminato; altero confianili, fed latire tuo interno plano aut calialiculato, priori accumbente vel illiud femiamples.ante.
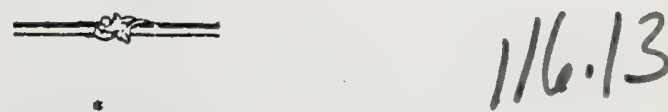

a.) Capfula integra, corollx \& faminum reliquiis bafi cintha. b.) Eandem transverfe feta, cara feminum infertione o.) Eadem delifieus d.) Senuiua feparata. e.) Nuclei pars fuperior denudatz, cum clahaza in vertice. f.) Alinumen integrum. G.) Ejus feltio longitudinalis, cuin fitu embryonis. H.) Embryo conduplicatus, feu juntiis crurious. I.) Idem, diduris cruribus \& in. figniter auctus.

Singulare eft, quod embryo, diductis bene cruribus, ipfan plantx radicem ex afe reprafentet, ut ille forfan totus in hanc tranfeat. COnf. DiI I.E.s. nov. gen. $t$. $\dot{X} I I$. fig. F. \& Herm. 1. c. Capfulx cxtera nunquam funt peilucidx, ut Linnxus vult, fed coriacex, craftx \& opacx, quales etiam Hermannes deferipfit \& quales no. ftrx funt, ab eodem ipfo olin in Ceylona lectx. 


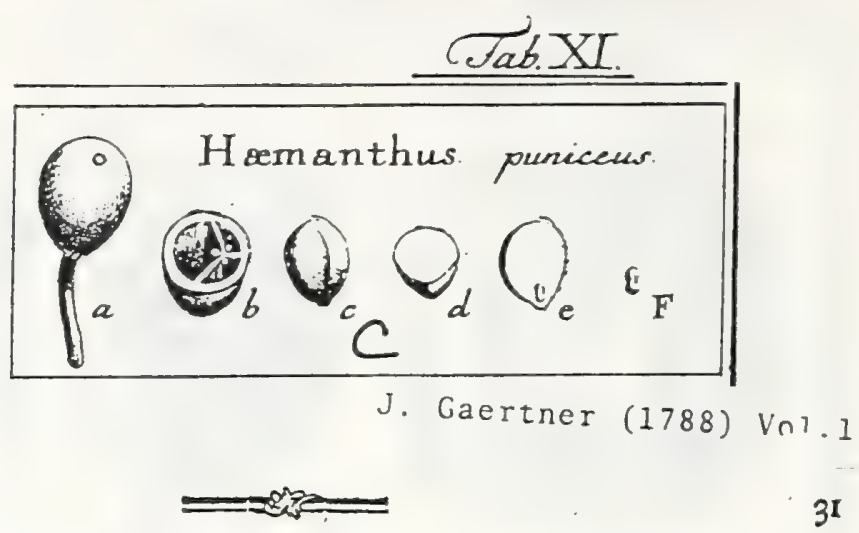

Liliaceae

XXXV. HÆMANTHUS. Tourn. t. 433. Linn. gen. 400.

Involucrum terminale, multiflorum. Cor. fexpartita. Stam. fex. Styl. fimplex. Racca infera rrilocularis. Semina folitaria Embryo dimidio albumine brevior \& in ejus bafi locatus.

H天MAXTHU puniceus. Tab. u. fig. 3.

Hamanthus colchici foliis, perinnthio herbaceo. DILL. h. elth. I67. t. I40. f: 2. ЕнRе'. decal. t. 44 .

Homanthus foliis lanceolato-ovatis undulatis erectis. L IN N. $\int y / t . v e g .316$.

PER. Bacca infera, obovata, carnofa, coccinea, trilocularis. Caro mollis 2 tenuis. Diflepimenta membranacea. Loculamenta plerumque inxqualia, unico, majore facundo, \& duobus minoribus Rerilibus, vel \& plane obliteratis.

REC. tubcrculum misimum, carnofum, in medio anguli loculamentorum interni.

SEx. in fungulo loculamento unicum, per maturitatem erectum, antea horizontale, ovatum, deorlum anguftatum, obfolete triquetrum, pallidum.

I. т. Simplex, membraiaccum, tenuifinum, arche adıatum.

A. B. femini conforme, carnofum, durum, album.

E мв. fubcylindricus, utrinque rotundato-obtufus, rectus, lacteo-albicans, dimidio albumine brevior, prope feminis unbilicum locatus.

a.) Bacca istegra. b.) Ejus feftio transverfalis, cum infertione receptacaloram. c.) Senen feparatun, e majoribus. d.) Ejus felio transverfalis. e.) Albumen verticaliter fettum, cum fitu enibrjonis. E.) Embrjo feparatus, modice audus. 
Temerocallis cordata.

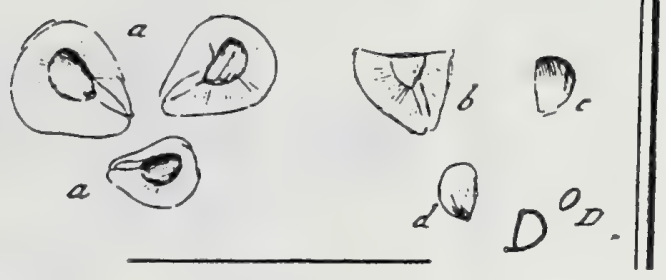

J. Gaertner (1788) Vol:2

$H E M E R O C A L L I$ S. vid. fupra p. 14.

Hererocalis cordata. Tab. 179. fig. S.

Hemerocallis folits cordatis venofss. THUNR. jap. 143 .

Jamma - Jakufo. japon. A Cl. Hoururs..

Capfula pollicaris longitudinis, ovata, angulata, fexlocularis, fexvalvis (Thronb.). Semina (a. b.) obovato - taiangula, foliaceo - compreffa, dia phana, marginata. Margo tenuiffmus, latifimus, membranaceus, aureo Splendens, transparens, a bafi verfus nucleum duabus lineis opacis notatus, quarum altera a funiculo umbilicali rectiufcula, altera vero fgmoidea, $\&$ ad albuminis latus flexa. Nucleus per integumentum externum trans. parens, obovatus, ferrugineo - fufcus. Albumen (c. d.) femine multo anguftius, carnofum, durum, album, fubpellucidum. Embryo (d. D.) minutulus, ovato-oblongus, compreffus, niveus.

Ev ab ipfo Cl. Thunezrglo per litteras certior factus fim, quod femins noltra omnino fint Hemerocallidis cordate; nondum tamen conviaus fum, quod Ipfum Jamma - fakufo fit genuina Hemerocallidis fpecies, quando quidem fructu fuo, a vulgari, per fingula puncta differat. 


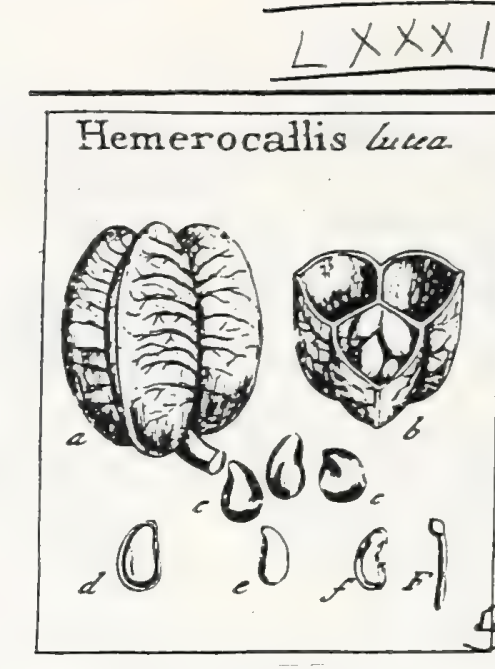

Liliaceae

J. Gaertner (1788) Vol -2

14

DXV. HEMEROCALLIS. LINN. ger. 433 . Liliafphodelus. TंOURN. inft. t. 179 .

Cal. nullus. Cor fexpartita, campanulata, xqualis, fuperne reflexa-patens. Stam. Sex, declinata, incurva. Ovar. fuperum, fubrotundum. Styl. fimplex. Stigm. trigonum. Capf ovata, trilocularis. Sem. plura fubglo-
bofa.

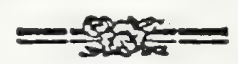

Hemerocallis lutea. Tab. 83. fig. 2.

Lilianplodelus luteo fiore. Crus. bif. x. p. I37: c. ic.

Asplodelus liliacens, luteo odorato flore. BESL. Eyjs. vern. IX. t. 5. f. 3.

Henerocallis foliis lineari Jubulatis carinatis, corollis farvis. LinN. Jyf. veg. 339.

Icon. JACQ. bort. 2. t. 139 .

PER. Capfula fupera, elliptica, utrinque profunde umbilicata, trigona, trilocularis, trivalvis. Valvulx coriacex, cinnamomeo-rufefcentes, extus e fulco depreffo, nervis transverfis elevatis, intus autem fepto medio longitudinali ftipatze.

REC. nullum, preter angulum centralem loculamentorum, e quo femina duplici ferie pendent.

SEM. plura, $6-8$ in quolibet loculamento, grandiufcula, ovato-globofa, verfus umbilicum acuminata $\&$ ad mutuum contactum angulata, aterrima, lavigata, fplendentia. Umbilicus linearis, brevis, niveus, prope apicem feminis.

IN T. duplex: exterins chartaceum, aridum, tenue; interins fpongiofum, adnatum, fpadiceum.

A L B. femini conforme, carnofum, album.

EMB. monocotyledoneus, longitudine fere albuminis, fubteretiufculus, leviter incurvatus, lacteus. Cosyl. fubclavata, angulato - compreffi. Rad. capitats, centripeto - fupera.

2) Capfula integtr b.) Eadem diftecta, eum fitu feminum naturali. c.) Seminz Mluta. 1.) Telta feminis aperta, cum litu \& figura nuclei c) Albumen deaudatam e) Ejusidem Sedio longitudioalis, cum fitu enbryanis. F.) Embryo culatus.

116.16 


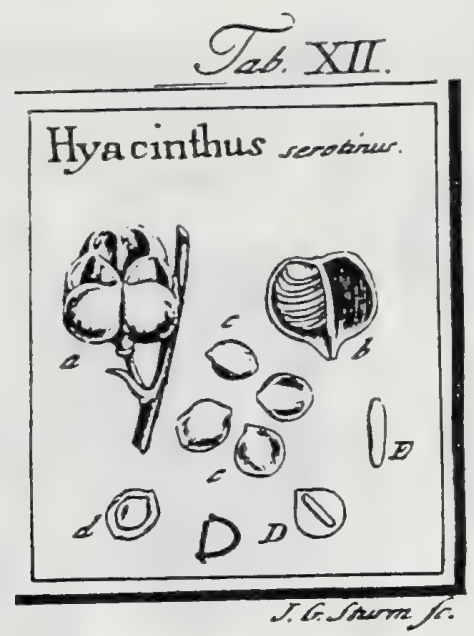

\section{Liliaceae}

J. Gaertner (1788) Vol.1

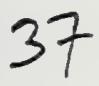

XLI. HYACINTHUS TOURN. t. 180. LINN. gen. 427

Calyx nullus. Corolla campanulata: pori tres melliferi juxta ovariuın. Stann. fex. Styl. funplex. Capfula fupera, trilocularis. Seunina numerofa. Embryo longitudine albuminis, sectus.

38

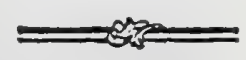

H У A CIN TH U S ferotinus. Tab. w: fig. 4.

Hyacintius obfoleti coloris, hifpanicus, ferotinus. CL u s. hifl. 1. p. 177. I78.

Hyacintlus Serotinus maximus. Best. hort. Eyfl. Vern. II. t. 16.f. I.

Hyacinthus petalis exterioribus fubdifinctis, interioribus coaduratis. LI N N. Jyfl. veg. 3?5.

PER. Capfula fupera, globofe trigona, bafi in brevem pedunculum conicum producta, coriaceo cruftacea, trilocularis, trivalvis, apice tantum dehifcens.

REc. margo internus diffepinentorum, cui femina funplici ferie longitudinali affixa.

SE s. decern circiter in fingulo loculainento, fuborbiculata, bracteata, utrinque plans, inargine retufo cincta, atra, fubfplendentia.

IN T. duplex: exterius papyraceum, tenue, aridum, nucleo multo latius, eidemque arche adhzrens; interius tenuifimum, pallidun.

А в. Sernine anguftius, obovatum, plano-compreffum, tenue, fubcartilagineum, aqueo-pallidum.

Eмв. monocotyledoneus, rectus, linearis, comprefius, lacteo albus, longitudine fere albuminis.

2.) Capfula deliifcens. b.) Valvula (eparata, diffepimenti margine feminifero. e.) Semina feparata. d.) Alusinen femine angufius denudatum, D.) Albumen diflęum, cum fitu embryonis. E.) Embryo solutus \& infigniter außtus. 


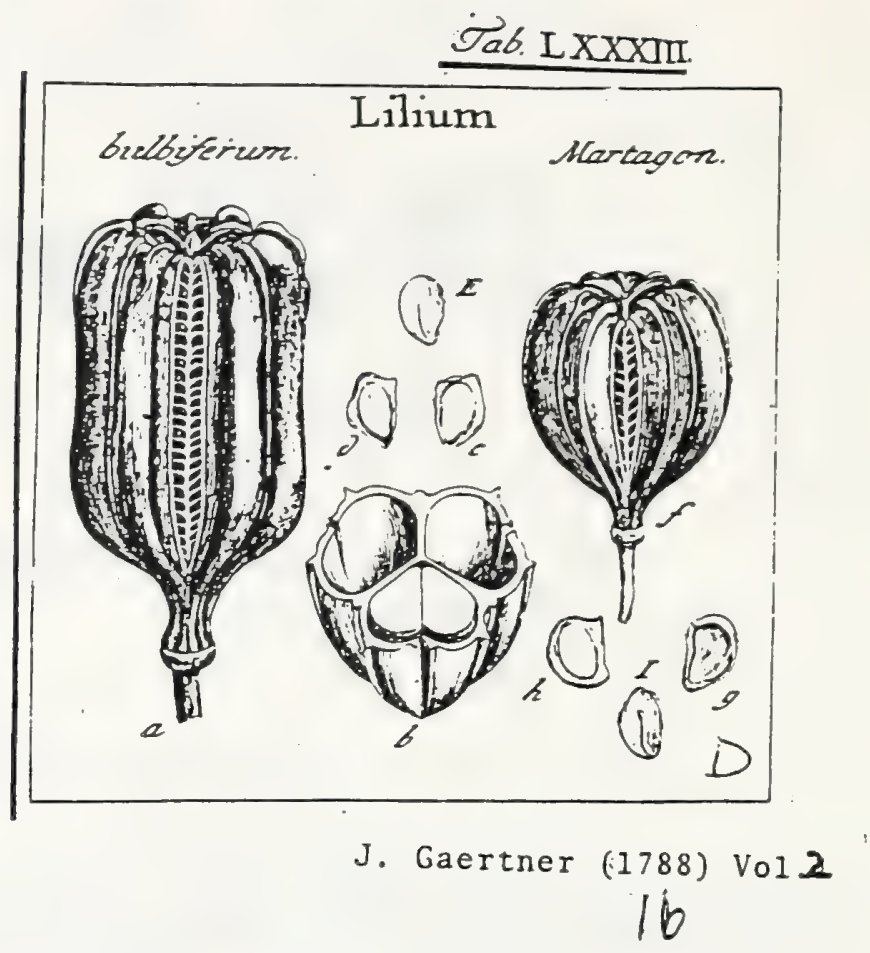

DXVII. LILIUM. TOURN. inft. t. I95. LINN. ger. 4 IO.

Cal. nullus. Cor. hexapetala campanulata : petalis apice incraffatis reflexis; unguibus intus linea canaliculata nectarifera exaratis. Stan. fex. Ovar. fuperum angulatum. Styl. fimplex. Stigm. triangulare. Capf. trivalvis: Valvis interjecto filo reticulato comexis. Semina plana, difcoidea.

Lilius bulbiferum. Tab. 83. fig. 4 .

Hemerocallis. Cas. epit. 616 .

Lilizen cruestum bulbiferum. BesL. Eyft. vern. V. t. 7. f. $x$.

Lilinus caule foliofo, foliis Julcatis gramineis, floribus campaniformibus intus foccofis. HALL. bift. n. 1232.

Lilizm foliis $\int p a r f i s$, corollis campanulatis ereatis: intus fcabris. LINN. $\int y /$. veg. 324 .

Icon. JACe. aufir. $3 . t .226$.

PER. Capfula fupera, prifmatica, rotundato-trigona, coftis fex dorfalibus fuperne membranaceo - alatis, totidemque nervis mediis longitudinalibus exarata, trilocularis, trivalvis. Valvulx coriacex, intus feptigerx, filo futuris interjecto \& fibrillis fubalternis pectinato connexæ.

REC. nullum : femina diffepimentorum margini centrali duplici ferie longitudinali affixa.

SeM. numerofa, difcoidea, plana, verfus umbilicum acuminata, extrorfum vero rutundita, fubmarginata, e cinnamomeo - rufefcentia.

IN T. duplex: exterius albunine latius, fubfongiofum; interins membramaceum, tesuiffimum, pallidum.

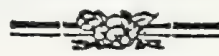

ALB. Semine anguftius, ovato acuminatum, compreffum, camofum, album.

EMB. monocotyledoneus, linearis, dimidio albumine longior, leviflime figmoideus, lacteus.

a.) Capfula integra. b.) Eadem transverfe feda, cum fitu feminum. c.) Semen feparatum. d.) Albumen denudatum integrum, E) Iden longitudinaliter apertum, sum figur $Q$ fitu Embryoais.

Lilium Martagan. ibid.

Afartagors. CASB. epit. 657.

Lilium foliis verticillatis, foribus pendulis, corollis rewolutis. HALL. bif. n. $x 233$. LiNN. Jy.t. veg. l. $c_{\text {. }}$

160nt. JACQ. asffr. 4. t. 35 r.

Capfula (f.) turbinata, coftis \& nervis fex, uti pracedens, exarata. Senimina (g.) numerofa, prioribus fimillima, aliquantulum tamen majora, craffiora \& evidentius marginata. Albumen (h.) fubellipricum. Embryo (l.) nrecedenti finilis. 


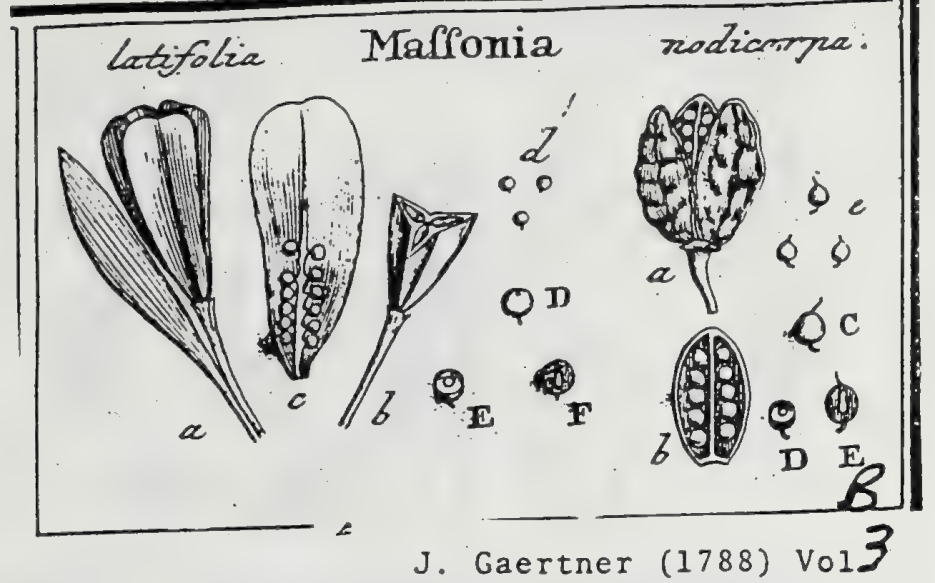

II. II A S S O N I A.

Tнгів. nov. gen. 39. LIN⿴. fuppl. pl. p. 27. gen. pl. ed. Schreb. 552. Juss. gen. p. 53. LaMAвсK ill.

gen. t. 233.

Cal. nullus, nifi corollam velis. Cor. fupera, bafi globoìe tumida, fupra fexfida. Stam. fex. Styl. unicus. Capfula triquetra, trilocularis, trivalvis. Sem. plura, globofa, atra, interdun utrinque appendiculata. Flores un: bellati, bracteis floralibus coloratis cincti, ut in Hrmantho.

Massonia latifolia. Tab. 182. fig. 2.

Mrafonia foliis fubrotumdis pasentibus, laciniis corollae patulis. Ait. bort. Eew. I: p. 405 . t. 3.

Maffonia foliis rotzndato - ovatis glabris. THunB, prodr. 60. Diff. nov. ger: pl. 2. p. 40 .

Mafonia folis orbiculatis glabris. LiN. fuppl. pl. p. 293. Syf. veg. ed. I4. p. 318. Spec. pl. ed. Willd. T. 2. P. I. p. 28.

A Cl. Thungerg.

PER. Capfula fupera, oblonga, inverfe pyramidata, membranacea, fubdia: phana, triquetra, trilocularis, trivalvis. Diffepimenta mediis valvis adnata, anguftilima, fuperne deliquefcentia, inferne feninifera.

REC. margo interior diffepimentorum, cui femina utrinque affixa, ut eorum feries in fingulo loculo genina fit.

SE M. plura, ad duodecim in quovis loculamento, atra, glabra, fpharrica, apice minutiffina areola impreffa, baf in mucronem ut funiculum umbi licalen breven durun definentia.

I.: T. fimplex, fubcoriaccum, tenue, arctifime adıatuns.

A L B. Sphaxicum, carnofun, durum, album.

Ex в. monocotyledoneus, fubulatus, niveus, dimidio albumine longior \& in ejus bafi lucatus.

\section{EXPLICATIO FIGURE.}

2) Capfula jnnioz, cum fpatha fiotali lanceolata, coloratz, quarum plures Bornm umbelism cinguat b.) Ejus fećtio transverfalis. c.) Valvulx, e capfula penitus matura \& grandiore,

faciet interna, enm diftepimento \& feminum infertione. d. D.) Sernina foluta. E.) Arbumen transterío diactum. F.) Ejus fectio longitulladis, cum fitu \& figura Embryonis.

2ISSsONIA nodicarpa. ibidem.

an MfajJuria angrufifolia. Linn.?

Mafonia e cap. bonae fpei. Thuss. in litt.

Capfula (a.) elliptico - ovata, opaca, alba, triquetra, trilocularis, trivalvis: valvulis ab impreffronibus feminum nodulofis $f$. puftulofis. Diffepimentum (b.) crafum, utrinque feminiferum. Semina (b.c. C.) in fingulo loculo dena feu fauciora, atra, globofa, apice in mucronem brevem fetaceum obliquum, \& baG in funiculum umbilicalem rigidum producta. Albunen (D.) ut in pracedenti. Embryo (E.) fubclavatus, niveus, dinidio albumine longior, atque vertici ejus, quam bafi propior.

Sive nova fit fpecies, five una ex jam cognitis, aliis enodandum relinquo; effentialiter $2 b$ omanibus differt, feminibus utrinque apiculittis \& qua Herhere anfie mondirin 
Tab. XVII
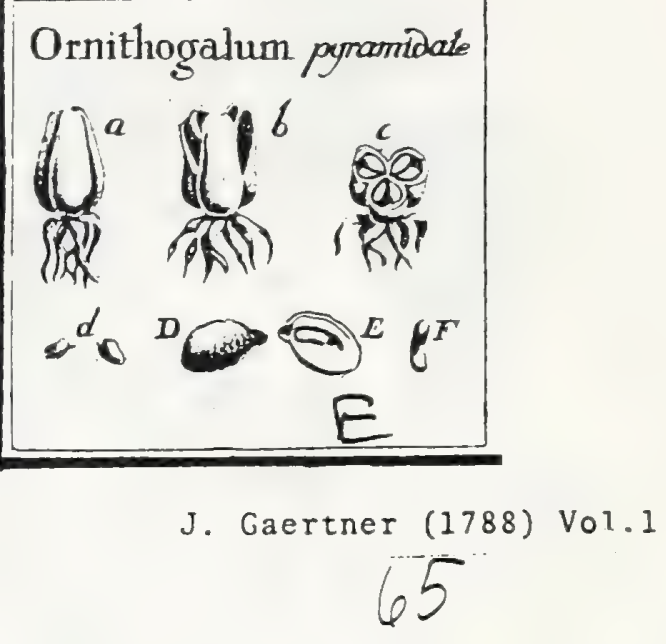

\section{ORNITHOGALTM. TOUR N. t. 203. LIN ger. $4 \mathrm{I} 8$.}

Corolla hexapetala. Stam. fex, alterna bafi dilatata, apice fxpe tricuspidata. Styl. unicus : ligmate obtufo. Capfula fupera, trilocularis. Sem. plura, horizontalia aut pendula. Embryo in axi feninis, longitudine dimidii albuminis.

Ornithogalum pyramidale. Tab. 17. fig. 3 .

Ornithogalum lafieum maximum. liess, hort. Ey/l. vern. V.t. I4. f. 2.

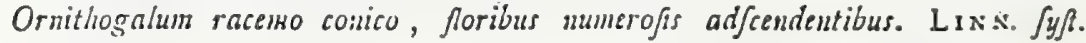
2 ecg. 327.

PER. Caplula fupera, oratn-pyramidata, membianacea, tenuis, albicans, trifulca, trilocularis, trivalvis: valvulis medio feptigeris.

REc. nullum, proter marginem Jiffepinzentorum contralen, cui femina duplici ferie lovizontaliser aflixa.

S Es. plura, fex vel olo in quolibct Inculamento, paucioribus tamen adolefcentibus, iisinue urato gluboís, ad umbilicum tuberculu roltratis, fubrugofulis, atris.

Ix $r$. furplex, fubcoriacem, nucleo arclifime adnatum.

A в . femini conforme, farinofum, durum, livefens.

E. в. monocotyledoneus, ectetiusculus, leviter curvarus, lacteo albicans, in axi feninis prope umbilicum locatus, dimidio albumine lungior.

a.b.) Capfula integra, \& dehifcens, c.) Eadem teansterfe ferta d. D.) Semina feparaia. E.) Semoco longitudinaliter fetum, cuin eubrjone intra albumen, F.) Enbrjo feparatus \& auflus,

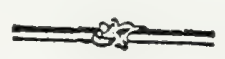

Ornithogaluin nutans.

Capfula ovata, trigona, nigra, Semina globofa, magnitudine feminum Raphani,
absque tuberculo ad umbilicum, undique foveolis parvis exara, fur a cantia. Embryonis fitus \& longitudo ut in pracedenti.

116.20 


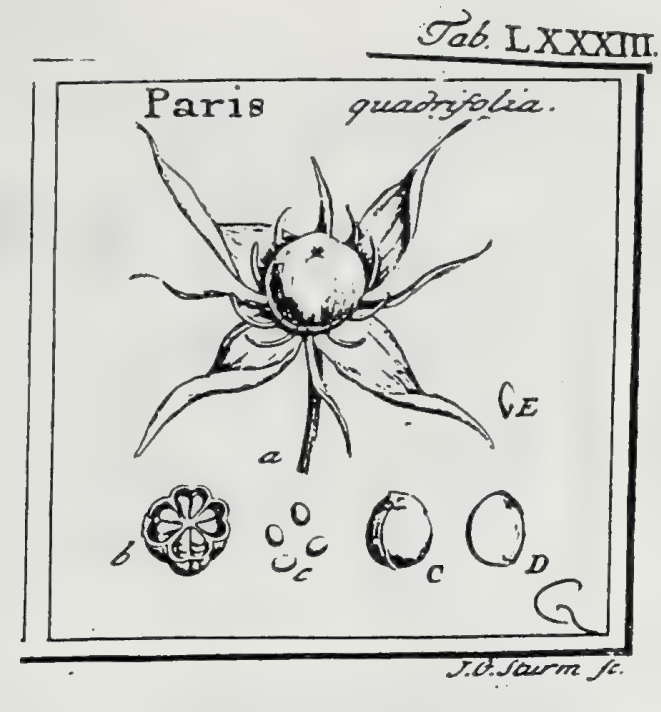

J. Gaertner (1788) Vol, 2

19

DXX. PARIS. TOURN. inf. t. Ir7. LIN gen. 500.

Calyx tetraphyllus. Cor. tetrapetala, petalis linearibus. Stam. odto. Ovar. fuperum, fubglobofum. Styl. quatuor. Bacca.quadrilocularis. Serm. plura, gemino ordine pofita.

Paris quadrifolia. Tab. 83. fig. 7 .

Herbu paris. CaM. epit. 835. Blakw. berb. t. 286. OED. flor. dar. t. I39.

Paris. Hall. bij. n. 1006 . LiNN. Jy?t. veg. 38 r.

PER. Bacca fupera, globofa, obfolete quadrifulcata, glabra, atro-carulefcens, fucculenra, quadrilocularis. Pulpa fubaquofa, evanefcens.

R Ec. nullum, prater angulum loculamentorum centralem, cui femina duplici ferie alfixa.

SEM. Tex 1. octo in quolibet loculamento, ovato - globofa, hilo filiformi a bafi ad apieem producto notata, ferruginea.

INT. Gimplex, membranaceum, albumini arcte adiatum.

A LB. Semini conforme, carnofum, pallidum.

ENB. monocotyledoneus, minutulus, ovato acuminatus, lacteus, in bafi albuminis prope unbilicum locatus. Rad. acuminata, centripeta.

2.) Bacea integra, vegeta, calyce corolla \& filamentis peraftentibus bali cinche b.) Eadem marceficens transverim fecta, cum infertione ferninum. c.) Semina foluta, magnitudiac naturali. C.) Semen auctum, inverfum, ut umbilicus cum bilo filiformi appareat. D.) Albumen longitudinaliter diTectum, cum fitu embryonis. E.) Enbryo folutus \& infiguiter autus.

Facilime minutulus embryo in albunine confpicitur, quando hoc per aliquot huras in aqua detinetur diffectum; tunc enim ifte, punctuli nivei specie prope unibilicum apparet. 


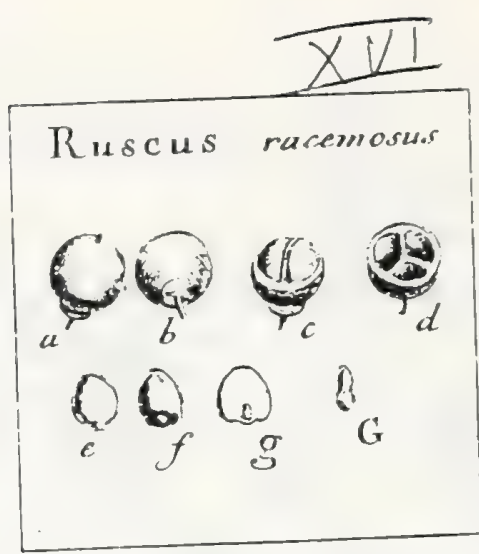

J. Gaertner (1788) Vol.1

60

\section{LXVIIII. RVSCVS. TOURN. t. 15. LIN}

Flores androgyni, aut fexu diftincti atque hi, in feparatis caulibus. Cal. hexaphyllus. Cor. nulla. Nectarium ceutrale, apice perforatum. M s s. Stain. fex. F e M. StyL unicus; nigmate obrufo. Bacca fupera, trilocularis, Semiua folitaria. Embryo dimidio femine brevior, in parte umbilico oppofita.

$R$ u scus racemofus. Tab. 16. fig. $s$.

Laurus alexandrina anguftifolia ramofa, frufu ad extremum ramofo. Moris. hifl. 3. S. $13 \cdot t \cdot 5 \cdot f \cdot 14$.

Rufcus racemo terminali hermaphrodilico. LIN N. Jyfl. veg. 896 .

PER. Bacca fupera, globola, carnofa, glabra, rubra, difco rotundo coriaceo albo bafi munita, trilocularis: loculanentis uno aut duobus fxpe per maturitatem oblitcratis.

REC. cicatricula parva in fuprema parte difepimentorum, cui feminum umbilicus fubterminalis intertus.

SEM. in fingulo loculamento, \& fxpe in tota bacca, unicutn, orato globofum, oblohete angulatum, fupra levitar acuminatum \& prope apicem umbificu laterali notasum; infra obtufum, pallide lutefccos, aut melinum.

IN T. fimplex, nembranaceum, tenuilimum, arcte aduatum.

A L B. femini conforme, carnolum, aqueo-pallidum.

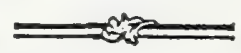

Es B. monocotyledoneus, teretiusculus, altera extremitate turgidiore, exteriore a alters attenuata, fubcomprefta, interiore, tertiam partem longitudinis albuminis vix fuperanse\& in ina ejus ac umbilico oppofita regione locatus.

a. b.) Bacca integra. c.) Ejus duo loculamenta aperta. d.) Sectio ejus transverfalis, e. f, Semea arte dorfali atque ventrali fpectatuu. g.) Albuminis fectio longitudinalis, G.) Embryo feparatur \&: auctus.

Sxpius accidit, ut in tota bacca nonnifi unicum maturefcat femen, eaque exinde fiat unilocularis, quale exemplum habet HALLERUS in hort. gatting. p. 78 ; \& dantur quoque biloculares, qualem fig. c. exhibet; fed naturalis numerus locula. meutorum eft ternarius, isque omnium frequentifimus.

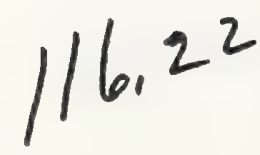




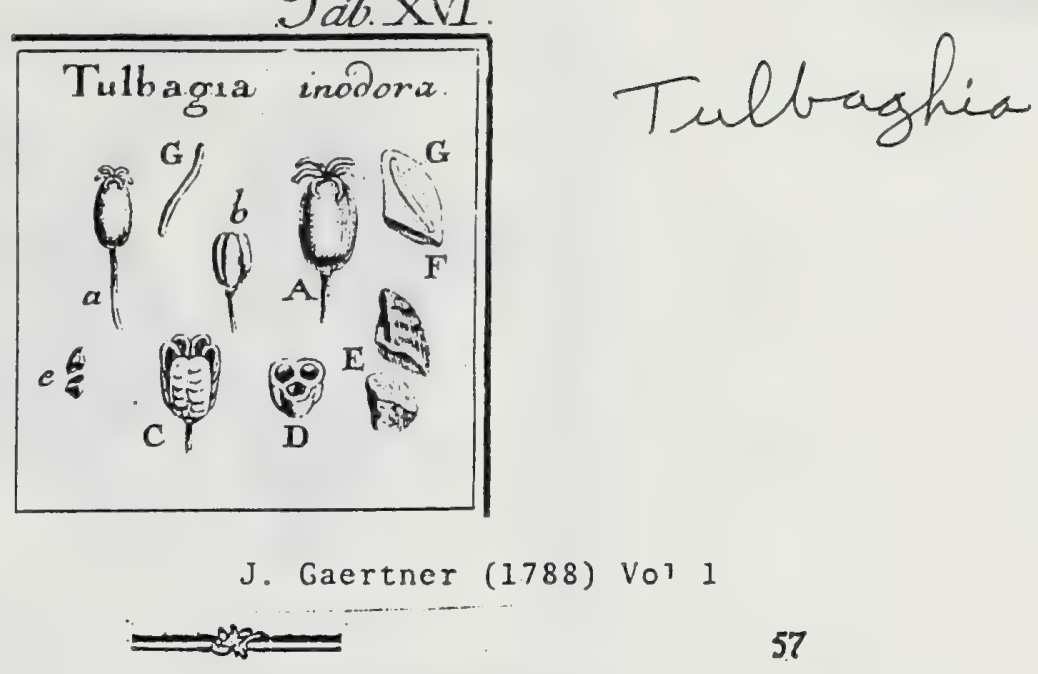

\section{TVLBAGIA. LIN}

Corolla monopetala, infundibuliformis: limbo fexfido.. Nectarium faucen coromans triphyllum: foliolis bifidis. Stam. fex. Styl. fimplex. Capfula fupera, trilo. cularıs. Semina genninata. Embryolongitudine feminis, in albunine obliquus.

TULBA GIA inodora. Tab. 16. fig. 3.

Tulbagia foliis fubfliformibus. L I N N. Juppl. 1932.

Ex herbario Bankfiano.

PER. Capfula fupera, corolla perfiftente, ore claufo lineari fexfido, veftita, ovatoo cyliudrica, trifulca, trilocularis, trivalvis: valvulis medio feptigeris.

REc. nullum, prxter marginem centralem diffepinentorum, cui femina affixa.

SEM. in fingulo loculaneuto gemina, triquetra, fibi mutuo incumbentia, ad locum mutui contaclus oblique.truncata, rugofiuscula, atra.

INT. fimplex, coriaceum, nucleo arcte adnatum.

A LB. feınini conforme, carnolusn, aqueo-pallidum, ab exteriori bafeos fuz angulo ad verticem usque canali obliquo gracili, pro recipiendo embryone exfculptum.

Eм в. monocotyledoneus, filiformis, fubfexuofus I. figmoideo curvatus, lacteo-albicans, longitudine fere albuminis, ejusque axern oblique fecans.

a. A.) Caprula corollà velita. b.C.) Eadern denudata. D.) Ejus fêtio transver(alis. e. E.) So mina feparata, F.) Albumen longitudiualiter fectum, G. G.) Embryonis fitus \& figura.

$$
1 / 6.23
$$




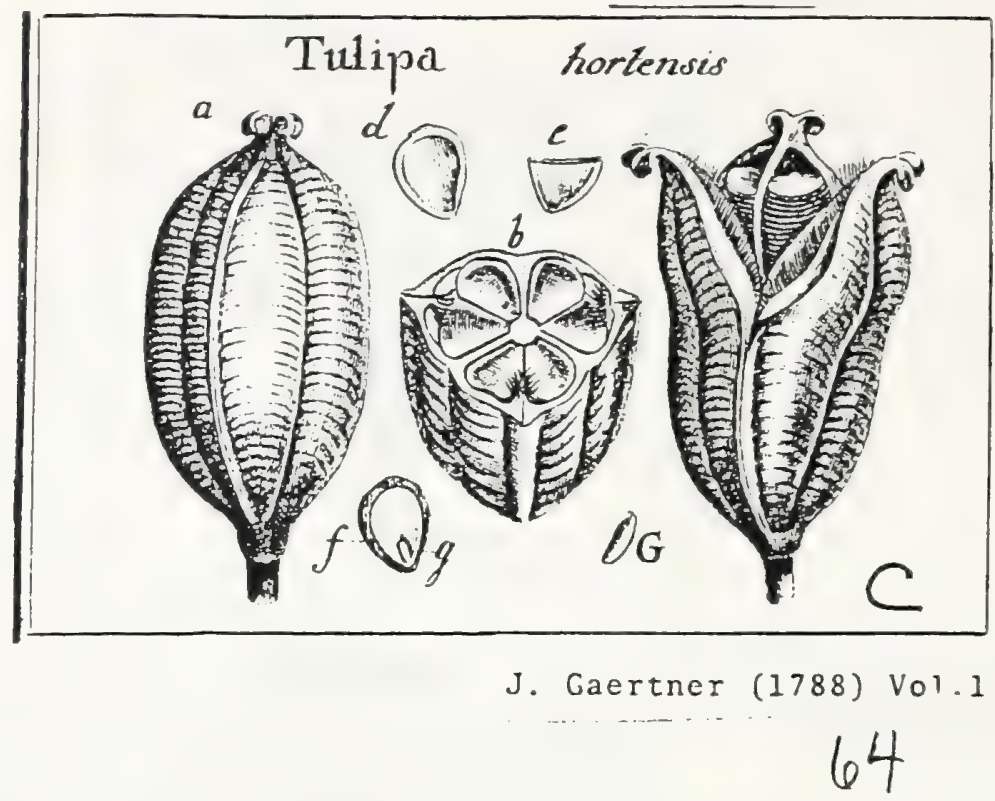

LXXIIII. TVLIPA. TOURN. t 199. 200. LIN gen. 415.

Corolla hexapetala, absque nectario. Stain. fex. Stigmata orario infidentia. Capfula fupera, trilocularis. Semina plana. Embrio ad unbilicum, tertiam partem albusninis longus.

TULiBa hortenfis. Tab, 17. fig. 2.

Tulipa. Besc. hort. Eyf. vern. II. t. 7. f. 4. 5. III. t. 10.f. 3.t. 17. f. 2. IV.t. I-g. Eंc.

Tulipa flore erefto, foliis ovato lanceolatis. L I N N. Jyf. veg. 325.

PER. Capfula fupers, ovato-prismatica, fligmate trilobo terminata, trigona, trifulca, transverfe ftriata, trilocularis, trivaluis. Valvulx medio feprigcrx, ad futuras vibrillis introrfurn verfis, candidis, fericeis, ciliatx.

REc. nullum, prater marginem centralem diffepimentorum, cui femina duplici ferie horizontaliter affixa.

SEM. nuinerola, oborata, verfus umbilicum angufata, utrinque plansa, marginata, rufefcentia.

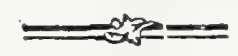

I т. duplex, membranaceun : exterius, circa periphctian in margincm prominulum, fubfungofum incraffatum.

A в. femini conforme, paulo tamen angufius, fubcartilagineum, tenue, diaphanum, album.

EM в. monocotyledoneus, lineari oblongus, compreffus, lacteo albicans, tertia albuminis parte paulo brevior, ad umbilicum pofitus.

a.) Capfula integra. b.) Eadem (ransverfe (e.?2, c.) Faden dehifcens. d.) Semen feparatum. e.) Idem transverfe fedtuin. f.) Ejusden \& albuninis fortio longitudisalis. g.C.) Enbrjo jußz, \&. aน ถิव magnitudine.

Ante plenam fructus maturitatem vibrillix in hac \& in Fritillaria, in tres renues membianas conglutinatx funt, qux feminum columnis iuteriectx, capfulas immaturas seddunt fexinculares. In hortenfi 'Tulipa, cupfula' quadriloculares non valde infrequentes funt.

$$
116.24
$$




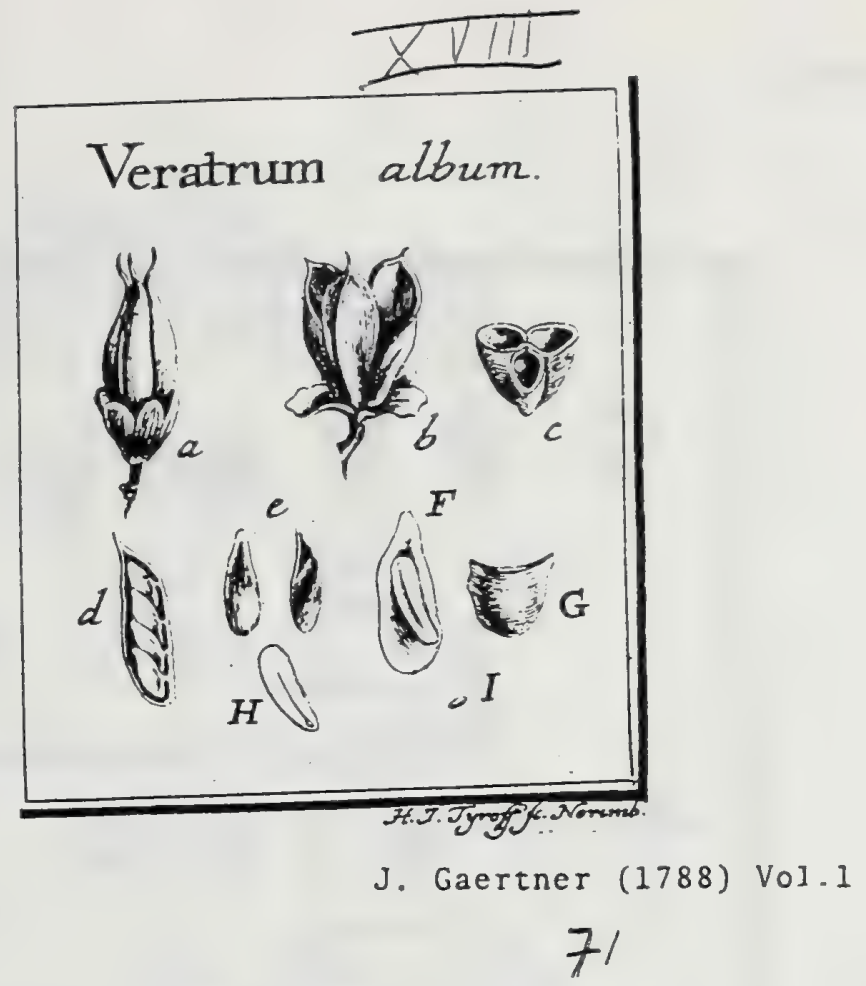

LXXXIII. TERATRUM. TOURN. t. 145 . LinN. get1. 1144.

Flores onnes hermaphroditi, fud nonnulli heriles. Cal. nullus. Cor. hexapetala Stam. fex. Siglotres. Capfula ties. Scminia bracteata. Embryo breviflumus in bali albuminis.

VER A т R U M album. tab. 18. fig. 4.

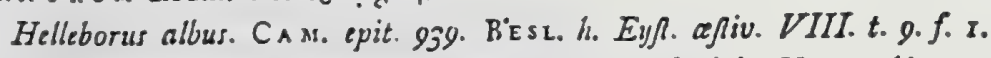

Veratrum Spica paniculata, foribus naribus EO Jeninis. HALL. hif. 2. n. 1204.

.72

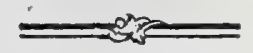

Veratrum racemo fupradecompofito, corollis treetis. L I N N. fiyl. veg. 902.

Icon. JA C C. cuftr. v. 4. t. 3.35 .

PER. Capfulx tres, fuperx, oblongx, comprefliuscula, bafi inter fe connatx, fupra folutx \& in flylum brevem filiformem definentes, uniloculares, futura interiore deliifentes.

REC. futurx dehifcentis margines, quibus femina in fitu erecto atque genniso ordine, uinbilicis fupra bafin fuam locatis, affixa.

SEM. plura, decem 1. duodecim, ovato oblonga, furfum angufiora, bracteata, lato nargine membranaceo cincta, fubconcava, varie rugofa, fpadicea.

IN T. duplex: exterius membranaceum, aridum, in marginem fensinis ampliatum; interius tenuifinum, nuclco arche aduatum.

А св. oblonguin, anguftum, compreffuin, oblique pofitum, carnofum, album.

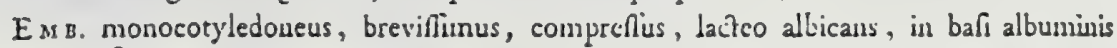
pofitus.

2.) Capfula integra. b.) Exdem deinifcentes. c.) Earum feetio transverfaiis. d.) Seminum inServio. e.) Seninz feparata. F.) Albunen denudatum. G.) Sennen transveríe fectuin, H.) At bumen longitudinaliter difciffum cum fitu embrjonis. I.) Embryo (ę̧aratus. 


\section{Liliaceae}

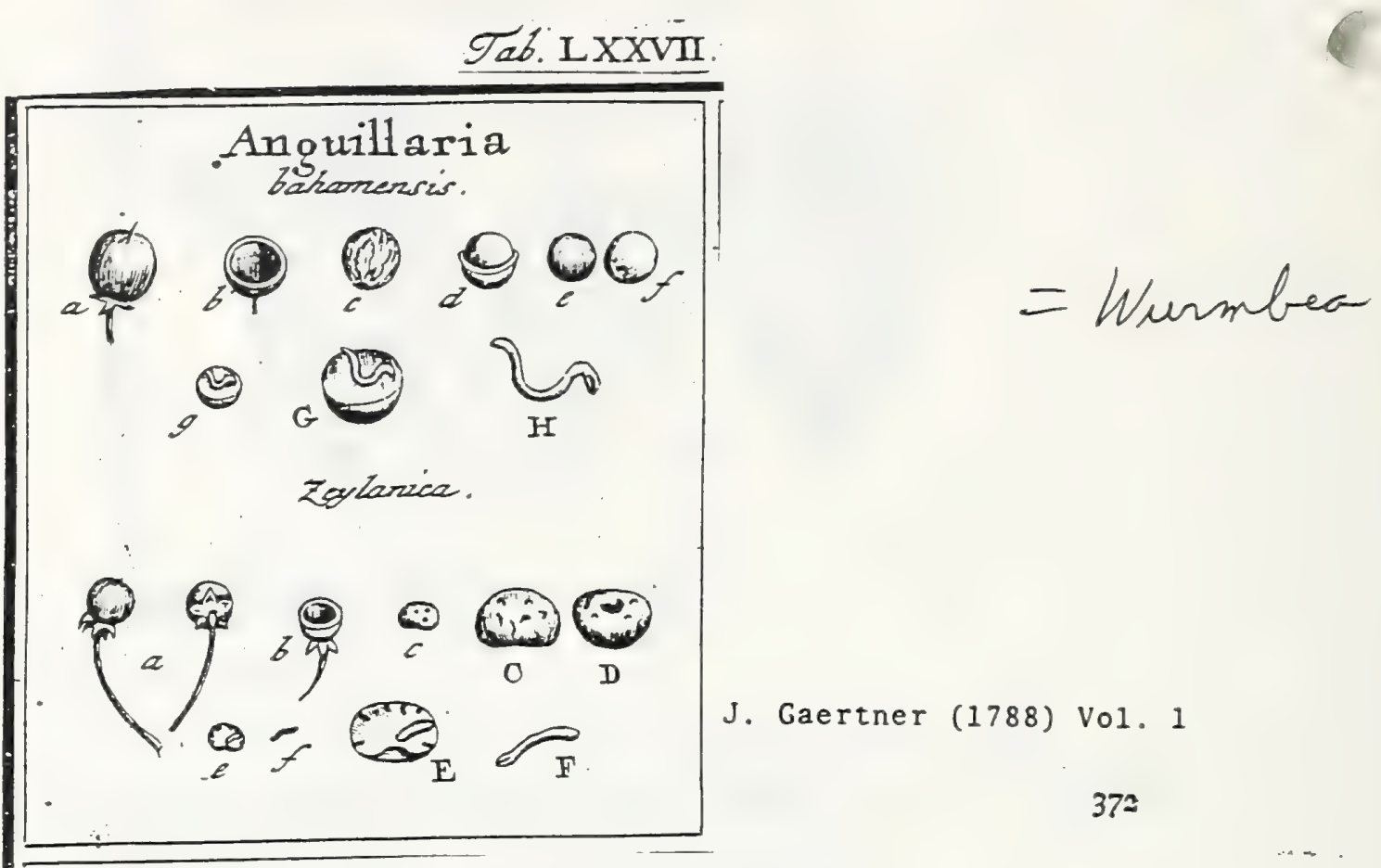

CCCCLXXXV. ANGUILLARIA.

Calyx quinquepartitus, foliolis ovato lancenlatis xqualibus perfifentibus. Cor. monopetala, ad bafin fere quinquefida, laciniis lanceolatis, calyce duplo longioribus. Stam. quinque, corollx inferta. Styl. unicus, filiformis: ftigmate fimplici. Bacca unilocularis, monofperma. (Ex fcliedis b. SolaNdRI.).

ANGUILLARIA bahamenfis. Tab. 77. fig.. L.

Heberdenia excelfa. Banks. herbar:

P.ER.. Bacca Supera, globofa, coriacea, glabra, nigra, unilocularis.

REc. nullom, proter cicatricem latam in fundo bacex, cui femen affixum:

SEN. unicum, globolum, inferne ainfla fovea umbilicali exfeulptum, fallidum.:

IN T. fimplex, crafiusculum, fungofo coriaceum, friabile.

A. B. fernini conforme, carnofum, durum, prope peripheriam obfoletifine runit natum.

EMB. tereriusculus, ferpentino flexuofus, transverfe in albuinine locatus, lacteus. Coty $L$ lincari oblongx, breviflinx. Rad. filiformis, longiflima, oblique furfum verfus peripheriam feminis \& baccx directa, centrifuga.

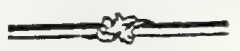

a. b.) Bacea integra \& difiecta. c.) Semen folatum. d.) Albamen ad mediam usque ab inte gunento denudatum, e.) Ejusdem pars fuperior. (.) Idem a Intere anbilicali fpectatun. g. G.) Iden difretum, cum embryonis fitu \& figura. H.) Embryo feparatus.

ANGUILLARIA zeylanica, ibid.

Badulam. Hers. mus, zeyl. 43. Lins. fi. zeyl. n. 600.

Tinus humilis zeylanica, foliis crafis venofis. Burs. zeyl. 222.t. 103 .

E collect. fem. hort. lugdb.

Bacca fplrarica (a), pracedenti dimidio minor, calyce quinquefido perfiftente excepta, unilocularis (b), pallite rufefcens l. fubrubicunda. Semen figura oculorum cancri, unicum (c. C. D.), femiglobofum, depreffiusculum, fupra obfoletifime frobiculatum (C.), infra planiusculum (D.) tovea umbilicali nigricantc cxfculptum, cetera fubfradiceum. Intcg. fimplex, tenue. Albumen (c. E..) fe. mini conforme, carnofum, ad peripheriam rimis \& fmubus modice profundis rumineum, album, fubfriabile. Embryo (f. F.) teretiusculus, longitudine dimiminatum, album, fubfiabin tre cutyl. bre-

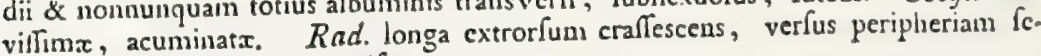
minis \& baccx directa, centrifuga.

Afinis efle videtur Mytfines. Naturalis feminum numerus forfan quinarius, in immaturo ovario ulterius inquirendus. 


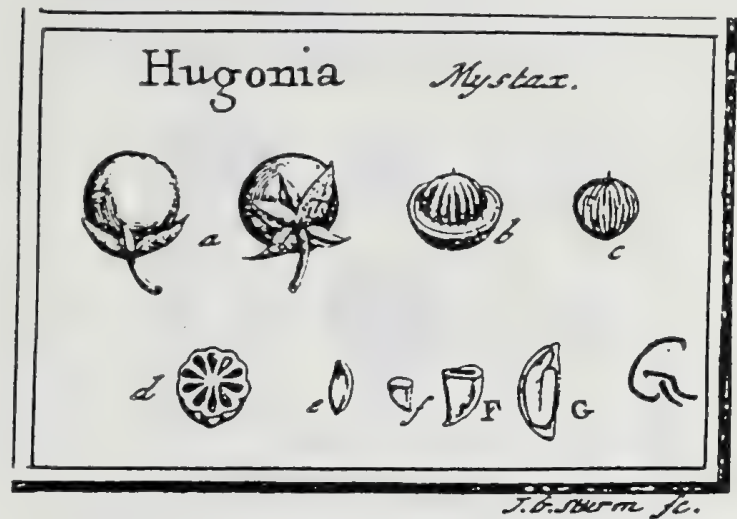

\section{J. Gaertner (1788) Vol.1}

281

CCCLIII. HVGONIA. LINN. gen. 83I.

Calyx pentaplayllus: foliolis coriaceis, tribus tomentofis \& duobus glaberrimis, nitidis. Cor. pentapetala. Stam. decem, in urccoluin connata. Styl. quinque. Drupa baccata: putamine friato, decemloculari.

Hugonxa Myfax. Tab. 58. fig. 7.

Modira-canni. R н е. D. mal. 2. p. 29. $t$. 29.

Hugonia fpinis oppofitis revolutis. LIN N. fyft. veg. $6 \mathrm{r} 2$.

Radalifawal. zeylonens. E collect. fem. hort. lugdb.

PER. Drupa baccata, fphrerica, fucculenta. Cuticula tenuifima, chartacea, tenax, alba, lavigatifima, fplendens. Pulpa fucculenta, per xtatem evanelcens. Putamen ofteun, fpharicuin, profunde ftriatum, decemloculare.

REC. nullum; femina apice aflixa.

$S_{E}$ s. in fingulo loculamento unicum, oblongum, utrinque attenuatum, in dorfo arcuatum, craftusculun, ad latcra planum, cuneiformi compreflun, pallidum.

IN T. fimplex, inembranaceuin, tenuc.

A . в. femini conforme, cralfiusculıın, carnofum, candidum.

EM B. longitudine albuninis, inverfus, luteus. Cotyl. oblongx, planx, foliacex, tenuillinx. Rad. teretiuscula, fupera.

a.) Eacca integra. b.) Putamen fuperne denudatum. c.) Idem penitus decorticatum. d.) Ejusdern fetio transverlalis. e.) Semen Separacum. f.f.) Ejus \& albuminis fêtio transverfalis. G.) Einbryowis fitus intra albumen. 


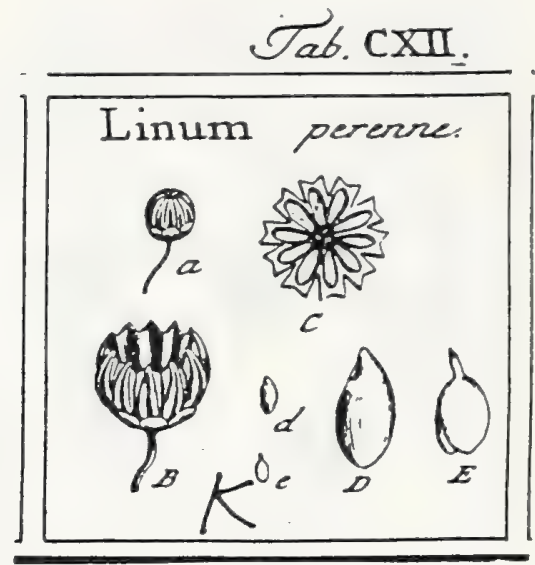

J. Gaertner (17.88) Vol: 2

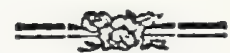

LINUas pereme. T:L. I12. fig. .I I.

Linum folvefire condeum perenne erechius, flore EO capitulo majore. RAY. Sor. 3. p. 36 . MiLL. ic. t: 166 .

Limun culycibus capfulisgue obtufis, foliis altenuis lauceolatis integerrimis. LINN. Sisto veg. 30 .

PER. Capfula magnitudine pifi, fphærica, ftriata, pallide ftraminea, decem locularis, decemvalvis. Valvulax cruftacex, fulco dorfali infcriptex, apice dehifcentes \& difepimentorum ope inter fe connexz. Difepimenta membranacca, conduplicana, Inminis fuis extrorfum partitis, ita valvularum marginibus inferta, ut, cun hx dehifcunt, illex corii follis adinftar explicentur.

KEC. nullun; femina margini centrali diffepimentorum affixa.

SEM. folitaria, ovata, fupra mucronata, compreffa, atra, fplendentia: umbilico minutulo oblongo infra apicen feminis.

IxT. fimplex: coriaceum, tenue, fuperficie externa in mucilaginem alban diaphanam ab aqua refolubili; interma, tenui lamina carnofá veftita.

A L B. nullun, prxter fuperficiem internain carnofam integumenti.

En B. magnitudine feninis, inverfus, viridis. Cotyl. ellipticx, fubfoliacex. Rad. teretiufcula, longa, fupera.

2 B.) Capfula integra \& dehifens. C.) Capfula dehifeentis fetio transverális, conduplieaturam \& iufertionem diliepimentorum oftendens. d. D.) Scmen fegaratum. c. E.) Eubryo denudatus.

Diffepimentorum in Radiola atque Lino fabrica, hactenus: fne pari eft, \& eficutialem hujus generis pribet characterem.

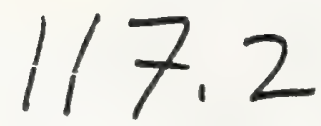




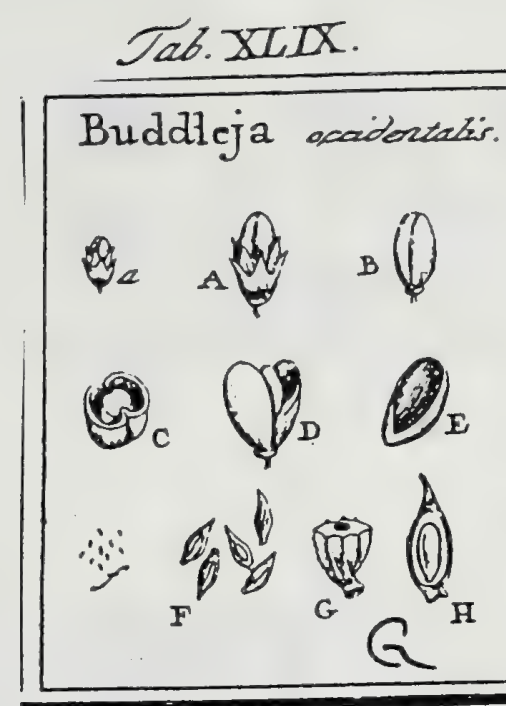

J. Gaertner (1788) Vol.1

226

CCLXXV. BUDDLEJA. LINN. gen. 140.

Calyx quadrifidus. Cor. quadrifida. Staın, quatuor. Styl. unicus. Capfula fupera bilulca, bilocularis. Diffepineutum duplicatum, valvis parallelum. Semina lub. fcubiformia.

Buddzeja occidentalis. Tab. 49. fig. 7.

Ophioxylon americanum, foliis oblongis mucronatis ieviter ferratis bardane in; far Jubtus lanugino/is. Pluk, phyt. t. 210. f. $I$.

Buddleja foliis lanceolatis. LINN. Ju/l. veg. 154.

Ex herbario Bankfiano.

P E R. Capfula parva, brevi tomento pubefcens, calyce \& corolla perfiftentibus pariter tomentofis, veflita, elliptica, fulco depreflo utriuque infcripta, bilocularis, bival. vis. Diflepinentum ex inflexis valvularum marginibus formarum, duplicatum; anguftum.

$R \in c$. fungolum, oblongum, in axi fructus pofitum, diffepimento firmatum.

SEM. numerofiffima, fubfcobiformia, atrinque acuminata \& extrorfum quafi caudata, compreffiuscula, früis elevatis fcabriusculis infcripta, pallide rufécentia.

IN T. duplex : exterius meinbranaceum, utrinque ultra nucleum productum, ut pro Arillo haberi polfet, \& in parte fua exteriore fubulato acuminatun; interius arach, noidtum ac vix ullum.

AL B, ovato oblongum, integumento brevius, carnolum, aqueo-pallidum.

Es в. longitudine fere albuminis, compreffiusculus, lacteo albus. Cotyl. oblongx, anguftx, planiusculx. Rad. brevifluna, acuminata, centripeta.

a. A.) Capfola calyce \& corolla veftita. B.) Eadem denudata, C.) Eadem diffecta. D.) Eadem dehifecns. E.) V'alvula (cparata. (. F.) Senink foluta. G.) Seman (ransverfe, \& H.) Hew Jougitodinalister fecturn, cum albuminis \& embryonis fitu atque fgura.

$$
1 / 8.1
$$




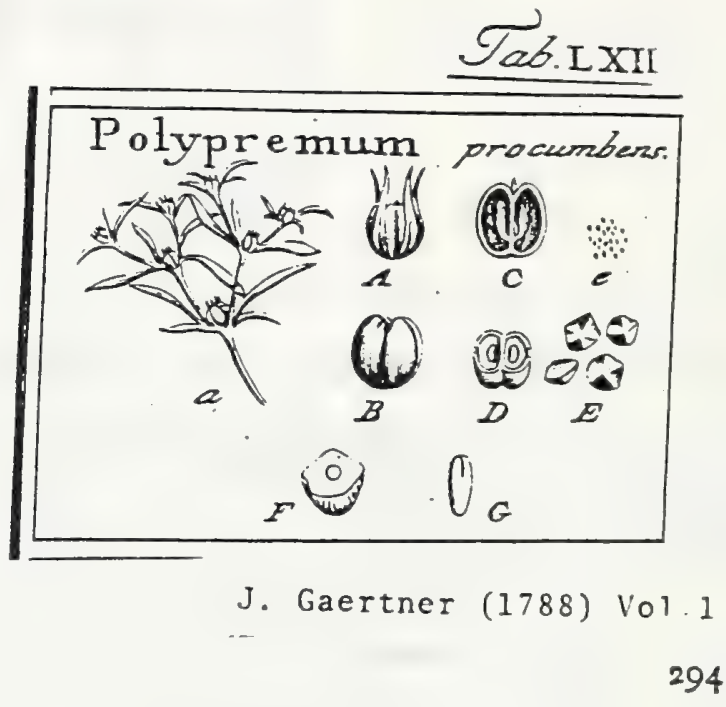

CCCLXXII. POLYPREMUM. Lin N. gen. 137 .

Calyx tetraphyllus. Cor. monopctala rotata quadrifida. Stain. quaruor. Seyl. unicus. Capfula bilocularis. Receptacula bafi affixa libera. Semina numcroia.

Poly REMUM procumbens. Tab. 6j. fig. 2.

Linum carolinianum. Р Е т I . gaz. 9.t. 5.f.6.

Polypremum. Lix s. Sys. veg. 153.

PER. Capfula parva, ovato globola, didyma, apice comprefla, bilocularis, bivalvis. Diflepinentum valvis contrarium.

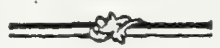

REC. oblongum, compreffum, fungofum, extremitate fua inferiori fepto utrinque affixum, cetera liberum.

SEM. uumcrofifima, minutifima, angulata, fubdiaphana, pallide fulphurea.

IN T. fimplex, tenuifimum, vafis reticulatum.

A \ . Scmini conforme, carnolum, fubpellucidum, pallidum.

Eмп. teretiusculus, rectus, lacteus. Cotyl. brevifinax. Rad. crafia, centripeta.

a.) Capfulie in axillis foliorum feftiles. A. B. ) Capfula calyce vefita \& denudata. C. D.) Receptaculi figura \& inferio. e. E.) Scmina feparata. F.) Albumen trausverie setum, cum fitu embryonis in medio. G.) Embryo feparatus. 


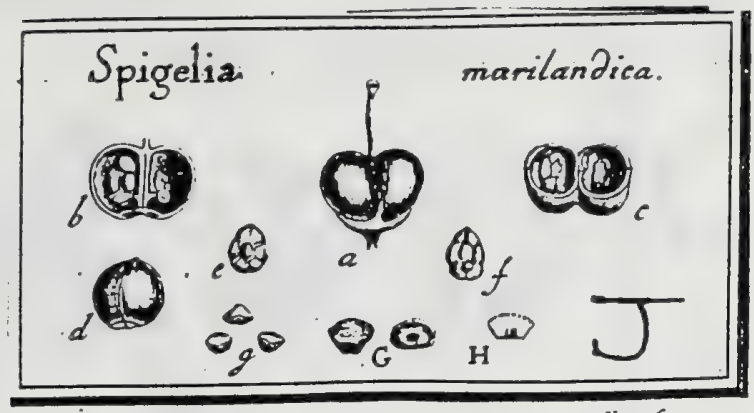

Sorstrouverse.

\section{J. Gaertnet (1788) Vol3}

\section{S P I G E L I A.}

LINN. gen. 209. ed. Schreb. 272. Ju'ss. gen. p. 143. LaMABCK

$$
\text { ill. gen. t. 107. Arapabaca. Plum. gen. t. } 3^{\text {r. }}
$$

Cal. inferus, quinquepartitus, perfiftens. Cor. monopetala, infundibuliformis; tubo longo, ad faucen fenfin increfcente; linbo quinquefido, patente. Stam. quinque; filamentis filiformibus, corolla brevioribus; antheris fagittatis, non exfertis, conniventibus. Ovar. fuperun, Ityio fimplici, tereti ; ftigmate fimplici. Capfula didyma, bilocularis, quadrivalvis. Rec. Jiberun, e diffepimento pedicellatum. Scm. plura, fubcuneata. Alb. carnofuns. Emb. . . .

Spsgelia marilandica. Tab. 198. fig. 10.

Periclimeni virginiani fore coccineo planta narilandica, fpica erelfa, folis com - jugatis. RAj. dendr. 32. CATESB. carol. 2. p. 78. t. 78 .

Lonicera (marilandica,) Jpicis terminalibus, -foliis ovato-oblongis acuminatis diftins is festibus. LiNx. Spec. pl. ed. 3. p. 249.

Spigelia caule tetragono, foliis omnibus oppofisis. LIN s. fyft. nat. ed. 13. T. 2. p. 734. Mlant. p. $33^{8}$. Sy.t. veg. ed. 14. p. 197. W'ILLD. Spec. pl. T. 1. P. 2. p. 825. PERSOON Jyn. pl. s. p. 28 r.

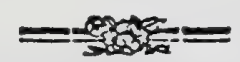

Icon. Hopz alt. edinb. 3. an. I7Z7. t. I. CURT. mag. t. 212. Ex collectione Cel. Desfontaines.

PER. Capfula fupera, calyci perfiftenti infiftens, coriaceo-membranacea, fubglobofa, turgida, fulco profundo didyna, transverfim latior, per ambitum fulco elevato cincta, bilocularis, quadrivalvis. Diffepimentum membranaceum, tenue, duplicatum, ex ipfis valvulis formatun, \& medio cum ipfis fenfu duplici dehifcens.

REc. in quovis loculo fingulum, fungofum, oblongum, papillofum, inferne in breviđimum pedunculum attenuatum, \& paulo fupra bafin diffepimento utrinque affirum, cxtera undique liberum, verticali-adicendens, relicto denique foraminulo per maturitatem e diffepimento deciduum.

SEM. plura, octo ad duodecim in quovis loculo, umbilicis fuis receptaculi papillis adhærentia, \& fibi invicem preffe approximats, dorfo rotundata, cxterum angulato - cuneata \& ad curpidem truncatum umbilico parvo inftructa, eminentiis minimis inxqualia, fpadicea.

I v T. fimplex, crafiufculum, membranaceum.

A \& B. femini conforme, carnofum, album.

E $\mathrm{MB}$. . . .

\section{EXPLICATIO FIGURR.}

2.) Capfula integra, non debifcens. b.) Eadem per valvulas ad latitudinem verticaliter dilfe\&z, enm fitu receptaculorum atque feminum. c.) Ejusdem fedio transveríalis. d.) Capfula loculamentum alterum, debifeentia ab altera feparatum, \& a dorfo (pectatum. e. \& f.) Semina in Iitt \& adhuc receptaculo adbzrentia, ab utraque paric fpectata. 8. G.) Eadcon fepzrat2. H.) Albaminis feltio verticalis. 


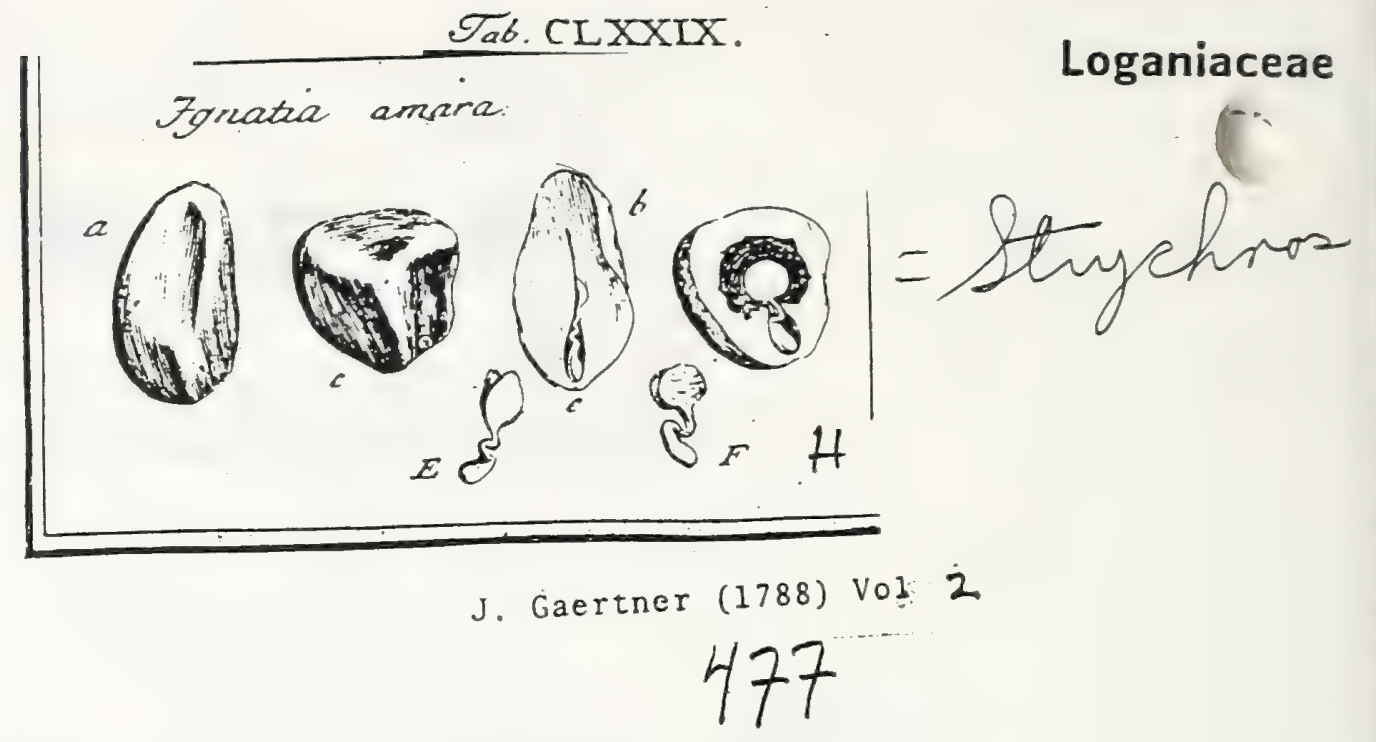

I G N A T I A. LINN. gen, I370.

IgNATiA anıra. Tab. 179. fig. 8.

Fubar St. Igratii. Drfic.

PER. Bacen pyriformis, unilocularis, polyfperma, cortice lignofo. (Limn.)

REC. . . . nullum? femina nidulantia aut parieti affixn?

SEM. plura, grandiufcula, difformia: alia (centralia?) oblonga, obtufiffime angulata; alia (parietalia?) breviora, quadrilatera: Jatero uno majore convexiufculo; thibus reliquis planis, triaugulis, in pyramidem obtufift. mam convergentibus. Color omnibus fordide fufcus aut fumofus; fuperficies rugis minutiflimis fcabrata; \& Umbilicus perforatus in margine aut in bafi.

IN T. fimplex, tenue, absque ullo villorum veftigio, albumini arctifime aduatum, ut ne fcalpendo quidem feparari pollic.

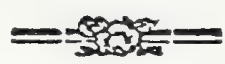

A L 8. corneum, durifinum, aut in aliis cartilagineo - coriaceum, ampla avi tate compreifa pro cotyledonibus exfculptum; cetera vel album, vel refina liquida fufca ita impragnatun, ut sunc totum, nunc folummodo juxa peripheriam, \& nunc in folo cotyledonum loculamento, colore nigro. imbutum fit.

EM 8. Iongitudine dimidii alburninis, lutefcens. Cotyl. omnium tenuifimz, orbiculatx aut ovato-lanceolatx, in petiolum definentes! Rad. clavata, extrorfum infigaiter incraffata, furfum vero attenuata \& conftanter Bexuofa.

a. b.) Semen centrale integrum \& difTeaum. c. d.) Semen parietale integrim \& difletam e. E.) Embryo feminis centralis. F. F.) Idem feuninis parictalis.

Ignatiam cum Strychno conjuxit Cl. JUSSIEU; nec carpologicum difcrimen inter hac genera admodum grande eft; nifi fint cotyledones petiolatx, quas, prxter Ignatiam \& Gyrocarpum, non alia hactenus oftendit planks.

$1 / 8.4$ 

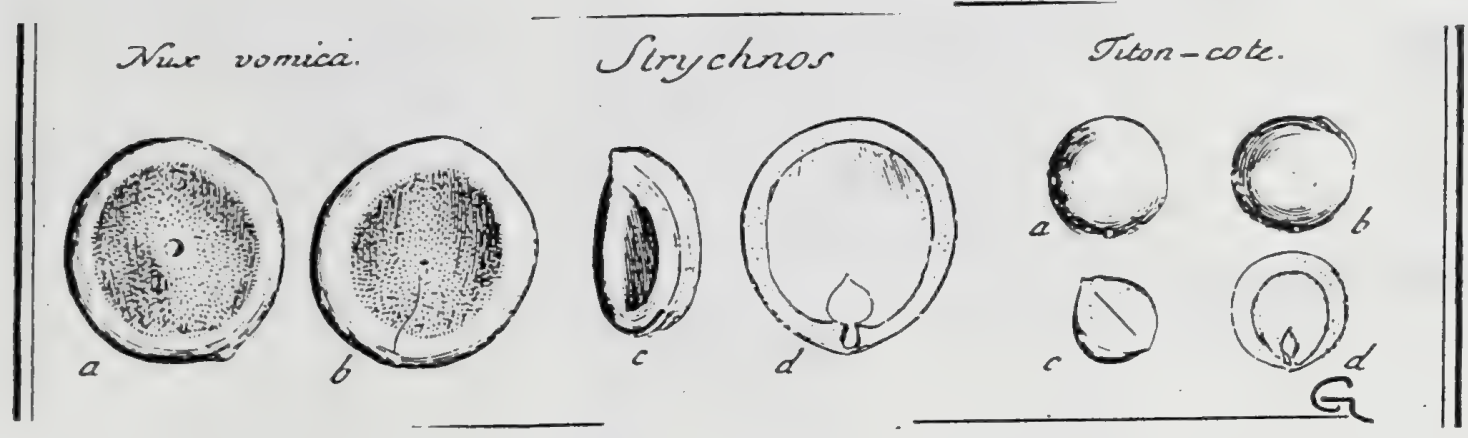

\section{J. Gaertner (1788) Vol $=2$;}

\section{6}

\section{S T R Y C H N O S. LINN. 'gen. 253 .}

Strychos Nux vomica. Tab. 179. fig. 7.

Camivam. RHEED. mal. s. p. 67. t. 37.

Nıx vonica. BLakw. berb. t. 335. ex hort. malab.

Strychuos foliis ovatis, cante inermi. LIXN. fyf. veg. $2=7$.

P E R. Bacca unilocularis, cortice lignofo_ Limm.), aut cruftacco fingili ( Jul.).

REc. centrale. (JuIf.)

SEM. plura, orbiculata, compreffo-plana aut leviffime convexu-cuncava, femper autem in ambitu aliquantum turgidula \& in ipfa peripheria, acie anguftr, f. Atria annulari filiformi circundata, utrinque fovecla parva in centro notata, e ftraminco albicantia cum intermixto fplendurc fericeo. Umbilicus tuberculatus in margine feminis.

Is r. fimplicifimum, tenuiffimum, aretifime adnatum, undique villis breviffimis appreftis \& quafi inter fe conglutinatis tectum.

A IB. cartilagineum, duriffimum, album, intus cavitate ampla, plano-comprelli, fere ad peripheriam usyue exfculptum.

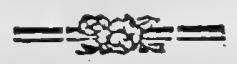

Eм в. loculamento fuo multoties minior, lacteus. Cotyl. cordate, acuminatx, tripiinervix, tenuifinax. Rad. clavata, breviufcula, ad umbilicum pofita, (fupera Juf.).

2.) Seminis latus conrexiufeulım, b.) Ejusiem pars concava c.) Albumen transverfe dideQume.

d.) Ejusden cavitas aperta cuas fitu \& figura enbryoais naturali.

Struchnos Titou - cote. ibid.

E Madagafcar. A Sereniff. Principe CdROLINA March. Bad.

Semina fubglobofa (a. b.) vel turgidiffme lenticularia, margine acuto (cs) anguftifimo in ambitu cincta, e ftramineo pallida absque ullo fplendore fericeo. Integum. ex villis conglutinatis, vix difcernibilibus. Albumen (c. d.) corneum, album, cavitate plana amplifima intus exfculptum. Embr. (d.) parvus, licteus. Cotyl. ovato - lanceolatx. Rud. brevis, extrorfum crnffior.

His fimillina \& alia femina, ab eadem Serenifr. Principe, cum nomine Makau-cojennia accepi, quæ nulla confpicua nota \& ne colore quidem aut magnitudine a prioribis differebant. Utrum igitur hac, mera fint priorum varieras, \& utrum alterutra eorum ad St. potatorum L. fpectent, aliis enodandum relinquo.

Aliro modo canum cadavera rigefcunt, qui Vomica nuce interficiuntur. Anne vero idem quoque in pifcibus eveniat, qui hoc pharmaco capiuntur, non reste memini. 


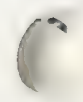

$\ell$

1 


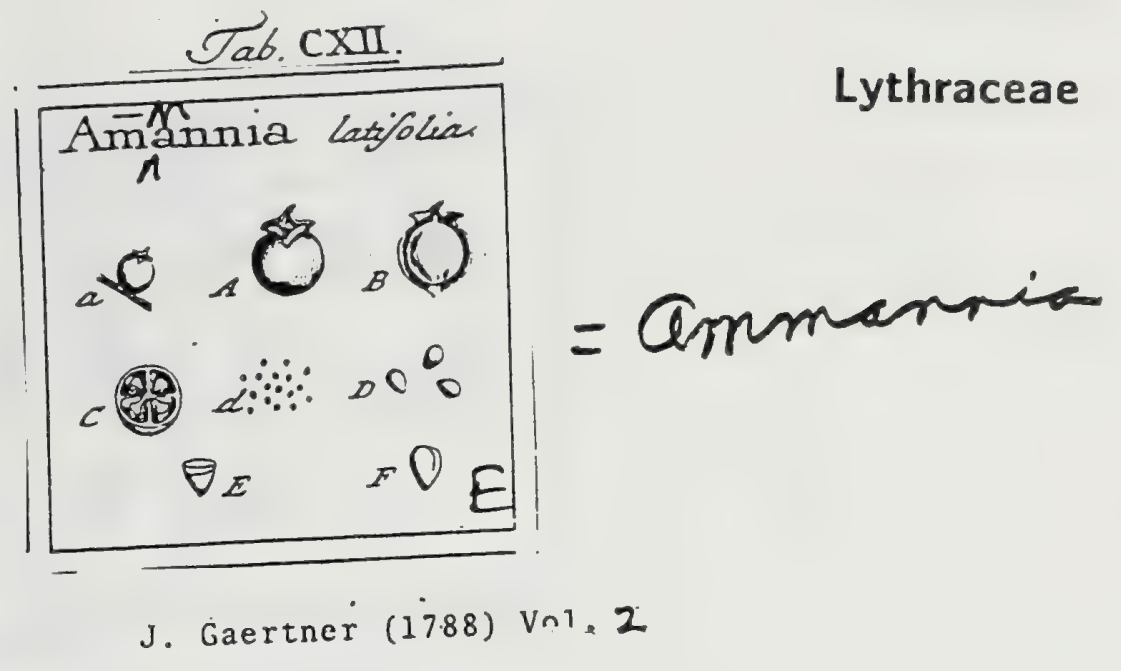

142

DCL. A M M N N IA. LINN. gen. I55.

Calyx campanulatus, octo dentatus, perfiftens. Cor. tetrapetala, aut nullit. Stam. quatuor, aut oeto. Ovar. fuperum. Styl. Gimplex. Bacca quadrilo. cularis, calyce veltita. Sem. numerofa.

Amsinnia latifolia. Tab. II2. fig. 5.

Aparines folio anomala, vafaulo feminali rotundo, femine minutifimo. Stoss. bijf. jam. I. p. 44. t. 7 . f. 4 .

Aumanuia foliis Jemiamplexicaulibus, caule tetragono, ramis erestis. LiNx. Jyft. veg. 162 .

Ex herbario Bankfiano.

PER. Bacca calyce perfiftente in Sphxram ampliato atque apertura fua in marginem erectum, edentulum, plicato-quadricornem contracto veltita, fubglubofa, fanguineo - rubra, mollis, quadrilocularis. Cortex \& diffepi-

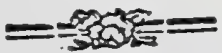

menta nembranacea, tenuia. Pulpa per maturitatem evanefcens, \&, precter carnofam receptaculi fubftantian, in adulto fructu nulla.

REC. quadrilobum, axi affixum, lobis verfus peripheriani baccx rotundatis, cralliufculis, verfus centrum autem cunciformi-comprefiss, carnofis, fanguinęo rutilantibus.

SEM. numerofa, parva, ovata, hine convexa, inde fxpius plana, aut angulata, fublplendentia, nec tainen layigata, luteo-fpadicea.

IN T. Finplex, fubcoriaceum, tenue, intus fubcarnofum.

A LB. nullum, prater laminam tenuifiman carnofam integumenti.

E в в. femini conformis, albus, fubpellucidus. Cotyl. ovatx; carnofx. Rad. conica, brevis, centripeta.

2. B.) Baeca ealyce obteta. B.) Eadem denudata. C.) Ejusdem fectio transverfalis, d. D.) Semisa feparata E) Semen transverfe (cetam. F.) Embryo deaudatus. 
Lythraceae

TabxuIV.

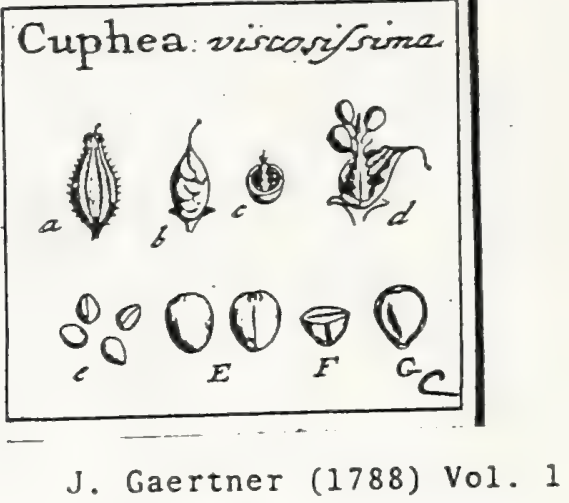

210

CCLV. CUPHEA. BROWN.

Calyx mbulorus quinquedentatus. Cor. pentapetala, calyci inferta. Stam. decena 1. dondecisls. Styl. unicus. Capfula unilocularis, evalvis, a receptaculo feminua giand facto rumpenda. Semina erecta.

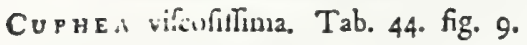

Jenn iace. hort. 2. t. 177 .

Lythrum foliis oppofitis petiolatis ovato oblongis fcabriusculis, floribus dodse

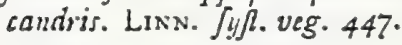

Ex horto regio Kewenfi.

PER. Capfula fupera, calyce veftita, ovato acuminata membranacea, tenuifuma, pelhucida, alba, a protuberantibus feminibus nodulofa, unilocularis, evalvis, de mum a procrefcente receptaculo itrcgulariter rumpenda.

REc. columnare, liberum, rigidum, cartilagineum, divifum in ramulos Jaterales fil; formes erecto patentes, femina fuftinentes.

SEM. pauca, ad decem, ovato rotundata, lenticularia, in altero Jatere linea recta in mi nutifimam verticis carunculain definente notata, teftaceo- fufca.

Ix T. duplex : coriaceum \& membranaceum; utrumque tenue.

A I B. nullum.

E s в. magnitudine feminis, erectus, lacteus. Cotyl. ovatz, fubcordatx, compre $\mathbb{I}_{x}$; carnolx. Rad. acuminata, brevis, infera.

2.) Capfula vefuita calyee nervis decem vifcofis villofis friato. b.) Eadem denedata. c.) Ejus fêtio transverfalis. d.) Kecrptac. maturum elongatum. e. E.) Semiua leparaia. F.) Sema. transverie fettum. G.) Idem longitudiuauter apertum, cum fitu \& figura enibryonis.

119.2 

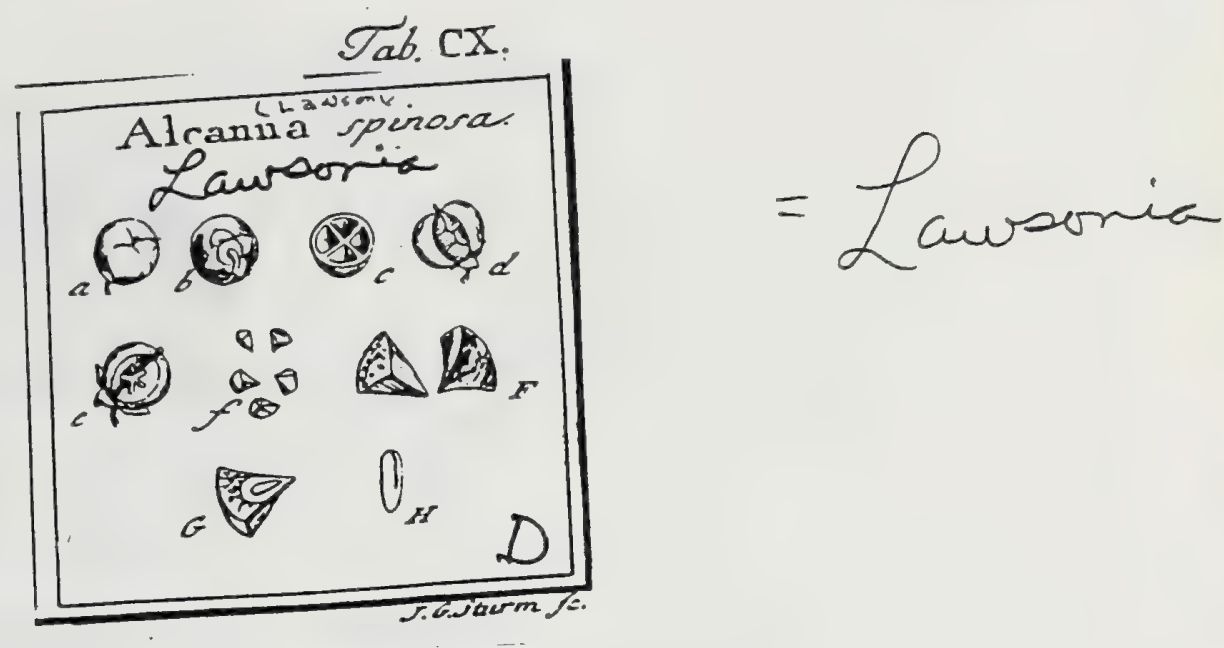

J. Gaertner $(17.88) \mathrm{Vn}^{1} \cdot 2$

133

DCXXXIX. ALCANNA. OfFIC. Lawlonia LINN. gen. 482.

Calyx quadrifidus, perfiftens. Cor. tetrapetala. Stam. octo. Ovar. fuperum. Styl. Gimplex. Bacca-ficca, quadrilocularis. Sem. plura, fuberofo corticnts.

alcanna Spinofa, Tab. I10. fig. 4.

Alail - anfcbi. RHEED. mal. I. p. 73. \&. 40 .

134

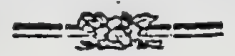

Cypris. RUMPH. amb. 4. p. 42. t. 17. apte.

Lanfonia ranis Jpinofis. LINN. Jy/t. veg. 562.

PER. Bacca ficca, globofa, apice depreffiufcula, ftyligera, obfolete quadrio fulca, fubcoriacea, temuiș, melina aut ochracea, quidrilocularis.

REC. parvun, fpongiofum, in angulis loculamentorum internis ex centro fructus efflorefcens, \& in brevifimos funiculos umbilicales divifum.

SEM. in fingulo loculo quinque ad noven, varie angulata, introrfum pyramidato - acuminata, ferruginea, fuberofo - corticuta.

INT. triplex: extimuin fungofum aut fuberofum, craffifimum ; medizms crufticeum, durum, albun, uvato acuminatum, , extcriori dimidio brevius \& angultius; intimum membsanaceum, tenuilininum.

$\Lambda$ L B. nullum.

E D1 B. cavirati teftxe feminis conformis, f. teretiufculus, lacteus. Cotyl. femicylindricx, longiufculz. Rad. brevis, centripeis.

2. b.) Basca integra c.) Ezdem difTêta. d.) Scmiua intra loculrmentum, ecu lapides pavinicnti, fibi mutuo junea. e.) Keceptac. centrale ex funiculis umbilicalibus fafciculatis. f. F.) Semina feparata. G.) Semen longitndinaliter diffectum, integumenti fuberofi, cruffacei \& membranacci formam oftendens. H.) Embryo folutus \& ançus.

Cum pericarpium, quocunque nodo preffum, in regulares valvulas non fecedat, illud tanto magis ad baccas ficcas referendum cenfeo, quod \& nonnunquam coloratum fic, $\mathbb{\&}$, tefte Rheedio, femina pulpa acidula circumfufa fint. 


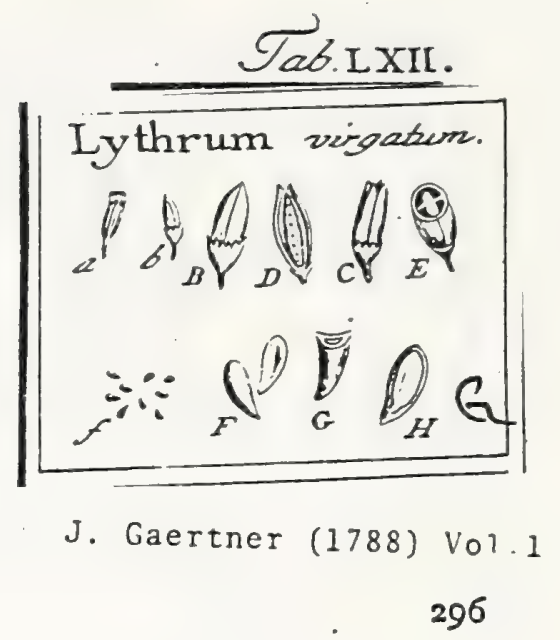

CCCLXXY. LYTHRUM. LIN gen. 670 .

Calyx monophyllus cylindricus, fex -1 . duodecin dentatus. Cor. hexapctala, calyci inferta. Stam. fex l. duodecim, c calyce oriunda. Styl. unicus. Caplula bilocularis. Receptac. adnatum. Scmina numerofa.

LY т н К U $M$ virgatum. Tab. 62. fig. 5 .

Lythum foliis oppofitis lanceolatis, panicula virgata, floribus dodecandris ternis. LiN N. Ji/f. veg. $44^{6}$.

Icon JACe. flor. auflr. 2. t. 7 .

PER. Capfula parva, ovatu ublonga, aut teretiuscula, obfolete bifulca, bilocularis, bivalvis: valvis maturis lape bifidis. Dilfepimentum valvis contrarium.

REC. lineari oblongurn, convexum, fungofum, fupto utrinque arcte adıatum.

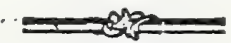

SE м. numerofa, parva, ovata, verfus umbilicum valde attenuata, hine convexa, inde plana, glabra, pallide lutea.

IN T. duplex: exterius membranaceum tenue; interius fubcoriaceum, fuperficie interna carnola.

A ¿ B. nullum, prater integumenti laminam internam camofam.

EM B. magnitudine fere feminis, lacteus. Cotyl. oblongo ellipticz, plano convexz. carnolx. Rad. teretiuscula, brevis, centripeta.

a. B. C.) Caplula calyce vertita \& denudata. C.) Fadem dehifcens. D. E.) Receptacull figura \& inlertio. f. F.) Semina leparata G. H.) Semen transverfe \& longitudinaliter diffetum, cum figura \& fitu embryonis.

$1 / 9.4$ 


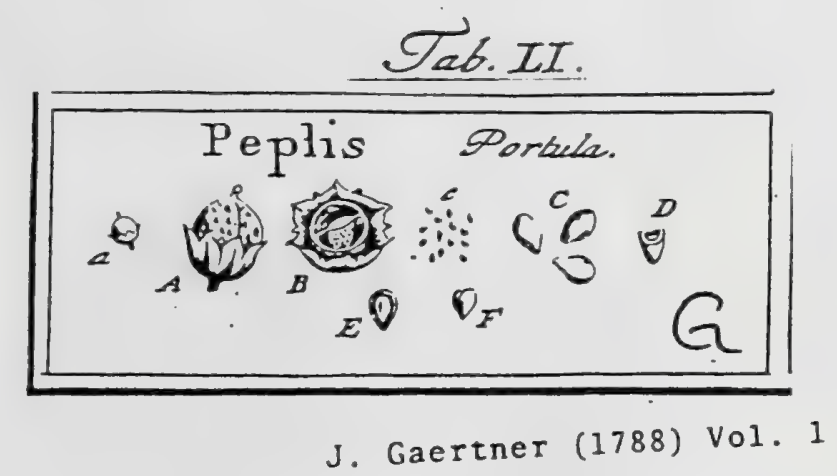

CCXCI. PEPLIS. LIN gen. 446.

Calyx campanulatus, duodecimdentatus: denticulis intercalaribus minimis. Cor. hexapetala, aut nulla. Stam. fex. Styl. onicus. Caplula fupera, bilocularis.: Semina numerofa, plano convexa.

PEx lis Portula. Tab. 51. fig. 4 .

Glaux altera fubrotundo folio. V A 1 L. paris.t. 15. f. 5. O E D E R. Jlor. dan. t. 64.

Peplis petalis fenis, fappij]me apetala. HА L. hif. I. n. 856 .

Peplis foribus apetalis. LIN N. J4ת. veg. 345 .

PER. Caprula parva, globofa, membranacca, tenuifima, z-protuberantibus feminibus nodulofa, bilocularis evaluis. Diffcpimentum niembranaceum, fulco capfulze extcrno refpondens.

Ne c. carnofum, fubrotundum, comprefíusculum, fepto utrinque adnatum.

SEM. numerola, circiter niginta in fiugulo loculamento, parva, obovato-acuminata, binc convexa, inde plana, pallida.

IN $T$. duplex : exterius membranaceum tenuifinum; interius albicans fuperficie interna caruola.

A L 8. nullum, prxter carnofain fupcrficien integumenti interni.

Exs. magnitudine fere ferninis, albus. Cotyl. ovatx, compreffx. Rad. acuminata,
breviluma, centripeta. a. A.) Capfula calyce excepta. B.) Fadem difrela. c. C.) Semina feparata. D.E.) Semen tranis
verie \& longitudinaliter diffe\&lum. F.) Einbryo (eparatus. 119,5 


\section{Liriodendrum. Tulipifera.}
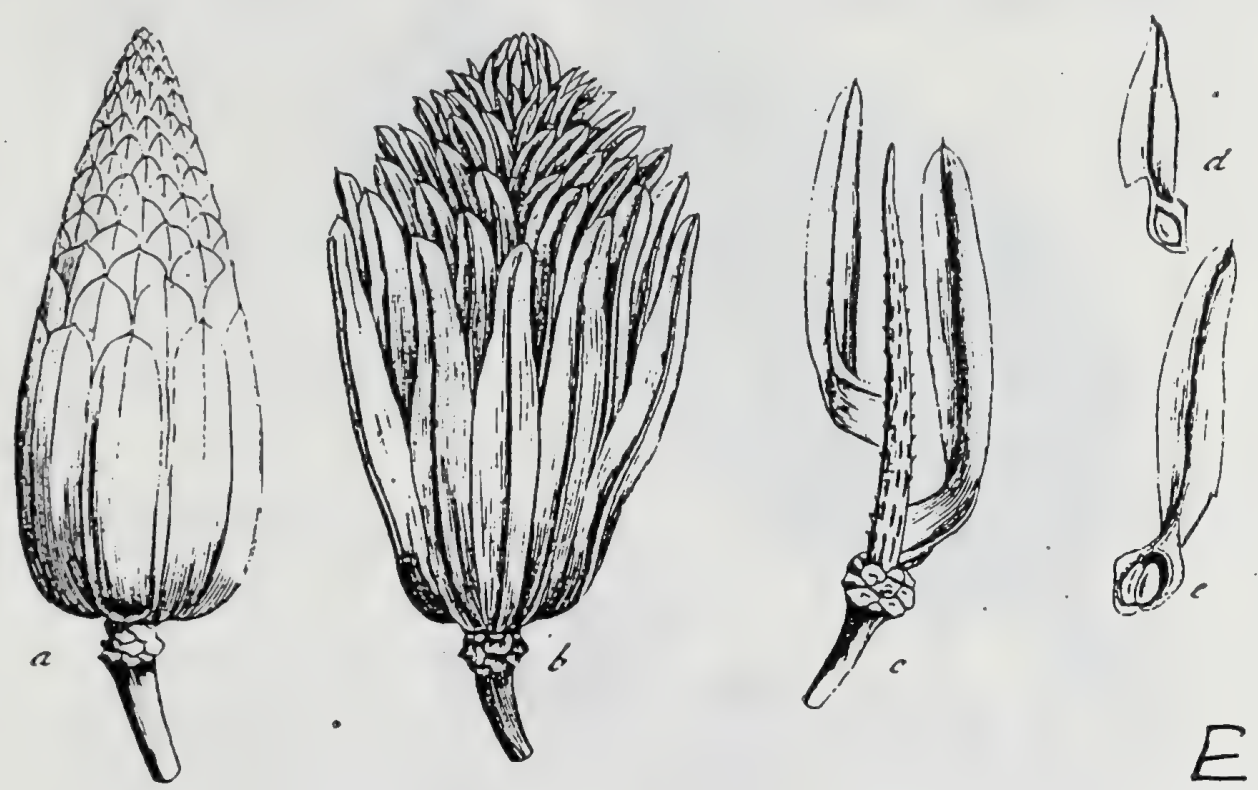

J. Gaertner (1788) Vol. 2 ;

\section{L I R I O D E N D R U M. LINN. gen. 6\$9.}

Calyx exterior diphyllus deciduus; interior triphyllus corollxformis. Cor. hesaperala, in campanam connivens. Stam. numerofa. Ovar. numerofa ill conum digefta, ftigmate fefflit. Samarxe uniloculares, I - 1. 2 fperınx, in Itrobilum collear

LIRIODENDRUM Tulipifera. Tab. 178. fig. S.

Tulipifera virginiana. Herm. lugdb. t. 6rz. Catesb. carol. x. \$. 48. Seligx. กง. $t .96$.

Liriodendrum foliis lobatis. EHRET, dec. t. so. LIN̦. fyfo zeg. 507.

\section{6}

Fк чст. Atrobilaceus, ovato-conicus, ex famaris furfum inbricatis.

PER. Samara coriacea, fuperne in alam lanceolatam aut ovitu-oblongam atque rigidulam producta, inferne autem incrallita in uncum introrfum intexum, comprelliufculum, fuberofum, rugofuin, unilocularem, evalven, cultro tamen facile verticaliter bipartibilem. Loculamentum lamina propria carm tilaginea lacvigata veftitum.

REC. commmene fubulatum, Scrobiculatum, fubvillofum; proprimm, funiculus umbilicalis filifornis, intra famarx alam ab ejus apice ad loculamentum" defcendens, ibique vel finaplex, vel bifidus, femina pendula fultincus.

SEM. folitaria in famaris fuperioribus, E confanter gemind in inferioribus, ovata, lenticulari - cumpretia, glabra, fublucida, gilva.

Is T. exterius cruftaceuin aut chartaceum; interius . . . .

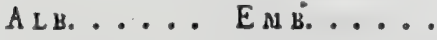

2.) Conus imnaturus e Carn!tta. h.) tlius ex hort. untan. Tigurino, jum jan dehiftens.

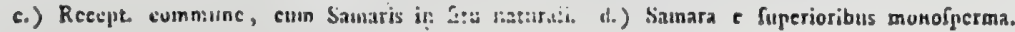

c.) Alis ex inferioribus difperma.

Supra quingintas Samaras diffecui, nec in unica mihi hactenus contigit reperitle fenen focundum. Limn:cus :ribuit Liriodendro cotyledones convo-

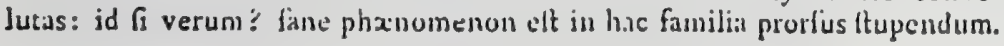




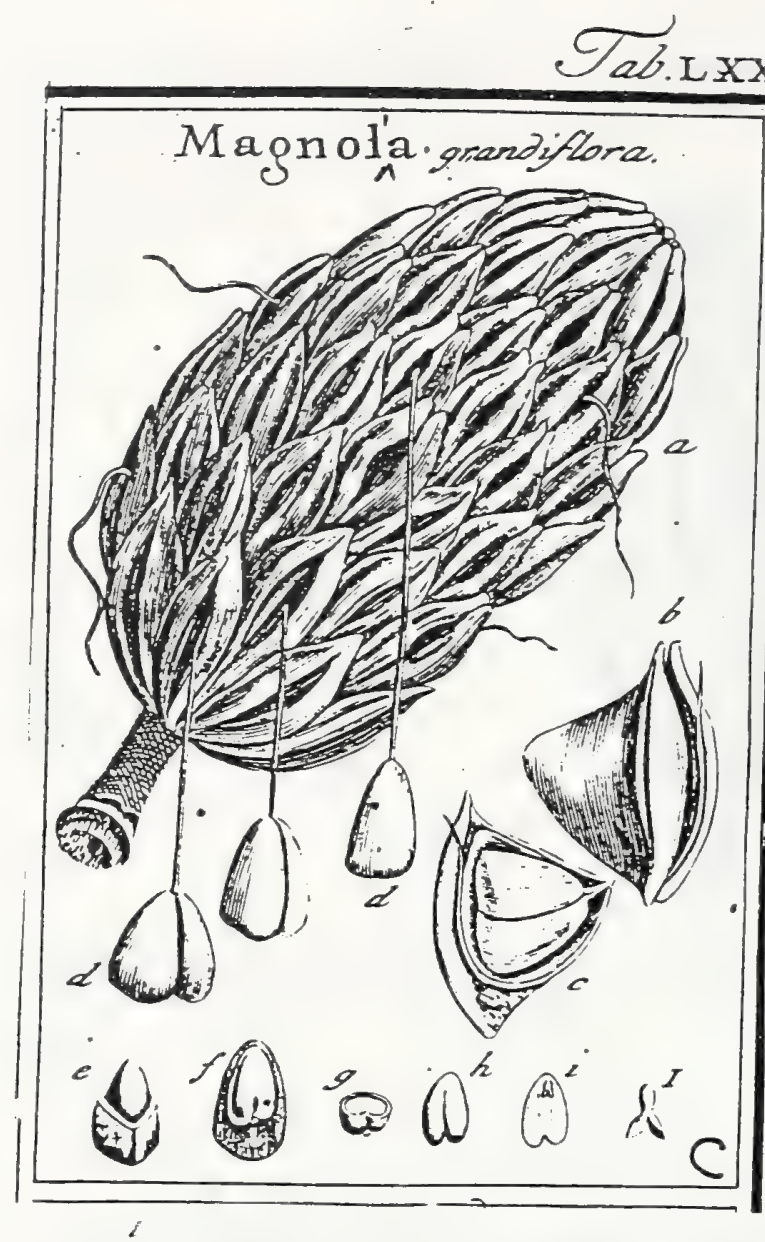

CCCCXLiI. MAGNOLIA. PI u m. gen. t. 7. L IN s. gen. 690.

Calyx triphyllus. Cor. enneapetala. Stam. plurima. Styl. plures. Ovaria bilocularia, difpernia. Capfulx maturx uniloculares, bivalves. Semina baccata.

MA G Nol i a grandilora, Tab, 7o. fig. 5 .

Magnolia naximo flore, foliis fubtus ferrugineis. Eн в Е т. diccad. t. 33.62.63.

Magnolia foliis lanceolatis perennentibus. L I N N. Jiff. veg. 508 .

PER. Capfulix plurimx, in fructum frobiliformem difpofitx, triangulx, cuneiformi comprefrx, coriacex, uniloculares, latere exteriori incraftato, fuberofo, pubefcen. te, dehiscentes. Loculamentum propria membrana chartacea veflitum, \& ad marginem fuum inferiorem atque anteriorem, ftylo perfiftente \& in lignofain fe. tam converfo, fipaturn.

REc. commane longum, teretiusculum, capfulis verticaliter pofitis undique tectum; proprium: funiculus umbilicalis fuliformis, demum omnum longiflumus, ex intimo caplulix angulo oriurdus.

SEм. regulariter gemina, rarius folitaria, parabolica, plano-convexa aut obfolete angulata, baccata, coccinea.

IN $\mathrm{r}$. triplex : extimum carnofum, in fetninis extremitate obtufa, crafifimum; medium fuboficum f. cruflaccum, tenue, orato cordatum, lenticulari compreflum, glabrum, tefaceuin, portione carnofa inulto brevius; intimum membranaceum, renuifimum, fpadiccum.

AL в. Seminis crufaceo integumento conforme, carnofum, duriusculum, album.

Е ห в. parvulus, rectus, lactcus, in anguniori albuminis extremitate locarus. Cotyl. breves, nvapo acuminatx, lubfoliacez. Rad. teretiuscula, globole incraftata, inum cap?ulx fundun refpiciens f. infera. refera. fo, Eadem Jongitudinaliter difcifa, cum fitu $\&$ figura eff Portio feminis carnofa fapera. feftum. h.) Albumen denudatum. 1.) Situs Embrjonis in albumine feminis. 8.) Semen transrerä 

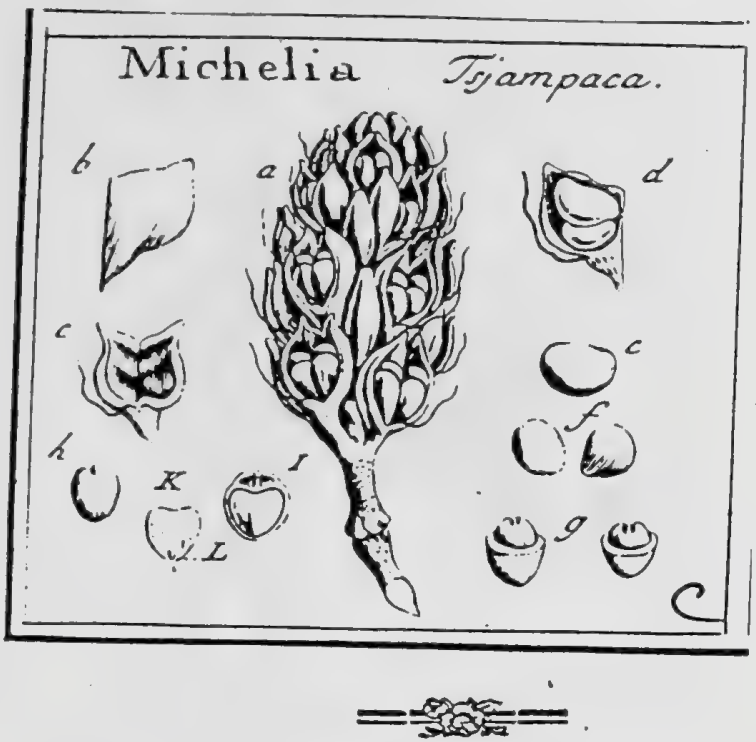

\section{M I C H E L I A. LINN. gen. Ggr.}

Culyx triphyllus. Cor. polypetala, petalis exterioribus majoribus. Stam. numerofa. Ovar. plura, in fpicam digefta. Styli totidem, capillares, intra futuran dehifcenten delitefcentes. Capf. plures, molles ut quafi

- baccatx, uniloculares, femibivalves. Sem: baccata, a duobus ad ofto.

\section{Mischelia Tsjampaca. Tab. 137.:fig: 4}

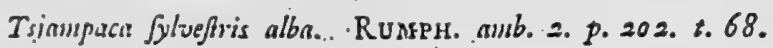

Michelial evorymoides foliis ovatis. "BuRM. flor. ind. 124 .

Miclielia foliis ovato-lanceolatis. Lrsw. Syft. veg. 508 .

\section{$\Lambda$ Cl. Thunbergio.}

PER. Capfulx plures, in fpicam ftrobiliformem digefex, verfus axem, in acien compreffx, extrorfum vero turgefcentes in dorfum convexum; fuperne in mucronem breven productx, inferne in pedunculum quafi elongatx, ante plenam maturitaten carnofx, demun fubcoriaccx, molles, ex aurautiacorubiginofic, uniloculares, latere externo dehifcentes: interjecto future ftylo capillari perfiftente.

REC. commune teretiufculum, inferne nudum \& a ftaminum lapfu cicatriculis rhomboideis teffulatum, fuperne autem capfulis felfilibus tectum; proprious nullum; fed fernina, absque ullo funiculo umbilicali, angulo capfularam interno in fitu horizontali affuxa.

SE M. unum, vel duo (quatuor Kumpls.), ovata, lenticulari turgida, baccata, rubra.

INT. triplex: extimum carnolum, terrue, coccineum, arcte adnatum; mediun offeum, atrum, in vertice $\int$ regione umbilico oppofita, cavernula parwa, mucronem acicularem continente, exfculptum; intimus membranaceum, tenuilfimum.

A L B. cordatum, lenticulari-compreffum, carnofum, duriufculum, album.

Es B. minutifimus, fubglobofus, in bafi albuminis f. prope umbilicum locatas. Colyl. breviffimx. Kad. infera.

2.) Frnelus integer. b.) Capfula feparata, a latere (pectata. c.) Eadem dehilcens. d.) Ejusdem fectio longitudinalis, cum fitu femiuum horizontali. e.) Semen folitarium. f.) Semina gcmella. 5.) Integum, carnofum fuperne tefectum. h.) Tefta feminis penitns denudata. I.) Eadem langitudinaliter aperta, cum alhimine in Geu naturati. K.) Albumen verticaliter difrectum, cuns Ëmbrynne (I..) in cjus bafi.

Mlichelia itaque folo majori feıninum numero, neque id fatis conftanter, .atque pericarpiis nullioribus \& fubbaccatis a Magnolia differt. Videndum tamen quomodo fe habeat fabrica feminum in Nichelia Champirion, antequam totum genus expungatur: numerus enin folus heic nihil valet, quanduquidem ipfus etiam Magnolix ovaria fint tetrafperma.

In meo fructus exemplo ne unicam quidem cápfulam tetrafpermam, fed omnes vel mono-1. difpermas faltem deprehendi. Peccavi igitur, quod ex Rumes cavi, quod illa pinxerim in fitu erecto, qunstulerim; \& magis adhuc pec. ac fibi mutuo impolita, ficuti fig. $d$, quum •deberent effe horizontalis. 


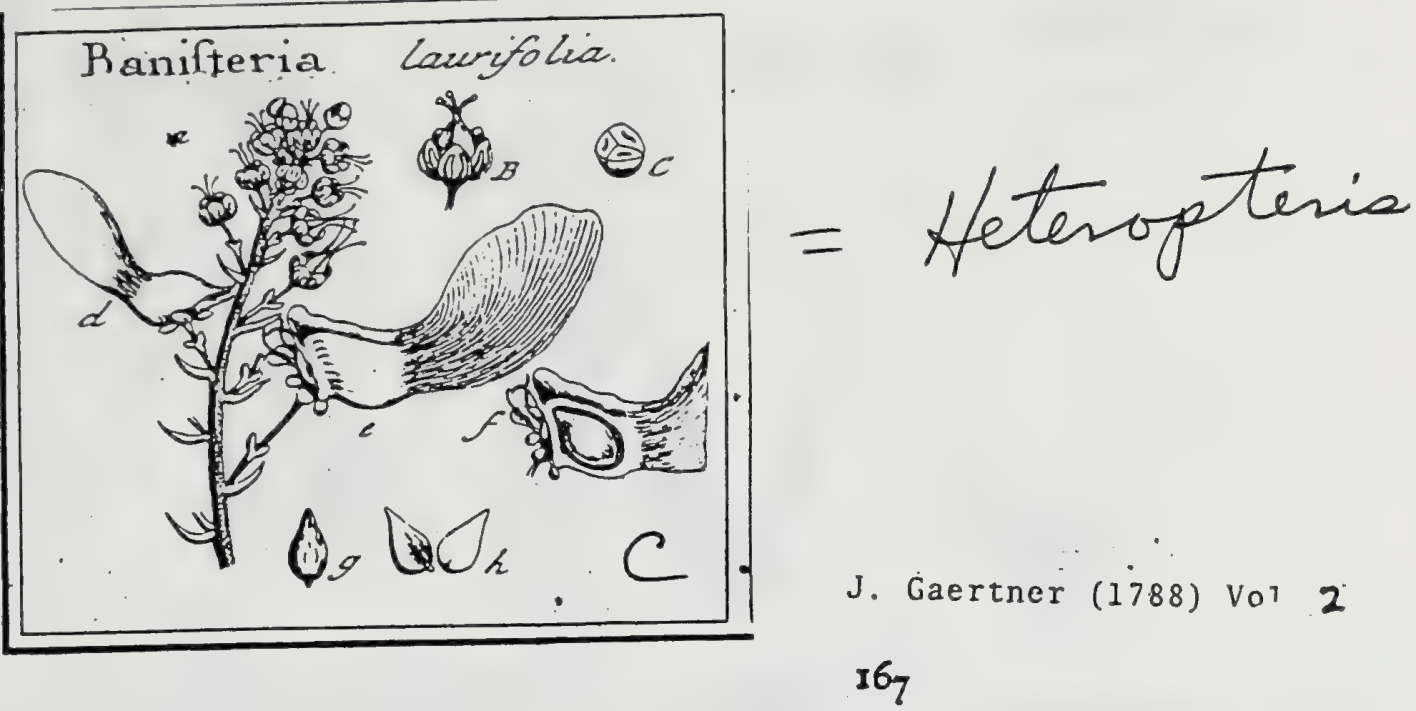

DCLXXX. B A N I S T ER I A. LINN. ğen. 573.

Calyx quinquepartitus : foliolis extus glandula gemina marginali. Cor. pentapetala, crenata, unguiculaca. Stam. decem. Ovar. tria, fupera. Styl. fimplices. Samarx tres: una tuntum adolefcente, uniadata. Embryonis cotyledones crafx , rectex.

Banisteria Jaurifolia. Tab. 116. fig. 2.

Banifteria folis ovato-oblongis rigidis, racemis terminalibus. L1sx. Ey/l. veg. 426.

Ex herbario BankGano.

PER. Samarx tres, e quibus unica tantum adolefcit, coriaceo-membranacea, ovaca, compreffiufcula, oblique decumbens, fericeo-fulva, antice perfiltentibus ftylis roftrata, fuperne crifta durfali ftipata, \& poftice ala membranaciea adfcendente terninata.

REC. nullum.

SEM. unicum, fubpiriforme, f. ex globofo ventre furfum valde acuminatum \& in oppofita extremitate parvo tuberculo terminatum, fufcum, aut fordide rufercens.

IN T. fimplex, membranaceum, renue.

A L B. sullum.

168

Es в. femini conformis, fuberectus, lutefcens. Cotyl. craffx; carnofx, planoconvexx, furfum infigniter acuminate. Rad. fubglobofa, exilifina, infera l: Atylo capfulic directe oppòfita.

2.) Pars recemi frugiferi. D.) Ovariz triz inmatura. C) Eadem trinsverfin diffefta. d.) Sacare immatura, introrfum tfietrpidata. c) Alis, matura, crifata. f.) Loculamentum apertum, eum fitu \& figura fewinis. 8.) Embrgo deaudatus. h.) Cotyledoser Separatz. 


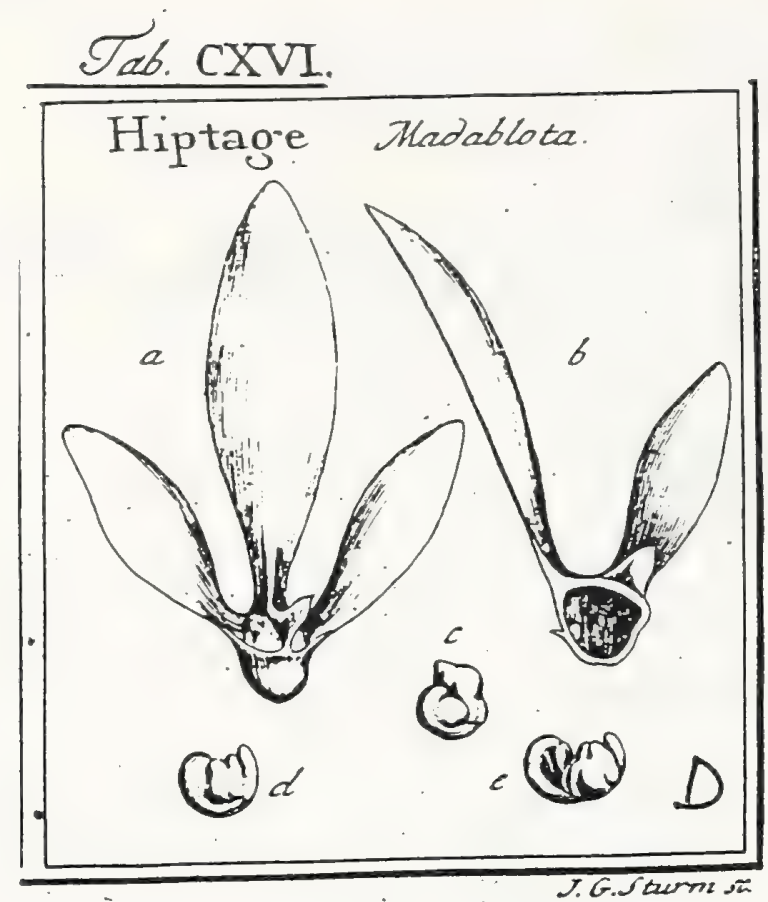

DCLXXXII. HIPT A.GE. Introd. p. I29. Gxrnera. Auglore Cl. SCHREB. gen. 735 .

Calyx quinquepartitus: foliolis extus unica glandula marginali Ptiputis. Cor. pentapetala, fubinzequalis, denticulata, unguiculata. Stam. decem. Ovar. unicum, fuperum. Styl. fimplex. Samara fubglobofa, fubquadrialata.

Hiptage Madablota. Tab. Ii6. fig. 4.

Sida-pou. RHERD. mal. 6.t. 59. fecundum Konigium, qui femina mifit.

Banifteria tetraptera f. Madablota. Sonner. it. ind. 2. p. 238 . t. r35. opt.

P z R. Samara fubglobofa $L$ inverfe parabolica, coriacea, tenuis, fpadiceo-lutea; ad latus, ftyli rudimenta notata; .. in vertice, crifta parva triangulari ftipata; \& in margine ipfo, tribus longiffmis alis coriaceis ovato lanceo. Latis munita, quarum media maxima.

R E C. nullum, prxter membranulam parvam, ftylo fubjectam, cui femen adhxret: SEM. unicum, reniformi-globofum, rugofun, gibbum, e ferrugineo-rufefcens. IN T. fimplex, nembranaceum, aridun.

A L B. nullum.

ENB. femini conformis, curvatus, albus. Cotyl carnofx, craftx, incifx, rugofx, conglobati, inxquales: interiori raulo minore. Rad. fubcylindrica, curva, fupera, $f$. verfus ftylum adfcandens.

a.) Captulus integra. b.) Eadem difrésa, cum rudimento Ayli atque receptaculi feminis. c.) Semea separatum. d) Embrgo deuudatus e.) Cotyledones paulo ab invicem didueta

$$
121.2
$$




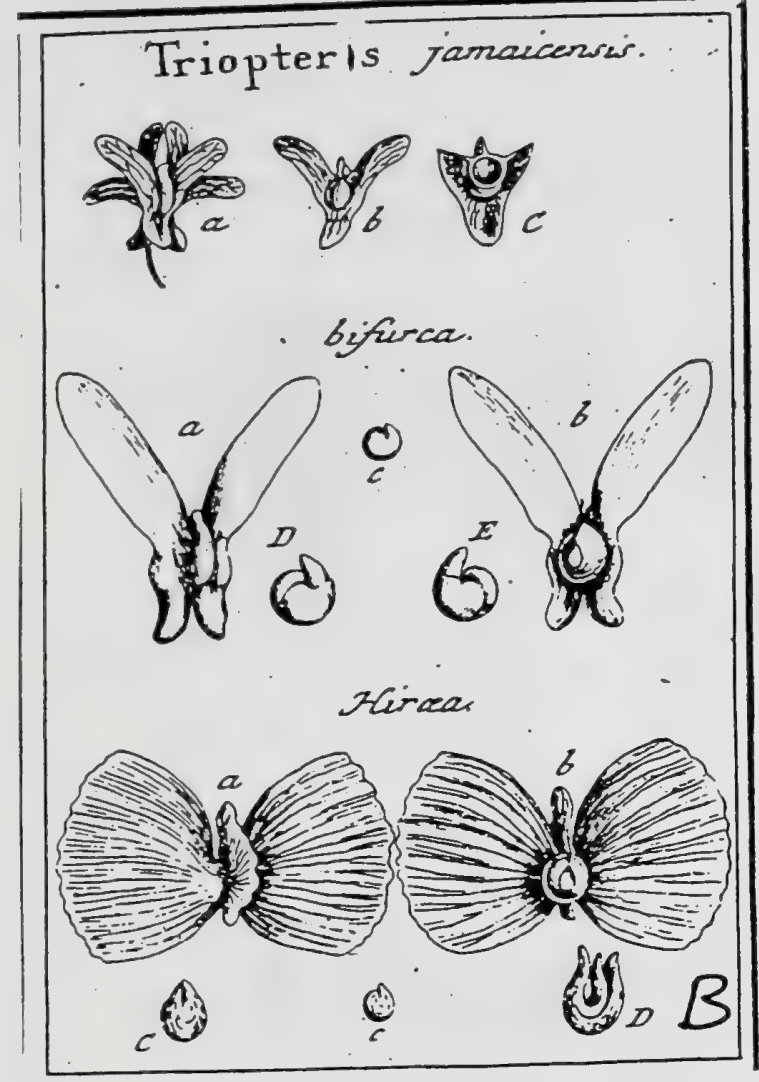

J. Gaertner (1788) Vol. Z

168

DCLXXXI. TRIO P T ERIS. LINN. gets. 574.

Calyx pentaphyllus. Cor. pentapetala, ungibus longis. Stam. decem. Ovar. tria, fupera. Styl. fimplices. Samarac tres, globufic, trialitic. Embryonis cotyledones crufix, curvatx.

ThIOPTERIS jamaicenfis:- Tab. 116. fig. 3.

Tiriopteris. Lins. Jyft. veg. 427 .

Ex herbario Eankfiano.

PE R. Sumare tres, fubglobofx, coriacex, dorfo trialatx. Ala inedia, angufta, lineari-oblonga, Jateralibus triplo brevior; laterales nembranacex, inferne in ligulam fimplicem, oblongam contuentes, fuperne vero divaricatz \& ovato - oblongr.

REC. nullum.

SEM. unicum, fubgiobofum, rubro-fufcum.

IN T. fimplex, membranaceum?

ALB..... ENB,.... forfan ut in fequenti?

a.) Samarx tres, in fitu naturali, pedunculo filiformi irnixx b.) Sanara feparata . \& a iatcre fuo vertrali fpectata. C.) Eudeat difieta.

TRIOpteris bifurca. ibid.

Ex herbario Bankfiano. Habitat cum pracedenti in Jamaica.

Samarx (a. b.) tres, globofre, precedentibus quadruplo majores, trialare. Ala media angufta, breviffina; dux laterales longifimx, fuperne atque inferne a fe invicem feparate atque leviter divaricatx. Somen (c.) reniformi globofum, rubro ferrugineun.

INT. duplex: exterins fubfurfuraceum, fieculan rubram, inftar feminum Orellanx, in aqua deponens; intcrius membranaceum, tenuilfimum, pallidum.

$A \subset \dot{B}$. nullum.

Eм в. femini conformis, curvatus, pallide albicans. Cotyl. carnofic, craffa, rinis vario modo incifx, corrugatx, conglobatx. Rad. cunica, crafia, curva, fupcra, fo apice fuo ftylum capfula refpicicns.

Itro Tropteris Hirxa. ibid.

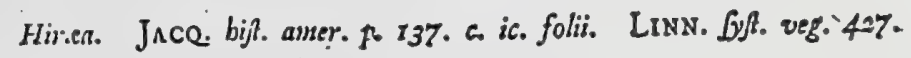

Ex herbario Bankfiano.

Samarx tres (a. b.), globafx, coriacex, tenues, trialatx. Ala media oblonga, angufta, repanda; dux laterales maximx, ex anguftifima bafi in amplam Jaminam rotundatam laxatx, Papilionis alas referentes. Semen (c. C.) ovato-globofum, furfum acuminatun \& quafi roftellatum, lineolis depreffis abruptis rugtium, ferrugineo rubrum. Integ. fimplex coriaceum, tenue. Alb. mullum. Embryo (D.) uncinato-curvatus, gramineo-viridis, profundis rugis exaratus. Cotyl. carnofie, craffx, extrorfum zcumiuate, curvatz, plano - convexx. Rad. tereti-acuminata, curvata, fupera. 


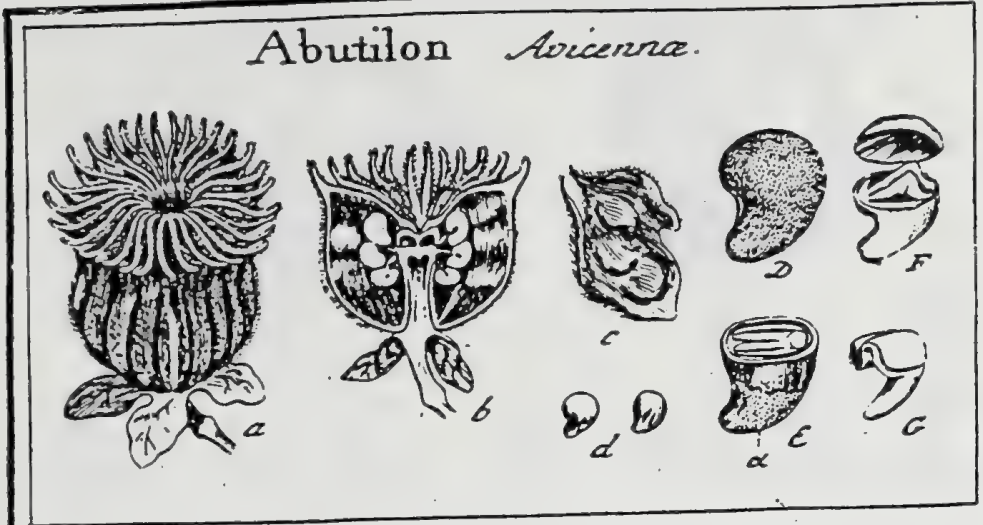

\section{A B U T I L O N. TOURN. t. 25 .}

Calyz fimplex, monophyllus, quinquefidus. Cor. quinquepartita. Sam. plurima; in tubum connata. Ovar. plura. Styl. nuultifidus. Capfo plures, in orbem pofitx, valvatex. Sem. pauca.

Asutilon Avicenux. Tab. 135. fig. I.

Abusilun. CAM. epit. 668. BEsL. Eyjl. afitiv. VI. t. so. f. $I$.

Abutilon folits tomentofis cordutis petiolutis, foliquis bicornibus. HaLl. bif. 11.1075. Sida foliis fultrotsusdo cordatis indivifis, pedurculis folio trevioribus, capfulis mudtilocularibus: corriculis bifidis. LiNs. fyjt. veg. 622.

PER. Capfulx plures, vicenx \& ultrn, in orbem pofitx, membranacex, comprellix, villofx, nigricantes, inferne anguftiores, fuperne latiores, quafi repando truncatx atque margine fuo exteriore in corniculum filiforine de. lintutes, uniloculares, femibivalves f. margine tantum fuperiore dehifentes.

REc. commone centrale, columuare, breve, fubcylindricum; partiule, funiculi umbilicales ex apice receptac. communis oriundi.

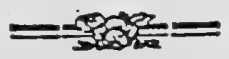

SEM. tria aut quatuor, reniformia, pruinofa $f$. punctis \& fetis minutiflmiș: confperfa, e ferrugineo fufca.

IN T. triplex: extimum tenuiffmum, fcalpendo tantum folubile; mediuns cartilagineum, fplendens, ferrugineum; intinntm membranaceum, albunini adnatum.

A L B. tenue, carnofum, album, intra cotyledonum plicas defcendens.

Es 8. magnitudine feminis, curvatus, luteus. Cotyl. foliacex, cynocepha. loideo-plicatx. Rad. teretiüfula, longa, centripeta:

a.) Fruefus integer. b.) Iew verticaliter diffeetus, eum infertione feminum. c.) Capfula feparata, Jchifcens. d. D.) Semina foluta. E.) Semen diffetum, cum iutegrimento pruinofo $\left(\alpha_{.}\right)$inferne relito, fupcrue autem derafo. F.) Albuminis carnofi theca aperta. G.) Embryo denudatus.

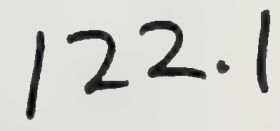




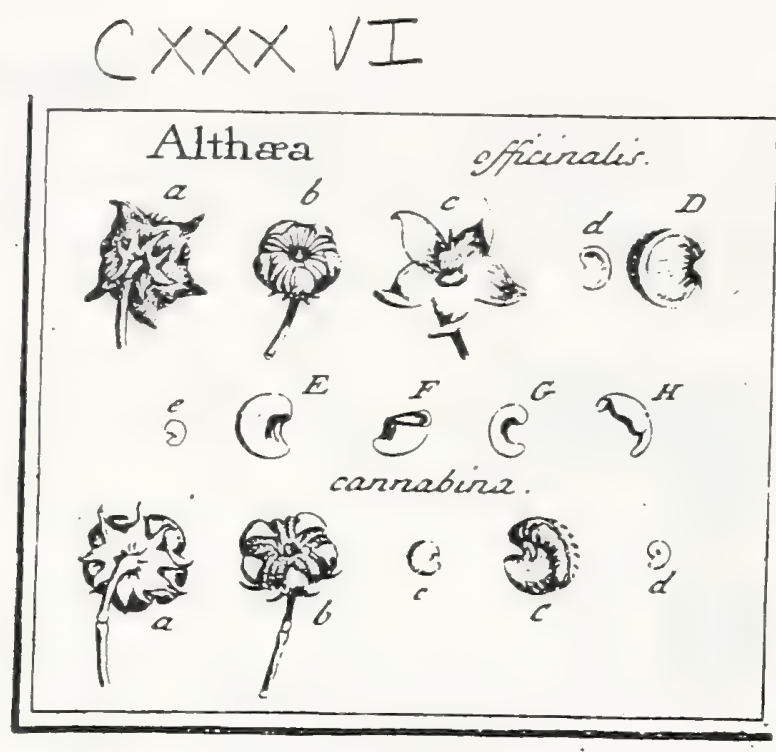

Malvaceae

J. Gaertner (1788) Vol: 2

$25 S$

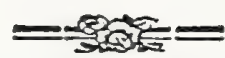

DCCXCI. A L T H IE A. Linn. gen. 839. Alcea. Linn. geñ. 840.

Calyx duplex, uterque monophyllus: exterior fex -1 . duodecimfidus; inte: rior quinquefidus. Cor. quinquepartita. Stam. plurima, in tubum can nata. Ovar. plura. Styl. multifidus. Capfule plures, in orbem pofite uniłloculares, monofperma. Recept. aptery'gium.

Althea officinalis. Tab. 136. fig. 3 .

Althea. Fuchs. biff. lat. 15. germ. ic.7. BLAKw. berb. t. 90. OED. f. dan. t. 530 . Alibsa tomentofa berbucea, carule evecto, foliis cordato lanceolutis obfolete trifidis. HaLl. biff. in. 2074 .

Althsa foliis fimplicibus tomentofis. LIN fyst. veg. 624 .

PER. Capfulx plures, circiter vicenx, in orbem pofitx, rotundato-rcniformes, triangulari-compreffx, undique claufx, in dorfo tomentofic, cetera impures, coriacex, non dchilicentes.

REc. conmmone centrale, in medio globofe tumidum \& fulcatum, in apice autem longo mucrone conico terminatum; propritm nullum aut funiculare.

SEN. folitaria, reniformia, compreffa, glabra, fufca.

IN T. triplex: extiansu ab epidermide tenuilfma; medium cartilagineum; iutsпиин membranaceum.

A L B. tenue, carnofo - menbranaceum, intra cotyledones receptun.

EN B. curvatus, luteus. Coryl. foliacex, cynocephaloideo-plicatx. Rad. longa: infera \& relative centripeta.

a. b.) Eruetus utroque calșce perfiftentc munitus. c.) Recept. commune. d. D.) Capfula a latere (pectata. e. E.) Semen integrum. F.) Idem diftectum. G.) Albumen embryonem obteEens. H.) Embryo denudatus.

Calyx exterior fxpe in hac fpecie feptemfidus eft.

ALTHÆA cannabina. ibid.

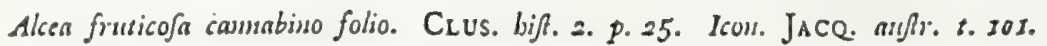
Altba foliis inferioribus paluatis, fuperioribus digitutis. LinN. l. c.

Fructus magnitudine procedentis, fed non tomentofus, cilyce exteriore (a) novemfido. Verticilli (b.) fedecimcapfulares. Capfula (c. C. ) renifornes, e fpadiceo fufcx, claufx, impuberes, linea dorfali longitudinali elevata \& in lateribus rugis parvis difitis flexuofis, inftar quorundan Anmonis cornuum, notatx. Semen (d.) reniforme, cinerafcens.

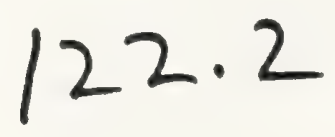




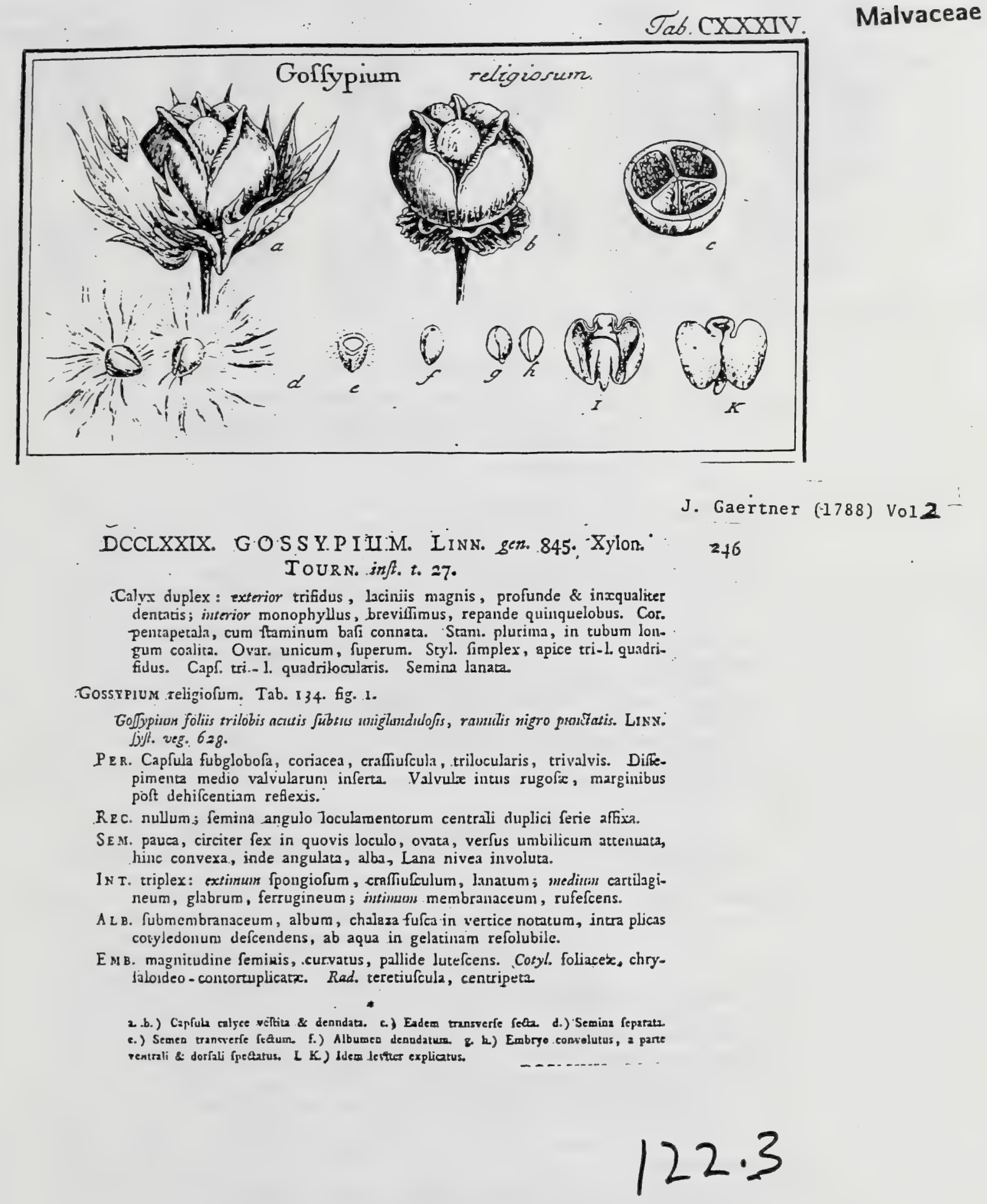




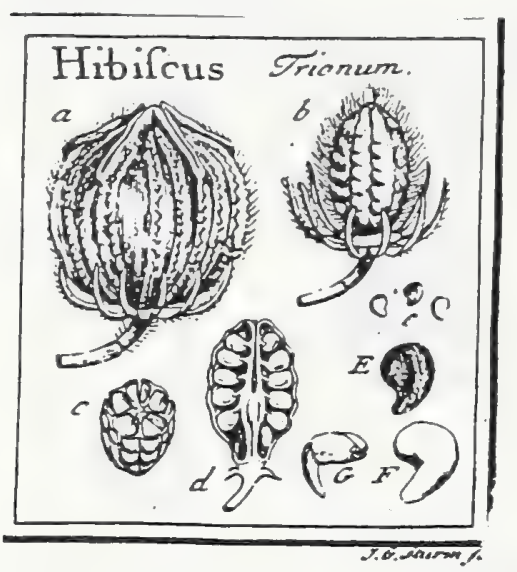

J. Gaert

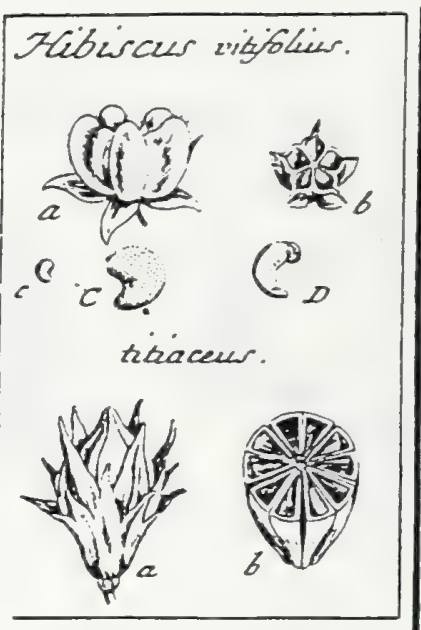

i

DCCLXXXIV. HIBISCUS. Linn. ger. 846. Ketmia. TOURN. t.26.

Calyx duplex: exterior polyphyllus; interior monophyllus, quinquefidus. Cor. qunquepartica. Stam. plurima, in tubum colnsata. Ovar. unicum. Styl. unicus, apice quinquetidus. Capf. finplex, quinquelocularis. Sem. plura.

Hisiscus Trionum. T:io. 134. fig. 6.

Alcea veficeria. CAMr. epit. 806. BESL. Ey'f. aftiv. VI. t. 2. f. I.

Hibifar folits tripartitis incifis, calycibus infatis. LIN fyre. veg. 63r.

PER. Capfula intra calycem infatum delitefcens, ovats, papyracea, a feminibus protuberantibus puftulofn, villofa, nigra, quinquelocularis, quinquevalvis. Diffepimenta medio valvularum inferca.

REC. nullum; femina margiii dilfepimentorum centrali, duplici ferie, affixa.

SEM. pauca, octo ad duodecim in finguio loculo, reniformia, compretfiufcula, punctis callofis minimis e cinereo ferrugineis confperfa, nigro-fufa.

IN T. triples: extimum tenuilimum; medium cartilagineum, craflum, atrum; intimus menbranaceum, cum albumine cohxrens.

$A L B$. tenue, farinofum aut fubcarnofum, album, intra cotyledones defcendens.

ENB. maguitudine femius, curvatus, lutefcens. Coty\% foliacex, cynocephaloideo-plicata. Rad. tetetiufcula, centripeta.

a.) Calšx maturus. b.) Caplula denudata, integra. c. d.) Eadem transverfin \& longitudinaliter diftcta, tum infertione femiaum. e. E.) Semina feparata $F_{\text {.) }}$ Albunen decortictum. G.) Em bryo denudatus

Husiscus vitifolius. Tab. 135 . fig. 4

Althed iudica vitis folio, fiore amplo farvo pendente. Henss. Ingdb. 26. t. 28 .

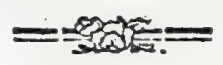

Hibifcus foliis quinguugularibus acutis ferratis, canle inermi, foribus cermuis. LINN. J3y. veg. 630.

Gienie-bierie. Zeylonenf. E collect. fem. hort, lugdb.

Capfula (a.) chartacea, rufefcens, fubvillofa, depreffufcula, pentagona: anguls comprellis alatis, quinquelocularis (b.), quinquevalvis, - ad alas delifcens. Semina (c. C.) in fingulo loculo fubquaterna, reniformia, elevatopuncticulata, fordide ferruginea. Enbryo (D.) curvatus, lutefcens. Reliqua ut in procedenti.

Hısiscus tiliaceus. ibid.

Poriti. Rhęd. mal. r. p. 53. Ł. 30. optime.

Hibifors folits cordutis ficbrotsudis indivifis acuminatis creszatis, caule arbores, calyce exteriore decendenstato. Lisis. bys. veg. 629.

E collectione Bankfian.

Calyx uterque (a) monophyllus: exteriơr femidecemfidus, laciniis alternis ninoribus; interior femiquinquefidus, laciniis xyualibus, longitudine capfulx. Capfula ovan (a), apice mucrontata, fericeo pubelcens, decemlocularis (b.), per maturitatem in decen porciones fponte fecedens. Loculamenta undique claufa, ad angulum centralem fitrilia, ut ibi dehifcere videantur. Semins ii fingulo loculo quingue, reniformis.

Abunde ab Hibifco differt, ut rectifime proprium Parior genus ex hac fpecie conftituerit Cel. ADANSON. Semina nonnifi immatura vidi. 


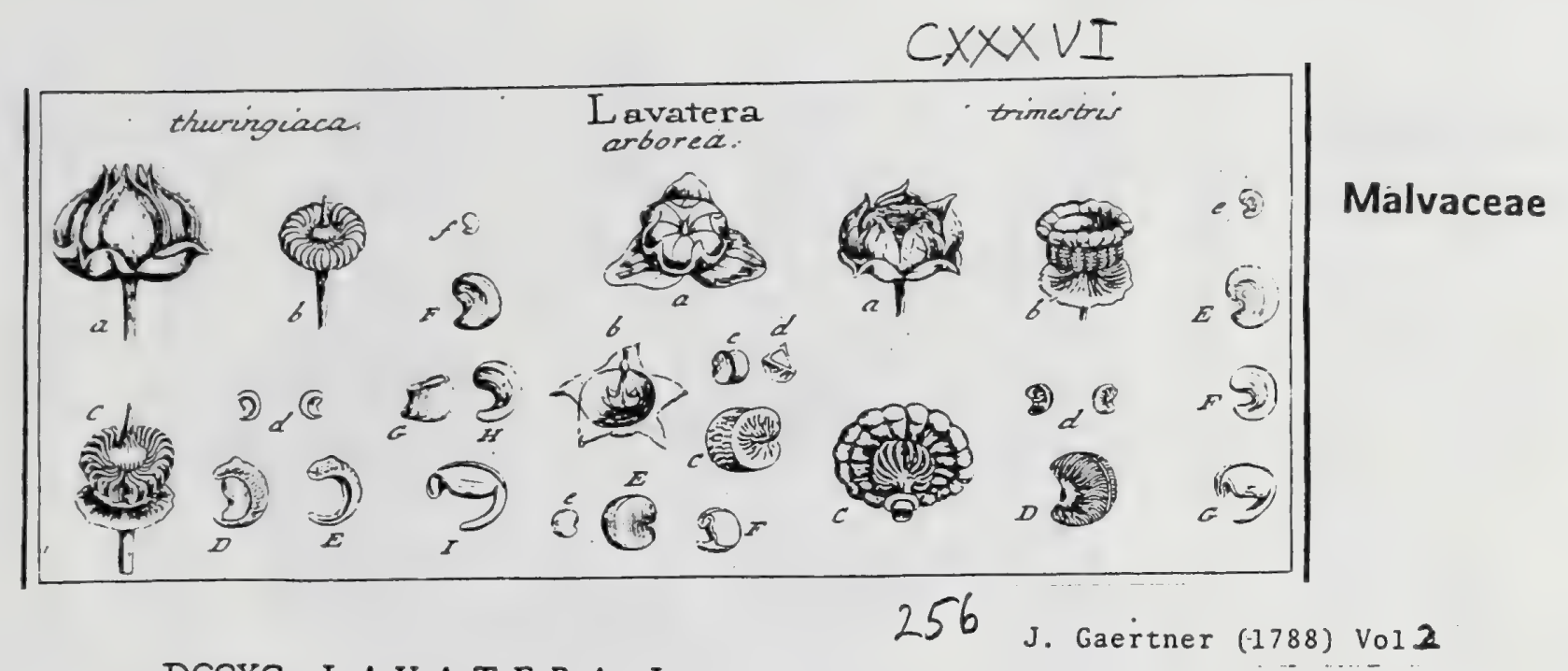

DCCXC. L A V A T E R A. LINN. gen. 842.

Calyx duplex, uterque monophyllus : exterior trifidus; interior quinque. fidus. Cor. quinquepartita. Stam. plurima, in tubum connata. Ovar. plura. Styl. multifidus. Capfula plures, in orbem pofitex, uniloculares, cvalves, monofpermx. Receptac. commune in plerisque?" inolendinaceum.

Lavatera thuringiaca. Tab. 136. fig. 2.

Alsher tharringinca. Cans. bort. 12. t. 6. Best. Eyft. afirv. VI. t. 5. f. I.

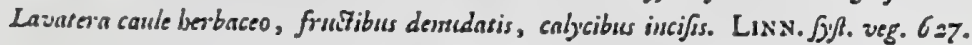

- Icous. Jace. anfir. 4. t. 311.

PER. Capfulx plures, viginti circiter, in orbem politx, fubchartacex, fabriulculx, reniformes, uniloculares, evalves, \& arcu tantum durfuli a lateribus fecedente dehifcentes.

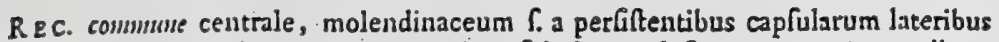
nultialatum, in mucronem conico-fubulatum definens; propritus nullum.

SE.8. folitaria, reniformia, compreffufcula, glabra, fubcinerea aut fufa.

IN T. triplex: extimun, epidernis tenuiffima; medirum cartilagineum, glabertimum, nigro-fufcum; intianun membranaceum, pallidum.

A L B. tcnue, carnofo-membranaceum, album, intra cotyledones defcendens.

EN U. curvatus, luteus. Cotyl. foliacex, cynocephaloideo-plicatx. Rad. infers \& relative centripeta.

a.) Calyx maturus, claufus. b.) Capiolarum verticillus denodatus. C.) Recepto enmanune me iendinaceum. d. D.) Scminz capfulx areu dorfali tecta c.) Arcus feparatus. fo F.) Semen folusum integrum. G.) Idem transverfe (ectum. H.) Albunen decorticatum. I.) Fmbryo folutus.

Latítera arborea. ibid.

Mntur arborefcers. BESL. Eyys. effiv. VI. t. G. f. $x$.

Livantera caule arboreo, folits feptemanguhmibses tomento fis plicatis, pedsusculis c(u)fertis unifloris axillaribus. LINN. \%. c.

Terticilli (: ) feptem-1. octocapfulares. Recept comniune (b.) fubulatum, apice glubulo conoidco terminatum, bafi autera lamellis parvis lunatis \& inter ipfa capfularum interltitia pofitis molendinatum. Capfulx (c. C.) reniformirotundatx, argute triquetre (d), membranacer, rugofx, undique claufix, pallide fpadicex, non dehifcentes. Semina (e. E.) reniformia, cinerafcentia Einbryo ( $\boldsymbol{H}_{\text {. }}$ ) lutefcens.

Lavatera trincftris. ibid.

Afalia folio vario. Вачк. prodr. 337 . c. ic. Jace. bort. t. $7=$

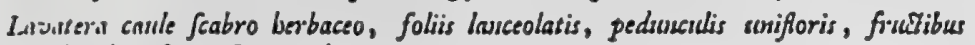
orbiculo sețir. LINN. l. c.

Fructus intra calycem ventricofum (a) nidulans, orbiculatus, depreffus, umtraculo peltato (b) tectus. Verticilli fubviginticapfulares. Recept. comniune (C.) inferne laminis rotundatis membranaceis ințer capfulatum interItitis pofitis molendinatum, fuperne autem in orbiculum fungofum, fufcum. concavum, incraftato marginatum \& in ambitu obtufe crenulatum, ampliatum. Capfulx (d. D.) reniformes, fufex, undique claufx nec dehifentes, in durfo linea elevata longitudinali notata, ad latera vero ftriis Alexuofis a peripheria verfus centrum ductis eleganter vemiculats. Semina (e. E.) reniturnia, ferruginea. Albumen (F.) tenue. Embryo (G.) luteiceus.

$S i$ in reliquis quoque. fpcciebus recepenculum fuerit molendinaceum, poterit id, uuscum calyce duplici monuphyllo, inter notas generis characterifticas referri.

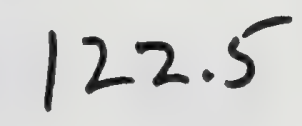




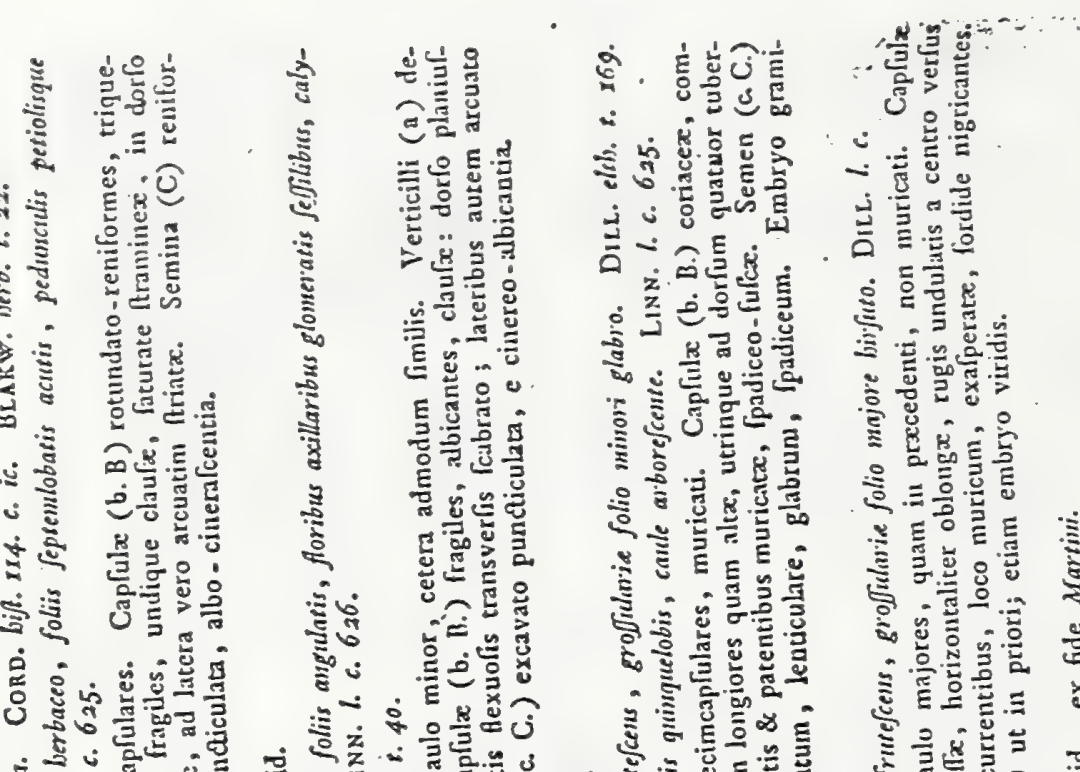

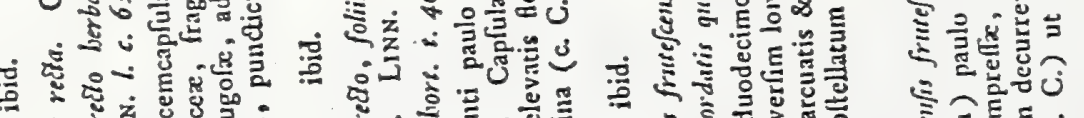

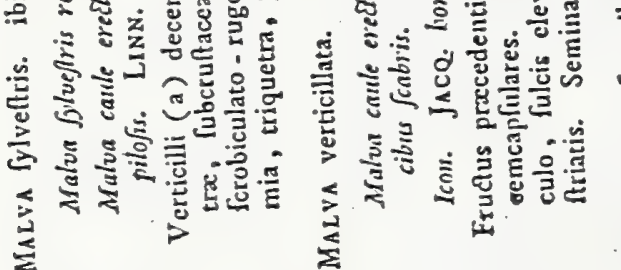

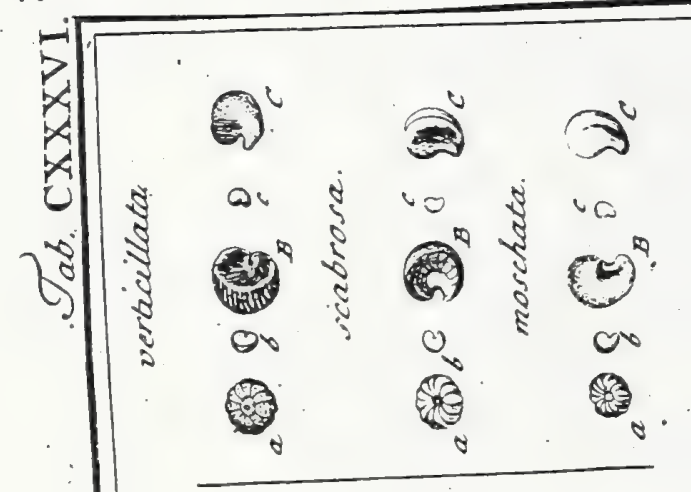

$\mid$

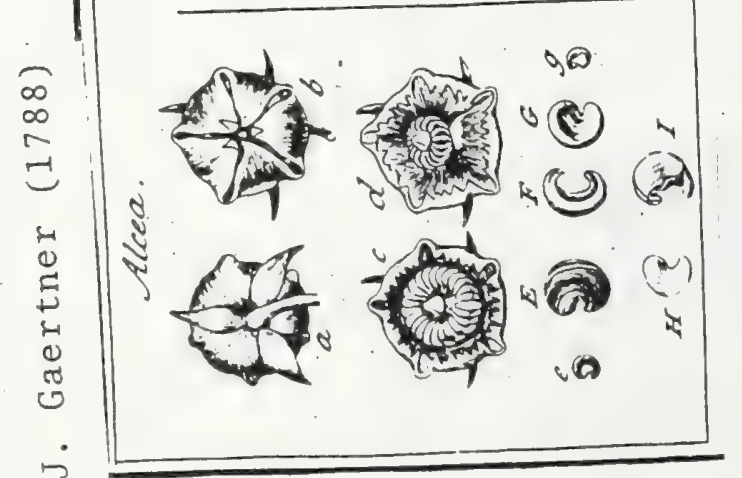

品

\section{Malvaceae}

น

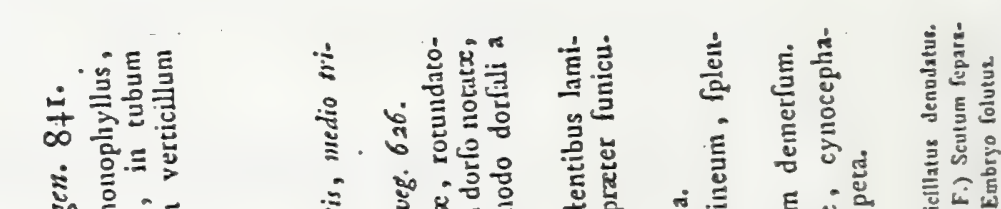

命高輬

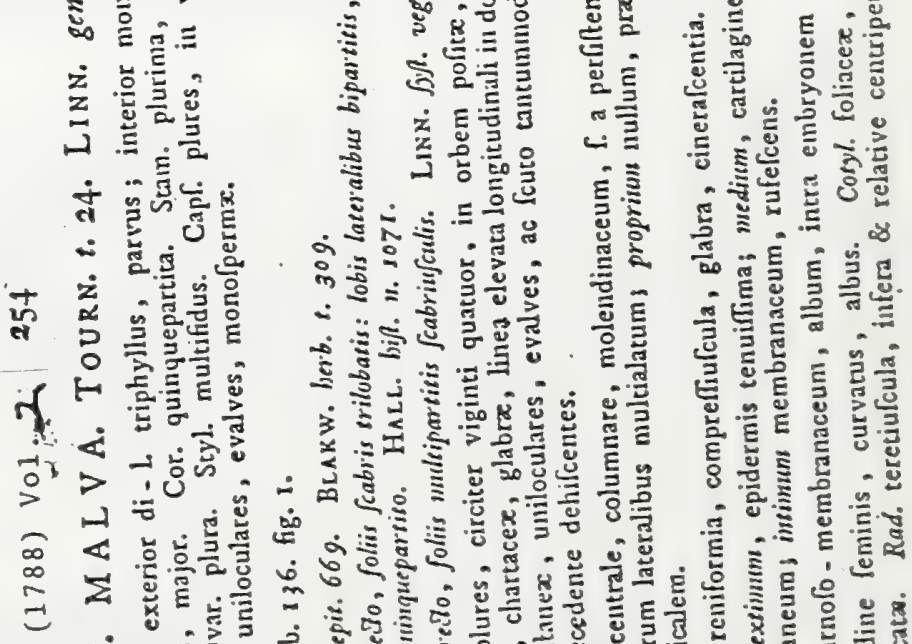

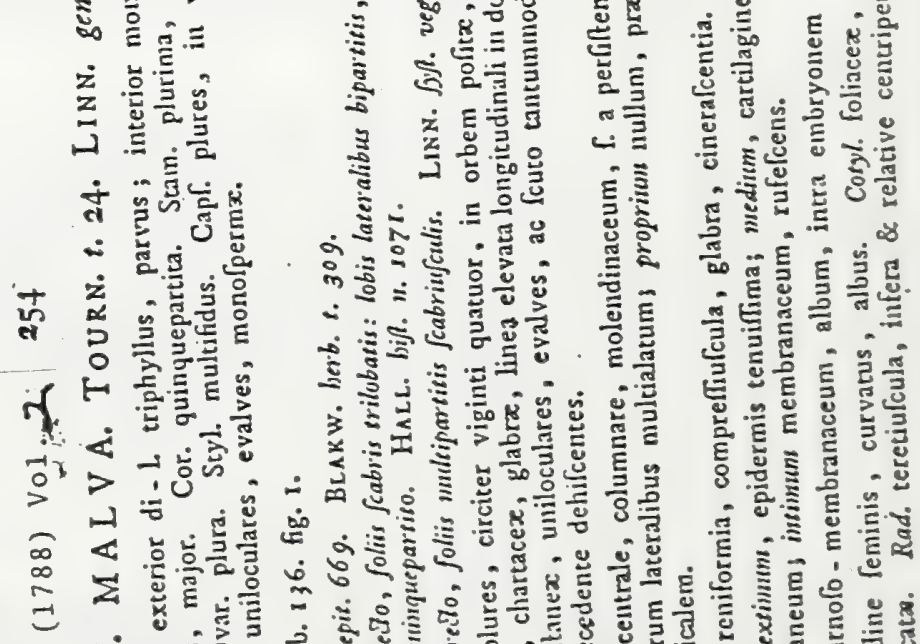

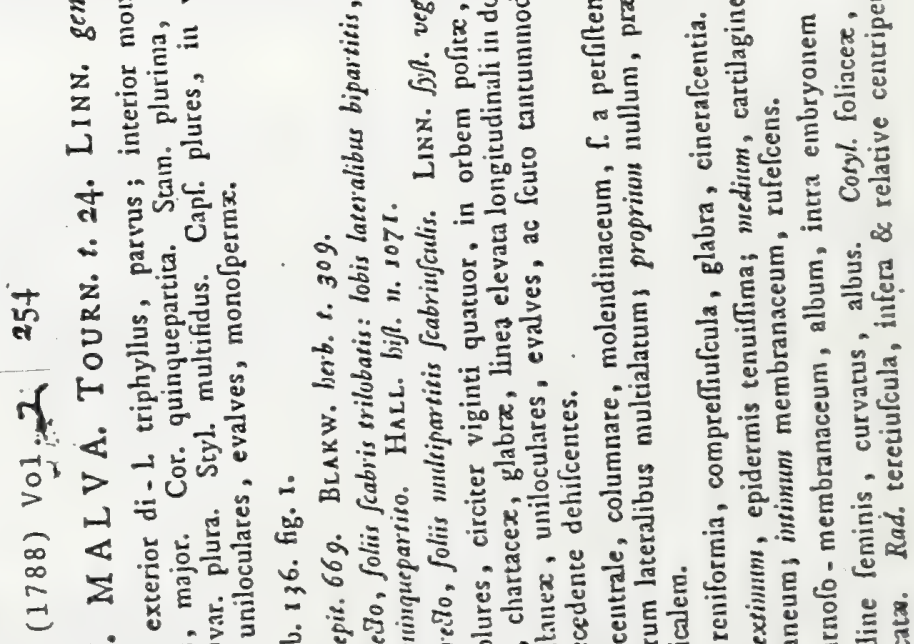

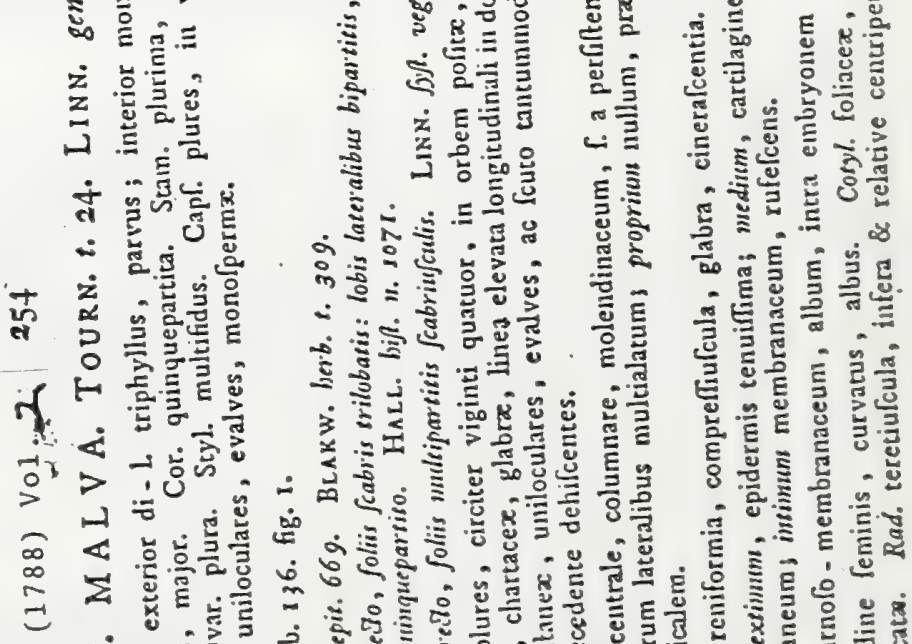

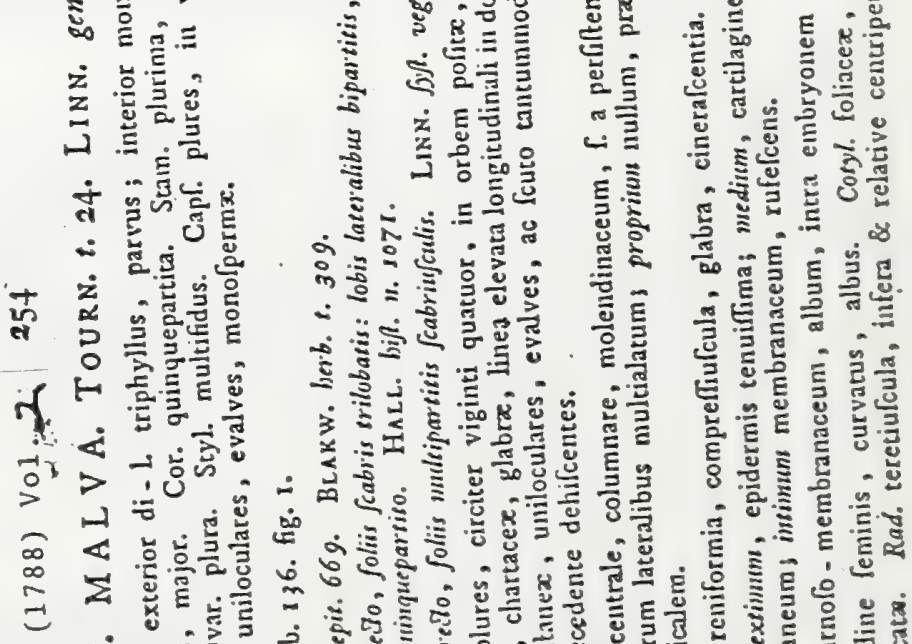

范

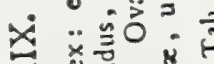

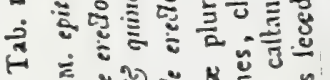

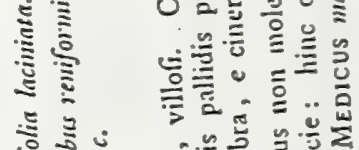

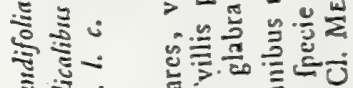

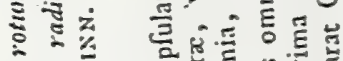

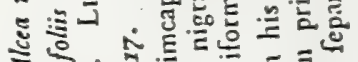
次 त 흥

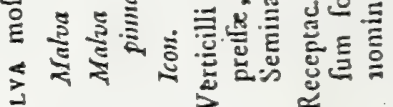
更 

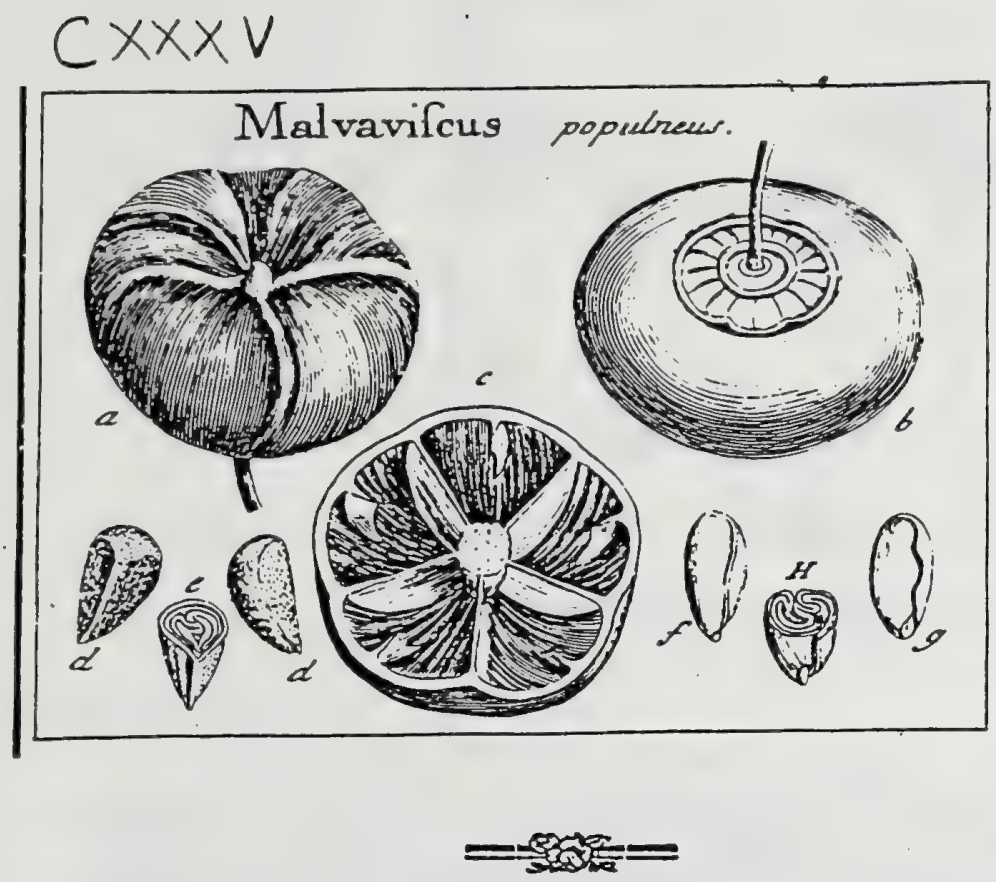

J. Gaertner (1788) Vol.2;

\section{M A L V A V I C U S. Dill. Juss. p. 273.}

Calyx duplex, uterque in variis varius. Cor. quinqueparita. Sani. plurima, in tubum connata. Ovar. unicum. Styl. fimplex apice decemfidus. Bacca pulpora, quinquelocularis. Sem. pauca.

Macvaviscus populneus. Tab. 135 . fig. 3 .

Bupariti. RHEED. mal. I. p. 51. t. $2 g$.

Novella littorea. RuspH. amb. 2. p. 224 t. 74.

Hibifcus foliis cordatis integerrimis, cunle arboreo. LinN. 6yt. veg. $6=9$.

E collectione Bankfiana.

PER. Bacca fubglobofa, depreffa, mucrone parvo in vertice umbonata, per exficcationem obfolete pentagona, femidecemlocularis, corricita. Cortex coriaceus, modice craffus. Pulpa lutea, fucculenta, fugax. Loculamenta nembrana propria, argenteo- jplendente veftita. Diffepimenca nembranacen, tenuia: horum quinque complen, a peripheria ad axen pertingentia; \& quinque incompleta, foli peripherix affura, introrfus autem brevi deliquefcentia.

Rxc. centrale, ovato-glabofum, fungofum, cum diffepimentis majoribas coinatum.

SEM- tria aut quatuor in fingulo loculo, grandiufcula, ovato-acuminata, hine convexa, inde angulata, tomento holofericeo fulvo pubefcentia.

IN T. triplex: exsintum cuticula tenuis, tomentofa; medisun coriaceum, tcnue, fragile; insiusun furfuraceo- membranaceum, rufefceus.

A L B. tenuifimum, carnofo-membranaceum, intra cotyledones defcendens-

Es B. magnitudine feminis, curvatus, horizontalis. Cotyl. foliacex, pallide livefintes aut cinerafcentes, punctisque fufcis minutiflinis confperfa, chrylaloideo-contortuplicarc. Kad. teretiufcula, nivea, centripera.

a.) Baeca integra, z patte fuperiore fpectats, b.) Eadcen inverfa, eurr ealyee exteriorc orbiculatu integerrimo perliftente. c.) Ejusder: fecto trankverfalis. d. d.) Semina feparata. e.) Simen transverfe diftedum. f.) Embryonic deruulati pars.dorfalis; \&. g.) Ejusdern btus veniralcL.) Cotyledoues transwerfim ledz. 


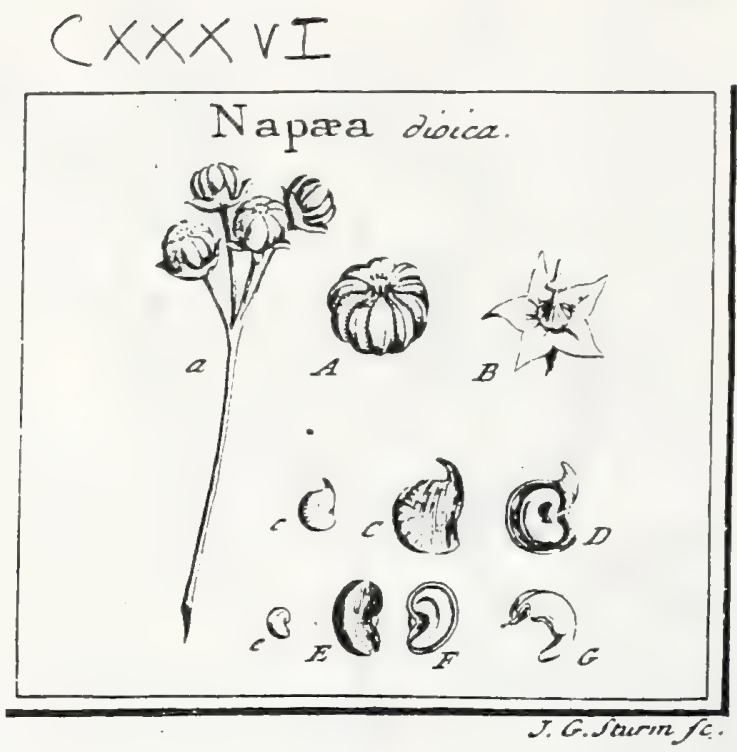

Malvaceae

$$
\text { J. Gaertner (-1788) Vol } 2
$$

$-59$

DCCXCII. N A P E A. LINN. gers. 847 .

Calyx fimplex, quinquefidus. Cor. quinquepartita. Stam. plurima, in tubum commata. Ovar. decem. Styl. decemfidus. Capfulx, decem, in orbem pofite, uniloculares, evalves, monofpermx. Recept. commune apterygium. Flores nunnunquam fexu diftincti, in feparatis plantis.

NAPEA dioica. Tab. 136. fig. 4

Abratlost folio profunde diffeito, pedrnaculis multifloris, mas \&o femisisa. Eнret. pit. t. 7. 8. TREW. nov. A. N. C. 1. p. 437. t. 10. f. x. 2.

Nupea pedunculis involucratis angulutis, foliis palmatis Scabris. LIN . Jyje. veg. 896 .

PER. Capfulx decem, in orbem pofite, femicirculares, apice in mucronem recurvum definentes, cuneiformi-comprefix, in dorfo convexx, lineaque media elevata notatx, ad latera planx ac verfus marginem dorfalem fubcrenulatx, uniloculares, evalves aut rarius in duas valvulas dehifcentes.

REC. commenus centrale, pyramidarum, fulcatum \& pyramidato quoque mucrone terminatuin; proprusm sulicm, aut funiculare breviffimum.

SEs. folitaria, reniformia, trigono-compreffa, fufea, obfoletiffime ftriata.

IN T. triplex: extimuin teinuitimum; iatdism cartilagineum; intimstum inembranaceum.

ALB. tenue, carnofo-membranaceum, cotyledonibus inmerfum.

En B. curvatus, palide luteus. Cotyl. fuliacex, cynocephaloideo - plicats. Rad. intera \& ritative centripeta.

a. A.) Fruons integer. B.) Recentac Asnudatum. c. C.) Capfria integra. D.) Eadem aperta cum fitu forinis. e. Fo:) Scmen folutum. F.) Albumen tunica fuz proprix indutum. G.) EmLr:u liparatts.

Habet utique Napxa affuitatem cun Sida atque Abutilo: attamen a priori, c.lpfulis una pluribus \& receptacuio communi manifefto; - ab dibutilo auten, iisdern capfuirs monofpermis, nec liquide valvatis, abunde differt.

$$
122.8
$$




\section{Tab. CXXXIV.}

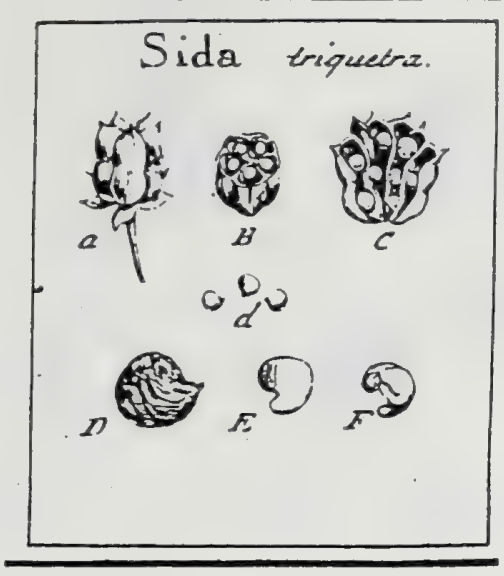

J. Gaertner (1788) vol, 2

\section{S I D A. LINN. ger. 837.}

Cillyx fimplex, monophyllus, quinquefidus. Cor. quinquepartita. Stam. plurima, in tubum connata. Ovar. unicum, fuperum. Styl. multifidus. Capf. fimplex, quinquelocularis, quinquevalvis. Sem. pauca.

SID A triquetrs. Tab. i34. fig. S.

Sida ramis trifulcatis. Jace. bif. aner. p. 195. bort. 2. to 118 .

Sidu foliis cordutis ferratis fublomento ofis: ramis triquetris. LiNs. Gyf. veg. $63 x$.

PER. Capfula ovato-oblonga, apice depreffiufcula, quinquecornis, rotusiditoquinquangula, quinquelocularis, quinquevalvis. Difrepimenta fulco ezterno refpondentia atque medio valvularum inferca. Valvulx pôft dehifcentiam apice bicornes.

REC. nullum; femina margini diffepimentorum centrali affixa.

З Ем. pauca, tria circiter in fingulo loculo, reniformi - globofa, nigricantiă, maculis cinerafcentibus pruinofis marmorata.

IN T., triplex: extimom tenuifrmum, fcalpendo folubile; mediums cartilagineum, atrum, lucidum; intimum membranaceum, albunini adhxrens.

A LB. carnofurn, tenue, album, intra plicas cotyledonum defcendens.

EM в. magnitudine feminis, curvatus', albus. Cotyl. Soliacex, cynocephaloideö, plicata. Kad. conica, longa, centripeta.

2.) Capfula integra. B.) Eadem difreda. C.) Valvulx tres, a parte fua interaa, cum feminuga infertione. d. D.) Seuniua (eparata E.) Albumer decorticatum. F.) Embryo denudatus. 


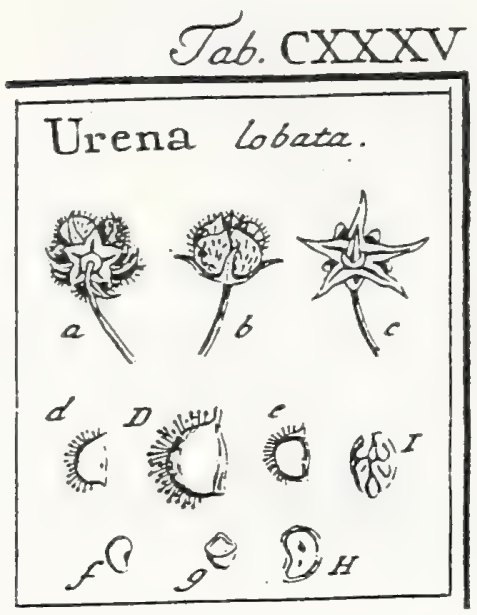

J. Gaertner (1788) Vol.2;

\section{2}

\section{U B E N A.' LINN. ger. 844}

Calyx duplex: exterior monophyllus quinquefidus, brevior; interior quinquepartitus, duplo longior. Cor. quinquepartita. Stam. plurima, in tubum cunnata. Ovar. quinque. Styl. fimplex, spice decemfidus. Capf. compofita ex cocculis quinque, glochidatis, evalvibus. Sen. folitaria.

URENs Jobata. Tab. 135. fig. 2.

Trifolio affinis, indic orientalis, xantijii facie. BREYN. cent. $8=6.35$.

Lrena fuica, xamelii facie. DiLl. elsh. 340. t. 319 .

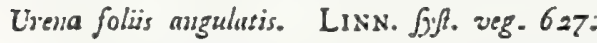

PER. Caplulx quinque, in fructum fubglobofum, rotundato-pentagonum coadunatx, coriacex, hinc convexx, fetisque glochidatis echinatx, inde cuneiformi angulatx, inermes, uniloculares, non dehifcentes.

REc. conmmune centrale, fubulato-pentagonum; partiale, funiculus umbilicalis . breviffinus, e medio anguli centralis ad medium feminis pertingens.

SE м. folitaria, reniformia, in dorfo craffiftuma, fubtilifime ftriata, cinerafcentia.

IN T. triplex: extinum tenuifimum, arcte adhxrens; medisn carcilagineun, glabrum, fufcum; intiassin membrauaceum, rufefcens.

A L B. vix ullum, 1. arachnoideum.

E M B. magnitudine feminis, curvatus, pallide lutefcens. Cotyl. foliacex, chryfuloideo-contortuplicata. Rad. teretiufcula, infera.

a. b) Frudus integer, a fupisa \& prona parte (petatus. c.) Rectpt. commnne, cam atroque calyce. d. D.) Capfula partialis clan[a. e.) Eadem aperta cum iufertione (cminis. f.) Semen feparztum. g.) Idem transterfe (tedom. H) Nacleus propria membrana veftitus. I.) Enubryo denovarus, a parte ventrali fpechatus.

$$
122 \cdot 10
$$




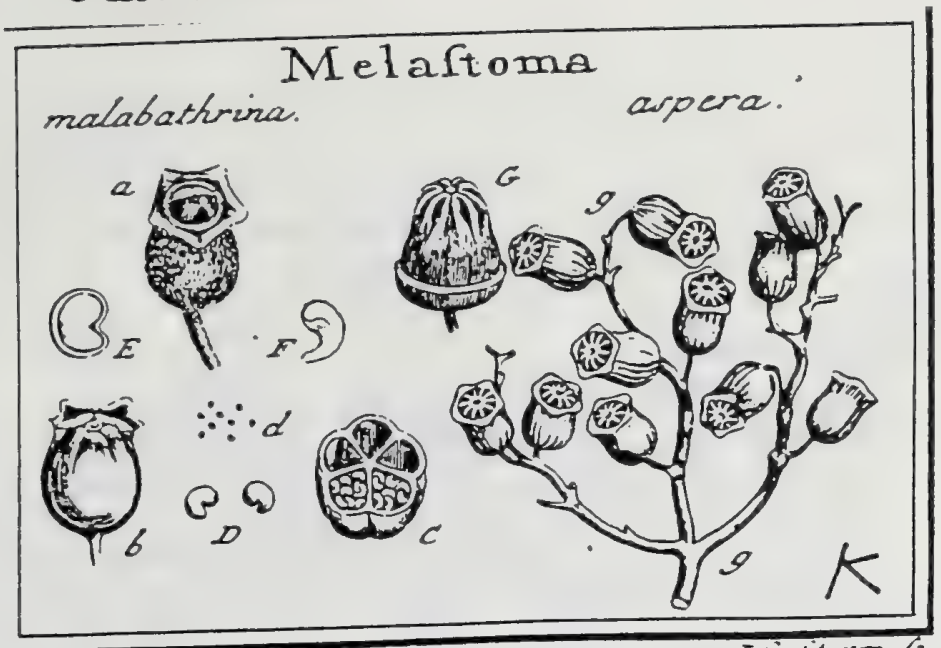

\section{J. Gaertner (1788) Vol -2}

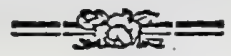

DCCXXT. M E L A S T O M A. LINN. ger. 544.

Calyx monophyllus, campanulatus, quinquederitatus, cum fructu non cou: natus, fed eum faltem veftiens. : Cor. pentapetala. Stam. decem. Ovar. fuperum. Styl. fimplex. Capfula pulpa molli farcta, quinquelocularis, apice quinquefariam dehifcens. . Receptac. nulla... Sem. numerola, in pulpa nidulantia.

Melastoma malabathrina. Tab. i26. fig. ir.

Kadali. Rheed. mal. \& p. 87. t. 42.

Melafoma quinquenervia birta major, capitulis fericeis villofis. BUR M. Zeyl. 155 . t. 73 .

Melufoma foliis integervinis quinquenerviis lanceolato-ovatis fabris. LINN. Lyft. veg. 404 .

E collect fem. hort. lugdb.

PRR. Capfula calyce urceolato fetisque rigidis appreflis fcabrato veftita, ovata, quinquelocularis, apice rimis quinque dehifcens. Loculamenta pulpa molli atro-fanguinea farcts.

REC. nullum, preter pulpam in qù femina nidulantur. .

SE x. numerofa, parva, reniformi globofa, gilva.

IN T. duplex: exterius cruftaceum, fragile; interius membranaceum.

A L B. nullum.

Eм ४. femini conformis, arcuatus, fublutefcens. Cotyl. plano - converz, crafix, breves. - Rad. tereti - attenuara, curvata, vaga.

2.) Capfula calyce veftita. b.) Eadem a parte anteriore denudata C.) Ejusdem (ectio transrcrfalis, cum litu ferinum d. D.) Serina feparata. E.) Seminis telta aperta, com membrana interna embryonem obtegeate. F.) Eisbryo deaudatus.

Melastoma afpera. ibid.

Katou-kulali. Rheеd. mal. 4 ' p. 9r. t. $4 \hat{3}$. bene.

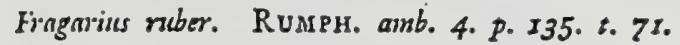

Arelaftoma foliis integervimis trinerviis lanceolatis fcabris. LInN. Jyft. veg. 404.

É feminar. Amitelod.

Calyx cylindrico - urceolatus, obfolete fulcatus, glaber. Capfula (g. g. G.) ovata, furfum leviter attenuata, quinquelocularis, apice rimis quinque dehifcens, rimarum marginibus relexis, ut incauto decem aperturze adeffe vidiantur. Semina valde exigua, procedentibus tamen per fingula momenta cuniornia. 
Melaftoma levigatr.

Ex herbario Bankfiano.

Fructus globofus, fulcatus, magnitudine bacex Ribefii rubri. Loculamenta quinque. Semina, in ratione ad magnicudinem pericarpii fui, grandia, angulata, lucida, lutefcentia, lata macula atra ad umbilicum notata. Embryo teretiufculus, fubfpiralis, unum fcil. \& dimidium fpirze gyrum abfolvens.

Pericarpii fabrica in hoc genere admodum varia elt. Alize enim fpecies pro. munt baccas veras fucculentas atque edules; alix vero capfulas, easque vel , cum calyce conferruminatas, f. inferas, vel fimpliciter ab eo veftitas, $f$. fuperas. Deinde etiam, utraque hæc pericarpia, etfi frequentius fint quinquelocularia, in aliis tamen 2. 3. \& quadrilocularia deprehenduntur: qualia in Aubletio exempla occurrunt. Effentia igitur generis, quatenus ex fructu hauritur, in folis feminibus exalbuminofis, intra pulpan mollem absque receptaculo proprio nidulantibus, atque embryone curvato dotatis, confiftere videtur. Hinc affinitas Melaftomx cum Myrtoideis, \& preftantia Juftanx plantarum coordinationis luculento iterum exemplo confirmata. 


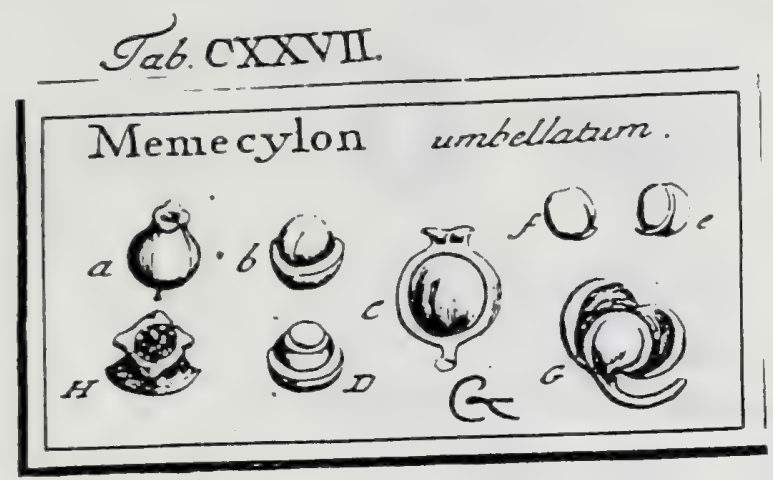

J. Gaertner (1788) Vol -2

Tab. CLXXIX.

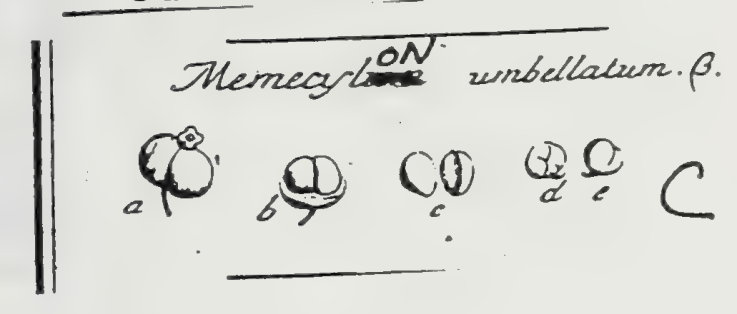

206

Calyx fuperus, quadridentatus, perfiftens. Cor. tetrapetala. Stam. quatuor aut octo. Ovar. inferum. Styl. Gimplex. Bacca infera, coronata, unilocularis, mono - 1. difperma.

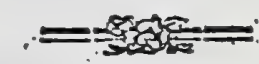

Menecylum umbellatum. Tab. 127. fig. 4 .

Cormus zeylanica jyluefiris altera, koratialsa diga. BuRs. 2eyl. 76. t. 31 .

Samara leta. Liwx. $5 y / 2$. veg. 159 .

Korakaba. Zeylonens. E collect-fem. hort. lugdb.

PER. Bacca infera, globofa, calyce perfiftente tubuloro intus octo friato \& in niarginem repande quadrangulum expanfo, aut eodem non ftriato ac fintpliciter quadridentato coronata, ftriis odtonis obfoletis infcripta, unilocularis, rufefcens. Cuticula coriacea, tenuis. Pulpa aquofa, fugax.

REC. nullum; femina fundo baccre late adıata.

SEN. duo, aut unicum, globofum, lxvigatifrmum, lucidum, dilute caftsneum, puncto depreffo in vertice notatum.

IN T. fimplex, chartaceum, elafticum, aridum.

$A L \dot{B}$. nullum, nec ejus veftigium.

EMB. magnitudine feninis, globofe convolutus; erectus, lutefcens. Cotyl. foliacex, fornicata \& in globum ita convolutx, ut exterior interiorem obtegat. Rad. longa, gracilis, arcuata, e medio embryonis dorfo oriun- da, \& dehinc in proprio cotyledonum fulco ad bafin feminis defcendens.

x.) Bacez integra. b.) Ejus fectio transverfalis cym fuperiore parte feminis denudata. C.) Ez Jem verticaliter diffedz, cum fitu fenuinis. D.) Tefta feminis clartacez, refesto vertics, aperta. c) Embrgo a doto fpectatus, radicula orium ofteadens E) Ejusilcm latus ventale. G.) Ca tyledones diducte. H) Calyx íparatus \& aufeus.

Baccam difpermam vide infra in Appendice.

Quun Korakalix i. e. Samarx Linn. bacca manifeftifime fit infera, cumque in plufculis cjus speciminibus, calyx cylindricus in fundo octo Ariis notatus $\&$ in margine integerrinus fuerit deprehenfus, quibus quippe notis fuum fignavit Memecylon Limneus: non dubitavi anbo hac in unum fundere genem, donec ex vivis plantis certiora innotefcant. 
Tab. 220 .

Melastomataceae

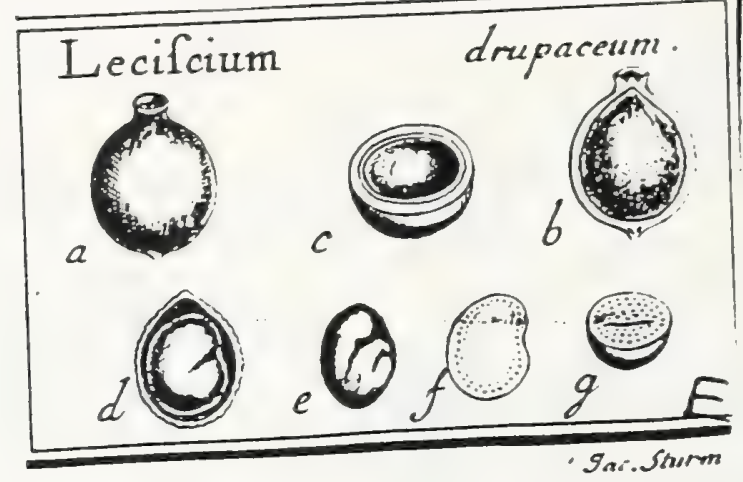

= Merrecylor

J. Gaertner (1788) Vol3

221

174. I E C I S C I U M. Sfientaren

Cal. . . Cor. ... Stam. . . Ovar, fuperums ftylo brevi 3 ftigmate con: cavo. Drupa baccata, ad verticem anfaca ; putamine chartaceo, uniloculari. Rec. nullum. Sem. folitarium. Alb. nullum. Emb. deformis. Leciscium drupaceum. Tab. 220. fig. S.

Ex collectione $\mathrm{Cl}$. Deseontaunes, fub nomine Cbryfopbylli.

222

PER. Drupa femipollicaris, baccata, ovata l. ovato-globofa, in vertice ftylo perfiftente breviffimo craffo concrvo \& intra hunc puncto callofo centrali inftructa, glabra, viridiufcula, Caro non admodum craffa, mollis, valis nutritiis intermixta, putamini adnata. Putarien ellipticum, apice nucro. nulatum, offeo-chartaceum, tenue, extus fabratum, evalve, uniloculare monofpermum.

REC. nullum.

Sem. unicum, e reniformi fubglobofum, ad ventrem rugis transverfalibus de. currentibus notatum, fufcum.

IN T. fimplex, membranaceun, tenue,

A L B. nullum.

EM B. femini conformis, inverfus, albus. Cotyl. craffx, carnofx, plano-convexx, vafis nucritiis intus ftipata, per ambitum arcte conglutinatr, ac cunbentes. Rad. breviffima, obtufa, lateralis, adfcendens.

EXPLICATIO FIGURE.

2.) Drupa integra. b.) Eadem longitudinaliter a carne denudatz, cum fitu putaminis, c.) Ejus dem feetio transverfalis, femise exculfo. d.) Putanea longitudialiter diffectum, cum Lemine in fitu. e.) Embryo folutus. f.) Idem longitudiaaliter diffectus, B.) Ejusidem feetio trapsverGalis.

123.3 


\section{Tab. CXXVI.}

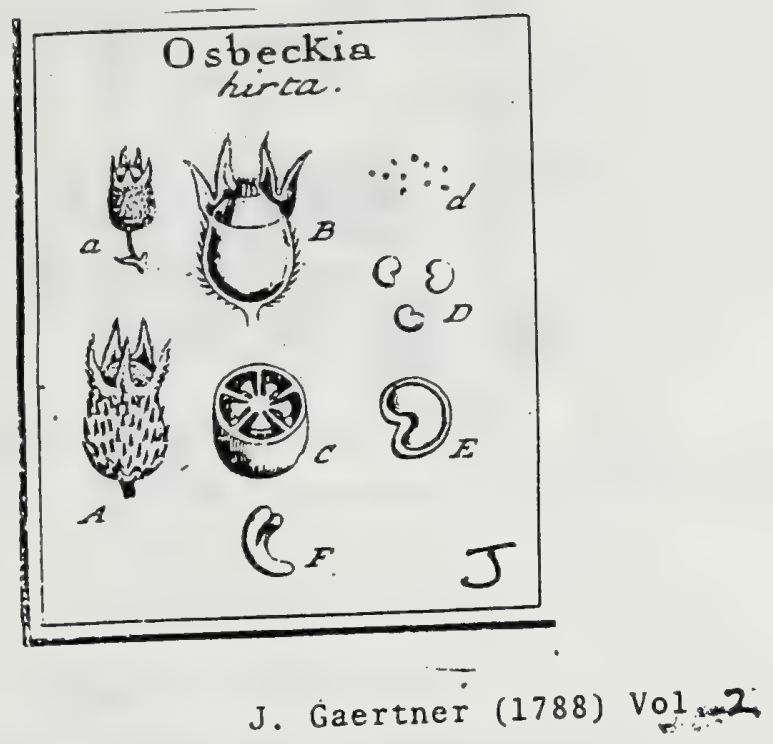

\section{O S B E C K I A. LINN. gen. 467.}

Calyx monophyllus cum ovario connatus, fupra quadrifidus, Segnentis fquama ciliari interftinetis, aut quinquefidus absque fquanis intercalaribus. Cor. tetra-1. pentapetala. Stam. octo 1. decem. Ovar. inferum, fetis rigidis coronatum. Styl. fimplex. Capfula infera, quadri - 1. quinquelocularis. Receptac. feminum lata, compreffa. Sem. numerofa.

OsBeckis chinenfis. Tab. 126. fig. IO.

Eclinoplora madrafpatana, fideritidis mon fesrato venoso folio, frufin capfulari cascalidis amulo. PLUK. plyyt. t. J73. f. 4 .

Osbeckia chinenfis. OsB. it. cliss. t. 2.

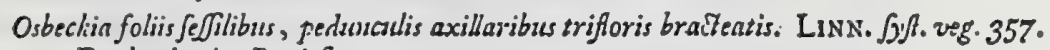
Ex herbario Bankfiano.

PER. Capfula infera, ovata, calyce fibi arcte adnato hifpido veftita, fetisque rigidis confertis, vix tamen in fquamulas contuentibus, in vertice coronạฒ, quisıquclocularis, quinquefariam apice dehifcens.

KEc. quinque, in fingulo loculamento fingulum, feniovatum, cuneiforni compreffum, hinc liberum, inde axi capfulze longitudinaliter adnatum.

SEM. nunetofiflima, parva, globofe reniformia, fubrufefcentia aut fordide Atraminea.

IN T. duplex : exterins cruftaceum, fragile; interius membranaceum, tenuifimum。

ALB. nullum, nec ejus veltigium.

En в. femini conformis, arcuatus, luteus. Cotyl. plano - convexx, breves, craffe. Rad. cotyledonibus longior, curvata, centripeta.

Q. A.) Capfuhn talyce veffitc. B.) Ejus alterun latus denudatum. C.) Ejusdem fuetio transverfalis, cum figura \& infertione reecptaculorum. d. D.) Scmina feparata integra. E.) Scminis tefia apertz. F.) Ėubrjo denudatus.

Anne hac potius Osb. Zeylanica? 


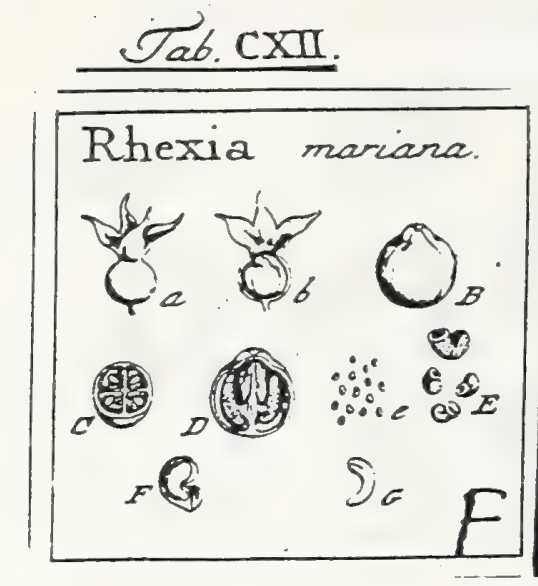

\section{J. Gaertner (1788) Vol. 2}

143

DCLI. R H E X A. LINN. ger. 468.

Calyx quadrifidus. Cor. tetrapetala, calyci inferta. Stam. octo. Ovar. fuperum. Styl. fimplex. Capfula calyce obtecta, quadrilocularis. Receptacula libera. Sem. plurima.

Rhexis mariana. Tab. I12. fig. 6 .

Lyfmachia non pappofa terre marime, leptoneuros, fore tetrapetalo rubello, folio EO caule birfutie ferruginea bifpidis. PLux. plyyt. t. 428. f. I.

Rbexia foliis ciliatis. LuNN. f3. veg. 357 .

Ex herbario Bankfiano.

PER. CrDfula iiitra calycem ventricufum, limbo quatrifido infundihuliformi terminatum latens, membranacea, tenuitrima, fubglobora, fupperne in brevens unbonem producta, quadrilocularis, apice quadrifariam dehifens. Diffepimenta menibranaces, medio valvularuin inferta.

REC. quatuor, fublunata, fungofa, ferobiculata, craffo pedmeulo laterali angulis loculamentorum interivis infra medium inferta, cetera undique liber:i.

SEM. numerofa, parva, feriatim elevato-punetata, pallida, teretiufcula, fim. plici gyro in cochlex formam torta, amplo umbilico concavo terminata.

IN T. fimplex, craftufculum, fuberofo cruftaceum, fragile.

A I B. nullun.

EMD. feninis cavitati conformis, teretiufculus, curvatus, lacteus. Coty\% breves, fenicylindricz. Rad. lunga, curva, centripeta.

I 44

a.) Capnla a calyec occultata. b. B.) Eadem denudata. C.) Ejusdem fectio transverfalis. D.) Rceptaculorum infertio \& forma. e. E.) Semina feparata. F.) Semen longitudinaliter apertum. G.) Embrjo denudatus.

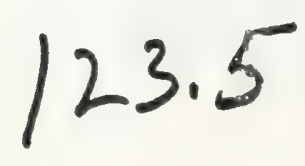




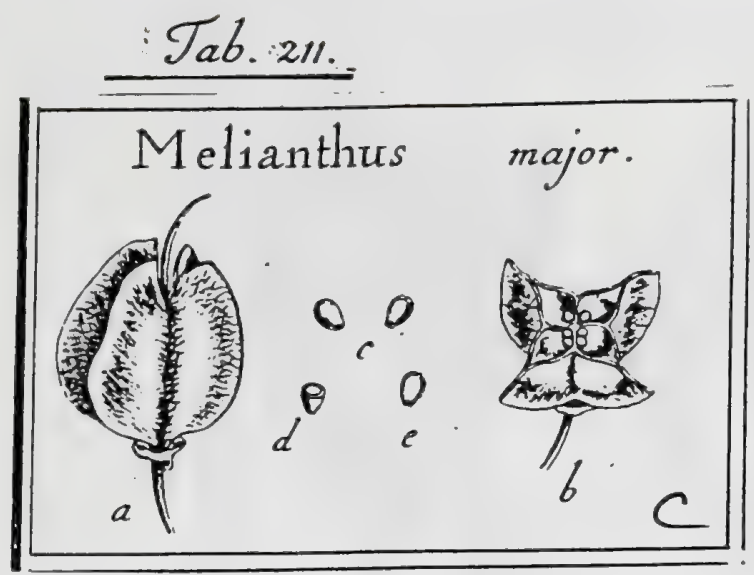

J. Gaertner (1788) Vol.3

558

\section{M E L I N T H U S.}

Tourn, inf. 245. Linn, gen. 795, ed. Schreb, ro68. Juss. gen. p. 297.' La ararc.K ill. gen. t. 552

Cal. maguus, coloratus, quinquefidus, perfiftens i laciniis inzqualibus, infima minima, deorfum gibba, cucullata, cava, glandulam nectariferam continente. Cor. pentapecala, quorum guatuor inferiora lanceolato-linearia, extra membranam glandulx inferta; in medio lateribus connexa, apice vero \& bafi diftincta; petalum quintum minimum aut his proximum, aut inter duas lacinias calycinas pofitum, matgine incifum. Stam. 4.; filamenta duo fuperiora diftinct3; duo inferiora autem breviora, bafi coalita; antherz cordatooblongx, incumbertes. - Ovar. fuperum; Atylus fimplex, fubulatus, perfiftens; ftigma quadrifidum: lacinula fuperiore majore. Capfula quadriloba, membranacea, fubinflata, quadrilocularis. Rec. o. Sem. in quovis loculamento gemina, altero abortante. Alb. carnofum. Emb. ...

Melantuus major. Tab. 21 r. fig. 3.

Meliuntisus africanus. HERM. Lugdb. 4I4. t. 415.

Neliantbus Aipulis folitariis petiolo adnatis, folis glabris. LinN. Spec. plo ed. 3. 8. 892. Syf. veg. ed. 14. p. 58 I. WILLD. Jpec. pl. T. 3. P. x. p. 40.Persoon fyut. pl. 2. p. 182.

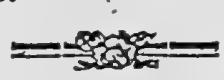

PER. Capfula fupera, calycis laciniis perfftentibus velita; ovata, membranacea, fubtilifime venofa, ad verticem profundilime incifa \& fulcis longitudinalibus ad pedunculum decurrentibus infcripta, ftylo perGiftente cum axi fructus continuo faftigiata, quadrilocularis, e viridi rufelcens. , Lobi matgine comprelfi, intus in vertice dehifcentes. Loculansenta infata, tetragona, difperma. Diffepimenta membranacea, fulcis loborum inferta.

REc. nullum : femina in ipfo loculamentorum angulo interno in 'medio axi papillulis minimis affixa.

SEN. in ovario virgineo in quovis loculamento gemina, quorum vero alterum per maturitatem conftanter abortat; foctum femen ovatum; turgidum, bafi umbilico parvo immerfo infGuitum, glaberrimum, nitidum, atrofulcusn.

INT. duplex : exterius teftaceun, fragile; inserius membranaceum, tenue, adnatuin.

A г в. femini conforme, carnofum, album:

EMB. . .

\section{EXPLICATIO FIGURE}

a.) Capfula integri, a calyce denudata. b.) Ejusdem fectio trantsveralic, ut fotas femiaum appareat, e.) Semina feparata, d. e.) Idem transverfe e verticali modo diffetum.

Semen maturum mihi nondum videre contigit; in capfulis vero immaturis M. comofs aque ac minoris L. loculamenta femper difperma deprebendi. 
6 


\section{$X C V$}

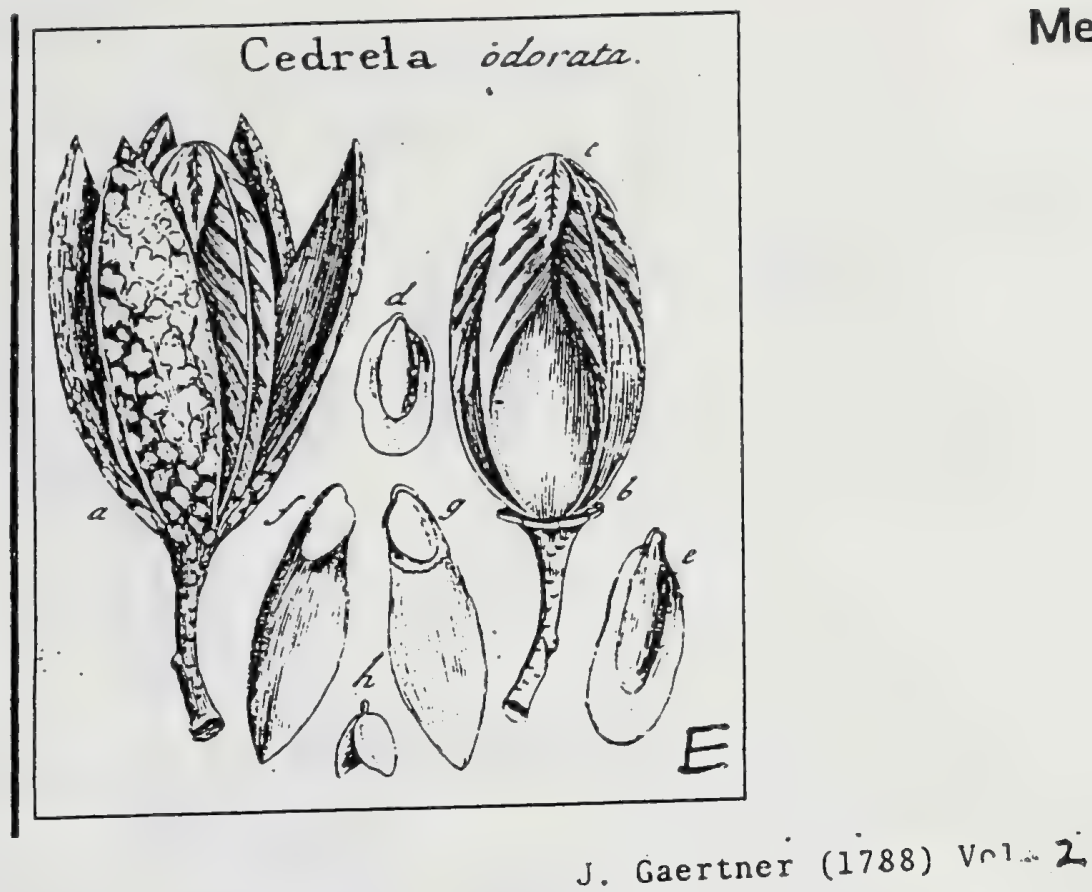

84

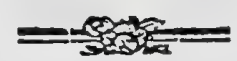

DXCII. CEDRELA. LINN, gers. 277 .

Calys quinquedentatus. Cor. pentapetala, receptaculo proprio quinquangulari inferta. Stam. quinque. Ovar. fuperum. Styl. fimplex; 1tigmate capitato. Capplula lignofa, quinqquelocularis. Semina imbricata, deorfun alata.

Ceprela odorata: Tab. 95. fig. 2.

Cedries barbadenfum, alatis fraxini folis. Plux. phyt. t. $557 . f . x$.

Cedrela foliis pinnatis, fioribses laxe racemofis, ligmo levi odorato. BROWN. jant. 158. t. 10: f. 1. c. ic. fructus immacuri.

Cedrela floribus paniculatis. LINN. $\lceil y /$. veg. $24 \pi$.

- A Cl.Storr. Prof. Tubing. \& femina matura a Cl. Srquorl. Efslung.

PER. Capfula fupera, e lignofo pedunculo continuata \& ipfa lignofa, fufca, pallidis maculis irregularibus undique confperfa \& quafi leprofa, intus rufefcenti fpadicea, quinuuelocularis, quinquevalvis: Valvulis ab apice dehifcentibus, bafi autem perfiltentibus, nequaquam caducis.

Rrc. lignofum, maximum, rufefcent - fpadiceum, glabrum, inferne ventricofum, pentagonum; fuperne profunde angulatum, quinque alatum atque infra apicem areolis quinque oblongis fungolis pallidis notatum, quibus ipg feminum umbilici gemina ferie inferuntur.

SEM. numerofa, deorfum imbricata, compreffa, difformia: froprema elliptica, media oblongo ovata, infima ovato lanceolata; omnia fuperne nucleo dotata, inferne in alam membranaceam definentia, e ferrugineo-cinnamomea.

IN T. Gmplex, membranaceum, tenue, ad nuclei fedem fpongiofum, incraffatum, fufcum.

ALB. ovatun, carnofum, compreflum, tenue, album, tetro odore alliaceo imbutum.

EMB. magnitudine fere albuminis, ejusdemque odoris, inverfus, lacteus, Cotyl. foliacex, tenues, ellipticx. Rad. brevis, fupera.

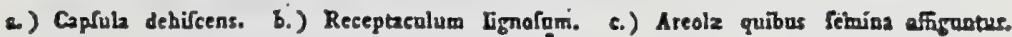
2. c. f.) Semina triplicis formix g.) Albamen deaulatum, h.) Embryo folutus. 


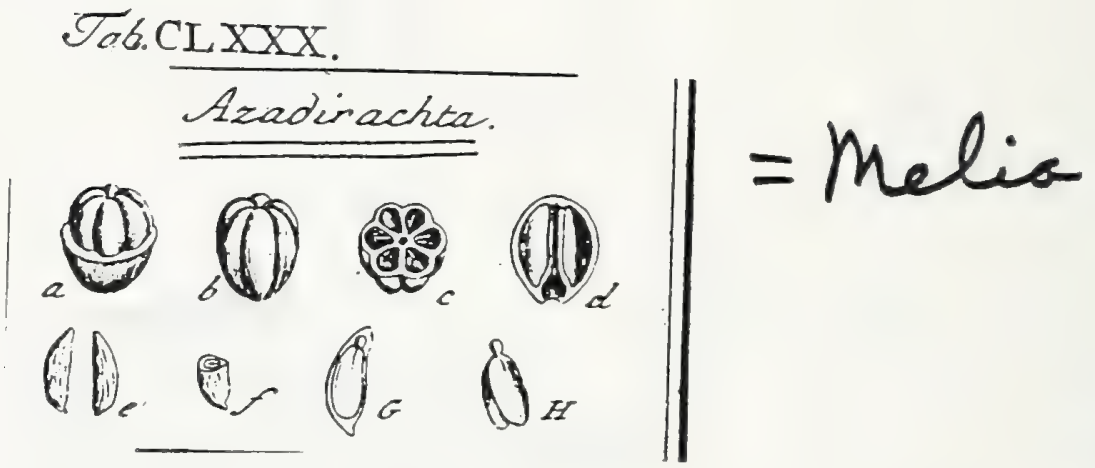

J. Gaertner (1788) Vol 2

MLVIII. ME L I A. Linn. gen. 527. Azedarach. TOURn. 1. 387.

Calyx minimus, quinquefidus. Cor. pentapetala. Stam. decem, connita in tubum cylindricum, apice decemdentatum, intus antheriferuns. Ovar. fuperum. Styl. Iiniplex capitatus. Drupa carnofi, putanine ad asem perfurato, quinqueluculari, pentafpermo.

Melia Azadirachta. Tab. 180 . fig. 9.

Avia - bepou. RHEed. mal. 4. p. 107. t. 5 2.

Azadiraclita indica. Conss. bort. s. p. 147. t. 76. BRERs. ic. 2. t. 15.

Mrelia foliis pimatis. LinN. Syl. veg. 400.

PER. Drupa baccata, elliptico - globofa, nigra. Cortex carnofo - pulpofus mollis. Putanen offeum, albicans, $5-1$. 6 fulcatum, $5-1.6$ loculare, intra bafu fuam ampla cavernula exfculptum, e qua canalis anguftus verfus apicem putaminis adfcendit, qui in cacumine fuo foraminulis 51.6 , in loculamenta aperitur.

REc. funiculi unbilicales breviffmi, ab axi ad feminis apicem per foramina Joculansentorum pertingentes.

S ₹ x. folitaria, oblunga, utrinque attenuata, cuneiformi comprefla, fubrugofula, e ferrugineo atra.

IN T. exterius chartaceum, aridum, tenue; interius arachnoideum.

A L B. Senini conforme, tenue, farinofum aut per emollitionem carnolum, niveum.

Ëмв. inverfus, albus, fagilifimus. Cosyl. elliptico-oblongz, plano-convesiulculz. Rad. brevilíma, capitellata, fupera.

a.) Drupz cortice fuo caraofo ad dimidium orbata. b.) Putamen integrom. c.) Idem transverfe diffeatum. d.) Ejusdem fedio longitudinalis, cuon axis anal: aperto E feminum fitu pendulo. e.) Semina (eparata. F.) Semen transverle diffectuon. G.) Embryonis litus intra albumen. H.) Embryo Colutus.

Sulcorum atque loculamentorum numerus in hac fpecie varius eft. Ita RHEEDE 1. c. putamen pingit glabrum \& unico nucleo foctum (quod tamen videtur plane erroneum aut ex abortu prognatum); Conselinus vero 1. c. quatuor faltem habet loculamenta; \& ego, in meo fpecimine, fex diftincta loculamenta coram video. His autem non obfantibus, maturalis numerws 
Tat IVIIL.

Meliaceae

Antelara jaonica.
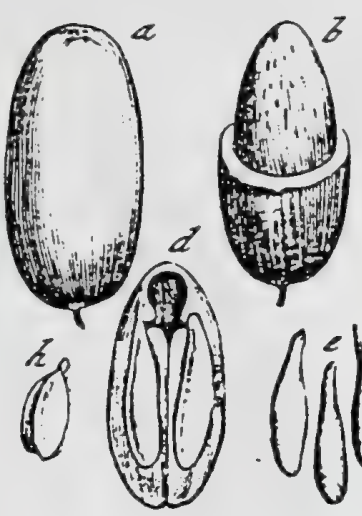

(foj)

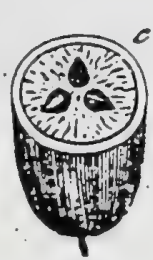

$\mathrm{U}^{9}$

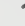

D

J. Gaertner (1788) Vol.1

277

CCCXLVIII. AN TELAA.

$\therefore$ Flos.... Drupa baccata fupera. Putamen triloculare cuin cavitate magna vacua prope verticem.

AN TEL E A javanica. Tąb. 58. fig. 2.

Lunu-medella. javan. E collect. fem. hort, lugdb.

PE R. Drupa baccata, ovato cylindrica. Caro, - in vetuftis, coriacea, tenuis. Putamen ofleum, durifimum, triloeulare, prope verticem ampla cavitate inani ex fculptum.

$\therefore$ REc. nullum; femina apice affixa.

$\mathrm{SEM}_{\mathrm{E}}$. in fingulo loculamento unicum, longum, furfum attenuatum, in apicem compreffum membranaceum definens, atrum, glabrum, lucidum. -

- IN T. duplex : exterius chartaceum, aridum, fragile ; interius membranaceum, rufefeens.

A L B. femine paulo brevius, oblongum, acuminatum, carnofum, album, tenue.

Es в. longitudine albuminis, inverfus, fubdiaphanus, fragilis, albus. Cotyl. oblongx, anguflx, plano-convexiusculx. Rad. breviftina, fupera.

a.) Drupa integra, b.) Putamen fuperne denudatam. c.) Drapa transterfim fecta. d.) Puraminis fectio longitudinalis, cum cavitate verticis \& feminum fitu. e.) Semima (eparata. f.) A Jbumen denudatum. g.) Embryonis in albumine fitus. h.) Embryo (eparatus,

Cave, ne hunc, pro Canarii fiuctu habeas: oinni enim Canario femen eft exalbuminofurn, \& cotyledones ad radiculam usque in tres lobos inxquales fectx.

125.3 
0 
Meliaceae

J. Gaertner (1788)

Tab.XCVI.

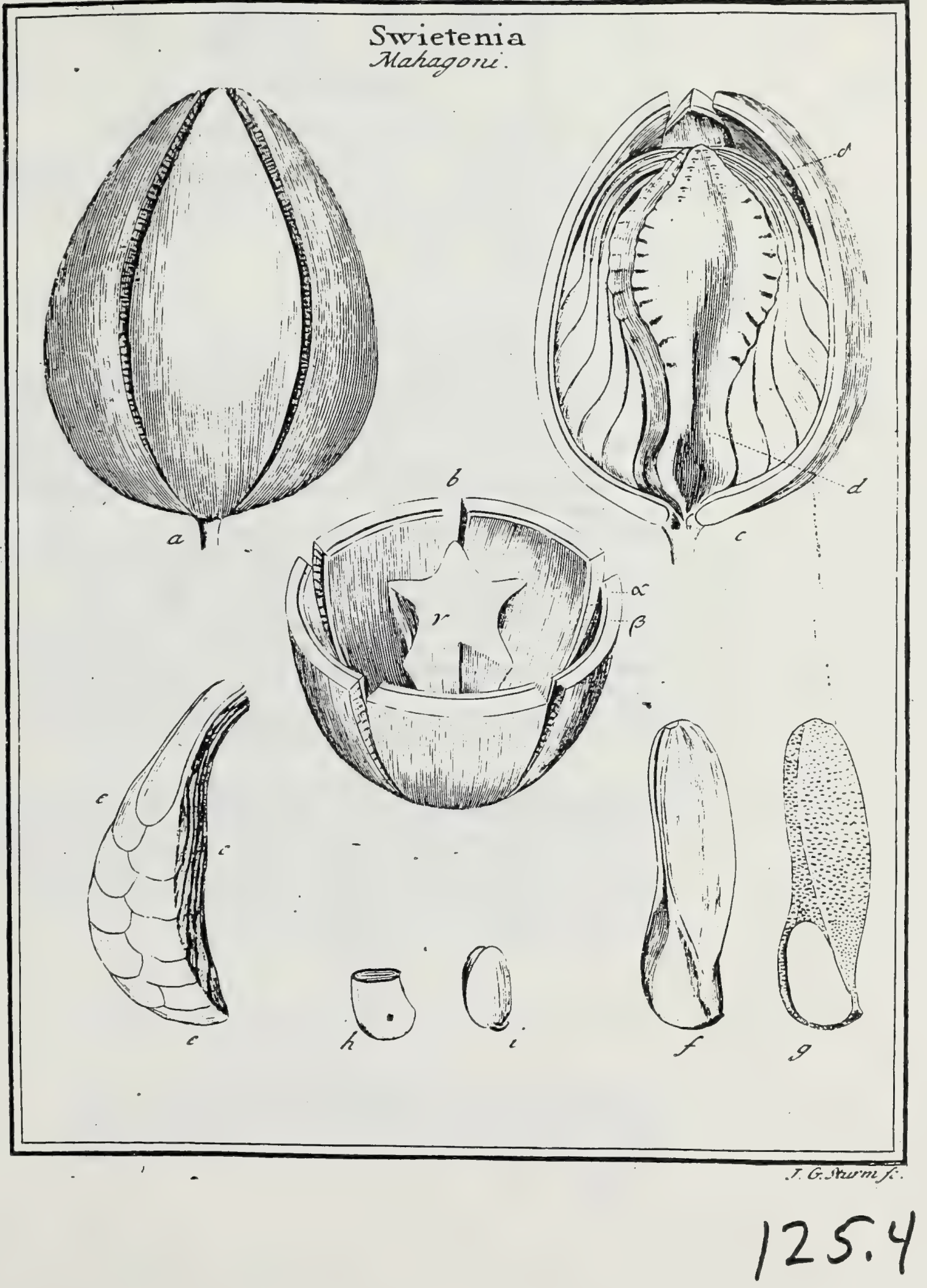




\section{J. Gaertner (-1788) Vol 2}

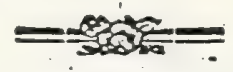

DXCVII. S W I E T EN I A. LINN, ger. 52 r.

Calyx quinquefidus. Cor. pentapetala. Nectar. cylindricum tubulofum: ore Antheras decem gerens. Ovarium fuperum quinqueloculare. Styl. fimplex, ftigmate capitato plano. Capfula matura unilocularis quinquevalvis. Semina imbrocata furfum alata.

Swietenis Mahagone. Tab. 96.

Arbor folis pinnatis nullo impari: nervo ad latus. CATEss. carol. 2. t.81? Swieteria. LiN. Jyf. veg. 399.

A Phil. Millero chefleano.

PER. Capfula grandis, lignofa, ovatx, furfum anguftata, unicolor \& rufefcen: ti fumora, prope verticen quinquelocularis, cetera vero ample unilocularis, quinquevalvis. Valvulx craffe, a bafi dehifcentes, caducx, intus lamina coriacea, craffa, Hexli, ipfis maguitudine ex affe xquali veftitz.

REC. centrale, liberum, lignofum, pentagonum, e bafi anguftiore furfum valde ampliatum \& incraffatum, ad apicen vero iterum atcenuatum \& in fingulo pyramidis latere genaina minimarum cicatricularum ferie notatum. quibus fermina inferta funt.

SEM. numerofa, in quinque fafciculos collecta, deorfum imbricata, comprefiz, e luteo rufelcentia aut cinnamomea, inferne nucleo dotata, fuperne in alam longam membranaceam defnentia

Is T. duplex: exterius membranaceum, circa nuclei fedem fpongiofum, intra dupliazuram fuam funiculum umbilicalen filiformem longifrmum coudeus; interius membranaceum, tenue, ferrugineum, albumen veltiens.

ALB. fubovatum, comprelfum, carnofum, tenue, fufcum, (an in recenti femine viride?) refinam l. terebinthinain fortiter redolens.

EM B. albumine paulo minor, lutefcens, erectus. Cotyl. ovatx, foliacex, tee nuilfinx. Rad. brevis, infer:t, fubadlcendens.

- 2) Capfula dehifeere incipiens. b.) Capfulx atque Reeeptaculi $\left(r_{0}\right)$ Retio transwerialis, ofterdens valvularum eraflitiom $(\alpha)$, atque laminam corizcann $(B)$, internam carum superseiem ohtegenten. c.) Capfula aperta. d.) Receptaculum cum fuis cicztrieulis ( $\delta$ ) duplici ferie poli. (is. e. e. e.) Fafciculus feminum imbricz:nrum. f.) Simen feperatum. g.) Albanen denudztua cum funiculo unbilicali intra alam. h) Altomea transverfe fectum i) Embryo feparatus.

Capfujas magnitudinem capitis infantis quandoque afrequi, mihi ab Aitoro affeveratum eft.

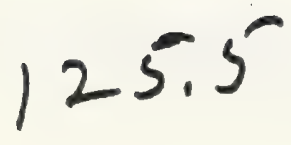




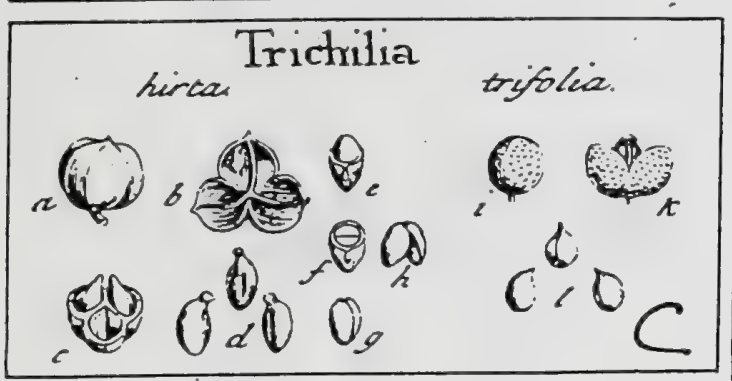

J. Gaertner (1788) Vol, 2

DXCIV. T R I C H I L I A. IIN. gen. 528 .

Calyx quinquedentatus. Cor. pentapetala. Neetar. cylindricum tubulofum, ore Antheras decem gerens. Ovar. fuperum. Stylus brevis: ftigmate tridentato. Capfula trilocularis. Semina folitaria, pendula.

TRICHILIA hirta. Tab. 95. fig. 5.

Evonymus caudice non ramofo, folio alato, frufu rotundo tripyeno. SLOAN. bilt. jam. 2. p. I03. t. 210. f. 2. 3.

Triclilia foliis pinnatis fublirfutis. LINN. Jyft. veg. 399.

Ex herbario Bankfiano.

P.e R. Capfula fubglobofa, rotundato trigona, trilocularis, apice trifariam dehifcens; bafi integerrima, poft dehifcentiam horizòntaliter patens.

REC. nullum; femina diffepimentorum margini centrali affixa \& ex eo pendula.

SEM. folitaria, aut fariffine. geminata, ovata, fuperne roftellata; fubbaccata, coccinea.

Is r. fimplex, membranaceo carnofum, tenue, in roftrum molle productum, coloratum, arctiffine núcleun complectens, nequaquam arillatum.

A L B. nullum.

EN B. magnitudine feminis, elliptico-globofus, iriverfus, melinus. Cotyl. carnofx, craffx, dimidiato-ovatz." Rad. minutiflima, puncticularis, fupera.

a. b.) Caplula integra \& dehifcendo, horizontaliter explamata. c.) Eadem transverim feaz. d.) Semina feparata. e.) Integumeatum feminis carnolum refectum \& aucleus fuperne denudatus. f.) Senixis (ectio transvet[alis. g. h.) Embryo deaudatus.

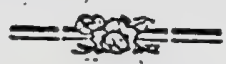

Trichilas trifolia. ibid.

Tribilia foliis teruatis. Jace. bift. anner. 129..t. 82. LiNs. fyff. veg. 399.

Ex herbario Bankfiano.

Capfula fpharica (i.), punctis pallidis fuper fundo fufco picaz, trilocularis, trivalvis $(k)$. Semina (1.) folitaria, filiformi - caudata, hinc gibba, inde angulata, bafi areola fufca notata, fimplici cuticula molli, in meic fpadicea, in probe maturis autem coccinea, tecta, neutiquam baccata. Nucleus
defuit. 
6 


\section{Menifpermum Coculur.}

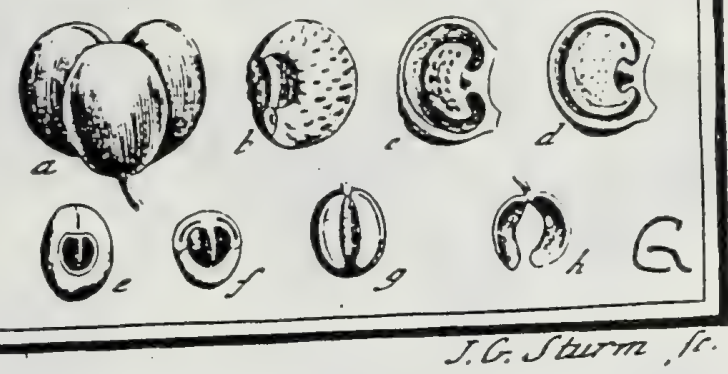

J. Gaertner (1788) Vol. $1 \mid 219$

MENisperau M Cocculus. Tab. 70. fig. 7.

Tuba baccifera. R чмР н. anbb. 5. p. 35. t. 22. f. B.

220

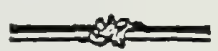

Natsjatam. R неED. mal. 7. p. I. t. I? B В А K

Menispermum foliis cordatis retufis nucronatis, caule lacero. Liss. Syl, veg. 992 .

Drupx, una, dux, tres (a) ovato globolx, carnolx, coccinex, glabrx, demuix fuinof $x$. Putamen fubglobofum (b.) offeum, feabriusculatum, hinc gibbum, in de in angulum compreffum, uniloculare (c.d.). Receptaculum fungolo fuberó fum, femiglubulum (c), pedunculo crafto putaminis parti ventrali infertum. 'S men (d.e.) folitarium, bullatum, glabriufculum, rufefcens, amplo, pro trani? mittendo receptaculo, foramine (e) pertufum, intus fulco elevato (f.) notatura. Albumen (f.g.) femini conforme, cafeofo carnofum, in duo loculamenta longi tudinalia, lateralia (f.), foliaceo compretta partitum. Embryo (g.h.) longitudine albuminis, inverfus, lacteo albus. Cotyl. lineari oblongx, foliacex, fecundum dorfuin albuminis curvatz, juxta $f e$, fed in propriis \& difcretis loculamentis pofitze ut altera alteram non contingat. Radic. (h.) teretiuscula, brevis, fupera.

Partium floris \& fructuum numerus, in variis, Menifpermi fpeciebus varius eft; in fola autem cotyledonum pofitione, non tantum omnes inter fe conveniunt, fed \& ab omnibus aliis hactenus cognitis plantis differunt; quandoquidem in folo Meiafpermo fingula cotyledon, fingulum \& fibi proprium in albumine inhabitet locula mentum; in omnibus autem reliquis, ambz cotyledones intra unicam cavitatem conclufx fint.

Natsjatam H. M. non quidem Cocculus Linnzi, fed Oflucinarum elle poteßt.

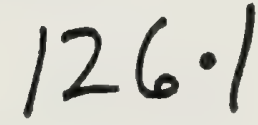




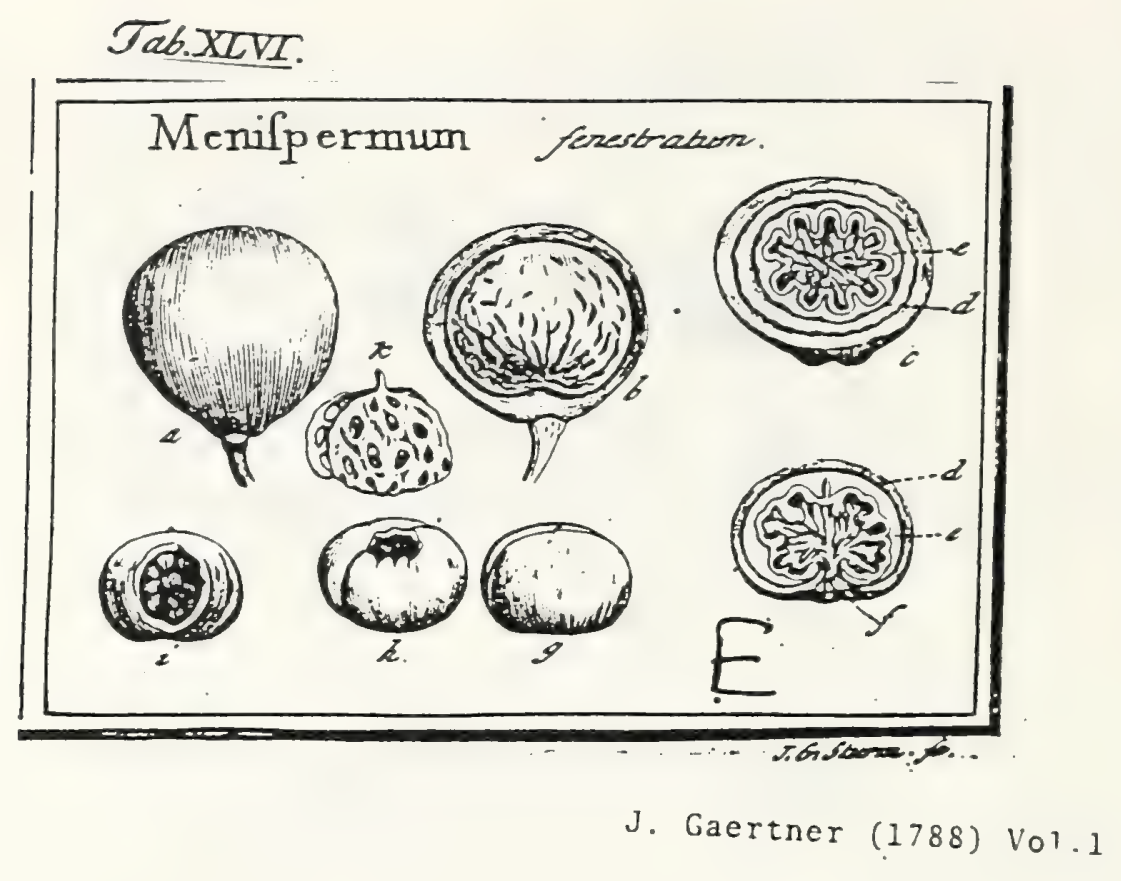

Menispermacea

219

\section{CCLXVIL. MENISPERMVM. TOURN. LIN gen. 213 R.}

Semen bullatum. Cotyladones Segregatz. Radicula Supera.

MENISPERM U M feneftratum. Tab. 46. fig. 5.

Waniwal. zeylonens. E collectione fem. hort. lugdb.

PER. Drupa baccata, obovata, folitaria, pubefcens, incana. Cortex tenuis, fer zta. tem coriaceus, putamini arctifime adnatus. Yutamen grande, reniformi $\mathcal{L}$ deprefte globolum, olleum, craflum, extus erofum, intus glabrum.

REc. Subftantia fungofo carnofa, e bafi putaninis, crafto pediculo, oriunda, mox in globum irregularem, totam feminis cavitaten replentem, ampliats \& in varios procefus irregularifimos, intra albuminis plicas receptos, formata.

S E M. unicum, fubglobofum, depreffiusculum, extus glabrum atque linea transver $f_{2}$ inferiptun, intus cavoin, mire anfractuofum, bullatuin, receptaculi fubftantia repletum, fubtus amplo foramine pertufun.

IN T. funplex, membranaceum, tenuifinum, pallidum.

AL8. Sernini conforme, amygdalino carnofum, tenue, album, ex duabus laminis carnofis conflatum, \& in duo loculamenta foliaceo comprefra divifum, in quorum fingulo, fingula cotyledon haret.

Eм в. magnitudine fere albuminis, inverfus, viridis, aut lutefcens. Cotyl. foliacex, tenuilTumx; in univerfum fubrotund $x$ \& concavx; fpeciatim vero ab impreffionibus receptaculi varie liexuofx \& crebris foraminibus perforatx ac quafi fenefratz; cx. tera, ita abinvicem fegregatx, ut altera dextrum, altera finifrum feminis latus te. neat \& ambx e dialnetro fibi oppofitx fiut. Rad. fubulata, breviffuna, fupera

a.) Drops integra. b.) Putamen denudatum. c.) Fructus totius fectio horizontalis d.d.) Sectio putaniois. e.e.) Sectio feminis ipfius f. albuminis. f.t.) Sectio receptaculi centralis, 5.) Semen decorticatum a parte fuperiori fpectatum. h.) Idem inverfum, cum amplo fuo foramine, per quod receptaculi fubftantia inirat i.) Portio albuminis effracta, ut interna (eminis cavieas pateac k, ) Embrjo reparatus.

\section{2}




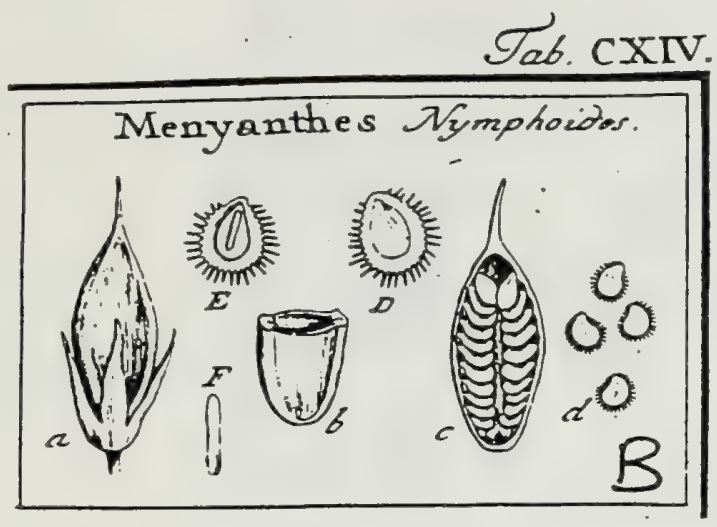

J. Gaertner (1788) Vol: 2

157

DCLXVIII. MENYANTHES. TOURN. inft. t. 15. LINN, gen. 202. Nymphoides. TOURN. inft.-t. $6 \%$.

Calyx quinquefidus. Cor. quinquefida, hirfuta aut ciliata. Stam. quinque. Ovar. fuperuni. Styl. fimplex, apice bifidus. Capfula unilocularis. Receptac. dateralia s" Oppofita. Sem. plura.

Mexranties Nymphoides. Tab. I14 fig. 4 .

Icors. OED. for. dass. t. s39.

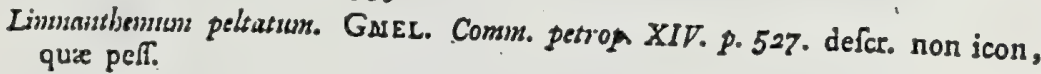
Nennumtles follis cordatis integerrimis, corollis ciliatis. LINN. Syjt. veg. 194.

PER. Capfula ovato - lanceolata, coinpreffiufcula"; ad margines incralfata \& rotundata, prinzum carnofa, tandem coriacea, tenuis, unilocularis, bi-
valvis.

Krc. nullum, precter incrafiatos valvularurn margines, quibus femina utrinque, duplici ferie longitudinali affixa.

SEN. numerofa, bracteata $f$. foliaces comprefa, margine membranaceo albo atque ciliato circumdata, ovata, aut obovata, in niedio pa!lide fpadicea.

INT. duplex: exterius chartaceum, in marginem \& cilia productum; interius membranaceun, viride, albumini adnatum.

A I в. cliipticum, femine anguftius, verfus umbilicum attenuatum, carnofum,
ayweo-pallidum. Eмв. longitudine albuminis, filifurmis, lactcus. Cotyl. breves, lineares. Rad.
longa; recta, centrifug;

158

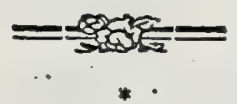

- b.) Capfula integra \& transverfiu feAs. c.), Valvula altera, eum fitu \& infertione (eminum d. D.) Semina feparata, intezra. E) Scminis \& albutninis fectio longitudinalis, cum fitu \& figura embryonis. F.) Einbrro Colutus.

Arenyanthes trifoliata. LinN.

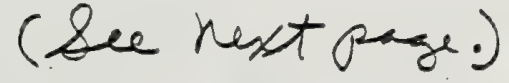

Icolt. BEsL. Eyf. veru. VII. t. T. f. 3. BLAKw. berb. t. 474. OED. fior. dan. t. 54I.

Capfula magnitudine circiter pifi mediocris, ovato globofa, aut ovato oblonga, utrinque fulco depreffo \& valvularum futuris contrario, infcripta, un:lucularis, bivalvis. Receptsc. in dorfo valvularum, fulco externo refpondentia, nequaquam vero ad futuras, ut in praccedenti. Semina, ex ovulis multis, nunnifi fex l. octo maturefcentia, ovata, turgide lenticularia, ut fere globofa, glaberrima, lucida, citrina aut ftramineo-lutea. Integum. exterius cruftaceum, fragile. Reliqua ut in pracedenti.

Multis itaque, nec levidenfibus notis, hac a priori differt, ut non erraverit, qui utrasque genere ftatuerit diverfas. 
Tab. CXCVIII.

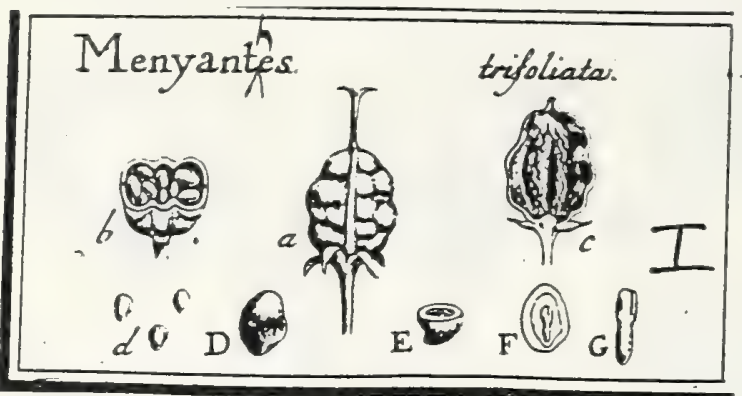

J. Gaertner (1788) Vol3

112

\section{I E N Y A N T H E S.}

Tотва. t. I5. Liñ. gen. 202, ed. Sclireb. 263. Juss. gen. p. 98. LAMAñ

Cal. fubcampanulatus, quinquepartitus, perfiftens. Cor. monopetala, infundibuliformis; tubo fubcylindrico, brevi: limbo quinquepartito: laciniis recurvo-patentibus, fupra villofis. Stam. quinque; longitudine fere lacinia rum corollx \& cum illis alterna; flamentis fubulatis; mutheris fagittatooblongis, erectis. Ovar. fuperum; ftylo fimplici, tereti; ftigmate bilobo. Capro ovato - oblonga, unilocularis, bivalvis. Rec. in dorfo valvularum. Sem. ovata, glaberrima. Alb. carnolum. Emb. coryledonibus diferetis.

Mexyanthes trifoliata. Tab. 199. fig. 9.

Trifolium majus. TAEERx. bift. p. 520 .

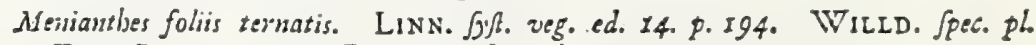
T. I. P. 2. p. 811. PERSOON fyn. pl. r. p. 171 .

Icon. BESL. Eyjz. vern. VII. t. I. f. 3. BLAKW. berb. to 474. OED. flor. dan. t. 54t. Ba TSCH. analys. fior. t. 12.

Conf. Carpol. Vol. 2. p. 158.

PER. Capplula fupera, coriacea, ovato-globofa, 1. ovato-oulonga, hine calyci perfiftenti infiltens, inde ftylo fuperne bilobo faftigiata, utrinque in medio valvularum dorfo fulco clevato inforiptal, finc inde a fenuinum protuberantiis irregulariter noduloli 1. pultulofa, unilocularis, bivalvis.

REc. in dorfo valvularum fulco citerno refpondentia, \& plerumque fulco medio bipartica, papillofa, in capfulan promimula.

SEM. ex plurimis ovulis nommili fex ad decen maturefcentia, ovata, turgide lenticularia, fere globofit, glaberrinsa, Jucida, umbilico ninimo inmerlo sotata, citrina, aut framineo-lutez.

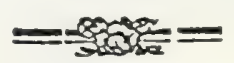

IN T. duplex: exterius craffum, cruftaceum, fragile; inserius membranaceun, tenuilimum, albumini arcte adnatum.

A L B. Semini conforme, fed paulo angultius, carnofum, album.

E B. albumine tertia parte brevior, \& in ejus parte inferiore locatus, teretioblongus, erectus, lacteus. Cotyl. tenues, oblongx, radicula paulo latiores, hine difcrecx, incumbenres. Rad. coryledonibus paulo Jongior, tereti-compreffrufcula, obtura, recta, umbilico externo obverfa, centrifugs.

\section{EXPLICATIO FIGURE.}

a.) Capfula integta, elaula. b.) Eadem transverfe diffecta eum litu femincm. C.) Va!rula altera feparata, Gitum reseptaculi reprefentans. d. D.) Scmina (eparata. E) Albumen traus-

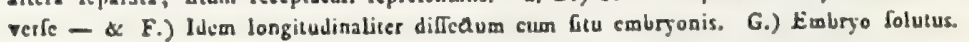

Menyanthis a Nymphoide vel Linmmanthemo diverfitas in partibus fructificationis \& frustu ipfo fat gravis eft, ut ad nutum Patris 1. a cum Celeberrimis in re herbaria Viris, Jussigu \& VEntenat, genera, a Tournefortio ftabilita, reftituere non dubiraverim. Inde huic prittinum nomen Meny: 、anthis fervavi, illi autem Limnanthemi haud incongruum effe cenfeo. 
Molluginaceae

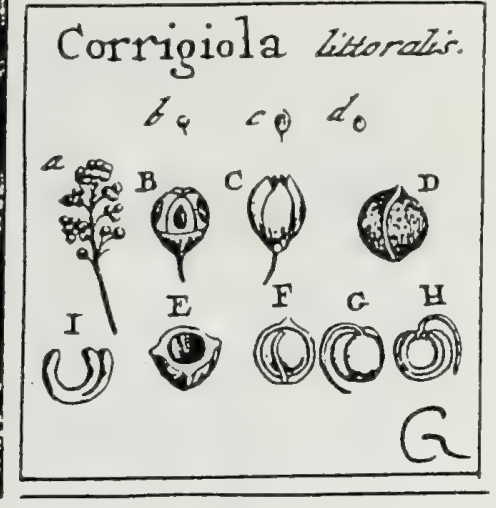

J. Gaertnet (1788) Vol.1

358

CCCCLXV. CORRIGIOLA. LIN $\mathrm{I} \cdot \mathrm{gen} \cdot 378$.

Calyx pentaphyllus, margine membranaceo albo. Cor. pentapetala. Stain. quinque. Styl. duo. Nux parva, rotundato trigona. Einbryo cyclicus.

Corrigiola littoralis. Tab. 75. fig. 3.

Alfine paluftris minor, folio oblongo repens. LIN D. alfat. t. 2. C. O $\mathrm{D}$ E R. f. dan. t. 334 .

Corrigiola. HA Lt. hifl. 1. 16. 842. L I N. Jyfl. vig. $297^{\circ}$

359

PER. Nucula parva, fore perfifiente tecta, globole trigona, cruftacea, rugato tuberculata, fufca, unilocularis, evalvis.

REc. funiculus umbilicalis filiformis, e bafi nuculx, ad apicem feminis, adfcendens.

$\mathrm{SE}$.. unicum, fubglobofurn, glabrum, rufefcens.

IN T. fimplex, membranaceum, tenuifimum.

$\Lambda$ \&. globofum, centrale, farinofum, candidiffimum.

Е мв. periphericus, teretiusculus, inverfus, annularis, pallide lutescens. Cotyl. feraicylindricx. Rad. teretiuscula, fupera.

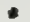

2.) Frutuum racemulus. b. B.) Calyx \& c.C.) Corolla nucem obtegentes, d.D.) Nucala denudata. E.) Ejus fetio transverfalis. F.) Semen intra tucem cum funiculo umbilicalio G. H.) Atbumen embryone cinßtum. I.) Embryo (eparatus.

28. 
Tab. CXXX

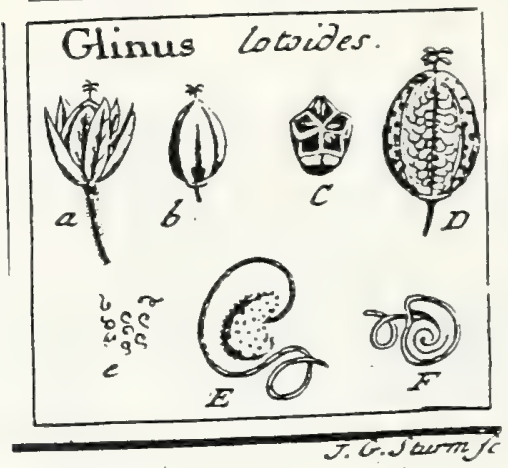

J. Gaertner (1788) Vol. 2 236

DCCLXVII. G L I N U S. LINN. gen. 6ro.

Calyx pentaphyllus perfiftens. Cor. pentapecala, pecalis anguftis, apice bi. 1. trifidis. Stam. quindecim ad viginti. Ovar. fuperum. Styl. unicus, apice quinquefidus. Capr. quinquelocularis, quinquevalvis. Recept vullum. Sem. nunerora.

Glinus lotoides. Tab. 130. fig. 12.

Alfme lozoides ficula. Bocc. fic. 2I. t. 1t. rudis.

Porinlaca batica, luteo flore, Spuria aquatica. BARR. $r m \cdot 47^{8} \cdot t \cdot 33^{6}$.

Glinus crule pilo/o, foliis obovatis. LinN. Jyf. veg. 455.

PER. Capfula ovato-pyramidata, pentagona, tenuis, a protuberantibus feminibus puftulata, quinquelocularis, quinquevalvis. Diffepimenta valvula rum medio inferti.

REc. nullum; femina per funiculos umbilicales filiformes omnium longifimos. angulo loculamentorum centrali affira.

SEM. uumerofa, circiter quinquagiuta in fingulo loculo, reniformi-roftellata, pundis elevatis craflis vagis confperfa, lucida, ferruginea.

IN T. duplex = cruftaceum atque membranaceum.

A C B. vix ullum, proter paucam fubltantiam farinofum in lateribus feminis.

EMB. magnitudine ferminis, Spiralis, albus. Cotyl. femiteretes, unum fpirz: gyrum abfolventes. Rad. dorfalis, centripeta.

a. b.) Caplula integra, clanta. C.) Ejus fectio trasverialis. D.) Loculamentum apertum, cum fuuiculis umbilicalibus. c. E) Semina (eparata. F.) Embrya.denudatus

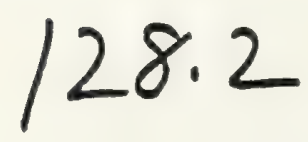




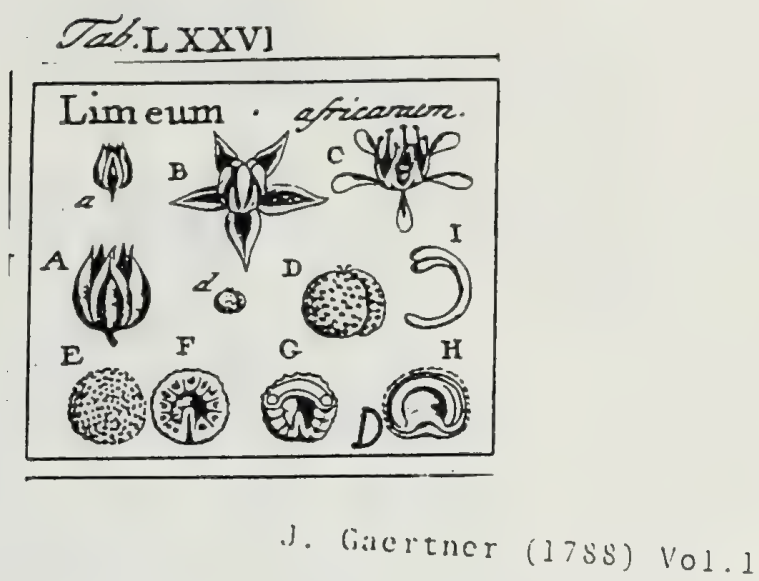

367

CCCCLXXVIII. LIMEUM. L In N. gen. 463 .

Calyx pentaphylius, marginibus membranaceis. Cor. pentapetala. Stam. feptem aut pauciora, filamentis baff dilatatis \& in Nectarii cupulam connatis. Sty\% duo brevillimi. Fruçus bipartibilis in femina duo hemilpharica, nuda, meniscata.

Li s.u st africanum. Tab. 76. fig. 5 .

Limeusis foliis oblongis petiolatis. L I v N. Jy/t. 2'c5. 352 .

Ex herbario Bankfiano.

PE r. nullum; fenina nuda, coadunata in fructum fpharicum, per maturitatem fponte bitrartibilcm.

REC. nullum, prater fuhnantiam fpongiofam in concava fominum parte.

Ses. dun, henifplaxrica, crecha, furdide ntaminea, hasc convexa, ferobiculato- feabrata, inde ampla cavitate inani exfeulpta.

IxI. dup!ca: cxlcriss coriaccum, mojice cratum; interius tcnuifinum, pailidum.

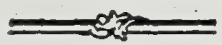

A L 8. Cemini conforme f. menifcatum, farinofum, candidifimum.

Eм в. teretiusculus, periphericus, fetnicircularis, lacteus. Cotyl. femicylindricx. Rad. longa, arcuata, infera.

2. A.) Calyx maturas. B.) Idem explicatus, eum corolla \& ftaminibus in fita. C.) Petala re: clinata, cam ftaminam coronala. d. D.) Fruetus integer. E.) Seminis dorfam. F.) Ejas ven.. ter. G.) Semen transverfe - \& H.) Idem verticaliter fettum, cum embryone ad peripheriam,

I.) Embryo folutus. 


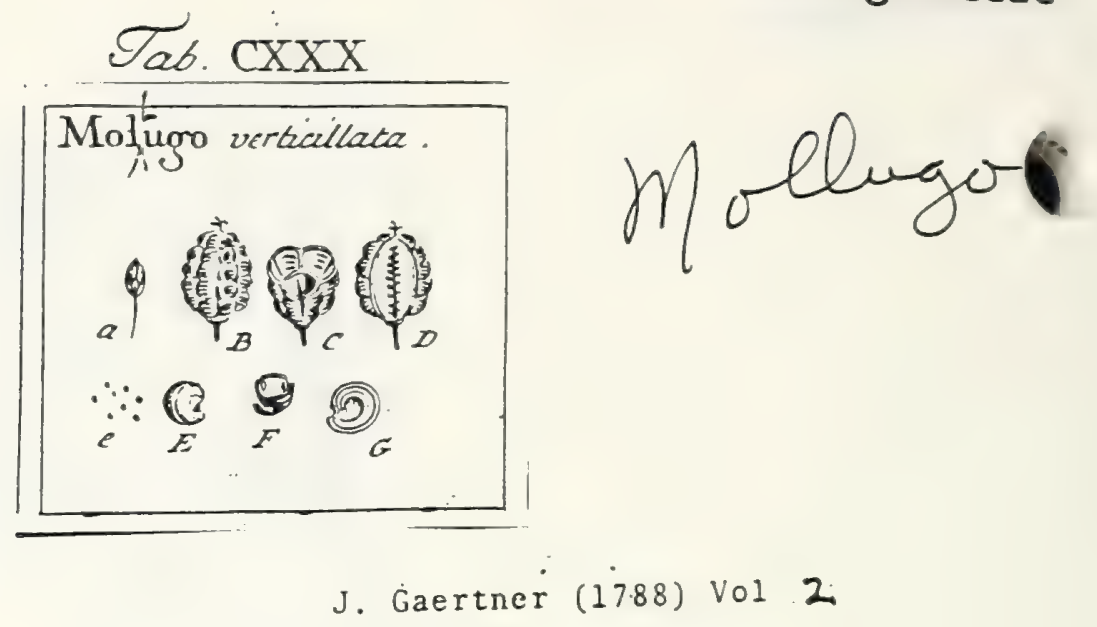

235

DCCLXVI. M O L L U G O. LINN. ger. 106.

Calyx pentaphyllus perfiftens. Cor. nulla. Stam. tria. Ovar. fuperum. Styl. tres aut unicus apice trifidus. Capf. trilocularis trivalvis. Recept nullum. Sem. plura.

Mollugo verticillata. Tab. 130. fig. II.

Alfme fpergula muriana, Latiori folio, fioribus ad nodos pediculis cartis circa

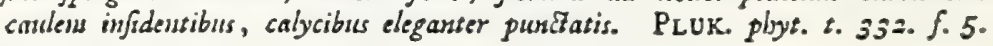

Alsme procumbens galii fucie. EHRET. pirt. t. 6. f. 3 .

Mollugo foliis verticillatis cuneiformibus acustis, caule fubdivifo decrurbente, pedurtculis wifloris. LiNs. Jj/. veg. 129 .

Per. Capfula ovata, rotundato - trigona, tenuis, a protuberantibus feminibus puftulata \& fimul arcuatis ftriis in ipfis puftulis eleganter exarata, trilocularis, trivalvis. Diffepimenta valvularum medio inferta.

R E c. nullum; femina per funiculos umbilicales angulo loculamentorum centrali affixa.

SEM. plura, circiter duodecim in fingulo loculo, fubglobora, roftellats, tribus lineis acutıs prominulis in dorfo exarata, glaberrima, lucida, ferruginea aut faturate caltunea.

INT. duplex: cruftaccum atqque membranaceum.

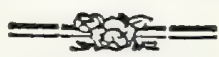

$\Lambda \perp$ B. farinofum, album, centrale.

Eм в. periphericus, annularis, lutefcens. Cotyl. femiteretes. Rad. centripeta.

2. B.) Capfula claufa. C.) Ejus fedtio transvertalic D.) Loculamentum apertum, cum funiculis unsbilicalibus ad axem. c. E.) Semina feparata. F. G.) Semiuis fectio transverfalis atque longitudinalis cum albuminis atque eobryonis fitu \& figura.

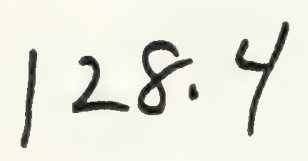




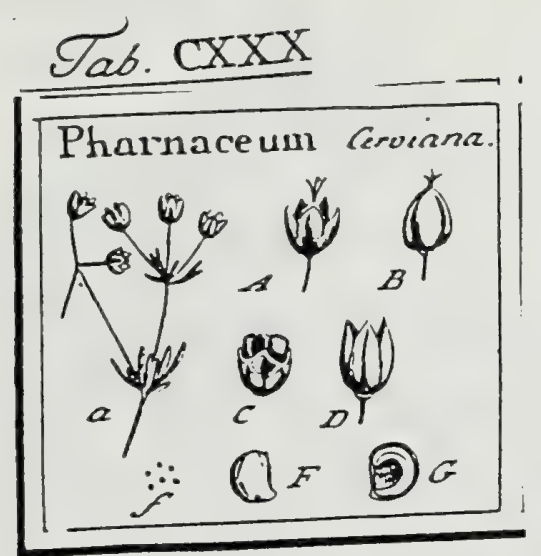

\section{J. Gaertner (1788) Vol. 2}

\section{4}

DCCLXV. PHARNACE.UM. LINK. gen: 379.

Calyx pentaphyllus, perfittens. Cor. nulla. Sam. quinque. Ovar. Supe rum. Styl. tres. Capf. trilocularis trivalvis. Recept. nullum. Senn plura. Pharniceum Cerviana. Tab. 130. fg. 10.

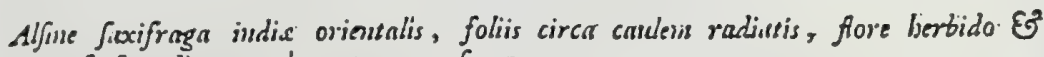
vruecofo. РLUK. plyyt. \$. 332. f. 11.

spergala propuruea minima. Вихв. сенt. $3 . t .6=f .2$.

$$
=\frac{-3 \times 2}{3}
$$

Pbaruacerun pedusculis fubumbellatis lateralibus, folia Linesriu equatibus. LINx. fy/t. veg. 297 .

PER. Capfula ovata, tenuis, obfolete trifulca, a protuberantibus feminibus leviter puftulata, trilocularis, trivalvis. Diffepimenta medio valvularuni inferta.

REC. nullum; femina per funiculos umbilicales brevifimos angulo centrali loculamentorum affixa.

SEM. plura, octo 1. decem in firfgu'o loculo, parva, fubrotunda, roftellata, in dorfo ftria filiformi unics notata, glaberrina, lucida, ruffo-ferruginea.

IN T. duplex : crultaceum atque membranaceum.

A L R. farinofum, album, centrale.

EMB. periphericus, hemicyclicus, lutefcens. Cotyl femiteretes. Rad centripets.

a.) Plantz fructiferz ramulus. A. B.) Capfula integra, nuda \& a calyce obteta. C.) Ejus fectio transverfalis. D.) Eadem in valvulas dehifeens. f. F.) Scmina feparata G.) Semen diffequm eum tigur \& Gtu albuminis atqque embryenis.

Solo Itaminum numero a fequenti genere differt.

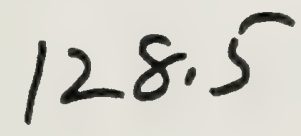


Molluginaceae

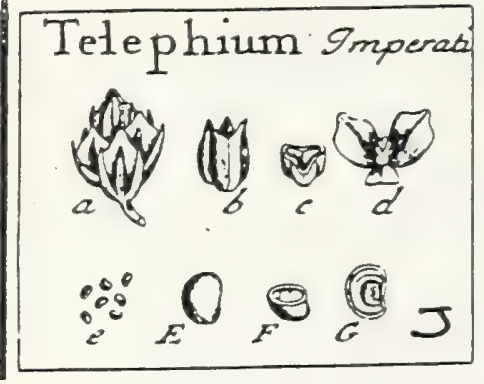

J. Gaertner (1788) Vol. 2

$22 I$

DCCXIVI. TELEPHIUM. TOURN. t. I28. LINN. ger. 377 .

Calyx pentaphyllus. Cor. pentapetala. Stam. quinque. Ovar. fuperuor. Styl. tres. - Capf. triquetra, unilocularis, trivalvis, polyfperma.

TELEphIUM. Imperati. Tab. 129. fig. 4.

Teleplizuns legitimum. CLus. bif. 2. p. 67 .

Telephisun foliis altenis. LINN. [y/t. veg. 297 .

222

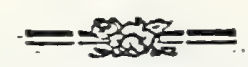

PER. Capfula ovata, fuperne in mucronem contracta, triquetra, in mediis lateribus ftria depreffa longitudinali notata, unilocularis, trivalvis.

REc. breve, columnare, Jiberum, inferne fcrobiculatum, fuperne funiculis umbilicalibus urevibus penicillatum.

SEn. plura, circiter duodecim, grandiufcula, ovato-globofa, fubreniformia, vix aut leviffime compreffa, minutifime elevato - puncticulata, glabra tamen \& fine fplendore aterrima.

INT. duplex: coriaceun atque membranaceum.

A L B. fubfarinolum, aqueo-glaucum aut album, centrale.

EM 1. periphericus, femicircularis, albus. Cotyl. femiteretes. Rad. infera \& fimul centripeta.

a.) Fruetus in racemulis terminalibus. b.) Cappula dehifens. C.) Ejus fedio transverfalis. d.) Receptac. denudatum. c. E.) Semina feparata, F. G.) Scmen diffeaum, cum Gtu albuminis \& embryonis.

128.6 


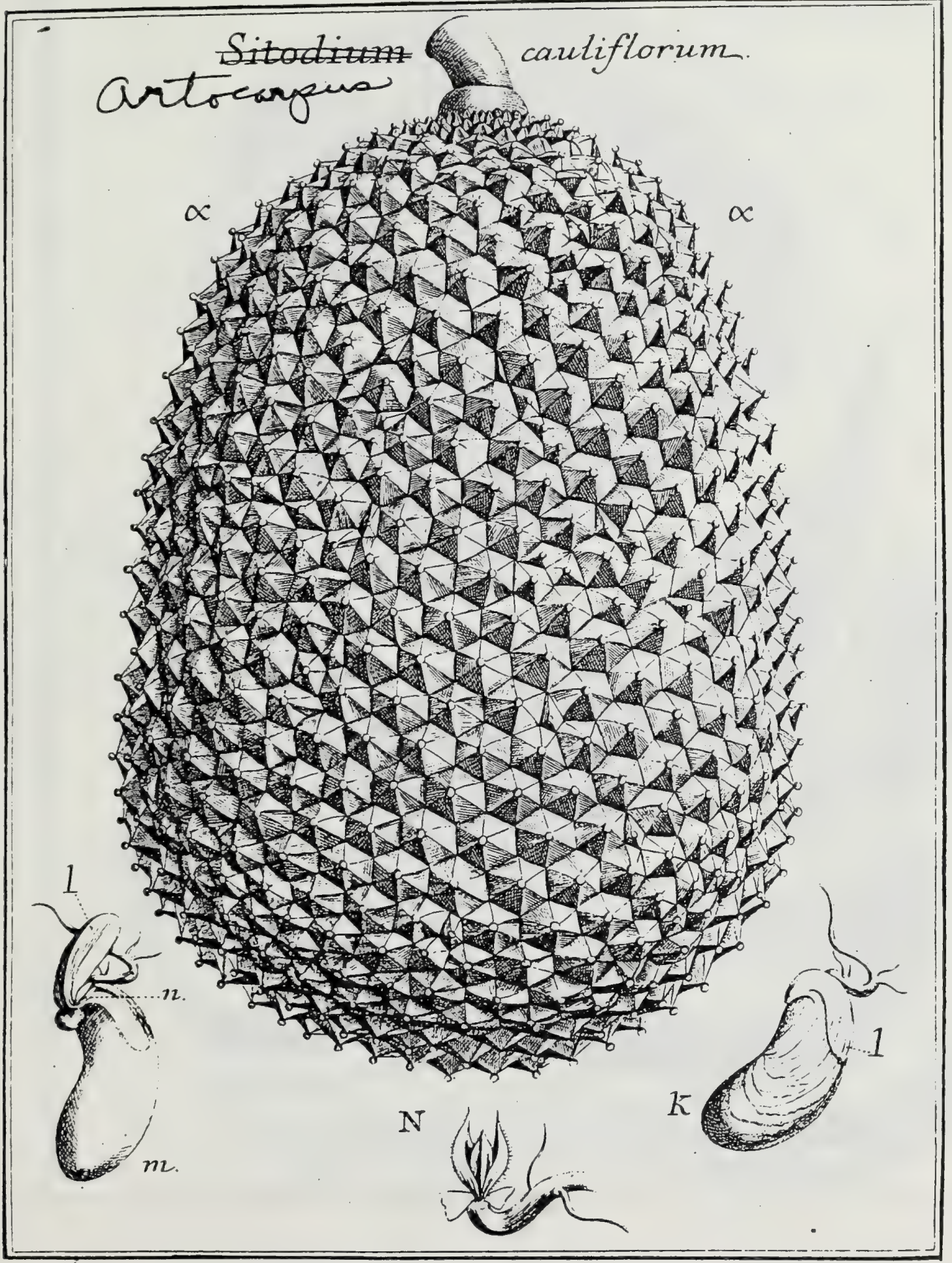




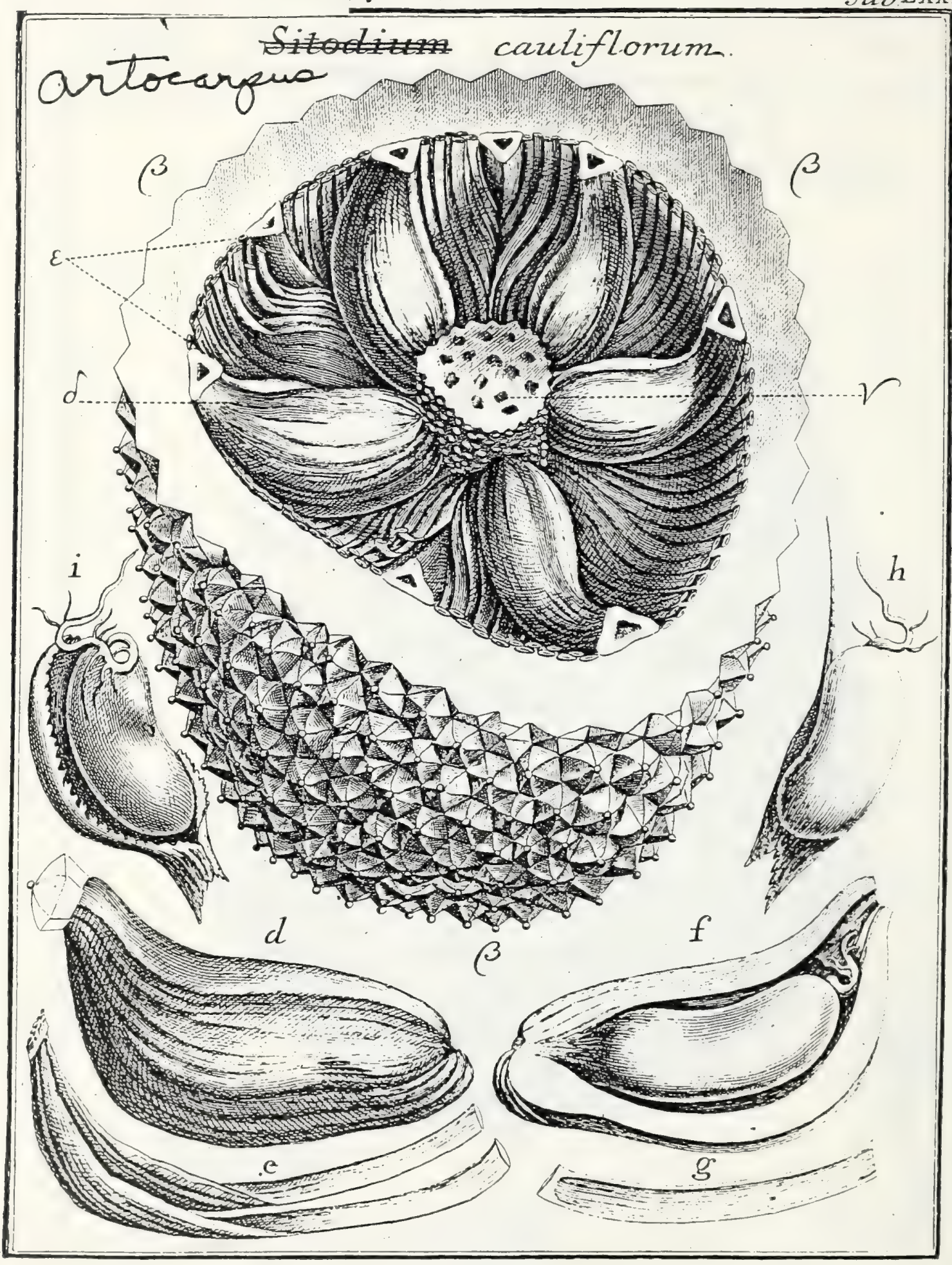

\subsection{8}


J. Gaertner (1788) Vol.1

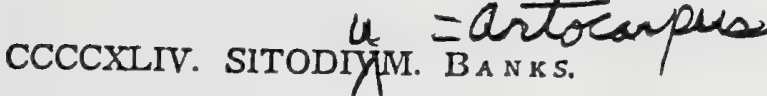

Flores fexu difineti in codem trunco. M A s. Amentum parvum, fubclavatum, e fquamis bivalvibus. Cor. nulla. Stam. unicum. F E M. Amentum lubglobofum, gemina diphylla colorata decidua involucratum, ex meris orariis compofitum. Cor. nulla. Styl. nullus. Stigma globofum feffile. Bacca compofita : univerfalis maxuna, polyxdro muricata; partiales numerofiltunx, uniloculares, monofyermaé.

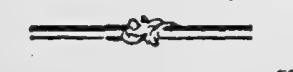

SIT ODIU M cauliforum. Tab. 7i. 72 .

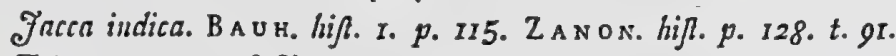

Tsjacca-maram, f. Facca. R н Е E D. mal. $3 \cdot p \cdot 17 \cdot t .26 .27 \cdot 28$.

Soccus arboreus. Nanca. R и м Р н. amb. I. p. 104.t. $30.3^{1}$.

Artocarpus foliis integris. LIN . Jy/l. vcg. 838 .

FRU C T U compolitus e pericarpiis baccatis apice inter fe connatis:

Bacca univer/alis inaxima, ovata, obfoletillime angulata, undique tuberculis hexaacdris, globulo callofo. praepilatis, muricata.

B. partinles, aggregatac, ad fingulum figma fex, inferius, receptaculo communi infertac, fuperius in tuberculum hexaaedrum connatae, quod cum vicinis, corticem baccae univerfalis efficit.

B. proprice numerofifimae, e quibus autem longe plurimae abortant. Abortiva lineares, comprefTae, fafciarum carnofarum fpecie maturescentibus adjacentes: Focundre, o:ato oblongac, verfus apicem angufatac, irregulariter angulatae, carnolae, craflac, uniloculares.

REc. commune columare, cylindricum, in axi fructus pofitum; proprium nullum, practer fundum baccae focundae partialis, cui feminis arillus affixus.

SEx. in fingula bacca partiali folitarium, oblongo reniforme, glabrum, e luteo rufefcens, arillatum.

Arillus membranaceus, tenuis, mollis, transparens, integerrimus, femen laxe cingens, umbilico affixus

IN т. duplex: exterius clartaceun, tenue; interius membranaceum, ferrugineum, vafis ex umbilico arcuatis infcriptum.

A L B. nullum.

Eм в. femini conformis, inverfus, anngdalino carnofus, albus. Cotyl. inaequales: altera maxima, totan fere feminis molem efficiens; altera multoties minor, priori fuperne accumbens. Plum. grandiuscula, tetraphylla, foliolis ovato acuminatis, conduplicatis, carinâ ciliatis, per paria oppofitis. Rad. tcretiuscula, fupera, fa. cile intra frudlum germinans.

$\alpha x$.) Bacca tniverfalis integra. $\beta . \beta . \beta$.$) Eadem transverím sefta, \gamma$.) Receptac commune.

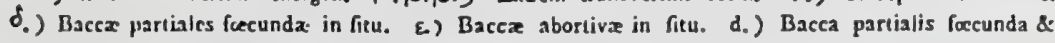
c.) Aiix dux abortive, folutx, magnitudine uarurali. f.) Bacea longitudinaliter aperta, cum feminis fitu. g. ) Baccz abortiva cavitas imanis. h.) Senten arillo teftum. i. ) Arillus apertus \& fenen denudatum. k., Scminis inrefurnentun iuternum, arcuato venofum. L.l.). Cotyledon minor in fitu, eademque reclimata. m.) Cotyledon major. n. N.) Plumula, cuin radicala germinante.

Neque ex fnliorum figura, neque ex fructuun fitu Sitodii fpecies, Catis certo defuniri polTe videntur. Nam quod folia fpeclat, illa fane in A. integrifolia Linn. fatpius perinde lobata funt, atque in altera ejus fpecie; quod autem fitum fructuum 


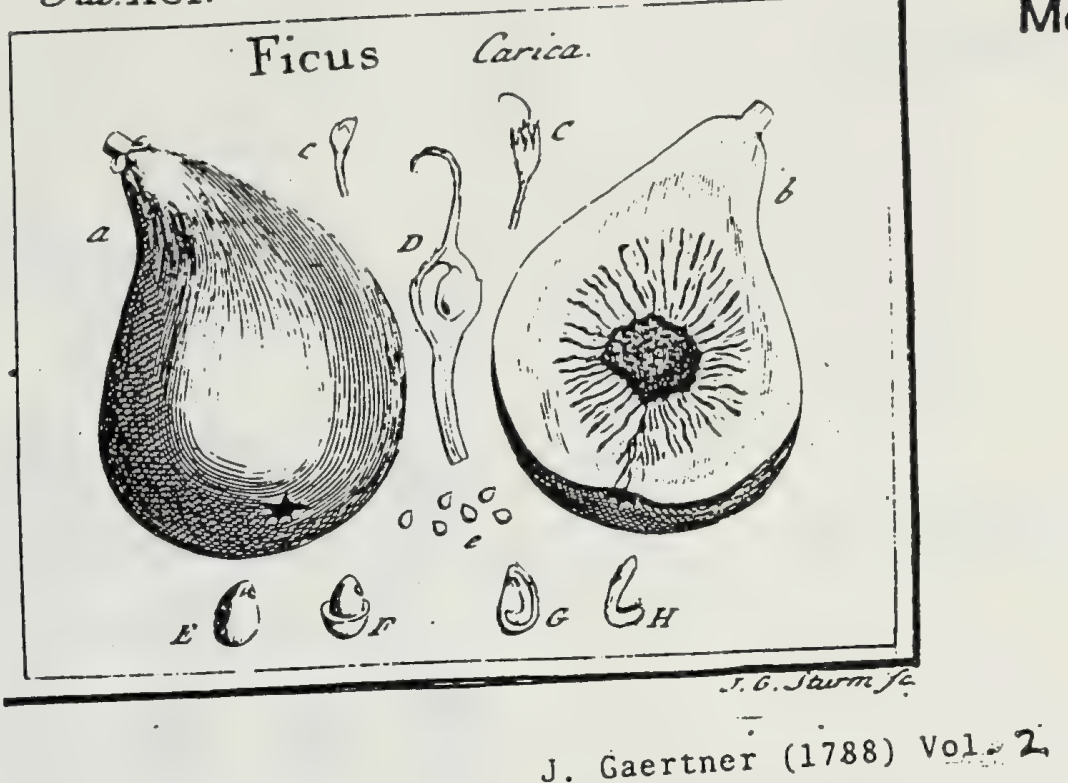

DIXXI. FICUS. TOURN. inft. t. 420. LINN. gen. II68.

Flores fexu diftincti, in eodem, vel in feparnto Receptaculo communu turbinato, carnofo, fquamis conniventibus claufo. MAS. Calyx campanulatus, trifidus, bafi in pedunculum Goris carnofum, fliformem, definens. Stam. tria. FEM. Calyx campanulatus, quinquefidus, bafi externa, in pedunculum fioris carnofum filiformem productus; interna, cum ovario conmiftus. Ovar. femiinferum. Styl. fetaceus, apice bifidus. Drupa monofperma.

Eıcus Carica. Tab. 91. fig. 7.

Ficues. DOD. pemst. 8 12. BLAKw. berb. t. 125. EHRET. decrd. 2. 73. 74. opt.

Ficus palmata. HALL. bift. $n .5607$.

Ficus foliis palmatis. LiNs. $\int y 2$. veg. 921.

FRUç. turbinatus, apice umbilicatus, e viridi \& rubro varius, carnofus, mollis, intus cavus.

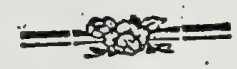

PER. Drupa minima, baccata, filiformi-pedunculata, calyce fupra medium fibi circumnato tecta, atque ftylo perfiftente terminata. Cortex gelatinofu-carnofus, fubpellueidus, demum exarefcens. P Putamen cruftaceum, tenue, fragile, femen xmulans.

REC. funiculus filiformis, e pedunculo floris oriundus, fuperne bifidus: crure altero in Itylum pergente, altero recurvo, femen pendulum fultinente.

SEM. putamini conforme, feu ovatum, furfum anguftatum, lenticulari compreffum, fub apice foramine umbilicali notatum, rufefcens.

IN T. fimplicifimunin membranaceum.

A L B. magnitudine \& figura feminis, craffum, carnofum, pallidum, febi inttar fragile.

Eмв. teretiufculus, uncinatus, inverfus, niveus. Cotyl. Semireretes, accumbentes, arcuare Rad. leviter incurvata, longa, fupera.

$\star$ a.) Eruetus integer. b.) Idem diffeetus. c. C.) Flolculus femineus matorus. D.) Cortex drupz cum funiculo ambilicali Seutinis c. E) Putaminis crufta integra. F.) Ezdem transverfe feca, cum femine ad medinat denudato, atque cieatricula fua umbilieali pro pria infignito. G.) Embryonis fitus in albumine. H.) Embryo folutus. Rectius forfan Utriculus, quam drupa, hoc pericarpium diceretur, qula tan-
dem in membranulam tenuem exarefcic. 


\section{Tab. CLXXIX.}

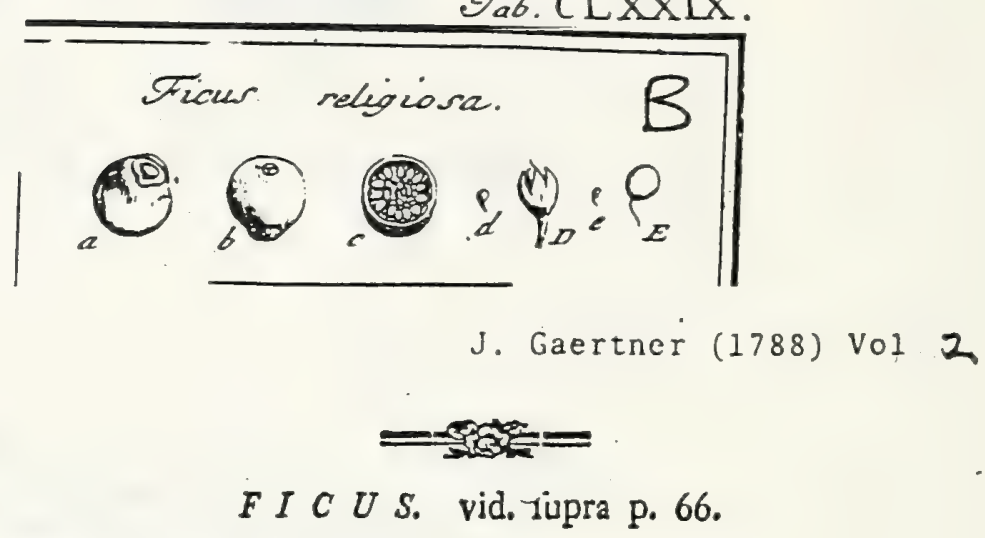

Ficus religiofa. Tab. 179. fig. 5 .

Arealu. RHERD. mal. 1. p. $47 \cdot$ t. 27.

Ficus foliis cordatis oblongis integerrimis acminatifimis. LiNs. bff. veg. 92I.

$E$ collect. fem. hort. lugdb.

Fructus (a. b. c.) magnitudine nucis avellanx minoris, leviter turbinatus, per exficcationem tenuis, chartaceus, gilvus, bari (a) munitus bractea florali monophylla, repande lobata, apice autem (b.) ftipatus fquamulis tribus minutulis, conniventibus, aperturam verticis claudentibus. Cavitas interna (c.) lota flofculis farcta. Flofculi feminei (d.D.) trifidi, nigro - fufci. Semina (e. E.) parvula, globofa, albicantia, glabra, cruftacea, lungo funiculo umbilicali capillari hærencia. Nucleus defuit.

Semina nigra dixit Rheede 1. c. quod utique de fofculis femina involventibus, non autem de feminibus ipfis verum.

Etiam in hac fpecie pericarpium proprium eft mera pellucida pulpola, per maturitatem exarefcens \& femen arcte claudens: hinc omnino Drupe nomen in charadere Ficus Carice expungendum, \& ejus loco Utricuhus. pulporus ponendus. 
Moraceae

$\mathcal{T}_{a b} \mathrm{xxveri.}$

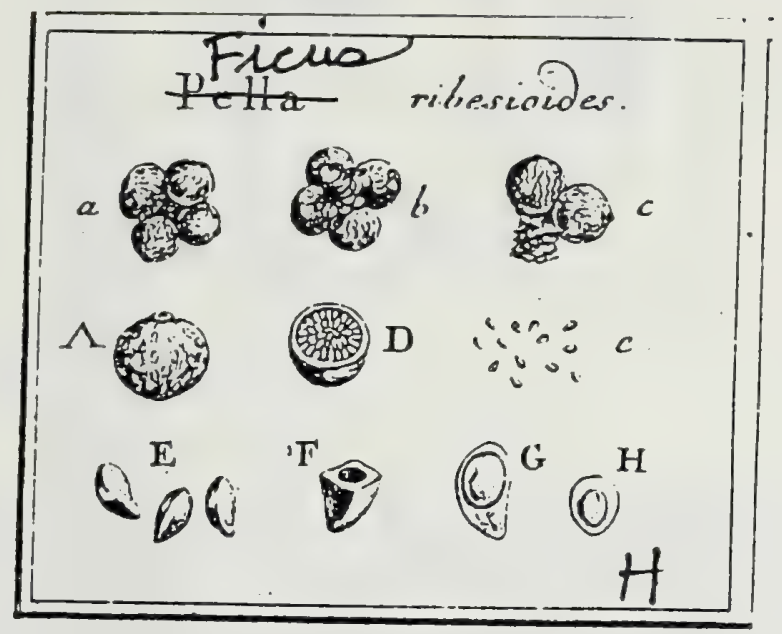

$$
\begin{gathered}
\text { J. Gaertner (1788) Vol.1 } \\
143
\end{gathered}
$$

CLXXI. PELLA.

Calyx edentulus fuperus. Cor. . Stam. ... Piff. . . Bacca infera, usiloculatis Semina numerofiffuna, nidulantua.

Pelia ribefioides. Tab. 28. fig. 8 .

Kiri-Palla. Zeylonens. E collect. Cem. hort. lugdb.

an Brmiflerioides. L I N N. flor. zcyl. p. 192. 4.407 ?

Embelia (Grodfularia) foliis ovato lanceolatis floribus tetrandris. RETz. f. $4 \cdot \mu^{\prime} \cdot 6 f^{\text {? }}$

PER. Bacca infera, globofa, in vertice, umbone parvo, concavo, edentulo, fulfulfio terminata, ceterun rubicunda, inaculis parvis rotundis variegata, uniloculais. Cuticula tenuifina. Pulpa fubaguofa.

REC. nullum; fersina in omnem direflionem intra pulpain nidulantia.

SEM. numerofifuma, parva, obovata, angulata aut rhombeo, compreffa, fubofira. Spadicea, glaberrima, nitida.

IN T. duplex: exterius cruftaceum, durum, fragie, prope umbilicum craffillinmuni interius membranaceum.

ALB. feminis tefta multo minus \& anguftius, ovatum, lenticulari compreffum, cariur fum, pallidum.

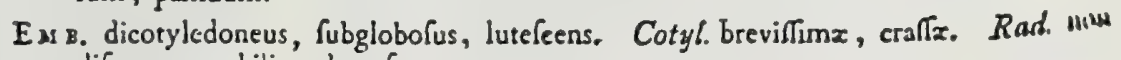
difereta, umbilico obverfa, vaga.

a. A. b. c.) Baccx in extrenitate ramorum feffiles, rernx aut quatemx, fquamis gemmarais Mul. fulta, rubicundx, Jeucoflafiz (A.). Selio bacez (D.) transverfalis, cum feminibus in filu. a $h$ )

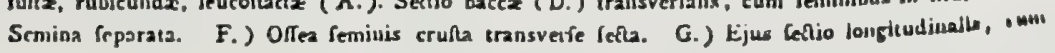
albuniue denudato. H.) Embryonis fitus intra albumea.

Racca fupera fecundum Retzium 1. c.

129.4 
Tab. CXXVI.

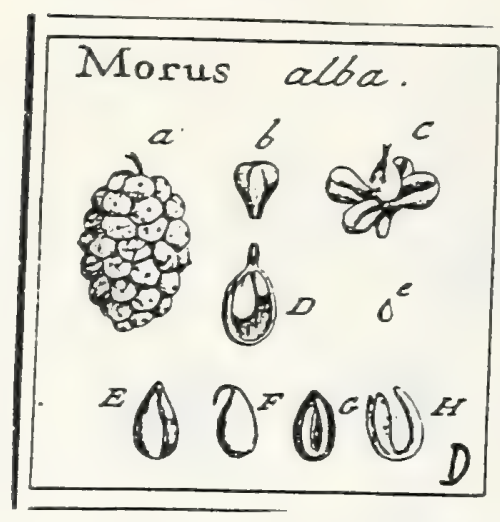

Moraceae

J. Gaertner (1788) Vol 2

I99

DCCXVI. MOR U S: TOURN. t. 362. LINN. gers. 1055 .

Flores fexu diftincti in eadem ftirpe. MAS. Cal. quadripartitus. Cor. nulla. 'Stam. quatuor. FEM. Cul. \& Cor, ut in mare. Ovar. fuperum. Styl. duo. Capfula utriculofa mollis fubdifperma calyce fucculonto tecta.

Morus alba. Tab. 126 . fig. 6.

Morus candida. DOD. pempt. 8 ro.

Morus foliis fabris femitrilobis $\mathcal{E}^{2}$ cordatis. HALL. bift. $\pi .16 \mathrm{tr}$.

Morres foliis oblique cordatis kevibus. Lins. Gyf. veg. $85 t$.

PER. Capfula calycis foliolis in baccam alban turbinatam conferruninatis tecta, ovato-acunimata, membranacea, pulpa molli farcta, unilocularis, demum in pelliculam tenuem femini fuperinductam exarefcens.

REc. nullum; femina, ope funiculi filiformis fibi aduati, capfulx apici affixa.

SEM. unicum, altero conftanter abortante, ovatum, furfuni attenuatum, fublenticulare, rufefcens.

Ix'. duplex: exterius cruftaceun, durum, fragile; interins membrauaceun, fpadiceun.

A L в. femini conforme, carpofum, album, cmbryonem includens.

200

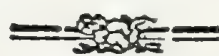

E ar в. uncinato - curratus, inverfus, "lacteus. Cosyl. ablongx, foliacex, asgufte, planx, incumbentes. Rad. teretiufcula, fuper.

a.) Spica feminea, matura b:) Calyx claufus. C.) Ejusdem ffegmenta diduda atque capfula denudata. D.) Capfula longitudiaaliter fcea, cum ovulis geminis. c. E.) Semen feparatur. F.) Blbumen integrnm. G.) Idem.diffetum, cum Gtu embeyonis. H.) Embryo folutuc

Proxime a Ficu diftato 


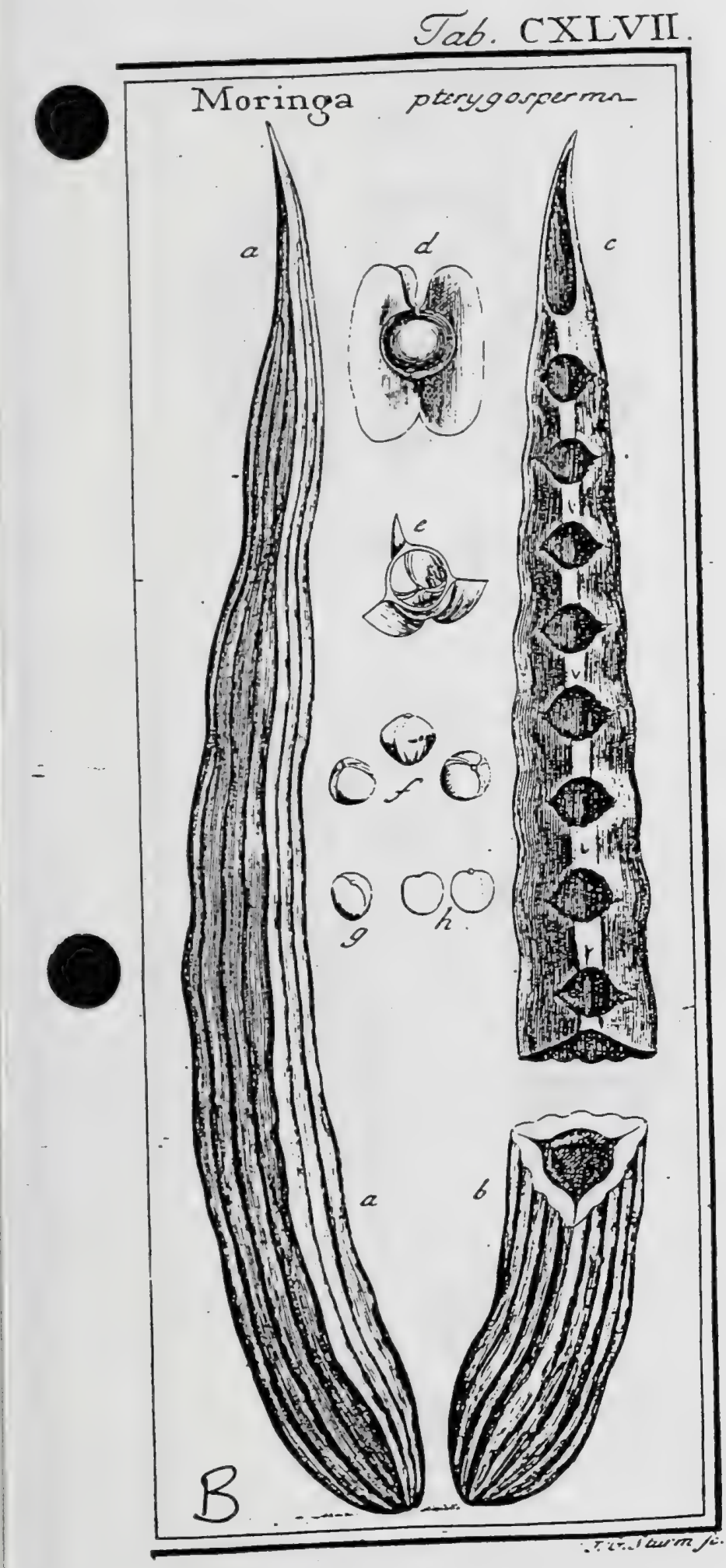

\section{Moringaceae}

J. Gaertner (1788) Vo1..2.

\section{M O R I N G A. Juss, $p \cdot 348$.}

Calyx profunde quinquefidus deciduus. Cor. pentapetak, petalis non unguiculatis xqualibus: quatuor inferioribus; uno fuperiore arrecto. Stam. decem, difcreta, inzequalia. Capf. longiffma, fubulata, trivalvis, unilocularis. Sem. globofa, triptera aut aptera, exalbuminofa. Embr. rectus.

Moringa pterygorperma. Tab. 147. fig. 2.

Muringu. RHEEd. nal. 6. p. sg. t. Ir.

Mforunga mas \& feniriro. RuMPH. ansb. 1. p. 18 4. t. 74.75.

Moringla zeylanica, foliorun pinnis pinnatis, fore majore, frufulu anguloso. BURM. zey\%. 162. t. 75 .

Guilandina inermis, foliis fubbipimatis: foliolisinferioribus ternatis. LiNN. Jyfr.veg. $39 \dot{8}$.

$E$ collect. fem. hort. lugdb.

PER. Capfula leguminoides, füngofo - coriacea, longiffima, fubulata, fulcata, triquetra, unilocularis, trivalvis. Valvulx craffe introrfum angulatx \& in ipfo angulo interno fcrobiculis amplis rotundis, pro feminibus, excavatx.

REc. cicatricula parva, in angulo valvularum centrali fupra finguluna fcrobiculom, e qua funiculus brevis ad femen defcendit.

SEM. plura, ad octodecim, fimplici ferie longitudinali digefta, fubglobora, obfolete trigona, fordide fufer, tribus Alis ovato-oblongis, membranaceis, aveniis, diaphanis, pallidis ftipata.

IN T. duplex: exterius coriaceum, tenue, in alas ampliatum; interius membranaceo - fpongiofum, oandidilfmum, tribus vaforum nutritiorum fafciolis notatum.

A L R. nullum, nec ejus veftigium.

EM B. turbinato-globolus, fubtrigonus, albus. Cotyl. craftifimx, plano-convexic, lubcoalize. Phun, nulla. Rud. globulofa, minutillima, fupera.

8.) Capfula integra. h.) Ejns fettin transverfalis, c. c.) Valvale part fuperior, a latere interno (pectats. d.) Scmen integrum. e) Intrgum. extetnnm transverfo fudam. f.) Nusicus propriz fuz membrana aivia.vefcitus. s.) Enlurso dembdatus. h.) Cotyledones feparata.

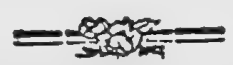

315

Moringa aptera, qux Balanus myrepfica \& Bees albus. Offic. habet femina procedentibus duplo grandiora, turbinata, rotunde trigona, nivea, abs. que ullo alarum veftigio. Interna autem corum ftruaura prioribus per fingula punda conformis eft.

Pericarpium Moringx, legumen dici nequit, quin femiwa non marginibus, fed ipfi valvularum medio affuxa funt.

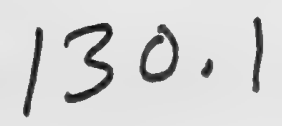




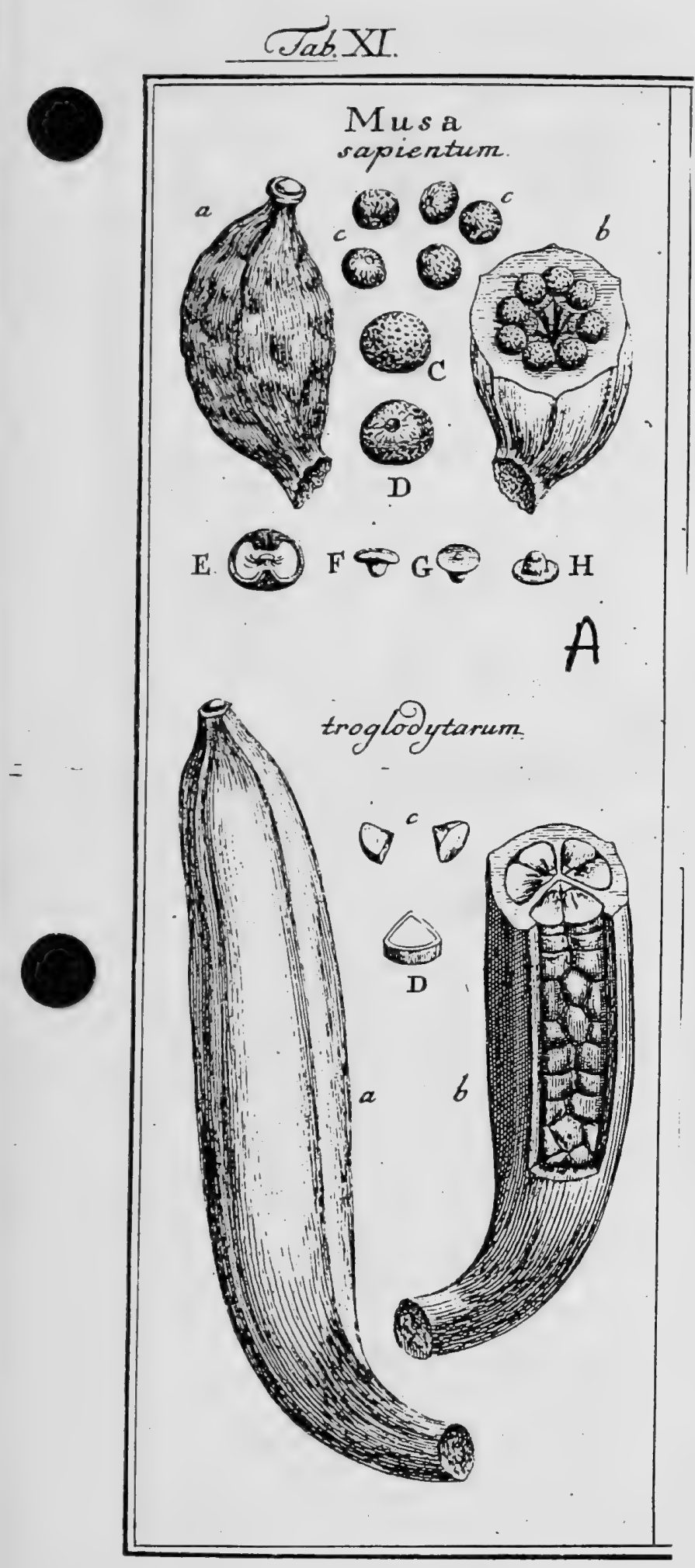

\section{Musaceae}

\section{J. Gaertner (1788) Vor.l}

XXXIII. MUSA. LIN gen. rr4t.

Flores omnes hermaphroditi: fummis, in fpadice fimplicifimo, abortivis. Spathz partiales multiflorz. Corolla dipetala. Stam. fex. Bacca inferz polyfperma. Albumen farinolum. Embryo verticilliformis.

MUs A Eapientum. Tab. Ir. fig. r.

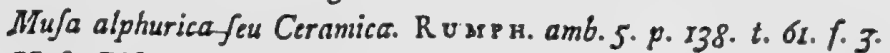

Mufa Pifang Batu feu Bidji. Ku sв в. S.p. 132.

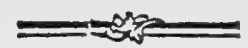

B. MTu a caudice maculato, frudfu refto rotundo breviore odorato. SLOAN. jam. 2. p. I47. Eн RE T decad. t. 21.22. 23.

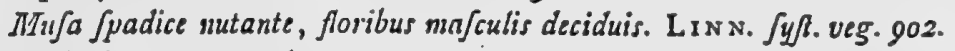

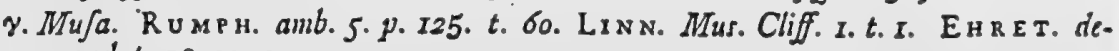
cad.t. 18. 19. 20.

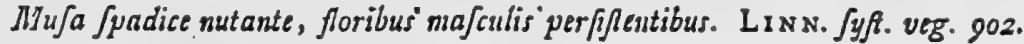

๔- . Mufa fructu baccato uniloculari.

PER. Bacca infera ovata, utrinque attenuata, obfolete hexagona, unilocularis. Caro mollis, fucculenta, per naturitateı, fecundum axis longitudinen, more cucumerum intus fecedens \& cavitate inani prodita, absque ullo diffepimentorum ventigio.

REC. nullum. Semina absque ordine in pulpa nidulantia.

SE M. plurima, fubglobola, rugofe tuberculata, fpadiceo fufca, aut nigricantia : umbbilico profundo, fubinfundibuliformi

IN $T$. fimplex, cruftactum, durum, nigricans, arcte nucleo adnatum, a parte umbilico oppofita valde incraffatum, \& obtufo proceffu intra albumen demerfun; ad iplum autem umbilicum, profundo foramine tubulofo perturum.

A в. candidifimum, friabile, lubfarinofum, fubglobolum, utrinque profunde umbilicatuin \& quafi ruminatum.

Eм в. parvus, in medio albuminis locatus, lutefcens, fungiformis: pileolo orbiculato, planiusculo, centrali; pedunculo fubconico, craflo, brevi, verfus umbilici foramen directo.

2.) Bacea exficcala \& vetufior, integra b) Eadem transverim fella c) Senins feparata, magnitudine naturati, C.) Semen zuAum, a parte fur verticali (pelatum. D.) Ejosdem latus in. ferius f. umbilicale. E.) Setio feninis verticalis, integument, slbuminis, \& embryonis formam atque fitum oftendens. F.G.) Embryo a parte fuperiore, \& $H_{\text {. }}$ ) Ldem 2 parte fuz inferiore $L_{\text {. }}$ usnbilicali '́pertacus.

Mus ^ troglodytarum. ibid.

Mufa tranofcopos. R ч м Рн. anib. 5. p. 137. t. 6r.

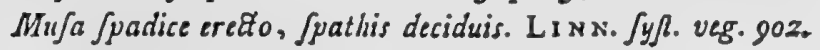

Mufa fruftu baccnto triloculari.

E collectione Bankfiana.

Bacea columnaris (a) utrinque attenuata, figmoideo curvatz, fexangularis, coriaceocarnofz, glaberrima, e viridi lutefcens, trilocularis. Diflepimenta (b) inembranacea, craffiuscula, prope axem confluentia \& inter fe connara. Semina numerofa, duplici feric in fingulo loculamento digefta, axi fructus affixa, varie anguJata \& lapidum pavimenti adinftar, absque interjecta pulpa, libi muruo juncta, verfus

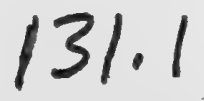

verfus umbilicuni acuminata (c), glaberrima, ferruginea, aut nigricantia, Integunientum (D) duplex; exterius coriaceum, craflum; interius umenbranaceum, pallidum. Albumen ..... Embryo ......

Hxc omnino genuina eft Ravenalx. โ. Heliconix fpecies; quia autem maturum ejus fructum infpicere milai non contigit, malui cam cum Mula relinquere, dontc certiora de interna feminis fabrica patefcant. 
Tab. 212.

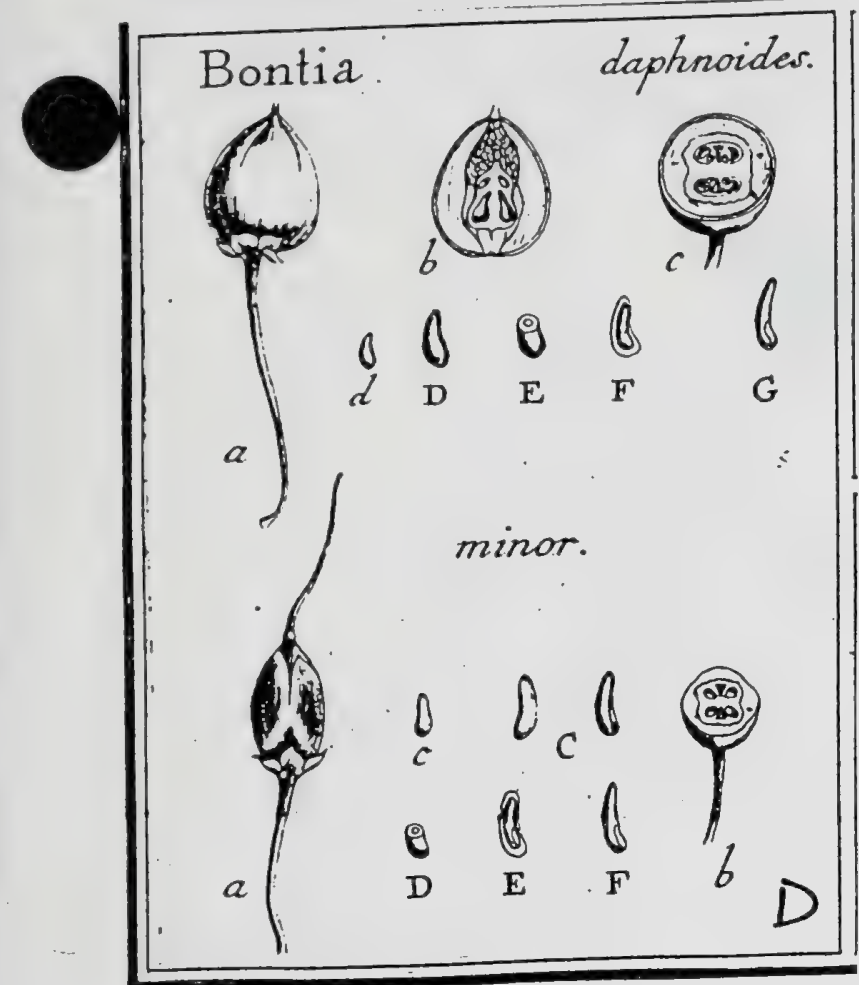

J. Gaertner (1788) Vol3 $\quad 168$

130. B $0 \mathrm{~N}$ T I A.

Pium. gen. t. 23. Linn. gen. 79r. ed. Schreb. ro6z. Juss. gen. p. 127. LAMARCK ill. gen. t. 546.

Cal. monophyllus, inferus, quinquepartitus; laciniis ovatis, acuminatis, perfiftentibus. Cor. monopetala, tubulofa, calyce multo longior, inzequalis, bilabiata; labio fuperiore erecto, enarginato : inferiore revoluto, femitrifido, hirfuto. Stam. 4. didynama; filamenta fubulata, longitudine corollæ; antherx erectx. Ovar. fuperum; ftylo filiformi, longitudine ftaminum; ftigmate obtufo, bilobo. Drupa ovata, baccata; putamine biloculari: loculamentis bipartitis, tetrafpermis. Sem. oblonga. Alb, carnofum. Emb. inverfus.

Bontra daphnoides. Tab. 212. fig. 3.

'Olea fylveftris barbadenfis', folio angufto pingui leviter crenato. PLuKN. alin. 269 . t. 209 . $f .2$.

Bontia laureolae facie. Dilc. bort. eltis. p. 57. t. 49. f. $57^{\circ}$.

Bontia foliis lanceolntis alcernis, pedunculis uriforic. LINN. fpec. pl. p. 890 . WILL. D. Spec. pl. T. 3. P. x. p. 394. PEKsOON Jyu. 2. p.'168.

Ex Infula Hifpaniola, a $D^{\text {no }}$ Porteau.

PER. Drupa baccata, ovata, furfum acuminata, calyci perfiftenti pedunculo longillimo fuffulto infiltens, ftylo longo filiformi faltigiata, a vertice fulcis quatuor ad mediam drupam deliquefcentibus exarata, glabra. Caro per maturitatem fuberofa, craffiufcula, ficca, pallida, leviter aromatica, cuticula tenui lavigata tects. Putamen ofleum, irregulariter ellipticum,

$$
=2 \operatorname{sic}=
$$

rotundato - tetragonum, fulcis duobus obfoletis oppofitis longitudinaliter exfculptum, craflum, farbrum, \& cum cortice intime conferruminatum, biloculare. Loculamenta duo, fubltantia offea crafla interpofita inter fe remota; feminibus quaternis, ofleis, inter $f_{\mathbb{E}} \&$ putamini adglutinatis, per paria imbricatis, \& medio canali triangulari inteltinctis fueta.

Rec. nullum : vafa umbilicalia ad bafin feminum intrant, \& nucleum fundo teltx alfigunt.

SEM. in quovis loculo quáterna, duo autem plerumque abortiva, offea, ad axim fructus inclinia, erecta, per maturitatem drupæ fubftancia offea inter fe \& putamini adglutinata, longẹ elliptica, bafi inçraffata, curvula.

IN T. duplex: exterius offeum; vix a putamine maturo feparandum; interius membraiaceun tenue, a bafi per dorfum verticem ufque vafis umbilicalibus ferrugineis \& in vertice ipfo in chalaza terminatis infignitum, pallidum, facile detrahendum.

A L B. femini conforme, vaginale, non admodum craffum, carnofum, album.

EM B. tereti - obloligus, leviter recurvus, inverfus, lacteus. Cotyl. craffiufcu. lx, curvula, dimitio embryone vir longiores, leviter undulato-plicacx, apice incraffatx, obtufx, incumbentes. Rad. teres, rectiufcula, obtufa, adfcendẹs, umbliico externo conrraria, fupera.

\section{EXPLICATIO FIGURIE.}

a) Drupa integra, ftslo deftituta, b.) Eadem cum putanine serticall modo difteta. c.) Ejur dem fectio transverfalis, eum fitu loculamentorum atque feminum. d. D.) Nucleas folutus, cum chalaza ad apicem. E.) Albumen transverfe diffectum. F.) Ejusdem fectıo lungitudinalis, cum embrone in fitu. G.) Embryo folutus,

Boxtra ninor. ibid.

\section{Ex colleciione Cl. Desfontaines.}

Drupa (a.) ovata, hine ftylo longiffimo fubulato-filiforni bafi nodulofo faftigiata, inde calyci infidens, obfoletifine rotundato-tetragons. Putamen (b.) carni fuberofx ficcx adnatur. biloculare, Sem. ut in priore. Nucleus (c. C.) ovato-oblongus, erectus, bafi extrorfum curvatus, ad axim bacce inclinis, pallidus. Int. \& $\Lambda \mathrm{lb}$. (D.) ut in priore. Emb. (E. F.) teretioblungus, curvulus.

Hxc forfan antecedentis tantum varietas, 


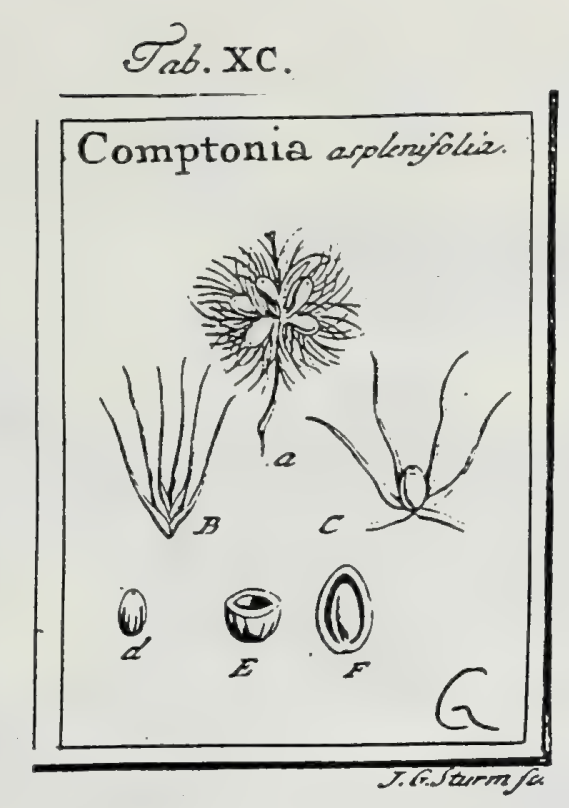

\section{J. Gaertner (1788) Vol 2 ;}

\section{COMPTONIA. BANKS.}

Flores fexu diftincti, in eadem ftirpe. MAS. Amentum cylindricum, undique laxe imbricatum fquamis concavis, reniformibus, acuminatis, cadu cis, unifloris. Cal. diphyllus, foliolis xqualibus, navicularibus, fquama amenti brevioribus. Cor. nulla. Filam. tria; calyce breviora, bifurca. Antherx fex, bivalves. FEM. Amentum ovatum, undique denfe imbricatum fquanis unitloris, ut in mare. Cal. hexaphyllus, foliolis per paria oppofitis, filiformibus, bafi tamen membranaceis, fquama amenti multoties longioribus. Cor. nulla. Ovar. fubrotundum; 'Atyl. duo capillares. Nux unilocularis, evalvis. Ex fchedis b. SolandR!.

Comptonia asplenifolia. Tab. 90. fig. 7 .

Myrti brabantica affinis americana, foliorum laciniis afplenii nodo divijss. PLUX. plyyt. t. 100. f. 6. . .

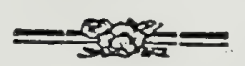

Liquidambar foliis oblongis alternating finuatis. LiNw. fyjto veg. 860.

Ex horto regio Kewenfi.

PER. Nux offea, elliptica, turgide lenticularis, nuda, glabra, nicida, obfolete ftriaca, fpadicea, unilocularis, evalvis.

Rec. nullum, femen fundo nucis afixum.

SEM. unicum, ovato-globofum, glabrnm, pallidum.

INT. fimplex, nembranaceum.

$\Lambda$ с в. .......

Eн.......

2.) Amentum femineum fubglobofum, calycibus perlifteutibus undigue eirratun. B.) Calnk fersincus fepantus. C.) Nux calyci fuo juncta. d.) Eeilem feparata. E.) Ejus feato transerfalis. F.) Eajem longitudinaliter fecta, eum fitu \& tigura feminis.

Fructus apud nos nunquam maturantur, \& cafx atque parvula fuerunt nuces, quot quot vidi, omnes; fed in Anetica magnitudiuem Avellanx affequi dicuntur. 


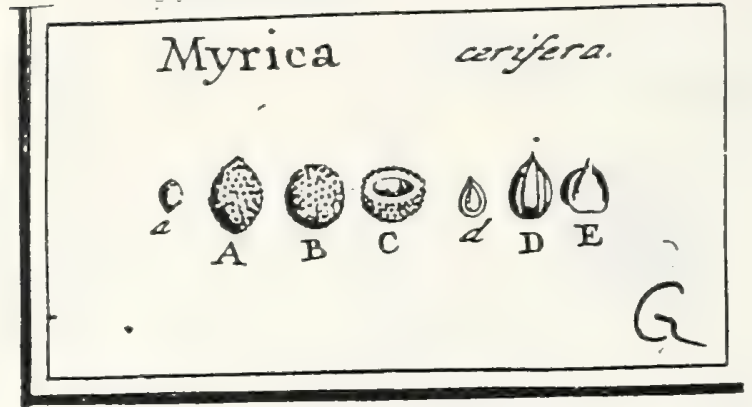

\section{J. Gaertner (1788) Vol.1}

CCXXX. MYRICA. LIN gen. no\%.

Flores fexu difincti, in feparatis truncis. Mas. Cal. tri-1. tetraphyllus. Cor, nulla: Stam-quatuor, 1. fex. FEM. Cal. \& Cor, ut in mare. Styl. unicus bifidus. Drü: pa fupera, unilocularis. Senen exalbummofum.

Myrica cerifera. Tab. 39. fig. 7.

MIyrtus brabantica fimilis carolinienfis baccifera, fructu racemofo feftali monopt reno. Pluk. phyt. t. 48. f. 9. Ca tesB. cajol. 1. t. 6g. Seligx. av. 2. t. 38.

Myrica foliis lanceolatis Jubfersatis, caule arborefcente. Levi. Jyfl. veg. 884.

PER. Drupa exfucca, furpera, parva, ovato globofa, bafi quatuor foliolis calycinis munita, fupra acuninata, undique tecta fulfftantia farinofa alba, plurimis granulis fufcis duris remixta, qux una cum inta farina totum drupz corticem in maturis fructibus efficiunt. Putamen ovato acuninatum, olfeun, crafiusculum, unilo" culare, evalue.

REC. nullum; femen areolx parrx in fundo putaninis adnaturn.

SEM. unicum, cavitati putaminis conforme, venis fuffis \& in bafi cicatricula albs in: fignitum, cetcra pallide luteum.

IN T. funpliciflimum, incenbranaceum, tenue.

Ar. в. nullum.

Esr. femini conformis; inverfus, albus. Cotyl. obovatz, carnofz, plano convexz, Radic. brevillina, teretiuscula, fupers.

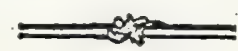

A. A. B.) Drupe matura integra. C.) Ejus fetio transverfalis. d.) Patamen bongitodinaliter apertum cuin (emine, magnitudine vaturali. D.) Idem autum. E.) Embryo deoudatus,

Adultum fructum conftanter farinofum reperio, \& talem quoque defcribunt MrLler garderr. dilion. \& Kalmius. itin. 2. p.335. Hinc de immaturo fructu loquitur LINNEUS 1. c. quando baccam dicit fucculeutam. 
J. Gaertner (1788)

Tab. XII.

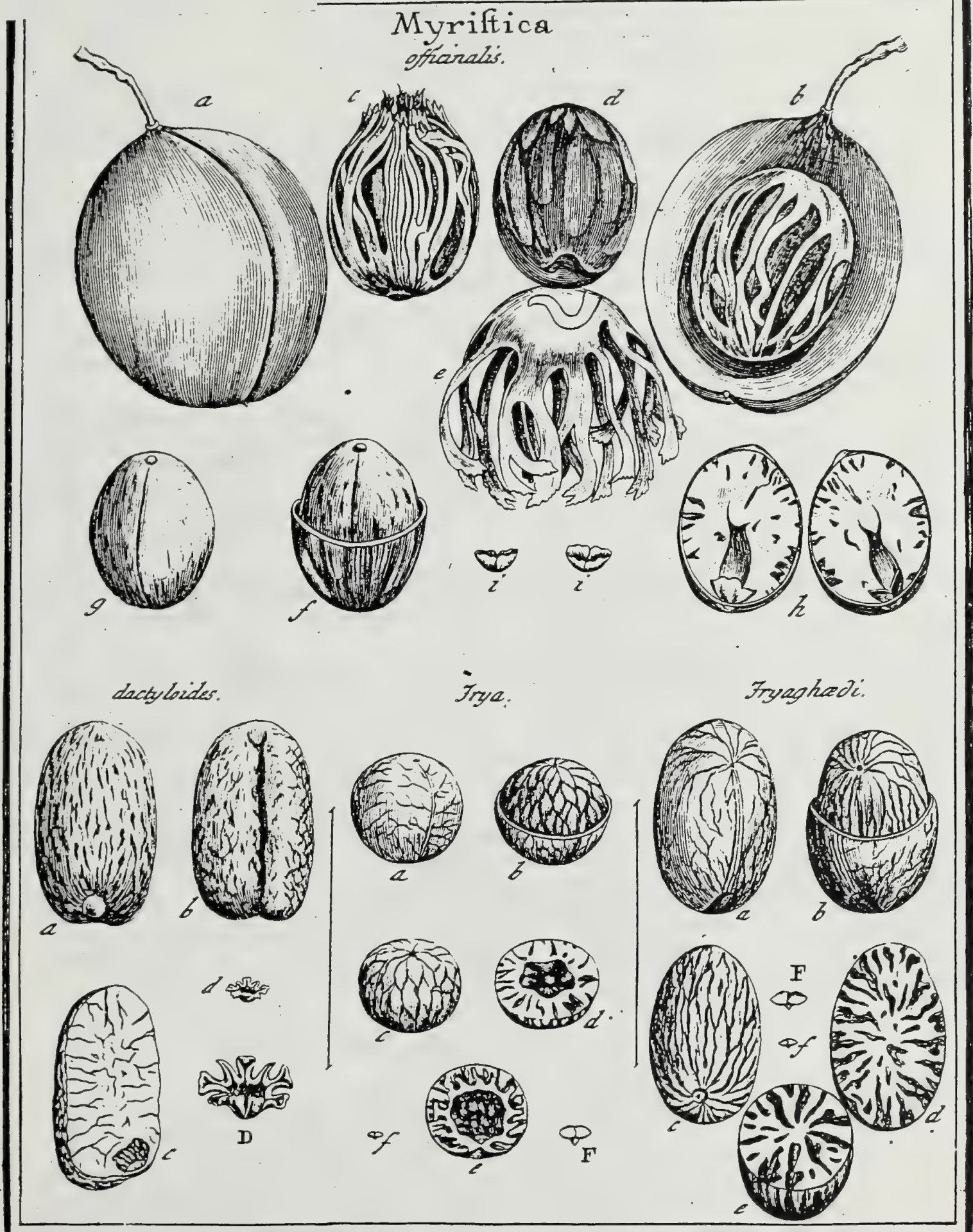

Jisoum 
Flores fexu diflincti in eodem trunco. M A s. Cal. trifidus. Cor. nulla. Stam. unictm craflum: antheris fuperne fefflibus. FE. Cal. trifidus, inferus. Cor, nulla. StyL unicus. Racca monof perma. Semen nucamentaceum: Arillo mulcifido: Albunine
ruminato.

MYRISTIC A ofticinalis. Tab. 4l. fig. I.

Nux myrifica mas. R U M P H. amb. 2. p. 24.t.5.

Mufcadier. Sonwerat. it.guineens. t. II6-II8.

Myrifica. Тнох в. a民̃. holm. 1782. edit. germ. p. 42. t. I.

Ex dono Cl. D. Hou TurN.

PER. Bacca, fupera, elliptico fphzroidea, hine fulco longitudinali parum deprefta infcripta, carnola, glaberrima, unilocularis. Caro crafla, folidiuscula, deinumi kxzrefcens in cruftan coriacean latere dehifceutem.

REc. nullum; femen ope arilli fundo loculamenti affixum.

SF. unicum, ovato globolum, nucamentaceum, arillatum.

Arillus, qui Macis offic. dicitur, carnolo coriaceus, rutilus, croceus aut fiavefcens; infra monophyllus, fupra multifidus: laciniis linearibus, fiexuofis, ramofs, furfum latescentibus apice fublaceris.

IN т. duplex: exterius: Naucus tenuis, fragilis, dilute caflanens, fplendens, $2 b$ im. preftionibus arilli vermiculatus; interius, membranaceo cruflaceum, fubrufcfcens, nucleo archifume adnatum \& intra ejus fubfantian, fuis proceflibus interais, aite

A z. Semini conforme, carnolo farinolum, runinatum \& ex albicanti ac fpadiceo colo. re variegatuin; inferne propria cavitate pro embrynne exfculptum, quandoque etian in medio, ca:itate inani donatum; cetera fragrans \& grate aromaticum.

Eм в. parvus, erectus, in patellx formain cxcavatus, lacteo-albus. Cotyl. carnolofoliacex, aj oras undulatx, erecto patentes, in cupulam bipartitam, fubhemifphxricam, jusictx. Rad. iufera, minimi tuberculi formá, coryledonibus fubject2.

a.) Bacen integra b.) Eadem longitudinaliter aperta, c.) Semen Mace veftitum. d.) Naucos dentudatus \& intexra Macis (e) reflexa. f.) Naūci pars dinidia fuperior refeta., t.) Seneo dems. datum. h.j Seminis fetio verticalis, raminatam albuminis fabricam, eum fitu embryouis offendens i.i.) Eimbryo feparatus.

Deberet hoc pericarpium ad Drupas referri, nifi obftaret arillus.

M YRISTICA dactyloides. ibid. fig. 2.

Nux indica oblonga, intrinfecus fimilis muci nofchata. В А и н. hif. I. p. 399.

Panam-palca. R нев D. Mal. 4. p.9.t.5.

Nux mofchata malabarica. V ALEN T. muf. I. epif. orient. $\mu .83 . t .4$.

Myrifica frufiu inodoro. LIN f. fl. zeyl. n. 588 .

Bacea ovato oblonga, e viridi flavefcens, cortice carnofo, craflo, molli. Macis, priori \& forına, \& colore fundis, fed odoris atque faporis haud ita giati. Naucus femini conformis, e nigro fpadiceus. Semen (a.b.) inodorum, ovato cylindricuin, cinerafcens, 1. fordide rufelcens, varie rugolum, hine (a) convexum, inde (b.) fulco depreffo infcriptum. Albumen farinofum, febi inftar rafile, infipidum, inodorum, rumisatum (c), ampla cavitate pro embryone, pauto fapra bafin exfculptum. Ensbryo (d.D.) grandiufculus, concavus. Cotyl. carnolo foliacex, erecto patentes: marginibus fimbriatis, plicato canaliculatis.

MYRISIICA Irya. ibid. fig. 3.

Nux zeylanica, mofchata rotunda fimilis, inodora minor. HeR s. nuนf. 49. B U R A. zeyl. 172. LIN N. zeyl. 13. 589 .

Irya. zeyloneus. E collect. fein. hort. lugdb.

Bacca.... Arillus.... Naucus (a) globofus, depreffiusculus, cruftaceus, tenuis, fragilis, fordide albicans, vafis capillaribus fuperficialibus infcriptus, zquabilis, non rugatus. Semen (b.c.) globolum, rugole tuberculatum, fufco fpadiceum. Albumen (d.e.) inodorum, ex fubnantia febacea, alba, rafili \& ex integumenti proceffibus, rufefcenti fpadiceis uninatum, amplifiuna cavitate inani in inedio exfculptum \& quafi bullatum. Embryo (c, f. F.) in fundo intius cavitatis, parvulus, viridefcens. Cotyl. ovatx, carnofo-foliacez, plaviusculx, horizoneali patentes. Rad. conica, infera.

MYR ISTICA Ilyaghedhi. ibid. fig. 4.

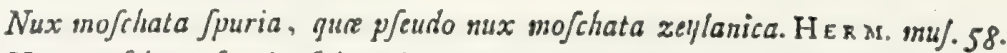

Nux mofchata fpuria fyluefris, caryophylli arboris folits oppofitis. BuRM. ff. zeyl. p. 173.t. 79 .

Irynghedhi. zeylonens. E collect. Cem. hort. lugdb.

Bacca... Mrillus..... Naucus orato ohlongus (a.b.), priori, tota fabrica, fimil. limus. Scmen (b. c.) putamini conlorme, profunde lliatuin \& rugatuin, co loris lateritii, 1. fi humedtetur, late cimabarini. Albumen (d.e.) valde ruminatum, ex albo \& rubro colore elcganter variegatum, ino:lorum: parte alba, lchacea, rafiii; rubra vero furfuraceo-pulverulenta \& friabili. Embryo (f.F.) 


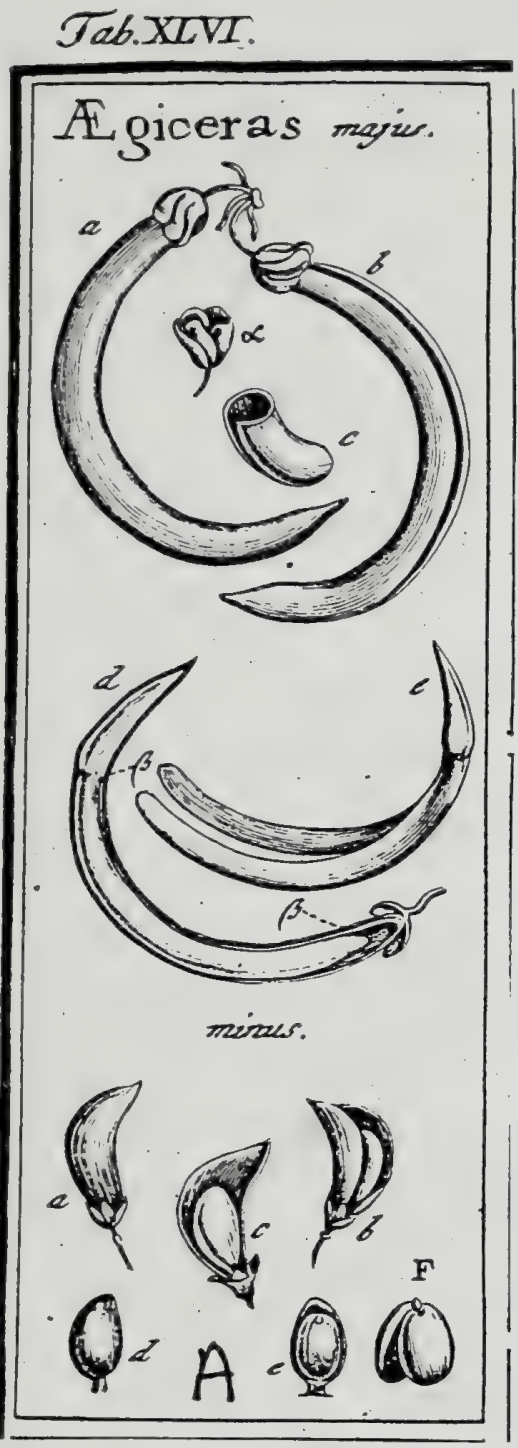

\section{J. Gaertner (1788) Vol..1}

216

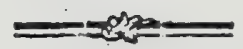

\section{EGICERAS.}

Calyx campanulatus, femiquinquefidus, coriaceus, perfiftens. Cor. pentapetata. Stam.

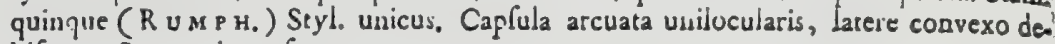
hifcens. Semen inverfun.

EGICERAS majus. Tab. 46. fig. I.

Mangium frutefcens corniculatum. R U M P H. anlb. 3. p. 117. t. 77.

Mangium floridum. R U M P H. l. c. 125.t. 83. ob calycem contortum.

Rhizophora folis ovatis, floribus confertis, fructibus arcuatis acuminatis. LINs: Syfl. veg. 367 .

Madan. EJ Kallu-haberelli. zeylon. E collect. fern. hort. lugdb.

PER. Capfula arcuata, tereti acuminata, coriacea, glaberrima, unilocularis, unival: vis: latere convexo dehilcens.

REc. funiculus umbilicalis filitornis, e bafi capfulx ad feminis apicem, in concavo ejus latere, decurrens.

SE sr. unicum, figura \& magnitudine cavitatis caplulx, fubacoccon.

IN T. tenuifinum, aut nullum $\int$. per maturitatem, capfulx aduatum.

$A \subset B$. nullum.

Es в. femini conformis, inverfus, viridis. Cotyl. femicylindricx, longiflunx, falcatz. Rud. tertia parte cotyledonibus brevior, craffa, conica, acuminata, fupera.

2.) Capfula integra, ๔.) Calyx contortus. b.) Capfula deluifcens. c.) Ejus feetio trausver(alis.

d.) Embryonis in capfula fitus. $\beta . \beta$.) Funiculus umbilicalis. e.) Cotyledones didutiz,

EG ICERAS minus. ibid.

Umbraculum maris. R О $\mathrm{P}$ н. amb. 3. p. 124.t. 82 .

Wri-Kieridi. E Kierinda. zeylon. E collect. fem. hort. lugdb.

Caplula pracedenti quadruplo brevior, lunata potius, quam falcata, obefa (a) co. riacea, rufefcens, glaberrima, fubtilithune ftriata, latere convexo (b) deliifcens. Semen fundo capfulz (c) aflixuin, ovarum (d.), fjadicemn aut rufefcens. Integumentum craffiufculum $(e)$, coriacen-lpongiolum. Albumen nullum: Embryo elliptico fphxroideus (c. F.), inverfus, pallide lutefcens. Cotyled. craf$f_{x}$, carnolx, plano convexx. Radic. globulofa (F.) miusutula, fupera.

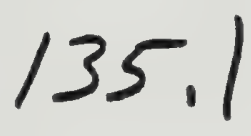




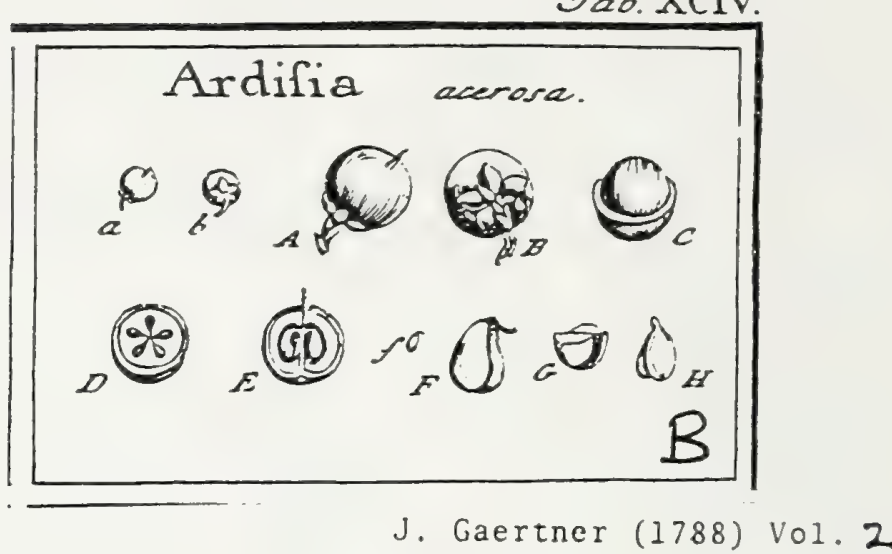

\section{DLXXXV, AR D Is I A.}

Calyz pentaphyllus, foliolis ovatis concavis perfiftentibus. Cor. hypocreteriformis, marcefcens. Tubus laxus, calyce longior. Limbus brevis quinquepartitus. Nectar. Squamulax quinque oblongx, bafi ovarii apprelfie. Stam. quinque, brevifima, fauci corollx inferta. Ovar. fubrotundunz fuperun. Styl. filiformis, Itigna fimplex. Bacen corticata, exfucca quinquelocularis. Loculamenta difpermia. Ex fchedis Sorandra.

Differt ab Epacri: Stigmate fimplici; pericarpio baccato; feninibus yeminatis.

ARdisia acerofa. Tab. 94. fig. 2.

Stiphelia acerofa. Soland. m/so

Epacris arborea, foliis Jparfis linearibus acutis patentibus fefflibus, racentis cernuis, floribus alternis. LIN $\sqrt{y} f$. veg. 198 .

Ex herbario Bankfiano.

PER. Bacca fupera, parva, exfueca, Spharica, ftylo brevi fubulato terminatz. Cortex coriaceus, tenuis, niger. Caro fungofa, folidiufcula, alba, quinquelocularis.

RzC. in fingulo loculamento fingulum, filiforme, breve, sitcro extremitate axi fructus infertum; altera, duo femina pendula fuftimens.

Sen. geminata, parvula, ovata, furfum attenuata, plano-convexa, rufefcentia.

IN T. fimplex, membranaceum, tenue.

A L B. nullum.

EM B. femini conformis, inverfus, albus. Cotyl. ovatx, carnofa, tenues. Fad. brevis fupera.

a. A. b. B.) Bacer integra, 2 fuperiore atque inferiore parte fpedatz. c.) Cortex ad dimidiun refectus \& caro fungola deaudata. D.) Bacca transverfe fecta. E.) Seminum in loeulamentis. fitus. f. F.) Semina geminata e funiculo umbilicali peadula G.) Eadem transveric feâz H.) Embrjo deaudatus

Enbryonem non fatis diftincte vidi, quare figura ejus.(H), dubia \& forfas albumini tribuenda.

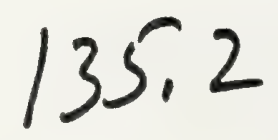




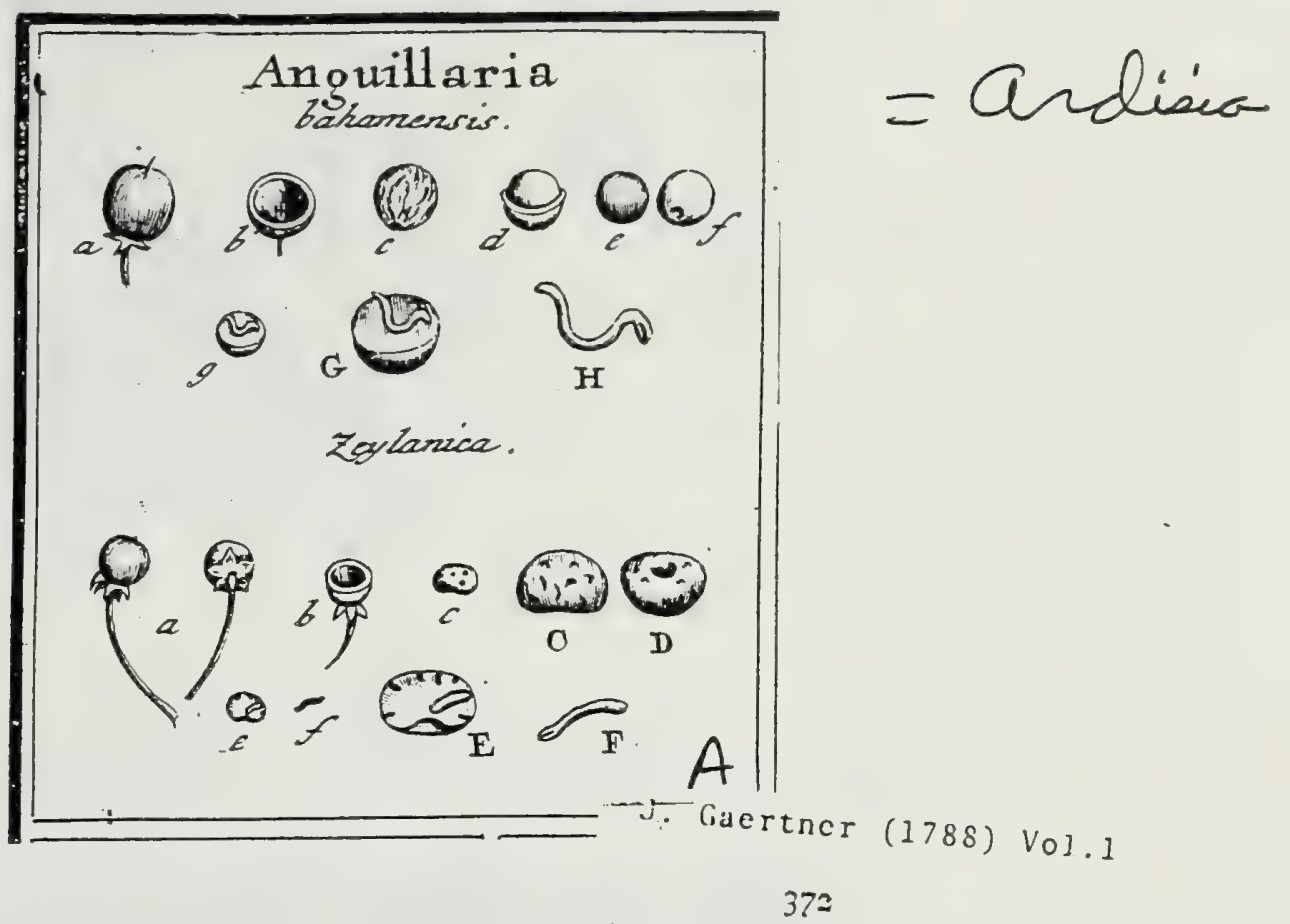

CCCCLXXXV. ANGUILLARIA.

Calyx quinquepartitus, foliolis ovato lancenlatıs xqualibus perfinentibus: Cor. mosopetala, ad bafin fere quinquefrida, Jaciniis lanceolatis, caly"ce duplo longioribus. Stam. quinque, corollx inferta. Sty!. unicus, filiformis: nigmate fimplici. Bacca unilocularis, monofperma. (Ex fcliedis b. SOLANDRI.)

ANGUIIIAR I A b3hamenfis. Tab. 77. fig. 1.

Hcherdenia excelfa. Basks. herbar.

PER. Hacca fupera, globola, coriacca, glabra, nigra, unilocularis.

RE.C. nullum, prater cicatricem latam in fundo baccx, cui femen affixum:

SEx. unicum, globofum, inferne ampla fuvea umbilicali exfculptum, fallidum.

IN T. fimplex, crafliusculum, fungofo coriaceum, friabilc.

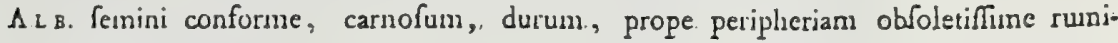
natum.

Es в. tereriusculus, ferpentino fexuofus, transverfe in albumine locatus, lacteus. Cotyl. lincari oblongx, brevilimx. Rad. filiformis, longillina, oblique furfum verfus pcriplicrian leminis \& baccx directa, centrifuga..

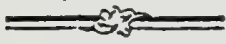

a. b.) Bacea integra \& diffectn, c.) Senen Solutum. d.) Albumen ad medium usque ab inte gumento denudatuu. e.j Ejuidem pars fuprrior. f.) Jden a latere unbilicali fpectatun. g. G.) Idcu diffecium, cum einbryonis fitu \& figura. H.) Ensbrjo (cparatus.

ANGUIII.ARIA zeylanica, ibid.

Badulam. Herm. mus. zeyl. 43. L I N. fl. zeyl. "s. 600.

Tinus humilis zeylanica, foliis crafjis venofis. Burm. zcyl. 222. t. 103.

E collect. fem. hort. lugdb.

Bacca fphrrica (a), pracedenti dimidio minor, calyce quinquefido perfiftente excejra, unilocularis (b), pallide rufefcens l. fubrubicunda. Semen figura oculorum cancri, unicum (c. C. D.), femiglobofum, depreffiusculum, fupra obfoletifime fcrobiculatum (C.), infira planiusculum (D.) tovea umbilicali nigricante cxfculptum, cetcra fublpadiccum. Integ. fimplex, tenue. Albumen (t. E..) femini conforme, carmofum, al puriphorian rimis \& finubus modice profundis ruminatum, album, fubfriabile. Embryo (f. F.) tcreriusculus, lonçirudinc dimidii \& nomunquam totius albuminis transverf, fubllexuolus, luteus. Cotyl. brcvillimx, acuminatx. Rad. Innga extrorfum crafiescens, verfus peripherian fcminis \& baccx dirceta, centrifuga.

Aflinis efle videtur Myrfines. Naturalis feminum numerus forfan quinarius, is inmaturo ovario ulterius inquirendus. 


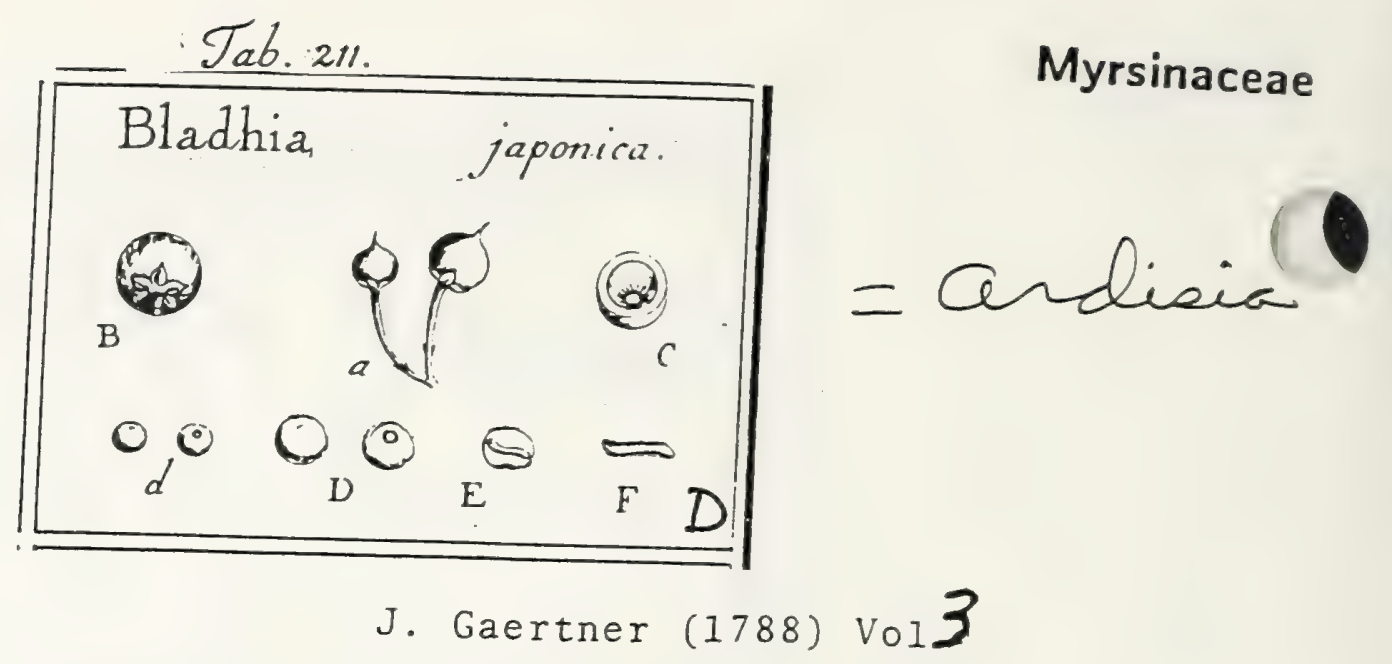

159

123. $B$ L A D H I A.

THUNB. nоv. gen. 6. f. jap. p. 7. Sснвев. geñ. 370 . Juss. gen. p. 421. LAMABCK ill. gen. t. 133 .

Cal. monophyllus, quinquedentatus, brevis, inferus, perfiftens; laciniis ovato - acuminatis, concavis, margine fubferratis. Cor. monopetala, rotata, tubo brevillimo, limbo profunditime quinquepartito; laciniis ovato-acuminatis, patentibus. Stam. 5. corolla paulo breviora; filamentis breviffmis, ad infimum tubum infertis; antheris ovato - acuminatis, baG emarginatis, coniventibus, bilocularibus. Ovar. fuperum; ftylo fimplici, filiformi ; ftylo fimplici, acuto. Bacca globofa, pulpofa, unilocularis. Rec. o. Sem. unicum bafi umbilicatum. Alb. craffum, fubcartilagıeum. Emb. vermicularis, transverlim adicendens.

BLAdhia japonica. Tab. 211 . fig. 4.

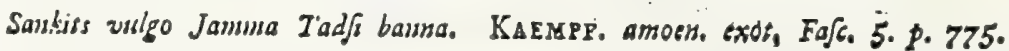

160

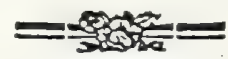

Bladbia foliis ferratis-glabris. Thunв. f. jap. p. 95 . Lins. Jyft. veg. ed. 14. p. 236. WILLD. Jpec. pl. T. I. P. 2. p. 1122 .

Bladbia foliis ternis ferratis glabris, caule bafi decumbente. PERsoON fy!s. 1 . p. 233 .

Icon. Тникв: 1. c. t. 18 .

Ex collectione Bankfiana, \&. Cl. Thunbero.

PER. Bacca globora, depreffiufcula, lange pedunculata, calyci infiftens, ftylo perfiftente fubulato faftigiata, unilocularis. Cuticula tenuis, glabra, coccinea. Caro cralliufcula, pu!pofa. Loculamentun fubglobofum, retufum, membrana propia pulpze adnata veftitun.

REc. nullum: funiculus umbilicalis breviffimus, ex fundo bacce, cui femen adhæret.

SEM. unicum, fuhglobofum, loculamento confimile, bafi retufum, umbilicatun; ad verticem vero mucrone exiguo obtufo infignitum, dilute ferrugineum.

INT. finplex, nembranaceum, tenue, adnatum.

A L B. femini conforme, duriufculum, carnofum, 1. fubcartilagineum, album.

$E_{M B}$ B. teretiufculus, ferpentino-Alexuofus, transverfe in albumine locatus, fubalcendens, lacteus. Cotyl. breviffme, ovati, obtufx, incumbentes. Rad. filiformis, cum cotyledonibus continuz, longifima, oblique deorfum verfus peripheriam feminis \& apice obtufo paululum verfus balin directa, ab umbilico remota, centrifuga,

\section{EXPLICATIO FIGURE,}

8.) Pars unbellula frogiferz B.) Bacea integra, z bafi rila C.) Efusdem featio transverfalis, Terine ablato, at in fundo baccze ciestricula, cui femen affixum eft, appareat. d. D.) Semen folutum, a vertice \& a bafi fpetatum. E.) Albumidis féaio verticalis, cum fitu \& forma embryonis. F.) Embryo folutuc

Ab Anguillaria, cui proxime accedic, embryone fubalcendente differt; hino Ophiofpermurum (VENT.) ordini affocianda eft. 


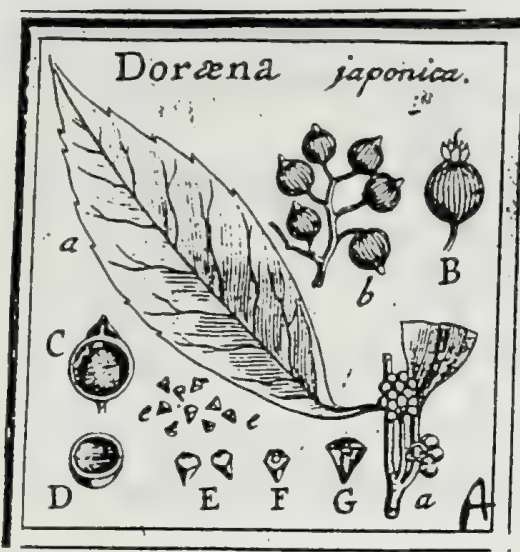

\section{J. Gaertner (1788) Vol 3}

\section{DORAENA.}

Iнилв. jap. 6. nоv. gen. 59. Linn. gen. ed. Schreb. 264.

$$
\text { Je'ss. gen. p. } 420 .
$$

Cal. quinquefidus: Jaciniis parvis, ovatis, concavis. Cor. monopetala, rotata; 'tubus fubcylindricus, calyce paulo longior: limbus quinquepartitus, xqualis. Stam. quinque. Ovar. fuperum, fquamulis quinque nectariferis coronatum. Styl. fimples; ftigma truncatum, emargiuatum. Bacca ficcs, fquamulis nectariferis, ftylo apprelfis, conice acuminata, unilocularis. Sem. numerola, parva, pyramidata.

Doraena japonica. Tab. 184. fig. I.

Doracua. Tuимe. jap. 84. Lisw, fyf. veg. ed. 14. p. 194. Spec. pl. ed. Willd. T. 1. P. 2. p. 812 .

A Cl. THUNBERG.

PE n. Angidion coriaceum, (Baccs fieca) globofum, umbone conico, ex fquamulis quinque ftylo arcte apprelfis, terminatum, nulciltriatum, unilaculare, magnitudine grani piperis.

REc. carnolum, liberum, bufi affixum, profundifime alveolatum, ut excuthis feminibus totum fetis hifpidum appareat.

SE s. numcrof., fupra quinquaginta, parva, angulata, verfus umbilicum asgute pyranidata.

IN T. Amplex, menbranaccum.

28

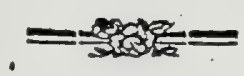

A L B. femini conforme, carnofum, aqueo-pallidum.

EMB. teretiufeulus, rectus, albus. Cotyl. breviffimx. Rad. cylindrica, certripeta.

\section{EXPLICATIO FIGURE.}

a. 2) Extremitas rami, cum florum inapertorum racemulo axillari. b) Racemus frugifer, cum angialiis magnitudiue naturali. B.) Angidion feparatum, cum fquamulis fiylum cingentiLus paululuon diductis. C.) Receptaculi corrmunis figura \& fitus. D.) Augidij cortex transverfim diffetus, e. e. E.) Semina (eparata. F.) Albumen transverle, \& G.) Idem longitudinaliter dificaum, cum fitu \& figura cunhryonts.

Squamulx pericarpium coronantes atque ftylum arctifime amplexantes, effentialem pricbent hujus generis characterem. Folia rigida funt ficuti
Lisuri. 


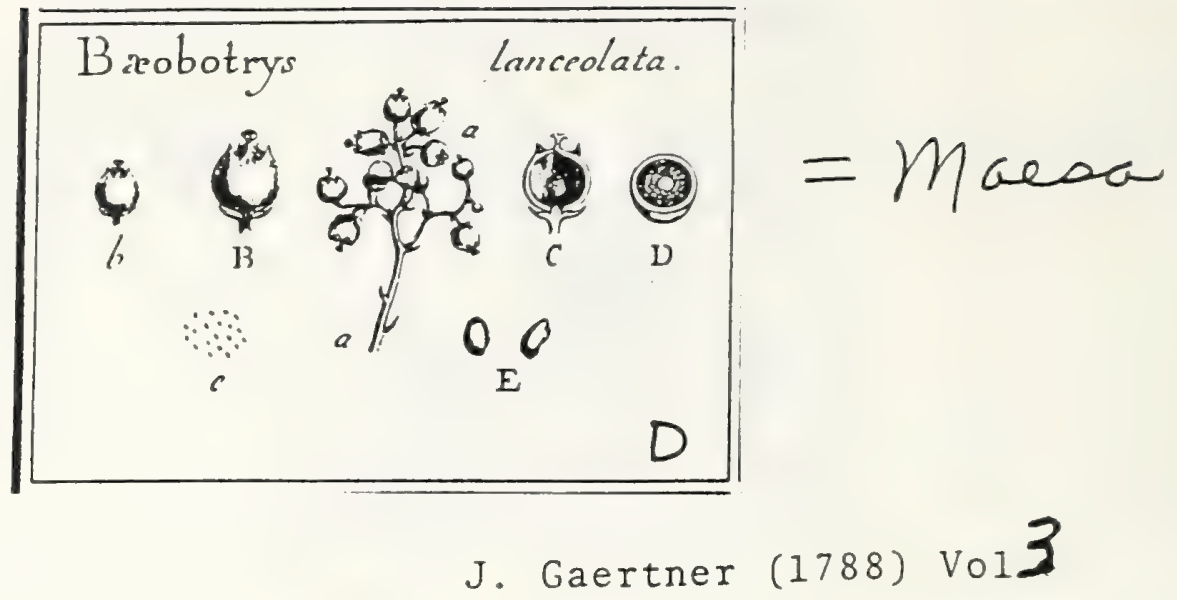

151

\section{II6. B A E B O T R Y S.}

Foвst. char. t. ri. Simreb. gen. 3 r8. Lamaвcx ill. gen. t. III. Maefa. Forsx, defc. p. 66. Juss. gen. p. I6r.

Cal. monophyllus, adnatus, femi-fuperus, quinquedentatus, bafi ftipulis duabus minimis inftruçus. Cor. monopetala, fubcampanulata; tubo brevi, paulo fub calycis divifura huic inferto; limbo quinquepartito, hiante. Stam. 5.; filamentis breviflunis, paulo fupra bafin tubi infertis; antheris cordatis. Ovar. feminferum; ftylo fimplici brevi; ftigmate capicato, fulco levi bipar-

$\times 52$

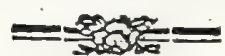

tito. Bacca fićca, femifupera, unilocularis. Rec. pedicellatum, carnofum.

Sem. numerofa, baccata. Alb. carnofum. Einb. . . ,

BAEOBOTRYs Janceolata. Tab, zIO. fig. 4 :

Baeobotrys foliis lanceolatis ferratis. VAHL fynb. bos. r. p. Ig. WILLD. Jpec. plo T. 1. P. 2. p. 993 : Pẹroon Jyn. 7. p. 275.

Icon $V_{\mathrm{AHL}}$ l, c. t. 6 ,

Ex collectione Bankliana.

PER. Bacca fícca, parva, globofa, femi - infera, a calyce nempe quinouedentato fere tifque ad verticem cum capfula connato veftita, ftylo \& ftigmate perfiftentibus faftigiata, unilocularis, polyfperma,

REc. ex axi capfulx pedicellatum, globofun,; baccatum, 1. carnofum, femina in peripheria pulpa obducta \& arcte fibi invicem approximata gerens. SEAr. numerofa, minutula, ovata 1. ovato - oblonga, hinc inde ab adjacentio bus compteffa, fufca.

IN $\mathrm{T}$, fimplex, membranaceum, tenue, albunini adnatum.

A I B. femini conforme, carnofum, fubrufum.

ENB. . .

\section{EXPLICATIO FIGURE}

a. a.) Ramulus frugifer. 'b. B.) Bacea integra. C.) Eadem longitudinaliter difreat, cum fit \& figura receptaculi. D.) Ejusdem fetio trasverális, cum fitu fequaugl. e. B.) Semina fepa. x214.

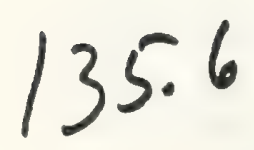




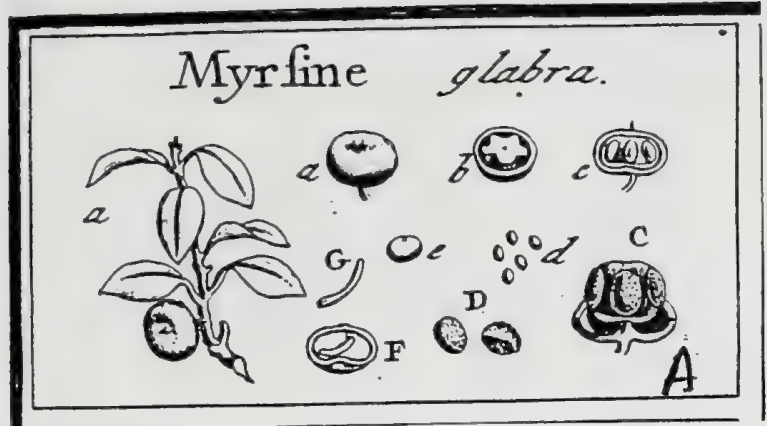

J. Gaertner (1788) Vol. 1

1

\section{MYRSTNE. LINN. ger. 26 g.}

Calyx quisquepartirus. Cor. monopetala femiquinquefida. Stam. quinque. Styl. unicus. Bacca unilocularis: Ovulis immaturis quinis; Cemine maturo unicn, aut gcmino.

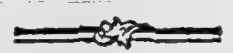

MYRsine glabra. Tab. 59. fig. I.

Vitis idea athiopica, myrti tarentine folio, flore ñto purpureo. Сом $\mathrm{M}$. hort: am/... . p. $223 . t .64$.

Mirfine africana. Linn. Sy/f.veg. 236.

PER. Bacca globofa, deprefía, pulpofa, nigro cxrules, rorulenta, glabra unilocularis. Cortex, ante plenam naturitatem, fubcoriaceus, ab interna fubfantia carnofo: fpongiofa facile fecedens, poftea vero tenuifimus \& cum pulpa cohxrens.

REc. in inmatura bacca globofum, quinque ferobiculis, quibus ovula innerfa, excas vatuin, tandem in pulpam mollem deliquefcens, ut femen maturum fundo baccz oblique affixum videatur.

SE 3. regulariter quinque, circa receptaculum in orbem pofita, e quibus autem vix. duo. Fed unicum duntaxat adolefcere folet, quod globofum, depreffum, aut he. nifphxricum, prope umbilicum fovea excavatum, cetera vero glabrum, rufefcens \& minutifime puncticulatum ef.

Ix т. duplex: exterius tenuiffimum, chartaceum, fragile; interius membranaceum, nucleo arctiffime adnatum, prope umbilicum fubliantia fpongiofa incraflatum.

A L в. femini conforme, carnofum, fubfriabile, album.

Ess 8. filiformis lutefcens, curvatus aut fubflexuofus, transverfin in albumine locatus. Cotyl. brevifimx, compreffa. Rad. longa, regulariter infera, fed fitu varia.

2.) Bacca integra, b.) Eadem immatura transverfim ferta. c.C.) Dvalorum in immaturo receptaculo fitas. d.D.) Semina immatura (eparata, e.) Semen maturom folitarium. F.) Ejus fetip verticalis, cuon fitu embryonis intra albumen, G.) Embryo feparatus.

MYRSINE fCabra. EX herbario Eankfiano.

Bacex magnitudine Ribefii rubri, Sphxricx, undique tuberculis parvis feabratx. Cortex fubcoriaceus, non coloratus, pallidus aut fubftramineus; reliqua ut in prace. deuti, falten minora omnia. 
Myrtaceae

Tab. XXXX.

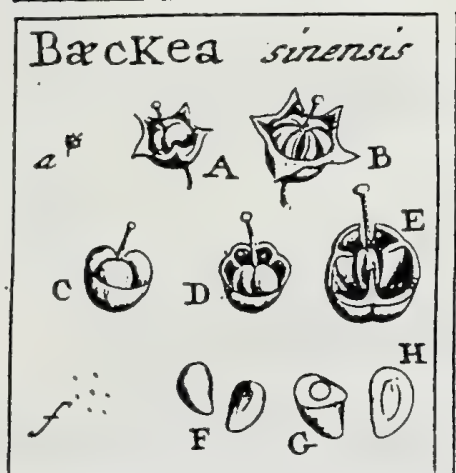

J. Gaertner (1788) Vol.1

157

CXCI. BXCKEA. LIN gen. 49 r.

Calyx pericarpio adnatus quinquedentatus. Cor. pentapetala. Stam. octo. Styl. unicus perfínens, apice globofo. Capfula femi infera, fubglobofa, tri-l. quadrilocularis. Semina pauca.

BECKEA chinenfis. Tab. 3r. fig. 7.

an Backea frutefcens. Oss. it. germ. 301. t. 1. LIN N. Jyff. veg. $375^{\text {? }}$ Ex herbario Bankfiano.

PER. Capfula parva, magnitudine capitis acicula, calyce ad medium usque fibi adnato, campanulato, quinquedentato vefita, flipra nuda, globofa, rotundato trigona, trilocularis, trivalvis. Diflepimenta valvis contraria.

REc. axis capfula incraffatus, fungolus, angulatus usa cum fylo perfiftens.

158 $S E x$. fex vel octo in fingulo loculamento, minutula, hinc convexa, inde comprefí
angulata, glabra, fubsplendentia, lutefcentia.

IN T. fimplex, fubcoriaceum, tenue.

$\Lambda$ г. femini conforme, carnofum, pallidunn.

EM B. teretiusculus, rectus, lacteo albus. Cotyl. minutiffunx. Rad. crafla cetnripeta;

a.) Cap[u]/2 integra. B. D.) Eadem dehifcens. C.) Eadem calyce exuta. E.) Ejus fectio transí verfalis. E. F.), Semina feparata. G. H.) Seniuis fectiones, cum enbryone intra albumen. $\mathrm{Ob}$ calycem fi uctui adnatum, videtur effe genuiua Bxckex fpecies, quamvis locula: mentorum numerus, characteri Linnxano non refpondeat.

$$
136.1
$$




\section{Tab. XXXV:-}

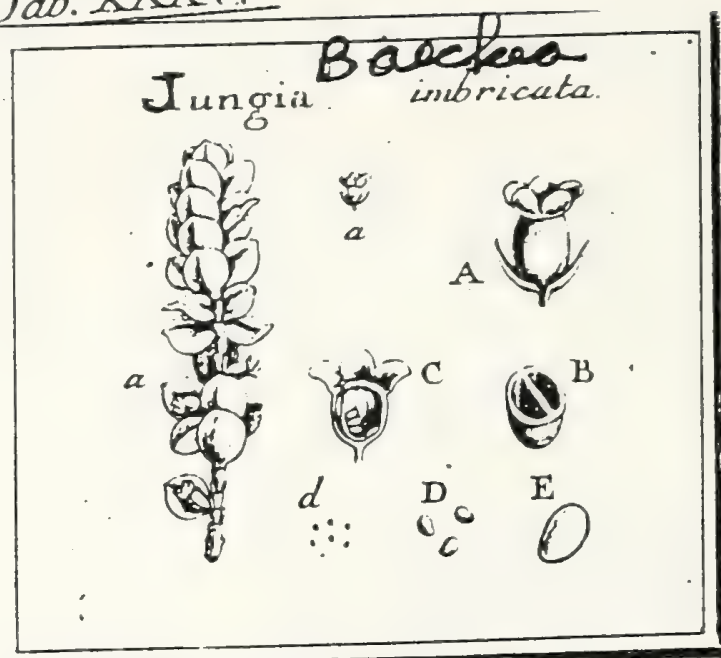

J. Gaertner (1788) Vol.1
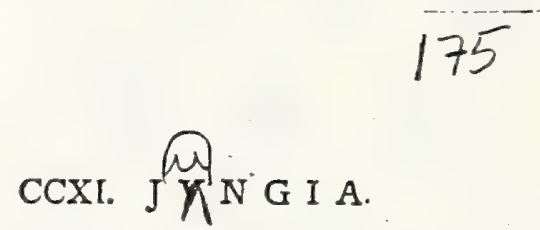

Calyx fuperus, quinquepartitus. Cor. pentapetala. Stam. quinque. Styl. unicus, nigmate globofo. Orarium immaturum biloculare. Capfula matura infera, unilocula. ris, coriacea, evalvis, apice amplo foramine dehiscens.

Jo N G IA imbricata. Tab. 35. fig. 5.

Philadelphus imbricatus. SOLAND. $m / s$.

Ex herbario Bankfiano.

PER. Capfula ir:fera, calycis dentibus rotundatis coronata", parva, ovata, fubcomprella, corizcea, glabra, fplendens, bi-l. fapius unilocularis, intra calycem anplo for anine hians.

Rec. rullum; femina diffepirsento, aut, eo deficiente, flylo, ad alterun capfulz Jatus declinato, affixa.

SE s. pauca, quaruor ad ofto, parvula, ovata, fufca.

176

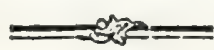

IN T. duplex: exterius cruftaceum, fragile; interius membranaceum.

$\Lambda\llcorner$ в. femisni conforıne, caruofum, fubfriabile, album.

Ess. minutifunus, prope umbilicum feminis locarus. Cotyl.....

a.) Fruticuli ramus. 2. A.) Capfula matura, bafi duabus fipulis munita. B.) Capfule immatura featio transverfalis. C. ) Capfula matura longitudinaliter aperta cum fitu ftyli atque feniuum, d. D.) Senina (eparata. E.) Albumen desudatum.

Jungia tenella, qux Philadelphus tenellus S o LA N $\mathrm{n}$. pracedenti toto fun habitu fimí. lima ent, nifi quod omnia minora atque tenetiora; calycis autem dentes in hac, non rotundati, fed triangulares; capfula vero \& femina ut in pracedenti.

Multa videtur communia habere cum Escalionia LINNEI, profertin cum Bacez vocabulum latifimam apud eum habeat fignificationem, atyue ipfe for $\int_{a n}$ fructum maturum non viderit: donec igitur certiora innotefcant, malui retisere nomen, quod primus firpi dedi, quam novum adoptare dubium.

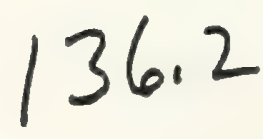




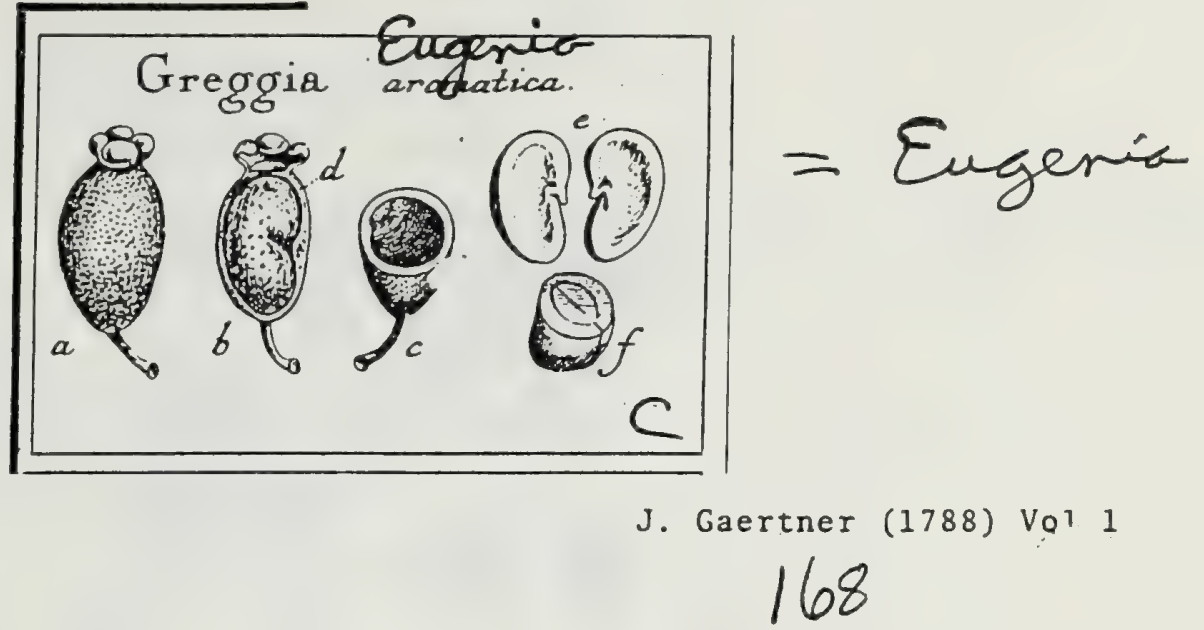

\section{GREGGIA. SOLAN D.}

Calyx quadripartitus fuperus: laciniis rotundatis, concavis, perfiftentibus. Cor. to trapetala.... Stam. numerofa, calycina.... Styl. unicus. Ovarium im: maturum biloculare: ovulis difiepimento affixis. Bacca unatura unilocularis, me nofperina. Semen reniforme, acoccon, Cotyledones conferrumiuatr. Rad. erferta, lateralis.

GreGGiA aromatica. Tab. 33. fig. 3.

Baflard Gloves. Angl. barbadens.

E collectione Bankfiama.

PER. Bacca infera, calyce grandiusculo coronata, obovato giobola, punctis elevati! fcabrata, coriacea, pallide framinea, unilocularis.

REc. nulluin in maturo fructu, prater cicatriculam parvam in altero latere parietis baccx interni, circa ejus medium.

SEM. unicum, grande, reniforıni oblonguın, carnofum, obfoletifiune fubfcrobicula: rum, acoccon.

Ix. T. nullum, vel parietibus baccx adnatum.

A L в. nullum.

Es в. dicotyledoneus, femini conformis, Cotyl. crafix, reniformes, per maturitatem fructus ita inter fe conferruminatx, ut vis feparari queant. Rad. parva, brevis, in concavo feminis latere pofita, apice fuo nunc furfun, uunc deorfun fpectans.

a.) Bacea integra. b.) Eadem longitudinaliter aperta, cum fitu Seminis. c.) Ejus folto trans verfalis. d.) Semen intra baccam. e.) Cotyledones feparatz, parte interna (pefiatx. l.) Farundem inter fe couferruminatarum fettio transverfalis, cum linea transverfali oblolcta, scpan. tionis indice.

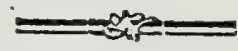

Ex vario radicula fitu, in femine maturo, liquet, quod naturalis ejus directio fit centripeta. Ab Eugeuia differt: fruclu baccato, nec drupaceo; \& femine reuifor-
sni, nec globofo. 


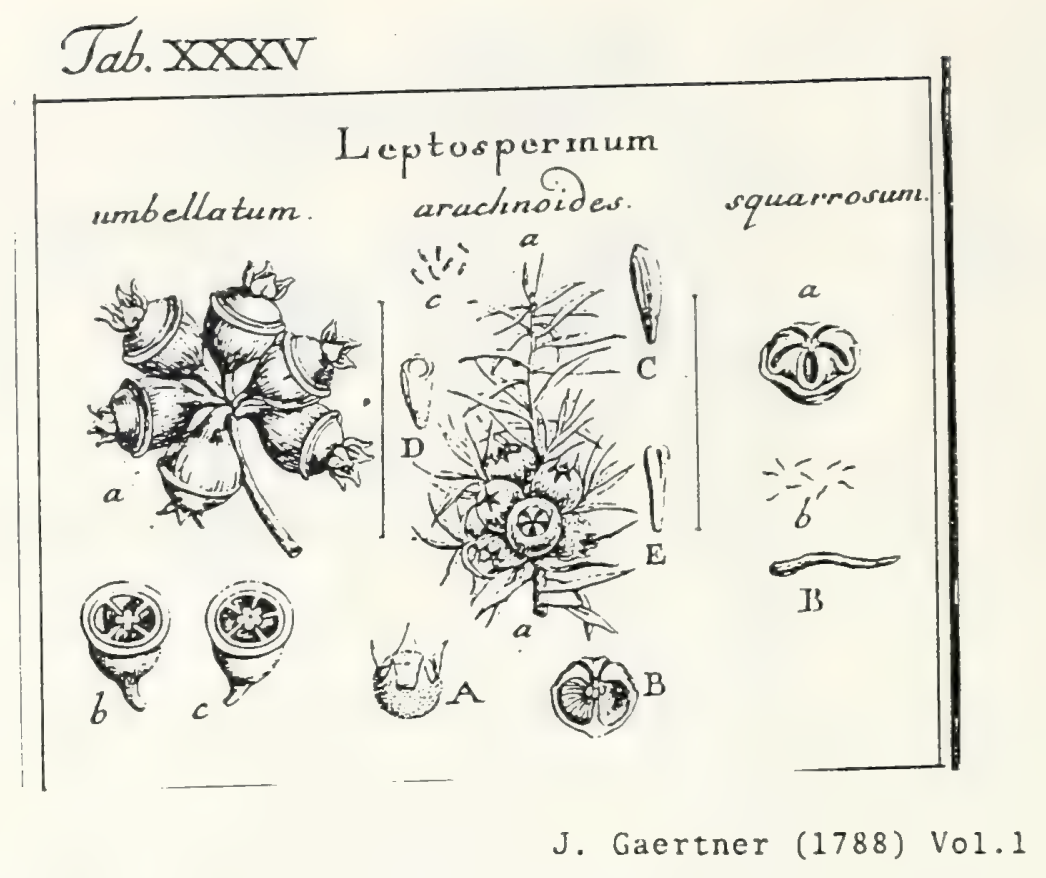

\section{LEPTOSPERMVM. ForST.}

Otnnia Metrofideri, prater Capfulas quinqueloculares.

LEPT OSPERMUM arachooides. "Tab. 35. fig. 3 .

Plibladelphus arachnoideus. SOLAxD. m/s. Ex herbario Bankfiano.

PER. Capfula femi infera, calyce tenuiffuno, lanato, quinquedentato corticata, glo: bofa, depreffiuscula, quinquelocularis, quinquevalvis.

REC. tuberculum globofum, ad internum finguli loculamenti angulum, axi fructis affixuin.

SEM. numerofifima, exigua, oblonga, extrorfun crafiescentia, angulata, ferruginea

IN T. fumplex, fubcoriaceum, tenue.

A L B. sullum.

E м в. dicotyledoneus, magnitudine femninis, fubclavarus, lacteo albus. Cotyl. fermicylindricx, breves. Rad. longa, teretiuscula, centripeta.

a. A. ) Capfulx globofx, fefriles. B.) Receptaculorum ałqque feminum fitus, c. C.) Seraina feparata.

D. ) Scmen transverfe fettum. E, Embryo denudacus.

LEPT OSPER MUM UMbellatum. ibid.

Metrofideros falicifolia V. SOLAN D. m/s.

Lignum leve alterum. R ом Р. amb. 3. p. 72. t. 45. quoad figuram capfulx.

Capfulx umbellatx (a), coriacex, crafix, fubaromaticx, cx duobus quafi hemiiphariis compofita, quorum alterum inferius, paulo majus , \& anguftiliino mar.

- gine horizontali cinctum; alterum vero fuperius, aliquantum minus, \& in vertice fun parva pyramide auclum, qux per maruritatem in parvulas, pro magnitudine fructus, valvulas dehiscit. Loculanenta (b.c.) quatuor, aut quinque, numero valuularum relpondentia.

LerTOSPF.R MU M fquarrofum. ibid.

Philadelphus fyuarrofus. So L A D. $m / s$.

Calyx arcte cum capfula concretus, margine inxquali repando edentulo tcrminarus. Caplula (a) Jubolobola, deprelTiuscula, umbilicata, quinquclocularis, quinque valvis. Semina (b.B.) limearia, nuınerofifima, ferruginea. 

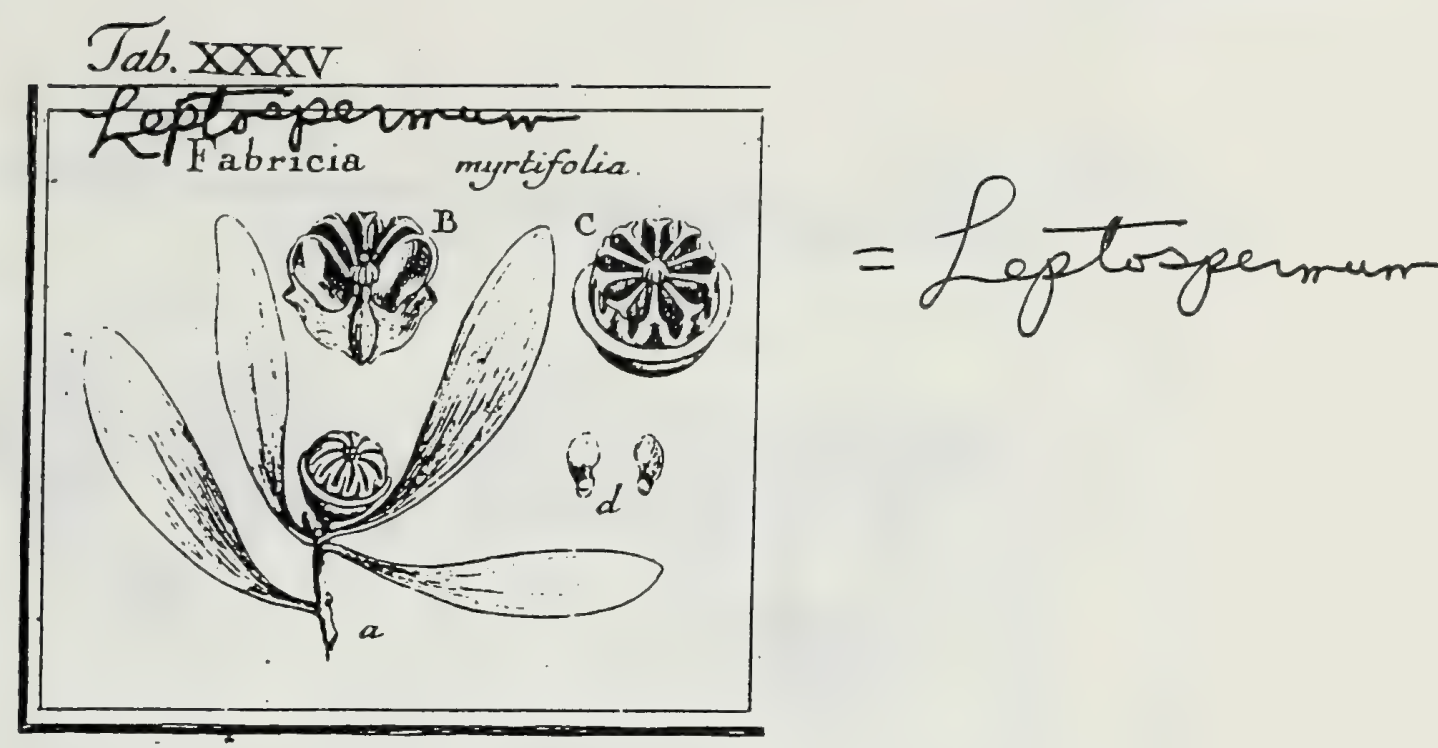

J. Gaertner (1788) Vol. I

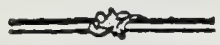

\section{CCX, FABRICIA.}

Calyx adnatus, hemifphxricus, quinquepartitus. Cor. petala quinque rotundata, concava, absque ungue feffilia. Stam. plurima, difereta. Styl, unicus, apice globofus. Capfula multilocularis. Sernina pauca, alata.

FABRICIA myrtifolia. Tab. 35. fig. 4 .

Philadelplus myrtifolius. SOLAND. $m$ /s. Ex herbario Rankfiano.

PER. Capfula femi infera, calyce, per maturitatem, edentulo crafto, aromatico, ad inedium usque corticata, fubglobola, umbilicata, coriacea, decemlocularis, decemvalvis.

REC. centrale, globofum, decemfulcatum.

SEM. in fingulo loculaunento unicum, aut duo, parva, compre $\int_{2}$, fufea, àa magna membranacea terminata.

IN T. fimplex, fubcoriaceun, tenue.

A \& B. nullum.

E м в. magnitudine cavitatis ferninis. Cotyl. . . . :

2.) Capfula matura deliscens. B.) Eadem longitudinaliter fetia, eum fita \& figura receptacult, c.) Ejusdem fentio transverialis. d) Semina Separata.

In Fabricia levigata, quz Philadelphus lavigatus SOL ^ N D. eadem ef omnium tructus partium fabrica, nifi quod loculamenta octo, \& intra fingulum, guinque ad octo fint femina parva, alata. 
Myrtaceae

Tab. XXXV:-

Melaleuca.

angustifolia.

suaveolens.

viridiflora.

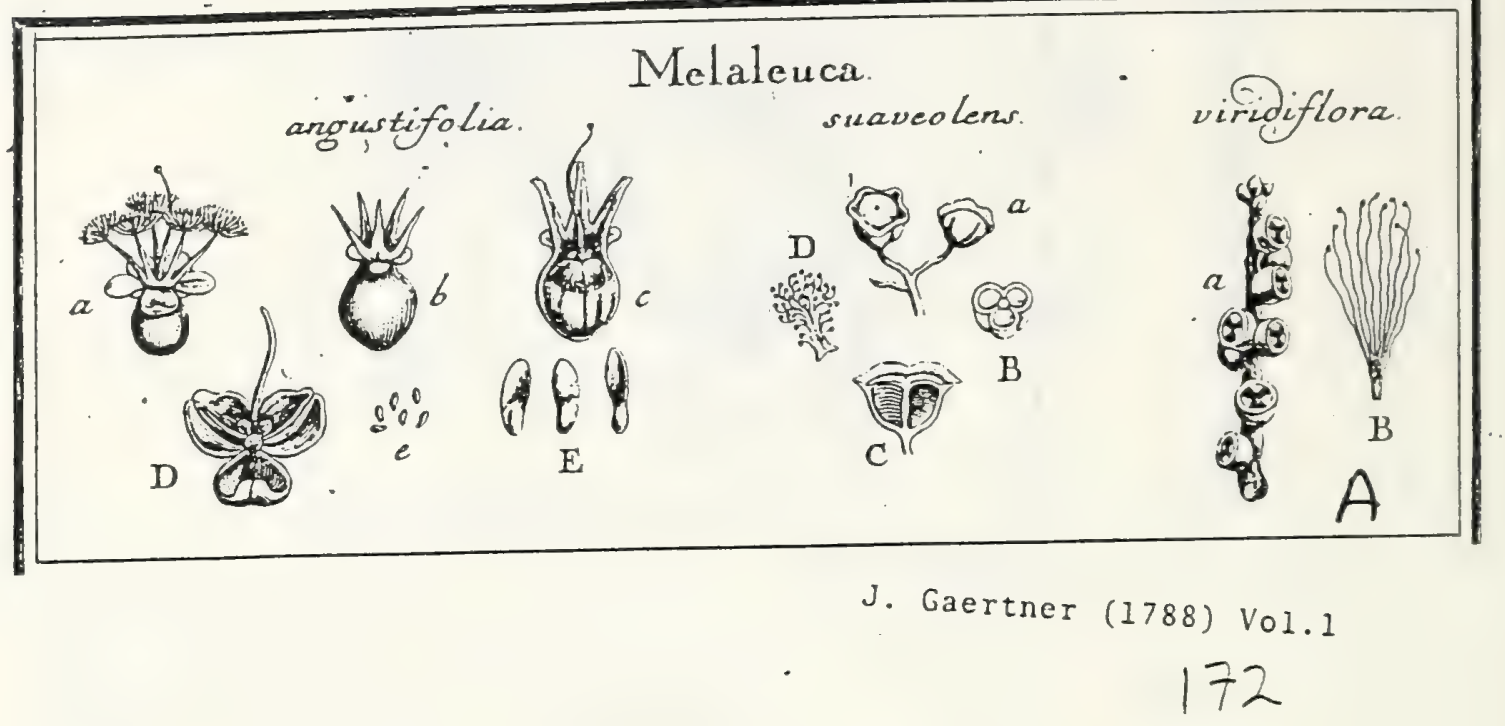

CCVII. MELALEVCA. LINN. gen. 1269.

Flos pracedentis, prater famina bafi in quinque fafciculos connata. Capfula infera, cuin calyce conferruminata, trilocularis. Semoina innmatura limeari paleacez; unz tura fxpius slata.

Melaleuca angufifolia. Tab. 35. fig. $x$.

Ex herbario Bankfiano, cum fequentibus.

PER. Capfula infera, calyce fibi arde adnato corticata, fubglotofa, trilocularis, tri-: valvis.

REc. tuberculum fungolum, glabofum, in fundo finguli loculamenti axi froctus ednatum.

173

Sem. numerola, parva, ovato oblonga, compreffa, fupra ala mernbranacea terminata IN T. fimplex, fubcoriaceum, tenue.

A L D. nullum.

Eas в. magnitudine feminis. Cotyl. .....

2) Frutus integer, cum corolla \& Raminibus. b.) Calyx maturus, cum palis faminiferis carilagincis. c.) Idem tongitudinaliter apertus, cuin capfula intcgra. D.) Receptacula in fundo localamentorum. t. E.) Semina feparata.

Melaleuca fuavcolens. Solann. ibid.

Calyx fublicmifphxricus, margine repando cinctus (a). Laminz quinque membranacex in filainenta antherifera (D.) divifx. Capfula immerfa, trilocularis (B.) Semina (C.) lineari paleacca.

Melaleuca viridiliora. Soland. ibid.

Calyx hemifphxricus (a.) craftus, edentulus. Capfula immerfa, trilocularis, trivalvis. Stamina (B. ) filiformia, longifima, bafi connata.

$$
136.6
$$


J. Gaertner (1788)

Tab. XXXNV.

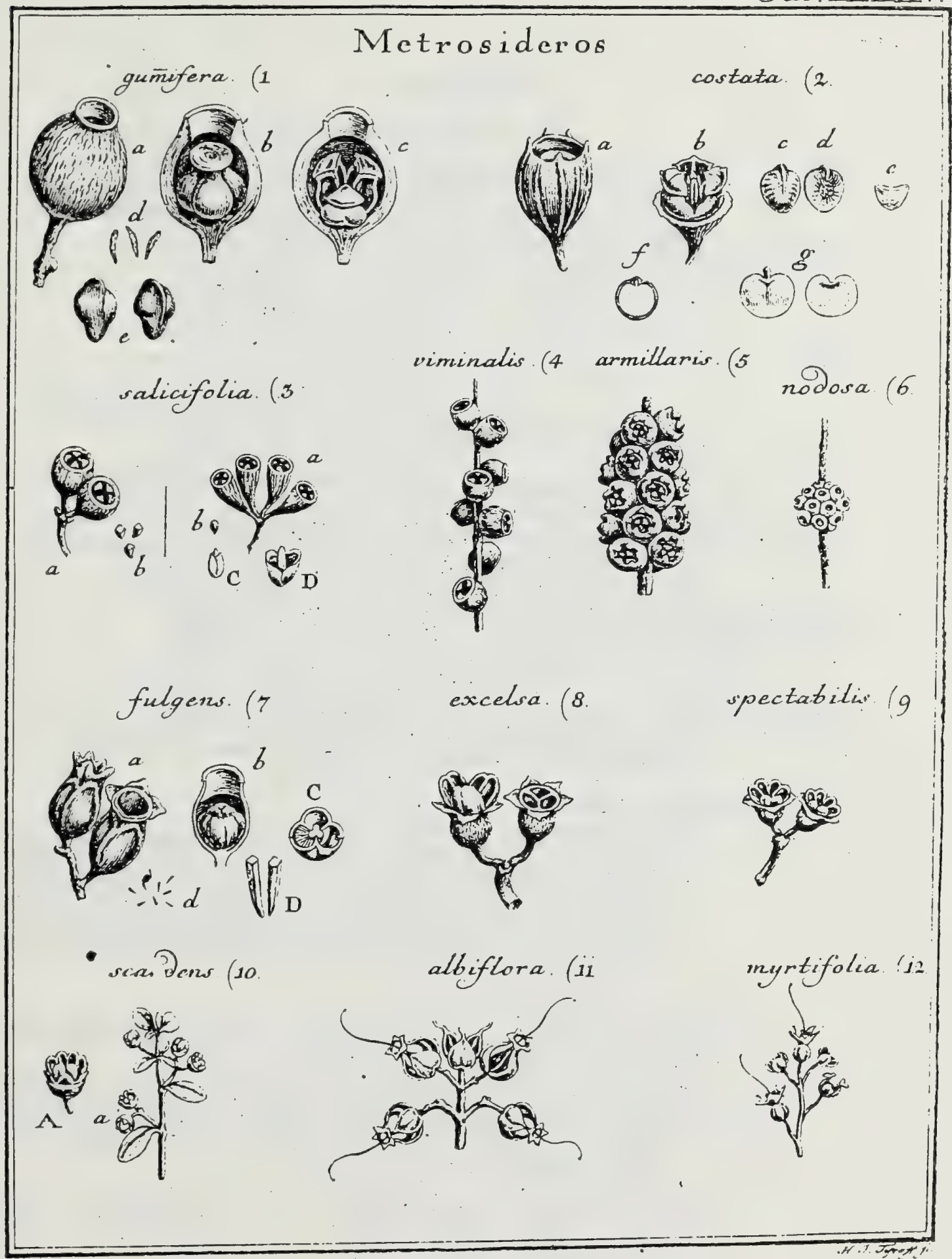

$136.7 \mathrm{~A}$ 


\section{METROSIDEROS. BAN K S.}

Calyx monophyllus, quinquedentatus. Cor. pentapetala. Stam. numerola, difcretz, calyci inferta. Styl. unicus. Capfula calycis ventie corticata, infra floris receptaculum pofita, tri-1. quadrilocularis. Semina imsnatura nuinerofifima, linearipaleacea; matura pacifirma, rotundata aut angulata.

Metrosideros gummifera. Tab. 34. fig. 1.

Metrofideros gummifere, cortice rugofo. Soland. $\mathrm{m} / \mathrm{s}$.

Ex herbario Bankfiano cum fequentibus.

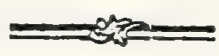

PER. Capfula infera, calyce globofo, fuberolo, edentulo, aromatico corticata, rotundato-trigona, difco plawo fungofo, calycis aperturam claudente ternnimata, trilocularis, trivalvis.

REC. tuberculum fubrotundum fungofum, ad finguli loculamenti ongulum internum. axi fructus adnatum.

Sex. numerofiftuma, lineari paleacea, rubro ferruginea, ferilia; inter hac quando. que unicum fertile, ovato globofum, aut fuborbiculatum, in vertice \& dorlo, fulco elevato notatum, gilvum, glabrum, fublucidun.

IN T. fumplex, fubcoriaceum, tenue.

A L B. nullum.

EM B. magnitudine feminis. ......

2.) Calyx maturus capfuiam oecultans. b.) Idem longitodinaliter apertus, cum capfula integra.

c.) Caplula deiilcelss d.) Senina calin, e) Semen foecundum, ab utroque latere fpectatum,

Metrosideros coftata. ibid. fig. 2.

Metrofideros gummifera, cortice glabro. Socand. m/s.

Calyx ovato globolus (a.), coltis quinque ad duodecim friatus, brevilime quinquedentatus, fuberolus, craflus, aromaticus. Capfula (b.) ut in pracedenti. Semen maturum (c.d. e.) fubrotundum, plano convexum, crifta brevi in vertice ac dorfo notatum, gilvum, glabrum. Alb. nullum. Embryo (f.) mag. nitudine feminis, inverfus, lacteo albus. Cotyled. (g.) orbiculatx, fubfolia. cex, planx, prope radiculam emarginatz. Rad. teretiuscula, brevis, fuperz.

Metrosideros falicifolia, ibid. fig. 3.

Metrofideros falicifolia $\alpha$. E $\beta$. Solınd. m/s.

a. Calyx fubglobofus (a.) truncatus, edentulus. Capfula inclufa, quadrilocularis. Semina parva (b.) angulata, ferruginea. Einbryo.......

ß. Calyx inverfe conicus (a.) duplo longior quam crafius, truncatus, edentulus. Capfula inclufa quadrilocularis. Semina inatura (b.) parva, obovata, lenticulari comprefra Alb. oullum. Cotyl. (C. D.) foliactex, rotundatx, replicatx, circa radiculan convolutx. Radic. (D.) in medio cotyledonum, teretiuscula, recta, centripeta, aut inferd

Metrosideros viminalis. Soland. ibid. fig. 4.

Calyx fubhenifphxricus, craflus, edentulus. Capfula immerfa trilocularis. Semina immatura minuta, angulata.

Metrosideros armillaris. Soland. ibid. fig. 5 .

Calyx fubglobofus, fuberofus, cralus, quinquedentatus. Capfula inmerfa, trilo. cularis.

\subsection{8}


Metrosideros nodola. Soland. ibid. fig. 6.

Calyces in medio ramulorum aggregati, fuberofi, fphxrici, edentuli, glaberrimi; fplendentes, nivei, parvuli. Capfulx immerfx, triloculares.

Metrosideros fulgens. Soland, ibid. fig. 7 .

Caly'x ovato oblongus, edentulus, aut dentibus quinque latiusculis (a.) coronatus; obfolete coftatus, coriaceus, tenuis. Capfula (b.) fubglobofa, dimidio calyce brevior, trifulca, trilocularis (C.) Semina immatura (d. D.) linearia, angulata; lucida, ferruginea.

Metrosideros excelfa. Sorand. ibid. fig. 8.

Calyx tomentofus, quinquedentatus, capfulx ad mediun usque adnatus. Capfula ovata, extra calycem prominens, pubefcens, trilocularis.

Metrosideros fpectabilis. Soland. ibid. fig. 9.

Calyx obfolete pentagonus, obtufe quinquedentatus, albo tomentolus. Caplula ca. lyce paulo altior, fubglobofa, trilocularis.

Metrosideros fandens. Soland. ibid. fig. 10.

Fructus parvus, magnitudine feminis Cannabis. Calyx henifphxricus, ad medium usque capfule adnatus, quinquedentatus. Capfula exferta (a. A.) fubglobofa, trilocularis.

Metrosideros albillora. Sorand. ibid. fig. Ix.

Calyx totus cum caplula intime connatus, e ventricola bafi furfum angufatus : quinque denticulis patentibus terminatus. Capfula trilocularis, trivalvis, dehifcendo ventrem calycis rumpens, manente denticulorum coronula integra.

Metrosideros myrtifolia. Soland. ibid. fig. 12.

Calyx arcte cum caplula connatus, fupra eam infundibuliformi patens, quinquedeatatus. Capfula magnitudine feminis raphau, fubglobofa, profunde trifulcata \& quali ex tribus globulis compolita, nigricans, trilocularis, trivalvis. 
-

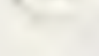

$\checkmark$

( 


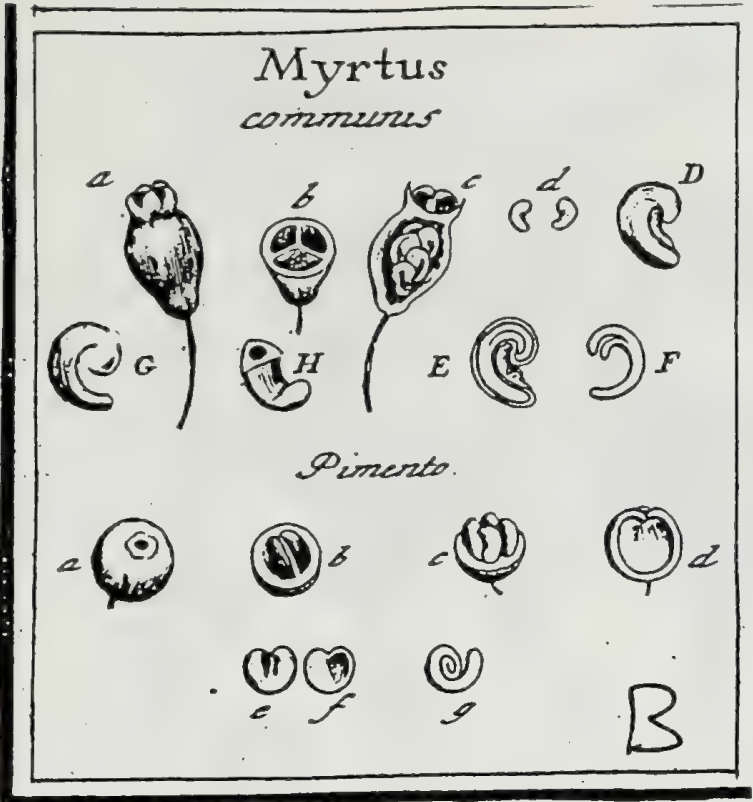

CCXXII: MYRTUS. TOURN. t. 409. LinN. gen. $\sigma_{17}$.

Calyx fuperus, quinquefidus. Cor. péntapctala. Stam, p'urima, calyci inferta: Sigl. unicus. liacca infura, bi-1. trilocularis. Semina fuborlca. Embryo curvatus.

Miretus communis. Tab. 38. fig. 2.

Myrtus. Best. hort. Eyff. apfl. frut. t. 12. f. I. B L A K ख. herb. t. II 4.

Mlyritus fluribus folitariis: involucro diphyllo. LIN N. Syft. veg. 46 t.

PFr. Bacca infera, fubovata, calyce perfifente coronata, fpongiolo carnofa, e czruleu sigricans, trilucularis.

REc. nullum, prxter angulum loculansentorum internum; cui femina aflixa.

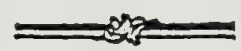

SEM. in fingulo loculamento quatuor 1. quinque, rarius plura, reniformia, gibba, albicantia, siiuda: parte dorfali fuboffea; ventrali, fubllantiâ fungofâ repleta.

IN r. Gumplex, cartilagineum, I. fubofeum, crafturn.

A ¿в. nullum.

E s B. ferminis cavitati conformis, teretiusculus, lacteo albus. Cotyl. femicylindricx, breves, incunnbentes. Radic. cotyledonibus duplo longior, fenicirculari-curvata, infura.

..) Bacea intepra. b.) Eadem diffeta. c.) Ejus loculamentum anterius apertum, cum fitu feminum. d. D.) Srmina feparata. E.) Semen longitudinaliter diffeaum, cum fitu embryonic F.) Embrjo reparatus, G.) Seminis tela, a fulnautia fpongiofa, que rexis pelvim repiet, repurzata. H.) Eadem transverfe fela.

Mrrtus Pinento. ibid.

Amomunt Clufii. Вачн. hiff. 2. p. 295 .

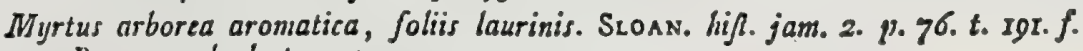

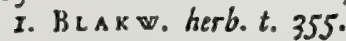

Myrtus foliis alternis. LIN No Syfl. veg. 462.

Bacca (plixrica, calyce planiusculo, depreffo quinquecrenato coronata (2.) carnofa, bilocularis (b.), grate aromatica. Receptac, in fuprema parte diffepimenti (d.). Semina Juo (c. e. f.), rotandato reniformia, hime convexiurcula (c. e. ), inde plana (f.), rufefcentia, non aitida. Integ. fimplex, fubmem. branaceuin, tenue. Albumen nullum. Embryo ( $g$ : terctiusculus. Cotyl. lineari acuminatz, brevilfunx. Rad. longifinna, cralla, fpiraliter convolura, adcendeus f. fupera. 


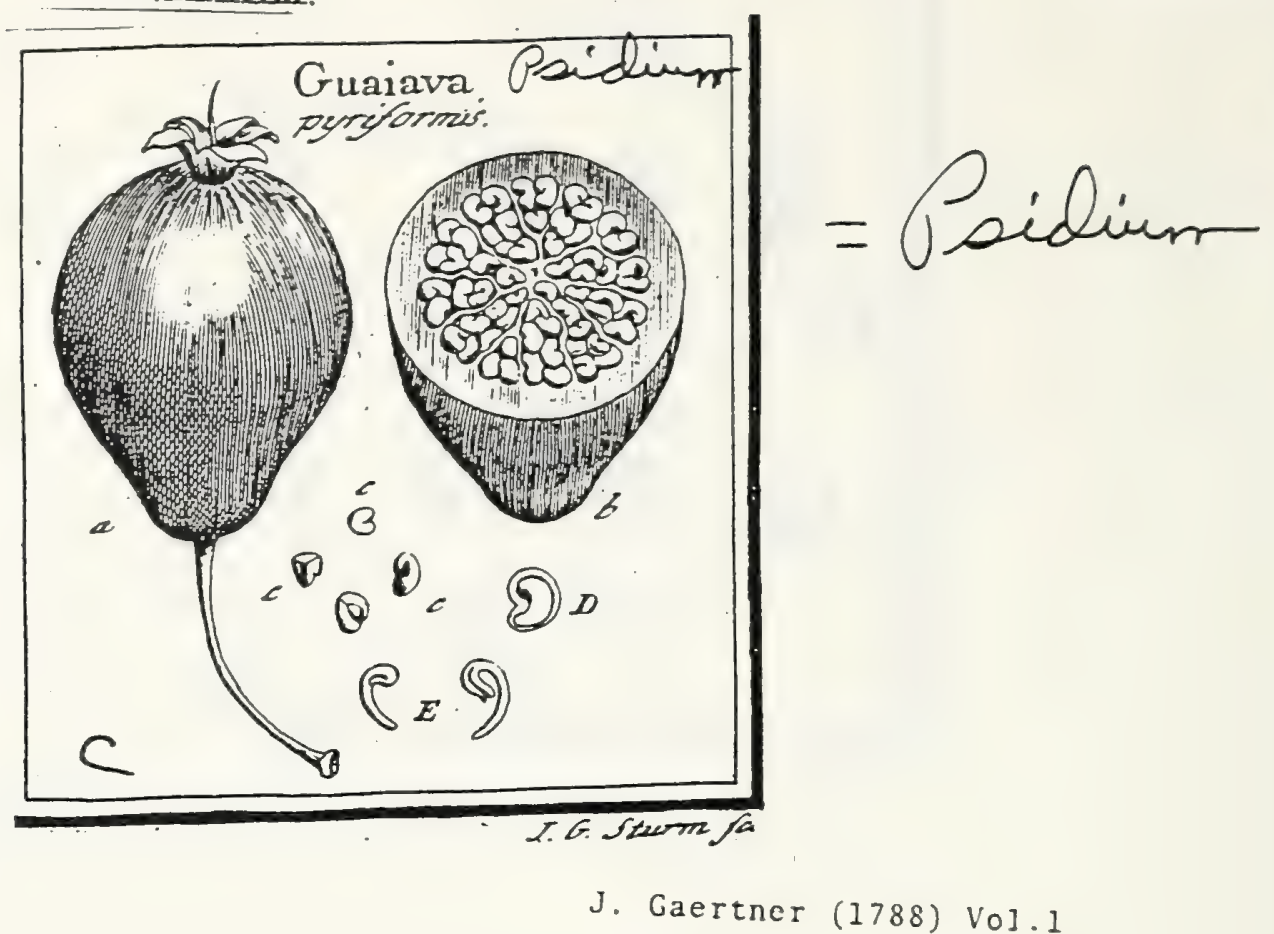

CCXXIII. GUAIAVA. T O URN. t. 443. Pfidium. Linn. gen. 615 .

Calyx fuperus, quinquefidus. Cor. pentapetala. Stam. plurima calyci inferta. Sty $L$ unicus. Bacca infera uni-l. multilocularis. Semina reniformia nidulantiz.

Gusjava pyrifornis. Tab. 38. fig. 3.

Guajava alba dulcis. Соммец. hort. am/f. t. p.12t. t. $\sigma_{3}$.

Guajaun foliorum ramis quadrangulis, fructu oblongo, carne rubente. Енгет. dec. $t .43$.

Pfidium folits lineatis obtufiusculis, pedunculis unifforis. L I xs. Jyfl. veg. 460 .

PER. Bacca infera, turbinata, longe pedunculata, calyce perfifenti corodata, carnofa, mulilocularis. Dillepimenta valde irregularia \& Expe fubdivifa, interficiis pulpa molli repletis.

REC. sullum ; fermina absque ordine in pulpa nidulantia.

SE ss. numerofiliuna, oflea, reniformi angulata, albicantia, glabra. 186 IN T. duplex : exterius fuboffeum, craftum; interius membranaceum, chalaza nigri:
cante notatum.

A ¿ B. nullum.

E s1 B. teretiusculus, arcuatus, aut fubfpiralis, lacteus. Cotyl. femicylindricx, bre: villusse. Rad. duplo longior, curvata, vaga. 2.) Bacca integrs. b.) Eadem transverfe fela. c.c.c.) Semina varie angulata. D) Seminis in
Qta aperia. E.) Embryo denudatus.

136.9 


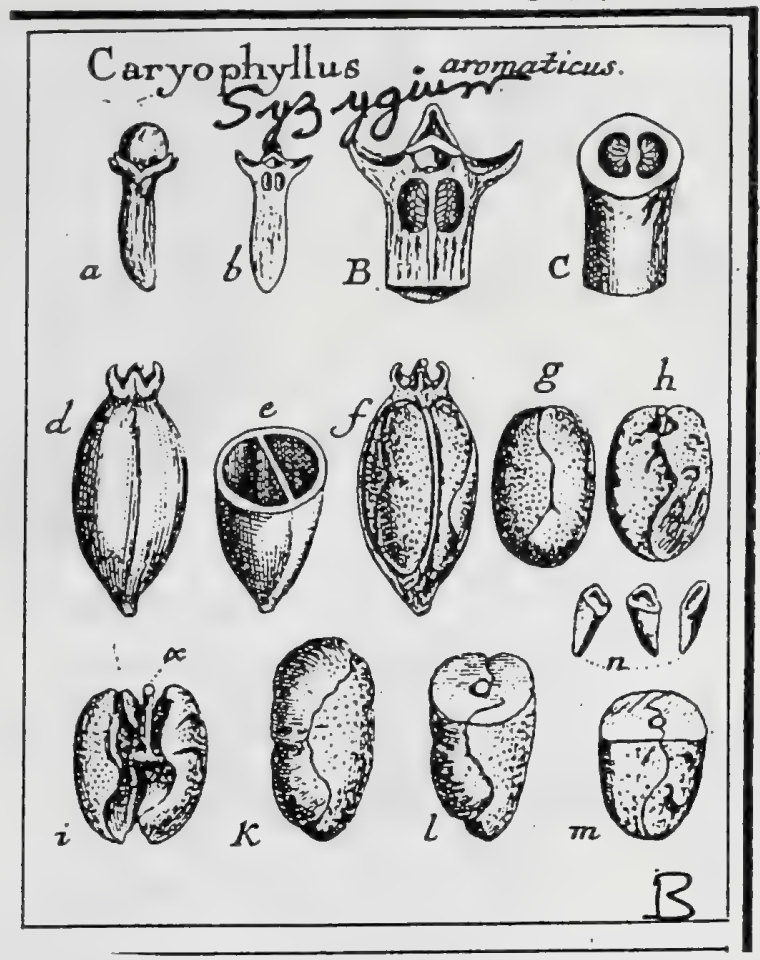

Myrtaceae

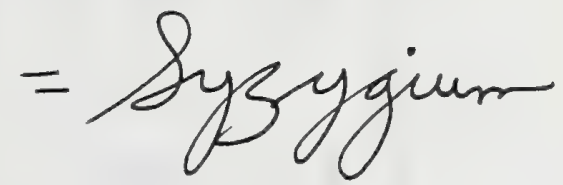

J. Gaertner (1788) Vol.1

\section{7}

\section{CARYOPHYLLUS. TOURN, t. 432. LINN. gen. 66g."}

Calyx finplex, quazrididentatus, fupełüs. Corolla tetrapetala. Stam. numerofiffuna (200.), in quatuor plaalanges difpofita atque vallo quadrangulari carnofo juxta calycis dentes inferta. Styl. unicus. Ovarium immaturum biloculare: ovulis in fingulo loculamento vigimti, fepto medio affixis. Bacca matura uni-1. bilocularis, mono- I difperma. Semen acoccon: cotyledonibus rediculam occultantibus.

CARyophyilus aromaticus. Tab. 33. fig. 2.

Caryophylluni, Tsjenke. Ruмpн. amb. 2." p. r. t. 1. Ëc.

Caryophyllorum arboris ramus. VALENT. muf. epift. órient. XIX. t. 2.

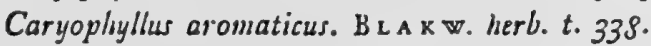

Caryophylhus. L IN N. Jyft. veg. 496.

PER. Hacca infera, coriacea, intra calycis perfifentis dentes vallo quadrangulari umbilicatz, elliptico Splixroidea, uni-l. bilocularis.

REc. nullum in maturo fructu; in ovario autem diffepimentum vice receptacuii fungitur.

$S_{E}$ S. unicum in fingulo locularncuro atque laujus cavitati fua forma refpondens, adcoque vel ovato cylindricum, vel dimidiato ovatum, bilobum, acoccon.

IN T. nullum in maturo fernine; in ovulis tenuifinum, arachnoideum.

A เ в. nullum.

168

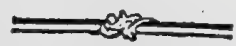

Ess B. dicotyledoneus, inverfus, femini conformis. Cotyl. craffx, carnofx, duriuc. culx, extus convexx, intus vario modo finuof $x$, fubinzquales. Rad. e ceatrox occultata.

a.) Ovarium immaturum f. Caryophyllus. b. B.) Ejus ferto iongitudiualis, cum ovulorum, infa

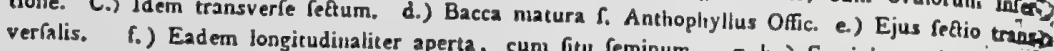
utraque. i.) Ejusdem cotyledones diduetse, cum fitu feminum. g. h.) Seminis zeminati faclén tarii figura. L.) Ejusdem Setio transverjalis, Ovula immatura insiguiter aukta. 


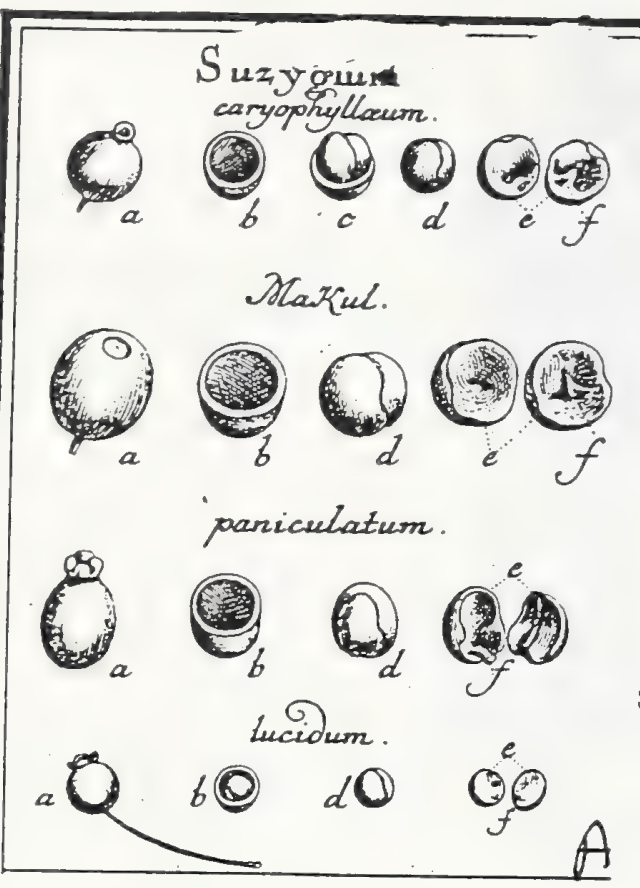

J. Gaertner (1788) Vol.1

166

\section{SYZYGIUM. BROWN.}

Calyx edentulus, aut q̨uadripartitus fuperus. Cor. tetrapetala. Stam. plurima, alyci inferta. Styl. uncus. Ovarium immaturum biloculare: ovulis paucis diffo: pimento affixis. Bacca matura, unilocularis monofperma. Semen acoccon; con. tyledonibus maximis, radiculam occultantibus.

Sizigium caryophyllxum. Tab. 33. fig. t.

Myrtus zeylanica. Lin , A. zeyl. 182?

Dam. zeylonens. E collect. ferm. hort, lugdb.

PER. Bacca infera, fphxrica, calyce edentulo coronata, unilocularis, per xtatem con riacea, tenuis.

REC. cicatricula parva, parieti interno bacex, paulo infra nedium infcripta.

S E M. unicum, globolum, grande, bilobun, carnofum, in maturo fruclu acoccon.

IN T. nullum; f. cum bacca conferruminatum \& a fcrine per maturitatem fponte, fecedens.

A L B. nullum.

Eмв. dicotyledoneus, figurâ \& magnitudine feminis. Cotyl. liemifplıxicx, fubinzo quales, carnofx, maximx. Rad. conica, pariva, cotyledonum luperficiei internz, paulo infra medium inferta, \& ab eis penitus occultata; in maturo fructu incerti firus, in ovario autem diflepimento obverfa $\int$. centripeta.

2.) Bacca jotegra. b.) Fadem transverie fefta. c.) Semel cavitatl bacez refporidess, d.) Idem e bstca exemtum. ef.) Colyledones a parte interus fpeftata, curn fitu \& figura radicula (f).

Srzyorum Makul. ibid.

Makul. zeylonens. E collect. (em, hort. lugdb.

Bacca ovato globofa (a.), areola rocunda plana, leviter deprefia, absque calycis vefligio unibilicata, coriacea, glabra, unilocularis (b). Senuen globofun (d.); bilobum. Cotyledones inaximx (e.f.), inxquales, convexo concavx. Radicula fubcentralis (f.) acuminata, oblique adicendens.

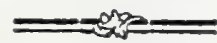

Srzyeturs paniculatum. ibid.

Eugenia pariculata. "Hort. ficc. Banks.

Bacca ovara (a.) coriacea, temuis, unilocularis (b.) calycis quadripartiti foliolis concavis coronata. Sencu (d.) ovato globolum, bilobum. Cotyledones (e. f.) valde inaquales. Ranic. (f.) teretiuscula, capitellata, ab interioribus oblique verfus exicriora defcendeus.

Srzygrus lucidum. ibid.

Eugenia lucida. Hort. ficc. Baxks.

Bacca (a.) magnitudine Piri, longifime pedunculata, fphririca, glabra, calyce quadrifido coronata, unilocularis (b.). Scmen (d.) globofum, bilobum. Co. tyled. heinifpharicz (e. f.), fubzquales. Radic. (f.) minima, acuminata; occultata.

Neque cum Eugenia, 'neque cum Myrto, Sed quodammodo cum Jambolifera fociari poteft Syzygium. Ab Eugenia differt, quod fructus maturus nequaquarn drupaceus, \& immaturus, polyfpermos fit; a Myrto, quod embryo femini conformis, nec fpiralis; \& a Jambolifera, quod baccx \& femina globola, nec cylindrica fint. Generatim in plautis Calycitloris baccatis, nifi generum no:zs 


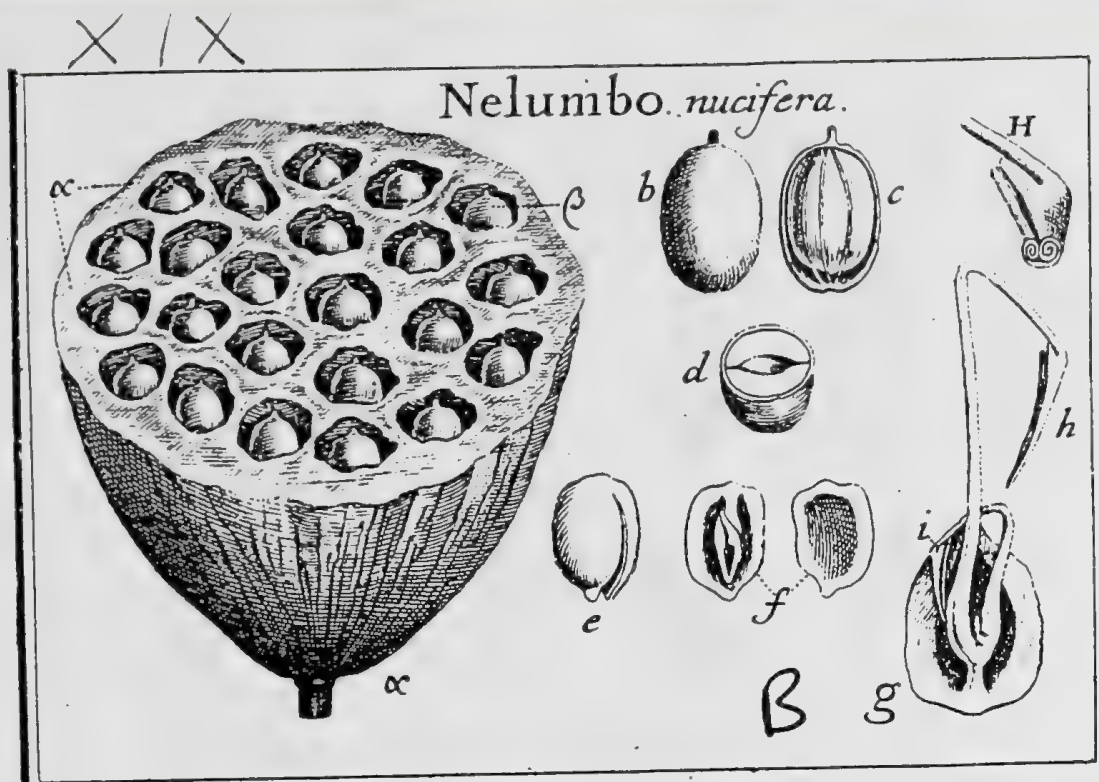

$-$
Nelumbonaceae

J. Gaertner (1788) Vol.1

Calyx pentaphyllus. Cor. polypetala. Stam. numerofa. Strli plures, fimplices. Pericarp. ex receptaculo lloris favolum. Nuces plures difcretx. Embr. geruninatss.

Neluм во nucifera. Tab. 19. fig. 2.

Tamara ES Bem-tamara. R нгел. mal. II. p.59-6t.t. $30.30^{\circ}$

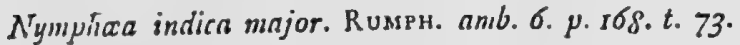

Nymphara indica; faba agyptia dita, flore incarnato. HERs. par. bat. t. 205.

Nymphera foliis peltatis undique integris. L $1 \times x$. fy/. veg. 49r.

PER. nulluin, nifi fructificationis receptaculum communc velis.

REC. commune inverfe conicum, fuberofum aut fungofum, fupra planum, alveolis rotundis difcretis, numero feminibus aquali, exfculptum; proprium, funiculus umbilicalis brevifiunus, e fundo alveoli ad bafun feminis porrectus, ejusque fora. mini unbilicali infertus.

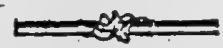

SE M. nucementacea, plura, a quindecin ad triginta, elliptico fphxroidea, aut rotundius globofa, apice fylo brevi perfifente terminata, bafi minutifiuno poro umbilicali notata, glabra, nigricantia, aut rufefcenti - fufca.

IxT. duplex: exterius coriaceo-corneum, durum, tenacifinum, evalve; interius, membranaceo fpongiofum, craftusculuın, vafis nutritiis filiformibus nipatum, rubio ferrugineum.

A L B. nullum.

VI's. cotyledoniformis, amygdalino carnofus, albus, fupra integenimus, infra bilobus; intus pro recipiendo embryone excavatus; extus feminis magnitudini \& figure conformis.

Емв. inverfus, in fuprema parte vitelli radicatus, gramineo viridis, germinans. Sca. pus teretiusculus, brevilfunus. Plumula diphylla: foliolis utroque margime involutis, petiolatis : petiolis foliolo longioribus, in medio replicatis.

a.) Receptaculum commune, naturali paulo minus, alveolis $\beta$.) (eminiferis exfculptum. b.) Nux integra. c.) Eadem longitudinaliter aperta, cum vafis nuclei nutritis. d.) Ejus \& vitelli Sertio transver[alis. e.) Vitellus decorticatus. f.) Idem bipartitus, cam fitu embryonis. g. h. L) Vitelli in qua germinare incipientis tacies \& magnitudo naturalis. H.) Plumula foliolum transverim fettum:

Receptaculum in aliis argute, in aliis parabolice conicum, in aliis fere hemifphzricum, $\&$ iterum in aliis ita depreflum, ut craftam placentam rotundam xmuletur. Etiam confiftentiâ variat: in aliis fcil. fungola, ut digitis facile comprimi queat; in aliis fuberofa \& iterum in aliis cruftacea \& dura eft. Denique \& cellularum numerus varius, nempe 2 duodecim ad triginta.

Ambigit Nelumbo inter plantas mono-\& dicotyledones: nam ad pofteriores, ex fabrica feminis, omnino fpectare videtur; fed veriflume ad priores pertinet, quum conftantiffune unicum duntaxat lub germinatione promat foliolum, nec alterum' prodeat, donec prius penitus evolutuin \& fuper aqua explicatum fit: uti hoc in quinquaginta \& pluribus nucibus, a b. LeRCHE acceptis, expertus foin. 
○

- 

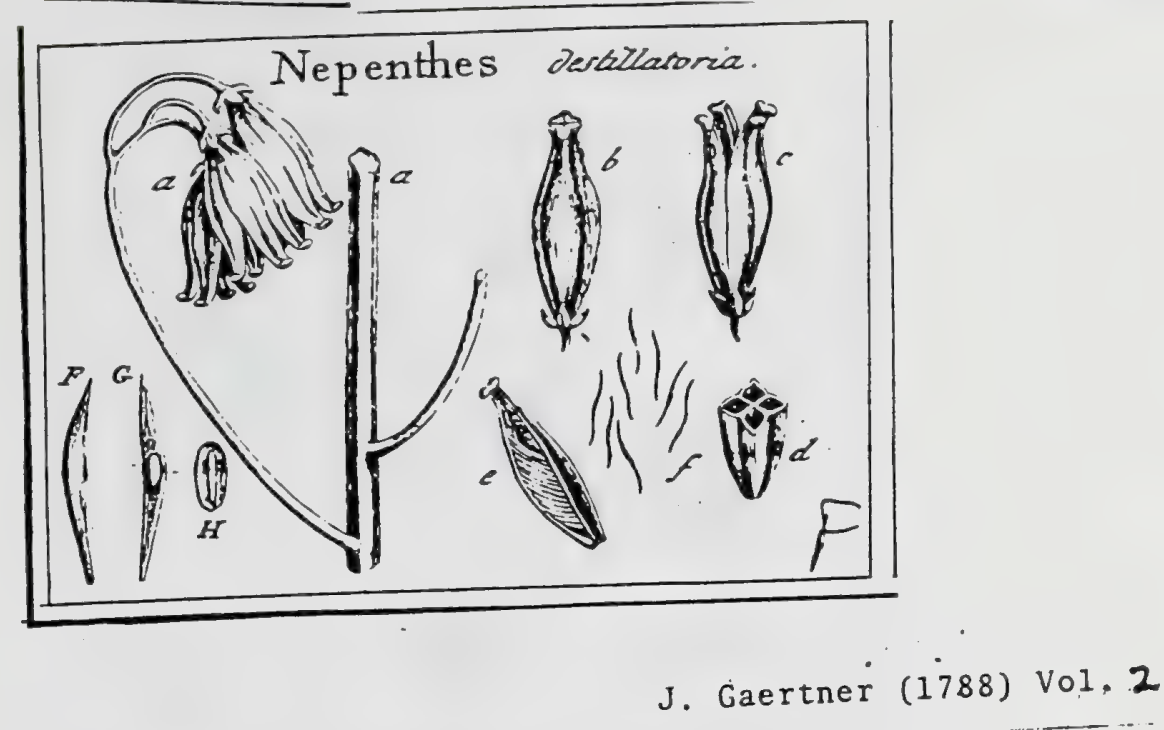

18

\section{NEPENTHES. LINN. gen. IoIg.}

Cal. inferus, quadripartitus, perfiftens, foliolis ovatis, acuminatis. Cor. nulla. Antherx quatuor ovario affuxx. Capf. fupera, quadrilocularis. Sem. lineari - paleacea.

Nepenthes deftillatoria. Tab. 83. fig. 6.

Utricaria vegetabilis zeylanensum. PLuk. phyt. t. 257. f. 3.

Cantherifera. RUMPH. amb. 5. p. 121. t. 59. f. 2.

Bandura zeylanica, in extreino foliorum folliculum peniformen expanfum babens. BURM. Zyl. 42 . t. 77 .

Nepentbes. Lins. Jyjt. veg. 820.

E feminario hort. Amftelod.

PER. Capfula fupera, oblonga, in medio ventricofa, utrique attenuata, difco deprelifo quadrangulari ex ftigmatibus quatuor felfilibus coronata, tetragoла, quadrivalvis. Valvulx extus linea depreffa, intus fepto longitudinali ftipatx.

- REC. nullum prater diffepimenta capfulx, quibus femina undique in fitu fuberecto affixa.

SEM. numerofifima, lineari oblonga, utringue attenuata, fordide ftraninea.

IN T. duplex, exterius fpongiofum, farctum, nucleo multoties longius; interius membranaceum, tenuilinum, ut vix ullum.

- ALR. ovato oblongum, teretiufculun, inferne fubacuminatum, carnofum, album, in medio feninis collocatum, \& a fpongiofa tefta fubftantia arcte involutum.

ENB. monocotyledoneus, filiformis, lacteus, longitudine fere totius albuminis. Rad. fubacuminata, infera.

2.) Pars racemi fnigiferi pedalis \& ultra: feapo obfolete pentagono, peltunculis primorihus diftitis, patenti alfecndeacibus; fecundariis plerumque terastis. b.) Culpfula iutegra. c.) Eudton ab

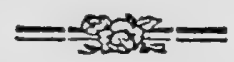

apice dehifeens. d.) Ejusdem fedio transverfalis. e.) Valvula a parte interna fpectata, cum feminibus fepio undique affixis. F. F.) Semina feparate. G.) Albumen integrum in medin feninc hxrcus. H.) Idem folutum \& longitudinaliter diffetum, com fitu \& figura Enubryonis. 


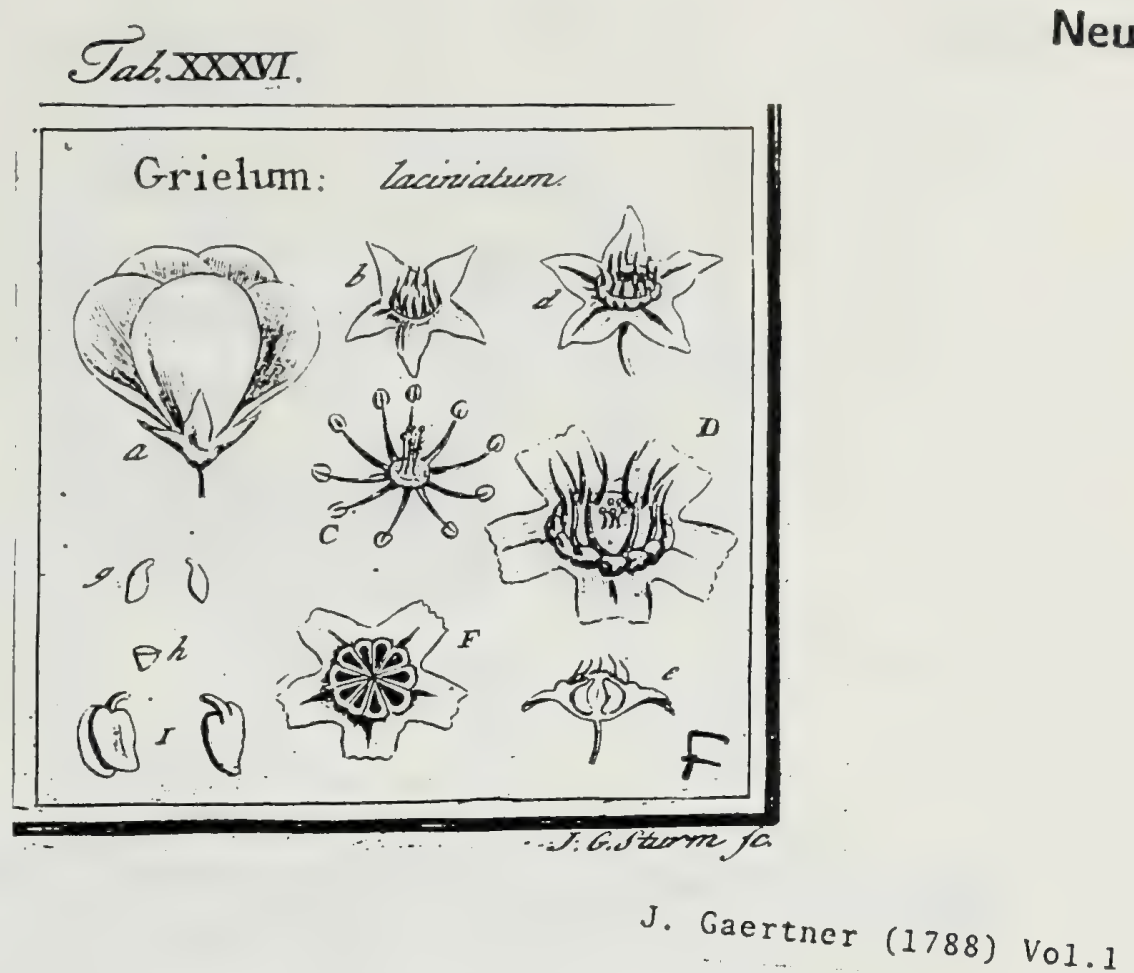

180

CCXVII. GRIELVM. LINN. gen. 1235 .

Calyx monophyllus, quinquefidus, in fructuın abeuns. Cor. pentanetala. Styl. quio: que. Capfula ex indurato calyce orbiculata, deprefla, quinque-1. decemlocularisi! Semina folitaria.

GRIELeM laciniatum. Tab. 36 . fig. 6.

Ex herbario Bankfiano.

- P Eк. Capfula infera, deprefta fubtus calyce fibi arcte ajnato corticata, fupra planius:cula, ac in ambitu, annulo ex tuberculis duris, fubolteis circumvallata, intra hune autem filamentis \& nylis ferfintentibus coronata, decemslocularis, evalvis. Loculansenta ad fingulos fylos gemina, oinuia tamen xyuabijter circa axem fructus in gyrum pofita \& fubltantix calycis profunde immerla.

REc. nullun; femina apici loculamentorum affixa.

SEM. in fingulo loculamento unicum, ellipticum, fupra roftellatum, plano-convexum aut lenticulari compieftum, e caltaneo-rufefcens.

In r. fimplex, fubcoriaccum, tenue.

A L н, nullum.

E s в. dicntyledoneus, inverfus, formá \& magnitudine feminis, luteus. Cotyl. cordato-eliipticx, fubfoliacex, nunc planiuscula, nunc intlexis marginibus fe unutuo amplexantes. Rad. teretiuscula, obliqua, fupera.

2.) Flos, magnitudine satorall, petalis cxruleis, unguibus $e$ livido lutefentibus, b.) Calyx immaturus, explicatus. C.) Stamioz cum piftillis. d. D.) Calyx maturas, tuberculoto vallo \& go: nilalibus perfiftentibus coronatus. e) Calycts fetio vertizalis, cum fitu (emninum naturali. r.) Fruftus trausverim feftus. b.) Semina feparala. b.) Semen transveric fetume 1.) Enabryo do nodatus. 
Tab. $x x \times 11$

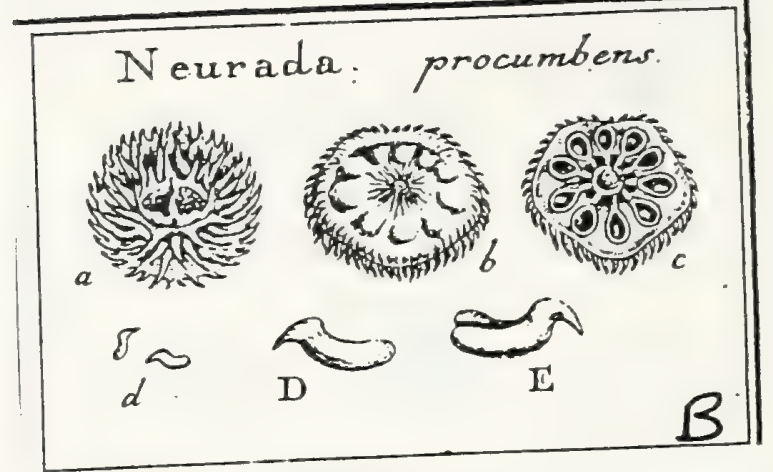

J. Gaertner (1788) Vol.1

CXCVII. NEURADA. LIN : gen. 587 .

Calyx quinquepartitus, fuperus. Cor. pentapetala. Stain. decem. Styl. decen. Cap. fula infera, orbiculata, fuperne inuricata, evalvis. Semina decenn ollea.

NEURADA procumbens. Tab. 32. fig. 4 .

Neurada. Lis x. Syf. veg. 438 .

Ex herbario Bankfiano.

PER. Capfula infera, deprefla, orbiculata, obfoletifime pentagona, fuberola, albo. tomentola, unilocularis, evalvis; fupra aculeis adicendentibus \& a peripheria ver. fus centrum gradatim longioribus inuricata; infra inermis, planiuscula aut leviter convexa, ad fenius torulóa.

REc. nullum, prxter funiculos umbilicales brevifimos, craftos, candidos, tubulofos, al axi-fructus radiatim ad femina porreclos.

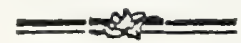

SEs. decein, ovato globola, fuboftea, nigro fufca, arcte cuin fubnantia pericarpii cohatentia, circa axem fructus in orbem pofita.

IN T. duplex: exterius fuboftcum l. corneum, craflum, durum, nigrum; interius membranaceum, teuue, rufifcens.

AL B. nullum,

E sт. dicoty]edoncus, cavitati tefx feminis conformis, figmoideo curvatus, lacteo al. bus. Cotyl. oblongx, furfum leviter falcatz, plano convexx. Rad. brevis, prope axem fruclus locata, rofellata : roftello acumirato, curvato , fimo L. apice ver. fus bafin fructus deflexo.

a.) Capfula integra. b.) Esdem a parte inferiori fpeftata. c.) Eadeni transverion foía, cum fitu fenimum \& funiculorum umbilicalium, d. D.) Nucleus feniunis decoricatus \& fola menibrana fua propris teीtus. E-) Embryo denudatus.

Poltet boc pericarpium, fecunduin rigorem, ad baccas exfuccas uniloculares referri; fed aptius ounnino videtur Capfulx nomen. 


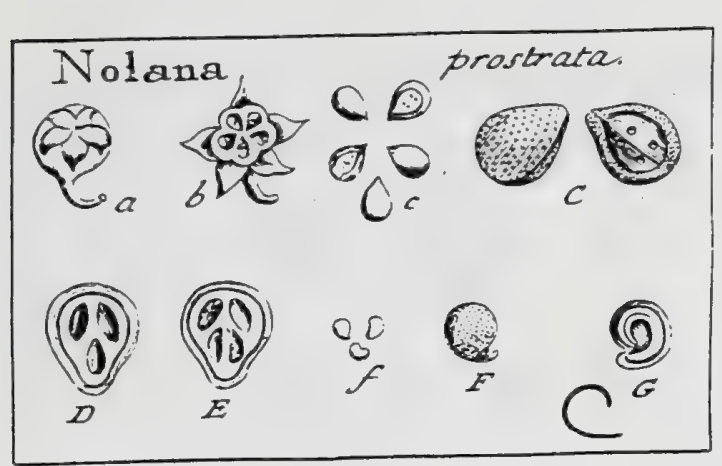

J. Gaertner (-1788) Vol2

242.

DCCLXXV: N O:L A:N:A: LinN. gen.:I93.

Qulyx monophy]lus, quinquefidus. Cor campanulata, limbo ampliato : fub quinquelobo. Stam. quinque.: Ovar. quirque. Styl. unicus,..1tignate. capitatos. Drupx, quinque, , decumbentes, tri - quinaueloculares. . Sem. folitaria.:-

SozAxs proltrata. Tabi. 132 fiğ. $.3:-$

Aropa foliis geminatis, calycibus poljicarpis, canle- biunifulfo: Gousx: bórt:. mons 5 . 106: c. ic.

Tigarim procumbeiss. Schusd. aruly. p. 67. t. 28 . optinie.

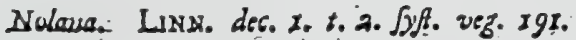

$$
=\frac{3}{3}=
$$

PER. Drupx quinque, in calycis pelvi decumbentes, parvx, carnofx, ovatoacuminatx, nigrx, fupra convesx, infra fubangulace, derafe atque foraminibus umbilicalibus pertufa. Cortex tenuis, carnofus, atro-purpureus. Putamen offeum, tribus 1 . quinque loculamentis bevigatifimis excavatum, non dehifcens.

REC. comnsume in fundo carnofo calycis, cui drupx ex centro radiantes \& horizontaliter decumbentes, affixx; propritum, nullum; prater cicatriculas umbilicales in druparum bafi.

SEM. folitaria, rotundata, roftellats, lenticulari comprefla, minutifime puнdiculata, alba.

Is T. fimplicifimum, membranaceum, fubfriabile.

A L B. femini conforme, carnofum, pallidum.

EM B. filiformis, fubperiphericus, annularis, lacteus. Cotyl. femiteretes, incumbeutes. Rad. verfus umbilicum directa, infera.

2.) Calyx maturus fructum fovens, b.) Recept. commane denudatum. e. C.) Drupz feparatx 2 prona atgue fupina parte rpectatz. D. E.) Settio drupx, cum loculamentis numero variis. f. E.) Semeu feparatum. G.) Idem diffetum, cum figur \& fitu embryonis intra albumen.

Nullum igitur dubium, quin Nolana in ordine naturali ad Solanaceas fpectet. Loculamentorum numerus varius; ternatius tamen \& quaternarius frequeritifimus, fenarium autem nonnifi in iconibus SchMidelı 1 c. vidi.

$$
140.1
$$


-

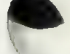

- 
Tab. 214 .

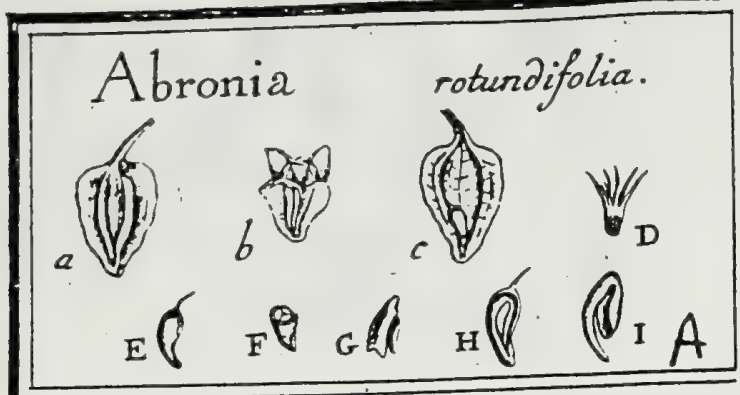

J. Gaertner (1788) Vol 3

188

141. $\triangle \mathrm{B} R O \mathrm{~N}$ I A.

Juss. gen. p. 448. LAMABCK ill. gen. t. 105 .

Tricratus. L'Hев Iт. monogr.

Involucrum florale polyphyllum, patens.

Cal. monophyllus, edentulus, cum corollà continuus, pentangulo-fabglobofus, petfiftens, femen occultans. Cor. monopetala, marcefcens; tubo longo, infundibuliformi; lımbo hypocrateriformi, quinquelobo: laciniis cord:tis. Stam. $5 . ;$ filamenta e fundo calycis affurgentia, \& bafi in vaginulam friatam perfiftentem connata, paulo fupra corollz tubo adhorentia, cxterum libera; antherz oblungx, non exfertx. Ovar. intra calycem ftaminum bafi coalitx impofitum 3 ltylo \& ftigmate fimplici Per. nullum. - Sem. unicum, intra calycem reconditum. Alb. centrale, farinofum. Emb. oblongo-convolutus.

ABRoNis uinbellata. Tab. 214. fig. 1.

Tricratus admirabilis. L'HeRıT. monogr. WILLD. Spec. pl. T. x. P. a. p. 80a: Abronia unbellata. PERsoon fin. 1. p. 176 .

Ex collettione $\mathrm{Cl}$. Desfontaines.

PER. nullum: calyx menbranaceus, obovatus, corolla emarcida faftigiatus, quinquealatus, fubintatus, Ic.sber, viridis femen occultat.

Rrc. femen ftaminum columnula, bal calycis arcte adnatze \& ftaminum reliquiis quinque - ciliatx, infidet.

182

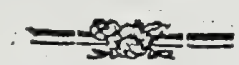

SEN. unicum, ob'ovato - oblongum, curvulum, vertice ftylo perfiftente faftigiatum, ad curvaturam juternam prope bafin umbilico fuperficiali pallido infignitum, fufcum.

IN T. Gmplex, meinbranaceum, craffufculum, facile detcahendum.

A I B. centrale, parvum, fere totum a cotyledonibus obtectum, bicorrie, farinofum, candidum.

ENB. magnitudine feminis, convolutus, albicans. Cotyl. foliacex, ovatz, obtufe, deflexx, circa albumen convolute, incumbentes. Rad. longa, arcuata, lineari-acuminata, comprefiufcula, defcendens, umbilicg externo
obverfa, infera.

\section{EXPLICATIO FIGURE.}

a.) Calyx integer, femen iocludens, b.) Ejusdem feaio transverfalis, c.). Idem longitudinaliter difteaus, cum femine in fitu. D.) Staminum columnula, filamentorun reliquiiis ciliata, E.) Semen integrum, feparacum. F.) Iilem transverfe fectum. G.) Albumen feparatum, (per errorem inverie depietum.) H.) Embryonis fitus intrá integumentum, I.) Idem folutus, 


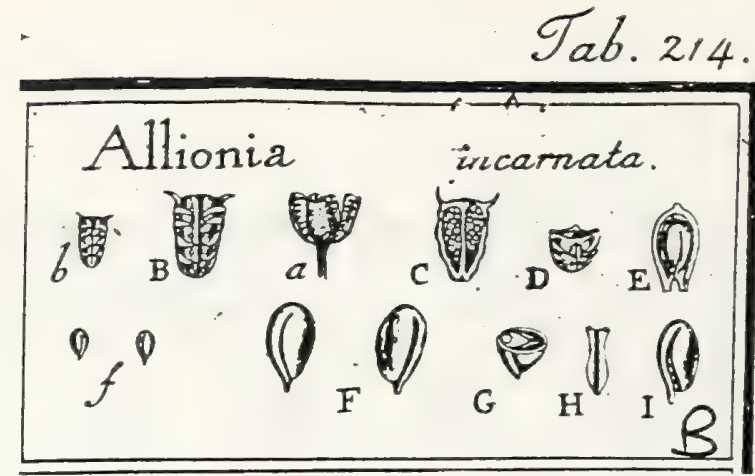

J. Gaertner (1788) voi. 3

142. A L L I O N I A. :

LinN. gen. I17. ed. Schreb. 151. Juss. gen. p. I95:

LAMARCK ill. gen. $t, 58$.

Involucrum forale tripartitum, triflorum, erectum, perfiftens: foliolis ovatis, fcabriufculis.

Cal. obfoletus, in corollam abiens. Cor. mopropetala; infundibuliformis; th. bus tenuis; limbus inæqualis, e latere externo productus, fubquadrifidus. Stam 4. ; filamentis fetaceis; antheris fubrotundis, Ovar- intra calycem oc cultun2; ftylo fimplici, ftaminibus longiore; ftigmate capitato. - Per. Capfula angulata, margine mulicata. Semen unicum, ovatum, bafi anfatum, Alb, centrale, farinofum. Emb. convolutus, cotyledonibus detexis.

Alliosia incarnata. Tab. 214 Eg. 2.

Wedelia. LOEFL: it. p. 180.

Allinuia foliis obligue cordatis, calycibus tripbyllis trifioris. Lins. Jpec. pl. p. 147. Syft. veg. ed. 14. p. 147. WILLD. Spec. pl. T. T. P. 1. p. 563. PEE. SOON $\int 3 \%$. s. p. $1=2$.

Icon. L'HeRIT. firip. t. 3 s,

Ex collectione Cl. Desciontaines, \& a $D^{\text {no }}$ Dupuis.

F R U C T. rotundato.trigonus, conftans ex capfulis tribus approximatis, \& invo. lucto tripartito connivente comprehenfis, felfilibus.

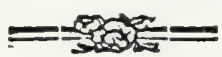

PER. Capfula angulata, ovato-oblonga, in vertice truncata, nargine aculeis extrorfum Gexis conniventibus' \& involucro forali adharentibus armata', medio fulco longitudinali fulcata \& duabus globulorum pedunculaturun feriebus inftructa; in dorfo vero, quo capfule fibi accumbunt, in fulcum jntermediuns elevatx; fecundum futuras in quatuor valvulas partibilis, ftraminea, unilocularis, monofperma.

REC. femen ope funiculi umbilicalis bifidi, ad utrumque latus feminis a bafi ad verticem fere adfcendentis, capfula adharet.

SÉn. unicum, loculamento paulo anguftius, ovatum, lenticulari-compreffufculum, bafi radicula protuberante quafi anfatum, glabrum, cinereum.

INT. fixples, menbranaceum, crafiufculum, facile detrahendum.

A L B. centrale, ligulatum, hinc fulco longitudinali pro radicula lectulo exaratum, inde in dorfun acutum elevatum \& cotyledonibus equitantibus immerfum, a quibus undique obtegitur, farinofun, candidilimum.

E M B. magnitudine fere feminis, ovatus, compreffiufculús, convolutus, lutefcens. Cotyl. ovatx, foliacer, ad radiculam deAexæ, circs albumen convolutx, 1. equitantes, concavre. Rad. cotyledonibus paulo longior, arcuata, compretfiufcula, linearis, obtufa th ad bafin'feminis defcendens, umbilico proxima.

\section{EXPLICATIO FIGURE}

2.) Fruaus integer. b. B.) Capfuls integra, a latere exteriore, \& C.) Eadem a parte lateriore vifa. O.) Ejusdem fectio transverfaliz. E.) Dorfun capfula, fecundum futuram fepasatum, bag iterum in duas valvulas partibile, cum femine in Geu. f. F.) Semen folutum, ab utraque parte fpectatum. G.) I Iem medio trausverfe diffetum. H.) Albumen folumem. 1.) Enibryo Separatus.

Capfularum fuperficies \& ipfarum aculei marginales toti in fubftantiam cryftallino-glutinofam aqua emolliuntur.

An revera congener $A$. viulacea $L$. ? 


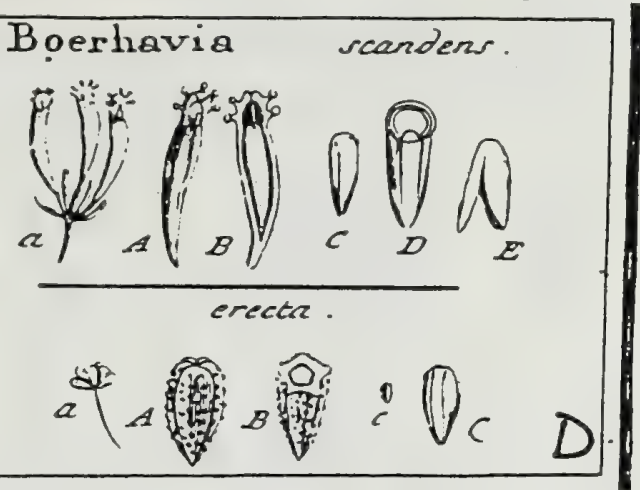

\section{J. Gaertner (1788) Vol. 2 208}

\section{B O E R H A V I A. LINN. gen. 9.}

Calyx inverfe conicus, fubangulatus, edentulus, cum corolla continuus, perfiftens, femen involucrans. Cor. monopetala, campanulata, integra. Stam. 1. 2. 3, e fundo calycis oriunda, bafi inter fe connata. Ovar. intra calycem. Styl. Gimplex. Sem. calyce claufo corticatum.

Bozrhavia fcandens. Tab. 127. fig. 6.

Valerianella curaffavica, fentine ajpero vifcofo. PLux. phyt. t. Ix3.f. \%. mala.

Boerbavin Jcandens. JAcQ. bort. I. t. 4 .

Boerbavia caule erecto, floribus diandris, foliis cordatis acutis. LiNs. $\int y 3$. veg. 5 .

PER. nullum, nifi integumentum coriaceum a calyce velis.

REC. nullum; femen fundo calycis affuxum.

SEM. unicum, fufiformi - clavatum, punctis callofis difitis confperfum, prope verticem autem globulis pedunculatis glutinofis radiatum \& in ipfo vertice umbone quinque frriato ac perforato terminatum, fordide fufcum.

IN T. duplex: exterizts, a calyce, coriaceum, femine ipfo longius; interius membranaceum, tenuifrmum, melinum aut rufefcens, fuperne ftyli reliquiis, tnnquam funiculo umbilicali ftipatum \& quafi e fornice integumenti externi pendulum.

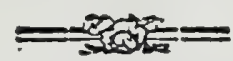

ALB. fatinofum, candidifimum, centrale, totum ab embryone obvolutum.

ENB. magnitudine feminis, cylindrice convolutus, albicans. Cotyl. foliacex, oblongx, incumbentes, circa albument, convolute. Rad. lineari -acuminata, compreffufcula, recta, ad bafin feminis defcendens.

a. A.) Semina corticata integra. B.) Integumentum carycinum longitudinaliter apertum, eum feninis veri atu \& infertione. C.) Semen decosticatum. D.) Albuminis \& embryonir featio transverialis, E.) Embryo folutus.

Bogr havin erecta, ibid. ex fide Martyni Stuttgard.

Boerhavia floribus panioulatis, feminibus pentagonis truscatis. LINN. maus. s15. melius quanı

Buerbavia caule ereifo glabro, foribus diandris. LiNs. fyfo. veg. 52.

Umbellix (a) pedunculara, fubfextlorx. Semina parva, inverfe pyramidata (A.), pentagorfa (B), undique tuberculis felfilibus glutinofis confperlia, fpadiceo-fufca. Embryo (c. C.) ovatus, deorfum acuminatus, albus, cetera priori Gnillimus.

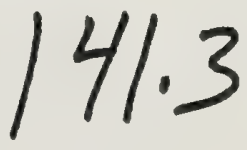




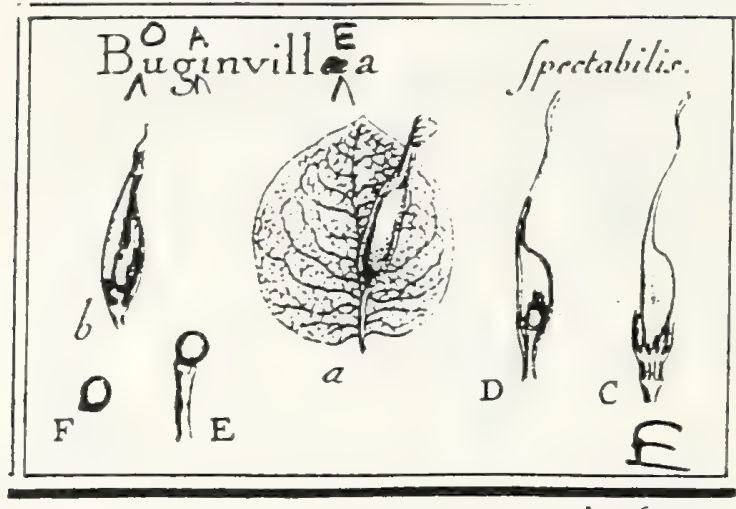

f.r....rnum, o.

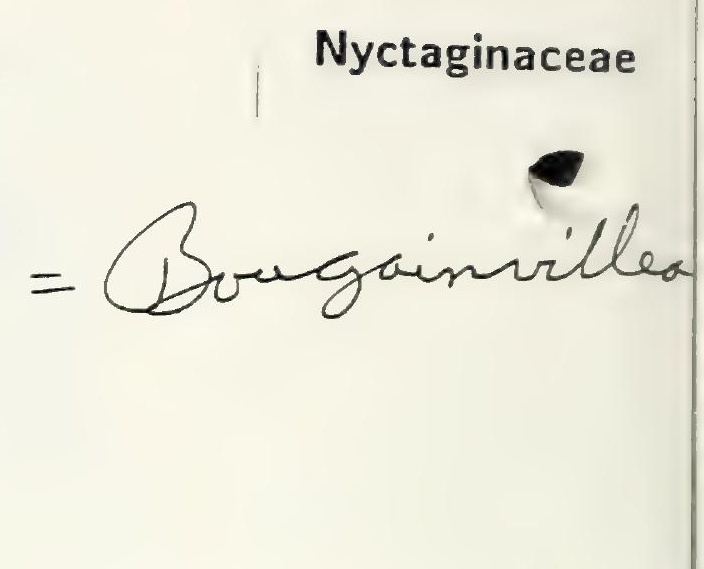

J. Gaertner (1788) Vol 3

\section{BUGAN VIILAE. \\ Juss. gen. p. 91, LaMARCx ill.gen..t. 294.}

Involucrum-forale bractearum, çordatum, venofum, prope bafip ex nervo principali florem dimittens.

Cal. monophyllus, inferus, tubulolus, bafi fubventricofus, furfum paululum anguftatus, cum corolla continuus, perfiftens, fructum occultans. Cor. monopetala, in calycem degenerans, tubulofa . infundibuliformis, limbo recto, fubintegro 1. dentato. Stam. octo; flamentis liuearibus, non exfertis, deor. fum in tubum breven bafi calycis infertum perfiltentem coalitis; antheris erectis, ovatis. Ovar. fuperum; ftylo fimplici, laterali; ftigmate Gmplici, pubefcente, obtufo. Capfuła preudo-leguminofa, fubintata, monofperma, Rec. funiculus umbilicalis, columnaris, Sen, unicum, fubglobofum, : Alb, ... Emb. . .,

Buginvillaea fuectabilis. Tab. 216. fig. S.

Buginvillaea. WILLD. Spec. pl. T. 2. P. T. p. 348 .

Buginvillaen braũeata. PERsoon fyr. I. p. 488 .

Ex collectione $\mathrm{Cl}$, Desfontaings,

PzR. Capfula intra calycem perfiftentem abfcondita, parva, pfeudoleguminofa, fubinfata, hinc in pedunculum a tubo flamentorum cinctum \& bafi

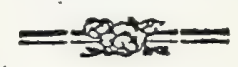

calycis infertum attenuata, inde in verticem lateraliter ad dorfum ftylo perfiltente faftigiata, membranacea, unilocularis, monofperma.

REc. funiculus umbilicalis validus, columnaris, ex fundo capfulx per pedunculum affurgens \& femen in fitu erecto fultinens.

SEM. unicum, fubglobofum, baf truncatum, nitidum, fufcum.

IN T, cratilifculum. ...

$\Lambda \perp$ B. . . E ES B....

\section{EXPLICATIO FIGURE.}

8.) Frutus integer, involucro forali inffitens. b.) Calyx longltadinaliter apertus, apfulam in fitu oftendens. C.) Capfula e calyce foluta, bafi flamentorum difco cylindraceo cincta. D.) Ejusdem fetaio longitudinalis, cum femine in fitu. E.) Fuaiculus umbilicalis feparatos, Semen fuftinens. F.) Semen Colutum.

Fructus in fpeciminibus noftris adhuc longe a maturitate diftabant, fortaffe defcriptio partium emendanda.

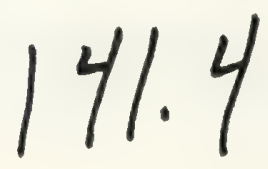




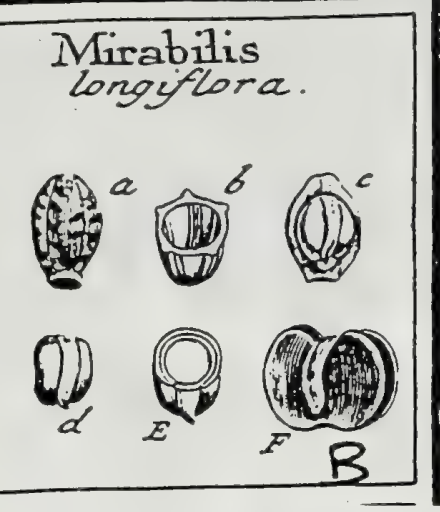

J. Gaertner (1788) Vol 2

DCCXXVI. M I R A B I L IS. LinN. gen. 242. Jalappa.

TOURN. inft. t. 5 O.

Involucrum fiorale pentaphyllum, campanulato patens. Cal. monophyllus, globofus, edentulus, cum corolla continuus, perfiftens, femen involucrans. Cor. monopetala, quinquefida. Stam. quinque, e fundo calycis oriunda \& bafi connata. Ovar. intra calycem, ftaminum placenta impofitum. Styl. fimplex. Sem. unicum, calyce iudurato involucratum.

Mirabilis longillora. Tab: 127. fig. 5.

Mirabilis floribus congeffis terminalibus longiJimis nutantibus, folitis fubvillofis. LiNs. act. bolm. 7755 . p. 176. t. 6. f. 1. Jyf. veg. 219 .

PER. nullum, nifi calycem velis induratum in Nucem coriaceam, ovatam, bafi contractam, obfolete pentagonam, fubrugofam, pubefcentem, e cinereo \& fufco nebulofum atque intus fafciis quinque longitudinalibus, a ftaminum impreflione, notatam.

REc. tuberculum fungofum, album, a ftaminibus bafi in placentam glandulofam connatis ortum, cui femen infidet.

SEM. unicum, ovato-globofum, glabrum, melinum sut rufefcens, hine fafciz longitudinali, a protuberante embryonis radicula, notatum.

IN T. fimplicifimum, membranaceun, tenue.

A L B. farinofum, candidifimum, centrale, totum ab embryone obvolutum.

Eмв. magnitudine feminis, globofe convolutus, erectus, lutefcens.- Cotyl. foliacex, fornicatx, incumbentes. Rad. lineari - acuminata, comprefia, arcuata, ad bafin feminis defcendens.

1.) Nux integra. b.) Eadem transverfim fecta. c.) Ejus feetio verticalis eum infertione feminis., d.) Semen feparatum. E.) Albuminis atque embryonis (edio transver(alis, F.) Eunbryo folutus \& explicatus.

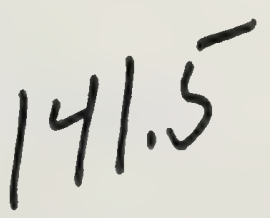




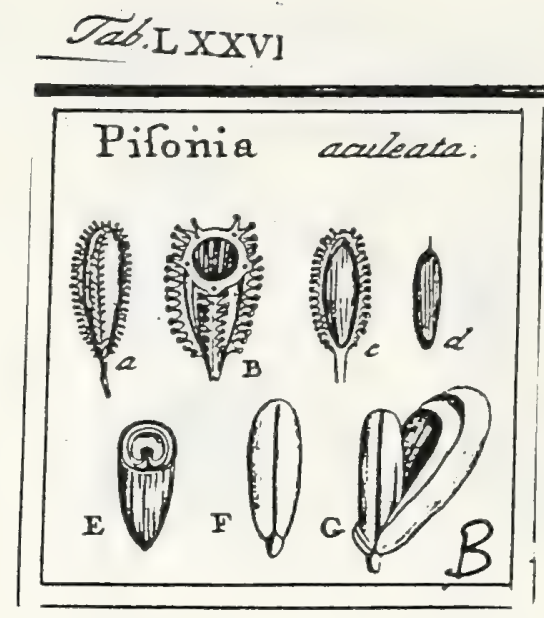

J. Galertucr (17s S Vol.

366

CCCCLXXVII. PISONIA. PLUM. gen. t. Ir. LINN. ger. II6z.

Calyx vix ulius. Cor. infundibuliformis quinquefida. Stam. quinque 1. Cex. Strl. unicus. Caplula lupera unilocularis evalvis. Semen unicum, embryone albumen
isvolvente.

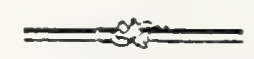

Pisoxi a aculcata. Tab. 76 . fig. 4 .

Pifonia aculiati, fructu glatinofo EO racemofo. Peun. ic. t. 22\%. f. I.

Pifunia fuinis axillaribus patcutiffmis. L I x x. f1/f. vis. 920.

Ex. heibario Bankliano.

PER. Caprula fupera, oblonga, obtufa, pentagona, coriacea, aculcolis glochidatis glutiilelis, duplici feric ad angulos poftis, muricata, nigro fufca, unilocularis: cralvis.

Rr. Cuniculus feraccus, apicem feminis atque capfula connedtens.

SEM. unichin, ohlongum, teretiusculum, deorfum leviter attenuatum, friatum, fulco depreli) longitudimali ab altcro latere infcriptum, atrum.

IXT. limplex, membranaceum, aridun, enue.

A Ł. centralc, cylindritum, fulco longitudinali profundo incilum, farinolum, canc:dilimum.

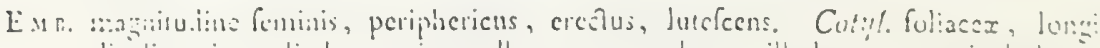
tulinditer in cylindrum circa albumen comolutx, illudque cotum inciujente. Rad. conica, bievis, infera.

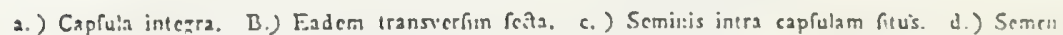

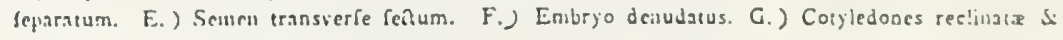
2is albumine nicdio fohtux.

Canfula certistume cralvis en, fecus ac Limnous, a Plumicri figura decepeus, fiatuit. Simpliecs duntavat glochidum feries in plantis dominicenfibus vidi? J a c. hiff. amer. $=7$.

\section{6}




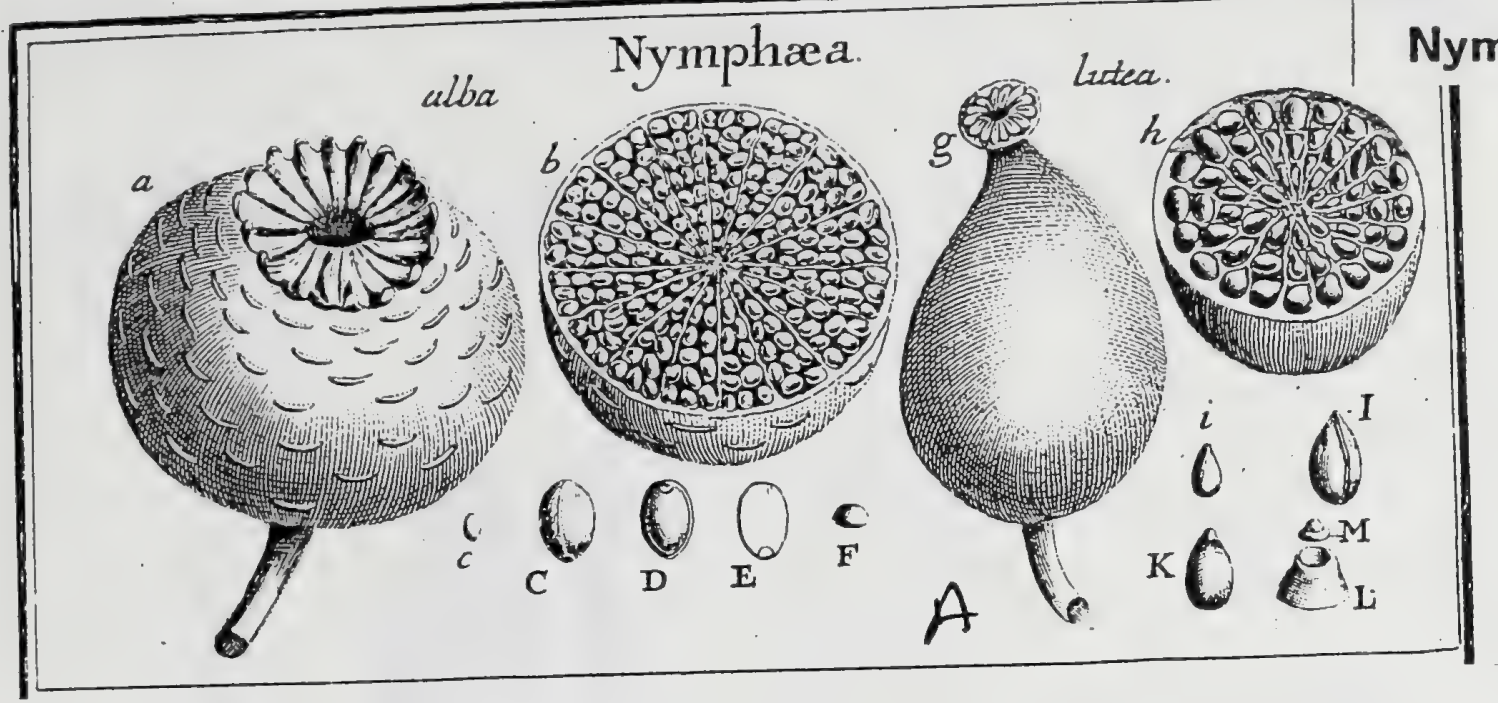

J. Gaertner (1788) Vol.1

LXXXIV. NYMPHEA, TOURN. t. 137. 138. L I xis. gen. 653 .

Calyx quadri-1. pentaplyyllus. Cor. polypetala. Stam. numerofa. Stỵl. nullus. Stigna orbiculatum, felfile. Bacca fupera multilocularis. Embryo extra albumed pofitus.

N Y M P н Ае a alba. Tab. 19. fig. I.

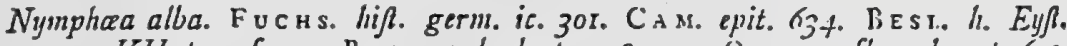
vern. VII. t. 3.f. 1. 2. B LA K w". herb. t. 498 . 499. OEDER. flur. dan. t. 602.

Nymphrea calyce quadrifolio petalis minori, fruttu fpharico. Haz L. hifs. 2. n. 1067 .

Nymphcea foliis cordatis integerrimis, calyce quadrifido. LIN.. Syfl. veg. 49 r.

PER. Bacca fupera, fpharica, filamentorum reliquiis cicatrila!a, Alicmate maximo, concavo, fulcato, crenulato, umbilicata, fubvigintilucularis. Curtex tenuis, co. riaccus. Yulpa loculamentorum gelatinola, per irtatcm in fubnantian fpongiofan exarciccins.

REc. nullum: Scmina in pulpa nidulantia, absque certo fitu vel ordine.

SEs. numerofultuna, elliptico fplaxroidea, glabra, fplendentia, hinc angulo obtufiffuno notata, e viridi lutefcentia, aut livida.

IN T. duplex : exterius coriacco-cruftaceum, per atatem fragile; interius membranaceum, tenuislinum, pallidum, chalaza fufca notatum.

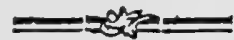

A гв. femini conforme, farinofum, candidifimum, friabile, foveola aperta ad bafin exfculptum.

Е м в. monocotyledoneus, lenticulari globofus, carnofus, lutefcens, foveolx albuiminis leviter innmerfus, nec ab hujus fubltantia, fed a folis integunentis femimis communibus contectus.

2.) Bacea integra. b.) Eadem transverfe feța. c. C.) Semen feparatum. D.) Albumen denu datum, clazlaza fuperne notatum. E.) Ejus fetio longitudivalis, cum fitu embryouis ad bafin. F.) Embryo (eparatus.

Nysiphea lutea. ibid.

Nymphase luteq. F Uсн s. germ. ic. 302. Сам. epic. 635. Best. h. Eyff. vern.

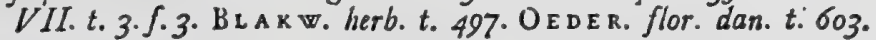

Nymphara calyce pentaphyllo petalis majori, frulitu conico. H A L L. hif.. n. 2066.

Nymphaca foliis cordatis integerrimis, calyce pentajhyllo majore. LIN $\mathrm{x}$. Syft. veg. 491 .

Bacca ampullaformis $(\mathrm{g})$. ovato conica, glaberrima, figmatis orbiculo fulcato, integerrino, peltato, cornata, fubquindecim locularis. Loculamenta irregularia, (h) Eeptis partialibus fubdivifa, ut quafi finguluin fenen intra propriam cellulam. Semina pauciora, fed duplo inajora (i. I.), orato acuminata, lutelcentia, glaberrima, sitida, angulo carinata, Albumen (K) ut in pracedenti. Embryo lenticulari conicus (L), foveola albuminis .(M) agglucinatus \& a folis integunentis fenzimis contectus. 


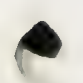




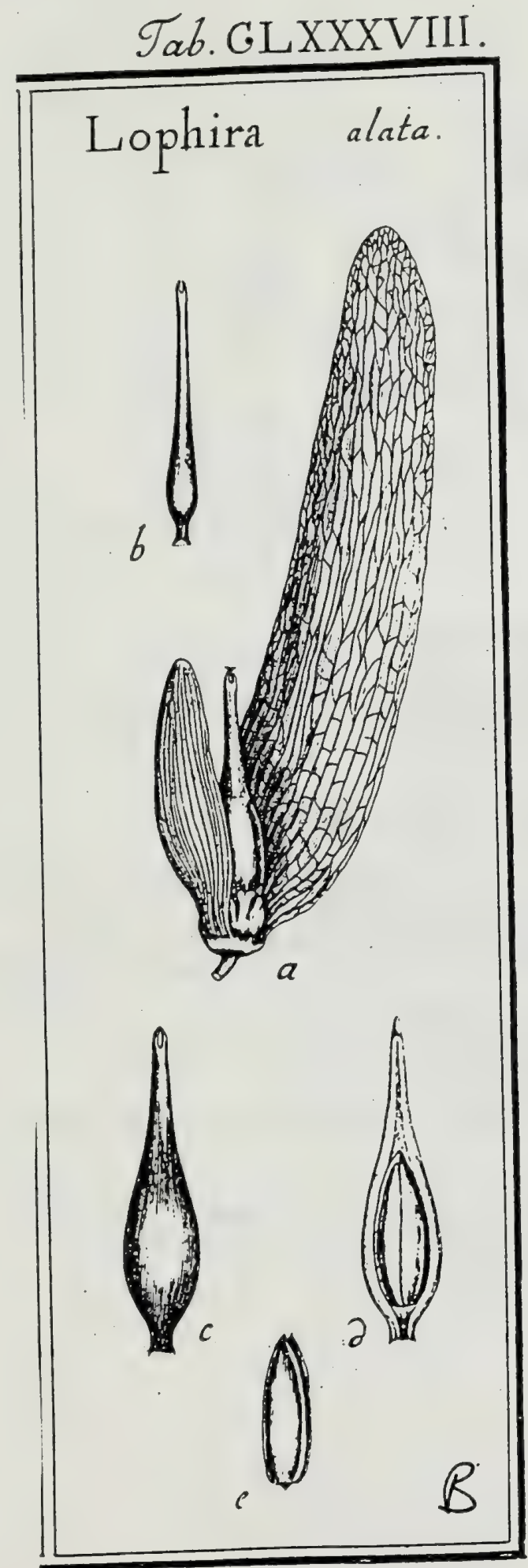

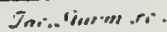

J. Gaertner (1788) Vol3

52

47. L O P H I A. Banxs. ef L Qentrex.

Cal. pentaphyllus, inferus, perfiftens; foliolis imparibus, lineari - nervolis, longifine reticulatis, bafi anguftatis, rigidis; unicum maximum ligulatum obtufum; alterum huic oppofitum plus triplo minus, eadem vero gaudens figura; tria reliqua paria, parva, ovata, concava, ficcitate lacera, unum oppofitum. Cor. ... Stam. plurima. Ovar. fuperum; ftylo fimplici, tereti, fubulato; ftigmate bifido, fubulato, acuto. Nux coriacea, unilocu. laris, evalvis. Sem. unicum. Alb. nullum. Emb. erectus; radicula infera. Lophira alata. Tab. I88. fig. 2.

Loplira alata. BANKS Mss.

Ex dono amicifimi $D^{\text {ni }}$ Decandolle.

PRR. Nux fupera, coriacea, longiffime elliptica 1. fufiformis, turbinata, ftigmate perGiltente bidentato inftructa, ad.bafin in collum brevem coarctata \& ibi cum calyce grandefacto arctiflme conferruminata, unilocularis, evalvis.

R E C. nullum; femen bafi nucis affixum.

SEM. unicun, cavitatem nucis replens, ovato-oblongum, acuminatum, bafí obtufun, rufefcens.

IN T. fimplex, membranaceum, tenue.

Eм в. Semini conformis, erectus, lacteus. Cotyl. carno[x, amygdalinz, plano convexx; bafi truncatx, umbilicatx; apice zcuminatx. Rad. brevifima, imnerfa, conico-acuminata, comprefiurtula, infera.

\section{EXPLICATIO FIGURTE.}

a.) Frutus integer. b.) Orarium immaturum. c.) Nux a calyce feparata. d.) Eadem longitudinaliter diffecta, cum embryone in fitu, adhzreate integumenti portiuncula ad ejus bafie. c) Embryo folutus.

$$
=
$$

Unica adhucdum hujus gencris fpecies mihi innotuit: foliis alteruis, Tongls. lanceolato-obcordatis, rigidis, exflipulaceis. Intorefcentia racemofa. Arbor Africam xquinoctialem inhabitans.

Genus itidem Acerum familix affine, fi fructum alatum uncamentaceum refpicinus; fed folia oppofita \& cotyledones rectre amygdaloidex huic ordini reluetantur 


\section{Ochnaceae}

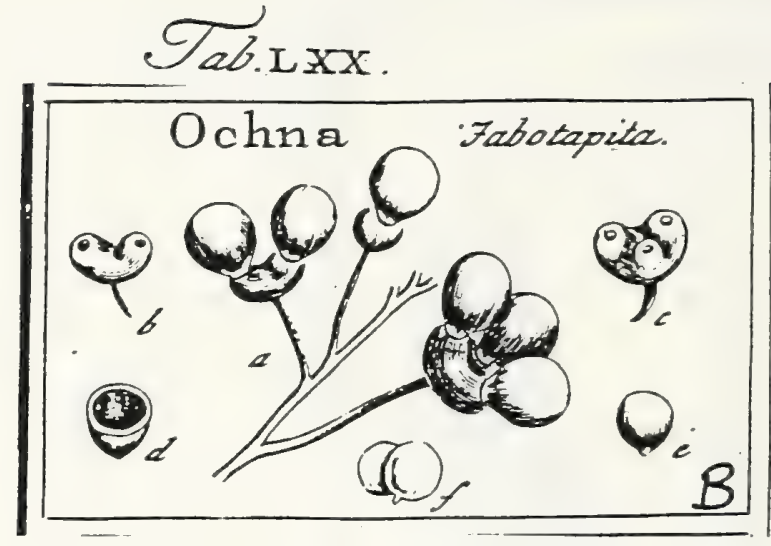

J. Gaertner (1788) Vol.1

$34 \mathrm{I}$

CCCCXXXIX. OCHNA. LIN gen. 657.

Calyx pentaphyllus. Cor. pentapetala. Stain. plurima. Styl. unicus. Baccae durae $\mathcal{L}$ tres receptaculo carnolo grandefacto infiftentes, uniloculares.

ОС н.х А Jabntapita. Tab. 70. fig. 2.

.Fabotapita myramidato flore luteo, frugtu rubro. P LU x. ic. t. 153.

Ochma racemis terminalibus. L I N N. fy/f. veg. 492.

E collectione Bankfiana.

PER. Baccae, una, duae, tres, raro plures, rotundato aut ovato globofae, fubcoriaceae, tenues, glabrac, atrac aut rubrae, uniloculares.

REc. commune, ex thalamo floris grandefacto carnofum; nunc fimpliciter globo. fum, nunc pro numero baccarum, bi-l. tricolle; yroprium nullum; femen bafi affixum.

SEs. folitaria, fubglobofa, magnitudine cavitatis baccae, pallida.

IN T. fimplicifimum, membranaceum.

A L B. nullum.

Eмв. fernini conformis, erectus, albicans. Cotyl. hemisphaericac. Rad. globulola, ıninima, infera.

2.) Pars raceni frugiferi, cum baccis namero, figura, \& fitu naturalibus. b.c.) Receptac commune bi-et tricolle. d.) Bacca diriera. e.) Semen folutum 1.) Embryo denudatos, 


\section{Ochnaceae}

\section{Tab.LXX.}

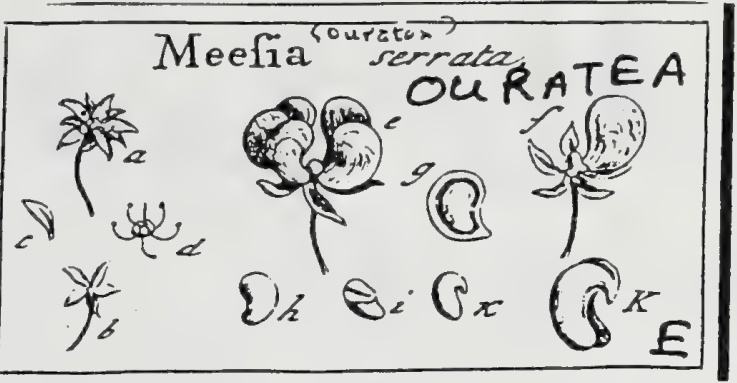

J. Gaertner (1788) Vol. 1

\section{CCCCXLIII. MEESIA.}

Calyx quinquepartitus, foliolis lanceolatis perfiftentibus. Cor. pentapetala, calyco paulo longior, petalis lanceolatis, patentibus. Stain. quinque, petalis dimidio breviora. Styl. unicus, fetaceus, longitudine ftaminum. Drupx quinque, obovato. reniformes, uniloculares, monofpermx.

MEEs ^ A ferrata. Tab. 70. fig. 6.

Tfjocatti. R H EED. mal. 5.p. $95 . t$. 48 .

Walkera. zeylonens. E collect. fem. hort. lugdb.

PER. Drupx baccatx quinque, obovato reniformes, difantes, erectx, rubre, demum fufc $x$ fubrugof $x$. Caro tenuis, per xtatem in cruftan corjaceam exarefcens. Putamen figuri drupx, fubofleum, uniloculare, evalve.

REC. conmane parvum, conicum, obtufum, fungolum, ad marginem, pro infertione druparum emarginatum; proprium, funiculus breviffmus, e putaninis bafi oriundus atque medio feminis lateri interno infertus.

SEs. folitaria, reniformia, tactu molliuscula.

Is r. fimplex, fpongiolo coriaceum, craftiusculum.

AL B. nullum.

E s в. magnitudine feminis, uncinato rofellatus, inverfus, albus. Cotyl. femilunatx; carnolx, plano convexi. Rad. tereti-acuminata, uncinulato dellexa, fupera.

a.) Flos integer. b.) Caljx. c.) Petalum. d.) Stamina cum nylo \& ovariis in globulum depreffum quinquetorulofum, coadunatis, e.) Fruktus maturus integer. f.) Drupse in receptac infertio. c.) Putamen longitadinalier spertum, cum infertione feminis. h.) Semen (eparatum. i.) Idea transverfe fequm. k.K.) Embryo desudatus. 
Tab. 224

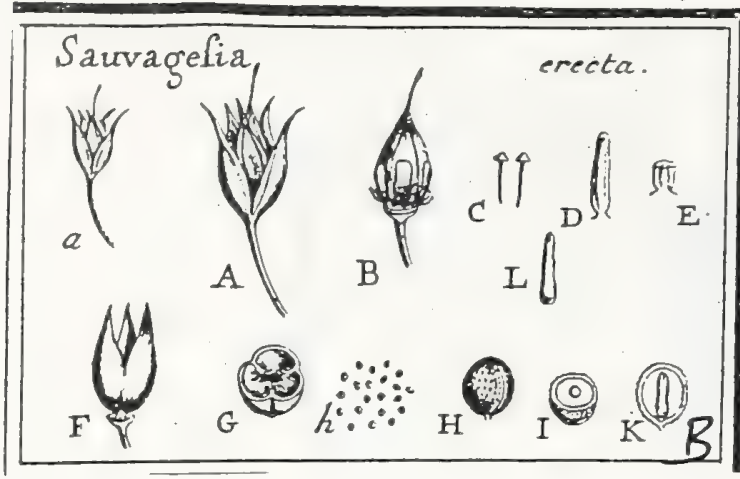

J. Gaertner (1788) Vol3

236

186. S A U V A G E I A. Jacq.

LINN. gen. 286. ed. Schreb. 401. Juss. gen. p. 426.

LAMABCK ill; gen. t. r40. Iron. BROWN jam.

t. r2. f. 2 .

Cal. profundiflime quinquefidus, erectus, perfiftens; laciniis lanceolatis, acuminato-ariftatis, margine fcariofis. Cor. petals quinque, cum lncinitis caly. cis alterna, \& cuin ftaminibus fub ovario inferta, ovata l. rloombeo-ovata, decidua. Corona ciliaris, corollam cingens \& huic ad bafin adnata; cilix plurimx, petalis ipfis breviora, ftaminiforınia, 1. capitulis cordatis faftigiata. Stam. decem, petalis dimidio breviora, intra petalorum feriem fub ovario inferta, inequalia; alterna fterilia, glandulaformia \& cum petalis alterna, lineari-oblonga, fubtetragona, vafculo intermedio protuberante longitudi. nali infignita 3. alterna fertilia, petalis oppofita, magis decidua, fubfertilia; antherz lineari-oblongx, tetragonx, apice dehifcentes. Ovar. fuperum, fubpedicellatum; ftylo fimplici, clivato; Atiginate fimplici, obtufuffulo. Capfula, ovato-acuminata, unilocularis, apice trivariam dehifcens. Rec. nullum, prater marginem valvularum inferioren introfexum, fimbriatum. Sem. plura, ovata l. glubufa. Alb. carnofum. Emb. erectus, tereciufculus.

SaUvagésia erecta. Tab. 224. fig. 5.

Iron berbaceus minor, foliis oblongis tenuifime crenulatis, fipulis ciliatis, fori: bus fingularibus ad alas. Brown jam. p. 179.

Saturgefia Adina. AUBL. guiar. 1. p. 25 t.

Sauvagefia. JACQ. ainer. po 77. LINN. Spec, pl, p. 249, Syf. veg. ed. 14. p. 244 W1LLD. Spec. pl. T. 1. P. 2. p. 3185.

Sauvagefia caule ramofsfino. procumbente erefoque, foliis lanceolato- ferrulatis lineatis, fioribus jubternis erefis. RuIz \& $\mathrm{P}_{\Delta \mathrm{VON}}$ fior. peruv. 3. p. II, PERsoun fyno I. p. 253.

1con. JACQ. 1. c. t. 5I. f. 3. ed. pit. t. 7\%. AUBL. J. c. t. 100. f. 2. Ex collectione Cl. Desfon'raines, \& ex dono Cl. Lambert.

PER. Capfula parva, elliptico-acuminata, a calyce perfiftente laxe amplexa: ta, \& ab iplo pedicello brevillimo dilcriminata, membranacea, rigida, fecundum futuris bafi trifulcal, ab apice ad medium usque trivariam dehi. fcens, fpadicea l. Jutefcens, unilocularis, trivalvis.

REc. nullum : prater marginen valvul:trum interiorem introflexum $\mathbb{E}$ in funi. culos breves rigidos fillum, quibus femina umbilicis adharent.

SEM. numerofa, millutula, ovita l. ovato-globofi, bafi mucromulata, ad lae tus a funiculo umbilicili adfentente \& undique cum integunento externo conferrunuato inliguta, elegantulime dcrobicuiato- punciata, fpadicez, centrifuga.

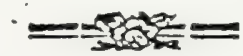

IN T. duplex: exterius crafiufculum, cruftaceum, fragile; inserius tenuifimum, adnatum, in vertice cbalaza pallida orbiculari notatum.

A L B. femini conforme, baf mucronulatum, carnofum, lutefcens.

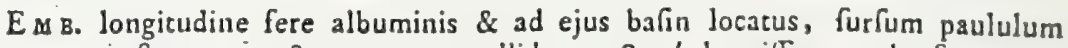
anguftatus, erectus, aqueo-pallidus. Cotyl. brevilinax, obtufe. Rad. longa, teretiufcula, bafi incrafiata, obtufilima, umbilico externo obverfa, centrifuga.

\section{EXPLICATIÓ FIGURE.}

2. A.) Fruetus integer. B.) Capfula integra, son dehifens, petalis, Staminlbus Aterilibus \& ciliis externis perfiftentibur ad bafin condecorata. C.) Cilia feparata, magnitudine valde aucta. D.) Stamen fterile, feparatum, integrum. E.) Ejusden featio transverfalis. E.) Capfula fepanata, debifeens. G.) Ejusdem fecio transverlalis, cum fitu \& forma seceptaculorum. b. H.) Semina feparata. I.) Ejusdem fectio transverfalis. K.) Idem longitudinaliter diffeđum, cum fitu embryonis intra albumen. L.) Embryo folutus.

Quoad fructus feminumque fabricam ad Sarothram accedit. 


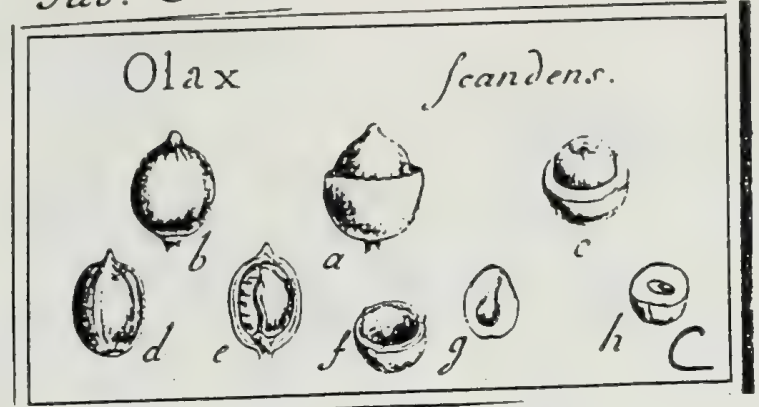

J. Gaertner (1788) vol3

\section{0 L A X.}

\section{LINn, gen. 45. ed. Schreb. 6r. Juss. gen. p. 153 .}

Cal. parvus, monophyllus, inferus, cupulatus, laxus, truncatus, ad limbum ciliatus, vix inxqualis, cum fructu increfcens, perfiftens. Cor. tripetala; petalis fundo calycis infertis, longis, angultis, verfus apicem fenfim latio. ribus, unico, l. duobus, 1. omnibus profunde bifidis: laciniis ovato-lanceolatis acutis. Appendices bini filiformes, nectariferi, ad utrumque latus filamenti \& cum ipfo ad medium petalum in lerti, bifurcati. Stam. tria, appendicibus intermedia; filamentis brevibus; antheris cordato-oblongis, erectis, bilocularibus. Ovar. fuperum; ftylo fimplici, filiformi, dimidiis petalis vix longiore; ftigmate fimplici, obcufo. Nux a calyce involucrats, unilocularis, monofperma. Rec. filiforme. Semen bafi umbilicatum. Nlb. carnofum. Emb. inverfus?

OLsx fcandens. Tab. 201. fig. 3.

Olax fcandens. ROXв. corom. pl. s. p. 2. t. 102.

Ex collectione Bankfiana.

PER. Nux parva, magnitudine nucis avellanx, ovato-globora, a calyce perfiftente cupulato fupra medium excepta, corticata, Jutea. Cortex craf. f:ufculus, carnofo-pulpolus. Putamen offeo-chartaceum, ovato - oblongum, fulcis tribus longitudinalibus elevatis \& in vertice apophyfi cruciato acuminata infignitum, bafi vero derafum, ante plenam maturitatem fubltatia fyongiofa alba intus veftitum, monofpermum.

REc. filiforme, e bafi nucis oriundum, \& in proprio fulco ad ventrem feminis fere ad apicem usque adfcendens, brevifíme tricufpidatum, ramo inter. medio femini inferto.

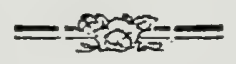

SEM. unicum, cavitati nucis conforme, bafi obliqu!e umbilicatum, \& ad ven: trem fere usque ad verticem fulco longitudinali a receptaculi impreftione inlignicum, albicans.

IN T. fimplex, membranaceuri, tenue, facile detrahendum.

A L B. fenini conforme, carnofum, album.

E м 8. elliptico-acuminatus, compreffiufculus; inverfus? Cotyl. ... Rad. . . .

\section{EXPLICATIO FIGURE.}

1.) Nix: integra, a calyce involucrata. b.) Eadem e calyce exemta. c.) Corticis fectio transverfalis cum putamine, ad molium usque ab illo denudato. d.) Patamen folutum, integrum. c.) Hem longitudinaliter diffeaum cum receptaculo \& femine in fitu. f.) Ejusitem fectio transverfalis, intus adharente fubftantia fpongiofa. g.) Albumen longitudinaliter \& - h.) ldem transscrfe fettum cum emhryonis lectulo.

Cum Rirps, a b. Patre Vol. II. p. 474. t. 179. defcripta, ab Olace Linn. quam masime fit aliena, idem nomen genericum huc repetere non dubitavimus. Licet charitcter generis, a nobis prolatus, aliquantun a Linnxano recedat, nullum tamen dubium reftat, quin noltra planta genuina Olacis fpecies fit.

Fructus in noftro fpecimine erat immaturus \& embryo in pulverem dilaplus; fed ob infertionen receptaculi f. funiculi umbiliculis \& ob fitum atque figuram lectuli embryonis fufpicio arridet, embryoneni etfe inverfum. \& inde hanc ftirpem a Sapotis eliminandam. Alia adhuc in vaftiffima collectione Bankfiana affervatur fpecies huic quoad fructum fimillima, fed femina pariter erant fatua. 


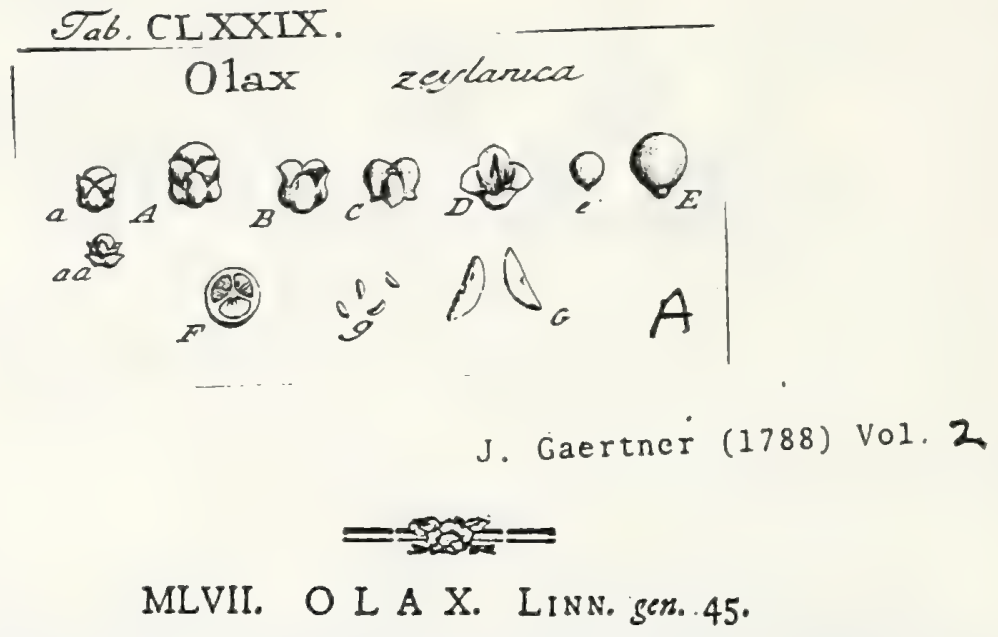

Calyx monophyllus, per maturitatem corinceus, deorfum infigniter gibbus, trifidus: dentibus obtufis. Cor. monopetala, calyce dimidio longior, perfiftens, coriacea, trifida : laciniis obtufis, fubinxqualibus. Nectar. tria (quatuor Limis.), margini angultifimo, ad interftitia filamentorum prominulo, inferta, caduca. Stam. tria, fubulata, breviffima, bafi laciniarum corollix inferta. Ovar. fuperum. Styl. fimplex, caducus. Bacca carnofa, trilocularis, polyfperma.

Olax zeylanica. Tab. 179. fig. I.

Olax Lins. zeyl. p. 14. Jyf. veg. 81 .

Induru. Zeylonens. $\mathrm{E}$ collect. fen. hort. lugdb.

PER. Bacca calyce \& corulla perfiftentibus femiveftita, parva, nagnitudine femmis raphani, carnofa, atra, trilocularis. Caro frma \& quati curiacea. Pulpa loculamentorum gelatinofit.

REC. ligulic membranacetc tenuilinnx, ex angulo loculamentorum centrali oriundx, \& radiatin verfus peripherian divergentes.

SE M. plura, 6. 1. 8 in fingulo loculo, parvula, oblonga, pallida, umbilico in nedio latere mteriori notata.

IN T. fimpicitimum, arachnoideum.

A L B. femini coniurne, pellucidum, carnofum I. ab aqua gelatinofum.

ENB. ......

2. a.) Fructus vetuftus, exficcatus, magnitudine natuali. 2) Idem ab aqua ferrente emollitus \& tum :fattus. A.) idem ializuiter zuetus, B. C) Calscis facics fuperior \& inferior. D.) Ca rolla cum tilanientis perfiftentibus. E. C.) Bacea integra. F.) Eadem diffecta. G. I) Semina Soluta.

Frud̂us nomifi inmaturos vidi, ommes inftructos corollis triandris, fed nećtariis acque ancheris, quod prius decilerine, deltitutis." Fis additum fuit Indw non xutem Mella - bola nomen: quare diverfam puto Arbore:s fercorariom Hurmanni ab Olace Linnxi, cujus fores, exceptis Necturiis, recte cum nultris fpeciminibus congruunt.

$$
144.2
$$




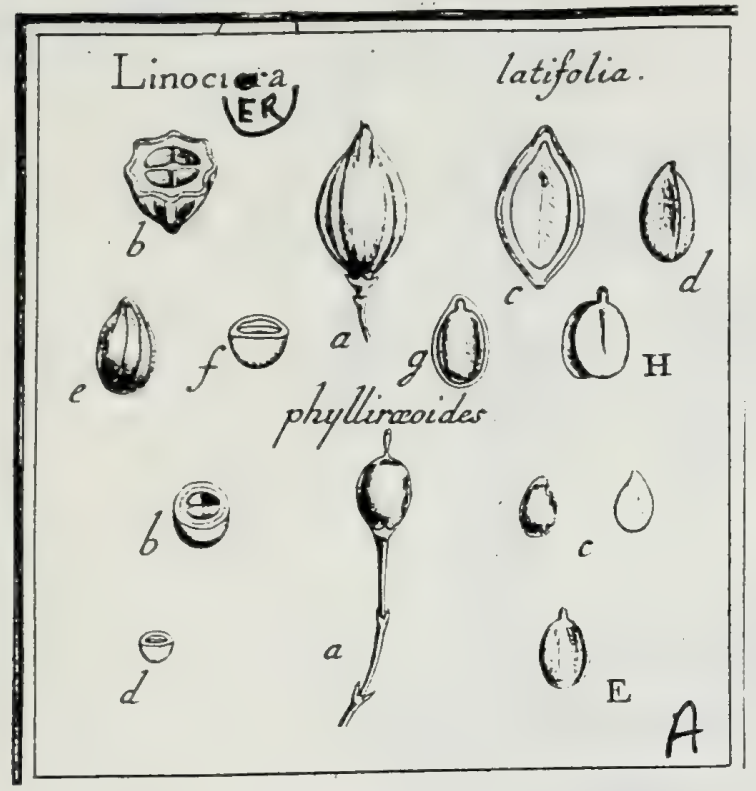

$\mathbf{x} 92$

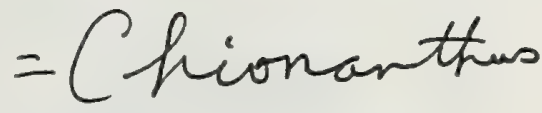

J. Gaertner (1788) Vol 3

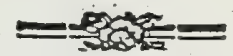

\section{r5I. L I N O C I ER A.}

Swarz flor. ind. occid. t. 2. Soнгев. gen. ryog.

C2l. monophyllus, parvus, quadripartitus, inferus, perfiftens. Cor, fubtetrapetala, 1. monopetala, profundilime quadripartita; tubo brevifamo; lacinus longis, linearibus, patentibus, reflexis. Stam. duo, oppolita ;-filamentis bre. viffimis, fub incifuris corollæe infertis; antheris linearibus. Ovar. fuperum; ftylo fimplici, brevi; ftigmate conico, compreffiufculo. Drupa ficca, bilocularis. Rec. funiculus umbilicalis brevis. Sem. folizaria, axipendula. Alb. carnofum, Emb; ovatus, inverfus.

Linocirra latifolia. Tab. 215 . fig. I.

Cbionantbus (domingen/ss,) foliis ovatis utrinque glabris, panicula terminali fubcymofa, calycibus laevibus. LAM. ill. gen. I. p. 30 .

Linocirra (latifoiia,) floribus paniculatis, pedicellis trifloris, floribus Sefribibus, foliis ellipticis acuminatis. VAHL enum. pl. 1. p. 46.

Ex Infula Hifpaniola cum fequente, a $D^{\text {no Porteat. }}$

PER. Drupa dimidio pollice vix major, ficca, ovats, urrinque atteriuata, octo: gona: angulis alternis majoribus; calyci perfifteuti infiftens, : in vertice. areola parva a lapfu Atyli notata. glabra, e ferrugineo luțefcens, : Caró tenuis, fungofa, maturitate exfucca, lutefceris. Putamen figura drupze, octogonum: angulis rotundatis; cum difiepimento parallele compreffiufculum, offeum, non admodum craffum, evalve, futuris : camed fpuriis oppofítis diffepimento contrariis intus notatum, $;$-biloculare: Difepimentum tenue, offeo-membranaceum, vtrinque ftria intermedia colotatiore infs gnitum. Loculamenta lanceolata, plano-convera, monofperma.

REC. funiculus umbilicalis brevis, incurvus, fimplex, e diffepimento paulum fub apice deofum porrectus, femen pendulum gerens.

SEM. folitari, inverfa, ovata, ad apicem brérifine \& obtufe mucronulata; plano-sonvera ' ftriis ex umbilico ad verticem fito divergentibus notata, leviter pubeicentia, fordide cinerea.

IN T. fimplex, membranaceum; tenue, adnatum.

ALB. tenue, carnofum, fordide album.

EM B. ovatus, 1. ellipticus, inverfus, compreffus, albus. Cotyl. ovatz, carnofx, fubfoliacex, plano convexiufculx, incumbentes; altera externa fulco elevato intermedio notata; altera vero interna carina intermedia infcripta. Rad. parva, ovata, difcreta, compreflufcula, obtufa; umbilico obverfa, fupera.

\section{EXPLICATIO FIGURE:}

2.) Drups 'integra. b.) Eadem medio transverfe diffecta. c.) Ejosdem fectio loagitudinulis fecundum fitum difepimenti, cum infertione funiculi umbilicalis. d. e.) Senes fepantam, a parte interna \& externa, vifum. f.) Albumen uransverfe fectum. 5.) Embryonis fitus intra albumen, a latere externo vifus, H.)-Embryo folutus, a parte loterna fpectatur

Linociera liguftrina. ibid,

Tboninia foliis lanceolatis paniculatis terminalibus, floribus erectis. SwARZ prodr. - p. 15.

Chionantbus folits lanceolatis, yaniculis terminalibus, foribus ereșis fubtetrapetalis. Persoon fyr. 1. p. 9.

Linocieru, WILLD. Spec. pl. T. т. P. x. p. 154. Sivarz for, ind. occid. J. p. 50. Linociern fioribus paniculatis pedicellatis, petalis refexis, fuliis lanceolatis. VAHL esium. pl. x. p. 46 .

Drupa (a.) baccata, parva, ovalis, ftylo clavato faftigiata, glabra, Caro tenuis, putamini adnata, Putamen (b.) figura drup $x$, chartaceum, tenue, biloculare, futuris fpuriis infignitum. Dilliepimentum tenue, futuris contrarium. Senina (c.) folitaria, inverfa, ovato-acuminata, pallida. Albumen (d.) \& Embryo (e.) ut in priore.

Cl. Willuenow l. c. loculamenta dicir difperma, forfan a mala Syarzï icone in errorem inductus. 


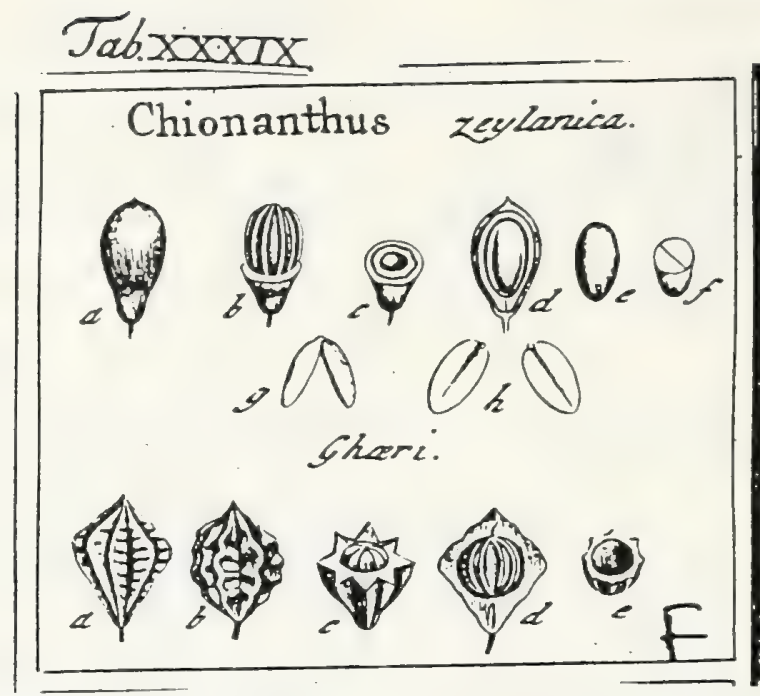

J. Gaertner (1788) Vor 1

189

CCXXIX. CHIONANTHUS. Linn. gen. $2 x$.

Calyx quadripartitus. Cor. monopetala, quadrifida, laciniis longifimis. Stam. duo. Styl. unicus. Drupa baccata fupera, putamine friato uniluculari.

Снionanthus zeylanica. Tab. 39. fig. 6.

Arbufcula zeylanica cotini foliis fubtus lanugine villofis, floribus albis cucuti modo lacinatis. PLux. phyt. $t$. 2fl. fig. 4 .

Chionantins pedunculis panicniatis multifloribus. LIאx. fy/. veg. 57.

Gharictagas. zeylon. E collcet. fem, hort. lugdb.

PER. Drupa baccata fupera, obovata, glabra, nigricars. Caro, in vetuflo fructu, tenuis coriacea. Yutamen offeum, tenue, extus ntiis fex 1 . octo elevatis filifurmibus nolatum, intus glaberrimum, uniloculare, evalve.

REc. nullum, prxter fundun drupz.

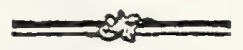

SE s. unicum, elliptico fphrroideum, fpadiceum.

IN T. funplex, coriaceum, tenue.

ALB. nullum.

Eав. Semini conformis, inverlus, lutefcens. Cotyl. ellipticx, plano convexz, craliz: carnolx. Rad. minutifiuna, globulofa, Supera.

a.) Drupa integra. b.) Putamen ultra medium denudstum, e. d.) Drapze fetio transverlatis atque longitudinatis. e) Semen decorticatum. r.) IJem transverfe fetlum, g. b.) Enbryoaic cotyledones ac radicula.

Chronanthus Ghari. ibid.

Ghari. Zeylonens. E collect. fen. hort. ligdb.

Drupa vetufa (a - do) uvata, utrisque attenua:a, fulcato angulata, ochracto fuica. Cortex fungofus, intus albicans, crailus (c.d.), in angulos fex ad dr cem, nunc fimplices, nunc fubdivifos \& undulatos, profunde divifus. Puta. snen fphxricum (d. c.), triis octo elevatis infcriptum, ofleum, uailoculare. Semen defuit.

$$
145.2
$$




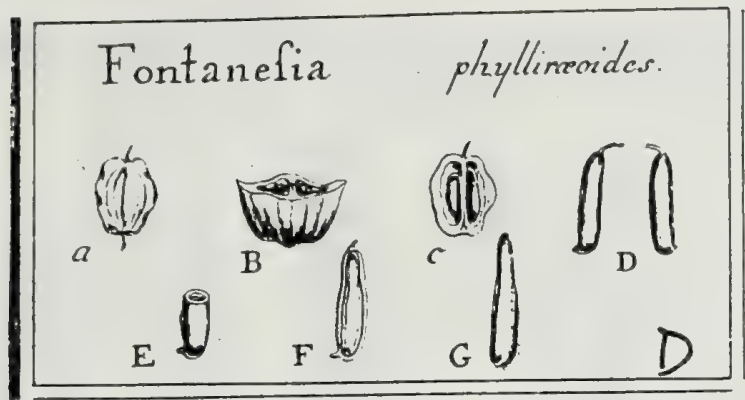

\section{J. Gaertner (1788) Vol3}

\section{FONTANESIA. \\ LA BILIARD. pl. Jyr. I. t. I.}

Cal. moisophyllus, minimus, quadripartitus, inferus, perfiftens. Cor. monopetala, profundiffime biloba; lobis biparcitis, ovatis, obtufis, patentilfimis. Stam. duo, oppofita; filamentis fetaceis, corolla longioribus, ad fifuram lo. borum corollz infertis. Ovar. fuperum; ftylo Gmplici, compreffo, ftaminibus breviore, bifido; ftigmatibus fimplicibus, acutis. Samara ovata $2-1$. 3-alata, 2-1.3-locularis: loculamentis monofpermis. Rec. funiculus umbilicalis trevis. Sem, oblonga, axipendula. Alb. carnofum, Emb. inverfus.

Fontinesia phyllirzoides. Tab. 21 \% fig. 2.

Fonsumefia. La Bilcard. 1. c. p. g. Wiled. Spee. pl. T. x. P, x. p. 5 a.

Persuon fy\%o T. p. 10. Vahl enum. plo s. p. 37.

Jcois. La BILLARD. 1. c. DuHaM. arb. ed. nov. t. 5. Ex dono Cl. La Billardiere.

PBR. Samara parva, obovata, emarginata, compreffa, ftylo perfiftente falti. giata, margine undulata, bi-l. rarius tri-alata, longitudinaliter ftriata, e ftramineo rufefcens, bi - l. rarius tri-locularis. Diffepimentum anguftifimum, alis contarium, fubduplicatum, I. canali compreffo per axem fruclus adfcendente excavalum.

REC. funiculus umbilicalis filiformis, fimplex, in fingulö loculamento finguJus; ex diffepimento paulo fub apice deorfum porrectus, feminis vercicem dorfumque adeuns \& ipfum peridulum gerens.

SEM. Solitaria, comprefiufcula, oblonga, 1. xyphiiformia, ad bafin mucrone dorfali inftructa, ferruginea.

Is T. fimplex, membranaceum, tenue, ad dorfum cum fuviculo umbilicali coloratiore undique conferruminatum.

- $\perp$ B. femini conforme, carnofum, tenue, vaginale, album.

$E_{N}$ B. magnitudine fere albuminis, oblongus, cultri obtufiufculi formam exacte referens, inverfus, lacteus. Cotyl. oblongx, obtufx, oblique rotundatz, radicula paulo latiores, ad dórfum vero cum radicula rectr, plano conves xiufculx, accumbentes. Rad. lineari-oblonga, cotyledonibus paulo an. guftior, atque brevior, recta, compreffufcula, obtufa, fupera.

\section{EXPLICATIO FIGURE.}

1.) Sumura bialata, integra. B.) Eadem medio thansverfe ditreàa; cam feminibu c) Ejue dem feltio rerticalis, cum fitu \& magnitudine naturali feminum. D.) Semina foluta. E.) Seminis fetio transverialis. F.) Albuminis feato vertiealis, eum embryone in fim. G.) Embryo Colutus.

Samaram trilocularem mihi nondum videre contigit.

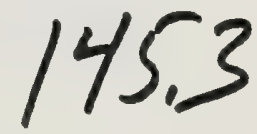




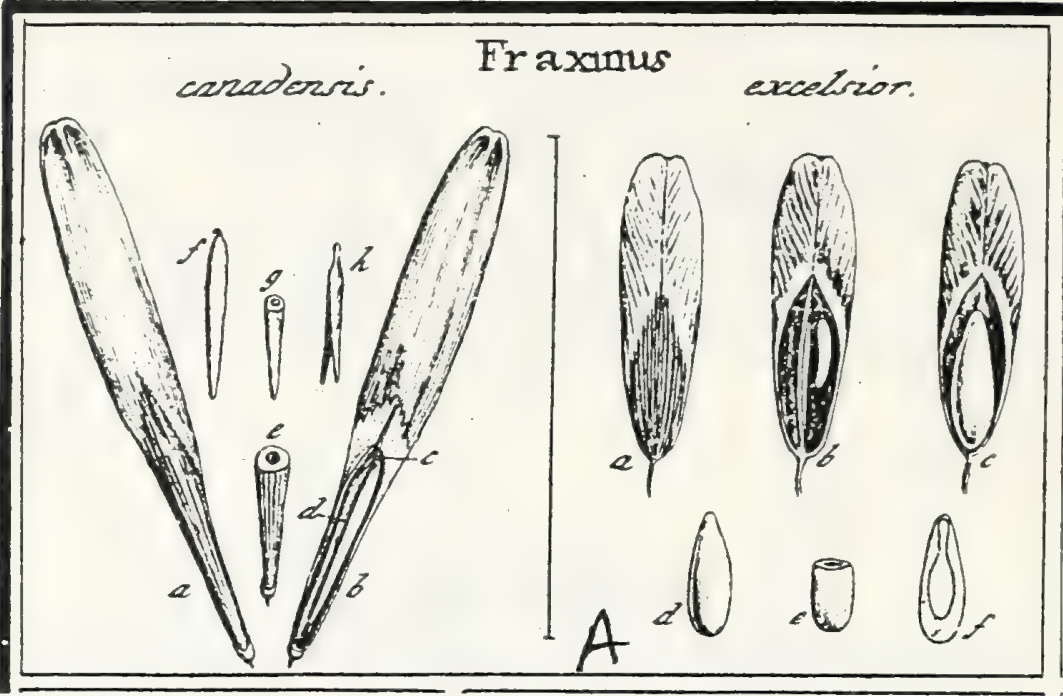

J. Gaertner (1788) Vo].1

CCLXIX. FRAXINUS. T O U R N. t. 343. LIN gen. II60.

Calyx nullus, aut quadripartitus. Cor. nulla, aut tetrapetala, Stam. duo. StyL unicus. Capfula bilocularis, fuperne foliaceo compreffa. Semisa pauca pendula.

Fraxinus excelfior. Tab. 49. fig. I.

Fraxinus. B I A $\Psi$. herb. t. 328 .

Fraxinus apetala, foliis pinnatis ferratis. Halr. hiff. I. 17. 528.

Fraxinus foliis ferratis, floribus apetalis. Lins. fyft. veg. 918.

PER. Capfula ovato oblonga, fupra foliacea, leviter emarginata, infra lenticulari com. prefía, fubcoriacea, bilocularis, evalvis.

REc. funiculus filiformis ex finguli loculamenti apice deorfum portectus, brevis, bi-L. trifurcatus, totiden ovula oblonga, pendula, in fructu immaturo gerens.

SEs. unicum, in fructu maturo, Inagnitudine \& figurá cavicatis capfulx, furfum an. guftius, compreflum, rufefcens.

IN T. fimplex, nembranaceum, tenue.

A L B. fernini conforme, carnolum, tenue, album.

\& E $_{\text {s. }}$ longitudine fere albuminis, fed anguftior, compreflus, inverfus, niveus. Cotyl. ellipticz, foliacex, 'teuues. Rad. lineari comprella, fupers.

a.) Capfula integra. b.) Ejus loculamenta \& feminam infertio in fruta intmaturo, c.) Caprula matura monolperma. d.) Semen feparatum. c. f.) Albunisis faliones, cum fitu \& figura em. bryouis.

Fraxivus canadenfis. ibid.

Fraxinus canadenfis alba Ef rubra. A Serenifs. b. m. CAROLINA. March. Badens.

Capfula bipollicaris \& ultrs, fuberofa, rigidula, fuperne in alam (a. b.) longe elliptican comprefta, inferue tereti acuminata, .ftriata, unilocularis (e.): altero fcil. loculameuto (d.) per inaturitatem obliterato. Semen tereti acusniwatum

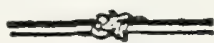

(c. f.), e brevifimo funículo curvo penduluin, rufefcens. Albumen (g.) carnofuin. Embryo (h.) compreftus, inverfus, albus. Coty 6 . limeari-acumi. natx, tenuilinna. Rad. terçtiuscula, fupera.

Non videtur fpecie differre a Frarino americana Linn.

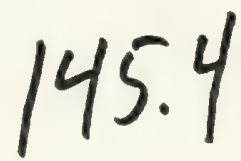




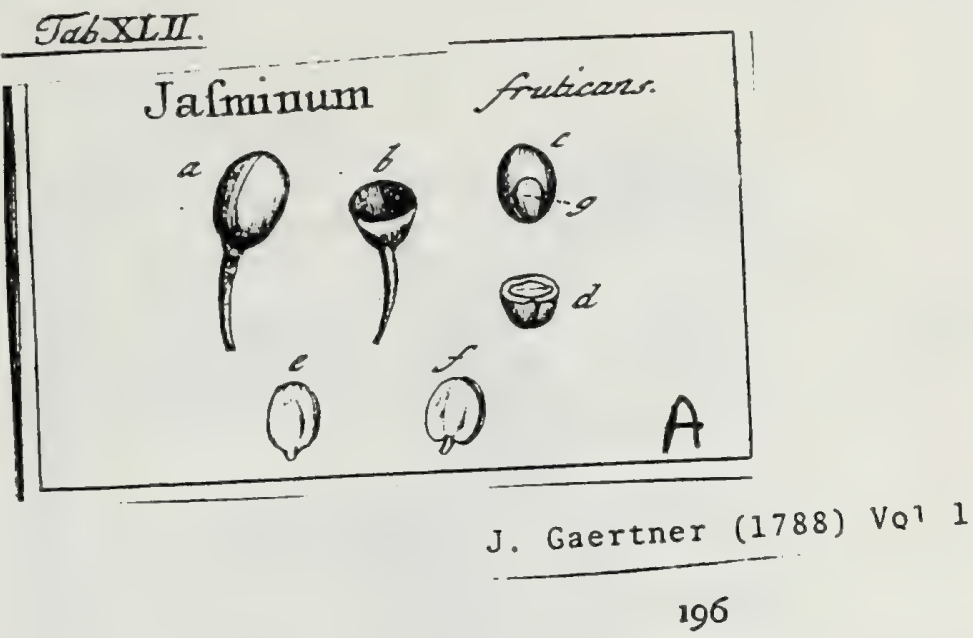

Oleaceae

CCXXXVI. JASMINVM. T ou RN, t.368. L INN. gen. 17.

Calyx quinquedentatus. Cor. monopetala, quinquefida. Stam. duo. Styl. uncus: Hacca lupera unilocularis. Semina bacex carne veftita.

jas

Polcmanium monjpeliense. B Es L. hort. Eyfs. vern. frut. t. II. f. 4.

jusinimum foliis alternis ternatis fimplicibusque, ramis angulatis. LINN. fufto. veg. 56.

PER. Bacca fupera, elliptico fphaxroidea, glaberrima, atropurpurea. Cuticula tenuiftima, diaphana pallida, per inaturitatem fponte a carne lecedens. Caro fucculenta, colorata, feuiuibus arctillune adnata, ut potius ad bxc, quann ad pericarpiun pertiseat.

REc. nulluin; femina fundo bacex affixa.

SEM. duo regulariter, e quibus vero plerumque unicum duntaxat adolescit, ellipticum, Ienticulari compreftum, carne baccx, fibi arctiflume adnata, veflitum.

Ix $\dot{T}$. duplex : exterius, carnofum, molle, fucculentum; interius fubcoriaceum, tenue, rufefcens, in fuperficie fua interna, prafertim verfus radiculan, amygdalino carnofum.

A 28. nullum, prater fuperficiem carnofan integumenti interni.

Eмr. mssnitudinc feminis, Jenticulari compreffus, exectus, lacteus. Cotyl. ovatx, carnulx, plano-convexiuscula. Rad. teretiuscula, brevis, infera.

a.) Becca integrs. h.) Ejus cuticula transverfim fedix, c.) Caro bacce excmis, femen veftiens, cum anı:с оо ovulo abortivo (g.) ad bafin ejus. d) Seminis baccati fellio trausvcrialis, c.) Semen a carue folutum. (.) Ejnbrjo denudatus. 


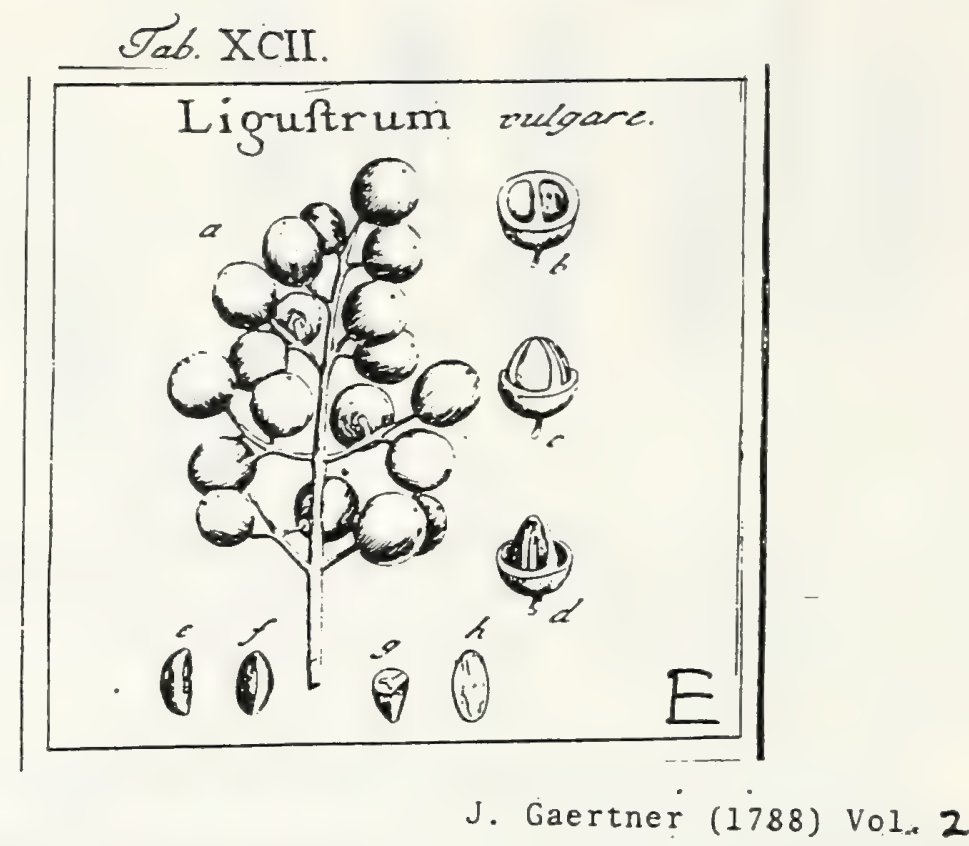

DLXXVII. LIGUSTRUM. TOURN. inft. t. 36\%. LINN. ger. Is.

Calyx quadridentatus. Cor. monopetala quadrifida. Stam. duo. Ovar. fuperun. Styl. fimplex. Bacca bilocularis. Semina geminata.

Ligustrus vulgare. Tab. 92. fig. 6.

Ligufirum. BesL. Eyft. veriz. frut. t. 13. f. 2. BLAKw. berb. t. 140. Hale. bifs. n. 530 .

Liguffrum foliis lanceolatis acutis, panicule pedicellis oppofstis. LiNN. fuff. veg. 56 .

PER. Bacca fupera, carnofa, fubglobofa, nitida, purpureo-atra, bilocularis. Caro fucculenta, coloris e purpura rubri. Loculamenta propria membrana tenuifinia veftita.

REC. nullum, preter duas cicatriculas in fingulo latere difepimenti, quibus Semina affuxa.

SE r. in fingulo loculamento gemina, vel \& rarius unicum: hoc, dímidiatoovatum; illa, oblonga, hinc convexa, inde angulata; utraque vero glabra, nitida, purpurco - atra, umbilico albicante fuperius notata.

IN T. fimplex, membranaceum, craffufculum, albumini arcte adharens.

$\Lambda L \mathrm{~K}$. fenini conforme, fubcarcilagineum, 1 . carnofum durum, candidum.

EMB. longitudine fere albuminrs, inverfus, lacteus. Cosylo ovato-lanceolatx, foliacex, in feminibus folitariis planx, in geminatis autem carisatz. Rad. teretiufcula, longa, fupera

2) Racemus cum baccis integris. b.) Loculamenta gemina, c.) Semina diffcpimento affixa. d.) Difrepimentum liberum, : cum duabus cicatriculis, e quibus femina pendent. e. f.) Sernina fuluta. g.) Abumen transverfe, \& h.) Idem verticaliter Sefum, cum figura \& fitu Embryonis.

\section{6}




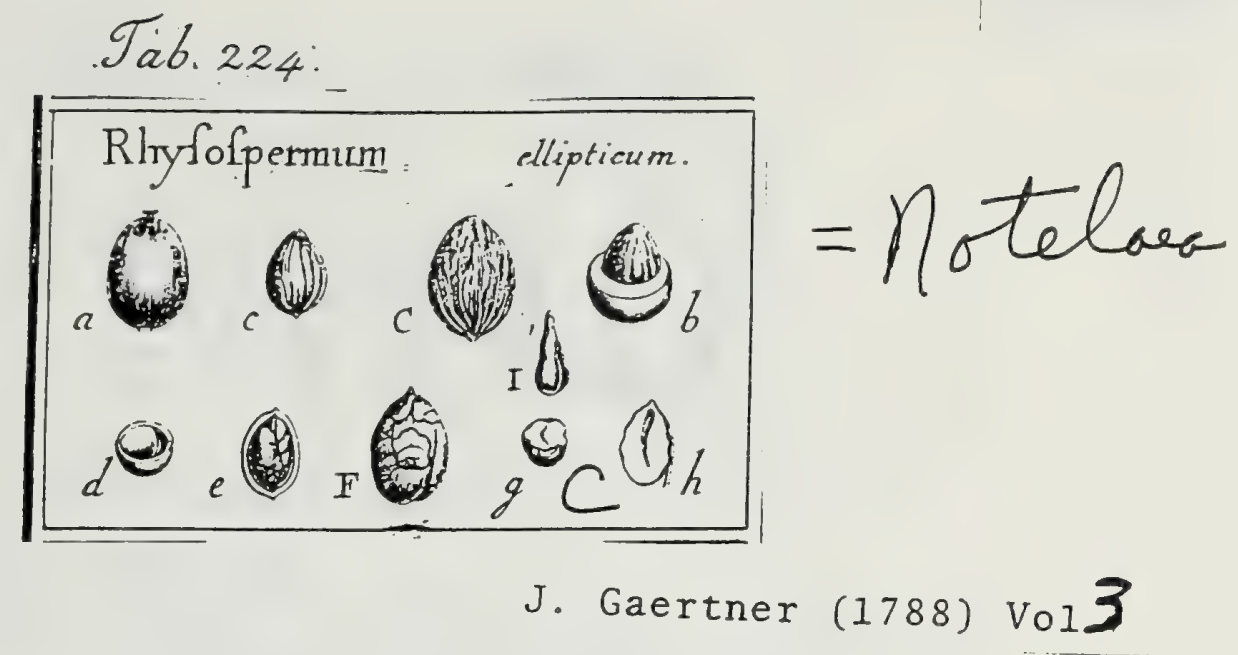

232

\section{R H Y S ÓS P E R M U M.}

Cal. ... Cor. ... Stam. ... Ovar, fuperum, ftylo nullos ftigmate bi, partito, reflexo, obtufo, Drupa ovata, baccata, unilocularis; putamine nervofo, bipartibili, monofyermo. hec. nullum, Senı, unicum, rugofum, inverfum. . Alb. carnofum, crafum. Emb. inverrfus,

Rhysospeasum nervofum. Tab. 224. fig. 2,

Habitat in Nova Hollandia. Ex collectione Bankfiana.

PER. Drupa ovato-élliptica, ad verticem ftigmate minimo bipartito inftruCa, baccata, fupera, glabra, purpurea, unilocularis. Putamen ellipticum, vix compreffiufculum 1. turgide lenticulare \& furfum paulo magis compreffum, leviter marginatum, extus nervis linearibus ramofis a bafi ad apicem usque -affurgentibus condecoratum, fecundum fururam in duas valvas cultro partibile, a cirne facile fecedens, \& bafi tantum ope vafo. zum umbilicalium ipfi arctius adnatum, modice crafun, offeum, lutefcess, uniloculare, monofpermun,

REc. nullum; pracer funiculum umbilicalem, e fundo putaminis affurgentem, \& cum integumento externo undique conferruminatum.

SEM. unicum, inverfum, ovatum, fulco profundo ad ventrem pro decurfu funiculi umbilicalis \& rugis ramofis in tota fuperficie exaratum, \& inde gyrofe tuberculatum, lutefcens l. ferrugineum.

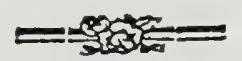

IN T. duplex: exterits membranaceum, a femine luhenter fecedens \& excepto ventre putamius luculamento adharens; interius membrinaceum, tenuiffimuı; intra gyrolitates albuminis defcendens, adnatúm.

A B B. femini coriforme, duriufculum, carnofum, lectulo magno centrali comprefio incurvo pro enbryone exfculptum, album.

E M B. albumine dimidio brevior \& in ejus axi prope verticem locatus, inverfus, Licteus. Coty\%. Longiffime ellipticx, verfus radiculam anguftatix, foliaceic, obtufa, incumbentes. Rud. conico-teretiulcula, brevis, obtufa, úmbilico externo obverla, lupera.

\section{EXPLICATIO FIGURE.}

c.) Druma intems. b.) Ejusdem reatin transverfalis, cum fitu putaminis, ad mediam ufque denudati. c. C.) Putamen feparatum, integrum. d.) Ejustem fectio transverfalis, cum adharente nutati. c. C.) Puramen feparatum, integrum. integumento feminis externo. c.) Idem .fecundum futuram longitudinaliter saram, cum diffectum. [eminis, F.) Srmen feparatum, paulo a yentre pedatio embryone. 1.) Embrgo folutus.

Integumentum feminis externum prxter ventrem loculamento putaminis arcle adharet, ut putamen primo ailpectu pro biloculari, femine altero aburtivo, haberi politi ; conf. fig. d.). 
Tab. XCIII.

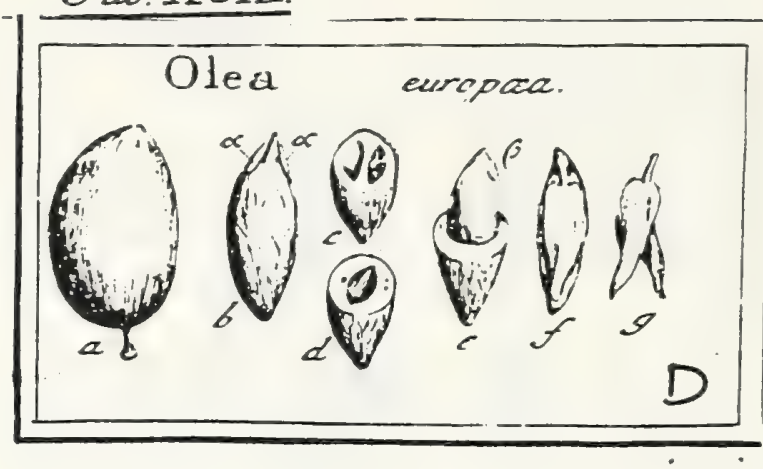

J. Gaertner (1788) Vol. 2

75

DIXXXII. O LEA. TOURN. inft. t. 370. IINN. ger. 20.

Calyx quadridentatus. Cor. monopeala quadrifida. Stam. duo. Ovar. fuperun, biloculare. Styl. finplex apice bifidus. Drupa baccata, putamine offeo, plerunique uniloculari, nonofpernio.

Orza europxa. Tab. 93. fig. 4.

Olea. Dod. pempt. 82x. BLakw. herb. t. 19g. bene. - jylueftis. BLakw. t. $2 x_{3}$.

Olen foliis lanceolatis. LIN S. Siff. veg. 57.

PER. Drupa fupern, baccata, elliptico-globofa, lutefcenti-viridis, demum nigra. Caro duriufcula, craffa, glauca. Putamen offeum, ovato-oblon-

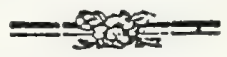

gun, utrinque acuminatum, fuperne ad apicem duobus callis oblongis lateralibus notatum, cetera obfoletifine rugofun, crafium, biloculare: Loculamento altcro fepiffme obliterato; altero folo fertili atque intus crufta cartilaginea licvigatifina veftito.

REC. filiforme, e fundo loculanenti oriundum \& ejusdem parieti adnatum, furfum ad femen pergens, cujus cicatriculx umbilicali mox infra apicem inferitur.

SEM. unicum, altero fcil. coniftanter abortiente, oblongum, teretiufculum, deorfum acuminacum, paulo infra verticem cicatricula umbilicali notatum, pallide gilvum aut ftramineum.

IN I. fimplicifimum, tenuiflimum, nembranaceum.

A L B. femini couforme, amygdalino-carnofum, oleofum, album.

En B. Iongitudine albuminis, inverfus, luteus. Cotyl. fubfulincex, cordatolanceolatx, verfus apicem flexuofie. Rad. teretiufcula, fupera.

2) Drup2 integra. b.) Putamen (eparattim, fub apice duobus eallis a. a.) notatum. c.) Iden transverfc feaum, cum altero loculamento obliterato. d.) Idem, cuin altero loculamento penitus deleto, \& fubfantia ofrea fbris capillaribus ligneis perforata. e.) Seminis pars fuperior denudata, cum cicatricula umbicali. B.). f.) Embryo in albuminc verticaliter diffecto. E.) Idem folutus. 


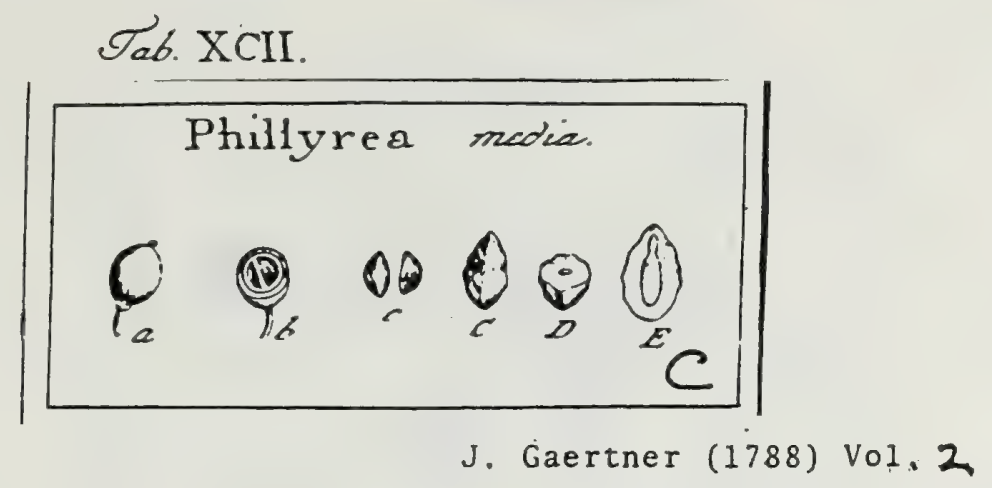

71.

DLXXVI. PHILLYREA. TOURN. inf. t. $36 \%$. LINN. gen. I9.

Calyx quadridentatus. Cor. monopetala, quadrifida. Stam. duo. Ovar. fuperum. Styl. fimplex. Drupa bilocularis. Semina folitaria.

Phulvrea media. Tab. 92. fig. 5.

Plillyrea III. Cxus. bif. 1. p. 52.

Plillyrea foliis ovato - lanceolatis fubintegerrinis. LINN. Jyft. veg. 57 .

Ex herbario Bankfiano.

PER. Drupa fupera, baccata, ovato - globofa, ftigmate globulofo terminata, nigra. Cortex carnofus, tenuis. Putamen chartaceum, tenuiflimum, album, biloculare.

REc. nullum; femina difepimento affixa.

SEM. folitaria, uno fxpius abortante, ovata, fupra leviter acuminata, hinc convexa, inde planiufcula aut angulata, rugofula, fpadiceo-rufefcentia.

IN T. fimplex, membranaceum, tenuifinum, albumini adıatum.

A L B. femini conforme, carnofum, candidiflmum, molle, ut fere farinofum.

E в. longitudine albuminis, inverfus, albus. Cotyl. lineari-oblongx, comprellix, planx. Rad. teretiulcula, fupera.

a) Drupa integra. b.) Eadern diffeta. c. C.) Scmina Solutz. D.) Abumen transverfe, \& E) Idem longitudinaliter ditreaum eum Embryone.

Erroneus eft Linnxi character generis effentialis a feminum numero defumtus; conftatilfime enim duo adfunt loculamenta, quare etiam naturalis feninum numerus non alius, quam binarius. 


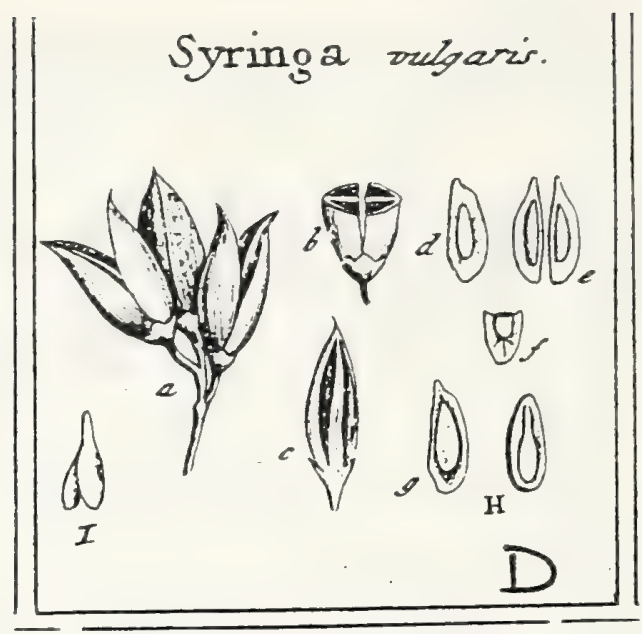

J. Gaertner (1788) Vol. I

CCLXXII. SYRINGA. LINN. gen. 22.

Calyx quadridentatus. Cor. monopetala quadrifida. Stam. duo. Styl. unicus. Capfula fupera, bilocularis, bivalvis. Senuina membranaceo margine cincta.

SYRINGA vulgaris. Tab. 49. fig. 4.

Syringa flore caruleo E? albo. Bess. hort. Ey/t. vern. frut. t. 1. f. 2. 3.

Syringa foliis ovato cordatis. HALL. hifl. I. n. 53r. LIN N. Ji/f. veg. 57.

PER. Caplula ovato lanceolata, coriacea, lenticulari comprefla, faturate cananea, b: locularis, bivalvis. Valvula naviculares. Dillepinuentum craffum, valvis contra; rium, dehifcendo bipartitum.

REc. nullun; femina fupremx parti diffepimenti utringne affixa:

SEs. in fingulo loculamento gemina, ovato oblonga, comprefla, membranaceo mos gine cincta, luteola aut rufelcentia.

IN T. Funplex, membranaceum, in marginem ampliatum.

$\Lambda_{\llcorner}$в. ovato oblongum, angufum, comprefium, carnofum, album.

Es B. longitudine fere albuminis, inverfus, niveus. Cotyl ellipricx, foliacex, tenviffunx. Rad. longitudine fere cotyledonum, lincari comprella, fupera.

2.) Capfule integrze \& dehifentes. b.) Capfula diffeta. co) Valvula (eparata. d. e.) Semina foiitaria \& gemiuata. f.) Semen transverfe feltuin, R.)! Albumen denudatum. H.) Idem longitudinaliter apertum, cum fitu \& Egura enibryonis. 1.) Einhryo Separatus. 


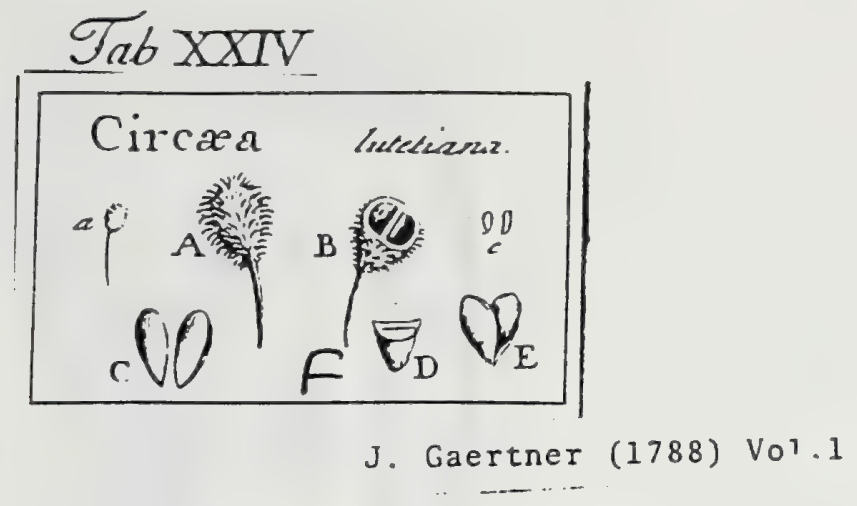

114

CXXXIV. CIRCÆAA. Tou RN. t. 155. LIN . gerr. 24.

Calyx diphyllus fuperris. Cor, dipetala. Stan-duo. StyL unicus. Capfula in: fera, bilocularis, hippida. Semiua folitaria.

Circen lutetiana. Tab. 24. fig. 6.

Circea. B Ess. hort. Eyff. afiv. III. t. 7. f. 'I.

Circac foliis fubcordatis fubferratis. HA LL. hif. I. 'n. 813.

Circac caule eretio, racemis pluribus, foliis ovatis. LiNN. fyf. "veg. 58.

Icon. OE DE R. flor. dan. $t .256$.

PER. Capfula infera, obovata, longiflme pedunculata, fetis rigidis uncinulatis albican: tibus undique hifpidata, fubeoriacea, fulca, bilocularis, evalvis.

REC. nullum; femina fundo loculamentorum affixa.

SEM. in fug ulo loculamento fingulum, obovatum, infra in umbilicum attenuatum: hiue convexum, inde planum; glabram, rufefcens.

IN T. funplex; membranaceum.

A ᄂ в. nullum.

E M в. dicotyledoneus, erectus, figurâ \& magnitudine feminis, albus. Cotyl. oboratz, carnofx: exteriore plano convexa; interiore utrinque plana. Rad. conica, brevifluna, infera.

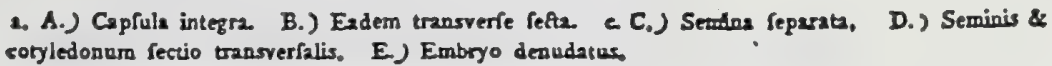




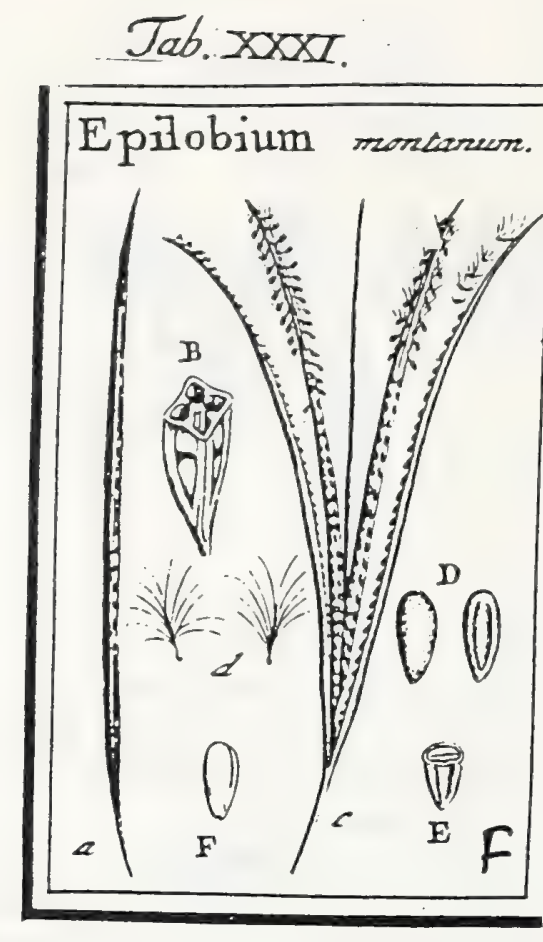

J. Gaertner (1788) Vol. I

157

CXC. EPILOBIUM. LIN gen. 471. Chmaenerion. Tourn. t. 157.

Calyx fuperus, tetraphyllus, deciduus. Cor. tetrapetala. Stam. octo. Styl. unicus. Capfula infera, longifina, quadrilocularis. Semina plurima, apice crinita Epsloвius montanum. Tab. 31. fig. 6.

Pfeudolyfimachium purpureum primum. D O D. pempt. 85 .

Epilobium foliis acute lanceolatis glabris dentatis. HaLl. hifl. x. n. 996.

Epilobium foliis oppofitis ovalis dentatis. LINN. Su/f. veg. 359 .

PER. Capfula infera, longıfiuna, gracilis, tetragona, glabra, quadrilocularis, quadrivalvis. Diffepimenta anguniffuma, valvis contraria \& receptaculi angulis refpondentia.

Rec. centrale, filiforme, profunde quadrisulcatum, femina gemino ordine pendula fullisens.

SE M. numerofa, circiter quinquaginta in fingulo loculamento, parva, obovata, deor. fum anguftiora, lainc convexa, inde planiuscula cum fulco medio elevato, undique puncticulata, Spadiceolutefcentia, apice pilis fimplicibus crinita.

I.T. duplex : exterius coriaceum; interius membranaceum: utrumque tenue.

A L B. nullum.

Ess. Semini conformis, dicotyledoneus, erectus, luteo albicans. Cotyl. plano convexx, longitndine dinidii embryonis. Rad. conica, crafta, infera.

2.) Capfula integra, b.) Eadem diffeta, c.) Eaden dedifcens, d. D.) Senina foluta

Semeu transverie fétum. F, Embryo denudatus.

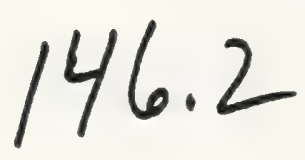


Onagraceae

Tab. CXXVII.

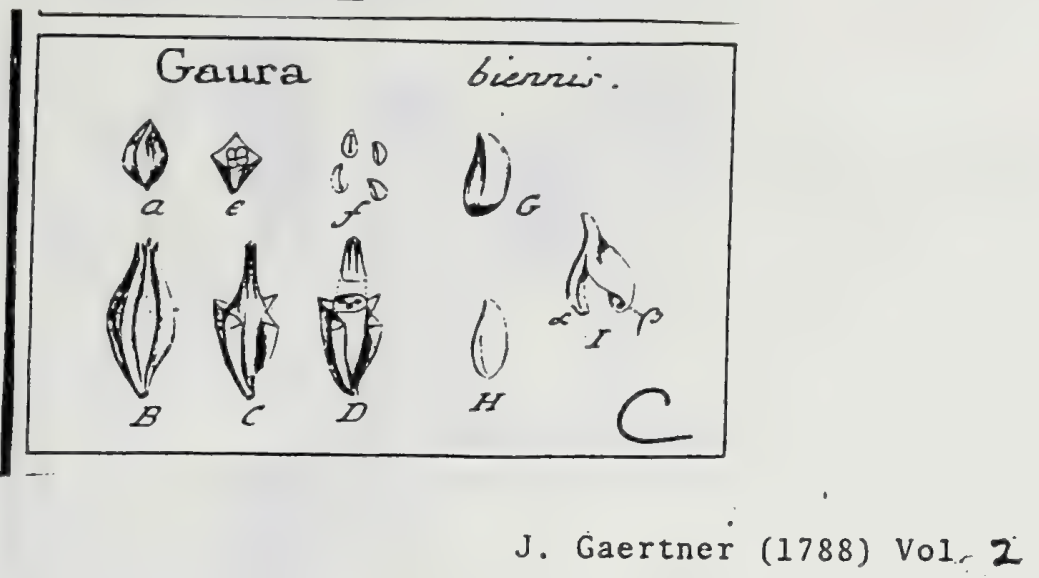

205

DCCXXIII. G A U R A. IINN. gen. 470 .

Calyx quadrifidus, fuperus. Cor. terrapetala. Stam. octo. Ovar. inferum, quadriloculare, ovulis quaternis aut pluribus. . Styl. Gimplex. Drupa ficca, infera, tetragona, fxpius unilocularis, monofperma, remanentibus tnmen diffepimentorum \& abortivorum feminum veifigiis.

GAUR A biennis. Tab. 127. fig. 2.

Lyfimacbia clumenerio fimilis foridana, foliis nigris punctis, capfulis carinatis in ramulorum cymis. PLUK. plyt. t. 428. f. 2.

Gaura. Lins. af. bolm. $775^{6}$. p. 222. t. 8. Lyf. veg. $35^{8}$.

PER. Drupa ficca, infera, parva, utrinque acuminata, tetragona. Cortex membranaceus, tenuis, glaber, fpadiceus, intus fpongiofus. Putamen offeum, oblongum, utrinque acuminatum, quadrialatum, quadri - aut uniloculare. Pars acuminata fuperior longe conica, quadrifida \& quafi in valvulas fecta; inferior leviter incurva ; bafi perforata. Alx craffe, inferne cum putamine coalitz, fuperne autem liberx \& a valvulis apicis aliquantum diftantes. Diffepimenta tenuia, membranacea, per maturitatem fape obliterata, ut ex quatuor loculamentis unicum duntaxat fuperfit.

REc. nullum; femina bafi affixa.

SEN. folitaria, unum aut quaterna, fubovata, furfum anguftata, hinc convera, inde angulata, ad balin callo fufco notata, cetera e fpadiceo. lutefcentia.

IN T. duplex: utrumque membranaceum, tenue.

A L B. nullum.

E s 8. femini conformis, inverfus, albus. Cotyl. foliacex, convolutx; altera exteriore maximam partem involvente alteram interiorem, utruque fuo margine introrfum convolutam.

a.) Drupa integra. e.) Eulem transverie feEz. B.) Putamen decortiatum. C.) Ejosdem alz refeaz \& apex denudatus. D.) Idem transverfe feaum, loculameata ventris \& valvulas apicis oftendens. f. G.) Semina (eparata H.) Embryo denudatus. I.) Idem explicatus, ut cotyleda nis internz ( $($ ) eonvolutio, \& externz (B) fornicata lamina melius in confpedum veniant.

Putaminis apice valvato cum Spathelin \& Nitraria convenit. Si femen unicum, tunc oblongum \& valde acuminatum eft; fed perperam Linnxus hunc numerum habuit pro natorali.

146.3 


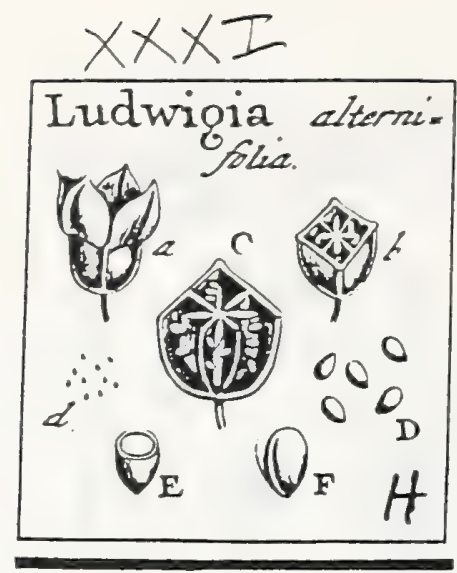

J. Gaertner (1788) Vol. I

158

CXCII. LUDWIGIA. Lin N: gen. 153."

Calyx quadripartitus fuperus. Cor. tetrapetala. Stain. quatuor. Styl. unicus. Capo fula infera, quadrilocularis. Receptacula ab axi fructus dintincta, utrinque fewinifera.

Ludvigin alternifolia. Tab. 31. fig. S.

Frutex faligneis folis, caule purpureo, capfularis. P IUK. phyt. t. 4I2. f. I.

Iudwigia foliis alternis lanceolatis, cause erefto. LIN s. fyf. veg. I $\sigma_{1}$.

PER. Capfula infera, calyce perfiftenti brevior, ex rotundata bafi cubica, quadrilocu. Jaris, ad angulos dehifcens. Diflepimenta inembranacea, hiuc valvularum medio, inde axi inferta, non fecedentia.

REc. lamina fungofa, comprefla, finguli loculamenti angulo interno affixa, utrinque feminibus obtecta.

SEM. numerofifuma, exigua, ovata, glabra, fublplendentia, pallide lutea.

INT. duplex : exterius crufaceum, tenue; interius membranaceum.

ALB. nulluin.

Exr. dicotyledoneus, femini conformis lutefcens. Cotyl. ovatx, plano convexz. Rad, acuminata, brevis, receptaculo obverfa.

a.) Capfula integra. b.) Eadem transverfe fecta. C.) Ejusdon fectio longitudinalls, cam infese tione resptaculoruin alque feminum. L D.) Semina foluta. E.) Scmen transverfe fequin. F.) Embryo Separatus.

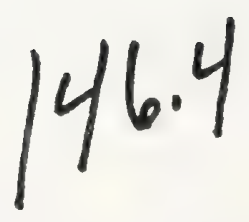




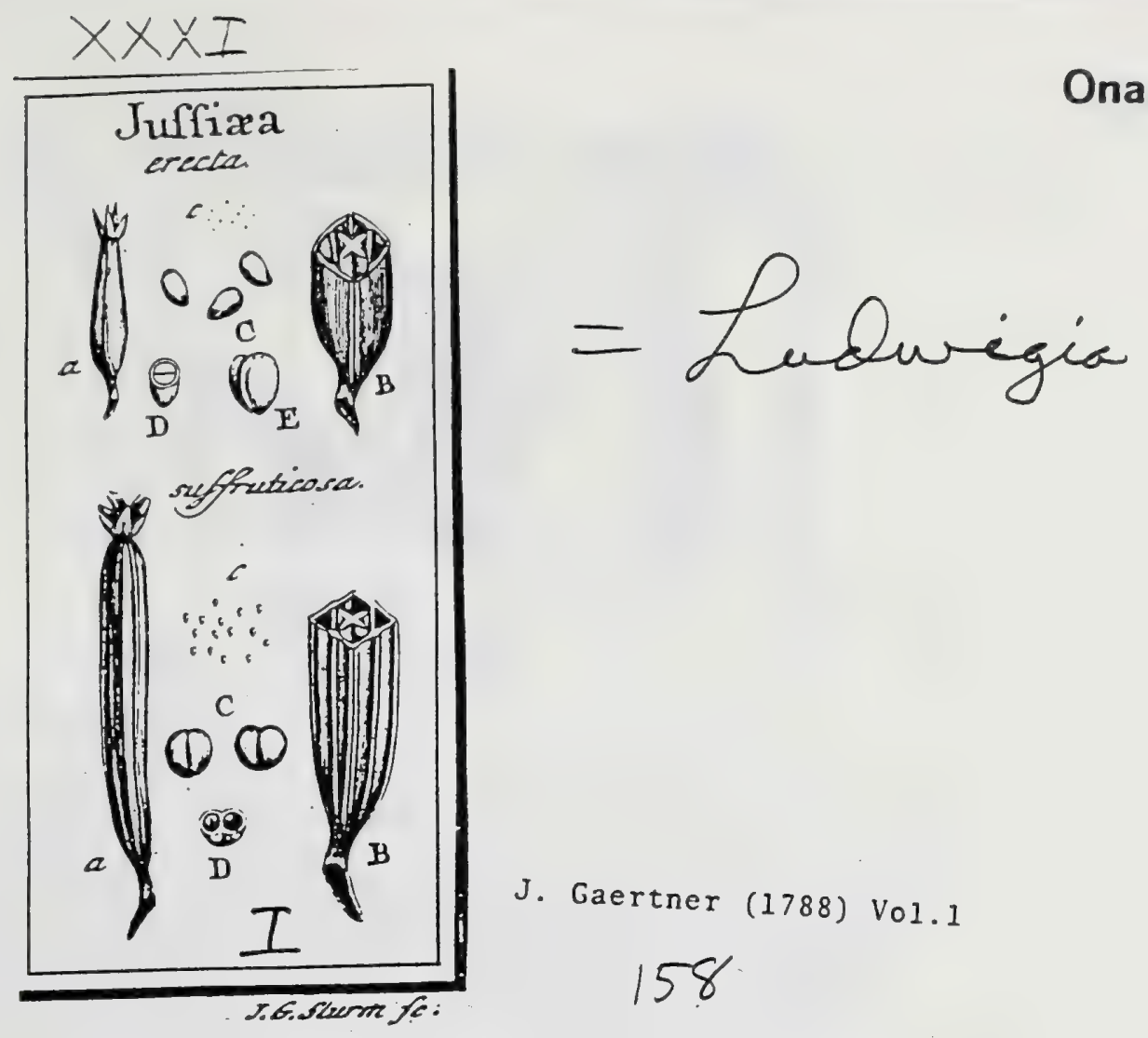

CXCIII. JUSSI EAA. L IN N. gen. 538 .

Calyx fuperus, quadri-1. quinque partitus. ' Corolla retra-1. pentapetala. Stam. oćto 1. decem. Styl. unicus. Capfula infera, columnaris, quadri-1. quinquelo. cularis. Receptaculusn $2 b$ axi fructus non difinsctum:

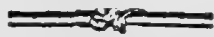

Jossien erecta. Tab. 31. fig. 9 .

Onagra perfice foliis amplioribus, parvo flore'tuteo. Pцus. ic. t. $r 75 . f .2$.

Fuffica erefta glabra, floribus tetrapetalis oftandris felflibus. LINN. fyft. veg. 403.

Ex herbario Bankfiano.

PEx. Caplula infera, calyce tetraphyllo coronata, pollicaris, rotundato tetragona, furfum leviter attenuata, glabra, quadrilocularis, quadrivalvis. Diffepimenta cum angulis receptaculi colixientia, anguftifmua.

REC. columuate, profunde quadrifulcatum, angulis compreffis diffepimento refpondentibus.

SEM, numerofifima, minuta, ovata, glabra, fplendentia, lutefcentia.

INT. duplex: exterius cruftaceum, tenue; interius arachuoideum.

A t. B. nulium.

Exв. dicotyledoneus, femini confurmis, lutcfecrs. Cotyl. ovatx, plano convexx. Rad. minima, acuminata, centripeta.

a.) Capiula integra. B.) Eadem transverfe fefra, cuin fita \& figura receptacull. c. C.) Semina feparatz. D.) Semen transverfe feftum. E.) Embryo deuudatus,

Jussiea fuffruticola ibid.

Herba vitiliginum. Ruмpн. amb. 6. t. 21. $f$. I.

Fuffaca erefta villofa, floribus tetrapetalis oftandris pedunculatis. LrNw. $\int y /$. veg. 403.

Mudunane zeylonens. E collect. fem. hort. lugdb.

Capfula bipollicaris (a.), tetragona, nervis prominulis in medio '\& ad margines valvularum Ariata. Receptaculum (B.) tetragono cruciatum, columnare. Semina numerofiltima (c. C.), ovato glubofa, utrinque fulco leviter deprefto infcripta, ferruginea, glabra, lucida, intus lepto partita (D.) biloculariz Embryo.....

Semen biloculare in fructu capfulari prorfus inconfuetum ef; forfan autem ideo hac femina bilocularia funt, quia calla ommia?

^ Ludarigia quidem fatis differt Juftixa, fabrica \& fitu receptaculi feninum; fed sefpectu Oenotherx, mere factitium \& imagimarium genus ef. 
Tab.xxx)II.

Onagraceae
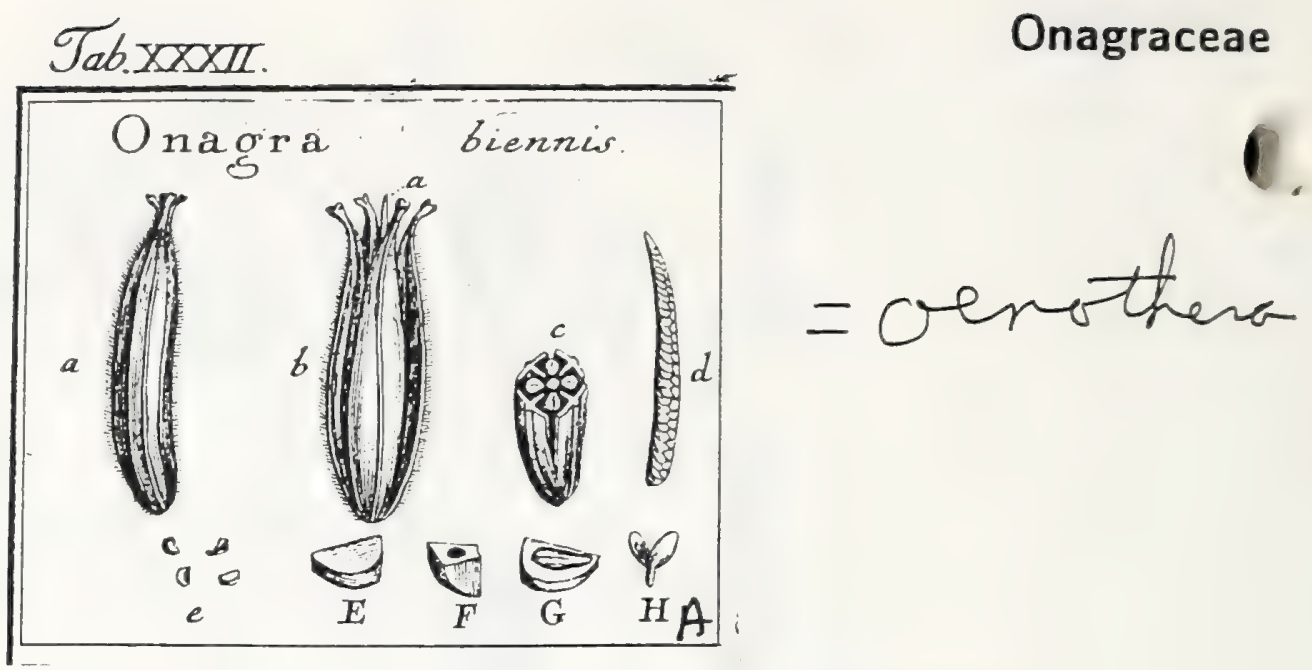

J. Gaertner (1788) Vol.1

159

CXCIV. ONAGRA. Tourn. t. 156. Oenothera. LIN . gen. 46 g.

Calyx fuperus, quadrifidus, deciduus. Cor. ectrapetala. Stam. octo. Styl. unicus. Capfula infera, columnaris, quadrilocularis. Receptac, ab axi fructus non difinictum. Seurina angulata, fungo 2.

160

ONagra biennis. Tab. 32. fig. I.

Oenothera foliis lanceolatis planis. MIL c. ic. t. 189. f. 2. OEDER. flor. dab. t. 446 .

Oenothera foliis ovato lanceolatis plnnis, caule hivfuto. H A L L. hifl. I. M. 994

Oenothera foliis ovato lanceolatis planis, caule muricato villofo. LINN. Sys veg. 358 .

PER. Capfula infera, non coronata, fubcylindrica, in flylum craffum quadrilobum de: funens, obfolete tetragona, villis molliffunis pubefiens, quadrilocularis, quadri: valvis. Diffepimenta valvis contraria.

REC. centrale, filiformi tetragonum: angulis cum diffepimento cohxrentibus.

SEM. numerofa, duplici ferie fibi imcunbentia, obliqua, fubfemilunata, utrinquè plana, fungofa, ferruginea.

I. T. duplex: exterius fungofum, crafrusculun, quafi arido-baccatum; interius meanbranaceum, tenuiftunum.

A L B. nullum.

Es в. dicotyledoneus, femine multo angufior, fubclavatus, lutefcens. Cotyl. ellip: ticx, plano convexx. Rad. teretiuscula, brevior, centripeta.

3. b.) Capfuia integra \& dehifcens. c) Eadem diffeta. d.) Receptaculum folutum, cum fems. nun fitu. e. E.) Semina (eparata, F. G.) Senuis féliones, cum fitu eubrjonis. H.) Embryo Separatus.

Onagra, five Oenothera, aut Oenuris fiutex eft arboris fpecie \&c. Drosc. IV. c. Irr. Ergo eadem quoque pro nomine Tournefortiano militat anctoritas. De Oenothera THEOPH. dilt. IX. c. 2s. id folumnodo certum, quod noftra nou lit.

$146 \cdot 6$ 


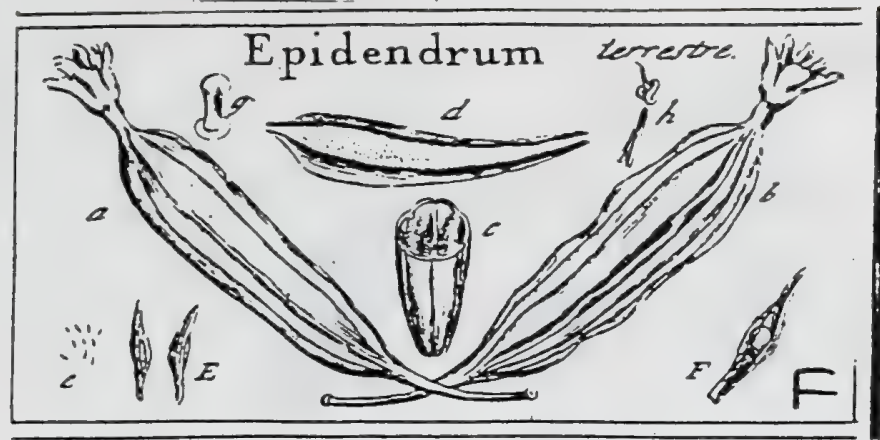

J. Gaertner (1788) Vol.1

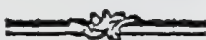

LIII. EPIDENDRTM LINN. gen. IOI6.

Petala fex: horuin quinque exteriora varia; fextum turbinatun, obliquum. Filamenta duo, lineari-acuminata, dorfo carinata, membranacea, fuperne in proceffum filiformeın, antrorfun flexum, definentia. Anthera biloba, alba, fpirali ductu inferipta, infra filamenti proceffum, in dorfo ejus pofita. Stylus craflus femicylindricus. Stigma bicolle, carnolum, fuperiori \& interiori parti ftyli adnarum. Capfula infera, unilocularis, trivalvis, feneftrata. Semina fobiformia.

EPIDENDRUM terrefte. Tab.14. fig. 6.

Angracum terrefre primum. R U « Р н. amb. 6. p. II2. $t .52 . f: 1$ ? ob ftylum. E collect. fem. hort. lügdb.

PER. Capfula infera, oblonga, fuperne paulo craffior, inferne rotunde trigona, tribus nervis pominulis, ad interftitia valvularum, totidemque friis depreffis, in ea. rundem dorfo, notata, unilocularis, trivalvis, fecundum nevos longitudinaliter dehifcens. Valvulx non decidux, navículares, fubcoriacex.

REc. fulcus elevatus, craftus, villofus, interno valvularum parieti infcriptus, earundemque externx trix deprefix refpondens.

SEss. numerofifina, minutifima, fcobiformi-arillata: detracto arillo fubglobofa, pallida.

Arillus membranaceus, tenuifimus, venolo reticulatus, transparens, albicans, fufiformi-fifulofus, femen in media fua cavitate condens.

IN T. fimplicifinum, tenuiftmum, pallidum.

A в в. fubglobofum, femipellucidum, carnolum, pallidum.

Es B. .......

2.) Capfula integrn, b.) Eadem delifcens, remanentibus valvolis, filo interjetto ab invicem dif: crevis. c.) Ejus fedio transverialic d.) Valvula feparata, cum receptaculo feninum villofo. e. E) Senina arillo fuo fufformi inclufa. F.) Arillus longitudinaliter apertus, cum fitu \& figura feminis. 8.) Stylus cum nigmate. h.) Stamen magnitudipe naturalli.

Sive quod femina nimis parva, five quod immatura fuerint, embryonem difcernere non licuit; nullum autem dubium ent, quin codem modo fe habeat, ut in Serapiade, aut in Vanilla, in qua minutiffimum globulum niveum zmulatur. At V2nilla femina arillo carent, \& lenticularia, atra atque lucida funt, \& in pulpa carnola nidulantur: quibus fignis Vanilla ab ommibus reliquis cognitis Epidendris differt.

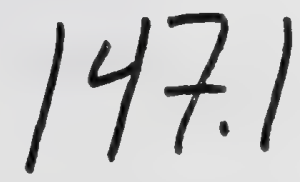




\section{Sab.XIV.}

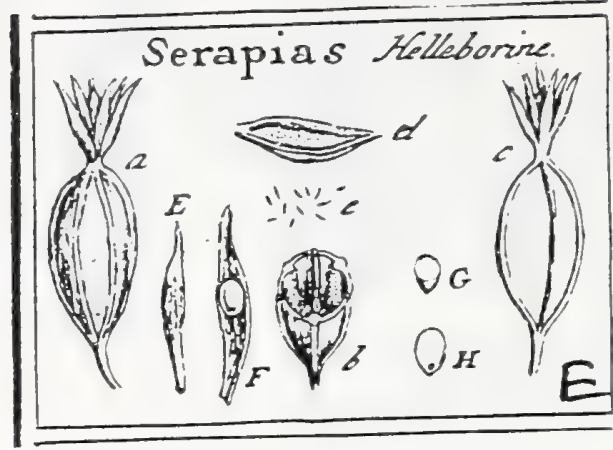

J. Gaertner (1788) Vol.1

\section{6}

LII. SERAPLAS. Linn. gen. ror2. Helleborine. Tourn, t. 290.

Petala fex: horum quinque in galex fpeciem conjuncta; fextum vero patulum, va. rio in variis modo figuratum. Antherx geminx, absque filamentis fungolx columnz femicylindricz infertx. Capfula infera, unilacularis, trivalvis, feneftrata. Semina fobiformia.

SER A PIAS Helleborine. Tab. 14. fig. 5.

Evipatais f. Helleborine. C A M. epit. 889.

Epipatis foliis amplexicaulibus ovato-lanceolatis, labcllo lanceolato. HA LL. hifl. 2. n. 1297.

Serapias (latifolia) bulbis fibrofis, foliis ovatis amplexicaulibus, foribus pendulis, LINN. Jyf. veg. 814 .

Icon. OE DER flor. dan. 811 . E' 287.

PER. Capfula infera, elliptice fphroroidea, unilocularis, trivalvis, nervis fex prominulis notata: horum tres, medio valvularum dorfo inferipti, cum ipfis caduci; tres vero reliqui, ad commifluras valvularum pofiti, \& poft earum lapfum perfiftentes. Valvulx fubnaviculares, a bafi dehiscentes.

REc. fulcus craftus, villofus, medio fingulx valvulx parieti interno infcriptus, 'cui Semina affixa.

S E s. numerofifima, minutiffuna, fcobiformi-arillata ; detracto arillo, ovato-globofa, glabra, nitida, pallide rufefcentia, fuperne tuberculo chalazino, \& inferne papilla umbilicali, utrisque nigricantibus, infiguita.

Arillus membranaceus, tenerrimus, vafculofo reticulatus, pallide fpadiceus, fufformi-finulofus, in cujus medio ventre ipfum femen lixiet.

I N T. fimplicifimum, arachnoideum, nucleo adnatum, pallide rufefcens.

A цв. femini conforme f. ovato-globofurn, inferius leviftune acuminatum, carnofum, pallidum.

Е в в. minutifimus, fubglobolus, formâ punctuli luteo viridefcentis, in extremitate al. buminis parieti valvularum obverfa, hareus.

2.) Caprula integra, b.) Ejus featio transverfalis. c.) Cofte tres, poft lapfun valvularum perfiftentes. d.) Valvula (eparata, a parte interna receptaculo villofo inferufta. e. E.) Semiua feobifurini arillo tefla. F.) Arillus longitudiualiter aperius, com veri feninis fitu \& fgura G.) Albunea cransverfe fefums. H.) Idem longitudinaliter difcifum, cum Gitu embryonis.

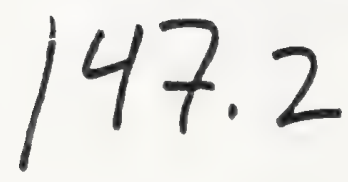




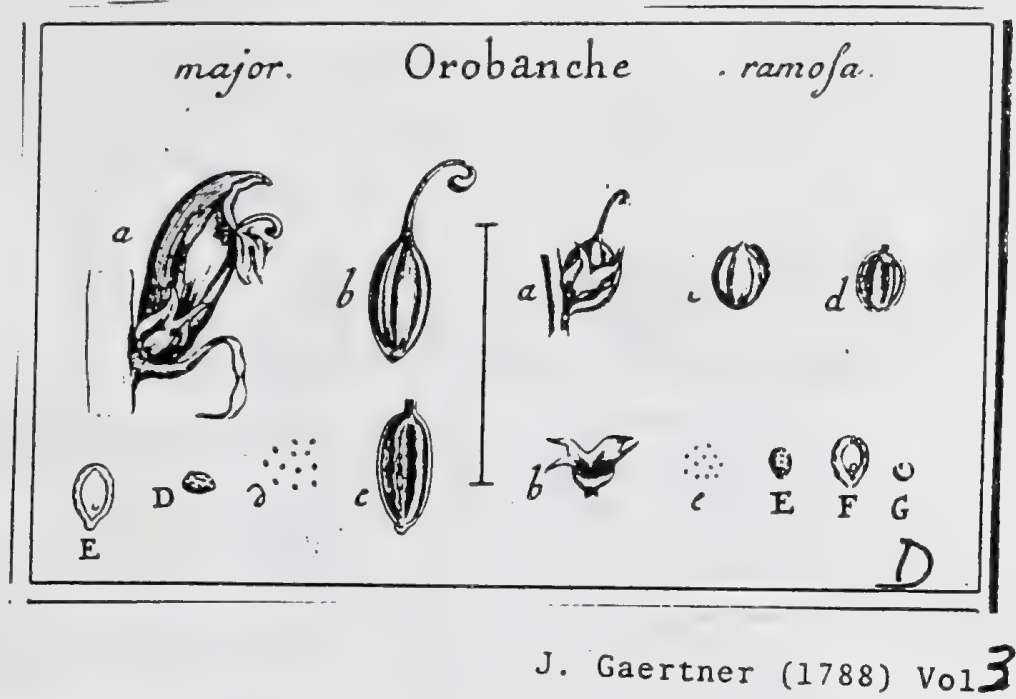

\section{O R O B A N C H E.}

Toún. t. 8r. LrNe. gen. 779. ed. Schreb. ro45. Juss. gen. p. ror. LAMARCX ill. gen. t. 55r.

Cal. quadri - 1. quinquefidus, bracteiformis. Cor. ringens, tubulo 5 , ventricofat; Jabio fuperiore fornicato emarginato: labio inferiore reflexo ttifido, lacinia intermedia majore. Stam. didynama. Ovar. bafi glandulofum; ftylo fimplici; ftigmate bilubo obtufo nutante. Capfula oblonga, bifulcata, unilocularis, bivalvis. Receptac. in quavis valvula duo, longitudinalia. Sem. numerofilima. Emb. excentricus.

OROBNKCHE elatior.

Grobancbe major. in lcone. Tab. 185. fig. 4:

$$
=3 x+2=
$$

Oiobanclse (major, canle fmplici pubefcente, calycibus bipartitis, laciniis bifidis, fansinibus corolla brevioribsus. LAa. Euc.

Orobanche caule fimplicifimo, corolis quadrifidis, fansinibus inferne pilofis; figmate obcordato, flylo fuperne glabro. SutTon aff. foc. lin. loud. 4. p. .778. t. 77 . WILLD. Jfeir pl. T. 3. P. I. p. 349.

PER. Capfula intra corollam perfiltentem emarcidam harens, oblonga, fubobliqua, levifime pubefcens, ftylo perfiftente inftruda, unilocularis, bivalvis. Valva a dorfo prius dehifcentes, papyracex, longitudinaliter bifulcx.

REC. in quavis valvula duo, lateralia, à fulcis externis orta, undulata, longitudinalia, fuperne contuentia, in cavitatem capfulic prominula, fungola.

Se s. numerofifima, ovata, elliprica, oblonga \& angulata, punctis excavatis reticulata, fufco-atra.

IN T. duplex, exterius craffufculum, carnofo-membranaceun : internum temuflinum, elafticum, albumini arctiffme adıatun.

ALB. femini conforme, utrinque mucronulatum, carnofum, album, trans. parens.

EMB. minutiffimus, fubglobofus, ad latus umbilici extra axem feminis pofitus, albus. Cotgl. brevifimx, obtufix. Rad. obtufifima, globofo-rotundata, centrifuga.

x.) Flos integer in fita. b.) Capfula folutz \& a dorfo dehifecns. e.) Valrula feparata cum Gitu receptaculotuuh d. D.) Semina (oluta. E.) Albures lozyitudinaliter diftectum, sum Eonbryo ne in fitu. 
$-13$

Orobanche ramofa. ijid.

Orobancbe ranofa. Bauh. pir.88. I. R. H. GuetTard mein. de 5.46. t. 9.

Orobanclse. Camerar. Epit. p. zir.

Orobarbbe caule ramofo, flore quinquepartito. Hall. belv. n. 296.

Grobanche caule ramofo, corollis quinquefidis. Lis.. Jjif. veg. ed. 14. p. 574 .

Orobanche caule rantsofo, corollis quikquefidis, braffeis ternis, calycibus brevibus profusde quadrifidis. Sutron. ald. Soc. lin. lonsd. 4. p. 285 . S.urtr bus. algh. to 184. WILLD. Jpec. pL 1. c. p. 353.

Capfula intra calycem profunde quadrifidum harens (a.b.), ovata, lenticulari-comprefia, ab utroque latere bifulcata, unilocularis, bivalvis (a). Receptacula in valvulis gemina, fulcis externis correfpondentia, fungora (d.).

44

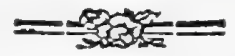

Semina minutifina, numerofifima, elliptica, punctis excavatis reticulata; cinerafcentia (e. E.). Albumen intra integumentun crafiufculum externunz \& elafticum internun inclufum (F.). Embryo glubofus, extra feninis axem juxta umbilicum pofitus, albus; cotyledonibus brevifimis obtulis; radicula obtufifina (G.).

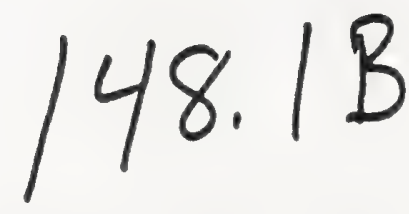




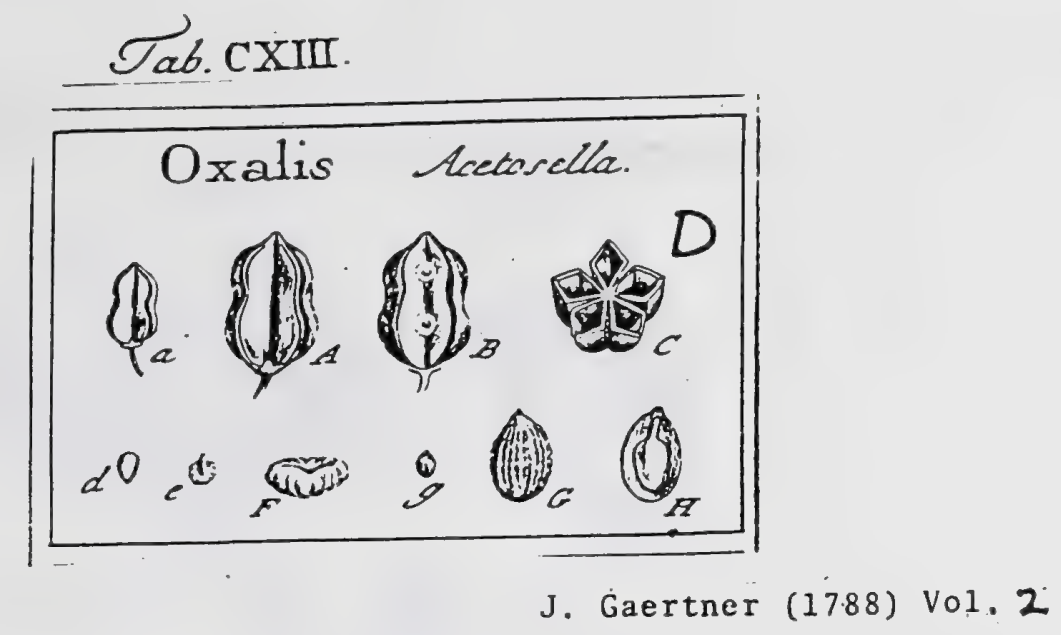

152

DCLXII. OXALIS. LINN. gen. 582. Ozys. TOURN. inft.t. ig.

Calyx quinquepartitus. Cor. petala quinque, unguibus connexa. Stan. decen. Ovar. fuperum. Styl. quinque. Capfula quinquelocularis, quinqueloba. Semina arillo carnofo elaltico obtectia.

Oxalis Acetolella. Tab. I13. fig. 5.

Trifolium acetofum. DoD. penzpt. 578 .

Lujula. BLakw. berb. t. 308 .

Oxj's fcapo unifioro, folis ternatis obcordatis, radice dentata. L. HALL. bift. 10. 928.

Oxalis fcapis uniforis, foliis ternatis: foliolis obcordatis pilofis. LINN. fyft. veg. 432.

PER. Capfula ovato-oblonga, memhranacea, diaphana, pentagona, quinqueloba, quinquelocularis, decemvalvis, ad angulos externos longitudinaliter dehifceus.

REC. nullum, proter papillas duas, annulo flavo cinctas, in angulo centrali loculamentorum, quibus fingulis, fingulum femen affixum.

SEM. duo regulariter, vix plura, intra arillum latentia, ovata, lenticulari compreffa, friis elevatis fcabris exarata, e Juteo rufefcentia.

Arillas carnofus, albus, femen totum involvens; primum glaber \& undique claufus, demum vero ab apice elaftice dehifcens \& in fo revolutus, corrugatusque femen cum ingenti impetu explodens.

IN T. fimplex, membranaceum.

A L B. carnofum, duriufculum, ut fere cartilagineum, album.

EMB. longitudine albuminis, inverfus, 1scteus. Cotyl. foliacex, ellipticx. Rad. teretiufcula, longa, fupera.

a. A.) Capfula integra \& dehifcens. B.) Ejusdem loculanientum anterius apertum, receptaculi papillas oftendens. C.) Eadem transverfim diffeQta. d.) Arillús integer. c.) Idem dehifcens. F.) Ileur poft excuffum femen corrugatus. g. G.) Semen denudatum. H.) Iden lungitudinaliter diflectum cum litu \& figure embryonis intra albumcn.

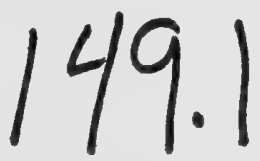




\section{Tab.LXV.}

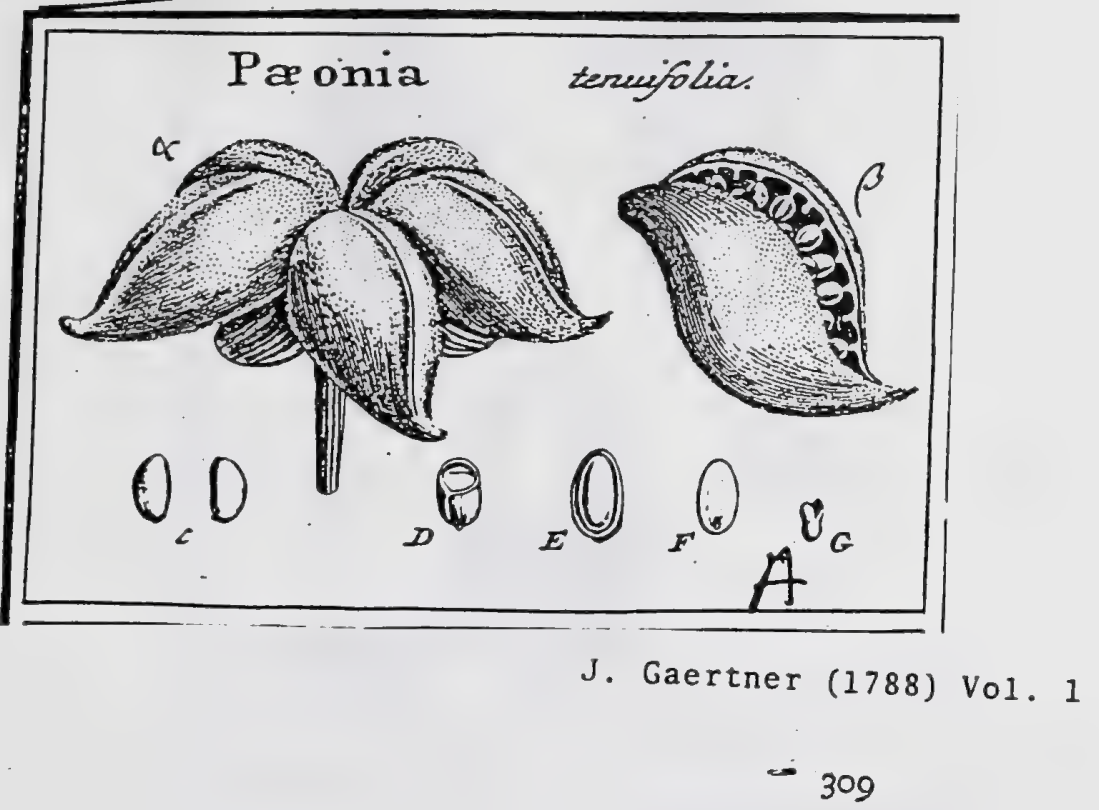

CCCXCUI. PEONLA. TOURN. t. 146. LINN. gen. 678 .

Calyx pentaphyllus. Cor. penta-I. pluripetala, rofacea. Stam. numerofa. Styl. bre-
viffimi. Capfulx fubquina viffimi. Capfulx fubquinz, leguminofx. Semina fubglobofa, nitida.

Peoni a tenuifolia. Tab. 65. fig. I.

- Paonia foliis linearibus multipartitis. LIN N. fa/c. 1. t. 5. fyf. nat. 502. $P E$ r. Capfulx leguminof dux ad quinque, ovatx, ventricofx, rofratx, reflexo pa-
tentes, pubefcentes, uniloculares, latere fuperiore $f$. interno dehifcentes.

REC. futurx dehifentis margo uterque, cui femina alternantia, duplici ferie aflixa. SEM. plura, elliptico fpharoidea, glabra, nitida, ferrugineo nigra, inferne umbilico
prominulo, oblique truncato, comprefto, \& ad alterum latus hilo filiformi notata.

IN T. duplex: exterius crufaceum, fragilc; interius tenuifimum, pallidum.

$\Lambda$ LB. fémini conforme, carnofurn, aqueo pallidum.

Е м в. fubcylindricus, minutulus, in bafi albuminis loeatus, lacteus. Cotyl. plano convexx, brevifimx. Rad. fubglobofa, relative centripeta.

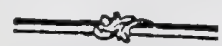

a.) Fratus comporitus, quinqueeapfularis.

feminum, c.) Semina foluta, D.) Semen ta ) Capfula feparata, delifcens, cum infertione denudatus, F.) Embryonis fitus intra albumen

Capfularum numerus ternarius in hac fpecie foparatus.

quinarium lxpe adfcendit.
.

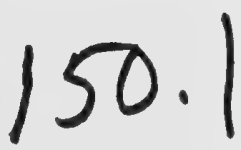




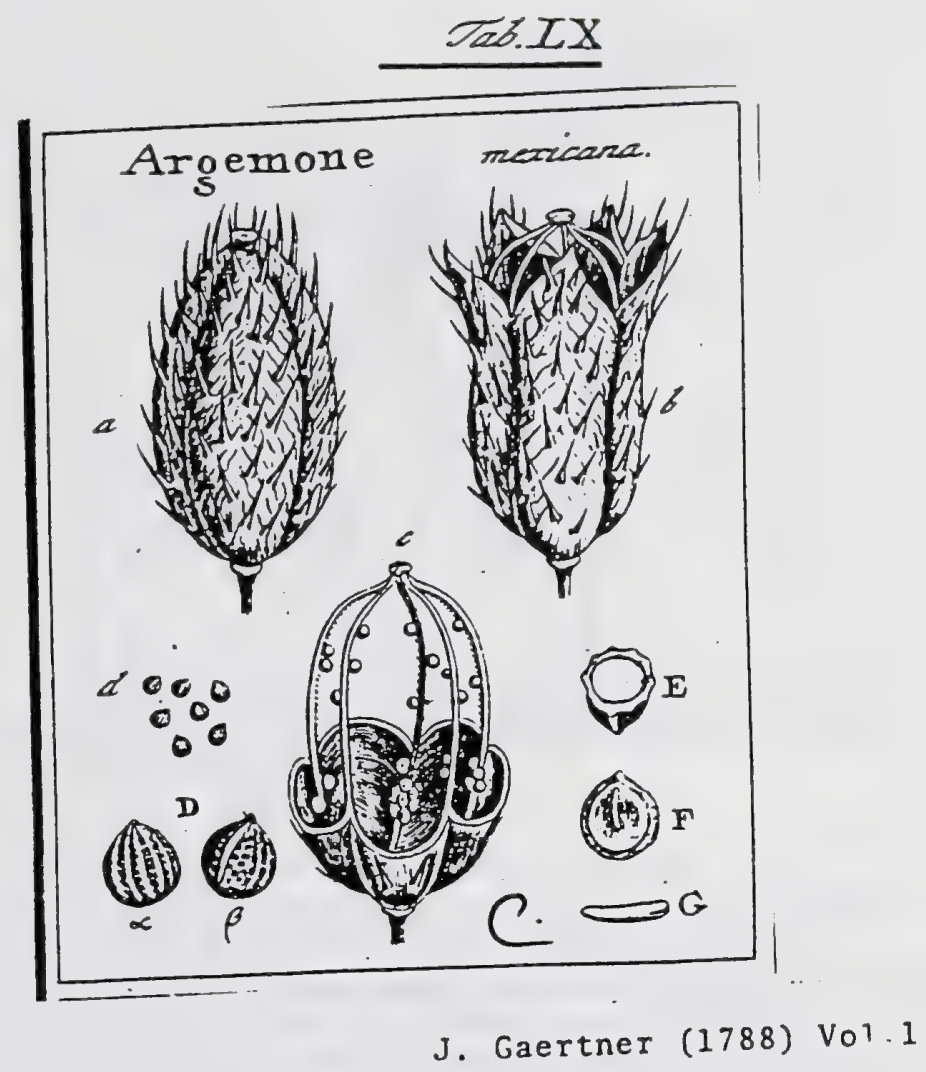

289

CCCLXII. ARGEMONE. T o R N. $t$. 221. Li Nin. gen. 649.

Calyx bi-1. triphyllus deciduus. Cor. pentapetala. Stam. numerofa. Stigma-capitatuin, parvum, quinquecrenatum. Capfula unilocularis, apice in valvulas delifcens. Recept. parictalia. Sem. plurima.

ARGEMONE mexicana. Tab. 60. fig. 2.

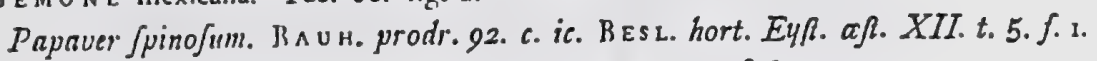
Argemone capfulis fexvalvibus, foliis fpino/is. LIN

PER. Capfula fupera, ovata, nigmate depreflo terınina!a, rotundato pentagona, fpinis fetaceis diffitis armata, unilocularis, femiquinquevalvis.

REC. nervi filiformes, angulis capfula introrfum prominulis adnati, poft dehifcentiam valvularum perfiftentes, in higma coëuntes.

SEM. numerofiftima, fphxrica, cancellato-fcrobiculata, ad alterum latus hilo comprelio flipata, atra.

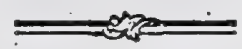

IN T. duplex: exterius crufaceum, fragile ; interius menibranaceum, chalazâ ferru. ginea notatum.

A L B. feınini conforme, carnofum; friakile, aqueo-pallidum.

Eмв. teretiusculus, dinidio albunine paulo longior, niveus. Cotyl. brevifimx. Rad. cylindrica, centrifuga.

a. b.) Capfula integra \& delifeens. c.) Receptac. denudata. d. D.) Semina feparata ; hine (a.) fimpliciter fulcato cancellata; inde ( $\beta$.) hilo compreffo notata. E. F.) Seminis \& albumiuis fetio. nes, cum fitu embryonis. G.) Embryo Separatus.

Valvularum \& receptaculorum numerus variat a quaternario ad fenarium.

Papaver canbricum LI N N. genuina ef Argemones fpecies, quia capfulam, valvulis, non autern poris, dehilcentem gerit. 


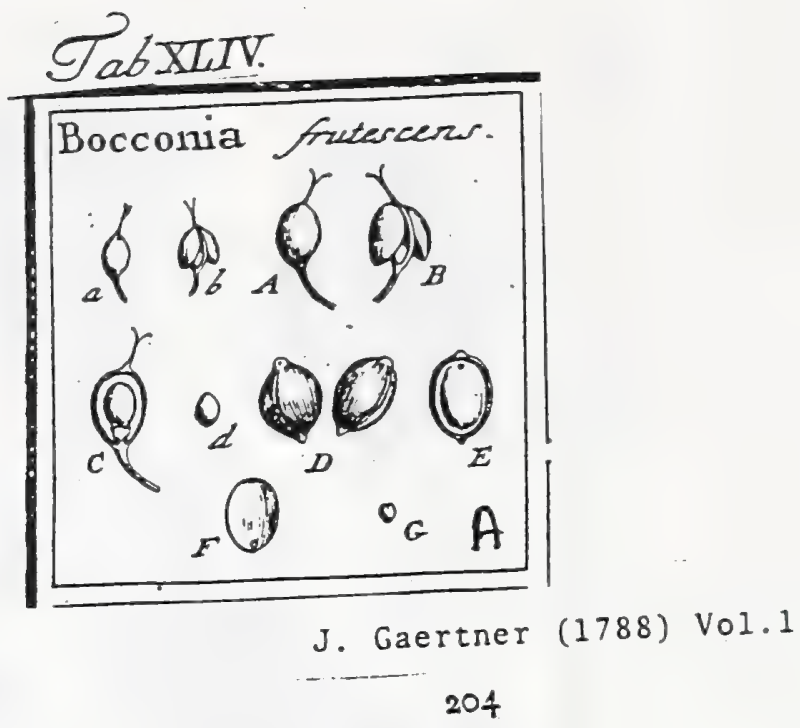

CCXLVI. BOCCONLA. Plum. ger. t. 25. Lin g. gen. 591.

Calyx diphyllus. Cor. nulla. Stam, duodecim. Styl. bifidus. Capfula filiquofa" unilocularis. Recept. pulpofum coloratum. Semen unicum globofum. Boccovia frutefcens. Tab. 44. fig. I.

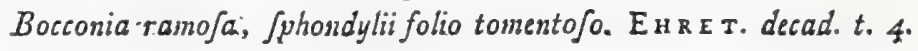

Bocconia. Lin.s. Ji/ft. veg. 44 I.

Ex herbario Bankfiano.

PER. Capfula filiquofa fupera, elliptica, fuperne in fylum bifidurn, inferne in pedunculum proprium elongata, turgide lenticularis, unilocularis, bivalvis. Valvulx. coriacex concava rufelcentes a bafi dehifcentes, perifleate filiculx futura integercima., filiformi, annulari.

REC. pulpa mollis, fernen involvens atque bafi capfulx affigens, cinnabarino rubra; demum exarefcens in membranam tenuern, pallidam, cellubofam, curn fernine? deciduam.

SEM. unicum, elliptico Spharoideum, fuperne levi umbone, inferne autern conico" mucrone notatum, ex altero latere hilo filiformi infruchum, glabrum, tefaceum aut nigrum.

IN T. triplex - extinum : cuticula tenuis ex pulpa indurata ; medium cruftaceum, duruin, fragile, ferrugineum aut atrum; intinum membranaceum, tequifimum; chalaza fufca in vertice notatum.

A.L. femini conforme, carnofun, friabile, flavum, aquam quoque juteo colore ungens.

Esв. minutifimnus, fubglobofus, albicans, in bafi albuminis locatus. Cotylo bre villunx. Rad. rotundata infera.

a. A.) Capfula integra. b. B.) Eadem dehifcens. C.) Sotura fuperftes eam exficeato feminis reeptaculo. d. D.) Semen feparatum. E.) Nucleus desudatus. F.) Albumen veruicaliter fellum, cum embryone. G.) Entbryo autiur.

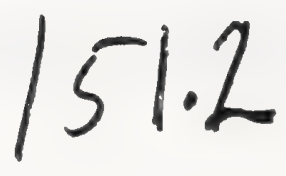




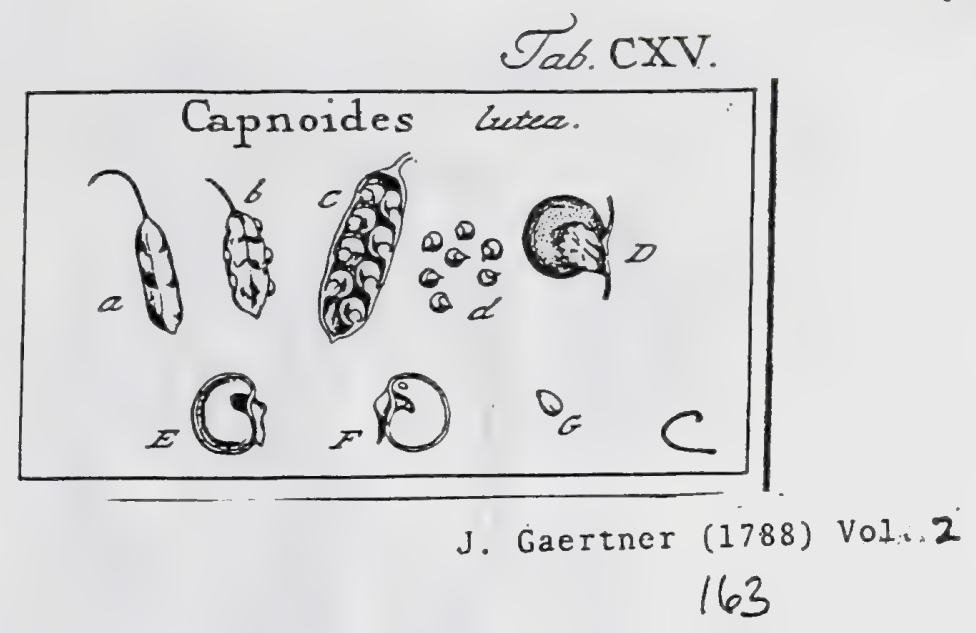

DCLXXV. C A P N OIDES. TOURN. inft. t. $23 \%$

Flores Fumarix fimiles. Capfula filiquofa, unilocularis, bivaivis. Semina receptaculo intervalvulari atfixa.

Carnoides Jutea. Tab. is . fig. 3.

PSeudofunaria fore luseo. Riv. tetrap. t. 74. bene.

Funtaria tingitans, radice fibrofa, perennis, fiore ex albo farvefcente, faliquis ctrtis. PIUK. pbyt. t. go. f. 2.

Funnaria filiquis linearibus setragonis, caulibus diffufss acutangulis. Lixw. Jjy. veg. 637 .

PER. Capfula filiquofa, oblonga, rhombeo-compreffa \& ad margines anceps, unilocularis, bivalvis.

REC. filiforme, valvularum marginibus interjectum, utrinqque femiferum.

SEN. plura, octo 1. decem, lenticulari-reniformia 1. roftellata, atra, fplendentia, punctis confertifinis, parum elevatis confperfa. Umbilicus glandula biloba crenulata aiba ltipatus.

IN T. duplex: cruftaceum fragile, \& membranaceum pallidum.

$\Lambda\llcorner$ B. reniformi - roftratum, carnofum, pallidum.

EM B. ninutifimus, ovato-globofus, lacteus, in roftro albuminis hærens. Cotyl. cralix, brevilimx. Rud. attenuata, centrifuga.

a. b.) Capfula integra \& dehifens C.) Valvula altern, cum infertione femimum. d. D.) Semina feparata, integrs E.) Albumen denudatum. F.) Idem longitudinaliter dirtecum, cum fitu eunbryonis, G.) Embryo folutus.

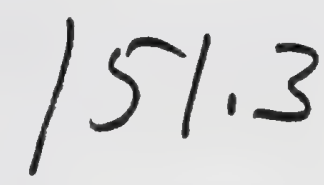




\section{Tab. CXV.}

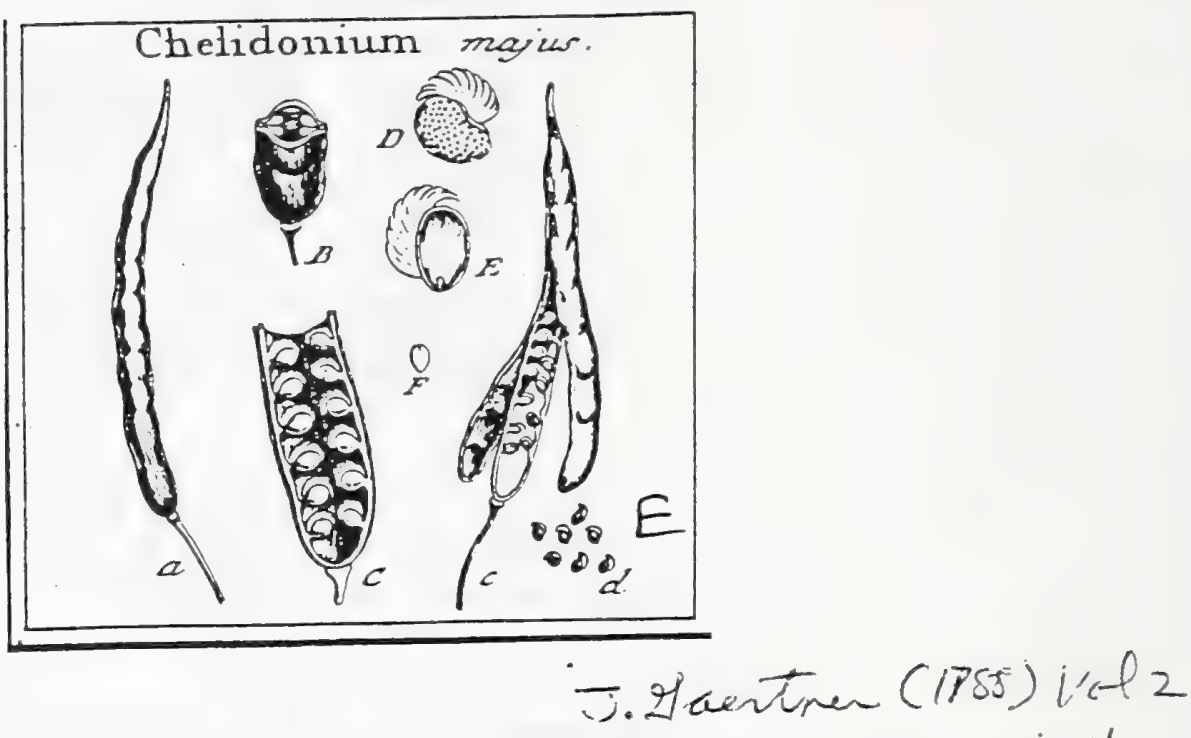

DCLXXVII. CHELI D ONIU M. TOURN. inf. t. II6.

\section{- LIN N. gen. 647.}

Calyx diphyllus. Cor. tetrapetala, regularis. Stam. numerofa. Ovar. fuperum. Stigma feffile. Capfula filiguofa, unilocularis, bivalvis. Semina bilateralia, crifta glandulofa fupra umbilicum.

Chelidonium majus. Tab. 115. fig. 5 .

Chelidonism najus. Fuchs. bift. lut. p. 865 . germ. ic. 496. BLsRw, berb. t. gI. OED. for. dant. 2. 542. \& 676 .

Cbelidonim lobis foliorum fubrotumdis. HALL. bij. n. $1059 \%$ -

Crelidonizm pedunculis zonbellatis. Lixs. [yfe. veg. $48 \%$.

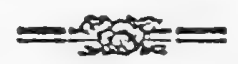

Ṕ ER. Capfula filiquofa, longa, fubanceps, ad feminum fedes nodulof, cetra glabra, unilocularis, bivalvis.

REC. filifurme, valvularum marginibus lnterjectum, utrinque duplici feminum ferie longitudinali ftipatum.

SEN. numerofa, parva, ovata; longitudinaliter obfolete fcrobiculata, fplendentia, nigro-fufca, in dorfo, paulo fupra umbilicum, glandula criftata compreffa alba infignita, qux poft lapfum fuum cicarricem oblongam relinquit.

IN T. duplex: cruftaceum, fragile; \& menbranaccum, fufco- Spadiceum.

A I B. carnofum, aqueo-pallidum.

EMB. minutiffimus, fubglobofus, albus, in baf $\int$ acutioni extremitate albuminis pofitus. Cotyl. brevilinix. Rad. attenuata, centrifuga.

a.) Capfula integra B.) Ejus foctio transverfalis, cum gemino femirum ordine in rtsoque datere. c.) Eadem dehifcens. C.) Valvula altern, cum infertione ferinum d. D.) Semina Scparata integra. E.) Seminis \& albuminis fetio longirudiaalis, fitum embryonis oftcndens. F.) Ėmbryo folutus \& infignifime suAns.

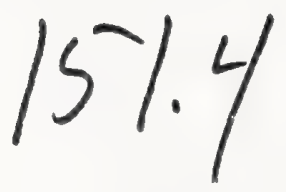




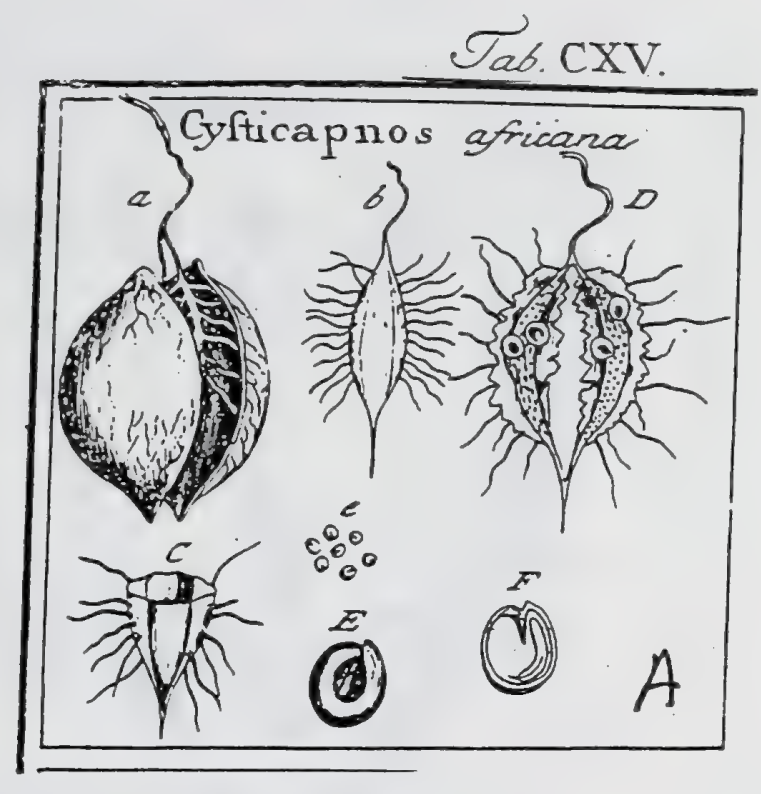

\section{J. Gaertner (17.88) Vol, 2}

Íbr

\section{CYS T I C A P N O S. BOERH.}

Flores Fumarix Gmiles. Capfula membranacea, unilocularis, intra Involucrum maximum, fubglobofum, bivalve, fubftantia arachnoideo-cellulofa farctum.

Crsticapnus africana. Tab. IIf. fig. I.

Cyficapuros africasa fcaxdens. BOERH. lugrll. 1. p. 310..t. 310.

Ftmaria alba veficaria, capreolss donata, fub exitunt autunni florens, etbiopica. PLuk. plyt. t. 335. $f \cdot \mathrm{j}$.

Futhtrin filiguis globofis acutis inflatis, foliis cirrbofis. Lins. fyft. veg. 637.

PER. duplex, compofitum ex cortice feu involucro externo, ab ipro ovario oriuncio, \& ex capfula, intra involucrum hxrente.

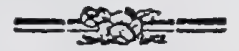

brohlucrum grande, fubcoriaceum, infatum, globofum, apice acuminatum, bivalve : valvulis intus fubltantia filamentofo-cellulofa ftipatis \& hujus ope cum capfula ipfa colicrentibus.

Capfula in axi involucri pofita, oblonga, utrinque filiformi-acuninata, comprelfiufcula, in medio membranacea, tenuifinna, diaphana, ad utrumque vero marginem incraffata, fuberofa, opaca, unilocularis, evalvis, a dehifente involucro irregulariter rumpenda.

KEC. nullum; fenima incraffatis capfulx marginibus affixa.

SEM. numerofa, rotundato - reniformia, verfus umbilicum levitcr comprefra, atra, glaberrima, fplendentia.

INT. duplex: exterius chartaceum, fragile; interins membranaceum, fufcum.

A L B. fubglobofum, roftellatum, grauulofe-carnofum, albicans.

E M s. teretiufculus, gracilis, leviter incurvatus, lacteus, in albuminis roftro collocitus. Cotyl. lineares, plaux, curvulæ. Rad. fulifurmis, centrifuga.

2) Invuluerum dehifeens. b.) Capfula integra, magnitudine anturili. C.) Ejus fedio trasverfalic, D.) Easlem 2 fecedentibus involucti valvulis difrupta, eum infertione feminum. e. E.) Sc miız fepartit. F.) Seminis \& albuminis fettio longitudinalis, cum fitu \& figura Embryoais.

Capfulam trivalvem dixerunt Linnzeus \& Adurfon, ab icone forfan Bocha. viana decepti, qua hac in parte a natura atqgue veritate recedit.

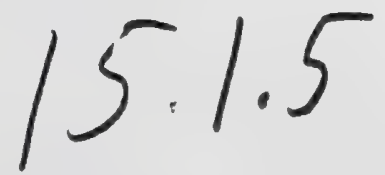




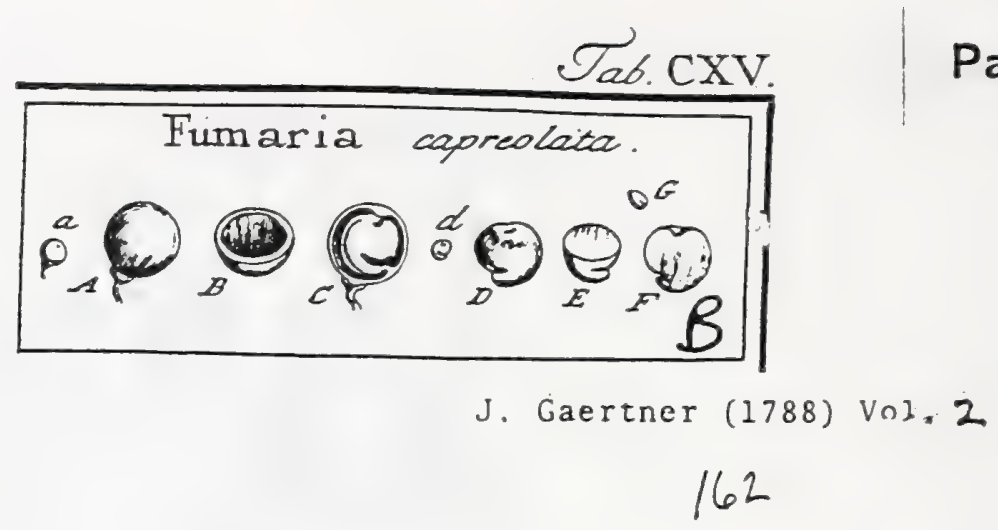

DCLXXIV. F UMAR I A. TOURN. inz/.t. 237. LINN. ger. 849.

Calyx diphyllus. Cor. tetrapetala, irregularis, frepe calcarata. Stam. duo, antheris in fingulo tribus. Ovar. fuperum. Styl. fimplex. Capfula uni Jocularis, evalvis, monofperma. Semen parieti affixum.

Fumaria capreolata. Tab. 115 . fig. 2.

Finnaria claviculis donata. MORIs. hif. 2. S. 3. t. 12. f. 3. OED. flor. dar. 丸̇ 340. Fummia pericarpiis molso/permis racemofis, foliis fcoudentibus Jubcirrbofis. LINN. fy $f$ t. veg. 637 .

PER. Capfula parva, fphærica, coriacea, dura, ut Nucula dici poffet, unilacularis, evalvis.

REC. nullum; femen parieti capfulx interno, paulo infra medium, ope funiculi umbilicalis brevifimi affixum.

S.EM. unicum, fubglobofum, fuperne fcrobiculo parvo exararum; inferne in roltellun breve productum, rufefcens.

IN T. fimplex, membranaceum, tenue.

A \& в. femini conforme, carnofum, lutefcens.

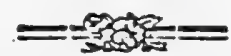

Eas в. minutifimus, ovato.globofus, in albuminis roftello pofitus. Cotyl. breviffmx. Rud. attenuats, centrifuga.

a. A.) Capfula integra. B.) Eadem dilfera. C.) Seminis in parictem infertio. d. D) Semeu integrum. E. F.) Albuminis fettio transverbalis atque longitudinalis, cum Gtu embryonis G.) Eubryo folutus.

Fumaria nobilis. Lisn.

Capfula matura herbacea, tenuis, friabilis. Semen grandiufculum, lenticuJuri roltellatum, atrum, glaberrimum, fplendens. Integ. duglex, exteriore chartaceo, arido, fragili. Reliqua ut in precedenti.

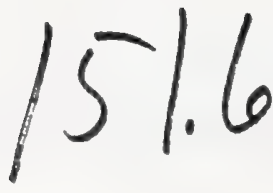




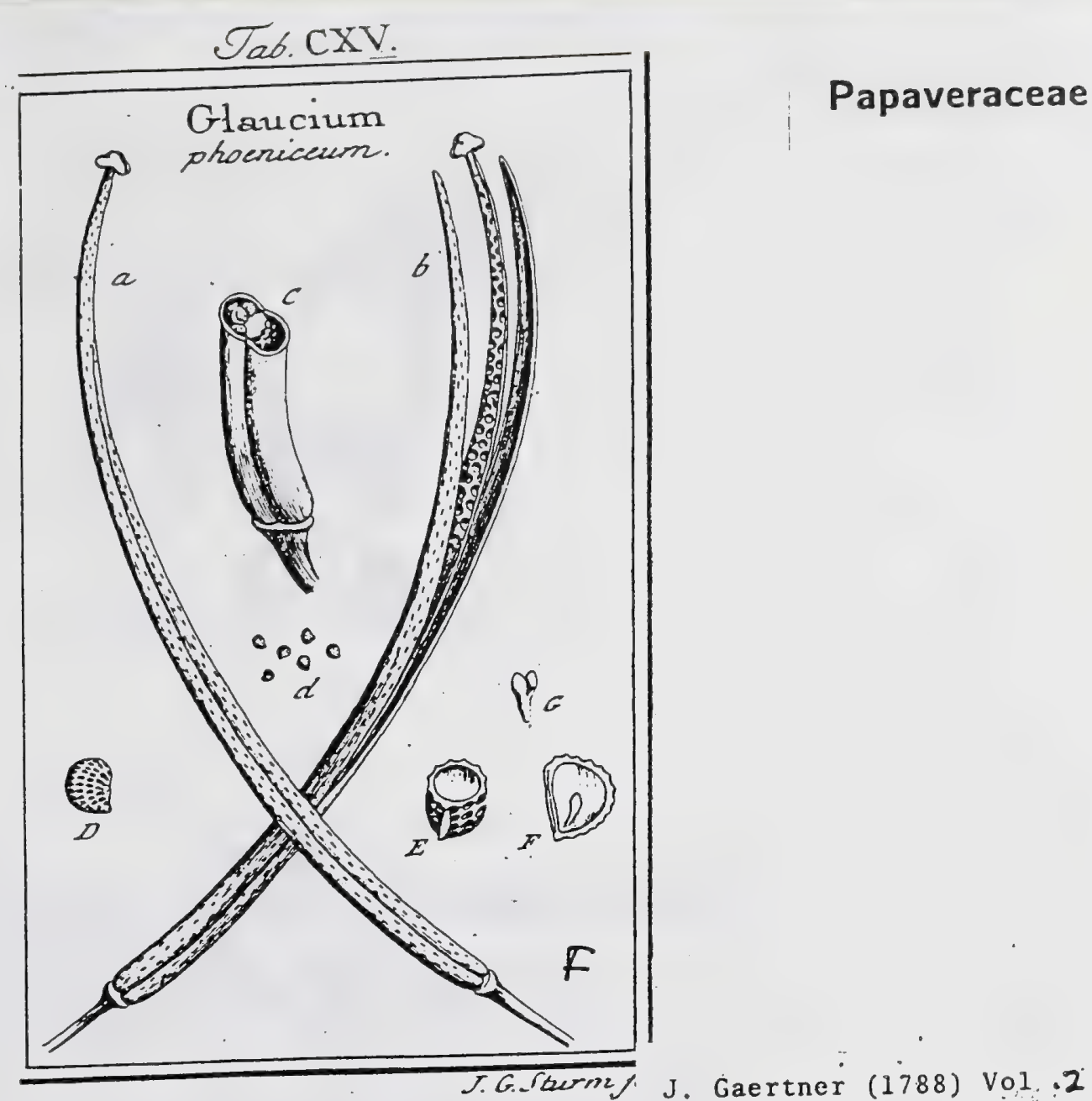

DCLXXVIII. GLA U CI U M. TOURN. inft. t. I30.

Flos Chelidonii finilis. Capfula filiquofa, bilocularis, bivalvis. Receptac. feminum centrale fungofum. Sem, numerofllima, globofa, raphe unilaterali, acuta, nuda.

Graucrum phœniceum. Tab. I1s. fig. 6 .

Papaver comiculatum, pboeniceo fore. Ceus. bift. 2. p. gr.

Chelidonium pedusculis unifloris, foliis felfilibus pimatifidis, caude bifpido. Lins. fyft. veg. 489 .

PER. Capfula Gliquofa, longifima (femipedalis \& ultra), fubulata, transverfim latior \& quafi ex duobus cylindris compreffis compofita, feris rigidis appreffis fcabra, bilocularis, bivalvis. Diffepimentum niarginibus valvularum interjectum.

REc. fungofum, crafum, a diffepimento non diftinctum, femina in profundis fcrobiculis, quin interdum intra fubltantiam furm inclufa, gerens.

SE M. numerofifima, parva, fubglubofa, altero Jatcre rectiufculo, ut ex globo. fis fubreniformia fint; ceterum foveolis quadratis per feries longitudinales digeftis pulchre areolata, altero latere colta $f$. raphe comprefia longitudimali inGgnita, nigricantia, aut ex cinereo fulca.

Is . duplex: cruttaceum, fragile; \& membranaceum, tenuiffimum.

A L B. carnofum, molliufculum \& fere friabile, aqueo-pallidum.

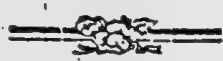

EM B. longitudine fere dimidii albuminis, teretiufculus, lacteus. Cotyl. breves, Rad. cylindrica, centripeta.

2. b.) Capfula integra \& dehifcens, cum receptaculi forma atque fitu. C.) Endern transverfe f:ez. d. D.) Seminz integra. E.) Seminis futtio transverfalis. F.) Ejusider atque albumiais featio vertiealis, cum titu embryonis. G.) Embryo folntus.

Glauciun luteun.

Papaver corniculatum. CAM. epit. 805. OED. flor. das. t. $5^{8} 5$.

Capfula longior, quam in pracedenti, cetera vero ei finilis. Semina ovato . reniformia, fcrobiculis multo frequentioribus, fed miinus profundis \& lineari oblongis exarnta, nigro-fulca. Rejiqua ut in priori. 


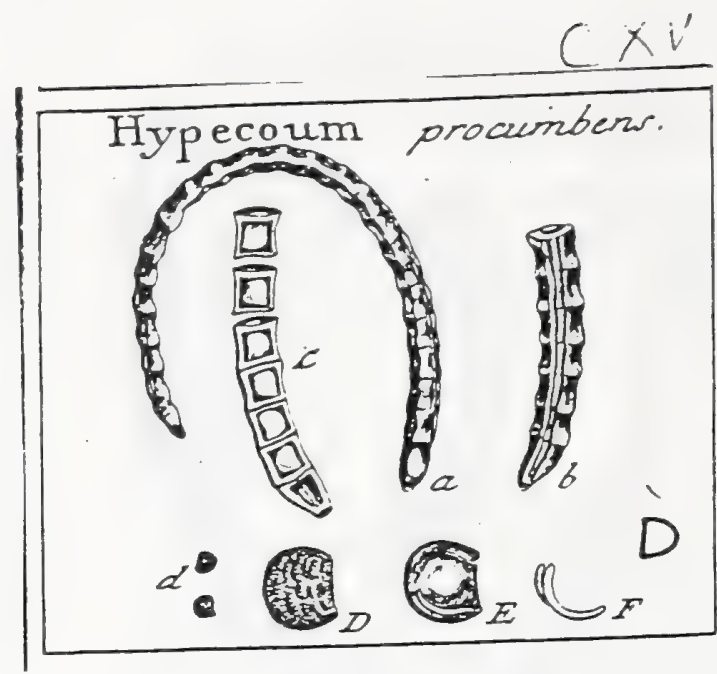

\section{DCIXXVI. HYPECOUM. TOURN. inft. 2. II5. LINN. ger. I IT.}

Calyx diphylius. Cor. tetrapetita, inaqualis: petalis trifilis. Stam. quatuor. Ovar. Superums. Styl. duo. Capfulis filiqquaformis, articulata, plurilocularis. Semina fulitaria, infertione bilaterali alteruante.

Hypecoum procumbens. Tab. 115. fig. 4.

Hypecoum. Dod. peinpt. 449.

Hypecoum filignis arcuatis comprefis articulatis. Lins. Jys. veg. 167 .

PER. Capfula filiquxformis, longa, arcuata, compreffa anceps, nodis transverfalibus articulata, atque ftriis longitudinalibus fulcata, multilocularis: loculamentis fimplici ferie longitudinali digeftis, vix fponte a fe invicem fecedentibus.

REC. nullum; femina angulo exteriori atque inferiori loculamentorum alternatim inferta, ut primum lxvạm, alterum dexteran, ac capfulix aciem umbilico fuo refpiciat.

SEM. folitaria, dena ad vicena in tota capfula, fubrotunda, altero latere quara truncata, lenticulari - conprefa, fubrugofa, elevato-punctata, nigro fufca.

INT. fimplex, fubcoriaceum, albumini arcte adnatum.

ALB. carnofum, durum, fulgranulofum, ad peripheriam aqueo-glaucum, in medio autem albidum.

EM R. filiformis, arcuatus, niveus, in bafi albuminis locatus. Cotyl. breviffimx. Rad. longa, curva, centrifuga.

a. b.) Capfula integra, \& transverfin diffectz C.) Loculamenta longitudiraliter apertz, eum

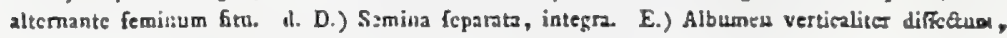
cum fitu eublrgonis. F.) Exbrgo folutus \& inGoniter alkalus.

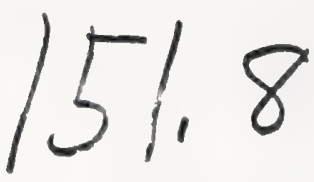




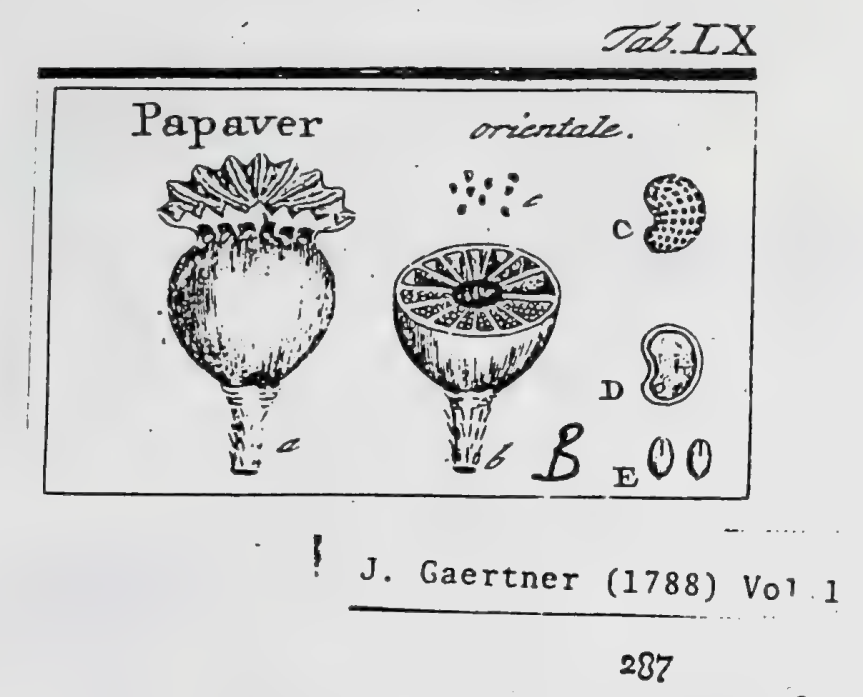

CCCLXIV. PAPAVER. TOURN. $t$. IIg. LINN. gen. 648 .

Calyx diphyllus deciduus. Cor. tetrapetala. Stam, numerofa. Stigma peltatum, radiatum, crenatum. Capfula uni-1. incomplete multilocularis, fub ftigmatis corona foraminibus dehifcens.

PAPAVER orientale. Tab. 60. fig. 4 .

Papaver orientale hirfutiffmmm, flore magno. TOUR N. it. 2. p. m. n8. t. 11 . Cоммel. rar. $34 \cdot t \cdot 34$.

Papaver capfulis glabris, caulibus unifloris fcabris foliofis, foliis pinnatis ferratis. Lis. s. fiyf. 2 cg. 490 .

PER. Capfula globofa, glabra, ainpla nigmatis pelta coronata, evalvis; in medio unilocularis; verfus peripheriam autem per fepta incompleta in concamerationes figmatis radiis numero pares divia, totidemque pariter foraminibus fub pelta figmatis dehilcens.

R E. c. diflepinenta ipfa incompleta, in utraque fua pagina, feminibus contecta.

SE M. numerofiffima, reniformia, friis longitudinalibus atque ferobiculis feriatim digenis egregic cancellata, fpadicco rufefcentia:

INT. duplex: exterius crufaceum, tenue, fragile; interius tenuiflimum.

A L B. femini conforme, carnolum, fubfriăbile, aqueo-pallidum.

Ex B. minutulus, ovato globofus, niveus, in anguftiori albuminis extremitate hxrens. Cotyl. brevilfumx. Rad. crafta, centrifuga.

a. b.) Capfula integra \& diferla. c. C.) Semina (eparata. D.) Seminis \&"albuminis fektio longitudinalis cuin fitu embryonis. E.) Enibryo feparatus. 


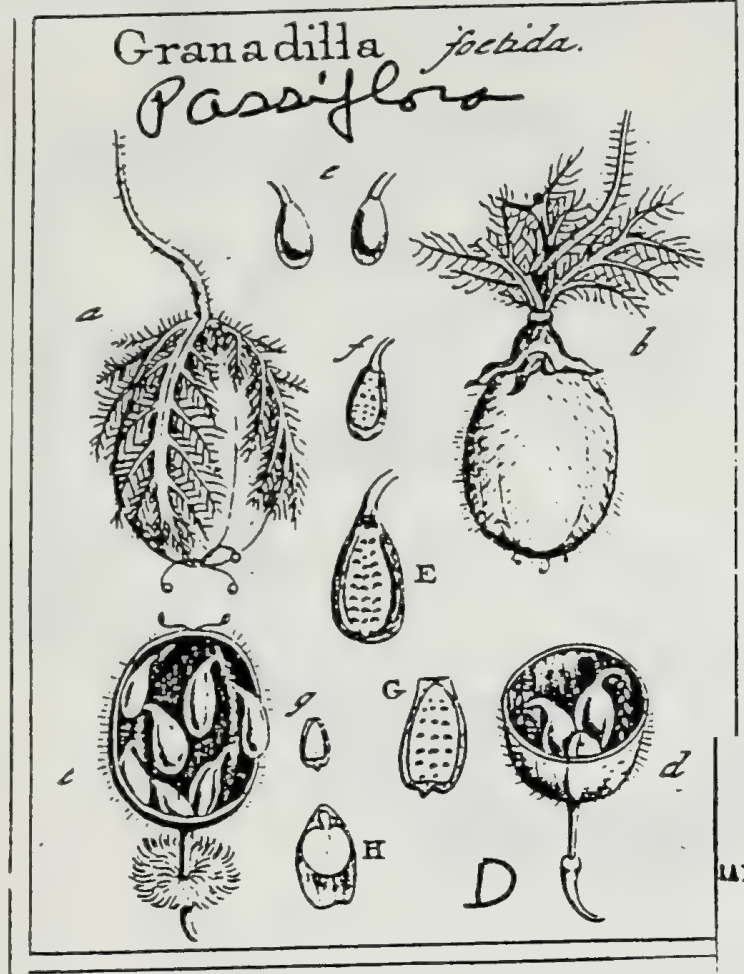

Passifloraceae

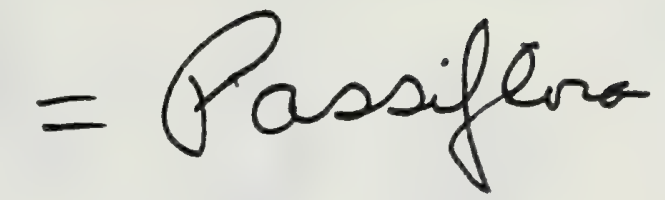

J. Gaertner (1788) koI: $2 \quad 479$

$G R A N A D I L L A$. vid. Vol. I. p. 289.

UNA DILLA normalis. Tab. 177 . fig. $\mathrm{t}$.

Pafiffora foliis bilobis bafi emarginatis: lobis linearibus obtufis divaricatis: intermedio obfoleto mucrorato. LiNN. by y. veg. 822.

Ex horto ducali Hohenheimenfi.

Bacca fphxrica (a - c.), herbaceo - carnofa, fexftriata, hirfuta, pallida; unilucularis, cava r. non farcta. Receptac. tria (c.), linearia, parietalia. Semina (f. F.) ex ovulis pluribus nonnifi tria l. quatuor maturefcentia, ovata, utrinque acuminata, turgide lenticularia, transverfim rugofa., nitida, ad alterum marginem funiculo umbilicali arcte adnato ftipan, ferruginea, arillo tecta. Arillus (d. E.) membranaceus, pedicellatus, albus, apice pervius \& denticulatus. Integ. exterius cruttaceun, fragile. Albumen (G.) curnofuni, duruin, niveum.

480

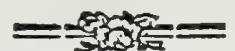

Granadilla fuberofa. ibid.

Palfifora foliis trilobis fubpeltatis, cortice fuberofo. LINN, l. c.

Icost. Jace. hort. 2. t. 163 .

Bacca ( $a-c$. ) elliptica, glaberrina, atro-cxrulea, tenuis, unilocularis, pulpa aquofi farcta. Ovula e receptaculis tribus parietalibus (c.) pendula. Semina (d. - G.) duodecim, obovata (f. F.), utrinque mucronata, Scrobiculata, ad alterum marginen funiculo umbilicali adnato ftipara, nitida, nigricantia, arillata. Arillus (E. F.) merabranaceu-pulpofus, tranfparens, non peduncu. latus: ore oblique truncato, edentulo. Telta feminis cruftacea, fragilis? Albumen (G.) niveum, ad normam teft:c fcrobiculatum. Embryo (H.) Joun? gitudine fere albuminis.

Granadilla Hondala. Tab. 180. fig. 10.

Clemutis indica folliculo aureo rotundo triangulo. HERM. mus. zeyl. 4t.

Hondali. Zeylonens. E collect. fem. hort. lugib.

Semina (a. b.) orbiculato - cordata, ad cordis finum pedunculo brevi ftipata, lenticulari-comprelta (b.), tuberculis acutis undique fcabrata \& inter horum interftitia foraminulis coecis pertufa, fordide nigricantia. Integ. duplex" exterins cruftaceum, durum, fragile, e fuperficie fua interiore (a.) proceflus fubulatos cavos \& foraminulis externis refpondentes promens, qui alte in albumen penerrant; interius tenuilfumum, pailidion. Aiburnen (c. d) femins confurme \& pariter pedunculo ftipatum, profundo foraminulentum, carnoe fum, album. Embr. (e. e.) albunine paulo minur, lutefcens. Coryls ovato-cordatse, juxta apicen ad alterum latus quafi pracifix, planx, foliacex. ommium tenuifimx. Rad. brevis, obtufa, in contrariam a feminis peduncula plagan directal.

Hondialx nomen diverfis plantis a Zinghalis tribuitur, ita procter modo dictam;

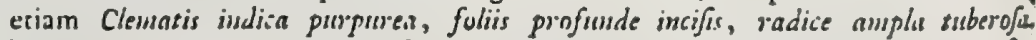

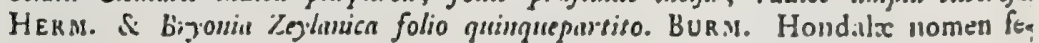
runt. Incertum igitur, nonne femina noftra funt Clematidis purpurex? at cerriffimum id, quod Bryouix elfe nequeant.

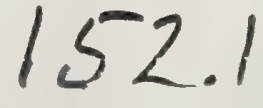


Passifloraceae

Passiffor

Tab. CLXXVII.

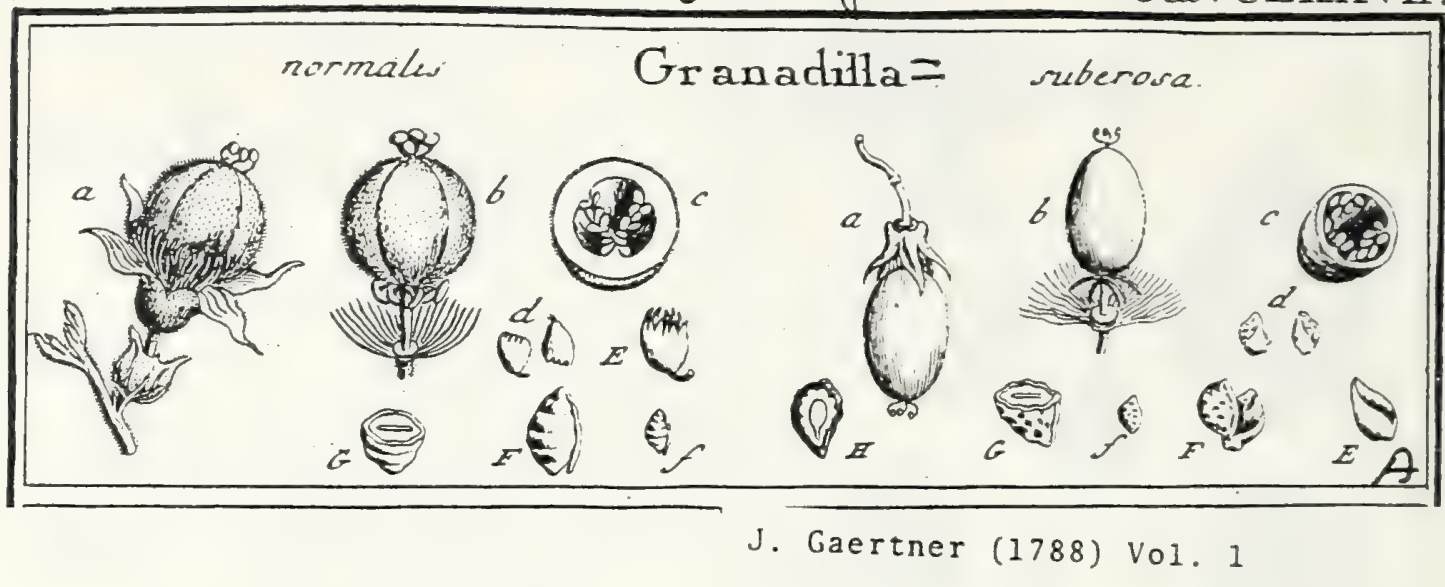

289

CCCLXV. GRANADIT.LA. TOUR K-t. $124^{\circ}$

Calyx pentaphyllus. Cor. pentapctala. Neclar. mu'tiradiatum. Stan. quinque. Seyl. tres. Bacea unilecularis pedicellata. Scmina baccata parietalia.

GRANADILla foetida. Tab. 60. fig. 5 .

Flos pafronis albus reticulatus. HIER. parad. 1.773 .

Pafffora foliis trilubis cordatis pilufis, involucris multifido capillavibus. Lrx. fyfl. vig. 823 .

290

PER. Bacea elliptico fpharoidea, pedicellata, villofa, tribus lineis fattratius coloratis longitudinalibus inferipta, extus viridis, intus fericco alba, membranacea, unilocularis. Cortex tenuis; pulpa nulla, fed cavitas vacua, inllata.

REC. linex tres, paricti baccx inferiptx, c quibus femina deorfum pendent.

SE s. plurima, vix duodecim apud nos maturefcentihus, baccata, e!liptica, peduncujata. Caro renuis, aquola, albida. Semen ipfum ovato oblongum, apice quafi pramorfum ac tridentatum, cetera comprefiusculum, ferobiculatum, faturate caftaneum.

Is I. triplex: extimum pulpofum, per xtatem exarcfecns; medium crufaceum, du. rum, fragile, profunde fcrobiculatum; intinum membranaccum, album.

A L B. ovato oblongum, fupra tutneatum, ab integumenti impreflionibus pariter fcrobiculatun \& fere cribratum, compietium, carnofum, album.

Ем в. dimidio fere albumine brevior, lactco albus. Cotyl. cordato orbiculatx, foliacex, tenuifinx. Rad. brevis, extrorfum craflior, centrifuga.

2. b.) Bacea integra. c. d.) Seminum in parietem bacca infertio. e.) Semina puipa veflita. f. F.) Semina denudata. g. G.) Albumen denudatum, uti tefa femisis fcrobiculatum. H.) Emiryonis figura \& fitus in albumise lougitudinaliter diffelo.

Albuminis fuperficies ferobiculata adco infrequens $e f$, ut $\mathrm{cx}$ hoc figno Granadillx femina facile agnofcas; vix enim in aliis haxc fabrica occurrit, praterquam in Guajaco, in unica Uvarix fpecie, \& in paucis quibusdam aliis.

152.2 


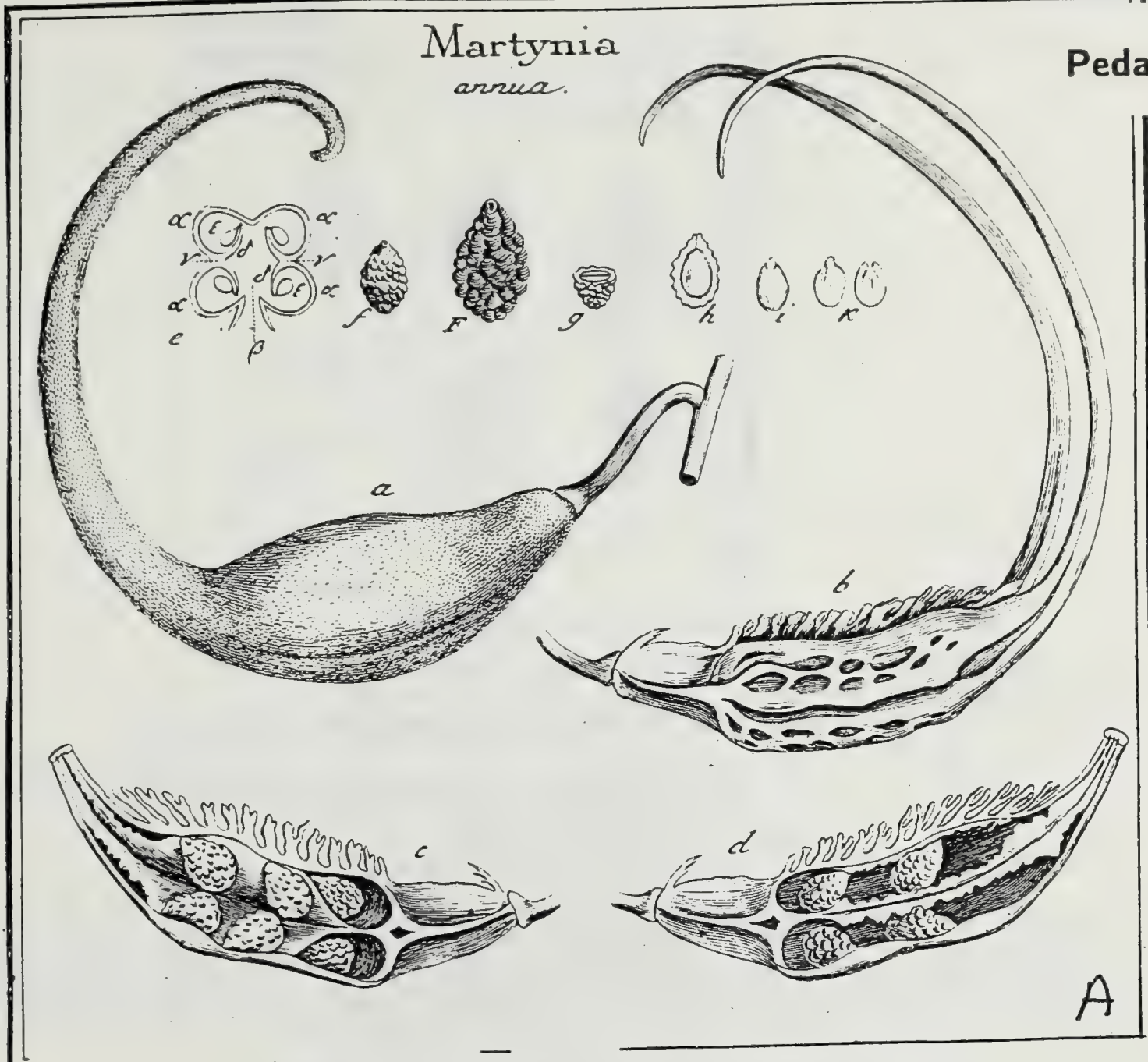

J. Gaertner (17.88) Vol. 2 I3r

DCXXXVI. M A R T Y N I A. LINN. gen. 753 .

Calyx quinquefidus. Cor. monopetala ringens. Stam. quatuor, inæqualia. Ovar. fuperum, quadriloculare. Styl. fimplex: ftigmate bilamellato. Capfula corticati, lignofa, roftrata, fjbquinquelocularis. Semina baccata.

MARTYNIA annua. Tab.110. fig. I.

Martynia annua villofa छे vifcofa, folio fubrotimdo, fiove magro rubro. MaRT. cent. I. p. 42. t. 42. EHRET. pict. t. I. f: 1 .

Mfartyuia caule raunofo, folitis cordato ovatis pilofis. MuLL. ic. t. 286.

Probofcidea. SCHмidel. analy. p. 49. t. 22. 13. opt.

Martynia caule rainofo, foliis integerrimis angulatis. LiNs. fyft. veg. 559 .

PER. Capfula lignofi, cortice coriaceo, tomentofo, bivalvi; caduco tecta, oblonga, bafi inxqualiter quadrialata, apice in longiflmum roftrum" incurvum producta, in medio autem rotunde quadrangula, fcrobiculata atque fulco deprefo utrinque infcripta, fubquinquelocularis, latere concavo, fimbria lacen munito, longitudinaliter dehifcens. Loculamenta vero quatuor; quintun autem enafcitur, quando difepimenta transverfalia per maturitatem a fe invicem recedunt \& in axi fructus fpatium inane relinquunt. Difiepimenta coriacea, craffo principio e fulcis lateralibus capfulx oriunila, mox autem in laminas transverfales, apice \& bafi deliquefentes, extenuata atque fibi mutno oppofita.

KE. c. nulium; fenina in fingulo loculo per feriem fimplicem longitudinalen difiepinemris affixa.

SEN. pauca, duodecim circiter in tota capfula; ovato acuminata, comprefliufcula, baccata, poft maturitatem tuberculato - rugofa, atra, cum internixto fplendore xneo.

IN T. duplex: exteriss, primo carnofum, deinceps fpongiofo - coriaceum, craf. fun; iitterins membranaceun, albun, tenue.

A L B. nullum.

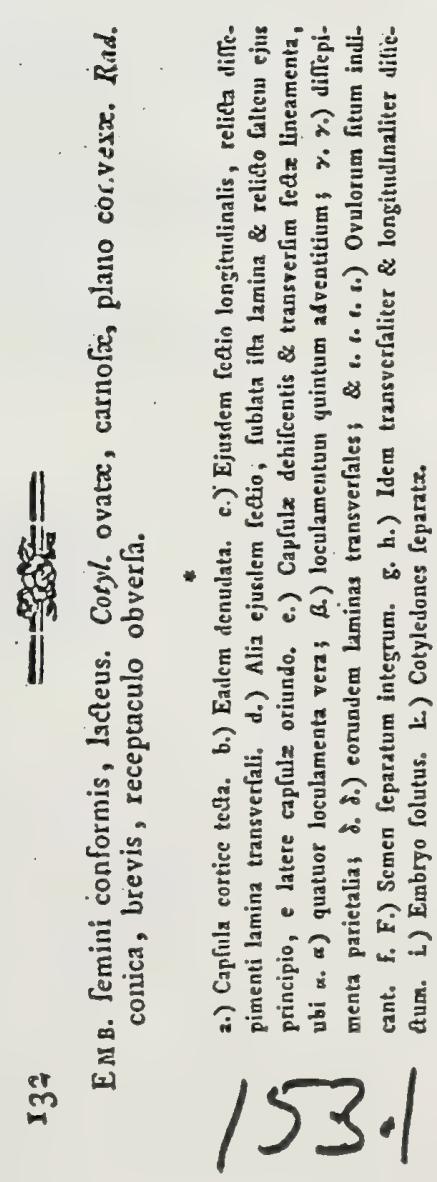




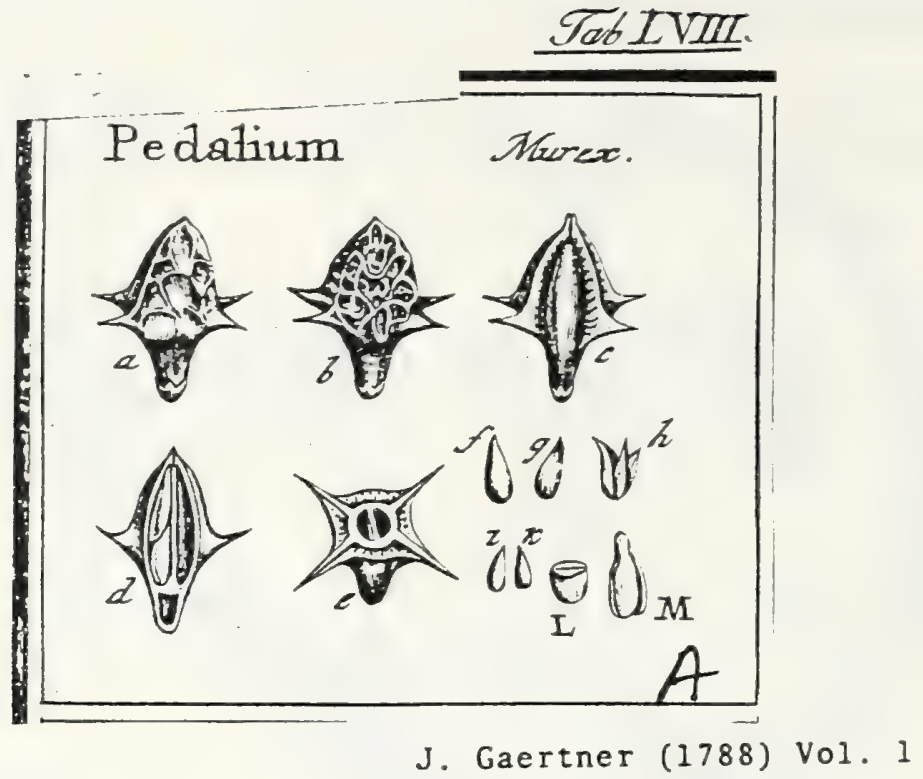

CCCXLVII. PEDALTVM. LiN . gen. 794.

Calyx quinquefidus. Cor. fubringens quinquefida. Stan. quatuor inxqualia, Styl, unicus. Drupa exfueca, quadrifpinofa, blocularis. Semina arillata.

PEDAIIU M Murex. Tab. 58. fig. 1.

Caka Mullu. Rhę, mal. Io. p. I43.t. 72.

Pedalium. Bu R s. Nor. ind. I39. t. 45. f. 2. L IN . fiff. veg. 580.

PER. Drupa exfucca, ovato pyramidata, tetragona, ad angulorum bafin fpinis quatuor horizontali patentibus pungentibus armata, inferne in pedunculuin inverfe conieum. producta atque calyce perfinenti excepta, rufécenti fufez. Cortex fuberofo fungofus, tenuis. Putamen oftenm, quadrialatum, fibris offeis türtuofis varie implexis crilparum, triloculare: Loculamentis dnobus fuperioribus fertilibus; tertio inferiore Aerili, Spurio.

REc nullum; femina diffepimento utriuque affixa, deorfum pendula.

SEs. in fingulo loculamento gemina, ovato oblonga, furfum astenuata, glabra, come prefíuscula, fụfa, arillata.

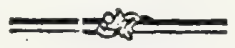

Arillus arido membranaceus, bivalvis: valvulis inzqualibus, fibi mutuo incumbentibus, atque feninis latus exterius obtegentibus, ad partem ventralem vero rima longitudinali dehifcentibus.

IN T. duplex: exterius coriaceum, tenue; interius membranaceum, intus fubcasnofum.

A L B. nullum, proter fuperficiem carnofam integumenti interioris.

E мв. magnitudine feminis, inverfus, lacteo albus. Cotyl. ovato oblongx, comprefius. culx. Rad. brevis, crafta fupera.

a.) Drupa integra. b.) Ejas entieula detracta cum fibris tortuofis putaminis. c.) Putamen a fibris intis repurgatum, quadrialatum. d.) Ejusdem rectio longitudinalis, Joculamentorum \& feminum fiturn oftendens. e.) Drupa transverfim fecta. f.) Arili valvula exterior. g.) Ejusdem valvula in(erior. h.) Vaivulx ambx in dorfo feminis (h) pofitx. i.k.) Semen denudatum: L.) Cotyledoo nes transverfin fectz. M.). Limbryo integer.

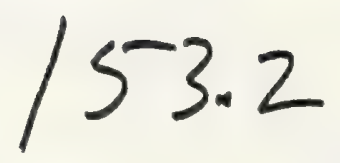




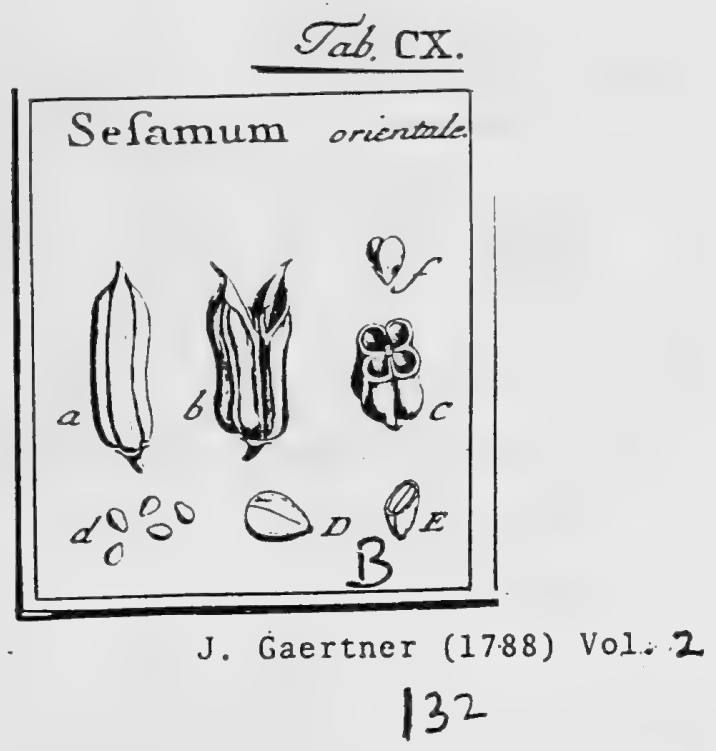

DCXXXVII. SESAMU M. LINN. gen. 782.

Calyz quinquepartitus. Cor. campanulata, quinquefida: lobo infimo majore. Stam. quatuor inæqualia, cum rudimento quinti. Ovar. fuperun. Styl. fimplex: ftigmate bilamellato. Capfula quadrifulca, quadrilocularis. Serm. plura.

Sesamum orientale. Tab. Iro. fig. 2.

Sefamum. RIv. monop. t. Ix4. bene.

Digitalis orientalis fefanum diffa. BurM. f. Zeyl. 87. t. $3^{8}$. f. 1.

Sefamum fotiis ovato oblongis integris. LINN. fyft. veg. 574 .

P.R. Capfula oblonga, acuminata, rotundato quadraugula, fulco depreffo in utroque latere inforipta, quadrilocularis, bivalvis. Dilfepimentum duplex: alterum craffius, folidum, e fulco valvularum dorfali oriundum; alterum tenuius, bilamellatum, ab infexis valvularum marginibus formatum.

REc. nullum, preter angulum centralem loculamentorum, cui femina longitudinaliter affixa.

SEM. numerofa, ovato-acuminata, compreffufcula, glabra, albicantia, a latere altero ftria tenui longitudinali infcripts.

IN T. duplex: coriaceum \& membranaceum, utrumque tenuifimum.

A L B. nullum.

$E_{M}$ в: Semini conformis, albus, fubpellucidus. Cotyl ovatz, carnofie, utrinque planiufculic. Rad. brevis, conica, horizontalis, centripeta.

2. b.) Capfula integra \& dehifeens. C.) Eadem transverfe ditecas. c. C.) Seminz feparatz D.) Scminis \& cotyledonum fetio transverális. C.) Embryo deaudatus.

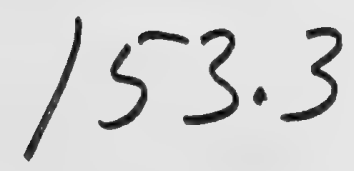




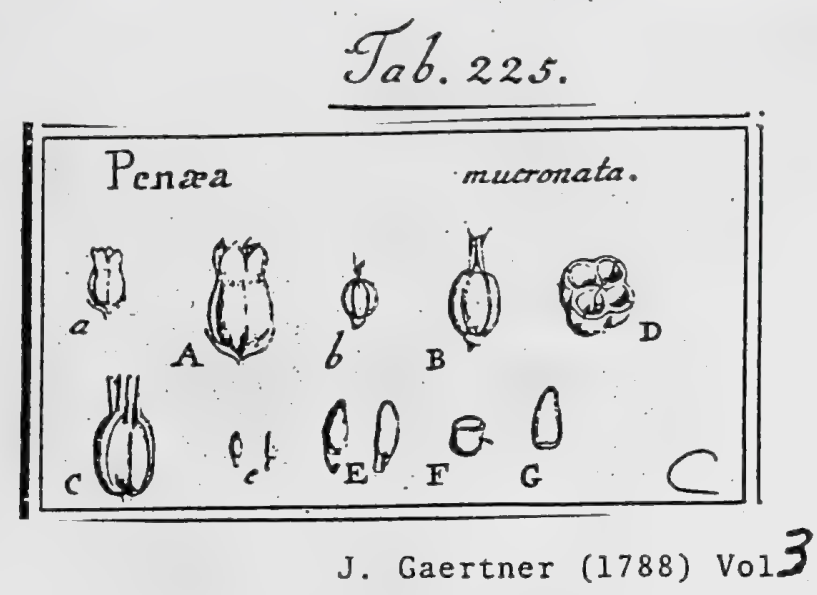

\section{P E N E A. \\ LINn, gen. 138. ed. Schreb. 182. Juss. gen."p. 4rg, LAMARG ill. gen. t. 78 .}

Flores $b_{2} f_{1}$ bracteis duabus, oppofitis, fubulato-linearibus 1 o ovatis inftrudi.

Cal. nullus: nifi corollam yelis. Cor. monopecala; tubo campanulato 1. infundibuliformi; limbo quadripartito, brevi. Stam. quatuor; filamenta bre villima, ad divifuras limbi jnferta; antherx erectx, utrinque emarginatz. Ovar. fuperum; Atylo fimplici, filiformi, 1. tetragono: angulis membranar ceis; ftigmate capitato, 1. cruciato - quadrilobn. Capl, chartaceo - coriacea, quadrifulcata, quadrilocularis, quadrivalvis; valvula.medio feptigera; loculamenta difperma Rec. nullum. Sem, bina, umbilico appendiculato ịnftructa, Alb. carnofum. Emb. ... .

Penaza mucronata. Táb. 225 . fig. 2.

Tithymals myr.jnites facie, arbufcula aethiopica, folio parvo e lata bafs in acutiff fruzum mucronem frubito definente, copitulis origuni. PLUKN. mant. p. 183.

Erica africana unedouis flore amplo, foliis cordiformibus in acumen defmentibns. RAJ. dendy. P. 97 .

Penuea foliis cordatis acuminatis. BERG. cap. p. 3a. LiNn. fyje. veg. ed. 14. p. 354.

fenasa floribus terminalibus, foliis acuminatis glabris. Тнимв. prod. p. $\$ 0$, WILld. Spec. pl. T. 1. P. 1. p. 626. PERSOON fyn. I. p. 134.

Ex collectione Delefertiana.

PzR. Capfula intra calycem coriaceum hærens, parva, ovato-oblonga, rotundato = tetragona l. quadriloba, ttylo perfiftente tetragono faftigiata; angulis membranaceis per fulcos caplula decurrentibus; nembránaceo - chartacea, ab apice cum ftylo per dorfum loborum quadrifariam dehifcens, guadrilocularis, quadrivalvis. Diđepimenta membransceo-claartacea, medio valvarum dorlo inferta, per axem cum valvulis fere ad bafin usqgạe dehifcentia. Luculamenta difperma.

REc. nullum : \{emina anguhs internis loculamentorum paululum callolis prope bafin unbilicis adhrerent.

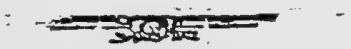

SEM. In quovis loculamento bina, erecta, accumbentia, ovato-öblonga, hine convexiufcula, inde plana, dorfo falcata, ventre rectiufcula, glibra, fu$f_{c a}$, bafi umbilico appendiculą̧o inftructa.

Umbilictus appendiculatus, difcretus, dimidium femen longitudine fere xquans, ovatus, fungofus, pallidus.

IN T. duplex: exterius coriaceum, craffiufculum; interius tenuifimum, adnatum, pallidum.

A L B. ovatum 1. ellipticum, bafi truncatum, cxterum femini oonforme, carnofum, lutefcens.

EN B....

EXPLICATIO FIGURE

1. A.) Fratus integer. b. B.) Capfula integra, denudata. C.) Eadern dehifcens. D.) Ejusdem fetto transperfalis. e. E.) Semina feparatz, ab utraque parte vifa. F.) Sener umbilico deftitutrm, transverfe diffetum. G.) Ejusdem Icttio longitudinalis.

In multiplici albuminis folidi \& (ut mihi vifum eft) bene maturi ex fpeciminibus, $a b$ ipfo Thunbergio collectis, nullum embryonis veftigium detegere valui; quare fufpicor, ovula frequentius imperfecta vel manca fœcundatione frui, aut embryonem effe ex minutiflimis. 


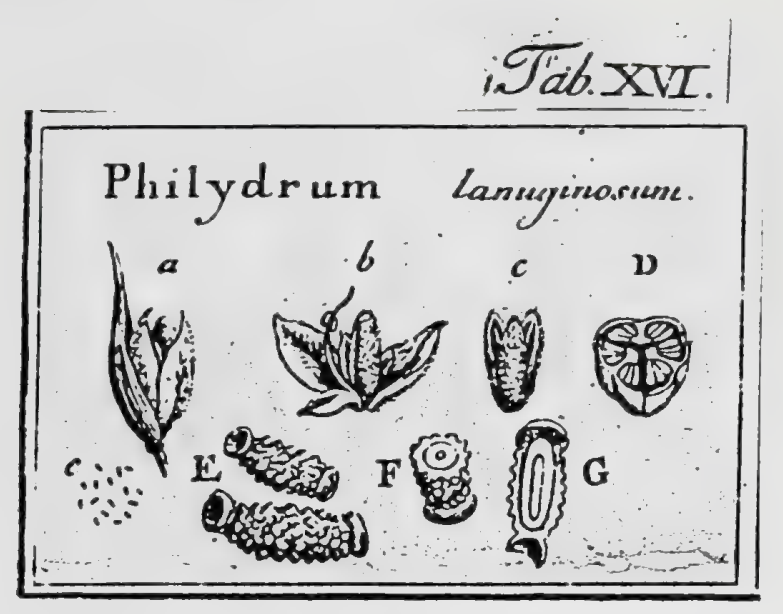

J. Gaertner (1788) Vol..1

Philydraceae

.62

\section{PHILYDRUM. BANES.}

Spatha fioralis monophylla, ovato acuminata, corolla longior. Cal. nullus. Corolla tetrapetala, flava: Petalis duobus exterioribus majoribus, ovatis; interioribus`dimidio minoribus, lanceolatis. Fulamentum unicum, liberum, fupra medium Antheris geminis fubglobolis. Stylus unicus. Capfula fupera, trilocularis. Semuina plurima, fubfcobiformia. (Ex fchedis b. Solandri.)

PнIL Х R U M lanuginofum. Tab. 16. fig. 10.

Ex herbario Bankfiano.

PER. Capfula fupera, oblonga, obfolete trigona, lanata, trilocularis, trivalvis: valvulis inedio feptigeris.

REc. margo diffepinentorum centralis, incraffatus, cui femina utriuque inffitu horizontali affixa.

SE M. numerofilima, misutifima, teretiuscula, undique tuberculis irregularibus fcabrata, fufco ferruginea; fuperne obtufa, quafi.pilçolo tecta; inferne elongata in umbilicum inembranaceum, pallide albicantem, profunde concavum.

INT. duplex : exterius fubcoriaceum; interius membranaccum, utrumque tenuiffimuin.

A L8. Femine brevius, cylindricum, carnofum, aqueo-pallidum.

EMв. monocotyledoneus, rectus, filiformis, longitudive fere albuminis.

a.) Capfula matura, (patha atque flore obvolata, b.) Capfula, didutis floris partibus, denudata. c) Eadem dehifcens. D.) Ejus fettio transverfalis, cum feminum infertione, e. E.) Semina oatarali \& außta magnitudine. F.) Semen uransverfe \& G.) Idem longitudialiter fe(tun, formam umbilici, abuminis \& embryouis exlibens,

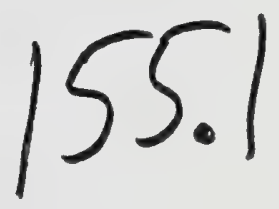




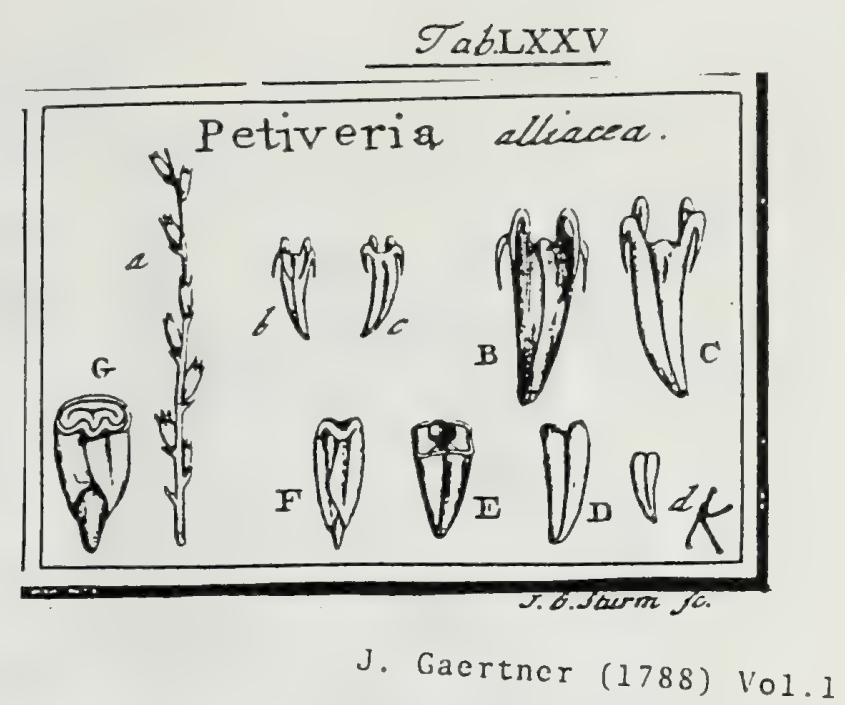

\section{CCCCXCII. PHYTOLACCA. Tourn. t.154. L I x x. gen. 588 .}

Calyx pentaphyllus perfinens. Cor. nulla, nifi calycem velis. Stam. odto, ad vi. ginti. Styl, decenn. Bacca decemlocularis. Semina lenticularia, nitida.

Pнуто о AсCA icolandra. (mexicana) Tab. 77. fig. 8 .

Phyjtolncen fpicis florum longiffinis, radice anmua. MItr. L. didt. ic. t. 207.

Phytolacca furibus icnfandris decagynis. L IN

PER. Hacca globola, vix deprefli, non fulcata, apice cxiguo puncto excavato notata \& decen ftylis perfillentibus terminata, glabra, exrulefcenti utra, pulpofa, deconlocularis. Loculamenta propria membrana tenerrima veflita. Pulpa atro. fallguinea.

REC. nullum; femina fundo loculanentorum prope axem fructus aftixa.

SFs. folitaria, Lenticularia, brevifime rofellata, glabra, nitida, atra.

$1 \times T$. duplex: exterius chartaceum, fragile; interius tenuifimum, pallide lutefcens.

$\Lambda$ \& в. centrale, farinofum, candidiflinum.

EM D. teretiusculus, periphericus, amnularis, e Aramineo albicans. Cotyl. Senniteretes. Rad. craflitie coryledonum, infera \& finul centripeta.

2.) Spica matura. b.) Bacca integra. c.) Ejus loculaments. d.) Seminum fitus, e. E. ) Se nina frparata. F.) Seineu transverfe feflum G.) Esnbryonis \& ajouminis fitus intra fenten. H.) Eubrjo feparatus.

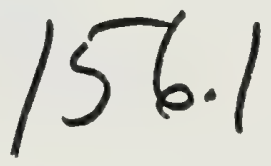


$\tau_{a b}$. L XXVII

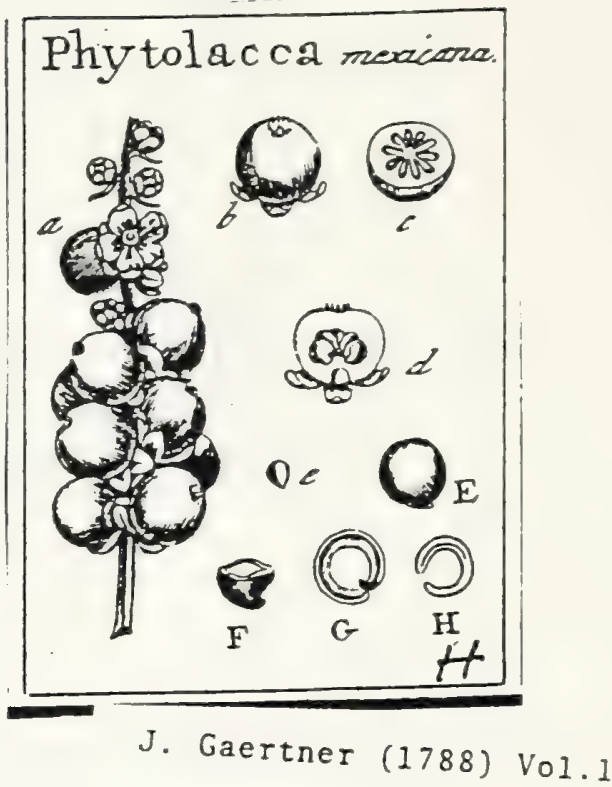

CCCCLXXIII. PETIVERIA. P lu m. gen.t. 39. Lis N. gen. 459.

Calyx tetraphyllus. Cor. nulla. Stam. [ex l. octo. Styl. quatuor perfifientes, demum extrorfum rellexi, fpinefcentes. Semen unicum, nudum, fupra fpinis reflexis armatum.

PETIVERIA alliacea. Tab. 75. fig. Ir.

Petiveria. ЕнRет. decad.t. 67 .

Peticcria floribus hexandris. LI N. Jy/. veg. 350.

PER. nullum, nifi femuis cruftam velis.

REC. nullum.

SE 3. unicum, cunciformi oblongum, rereti compreffum, hinc fulco elevato obfolcto, inde linca depreffa notattm, apice fpinis quatuor, primum crectiusculis, mox attem in dorfum rellexis, pungentibus, armaturn, fpadiccum, aut c viridipallidurn.

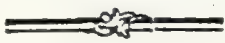

IN T. duplex: exterius coriaceum, tenue; interius membranaceum, ferrugineum, als bumini arcte adnatum.

A LB. farioofun, candidifimum, tenuc, lateribus prxfertim integumenti adnatum, \& in dorfo atque ventre deliquefcens, ut fxpe bi-l. quadripartitum appareat.

Eм в. magnitudine ferc ferninis, erectus, albus. Cotyl. foliacex, tenuifimx, fuperne in ventralem feminis partem replicat $x$, inferne vario modo contortuplicat $x$ \& circa sadiculan convolutx. Rad. tereti-acuminata, recta, infera.

2) Pars (pica (rugiferx. b. B.) Seminis dorfum. c C.) Ejus venter. d.D.) Albumen interna feminis membrana veftitum. E.) Idem diffectum. F.) Embryo denudatus, a parte veatrali Spectatus. G.) Cotyled, transverfim fectx.

In fcminibus apud nos maturefcentibus, haud raro unicam duntaxat cotyledonem de. preliendi; naturalis tamen \& frequentufumus numerus binarius ef. 


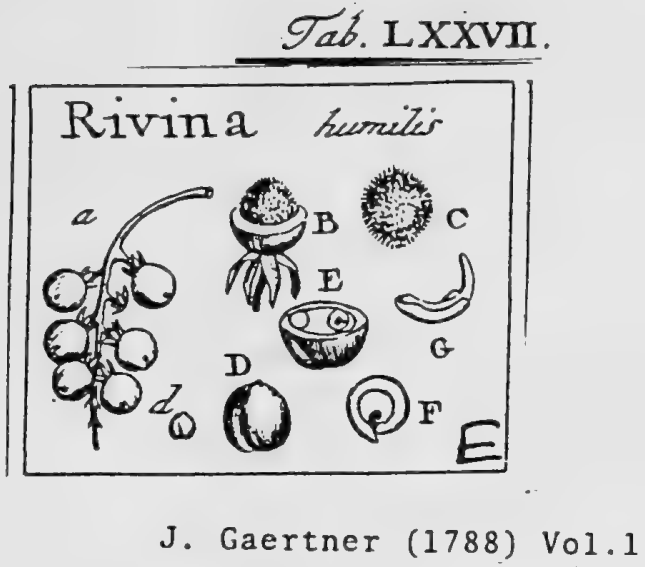

CCCCLIXXIX. RIVINA. P L U n. geis.t. 39. I I N. gen. 164.

Calyx nuilus, nifi corollam velis. Cor. tetrapetala perfiftens. Stam. quatcor, ad duoilecim. Styl. unicus. Hacca monofperma. Semen feabrum.

RIVזה humilis. Tab. 7\%. fig. 5 .

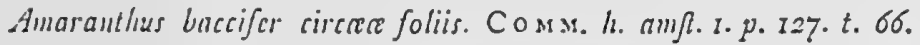

Ririnin foribus tetrantris. Lix x. Sy/. veg. 165 .

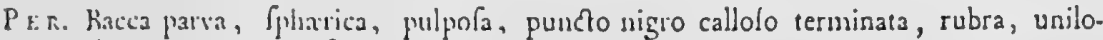
cularis. Pulpa aquofa, lutco tingens.

$R$ : c. sultum; fcmen bafi aflixum.

Sf.». unicum, honticulare, fculis mollibus feabrum, fub cuticu!a cxtcrna glaberrimum, nitidum, arrum.

Ixт. tiplex: cxtimum mombranaccum, tenve, Settilis fabratum; medium clastace. um, tenuilimum, fragile; intcrius memblyanzecum, pallide luieum.

A 1. п. centrale, furinofum, candidialinum.

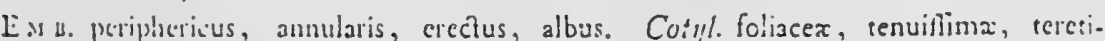
convoluta: cxteriore, ampleante interiotcm, utroque margine introrfun convo. lutan. Rat. tcicti acuminata, infera.

a.) Bacs:e in racenis errunis. U. C.) Scenen intra haccam \& feparatum cuticula fua extrris fcabra imfun. d. D.) Jjem denudarsn. E.) Idem iransverfe fefinn. F.) Enibryo albunaw cingens in fitu natura!i. G.) Ideni refupinatus, conyedunum convolutionem of endens.

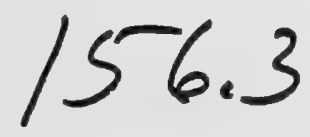



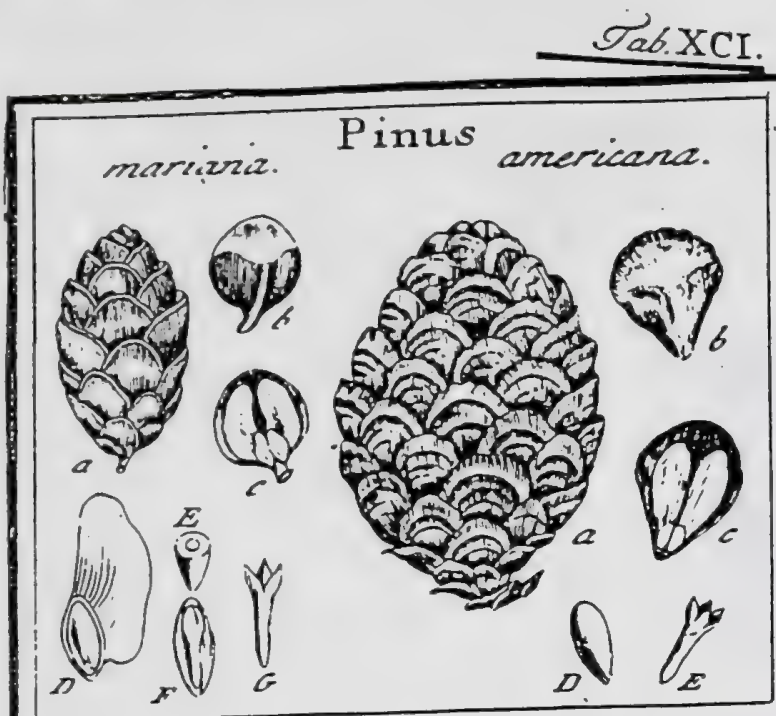

J. Gaertner (1788) Vol.. 2

50

\section{PINUS. TOURN. inft. t. 355. LINN. gen. IO77.} Ahies. TOURN. t. 353. Larix. TOURN. t. 357.

Flores fexu diftincti, in eadem Rtirpe. MAS. Amentum conicum ex Calycibus tri-1. tetraphyllis. Stam. plura, filamentis connatis. FEM. Amentum ftrobilaceum, imbricatum fquamis coriaceis, biforis. Cal. nullus. Cor. nulla. Ovar, minima, ad fingulam fquamam gemina. Styl Gimplex. N'ux unilocularis, evalvis; alata.

Pısus mariana. Tab. 91. fig. J.

Abies foliis folitwiis apice acuminatis undique jannos cingentibus, conis ovatis. SELIGM. Av. vol. 5. t. Ir.

Abies foliis linearibus actutis, , conis minimis. Mall. gard. dif.

FR UCT. Strobilus ovatus, parvus, vix extimo pollicis articulo magnitudine xqualis, imbricatus fquanis coriaceis, unguiformibus, rotundatis, gilvis, in ratione ad conum ipfun grandiufculis.

PER. Nux parvula, offea, unilocularis, evalvis, tota veltita epidermide in alam membranaceam, nucula longiorem \& ex altera parte redam, ex altera vero gibbam, ampliata.

REC. nullum, proter fuperficiem fquamanum internam, cujus baf geminx nuces affixix.

SEM. unicum, cavitati nucis conforme, pallide lutefcens.

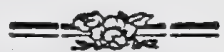

Ix T. Gmplicifimum, tenuiffmum, membranaceum.

A I в. craffum, carnolum, candidun.

E м в. longitudine fere albuminis, teretiufculus, erecus, heteus. Coty tres, brèviflima, angulatx, carnofx. Raid. teretiufcula, longa, infera.

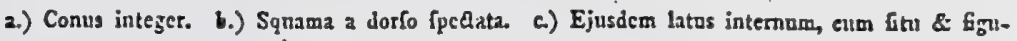
sa Nuculirum. D.) Nucis putamen apcrtumi cum femine, E. F.) Albumen transverfaliter s. longitudinaliter diffeaum, Embryonis fitum oftendens. G:) Embryo feparatus.

Pinus americana. ibid.

Abies foliis linearibus obtufufculis bifariane verfis, conis fubrotundis. MrLc. gard. diat.

Strobilus (a) magnitudine \& forma ovi gallinacei minoris, totus e fpadiceo cinerafcens. Squamæ (b.) coriacex, craffx, triangulares, latere exteriore rotundato, fubcrenulato. Nucula (c) paulo minores, quam in precedenti, $\mathrm{ab}$ exteriore faltem latere membrana alari veltitx. Alix ovato oblongz, fubxquilaterx, vel faltem latere exteriore non adeo gibbx, ut in priori. Semen (D.) ovatum, deorfum acuminatum. Embryo (E) Gitu \& figura procedenti funilis, fed lobulis cotyledoneis quateriis.

Pinus Picea. LinN.

abies. Cans. epit. 48.49. Oelhaf. arb. 25. t.5-8. - mas. Blakw. berb. t. 203.

Weis Tanne. Gern.

Strobilorum fquamx amplx, deltoidex, fupra rotundatx, infra roftellatz \& e bafi fua, ligula dorfali membranacea, fpatulata, recurvoque mucrone terminata, appendiculatx. Nuces grandiufculx, inembranacex, varie angulate, gilva. Ala, nucem ex altera parte totam, ex altera vero ad dimidium faltem obtegens, membranacea, furfum ampliata, apice oblique truncata. Albumen giboum, opacun. Embryo pentacotyledoneus; lutefcens.

Pinus Abies. LiN.

Picea. Cans. epit. 47. BLakw. to 198. Oed. flor. dam t. 193. OrLhap. arb. 35. $t .9-16$.

Rosls Tamus. Germ.

Strobilorum fquamx obovato rhomboidex, apice in mueronem truxncatum definentes, nou appendiculatx. Nuces parvulx, ovatz; deorfum acuminatx, comprelfiffulx, cruftacex, nigro fufcx. Ala, nucem a latere externo faltem obtegcns, nembranacea, elliptica, tenuis. Albumen fubpellucidum, ayueo-album. Embryo endeacotylcdoneus, lacteus. 


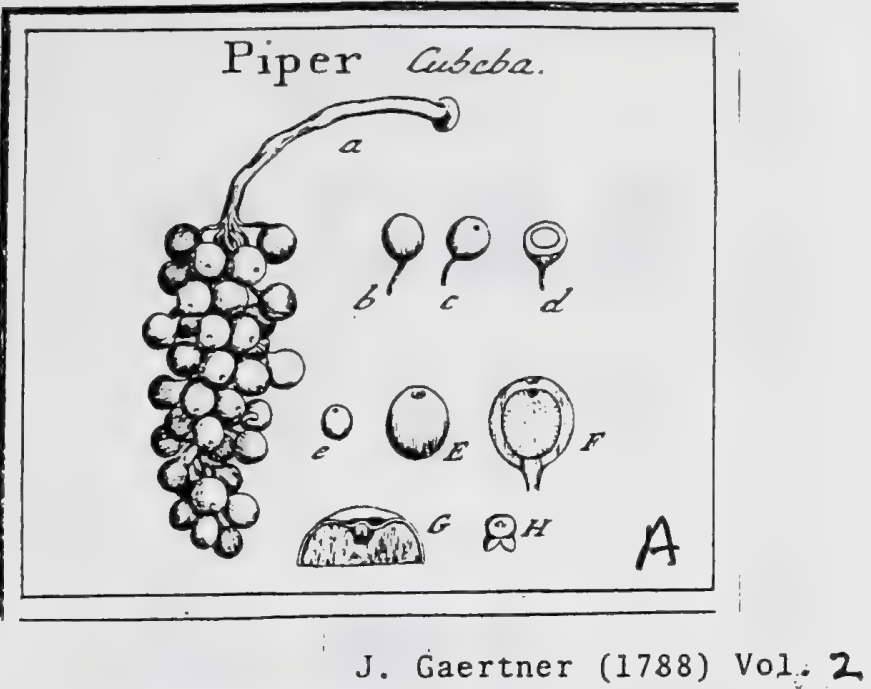

\section{7}

\section{P I P E R. LINN. gen. 43 .}

Fructificationis partes in fpicam filiformem digetre. Cal. nullus. Cor. nulla. Stamina incerto numero Ovariis intermixta. Bacca unilocularis.

Piper Cubeba. Tab. 92. fig. I.

Piper caudatum. Bess. mus. p. 7. t. 3.

Piper foliis oblique ovatis $\int$. oblongis venofis acutis, Spica folitaria pedunculata oppofritifolia, frulitibus pedicellatis. LiNN. fyf. veg. 74.

Рёв. Bacca carnofa; globofa, apice-obfolete umbilicata, bafi pedicellata, rubra, vel per vetuftatem fumofa, glabra, unilocularis. Caro modice craffa, demum in pelliculam coriaceam exarefcens.

REC. nullum; caro undique femini adnata.

SEM. unicum, füblobofum, fuperne exigua foveola tmbilicatum, ferrugineo. fufcum, rugofulum.

INT. fimplex, membranaceum, albumini arde adnatum,

A L в. femini conforme, fubgranulofum, friabile, pallide lutefcens, aromaticum, acre, foveola exilifima prope verticem exfculptum.

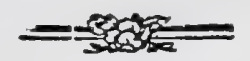

EM B. nimutiffmus, inverfus, lacteus, in propria albuminis cavitate, folo integumento ut in Palmis claufa, locarus. Cotyl. dux minutiffimx, papillares, divergentes. Rad. difcoidea cum acumine medio, fupera, integumento feminis affixa.

2) Racemus longe peduneulatus. b. c.) Bacex folutx, integra. d.) Bacer transverfim fe $\theta$ a. 8. E) Semen denudatum. F.) Bacez aiqune Seminis fectio verticalis. G.) Cavitas in fupremo albumine, exabryonem clavdens H.) Embrgo folutus.

Piperis nigri \& albi fructus, in officinis venales, funt baccx immaturx, integre, aut decorticatx, albumine imperfecto, cavo, fed nullo vifibili embryone, vel ejus loco, fquamula faltem rotundula \& carnofa dotatx.

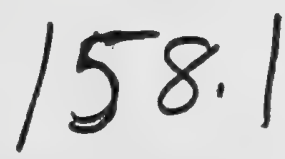


.

6

- 


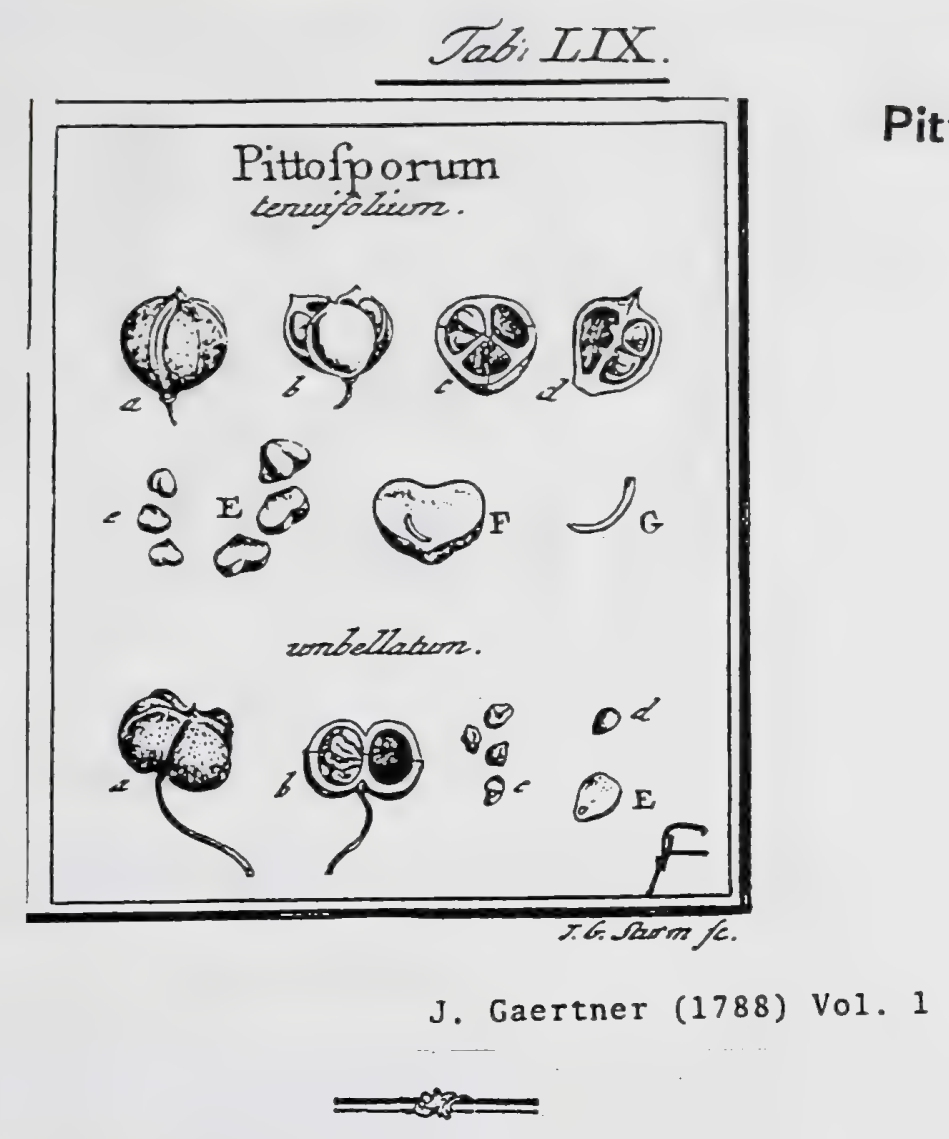

286

\section{PITTOSPORUM. Ban $\mathbf{\text { s. }}$.}

Calyx pentaphyllus inferus deciduus. Cor. pentapetala, petalorum unguibus concavis in tubum urceolatum conniventibus; laminis ipfis ovato oblongis patentibus: Stam. quinque. Styl. unicus filiformis. Capfula trilocularis: loculamentis refina liquida Tcatentibus. (Ex feliedis b. Solandri.)

PIт т Os por U⿱

Ex herbario Rankfiano.

PER. Capfula fubglobofa, apice mucronata, obfolete trigona, trilocularis, trivalvis; extus fubrugola, fumofa; intus fpadicea, fucco refinofo lutefcente fcatens. Diffepimenta valvis contraria.

REC. nullum, prater funiculos breves, craftos, e diflepimentorum margine centrali utrinque oriundos.

SEM. tria, aut quatuor in fingulo loculamento, varie angulata, plerumque gigartoidea, atque fulco parun profundo in dorfo infcripta, atra, nitida, terebinthinaceo fucco illita.

I. T. duplex: exterius coriaceum, atrum; interius ferrugincum a nucleo non fecedens.

A L в. femini conforme, cartilagineum, duriffunum, prope peripherian glaueum, ver* fus centrum albicans.

EмB. filiformis, arcuatus, niveus, fxpe fatis remote ab umbilico locatus, ut difficulter reperiatur. Cotyl. minutiffunx, brevifiunx. Rad. longa, arcuata, centripeta.

2. b.) Capfala integra \& dehifeens. c) Eadem difieta. d.) Valvula feparata cum feminam infervione. e. E.) Semina folata. F.) Embryo intra albumen. G.) Idem (eparatus.

PIT T OSPORU M umbellatum, ibid.

Pittofporoides umbellata. SOLAND. $m / s$.

Capfula fubglobofa (a.) biventris, transverfim latior, apice mucronata, utrinytre fulco deprefto \& ad margines fulco elevato, ex prominula futura, infcripta, undique pundis elevatis feabrata, bilocularis (b.), bivalvis. Dillepimentum valvis contrarium, feminigerum. Loculamenta, ut in priori, unctuofa. Semina in fingulo loculamento quatuor, valde irregularia ( $\left.c_{0}\right)$, rugofa, atra, fplendentia. Albumen (d.) carnofum, molle, fanguineo - fufcurn. Embryo (E.) minutiftimus, fubglobolus.

Flores poflerioris fpiciei defiderantur, \& leınina quoque cjus non plenam maturtatem nacta fuifle videntur, quare embryonis vera forma adlue dubia. 


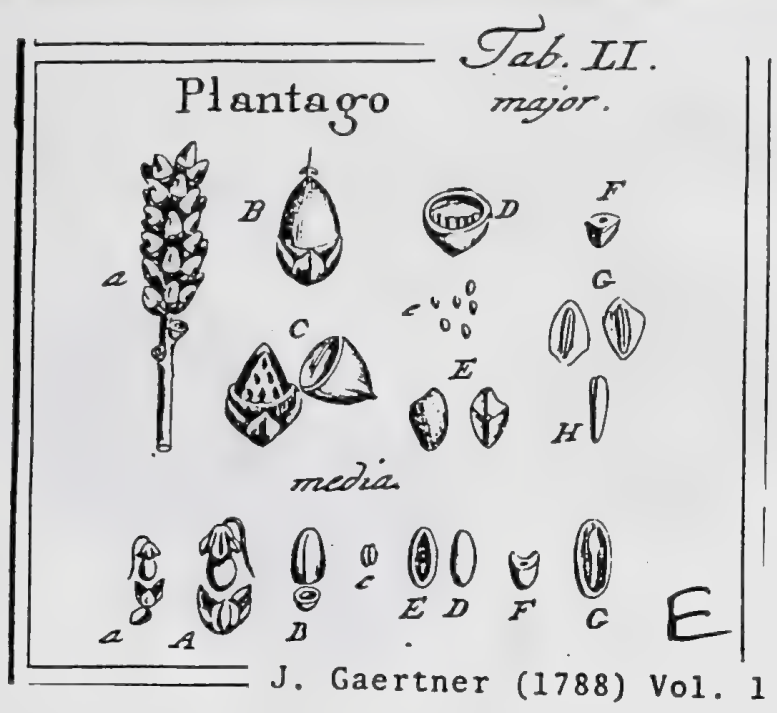

CCXC. PLANTAGO. Tou R. t. 48 . LinN. gen. 142 .

Calyx quadrifidus. Cor. quadrifida perfiftens. Stam. quatuor. Styl. unicus. Capfuls: fupera bilocularis circumfcifla. Diflepimentum snobile. Semira folitaria, aut uno plura, mucilaginola.

- Seuninibus uno pluribus.

PLANTAGO major. Tab. 51. fig. 3.

Plantago major. СА м. epit. 26r. BLA к ए. herb. t. 35. OЕ DER. fl. dan. t. 46 r.

Plantago foliis petiolatis ovatis glabris, fpica cylindrica. HA L. hifl. 1. n. 660 .

Plantrgo foliis ovatis glabris, fcapo tereti, fpica flosculis imbricatis. Lixix. Syf. veg. 155 .

PER. Capfula fupera, corollâ emarcidâ veftita, ovata, papyracea, bilocularis circumat fcifl. Diffepimentum meinbranaceum, per maturitatem liberum.

REc. carnolum, fcrobiculatum, diffepimento utrinque adnatum.

SEsr. pauca, novenz circiter in fingulo loculanento, fubovata, hinc leviter convexa, inde angulata cum medio umbilico ventrali, pallide fufca.

IN T. fimplex, membranaceum, arcte adnatum, fuperficie in unucilaginem pellucidam; ab aqua, convertibili.

A LB. Semini conforme, duriusculum, carnofum, album.

EM B. teretiusculus, longitudine albuminis, e regione umbilici pofitus, erectus, lacters. Cotyl. lineares, longx. Rad. brevis, acuminata, infera.

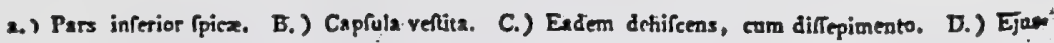
dem ferio transverfalis. C.E.) Semina folata. F.G.) Albuminis feationes, cum fitu \& figura oinbryonis. H.) Embrjo Separatus.

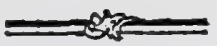

\section{PLANTAGO Coronopus.}

Capfula ovato conica. Semina in fingulo loculamento quatuor, parva sngulata, rufefcentia: unbilico ventrali albo. Embryo rectus, luteus. Cotyledones Jongifinze, lincares.

$$
\text { * Seminibus folitariis. }
$$

PIANTAGO media. ibid.

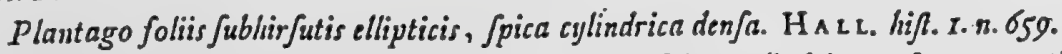

Plantago folis ovato lanceolatis pubefcentibus, fpica cylindrica, fcapo tereti.

LiN 31 . S4f. veg. 155 .

ICON. OEDER. flor. dan, t. S8I.

Capfula calyce \& corolla $(a, \Lambda$.$) veftica, cylindrico ovata (B), paulo lupra bafin de-$ hilcens, ut operculum inajorem capfulx partem efficiat. Diflepimentum tenuiffimum, per inaturitatem fere evanelcens. Semen in fingulo loculamento unicum (b), oblongo ellipticum, hine (D.) convexum, glabrum; inde (E) concavum, tuberculo unibilicali medio notatuní e corneo lutefcens, nitidum, mucilaginofum. Albumen durum pallidum. Embryo dorfalis (F.), erectus, niveus. Cutyl. lineari-oblongx $(G)$, radiculà breviores. Rad. filiformis, curva, infera.

Hujus fabricx porro quoque funt Plantago lanseolata, virginica', $P \int y$ llium $E^{3} c$. 


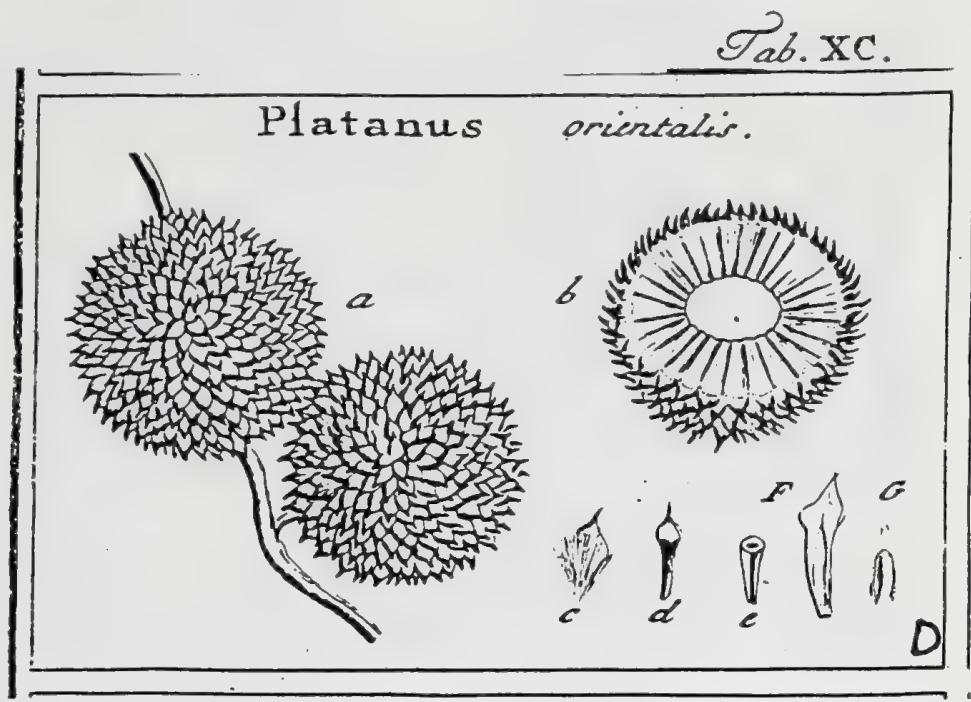

J. Gaertner (1788) Vol: Z

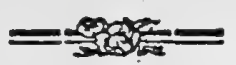

DLXII. PLA T ANUS. TOURN. inft.:t. 363. LINN. gen. 1075.

Flores fexu diftincti, is eadem ftirpe. MAS. Amentum globofum ex meris fquanulis Jinearibus atque filamentis antheriferis compofitum. FEM. Ameitum globofum ut in mare, fed grandius, \& ex fquamulis breviffmis, fpatulatis, pubefcentibus, atque Ovariis filiformibus, prope apicem -globulofe incraffatis atque Itigniate incurvo terminatis compolitura. Semen clavatum, apice roftellatum, bari pilofum.

Pratanus orientalis. Tab. 9a. fig. 5.

Plataruce. Clus. bjf. x. p. g.

Platmus foliis palinatis. LiNN. Jyft. veg. 859.

PER. nullum, nir feniuis cruftam fuberofam velis.

IN T. consnzure globofum, fuberofum, undique feminibus denfiffume congeftis ftipatum, cetera per maturitatem nudum, absque ulla vifibili fquamula.

SE r. nudum; unicum, clavatum, ex pedunculo fubulato, compreffufculo aut fubangulato in capitulum globofum incraffitum atque ftylo I. ftigmate perfiftente mucronatum; ad bafin vero crinitum Pilis fulvis, Gmplicibus, rectis, longitudine fua capitulum non excedentibus.

INT. duplex: exterius crafum, fublignofum, non dehifcens, at facile a bafe furfum fiffle, ut pro Capfula haberi pofet; interits membranaceum, te. nuifirmum, pallidum.

A 1 B. nullum.

ENB. oblongus; compreffus, inverfus, lutefcens, telta ferainis multo brevior: Cotyl. lineares; fubfoliacex. Rad. teretiufcula, fupera.

a.) Amentum feminam integram. b.) Idera ditectum, cum feninibus receptzeulo communi infertis c) Sernen bafi crinitum d.) Idem, exculis crinibus. e.) Ejus pedunculus transverte featus. F.) Tofta feminis longitudiaaliter aperta, cum aucleo, propria fuz membram Telito. G) Embryo denudztus.

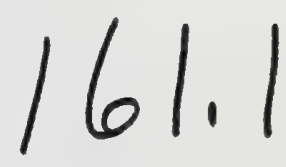




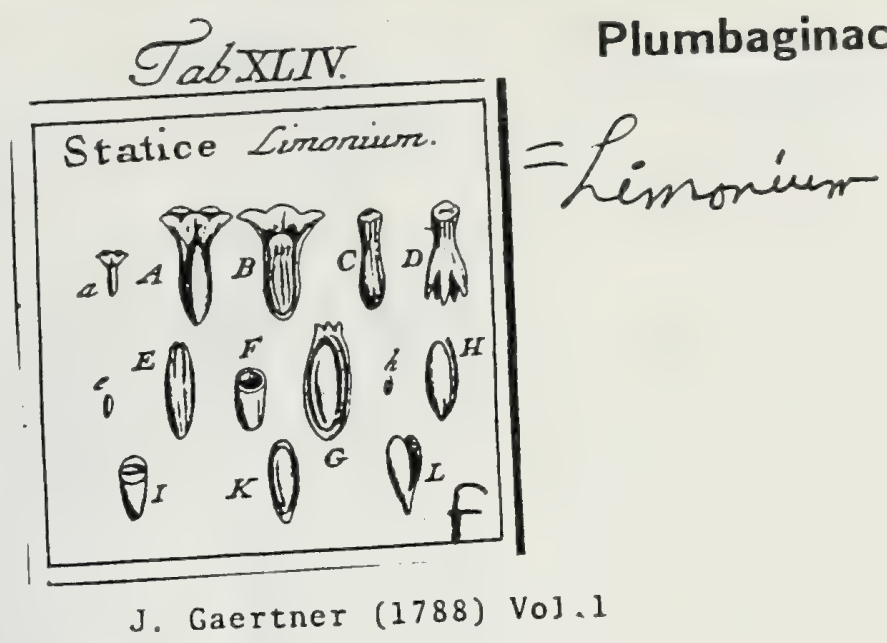

210

CCLVI. STATICE. Tor RN. t.177. LINN. gen. 388 .

Calyx monophyllus aridus perfitens. Cor. pentapetala, perfiftens, pericarpium obvolvens. Stain. quinque. Styl. quinyue. Capfula unilocularis evalvis. Serpeo erectum, e longo funiculo pendens.

Statice Limnnium. Tab. 44. fig. 10.

Limonium. B I A $\mathrm{X}$ W. herb. t. 481 . OEDkк. flor. dan. t. 315 .

Statice fcapo paniculato tereti, foliis lavibus enerviis fubtus mucronatis. I INN. $\int y / t . v e g .300$.

PER. Capfula calyce \& corolla perfinentibus veflita, oblonga, teretiuscula, membranacez, apice quinquecufpidata, unilocularis, evalvis.

REc. funiculus filiformis undique liber, e vertice capfulx ad bafin feminis defcendens, illudque in fitu erecto fultinens.

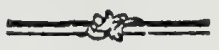

2II

SEM. unicum, teretiusculum, utrinque leviter attcnuatum, glabıun;, fubferrugineum IN T. fimplex, coriaceum, albumini adnatum.

ALB. farinofum, candidiflmum, bipartitum, integumento utrinque longitudinaliter adnatum.

Eмв. longitudine fere feminis, erectus, compreflus, lutefcens. Cotyl. lineari oblongx, plano convexx, tenuiflinx. Rad. teretiacuminata, brevis, infera.

a. A. B.) Calyx caplulam veliehs. B. C. D.) Corolia, quali in calyptram bafi quinquédam conver[2, eapfulain obvolveus. e. E.) Capfula denudata. F.) Ejus fetio transverfalis. G.) Eadem longitudiualiter aperta. h. H.) Semen feparatum, cum fuo fusiculo umbiliali. I) Albumen transverfe (ętum. K.) Ejus fetio Jongitudinalis, cum embryous in fitu. L.) Embryo feparatus.

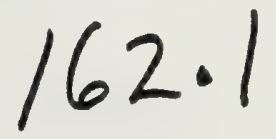




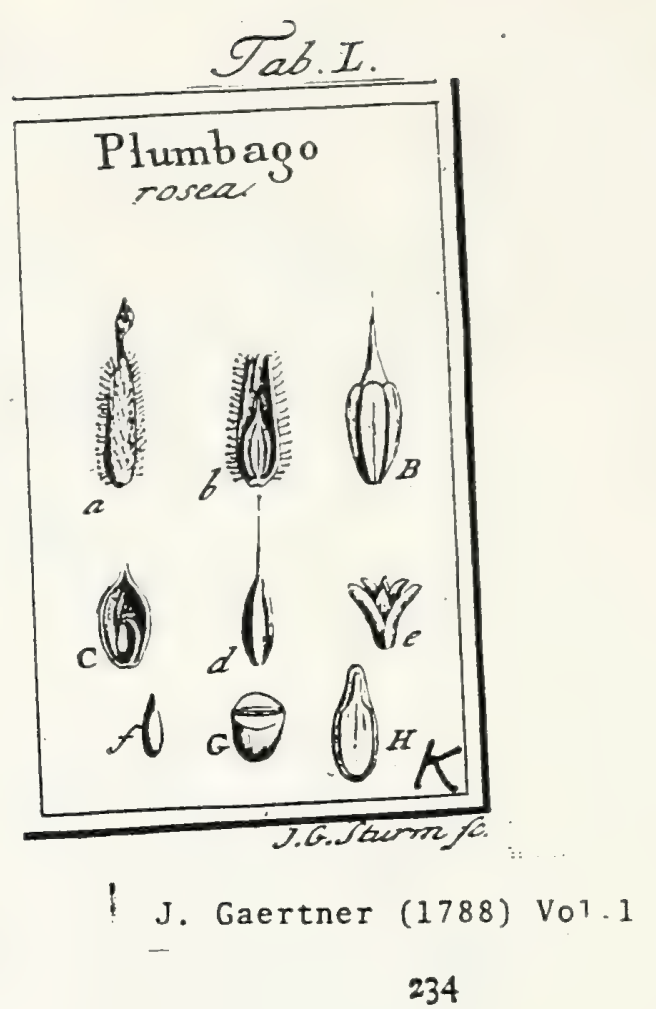

Plumbaginaceae

CCLXXXVII. PLVMBAGO. TOURN. t. 58. Linn. ger. 213 .

Calyx tubulofus quinquedentatus villis capitatis glutinofis confperfus. Cor. infundibuliformis. Stam. quinque: filamentis bafi dilatatis fornicatis. Styl. uncus. Capfula fupera unilocularis. Recept. filiforme liberum. Semen unicum inverfum.

P I U в в G о rofca. Tab. 50. fig. Ir.

Radix veficatoria. R им Р н, amb. 5. t. I6s.

Plumbago foliis petiolatis ovatis glabris fubdenticulatis, caule geniculis, gibbofis. Livx. fyj. veg. 199.

PER. Capfula calyce perfiftente veftita, ovato oblonga, in fiylum fubulato-fetaceum definens, obfolete pentagona, unilocularis, quinquevalvis.

REc. funiculus unbilicalis filiformis, e bafi caplulx oriundus, apice recunvo femen pendulum fuftinens.

SEM. ияicun, oblongum, fupra acuminatum, teretiusculum, fanguineo atrum aut ferrugiueun.

IN T. fimplex, membranaceum, albumini adnatum.

A L в. femini conforme, fubfarinofum, candioifimum, fuperius integerrimum, in fcrius bipartitum, 1. ad latera ita extenuatum, ut bilobum appareat.

Ess. longitudine albuminis, compreffus, inverfus, lutefcens. Cotyl. ovato oblongz, foliacex. Rad. tcreti acuminata, recta fupera.

2. b.) Capfala ealyce vefita, B.) Copfula immatura, fubturbinata, C.) Receptaculum filiforme d) Capfula matura integra. e.) Esdem defiicens. 4.) Semen (eparatum. G.) Albumen trasverfo Sefum. H) Idcm longisudinaliter apertum, cum fitu \& figura embryonis. 


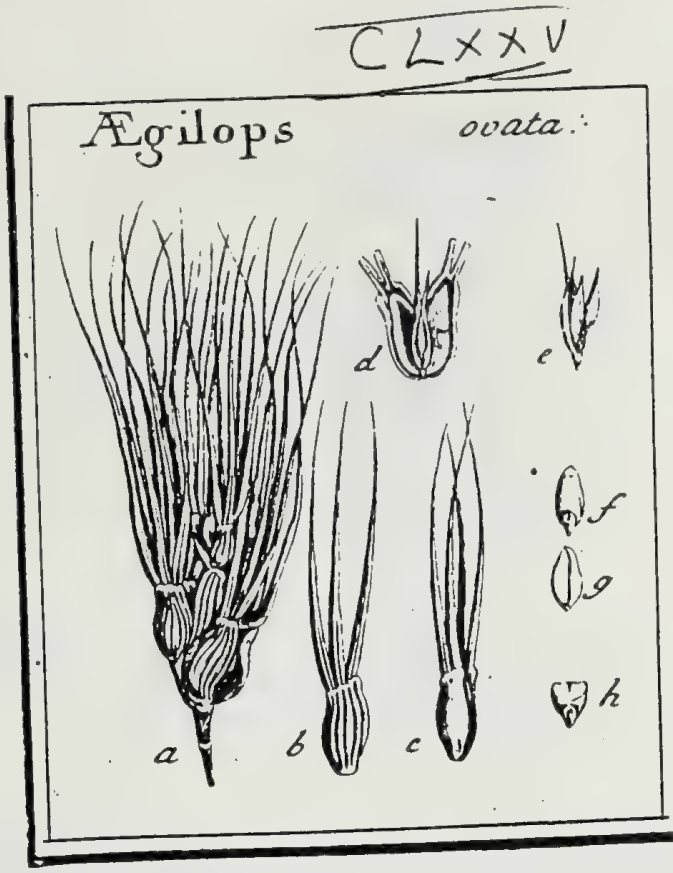

Poaceae

\section{J. Gaertner (1788) Vol. 2i}

\section{MXLVIIl. E G I L O P S IINN- ger. ri5o. 468}

Flores in eadem loculta fexu diltincti. Locultie in raphidis articulis compreflis alternantes, fubquadriforix, bivalves: valvis coriaceis, varie in variis ariftatis. Fl. bermaplyoditi duo. Cal. nullus. Cor. bivalvis: valvula majore chartacea, ariltata; ninore membranacea, mutica. Fl. mafculé unus aut duo, per onmia hermaphrodicis finiles, nifi quod triplo minores. Semeu liberum, tectum.

EgILOPS ovata. Tab. 175.

Egilaps. DOD. pempt.73. CAM. epit. 928. f. 2.

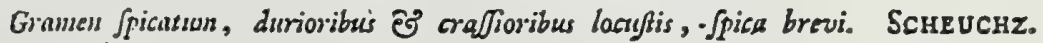
agroujt. $r$ r.

Egolops fpica ariftata, calycibus ounsibus triarifatis. LIsw. fyft. veg. go7.

A Cl. Thunbergio \& Dr. Roenero.

PER. nullun. Calyx \& corolla perfiftentes obtegunt femen, tandemque dinittunt.

REc. nullum.

$S$ E. s. Liberum, oblonge ellipticun, hinc convexum, inde planiufculum cum rima longitudinali, melinum aut rufefcens, circa verticem late cinerafcens.

IN r. membranaceum, fimplicifimum.

A L B. firinofun, , femipellucidum.

Scvr. ovatum, albumine tertia parte brevius, \& in ejus dorfo locatum.

E

a.) Spica integra, ex (peciemine infolenter grandi, b.) Locufte valvala (eparitai c.) Flafe. herınaphroditi in fitu naturaii, d.) Iidem diduct, cum fitu flufe. fferilium. e.) Fofis Aeriles

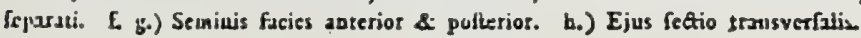




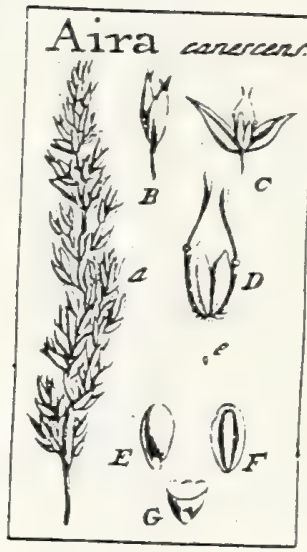

$$
\text { J. Gaertner (1788) Vol. } 1
$$

VII. AIRA. LIN. gen. $8 I$.

Calyx bivalvis, biflorus: flosculis fubfefflibus, calyce vix longioribus. Cor. bjvalvis mutica, aut e bafi ariftata. Semen liberum, tectum, hiac fulcatum.

AIR A canescens. Tab. 1. fig. ?.

Gramen fotiolis junceis oblongis, radice alba. C. B. Moris. hip.3.S.8.t.3.f. zo.

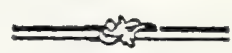

Avena diantha, foliis fetaccis, panicula fritan, arifis clavalis. HALL. hil. 2. n. 1483 .

Aira foliis Jetaceis: Jummo fpathaceo paniculam inferne obvolvente. LIN Sy . Sy. veg. 112 .

PER. nullum: corolla femen fovet \& dimittit.

REc. nulluin, prater fundum corollx.

SEM. unicuin, parvulum, ovatum, inferne angufatum, hine convexum, glabrum, inde fria media elevata inter duos fulcos deprefios notatum, rufescens.

INT. fimplex, membranaceum.

A Ł B. farioofum, duriusculum, fallidun.

SCUT. minimum, fubrotundum.

Es в. linearis, reीus, minutiflunus. Rad. funplex, acuminata.

a.) Tanicula iutegra. B.) Locufá feparata. C.) Eadem didufis valvulis calgcinis. D.) Corolls e

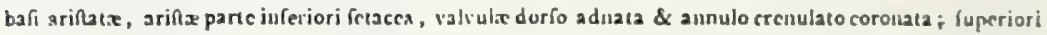
Jibcra, fetaceo clavata. c. F⿻) Scmendenudaım, a parte dorfali fpetatum. F.) Ejusden pars ventralis fulcata. G.) Albumen transverle fofium, cum ausexo ad bafin ejus fcutello cotgledoneo. 


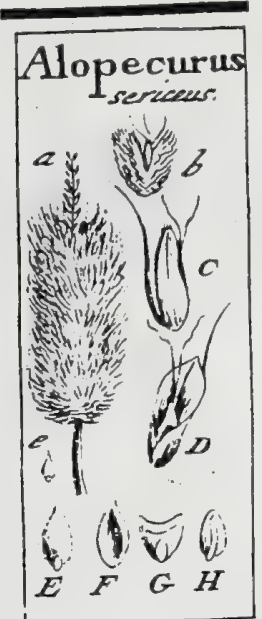

J. Gaertner (1788) Vol.1

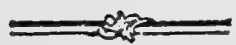

\section{ALOPECURUS. LINN. gen. $7 \delta$.}

Calyx uniflorus, bivalvis. Cor. uniglumis. Seınen liberum, tectum, breve, line fulcaturn.

A I OPECURUS fericeus. Tab. I. fig. 2.

Gramen alopecuro fimile glabrum cum pilis longiufculis in fpica, onocordon denominatum. ВА $\mathrm{H}$. hift. 2. p. 475 .

PER. nullum.

REc. nullum: femen fundo calycis adnatum.

SEM. unicum, corollâ tectum, liberum, ellipticum, utrinque acuminatum; hinc con: vexum, glabrum, inde concavum, ftriâ mediâ notatum; rufefcess.

IN T. membranaceum, arcte adnatum.

A L B. pallidum, fubdiaphanum, farinofum, duriufulum.

Sc u T. oblongum, dimidio albumine brevius.

Ex в. linearis, rectus, monocotyledoneus, niveus. Rad. fimplex, acuminata, infera.

2.) Spicze pars inferior. b.) Flofculus feparatus. C. D.) Corolla 2 fronte \& a latere fpeinata. e. E.) Seminis pars dorralis, convexa. F.) Ejusdem latus vestrale, concavuin. G.) Albumen transverfe fettum. H.) Scutellum cotyledoneum cuns fuo embryone, in fitu uaturali.

Proxime hoc gramen ad Alop. bulbofum accedit, ut tamen vix pro mera cjus varietate haberi queat. Spica ei cylindrica, pollicaris, denfifime villofa, cinerafcens, fericeo fplendens. Calycis glumx bali connatx, angufx, acuminat $x$, xquales, undique villis longis, flexuofis, tectx. Corolla membranacea, diaphana, e bafi ariftata: arifa fetacea, floribus dimidio longiore. Culmus infra fpicann longe uudus, craffus, glaberrimus. Folia inargine fcabra. 


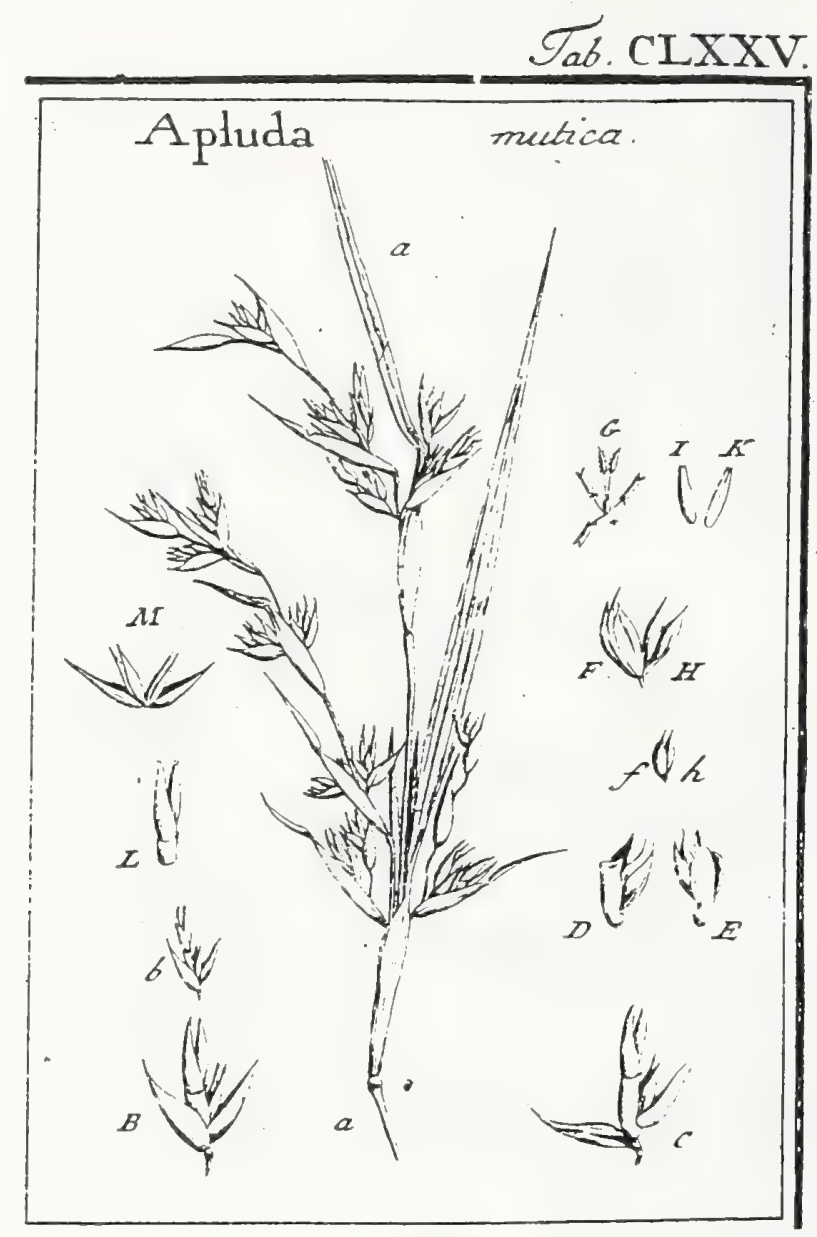

\section{J. Gaertner (1788) Vol, 2}

\section{A P L U D A. LINN. gen. II4?}

Flores in eadem locufta fexu diftincti. Locuftarum calyx bivalvis: valvula najore receptac. florum fuppofita; minore autem ejus margini fupra bafin inferta! Receptac. florum (Gluma. Limn.) cartilagineum, bilamellatum, quadriforum: lamina anteriore oblique truncata, breviore; poffe: ine ob. longa, acuminata. Flores inferiores inter laminas receptac comprehenf, gemini : altero hermaplirodito; aliero femineo; flores frperiores perinde gemini, mafculi, apici laminx truncatx verticaliter infiftentes. HERM. Cal. nullus. Cor. univalvis, obovata, naviculari comprefia, line membranacea, ftriata, inde coriacea glabra, apice tridentata: dentibus duobus lateralibus brevioribus, fetaceis; tertio intermedio in ariftan breven producto. Stam. tria. Styl. manifefte duo, fetacei, ftignatibus fubulatis craffis hirfutis. FEM. Cal. nullus. Cor, bivalvis menibranaces. Ovar. teretiufculum. Stigmata duo, fetrilia! MIAS. Cal. cómmunis bivalvis, valvula fingula continente Corollulam membranacean bivalven, valvulis acuminatis, xqualibus.

APLUDA mutica. Tab. 175 .

Apluda foliis lanceolutis, fofculis onnibus muticis. LINN. Sy.t. weg. 906.

A Cl. Thunkergio.

PER. תullum. Seme nudum, liberum, deciduum.

- Rec. nullum.

SEN. feminis lineari - oblongum, fubteretiufculum, fo hine convexum, inde fulco longitudinali exaratum, glabriufculum, e luteo-ferrugineuni: berma. phroditis effuctum, 1. certe femineo dimidio minus.

IN T. fimplicifimum, membranaceum.

A в. femini conforme, farinofum,

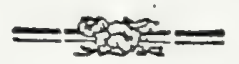

SCvT. ninutulum, albumine fextuplo brevius, in convexi lateris bafi pofitun. ENB. ninutifinus, linearis, rectus.

a. a) Graminic Aorentis raoulus, com partiua fitu \& magnitndine asturali b. B.) Locu as integra, feparata. C.) Ejusdem ralvulx calycinx diluax, \& receptas. deaudatum, D.) Receptaculum cum Bofculis infcriorihus a latere anteriori (pectatum E) Ejusdem facies pofterior. f. F.) Corolk fioris bermaphrediti. G.) Ejusdeus senitalia feparata h H.) Corolla Auris feminci. I.) Ejusdem (emen a Jorfo, \& K.) a veutre fpectatum. L.) Flofeuli mafeuli is litu, naturali M.) Eorundem calyx comununis diduatus, atgue corellulx gerinz deaudatx.

Nou uno itaque in loco generis claracter Linnaxanus exnendandus eft. 


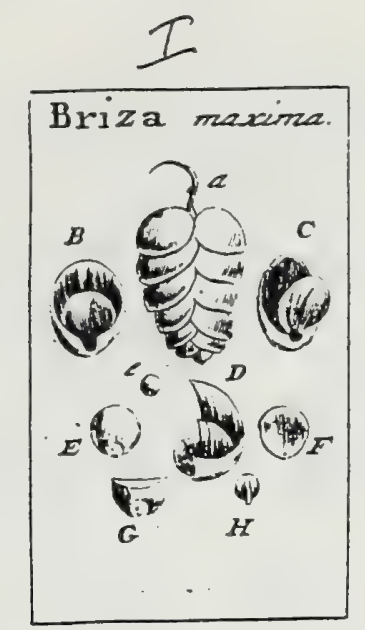

Poaceae

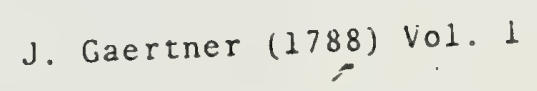

VI. BRIZA. Linn. gen. 84 .

Calyx bivalvis multiflorus. Cor. inxquivalvis: glumis cordatis, obtufis: interiore minure. Semen compreffum, corolix adnatum, exfulcum.

BRIZA maxima. Tab. x. fig. 6.

Briza Jpiculis racemojis. JACe obs. III. p. Io. t. 60.

Briza Jpiculis cordatis: flosculis Jeptendecim. LiNe. Jyf. veg. 115.

PER. nulluin, nifi corollam velis, parte fua inferiore coriacea, glabra, nitida, femen obtegentem.

REC. nullum: fernen majori valvulx corollx adnatum.

SEN. unicum, orbiculatum, compreffun, hinc leviflune convexum, inde planum, fria media elevata notatum, pallide fpadiceum.

IN T. inembranaceum, tenuifmumu, in dorfo feminis cun corolla conferruminatum.

A в в. farinofunr, pallidum, fubdiapbanum.

Scu T. minimum, fubrotundum.

Eмв. Lincaris, rectus. Rad. funplex, brevifiuna.

2.) Spricula ovata, diftiche imbricata corollis utrinque feptenis f, oftonis: fupremis confanter fterilibus. B.) Corolle pars concava. C.) Ejusdem valiule leviter diduâx. D.) Ejusdem fertio lougitudinalis, fitum feminis inter valvulas oftendens. e. E.) Sentis latus dorfale. E.) Ejusdem pars veutralis, plana.

G.) Aibunien transverfe fetium. H.) Scutellum cum Embryone. 


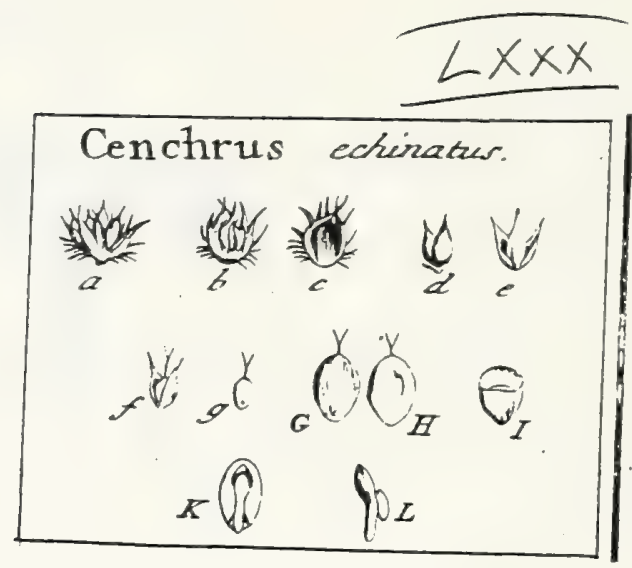

J. Gaertner (1788) Vol 2

\section{CENCHRÜS. LINN. gen. Ir49.}

Involucrum conimune monophyllum, hifpidum, lacerum, bi-tri-quadriflorum. Flores geminati, altero mafculo, altero hermaphrodito. Calyx \& Corolla bivalves: valvulis acuminatis, muticis. Semen exfulcun, liberum, tectum.

Cenchrus echinatus. Tab. 80. fig. 3.

Gramen americantm, Jpica eclinata, majoribus locuffis. PLuk. phyt. t. gz. f. 3 .

Pmicaftrolla americana nuajor annula, Jpica laxa purptorafcente. Mich. gens. p. 36. t. $3 \%$.

Cencirus Spica oblonga conglomerata. SCHREB. gram.2. p. 9. t. 23. f. s. LiNs. Jy.t. veg. 907 .

PER. \& REC. nullum:

SEM. liberum, calyce \&'corolla perfftentibus tectun, ellipticum, plano-con' vexum, pallide ferrugineum.

IN T. fimplex, membranaceum.

A L B. farinofum, duriufculum, album.

Scur. ellipticum, dimidio femine paulo longrus ac in ejus latere plano locatum!

EM B. linearis, reckus, intra fcutelli rimam delitefcens.

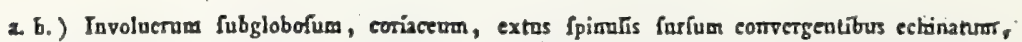
intus (c) glabrom, cetera monophyllum, fupernc autem in varias lacinias fpinefas fectum, \& a latere, quo culmam refpicit, Gifurs longitudinali ad barin ufque divifum Florculi fefribes, plerumque gemini (d), etiam terni aut quaterni, fed hi fatni \& mcre membranacei. c.) CzJyx cum coro[z. E) Corolla femen includens g. G.) Seminis Latus convexum. H.) Ejusdem pars piana, feutelligera. L) Albuminis fedio transver(adis K.). Scutcllum cum Gtu embrgo ais L) Embryo Eeparatus. 


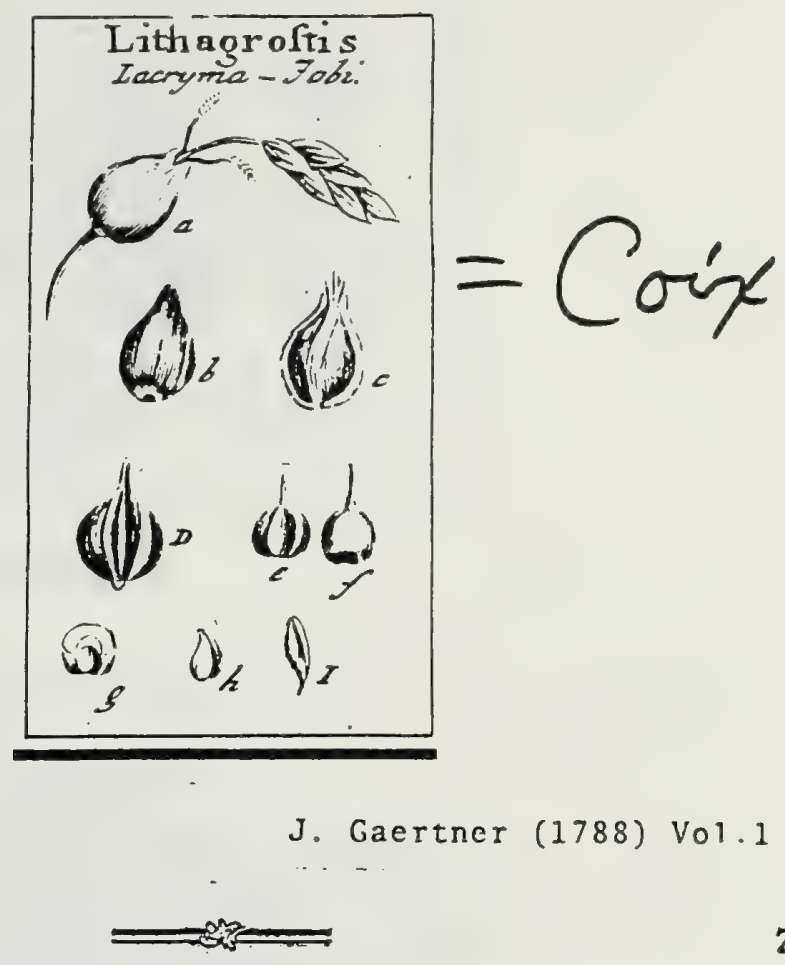

\section{LITHAGROSTIS. Lacryma Fobi. TourN. t. 306 . \\ Coix. LIN N. ge1?. I043.}

Flores mafculi in fpica pedunculata, involuerum femineum perforante. Fenninçi flores gemini, clanfi involucro monophyllo, demum lapidefente. Semen liberum, bifulcum, involucro lapideo tectụm.

LIтна G колт Is Lacryma jobi. Tab. 1. fig. I0.

Lythospermum plinianum. Lов. advers. $p$. I6.

Lacryma gobi. Dod. cereal. 7o. BesL. Eyf. afiv. XIII.t.6.f.r. Russpr. amb. 5. t. $75 \cdot f \cdot 2$.

Coix feminibus ovatis. Linn. Sy/l. veg. 842.

PER. nullum, pretcr involucrum femineum craftum, lapideum, ovato-conicum, apice \& bafi perforatum, glabrum, nitidum, fubviolaccum, aut Lividum, femen maturum claudcus, nee dimittens.

REC. nullum: femen fundo corollx affixum.

S E M. unicum (altero flosculo fenineo confanter abortiente), grandiusculum, fubglobn. fum, hinc gibbum, inde lato \& profundo fulco exfculptum, fuperne ftyto perfinente rollratum, inferne foveola umbilicali nigra exaratum, rubro-ferrugineum.

IN T. fimplex, membranaccum; tenue.

$\Lambda\llcorner$ B. farinofum, candicum, friabile.

Sc u t. ovato-oblongum, craffum, longitudine fere feminis, antice lato \& profundo fulco excavatum, ut fere bilobum.

Iм в. linearis, fubincurvus, longitudine fcutelli : Plunz. compreffa. Rad. funplex, brevis, retroliexa.

a.) Spiea ma[cula cum involucro femineo. b.) Involucrum maturam, integruın. c.) Idem long̨itudinaliter apertum. D.) Corolla fertilis, femine pragnans. C. f.) Semen denudatum, ab utroque latcre (pêtatum. 8.) Albunuinis \& Scuteli felio transverfalis. h.) Scuteliun a latere fpefatum. L) Embryo f́paratus.

Coix, palmx nomen en. Theophrastes hin. I. c. 16. proximam a palmis facit Coicein, \& Plinius, cum de ficciorum palınaruin turba agit, diferris verbis ait: in Ethiopia gignitur in frutice ramis cubitalibus, fulio latiore, pomo rotundo, Sed majore quain mali amplitudine: Cuicas vocant. L. XW. fect. 9. p. m. 685. 


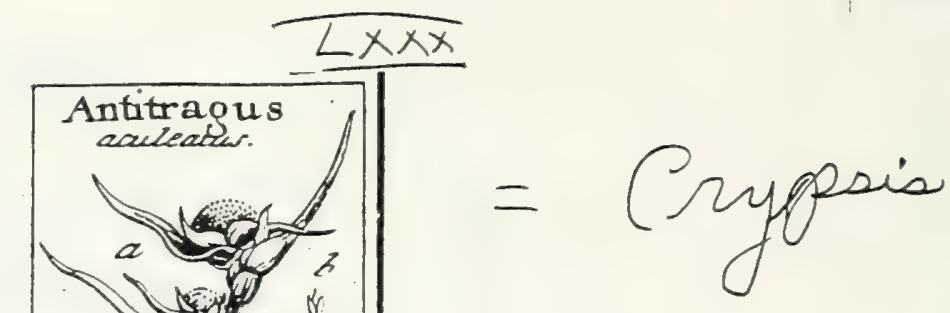

\section{ANTITRAG US. 7}

Flores capitati, duobus aut tribus foliis, bafi ventricols, involuerati. Cal. unitorus, bivalvis; valvulis inxqualibus, compreflo-carinatis. Cor. æquivalvis. Stam. duo aut tria. Semen nudum, exfulcum : Scutello marginali.

Antitragus aculeatus: Tab: 80. Ag. 7 .

Gramen aculeatum. CAN. epit. 745 .

Gruminis Jpecies fingularis - an Dactylis. PALL. it. rutb. 2: p. 733. t. K. f. I. \& tab. Q. f..2.

Schoenus aculeatus. SCHRER. gram. 2. p. 6: t. $3=$.

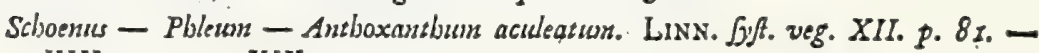
$X I I I$. p. $92 .-X I V \cdot p \cdot 73$.

PER. nullum.

REC. commone conicum tuberculatum, undique fofculis techum 3 partiale nullum.

SEM. liberum, exfulcum, calyce \& corolla perfiftentibus laxe cinctum, fubellipticum, lenticulari compreffum, pallidum, ad fcutelli fedem fufcum aut caftaneum, glabrum, non fplendens.

IN T. fimplex, tenuifinum.

A \&B. farinofum, album, fubtranfparens.

Scur. lineari - lanceolatum, longitudine fere ipprus feminis \& ad alcerum ejus marginem pofituns.

EмB. longus, fubulatus, lutefcens.

a.) Capitula matura, fubglobola. b. B.) Flofeulus feparatus. c. C.) Semen a latere fpetatum. D.) Albumen transverfe feetum, enm fitu seutelli. E) Scutcllum folutum cum foo Embryone.

$\triangle$ Schoeno abunde differt embryone fcutellato; a Phleo, calycis \& Scutelli cotyledonei forma atque fitu; \& ab Anthoxantho, defectu neckarii ariftati, ut \& tota fua facie externa. Ergo proprii generis planta, cui cum Kali $\int$. Trago aliqua fimilitudo eft. Anne autem jam Plisıo nota fuerit? quando inquit: Eft alia berba Tragos, femipedem alta, fruticofa, fme foliis, pufilis racemis rubentibus, grano sritici, acuso acumine, Ë ipfa in maritimis nafcens: L. XXV. fect. I7. p. m. 440. - id aliis enodandum relinguo. 


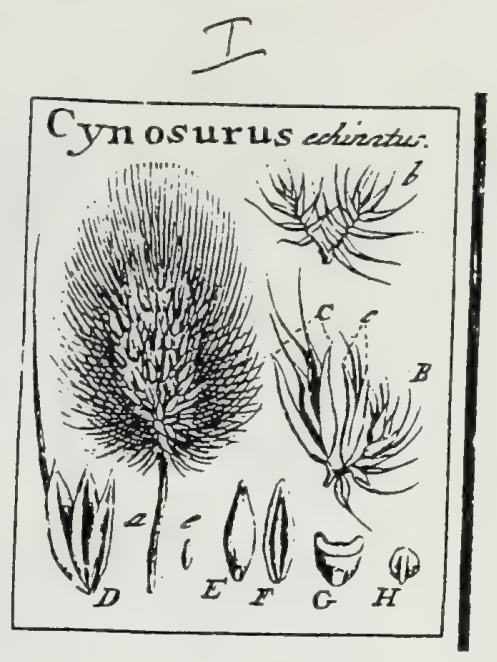

\section{J. Gaertner (1788) Vol. 1}

VIII. CYNOSURUS. LINx. gen. 87. 5

Involucra pectinata, aut pinnata, foribus fubjecta. Cal. bivalvis, bi -. $\Upsilon_{\text {. }}$ quadriforus.

Cor. biglumis, calyce longior. Semen liberum, tectum, hinc fulcatum.

Crxos U R U echinatus. Tab. I. fig. 8 .

Gramen cum cauda leporis afpern, f. Spica murine. B^ он. hift. 2. p. 474.

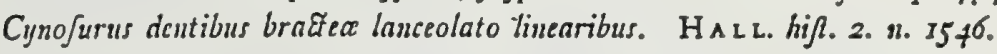

Cynofurus brafteis pinnato-paleaccis ariflatis. LINN. fyf. veg. 116.

PER. nulluin: corolla fumen fovet atque dimittit.

REc. nullum, prxier fundum corollx.

SEM. unicum, oblongum, utrinque acuminatum, apice pubescens, hinc conrexum, glabrum, inde concavuin, linea elcrata objuleta notatum, fpadiceun, aut rufesccns.

IN T. fimplex, adnatum.

A в в. farinofum, candidum.

ScUT. fubrotundum, minimum

Ess в. Lincaris, redus, lactcus. Rad. funplex, acuminata.

a.) Racemus ovatus, conglolatus, fecundus. c.) Involucrum partiale feparatum, filiforme, rig:-

duns, bi - f. rarius trifurcaturs, foliolis linearibus, alternis, fetaceo-acuminatis, pinnatune c. c.)

Locultix folitarix, rarius geminx, involucro fupra bafin inferix. e. E) Semiuis latus dorfale. F.) Ejusdean pars ventraiis concava. H.) Scutcllum cum cmbryone.

D.) Corolla femine pragnans.

Calyx bi \& triflorus, bivalvis, membranaceus, tenuifimus, oblongus, acuminatus.
Cor. biglumis, rigidiuscula : gluma interior

G.) Albumen uansverfe fectum. concava, infra apicem ariflata: arifla fetacea, recta, loculis duplo longiore. 


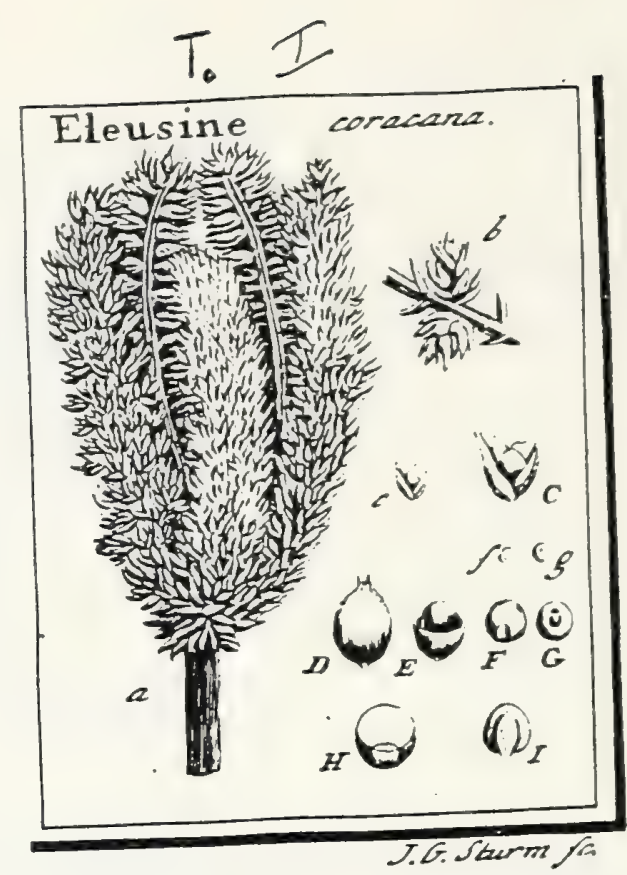

J. Gaertner (1788) Vol.1

Calyx bivalvis, quadriflorus. Cor. biglumis, inxquivalvis. Capfula membranacca, usulocularis, evalvis, monosperma. Semen globofum.

8

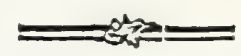

EIEVSINE coracana. Tab. r. fig. Ir.

Gramen dafylon orientale majus framentaceum, femine napi. $\mathrm{P} \_$Ux. phyt. t. 91. f. 2.

Cynofurus fpicis digitatis incurvatis, culmo comprefjo erelto, foliis fuboppofitis. LINN. Syflo veg. II7. SCHкER. gram. 2. p. 7 t. t. 35 .

PER. Capfula ovato-globofa, membranacea, tenuis, diaphana, unilocularis, evalvis.

REc. nullum, proter cicatriculum in fundo capfulx, cui femen, cxtera undiyuc liberum, affixum.

SEM. unicum, globofum, bafi fovea umbilicali atra exfculptum, glabrum, rubro fer. rugineun.

INT. fimplex, membranaceum, ar.te adnatum.

A в. fernini conforme, farinofum, candidum, friabile.

$\mathrm{S} C$ U T, rotundatum, longitudine dimidii albuminis.

Es B. oblongus, lacteus. Plum. lineari-oblonga, comprefta. Rad. finplex, brevis, infera.

2.) Culmi pars fuprema, (́picis heteromallis terminata, b.) Loeunx compreffrx, rhacheos lateri externo alternatim affixa. c. C.) Corolla feparata. D.) Capfula, naturali major. E.) Ejus ferito crauso

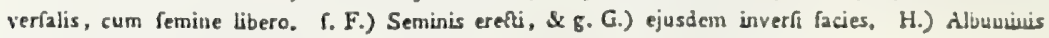
\& Scutelli felio trantsver(alis. I.) Scutellum feparatum cum Enobryone.

ELEUSINE indica.

Gramen dafyloides fpicis deorfum arißatis. Burs. Zcyl. 106.t. 47. f. I.

Cynofurus fpicis digitatis linearibus, culmo compreffo declinato bafin nodofo, foliis alteruis. LINN. Syf. veg. 117 .

Spicx quatuor $\int$. fex horizontali patentes, e craffiori bafi verfus apicem fenfun attenuatx, inferne floriferz. Spiculx partiales fubquadriflorx. Capfula \& f cmen, priori funillina, teria faltem parte minora omnia.

Pericarpio vero \& facile confficuo, non tantum a Cynofuro, fed \& ab omnibus reliquis cognitis graminibus, abunde differt. Cyuofurus agyjtiacus, effi habiru externo finulis, hujus tamen generis mon en. 


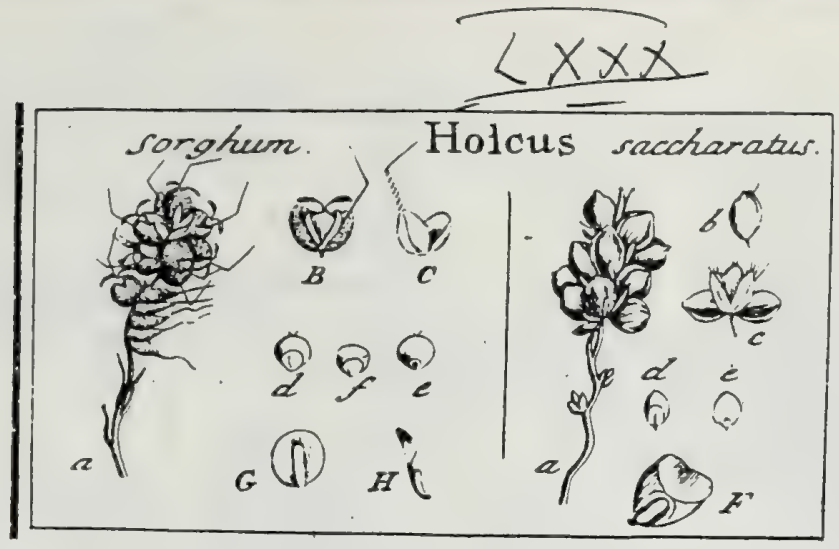

Poaceae

DII. HOLCUS. LINN. gen. II46. 2

J. Gaertner (1788) V01, 2

- Flores mafculi atque hermaphroditi in eodem culmo, quin frepe intra eundem calycem communem : ifti corolla deftituti. Cal. bivalvis, uni-bitritorus. Cor. bivalvis: valvula altera e dorfo ariftata. Semen exfulcum, nudum aut calyce tectum.

Holcus Sorghum. Tab. 80. fig. 2.

Sorgli album. Milizum indicum. B४Uн. bif. 2. p. 449.

Sorgbum fructu albo. BESL. Eyft. autums. II. t. $t_{3} . f_{0} 2$.

Holcus panicula comriata ovali, locuftis bermapbroditis ovatis villofis, feminibus rotundis comprefis. MIRG. AL. belv. VIIII. p. 125. t. 4. f. 3.

Holaus glumis villofis, fentinibus compreftis arifatis. Lins. Jyft. veg. 759.

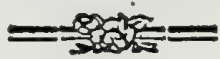

PER. \& REC. nullum.

SÉN. nudum, liberum; fulgiobofum', utrinque compreffufculum, absque

fplendore glabrum, lacteo - albuin, puncto umbilicali nigro.

-IN T. fimplex, membranaceum, arcke adnatum.

A LB. fenimi conforme, fubcartilaginofum, opacum, album.

Scu t. rotundatum, longitudine dimidii fere feminis.

EMв. linearis, figmoideus, lutefcens.

2.) Ramulus paniculx maturx feparztus, calycibus mafculis fubulatis atque hermaphroditis lubglobolis flipatus. B.) Flofculus hermaphroditus, naturali paulo -major, calyce membranaceo. villofo, albo. C.) Corolla bivalvis, membranacea, tenuifiera, diaphana, rofeo colore fuffura \& ad margines villora: Arift dorfali tortili, geniculata, caduca d. e.) Semen nudum, ab utrom que latere [pedatum. F.) Ejusdem it \& albuminis fedio transverfalis G.) Seutellam cotyledoneum sum Gitu embryonis. H.) Embryo Colutus.

Varietates hujus infigniores funt:

Holcus bicolor: Lins. 1. c.

Calyx maturus cartilagineus, ater, fplendens. Semen nudum, proce: denti per fingula puncta adeo fimile, ut demtis calycibus aullo modo ab invicem diltingui queant.

Holcus rubens.

Sorgbum frusu rribro. BESL Eyf. autumm. II. \&. T3. f. 1?

Cbolonsore - mille. Caffris. A Serenifr. CAROLINA March. Bad. miffus.

Calyx maturus cartilagineus, dilute "ciftaneus, glaberrimus, fplendens, femine dimidio brevior. Semina nuda, obovato globofa, verfus bafin valde acuminata, rutilantia 1. fubfanguinea, non fplendentia. Scut. cotyled. grande, dimidio albumine, Jougius.

Holcus faccharatus. ibid.

Milisum arundinacesum frive indicum, fensine fubrotundo. Moris. biff. 3. S. 8.

t. 5. f. 7. ob toiculos turbinatos.

Sorgum Battari. RuMPH. anbb. 5. p. 594 t.75. f. 1. fecundum LiNN.

Holcus panicala Sparfa laterali, locupis bermaphroditis villofis ellipticis, fentinibus ovalibus. MiEG. AB. belv. VIII. p. Irg. t. 4. f. x.

- Holcus glumuis villofis, Jeminibus omnibus ariftatis. Lins. $L$ C.

Panicula oblonga, laxa: Racemalis maturis (a) horizontaliter patentibus. Fla res (a.b.) fere obovati, obfolete angulati. Calyx (b.c.) uniforus, valvulis maturis coriaceis, glaberrinis, fplendentibus, ftramineis aut ferrugineis, femen arctc claudentibus. Corolla (c) membranacea, tenuifima, ad margines villora: Arilta dorโali-fetacea, brevi, geniculata. Semen (d.e.) ellip-

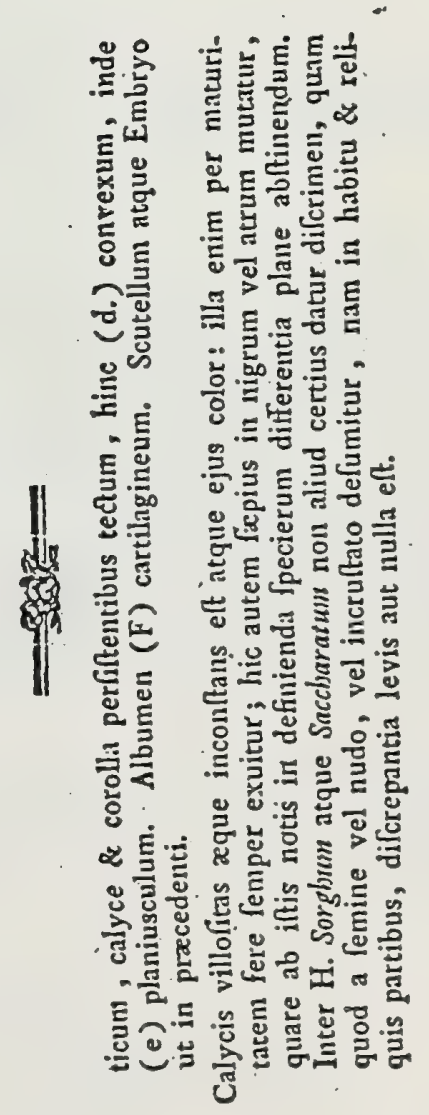




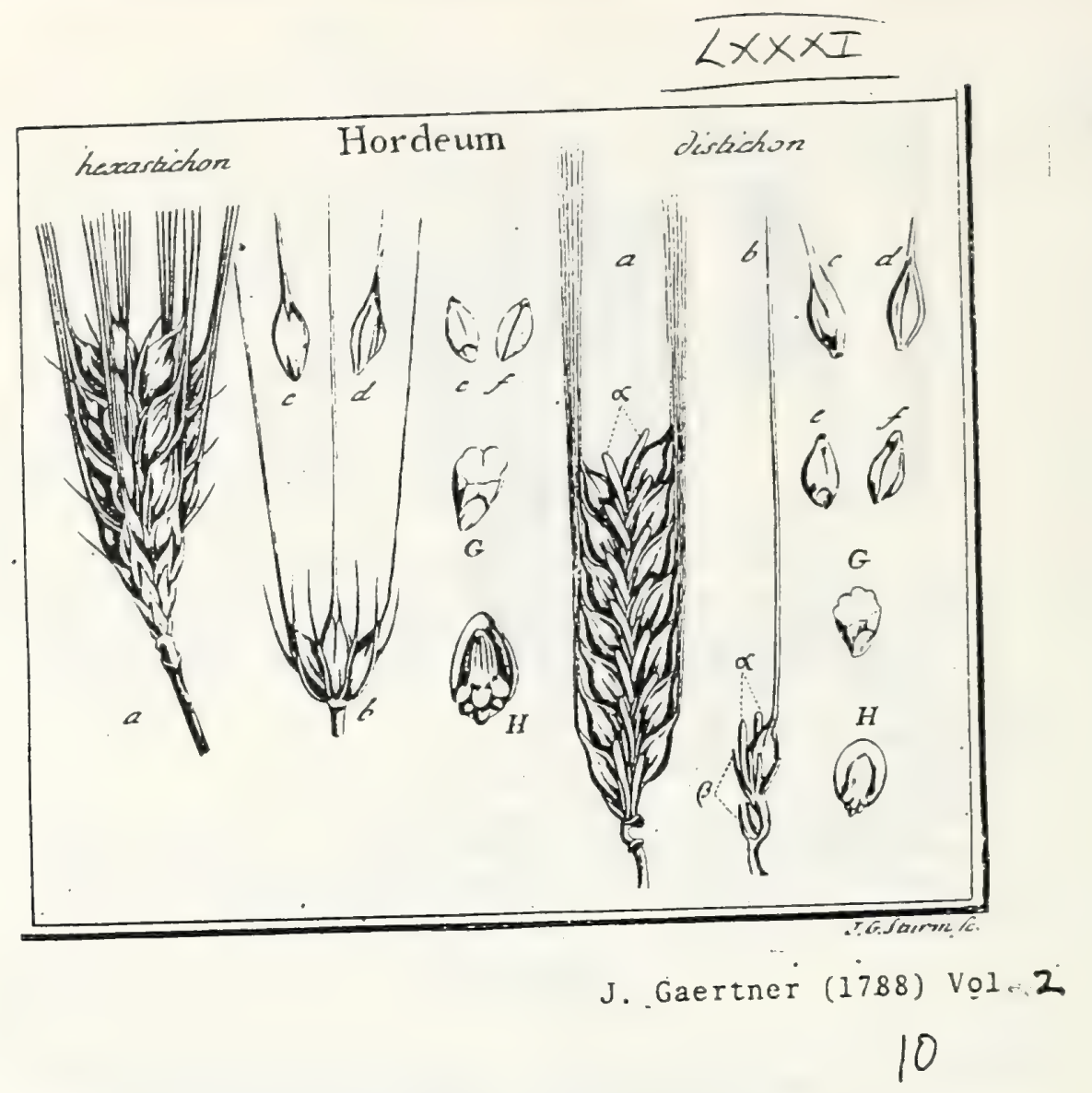

DX. HORDEUUM. TOURN. inft. t. 295. LINN. gen. 98.

Flores fpicati, ad fingulum. racheos denticulum terni. Cal. uniflorus, bivalvis: valvulis anguftis, acuminatis, diftantibus, involucrum (fic dicum) hexaphyllum junctin formantibus. Cor. ariftata. Semen corolla cortica. tum. Embryonis radiculæ fenæ.

Hordeur hexaftichon. Tab. 81 . fig. 3.

Horderm polyficbons bybernum. BAUн. theatr. 439. MORIs. bif. 3. S. 8. t. 6. f. 3 .

Hordeum fpica polyficha, foribus omnibus bermaphroditis, longe miffatis. Hall. bijt. n. 1534 .

Hordeum flofculis omnibus bermapbroditis ariftatis, feminibus fexfariam aqualiter pofitis. LiNN. fyr. veg. 125.

PER. \& REC. nullum. Corolla matura coriacea femen involvit, nec dimittit.

SEM. ovatum, utrinque acuminatum, fubanguiatum, area dorfali planiufcula, ventre gibbo, profunda rima cæfo.

IN T. tenuiffmum, membranaceum, lividum.

$\Lambda$ L. farinofum, durum, album.

Sc U T. ovatum, quartam feminis partem longum, niveum.

Eмв. compreffus, oblongus. Plum. linguiformis. Radic. papillofx, fenx, duplici ferie polite.

a.) Spica matara troncata b.) Flefeali racheos denticulo inftentes. c. d ) Corolla matura faeies anterior eft pofterior. e.) Seminis decorcieati pars doralis. f.) Ejusdem latus ventrale. G.) Albumen transerfe feCum. H.) Scutellam cum Embryone denudato.

HORDEUM diftichum. ibid.

Hordeum vulgare diffichum. Morıs. bif. 3. S. 8. 6. 6. f. x.

Hordenm fiofculis lateralibas mafculis musticis, feminibus angularibus imbricatis. LINN. Wyyt. veg. L c c

Spica (a.) compreGiufcula, feu transverfim latior quam craffa, duplici ferie flofculorum defectivorum $\left(\alpha_{*} \alpha_{0}\right)$ in utroque latere plano, atque fimplici ordine florum fertilium ad utrumque marginem ftipata. Calycis valvulx (K.) linearcs, corolla dinidio breviores. Corolla matura (b. c. d.) coriacea, angulara, femini adnara, apice definens in Ariftam fibi fedecies lon-

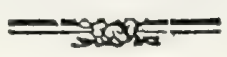

II

giorem. Semen decorticatum (e. f. G.) ovatum, fulcatum, angulatum. Scutellum (H.) rotundatum. Embryonis radiculx fex, papillares. 


\section{Tab: CL XXXI}

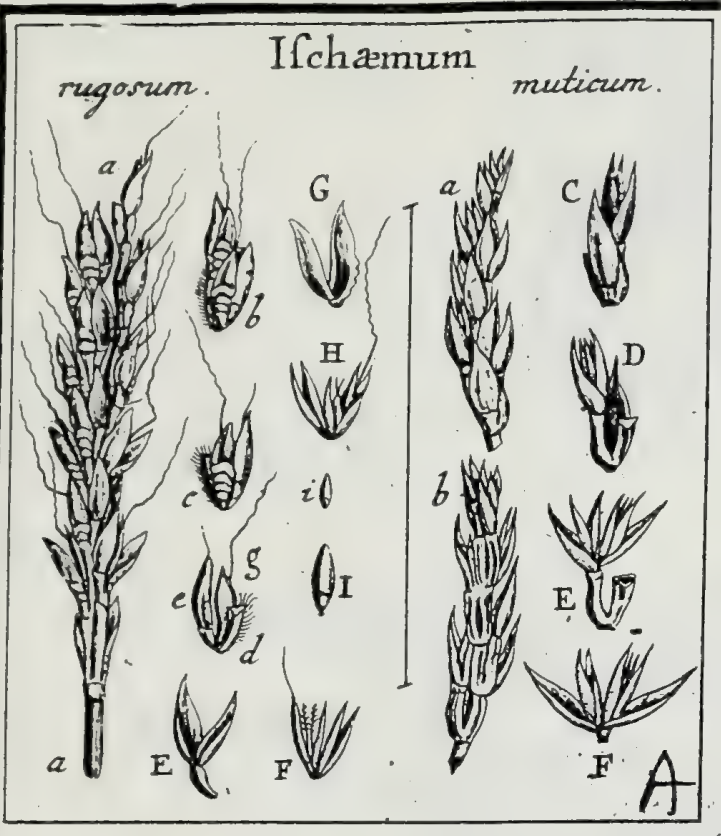

\section{I S C H A M U M:}

LINN. gen. I148. ed. Schreb. 1569. Juss. gen. p. 30.

Spica lineari - oblonga, fimplex aut bipartita, articulata, per articulos fecedens. Articuli bicrures, apice alternatim locuftiferi, \& praterea aliz loculta feffili, ad bafin fuam externam muniti. Locuftre omnes bivalves, biflorz: fiofculo altero hermaphrodito fertili; altero mafculo, fterili. Flofculorum corollulx bivalves, mutice at e dorfo ariftatz.

Ischazarum muticum. Tab. 181. fig. 1.

Tagadi. RHEED. bort. mal. 12. p. g1. t. $4 \%^{\circ}$.

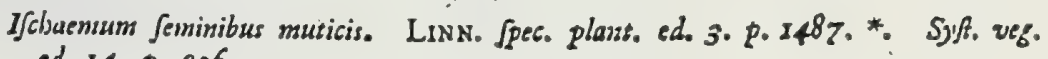
ed. 14. p. 966.

A Cl. Thungergio cum fequenti.

PER. nullum.

Rec. nullum.

SE n. hermaphroditis oblongum, fponte deciduum, fpadiceum aut rufefcens. A L B. farinofum.

Sc ит. quarta feminis parte brevius, \& in ejus dorfo convexo politum.

Es 8. monocotyledoneus, linearis; minutus.

\section{EXPLICATIO FIGURE.}

a.) Spicx bipartitz pars exterior convexiu[eula, b.) Ejusiem Iatus interaum, planom, oppofirz libi fpicz (edioni axQe adpreflum. C.) Arcieulus folutus locuttifer, a parte exteriore fpetatus. D.) Idcm a parte interna vifus, cum locula inferiore felfli clauk, fuperiote auten leviter didue.2. E.) Articulus bicruris, exculta locufta inferiore, audus; faperiore autea bivalvi \& biflora, valde diduda, adbuedum muaitus. F.) Locula inferior feparats, cum flofculis fuis geminis.

ISCHAEMUN rugofum. ibiden.

Spica bipartita (a. a.), articulata. - Articuli juncti (b.) alternatim a dorfo \& latcribus locuftiferi. Articuli finguli (c. d.) bicrures: crure breviore (e. E.) locuftifero; longiore autem (d.) articulum proximum fuftimente:

inter crura finguli articuli \& ab ejus latere externo (c. g.) locufta aliz, fubfelfilis, longaque arifta geniculata munita. Locufta pedicellatn (e. E.) bivalvis, bilora : toofculo altero (F.) hermaphrodito, diftylo, fed in meis exemplis abortivo; alsero mafculo penitus fterili. Corollulx folculi utriusque bivalves; fed valvula exterior foris hermaphroditi in arifam brevem fetaceam rect: valvis \& bifora; fed valvula ejus exterior a bafi ad medium ufque pro fundis rugis transverfalibus exarata, ut tota fpica exinde prorfus fingularem nancifcatur formam. Flofculorum gemellorun (H.) alter mafculus, fterilis bivalvis muticus; alter hermaphroditus, inxquivalvi - biglunis: gluma interiore, angutiore, breviore nucica; gluna autem exteriore, majore, apice bifida, $\hat{\alpha}$ ex dorfo longà ariftà geniculatà \& tortili inftructa. Semen (i. I.) nonnifi in his ultimis flofculis reperi, ovali-oblongum, \&
quale fupra, defcriptum.

Non puto effe Ifchxmum ariftatum Linn., quia certiflime rugas transverfales locuftx felfilis, in fua defcriptione non filuiffer; \& quia Cl. ThunberGlos huic gramini nonen fpecificum aut triviale addidiffet, quod autem non fecit. Hinc ut novam fpecien propono, donec certiora innotefcant.

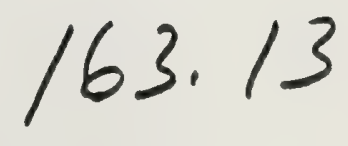




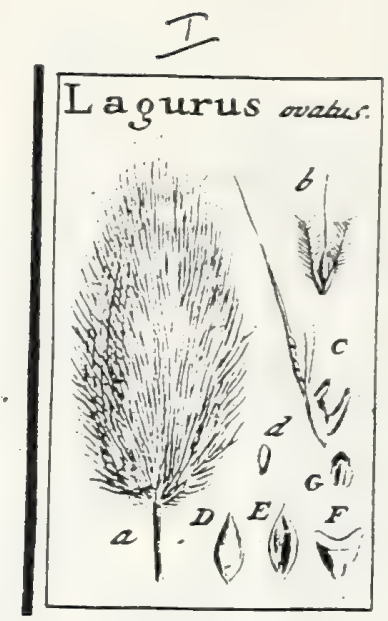

Poaceae

$$
\text { J. Gaertncr (1788) V01-1 }
$$

V. LAGVRVS. LiNa. gem. 92 .

Calyr unilhorus, bivalvis: arifa terminali, plumofa. Cor, inxquivalvis: gluma ma. jure ariflis tribus, nudis. Semen liberun, techum, hine fulcatum.

Lagurus ovatus. Tab. 1. fig. 5 .

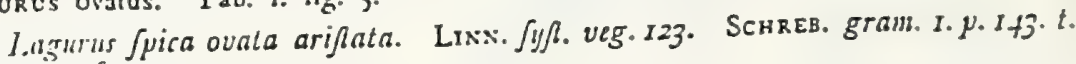
19. $\int \cdot 3$.

PF.k. mullum: corolla matura, calyce rigidior; femen fovet ac dimittit.

4

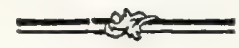

REc. nullum, proter fundum corollix.

SEM. unicum: ovatum, utrinque acuminatum, hine convexum, glabrun; inde concavum atque fria incdia elevata notatum; fpadiceum.

IxT. fimplex, adnatum.

A L B. farinofum, pallidum, fubdiaphanum.

S C U T. ovatum, brevifinum.

Em d. linearis, rectus, lacteus. Rad. fumplex, acuminata.

a.) Spica matura, integra. b.) Flosculus feparatus. c.) Corolla (enine pregnans. d. D.) Seminis dorfun. E.) Ejusdem pars ventralis. F.) Albumen transverfe fefturn, G.) Scutcllum cotyledoneun cum Embryoue. 


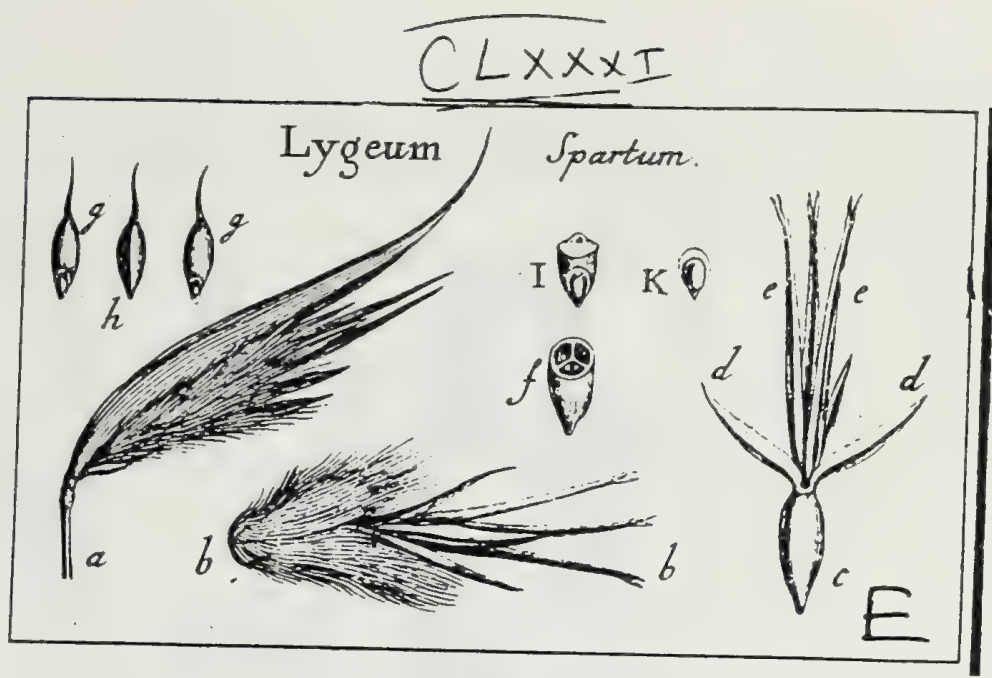

J. Gaertner (1788) Vol 3

5. L.Y G E U M.

LIN gen. pl. 70. ee. Schreb. 99. Juss. gen. p. 33.

LA $\mathrm{ABCX}$ ill. gen. $t .39$.

Spatha floralis monophylla, oblonga, ftriata, acuminata, in ariftam mollem de. finens, parte fus inferiore longitudinaliter dehifcens, unicum fructum continens. Cal. proprius fuperus, quadri - 1. hexaphyllus, bi - 1 . triflorus: fo. liolis exterioribus per maturitatem pericarpio longioribus, lanceolato-oblon. gis, carinatis, paleaceis, rigidis; interioribus fructu duplo longioribus, ex ejus difiepinentis nafcentibus, lineari-fubulatis, apice bifidis, introrfum carinatis, paleaceis, Bexilibus. Cor. nulla, nifi calycem velis. Stamina intra Gngulas calycis valvulas geminatas, s. intra ejusdem foliola interiora atque exteriora, tria, adeogue in univerfum fex l. novem. Styli in Gngulis calycinis conjugationibus finguli. Nux hirfutiflema, bi $=1$. trilocularis, bi -1 . trifperma.

LYGeU S Spartum. Tab. $18 \mathrm{I}$. fig. S.

Sparsun berba, alserum CLus. bifs. 2. p. 220 . c. ic.

Lygetum LOEFL. it. p. 11. 365. t. 2. LinN. Syft. veg. ed. 13. p. 103. Spec. pl. ed. Willd. T. x. P. I. p. 316 .

A Cl. Thunberg.

PER. Nur coriacea, dura, infera, hirfutifima, oblonge elliptica, bafi attenuata, apice perfiftentibus calyciums foliolis coronata, bi - 1 . trilocularis, non dehifcens. Diffepimenta membranacea, tenuia, fuperne in calycis foliola interiora elongata.

REc. nullum.

SEM. in fingulo loculo unicum, oblongum, hine convexum, inde planum aut angulatum, perfiftente ftylo fibi proprio terminatum, e einnamomeo ru-
fefcens.

IN T. Gmplicifrmum, membranaceum, facile detrahendum.

A Lв. farinolum, candidifimum, friabile.

ScuT. fubrotundum, carnofum, album, in dorfo feminis.

E s B. ovato-oblongus, deorfum valde acuminatus, craflus, lutefcens.

\section{EXPLICATIO FIGURE.}

a.) Spatha dehifcens. b. b.) Nox feparata, pilis undique contecta. c.) Easem denudata, cum tribus foliolis calycinis. (d. d.) exterioribus, totilemque (e. e.) interioribus, f.) Nux trilocuI: $\because$ is transverfe diffecta. g. g.) Semina 2 dorfo, \& (h.) a ventre (pedata. I.) Seminis fectio transverfalis. K) Scutelium cotyledoneum cum Embryone.

Pericarpium fricte loquendo mullum adeft, fed calyeis venter in nucem fpuriam induratus, sillud faltem xnulatur, ut in Xanthio \& Ambrofia. Hinc quoque fenina Lygei haud magis tecta nut infera dici debent, atque atque propriis Gquidem perinde intra calycis proprii ventrem conclufat atque propriis fuis itylis dotata fint.

Meum exemplum ex is fuit, qux Loflingius l. c. dicit rariora, \& qux mihi videntur nagis naturalia, propter numerum fartium ternariun, in mово. 


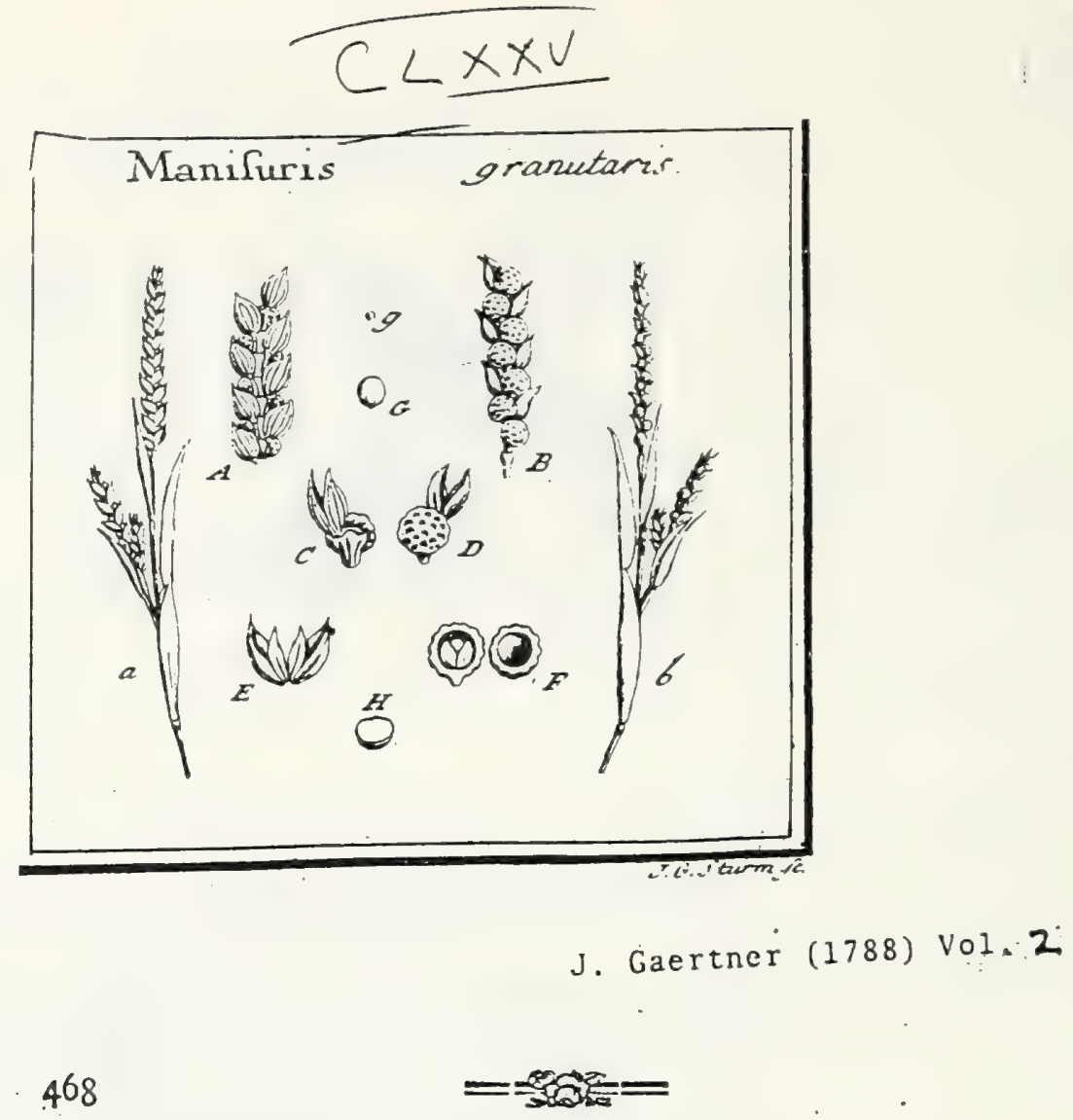

MXLIX. M A N I U R I S. Linn. gen. I334.

Flures in eadem fexu diftincti. Spica fubulata, articulata, per articulos difedens: articulis fingulis biforis. HERM. in articulurum latere ventrali plano feifiles, fubglobofi. Cal. coriaceus bivalris: va!vula. pofervore a rachidis articulo vix diftinct:a: V. auteriore fubhicnifpharica, profuside fcrubiculata, per maturitaten teftaceo-fuica. Cor. membranacea, tenuiffinn, bivalvis. Ovar. fubrotundun. MARES in dorfo fpicx nlernąrim inbricati \& ad finguli articuli marginem fupremum lateralem pofiti finguli, ovato-acuminat, hinc convexi ftriati, inde concavi. Cal. coriaceus, bivalvis: valvis xqualibus, naviculari comprelfis \& ad marginem in carinan acutam prominulam definentibus. Cor. nembranacea, tenuiffma, bival. vis. Semen calyce tectum.

Dlanisuris granularis. Tab. 175 .

\section{A Cl. Thunbergio.}

J'ER. nullum. Calyx hermaphr. per maturitaten induratus \& fere nucamennoceus femen arcte claudit, nec dinittit.

REc. nullum.

SE M. parvulum, fubrotundum, hinc convexum, inde planiufculum, rubicundum.

IN T. fimplicifrimum, membra!naceum.

A L B. farinofun, durum.

ScVT. fubrotundum, minutulum, in baG lateris convesi.

ENB. ninutifimus, linearis.

2. A.) Graminis \& fpicx facies dorfalic b. B. ) Ejusilem pars ventralic, C.) Articulus fepara. tus, cum infertione \& figura floris mafculi. D.) Idem scverfus, cun fitu E forma fot. bermaphroditi E.) Flos mafculus explicatus. F.) Nlermaphroditi calycis valvulic ficarata, cum curclla femeu ebtegente. g. G.) Semen Separatum, iuscgrum. H.) IJen transveríe difictum.

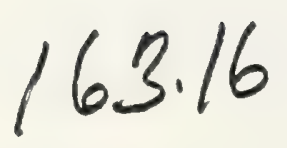




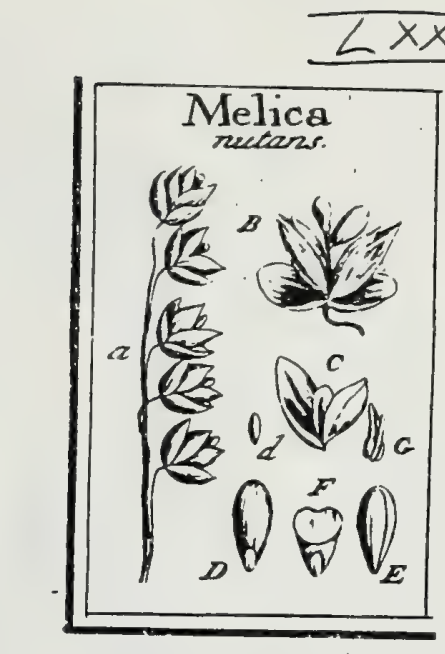

J. Gaertner (1788) Vol.. 2

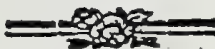

\section{MÉLICA. LINN. ger. 82.}

Calyx bivalvis, biforus cum Rudimento unius aut duorum fofculorum fatuorum. Corolla inxquivalvis, mutica. Semen fulcatum, nudum.

Melica nutans. Tab: 8o. fig. 4.

Gramen montanun avenaceurs. Moris. bif. 3. p. 215. S. 8. t. 7. f. 48 .

Pon paricula laxa, locuftis mitcoutibus diantbis, alterno fiofoulo immerfefo. HaLl. bif. n. 1472.

Nelica petalis imberbibus, panicula nutante fimplici. Schnzв. grams. x. p.62. t. 6. f. 2. LINN. Gyfor. veg. 112.

PER. \& REC. nullum.

SEM. nudum, Jiberum, ovato-oblosigum, deorfum attematum, fubteretiusculum, hinc convexum, inde fulco longitudinali medio infcriptum, cetera glabrum, lucidum, quafi oleo illitum, faturate fpadiceum, ut fere caftaneum.

IN T. fimplex, tenue, membranaceum.

A L B. farinofum, album, fubtraniparens.

SCU T. oblongum, quarta parte femmis brevius, anguftum, profundo fulco infcriptum.

E.MB. linearis, rectus, lutefcess.

2) Paniculs pars fuprema comi loctrtis. B.) Locufta naturalis major, eum doobus flofculis fertilibus, totidenque incompletis pyriformibus. C.) Corollz valvulz didueze d. D.) Seminis parz convera, feutelligera. E) Ejusdem pars ventrilis fulerta F.j Albumen transverfe fccum. G.) Scutellus cum Embryone. 


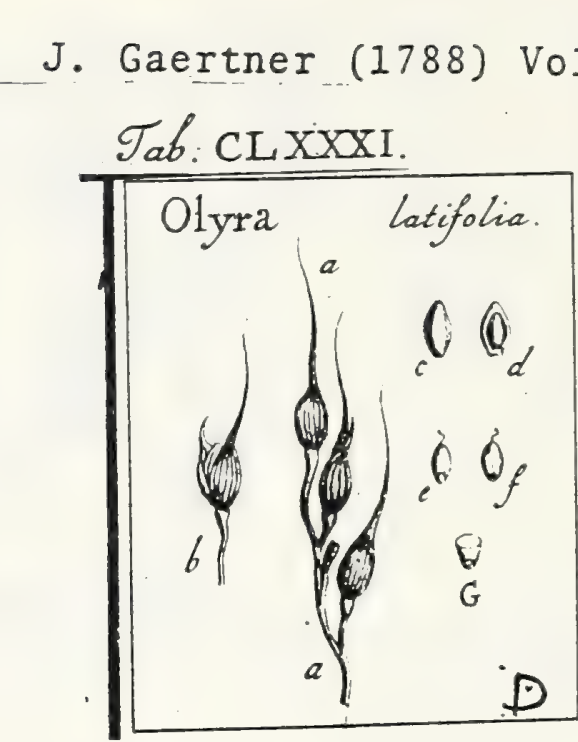

J. Gaertner (1788) vol3

\section{OL Y R A.}

IrnN. gen. pl. 1045. 'ed. Schreb. 1406. Juss. gen. p. 33 . LAMABCK ill. gen. t. 751 .

Flores fexu diftineti in eadem panicula : mafculi infra focmineos. MAS. Cal. bivalvis unilorus: valvulis lanceolatis, altera in ariftam definente. Cor. bivalvis. Stam. tria. FEM. Cal. bivalvis uniflorus: valvis ovato-acuminatis concavis; altera extus multiftriata, in ariftam longam fexilem defi. nente; altera 3 - l. 5. ftriata, brevi mucrone terminata. Cor. bivalvis, perfiftens, demum fublapidea, femen incruftans, nec dimittens. Styl. Gmplex perfiftens. Semen tectum corolla fublapidefcente.

Olyre latifolia. Tab. I8I. fig. 4 .

Gramen paniceun majus, fpica fimplici levi, granis petiolis infrdentibus. SLOAN. bij. jain. x. p. 107. t. 64. f. 2.

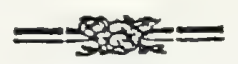

Olyra. Lins. Syys. veg. ed. 14. p. 842.

Obyra (paniculata) panicula torminali, culmo ramojo. SWARTZ prod. E. 2 . A Cl. Thunbergio.

PER. nullum, fed ejus loco valvula corollx cartilaginex aut fublapidex, leevigatifimæ, fplendentes, pallide albicautes, qux femen arctifime claudunt, nec dimittunt.

REC. nullum.

SEs. ellipticum, a dorfo paulo magis convexum quam a ventre, ibi vero glabrum, heic linea longitudinali infcriptum, fpadiceum, ftylo perfiftente terminatum.

A LB. farinofum, durum, candidifimum.

Sc U T. fubrotundum, quinta albuminis parte brevius, \& in ejus dor[o locatum. Eм в. minutifimus, linearis, rectus.

\section{EXPLICATIO FIGURE.}

a. a.) Pars racimi sorum femineorum. b.) Calyx maturus hians c) Corollx induratx latus dorlale. d.) Ejusdem pars ventralis, ubi valvulx exterioris margo, eeu ennulus, interiorem ampleatur. e.) Seminis dorfua. f.) Ejosdem veuter. G.) Albamen trasveríe diffeaum, eum feutello cotyledoneo in bafi. 
Tab. CLXXXI

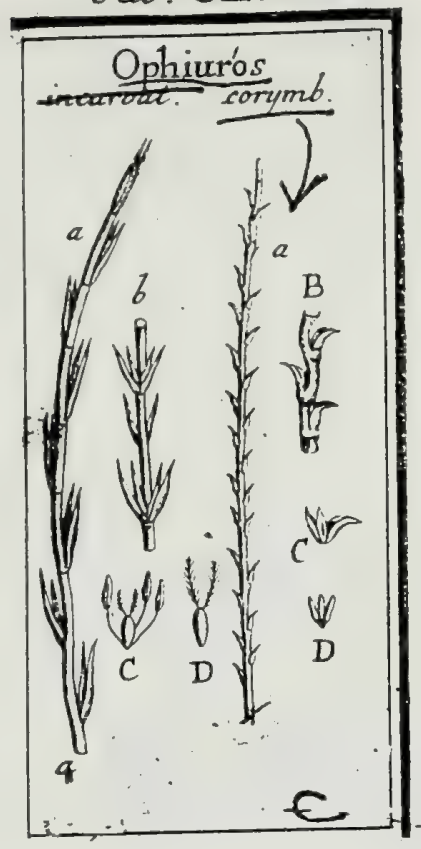

J. Gaertner (1788) VQI. 3

\section{3. $O$ P H U ROS.}

Rottballia LINN. \& Juss. I. c.

Spica filiformi oblonga, apparenter faltem articulata, fed vere continua. Ar. ticuli fpurii teretes, ad Gofculorum fedem fcrobiculato-excavati: unibori, flofculis alternantibus, fimpliciffmis, omnibus hermaphroditis. Cal. fimpliciflimus univalvis, aut bipartitus: fegmentis collateralibus, Eapo obverfis. Cor. bivalvis; valvula altera exteriore \& altera interiore feu fcapo accunibenti. Stam. tria. Ovar. fubrotundum. Styl. duo.

Oryos jucurvata. Tab. 181. fig. 3.

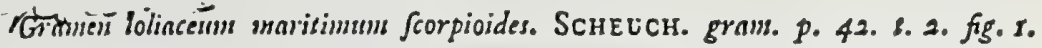
Aegylops fpica fubulata mutica lavi.incurva, calycibus uniforis. LINN. Spec. plo ed. 3. 1. 8490 . *

Rortboellia spica tereti - fubulata, gluma calycisa fubulata adpressa bipartita. Linn. Suppl. p. I14. Syft. veg. ed. 14. p. 124 .

Rortboellia spica tereti - fubulatn incruvata, glusna calycina bivalvi fubulasa ad. prefla. Lisw. Spec. pl. ed. Willd. Tom. 1. P. 1. p. 463.

S ₹ M. naturum in neutra fpecie vidi.

\section{EXPLICATIO FIG URE.}

2. a.) Spica fuhulata, apparenter articulata, feul integerrima \& contioua. b.) Bars ejus reparat2, cum calycibus \& corollis didudis, quz alias sachidl prete aceumbunt, \& finus ejus arde claulunt. C.) Genitalia foris perfeati betmaphroditi. D.) Ovarium cum fylis late plumofis, fofenlorum (per abortum) femineorum.

Multo frequentius in bac fpecic reperiuntur flores fominei, quam hermaphroditi; \& tamen fulpicio eft, illos non nifi per abortum ex his gigni, prafertim in plantis cultis, qualis eft meum exemplum.

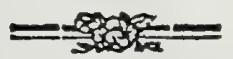

OpHIURos corymbora. ibidem.

Aogilops (exaltata) Spicis filiformibus muticis corymbofis. LiNn. Mrant. P. 575. *

Rottboellia spicis aggregatis lateralibus filiformibus, flofculis bivariis patentibus folis bafs ciliatis. LINN. Supp!. 1. c. Syle veg. 1. c. Spec. plant. ed. Willd. 1. c. $p .466$.

Spicx partiales (a. a.) fubresqui-digitales, rectx, frictx, teretes, pfeudoarticulatx, craffitie fili emporetici tenuioris. Flores alterni, primum arcte adprelfi, demum recurvato patuli. Calyx (C.) coriaceus, mono: phyllus, fimplicifimus. Corolla bivalvis tenuifima, genitalia involvens. Stamina tria. (D.) Ovarium ....

In plusquam quadraginta floribus genitalia fominea fruftra quafivi, nec eorum vel ninimum deprehendere potui veltigium. Anne igitur planta naturaliter dioica, aut in meo Ppecinine cafu faltem nafcula. Etiam hoc fingulare habet lixe planta, quod ex vagina foliorum, unde aggregatz nafcuntur fpicze partiales, qua demum formant paniculaın fpicato - virgatam, finul quoque numerofz proveniant vibrifiz feu palez fubulatofetacex; quas hactenus in nullo alio gramine vidi, \& qux forfan fuerint Limuxi cilia in bag foliorun.

Non poffe hafce duas plantas cum Rottbcollia combinari, fiquidem characteres e partibus fructificationis haufti, pluris valeant, quam illi ex fallaci habitu externo deducti, plane liquidum effe opinor. Proximam affinita. tem cum Digitaria habere videtur 0 . corymbofa, fi ejus flores melius erunt cogniti. 


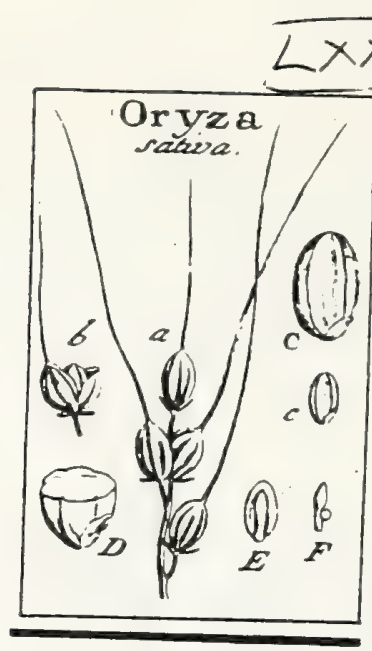

J. Gaertner (1788) Vol, 2

DV. ORYZA. TOURN. inft. t. 296.

Calyx uniflorus, bivalvis, corolla multoties minor. Cor. bivalvis, valvulis navicularibus fulcatis: altera ex apice ariftata. Stam. fex. Semen exful. cum, inclufum, liberum, aut corolla adnatz incruftatum: Scutello marginali.

Oryza fativa. Tab. 80. fig. S.

Oryza. Dud. pempt. 509. Casr. epit. 192. Lins. Jyf. veg. 345.

PER. \& REC. nullum. Corolla pallide ftramínea, Jongicudinaliter fulcata, cruftacea, femen arcte claudit, nec dimirtic.

SEM. ellipticum, lenticulari compreffum, duabus in utrogre latere atque unica in ventrali acie Atriis obfoletis notatum, pallide albicans,

Ix T. tenuiffimum, arctiffime adnatum, ut vix ullum.

AL B. farinofum, duriflumum, femipellucidum, albicans.

6

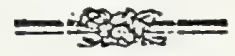

Scut. ellipticum, tertia feninis parte brevius, : \& in- ejus acie dorfali politum. Em B. linearis, rectus, niveus.

2.) Panieula racemulus. h.) Corolla aperta cum femine. in fitus. c. C.) Scmen 2 latere (peatum. D.) Albuminis fectio transverfalis, cum fitu Scutclli in acie .feninis Jorfali. E) Scu. teflum a fronte fpedatum. F.) Embryo Solutus.

Oryza Paddy-kooning funatrana. Calycis valvulx lineari acuminatz, appreffx, fplendentes, nivex. Corolli maturx theca cruftacea, oblonga, ftriata, utriuque acuminata, fubfalcata, extus fulva, intus pallida. Semen ob. longun, curvulum, ftriatum, . compreffum, pallidum, fubtranfparens.

Oryza in ficcis crefcens, Ebbas dicta. Cum precedenti a Car. Millero e Sumatra miffa. Calyx ut in priori, fed fpadiceus. Corolla theca ellipticooblonga, non falcata, fed altero tantum latere paulo magis gibba, fordide litea, fubpubefcens. 'Semen longe ellipticum, ftriatum, album, opacum.

$$
163.20
$$




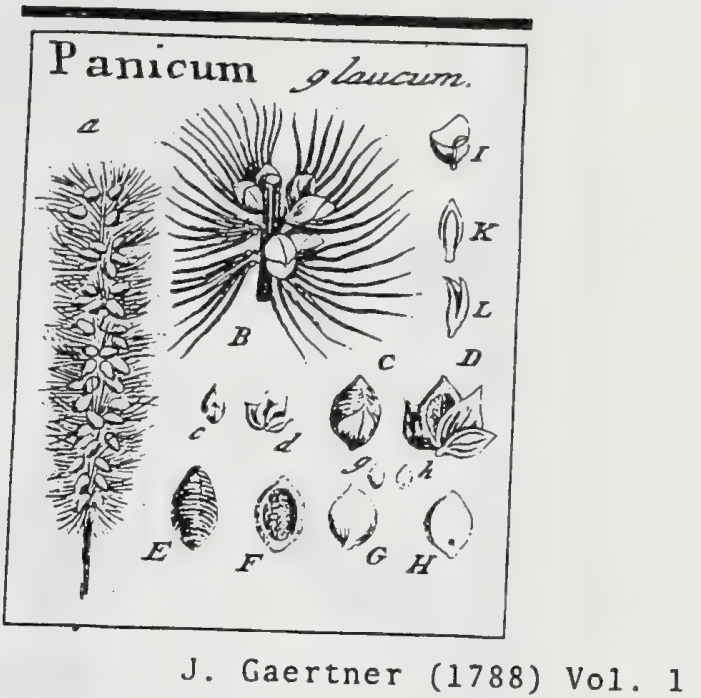

III. PANICUM. IINN. gen. 76 .

Calyx uniflorus, trivalvis. Corolla matura cruftacea. Semen corollâ corticatum, exfulcum.

PAN ICUM glaucum. Tab. I. fig. 3 .

Panicum fpica tereti, involucellis biforis fafciculato pilofis, fominibus undulato rigofis. LIN J. Jyfl. veg. 105. SCHREB. gram. 2. y. 21. t. 25 .

PER. nullum : femen corticatum corollâ, per inaturitatein cartilagineo - crufaceí, claufa, bivalvi: valvula altera convexa, transierfe undulato-rugofa; altera planiufcuja, punctis minutiffunis elevatis confperfa; utraque fordide fufea, aut e cantaneo fumofa.

REc. nullum, prater fundum corollx, cui fernen affixum.

SEM. ovato-acuminatum, plano-convexum, glaucusn, area umbilicali nigro-fufa.

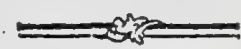

IN T. fimplex, membranaceum, adnatum.

A г в. farinofum, durum, candidum.

SCu T. lanceolatum, dimidio albumine longius.

E s B. lineari-lanceolatus, monocotyledoneus, flavefiens. Rad. funplex. infera.

a.) Spicx maturx pars inferior. B.) Involucrum (afciculato fetsceum floribus fubjętum. c. C.) Flos femine pragnans. d. D.) Idem, diduetis valvulis calycinis. E.) Corollie matura latus convexunL. F.) Ejusden pars plana, puntata, E. G.) Semen decorticatum a parte dorfati - h. H.) Idem a parte ventrali (petatum. I.) Albumen transverfe fêtum. K.) Scutellum cotyledoncum folutum. L.) Idem a Latere fpctatum cum embryone e fulco fcuteli extrafto. 


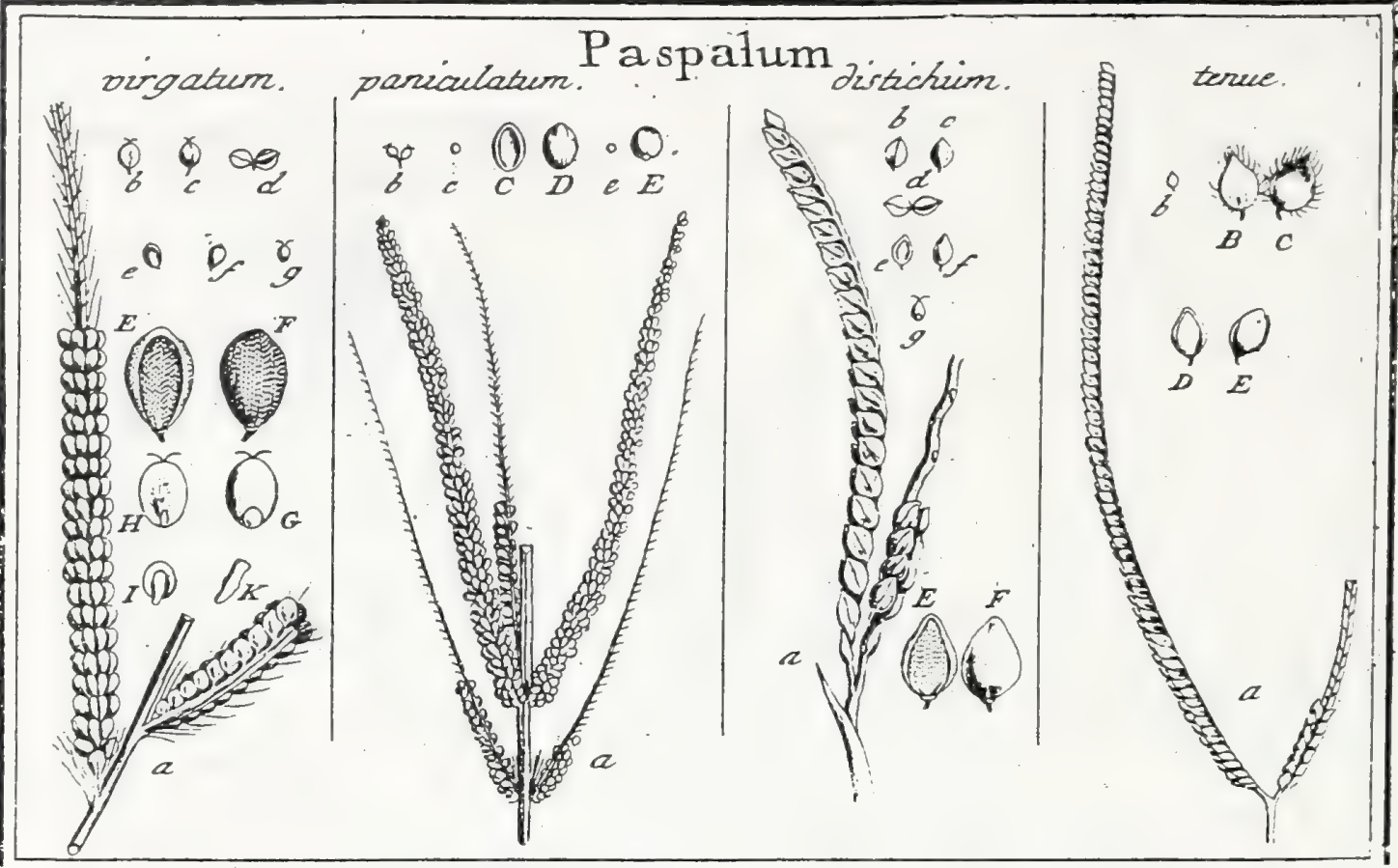

\section{PASPALUM. LINN. gen. 75.}

Flores in altero latere racheos linearis fecundum longitudinem digefti. Cal. uniforus, bivalvis, ovato rotundatus. Cor. bivalvis, calyci æqualis, pet maturitatem femen irvolvens, Semen corolla corticatum, exfulcurn, plano-convexum.

P.ASPALUM virgatum. Tab". 80 . fig. I.

Gramen dactylon majus, panicula longa. fpicis plsorimis urudis crafis. SLOAN. bif.. jam. I. p. 112. t.69. f. 2.

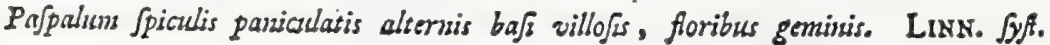
veg. 105.

PER. nullum, preter corollx maturx cruftam corneam, faturate ferrugineam aut caftaneam, bivalvem: Valvula exseriore convexa, punctis excavatis longitudinaliter ftriata atque margine fuo infexo compledente vo interiorems planiufculam, obfolete puncticulatam.

REC. nullum.

SEN. ellipticum, plano - convexum, fpadiceurs.

IN T. fimplex, membranaceum, arçe adnatum.

LLB. femini conforme, farinofum, duriufculum, album.

SCUT. orbiculatum, tertiz parte albuminis brevius.

EMB. linearis, comprefrufculus, lutefcens.

2.) Spicula eum fitu frofculorum quadruplici ferie longitudinali in rachi mesabranacea digefromm. b. c.) Flofsuli maturi facies anterior \& pofferior. d.) Calycis valrulx diduez:. eE.) Corollz croftacer latus planum. f. F.) Ejusdem pars convexz dorfalis. g.G.) Seninis decortionti dorfun (cutelligerum. H.) Ejusdem pars ventralis planz. L.) Scutellum cum els. brgone. K.) Embryo feparatus.

Calyces in meis exemplis xquivalves funt, nee Valvula exterior breviflima, ficuti habet LINNĖUS 1. c.

PASPALUM paniculatum. ibid.

Granen miliacetm panicula viridi E. purptrea. SLOAN. bifs. jam. I. p. I15.t.72. f. 2 .

Pajpalum spicis pariculatis verticillato aggregatis. LINN. l. c.

Panicula fcapus, ut in pracedenti, triqueter, fpiculis (a) inferioribus oppol. tis, mediis ternato-verticillatis, fummis alternis: omnibus ad bafin barbatis, cetera autem multo gracilioribus, quam in priori, atque irregularibus fofculorum feriebus ftipatis. Flofculi (b) pufilli, in communi pedunculo capillari gemini, plano convexi. Crufta feminis (c. C.D.) corracea, glabra, nitida, vix ftriata, ftraminea aut pallide viridis. Semen (e.E.) rocundatum, plano-convexun, pallidum. Reliqua ut in praccedenti.
J. Gaertner (1788) Vol 2

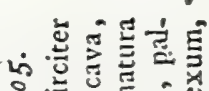

กั

ั0.

จ. 离元。

ริ용

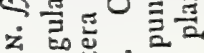

焉焉的

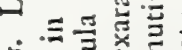

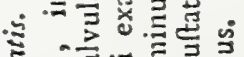

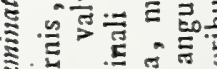

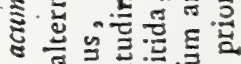

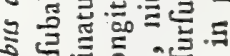

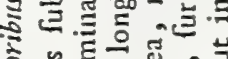

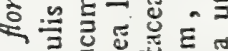

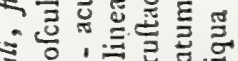

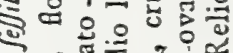

ए \&

究.

हैं.

ذृ के

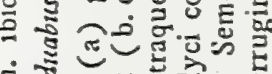

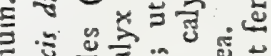

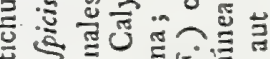

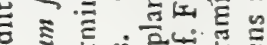

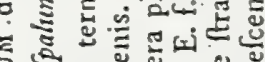

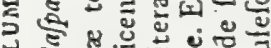

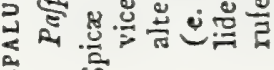

a

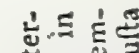

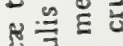

함을 을

这药

.

$\infty$ 它记

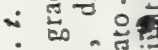

वं की

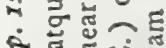

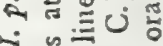

¿

\%

ฐ

遅을

ㄴ.

ن. ने

ต

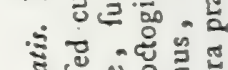

远胥

:

,

施.

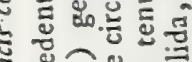

웠

三

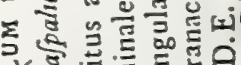

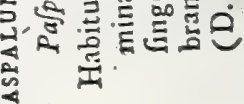




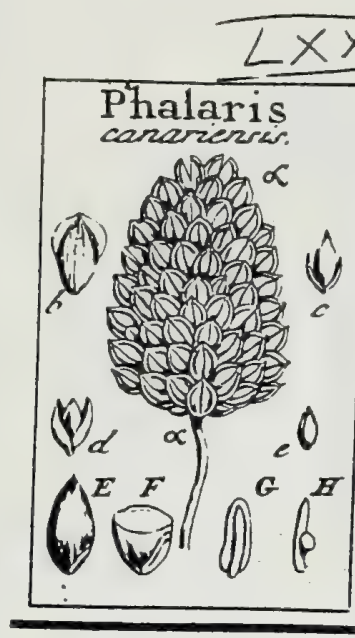

\section{J. Gaertner (1788) Vol 2}

\section{PHALARIS. LINN. ger. 74.}

Involucrum uniflorum, bivalve: walvulis compreffis, navicularibus: carina fupra medium membranaceo marginata. Calyx bivalvis, inxqualis, corolla dimidio brevior. Cor. bivalvis, fubxqualis. Semen liberum, corolla incruftatum, exfulcum : Scutello-marginali.

Phalikis camarienfis. Tab. 80 . fig. 6.

Phalaris major, fernine albo. MORis. hift. 3. S. 8. t. 3. f. $x$.

Plsalaris paricula fulqovata fpeciformi: glumis carinatis. SCHREB. gram. 83 . t. 10. $f .2$.

Pbalaris canarienfis, \& bulboja. LINN. 'fyft. veg. 103.104.

PER. nullum, preter corollx maturx cruftam coriaceam, glaberrimam, fplendentem, cujus valvula altera, alteram fere totam complectitur atque femen arQfe claudic.

REC. nullum.

SE S. ovato acuminatum, lenticulari compreffum, turgiduluni, melinum; margine altero linea nigro fufca notatum, altero ad bafn fcutelligerum.

IN T. membranaceum, tenue.

A L в. farinolum, candidum.

SCU T. oblongum, dimidio femine brevius, marginale.

EM в: teretiufculus; rectus, lacteus.

m.) Panicula matura, naturali dimidio minor. b.) Involuerum claufum. c.) Calyx cum enrolla. d.) Corollx valvulx didutze e. E) Semen a latcre (pectatum. F.) Albumen trussverfe (ctum cum fitu Scutelli. G.) Seuttlum a fronte [pectatum. H.) Embryo Ieparatus.

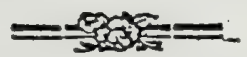

Corolle nuature theca colore multum variat, deprehenditur enim lactea, ftramineo abicans, cinerafcens, livida, fpadicea, caftanea, quin \& nigra; femper auten glabra \& fplendens elt. 


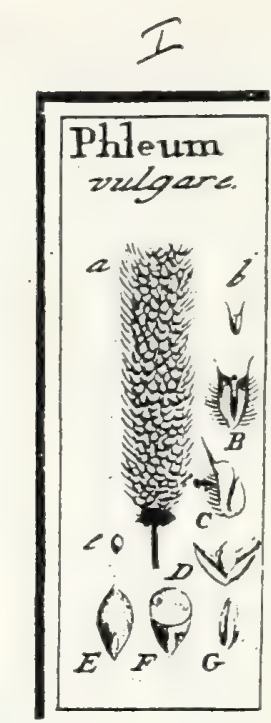

J. Gaertner (1788) Vol.1

\section{CENTURIA PRIMA.}

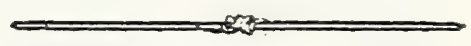

\section{PHLEUM. IINN. gen. 77 .}

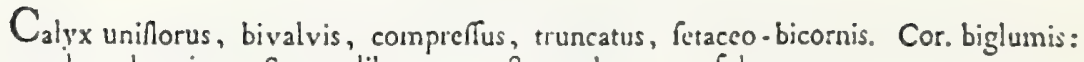
calyec brevior. Semen liberum, tectum, breve, exfulcuin.

PнLеU m nodofum. Tab. t. fig. $x$.

Gramen typhinum. Lов. ic. то. ОедеR. flor. dan. t. 380 . SCH Reв. gram. 1. $t . .14$.

Phleun caule imo bulbofo declinato, glumis calycinis oblique truncatis. HALL. hif. 2. n. 1530.

Phlesm fpica cylindrica, culmo adfcendente, foliis obliquis, radice bulbofa. LIN N. Sy/. veg. 108 .

PER, nulluins.

REC. nullum, proter fundum calycis, cui femen affixum.

SEs. unicum, corollit tcclum, parvum, fubturbinatum, exfulcum, fpadiceum, fuperficie insuquabili, vix tamen ruşola.

IN T. finplex, inembranaceum, tenuifinum, arete adnatum.

A เв. pallidum, farinofum, duriusculum.

St: $<$ T. oblongum, carnofum, album, tertia feminis parte brovius.

Es в. Lincaris, rectus, compreffiusculus, monocotyledoncus, lafteus. Rad. finglex, fcurcllo immerfa, infera.

\section{EXPLICATIO FIGURE.}

a.) Spicx maturx pars inferior. b. B.) Flofculus feparatus. C.) (ilvcis valvula slera cuni Curolia femen infute. D.) Coroliz bicluntis: gluma majore tridentala: denticulis duohus lateralitias menibranaceis, iertio inermedio, fulifurmi - arifato. e. E.) Semen denudacum. F.) Albamen trausverfe rettum, andexis ad bafin ejus, foulello cotyledonco arque Ëmbryone.

\subsection{4}




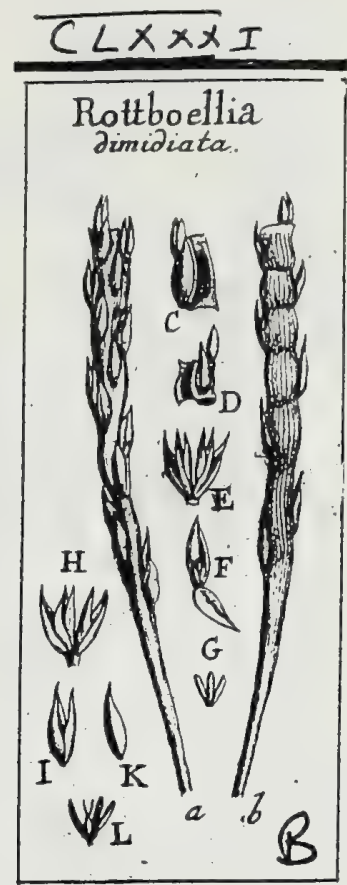

\section{J. Gaertner (1788) Vol3}

2. R $O$ T T B $O$ E L I I A.

Lixi. Juppl. gen. 1360. gen. pl. ed. Schreb. i563. Juss, gen. p. 31. L А MABCK ill. gen. t. 48.

Spica lineari-oblonga, articulata, ad articulos difcedens. Articuli finguli ftipati locultis duabus, in articulorum fcrobiculos immerfis: altera fuperiore, altera inferiore, cum vicinis alternantibus. Locufta fuperior bivalvis, biflora : forculis mafculis, bivalvibus. Loculta inferior perinde bivalvis \& biflora, fed folculo altero neutro, altero autem hermaphrodito, \& alterutro eorun, pro fitu fuo interno aut externo, nunc univalvi, nunc bivalvi. Ovar. hermaphroditis oblongum cum ftylis duobus fimplicibus.

Rottboellia dimidiata. Tab. 181. fig. 2.

Kotzboellia Jpica dimidiata compref $\sqrt{11}$ lineari : latere exteriori aggregato - flofculofo, interiori lavi mudo. LiNis. Suppl. 124. * Syje. reg. ed. 14. po 324.

* Spec. plant. ed. Willd. Toin. I. P. I. p. 466.

Rostboellia Spica dimidiata comprefJa lineari. Тнимв. Prodr. 23.

A Cl. Thunergeio.

SEM. maturum non vidj.

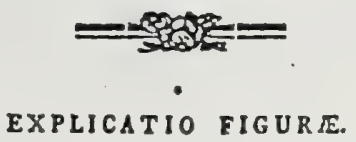

EXPLICATIO FIGURE.

a.) Spicz sbropix pars anterior fofeulifera. b.) Ejusdem latus pofterius nudum \& fubtilifime fexuole ftriatum. C. D.) Articuli duo proximi feparati, ferchiculato excavati, cum lita locufarum. E.) Locufta fuperior, cum fuis Hofeulis mafeulis geminis bivalvibus. F. G.) Flofculos mafculus explicatus, cum sitheris in fitu, \& [eparatis. H1.) Locufta inferior, bivalvis \& biflura. J.) Flofculus neuter, nuac unica valvula plana, locuftz valvz oppofitz, excitstus; nune vero bivalvis absque ullo Ataninis aut ftyli veftigio. K.) Flofculus hermaphroditus hivalvis, aut f flofculus neuter bivalvis fit, tune fimplieiter univalvis. L.) Antherz tres lineares, longitudine fere corollulz. Ovarium oblongum. Styli duc

Quid hxc a duabus mox fequentibus differat, vel coceus videt. 
Poaceae

Tab.LXXXII

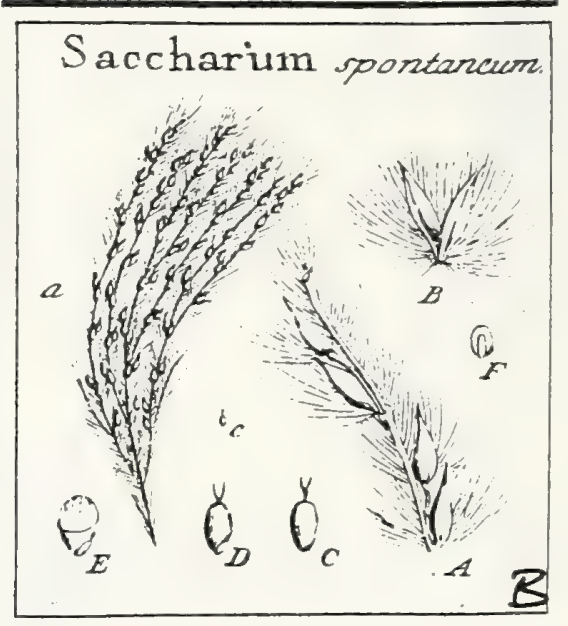

J. Gaertner (1788) Vol 2

DXII. S A C C H A R U M. LINN. gen. 73.

Calyx bivalvis, uniforus, extus ad balin longa lanugine ftipatus. Cot. bivalvis aut nullia Semen liberum, exfulcum.

Saccharum fponaneum. Tab. 82. fig. 2.

Kerpa. Rherd. mal. 12. p. 85. t. 46 .

Saccharnun foliis corroolusis, parnicula effufa, Jpicis capillaribus fimplicibus, fioribus remotis involucratis geminatis: altero pediunculato. LIN. Jyj. veg. 103. Ex herbario Bankfiano.

I2.

PER. \& Rec. nullum. Calyx aut corolla femen laxe involvit \& fponte dimittit.

SEN. minutulum, ovato globofum, obfoletifrme trigonum, exfulcum, pallide rufefcens.

IN T. tenuifimum, membranaceum.

A L B. farinofum, aqueo-pallidum, fubtranfparens.

SC U T. fubrotundum, quartam feminis partem longum, niveum.

EMB. linearis, rectus, lutefcens.

a.) Panicula portio. A.) Flofculorum fitus proprios. B.) Calycis, ba $\$$ lamati, valvulx diduaz,

c. C.) Semen a ventre, \& D.) idem 2 latere fpecatum. F.) Scutellum cum Embryone.

Corollam univalvem, quam LINNEus mant. p. 383. huic gramini tribuit, in meis exemplis fruftra quxívi.

163.26 


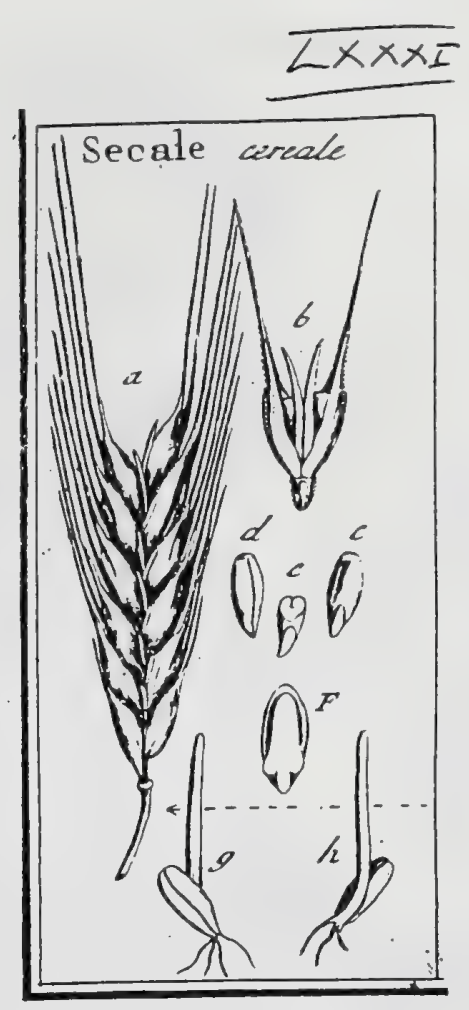

Poaceae

J. Gaertner (1788) Vol 2

DIX. SECALE. TOURN. inf. t. 294. LINN. gen. 97. 9

Flores Spicati. Calyces bivalves, biflori, in fingulo racheos dente finguli. Cor. bivalvis: valvula altera ex apice ariftata. Semen liberum, audum, fulcatum, vertice obcufo. Enbryonis radicula ternx.

Secale cereale. Tab. 8i. fig. 2.

Secale. Fucurs. germ. ic. 439. Dod. cereal. p.50. Cam. epit. xgo. Moris. bijf. 3. S. ช. t. 2. f. x. BLAKW. berb. t. 424.

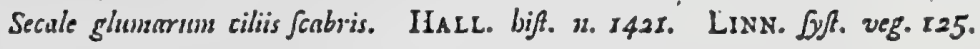

Per. \& Rec. nullum. Corolla femen dimittit.

SEM. oblongum, apice pubefcens \& quafi truncatum, inferne anguftatum \& valde acuminatum, hinc triquetro convexum, inde profundo fulco infcriptum, melinum.

INT. tenuiffimum, membranaceum.

A \& B. farinofun, duriufculum, album.

Scur. ovato-oblongum, tertiam circiter feminis partem xquans, ladeum.

EM B. oblongus, lutefcens. Plun. oblonga, compreffa. Radicula tres, fubcylindrice.

Io

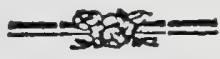

2.) Spica maturz \& truncatz pars inferior. b.) Locufa feparatz c. d.) Seminis facies anterio \& pofterior. c.) Albumen transverfe SeQum. F.) Seutellum cum Eubrgone denodato. g. h.) Semen germinans: vagina cotyledonea faturate purpurca.

$$
163.27
$$




\section{$\overline{C L X X V}$}

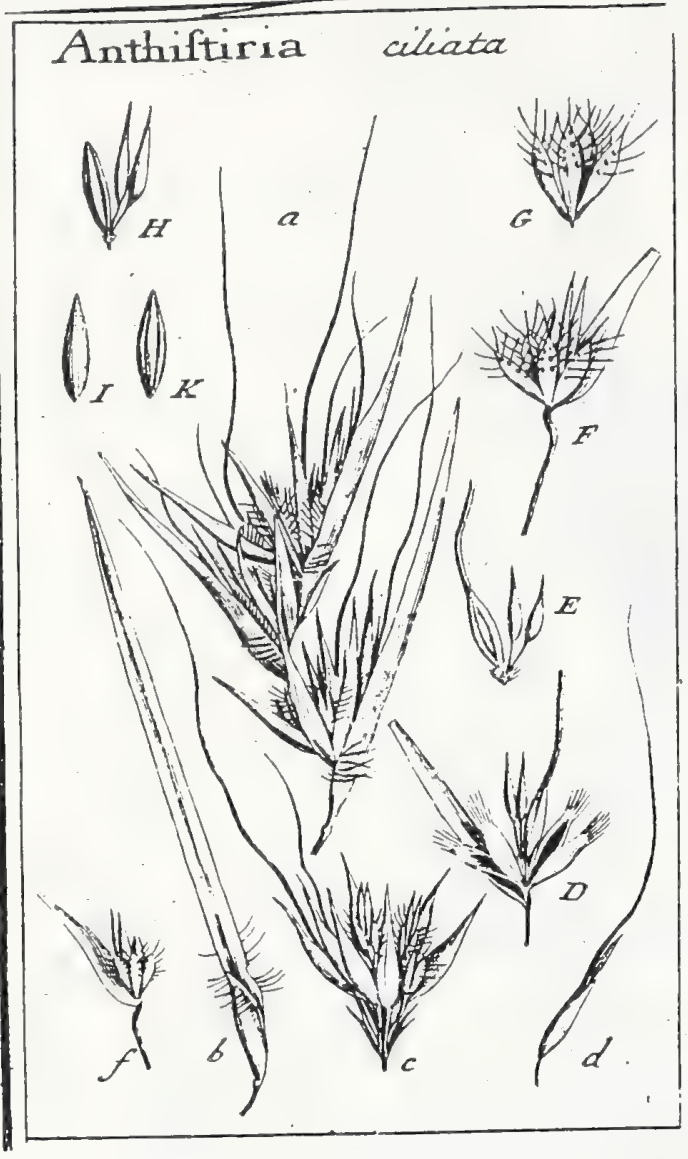

- Tremeta

Poaceae

J. Gaertner (1788) Volz

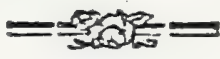

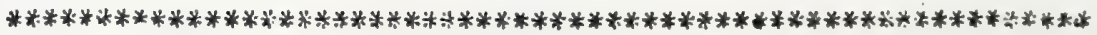

\section{A P P E N D I X.}

\section{A N T H I S T I R I A. LINN. gen. I359.}

Flores in eadem loculta feru diftincti. Locultx pedicellatx, fafciculate. foliololo florali longo ftipatz. Calyx communis triforus, quadrivalvis: valvulis oblongis, xqualibus, apice \& marginibus papillofo-pilofis. FL. bermuphroditus unicus, feftilis in receptaculo brevi, lanuginofo. Cal. bivalvis, chartaceus, perfiltens, muticus, aut Arifla longilfina tortili, e bafi interna valvulx majoris inftructus. Cor. nulla, aut menbranxcea, obfoleta. Flor. mafculi duo pedicellati, bivalves, mutici; interdum nulli. Sem. calyce proprio corricatum.

Asthistiria ciliata. Tab. 175 .

Anthiftiria. LINs. fj'f. veg. XIV. p. 153. Juppl. Ir3.

Andropogon quadrivalve. LiNs. Sy/l. veg. XIII. P. 758 .

F. Andropogon panicula cermu, calyce exteriore multiforo cilinto, ariffis corm tortis pilujis. Thunв. jap. 40. LINN. Jyft. veg. XIV. p. 903.

a Cl. Thuniergio.

PER. nullum. Calyx Goris hermaphroditi per maturitatem chartaceus, e ferrugineo-nigricans, femen arcte claudit, nec dimitrit.

REC. nullum, nif lanam aut fetas ferrugineas velis, flori hermaphrodito fubjectas.

SEM. oblongum, utrinque attenuatum, hinc convexum, inde fulco longitudinali exaratum, pallidum.

IN T. membranaceum, Gmplicifimum.

A L B. farinofum.

Scv'r. quinta parte feminis brevius, \& in ejus parte convera politum.

E M B. minutulus, linearis, rectus.

2.) Paniculs pars fuperior. b.) Folium paniculx; vagina \& bafi papillofo-pilofum. c.) Luculftarum fafciculus, in axillis foliorum fefilis. d.) Loeufta ariffara, foliolo fuo flotali obvoluta. D.) Easem autła, cum foliolo forali \& valvulis calycis communis expleatis. E.) Ejusdem Hufculi feparati, cum fuo receptaculo lanugioofu. f. F.) Locufta musica. E.) Ejas calyx fepa. satuş. H.) Ejusdem Hofculi Separati. I.) Seminis calyce maturo corticati latus dorfale. K.) Ejusdem latus věntrale.

Specimina indica habent: Vaginas foliorum parce \& breviter pilofas. Locafias in fulciculus colletas, quinas ad feptenns. Calyces communes in foliolis floralibus felfiles. Recepsac. brevifime hirfutum aut lanuginolum fulvum.

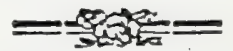

Corollas fiofc. hermaphrod. nullas, aut vix difcernibiles; de:iqua fofculos. ariftatos in fingulo fafciculo binos aut ternos, totidemque in fingulis calycilus communibus fiores mafculos pediceilistos.

Japonicum autem exemplar habuit: lagirns foliorum late \& longiffume pilofas. Locrifas pancas, interdum folitarias, nec bafi pedunculis fuis in unum

- firciculum conferruminatas. Calyces conmunes intermedio pedunculo, a foliolo fiorali (quod Calyx extimus Thunb.) feparatos, fxpe unitoros. Receptac. fetofun longitudine fere dinidii calycis. Corollam in flore hermaphrod. manifeltan, membranaceanı: valvula altera lanceolata; altera in ariftam converfa; denique fofculos mafculos juxta hermaphroditum mullos, aut obfoletos, nec manifefte pedicellatos. His tamen non obltantibus, ne fpecie quidem hanc a priori differre cenfeo, quum prater calyces communes quadrivalves, utrisque etiam unus idemque fit habitus externus. 


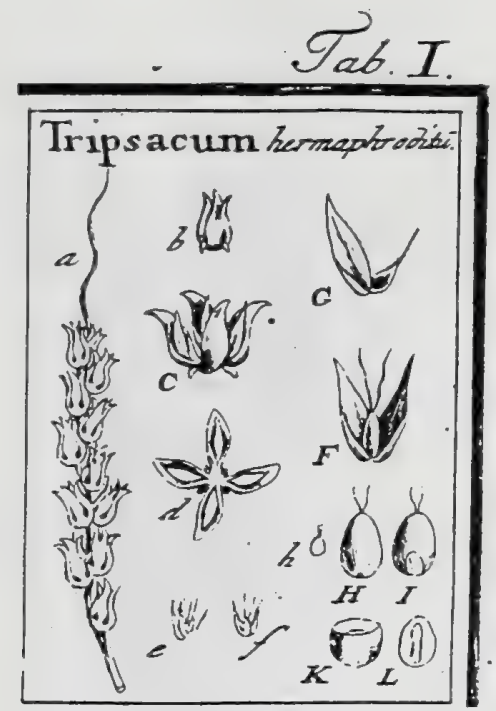

\section{J. Gaertner (1788) Vol.I}

IV. TRIPSACUM. LINN. gen. I044.

Florcs involucrati, fexu nonunnquan diftincti in eodem culmo. Involucrum coria. ceutn, profunde divifum: Jaciniis funu intermedio difcretis. Cal. bivalvis, unitiorus. Cor. biglumis. Seinen liberum, tectum, exfulcum.

Trirsncu.u hermaphroditum. Tab. I. fig. 4.

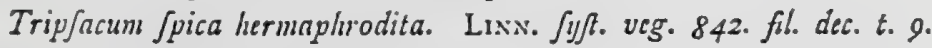

PER. nullum: involucrum induratum flores \& femina obtegit.

REC. nulluin, prxter fundum coroll $x$, cui femen affixuin.

SEm. unicum, parvum, fubellipticum, modice compreffum, glabrum, exfulcum, c fpadiceo lutescens.

Is T. funplex, membranaceum, adnatum.

A L B. farinofum, duriusculum, candidum.

Sc u r. ovatum, dimidio albuinine paulo brevius.

Es в. oblongus, rectus, monocotyledoneus. Rad. fumplex, apice incraftata.

a) Spicx maturx pars inferior. b. C.) Involucrum foris (eparatun. D.) Ejusden laciniz diduate, finşula claudente flosculum fingulum, hermaphroditum. c.) Flos feparatus. f. F.) Corolia femea obresciss. G.) Caljcis valvulx. H. H. I.) Seninis Jatus utrumque, K.) Alburucu transverie (âtum. L.) Scutclium cotyledoncum. 
Tab. I XXII

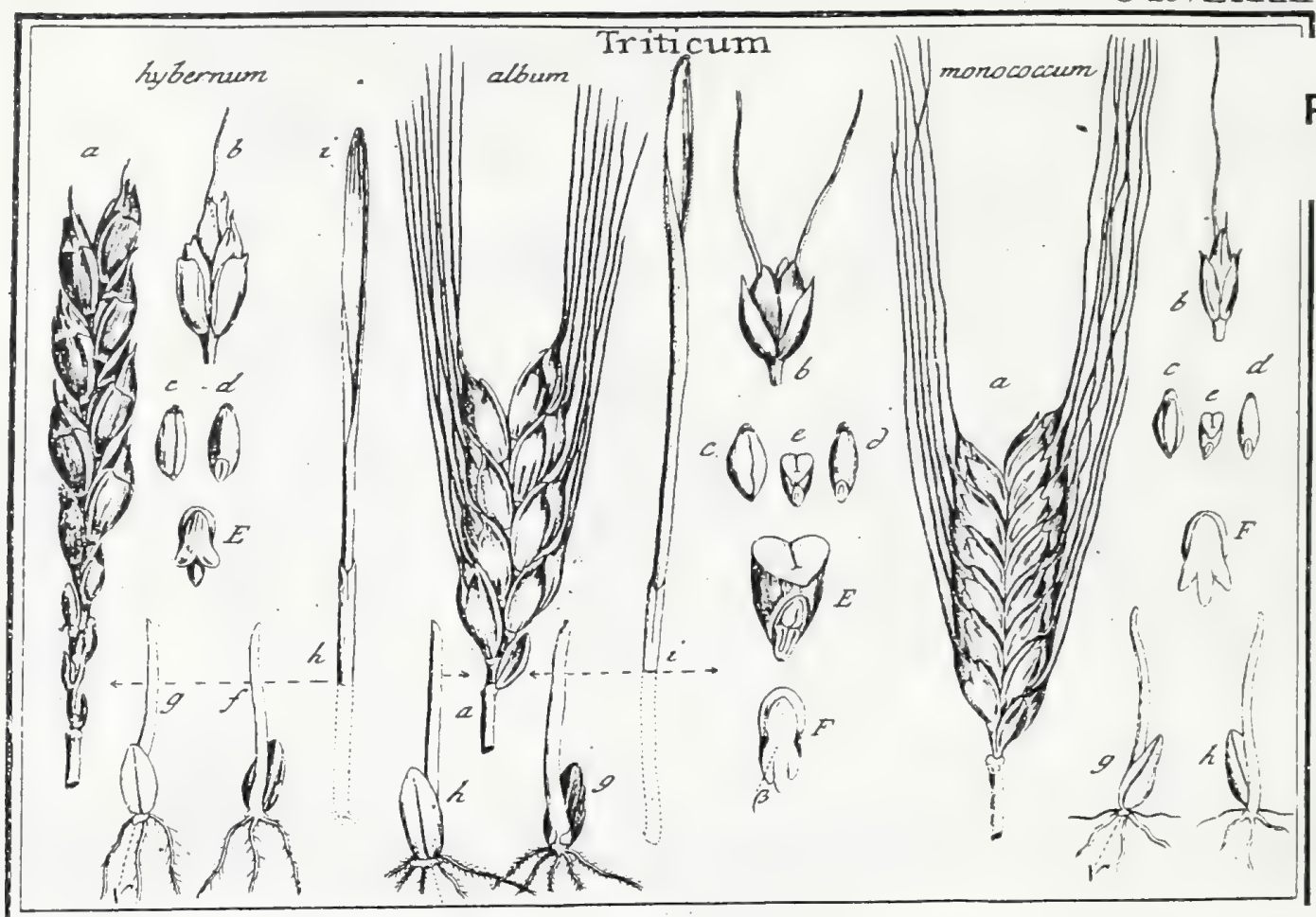

Poaceae

\section{TRITHCUM. TOURN. inft. t. 292. 293.}

Flores fpicati. Calyces bivalves, fubmultiflori, ad fingulum racheos dentem finguii. Cor. bivalvis : vallula exteriore fxpe ex apice ariftara. Semen fuleatum, nudum aut corolla incruftatum. Embryonis radicula ternz.

Triticum hybernum. Tab. 81. fig. 1.

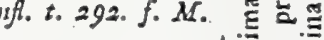

M. A. BLaKW. kerb. t. 40. f. II. III. GLeich. t. 16.

Triticum locufis imbricatis quadriforis, glabris muticis. HaLL. bift. n. 1422. a. .

Triticun calycibus quadriforis verztrico/is Levibus imbricatis fubmuticis. LINN. [j]f. veg. 226 .

PER. \& REC. nullum. Corolla per maturitatem coriacea femen involvit.

SEN. ovatum, utrinque acuminatum, apice pubefcens, hinc triquetro-convexum, inde fulco profundo exarntum, melinum aut fubrufefcens.

IN T. tenuiftimum, membranaceum.

A L B. farinofum, friabile. candidum.

ScUT. ovatum, vix tertia feminis parte longum, lacteum.

EMB. ovato-oblongus, lutefcens. Pluns. fubparabolica, comprefis. Radic. tres, fubcylindriç, in Scufelli ba jị nidulantes.

2.) Spics araturx truneatx pars inferior. b.) Locula, racheos denti infiftens, feparata: Calgee bivalvi, emarginato - trusealo: Corollis quatcrnis L quinis, nuticis aut ex apice ariftatis: Ariftis ip corolla raro longioribus. c.) Seminis pars ventralis, fulco exarata. d.) Ejusdem latus dorfale fcutsligerum. E.) Scutcllum a frnnte fpectatum cam Embryone toto dcnudato. f. s) Бcmen germinans, producens deorlum lucinglam carnofarn $(r), e$ feutello oriundam, fur- of fum vero vaginam cotyledoncam $(h)$, membnanacesm, purpurafentem, $c$ qui demum rupta, 气옹 verum folium stamincum (i.) truditur,

Triticur album. ibid. Triticuns arifis longioribus, fpica alba. Baur. pis. 21 . Tounn. infl. t.293.
f. E."

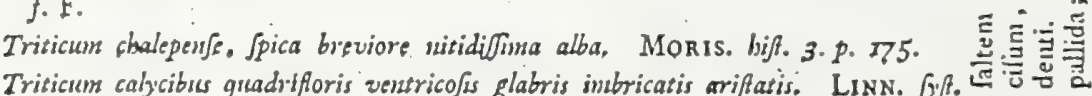

Trisicem calycibsus qreadifforis ventricofis glabris imbricatis ariftatis. LiN. Sy.f. veg. l. c.

Jeon. Sem. MAlpigh. Op. amm. p. m. 8g, 6. 54. $f .3=5 . A-G$.

Spica, heic truncata (a), fubquadrangula, difticha, arcte imbricata Locr/fis (b.) tri - 1. quadrithoris s flofculis duobus inferioribus folis fertilibus. Calycis glunix leviter ventricofx, glaberrinx, nitidx, albx, in dorfo argute carinatx, nucrone fubadunco terminatx. Corollx fertiles longifimis arifis ex apice inltruade: reliqux muticx, Semen (c, d.) priori fimillimum, paulo

它咅

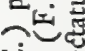
1. 일 逢

ธี Еّ

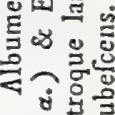
论苛 造记

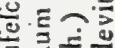
를

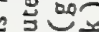
品 $\dot{\bar{\varepsilon}} \mathrm{E}$ 운 -
J. Gaertner (1788) VQ1.2 


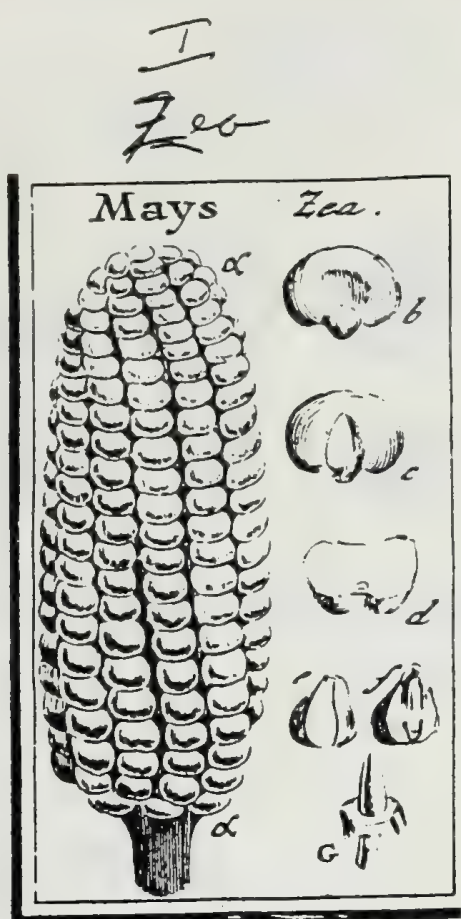

Poaceae

\section{J. Gaertner (1780) voi. 1}

Flores mafculi in fpicis linearibus paniculatis fupra femineos in eodem culmo. Spica feminea cylindrica intra vaginam foliaceam. Styl. unicus, filiformis, omnium longillimus. Semen nudun, nitidum, coloratum, maximum.

Mays Zez. Tab. r. fig. 9.

Frumentum turcicum. Fuchs, hiff. germ. ic. 473. Cas. epit. Ig6.

Mays granis aureis. Toura. infl. p. 53. BLAxw.herb. t. 54 . a. b.

Zea. LINN. Jyjt. veg. 84 r.

PER. nulluin.

REC. conmune cylindricum, fubpedale, craflum, fuberofo fungofum, alveolatum, undique tectum feminibus, per leries longitudinales digeftis.

SE 3r. unicum, in tota gente graminea maximum, hinc rotundatum, lavigatum, nitidum, coloratum, inde angulatum, fungofum, pallidum.

IN T. fimplex, chartaceum, diaphanum, arcte adnatum.

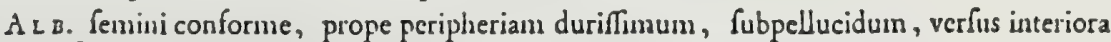
farinofum, candidum, opacum.

$S c$ u T. longitudine ferefeminis, carnofum, crafium, hinc planiusculum, rima longitudirali incifun, inde gibbum, convexum, albumini agglutinatum.

Ess. oblongus, albus, intra rimam fcutelli latens. Pham. cralituscula, fubulata. Rad. fumplex, conica, infera.

a.) Frutus, naturali multoties ninor. b.) Seminis btus fuperius. c.) Ejusdem latus inferius, feutelligcrum. d.) Albuninis \& feutelli fęlo transverfalis. e.) Scutellum feparatum, a parte amteriore Speftacum f.) Idean, renocis rimz labris, ut embrjonis fitus \& ucxus in coufpcitum prodeant g.) Embryo folutus, relitta portione camola, qua mediante ficutello affigitur.

Seminis figura, in univerfum, duplex eft, vèl angulata, vel rotundato - fubreniformis \& funul leviter compreffa; at color ejus multis modis variat: oinnium frequentilfimus eft aureo-fulvus, tunc electrinus \& framineus; poftea ruffus, plumbeus, albus; denique violaceus atque nigricans. Habentur etiam grana variegata, \& Spicx feminibus diverficoloribus varix; de quibus omnibus vide Tour.s. l. c.

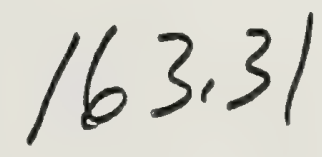




\section{Tab.LXXXII}

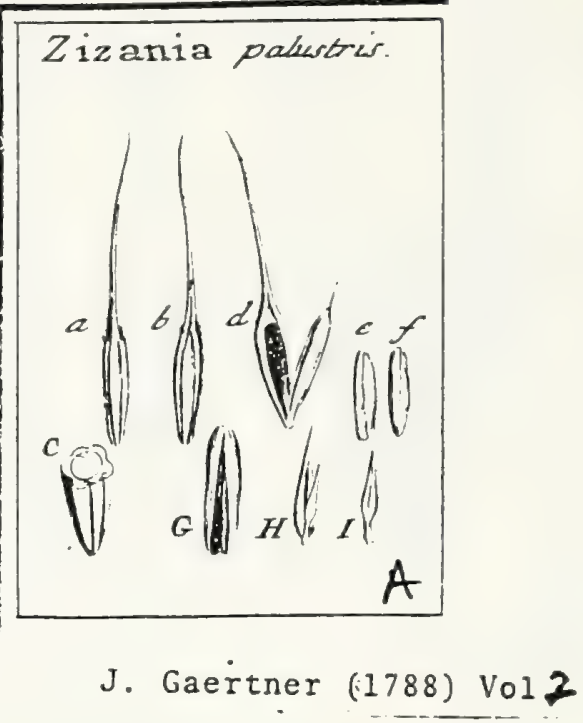

DXI. ZI Z A N I A. LINN. gen. 1062.

Flores mafculi \& feminei in eodem culmo. MAS. Cal. nullus. Cor. bivalvis, mutica. Stam. fex. FEM. cal. nullus. Cor. bivalvis, ex apice ariftara. Semen fulcatum, corolla incruftatum.

Zizania paluftris. Tab. 82. fig. I.

Zizania fylveftris aftrorgens tenuis Eo ramosa, paricula laxa racemosa. Brown. bif. jams. 340 :

Zizania panicula inferne racemofa, Juperne fpicata. ScHreB. grant. 2. p. 54 . t. 29 .

Zizania panicula inferne racenrofa mafcula, fuperne fpicata feminea. LiNs. Jyst. veg. 855 .

PER. \& REC. nullum. Corolla matura coriacea femen arcte claudit, nec dimittit.

SE \&. oblongum, teretiufculun, inferne paulo anguftius, nigro aut ferrugineo - fufcum, hinc convexum ftria notatum, inde fulco parum profundo exaratum.

INT. Simplex, membranaceum.

A L B. farinofum, durum, ex aquo ant livido albicans.

SCU т. lineari - lanceolatum, acuminatum, longitudine fere albuminis.

Eм в. figura \& Iongitudine fcuteli , lutefcens.

2.) Corolla matura 2 dorfo fpectata, ad ortum arifz fubulato - fetacez barbatz b.) Ejusdean latus ventrale. C.) Ejusdem nec non Albuminis featio trasverfalis, qua angulata cotolla forma \& valvularum fuarm arca commilfura monftratur. d) Valvulic didate, atraque fed inxqua. liter ariftata. .) Scminis pars dorfalis fuleata. E.) Ejusdem Latus convexum fraia tenui nota. tum. G.) Albumea deaudatum. H) Scutcllum embryoni jundum. 1.) Embrjo feparatus. 


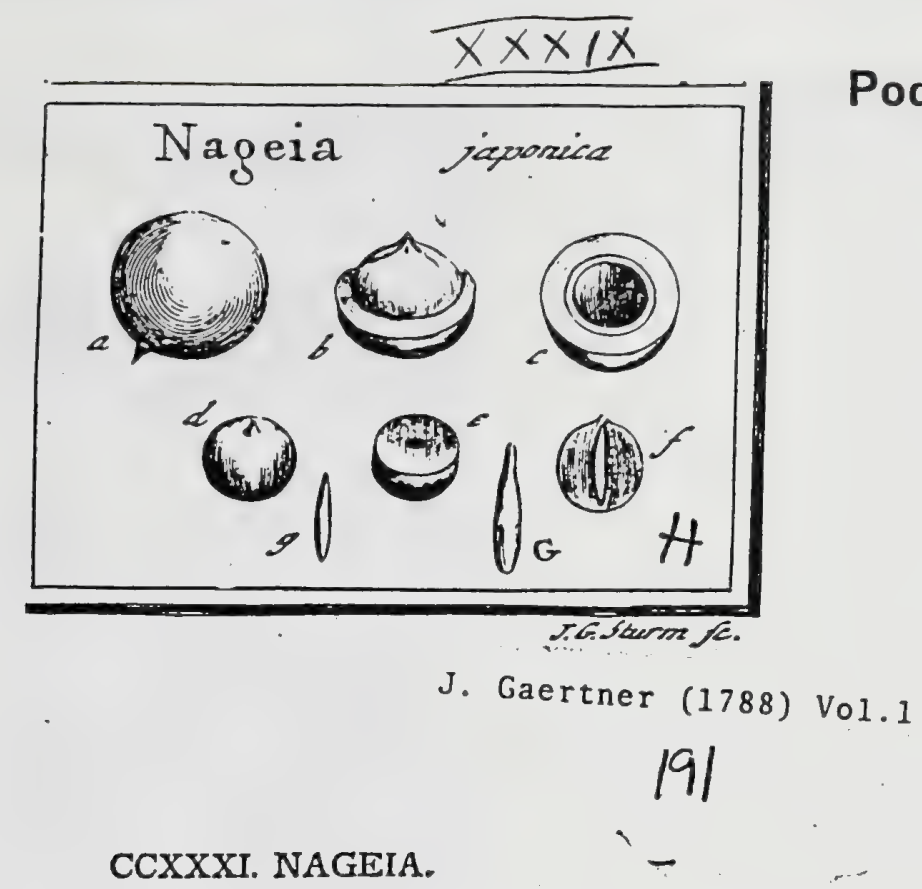

Flores in amentum collecti. Cal. di-1. tetraphyllus. Cor. nulla, Stam, quatuor.

Siyl. duo. Drupa baccata fupera unilocularis. Semen albuminofum.

Nageza japonica. Tab. 39. fig. 8 .

Nagi Kамpғ. amoen. 773 . ic. 874.

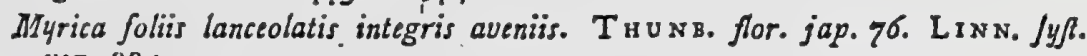
veg. 884 .

Ex dono $\mathrm{Cl}$. Houtuys.

PER. Drupa baccata fupera, fpharica, per maturitatem atro purpurea, rorulenta. Cortex carnofus, fucculentus, modice craffus. Putamen fpharicuin cum mucrone acuminato in vertice, ofteum, tenue, fragile, uniloculare, evalve.

R.EC. nullum; femen apice affixum.

SEM. unicunn, puraninis cavitati conforme, rufelcens.

IN T. fimplex, membranaceum, tenue.

AL. fimini conforme, craftilimun, amydaliuo-carnofum, album.

Eм в. fubfufformis, longitudine fore albuminis, inverfus, lacteo-albus. Cotyl. dinidio embryone. paulo breviores, plano convexx, oblongx, deorfum angultiores. Rad. longa, tereti attenuata, recta, fupera.

2.) Drupa integra. b.) Putamen fuperine deaudatum. c.) Drupa difreda, d., Semen fepara. tum. e. f.) Albumen transverfe \& longitudiualiter feetum, eum ficu embryonis. g. G.) Enbrye Irparatus.

Nec carpologice nuultum a Myrica dillat.

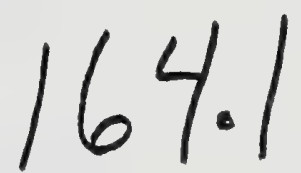




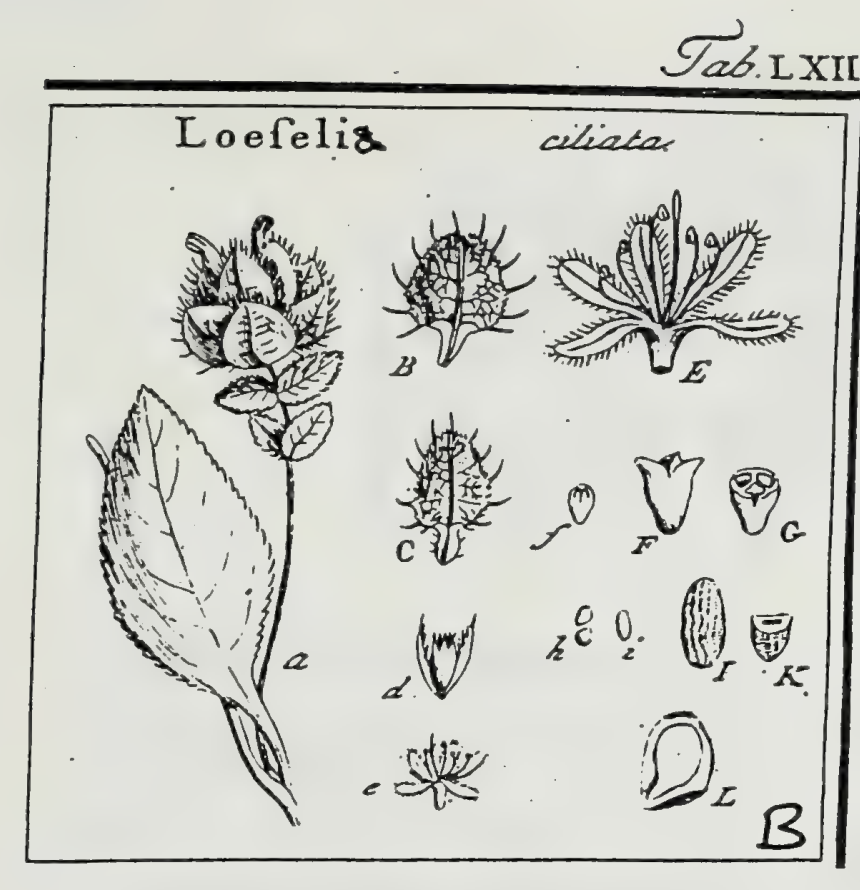

J. Gaertner (1788) Vol.1

CCCLXXIII. LOESELIA. Lin $\mathrm{N}$. gen. 767 .

Calyx monnmyyllus mbulofus quinquedeneatus. Cor. monopetala profunde quinque. fida: laciniis oblungis ciliatis. Stam. quinque inaqualia. Styl. filitormi clavatus. Caplula trilocularis, apice dehifeens. Semina folitatia aut gemina, mucilaginola. LOESEl IA ciliata. Tab. 62. fig. 3.

Royenn foliis acute dentatis ES veluti fpino/is, flore luteo. Houst. $m / s$.

Luefelia. L I x. N. f4/. veg. 567 .

PER. Capfula parva, calyce veftita, obovata l. turbinata, tenuis, albicans, trilocularis, apice trifarian dehifcens. Septa valvis contraria.

REC. nullum; fernina angulo loculamentorum interno affixa.

SEM. unum, aut duo in fingulo loculainento, oblonga, hinc convexa, 'inde obfolete angulata, pallide rufelcentia, lineolis abruptis transverfalibus, per feries longitudinales digentis \& faturatius coloratis picta.

Ix $T$. finplex, nembranaceum; fuperficic ab aqua in mucilagincm pellucidam refolubili.

A L B. femini conforme, carnolum, aqueo-pallidum.

E s. magnitudine fere albuminis, comprellus, erectus, lacteus. Cotyl. foliacex, in ferminibus geminatis fubrotund $x$, in folitariis, ovato oblongx. Rad. tercti acuminata, inifcra.

a.) Ramulus foriferus axillaris, bafi nudus, apice foliis, a caulinis diverfifimis, oppofitis, in Aro. Ulum imbricatis, veftirus. B.) Foliolum flomle ex inferionibus. C.) Aliud ex fuperioribus $f$. itucrioribus. d.) Calyx, duabus braftris forali!ns membranaceis, fetaceo deutatis, ftipatus.

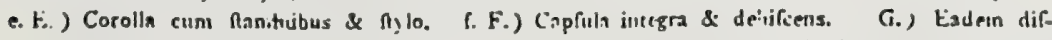
fecta, h.) Sentina geminata, i. J.) Senen filitarium, K. L) Aburinis feltiones cum fitu \& Ggura enbryonis.

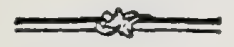

Stamina quinque in omnibus fueciminis mei floribus reperio, quorum unum, religui brevius, ad dimidium fere longitudinis fux, proxinix lacinix corollx adnatum ent* reliqua filamenta tubo inierta funt. 


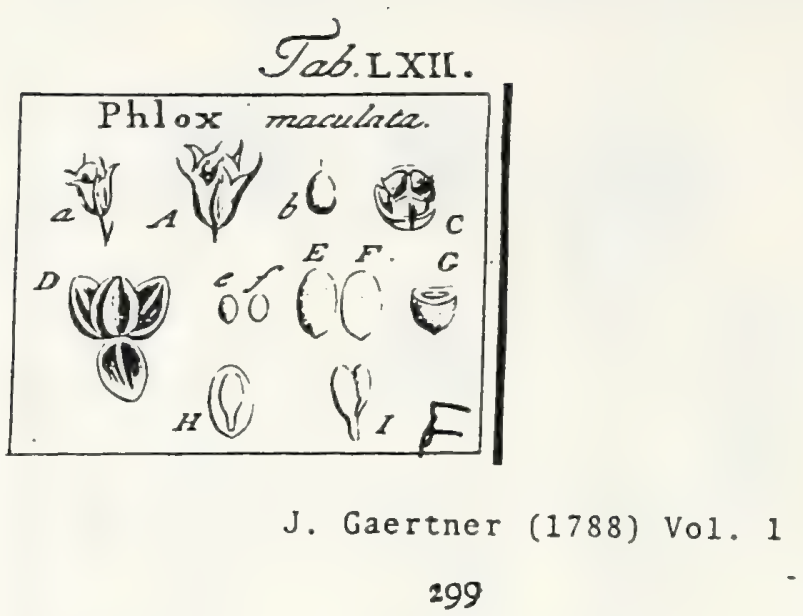

CCCLXXLX. PHLOX. LIN IN. gen. 214.

Calyx monophyllus, anguiarus, esinquedentatus. Cor. infundibuliformis. Stam. quia. que inxqualia. Styl unicus. Paigmate triplici. Capfula triloculars. Semina folitaria.

$\mathrm{P}_{\text {н }}$ О $\times$ maculata. Tab. 62. fig. 9

Phlox foliis lanceolatis lacizes, racemo oppofite corymbofo. LIN fulf. veg. 199.

Icoll. J A C Q. hort. 2. t. 127 .

PER. Capfula ovata, calyce membranaeen diaphano, contis quinque viridibus friato veftica, glabra, trilocularis, crivalis is Difepinenta axi aduata, valvis contraria \& $a b$ iis per maturitatem, non reso $2 b$ axi, fecedentia.

REC. axis capfulx, triquetro alaros, cujor bafi fermina affixa.

SEM. in fingulo loculamento unixtm, ellipticum, plano-convexum, in parte planz Aria elevata notatum, fufcum, foperficie inzquabili, quafi adrofa.

IN T. fimplex, membranaceurn,

A L в. Temini conforme, craftum, cranofum, albuin.

EM в. Iongitudine albuminis, corspreftus, erectus, gramineo viridis. Cotyl. ellipticx, fubfoliacex, Rad. teretiuscula, inferz.

•

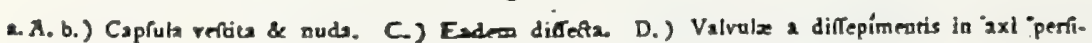

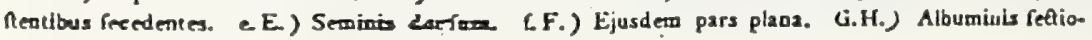
nes cam fitu embr)onir. I.) Embrogo

$$
165.2
$$




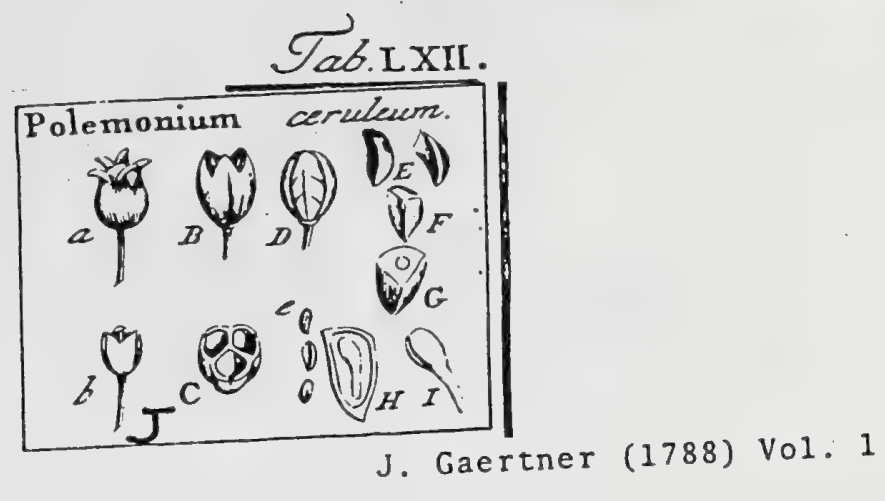

CCCLXXX. POLEMONTII. TOURN. t. 6I. LINN. gem. $217^{\circ}$

Calyx quinquedentatus. Cor. moogesba rotata. Stam. quinque : filamentis bafi dilatatis, membranaceis. Sty $L$ aricsis, figmate triplici. Capfula trilocularis. Semina angulata, umbilico laterali, e regione embryonis.

Polemoniess czruleum. Tab. 62. fiz ta

Valeriana graca. Dod pempt. 352 BEs2. hort. Eyft. affiv. IX.t. II. f. 2.3.

OEDER. for. dafl. t. 255 .

Polenonium folits pinnatis, floribus ereftis, calycibus tubo corolle longioribus. LXN.N. Sy/. veg. 205.

PEr. Capfula calyec veflita ovato globofa, obfolete trifulcata, tenuis, fubpellucida, trilocularis: apice trifariam dehifeens. Diffepimenta valvis contraria.

REC. nullum; lemina angulo loculamentorum interno afixa.

$S E$ s. Fex, duplici ferie in fingulo loculamento pofita, varic angulata, fuperficie crofa, obfcure ferruginea. Umbilicus in media parte ventrali.

IN T. fimplex, frongiofo membranaceum, tenue.

AL B. Pernini conforme, carnofun, pallidum.

Е м в. longitudine alburninis, compreffus, Lacteus. Cotyl. ellipticx, foliacex. Rad. teretiufcula, longa, fubobliqua, infera.

a.) Capfula veftita. b. B.) Eadem nuda, dehifeens. C.) Ejus (etio transverfalis. D.) Seminuma fitus. e. E.) Semina feparata. F.) Umbilicus albicans is ventre fexinis, G.H.) Embryo intra ate bumea. I.) Idem Separatus. 
c

(1)

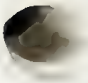




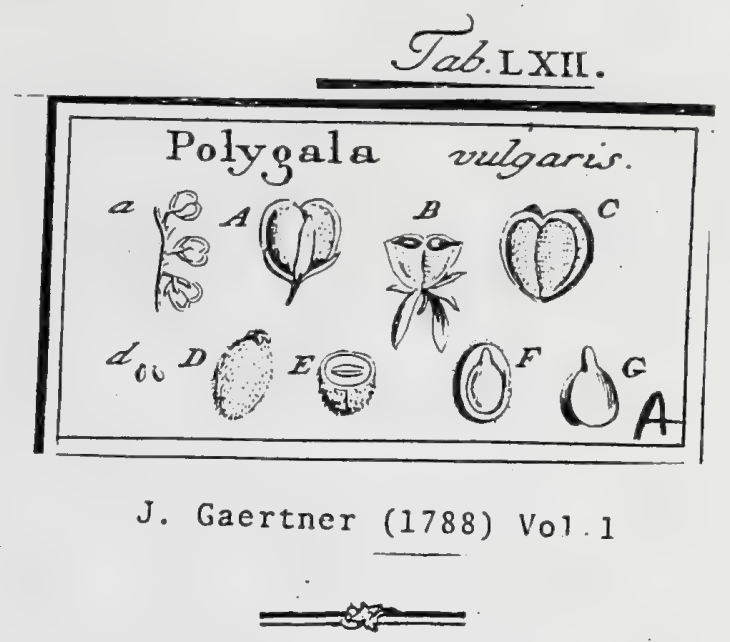

CCCLXXI. POLYGALA. TOURN. t. 79. LINN. gen. 85r.

Calyx pentaphyllus: foliolis duobus majoribus, ante feminis maturitatem coloratis, deinceps viridibus. Cor. tripctala irregularis. Stam. ucto. Styl. unicus. Cap. fula bilocularis. Semina folitaria, unbilico glandulofo.

POLYG AL A vulgaris. Tab. 62. fig. I.

Polygala vulgaris major. Varle. paris. 16r. t. 3r.f. I. OEDER, flor. dan. t. 5 I6.

Polygala caule ereffo, foliis linearibus acutis. H A L L. hiß. I. "3. 344 .

Polygala floribus criflatis racemofis, caulibus herbaceis fimplicibus procumbentibus, foliis lineari lanceolatis. LI N N. $\int 4 /$. veg. 638 .

PER. Capfula parva, obcordata, utrinque fulco infcripta, compreffa, membranaceomarginata, punctis minutis feriatis exarata, bilocularis, bivalvis. Diffepinentum valvis contrarium.

REC. cicatricula parva in fuprema parte diffepimenti.

SEM. folitaria, ovata, ferruginen fufca, villis albicantibus undique confperfa, hilo lineari ad alterum latus notata. Umbilici caruncula glandulofa alba inxqualiter trifida: laciniis duabus majoribus xqualibus; tertia minore; omnibus lineari acuminatis, reflexis, in fpeciem coronulx umbilico fuperimpofitx coadunatis.

IN T. fimplex, fubcoriaceum, tenue.

A L B. femini conforme, tenue, carnofum, pallidun.

Е мв. albumine paulo minor, inverfus, viridis, aut in vetuftis luteus. Cotyl. elliptico rotundatx, plano-convexiusculx. Rad. teretiuscula fupera.

2. A.) Capfula integra. B.) Eadem difrerta. C.) Ejus margines delifcentes. a. D.) Semina foJata, cum coronuiz umbilicali in vertice. E. F.) Embryo intra albumen difectum. G.). Idem feparatus.

Umbilici xque ac embryonis forma \& fitus, utique proximam Polygalx cum Titlymalis aftinitaten indicant, ut recte docuit ADAssovus.

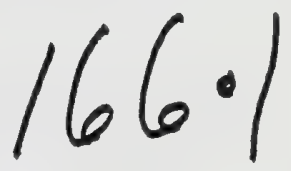




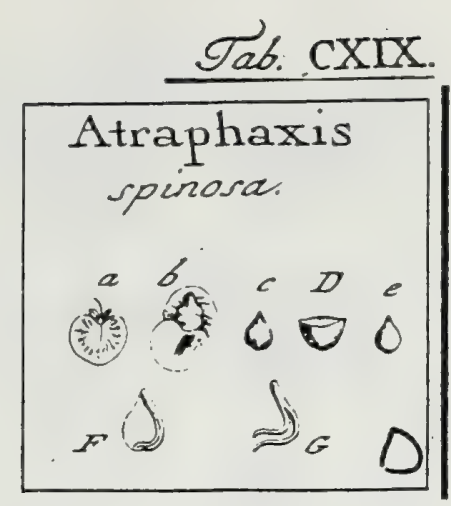

J. Gaertner (1788) Vg1. 2

181

\section{ḊCXCVI. A T R A P H AXIS. LinN. gen. 449.}

Calyx tetraphyllus: foliolis dugbus exterioribus, . lineart - lanceolatis; duo bus interioribus fubrotundis, maximis, per maturitatem femen occultantibus. Cor. nulla. Stam. fex. Ovar. fuperum. Stigmata duo, capitata Semen nudum, lenticulare. Embryo unilateralis: cotyledonibus incunbentibus.

ATraphaXis fpinofa. Tab. 17g. fig. 4 -

Ariplex orientalis, frutex aculeatus, fore puldbro. BuXs. cent. x. p. Ig. t. 30. DiLL. elth. 47.6 .40$.

Amaphuxas ramis fpirofis. - LrNs: Lyf.' veg. 345.

PER, nullum. Calys perfiftens femen obtegit.

REC. nullum.

SEM. unicum, ovato-2cuminatum, compreffum, in marginem acutiffmum fubandulatum definens, cerera glabrum, lucidum, Ýpadiceum.

IN T. duplex: exterius chartaceum, tenue, facile fecedens; inserius membrana. ceum, ferrugineum, chaliza atra in bafi notatum.

A L 8. fermini conforme. Encinofum, exndidifrmura.

$E_{M}$ в. unilateralis, teretiufculus, inverfus, fublutefcens. Cotyl. lineares, in cumbentws, longx, fecundum femiris marginem curwatx. Rud tareciufo cula brevis, fupera.

a. b.) Calyx. (emen obtegens - c.) Sernea denndatpm integram. D) Idem diffetane. e.) Albumen decorticatuon. F.). Embryonis fitus in albumine. G.) Eimbryo deaudatus 


\section{TabXLV}

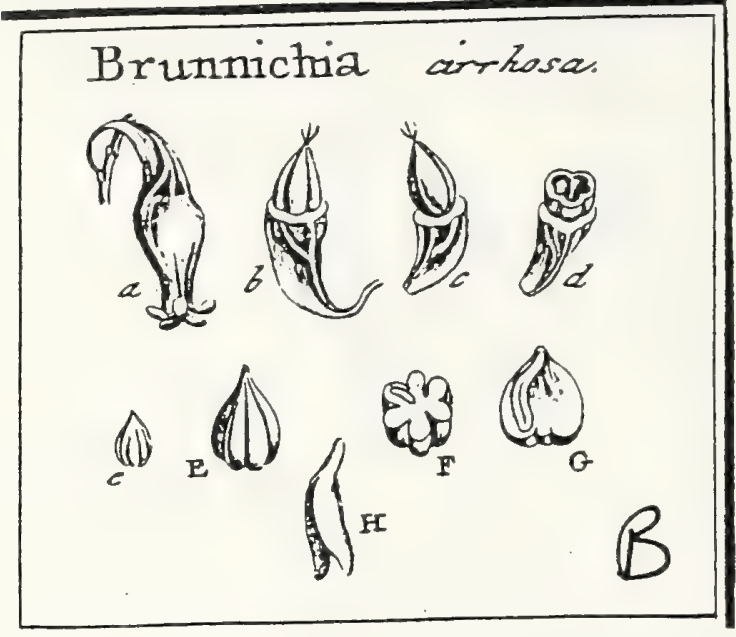

J. Gaertnet (1788) V0.1.1

\section{BRVNNICHIA. BANES.

Calyx monophyllus, per maturitatem coriaceus, glaberrimus, nitidus, fuperne cuarctatus, angulatus, quinquefidus: laciniis obtuhs, anguftis, revolutis; inforne ventricolus \& elongarus in pedunculurn planum, verfus bafin filiformi attenuartim, acuatum, hinc acutum, inde iucraffato bifuleum. Cor. nulla. Stam. decem, ra-

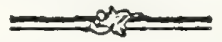

rius octo. Styl. tres: Rigmatibus bifidis, obtufis, divergentibus. (Ex fchedis SorANDR1.) Capfula fupera unilocularis, monofperma. Semen inverfum lobatum.

BRUNNICH I A cirrhofa. Tab. 45. fig. 2.

Ex herbario Bankfiano. Habitat in Bahama.

PEr. Capfula fupera, pyranidata, trigona, trifulca, cruftacea, tenuis, unilocularis; evalvis.

REc. nullum ; feinen fundo caplulx affixum.

SEM.-unicum ovato pyramidatum, acuminatum, fulcis profundis longitudinalibus in fex vel pauciores lobos divifum, nigro fufcum.

IN T. fimplex, membranaceuin, atro fanguineum. 1. fufcum.

A цв. Cernini conforme, profunde lobatun, fariuofum, candidifimum, friabile.

E м в. longitudine feminis, inverfus, lateralis, leviter curvatus, lacteus. Cotyl. foliacex; lineari-lanceolat $x$, fubHexuof $x$, accumbcntes. Rad. teretiuscula, obliqua, fupera.

a.) Calyx maturus, pendulus, b.c.) Cappula denudata, d.) Eadem difreata. e. E.) Semen fola. tunı. F. G.) Albumen transverfe \& lougitudinaliter feftum, cum fitu \& figura embryouis, $H_{0}$ ) Embryo Separatus.

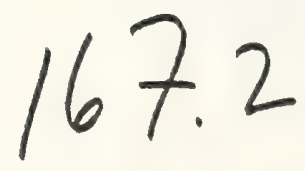


$T_{a b}$. CLXXXIV.

Polygonaceae

O

Pallafia easpica.

- Calligonum

J. Gaertner (1788) Vol3

28

26. P A L L A S I A.

Liñ. fuppl. pl. p. 37. gen. pl. ed. Schreb. 834.

Juss. gen. p. 83.

C21. pentaphyllus, foliolis ovatis obtufis fubiraqualibus perfftentibus reflexis. Cor, nulla, nifi calycem velis. Stam. 12 -15: perfiltentia. Ovar. fuperun. Styl. tres, ftigmatibus capitatis. Nux comprelle tetragona, coriacea, unilocularis, evalvis, angulis ala duplici membranacea intructis. Sem, unicum, erectum.

Pallasia cafpica. Tab. I84. fig. 2.

Pierococcus apjiyllus. PALL. it. rutb. 2. p. 738. t. S.

Pallafia pterococcus. Pallas. flor. rofs. 2. p. 70. t. 77. 78 .

Calligonum fructibus alutis, alis membranaceis crifpis dentatis, L'HERIT. AD. Soc. Limn. Lond. 1. p. 180.. WILLD. Spec. pl. T. 2. P. 2. p. $9=7$.

Pallafia. Lixin. Suppl. p. 252." Syft. veg. ed. 14. p. 455.

A Cl. THunberg.

PEx. Nux coriaces, ovata, utrinque acuminata, verfus bafin contorta, comprelfe tetragona, fordide fufca aut nigro-eaftanea, unsdocularis, evalvis. Anguli collaterales approximati, prominemes: fingulo, duplici ala maxi$\mathrm{ma}$, ovato-rotundata, Itriata, in ambitu ferrito-lacera, pillide ftraminea, atque per maturitatem laminis fuis contortis tot:m nucem abfondente, inftructo. Loculamentum ab introrfum prominenti angulo acuto ex uucis lateribus anguftioribus cruciato - guadrangulare.

29

R z c. nullum; femen fundo nucis arcte adnatum.

Ses. unicum, ovato-acuminatum, cruciato-molendinaceum, fpadiceum, aut pallidum, ad bafin nigro-lphacelatum.

IN T. fimplicifimum, albumini arctiofime adnatum.

A L B. fenini conforme, farinofun, c:Indidiffimum.

EN8. linearis, erectus, compreffus, fublutefcens, longitudine fere albumi. nis. Cosyl. lineari-oblongie, angutilinz, tenuifinx. Rad. filiformis, infera.

EXPLICATIO FIGURE.

a.) Nux integra in Gtu pendulo. h.) Ejus fedio transverfalis, cum alis ad Gingulos angulos geminatis. c.) Eadem excullis alis plane denudata, cum calyce ftạminibus \& Aylis perǴftentibus. d.) Seusea decorticatura. E.) Ejus \& albumiais featio transverfälis. E. E.) Embrjo Sepa

Sxpe albuminis latus longius alterum penitus deficit, atque embryo $a b$ uno latere folo feminis integumento proprio contectus elt. Differt a congeneribus fuis embryone cerrilune erecto, nec inverfo, uti $\mathrm{Cl}$. Pallas it. 1. c. imnuilie viderur. Embryonem primum pro monocotyledone habui, quia cotyledones inter fe conghtunatx, nec fponte nec cultro dividuntur ; fed transverfm fectx maniteltan rimam transverfalem oftendunt, ut de earum vero mumero dubium elie non poltit.

167.3 


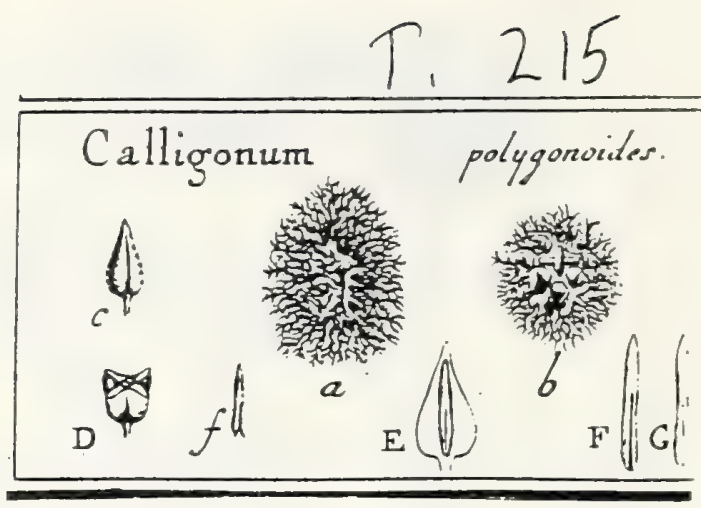

J. Gaertner

\section{r58. C A L L I G O N U M.}

Linn. gen. 680. Juss. gen. p. 83. Lamaвок ill. gen,

t. 410. Polygonoides. 'T'טuRs. inft. t. 478 .

Cal. pentaphyllus; foliolis ovatis, obtufis, fubxqualibus, perfiftentibus, reflexis. Cor. nulla; nif calycem velis, Stam. 12-15; filamentis brevibus, calycis bafi infertis, perfiftentibus. Ovar, fuperum; ltyli tres, (rarius duo 1. quatuor, ) breves. (ttiginatibus capitatis. . Nux curiacea; tetragona : angu* lis alá duplici fpinuloßa aut integra inftructis; uńlocularis. Rec. nullum. Sem. unicum, quadrilobum. Álb. farinofum. Emb, inverfus, Jinearis.

Calligonum polygonoides. Tab. 21 s. fig. 9.

Polygonsides'orientale ephedrae facie. Tourn. it. 2. p. 147 . cum icone. Calligonzum. Linn. Jpec. pl. p. 748 . Syft. veg. ed. 14. p. 502 .

Calligonum fructibus- cancellatis fetis ramofis rigidis.. L'Herıt. Ar. Soc, Linn,', Lond. I. p. r7g. WIItD. Spec. pl, T. 2. P. 2. p. g:6." PEBSOON Jyn, a. p. 19 .

Ex Aegypto ab amicifimo Dao Delile.

PER. Nux fere pollicuris fupera, ovata, furfum acuminata, tetragoнa, coria: cea, caltanea l. Spadicea, unilocularis, evalvis. 'Anguli nucis duplici ala membranacea angufta per ambitum cancellato- Ppinulofa 1 . muricata inftrucli : Spinulx rigidx, apice 'trifidx \& çum proxinis adeo intertexta, ut nux toca abfcondita fit. Loculamentum cruciaso-quadrilobum.

REc. sullum, femen fundo nucis, arcte adnatum.

SEM. unicum, erectum, elliptics - acuninatum, cruciato-molendinaceum, 1 ; quadrilobum, lobis furfum in angulos abeuntibus, fpadiceum 1. ferrugineum.

IN T. fimpliciarimum, albunini arce adnatum.

A L B. femini conforme, farinofum, candidifimum.

$E_{M B} \dot{B}$ linearis, albumine paulo brevior, neo ipfius apicem attingens, inverfus, rectus, teretiufculus, liscteus. Coryl. lineares, longze, fulco levi diftinctr, femiteretes, obtufre, accumbentes. Rad. linearis, teretiufcula, cotyledonibus paulo brevior, unbilico exterrio contraria, fupera.

\section{EXPLICATIO FIGURA}

a.) Nax Integra. b.) Ejusdem (edio transverfalis, e.) Semen feparatam. D.) Alburniais (ectio iransvetfalis. E.) Idem fecundum lobos oppofitos loogitudinaliter diffeckom, cum fisa embryoais. f. F.) Eabryo folutas.

Ex his liquet Pallafiam, cujus character p. 28. hujus operis proftat, a Calligono genere non effe diverfim; cum in ambobus embryonis fitus atque forma endem fit. Fig. G.) emendatan embryonis C. Pallafie figuram Gittit, ad exempla probe matura ex collectione Cl. Desfon tasses confectam; cujus itaque defcriptio ibid. p. 29. Gic mutanda:

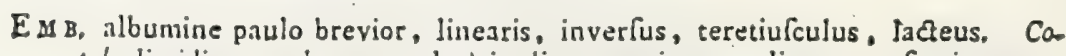
by. dimidiam embryonem lorigitudine mentientes, lineares, femiteretes, medio paulo cralfiores, obtufiufculx, Rad. tereti-oblonga, acumainata, rupera. 


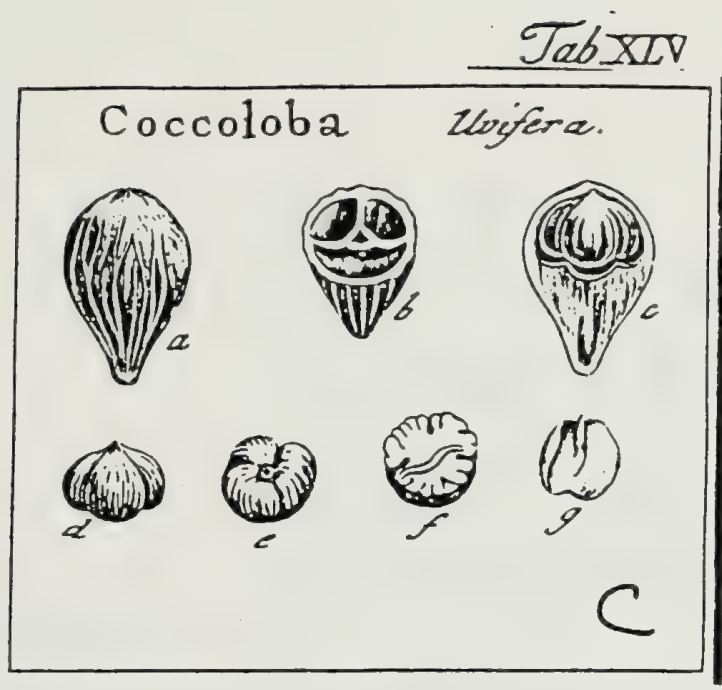

J. Gaertner (1788) Vol.1

CCLXI. COCCOLOBA. LIN ger. $496 . \quad 214$

Calyx monophyllus, quinquepartitus, coloratus, dcmum baccatus, claufus. Cor. nulla. Stain. octo. Siyl. tres. Drupa ex calyce baccato monofperma. Semen iaverfum, lobatum.

Соссогов а Uvifera. T2b. 45. fig. 3.

Guajabara racemofa, foliis coriaceis fubrotundis. $\mathrm{P}$ u uss. ic. $t .145$.

Coccoloba foliis cordato fubrotundis nitidis. LIN N. Jifl. veg. 379.

PER. Drupa fupera ex calyce baccato formata, obovata, purpurca rolcida, per xtatem nigra, rugofa. Caro pulpofa mollis in cruflam temucm exarefcens. Putanen chartaceum, tenuifinum, cum carne intine conferruminatum, femitriloculare. Diffe-: pimenta unembranacea angufta, in fundo faltem drupa reperiunda.

REc. tuberculum parvum fungofum, ex concurfu diflepinentorum formatum, in bafi fructus.

SEм. unicum, fubglobofum, fupız acumninatum, infra profunde umbilicatum, trilobuin, Ariato rugnfum, ferrugineo fufcuin.

IN $T$. fimplex, inembraıaceuin, arcte adnatuin.

A L в. Semiui contorıne, profundis runis cxlum, farinofum, candidifinum.

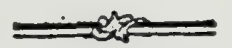

Ess 8. longitudine ac latitudine feminis, foliaceo compreflus, inverfus, niveus. Cotyl. foliacex, rotundatx, tenuiltunx, trausverfun flexuofx. Rad. fubulata, brevis, fupera.

2.) Drups exficcats. b.c.) Ejusden fertio transverfalis \& longitudinalis, eum feminis fitu. d., Semen a parte fupcriori, \& e.) Idein a parte inferiori fpeelatum. f., Albumen transverfe fetum, cum ficu embryonis. g.) Einbryo (eparatus. 


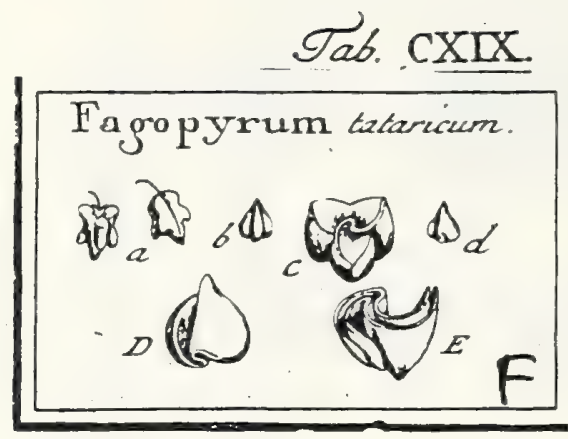

DCXCVIII. F A GO P Y R U M. TOURN. inft. t. 290.

J. Gaertner (1788) Voî. 2

Calya quinquefidus, perfittens, fenine multoties brevior. Cor. nulla.

Stam. octo. Ovar. fuperum. Styl. tres. Sermen mudum, triquctrum.

Embryo centralis, cotyledonibus foliaceis, transverfim texuofis.

EAgóiynuar tataricum. Tab. I19. fig. 6.

Fagotriticum fibiricum. Linv. af. bolm. 1744. edis. gerin. p. 105. t. 4 .

Polygonum foliis cordato fugittatis, caule inemsi ereigo, Jeminibus fubdentatis. LiNN. fygle veg. $3 ?^{8}$.

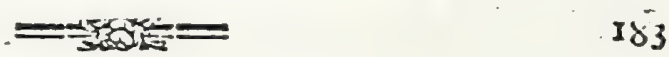

PER. nullum, nifi feminis cruftam velis.

REC. nullum.

SEM. unicun, triquetrum, bafi cordatum, apice pyranidato-mucronatum, ad angulos dentatum aut repandum, fordide cinereum.

IN T. duplex: exterins cruftaceum f. nucamentaceum; inferius membrallaceum, bafi chalaza fufca notatum.

$\Lambda$ L B. cordato - pyramidatum, triquetrum, bipartitum, farinofum.

E м в. centralis, inverfus, lutefcens. Coryl. magnitudine fere albuminis, foliacex, tenuidlinx, transverfim dexuofx. Rad attenuata, brevifina, fupers.

a.) Siminz integra. b.) Albumen denudatum C.) IJem transierfe fectum, a cotyledonibus bipartitum. d. D.) Embrgo denudatis. E.) Cotyledones transverfim fedz. 


\section{T. CXXV111}

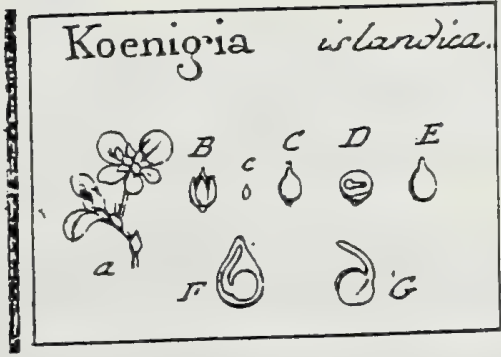

J. Gaertner (1788) Vol. Z

212

DCCXXXII. K O E N I G I A. LINN. ger. I24r.

Calyx triphyllus, perfiftens. Cor. nulla. Stam. tria. Ovar. fuperum. Stigmata duo l. tria feffilia. Sem. unicum, nudum, inverfum. Cotyl. orbiculate, accumbentes.

Koenigia islandica. Tab. 128. fig. 3.

- Koenigia. OED. flor. dms. to 488. LINN. $\sqrt{2} /$. veg. rag.

Ex herbario Bankfiano.

PER. nullum; calyx perfiftens femen fovet, nec illud penitus obtegit.

REc. nullum, prater fundum calycis.

SEM. unicum, ovatum, apice \& bafr leniter attemutum, glabrum, e caftanea rufefcens, ftigmatibus perfiltentibus terminutum.

Ixt. fimplex, coriaceum, tenue.

A L B. Semini conforme, carnofum, craffum, album, embryonem involvens.

Es B. longitudine feminis, .inverfus, albus. Cotyl. orbiculatx, fubfoliacex, planx, accumbentes. Rad. teretiufcula, furfum incurvaca, fuperi.

a.) Frudus in rofulis foliaceis terminalibus fenfiles. B.) Calyx femen eingens. c. C.) Semen Separatum. D. Y Ejus fectio transves[alis. E.) Albumen integrum. F.) Idem diffcaum cum forma \& frta embryonis. G.) Embryo folutus. 


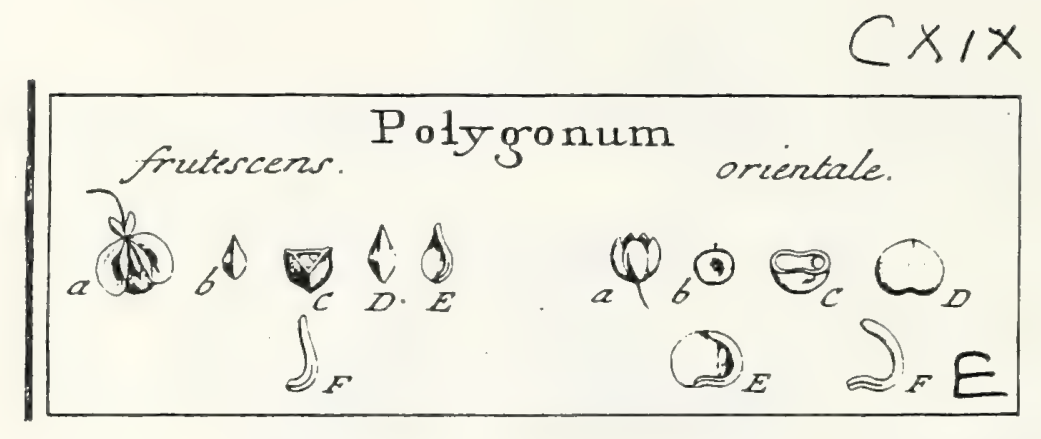

J. Gaertner (-1788) Vol 2

\section{POLYGONUUM. TOURN. ixft. t. =90. $|8|$ LINN. gCit. 495.}

Calyx pentiphyllus, foliolis per maturitatem xgualibús aut inæqualibus, ca. loratis aut excolocibus, fed conftanter a fermine liberis. Cor. nulla, niff calycem relis. Stam. veto. Ovar. fuperum. Styl. tres. Semen nudum, fixpius trigonum. Eubryo unilateralis, cutyledonibus incumbersibus.

182

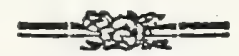

Pozygonum fruteficens. Tab. IIg. fig. .5.

Polygomun fiuticofum, patalis dnobus exterioribus refiexis, Gared. fibir. j. t. 1s. f. 1.2.

Polyzontiu caule fruticofo, calycinis foliolis duobus refexis. LiNs. Jjt. veg. $j 76$.

PER. nullum, nifi exteriorem feminis cruftam velis.

REC. nullum; femen fundo calycis affixum. .

SEM. unicum, ovato acuminatum, triquetrum, lucidum, e caftaneo nigricans.

IN T. duplex : exterins cruftaceo - coriaceum; interius membranaceum, rufun.

A L B. farinofunı, candidiflimum.

Eмв. unilateralis, teretiufculus, inverfús, lacteus. Coty\% breves, curvatx, incumbentes. Rad. longa, fupera.

a.) Calyx maturus, fecren obtegens b.) Semen denudatum, intszrum. .C.) IJem difteçums. D.) Albumen decorticatum. E.) Enabrgonis in albumine fitus. F.) Embryo folutus.

Potrgonum orientale. ibid.

Perficaria orientalis, nicotiane folio, calyce flormu prupureo. TOURN. af. gal. 1703 . edit. gernt. p. 365. t. 9. Com. rar. t. 43. MiL.. ic. t. 20 r.

Polygonum floribus beptandris dignnis, folits ovatis, caule ereifo, fipulis birgutis bypocrateriformibus. LIN S. Jy/t. veg. 377.

Calyx (a) quinquefidus, xqualis. Stam. 6. I. fepten. Glandula lutea ad bafin linguli ltaninis. Semen (b. c.) fubglobolum, in utroque latere compreffufculum, nigrum, fplendens. Integum. exterins cruftaceum, durum, fubfragile; isscrins rubro ferrugineum, curn chalaza fufca in bafo. Albumen (D) farinofum. Embryo (C. E. F.) unilateralis arcuatus inverfus, fublutefcens.

Crufta feminis exterior iu variis Polygoni fpeciebus fatis crafia atque dura eft, ut pro Pericarpio nucamentaceo haberi politi. 


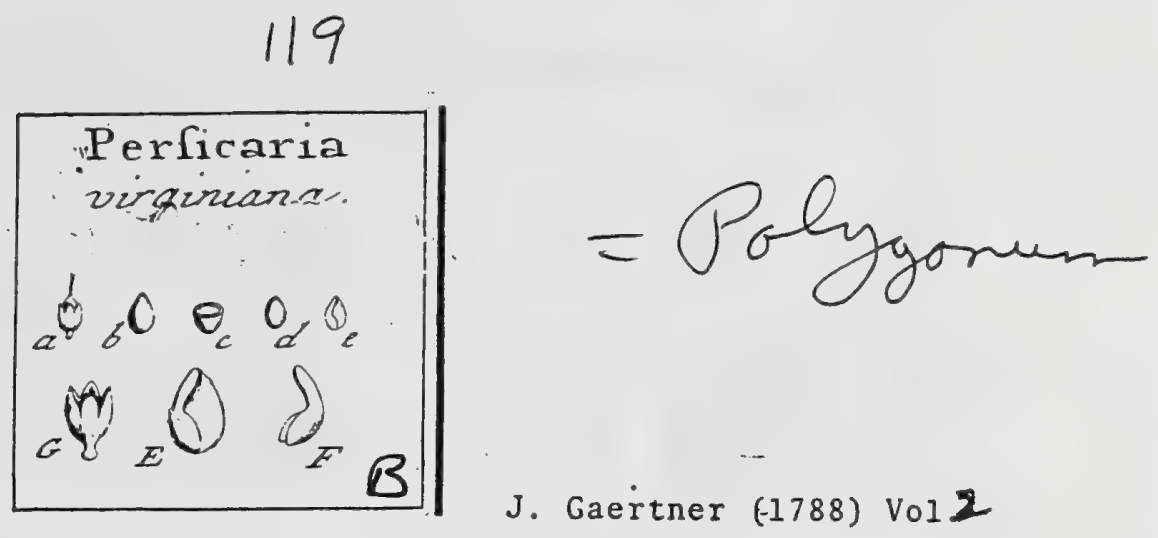

DĆXCV. PER̈SICAR I A. Tovara. ADANS. 180

Calyx monophyllus, quadrifidus, perfiftens. Cor. nulla. Stam.iquinque, Ovar. fuperum. Styl. duo, fliformes. Semen nudum, lenticulare. Embryo unilateralis: cotyledonibus accumbentibus!

Persicaria virginiana. Tab. 119. fig. 3 .

Perficaria frutefcents maculofa virginiana, fiore albo. Morıs. bift.:2. p. 389.

Polygontm floribus pentandris feinidigynis, corollis quadrifidis megralibus, foliis vuatis. LINN. Lyft. veg. 377 .

YBR. nullum, nif feminis integumentum cruftaceum velis.

REc. nuthrm; femen fundo calycis adnatum.

SEM. unicum, ovatum, lenticulari : compreffum, glaberrimun, Jucidum, pallide caltarteum.

IN T. duplex: exterius cruftaceum, tenue, fragile in isterius membranaceum, chalaza ferruginea in bafi sutatum.

A I B. carnofum, aqueo-pallidum.

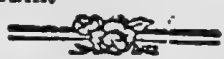

$18 \pi$

$E_{X}$ B. unilateralis, inverfus, albicans. " Cotyl. ovato - lanceolate, foliacez, accumbentes, alterum albuminis latus rima verticali fecantes. Rad. te. retiulcula, ad angulum obtufum cum cotyledonibus commiffa, fupera.

2. G.) Calyx maturus femen fovens, b.) Semen denndatum intsgrum. c.). Idem transvetf

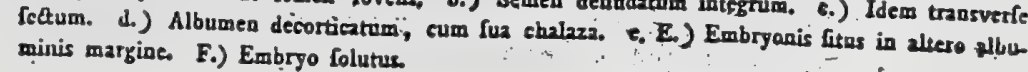


$\sigma_{a b}$. CXIX.

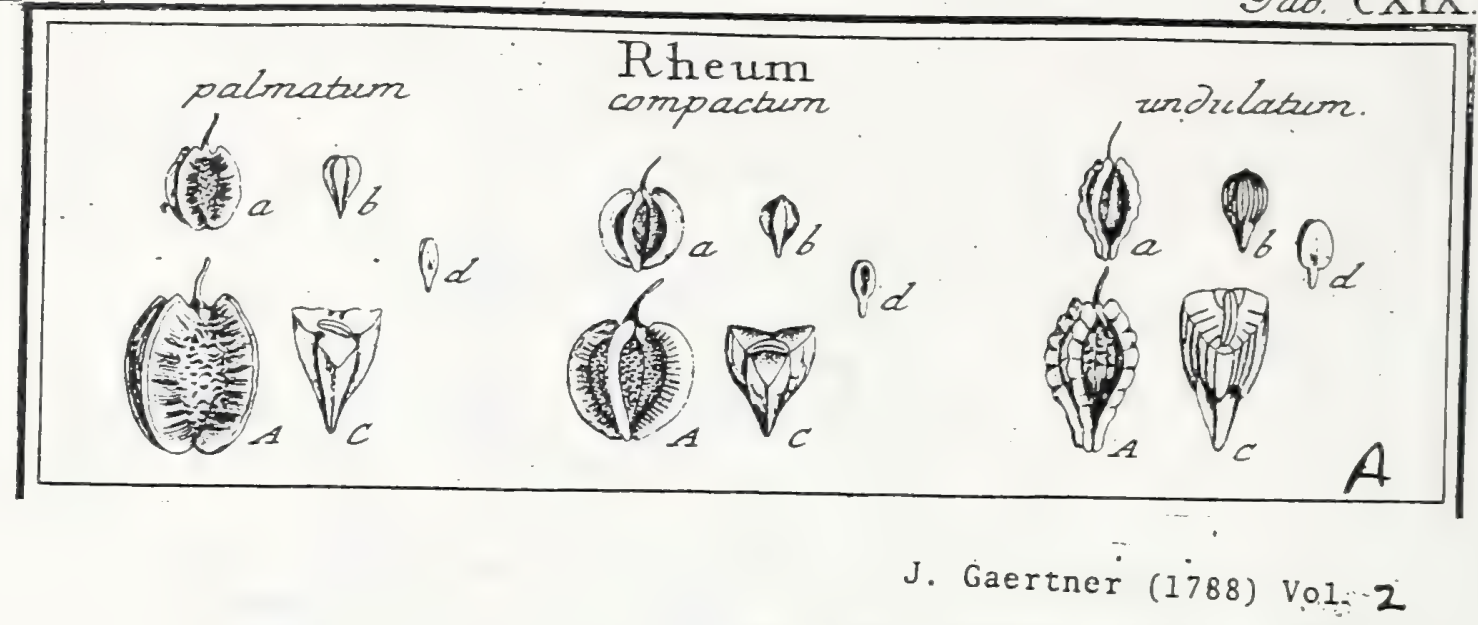

\section{RHEUM. LINN. gen. 506. Rhabarbarum. 177 TOURN. t. IS.}

Cal. nullus. Cor. monopetala, fexfida: lacinis alterniṣ majoribus. Stam. novem. Ovar. fuperum." Stigm. tria, plumola. Señ. unicum, nudum, triquetro - alatum. 'Embryo ceutralis; rectus : radicula extra albumen porrecta.

Rнечм palmatum. Tab. I19. fig. I.

Rhabarbarum fmenfe. BlAkw. berb. t. 600, a. b. optime.

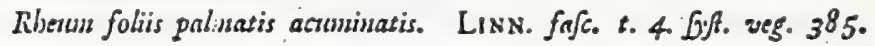

P ER: nullum, nifi ferinis integumeutum externun.

Rec. nullum.

SE M. unicum, ovato-ellipticum, apice \& bafi emarginatum, triquetrum: lateribus fubfcrubiculatis, rugofis; anguls alatis, membranaceis, glabris.

INT. duplex, membrainaceum: exteritus fpodiceum, in alas ampliatum; ixterius faturate rufefcens, albumini adnatun.

A I B. ovato - pyramidatum, triquetrum, embryone brevius, f. ad radicula fedem deficiens, farinolum, bipartitum, niveum.

EM B. inverfus, rectus, centralis, albus. Cosyl. ovato-oblongx, leviter concavx. Rad. fubulati, exta albumen porrecta, fupera.

$\mathbf{r} \div 8$

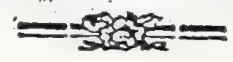

*

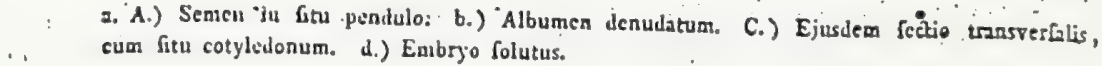

RHEUM compactum, ibid. Rhetum foliis cordatis glabris narginibus funtatis, fpicis divifis mutantibus. Níl.
ic. t. 218 .

Khen foliis fublobatis obtufffimis glaberimis lucidis dentatis. LiNN. l. c. a

Semen (a.A.) rotundato-cordatum, triquetrum : lateribus elevato-punctatis, fufco - viridibus, lucidis; angulis membranaceis, ftriatis, ferrugineis. Al-
bumen (b. C.) \& Embryo (d.) ut in prxcedenti.

RuEus undulatum. ibid.

Kheum foliis fubvillofis. LINN. amoen. 3. p. 212. t. 4.

Kheun foliis friboillo $\sqrt{2}$, petiolis aqualibus. LINN. fyft. veg. 1. c.

Semen (a. A.) ovato-pyramidatum, triquetrum: lateribus obfolete ftriatis, ferrugineo-fufcis; angulorum alis anguftis, undulatis, e luteo-rufefcentibus. Albumen (b. C.) farinofum, profunde fulcatum, ad radicula fedem late de. ficiens. "Emibryo (d.) ut in præcedentibus." 
DCXXIV: R U M EX. LINN. gen. 45I. Lapathum.

TOURN. inft. $\tau_{0}=97$.

Cal. hexaphyllus, foliolis tribus majoribus, perfiftentibus, $f_{x p e}$ globuliferis. Cur. nulla. Stam. fex. Ovar. fuperum. Styl. tres. Semen-tectum, triquetrum. Embryo periphericus.

Rumex Patientia. Tab. IIg. fig. 2.

Lapatbum fativums. DoD. pempt. 648. BLAKw. besb. to 489 .

Rumex foribus bernaphroditis valuulis integerrimis; ionica granifera, foliss, ovato - tarceolatis. LINN. Jy3. - veg. 346 .

PER. nullum; calycis valvulx majores, ovatx, integerrimx, venofo reticulatx, quarum unica granifera, femen obtegunt.

REC. nullum.

SEM. unicum, ovato:acuminatum, acutifime triquetrum, fpadiceum, lo cidum.

IN T. duplex: aterius coriaceo - chartaceum; interitus membranaceum.

A L B. fenini conforme, farinofum, candidum.

EM B. periphericus, inverfus, curvatns; albus. Cotyl. lineares, incumbentes, juxta bifin albuminis infexx. Rad. teretiufculn, fupera, ultra alburmen porredia.

1. b.) Calycis valvulz cum fun glandula aid bafin. c.) Semeri denudatum integrum." D.) Ejusdem fictio transveralis. Eo) Eimbryo ad latus albuminis pofitus.

Ruasex obtulifolius. : ibid.

I.aprosbum. CAM. epiz.2z28.

Ilumex foribus bermaplooditis: valunlis dentatis graniferis, foliis cordato obloнgis obsufrufculis crenulatis. LiNN. fyf. veg. 347 .

Calycis maturi valvulx majores (a. b.) fubferruginex, cordatix, reticulate, profunde \& tenuiter dentatx, omnes graniferx. '-Semen (c.) triquetrum, fpadiceum, fplendens. Albumen ut in praccedenti. Embryo (D.) unilateralis, teretiufculus, levifime curvatus, izverfus, albus.

RUArex fainguinieus. ibid.

Lapatbum ribens. Dod. pempt. 650. Cıм. epit. 229. BLakw. berb. 492. Runtex floribus bermiaplroditis: valunlis integerrimis; wuica granifera, foliis cordato - Imceolatis. LiNN. fyft. veg. 346 .

Calycis maturi valvule majores (a. b.) ferruginex, ovate, integerrimé, parvx, nunc gianiferx omaes, nuuc duxe tantum, nunc \& unica fola: granum autem unum reliquis conftanter majus, . \& fufco rubrum. Semen (c.) parvulum, fufcum, lucidum. Embryo (D.) lateralis; vix autem "levifime curvatus.

RuḾrx fpinolus." ibid.

Beta cretica femine aculeato. BAur. prodr. 57. c. іс, Baur. bij. 2. p. 963. c. ic. Rumex foribus androgynis: calycibus feinineis monophyllis: valundis exterioribus refexo - zmcinatis. LiNn: Jyff. veg. 347.

Involucrum femineum fuberofum, monophyllum, fubpyramidatum (a), ferobiculato - reticulatum, fpinis tribus refexis pungentibus ad apicem armatum. Semen (b.) ovato acuninatum, fuperne triyuetrum, inferne autem rotunda. tun \& in bafi, lata cicatrice umbilicili notatum, Alavcfcens, fplendens. A bumen (c. d. e.) frinolum, centrale. Embryo (f.) linearis; albus, periphericus, annuli adinftar totum albumen ambiens. Cotyl. Iongiffimx, planx, incumbentes. Rad, teretiufcula, brevis, fupera.

R tuex bucephalophoris. Sbil.

Acetofa, ocymi folio, bsceppatojhoros. CoLUm. ecply: x. p. 151. t. 150 .

Rumex floribus bermaphroditis: valuis dentatis undis, pedicellis planis refexis irecraffatis. LiNn. $\sqrt{3}\}$. veg. 347 .

Calycis maturi (a. A.) pedunculus caltus, comprefius, recurvatus, femicanaliculatus. Valvula exteriores minimx, reflexx, pedunculo appreffix; imteriores multo grandiores, fubtriangulares, fetaceo dentatx \& ad bafin glandula planiufcula retroverfa munite Sement (b.) parvum, fpadiceum, lucidum. Embryo (C.) undateralis, rectiufculus, inverfus.
J. Gaertner (1788) Vol, 2:

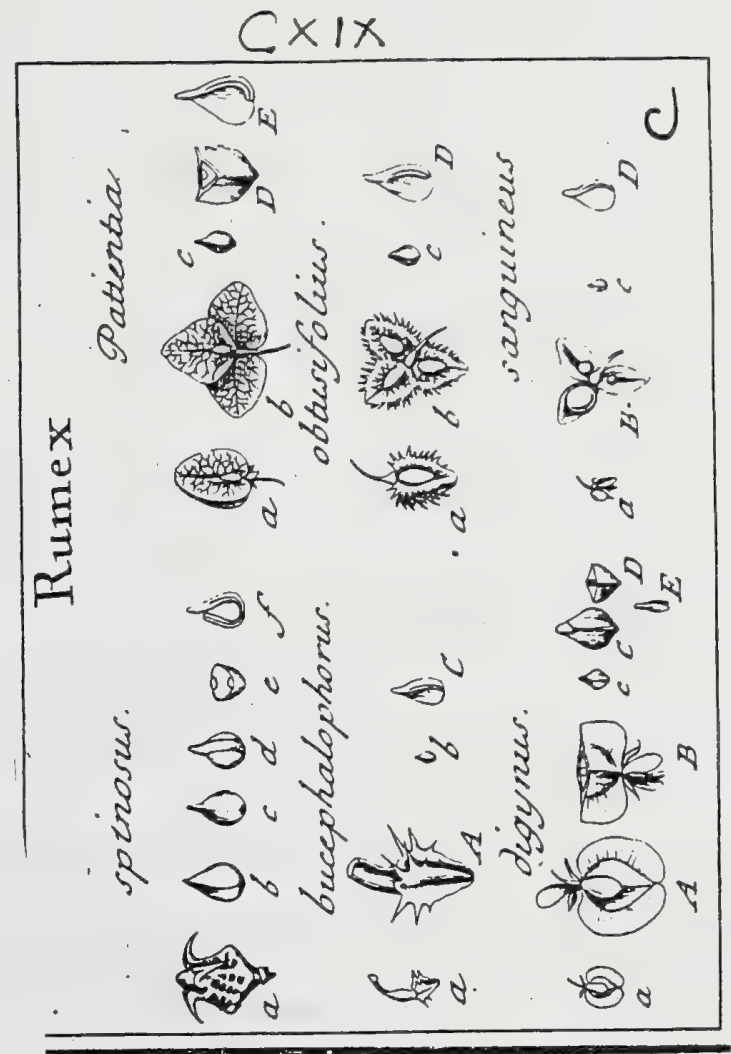


Portulacaceae

Tab. CXXIX.

Claytonia sibirica.

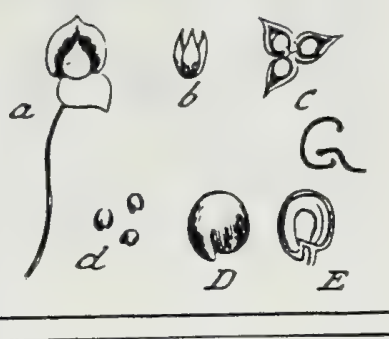

J. Gaertner (17.88) Vol. 2

221

DCCXIV. C L A Y T O N I A. LINN. ger. 287.

Calyx diphyllus. Cor. pentapetala. Stam. quinque. Ovar. fuperum. Styl. unicus, apice trifidus. Capf. unilocularis, trivalvis, trifperma.

Claytonia fibirica. Tab. 129. fig. 3.

Limia. Lisw. act. up]. 1746. p. 130. t. 5. af. bolm. 1746. p. 137. t. 5.

Claytonia folits ovatis. LiNN. Jyf. veg. 245.

PER. Capfula amplis calycis perfiftentis valvis obtecta, ovata, apice in mucronem producta, chartaceo-elaftica, tenuis, unilocularis, trivalvis.

REC. nullum; femina ope funiculi umbilicalis brevifimi fundo capfulac affixa.

SEM. tria, fubrotunda, roftellata, lenticularia, minutiffme puncticulata, glabra tamen, lucida, anthracina.

IN T. duplex: crufaceum atque membranaceum.

A L в. farisofum, niveum, centrale.

Eм в. periphericus, annularis, lutefcens. Cotyl femiteretes, incumbentes. Rad. filiformis, infera.

a.) Capfula claula enm calyce. b.) Eadem dehifcens. C.) Valvula reclinatz cum infertione feminam. d. D.) Semina feparata. E.) Semen difreatum cum Ggura \& fita albuminis atque embryouis. 


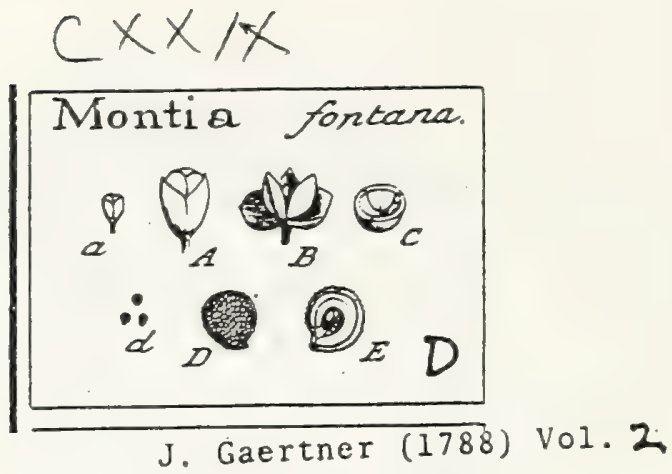

DCCXIIV. MON T I A. IIN gen. IOr.

Calyx diphyllus. Cor. monopetala, trifida, irregularis. Stam. tria. Ovar. fuperum. Styl. tres. Capf. unilocularis, trivalvis, trị̂perma.

Movitia Fontaila. Tab. 129. fig. 2.

Alfmoides annua verna. Valt. paris. t. 3. $f .4$.

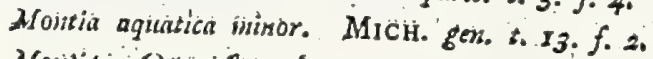

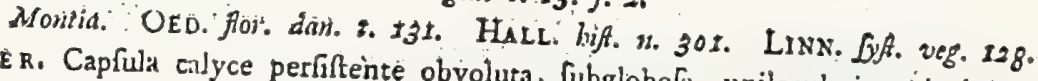

REc. nullum; femina ope funiculi afticas

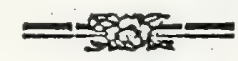

22 I

SEM. tria, turgide lenticularia aut fubglobofa, roftellata, denfillme tuberculato - fcabraca, atra.

INT. duplex: cruftaceum atque membranaceum.

A L B. carnofum, aqueo-pallidum, centrale.

Es B. periphericus, annularis, lutefcens. Coryl. femitereres, incumbentes. Rad. infera.

a. A.) Capfula calyee tecta. R.) Eadem deaudata ac dehifeens. C.) Ejusdem featio transverca. lis, cum funiculis ambilicalibus. d. D.) Semina feparata. E.) Semen diffezum cum figura \& fitu albumiois atque embryonic.

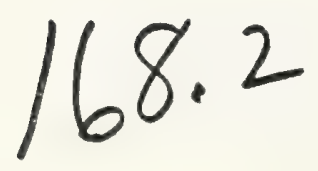




\section{Tab. CXXVII.}

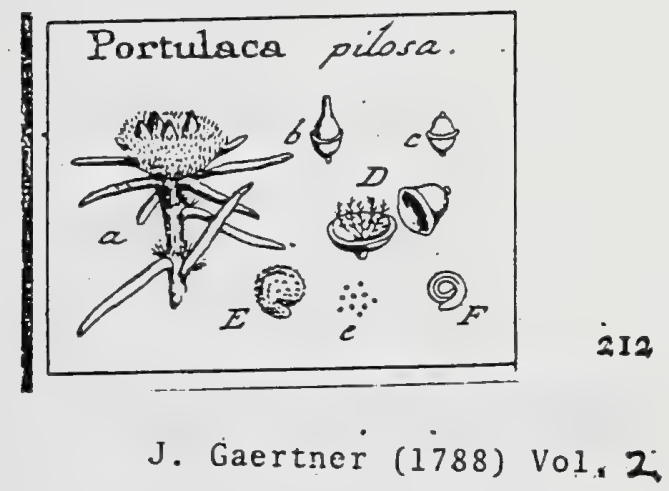

DCCXXXIII. PORTULACA. TOURN. t. II8. LINN. gen. 603.

Calyz diphyllus, fuperus, caducus. Cor. pentapetala. Stam. plura, ad viginti. Ovar. feniinferum. Styl. unicus, apice quinquefidus. Capfula unilocularis, circumifciffa. Receptac. quinque, libera, diffita. Sem. numerofa.

Portulaca pilofa. Tab. 128. fig. 4 .

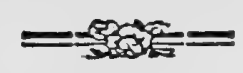

Portulaca curafarica, angugio longo hucideque ${ }^{-}$folio, proczunbens. Cossis. burt. 1. p. 9. t. 5.

Portuluca curafavica lanuginofa procranbens. Herar. parad. t. 215 .

Portulaca folits fubulatis alternis: axillis pilofs, floribus feffilibus terminalibus. LiNN. Jyft. veg. 445.

PER. Capfula femiinfera, corolla perfiltente emarcida tainquam calyptra teça, elliptice globofa, circa medium prominulo margine cincta, unilocularis, circunicilfa: valvulis hemifphrricis, fubxqualibus.

R E c. quinque, libera, diltạntia, filliformia, ramofa, erecta, fundo capfulæ affixa.

SEM. numerofa, parva, reniformi-roftellata, tuberculis minutiflimis acutis per feries paraljelas digeftis fcabrata, atra.

I N T. duplex: exterius cruftaceum, fragile; interius membranaceum, ferrugineum. A L B. vix ullum, proter fubfantiam farinofam albam paucam in centro feminis. E⿺ B. teretiufculus, fpuralis, albus. Cotyl. femiteretes. Rad. longa, centripeta.

2.) Fruens in extremitate mmorum feflics. b.) Capfula cum corolla perfiftente. c.) Eadem denudsta. D.) Ejus valpula feparatie, cum receptaculis feminum. C. E) Seminz feparati. F.) Embryo denudatus.

Receptacula feminum Portulacam ab omnibus cognitis generibus diftinguunt, \& hactenus fine alio funt exemplo. 
6

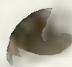

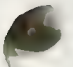



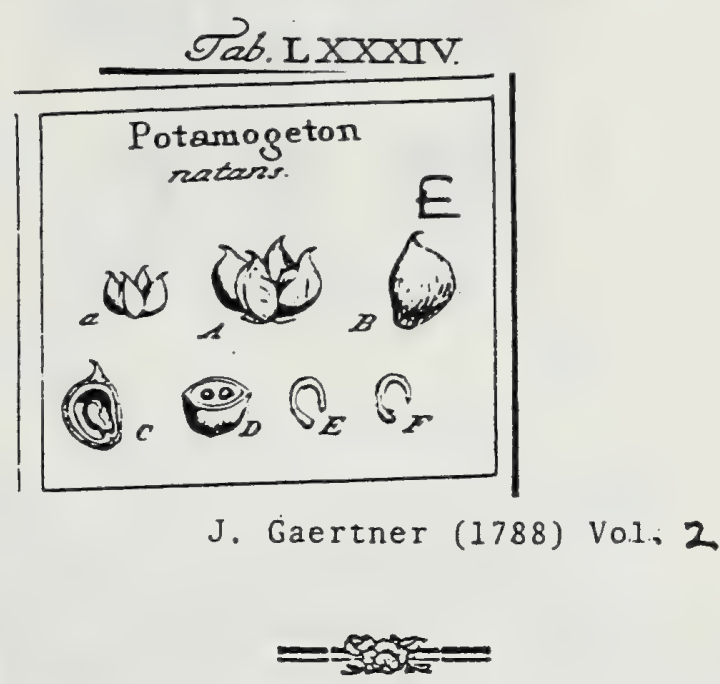

DXXV. POTAMOGETON. TOURN. inf. t. 303. LINN. gen. 174 .

Cal. nullus. Cor. tetrapetala. Stan. quatuor aut octo. Ovaria quatuor: ftylis fimplicibus, brevifimis, recurvis. Drupz quatuor uniloculares. Semen uncinato incurvum.

Potamogeton natans. Tab. 84 fig. 5 .

Potamogeton. Fuchs. bift. lat. 651. germ. ic. 37 I.

Potantogeton foliis furmis oblongo ovatis petiolntis natantibus. HaLL. bift. 13.843 . LIN . Dyt. veg. 168.

PER. Drupx fuperx, quatuor, exfucc $x$, ovatx, hinc gibbx, inde in aciem redam comprefix, ftylo brevi recurvo terninatx. Cortex per maturitatem coriaceo - membranaceus, tenuis. Puamen fubolleum, femibiloculare, feu in dun crura teretia, ope fepti incompleti divifum:

REc. nullum: femen fundo loculamenti affixum.

SEM. teretiufculum, furfum attenuatum, uncinato - curvatum, pallidum aut rufefcens.

IN T. Gimplicifrimum, tenue, membranaceum.

A L 8. nullum.

Ess B. magnitudine feminis, uncinatus, albus. Kad. incraffata, infera, in lo culamenti putaminis crure exteriore locati.

a. A.) Drupx aspregatz. B.) Drupa fingula, integra. C. D.) Eadem longitudinaliter \& trans verfim feca, putaminis fabricam internam oftendens. E.) Semen membrana fua tectum. F.) Embryo denudatus.

Potamogetonis embryoni duas cotyledones breviffimas, tuberculorum rpecie, ADANsonus fam. 2. $p \cdot 467$. tribuit; Sed illas ego, omni quamvis data opera, reperire non potui. 


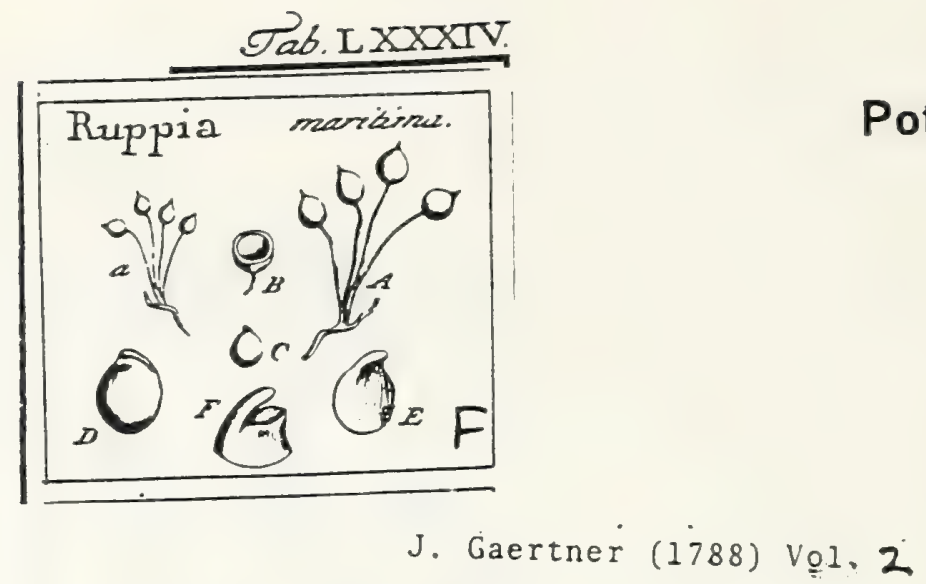

DXXVI. R U P P I A. LINN. gest. 175.

Spatha nulla. Spadix ex axillis foliorum, fliformis, brevis, partibus mafcuJis \& femineis communis. Anthere octo, feffles, nudx, in fpicam ovatan diftich:m digeltx. Ovaria aggregata, quaterna aut plura, in anteriore \& inferiore, - totidemque in pofteriore ac fuperiore fpic $x$ facie inter antheras pofira. Nuculx quaruor aut plures, monofpermx, pedicellata: pedicellis longiflmis, ex uno fpadicis maturi, infigniter elongati, puncto oriundis.

Ruppia maritinal. Tab. 84. fig. 6.

Fucus feruincens. LOB. ic. 255 . OED. flor. dast. t. 364 .

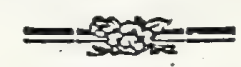

Potansogeton pufsllum alteruns, fensinibus fongulis longis pediculis infidentibus.

Plur. phyt. t. 248 . f. 4. Ra.j. angl. 3. t. 6. f. t.

Bucca feriea maritima, foliis acutidimis. Mich. gen. p. 72. t. 35 .

Ruppia. Lisw. Jy/. veg. $16 \mathrm{~g}$.

PER. Nuces quatuor aut plures, aggregatx, pedunculat $x$, ovato - acuminata, corticatic. Cortex coriaceo - membranaceus, tenuifrmus. Putnen cruftaceun, nigrum, uniloculare, evalve.

R \& c. nullum, preter nucis pedunculun longifimum, filiformem.

SEM. unicun, ovato globofum, fupra leviter acuminatum, pallidum.

Ix T. fimplicif̆mum, membranaceum, tenue.

A L B. nullum, nifi Vitellum velis.

VIT. figura feminis, amygdalino-carnofus, albicans, fubtranfparens, canali

1. fulco brevi, in vertice exfculptus, in quo embryo jacer.

EMB. incompletus, teretiufculus, parte fua pofteriore \& inferiore in vitello rndicntus, reliqua vero liber \& folutus in ejusdem fulco decumbens.

a. A.) Nuces pedunculata integrx. B.) Nux transverfim fecta. C.) Somen propriz fuz membrana veftitum. D.) Vitellus a parte anteriore fpetatus, eum rima verticis, embryonem a corpore vitelli lifcernente. E.) Vitelli fetijo longitudiualis, intacto embryone, ex ipfa Vitelli fubftantia oriundo. F.) Embryo paululum elcratus \& extr Vitclli fulcum protratus.

Plantam forentem nunquam vidi; hinc characterem floris \& inforefcentix ex Adansono \& Oederi icone mutuatus fum. Secundum Rajum atque MicheLU mafculax partes, a femineis, longo fpatio remotx, atque ha, in diftinctis fpadicibus filiformibus collocate funt.

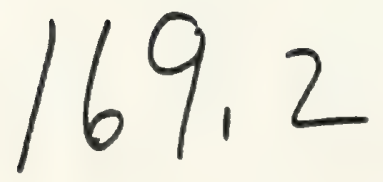




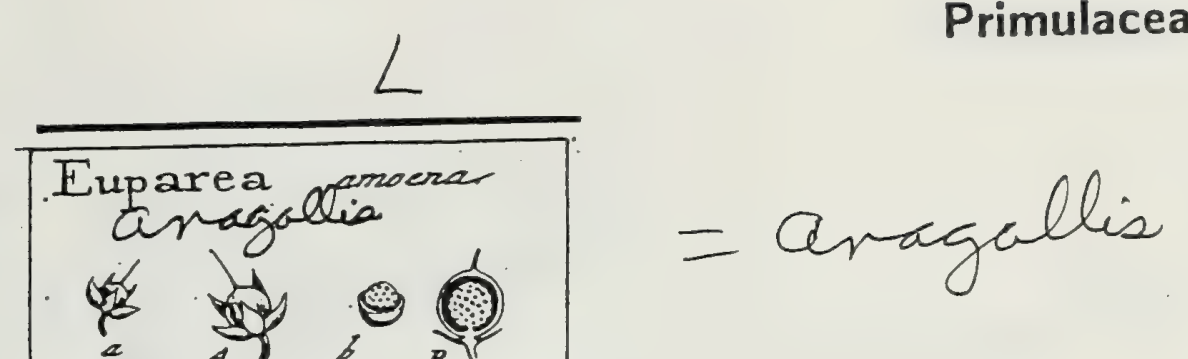




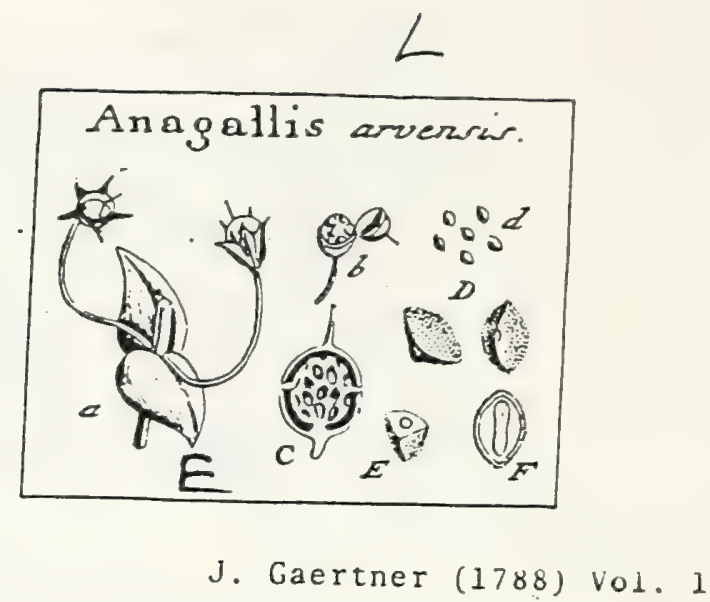

CCLXXXII. ANAGALLIS. TOURN.t. 50. LinN. gen. $206^{2} 30$

Calyx quinquepartitus. Cor. rotata. Stam. quinque. Styl, unicus. Capfula unilo cularis circumfcilfa. Recept. liberum. Semina plura : umbilico ventrali e regione
embryenis.

ANAGallis aryenfis. Tab. 5o. fig. 6.

Anagallis. Blakw. herb. t. 43: E 274. Oenfr. flor. dan. t. 88.

Anagallis "caute procumbente, foliis ovato lanceolatis, calycis fogmentis lanceolatis E fubulntis. H A L L. hifl. 2. n. $\sigma_{25}$. $\sigma_{26}$.

Anagallis foliis indivifis, caule procumbente. LiN N. Juft. veg. 296.

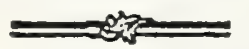

PER. Capfula Sphzrica, glabra, quinque lineis coloratis notata, unilocularis, circumfcifra.

REc. globofum, fungofum, alvẹolatum, liberum.

SE ss. plurz, circiter triginta, trigoụ, ovata, utrinque fubacuminatz, punetato feabra, e fufco ferruginea. Umbilicus in medio ferminis ventre.

IN T. duplex : coriaceum \& membranaceum; utrumque tenue.

A \& B. ferniui cünforme, carnofum, duciusculum, aqueo-pallidum.

Eмв. teretiusculus, sectus, tacteus. Cotyl. femicylindricz, breves. Rad. longa, crafla, infera, aut a centro deviza.

a.) Capiula integra, b.) Eadem dehifcens. C.) Receptac, integrum d. D.) Semina Separats.

E. F.) Albominis foltiodes, cum fitu \& Gigura embryonis.

Semina hemifpharica cava, qux Hallerus l.c. habet, nunquam vidi.

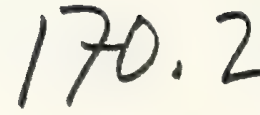


$L$

Primulaceae

Centunculus meimen.

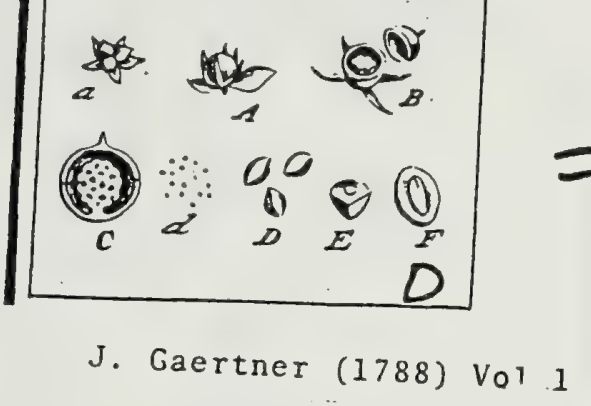

CCLXXVIII. CENTUNCULUS. LiNN. gen. 145 .

Calyx quadrifidus. Cor. quadrifida. Stain. quatuor. Styl. unicus. Capfula unilo cularis circumfciffa. Receptac. liberum. Semina plura: umbilico ventrali e sogione embryonis.

Centunculus minimus. Tab. 50. fig. 2.

Anagallis paludofa minime. VAILL. paris. 12. t. 4. f.2. OEDER. for. dais: t. 177 .

Cintunculus. LiN . fyfl. veg. 158.

$P_{E R}$. Capfula fubglobofa, parva, fyylo brevi terminata, unilocularis, circumfeifta.

REC. globofum, fcrobiculatum, fungofum, maxinum, liberum.

SEM. plura, circiter viginti, fubovata, angulata, ferruginea. Umbilicus in ventre.

IN T. duplex: coriaceum \& membranaceum; utrumque tenue.

$\Lambda$ L B. Sernini conforme, carnofum, album.

Eм в. teretiusculus, dacteus. Cotyl. breviflunx, obtufx. Rad. crafla, a centro deviz,

a. A.) Capiula integra ferfiles, B.) Capfula dehifcens. C.) Receptaculum denudatuma d. D.) Secuila leparata. E. F.) Albuminis fectiones cum embryone. 


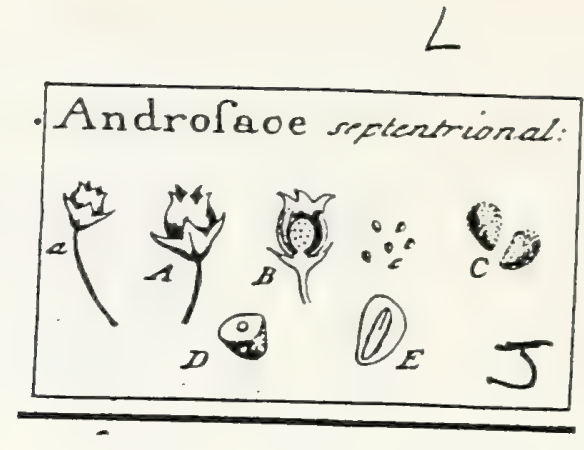

\section{J. Gaertner (1788) Vn' I}

CCLXXXIV. ANDROSACE. TOURN. t. 46. LIN 231 ger. 196.

Calyx quinquepartitus laxus. Cor. hypocrateriformis quinquepartita: faucis annule tumido. Stam. quinque, intra tubum. Styl. unicus. Capfula uniloculars, apice quinquefariam dehif́cens. Recept. liberum. Scmina plura: umbilico ventrali

ANDROSACE leptentrionalis. Tab. 50. fig. 8.

Androface montana, flore minore. Bu X B. aft. petrop. 2. p. $360 . t .23 . f .2$ OEDER. flor. dan. t. 7 .

Androface foliis lanceolatis dentatis glabris, perianthiis angulatis corolla bre? vioribus. Lisn. Jy/l. veg. 192.

PEк. Caplula ovato globola, unilocularis,-apice dentibus quinque acutis dehifcens.

REc. columnare, obovatum, fungofum, frobiculatum, liberuin.

S.EM. plura, circiter triginta, ovata, varie angulata, elevato punctata, fpadicec, fufca. Uimbilicus in parte ventrali.

IN T. duplex: fpongiofo coriaceuin \& membranaceum; utrumique teque.

A L B. Cemini conforme, carnolum, aqueo-pallidum.

Eмв. teretiusculus, e regione umbilici pofitus, lacteus. Coty/. femicylindrica. Rad longa, crafta, unfera fo a centro devia.

A. A.) Capfula cum calyce. B.) Receptre integrum. c. C.) Semina (eparatz D. E.) Albor. niuis fetiones, cum fitu \& figura embryodis. 
Tab. CXCVIII.

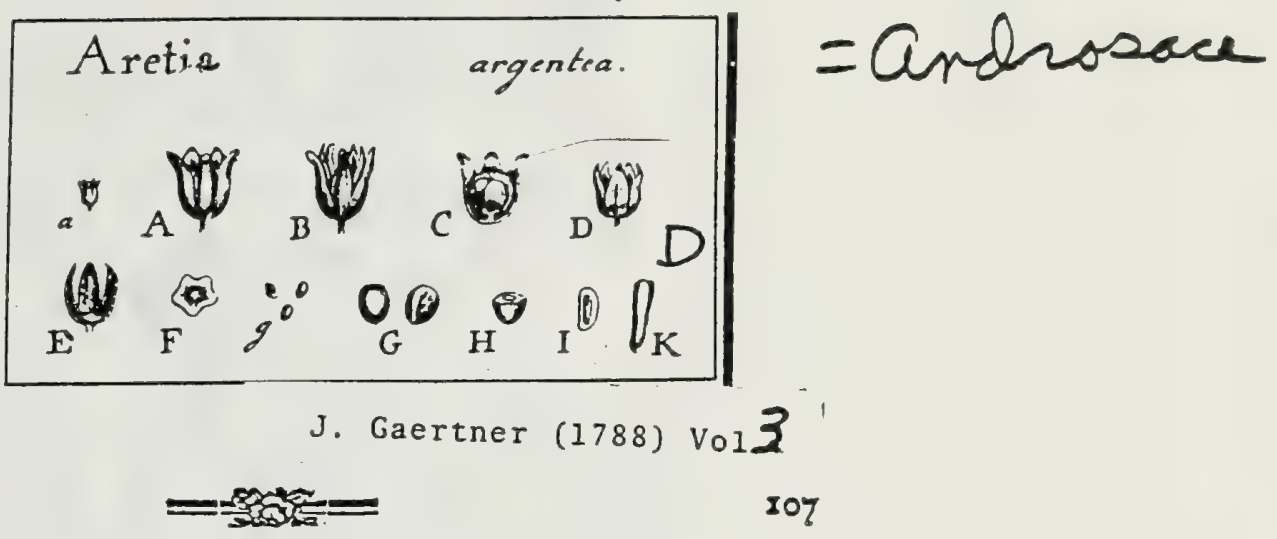

\section{A RETI A. HALI.}

LINN. gen. 195. ed. Sclireb. 256 . J'ss. gen. p. 96 .

Cal. monophyllus, inferus, campanulatus, quinquefidus, perfiltens. Cor. monopetala, regularis; tubo cylindrico, fauce glandulıs paululum coarctata ; limbo quinquepartito, plano: Jaciniis rotundatis, 1 emarginatis. Stam. 5.; filamentis brevibus, medio corollax. cubo infercis; antheris erectis, non exfertis. Ovar: fuperum, ftylo fimplici \& ftignate capteato inftructum. Capr. fubglobufa, unilucularis, quinquevalvis. Rec. cupula parva in fundo capfula. Senr. quinque. Alb. carnofun. Emb. erectus.

ARETIA argentea. Tab. 198. fig. 4

$$
\text { In,alpibus pyrenaicis legit amicifimus } D^{r} \text { Stroyerer. }
$$

PER. Capfula minina, fupera, intra calycem perfiftentem inclu\{a, fubglobofa, 1. deprelliufcula, rotundato - pentagona, pedunculo brevifino infidens, ab apice dehifeens, unilocularis, quinquevalvis. Valvula coriaceo - membranacere, tenues, dehifcendo campanulato-patentiufculx apicibus paululum inflexis, extus rufefcentes, intus albidx.

Ẽ c. Cupula planiufcula, 1. fubbemifphxrica, rowndato - tri - 1. quinquedentata, intus per fulcos in columnula centrali confluentes in tres $\perp$ quinque loculos divifa, carnofo - membranacea, fundo capfula affixa.

SEM. quinque, per abortum vero regulariter tria, erecta, fubovata, deorfum paulo acutiora, hinc convexa, inde planiufcula \& a vicinis compreffs, umblico minimo ad ipforum balin receptaculi angulis internis adharentia, fcabriufcula, obfcure fufca.

IN T. fimplex, nembranaceum, tenue, ab albumine vix difernendun, $\&$ ipfi arctillime adıatum.

A гв. Femini conforme, carnofum, flivefcens, opacum.

Es B. filiforni-teres, comprelliufculus, rectus, longitudine fere albuninis. eredtus, viridufculus. Cosyl. plano convexiulcule, ter:iam embryonis partem mentientes, oblonga, non difcretx, obtulix, incumbentes: Rad. teres, obtufa, infera, unibilico obverfa.

\section{EXPLICATIO FIGURE}

- A.) Capfula non debifens, calyce inclufa. B.) Eadem debifcens cum ealyce. C.) Calgx refticalitcr diffectus cum eapfula claufa D.; Capfula t:parata, dehifcens. E) Receptaculi cupula quinquedentata in fundo eapfulx aperte. F.) Cupulx, in tnculamenta quinque div.fx, facies intersz. g. G.) Simina fuluta, ab verayue parte fpectata. H.) Albumen transverfic - \&. 1.) IJem verticali modo difresłum cou Gitu cmbryonis. K) Embrẹo folutus.

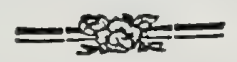

Numens femintm naturalis in hoc genere quinarius, per abortum autem duorum in nonnullis fpeciebus, uti in moftra, evadit termarius.

Stirps Corei affinitate proxima, nec cum Androface ullo modo commifcenda. 


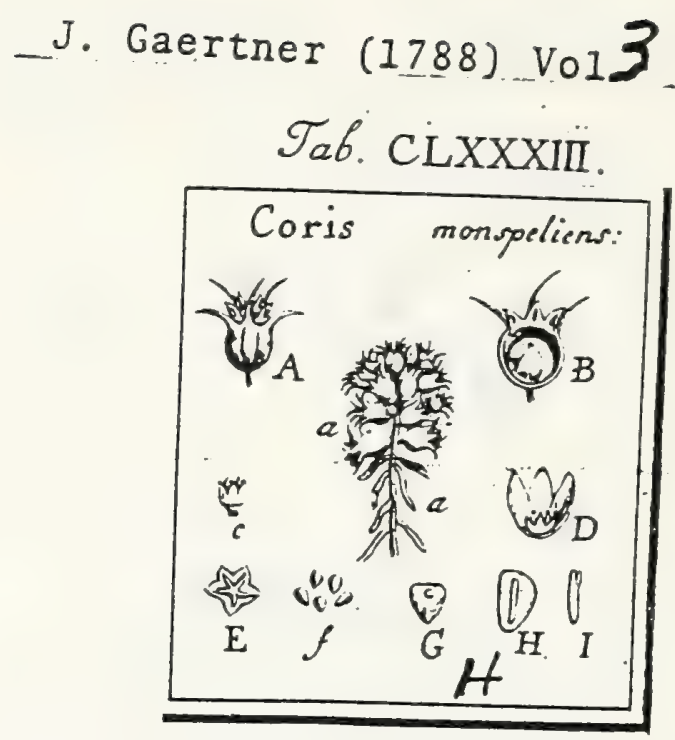

J. Gaertner (1788) vol3

\section{CORIS. $\quad 26$}

Tогвл. inft. t. 423. LinN. gen. 243. ed. Schreb. 329.

Juss. gen. p. "96. LAMARCK ill. gen. t. 102.

Cal. monophyllus, ventricolus, apice quinquedentatus; dentibus nigro-fphacelatis, extra dentes fetis aut fpinis quinque pungencibus armatus, capfulam occultans. Cor. tubulora, quinquefida, irregularis. Stam quinque. Ovar. fuperum. Styl. \& Stigmá fimplex. Capfula globofa, unilocularis, quinquevalvis. Sem. quinque.

Coris monfpelienfis. Tab. 183. fig. 8 .

Symplytum petraum. Cam. epit. 699 .

Coris. LINN. Jyft. veg. ed. 14. p. 2rg. Spec. pl. ed. Willd. T. 1. T. 2. p. 1000.

PER. Capfula globofa; intra calycem perfiftentem Jatens, unilocularis, ultra medium, in quinque valvulas dehifcens, \& infra has integerrına, hyalina.

REC. Cupula parva, fubhemifpherica, quinquedentata, intus per leptula tenuifina in quinque loculos divifa, carnofa, fundo caplula affisa.

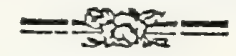

SEM. quingque, fubovata, deorfum acutiora, angulata, atra, angulis internis loculorum receptaculi mediante funiculo umbilicali brevifimo affixa.

In T. fimplex, nembranaceun, arctióime adıatum.

A L B. Semini cunforme, crafrum, carnolum, aqueo-glaucum, opacum.

ENB. filiformi - teres, Jongitudine fere albuminis, rectus, niveus. Cosyl. brevilinix. Rad. longa, infera.

\section{EXPLICATIO FIGURE.}

a. a.) Spica ex calycibus maturis. A.) Ealyx auaus integer, cum dentibas fuis nigto fphacelatis \& Spinis quinque extra dentes pofitis. B.) Idem longituiinaliter apertus, cum caprula clallfa. c.) Capfula dehifcens, ongitudine naturali D.) Receptaculi cupuia quiaquedentata, in fundo capfulx apertx. E.) Cupulx in loculamenta divifx facies ioterna. f.) Semina fuluta. G.) Albumen transverfe, \& H.) Idam lougitudialiter diffeQuu, eum-Gitu embryonis. 1.) Eulbryo reparatus. 


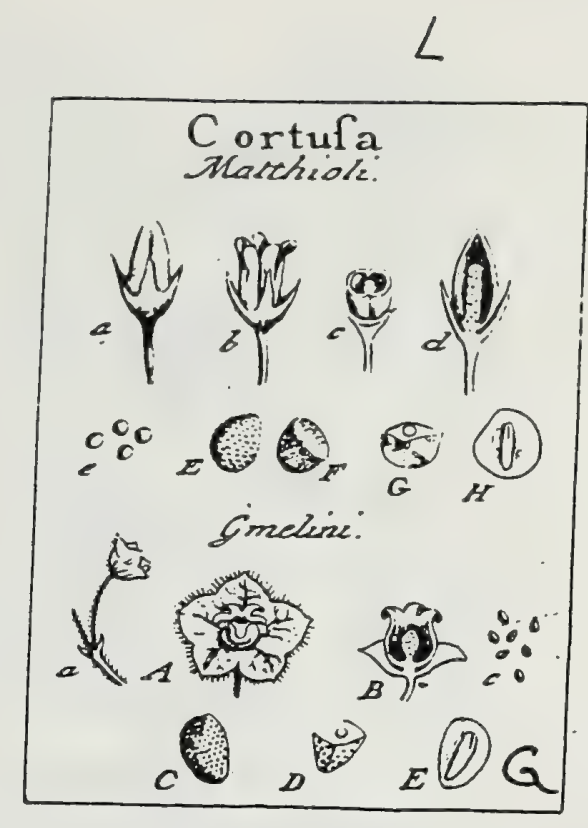

J. Gaertner (1788) Vol. I

CCLXXXIII. CORTUSA. LIN. gen. 198. 231

Calyx quinguepartitus. Cor. infundibuliformis: tubo fenfim ampliato in limbum quinquefidum aqualem, fauce nuda. Stam. quinque antberis linearibus tubo corollx irfidentibus. Capfula unilocularis, bivalvis. Recept, liberum. Sem. plura: umbilico ventrali, e regione embryonis.

Cortusa Matthioli. Tab. 50. fig. 7.

Cortufa malthioli. Clus. hi/l. r. p. $30 \%$.

Cortufa calycibus corolla brevioribu: LINN. fy $\Omega$. veg. 193.

PER. Capfula ovato oblongz, utrinque fulco deprefliusculo infcripta, unilócolaris, bivalvis: valvis maturis apice fxpe bifidis.

REC. columnare cylindricum, ferobiculatum, dimidia capfula paulo longius, liberum.

SE u. plura: inferiora fubrotunda; fuperiora magis ovata, utraque hine leviter convexa, inde obtufilfune angulata, punctis elevatis contiguis confperfz, ferrugineo fulca. Umbilicus minimus, in medio, aut in bafi ventris.

IN T. duplex: coriaceum \& membranaceum; utrumque tenue.

A L в. Гemiú conforme, carnofum, aqúeo-pallidum.

Es в. Linearis, rectus, lacteus. Cotyl. fomiteretes. Rad. longa, inferz.

a.) Capfala integra b.) Fuden delisicens. e.) Fjus fedio transverfa. d.) Receptac, integrom. e. E.) Seriuna feparate F.J Seminis veutes. G. H.) Albuminis feotiones, cum Gitu \& figura enbryouis.

232

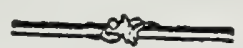

Cortusa Ginelini. ibid.

Andraface minima. Stell. Gmex. flor. fib. $4 \cdot p \cdot 79 . t$. 43 f. x. non bona,

Cortufa calycibus corollam excedentibus. Lins. fyft. veg. 193.

Ex dono Cl. Laxinanni.

Capfula parva, ovato globofa, calyce campanulato (2. A.) excepta, apice quina (K.) fpongiofun. Semina (c. C.) circiter vigini, fubovatac. ovato oblongunio punclato fcabrata, ruffo. fu (c. C.) circiter viginti, fubovata, varie angulata (D.) (E.) teretiusculus, lacteus. Hxe genuina ef Androfaces fpecies \& nihil cum Cortula cominume babet, przter:
quam longos foliorum petiolos. 


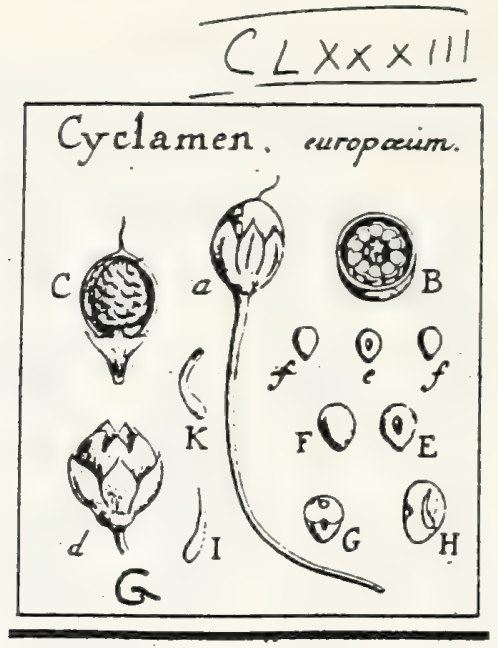

23. . C Y C L A M E N.

ToJRN. inf. t. 68. LINN. gen. 20I. ed. Schreb. 262. Juss. gen. 97. LAM A RCK ill. ger. t. 100.

Cal. femiquinquefidus, perfiftens. Cor. quinquefida, tubo brevi, haciniis longis refiexis. Stam- quinque; autheris conniventibus. Ovar. fuperum. Styl. \& Stigna fimplex Capjula globofa, unilocularis, chartacea, apice quinquefarian dehifcens. Receptac. liberun, pedunculatum, baccatum, fenina immatura obtegens. Sem. plura, ovata, cum fcrobiculo umbilicali, ventrali.

Cyclanes europreum. Tab. 183. fig. 7 .

Cyclaminus. Carr. epit. 35 .

Cyclamen fore cernuo, Segmentis revolutis. HaLl. belv. ห. 635 .

Cyclamen corolla vetrofexa. Lins. Jyf. veg. er. x4. p. 294 Spec. plo er. Willd. T. r. P. 2. p. 80 g.

ICOn. LOBEL. Icon. 604. BLACKW, berb. 2. t. 147. JACQ. for, auftr. 5. t. 40 工。

Per. Capfula globora, bafi calyce perfiftente munita, chartacea, tenuis, unilocularis, apice quinquefariam delifcens.

REC. ante plenam maturitatem totum carnofun, laminaque carno fa femina obvolvens, poftea fpongiofum \& femina fuperficiei faltem immerfa gerens; catera fubglobofun, crafe pedunculatum, Jiberum.

SEM. plurima, multis tamen abortientibus, ovato-elliptica, hinc convera, inde foveola umbilicali in medio ventrc exarata, e luteo-rufefceutis.

IN T. Gimplex, albumini arctifime adnatum.

A L B. cartilagineum, fenini conforme, pallidum.

EM. tereti-acuminatus, niveus, fubcurvatus, extra axem prope dorfum albuninis ita locitus, ut curvuli fcapi arcus (cum Cotyledonibus incumbentibus feniterctibus acuminatis brevillimis) umbilicum refpiciat, incrailuta autem Kadicula verfus peripheriam vergat, \& re ipfa centrifugat fit, licet ob riceptaculum comnune inferis aut centripetis anummerari debeat.

\section{EXPLICATIO FIGURE.}

8.) Fruatur immaturus. B.) Idem transverfe difreâus. C.) Ejusdem feaio Jongitadinalis, cum receptaculi comnunis fitu \& Ggura. d.) Capfula matura apice dehifeens. e. E.) Semiaia facies ventralis. f. f. F.) Ejusden latus dorfale. G.) Albumen transverfe diffectum. H.) Ejusdem fettio longitudinalis per medium ventrem \& dorfum inftituta, cum Embryonis fgura \& fitu. 1. (K.) Embryo folutus \& inGgnilime graudcfactus.

Longitudine \& curvatura aliquasıtum variat hic Embryo: in aliis enim fere ipfus albuminis longitudinis eft; \& contra in aliis vix dinsidio albumine paulo longior. Et ita quoque in aliis figmoideo - aut arcuato - curvatus eft; in alis vero fere reclus; fed in omnibus conftanter excentricus.

(Enbryo in hac ftirpe admodum fallax eft; in plurimis enim exemplis; qux Pater defunctus forutinio fubjecit, ad unum omnes invenit totos folidos; quanvis omnes oculorum intenderit nervos, optimasque adhibuerit lentes Naermanas, ut geminam detegeret cotyledonem, fed fruftra. Ex figura autem K.), poft defcriptionem factam adjecti, elucet, ipfum tandem denique unicum ex centenis reperiilfe embryunem dicosylodoneum, de quo autem in defcriptione ne verbulum quidem fecit. Embryo itaque revera dicotyledoneus eit, cotyledonibus autem, in plurimis exemplis, 


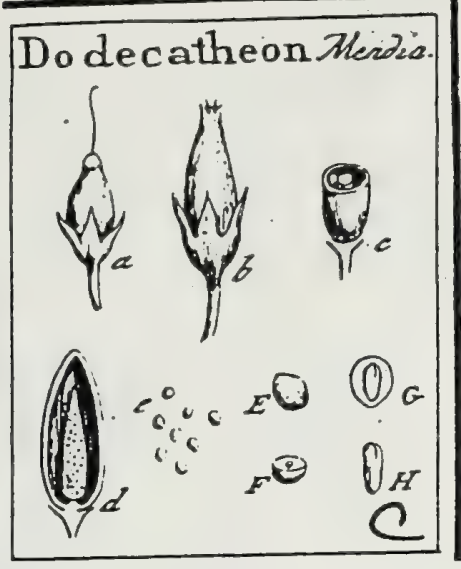

J. Gaertner (1708) Vol. 1

CCLXXXV. DODECATHEON. LIN gen. 200. 232

Calyx quinquepartirus. Cor. rotata: fauce nuda. Stam. quinque, tubo infidentia. Styl. unicus. Capfula fubcylindrica, unilocularis, apice quinquefariam dehifcens. Recept. liberum. Sem. plura: umbilico ventrali.

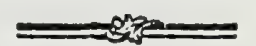

Dodecatheon. Meadia. Tab. 50. fig. 9.

Meadia. Catess. carol. 3. p. I. t. I. Ehret. decad. t. I2. Mrlr. dit. ie. t. I74. Seligm. av. 2. t. 104 .

Dodecatheon. Lins. Jilf. veg. 194.

PER. Capfula ovato oblonga, demum fubcylindrica, chartacea, rufefcens, unilocula. ris, apice dentibus quinque brevibus dehifcens.

REc. columnare, pedicellatum, tereti acuminatum, fcrobiculatum, liberun.

SEM. numerofa (fed pleraque apud nos abortientia) ovato rotundata, turgide lenticuLaria, fubrugofa, luteo rufefcentia. Uinbilicus in medio ventre obfoletus.

IN T. funplex, inembranaceum, tenuifimum, nucleo adnatum.

AL8. Sernini conforme, fubfarinofuin, candidum.

EMB. teretiusculus, rectus, bacteus. Cotyl. breves, femicylindricz. Rad. crafla, infera.

a.) Capfuia integra, e minoribus. b.) Eadem dethifcens. c.) Eadem diffecta. d.) Receptaculum denudatum. e E.) Semiua feparzin. F. G.) Abuminis fectiones, cum embryanis fitu \& figura, H.) Embryo feparatus. 


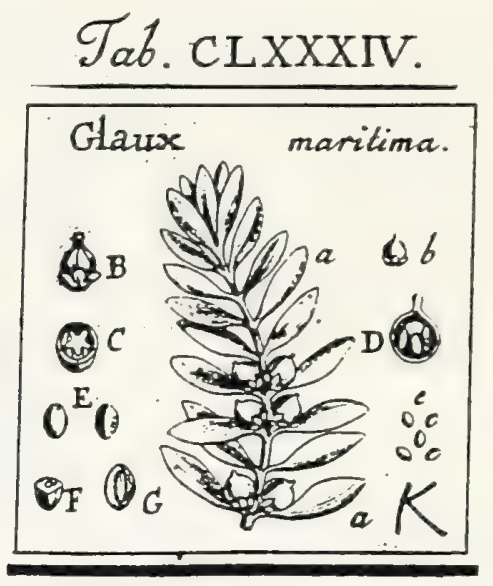

\section{J. Gaertner (1788) Vol3}

\section{G L A U X.}

Tourn. inft. t. 60. LINN. gen. 29s. ed. Schreb. 408.

Juss. gen: p. 333. LAMABCX ill. gen. t. IAI.

C2l. campanulatus, coloratus, quinquelobus; lobis revolutis. Cor. nulla, nifi calycem velis. Stam. quinque. Ovar. fuperum. Styl. brevis, ftignate obturo. Cap globofa, unilocularis, quinquevalvis. Sem quinque, receptaculo libero immerfa.

Glaux maritinz. Tab. 184. fig. I1.

Alime bifolu, frudu coriandri, radice genieulata. LoRs. pruf. I3, t. 3.

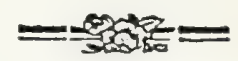

Glaux. Lins, fylo veg. ed. 14. p. 249. Spec. plo ed. Willd. T. I. P. 2. p. 1210.

Icon. OED. flor. - dan. t. 548. mediocr.

PER. Capfula globofa, magnitudine grani piperis, ftylo brevi perfiltente mucronata, coriacea, pallida, nervis quinque viridibus infignita, unilocularis, quinquevalvis.

REc. liberum, fubglobofum, fuberofum, albicans, fcrobiculis quinque profundis, pro recipiendis feminibus exfculptum.

Sem. quinque, fubelliptica, hinc convexiufcula, inde angulata, ferruginea.

INT. Iimplex, membranaceum.

A L B. femini conforme, carnofum, pallidum.

EM B. teretiufculus, longitudine fere albuminis, niveus, in axi pofitus. Cory. breves, femiteretes. Rad. longa, infera, 1. centripeta.

\section{EXPLICATIO FIGURE.}

x. a.) Ramulus cuns eaplulis (aliquantum jufto grandioribus) in Gtu naturali. b. B.) Capfula feparata integra. C. D.) Ejusdem fectis transver(alis \& rerticalis, cum fioura receptaculi \& fitu feminum. e. E.) Semina foluta ab utroque latere (pectata. F.) Albuminis fectio sransverSalis. G.) Idem longitudinaliter diffcetum, cum fitu \& figura Embryonis.

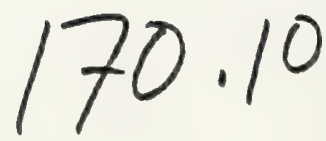




\section{J. Gaertner (1788) Vol3}

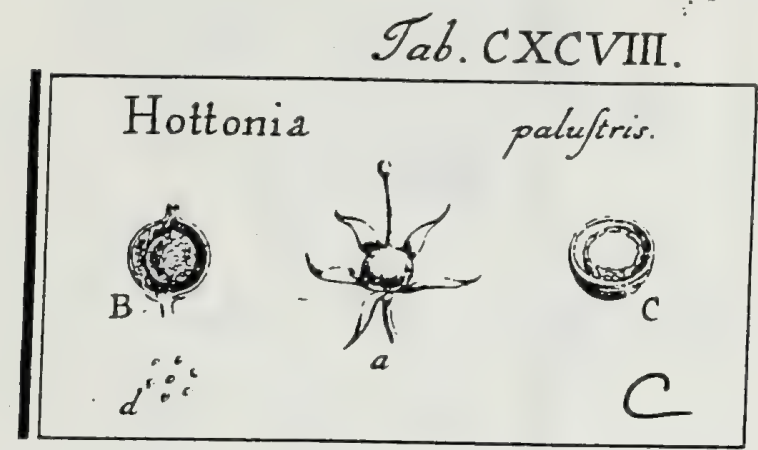

J. Gaertner (1788) Vol 3

106

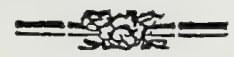

\section{HOT TON I A.}

Linn. gen. 203. ed. Schreb. 265. Juss. gen. p. 95. Lama в ill. gen. t. ro0. Stratiotes. VAILI, act. gall. 17'́g.

Cal. inferus, profunde quinquepartitus; perfiftens. Cor. monopetala; tubo brevi, cylindrico; limbo quinquefido, plano. Stam. 5.; flamentis brevibus, fubulatis, laciniis corollz oppofitis; antheris oblongis, non exfertis. Ovar. fuperum; ftylo fimplici, ftigmate globofo. Capf. fupera, unilocularis, (evalvis?) poiyfperma. Rec. fungofum, pedicellatum, liberum. Sem plurima, fubylobofa. Alb. carnofum. Enib....

Hotroxia paluftris. Tab. 198. fig. 3.

Myriophyllum alterim. Matrнioc. p. 1268.

Hottonia florum verticillis fpicatis. HalL. belv. $n .632$.

Hottonia pedtuncula verticillato multiforo. LiNN. Jpec. pl. p. 208 . Syft. veg. ed. 24. p. 294.

Hottonia floribus verticillatis pedunculatis. WILLD. Jpec. pl. T. I. P.2. p. 812 PERSOON fyn. plo x. p. 17 r.

Icon. OED. flor. dar. t. 487 .

PER. Capfula globofa, l. obfoletifime rotundato-pentagona, hinc calyci perfiftenti infiftens, inde ftylo longo faftigiata, membranaceo - coriacea, unilocularis, evalvis?

REc. fungofum, centrale, globofum, liberum, breviter pedicellatum, fuperne apiculatum, impreffionibus rotundatis a feminum adhxfione fcabratum.

SEM. plurima, fimplici ftrato receptaculo adbzrentia, denfe approximata, fubglobofa, 1 elliptica.

IN T. fimplex, menibranaceum.

A L B. femini conforme, carnofum, album.

EMB....

\section{EXPLICATIO FIGURE,}

a.) Capfula integra eom ealyec. B.) Eadeon vcrticali modo diffecta cum fitu \& forma reecptaenli. C.) Ejusdén \& receptacali fectio transverfalis cum feminibus in fitu. d.) Semioz foluta,

Capfulam maturam nondun vidi, in immatura ne minimum futurarum veftigium adeft; alii itaque dubiun folvant, num capfula vere fit evalvis, an per maturitatem apice tantum dehifeens? 


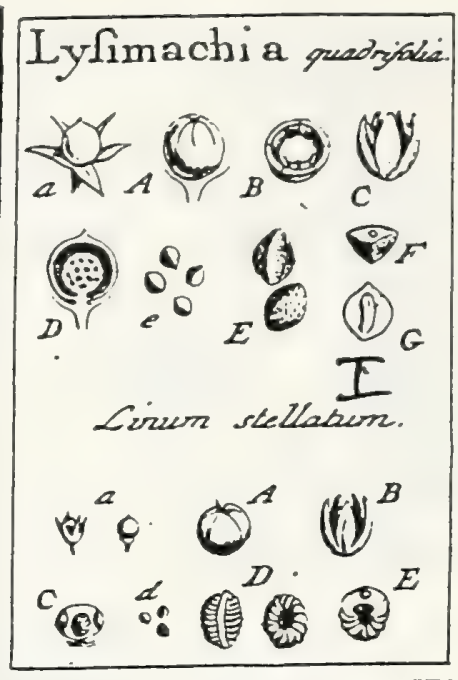

J. Gaertner (1788) Vol. I

CCLXXX. LYSIMACHIA. TOURN. t. 59. LINN. gen. 205. 229

Calyx quinquepartitus. Cor. rotata. Stam. quinque. Styl. unicus. Capfula unilocularis, quinquevalvis. Receptac, liberum. Semina plurz: umbilico ventrali e regione embryonis.

Lysizxachis quadrifolia. Tab. 50. fig. 4.

Lyfimachic crnadenfis lutea foliis jalappa. WALtн. hort.' $t$. 12.

Ly/machia foliis quaternis. petiolo ciliatis, pedunculis quaternis uniforis. LIN

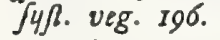

PER. Capfula Pharica, quinque lineis in vertice confluentibus inferipta, unilocularis, quinquevalvis.

REC. globofum, fungofun, Scrobiculatum, liberum.

SEM. plura, fed 3. 1. 4. faltem maturefcentia, fubrotunda, hinc levifime convexa, inde angulata, coufertiffume elevato punctata, ferruginea. Ümbilicus ventralis fubobfoletus.

IN T. duplex: coriaceum \& membranaceum: utrumque tenue.

A Lв. fernini conforure, carnofun, album.

Es в. teretiusculus, gracilis, lacteus. Cotyl. femiteretes. Rad. longa, infera l. a centro devia

a.) Capfula integra. B.) Eadem difecta. C.) Valvulx delificentes. D.) Receptacuium into grum. e. L) Senina feparata. F. G.) Alburinis fectiones cum fitu \& Ggura embryouis

Lysimachis Linum Rellatuin. ibid.

Linum minimum fellatum. MAGNor. mon $\int$. 163. ic. I6z

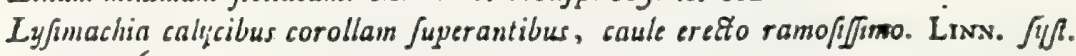
veg. syb.

Capfula parva, Ipharica (a. A.), unilocularis, quinquevalvis (B.). Receptacufurn globolum (C.), deprefliusculum, fungolum, album. Seinina duo, aue ria, raro plura, minucula (d.), ovato globufa, meniscoidea; bisc con-

vexa (D.), trancverfin frriata; inde ampla fovea umbilicali excavata (E. F., $\&$ radiatim fulcata, fumola. Embryo e regione unbilici (F.) pofitus, lacteus,
erectus. 


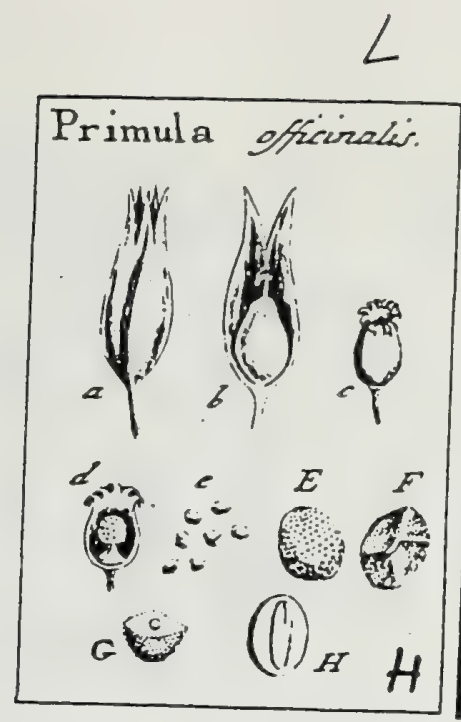

\section{J. Gaertner (1788) Vol. 1}

CCLXXXVI. PRUMULA. TourN. t. 47. LIN gen. 197. 233

Ca! yx tubulofus, quinquedentatus. Cor. infundibuliformis: fauce nuda. Stam. quinque. StyL. unicus. Capfula unilocularis, dentibus decem dehifeens. Recept. Liberum. Scm. plura: umbilico ventrali.

Primula veris. Tab, 50. fig. ro.

Primula. BLA X Wr. herb. t. 52. E 226. O E DER. flor. dan. t. 194. 433. 434.

Primula foliis hirfutis rugofis dentatis fcapis unifloris. HALL. hifl. 1. n. 308 . 309. 310.

Primula foliis dentatis rugofis. Lis.. fifl. veg. 192.

PER. Capfula ovata, furfum angufior, glabra, unilocularis, apice dentibus décem recurvis brevibus dehifcens.

REc. globofun, pedicellatuin, fcrobiculatum, liberum.

$S_{E \text { M. }}$ plura, circiter triginta, fubrotunda, hine levifime convexa, inde obfolete angu. Lata, punchis elevatis fcabrata, nigricantia. Unbilicus in medio ventris.

IN T. duplex: exterius coriaceo-spongiofum; interius membranaceum.

$\Lambda\llcorner$ в. Femini conforme, carnofurn, durum, candidurn.

Ем в. teretiusculus, е regione umbilici pofitus, Lacteas. Cotyl. breves. Rad. longa, crafra, infera.

234

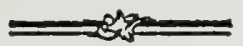

2.) Capfuiu salyce augulato vertita, b.) Eadem denudata. c.) Eadem delificens, d:) Recept. into grum. e. E.) Senniuis dorfuin. F.) Ejus venter. G. H.) Albuminis fetiones, cun Gu \& Ggurd enubryouis. 


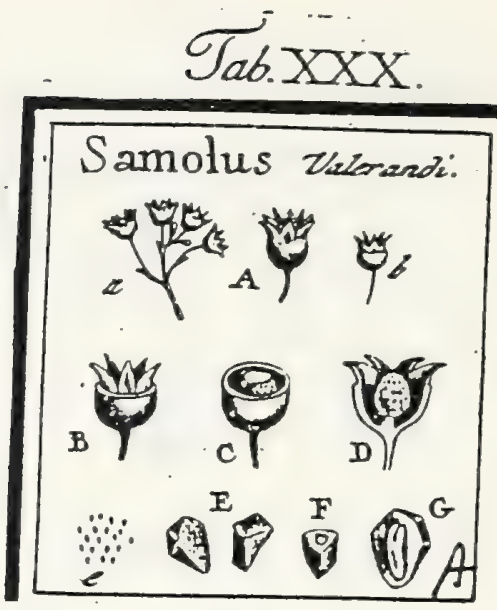

J. Gaertner (1788) Vo].1

\section{6}

\section{SAMOLVS. TOURN. t. 60. LINN. gen. 222.}

Calyx pericarpio adnatus, quinquedentatus. Corolla hypocrateriformis, quinque: fida: lacinulis quinque accefforiis ad bafin divifionum. Stann. quinque. Styl. unicus: Capfula infera, unilocularis, apice quinquevalvis.

S A Motus Valerandi. Tab. 30. fig. I.

Alfine aquatica, foliis rotundis beccabunga. MOR is. hif..2. f.3.t.24.f.28.

Samolus. HAL1. hifl. I. n. 707, LIN S. Jyfl. veg. 212.

ICOn. OEDER. flor. dan. t. 198 .

PER. Capfula infera, fubglobiŕa, parva, inferne calyce fibi adnato vefita, fuperne nuda, unilocularis, Temiquinquevalvis.

REc. globolum, grandiusculum, fpongiofum, ferobiculatum, liberum, pedicellatum.

S F. n. nunerolifima, exigua, angulata, minutilline pundata, ferrugineo-fulca

IN T. firnplex, membranaceum, tenue.

A є в. fe:sisi conforme, carnofum, aqueopallidum.

Емв. dicoryledoneus, teretiusculus, fubincurvus, lacteo albus. Cotyl. femiteretes, bre. ves. Radic. crafta, cylindrica, centripeta.

2.A.) Capfula calyce vefita. b. B.) Calycls dentes referl in apiula fuperne valvata. C.) SeAtio 2. A.) Capfula calyce vetica transver(alis, \& D.) longitudinalis cum fitu \& figura receptaculi. e. E.) Semina feparaca E.) Albumen trausverfe feAtum. G.) Idem longitudinaliter dififfum cum fitu embryoois. 


\section{J. Gaertner (1788) Vn13.}

\section{Tab. CLXXXIII}

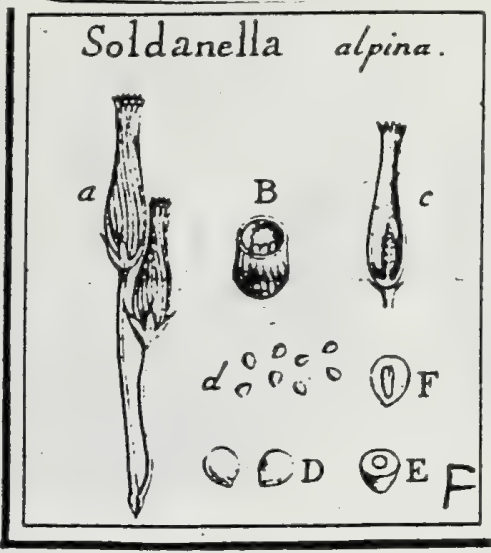

J. Gaertner (1788) Vol. 3

\section{SO L D N E I L A. 24}

Tous n. inf. t. 16. LIN gen. 199. ed. Schreb. 260.

Juss. gen. p. 97. LA BIABCK ill. gen. t. 99 .

Ca1. quinquepartitus, perfftens. Cor. campanulata, ore lacero multifida: Stam. quinque, filamentis apice bifidis; antheris fagittatis adnatis. Ovar. fuperun. Styl. unicus. Capfula oblonga, oblique multiftriata, unilocula. ris, apice dentibus fubdenis debifcens. Sem. plura.

SOLdanella alpina. Tab. 183 . fig. $\mathrm{C}$

Soldarella alpina CAMr. epit. 254.

Soldanella alpina rotundifolia. B. MORIs. bif., 2; S. 3. t. 15. f. 8:

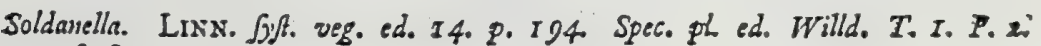
p. $8 \theta 8$.

Icon Jace auftr. t. $: 3$.

PRR. Capfula oblonga, teretiufcula, furfum leviter gracilefcens, ftriis nume. rofis longitudinalibus \& paululum obliquis exarata, unilocularis, apice dentibus $6-10$. brevibus dehifcens.

REc. columnare, centrale, liberum, pedicellatum profunde \& quafi lamellatim fulcatum, dimidia capfula brevius.

SeM. numerofa, ovata, verfus umbilicum acumirata, angulata zut utrinque convexa, glabra, fufco - ferruginea.

Ix T. Gmplex, membranaceum.

A I B. carnolum, aqueo-pallidum, tenne.

EM B. fubcylindricus, rectus, hacteus Cotgl. femiteretes. Rad, centripets.

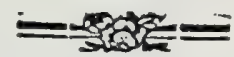

\section{EXPLICATIO FIGURE}

a.) Capfula integra. B.) Ejus feetio transverlalis. c.) Eadern longitudinaliter diffects, com Gitu \& figura receptaculi. d. D.) Semias foluta \& (d.) paululum in a qua turgefada; nam exficata multo minora funt. E.) Albumen trasverle, \& F.) IJem longitudinaliter difeaum eum fits \& Gigura Embrgonic. 


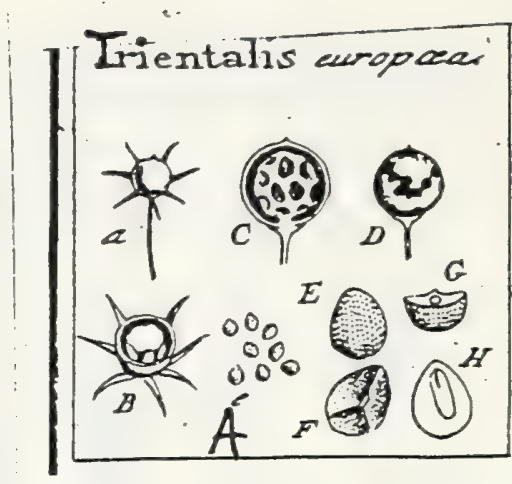

$$
\text { J. Gaertner (1788) Vol.1 }
$$

¿CCLXXVII. TRIENTALIS. LIN gen. $46 \mathrm{r}$.

Calyx heptaphyllus. Cor. heptapetala. Stam. quinque ad feptem. Styl. unicus. Racca ficca fupera, unilocularis. Receptac. liberum. Semina depreffa : umbilico ventrali e regione embryonis.

Trientalis europza. Tab. 5o. fig. x.

Pyrola al/ines fore major. BAun, prodr. 101. c. ic. OEder. for. dan: t. 84.

Alimanthemos. Asм. Coninent. petrop. IX. p. 3io. t. 13.

Trientalis foliis lanceolatis integerrinis. L I N N. Jyfl. veg. 352 .

PEr. Bacca exfucca membranacea, tenuilluna, fubdiaphana, fpharica, unilocularis. eralvis.

REC. globolum, alveolatum, fungofum, maximum, liberum.

SE s. pauca, circiter octo, fubovata, depreffiuscula; hinc levifune convexa, inde angulatz, punctis excavatis notzta, atra U'mbilicus in media parte veatrali, albus, minimus.

IN T. fimplex, coriaceum, tenue.

A L B. femini conforıne, carnofurn, album。

Ess B. lineari-oblongus, comprefliusculus, lactens. Cotyl. plano convexz, tenues. Rad. recta, infera, aut oblique deorfum verfa

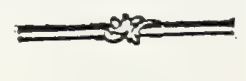

2.) Bacea integra B.) Fadem transverfiun (ecta. C.) Receptaculum integram, D.) Baces ate a. ) Bacea ilterrater delifens. e. E.) Seninis dorfum. F.) Ejusdem veater cum umbilico. G. Aloumivis lectiones, cum fitu \& figura embryonis. 
Tab. XIVII.
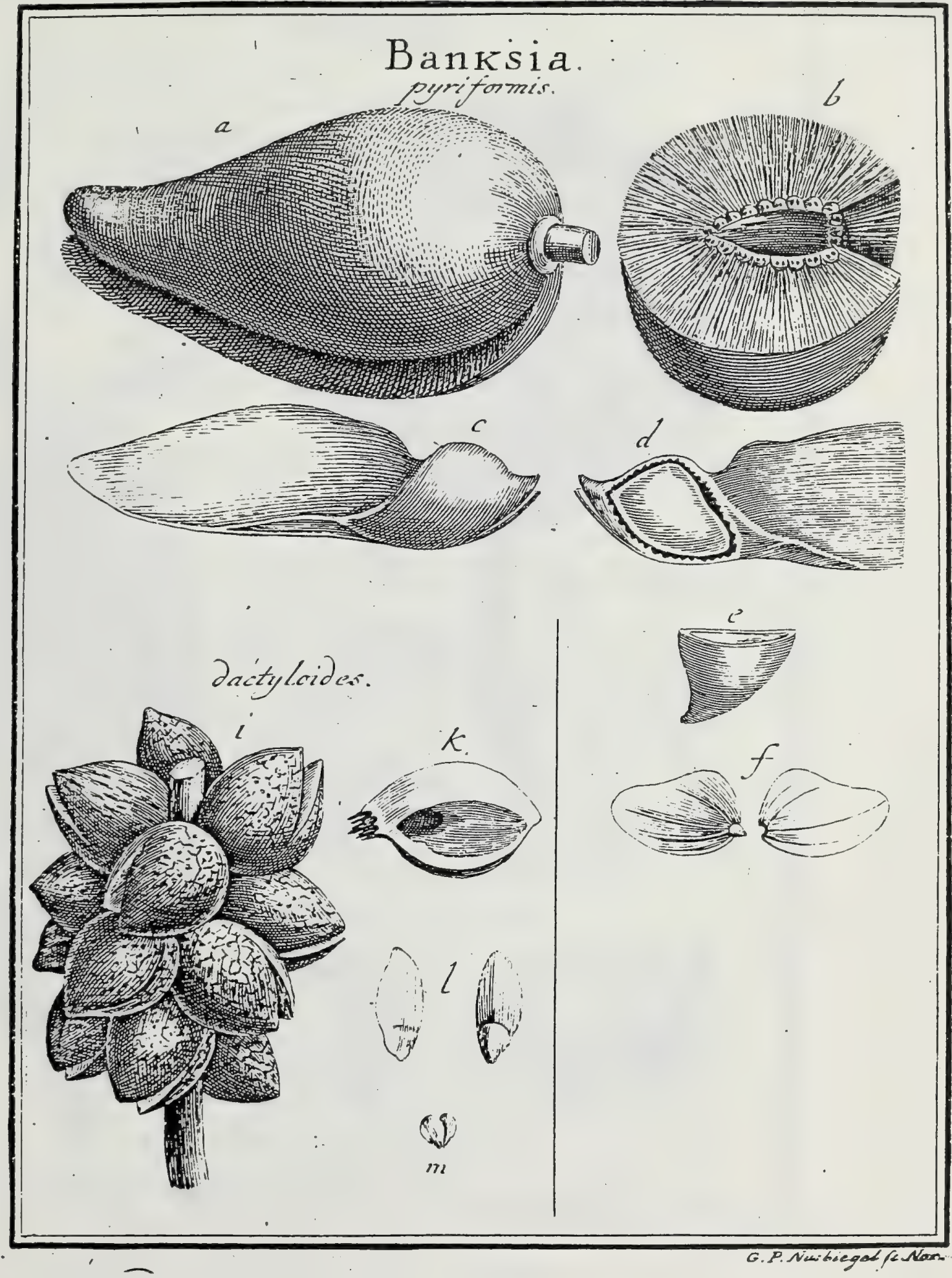

G.P. Niwibiegot fe Noon

$$
171 \cdot 1 \mathrm{~A}
$$




\section{J. Gaertner (1788)}

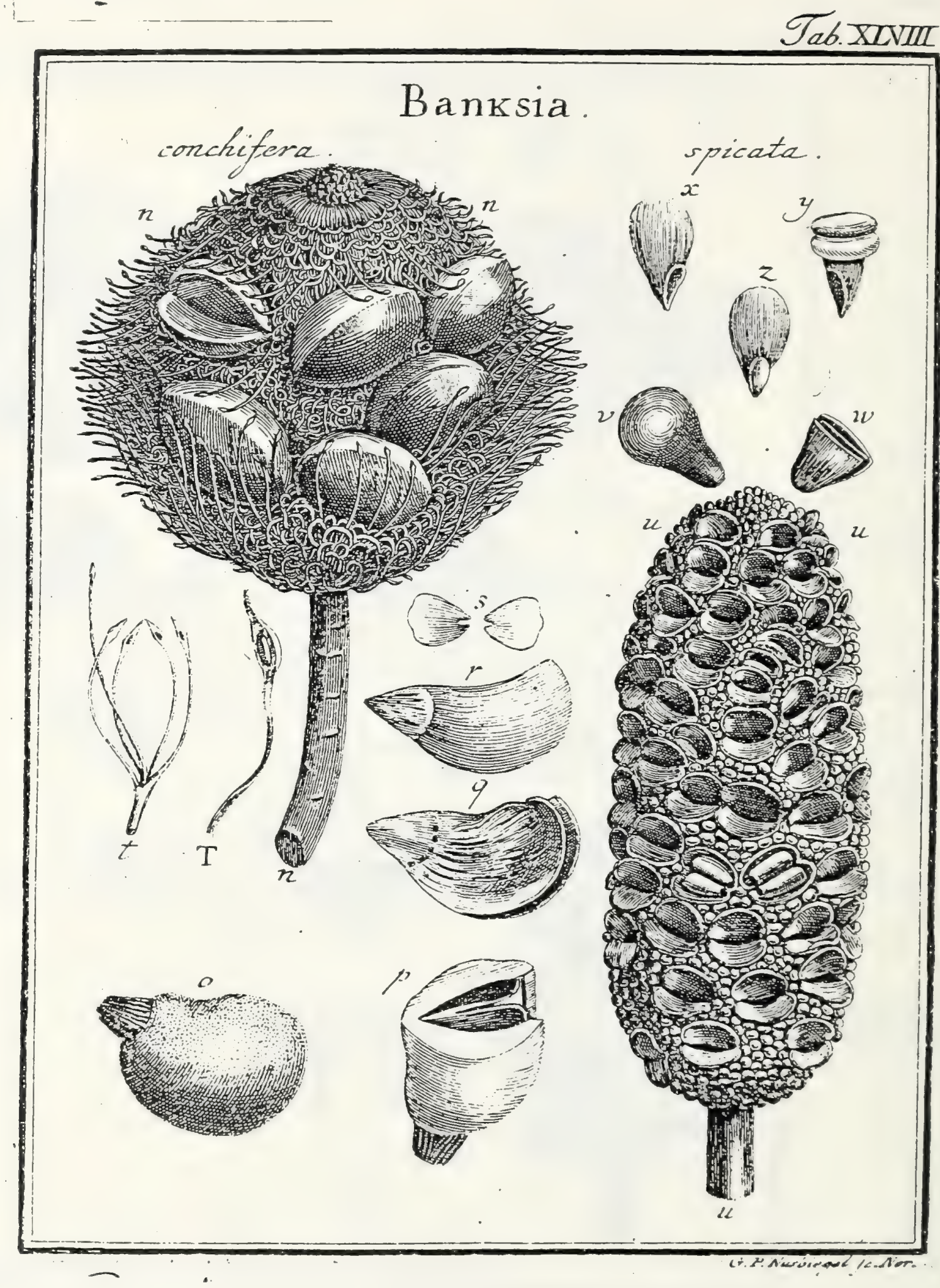

$171.1 B$ 
Calyx quadrifidus, inferus. Cor. monopetala, quadrifida : tubo brevifimo - lacinïs longis, lineari lanceolatis. Autherx quatuor in propria laciniarum corolle foveola feftules. Styl. unicus filiformis; figmate pyramidato. Capfula disperma, unilocula. ris. 1 bilocularis, interjecto feminibus dilfepimento snobili.

- Capfula uniloculari.

BANK I A pyriformis. Tab. 47. fig. I.

E collectione Bankfiana, cum fequentibus.

PER. Capfula in toto genere maxima, tres pollices longa, inverfe pyriformis lignola, crallifima, brevi tomento cinerafcente, mali perfici ad iuflar, pubefcens, unilocu. laris, latere inferiore longitudinaliter dehiscens.

REC. nullum, przter funiculum umbilicalem filiformen e fundo capfulz ad feminis latus exteruum productum.

SE 28. duo, hinc convexa, inde plana, in alam maximam membranacean, avenian elongata, e cinnamouneo ruféfeutia

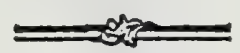

Is 1 . duplex, exterius membranaceum, in alam ampliatum; interius coriaceum, tenue, subro ferrugineum.

A L B, Hullum.

Eu B. magnitudine \& figura cavitatis feminis, ereetus, albus. Cotyl. Spharice.triangulares, planiusculx, carnolx, tenues, tri-1. quinquenervix. Rad. conica, parva, infera.

c) Capfula dehliceas, magnitudine naturali b.) Ejus fetlo transverialis. c.) Semen integrara.

d.) Ejus nucleus denudatus. e) Ejusdem pars inferior plano convexiuscula transverfim felta, E)

Cotyledones feparatze.

BAN KSI A dactyloides. ibid. fig. 2.

Fruclus in mediis ramis (i) aggregati. Capfulx pollicares, ovato globolx, lignof $x$; craf $x$, uniloculares, bivalves. Loculamentum excentricum $(k)$, valde compreflum. Scmina duo (l. ) plano-convexa, alata, fpadiceo-fufca. Embryo (m.) obovatus, gramineo viridis: Cotyled. plano convexis tenuibus. Radic, acuminatz, brevis, infera.

BAंN K I A mufculiformis.

Fru民̆us mufculiformis. R ч м в н. amb. 2. p. 185.t.60. (ob femina duo alata.)

Capfula pollicaris \& bipollicaris, ovato conica, acuininata, lignola undique, tuberculis lubrotundis, aut muricibus transverfis anfractuofis exafperata, e fufco \& ferrugineo varia, unilocularis. Semina duo alata, fpadiceo nigricantia

* Capfula bilocolari: fepto mobili bifido.

B A X X s I a conchifera. Tab. 48. fig. I.

Bankfia foliis linearibus in petiolum attenuatis aqualiter ferratis apice truncatis cuns nuctone. LIN . Juppl. 126. Jy/. veg. I61. LIN N. l. c.

Flores \& fructus in amentum globofum (n.n.n.), grande collecti. Capfula (o.p.) fubreniformi-globofa, conice pedunculata, crafla, lignofa, fulvo vellere pubelcens, bilocularis (p.). latere gibbo dehifcens. Diffepimentum (p. q.) liberum, figurâ \& magnitudine catitatis loculamenti, coriaceo lignofum, femibifidum; laminis per maturitatem reflexis, claflicis. Semen (r.) in fingulo loculamento unicum, grandiufculum, alatum, nigro fuftcum. Embryo obovatus, erectus, albus. Cotyl. (s.) tenues, fubfoliacer. Rad. acuminata, infera

Corolla, etiam in lac fpecie, manifene monopetala ( $\mathrm{r}$ ) : tubo brevi; laciniis lincaribus, longiffunis, apice lancenlatis \& foveola antherifera (T) in lasere fuo iutcrno notatis. Stylus corolla longior, rigidus, pyramidato capitatus.

BANX3I A fpicata. ibid. fig. 2.

Bankfia foliis cuneiformibus integerrinis fubtus tomentofo albis. Lrws. Juppl. 127.

Flores \& fructus ante maturitateın tomeato niveo pubefcentes, in amentum crlindri: cum (u. u. u.) digelli. Capfula coriacea, fuperne orbiculata, rurgide lenticu. laris ( $\left.v_{0}\right)$, inferne in roftrun conicum, compreflum producta, intus nigra: bilocularis $\left(w_{0}\right)$, apice dehilcens. Dillepimentum $\left(x, y_{0}\right)$ liberum, rigidum. bifidum, launinis retlexis $\left(y_{0}\right)$, elaflicis. Semen $\left(z_{0}\right)$ in fingulo loculamento unicum, alatum, nigro fúfcum. Einbryo femini conformis, obovatus, deor? fum acuminatus.

Character Linnxanus hujus generis nonnifi in duas pofteriores fpecies quadrat, \& praterea quoque in eo peccat, quod corollam ftatuat tetrapetalatn \& quod dif. fenimentuin mobile cum femine confundat. 


\section{J. Gaertner (1788) vol3 Tab. 220 .}

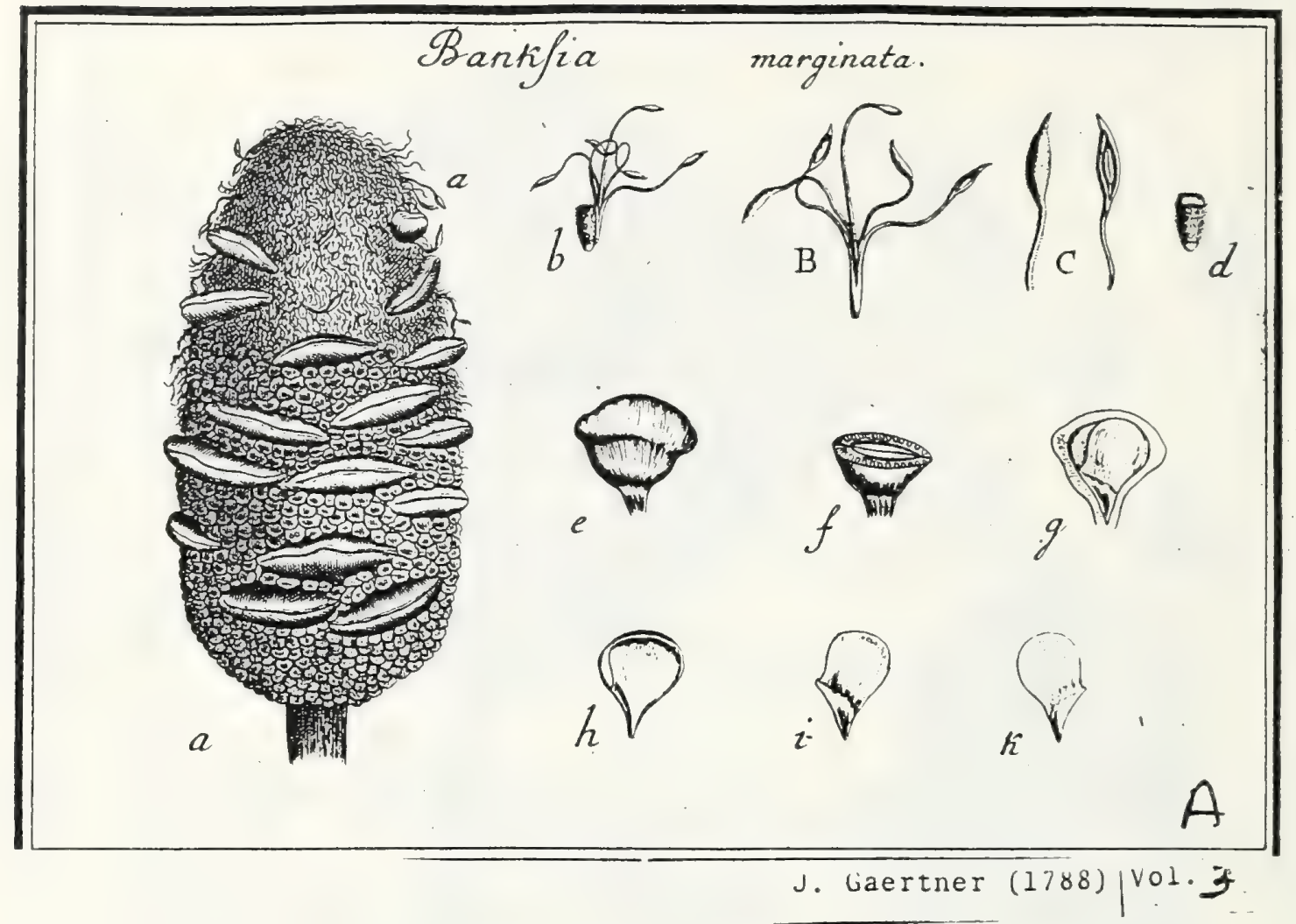

B ANKS I A. Conf, Carpol. Vol, I. p. 22r,

Banksia narginata, Tab, 220, fig. I,

all Banskfia marginata. CAv. ic. 6. t. 544 ?

a Cl Labillardiere,

218

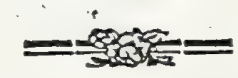

Flores \& fructus in amentum (a.s.) cylindraceo - oblongum, tri-quinquepollicare congefti.

Cal. nullus. Corolla (b. B.) monopetala, quadrifida; tubo brevi: Jaciniis linearibus, longiffimis, extus hirtis, ad apicem (C.) inæqualiter lanceolatis, cochleariformibus, extus convexis, intus margine involutis, J. foveola antherifera exfculptis. Stam. 4 ; filamentis brevibus, foveularum bafi infertis; anthéris oblongis, bilocularibus. Ovar. fuperum, ftylo fubulato; ftigmate incraffato,

Capfulx (e.) horizontales, fquamis (d.) hirfutis oblongis ferrugineis arde fibi approximatis difcriminatx, femipollicares, coriaceo-ligriofx, irregulariter ovatx, transverfm paulo latiores, fuperne orbiculatæ \& leviter marginatx, inferne in pedunculum brevem conicum attenuatx, lxvigotæ, fufcx, intus nigrx \& fibris dilutioribus $(f$.$) intermixtx, a vertice per ventrem dehifcen-$ tes, biloculares, fubbivalves. Loculamentum lenticulari-comprefum, deorfum accuminato-attenuatum. Difepimentum (g. h.) loculamenti forma \& longitudine, liberum, coriaceo-lignofun, apice fenibifidum; laminis per maturitatem elaftice dehifcentibus: compreffum, ad marginem fuperiurem prope baGn foveola oblonga pro funiculo umbilicali exfculptum. Rec. nulJum: proter funiculum umbilicalem filiformem, in propria foveola diffepimenti ex fundo capfulx ad feninis latus fuperius adfcendentem \& ibi-infertum. Sem. (g. i. k.) in fingulo loculamento fingulum, erectum, lnculamento fuperne paulo angultius, in alam fublateralem membranaceam rotundatain ampliatum, deorfum acuminatum \& nucleo protuberante fufco iufignitum, e fufco ipadiceum. Embryo erectus. Rad. umbilico externo contraria, infera. 


\section{J. Gaertner (1788) Vol 3}

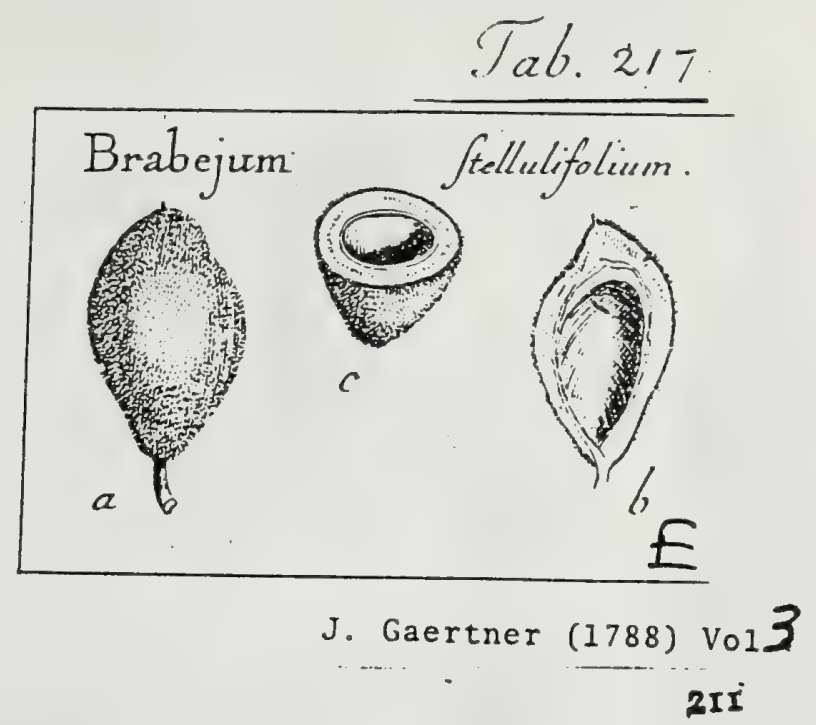

I66. B R A B E J U M,

LiNn. mant. p. 168, SchreB. gen. I580, Juș. gen. p. 79.

LАMAве X ill. gen. t. 847 .

Flores in fpicas congefti, terni ex bractea communi ovata, maxima ex parte mafculi hermaphroditis paucioribus mirti.

Cal. nullus. Cor. monopetala, infundibulifornis, quadri- (L rarius in mafcu. lis floribus quinque -) partita; laciniis linearibus, ad apicem reyolutis. Stam, quatuor; filamenta ad bafu laciniarum corollx inferta; antheræ filamentis intus adnatx, cordatze, erectx. Ovar, fuperum; ftylo fimplici, filiformi ; ftgmate obtufo. Drupa ficca, denfilirme villora; putamine uniloculari. Sem, unicum. Alb. ..., Emb, ..,

BraвEJUM ftellulifolium. Tab. 217. fig. 5.

Anrygdalus aetbiopica, frudfu bolofericeo. BREYN. cent. I. t. $x$.

Arbor aethiopica bexaplyylla, foliis circa canlens ad intervalla fenis. PLoK. glm. p. 47. t. $265 . f .3$.

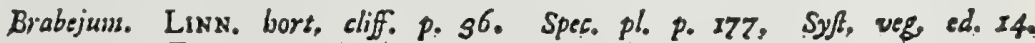
p. 910. Thunb. prod. p. ji. Persoon fyn, $t, p .117$.

Ex collectione $\mathrm{Cl}$, Desfontaines,

PER. Drupa pollicaris \& ultra, fupera, rhombeo-obovata, ad unum latus paulo crafiror, breviter pedunculata, ftylo brevi ad yerticem inftruda, corticata. Cortex coriaceus craftiufculus, extus capillis linearibus brevibus denfifime in holofencum molle \& gilvum conftiparis obtectus, intus pu. tanini slbicanti adnatus, duriufculus. Putamen fuboffeum, ad verticem incraffatum, uniloculare, evalve. Loculamentum compreftufculum, in: tus glabrum, ad verticem magis gibbum.

Rec. nullum; femen bafi putaminis adhrerens,

SEN. unicun, erectum. ...

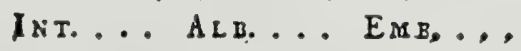

\section{EXPLICATIO FIGURF}

a.) Drups integra b.) Ejusden fedio longitudiaalis. c.) Eadem transverfe direta.

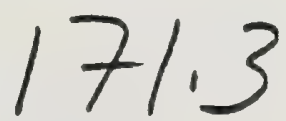


J. Gaertner (1788) vol3.

Tab. 215 .

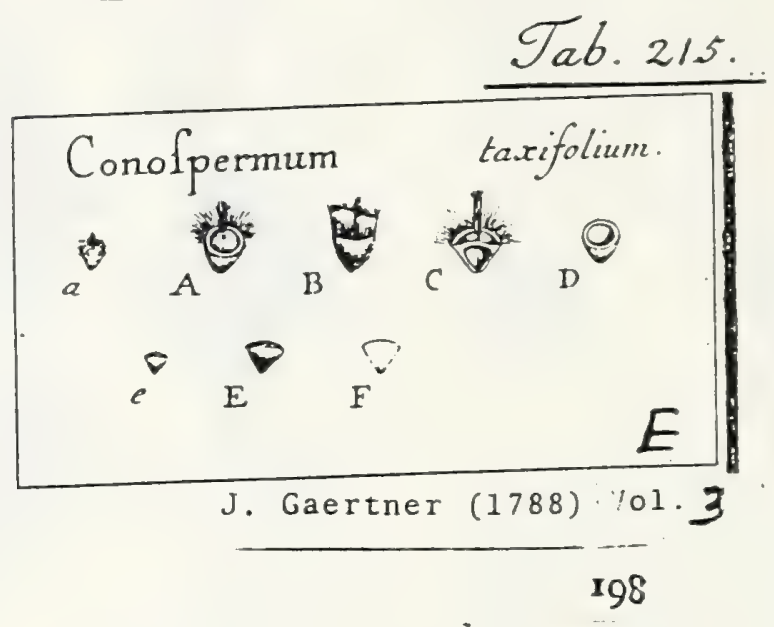

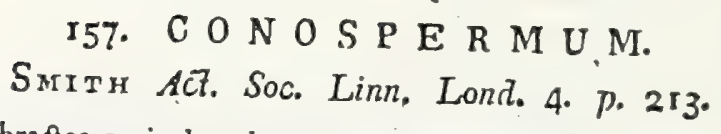

Flores bafi bractea auriculata longe mucronata veftiti.

Cal. nullus, prater corollams. Cor. monopetala, tubulofa, deciduas tubus longus, extus hirtus; Limbo inaquali, bilabiato: labio fuperiore ereço'; ova.

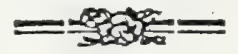

199

to, mucronulato, fornicato, margine revoluto; inferiore paululum defexo, tripartito: laciniis linearibus, intermedia paulo minore. Stam. quatuor, ad labium fuperius adfcendentia; filamentis brevillimis, fauci infertis, balig glanduliferis; antheris ovatis, unilocularibus, fuperioribus dorfo connatis, Jateralibus connatis. Ovar. fuperum, cillatum; ftylus longitudine corollax; ftıgma medio tortuofum, incraffitum, ad fornicem labii fuperioris fexum, obtufum. Nux inverle conica, cillis curonata, coriacea. Sem. folitarium. Alb. carnofum. Emb. . . .

Conospernum taxifolium. Tab. 215 . fig. 7 .

Habitat in Nova Hollandia, ex collectione Bankfiana.

P\&R. Nucula parva, inverfe pyramidata l. conica, turbinata, extus fetulis minimis rectis hifpida, ad verricem vero per ambitum ciliis longis rectis denfisque coronata, in vertice ipfo paululum immerfo convexiufculo glabṛo fafciculo fetarum erectarum penicilliformi condecorata, coriacea, ficca, cor tice deftituta, a bafi in valvulas quatuor cultro fillilis, rufefcens, unilocu. laris, monosperma.

R QC. nullum; femen apici loculamenti leviter adharet.

SEM. unicum, cavitatem nucis exacte replens, turbinatum, inverfe conicum, ad verticem convexiufculum, dilute ferrugineum.

I $\mathrm{T}$. Gimplex, membranaceum, tenue, facile detrahendum,

AL D. femini conforme, crafuin, carnofum, candidum.

$E_{M B}$....

EXPLICATIO FIGURE.

a. A. B.) Nucula integra. C.) Ejusdem feato longitudinalis, eom futora ad balin. D.) Eadem transverfe feaz. e. E.) Senen feparatum, jntegrum. F.) Albumen verticali modo difeaum.

In multiplici albuminis fectione nullum embryonis 1. cotyledonum veftigium inveni; bafis vero mucronulata radicula fpeciem habuiffe mihi vifa eft.

- Cxterum phxnomenon memorabile dignum non infrequens in femiuibus hujus plagx obfervavi, quod albumen cum lectulo plane fit efformatum, quamvis nullum embryonis veltigium adfit, in aliis quidem ejusdem fpeciei feminibus obvium. 


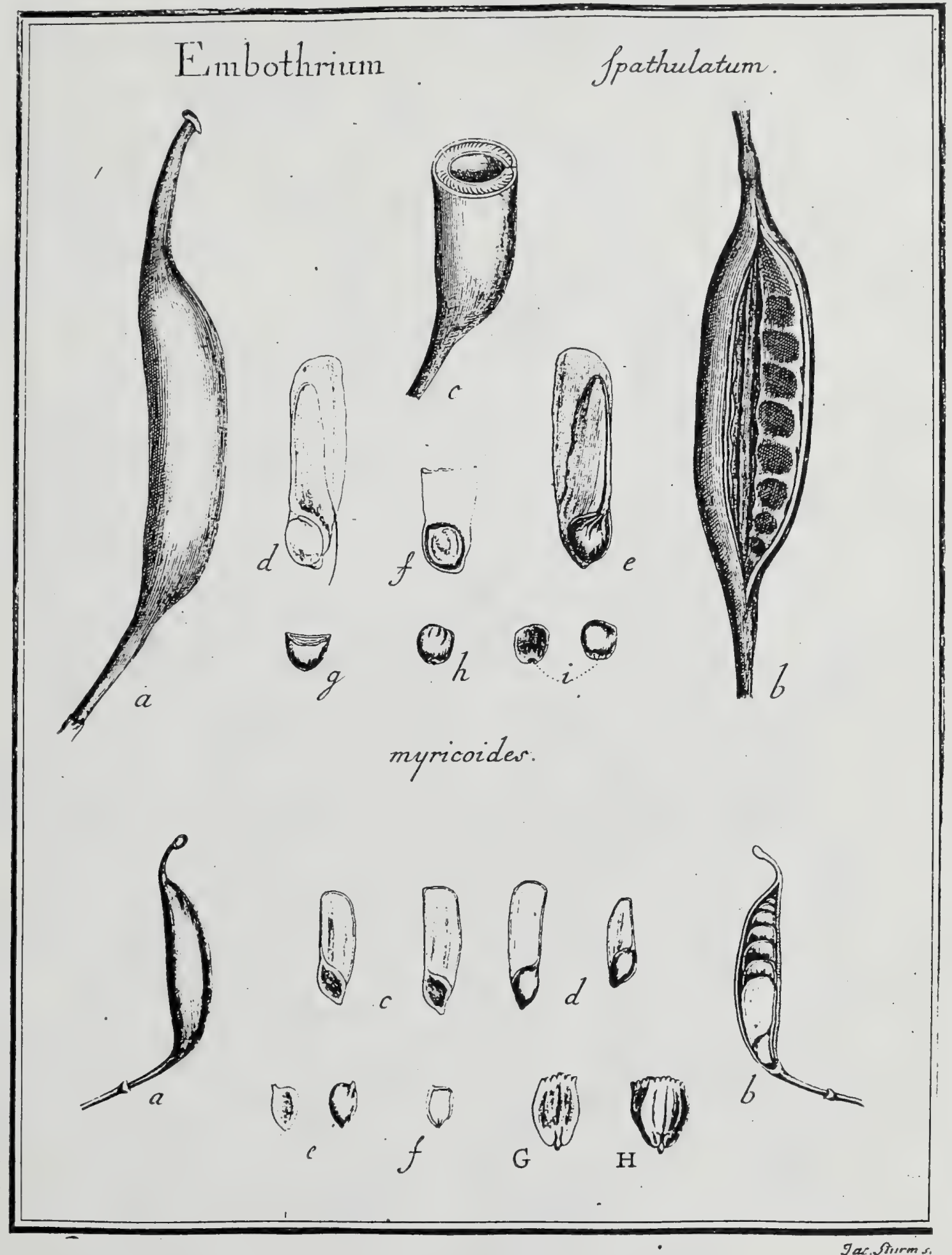




\section{r69. E M B O T H R I U M. 214}

FовSт. char. gen. t. 8. LIN Juppl, p. I6. Sснвев. gen. 145. Juss. gen. p. 29, LaAIACK ill. gen, t. 55. RuIz \& PAvON prod. $t$. 3 .

Cal. nullus. Cor. longa, decidua, ante foecundationem tubulols, apice fub: intata, obtura; poft foccundationem vero nunc monopetala, quadripartica; laciniis linearibus, apice paululun dilatatis, aut rectis, aut revolutis, foveola ftaminifera inftructis; nunc pecala quatuor, linearia, ad bagn ovari inferta, apice antherifera. Glandula nunc nulla; nunc unica, truncata, fquamiformis; nunc dux, tres, l. quatuor, ovario fupra iufertionem corollix, 1 . bafi ovarii aduatre. Stam. quatuor, fubfelfilia, laciniarum corolla 1. petalarum foveolis immerla; filamentis nunc brevibus, nunc vix ullis; antheris ovatís, l. oblongis. Ovar. fuperum; ftylo nunc fimpliçi, lineari, incurvo: nunc fubnullo $\mathrm{l}$. brevifimo; ftigmate peltato, deflexo. Folliculus coriaceus, ad ventrem Jongitudinaliter dehifcens, polyfpermus, Rec.nullum. Sẹ, ad utrumque latus folliculi furfum imbricata, alata. Alb. nullum, Embe. erectus.

EMBOTHRiUm fpathulatum. Tab. 2 is.

Embothrium Spatbulatum. CA4. ic. t. 388 .

A Cl. Lambert, \& ab anricifimo $D^{\text {no Decandolle. }}$

PER. Folliculus tri-1. quadri-pollicaris, oblongus, ex pedunculo longo daclio nato incraffarus, teretiufculus, inde in ftylum longum perfiftentem incurvum ftigmate inftructum atrenuatus, Juplicatus; lamina exteriore tenui, membranacea: interiore coriace, cra $\mathbb{R}_{2}$ ex fibris firmis candidis divergen, tibus confiata; catarum glaber, fufcus, ă ventrem longitudinaliter dephifcens, unilocularis, polyfpermus. Loculamentum compreffrufculum, oblongum, utrinque acuninatum, ad marginen futurx in utrogue latere ferie foveolarum a feminum impreflionibus exfculprum, membrana propria tenui, dehifcente folliculo, per dorfüm rumpente veftitum,

REc. nullum: funiculi umbilicales filiformes, a membrana loculamenti prapria prope futuram provenientes, falcati, ad marginem feminum exter-

$$
=\text { Joste }
$$

num producti, adfcendentes, \& demum in fumma ala refexi \& nuclei apicem adeuntes, undique cum ala feminis coaliti. SE a. ovata, ad urrumque latus folliculi furfum imbricata, convexitate foveolis
commiff, hinc plana, inde ad bafin nucleo protuberante inxqualiter lenticulari-convexo infignita, in alam longam membranaceam producta, fubinverfa, fumofa, 1. e rufo fufca.

IN T. duplex, utrumque in alan feminis ampliatum: exterius tenue, membra naceum; interius cum funiculo unbilicali connatum, membranaceo-chartaceum, album.

A L B. nullum.

E \& B. figura \& magnitudine fere nuclei, erectus, viridiufculus. Cotyl. fuborbiculares, plano - convexiufcult $x$, crafiufeula, carnofx, bafi paululum fiffa. Rad parva, fere tota intra cotyledones recondita, conica, umbilico esterno contraria, infera.

\section{EXPLICATIO FIGURE.} 9.) Folliculus integer. b.) Idem longitudinaliter dehifens feminibus excufts, ot foveolz pro bilicali e.) Idem ab altero latere vifum. f.) Nucleus denudatus. §.) Pars ferminis iaferior, to Cotyledones feparatz, a parte interas vilz.

Enвothrium myticoides. ibid.

Habitat in Nova Hollandia. Ex collectione Bankfiana, \& a Cl. LAmbert:

Folliculus (a) Sesquipollicaris, coriaceus, ex pedunculo tenui incraffatus, comprefliufculus, in ftylum incurvun brevem attenuatus, ad ventrem longitudi naliter dehifcens, unilucularis, polyfpermus. Rec, ut in priore. Sem ab. (b.c. d.) in utroque latere furfum imbricata, erecta, indique connato margitufifrmam producta, a funiculo umbilicali cum ala undique connanvexo innata, ad bafin nucleo (c.) protuberante in priore. Embryo (f. G. H.) ca. fignita, e rufo fufca. Integ. \& Alb. Ut in plbus Cory obclliptice, hine

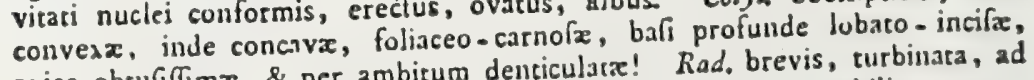
apice obtufifimx, \& per ambitum denticularx! Rad. ecta, umbilico contraria, infera. 


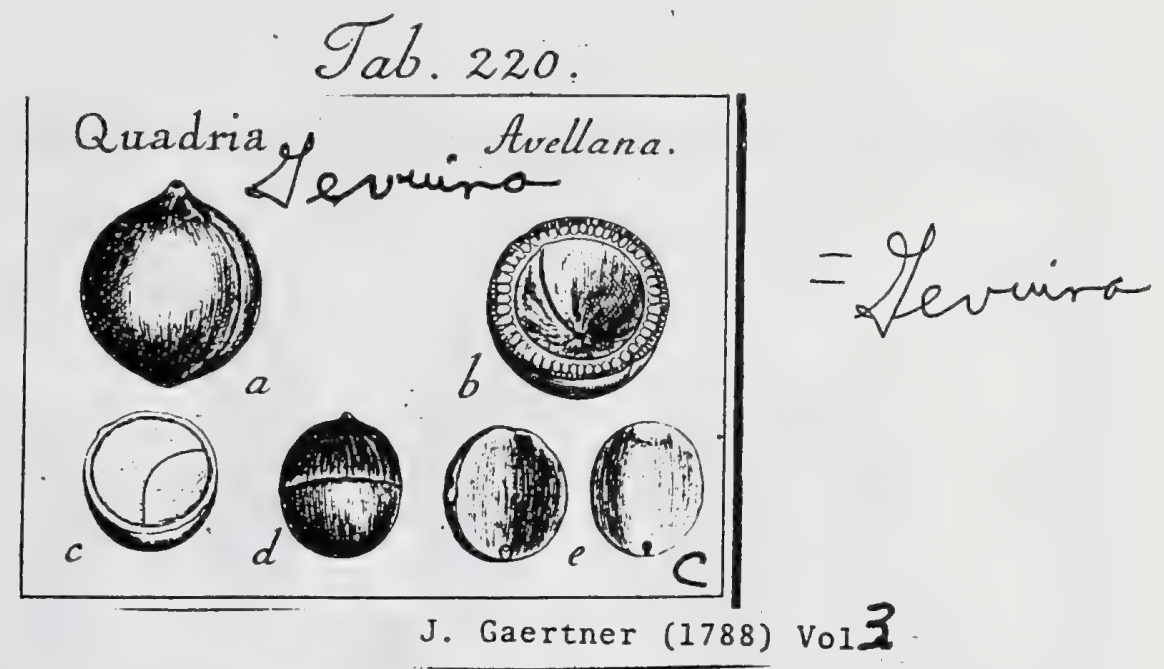

173. Q U A D R I A.

Rurz \& PAvon prod. t. 33. Gevuina. Morrw. chil. p. 198.

Juss. gen. $p .424$.

Cal. nullus. Cor. petala quatuor, infra akatium inferta, linearia, cruciatim difpofita, patentia, tribus reflexis unico erecto, apice latiora \& foveola parva infructa, antherifera, decidua. Stam. quatuor, intra petalorum foveolas fubfellilia; filamenta brevilfima; antherz cordatx. Ovar. fuperum; ftylo fimplici, fubulato, apice incurvo, longitudine petalorum. Drupa baccaca; putamine monofpermo. Rec. nullum. Sem. unicum, Alb, nullum, Emb, erectus; rad. abfcondita.

QUADRIA Avellana. Tab. 220. fig. 4 .

Gucoina Avellana. PERsoon fyrr. 1. p. xis.

$$
=
$$

Quadria (beteropbylla, ) folits pinnatis bipinnatisque, sacemis longis fimplicibus. Ruiz \& Pavon for. peruv. J. p. 63. t. 99. f. 6.

Ex Collect. Sem. Mur. Parif,

PEk. Drupa vix pollicaris, globofa I. ovato-glohofa, fupera, utrinque mucronulata, baccata, fulco levi longitudinali infcripta, glabra, per zetatem ferrugineo-fulca. Caro non admoilum craifa, extus cuticula tenui veltita, intus putamini undique adnata, \& intra ejus productiones inmerfa. Putamen craffiufculum, ex fibris fublignolis 1 . chartaceis in carnem prominulis conferruminatum, firmum, intus fcabriufculum, rufefcens, uniloculare, monofpermum.

REC. nullum: prater funiculum umbilicalem, filiformem, cum integumento externo undique conferruminatum, ex fundo putaminis \& in proprio ejus fulco ad feminis apicem adfcendentem.

SE M. unicum, cavitatem putaminis exacte replens, globofum 1. ovato-globofum, utrinque mucronulatum, rufefcens.

IN T. duplex : exterius coriaceum, crafiuffulum, a femine lubenter fecedens; interius membranaceum, embryonis baff arctius adhærens; cbalaza maxi$\mathrm{ma}$, ınitrxformis, torum leminis hemifphærium fuperius occupans, integumentum ipfum incraflans, fufca.

A L B. nullum.

Eм в. femini conformis, globofus, erectus, hemifphrrio fuperiore a chalaza depreflus, lacteus. Cotgl. crafx, amygdalino-carnofx, fubxquales; altera plerunque majore, Jongitudinaliter excavata: altera minore, ab illa excepta. Rad. nuinima, ovata 1. fubglobofa, obtufa, penitus intra cotyledonum bafin recondita, umbilico externo obverfa, infera.

\section{EXPLICATIO FIGURE}

a.) Drapa integta. b.) Eadem medio transverfe diffeda, femine excuffo. e.) Semen transverfe feaum. d.) Idea detratao integumento externo, ut ebalazz ad ipfus verticem appaseak. 


\section{J. Gaertner (1788) Vol 3}

Tab. 219

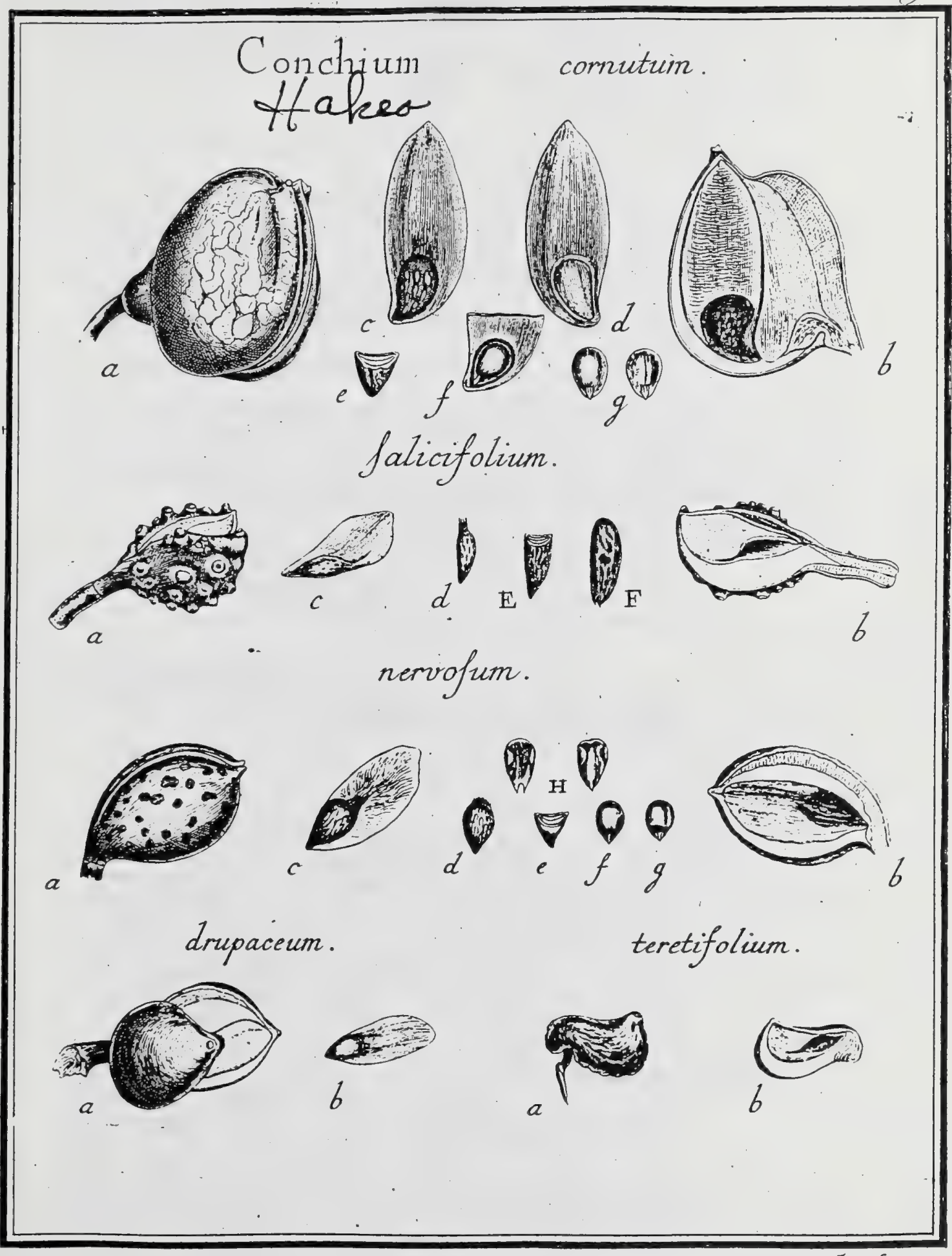

IT: Sturm se 
Surti ACt. Soc. Linn. Lond. 4. p. 115. Hakea

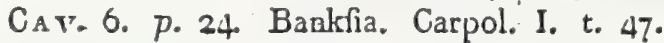

Ca]. nullus. Cor. profundiffime quadrifida, 1. terrapetala: petalis longis, linea: ribus, apice fupra foveolatis, antheriferis. Stam. quatuor; filamenta fubrulla: antbere foveolis pecalorum iufidentes. Ovar. fuperum; ftylo finplici, filiformi; ftigmate turbinato, mucronato. Capfula corcicata, ligno[a, dactyloides, ventre hongitudinaliter dehifens, unilocularis. Rec. nullum, prater funiculum umbilicalem. Sera, gemina, alata. Alb, nullum, Eıb, erectus, carnofus.

Conchum cornutum. Tab. 219.

Habitat cum fequentibus in Nova Hollandia prope Port Jackson. Ex collectione Bankfiana.

Fr U CT. Capfulx congregatx, circum ramos difpolitx.

Per. Capfula, fesqui-1. bipollicaris, fubglobola, ex peduuculo brevi crafto incraflata, ad apicem brevilime roftrata, corticata, lignofa, crafis, unilocularis, difperma. Cortex tenuis, coriaceus, per maturitatem capfule rimofus, e cinereo ferrugineus. Loculamentum lanceolstum, utrinque acuminatum, excentricum, valde comprelfum, capfula ipfa dimidia parte anguftius prope ventrem longitudinaliter locatum, ad bafin foveola profunda fcrobiculata exfculptum.

R Ec. nullum: prater funiculum umbilicalem filiformem, e fundo capfulx enatum' \& fensinis apicem adeuns.

SEM. gemina, in alam tenuem ampliata, nucleo obovato hinc plano inde len. ticulari-convero \& eminentiis obtufis [crobiculato inftructa, fubinverfa. fumofa, 1. e cinnamomeo-fulca.

IN T. duplex: exterius membranaceum, in alam extenuatum; interius membran naceo-chartaceum, tenue, nucleum obvolvens, lutefcens.

A L B. nullum.

E $\mathrm{NB}$ B. nucleo conformis, erectus, plano-convexus, lacteus. Cotylo obovate, obcufulinz, amygdalino-carnofi, hinc convexre, inde concavie Lo plas. niulcula, bafí incifx. Rád. brevis, intra cotyledones immerfa, tereticonica, acuminata, umbilico exteruo contraria, infers.

\section{EXPLICATIO FIGURE}

a.) Capfula integra, levites dehifcens. b.) Dimidiz capfulz pars, cum locolamento. c. d.) Se men feparatum, ab utraque parte vifum. e.) Nuclei fetio transverlalis. f.) Embryonis fitus

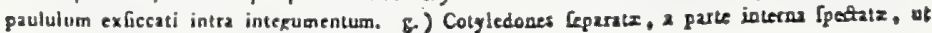
cadiecula infectio in confpectum venizt

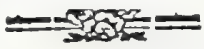

Coxснти falicifolium: ibid.

Capfula (a.) pollicaris, ex pedunculo valido ovato-globofa; ad dorfum re. ctiufcula, per ventrem vero magis gibba, apice mucronulata, craffa, verctiufcula, per ventis confperfa, ceterum glabra, corticata, lignofa, ad venrucis validis dicretis conifcens, unlocularis, fubbivalvis Correx tenuis, uren longitudinalimentü (b.) valde compreffum, ad dorfum capfulx locacoriaceus. Loculanentum (b.) valde comprefum, ad dorfum capfula locacun, ad bafin lectulo profundo pra nucleo inftructum. Senina (c.) gemina, ex acuminata bafi irregulariter obovata, ala magna ampliata, bafi nucleo (d. E) ovato-oblongo, plano-convexo leviterque fcrobiculato inftructa, โpadiceo-fufca. Int, \& Alb, ut in priore. Embryo (F.) nucleo conformis, erediceo-fufca. Int, \& Alb, ut in prote, obtufa, bafi fffx, amygdalino-car. nofx, extus obfolete rugofx, Rad, parva, conico-acuminata.

Conchum nervolum. ibid.

Capfula (a.) pollicaris \& ultra, ovato-globofa, craffa, per dorfum longitudinaliter fulcata, apice mucronulato-acuminata, corticata, Jignofa, ventre longitudinaliser dehiccens, cinerea, unilocularis. Cortex tenuis, coriaceus, glaber, per maturitatem ephelide confpurcatus. Loculamentum (b.) valde compreflum, obovatum, ad velitrem capfula locatum, bag fuperae foveo Jemina (c.) gemina, fpadiceo - fulca, nucleo (d.é.) obovato plinoconvexo leviter fcrobiculato inggnita. Embryo (f. g.) obovatus, erectus. Cotyl. (H.) cordatx, leviter plicata; lobulis Lateralibus introtexis. Rad parva.

Conchiur drupaceum. 'ibid.

Capfula (a.) pollicaris, ovato-acuminata corticata, lignofa, e luteo fpadices. Corter carmofo-coriaceus, epidernide glabra levigata tectus. Loculamentum ad yentrem capfula depreffum, Semen $\left(b_{\text {, }}\right)$ longe ellipticum. 
220

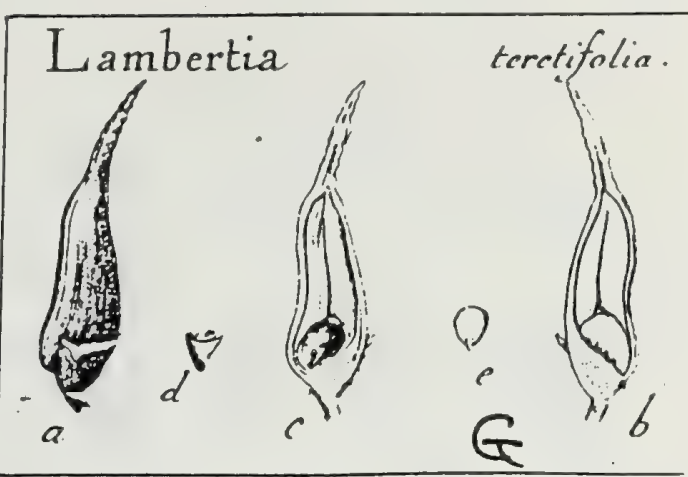

J. Gaertner (1788) Vol3

\section{L A M B E R T I A. \\ Sмгтн Act.' Soc. Linn. Lond. 4. t. 20.}

213

Flores in capitulum oblongum, bracteis coloratis lineari - lanceolatis involu. cratum; congelti.

Cal. nullus; nifi bracteas involucri fumas. Cor. monopetala, profundiffime quadrifida, decidua; Jacinix fubulato - lineares, in tubum longum fubtetragonum medio ventricofum conniventes, apice - Stam. quatuor, fubfelfilia; filamentis brevilfimis, fub. apice laciniarum corollx inferca; antherx lineari-oblongx, dezexx, biloculares. Ovar. fuperum; ftylo longifimo, filiformi, hirto; ftigmate Gmplici, oblongo, tetra gono, acuminato. Capfula cornuta, lignofa, unilocularis, bivalvis. Rec. nulluin. Sem. duo, alats. Alb. nullum. Emb. erectus.

IANBERTIA teretifolia. Tab, 217. fig. 7 .

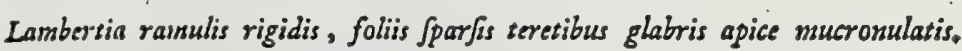

Habitat in Nova Hollandia, a Cl. Lambert.

PER. Capfula fefquipollicaris, oblonga, compreffufcula, ad ventrem magis gibba, in roftrum anguftum acuminatum attenuata, ad bafin obtufa gibba \& pedunculo brevi infidens, ad utrumque latus prope bafin proceffu transverlo membranaceo inftructa, lignofa, unilocularis, bivalvis. Valvule per dorfun \& ventrem longitudinaliter dehifcentes, bafi vero connatx. Loculamentuin curvato-lanceolatum, valde compreffum, bafi vero fovea rotundata exfculptum.

REc. nullum: funiculus umbilicalis filiformis, brevis, ad bafin feminis adfcendens \& mox cum integumento conkuens.

S I M. gemina, hinc valvis commiffa, lenticulari-convexa; inde fbi contigua, plana, elongata in alam lanceolatam l. ligulatam, acuminatam, leviter ob. liquam, e fufcu ferrugineam; rucleus paululum obliquus, cordarus, mas. gine acutus.

IN T. duplex : exterius membranaceum, in alam tenuem protrsctum 3 interius corlaceum, tenue.

A L B. nullum.

EN B. nucleo conformis, obovatus, plano-convexus, eredus, albus. Cotyl. ovate, amygidalino curnolx, incumbentes. Rad, conica, brevis, umbi. Jico externo consrara, intera.

214

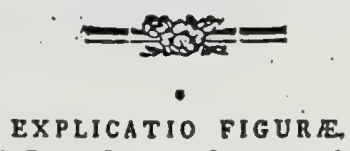

a.) Capfula integra b. c.) Eadem fecundum futuram divifa s valrula alterz (b.) femen in fitu; altera (c.) a femine liberata, loculameati furmam oftendens, d, ) Nucleus transverfe diffetus. e.) Embryo feparatus.

Specimina mes non probe erant matura; hỉnc embryonis figurá denuo ro; -cognolcenda. 


\section{Tab. 220}

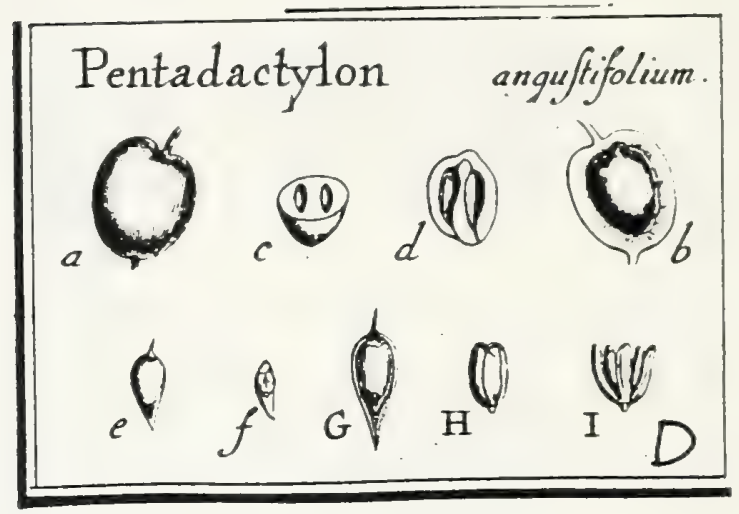

J. Gaertner (1788) Vol 3

\section{PE N T A D A C T YLUN.}

Cal. ... Cor. ... Stam. . . O Ovar, inferum; ftylo finsplici, filiformi, ftriato, perfiftente. Drupa baceata. Putamen offeum, biloculare. Rec, nullum. Sen. folitaria, erecta, apiculaca; nucleo dilfmili. šsu. nullum. Emb. erectus, lobis coryledoneis quinis,

Pentadactylon anguftifolium. Tab. 220. fig. 3.

Habitat in Nova Hollandia prope Port Jackron. Ex collectione Bankfialia.

PER. Drupa magnitudine cerafi nínoris, ovata, paululum obliqua, depreffiufcula 1. ad verticem leviter umbilicata, \& ftylo perfiftente faftigiati, breviter pedunculata, baccata, compreffiufcula L. turgide lenticularis, glabra, viridiufcula. Caro cuticula tenui' veftita, mollis, cum villis. putamini arctillime aduatis intime commixta, pallida. Putsmen cordato-ova-

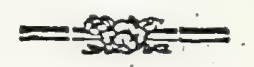

tum, turgide lenticulare, a carne difficulter feparandum, bafi cicatrice um. bilicali infignitum, craffum, ex glomerulis fabulofis minimis compagina. tum, durum, rufo-fufcum, biloculare. Loculamenta ex acuminata bafa obovata, curvula, compretliufcula, margine lateribus putaminis obverfa, apice mucronulato-acuminata, monofperma.

REC. nullum: femina loculamentorum bafi a.tharent.

SEM. Folitaria, erecta, curvula, obovata, deorfum acuminata, ad verticem obtufa \& in apiculam protracta, compreffiufcula, fpadices l. Gavicantia.

I N T. duplex: exterius coriaceo-cruftaceum, fragile, ultra nucleum bafi protractum; interius membranaceum, tenue, nucleum arcte includens, ad verticem cbalaza ferruginea notatum, facile detrahendum, album.

A L B. "nullum.

E \& B. femini paulo brevior, erectus, ovatus, nd verticem leviter umbilicatus, compreffiufculus. lacteus. Cotyl. lobi quini, lineares, obtufi, carnofi. Rad. brevifrma, obtufiufcula, umbilico externo obverfa, infera.

\section{EXPLICATIO FIGURE.}

2.) Dropa integra. b.) Eadem longitudinaliter diffecta, cum putamine in fitv. c. d.) Putareo transverfe \& longitudinaliter diffectuon, cum fiu \& forms loculamentorum. c.) Semen feparz tum. f.) Ejusdem fetio trunsverfalis. G.) Integumenti externi pars ablats, ut noclei fusu intra ipfum appareat. H.) Embryo folutus. I.) Idem lobis cotyledoacis, a fe inpicem didatis.

Lobi cotyledonei profundiffime \& zqualiter divif, ut embryo omni jure po. lycotyledoneus dici polfit. 


\section{J. Gaertner (1788) Vo13}

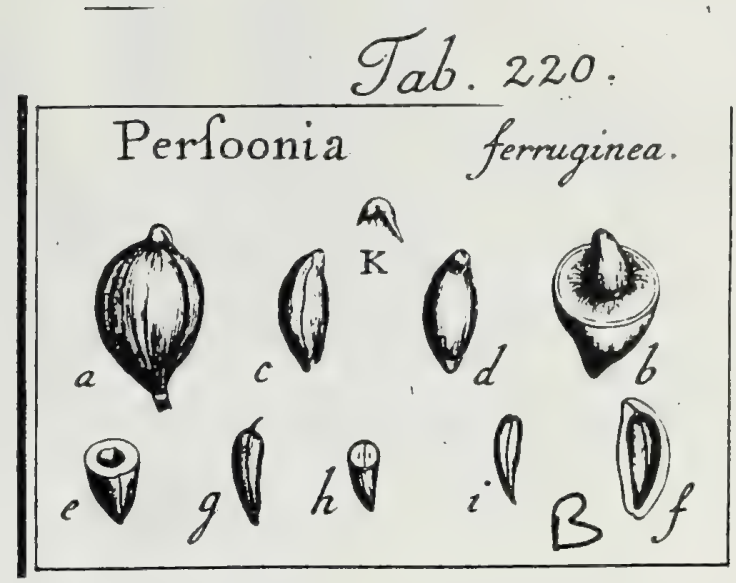

J. Gaertner (1788) Vol3

1.7. PER S 0:0 N'I A. $\quad 218$

\section{Sмгтн ACZ. Soc. Linn. Lond. 4. p. 215.} Cal. nullus. Cor. tetrapetala: petalis primum conice conniventibus, deinde rerii. Stam. quatuor; filam. ...3 anthetis linearibus, deinum refexis. Ovar. fuperum; ftylo fimplici ; Ptignate obtula. Drupa baccata, unilocularis." Putamen uniloculare. Rec. nullum. Sem, unicum, erectum. Alb. nullum. Eimb. erectus.

Persoosia ferruginea. Tab. 220. fig. 2.

Habizat in Nova Hollandia prope Port Jackfon. Ex collectione Bankfiana.

Pra. Drupa mediocris magnitudinis, baccata, obovata,-paulum obliqua, ful. thy lo perfiltente hirto ad drupam retexo \& jpfi ad. 219

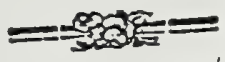
preffo faftigiata, purpurea, unilocularis.' Caro mollis, a cortice craffiufculo inclufa \& cum villis putavatum, turgidum, ad ventrem rediufculum, ta, lutercens. Putamen ovatum, turgidum, ambilicali pallida inftructum, in dorfo vero magis gibbum, bafi area parva umum leviter fulcatum \& futsapice fulcu levi bicufpidatum, ad latera deolis fubulofis minimis conflatum, ris fpuriis inlignitum, crafum, ex glomerulis Loculamentum obovatodurum, e rufo-fufcum, uniloculare, evalve.

oblonguin, apice mucronulato - apiculatum.

REC. nullum: Semen bafi putaminis a

SEM. unicum, ex obovato oblongum, ad verticem, curvulum, ad utrumque minata mucronulatum, deorfum acumillidum 1 . Jutefcens. latus fulco elevato teivui inltruente detrahendum, ad apicem in apiculam

IN T. fimplex, nembranaceum, facile detrainea infigtritum. acumiuat

curvulus, erectus, lacteus, Cotyl. ovato-oblongx.

Es B. femini conformis, curvulus, incunbelites. Rad. brevis, cum cocarnofx, obtufx, plano - collvexx, licunbenbilico externo obverfa, intyledonibus continua, fera.

\section{EXPLICATIO FIGURE,}

3.) Drupe integra. b.) Eadem medio transverfe difteda, cum putanine fo the co longitudi-

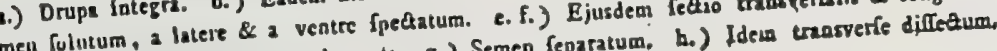

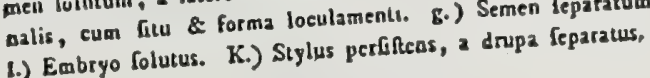




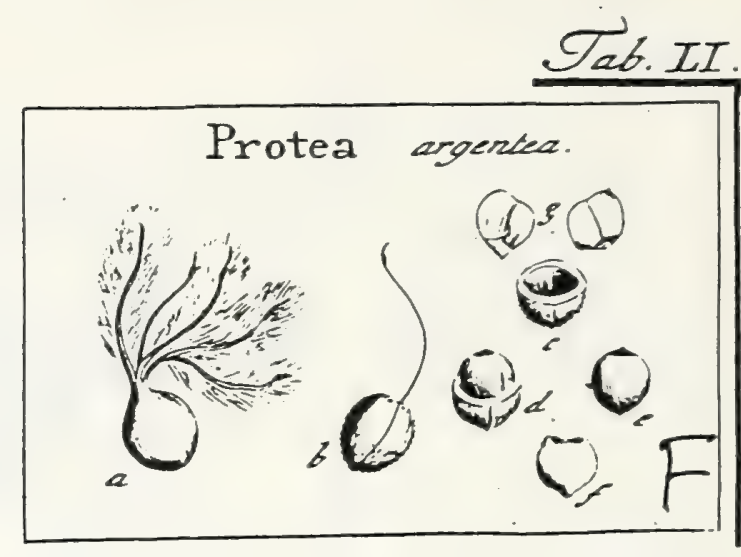

\section{Proteaceae}

J. Gaertner (1788) Vo' 1

CCXCIV. PROTEA. LINN. gen. no.

Calyx nullus. Cor. monopetala, quadripartita. Antherx quatuor, petalis infra apicein infertx. Styl. unicus. Nux tupera unilocularis, evalvis.

PLOTE A argentea. Tab. 5I. fig. 7.

Conocarpodendron foliis argenteis fericeis latifimis. BOE R H. lugdb. 2. t. I95.

Proten fuliis lanceolatis argenteo tomento/is ciliatis, caule arboreo, snpitulis globofis. TH UNB. LIN N. Juf. veg. 1 q 1 .

Ex herbario Rankfiano.

PER. Nux corol!a perfiftente veflita, oflea, obovata, turgide lenticularis, utringtic in medio linea tenui inferipta, unilocularis, evalvis; cultro eamen fecundum marginem firtiis.

REc. nullun, pratcr cicatriculam fubfungofan in apice loculamenti, exi femen affixum.

SEx. unictrnt, obnvatum, obefum, albrin, fuperne ampla clialaza nigra gotaturm.

IN T. funflex, membrasaceum, diaphanum, failidum.

A s. nulluin.

EMB. Cemini conformis, eredus, albus. Cotyl. obovatx, craftx, plaso convexx, am!gdaliuo carnofx. Plunn. acunimata, uninutifhnz. Rad. conica, brevillnna, infira.

240

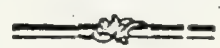

a.) Corolla quadricadata, fericeo plumofa, nucem ventiens. b.) Nux denadata. c.) Eadem dith feAta. d.) Seminis in nuce fitus, c.) Idem folutum. f.) Embryo deuudatus, g.) Cotylecican repantz. 


\section{7}

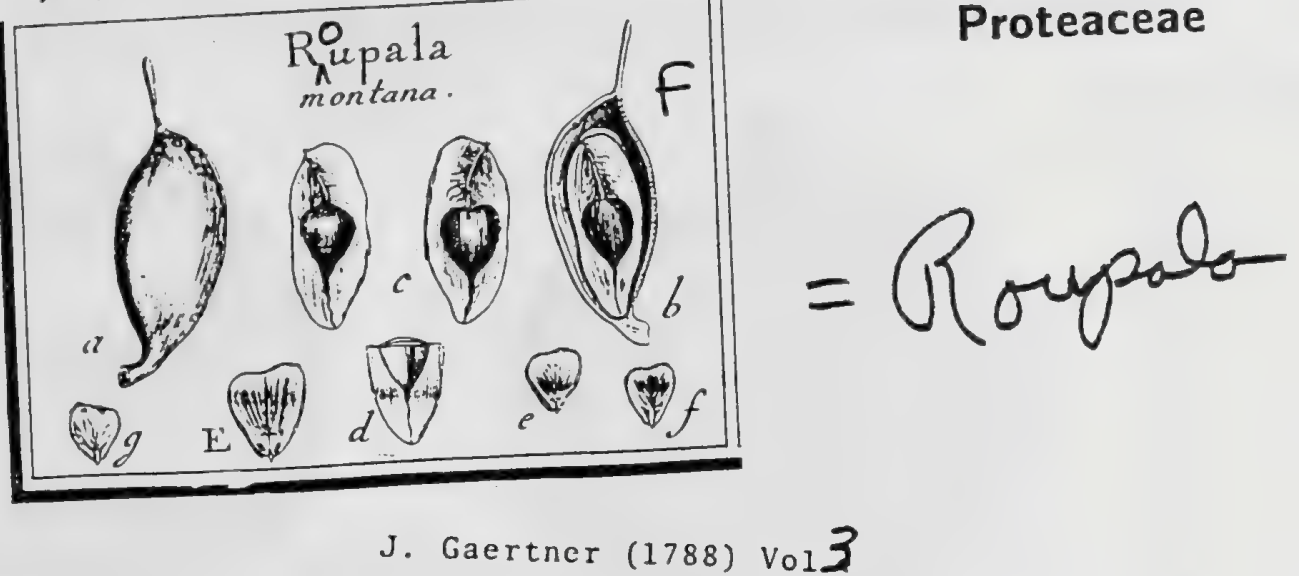

212

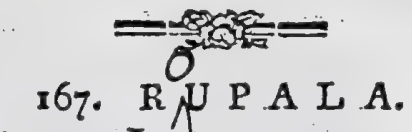

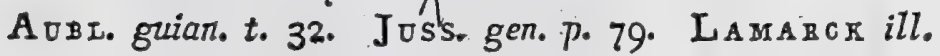
gen. t. 55 .

Cal. nullus. Cor. quadripārtita ; laciniis longis, ex angufta bafi fpathulatis, fupra concavis, obtufis, ad bafin ovarii infertis, patentifimis, caducis. Glandulx quatuor, nectariferz, ad bafin ovarii, cum corollx laciniis alternx. Stam. quatuor; filamentis brevifimis, ad medias corollæ lacinias infertis, erectis; antheris oblongis, obtufis, bilocularibus. Ovar. fuperum; Itylo fimplici, tereti, longo, clavato; ftigmate fimplici. Folliculus compreflus, coriaceo - lignofus, unilocularis. Rec. nullum. Sem. gemina, inverfa, comprefia. Emb. cordatus, erectus.

RUPAla montana. Tab. 217. fig. 6.

Roupala. AUBL. guian. I. p. 83. WiLld. Jpec. pl. T. I. P. 1. p. 536. PERSOON Jyn. I. P. 117 .

Ex collectione Bankfiana.

P E R. Folliculus pollicaris, coriaceo-lignofus, preudoleguminofus, oblique ovatus; hinc fty lo longo filiformi - clavaro fublaterali faltigiatus, inde in pedunculum brevem ad dorfum fubrecurvum attenuatus, lenticulari-compreffus, dorfo autem paulo cralisor, ad ventrem gibbofiorem longitudinaliter dehifcens, extus glaber, intus membrana argenteo-fericea veftitus, fufcus, unilocularis, evalvis. Loculamentum Jenticulari - comprelfum, feminibus paulo latius.

REC. nullum: ad utrumque latus folliculi in fupremo ventre papillula parva per dehifcentiam dimidiata, cui femen fui lateris ope funiculi umbilicalis, undique cum Semine connati \& per totam ipfius longitudinem balin usque decurrentis; affixum.

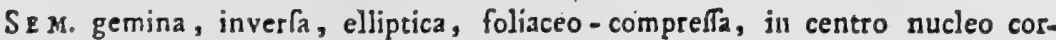
dato fufco leviter protuberante notata, fpadicea 1 . ferruginea.

IN T. fimplex chartaceum, firmum, in latum marginem tenuem membrana: ceum productum.

A L B. nullum.

E M B. magnitudine \& figura nuclei, cordatus, compreffus, hinc convexus, inde leviter concavus, erectus, albus. Cotyl. foliacex, amygdalino-carתofx, nervolic, bafi filla: Jacinulis auriculatis in lectulum pro radicula excavatis; accumbentes. Rad. parva, conico-acuminata, a cotyledonum lacinulis ablcondita, umbilico externo e diametro contraria; infera.

\section{EXPLICATIO FIGURE.}

a.) Folliculus integer. b.) Ejusalem fedio lungitudinalis, cum ferninibus in fitu. e.) Setuea (eparatum, ab utraque parte vifum. d.) Ejusdem fectio transverfalis. e. E) Embryo folutus. f. 8.) Cotyledones feparatx, ut iufertio sadicula vifui pateah.

$$
=
$$

Embryo in hoc, uti in fequentibus hujus ordinis generibus, oleo unguinofo fcatet. 


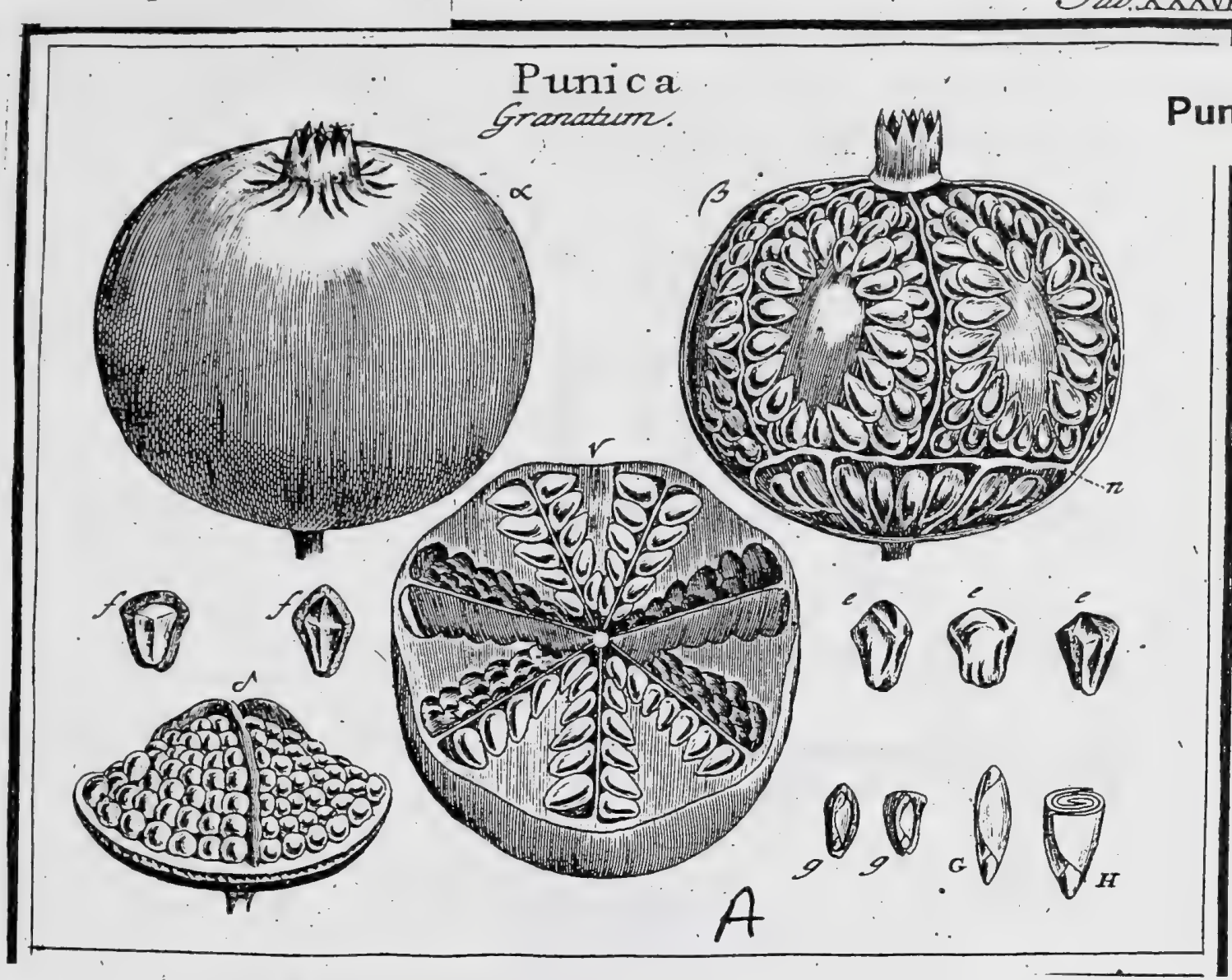

CCXXI. PVNICA. TOURN. t. 402. LINN. gen. 6r8.

Calyx fupcrus, quinque-l. decemfidus. Petala quinque. Stam. plurima, calyci inferta
Styl. uuicus. ba:cats.

J. Gaertner (1788) Vo1.1

Punica Granatum. Tab. 38. fig. 1.

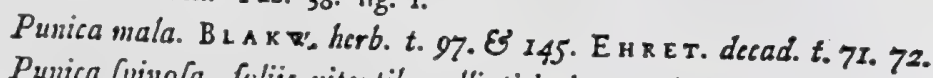
Punica fpinofa, fuliis nitentibus ellipticis integerrimis, foribus Jeftibus. HALI.
hifl. 2. n. 10y9.

Punica foliis lanceolatis, caule arboreo. $\operatorname{LIN}$. fyf. veg. 462.

PER. Bacca infera, grandiuscula, calycis tubo acute dentato coronata, globofa, depreffiuscula, fungofo carnola, coriacso corticata, diajhragmate transverfalt in duas concannerationes inxqua!es divifa: Camera fuperior major, feptem 1. noven locularis: loculamentis; lepto mombranaceo, tenuilimo, ab in vicen feparatis. Inferior camera multo minor, lurfum conice excavata, leptis pariter membranaceis. tenerrimis in tria loculamenta divila.

REC. in camera fuperiore: proceflus cuneiforınes fubflantix carnofx, a parietibus bac: $c x$ verfus axein tendentes \& undique fcrobiculis exfculpri, quibus femina inferta. In camera inferiore: proceffus irregulares, vel \& ipfe fundus baccx, plurimis alveolis irregulariter exiculptus, quibus femina inhxrent.

SEM. numerofiffima, , baccata, varic angulata, pellucida, rubro colore fxpius fuffufa inftar cryftalli fplendentiz.

IN T. duplex : exterius cuticula tenerrima, pulpain aquofam coërcens; interius cruftaceum, varie angulatum, craffum, candidum, durum.

A L. B. nullum.

EM B. figurâ \& maguitudine cavitatis cruftx feminis, oblongus, utrinque attenuatus, lacteo-albus. Cotyl. foliacex, tenuifinnx, fecundum axem nuclei fpiraliter convo. lutx. Rad. teretiuscula, brevis, verfus peripheriam fiuctus dirceta, centrifuga.

a.) Bacca integra, naturali millor. $\beta$.) Eadem detracto in latere anteriori ejus cortice coriacto

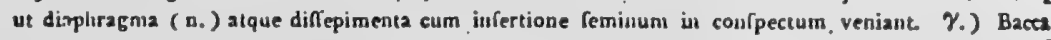
transverfim fecta, eum receptaculis atque diffepimentis, aliquantum magis regulariter reprafentatis: quam in maturis fructibus plerumque reperiri folent. $\delta$.) Situs feninuus in camera inferiore. e.ce) Seniwa magnitudine naturali. S.f.) Gigarti iutra pulpam figura variz. g.g.) Ejusdem fectio longl tudinalis, cum cmoryoue denudato. G.) Eimbryo infigtiter auctus. H.) Cotyledones transverfim fectx, cum toliolorum g) ris fpiralibus.

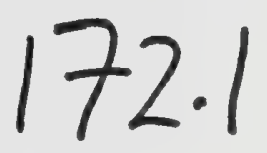


6

6 


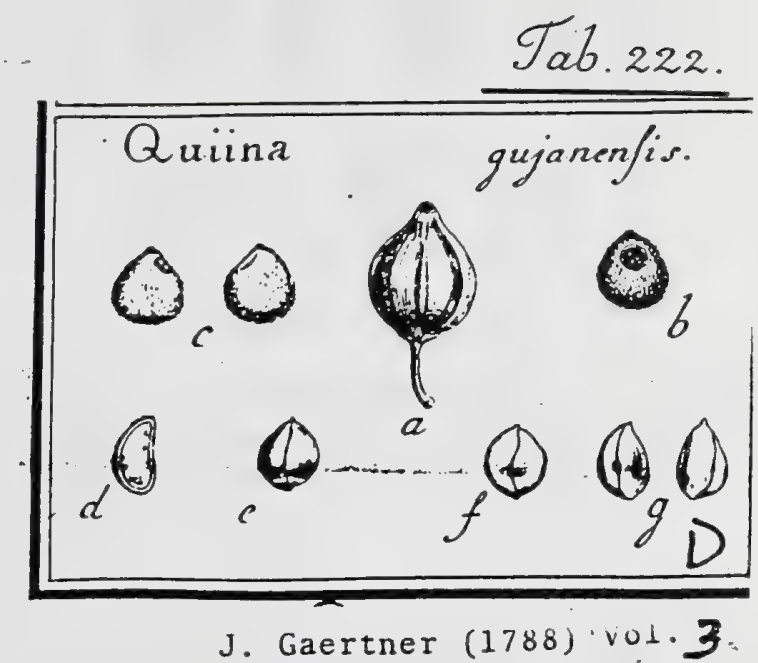

227

179. Q U I I $N$ A.

A UвL guian. t. 379.

Flores ftipulis duabus bafi muniti.

Cal. monophyllus, parvus, inferus, quadripartitus, perfiftens; laciniz ovate; acurx. Cor. ... Stam. ... O Ovar. fuperum; ftyl. ... Atigm. ... Bacca ovato-mucronata, apice umbilicata, dipyrenz. Pyrenx chartacex, extus hirfutz, monofpermx. Sem. folitaria, inverfa, fpadicea. Alb. nullum. Emb. inverfus; radicula puncticulari.

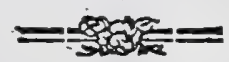

QUirNa gujanenlis. Tab. 222. fig. 4

Quiina. A UBL. 1. c. app. p. 19.

A Cl. A. L. de Jussieu.

PER. Bacca magnitudine cerafi minoris, ovata 1. ovato.globola, furfum in mucronem brevem obtufum apice umbilicatum protracti, pulpofa, longitudinaliter ftriata, pedunculo tenui \& calyci perfiftenti infiftens, glabra, Jutefcens, unilocularis, dipyrena. Pulpa crafiufcula, mollis, ficcitate fere evanida. Pyrellx geminx, arcte fibi approximatx, accumbentes, corda. tx, plano-convexx, chartacex, ad verticem area umbilicali communi orbiculari fufca immerfs infignitx, extus fetulis denfiffmis rectis lutefcentibus confperfx, intus glabre, uniloculares, monofpernix.

REC. nullum: proter vafa umbilicalia e pedunculo affurgentia \& arex umbilicali inferta.

SEM. folitaria, ovata 1. fuborbicularia, utrinque mucronulata, plano-convexa, bafi paulo craffiora, inver̀fa, dilute ferruginea.

IN T. Ginplex, membranaceum, tenue.

AI B. nullum.

Es B. femini conformis, inverfus, albus, Cotylecraffe, amygdalino-carno$f_{x}$, hinc arcuate, inde planiufculx, 1 . leviter undulat $x$, accumbentes. Rad. minima, puncticularis, umbiliso externo proxima, fupera.

\section{EXPLICATIO FIGURE.}

a.) Bacca integra. b.) Pyrenz a carne folute \& fibl adglutinatz, cum atez umbllicali Integra. c.) Exdem folutz, parte interiore vifx, eum stea unbilicali dimidiata laterali. d.) Pyrenx fedio longitudinals. e. f.) Embtyo Solutus, ab utraque parte fpetatus. r.) Cotyledones Esparatz.

Proxime accedic ad Murrayam. 
.

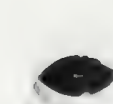




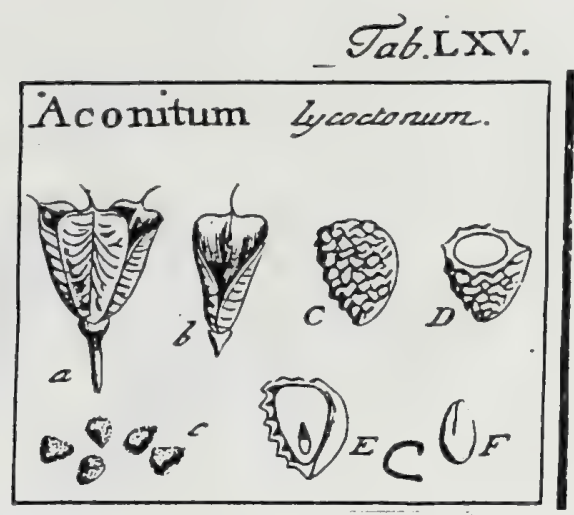

\section{J. Gaertner (1788) Vol.I}

CCCXCVI. ACONITUM. Tourn. t. 239.240. Linn. gen. 682. $3 / 1$

Cal. nullus. Cor. pentapetala: fupremo galeato. Nect. duo pedunculata. Stam. plurima. Styli fubquini. Capfulz leguminofx tres 1. quinque. Semina arido baccata.

A CONITU N lycodonum. Tab. 65. fig. 4.

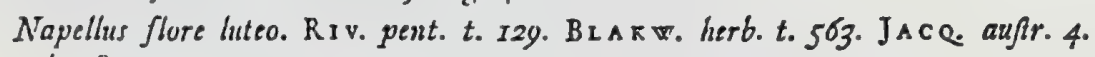
t. 380 .

Aconitum foliis hirfutis femitrifudis, lobis duplicato triffdis. HALr. hif. 2. n. 1200.

Aconitum foliis palnatis multifidis villo/is. LIN N. J4fl. veg. 504

PER. Capfulx tres 1. pauciores leguminofx, teretiusculx, filiformi roftratz, venis arcuatis ftriatx, Spadiceo-fufcx, uniloculares, introrfum dehifcentes:

REc. margo futurx dehifcentis, cui fenina duplici ferie aftexa.

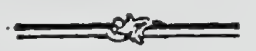

S E M. plura, ad duodecim, fubturbinata, arido baccata, ferobiculato rugofa, nigra, a alterum latus hilo compreffo, quafi alato, flipata.

IN T. duplex: exterius laxum, aridum, rugofum, intus cellulofum; interius tenuiff: mum, rufefeens.

A \&. obovatum, carnolum, duriusculum, pallidum.

E s B. parvulus, in bafi albuminis pofitus, ovatn acuminatus, niveus. Cotyl. oblongx; acuininatz. Rad. crafta, fubglobofa, relative centripeta.

2) Fratas tricaplukris dehifens. b.) Capfula feparata. C. C.) Semina foluta D.) Semen transverfe, \& E.) Idem longitudinaliter fectum, cum fitu embryonis. 


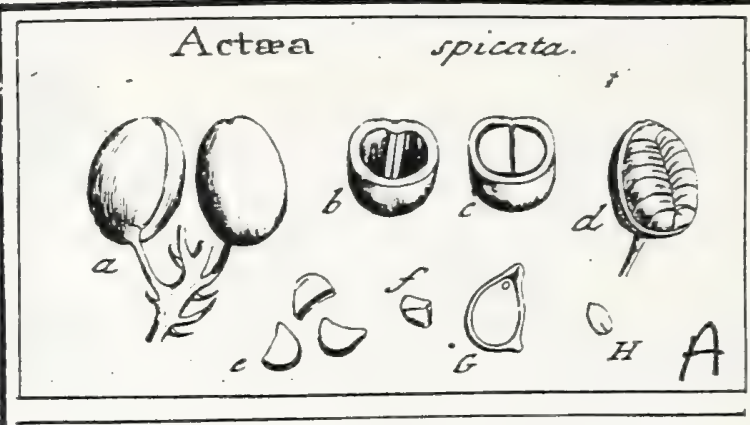

J. Gaertner (1788) Vol 2

DCLXV. A C T E A. LINn. gen. 644. Chriftophoriana. 154 TOURN. inft. t. 154 .

Calyx tetraphyllus. Cor. tetrapetala. Stam. numerofa. Ovar. fuperum. Śtigma feffile. Bacca mollis, unilocularis. - Semina plana, lateri altero baccie longitudinaliter affixa.

ACtea f́picnta. Tab. 114. fig. I.

Chriffopborianza. Clus. bift. 2. p. 86. BesL. Ejff. afitu. X. t. 3. f. x. Blakw. berb. t. 565. OED. flor. dain. t. 498 .

AJaa foliis circumferratis, duplicato pimnatis, pimula extrema trilobata. HALL. bijt. n. 1076 .

Alada racemo ovato, finctibus baccatis. Lins. Jyjt. veg. 488.

Pzr. Bacca ovato - globofa; excentrice pedunculata; ab altero latere fulco tenui depreffo inféripta, glabra, atra, unilocularis. Caro mollis pulpofa, fucco purpureo - rubro Fcatens. Loculamentum propria membrana veftitum.

REc. fafcix dux, albx, in latere bacce fulcato, quibus femina duplici ferie fibi incumbentia longitudinaliter affixs.

SEM. plura, decem circiter vel duodecim, fubfemicircularia, utrinque pians, margine arcuato glabro, altero autem recto, fulco longitudinali depretio inferipto; cetera faturate caftanea, punctis minutiffmis excavatis confperfa.

IN T. duplex: exserius coriaceum; interius membranaceum.

ALB. fenini conforme, carnofum, aqueo-pallidum.

EM B. ninutulus, in extremitate umbilicali albuminis hxrens, fubovatus, niveus. Cutyl. brevidininix, obtulic. Rad. attenuata, centrifuga.

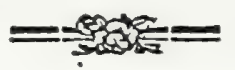

*

2.) Bacez integra. b. c.) Exilem diffeda, cum \& absque feminibus. d.) Seurisa duplici ferie fibi incumbentia. c.) Eadem feparata. f.) Semen transverfiun \& G.) Idem longitudinaliter diffeâm cum figura \& Gtu albuminis atque embryonis. H.) Embryo folutus \& infigaiter auAus.

\section{2}




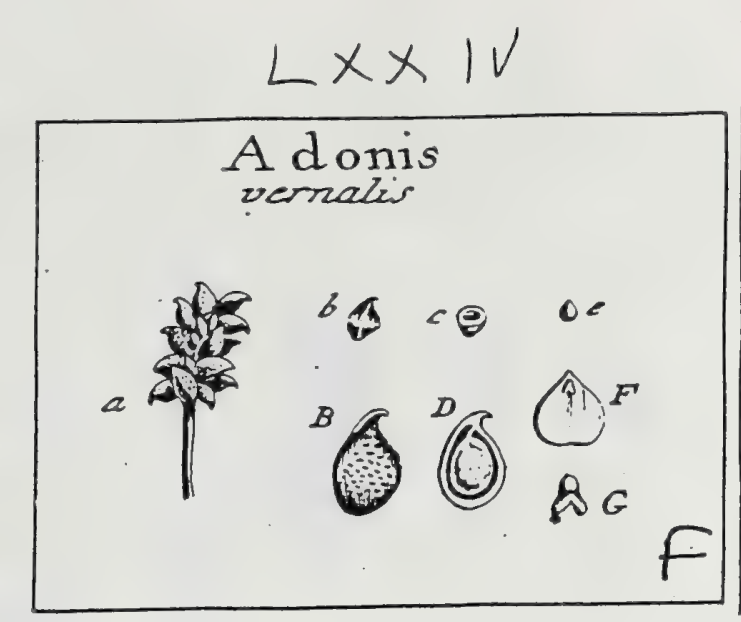

\section{J. Gaertner (1788) Vol. 1}

CCCCLIX. ADONIS. Linn. gen. 698. $\quad 35.5$

Calyx pentaphyllus. Cor. polypetala. Stam. numerofa thalmea. Styl. breves perfinentes. Capfulae ṕlures roftellatae. Embryo inverfus.

A DON Is vernalis. Tab. 74. fig. 6 .

Helleborus hippocratis. B LARष. herb. t. 504. MILI. diż. ic. t. 14. J A c Q flor. aufs. $t$. 44 .

Adonis radice perenni, flore dodccapetalo. H.i... hift. 2. "1. 1157 .

Adonis flore dodecapetalo, fructu ovato. Lix s. fuft. veg. 514.

PER. Capfulx plures, circiter viginti quinque, in fpicain ovato cylindricam digeflx, fubglobof $x$, recurvato roftellatx, fubcoriacex, extus rugof $x$, intus lamina cartilaginea nitida veftitx, uniloculares, evalves.

REc. commune fubulatum, nudum; proprium, funicußlus brevis e roro capfulz in feminis apicem defcendens.

SEм. folitaria, fubglobola, apice mucronata, rugofa, gramineo-viridia.

IN T. fimplex, membranaceum.

$\Lambda$ L в. femini conforme, carnofum, album.

Eм в. minutulus, teretiusculus, inverfus, lacteus, in fuprema parte albuminis haerens. Cotyl. breviffunac. Rad. rotundata fupera.

a.) Fructus integer. b. B.) Capfula feparata. c.) Eadem transverfe feta. D.) Semen e funi. culo pendens, c.) Semen folutum. F.) Embryo intra albumen, G.) Idem feparatus.

Dignofcitur ab A. autumnali, capfularum mucrone reflexo \& longiore. HA \&.. 1. c. 


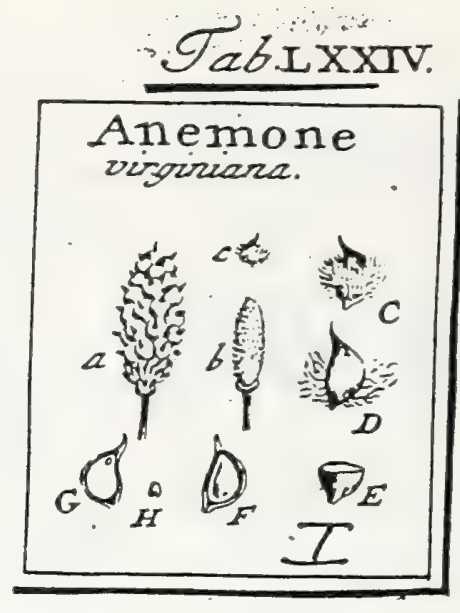

J. Gaertner (1788) Vn'.1

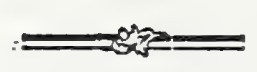

\section{CCCCLXII. ANEMONE. Tourn. t. 147 . LIN gen. 694 .}

Flores frepe involucrati, Cal. nullus. Cor. penta-enneapetala. Stam. numcrofa thalainea. Styl. perfiftentes. Capfulx plures mucronatz, aut caudatx. Embryo inverfus.

ANE MONE virginiana, Tab. 74. fig. 9 .

Anemone virginiana, tertia fimilis, flore parvo. HER M. parad. 18. $t .18$.

Anenone pedunculis alternis longi/smis, frutabus cylindricis, feminibus hir futis muticis. LIN N. Jy/f. veg. 510 .

PER. Capfulx numerol $x$, fupra quinquaginta, parvx, feminiformes, compreitiuscul $x$, ovat $x$, utrinque acuminatx, fubcoriacex, fupra in roftrum breve definentes, nigro fúcx, infra, lanâ albâ involutae, uniloculares.

REc. commune cylindricum, villofum; proprium funiculus brevifimus ex apice capfulae.

SE ir. folitaria, ovata, comprefliuscula, furfum angufata, pallida.

IN T. fumplicillimun, membranaceum, tenue.

A L B. Semini conforme, carnofum, album.

Es в. exilifimus, fubglobofus, inverfus, niveus, in fupremo albumine baerens. Cotyl. brevifimae. Rad. rotundata, fupera.

a.) Fructus integer. b.) Receptaculum. c. C.) Capfula (eparata. D.) Eadem anterios 2 [ana denadata. E.) Eadem differa, F.) Semen denudatnm. G.) Embrjonis fitus intra albumen. H.) Ensbryo feparztus.

$$
174.4
$$




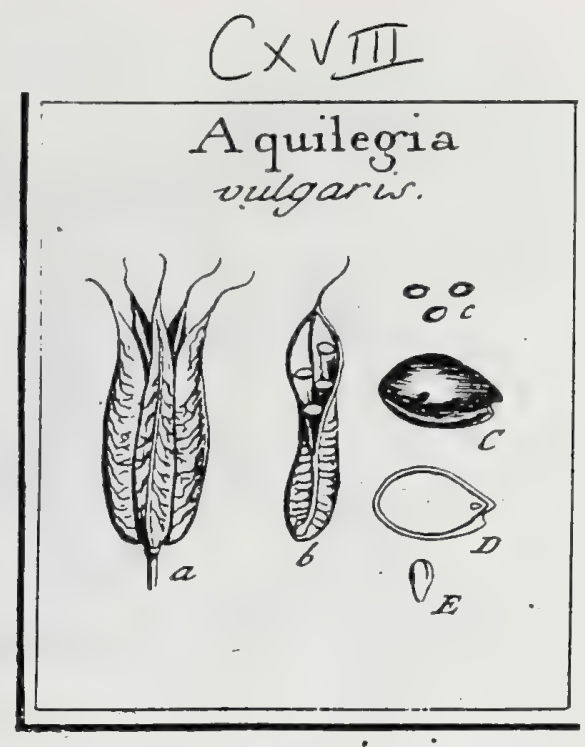

Ranunculaceae

J. Gaertner (1788) Val 2

175

DCXC. A QUILE G I A. TOURN. inf. t. $242^{\circ}$ LINN. gen. 684.

Calyx nullus, nif corollam velis. Cor. pentapetala. Nectar. quinque, calcarata. Stam. numerofa. Squainæ decem, plicatx, inter ftamina: atque ovaria. Ovar. fupera. Styli fimplices. Capfula :quinque, beguminofie, roftraze. Sem. plura, lucida.

AQUiLegia vulgaris. Tab. 118. fig. 3 .

Aquilegia. BLAKw. berb. to 40 g. OED. fior. dagt. t. 695 .

Aquilegia folitis trilobatis, lobis petiolatis tripartitis fubrotundis obtufe dentasiso HALL. bift. ห. 2295.

Aquilegia medariis incurvis. Lins. byft. veg. 505.

PER. Capfulix quinque, bafi tantum connexz, nervis elevatis reticulatx, erectr, teretiufcula, fupra in roftrum filiforme attenuatr, uniloculares, latere intèrno dehifcentes.

REC. nullum; femina duplici ferie futurx dehifcenti affixa.

SEM. numerofa, ovata, altero latere cofta longitudinali notata, glabra, atra, fplendentia. Umbilicus emarginatus. .

IN T. duplex: exterius chartaceum, aridum, fragile; interins menbranaceum, pallidum, chalaza ferruginea notatum.

578

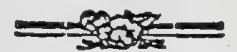

A L 8. carnofum, duriufulum, pallidum.

Е м. exiguus, in extremitate adbuminis unbilicali locatus, albicans. Cotyl. compreffix, brevifinic. Rad. teretiufcula, re!ative centripeta.

2.) Fruatus integer. b.) Capfula Separata, dehifeens, eum infertione feminum. c. C.) Semuins foluta D.) Seaimis \& albuninis featio lungitudialis cum fitu \& figur embronis. E.) Embryo feparatus. 


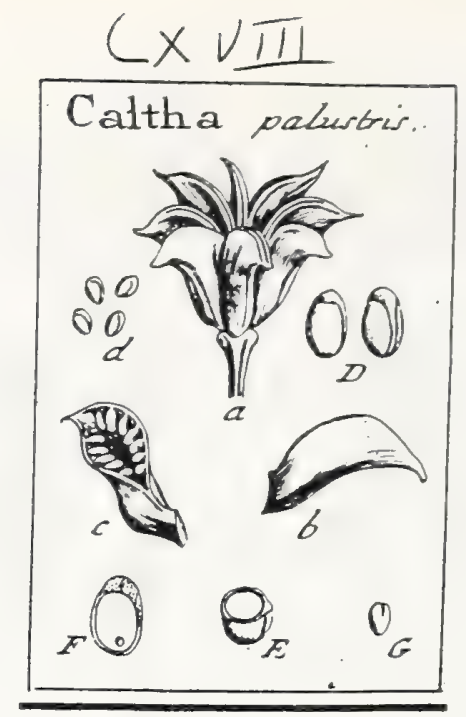

Ranunculaceae

J. Gaertner (1788) Vol 2 ;

DCXCI. CAITHA. IInn. ger. 703. Populago. 176 TOURN. inf. t. 145 .

Calyz nullus. Cor. pentapetala. Stam. numerofa. Ovar. fupera. Styl. nulli. Stigm. felfilia. Capfulx quinque ad decem, comprefie, patentes, uniloculares. Sem. plura.

Caltha paluftris. Tab. 118. fig. $40^{\circ}$

Caltba palufris. BeSL. Eyft. byent. t. 4. f: 2. vern. VII. t. 5. f. x. OED. for. dan. t. 668 .

Caltba. LiNn. Jyfe. veg. 5!9. Hall. biff. n. II88.

PER. Capfulx fex ad quindecin, in capitulum collectx, erecto - vel fi pau: ciores fuerint, horizontali - patentes, compreffæ, extrorfum curvatx, acuminate, uniloculares, Jatere fuperiore dehifcentes.

REC. nullum; femina valvularum futuræ, gemino ordine, affixa.

SEM. plura, circiter quindecim, ovata, aut ovato-oblonga, glabra, rufefcentia, colta longitudiuali, in crafum verticis tuberculum definente, ab altero latere notata.

IN T. duplex: exterius chartaceo - curiaceum, fubftantia fungofa alba in vertice feninis farctum; interins membranaceum, tenuifimum, fufcum.

$\triangle$ L B. carnofum, femine paulo brevius, album.

EM 8. minutus, ovatus, latteus. Cotyl. brevifimx. Rad. crafa, relative centripeta.

a.) FruAus integer. b. ๕.) Capfula feparata, integta \& dehilcens. d. D.) Semina folutb. E. F.) Seminis fcetio longitudinalis atque transverfalis, cum fitu cmbryonis. G.) Embrgo fcparatus.

$$
174.6
$$




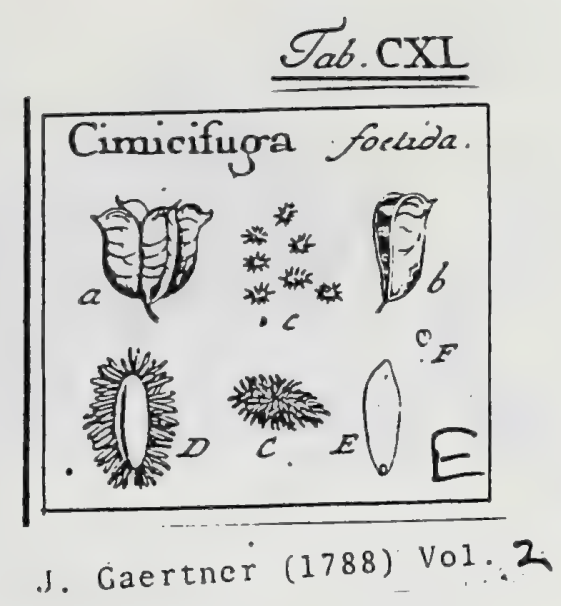

DCCCX. C I M I C I F U G A. LINN. gen. I282.

Calyx tetraphyllus. Cor. tetrapetala, petalis urceolatis Stam. plura. Ovar. Dlurn, in ftylum fimplicem definentia. Capf. quatuor aut duplo plures, oblongx. Sen. plura, fquamis linearibus echinata. Planta ficpe diphyta.

Cimiciruga foctida. Tab. 140. fig. 5 .

ATaa racemis paniculatis, fruthibus quadricapfularibus. LrNw. $\int p \cdot p l \cdot 723$.

Cimicifuga. GMEL. frbir. 4. p. 181. t. 70. LINN. amoen. acad. 7. t. 6.f. 2. $\int y j t$. veg. 505 .

PER. Capfulx quatuor, nunc pauciores, nunc duplo plures, oblongx, reticulato venofx, ftylo bieviffino recurvo roltrate, uniloculares, futura interiore dehifcentes.

REc. nullum ; femina future dehifenti fecundum totam fuam longitudinem affixa.

SEM. plura, oh'onga, undique fquamulis membranaccis, lineari-oblongis, Acxilibus, pallidis, ubtecta.

Ix T. fimplex, membranaccun, tenuifimum.

A s oblongum, teretiufculum, carnofum, fubolcolum, molle, aqueo-pallidum. E 8. nimutifimus, globulofus, in extremitate albuminis umbilicali locatus. Cotyl. brevifimx. Rad. relative centripeta.

* Comina ruluta a.) Fruaus qualtrieapfularis, integer. b.) Capfula feparatz, dehileens, e. C.) Semina fuluta. D.) Scminis infizaniter auti dorium 2 palcis sepurgat cunt fitu \& Gavura embrganis F.) Embryo folatus.

Quid Linnxus fyft. veg. 1. c. per dehifentiam future luseralis intelligat, me penicus fugit: conftanter autem capfulas has, futura fua ventrali, ficut ponues congeneres, dehifcere, id quidem fatis certo fcio. 


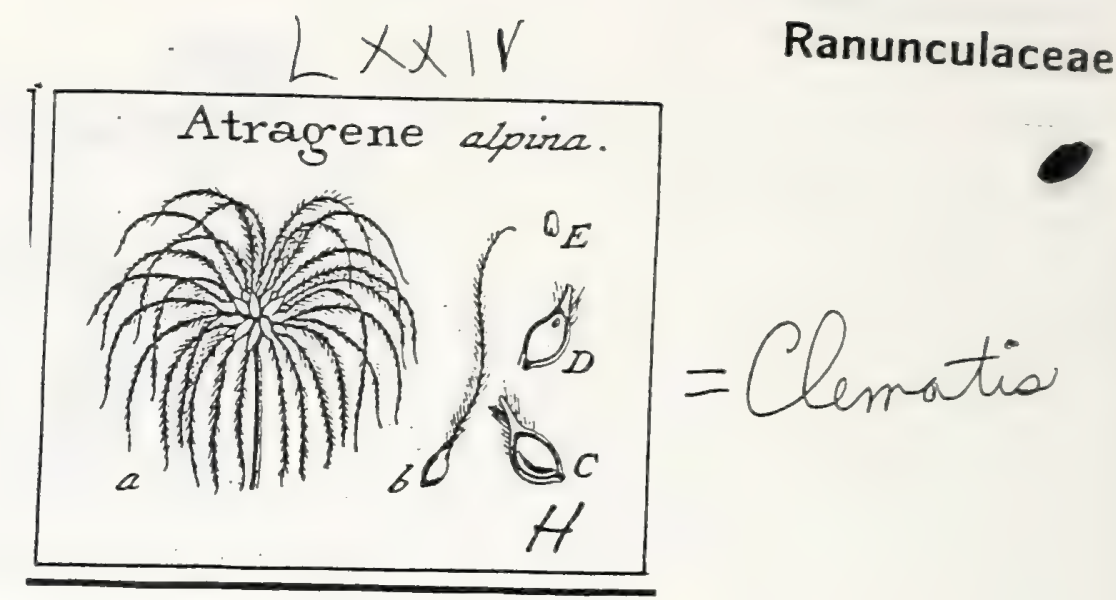

J. Gaertner (1788) Vol.1

CCCCLXI. ATRAGENE. LIN g. gen. 695. $3560^{\circ}$

Calyx tetraphyllus. Cor. dodecapetala. Stam. numerofa: filámentis exterioribus peraloidcis diantheris. Styl. perfinentes. Capfulax plures plumofo caudatz. Embryo interfus.

ATR $A$ GENE alpina. Tab. 74. fig. 8.

Clematis alpina geranifulia. Pr.ur. phyt.t. 84. f. 7. MrLL. dit. ic. t. 248 . CRANz. fafc. 2. t. 5. Jace. auffr. 3. t. 24 r.

Atragene foliis ternatis, foliolis trifoliis acutis. HaLI. hifl. 2. n. n145.

Atragene foliis duplicato ternatis ferratis, petalis exterioribus quaternis. LIN $\int y / 3$. veg. 511 .

PER. Capfulx plures, circiter 25-30, feminiformes, coriacex, tcnues, glabrz, ovatx, utrinque attenuatx, turgide lenticulares, in fetan longifimam plunofam defincntes, uniloculares.

REc. commune, globofum, parvun, pubcicens; proprinin, funiculus umbilicalis, a cauda ad bafin feminis defcendens.

S.E M. folitaria, ovata, lenticulari compreffa, pallida,

IN T. fimplicifinum, inembranaceum, tenue.

A L в. Semini conforme, carnofum, album

Em B. exilifimus, terctiusculus, inverfus, lacteus, in fuprena albuminis parte harens. Coty!. breviffunz. Rad. teretiuscula, fupera.

1.) Fruflus integer. b.) Capfula (eparata. C.) Nucleus denudatus. D.) Embryouis fitus in atbumine E) Embryo feparatus. 


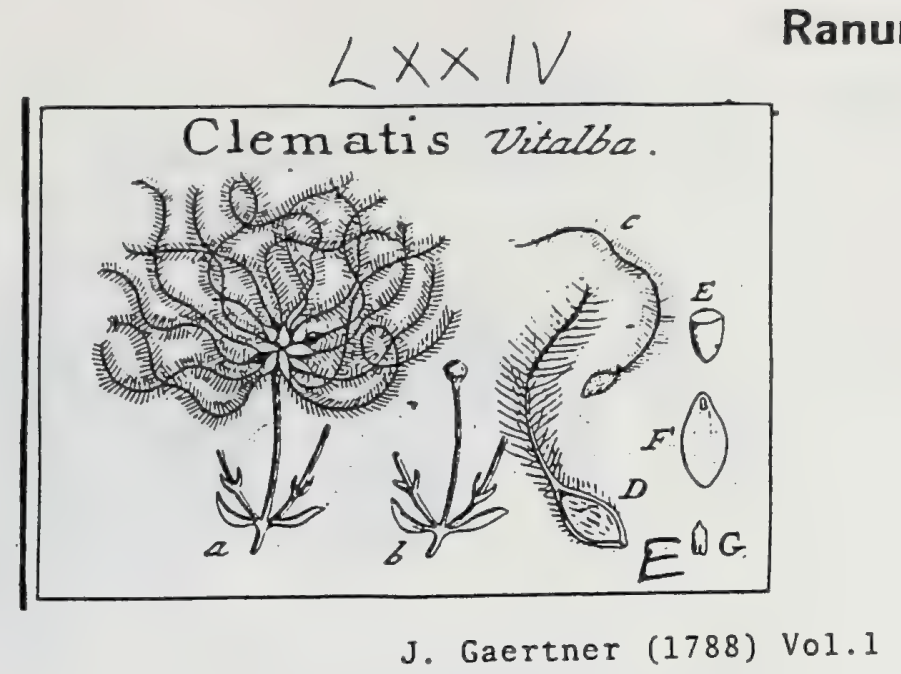

CCCCLVI. CLEMATIS. TOURN. $t$. 150. LIN

Calyx nullus. Cor. tetra-1. hexapetala. Stam. plurima, thalamea. Styl. perfiftentes. Capfulae plures caudatae. Recept. capitatum. Embryo inverfus.

Сzем А т Is Vitalba. Tab. 74. fig. 3.

Vitalba. DOD. pempt. 404. J A ce. auftr. t. 308.

Clenatis caule feandente, foliis pinnatis ovato lanceolatis, petalis coriaceis. HALL. hift. 2. n. 1142.

Clematis foliis pinnatis: foliolis cordatis fcandentibus. L IN N. fyft. veg. 512.

PER. Capful $x$ a femiuibus non difinct $x$, plures, circiter viginti, membranacex, tenues, rubicundx, villis albicantibus confperf $x$, in letam plumofam longifinain definentes, non delifcentes.

REC. commune fubglobolum, parvum, villofum; proprium nullum, aut obfoletum. SEM. folitaria, elliptica, turgide lenticulatia, pallide lutefcentia.

IN T. fimpliciftunum, membranaceum.

$\Lambda$ L. femini conforıne, carnofum, duriusculum, album.

E s. minutifimus, inverfus, niveus, in fuprema albuminis parte locatus, Cotyl. brevifinx. Rad. crafta, fupera.

a.) Frutas integer. b.) Receptaculum. c.) Caplula caudata, claufa. D.) Eadem aperta, cum fenine in fitu. E.) Albumen transverfe fetum. F.) Embryonis figura \& fitus intra albumen. G. Embryo Separatus.

Semina pro nudis recte haberi poffent, quia confpicuus funiculus umbilicalis non adeft. 


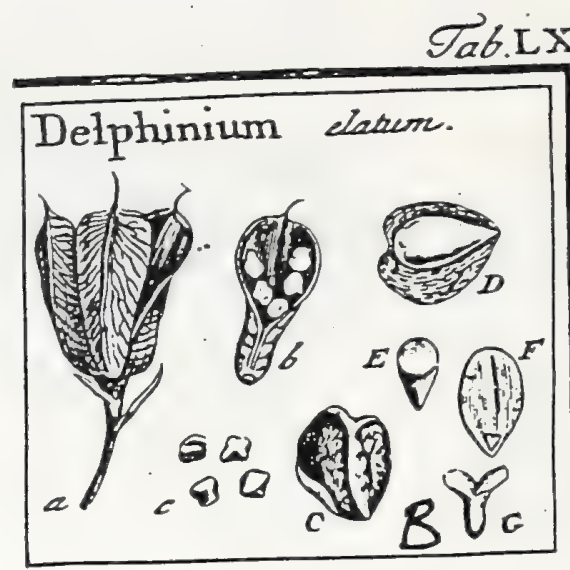

I. Gaertner (1788) Vol.1

CCCXCV. DELPHINIUM. T ou RN. 241. LinN. ger. 681.

Calyx nullus. Cor. penta-1. hexapetala. Nectar. bifidum, calcaratuin. Stam. plu-

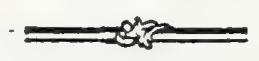

rima. Styl. unus ad tres. Capfula leguminofx, fubternx. Sem. plura, arido baccata, irregularia.

DelPHin IU clatum. Tab. 65. fig. 3.

Aconitum I. CAs. epit. 829 .

Delphinium triflignum, foliis Semiquinquelobis acute Serratis, petalis interioribus quateruis barbatis. Hall. hifl. 2. n. 1201 .

Delphinium nettariis diphyllis: labellis bifidis apice barbatis, foliis incilis, caule eretio. LIN N. Jiff. veg. 503.

Icon. Mni.t. diq. ic. t. 250. f. 2.

PER. Capfulx tres 1. pauciores, leguminofx, fubteretes, filiformi roftratx, venis obliquis Ariatx, fpadicex, uniloculares, introrfum dehifcentes.

REC. margo internus future dehifcentis, cui femina duplici ferie aftixa.

- SEN. plura, quatuordecim \& ultra, irregularia, arido baccata, fufca, cum aliquo fplendore.

IN T. duplex: extcrius laxum, fpongiofo membranaceum, aridum; interius membranaceum, tenuifimum, chalaza nigricante notatum.

$\Lambda_{\mathrm{L} B}$. ovatum, verfus umbilicum attenuatum, carnofum, aqueo glaucum.

Ess. exilis, in acuminata parte albuminis pofitus, niveus. Cotyl. breses, planius. culx. Rad. teretiuscula, relative centripcta.

2.) Frutus deliifcens. b.) Capfula feparata, cum fitu (eminam. c. C.) Semina folata D.) Albumen denudatum. E.) Idem transverie fefum. F.) Embryo intra albumen. G.) Iden feparatus.

\subsection{0}




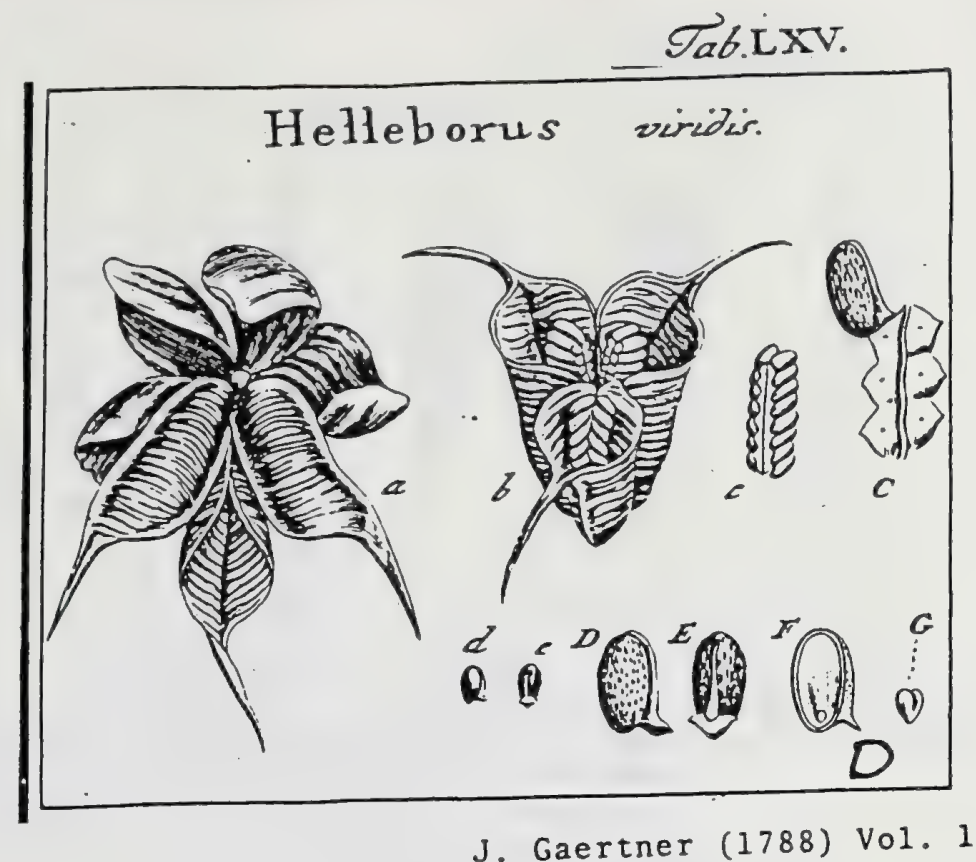

Ranunculaceae

J. Gaertner (1788) Vol. I

$3^{10}$

CCCXCIV. HELLEBORUS. TOURN. $t$. 144. LIN N. gen. 702.

Calyx pentaphyllus, interdum coloratus, Cor. nulla. Nectar. tubuiofa, bilabiata. Stam. numerofa. Styli quinque vel plures, perfiftentes. Capfula legumicofz sofratz. Semina numerola.

HELLEBORUS viridis. Tab. 65. fig. 2.

Helleborus niger fttriacus. B L A $\mathrm{k}$ w. herb. t. 509. 5 ro.

Helleborus foliis multipartitis ferratis, caule paucifloro. HaLL. hiff. 2. n. IIg2.

Helleborus caule bifido, ramis foliofis bifloris, foliis digitatis. L\&N N. fyjt. veg. 519 .

Icon. J A c Q. flor. auflt. 2. $t$. 106 .

PER. Capfulx tres, leguminolx, communi pedunculo brevi infiftentes \& fupra calycis fundum elevatx, oblongx, compreffiusculx, ncivis transverfalibus rugatx, ad margines acutx, in roftum longum lineari acuminatum definentes, uniluculares, futura interiore dehifcentes.

REc. falcia membranacea alba, utrinque ferrata, ex umbilicorum bafi planiuscula forinata, \& luturx dehifcenti agglutinata, femina duplici feric digena luftinens.

SEM. plura, fedecim circiter in fingula capfula, cylindrico ovata, fubrugofula f. quafi adrofa, e plumbeo nigricantia, ab altero latere, hilo, in latain tubam umbilicalem ampliato, flipata.

INT. duplex: utrumque membranaceum, tenue.

A L B. femini conforme, fabulofo carnofum, duriusculum, aqueo-glaucum.

Eмr. minutulus, in imo albumine pofitus, fubglobofus, lacteus. Cotyl. brevifimx, obtufx. Rad. conica, relative centripeta.

2.) Frnftus integer. b.) Capfulz dehifcentes. c. C.) Fafciz cui femina affixa, d. D.) Seminis latus externam. e. E.) Ejusdem latus internum cum hilo in tubsm umbilicalem ampliato. F.) Seminis fetio longitudinalis, cum fitu embryonis intra albamen. G.) Embryo feparatus, 


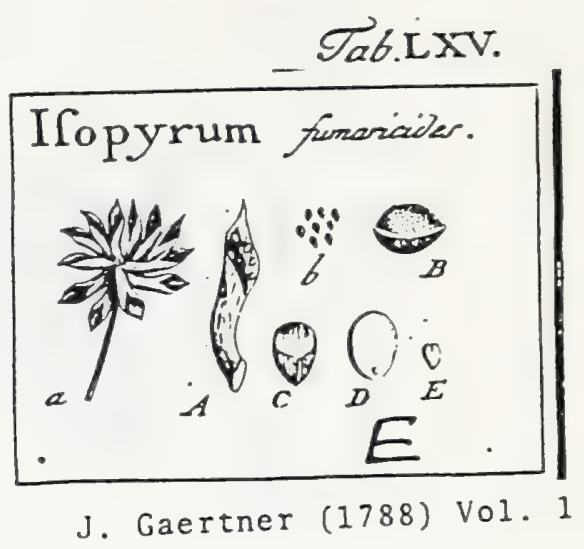

CCCXCVII. ISOPYRUM. LIN g. ger. 7or.

Calyx nullus. Cor. pentapetala regularis. Nectaria tubulata trifida. Stam. plura. Styl. plures. Capfulx plures leguminof $x$. Semina globofa.

Is OPYRUM fumarioides. Tab. 65. fig. 5 .

Helleborus fumarice folio. A м м. ruth. 74.t. 12.

Ifopyrum fipulis fubulatis, petalis acutis. LiNn. $\sqrt{y / f .}$ veg. 518 .

PER. Capfulx decem ad quindecin, leguminofx, compreffiusculx, fetaceo-roftellata, iutrorfum curvulx, venofx, pallidx, tenues, uniloculares, introrfum dehifentes. REC. margo futura deliicentis, cui femina duplici feric affixa.

SEM. plura, parva, ovato globofa; elevato puncticulata, nigricantia, ad alterum latus hilo lineari notata.

IN T. duplex: utrumque membranaceuin, tenue.

$\Lambda$ டв. Fernini conforme, camofuin pallidum.

EMB. minutifinus, fubglobofus, in imo albunine pofitus, niveus. Cotyl. brevifimx. Rad. fubconica, relative centripeta.

a.) Frotus completus. A.) Caprula feparata. b. B.) Semina soluta. C.) Semen transierie Settum. D.) Embryo intra albumen. E.) Idem Separatus. 


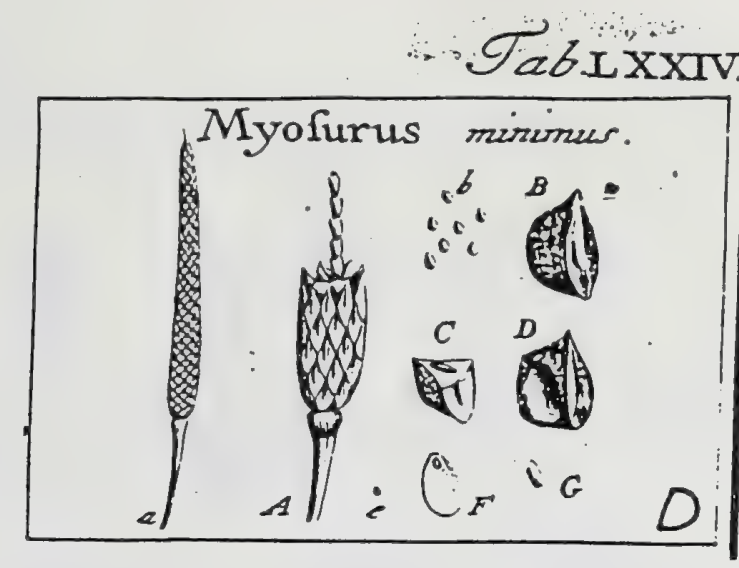

\section{J. Gaertner (1788) V01.1}

CCCCLVIII. MYOSURUS. LINN. gen. 394. 354

Calyx pentaphyllus deciduus. Cor. pentapetala : unguibus poro nectarifero. Stam quinque ad duodecim. Styl. nullus. Receptac. fubulatum. Semina fungofo cors: ticata, pendula. Enbryo inverfus.

Myosurus ininimus. Tab. 74. fig. 5 .

Canda muris: Dod. pempt. 112. OEd. fl. dan. t. 406 .

Miyofurus. Hatl. hift. 2. n. II59. LinN. Jilft. veg. 308 .

PER. Caplulx plurinx, fungofo coriacex, a feminibus ipfis non diflindtx.

REC. commune lubulatum, nodulofum, longiffinum, capfulas in fitu verticali funit nens; proprium, funiculus capillaris, fuperiorem loculamenti extremitatem intrans atque femen in fitu penduio fuflinens.

$S E$ s. numerofifima., cunteiformi compreffa : latere exteriori ferrugineo, lineari lanceoJato, fulco medio elevato notato; lateribus reliyuis femiovatis, planis, nigrican: tibus, in acutiffumum angulum convergentibus.

IN T. duplex : exterius coriaceo fpongiofum, nucleo multoties majus, atque intus laminấ chartaceî laxvigatñ in loculamentum ellipticum formatum; interius tenuifímum, lutefcens, nucleo adnatum.

N LB. ellipticum, comprefum, carnofum, duriusculum, pallidum.

Eм в. minutiffunus, teretiusculus, lacteus. Cotyl.. trevilinnx. Rad.. teretiuscula; umbilico \& receptaculo obverfa, fupera.

a.) Froflus interer. A.) Pars receptaculi deaudata, cam fitu capfularum. b. B.) Capfule f. Se-; mina feparatz. C.) Crufte exterioris fettio transverfalis. D.) Ejusdem fetio longitudinalis, eum !

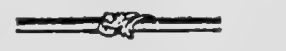

funiculo umbilieall, loeulamentum fuperne intrante. e.) Nucleus feparatus. F.) Embryonis Ggura \& fitus, intra albumea. G.) Embryo feparatus.

Embryo apparenter quidem inverfus atque radicula fupera eft, quoniam vero receptaculo non oppofitus, fed prope ipfum umbilicuin collocatus eft; ipfa quoque radicula inferum re vera tenet locum, ficut in Ranunculo.

Sulcus elevatus in exteriori caplulae latere, nihil aliud effe videtur, quam fylus, ovario longitudinaliter adnatus. 


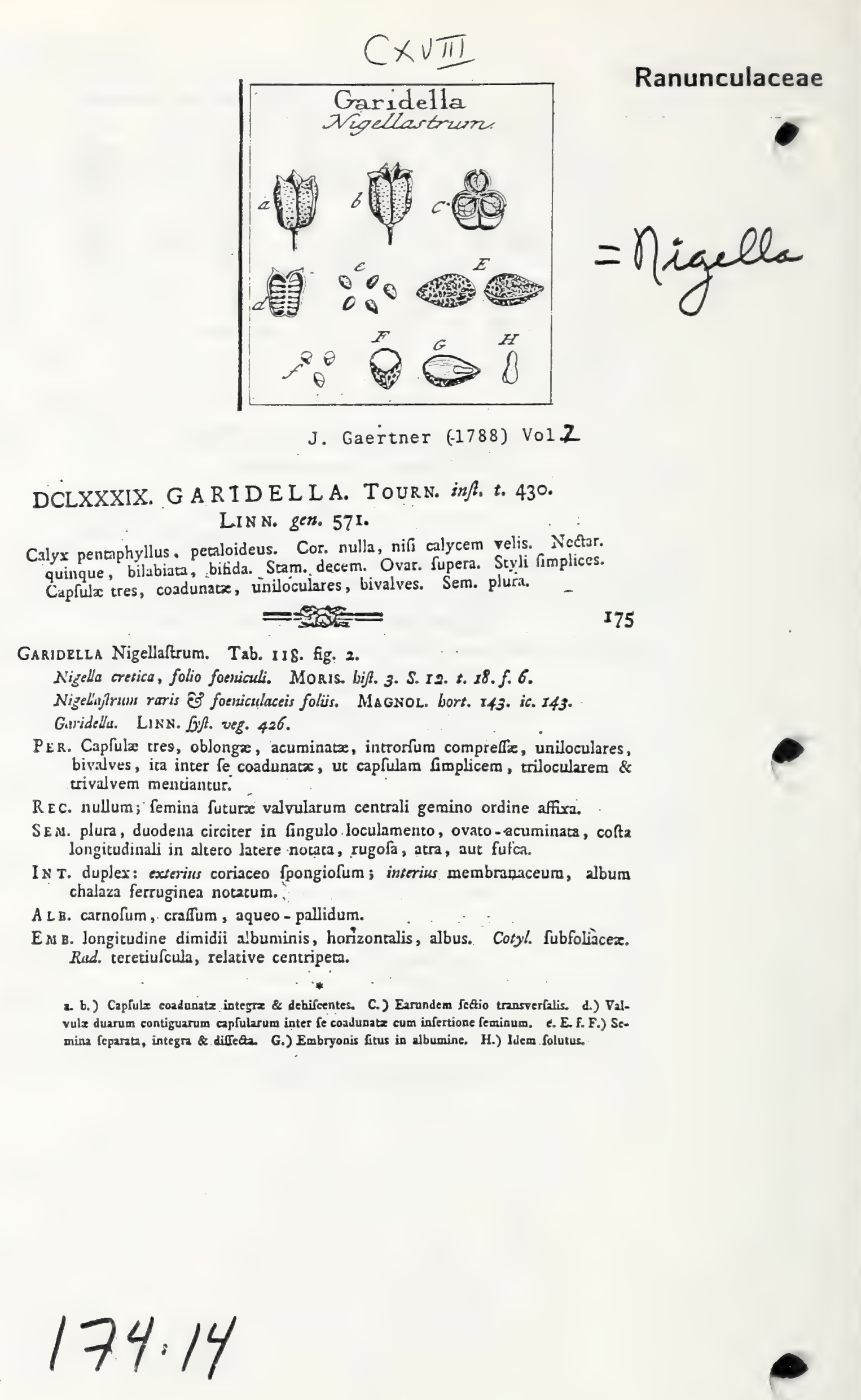


Tab. CXVIII.

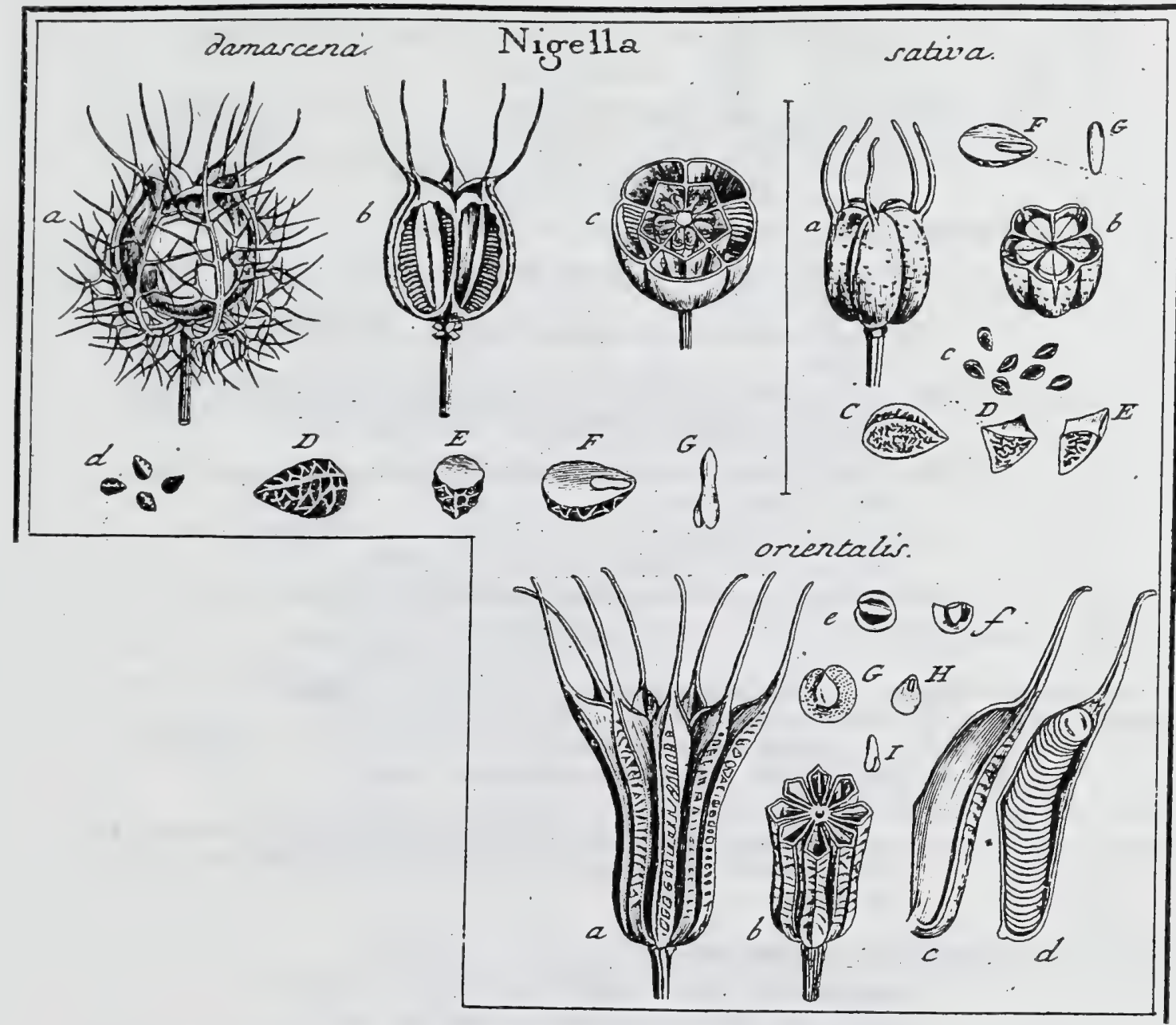

$174.15 A$ 


\section{J. Gaertner (1788) Vol.2}

\section{NI GELI A.' TOURN. inf. t. I34. LINN. gert. 685 .}

Calyx pentaphyllus, foliolis petaloideis. Cor. nulla. Nect. quinque aue plura, bilabiata. Sem. numerofa. Ovar. fupera, in ftylos fimplices defnentia. Capfula plures, difcretx aut in unam coadunatz, roftraxe, introrfum dehifcentes. Sem. numerofa.

Nigella Gativa. Tab. 118. fig. I.

Melentbizan fativum. Caxs. epit. 551. Besz. Eyfr. aftrv. II. t. Te. f. 2. MiLL. ic. t. $287 . f . x$.

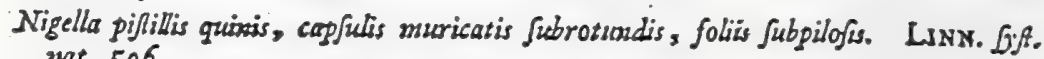
nas. 506.

PER. Capfula fimplex, ovata, rotunde pentagona, itylis perfiftentibus filiformibus quinqueroftrata, punctis callols fparfis fcibrat, quinguelocularis, apice introrfum dehifcens.

REC. nulum; femina gemint ordine longitudinali angulo I margini centrali difepimentorum affixa.

SEs. plurima, ovata, verfus umbilicum acuminata, cottis glabris acutis varie augulats \& inter eas rugofa, fpadicea, aut furca.

IXI. duplex: exterius fubcoriaceum, fpongiofum, interius membranaceum.

A Es. ovato-acuminatum, aut femini conforme, craffum, carnofum, aqueopallidum, debili anifi aut curiandri odore imbutum.

Eм в. longitudine dimidii albuminis, lacteus, horizontalis. Cotyl. planiufcula, breves. Rad. longa, recta, centripets.

2. b.) Caplula integra \& diffecta, cum infertione feninum. c. C.) Semina feparata integta, \& D. E.) Eadem dificeta. F.) Albumen longitudinaliter diffeetum, cum fitu Embryonis. G.) Einbryo feparatus.

Nigelia damafcena. ibid.

Nigella borteriss. Brakw. berb. t. 558. MiLL. ic. t. 187 . f. 2.

Nigella foribus invobucro foliofo cinctis. LiNs. $5 y$ f. veg. 506 .

Capfula fimplex (a. b. c.), fubglobofa, filiformi-quinqueroftrata, quinquelocularis (c.), inflata: loculfmentis feil. verticaliter, upe membraux tenuifimx diaphanæ albæ (b. c.) divifis in concamerationem exteriorem majorèm inanem, atque interiorem, minorem, feminiferam. Sémina in quovis loculo circiter viginti quatuor, ovato - acuminata, colta fi: raphe longitudinali in altero latere notata, rugofa, elevato punctata, atra. Albumen (E. F.) carnofum, craffum, aqueo-pallidum, vix aut plane non odoratum. Enbryo (F. G.) lutefcens. Cotyledones fubfoliacex. Radicula teretiufcula, centripeas.

Nigella orientalis. ibid.

Nigella cbalepenfis lutea, corniculis longioribus. MORIs. biff. 3. S. 12. t. 18. f. 10. Nigella pifilitis denis corolla longioribus. LINN. Lyfo veg. 506 .

Capfula compofita (a. b. ) ex capfulis leguminolis (c. d.), partialibus, octonis aut denis, ultra medium fux longitudinis inter fe inferne connatis, fuperne vero liberis atque modice $a b$ invicem divergentibus, hinc rugofis atque angulatis, inde comprelisis \& glabris, in roftrum quoque compreflum definentibus, atque futura fua interna dohifcentibus. Semina (d. e. fi) rotundata, compreffa, fufca, lato nargine membrnnaceo ciricta. Albumen (G. H.) feminis nargine multo anguftiös, carnofum, pallidum, inodorum. Enibryo (H. I.) fubcompreffus, linearis, lacteus. Cotyl breves. Radic. relative centripeta.

$$
174.15 B
$$




\section{Tab.LXXIV.}

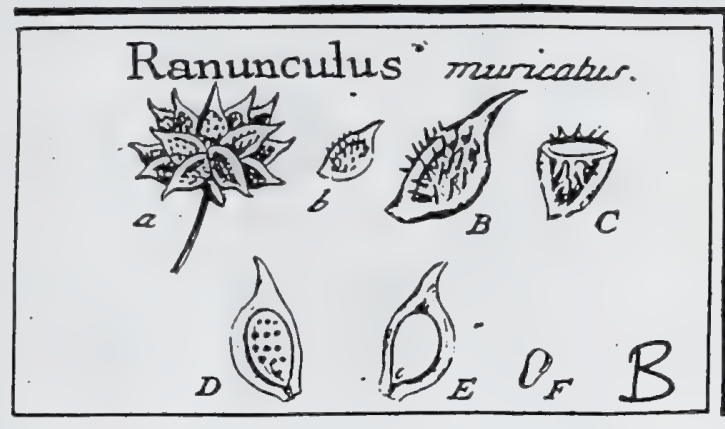

\section{J. Gaertner (1788) Vol. 1}

CCCCLVII. RANUNCULUS. Tourn. t. 149. LIN g. gen. 699. 353

Calyx pentaphyllus deciduus. Cor. pentapetala: unguibus poro nectatifero. Stam. plurima, thalamea. Styi. breves perfiftentes. Semina incruftata, erecta.

RANUNCULUS muricatus. 'Tab. 74. fig. 4 .

Ranunculus fyluefris III. Don. pempt. 427. OEDER. fl. dals. t. 219.

Ranunculus feminilus aculentis, foliis tripartitis, lobis longe petiolatis bipartitis E' tripartitis, acute incifis. HaLL. hifl. 2. n. 1176 .

Ranunculus arvenfis ES muricatus. LiN N. Sißß. veg. 518. n. 37. 38.

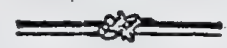

PER. Capfulz plures coriacex, a feminibus ipfis non dintinctx.

REC. commune nullum, prater fundum calycis; proprium foniculus brevifimin obfoletus, balin capfula intrans.

SEM. plura, ad duodecin, ovato lanceolata, rofrata, compreffa, margine callöoto duro, albicante, glabro cincta, in medio difco fubferrugineo aculeolis brevibing horizontaliter patentibus, utrinque echinata.

IN T. duplex: exterius coriaceum; interius membranaceum, tenuifinum.

A Lв. ovatum, compreffum, ab impreffionibus aculeorum inæquabile, carnofum, albuen.

E M B. minutulus, erectus, albus, in bafi albuminis locatus. Cotyl. obovatx, planiuse? culx. Rad. teretiuscula infera. 3.) Frufius integer. b. B.) Capfula f. (emen feraratum. C.) Idem transverfe featum, D.) As.j
bumen denudatum. E.) Embryonis fitus intra slbumen, F.) Embryo Separatus. 


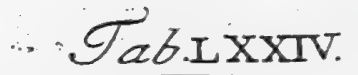

Ranunculaceae

Thalictrum sibiricum

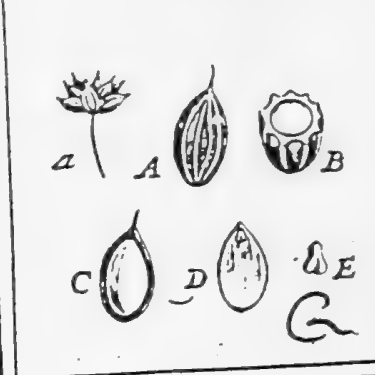

J. Gaertner (1788) Vol. 1

CCCCLX. THALICTRUM. TOURN. t. 143. LIN gen.697. $353^{\circ}=$

Calyx nullus. Cor, tetra-1. pentapetala, Stam. odto 1. plurina thalamea. Styl. breves. Capfulx plures roftellatx. Embryo inverfus.

TH A ICT RU M fibiricum. Tab. 74. fig. 7.

Thalifrum foliis tripartitis: foliolis Jubreflexis argute incifis, floribus ccrnuis. LIN N. Jyft. veg. 513 .

356

Pe R. Capfulz quinque, ad octo, fpongiofo coriacex, parvx, feminiformes, oratz. roftellatz, fulcatx, uniloculares, evalves.

REc. commune, anguniffumum; proprium, funiculus umbilicalis tenuifimus, a caps fula vertice ad feminis bafin defenders.

S E s. folitaria, ovata, fupra attenuata, e fpadiceo-rufefcentia, tuberculo fufco ad bafiat? notata.

IN T. fimplicifimum, membranaceum.

А в. femini conforme, carnofum, durum, pallidum.

E M B. minutus, inverfus, lacleus, in fuprema parte albuninis pofitus. Cotyl. comprefTae. Rad. teretiuscula fupera.

2.) Fratus integer. A. B.) Capfula integra \& diffetta, C.) Nueleus denadatus. D.) Extfya nis fitas intra albumen. E.) Embryo separatus.

174.17 


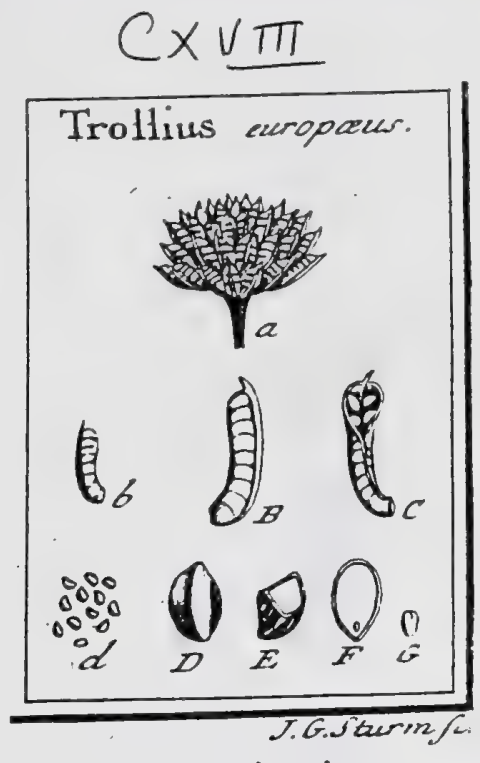

Ranunculaceae

J. Gaertner (17.88) Vol, 2

DCXCII. T R O L L I U S. LINN. gen. 700. 176

Cal. nullus. Cor. polypecala. Nectar. novem, lincaria. Stam. numerofi. Ovaria plura, fupera. Styl. nulli. Stigm. acuminata. Capfulx plures, in capitulum colleckx. Sen. plura.

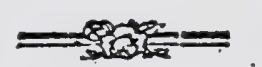

Troclius europzeus. Tab. IIs. fig. s.

Raniunculus fiore globofa: DOD. penpe. 427 . CAM. epis. $3^{85}$. OED: fior. dats. t. 133 .

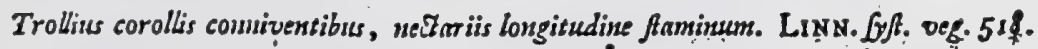

PER. Capfulse leguminofie plures; fupra trigina, in capitulum collecte- tereuiufcula, incurve, nervis transverfalibus notate, apice mucranate, uniloculares, latere interno dehifcentes.

Rzc. nullum: femina future dehifcenti affira.

S $\varepsilon$ N. plura, circiter duódecin in fingula capfula, parva, angulata, glabra.

IN T. duplex: chartaceum, aridum; atque membranaceum, tenuifimum.

$A L$ в. femini cohforme, carnofum; album.

E s B. minutus, fubglobofus, niveus. Cotyl. brevifima. Rad. relative centripeta.

a.) Erutus integer. b. B. C) Capiula feparata, integra \& dehifcens. d. D.) Sepmina Lafuta

E. F.) Seminis fetio transverfalis atque longitudinalis. G.) Embryo folutus. 


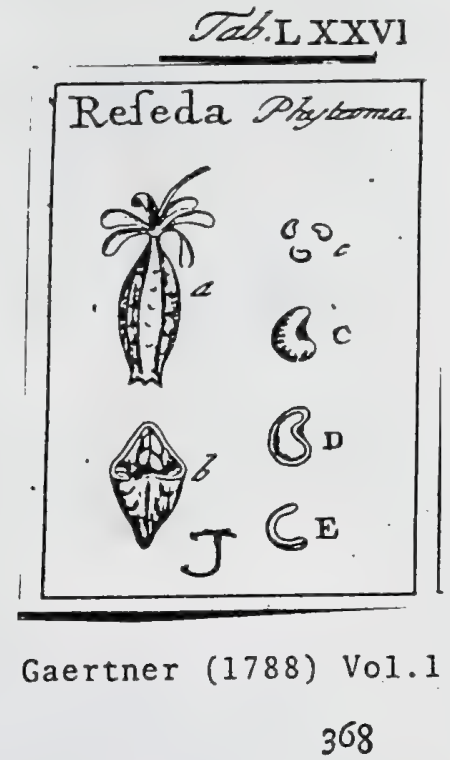

CCCCLXXX. RESEDA. TourN. t. 238 . LIN gen. 608 .

Calyx quadri-1. fexpartitus. Cor. quadri -1 hexapetala, laciniata. Stam. octo, duodecim, aut plura. Styl. tres l. quatuor. Capfula apice pervia. Recept. parietzlia. Semina numerofa, fubreniformia.

RESEDA Phytevma. Tab. $76 \%$ fig. 7 .

Rrfedre affinis Plinteuna. ВАUн. prodr. 42. e. ic. J A c C. auflr. 2. t. 232.

Rrfedn foliis radicalibus integris, caulinis integris $\mathcal{E}$ fenitrilobis, calycibus fexfutis florem fuperantibus. HaLl. hifh. 2. "1. 1057.

licfirin fuliis integris trilobisque, calycibus maximis fexpartitis. Lxwa. fyfl. i.g. 478 .

P ER. Capfula membranacea, ovato oblonga, trigona, in lateribus fria deprefta infcripta, unilocularis, apice tridentata, pervia.

RE. . anguli capfulx, aliquantum incraftati, quibus femina duplici ferie affixa.

SE ม. plura, circiter viginti quatuor, reniformi incurva, rugis munutiflimis fcabrata, cincreo fpadicea, aut albicantia.

IN T. triples: extinum fellicula tenuis, transparens; medium crullaceum fcabrum, ferrugineum; intimum membratuaceum, intus carnolum.

A в в. nullum, prater tcnuifimam laminam carnofan integumenti interni.

E.M . tcretiusculus, arctrattis, inxerfus, luteus. Cotyl. carnofx, crafliusculx, plano convexix. Rad. attenuata, fuperiorem feminis paitem tenens, centrifuga.

a.) Capfula integra. b.) Eadem diffcta cum ferninum fitu. c. C.) Semina foluta. D.) Nucleus denudatus. E.) Embryo (eparatus.

$$
175.1
$$



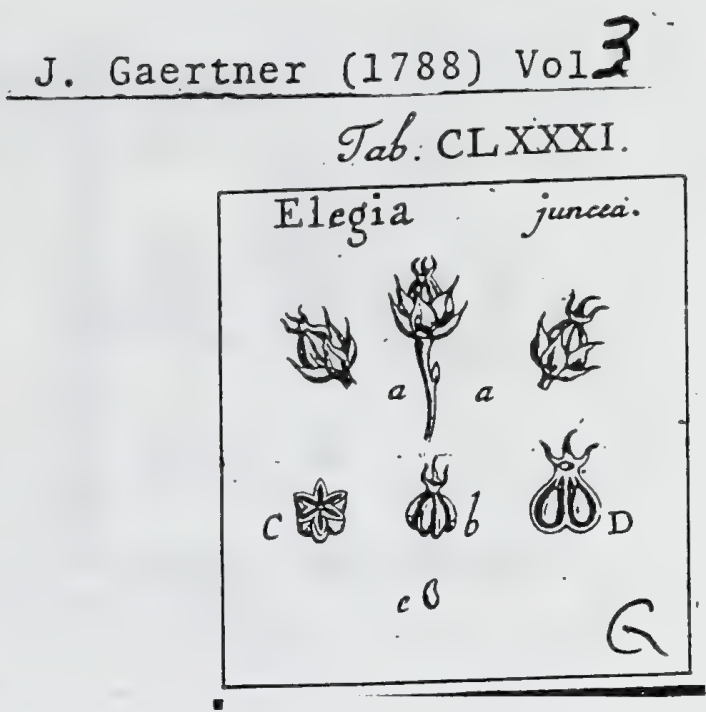

J. Gaertner (1788) Vol3

\author{
8. E L E G I A.
}

LIXx. mant. 2. p. r62. gen. pl. ed. Schreb. r494

Flores fexu diftincti in feparatis plantis. MAS. Spica ovata, ex numerofis fquamis calycinis uniforis \& ex corollulis hexapetalis triftemonibus, ut in Reftione compofita. FEM. Flores glomerati, fpathis partialibus vagis interftineti. Cal. fubhemifphxricus, imbricatus fquamis quinis- feptenis, cartila-

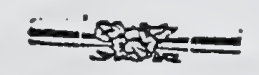

gineis, concavis, ovatis, argute acuminatis, angulo dorjali fubcarinatis, inxqualibus. Cor. nulla, nec ejus veltigium in maturo calyce; (at fecun. dum Linnzum \& Rottbollium hexapetala). Capfula ovato - pyranidata, tribus ftylis perfiftentibus terminata, ftellato-hexangularis, fexlocularis.

Eérgia juncea. Tab. 181. fig. 7 -

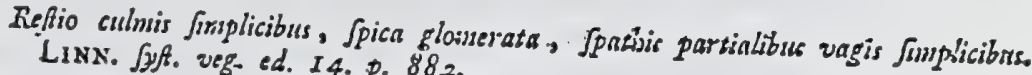

Juces. LINN. mant. 2. p. 297.

A Cl. Thunberg.

PER. Capfula fupera, coriaces, ovato - pyramidata, apice tribus ftylis perfifexlocularis, ad angut tribadri - \& frequentifime hexagono - ftellata, tri-

R.E. fruczus nullum angulos externos dehifcens.

niculus umbülicalis crafus, brevis, calycis arctifime adnata ; Serzanis fufemeuque pendulum fuftinens, ex apice loculamentorum oriundus,

$S p N$ in Gingulo loculo fingula ferrugineum.

IN T. Gimplex, membranaceum

A L B. . . . .

$E_{M B} B_{r} \ldots$

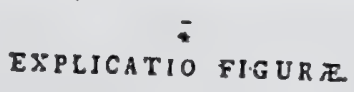

a. a.) Calyeer feminci maturi feparati. b.) Capfula denudata integra. C. . Eajen transterie diffead. D) Ejusdem featin longitudinalis, cum duobus bculis apertis, feminumgos infertio nc. e.) Semen caltum, feparatum, magnitudine naturali.

Liquet ex his, Elegriam, Willdenoviam \& Reftionem ex fpicarum mafcula. rum \& ex totius habitus externi confenlu, dretilfmo utique affinituris bus, in unum effe junctis; fed \& perinde hyuet, quod his non obftantiinter Reftionem genus compingi abfolute nequeant: figuidem difinctiva binationem prorfo Willdenoviam figna, fatis fint gravia, ut earum cum-

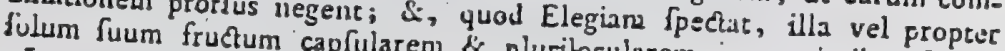
nōn poffet, G \& onaia reliqua elfent paria.

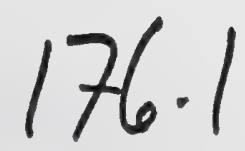




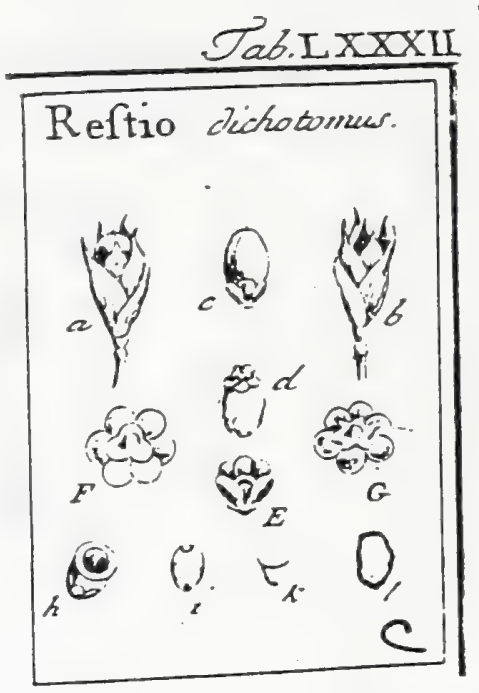

J. Gaertner

(1788) Vol 2

I2.

\section{R ES T I O. LINN. gen. I33I.}

Flores mafculi \& feminci in diftinctis culmis. MAS. Spica ovata, imbricata funamis urififoris membranaceis. Cor. hexapelata, perfiftens. Stam. tria. FEM. Involucrum fpicfforme, uniforum, ovatum, imbricatum fquamis quatuor 1. fex, membranaceis, ovacis, longe acuminatis. Cal. nullus, fed ejus loco orbiculus Spongiofus; corollx ad aliquam diftantiam fub. jectus, nunc rotunde trilobus, nunc vero ftellato-fexdentatus. Cor. membranacea, hexapelata: petalis rotundatis, concavis, fpadiceis, margine albis. Styli tres. Nux lapidea unilocularis. Semen unicum, fubglobofum.

Rest10 dichotonus. Tab. 82. fig. 3 .

Equifetum junceum nigrinodium. BREYN. Cent. $176 . t .9$ r.

Reftio dichotomus, fcapis floriferis longifinis, pmiaula filiformi untante laxa, spicis ablongis fquarrofiss. RoTTB. defcr. p. 2. t. I. f. I. mas.

Refio culmis dichotomis, Jpicis folitariis. LINN. fyft. veg. $88 \mathrm{~s}$.

Ex dono Cl. Thunbergil, qui monuit, effe varietatem majorem $R$. dichotomi communis.

PER. Nux elliptico globofa, lapidea, glabra, extus \& fractura nigro.caftanea, intus pellicula alba veftita, unilocularis, evalvis, corolla perfiftente bafi cincta.

Rec. nullum : femen vertici nocis affuxum.

SEM. unicum, ovato - globofum, pallide ftramineum aut rufefcens, lata ares umbilicali nigro - fufca in vertice notatum.

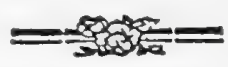

IN T. fimplex, membranaceurn, tenue.

A LB. femini conforme, carnofum, aqueo - pallidum.

EN B. fubcylindricus, brevifimus, monocotyledoneus, in bafi albuminis locatus.

2. b.) Involucrum femineum aucem excipiens c. d.) Nux in fitu naturali atque inverio, cum a.ihxrentibus fabi feminei floris icliquiis. E) Corolla Separata. F. G.) Eadem inveriz, cum orbiculo fungofo, trilobo, aut fexdentato. h.) Nux transverfe feta i.) Semen in fitu natarali, cum furea verticis area. K.) Albumen transverfe $-\&$ l.) idem longitudinaliter fetum.

Floris mafculi characterem LiNNeUS rectius, quam RotTBOELlius tradidit; fed feminei foris character Linnæanus, maximam partem ertoneus elt, \& præter falfam fructus fabrican, id quoque peccat, quod femineas fpicas, mafculis Gmiles, adeoque \& multilloras, inıuat. Monemus cetera, quod in noftris exemplis ne unicum quiden femen fuerit probe maturum; quare alii in veram fedem Embryonis ulterius inquirant: nam poterit ille forfan in vertice feminis, fub area uıbilicali effe locatus, etfi Sclerix \& congenerum fabrica, id fuadere non videatur. 
J. Gaertner (1788)'voi.3

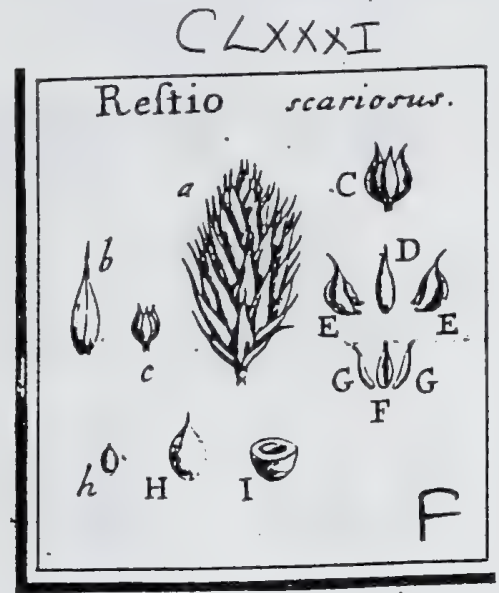

J. Gaertner (1788) Vol

\section{R E S T I 0 .}

Linn. gen. r33r. cd. Sclireb. 1495. Juss. gcm. p. 44.

L A NIA B C K ill. gen. t. 804 .

Flores fexu diftinai in diverfis ftirpibus. MAS. Cal. fquamx menbranncex, uniflora, in fpicam ovatam digeftx. Cor. hexapetala, petalis membranaceis, oblongis perfiftentibus. Stamina tria. FEM. Cal. fquami membranacex. unitore, in fpicam ovatam, mari fimillimam digeftx. Cor. hexapetals.

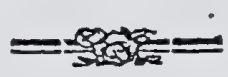

calycis fquama femper brevior : petalis perfiftentibus, membranaceis, inxqualibus : exterioribus tribus plerumque majoribus; interioribus minoribus $\&$ angu(tionibus. Ovarium fuperum. Styl. duo'l. tres. Nucula lapilea, feffilis, unilocularis, evalvis, monofperma.

Restio feariofus. Tab. 181. fig. 6.

Teftio culmo fsinplici foliofo fpicarum fquamis lanceolatis feariofss. THUNB. Diff. de Refione p. I5. "1. 22.

A Cl. Thunberg.

PER. Nucula parvi, ovato-acuminata, lenticulari-comprefra, ad margines acuriffima, lapidea, rufefcenti-ferruginea, nitida, unilocularis, evalvis.

REc. nullum, nec ejus veftigium, fed inucula in fundo corollse feffilis.

SEM. unicum, cavitati nucis conforme, ex loculamenti apice pendulum.

ALB....

Емв....

\section{EXPIICATIO FIGURE.}

2.) Spica feminea integra. b.) Calycis fyuama feperata. c. C.) Corolla iategrz, a dorfo feo parte fua exteriore \& cunvexa Spedata. D. E. E) Petala exieriora feparata: bosum duo latesalia (E. E.) Haviculariz, earioa in onargineun memuranaceum definente. F. G. G.) Petala interiora, nucis ventri \& lateribus aecumbentia. b. H.) Nucula integra, feparata. 1.) Ejus redio transverf́alis.

Corolla feminea in variis varia: in $\mathrm{R}$. Scariofo, fpicifero, diftacbio Rotrb. t. 3. f. f. \& aliis, plano - convexa, brevis, \& duobus petalis navicularibus ftipata eft; contra autem in aliis oblonga, atque petalis omnibus fubxqualibus. dotata deprehenditur, ut in R. triticeo \& thyrfffero. Rotru. t. 3. f. I. 4 . 


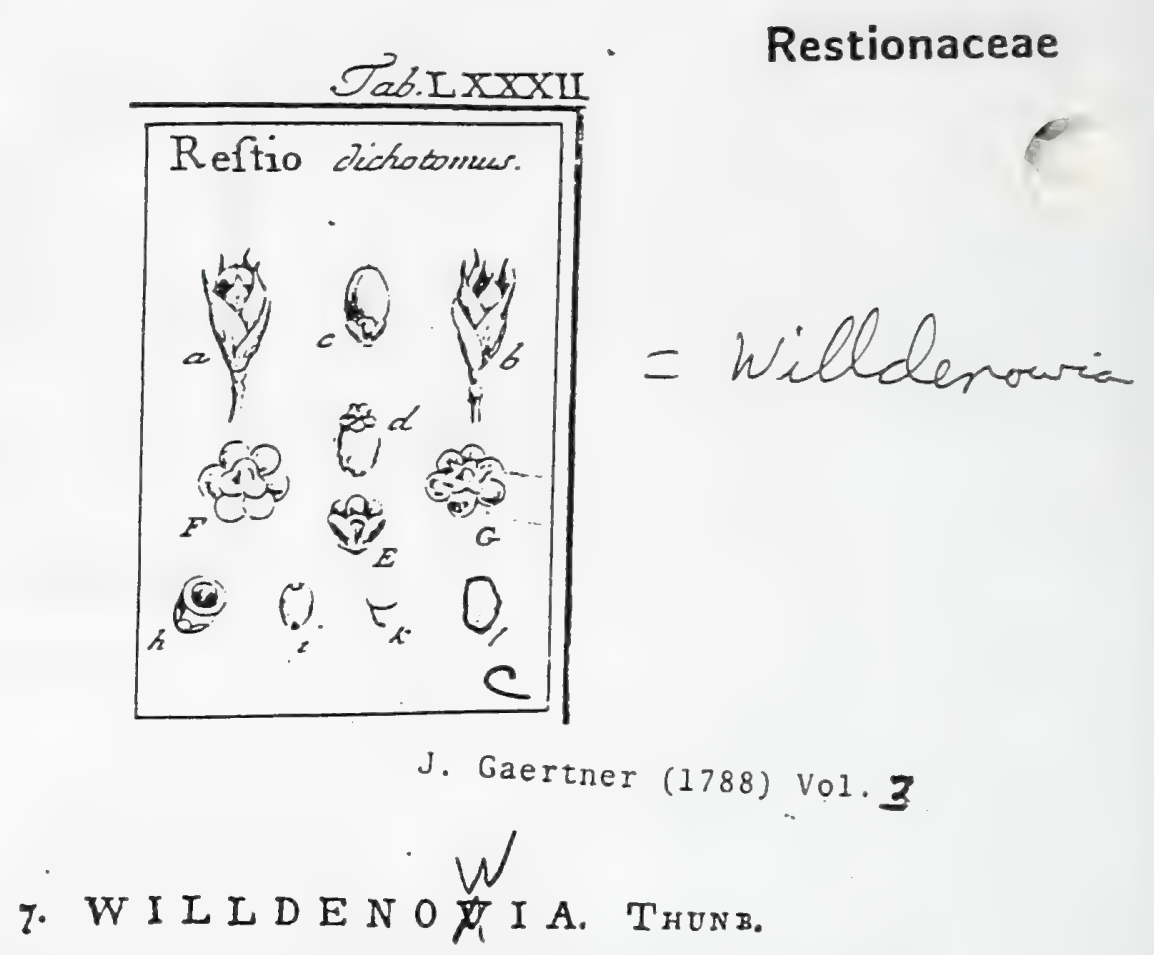

Flores fexu diftincti in feparatis ftirpibus. MAS. Spica ovata ex numerofis fquamis calycinis unitoris, \& ex corollulis hexapetalis triftemonibus compofita, ut in Reftione. FEMI. Flos folitarius, plerumque terminalis. Calo turbinatus, imbricatus fquanis coriaceis, concavis, ovatis, acuminatis, inzqualibus. Cor. hexapctala, petalis rotundatis, concavis, zqualibus, fcariofis; baf munita receptaculo proprio fungofo, tri-1. feslobato: Nux lapidea, unilocularis, evalvis, monofperma.

WILLdeNovia teres. THUN8. in litt.

Equifetum junceums nigrinodiun, BREYN. Cent, 376. :. gro

8

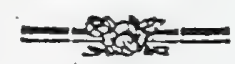

Reftio (dichotonus) Scapis foriferis longifimis, panicula fliforml nutante laxa; Jpicis oblongis fquarrofis. RoTIR pl. defor $E^{\circ} i c_{0} p .2$ t. I. f. I mas.

Refio culno proftiato, ramis fliformibus fecundis adjecendentibus, fpicis terminalibus pluribus. FrIs. defar. I772. p. IO. n. 3.

Reftio culmis dichosomis, Jpicis folitariit. LiNN. Syft. veg. ed. 14. p. 88x.

Reftio dichotomus. Carpol. noftr. T. 2. p. 12, t. 82, f. 3.

PER. Nux elliptico-globola, lipidea., glabra, extus \& fractura nigro- caltanea, intus pellicula alba veftica, unilocularis, evalvis, corolk perGiltente bafi cincta.

$R$ Ec. nullum : femen yertici nucis affuxum.

SEN, unicum, ovato-globofum, pallide ftramineum aut rufefcens, lata area umbilicali nigro-fufca in vertice nocatum.

IN T. Gimplex, membranaceun, tenue.

A L . femini conforme, carnofum, aqueo-pallidum.

EM B. fubcylindricus, breviflimus, monocotyledoneus, in bafi albuminis locatus.

\section{EXPLICATIO FIGURE.}

2. b.) Inroluerum fearineum nucem exeipiens. c. J.) Nux in Gtu naturali atque inverfo, cum adharentibus Gibi feminei Horis reliquiis, E.) Corolia feparata. E. G., Eadem inverfa, eum orbiculo fungofo, trilobo, aut fexdentato. h.) Nux transrerfe fefa. i.) Semea in Gtu naturali cum fufca vetricis area. K.) Albumea transverfe $-\&$ L) idem longitadinaliter feetrm.

Quamvis defcriptioni partium feninearum hujus plactz, in Operis noftri Vol. 2. I. c. tradita, nil quidquam addendum habeamus, melius tamen effe duximus, illam verbo ad verbum huc transferre, ut comparatio cum procedenti nec non cum requenti genere reddatur facilior. Difcrimen effentiale inter Willdenoviam \& Reftionem confiftic itaque : $1^{\circ}$ in Calyce femineo folitario turbinato \& ex fquamis pluribus imbricato. $2^{\circ}$ in Corolla uniformi rofacea atque bafi proprio receptaculo fungofo munita; \& $3^{\circ}$ in Nuoe, corolla fua quadruplo longiore \& conftanter folitaria. 


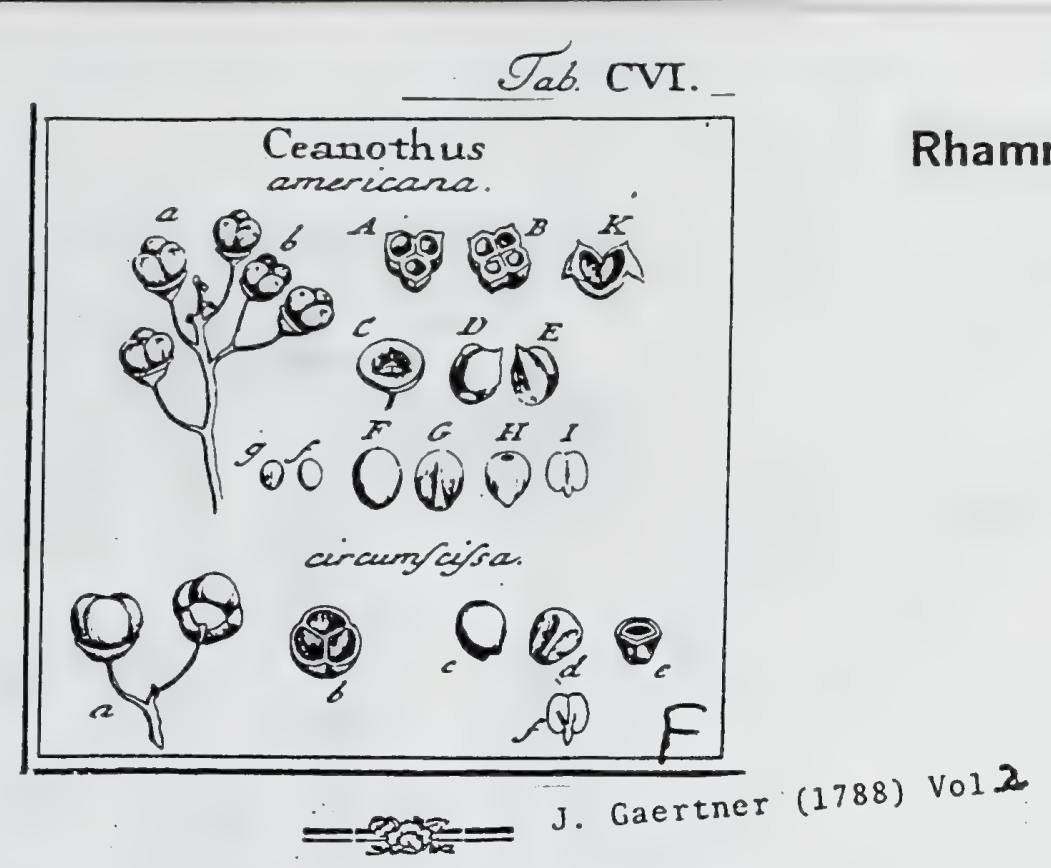

Calyx monophyllus, quinquefidus. Cor. pentapetala: petalis unguiculatis, lurmieato faccatis. Stam. quimg̨ue. Ovar. fuperum. Styl. femitrifidus. Capfula corticata, tricocca. Semina folitaria.

Ceanothus americana. Tab. 106. fig. 4.

Evonymus novi belgii, comi femine foliis. Сомм. bort. amf. r. p. 167. t.86.

Cennothus anericanus. EHRET. decad. t. 94. MiLl. ic. t. 86.

Ceanoshus foliis trinerwiis. LINN. Jy/l. veg. 2.35 .

РЕв. Capfula fupera, uri-1. tetracoccal, corticata. Curtex ante maturitatem herbaceo carnofus, mollis, poltea vero exarefcens in cuticulim tenuem, tubercula fpongiofa ac criftas anguftifimas in vertice \& dorfo cocculorum formantem. Cocculi tres 1 . quatuor, cartilaginei, tenues, intus lxvigitiffimi, futura interna elaftice dehifcentes \& per maturitatem finonte a $f_{e}$ invicen fecedentes.

R.E c. commume, calycis difcus concavus, cui cocculorum bafis derafa affixa; proprinm, funiculus umbilicalis brevilfimus, per foranen bafeos cucculorum intrans \& ad femina pergens.

SEM. folitaria, ovato-rotundata, linc convexn, inde obfoletillime angulata, fpadicer, fplendentia.

IxT. duplex: exterins cruftaceum; tenue, fragile; incerins nembranaceum, chalaza ferruginea in vertice feminis not:tum, intus-fubcarnofum.

A L B. vix ullum, proter laminam integumenti interni carnofam, albam.

Eл в. magnitudine feminis, erectus, lutefcens. Cotyl. fuborbiculatx, planx, carnolix, craffx. Rad. brevis, infera.

2. A. b. B.) Capfulz tri - \& tetraeocez C.), Calycis perfiftentis difcus, cocculis pro receptacule communi inferviens. D E.) Cocculi a parte dorfali \& veutrali fpectati. K.) Cocculus dechifcens. F. F. g. G.) Semen ab utroque laterc (pettatum. H.) Intcyumeatum nuclei, proprium, chalaza in vertice notatum. I.) Embryo denudatus.

Ceanothus circumfciffa. ibid.

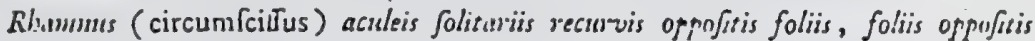
bifiriis obcordutis. LIN.. Juppl. 152. fyjl. veg. $=35$.

Hun - midi. Zeylonenf. E collect. fcm. hort. lugdb; \& ex Infula Mauritii per Cl. Hermann. Profo argentor.

Capfula (a. b.) fubglobofa, calycis difco rotundato arcte adnata, rotunde trigona, extus rufefcens, intus albicans, trilocularis (b.), non nili proffione in tres valvulas dehifcens. Diffepinenta fimplicia, medio valvuliarum inferta, chartacez. Semina (c. d.) folitaria, fubrotunda, hisce convexil, inde oblo-

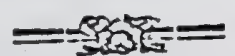

III

lete angulata, teftacea aut nigro fufca, non Pplendentia. Integunsentum exterius (c) cruftaceum, crafum, durum; interius tenuilfinaum, fpadiceun. Albumen curnolum, modice crafum, albun. Embryo (f.) erectus, lutef cens. Cotyled. planix, carnofe, fubrotundx. Radic. bievis, infera.:

Ambigit hace inter Ceanothum atque Rhananun, ut tamen priori magis videatur vicins, propter pericarpium exfuccum, pretTone in valvulas regulares dehif cens, atque incus manifelta nembrana chartacea duplicatum. 


\section{J. Gaertner (1788) Vol 3 \\ $\mathcal{T}_{a b}$. CLXXXIII.}

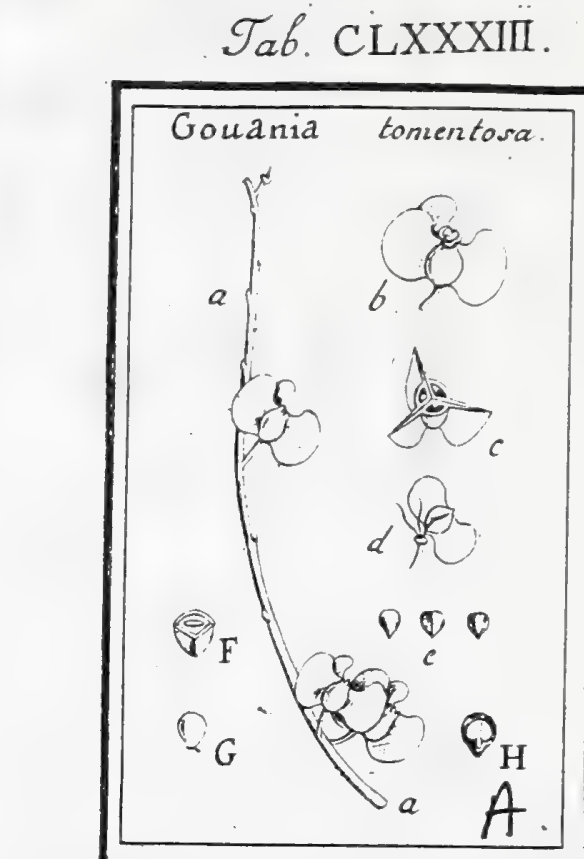

J. Gaertner (1788) Vol

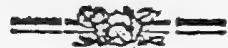

Jace. amer, p. 263. Lrin. gen. Ir57. ed. Schreb. I592. Juss, gen. p. $38 \mathrm{r}$ : LАМАВK ill. gen. t. 845 .

Calyx fuperus, turbinatus, qninquefidus. Cor. pentapetala, petalis cuculla: tis ftamina obtegentibus. Stam. quinque... Ovar. inferum. . Styl. tres: Samara tres in fructum triquetrum trialatum coadunata. Sen. folitaria. Flores fteriles fape fertilibus inixti.

Govania tomentofa. Tab. I83. fig. I.

Gouania foliis tomentofis. JACQ. bif. amer. p. $2 \sigma_{3}$.

an Gounnia (crenata, ) folis ovatis crenatis fubvillofis breviter petiolatis. LAMARCK EIE.?

A Cl. Thunberg.

F R U.CT. inferus, calycis tubo perfiftente triplicato coronatus, triqueter, trialatus, tripartibilis, $f_{a}$ ex tribus famaris conipofitus.

PgR. Samara parva, hinc convexiufcula, inde angulata, ovata, deorfum acuminata, utrinque ala magna rotundata fragili terminata, milocirlaris, evalvis, chartacea, fubfuica.

REC. commane, fetx tres capillares famararum apici obtufo infertx; proprium nullum, femina fundo loculamenti alfixa.

SE N. Solitaria, in univerfun tria, ovata, deorfum acuminata, hinc valde convexa, inde angulata, levigatifima, fplendentia, atra aut caftanea.

IN T. duplex : exterins cruftaceum fragile; interius membranaceum.

A L B. femini conforme, carnofun, albun.

E м в. erectus, longitudine fere albuminis. Cotyl orbiculate, foliacex, planx. Rad. teretiufcula, difcreta, infera.

\section{EXPIICATIO FIGURE.}

3. 2.) Raccmi frucifcri pars. b.) Fru\&us reparatus, aliqquantulum naturali major. c.) Ejus feQtio transverfalis. d.) Receptacultum commune trifctofum, cum faunarz folitarix facie interna. e.) Senina integra, ab utroque Iatere fpeaata. F.) Seninis feato transverfalis. G.) Albumea denudatum. H.) Ejus fectio verticalis, cum fitu \& Gigura Embryonis.

Huc omnino fpectat Retinaria fcandeus. Carpol. Vol. 2. p. 187. t. 120. 


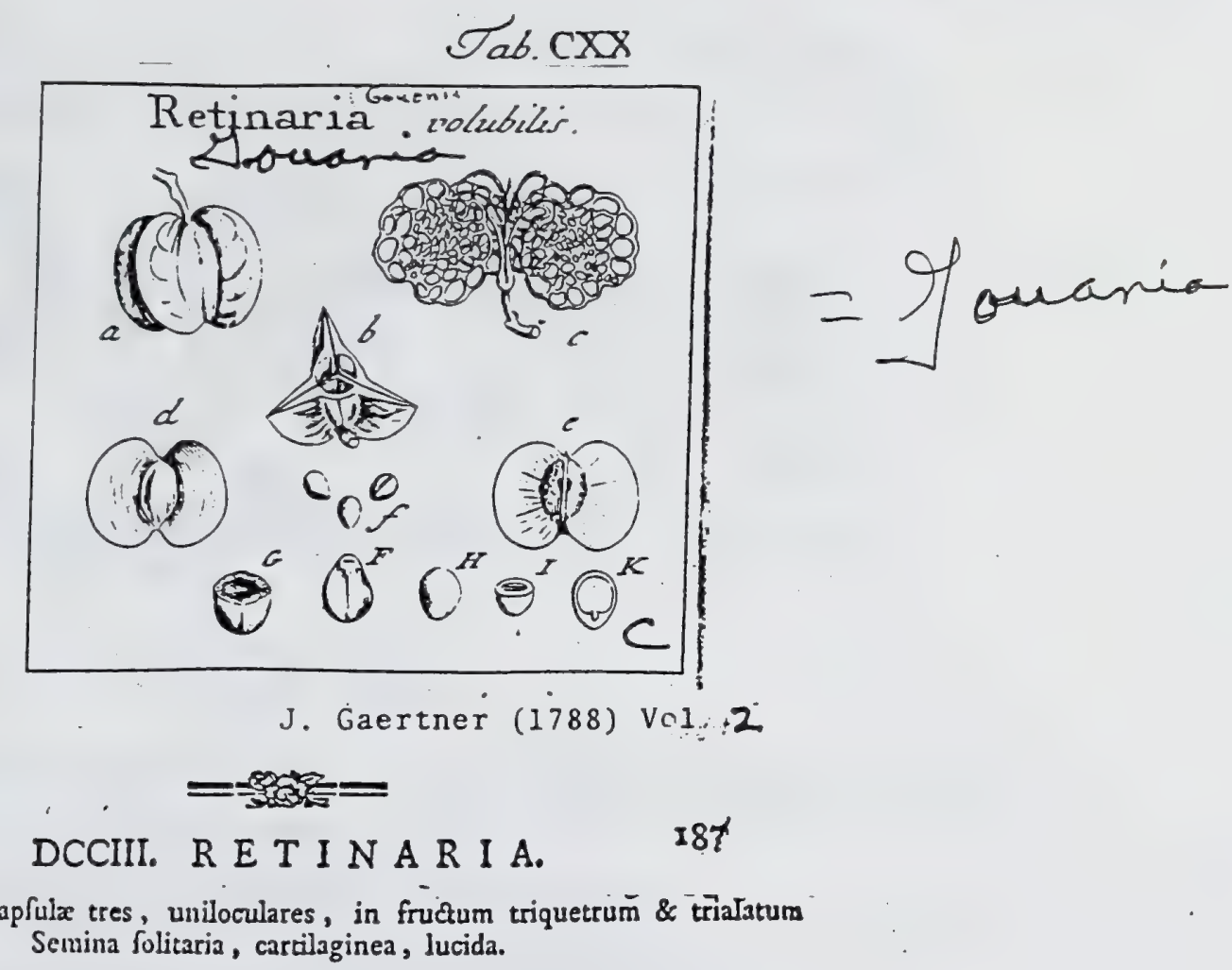

Retinaria fandens (volubilis in Icon.) Tab. 120. fig. 4

Arbrifeall grimpant de lisle de France. A Cl. Hermans.

PER. Capfula tres, ope corticis communis in Fructum triquetrum, rotunde trialatum ac trifariam dehifcentem coadunatz. Cortex tenuis, ex epidermide fugaci \& reticulo fibrofo capfularum dorfo incumbenti compofitus. Capfulx partiales cruftacex, duriufculx, ad utrumque fuum marginem in alam rotundaram, fuberofam \& febi adinftar fragilem ampliacc, hinc de. preffufcul $x$, albx, inde angulace \& ferrugineo-fphàcelatx, uniloculares, evalves.

REc. commune in asi fructus pofitum, fexfidum, filiforme: filis per pariz , junctis, fecundum angulum ventralem capfularum adfcendentibus, deinde vero.in carundem dorfum refexis atque fibrofum rete formantibus, cujus ope capfulx in fitu pendulo puft dehifcentiam fructus fuftinentur; propriuns nullum, prxter cicatriculam in fundo loculamentorum, cui femina affixa func.

SEM. fulitaria, ovata, deorfum anguftata, compreffiufcula, dura, faturate caftanea, lucida, rimula umbilicali tiansverfali in bafi notuta.

1* T. duplex: exterins cruftaccum, cralfum, durum, ix fibris contiguis horizontalibus, inftor gypfi ftriati, conpaguatum; interius membranaceum, tenuifrimum, fufcum.

A \&. carnofum, modice crafum, pallidum, fed ab aqua emollitum niveum.

E м в. magnitudine fere albuminis, erectus, dicotyledoneus, lutefcens. Cotyl. orbiculatx, foliacex, tenues. Rad. teretiufcula, brevis, infera.

$$
\text { *. }
$$

a.) Freaus integar. b.) Idem transverfe diftcaus, e.) Receptac retiformì d.) Capfulz partialis latus dor(ale. e.) Ejuisdem facies ventralis f. F.) Semina fepanta G.) Tefta feaninis transverim (ecta. H.) Albumen integrum. 1. K.) Idem transver(aliter atqque longitudiaaliter difectum, cum litu \& figura Embrgonis.

Refert ita Diofcorex fructum, ut ab externa fimilitudine deceptus, Gingulariffimam ejus fabricam internam ferutari neglexiffem, nifi id cafu fuiffet factum.

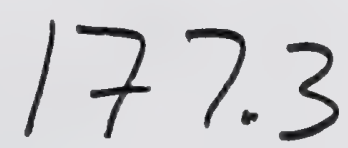




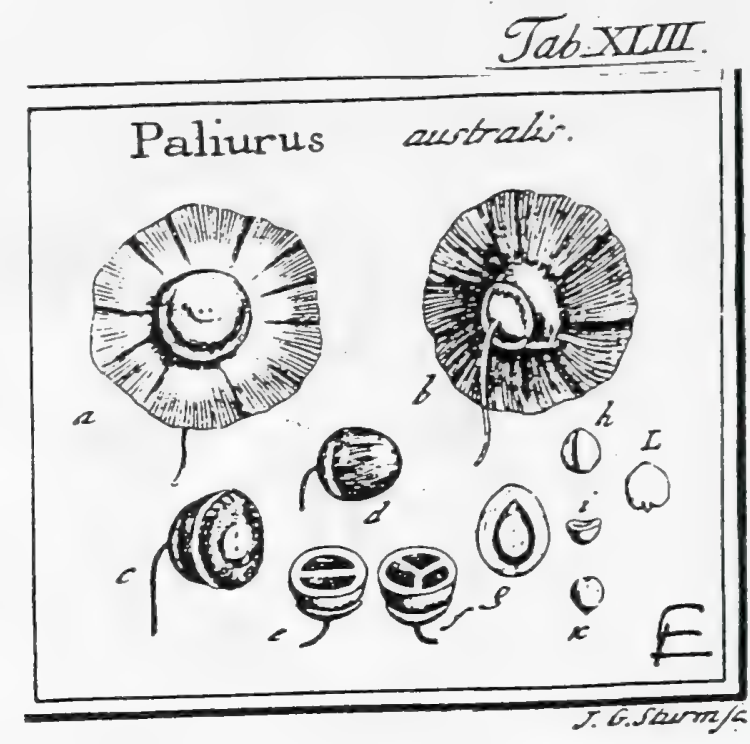

\section{J. Gaertner (1788) Vol.1}

\section{PALIURUS. TOURN. $t .387$.}

Calyx quinquefidus. Cor. pentapetala, parva. Stam. quinque. Styl. tres. Drupa exfucca, bi-1. triloculatis, orbiculo lato membranaceo coronata.

Pariurus auntralis. Tab. 43. fig. 5 .

Paliurus. Do d. pempt. 756. Rest. hort. Ey/. autum. III. t. g. f. I. ,

Rhannus aculeis gentinatis: inferiore refexo, floribus trigynis. LiN Juf. veg. 234

PER. Drupa exfucca, bafi calyce circumfciffo vefita, apice orbiculo membranaceo la. tifluno, friato \& horizontaliter patente coronata, fpadicea. Cortex tenuis, \{pongiofo membranaceus. Putamen offeum, ovato globofuns, bi $-L$ triloculare.

REc. nullum; femen fundo. loculamenti afixum.

$S_{E}$ 3. unicum in fingulo loculamento, fuboratuin, compreffum, plano convexiusculum, glabrum, Tubuitidum, faturate caftancun: umbilico alüicante.

INT. duplex: exterius coriaceum \& fere cartilagineum; interius membranaceum; fpadiceum, chalazá verticis fufca.

A в. nuلlum, aut lamina carnola tenuis integumenti interni.

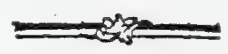
Es m. magnitudine feminis erectus, lutefcens. Coty!. orbiculatx, compreffx, frabito
liacex. Rad. acuminata, brevis, infers.

2. b.) Drupa integra. c. d.) Putamen integrum \& decorticatum. e. f.) Idem diffetum, bi- \& tri: loculare. g. ) Ejusdem fectio longitudinalis. h.) Semen folutum. i.), Idem. transverie fecrum k.). Nucleus clialaza in vertice notatus. L.) Embryo denudatus.

Inter Rhamnum, Zizyphum, Paliurum \& Alateraum, mulo majus in partibus Horis atque fructus datur difcrimen, quam inter Cratrgum, Meipilum, Sorbum at" que Pyrum: ergo male in unum Khamni genus conftipantur.

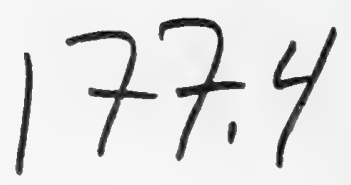



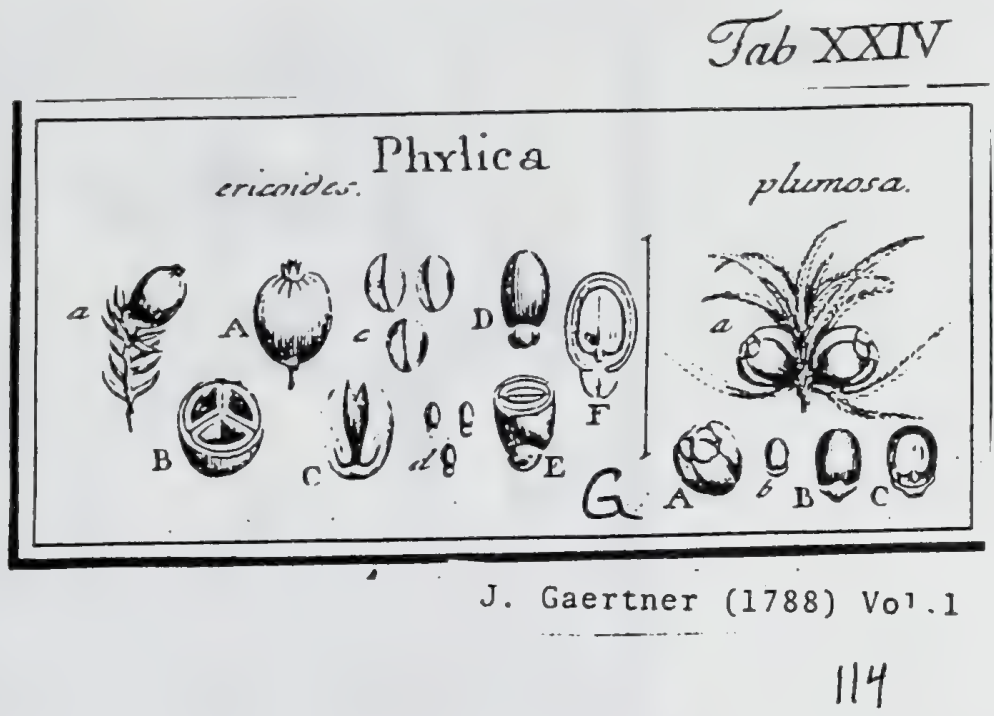

CXXXV. PHYLICA. LiN N. gen. 266.

Calyx quinquepartitus, fuperus. Cor. nulla. Nectar. pentaphyllum. Stam. quirque. Styl. unicus. Capfula infera, tricocca, coronata. Semina folitaria, umbilico exferto carnofo.

Р日 II I A ericoides. Tab. 24. fig. 7.

Alaternoides africana erica foliis, fioribus albicantibus $\mathcal{E}^{\prime}$ mufco/is. Cозм. hort. amfl. 2. p. I. t. $x$.

Phylica foliis linearibus verticillatis. LrN N. fyf. veg. 235 .

PER. Capfula infera, ovato globofa; calyce perfiftente albo, villolo, acute quinque"; dentato coronata, trilocularis, tricocc2 Epidermis membranacea, fub?triata? nigra. Cocculi cartilaginei, tenues, hinc convexi, inde angulati : angulo in:terno elaflice dehifcente.

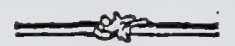

REC. nullum; fernina fundo loculamentorum afixa.

SEM. in fingulo loculamento unicum, oblonge ellipticum, laine convexum, inde obfoletifime angulaturn, ferrugiseun, lucidum, ad bafin umbilico craffo, fungofo, altio, terminatum.

IN T. dtrplex: exterius corisceo crufaceun, durum; interius membranaceum.

ALB. Sernini conforme, carnofun, craffum, album.

Eм в. dicotyledoneus, erectus, magnitudine fere albuminis fed compreflus, luteus. Cotyl. planz, fubfoliacex, ovato cordatx. Rad. brevilfuna, recta, infera.

a. A.) Capfula integra. B.) Eadem diffecta. c. C.) Cocculi tres claufi, \& unas dehif(ens, naturalibus major. d. D.) Semiun (eparata. E.) Semen uransver(e, \& F.) Idem loagitudinaliter fectum, cum figura \& fitu eubryonis intra slbumen.

Physica plumofa. ibid.

Alaternoides africana rofmarini latiori $\xi$ pilofiore folio. Сомм. pralud. $\sigma_{3} . t .13$. Phylica foliis linearifubulatis, fummis hirfutis. Lisw. fuft. veg. 235.

Capfula fubturbinata (a. $\Lambda$.) rotundato trignna, fertuginea, glabra, apice terminata areí ampliuscula tricolli, margine meinbranaceo anguftifimino, edentulo (a lapfu calycis) circumdata. Cocculi tres, ut in pracedenti, fed pauio majores. Semsina (b. B.) elliptica, faturate cafanea, glabra, non vero lucida. Umbilicus ferninis bafin late cingens fongofus albus. Albumen \& Embryo (C.) ut in precedenti.

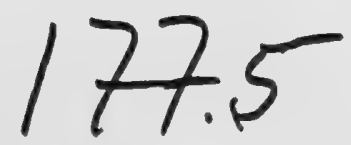




\section{Tab. CVI.}

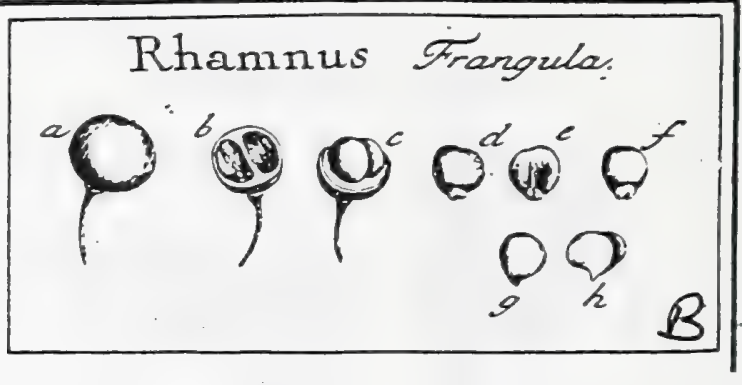

\section{J. Gaertner (1788) Vol 2}

DCXVI. RHAMNUS. TOURN. int. t. 366. LINN. gen. 265. Frengula. TOURN. t. 383. Alaternus. TOURN. 2. 365.

Calyx campanulatus, quinquefidus. Petula quinque exigun, calycis dentibus interjecta. Stam. quinque. Ovar. fuperum. Styl. Gmplex. Bacca carnofa, bi-l. trilocularis. Semina folitaria, cartilaginea.

Rhanvus Frangula. Tab. 106. fig. 9.

Fiangula. CAM. epit. 278. BLAKw. berb. t. 152. Oeder. for. das. to =79.

Khbanmus inermis, foliis ovato-lanceolatis integris, floribus quinquejidis androg)nis. HaLL. biff. n. $82 x$.

Rhamuns inerinis, floribus monogynis bernaphroditis, foliis integerrinuis. Lisw. Syit. veg. 234 .

PER. haccit globofi, glabra, atra, fucculenta, bi-1. rarius trilocularis; diffepimento teiruifimo, per maturitatem fere evanefcente.

REC. nullum; femina fundo baccx affixa.

SEN- folitaria, ovato - rotundata, plano-convexa, aut a parte interiore obtufilfme angulata, bafi in unbilicum cartilagineum \& valde turgidum producta, glabra, ruferentia.

INT. duplex: exterius fubcartilagineum, craffufculum, prope unbilicum deliquefcens, nec eum obtegens; interins membrituaceum, bati in unibilicuin cartiligineum intunclestis.

A L r. ovatuin, carnofun, aibum, inferne valde acuminatum.

Ea в. magnizu!lise fere a'buminis, credus, Juteus. Coryl. uhovatx, carnorix,

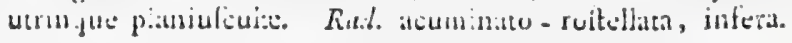

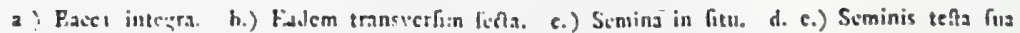
verfiti facics ext.riur \& iatcrinr. f.) Stonen fola fua memblasua interua, bafi in umbilicum

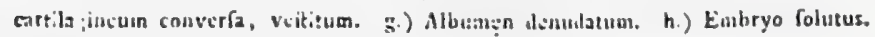

Similis lubicica unibitici vix alibi oscurrit, procicryuam in Phylica.

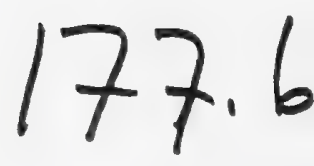




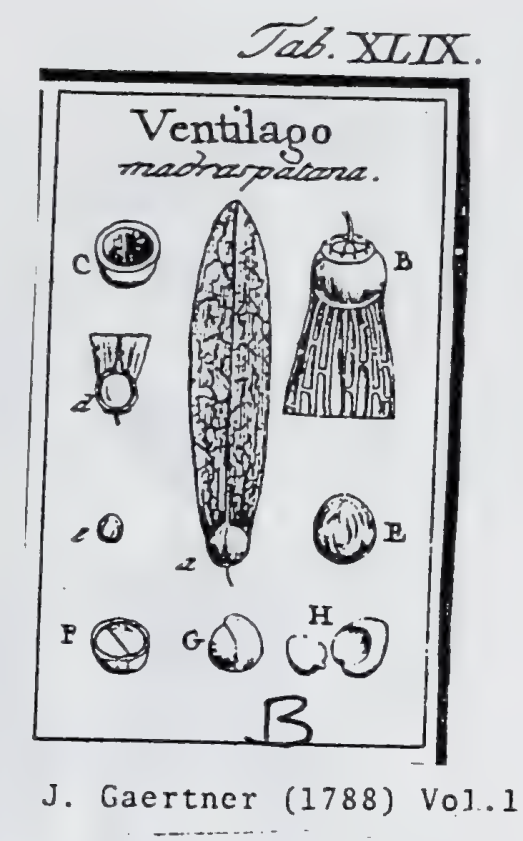

\section{VENTILAGO.}

Calyx monophyllus, intra marginen integerrinum, edentulum, obfolete decem. friatus. Cor..... Stam.... Styl..... Capfula fupera, fphxrica, ala longiffima terminata. Semen folitarium.

Ventilago madralpatana Tab. 49. fig. 2.

Funis viminalis. R И М н. amb. 5. p. 3.t. 2.

E collect. Bankfiana.

PER. Capfula Sphrrica, calyce perfiftente ftipata, glabra, ala membranacea, longe elliptica terminata, fibrofo coriacea, parva, unilocularis, evalvis.

REC. nullum; femen bafi aftixum.

SEM. unicum, fubglobofum, rubro ferrugineum.

IN T. fimplex, znembranaceum, tenue.

$\Lambda$ \&. nullum.

Esг в. femini conformis, erectus, lutefcens. Cotyl. craftx, carnofx, plano convexz, inxquales: altera fxpe duplo minore. Rad. globulofa, minima, infera.

2. B.) Capfola integra cum calyce. C. d.) Esdem differta, cum fitu feminis. e. E.) Semen fo paratum. F.) Idera transverim felum. G.) Embryo denudatus, H.) Cotyledones (eparata.

Ob feminis fabricam proxime 2 Triopteride difare videtur. 


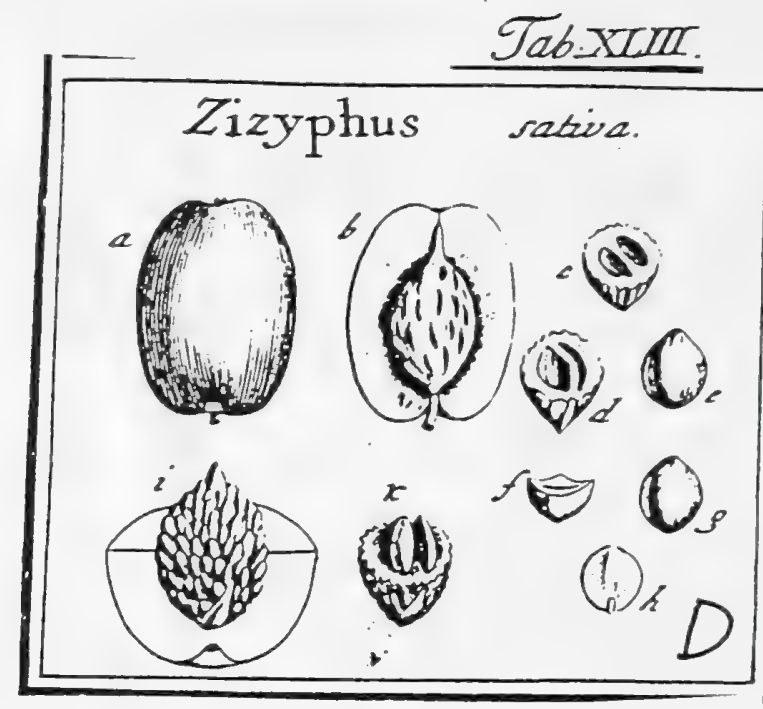

J. Gaertner (1788) Vol.1

202

\section{ZIZYPHUS. TOURN. $t$. 403.}

Calyx pentaphyllus. Cor. pentaperala. Stam. quirqque. Siyl. duo. Drupa baccata: putamine furura ad bafin elevata fpuria paliida.

Zizrphus fativa. Tab. 43. fig. 4.

Zizyphus. Dod. pempt. 807. Bцакw. herb. t. $56 \mathrm{~g}$.

Rhamnus aeuleis geminatis: altero recurvo, floribus digynis, foliis ovato oblongis. LIN N. $\int y$ fl. veg. 235.

Per. Drupa baccata fupcra, ovato oblonga, utrinque fubumbilicata $\int$. obtu $\int_{2}$, glabra, corcinea. Caro granulofa, dulcis. Putamen offeurn, ovatum, utrinque acumisatum, fcrobicularo rugofum, ad bafin callo transwerfo, prominulo, comprefto, acurainato, quari futura incompletá, notatum, biloculare, cvalice.

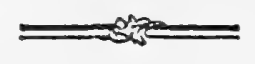

REC. nullum; femen fundo loculamenti affixum.

SEM. in fingulo loculanento unicum, rotundato ovatum, comprefluseulum, planosconvexum, rufefeens, ad umbilicum nigricans.

IN T. duplex: exterius coriaceun, glabrum, fublucidum; interius membranaceum, album, chalaza fufca in vertice notatum; intus fubcarnofum.

A I B. nullum; prater fuperficiem carnofum integumenti interni.

Ess. magnitudine femunis, ertêns, albus. Cotyl. fuborbiculatx, carnolz, tenues. Rad. parva, teretiuscula, isfera.

a.) Drupa integra. b.) Putamen denudatum. c. d.) Putaminis bilocularis fertio transveria. e c) Semen integrum \& differtum. g.) Nucleus chalaza fufca in vertice notatus. b.) Embryo denudatus.

2izxphus Jujuba. ibid. fig. i. k.

Malus indica. Rumpn. anb. 2.p. $\pi 1 \%: t .3^{6}$.

Perim-toddali. Rheеd. mal. 4. p. $85 . t$. 4I. BLAKw. herb. $t .388$.

Rbamnus aculeis folitariis recurvis, pedunculis aggregatis, foribus Jemidigynis, folits retufis Jubtus tomentofis. LIN

Diupa fubrotunda, magnitudine Porni borsdorftiani, Putamen (i.) ovato - globofum, tubcrculato muricatum, bafi callo transverfali prominulo acuminato notatum, confanter biloculare (k.). Reliqua ut in pracedenti.

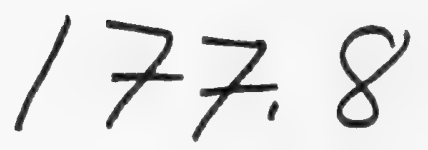




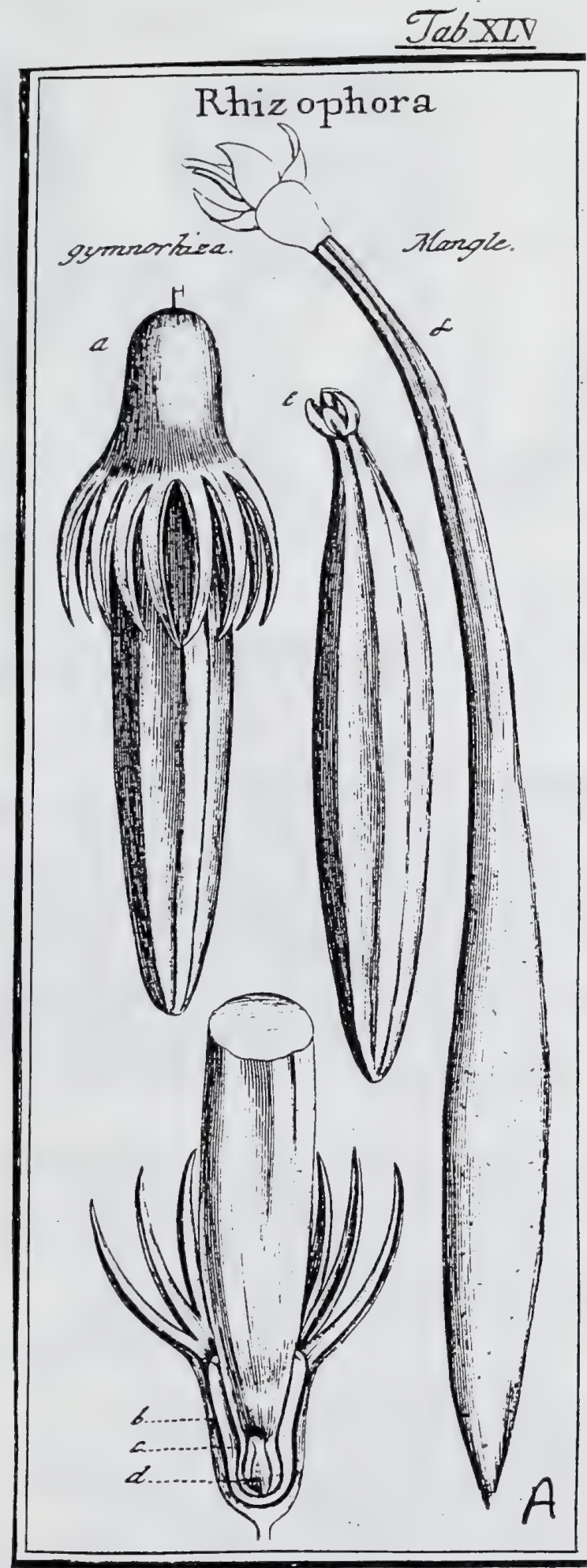




\section{J. Gaertner (1788) V01.1}

\section{RHIZOPHORA. LINN. gen. 592.}

Calyx monophyllus, quadri-l. multıpartitus. Cor. tetra-l. pluripetala. Stanı. octo, ad fedecim. Styl unicus. Semea unicum inverfum: radicula germinante longilima

R ніzогі:о a Mangle. Tab. 45. fig r.

Mangiun cardelarium. R U м P н. amb. 3. p. 108.t. 7 r. 72.

Rivizophora gedunculis bifidis trifudisqae, fruftibus fubulato slavatis. I 1 cQ hifb. amer. 174. t. 89 .

Rhizophora foliis acutis, fruatibus fubulato clavatis. LIN N. fy/. veg. 442.

PER. nullum, nifi caljeis ventren velis, cui femen arcte adnaturn.

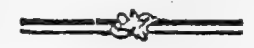

REc. nullum, przter calycis parietein internum.

SEM. unicum, ovatum, bafi gibbum, fcabriusculum, fufcum, fylo terminatum, denum a procrécente radicula apice rumpendum.

IN T. fimplex, cralfum, carnofo coriaceum, a calyce nunquam fecedens.

A L B. in fundo feminis locatum, calyptrzforme, glandulofo carnolum, aurantiacum.

VI т. Subcylindricus, fibrolo carnofus; inferne rotundatus \& capitellatus, albuminis cavitati inmillus; fuperne fifulofus \& cum embryonis radicula conferruminatus.

Es в. inverfus, viridis, intra femen germinans ejusque integumenta, procrefcente fua radicula rumpens. Cotyl. quatuor aut fex, foliacex, plicato convolutz, ib conum gracilem fubulatum convergentes. Rad. matura longiflima, fubulato clavatz, fpa. dicea, punctis callofis hinc inde confperfa, fupera.

๙.) Radicula matura, naturali nulto minor, calyci \& feminis tefix juntas.

Rcliquas partes, mihi non vilas, defcripfi ad figuras J A ce. tab. 89 , ubi feminis tella. fig. 5. Albumen. fig. 3. Vitellus. fig. 2. \& Cotyledones in conum convergentes fig. 4. reprxfentantur.

Rн І ООРнов А gynmorrhiza, ibid.

Mangium celfum. R U M P H. amb. 3.p. 102. t. 68 .

Rlizophora foliis ovato lanceolatis integerrimis, radice terra fuperimpofita. LIN N. Jyjl. veg. 442:

B. Mnngium minus. R ч м Р н, amb. 3. p. 106. t. 69 .

Rhizophora frutibus cylindricis obtufis. LIN N. fifl. vìg. 442.

भ. Mangium digitatum. $\mathrm{R}$ U $\mathrm{P}$ н. amb. 3. p. 207.t.70.

E colleclione hankfiana.

Calyx maturus (a.b.) coriaceus, craftus, 12-14. partitus: fegmentis lineari-2cuminatis, incurvis. Seminis tcfla (c) carnofo-coriacea, inverfe parabolica, fuperne zquabiliter truncata, undique libera, calycis ventri tota immerla. Embryo (a.d.e.) inverlus, e viridi fpadiceus. Cotyl. quatuor, hinc cunverx (e), inde angulars, foliacex, contortuplicatx, in glubum convergentes (d.), gramineo virides. Radic. undique ab integumentis libera, clavato cyfindica, cibfulete sugulaja, glaberima, sitida, tripollicaris, podalis \& ulira, obtufiufcula aut acuminata. 


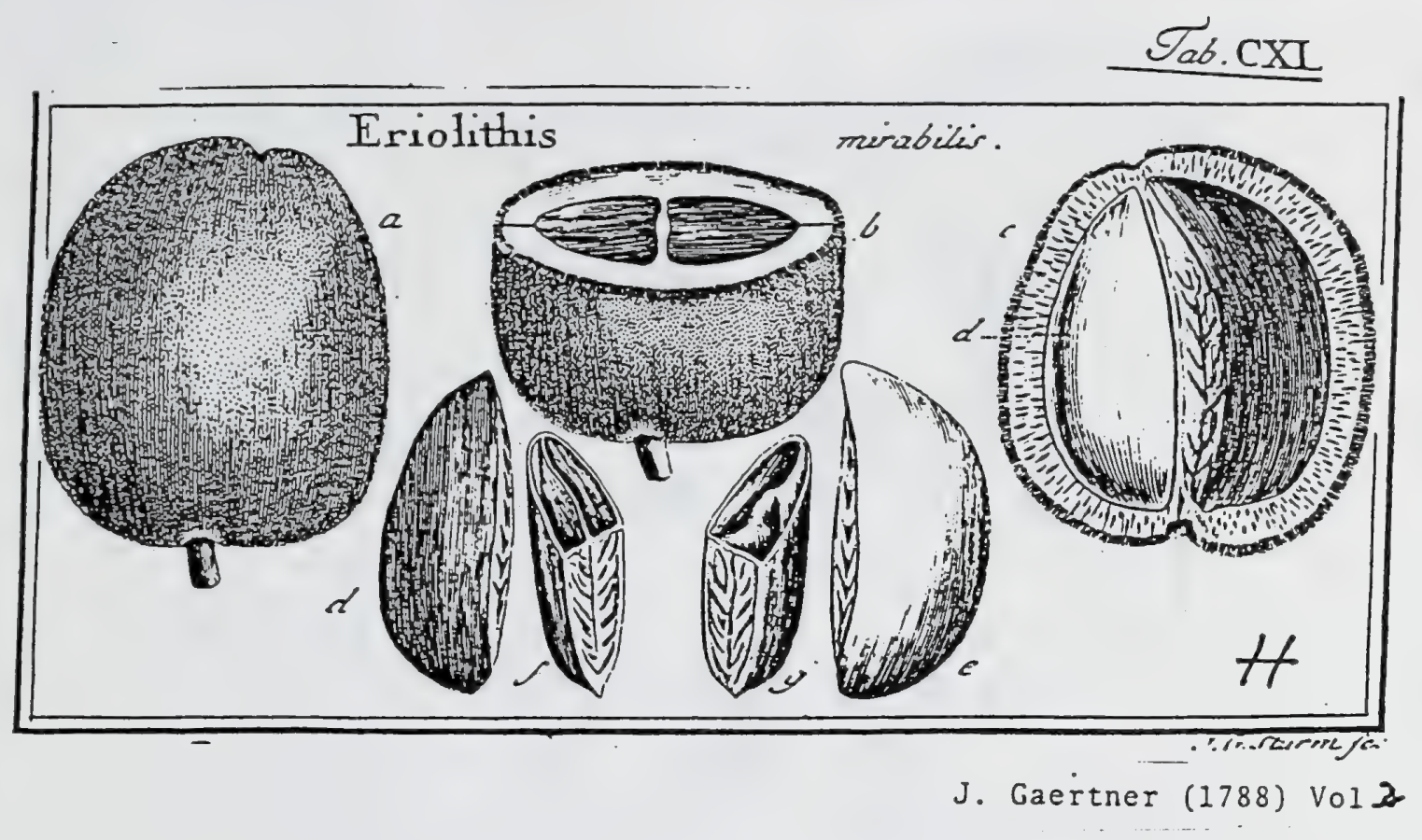

Rosaceae

DCCCXIII. ER I O L I T H I S. 277

Flos .... Nux lapidea, denfifrme villofa, bilocularis, evalvis. Sem. folitaria, bilocularia!

ERıolıtus mirabilis. Tab. 140. fig. $\delta$.

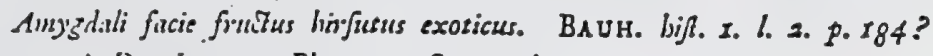

$\Lambda$ Dn. Lasc. Pharmac. Stutgard.

PER.. Nux lapidea, durifima, ovalis, lenticulari - comprefra, extus capillis brevibus, rectis, denfitfime in holofericum molle \& gilvum conftipatis, obtecta, intus lamina offea glabra \& Spadicea veltita, bilocularis, vix niĞ cunco in duas valsas partibilis. Diffepimentum offeum, tenue, rugis obliquis infcriptunt, valvis contrarium.

REc. nullun; lenisis rugofx dilfepimenti fuperficiei fecundum totam fuam longitudinem adherencia.

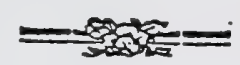

SEx. folitaria, grandia, oblonga, utrinque acuminata, compreffe triquetra; hinc convexa \& in dorfi acuiam carinam declivia, inde planiufcula \& ad normam inxqualieatum diffepimenti rugata, cetera e caftaneo fufca, bilociu.
'laria.

INT. duplex: exterins chartaceun, aridum, fubfragile, ope laminxe nembra. nacex verticalis \& a dorfo ad ventrem ductx, in duo loculamenta undique
claufa \& fubrqualia divifum; imterius membranaceum.

A В...... E EB. .....

2.) Nux integra. b.) Ejus feettio transperfalis. c.) Valvula altera feparata, eum fata feminis d. e.) Seurima folata. f. g.) Tefta feminis transverfim difreca, cum luo difiepimento proprio.

Accepi fingularifinum hunc fructum fub nomine Ademonie - Totaklie, f. AL mandras de Peni. At Totakke LAETII. Ind. occid. 1. 17. c. 4. diverfilimus \& verifimiliter Mammex fructus elt. Almandras auten de Perr, tefte WORMIO mus. p. $18 x$. funt fructus triangulares, qui unicum duntaxat continent nucleum. Ignotum itaque \& incompletum fructum filere nolui, it alii, data occafione, curatius in feminis fabricam inquirant \& lactenus deficientia fuppleant

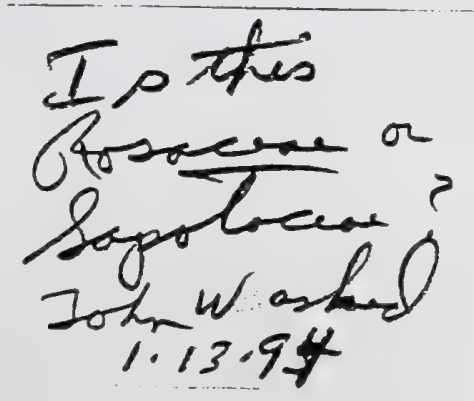




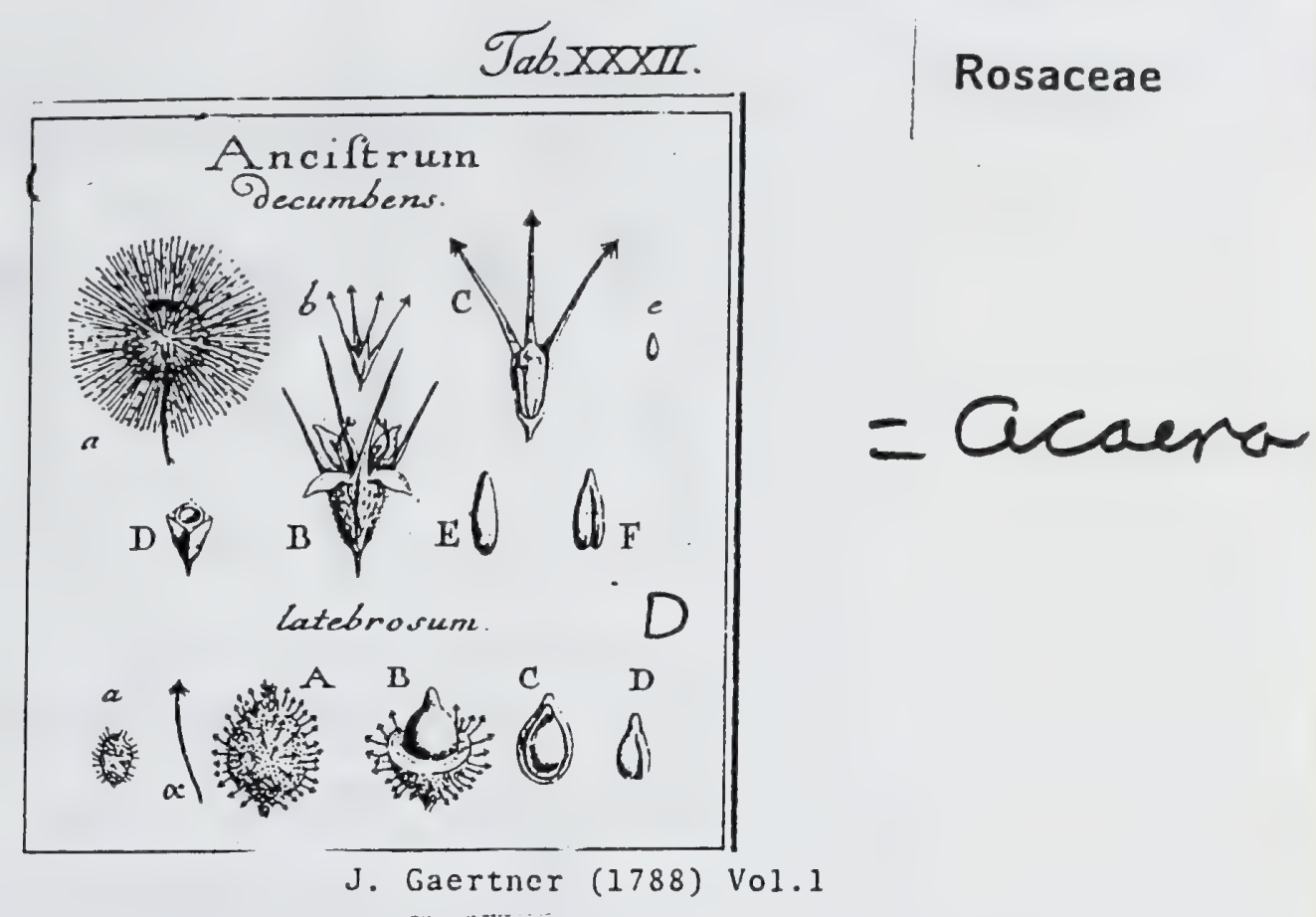

CXCVIII. ANCISTRUM. LINN. gen. 1354.

Calyx monophyllus, ovario adnatus, quadridentatus, fetis glochidatis armatus. Cor. tetrapetala. Stam. duo. Styl. unicus. Sernen calyce incraftato coricatum. Axcistrum decumbens. Tab. 32. fig. 5 .

Ancifirum anferinafolium. Forst. gen. 2.

Ancifirun fanguiforba. Lin N. Jy/2. veg. 73 .

Ex herbario Hankfiano.

PER. nullum, prater calycem, fernen obveflientem, inverfe pyramidatum, tetragouum, quadridentatum: dentibus fetaceis rigidiusculis, longis, apice glochidatis.

RE c. nullum ; fernen fundo calycis affixum.

SEM. unicum, oblongum, furfum leuiter attenuatum, pallide lutefcens, bafi artola nigra umbilicali nocatum.

IN T. fumplex, mombranaceum, tenue.

A LR. Bullum.

Ex B. dicotyledoneus, inverfus, fennini conformis, lutefeens. Cotyl. oblongx, caro nofix, plano convexx. Rad. teretiuscula, brevis, fupera.

a.) Frufrus conglohatux, fpliaricus. b. B. ; Flos f(paratus. C.) Calyx matorus fongitudiraliter ajertus. D.) F.jusdem fcatio tratssierfalis. E. E.) S(nien frparatum, F.) Enibrjo des:udatue.

164

Ancistrum latebrofum. ibid.

Ex herbario Bankfiano.

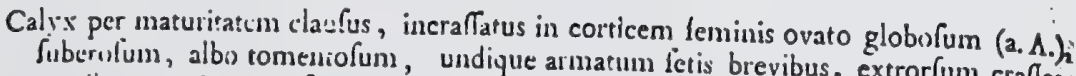
centibus, $\&$ in apice fuo, aculeolis quatuor retroverfis $(\alpha$.$) glochidatis. Seuner$ - unicum (B.) orato globofum, fupra in umbonem $\left(\alpha_{\text {. }}\right.$ ) glochidatis. Seunen dum. luteguinentum duplex: exterius (C.) coriaceum durum, crallum, palli: tamen inentiens; interius membranaceum, tenuilfinum. Albumen prorfus nul: lum. Embryo (c. D.) femini conformis, inverfus, lutefcens. Cotyl. ovatz, craffx, carnolx, plano convexx. Rad. teretiuscula, brevis, fupera.

Diverfa aliquantum en hujus fructus a prioris fabrica, ut hic inter drupas, cum Pim. pinclla, rcterri poffet; fed difcrimen leve \& reliquarum partium fabrica in utra. que Specie eadem ent. 


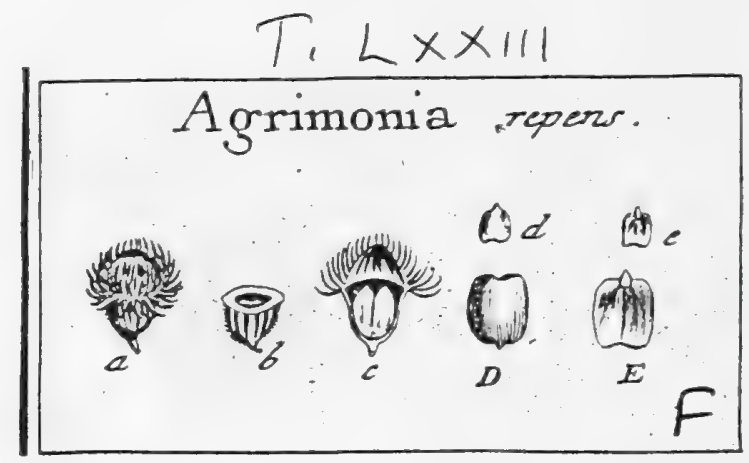

Rosaceae

J. Gaertner (1788) Vol.1

CCCCXLVII. AGRIMONIA. Tourn. t. 155. Lixn. gen. 60\%. 347

Calyx monophyllus, quinquedentatus, echinatus. Cor. pentapetala. Stann. fubduode. Ina, calyecina. Styl. duo. Scmina duo, calyce veltita.

AGrianonia repens. Tab. 73 . fig. 3 .

Agrimonia foliis caulinis pinnatis: impari feffli, frutibus hifpidis. LI NN. Syfl. veg. 448 .

PER. nullum. Calyx maturus, bafí fulcatus, in medio fetis uncinulatis hifpidus \& in apice paleis ferrugineis comniventibus claufus, femina foret.

REC. nullum, prixtcr fundum calycis.

Skm. duo, interdun unicum, aut tria, ovata, compreffiuscula, fupra mueronata, infra quafi truscata, glabra, ferruginea.

IN T. duplex: exterius tenue, fpadiceum, femen laxe ambiens, ut pro capfula haberi poflet; interius coriaccum, forrugineum, lata chalaza nigra notatum.

A \& B. nullum.

Емв. femini confornis, inverfus, albus. Cotyl. fubovatx, bafi emarginatx, plano convexx. Rad. conica, parva, fupera.

a.) Calyx integer. b.) Ejus pars inferior, fulcata. c.) Semisum fitus intra calscem. d.D.) Semina eparata. e. E) Cotyledor altera, intus (pectata.

Calycem in loculamen'ta partitum, mihi nondum, ut aliis, videre contigit: forfan laxam feminis tunica:n, iffi, pro feptis habuerunt. 


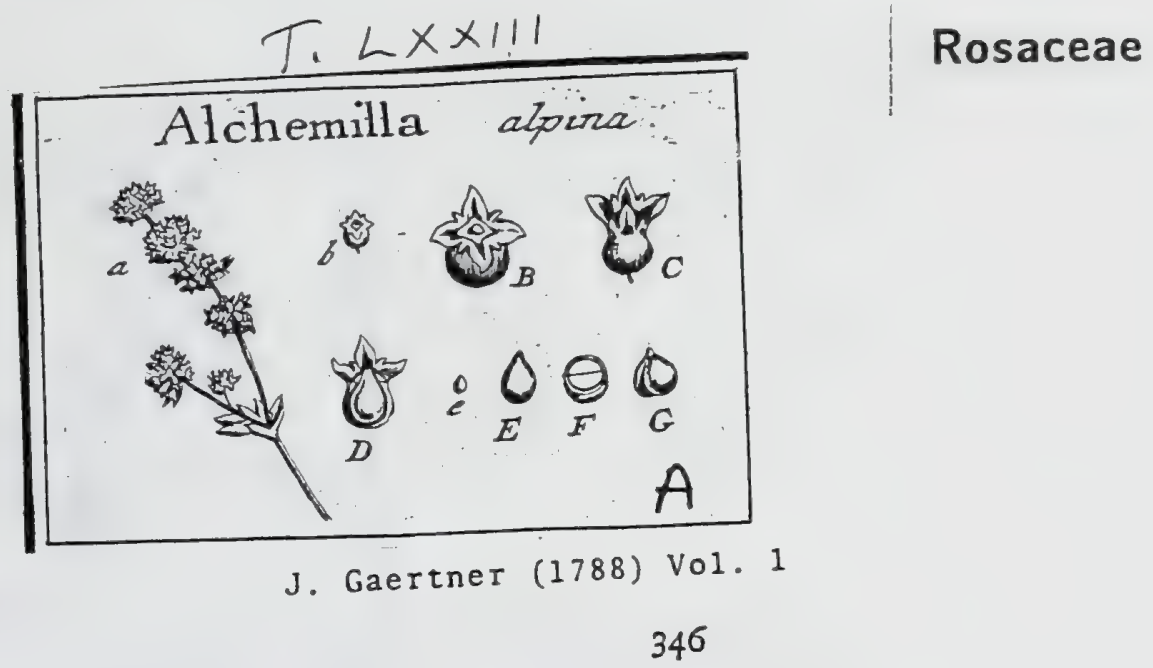

CCCCXLV. ALCHEMILLA. T OU R N. t. 289. LIN N. gen. 265.

Calyx octifidus. Cor. nulla. Stan. quatuor. Sty'L unicus. Semen unicum calyce véfititum.

A С и M ILA alpina. Tab. 7\%. fig. 1.

Stellaria argentea. C A M. epit. yog. O ED ER. flor. dan. t. 49.

Alchemilla foliis digitalis, apice dentatis, fericeis. HA L L. hifl. 2. 13. 1567.

Alchemilla foliis digitatis ferratis. I. I x N. Jyf. veg. 166.

PER. nullum; calyx obturaculo fungofo g̨uadrangulo claufus, fomen fovet.

REC. nullum, prxter fundum calycis, cui lemen affixum.

SEM. unicum, lenticulari globofun, fupra inucronatum, glabrtm, albidum.

INT. duplex: exterius cruftactum; interius membranaccum, nigro fufcum.

A L B. nulluin.

Eмв. femini conformis, inverfus, a!bus. Cotyl. hemifplaxricx. Rad. conica, brevis, fupera.

2.) Kamulus cum (ruRtibus, b. B.C.) Calyx maturus integer. D.) Semen intra calycem, e. E.) Idem feparatum. F.) Idem transverie feftum, G.) Embryo denudatus. 


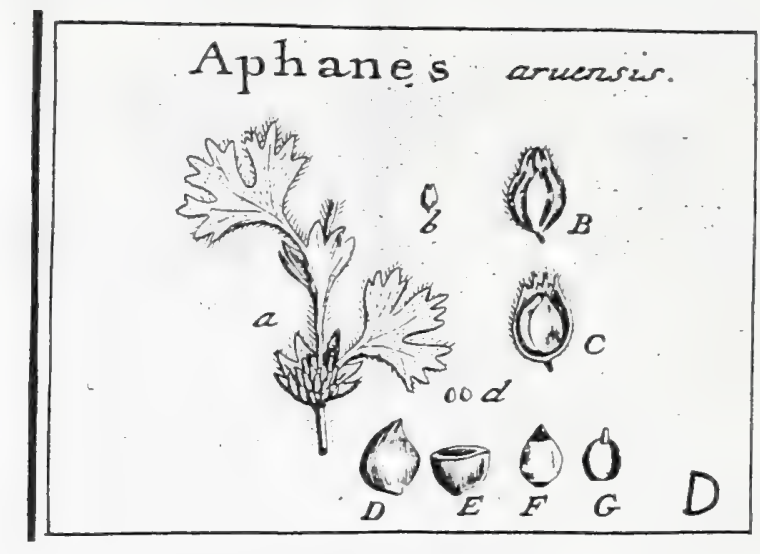

\section{J. Gaertner (1788) Vol.1}

CCCCXLVI. APHANES. LinN. gen. 166. 346

Styli \& femina duo, reliqua omnia Alchemillx.

A PHANES arvenfis. Tab. 73. fig. 2.

Alchemilla minima montana. Co c. cephr. 146. t. 148.

Alchemilla hirfuta, foliis trilobalis, lubis biet tripartitis. HALI. hiff. 2. n. 1569 .

Aphanes. Lin s. Jifl. veg. 167 .

PER. nullum; calyx ventricofus, friatus, villofus, orepsrvius, femina fovet.

REc. nullum; femina bafi affisa.

SEM, unum, aut duo, ovato acuminata, Jenticularia, glabra, fubnitida, pálida.

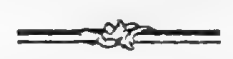

In r. duplex: exterius cartilagineo cruftaceun, craflusculum. album; interius mem. branaceum, ad apicem crruleum aut nigrum, catera pallidum.

A I B. nullum.

Eм в. Cemini conformis, inverfus, albus. Cotyl. obovatx, tenues. Rad. conica, brevis, fupera.

1.) Fruetus in axillis foliorum fe(Gles. b. B. C.) Calyx maturus intezer \& diffęus. d. D.) Semina Scparata, E.) Semen transverfe fectum. F.) Nucleus decoiticatus, G.) Embryo denudatus.

$\mathrm{Ab}$ Alchenilla leparari non meretur, fiquidem in hortenfi planta frepius, in fpontanea autem fere confanter unicum duntaxat reperiatur femen.

\section{4}




\section{Rosaceae}

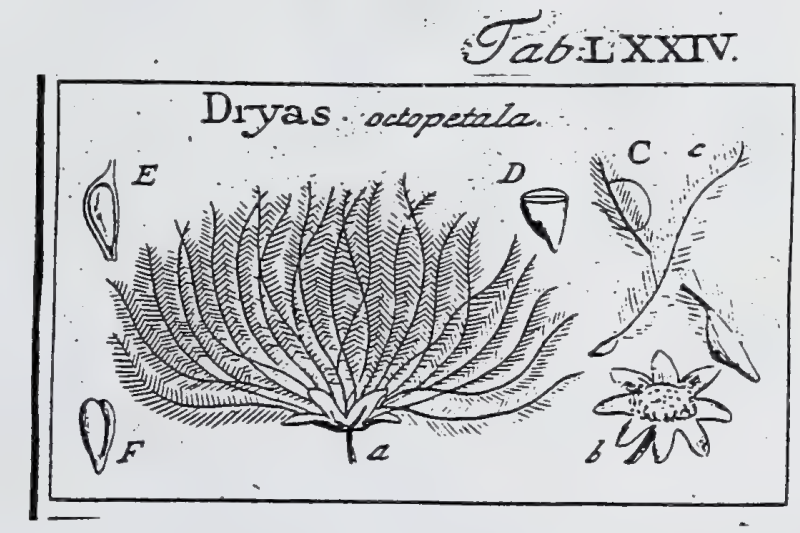

J. Gaertner (1788) Vol. 1

CCCCLV. DRYAS. LINN. ger. $637 . \quad 352$

Calyx octo-1. decemfidus. Cor. penta 1. octopetala. Stam. plurima, calycina. Styl. terminales. Receptac. depreffum, latum. Semina numerofa, nylo plumolo caudata.

DR Y A s octqpetala. Tab. 74. fig. 2.

Chamadrys III. Clus. hift. 2. p. 351. OE D ER. fl. dan. t. $3^{\text {t. }}$

Dryas floribus oftopetalis, foliis ovatis fubtus albifsmis. H^LL. hift. 2. ๓. 1133. . Drias oftopetala, foliis fimplicibus. LinN. Jyf. veg. 481.

PER. nullum, praeter cruीan terninis.

REc. conicum, depreftum, fcrobiculatum, pubefcers.

S E M. numerofa, oblonga, hine gibba, inde rectiuscula, comprefia, fubvillofa, rufefcentia, inferne angunata, fuperne in fetam plumofain, Hexilum, fcmine octuplo longiorem, definentia.

Ix T. duplex: exterius coriaccum tenue; interius membranaceum, pallidum.

$\Lambda$ L B. nullum.

Е м в. cavitati feminis conformis, erectus, albus. Cotyl. ovato oblongac, plano convexae, tenues. Rad. conica, brevis, infera.

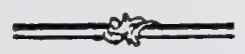

a.) Calyx maturas, cum feminibus. b.) Receptaculum. c. C.) Semen feparatum. D.) Idem dirfeetum. E,) Nucleus denudatus. F.) Embryo Separatus. 


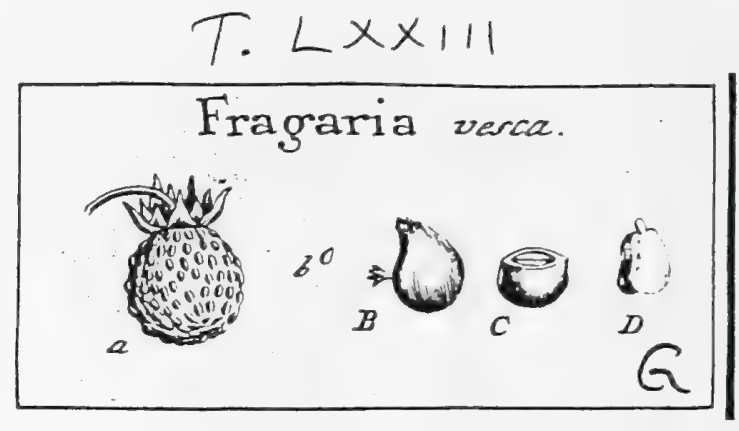

J. Gaertner (1788) Vol.1

CCCCLII. FŔAGARIA. TOuRn. t. I52. Lin N. gen. 633.350

Calyx decemfidus. Cor. pentapetala. Stam. plurima calycina. Styl. daterales. Receptac. commune baccatum, coloratum. Semina nuda glabra.

FRAGARIA ref́ca. Tab. 73. fig. 8.

Fragaria. BLA x w'. herb. t. 77. GLEICH. t. 30 .

Fragaria foliis teruatis, fagellis reptans. H A L.. hift. 2. n. III2.

Fragaria flagellis reptantibus. L IxN. $\sqrt{y} \sqrt{t}$. veg. 476 .

YER. nullum. Calyx maturo receptaculo anguntior.

REc. carnofum, ovato globofum, maximum, fxpius coloratum, plerumque deciduom.

$S_{L}$ s. numerofa, parva, ovato acumiusta, compreffiuscula, glabra, nitida, rufefcentia.

INT. duplex: exterius coriaceum; interius membranaceum, chalara lutelcente nota. tum, intus fubcarnofum.

A L в. nulium, nif tenuifimam velis fuperficiem carnofam integumenti interni.

Ex в. Semini conformis, inverfus, albus. Cotyl. ovatx, planiusculx. Rad. brevis; terctiuseula, fupera.

2.) Receptac. maturam, cum feminibus. D.) Embryo denudatus.

$*$

b. B.) Semina feparata. C.) Semen transverfe fretum. 


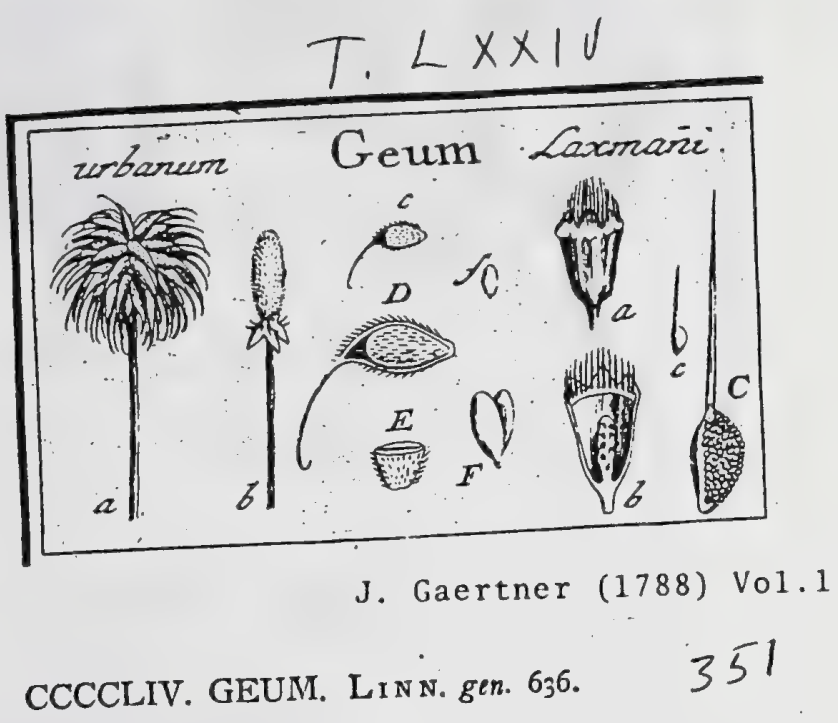

Calyx deccmfidus. Cor. pentapetala. Stan. plurina calycina. Styli terminales. Recept. commune columnare. Sem. plurima, flylo geniculato ariflata.

GEu M urbanum. Tab. 74. fig. 1.

Caryophyllata. Dod. pempt. 137. BLAK w. herb. t. 253. OED. flor. dan. t. 672.

Geum foliis pinnatis, pinna ultima trilobota, floribus patulis, tubis aduncis. HALL. hist. 2. n. 1130 .

Geum floribus erettis, fructihus globofis villofis: ariftis uncinatis nudis, foliis lyratis. LI N. Jyft. veg. 480.

PER. nullum, nif feninis crufam relis.

REc. columnare, cylindricum, villofum.

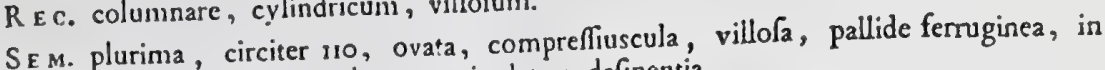
ariflam declivem, nudam, uncinulatam definentia.

IN T. duplex: exterius coriaceum, nucleo paululum amplius, in ariftam attenuatum; interius membranaceum, tenuiflimum, pallide framineum.

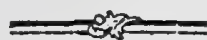

A L в. nullum.

Е м в. ellipticus, comprefliusculus, albus. Cotyl. oblongx, tenues. Rad. brevis; infera.

a.) Fructus integer. b.) Receptaculum. c.) Semen feparatum. D.) Nucleus denudatus, . E, Semen transverle fectum. f. F.) Embryo decorticatus.

GEU M Laxmanni. ibid.

Dryas geoides. PA L as itin. 3. $p .732, t$. $Y$. f. . B. c. Jace. hort. $4 . t .68$.

Dryas pentapetala, foliis pinwatis: pinnis extimis confluentibus. L INN. Syft. veg. 481.

Calyx maturus (a) fub́campanulatus, dentibus quinque majoribus conniventibus, \& filaınentis faminum fetaceis rigidis perfiftentibus, claufus. Receptac. cylindricum (b.), gracile, fcrobiculatum, nudum, calyce paulo brevius. Semina (c. C.) numetofa, obovata, hinc gibba, inde in carinam rectam comprefta, punctis ele. vatis undique fcabrata, fufco ferruginea. Arifla recta, acicularis, feinine duplo longior, ejusque vertici inarticulata, glabra, per maturitatem fponte decidua. Reliqua ut in pracedenti.

Propter calycem maturum campanulatum; corollam flavain pentapetalam; receptaculum elongatum; \& ariflas nudas geniculatas, Gco, quam Dryadi propior efle videtur. Folia utrinque pubefientia, fubtus caefia, \& tota facies Gei ef. 


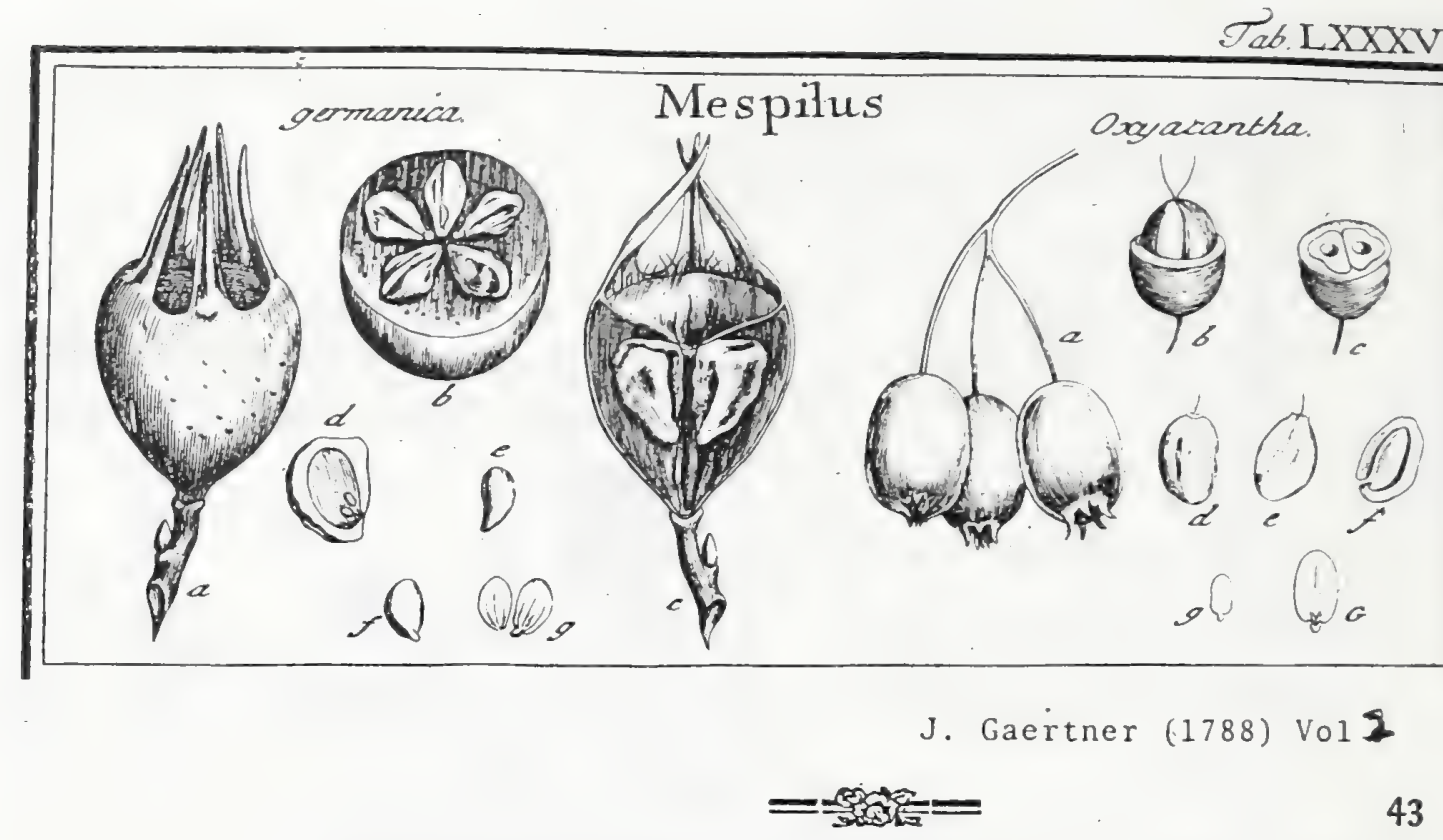

DXLVIII. MESPILUS. TOURN. inft. t. 4 ro. LINN. gex. 625. Cratægus. LINN. gen. 622.

Calyx fuperus, quinquefidus. Cor. pentapetala. Stam. viginti \& plura. Ovar. inferum, loculamentis ftylorum numero xqualibus. Bacca coronata, di - I. pentapyrena: ofliculis unilocularibus, difpermis.

Mespilus germanica. Tab. 87. fig. I.

Mefpilus. Dód. peinpt. 80 T. BLAKw. berb. t. 154.

Meepilus folizs elliptico lanceolatis ferratis, calycibus longiJimis perfigentibus. HaLt. hijl. 11. 1094.

Mefpilus inermis, foliis lanceolatis fubtus tontentofis, floribus folitariis feftibus. LiNs. Syfr. veg. 466 .

PER. Bacca infera, turbinata, ampla area deprefa in vertice umbilicata, \& quinque foliolis calycinis linearibus coronata, carnofa, helvola, pentapyrena. Caro craffa, granulis callofis remixta. Officula laptdea, gibba, rugofa, unilocularia.

REC. funiculi umbilicales capillares, e bafi loculamentorum ad femins pertingelltes.

SEM. in fingulo loculo gemina, uno plerumque abortante, obovata, lenticulari - compreffa, deorfum valde acuminata, albicantia, chalaza fufca in vertice notata.

INT. fimplex, menbranaceum, intus lamina carnofa alba auchum.

A L B. nullum, nifi nttegumenti fuperficiem internam carnofam velis.

Е м в. femini conformis, erectus, albus. Cotyl. ovatx, plano-convèxx, tenues. Rad. brevilima, obtufa, infera.

a.) Bacea integra. b.) Fjus fettio transverfalis, oficulonum numerum ofendens. c.) Ejusdeum fistio Iningitulinalis, cum p5renis a latere fretatis, d.) Loculamentum officuli apertum, euin ovulis ia fitu maturati. e.) Scmen maturum feparatum. F) Embryo denudatus. 5.) Cotyledonts fepratatx.

Mrespicus Oxyacantha, ibid.

Spina albis. BLAKw. berb. t. 149. OED. for. dar. 6. 634. Jace. anfir. 3. t. 292. f. a.

Meepilus fpinofa, folis glabris ferrattis retufis trifidis. HaLc. bif. n. 1087 .

Cratagus foliis obtufis fubtrifidis ferrasis. LiN . Jy/. veg. 465.

Bacca ovalis-(a), coccinea, apice umbilicata \& calycinis denticulis coronata, farinofo-cirnofi, mono-di-(b.c.), tri-l. tetrapyrena. Officula lapidea, ovata (d. e.), plano - convexa, qut varie angulata, unilocularia (c. f.).

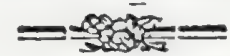

Semen oblongum (f.), pallidum, chalaza ferruginea notatum. Albumen \& Embryo (g. G.) ut in pracedenti.

Singulare eft in hoc genere, quod per maturitatem fructus, officulorun vertex ficpe denuderur; quin in Mefpilo folio rotudiori non ferrato, fructu nigro. Aмs. ruth. gоs. t. 34. pyrenx ad medium fere denudatx reperiuntur: ut inter Mefpilum \& Rofam nexus a fructu fit palpabilis. 
Rosaceae

$$
\text { T. } L \times x \| 11
$$

Comarum patestre.
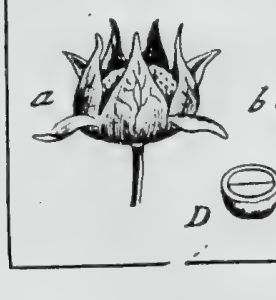

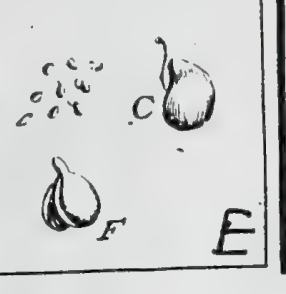

J. Gaertner (1788) Vol. I I

CCCCLI. COMARVMI. LIN . gen.638. CCCCLI. COMARVII. LIN N. gen. 638.
Calyx decemfidus. Cor. pentapetala. Stam. plurima, calycina. Sn'L plares laterales.
Keceptac, commune globufum, villofum. Semina nuda glabra.

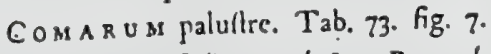

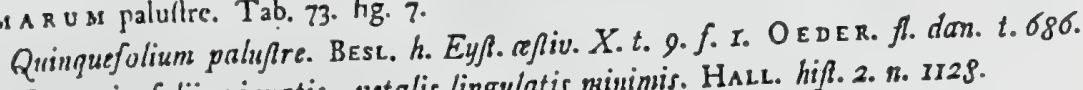

Fragaria Soliis pinnatis, petalis lingulatis minimis. HALL. hift. 2. "2. 1129.

Comarum. LIN N. Jy/t. veg. 48 r.

350

PER, nullum. Calyx maturus connivens, femina obtegit.

REC. commune fungofurn, globofum, villofum, grande.

S E M. numerofa, parva, ovato fubioficllata, glabra, e calaneo-rufefcentia.

Is T. duplex: exterius crufaceum; interius membranaceum, album.

ALB. nullum.

Exв. Cernini conformis, inverfus, albus. Cotyl. fubrotundx, plano convexx. Rad. teretiuscula, fubobliqua, fupera.

a.) Caiyx maturus.

b.) Recegtac. commune.

c. C.) Senisia feparata.

D.) Semen diffetum.

E.)
- Potentilla 
Rosaceae

$$
T . L \times \times 111
$$

Pentaphyll Proentive

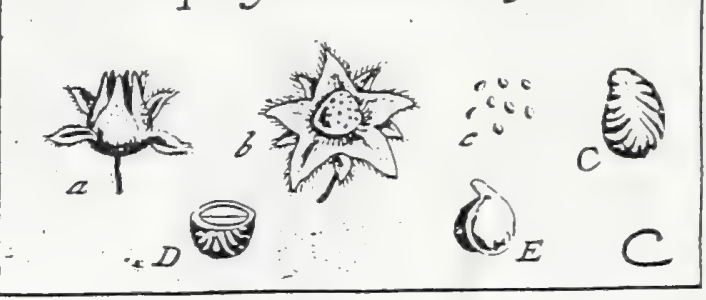

J. Gaertner (1788) Vol.I

$=$ Potentien

CCCCL. PENTAPHYLLVM. TOURN. t. 153 .

349

Calyx decemfidus. Cor. pentapetala. Statn. plurima calycina. Styl. plures. Receptac. commune fungofum, tuberculatum. Semina nuda, rugofa,

I'EX:TAPHSTLUM norvegicum. Tab. 73. fig. 6.

Trifulium huteum tormentilla folio. B A R R. ic. TIO. OEDER. f. dan. t. 17 T.

Frngaria foliis ternatis hirfutis, caulinis tripartitis fipulis ovato lanceolatis. HA LL. lifi. 2. n. IIIS.

Patertilla fuliis ternatis, caule dichotomo, pedunculis axillaribus. L Ixx. fu/t. 2'rs. $47 \%$.

PER. nullum. Calyx maturus comnivens femina obregit.

R E c. commtne fungolum, conicum, tuberculatum, calvum.

SEM. numerofa, parva, fubovata, fupra oblique mueronata, lenticulari comprefia, rugis deorfun, verfus utrumque feminis marginem divergentibus notata, ffadiceolutefcentia.

Ix T. triplcx: extimum coriaceum, rugis infcriptum; medium cruflaceum, glabrum, cralliusculum; intintun membranaccum, rubro ferrugineum.

A I B. nullum.

Eмв. Cemini conformis, inverfus, lacteus, Cotyl. orbiculatz. Rad. teretiuscula, obligua, fupera.

2.) Calyx connivens. b.) Idem explicatus, cum receptaculo nudo. c.C.) Semina folutz. D.) Se men diđectum. E.) Erabryo denudatus.

Scmina, fupra dicto modo rugofa, in omnibus fere Pentaphylli fueciebus reperio, \& ita quoque ea adumbravit rudiuscule $G_{R E} W_{1}$ US anat. tab. 73.

179.10 


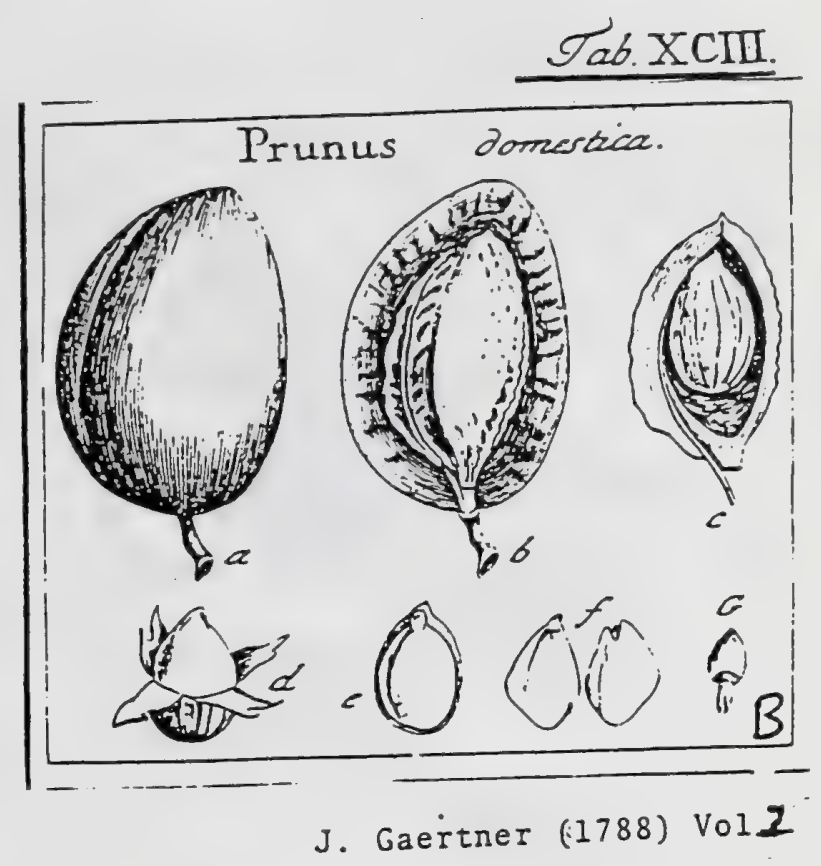

DLXXX. PR U N US. TOURN. inf.t. 398. LINN. gen. $260^{\circ}$

Calyx inferus quinquefidus. Cor. pentapetals. Stam. calycinạ viginti \& plura. Ovar. fuperum. Styl. fimplex. Drupa baccata, putamine glabriufculo, futuris prominulis.

Rouwus domeftica. Tub. 93. fig. 2.

Proous damacena. Blakw. berb. t. 305.

Prumus foliis ferratis birfutis ovato - lanceolasis, floribus longe petiolatis. HALL: biff. n. 1079.

Fronus pedunculis fubfolitmriis, foliis lanceolato-ovat is convolutis, ramis muticis. Lins. Jyft. veg. 463 .

PER. Drupa fupera, baccata, ovalis, altero latere paulo magis gibba atque itsis depreffa infcripta, carulea, rorulenta. Caro tavefcens, mollis. Puamen offeum, ovatum, utrinque acuminatum, lenticulari - compreffom, obfolete fcrobiculatum, uniloculare; cultro fecundum futuras fuifile. Sutura altera gibbofior, fimplex, prominula, acuta; altera rectior, fulco medio bipartita, angufta, crenulata.

REC. funiculus umbilicalis filiformis, in proprio canali putaminis futurse acutec infcripto decurterts atque femini infra apicem fuum infertus.

Sz). unicum, ovato - acuminatum, lenticulari - compreffum, caricate puraminis minus, e ferrugineo-rufefcens $f$. cinnanomeum.

INT. duplex, utrumque membranaceum; terne.

AL8. carnofum, album, tenuifimum, ut vix ullum, nifi circa radiculam embryanis.

Ess. femini conformis, inverfus, Incteus. Cotyl. obovatx, carnofix, plano convexz. Plum. diphylla, compreffa. Rad. iucraffita, ovaco-acumiliata, fupera.

2.) Dropa integrz b.) Potaminis is carae Lins \& Gigarz c.) Ejusien valvuth altera cum cmine integro. d) Albumen fupene denudatum. c) Idem verticaliter diffecium, cun cmbryone in fitu. E) Cotgledones separza. G.) Plumula cur ralicula folota \& auets 


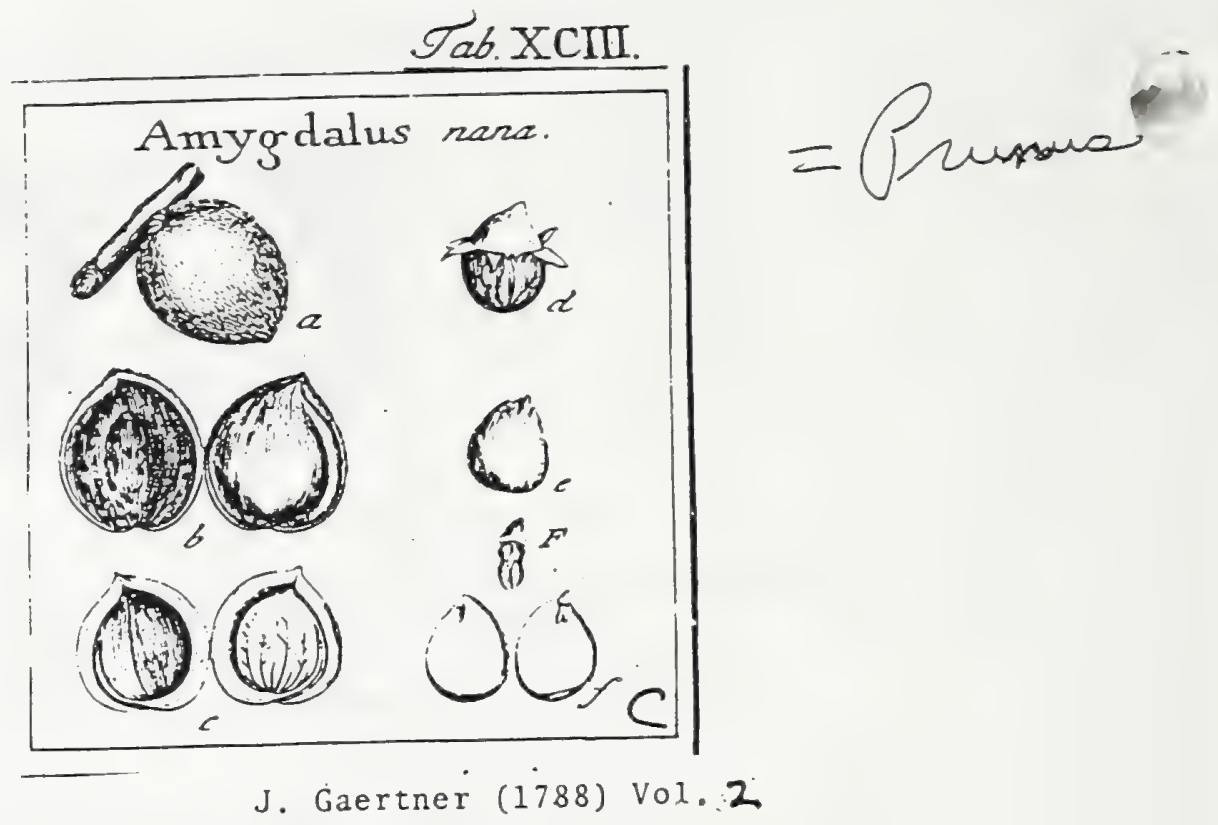

DLXXXI. AMYGDALUS. TOURN. inf. to 402. LINN. ger. 6 ig.

Calyx inferus quinquefidus. Cor. pentapetala. Stam. calycina vigint \& plura. Ovar. fuperum. Styl. fimplex. Drupa pubefcens, biccata aut exfucca: putamine glabriufculo aut fcrobiculato; luturis prominulis.

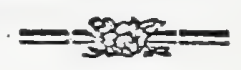

Amygdalus nama. Tab. 93. fig. 3 .

Armeniaca perfice folitis fruffu exficco. AMM. Futb. 273. t. 30 .

Amygdulus foliis bafi attenuatis. LiNN. Jyzt. veg, 462 .

PER. Drupa fupera, exfucca, rotundatio-acuminata, turgide lenticularis, feffilis. Cortex coriaceus, per maturitaten altero latere dehifcens, extus tomentofus, albus; intus ferrugineus, cavernulofus. Putamen offeum, figura corticis, glabrum, bivalve: Sutura altera tenui, anguftiore; altera incraffata, latiore; utraque integerrima, glabra.

REC. funiculus umbilicalis fliformis, in canali proprio futurze crafioris ad feminis apicem adfcendens.

SEM. unicum, ovato - rotundatum, fupra acuminatum, turgide lenticulare, pallidum, venis rufefcentibus pictum.

IN T. duplex: utrumque membranaceum, interioris fuperficie interna carnofa, alba.

A L B. nullum, prater laminam tenuifimam carnofam integumenti interni.

Емв. femini conformis, inverfus, lacteus. Coty. fubhemifpharicx, carnofx. Plum. diphylla, foliolis ovato acuminatis conduplicatis. Rad. brevis, conica, fuperd.

a.) Dropz integra. b.) Putamen, altera corticis valvula reflexa, dentuatum, integrumb c.) Valvulx putzminis apertx, cum femine in fitt. d.) Integumentum (eminis internam fuperne denudatum. e.) Embryo denudatus. f.) Cotgledones feparatx. F.) Radicula \& Plumula aucka.

Uti certi inter Padun, Cerafum, Armeniacan \& Prunum non dantur limites, ita nec inter Amygdalum \& Prunum verum datur difcrimen genericun. Sola differentia, eaque fatis frivola, confiltit in pubefcentia corticis drupx: nam pori putaminis, in A. nana \& in nomullis iplius A. commmunis varietatibus plane defunc. 


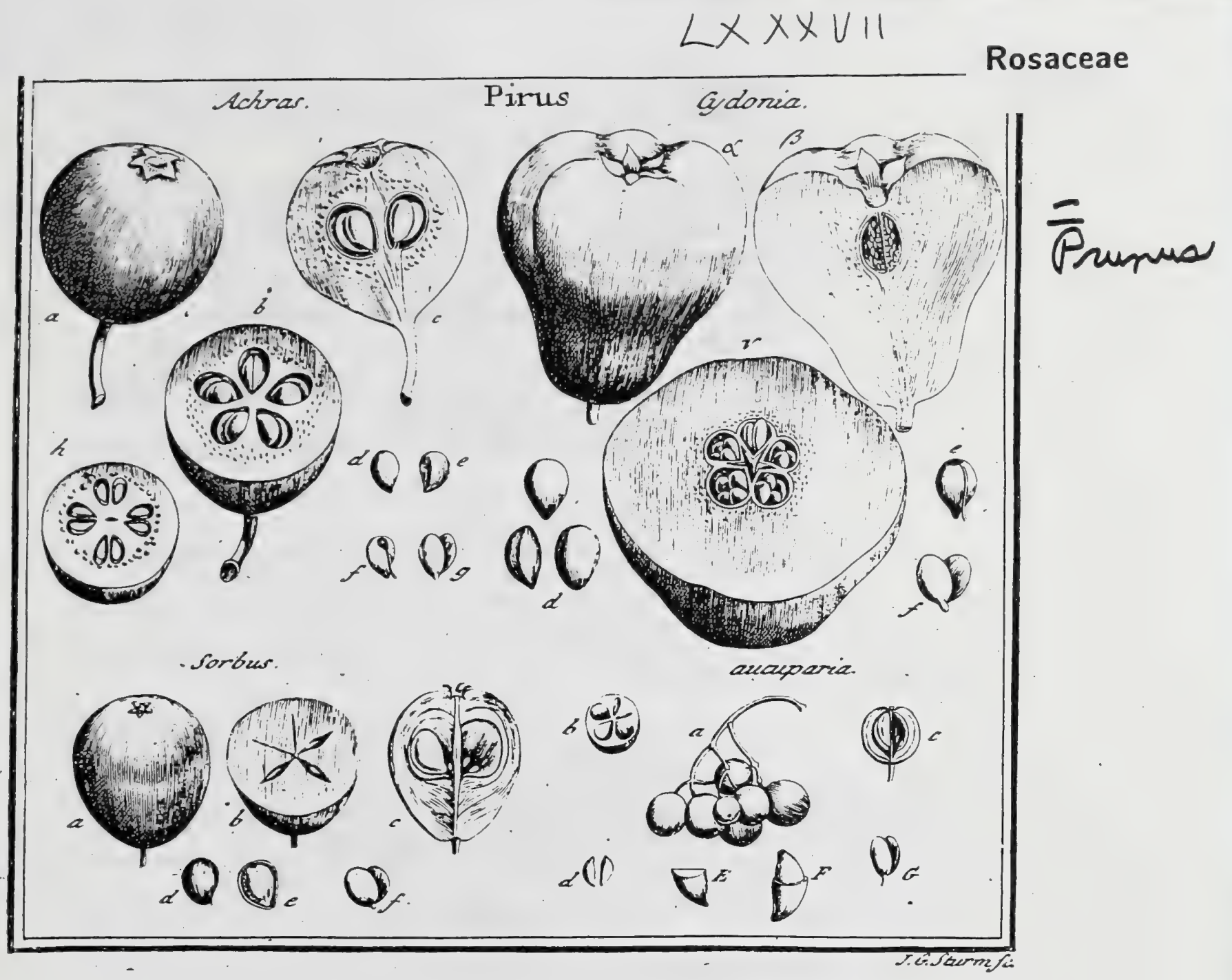

$179.13 \mathrm{~A}$ 
DXLIX. PYR US. TOURN. inft. 2. 404. LINN. gen. 626.

Malus. TOURn. t. 406 . Cydonia. TOURn. t. $405^{\circ}$

Scorbus. LIN s. gen. 623 .

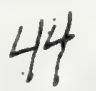

Calyx fuperus, quinquefidus. Cor. pentapetala. Stam. vigint \& plum. Ovar, inferúm. Baccạ pomacea, loculamentus membrana propria veftitis, bi -l. poly\{permis.

(PIRus Achras.) Tab. 87. fig. 25.

Pinus fyluefris. DoD. pempt. 799.

Pirus folits ovato lanceolatis ferrutis glabris. HALL. bifl. "1. I0g6.

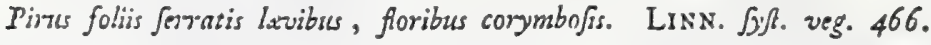

PER. Bacca infera, fubturbinata, carnofa, quinquelocularis. Caro folida, callis lapidefcentibus prope loculamenta referta. Loculamenta membrana coriacea, elaftica, lavigata intus veltita.

Rrc. funiculi umbilicales breves e fundo loculanentorum ad femina pertingentes.

SEN. in frngulo loculo gemina, obovata, deorfum acuminata, plano-convexa, glabra, atra, aut caftanea.

IN T. duplex: exterius coriaceum; interinus membranaceum, chalaza rufefcente in vertice notatum, intus tenui lamina camofa alba veftitum.

A L в. nullum, prater integumenti interni fuperficiem carnofam, prope radiculam paulo crafliorem.

E ді в. femini conformis, erectus, lacteus. Cotyl. ellipticx, carnofx. Rad. brëvis, infera.

a.) Bacea integra, b. c.) Eadem transverfe \& longitudinalites feda; cum infertione \& fir feminum. d. c.) Scmen ab utroque latere fpetatum. f.) Integumentum internnm, cum fua cha laza atque funiculo umbilicali elongato. E.) Embryonis cotyledones diluezr.

Variat interdum loculamentis quaternis, bipartitis monofpermis, uti fig. h. oftendit; fed cultx Piri varienates fere innumerx funt, atque centum \& duo diverfa Pira, a Kïoopıo delineata \& colorata, confpicere licec in ejus Pomologia tab. $1-10$.

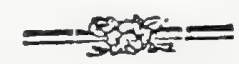

Pirus Cydonia. ibid.

Cydonea, Mala cotonea majora. BLAKw. berb. t. 157. JACQ. auftr. 4. t. 342.

Pirus foliis integerrimis, fioribus folitariis. LIN fyjl. veg. 467 .

Quince. GREw. anat. t. 67. f. 5. male cum feminibus pendulis.

Bacca infera, turbinata $(\alpha)$, pubelcens, fuperne torofa \& profunde umbilicata, quinquelocularis $\left(\gamma_{0}\right)$, per maturitatem intus ad axem debifcens. Loculamenta membrana coriacea craffa fericeo - candida veftica. Ovula, in fingulo moctina, funiculis capillaribus affixa, Semina (d.) ovata, varie angulata, rufefcenfuniculis capillaribus afru, coriaceo, per aquan valde mucilaginofo; interno membranaceo, lata chalaza ferruginea (e) \& funiculo unbilicali ftipato. Embryo (f.) femini confornis, erectus, lacteo :albus.

PIRUS Sorbus ibid.

Sorbus fativa. BLAKw. berb. t. I74. JAce. alfib). 5. t. 447.

Mefpilhs foliis pinnatis frubtus villo/is. HaLL. bijf. 13. 1092.

(Sorbus folitis pimatis fubsus villofis. LiNN. fyft. veg. 465.)

Bacca infera $(a-c)$, fubturbinata, pollicaris, e viridi, luteo \& rubro varia. Loculamenta quinque (b.), duobus aut tribus fepe abortientibus, fertilibus vero membrana chartaces (c), tenui \& intus lacvigata veftitis. Ovula in fingulis loculamentis conftanter duo, femen autem (d.) fxpius folitarium, pro mole bacce grandiufculum, lenticulari compreflum, fufefcens. Integu- menta (e.) \& Embryo (f.) ut in procedentibus.

PIR Us aucuparia. ibid.

Sorbus tonminalis. BLAKw. berb. t. 73 .

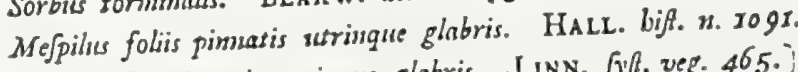

Sorbus foliis pimatis utrinque glabris. LINN. 6ylt. veg. 465.j

Bacca fphxrica, magnitudiue pifi majoris (a), e luteo-miniata \& tandem coccinca : carne flavicante, fubfarinofa. Loculamenta quinque-(b.): duobus vol tribus ficpe abortientibus; fertilibus membrana tenuifima chartacea veftitis. Ovula (c) in loculis gemina. Semina etiam duo (c. d.) oblonga, utringue acuminata, plano-convexa (E). Chalaza in tuberculum fufcum (F.) contracta. Embryonis (G.) radicula longa, acuninata. 


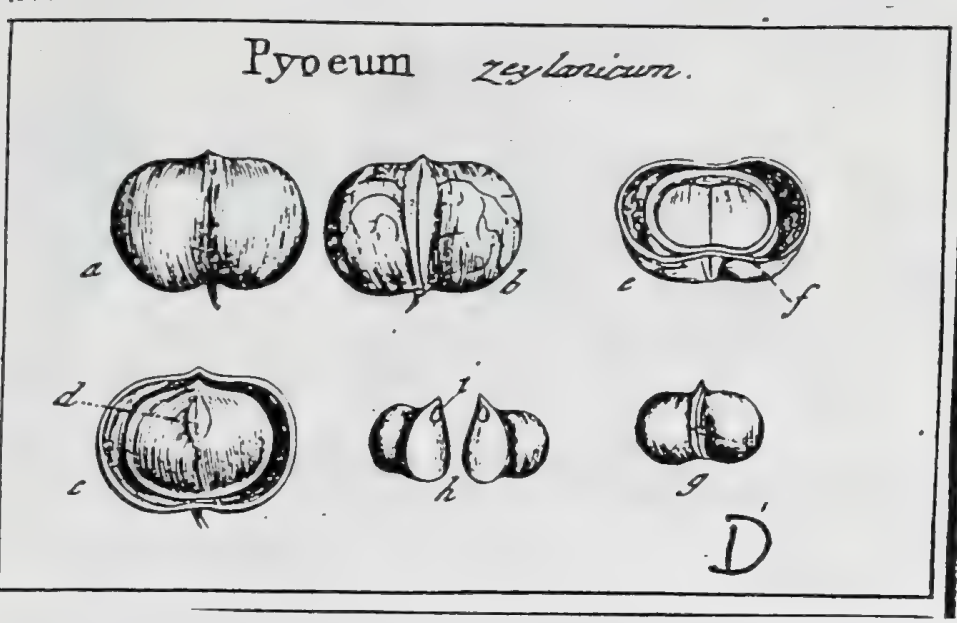

J. Gaertner (i i 88 ) Vol. 1

\section{PYGEV M.}

Flos.... Drupa ficca, transverfim latior. Semen baccarum, altero lateri putaminis; affixus.

PYGEUM zeylanicum. Tab. 46. fig. 4.

Gul-morre, zeylonens. E collect. fern. hort. lugdb.

PER. Drupa exfucca, fulglobofa, transverfin latior \& in gibbam rotunditatem pulvinata, in medio utrinque leviter compreffa, unilocularis, evalvis. Cortex tenuis, in recenti fruetu carnolus. Puttamen chartaceum, elafticum, albicans, in altero btere futurâ fpuriâ longitudinali, incraftatis quafị labris praditâ, notatum.

REC. nullun; femen parieti putaminis a latere futurx fpuriz affixum.

SEM. unicum, grande, figurâ ipfius putaminis, baccatum, unulle, ab altcro latere, area unbilicali ovata, fupra unedium, infignitum.

IN т. fimplex, carnolo pulpofure, molle, extus tenuifima pellicula pulpam coercente, a putamine difcreturn, intus ipfi embryoni adnatuns.

$\Lambda$ Lв. nullum.

Е вв. grandiusculus, pericarpio conformis, inverfus, lutefcens aut viridis. Cotyl. om suum crafTuhunz, hinc infigniter gibbx, inde planx, fupra in brevern mucronem productx. Rad. minima, conica, fupera, intra mucronem cotyledonmin laters.

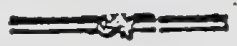

2.) Drupa integra, b.) Putamen denudatum, a parte futarze fpuriz (petratum. c.) Idem longl2.) Drupa integra, b.) Putamen denudatum, \& parte futara (puriz (peexatum. c.) Idem longlminis \& feminis fectio transverfalis. r.) Integumentum feniuls carvofo pulpofurr. 6.) Embryo in fitu naturali. h.) Cotgledones feparatz. 1.) Radicula. 


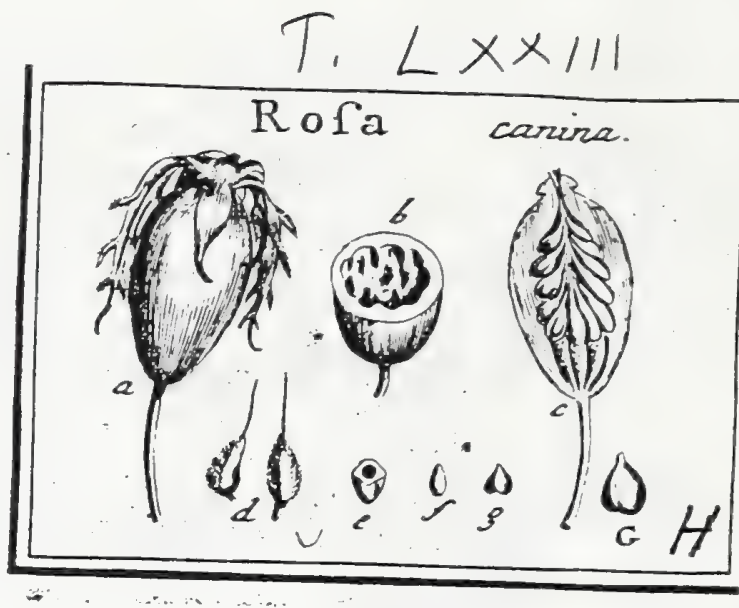

Rosaceae

J. Gaertner (1788) Vחi 1

CCCCXLVIII. ROSA. TOURN. t. 408. Limn. ger. $\sigma_{3}$ r. 347

Calyx ventricofus, quinquefidus, demum baccatus, coloratus. Cor.pentapetala. Stam. plurima calycina. Styl. plures. Semina plura, fuborTea.

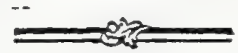

Ros a canina. Tab. 73. fig. 4.

Ro/a canina. DO D. pcmpt. 187. BLA K Tr. herb. t. 8. OEDER. f. dan.t.555.

Rofa Jpinis aduncis, foliis Jeptenis, calyeibus tomentofis, Jegmentis pinnatis E' Jemipinnatis, tubis brevifinis. H a r. 1. hif. 2. n. Iror.

Rofa germinibus oratis pedunculisque glabris, caule petiolisque aculentis. LINN. Jilf. veg. 474 .

PER. nullum. Calyx maturus baccatus, ovatus, glaberrimus, coccincus, apice nunc pervius, nunc obturatus, femina fovet.

REC. nullum; femina parietalia, foveolis fubllautix carnofac calycis immerfa; centralia auten, pedunculis carnofis, croceis, fubvillofis nipata.

SF.M. plura, circiter triginta, offea, ovato acuminata, angulata, fetis albis fericeis confperfa, nylo perfintente terminata, pallida.

IN T. duplex : exterius offeum, crallum, intus lacvigatum, nitidum; interius mem. bra:aceum, fubferrugineum, bafi chalaza fufca notatums.

A ᄂ B. nullum.

Es в. femini conformis, inverfus, albus. Cotyl. ovatae, crafrae, carnofae. Rad. brevifima, fupera.

2.b.) Calyx maturus integer \& diffectus. c.) Seminum fitus intra calvcem. d.) Semina (eparata, e.) Serninis tefra diffecta, fo) Nucleus feparatus. g. (J.) Embryo denudatus. 


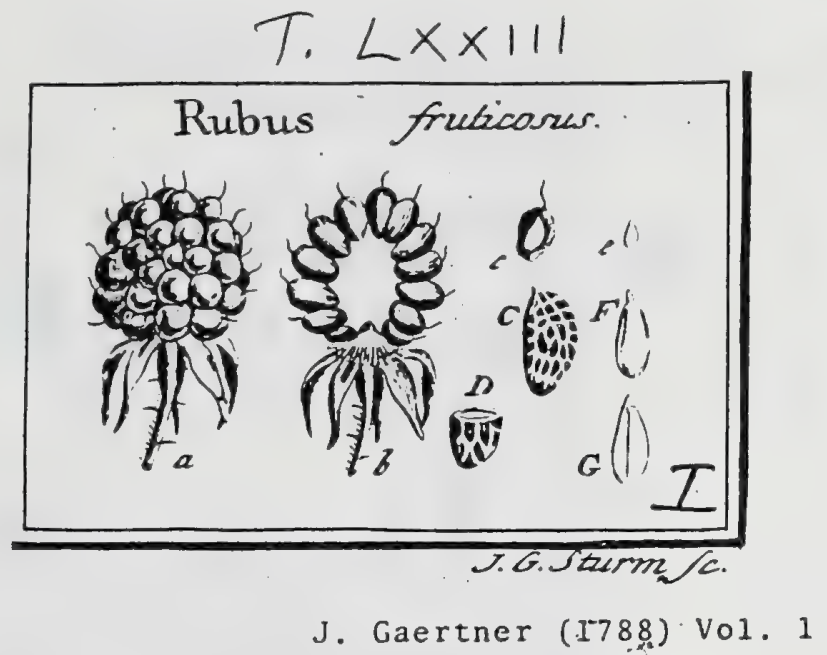

CCCCLIII. RUBUS. TOURA. t. 3\$5. Linn. gen. 632. 350

Calyx quinquefidus. Cor. pentapetala. Statn. plurima calycina. Styl. ex apicc orarii. Receptac. commune conicum. Semina plurima baccata, in baccam compo-; fitam conferruminata.

RuBus fruticofus. Tab. 73. fig. 9 .

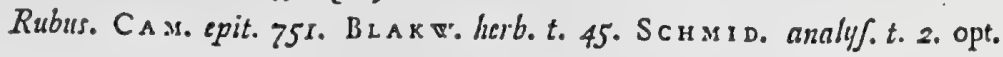

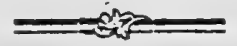

Rubus caule fpinofo ferpente, folits quinatis. E ternatis fubtus fubtomentofis, bacea lavi. Hall. hift. 2, n. Itog.

Rubus foliis quinato digitatis ternatisque, caule petiolisque aculcatis. Lin $\times$. Jifl. veg. 475 .

PER. Bacca univerfalis ovato globofa, per maturitatem intus concava decidua; compofira e Baccis partialibus numerofis, circiter quinquaginta, ovatis, fucculentis, atropurpureis, glaberrimis, nitidis, monopyrenis.

REC. fungofun, conicum, breve.

SEM. Colitaria, ovata, fupra anguftata, lenticulari comprefta, reticulato rugola; pallide teflacea.

IN T. duplex: exterius crufaceo-coriaceum, craflum; interius membranaceum: fuperficic interna fubcarnola.

A z. B. nullum, proter integumenti fuperficiem tenuiffune carnofan.

Eм в. femini conformis, compreftus, inverfus, albus. Cotyl. ovato-oblongx, tenues. Rad. conica, brevilima; fupera.

a.) Fruatus integer. b.) Receptac, commune, cum bacea univerfali difteda. c.) Semen intra bazcam partialem. C.) IJem naturali majus. D.) Idem diffectum. e.) Nucleus decorticatus, F.) Embryo denudatus. G.) Cotyledon altera a parte interiori fpectata. 


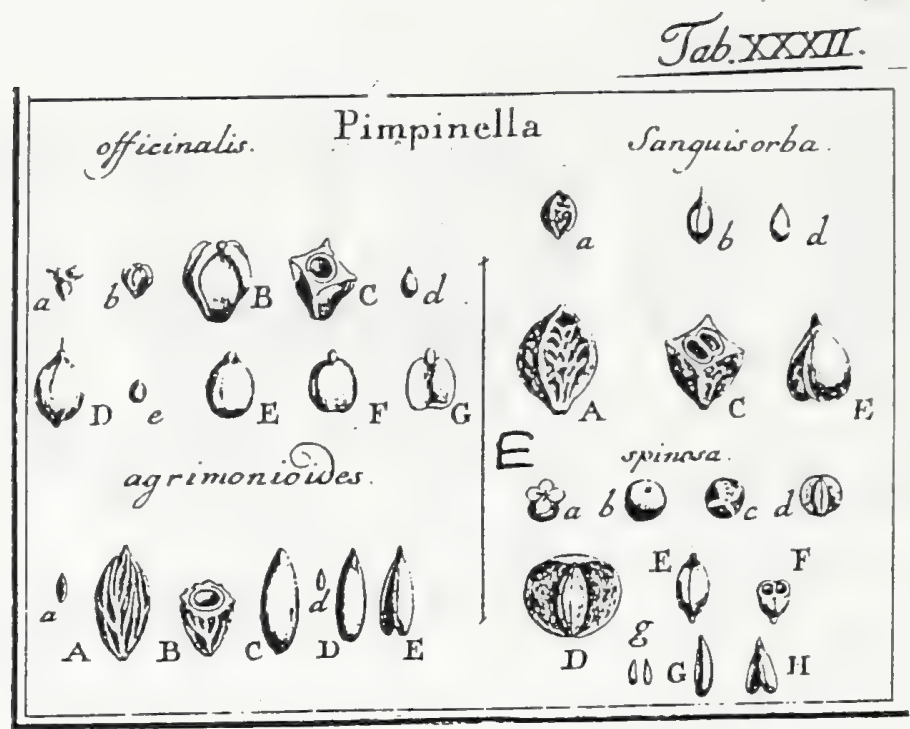

\section{Rosaceae}

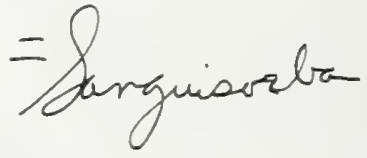

CXCVI. PIMPINELLA. Tou R N. t. 68. Sanguiforba. Linn. gen. 146.

Poterium. LIN gen. so6g.

Flores in aliis hermaphroditi puri, in aliis fexu diftincti in eadem planta. Cal, quadripartitus fuperus: in fructum abeuns. Cor. nulla. Stam. quatuor, aut plurima. Styl. unicus, aut duplex. Drupa exfucca infera, uni-1. bilocularis. Semina inverfa.

Pimpinella ofticinalis (fructu glabro.) Tab. 32, fig. 3.

Ex horto \& fide MARTYNI Stutgardiens.

PER. Drupa exfucca, infera, parva, fubturbinata, glabra, quadrangula: angulis verfus apiccm in quatuor alas membranaceas extenuatis. Cortex membrallaceo (pongiofus, tenuis, undique glaber. Putamen chartaceum, ovato globolum, uniloculare.

REC. nullun; femen bafi affixum.

SEM. unicum, ovato globofum, fuperne mucronatum, inferne ampla area umbilicali nigro fufca notarum, ceterea album.

IN T. Cmplex, membranaceum, tenue.

A L B. nullum.

Eм в. dicotyledonens, inveríus, femini conformis, albus. Cotyl. carnolx, planoconvexx. Rad. brevifius, exferta, fupera.

2. b. B.) Fructus integer. C.) Iden difectus. d. D.) Putanten derudatum. e E) Semen docorticatum. F.) Einuryo. G.) Cotyledon a parte interua.

A vulgari P. officinali multum hic fructus differt \& forfan P. canaden/is eft; quod aلiis cnodandun rclinquo.

162

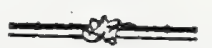

Pimpinella agrimonoides. ibid.

Pimpinella agrimonoides. Bосc. fic. p. 57. t. 30.f. I. A. B. C.

Poterium inerme, caulibus teretibus friatis. L IN N. Jifl. veg. 857

Drupa parrula (a.), ovato oblonga; utrinque attenuata, rugofa (A.) obfolere tetragons, fpadicea, unilocularis. Cortex coriaceus, tenuis. Putamen (C. cartilagineum uniloculare, extus ferrugineum. Semen (d. D.) terecia cumin tum, Spadiceum. Embryo (E.) magnitudine fernuis, inverfus.

Pimpinella fanguiforba. ibid.

Pimpinella. В L А к

Pimpinella polyfemon. HAIL. hifl. I. n. 706 .

Poteriuns inerme, caulibus fubangulatis. Lins. filf?. veg. 857 .

Drupa ovata, utrinque acuminata (2. A.) quadrangularis: angulis comprefis (C.) acutis; lateribus fcrobiculato rugofis. Cortex coriaccus, funco fradiccus, au rubicundus. Putamen (b.) chartaceun, ovatum, biloculare. Semina ovato acunninara (d.), plano-convexa, pallide lutea, areâ bafeos ferrugineâ. Eubryo (E.) inverfus, magnitudine feminis.

Pimpranela finola, ibid.

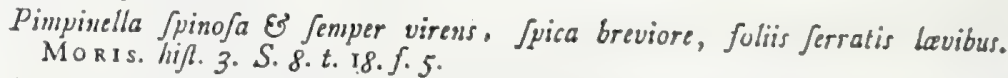

Poterium $\int$ pinis ramo/is. LIN N. Jyß. veg. 857 .

Drupa globofa (a. b.), verfus bafin oblolete angulata (c.), rubicunda, Cortex fpongiofus, crafliflumus d.D.). Putamen (D.E. F.) ellipsicum, utrinque acuminatum, ofteum, biloculare. Semins (g. G.) fensitcretia, pallide luteols : area bafeos cantanea. Embryo (H.) inverfus femini conformis. 


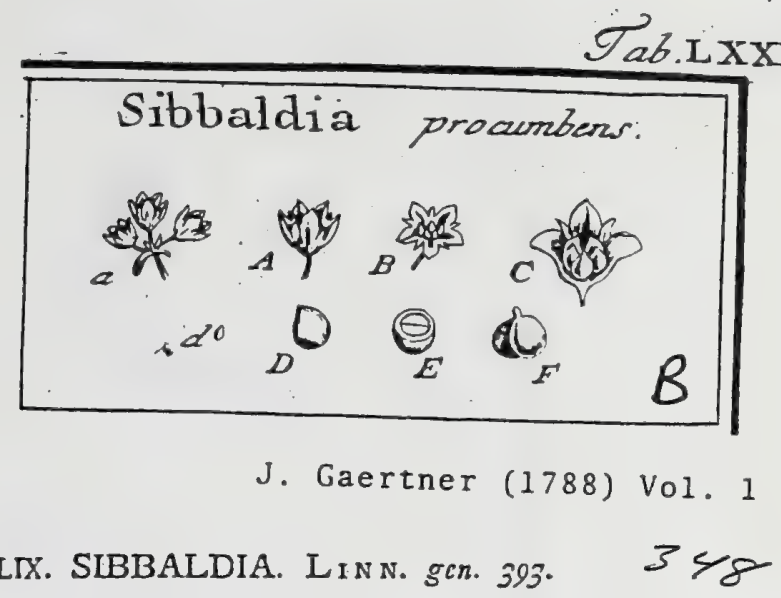

CCCCXLIX. SLBBALDIA. LIN . gen. 393. 358

Calyx decemfidus, dentibus alternis najoribus. Cor. pentapetala. Stam. quinque calycina. Sty $\perp$ quinque laterales. Semina quinque nuda.

SI В В AL DIA procumbens. Tab. 73. fig. 5 .

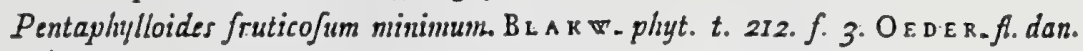
t. 32.

Fragarin foliis ternatis retufis tridentatis, fore cali;i aquali pentafemone. Hall. hifl. 2. "11116.

Sibbridia foliolis tridentatis. L I N N. Jy/l. vieg. 308 .

PER. nullum. Calyx immutatus femina continet.

REC. nullum.

S вм. quinique, farra, fubglobola, fupra acuminata, glabra, luten-fpadicẹa.

IN T. duplex: exterius fuboffeum, craftusculim; interius suenub:anaccum.

$\Lambda$ \&. nullum.

Ex в. femini conformis, inverfus, albus. Cotyl hemifplixricx. Raibrevis, fupera.

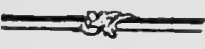

2. A. B.) Calyx maturus. C.) Seminum fitus intra calycem, d.D.) Semina feparata. E.) Scmen diffectum. F.) Einbryo denudatus. 
6.

6

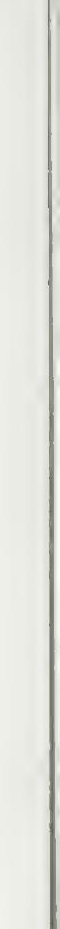

8 


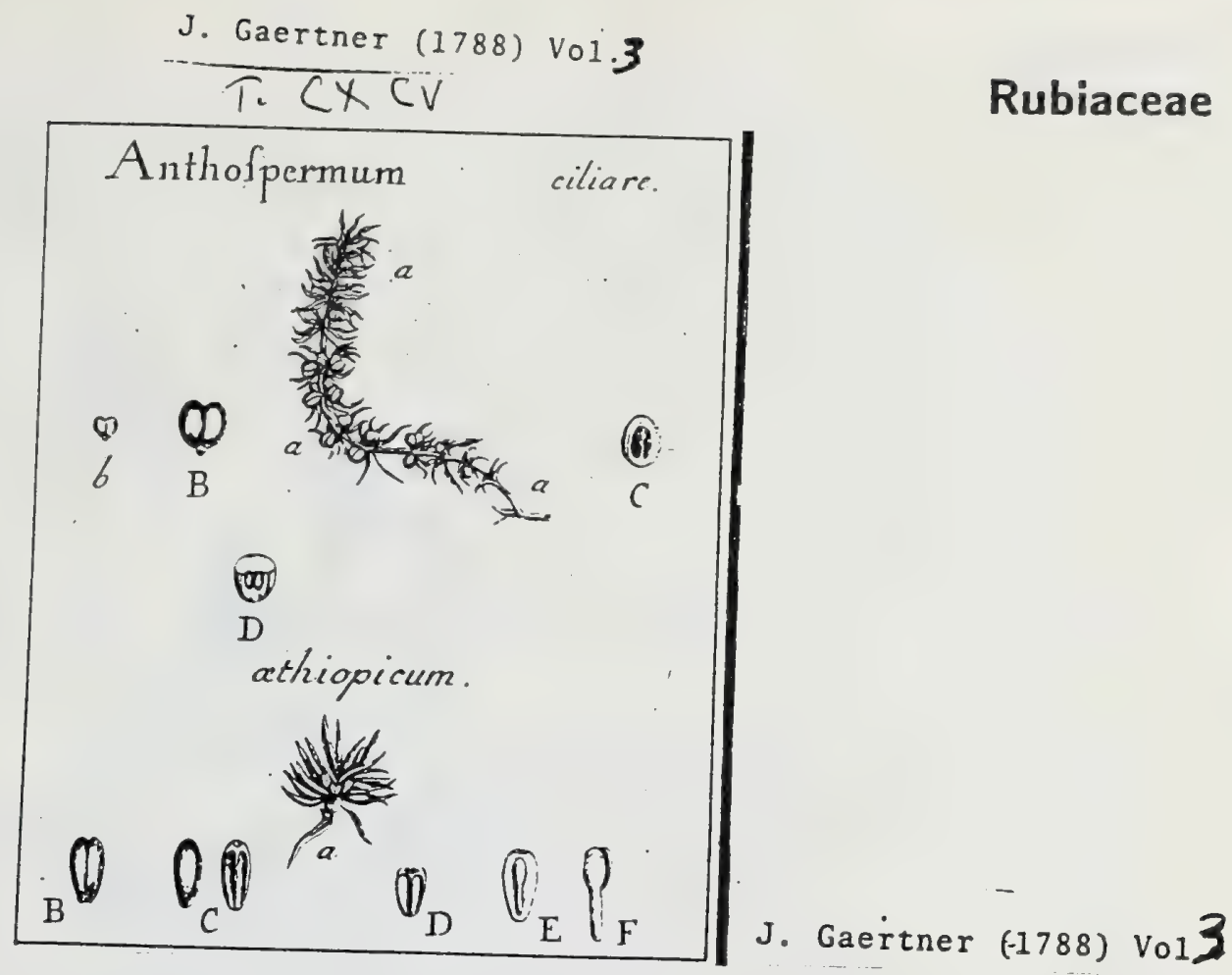

\section{A NTHOS P E R M U M. 87}

LIкк. gen. 1164. eत. Schreb. -150r. Juss. gen. p. roT.

Tournefortia. PONTED. epif. Ir.

CaI. fuperus, minimus, quadridentatus, deciduus. Cor. monophylla : tuho conico, brevi ; limbo profunde quadriparoto: laciniis ovato-oblnngis, revalutis, obcufis. Stan .4; filamentis capillaribus, erectis, infimo tubo

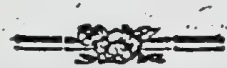

inTertis, corollam vix xquantibus; "antheris terragonis, oblongis, erectis.' Ovar. inferum; fyl. . . .; ttigm. .... Sem. duo. Alb. fubcartilagineum. Emb. dorfalis, erectus.

Anthospermux ciliare. Tab. 195. fig. 6 .

Clinopodium africanum procusabens p̧yllii foliis Eे capisulis cum cauliculo lanmgine veftitis. PLUKN. mant. 51. t. 244. f. 5.

Antbojpermum foliis carina margineque ciliatis. Lixis. Jpec. pl. p. 1512 . Syf. veg. ed. 14. p. 9ro.

A Cl. Thunberg cum Sequente.

PER. nullum; prater cuticulam tenuiflimam femina leviter obtegentem:

REc. nullum; femina pedunculo brevifimo bidentato bafi affixa, \& latero ventrali Gbi invicem juncta.

Sz r. duo, infera, exigua, glabra, fubglobofa 1. fubelliptica, hinc convexa, inde foveola ovata bafi feminis propiore \& nervo intermedio bipartita exfculpta o 1. menifcoideo-umbilicata , fufca.

IN T. fimplex, membranaceum, validum, albumini arctiffume adnatum.

A L B. femini conforme, menifeatum, ...:

EMB. ....

\section{EXPLICATIO FIGURE.}

a. 2. 2.) Ramulus frogifer. b. B.) Senina gemina a ranglo feparzta. C.) Semen folatum, ventre fpectatum. D.) Albumen medio transveríe feetrom.

In plurinis feminulis mihi non contigit, invenire ullam embryonis umbram ANTHOSPERMUN xthiopicum. ibid.

Frutex africanus ambram spirans. PLUKN, alm. 159. t. 183. f. x WALT. bort. 24. t. 9 .

Anthospermutus. LIN . Bort. cliff. 455 . t. 27.

Antlospermum foliis levibus. Lixis. Spec. pl. p. $151 x$. Syft. veg. ed I4. p. 9 rg.

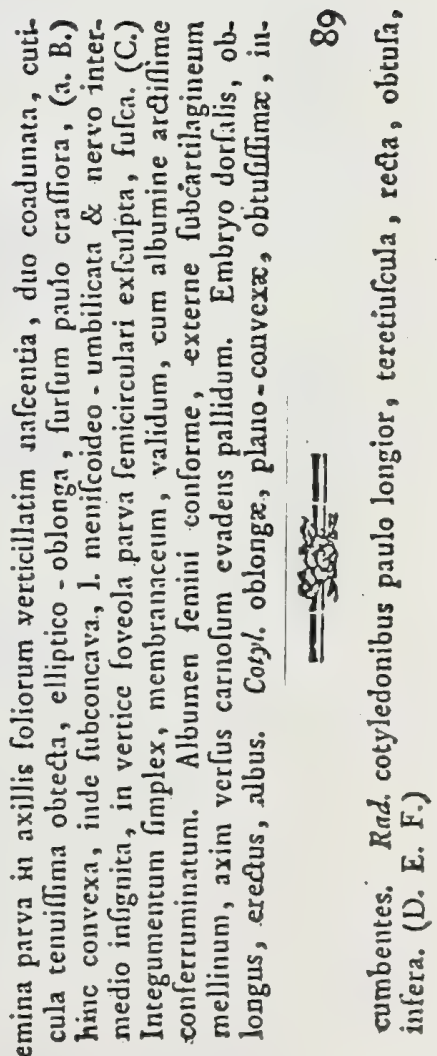




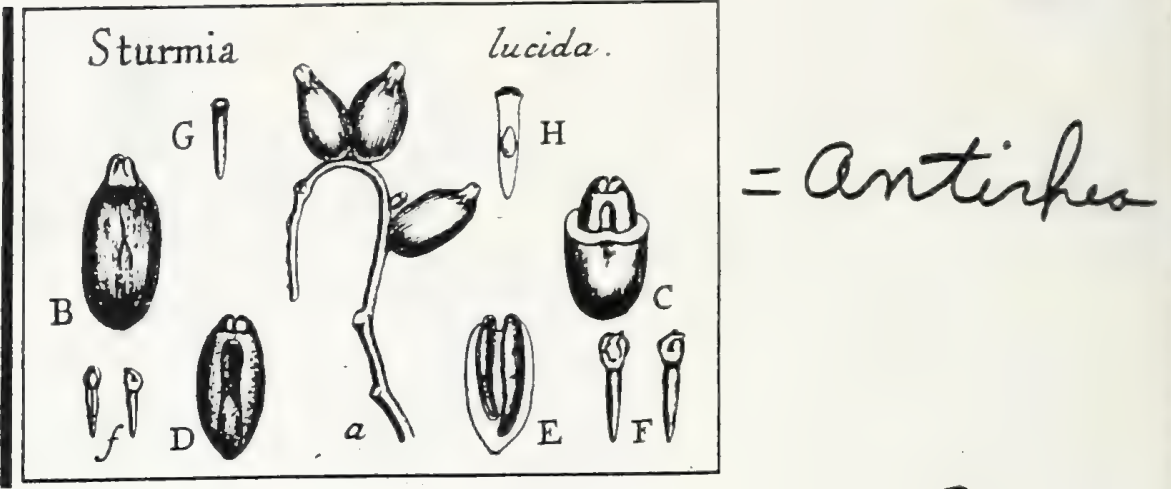

69

58. S T E N O S T O M U M.

J. Gaertner

Cal. fuperus, parvus, quinquedentatus per maturitatem inæqualis, perfiftens. Cor. monopetala, infundibuliformis; tubo longo, ad faucen ampliato; limbo quinquefido: Jaciniis lanceolatis, obtufiufculis; reßexis, glabris. Stam. quinque; filamentis brevibus; antheris oblongis, exfertis, didymis. Ovar. inferum; ftylo tereti, fuperne incraffato; ftigmate bilobo. Drupa infera baccata, putamine biloculari. Semina duo, inverfa, umbilico appendiculato inftructa. Alb. carnofum. Embryo inverfus, centralis.

Stenostomum lucidum.

Sturmia lucida in Icon. Tab. 192. fig. 3.

Laugeria foliis oblongis obtufss integris membranaceis nitidis, racenis dicbotonis. drupis nucibus bilocularibus. SWARTZ prod. p. 48. Fl. ind. occid. x. p. 475 . WILld. Jpec. pl. T. x. P. 2. p. 1082. Persoon fyn. plo. I. p. 203.

Icon. VaHL fymb. bot. t. 57.

E collectione Bankfiana.

PER. Drupa infera, baccata, oblonga 1. ovata, feffilis, compreffiufcula, calyce quinquedentato per maturitatem vero inxquali connivente obturo coronata, rubra. Caro crafliufcula, firma, putamini arcte adnata, Aavefcens. Putamen oblongum, dactyloideum, craffum, granulofo-ofeum, comprefiufculum, utrinque fulco longitudinali rotundato ad bafin putaminis fubltantia offea repleto ad verticem autem pervio inferiptum, \& hinc apice derafo bifidum, biloculare, difpermum. Locolamenta ex membrana coriacea confata, intus levigata, cum materia offea intime connata, fubulata, verfus axim putaminis incurva, fuperne foraminulo lacero hiantia.

REC. nullum; prater fafciculum vaforum umbilicalium in pedunculo oriundorum in fulco putaminis ad ejus verticem afcendentern.

SzM. duo inverfa ; in fingulo loculo fingulum, capitato - fuffiforme, in dorfo funiculo umbilicali rufefcenti notatum, lutefcens, appendiculato-umbilicatum.

Umbilicus in vertice feminis incrafatus; hinc oblique decufatus, \& fulco elevato ad dorfum increfcente atque cum funiculo umbilicali continuo infcriptus; inde, ubi ab albumine ceu articulo fecedit, foveola parva excavatus, granulofo- farinofus, rufefcens.

IN T. Simplex, membranaceum, albumini arcle adnatum.

AL в. Sereti-fubulatum, vertice obtufo converiufculo foveolx umbilici inher rens, carnofum, leviflime viridulum.

Es B. minimus, in medio albumine locatus, inverfus, ovatus, pallide viridis. Corgl. brevillimx, obtufe, non difcretx. Rad. conica, obtufa, umbilico externo obversa, fupera.

\section{EXPLICATIO FIGUBE.}

a) Pars racemi frugiferi. B.) Drupa feparata. C.) Eadern, putamine ad mediun usque a carne dinudato. D.) Patamen feparatum. E.) Idem lungitudinatiter diftedum cum litu \& directione loculameatorubs f. F.) Scmina integra saturafi \& avera magnituline. G.) Albumen ab umbilico appendiculato feparatum. H.) Idem cum fitu Embryonis.

Quantacunque etiam Laugerix cum noftra planta in habitu externo fit affnitas, carpologice tamen in unum genus compingi nequeunt; novum itaque ex ea haurire genus, non dubitavi.

Quibus contingit recentia videre femina, in umbilici conditionem plane inufitatam, \& ejus cum albumine nexum attente inquirant; tres tantummodo drupx, quas diffecare mihi licuit, nondum fat lucis in fingularifimam hujus piante feminum compagen fuderuut, cum fenina non fatis 
J. Gaertner (1788) Vo13

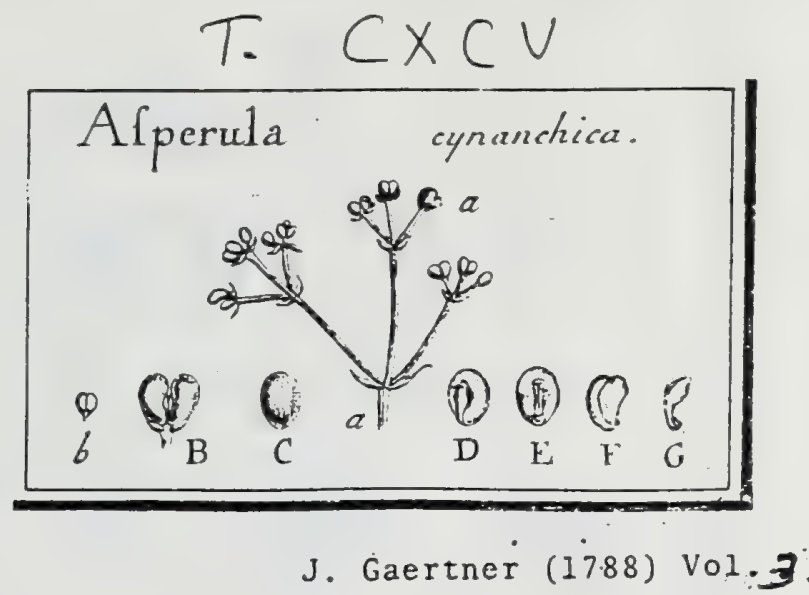

73. A S P R U L A. 89

LINN. gen. 121. ed. Schreb. 157. Joss. ger. p. 196.

LaMABCI ill. gell. t. 6r.

Cal. fuperus, parvus, quadridentatus, deciduus. Cor. monopetala, infundibulifirınis; tubo longo, cylindracen; limbo quadri - (1. rarius tri-) partito. Stam. 4. (1. rarius 3.); filamencis brevibus, fummo tubo infertis. Ovar. infer un, didymum; Itylo filiformi, apice bifido, \& Atigmate capitato. Sem. duo, jnfers, non nenifata. Alb. fubcarcilagineum, folidum. Emb. dorfalis, curvatus, erectus.

ASPERULA cynanchica. Tab. 195. Eg. 7.

Galium album minus. TABERN. bif. 433. $f .=$

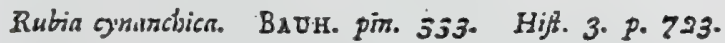

Ajperula caste firmo, ramofo, folits linearibus quaternis, fummis conjugatiso HaLL. belv. u: 730 .

Afpertla foliis quaternis linearibus : froerioribus oppofitis, caule ereĨo, floribus quadrifitis. Lisk. Jyt. veg. en. 14. p. 149. Spec. plo ed. Willd. T. I. P. 1. p. 579 . PERSOON JyH. pl. J. p. 124

PER. nultum; proter cuticulam tenuem e cinereo viridefcenten feminibus adnatam, fed ficile detrahendain.

Rec. nullum; femina bafi pedunculo affixa, \& ad ventrem condunata.

SzM. duo (alcero nonunq̨uan abortiente), infera, parva, obelliptica, fubgla bofa, punctis minimis callofis exafperata, ad ventrem umbilico longitudinali ad bafin ufque decurrente fufco callofo inftructa, tota fulida.

IN T. fimplex, membranaceun, albunini arctiffine adnatum.

A L 8. femini conforme, fubcartilagineum, folidum, cinereum.

EMB. crectus, dorfalis, curvatus, albus. Cotyl. ovatx, tenuiffimix, obtufx, cum radicula curvatx, incumbentes. $R a d$. cotyledones longitudiue xquans, tereciufcula, incurva, umbilico externo obverfa, infera,

\section{EXPLICATIO FIGURR}

a. a.) Ramulus frugifer. U. B.) Serína duo coadunata. C.) Semen a dorfo fpectatum. D.) Lilem a rentre vifum, remanente callo a temine altero abortivo. E.) Uabilici figura \& fitus in feminis ventrc F.) Albumen verticaliter featum cum fitu \& curvatura cobbyonis. G.) Emiryo Ecyazatus 


\section{J. Gaertner (1788) Vol3. \\ Tab. 225 .}
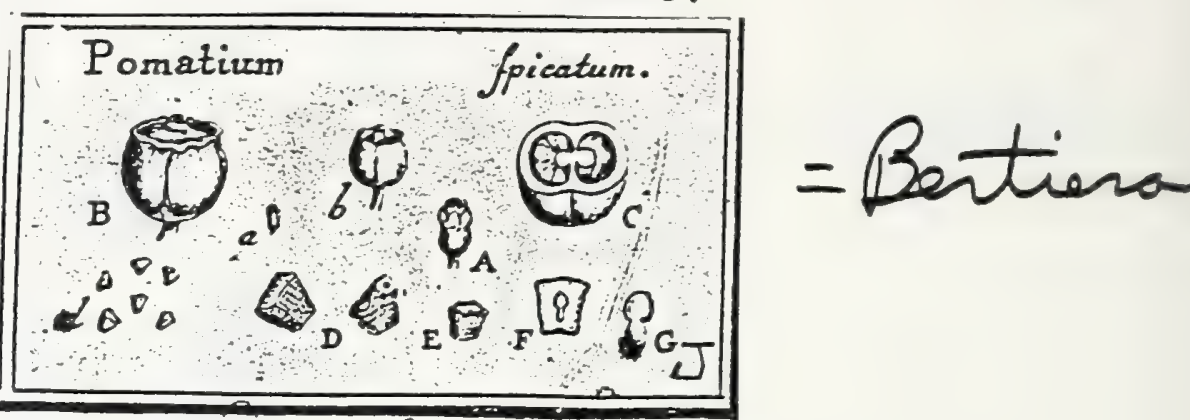

\section{P O M A I U M. .}

Cal. monophyllus, fuperus, quinquefidus; laciniis brevibus obtufis, deciduis relido circulo membranaceo denticulato - lacero, Cor. ... Stam. ... Ovar. inferum; ftylo fimplici; ftigm. . . . Bacca fubglubofá, fulcato didyma, calycis reliquiis coronata, bilocularis, polyfperma, Rec. fungofa, medio diffepimento utrinque inferta, Sem, numerofa, angulata. Allb, carnofum. Emb. erectus; rád. difcreta, centripeta,

Pomatiuar fpicatum. Tab. $22 \%$. fig. 10,

Genif'a labiata, L'Herit. Collect,

Habitat in Africa. Ab amicifimo $D^{\text {ae }}$ Deçannolle.

PER. Bacca parva, magnitudine pifi, fubglobofa, fulco obfoleto fubdidyna , deprefinufcula, calycis rudimento membranaceo angufto inxquali fub vertice quafi operculo inftrufta, \& in vertice ippo ftyli reliquiis mucronstoumbonata, glabra, bilocularis, polyfperma. Caro non admodum crafa, firms. Difepimentum membranaceo-carnofum, fulco externo obverfum,

REC. fungofo-carnofa, fubglobofa, medio diffepimento utrinque affixa, funi, culis umbilicalibus brevillimis hifpidula.

SE M. numerofa, parva, arcte fibi approximata, centripeta, augulata, irregu fariter truncato - pyramidata, lateribus planiufcula, foveola umbilicali minima inftructa, punctís minimis excayaris reciculata, fpadicea l, -ferruginea,

I $\$$ T. fimplex, cruftaceum, crafiufculum, fragile,

$\Lambda$ L. fermini conforme, carnofum, pallidum,

E \& в. minimus, albumine dimidio fere brevior, \& ad ejus bafin locatus, ereClus, albus. Cotyl, ovatx, bafi truncate, plano - convexiufculx. Rad. ovatooblonga, turbinața, cotyledonibus paulo longior, umbiliço extemo ob* verfa, centripeca.

\section{EXPLICATIO FIGURE,}

a. A.) Orarium immaturum. b.'B.) Bacea integra, C.) Ejusden fedio transverlalis, eum forma receptasulorum \& Gitu feminum d. D.) Serwina feparata, E.) Seminis fectio transper. [alis. F.) Eabryonis fitus intra albumen G.) Embryo folutus.

Caulis fuffructicofus pubefcens; tores breviffime pedunculati, in fpicam fub. cumpofitam denfam congelti; folia oppofita remota, breviter pedunculata, ovato-lanceolata: fubtus ferruginea, nervofa, pubefcentias ftipula interfoltacex connatx, vaginantes, longx, lonceolatre, perfiftentes.

Genus Hamelia affaitate proximum \& precipue bacca biloculari ab illa diverfum. 


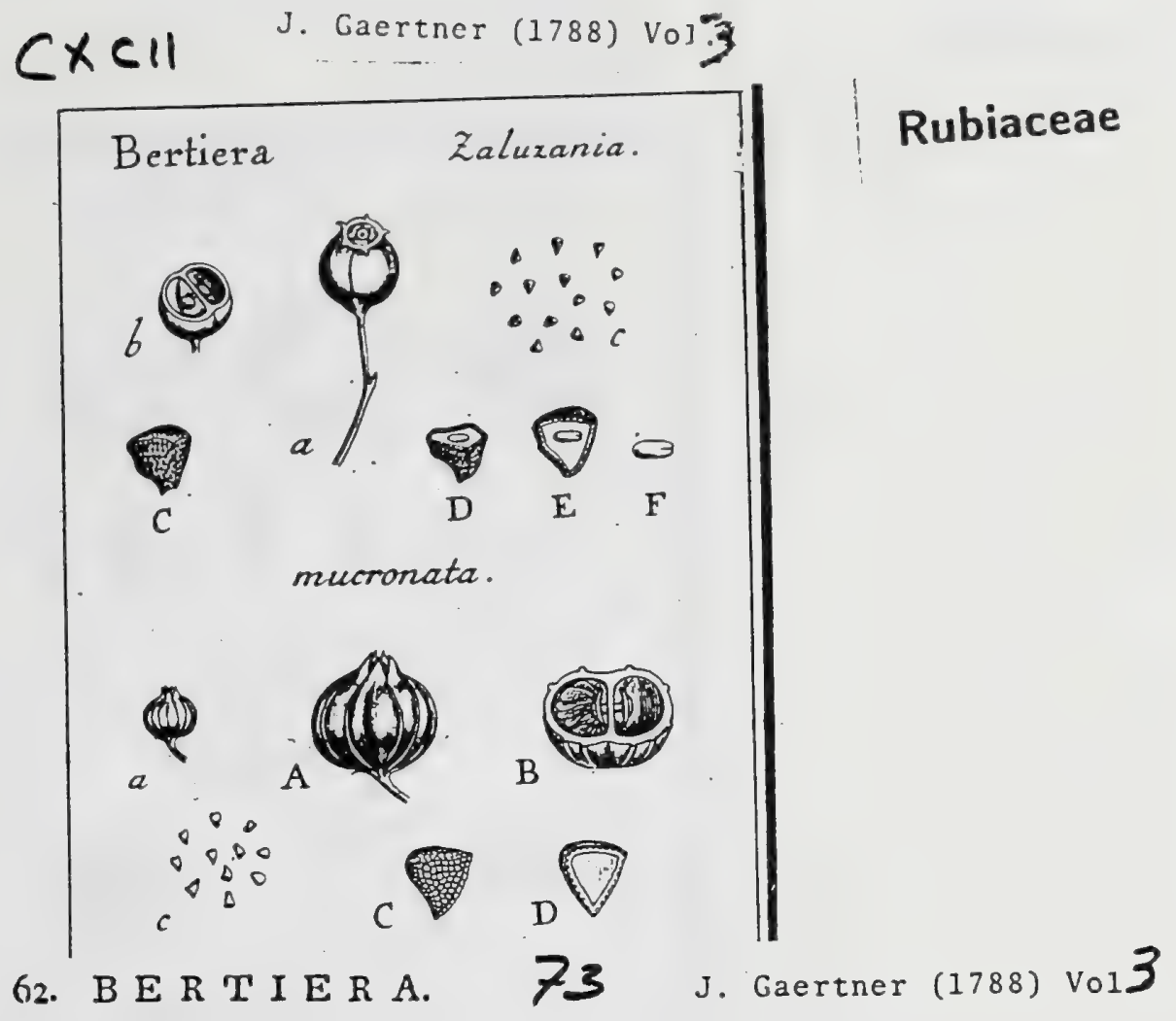

Atв. gily. t. 69. Sснвев. gen. 304. Juss. gen. p. 200. LАмавск ill. gen. t. 16j.

Cs]. monsphyllus, fuperus, turbinatus, villofus, quinquedentatus : dentibus erectis. Cor. monopetala, tubulofa, fauce villofa; limbo quinquefido: lacinis patentibus. Stam. quinque; filamentis brevifimis, in fupera tubi parte infertis; antheris linearibus, apice mucronatis. Ovar. inferum; ftylo limplici, filiformi, corollam non fuperaute; ftigmate bifido, lanceolate lanillato. Bacca infera, cilyce perfiftente coronata, bilocularis, yolyfperma. Recept. centro difepimenti aduatum, fungiforme. Sem. centripeta, angulata. Alb. fubcartilagineum. Enb. transverfus; rad. centrifuga.

Brrtiera Zaluzania. Tab. 192. fig. 7.

Zaluzania Conmers. M/s. \& Ic. ined.

E collectione Cel. Desfontaines.

PER. Bacca infera, fubglobofa magnitudine pifi majoris, intra calycem prominulum quinquedentatum relexum late umbilicata \& annulo parvo protuberante atque foveola puncticulari in centro notata, bifulca, pedunculo longo ftipulis foliaceis parvis ad infertionem armato infidens, bilocularis, polyfperma. Caro valde debilis, maturitate in membranam coriaceam coarctata, atrocœrulea. Diffepimentum membranaceum, tenue, fulco externo infertum.

R \& C. in centro difepimenti ab utroque latere infertum, breviter pedicellatum, capitulo fungofo difcoideo in bacce cavitatem prominulum.

SE м. plurima, pyramidata, angulata, punctis minimis elevatis confperfa, hine rotundata, inde a vicinis angulato - conica, \& ad umbilicum in apice coni locatum foveolà parvà notata, atrofufca, centripeta.

IN r. fimplex, craffiufculum, fragile, ab albumine facile feparandun.

A L B. Semini conforme, duriufculum, carnofum, 1. fubcartilagineum, fordide mellinum.

EN в. minutus, centralis, oblongus, teres, tenerrimus, aqueo-pellucidus, transverfus. Cotyl. breves, arctiffime inter fe adglutinatæ. incumbentes, obtufa. Rad. longa, teres, obtufiffima, ab umbilico externo ayerfa, centrifuga.

\section{EXPLICATIO FIGURE.}

1.) Baces integra. b.) Eadem transverfe diffetza cum diffepimento \& receptaculis in titu: c. C.) Semina folnta. D. E.) Albumen transverle \& loagitudinaliter fectun cum Gitu embryonis. F.) Embryo Separatus value auelus.
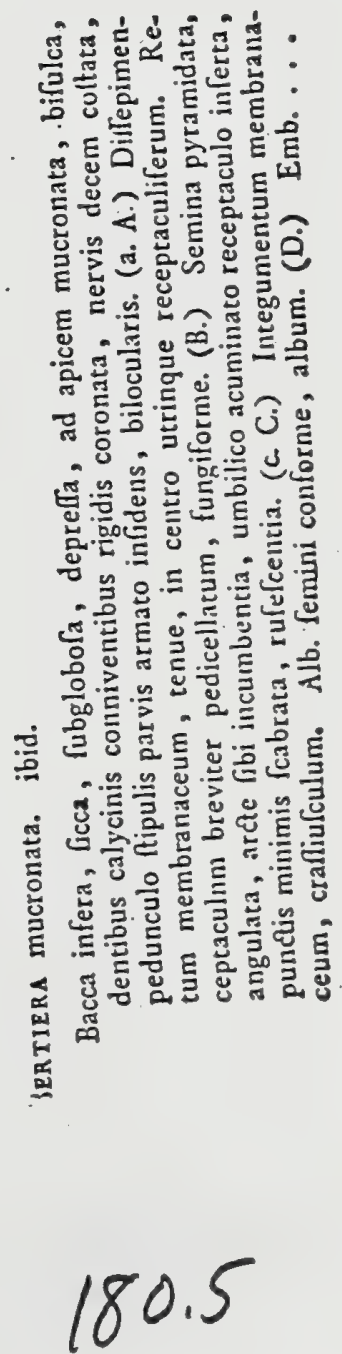
J. Gaertner (1788) Vor 3

Tab. CXCVI.

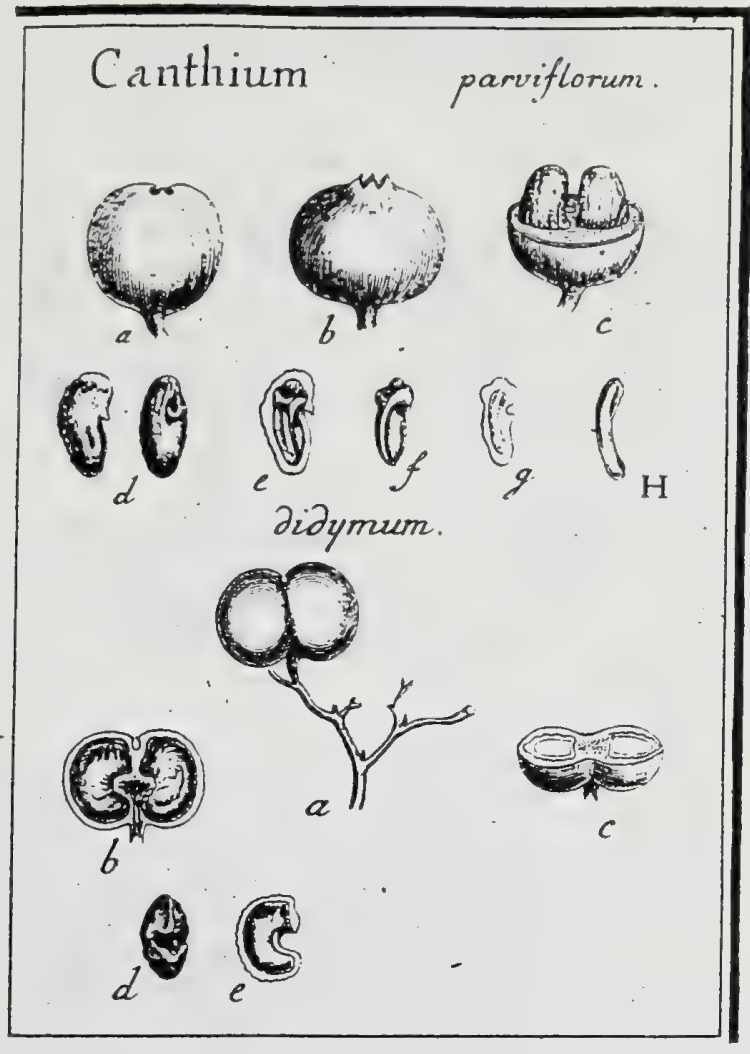

$180.6 \mathrm{~A}$ 


\section{C A.N T H I U M.}

Lamarck dict. r. p. 602.. Juss. gen. p. 204.

Webera. Sснвев. gen. 1733 ?

Cal. parvus, monophyllus, fuperus, quadri- (1. quinque -) dentatus: dentibus rectis, acutis. Cor. monoperala, tubulora; tubo brevi, cylindrico; limbo quadri - (1. quinque -) fido: laciniis ovatis, acutis. Stam. 4. (1. 5.) exferta; filamentis brevillimis, ad faucem corolle fub incifuris infertis; antheris cordato-oblongis. Ovar. inferum, ftylo fimplici tubum xquante \& ftigmate capitato patelliformi munitum. hisca compreffiufcula, coronata, dipyrena; pyrenis olfeis, monofpermis. Sem. inveria, incurva. Alb. cornofum. Emb. anverfus; rad. longilina.

Caxinum parviluram. Tab. 196. fig. 5.

Webera fpinofa, foisis fubrotundis, cymis paucifioris axillaribus pedurculatis, fioribus setrandisis. WILLD. Spec. pl. T. 1. P.2. p. 1224 .

Canthium (parviflorum,) folis ovatis petiolatis fpinis vix lungioribus, dentibus calycinis acutis brevilfinis, baccis mudis unbilicatis. LAM. dia. 1. p. 602. Persoon fyst. pl. 1. p. 200.

Icon. RoxB. corom. pl. T. t. 5 I.

Ex coliectione Bankfiana.

PrR. Bacca fubglobora l. ovata, compreffiufcula, ]. transverfim paulo latior, infera, calyce quadridentato coronata, nucen avellanam magnitudine xyuans, cocrulea, dipyrena. Caro crafliufcula, pyrenis arcte adnata, granulis callufis remixta, viridis. Pyrenx carne interpofia quafi dillepimento disjunctx, oflex, reniformi-oblongx, compreiliufculx, ad verticem latiores \& in margiliem acutum coarctatx, batin verfus magis attenustx ubcufie, ad ventrem hilo parvo defuper procelfu munitx, obfolete fcrobiculati, cultro fecundum futuras filliles, uniloculares, monofperme.

REc. funiculi umbilicales, filiformes, e bacce pednnculo oriundi, hilum pyrenarum perterebrantes $\&$ ad umbilicum feminis hilo obverfum pertingentes.

SeM. Folicaria, in-cyuali-oblonga, incurva, capitellata, \& apicula comprefra rotnndata in vertice terminata, ad ventrem vero ruga oblunga circulari cineta, in qua ares atra lub umbilico parvo inmerfo fita eft, fufca.

IN T. finplex, membranaccum, tenuilimum.

A L в. Semini conforme, carnofum, pallidum.

EMH. in axi altuninis locatus, longus, compreffufculus, incurvis, inverfus, albus. Cuty! breves, oblonge, rectix, plano-convexx, aciumbentes. Ras. longitima, comprella, incurva, furfum latitudine increficens, nervo intermedio in apiculam parvam rerminato notata, ab unbilico externo averla, fupera.

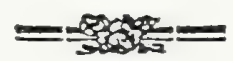

*

\section{EXPLICATIO FIGURE.}

a.) Bacca intera. b.) Eadem ä Roxborgii icone defumta, e.) Pyrenx ad mcdium ufque carne denodatx. d.) Exdem penitus 5olutx, a latere \& 2 ventre fpeasis. c.) Ejusdena fictio verticalis cum fermine in fitu. f.) Scmen folutum, a parte vestrali fpedatum 5.) Albumea longitndinaliter diffedtum cum embryone in fitu. H.) Embryo folutus.

Tfjerou Bara RHEED. mal. 5. p. 73. t. 37. ob calycem integerrimum \& corollam quinquefidam non hujus loci; an nova hujus generis fpecies?

Canthiual didymum. ibid.

Karden. Kara. Rhezd. mal. 5. p. 71. t. 36 .

Webera cymofa. Collect Bañkfian.

Bacea lenticulari-comprefra, didyma, utrinque emarginata, purpureo-fubco:rulea, dipyrena. (a.b.) Caro flavefcens, pulpola. Pyrenx pulpa interftin$c t x,(c$.$) olfex, reniformes, craffx, rotundato-fcrobiculatx, hinc margine acuto$ cinctx, inde in ventre hilo profundo inftruct $x$, cultro fecundum futuras fillles, uniloculares, monofpermx. (d.) Rec. ut in priore. Semina folitaria, renifornia rugofi. (c.) Emb. ....

Semina erant callit, nec plures baceas diffecare licuit, hine de embryone nihil addere polfum. An \& reliqux plantie pentandrx, huic generi adfcriptx, vere congeneres?

Planta in collectione Bankfiana fub nomine Weberz gimose. WILID. affervata certiflime non eadem cum planta Willdenovii, quam bacca fphxrica magnitudine juniperi gaudere ait; conf. Spec. pl. T. I. P. 2. p. 1224 .

cuoad fructus \& feminum fabricam hac Itirps proxime ad Vangueriam accedit. 


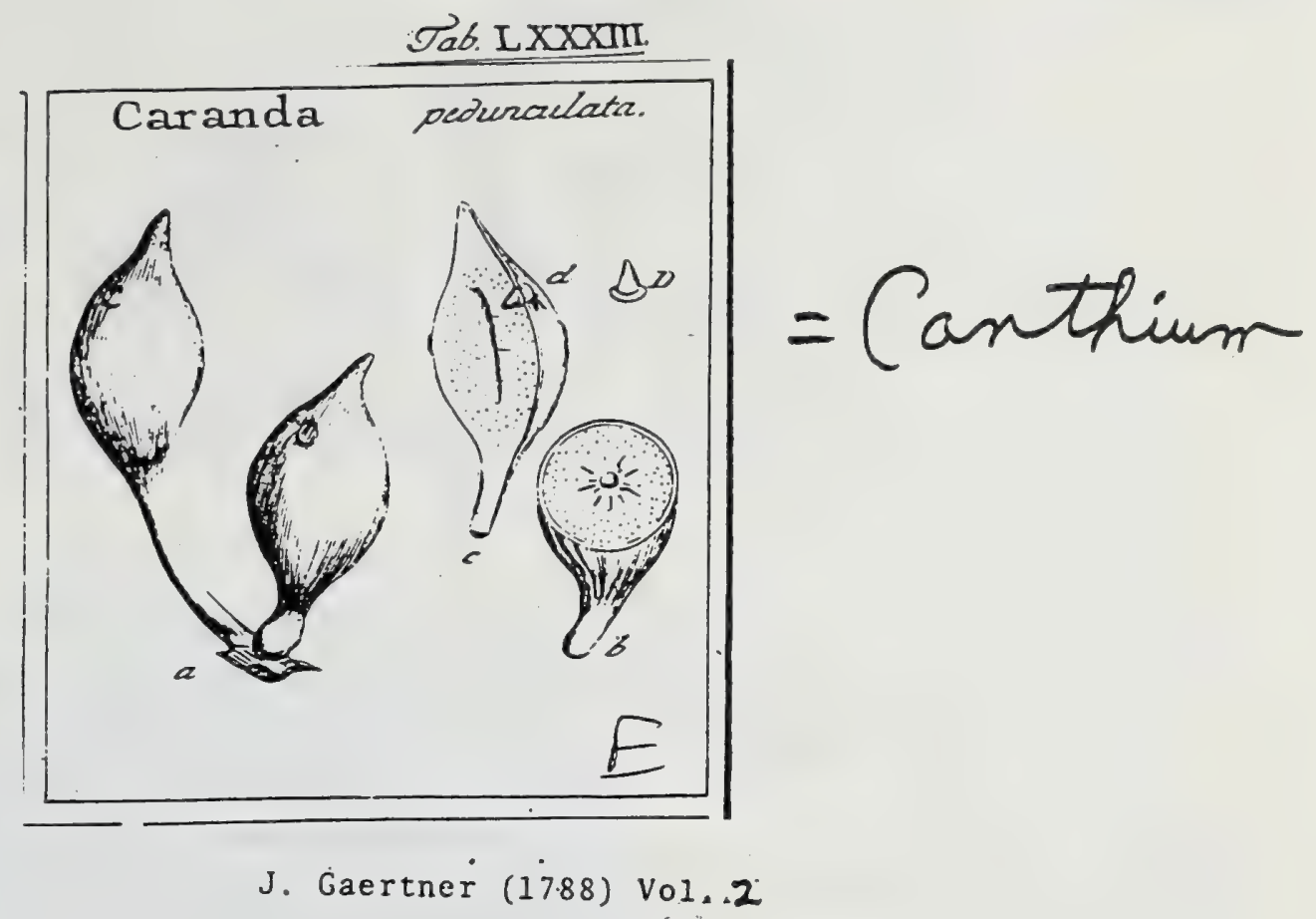

DXVIII. C A R A N D A.

Spidir .... Spatha .... Cal. triphyllus coriaceus. Cor nuila Ovaria intra eunden florem uno plura. Semen fuperum nudum pedicellatum! embryone laterali.

Caranda pedunculaca. Tab. 83. fig. 5.

Glalkarande. Zeylonens. E collect. fem. hort. lugdb.

$P E R$. nullum.

REC. fundus calycis, cui unum, duo, an regulariter tria? femina affixa funt.

SEM. fuperum, nudum, grandiufculum, fubclavatum, feu ex pedunculo te. reti, plus minus longo, in ventrem ovato globofum intumefcens \& deinceps iterum in mucronem conicum, fubcompreffum, coarctatum, glabrum aut obfuletifime ftriatum, cinmamomeo - fpadiceum, Papillula embryonirega, pallida, paulo infra verticis mucronem, notatum.

IN T. fimplex, coriaceum, arctifime albumini adnatum.

ALB. figura \& magnitudine feminis, fuberofo-cartilagineum, fordide albicans, punctis fufcis \& ftriis obliquis, ex axi radiatim divergentibus, fubruminatum, in medio cavitate longitudinali angufta \& cylindrica exaratum, ac in latere alia cavernula embryonifera exfculptum.

EMB. monncotyledoneus, pyramidatus, lacteus, lateralis. Rad. orbiculata, centrifuga.

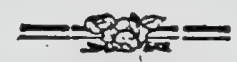

a.) Semina duo, naturali magnitudine, ealycis reliquïis bafi cincta. b.) Semen transverfe c) idem longitudinaliter fedum, albuminis fabricam \& embryonis redem oftendens. d. D.) Embryo naturali \& auda magnitudinc.

Glal, Zeylonenfibus fignificat lapidem; adeoque Ghalkarande eft Carande, lapidea, in contradiftinctionem Carandie, Carendang aut Curandas, qux fecundum Bontium, Prunus fylveftris, aut fecundum iconem Rumpr. amb. 6. t. 25. gennuina Randix aculeate fpecies eft. Carandam noftram ad Pulmas pertinere, vel coccus videt. 


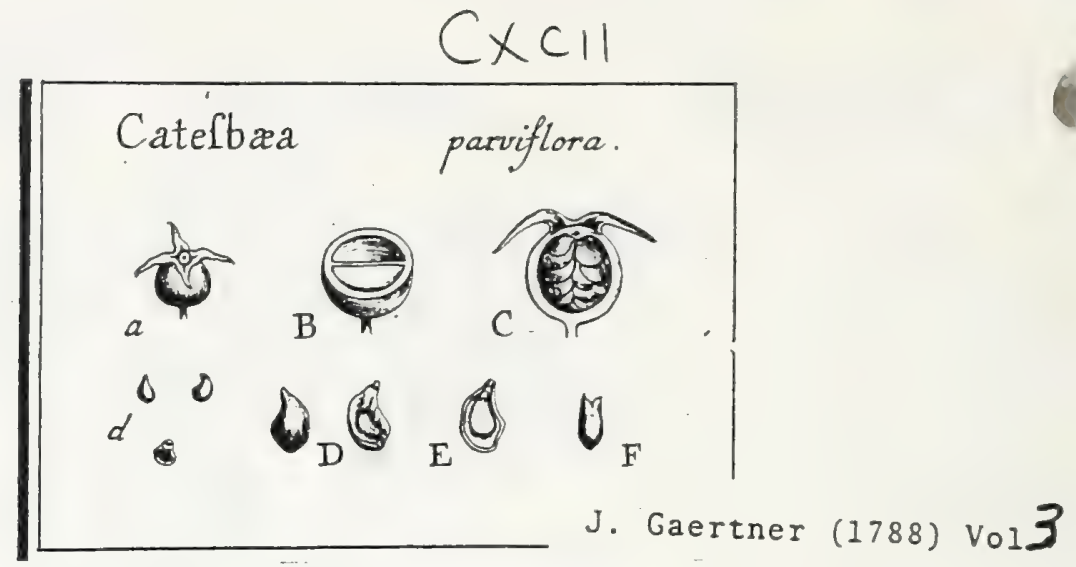

\section{C A T E B A E A.}

Liñ. gen. 130. ed. Schreb. r66. Juss. gen. p. rg9.

LA SIABCK ill. ger. t. 67 .

Cal. Cuperus, quadridentatus, cum fructu increfcens. Cor. monopetals; tubo longifino, infundibuliformi, ad limbum increfcente; limbo quadri. lobo. Stam. quatuor; filamentis ad bafin corallx infertis, Jongiflmis; antheris oblongis, exfertis. Ovar. ftylo fliformi, tubum corolla longitudine xquante; Itigmate bidentato. Bacca globofa L oblonga, infera, calyce perfiftente coronata, bilocularis; diffepinento membranaceo, integerrimo.

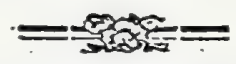

Recépt. fungofum, utrinque fummo diffepimento affisum. Sem. numerofs, fquamiformia, imbricata. Alb. carnofum. Emb. inverfus.

Cerpsbaza parvilora. Tab. 192. fig. 2.

Rbamius folits buxeis mininis confertin nafcentibus, Jpinis longis arnsata. SLOAx: bift. 2. p. soo. t. 207. f. I.

Catesbaea corollis tubo tetragono abbreviato, baccis fubrotundis. SWARTZ prod: 30. VAHL Jymb. 2. p. j3. Eं Ecl. I. p. 12. WiLLD. Jpec. plo T. x. P. r. p. 608 .

E Collectione Bankliana.

P ER. Bacca infera, parva, globofa, intra calycem perfiftentem refexum umbilicata, atra, bilocularis, polyfperma. Caro debilis, granuloro-pulpofa, firma. Difepinentum membranaceum tenuifimum, integerrimum, duobus oppoGtis calycis angulis internis obverfum.

REc. in fummo diffepimenti apice ab utroque latere fub vertice baccx unbilicato affixum, fungofum, cui femina funiculis unbilicalibus brevibus aflixa.

SEM. numerofa, inverfa, ị quovis loculamento in duos fafciculos collecta, deorfum imbricata, coinprelía, fquamiformia, ad umbilicum unguiculata, hinc convexa inde concava, margine interno rectiufcula, externo arcuata, furca.

IN T. fimplex, coriaceum, craftiufculum.

ALB. femini paulo anguftius, umbilico propius, compreffun, hinc curvatounguiculatum, inde obtufum rotundatum, carnofum, fere medullare, album.

EM B. minimus; inverfus, in unguiculata albuminis parte locatus, teretiufculus, furfum fenfim incraffatus, niveus. Cotyl. brevilime, fub angulo acuto divergentes, ad fcspum crafinfculx, acutx. Rad. teretiufcula, longa, fenfim incrafata, conica, obtufa, umbilico externo \& Gimul receptaculo obverfa, fupera.

\section{EXPLICATIO FIGURE}

a.) Bacea integra. B.) Eadem transverie difreta cum fitu diffepimenti. C.) Eadem longitudinaliter fita, cum ferriutbus in Gtu. d.) Scmina foluta. D.) Eadem marnitudine auta, 2 dorio \& a ventre frectata. E.) Albunen longitudinaliter dificaum cum embryone in fitu naturali. F.) Embryo foluus vilde autus.

Cel. Jussigu 1. c. Catesbxx, uti Fernelix, difepimentum perforatum tribuit; fortafie tale ridit in C. Spinoja. LINN., a me nondum vifa; Gs huic revera competis difepinentum incompletum, cum noftra congener effe nequit. 


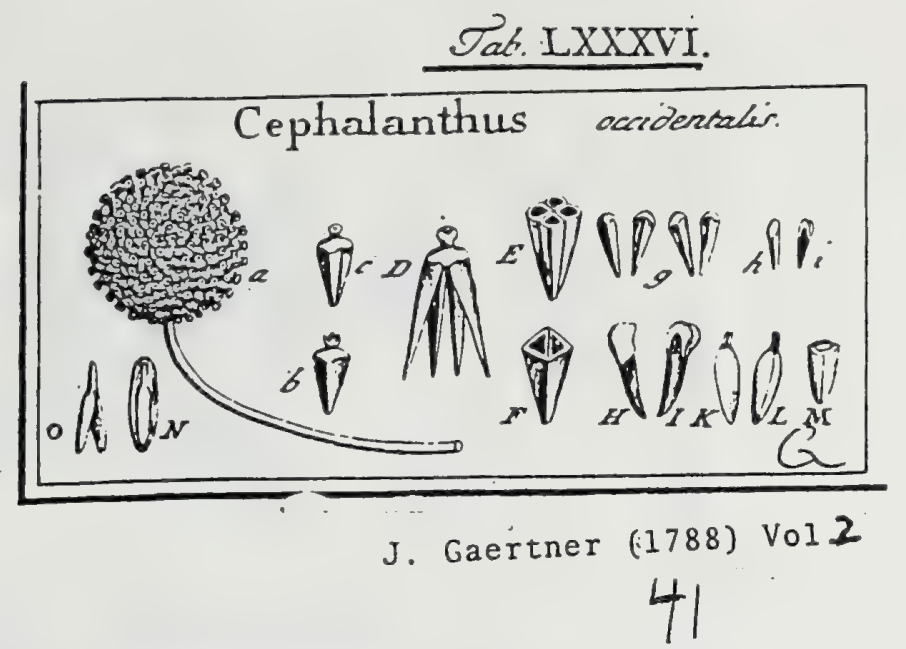

DXLVI. CEPHALANTHUS. LINN. ger. II3.

Receptac. commune globofum, fructus in pilam fphxricam longe pedunculatam colligens. Cal. fuperus, monophyllus, quadrifidus. Cor. monopetala, quadrificia. Stam. quatuor. Ovar. inferun. Styl. fimplex. Capf. quadripartibilis. Sem. Solitaria.

Cephnlanthus occidentalis. Tab. 86. fig. 7 .

Scabiofu dendroites anzericana, ternis folits caulen ambientibus, fioribus ocbroleucis. Plúx. plyyt. t. 77. f. 4.

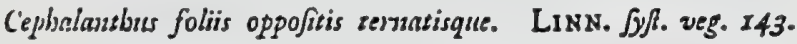

РЕ в. C.ppfula infera, calyce perfiftente coronata, -inverfe pyranidata, glabra, coriace:a, e ftramineo - rufefcens aut lateritia, quadrilocularis, quadripartibilis: Juculanentis duobus frepe abortientibus; omnibus vero evalvibus, nec unquam $\int_{\text {ponte }}$ dehifcentibus.

REC. consinuse globofum, nudum; proprium nullum, prater epiphyfin callofam, nivean, fellam equinam quodammodo referentem, feminisque vertici adnatam, cujus ope hoc ipfum e loculamenti fui fornice pendet.

SEM. quatuor, aut duo, in fingulis vero loculamentis fingula, oblonga, hinc planiufcula aut angulata, ande convexa, fuperue craffiora atque epiphyfa callofis terminata, inferne acuminata, rubro - ferruginea.

IN T. duplex, pixter loculamenti thecam: exterius fubcoriaceum, tenue, nucleo longius, \& fuperne in roftrum umbilicale productun; interius membra. naceum, tenuiffmum, albumini adnatum.

A L B. ovato. oblongum, compreffifculum, fubcartilagineum, album.

E в 8. longitudine albuminis, inverfus, fublutefcens. Cotyl. oblongx, foliacex, utrinque planx. Rad. teretiufcula, gracilis, fupera.

a.) Fruttus integer. b. c.) Capfula integra, calyce perfiftecterminata. D.) Capfult quadripartihilis portiones a fe inviecm diduetx. E. F.) Capfula transverfin feetz, bi - aut quadrilocularis. g.) Portiones Capful fe invicera penitus leparate, integerriman, evalves. b. H.i.I.) Seminis dcuu!nti facies ntrayue cum fuz epiphyfi callora terminali. K. Lo) Seminis figura propria, poft excutram epiphylin. ML) Ejusdem fectio transperfalis N.) Embryonis in albumine fitus. 0.) Eunbrso folutus.

Senina lanuginofa dicit LiNnkeus, atque Millerus gard. dï. capfulas globofas \& villofas iftatuit. At rihil horum fumile ego vidi unquam, quin,

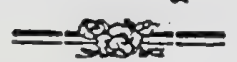

capfulx ab ipfo MiLLERo, Chelfea ad me Petropolin miffx, glaberrimx \& figurx noltrx. b. finillimix erant; \& tales quoque fuerunt in fructu completo. a. quem benevole mecum communicavit. Cl. StorR Prof. Tubing. 


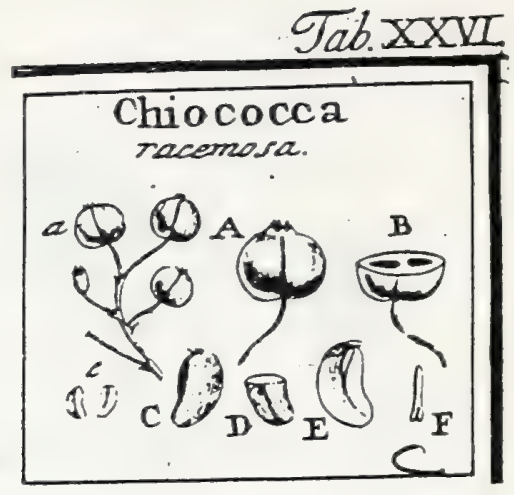

J. Gaertner (1788) Vo1. 1

\section{CHIOCOCCA. Lin}

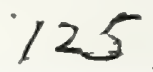

Calyx fuperus, quinquedentatus. Cor. infundibuliformis: limbo quinquefido regulari. Stam. quinque. Styl. unicus. Bacca infera, comprefra, bilocularis, Semina foltraria, pendula.

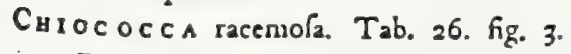

Periclymenum racemofum, fore flavefcente, fruffu nivea DILL. h. elth. tab. 228 . f. 295 .

Jasminum folio myrtino acuminato, fore albicante rackmofo. S $10 \wedge x$. hif. jam.

2. p. 97. t. $788 . f .3$.

.126

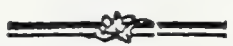

Chiococca fcandens, foliis lato lanceolatis, froribus lateralibus paniculato racemo/is, dente fipulari unico. LI N N. Sufl. veg. 215.

Ex herbario Bankfiano.

PER. Racea infera, parva, fuborbiculata, lenticulari compreffa, utrinque fulco medio obloleto infcripta, calyce perfiftente coronata, carnola, alba, fubtransparęns, bilocularis. Loculamenta propria membrana veftita \& a fenninibus undique diféreta.

REc. funiculus brevis filiformis, ad fuperiorem extremitatem loculanentorum, e quo fernina pendent.

SEM. in fingulo loculanento unicum, ovato oblongum, compreffum, nigrofufcum.

IN T. fimplex, nembranaceum, tenue.

ALB. Semini conforme, carnofum, aqueo pallidum.

E 9 в. dicotyledoneus, inverfus, teretiufculus, dimidio albumine paulo brevior, lacteu albicans. Cotyl. breves, femicylindricx. Rad. teretiuscula, longior, recta; fupera,

2.) Pars racemi eum baceis integris. A.) Bacea feparata, naturali múlto major. B.) Eadem dif refta. c. C.) Semina cum funiculo umbilicali. D.) Albumen transverfe feturn. E.) Idem longhtudiusatiter spertum, cum fitu embryonis. F.) Embryo feparatus.

Bacca certiflune bilocularis eft, ut recte quoque habet $B$ R $\circ$ w. hilt. jam. p. 164 . 


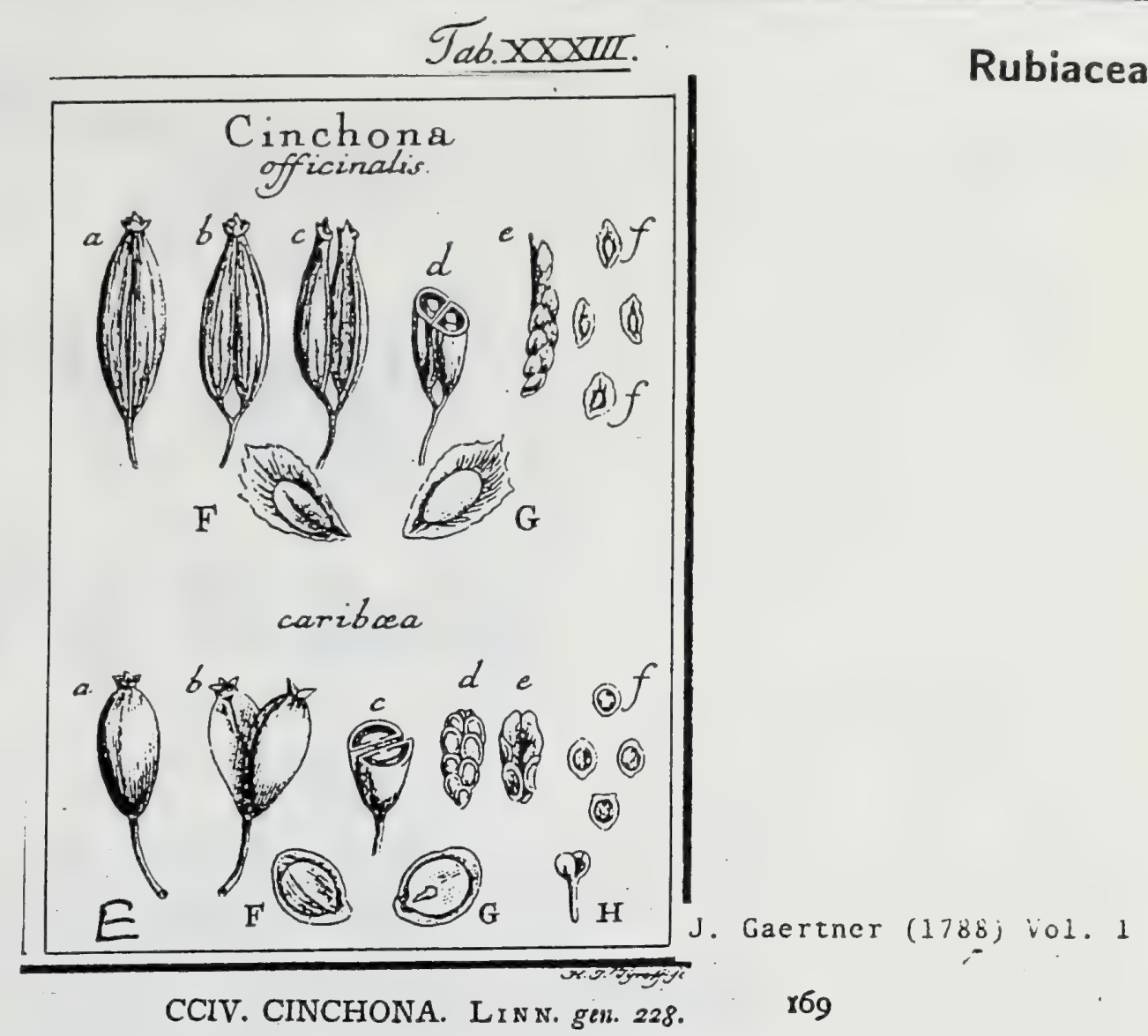

Calyx quinquedentatus fuperus. Cor. infundibuliformis: limbo quinquepartito. Stam. guinque. Styl. unicus. Capfula infera, bilocularis, bipartibilis. Senuina brzcteata, furfum imbricata.

Cinchons officinalis. Tab. 33. fig. 4 .

Quinquina. Connam. ađt. gall. 1738. Commerc. lit. Nor. 1744. g. 223.t. r. f. Ir Huтн. trafi. de Cort. peruv. tab. I. 2.

Cinchona foliis ellipticis fubtus pubefcentibus, corolla limbo lanato. LIN.N. fyf?. veg. 213 .

Ex herbario Bankfiano.

PER. Capfula infera, calyce perfiftente coronata, ovato oblonga, furfum attenuata, transverfe latior; extus fufca, nervis obfoletis in dorfo ftriata; intus glaberrima, albida, bilocularis, bipartibilis, a bafi dehifcens.

REC. fubulatum, rhombeo tetragonum, diffepimento toculamentorum longitudinaliter affixum, feminibus furfum incumbentibus tectum.

SEM. plura, ad fedecin in fingulo loculamento, fubovata, foliaceo comprefta, lato margine membranaceo denuculato cincta, e fpadiceo rufefcentia.

IN T. funplex, fpongiofo membranaceum, in marginem feminis anpliatum.

ALB. ovatum, compreffum, carnofum, pallidum, cavitate parva pro eunbryone ad bafin exfculptuin.

Евв.......

a.) Capfula integra. b.) Eadem a bafi dehifcens. c.) Eadem bipartila d.) Ejasdem fettio transverlalis, cum fitu receptaculorum. e.) Recrptaculun folutum, undique faninibus conteâm. f. F.) Semina feparata. G.) Albumen denudatum.

Crichona caribra ibid.

Cinchona pedunculis nniforis. J a c c. hifl. amer. 6r. t. 279. f. 95. Obf. II. p. 27.

t. 47. LIN N. $\int y / l$. veg. 214 .

Ex herbario Bankfiano.

Capfula pracedenti ininor, obovata (a. b.), xquabiliter erafta, bilocularis (b. c.), bipartibilis, a vertice dehifceus. Recept. comprefliusculum, oblonguu (d. c.c.), hine convexum, inde planiusculum, ope membranx intergerinx finguli loculamenti diltepimento (c.) affixum, undique (d.e.) feminibus furfum incusnbentibus tectuin. Semina duodecim, bracteata, fubovata (f. F.), rufefcentia, margine membranacco pallidiore, integerrimo cincta. Albumen ut in prace-

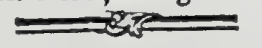

denti, rotundato ovatum. Embryo parvus, niveus in extremitate albuminis in. feriori (G.) harens, Cotyl. rotundatx (H.) foliaccz. Rad. teretiuscula, recta, infera. 


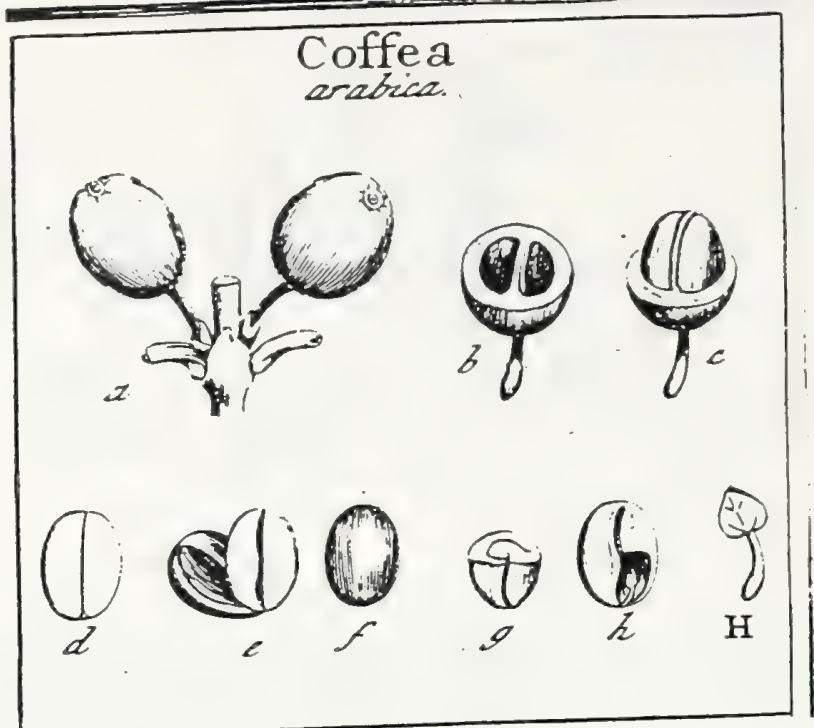

J. Gaertner (17.88) Vol. I

CXXXLX. COFFEA. Lin g. gen. 230. 118

Calyx fuperus, quinquedentatus, minimus, caducus. Cor. monopetala, infundihuli: formis. Stam. quinque. Styl. unicus. Bacca infera, uni-1. bilocularis. Sernina folitaria, rimá ex altero latere cxª, arillata.

Coffea arabica. Tab. 25. fig. 3 .

Coffee. Brakw. herb. t. 337 .

Coffen floribus quinquefidis difpermis. $\mathrm{L} I \times \mathrm{N}^{-}$- fist. veg. 215.

Icon fem. Grew. anat. t. 77. f. 1 - 5. GLEICHEN. append. p. 22. t. 10.

PER. Bacca infera, elliptico fphzroidea, areola circulari \& intra eain pundo callolo in vertice notata, carnofo pulpofa, bilocularis, rubra, tandem violaceo nigra. Pulpa fubgelatinofa. Dillepiunentum valculoro-carnofum.

$R E C$. nullum, proxter diffepimenti vala, riman feminum intrantia.

$S_{E M}$. in fingulo loculamento unicum, ellipticum, hinc convexum, inde planiusculum, riná longitudinali, introrfuın flexuofa cxfum, pallide glaucum, arildatum.

Arillus chartaceus, elafticus, diaphanus, femen laxe cungens, totumque oc. cultans.

IN T. fimpliciftumum, tenuifimum, ardiffune adnatum.

А с в. Seınini conforme, craftum, a latere ventrali introrfum convolutum, cartilagineum, durum, fublividum aut pallide melinum.

Емв. dicotyledoneus, erectus, tcrtia albuminis parte brevior \& in ejus dorfo prope. bafin locatus, leviter curvatus, lacteo albus. Cotyl. cordatx, foliacex. Radic. fubclavata, curvula, infera.

a.) Bacea integra. b.) Eadem differts. c) Semina arillo teta in fitu naturall. d.) Arilli lates ventrale c. f.) Semina arillo exuta, ab utroque latere fpertata. g.) Albumen transverfe fétum b.) Idem, demta portiose quze embryonem obtegit. 1.) Embryo Separatus. 


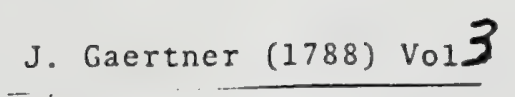

\section{Tab. CLXXXII.}

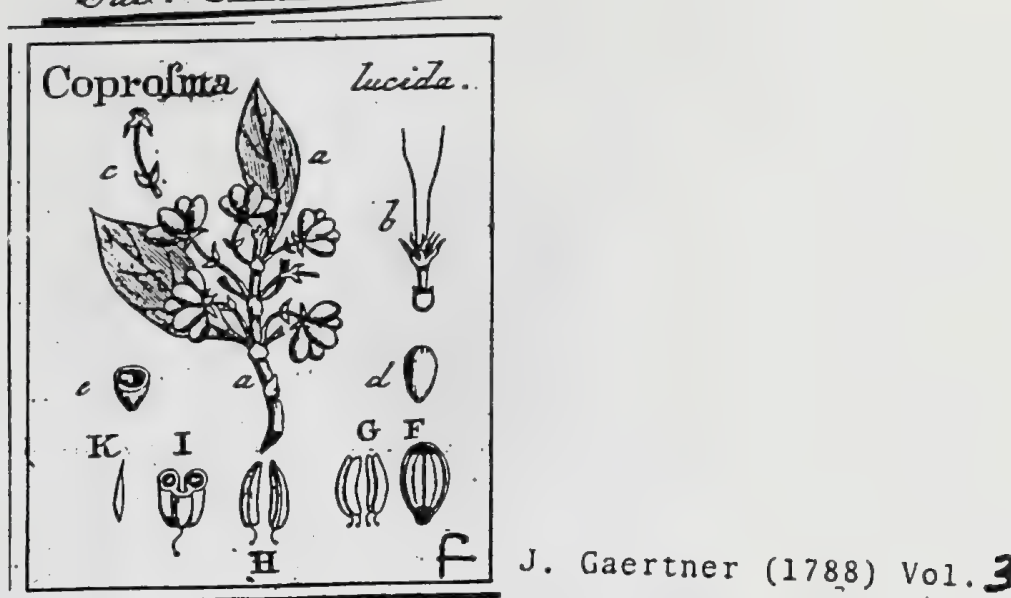

$=-2$

\section{COPROS M A.}

Fовот. gen. n. 69. LiNN. Juppl. pl. p. 24. gen. ed. Sclireb. r593. Juss. gen. p. 205.

Cal. fuperus, breviffimus, quinquedentatus, caducus. Cor. infundibuliformis, quinque - feptemfida. Stam. quinque - 1. feptem. Ovar. inferum. StyL
duo longifini. Bacca unilocularis. Sem. octo, arillata.

Coprosma lucida. Tab. 182. fig. 6.

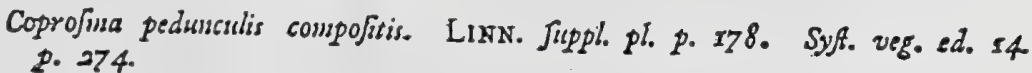
A Cl. THUNBERG.

PER. Racca infera, non coronata, acinofa, parra, ovata, atra, unilocularis.

REC. fratins fubrotundum, hifpidum, bafi duobus foliolis relexis involucratum, binis - fenis baccis ftipatuin; feminis pedicellus capillaris ad fingu-
lum arillum e fundo baccie pertingens.

SEM, octo, fubulata, arillata.

Arifli oblongi, furfum attenuati, in dorfo fulco elevato, rotundato, \& in ventre rima longicudiuali exarati, biloculares, loculis ope membranx fulci dorfalis inter fe connexis: horum duo conftanter fibi juncti, totidemque pedicellis capillaribus brevifinis inuixi, unde in bacca longisudinaliter aperta duo tantum arillorum femina mentientium fafciculi apparent, etfi eorum in univerfum furt quaterni, quorum fingulus ise. rum duo in $\mathrm{Te}$ continet femina

Ix T. Impliciflimum, tenuifimum

A ᄃ B. ...

ENB....

\section{EXPLICATIO FIGURFE}

1. a.) Ramulus frugifer. b.) Orarium imuaturum, cum calgce, corolla, \& \&.clis c.) Re ceptaculum fruetus, bafi foliolis duobus iuvolucratuon of in inedio fuo pedunculo fquamulis ge minis fubftipularibus ununitum. d.) Bacca integra, ab aqua paululum turgcfaA2. C.) Ejus feQio transverfalis. F.) Ejusdem feQio longitudinalis, eum Gtu arillorum per paria Gbi jundorum, \& in duo corpura oblonga intra baccam difpulitorum. G.) Iitem arilli e bacea excmti. H.) Alterum arillorum par, in fingulos arillos folutum. L) Arilli feaio transverfalis, confpicilli vuläaris-forman reprefentans, cum duobue fuis loculis, per folam membranam fulci dorfa.

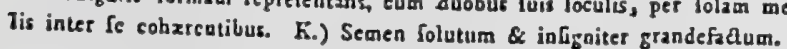

Nequaquam ad Lmbelliferas, fed omnino ad Rubiaceas hace ftirps pertinet, uti vel ex folis ftipulis interfoliaceis atque infero ovarii fitu facile conjicere licet. Calycis litum fuperum \& arillorum fingulariffimam formam, con$=-802=$

jugationem atque numerum diftinctifime \& repetito vidi; unde etiam de feminum numero certiffmus fum ; fed fenima ipfa mihi videre non_contigit,

(Icon Forfteri, l. c. fig. h. i. k. de hac fpecie tradita, cum noltro fpecimise non prorfus convenit, forfan generice inter fe differunt; cum Forfterus
fux planta baccam tribuit difpermam.) 


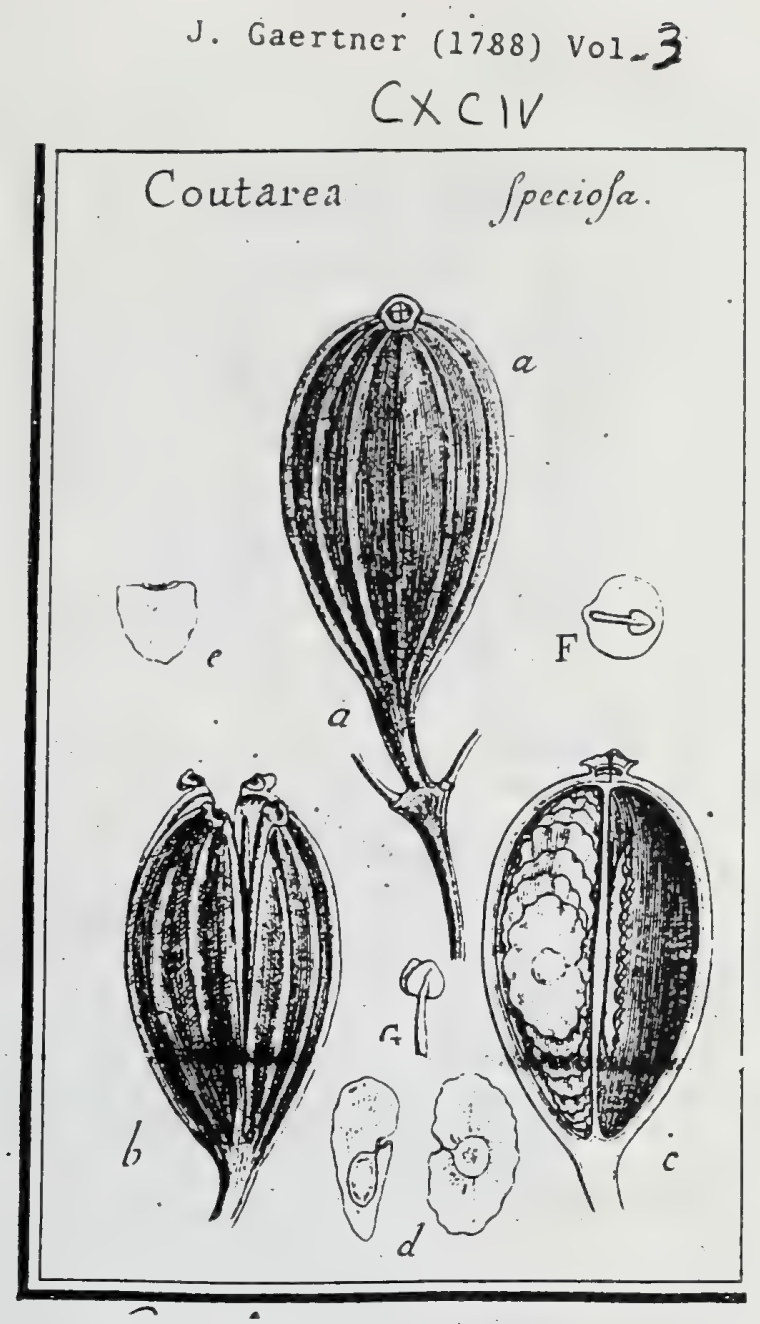

Rubiaceae 


\section{COU T A R A. 79 \\ t. 257. Portlandia. Sснвев. gen. 299.}

Flores bafi bracteis duabus ariftatis deciduis muniti.

Cal. monophyllus, fuperus, turbinatus, ad limbum ampliatus; limbo 6. (1. ז2rivis 7.) partito, deciduo: laciniis rectis ariftatis. Cor. mogopecala, ovarii difco inferta, infundibuliformis, furfum fenfim ampliata, incurva, fub fauce ventricola; limbo 6. (1. 7.) partito: laciniis brevibus, cordatis, acutis, patentibus, recurvis. Stam. 6. (1. 7.); filamentis longitudine tubi linearibus, ad bafin corolly infertis; antheris longis, erectis, fubulato-linearibus, ex. fertis. Ovar. inferum, ftylo fimplici filiformi ftamina longitudine æquante, \& ftigmate capicato fulcato munitum. Capf. coriaceo-chartaces, obovata, comprefla, bilocularis, fubquadrivalvis, polyfperma. Rec. fungofum. Sem. alis membranaceis cincta, compreffa, erecta. Rec fungofum. Alb. carna

Coutarea fpeciora. Tab. 194. fig. 2.

Portlandia foribus bexandris. JAce. amer. p. 63. t. 182, f. 20. LINk. szant. p. 45. Syft. veg. ed. 14. p. 213.

Portlandia fioribus bexandris, tubo fubincurvo, pedunculis ternatis, folis ovatic SWARTZ f. ind. occid. 2. p. 385. WILLD. Spec pl. T. 2. P. 2. p. 936 .

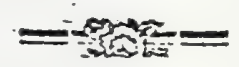

Coufrea Ipeciofa AcBL. guy. r. p. 314. Persoox fyr. pl. r. p. 392.

E collectione Cel. Desfontaines \& ex dono $D^{\text {gi }}$ Dupuis.

PER. Cupfula infera, e pedunculo crafiufculo obovata, compreffa, utrinque miedio vix carinata, in vertice obtuGlino calycis rudimento angulato coronata \& intra hunc annulo callofo a corollz lapfu infignita, ex duabus Janinis conferruminata : exteriore rufefcenti coriacea \& nervis obfoletis longitudinalibus ftriata, interiore chartacea glaberrina helvola; bilocularis, a vertice quadrivariam dehifcens : dehifcentia ád diffepimenti inferrio. nem profundifinia, ad marginem vero vix ad mediam capfulam pertingente. Diffepimentum a valvularum margine infexo ortum, angultiftmum, poft dehifcentiam capfulx a valvis fecedens, utrinque acuninatum.

REc. fungofum, oblongo-acuminatum, fubliberum, hinc proceffubus papillaribus longitudinalibus comprelisis fcabratum, inde radice anguftiore convexa medio fepto utrinque adnatum.

: SEM. plura, circa viginti in quovis loculo, reniformia, arcte fibi verticaliter approsinata \& pelvi receptaculi procerubus affixa, foliaceo - comprelía, Jato margine mémbranaceo undulato cineta, e fpadiceo rufefcentia.

IN T. fimplex, reticulato-membranaceum, in marginem feminis diłatatum, albumini arcte adıatum.

A L B. orbiculatum, L ovatum, ad umbilicuns in mucronem productum, com. prefium, hinc converiufculum inde vix concavum, duriufculum, carnofum, furdide mellinum.

- Es B. rectus, dimidio albumine longior \& in ejus diametro umbilicum verfus locatus, pallidus. Cotyl. foliacex, cordato-obtufa, nervo intermedio valido fimplici inftructie, accumbentes. Rad: longa, recta, cotyledonibus duplo fęre longior, fubclavata, teretiufcula, apice conico obtufo mucroni albuminis \& fimul umbilico proxims, centripeta.

\section{EXPLICATIO FIGURE.}

a. a.) Capfula integra. b.) Eadem dehifcens cum diticpimenti parte fuperiore a ralvis fecedente. r.) Valva utriusque fedio verticalis ad dehifentiam marginalem cum fitu feusinum \& receptaculi. d) Semina foluta. e.) Idear transverfe fectum. F.) Albuminis fectio horizontalis cuia embryone in Gitu. G.) Embryo folutus, cotyledonibus paululum a fe invicem didudis. 

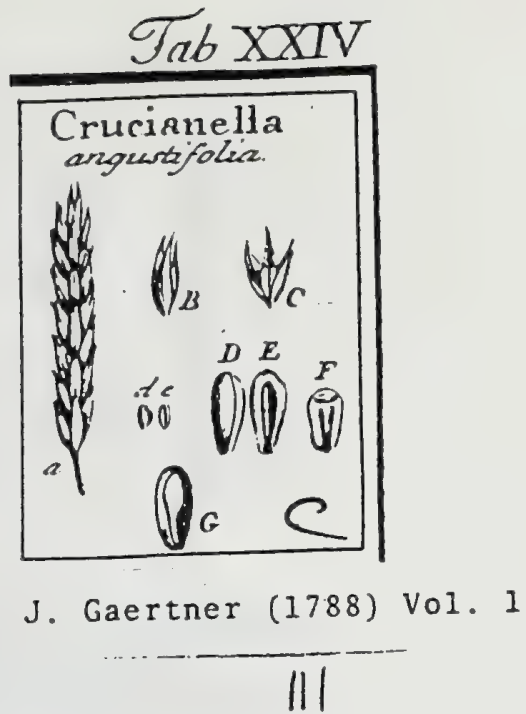

CXXXI. CRVCIANELLA. LiNn. gen. 126. Rubeola. Tourn. $t$ so:

Involucrum ad fingulos flosculos di-l. triphyllum, paleaceum. Cal. nullus. Cor. infundibuliformis, tubo filiformi. Stam. quatuor. Styl. unicus. Semina duo, infera, nuda, calva.

Crucianet. La angunifolia, Tah. 24. fig. 3.

PJeudo rubia spicata angufifolia. $\mathrm{M}$ O R Is. hif. 3. S. g. t. 22. f. penult.

Afperula fpicata glumis floralibus maximis. HALL. hifl. goett. 187.

Crucianella ereata, foliis fenis linearibus, floribus fpicatis. LIN N. Jy/6. veg. I5I.

PER. nullum, proter externam feminis tunican.

REC. nu!luin; femina coadunata, bafi affixa.

- SEM. duo, infera, oblonga, furfun craffiora, apice rotundata, calva ; hinc convexa;, tenuiffmaque linea longitudinali inferipta; inde planiuscula, linea media prominula inter duos fuicos depreflos notata.

IN T. fimpliciltimum, tenue, arcte nucleo adnatum.

A ᄃ B. femini conforme, fubcartilagincum, aqueo.pallidum.

Es B. dicotyledoneus, crectus, dorfalis, lacteo albus. Cotyl. ellipticx, foliacez. Rad filiformis, fubrecta, inferz.

x.) Spica frugilera, B C.) Involucrum florale femina claudens, d.D.) Seninis dorfam. e. E.) Ejusidem gars ventralis fulcata. F. Albumen transverfe fethuin. G.) Embryoin dorfo albuminis.

Involucrum flora'e perperam a LINN $\varepsilon$ o calyx dicitur; in tota enim hac familia uon datur calyx inferus, sifi raritine monopliyllus. 


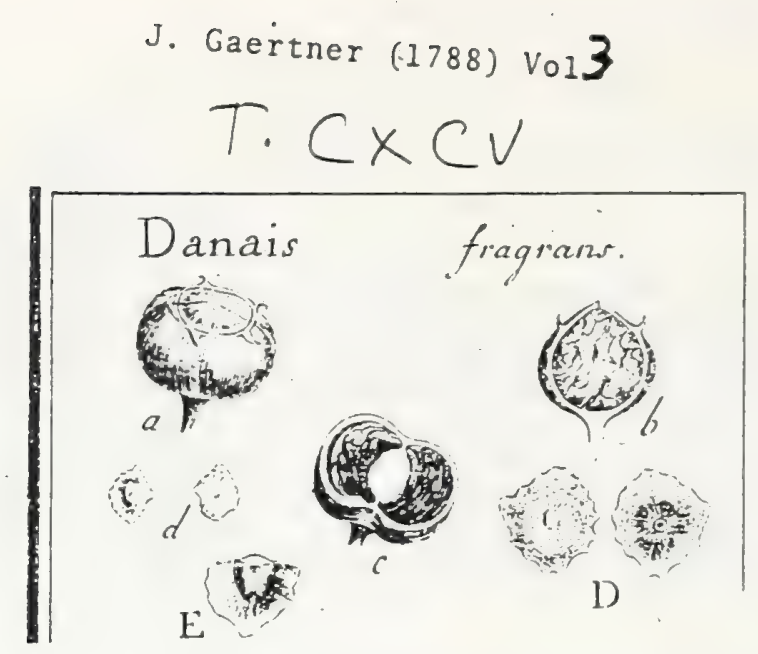

\section{D A N A I S. Commers. 83}

Tæderia. Juss. gen. p. 20j. Ladrabcx ill. gen. t. 166. f. 2

Stirps per abortum feruum dioica.

MAS. Cal. fuperus, minimus, quinquedentatus. Cor. infundibuliformis , tubulofa, intus hirta; limbo quinquepartito: laciniis anguftis, acuminatis, patentibus. Stam. 5. 1. rarius 6.; filamentis longis, tubum multuin fupeazncibus \& paulo fupra ejus medium infertis, linearibus; antheris fubulatis, incunibentibus. Ovar. incompletum.

FEN. Cal. \& Cor. ut in mare. Staminun rudimenta intra tubum inelu[a Ovar. inferum, didymum, ftylo Jongo filiformi apice bifido \& ftigmatibus Gmplicibus inftruclum. Capf. infera, fubglobofa, coriaceo - chartacea, didyma, calyce perfiftente coronata, bilocularis, bivalvis. Rec. fungofum, diffepimento utrinque adnatum. Sem. bracteata, verticalia, imbricata. Alb. carnofum Emb. ...

Dasais fragrans. Tab. 19.5. fig. 2

Paderiu cymis multifloris, corollarun laciniis angufris patentidurris, gemisalibus exfertis. LAMARCK dit. 2. p. 260 .

Pederia faminibus exfertis. WILLD. Spec. pl. T. 1. P. = p. 1219.

Danais (fragrans, $\beta$. coronata,) capfulis levibus calyce perfifleate coronatis Persoon fyn. pl. 1. p. 198 .

E collectione Cel. Desfontaines.

PE R. Caprula fubglobofa, compreffurcula transverfe paulo Jatior quam erafía, intati, didyma, dentibus parvis calycinis remotis fub vertice obtule umbonato coronata, ex duabus laminis arcte fibi adglutinatis yiridiufculis collculoribus conferruminata : exteriore coriacea, tenui, glabra; interiore chartacea, paulo craftrore, intus levigata; ad latitudinem ab apice ad medium usque dehifcens, bilocularis, bivalvis: Difepimentum membranaceum, fulco externo. obverfum, valvis contrarium.

Rec. fungofum, diffepimento utrinque adnatum, ellipticum, acuminatum; lenticulari - converum, \& tuberculis parvis undique exalperatum.

Sex. תumerof3, verticaliter circum receptaculum ftrato fimplici imbricata, lenciculari - convera, intra integumentum externum involucrans incluba,

84 ceterum orbiculato-bracteata, hinc convexa \& in centro umbone minimo

.84 inftructa, inde concava medio autem convexa \& umbilico parvo centra]i. inftrucha, lutefcentia.

IN T. duplex; exterius fpongiofo-membranaceum, in centro inter duas laninas femen fovens, per ambitum inæqualiter denticulatum: interius icidem membranaceun, tenuifimum-, albumini aretilime adnatum.

A \& B. femini conforme, carnofum....

EM $\mathrm{B} . .$.

\section{EXPLICATIO ETGORE}

2.) Capfula integra. b.) Eader verticaliter ditteca cam fitu feminum naturali. c.) Ejusdem fettio transveríalis cum receptaculis diffepimento adnatis. d- D.) Semina foluta, ab utraque parte fpetzis. E.). Idem medio transverfe fectum.

Kullum dubium reftat, quin Danais diverfim a Pxderia conftituat genus, uti jam pridem Cel. VENIENAT in Infl. regn. veg. $V$. 2. p. 584 . ftatuerat.

Capfula in noftro fpecimine crat immatura \& inde capfulx Jamina exterior adhuc valde tenuis; duplicitas igitur laminarum in icone iterum omilla; femina quoque omnia erant caffa; alii itaque, quibus licet matura videre Iemina, in embryonis. formam atque Geum inquirant. 


\section{Tab. CLXXXII.}

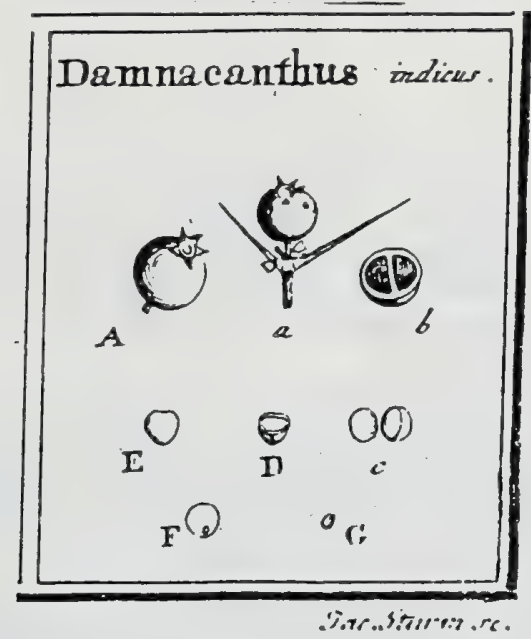

J. Gaertner (1788) Vol3

\section{D A M A C A N T H U .}

Cal. fuperus, quinquedentatus, minimus, perfiftens. Cor. . . . Stam. . . . Ovarium inferum. Bacca coronata, bilocularis. Sem. folitaria.

Damnacanthus indicus. Tab. 182. fig. 7 .

A Cl. Thunbere. fub nomine Cariffae Spinarum.

P ₹. Bacca infera, denticulis calycinis \& intra eos annulo albo, a lap̣fu co. rollz, coronata, pifformis, rubra, acinora, bilocularis.

REC. nullum : femina fundo bacce affixa.

SEM. folitaria, fubrotunda, hinc convexa, cum ftria tenuifima dorfali, inde planiufcula, glabra, pallide ftraminea.

Ix T. duplex : exterius cruftaceum; tenue, fragile; interius tenuifimum albumini adnatum.

A I B. cartilagineun, aut carno「um, durum, crafum, pallidum.

EM B. minutifimus, ovato - conicus, niveus, in bafi albuminis. Cotyl. brevifo Gima. Rad. obtufa, infera.

\section{EXPLICATIO FIGURE.}

2. A.) Bacea integra, naturali \& auta magnitudine. b.) Ejus featio transverfalis. c.) Semina a dorfo \& ventre fpeâata. D.) Semen tränsverfe diffectum. E.) Alhumen denudatum, integrum. F.) Ejas featio verticalis, can fitu embryonis. G.) Embryo folutus \& infigaiter au\&us.

Neque ad Carifam, neque ad Arduinam noftra pertinet, fed proprii generis planta eft, cum ambabus bacca eft fupera; novum icirco illa nomen

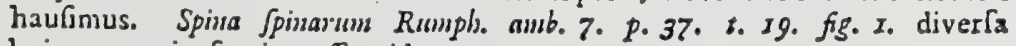
hujus generis species effe videtur.

(Ad Canthium LAm. inter omnia, quæ novi, genera proxime accedit, a quo vero differt embryone minimo infero; Canthio vero ex fide Roxz. Corom. pl L. S1. contigit embryo magnus centralis.) 


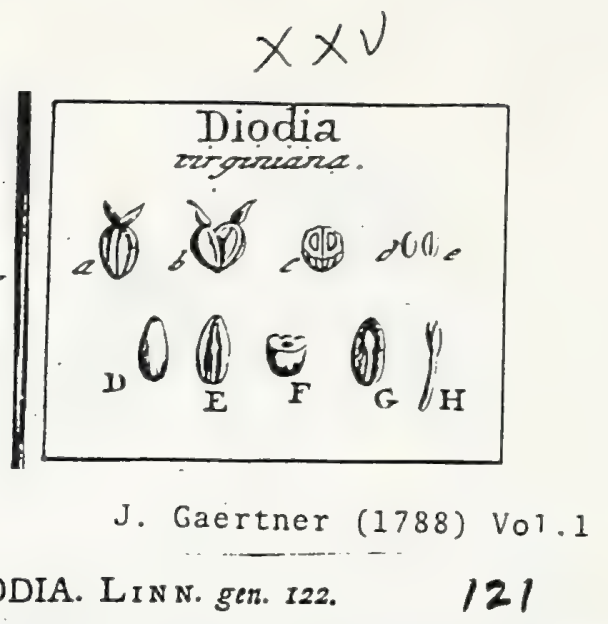

Calyx fuperus, di-1. tetraphyllus: foliolis duobus majoribus longitudine dimidii fructus. Cor. monopetala infundibuliformis. Stan. quatuor. Styl. unicus. Capfula infera, bilocularis, bipartibilis. Semina folitaria: ventre fulcato.

DIODIA virginiana. Tab. 25. fig. 7 .

Diodia. LIN N. Syfl. veg. 149.

Ex herbario Bankfiano.

Prв. Capfula infera, parva, orato globola, ofto fulcata, bilocularis, per maturitatem bipartibilis, evalvis, pallide fpadicea.

R Ec. nullum; femina medio diffepinenti affixa.

SEM. in fingulo loculamento unicúm, ellipticum, nigricans; hine convexum, glabrum; inde duobus. fulcis depreflus cum linea media elevata infcriptun.

IN T. fimplex, membranaceum, aretiflune adnatum.

A L в. formå \& magnitudine feminis, fubcartilagineum, non valde durum, aqueopallidum.

E в. dicotyledoneus, erectus, dorfalis; longitudine fere albuminis; leviter curvatus, lactco albus. Cotyl. lanceolatx, foliacex. Rad. longa, filiformis, infera.

a. b. ) Fruâus integer \& biparcirus. c.) Idem diđęlus, d. D.) Seminis dorfum. c. E.) Ejusdem venter. F.) Albumen transverfe felum. G.) Embryo in dorfo (euriuis. H.) Jdem feparatus.

Superficies capfularum (xpe minutifmis fquamulis linearibus, acuminatis, paleaceis, albis, prxfertim verfus apicen fructus feabrata of, qux autem in maturo fructu facile deterguntur, ut hic plerumque glaber fit. Calyx etiam in aliis fimpliciter diphyllus, in aliis vero inxqualiter tetraphyllus deprehenditur, pofieis nempe ad interfticia duorum folionm majorum, aliis duobus minutiftumis: \& hic quo. que auncrus videtur maxime naturalis. 


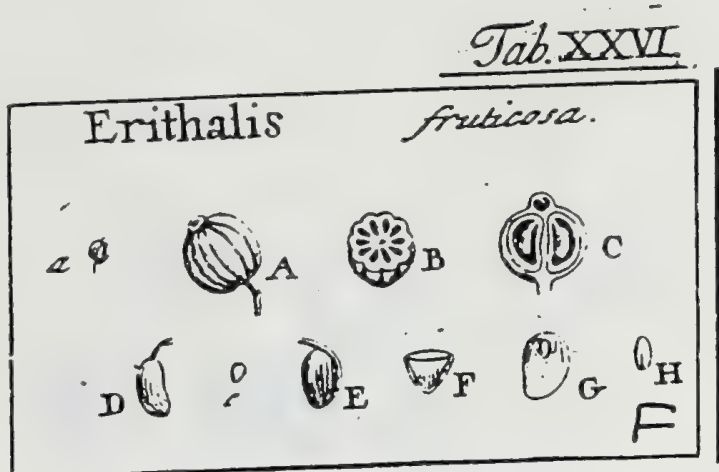

J. Gaertner (1788) Vol. i

CLIV. ERITHALIS. LIN gen. 238 .

Calyx fuperus, quinquedentatus. Cor. quinquepartita. Statn. quinque 1 fex. Styl, unicus. Hacca infera, decafperma.

ERIT н ALIS fruticofa. Tab. 26. fig. 7.

Sambucus ligno duro odoratiffmo s. Santalum racemofum foliis obtüfis. Рцuм. ic. t. $249 . f .2$.

Erithalis fruticulofa foliis obovatis crafis nitidis oppofitis, pedunculis ramo/is ad alas fuperiores. B R O W N. jam. 165. t. 17. f. 3 .

Eritlalis odorifera arborea ereda. J A C C hift. amer. 72. t. 173. f. 23 ?

Erithalis. LIN S. Jyf. veg. 218 .

Ex lierbario Bankfiano.

PER. Bacca infera, parva, globofa, calyce edentulo coronata, fulcata, octo-l. decemlocularis : loculameutis offeo crufaceis.

R E c. funiculus umbilicalis ex fummo loculamenti apice, per feminis dorfun decurrens.

SEs. in fingulo loculanento unicuin, pendulum, ovatum, lenticulari compreffum, rufefcens.

IкT. fimplex, membranaceum, tenue.

A в в. fonini conforme, carnofurn, molle, aqueo-pallidum.

Exs. dicotyledoneus, inverfus, fubovatus, minutus, lacteo albus. Cotyl. brevifiunx, acuminatx. Rad. ovato conica, fupera.

2. A:) Bacea integra. B.) Eadem transverfe feta. C.) Ejus feâio verticalis cum fitu feninum pendulo intra loculamenta crufaces. D.e.E.) Sement cum (unicuii umbilicalis decurfu, F.) Idem transverfe, \& G.) longitudiustiter fêtum, cum fitu embryonis iutra aloumen. H.) Eunbryo feparatus,

Poffet bacea, cum JA ceur 0 1. c. dici unilocularis, quia caro officulis arcte aduata ch; quoniam vero intra ip $\Upsilon_{2}$ officula longus adef funiculus umbilicalis. \& femen libere pendulum ac proprio colore dotatun: ideo ifla officula non pro tefla feminis. fed pro offea loculamentorum tunica habemus. Catera mouendum, quod fructus nolri, ob parvitatem fuam, non videantur plene maturi. 
J. Gaertner (1788) Vol.3

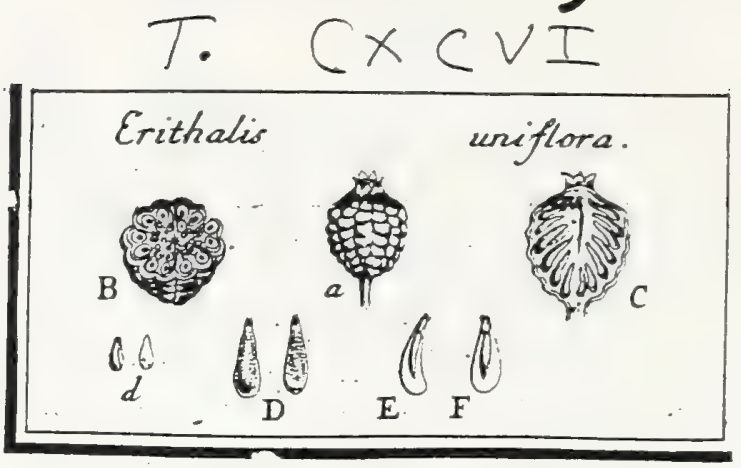

\section{J. Gaertner (178:): Vol. 3}

ER I TH A L I S. Conf. Carpol. Vol I. p. I29.

ERITHalis unifora. Tab. 196. fig. 4

Eritbalis uniflora. BANKS M/s.

Bacca obovata 1. globora, infera, furfum in calycem ferdentatum patentiufculum attenuata, fulcis fex profundioribus totidemque minoribus exarata, \& paulum fub vertice a feminum bafi protuberante usque ad bafin baccre tuberculata, rubra, fex-locularis, polyfperma. Caro pulpofa, rubicunda, epidermide tecta, feminibus undique adnata. (a. B.) Diffepimenta membranacea, tenuia, cum maturitate fere penitus evanefcentia; \& vix difcernibilia. Rec. nullum; nifi axim carnofum, a carne ipfa non difcretum \& cavitate fubu. lata excavatum fumas. (C.) Semina plurima, parva o verticillatim circum axim bacce locata $\&$ ad peripheriam defluentia, curvula, longifime elliptica, plano-convera, ad bafin rotundata obtufi $\widetilde{T i m a}_{1}$, spice autem fimbriatoumbilicata \& axi bacce arctius adharentia, fcabriufcula; pallida. (d. D.) Integumentum duplex: exteriss ex fibris offeis intertextis compaginatum, cralfum; interius membranaceum tenue, in funiculum umbilicalen crafum ad apicem feminis coarctatum. Alb. femini multo angultius, lubulatum, udi femen ipfum incurvum, carnofum, album. (E. F.) Emb. . . .

Uti in nonnullis aliis hujus ordinis ftirpibus, ita \& in hoc genere notx difinctivx fpecierum melius ex fructu quam ex aliis partibus defumi puterunt. 
J. Gaertner (1788) Vol 3

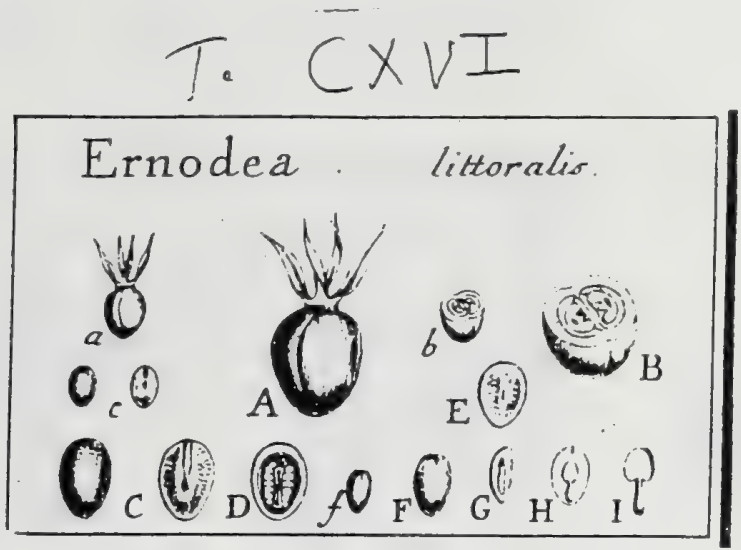

Rubiaceae

94

\section{ER N O D E A \\ Swarzz prod. p. 29. Sснвев. gen. 1 zi8.}

J. Gaertner

(1788) V013 LAMABCK ill. gen. I. p! 275 .

Cal. monophyllus, quadripartitus: laciniis lanceolatis, ereckis, acutis, perfiftentibus. Cor. monopetala, infundibuliformis; tubo cylindraceo, calycem fuperante; linbo quadrifuto: lacinis lanceolatis, revolutis. Stam. quatuor; filamentis fubulatis, imo fere tubo infertis, corolla paulo Jongioribus; antheris fagittatis, crectis, exfertis. Ovar. inferum, ftylo fmplici, longitudine tasminum, apice bifido; fligmata obcufa, limplicia. Bacca parva, coronata, bifulea, dipyrena: pyrenis bipartibilibus, monolpermis. Sem. folitariz. Alb. cartilasineum. Emb. erectus : cotyl. foliaceis, difcretis.

ERNODEs littoralis. Tab. sy6. fig. 6.

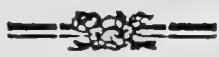

Thymelea bumtior, foliis acutis atro-virentibus. SLOAN. bif. $=$. p. 93.20 .289 . f. x. 2 .

Kunxia littoralis repens, foliis rigidis oblongis oppofstis, floribus fingularibus. BHOWN. jain. p. Ifo.

Enodec. Siwartz prod. p. 29. VAHL fymb. bot. =. p. 28. Willd. Jpec. pl. s. p. $61 \pi$.

Ernoden foliis lanceolatis quirquenerviis, foribus fefilibus. Lass. ill. gen. n. 1450. Persoon Jyn. plo 1. p. 131 .

Ex collectione Cel. Despontaines, \& a Do Poiteau.

PER. Bacca parva magnitudine grani piperis, fubglobola l. obovata, fulco longitudinali utrinque infcripta \& fubdidyma, infera, çalyce perfiltente coronata, viridiufcula, dipyrena. Caro debilis, pyrenis arcte adıata, lutefcens. Pyrenæe arctifime fibi approximatz, obovatx, offeo-chartacex, fetulis minimis confperfx, hinc convexx, inde planiufcula. \& a vertice ad medium usque fulco elevato in foveolam oblongam \& foraminu. lum, quo funiculus umbilicalis intrat, terminato infcriptx, bipartibiles, monofpermx; pars pyrenx plana ceu operculo facile a parte concava fecedit, \& intus a feninis protuberantiis longitudinalibus fubconcava eft.

R E c. nullum; femen funiculo umbilicali brevillumo rimæ partis planz pyrenes altixum.

SEM. in utraque pyrena fingulum, obellipticum, hinc convexum \& ad verticem dorfum verfus fulcatum, inde ob margines transverfim rugofos \& ad ventrem inflexos concavum, umbilico longitudinali exferto linta interme. dia infcripto infignita, ferruginea.

Is $\mathrm{T}$. fimplex, membranaceum, tenuifimum, albumini arctifime adustum.

$A$ L B. femini conforme, cartilagineum, fordide pallidum, 1. pallide fufcum.

EMB. dorfalis, erectus, longitudine altuminis paulo brevior \& bafi cjus pra pior, reclus, Jacteo-albus. Coty!. foliacex, tenuillimic, uvato-curdatie, fubrilitrine nervofic, incumbente; F. id. coiyledonibus pitulo lonjior, clavata, reça, obtußa, ab umbilico dec'inis, infera.

\section{EXPLICATIO FIGURFE}

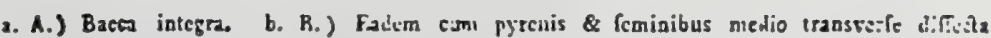

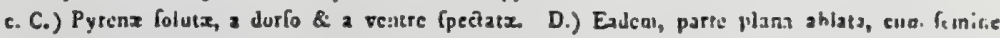
in fitl . vestre (pcdato. E.) Facies interna partis planz pyrencio f. F.) Scm:u itratsut.m, 3 durfo rifum. G.) Albumen cum embryone longitudinaliter fe尺tum. H.) Ejurden fuediu ha:izontalis cum fitu C. forma embryonis, 1.) Embryo folutus. 
J. Gaertner (1788) Vo1.3

Rubiaceae

$T \cdot C \times C V I$

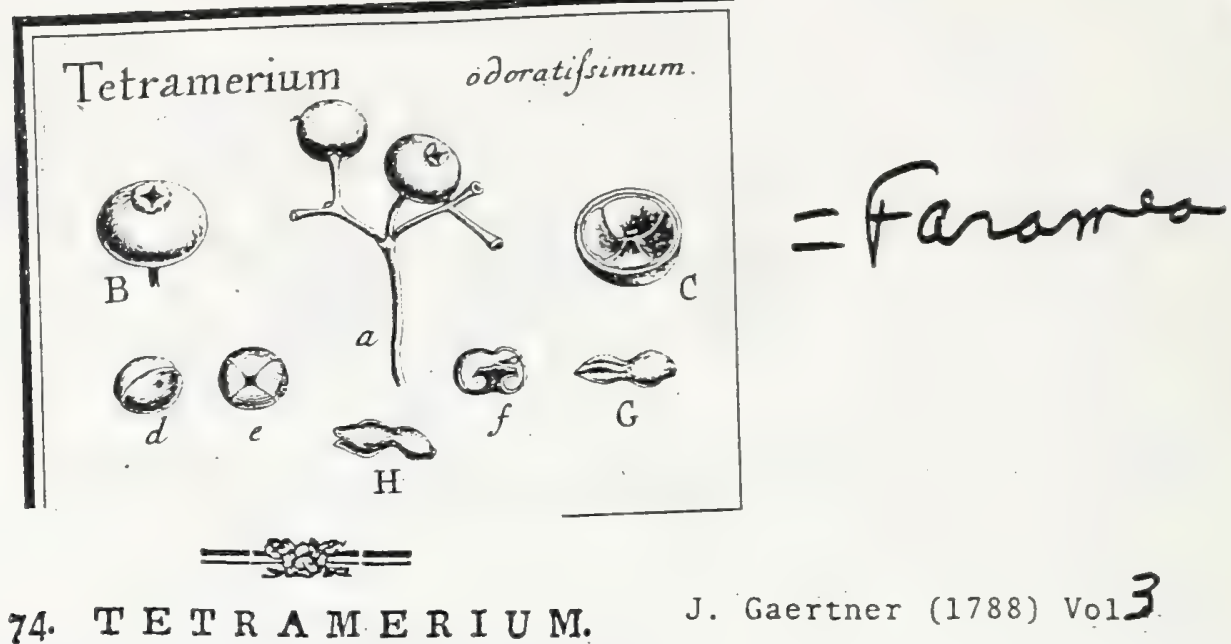

Cal. fuperus, parvus, laxus, obcufe quadridentatus, perfiftens. Cor. monopetala, infundibuliformis; tubo cylindrico, ad faucem incraffato; limbo quadripartito: laciniis longis, lanceolatis, acuminatis, patentibus Stan quatuor; filamentis breviffimis, paulo fupra medium corollz tubum infertis; antheris oblongis, incumbentibus, rectis, vix e fauce corollie prominulis. Ovar. inferum, ftylo fimplici longitudine tubi \& ftigmate bificlo inftructum. Drupa ficca, deprelfiufcula, coronata, monofperma. Seinen fubglobofum, tetran. gulo-menifcatum. Alb. cartilagineum. Emb. lateralis.

Tetramerium odotatifimum. Tab. 196. fig. I.

Jafmintm forte arboreum foliis ex adverfo nafcentibus oblongis acuminatis. SLOAN. cat. 26 g. bif. 2. p. 97 .

Pavetta? fuliis oblongo - ovatis oppofitis, fipulis fetaceis petiolis interpofstis. BR OWN. jam. 142. t. 6. f. 1. optine.

Jafminum arborefcens lauri foliis, fore albo odoratifmo. PLUM. cat. pl. p. 77 . pl. amer. p. 150. t. 156. f. 2. male.

Ixora (americana,) foliis ternis lanceoluto - ovatis, floribus thywfoideis. LiNs. amoen. acad. 5. p. 393. Spec. pl 3. p. 260 . Syf. veg. ed. 14. p.153. Spec. pl. ed. Willd. T. 1. p. 6zo. PERsOoN fyn. pl. x. p. 130.

Coffea (occidentalis,) floribus quadrifidis, baccis monofpermis. JACQ. amer. p. 67. t. 47. LINN. Spec. pl. p. 246 . Syft. veg.ed. 14. p. 215. PERsuON fyn. pl. x. p. 209.

Coffer foliis oblongo - lanceolatis acuminatis, panicula paucifora trifida terminali, corollis quadrifidis, baccis monofpermis, ramulis setragonis. WILLD. Spec. pl. T. x. P. 2. p. 974 .

Ex infula Hifpaniola a $D^{\text {no }}$ Portrau.

PzR. Drupa parva magnitudine pifi majoris, globofa, l. obfoletifime rotundato - tetragona, deprefisufcula, infera, calyce parvo obtufe quadridentato connivente coronata, viridiufcula, monopyrena. Caro debilis, firma. Putamen ofeo-chartaceum, albidum, intus levigatillimum, \& zonis duabus altera ad verticem putaminis evanefcente quadripartitum, bafi autem in columnulam tetragonam fubltantia cellulora repletam atque in umbilicum callofum degenerantem congeltis, monofpermum.

Rec. nullum: nifi columnulam tetragonam ad bafin putaminis e fulcis oriundam \& in ejus axi adicendenten fumas, qux per umbilicun feminis in cavitatem menifcoideam intrat, \& ibi in umbilicum ipfum abit.

SEN. unicum, totam putaninis cavitatem replens, fubglobofum, deprefiuf-

91 culum; hinc convexum \& fulco in duo hemifphreris divifum, inde in bafi tetragono - umbilicatum \& fovea magna inxquali menifcatun, cinereum. Chaliza fufcil ad latus feminis paulum fub vertice.

INT. fimplex, membranaceum, validum, arcte cum albumine cohxrens.

A L B. Feniui conforme, cartilagineum, menifatum, fordide atrococruleum.

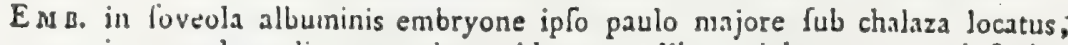
minutus, lateralis, curvulus, oblongus, dilute violaccus. Coty!. fubliaHjtie, ubtufe, convexo - concavas 1. cochleariformes, nervo intermedio violaceo valido percurlix, diferetx, incumbentes. Rado cra $\mathbb{G}_{2}$, inx qualiter ovata, verlus cotyledones in collum breve angultata, peripherica, lateralis, ab umbilico extermn ramenn 
J. Gaertner (1788) Vol3

T. CXCI

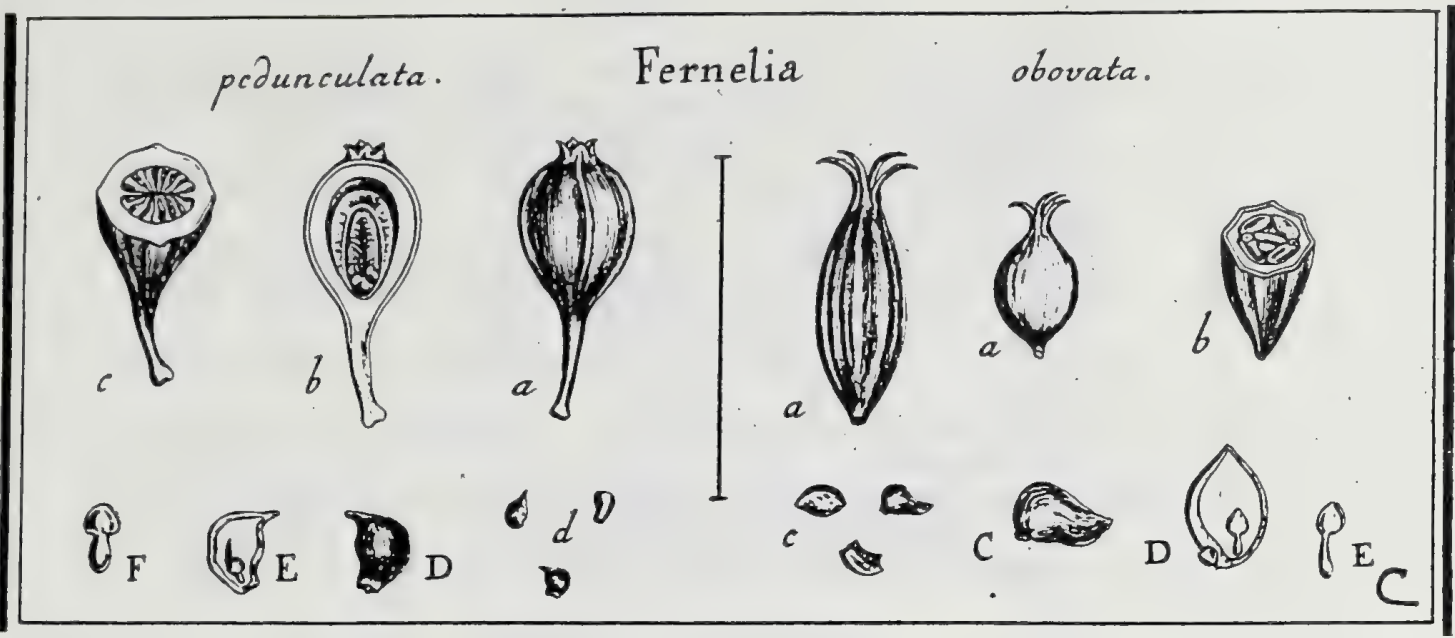

J. Gaertner ( 1788$)$ Vol 3

53. F ER N E L A C. Commers. $6 /$

Juss. gen. p. 199. LA MARCK ill. gen. t. 67. f. $r_{\text {。 }}$

Cal. monophyllus fuperus, quadrifidus; Jaciniis fubulatis. Cor. monopetala parva, breviter tubulofa; limbo quadrilobo: laciniis obtufis, patentibus. Stanı. quatuor; filamentis brevibus, ad baln tubi infertis; antheris fubrotundis, non exfertis. Ovar. inferum, ftylo finplici; ftignate bifido. Bacca infera, calyce coronata, bilocularis; dillepimento incompleto, elliptico, femilunari, feneltrato. Senina numerolit. Alb. carrilagineun. Emb. fubdorfalis, radicula centripeta.

Frkзгlia pedunculata. Tab. 191. fig. 3.

Ab amicifimo D. Decandolle fub nomine $F$. buxifolia accepta, \& ex collcationie Delelértiana.

PER. Bacca elliptica 5. pyriformis, in pedunculum bacc:ım longitudine xquantem : attenuatit, callyce quadridentato coronata: dentibus brevillimis; obfoletilime rotundato-tetragona, fulcis elevatis cum dentibus calycinis cominuis cuftata, bilocularis, polyfperma. Caro cratifufcula, firma, ru- . fefcens, eplidermide vidida veltita. Diffepinentum incompletum !. fenc- 
Itratum, femilunare parietibus bacco infertum, carnofum margine acui tun ; cornubus verfus bacca pedunculum valde atrenuatis, \& fere evanefcentibus; feneftra oblonga 1. elliptica ad bafn baccx latior.

REC. Subellipticum, mạgini diffepimenti affixum \& ad ejus cornua evane[cens, papillofo - fungofum.

SEX. numerofa, circa quadraginta in quovis loculo, imbricata, compreftur. cula, varie ab incumbentibus angulata, in vertice mucronulats, ad umbilicum truncata, rugis minimis fcabrata, fufca.

IN T. fimplex, coriaceo-membranaceum, crafiufculum, albumini arctifime adnatum.

A \& B. femini conforme, albito - cinereum, in peripheria cartilagineum, in centrp carnofum.

E n B. minimus, erectus, inferus, paulum ad dorfum feminis vergens, niveus. Cotyl. incumbentes, fübrotunda, craffiufculx. Fad. recta, oblonga, crafia, obtufa, umbilico externo obverfa, centripeta.

\section{EXPLICATIO FIGURE}

1.) Baccz integra. b.) Eadem longitudinaliter difecta cum dificpimento \& receptaculo in fitu. c.) Eastem iransverfe fecta cum feminibus in fitu. d. D.) Semina foluta. E.) Albumen longitudinaliter diffetum cum embryone in fitu naturali. F.) Embryo folutus \& valdopere autus.

Mala Lamarckii figura magis in hanc quam in requentem plantam quadrat; aliis itaque enodandun relinquo, num noftra $F$. pedunculata vera fit obovata LAM. \& inde fynnonima infra allegata ad hanc potius fint transferenda?

FERNELIA cbovata. ibid.

Fernelia laciniis corollarum acutis, baccis ovalibus. LaM. ill. gen. n. 1479 .

Coccoopprilum (uniforum, coule ereito fruticofo, foliis ovatis acuminatis, fedunculis axillaribus zniforis, figmatibus capitatis. WVILLD. Spec. pl. T. 1. p.618?

E collectioue Cel. Desfontaines, fub nomine $F$. obovate.

Bacca infera, oblonga 1. ovata, 1. globo[a, calycis laciniis fubulatis fuperne patentibus coronata, rotundato - octogona (a. a.) fubbilocularis. Caro debilis, firma, dilute rubra. Difiepinentum incompletun angultiflimum. Receptaculum margini diffepinenti adnatum, fungofum. Semina duabus feriebus in quovis loculamento horizontaliter imbricata, alternatim inter jacentibus Jongitudanalibus ex utruque latere, (b.) in quovis loculamento circiter triginta polymorpha, hinc inde compreffa, angulata. rugis mininis fcabrata, unbilico appendiculato parvo fungofo inftructa, ferruginea (c. C.). Integumentum duplex : exterius coriaceum, crafliufculum, ab albumine facile fecedens; inserius membranaceum tenuifrnum,

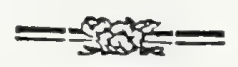

albumini aretifrme adnatum. Albumen femini conforme, totum cartilagineum, corneo - transparens. Enb. erectus, dimidio albumine paulo brevior, dorfo feminis propior quam ventri, leviter curvatus, ad bafin feminis locatus. Coryl. craifiufcula, cordatx, incunibentes. Rad. cotyledonibus duplo longior, curvata, fubclavata, umbilico feminis \& fimul receptaculo obverfa (D. E.)

Altera hace Fernelix fpecies a priore \& fequente calycis laciniis longioribus maturitate non abbreviatis \& embryonis forma recedit, fpecies itaque facilius fruclu dignofeendxe funt, quam foliis. Bacca in hac rectius forlan
unilocularis dicenda. 


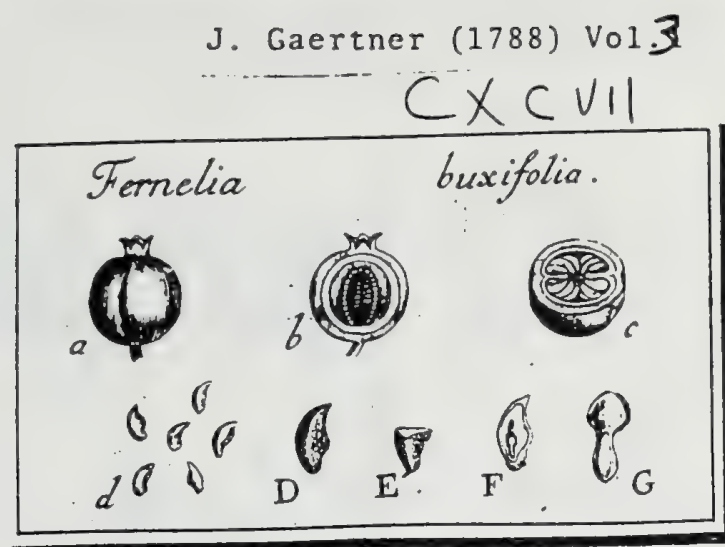

J. Gaertner (1788) Vol3

Fernezia buxifulia. Tab. 197. fig. 6.

$$
63
$$

Fermelia laciniis corollurum obtufis, baccis pifformibus. LAMARCK ill. gen. $n_{0} 1478$. E collectione Cel. Desfontaines.

Drupa parva, globofa, corticata, leviter fuleato - didyma, calyce breviter tubulofo quadridentato coropata, bilocularis (a.). Cortex carnofus crattisufculus. Putamea odjeo-chartaceum, fecundum fulcos in duo hemifphxria fillile, marginibus acute intexis diffepimentum incompletum 1. feneItratum formantibus. Receptaculum fungofum, ad marginem difepimenti incompleti adnatum \& diffepimentum fere integrans. (b) Semina pluri$\mathrm{ma}$, hine cratliora rotundata, inde acuta rotundato - emarginata l. inxqualia, ad latera plana, umbilicis obtufis ad centrum drupæe convergentia, fubrilifime rugofo - ftriata, fufca. (c. d. D.) Integumentum fimplex, crafiuficulum, ex fibris intertextis conflatum, adhærens. Albumen femiתe paulo anguftius, fubcartilagincum, in inedio foveola lanceolata comprelfa \& cum embryonis lectulo coharente inftructum, pallidum. Embryo minimus, fubdorfalis, in parte inferiore albuminis ad umbilicum locatus, rectus, albus. Coryl. ovatx, obtufifimx, difcretx, comprellix. Rud. cotyledonibus paulo longior, clavata, leviffime apiculata, centripeta (E. F. G.).

Fernelia nequaquam cum Coccncypfilo ob diliepimenti diverfam fabrican commilcenda, fi Brownei iconi fides babenda. 


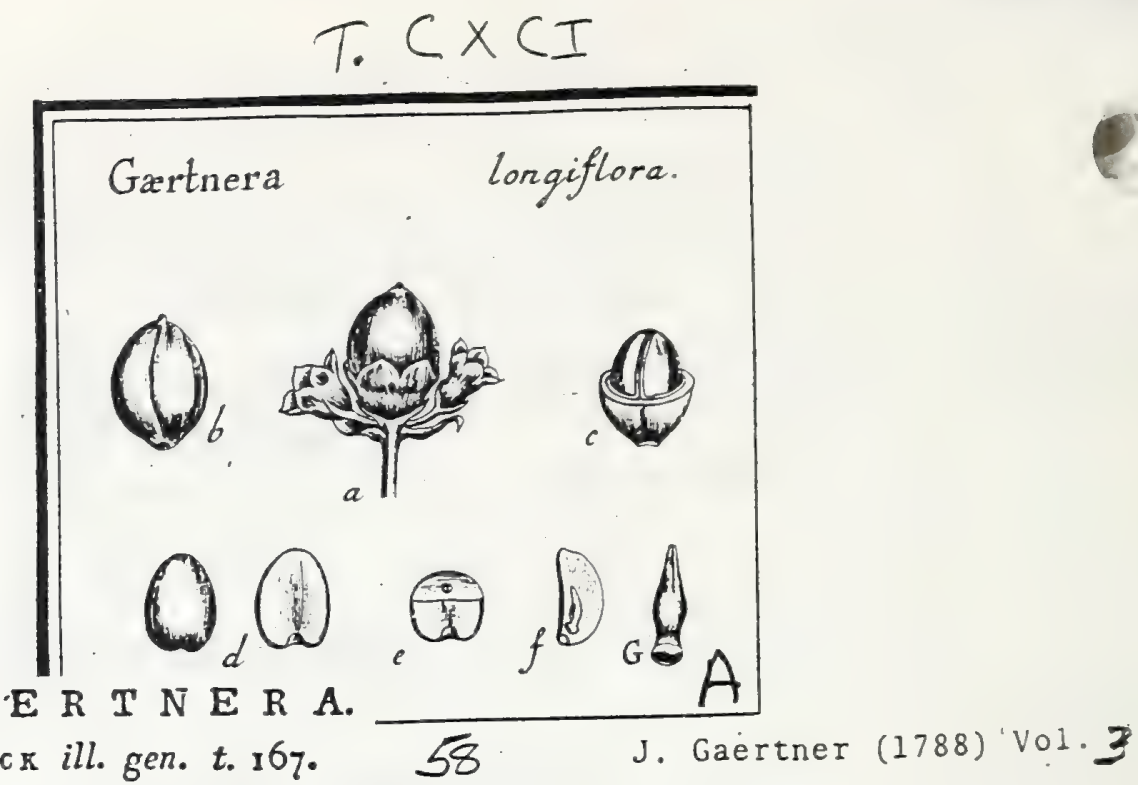

Cal. monophyllus, inferus, turbinatus, canipanulatus; limbo aut profunde quinque dentato, aut undulato; dentibus mucronulatis; bafi bracteis duabus oppofitis lineari- lanceolatis carinatis inftructus, perfiftens. Cor. monopetala, infundibuliformis; tubo cylindrico; limbo quinquepartito, patente : Jaciniis lanceolatis, obtufis. Stam. quinụue, filamentis brevifimis, ad mediam corollam tubo infertis; antheris oblongis, bilocularibus, erectis, non exfertis. Ovar. fuperum; Atylo Gmplici, filiformi, corollaw fuperan-

te, apice bifido; ftigmatibus fimplicibus relexis acuminatis (capitatis Lam) Bacca exfucca, dipyrena: pyrenis monofpermis. Alb. cartilagineum. Emb. pugioniformis, inferus, erectus.

GarRtiera longibura. Tab. I91. fig. I.

Coffeue species. Conners. Ic, ined.

Ex dono Cel. A. DE Jussieu \& ex collectione Cel. Desfontaines. Habitat in Madagafcar.

PER. Bacca Гipera, elliptico-acuminata, magnitudine nucis avellanx minotis, puncto callofo in vertice notata, levilime bifulca, a calyce per maturitatem ampliato ad tertian fere partem amplexsta, dipyrena, carnora, (rubra!) Caro debilis, duriufcula. Pyrenc chartacex, elliptice, hinc convexx, inde planx, mousperms.

Rec. nullum; femina ad partem ventralem bafeos pyrenx cicatriculx funga fx infidencia.

SEM. in quavis pyrena fingulum, totam ejus cavitatem replens, ellipticum, ad barin partis ventralis umbilicatum, hinc convexum, inde planiufculum, margine rotundatum, fufcum.

Is T. fimplex, membranaceum, tenuifimum, albumini arctifime adnatum.

A LB. fenini cunforme, crafum, cartilagineum, caftaneo-fufcum. .

ENB. dicotyledoneus, pugioniformis, crectus, tertiam albuminis partem longitudine xquans, ad bafin feminis locatus $\&$ propior ventri quam dorfo, leviter curvatus, in ficco fifcus. Cotyl. fubulatx, accumbentes, tertia embryonis pai paulo breviores. Rad. longa, curvula, curbinatd, faspo cum cotyledonibus incraftatis continuo turgido in collum coarctata \& iterum in capitylum oblique truncatum obtulum rotundatum conglubata, foveulic umbilicali albuminis obverfa, infera.

\section{EXPLICATIO FIGUR.E.}

x.) Ramulus frugifer cum calycibus inanibus. b.) Bacca foluta, c.) Eadem transrerie fcas cum pyrenis, ut appareant femina in fitu. d.) Semina fiparala a dorfo \& a veutre fpecala. c.) Albumen trasverfe \& f.) Idcm longitudianliter diffeatum cum embrgone in fill G.) Enbryo folutus \& infigniter 2udus.

Ob fructun inferum a Rubiaceis alienum eft hoc genus; licet in onnibus reliquis partibus c. g. Atipulis interfoliaceis, albumine cartilagineo, embryonis fitu \& denique in toto plantx habitu Rubiacearum faciem omuino pra fe ferat hac ftirps ab inventore ad Coffeam fallo relats, 2 qua \& embryonis forma fingularilima \& plane inufitata valde differt. Complures in locupletulinis herbariis Cell. de Juffieu \& Desfontaines vidi 


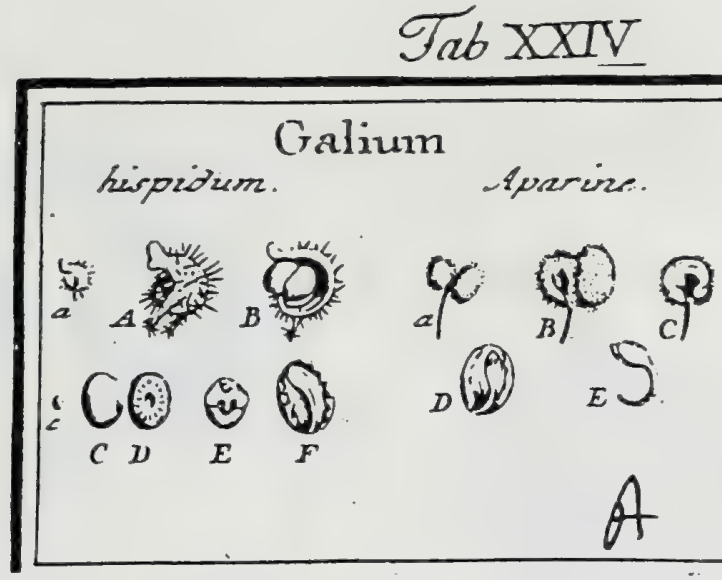

J. Gaertner (1788) Vol.1

109

CXXIX, GALIVM. HAIL. LINN. gen. 125. Valantia. LINN. gen. IISI.

Flores hermaphroditi, intermixtis fxpe mafculis. Cal.obfoletns, aut minimus, quadridentatus. Cor. campanulata, brevis. Stam. quatuor. Sty' unicus. Semina duo infera, fubglubofa.

QA l I Ua hiffidum. Tab. 24. fig. I.

Aparime femine lavi. V 112 L. paris. 14. $t .4 \cdot f \cdot 3$.

IIO

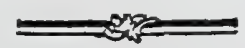

Galium foliis fenatis ferratis, petiolis trifloris incurvis. H a z L. hifl. 1. n. 725 .

Valantia floribus masculis trifudis hermaphroditici germini hifpido infiftentibus.

LIN N. Jiy ft. veg. 908.

PER. nullum, prater cuticulam tenuiffinam, femini adratum.

REC. nullum; femina bafi affixa \& latere fuo interno fibi mutuo juncta.

SEM. duo, infera, parva, ovato globola, fordille fufca; line gibba, glabra; inde fo. vea rotunda excavata \& circa ejus aperturam punctis callofis albicantibus conf́perfa.

IN T. fimplicifimuin, tenuifimum, arcte nucleo adlizrens.

A L в. menifcatum, fubcartilagineum, e corneo mclinum, aut pallidum.

Eм в. dicotyledoneus, erectus, dorfalis, curvatus, lacteo albus. Cotyl. ellipticx, tenuif: finn , breves. Rad. filiformis, arcuata, cotyledouibus triplo longior, infera.

1. A.) Peduneulus forum communis, per maturitatem in laminam fornicatam, extus hifpidam, ampliztus, qux fructum obtegit, \& ad utrumque latus in pedicellum flosculorum abortivorum porrigitur. B.) Fructus integer, intra pedunculi fornicem latens, c.C.) Sernisis pars convex2. D.) Ejus pars ventralis. E) Albumen transverfe fectum. F.) Embryonis fgura \& (itus in dorfo albuminis

G A I U M Aparine. ibid.

Aparine. B L A K w. herb. t. 29.f. 3. O E D E R. flor. dan. t. 495.

Galium feminibus hirfutis, caule ferrato, foliis fenis linearibus lanceolatis ferratis, petiolis unifloris. Ha LI. hift. 1. n. 723 .

Galium foliis oftonis lanceolatis carinatis fcabris retrorfum aculeatis, geniculis viliofis. fruttu hifpido. L I N N. $\int y \int t$. veg. 15 t.

Fructus pedicellatus (a), ficcus, parvus, compofitus ex feminibus duobus (B.) fubglobolis, undique fetis uncinulatis hif́pidis. Integ. duplex; exterius membra. naceum, una cum fetis facile detergendum. Albumen meniscoideum, (C.) craffun, cartilagineum, coloris cornei. Embryo (D.E.) pallide lutescens.

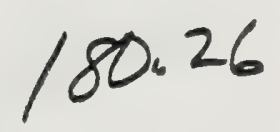


Rubiaceae

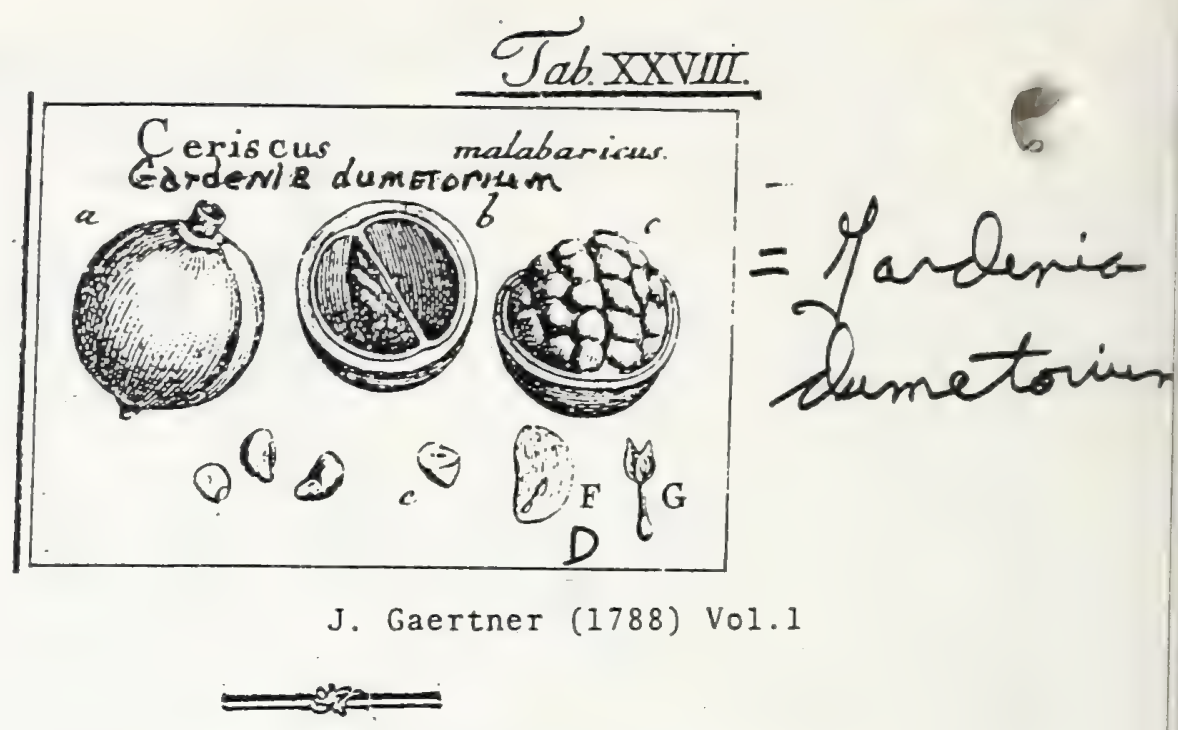

CLXVII. GARDENLA. LIN N. gen. 296.

Calyx tubulofus, quinquefidus, fuperus. Cor. monopetala, infundibuliformis, con. torta, coriacca. Stam. quinque. Styl. unicus clavatus, bilobus. Drupa baccata, bilocitaris. Scmina incumbentia, pulpa inolli inter fe.connexa.

Gardexia dumetorum. Tab. 28. fig. 4.

Cerifcus malabaricus. in Icon.

Gardenia Spino/a, Spinis Jupra axillaribus, corollis utrinque hirfutis. REтz: fafc. 2. p. 14. E fafc. 3. p. 27.

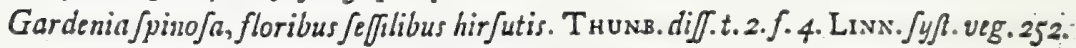
E collećtione Bankfiana atque fem. hort. lugdb.

PER. Drupa infera, globofa aut elliptico fpharoidea, calycis tubo tereti perfintente coronata, camofa, glabra, lutefcens, aut fulva. Caro mollis, modice crafta. Putamen figura drupx, utrinque fulco obfoleto infcriptum, offeum, tenue, fragile, biloculare, intus lavigatifiunum.

REc. nullum, prater fubflantian glutinofo pulpofam, qux femina undique obvolvit, eaque \& inter $\int_{e}, \&$ cum parietibus difepumenti connectit.

$S \varepsilon$. in fingulo loculainento plura, fedecim \& ultra, grandiuscula, erecto incumbentia, hinc convexa crafta, inde cuneiformi angulata, femitransparentia, melisa

IN T. finplicifimum, arachnoideum, ut vix ullum.

A в в. femini conforme, cartilagincum, durilimum, fubpellucidum, lutelcenti-pal. lidum.

EM B. dicotyledoncus, crectus, longıtudine dimidii fere albuminis, \& in ejus extre mitate inferiori pofitus, lacteo albus. Cutyl. ovato lanceolatx, foliacex, venofz. Rad. recta, dcoifuin clavata, miera.

2.) Drapa integra. b.) Eadem dirTera. c.) Semina in fitu. a.) Eadem foluta. e.) Albumen transverfe fêtum. F.) Ejus fectio longitudiualis, cum fitu embryouis. G.) Embrjo (eparatus, 
Rubiaceae

\section{J. Gaertner (1788) Vol3}

\section{$T_{a b}$ : CXCIV.}

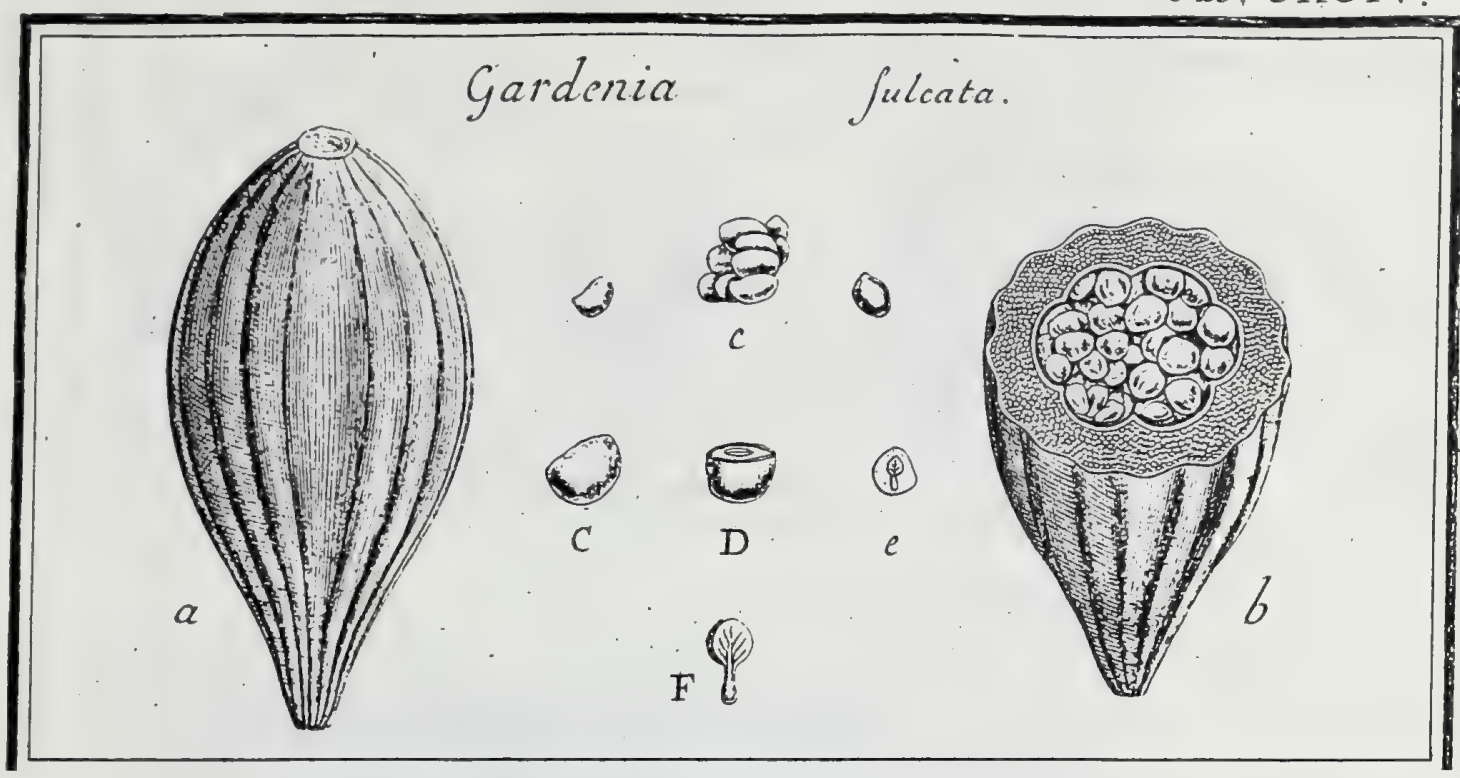

CXCIII

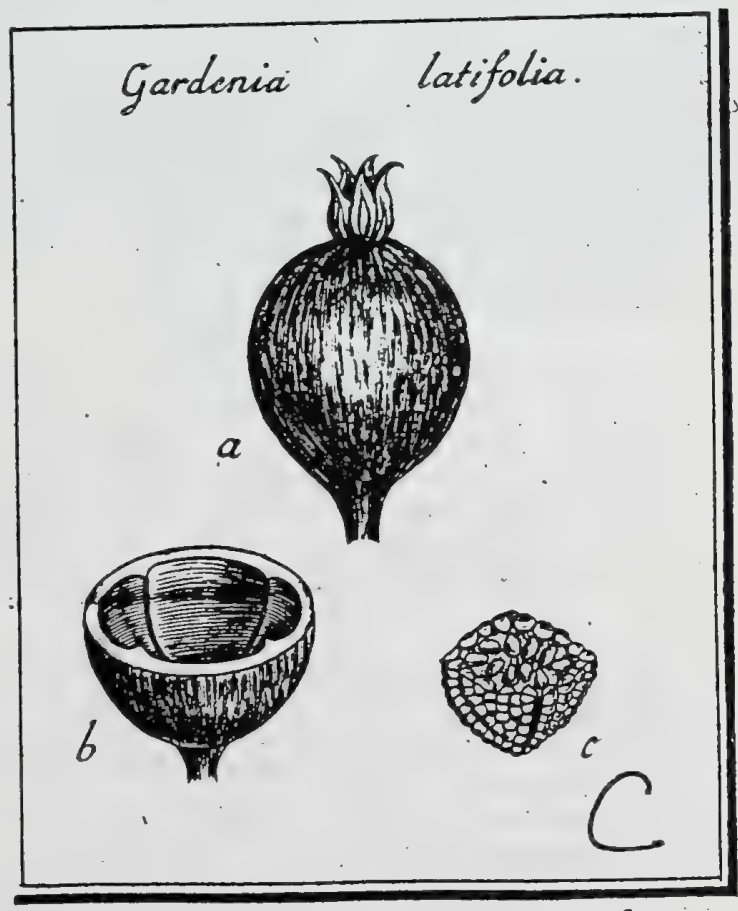

$180.28 \mathrm{~A}$ 
$G A R D E N I$ A. vid. Carpol. Vol. I. p. ז40.

Vol. II. p. 480 .

Gardenis lacifolia. Tah. 193. fig. 3.

Gardenit inerrnis, fuliis ovato. fubrotundis, corollis bypocrateriformibus, laciniis calycinis fubulatis obsufe carinatis. AIT. bort. Kew. I. p. 294. WILLD. Spec. pl. T. x. P. 2. p. 1226. Persoon. Jyn. pl. 1. p. 198.

Ex horto regio Kewents.

Bacca obovata 1 . fubglobora nucis juglandis magnitudine, hinc in pedunculum cralfsufculum attenuata, inde calyce quinquepartito rigidiufculo coronata, pallide occhracea, corticata, unilocularis. a.) Cortex lignofo-fuberofus, craf́fus, extus longitudinaliter obfolete fulcatus 1. rugofus, intus membranà tenerrimà levigatà veftitus \& quatuor diffepimentis incompletis anguftifimis inltructus. Caro mollis, vetuftate fufca, cum feminibus undique in illa inordisate nidulantibus in corpus rotundato - zetragonum compaginats, diffepimentis incompletis fulcis quatuor correfpondentibus adhxrens. Semina plurima parva, ovata, pallida. (b. c.)

Gardenia fulcata. Tab. 194 fig. I.

Ex dono $D^{\text {ni }}$ Dupurs.

Bacca grandiufcula, lutefcens, obovata Lelliptica, deorfum in pedunculum craffum attenuata, profunde coftato. fulcata, 1 . fulcis elevatis longitudinalibus obtufis angulata, calyce coronata, corticata, unilocularis (a.) Cortex lignofus, craffillimus, ex epidermide tenui grabra \& ex fibris lignolis filiformibus rigidis fubftantia granulofa junctis compaginatus; intus membrana chartacea levigata \& in fex lobos facile a cortice fecedentes divifa veftitus. Diffepimenta incompleta adeo angufta, ut eorum vix adfit veftigium, qux nounifi a curvatura levifima loborum lamine chartacere indicantur. Caro mollis, pulpofa, excolor 1., ut in vetufto fpecimine apparet, flavefcens, undique feminibus nidulantibus referta \& cum ipfis in unum corpus, quod nounifi juxta peripheriam cum cortice cohxret, commixts. Rec. nullum; femins absque ordine in pulpa nidulantur. (b.) Semina plurima, parva, orbiculata l. irregulariter ovata, lenticulari - compreffa, flavefcentia, ad marginem femicanali pro decurfu funiculi umbilicalis inftructa \& areola parva conculore notata: (c. C.) Int. fimplex membranaceum, tenue, lubenter $a b$ albumine fecedens. Alb. femini conforme, cartilagineum, fufcum, opacum. Emb. rectus, tertiam albuminis partem longitudine fere fuperans, niveus. Cotyl. orbiculatx I. fubovatx, foliacex, nervofx. Rad. reca, longitudine cotyledo-

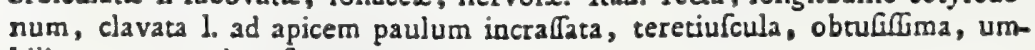
bilico externo obverfa, vaga

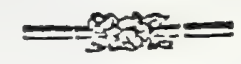

Utrum revera nova Gt fpecies, an una ex jam cognitis, fortaffe G. florida, aliis enodandum relinquimus. Quamvis noftrum fpecimen ab infectis fic mutilatum, calyce ninirum coronante orbatum, fatius tamen efle duximus, iconem frucus caterum inmutati tradere, quam hunc a cxteris cognitis Gardeniz fpeciebus diverfum filentio plane proterire, ut tandem verus hujus generis character carpologicus eruatur. Corticis compages hujus fpeciei eadem eft $a c$ in G. Thusbergia Carpol. T. 177. at diffepimentorum conditio diver a. $^{2}$

Quod fi Pericarpii diverfitatem inter plantas ad Gardenix genus vulgo relatas refpicimus, in duo genera leparandas effe cenfemus: unum Gardenie gaudens baccis calyce quinquedentato coronatis unilocularibus \& diffepinentis incompletis inftructum; alterum Cerifci, (a Pofoqueria folo defectu receptaculi diverfum, ) baccis calyce tubulofo aut rudimento calycis verrucofo coronatis, bilocularibus; inde G. Rothmannia 1. c. ad Cerifcum amandanda effet. Ex quibus certe elucet, Gardenix genus ultro effe examinandum, utrum \& obfervationes anthologicx hane feparationem fuadeant, an vero genus uni-
cum retinendum Gt, \& a pericarpiorum diverfa conditione refpectu diffepimentorum \&a. divifionis tantum momentum fumendum. 


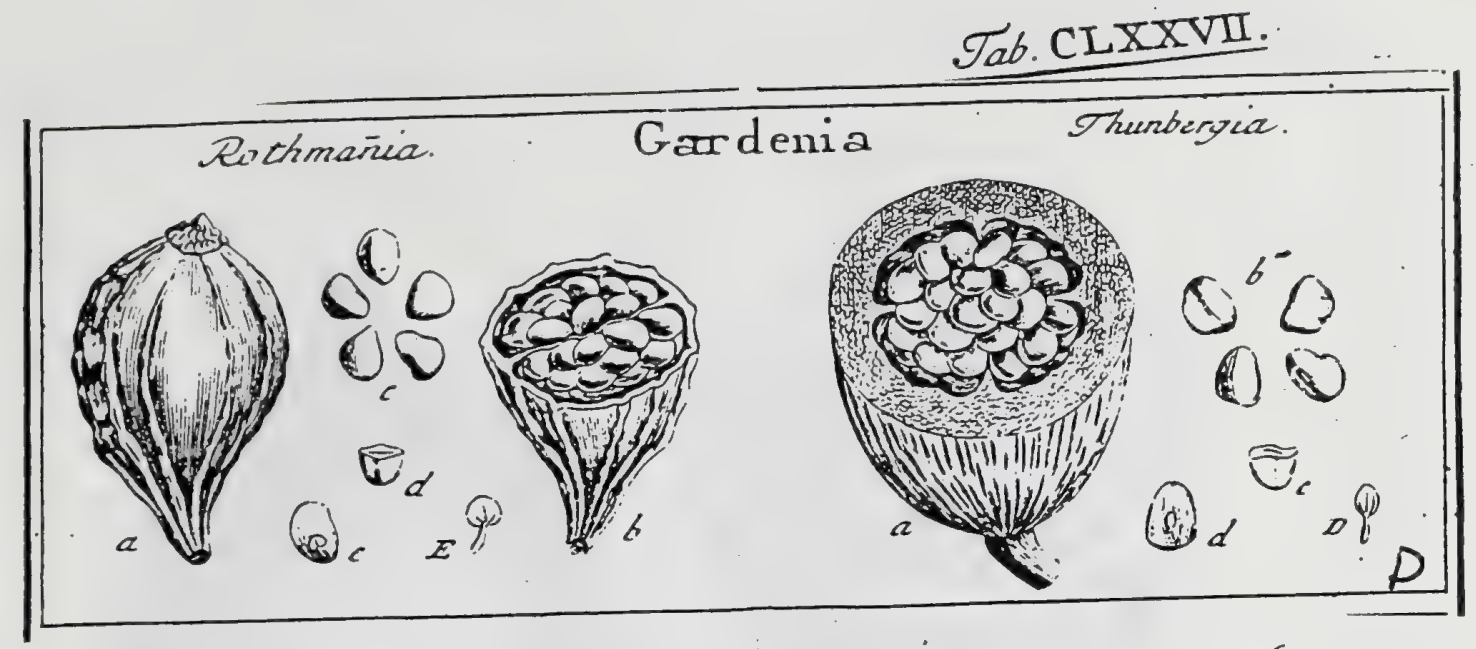

\section{J. Gaertner (-1788) Vol Z}

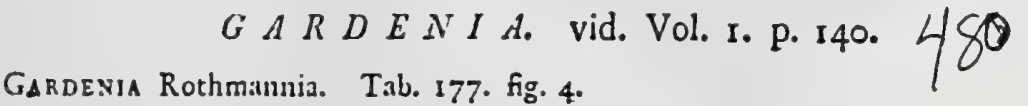

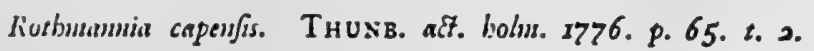

Gardenia imermis, corollis acutis fubcampanulutis, calyce glabro, foliis oblongd

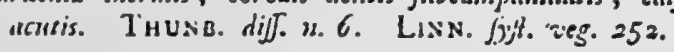

A Ci. Thusberg. cum léquenti.

$=$ 35

Bacen turbinata (a.), corticata, Jupra umbone conico rugato atque fulcato faltigiata, infra in bafin roftratam gracilefcens \& ex ea fulcis elevatis nodu. lofis diftantibus fubduodenis longitudinaliter ftriata, nigra, fubbilocularis. Cortex (b.) coriaceus, per xtatem fragilis, tenuis, interne ad fulcorum fedem quafi plicatus. Caro fpongiofa, nigricans aut fufea, cum corrice tantum uno, duobus, aut tribus locis cohæreins, cetera vero ab illo difereta \& tnta folida, ut circa peripheriam duntaxat diffepimentorum rudimenta quxdam adefre videantur. Receptac. nullum, fed femina absque ordine in pulpa nidulantia. Semina (c.) plurima, irregulariter ovata, lenticulari - compreffa (d.), nigro-fufea, opaca. Integ. fimplicifimum, tenuifimum, arctifime adnatum. Album. cartilagineum, durum, coloris pallide cornei. Erabryo (e. E.) dimidio albumine brevior. Cosyl. orbiculate, trinervix, tenuifunze. Rad. extrorfum craffefcens, vaga.

Baccam haud incongrue unilocularem duntarat ftatuit THUNB. 6. 6.

CARDENIA Thunbergia. ibid.

Thambergia capenfis. MoN5. ad. bolm. 2773. p. 288. t. xr.

Gardenia inermis, corollis obtufis, calyce tereti, foliis ovatis acutis. THUNB. dif. n. 3. t. 2. f. 6. LIN. byjt. veg. t. c.

Baccr ovalis (a.), gmandis, e ftramineo pallida, corticata. Cortex lignofus, craffiffimus, ex cpidermide tenui rugofula, \& ex fibris ligneis filiformibus compaginatus, intus ftipatus diffepimentis quatuor incompletis anguftis coriaceis. Caro mo!lis, in vetufto fructu rufefcens, undique feminibus nidulantibus referta, \& juxta peripheriam faltem in quatuor lobos, neutiquam autem in vera loculamenta divifa. Semina (b.) numerofa, precedencibus per fingula puncti fimillima, nifi quod paulo magis compreffa (c.). Embryo (d. D.) atro-viridis. Cotyl. ellipticx, trinervix. Rad. longiufcula, vagz

Ingens dąur difcrimen, refpectu pericarpii, inter plantas ad Gardeniam vulgo relatas. Si tamen omnes unius fint generis naturalis, melius fane ex fructu, quam ex ulla alia parte, differentix earum fpecificx poterunt hauriri. 



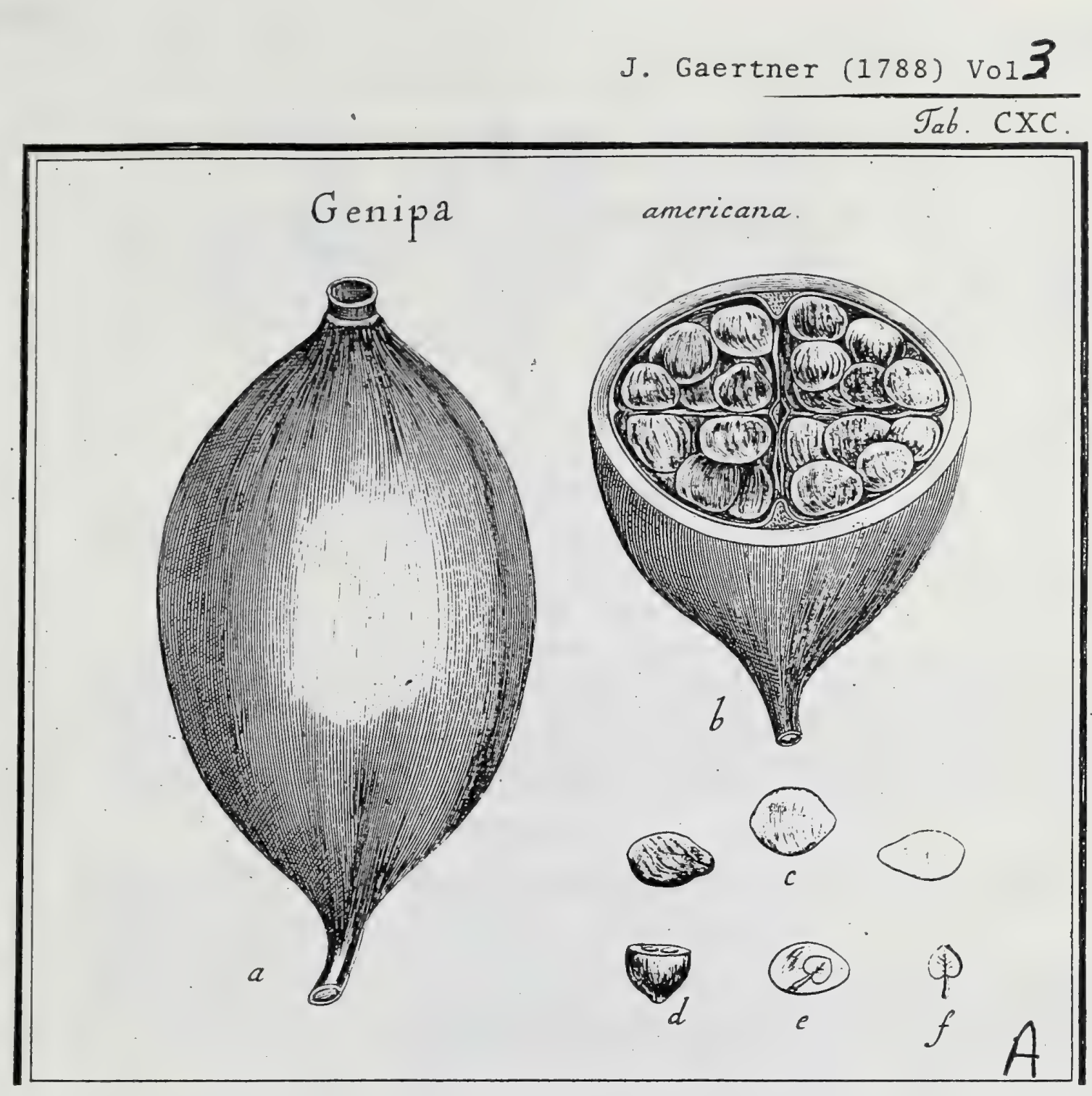

$180.30 \mathrm{~A}$ 


\section{GEN I P A.}

Tочвк. t. 436. 437. LіNл. gen. 240. ed. Schreb. 34t. Juss. gen. p. 201. Gardenia. LASTACK ill. gen. t. 158 .

Cal. monophyllus, fuperus, cylindricus: limbo sequali truncato: Cor. monopetala: tubo brevi infundibuliformi : limbo magno rotato patente quinquepartito. Stam. quinque; antheris in fauce tubi feltilibus, longis, cum corolla incifuris correfpondentibus, exfertis. Ovar. inferum; ftylo fimplici; Rigmate turbinato ad apicem attenuato. Bacca infera, calyce coronata, corticata, fubquadrilocularis. Sem. plurima, in pulpa nidulantia, horizontalia. Alb. cartilagineun. Emb. radiculà vagà.

Genipa americana. Tab. Igo. fig. I.

Janipaba. MARCGR. braf. po 92. Pis. braf. p. 67o

Genipa fizldu ovaso. Plum. Cat. p. 20 :

Cenipa folis lanceolatis. PLUs. ic. pl. amer. to $r_{3} 6$.

Gardenia inermis, foliis oblongo - lanceolatis, pedunculis rxillaribus multifioris, corollis isypocrateriformibus, tubo abbreviato. SWARZ obf. 84. WVILLD. Spec. pl. T. I. P. 2. p. 1228 .

Geripa. Lisix. Jpec. pl. p. 251 . Syyf. veg. ed. 14. p. $22 \%$.

Ex collectione Deleffertiana, \& ex inf. St. Donin. a D. Portiu.

PER. Bacea magna, infera, ovata, turbinata, utrinque attenuata hinc irt pedunculum craffiufculum inde in calycem membranaceum ruga circulari a bacca difcriminatum, corticata, fubpubefcens, pallide viridis, fubquadrilocularis. Cortex craffus, carnofus, e viridi Eavefcens, duriufculus, intus membranà tenui levigatà veftitus. Diffepimenta quatuor incomple-

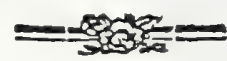

ta, furfum deorfumque deliquefcentia, falciformia, quorum duo oppofita tenuiora \& angultiora, (nonunquam anguftifima,) a membranà duplicatà baccan intus obveftiente profecta; duo altera autem crafiora \& latiora a parietibus baccx circa medium ejus in fulcum incraflatis \& membrana obduchis, quie margine dentato-lacero cum pulpa confluit, product. Pulpa mollis, fulcis quatuor, quorum duo oppoliti profundiores, in totidem lobos longitudinales neutiquam vero difepimentis divifa, femina involvens, excolor, faporis grati fubacidi.

RE.c. nullum; nifi funiculos umbilicales maturefcendo autem evanefcentes \& in pulpam refoluto: fumas.

S.EM. plurima, ftratis horizontalibus circum centrum commune parvum angulatum locata, in pulpa nidulantia, ovato - orbiculata 1. elliptica, conipreffa \& vix lenticulari-convexa, per ambitum obtufa, e rubro flavefcentis.

I N T. Gmplicifimum, membranaceum, tenuiflimum, albumini arctillime adnatum.

A L в. Semini conforme, cartilagineum, pallide mellinum, ad radiculx fitum Chaluza fufcì notatum.

EM B. extra albuminis axim locatus, \& parti ejus anguftiori propior, illud oblique fecans \& tertiam ejus partem magnitudine fere fuperans, rectus, albus. Cotyl. foliacex, cordatx, nervofx. Rad. fubclavata, ad partem latiorem albuminis fefe vergens \& apice peripherix ejus proxima, cotyledones longitudine equans, vix fenfibiliter curvula, obtufa, vaga.

EXPLICATIO FIGURE.

a. Baces integra. b.) Eadem medio transverfe diffecta, cum fitu feminum in pulpa horizontaliter nidulantium. c.) Seunina (oluta. d.) Albuminis fectio transverfalis. e.) Ejusdem fedio horizontalis, cum embryoue in fita \& magnitudine naturali f.) Embryn folutus.

Diffepimenta incompleta latitudine valde variant, in aliis exemplis diffepimenta, a duplicatura membranx baccam interne veftientis orta, adeo angufta funt, ut nonnif rugam longitudinalem reprefentent, uti in noftra icone, videre licet; in alis autem multo latiora \& in proceffum falciformem products funt.

Cell. Lamarck \& Swarz Genipam Gardenix junserunt fine dubio ob fimilem habitum externum, diverfus autem embryonis fitus intra albumen huic commixcioni contrarius eft, fi \& reliquas partium fruelificationis \& pericarpiorum differentias haud futiles pratervidemus. 


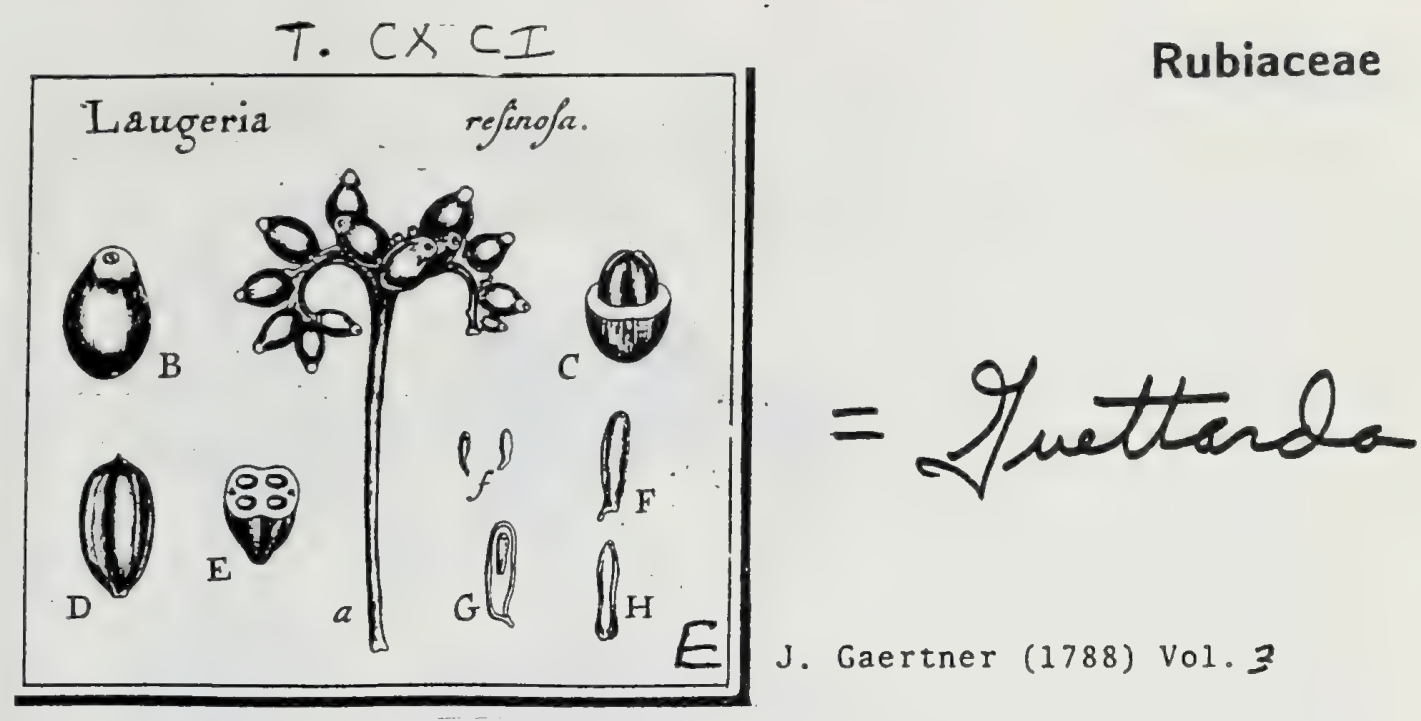

55. L A U G ER I A.

JAce. amer. p. 64. Linn. gen. 259. ed. Schreb. 354.

Juss. gen. p. 206.

Cal. monophyllus, fuperus, minimus, deciduus; limbo inxquali. Cor. monapetala, . longa, tubulora, gracilis; limbo quinquefido: Jaciniis planis, obtufis. Stam. quinque; filamentis breviffimis, fuperiori parti corolla infertis; antheris linearibus, non exfertis. Ovar. inferum; ftylo finplici filiformi, corollam fuperante; Atigmate capitato. Drupa infera, carnofil, non coronata; putamine quadri-1. - quinqueluculari. Sem. quatuor L. quiuque, eresta.

Alb. carnofum. Embr. inverfus.

LAUGeria refurofi. Tab. 191. fig. 5.

Langeria foliis lato - lanceolatis glabris fubtus glaucis, fpicis axillaribus bifidis, ramis apice refonofis. VAHL. eclog. 1. p. 27. WILLD. Spec. pl. T. x. Y. 2. p. 1082.

E collectione Cel. Desfontaines.

PzR. Drupa baccata, parva, infera, elliptica, ad verticem paululum attenuata, turbinata vel obfoletifime tetragona, feffilis, areola parva \& intra eam puncto pervio in vertice umbilicata, atrocerulea, ficcitate albido-pruinata. Caro craftufcula, pulpofa. Putamen offeum. oblongum, rotundato - tetragonum, vertice obtufiufculo mucronulatum, bafi vero nlagis attenuatum, ad latcra duo oppolita longitudinaliter fulcatum, ner-

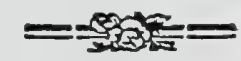

vis quatuor dorfalibus notatum, quadriloculare; loculamentis remotiufeu. lis, oblongis, fuperne claufis; quodvis loculamentum inferne canali.laterali in axi putamitus cum reliquis coincidenti perforatum.

REC. nullum; femina intra canalem incurvum bafilarem putaminis arcte hxrentis.

Sex. quatuor: in fingulo loculo fingulum, oblongum, teretiufculum, erectum, bafi attenuatum \& ad latus internum in proceffum brevem curvulum producum, vafis umbilicalibus in dorfo notatum, e ftramineo rufefcens.

IN T. fimplex, membranaceum, tenuiffmum, albumini arctifime adnatum.

EMB. minutus, excentricus, vertici feminis propior quam baf, rectus, inverfus, teretiufculus, dimidium albumen longitudine xquans, niveus. Cotyl. comprelijufcula, oblongx, obtufx, ad fcapum increfcentes, dimidio embryone paulo breviores. Rad. longa, clavata, recta, obtura, Supera, umbilico externo contraria.

\section{EXPLICATIO FIGURE.}

a.) Panicula frugifera magnitudine nacurali. B.) Drupa integra (eparata. C.) Eadem a carne usque ad mediuso denudata cum putamine integro in fitu. D.) Putzmen feparatum. E.) Idem transverie fectum, cum fitu loculamentorum \& canalium triangularium vafa nutrientia vebentium. f.) Semina foluta. F.) Idem magnitudine valde autum \& paulum a dorfo fpectatum, ut funiculi nubilicalis ad verticem afcenfos appareat. G.) Albumen longitudinaliter fetom cum fiu. embryonis. H.) Embryo feparatus \& infigniter andus.

Noltram plantam veram Laugeriz fpeciem effe, non plane fum convictus; quaternarius quidem loculamentorum numerus illud difuadere videtur. Alii itaque, quibus Laugerix genuinz fruchum, qux Cel. Jacquinio characterem genericum fuppeditavit, infpicere contingit, dubium folvant Totum genus recognofcendum: L. lucida, de qua infra, certe non congener. 


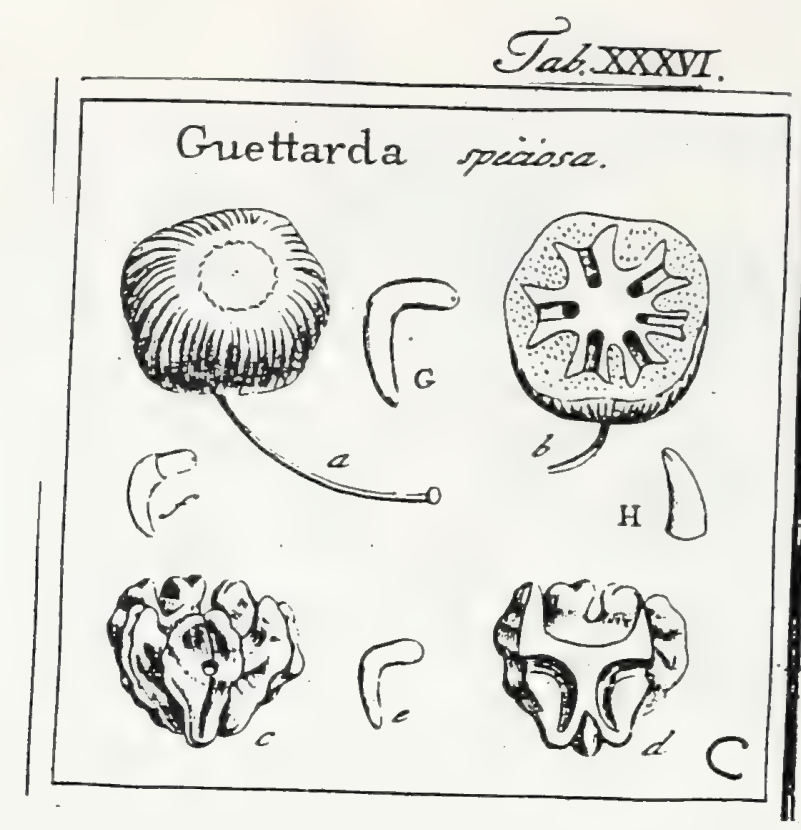

J. Gaertner (1788) Vo1. I

579

CCXVI. GITETTARDA. LIN gen. 1064 .

Flores hermaphroditi, aut fexu difincti in eadem firpe. Cal. cylindricus, brevifimus, deciduus, luperus. Cor. monopetala infundibuliformis. Stam. fex ad novem. StyL unicus. Drupa ficco baceata infera. Putamen offeuin lobatum, in peripheria pro loculamentis perforatum.

GU E T T A RD A Speciola. Tab. 36. fig. 5.

Halefia arborescens, foliis fubrotundis fubtus argenteis, fpicis florum".bigeminis, fuflentaculis longis alaribus. B R 0 w N. hif. jam. 205. t. 20. j. t.

Guettarda. L x N. Jyft. veg. 855 .

E collect. Bankfiarza

PER. Drupa baccata ficca infera, lata in vertice area rotunda notata globofa, depreffiuscula, fubtorola, obfolete nriata, fpadicea. Cortex craftus, fuberofo fungofus. Putanen offeum, utrinque profunde umbilicatum \& in anbitu in quatuor 1. fex lobos varie rugatos divifum, decurticato Juglandis nucleo fumillimum. Lobi Eubinxquales, intus exleulpti loculamento tereti \& gnomonice curvato, cujus alte. rum crus deorfum vergit, alterum vero horizontale, in ipfo lobi medio latere, rotundo foratnine hiat.

REC. nullum.

SEm. in fingulo locularento unicum, tereciusculum, gnomonice curvatum, pallidum.

IN T. Smplex, membrauaceum, tenve.

A \& B, nullum.

180

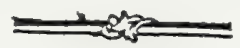

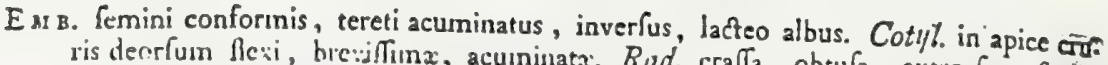

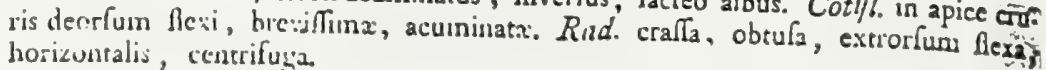

2.) D:ıpa integra. b.) Ejusdem fetio transverfalis, cum numeto \& fitu leculamentoram, c.) Pè? eamen Separarum integrum. d.) Idem longirudinaliter fefium, loculainentorum curvaturam oftendengy e.) Sensen feparatum. f.) Idem, detrati ejus tunica prope radicule extremitatem. G.) Embryo:
denudatus. H.) Cruris iuferioris pars, in duas cotyledones brevifimas fe?ta.

Revitimas se.t.

Rava-pou, R h EED. mal. 4. p.99.t. 47. 48. qux Cadamba jasminillora. Sonneratr it. inaic. Ef clin. $2 . p .228 . t$. 128 . inequaquain Nyctanthes, fed gcnuina ef Gueiptardx pecies; contra vero, Guctarda coccina AUBLET. guian. p. $317 . t .123$.
diverf gencris planta eft. 


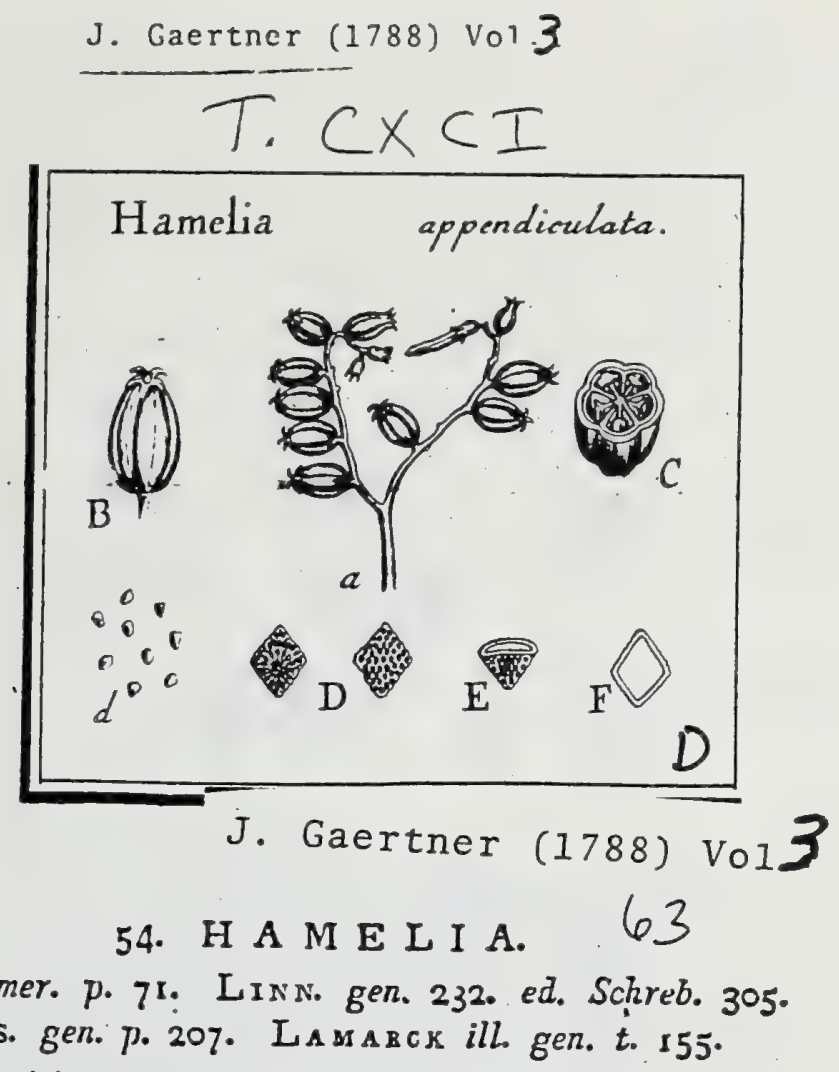

\section{JAcl. amer. p. $7 \mathrm{r}$ : LINN. gen. 232. ed. Schreb. 305 Juss. gen. p. 207. LAMABCK ill. gen. t. 155 .}

Cal. fuperus, minimus, quinquefidus; laciniis acutis: Cor. nonopetala ; tubo longillimo, pentagono, bafi ampliato; limbo xquali, quinquepartito; laciniis acutis. Stam. quinque; flamentis fubulatis, ad medium corolla cubum inlertis; antheris linearibus, ad faucem corolla pertingendibus, Ovar. in-

ferum; Atylo unico, longitudine tubi; ftigmate obtuto. Bacea infera, fulen: ta, calyce perfiftence coronata, quinquelocularis. Rec. membranacea, margine bifida. Sem. plurima, comprefla. Alb. carnolum. Enls. erectus.

Havelia appendiculata. Tab. 191. fig. 4

Ex collectione Cel. Desfoytaines. Habitat in Porto - Rico.

PER. Bacca parva, ịfera, elliptica, rotundato - pentagona, quinquefulcata, nervis intermediis dorfalibus notata, calyce perfiltente parvo retiexo quitiquefido coronata, \& irtra illum ftyli rudinento mucronata, quinguejocularis, polyfpercia. Caro debilis, rufefens, coriacen. Didlepinenta cun membrana bacca interna continua, tenuifima, menbranacea.

REc. quinque, in fingulo loculamento fingulum, niembranaceum, tenuifi. tnum, hinc axi baccx longirudinaliter in dilippimentorum. angulis adnatum. inde margine libero bifium: limbis retexis.

SEM. plurima, parva, inter recepracula \& difepimentnrum parietes in pulpa verticaliter harentia, compreltuffula, hinc convexa inde plana vel vix fenfibiliter concava, varie angulata, punçtis minimis excavatis \&.in fuperficie convexa e centro feriebus divergentibus reticulata, rufefcencia.

IN T. fimplex, membranaceum. . .

A L B. femini conforme, carnofum, album.

EMB....

\section{EXPLICATIO FIGURE.}

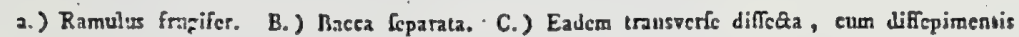
atque receptaculis in fitr. d.) Scmina foluta. D.) Eadem magnitudine aueta ab utraque paste fpectata. F.) Albumen transverfe \& F.) Idem longitudinaliter fectum.

In plurimis, qุux difecui, Teminibus ne quidem embryonis umbram detegere valui.

Species, ut videtur, nova gaudet foliis longe petiolatis, E' in mucrouens lorgusn apice productis. 
$\mathrm{CXCH}$

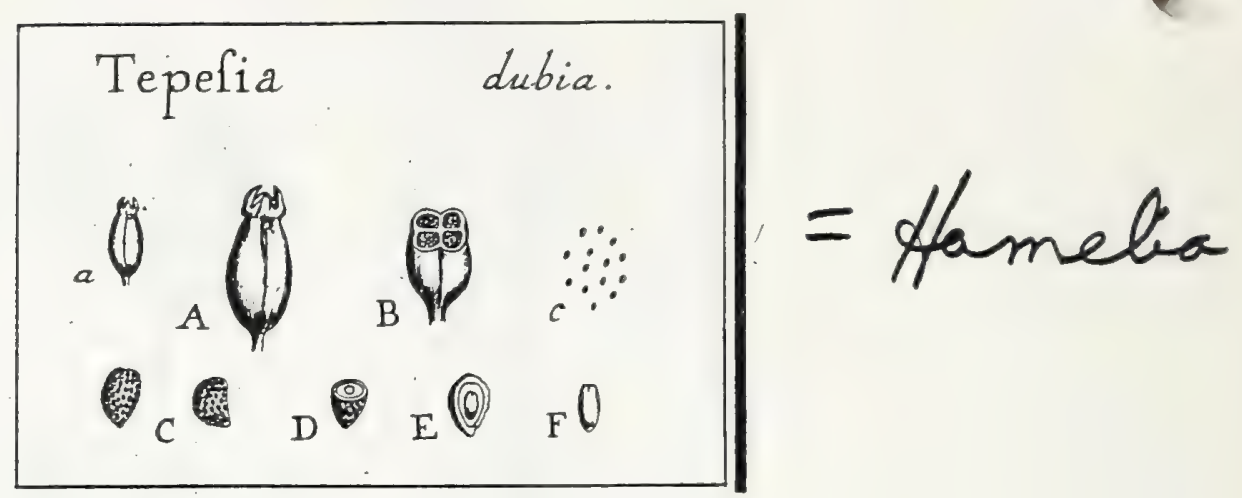

J. Gaertner $(1788)$ Vol.3

\section{6r. TE P E S A.}

Cal. moisophyllus, fuperus, quadridentatus; dentibus inxqualibus duobus oppofiris najoribus exterioribus erectis incurvis; duobus ninoribus conniventibus, cum majoribus alternantibus; omnibus obtufufculis, bafi gibbis, fulco intermedio dorfali elevato ad apicem excurrente notatis, perfiftentibus. Cor. . . Stam. . . Bacca infera, oblonga, coronata, quadrilocularis. Sem. plurima, in pulpa nidulantia. Alb. carnofum. Rad, vaga.

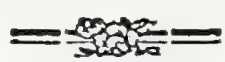

Tepesta dubia. Tab. 192. fig. 6.

Ex dono anicifimi Dal Drcandolle e cllectione Cel. I'Heritier fub nonine Petefic. Habitat in Chili?

PER. Bacea parva, infera, elliptico-oblonga, furfum paululum attenuata, rotundato - tetragona, calyce balfi gibbo coronata, fulcis oppofitis cum laciniis calycinis minoribus continuis carinata, bilocularis. Caro admodum debilis, rufefcens. Diffepımenta tenuilfina, membranacea, lateribus bacex adnata, lutefcentia.

Rec. nullum; femina in pulpa molli nidulantia \& undique membranz, difepinentorum totan internam baccx fuperficiem obveltientis, achrentia.

SEN. plurina, minuta, ovato-oblonga, rotundata, vel hinc inde ab incumbentibus compreffo - angulata, ad umbilicun mucronata, punctis excavatis reticulata, rufeicentia, vaga.

IN T. fimplex, nembranaceum, craffufculum, in aqua ad fuperficiem in nimbum unucitàginofun pellucidum fefe emolliens, albumini arcliffime adnatum.

A L B. femini conforme, carnofum, album.

EMB. rectus, in centro albuminis locatus, tereti-oblongus, erectus, albus Cotyl. brevifimx, obtufie. Rad. longa, tereti-oblonga, obtufiufcula, umbilico externo obverfa, vaga.

\section{EXPLICATIO FIGURE.}

3. A.) Bacea integta. B.) Easlera transverfe fedu cum didepimentis atque feminibus in fied. c.) Semina foluta. C.) Eadem formx diverfx unagaitudine auda. D. E.) Albumen trasverfe \& longitudialiter diffetum eum fitu embroais. F.) Embrgo folutus magnitudiae valde audus. 
J. Gaertner (1788) vol.3

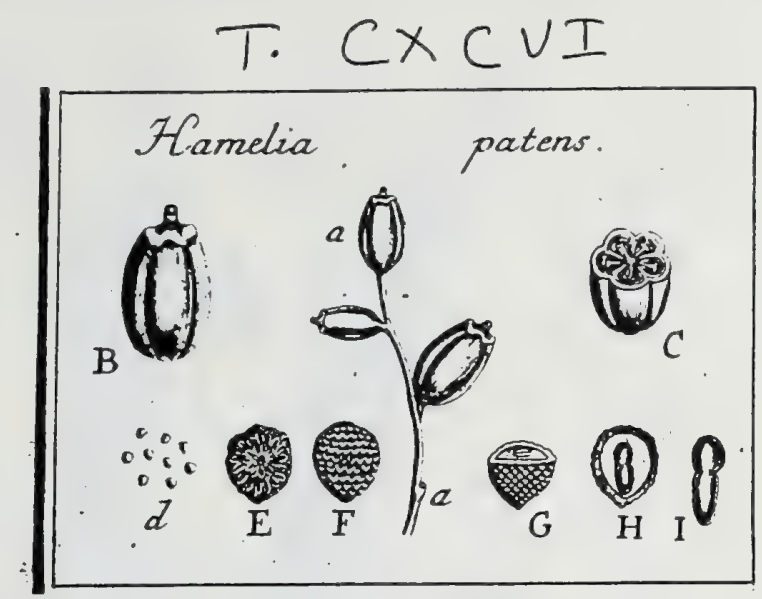

J. Gaertner (1788) Vol.3

Hamelia patens. Tab. 196. fig. 3 .

Hansellis racemis patentibus. JAce. amer. p. 72. t. 50 . Lisx. Jpec. pl. 246 .

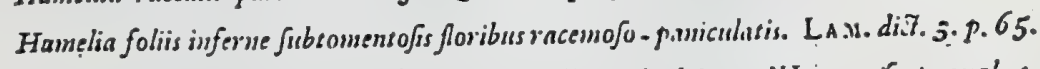

Himellia folits, fubtus zomentofis tubo corollue gylindrico. L'HERIT. Jert. angl 4.

Hamellia coccinea. SWAKTZ prod. p. 46.

Hamellia raceunis terminalibus coloratis, folits ternis villofo-puhefresstibus. SWARTZ obf. 77 . WILLD. Spec. pL T. T. P. 2. p. 980 .

二

Harmelia ramis fulcatis, foliis $3-4-$ oblongo - lanceolatis pubefcentibus, fioribus

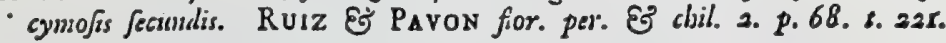

Ex lufula Hifuaniola a Doo Poiteau.

Bacca parva, oblonga, infera, fellilis, calyce obtufiffimo quinquedentato coronata \& Ityli rudimento truncito faftigiata, quinque fulcata, aurantia, quinque locularis. (a. B.) Caro debilis, rubicunda. Diffepimenta membranacea, cun membrana bacce interna continua, fulcis exterinis obverfa. Receptacula ut in fpecie antecedente, \& in locu!amenta ex axillis difepimentorum prominula. (C.) Semina plurima, exigua, erecta, compreffufcula 1. hinc convexa, inde planiufcula, angulata, verfus umbilicum in apicem producta, puctis excavatis ad latus externum e centro radiatim difpofitis (E.) fcabrata, e fufco rufefcentia. (d. F.) Integumentum Gmplex, crafiufculum, cruftaceum. (G.) Albumen carnofum, femini conforme, albuns. Ensbryo rectus, oblongus, lacteus, inferus. Coryl. oblongx, craffiufculx difcretx, plano-convexx, incumbentes. Rud. cotyledonibus paulo longior, conico-teretiufcula, obtufa, umbilico externo obverfa, cemtripets. (H. L.) 


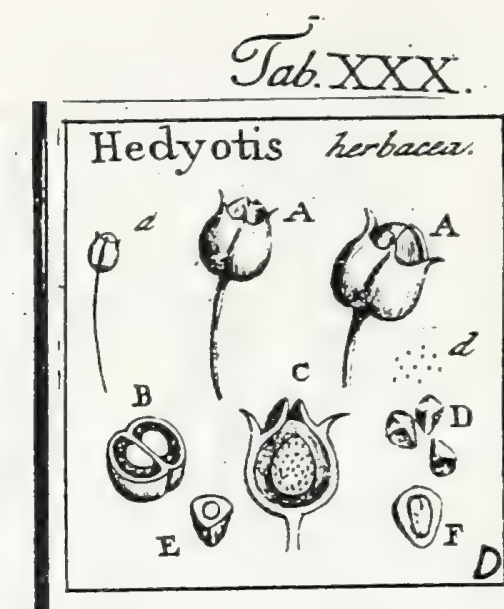

\section{J. Gaertnet (1788) V01.1}

CLXXVIII. HEDYOTIS. LIN gen. II8. 148

Calyx pericarpio adnatus, quadridentatus. Cor. monopetala, infundibuliformis. Stam, quatuor. Styl. unicus. Capfula infera bilocularis, apice compreffa. Receptacula dillepinento undique adnata.

HEDYOTIS herbacea. Tab. 30. fig. 4.

Hedyotis foliis lineari lanceolatis, caule herbaceo dichotomo, pedunculis geminis: LI N N. fy/f. veg. 147 .

Ex herbario Bankfiano.

PEк. Capfula, infera, parva, calycis dentibus infra apicem coronata, fubglobofa, bifulca, bilocularis, apice compreffa, rima transverfali dehifens. Diofepimentum rimx contrarium.

REc. fubrotundum, convexum, fcrobiculatum, medio diffepimenti utrinque totun adnatum.

SEм. numerofifima, parva, angulata, glabra, fufca.

IN I. fimplex, fubcoriaceum, tenue.

A L B. femini conforme, carnolum, pallidum.

E s в. dicotyledoneus, teretiusculus, longitudine albuminis, lacteo albus. Cotyl. bre-" villunx. Rad. longa, crafta, centripeț.

a. A. A.) Capfula integra, \& apice rima transverfa detiscens. B.) Eadem diflecta. C.) Ejus fectio lougitudiualis cum figura receptaculi. d. D.) Semina separala, EF.) Albuminis fectio transverfalis \& lougitudinajis, cum fitu \& Ggura embryonis. 


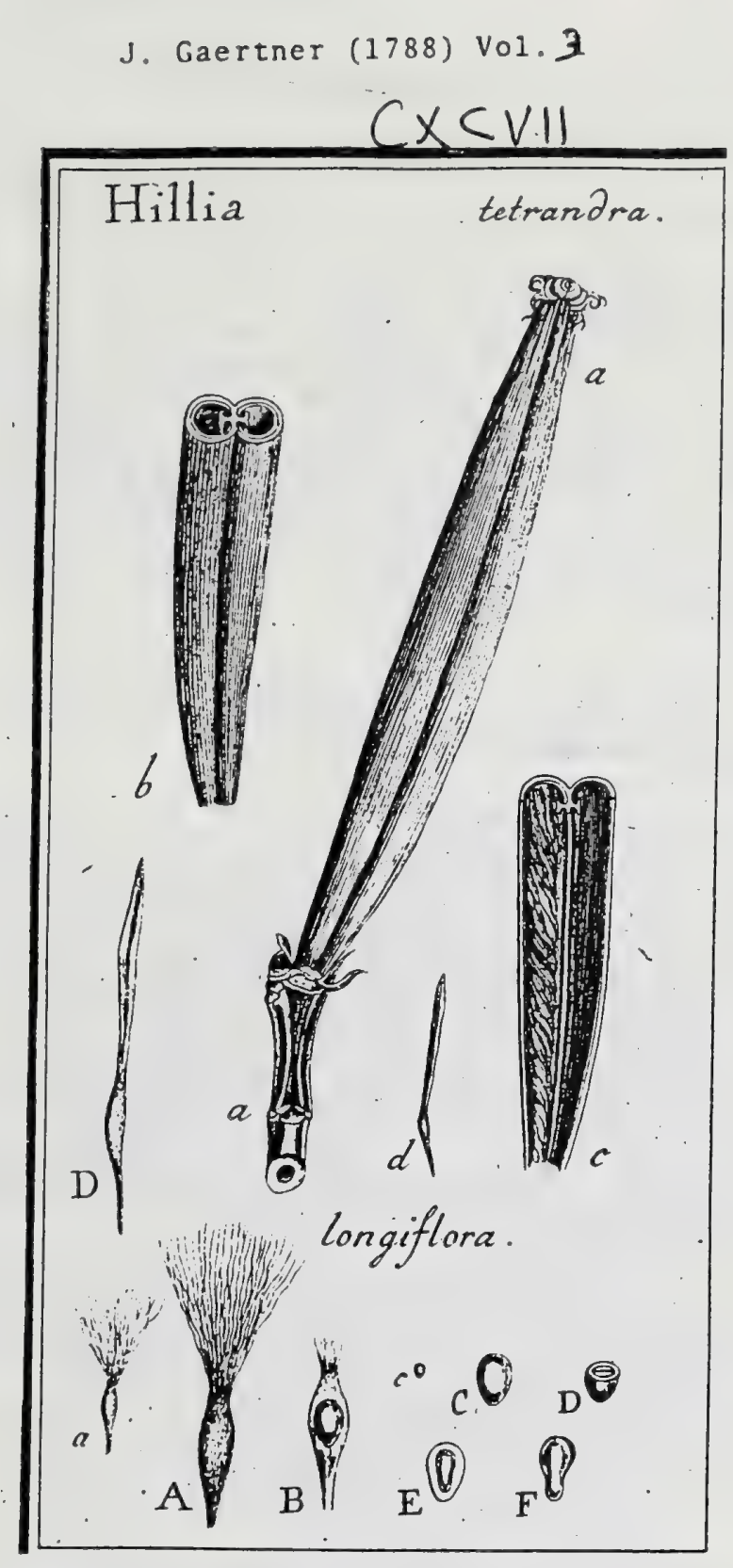

Rubiaceae 


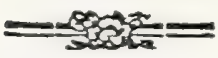

\section{H I L L I A.}

JAc Q. amer. 96. LINn. gen. 444. ed. Schreb. 60r. Jiss. gen. p. 202. LABABCK ill. gen. t. 257 .

Flos bafi bracteis fex foliaceis calyciformilus deciduis cinctus.

Cal. monophyllus, fuperus, bi-L quadrifidus: Jaciniis angultis, acutis, perim ftentibus. Cor. monopetala, tubulufa: tubo longifimo, cylindraceo, ad fiucem ventricofo, fulcato; linbo magun, patente, acute quadri-1. fex partiro: lacinis planis, obtufiufculis. Stam. 4.1.6. ; filanentis brevilfimis, linearibus, paulo fub fauce corolle infertis; antheris oblongis, erectis, non exfertis. Ovar. inferum, Ity!o fimplici cráro loneitudine tubi \& Atignare bisdo inftructum. Folliculus inferus, calyce coronatus, bilocularis, bivalvis. Rea diffepimento utrinque affurun, bilobum. Semina furfum imbricata, canda finplici membranacea, 1. crinita aucta Alb. carnofun, exiguun. Enb. ereclus.

Hillia tetrandra. Tab. 197. fig. I.

Hillia corollis quadrifidis zetrandris, lacinis ovntis acutis. SWARTZ pro... 58 . Fl. ind. occid. 1. p.630. W1LID. Spec. pl. T. 2. P. x. p. 240. PERsoon fyn. pl. 1. p. 392.

Icon. Swartz ic. pl. ind. occid. I. t. It.

PrR. Capfula folliculiformis infera, oblonga, rotundata, comprefinufcula, 1. paulo latior quam craffia, fulco longitudinali didyma, cal:"ce perfiltente coronata \& intra hunc circulo calliofo a corollx lipfu \& umbone deprelfo infignita, levfter ftriata, bilocularis, bivalvis. Vat vic ab apice dehifen. tes duplicartx: lamisa exteriore craffore coriacea, intericire chartaceomembranacen, intus lavi. Diffepimentuus membranaceum, angultum, fulcis externis obverfum.

REC. Jamina tenui diflepimento utrinque longitudinaliter affixum, \& margine libero incratlitum, obtufum, 1 . fulco longitudinali leviter bilobum, ftrintum, fungofum.

SEM. numerofiefina, erecta, furfum imbricata, obovata, compreffufcula, intra integumentum fpongiofo - membranaceum fufiforme hxrenta, ditute ftraminea, 1. ferrugines.

IN T. duplex : exterius fpongiofo-menbranaceum, crafum; hinc umbilicum verlus attenuatum truncatun: inde autem in membranam longam ligulatrin extenuatum, in media cralfitie femen foveus, rufefcens; insorizs nombranaceun, tenue, albumini arcte adnatum.

A гв. Femini conforme, carnofum.

EмB.....

98

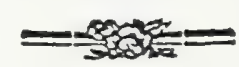

\section{EXPIICATIO FIGURE-}

2. 2.) Folliculus integer, brateis aliquot calyciformibus bair veftitus \& peduncnlo frutifero infidens, b.) Idem medio transverfe diffeetus, c.) Ejusdem fectio verticalis cum fitu receptaculi atqque feminum. d. D.) Semiaz folutz.

HILLIA longifora. ibid.

Fereiria. VANDELII in Roemer pl. bijp. x. p. 98. t. 6. f. 8.

Hillia parafitica. Jace amer. p. 96. t. 66. Linn. Jpec. pl. ed. 3. p.166x. Hillia corollis fexfidis, laciniis lanceolatis revolutis, foliis ovatis acutis. SWARTZ prod. p. 58. Obs. bot. x35. t. 5. f. x. WILLD. Spec. pl. T. 2. P. x. p. 239. PERSOON Jyyl. pl. I. p. 392.

Semina (a. A.) ut in priore intra integumentum fpongiofo-membranaceum inclufa, minutula, ovata, 1. elliptica, comprefitufcula. (c. C.) Integunentum duplex: exterius fubmembranaceum, fuffiforme, hinc convexum, inde planiufculum, ex ipfis crinibus "contextu cellulofo mixtis conftipatum, in medio femen fovens, bafi attenuatum, in vertice autem in crines fimplices longos folutum, e cinnamomeo - rufefcens (B.); interius membranaceum, tenuiffimun, albumini arete adnatum. Alb. femini conforme, exiguum, carnofun, album. Emb. grandiufculus, erectus, longe ellipticus, bafi albuminis vix propior quam apici, comprefiufculus, fere, medullaris, pallide viridulus. Cosyl. ovatx, plano - convexx, radicula cratiores. Rad. brevis, craffa, obtufilina, umbilico externo obverfa, infera. (D.E. F.)

Embryonis mollities pene medullaris ejus inveftigationem in hac ftirpe quam maxime difficilem reddit.

'An radiculx fitus in hac ftirpe, uti in Cinchona, vere inferus dicendus? cum in utroque genere radicula fub angulo quidem acutifimo receptaculum refpiciat. 


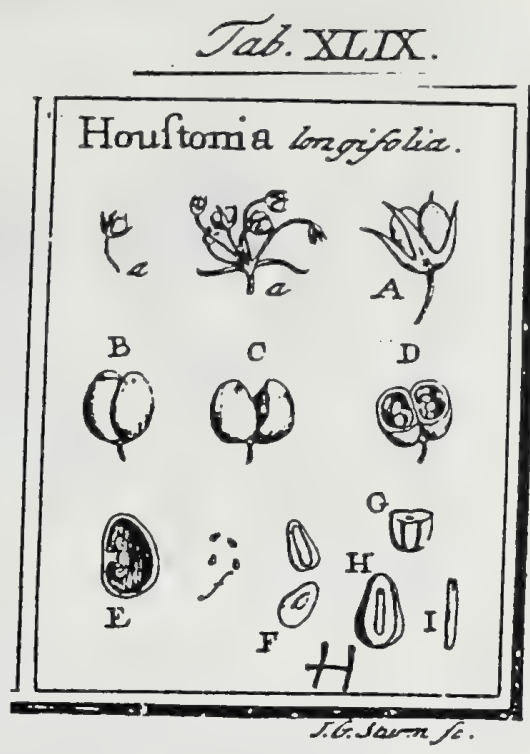

J. Gaertner (1788) Vo1.1

226

CCLXXVI. HOUSTONIA. LIN $\mathrm{N}$. gm. 124

Calyx quadripartitus. Cor. monopetala infundibuliformis, quadrifida, Stam. quas: tuor. Styl. unicas. Capfula fupera, bilocularis, bipartibilis. Semina pauca.

Houstonis longifolia. Tab. 49. fig. \&.

Ex Lerbario Bankfiano.

PEx. Capfula fupera, bipartibitis, calyce manophyllo quadripartito bafi cincta, apice comprefta, bifulca, bilocularis, fupra transvedfe dehifcens.

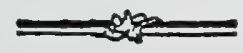

REc. fungofum, fubglobolum, pediccllatum, mcdio diffepimento finguli loculamenti aftixum, per maturitatem una cum feminibus deciduun.

SE ss. pauca, tria 1. quatuor in quolibet loculamento, parva, ovatz, compreffiuscula, in dorfo, fulco elevato longitudinali; in ventre autem media cicatricula unbilicali notata, nigro fufca.

IN T. funplex, fubcoriaceum, tenue, puncticulatum.

A в. Senini conforme, carnofum, durum, aqueo pallidum.

Ем в. filiformis, dorfalis, rectus, lufeolus. Cotyl. brevirfimx, fubfoliacex. Rad. longa, recta, infera, f. funduin cap̧fule refpiciens.

2. 2. A.) Caplula calyce reflita. B.) Eadem denudata. C.) Eadem bipartita. D.) Ejusdem fectio transver(ális. E) Loculamentum (eparatum cum fitu receptaculL f. E.) Senina foluca. G.) Semen transverfe fectum. H.) Embryo in dorfo albuminis deaudatus. I.) Idem feparatus \& infigniter anctus.

Receptaculum globolum, una cum fenuinibus deciduum, videtur Linnzo pro femine unico impoluifle. 


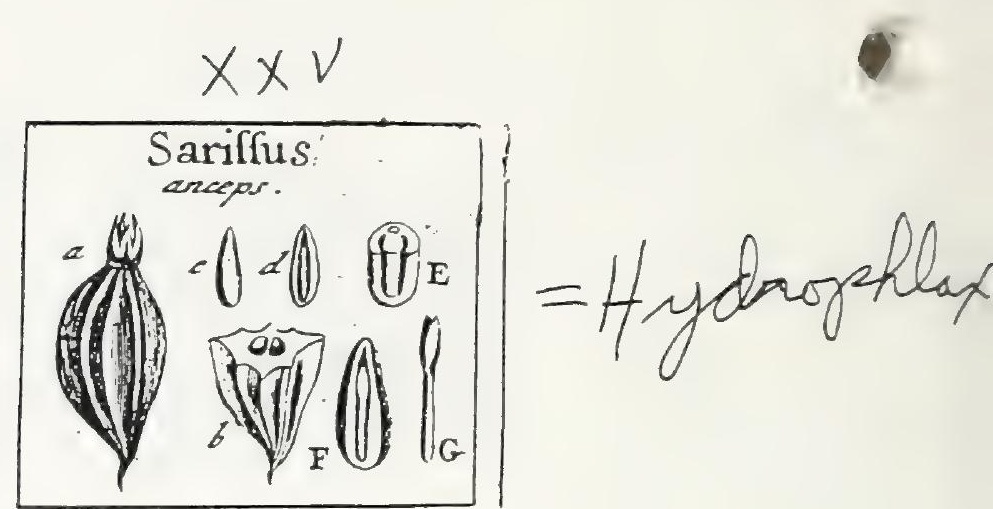

J. Gaertner (1788) Vค̧ 1

\section{SARISSUS.}

Calyx monophyllus, brevis, acute quadridentatus, fuperus. Cor.... Stam.... Styl. unicus. Bacca exfucca, infera, compreffa, bilocularis, fulcata, Semia folitaria, oblonga : embryone dorfali, recto.

Sarissus anceps. Tab. 25: fig. 4.

Hen - Taccada. Zeylon. E collect. fem. hort. lugdb.

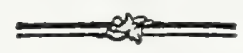

PER. Bacca exfucca, Infera, ovata, utrinque acuminata, lenticulari compreffa, tribus, in quovis latere, fulcis acutangulis exarata, \& ad oras infigniter attenuata, it fere alata, glaberrina, rufefcenti- padicea. Subftantia prope peripheriam fungofa, verfus centrum fuberofa, duriuscula, \& in duo loculannenta oblonga partita. Diffepimentum nembranaceum, tenuifimum, integerrimum.

REC. nullun; femina diffepinento longitudinaliter adharentia.

$S E$ s. in fingulo loculamento unicum, oblongum, furfum attenuatum, hinc convexum; glabrum; inde duobus fulcis profundis cun media linea elevata exaratum, nigro fulcuin.

IN T. fumplex, tenuifrunum, arctifime adnatum.

$\Lambda$ LB. Scmini conforne, cartilagineum, durum, album.

E s. в. dicotyledoneus, erectus, in dorfo albuminis locatus, lacteo albus. Cotyl. lanceolatz, foliacez. Rad. teretiuscula, cotyledonibus triplo longior, recta, infera.

a.) Bacea integra, b.) Eadem difteara. co d.) Seminis latus utrumgate. E.) Albamea', transverie fectum. F.) Embryo in albuminis dorfo. G.) Idem feparatus.

Multuin affinis videtur Pfychotrix, a qua differt calyce quadridentato \& bacca noa bipartibili. 


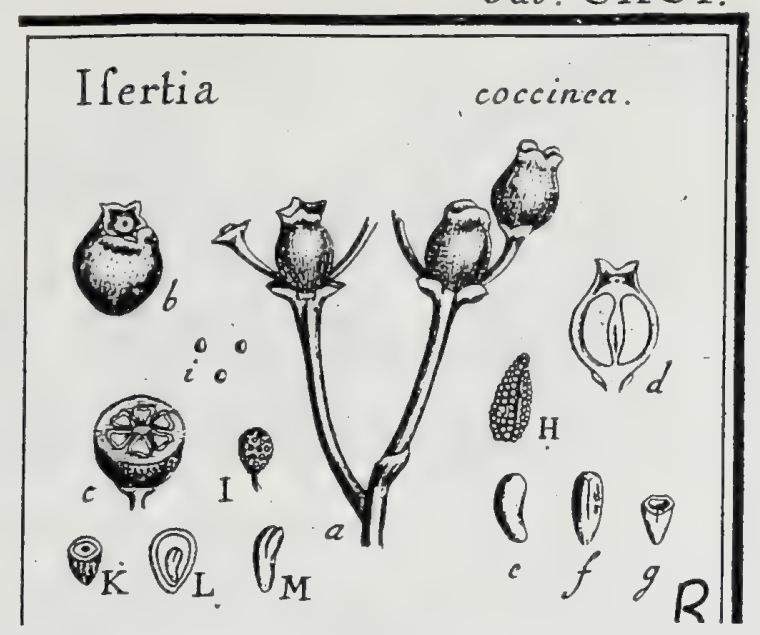

\section{I S E R I A.

Schreв. ger. pl. 602 . LAmarcK ill. gen. t. 259 . Guettarda. A U в I. Guyan. t. 123.

C21. monophyllirs, fuperus, campanulatus: limbo fexdentato per maturitatem in:equali. Cor. monoperala, infundibuliformis, ad bafin annulo ovirium coronante infiftens; tubo longo, curvulo; limbo fexpartito, laciniis rectis, acutis; fauce villofi. Stam. fex; filamentis brevi:limis, fupra corollx faucem infertis; antheris oblongis, bilocularibus, medio dorfo filamentis adnatis, nou exfertis. Ovar. inferum; ftylo unico, filiformi, tubum corollze xyuante; ftigmate capitato, fex-lobato. Bacca calyce perfiftente coronata, unbilicata, hexapyrena. Pyrenx iniloculares, poiylperma. Semina rotusadatopyramidata. Alb. carnofum. Emb. radicula cancripetin

Isertia coccinea. Tiab. 191. fig. 2.

Guettarda (coccinea) folio amplifimo, ovato, acuto; flontm racemis eredis, terminalibus, fruc̃u coccineo. A U BL. guyan. I. p. 317 .

Jfertia folitis lanceolato - ellipicis fubtus villoso - incanis acuminatis utrinque acurtis, peduncrelis raceinofis bificlis. VAHL ed. 2. p. 27. WILLD. Spec. pl. T. =. P. 1. p. 240.

Ab amicifimo D. Dupuls, Botan. Paris.

P R R. Bacca infera, nucis avellanx minoris magnitudine, globofa vel elliptica, fupra calycem undulato-dentatum paululum attenuata, umbilicita, in vertice rudimento ftyli fungiformi inttructa, bafi bracteis duabus brevibus oppofitis veltita, coccinea, hexapyrena. Caro crafiufcula, firma, eaccinea, ficcitate nigrefcens, dulcis. Pyrenre offex, fubellipticx, angulatx, vertice obtufx, furfum attenuatx, dorfo leviter fulcatx, ad latera planiufculz, ventre acuto rimi hiantes duabus laminis fub angulo acuto intruflexis, polyfuermie.

REC. commune pyrenarum nullum; nifi vafir filiformia e pedunculo oborta, \& pyrenarum rinam ad partena velltralem adeuntia fumas; proprian feminum crifla duplicata ab introtexis laminis pytentarun, fungola cillofitate fmbriata, cui fenina funiculis unbilicalibus affixa.

SEM. plurima, paucis tamen adolefcentibus, funiculis umbilicalibus maturitate denique in pulpan refolutis inter fe cularentia, in fex l. ofto feries lungitudimales difpofita, parva, pyramidata, angulata, vertice obtufo rotun-

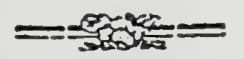

data, inde acuta, funiculo umbilicali inftrueta, punctis excavatis reciculati, fufca.

IN T. duplex; exferius cruftaceun, fragile, craffufculum, ab albumine lubenter fecedens; interims membransceum, tenuilimum, albumini arctilizne adnatum, albido - fufcuns.

ALB. Fenini confurme, cirriofun, album.

E в . teretiufculus, erectus, leviter incurvatus, ad bafsin albuminis locatur, niveus. Cosyl. cralliufculx, obtulix, dimidio embryone vix breviores, incumbentes. Rud. conico-teretiufcula, longa, obruliufcula, centripets. 


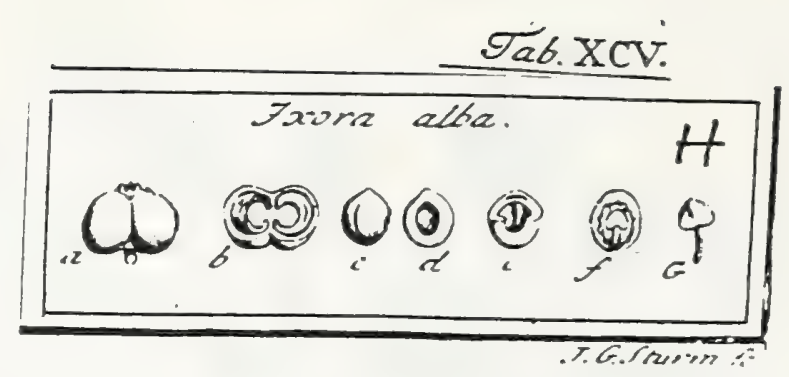

J. Gaertner (1788) Vol. 2

\section{$I X O R$ A. Conf. Vol. I. p. I77.}

IXora alba. Tab. 95. fig. 8.

Bemfchetti. RheEd. mal. 2. p. Ig. t. I4.

Iusininum indizum, folio lanori, inodonum umbellatum. PLUK. phyt. t. sog. f. 2. Jxora foliis lanceolato ovatis, froribus fafciculatis LINN. Jyft. veg. 153.

Bacca didyma, transverfe latior quam crafa, calyce perfiftente quadridentato coronata (a.), carnofa, tenuis, bilocularis (b.), rubra. Receptaculum ex diffepimento oriundum (b.) pulpofum, feminis cavitatem replens. Semina folitaria (b. c. d.), hemifphærico bullata (e), melina. Integurnentum timplex, membranaceum, non arcte adnatum. Albumen cafeofum, molle, albicans, per xtatem rancidifimum. Embryo dorfalis (f. G.), dimidio albumine paulo longior. Cotyledones cordatz, tansverfim latiores. Radicula curvata, anceps f. a latere comprefia, purpurafcens infera. 


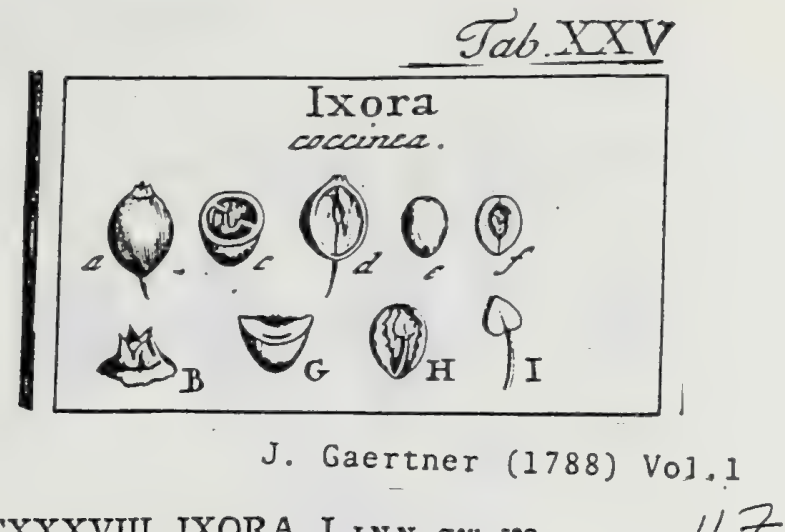

CXXXVIII. IXORA. LIN N. gen. rзo.

Calyx fuperus, quadridentatus, minimus. Cor, monopetala infundibuliformis." Stam. quatuor. StyL unicus. Bacca bilocularis. Semina lolitaria; albunine carnolo, molli.

IXOR A coccinea. Tab. 25. fig. 2.

Sclietti. Rневd. mal. 2. p. 17. t.13.

Flamna fylvarum. Ruм вн. anib. 4. p. 105. t. 4 6.

Fasminum flore tetrapetalo. BuRM. fl. zcyl. 125. t. 57.

Ixora foliis ovalibus femiamplexicaulibus, floribus fafciculatis. LIN.$\sqrt{4} \int t$. veg. i52.

Ratambala E Hen-ratambala. Zeylon. E colleet. fem. 'hort. lugdb.

PER. Bacca infera, carnola, ovato globola, cal cis destibus quatuor erectis acuminatis coronata, nigta, bilocularis. Loculamenta, propria membrana albicante, vefita, a feminibus probe difcreta. Dillepimentum parvo foramine ovali, fupra medium, perforatum.

REc. fubnantia carnofa in foramine difrepimenti bxrens \& per totum feminis latus in. ternum diffufa.

SEM. In fingulo loculamento unicum, ovato rotundatum, hine convexum, glabrum, nudum, inde leviter concavum, fubftantia fpongiofa, a receptaculo, tectum, ferrugincuin aut rufelcens.

Is T. fimplex, membranaceun, facile de nucico fecedens."

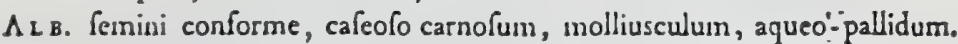

Es в. dicotyledoneus, erectus, dorfalis, longitudine fere albutninis, lacteo albus. 'Cotyl. cordatx, foliacex. Rad. filiformis, coryledousibus duplo lougior, curvata, infera.

a. B.) Bacea calycis denticulis coronata. c.) Fadem transverfe fecta, cum foramine diffepimenti. d.) Ejusdem fectio longitudinalis, cum obturato diffepisenti foranine. e. f.) Semiois latus utrumgue. G.) Idem transverfe fectum. H.) Denudatus in albuunius dorfo embryo. I.) Idcm (cparatus \& 2uctur.

Quatuor femina Ixorx tribuunt I.sNexus \& ADANson, ex horti malab. figura \& defcriptione, mutuo fumta; fed nec ego unquam duobus' plura vidi, nec RusspHIUS 1. c. qui etiam in baccis minoribus unicum duntaxat reperiri allerat.

Eque parum igitur eी, quod fruclus, quam quod fores Ixorz atque Pavctix abinyicem difant, \& totum difcrinen eo redit, quod in Lxora: $1^{\circ}$. loculamenta, pro-

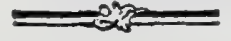

priâ membranå veftita; $2^{\circ}$. albumen carnofum, \& $3^{\circ}$. embryo dimidn femine longior fit. In Ixora alba, femen eft menúfoideum \& embryonis radicula cla. vato-anceps, ut alio loco dicetur. 


\section{J. Gaertner (1788) Vol.3 \\ $C X C \vee 11$}

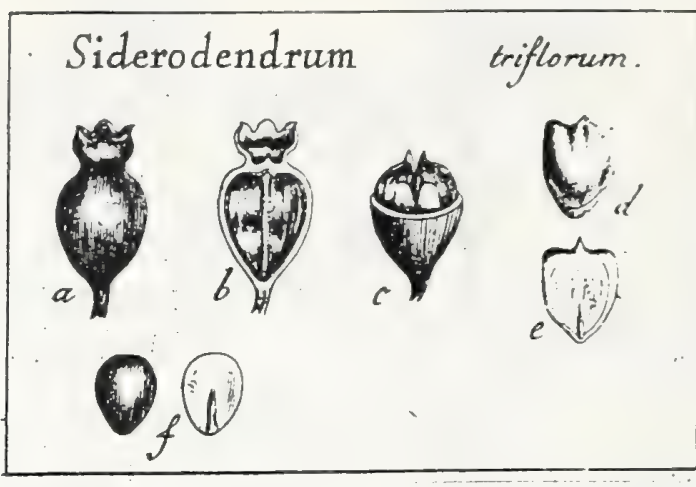

J. Gaertner (1788) Vol

\section{S I D E R O D E N D R U M..}

\section{Sснвев. gen. I6g. Sideroxyloides. Jacl. amer. p. $\mathbf{r}$.}

Cal. minimus, quadridentatus, fuperus. Cor. longa, tubulofa : tubo cylindraceo, fubincurvo; limbo quadripartito: laciniis brevibus, planis, reflexapatentibus. Stam. quatuor, fubfelfilia, infra incifuras corolla inferta: antheris linearibus, erectis, exfertis. Ovar. inferum; ftylo filiformi, langitudine tubi; ftigmate oblongo, obtufo. Bacca obovata, coronata, dipyrena : pyrenis monofpermis. Alb. ... Emb. ...

SIDERODENDRUM triflorum. Tab. 197. fig. 4

Sideroxylum anericanums, folignum doritic ferrum amulans. PLUKN. alm. 346. t. 224. $f .2$.

sideroxyloides ferreums. JAce. anuer. t. $775 . f .9$.

Siderodendrum triforims. VAHL ecl. 1. p. 10. WILLD. Spec. ph. T. I. P. I. p. 6r2. PERSOON Jyn. pl. x. p. rzi.

E collectione Bamkriana.

PER. Bacca pifo paulo major, e pedunculo tenui obovata, infera, intra calycem grandiufculum obtufe quadridentatum obtufe umbonata, dipyrenz. Caro debilis, firma, flavefcens. Pyrenx arcte approximatx, offex, cordatx, in vertice apicula minima fafligiatx, fubbivalves, monofpermic; valvula altera externa convexa, glabra, \& fulco dorfali acuto infcripta: altera interna plana tenuiore, ad bafin ab externa lubenter fecedente \& fulco fubulato inftructa, ad parten auten fuperioren cun illa connaxi.

REC. nullum : pyrenx fulcis ad ipfarum bafin pedunculo bacex affixx; \& femiıa umbilicis valvulse planx pyrenarum adhxrentia.

SRN. ill quavis pyrena fingulum, obcordato-ellipticum, hinc convexum, inde planum, umbilico fubulato ad bafin partis planx inftructum, ferrugineum.

102

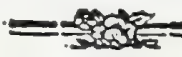

Is T. fimplex, membranaceum, tenue.

A ц в....

EMB...

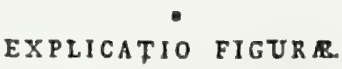

3.) Bacez integra. b.) Eadem verticali modo feda cum pyrena altera in fita. d.) Pyren foluta a dorfo, \& e.) Easem a ventre fpectata f.) Semen folutum, ab utraque parte vifum. 


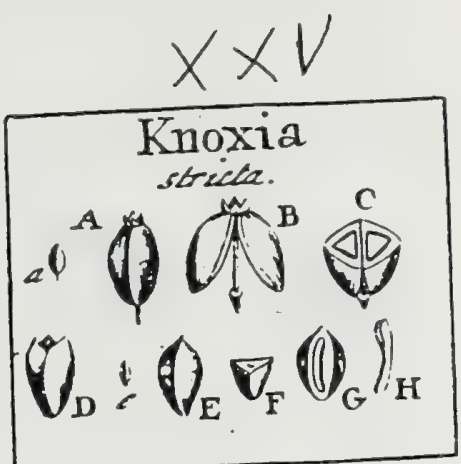

J. Gaertner (1788) vol. 1

CXLIV. KNOXIA. LINN. ger. 233 . $\quad|2|$

Calyx fuperus, quadridentatus, brevifimus. Cor. monopetala infundibuliformis. Stam. quatuor. Styl. unicus, Capfula infera, bilocularis, bipartibilis : fegmen. tis axi filiformi affixis. Semina folitaria.

122

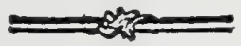

KN OXIA ftricta. Tab. 25. fig. 8 .

Ex herbario Bankfrano. Habitat in Ceylona, unde miffa a Kanigio.

PER. Capfula infera, pärvula, ovata, rhombeo-compreffa, 'glabra, bilocularis, bipar: tibilis. Segınenta triquetra, extus fpadicea, intus colorata, atra, Ixvigatifiuma; nunc fponte, nunc ex levi preffione, apice trifarian dehiscentia, coriacea.

REC. commune, filiforme, apice bifidum, ut in Umbelliferis; proprium nullum, prz. ter cicatriculam in fundo loculanentorum, cui femina aftuxa.

SEN. in fingulo loculamento unicum, fubovatum, utrinque acuminatum, triquetrum, glabrum, rufelcens.

IN T. fimplex, membranaceum, non ita arcte adnatum.

A. B. Cemini conforme, carnofum, molliusculum, aqueo-pallidum.

Eм в. dicotyledoneus, erectus, dorfalis, longitudine fere alburninis, lacteo albus. Cotyl. oblongx foliacex. Rad. filiformis, longa, curvula, infera.

a. A.) Fruatus integer. B.) Idem ab axi dehiscens. C.) Idem transverle fetus. D.) Caplule fer. unentum apice trifariam defriscens. e.E.) Semen feparatum, F.) Albumen transverie fectum! G.) Embryo in dorfo Seminis. H.) Idem feparatus, 


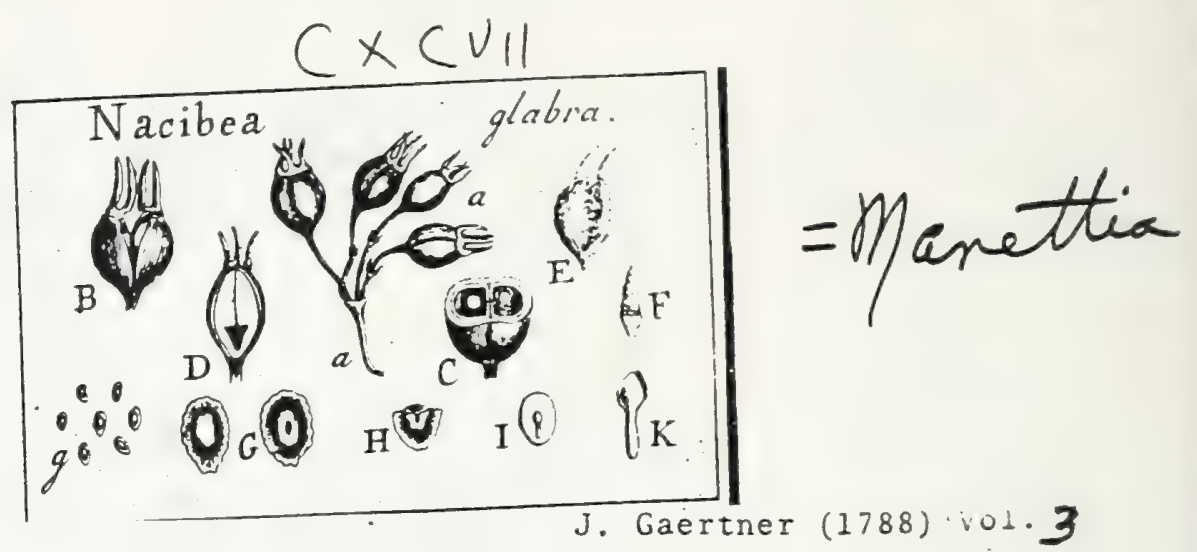

83. N A C I B E A.

A UвL. guy. t. 37. Juss. gen. p. I9g. LAмAвск ill. gen.

t. 64. Manettia. Sснвев. gen. I8r.

Cal. monophyllus, fuperus, quadri-1. oftofidus, perfiftens. Cor. monopetala, hypocrateriformis, ad faucem coarctata; limbo quadripartito, plano, intus hirto. Stam. quatuor; filamentis filiformibus, fupra medium tubum infertis; antheris oblongis, erectis, non exfertis. Ovar. inferum; ftylo filiformi, longitudine tubi, ftignate bifido, obtufo. Capfovata, coronata, dicocca. Rec. fungofum, liberum. Sem. plura, parva, margine membranaceo cincta. Alb. carnofum. Emb. erectus, radicula infera.

Nacibea glabra. Tab. 197. fig. 5.

Manettin Lygifrum. Collect. Banks.

PER. Capfula parva, ovata, compreffiufcula, 1. transverfe paulo latior, leviter bifulca, infera, calyce recto quadrifido coronata, corticata, quadrivariam dehifcens, dicocca. Cortex debilis, carnofo - fungofus. Dehifcentia altera ad fulcos maxima, cocculos feparans \& ad pedunculurn ufque decurrens; altera huic contraria, brevis \& vix ad calycis infertionem pertingens. Cocculi ovati, utrinque acuri, ofleo - chartacei; hinc convexi \& apice breviter dehifcentes; inde plani, medio linea recta longitudinaliter ad bafin ufque dehifcentes, \& paulo fupra bafin foraminulo triangulari a receptaculi Japfu hiantes, intus lrevigati.

REc. in utroque cocculo fingulum, liberum, fungofum, oblongum, curvulum, \& bafi laminx tenui triangulari foraminulo cocculorum ad partem ipforum planam inhxrcuti adnatum, feminibus tectum.

SE r. plura, parva, umbilicis receptaculo adharentia, ovata, bracteata, angufto nargine membranaceo inæquali cincta, hinc convera inde fubconcava, umbilico centrali oblongo notata, fufca.

IN T. Implex, fpongiofo-membranaceum, in marginem feminis ampliatum. Lв. ovatum, compreffo-Ienticulare, carnofum, pallidum.

$=$

E\&B. parvus, in extremitate inferiore albuninis hrerens, erectus, albus. Cotyl. Janceolatx, foliscex, incumbentes. Rad. longa, reda, teretiufcula, ab umbilico externo declinis, infera.

\section{EXPLICATIO FIGURE.}

a. a.) Ramulus fragifer. B.) Capfula dehiferas. C.) Eadem medio transverfe difreta eum a. a.) Ramulus frasifer. B. Cocculus alter feparatus, cortice adhue veftitus, non dehifcens. E.) Iden debilcens. F.) Receptaculuon feparatum, laminx cocculi triangulari affixum. 5. G.) Semina folsb. H.) Seminis. fettio transverfalis. I.) Albumen verticali modo diffectum cum fítu embryonis. K.) Embryo folutus.

Cum magna de hac fpecie apud auctores eft confufio, fatius effe duxi, Aubletii nomen genericun cum Cel. Jufrixo retinere, donec certiora de vero Manettiz Lins. charactere innotefcant. Cel. Swartz prod. p. 37. Petefiam Lygiffum. Lis.. Spec." pl. ed. 2. p. 260 . \& Lygiftum. Brows. jan.

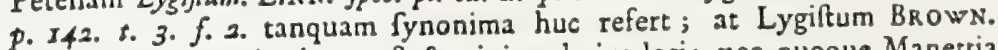
certe proprii generis planta eft \& minime hujus loci; nec quoque Manetia Lygifrtm. SWARTZ noftra effe poteft, cum in $O b \int . p$. 47. fux planta pedunculos axillares unifloros \& calycem octophyllum tribuat, quod in noftra 


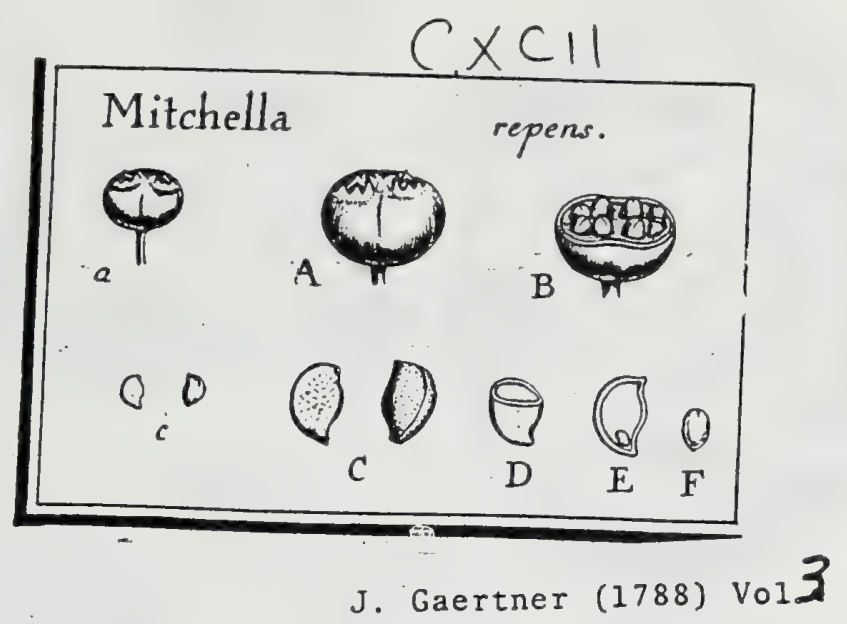

\section{M I T C H E L L A.}

Linn. gen. I34. ed. Schreb. 174. Juss. gen. p. 205. LAMAвсK ill. gen. t. 63 .

Flores genini, ovariis duobus coadunatis infdentes. Cal. duo remoti, quadridentati, eredi, perfiftentes. Cor. monopetala, infundibuliformis; tubo cylindrico; limbo quadripartito, patente, ad faucem hirto. Stam. quatuor; filamentis filiformibus; antheris oblongis, vix exfertis. Ovar. inferum geminum; ftylis Gmplicibus, fliformibus; ftigmatibus quadripartitis. Bacce inferx, geminx, ex duobus ovariis coadunatis in unam conferruminate, calycibus coronate, depreffic. Sém. in fangula bacca quatuor. Alb. fubcartilagineum. Emb. oblongus, inferus.

Mitchella repens. Tab. 192. fig. 4.

Syringa baccifera, myrti fubrotundis foliis, floribus albis gemellis. PLUK. ainaltb. 398. 8. 444. f. 2. CA TESB. carol. x. p. 20. t. 20.

Buccifera mariana, clematis daphnoides minori fulio. РЕт. gaz. t. x. f. 13.

Chamaedupluse. MiтCH. gen. 27.

Mitcbellit. Linn. amoen. acud. 3. p. 16. Syjf. veg. ed. 14. p. 153. Spec. pl.

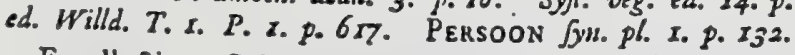

E collectione Cel. Desfoxiaises, \& ex dono Cel. C. Sprenger Prof. Hallenf.

PER. Bacax gemirlx infers, in unicam fubylobofam didymam depreffufcu: lam calycibus duobus perfiltentibus remotis erectis coronatam \& intra illos

umbilicatam coalitz, tetra[permx. Caro fulpofa, mollis, rufefcens, inter baccas geminas defcendens, \& fic diffepimentum cralfiufculum fulcis externis obverfum formans.

REC. nullum; fenina undique carni adnata, \& funiculis umbilicalibus fundo bacce arclius adhxrentia.

SEN. In utraque bacea quatuor, circuin axem partialen locita, carne interpofita a fe invicem disjuncta, obovata, utrinque mucronulata, rotundato trigona, hinc oblique convexa, inde plana, fulco dorfali Jevifimo ab umbilico ad bafin orto \& paulum fub vertice in lineolam fufcam excurrente notata, fetulis albidis confperfa, e rufefcenti itraminea.

1x T. duplex : exterius coriaceum, ab albumine lubenter fecedens; interius firmum, elafticum, membranaceum, cum albumine arctilsme connatum, ad verticem cbalaza fufea calyptraformi notatum.

ALB. femini conforme, duriufculum, carnofum l. fubcartilagineum, fordide ftramineum.

E $\$ B. minutus, tereti-oblongus, niveus, erectus, inferus. Cotyl. breviffimx, obrufz. Rad crafla, tereti-oblonga, mucronulata, infera. 


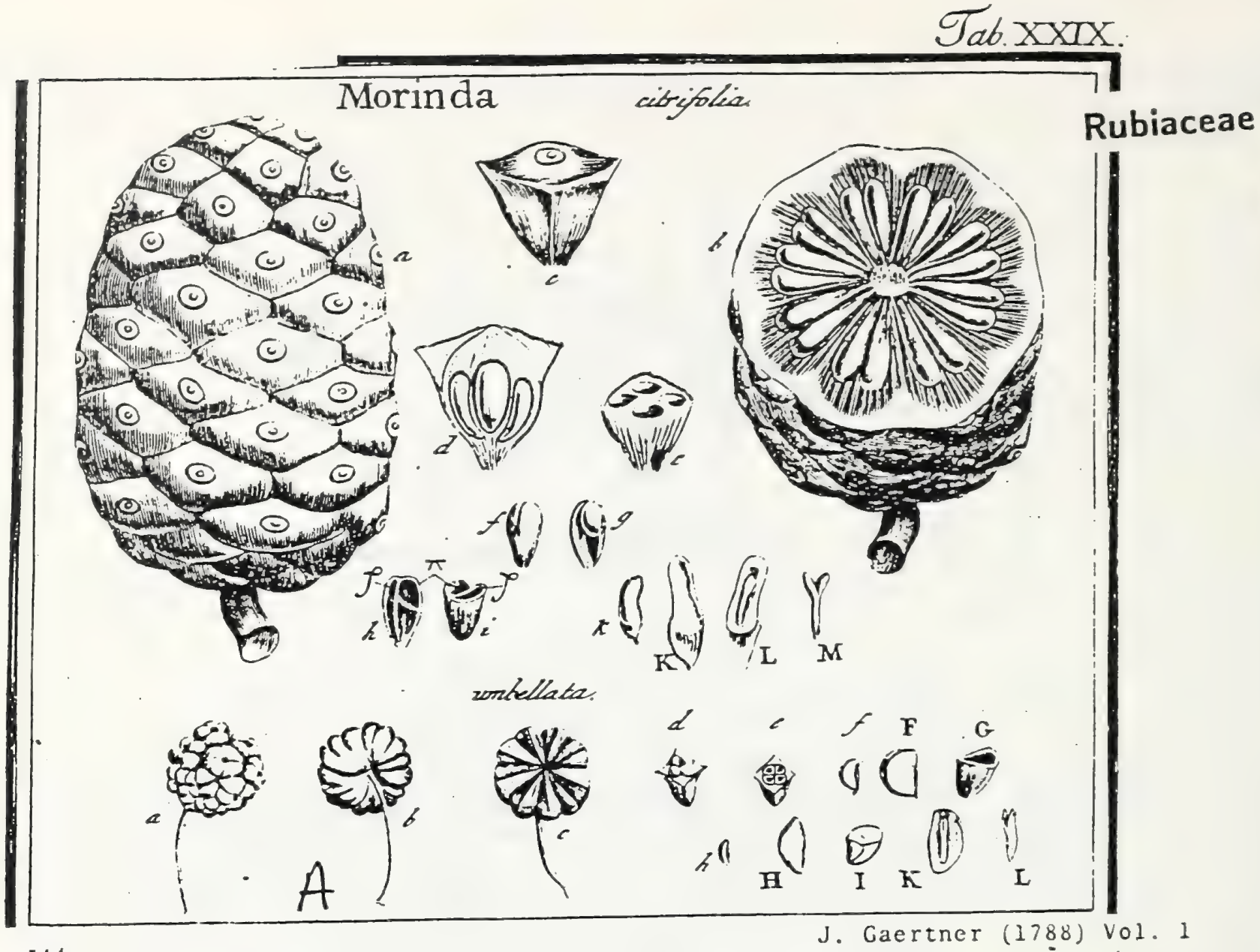

144

CLXXIII. MORINDA. LIN N. gen. 235 .

Flores aggregati, monopetali, Superi. Stain. quinque. Styl. unicus. Baccz inferz, aggregatx, angulatx, fxpe conferruminatx; quadriloculares. Semina folitariz, erceta.

MORIN DA citrifolia. Tab. 29. fig. I.

Coda-pilava. Rheed. mal. 1. p. 97. t.52. bene.

Bancudus latifolia. R м Р н. amb. 2. p. $158 . t$. 99 .

Morinda arborea, pedunculis folitariis. L I N. Jyfl. veg. 217. Ex collectione Bankliana.

PER. Baccx poft fingulos flores fingulx, infer $x$, in fructum ovato-conoideum, inamillis depreftiusculis teffulatum conglobatx, carnofx; fupra occllo rotundo not2$t x$, convexiuscul $x$, infra rhombeo cuneiformes, inter fe conferruminatx, quadriloculares.

RE. C. nullum; femina bafi loculamentorum affixa.

SEM. in fingulo loculamento unicum, obovato-oblongum, hine leviter convexum, inde concavum cum protuberantiz fubglobola inani ad alterum latus fub vertice feminis pofita.

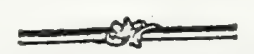

IN T. duplex : exterius cartilagineo-cruftaccum, durum, biloculare: loculamento altero coinpreflo, dorfali, feccundo, majore; altero minori, ventrali, inani, a protuberantia feminis globofa formato: interius inembranaceum, inferne in laminam triangularem, quafi in alam, ulera nucleum productum.

A в. oblongum, compreltum, obfolete convexo-concavum, fubcarlilagineum, album.

E s 8. dicotyledoneus, erectus; dimidio albutnine longior, niveus. Cotyl. ellipticx, foliacex. Rad. cotyledonibus duplo longior, lineari comprefta, recta, infera.

180.47

Frutus integer. b. Idem transerfe Seftus. c.) Bacca reparata integra. d.) Eadem longia.) Frutus integer. tudinaliter, \& e.) transverfim fefta. f.) Seminis dorfura. g.) Ljusdem pars ventralis. h. (oculamentum (purium. feminis longitudinaliter apezta, \&. K.) Nucleus propria fus membrana vefitus. L) Albumen lonQ. ६.) loculamentum foecundum. k. K.J Nuch

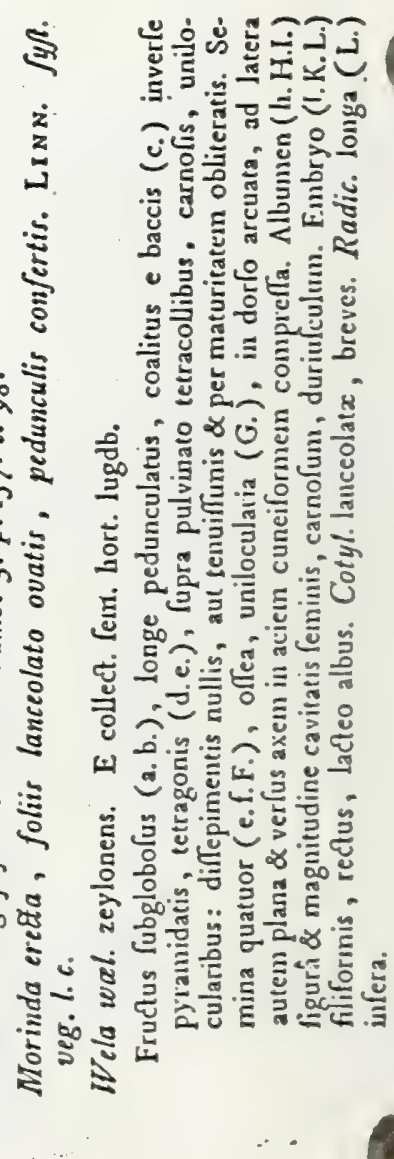




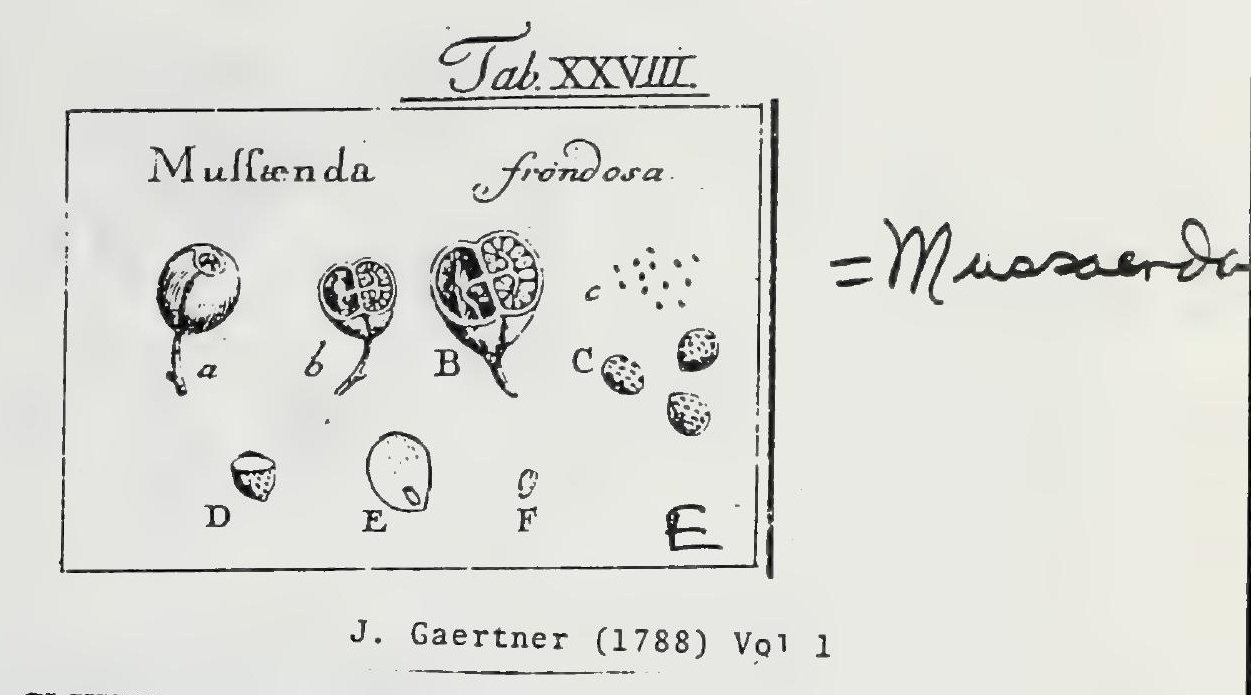

\section{MUSSÆENDA. LINN. gen. 24 r.}

Calyx quinquepartitus, fuperus. Cor. inonopetala infundibuliformis: tubo longo gra cili. Stam, quinque. Styl. unicus. Bacca infera, bilocularis. Receptacula di-
nincta, jugiformia. Semina numerofifrma.

Mussenda frondofa. Tab. 28. fig. 4 .

Mufanda zeylanica, flore rubro, folio ex florum thyrfo prodeunte albo. Burs. zeyl. $165 . t$. 76.

Mufrenda. Zeylonens. E collect. fem. hort. lugdb.

2n Belilla. R н е D. mal. 2.p. 27. t. 18?

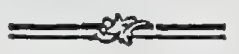

Folium principifla. Ruмгн, amb. 4. p. III. t. 51 ?

Gardenia inermis, corollis acutis : calyce hirto foliis ovatis acutis. LINN. Syft. veg. $25=$ ?

PER. Bacca infera, ovato. globol 3 aut fubturbinata, annulo prominulo albicante, s Iaplu calycis, \& intra iftum, tuberculis quinque minutis, a nutritiis ftaminum vafis, in vertice notata, fulco obfoleto longitudinali utrinque infcripta, glabra, nigra, bilocularis. Cortex tenuis, per maturitatem coriaceus. Pulpa aquofa, demun evanefcens.

REC. lamina ovata, fungo $\sqrt{a}$, in formam jugi bovini flexa, atque ope alius Iaminz transverfalis medio difrepimento utrinque aftixa, ut ex harum concurfu, cruxilla burgundica, Rumphio dicta, in medio fructu formetur.

Ses. numerofifuma, parva, fubovata, lenticulari compreffa, punctis elevatiff fcabrata, pallida.

IN T. fimplex, coriaceum.

A L B. Cemui conforme, carnofum, aqueo pallidnen.

Eмв. dicotyledoneus, minutus, fubovatus, albus. Cotyl. brevifimx, obtufx. Rad. crafla, receptaculo obverfa, cenitripeta.

a.) Bacca integra. b. B.) Eadem diffefla, cam figura receptaculi atgute fita femiram, c.'C.) Senina foluta. D.) Semen transverfe fectam. E.) Albuminis fectio longitudinalis, cum fitu exbryonis. F.) Embryo Separatus.

Bellila Hort. Mal. baccis oblongis \& feminibus nigris; Folium principi Ja Rumph. fructibus fere cylindricis \& extus fcrobiculatis; denique, Gardenia Muffanda Lins. baccâ lignofá \& feminibus per feries longitudinales digeftis, ita a noitra differunt, ut vix aufin oinnes pro una eadenque habere fpecie. Quod autem noftra fit genuina Mufianda zeylonenfium, id teflatur feliedula, propria Y. Hersansi inanu fcripta, \& in vitrea pliala una cuin fructibus in hort. lugd. aftervata. 


\section{Tah. CXCV.}

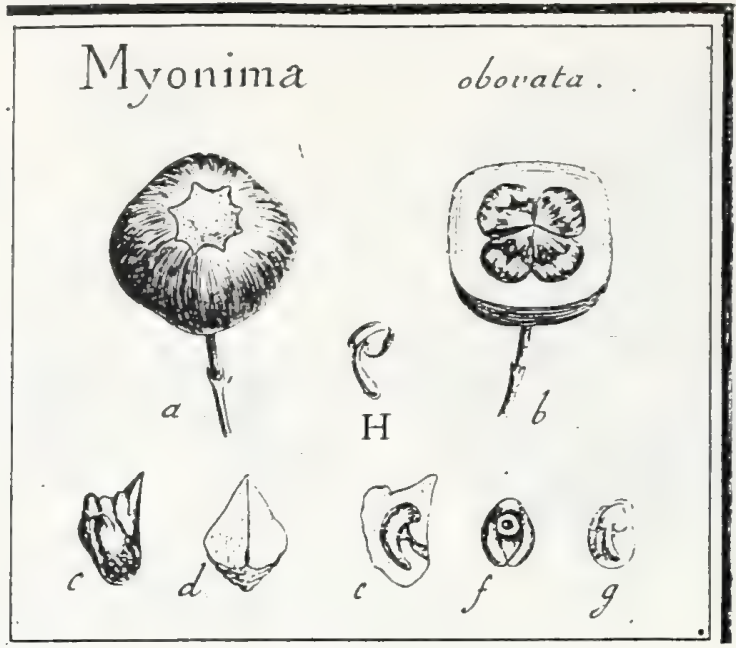

J. Gaertner (1788) Vol 3

\section{M Y O I M A. Commess. 86}

Jess. gen. p. 206. Lамавск ill. gen. t. 68.

Cal. monnphyllus, fuperus, mirrimus, deciduus: limbo fubintegro, 1. inzqus: liter octodentato. Cor. monopetala, breviter tubulofa; limbo obtufe quadripartito. Stam. 4.; filamentis brevibus; antheris oblongis, exfertis. Ovar. inferun, itylo fimp̧lic: \& ttigmate craffufeulo inftructug. Bacea infera, fubjlobofi, non coronirta. tetrapyrena; pyrenis monofpermis. Sem. me nifcuideo-umbilicata. Enab. dorfalis, erectus; radicula infera.

Mronima obovata Tib. 195. fig. S.

Afyoitina fuliis obozatis obtuses, baccis obtufe tetragonis. LAsARCK ill geth 17. If82. Dif. 4. p. isy.

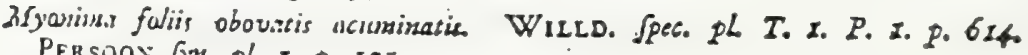
Persoon for. pl. x. p. 131.

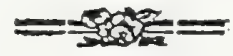

\section{E collectione. CeI Desfontaines.}

PER. Bacea infera, fubglobora, rotundato-tetragona, deprefrufcula, um bone obtufilimo \& lata area pallida intra calycis rudimentum obtufe oda. dencatum 1 . inxquale in vertice inggnita, pedunculo tenui infidens, rubra, tetrapyren. Caro folida, cralfi, granulofa, pyrenis arcte adharens, Alavefcens. Pyrenæ ofese, crafix, hinc inxquales in vercice nimirum furfum acuminate $\&$ in dorfo procelfubus mammitaribus gibbx, ad balin vero incrafratx obtufx, inde cuneatx parietibus planis, \& ad angu lum bafilarem rima parva pro introitu funiculi umbilicalis infignita, ma nofpermx.

RE c. commone nullum: pyrenz enim arctifime fibi approximatz \& carni undique adnatx; propriun feminum funiculus umbilicalis brevis, in proprio canali pyrenx infcripto umbilicum in pelvi fitum adeuns.

SIM. folitaria, cavitati pyrenarum exade refpondentia, compreffo - reniformia, furfum attenuata, hine in dorfo latifima convexa marginibus obtufss rotundatis in ventrem releris, inde in ventre fubconcava vel leviter me nifara, \& paulo fupra medium pelvim foveola parva rotundata umbilicali infignita, rufa.

IN T. Gimplex, membranaceum, tenue, albumini arete adnatum.

A L B. Semini conforme menifestum, duriufculum, carnofum, flavefcens.

E\&B. dorfalis, curvatus, erectus, bafi albuminis paulo propior, \& illud longitudine fere xquans, pallide lutefcens. Cotyl. cordatx, obtufx, craffiufcula, nervo intermedio a radicula oriundo percurfa, incumbentes. Rad. "cotyledonibus paulo longior, \& cum illis curvata, tereciufcula, ab umbilico externo declinis, infera.

\section{EXPLICATIO FIGURE.}

x.) Bacea integra. b.) Eadem medio transverfe feat cam pyrenis in Gth 2 carne ad medium usque denudutis. c.) Pyrena Coluta, a dorfo \& d.) Eadco a ventre (pectata. c.) Ejisicm Sectio rerticalis cam femine in fitu. f.) Semen folutco, a ventre fpedatom. E.) Enbryonis figur \& fitus in dorto albuminis. H.) Embrgo fulutus cotylojonibus paululum a fe iovices didutis 


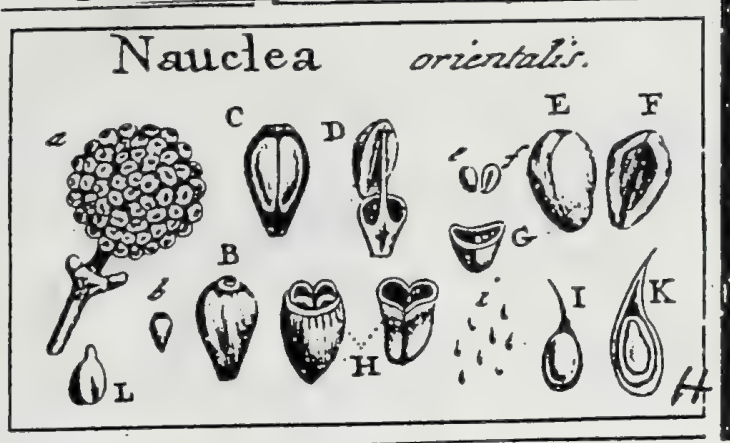

J. Gaertncr (178s) Vol.1

\section{NAVCLEA. LIN $\mathrm{N}$. gen. 223 .}

Calyx monophyllus, edentulus, pericarpium incruftans. Cor. fupera, monopetala: tubo fliformi Stam quinque. Styl. unicus. Capfula infera, calyce corticata, bicocca, bilocularis, polyfperma. Semina fetaceo-caudata.

NAUCLEA orientalis. Tab. 30. lig. 8.

Kátu-tsjacca. R н е в D. mal. 3. p. 29. t. 33 .

Bancalus. R ч м Р н. amb. 3.p. 84.t. $55 \cdot f$. х.

Nauclea. I. I N N. Syfl. vig. 212.

Ex herbario Bankfiano.

PER. Capfula infera, parva, turbinata, corticata, annulo callofo a laplu floris in vertice coronata, glabra, bicocca. Cortex coriaceus, apice a dehiscentibus cocculis aperiendus, Cocculi duo, cartilaginei, duri, albicantes, hinc convexi, inde leviter concavi, uniloculares, apice bifariam elantice dehifcentes.

REc. triplex: $1^{\circ}$. fruftificationis, globolum; $2^{\circ}$. fruftus, filiforme, cocculis interjectum, earundemque parti fupremx, ut in Umbelliferis, infertum; $3^{\circ}$. Seminis, nervus prominulus futurx cocculorum dehiscentis, e quo fernina pendent.

SEM. in fingulo cocculo circiter fedecim, parvula, ovata, comprefituscula, aut fubangulata, membranacco marginata, fuperne in caudam fetaceam attenua:a, rufescentia.

IN T. duplex, exterius membranaceum, nucleo amplius, in caudam \& marginem feminis extenfum; interius, arachnoideum.

A в . ellipricum, feminis integunento anguftius, Jenticulari compreflum, carnofum, pallidum.

EM B. dicotyleiloneus, inverfus, Inngitudine alburnisis, uiveus. Cotyl. elliptica, folizccx. Kad. oblongz, comprefla, fupcra.

2. Frufus integer. b. B.) Capfula iutegra. C. ) Cocculi intra corticem in fita inaturali. D.) Receptaculun fruftus filiforne, e. E.) Cocculi dorfum. (. F.) Ejus pars ventralis. G.) Idmu transverfe (ectus. H.) Eorundm modus dehiscondi. i. l.) Scuisia feparata. K. ) Seminis \& aluutuinis rectio lougitudinalis, cum futu \& figurn mubryonis. 


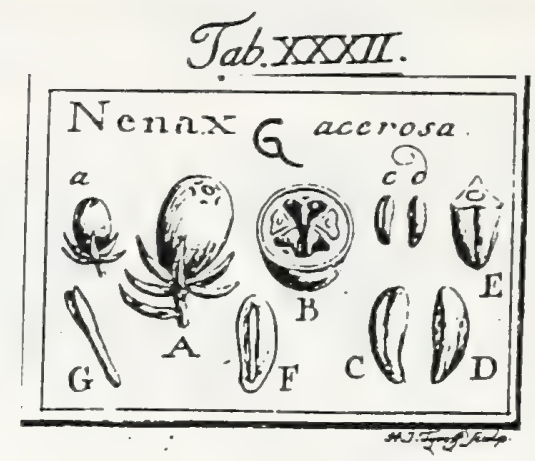

Rubiaceae

J. Gaertner (1788) Vol.I

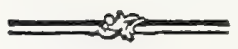

\section{NENAX.}

Calyx fuperus quinquepartitus. Cor.... Stam. .. Styl. . . Bacca exfucca infera, in medio yacua: loculamentis fertilibus parietalibus, monofpermis.

Nenax acerofa. Tab. 32. fig. 7 .

Cliffortia acerofiz. Hort. ficc. Banks.

an Cliffortia foliis filiformibus triquetris glabris integerrimis. L I N . Jyft. veg. 893 ?

PER. Bacca exfucca infera, elliptico fphxioidea, in vertice foveola rotunda \& circa eam cicatriculis quinque, a lapfu Horis, notata. Cuticula tenuis, membranscea. Caro coriacea, dura, in inetio anpla cavitate inani exfculpta, \& circa peripheriain loculamentis, regulariter quinque, fed tribus plerumque abortientibus \& Subobliteratis, Mipata.

REC. nullum; femina bafi loculamentorum affixa.

SEM. in fingulo loculamento unicum, oblongum, triquetrum, in dorfo fulco depreffiusculo inferiptum, minutilline puncticulatum, ferrugineo fufcum.

INT. fimplex, coriaceum, tenue.

A в в. Feınini conforme, durum, fubcartilagincum, album.

Es B. dicotylednneus, ereclus, linearis, fublividus. Cotyl. oblongz, foliacez, tenuiffimx. Rad. longa, lineari compreffa, infera.

2. A.) Baces integra. B. ) Ejus feftio transverfalis, cum duobus loculamentis fertilibus, stque tribus ferilibus fubobliteratis. C. C.) Seminis dorfum. d. D.) Ejus pars ventralis. E.) Albumen transverie fectum. F.) Ejusdem fectio longitudinalis, cum Gitu embsyonis. G.) Embryo fe paratus.

Quxcunque etiam fit Roris fabrica, ad Cliffortiam hac planta referri nequit. Nam five Cliffortix unicum tribuas fomen, uti LINA EUS vult; five cum ADANSONO terma ei allicribas, neuter convenit numerus, \& quod caput eft, fecundum Adassonum femina Cliffurtix funt inverfa; un Nenace autcin embryo erectus eft. 


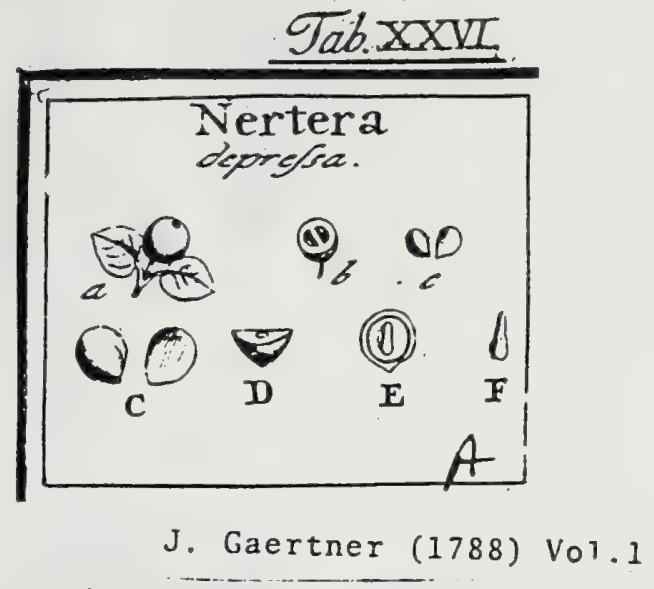

\section{NERTERA. BANKS.

Calyx nullus. Cor. monopetala, infundibuliformis, quadrifida", fupera. Stam. quatuor. Styl. duo. Bacca infera bilocularis. Semina folitaria. (Ex fchedis b. SO L A N D R I.)

Nertera depref́a: Tab. 26. fig. I.

Ex herbario Bankfiano. Habitat in regionibus antarcticis.

PER.. Bacca intera, parva, fphxrica, carnofa, rubra, apice cicatricula iotunda a laplu. corollx notata, bilocularis.

REc. aullum; femina fundo loculamentorum aftixa.

SEM. in fingulo loculamento unícum, fubrotundum, ad bafin acuminatum, planoconvexum, glabrum, nigricans.

INT. duplex: exterius coriaceurn; interius membranaceun; utrumque tenue.

A L в. figurá \& magnitudinefeminis, carnofum, viride, in adulto fructu fulcum.

E в. dicotyledoneus, inverfus, teretiusculus, longitudine fere albuminis, lacteo-albus. Cotyl. fubovatz, angufix, compreflx. Rad. cylindrica, fupera

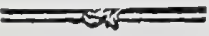

1.) Bacea integra, b.) Eišem difcifra. c.C.) Semina ab utrogue latere (pectata. D.) Albumen transverfe fectum, E) Senuivis \& albuminis feetio verticalis, cum fitu embryonis, F.) Embryo feparatus. 


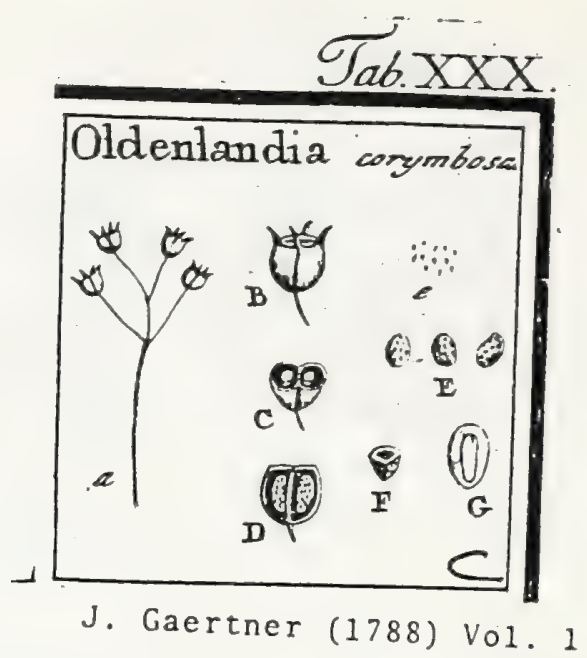

CLXXVil. OLdENLANDIA. Plum. gen. t. 36. Linn. gen. $154 \cdot 147$

Calyx pericarpio adnatus, fuperne dentibus quatuor liberis fubulatis. Cor. monopetala, quadrifida. Stam. quaruor. Styl. unicus. Capfula infera bilocularis. Receptacula libera, bafi tantum difTepimento adnata.

OLDENLANDIA corymbola. Tab. 30. fig. 3 .

- Oldenlandia humilis hyJopifolia. Eн в ет. piz. t. 2. f. I.

Oldenlandia pedunculis multiforis, foliis lineari lanceolatis. L IN N. fy/. veg. 162.

148

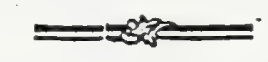

PER. Capfula infera, parva, ealycis denticulis diffitis coronata, fubglobola, didyma, bilocularis, apice rina transverfali dehiscens. Diffepimeutum rimx contrarium.

REc. oblongum, fungofum, ferobiculatum, pedunculo laterali, diffepimenti parti inferiori infertum, cetera liberum, in fungulo loculamento fingulum.

SEм. numerofifima, minima, fubglobola, punctis elevatis fcabrata, ferruginea.

IN T. fimplex, fubcoriaceum, tenue.

A L в. Cemini conforme, carnolum, album.

Es в. dicotyledoneus, teretiusculus, longitudine albuminis, lacteo albus. Cotyl. ore: villimx. Rad. longa, crafta, centripeta.

a. B.) Capfula integra. C.) Eadem transverfe, \& D.) longitudinaliter fefta, cum fitu \& infertione receptaculi. c. E) Semina (eparata. F.) Semen trausverfe fectum. G.) Albuminis (ectio longita: dinalis, cum fitu embryonis. 


\section{Opercularia} zumbellata.
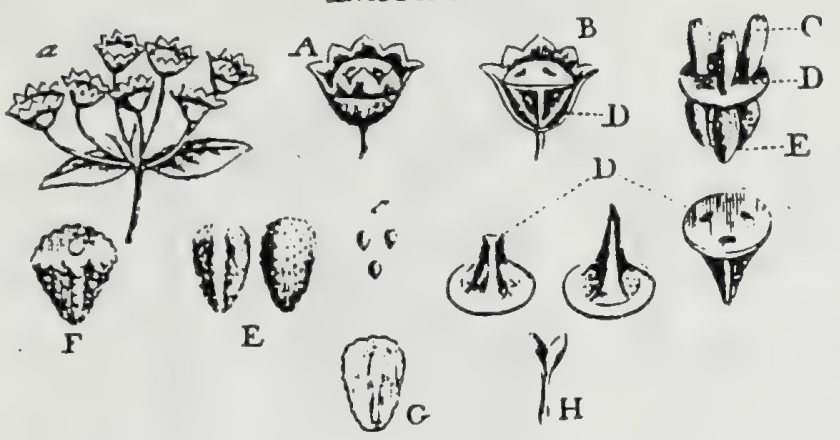

Rubiaceae
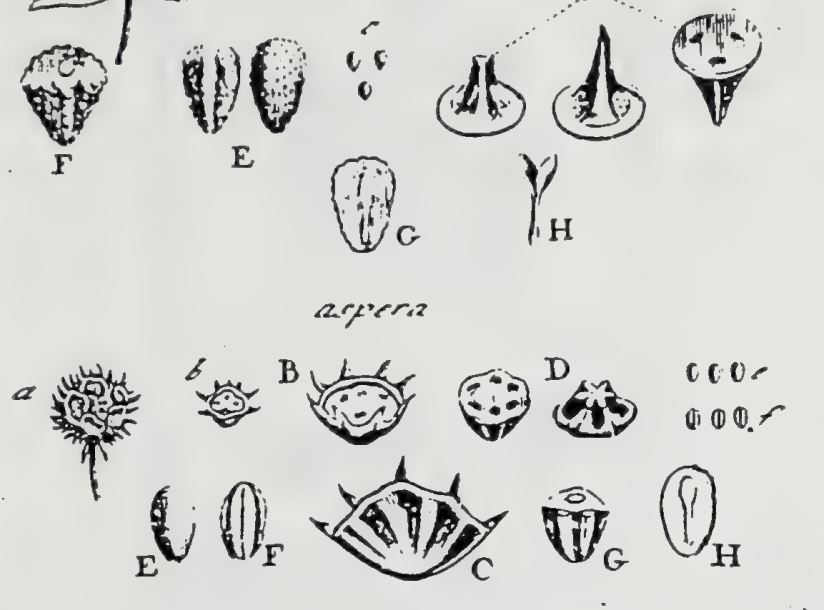

\section{OPERCVLARIA.}

Flos compnfirus. Calyx commmuis monoplyyllus, inxqualiter dendatus, claufus receptaculo communi, lupra liorifero, iufra femintgero, fer maturitatein caduco!

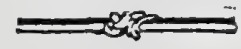

OPERCULARIA umbellata. Tab. 24. fig. 4.

Pomax umbellata. SOLAN D. miss.

Ex herbario liankfiano. Habitat in Neo-hollandia.

PER. nullum, nifi communem velis floris calycem, campanulatum, feptem 1. no. vem dentibus inxqualibus incifum, intra cujus cavitatem femina, numero corolJularum xquali, clauduntur.

REc. commmı fungofuin, fupra planum, corolliferum, rotundatum, aperturam calycis prope dentes exacte obturans; infra pyramidatum, fulcato angulatum: an. gulis in diffepimenta libera productis, quibus cavitas calycis in loculamenta feminum numero xqqualia difpefcitur. Rec. proprium: cicatricula parva ad angulum internum loculamentoruin, e qua feinina deorfnum pendest.

SE x. in fingulo loculamento partiali unicum, in toto autem fructu plerumque tria, raro quatuor, obovata , tuberculis \& rugis varie fcabrata, hinc leviter conveva, inde fulco prominulo angulata, atra.

INT. fimplex, membranaceum, arctiflume nucleo adnatum.

A I в. femini conforme, carnofum, durum, aqueo-pallidum. '

EM B. dicotyledoneus, erectus, longitudine fere albuninis \& in axi ejus locatus, lacteo albus. Cotyl. oblongx, foliacex. Rad. cotyledonibus paulo longior, teretius. cula, recta, infera.

a.) Umbella (rugifera, magnitudine naturali. A.) Calyx operculo claufus. B.) E]us feetio verticalis, loculanenta ab operculo formatz oftendens. C. D.) Corolluls operculo infiftentes. D. E.) Sensina operculo inferne affixa. D. D. D.) Operculum feu recrptaculuna commune (eparatuin. e.) Seaina magnitudine naturali. E.) Eadem ab utroque latere fpefata. F.) Albuinen transverfo fectum. G.) Ejusdem fectio longitudiualis, cum fitu embryonis. H.) Embryo feparatus \& infige niter auctus.

Huic, fpeciei funt hofculi in difco tres, difiti, Corollulx tridentatz. Stam. unicum. Siylus unicus, aut rarius duplex.

OPERCULARIA alpera. ibid.

Rubioides afpera. Soland. m/s.

Ex Lerbario Bankfiano. Habitat in Nco-Selandia.

Calyces comınunes in capitulum globolum (a.) pedunculatum congefi, fubliemifphrrici (b. B.), fulcati (C.), iex ad novem dentibus inxqualibus acuminatis in: cifi. Receptaculum commune fublicmifpharicum (D.), quadi-1. fexfulcatum. Semina (e. E. f. F.) quatuor I. Sex, ohovata, fufca, hinc convexiuscula (e. E.) i inde fulcis duobus elevatis (f. F. G.) fungofis, albicantibus notata. Nlbunea. aqueo glaucuin. Einbryo (G. H.) ut in pracedenti.

Huic funt Corollulx, ad fingulum calyecm quatuor 1 . fex, infundibuliformes, albz: Tubo fuperne ampliato, duplo, quan calyx, longiorc: Limbo quadri-1. quin-
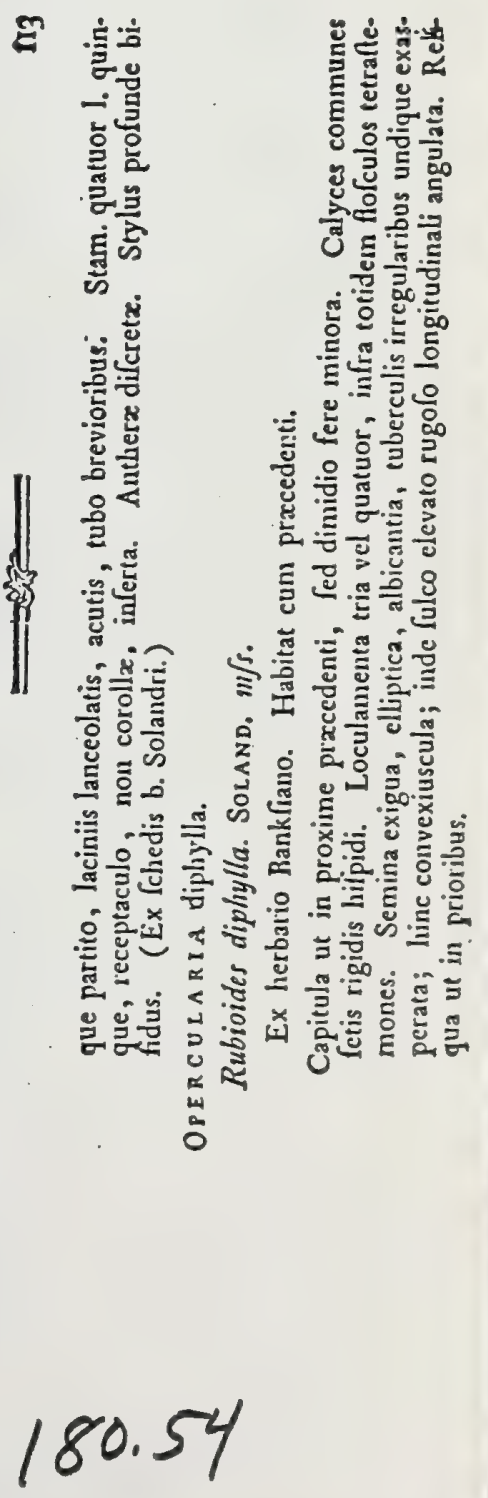


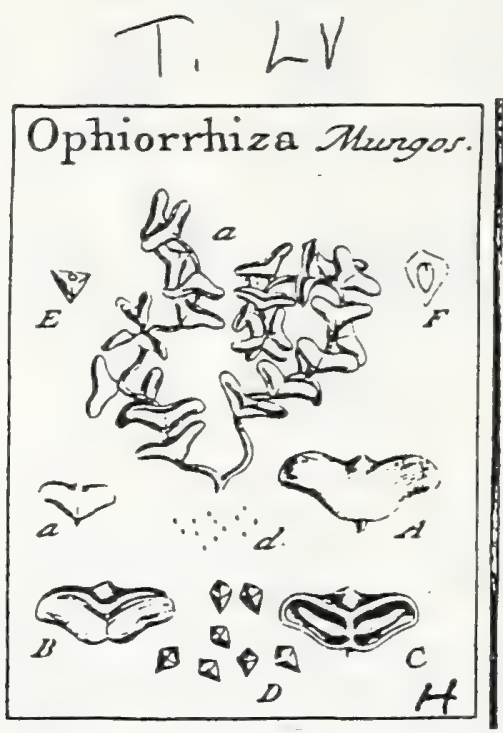

J. Gaertner (1788) Vol.I

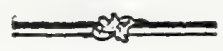

\section{OPHIORRHIZA. LINN. gen. 210.}

Calyx quinquepartitus. Cor. infundibuliformis. Stam. quinque. 'Styl. unicus, nig. mate duplici. Capfula biloba, Recept. libera, pedicellata, Sem. uinina an. gulata.

OPHIORRHiza Mungos. Tab. 55. fig. 10.

Ophiorrhiza folits lanceolato-ovatis. L I N N. mat. med. t. I. $\int y /$. veg. 197.

Ekawerya E' Naghawalli. zeylonens. E collect. fem. hort. lugdb.

PER. Capfula transverfim latior f. biloba, lobis oblongis, horizontali divergentibus, obtufis; fuperne in aciem inembranaceain comprefla ; infenue fubventricola, fulco medio utrinque inferipta, bilocularis, fecundum marginem fupenorem dehifens. Diflepimentum angufilifumum, val vis contrarium.

REC. longum, gracile, tereti acuminatum, inferne in brevifiumum pedunculum attenas. tum atque medio diflepimenti utrinque affixum, extera undique liberum, hori. zontali-adfcendens, per maturitatem deciduum.

SE 3r. numerofifima, exilifima, varie angulata, verfus umbilicum infigniter acumis: nata, ferruginea.

IN T. fimplex, coriaceum, tenue.

A 1B. fermini conforme, carnofum, duriusculum, aqueo-pallidum.

Eas B. obovato-acuminatus, lacteus. Catyl. brevifiunx. Rad. conica, centripeta.

a.) Pars corymbi, compoliti ex f́picis duabus filiformibus, cum espfulis feffilibus. 2. A.) $C_{i}$ fula claufa. B.) Eadem detificens. C.) Loculaments aperta, cum fita receptaculio d. D.) So' mios (eparata. E. F.) Embryonis figura \& fitus inera albumea.

Hane toto colo a vera Radice Mungos. Kespr. amoen. p. 578 . diftare, quilibet; ex comparatis defcriptionibus fructus, facile intelliget. 


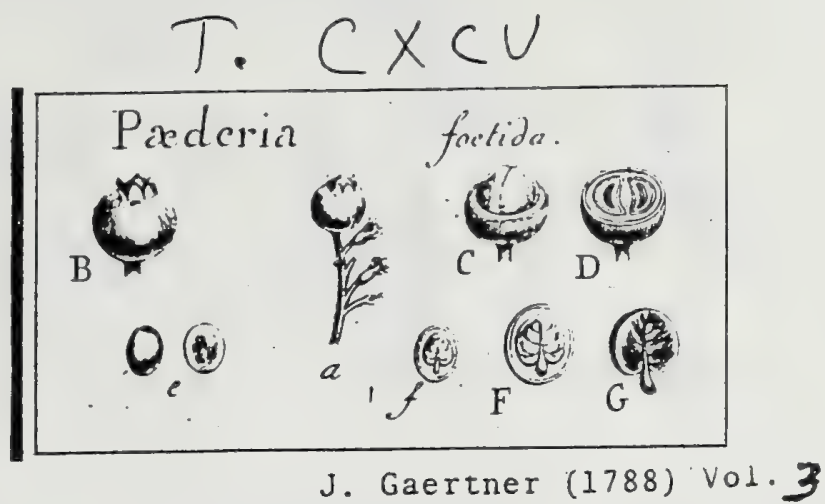

6. PAEDERIA. 84

Liñ. mant. p. \%. gen. ed. Schreb. 412. Juss. gen. p. 205.

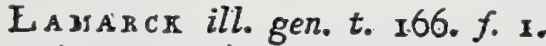

Cal. fuperus, parvus, turbinatus, quinquedentatus, perfiftens. Cor. mono: petala; tubo infundibuliformi, intus hirto 3 limbo quinquepartito, plano: laciniis brevibus, acuris. Stam. quinque; filamentis breviffimis, fubulatis, medio tubo infertis; antheris oblongis, erectis; non exfertis. Ovar. inferum; ftylo fimplici longitudine tubi, apice bifido: ftiginatibus fimplicibus. Bacca parva, infera, calyce coronata, difperma. Sem. lenticularia, fubglo bofa. Alb. carnofum. Emb. magnus, dorfalis, radicula infera.

Pazderia fatida. Tab. 195. fig. 3.

Convolvulus foetidus. RUMPH. amb. 5, p: 436 . t. 160 .

Apognium foetidum. BURM. fl. ind. p. $7 x$.

Paderia cymis panciforis, corollarum lacinies avalibus, gexitalibus fubinclusw. LARUKCK dia. 2. p. 259.

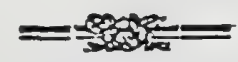

Paderia. LINw. mant. p. 52. Syft. veg. ed. 24. p. 250 . Spec. pl. ed. Willd T. x. P. 2. p. 1219. THUNB. jap. p. 106. PeRsoON fyn. plo I. p. 2xo.

Icon. KanPF. ic. fel. pofth. to g.

E collectione BankGana.

PER. Bacca infera, parva magnitudine pifi, globofa, I ovata, calyce quirquedentato erecto coronata \& intra hunc in vertice umbone callofo faftigiata, epidermide fragili lutea tecta, unilocularis, difperma. Caro ad modun debilis, valis nutricis filiformibus femina amplexantibus percurfa.

REc. nullum; femina umbilico ad bafin feminum fito bafi baccx adnata.

SEM. duo oppofita, erecta, orbiculata, lenticulari - fubglobofa, 1 . hinc convera, inde planiulcula 1. leviter concava, ad bain lateris plani umbilico parvo notasa, atro - fufcar

Ix r. fimplex, membranaceum, $a b$ albumine vix fecedens.

A L B. femini conforme, duriufculum, carnofum, pallidum, vetultate autem pallide mellinum.

Exв. magnus, exectus, vix ex centro albuminis ad ejes bafin depreffus, curvulus, lacteus. Cotyl. foliacex, cordato-orbiculatx \& ad radicula infertionem profunde incifx, obtufifimze, hinc convexx inde autem concanze, nervofx, incumbentes. Rad. brevis, incurva, e nervo cotyledonum intermedio oriunda, clavata, obturfa, umbilico externo obverfa, infera.

\section{EXPLICATIO FIGURE.}

c.) Pars tacemi frogiferi cum ovariic quibusiam inmaturis, B.) Batea integra: $C_{\text {f }}$ ) Eadem cum feminihus in fitu, a carne ad medium usque denudatis. D.) Ejusilem \& leminum fedio transverfalis. c) Scmen folutum, ab utraque parte fpecatum. E. F.) Albumen verticali mode difietarm cum embryone in fitu. G.2 Embryo falutus. 


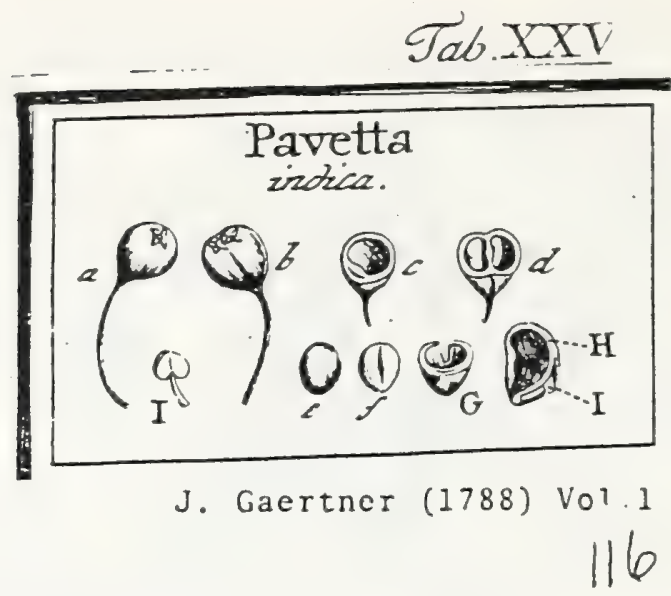

Rubiaceae

CXXXVII. PAVETTA. LinN. gen. 132.

Calyx fuperus, quadridentatus mininus. Cor. monopetala infundibulitormis. Stam. quatuor. Styl. unicus. Bacea bilocularis. Semina folitaria, bullata: albumine, cartilagineo.

PAVE T T A indica. Tab. 25. fig. I.

Pavelta S. Malleamothe. Rheеd. Mal. 5. p. 19. t. 10.

Flamma fyluarum peregrina. R Ч М $\mathrm{P}$., ainb. 4. p. 107.t. 47 .

Pavetta. Burss. flor. ind. 53. $t .13 . f .3$.

Pavetta foliis oblongis utrinque acuminatis, umbellis terminalibus fafciculatis, calyce brevi acuto. LIN

E collect. fem. hort, lugdb.

PER. Bacca infera, carnofa, fubglobofa, aut fubturbinata, fimplex, aut didyma, ca. lyce nituto albicante, unico aut gemino coronata, bilocularis, per xtatem atre. Caro tenuis, in vetufto fructu tota fungofa, feminibus arcte adizxrens.

REc. nullum, prater carnem difepimenti, qux feminum cavitatem intrat, eaque fibi affigit.

SEMr. in fingulo loculamento unicum, fubglobofum, hine convexum, inde planiusev. lum, rima longitudinali incifun, \& intra banc amplifuna cavitate exfculptun $\mathcal{f}$ bullarum, glabruin, nigrum.

IN T. fimplicilimun, tenuiffmum, arcte adnatum.

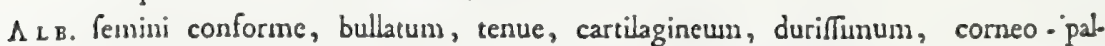
lidum

EMB. dicotyledoneus, erectus, curvatus, dimidio albumine brevior, \& in ejus parte infina atque exteriore pofitus, lacteo albus. Cotyl. cordarx, foliacex, renuifis: mzx. Rad. teretiuscula, curva, infera.

a. ᄂ.) Baces fimplex \& didyma, c.) Bacex prioris fectio, cum altero loculamento fubobliterato d.) Bacca pofierioris, manifefte bilocularis fectio. e. f.) Seminis atrungque latus. G.) Albumea uransverfe fectum. H.) Idem verticaliter diffectum, cum embryone (I) ad bafiu ejus bereote 1.) Embrjo Separatus \& acctur,

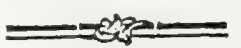

$\mathrm{II7}$

Gemini flores, non tantum in baccis babitioribus \& didymis, fed \& in fimplicioribus ac minoribus fxpifime reperiuntur: ut fere crediderim gemellos flores in Pavctta effe saturales, ficut in vartiis Caprifoliis. 


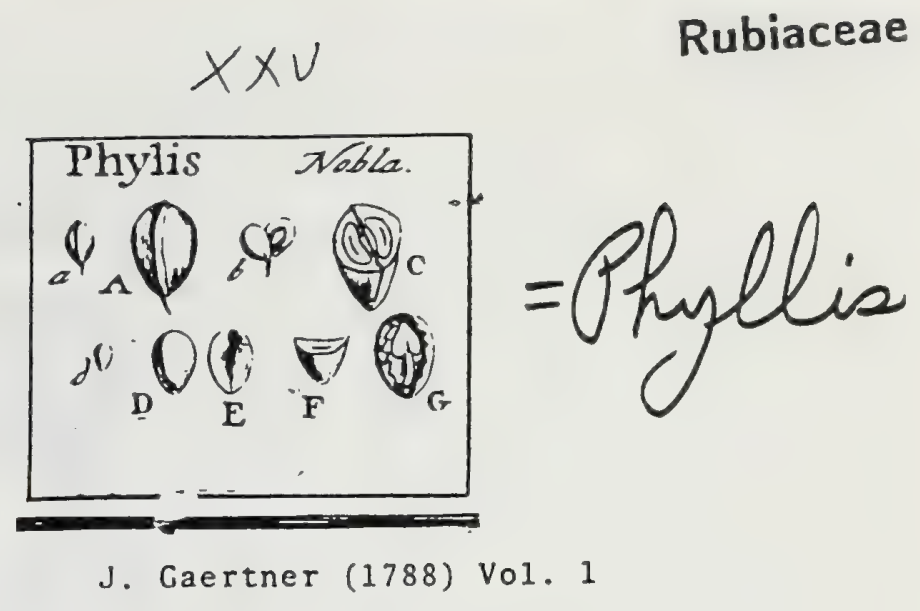

\section{PHYLLIS. LINN. gen. 223. $\quad 12: 3$}

Calyx obfoletus, aut nullus. Cor. monopetala, fupera, profunde quinquefida. Stam. quinque. Styl. duo. Capfula infera, bilocularis, bipartibilis. Semina Colitaria, plano-convexa.

Рн чLlis Nobla, Tab. 25. fig. 10.

Valerianella canarienfis frutefcens, fimpla nobla difia. Dirz. h. elth. 405. t. 299.

Phyllis fipulis dentatis. LIN N. Jy/b. veg. 270.

PER. Caplula infera, cruflacea, obovata, rhombeo-aut lenticulari-compreffa, bìlocuLass, bipartibilis. Crufta in dorfo \& lateribus coriacea, crafla; in parte autem ventrali, nembranacea, fubdiaphana, alba.

R.E. nullum; femina bali aftixa.

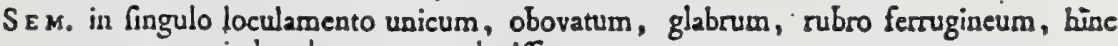
convexum, inde planum; aut leviftune concavum.

IN T. fimplicifimum, tenuifimum, arcte adnatum.

A с в. Semini conforme, carnolum, duriusculum, album.

Ex в. dicotyledoncus, erectus, vix curvatus, dorfális, lacteo albus. Cotyl. cordatz, foliacex, grandiesculx. Rad. filiformis, infera.

2. A.) Fruthus integer. b.) Idem dehifcens. C.) Idem transverfe fethus. d.D.) Seminis dorfum, E.) Ejus pars ventralis. F.) Albumen transverfe feftum. G.) Embryo in dorfo albuminis.

Poffent, cum LINN $\bar{E} 0$, femina dici nuda ; cum tamen diverfo a crufta fua gaudcant colore, \& $a b$ hac undique foluta fint $2 c$ facilline $a b$ ifta feccdant, rectius, cun ADANSONO, pericarpio concludi flatuuntur. 

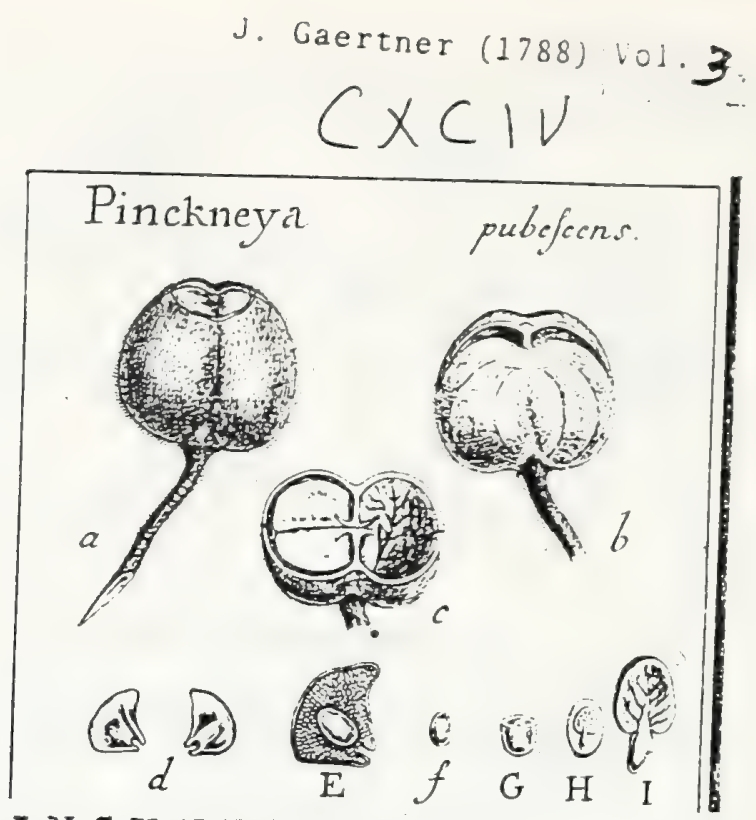

\section{P I N C KNEY A. MICHAUX flor. bor. amer. p. I03.}

J. Gaertner (1788) Vo1

$\mathrm{C}_{2}$ l. oblongus, turbinatus, inferus, quinquepartitus; laciniis rectis, IanceoJato-fubulatis, acutis, patentiufculis, deciduis, fubxqualibus, una vel dua. bus in bracteam foliaceam coloratam apice dilatatis. Cor. monopetala in-

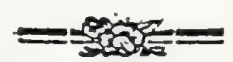

fundibuliformis; tubo longo fenfim paulum ampliato, fauce patente; Timbo quinquepartito: laciniis oblongis obtufis refexis. Stan. quinque; filamentis filiformibus, tubum fuperantibus \& ad ejus bafin inTertis; a mtheris oblongis "ncumbentibus. Ovar. inferum, ftylo fimplici filiformi \& ftigmate obtufo bilobo prxpilatum. Capf. infera, coriaceo-chartacea, fubglobofa, fulcatodidyma, bilocularis, bivalvis. Rec. in utroque loculamento gemina, fun. gofo-nembranacea. Sem. plurima, biferiatim horizontaliter fibi incurnbentia, compreita. Alb. carnofum. Emb. cotyledonibus foliaceis, concavis, radicula centripeta.

Prackneid pubefcens. Tab. 194. fig. 3.

Pinchingn (pubens,) foliis ovalibus, utrinque acutis, fubtus fubtonsentofus. MLchaux for. bor. amer. I. p. 105. t. J3.

Pinknea. PERSOON Jyul. pl. 1. p. 197.

E collectione Cel. Desfontaines \& ab amicif. Dao DBCandolle.

Per. Capfula infera, fubglobofa, comprefriufcula l. transverfe paujo latior quam crafa, turgiđa, fulco intermedio didyma, in vertice areà latà annulo cinctà lineari a calycis lapfu notata, ex duabus laminis conferruminata: exterioue coriacea, tenui, fetulis minimis albis hifpida \& nervis octo longitudinalibus infcripta, rubicunda; interiore chartacea, glabra \& nervis analtomofantibus reticulata; bilocularis, bivalvis: valvis ad medium us que cum diffepimento dehifcentibus. Diffepinentum membranaceum, valvis contrarium \& fulco externo adnatum, dehifcendo bipartitum.

RE.C. in quovis loculametrto gemina, ex marginibus difcpimenti fifr refexis orta, intra Joculamenta prominula, furfum deorfumque deliquefcentia, angulta, fungolo-membrauacea, patentia.

S.EN. Iumerofa, in quovis locularuento binis ftratis horizontalibus imbricata \& emarginatione unbilicali receptaculis commifa, integumento laxo involucrante ampliata, parva, oblonga l. fubreniformia, comprefiufcula, proxine ad emarginationem hxrentia, pallida.

IN T. duplex : exserius laxifimum ita, ut in involucri formain anpliatum fit, conpreffum, quadrantem fere circuli referens \& ad angulum umbilicalem profuade emarginatum, faccatum, ex membrana tellui minutifime hexagono-reticulata confatum, pallide framineum; interius itider membeanaceum, tenuilinum, albumini arctifime adnatum.

A L B. fenini conforme, exiguum, camolum, album.

.E м в. nagnitudine fere albuninis, rectus, umbilico paulo propior, niveus. Cotyl foliacex, ovato-cordata, nervofix, hinc convexx, inde concava, incumbentes. Rud. cotyledonibus brevior, cra $\mathbb{T a}_{2}$, conica, in nervum cotyledonum ercurreas, difcreta ad receptaculum paululum incurva, umbilico externo obver $\sqrt{a}$, centripeta. 


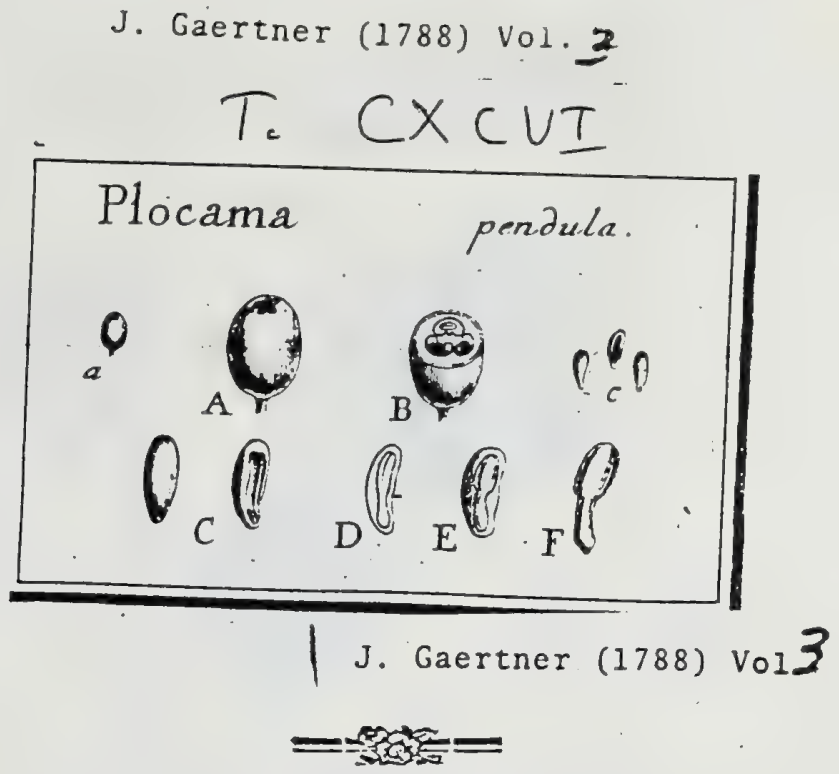

\section{P L O C A M A.}

AIт. hort. Kew. I. p. 292. Sc нгев. gen. I738.

Cal. monophyllus minimus, fuperus, quinquedentatus, periftens. Cor. campanulato-tubulorá; linbo quinquepartito. Stam. quinque; filamentis brevibus, tubo corolle infertis; antheris linearibus, incumbenti-erectis. Ovar. inferum; ftylo Gmplici, filiformi-fubclavato, ftaminibus longiore; ftigmate obtufo. Bacca minima, ovato-oblonga, coronata, trilocularis, trifperma. Sem. oblonga, marginibus ad ventrem infexis umbilicata. Alb. fubcartilagireum. Emb. dorfalis, rad, infera.

Procama pendula. Tab. 196. fig. 7 .

Plocama. AIt. bort. Kew. I. p. 2g2. WiLLD. Jpec. pl. T. 1. P.2. p. I210.

Ex horto regio Kewenri.

P R R. Bacca minima, oblonga, 1. ovato-oblonga, vix fenfibiliter rotundatotrigona, infera, calyce quinquedentato adpreffo coronata, \& intra idtum umbilicata, rubra, trilocularis, trifperma. Caro epidermide tecta, pulpofa, rufefcens, Loculamenta membranacea: membrana tenui albida, extus cum carne arctilfme conferruminata, intus laxigata.

REc. nullum; femina funiculis umbilicalibus breviflmis loculamentorum bafi affixa.

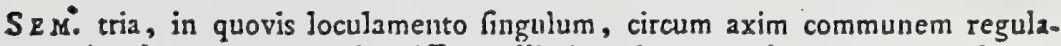
riter locata, erect3, longiffme elliptica, incurva, hinc convexal glabra, inde marginibus revolutis fubconcava l. menifara, foveola longitudinali nervo intermedio bipartita, bafi umbilico minimo inftructa, nitida, atrofurca.

Ix T. Gimplex, membranaceum, albumini arctifime adnatum.

A L B. femini conforme, fubcartilagineum, lividum.

EMB. erectus, dorfalis, curvulus, longitudine fere albuminis, lacteo-albus. Coryl. oblongx, radicula multo latiores, plano-convexx, obtufx, incumbentes. Rad. Jongitudine cotyledonun, fubclavata, leviter incurva, brevilline conico-acuminata, umbilico externo obverfa, infera.

\section{EXPLICATIO FIGURE.}

2. A.) Bacea integra naturali \& auAa magnitudinic. B.) Eadem eum feminibus medio transicte difraa. e. C.) Semina fuluta a dorfa \& a ventre fpectata. D.) Albumen longitudinaliter diffeAum. E) Embrțonis figura \& fitus in dorfo altuminis. F.) Embryo folutus valje auctus

J. F. Gmelin in fylt. nat. nomen in Placoma pervertit, \& Perfoon in Synopi eum fequutus eft. 


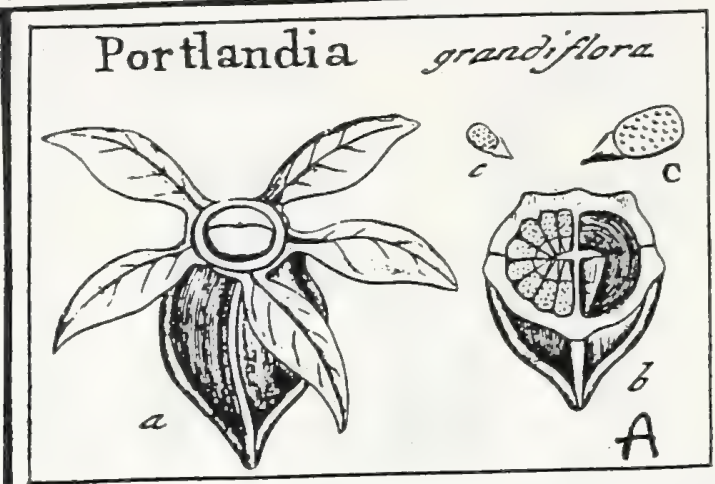

J. Gaertner (1788) Vol 1

153

\section{PORTLANDIA. LINN. gen. 227.}

Caijx pentaphyllus fupcrus. Cor. clavato-infundibulifornis. Stann. quinque 1. Cex. Styl. unicus. Capfula infera, cofato-angulata, bilocularis, bivalvis, polysperma.

PORTLANDIA grandifora. Tab. 3r. fig. I.

Portlandia foliis majoribus nitidis ovatis oppofitis, floribus ampliflimis. B R 0 ज $\mathrm{N}$. liff. jam. 16 4. t. 11. S. $x$.

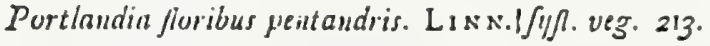

E collectione Bankfiana.

PEr. Capfula infera, calycis foliolis ovato lanceolatis patentifinis coronata, fubturbinata, coriacea, inxqualiter pentagona, ad angulos fulco e!ciato rotundato conata, bilocularis, bivalvis. Diffepimcntum tenue, valvis contiarium.

REc. lamina coriaceo lignofa, angufta, tenuis, difepinento utrinque longitudinaliter ajuata.

SEM. plurima, elliptica, craftuscula, utrimuve plana, pundis cleratis confperfa, rufelientia, horizontalia: unblilico ante plenam maturitatem carnolo, albo, acumsnato pyramidali.

INT. duplex: exterius coriaccum, craffum; interius membranaceun.

A в в........

EMB. . . . . .

a.) Capfula integra. b.) Eadem eransverfe fecta, cum fitu feminum. c. C.) Semiua feparata. isiniatura. 


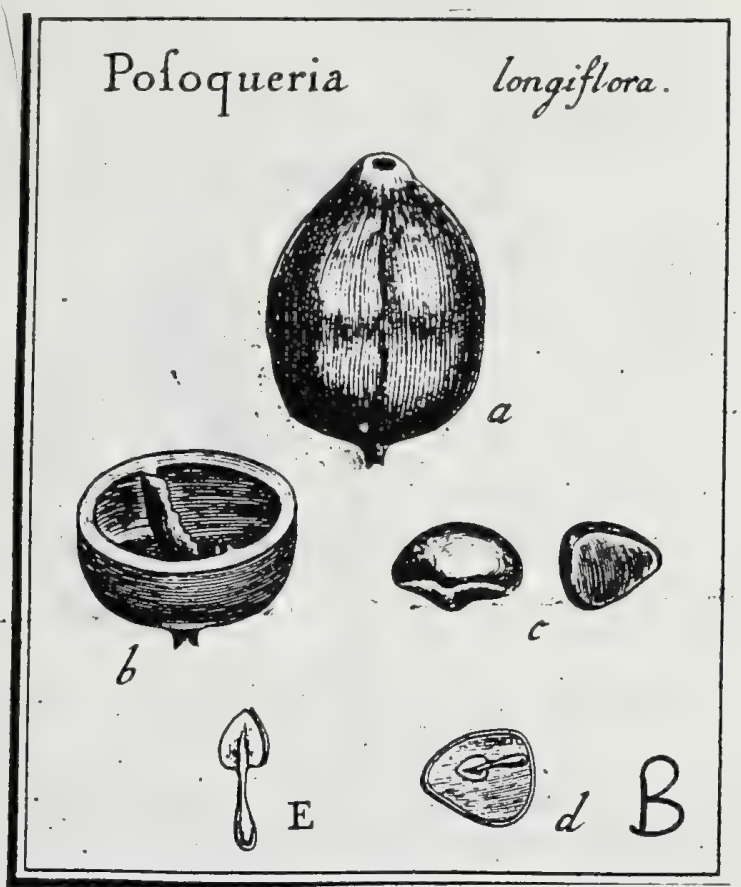

\section{POSOQ UER I A.}

A UBI. glly. t. 5r. JUSS. gen, p. 201. L A

t. I63. Cyrtanthus. S' CHEB. gen. 302 .

Cal. monophyllus, fuperus, turbinatus, rectus, quinquedentatus, deciduus: Cor-inonopetala tubulofa; tubo longilinno, cylindraceo, ditco ovarii inferto, recurvo, fauce villofa vix ampliata; limbo quinquefido: laciniis anguftis, reflexis, obtufis. Stam. quinque; filamentis brevibus fubulatis, incurvis, intra faucem corolla ad inciluras infertis; antheris oblongis, utrinque acuris, incurvis, bafi filamentis affixis, exfertis. Ovar. inferum; Atylo fetaceo, longitudine tubi corollx; ftigmate trifido, acuto. Bacca corticata, calycis reliquiis coronata, bilocularis. Rec diffepinento utrinque adnatum, pulpofum. Sem. plura, baccaca. Alb. cartilagineum. Emb. ilicurvus, radicula vaga.

Posolueria longifora. Tab. 193. fig. 2.

Solena. WILLD. fpec. pl. T. x. P.2. p. g6. Persoon fyn. pl. z. p. 205.

Pofoqueria longifiora. AUBL. gily. I. p. J34.

\section{Ex dono Dai Duruis.}

PRr. Bacca ovata 1. elliptica, infera, cortieata, ovum gallinaceum magnitudine vix xquans, ab impreflionibus fenimum levitinme rotundato-nodofa, in umbonen furfum attenuata \& intra calycis dentes inxquales inflexos umbilicata, vix fenfibiliter bifulca, Jutea, biloculatis. Cortex craftiufculus carnofus, ficcitate autem fungofus, faporis grati fubdulcis, flavefcens. Diffepimentum membranaceum, tenue, cum membrana corticem intus ve. ftiente tenuifima contiuuum, faccidun.

REC. - .

Sex. quinque ad fex in quovis loculo, pulpa molli rufefcenti baccata, arcte fibi approximata magnitudine pifi, hinc convexa, inde a vicinis cuneiformi angulata, lutefcentia, Chalaza fufca notata.

I x T. fimplex, meinbranaceum, tenue, albumini arctirime adnatuq.

A L B. Cemini conforme, cartilagineum, fordide mellinum, corneo-transparens.

ENB. dorfalis, levifTime incurvus, tertia albuninis parte brevior, albus. Co-

I B. cordatx, foliacex, acuminatx, nervo intermedio valido cum radicula continuo percurf $x$, incumbentes. Rad. cotyledonibus duplo fere longior, clavata, leviter incurva, obtufifima, unbilico \& chslaza obverfa, viga.

\section{EXPLICATIO FIGUR:}

a.) Bace integra. b.) Eadem medio transverfc diftecta. c.) Searina foluta diverfx formx. d.) Albuariais feato horizontalis cum Gitu embryonis. E.) Einbryo Solutus.

Fructus icon Aubletiana tota erronea; vel falten valdopere alienata, fenina autem cun Hoftris ex affe $x$ mula funt, ita, ut nullum dubium reftet, quin hic fructus ad Pofoqueriam Aubletii pertineat.

D nommantum alm narte diffepimenti in noftro fpecimine erat ablatun. 


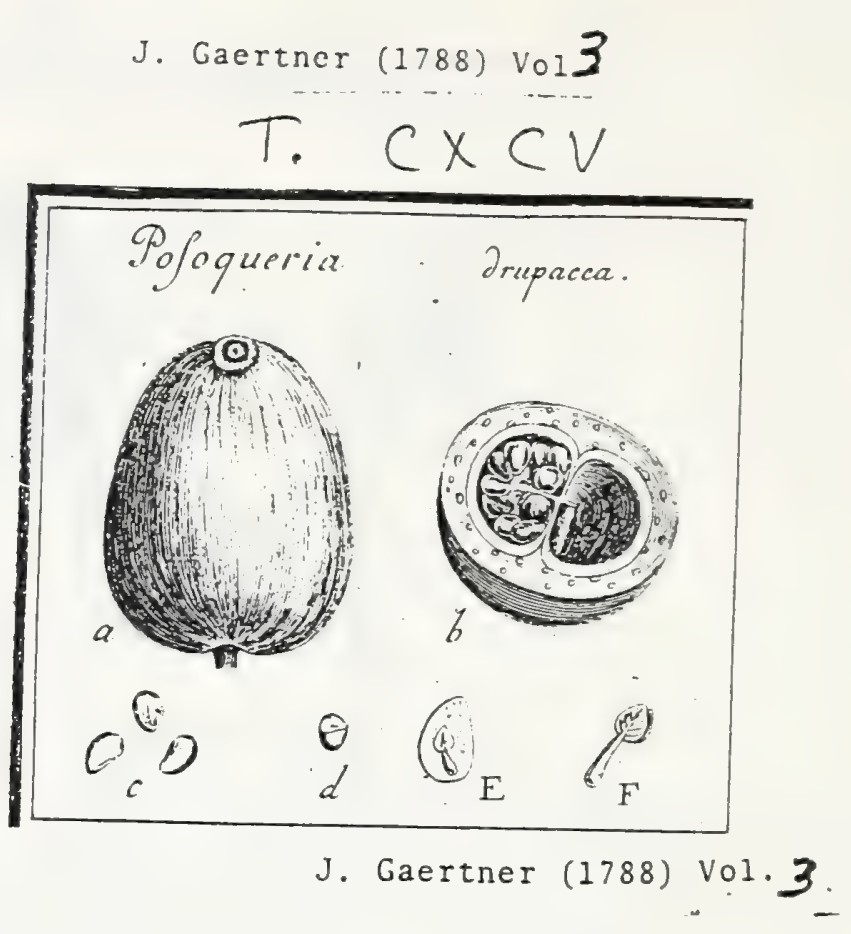

Rubiaceae

Posolueşia drupacea. Tab. 195. fig. I.

77

E collectione feminum hort. Lugd. Bat., \& ex inf. Java a Cel. Prof. BKugmanns.

Drupa grandiufcula, baccata, oblonga, vix comprefla, bafi umbilicata, vertice autem ruga circulari fubsequali coronata \& intra hanc areolà parvz̀ elevatá planiufculà umbonata, rubra. (a) Caro crara, firma, fibris \& trabeculis offeis intermixta, favefcens. Putamen offeun, didymum, craffun. Diffepimentum ex duplicatura laminarum ollearum putaminis conEatum, in medio autem in membranam tenuen extenuatum. Receptaculum medio dilfepimento utrinque ope lamine integerrimx longitudinaliter adnatum, maximum, oblongum, carnofo-pulpofum, cum pulpa femina obvolvente confluens \& ipfa ftrato unico in peripheria nidulantia gerens. (b.) Semina numerofa, circa quadraginta in quovis loculo \& plura, incumbentia, pulpà a receptaculo proveniante obvoluta, hinc cralinufculs convexa, inde cuneiformi angulata, ad umbilicun in extremitate obtuliore locatum Chalaza fulca notata, fubtransparentia, mellina. (c) Integuroentum fimplex, colore quidem obfcuriore facile ab albuniue difcernendum, fed ipfi arcillime adnatum. Albumen femini conforne, cartilagineum, corneo-transparens, e Jutefcenti pallidum. Embryo dimidiun albumen longitudine fuperans \& ad ejus dorfum fefe vergens, prope unbilicum locatus, leviter curvatus, albus. Cotyl. cordatx, radicula paulo breviores, foliacex, acuminatx, nervofx, iucumbentes. Kad. Jongal , leviter incurva, clavata, obtufifima, umbilico externo obverfa, vaga. (d. E. F.) 

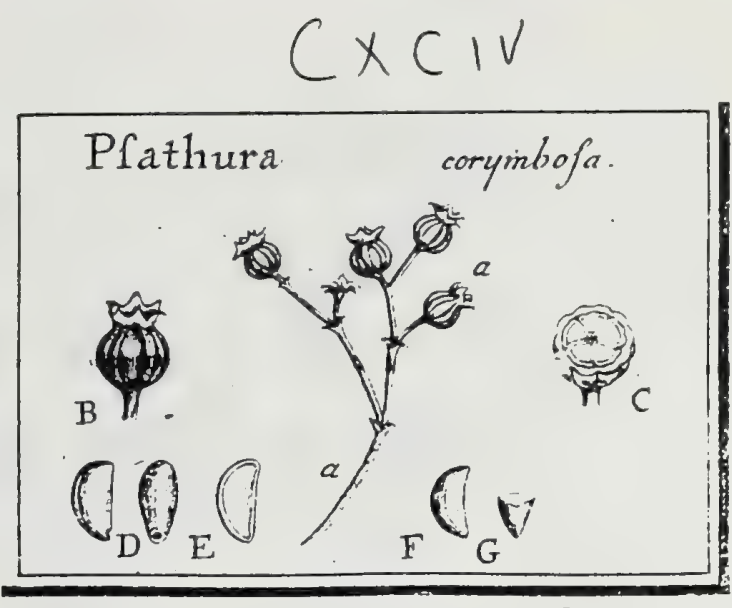

\section{J. Gaertner (1788) Vol. 3}

\section{I- P S A T U R A. Commers. 82}

Joss. gen. p. 206. LAßABCK ill. gen. $t .260$.

Cal. monophyllus, fuperus, fexdentatus, perfiftens. Cor. monopetala, intus barbata ; tubo brevifimo; Jimbo fexdentato, patente, plano; dentibus acutis. Stam. Fex; filamentis breviffinis, infra faucem corollx infertis; antheris oblongis, erectis, didymis. Ovar. inferum; ftylo fimplici, fliformi ; Itigmatibus 3. 1. 4. lamellatis, acutis. Bacca infera, parva, globofa, fulcata, coronata, hexapyrena. Semina folitaria, exeda. Alb.. carnofum.- Emb. . . .

Psithura corymbora. Tab. 194. fg. 4 .

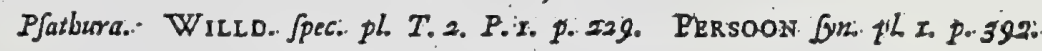
E collectione Cel. Drsfontaines.

PE R. Bacca parva magnitudine grani piperis, globofa, fulcato - ftriata, intra calycem perfittentem fexdentatum in vertice umbilicata \& umbone minimo. in centro ftipata, obfcure coerulea, hexapyrena. Caro debilis, . pulpofo. farinofa. Pyrenix offex, erectx, arctiffime fibi approximatx, hinc rotundato-gibbs, inde cuneato-acutre \& ab bafin umbilico parvo pervio inftructix, monofperma.

REC. nullum; pyrenæ \& femina ope funiculorum umbilicalium ad bafin affuxz.

SEM. folitaria, cavitatem pyrenarum exacte replentia, rotundato - cuneata, erubro ftraminea.

Ix r. fimplex, membranaceum, tenue:

A. B. femini conforme, carnofum....

EMB....

\section{EXPLICATIO FIGURE:}

2. 2.) Corymbi frugiferi pars B, Bacca iutegra, magnitudiac auctian C.) Eadem medio tranci-

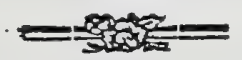

werle aileta cam fitu pyrenarum. D.) Pyrenx feparatz, a hatere \& a ventre Ipechat;. E) Py:rene frato vertiealis cum fitu feminis. Z.) Scmen folutum. G.) Albumen transverfe diffectum

Pfathura pyrenis \& feminibus erectis \& bafi bacca affixis effentialiter ab Erythali diver ${ }^{2}$. 


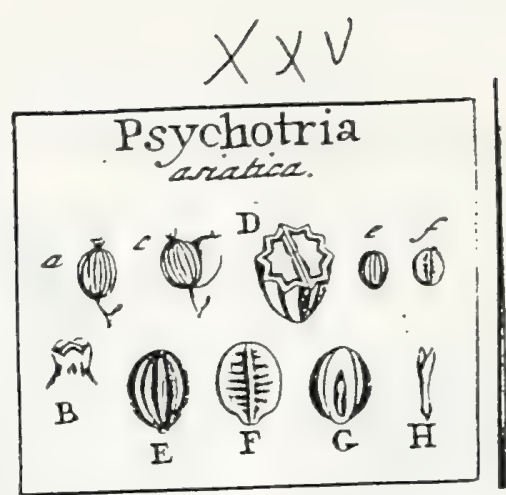

J. Gaertner (1788) Voi. I

\section{PSYCHOTRIA. LINN." ger. 229.}

Calyx fuperus, quinquedentatus. Cor, tubulofa. Stam. quinque. Styl. unicus. hacca infera, per maturitatem exfucca, coriacea, bipartibilis, bilocularis. Semina folitaria, dorfo fulcata.

Ps:c нот I A afiatica. Tab. 25. fig. 6.

Pfychotrophum fruticofum foliis amplioribus ovatis, flipulis rigidis interpofitis. kRows. hift. jam. 16o. t. 17. f. 2. bene.

P/ychotria fripulis emarginatis, foliis lanceolato ovatis. IIN s. Jyf.veg. 214 .

Ex herbario Bankfiano \& e collect. fem. hort. lugd.

PER. Bacca parva, ovato globola, calyce brevi quinquedentato coronata, fulcis in univerfum decein longitudinalibus, profundis exarata, bilocularis, per maturitatem coriacea, ficca, bipartibilis, ftramineo- fpadicca.

REc. nullum; femina fundo loculanentorum aflixa.

$\mathrm{SE}$.r. in fingulo loculanento unicum, hine planiusculun, transverfe rugofulum, atque linea media elevata notatum; inde convexuın, tribus fulcis majoribus dorfali: bus, \& duobus minoribus marginalibus exaratum, atrum.

INT. fumplex, membranaceum, arctifime adnatum.

А ц в. femini prorfus conforme, cartilagineum, durum, aqueo-pallidum.

E м B. dicotyledoneus, erectus, albumine dinidio brevior \& in ejus dorfo locatus, lacteo-albus. Cotyl. lanceolatx, foliacez. Radic. terctiuscula, fubcurva, infers:

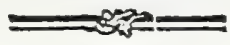

2. B.) Bacea calyet coronata integra. c.) Eadon (ponte partita. D.) Ejus atque feminum Sectio transverfalis. c. E.) Semiais latus dorfale, f. F.) Ejusdem pars ventralis. G.) Fmbryopis fitus in dorfo albuminis. H.) Embryo feparatus.

Fructus jamaicenfis adeo funilis eft zeylanico, uti ovo, ovum. Ergo dubium, anne $\mathrm{P}$ fychotria cartaginen/is, cui baccx fint molles, uniloculares \& rubrz, ad hauc fpectet fpeciern. Conf. JAce. amer. p. 65. 
Rubiaceae

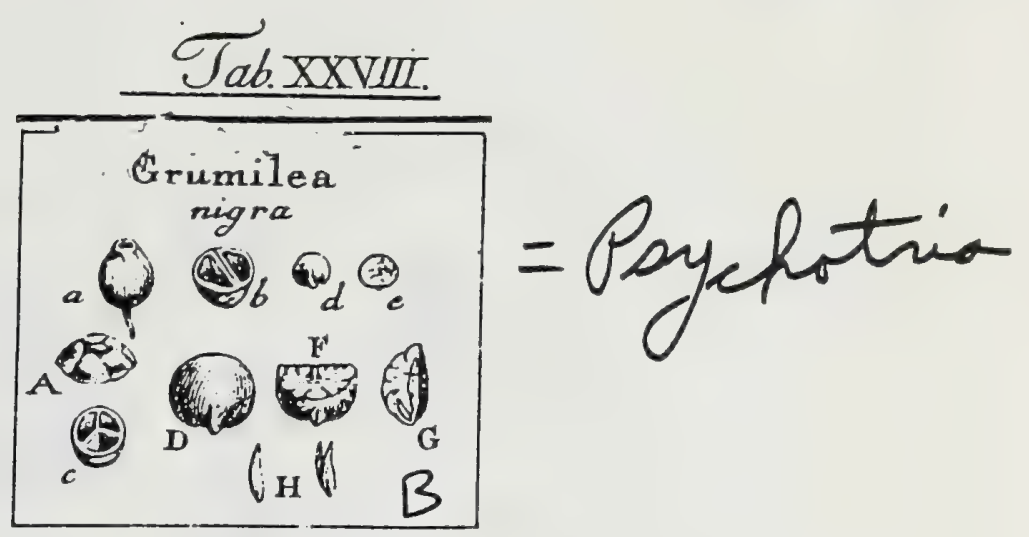

J. Gaertner (1788) Vol.l

CLXV. GRUMILEA. $\$ 38$

Calyx quinquedentatus, fuperus. Cor... Stam.... Styl. ... Bacea infera bi-1. trilocularis. Senina folitaria : albumine grumofo.

Grumilea nigra. Tah. 28. fig. 2.

Kogdala zeylonens. E collect. fem. hort. lugdb.

PER. Bacca infera, calycis dentibus quinque rotundatis conniventibus coronata, ovato glubofa, per xtatem fuberiacta, atra, bi-aut rarius, trilocularis. Diffepimentum in baccis bilocularibus rima bipartitum; in trilocularibus vero folidum.

REc. nullum; femina fundo locularncutorum affixa.

$S_{E M}$, in fingulo loculamento unicum, nune angulatum, nunc frequentius rotundatum, plano convexum, prope bafin Leviter unucronatum, undique rugofum \& fere rimolum, nigro fufcum.

IN r. fimplex, fobcoriaceum, arcte adnatum.

A \& B. femini conforme, fubcartilagineum, rimis \& fiffuris profundis in lobulos irregulares, inter fe tamen cohxrentes, divifum, album.

Еив. dicotyledoneus, eredlus, parvus, leviter curvatus, prope dorfum in bafi albumisis pofitus, lacteo albus. Cotyl. lanceolato acuinisatx, plano convexx. Rad. conica, brevilluma, infera.

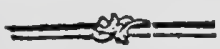

2. A.) Bacea integra, calycis dentibus coronata, b. c.) Eadem bl-\& trilocularis, transverfim 2. D.) Serninis dorfun. e.) Ejusdem pars ventralis. F.) Albumen transverfe (edum. G.) Ejusden reatio lougitudinalis, cum fitu etnbryonis. If.J Embryo feparatus.

Videtur ad Stellatas pertincre, \& prope a Pfychotria abefle. 
Tab.XXVI

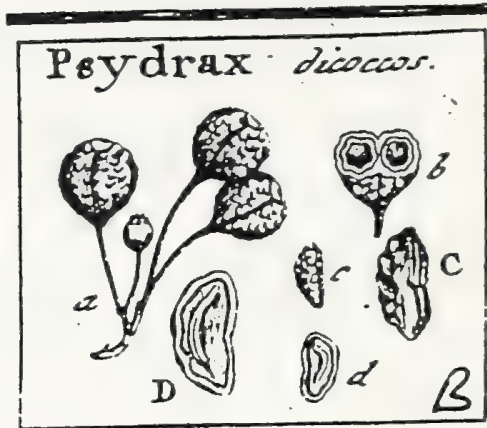

J. Gaertner (1/8\%) Vol. I

\section{CXLLX. PSYDRAX.}

Calyx quinque dentatus fuperus. Cor. quinquefida. Stam.... Styl.... Bacca infera, bilocularis, dipyrena. Embryo fubcurvus.

PSY DRAX dicoccos. Tab. 26. fig. 2.

Dicoccos zeylanica althea flore. P. HERMANN, in fchedula, fructibus his in loort. lugdb. anervatis, adjecta,

PER. Bacca inferra, obovata, transverfe latior, utrinque fulco depreffo infcripta, fupra; area planiuscula a lapfu fioris notata, carnofa, tuberculata, nigra, bilocularis, dipyrena. Caro fungola. Oflicula oblonga, urrinque fubacuininata, hinc convexa, gibba, rugato ferupofa, inde glabriuscula, fulco lineari. prominulo, \& in medio ejus umbilicali foveola notata.

REC, nullum: pyrenx, carni baccx arcte adnatx; lemina vero pyrenarum cavitatern exacte replentia.

SEM. unicum in fingulo officulo; ferrugineum.

IN $\tau$. fimplex, membranaceum, facile fecedens.

$\Lambda$ L B. Cenini conforme, amygdalino-carnolum, album, extus, ab impreflionibus pyrenz, varie fcrobiculatum.

Е м в. dicotyledoneus, inverfus, filiformis, prope dorfum abuminislocatus, figmoideo curvatus, lacteo albus. Cotyl. lineares, planiufculz, longz. Rad. cotyledonibus paulo brevior, teretiuscula, fupera, purpurascens.

a.) Racemulus cum baccis, magnitudine naturali. b.) Bacca difiec(a. c. C.) Ofliculum Separatcm d. D.) Ejus fectio longitudicalis cum albumiuis \& embryonis figusa \& fitu saturali 


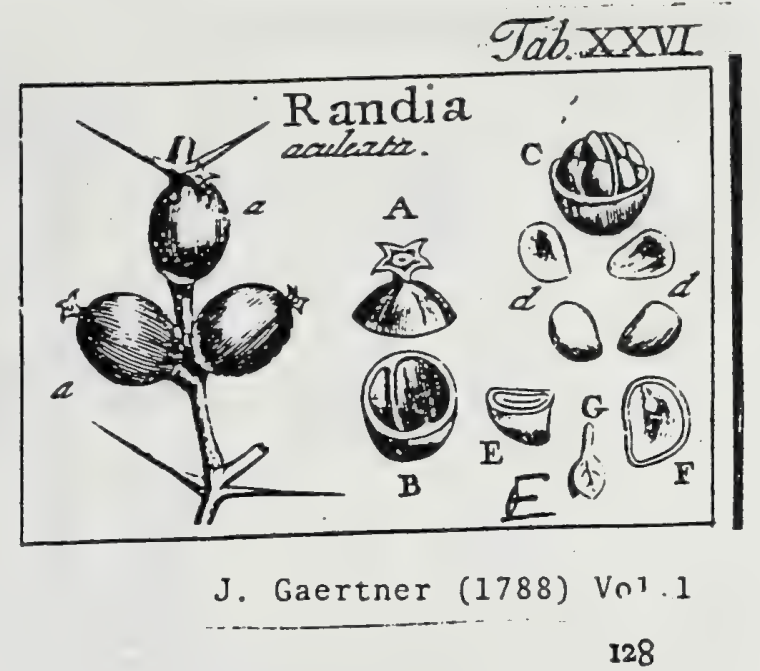

CLIII. RANDLA. LIN . gen. 211.

Calyx fuperus, quadri-l. quinquedentatus. Cor. monopetala: limbo quadri-l. quinquefido. Stam. quatuor aut quinque. Styl. unicus. Bacca infera, coriacea, bilocula. ris. Semina plura.

RA ŃDis aculeata. Tab. 26. fig. 6.

Randia foliis fubrotundis confertis, fummis ramulis bispiniferis, floribus folitariis. B R OW N. jam.t. \&.f. $\mathrm{I}$.

Randia ramis bispinofis. Lin s. fijf. veg. 197 .

E collectione Bankfiana.

PER. Bacca infera, ovato globola, calyce perfifente coronata, atra', bilocularis. 'Cor: tex coriaceus, craffiusculus, evalvis. Caro pulpola, mollis. Diffepimentum tenue, membranaceo carnofum, per maturitatem a lateribus corticis fecedens, remanen: te tamen fulco elevato, loculmnentorum terminos definiente.

REc. nulluin, prater fubftautiain pulpofam, cujus ope femina parietibus diffepimenti utrinque affiguntur.

SE巛. in fungulo loculamento quatuor aut quinque, furfum incumbentia, ovata, gran.) diuscula, hine leviter convexa, inde plana aut concava, nigricantia.

INT. duplex: exterius coriaceuın, craihusculum; interius membranaceum.

$\Lambda$ Ł в. femini conforme, carnolum, duriusculum, obscuri \& forfan in recentibus feminibus viridis coloris.

E M B. dicotyledoneus, inverfus, dimidio albumine brevior. Cotyl. ovato acuminatx, foliacex, venofx. Rad. teretiuscula, recta, fupera.

1.8.) Bacea integra. A.) Cajyx perifiens. B.) Cortex eam fulco, eal diffepimentom infertate C.) Semina diffepimento affixa. d.d.) Semina foluta, ab utroque latere fpetata. E, Semen trants veríe fetum, F.) Ejusdem \& abuminis fertio longitudinalis, cum fitu embronis. G.) Embrin reparatus.

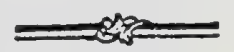

Non liquet, cur IINN $\mathrm{I} \cup \mathrm{S}$ 1. c. baccam dixerit: unilocularem, cortice capfulari; nam diflepincatum inanifeftum adfit, contra vero, valvula aut divifiouis in cortice nullum prorfus reperiatur veftigium. 


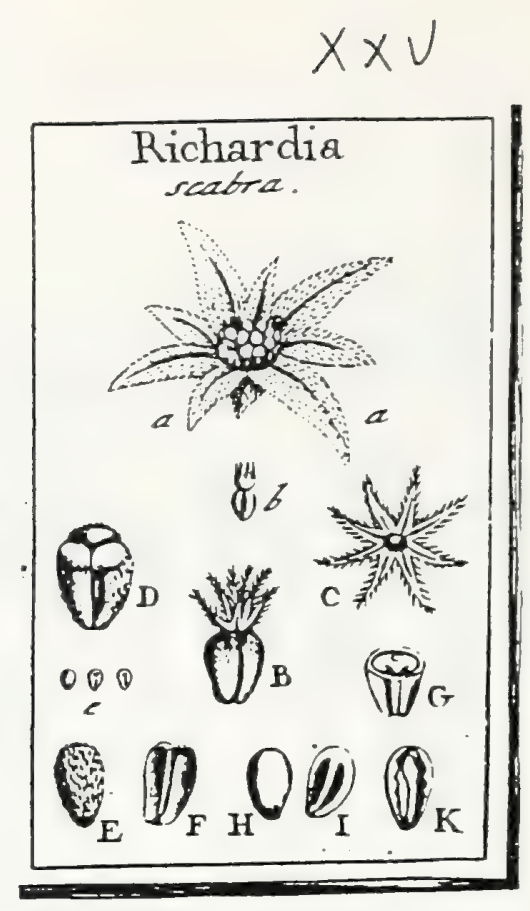

Rubiaceae

\section{J. Gaertner (1788) Vol.1}

\section{RICHARDIA. LIN gen. 439. 123}

Calyx fex-l. odtopartitus, hifpidus, fuperus, longitudine fructus: Cor. monopetalz, fubcylindrica. Stam. Fex L octo. Styl. unicus trifidus. Fructus inferus tripartibilis. Semina folitaria.

\section{4}

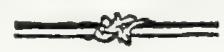

R I С н A D IA fabra. Tab. 25. fig. II.

Richardia. LI N N. Syfl. veg: $34 I$.

Ex herbario Bankliano.

PER. Capfula infera, coropofita, tricocca, inverfe conica, fubtrigona, trilocularis; tripartibilis. Cocculi coriacei, evalves, oblongi furlum craffiores, hinc con̨vexi, fcabri; inde glabri, angulati, in fulcun longitudinalem prominentes.

REc. commune nullum, prater fulcuin medium, cujus ope cocculi inter fe colixreat; proprium pariter nullum; fed femina bafi affixa.

SEM. in fungulo cocculo unicum, obovatum, rufefcens, hinc convexum, 'glabrum; inde fulcis duobus depreflis cum fria media elevata inferiptum.

IN T. fimplicițnum, tenuiftunum, arcte adnatum.

A L B. femini conforme, fubcartilagineum, durum, pallidum.

E м в. dicotyledoneus, erectus, dorfalis, longitudine albuminis, lacteo albicans. Cotyl. ellipticx, breves, foliacez. Rad. longa, comprefta, linearis, leviter curvatz, infera.

2. 2.) Capitulam terminale ex verticillo foliorum laneeolatoram, feabroram, fruAus fertiles cingentium, b.B.) Fruttus feparatus integer. C.) Calyx explanatus, D.) Frutus f. Capfula tricocca, cabyce fuo orbata. E. F.) Cocculus feparatus, ab utroque latere fpefatos. G.) Ejusdem atque ieminis fectio transverfalis. H. J.) Semen ab utroque latere (pectatum. K.) Embryo in dorfo albuminis.

$\mathrm{Ob}$ rationes unodo fupra dictas etian hunc fructum_ ad cappulares, referinnus. 


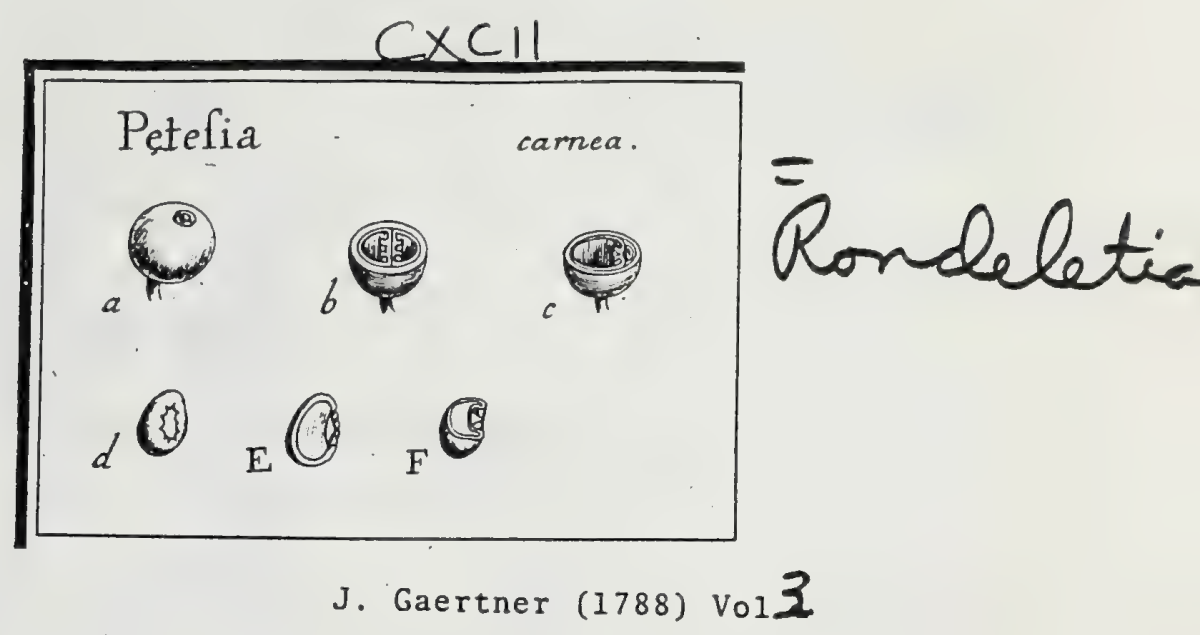

56. P E T E S I A. - 66

Brown. jam. t. 2. f. 3. LINN. gen. 133. ed. Schreb. 170.

Juss. gen. p. 199 .

Cal. monophyllus, fuperus, parvus, quadridentatus, deciduus. Cor. monopetala infundibuliformis; limbo ampliato, quadripartito. Stam. quatuor; fila." mentis brevibus, fundo tubi inferris; antheris oblongis, in fauce corollz hærentibus. Ovar. inferum; ttylo fimplici; ftigmate bifido. Bacca dipyrena; pyrenis monofpermis. Recept. ovato-cupulatum. Sem. menifcoideo-umbilicats.

Pétrsis carnea. Tab. 192. fig. 1.

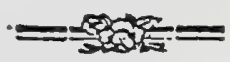

Petefia folits oblongo lanceolatis levibus: cynis terminalibus trifidis. Forst. prod n. 51. WILLD. Spec. pl. T. 1. p. 613.

Ex herbario R. Fonster, quod runc in mufeo Cel. Lambert Londini aljervatur.

P в в. Bacca infera, parva, globofa, pifformis, calycis rudimento denticulato cum epidermide continuo coronata, \& intra illum areola parva in cujus centro papillula callofa notata, pedunculata, atro-corulea, dipyrena. Caro debilis, firma, farinofo-pulpofa. Pyrenz fublemticulares, alters plerumque abortiente, fubellipticx, vel ad verticem paululum attenuatx. coriacex, monofpermx.

REc. cupula membranacea, oblonga, parti ventrali planx pyrenx in centro adnata, limbo autem hilo feninis immerfa.

SEM. in fingula pyrena fingulum, fubellipticum, totam pyrenz cavitatema replens, dorfo converum, ventre planiufculum, menifcoideo-umbilicatum 1. hilo magno pro recipiendo receptaculo inftructum, \& intra illum umbilico converiufculo fungofo albo notarum, fufcum.

IN T. duplex: exterius membranaceuin, crafrufculum; inserius tenuifimum, arachnoideum, albumini arctilfme adnatum.

A LB. ad umbilicum concarum, cxeterum femini conforme, cafeofum, ferrugineo - fufcum.

EMB....

\section{EXPEICATIO FIGURE.}

2.) Batca integra. b.) Eadem transwerfe diftecen cum pyrenis \& receptaculis in fitu. c.) Fadem pyrenz altera abortiva. d.) Semen (cparatum a ventre freetatum E.) Albumen longitudinatitor \& F.) Idem transverle fedums.

Albumen in maturo Femine procul dubio cartilagineum? 
J. Gaertner (1788) Vol 3

$T_{a b}$. CLXXXIV.

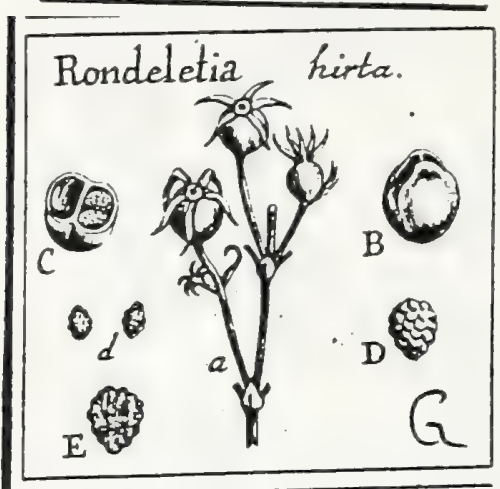

J. Gaertner (1788) vol3

33

\section{I. RON D E L E I I A.}

PIUdr. gen. t. 12. LinN. gen. 224. ed. Schreb. 296.

Juss. gen. p. 201.

Cal. Superus, quinquefidus, perfiftens. Cor. infundibuliformis, fauce ventricofa: limbo quinqueparcito, obtufo, plano. Stam. quinque. Ovar. inferum. Styl. fimplex. Capf. infera, fubglobofa, coronata, bilocularis, apice dehifcens. Ser. duo 1. plura in fingulo loculo.

Rondeletia hirta. Tab. 184. fig. 7 .

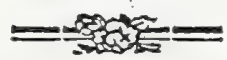

Rondeletia foliis petiolatis ovato - oblongis acutis pilofis - paniculis trichotomis axillaribus. Ait. bort. Kew. I. p. $2=7$.

Rondeletia foliis oblongis aciminatis •birtis rigidis fubtus nervofis, pedunculis axillaribus tricliotomis erefitis. SWARTZ prodr. 41. fl. ind. occid. I. p. 373. Willd. Spec. pl. T. I. P. 2. p. 933.

A Cl. Thunbehg.

PER. Capfula infera, fubglobora, coronata, coriacea, bilocularis, ab apice ad nedium dehifcens. Difepimentum valvis contrarium, tenue.

REC. nullum; femina umbilicis fuis diffepinento utrinque affixa.

SEN. duo, aut per abortum folitaria in fingulo loculo, irregulariter angulata, fcrupofa feu tuberculis atque foveolis inordinate fcabrata, a latcre diffepimeuto contiguo, minutifíno umbilico notata, fordide fufca.

Ix T. fimplex, membranaceum, tenue.

A L B. fenini conforme, cafeofum, nigro-furcum, opacum.

EXB....

\section{EXPLICATIO FIGURE.}

2) Pars saeemi frogiferi. B.) Capfula calrce fwo exuta; apice dehifcens. C.) Ejus fecio eransverfalise-d. D.) Semina feparata. E) Albuninis fectio longitudinalis.

Quanvis omni adhibita diligentia \& inftituta multiplici albuminis fectione, tamen neque in hujus neque in alterius fpeciei, fub nomine Kondelecix virgate milf:, Seminibus ullum embryonis veltigium detegere potui." Hinc fufpicor, femina frequentius. effe calla, \& embryonem ex nunutilimis. 


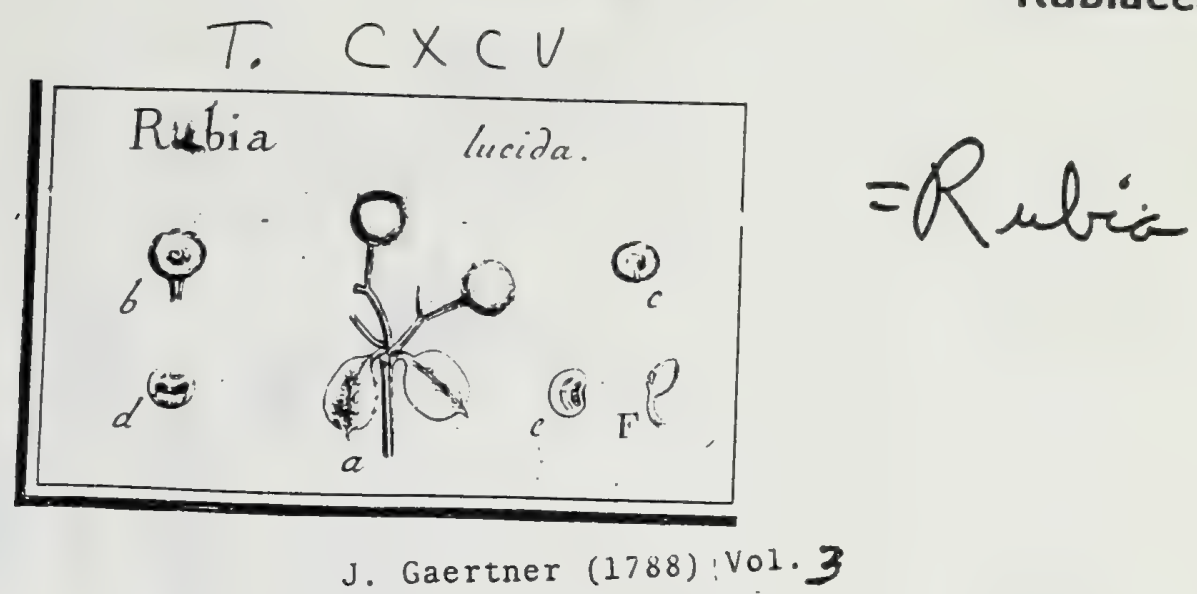

\section{RU B I A. 85}

Tourn. infi: t. 38. LINN. gen. $12 \%$. ed. Schreb. I64

Jíss. gen. p: 197. LA BABCK ill. gen. $t 60$

Cal. fuperus, minimus, quadridentatus, deciduus Cor. monopetala, camprnulata, quadri - (rarius tri-1. quinque - 1. fex-) partita. Stam. 4. (rarius 3.1. 5. . 6.) filamentis fubulatis, corolla brevioribus. Ovar. inferum, didymum, fylo fuperne bifilo \& Atigmatibus capitatis propilatum. Semina duo, baccaca, infers. Alb. menifcatum, fubcartilagineum. Emb. dorfalis, cotyledonibus leviter plicatis.

RòBIA lucida. Tab. 195. fig. 4

Rubia foliis perennastibus fenis ellipticis hucidis caule levi. IINN. fyff. nat. ed. rs.' p. 732. Syf. veg. ed. 14. p. 552 . Spec. pl. ed. Willd. T. 1. P. 1. p. 605. E collectione Cel. Despontaines.

P \& R. nullum; nifi cuticulam atro-coruleam fubcarnofam femina obtegentem fumas.

R E c. nullum; femina pedunculo infidentia \& Gbi invicem in pariete ventrali jundas.

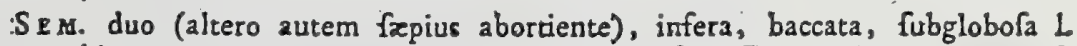
hinc convexa, inde planiufcula \& in centro foveola rotundarà excavata, L menifoideo - umbilicata, funiculo brevifimo umbilicali ad bafin partis ventralis inftricta, atra.

Iพ I. Cimplex, merabranaceum, validum, albumini arctifime adnatum:

A L B. femini conforme, menificoideo-umbilicatum, l. loculamento fpurio ercavatum \& umbilici difco claufum, fubcartilagineum, cinereum.

Ex B. dorfalis, erectus, curvatus, albus. Cotyl. ovatx, fubfolizcex, leviter figmoideo-plicatr, incumbentes marginibus dinotis. Rad cotyledones longitudine rquans, teretiufcula, cum cotyledonibus incurwa, ॠix Senfbiliter clavata, inferz.

\section{EXPLICATIO FIGURE.}

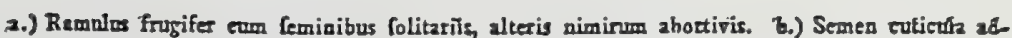
the veftinum, \& a parte ventrali (petatum. c.) Idece a cuticula \& 2 carne denudatum. d.) AL

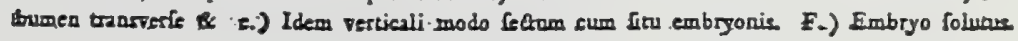




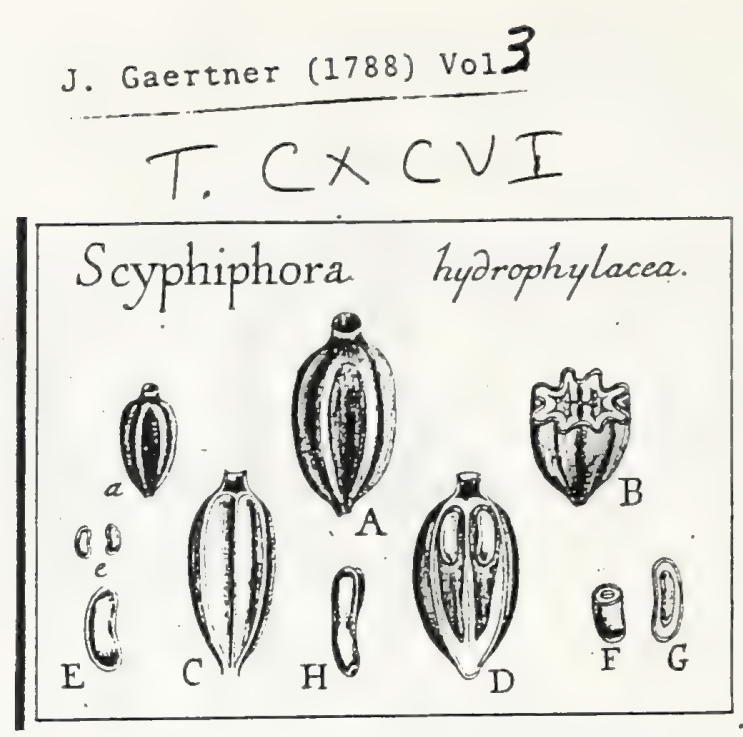

J. Gaertner (1788) Vol.Z

\section{S C.Y P H I P H O R A. Haentrenf.}

Cal. monophyllus, fuperus, cylindraceus, brevis, truncatus, integerrimus. Cor.... Stam.... Ovar. inferum. Bacca parva, exfucca, octo fulcata, dipyrenas pyretus monofpermis. Sem. oblonga, curvula. Alb. carnofum. Emb. erectus, centralis, curvulis.

Scrphiphora hydrophylacez. Tab. 196. fig. 2.

Hydroplylax. Collect. BankGan.

P \& R. Drupa ficca, parva, ublonga, compreffiufcula, fulcis octo longitudinali. bus infculpta, infera, calyce truncato membranaceo coronata, dipyrena. Caro fubcrofo-amylitces, exfucca, epidernide valida glabra tecta, albida \& pyrenis arcte adnata. Pyrenx oblungx, hinc fulcis elevatis acutis infignitx, inde fibi approximatx planiufculx, \& linea internedia longitudi. rali inforiptx, fubollex, rufefcentes, uniloculares, monofpernix.

$9^{2}$

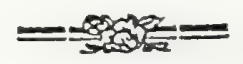

R B C. nullum; pyrenx in axi drupx fubftantia cellulofa junctx; ad apicem vero \& in bafi fibi arcaius adharentes; fenaina funiculo umbilicali deftituta.

SEM. folitaria, in fumma pyrenarum parte locata, reniformi-oblonga 1. leviter incurva, teretiufcula, utrinque obtufa, lutefcentia.

Is T. Gmplex, membranaceum, tenue.

A L B. femini conforme, carnofum, album.

E $\dot{M}$ B. cum albumine concentricus, oblongus, erectus, teretiufculus, leviter curvatus, albus. Cotyl. oblongx, plano-convexz, radicula paulo latiores, obtuffifimx, -sccumbentes. Rad. cotyledonibus paulo longior, leviter curvata, conico-teretiufcula, ad fcapum paululum gracilior, obcufa \& ad apicem macula obfcura notaca, infera.

\section{EXPLICATIO FIGURE.}

3. A.) Drapa integra azturali \& anda maznitudinc. B.) Eadent transverle diffeca. C.) Pyrega ab alterz foluta, carne \& epidermidle alluc veftita. D.) Pyrenz verticub godo dificets

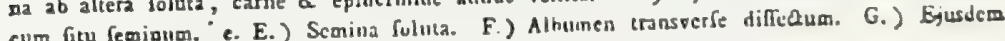
fettio verticalis cum fitu embryonis. H.) Embryo fulutus, valds audus. 


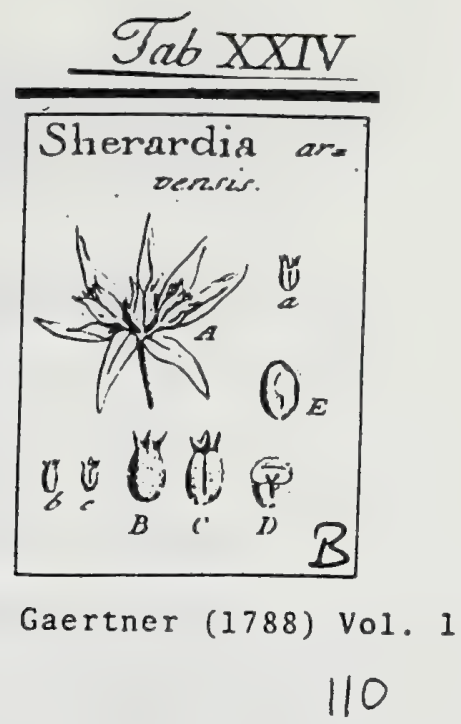

CXXX. SHERARDIA. DiLL. LINN. gell. I2O.

Calyx quadridentatus, perfiftens. Cor. infundibuliformis, Jonga. Stam. quatuor. Styl. unicus. Semina duo, nuda, calyce perfinente coronata.

SHERARDIA arvenfis. Tab. 24. fig. 2.

Sherardia foliis Jenis lanceolatis, floribus Sefflibus umbellatis. HaL L. hift. I. n. 734.

Sherardia foliis omnibus verticillatis, floribus terminalibus. L I N N. J4 fl. veg. 148.

ICON. OE D E R. flor. dan. t. 439.

PER. nullum, prater cuticulam tenuiftunam feunina obveflicatem.

REC. nullum; femina coadunata, bafi affixa.

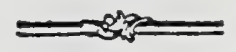

III

SEM. dtro, infera, ovata, calycis rupti denticulis coronata, fpadicea, fetis minutilfınis, apprefits confpera, hisc convexa, inde rima longitudinali, introrfum ampliata, exarata.

IN т. fimplex, membranaceum, tenue.

A \& B. Semini conforme, corneum aut cartilagineum, melinuns.

E 4 в. dicntyledonetrs, erceीus, dorfalis, lacteo albus. Cotyl. ovato-cordatz, foliacex. Rad. filiformis, curvata, infera.

a. 2.) Fructus terminales folioram verticillo cincti. b. B.) Seminis dorfum. c.C.) Ejusdem pars ventralis. D.) Albumen transverfe fectum. E.) Embryo in fitu naturali,

Sola feminis corona ab Afperula differt. 


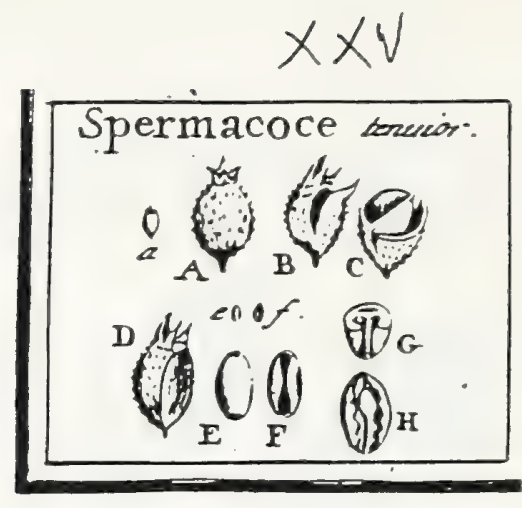

Rubiaceae

J. Gaertner (1788) Vol.1

\section{SPERMACOCE. LINN. gen. IIg.}

Calyx quadridentatus fuperus. Cor. monopetala infundibuliformis. Stam. quatuor, StyL unicus. Capfula infera, bilocularis, non bipartibilis. Semina folitaria: uarginibus in ventrem convolutis.

SPERMA C OCE tenuior. Tab. 25. Fig. 9.

Spermacoce verticillis tenuioribus. DIL1. h. elth. 370. t. 277 .

Spermacoce glabra, foliis linearibus, faminibus inclufis, floribus verticillatis. LIN S. Jyft. veg. I 48 .

PER. Capfula infera, parvula, hirta, quatuor calycis dentibus coronata, crufacea, rigidula, bilocularis, non bipartibilis. Loculamentum alterum claufum; alterurn dehiscens ad medium ufque fax longitudinis, valvulâ unidentará.

REc. nulluin, prater cicatriculum prope bafin dillepimenti, cui femina affixa.

$S_{E M}$. in fingulo locularnento unicum, parvum, ellipticụn, ferruginenm, hipe convexum, glabrum, inde, ob margines in ventrem couvolutos, concavum.

INT. fimpliciffumum, tenuiffmum, arctiflune aduatum.

A l в. femini conforme, cartilagincum, durum, aqueo pallidum.

Еив. dicorylcioneus, erectus, dorfalis, curvatus, Lacteo albus. Cotyl. elliptica, foliacez. Rad. filiforusis, infera.

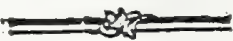

2. A.) Capfula integra. B.) Eadem deliscens, C.). Ejus fetio transverfalis. D.) Loculamentem claufum. e. E.) Semiols dorfun. (. F.) Ejus venter. G.) Albumen transverfe (eatum. H.) Embryo in dorfo renimis.

Nefcio anne fingularis ifte dehifcendi modus, quem in omnibus meis fpeciminibus reperio, fit raturalis \& anne buic fpeciei proprius, utrumve mere fit fortuitus? id autem certius fcio, quod capfula, vel cultro tentata, bipartibilis non fit: 


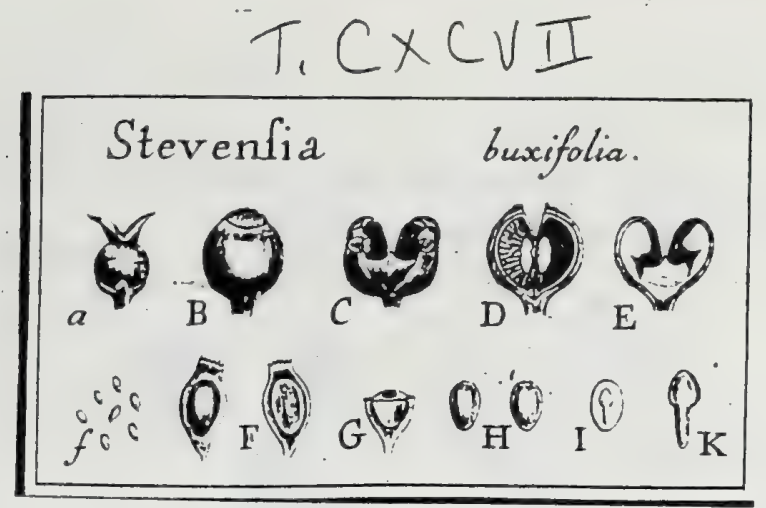

80. S T E V N S I A.

PoIr. Annal. muf. par. hift. nat. 4. t. 60.

Flos bafi bracteis quatuor calyciformibus perfitentibus, duabus oppofitis paulo majoribus, nunitus.

Cal. Superus, bipartitus: laciniis lanceolatis, patentibus, deciduis. Cor. monopetala, tubulofa, extus pubefcens: tubo cylindrico, ad faucem vix ampliato, longitudine cillycis; limbo 6. 1. 7. partito: laciniis oblongis, öbtufis, reflexis. Stan. 6. I. 7., feflilia, ad faucem corolla inferta; antheris fubulatis, erectis, bilocularibus, non exfertis. Ovar. inferum; ftylo fimplici, filiformi, longitudine corollx; ftigmate bilamellato: Jaminis ovatis, patentibus. Capfula infera, ex duobus cocculis corticatis polyfpẹrmis compaginata, quadri-

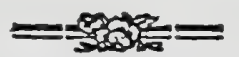

variam dehifcens. Rec. fungofa, lenticularia. Sem. membranacea 1 bracteata, horizontalia. Alb. carnofum. Embr. rectus, rad. centripeta.

Stzvensia buxifolia. Tah. 197. fig. 2.

Stevenfia. Poiteau Amal. mus. parif. bif. nat. 4. p. 235. Persoon fymo pl. I. p. 392.

Ex dono $D^{\text {ni }}$ Qoitenu.

Pex. Capfula parva, globoða, 1. ovata, bafi bracteis quatuor calyciformibus perfiftentibus infiftens, in vertice autem calyce bipartito ante plenam maturitatem deciduo poftea vero area lata villofa coronata, fufca, albido pruinata, corticata, quadrivarian dehifcens, dicocca. Cortex coriaceus, tenuis, cocculis arcte adnatus. Cocculi duo coadunati, fuborfei; hinc convexi, \& ad-bafin ufque dehifcentes; inde plani \& cum altero cocculo leviter cohxrentes, ante dehifcentiam puncto callofo, cui receptaculunı affixum, in centro notati, poft maturitatem vero a dehifentia dorfili fere ad bafin ufque in duo crura dilacerati, remanente in medio lanina libera apiculata.

Rzc. in utroque cocculo fingulum, puncto callofo in centio partis planx cocculi affixum, fungofum, lenticulare, hinc convexum, inde planiufculum \& eleganter radiato-ftriatum, deciduum, fufcum.

SE s. parva, numerofa, bradeata, horizontaliter fibi incumbentia, longe elliptica, margine menbranaceo angultifino ad apicem denticulato \& paulo latiore, ad bafn vero iis unguem attenuato cincta, hinc convexa, inde planiufcula nucleo in medio leviter protuberante, ferrugines, 1. e rufefcenti lutea.

Is T. duplex : exterins fpongiolo-membranaceum, in marginem feminis productum, facile detrahendum; interius arachnoideun, tenuiltimum, albumini arctilsine adnatum.

A L B. ellipticun, lenticulari - compreffun, duriufculum, carnofum, pallidum.

EM B. rectus, parte inferiore albuminis vix propior, oblongus, niveus. Cotyl. fubfoliacex, ovatx, difcretx, incumbentes. Rad. cutyledonibus vix longior, rceta, conico-teretiufcula, obtufa, umbilico cxterno obverfa, centripeta.

\section{EXPLICATIO FIGURE.}

a.) Caplula integta, calsce polf maturitatem deciduo coronata. B.) Eadem a calyce \& ftipulis bafilaribus denudata. C.) Eadem dehifcens. D.) Ejusdem \& coeculorum fertio verticalis cum futu receptaculoruun atg̨ae femiuum. E.) Cocculus feparatus debifcens, a parte interna plaus fpettatus. 6.) Semina folutz. F.) Eadem a parte fuperiore \& inferiore fpecata. G.) Semen medio sransverfe diffeaum. H.) Albumen fepzratum. I.) Ejusdem feeio verticalis cum fin embryoujs. K.) Embryo folusus.

Pracl. PoItea J I. c. aliam paulo embryonis figuram tradidit, a noftra diver: fam; at in plurimis, qua diffecui, feminibus talem embryonem femper 


\section{J. Gaertner (1788) Vol.3 \\ Tab. CXCII.}

Rubiaceae

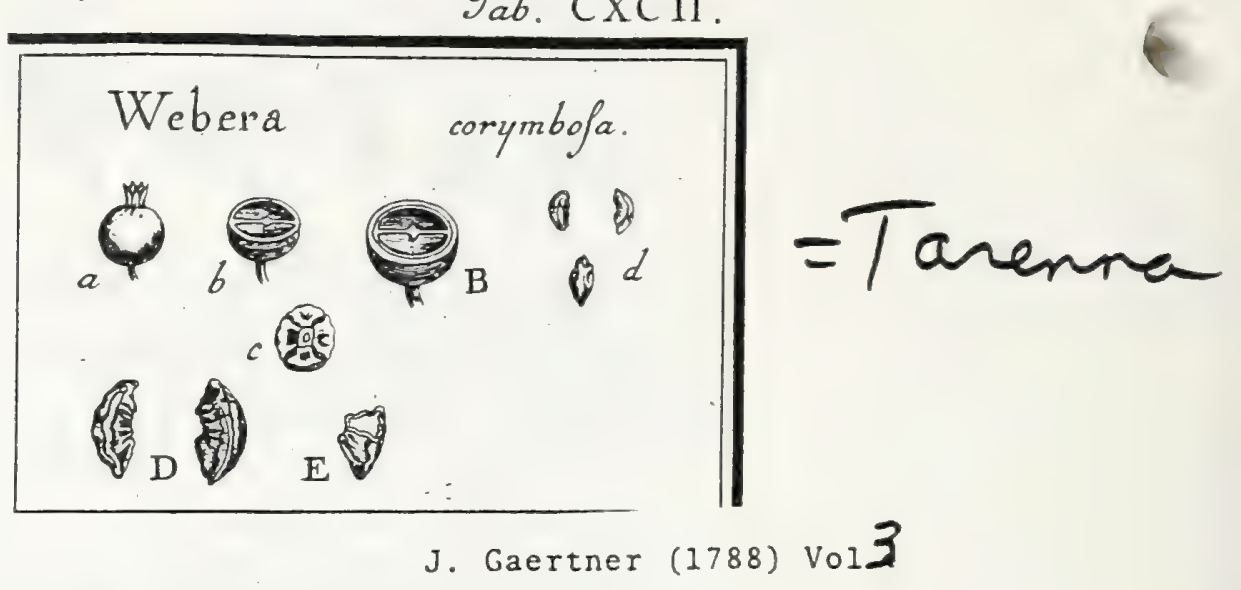

\section{W E B ER A.}

Sснвев. gen. I733. Chomelia Linn. gen. ed. 2. n. I67.

Cal. monophyllus, fuperus, quinquefidus; laciniis erectis, acutis, perfiftentibus. Cor. monopetala infundibuliformis; tubo longo, ad faucem fenfim ampliato; limbo quinquefdo, laciuiis ovato-oblongis, acutis, recurvis; in. ferne medio villofis. Stam. quinque; filamentis breviffimis; antheris linearibus, apice membranaceis, Joculis in fuperiore latere fingulx antberx dehifcentibus. Ovar. inferum; ftylo unico, tubum fuperante, longitudinaliter friato; ftigmate oblique clavato, decangulato-alato. Bacca infera, globo$\sqrt{3}$, calyce coronata, bilocularis: loculamentis tetrafpermis. Recept. funga fum, in centro diffepimenti utrinque affixum. Sem. angulits, hilo infrues.

Wegera corymbola Tab. 192. fig. 5.

Crupi. RheEd. bort. mal. 2 . 37. t. 23 .

Roncteletia (afratica) foliis petiolutis oblongis acutis. LiNw. Jpec. pl. p. 244 Fl. 2e\%l. So. Syft. zeg. ed. 14. p. 212.

Webera inermis, folitis oblongis acutis, conymbo serminali. WILLD. Spec. pL T. I. P. 2 p. 3224.

Cantbium corynsboflim. TRRsoon fyn. pl. i. p. 200 .

E collectione Cel. Desfontaings.

Pzk. Bacca fphzrica, pifformis, infera, calyce perfiftente recto coronats, atra, bilocularis: loculis tetrafpermis. Caro debilis, frma, membrane chartaceze lutefcenti intus nitidx adnata. Dillepimentum chartaceum, cum loculamentis connatum, tenue.

REC. papillula parva, tetragona, breviffime pedicellata, fungofa, utrinque difepimenti centro adnata, femina inter fe connectens.

Sex. in fingulo loculo quaterna, cruciatim receptaculo ita affixa, ut unum bacce verticem, alterum ejus bafin \& duo reliqua latera dorfo fuo refpiciant, angulata, fubreniformia, hinc convera, inde cuneata \& ad umbilicum hilo inftructa, rugofa, rugis lateralibus ad unbilucum convergentibus, fufca pulpa tenui sara obducta.

IN T: fimplex, coriaceum.

A L B. femini conforme, cafeofum.

ENB....

\section{EXPLICATIO FIGURE.}

2.) Bacez integra, b. B.). Eadem transverfe feEa cum diffepimento \& receptaculi infertione. c.) Scmina cum receptaculo is fitu naturali. d. D.) Semina foluta. E.) Albumen transverle difictur

Seminum numerns naturalis in quovis loculo omnino eft quaternarius; fed de vero feminum fitu adhuc dubium reftat. RHERDE l. c. illum deferibit obliquum in formam crucis Andrexz \& in meis, immaturis quiden, $f_{\text {pecininibus fitus cruciatus videbatur erectus. Ii, quibus recentes baccas }}$ videre licet, dubium folvane. Canthium LAM. ab hoc genere diverfifimum.

Ne maximam in re botanica noninum confufionem adaugeamus, Webera nomen, a Cl. Schrebero inditum, retineri fatius efle duximus; quamvis jam in mufcorum ordiue exiftat geus, ab HEDWIGIO hoc nomine unfignitum. 
Rubiaceae

J. Gaertner (1788) Vol. 3.

Tab. CXCVII :
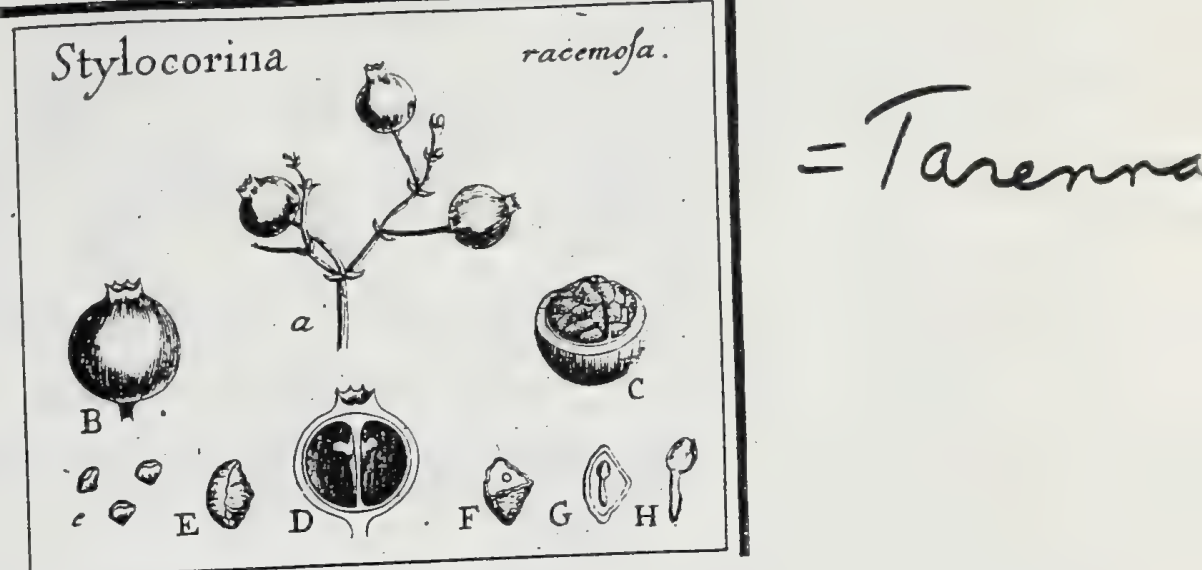

\section{8r. S T Y L O C O R I N A. \\ CAVAN. ic. 6. t. 368 .}

J. Gaertner (1788) Vol3

100

Cal. monophyllus, parvus, fuperus, turbinatus, ad limbum paulo corarcta: tus, quinquedentatus: dentibus brevibus acutis, incifuris rotundatis. Cor. monopetala, tubulofa: tubo fuucem verfus fenfim ampliato; limbo reflexopatente, quinquepartito: laciniis oblongis, acutis, tubo longioribus. Stam. quinque; filamentis brevilfimis, incurvis, fub incifuris corollie infertis; antheris longis, lineari-fubulatis, acutis, bafi emarginatis, exfertis. Ovar. inferum; ftylo fubclavato, longitudine ftaminum; ftigmate fimplici. Bacca gla bofa, calyce perfiftente coronata, bilocularis, polyfperma. Rec lanina truncita diffepimento utrinque inferta. Sem. plura, angulata. Alb. fubcartilagineum. Emb. longus, cotyledonibus obliquis.

STYLocorina racemora.

Stylocoring. CAv. ic. I. G

A Cel. A. L. de Jussied.

PER. Bacca parva magnitudine pif, globofa, depreffiufcula; fupera, calyce perfiftente coronata, corticata, bilocularis, polyfperma. Cortex carnofus, debilis, intus membrana tenui veftitus, Eavefcens. Diffepimentum membranaceum, tenue, a membrana interna profecium, integerrimum. Pulpa mollis, femina undique obvettiens, flavefcens.

REC. Lamina membranacea, diffepimento utrinque adnata, tenuis, angufto principio ad bafin baccex oriunda, fenfim increfcens atque paulo fupra medium diffepimentum terminata, ceu ramulo in loculamentum prominula \& ibi craffior in funiculos umbilicales brevilfimos pulpofos foluta.

SEN. plura, decem ad duodecim in quovis loculamento, parva, furfum imbricata, hinc rotundata, inde a viciniis varie angulato-cuneata, eninentiis minimis fcabriufcula, rufefcentia.

IN T. fimplex, craffiufculum, cruftaceum, ab albumine vix fecedens.

$\Lambda$ L B. Semini conforme, duriufculum, carnofum, l. fubcartilagineum, pallide lutefcens.

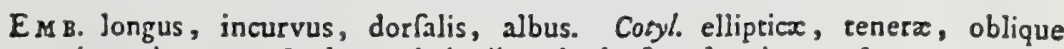
incumbentes. Kad. cotyledonibus duplo fere longior, recta, teres, fub tilifrme apiculata, vaga

\section{$=$ =90 \\ EXPLICATIO FIGURE.}

$10 x$

-i.) Pars reemi fruciferi, B.) Bacca intertr. C.) Eadem transverfe fecta cum feminibus is

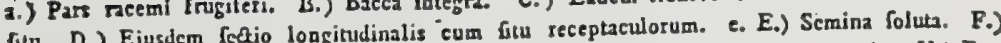
fitu. D.) Ejusdem feetio longitudinalis cum fitu receptaculorum. e. E.) Scmina foluta. F.) bryo folutus.

Albumen quoad duritiem fubeartilagineum, quoad fubftantiam vere carnofum.

Radicula ante plenain maturitatem videtur effe centripeta. 


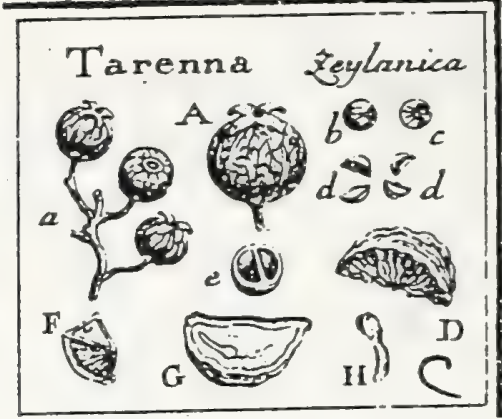

J. Gaertner (1788) Vol. I

\section{TARENNA.}

Calyx quadripartitus fuperus, Jaciniis lineari oblongis reflexis perfiftentibus. Cor... Stam. ... Styl.... Bacca infera, biloculatis. Semina plura, femilunata. Embryo dorfalis.

TArenia zeylanica. Tab. 28. fig. 3.

Tarenna. Zeylonens. E collect. fein. hort. lugdb.

PER. Bacca infera, calyce quadrifido patuio coronata, fphxrica, früis octo l. decem filiformibus notata, rugofula, atra, nitida, bilocularis. Caro in vetuftis fubcoriacea tenuis.

REc. fublantia fungolo carnola, diffepimenti medio utrinque adnata, femina in glomerem hemifpharicum colligens, \& diflepimento affigens.

SEX. in fingulo loculamento quatuor 1. fex, transverfe f. horizontaliter pofita; bine arcuata, crafiora, inde cuneiformi comprefta \& in aciem rectann extenuata, rugo〔a, atra.

IN T. duplex : exterius craffum, cruftaceum, aridum; interius membranaceum pallide Spadiceuin.

A L B. Femini conforme, carnolum, album.

EMB. dicotyledoneus, horizoutalis, dimidio albumine brevior, \& in curvato ejus dorfo locatus, lacteo albus. Cotyl. fuborbiculatx foliacex. Rad. coryledonibus duplo longior, teretiuscula, curia, verfus peripheriam diffepimenti direeta \& a centro remotifima.

2.) Portio cyma ramolifima, cum baccis (2. A.) integris. e.) Bacca transverim (efta. b.) So ininum acervuius hemifp'ixricus, a parte convexa (pextatus, c.) Iden a parte plans reprafentatux, cum portione fubnanciz fungofx in medio, qu.e femins connetit. d. D.) Seusina foluth F.) Semen transverfe folum, cum radicula prope dorfum locata. G.) Ejusdeat fetio longirudinalis, cum fitu embryonis intra albumen. It.) Enbryo Separatus.

Singularifima en pofitio radicularum in hoc fruclu baceato, atgue illi in filiquis quodammodo analoga: nempe primi feminis radicula dextram; fecundi, finifran; tertii ircrum dextram, \& fic porro, refpicit; atque id tanto magis fungulare, quod femica centro, ncc parietibus fructur aftixa fint. 


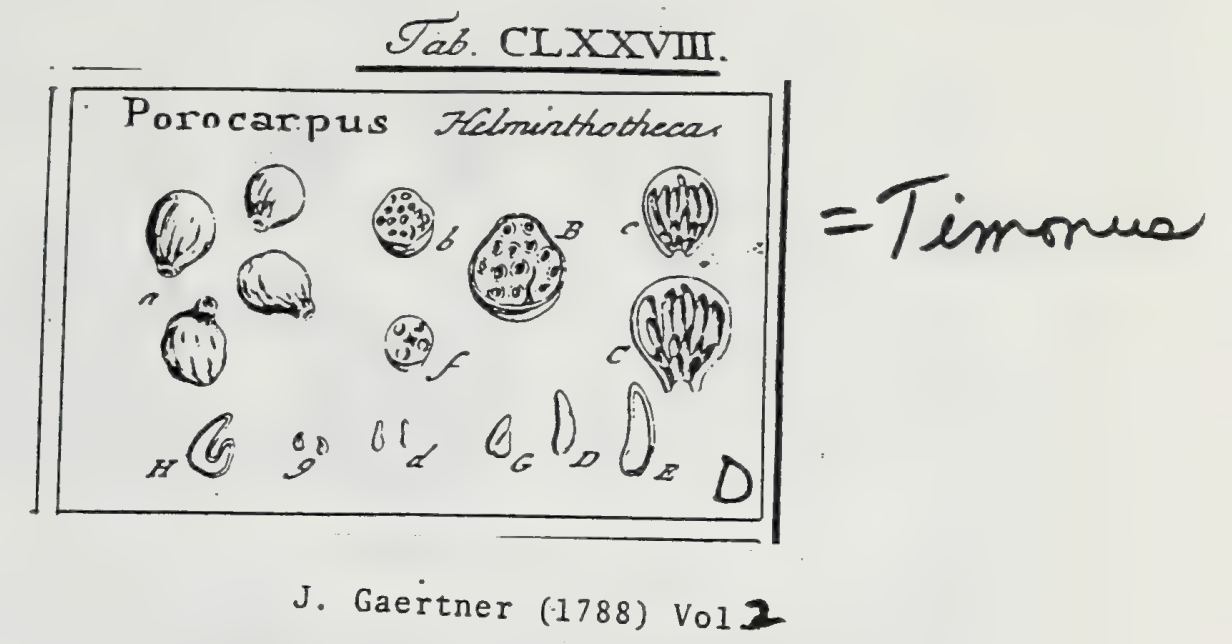

\section{P O R O C A R P U S. 473.}

Flus .... Drupa carnofa, putamine mulë̈oculari; loculamentis teretiufculis bafi confluentibus monofpermis.

Porocarpus Helninthotheca. Tab. 178. fig. 4 .

kette - kubula. Zeylonens. E collect. Sem. hort. Igdb.

PER. Drupa parva, obovato-globofa, gibbofa, rugufa, verfus bafin anguftata atque forani:ıe amplo pertufa, nigra. Correx in vetulto fructu tenuifri- mus. Putamen fublignofum, modice durum, fpadiceo fufcum, loculamen:is numerofis te:ceibus, juxta \& fupra fe invicem pofitis atque intus diftincta lamina albicalite veftitis, exfculptun, prope bafin, a confluentibus loculorum cxtremitatibus inferioribus, irregulariter cavernofum.

REC. nullum, proter fubltantiam pulpofam, putaminis cavitatem cavernofan replentem, e qua femina sutrinentun fuun hauriunt.

SEM. in fingula putaninis cellula fingulum, teretiufculum; fpadiceum.

Is.T. finplicilinum, membranaceum.

A L B. fenini conforme, carnofum, pallidum.

ENB......

2.) Drupx integiz, tarix magnitudinis atque formz, b. B.) Drapz transverfim feQz. c. C.) Ejusdim fotio verticalis. d. D.) Semen folutum. E.) Idem longitudiaaliter diffequm.

In eadem phisla; \& alii fructus, ejusdem quidem nominis, fed diverfilimx ac fequentis erant fabricx:

Drupa globofa (f.), magnirudine Pif, nigra, prxcedenti fimilis, fell bafi non adeo ample perforata. Cortex tenuis. Pummen lapideum, extus \& fracturà atrum, quadriloculare, ad axem cnnali angulolo perforatum (f): Semina (g. G.) folitaria, quafi conduplicara, angulata, nigricancia. Integ. limplex, arctilfime adnatum. Albumen $\left(H_{.}\right)$ femini confurme, carnofum, durum, aqueo-glincuin. Embr. perinde defuit. Hixc uon poteft cum priori unius effe generis naturalis. 


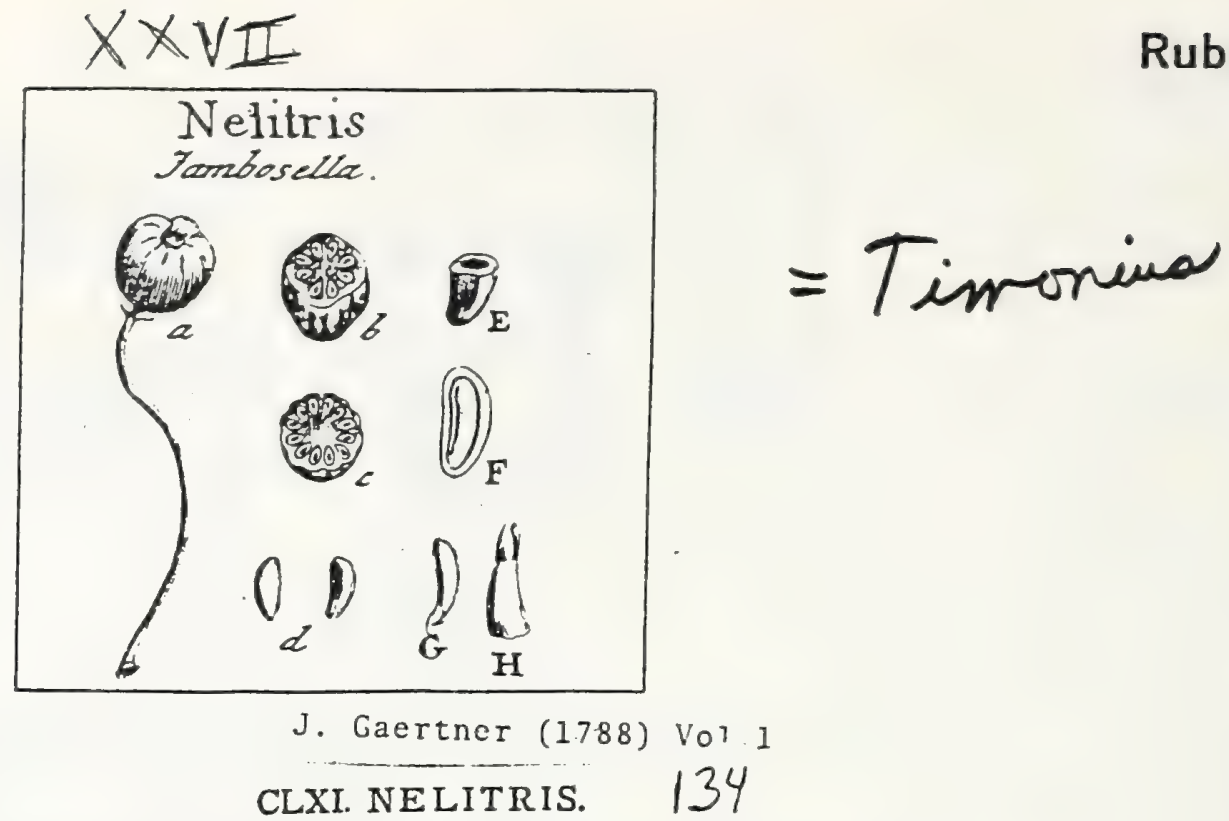

Calyx fuperus, quadri-1. quinquedentatus. Cor.tetra-1. pentapetala. Stam. plura.

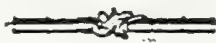

Styl. unicus. Bacca unilocularis polyfperma. Semina offea: embryone inverfo, clavato.

NeLitris Jambofella. Tak. 27. fig. 5.

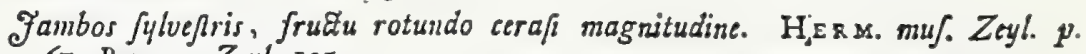
67. B U R M. Zeyl. I25.

Decaspermum fruticofum. Fors T. gen. n. 37.

Pfidium foliis ovatis acuminatis planis, pedunculis unifloris brafteatis. LINN: [y/l. veg. $46 x$.

Wal-jambu. Zeylonens. E collect. fem. hort. lugdb.

PER. Bacca fubglobofa, obfolete torulofa, carno 2 , unilocularis; fupra calyce floris quinquedentato coronata, infra definens in pedunculum longiffimum, prope bafin fructus, duabus Sipulis lineari acuminatis oppofitis, minutis, fiparum.

REc. nullum; femina undique carni baccx adnata.

SEs. plura, duplici lerse in orbem pofita: fuperiora octona; inferiora duodena aut plura: omnia oblonga, hine convexa, crafta, arcuata; inde recta, in angulum cuneiformen compreila; czterum fuboltea, pallide teftacea.

IN T. duplex: exterius cruftaceo offeum, craflum; interius membranaceum, tenuiflmum, rufefcens.

$\Lambda$ LB. nullum.

Eм в. dicotyledoneus, inverfus, albus, magnitudine \& figura feminis, Jevifime tamen curvart:s. Cotyl. minutulz, ovato lanceolatx, in imz feminis parte locatz. Rad. maxis a, oblonga, furfum craffefeens, fupera.

a.) Baca integra. b.) Eadem paulo infra verticers diffela, cum oftonis tantam in circulum pofitis Seminibus. c.) Alia ejus fettio circa medium, cum feminibus duoderis. d.) Semina Separata. E.) Seroinis tefta offea transverfe fectz. F.) Fijusdem fectio longitudinalis. G.) Embrjo desudatos in fta uaturali, H.) Ejus inferior portio teverfa, cum diductis paulalum cotyledonibus.

Parum utique en, quod a Guajava dillat; differt autem: $1^{\circ}$ Seminibus inverfis, nee in omnem fenfurn pofitis; $2^{\circ}$ iisden rectiusculis, nec reniformibas; \& $3^{\circ}$ plenario difiepimentoram defectu. 


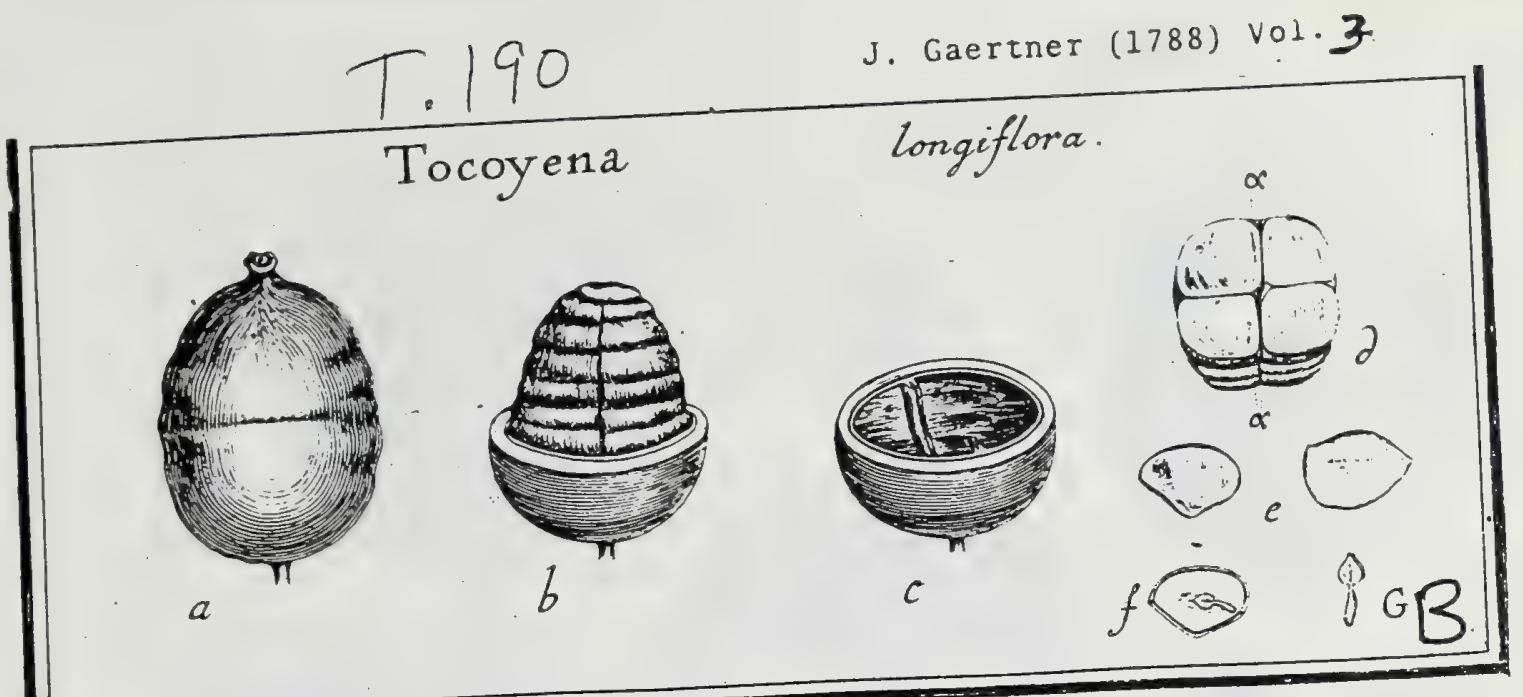




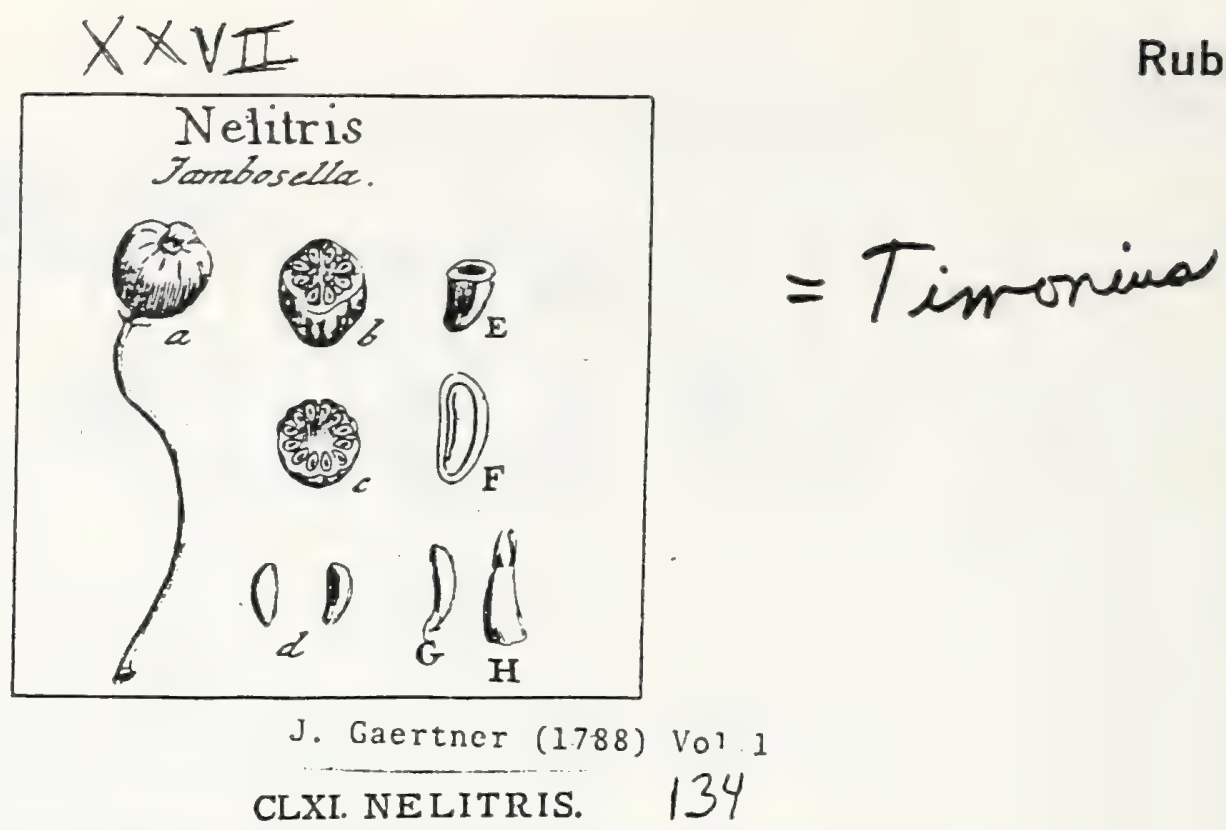

Calyx fuperus, quadri-1. quinquedentatus. Cor.tetra-1. pentapetala. Stam. plura.

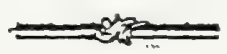

Styl. unicus. Bacca unilocularis polyfperma, Semina offea : embryone inverfo, clavato.

NeLitris Jambofella. Tab. 27. fig. 5.

Fambos fylvefris, fruău rotundo cerafi magnitudine. H, Ехм. muf. Zeyl. p. 67. B U R M. Zeyl. 125.

Decafpermum fruticofans. Fors T. gen. n. 37 .

Pfidium foliis ovatis acuninatis planis, pedunculis uniforis brafteatis. LINN: [y]?. veg. $46 x$.

Wal-jambu. Zeylonens. E collect. fem. hort. lugdb.

PER. Bacca fubglobofa, obfolete torulofa, carnoGa, unilocularis; fupra calyce floris quinquedentato coronata, infra definens in pedunculum longiflimum, prope ba. fin fructus, duabus nipulis lineari acuminatis oppolitis, minutis, fipatum.

REc. nullum; femina undique carni bacex adnata.

S ₹ s. plura, duplici lerse in orbem pofita: fuperiora octona; inferiora duodena aut plura: ornnia oblonga, hinc convexa, cralla, arcuata; inde recta, in angulum cuneiformen comprefta; cxterum fuboftea, pallide teftacea.

IN T. duplex: exterius crufaceo ofleum, craffum; interius membranaceum, tenuifimuin, rufefcens.

$\Lambda$ L B. nullunn.

E « в. dicotyledoneus, inverfus, albus, magnitudine \& figura feminis, levifime tamen curvatt:s. Cotyl. minutulx, ovato lanceolatx, in ima feminis parte locatz. Rad. maxina, oblonga, furfum craftefcens, fupera.

a.) Bacca interra. b.) Eadem paulo infra verticern diđefta, cum Qtonis tantum in circalum pofius feminibus. c.) Alia ejus feltio circa medium, cum feminibus duodenis. d.) Semira (eparata. E) Serwinis tefta oflea transverfe fecta. F.) Ejusdem fectio longitudiualis. G.) Embrjo denudatas in Gla saturali. H.) Ejus inferior portio treverfa, cum diductis paululam cotyledouibus.

Parum utique ef, quod a Guajava dillat; differt autem: $1^{\circ}$ Seminibus inverfis, nee in omnem fenfum pofitis; $2^{\circ}$ iisdem rectiusculis, nec reniformibos; \& $3^{\circ}$ plena rio dilfepimentoram defeclu. 
Rubiaceae

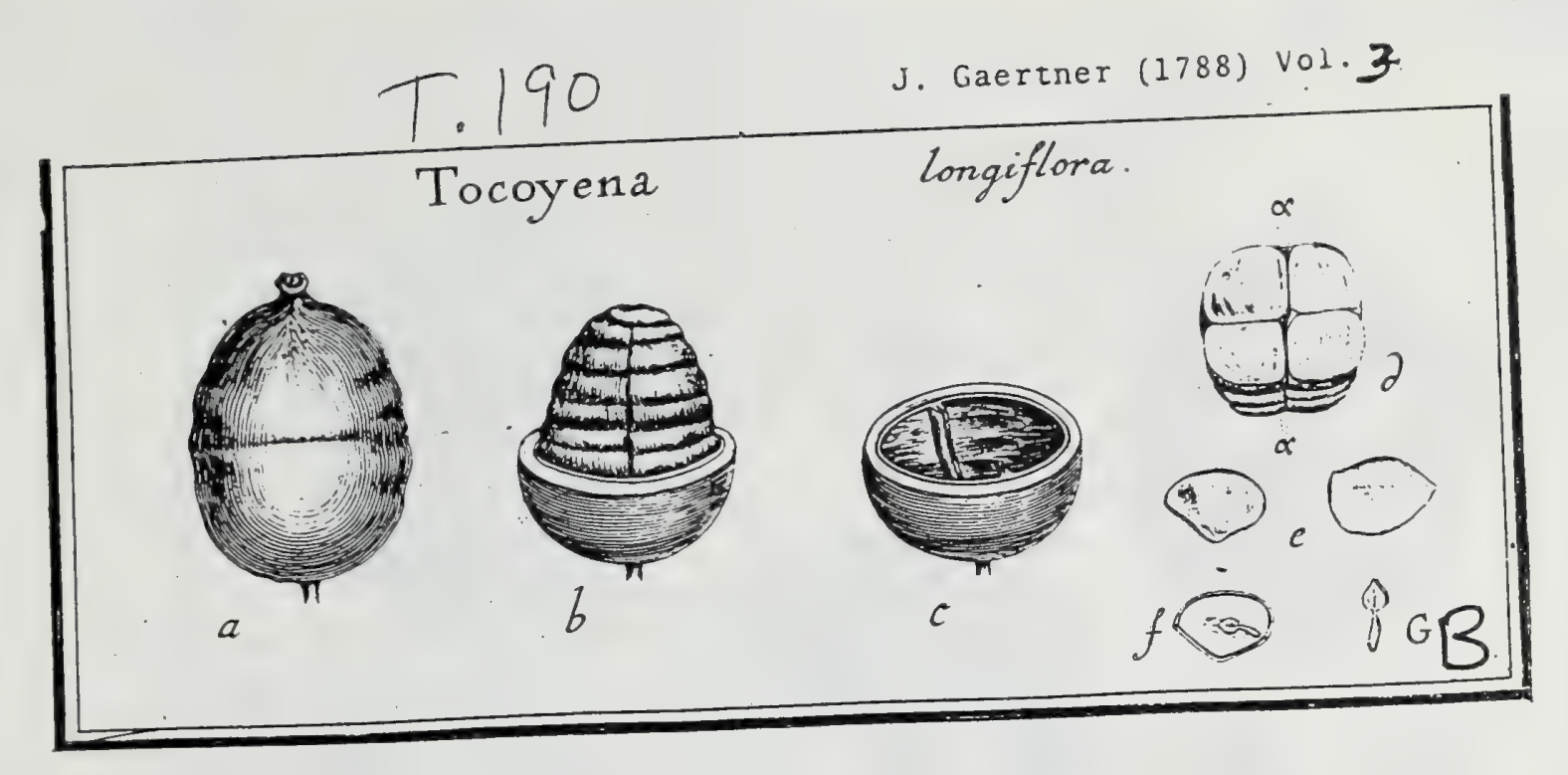

$180.82 \mathrm{~A}$ 


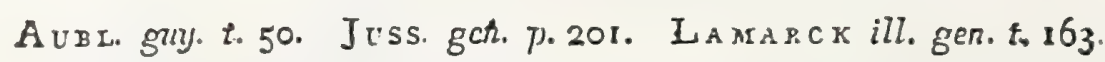

Cill. monophyllus, inferus, oblongus, turbinatus, quinquedcutatus, deciduus, bafi ttipulis duabus caducis ttipatus. Cor. monopetalla, tubulof:a, difco vr:trii. infulens: tubo longillimo, ad fatucen awpliato: Jimbo yuinquepartito. S:sn. quinque, in fauce corollac fubfenilia ; antheris xix cxlertis. Ovar. inferum; ftỵlo limplici longitudine tubi, fuperne incratlito, fub ftignate rurfim angulfato; ttigante bilobn, dancellnto, uvito, obtufo. Drupa ob. Jongat, baccité, calycis rudimento in vertice anfata, fubbilucularis, polyfperma. Sen. Itratis horizontalibus in pulpa in quatuor lobns difyolita, compreli. Alb. cirtilagineum. Enb. radicula criftid dilepimenti incumpleti utriusque lateris obverét.

Tocurene longitora. Tabe 190. fig. 2

Tocoyena. ACBL. gny. T. r. p. 13 r.

UCriasa. WVILLD. Spec. pl. T. I. P. 2. p. 961.

Icon ad exempla, in collectione Teminum Murei Paritienfis affervatz

QER. Drupa baccata, infera, nucis juglandis minoris nagnitudine, fubglobofa 1. oblunga, hinc pedunculo brevi infiatens, inde rudimento calycis capitellato denrelfo faltigita, $\&$ intra boc areo! a callofia atque in hujus centro puncto excatvato notata, ad quatuor onpofitil latera ab imprelfionibus feminum transverle undulato. noitofa, flavefcens, fubbilocuiaris. Caro debilis, duriufcula, flusefcens. Putamen ca fibris olleo-Jignofis compaginatum, 1. offeo-coriaceum, figura drupx, tenue intus levigatifinum. Diffepimentum incompletum, anguftifinum, bif.lum, cum putamipe arślilinie conferruninatum.

REc. nullum; femina ante maturitaten funiculis umbilicalibus, in fulco marginis fenimum interno locitis, maturefecendu :utem in pulpam refolutis,

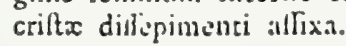

S.e m. numerofa, triginta ad triginta fä, in Faipa mol: mucilaginofo-faccharinta 2tropurpurea ftratis horizontalibus afyalitus libi ia:cunbentia \& in quatuor lubos pulpa junctos nec difiepiniento ullo disilus congelta, Jobis unis per puria ad apicen \& bafm fenime unico junctis, comprella, ro:und:to - I irregulari-triangulatia, ad marginem extermin cratforem obwfit, ad intcroun autem carinatum asuta, atrofufais.

Ix т. limplex, tenue, crufaceum, fragile, albumini (excerio margine femisum iuterno corinsto) undique :ıckithime adnatum.

A.в. femini confornc excepto margine interno paululum ratrato, cartilayinetim, exterme pallide fufcum; imerne fordide mollinus, in centro fo-

veolà compreffa lanceolato - cordatà cotyledonum dimenfionem multum fuperante excavatum.

$E_{M}$ B. parvus, dimidian albuminis partem longitudine fere mentiers, albumen ex angulo externo umbilicali ad difepimentum incompletum locato dingonaliter fecans, leviter incurvus, ladeo-albus. Cotyl. cordatx, foliacez, nervofz. Rad. cotyledonibus duplo longior, fubclavata, teretiufcula, curvula, obtufa, a centro bacce remotiflima \& in quovis ejus lobo difepimento incompleto fui lateris obver $\{$.

\section{EXPLICATIO FIGURE.}

a.) Drupa intexra. b.) Eadem transverle diffecta, feminum hemilphxrium alterum, ex lobis binis in ipfonum bafi \& apice femine unico conjugatis junctum, in fitu fovens. c.) Eadem racua, ut excufts feminibus diflepimentum incompletum bifitum in confpeetum veriat. d.) Semi$\mathrm{na}$ ex bacea in fitu exemta, zhlatis aliquot feminum ftratis. $\alpha_{,} \alpha_{0}$ ) Regic feminum umbilicalis \& radicula fedes, diffepincnio incompleto obverfa. e.) Semina feparata, \& a pulpa denudata. f.) Albuminis fectio horizontalis, cum Gtu corbryonis diagonali. G.) Eorbryo folutus \& magnitudine auchus.

Tarennx, ftirpi hujus ordinis Carpol. T. I. p. 139. defcriptz, fimilis cm. bryonis fitus competit, cxterum inufitatus.

Albumen radicem aduftam Dauci Carosae LinN. redolet.

Icon, quam à fructu Tocoyenx tradidit Aubletius tota erronea vel faltem pelfima, ut \& Cel. Julfixum cxeroquin \& in fructuum defcriptionibus accuratifrmum in errorem induxeric. Fructus enim: $1^{\circ}$ non elt bacca fed vers drupa putamine osseo-coriaceo intus levigato dotata; $2^{\circ}$ nec calyce quinquedentato coronata, fed capitello obtufo, in medio difco callofo $a b$ infertione coroll $x$ notato, faftigiata; $3^{\circ}$ nec bilocularis: fed revera unilocularis, femina enim omnia mediante pulpa inter fe fuat connexa, nec lobi alio modo quam pulga ipfa interftucki. 


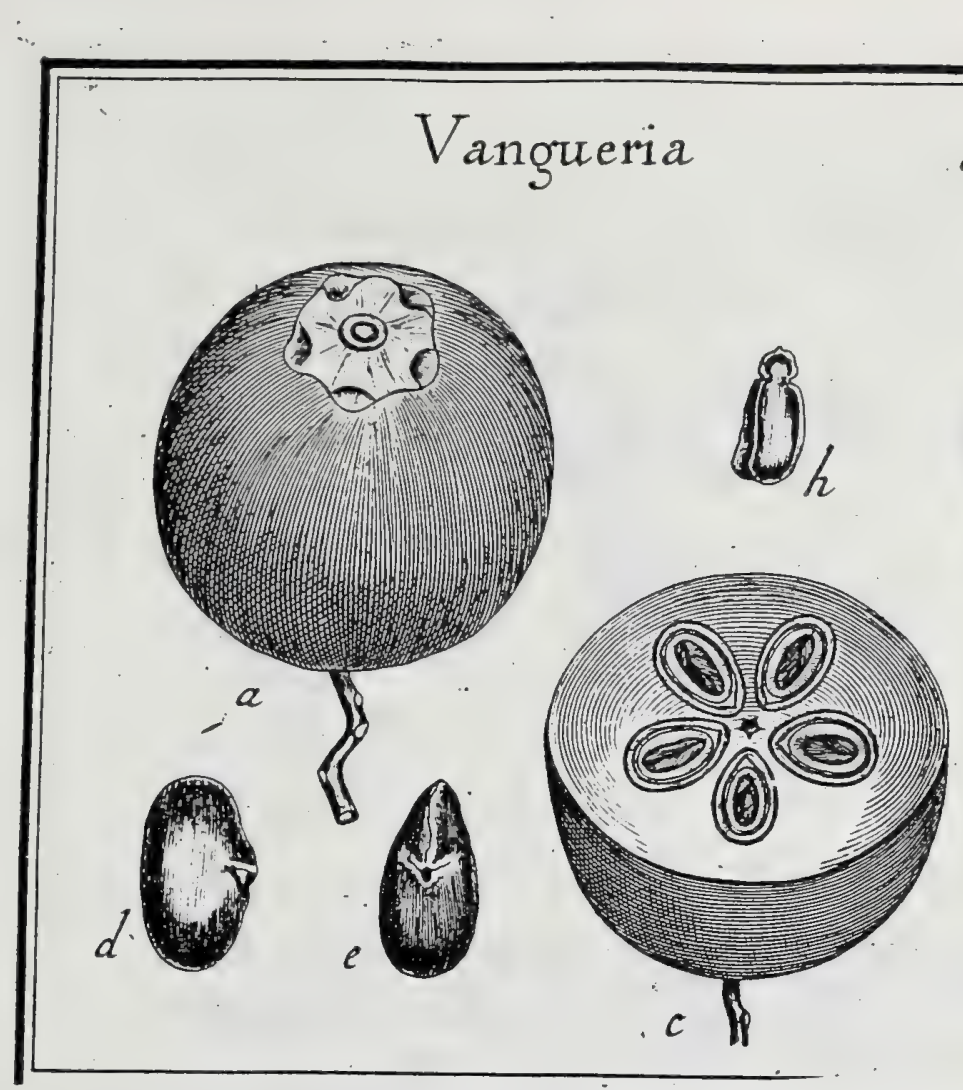

cymofa.

Rubiaceae
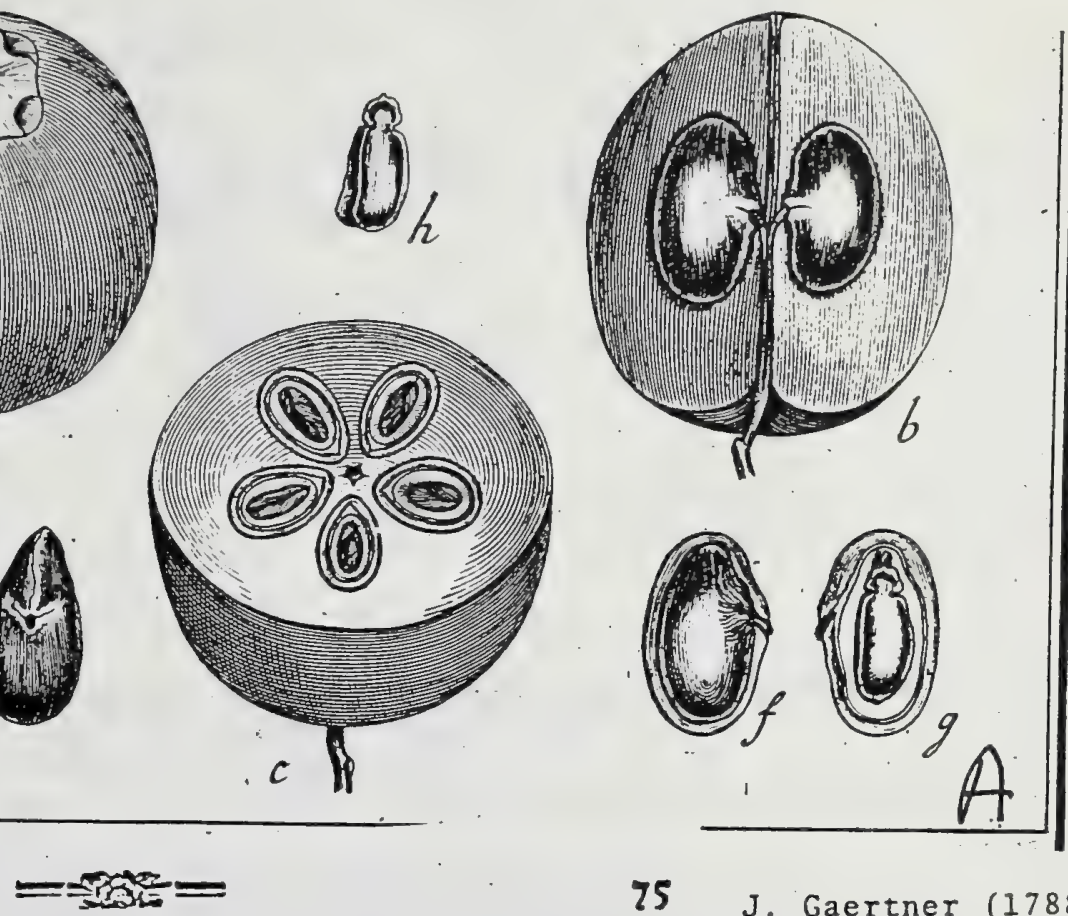

63. VA N G U R I A.

J. Gaertner (1788) Vol3

Juss. gen. p. 206. LAMAвCK ill. gen. t. r59.

Cal. monophyllus, fuperus, minimus, quinquedentatus, deciduus: dentibus acutis, patentibus. Cor. monopetala, parva, tubulofa; tubo canpanulatoventricolo, intus' hirto; limbo quinquepartito: Jaciniis lanceolatis, acutis, retexis. Stam. quinque; filamentis brevibus; antheris oblongis, vix exfertis. Ovar. inferum; ftylo finplici, filiformi, Itaminibus longiore; ftigmate capitato (bilamellato. VAHL.). Bacca pomacea, infera, noll coronata, pentapyrena. Alb. carnolum. Emb. inverfus.

Vanguera cymola. Tab. 193. fig. I.

Vavanga chimenfis. Rонв. af. foc. bif. nat. bafn. T. 2. P. I. p. 207. t. 7 .

Vangueria (edulis.) VAHL fymb. bot. 3. p. 36. WILLD. Jpec.pl. T. 2. P. 2 p. 976 .

Valiguiera. PERsOon fyn. pl. I. p. 205.

Vavengue Gallis. E collectione Deleffertiana.

PER. Bacca grandiufcula, pomacea, infera, globofa, baf umbilicats, in vertice area ampla irregulari-pentangulari notsta, \& in hujus centro foreola rugà circulari cinctà exfculpta, pentapyrena. Pyrenx circum axem baccx regulariter locatic, remorx, offex, reniformi-oblongx, in vertice margine acuto terminatx, bafi vero craltiotes obtufx, ad medium ventrem umbilico furfum prominulo 1 ruga transverfali notatæ, fcabriufcula, monofpermx.

REc. nullum; nifi funiculum. umbicalem filiformem ex pedunculi vafis oriundum fumas, qui in proprio canali pyrenx inferipto feminis umbilicum in ventris medio "pofitum adit, \& ibi fibris radiatin divergentibus cum integumento leminis contluic.

Se s. in fingula pyrema fingulum, oblongum, compreffufculum, ad verticem in marginem acutum attenuatum, rufefcens.

Is T. fimplex, membranaceun, albumini adnatum.

A L B. femini conforme, vaginale, ad verticem rima radiculam latitudine zquan. te fulum, carnofum, album.

E $\mathrm{A}$ 8. magnus, in medio albumine locatus, 1. vix vertice feminis propior, compreftiufculus, oblongus, leviter incurvus, ficcitate dilure fufcus, inverfus. Cotyl. longx, curvato-oblongx, plano-convexiufcula, obtufílimx, Ggmoideo-convolutx, accumbentes. Rad. difcreta, obtufe cordata, apicula minima terminata, comprefla, per ambitum acuta, ab umbilico externo averfa, fupera.

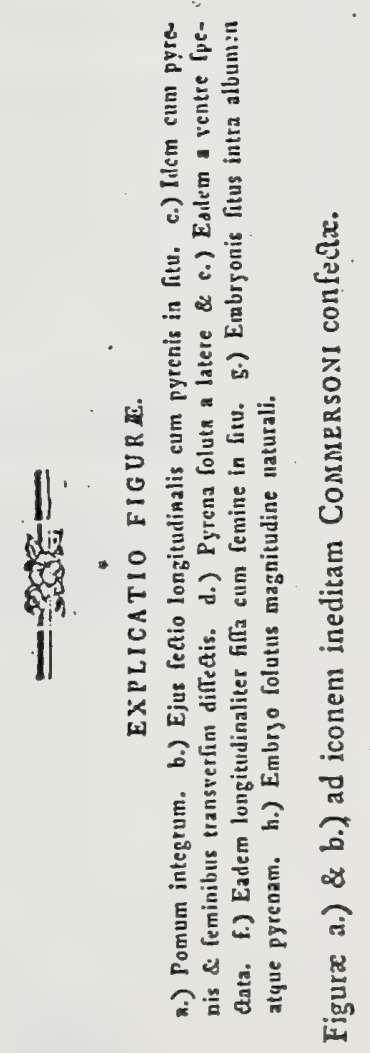

is

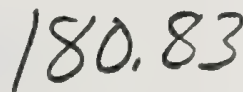




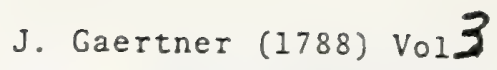

Tab. CLXXXIV.

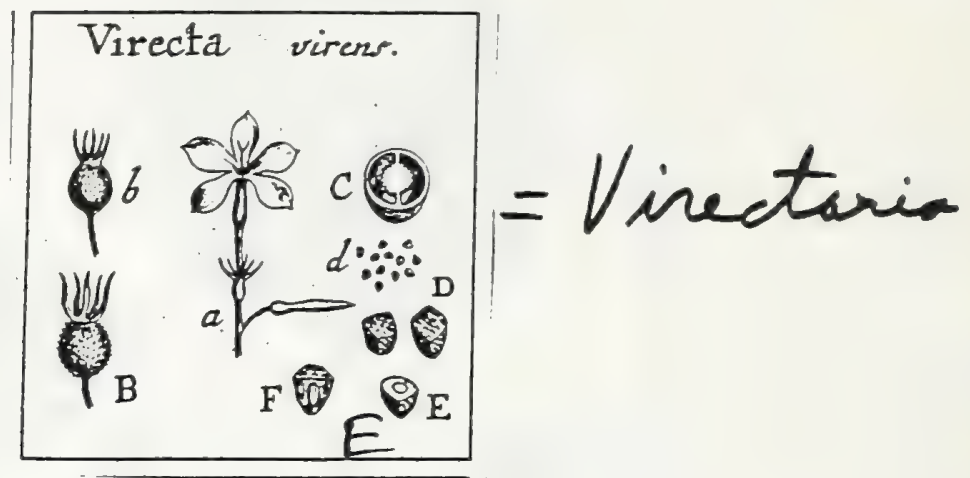

J. Gaertner (1788) Vol 3

\section{VIRE C TA. $3^{\mathrm{T}}$}

\section{Lixn. fuppl. pl. p. 17. gen. cd. Sclireb. 312.}

Juss. gen. p. 200.

Cal. fuperus, perfiftens, margine membranaceo anguftiftimo, \& extra hune dentibus quinis fubulatis longis fructum coronans. Cor. monopetala, infundibuliformis: limbo quinquelobo zquali; lobis obovatis. Stam. qunrque. Ovar. inferum. Styl. fimplex. Capfula pifformis, dentibus calycis fubuJatis coronata, bilocularis, bivalvis"' Sem. numerofa, receptaculo centrali affix:t.

VIRECTa virens. Tab. $184^{\circ}$. ffo. 5 .

livela virest. Cl. ТнимвекG. in litt.

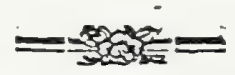

PEs. Capfula infers, margine anguftifimo, dentibusque calycis quinque fubu: latis coronata, globofa, fetulis minimis rigidis hifpida, nervisque quinque longitudinalibus deprefliusculis infignita, nec tamen angulata, bilo. cularis, bivalvis? diffepimento nembranaceo valvis contrario.

R\&C. carnofum, centrale, cum difepimento connatum, profundifime alveolatum, ut excußis feminibus, totam ejus fuperficiem obtegentibus, hifpidum appareat.

SE s. numero氏a, parva, angulata, excavato- pundata, fpadicea.

IN T. Gimplex, membranaceum.

ALB. carnolum, aqueo - pallidum.

E мв. cylindricus, albus. Cotyl obtufx, brevifimx Rad, centripeta

\section{EXPLICATIO FIGURE.}

2.) Flos integer magnitudine naturali b. B.) Capfula matura, iategra. C.) Ejus featio trans:verfalis, cum receptaculo \& diffepimentis. d. D.) Seminz foluta. E. F.) Albuainis feftio transver[alis \& longitudinalis, cum fitu \& figura Embryonis.

Capfula certifine bilocularis eft; utrum vero bivalvis lat, uti ex meo fpecimine apice hiante quodammodo conjicere licet, certo non affirmaverim. Quid LINNeUs per receptaculum una fenimum ferie obternum voluerit? ego non intelligo: nam in carnolis receptaculis alia feminum pofitio, nif qux totam fuperficiem fimplici feminum ftrato obtegat, non datur, exceptis feminibus nidulantibus. 


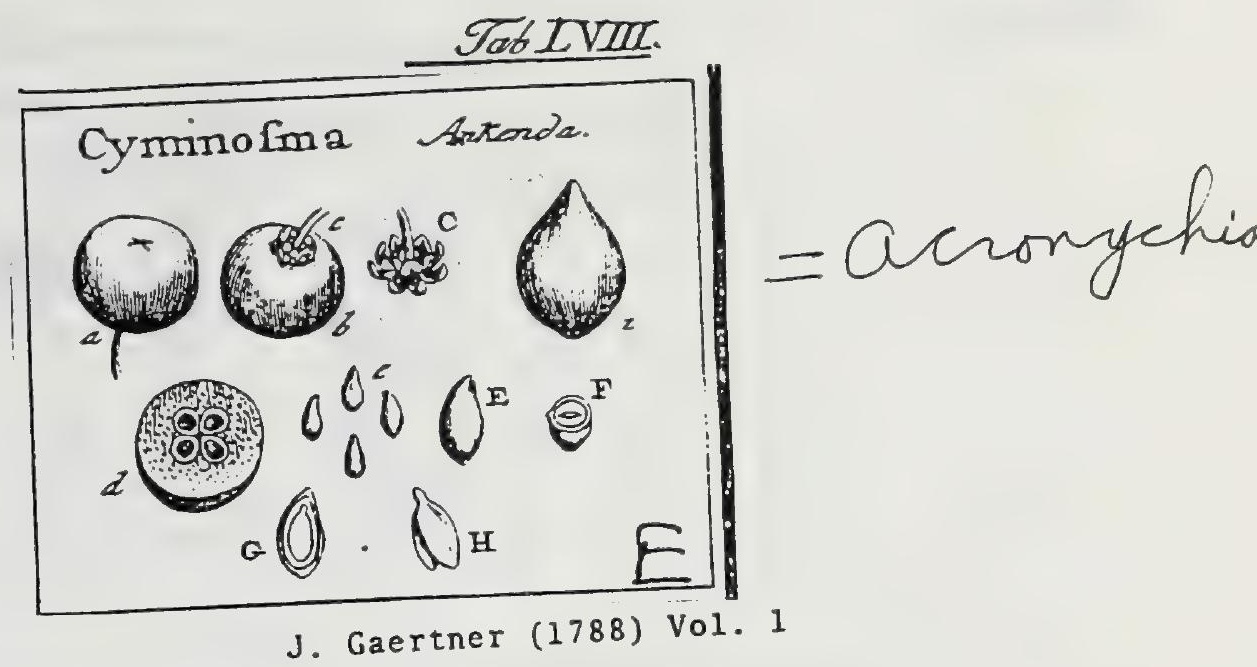

\section{CYMINOSMA.}

Calyx tetraphyllus inferus. Cor-octopetala: peralis oblongis, extus fubpubefcentibus: Styl.... Bacci quadrilocularis. Semina folitaria, inverfa.

CrMinosma Ankenda. Tab. 58. fig. 6.

Arbor zeylonica cuminum redolens, Ankenda dida. HE R M. mus. 23. R U R M. flo zetl. 27.

Ankanda. zeylonens. E collect. fem. hort. lugdb.

PER. Bacea globola, deprefliuscula, carnola, quadrilocularis. Caro craffa, in vetufto tructu fuberofa, fibris tenacioribus fublignofis, crebertimis intertexta, cuminum redoleus. Loculamenta intus propria meinbrana chartacea, aut cruflacca veltita,

REC. nullum; femina angulo interno loculainentorum affixa.

SE s. in fingulo loculamento unicum, ovato acuminatum, line convexum, inde in angulum compreflum, nigro fufcum, aut atrum. angulum compreflum, nigro fulcum, aut atrum.
IN T. duplex: exterius crufaceum, tenue, fragile; interius membranaceum, chalaza
fufca in extremitate obtufiore notatum.

A L B. femini conforme, carnofum. friabile, aqueo-palliduin.

Es в. longitudine albuminis, inverfus, albus. Cotyl. ellipticx, foliacex, tenuịifimx. Rad. brevis, fupera.

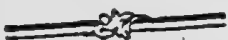

a.b.) Bace intert2. c.C.) Flos in fructu perfitens, calyeis \& corollz foliolis refiexis, d.) Bacea C.G.) Seminis fectiones, cum fitu embryonis intra albumen. H.) Embryo feparatus.

Baccx dantur \& alix, ovato acuminatx (i), tota autem reliqua fructura nec non odore etiain prioribus fimiles; \& his quoque fubef calyx tetraphyllus \& corolla octopetala; fed petala funt linearia \& calycinis foliolis triplo longiora; quud non in pracedent1.

Diverfiffimain hane effe Ankendam ab illa, quam LIN $\mathrm{x}$ US in flor. zeyl. n. 185. ad Myrtum retulit, ex dictis fatis liquidum $e \cap$. 


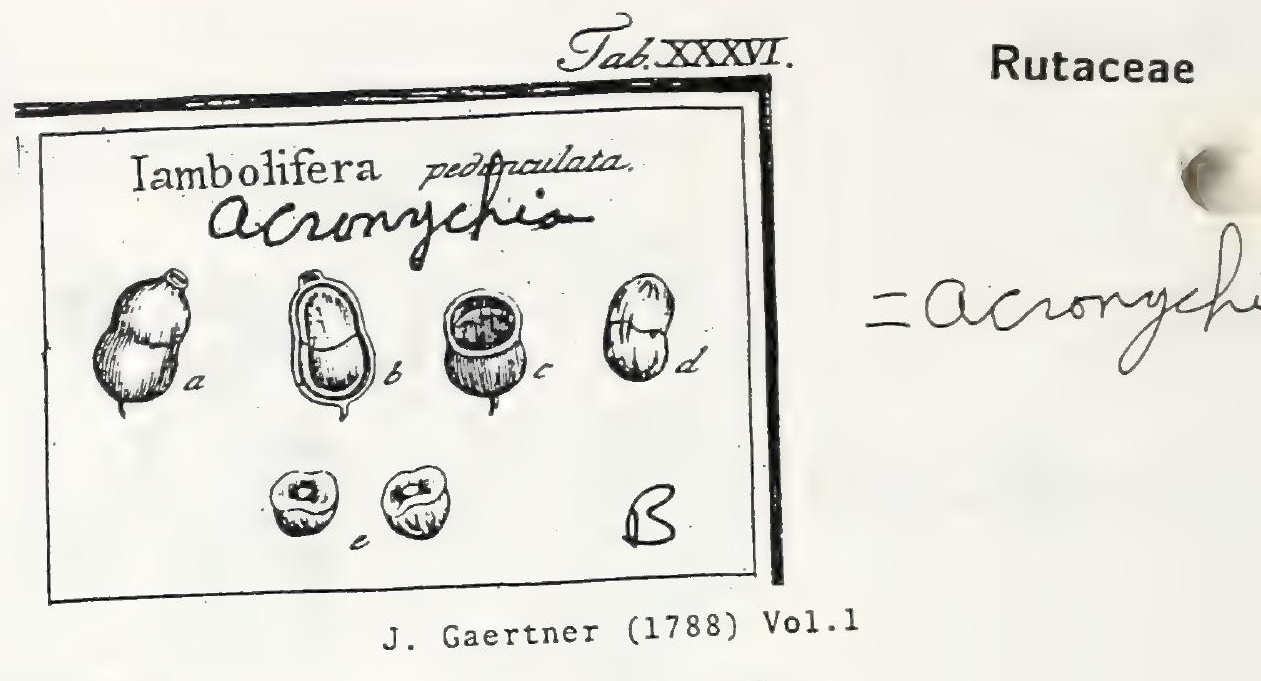

178

CCXV. JAMBOLIFERA. Linn. gen. 479 .

Calyx quaúridentatus fuperus. Cor. tetrapetala. Stain. plura. Styl. unicus. Ovariumid immaturum biloculare: ovulis fepto affixis. Bacca matura unilocularis monof perma, Semen acoccon. Cotyled. gibbx, radiculam occultantes.

JAMв ОLIFER A pedurculata. Tab. 36. fig. 4 .

Jambolana. R И м Р. amb. x. p. 131.t. 24 .

Caryophyllus Tangu aromaticus malabaricus, folio E' fruffu maximo. P 10 ix? phyt. t. 274. f. 2. bene.

Gambolifera. Lin N. Jyfl.veg. 360 .

E collect. Cern. hort. 'lugdb.

PER. Bacca infera; calycis bafi annulari edentula coronata, orato cylindrica, in medio leviter anguftata, coriacea, tenuis, unilocularis.

.

REC. cicatricula cum ruga transverfali prominula in altero latare bacez.

SEX. unicum, figura \& magnirudine cavitatis baccx, acoceon, carnofum, durum, bipartibile.

IN T. nullum f. lateribus baccx adnatum.

A L B. nullum.

"EM в. dicotyledoneus, femini conformis. Cutyl. craflifinx, fubparabalicx, nutuo fibi incuibbentes, ut planum contactus horizontale fit. Rad. acuminata, minima, in centro partis planx f. concavx coryledonum pafita \& ab eis penitus accultata.

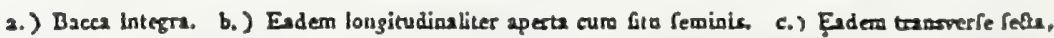
plicam receptaculi ofteadens. d.) Semen deaudatum. e.) Catyledones feparaz, cum radicula in medio.

Sola baccx \& feminis figura oblonga a Syzygio differt, nam ftaminum numerus, fecundun Rumphium L. c. multo major ell, quan Limneus ex fpecimine incom. pleto tradidit. 


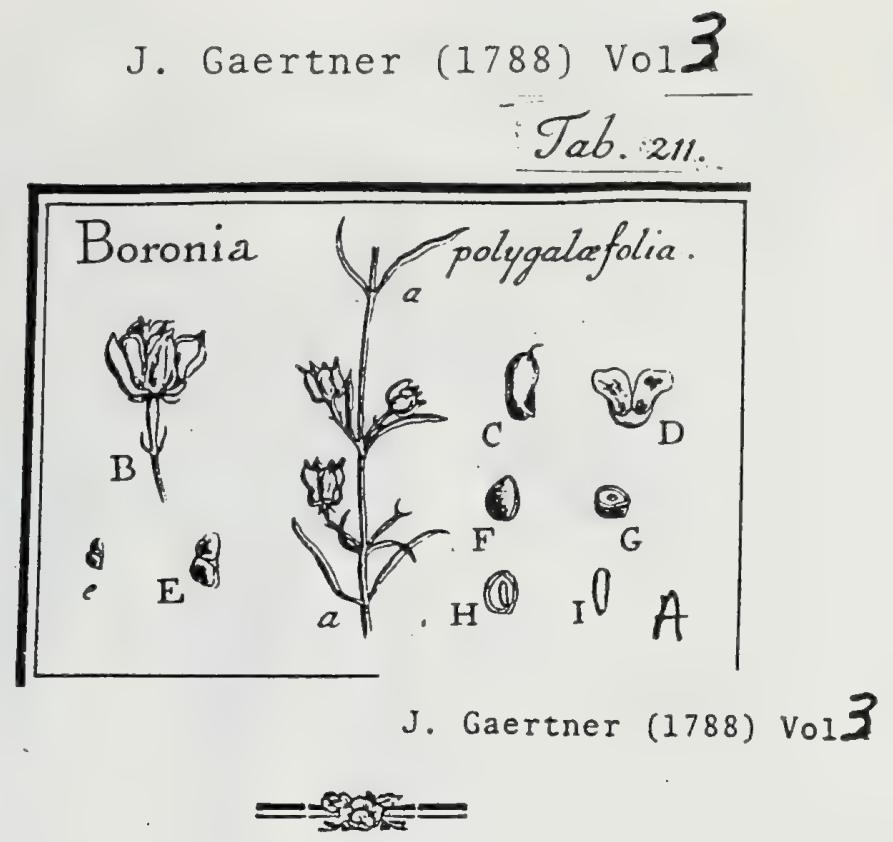

r20. B O R O N I A:

Sirtт ACt. Soc. Linn. Lond. Vol. 2. p. 350.

Cal. parvus, quadrifidus, inferus, perfiftens: laciniis ovato-acuminatis, pa: tentibus. Cor. tetrapetala; pétalis calyce multo majoribus, ovatis, concavis, apice obtufe mucronatis, perfiftentibus, \& cum frudu grandefcentibus, Nectarium coronatum. StanT. 4.; filamentis ciliatis, incurvis; antheris infra apicem filamentorum pedicellatis. Ovar. fiperum; ftylo brevifimo; ftigmate capitato. Capf. quadriloba, tetracocca ; cocculis corticatis; difpermis. Sem. fubovata. Alb. carnofum. Emb. erectus, oblongus.

Borosis polygaliffolia. Tab. 211 . fig. I.

Habitat in Nova Hollandia. Ex collectione Cl. Laubert.

PER. Capfula parva, calyci perfiftenti infiftens \& petalis grandefactis involucrata, obovata, quadriloba, ex quatuor cocculis corticatis coadunatis conflata, rufefcens. Cortex coriaceus, obovato-oblongus, lenticulari-' compreffus, apice mucronulatus. Cocculi compreffufculi, obovati, papyracei, lutefcentes, difpermi.

REC. conmme nullum : cocculi fundo \& centro calycis adnati; proprizm, funiculus umbilicalis communis per hilum cocculorum intrans, femina fibi impofita in fitu erecto fuftimet.

SEx. in quovis loculo gemina (nonunquam vero unum 1. alterum abortat,) fubglobofa, l. turgide lenticularia, bafi ad umbilicum mucronulata, \& ad ventrem apicem ufque fulco acuto infignita, eminentiis minimis fcabriufcula, fulca.

Ix T. duplex: exterius teftaceum, fragile; isterius membranaceun, tenue, adnatum.

AL B. fenini conforme, ad baGn uti femina ipfa mucronulatum; carnofum, album.

$$
\text { - . }
$$

EMB. obovato-oblongus, centralis, erectus, longitudine fere albuminis, albus. Cotyl. rectx, ovatx, plano-convexx. Rad. cotyledonibus paulo brevior, recta ; teretiufcula, conica, mucronulata, umbilico externo obverfa, infera.

\section{EXPLICATIO FIGURE.}

a. a.) Ramulas frugifer. B.) Capfula feparats, dehifcens, calyce \& corolla perfifientibus veftita. C.) Cocculus integer, cum cortice. D.) Cocculi dehifcentis, a cortice liberati, facies interaz c. E.) Semina getnina, a cocculo foluta. F.) Semen feparatum, a parte ventrali fpectatum. G.) Ejusdem fettio tsansverfalis. H.) Embryonis fitus intra albamen. I.) Idem folutus. 


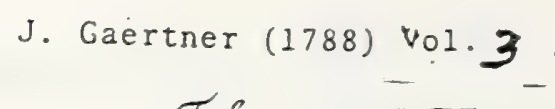

Rutaceae

Tah CLXXXV.

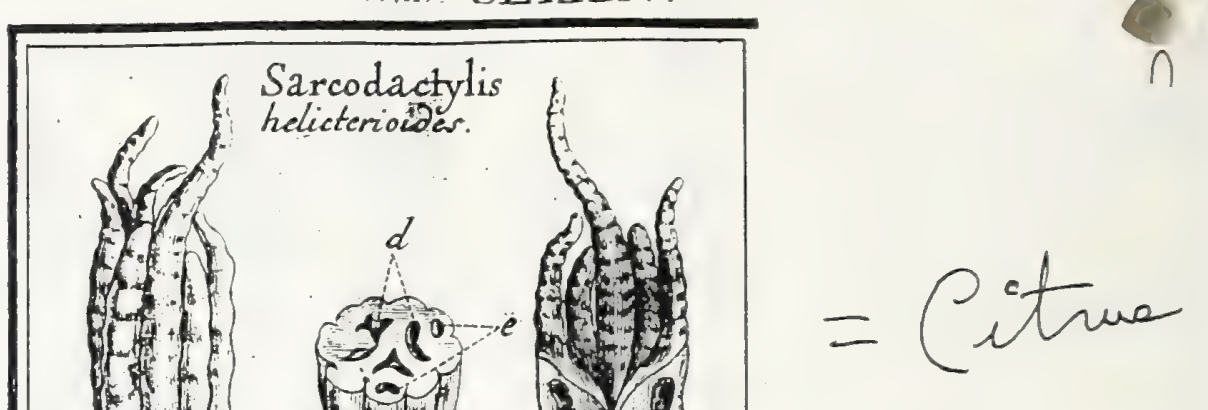

Flos .... Bacca. carnofa, coccinea, oblonga, fulcata, ex fulcis in pro. celfus teretes digitiformes producta \& in virtice profunde infundıbuliforıi umbilicita. Semina in loculis legregatis fparfis pauca.

Sarcodactilis helicteroides. Tab. 185 . fig. $I$.

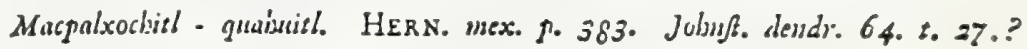

E Guiana belgica.

Pв R. Bacca carnofa; coccinca aut rubra, cylindraceo-oblonga, fupra calycem monophyl!una repande quinquelobum breviter pedunculaca, fulcis rotundatis longitudinalibus exarata \& ex is in procellus circiter leptenos,

40

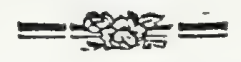

dactyloideos, valde inæquales, verrucofos \& erectos producta, ac intra iftos procelfus late \& profunde infundibuliformi umbilicata atque lacunofa. Caro per xutem fungofa, helvola. Loculamenta plura fecundum fulconum longitudinem dilpofita, fegregata, oligofperma.

REC. nullum; fenina loculorum angulis internis affixa.

SEM. plura, fed in loculis fingulis folitaria, gemina, aut rarifime terna; fub. ovata, Jenticulari - comprefa, rufefcentia aut pallide caftanea.

IN T. membranaceurs.

A $\perp$ B. . . . .

EMB. . . .

\section{EXPLICATIO EIGURE.}

a) Bacea integrz. b.) Ejus fetio transver(alis. c.) Eader longituliaaliter ditrects. d.) C2vernz vacux ex bafibus interois datylorum irregulariter confluentibus enatx. e. e. e.) Seminum leculamenta, juxtz fulcos in longitudiaem digefta.

Hernandii miferrima figura, hanc potius ftirpen, quam Helifferens apesalams indigitare videtur, prafertin cum in defcriptione dicat: pro famine exit guafs manus aut potius pes avis coloris fanguinei \&a. Cum Helictere, ob fructus confiftentiam \& loculamentorum difpofitionem fociari nullo modo poteft. 


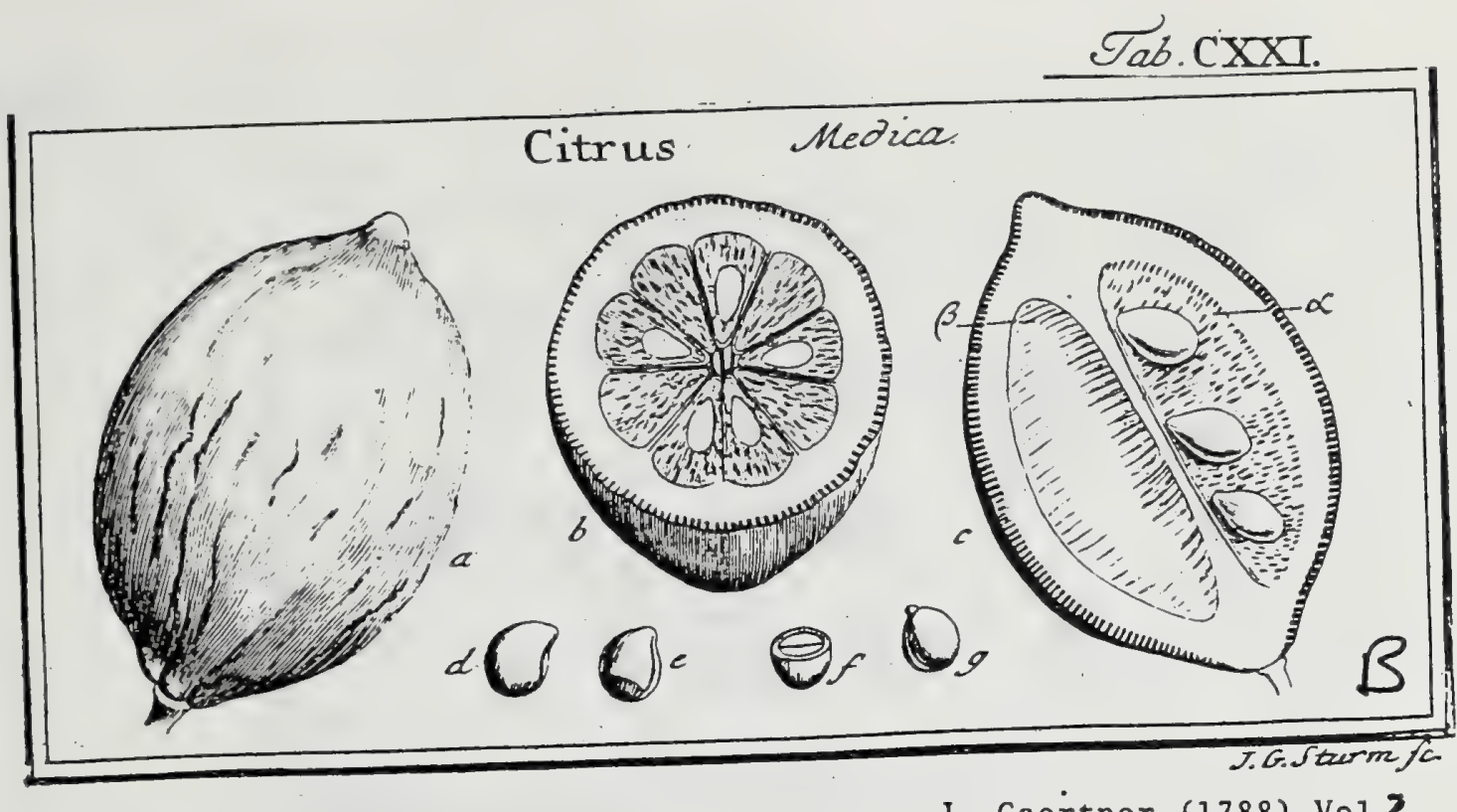

J. Gaertner (-1788) Vol 2

DCCV. CIT R U S. TOURN. inft. t. 395.396. LINN. gen. gor.

Calyx quinquefidus. Cor. pentapetala. Ștam. viginti aut plura, filamentis varie inter fe connatis. Ovar. fuperum. Styl. fimplex. Bacea corticata plurilocularis: pulpa molli veficulofa. Semina pauca.

Citrus Medica. Tab. 121. fig. 2.

Citria malus EO Limonia malus. BLAKW. berb. t. $3^{61} \cdot 3^{62}$,

Citrus petiolis linearibus. LINs. $5 y$ t, veg. 697 .

PER. Bacca ovata, fuperne vel \& utrinque mucronata, obfolete rugofa, excavato puncticulata, feptem - ad unđecimlocularis, pulpofa, corticata. Cortex duplex: exterior tenuis, favefcens, glandulis miliaribus numerofiufimis oleun fragrantifimum fundentibus fatens; interior cralfiur, albus, coriaceo - fungofus. Diffepimenta ex duabus laninis membranaceis tenuiffimis atyue diuphanis compofita, prope axem in ftellre formam connata, juxta peripheriam corrici inferta. Loculamenta farcta carne pulpofa, pro-

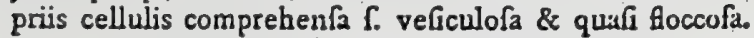

REc. nullum; femina angulo loculamentorum centrali affixa.

SEM. pauca, unum ad quatuor in fingulo loculo, fubovata, verfus umbilicum angultata, lenticulari compreffa aut obfolete \& varie angulata, ad alterum marginem raphe longitudinali notata, pallida.

Is T. duplex: exterius coriaceo - chartaceum, diaphanum; interints membranaceum, ad alterum latus funiculo umbilicali adnato ftipatum, $\&$ in obtufiori fun extremiate, latiffma chalaza ferruginea notatum.

A L B. nullum.

EM B. feniuli conformis, Jutefcens. Cotyl. carnofx, plano-convexse Rad. parva, adfcendenti-centripeta.

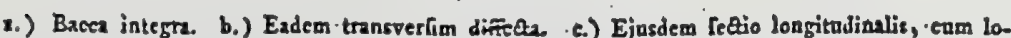
culamicnto altcro (a.) aperto, eltero (B) autem 2 diffepimenti lamina friata clavfo. L) Semen feparztum. c.) Ejusiem membrana interna, cum fuz chalaza \& funiculo umbilicali f.). Semen transverfe fectum. 8.) Émbryo denudatus.

190

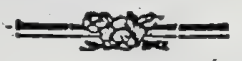

Szxpe nucleus in tres, quinque, fex, lobulos cotyledoneos partitus deprohenditur; quin in Citreo decrmano non femel embryonem in $18-20$ fquanulas $f$. bracteolas cotyledonens divifum vidi, qux facillime a $f e$ invicem fecedebant, nec ulla communi radicula erant commexx. Hujus proternaturalis tabricx mentionem facit quoqque Cl. Jusșieu. gen. p. $26 \%$. 


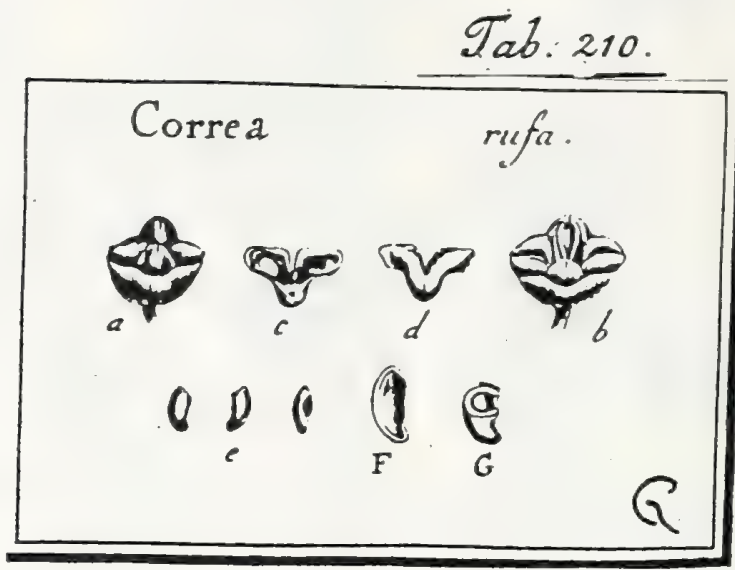

J. Gaertner (1788) Vol.

\section{II9. COR R E A.}

\section{Sмгтн ACt. Soc. Linn. Lond. 4. p. 2rg. Mazeutoxerori.} LA BILLARD. it. t. I7 \& 18.

Cal monophyllus, cupulatus, quadridentatus, inferus, perfítens. Cor. tubu

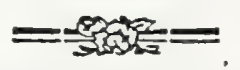

lo $\Upsilon_{3}$, tubo longo, infundibuliformi, fubintegro, bafi quadrivariam filfo, calyci inferto; fiffuris in tubo iterum adglutinatis; limbo quadrifido; laciniis ovatis, acutis, patentiufculic. Stam. 8.; filamentis tubam fuperantibus, imo calyci cum corolla infertis, alternis longioribus linearibus, alternis paulo brevioribus ad bafin membranaceis dilatatis; antheris mitraformibus, cordatis, 1. oblongo-cordatis, incumbentibus, bilocularibus. Ovar. fuperum, pubefcens, tetragonum; Itylo fimplici, fetaceo, Itaninibus paulo breviore; ftignate fumplici, acuta. Capr. coriacea, fubquadriloba, quadrilocularis, tetracocca. Sem. gemina, reniformia, Alb. ... Emb. ...

\section{Correa reflexa.}

Correa rufa, in Icone Tab. 2 io. fig. 7.

Mazestaxeron kefexum. La Billand. Voy. a la recb. de la Pegroure a. P. 11. t. 19.

Correa fuliis ovatis refexis, corollis oglindricis. УENT. bort, malm. p. Is. PEKSUON fril. I. p. 4 Ig.
A Cel. La Billardierz.

Prr. Capfula fubglobofa, a calyce fupra medium arcte amplexata, villofa, furfum femiquadriloba, fo ex quatuor cocculis corticatis coadunatis confata. Cortex coriaceus, ab apice intus cum cocculis dehifcens, baficalyci arcte adnatus. Cocculi chartacei, lutefcentes, difpermi, per abortum vero plerumqque monoofpermi.

REC. commune nullum; proprizun funiculus umbilicalis brevis.

SEM. in unoquoque cocculo ante maturitatem genisna, quorum vero alterum ut plurimum abortat, hinc rarifime in cocculo fingulo uno plura, quod e reniformi oblongun, ad hilum umbilico inftructum, fufcum.

IN T. duplex: exterius teltaceum, fragile; inserius membranaceum, tenue, albumini adnatum.

'A L B. femini conforme, carnofum, albun.

$E_{M B}$.

\section{EXPLICATIO FIGURE.}

2.) Capfula integra. b.) Esdem debifcens. c.) Cocculus feparatus dehilcens, enom femioe in fiu. d.) $1 \mathrm{dem}$ a durfo vifus. c) Scmina (oluta. F.) TeRz verticali modo diffecta. G.) Ejusdear feato transverGalis. 


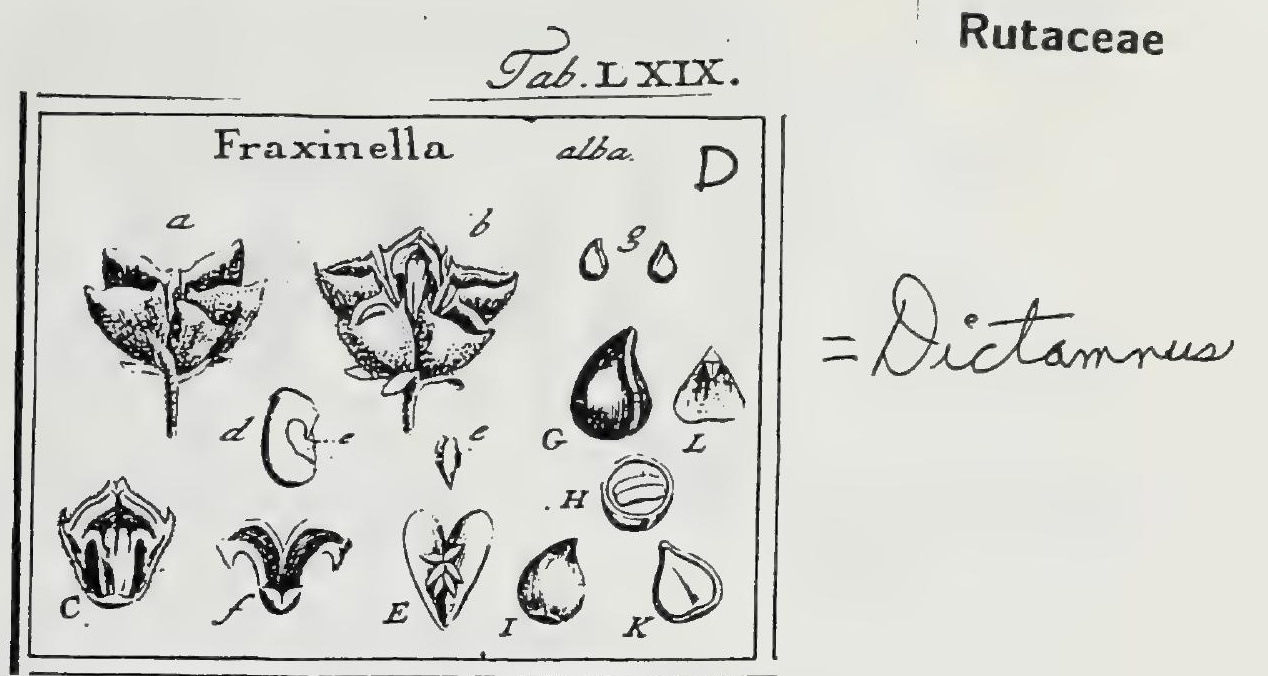

J. Gaertner (1788) Vol.1

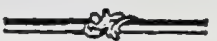

\section{CCCCXXXIV. FRAXINELLA. To $R$ N. t. 243.}

Calyx pentaphyllus. Cor. pentapetala. Stam. decem. Styl. unicus. Capfulz quinque uniloculares, introrfum elaftice dehifentes. Semina nitida.

FRAXINELLA alba. Tab. 69. fig. 4.

Fraxinella. Crus. hif.. 1. p. 99. B Es s. h. Eyjf. vern. IX. t. 5. f. I. RI v. pent. t. 134. 135. H A L I. hifl. I. n. 1029."*

Diffaninus albus. B L A $\mathrm{x}$ w. herb. t. 75. MILL. ditt. ic. t. 123. J A c Q. fl. auftr. 5. t. 428 .

Difáannus foliis pinnatis, caule fimplici. LIN N. Juft. veg. 397 .

PER. Capfulx quinque, margine interno in fructum fellatum coalitx, triangulares, coinprefix, corticatx. Cortex herbaceus, tomentofo fcaber, latere fupremo ad angulos culpidato. Lamina interna cartilaginea, formata in cocculum ovato oblonguin, fuperne oblique truncatum, ad latus internum vero profunde emarginatum \& pro recipicndo receptaculo excifum, unilocularem, introrfun elaftice dehifcenten.

REc. fquarnula cordato acuminata, incifuram cocculi centralem claudens, intus papilulis conicis umbilicalibus munita.

SE M. fex l. octo in qualibet capfula, quorum fxpe unicum, aut duo faltem adolefcunt, globofa, furfum rofellata, atra, glaberrima, nicida. Umbilicus linearis, niveus, mox fub ronello.

IN T. duplex : exterius chartaceum, aridum, fragile; interius albicans, chalaza fufca ad bafin inlcriptum.

A в . Scmini conforme, craffum, carnofum, album.

EM B. magnitudine fere albuminis, compreffus, inverfus, niveus. Cotyl, obovatx retu$f x$, craflx, utrinque planx. Plum. diphylla acuminata. Rad. conica, brevis.

a. b.) Fruftus integer, \& delif(cens. c.) Cocculus cum cortice a latere interno (petatas. d.) Cocculus integer decorticatus. e. e. E.) Receptaculum (eminum. F.) Cocculus delificens. g. G. ) Se mina foluta. H.) Seminis unacum fuis interancis (eetio transverfalis. I.) Nucleus decorticatus cum fua clıalaza. K.) Embryo intra albumen. L.) Cotyledon altera, cum plumula. 


\section{Rutaceae}

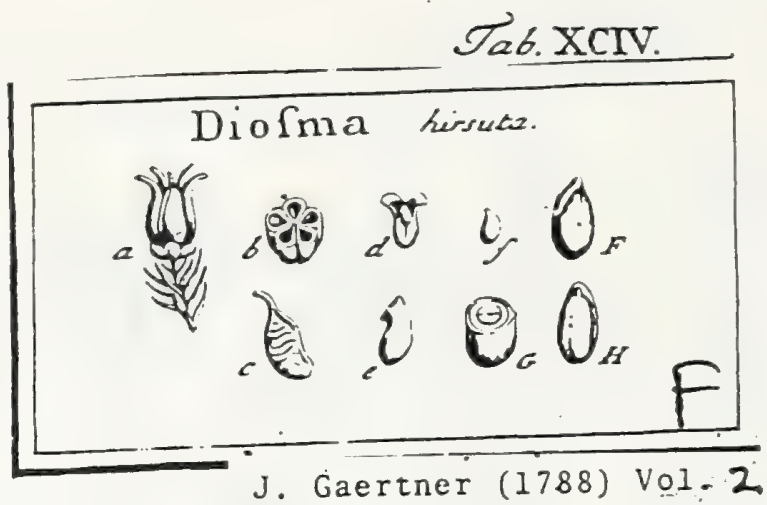

82

DX.c. D I O S M. A. LinN. gen. 272.

Calyx quinquepartitus. Cor. pentapetala. Nectar. quinque ovario impofita. Stam. quinque. Ovar. fuperum, angulatum. Styl. fimplex. Coc culi tres ad quingue elaftici coaliti. Semina folitarin.

Diosma hirfuta. Tab. 94. fig. 7 .

Spiran africana odorata, foliis pilofis. Comm. rar. 3. t. 3 .

Diofma foliis linerribus birfutis. Lins. fyf. veg. 238 .

P RR. Capfula fupera, compofiea ex cocculis quinque elafticis ad axem inter fe coalitis. Cocculi oblongi, comprefiufculi, transverfim obfolete rugofi, fupra in roftrum fubulacum definentes, extus nigro fufce, intus membrana cartilaginca alba elaftica veftitx, uniloculares, futura interiore elaftio dehifcentes.

REc. nullum; femina ope umbilici fungofi cocculis fub roftro affira.

SEM. folitaria, oblonga, turgide lenticularia, glaberrima, nitida, atra, sumbilico albo, lineari, fungofo, ad latus internum fub apice notata.

IN T. duplex: exterius cruftaccum, tenue, fragile; interius membranaceum pallidum, ad bafin chaiaza fufca parva notatun.

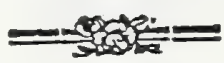

ALs. carnofunt, pallidum, temue.

Емв. magnitudine fere feminis, inverfus, albus. Cotyl. oblongx, carnofx; plano-convesz. Rad. tubercularis, parva, fupera.

2.) Frutus integer. b.) Idem transverfe fetus. c.) Coceulus feparatus. Le.) Membrans eacculi elaftica. f. F.) Semen feparatum integrum. G.) Idem trasterie fedam. H.) Egabryonir Gigura \& Gitus intra albumer. 


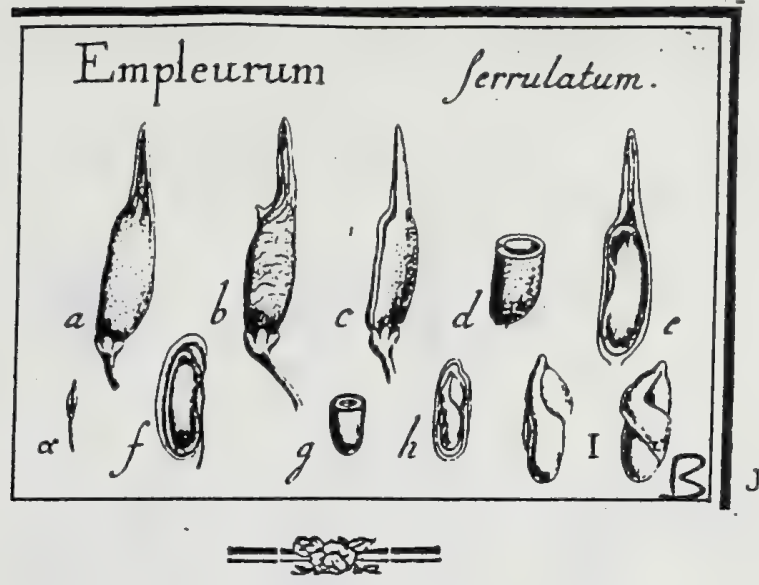

12r. E M I E U R'U M. Soland.

\section{LamaвCK ill. gen. t. 86. Juss. gen. p. 298. \\ Sснвев. gen. 1765 .}

Flores nafculi 3. fomineis difcreti in eadem ftirpe.

Cal. parvus, turbinatus, inæqualis, fcrobiculato-glandulofus, quadridentatus, inferus, perfiftens. Cor. o. Stam. 4. exferta; filamentis fubulatis, calycem fuperantibus; antheris magnis, erectis, fubtetragonis, apice glandulofis, utrinque dehifcentibus. Ovar. fuperum, roftratum; ftylo brevi, Gmplici, laterali ; ftigmate fimplici. Folliculus oblongus, roftratus, monococcus; cocculo (per abortum feminis alterius) monofpermo. Sem. ex oblongo reniforme, nitidum. Alb. carnofum. Enb. inverfus, cotyledonibus imparibus, convolutis !

EnPLeURUM ferrulatum. Tab. 211. fig. 2:

Diofma unicapfularis. LiNs. Suppl. p. 155:

Diofina (enfata,) foliis lanceolato - enfatis crenatis glabris, capfulis unilocula: ribus. THUNB. prod. p. 43.

Einpleurum fermilatum. LamarcK did. 2. p. 340. AIt. bort. Kew. 3. p. 340: WILLD. Spec. pl. T. 4. P. x. p. 333.

. Ex Collectione BankGana, \& ab amicifrmo Doo Decandolle.

PRR. Cocculus Gmplex, (rarifine geminus, Arr.) calyci perfiftenti parvo infidens, ovato-oblongus, comprelfiufculus, prope verticen in roftrum compreflum lateralem elongatus, corticatus. Corter folliculifornis, coriaceus, fcrobiculato-punctatus, ad ventrem fub vertice dehifcens. Cocculus chartaceus, ex oblongo reniformis, loculanento corticis paulo brevior, comprelfiufculus 1. lenticulari - convexus, ad ventrem hilo longo feneftrato notatus, naturaliter difpernus, per abortum vero feminis alterius frequentifime monofperinus, lutefcens.

REC. funiculus umbilicalis filiformis, e bafi capfule affurgens \& per hilum cocculorum intrans, femina in Geu fuftinet.

SEM. gemina, unum alteri impofitum, qux vero ambo rariffime ad maturitatem perveniunt, altero enim plerumque abortante; maturum exinde oblongo - reniforme, cumpreffiufculum, lenticulari - convexum, unbilico exlerto \& ex hilo cecculi prominulo pallido infgnitum, levigatifrmum, nitidum, atrum.

IN T. duplex: exterins teftaceum, fragile; interius membranaceum, tenuifrmum, adnatum.

AL 1. femini conforme, tenue, carnofum, album.

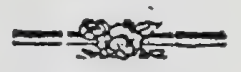

EM 8. compreffiufculus, oblongus, centralis, inverfus, albus. Cotyl. oblongx; carnofre, fpiraliter convolutx, inxquales; altera rectiufcula, obtufa; altera anguftiore \& breviore, circum majorem voluta. Rado parva, brevis, obtufa, unibilico externo proxima, lupera.

\section{EXPLICATÝó FIGURE.}

2. b.) Capfuia integra. e.) Eadem detircens. d.) Corticis festio transverfalis. e,) Coscull non dehifcentis fieus intra oorticem. f.) Cocculus fecunduen futuram Gffus, cum feminibus in Gitu. k.) Umbilicus Separatus, . cum funiculo umbilicali. g.) Semen medio transverfe diffectum. h.) Ejusdeas fettio verticalis, eupm embryonis fitu intra albumen. I.) Embryo folutus, ab utra. 


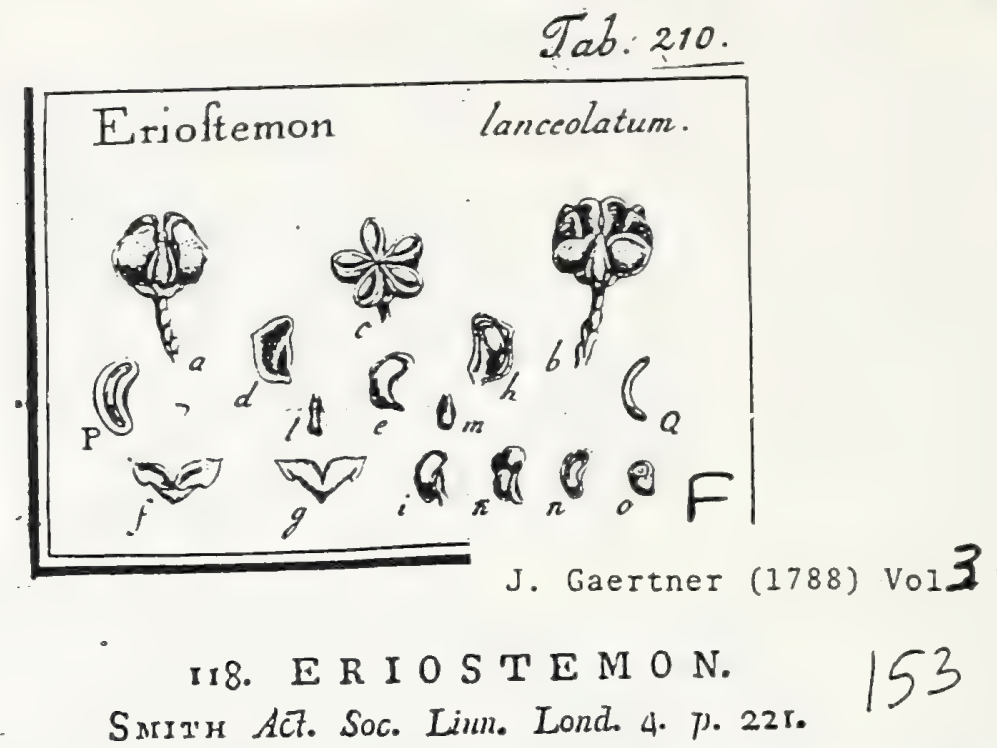

Cal. parvus, moriophyllus, urceolatus, quinquepartitus, inferus; lacinix ovatx, obtufa, erectx, margine ciliatx, perfftentes. Cor. calyce multo major, peut iperala; petalis ovatis, obtufis, pubefcentibus, infra ovarium in angulo calycis infertis. Stam. 10. petalis breviora; filamentis linearibus, Ggmoideo. curvatis; compreffis, infra ovarium ubi petala infertis; antheris ovatis, erectis, fetula ad curvaturam filamentorum fuperiorem affixis, bilocularibus. Ovar. fuperum, pentagonum; ftylus fimplex, pubefcens, e bafi ovarii afturgens, longitudine Itaminum; ftigna capitatum. Cocculi 5. corticati, bafi coaliti. Sem. in quovis loculo gemina (alteto autem plerumque abortiente), unbilico exferto pricdica. Mlb. carnofum. Emb. inverfus, curvatus, teres.

$\mathbf{r j 4}$

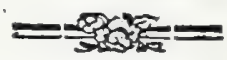

ERrostemon lanceolatur. Tab. 210. fig. 6.

Eriofemon folis lanceolatis fubrugofis. Saith 1. c. PERSOON fyito 1. p. 465. E collectione Bankliana.

PrR. Capfula fupera, calyce perfiftente veftita, ex cocculis quinque corticatis ad bafin inter fe coalitis compofita. Cortex coriaceus, fubovatus, ad apicem oblique truncátus, coniprelīufculus, rufefcens, extus fcrobiculato punctatus, intus vafis ad latus intermuin adfcendentibus eleganter pictus. Cocculi fubovati, compreffiufculi, furfum attenusti, deorfum acuminati, ad ventrem foramine ovato hiantes, albi.

REC. nullum; nif umbilicum sppendiculatum e cocculis prominulum \& in proprio lectulo corticis Gtum fumas.

SEM. in ovariis virgineis bina, rarifine tamen maturantia, altero enim fre. quentifiıne aburtivo; maturans reniforme, ad hilum planiufculum, nitidum, atro-fufcum, umbilicatum.

Umbilicus appendiculatus, hilo feminis adnatus, fungolus, oblongus, apice truncatus enarginatus l. bicufpitatus, intus longitudinaliter fulcatus, pallidus.

IN T. duplex: exterius teftaceum, fragile, craftufculun, fufcum; interius membranaceum, tenuifimum 1 . arachnoideum, facile detrahendum.

A L B. femini conforme, ad apicem compreffufculum, carnolum, album.

$E_{M}$ B. longitudine fere albuminis, curvatus, filiformis, teres, inverfus, lacteus. Coryl. tertiam embryonis partem longitudine mentientes, arcuatx, plano. convexx, apice conice acuminatx, incumbentes. Rad. Jonga, vix clava. ta, arcuata, obtura, ab umbilico remota, fupera.

\section{EXPLICATIO FIGURE}

a.) Capiuli integra, non dehifoens, bi) Eadem dehifeens, cooculis \& feminibus opbata: c.) Ejusderx fedio transverfalit. d.) Corticis facies interna. e.) Coccoius feparatus, non de. bifiens. f. g.) Idepe dehifcens, a ventre \& a dorfo fpectatus. h.) Seminis ficus intra coccur Jum, cortice adhuc veftitum. i.) Semea folitzrium, feparatum. k.) Staina gemias, matura. 1. m.) Umhilicus feparatos, a facie interna \& exteraz vifus. a.) Albuminis fitur incrn tefam. -) Semen transvetfe fectum. P.) Embryonis Geus istra albamed. Q.) Idem feparatus. 


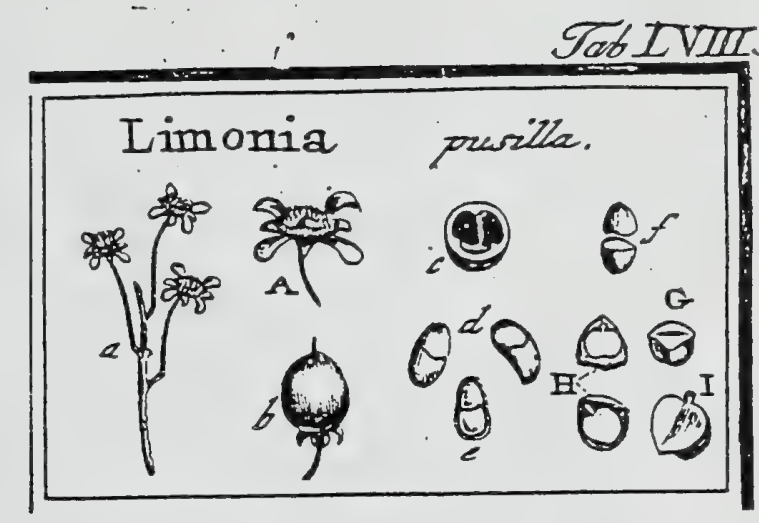

J. Gaertner (1788) Vol. 1

\section{LIMONIA. LINN. gen. 534.}

Calyx -quadi-1. quinquefidus. Cor. tetra-1. pentapetala, calyce duplo longior. Stam. decem-1. numerofifima, petalis breviora. Styl. unicus. Bacca trilocularis. Pulpä a loculamentis difcreta, femina arilli adinfar involvens.

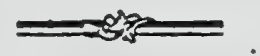

Limonia pufilla. Tab. 58. fig. 4.

Malus limonia lentifci folio zeylanica, frutu minimo; wvarum magnitudine. PLux. alm. 239?

Khatu-Kurundu. zeylonens. E collect. fem. hort. lugdb.

PER. Bacca elliptico fphxroidea, ftylo brevi terminata, carnofo-coriacea, intus tribus fulcis prominulis in tres loculos incompletos divifa. Pulpa, undique a loculamentis per membranam propriam tenuifimam fegregata, $\&$ in tres folliculos molles oblongos formata, in quibus femina locantur.

REC. nullum; femina in pulpa folliculorum hxrentia.

SEN. in fingulo folliculo gemina, rarius terna, fibi mutuo impofita, ad mutuum contactum oblique \& irregulariter truncata, cetera fubovata, hinc convexa, inde an gulata, nigra, fublplendentia.

IN T. duplex: exterius crufaceum, tenue, fragile; interius membranaceum, rufefcens.

ALB. femini conforme, craftum, carnofum, album.

Eнв. longitudine albuminis, compreffus, inverfus, gramineo viridis. Cotyl. fuborbiculatx, foliacez, tenuiffimx. Rád. brevis, fupera

2. A.) Flores in racemo longo, longifime pedaneulati: pedanculis bafi articulatis, tetrapetali, polystemones. "b.) Bacea integra, c.) Eadem diffeta, d.) Folliculi pulpofi claari. e) Unos corum longitudinaliter apertus, cum fitu feminum. f.) Semins feparata, G.) Albamen transverfe fethum. H.) Embryonis fitus intra albumen. I.) Embryo (epantus.

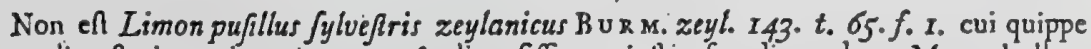
alius Boris partium numerus \& diverfiffunus inflorefcendi modus. Monophyllam tamen \& hanc effe, ex zeylanico nomine conjicere licet: nam Khatu-kurundu, fignificat Cinnamomum fpinofum, atque hinc fufpicion: locus eft, quod firps noftra, foliis \& externo habitu, Cinnamomo fimilis, fed fpinis fuis, diverfa fit. 


\section{Rutaceae}

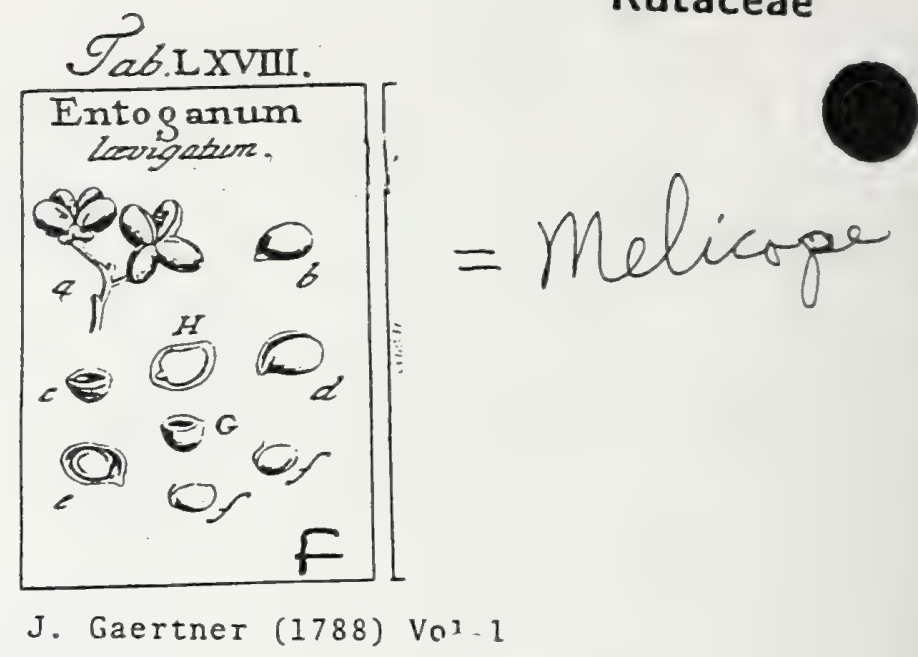

\section{CCCCXXVII. ENTOGANUM. B A n $\mathrm{s}$. =}

Calyx quadripartitus perfifens. Cor. tetrapetala, bafi urceolata tetragona, limbo patens. Petala ovato oblonga, acuta, calyce longiora. Nectar. glandulz quatuor, magna, didymx, ovaria cingentes. Stam. octo, receptaculo extra nectarium in. ferta, fubulara, erecta, petalis breviora. Ovaria quatuor fupera, ovata, intus anguiata, fuperne mediante nylo connata. Styl. unicus, filiformis, naminibus Jongior, decilluus. Stig. tetragonum, explanatum, centro concavum. Ex fchedis b. SOLANDRI.

ENTOGANUM Lxvigatum. Tab. 68. fig. 6.

Melicope... Fors I. char.

Ex herbario Bankfiano.

PEr. Capfulx quatuor, membranaceo- coriaceae, ellipticae, bafi introrlum mucro: natae, lenticulari compreflae, divaricatae, uniloculares, margine fuperiore dé. hifcentes.

REC. funiculus capillaris, e fuperiori capfulae margine ad inferiorem \& interiorem fe; minis extremitatem delcendens.

SEM. Solitaria, elliptica, lenticularia, glabra.

IN T. duplex: coriaceum atque inembranaceun; utrunque tenue.

A L B. fenini conforme, carnolum, album, modice craflum.

Е м в. magnitudine fere albuminis, comprefius, pallide luteus. Cotyl: ovatae, folis. ceae, tenues. Rad. brevis, infera.

a.) Frutus integer. b.) Capfúla feparata, c.) Eadem transverfe differr. d.) Eadem dehifeas: e.) Funiculi umbilicalis infertio. f. f.) Semina ieparata. G.) Adburaen transferfe fetura. H.) Embryonis figura \& fitus intra altumen. 


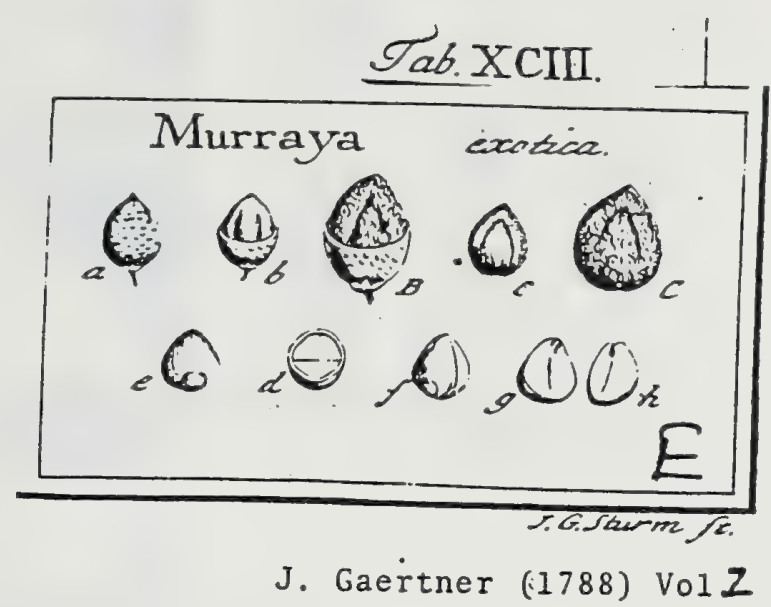

DLXXXIII. M U R R A Y.A. LINN. gen. I34r.

Calyx monophyllus, brevis, quinquefilus. Cor. pentapena. Nectar. campanulatun, ovarium cingens. Stuin. decem. Ovar. fuperum. Styl. finplex: ftigmate capitato pentagono. Bacca exfucca, unilocularis monofperma.

Murraya exotica. Tab. 93. fig. 5.

Camunium japonicum. RUMPH. amb. 5. p. 29. t. 88. f. 2.

Marfana buxifolia. SONNERAT. voy. ind. 2. p. 245. t. 139.

Murraya exotica. LINN. $\int 3 \%$. veg. 398 .

Buis de cbine. A Sereniff. Princ. CAROLINA March. Bad.

PER. Tacca exficca, fupera, globofa, brevi acumine terminata, punctis elevatis aut tuberculis miliaribus obfolete fcabrata, coriacea, tenuis, unilocularis.

R в c. nullum; femen fundo baccx affixum \& cum cuticula fua undique cohxrens.

SEM. unicum, magnitudine fere baccx, fubglobofum, fbris mollibus breviffinis, apprefis undique contectum, albidum aut pallide Aramineum.

INT. fimplex, chartaceum, tenue, facile fecedens, bafi interna lata area chalazina, caltaneo fufca notatum.

A L. B. nullum.

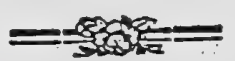

Es B. fenini conformis, inverfus, pallide viridis, ad bafin mamilla depreffiufula in altera cotyledone infignitus. Cotyl. rotundatz, carnofa, plano convexx inxquales: altera minore tenuiore; altera creffore \& ad bafin mamilla infignita. Rad. teretiufcula, alba, fupera, intra cotyledones latens.

.) Bacea integra. b. B.) Ejus cortex ad medium ufque detratus. c. C.) Semen denudatam. a) Idem transverie fcetum, inxqualem cotyledonum crafitien oftendens. c. f.) Embryo denudatus cum manilla fus, craftiori cotyledoni imprefta. g. h.) Cotyledones feparatz.

Propter fitum chalazx excentricum fufpicor ovarium inumaturum effe biloculare aut difpermom. 


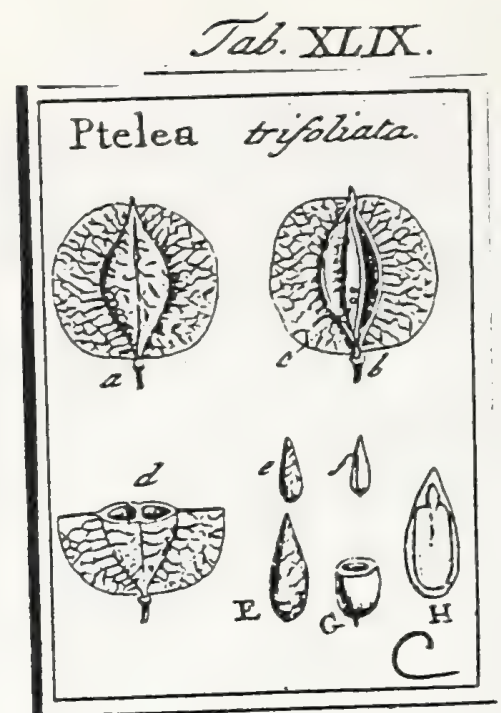

J. Gaertner (1788) Vol.1

\section{PTELEA. LiNk. gen. 152.}

Caljx quadripartitus. Cor, tetrapetala. Stam. quatuor. Styl. unicus. Capfula fupera bilocularis margine membranaceo alata. Ovula gemina. Semina folitaria.

Pterea trifoliata. Tab. 49. fig. 3.

Fraxinus virginianus trifolius, ulmi famaris. DuLl. h. elth. 147. t. 122.

Ptelea foliis ternatis. TREw. rar. 12. t. g. LiNn. Jyffoveg. 160.

$P_{E R}$. Capfula membranacea . comprefla, in medio leviter turgidula \& fulco longitudinali obfoleto utringue infcripta, ad latera amplo margine membrawaceo, venolo, rotundato alata, bilocularis, evalvis.

RIc. nullum, prater duo tubercula minima, in utroque diffepimenti latere pofita, quibus totidem ovula, furfum directa, in immaturo fruchu aftixa funt.

SEM. in fingulo loculamento, vel \& in toto fructu maturo, unicum, oblongum, tere tiusculum, furfum attenuatum, atrum; rugofulum, minutifine puncticulatum? fupra bafin minuta cicatricula umbilicali alba notatum.

IN T. duplex: exterius cruftaceum, aridum, tenue, fragile; interius membranaceum. claalaza fufca ad bafun notatum

A г в. Remini conforme, carnolum, pallidum.

Е в. longitudine fere albuminis, inverfus, niveus. Cotyl. ovato oblongx, obture, fubfoliacex. Rad. brevis, teretiuscula, fupera.

a.) Capfula integra, b.) Eadem longitudinailter aperta, cam clcatriculis (c.) quibus ovula inferta funt. d.) Ejusders fetio transverialis. e. E.) Sernen folutum. f.) Nucleus, G. H.) Albuminis fertiones, cum fitu \& fiqura embryonis. 


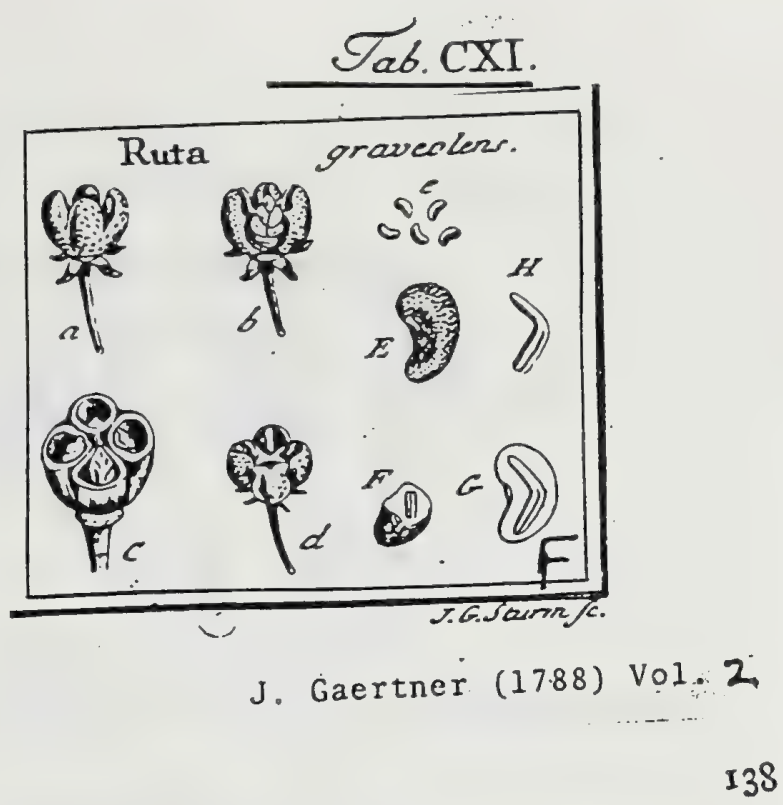

\section{R U T A. TOURN. inf. t. I33. IINN. gen. 523.}

Calyx quadri - 1. quinquepartitus. Cor. tetra - 1. pentapetala. Stam. octo, 1. decem. Receptac. poris octo 1. decem, melliferis. Ovar. fuperum. Styl. fimplex. Capfula quadri-1. quinquelocularis, fubfemllobata, inter lobos dehifcens. Sem. plura, reniformi-angulata.

RUTa graveolens. Tab. III. fig. 6.

Ruta. graveolens bortenjis. DoD. pempt. Ing. BLAxw. berb. t. 7.

Ruta foliis duplicato pimatis, lobulis ovatis. HaLL. bifl. n. $100 \mathrm{3}$.

Iuuta foliis decompofuis, floribus lateralibus quadrifidis. LINN. $\sqrt{3} y$. veg. 397.

$$
=\frac{30}{3}=
$$

PER. Capfula fubglobora, fcrobiculato - punctata, fuperne femi quadri - 1. quinqueloba, totidemque intus loculamentis dotata, inter lobos quadri-1. quinquefiriam dehifcens.

REc. quatuor 1. quinque, ovata, carnofa, fcrobiculata, fingulis loculamentorum angulis internis affixa.

SEM. fex circiter in quolibet loculamento, oblonga, reniformi-angulata, rugis minutiffinis fcabrata, cinerafcentia: umbilico in media renis pelvi pofito.

Is T. fimplex, coriaceun, durum, crnffiufculum.

$\Lambda$ L B. carnofum; craflum, aqueo - pallidum.

E s. lörigitudine fere albuminis, arcuatus vel ad angulum obtufum inflexus, inverlus, in recenti femine viridis. Cotyl. lineares, carnofx, compreffie. Kad. teretiufcula, longa, fupera \& fimul centripeta.

a.) Capiula quadriloba, integra b.) Eadem, lobo uno refedo, cum feminum fius naturali. C.) Eadeu cum receptaculis fuperne denudatis. d.) Eadem quadrifariam debifecns. c. E.) Seunina feparata. F. G.) Seminis \& albuminis fedio transverfalis atque longitudinalis, eum fitu \& figura embryonis. H. Embryo folutus. 


\section{J. Gaertner (1788) Vol3 \\ Jab. 225 .}

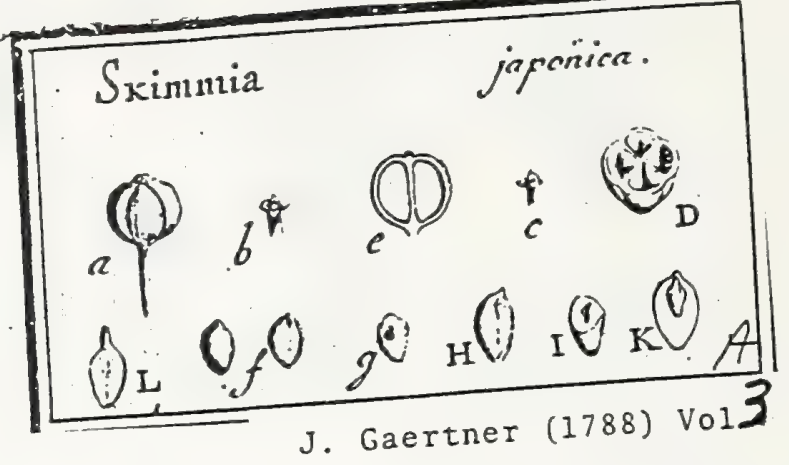

xgr. S K I M M I A.

Tнолв. jap. p. 4. gen. nov. p. 5\%. Sснвев. gen. 200. Juss. gen. $p .425$.

Cal. monophyllus, minimus, quadri-1. rarius quinquepartitus, inferus, perfiftens; laciniz brevifimx, acuminatx. Cor. petala quatuor, (1. quinque,) minuta. Stam. quatuor, fubfeffilia. Ovar. fuperum; ftylo fimplici, tetragono; ftigmate ... Bacca fubg!obofa, rotundato-tetragona, quadrilocularis, tetrapyrena; pyrenx inverfx, monofpermx; Rec. nullum. Sem. folitaria, inverfa, Alb. carnofum. Emb. minutus, inverfus.

Skiмms japonica: Tab. 225. fig. I.

Sin San vulgo Mijama Skinmi. KrempF, amoen. fafc. 5. p. 779.

Skimmia. Thunb. f. jap. p. 62. Linn. fyf. veg. ed. 14. p. 157. WILLdi jpec. pl. T. I. P. I. p. 67I. PERSOON Jjn. I. p. 145.

\section{A Cl. Thunberg.}

PER. Bacca parva, fubglobofa, depreffiufcula 1. ad verticem vis umbilicata; bafi paululum retufa, rotundato-tetragona, 1 quadriloba: lobis rotundatis; hinc calyci minimo infiftens, inde ftyli rudimento tetragono faftigiata, rufécens, quadrilocularis, tetrapyrena. Caro debilis, farinaceopulpofa, intra pyrenarum diftantias defcendens \& diffepimenta tenuilfima formans. Pyrenæ quatuor, fubovace, hinc convexx, inde ad latera planiufcula cuneatse, inverfie, ad verticem anguli interni hilo parvo inltru. ctæ, chartacex, tenues, lubenter a carne difcedentes, glabrx, pallidæ, uniloculares, monolpermx.

REc. nullum: proter vafa umbilicalia, e pedunculo bacca provenientia, \& in axi fructus umbilicos pyrenarum \& feminum adeuntia.

SEM. folitaria, pyrenarum figura, inverfa, ad verticem cicatricula umbilicali alba hilo externo obverfa infignita, fpadicea l. ferruginea.

I N T. fimplex, membranaceum, craffiufcalum, facile detrahendum.

A L 8. femini conforme, carnofum, lutefcens.

EMB. minutus, in fuprema albuminis parte locatus, rhombeo-ellipticus, in. verfus, lutefcens. Cosyl. rhomboidex, obtufx, longitudinaliter plicatze, 1. equitantes, foliacex, incumbentes. Rad. brevis, tereciufcula, obtura, umbilico externo obverfa, 'fupera.

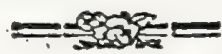

EXPLICATIO FIGURE.

a) Bacea Integre. b. c.) Calyx fepantus, pedunculo junctus. D.) Setio bacce trantverialls, pyrenis exculGs. E.) Eaden longitudinaliter dimiliata, cum Gitu ryreusrum. f.) Pyrena leparaka, dorfo \& a veatre fpeclata. g.) Eadem trasuerife diffecta que femiac. H.) Semea folutum, a yentre vifurn, cum cicatricula umbilicali ad verticem. I, ) Albumea transverít diffectum. K.) Embryonic Gitus incra albumea. L.) Embryo folutus. 


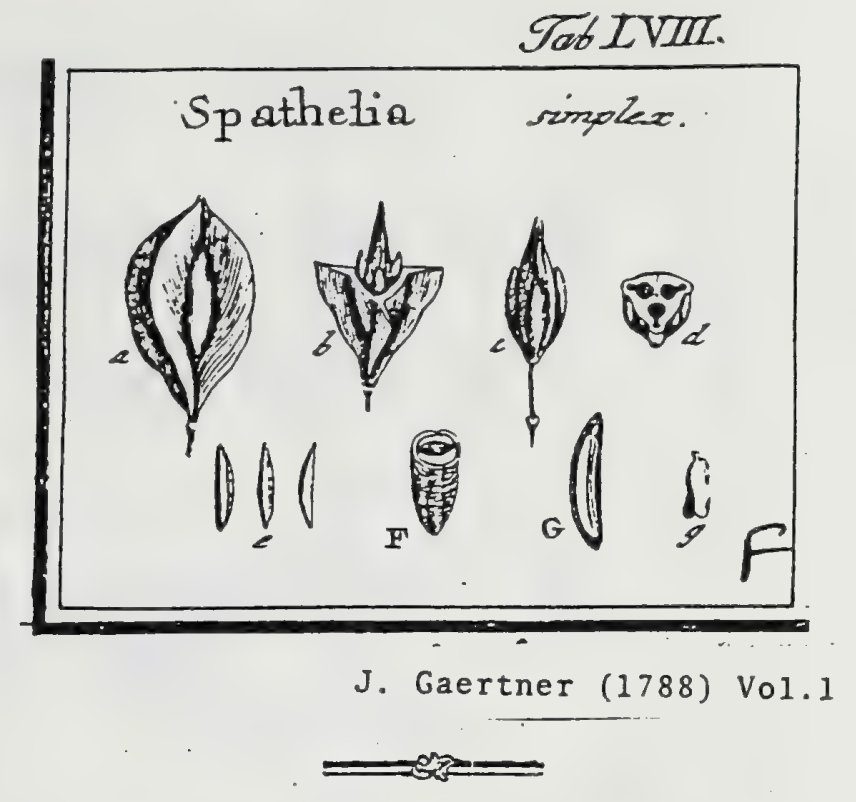

\section{CCCXIIX. SPATHELIA. LIN gen. 373 .}

Calyx pentaphyllus inferus. Cor. pentapetala. Stam. quinque. Styl. tres. Dropa zet fueca, bi-1. trilocularis. Loculamenta canali laterali refinifero ftipata. Semina fó litaria fibrola.

SPA т негі A fimplex. Tab. 58. fig. 3 .

Aceri aut paliuro affinis arbor caudice non ramofo, foliis forbi, floribus räce mofis purpureis, fructu tribus nembranis alato. SLOAN. hift. jam. 2. p. 28. t. 17 I.

Spathelia. Lix n. Jyft. veg. 296.

Ex herbario Bankfiano.

PER. Drupa exfucca, ovata triquetra, glabra, fpadicea. Cortex membranaceo fungo:fus, in alas rigidas fragiles ampliatus. Putamen triloculare lapideum, ovato acu: - minatum, longâ fetâ rigidâ pedunculatum, rotunde trigonum : angulis atque loculamentis appendice teretiusculâ, fuperne in mucronem prominente, interne aufs: tem canaliculatâ atque refiná liuidâ fcatente, fipatis.

REc. nullum; femina cum loculamentorum latere externo cohxrentia.

SEM. in fingulo loculaménto unicum, teretiusculum, utrinque acuminatum; hine nbi canalem refiniferum refpicit, fulco leviter deprefto infcriptum, rubro-ferrugineumi.

IN T. fimplex, coriaceum, e fibris transverfalibus rigidis, cocculi bombycini adinftat: contextum, \& cum putamine, prope canales refiniferos, ita cohxrens, ut absque: laceratione vix ab eo folvi polit.

A L в. ferinini conforme, modice craffurn, carnolum, album.

Eмв. longitudine albuminis, inverfus, niveus. Cotyl. lincari-oblongx, compreftx; : nues. Rad. brevifíma fupers.

2.) Drupa integra, b.) Patamen fuperne denadatam cam prominulis canalium refiniferorum macro nibus. c) Idem, totum cortice exutum. d.) Ejusdem fectio transverfalis. e.) Semina feparita F.) Tella feminis fibrola textura, cum albumine transverfin íccto. G.) Embryo intra albumen," 5.) Idem detudatus, magnitudine naturall,

Dantur in eadeın arbore alii quoque fructus, Ienticulari-comprefi \& duabus tantuma alis infructi ac biloculares, totâ autem reliquâ ftructurâ prioribus fumillimi. 


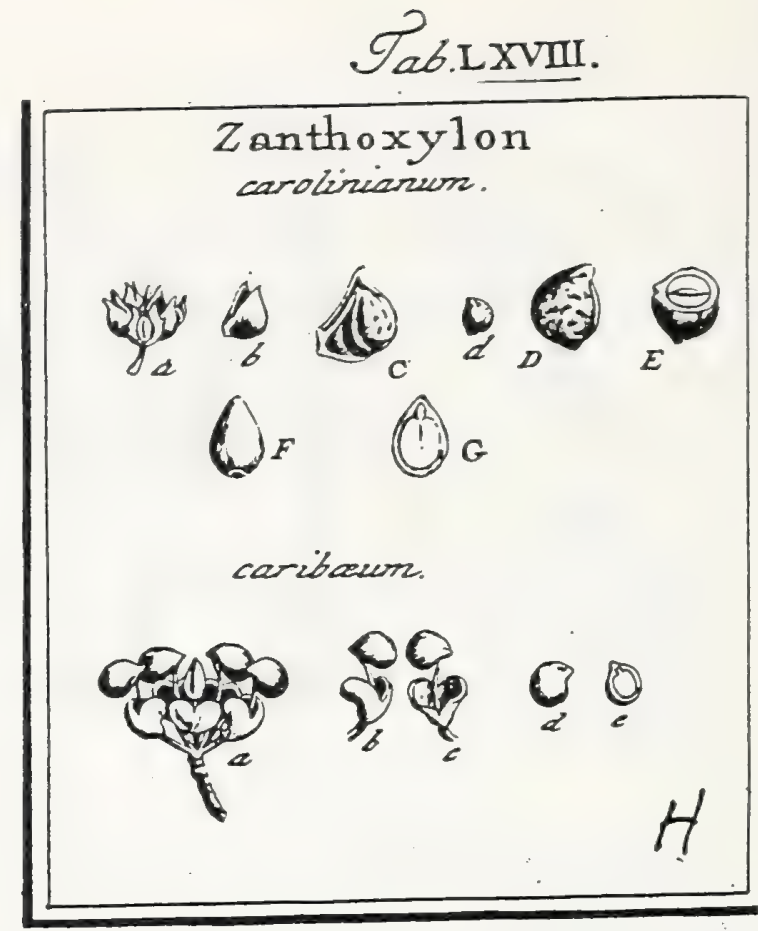

Rutaceae

J. Gaertner (1788) Vol. 1

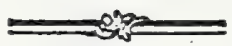

CCCCXXIX. ZANTHOXYLUM. LIN N. ger. nog.

Flores fexu difincti in feparatis truncis. Mas. Cal. quinquepartitus. Cor. nulla. Stam. quinque. Fes. Cal. quinquepartitus. Cor. nulla. Styl. quinque. Capfulae quinque uniloculares, introrfum dehifcentes. Semina folitaria, pendusa.

Zактноху

Xanthoxylt:m Clava Herculis. MIL I. gard. dita.

Zanthoxylum foliis pinnatis. L IN N. Ji/f. veg. 884 .

Ex herbario Bankriano.

PER. Capfulac quatuor 1 . quinque, in calyce feffiles \& bafi inter fe junctae, hine gibbae, inde in angulum compreffae, fupra acuminatae, uniloculares, bivalves.

REC. funiculus fetaceus, a bafi capfulae, ad apicem ferninis, adfcendens, capfula brevior.

SEM. folitarium, ovato globofum, fupra mucronatum, hine gibbum, inde friz depref$f_{a}$, pro recipiendo funiculo umbilicali, exfculptum, foveolis irregujaribus \& obfoletis rugatuin, atrum, lucidum.

IN T. duplex: exterius fublapideum, craffum, durifhmum; interius fpongiofo-membranaccum, paliidum, chalaza fufca in bafi notatum.

$\Lambda_{\perp}$ B. cavitati feminis conforme, craftum, carnofum, album, friabile.

EмB. magnitudine fere albuminis, compreflus, inverfus, lutefcens. Cotyl. ellipticae, foliaceae, tenuifimae. Rad. teretiuscula, fupera.

8.) Fructus maturus. b.) Capfula feparata. C.) Funiculi umbilicalis infertio, d. D.) Semen folutum. E.) Ejus fectio trausverfalis, F.) Nucleus decorcicatus cum chalazs, G.) Embryonis figurz \& fitus intra albumen.

ZАNтнОXY

Fagara fraxini folio. D и н А м. arb. germ. p. 165.

Xanthoxtilum fpinofum Sloani. MıL. gard. diż.

Ex herbario Bankfiano.

Capfulac quinque, poft calycis lapfum pedicellatae (a. b. c.), a fe invicem remotae, renifurmi curvatae (b.), uniloculares, f(mibivalves (a. b.), margine interiore toto (c) dehifecntes. Funiculus umbilicalis filiformis, crafiusculus, per maturitatem alte fupra capfulam clatus, femina in ficu fere horizontali $(a-c$.) fuftinens. Semen $(a-d$.$) lentsculari globofum, rofellato acuminatum, glaberrimum,$ atrum, sitidum. Integ. extcrius cruftaceum, fragile. Albumen \& embryo (c.) ut in praecedenti. 


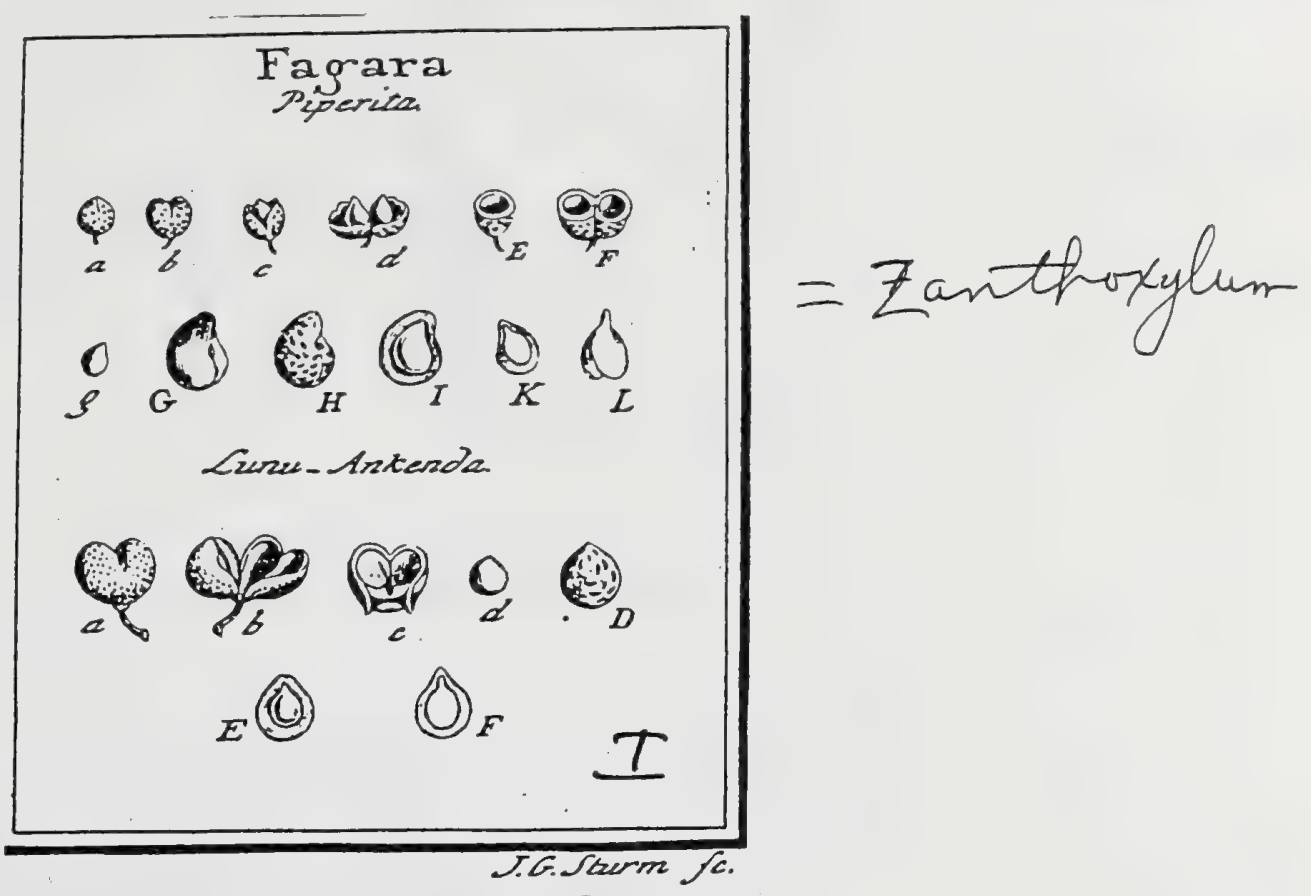

J. Gaertner (1788) Vol.1

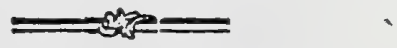

CCCCXXX. FAGARA. Linn. gen. 250.

Calyx quadrifidus. Cor. tetrapetala. Stam. quatuor. ad octo. Styl. unicus. Cap. fula uni -1 . bilocularis. Semina folitaria, nitida.

FA GA RA piperita. Tab. 68 . fig. 9.

Piper japonicum Sio.E Sanfio K.empғ. amoen. 892. ic. 893.

Fagara foliolis crenatis. Li . . Sy

PER. Capfula parva, fubglobofa, fimplex aut didyma, coriacea, extus punctis callofis feabrata, intus lamina chartacea elaftica, duplicata, uni-aut bilocularis, bivalvis

REc. nullum manifeftum; femen futurx dehifcenti in medio affixum.

SEN. unicum in fingulo loculamento, globofum, fuperne leviter acuminatum \& con. preflum; ad medium latus internum parvo umbilico notatum, fubofleum, atrum, nitidun.

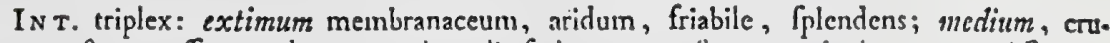
faceo offeum, durun, tuberculis fcabratum, teflaceum; intimum, tenuifimum, palliduin, meinbranaceum.

A \&8. cavitati feminis conforme, carnofun, friabile, album.

E s 8. magnitudine fere albuminis, compreffus, inverfus, niveus. Cotyl. ellipticx; foliacex, tenues. Rad. teretiuscula, lupera.

a.c. E.) Capfula fimplex, unilocularis. b. d. F.) Alia didyma, bilocularis, g. G.) Semen (epa-" ratum. H.) Integumentum medium offeum tuberculatum. 1.) Nucleus denudatus, K.) Embrgo intra albumen, L.) Idem feparatus.

In japonicis fructibus, capfulx plerxque funplices; contra in clinenfibus, didymae frequentiores funt. Yolteriores, cum multis aliis feminibus chinenfibus, debeo humanitati Du. D. Livd.

FAGARA Lunu-ankenda. ibid.

Lunu-ankenda. zcylonens. E collect. fern. hort. lugdb.

Capfulac ounncs didyınac (a.), biloculares (b.), intus membrana elaftica (co) duplicatac, triplo majores, yuam praecedentes, fed minoribus tuberculis, aut punctis faltem elevatis \& denfillume pofitis feabratac. Semina (d.) rotundata, lenticularia, atra, nitida, folitaria, aut rarius gemina in alterutro loculatrentorum. Integum. extimum \& intimun, ut in praccedenti, membranaccum; fed inedium (D. E.) Japideun, cralfillinum, rugofum, totum, quiss iplâ fracturâ nigrum. Nucleus (E.), Albuinen \& Einbryo $\left(F_{.}\right)$, ut in priori, faltem majora omnia. 


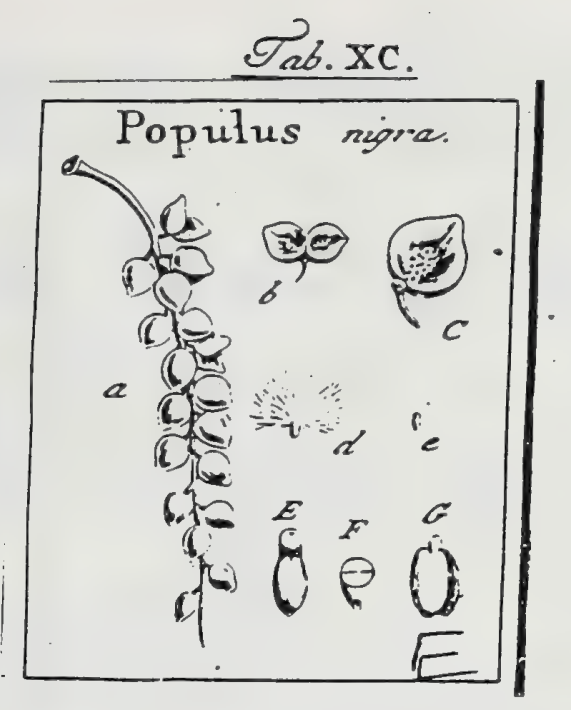

J. Gaertner (1788) Vol 2

DLXI. POPULUS. TOURN. inft. t. 365 . LINN. gen. II23. 56

Flores fexu diftincti, in feparatis ftirpibus. MAS. Amentum juliforme, laxe -imbricatum fquanis oblongis, margine laceris. Cal. infundibuliformis, inxqualiter bilabiatus. Cor. nulla. Stam. ofto. FEM. Amentun, Squamx \& Calyx ut in mare. Ovar. ovato-acuminatum. Styl. nullus: ftigmata quatuor. Capfula unilocularis, bivalvis. Semina inverfa.

Populus nigra. Tab. 90. fig. 4

Populus nigra. CAMs. epit. 66. Dod. pempt. 836. BLakw. berb. t. 248.

Populus foliis glabris, cordato rlbomboideis ferratis. HaLL. bift. $n_{0} 1632$.

Poprdus foliis deltoidibus acuminatis ferratis. LINN. fyf. veg. $88 \mathrm{~g}$.

PER. Capfula ovan, ad verticem compreffufcula \& fubscuminata, cetera turgi. de lenticularis, unilocularis, bivalvis: Valvulis concavis, nequaquam roItrutis aut recurvatis, fed horizontaliter patentibus.

REc. tubercula acuminata, minutiffima, valvularum parieti dorfali, a bafi ad nedium ufque inferm, quibus femina affixa.

SEM. numerofa, parva, oblonga, teretiufcula, albicantia, in vertice crinata: Crinibus albis, undulatis; femine quadruplo longioribus.

IN T. fimplex, membranaceum, craffufculum.

A L B. nullum.

EM B. femini conformis, inverfus, luteus. Cotyl ovate, criffe, plano-convexz. Rad. brevifima, globulofa.; fupera......

$$
\text { *. }
$$

1.) Racemus maturus, cam eapiulis pedicellatis, claufis, b. C.) Caplule dehifeertis valvula intus (pedats, eum receptacolis feminom. d.) Semen lana crinitum. e. E) Idem, excuffis erinibus F.) Ejusdem \& cotyledonum fedlo transver(alis. G.) Embryo denudatus, in fity maturali.

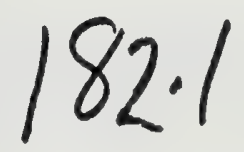




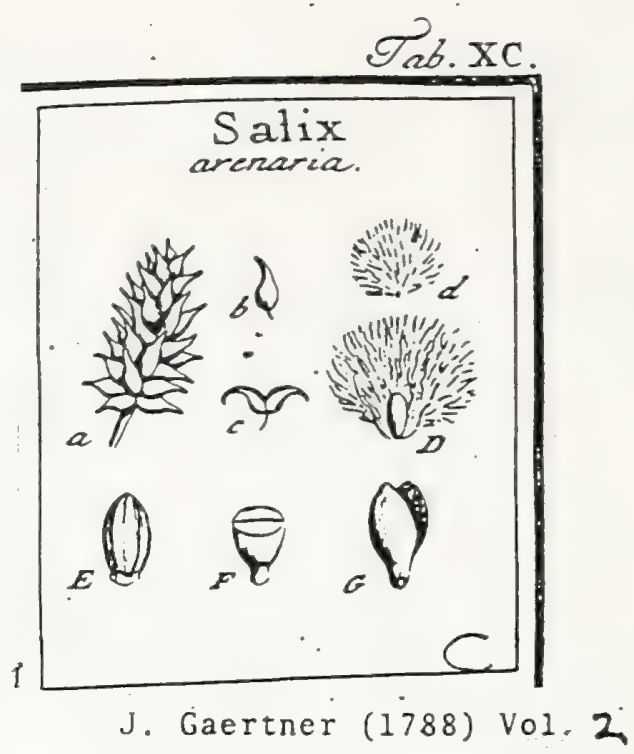

DLX. SAIIX. TOURN. inft. t. 364. LINN. ger. IOg8.

Flores fexu diftincti, in feparatis ftirpibus. MAS. Amentum juliforme, ovatum aut cylindricum, longum aut brevifrmum, inbricatum fquanis lanceolatis, uniforis, bafi interna fquamula minuta, planit aut cylindrica, auctis. Stam. unum ad quinque. FEM. Cal. nullus. Cor. nulla. Ovaria tereti - acuminata in fpicam denfim juliformem congcita, \& ad bafin fyua. mula lanceolata, fibi paulo breviore, ftipata. Styl. nullus: Stigmata duo. Capfula unilocularis, bivalvis. Seniua erecta.

SALIX arenaria. Tib. 90. fig. 3.

Sulix pronilu, foliis utringuge candicantibus Es lanuginofis. GMEL. fib. X. p. 746 . t. 36. f. 2 .

Sullix foliis integerrimis ovato lanceolatis fubrus fericeis, julis tomentofis. HaLL. bijl. s. 1642 .

Salix foliis integris ovatis acutis fupra fubrillofis, fubtus tomentofis. LINN. fyje. veg. 880 .

PER. Capfula ovato-roftrata, unilocularis, bivalvis: Valvulis dehifcentibus apice revolutis.

REc. nullun. Semina parieti interno valvularum, in fitu erecto, affixa.

56

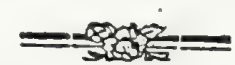

SEM. plura, octo ad Sedecim, ovata, parvula, undique crinita: Crinibus ferł. ceo-albis, fimplicibus, longitudine capfulac.

Ixт. Complicifimun, membranaceun, pallidum.

A L B. nullum. EM B. Remini conformis, erectus, viridis. Cotyl. ellipticx, plano- convexx.
Rad. attenuata, infera.

2) Spica matara. b.) Capfula claula c.) Eadem dehifcens. d. D.) Semen crinitum. E.) Idem. exculis crioibus. F.) Ejusdern fectio transverfalis. G.) Embryo denudatus in fitu naturali 


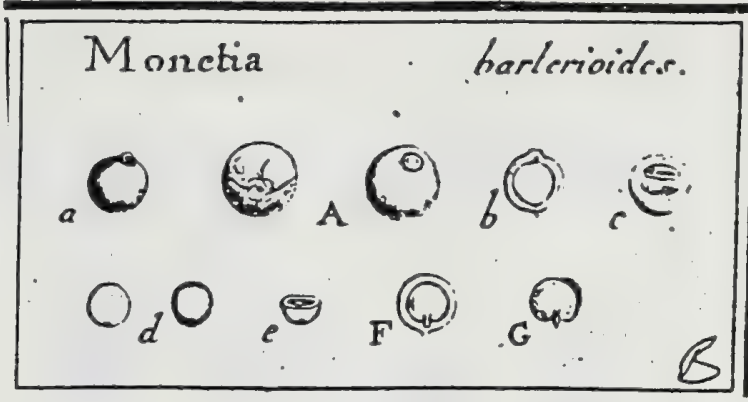

J. Gaertner (1788)'Vol. 3

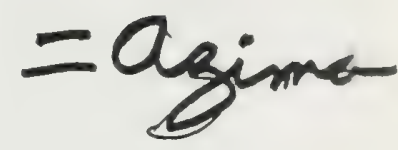

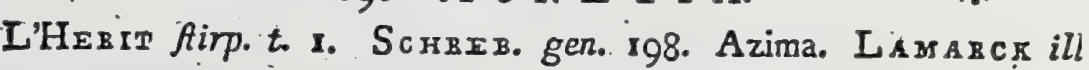 gen. t. $80 \%$. Juss. gen. p. 425.}

Cal. monophyllus, inferus, ventricofus, campanulatus, tri-1. quadrifidus perfiftens. Cor. petala quatuor, cum calycis dentibus alterna \& ipfis lon. giora, linearia, acuminata, apice recurva. Stam. quatuor, fub ovario in. ferta, cum peralis alterna; filamenta fubulata; sutherx incumbentes. Ovar. fuperum; ftylo brevi, conico; ftigmate acuto. Bacca parva, corticata, bi. locularis. Rec nullum. Sem. duo, compreftufcula, ereda. Nb. carno. fum. Emb. erectus.

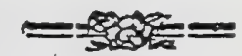

Monetis barlerioides. Tab. 225 . Ag. 6.

Lycium indicum fpinis quaternis ad foliorum fringulum exortum. SẸB, thef. 8. . p. 21. t. $13 . f_{0}^{\prime} x_{0}$

Azyma (tetracantba,) foliis oppofitis petiolatis ovato - lanceotatis glabris aplce pungentibus, fpinis ftipularibus quaternis, LAs. dia. 1. p. 343. PkRsOON Jyn. x. p. 145.

Monetia. L'Herit, 1. c. p. T, ThunB. prod. p. 28.

Monetia fpinis quaternis, foliis utrinque glabris, WILLD. Jpec. pl. T. I. P. X. p. 669 .

Ex collectione Bankfiana,

PER. Bicca parva, magnitudine pif̊, ovata l. ovato-globofa, bsfi reliquiis infiftens, ad verticem mucrone callofo obtufitrmo \& intra hunc. linea circulari a Ityli Japfu infignita, corticata, intus pulpofa, glabra, lutea, bi, locularis. Cortex tenuis, çoriaceus, Pulpa molliș, cortıci adhxrens, ficcitate evanefcens. Diflepimentum tenue, pulpofum. Loculanenta membrana tenuiftma veltita, monofperna.

REc. nullum: prater funiculum umbilicalem brevịfimum, quo mẹiante femina loculamentorum fundo alfixa,

SEM. folitaria, erecta, orbiculata, compreffufcula, L intus plana, extus leviter convexiufcula, per ambitun obtufa, bafi cicatricula umbilicali parva notata, glabra, ferruginea 1 . fpadicea.

Is $\mathrm{T}$. duplex, utrumque membranaceum; exterius firmum, facile detrahendum; interius arachnoideum, adnatum,

A L B. femini conforme, carnofum, albun.

E ar в. centralis, albumine pauto minor, erectus, albus. Cosyl. magıx, orbiculares, foliacex, bafi profunde fiffx: lobälis obtufis. Rad. teretiufcula, cotyledonibus paulo brevior, conce acuminata, intra cotyledenum filfuram adfcendens, umbilico externo obverfa, infera.

\section{EXPLICATIO FIGURE.}

a. A,) Bacca integra, a bafi \& a vertiç fpectata. b,) Ejusdem fectio longitudiualis, eum fitu feminis intra locuium. c.) Eadem cum feminibus (transverfe diTera. d.) Semen folutum, ab utroque latere fpedatum. e.) Ejnsdem fedtio transyerfalis. F.) Albuminis feaio longitudinalis, cum fitw embryonis, G.) Embryo folutus,

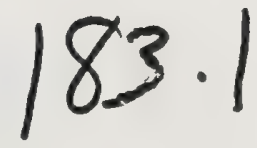




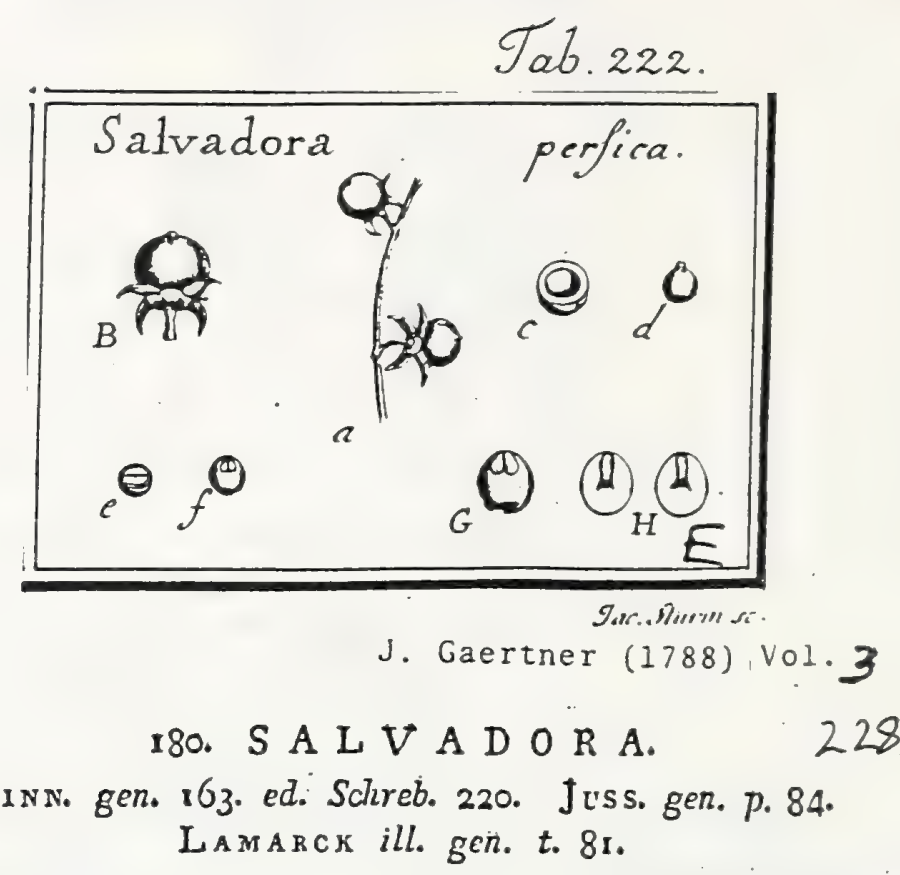

Cal. monophyllus, parvus, inferus, quadripartitus, perfiltens. Cor. monopetala, quadrifida; laciniis ovatís, reflexis, cum calyce alternis. Stam. qustuor, ad divifuras corolla inferta; filamenta fetacea; anthers erectx, fub. rotundx. Ovar. fuperum; ftylo brevi, Gimplici; ftigmate obtufo, concavo. Bacca globofa, unilocularis, monofperma. Rec. nullum. Sem. folitarium, inverfum, integumento chartaceo inltructum. Alb. nullum. Emb. inverfus; radicula abfcondita.

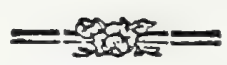

Salvadora perfica. Tab. 222. fig. S.

Rivira paniculata. Liss. J3\%, nat. ed. jo. p. 899.

Cifus (arborea, ) folitis oblongis integris crafis. Fursk. defc. p. 32. 4.8.

Entelia (Grofularia, ) foliis ovato - lanceolatis oppofitis, foribus tetrandris. RETZ obf. 4. p. 24 .

Salvadora. Garcin. all. angl. 1749. n. 497. Lins. amoen. acad. 3. p. 23. Spec. plo p. 178 . Syf. veg. ed. 14. p. 166 . WILLD. Spec. plo T. I. P. $x_{0}$ p. 695. PERSOON fyn. I. p. 149 .

Icom. Vahl fymb. bot. 1. t. 4. Roxв. ph. sorom. to 26.

Ex collectione Bankfiana.

PER. hacca parva, magnitudine pifa, pulpora, globola, apice mucronulata, bafi corollx \& calyci perfiftenti infiftens, glabra, lutea, unilocularis. Caro craffiufcula, pulpofa, mollis, cuticula tenui inclufa, lucefcens, femini non adhærens.

REC. nullum; præter funiculum umbilicalem breviffnum validum ad verticem feniunis, quo mediante femen pulpre adharet.

SE M. unicum, ovato-globofum, apice mucronulatum \& area umbilicali inftructum, inverfum, lubenter a carne fecedens, glabrum, lutefcens.

- IN T. fimplex, chartaceum, validum.

A L B. nullum.

Eмy. magnitudine fere feminis, ellipticus, inverfus, albus. Cotylocrafre, amygdalino-carnof $x$, plano-convexa, ad apicem rima fiffe \& glabellis duabus 1 . lobis notatx. Plums. minima, bidentata. Rad. oblonga l. fubclavata, tertiam embryonis parten longitudine mentiens, in proprio lectulo intra cotyledones demerfa \& plane ablcondita, recka, adfcendens, unbilico externo obverfa, fupera.

\section{EXPLICATIO FIGURE.}

a.) Pars racemuli frugiferl. B.) Bacea feparata, integra. c.) Ejusded fertio transverialis, feo mine exculfo. J.) Simen Ieparatum, integrum. c.) Idem transverfe diffequm. f. G.) Embryo folutus. H.) Cotyledones feparatx, a parte interna fpectatx, cum forma \& infestione radicule. 


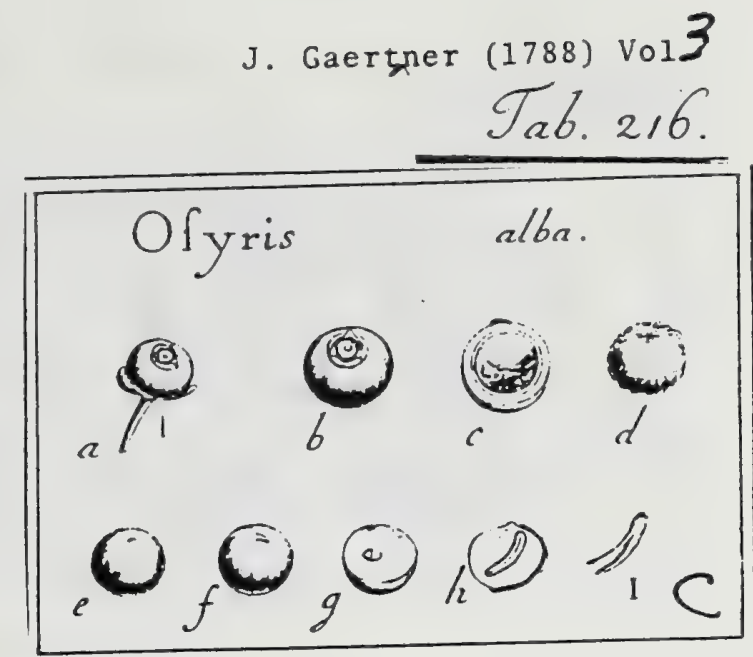

J. Gaertner (1788) vol 3

16r. O S Y R I S.

LINN. gen. Iror. ed. Schreb. 1497. Júss. gen. p. 75; Lamaвcs ill. gen. to 802. Cafia. Tо ОвN. inft. t. 488.

Flores rarius hermaphroditi, frequentius fexu diftincti in diverls plantis.

Ma s. Cal. monophyllus, turbinatus, trifidus. Cor. nulla. Stam. tria; fila: mentis breviffimis.

FOR M. Cal. ut in mare, minimus, perfiftens. Cor, nulla. Stam. rudiments tria. Ovar. inferum; ftylo fimplici, longitudine ftaminum; ftigmate tripartito, patente. Drupa globofa, calyce adprefo coronata. Putamen cruftasceum, uniloculare, monofpermum. Sem. unicum, globofum, erectum. Alb. craffifimum, carnofum. Emb. inverfus, obliquus.

OsYris alba. Tab. 216. fig. 3.

Cafia pontica monfpelienfrump." CАM. epit. 26. Lов. ic. 439.

Qbyris folitis linearibus, acutis. LOEFL. it. p. 269.

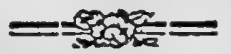

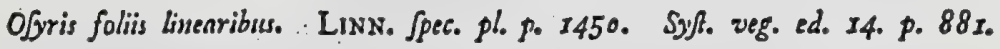

ab amicifino $D^{\text {re }}$ Colsman, med. Hafn., \& ex dono Drit Rozmer.

P E R. Drupa parva, juniperi galbulum vis excedens, baccata, globofa, fubin-

- fera, 1 . calyce minimo adnato paulum fub vertice nudo mucronulatoque coronata, glabra, rubra. Caro debilis, coriacea, aduata, lutefcens. Putamen globofum, ad verticem mucrone cruciato-trilobo inftructum, cruftaceum, fragile, tenue, evalve, uniloculare, monofpermun.

R\&C. nullum: femen fundo putaminis ope funiculi umbilicalis brevis femini adprelfi adnatum.

SE N. unicum, cavitatem putaminis exade replens, globofum, in vertice mucronulatum, erectum, pallidum.

IN T. fimplex, membranaceum, tenue, albumini adnatum.

A L B. fenini conforme, craffifimum, carnofum, album.

$E_{M \text { B. }}$ inverfus, prope verricem albüminis \& citra ejus axem locatus, oblique. defcendens, ad axem incurvus, teretiufculus, medio paulo craffior, lacteus. Cotyl. femiteretiufcule, I leviter incurve, attenuatz, longx, incumbentes. Rad. brevis, conico-teretiufcula, mucronulata, umbilico contraria, fupera.

\section{EXPLICATIO FIGURE.}

a. b.) Dnipa integra diveríz magnitudinis. c.) Eadem medio transverie dilteaz. d.) Putamen integruni, feparatum, paulo a vertice fpedatum. e.) Semen folutum, a vertice, \& f.) Idem a bafi vifun. 5.) Albumen transverfe diffeature. b.) Ejusdem feaio verticalis, cum fitu embryonis. I.) Embryo folutus. 
J. Gaertner (1788) vol 3

Tab. 225.

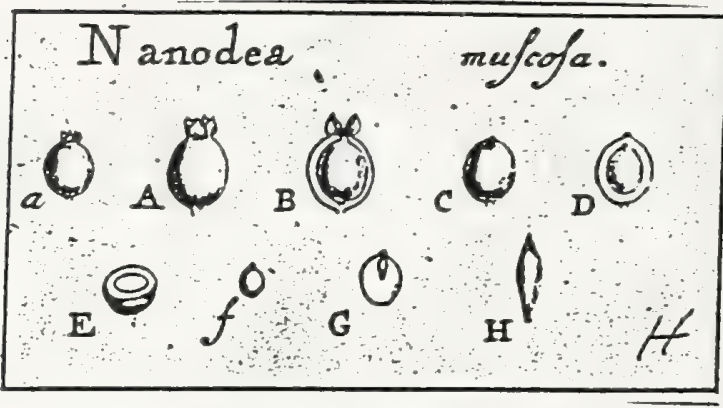

J. Gaertner (1788) Vol. 3

\section{N. A N O D E A. Banks.}

Cal. monophyllus, fuperus, quadripartitus; tubo brevi $\mathbb{C l}_{\mathrm{m}}$; laciniis brevibus, cordatis, acutis, nargine introlexis. Cor, nully. Stam. quatuor; flamenta brevifima, calycis laciniis oppolita \& ad ipforum baGn inferta; antherz... Ovar. inferum, oblongum; ftylo fimplici, conico, brevi; ' ftignate bipartico, obtufo. Drupa baccata, calyce coronata; putamine uniloculari. Rea nullun. Sem. unicum. Alb. carnofum. Emb. inverfus.

NANODEA mulcola: Tab. 225 . fig. 9.

Balenerdia." Commers. MSs.

Habitat ad fretum Magellanicum, Staaten Land \& Cap. Horn. Ex col. lectione Bankfiana, \& a Cl. Desfontaines.

PER. Drupa parva, magnitudine pifi, baccata, ovata, fulcis quatuor leviffmis elevatis infignita, calyce coronante faftigiata, feflilis, glabra, crocea. Caro mollis, non admodum crafia, putamini adnata. Putamen ovatum, apice mucronulatum, compreffiufculum, 1. turgide lenticulare, crafiufculum, uniloculare, evalve, monófpermum.

REc. nullum; femen baf putaminis arctius adhæret.

SEM. unicum, cavitati putaminis conforme, ovatum, apice mucronulatum, compreffiufculum, erectum, lutefcens.

I т. Gimplex, membranaceum, facile detrahendum.

A L B. femini conforme, craffum, carnofum, lutefcens.

EM B. mininus, vix terciam albuminis partem longus, \& in fuprema ejus parte locatus, compreffiufculus, inverfus, albus. Coryl breviffimx, ifseari-acuminate. .Rad. magna, longa, rhomboidea, conico-acuminata, umbilico externo contraria, fupers.

\section{EXPLICATIO FIGURE}

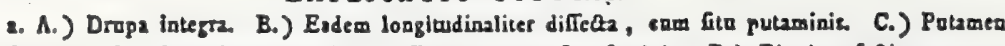
folatwom. D.) Idem longitudiazliter diffeQum, eum fitu feminis. B.) Ejusdera fetio transverfalis. f.) Semen folutum G.) Albumen longitudioalicer diffetum, enm embryone in fict. H.) Embrgo folutus, quam maxime autens.

Planta parva caule Gmplici, debili, filiformi; foliis fparfis, linearibus, acutis; Aloribus paucis, terminalibus, feflilibus, intra foliurum cefpitem congeftis. In familiis naturalibus affinitate proxime ad Thefum accedit. 
Santalaceae

Tat. IXXXVI.

Thesium affinum.

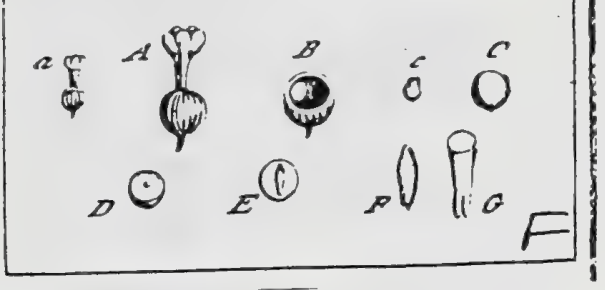

J. Gaertner (1788) Vol. 2

40

DXLV. T H E S U M. LINN. gen. 292.

Calyx monophyllus, fuperus, intus coloratus, quadri-1. quinquefidus. Cor. nulla. Stam. quinque, calycis tubo inferta. Ovar. inferum. Styl. fimplex. Nux unilocularis, evidvis.

Thesium alpinum. Tab. \$G. fig. 6.

Thefizun foribus fubfefilibus, peduaculis foliofis, foliis linearibus. Ger. provinc. 442. t. 17. f. $x$.

Thefrum caule diffufo, floribus alaribus, foliis linearibus. HaLl. bijf. n. 1574 . Thefium raceno foliato, foliis linearibsis. LiNn. Jyßs. veg. 249.

Icon. JAce. flor, auffr. 5. t. 416 .

Ex herbario Bankfiano.

PER. Nux infera, ex indurato calycis ventre enata, cruftacea, fphrerica, nervis longitudinalibus fubramofis ftriata, unilocularis, evalvis.

REC. nullum. Semen bafi affixum.

SEM. unicum, globofum, pallidum.

IN T. fimpliciflimum, tenuifimum, membranaceum.

А L в. femini conforme, carnofum, pallidum aut luteolum.

EMB. longitudine fere albuminis, teretiufculus, inverfus, albus. Cotyl. angultz, acuminace, breviflimz. Rad. fufforni-incraffata, longa, fupera.

$4 I$

a. A.) Nux integra, ealyce perfiftence coronatz. B.) Ejus (caio transverfalis c. C.) Semen feparatum. D. E.) Albuminis fectio transverfalis \& longitudinalis, cum fitu embryonis. F.) Fınbrjo folutus. G.) Ejusdem pars inferior, eum Cotgledonibus infigniter auctis.

184.3 
(

$\theta$ C. 


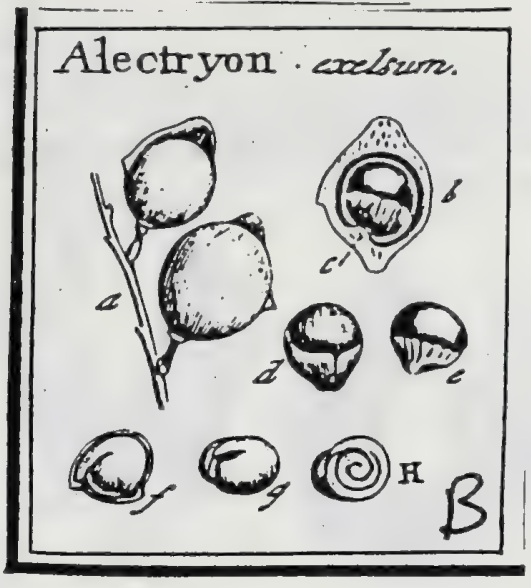

J. Gaertner (1788) Vol..1.

216

\section{ALECTRION.}

Flos.... Racca ficca unilocularis, fuperue in criflam comprefta. Semen unicum: Arillo incompleto pulpofo.

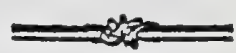

I $\mathrm{ALECTRYON}$ excelfuin. Tab. 46. fig. $a$.

Evonymoides excel/a. SOLAN D. $m / s$.

E collect. Bankliana.

P.ER. Bacca fupera, coriacea, globofa, in vertice \& ad alterum latus dimidium, margire coriaceo in crillain compreflo aucta, pubefcens, ciserea aut fumola, unilocularis.

REC. tuberculum parvum, fupra bafin loculamenti in larere baccx critato.

SEM. unicum, fubglobofum; fuperne convexum, Irvigatifimum, fpeculi inflar lucidum, nigro purpureun; inferne obtufe conicum, lordide albicans, derafum, \& arillatun.

Arillus incompletus, bafin faltem feminis obtegens, eique arcte adharens, pulpofo glandulolus, tenuis, atro-fanguineus.

In T. duplex: exterius crufaceum, durum, tenue, fragile; interius membranaceum, e Jutto-rufelcens.

A с. B. nullum.

Емв. magnitudine feminis, fubglobolus, depreffiusculus, albus. Cotyl. carnof $x$, craf$f_{x}$, utriuque planiusculx, fpiraliter convolutz. 'Rad. brevis, trianguläri-acunirsata, comprefla, fuperne e cotyledonibus oriunda, \& dehine in latus umbilico directe oppofitum delcendens, fuoque apice fundum baccz refpiciens.

a.) Bacca integra, b.) Eadem diffecta. c) Seminis infertio. d.) Sernen folutum arillo ad bafin veficum. e) Ejusdem bafis deuudata. f.) Tefla feminis aperta, cura roftello embryonis in contra. riam ab umbilico plagam directo. z.) Nucleus folutus. H.J Embrjo denudatus,

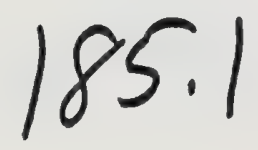




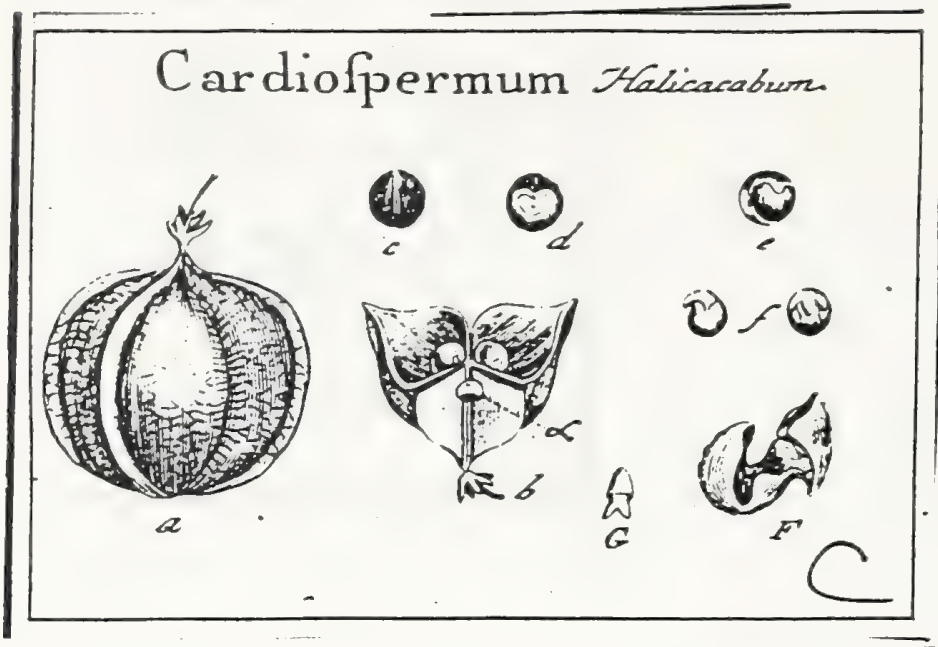

J. Gaertner (1788) Vol.1

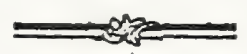

\section{CCCCXCVII. CARDIOSPERMVM. LIN gen. 498.}

Calyx pentaphyllus. Cor, tetrapetala. Nectar. tetraphyllum inxquale. Stam. octo. StyL tres. Capfulx tres inflatz, ad axem connatx. Semina globola.

Cardiospermum Halicacabum. Tab. 79. fig. 2.

Pifum cordatum. B EsL.h. Eyf. a/iv. XIII.t. Ir. f. r.

Veficaria. R I v. tetrap. t. 219.

Cardiofpermum foliis lavibus. LIN N. J4ft. vig. 380.

PER. Capfulx tres, inflatx, membranacex, venofo reticulatz, margine dorfali membranaceo anguflifimo alatz, coadunatz \& ad axem inter fe connatz, ut unicam capfulain trilubatam mentiantur; cxtera uniloculares, evalves.

REc. tuherculum fungofum, album, medio angulo mterno capfularum adnatum, cui femen lata cicatrice unbilicali affixum.

SEM. folitaria, globofa, atra, cicatrice umbilicali alba cordata infignita.

In т. funplex, conaceo-cruftaceum, durum, extus atrum, intus ferrugineum.

A r. B. nullum.

Eмn. glnbolo-rontellatus, albus. Cotyl. carnolx, craftx, inzquales: alters majore, profundo finu, pro recipienda minore altera, exfculpta. Plum. bicornis, minima. Rad. conica, comprefla, roltellata, centripeta.

$\rightarrow$

x.) Frallus integer. b. , Capfulz daze transverfim feax, cam recepacalo feminis ( $\alpha$ ), angrlo interno (ertiz caplula refeftz adnato. c.d.) Semen ab utroque latere fpetatum, e:) Nucleas denudatus. I. F.) Cotyledones inzquales, G,) Plamula \& radicula feparata.

Semina ex India orientali delata, fupra dictis dimidio fere minora, \& embryonis cotyleduncs, in lanninam craifan carnofam complanatz ac fpiraliter convolutz crant.

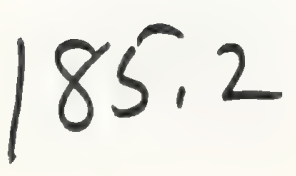




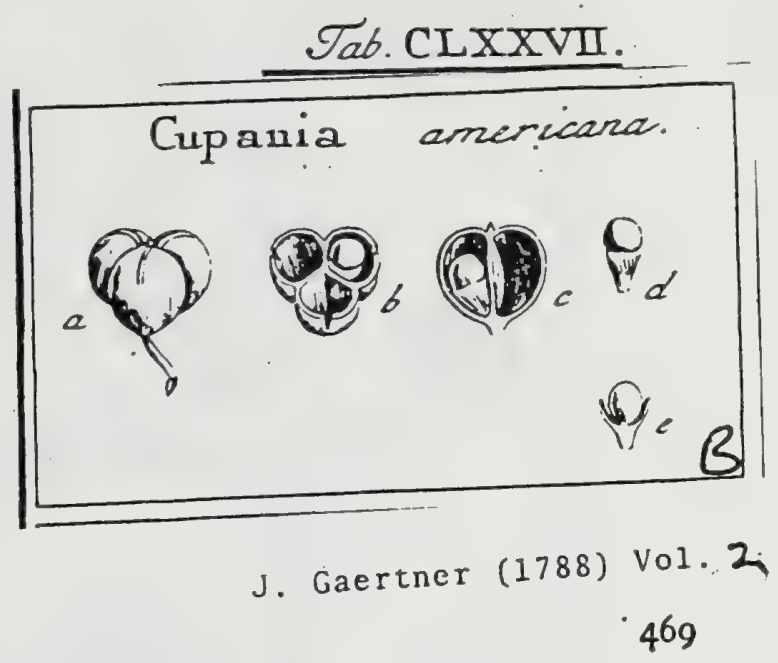

MLI. C U P A N I A. Plum. t. I9. SChreb. ger. 645.

Cal. quinquepartitus. Cor. pentapetah, petalis fuperne cucullatis. Stans. octo. Ovar. fuperum. Styl. trifidus. Capf. trilocularis. Sem. folitaria, arillata.

Cupasia americana. Tab..177. fig. 2.

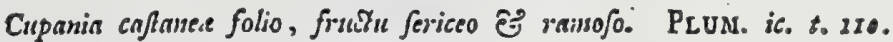

Cupaniar ameericaun. LiN. Syft. veg. 864.

Ex herbario Bankfiano.

PE r. Capfula curiacea, turbinato - trilaba, trilocularis, apice trifarian dehifcciss, fufco ferruginea. Valvularun futura verfus apicem in fulcum anguItum prominula; latern auten protindo fulco medio exaratx, cui interue dillepinenta refpondent.

REC. Mullua ; fensina bafi loculamentoruni affixa.

SE M. folitaria, elliptice globofa, fufea. arillata.

Arillus incouspletus, fipmuinio - membranaceus, fordide albicans, infun. dibuliformis: roltello fulido; cupula autem femen ad dinidiun invol. vente \& in marginem repandun edentulum definentc.

IN r. exterius coriaceun.

A в. ..... (nullum JuI.) E М в. ....

2.) Capfula integra. b.) Eadiem transveric diffeda, e.) Valvala feparata. d.) Sewen arilto veftitum. c.) Iden cum srillo dificto.

Capfula inferne integerrima cft, \& vix ad dimidium longitudinis fux in valvulas folvitur. Semina in ommibus meis exemplis folitaria tantummodo deprehendi. Anne igitur noftra jamurcenfis p!anta, a dominicenfis. Specie diver $\int_{3}$, cum huic polteriori fit fructus Sericeo 2lbus \& femina in loculis gemella!

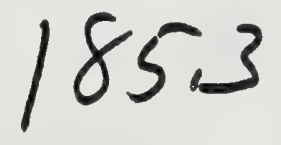




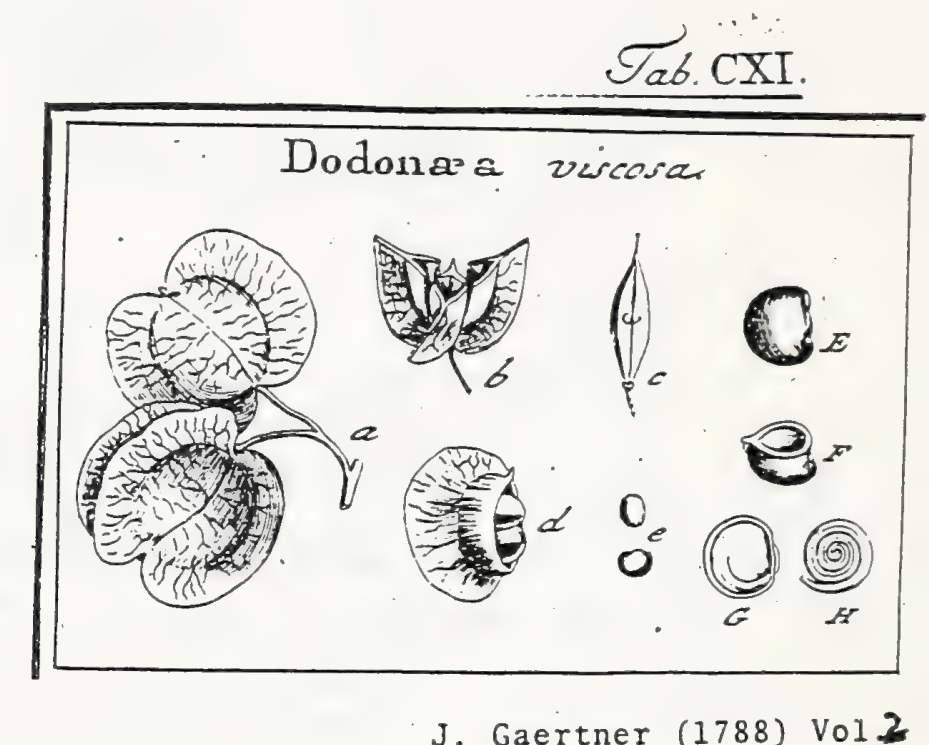

DCXI, DO D N I A. LINN. gen. I303.

Calyx tri-1. tetraphyllus. Cor. nulla. Stam. fex, 1. octo. Ovar. fuperum. Styl. fimplex. Capfula trialata, trilocularis. Semina geminati.

Dodones vifcofa: Tab. III. fig. I.

Coryophyllafer littorens. RUMPH. amb. 4. p. 110. t. 50 .

Triopteris erecia frutticoja, foliis oblongis acuminatis, ramulis gracilibus. Brows. bif. jam. 191. t. 18. f. I.

Dodonea folits oblongis. LINN: fyyto veg. 362 .

PER. Capfula membranacea, tenuis, reticulato - venofa, bi - 1. trilocularis, trivalvis; valvulis navicularibus, carina in margiien membrariaceum Latum rotundatum ampliats. Diffepimenta axi fructus adnata, futuris valvularum obverfa.

REC. axis fruetus a lapfu valvularum perfittens, triqueter, cujus medio femina ope duorum tuberculorum minimorum affixa.

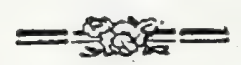

SEM. in fingulo joculamento gemina, fubrotunda, turgide lenticularia, verfus dorfum autem in acutam aciem compreffa, atra, glabra, dura.

Ix T. duplex: exterius fuboffeum aut cruftaceun, craffun; interins membraszceum, tenuc, ferrugineum.

A L 8. nullum.

Eм B. longifimus, fpiraliter convolutus, lutefcens. Cotyl. carnof $x$, fublineares, in exterioribus convolutionibus anguftiores, verfus interiora vero fenfim latefcentes, ut centrum in lenticularem convexicatem turgeat. Rot.s. triquetra, in extimo gyro pofita, centripeta.

E) Capfula integra, bi- \& trialata. b.) Capfulx Jebifcentis fectio trantrctialis. r.) Receptaculum a lapfu valvularum perfitens d) Valvula feparata c. E) . Semina integra F.) Tefa feminis transverfm fedz G.) Ejusdem fectio longitudinalis, cumequcleo, proptia fur membrana alhuc veftito H.) Embryo denudatus. 


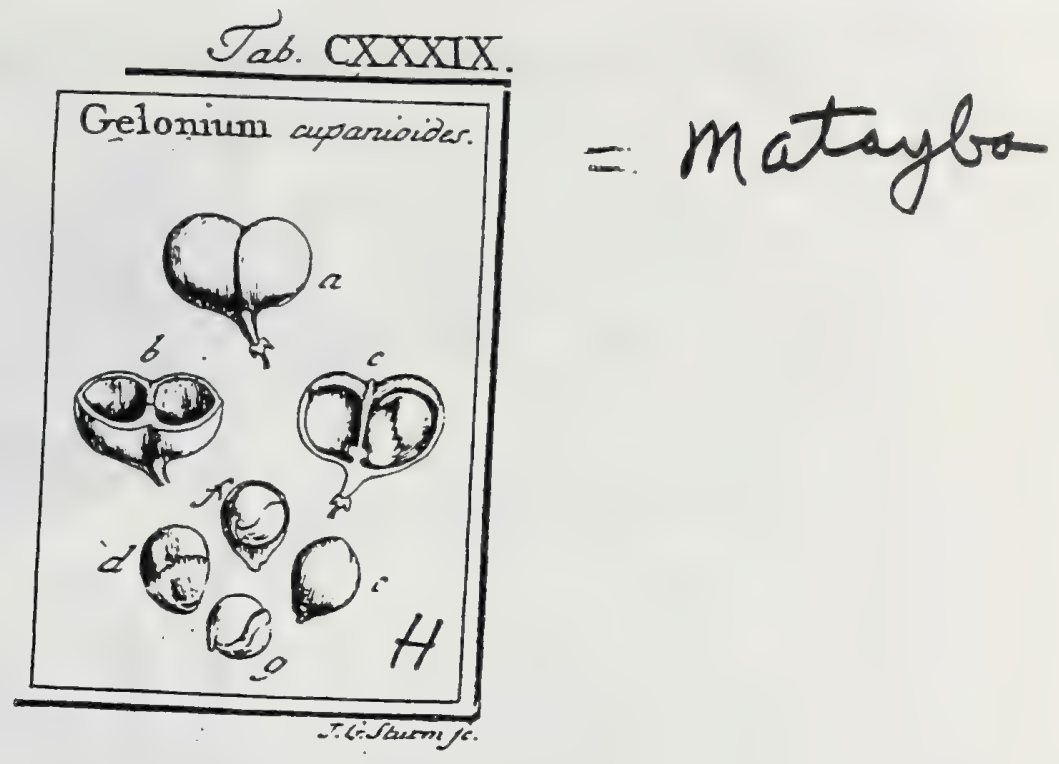

\section{J. Gaertner (1788) Vol, 2}

\section{GE L O N I U M.}

Calyx inferus, parvus, tii-l. quadridentatus, perfiftens, reflexus. Cor.... Capf. obcordata, buocularis. Jein. fulitaria, nitida, iacomplete arillata.

272

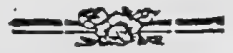

Gezoxidn cupanioides. Tab. 139. \&g. \&.

Arboris elegantis fruthus ex fylvis infulc Mauritii. Cl. Heras. in lilt.

PER. Capfula fupera, coriacea, obcordata, didyma, ad latera in marginem. angultum atrenuata, bilocularis, femibivalvis f. rima transwerfali vix ad, medium dehifens. Difepimentum valvis oppofitum.

REc. tuberculum parvum, prope bafin loculamentorum diffepimento utringug infertum.

SEM. folitaria, ovato-globofa, verfus bafin attenuata $\&$ in rofteilum conicum definentia, nigro-caltanea, fplendentia, femi-arillata.

Arillus incomplesus, membranaceus, (in recenti femine forfan glandusofus) feninis dimidiam partem inferiorem obregens, fupra obliyue stuncatus, ad oram lacerato - denticulatus, e cinereo-allicans.

Ix T. Gimplex, chartaceum, aridum, tenue, fragile.

A ¿ B. nullum.

EAB. fubglobofus, fordide albicans, in aqun autem brevi viridefcens. Coty 2 carssofx, craffx, ad commifiuram repandix ac finuofic. Rud. brevis, comprefia, triangula, in infimo feminis dorlo pofita \& quafi centrifuga.

2.) Capfula integra b.) E.xdem transverfe feeta. c.) Ejusilem fectio longituilinalis, eum fite icminis. a.) Scmen feparatum, arillo veftitum, c.) Jiem ah arillo denudatum. f.) Ifem row

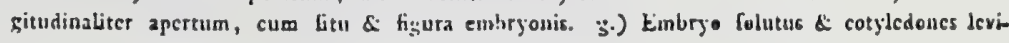
ser diducte

Anne Cupaniz vera fpecies, pericarpiis bilocularibus.

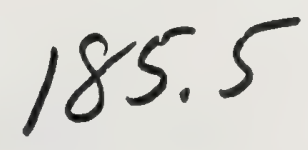




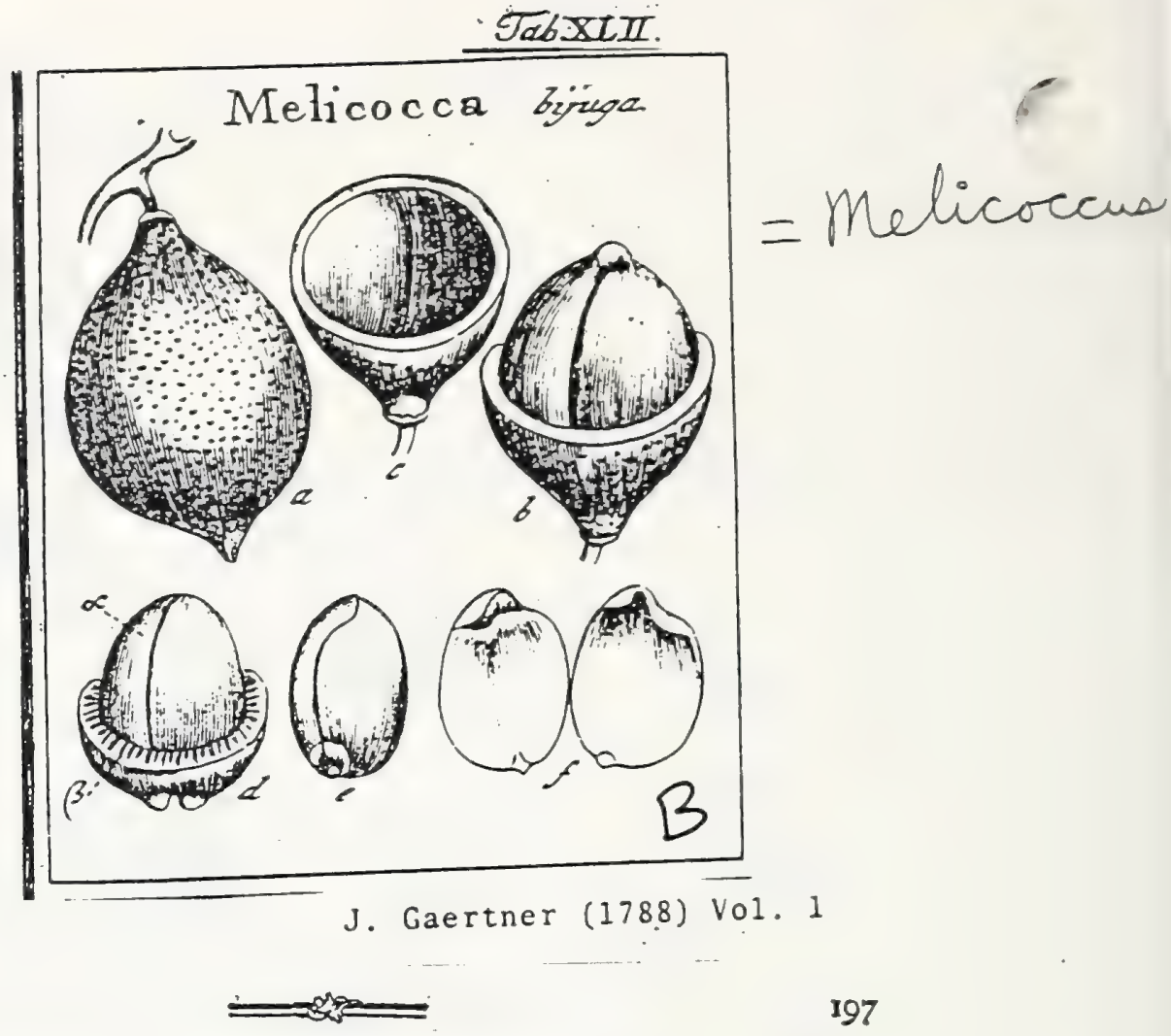

CCXXXVII. MELICOCCA. LIN ger. 472.

Calyx quadripartirus. Cor. tetrapetala. Stam. octo. Styl. unicus. Bacca fupera, coriacea, unilucularis. Semen baccatum.

MElicocca bijuga. Tab. 42. fig. 2.

Nux americana foliis alatis bifidis. COMMEL. hort. amf.. I. p. 183.t. 94

Melicocca. J A c Q. hifl. amer. p. 108.t. 72. L IN s. Jyf. veg. 360.

E collectione Bankfiana.

PER. Bacca fupera, ovata, glabra, vel granulis miliaribus fcabrata, utrinque, vellfupra tantum acumisata, coriacea, craifiuscula, unilocularis: loculamento in altero latere fulco prominulo notato.

REC. nullum; feinen fundo baccx affixum.

SEM. unicum (rarius duo vel tria) magnitudine cavitatis bacex, gelatinofo baccatum, fulco medio obfoleto infcriptum, fupra leviter mucromatum, infra umbilicali fovea exfculptum.

In т. duplex: exterius pulpofum, molle, acido-dulce, femini pertinacifime, pericarpio autem nequaquam adratum, fubdiaphanum; interius chartaceum, tenue, album, per ztatem fragile.

A в в. nullum.

Е м в. femini conformis, elliptico fphxroideus, eredtus, albus. Cotyl. amygdalino carnof $x$, craflx, plano convexx, in vertice fxpe retufx. $R a d$ - parva, infera, conica, areola pallidiore ad exortum fuum cincta.

a.) Bacea integra. b.) Ejus pars fuperior refefí com femine ad medium ueque denodato. c) Pars inferior baccx evacuata. d.) Semen feparatum; $\alpha_{0}$ ) ejus integumentum internum characeum, \& $\left.\beta_{0 .}\right)^{\circ}$ pulpa gelatinofa. e.) Enibryo denudatus. f.) Cotyledones feparata. 


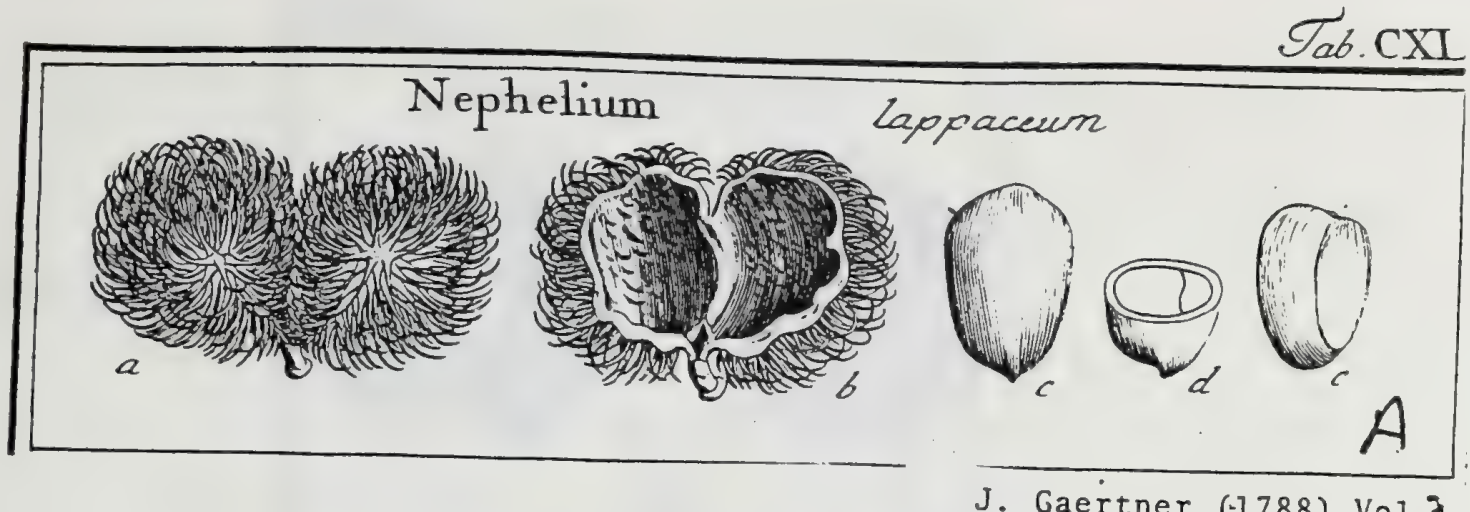

J. Gaertner (-1788) Vol 2

272

\section{N E P H E I U M. LINN. sen. 12\%.}

Flores fexu diftincti in eadem ftirpe. MIAS. Cal. quivquedentatus. Cor. nulla. Stam. quinque FEN. Cal. quadrifidus. Cor. nulla. Ovar. duo, fupera. Styl. duo fingulis. Capf. dux, nuricatx, unilocularcs, monufpermic.

Nërieluus lappaceum. T2b. 140. fig. I.

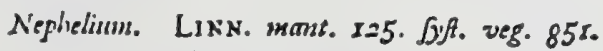

$\triangle \mathrm{CL}$ THUNBERG.

PER. Caplulx dux, quarum vero altera fxpius abortat, coriacex, craffx, ovatx, turgide lenticulares, extus fetis fubulatis Aexilibus muricatx, intus fcrobiculato-fcabrofie, uniloculares, nargine interno dehifcentes.

REC. nullum; femen fundo capfulix adnatum.

SEN. Folitaria, grandia, ovata, leviflime comprefla, fubbaccata.

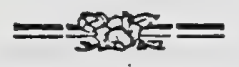

IN T. duplex: exterius membranaceun; tenue, in vetufto fenine rugofulun, in recenti autem pulpa farctum; interius coriaceun, crallum.

A L R. nullum.

Es B. femini conformis, inverfus, albus. Cotjl. carnofx, craffx, inxquales; feminis latitudini contrarix: altera fcil. majore, dorfum - \& altera minore, ventrem capfulx refpiciente. Rad. brevifima, fubacuminata, imnerfa, fupera.

a.) Frudus integer, ex duabus capfulis compofitus. b.) Capfula folitaria, dehilcens, a parte ventrali fpedata. c.) Semen integrum. d.) Idem transverfe feâus, cotyledonum Gtum Latitudini contrarium ofteudens. e.) Embryo denudatus.

Solus embryonis fitus inverfus, fi vel omnia reliqua effent paria, negat focietatem Nephelii cum Ambrolia \& Xanthio. Caftuleis, ni fallor, ob gemellos ad fingulas capfulas ftylos, \& defectum albuminis, propior. 


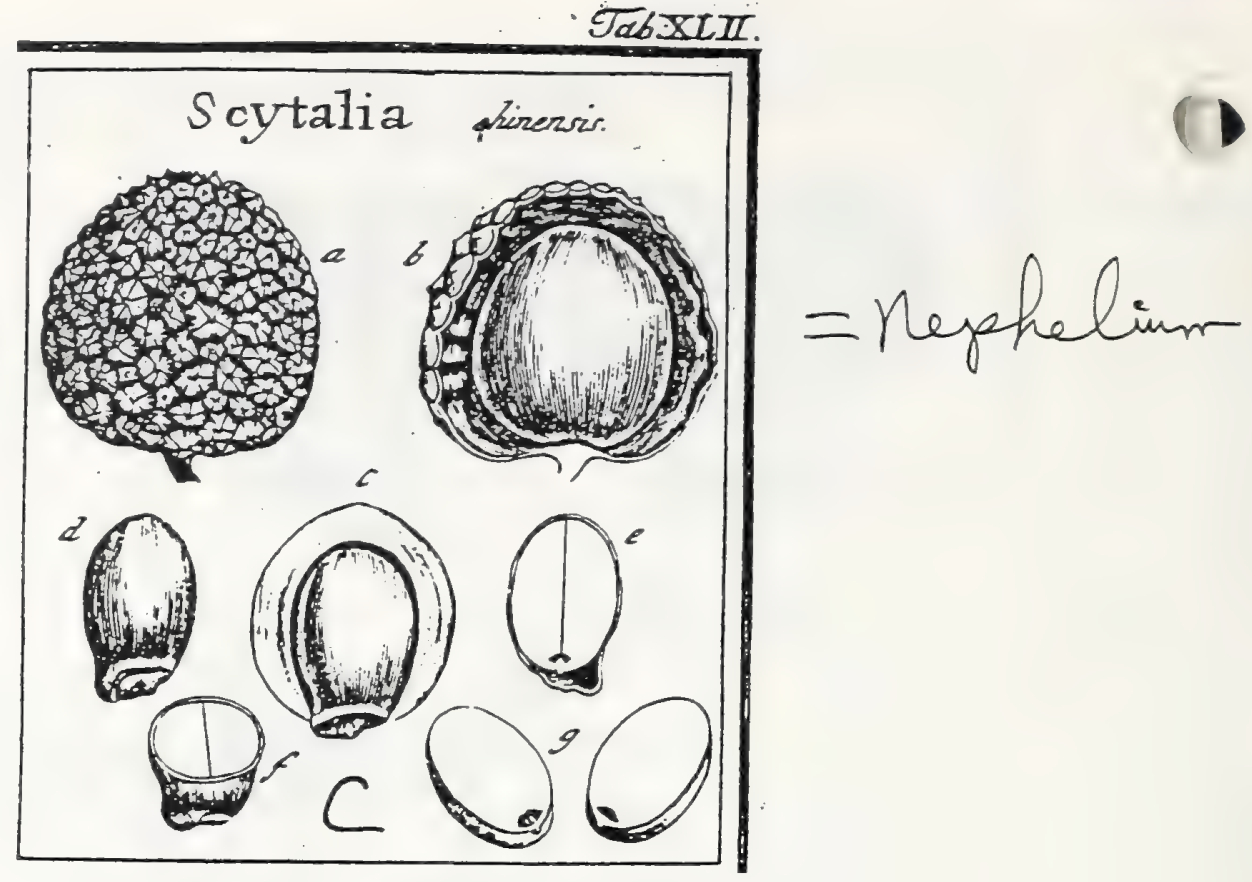

J. Gaertner (1788) Vol.1

\section{SCYTALIA.}

Calyx brevifinus, monophyllus, edentulus, aut obfoletifinne quinquedentatus. Cor. pentapetala. Stam. fex ad octo: filamentis bafi villofis: antheris bilobis. Styl. finnplex; fligina bipartitum. Bacca exfucca, unilocularis. Semen unicum; Arillo baccato.

Sey tar ia chinenfis. Tab. 42. fig. 3.

Li-ci EO Lumyen. Joнnst. dendr. p. 475. t. 136 .

Li-tchi. Commfrc. lit. Nor. 1738. p. 126. t. 6.f. 8. Sonnerat. it. ind. E clin. 2 p. 230. t. 129. opt.

E collectione Bankfiana.

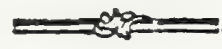

PER. Bacca exfueca, fupera, ovato glnhofa, coriacea \& corii quoque coloris, extì ur dique tuberculis fcuriformibus, angulatis \& in centro fuo apiculatis fcabrata, ip
tus glabra, inflata, unilocularis, fragilıs.

R Ec. nullum, proter fundum bacez modice elevatum, cui femen late affixum.

SEM. unicum elliptico globofum, bafi deraf̂̃ oblique truncatum, helvolum aut dilut caftaneum, glaberrimum, nitiduin, arillatum.

Arillus ovaro globofus, magnitudine fere cavitatis bacex, glaberrimus, ater? carnofus, crafius, circa bafin folummodo fcmini adnatus, cetera ab ipfo \& fericarpio undique folutus: caro mollis, confiftentia Pruni damasceni.

IN.T. fimplex, cruftaceum, durum, tenue, nucleo arcte adhxrens, a bafi tamen ejü: folutum, ibique fubftautia fungofa $2 \mathrm{lba}$ farchuin.

A I в. nullum.

Es в. femini conformis, erectus, albus. Cotyl. dimidiato ellipticx, amygdalino car: nof $x$, craffx, per maturitatem fxpe pertinacifime inter fe conferruminatx. Plum. minutifuma, diphylla, acuininata $R$ ad. globulola, minutula, infera.

a. ) Baca integrn. b.) Eadem aperta \& Arllius integer denudatus, c) A riltur verticaliter differtus, fermet ampletiens. d.) Semen denudatum. e.f.) Seminis fectio longitudipalis \& uausver[alis, s.) Cotyledones feparats, cum fitu piumulxe \& radiculx.

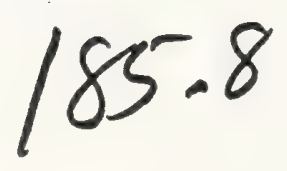




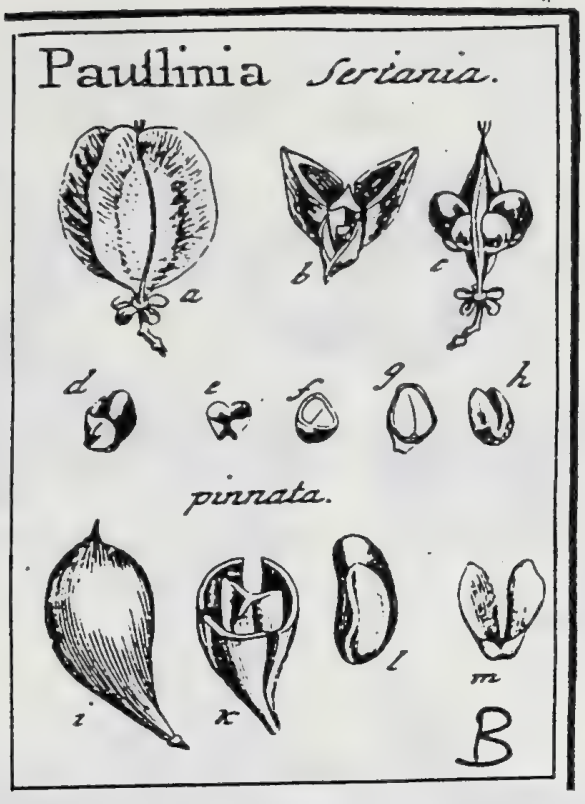

J. Gaertner (1788) Vol. 1

CCCCXCVIII. PAVLLINIA. Liñ. gen. 49\% 381

Calyx pentaphyllus. Cor. tetrapetala. Nectar. tetraphyllum inxquale. Stam. octo:Styl. , trilocularis, trivalvis. Semina cicatrice umbilicali fungofa, biloba.

PA UนะI I I Seriana. Tab. 79. fig. 3.

Seriana fcandens, triphylla Ë racemofa. P \& v M. ic. t. 113. f. 2 .

Paullinia foliis ternatis, petivlis nudis, foliolis ovato oblongis. LIx.N. fuft.

veg. 379 .

Ex herbario Bankfiano.

PER. Capfula ovata, trigona, trialata, trilocularis, trivalvis. Valvulz naviculares, $x$ co riacex, venolo-friatz, fubfulvx. Diflepimenta axi adnata, \& valvularum futuris refpondentia.

REc. tuberculum fungofun album, axi fructus, paulo fupra bafin finguli loculamenti adnatum.

SEM. folitana, trigono globofa, glabra, nitida, atra ; cicatrice umbilicali fungofa, cordato-biloba, arcte aduata, alba, ad bafin veflita.

IN T. duplex : exterius chartaceum, aridum, fragile; interius membranaceum, pallidurn.

A 1 B. nullum.

E s в. Semini conformis, ereclus, albus. Cotyl. carnofx, craffx, ' per maturitatem frepe ita inter fe conferruminatx, ut feparari nequeant. Rad. globulofa, minima, infera.

2.) Capiula integra. b.) Eadem diffeta. c) Axis frulus, i lapfo valralaram perfirtens, cum infertione ferninum. d.) Semen (eparatum. e.) Ciatricis umbiliealis forma, qualls effet, fi a femino feparni poffet. f.) Semen transverte feftum. 5.) Ejasdem fetio longitadinalis, cum fitu radiculs: L.) Embryo denudatus.

PAULLINIA pianata ibid.

Cururs-ape. Pis. bras. 114. c. ic. mediocr.

- Paullimia pinnata. SС нгци G. de Lepro. tab. r. bene.

Paullinin foliis pinnatis, petiolis marginatis, foliolis nitidis. JA ce. obs. 3. tab. 6t. $f$. 12. quoad fol. Lus N. $\int 4 f$. veg. 380.

Capfula obovara (i), fublignofo-coriacea, fubtiliffime friata, fufco-ferruginea, trilocularis (k.), trivalvis. Difepimenta membranacea, tenuifima, axi adnata, non futuris, fed valvularum medio refpondentia. Receptac fungolum, fupra bafin axeos, ut in precedenti. Semen (1.) ovato oblongum, glabrum, nitidum, atrom: Cicatrix umbilicalis fungola, alba, aretiflume adnats, biloba (m.), utrumque feminis latus ultra medium obregens. Reliqua ut in pracedenti.

Infertio feninum in Cururu, perinde fe habet ac in Seriana, fecus atque voluat Lin: uxus gen. $\mathrm{pL}$ p. 196. fed in diflepimentorum fitu, notabile inter utrasque intercedit diferimen, ut modo annotavimus. 


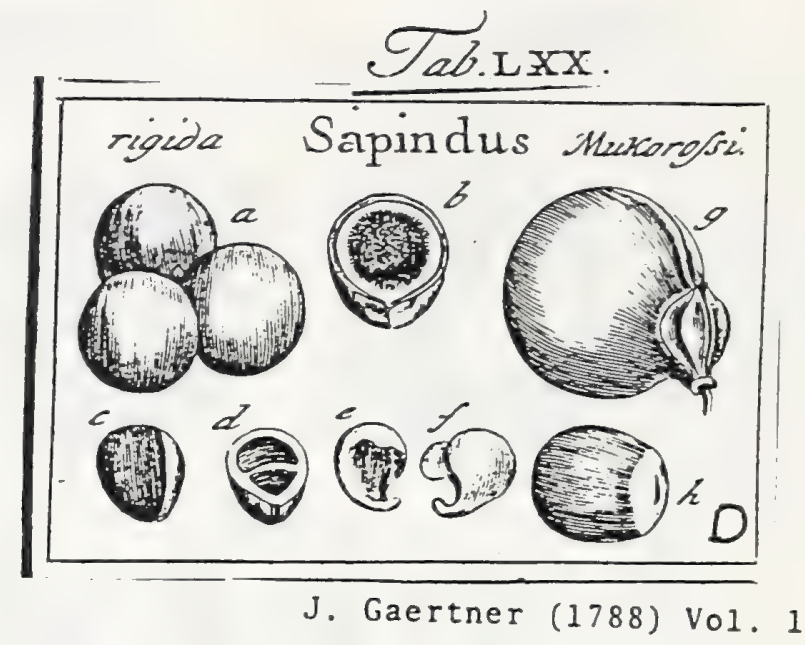

341

$u$

CCCCXL. SAPINDXS. Lin N. ger. 499.

Calyx tetraphyllus. Cor. tetrapetala. Stain. ncto. Styl. tres. Dropae baccatae, tres, coadunatae. Putamen biloculatc. Semina folitaria.

SA PINDUS rigida. Tab. 70. fig. 3 .

Sapindus foliis quaterue pinnatis, rigidis acutis. MrLL. dia. n. 2

E collecilione bankfiana.

PER. Drupac carnofae, duae ad quatuor, Sphacricae, absque intermedio receptaculo fibi coadunatae. fupra brevi mucrone erecto inftuctae, rubrae. Caro tenuis, introrfum in lubflantiam fpongiofo tomentofam, albam eftloreicens, putamen arcte

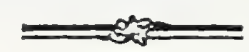

cingens. Putamen trigono globofum, offeum, nigrum, ex fibris comeis horizon. talibus (ficut in Camirio Rumphii) compofitum, biloculare, evalve. Loculament fubinaejualia; altero, rctro alterum pofito!

REC. commune nullum; proprium, nullum ; femen vertici loculamenti adhaerens.

$S E$ is. in fingulo loculamento unicum, obovatum, angulatum, pallidum.

IN T. fimplex, nembranaceum.

A ᄃ в. nulluin.

Ess. femini conformis, erectus, albus. Cotyl. obovatac, carnofae, figurae loculad menti adaptatae: concavae feil. aut angulatae. Rad. fubulata, in anteriori femine recta, in pofteriori antrorfum curvata, in utrisque vero infera.

a.) Fruftus integer. b.) Drupe caro transverfim feta. c) Putamen integrum. d.) ISem tran verfe feftum. e) Semen ex loculameuto pofteriori, f.) Embryo denudatus.

SA PIN D Ù S Mukorofr. ibid.

Sapindus foliis alternis. Т н

Ex dono Dn. Dr. Houtuys.

Baccac tres, e quibus duae abortivx, ovatae, utrinque acuminatae, triquetrae; tertia adolescens (g.) maxima, globofa, furtra prominula in ambitu notata, antror. fum attenuata, carnofa, tenuis, intus membraná chartactí glabra, veftita. Ofraculum (h.) ovatum, antice quafi truncatum, atque rima verticali, umbilicali, notatum, inxqualiter biloculare. Sernina unatura non vidi. 
J. Gaertner (1788) Vol3

Tab. CCI.

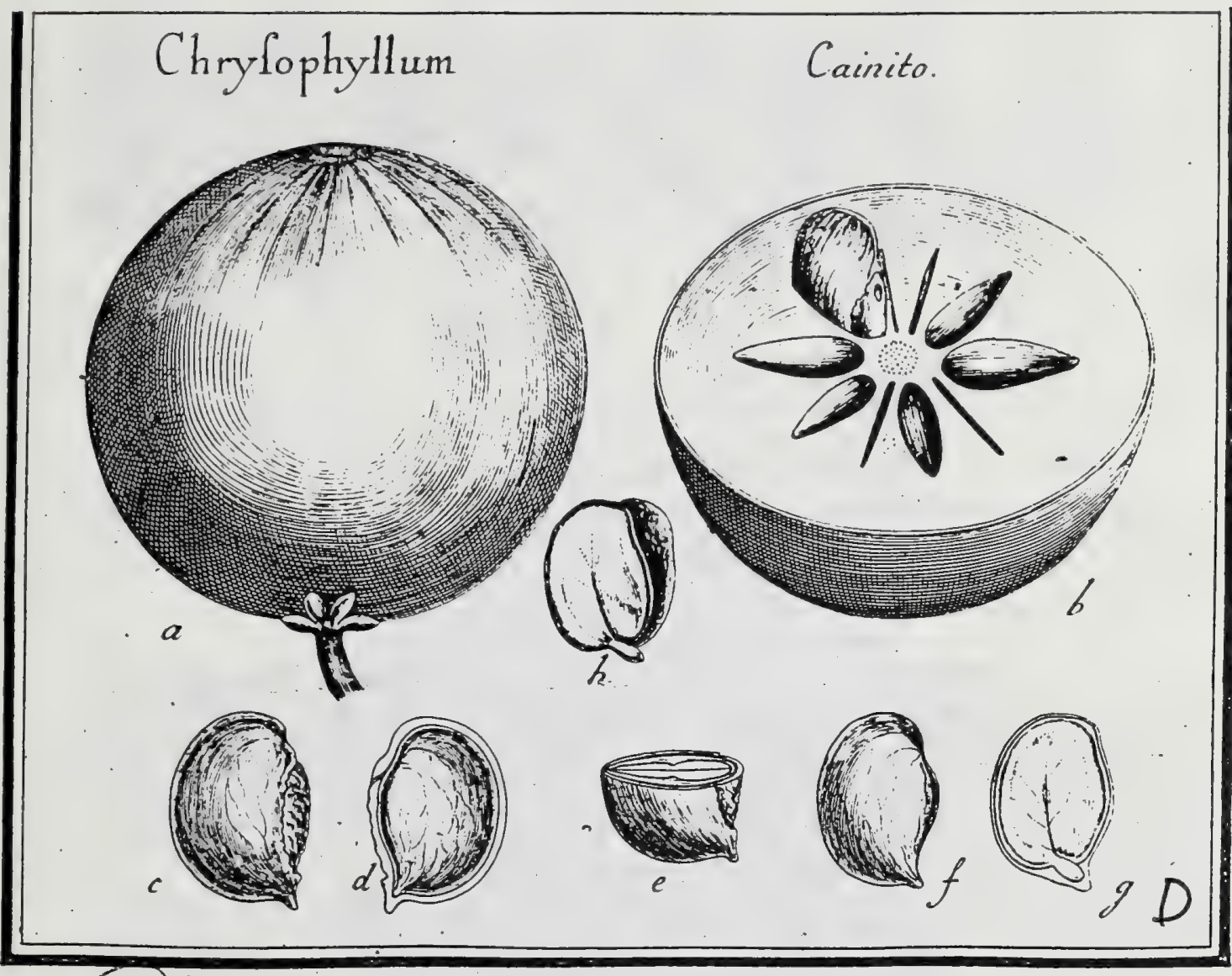


ill. gen. t. 120. Cainito. Plum. gen. t. 9 .

Cal. parvus, quinquepartitus, inferus, perfiftens. Cor. monopetala, campa que; filamentis brevibus, fubutate: laciniis eubo brevioribus. Stam. quinniis oppolitis, conis a corollx dacirum; tylo fimplici, brevifimo; ris, monofpernor, brevitimo; ftignate fubquinquefido. Bacca uniloculaarea umbilicali al ventecemlucularis, decafperma. Semina offeo-teftacea, mun. Erab. maguus, Chrisorhillua Camito. Tab. 201. Gig. 4.

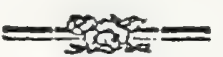

Caimiso. LAET. amer. 390.

Cainiso folio frubtus aureo, firutu maliformi. PLUM. gen. p. 10.

Chryfoglyyllum folits ovatis fuperue glabris farallele friatis, fubtus tomentofonitidis. LINN. bort. cliff. p. 49.

Chnyfoplytlum foliis ovatis parallele friatis, fubtur tomentofo vitidis. JAcQ. amer. p. 51. LINN. $\int y /$. veg. ed. 14. p. 231 . WILLD. Spec. pl. T. 1. P. z: p. 1083 . PERSOON Jyn. pl. $\pi . p .=36$.

- Icon. JAce. amer. t. 37. f. I. pil. t. 51 .

Ex infula Hifpaniola a $D^{\text {no }}$ Portenu.

PER. Racca magna, pomacea, fubglobofa, depreffiufcula, bafi calyci perfiftenti quinquepartito infiltens, in vertice area colorata in radios divergentes foluta notata, e flavo \& viridi rofea, decemlocularis, decafperma. Caro epidermide tenui glabra tecta, crađa mollis, fubglutinofa, ad peripherian carnea, centrum verfus pallida aut fordide albefcens. Loculamenta decem, membrana propria lixvigata ad angulum vero internum eva. nefcente tenuilima veftita, ex his duntax:t quatuor l. quinque fecundantur, reliqua vero in rimas lineares inanes abeunic.

REC. nullum; femina angulo centrali loculamentorum per totam fere longitudinem fuam adnata, \& affixa per funiculos umbilicales filiformes e pedunculo baccx oriundos $\&$ in ejus centro ad apicem arex umbilicalis adfcendentes, quo proprium canalem teltx infcriptum adeunt, \& per totam ejus fuperficiem internam in ramos, ad radiculan feminis decurrentes, dividuntur.

SEM. folitaria, lenticulari - compreffa, ad marginem internum ventralem.craffiora, elliptica, ad bafin in proceffum curvulum brevem acutum products, inde fub vertice rotundato ad marginen internum entarginatotruncata, \& ad ventrem area longa elliptica umbilicali derafa pallida immerfa atque ad hujus apicem umbilico parvo notata, glaberrima, fplendentia, nervis protuberantibus infignita, diluce caltanea, l. ferruginea.

Ix T. duplex; exterius offeum, durum, fragile, paulo fupra medium ventrem canali adfcendente perforatum, intus menbrana propria vafculofa, a vafis unbilicalibus oborta, veltitun; interiss nembranaceum, tenuifimum, facile detrahendum, dilute ferrugineum.

A I B. femini conforme, carnofum, ad latera modice craflum, verfus marginem vero, excepta ejus parte bafilari acuta, in membranam tenuem extenuatum, album.

EM в. magnitudine fere albuminis, erectus, fubincurvus, albus. Cotyl. cordato.ovatx, obtufifinix, carnofx, ad marginem internum craftiores, impreftronibus undulatis raris inaquales, fulco intermedio longitudiuali bipartixc, leviflime nervofre, accunibentes. Rad. brevis, capicellata, oblon-

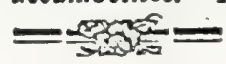

ga, teretiufcula, obtula, oblique defcendens, ab umbilico externo declinis, infera.

\section{EXPLICATIO FIGURE.}

a.) Bacca integra. b.) Eadem transverfe fecta cum loculamentis \& femine in fitu. c.) Scmen folutum. d.) Idem transverfe diffectun. e.) Tefta longitudinaliter aperta cum nucleo in fits. f.) Albumen feparatum, imtegumento interiore veftitum, \& nervorum imprefionibus, a membrana teftx propia ortis, iuggnitum. 5.) Embryouis fitus intra albumca. h.) Embryo feparatus, cotsledonibus paulo a fe invicem didutis, 


\section{J. Gaertner (1788) Vol3

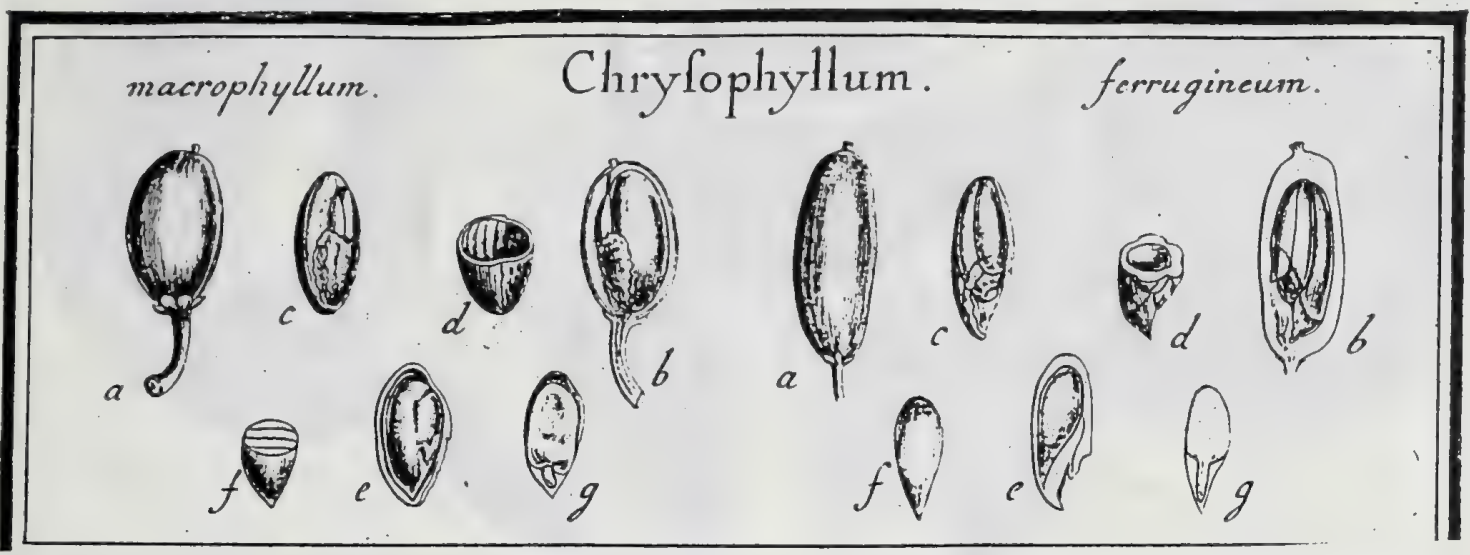

J. Gaertner (1788) Vol.3

Chrysophyllum macrophyllum. Tab. 202. fig. I.

Bumelia (nervo $\sqrt{a}$, ) foliis alternis ellipticis fubtus difcoloribru, floribus aggregatis lateralibus axillaribusque toment ofss pedunculatis. VAHL ecl. $1 . p .28$. WILLD. Spec. pl. T. I. P. 2. p. 1087. PERSOON fyz. pl. I. p. 237.

Chryfophyllum foliis obovatis, fubtus parallele nervofis, glaucis, vix tomentofis. LAMARCK ill. gen. n. 2474.

Ex infula Hifpariola a $D^{\text {no }}$ Porteau, cum fequente.

Bacca (a.) ovato - oblonga, fubreniformis, 1. ad dorfum magis convexa; vir fenlibiliter compreffa, in vertice planiufculo extra axim obtufe mucronulata, f. Itylo perfiftente nunita, ad bafin vero calyci \& pedunculo craffiufculo infiftens, glabra, unilocularis, monofperma Caro tenuis, rufefcens. Loculamentum membrana propria tellui, ad narginem arex umbilicalis cum femine cohxrente, veftitum. Receptaculum nullum; femen, ut in priore, ad aream umbilicalem baccre adnatum. Semen (b. c.) unicum, ovato-oblongum, compreffiufculum, infra verticem glabella tripartita \& a medio ventre ad bafin ufque lata area umbilicali cordata pallida paululum immerfa notatum, Javigatum, occhraceum. Integumentum duplex; exterizs (d.) telta chartaceo-cruftacea, fragilis, menibrana vafculofa intus veftita: interius membranaceum, tenue, album. Albumen (e. f.) cavitati teft -conforme, evidentius compreffum, iuxqualiter ellipticum, ad bafin acuminatum, ad latera modice craffum, ad marginem vero in membranam tenuifimam extenuatum, carnofum, album. Embryo (g.) magnus, curvulus, erectus, albus. Cotg\% magnitudine ferc albuminis, fubelliptica, ad apicem craffiores, bafi vero oblique truncatx, margine obtufifinix, carnofx, impreflionibus rotun. datis infignitic. Rad. brevis, capitellata, curvula.

CHRYSOPHYLLU ferrugineum. ibid.

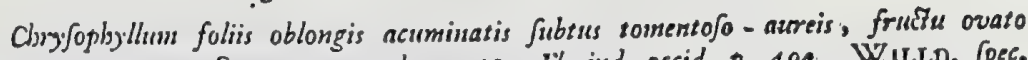
monopyreno. SWaktz prod. p. 49 . $\%$ ind occid. p. 480. WILLD. Spec. gl. T. I. P. 2. p. 1083 . PEksoos fj\%. pl. I. p. 236.

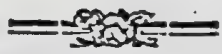

Bacea (a.) ovato - cylindrica, levifime fubreniformis, bafi angultata, compreffrufcula, ftylo brevilfimo extra axim polito quinque crenulato faftigiata, calyci minimo inliltens, glabra, cxrulefcens, unilocularis, monofperma. Semen (b. c.) unicum, larvam xmulans, cylind:aceo-oblongum, hinc obtufam, inde acutum, glabellis quatuor maximis \& infra has lata area umbilicali emarginata inxquali nec non umbilico prominulo infignitum, glabrum, e cinereo ftramineun. Integumentum duplex; exterius (d.) tclta offea, crafiufcula, cavitate elliptica obliqua ad bafiu acuminata exfculpta, \& menbrann propria pertexta: insesius membranaceum, tenue. Albumen (e. f.) cavicati telta conforme, acuminato-ellipticum, l. ad ventren oblique truncatum, bafi acuminatum, ad latera modice crafium, ad margineın vero partis fupcrioris tenuilfinum, carnofun, albun. Embryo (g.) magnus, curvulus, albus. Cosyl. Jatitudine albuninis, fed dimidia ejus parte brevio. res, ellipticx, bafi truncatx, carnofx. Rad. cotyledonibus vix brevior, curvula, teres, conico-acuminata.

Inter Sapotas non dantur pyrenx; hinc nomen triviale huic fpecici a Cel. SWARTZ inditum, mutandum elfe cenfemus. 


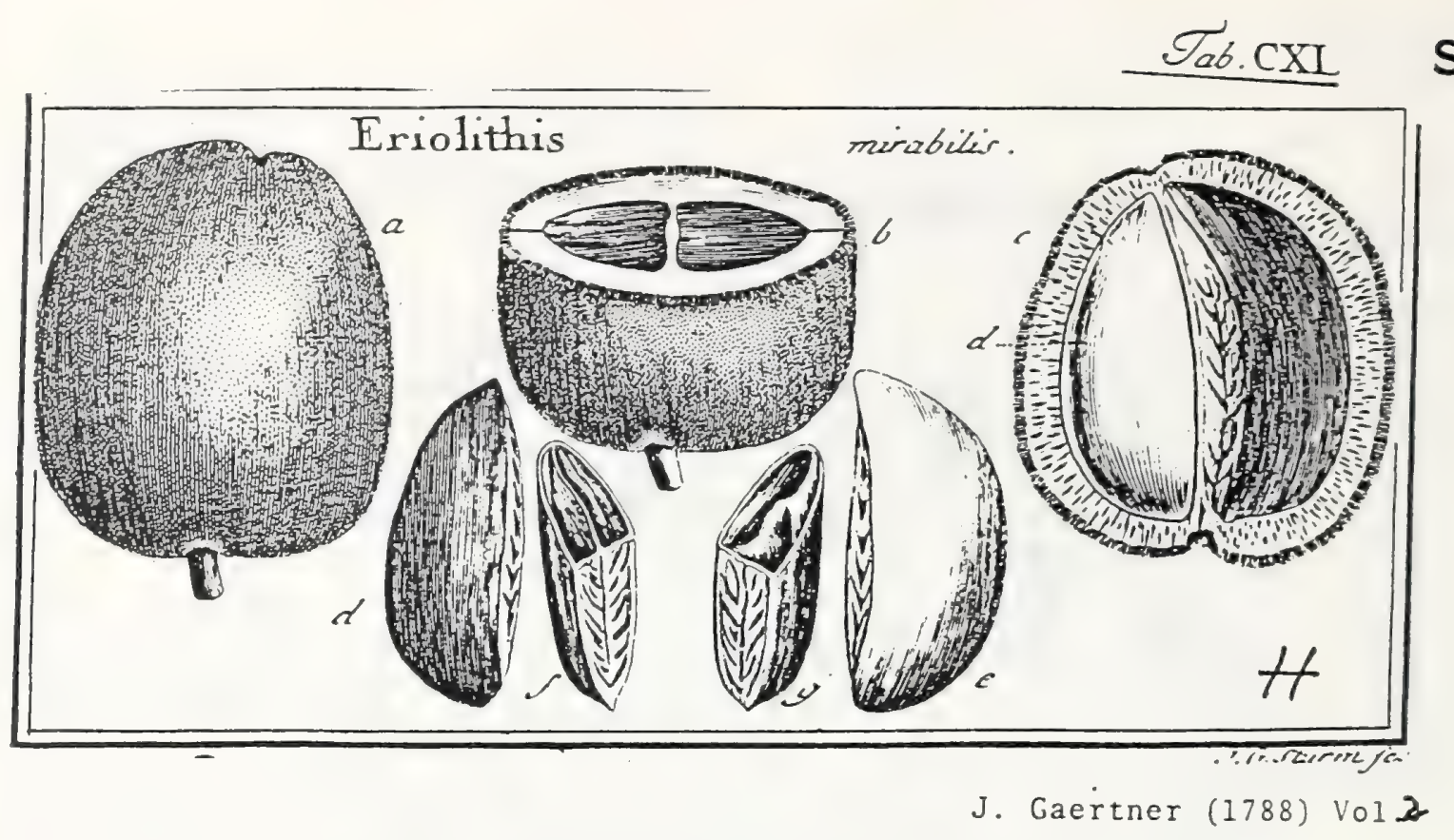

Sapotaceae

\section{ER I O L I T H I S. 277}

Flos.... Nux lapidea, denfillme villofa, bilocularis, evalvis. Sem. folitaria, bilocularia!

ERIolithus mirabilis. Tab. 140. fig. $\delta$.

Am)'gdali fracie frutus hinfutus exoticus. BAUH. bif. 1. l. 2. p. 184 ?

A Dn. Lasc. Pharmac. Stutgard.

PER. Nux lapidea, durifina, ovalis, lenticulari-compre何, extus capillis brevibus, rectis, denfilfime in holofericum molle \& gilvum conftipatis, obtecta, intus lamina offea glabra \& Spadicea veltita, bilocularis, vix nifi cunco in duas valvas partibilis. Diffepimentum offeum, tenue, rugis obliquis infcriptum, valvis contrarium.

REC. nullum; fenina rugofic diffepimenti fuperficiei fecundur totam fuam longitudinem adhrerentia.

SEM. folitaria, grandia, oblonga, utrinque acuminata, compreffe triquetra; hinc convexa \& in dorfi acutarn carinam declivia, inde planiufcula \& ad normam inxqualicatum difepimenti rugata, cetera e caftaneo fufca, bilocu. laria.

INT. duplex: exterins chartaceun, aridum, fubfragile, ope laminze membrim nacex verticalis \& a dorfo ad ventrem ducta, in duo loculamenta undique claufa \& fubæqualia divifum; interius membranaceum.

$\triangle \perp$ B. . . E E EB. . . . .

a.) Nux integra. b.) Ejus feetio transterfalis. c.) Valvula altera feparata, eum fita feminie d. e.) Seniua foluta. f. g.) Tefta feminis transverfim diftedz, cunt fuo diffepimento groprio.

Accepi fingularifinum hunc fructum fub nomine Adenzonie-Totakle, $\int$. Ah mandras de Perto. At Totalike LAĖTH. Ind. occid. 1. 17. c. 4. diverfilfimus \& verifimiliter Mammex fructus eft. Almandras auten de Per , tefte Wormo mus. p. $18 \mathrm{y}$. funt fructus triangulares, qui unicum duntaxat continent nucleum. Ignotum itague \& incompletum fructum filere nolui, it alii, data occafione, curatius in feminis fabricam inquirant \& lactenus deficientia fuppleant 


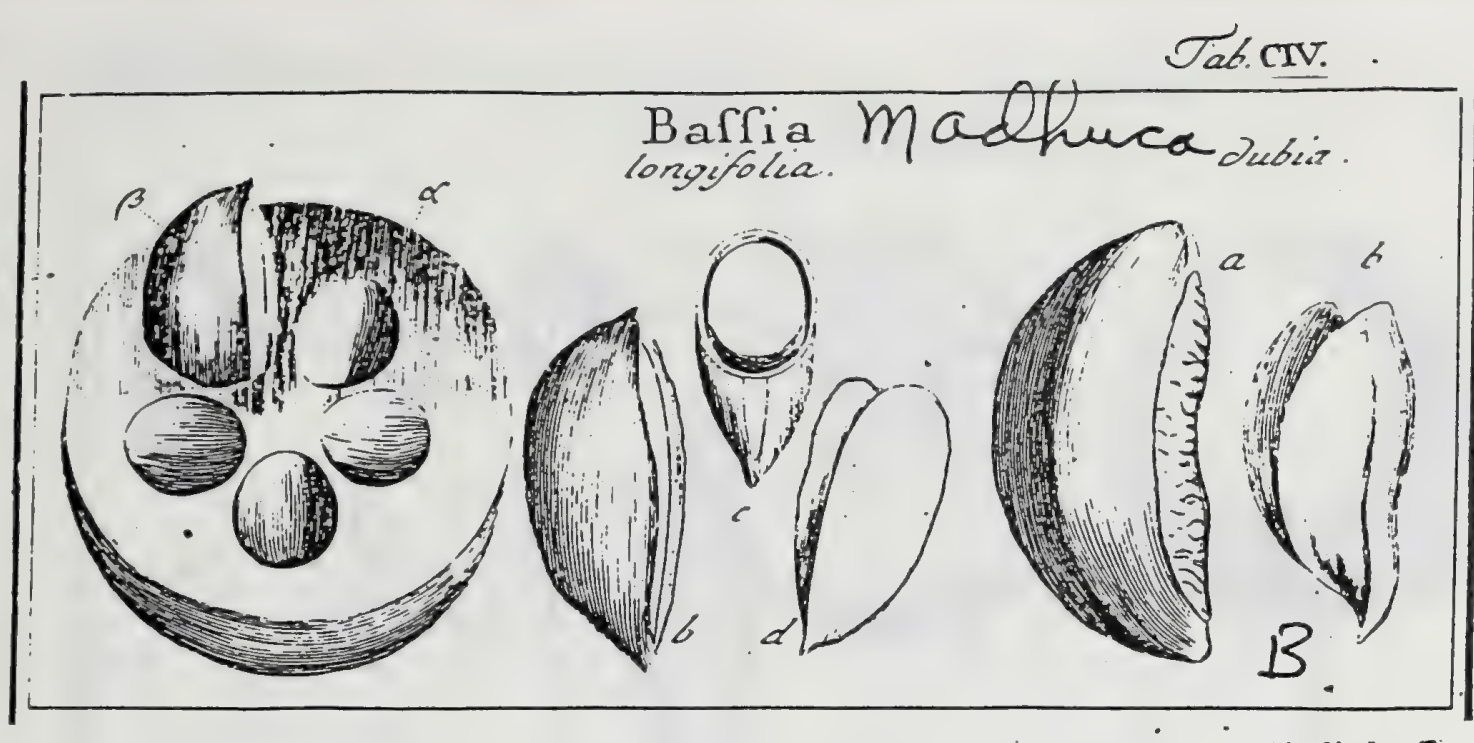

J. Gaertner (17.88) Vol, 2

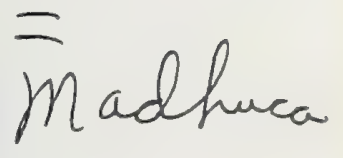

\section{B A S I A. LINN. ger. 1347. 104}

Calyx tetraphyllus. Cor. octifida: tubo inflato. Stam. Fedecim. Ovar. fupe. rum. Styl. fimplex. Bacca quinquelocularis. Sem. folitaria, nitida, umbilico longitudinali derafo ad marginem internum.

BNssin longifolia. Tab. 104. fig. 2.

Bafia. LiNs: mant. 555. \& 563 . $\int y f$. veg. $44 \mathrm{r}$.

E collect. Bankfiana. Semina ab ipfo Konigio miffa; etian e oollect. fem. hort. lugdb. cum nonine (ex Linnzo) Miele. Zeylonenfium.

PER. Bacca carnofa, lactefcens.

REC. nullum prater loculamentorum asgulum internum, cui femina bongitu. disaliter affixa.

SEM. quinque, in fingulo loculo fingula, oblonga, levifime compreffa, nunc utrinque acuminata; nunc verlus bafir falcem attenuata, fuperne vern obrufa, glaberrima, nitida, lutea, fafcia umbilicali alba in latere ventrali notata.

IṇT. duplex: exteritus cruftaceum, tẹne, fragile; istarius membranaceuns ruferceis.

A L B. nullin, nec ejus veftigium.

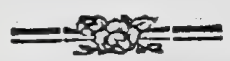

EM 8. femini conformis, maximus, erectus, albus. Cotyl. oblongo - ellipticz, crrnofe, cralfie, plano - convesx. Rad. brevis, a cotyledonibus non difcreta, acuminata, infera.

«. B.) Bacex \& fitus feuinum adumbratio idealis. b.) Scmen fcparatum, integrum, ad naturam expreffum c.) Ejusicem \& cotgledonum fetio transverfalis. d.) Embryo denudatus.

Bassia dubia ibid.

Conf. Visdoricuns fylvefre 1. RUMPH. amb. 3. p. 194.

Semen grande (a.), fubfemilunntum, lenticulari compreffum, glabrum, nitidum, faturate caftaneun, preter aream umbilicalem oblongam, prominulam, falbram, pallide albicanten. Tefta feminis craffa, lapidea, durifima. Integumentum internum membranaceum, albicans. Albunien prorfus nullum. Embryo (b.) cavitati tefte conformis, albus. Cotyl. ovato oblonge, ucuninatx, carnofic, craffe, intus planx, extus angulo obtufo carinatc. Radic. critfa, acuminata, fubrecurva, infera.

Dilficulter femina Baffix, ob externi fui habitus conformitatem, a Sapote feminibus difcernuntur, nifi ad albumen attendas, cujus in Baflia ne veftigium quidem adeft. Integumentum quoque internum in utraque fpecie frepius deficere videtur. 


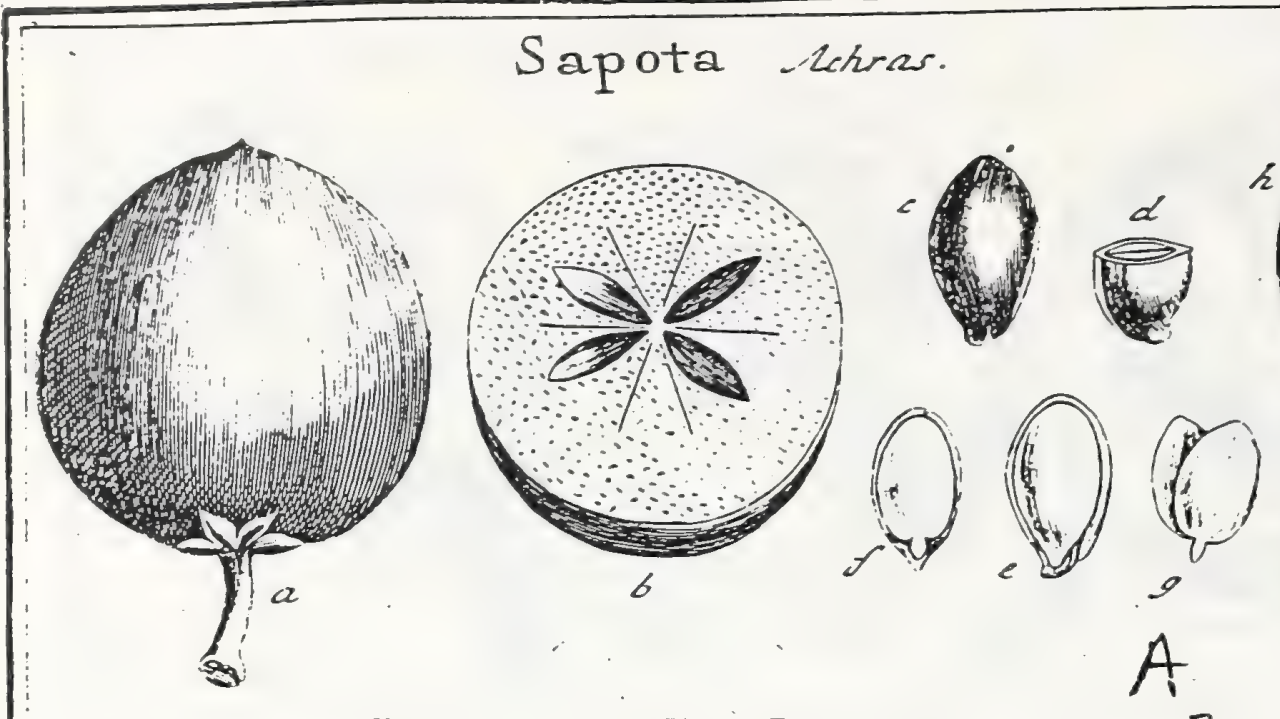

DCIX. SA POT A. PLUM. gen. t. 4,103

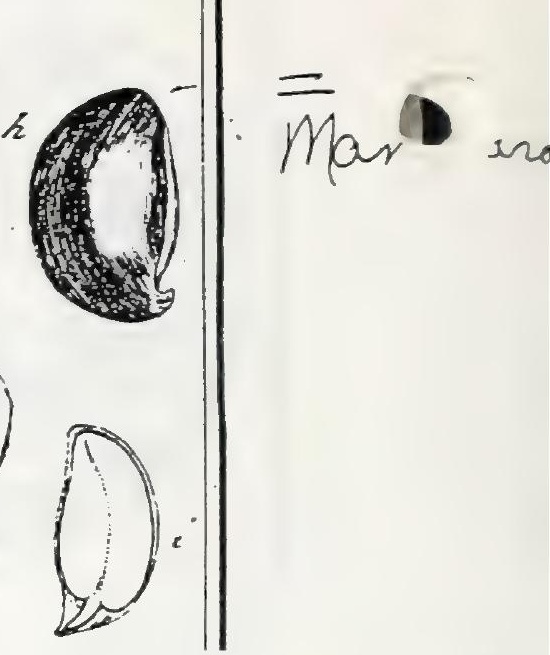

Calyx hexaphyllus. Cor. monopetala ovata: limbo fexfido; fauce fqusmis fex, eum corollz fegmentis alternantibus munita. Stam. fex. Ovar. fuperum. Styl. fimplex. Bacca decemlocularis. Sem. folitaria, nitida, umbilico longitudinali lineari derafo ad marginem internum.

SAPOTA Achras. Tăb. 104. fig. I.

Sapota frutchu ovato majore. Prum. gerr. 43.

Acbras fintite elliptico fcabro majore. BRown. jaul. 200. t. 19. f. 3.

Aclsras fioribus bexandris. JAce. bift. amer. 57. t. 4r.

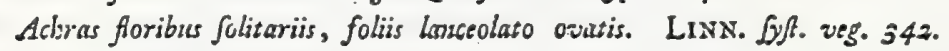

$E$ collect: Bankfiana.

PER. Bacca fubglobofa aut ovata, obtura aut in brevifimum mucronem definens, glabra aut punctis miliaribus exalperata, carnofa, calyce perfiftente bafi munita. Carı grauulofa, duriufcula. Loculamenta decen, membrana propria tenuilfima veftita, tribus faltem vel quatuor foccundis, reli. quis fterilibus \& in rimas lineares compreffis.

REC. nullum, proter angulum centralem loculamentorum, cui fenina per totam fere longitudiriem fuam adnata.

SEM. folitaria, lenticulari compreffa, elliptica, verfus bafin anguftata \& extrorfum curvata, feu' quafi rotundato - truncata, cetera glaberrima, fplendentia, faturate caftanea \& ad marginem fuum internum umbilico lineari longo albo, quafí calcareo notata.

IN T. duplex: exteriss cruftaceum, durum, fragile; interius membranaceun, tenuifrimum, rufefcens.

A L B. ellipticum, verfus bafin infigniter acuminatum, carnofum, album; modice crafum.

Ess. magnitudine fere albuminis, erectus, luteus. Cotyl. foliacex, planx, ellipticx, ad radiculam leviter emarginatx. Rad. teretiufcula, brevis, recta, iufera.

104

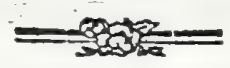

\section{$*$}

2.) Bacez integra. b.) Eadem transvetfim fecta. c.) Semen integrum. d.) Iden transverfe fectum. e.) Ejusdem feate longitudinatis, cum albumise integro atque propria fuz micmbrana veftito. f.) Albumen longitulimaliter diffetum, cum Embryone in. futu. g.) Embryo fulutus.

Sapota mammofa. ibid. Acluras frufu maximo ovato, femruibus parcioribus oblongis trorgidis. BRown:
bift. jam. $20 \mathrm{I}$.

Acloras foribus pentandris. JAce. bifl. anser. 5 f. t. 182. f. 19. folium.

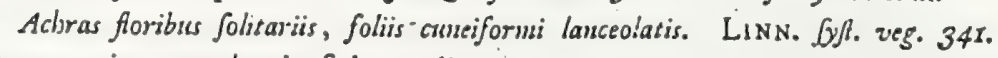

Bacca ut in pracedenti, fed grandior. Semen quoque grandius (h.), ovatum, turgide lenticulare, bafi in roftellum aduncum, non ut in prxcedenti extrorfum, fed introrfum productum, cetera vero glaberrimum, fplendens. lutefenti caftaneuns. Albumen carnufum (i.), album, utrinque acumin:tuna \& quafi fenilunare. Enbbryo (i.) erectus, luteus. Cotyl. foliacex, tenues, cordato lanceolatx. Radic. fubulata, incurva, infera.

Magnitudo \& figura baccx varia eft, at femen bafi introrfun roftellatum, banc abunde a pracedenti diftinguit. 


$$
0
$$


D. 
J. Gaertner (1788) Vol. 3

$T_{a b .206 .}$

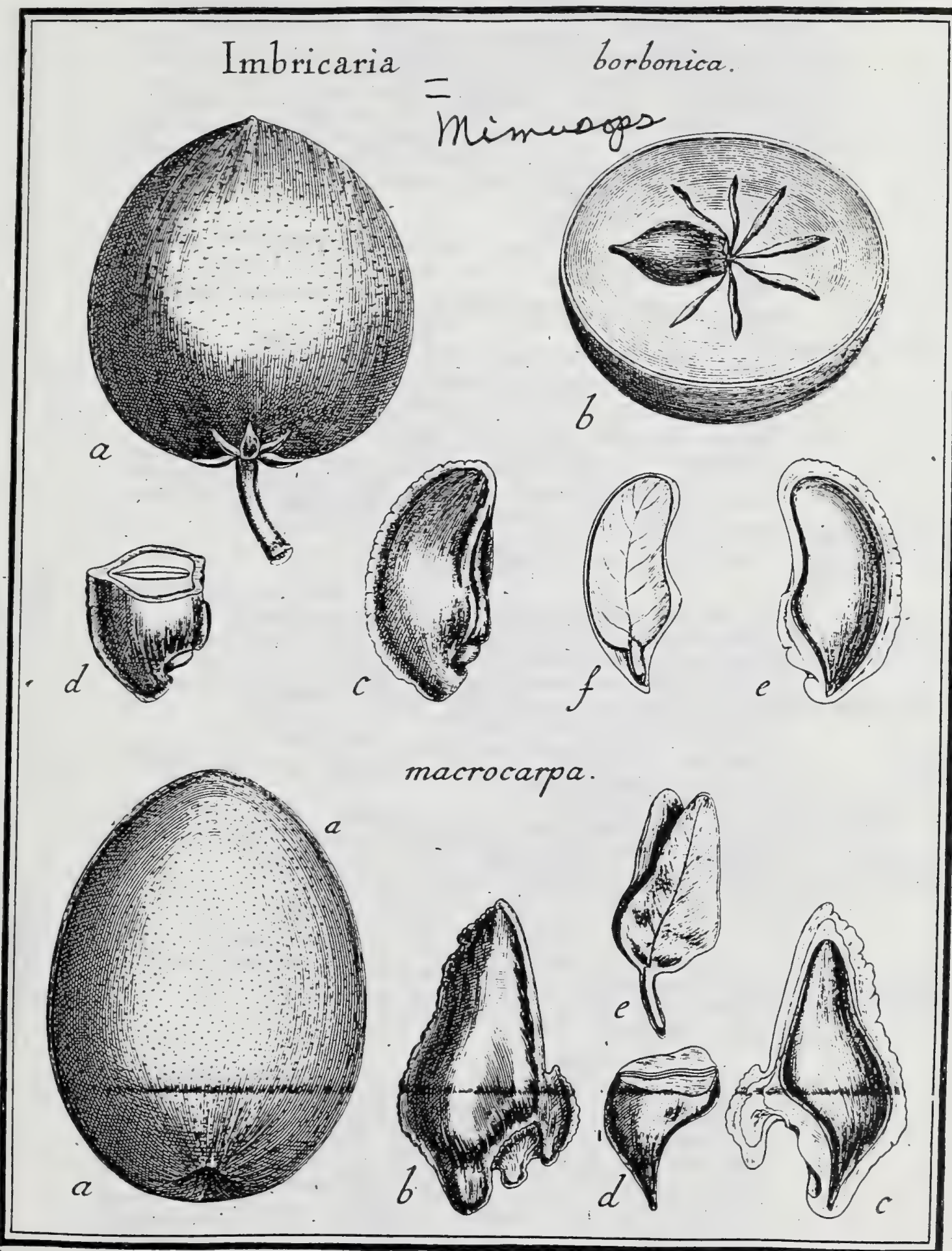

-

Iac. Shurm di. 


\section{I M B R I C A R I A. Commeri. 133 \\ Juss. gen. p. 152. LAMARCE ill. gen. t. 300 .}

Cal. monophyllus, inferus; oftopartitus; laciniis duplici ordine difpoltis: exterioribus majoribus, coriaceis, lanceolatis, acutis: interioribus membranaceis; omnibus perfiftentibus. Cor. monopetala, planiufcula, longitudine calycis; tubus brevifmmus; limbus octopartitus: laciniis iterum ter quaterve ad medium ufque in lacinulas lineares 'ceu in radios divifx; appendices petaloidei ofto, filiformes, intexi.' Stam. ofto; filamenta brevia, tubo corolla inferta, \& ipfus laciniis oppofitá, cum appendicibus vero alterna. Ovar. fuperum; Itylo fimplici, fubulato, longitudine laciniarum corollz; ftignate obtufo. Bacca octolocularis; nauci irregulares, monofpermi. Rec. o. Sem. folitaria. Alb. carnofum. Embr. incurvus.

I.rBRICARIA borbonica. Tab. 206.

Minufops (Inbricaria,) folitis alternis, apice ramorum confertis, ovatis, obtufs;; retufis; fructibus polyspermis. WILLD. Jpec. pl. T. 2. P. 1. p. 326.

Imbricaria (maxima, ) calycibus odoplyllis, fruIfu fubrotzendo. LAMARCX dia. 4. p. 433 .

Ex Collect. Seri.' Muf. Parif. \& a Cl A. L. de Jussiru.

PIR. Bacca ovata; aut fubglobofa, obtura, 1 in brevifimum mucronem def: nens, calyci perfiftenti infidens, punctis minutis callofis undique fcabrata, carnofi, octo-locularis: naucis folitariis. Caro epidermide valida inclufa. Loculamenta octo, quorum vero per maturitatem quatuor l. plura abortant, \& plane evanefcunt. Nauci fubovati, turgiduli, I. lenticulari-convexi, margine dorfali fulcato transverfe rugofo attenuati, ad ventrem vero rectiufculi, crafa \& paulo fupra balin area umbilicali parva immer-

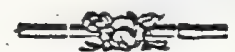

fa, nec non umbilico protuberante infigniti, offei, duri, glabriufculi, intus membrana propria continua veltiti, fufci, monolperni.

REC. nullun; nauci ope arex umbilicalis ad bafin bacce carni adnati.

SEM. Solitaria, cavitatem naucorum exacte replentia, arcuata, margine dorfali acuta, ad medium ventrem gibbofe incraffata, yerfus bafin attenuato. acuninata, erecta, dilute ferruginea,

IN T. Gmplex, membrapaceum, facile detrahendum,

A L B. femini conforme, ad latera craffum, ad marginem vero tenue, duriufcúlum, carnofum, albuin.

EM B. magnitudine, fere albuminis, ovatus, curvatus, erectus, albus. Cotyl. foliacex, ovatx, planx; accumbentes. Rad. teretiufcula, curvula, ab umbilico externo averfi, infera,

\section{EXPLICATIO FIGURE,}

a.) Bacea integra. b.) Ejusilem feêtio transver(alis. c.) Naucus feparatus, d.) Idem cuḍ femine transverfe diffectus. e.) Seminis fitus intra naucum. 5.) Embryo intra albụmea:

IMBRICARIA macrocarpa. ibid,

A Cl. A. L. de Jussiev,

Bacca (a. a.) ovata, l. elliptica, 5. 1. 6, pollices Jonga, punctis minimis callor fis exafperata, bafi umbilicata, octolocularis; loculis vero 4. 1. pluribus abortientibus. Nauci (b,) folitarii, irregulari-ovati, furfum anguftiores, per marginem acutum transverfe rimofi, comprefiufculi, inxquabiliter convexi, ad bafin in mucronem craffum obcufum producti, ad ventrem yero emarginat,, 1. procefu compreffo elliptico aucti, \& intra finum area umbilicali parva nec non umbilico protuberante magno inftructi, fcabriufculi, 1. glsbri, offei, per marginem fiffibiles, occluracei, monofpermi. Semina (c.) folitaria, cavitatem teftx exacte replentia, a medio crafiore furfum anguftata-obtufa: verfus bafin yero in mucronem longum attenuuta, acuminata, pallida. Int. ut in priore. Albumen (d.) femini conforme, ad latera \& ad bafin crafum, margine vero fuperiore valde tenue, duriufculum, carnofum, album. Embryo (e.) magnitudine fere albuminis, erectus, curvatus, Iacteo-albus. Cotyl. magnx, folizcex, planx, elliptico-rhomboidex, obtufx, parallele ftriatx, margine vix incraifatx, accumbentes. Rud. terenufcula, tertiam cotyledonum partem longitudine mentiens, incur$\mathrm{va}$, conice acuminata, ab umbilico externo remota, infera.

Si nauci irregulares excipias, Imbricariam a Mimulope vix dignofcendam effe, ex antecedentibus apparet, ideoque forfan melius cum cel. SNITH vid. A: Linn. Lond. Vol. 5. p. 258. inter fe junguntur. Cxterum Sapota, Phlebo- 


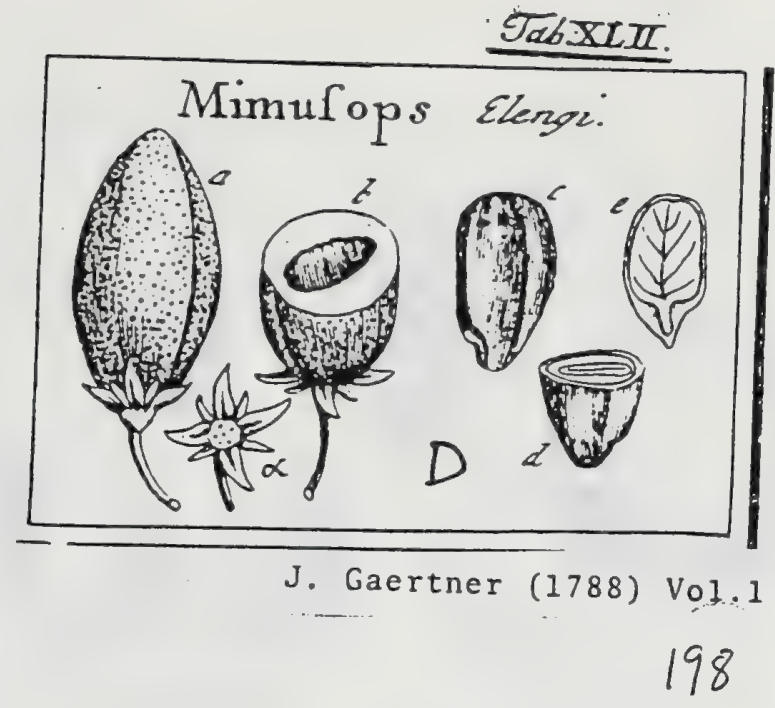

CCXXXIX. MIMVSOPS. Lin N. gen. 478 .

Calyx octopartitus: foliolis acuminatis, alternis majoribus. Cor. polypetala. Stanz: octo, pilora, Styl. unicus. Bacca unilocularis. Setmen durum, nitidum.

Miмus.o 8s-Elengi. Tab. 42. fig. 4.

Elengi. R н е г. mal. I. p. 33. t, 20.

Flos cuspidum. R и м Р н. $a m b .2 . p$. r89. t. бз.

Mimufops foliis alternis remotis. L Ix x. $\int y /$. veg. 360 .

Munamal. zeylonens. E collect. iem. hort. lugdb.

PER. Racca fupera, ovata, calyce perfifiente bafi munita, ab altero latere fulco oblo: lcto infcripta, undique punctis minutiflunis callofis fcabrata, carnofa, crafta, unilocularis.

R E c. nullum; femen fundo loculamenti affixum.

SEM. unicum, ovato oblongum, prope bafin in mucronem brevem craftum contrac. tuin, lenticulari coinpreftum, vel \& ad latera planiusculum, ad margines vero angulo carinatum, glaberrinum., lucidum, Spadiceo luteưn.

Ixт. duplex : exterius crufaceun, durum, craflufculum; interius membranaceum. tenuiftrmum.

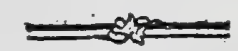

AL. Cemini conforme, prope umbilicum valde acuminatun, in lateribus craftum, ad margines tenue, carnofum duriufculum albuun.

LE B. magnitudine fere albuminis, compreflus, erectus, lactev-albus. Cotyl. foliacez, tenues, ovato oblongx, venolx. Rad. lineari oblonga, compreffiuscula, infera.

a.) Bacea Integra b.) Eadem discifis. a.) Calyx feparatus magnitadine natarall c) Semea Separatuin, d.) Idem urausverfe feQun, e) Albuminis fedio lougitudinatis, curn Embryonls fgars \& Geu. 


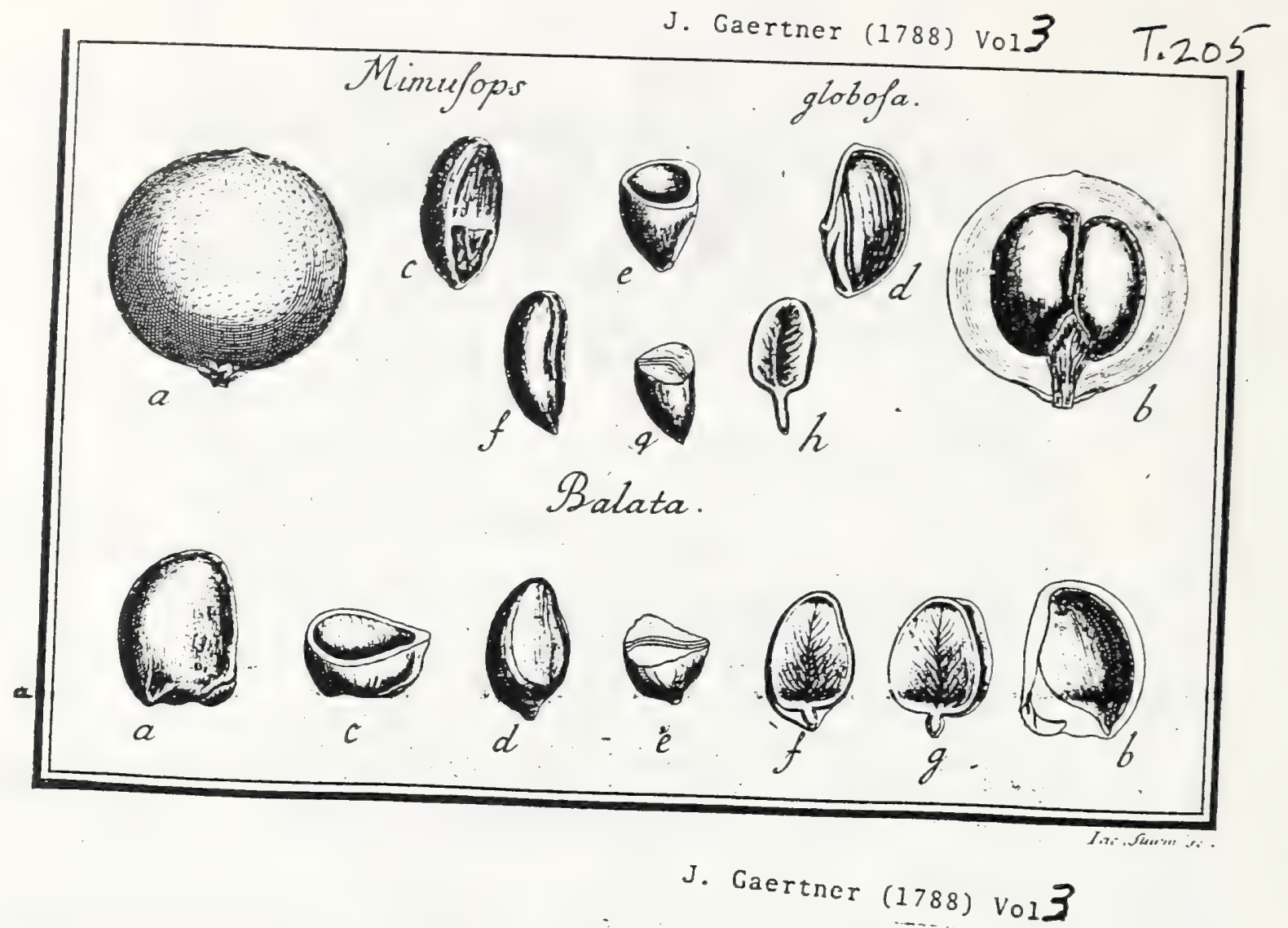

$M I M U S O P$ S. Conf. Carpol. Vol. I. p. r 98.

Mirsusors globola; Tab. 205. fig. 2.

Ex Collect. Delefiert.

Bacca (a.) globola, paululum deprefia, calyci perfiftenti fexpartito ex duplici laciniarum ordine contato infiftens, epidermide eminentiis 1 . punctis minutis fabrata, bi - (an potius quinque -) locularis. Caro craffa, pulpofa, gummofo-refinofa. Loculamenta membrana tenui veftita. Nauci (b.) plures, quorum vero rarius plures quam duo maturefcunt, fubovati (c. d. e.) compreffiufculi, lenticulari - convexi, ad ventrem vero planiufculi \& ad ejus bafin area umbilicali triangulari immerfa nec non umbilico ligulato inftruci, craffufculi, offei, membrana continua ferruginea intus veftiti, Iavigati, nitidi, cinnamomei. Semen (f. ) ovato-oblongum, rotundato - trigonum, erectum, dilute ferrugineum. Integ. fimplex, membranaceum. Albumen (g.) ad latera \& ad bafin craffum, ad marginem vero fuperiorem valde tenue, duriufculum, carnofum, album. Embryo (h.) magnicudine fere albuminis, curvulus, erectus, lacteus, Cotyl. ovate, bafi truncatx, foliaceo-carnofx, leviter plicatx, accumbentes. Rad. teretiufcula, curvula, dimidias cotyledones longitudine aguans, obtufa, ab umbilico externo arer $\{$, infera.

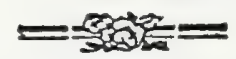

Mrnusops Balats. ibld.

Acbras (Balata, ) foliis ovato - oblongis, fubtis cincrris, fructu viridi, olivae: formi. AUBL. guiars. 1. p. 308?

Graines de Eulata. Collect. Sem. Mur. Parif.

Nauci (a. b.) ovati, baG truncati, 1. rotundato - triangulares, ad bafin hine nucronulati; inde area umbilicali parva \& unbilico exferto inftrucci, turgiduli, inequabiles, glaberrimi, lucidi, ferrugitei, monofperni. Semen (c.) cavitatem nauci replens, ad bafin acuminatum cuneatum, ferrugineum. Int. ut in priori. Albumen (d.) femini conforme, reliqua ut in antecedente. Embryo (e. f.) magnitudine fere albuminis, compreffus, paululum plicatus, lacteo-albus. Coryl. foliaceo-carnofx, planiufculx. Rad. brevis. 


\section{Sapotaceae}

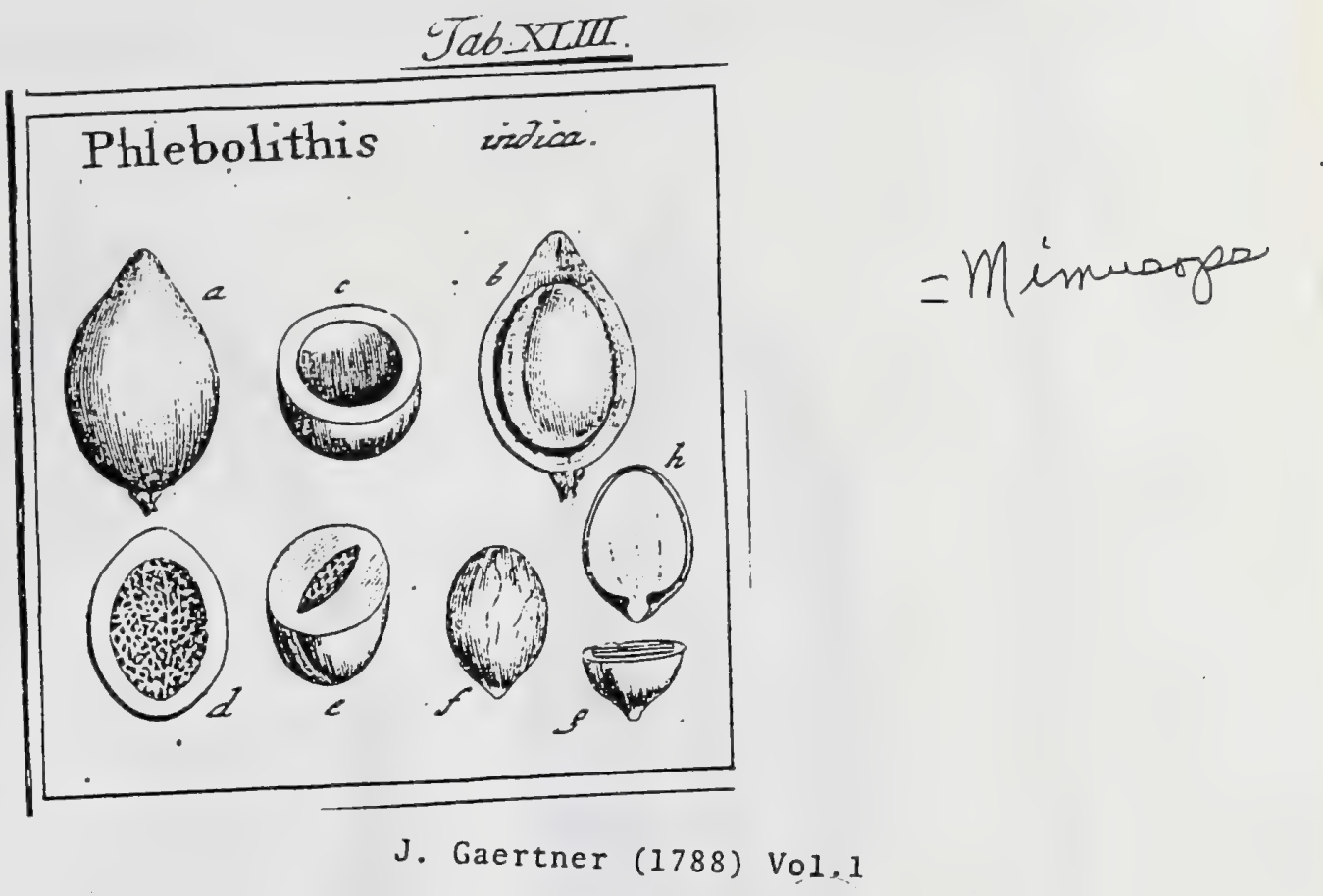

\section{PHLEBOLITHIS.}

Flos ... . . Backa unilocularis monorperma. Semen lapideum, intus venis niveis pertextum.

Phledolithis indica. Tab. 43. fig. 2.

Ex horti Amftelodamenfis feninario.

PER. Bacca fupera, ovato acuminata, carnoLa, unilocularis, Loculamentum membrana propria tenuilfima veflitum.

REC. nullum; femen fundo baccx affixum.

SEM. unicum grande, elliptico fphxroideum, oblolete compreftum, glaberrimum, nitidum, fpadiceo-luteum, ad utrumque marginem cingulo calcarto albo, convexiusculo, prope bafin latiore, furfum vero fenfim deliquefcente circumdatum.

IN T. duplex: exterius lapideum, duriffunum, craftifimum, intus cavitate compref $\mathbb{T}_{2}$ pro recipiendo nucieo exiculptum atque numerofifimis vafis, eburnei candoris, e cingulo calcarco oriundis \& dendritarum more ramofis, fuper fundo ochraceo, elegantiflume pictum; interius, incmbranaccum, tenuillinum, pallidum.

$A\llcorner$ B. cavitati $t \cap x$ confurıne, ovatum, deorfun acuminatum, lenticulari comprefium, calnofun, album.

Eмв. magnitusine fere albuminis, erectus, niveus. Cotyl. ovatx, folincex, planz. Rad. capittllata, comp̧refTa, brevis, infera.

a.) Bacen integra. b.) Ejusden fello Longitudinalis cum fitu feninis. e.) Eadem transverie feta. d.) Teftze feminis facies interna, niveis venis pian. e.) tjusdem fetio transverfalis, cun cavitate compreffa pro uncieo. (.) Nucleus denudatus. 8.) Iuen trausverfe feltus. h.) Albusen verucaliter diffextum, cum fitu \& figura embryouis.

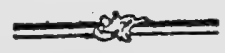

Mimuropi affinis \& forfan genuina ejus fpecies eft, nam \& Mimufopis Kaukito neen, hilum album in latere gerit, fi fida ejus figurs in Rumpuro. 
J. Gaertner (1788) Vol3

$T_{a b} 203$.

Lucuma = Pouteria mammofum.
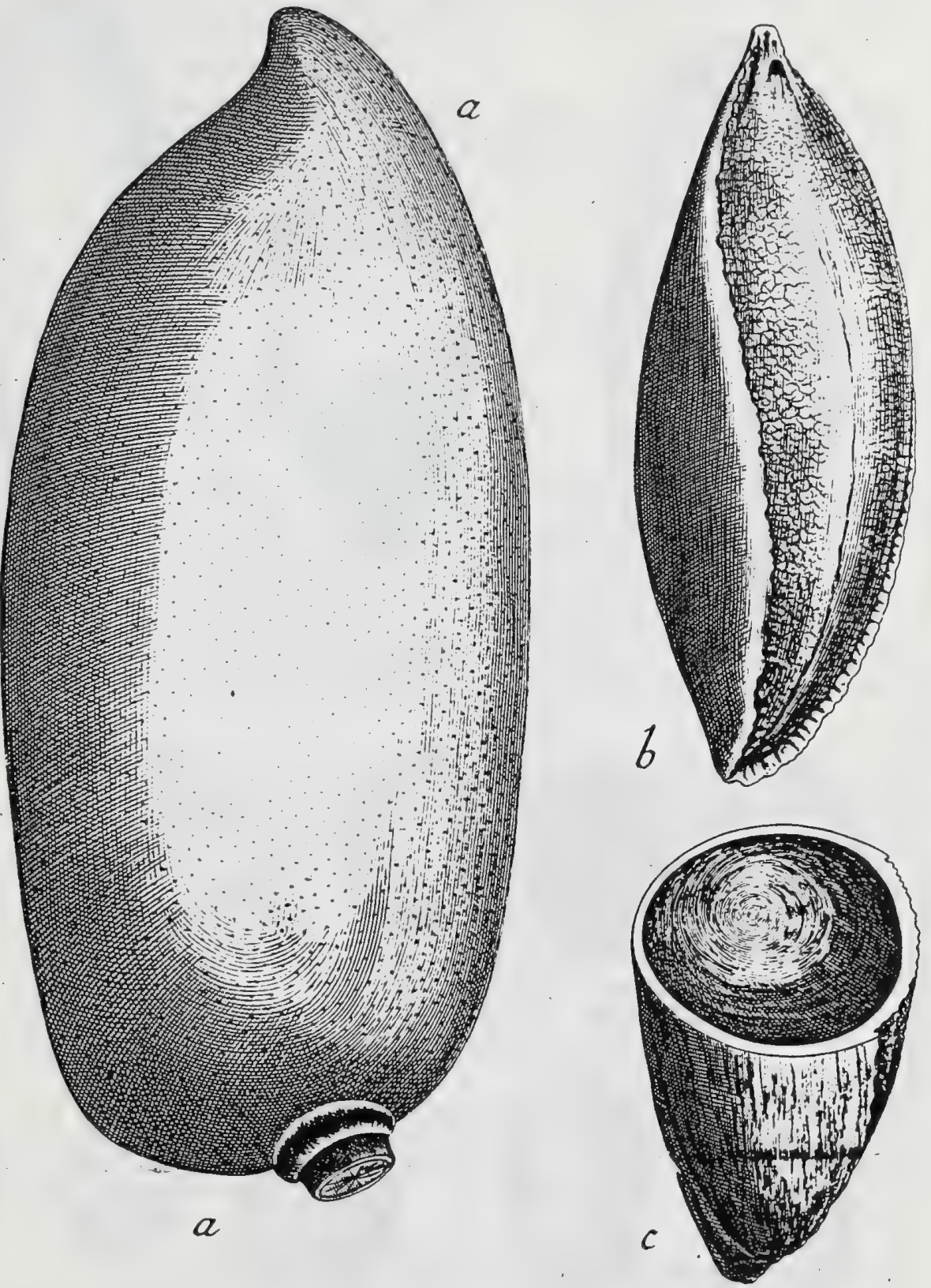

Tas . Srromer se 


$$
\begin{aligned}
& 000 \\
& 000000 \\
& 0.000
\end{aligned}
$$


Juss. gen. p. 152. Achras. LIN g. gen. 438. ed. Sclireb. 593 .

Cal. quinquepartitus, deciduus, inferus. Cor. monopetala, quiuquepartica ; tubo cainpanulato, medio ventricofo, intus fquamis quinque aueto. Stam. 5.; filamenta ad medium corollx tubum inferta, cum fquamis sleerna, fubu. Jata; antherx oblongx, incumbentes. Ovar. fuperum; ftylo fimplici: ftigmate obtufo. Bacca nauciphora, decemlocularis: loculamentis vero ad unum omnibus plerumque ঐbortivis, Nauci turgidi, offei, uniloculares, area umbilicali maxima notati. Rec nullum, Sem. folitaria, Alb. nullum.

Emb, maxinus, erectus; rad. minima,

Lucuna mammolum. Tab., $203 .-\& 204$.

Nalus perfica maxima, foliis magnis, integris longis; frudu inagno, oblongo. feabro; oficulo partint rugofo parsin glabro. SLOAN bijt. jam. 2. p. 124. t. 218 .

Arbor americana' pomifera, frondo/is ramulis; foliis amplis longioribus obtufis duris छे venosis nsargine aequali. PLUK, alin. pe 39. t. $268 . f .2$.

Aclvas frufu maximo ovato, fentuibus pascioribus oblongis turgidis. BROWN jan. p. $20 \mathrm{~s}$.

Acluras floribus pentandris. JACQ. amer. 9. 56. 8. I8s. f. Ig.

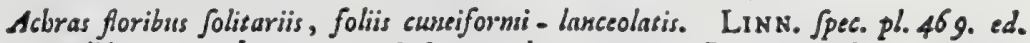
Willd. T. 2. P.i. p. =24. Syft. veg.ed.14. p. 34t. PEBsonn fyn. x. p. 235.

Icon feminis. CLus. exot. l. 2. c. 29 . f. $x$.

Pain depice. Gall. Cullect. Seni. Mul. Par.

Ex dono Cl. Dupurs. Botan. Parif.

PER. Bacca magna, mammora, fupera, oblonga, 1. ovato oblonga, ad apicem obtuffitime mucronata, pedunculo valido infidens, fcabriufcula, pulpofa, ferruginea, 1. cinnamomca, decemlocularis; loculamentis vero omnibus evanefcentibus, excepto unico membrana tenui veftito, \& nauco unico foeto. Caro pulpofa; epidermide valida punctis minutis undique exafpe rata inclufa, mollis, glutinolo-faccharata, fere infipida, dilute cinnama mea, 1. e carneo fubrubens. Nauci decem, quorum vero nonnifi unicus ad maturitatem pervenire folet, maximus, ovato-oblongus, utrin: que acuminatus, turgidus, in dorfo levigatiffmus, nitidus, ferrugi-

neus, 1. cinnamomeus, margine prope arenm umbilicalen colore dilutiore fucatus; ad ventrem vero area unbilicali maxima, tertian nauci partem mentiente inæquabili fcibra pallida, exfculptus, paulo fub vertice umbilicum immerfum, quo vafa umbilicalia intrant, gereus, offeus,

, durus, craffiufculus, unilocularis, monofpermus.

REC. nullum; naucus loculamento ope arese umbilicalis \& vaforum umbilicalium carni adnatus.

SEM. in quovis nauco fingulum, ejus cavitaten exacte replens, ovato-oblongum, torofum, 1. vix comprelfum, apice obtuffifimum, rotundatum, oblique truncatum, verfus bafin conicum, album.

Ix T. Gmplex, membranaceun, facile detrahendun.

A \& B. nullum.

E N B. maxinus, fenini conformis, erectus, albus. Cotyl. maximx, craffifimx, amygdaloideo-carnofx, plano-convexx, leviter undulato-plicatx, accumbentes. Rad. minima, obtufa, unbilico externo e diametro oppo: fita; infera.

\section{EXPLICATIO FIGURE.}

a. a.) Bacea intogra. b.) Naucus feparatus. c.) Idem medio transverfe. fedus. d. e.) Emo bryo feparatus, \& ab utraque parte vifus. f.) Ejusdem featio trasvetfalis.

Lucuma Rivicoa. Tab. 204.

Graines $d u$ bois Rivicoa de baute Tiette. Collect. Delefrert.

Naucus (a.) ovatus, 1. fubglobofus, nitidus, fufcus, ad ventrem area umbilicali maxima pallida \& fub vertice umbilico triangulari infigmtus, offeus (b.) fragilis, intus membrana propria vafculofa pertestus. Semen (c.) cavitati teftz conforme, in vertice leviter fulcatum, \& per tutam fuperficiem vafo- rum impreffionibus notatum, bafi mucronulatum. Int. ut in priori. Embryo femini conformis, ovatus, albus. Cotyl. (d.) craftifimx, carnorx, foveola internedia tenticulari difcretx, margine tantum contigux, accumbentes. Rad. (e.) brevifima, parva, obtuða, inltir tuberculi albidi ex embryone prominula, infera.

An hac fpecies, ob membranam nauci internam vafculofam Vitellarix potius congener fit, aliis enodandum relinquo. 


\section{J. Gaertner (1788) Vo13}

Lecuma pallidum. ibid.

Graimes de Balats bustard de buruse Tieste. Collest. Deleffert.

Naucus (a.) oblongus, levigatus, ad ventrem ab oppofito comprefius, pla. niufculus, pallide ftramineus, intus membrana propria continua rufefcenti

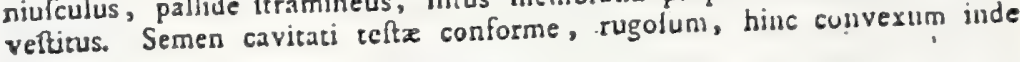

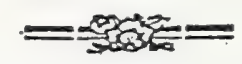

planum. Integ. ut in reliquis. Embryo (b.) Seminis formx exacterefpon: dens, erectus, albus, Cotyl, frafix, incumbentes. Rad. ut in prioribus.

Lucuma dominigenfe. ibid.

A Doro Porteav.

Naucus (a.) rotundato - trigonus, ad latera ventrem verfus obtufe cuneatus, lxvigatus, nitidus, dilute caltaneus, membrana propria intẹna contnua ferruginea intus veltitus, Semen cavitati teltze conforme, rotundatotrigonum, in dorfo longitudinaliter rugofum, erectum, albuin. Integ. ut in reliquis. Embryo (b.) femen exacte reprefentans, eredtus, albus. Cotyl. (c.) leviter texuolx, carnofx, crafie, fubincumbentes. Rad. ut in prioribus.

Sapotarum femina, propriis characteribus infignita, diftincto Naucorum nomine in pofterum defignare juvat.

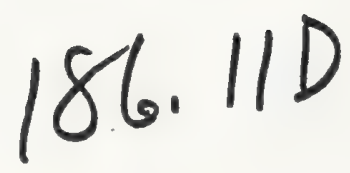




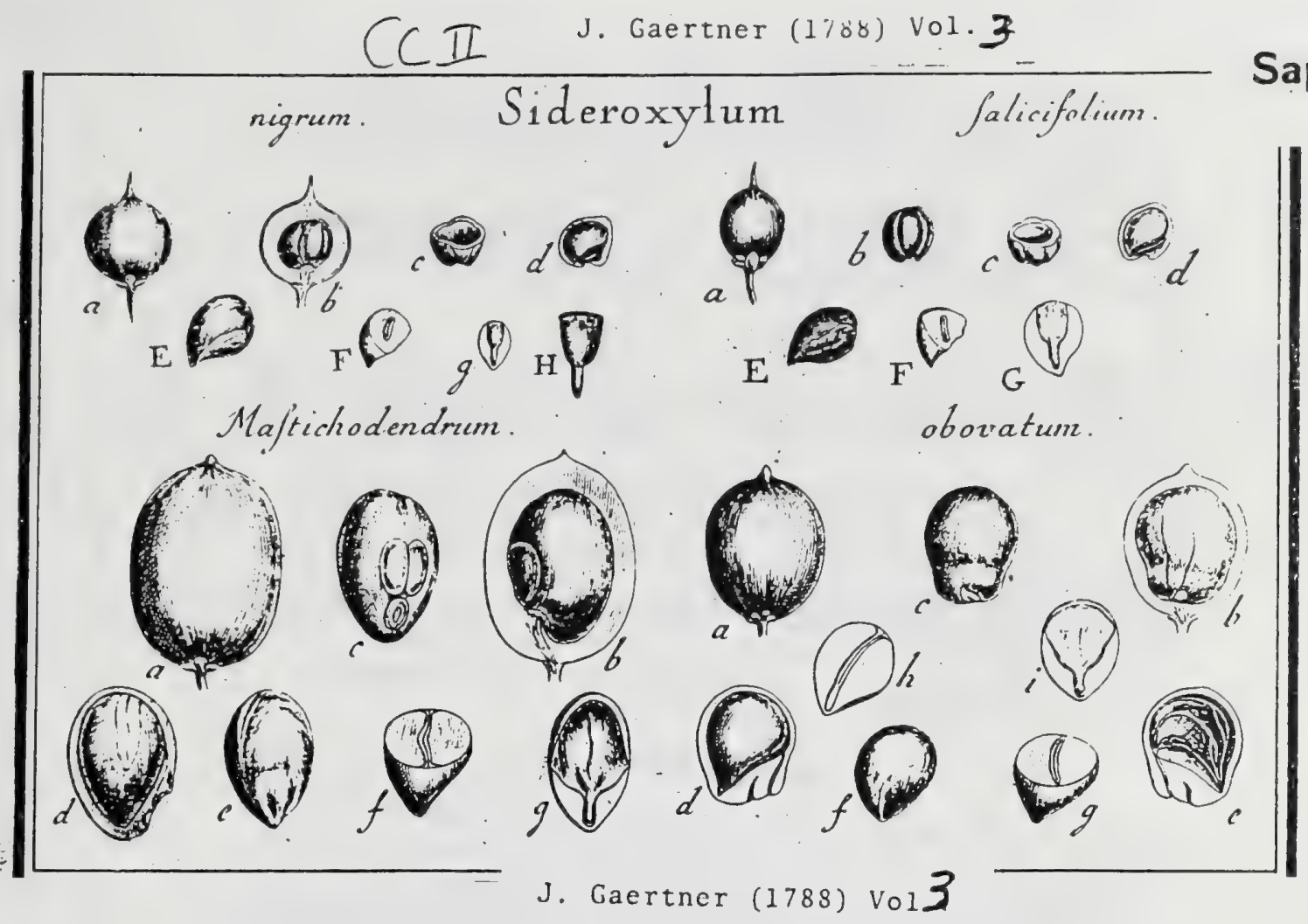

99. S I D E R O X Y L U M.

123

LINN. gch. 264. ed. Schreb. 357. Juss. gen, p. I5r.

LAMARCK ill. gen. $t$. 120.

Cal. parvus, quinquefidus, inferus, perfittens. Cor. monopetala, rotats, quinquefida: lacinix ovatx, obtufa, bafi appendicibus quinque ferratis, cum laciniis alternis, lanceolatis inftructx. Stan?. quinque, laciniis paulo breviora, cun appendicibus alterna; filamentis lubulatis; antheris incumbentibus. Ovar. fuperum; ftylo fmplici, longitudine ftaminum; ftigmate obtufo. Bacca unilocularis, nonofpermi : loculamentum membrima propria veftitum. Rec. nullum. Sen. unicum, lxvigatum, bafi unibilicatum, tefta offea inftructum. Alb. bafi oblique truncatum, fubcartilagineum. Emb. oblique adfcendens, cotyledonibus foliaceis, apice ad utrumque latus fupra albumen retlexis, incumbentibus; rad. declini, infera.

\section{SIDEROXYLU.M nigrum.}

Ex infula Hifpaniola a $D^{\text {no }}$ Portead, cum fequente.

PER. Bacca parva, globofa, mucronato-apiculata, calyci quinquefido perfiftente infiftens, glabra, nigro.cœrulea, unilocularis, monofperna. Caro craffiufcula, dulcis. Loculamentum nembrana propria tenui veftitum.

REC. nullum; femen umbilico bafi bacex adnatum, \& cum vafis pedunculi cohicrens.

SEN. unicum, rhimboideo - fubglobofum, compreffiufculum, rotundato - te? tragonum, bafi torofe umbilicatum, levigatum, fufcum.

IN T. duplex; exterius offeo - teftaceum, cavitatibus duibus exfculptum : altera majore nuclei fubglobofa \& membrana - vafculofa pertexta: alcera inferiore minore, $f$. umbilico dilatato \& vafa umbilicalia ducente, tentorio offeo obliquo tenui, ad angulum fuperiorem a vafis umbilicalibus perterebrato, a cavitate fuperiore difcriminata : interius membranaceum, tenae, ferrugineum.

A I B. cavitati teftæ conforme, fubglobofum vel ill vertice \& dorfo convexum, ad bafin acuminatum, infra vero oblique decufatum, planiufculum, craffum, fubcartilagineum, album.

EMB. albumine paulo longior, oblique adfcendens, margine dextero ad planitiem albuminis declinis, albus. Cotyl. dimidio albumine longiores, fubellipticx, ad apicem truncate, marginibus fuprat albumen em:nentibus $\&$ ad utrumque latus albuminis refexis, foliacex, leviter convexæ, fub\& ad utrumque latus albuminis reteib, follacer, levior, teres, recta, obtufa, ab umbilico externo declinis, infera. 
3.) Bacca integrz, b.) Eadem longitudinaliter diltceta cum femine in fitu. e.) Tefta transverfe feta. d.) Ejusdem fetio luogitudinalis cum (itu nuclei. I.) Nucleus (rolutos. 'F.) Almen transverfe diffetum. 5.) Embryonis fitus intra albunen. H.) Embryo folutos, a parte Ioperiore рpeQtatus.

Rami graciles. Folia lanceolata, longe petiolata, obcufa, margine undulata, utringue glabra, fupra nitentia. Pedunculi pauci 2.1. 3., breves, ex axillis foliorum ad fummos ramos prodeuntes.

SIDRROXYLUM falicifolium. ibid.

Salicis folio lazo fplendente avbor, floribus parvis pallide luteis pentapetalis e ramulorum luteribus confersins exeuntibus. SLOAN. jams. 170. bif. 2. p. 98; t. $206 . f .2$.

Acbras?" foliis oblongis nitidis utrinque produgis, foribus confertis, fafciculis infral frondes fparfis. BHows. jain. p. 201. t. 17. f. 4.

Acbras (fulicifulia, ) floribus confertis, foliis lanceoluto-ovatis. LINs. Spec. pl. ed. 3. p. 470 . Sy.f. veg. ed. 14. F. 342.

Bumelia (Sulicifulia,) foliis lunceolato - ovatis acuminatis, pedrasculis confertis axillaribus EO laseralibus. SwARTZ prod. p. 50. Flor. ind. occid. p. 49r.

Sideroxylum inerme, folits ovato - Innceolatis acuminatis fupsrne fflendeutibas; floribus confertis laieralibui. LamaRCK ill. gen. n. 2458.

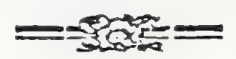

Bacca (a.) parva, ovata, mucronato - roftellaza, infera, glabra, lutea, unilocularis, monofperma, (rarius bilocularis, difperma. Swartz.) Caro debilis, pulpofa. Semen (b.) fubglobofum, longitudinaliter quinque -1 . fexfulcatum, bafi umbilicatum, glabrum, fufcum. Integumentum (c.) ut in priore. Albumen (1. E. F.) cavitati teftx conforme, rotundato - trigunum, bafi oblique undulato-truncatum \& fulco intermedio elevato infignitum, deorfum acuminatum. Embryo (G.) ut in priore.

Cel. WILlnenow in Spec. pl. T. 1. P. 2. p. 2086. hanc fpeciem curn fequente commifcuit.

Sideroxylum Maftichodendrum. ibid.

Cornus foliis laurinis, frufizu majore luseo. Caress. car. 2. p. 75. t. 75 .

Sidcroxyluin Mafticlodendrum. JAce. collet. 2. p. 253. t. 17. f. 5 .

Sideroxylon inernse, foliis perennantibus lanceolasis acusis; floribus luteis. LaMARCK ill. gen. $n$. 2456 . t. 120. f. 2 .

Acoma jazue, 1. Apricot des bois. Collect. fem. Mul. Parif.

Bacca (a.) ovato-oblonga, pollicaris, utrinque obtura, hinc calyci perfiftenti infiftens, inde mucronata, glabra, lutea, unilocularis, monofperma. Caro crafliufcula, mollis, epidermide tenui tecta. Semen (b. c.) unicum, obovatum, l. ellipticum, turgidum, ad ventren glabella ovata bipartita \& infra hanc paulo fupra bafin feminis area umbilicali alba immerfa atque in hujus centro umbilico parvo infiynitum, levigatifimum, fufcum 1. obfcure caftaneum. Integumentum duplex: exterius (d.) telta offea, bafin verfus craffior evadens, iu proprio canali ab umbilico externo incipieute \& ad medium feminis ventrem intus termiuato vafí umbilicalia, in membranam vafculofam teftx intermm foluta, transmittens: interius membranaceum, tenue, occhraceum. Albumen (e. f.) cavitati telt $x$ conforme, ellipticum, ad latus ventrale bafin verfus oblique truncatum, planiufculum, \& a bafi acuninata fulco elevato inftructum, in vertice autem ftria alba bipartita ad utrumque latus fupra medium decurrente nutatum, crafum, fubcartilagineum, albun, 1 . dilute Atramineum. Embryo (g.) magnus, albumine ipfo longior, oblique adfcendens, albus. Coryl. ovatx, cochleariformes, margine fupra albumen reflexx, foliacex, inftar fellx equeftris longitudinaliter fulcatze. Ral. dimidis cotyledonibus paulo brevior, teres, obtura.

Sidzroxylum obovatum. - ibid.

Bois d'acouna. Collect. Delefiert.

Bacca (a.) fubglobofa, l. obovata, mucronata, glabra, lutelicens, monofperma. Semen (b. c.) unicum, obovatum, utrinyue obtufum, comprelisufcus. 


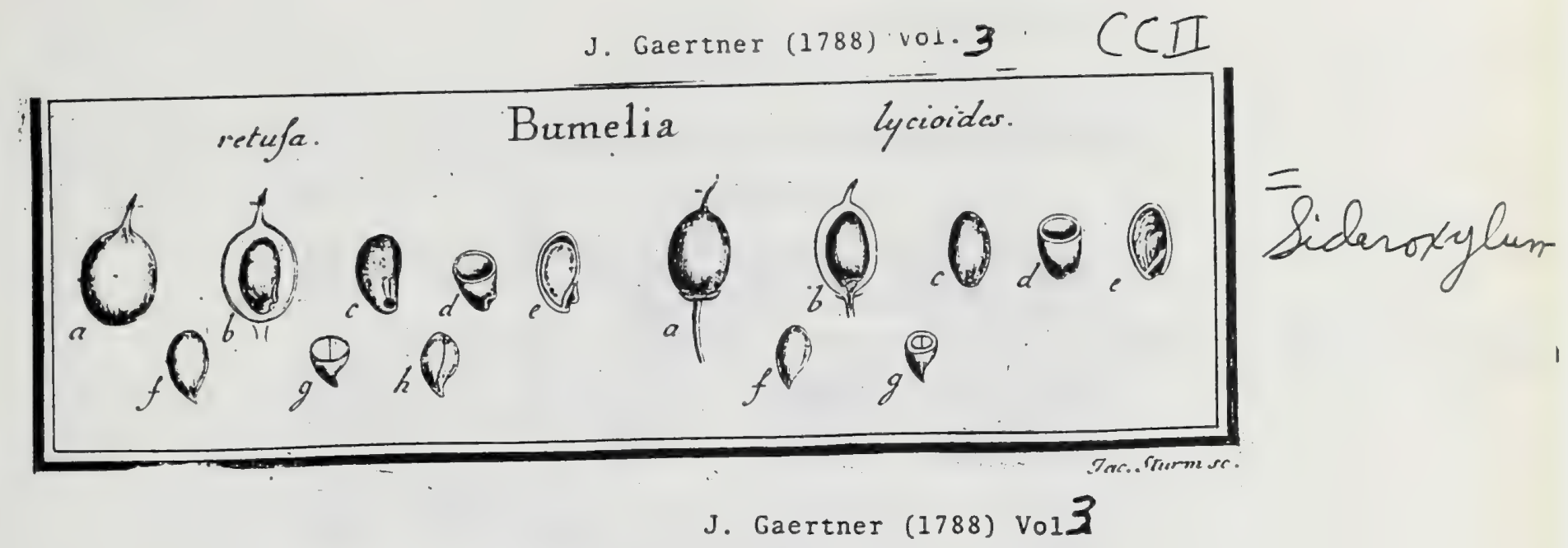

\section{B U M E L I A. 126}

SWARz prodr. p. 49. fl. ind. occid. t. 8.

SCHREB. gen. $173^{6}$.

Cal. quinquepartitus, inferus; laciniis ovatis, obculis, concavis, perfiftentibus. Cor. monopetala, tubulofa quinquefida; tubo cylindrico, brevi, infra faucem fquamis quinque acutis neetariferis conniventibus \& corollx lacinüs oppofitis sngultato; limbo quinquepartito: laciniis ovatis, patentiufculis, concavis, ad bafin appendicibus duabus ferratis, cum lacinis alternis, munitis. Stans. quinque; filamentis longitudine laciniarum corollax, fubulatis, ad faucen corollx inter appendices infertis; antheris incumbentibus. Ovar. fuperum; ftylo fimplici, fubulato, ftaminibus breviore; ftigmate acuto. Bacca ftylo perfiftente faftigiata, anilocularis, monofperma. Rec. nullum. Sem. unicum, teftaceum, fupra bafin umbilicatum. Alb. tenuiffmum. Emb. ereclus, curvulus; cotyledonibus craffis; radicula minima.

Bumelia retufa. Tab. 202. fig. 3 .

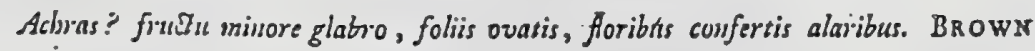
jail. p. 201. "1. 7 .

Bunelia foliis cuneato - ovatis retufis rigidis; pedunculis conferitis axillaribus. SWARTZ prod. p. 49. Fi. ind. occid. p. 490. WILLD. Spec. pl. T. I. Y.2. p. 1086. Prrsoon fym. pl. x. p. 237 .

Ex collectione Bankfiana. 


\section{$=-320$

PER. Bacca parva, ovata, fupera, ftylo perfiftente mucronato - roltellata, glabra, unilocularis, monofperma. Caro mollis, craffiufcula, Alavefcens. Loculamentum membrana tequi veftitum.

REC. nullum; femen ope are:e umbilicalis prope bafin bacex adratum.

SEN. unicun, irregulari-cllipticum, 1. in dorfo magis convexum, ad ventrem rectiufculum \& glabella bipartita notatum, turgidulum, vix compreffum, paulo fupra balin umbilico ovato inltructum, glaberrinum, nitidum, livido - fufcun.

INT. duplex; exterins offeo - teftaceum, cavitate altera majore acuminatoelliptica pro nucleo, attera minore ad bafin oblique adfcendente pro vafis umbiliculibus exfculptum, intus membrana vafculofa ferruginea veftitum: interius arachnoideum, fimpliciffimum, album.

A L B. membrana tenuis, carnofa, laçeo-alba, a transparente embryone ferrugineo violncea, embryonem includens, ad bafin apiculatam paulo crafior.

EMB. cavitati teftre confermis, ellipticus, 1. obovatus, bafi acuminatus, magnus, eiectus, dilute ferrugineus. Cotyl. craffx, plano-convexz, fubcartiliginez, incumbentes. Rad. brevillima, curvula, conico - acuminata, unbilico externo vix obverfa, infera.

\section{EXPLICATIO FIGURE.}

a.) Bacea integra, calrce defituta. b.) Eadem lonsitudinaliter diffecta cum femine in fitu. c.) Semen folutum, a ventre fpectatum. 1) Tefta inanis, transverfim feda." e.) Ejusdem fetio longitudinalis cum nucleo in fitu. f.) Albuaren Icparatum. 5.) Ejusjem \& eubryonis fetio eransvetfalis. h) Embrjo folutus.

Bumelia lycioides. ibid.

Sideroxylum Spinofum, foliis deciduis. Duhan, arb. 2. p.260. t. 68. WaNGENH. amer: '117.

Sideroxylum fpinofum, foliis deciduis lanceolutis venofis. Lamarck ill. ger. n. 2463 .

Sideroxylon fpinofsun, ereisum: foliis lato - lanceolatis, utringue glabris. Michaux fior. bor. amer. x. p. 222.

Sideroxylum Jpinofum, foliis deciduis lanceolatis. LINN. Jyf. veg. ed. 14. p. 232. WiLLD. Spec. pl. T. I. P. .2. p. sogo.

Busmelia lycioides. Persoon fjn. pl. 1. p. 237.

Ex collectione Cel Despontajnes.

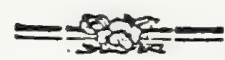

Bacca (a.) parva, ovata, in vertice ftylo perfiftente mucronato-roftellata, bafi calyci perffftenti patentiufculo infiftens, glabra, viridiufcula, unilucularis, monofperma. Caro pulpofa. Semen (b. c.) ellipticium, turgidum, in dorfo magis convexum, per vafa umbilicalia bafi baccx affixum, ad bafin umbilico pervio, in loculamentum fpurium intra teftam oblique adfcendens dilatato, inftructum, lutefceus. Integumentum exterius (d. e.) ut in priore; interius fimplicifimum, album. Albumen (f. g.) aute maturitatem craffiufculum, carnofum, album. Embryo ut in priore.

Neque foris varia conditio, neque corollæ additamenta, nec denique feminum numerus in Cryfophyllo, Sideroxylo \& Bumelia ad condendos certos generum characteres fufficiunt, uti ex confufione fpecierum; ad hxc genera ab auctoribus relatarum liquet; fed, uti videtur, fola albuminis conditio \& embryonis fitus atque forma, in his ftirpibus conftantifima, incertos hos characteres mederi valent.

\section{$186.13 B$}




\section{J. Gaertner (1788) Vo13}

$T_{a b}$. C CI.

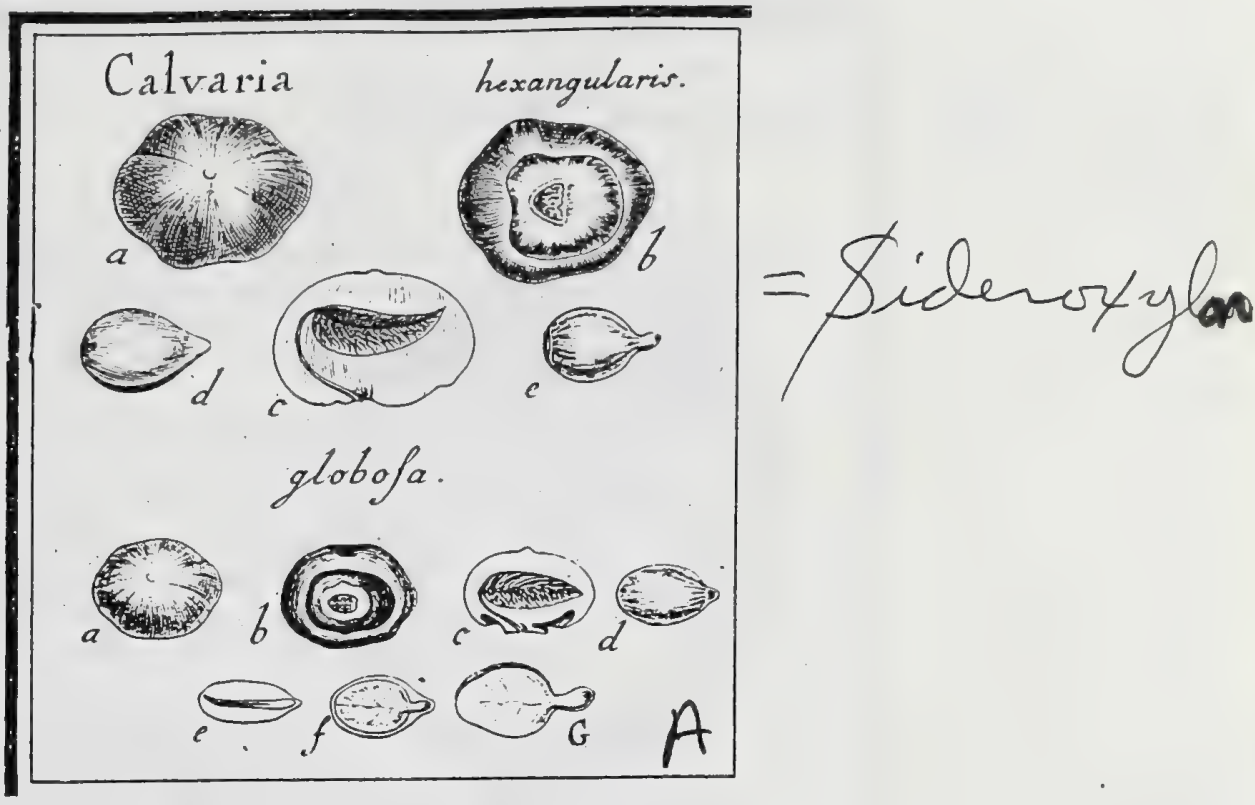

J. Gaertner (1788) Vol3

Tab. C C.

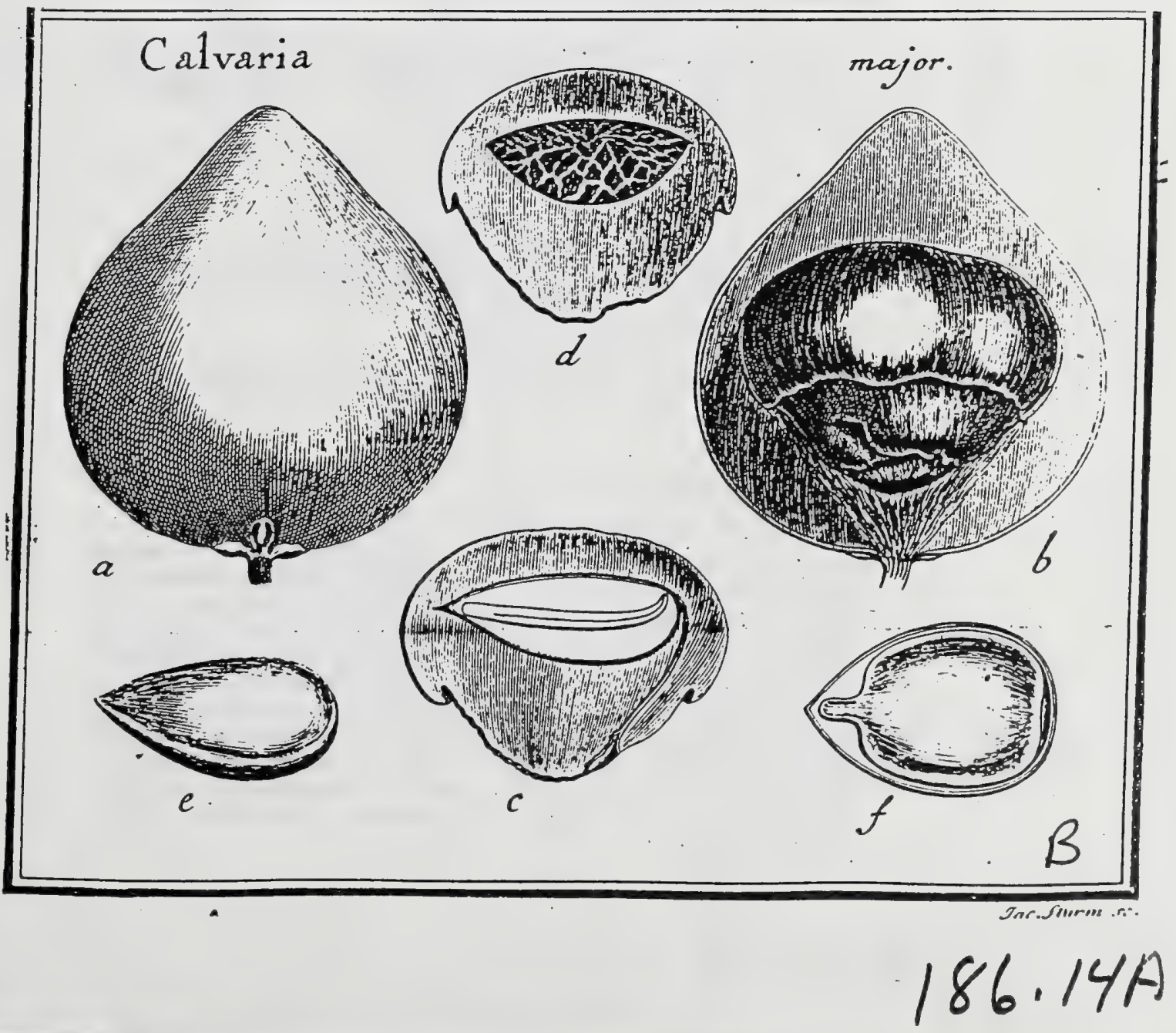




\section{C A L V A R I A. Commers.}

Cal. parvus, quadripartitus, inferus; foliolis ovatis, obtufis, perfiftentibus. Cor. ... Stam. . . O Ovar. fuperum. Styl. . . Stigm. . . Bacca pomacea, monofperma. Rec. nullum. Sem. horizontale, tefta offea crafGiflama, intus membrana propria vafculora veftita, inftructum. Alb. carnofum, ad marginem tenuiflimum. Enb. horizontalis; cotyl. foliaceis; rad. curvula.

Calvaria major. Tab. 200. fig. 2.

an Calvaria cerebellina? Comares. ic. ined.

E collectione feminum Mur. Parif.

Pzr. Bacca carnofa, lactefcens, fupera, ovata, ovum anferinum eraffitie fuperans, fed paulo brevior, 1. e bafi craflifima furfum conice attenuata, ob. tufa, turbinata, glabra, rufefcens, monofperma. Loculamentum membrana propria tenuifima, ex valis pedunculi oriunda \& totum femell obvolvente, veftitum.

REC. nullum; femen lata area umbilicali fundo baccx adnatum.

SEM. unicum, grande, fubglobofum, in duo hemifphæria difcriminatum; hemifphxrio fuperiore depreffufculo, inxqualiter ovato, l. calvariæ formam ex affe referente, paulo fupra medium levigatilfimo, fpadiceo-ferrugineo \& margine acuto terminato: inferiore obtufe umbonato, anguftiore, fca. bro, 1. ufque ad hemilphxrium fuperius ex lata area umbilicali formato, \& foraminibus umbílicalibus inxqualibus, plerumque tribus, infignitu.

IN T. duplex; exterius offeum, crafifimum, intus cavitate-compreffa pro recipiendo nucleo exfculptum, atque venis albidis, e valis unbilicalibus obortis per foramina feminis bafilaria ingredientibus \& in propriis canalibus fubftantix offex inferiptis, ad obtufam feminis partem adfcendentibus, tum in angulo ipfo cavitatis egredientibus, dentritarum more ramofis, eleganter pertextum: interiss, mcmbranaceum, tenuifimum, pallidum.

A I 8. cavitati teftx conforme, s!! tico - acuminatum, compreffuifculum, 1. inxqualiter lenticulari-convexum, convexitate fuperiore minore, medio craffum, ad marginem vero in membranam tenuem attenuatum, carnofum, album.

E в в. magnitudine fere albuminis, horizontalis, niveus. Cotyl. ovatx, foliz. cex, fubconcavie, apice recurvato - adfcendentes, levifime nervof $x$, incumbentes. Rad. brevis, capitellata, compreffa, ab umbilico externo remora, interno autem contraria, lateralis.

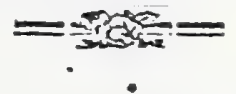

\section{EXPLICATIO FIGURA.}

a.) Baeca integra. b.) Eadem longituditalliter diffecta cum fitu feminis. c) Semen longitudi-

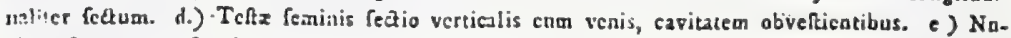
clews feparatus. f.) Embryonis fitus intra albumen.

Embryonis figura ad fpecimen ab infectis valde corrofun facta, \& ex parte ad conjecturam integrata eft, hinc in noftra icone ejus figura non latis certa.

\section{Calvaria hexangularis. Tab. I20. fig. I.}

Noix du bois de compagnie. Ex collectione Deleffertiana, cum fequente.

Semen (a. b.) nuce avellana paulo majus, depreffiufculum, obfolete hexangulo-ellipticum, ad fulcos ab adnata membrana loculamenti ftriatum, cietera niridum, lutefcens, in fummo vertice obtufe mucronulatum, ad bafin vero lata irregulari area unbilicali fabrata \& in hujus centro umbilico triangulari, ex congerie foraminulorun pro introitu vaforum úmbilicalium formato, infignitum. Integumentum duplex; exterins (c.) offeum, craffifimum, cavitate compreffa, venis anaftomofantibus pertexta, exfculptum; interius tenuifhmum. Albumen (d.) elliptico-acuminatum, lenticularicompreffum, acunine adfcendente curvulum, ad marginem tenuilfimum, carnofum, album. Embryo (e.) horizontalis, magnitudine fere albuminis. Cotyledones ovate, obtufix, apice recurvato-erectiufculx. Radicula brevis, curvula.

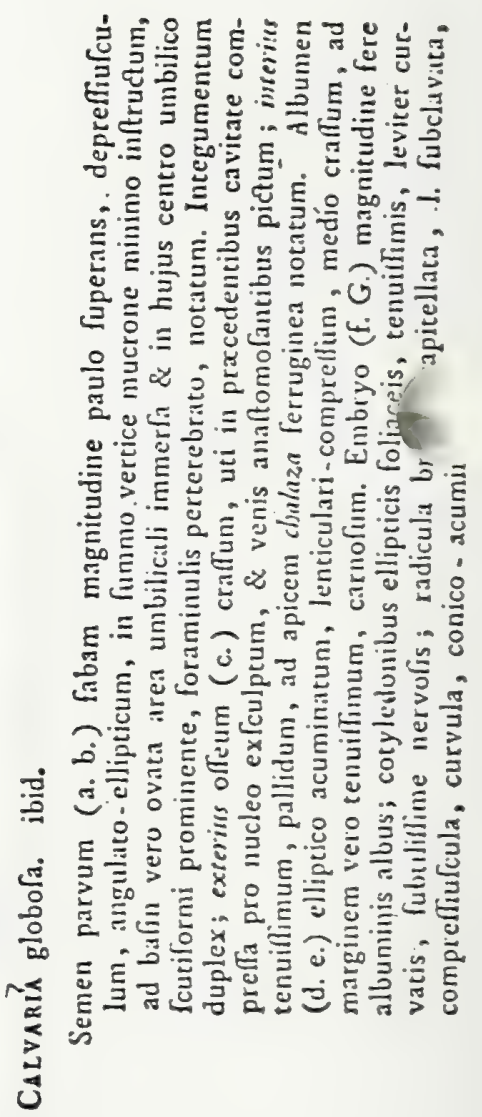


Sapotaceae

J. Gaertner (1788) Vol3

Tab.207:

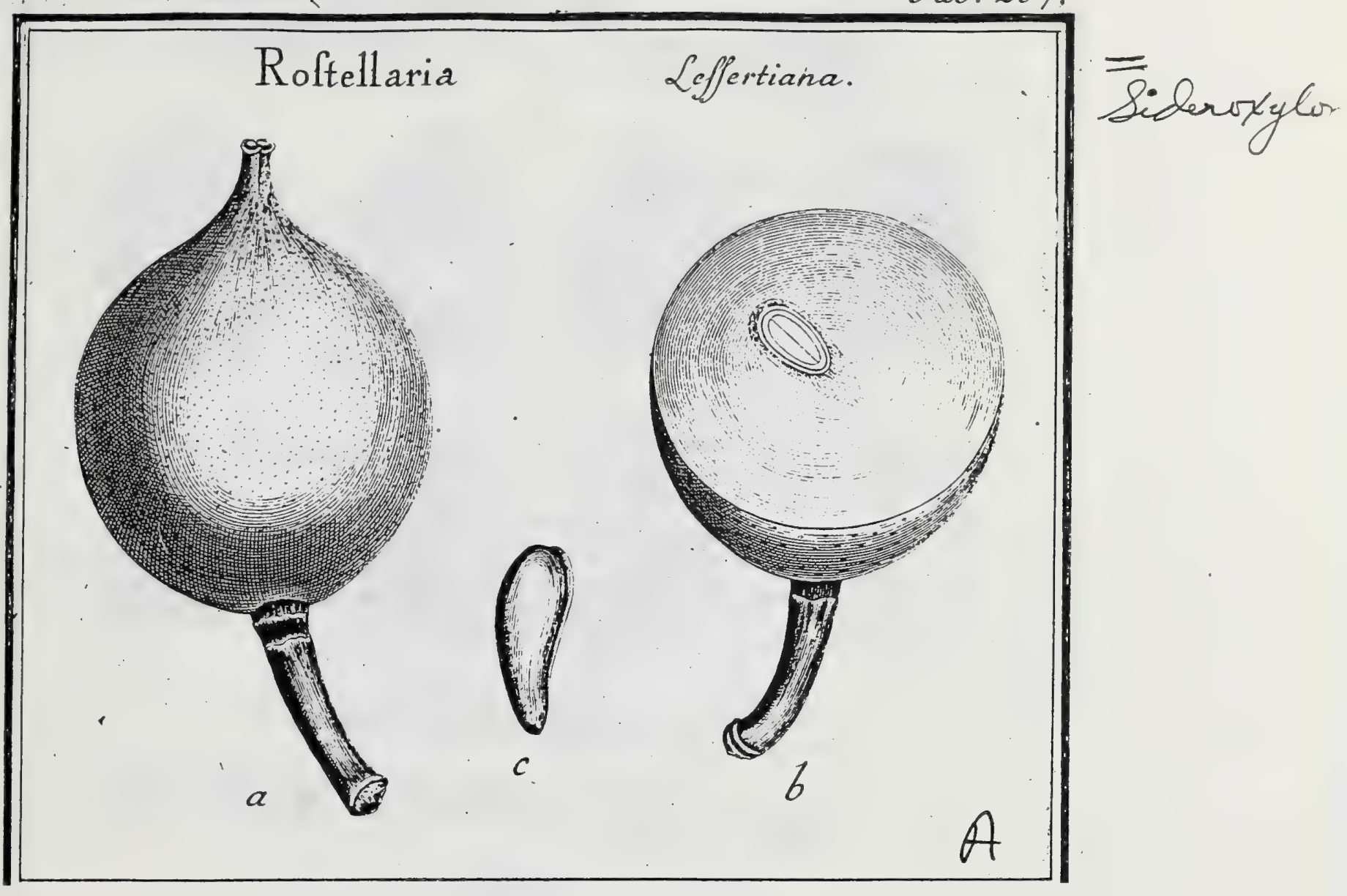

$186.15 A$ 


\section{J. Gaertner (1788) Voi. 3}

104. ROSTELLARIA.

Cal. ... inferus, deciduus. Cor. ... Stam.... Ovar. fuperum; Atylo fimplici; (tigmate concavo. Bacca carnola, in ftylum perfiftentem attenuata, unilocularis?. Naucus unicus, monolpermus. Rec. o. Sem. folitariun. Alb. carnofum, tenue. Emb. obovatus; cotyledonibus crađts; rad. brevi, obtufillima.

Rostellarda Leffertiana. Tab. 207. fig. I.

Ex Collect. Deleffert.

PER. Bacea grandiufcula, ovata, fupera, in ftylum perfftentem craffum apice truncato - Jacerum attenuats, pedunculo valido fuffulta, punctis plurimis callofis confperfa, viridis, unilocularis: Caro ab-epidermide valida-inclufa, crafiffima, firma, pallida, vafis plurimis minimisque intermixu. Loculamentum unicum? obovato - oblongum, comprefluifculum; extra axim fructus Gtum, ex fubftantia coloratiore \& magis firma quam caro ipfa formatum, ceterum cum illa undique connatum. Naucus unicus, obovato - oblongus, compreffiufculus, lenticulari - convexus, ofeus, area uribilicali ad bafin notatus, glaber, fufcus.

REC. nullum; náucus baG Joculamento adnatus.

SEM. unicum, nauci cavitati confimile, fubclavatum, l. obovatum, utrirque obtufum, compreftufculum, pallidum.

Ix T. fimplex, membranaceum, facile detrahendum.

AL D. Cenini conforme, tenue, carnofum, album.

Eмв. obovato-oblongus, compreffiufculus, incurvus, eredus, albus. Cotyl. longx, carnofx, crafilifculz, plano-conves $x$, accumbentes. Rad. cralis, non difcreta, obtuGGima, vix comprella, infera.

\section{EXPLICATIO FIGURE}

2.) Batẹ intejta. b.) Eadem medio transverfe diffeta. c.) Eabryo feparatos.

Folia oppofita, magna, ovata, corjacea, breviter pedunculata, margine undulata, hinc glaberrima, inde ex nervo intermedio parallele fubriliter ftriata.

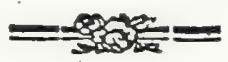

Ob loculamenti Gtum citra axim bacce fufpicio arridet, fruatum effe plurilocularem, quamvis obliterati loculamenti ne minimum detegere potui veftigium. Hac ftirps proxime a Bumelia diftat. 


$$
\begin{aligned}
& \text { J. Gaertner (1788) Vol3 } \\
& \text { Tab. } 205 .
\end{aligned}
$$

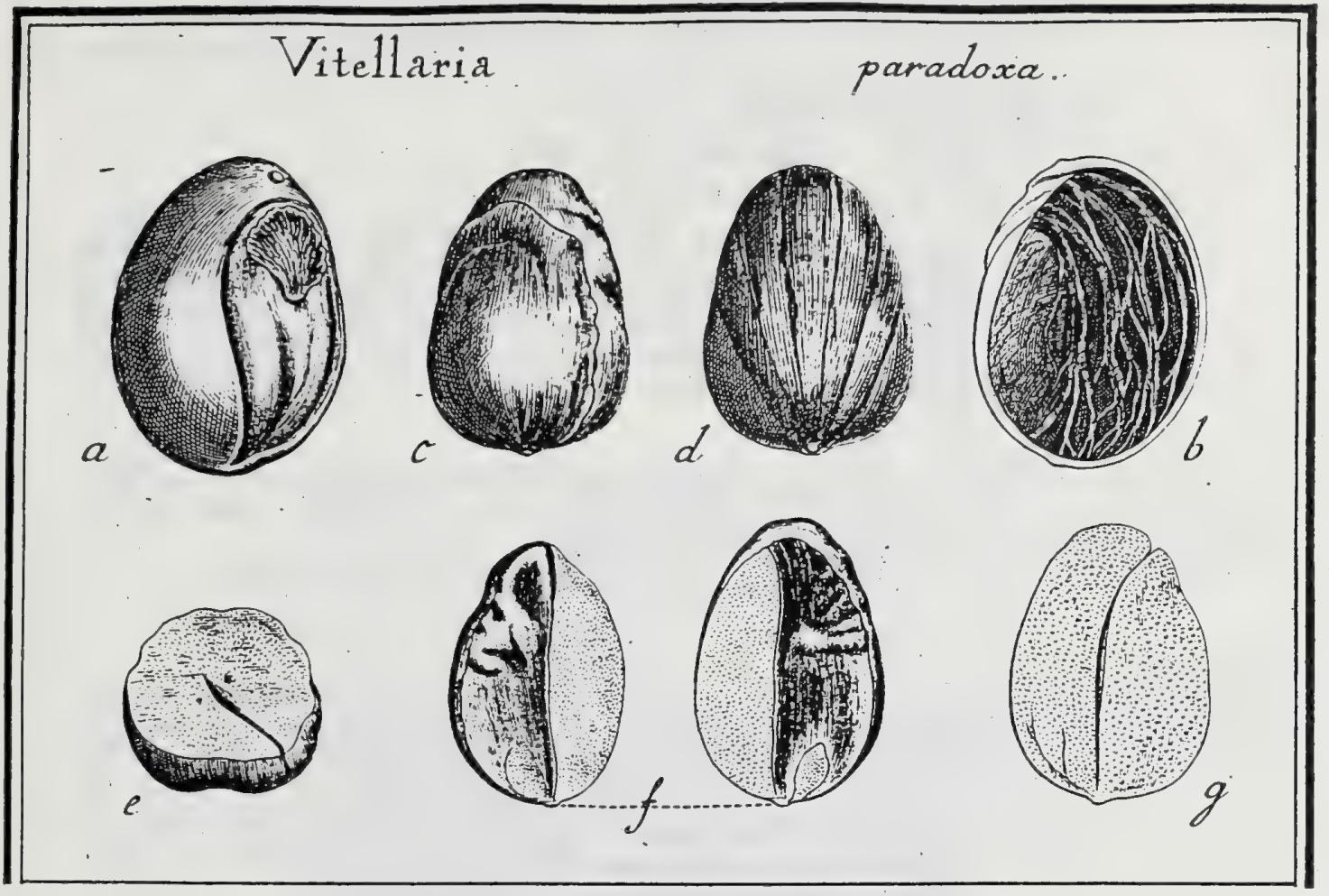

$$
186.17 \mathrm{~A}
$$




\section{J. Gaertner (1788) Vol.3}

102. VITELLA I I .

Cal. ... Cor,... Stam. ... Ovar. ... Bacea nauciphora; naucis unilocularibus, monolpermis, membrana walculora intus pertertis. Semina folitaria. Alb. nullum. Emb. erectus, cotyledonibus leviter-plicatis, Jongitudinaliter ad medium ufque conmatis; rad, parva, protuberante, infera.

Vircllaria paradbaa. Tab. 205. fig. I.

Pairs d'epice, Culleet. Sem, Muf. Parif.

Jaume de Tounf. Collect. Delefert.

PER. . . (nonduin vidi.) Naucus ovato-globofus, 1. ovatus, in dorfo nitidus, glaberrinus, dilute fufcus; ad ventrem vero area umbilicali pallida feabriufcula immerfa \& fub vertice umbilico exferto triangulari notatus, ad quem fulfus obfoletus a balf nausi affurgit; intus membrana propria vafculofa ele:anter pertextus, cujus rami a vertice per dorfum finduntur, \& ad bafin ufque defcendunt; offeus, craffufculus, unilocularis, monolpermus.

REC. - . .

SEM. in Gingulo nauco fingulum, ejusdem cavitati exacte replens, ovatum, 1. ovaro-globofum, fulcis obfoletis a vertice per dorfum oblique decurren. tibus exiratum, erectum, rufefcens.

INT. fimplex, membranaceum facile detrahendum, ferrugineum.

A L B. nullum.

132

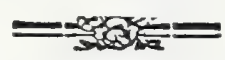

E M 3. magnus, femini conformis, ereaus, rufefcens. Coigl. crafrifimx, hine per totam longitudinem leviter plicatx \& trabecula unica ad bafin connatx, altero dimidio embryonis latere fere a vertice ad radiculam ufque connatz, amygdalino-carnofx, ex fubltantia alba cum punctis rufis intime nixtis \& valis percurfa compofitix, accumbentes. Rad. minima, adpreffa, cindore $a b$ embryone diltincta, obtufa \& quafi ex ensbryone protuberans, -vara in cotyledonum fubftantiam dimittens, ad ventrem vergens, infera, umbilico externo e diametro oppufita.

\section{EXPLICATIO FIGURE.}

a.) Naucus integer. b.) Idem longitudinaliter fedus, at meabrana vifcolofa vifui pateat. c. \& d.) Semen feparatum, a ventre \& a dorfo fpetatum. e) Embryo transverfe difrctust. f.) Ejusdem fectio longitudinal is fecundum fifuram eotyledonums. 8.) Idem verticali modo per Latera fectus cum valis, e radicala in cotyledonum lobos egredientibus.

In alia minori hujus generis pecie, nuperrime a Cl.LAMBERT accepta, eandem embryonis \& cotyledonum fabricam in nulla alia, quam novimus, ftirpe obviam, quam maxime fingularem \& plane inauditam invenimus.

Non certo affirmaverim, utrum noftrum genus cum illo, quod Cel. RicHaRD condidiffe perhibent, unum idemque fit, an ab hoc diverfum. Denominatio gallica, pluribus quidem e Sapatarum ordine communis, nobis fuppe: ditavit nomen.

\section{$186.17 B$}




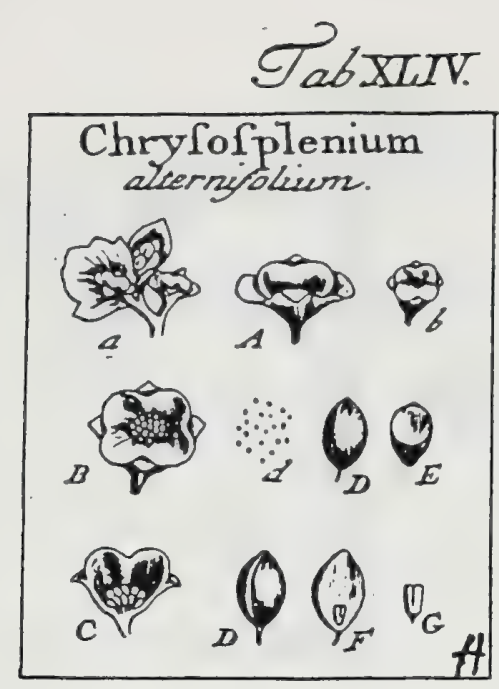

\section{J. Gaertner (1788) Vol. 1}

CCLII. CHRYSOSPLENIUM. TOu RN. $t$. 60. LIN N. gen. 558 .

Calyx quadri-1. quinquefidus, coloratus, pcricarpio inferne adnatus. Cor. nullic Stam. oclo 1. decem. Styi. duo. Capfula ferni infera, unilocularis, Semibivalvis: Senina plura erecta.

Chrysosrlexic:s alternifolium. Tab, 44. fig. 7.

Saxifragn aurea. B EsL. hort. Ey/. lyyem. t. 6. f. 5. O E DER. flor. dan. t. 366.

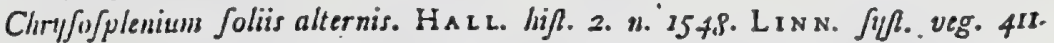

PER. Capiula parva, calyci ad inediuin usque aduata, obcordata, lenticulari com? preft3, unilocularis, ab apice ad medium, bifariam dehifcens: laciuiis emargiuaris, horizuntaliter patcntibus.

REc. nullum; Cemina per funiculos capillares fundo capfulx affixa.

SEs. plurima, circiter quinquaginta, minutula, ovoidea, ab altero bere bilo filiformi notata, glabia, lucida, rubro ferruginea aut caftanea.

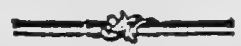

IN T. duplex: crufaceum, durum, fragile; \& membranaceum, tenuifimum.

A L s. Femini conforme, carnofum, aqueo pallidum.

Ex B. fubcylindricus, minutulus, niveus. Cotyl. feniteretes, longiusculx, Rad. brea vistuma, acuinirata, infera.

a. A.) Caprula integra b. B.) Eadem dehifcens. C.) Nexus capfulx cum calyce \& feminum in(erio. d. D. D.) Semiuk Separata. E. F,; Embryonis fitus in albumine diffedro, G.) Embryo fepsracus.

Capfulan birofirem volunt Tournefortius, Hallerus, Linnzus \& Adaufon; anne ita fit in Ch. oppofitifolio? me hactenus latet. 


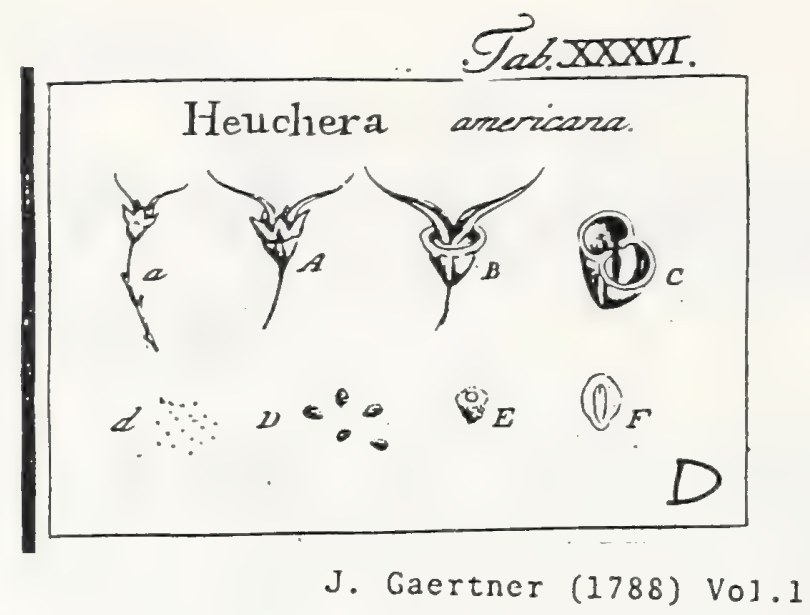

CCXIII. HEVCHERA. LINN. gen. 320 .

Calyx fuperus, quinquedentatus. Cor. pentapetala. Stam. quinque. Styl. duo perfiftentes fubulato fetacei, longi, divergentes. Capfula infera, calyce corticata, bilocularis, intra flylos foramine dehiscens.

HЕ UС н в А amcricana. Tab. 36. fig. 2.

Cortufa americana, flore fqualide purpureo. HER M. parad. t. I3I. PL U . phyt. t. $58 . f .3$.

Heuchera fcapis fuburdis, thyrso elongato, foliis radicalibus: longe petiolatis feptenlobis, bis acute crenatis. LIN N. Jy $\int . v e g .266$.

PER. Caplula infera, calyce arctifline adnato corricata, turbinata aut inverfe conica ac fupra plana, biroftris, bilocularis, inter roftra foramine amplo dehiscens. Diflepimentum, per maturitatem, rima s. hiatu profunde divilum.

REC. nullum prater incraftatan diffepinenti parten mediam, cui fewina affixa.

SEM. numerofillima, minuta, angulata, pundato fcabra, fufca.

IN T. fimplex, fubcoriaceurn, tenue.

A \& B. Cemini conforme, carnofum, aqueo.pallidum.

Em d. dicotyledoneus, teretuuscụlus, lacteo albus. Cotyl. brevifimx. Rad. cylindrica, ceutripeta.

2. A.) Caplula integra, caljcis denticuils coronata. B.) Eadem nuda, foramine inter roftra deinis

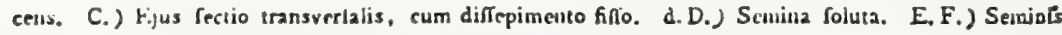
fectiones, cum fitu \& figura entbryonis intra albumen.

- Capfula quodammodo circumfcilla dici poliet, ế enim leviter digitis pref̂á, cornua unacum distipincme \& operculo capjula decidunt, atque margincm ejus fuperiorem reliaguunt glabrum \& intcgerrimum, ut itaque jponte decidere polic vide. entur.

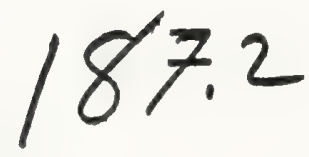




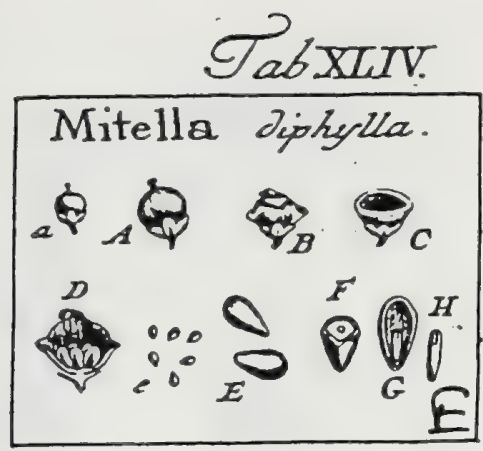

J. Gaertner (1788) Vol.1

CCLII. MITELLA. TOURN, t. 126. LIN gen. 56I.

Calyx quinquefidus. Cor. pentapetala laciniata. Stam. decem. Styl. unicus pritig ma globofum bifidum. Capfula fupera unilocularis femibivalvis. Semina pario erects.

Mitella diphylla. Tab. 44. fig. 6.

Sanicula $\int$. Cortufa indica. flore fpicato fimbriato. DODART. mem. edit. geria, 323. $t .27$.

Mitella fcapo diphyllo. LI N N. S!y 2 . veg. 415.

P E r. Capfula parva, fubrotunda, fupra fylo brevi \& duplici figınate globulofo termin nata, infra cuin calyce conferruminata, coriacea, turgide lenticularis, ab apice ad medium usque bifariain dehilcens: laciniis revolutis xqualibus, altera fylifera.

R E c. nullum; femina per funiculos capillares fundo capfulx affixa.

SEM. pauca, circiter octo, obovata, deorfum infigniter acuminata atque angulata, gita berrina, lucida, atra.

IN T. duplex: exterius crufaceum, tenue, fragile; interius tenuifimum, pallidum:

A L B. femini conforme, caruofum, aqueo-pallidum.

E в. teretiusculus, vix longitudine dimidii a!buninis, niveus. Cotyl. femicyliadri, cx brevifluax. Rad. lunga, cralta, infera.

a. A.) Capfula integra. B.) Eadem deliileens. C.) Ejus fectio transverfalis. D.) Seminum b̆ (ertio. e. E.) Senuiı (oluta. F. G.) Senuiuis fectiones, cum (itu embryouis, H.) Embryo fa: paratus.

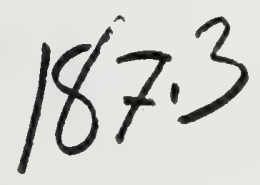




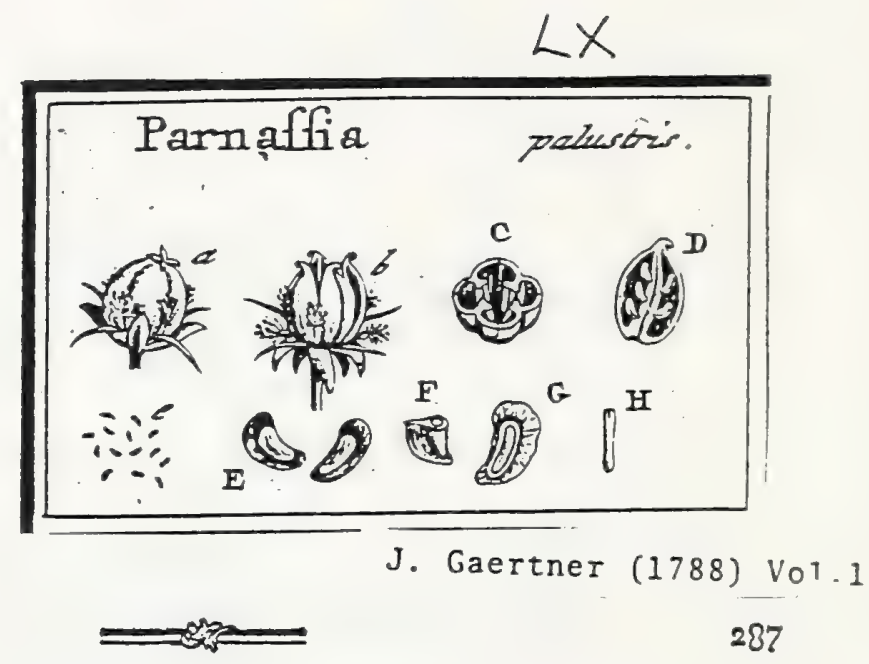

CCCLXI. PARNASSIA. TOURN. $t$. $12 \%$. LINN. gel. 384.

Calyx quinquepartitus. Cor. pentapetala. Nectar. quinque inembranacea, pilis ca. pitcllatis ciliata. Stam. quinque. Stigm. quatuor fertitia. Capfula unilocularis. Receptac. parietalia. Sem. membranaceo inarginuata.

PARnAssia paluntis. Tab. 60. fig. I.

Gramen parnafl. BesL. hort. Eyfl. afliv. VIII. t. II. f. 3. OEden. fl. dan. t. 584.

Parnaffic. 'H A L L. hifl. 1. n. 833. LIN N. J4/. veg. 299.

PER. Capfula ovato globola, quatuor figmatibus reflexis terminata, obfolete quadrifulcata, uni-1. incomplete quadrilocularis, quadrivalvis.

REC. quatuor, fpongiofa, oblonga, angufta, mediante lamina intergerina capfulx parieti affixs.

SEM. uumerofitima, grofto modo fcobiformia, in medio, nucleo oblongo turgidulo dotata, ad latera vero nargine membranaceo cincta, rufelcentia.

IN T. duplex: exterius membranaceum, tenue, ad alterum pracipue feminis latus is marginem expandun; interius fubcoriaceun, craflius, rufefcens.

A \& в. nullum.

EM в. cylindricus, lacteo albus. Cotyl. brevifimx, obture. Rad. longa, recta, centrifuga.

a. ᄂ.) Capfula integra \& dehifcens. C.) Ejus fetio transverfalis, D.) Valvula com feminam receptaculo feparati. e. E.) Semina foluta. F. G.) Semen transverie \& longitudinaliter apertum, cum fitu embryonis. H.) Embryo (eparatus.

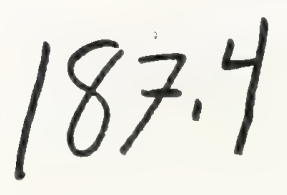




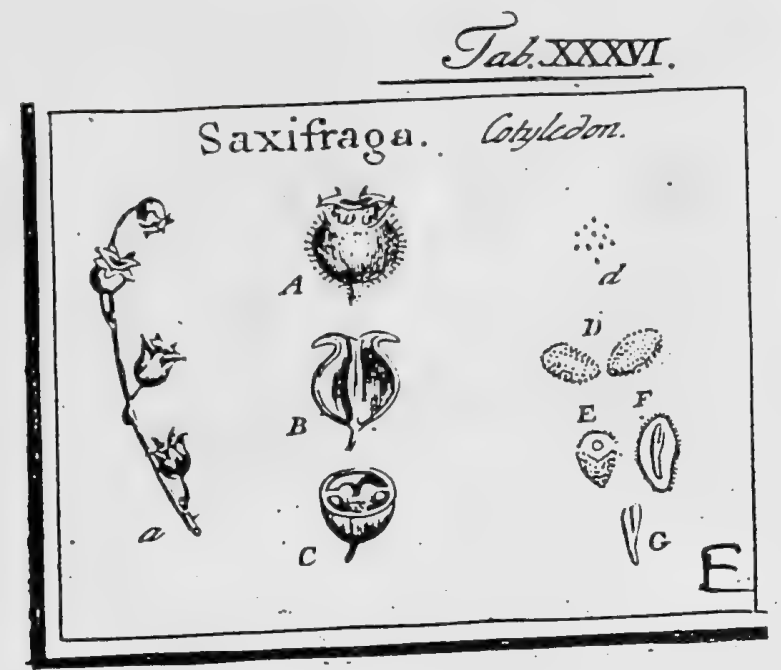

J. Gaertner (1788) Vol.I

CCXIV. SAXIFRAGA. Tour N. t. 229. LinN. gen. 559.

Calyx nunc pericarpio adnatus, nunc ab co folutus, quinquedentatus. Cor. pentapetala. Stam. decem. Ayl. duo. Caplula infera, aut folummodo vefita, bilucularis, intra nylos foramiuc dehisens.

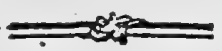

SAXIFRAG A Cotyledon. Tab. 36. fig. 3.

Saxifraga fotiorum ora cartilaginea ferrata, petiolis paucifloris, petalis puntos tis. HA L. hift. 1. 12. 978.

Saxifraga foliis radicatis aggegatis lingulatis cartilaginco Jerratis, caule pang culato. L I N N. fyjt. veg. 411 .

Icon OE DE R. flur. dan. t. 24 r.

Pร.к. Caplula lubglobofa, calyce libero veflita, bilocularis, biroftris, inter roftraires flexa foramine dehiscens. Diffepimentum membranaceum, in medio incrallatugit per inaturitatem hiatu profunde divifum.

R.c. rullum prxter incraffatam partem diffepimenti, cui femina aftixa.

SEsr. numerofa, exigua, ovato acuminata, angulata, punctis apiculatis minutifining fcabrata, nigricantia.

I $\mathrm{T}$. fimplex, fubcoriaceum, tenue.

$\Lambda$ г в. feinim conforme, carnofum, aqueo pallidum.

E s в. dicotyledoneus, teretiusculus, lacteo albus. Cotyl. femicylindricz. Rad. longt, tudine coryledonum, recta, centripeta.

a. A.) Capfula integra. B.) Eadem longitudinaliter difci Ea. C.) Fjusdem tetio transverfalis, eum

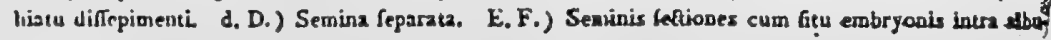
men. G.) Embryo frparatus,

Saxifraga igiur, Heucbera atque Hydrangea in partibus fruclificationis non eflentialt ter differunt, \& polfet Heuchera, Saxifraga pentandra, atque Hydrangea, Sast: fraga arborea dici.

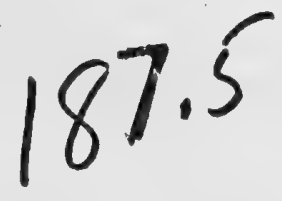




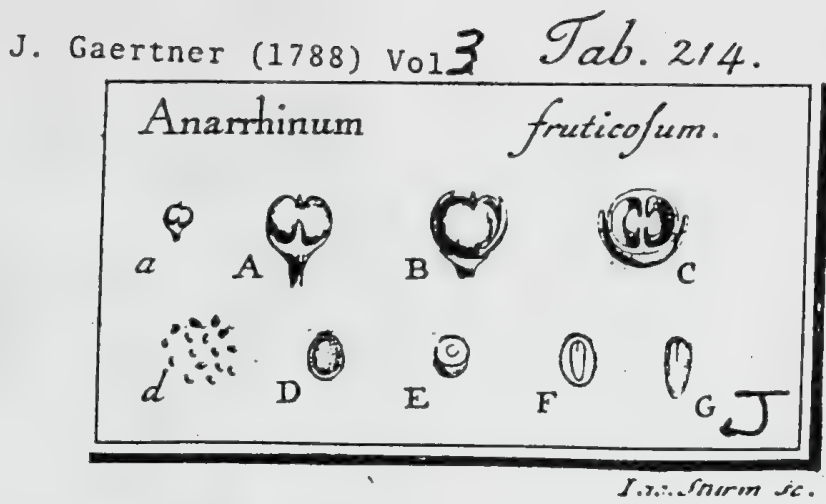

J. Gaertner (1788) Vo13

150. A N A R R H I U M. 190

Desfont. A. alt. 2. p. 5r.'Antirhinum. LIN J Juss.

Cal. quinquepartits, perfiftens. Cor, ringens, tubulofa, bafi calcarata; fauce patente, pidato prominulo deftituta, bilabiatil; labio fuperiore bilobo erecto

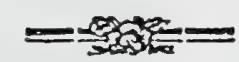

rgI

obtufo, inferiore trilobo. Stam. i. didynama, non exferta. Ovar. fuperun, ftylo \& itigmate fimplici. Capfula obcordato-fubglobofa, ad latera yb apice valvalis linearibus dehifcens, bilocularis. Rec. fungofa, dilfepimento utrinque affixa. Sem. numerofa, punctis elevatis exalperata. Alb. carnofum. Emb. curvulus.

ANARRHINUM fruticofum. Tab. 214. fig. 10.

Anarbinum frutefcens, ramis virgatis filiformibus, foliis perennantibus imis $\int p a-$ tulatis, racemis interruptis, corollis ecaudatis. DESFONT. f. atl. 2. p. 52.

Anarbiumm foliis inferioribus cuneiformibus tridentatis, fuperioribus lineari-lanceolasis integerrimis, racemis filiformibus, caule frutefcente. WILLD. Spec. pl. T. 3. P. x. p. $26 x$. PERsCoN fyn. 2. p. 159.

Icon. DesFont. 1. c. t. 142 .

Ex collectione Cel. Desfontaines.

PER. Capfula parva, obcordato-fubglobofa, compreffiufcula, 1. turgide len: ticularis, coriacea, calyci perfiftenti infiftens, ftyli reliquiis faftigiata, in ambitu per valvulas duas oppolitas lineari-oblongas a vertice ad balin ufque a capfula difcedentes dehifcens, bilocularis. Diffepimentum coriaceum, lateribus capfulac circumcirca adnatum.

REc. fubglobora, breviffime pedicellata, 1. paululum a diffepinsentodifantia, cui in utroque latere in medio affixa, fungofa, tuberculis acuminatis fcabrata, quibus femina adhxrent.

SE M. plurima, ovata, punctis minimis elevatis fcabrata, 1. muricata, atra.

IN $\mathrm{T}$. duplex : exteritus craffiufculum, coriaceo-membranaceum, reticulatum; facile detrahendum; interius membranaceum, tenue, adnatum, fordide fufcum.

A L B. Semini conforme, carnofum, album.

E M B. longitudine fere albuminis, fubclavatus, erectus, mollis, aqueo-pallidus. Cotyl. Semiteretes, dimidium embryonem vix mentientes, obtufx. Rad. longa, conica, crađa, obtufa, umbilico obverfa, centripeta.

\section{EXPLICATIO FIGURE.}

a. A.) Capiuiz integra. B.) Eadem dehifens. C.) Ejusden fectio transverfalis. d. D.) Semina feparats. E. F.) Albuminis fectio trasverfalis \& longitudinalis, cum Gitu \& forma embrgo. nis. G.) Embryo folutus. 


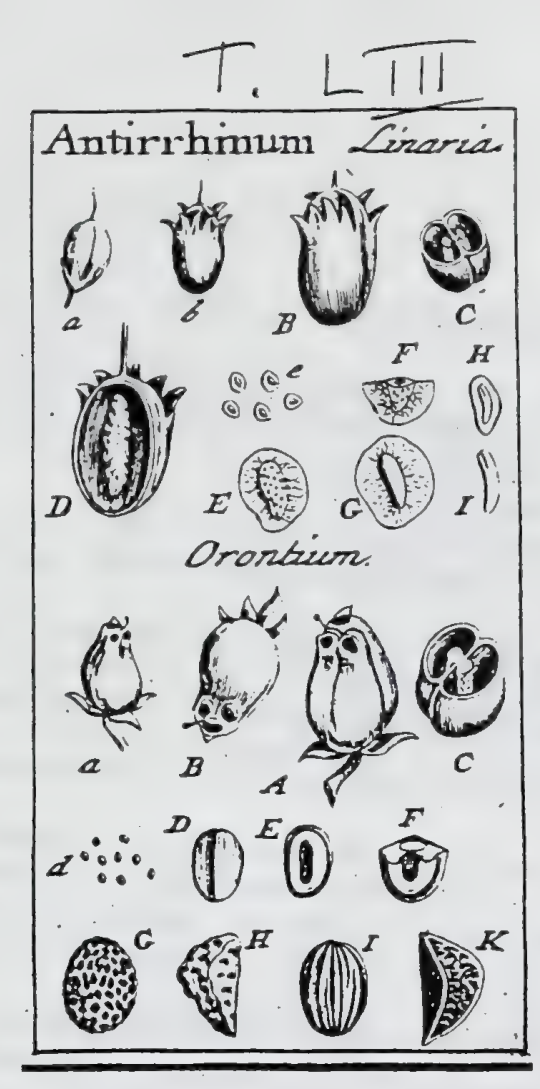

Scrophulariaceae

188.2A 


\section{J. Gaertner (1788) Vol. I}

\section{ANTIRRHINUM. TOURN, t. 75. LinN. gen. 750 .}

Calyx pentaphyllus. Cor. perfonata, bafi gibba aut calcarata. Stam. quatuor aut quinque. Stigma fimplex. Capfula bilocularis, apice in lacinulas retiexas dehif. cens. Semina numerola.

AN TIRRH IN UM Linaria. Tab. 53. fig. 7.

Linaria. R I v. monop. t. 83. f. I. B L A x $\nabla$. herb. t. II5.

Antirrhinum foliis linearibus adfcendentibus congefis, caule eretto fvicato. Hast. hift. I. n. 336 .

Antirrhinum foliis lanceolato linearibus confertis, caule ereto, spicis terninati. bus fefslibus, floribus imbricatis. L I N א. Ji/f. veg. 557.

PER. Capfula elliptico fphrcoidea, utrinque fulco deprefto infcripta, bilocularis, apice utrinque in lacinulas $3-5$, fubxquales recurvas dehifeens, relicto inter utramque aperturam areu Rapediformi itylifero. Dillepinentum funplex, membranaceum.

REc. oblongum, fungolum, tuberculis acuminatis fcabratum, hine convexum, inde planiusculuin, per membranain intergerinain cum dillepimento utrinque cuhxrens.

S Eм. plurima, horizontaliter incumbentia, bracteata, rotundata, nigricantia, fubfplendentia: difco orato feabriusculo; margiue lato membranaceo, ad umbilicum emarginato.

IN T. duplex: exterius papyraceum, aridum; interius membranaccum, tenue.

$\Lambda$ \& в. ovato oblongum, femine multo anguftius, coinpreflum, carnofun, album.

EM E. filiformis, levilline curvatus, niveus. Cotyl. Jemiteretes. Rad. Ionga, centripeta.

a. b.) Capfula integra \& dehifcens. C.) Eadem dilfets. D.) Receptaculi forına. e. E.) Senina (rparata. F.) Semen transverfe (ectum. G.) Albumen deaudarum. H.) Ejusdem fectio longltudiwalis cum fitu embryonis. I.) Embryo (eparatus.

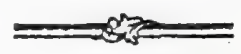

ANTIRRH INUM triphyllum. fig. $\mathrm{H}$.

Linaria hispanica. C l us, hif. I. p.320. - ficula. Bocc. fic. 44. t. 22.

Capfula ovata, bifulca, Linarix in modum dehifcens: valvulis tridentatis. Semina (H.) angulata, fubtriquetra, difite fcrobiculata, ad angulos non marginata, fuica.

ANTIRRHINUM Orontium. ibid.

Antirrhinum fylueftre. B Es L. hort. Eyfs. afiv. I. t. g. f. 3. - arvenfe. RIv. $t$. 82. $f .2$.

Antirrhinum foliis ellipticis obtufis, floribus fparfis, colycibus fubulatis longiffimis, calcare breviffmo. HA L. L. hift. T. n. 334 .

Antirrhinum corollis ecaudatis, floribus fubfpicatis, calycibus corolla longioribus. LIN N. Si/f. veg. 557 .

Canfula (a. A. B.) orato pyramidata, bafi gibba, obliqua, apice tribus foraminibus dehifcens. Receptac. (C.) tereriusculum, absque intermedia lamina diffepimento adnatum. Semina (d - F.) elliptica; hinc (D.) glabra ex medio angulo in inarginem lateralem angufum (F.) declivid; inde (E.) convexa, fungofa, fovea longitudinali profunda (F.) exfculpta. Albuinen \& embryo ut in pracedentibus. Color feminum ferrugineus.

ANTIRRHIXU M majus. fig. G.

Antirrhinum. Riv. monop. t. 82. f. I.

Capfula pracedentis fed major, trifora. Semina (G.) fubglobola, ferruginea, foveolis contluentibus ferobiculata.

Secundum HAzLERUM, femina huic angulofa, atra: mea diverfifima, ex fide MARTYNi tecenfui.

ANTIRR II INU nimus. fig. I.

Linaria arvenfis minima. R Iv. monop.t. 85. OEDER. flor. dan. t. 502.

Capfula ovalis, magnitudine feminis raphani, Linarix in modum bifora: valvulis bi-1. tridentatis brevilfimis. Semina (I.) ovato-aut fphxrico-globofa, fulcis acutis profundis Inngitudinalibus exarata, lutco-ochracea. aut comprefliuscula: angulis acutis marginatis glabris; interficuis vermiculato ru. 


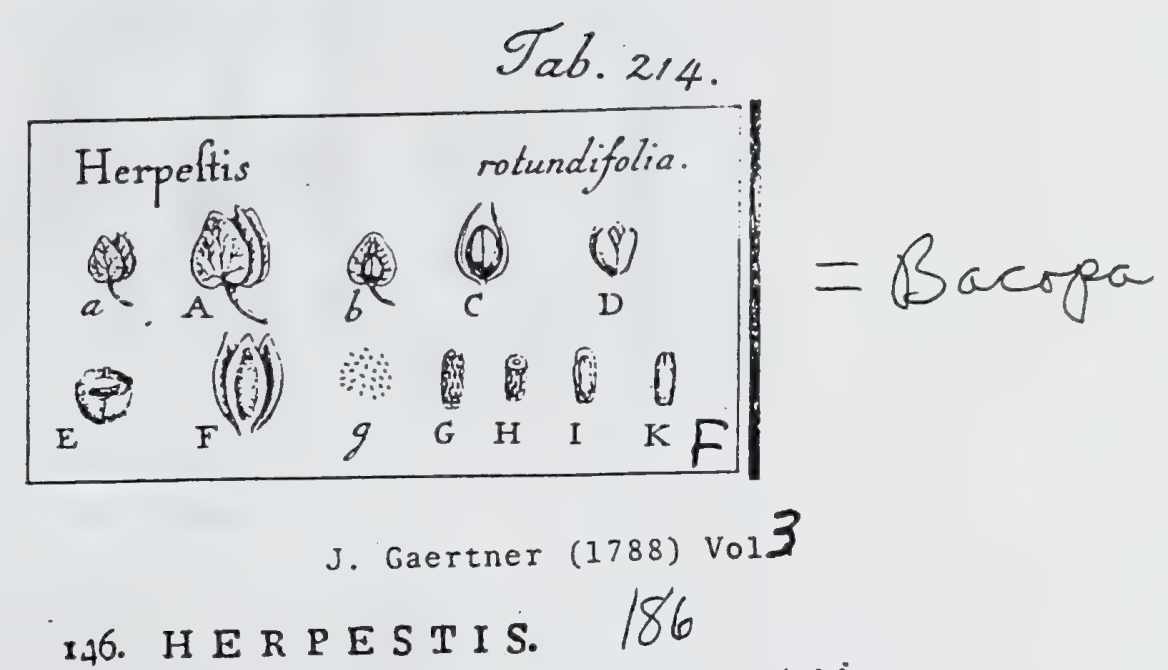

Cal. pentaphyllus, inxqualis, perfiftens; foliolis tribus extetiotibus cordatis; reticulato-venoGs: interioribus duobus fubulatis, conniventibus, acueis. Cor. monopetala ... Stam. ... Ovar. fuperum; Itylo fimplici, ftrgm. ... Capr. ovata, bilocularis, quadrivalvis: diffep. cum altero valvularum päre parallelum. Rec. difepimento utrinque adnata. Sem. numerofa, oblonga. $\mathrm{Nb}$. carnofun. Emb. ovato-oblongus : rad, centripeta..

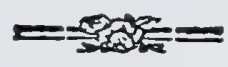

HeRprstis rotundifoliz. Tab. 214. fig. 6 ,

an Monniera rotundifolia? Michi uX fier. bor. niser. 2. p. 22.

Ex America feptentriomali a $D^{\circ 0}$ Bosc, ex collectione Cel. DesfoxTAINES,

PER. Capfula parva, ovata, iatra calycem maturitate grandefaetum recondita, longitudinaliter dehifcens, bilocularis, quadrivalyis. Valvulx xquales, membranacex, tenues, fubdiaphasix, ficcitate tortiles. Diffepimentum membranaceum, cum altero pare valvularum parallelum \& jpfarum future infertum, altero pari autem contrarium, ovatun, acuminatum.

REc. difepimento utrinque affixa, ovato-acuminata, convexiuffula, exigua, eminentiis minimis feabriuicula,

SEN. numerofa, minima, oblonga, utrinque obtufa, punctis excavatis longitudinalibus reticulata, bafi umbilicaka, centripeta, fufca,

IN I. finplex, membranaceum, tenue,

A \& в. femini conforme, carnofum, album,

EA B. longitudine fere albuminis, tereti-oblongus 1. cylindricus, erectus, albus. Cotyl. breves, obtpixe. Rad, tẹres, longa, obtufa, umbilico eqtegrno obyerfa, centripipeta

\section{EXPLICATIO FIGURE.}

2. A.) Frutas integer. b.) Capfulx fitus intra salycem, ahlatis duobas foliolis exterioribus majoribus. C.) Capfula integra, non debifcens, cum duobus foliolis calycinis fubalatis conniventibus bafi capfulx affixis. D.) Eadem plane denulala, deluifent. E.) Capfula fetio transsverfalis. F.) Valrulze dux ablatx, ut diftepimenti forolz \& Gtus appzrext. 5. G.) Semioz feparata. H. I.) Ejusdem fetio tracrverfal is aque ac lopgitudinalis, eum albumine \& fito embryonis. K.) Embrgo Solutus, 


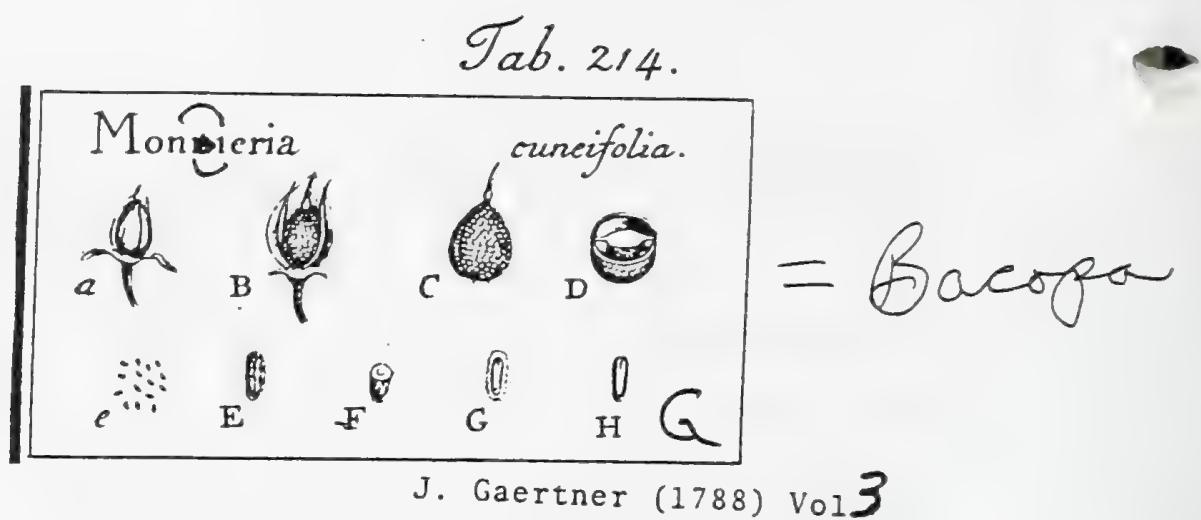

\section{MON N I ER I A, 187 \\ Bвоixn jam, t. 28. f. 3. Gratiola. Lrnn: gen. 29. ed. Schreb. 37. Juss. gen. p. 12 r.}

Cal. bali bibracteatus, pentaphyllus, inxqualis, perfiftens; foliolis tribus exterioribus fubcordatis, alterum altero majore: interioribus duobus lineariSubulatis, acuminatis, nervo iutermedio notatis, futurz capfule oppofiris. Cor. lubcanpanulata, fubxqualis; tubo recto, longitudine calycis; limbo quinquepartito: laciniis fubroqualibus, obtufis. Stam. 4 didynama; filamenta tubo inferta, du' longiora corolix tubum xequantia; antherz ovatz, conpreffic. Ovar. luperum; ltylo filiformi, paululum iucliuato; ftigmate ca-

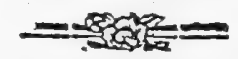

pirato. Capfula membranacèa, bilocularis, bivalvis; diffep. valvis paralleto: Rec. diffepimento affixa. Sem. numerofa, oblonga. Alb. carnofum. Enzb: tereti - oblongus; rad. centripeta.

Monnieria cuneifolia. Tab. 214. fig. 7 .

Monniera glaberrima: foliis cumearo - obovatis Superye obfolete fubcrenatis: pedurs: culis folia fubaequantibus, Michaux for: bor, amer, 2. p. 22. PERSбON Lyn: 2. p. 266 .

Ex America feptendrionali a Dao Bosc, ex collectione Cl. DesponIAINES.

$P$ RR. Capfula parva, ovata, ftylo perfiftente curvulo fupra bafin in nodưlum incraffato faftigiata, ad futuras Jongitudinaliter fulcata, a feminibus pra tuberantibus poncticulato-teffalata, bilocularis, bivalvis. Valvulx naviculares, membranacex, tenues, longitudinaliter dehifcentes. Difepimen: tum membranaceum, valvis paralleium.

REC. ovatum, diffepimento utrinque adıatum, convexiufculum, fcrobiculato: punctatum, fungofum.

SE M. numerofa, minutuda, oblonga, punctis oblongis immerfis reticulata, um. bilico parvo ad bafin inftructa, centripeta, ferruginea.

IN T. fimplex, membranaceum, tenue.

AL B. femini conforme, vaginale, carnofum, album.

$\mathrm{E}_{\text {M B. }}$ fermine paulo brevior, tereti - oblongus; erecturs, albus. Cotyl. breves, obtufa. Rad, oblonga, obtufa, umbilico externo obverfa, centripeta.

\section{EXPLICATIÓ FIGURE}

a.) Fruaus integer. B.) Foliola duo calyeina exteriora ablats, ut exprola in fito appazcac C.) Capfula integra, feparatz D.) Ejusdem \& diffepimenti feato transveffalis. e. E.) Semiaz foluta. F.) Albumivis feetio eransverfalis. G.) Idcm longitudionatier difreturm, cum forma \& fitu embryonis. H.) Enabryo folutus.

Gratiola Monnieri \& fortaffe etiam virginiana L. (Carpol, I. p. $25 \mathrm{I}_{\text {p }}$ ) buc referendx. 
Tab. CXCVIII.

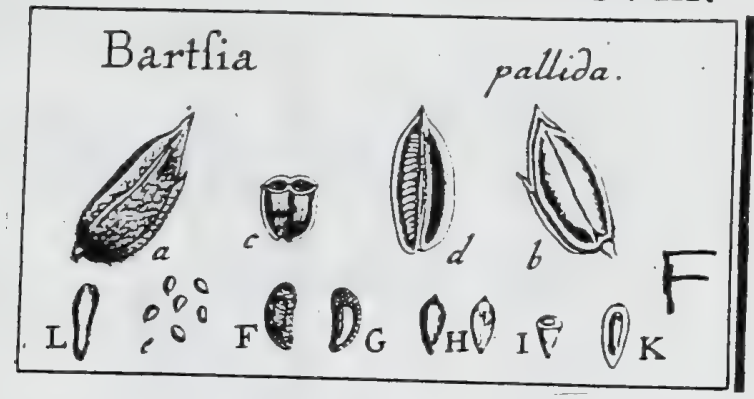

J. Gaertner (1788) Vol 3

109

\section{B A R T S I A.}

Lixi. gen. 739. ed. Schreb: 996 . Juss. gen. p. 100.

Cal. bipartitus; laciniis xqualibus, oblongis, corolla paulo brevioribus, hirfutis, bident.ntis: dentibus longis, angultis. Cor. ringens, tubulofa, curvula, bilabiata; labio fuperiore integerrimo, recto: inferiore trifido, reflexo, fornicato, laciniis angultis oblongis obtufis. Stam. quatuor, didynama, ad Jabium fuperius alfurgentia. Ovar. fuperum, oblongum; ttylo fimplici, ftaminibus longiore; ftigmate capitato. Capfula oblonga, acuminata, comprelfa, bilocularis, bivalvis. Rec. nullum. Sem. plura, integumento involucrante daso inltructa. Alb. carnofum, exiguum. Emb. oblongus, rad. centripeta.

Bartsia pallida. Tab. 198. fig. 6.

Pedicularis foliis lini anguffioribus. TouRs. inf. $77=$

Bartfic fottis alternis bidentusis. LiNN. amven. acad. 2. p. 356.

Burtfia folitis lanceolusis indivifis, foralibus incifis. GMEL. fib. 3. p. 201. t. 45. Bartfia foliis alsernis lunceolutis integervinis, floralibus ovasis dentatis. LINN. Jpec. pl. 859. Syy. veg. ed. 14. p.547. WillLd. Spec. pl. T. 3. P. 3. p. 186.

\section{A Cel. Thunberg.}

PER. Capfula oblonga, comprefra, ad marginem attenuata, fuperne acuninзta, fulco intermedio didyma, coriaceo-membranacea, rufefcens, bilocularis, bivalvis. Diffepimentum valvis contrarium, fulco externo obverfum, anguftum, nembranaceum, cum valvis longitudinaliter dehileens.

REc. nullum, prater papillulas difepimento utrinque ad dehifeentixe futuram inpolicas.

SEN. numerofa, intra integumentum laxum involucrans hxrentia, oblonga, 1. Jonge obelliptica, ad verticem apiculata, ad balin vero umbilico parto notati, hinc convexa, inde planiufcula, e rubro lutefcemia.

IN T. duplex : exicerits fubreniforme, reticulato-membranaceum, laxum, fac catum, femen in medio fovens, pallidum; interius itidem membranaceun, - tenue, albumini arcte adiatum.

A \& r. fémini conforme, carnofum, exiguum, album.

EN B. Sermini fere cunformis, oblongus, comprelinufculus, erectus, albus. Coryl. ovatx, obtufie, dimidium eabryonem fere reyuantes, plano-convexx, accumbentes. Rat cotyleduribus palulo Jongior, tereri-conics, obtula, umbilico externo obversa, centripeta.

\section{EXPLICATIO FIGURE.}

x.) Capjula a calyce inclufa, b.) Eadem claufa, \& a calycis lacinia altera denudata. c.) Fijusdem featio transverfalis. ¿) Valsula altera cum fita diffepimenti atque forninum. e.) $S$ mina integra, foluta. F.) Idem magnitudine auctum. G.) Intequnentum externam idvolucrans, apertum \& femen io medio fovens. H.) Semen ex intejumento exemrum, ex utraque parte fpectatum. \&.) Albumen transverfe feetum. K.) Ejusdem fettio verticalis cum fitr embryonis. L.) Embryo folurus.

Character genericus Bartixx, a Linnzo prolatus, ad noftram ftirpém ninime quadrat, cujus fpecies reliqux forte ad Rhinauthum \& Melampyrum amandandac funt. 


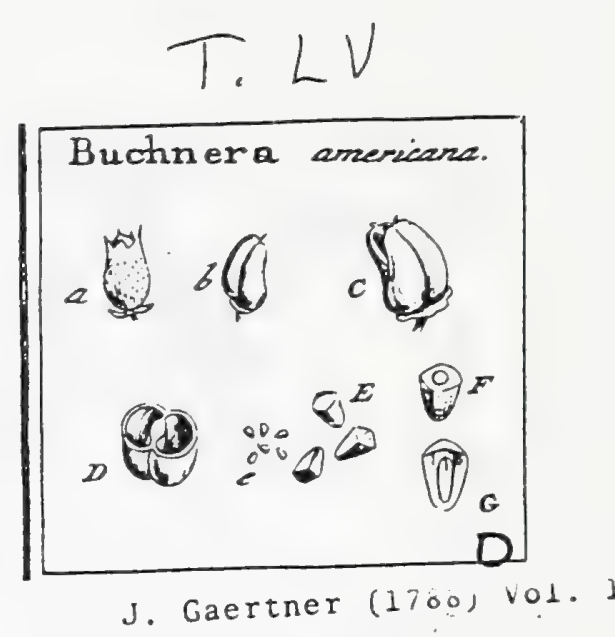

CCCXXI. BUCHNERA. LIN N. gen. $77^{2}$.

Calyx quinquedentatus. Cor. infundibuliformis, limbo quinquefido zquali. Stam. quatuor, in:qualia. Stigm. fmilex. Canfula bilocularis. Diflepimertum limplex valvis contrariuin. Sem. nuinerofa, parva.

BUCH NERA americana. Tab. 55. fig. 2.

Buchnera foliis, dentatis lanceolatis trinerviis. L IN N. $\int y \int$. veg. 57 .

Ex herbario Bankfiano.

PER. Capfula ovato-pyranidata, fubincurva, altero larere bali deorfum gibba, bifulca, bilocularis, femibivalvis $\int_{0}$ ad mediun faltem dehifens. Diffepimentum fimplex, valvis contrarium.

REc. oblongum anguftum, fungolum, totum cuin diffepimento connatum.

SEM. nuinerola, parva, angulata, ferruginea.

INT. funplex, meinbranaceum, tenue:

A L B. femini conforme, carnofum, aqueo-pallidum.

Eм в. cylindricus, rectus, lacteus. Cotyl. breves, obtufx. Rad. crafra, centripeta.

a. b.) Capfula calyce veftita, \& denudata, integra. C.) Eadem deliicens. D.) Ejas fetrio transverfalis. e. E.) Scmina feparata. F, G.) Embryo intra albuinen. 


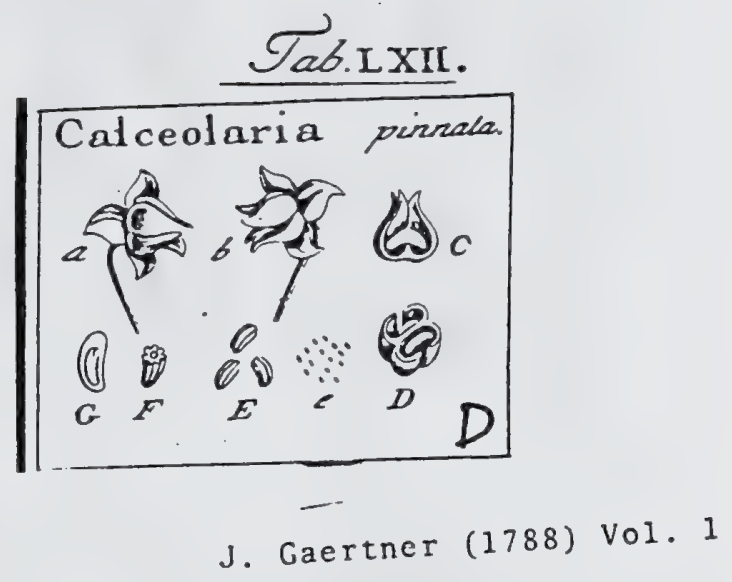

\section{CALCEOLARIA. LIN 2.296}

Calyx quadripartitus xqualis. Cor. ringens infata. Stam. duo. Styl. unicus. Capo. fula bilocularis. Receptac. transverfuin, Sem, numerofa.

CALCEOLARIA pinnata. Tab. 62. fig. 4.

Calceolaria foliis fcabiofa vulgaris. F EviL. peruv. 3.t. 12. f. 7 .

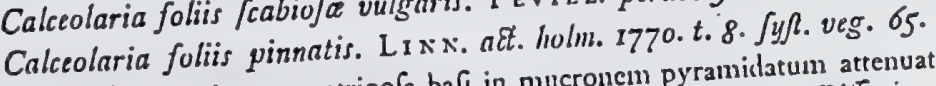
Calceolaria foliis pinnatis. $\mathrm{L} x \mathrm{x}$, act.
PER. Capfula tenuis, ex ventricofa bafi in mucroncm pyramidatum attenuata, profunde
bilulca, bilocularis, bivalvis: valvis maturis apice bifidis. Diflepimentum valvis. contrarium.

REC. fungofum, transverfe oblongum, extremitatibus dellexis, m

proprio utrinque diffepimento affixum, cetera undum crafiora, pallida, frïs $5-7$.

SEM. numerofiffima, parra, teretiuscula, extrorfat

capillaribus, crenulatis, longinudime.

I. T. fimplex, mentorine, carnofum, pallidum.

A L B. Senini conforme, carnofum, pallidum.

a. b.) Capfula integra \& dehifcens. C. D.) Recopt. figura \& infertio. c. E.) Semina foluta. F.) Semen transverfe fetum. G.) Embryo inura al bumeth 


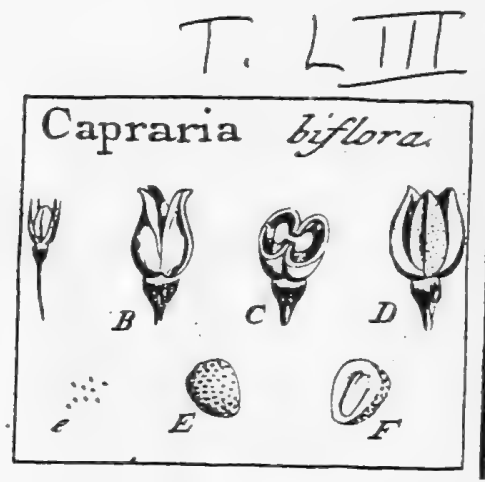

Scrophulariaceae

J. Gaertner (1788) Vol.1

CCCIX. CAPRARIA. LINN. gen. 768. 250

Calyx quinquepartitus. Cor. campanulata quinquefida acuta. Stam. quatıor inzqua lia. Stigina bilancllatum. Capfula bilocularis. DifTepimentum duplicatum ex inflexo valvularum margine.

Casraria bifura. Tab. 53. fig. 9.

Capraria curafavica. Hers. parad. no. ic. rzo.

Caprarin foliis alternis, poribus gentiuis. Jacc. hifl. amer. t. 115. L IN s. fyl? eeg. 5 b-

PER. Canfula ovato-oblonga, parva, utrinque fulco inferipta; bilocularis: valvulie: per maturitatem bilidis. Diflepimentum duplicatum, ex inllexis valvularuas mas. ginibus formatum.

Rec. oblongum, fungofum, cum axi, non cum diffepimento connatum, per maturit ta:em libcrum.

SEs. numerof́, exigua, fubglobola, angulata, fcrobiculata, pallide lutea.

IN T. funplex, fubfpongiofum, tenue.

A LB. Cemini conforme, carnofum, album.

Em в. teretiusculus, lacteus. Cotyl. breves. Rad. crafta, centripeta.

a. B.) Capiula integra \& dehifcens. C.) Eaden diffeta. D.) Recept. materum Liberan. e. E.) Semina Separata. F.) Embryo intra aibumer. 


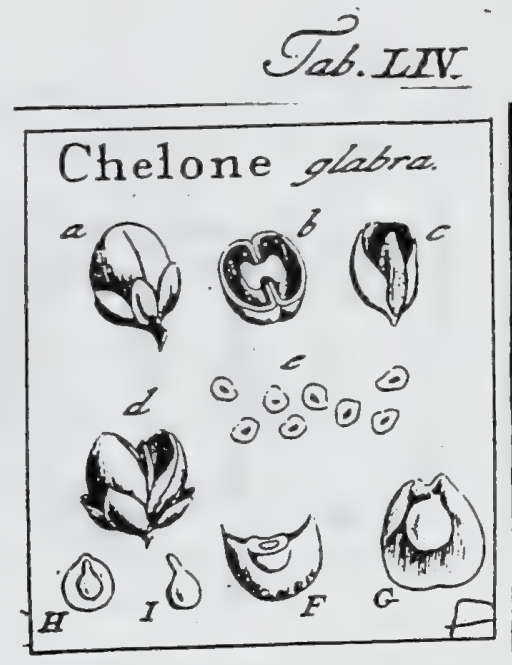

\section{J. Gaertnet (1788) Vol.1}

CCCXVIII. CHELONE. Lin N. gen. 748 .

Calyx quinquepartitus. Cor. ringens. Stam. quinque : uno nerili. Stigm. fimplex. Capfula bilocularis. Diffepimentum duplicatum, ex iuflexis valvularum marginibus. Seinina bracteata, membranaceo marginata.

Снецоле glabra. Tab. 54. fig. 6.

Chelone foribus fpeciojis pulcherrimis. Mnt. diz. ic. 62.t. 93. Eнret. decad. t. 88.

Chelone foliis petiolatis lanceolatis ferratis: Jummis oppofitis. LINN. fyfo. veg. 553 .

PER. Capfula ovato globola, utrinque fulco infcripta, glabra, bilocularis, bivalvis. Diflepimentum duplicatum, ex inflexis valvularum marginibus formatum.

REc. nblongum, fupra acuminatum, fungofum, in axi capfulx pofitum, cum diffepincuto non conuatum.

SEM. nuinerof́a, fubovata, bracteata, lato margine meinbranaceo cincla, conicava, deorfum imbricata, fufco lpadicea.

INT. duplex, utrumque menbranaceum, tenue.

$\Lambda_{\text {L }}$. fubrotunduın, femine inulto anguftius, compreflum, carnofum, album.

Емв. inverfus, lacteus. Cotyl. orbiculatz, plano-convexiufculx. Rad. terctiuscula, ad umbilicum pofita, fupera, feu potius centripeta.

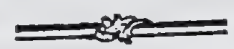

\section{$*$}

a.) Capiula integra. b.) Eadem dicteda. c) Ejus valvula altera, com receptaculo. a.) Eadem a Semin (olura. F. G.) Albuminis figura \& fitus. H.) Albumen diffetam cam figura embryonis. 1.) Embryo Separatus. 


\section{J. Gaertner (1788) Vol3 \\ Tab. CXCVIII.}

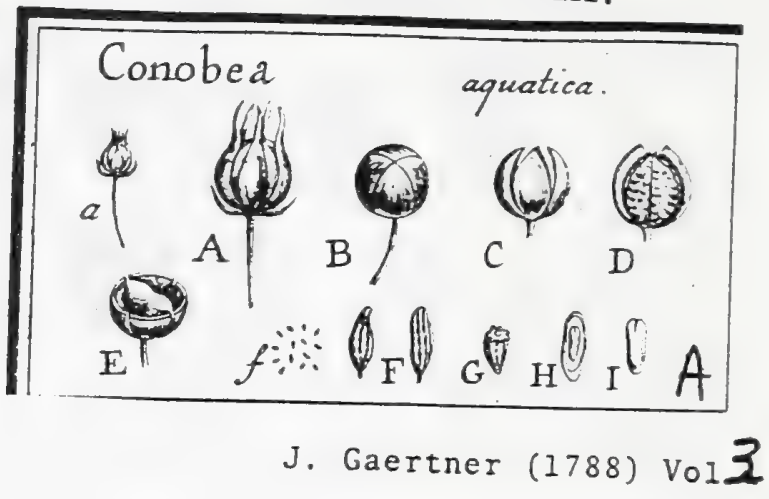

\section{C O N O B E A.}

Aивц. guy. t. 258. Juss. gen. p. 97. Laмавст ill. gen.

t. 522. Conopea. S с нREB. gen. 1042.

Flos bafi bracteis duabus fubulatis acutis munitus.

Cal. monophyllus, inferus, profunde quinquefidus: laciniis lanceolatis, acutis, perfiftentibus. Cor. monopetala, ringens, tubo fenfim ampliato; limbo bilabiato: labio Juperiore emarginato, inferiore inxqualiter trilobo. Seim. qua. tuor didynana; filamentis fetaceis, inzo fere tubo infertis; antheris fagittatis. Ovar. fuperum, Rylo finplici hirfuto \& Itignate bilobo inftructum. Capf. globofa, bilocularis, yuadrivalvis. Rec. fungofum, medio leviter fulcatum. Sem. nunerofa, oblongo - inaqualia. Alb. carnofum. Enb. teretiufculus, rad. centripeta.

Coxorea aquatica. Tab. 198. fig. 1.

Conobea. Aubl. guy. 2. p. 639. WILLD. Jpec. pl. T. 3. P. 1. p. 344.

E collectione Cel. Desfontalnes.

PER. Capfula fupera, intra calycem perfiftentem inclura, parva, vix granum piperis menticns, globora, bilocularis, quadrivalvis. Difepimentum lanilu membranacea, tenuifima, margine anguftilimo ad valvularum futu-

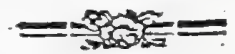

ram inter paria inferta. Valvulx xquales, tenues, membranacez, dia: phanz, fubnaviculares, utrinque acutz.

REC. fungofum, laminx tenuifinix diffepimenti utrinque adratum, latitudine diametrum capfulie mentiens, apice bidentatum \& medio leviter longitudinaliter fulcarum, compreffum, convéxiufculum, papillofun.

SE s. numerofa, minuta, irregulariter oblonga, longitudinaliter reticulatofulcata, \& ad bafin brevi funiculo umbilicali albido inftructa, rufefcentia, 1. ferruginea.

IN T. fimplex, crafiufculum, membranaceum, reticulato-vafculofum.

ALB. femini ad bafin paulo anguftius, carnofum, pallidum.

EM B. centralis, erectus, tereri-oblongus, albus. Cotyl. breves, crafiufculx; obtufiftmx. Rad. longa, teres, vix fenfibiliter conica, obtufa, centri= peta, umbilico externo obverfa.

\section{EXPLICATIO FIGURE.}

2. A.) Capfula integra, calyce veftita, B.) Enclear a ealyee denuciata, claufa. C.) Eadem de-

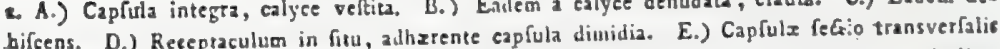
con receptaculo. F. F.) Semina foluta. G.) Albumen trasserfe - \& H.) Idem vercialiter ditetum cum fitu embryonis. I.) Einbryo folutus.

Aubletii icon quoad calycis lacinias \& receptaculi formam 2 noftra valde recedit, ut pro diverfis plantis haberem, nifi in omnibus reliquis partibus ex affe inter fe convenirent; perfuafum mihi igitur eft, noftram plantam cum Aubletiana unam eandemque effe fpeciem. iconem autern fructus 1. c. a pichore fuiffe alienatam. 


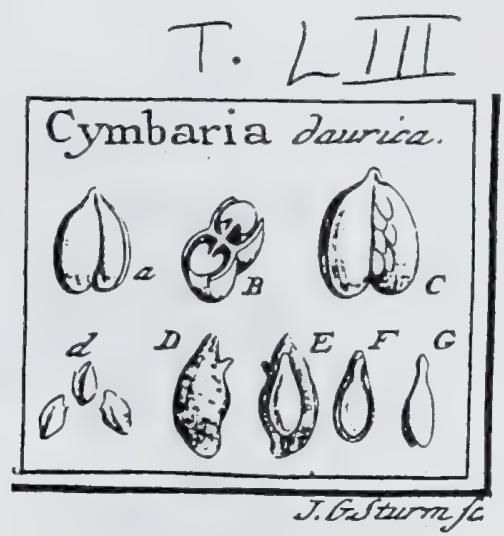

\section{J. Gaertner (1788) Vol. I}

CCCXII. CYMBARIA. LIN gen. 75 r. 252

Calyx decemdentatus. Cor, ringens, Stan. quatuor inxqualia. Srigm. fimplex. Capfula fubcordata, inembranacea, bilucularis. Receptacula reniformia, maxima. Se: mina comprefla.

CУ M B A I A daurica. Tab. 53. f:g. 12.

Cymbaria daurica pumila incana, linarice folio, magno flore luteo guttato: А м м А . ruth. 47. t. 1. f. 2.

Cymbaria. Lins. Jyfl. veg. 558 .

Ex dono Cl. L A X M A N I.

P E R. Capfula clliptico cordata, mcumbranacea, tenuis, fufco-fpadicea, utrinque fulco: profundo inferipra, bilocularis, bivalvis, margine faltem dehifcens. Valvule per. maturitatem receptaculo angufiores. Diflepimentum valvis contrarium.

REc. grande, fungolum, candidum, hinc convexum, inde reniformi concavum, \& mediante lamina intergerina fepto utrinque affixum.

SEM. pauca, 12-16: circiter in fingulo loculamento, oblonga, compreffa, margine membranaceo irregulari cincta, ex umbilico fubterminali pendula, deorfum imbricata, Spadicca.

IN T. duplex: exterius fponginfo membranaceum, nucleo latius; interius membranaceum, pallide lutefcens, fuperficie interna carnofa.

A L B. nullum, prater fuperficiem carnofan integumenti interni.

Eм в. inverfus, rectus, lutefccus. Cotyl. cllipticx, fubfoliacex. Rad. teretiufcula, cotyledonubus dimidio brevior, fupera.

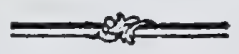

a.) Caprula matura. B.) Ejus feltio transverfalis, C.) Situs feminum in receptaculo alterios loculamenti denujato. d. D.) Semina feparata. E.) Nucleus denudatus. F.) Integamentum interius apertum, cum fitu embryonis. G.) Enbryo feparatus. 

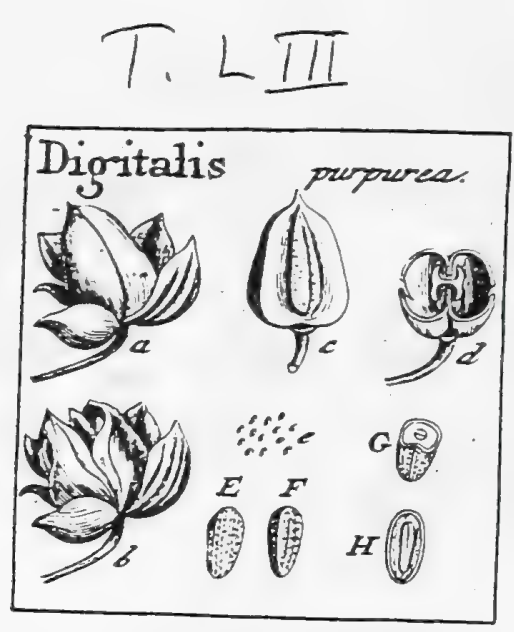

\section{J. Gaertner (1788) Vol.1}

CCCVI. DIGITALIS. TOURN. t. 73. LINN. gen. 758. 247

Calyx quiuquepartitus. Cor. campanulata, yentricola. Stain. quatuor inzqualia. Stigma fimplex. Capfula bilocularis: difepimento duplicato ex intlexis valvularuw marginibus. Semina numerofa, fubprismatica.

Digit alis purpurea. Tab. 53. fig. 6.

Digitalis. RIv. monop. t. 204. BLAX W. herb. t. 16. OEDER. flor. dan. t. 74 .

Digitalis foliis ovatis, galea fimplici. HA L1. hiff. 1. n. 330 .

Digitalis calycinis foliolis ovatis acutis, corollis obtufis: labio fuperiore integro. LINN. Jyje. veg. 562 .

PER. Capfula ovato pyramidata, fubpubefcens, bilocularis, bivalvis. Diffepincntum ex marginibus valvularum introrfum ilexis formatum, duplicatum. Valvulx per maturitaten fxpe in lateribus runâ hiantes.

$R E c$. oblongum, fungofurn, hine couvexum, inde fubeoneavum, mediante lamisa

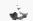
integeriina cum axi fructus, mon autcon cum dilítepimento connatum.

248

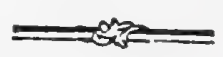
SEM. numerofa, parva, fubparallclipipedea, ab altero latere fulco longitudinali exfculpta
$i$ undique punctis excavatis fubferiatis confperfa; fetruginea.

IN T. duplex: exterius fubfpongiofum; interius membranaccum, tenuifimum.

A B. Semini conforme, carnolum, pallide albicans.

Ess 8. cylindricus, lacteus. Cotyl. Senniteretes. Rad. crafta, centripeta.

a. b.) Capfula integra \& deirifens, c.) Receptaculum. d.) Capfula difTeta. e. E., Semina ie parata. F., Seninis latus fulcatum. G. H.) Albuniuis fettiones cum fitu \& figura embryonis. 


\section{Scrophulariaceae}

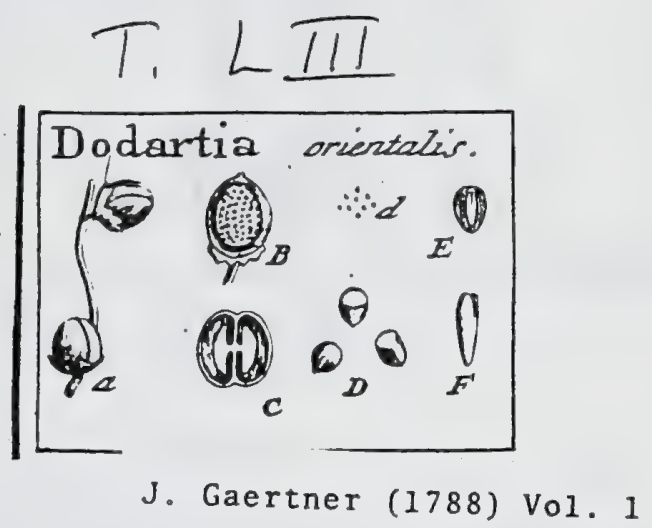

CCCIII. DODARTIA. Tours. t. 478. Linn. gen. 780. 245

Calyx quinquedentatus. Cor. ringens. Stam. quatuor inxqualia. Stigma bifidum. Capfula fubglobofa, bilocularis. Sem. plura angulata.

DODA R T I A orientalis. Tab. 53. fig. 3.

Dodartia orientalis, flore purpurafcente. Tou RN. it.3. p. 208. MIL. diat. ic. t. 27.

Dodurtia foliis linearibus integerrimis glabris. LinN. fy/. veg. 574 .

PER. Capfula fubglubofa, membranacea, tenuis, utrinque linea depreffa infcripta, bilocularis, raro fponte deliifcens.

REc. fubrotundum, ferobiculatum, plano convexum, per laminam intergerinam diffepimento utrinque annexum.

SEM. numerola, parva, fubglobola, angulata, glabra, cinereo fufea.

\section{6}

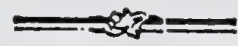

IN T. duplex : exterius tenuifunum; interius fubcoriaceum, minutifime excavazo punctatum, fufcom.

A L B. femini conforme, carnofum, aqueo-palliduin. Ens. teretiusculus, reâs, lacteus. Cotyl. femicylindricz, breves. Rad. crenta.
centripeta. A.) Capfuis integrs. B ) Receptac. (crobiculatum. C.) Capfula direeta. d. D.) Semina (epariia
E.) Albumen diffetum cam embryone. F.) Embryo feparstas, 


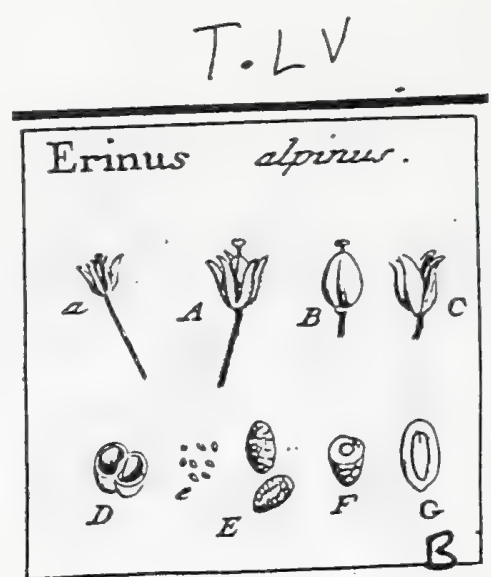

J. Gaertner (1788) Vol. I

CCCXXV. ERINUS. LINN. ger. 77r. Ageratum. T ourn. t. $422.26 t$

Calyx pentaphyllus. Cor. infondibuliformis, limbo quinquefido fubrquali. Stam. quatuor inxqualia. Stig. capitatum bilobum. Capfula bilocularis. Diflepimen. tum duplicatum. Sem. plurima, parva.

ERINUS alpinus. Tab. 55. fig. 5.

Ageratum purpureum. DALECH. hift. $1784^{\circ}$

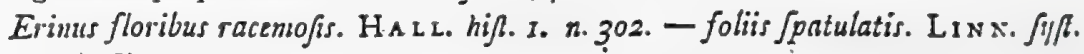
veg. $57^{\circ}$.

PEк. Capfula parva, ovata, utrinque fulco inferipta, bilocularis, bivalvis: valvulis maturis ad medium usque bifidis. Diffepimentum duplicatum, ex inflexis valvularum marginibus formatum.

REC. oblongum, compreffiusculum, diffepimento non adnatum.

SEM. numerofa, parva, ovata, ferruginea, tuberculis confertis obfoletis fcabrata.

I $\mathrm{T}$. fimplex, fubcoriaceuin, tenue.

A \& в. femini conforme, carnofum, duriusculum, aqueo-pallidum.

Eм в. cylindricus lacteus. Cotyl. brevifinıx, obtufx. Rad. crafta, centripeta:

2. A. B.) Capfuta calyce glatinofo veftita - \& denudata. C.) Eadem dahilcens. D.) Ejos fotio trapsverfalis. e. E.) Semina feparata. F, G.) Embrjonis intra albumen fitus \& figura. 
T. L I V

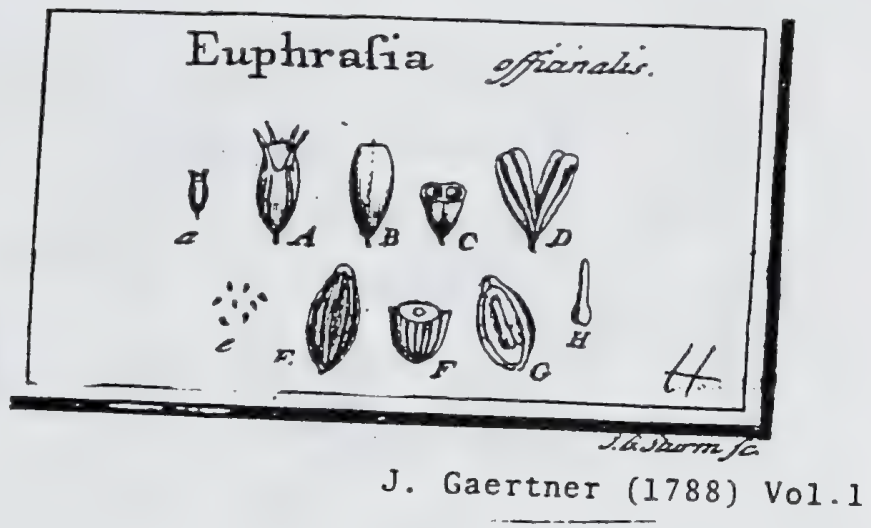

CCCXX. EUPHRASIA. TOURN. t. 78. LIN gen. 74r. 257

Calyx quadrifidus. Cor. ringens. Stam. quatuor inxqualia: antheris inferioribus altero lobo bafi fpinofis. Stigm. fimplex. Capfula bilocularis. - Seminz pauca, deorlum incumbentia.

EUPн RAsin officinalis. Tab. 54. fig. 8.

Euphrafia. RIv. monop. t. go. f. 1. B LA X

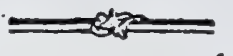

Euphrafia foliis ovatis lineatis argute dentatis. H A Lr. hiff. n. 303. LIN . fiff. veg. 549 .

PER. Capfula parva, ovato oblonga, fuperne comprefra, bilocularis, apice transvers fim delifcens. Diffepimentum anguilum, valvis contrarium.

REC. nullum; femina diffepimento affixa, deorfum fibi mutuo incumbentia,

SEM. pauca, quatuor 1 . fex in fingulo loculamento, exigua, ovato oblonga, mats gine membranaceo albo, nunc utrinque, nuuc ex uno tantum latere cincta, lona gitudinaliter friata: frriis linearibus albis; interftitiis pallide ferrugineis. Umbile: cus compreffus in parte fuperiori feminis.

IN T. finplex, membranaceum, tenue.

A.L. femini conforme, carnofum, aqueo-pallidum.

Es B. teretiusculus, longitudine fere albuminis, lacteus. Cotyl. breviffmx. Rad. longa, crafra, fupera, ad umbilicum converfa.

a. A.B.) Capfata calyce reftita \& denudata integra. B.) Eadem diffeta. D.) Diffepiment fitiest c. E.) Semina feparata. F, G.) Seminis fetiones cum fitu embryonis intra albumen, H.) Embjyos Separatos.

Euphrasia Odontites. OEder. flor. dall. t. 655 .

Capfula \& diffepimentum ut in pracedenti. Semina ovata, ex altero latere margines membranaceo cincta, candidiflima, fulcis elevatis longitudinalibus, friisque fime: libus transverfalibus eleganter cancellata.' 


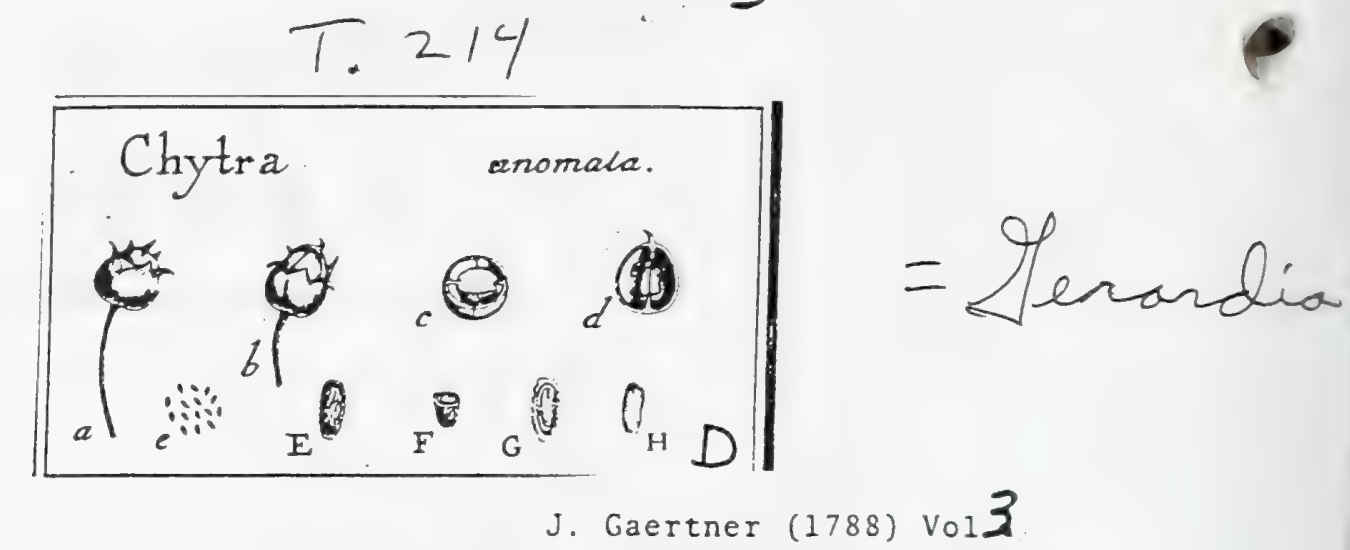

\section{Cal monophyllus, tubulors, 1 , \\ 144. C H Y T R A. 184 \\ tatus, perfiftens. Cor. . Stameampanulatus, bafs ventricolus, rezden: \\ Capf. ovata, bifulcata, bilocularis, bivalvis; difierum; Itylo fimplici . . . Rec. fungofum, adnatum. Sem anderof obis; dilfepimento valvis pontrario. tereti-oblongus, centripetus.}

Chytra anomala. Tab. 214 . fig. 4.

Ex collectione $\mathrm{Cl}$. Desfontaings fub nomine Peripeace. PER. Capfula ovata, l, ovato-elliptica, a calyce fupra medium excepta, apico
ftyli reliquiis faftigiata, utrinque fulco intermedio longitudinali exarata, coriacea, apice tantum dehifcens, bilocularis, bivalvis. Difepimentum

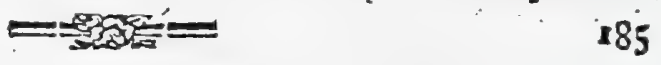

coriaceo-membranaceum, tenue, valvis contrarium \& ipfarum fulco externo infertum.

REc. diffepimento utrinque bali lata adnatum, ovatum, margine liberum, fungofum, punctis minimis elevatis fcabriufculum, quibus femina umbilicis adluarent.

SEM. pumerofa, minutula, oblonga, utrinque obtufa, ftriato-reticulats, bafi umbilicata, centripeta, fpadicca.

IN T. duplex: exterius membranaceo-reticulatum, tenue, Jaxiufculum, facile detrahendum; interius externo paulo brevius, crafiufculum, valıdum. 1 fubchartaceum; Lutefcens intus cum damina tenui caenofa intime conferrumizatum.

A L B. nullum! nifi laminam tenuem carnofam ab integumento interno non feparabilem fumas.

EM в. erectus, tereti-oblongus, utrinque obtufus, lacteo-albus. . Cofyl. breyes, obtufx Rad.teres, longa, obtufa, umbilico externo obverla, centripeta.

\section{EXPLICATIO FIGURE}

a.) Capfula integra. b.) Eedem dehifcens. e.) Ejusdem fedio transverfalis d.) Valvala sike I2, cum diffepimento \& receptaculi fitu. e. E.) Semina feparatz E. G.) Ejasdem feéto transvertalis \& loagitudiaalis, cam fitu embryonis. H.) Eubryo folutas.

. Integumenti interni fabrica \& ejus cum albumine mixtio in hac ftirpe qusm maxime Gingularis \& exceptis Sebeftinis veris plaue inaudita. 


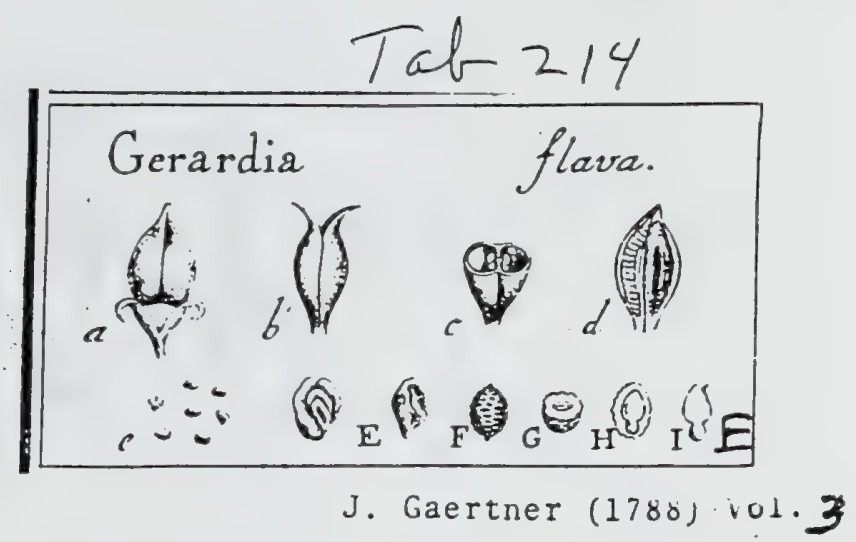

\author{
r45. G E R A R D I A. \\ 185 \\ Plusr. gen.t. 12. Linn. gen. 747. ed. Schreb. roo4. \\ Juss. ger. p. irg. Lasiarcx ill. gen. t. 529 .
}

Cal. monophyllus, inferus, quinquefidus, perfittens. Cor. monopetala, ringens, tubulofa, bilabiata; labio fuperioré erecto, latiore, emarginaro : inferiore rellexo, tripartito. Stam. 4. didynama. Ovar. fuperum; Pylo fimplici; ftigmate obtufo. Capfula coriacea, roltrata, bilocularis, bivalvis: difepimento valvis contrario, \& cum iplis longitudinaliter dehifente. Rec. anguftilima, diffepimento longitudinaliter affixa. Sem. numerola, integumento laxo gyrofo aucta. Alb. carnofum. Emb. ovatus: rad. difcreta.

Gerardia flava. Tsb. 114. fig. 5.

Digitalis procerior fioridana, jaceae nigrae difectis foliis, fioribus albis anspliori-

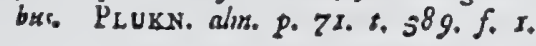

Anonymos fioribus flavis Jpectiofis di -it:li aequalibus: Grov, virg. p. 94.

Gerardia folis lanceolatis pinnato - dentatis, caule fimmplicifinto. Lris. Jpec. plo p. 848. Syfo. veg. o1. 14. p. 553. Willu. free. pl. T. 3. P. 1. F. 223. Michaux fior, bor, aimer, 2. p. I9. Persoum fon, 2. p. 154.

Ex collectione $\mathrm{Cl}$. Despontainge.

PER. Capfula coriacea, ovati, utrinque attenuata, hine calyci inffiftens; inde in roltrum acuminatum protracta, compreffiufcula, Jongitudinaliter biful. cata, fetulis minimis confperfa, ab apice dehifcens, bilocularis, bivałvis. Diffepimentum anguftum, furfum deliquefcens, fulcis externis infertun, \& inde valvis contrarium, medio vero cum ipfis longitudinaliter dehifcens.

REC. angufta, fungofa, mediante lamina tenui duplicata angufta difepimenti futurx inferta, \& cum dehifcente capfula bifida.

SEX. plurima, inæquabilia, integumento externo gyrofo ampliata, pallida; nucleus fufcus ovatus, punctis excavatis transverfis fcabratus, bafi ope funiculi umbilicalis brevis integumento externo arctius adhærens \& per ipfum transparens.

IN T. duplex : exterius laxiffimum, membranaceum, in plicas. fuperficiales gyrofas ampliatum, hinc inde nucleo adhærens, reticulatum, pallidum; inserius ftriis transverfis reticulatim difpofitis infignitum, adnatum, firmum.

A L 8. nucleo conforme, carnofum, album.

EMB. ovatus, erectus, compreffiufculus, ladeo-albus. Cotyl. elliptice, fubfoliacex, 1. plano-convexiufculx, obtufx. Rad parva, difcreta; 'ovata, obtufa, umbilico. externo obverfa, centripeta. .

\title{
EXPLICATIO FIGURE.
}

2.) Caplula integra. b.) Eadem a calyce denudata, dehifcens. c.) Ejusden fealo transverfatis, enm fitu \& forma receptaculorum. d.) Valvala altera feparata, ean feminibus in fitu. c. E.) Semida feparata. F.) Nucleus, ab integuneato iaterno desudatw, bafi fouiculo umbir lieali breviftimo inftruAtus. G. H.) Mlbumen traosverfe \& Longitudiaslicer diffetum, cum fro \& forma embryónis. I.) É⿴囗十)

Proxime a Bartfia po iog. to 198. diftat. 


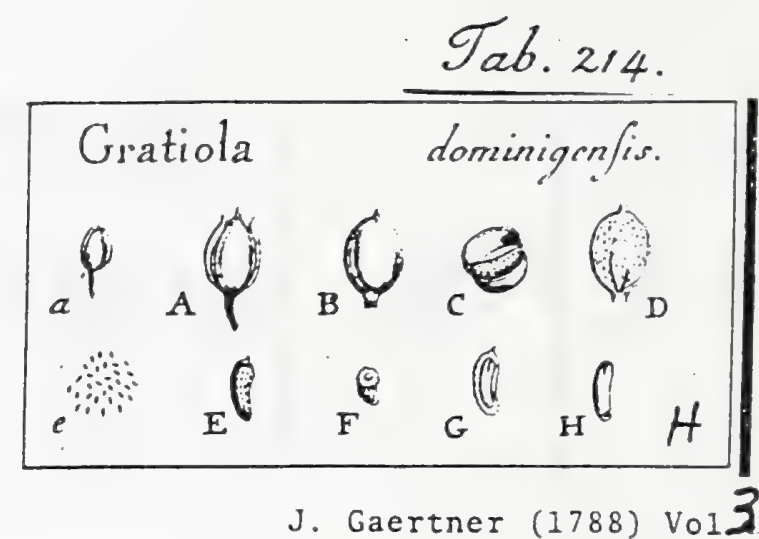

\section{G R A TIOLA.}

LINN. ger. 29. ed. Schreb. 37. Juss. geñ. p. 12T. LAMARCX ill. gen. t. 16. f. I.

Cal. profundiflime quinquepartitus, nudus; laciniis in:equalibus, majoribus ovatis, acutis, unica vero lineari cxteris longiore. Cor, monopetala, tubu-

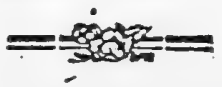

Jofa, inrequalis; tubo longo; limbo fubbilabiato, 1. quadripartito; lacinia fuperiore fubrefexa emarginata paulo latiore, tribus reliquis xqualibus re. ctiufculis obtufis. Stan. 4., quorum duo caftrata; filamentis filiformibus, longitudine tubi; antheris ovato-cordatis, bilocularibus. Ovar. fuperum; ftylo filiforni, cotolla paullo breviore; Itigmate bilamellato, obtufo. Capf. membranacea, parva, bilocularis, bivalvis: diffepimentum valvis parallelum. Rec. valde exiguum. Alb. carnofum. Emb. curvulus.

Gratiola dominigenfis. Tab. 214. fig. 8.

Gratiola glabra, pedunculis brevibus folitariis oppofitis, foliis ovatis fefilibus Subquingruenerviis.

Habitat in Inf. Hifpaniola, a Do Poltedu.

P z R. Capfuls parva, a calycis laciniis obtecta, ovata, bifulca, lutefcens, bilocularis, bivalvis. Valvulze naviculates, membranacex, fubdiaphanz. Difepimentum membranaceum, tenuifimum, valvis parallelum.

R g c. fuperficialia, 1. faltem maxime exigua, difepimento utrinque adnata, \& yix ab ipfo difcriminata, puncticulata.

SEM. numerofa, minuta, ovata, ovato-oblonga, obfolete angulata, ad verticem mucronulats, curvula, fcrobiculato-reticulata, ftraminea.

IN T. Gmplex, membranaceum, tenuc.

A LB. Semini conforme, carnolum; album.

EM B. albumine paulo brevior, teretiufculus, ovato-oblongas, 1. fubclavatus, curvulus, erectus, aqueo-pallidus. Cosyl. breves, femiteretes, obtufx, Rad, longa, obtufurcula, umbilico obver ${ }_{2}$, centripeta.

\section{EXPLICATIO FIGURE.}

1. A.) Frutus intezer. B.) Capfula feperata, non dehifeens. C.) Ejusden fetio trasterlalis, D.) Diffepimentum valvulz alteri adtarons. c. E.) Semina folata. F.) Albuened trasurerfe diffeaum G.) Embryonis fitus iatsa albumen. H.) Idem Separates. 


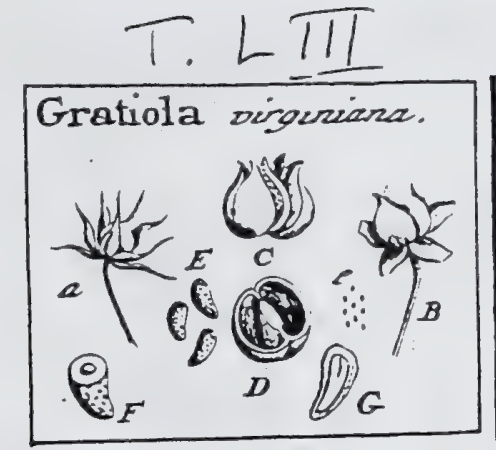

J. Gaertner $(1788)$ Vol.1

CCCXI. GRATIOLA. Lixn. gen. 29. 251

Calyx quinquepartitus, bafi auchus folinlis tuobus accefinisiis. Cor. monopetala irregularis. Statn. quatuor: duobus nerilibus. Stigm. bilabiatum. Capfula bilocularis. Diffepimentum fimpiex, valvis parallelum.

GR A T IOL A virginiana. "Tab. 53, fig. 11.

Gratiole affinis chamadryoides. $\mathrm{P}_{\llcorner} \mathrm{u}$ K. phyt. t. $193 . f .2$.

Gratiola foliis lanceolatis obtufis fubdentatis. Lis s. $\int y / t . v e g .67$.

252

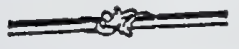

PE Capfula fubglobofa, acuminata, utrinque fulco infcripta, bilocularis, bivalojs valvulis apice $f_{x p e}$ bifidis. Diffepinentum fimplex, valvis parallelum, earumcuue futurx inlertum.

REc. rotundato acuminatum, modice convexum, diffepimento utrinque arcte ads natum.

Sex. numerofa, exigua, oblonga, extrorfum craftiora, punctis excaratis reticulata, fublpadicea.

Ix $x$. fimplex, membranaceum, tenue.

A L R. fernini conforme, tenue, carnolum, album.

E s 8. fubclavatus, levifime curvatus, lacteus. Cotyl. Semicylindricx, breves. Rad: tereti-attenuata, Jonga, centripera.

a. B. C.) Capfula integra \& dihiscens. D.) Ejus fetio transverfalis. e.E.) Senina (eparala. F.G.) Embryoais fitus intra albumen. 


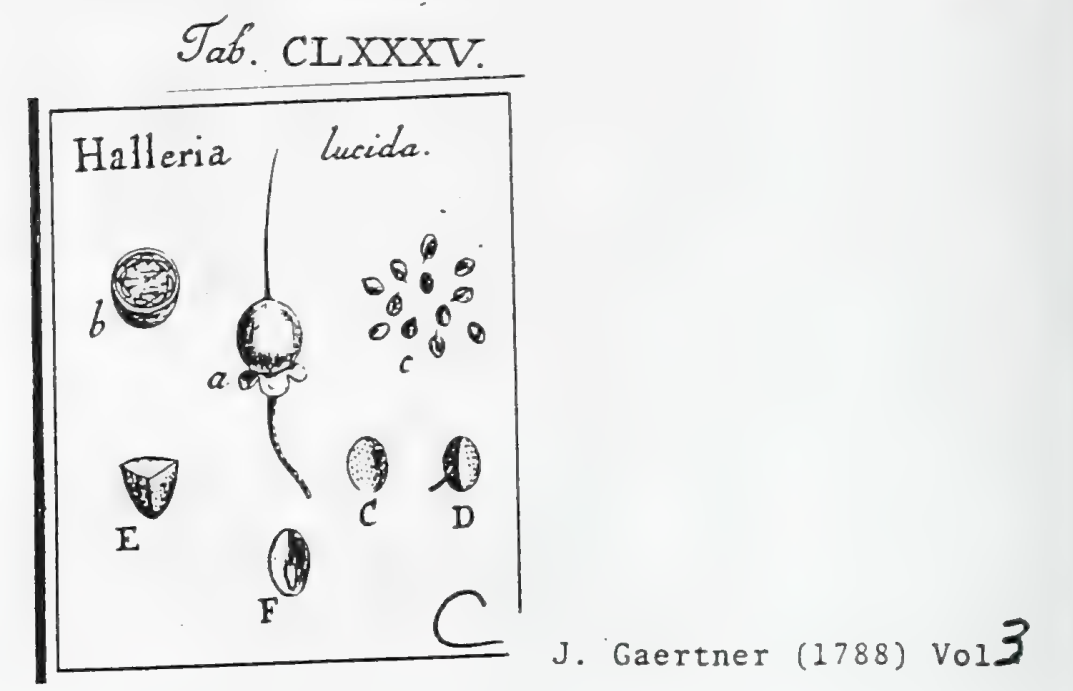

39. H A L ERIA. 4r

Lгñ. gen. 76ı, cd. Schreb. 1020. Jiss. gen. p. II\&.

LAMARCK ill. gcn. t. 546 .

Cal. trilobus perfiftens, lobo uno majore. Cor. infundibuliformis, fauce ventricofa; limbo eredto quadrifido, lacinia fumma najore enarginata. Stam. quatuor, didynama. Ovar. fuperum. Styl. fimplex perfiltens, demum Jun giltimus. Baccit globofa, pulpura, unilocularis Sem plura, umbilicis $c x$ ventre capillaribus.

Helzeria lucida. Tab. 185. fig. 3.

Lunicera foliis lucidis acuminatis dentatis, frutu rotumb. BUR.s. afi: 244. t. 8 \%. f. 3 .

42

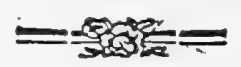

Halleria (lucida, ) foliis ovatis, corollis bilabiatis, calyce triphyllo. THUNB, Nov. alt. upf. 6. P. 39.

Halleria. LINN. Jjy. veg. ed. 14. p. 564 .

Halleria foliis ovatis acuminatis ferratis, corollis bilabiatis, calyce tripbyllo, faminibus exfertis. WILID. Spec. pl. T. 3. P. 1. p. j10:

\section{A Cl. Thunberg.}

PRr. Bacca fubglobofa, Atylo perfiftente longifimo terminata, bafique calyce trilobo excepta, cellulofo-pulpofa, mollis, unilocularis.

REc. funiculus unbilicalis capillaris, ex interno feminis latere oriundus, feminaque cellulofx fubftantie affigens, qux circa fingulum femen propriam quaf thec:m format.

SEM. plura, ab octo ad duodecim, comprefiufcula, fubelliptica, convexiufcula aut plana, inde angulata, confertim puncticulata, fufca.

IN I. fimplex, membranaceum, arctifime adhorens.

A L в. femini conforme, carnofum, duriufculum, aqueo-glaucum:

ENB. fubcylindricus, dimidio albumine brevior, \& in ejus bafs locatus, albus. Cotyl. brevifima, obtufx. Rad. teretiufcula, infera, aut ob varium feminum fitum vaga.

\section{EXPLICATIO FIGURE.}

a.) Bacea integra. b.) Ejus fectio transverfalis, cum Gitu feminum; e.) Semina foluta; C.) Seminis dorfun. D.) Ejus latus internum cum funiculo umbilicali. F.) Albumen transterín fetum. G.) Ejusdem fectio verticalis cam Gitu \& Gigura Embryonis. 


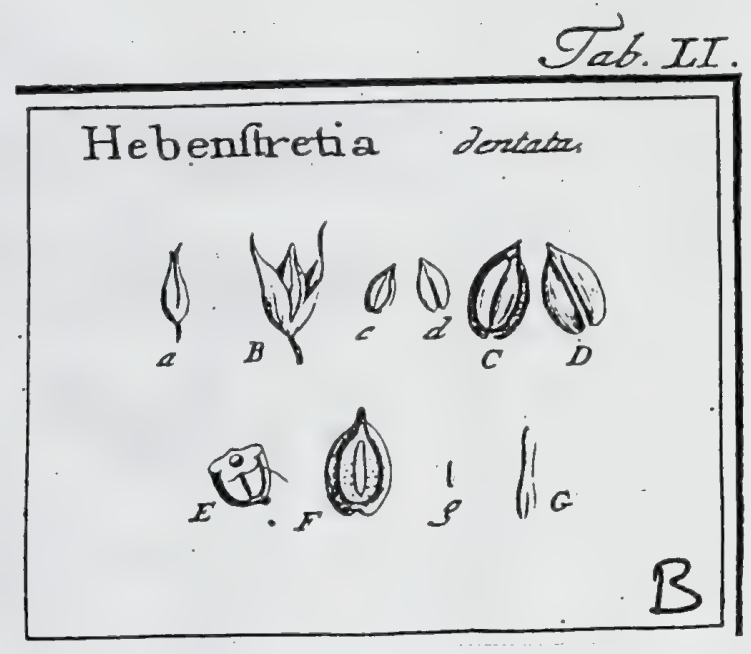

J. Gaertner (1788) Vol. 1

238

\section{HEBENSTRETIA. LIN gen. 770.}

Calyx ultera medium bifidus: lacinia altera duplo longiore. Cor. unilabiata : labío extrorfum ampliato, apice trilobo: Inbulo medio bifido; lateralibus emarginatis: Stam. quatuor, margini corollx extra tubum inferta. Styl. extrorfum incraffatus. Capfula unilocularis bivalvis. Sem. duo.

Hebenstretia dentata. Tab. 5i. fig. 5.

Valerianella africana foliis angufis, flore macula rubicante notato. Cox 2. hort. amf. 2. $t .509$.

Hebenfretia foliis linearibus dentatis, fpicis lavibus. LIN

PER. Capfula orato acuminata, in fylum definens, fubmembranacea, lenticulari-com: prefla, unilocularis, bivalvis.

REc. nullum; femina fundo capfulx affixa.

S E s. duo, fubelliptica, apice acuminata, bafi leviter emarginata; hine convexa, qua: tuor in univerfurn fulcis craflis rotundatis elevatis notata, inde plana, linea fimplici, media, friata; pallide framinea.

Ix т. duplex : exterius fungofum, craffum, duriusculum, nucleo multo latius; interius membranaceum, ferrugineum, fuperficie interna carnofa.

^ L 8. nullum, nifi carnofam fuperficiem integumenti velis.

E 1 8. cylindricus, rectus, inverfus, albicans. Cotyl. oblongx, plano-convexx. Rad. cotyledonibus fesquilongior, fupera.

a.) Capfula integra. B.) Eadem dehifeens eum (eminibas, c.C.) Seminis dorfum. d. D.) Ejar venter. E.) Crufa feninis dirfetea. F.) Eadem longitudinaliter sperta, cum nucleo. 8.) Nucleus, 8. G.) Enabryo denudatas. 


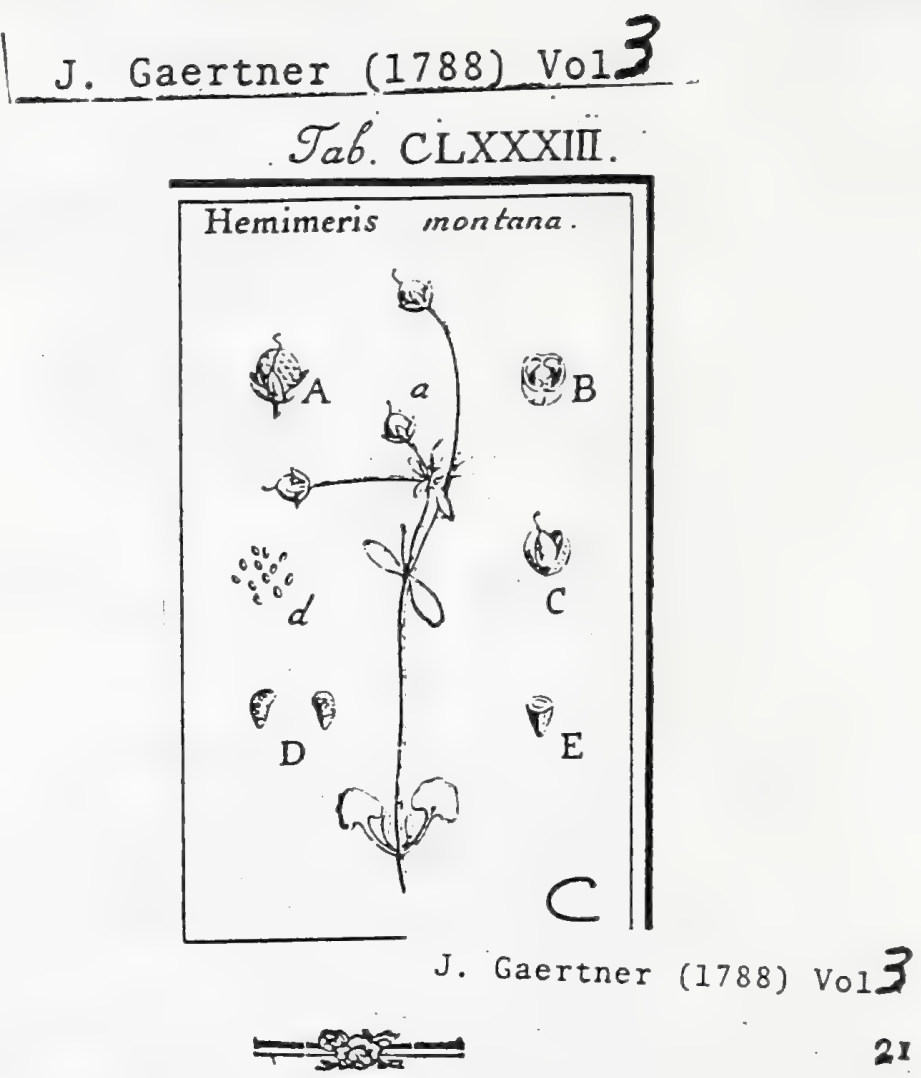

\section{Ig. H E M I M E R I S.}

THणNB. nov. gen. 74. LINN. Juppl. pl. p. 45. gen. ed.

Sclireb. 1016. Juss. gen. p. 120 .

Cal. monophyllus, quinquepartitus. Cor. monopetala, rotata, quinqueloba: lacinia una majore obcordata. Stam. duo aut quatuor didynama. Ovar. fuperum. Styl. fimplex. Capf. fubglobofa, bilocularis. Difep. valvis contrariun. Sem. numerofa.

Henimer1s montana. Tab. 183. fig. 3.

Henimeris diandra, foliis oppofitis ovatis ferratis, cande ereifo. LIN . fuppl. pl. p. 280. Syjt. veg. ed. 14. p. 56 1. Spec. pl. ed. Willd. T. 3. H. I. p. 282 .

\section{A Cl. Thunberg.}

PER. Capfula parva, fubglobora, tenuis, a feminibus protuberantibus puftulata, bilocularis, bivalvis. Diffepimentum valvularum medio dorfo \& fimul receptaculo infertun.

Rec. oblongum, craffum, fungofum, folidum, cum diffepimento connatum.

Sen. numerofa, parva, orata, deorfum acuminata, angulata, elevato puncti: culata, rufefcentiz.

IN T. fimplex, membranaceum.

A L B. femini conforme, carnofum, aqueo-pallidum.

EмB.....

\section{EXPLICATIO FIGURE.}

2.) Plantula fere integra, cum capfulis magnitudine naturali. A.) Cepluią integra, antea B.) Esdem transterfe diffedz, enm receptacolo ceatrali folido. C.) Ejusdem valvulz debifceto tes. d. D.) Seuninz leparata iategra. E.) Ejus featio transverfalis.

Major gibbofitas loculamenti alterius, minime debet inter figna generis charaderiftica recipi, ut vult Linn. jun., fiquidem in ipfa noftra fpecie penitus deficiat. Nec bona clt Linnxi H. monsanae phrafiuncula Ipecifici, quandoquidem in meo exemplu folis fuperiora fine oblonge-elliptica \& integerrima; inferiora autem reniformia, crenata $\&$ ex renis pelvi petiolaca: ut fane de fpecie mex plantx dubieafem, nif eans ab iplo gemeris inventore habuifen. 


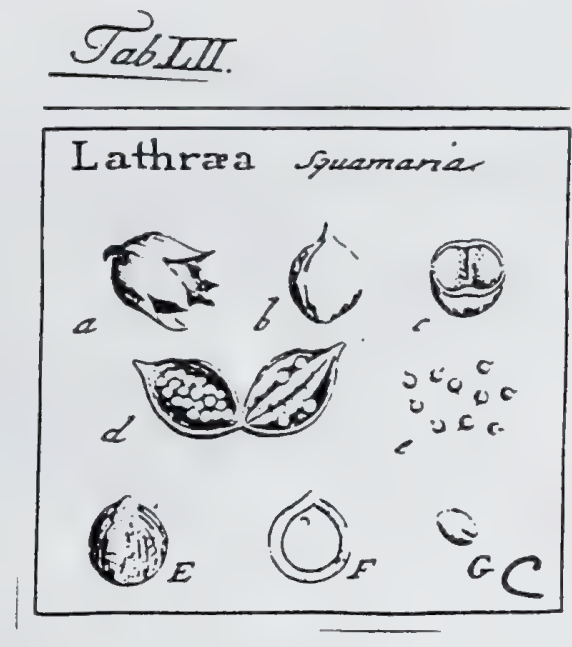

J. Gaertner (1788) Vol.1

CCXCVIII. LATHREA. LIN . gen. 743 .

Calyx quadripartitus. Cor, ringens, Stam, quatuor inxqualia. Styl. unicus. Capfula: unilocularis. Receptacula fungofa lateralia. Embryo excentricus.

LATHREA fquamaria. Tab. 52. fig. 3.

Squamaria. R I v. monop. t. 89. f. 2. BLA א t. 136.

Lathrae caule fimpliciffmo, corollis pendulis: labio inferiore trifido. HALL hiff: I. n. 297. LIN $\int \mathrm{N} / \mathrm{f}$. veg. 550 .

PER. Capfula fulgglobofa, mucronata, obfolete bifulca, papyracea, unilocularis, bivalvis.

REc. fulcus elevatus, craftus, fpongiofus, bifidus, fingula valvulx parieti interno lor:gitudinaliter adnatus, per maturitatem fxpe obliteratus, cui femina affixa.

SEs. numerofa, circiter quadraginta, fubglobofa, fpongiofa, cinerafcentia.

IN T. fimplex, fungofum, craflum, extus reticulato-celluloluın.

A LB. femini conforme, fed anguftius, grauulofo carnofum, duriusculum; aquecé glaucum.

Em 8. minutiffimus, fubglobofus, lutefcens, extra axem feninis pofitus. Cotyl. brej vifumx, ubtulx. Rad. ovato acuminata, centrifuga.

1.) Capfula vefita. b.) Eadem denudata. c.) Eadem dilfeta. d.) Ejus valvulz dehlreates cam reeptacalo fpongiofo. e. E.) Semina fepanta. F.) Seminis \& albumisis fetio longitudinalis, cam embryonis fitu excentrico. G.) Enibryo (eparatus. 


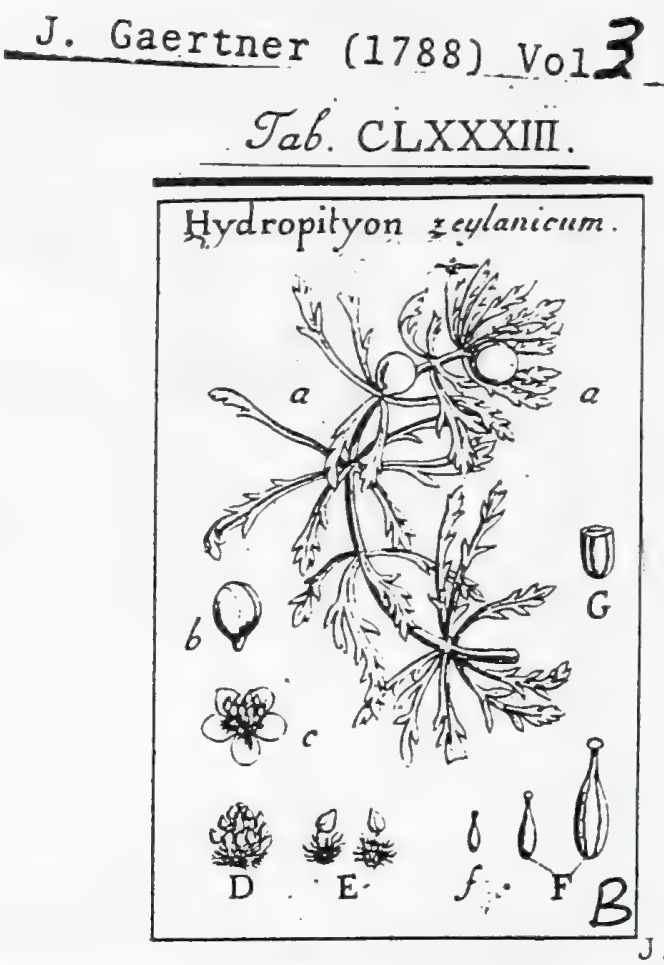

18. H Y D R O P I T Y N.

Cal. inferus, pentaphyllus: foliolis ovatis concavis magnis incumbentibus. Cor. pentapetala, calyce paulo brevior: petalis ovato-rotundatis concavis.

Stam. decem: filamentis craffis brevibus, apice dorfo antherarum \& bafi re: ceptaculo genicalium carnofo \& molliter longeque villofo infertis: antheris obefis, cordatis, bilocularibus. Ovar. fuperum, oblongum, definens in faylum fimplicern, ftigmate orbiculato prxpilarum. Capfula monofperma, aut Semen nudum, compreffum, fulcatum.

HYDROHTY YN zeylanicum. Tab. 183. fig. 2.

Tfunda-tfiera. RHEED. mal, 12. p. 7r. t. 36 .

Hottonia flore folitario ex foliorum alis. BURM. zeyl. I21. to 55. $f$. I.

Hottonia pedunculis axillaribus unifioris. LINN. Syfo. veg. ed. 34. p. 195.

Hottonia pedunculis axillavibus, foliis multifidis. WILLD. fpec. plo T. I. P. . . F. 813 .

A Cl. Thunberg.

PER. Capfula unilocularis monofperma; aut Semen nudum ovato-oblongum, compreffum, utrinque elevato - trifulcatum: pofterius milis magis videtur verifinile.

REC. . . .

SEM....

INT....

A. B. ...

EIS. . .

\section{EXPLICATIO FIGURE.}

2. x. ) Ramulos floridus. b.) Calyx cum foliolis fuis fibi matoo incambentibas \& ex partb occultantibus. ce) Corolla explanata. D.) Stzmina in receptaculo carnofo \& carnolis quoque tillis longitudine fere ftaminum ftipato. E.) Stamina feparatz ab ateriore \& pofferiore parte fpectata. f. F.) Ovariam immaturum, magnitudiae asturali \& audz. G.) Idem transverfe ditteturn.

Ipfe Linnæus in Syft. nat. ed. x2. p. I s2. de genere hujus plantx \& rectiffime quidem dubitavit, nam cuin Hottonia ne umbram quidem conformitatis habet, \& per fe ab omnibus reliquis generibus diftinctum eft. Sufpicor fructum maturum effe Semen nudum aut Nucem coriaceam, Jongitudinaliter fulcatam \& monofpermam. In ovario nimis imnaturo nil intus diftincti vidi, prater rimam transverfalem absque ullo diffepinenti veftigio. 


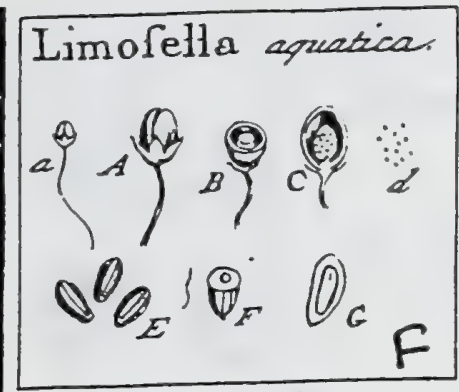

J. Gaertner (1788) Vol.1

228

CCLXXIX. LIMOSELLA. LXN N. $g e n .77^{6}$.

Calyx quinquefidus. Cor. quinquefida. Stam. quatuor per paria approximata. Styl. unicus. Ovariunn biloculare. Capfula matura fubunilocularis, bivalvis, Sem. plura.

Limosella 2quatica. Tab. 5o. fig. 3.

Plantaginella. Rupp. flor. jen. 2. p. 23. t. 6. Oeder. flor. dan. t. Ǵ.

Limofella. H A I L. hifl. I. n. 300. LIN N. Syf. veg. 572.

PER. Capfula ovata, parva, utringue linea depreffa inferipta; fuperne unilocularis, inferne fepto membranaceo obfoleto divifa, bivalvis.

REc. nvato oblonguin, fcrobiculatuin, prope bafin membrana transverfali terivifima cum valvulis colixrens, catera liberum.

SE 2. plurima, parva, ovato oblonga, fubangulata, obfolete ftriata \& minutifimis li neolis transverfalibus quafi cancellata, rufefcentia.

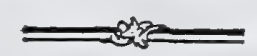

IN T: duplex : coriaceum \& craflaceum; utrumque tenue.

A L 8. femini conforme, carnolum, album.

Емв. teretiusculus, rectus, lacteus. Cotyl. femicylindricx. Rad. crafta, centripeta.

a. A.) Capfula hitegra, B.) Esdem difecta. C.) Recepiteulum integrum. d. E.) Semina (o. parata. F. G.) Albuminis fectiones cum fitu \& Gigura embryonis.

Fructos omnino ad pericarpia bilocularia fpectat, ut recte habet ADANSON. 


\section{Tab. CLXXXIV.}

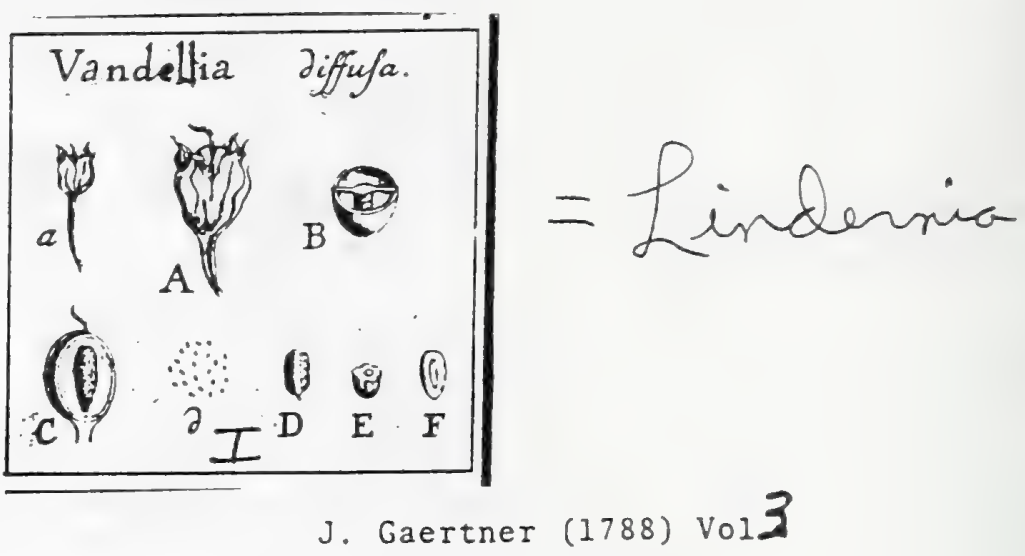

33. $V$ A N D ELI I A.

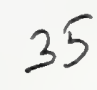

LrÑ. mant. 7) 12. gen. cd. Schrcb. ro40. Juss. gen. p. 122.

LAMARCK ill. gen. t. 522 .

Cal. quadripartitus: lacinia fuprema fubbifida. Cor. irregularis, bilabiata : labio inferiore bilobo. Stam. quatuor, didynama, ouorum duo altiora: anthera per paria connexa. Ovar. ftylo unico; ftigmatibus duobus reflexis. Capr. oblonga bilocularis. Difepinentum fimplex, valvis parallelum.

Vandelia diffura. Tab. 184 . fig. 9.

Vauddellit. Lins. Mfaut. p. 89. Syj. veg. ed. I4. p. 573.

V'andellia foliis fubrotundis fubfefilibus. VAHL eclog. 2. p. 47. WILLD. Spec. pl. T. 3. P. T. p. 343 .

Ex herbario Cel. Desfontaines cum fequente.

Per. Cap\{ula parva, oblonga vel globofa, a calycis laciniis arcte adprefis fere abscondita, biloculiris, bivalvis.' Diffepimentuin Gimplex, membranaceum, valvis parallelum, illarumque futuris infertum, fuperne ftylo caduco ftipatum.

REc. ovato-oblongum, medio diffepimento ab utroque latere arche adıatum, convexum, fpongiofum.

SEM. numerofa, exigua, obJonga, vertice obtufa, bafi mucronata, \& ibi funiculo umbilicali brevifimo inftructa, punctis excavatis in fex vel feptem feriebus longicudinaliter difpofitis reticulata, fpadicea.

IN T. fimplex, tenuifimum, membranaceum.

A L в. ' femini conforme, duriufculum, fere cartilagineum, fpadiceum.

E м в. rectus, teretiufculus, albus. Cotyl. brevifimx. Rad. longa, attenua$[$, centripeta.

\section{EXPLICATIO FIGURE.}

1. A.) Capfula calyce permanente veftita. B.) Eadem denudata \& medio transverfe fete. C.) Difrepimentum cum receptaculo in fitu, adharente valvula altera. d. D.) Semina feparata,

E.) Aluumen transverfe - \& F.) idem longitudinaliter diffe\&um, cum Gtu Embryonis.

VANDELLIM lanceolata.

Calycis laciniz lineares, nervo intermedio ad pedunculum ufque decurrente ut in V. diffufa ftipatz. Capfulx graciliores, magis oblongx, utrinque attenuatx. Semina magis rotundata; reliqua vero omnia ut in priore. 


\section{Tab. CLXXXIV.}

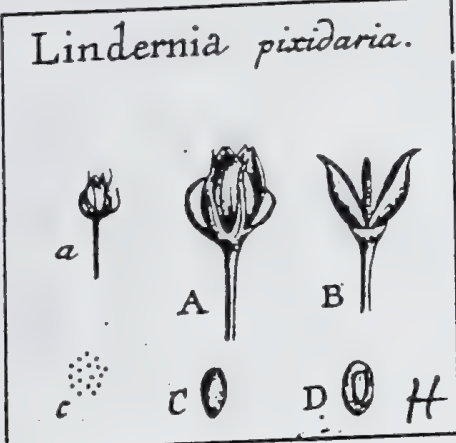

J. Gaertner (1788), Vol.3

\section{L I N D E R I A.}

LINN. gen. ed. Schreb. rozi. Juss. gen. p. 122.

LAMABCK ill. gen. t. 522.

Cal_ quinquepartitus: laciniis aqualibus. Cor. monopetals, irregularis: labio fuperiore emarginato, inferiore trifido, lacinia intermedia najors. Stam. quatuor didynama, duo inferiora filamentis adfcendentibus, anthera longioribus, dentatis. Ovar. ftylo filformi; ftigmate emarginato. Capf. unilocularis, bivalvis. Receptac. liberum.

LIKDEKNia pixidaria. Tab. 184. fig. S.

Grutioln floribus peduneulatis, foliis ovatis crenatis. Gros. تrirg. 129.

Ruellia pedunculis folitartis umijoris longibudine folionum. GROx. ving. $73^{*}$

Pyxidaria repens amuna, finfoulis monopotalis umilnbintis. Linderns. alfat. I. p. 152. t. 1. \& 2. p. $=67$.

Capraria gratioloides. LiNn. free. pl. ed. 3. p. 876 .

Linderuic. ALL1ON. Airp. aliq. 178. t. 5 .

Lisdernia folies ovalibus integerrimis feflilibus, pe:tunculis folitariis. L1Ne. Gyf. vez. ed. 14. p. 567.

Lindernia foliis oblongo-ovatis integerrimis trinerviis Sefilibus, pedunculis uxillaribus unifioris camle procuabeute. WILLD. fpec. pl. T. 3. P. I. F. 525.

PER. Capfula parva, ovalis, apice in mucronem obtuliufculum terminata, compreffa, unilocularis, bivalvis. Valvulac nervo intermedio dorfali no. tatx, apice bidentatx, tenerrinix, fubdi.tphanx.

REc. liberum, cylindraceo - clavatum, fpongiofum, punctis minimis excavatum.

SEM. plurima, minuta, polymorpha, ovata, oblonga \& fubreniformia, rugis vix difcermibilibus fcabrata, rufefcentia vel rufofufca.

IN T. fimplex, nembranaccum, tenuifimum.

A I B. Semini conforme, carnofum, album.

Е м в. rectus, oblongus, niveus. Cosyl. obtufx, brevifimx. Rad. obtufa, crafliufcula, centripeta.

\section{EXPLICATIO FIGURE.}

2. A.) Capfula integra calyce veftita. B.) Eadem a calyce denudatz, çun receptaculo in fitu. c. C.) Scmina foluta. D.) Albumen longitudinaliter difięurn, cum fitu \& Ggura Embryunis.

Cel. Jussıgu capfulam ftatuit bilocularem; nec ego talem invenire potui unquam. 


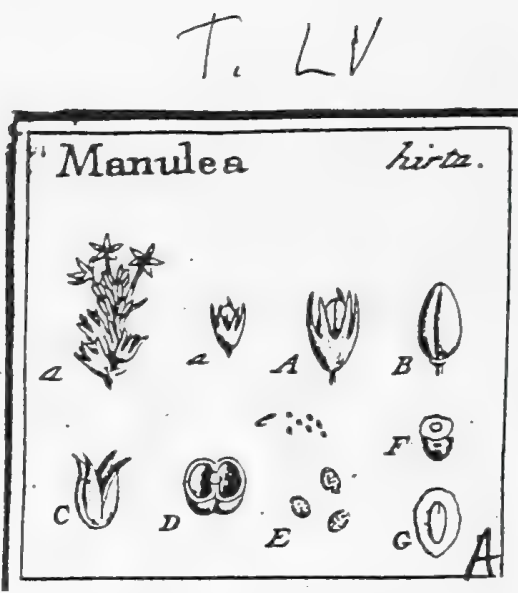

Scrophulariaceae

J. Gaertner (1788) Vol. 1

CCCXXI. MANULEA. Linn. gen. 1264. 258

Calyx quinquepartitus. Cor. infundibuliformis quinquefida, fubirregularis. Stam. quatuor inxz̧ualia. Stig. fimplex. Capfula bilocularis: diffepimento duplicato ex. inflexis valvularum marginibus. Sem. plurima, parva.

Manulea hirta. Tab. 55. fig. I.

an Selago hirta, fyicis longifimis, foliis obovatis. LIN Suppl. 285. Jyfi., veg. 569 ?

Ex herbario Bankfiano.

PER. Capfula parra, orato oblonga, utrinque fulco inferipta; bilocularis, bivalvis: vaivulis maturis ad medium usque bifidis. Dilfepimentum duplicatum, ex inflexil valvularum marginibus formatum.

REc. centrale, columnare, oblongum, compreffiusculum, diffepimento non atd. natum.

SEM. numerofa, parva, fubglobofa, obfolete angulata, fcrobiculis feriatis exasaty. alba.

Is $\mathrm{T}$. duplex: exterius cruftaceo-coriaceum; interius membranaceum, tenuifimun. A В. fcmini conforme, tenue, carnofum, aqueo-pallidum.

Ем в. cylindricus, lacteus. Cotyl. breves, obtufx. Rad. crafra, centripeta.

a.) Pars fpice fruttigetz. 2. A. B.) Capfula calyce vefita \& nuda, integra. C.) Eadem quadrifarlam de'tifcens. D.) Eadem differta, e E.) Semina feparata. F. G.) Embryouis intra albumier fitus \& Ggura.

A Selagine, non tantum hxc, fed \& omnes reliqux frecies polyffermx removend $x$ funt. 

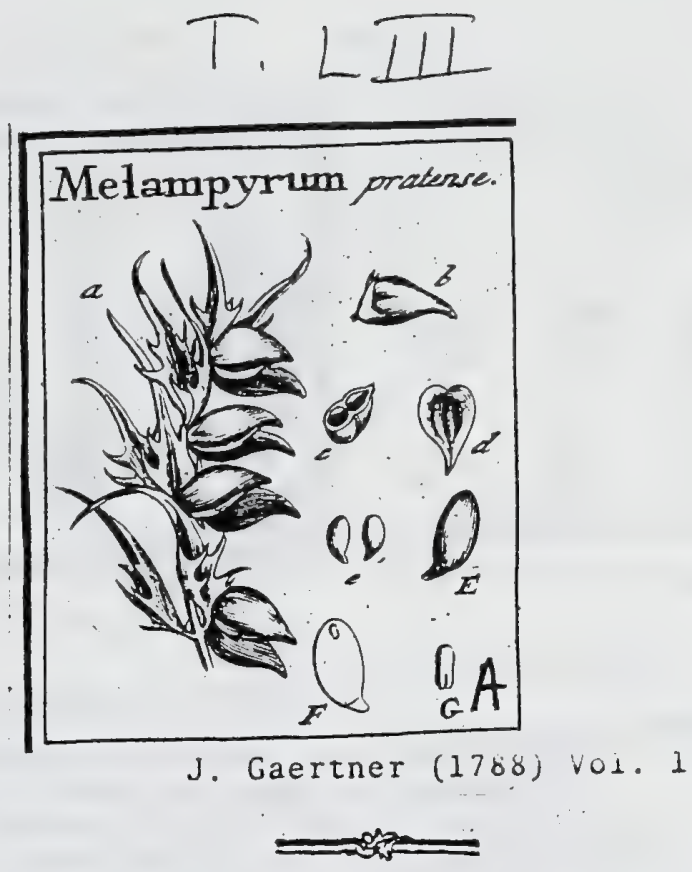

\section{CENTURIA QUARTA.}

\section{MELAMPYRVM. Tour r. t. 78 . LinN. gen. 742.}

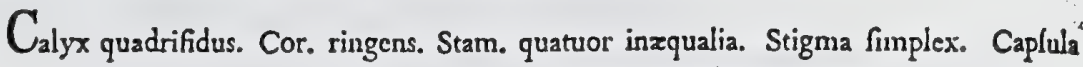
comprefía bilocularis. Semina folitaria. Embryo umbilico contrarius.

MELA mPYRU m pratenfe. Tab. 53. fig. I.

Parietaria Sylveftris. B Est. hort. Eyfl. aftiv. XII. t. 2. f. 2.

Melampyrum foliis imis integerrimis, mediis dentatis, foralibus hafatis. HALr. Jiff. .. n. 308 .

Melampyrum floribus fecundis lateralibus, foliorum conjugationibus renotis, torollis claufis. LIN N. Syfl. veg. $55^{\circ}$.

$P E R$. Capfula ovata, in roftrum fimuin attenuata, comprefía, fulco longitudinali utrin. que infcripta, extus fulca, intus fericeo al ba, bilocularis, margine fuperiore dehifcens. Diffepinentum valvis contrarium, anguftifimum, obfolefcens.

REc. cicatricula minima, in fundo finguli loculamenti.

S Ем. folitarium, ovato gblongum, glabrum, palbicans, fubnitidum, inferne in roßellum umbilicale conicum fpongiofum elongatum.

IN T. duplex, utrumque membranaceum, tenue.

$\Lambda\llcorner$ в. oblongo ellipticum, carnofum, durum, albicans.

Ess B. brevifimus, in fuprema \& uninbilico contraria albuminis extremitate locatus, cylindricus, niveus. Cotyl. breviffmix, obtufx. Rad. cralfa, fupera.

2.) Fruftrs axillares, feeundi. b.) Capfila integra. c.) Eadem diffeta. d.) Eadem dehifcens, e. E.) Semina Separata. F.) Seminis fello lougitudinalis, cum fitu embryonis in albumine. G.) Embryo feparatus. -

MELAMPYRU arvenje.

Capfulx priori funiles, fed gibbofiores \& dihifeendo apice bifidx. Scmina dinnidio majora, quam pracedentis, pallide lutefcentia, nitida, roflello craflo fungóo alba. Eınbryo vix dinnidio ábuinise brevior, umbilico contrarius. 


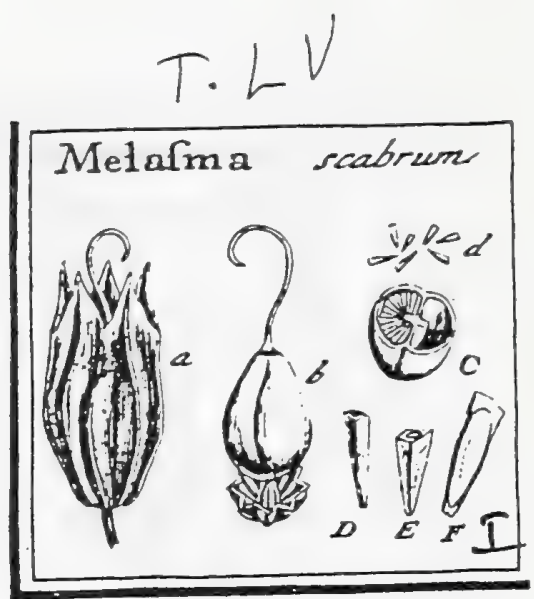

J. Gaertner (1788) Vol. I

CCCXXIV. MELASMA. BERG.

Calyx quinquedentatus, ventricofus, laxus plicato-decagonus. Cor. ringens, gibba: Stam. quatuor inxqualia. Stig. fimplex. Capfula pedicellata, bilocularis. Diffepimentum valvis contrarium. Seus, numerofifinna, fubpaleacea.

Merasma frabrum. Tab. 55. fig. 4.

Mela/ma. Berg. cap. 162.t.3.f. 4 .

Nigrine vifcofa. LIN N. mant. 512.

Gerardia fcabra, foliis lanceolatis inferme ferratis, caule tetragono. LIN $\sqrt{4}$ /. veg. 553 .

Ex herbario Bankfiano.

P E R. Capfula intra calycem maximum campanulatum nigrum latens, ovato pyramidata, apice comprefra, bifulca, chartacea, tenuis, bijocularis, bivalvis. Dillepiurentum fimplex, valvis contrarium.

REC. coriaccum, compreflum, anguftiffunum, difepimento utrinque longitudinaliter adnatum.

SE M. numerofiüina, paleacea, lineari cunciformia, comprefta, inique angulata, fpadicea.

IN T. fimplex, nembranaccum, venis reticulatum, nucleo paulo amplius.

$\Lambda$ в........

Esв.......

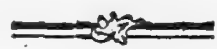

a.) Calyx maturus, b.) Copplula denudata, calycis prominentiz conicz infirtens. C.) Ejas fe(No transverfalis. d. D.) Semina foluta. E. F.) Integumenti fertio transverfalis \& longitudinalis, cum cavitate inani pro nucleo. 


\section{Scrophulariaceae}

J. Gaertner (1,0o; Vol. 3

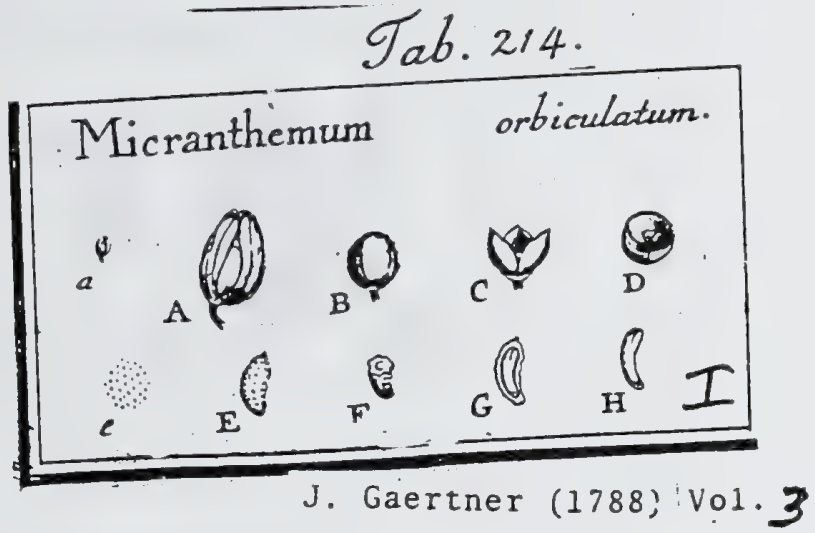

149. I I C R N T H M U M. 189

Mighadx fior. bor. amet. 1. po ro. Globifera.

GMEI. fyft, veg. I. p. 32 .

Cal. profundifime quadripartitus, inferus, perfiftens; laciniis oblongis, obtuGs, 1. fublparulatis, duabus fuperioribus anguttioribms. limbo quadripartito, calyce paulo longior, fubcampanulata; tubo, religuis zqualibus obtufis pasenfubbulabiato: Lacinia fuperiore minore

190

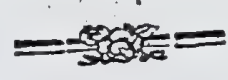

tiufculis. Ovar. fuperum; ftylo fimplici, declinato, longitudine ftaminum; ftigmate ca: Ovar. fuperum; ftylo fimplici, declinato, longitudinats, trivalvis. Rec. bre-
pitato, deprefo. Capf, minima, globofa, unilocularisula, Alb, carnofum,
ve, penicilliforme. Sem. minutifima, oblonga, angliata, Alb. Emb. oblongus, curvaulus,

Micranthemur orbiculatum. Tab, 214, fig, 9,

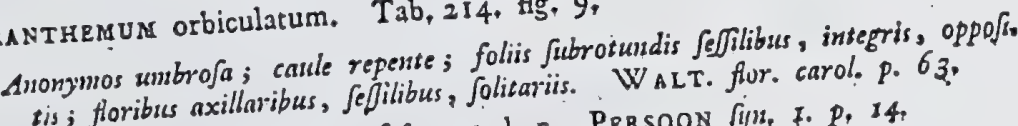

Globifera zumbrofa. GMEL. Jyft. veg. 1. c. Persoon finn. 7. p, 14.

Micrantbemum. MichauX 1, c. VAHL enum. plo 1. p. 54.

Icon. MichauX 1. c. t. 2.

Ex Carolina a $\mathrm{D}^{\mathrm{no}}$ Bosc, ex collectione Cl. Desrontaines.

PER. Capfula minima, globofa, l, ovato-globofa, intra calycem perfiftentem paulo obliquum recondita, memb.

valvis. Valvula naviculares, acurx.

REC. columnate, breve, liberum, penicillfor feminula umbilicis adharent.

filiformibus divergentibus hiva, 1 ovato-oblonga, - curvula, apice mur

SEM. numerofa, ininutifima, ovata, Lovata, fcrobiculis minimis .trạnsyerfis cronulata, bafi vero

IN T. fimplex, membranaceum, tenue,
A LB. femini conforme, carnofur, aqueo-pallidum,

EMB. longitudine fere albuminis, oblongus l. fubclavatus, rect, obtufx. Ráa, ter curvarus, ereaus, lacteus, centripeta.

longa, tereci-attenuata, centripeta

\section{EXPLICATIO FIGURE}

B.) Caplula interra, claufa. C.) Eadem dehilcens. D.) Ejurdem fedio receptaculo iu fundo. e. E.) Semina feparata. F.) Semen transverfe fectum

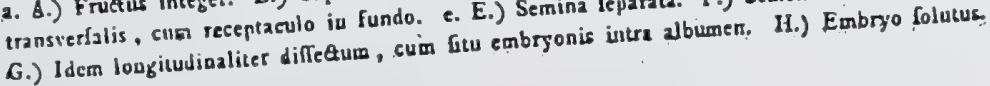




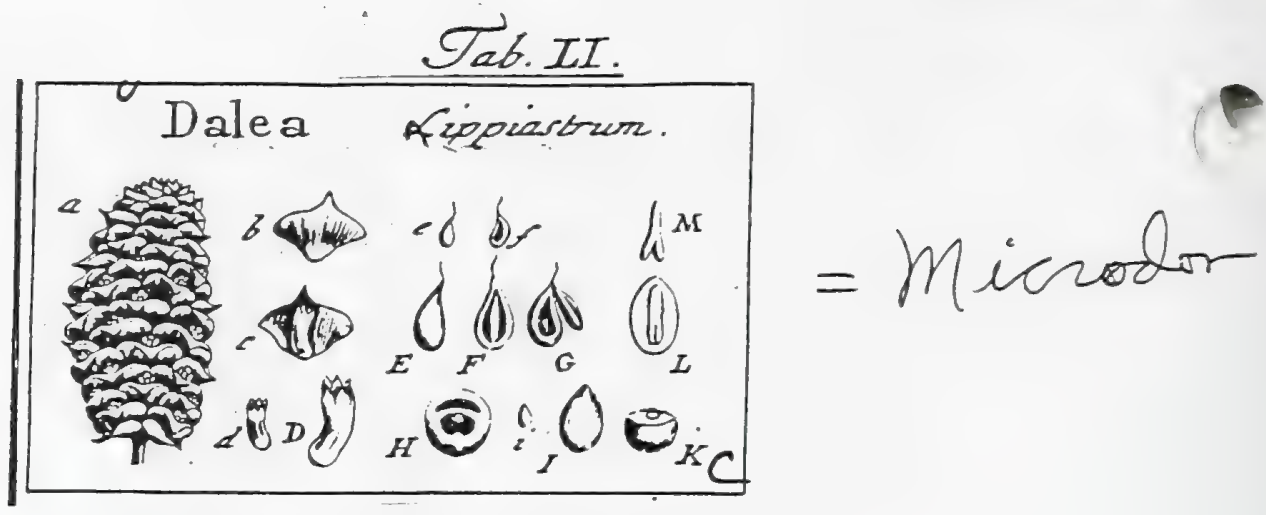

J. Gaertner (1788) Vol.1

CCLXXXIX. DALEA.

Flores in f́ica frobiliformi. Cal. tubulofus, comprefius, bilabiatus, quinquedentatus. Cor. ringeus. Stan, quatuor. Sty!. unicus. Ovula duo. Semen unicum, audum, inverfun!

DALE A Lippiaftrum. Tab. 51. fig. 2.

Lippia capitulis ovatis, foliis linearibus integerrimis. LIN $\operatorname{LN}$. Ex herbario Bankliano.

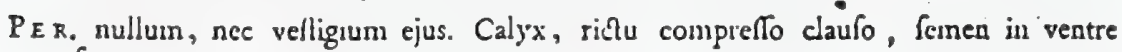
fovet.

REc. nullum, prater fundum calycis, cui femen affixum.

SE Ns. unicuin (abortante fcil. confanter ovulo altero) ovato acuminatum, fuperne in nylum breven elongatum, hinc convexum, gibbum; inde planiufculum, aut concavum, abortivi ovuli rudimento fub apice nipatum, cinereu-fufcum, I. rufefcens.

IN T. duplex: exterius cruftaceum durum, in dorfo paulo craffius, quam in ventre; interius membranaceum, tenuillinum, pallide luteum.

A L. B. plano.convexum, ovato acuminatuin. carnofun, album.

236 Ess в. longitudine albuminis, teretiusculus, inverfus, niveus. Cotyl. lineares, placuín
cula. Rad. longa, recka, fupera.

a.) Spica matura integra, b.) Squamx floralis

calyce. d. D.) Caljx memibranaceus, extrorfum curvatus f. F.) Fijusdem venter. G.) Ovulam abortivum curvatus, nigricans. e. E) Seminis dorimet

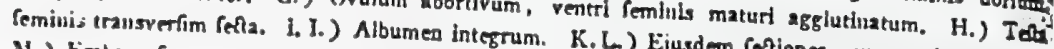
M.) rimbryo reparatus. Vel lolus embryonis fitus inverfus, hane, a Lippia, reddit difinetifimam. Abors
tus ovuli alterius, a fola curvatura calycis provenire videtur, nain in Cigmate,
nulla aden labes. 


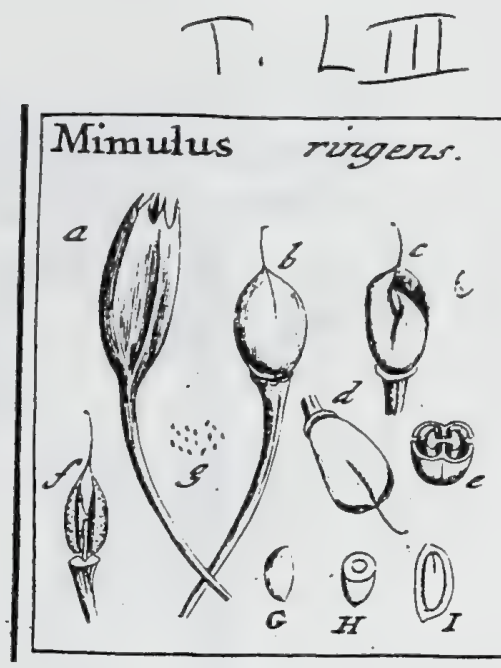

J. Gaertner (1788) Vol. 1

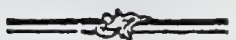

CCCII. MINTVLVS. Linn. ger. 783 .

Calyx prifinaticus, quadri-l. quinquedentatus. Cor. ringens. Stam. quatuor, inxqualia. Stigna bifidun. Capfula ovalis, bilocularis, apice dehifeens, Semina glabra utrinque puncto apiculata.

MIMU Lus ringens. Tab. 53. fig. 2.

Euphrafia floridana, lyfimachio glabra filiquofa foliis, quadrato crule, ramofior. PL U. phyt.t. 393.f. 3.

Mimulus ereftus foliis oblongis linearibus fefflibus. LIN N. h. upf. t. 2. Jy/. veg. 575 .

PER. Capfula calyce pentagono veftita, ovalis, bilocularis, apice transverfim dehifcens. Diffepimentum membranaceum, valvis contrarium

REc. oblonguin, fpongiofum, excavato punctatum, ope membranx intergerinz diftepimento utrinque aduatum.

SEM. numerofifima, exigua, ovato oblonga, glabra, pallide ftraminea, utrinque puncto prominulo rufefcente apiculata.

IN T. fimplex, membranaceum, tenue.

A L B. femini conforme, tenue, carnofun, aqueo-pallidum.

EM B. cylindricus, longitudine fere feminis, lacteus. Cotyl. femiteretes, breves. Rad. crafia, centripeta

2.) Capfula ealyce angulato veflita b.) Eadem denudata. c. d.) Eadem dehifcens \& fapé per maturitatem in fupremo latere rimam agens. e.) Ejusdem fetio trausverfalis. f.) Receptacalum feor(um fpefatum. g.G.) Semina feparata. H.I.) Albuminis fetiones cum fitu \& figura embryonis. 


\section{Scrophulariaceae}

J. Gaertner (1788) V01.3

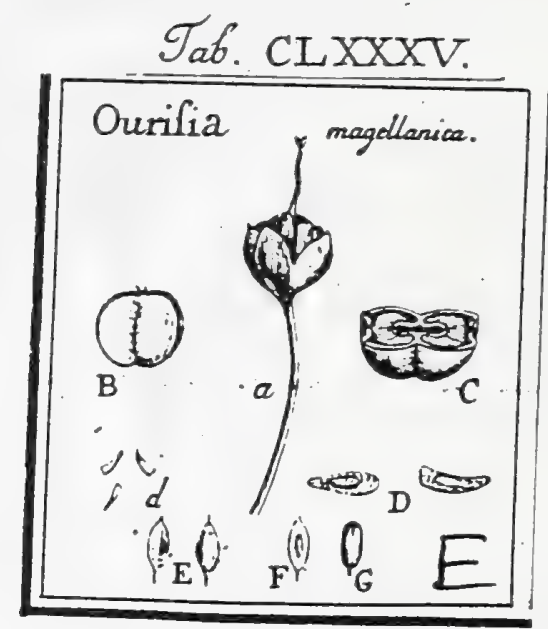

J. Gaertner (1788) Vol.3

\section{4r. OUR I S I A. Coßrmers. Juss. gen, p. 100.}

Cal. bilabiatus; labio altero bilobo, altero trilobo: laciniis ovatis acutiufculis, margine brevifime ciliatis. Cor. monopetala, campanulata; fauce ampliata; limbo quinquelobo, fubxquali. Stam. quatuor, didynama. Ovar. didymum; ftylo fimplici, filiforni ; ftigmate bifido (capitato. Juss.). Capfula marginata, bilocularis, hivalvis. Recept. fungofa, diffepimento adnata, \& cum valvis farallele dehifcentia. Sem, nemerofa, fcobiformia, Embr. reetus; radicula centripeta.

Ourisia magellanica. Tab. 185. fig. 5 .

E collectione Cel. Despojitaines.

PER. Capfula globofa, transverfe latior, compreffufcula; medio utrinque fulcata, margine imerfo zonata, apice dehifcens, bilocularis, bivalvis. Diffepimentum valvis contrarium, fulco valvularum \& fimul receptaculis ab utroque latere infertum, anguftiffimum, membranaceum. Valva transverfim rugofx, papyracex, marginibus inflexis, futuris prominulis.

Rec. duo in quovis loculo fungulum, oppofita, ovata, inter fe \& cum diffepimento utrinque intime conferruminata, cum valvis parallele dehifcentia, ex lamina fungofa in ferri equini formam flexa \& in medio cavum feu loculamentum fpurium, utrique receptaculo commune relinquente, conflata.

SeM. numerola, parva, intra involucrtm (arillum) fufformi-faccatum, mcmbranaceum, tenue, vafculofo-reticulatum, ferrugineum, medio hxrentia, ovata, hinc convexa inde plana, urrinque acuminata, ad bafun funi. culo umbilicali inftructa, ad apicem Clalaza pallide rufefcenti nocata, centripeta.

INT. feminis proprium fimplieiffmum, membranaceo-arachnoideum, tenuili: num, albunini arctilime adnztum.

ALB. femini conforme, carnofum, albun.

EM в. minutifinus, rectus, teres, niveus. Coty\% •brevifimx, incumbentes, obtura. Rad. longa, teres, conico-acuminata, apicula breviffina terminata, centripera.

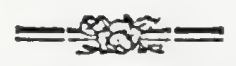

\section{EXPLICATIO FIGURF}

a.) Capfula calyce inclufa \& Bylo fuperftite ftipata. B.) Eadem Soluta, magnitudiné paululum auda. C.) Ealcm audior, transverfe fecta, cun diftepimenti, receptaculi atque femiaum Gtu. d. D.) Semina feparata. E.) Eadem ab involucro folutz a ventre \& a dorío fpectata. F.) Albumen longitudinaliter diffeetum, cum embrjode in fita. G.) Embrgo feparatus \& infigniter audus. 


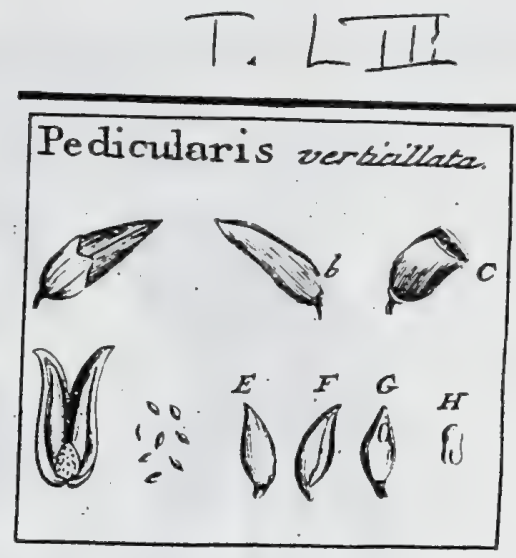

\section{J. Gaertner (1788) Vol.1}

CCCV. PEDICVLARIS. TOURN. t. 77. LINN. gen. 746

Calyx quinquefidus. Cor. ringens. Stan. quatuor inaqualia. Stigma fimplex. Capluth bilocularis. Semina pauca. Embryo umbilico contrarius.

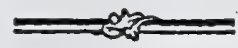

PEDICULARIS verticillata. Tab. 53. fig. 5 .

Pedicularis foliis pinnatis quaternis, floribus purpureis fpicatis. HAzl. hifl. I. n. 3 is. t. 8. f. 2.

Pedicularis caule fimplici, foliis quaternis. LIN N. Syf. veg. 55 I.

Icon J A c Q. fl. auffr. 3. t. 206.

PER. Capfula oblonga, attenuato roftrata, compreffuscula, membranacea, tenuis, bilocularis, margine fuperiore paulo convexiore longitudinaliter dehilcens. Diflepinentum anguftifimum, valvis contrarium.

REc. parvum, fubglobofum, diffepinento prope bafin affixum.

SEM. Pauca, circiter decem in fingulo loculamento, ovata, angulata, utrinque acuminata, altero datere bilo membranaceo angufo albicante fipata, puncticulato friata, fufca. Unbilicus roftcllatus incurvus, ex integumento formatus, non caliofui.

IN T. fimplex, tenue, membranaceum.

A L в. Sernini conforıne, camofum, aqueo-glaucum.

EM B. dimidio alburnine paulo brevior \& in ejus extremitate fuperiori locatus, rectus, lutefcens. Cotyt. feunicylindriez. Rad. crafta, obtufiuscula, fupera.

a. b.) Capfula integra \& deliicens. C.) Eaden differa. D.) Sitrs receptacalf. C E, Semina feparata. F.) Seminis latus bilo membranaceo notature. G.) Erobryo jntra albumen. H.) Idem Sepacatus.

Quid fint Pedicularis Semina tunicata, Linnzo dicta? me fugit. 


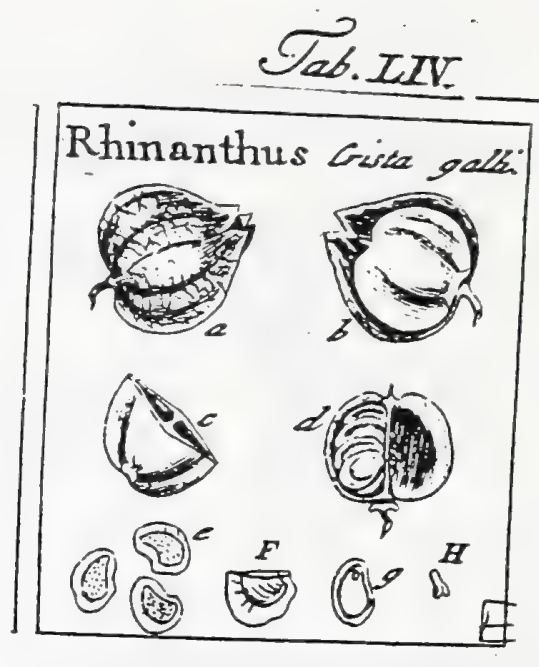

J. Gaertner (1788) Vol.1

CCCXVII. RHINANTHVS. L IN N. gen. 740.

Calyx quadridentatus. Cor. ringens. Stam. quatuor inrqualia. Stigm. fimplex. Caplula comprefla bilocularis. Scinina pauca. Embrjo ab umbilico remotus. Rhinaxthus Crifla galli. Tab. 54. fig. 5.

Crifla galli. R I v. t. 92. f. 2.

Alettorolophus calycilus glabris. H a L L. hif?. 1. "1. 3'3.

Rhinanthus corollis labio Jupericre comprefiu breviurc. LIN N. Juf. vig. 549.

256

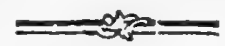

PER. Capfula rotundata, transverfe !atior, fuperne emarginata, ad latera membranacé comprefta, in medio lenticularis, bilocularis, biralvis. Difepimentum anguflifi: mum, valvis contrarium.

REC. tubercula carnofa pyramidalis, e medio diffepimenti utrinque prominentia.

SEM. pauca, octo ad duodecim in fingulo lnculamento, comprefta, reniformia, in medio fpadiceo cinerea fcabriufcula, ad oras margine membranaceo albicante cincta.

IN T. duplex, utrumque tenue, membranaceum.

A L в. ovatum, furfum, $\int$. in extremitate ab umbilico remotiore, acuminatum, com: preftum, carnolum, albicans.

Es в. terctiusculus, minutus, inverfus, lacteus, in remotitima ab umbilico albuminıs parte locatus. Cotyl. minutulx, compreflx, fubfoliacte... Rad. cylindrica, craffiuscula, fupera.

a. b.) Capfula ealyce bifolio quadridentato têa, eademque denadata. c.) Ejus Sefio transverials. d.) Loculanenta aperta. e.) Semina feparata. F.) Semen iransverfe, \& 8.) Idem longitudinalite difretum, cum fitu embryonis. H.) Enibryo ięraratus, 


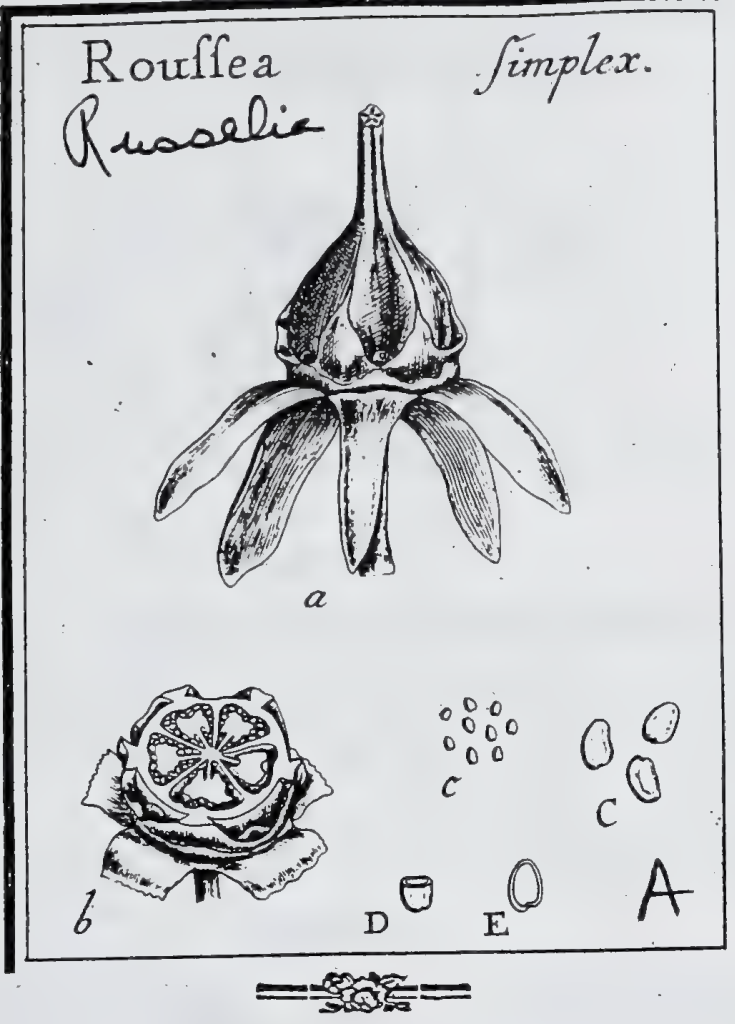

J. Gaertner (1788) Vol3

\section{R O U S S E A.}

Sarтн ic. ined. $t$. 6 . LaMARck ill. gen. $t$. 75 .

Calyx (quadri - Smitr l.) quinquefidus, coriaceus, perfiftens; laciniis lanceolatis, patentibus. Cor. fubcampanulata; tubo brevi, fubglobofo, intiato, furfum vero paululum coarctato; limbo $(4,-$. $)$ quinque - partito: laciniis acu. tis, reflexis. Stam (f.l.) S., filamenta corollam multo luperantia, erecta, conniventia, comprelfa, verfus apicem angultata; (ovario inferta?) anthe. $r x$ rectie, fagitcata. Ovar. fuperum, attenuatum in ftylum fimplicem longitudine ftaminum (tetra - 1.) pentagonum perfiftentem; thigmate fimplici, truncato, concavo, ftellato. Baccil ovato - pyramidata, in ftylum perfiftentem attenusta, (tetra - 1.) pentagona, (quat(qri - 1.) quinquelocularis. Rec. carnofa. Sem. numerofa. Alb. carnofum. Emb....

Roussea finplex. Tab. 212. fig. 1. .

Rouffea. WILld. fpec. pl. T. 1. P. I. p. 607. PERSOON fyr. I. p.130. Icon. SмITH. 1. c.

P B n. Bacca lupera, grandiufcula, bafi cum calyce perfittente arcte conferruminata, ovato - pyramidata, in ftyluin craffufculum, uti bacca ipfa, (tetra - l.) pentagonum attenuata, carnofa, intus pulpo[a; latera leviter concava, ad bafin bacce immerfa \& macula triangulari (a filamentorum lapfu?) infignica; anguli vero acuti, cum laciniis calycinis a1terni, deurfum in carunculas crafas triangulares bafi colicrentes dilatati; cæterum glabra, (quadri - 1.) quinquelocularis. Caro craffufcula, firma. Diffepiinenta carnofo - membranacea, hinc in axem fructus confluentia, inde lateribus baccx inferta. Pulpa mollis, femina obvolvens.

REc. ovato - oblonga, angulata, dorlo craffifima \& medio longitudinaliter carinata, inde anguftiora \& fulco profundo Jatoque exarata, cui lamina intermedia longitudinalis inferta, cujus ope receptacula angulo loculamentorum interno affixa funt, fungofa, punctato- fcrobiculata.

SE M. numerofa, parva, cordato - ovata, umbilico minimo in!tructa, lenticulari-compreffiufcula, margine paulum incraflata, centripeta, ftraminea, 1. pallide ferri:ginea.

IN T. duplex: exterius coriaceum, craftiufculum; interius membranaceum, tenue.

A L B. femini conforme, carnofurm, album.

EM B. . . 


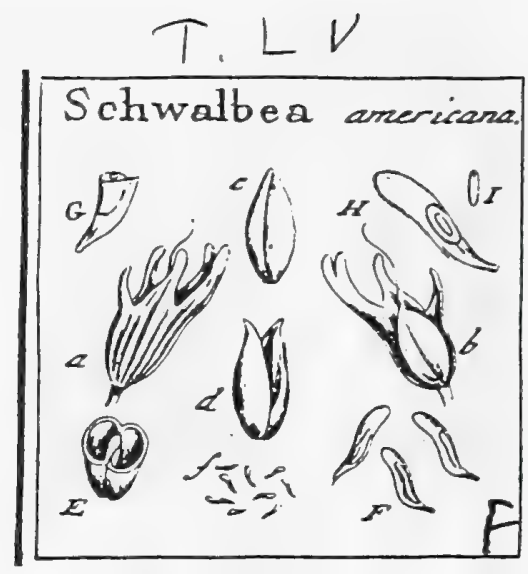

J. Gaertner (1788) Vor 1

CCCXXIII. SCHWALBEA. LIN gen. 744. 2 259

Calyx quadrifidus, lobo fuperiore brevilimn; duobus lateralibus aqualibus; infimo longilfimo, apice bifido. Cor. ringens. Stam. quatuor, inxqualia. Stig. fimplex. Capfula bilocularis. Dițepimentuin duplicatum. Semiza paleacea.

SCH A 1. nE A americana. Tab. 55. fig. 3.

Schualber. LIN N. Syfh. veg. 55I.

Ex herbario Baukfiano.

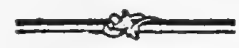

PER. Capfola elliptico acuminata, glabra, fulco obfoleto utrinque inferipta, bilocula: ris, bivalvis: valvulis maturis apice interdum bifidis. Diflepimentum duplicatunn ex inflexis valvularum marginibus formatum.

REc. oblonguin, anguftum, comprefiusculum, difiepimento non adnatum, per ma. turitatem caducum.

SEs. numerofiftuma, parva, paleacea, verfus umbilicum acuminata, extrorfum iftefcentia, fine rotundato. Nucleus turgidulus in medio feminis, ad alterum ejus. latus.

IN T. duplex: exterius membranaceum, utrinque ultra nucleum longe protenfum; in: terius arachnoideum, albumini adnatum.

A L. B. ovato oblongum, compreftrusculum, carnolum, aqueo pallidum.

Eм в. cylindricus, rectus, lutefcens. Cotyl. brevifimx, tenues. Rad. longa, centripeta.

a.) Calyx bafi ventricofus, friatus, capfulam veniens. b.c.) Capfula denudata. d) Eadem de hifcens. E.) Ejus fetio transverfaiis. f. F.) Semim folate G. H.) Seminis feltiones, cam em: bryone intra albumen. I.) Embryo feparatas. 

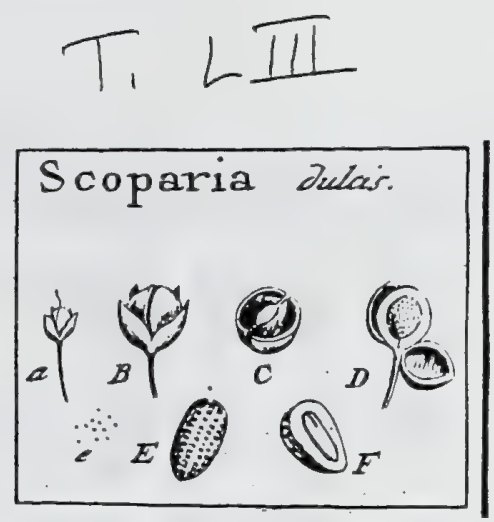

J. Gaertner (1788) Vol. I

CCCX.SCOPARIA. LINN. gen. 143 .

Calyx quadripartitus. Cor. rotata, quadrifida. Stam. quatuor fubxqualia. Stigma fimplex. Capiula bilocuiaris. DifTepimentum membranaceum, fimplex; valvis parallelum.

SCOPAR1A dulcis. Tab. 53. fig. 10.

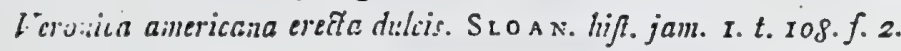

Scopuria foliis ternis, floribus pedtuneulatis. LIN N. Syf. veg. 157 .

PER. Capfula parva, fphxrica, utrinque fulco infcripta, tenuis, bilocularis, bivalvis. Dilfepinentum membranaceu:n, tenuillimum, diaphanum, valvulis parallelum, earundemque futurx affixum.

REC. orbiculatum, deprefiufculum, Spongiofum, difépimento utrinque adnatum.

$S E$ s. numerofa, minutula, ovato globofa, obfolete angulata, fcrobiculis minutiffinis feriatim pofitis cxarata, fubferruginea.

IN T. fimplex, fpongiofuin, tenue.

A I B. femini conforme, carnofum, pallidum.

Емв. teretiufculus, lacteus. Cotyl. breres. Rad. longa, craffa, centripeta.

2. B.) Capfula integra \& dehifcens. C.) Hadem difesta. D.) Receptac. diffepimento adaatum.

e. E.) Senaina (eparata, F.) Einbryo inura albumen. 


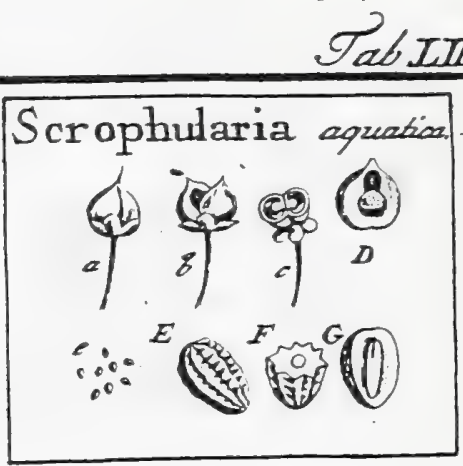

J. Gaertner (1788) Vol. 1

CCCVIII. SCROPHULARIA. TourN. 't. 74. L I Nis. gen. 756 .

Calyx quinquefidus. Cor. fubolobofa: labio fuperiore intus fquamula accefloria auchn. Stain. quatuor inxqualia. Stigma finplex. Capfula bilocularis: difiepimento du. plicato, per maturitatem foramine pervio.

250

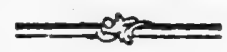

Scrophularia equatica. Tab. \{3. fig. 8.

Scrophularia aquatica. P.LA KW. herb. t. 86. OEDER. for. dari. t. 507 .

Scrophularin caule quatrangulo alato paniculato, foliis ovato lanceolatis. Hînz hil. I. p. 325 .

Scrophularia foliis cordatis obtufis petiolatis decurrentibus, caule membranis ins gulato, racenis terminalibus. Lixis. Sijf. veg. 560 .

PER. Capfula fubglobofa, acuminata, bifulca, glabra, bilocularis, bivalvis. Dillephe mentum duplicatum, ex inflexis valvularum marginibus formatum, per maturita. tem foraminie ovali pertulum, cetera integerrimum, bipartibile.

REC. orato oblongum, fpongiofum, diliepimento utrinque adnatrın, per maturita: tem contractum in tuberculum craffum, bafi foraminis ovalis aflixum.

SEss. plurima, ovato globofa, per xtatem fulcata \& transverfun rigofula, ut cancellata anparcant, nigro fulica.

IN r. fimplex, inembranaceum, tenue.

A I B. femini conforme, carnolum, aqueo- pallidurn.

Eм в. teretiusculus, rectus, lacteus. Cotyl. breves. Rad. longa, crafta, centripera.

a. b.) Carfula integra \& delisicens. e.) Fjus feqio transverfalis. D.) Difrepimentum maturum: cum foramine \& receptaculo contrato. e. E.) Sernima feparata. F. G.) Aiburninis feftiones, cam Gitu \& Ggura crabryouis 


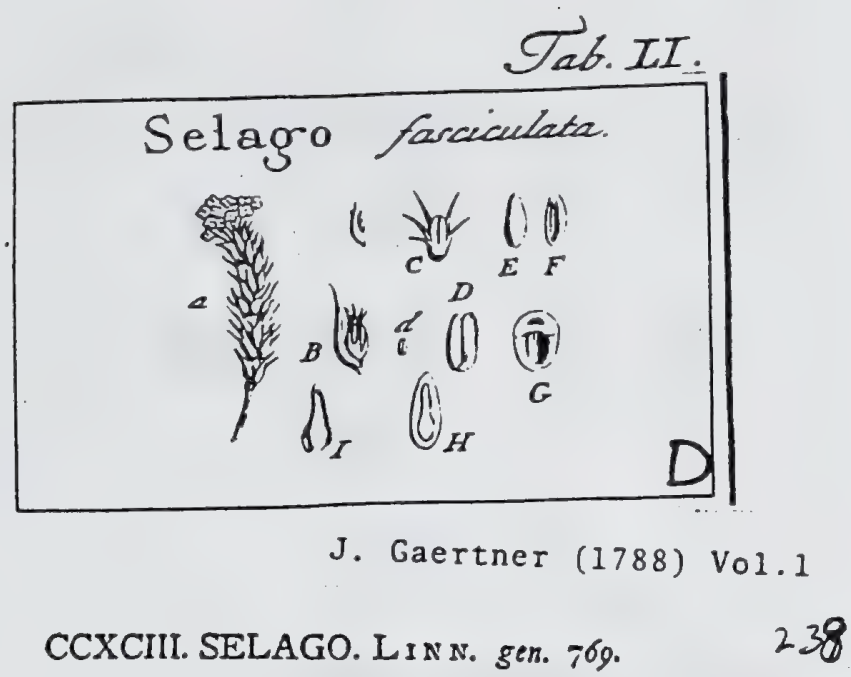

Calyx quinquefidus. Cor. tubus filiformis; linıbus fubrequalis. Stam. quatuor. Sty. unicus. Semina duo, nuda, inverfa.

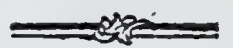

SEL A co fafciculata. Tah. 5t. fig. 6.

Selngo corymbo multiplici, foliis obovatis ferratis glabris. L I N . Jyft. veg. 568. Ex lierbario Bankfiano.

$P E R$. nullum; fernina calyce veflita.

REC. nullum, preter fundum calycis, cui fenina affixa.

SE M. duo, parva, oblonga, hinc convexa, inde fulco excavata, fufca.

IN T. fimplex, meinbranaceum, arcte adnatum.

$\Lambda\llcorner$ B. femini conforme, duriusculum, carnofum, album.

Eмв. Jongitudine fere albuminis, inverfus, niveus, Cotyl. fubfoliacex, ellipticx, bre. yes. Rad. longa, recta, fupera.

a.) Pars corymbi. b. B.) Brattea floralis, bafi gibba cum calyce. c.) Calyx maturus feparatus, dentibus fetaceis pungentibus. d.D.) Semina coadunats. Em) Seminis dorfum. F.) Ejusdem venter. G. H.) Albumluis feltiones cum fitu embryonis. 1.) Enbryo feparatus. 


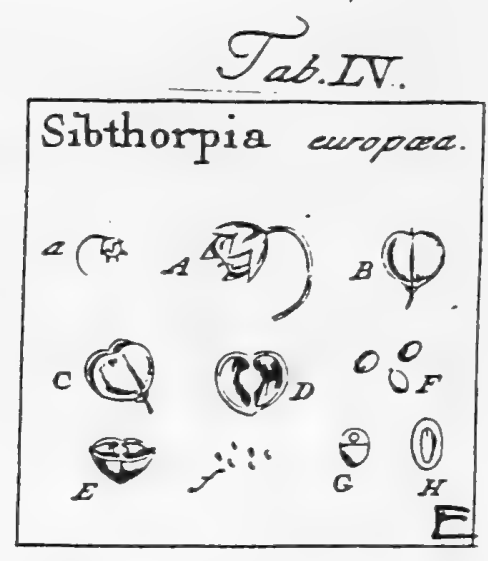

\section{J. Gaertner (1788) Vor}

CCCXXVI. SIBTHORPIA. LIN gen. gen.

Calyx quinquepartitus. Cor. quinquepartita rotata. Stam. quatuor, inxqualiz. Stig. fimplex. Capfula comprefla bilocularis. Dillep. contrarium. Sem. pauca.

SIв T H ORPIA europara. Tab. 55. fig. 6.

Alfine fyuria pufilla repens, foliis faxifrage aurea. P IU . phyt. $t$. $7 . f .6$.

Sibthorpia foliis reniformi fubpeltatis crenatis. Lin N. fyjl. veg. 572.

PER. Capfula parva, cordato-rotundata, utrinque fulco infcripta, Ienticulari comprefla, bilocularis, bivalvis. Diffepimentum fimplex, anguftifimum, valvis con. trarium.

REc. fubglobofum, Spongiofum, tuberculatum, medio difepimenti utrinque adnatum.

SE.M. pauca, circiter fex in fingulo loculamento, parva, ovata, plano convexa, aut fubangulata, fulca.

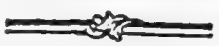

IN T. fimplex, membranaceum, tenue.

$\Lambda$ L. femini conforne, carnolum, album.

E s 8. teretiusculus, lacteus. Cotyl. brevilinnz. Rad. craffa, centripeta.

a. A. B.) Capfula cam, \& absque calyce. C.) Eadem dehifcens, D.) Valvula altera cum ra \& figur embryonis. 

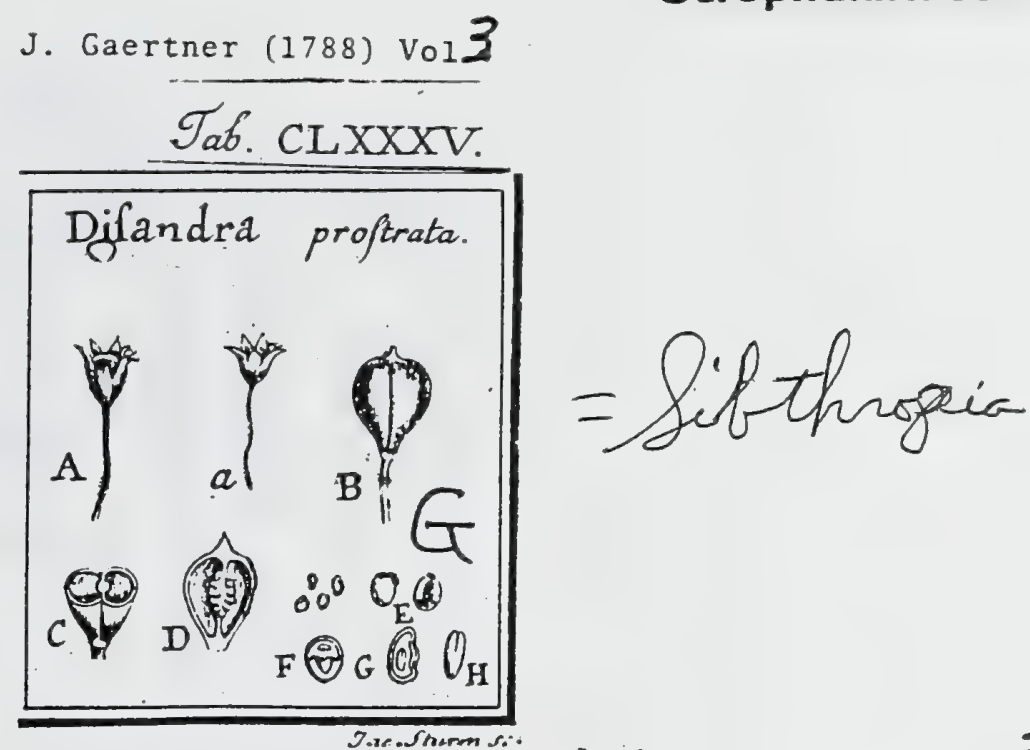

\section{J. Gaertner (1788) Vol3}

43. D I S A D R A. - 46

Lidn. Juppl. p. 32. gen. pl. cd. Sclireb. 62\%. Jrss. gen. p. 99. LASI A BCX ill. gen, t. 275 .

Cal. monophyllus, s 1.8 partitus perfiftens. Cor. xqualis, monopetala, ra tata: tubo brevifimo: limbo 5 l. 8 lobato. Stam. 51 . 8 ; filamentis xqualibus; antheris fagittatis. Ovar. Itylo fimplici, filiformi; ftigmate fimplici. Capfo pyriformis, mucronata, bilocularis, bivalvis. Diffep. valvis contrarium. Recept. ovatum ${ }_{n}$ diffepimento urrinque adnatum. Sem. plura, menifcats. Embr. centripetus.

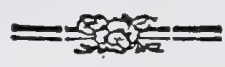

Disandra proftrata. Tab. 185. fig. 7 .

Plasta. PLUk. plyyt. 257.

Sibtorpia (peregrina, ) foliis reniformibus crenatis, pedinculis geminis. LINN. Spec. pl. $=$ p. 880 .

Difandra (profirata.) Lisw. Jyz. veg. ed. 14. p. 352. Spec. plant. ed. Willd. T. =. P. s. p. 282.

Ex herbario Cel. Desfontaines.

PER. Capfula parva, pyriformis; mucronata, utrinque fulco longitudinali iiz fcripta, vertice fetis albis adfperfa, apice dehifcens, bilocularis, bivalvis. Diffepimentum fimplex, membranaceum, anguftum, valvis contrarium.

REc. ovatum, fpongiofum, tuberculato - rugofun, medio difepimento utristque adnatum.

SE s. pauca, octo ad duodecin in fingulo loculamento, parva, ovata vel oblonga, hinc convexa, inde marginibus in ventrem reflexis concava, vel menifcata, glabra, fufca. Umbilicus in medio feminis ventre intra rimam.

IN T. fimplex, membranaceum, tenue, in fuperficie ad mucilaginem cryftallinam pellucidiffmam fub aqua fefe emolliens.

$\Lambda$ L. femini conforme, carnofum, album.

E s в. teretiufculus, Jacteus, extra albuminis centrum pofitus, bafis propior quam apici. Coryl. dimidium embryonem fere xquantes, obtufx. Rad. crafla, obtufufcula, centripeta.

\section{EXPLICATIO FIGURE.}

a. A.) Capfula integra intra calscem 6 partitum hxrens. B.) Eailem a ealyce denudata. C.) Eadem medio transverfe diffeets, cum diffepimenti \& receptaculi fitu. D.) Valrula altera cum receptaculo: e. E.) Semina foluta. F.) Albumen transverfe \& G.) Idem Jongitudinaliter fe Qum, cum embryone in Gitu. H.) Embryo feparatus.

Difcrimen genericum Difandra a Sibthorpia non adnodum grave, in fructu tamen \& feninum figura atque embryonis fitu.magis à fe invicem recedunt, quam in tore. 


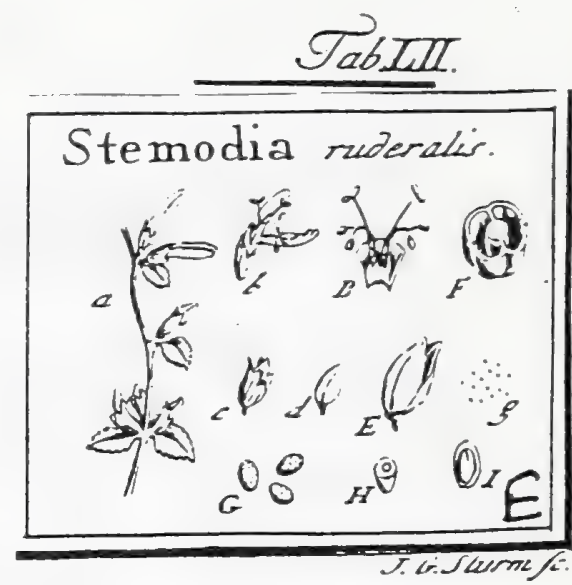

J. Gaertner (1788) Vol.1

CCC. STEMODIA. LI N N. gen. 777 .

Cal. quinquepartitus. Cor. bilobiata. Stam. filamenta bifida, dianthera. Caplula bilocularis: fepto valvis contrario. Semina minutula.

STEMODIA ruderalis. BANXs. in litt. Tab. 52. fig. 5 .

PER. Capfula parva, elliptica, mucronata, utrinque hinea depreffa inferipta, bilocularis, bivalvis. Difepimentum angufum, valvis contrarium,

- REc. fubcylindricum, fungofum, puncticulatun, cum diffepimento non connatun.

S.M. numerofirfuna, misutifima, fubovata, puncticulata, fufca.

IN T. fimplex, membranaceum, tenue.

А вв. fcmüi conforme, carnolum, pallidum.

Eмв. tcretiusculus, rectus, niveus. Cotyl. breves, plano convexx. Rat. craffa, centripeta.

a.) Flores diftiti, fubfefiles. b. B.) Staminum flamenta fuperiora fimplicia, inferiors bifida, c.) Capfula calyce vefúta. d.) Esadem denadata. E., Eadem de!iicens. F.) Ejus \& receptaculi feetio transveríalis. g.G.) Semina feparata. H.I.) Albuminis feliones, cum fita \& figara embrgonis. 


\section{Tab. cLXXXIV.}

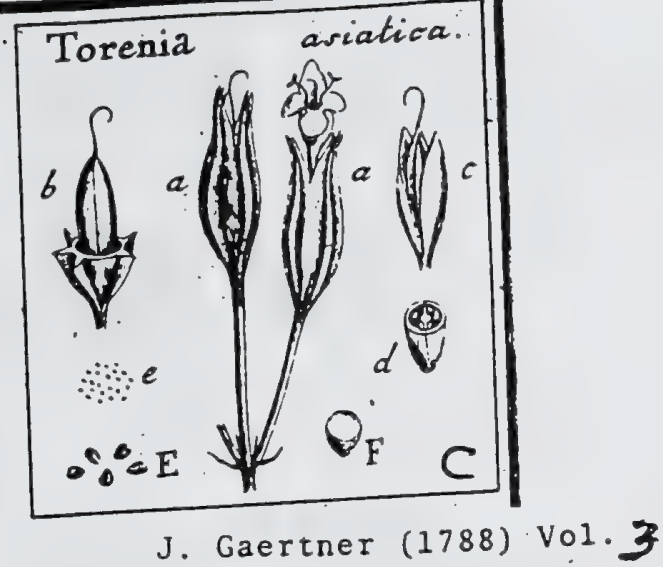

29

\section{TOREN I A.}

LINN. gen. 754. ed. Sclireb. 1011. Ju'š. gen. p. 122

Cal. monophyllus, ovato - oblongus, angulatus, fupra bifidus: anguli lateris alterius terui, membranacel, in totidem culpides labii luperioris excurrentes; aiterius lateris anguli gemiui, pariter nembranaceo alati, fimplici i. rarius duplici cufpide ternviatiti. Cor. monopetala. tubulofa, fauce ampliata, limbo quadrilobo, inxquali. Stam. quatuor didynama; duobus brevioribus anthera fimplici furtili; duobus auten longioribus antheris geminis divaricatis, effoxtis. Ovar. fuperum. Styl. fimplex, ftigınate bifido. Capr. elliptico-oblonga, bilucularis, bivalvis. Sem. nunerofilima, ninutifima.

'Torexia afiatica. Tab. 184. fig. 3 .

Kaka - pu. Rнгед. mal. g. p. 103. t. 53.

Euplorafiae afoninis pusilia planta. PLUK. plyye. t. 373. f. 2.

Toresia. Liss. Bj: veg. ed. 24. p. 559.

Torenia glabra, caule rejente. WILLD. Jpec. pl. T. 3. P. 1. p. 265 .

Icon. LAMARCK ill. gen. t. 523. f. 1 .

\section{A Cl. Thunierg.}

PER. Capfula elliptico-oblonga, membranacea, tenuifina, fubtransparens, bilccularis, bivalvis, calyce perfftente tecta. Difepimentum valvis parallelum, membranaceum.

REC. lineari - oblongum, convexum, diffepimento utrinque adnatum.

SE is. numerofiftima, minutifima, fubovata, tuberculato inæquabilia, pallide fulphurea, fubdiaphana.

IN T. fimplicifimum.

A L B. sarnofum, aqueo - pallidum.

Ens. ....

\section{EXPLICATIO FIGURE.}

a. 2) Calyx eum \& absque corolla a. Eadem dehilcens, cum difiepimento \& receptaculo eidem adnato. d.) Ejusdem Sestio transverfalis, e. E.) Semina folutz F.) Albumiais feetio transverlalis.

Corollx figura in icone noftra non fatis certa eft, utpote ad fpecimen valde mutilatum facta \& ex conjectura integrata: Embryonem ob fummam partium feminisque ipfus minutiem difinguere non valui. Capfula \& calys per aliquod tempus in aqua detenta eam luteo colore inficiunt. 


\section{J. Gaertner (1788) Vol 3 \\ Tab. CXCVIII.}

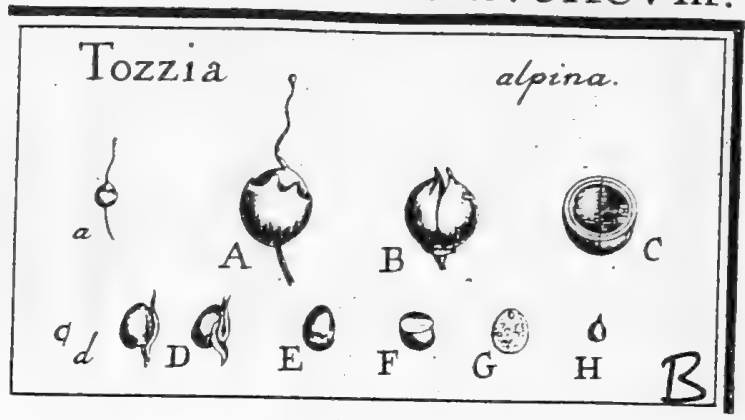

85. TO Z Z I A. J. Gaertner (1788) Vol3

Miсн. gen. t. 16. Liñ. gen. 745. ed. Schreb. roo2.

Juss. gen. p. 97. LAMABCK ill. gen. t. 522 .

Cal. monophyllus inferus, parvus, tubulofus, 4. 1. 5. dentatus, perfiftens. Cor. monopetila, tubulofi, tubo calyce longiore, ad faucem parum infato; limbo planiufculo, bilabiato: labio fuperiore bificto, inferiore trifido laciniis rotundatis. Stam. 4., didynama; antheris didymis, bafi ariftatis. Ovar. fuperum; Atylo filiformi longitudine tubi, \& ex parte ventrali ovarii affurgente; Itigmare capicato. Nucula a calyce involucrita, corticata, bivalvis. Sem. unicum, unbilico appendiculato inftructum. Alb. carnofum. Emb. puncticularis, inverlus, rad. fupera.

Tozzu alpina Tab. 198. fig. 2.

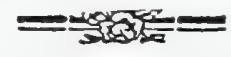

Anonyma F. Gregorii densata radice. Colum. ecplor. 2. p. 49. t. 50.

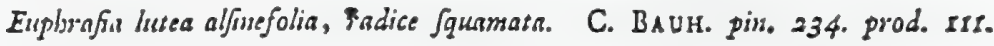

Enploragia con radice fquamata. ZANON. nov. p. 224. t. 272.

Tozzia. LIN Spec. 844. ed. Willd. T. 3. P. x. p. 202. Syft. veg. ed. 14 f. 55 T. Crasz aufro. p. 305.

Jcors. JACQ. aufir. t. 265 .

PER. Nucula minima corticata, fupera, intra calycem perfiftentem per maturitaten fubobliguum ad verticem usque arcte obvolucrata, globora, ftylo perfiftente ad infertionem paululum ad dorfum recurvo faftigiata, unilocularis, bivalvis. Cortex tenuis, coriaceus, viridis. Putamen tenue, chartaseum, ab apice lateraliter cum cortice dehifcens, intus glabrum \& fulco elevato valvulis contrario infignitum.

REC. nullun; femen ope umbilici appendiculati ad partem ventralem putaminis paulo fupra ejus bafin fulco affixum.

SEM. unicum, nuce paulo angultius, ovatum, I. ellipticum, umbilico appendiculato fungofo-membranaceo ad imum ventrem inftructum, caftaneum.

INT. finpley, menbranaceum, tenuifimum, albumini arcte adharens.

$A\llcorner B$. Femini conforme, craffum, ad peripheriam granulofa-carnofum, fufeum, in axi vero paulo dilutius medullare.

$E_{M}$ в. inverfus, minutifimus, vel folummodo punctum medullare, ellipticum, in vertice albuminis hxicns, dilute caltaneum. Cotyl. . . Rad. acumintata, ab umbilico averईa, fuperis.

\section{EXPLICATIO FIGURE.}

a. A.) Xucula integta, intra calycem inclura, non dechifcens. B.) Eadem calyce \& ftyilo orbata, dehifiens. C.) Ejusdem fectio transicrfalie, d. D.) Scunen folutum, latere \& a ventre fpeetaum, cum umbilico appendiculato. E.) Iitem ab umbilicu folutum. F.) Albumen transverie

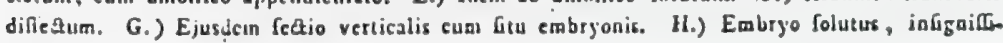
מie auţus.

Calycem in exemplis ex Suevix fuperioris fubalpinis femper inveni quadridentatum, in exemplis vero helveticis eundem obfervavi quinquedentatum.

Cotyledones in embryone difcernere non valui, vel ob maximam partiurm minutiem, vel ob imperfeclan feminum naturitatem. 


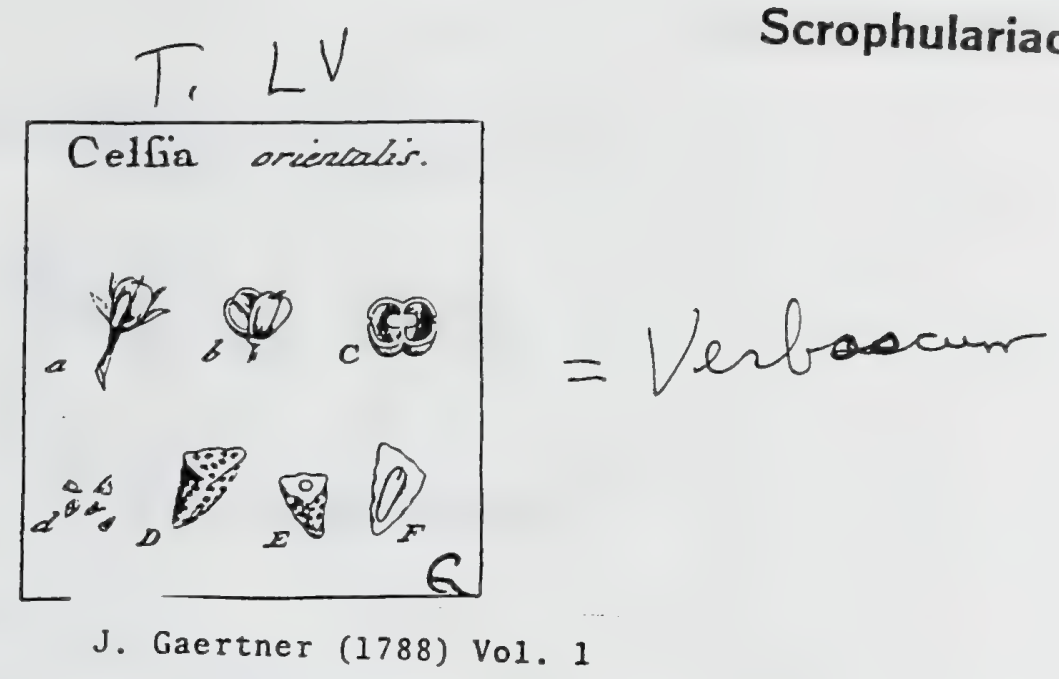

CCCXXVII. CELSIA. LIN gen. $75 \% .262$

Calyx quinquepartitus. Cor. quinquepartita rotata. Stain. quatuor: filamentis bar. batis. Stig. fimplex. Capl. bilocularis. Diffepinentuin fumplex valvis coutra. rium. Semina angulata.

Cezsia orientalis. Tab. 55. fig. 7.

Blattaria orientalis agrimonia folio. Bux B. cent. I. t. 20.

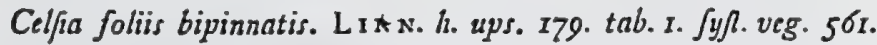

PER. Capfula obovata, apice comprefta, utrinque fulco inferipra, glabra, bilocularis, bivalvis. Dillepimentun fimplex, valvis contrarium.

REc. femicylindricum, fungofum, diflepimento utrinque adnatum.

SEM. numerofa, parva, triquetra, aut varıe angulata, verfus umbilicuın acuminata, profunde fcrobicutata, cinereo fufca.

IN T. duplex : exterius coriaceun; interius membranaceum, utrumque tenue.

$\Lambda\llcorner$ в. femini conforme, carnofum, aqueo-pallidum.

Eмв. teretiusculus; lacteus. Cotyl. femicylindricx breves. Rad. crafta, centripeta.

2.) Capfoh integra. b.) Eadem dehifcens.

rata. E. F.) Embryonis figura \& fitus intre albumea.

C.) Ejus fettio transwerfalis. d. D.) Semina (epa- 


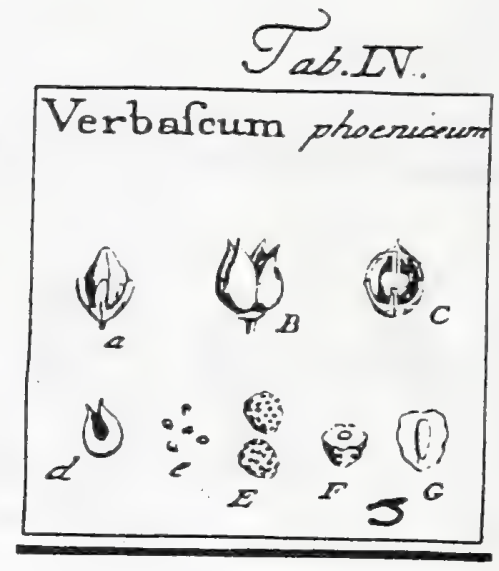

\section{J. Gaertner (1788) VoJ 1}

CCCXXVIII. VERBASCUM. Tou R N. t. 6I. L IN N. gen. 245.262

Caly'x quinquepartitus. Cor. quinquepartita rotata. Stam. quinquc: filamentis barbatis. Stig. fimplex. Capfula bilocularis. Diftepinentum duplicatum ex inflexis valvularum marginibus. Semina plura.

VERB Ascu M phaniccum. Tab. 55. fig. 8 .

Verbafcum foliis ovatis nudis erenatis radicalibus, caule fubnudo racemofo. LINN. Silfl. veg. 219 .

Icon JACQ. auflr. 2. t. I25.

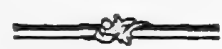

PER. Capfula ovato acuminata, utrinque ftria lopgitudinali inferipta, coriacea rigida, bilocularis, bivalvis: valvis maturis fxpe ad medium usque bifidis. Diflepunentum duplicatum, ex inflexis valvularum marginibus formatum.

REC. ovato globofum, fpongiolum, in axi fructus politum, per maturitatem deciduum.

SEM. plura, ovato globola, fubangulata, ferobiculata, fufca.

IN T. duplex, coriaceum \& membranaceum, utrumque tenue.

$\Lambda\llcorner$ B. femini conforme, carnofum, aqueo-pallidum.

E Mъ. tereti-compreffus, rectus lacteus, Cotyl. oblongx, anguftx, fubfoliacex. Rad. brevis, gracilis, centripeta.

a. B.) Capfula integra \& dehifcens. C.) Ejus fetio tranover(alis. a) Valvala a parte interna (potata, e, E.) Scrinina (eparata, F. G.) Embryo intra albumen. 


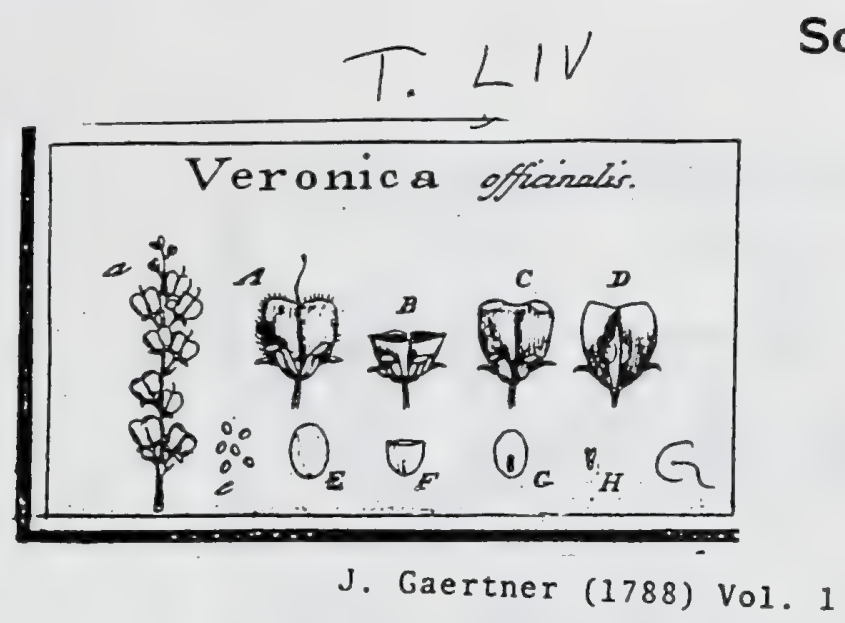

CCCXIX, VERONICA. TourN.t. 6o. LINN. gen. 25. 257

Calyx quadri-1. quinque partitus, Cor. limbus quadripartitus, lacinia infima anguftivie. Stam. duo. Stig. fimplex. Capfula bilocularis, apice emarginata.

VERONICA Officinalis. Tab. 54. fig. 7.

Veronica. RIv. monop. t. 93. f. 2. BLAKW. herb. I43. OEDER. flor. dan. t. 248 .

Veronica caule decumbente, foliis fcabris petiolatis ovatis, ex alis recemoja. HALL. hifl. I. n. 540 .

l'eronica fvicis lateralibus pedunculatis, foliis oppofitis, caule procumbente. LINN. fiff. veg. 58 .

PER. Capfula parva, obcordata, utrinque fulco infcripta, comprefta, fubvillola, bilocularis, apice transverfim dehifcens.: Diffepimentuin angultiffinum, valvis contrariuun.

REc. tubercula carnofa, conica, medio diffepimenti utrinque adnata.

SE 3. pauca, fex l. octo in fingulo loculamento, elliptica, compreffa, fere bracteata absque margine membranaceo, glabra, lutea.

IN T. finplex, membranacenn, tenuilitumum.

А вв. fernini conforme, lutefcens, fubcartilagineum, durum.

EMв. ininutulus, rectus, niveus. Cotyl. brevifinnx. Rad. longa, cylindrica, centripeta.

2. A.) Capfula Integra. B.) Eadem difrêta. C.) Eadem apice deliifcens. D.) Valuila altera cum receptaculi papillulis, e. E.) Semina foluta. F. G.) Albuminis; fetiones, cum fitu embryonis ad umbilicum. H.) Embryo feparatus, 
$-$ 


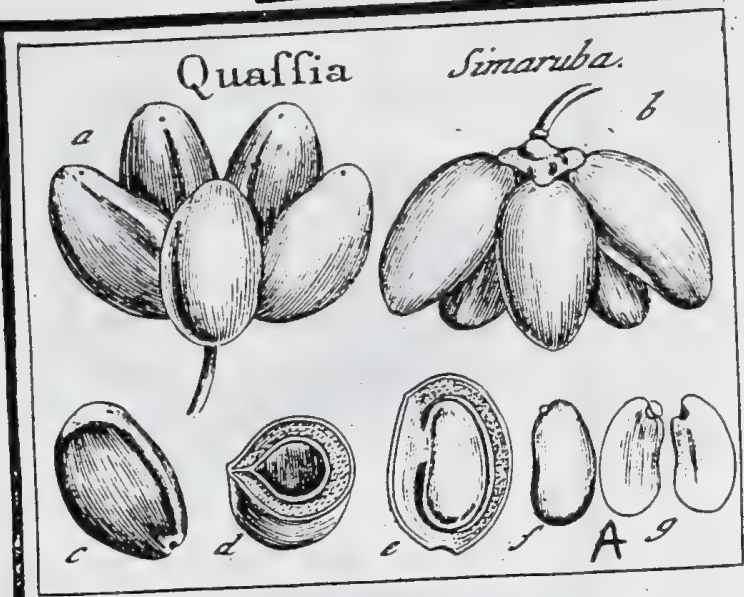

J. Gaertner (1788) Vol.1

CCCCXXXVIII. QVASSIA. LiNN. gen. 229.

Calyx pentaphyllus. Cor. pentapetala. Nectar. pentaphyllum. Stam. decem. Styl. unicus. Paccx quinque, diftantes, uniloculares, monofpermae.

Quassia fimaruba. Tab. 70. fig, 1 .

Simaruba amara. A u в L. guian. 859. t. 33 I. 332.

Quafia floribus monoicis, foliis abrupte pinnatis: foliolis alternis fubpetiolatis, petiolo nudo, floribus paniculatis. LIN $\mathrm{L}$. Jigl. vig. 401.

E collectione Bankfiana.

PE R. Baccae quinque, erecto patentes, ovatae, hinc convexac, inde angulo obtufo carinatae, nigrae, glabrae, uniloculares. Caro fungofa, crafta, duriuscula. Loculamentum meınbrana propria cartilaginca vefitum.

R Ec. commune parvum, carnolum, fulpentagonum; proprium, lacinula membranacea tenuis, ex angulo loculamenti incerno oriunda \& icminis lateri infra ejus apicem inferta.

SE s. folitaria, ovato oblonga, fupra levifime compreffa, infra rotundato-iucraffata, pallida.

IN T. fimplex, meinbranaceuin:

$\Lambda$ L. nullum.

Eм в. femini conformis, inverfus, graminco-viridis. Cutyl. orato oblongae, craftae, plano convexac. Plum. minutiflima, comproffa. Rad. capitata, bievis, fupera.

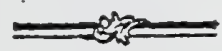

a.b.) Fraftus integer. c.) Bacca feparata. d.e.) Ejus fellio transverfalis \& longitndinalis, cum figura atque infertione (enuinis. f.) Embryo denudatus. \&.) Cotyledones feparatz.

Baccac, an meis, atrae, glaberrimae, nitidae, in Aubletianis autem figuris, extus vafis ramufis pictae funt. Ambigit hoc pericarpium inter baccam atque capfulam, per maturitatem enin introrfum fponte dehifcere videtur. 


\section{CLUI}

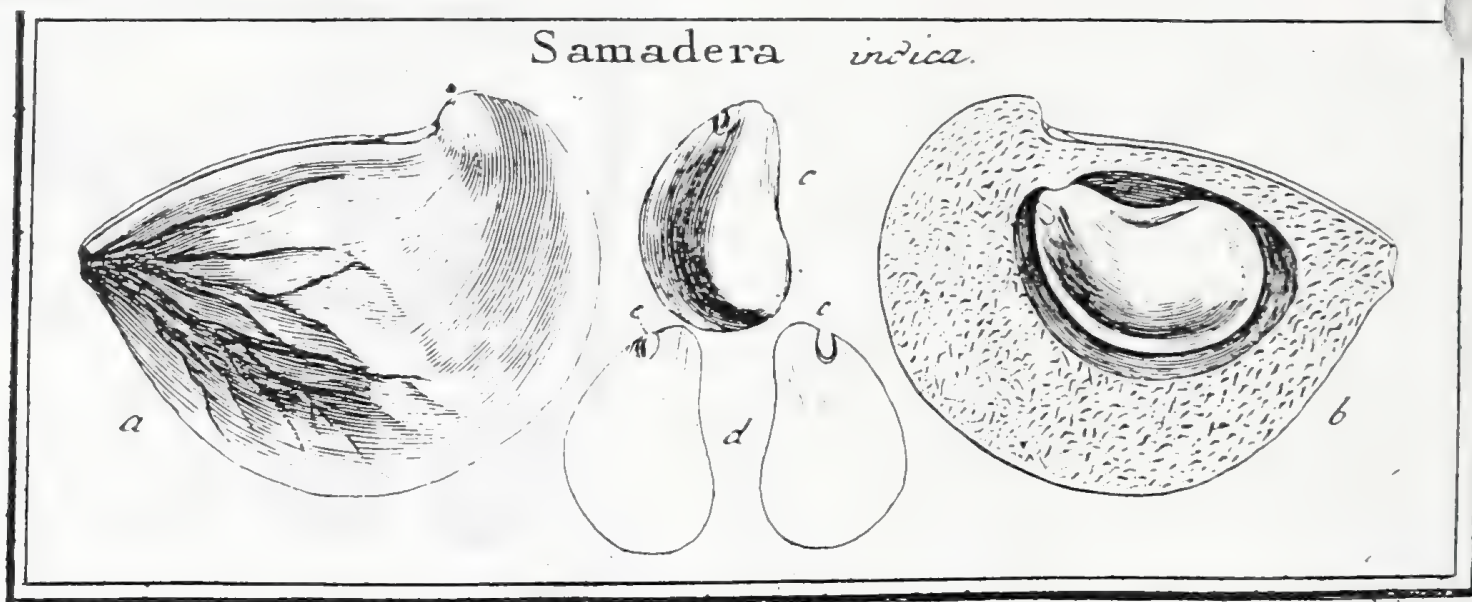

J. Gaertner (1788) Vol. 2

DCCCC. S A M A D R A.

Flos .... Nux femilunata, compreffa, unilocularis, monofperma. Sem, exalbuninofum. Embryonis radicula retro bafin cotyledonum pofita!

Samadera indica. Tab. 156 . fig. 3.

Samndera. javau. E collect. fem. hort. lugdb.

PER. Nux fuberofo-lignofa, fubfemilunata, lenticulari-compreffa aut convesaconcava $f$. cochleariformis, in medio valis prominulis obfolete varico $\sqrt{3}$, verfus peripheriam autem glabra atque in aciem fenfin extenuata, unilocularis, evalvis. Margo fuperior rectiufculus, craffus, fulco longitudinali atque tuberculo oblongo 11 fra apicem notatus; niargo inferior infigniter arcuatur. integerrimus, in aciem compreffus. Superficies glabra, fubfplendens. Color gilvus aut e luteo - fpadiceus.

REC. tuberculum craffum, in fuprenia loculanenti parte, cui femen affixum.

SEM. unicum, grande, obovato - falcatum, turgide lenticulare, glabrum, luteo 1. cinnamomeo-rufefcens.

In T. fimplex, coriaceum, crafiufculum.

A L B. nullim.

E M в. femmi conformis, albus. Coty obovatx, retro extrenitatem umbilicalem lacuna in margine fuo extctiori inciðx. Plums. nulla. Rad. ovata, compreffa. cotyledonum lacunam dor[alem replens, \& a feminis receptaculo averईa, fupera.

a.) Nux integra. b.) Eadem aperta eum infertione feminis. e.) Semen folutum. d.) Cotgledones feparatze e. e.) Lacuna dorialis cotyledonum, cum Gitu radicula.

Magnitudo nucis varia: dantur enim vola manus nulto majores, \& dantur quoque alix vix pollicares, \& ex angulto principio in formam alx Mufarum fenfim ampliatx; cujuscunque autem figurx \& magnitudinis fint, femper aliquantum concava $\int$. cochleariformes deprehenduntur. Sufpicor fructum completum ex duabus nucibus, horizontaliter oppofitis, effe contatum, eumque ad Contortarum familiam fpectare.

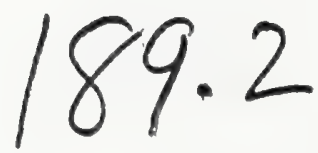


Tabi IIX.

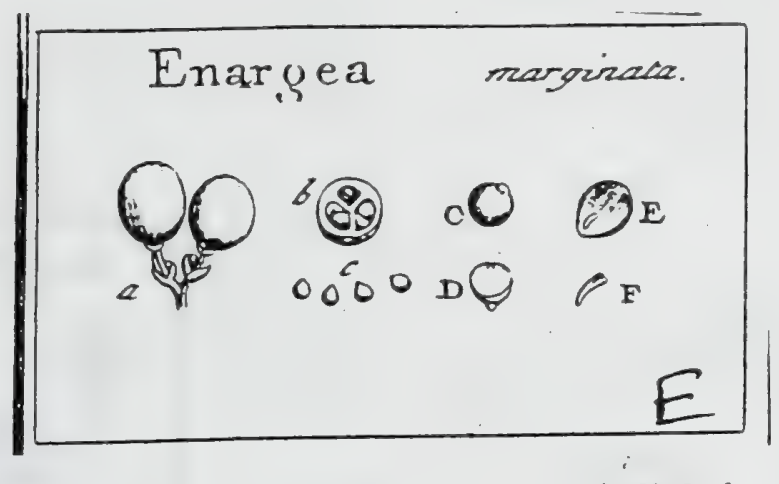

J. Gaertner (1788) Vol.1
Smilacaceae

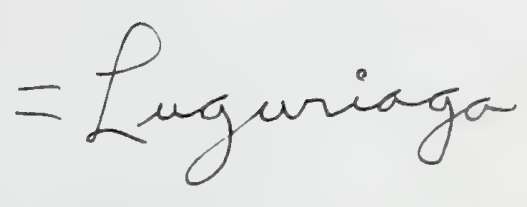

283

Calyx nullus. Cor. hexapetala: petalis oblongo ovatis, concavis, acutis; tribus interioribus, totidemque exterioribus; omnibus infra nedium duabus maculis viridibus notatis. Stan. fex, petalis duplo breviora. Styl. unicus, craflus, trigonus. Bacca trilocularis. Semina pauca. Ex fchedis b. Solandri.

Exarcea marginata. Tab. 59. fig. 3.

Ex herbario Bankfiano. Habitat in Terra del Fuego.

PER. Racca elliptico fphxroidea, carnofa, confffentia baccarum Vitis idxx, hinc rubro purpurea, inde albida, trilocularis.

REc. nullum; femina interno loculorum angulo affixa.

SE M. quatuor 1. quinque in fingulo loculamento, glubofa, rufefcentia.

Ixt. fimplex, membranaccum; tenue.

$\Lambda$ L в. fernini conforme, carnofum, durum, craflum, album.

EM B. teretiusculus, levifime curvatus, tertia albuninis parte brevior \& in bafi ejus locatus, lutefcens. Cotyl. breviltunx. Rad. longa centripeta.

a.) Bace integrs. b.) Eadem diffeta. c. C.) Semina feparata. D. E, Albuminis fetiones, cum fitu \& figura embryonis, F.) Eimbryo reparatus.

190.1 


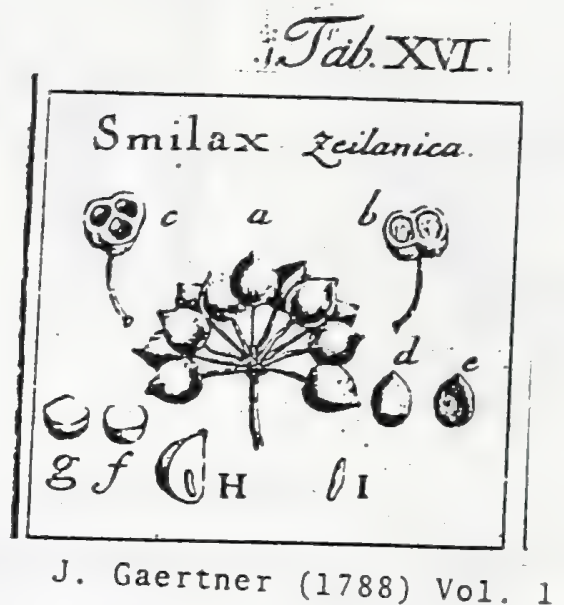

LXVIII. SMILAX. TOURN. t. 421. LINN. gen. II20.

Flores fexu difindi in feparatis truncis. Calyx hexaphyllus. Cor. nulla. Mas. Stam. fex. F es. Styli tres. Bacca fupcra, trilocularis. Scm. folitaria pendula Embryo longitudioc dimidii albuminis, in regione feminus umbilico contraria.

S s 12 a X zeylanica. Tab. 16. fig. 7 .

- PSeudo chind amboinen/is. R U м Р н. amb. 5. p. 437.t. 261 .

Sinilax caule aculeato angulato, foliis inermibus: coulinis cordatis; rameis ovato oblongis. Lixi. Syf. veg. 887 .

Riri-bonaiwal, zeylonens. E colled. fem. hort. lugdb.

60

PER. Bacca fupera, globofa, acuminata, bi-aut trifulca, flavefcens, demum nigra, biaut trilocularis.

REc. cicatricula parva in fuprema parte diffepimentorum, e qua femen pendet.

SEA. in fingulo loculanento unicum, ovatum, fupra acuminatum \& parvo tuberculo fungofo umbilicali terminatum, infra obtufiusculum, hinc convexum, inde pla. num, aut angulatum, glabrum, rufefcens.

IN T. fimplicifimum, membranaceum, tenue, arctiffine adnatum.

A L в. figurá feminis, cartilagineum, durum, aqueo-pallidum.

Ex в. monocotyledoneus, teretiusculus, rectus, lacteo albicans, dimidio albumine bre. vior, in regione feminis umbilico oppofita collocatus.

a.) Fruetus umbellatus. b.e.) Bacca bi-et trilocularis transverim fęta, d.e.) Senina feparata, ab utroque latere (peflata. f.g.) Seninum fectio trassverfalis. H.) Albumen longitudinaliter difSectum, cum embryone in fitu naturali. I.) Embryo feparatus \& suctus.

Smilaci afpere, in acinis rubris majoribus nucleos ternos, in minoribus vero fingu. los, nigros, durosque efle, jam annotavit PIINIUs. L. XVI. fect. 63.

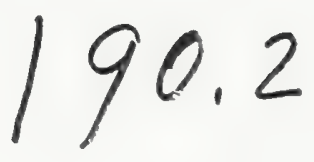




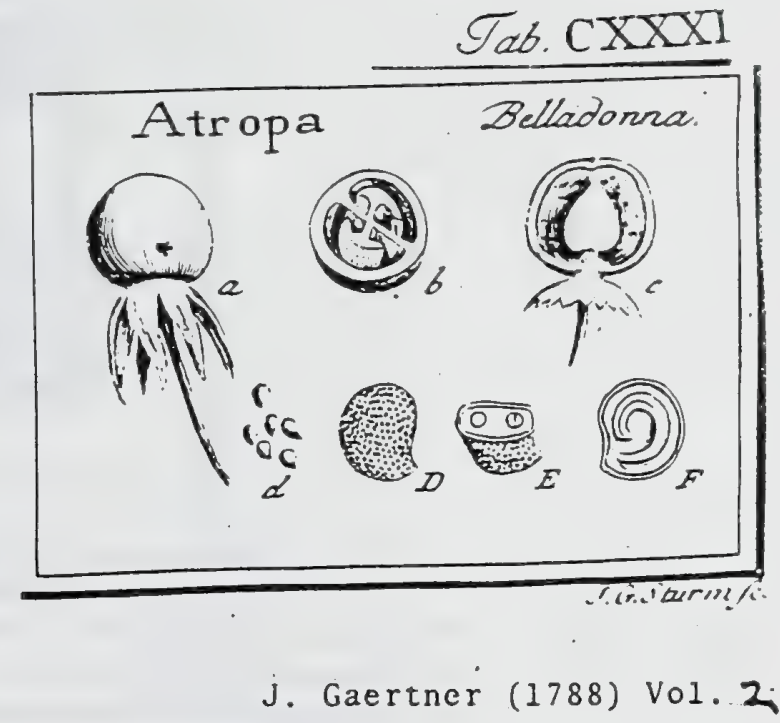

\section{A T R O P A. LinN. gen. 249. Belladonna.} TOURN. inf. t. I3.

Calyx monophyllus, quinquefidus. Cor. cylindrico-campanulata, quinquefida. Stam. quinque, antheris diftantibus. Ovar. fuperum. Styl. finplex, ftignate capitato. Bacca bilocularis, calyci infidens. Recept. difcretum \& a fepto diftans. Sem. plurima.

Atropa Belladomia. Tab. 131. fig. 5.

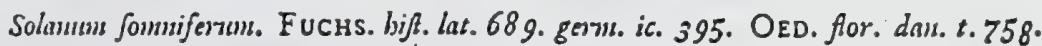
Belludonna. MiLl. dict. ic. t. 62. BLAKw. berb. t. 564 .

Belludonna caule berbaceo brachiato, foliis ovato - lanceolatis integerrinis. HaLc. bijt. 2.579 .

Atropa caule berbaceo, foliis ovatis integris. LIN fy?. veg. $22 x$.

$P \varepsilon$ R. Bacca calyci perfiltenti infidens, fubglobofa, ftria depreita longitudinali utrinqué infcripta, pulpofa, glabra, nitida, atra, bilocularis. Cuticula tenuis. Pulpa atro - purpurea.

REc. lamina fungofa, crafra, convexo-concava, ope laminx intermedix longitudinalis diflepimento utrinque ad asem affixa.

SE M. numerofa, fupra centum in fingulo loculo, rotunda aut ovata, fubroftellata, compreffiufcula, minutifrme fcrobiculata, e cincrico-lulca.

INT. duplex: coriaceun atque meml ranaceum.

A L E. Cemini conforme, granulofe - cirnufum, album:

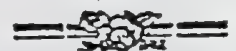

Eив. fubperiphericus, hamato - curvatus laceus. Cotyl. femiteretes. Rado centripeta.

2.) Bacea integra, cum calyce reflexo. b.) Ejus fotio transverfalis cum receptaculorum iafertione. c.) Recept. pírs convexs, nudz. d. D.) Semiua (eparata. E. F.) Semen ditedurt, cum figura \& fitu embryonis in albunine.

Scopo nullatenus fatisfacere poflunt vel exquifitilimx \& completifimx icones Belladonnx, ad pracavenda damna, in nonnullis regionibus per fcholas diftributx, quoniam ifte a juventute, ut cum ftupore expercus fum, vel non intelliguntur, vel nimis cito e puerum elabuntur memotia. Multo itaque, me judice., fatius foret, fxpe pueris inculcare monitum, captui eorum accomodatifimum, nempe ut fibi caveant ab omnibus Cerafis nigris, in quibus loco unius lapidis, plura fint granula parva. Ita nempe facillime difcent vitare efcam lethalem, cum fingulum procepti verbum, ctaram in pueri mente excitet ideam, nec tamen ejus gravet memoriam, ingeniumve requirat acutum. 


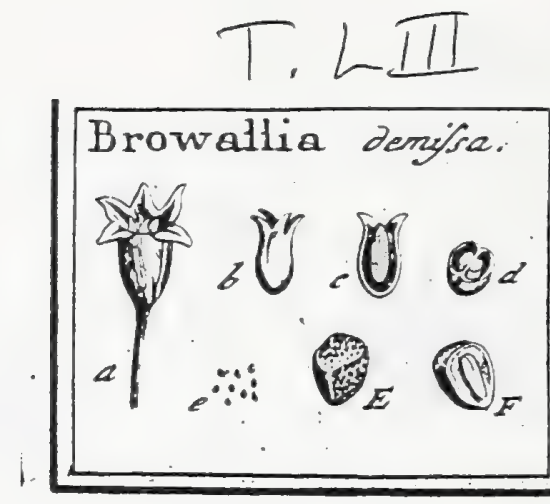

$$
\text { J. Gaertner (1788) Vח' I }
$$

CCCIV. BROTWALLIA. LIN . gen. 773. 246

Calyx quinquedentatus. Cor. hypocrateriformis. Stam, quatuor inxqualia. Stigma qua drilobuin. Capfula bilocularis, apice quadrivalvis. Semina parva, angulata.

B R OW A z 1 A demilia. Tab. 53. fig. 4 .

Browallia pedunculis unifloris. LIN 1 . h. Cliff. t. r7. S4fl. veg. 572.

PER. Capfula calyce veftita, ovato oblonga, bilucularis, apice quadrifariam delilcent: DilTepimentum inembranaceum, tenue, per maturitatem a parietibus caplule fecto dens, ut uniloculatis appareat.

REc. oblongum, fungofum, fcrobiculatum, diflepimento arefe adnatum.

SEM. numerola, parva, angulata, foveolis \& punctis minutifiunis exarata, luteo-r.t. fefcentia.

IN T. duplex: exterius fpongiofum, tenue; interius membranaceum, pallidun.

A L B. femini conforme, carrofam, albam.

Ex в. teretiufculus, niveus. Cotyl. femicylindricx breves. Rad. crafla, centripeta. -

a.b.) Capruis veftita \& denodata. c) Rexept. cum diffepimento connatum. d.) Capfula differs: e. E.) Semiua feprata. F.J Ėmbrjo inera albumen.

Capfulan medix magnitudinis fintunt figurx a-d. dantur duplo grandiores.

Pofitio floris in hoc genere fingularis $e f$, nam pedunculus; vel e regione, vel ad. latera petiolorum inieritur, ficut in Solasaceis. 


\section{Brunfelfia}

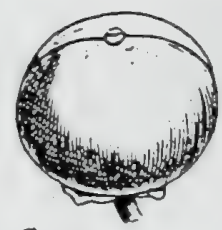

a
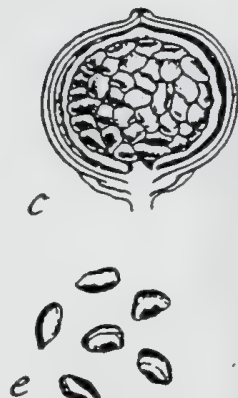

americana
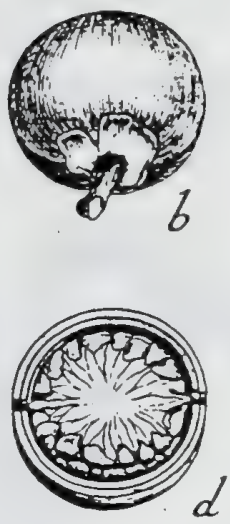

J. Gaertner

(1788)

vol 3

\section{7}

129. B R U N E L S I A.

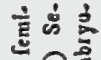

䒠总

要紊

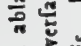

PER. Capfula globofa, depreffiufcula, pollicem transverfum craffa, in vertice obtufe nucronulata, \& intra mucrontem umbilicata, calyci perfittenti per maturitatem inxquali infiltens, fubbatcata, duplicita, auranta, bilocte laris, bivalvis. Lamina exterior crallior, corlaceo-ciarnola, intus lavigats. adglutinata; interior paulo telluior, chartacea, finofum, a receptaculu aud Dillepinentum angultithmum, nenbranaceo-carnofum, a

valvularum futuram productum, \& cum his parallelum. globofum, car-

REC. baccatum, centrale, cratle \& brevilinne peas membranaceas degenerans, nofum, ficcitate autcm in productiones fiv

SEM. plurima, $20-36$. in quovis loculamento, rotundato.angulata, 1. hinc convesa, inde cuneata, \& prope bafin umbilico minimo inftructa, fufca.

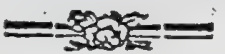

INT. duplex: exterius cruftaceum, craffufculum, fragile, glabrum; interiur membranaceum, dilute ferrugineum, facile detrahendum.

A I B. Senini conforme, carnofum, album.

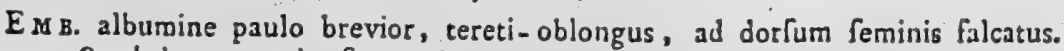
Cotyl. breves, obtufx, rectx, incumbentes. Rad. teretiufcula, longa, falcata, umbilico obverfa, centripeta. 


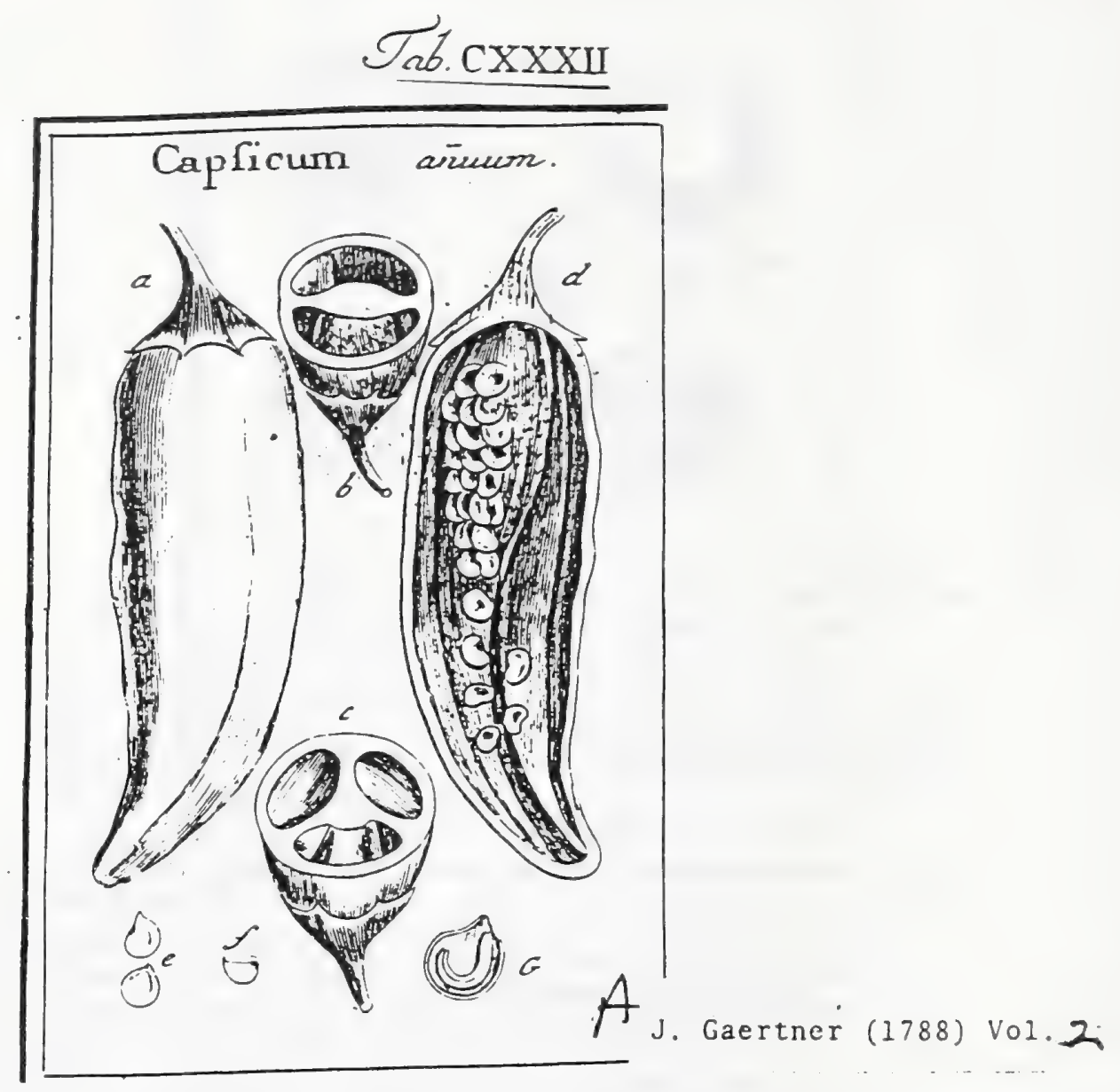

DCCLXXIII. CA P S I C U M. TOURN. t. 66. LINN. ger. 252.

Calyx quinquefidus. Cor. rotata. Stam. quinque, antheris convergentibus. Ovar. Superum. Styl. fimplex, ftigmate obtufo. Bacca cava, muliformis. Recept, non difcretum. Serr. compreff.

Capsicum anuuum. Tab. 132. fig. I.

Piper indicums. BESL. Ejgt. autuins. I. t.6-13. BLAkw. berb. 't. 129.

Capficum anmum \& grofrum: LiNs. bift. veg. 226.

PER. Bacca carnofa, multiformis, lavigatifima, nitidiffima, coccinea aut lutea,

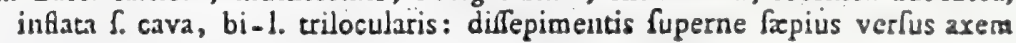
deliquefcentibus.

REC. in fundo bacca folidum, ovato-conicum, cum difepimentis intime connatum, ut femina sonuulla ipfis quandoque feptis affixa fint.

SEN. numerofa, fubreniformia aut rotunda, roftellata, plano-comprefa, glabra, albicantia aut pallide ftraminea.

I.s T. duplex:'coriaceun atque membranaceum, 'utrumque tenue.

A L 8. Semini conforme, carnofum, pallidum.

E в. Subperiphericus, hemicyclicus, hodeus. Cotyl. Semiteretes. Rad. centripeta.

2.) Bacea integra. b. c.) Eadem transverlim fets, bi-\& trilacularic d.) Ejusdem fetio longitudinalis, cum receptaculo fecolnum e.) Semina separata E.) Semen transveríe fectum. G.) Einbryo intra albumen.

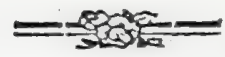

Naturalis loculamentorum - numerus videtur effe binarius, nam. S.triloculares bacci, evadunt verfus apiccm biluculares. 

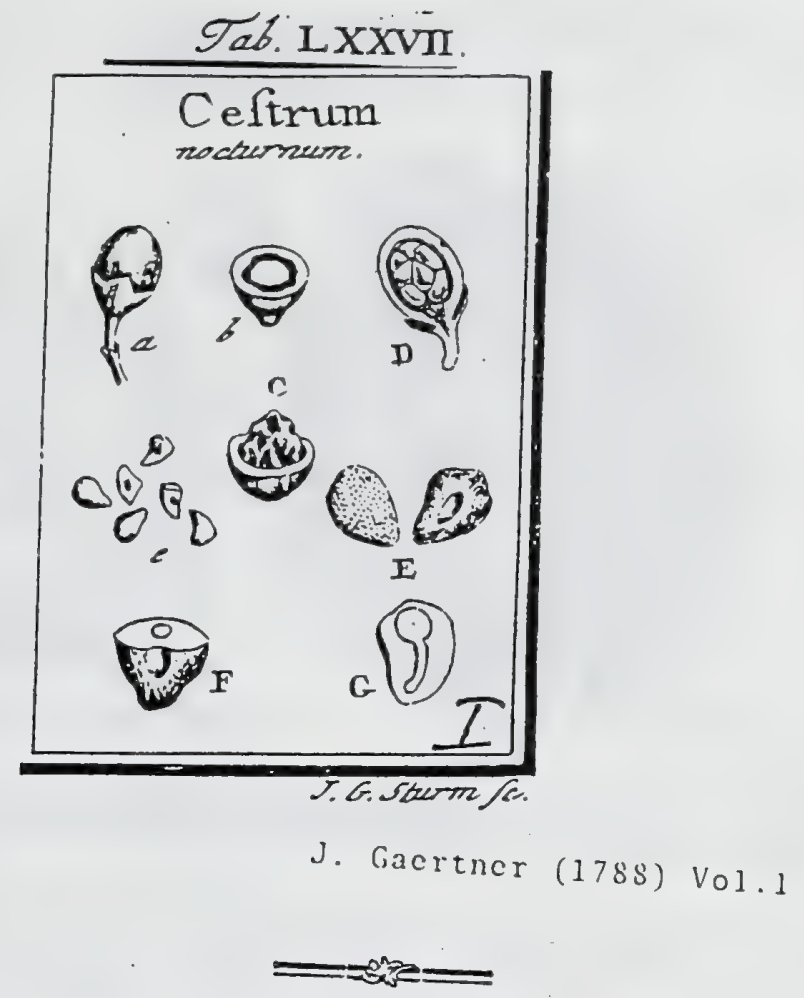

\section{CCCCXCIII. CESTRUM. LIN gen. 26 I.}

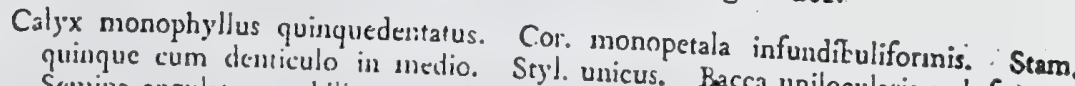
Scmins an:quatata, umbilico ventrali concavo. CESTRUM nochunum. Tab. 77. fig. 9.

Siyringa laurifolin jomaicenfis, floribus ex flavo pallefcentibus. Pluk, phyt..t. $\sigma_{4}$.
$f .3$.

Jasminoides foliis pishaminis, flore virefcente noEtu odoratifrmo. D I L L. elth.
183. t. 153 . f.185. Cefrum fluribus pedru

Ex licrt:ario Baukfiano. . cularis.

1: ir. grande, carno:um, Jiberum, fcrobiculatum.

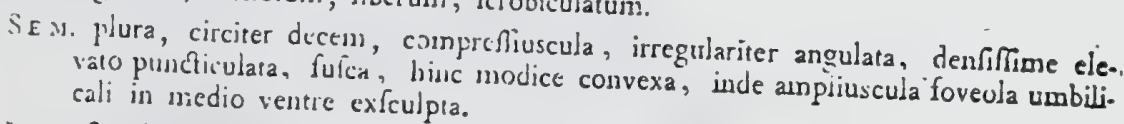

IN 1: frmplex, nembranaceum, nucleo arcte adriatum.

A.B. Scmini conforme, carnolum, duriusculum, album.

Ex в. longitudine fere albuminis, modice curvatus, albus. Cotgl. orbiculatix, folia-
cex, planx. Rad. coryledonibus dinidio longior, terctiuscula, curata derfun aut ad Jatera, pro vario leminumin fitu, diecela.

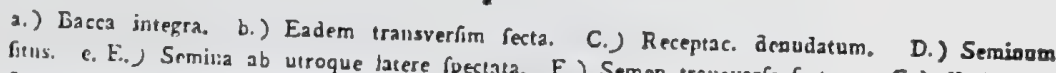
fitis. e. E., S Smilia ab utroque tatere (pectata. F.) Semen trausverfe fectum. G.) Embryonis
figura $\&$ fitus intra albumen.

Duoloculamenta, qux Adaxsonus hatuit, forfan in immaturo ovario adfont, fed in matura bacca, dillepinenti ventigium nullum apparet. Cetera, a Lycio \& ab tyledonibus foliaceis, nec femitercibus, enbryone non annulari aut. Spirali; \& co 


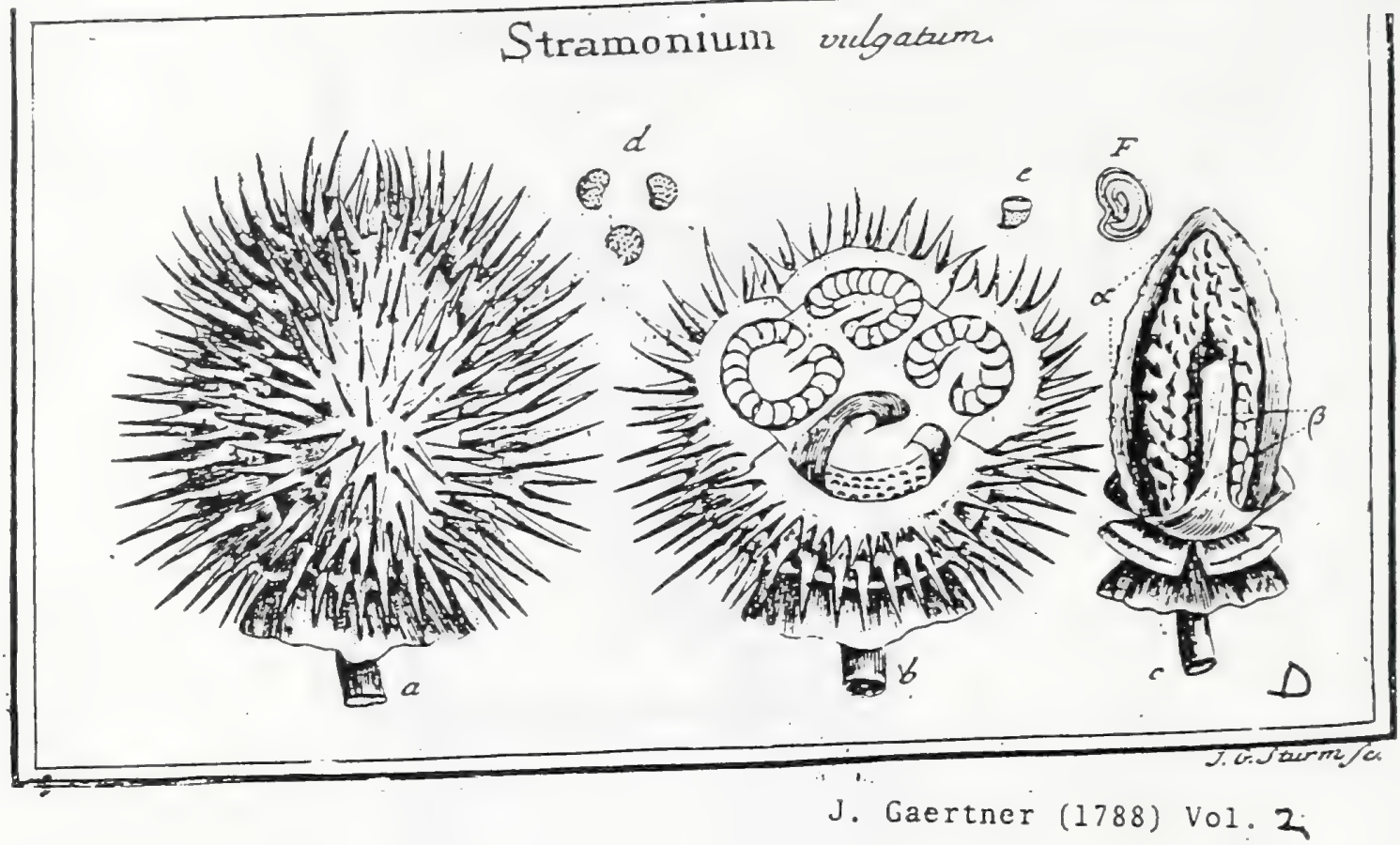

$=$ Latur

\section{S T R A M O N I U M. TOURN. t. 43. 44.}

Datura. LIN gen. 246.

C.alyx tubulofus, angulatus, quinquedentatus, bafi refexa perfiftens, cetera caducus. Cor. infundibuliformis, plicata, maxima. Stan. quinque. Ovar. fupcrum. Styl. fimplex, ftigniate incrafato bifido. Capf femiquadrilocuLaris. Reccpt. difcreta. Sen. mumerofa.

Stramonium vulgatum. Tab.132. fig. 4

Stramunium. BLAKw. berb. t. 353. OED. flor. drus t. $43^{6}$.

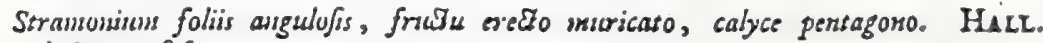
bif., $n .586$.

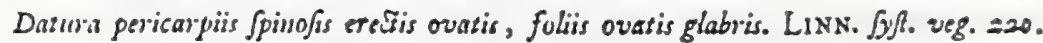

PER. Capfula refidux calycis bafi reflexx infidens, ovata, rotundato-tetragona, aculeis pungentibus echinata, inferne quadri-fuperne bi-locularis, quadrivalvis. Dilfepimenta futuris obverfa, inæqualia: alsero crafiore, recepaculifero, ad spicern capfulz pertingente; alsero autem teuniore, audo \& paulo fupra mediun capfulz deliquefcente.

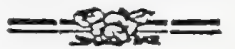

Rzc. numero loculamentorum xqualia, fuperius nempe gemina, \& inferius quaterna, diffepimento crafriori ope laminx intergerinz inferta, cetera a diffepinentis undique difcreta, crafra, convexo-concava, fungofa, mamr millari - tuberculata.

SEM. numerofa, reniformia, craffa , compreffiufcula, ferobiculato-feabrata, colore varia, nigra, ferruginea, cinerea aut alia.

IN T. duplex: exterius cruftaceum, craffum, durum; interius'membranaceum, tenuifrimum.

A I B. femini conforme, carnofum, aqueo-pallidum.

EN R. fubperiphericus, hamato - curvatus, lacteus. Cotyl. femiteretes: Rad. centripeta.

2) Caplula integra. b.) Eadern dirfecu, com receptaculorum atque ferinum infertionc. c.) Re. reptac. feparatz, fepto majori $\left(\alpha_{0}\right)$ affixa \& inferne feptum brevius ( $\left.\beta_{0}\right)$ inter fua crorz reopientia. d.) Seminz feparata. e.) Seminis feAtio transverfalis. F.) Embryo intra albumen. 


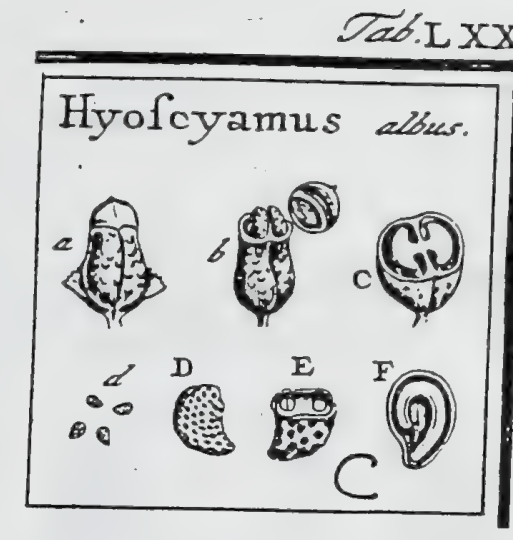

J. Gacrtner (178s) Vol.I

\section{CCCCI,XXXI. HYOSCYAMIUS. TOURN. $t$. 42. LINN. gen. 247.}

Calyx monophyllus campanulatus. Cor. monopetala, infundibuliformis irregularis. Stam. quinque. Styl. unicus. Capfula bilocularis circumfciffa. Semina plurima reniformia.

Hroscr. a mus albus. Tab. 75. fig. 8.

Hyoscyamus albus. Best. h. Eyfl. afiv. VIII. t. 8. f. 2. B А к к w. herb. t. III.

Hyoscyanus foliis petiolatis finuatis obtufis, floribus fefflibus. LIN Jy ft. veg. 220.

PFr. Cap̧ula calyce veflita, membranacea, a protuberantibus feminibus nodulofa, ovata, inferne ventricofa, utrinque ftria deprefra notata, bilocularis, fupra medium circumfcil Ta: operculo terminali convexo.

RE.c. fungofum, fcrobiculatum, ovato oblongum, plano convexum, mediante lamina intergerina utrinque diffepinento affixum.

SEм. numerofifima, parva, fubcompreffa, ineurva aut reniforınia, denfe fcrobiculata, cinerascentia.

IN T. duplex: exterius coriaceum, duriusculum, craftum; interius membranaceum, albicans.

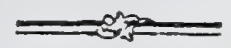

A L в. Semini confurme, carnofum, aqueo-pallidum.

EMD. teretiusculus, arcuatus, intra albumen, fed prope dorfum feminis locatus $3:$ mo. veus, Cotyl. femiteretes. Rad. longa, centripeta. a. b.) Capfula cianfa \& delifcens. C.) Receptac, figura \& infertio. d. D.) Semina Separata. E')
Semen transverfe featum. F.) Embryonis figura \& fitus intra alburner.

Hroscrames Scopolia.

Calyx maturus inliatus. Caplula fubglohola, coriacea, rufefeens, in inedio fere circumscirTa. Receptac. totum adnatum. Semina grandiuscula, reniformia, poris: denliffme \& feriatim digeftis eleganter puncticulata, pallide lutescentia. Reliquáa ut in procedcuti. 


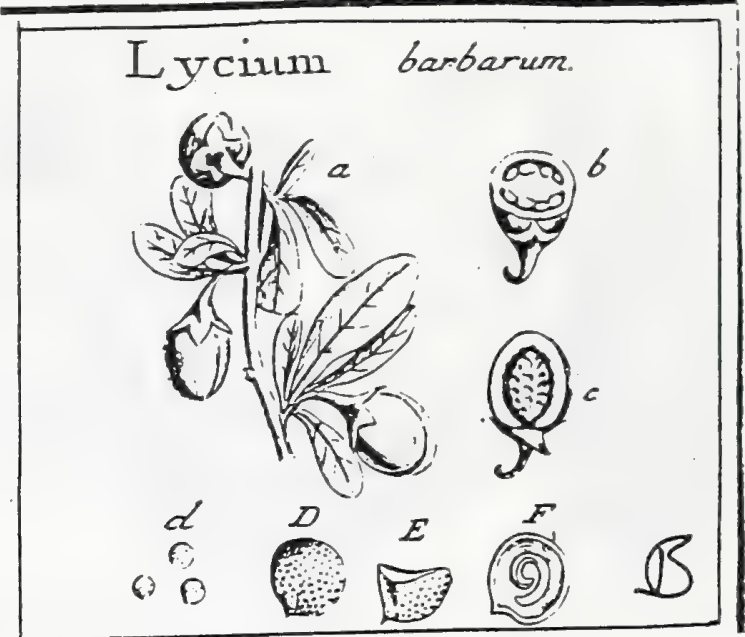

J. Gaertner (-1788) Vol 2

DCCLXXIV. L Y C I U. M. LINN: gen: 262 . 242

Calyx monophyllus, , brevis, tri- quinquefidus. Cor. infundibuliformis; quinquefids. Stam. quinque, bafi villofa, extra faucem prominula. Oma fuperum. Styl: fimplex, Itigmate incraflato bifido. Bacca bilocularis. Recepti centrale, folidum: Sem: plura:-

LY C1UM barbarum. Tab. 132. fig. 2 a

Lycium fotius oblongo- lanceolatis, foribius folitariis pntentibus alaribus, ramonun: spinis rarioribss. EHRET: decrd. t. 68:

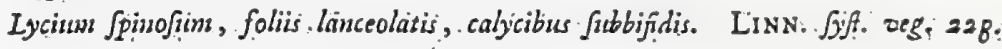

PiEk. Bacca carnofu, avata, urringue ftria deprefla longitudinali inferipta, glaw. bra, nitida, e minia rubra, bilocularis. Diffepimentun carnolum, angu. ftum, fulco externo refpondens.

REC, ovato - globofum, carnofum, fcrabiculatura, .rubrum, cum diffepimento intime connatum.

SE N. plura, duodecirn circiter-in fingulo locula, fubrotunda, compreffa; elesvato- puncticulata, albicantia:

Is T. duplex; utrumque membranaceim.

A L B: femini conforme, carnofum, aqueo - pallidurm:

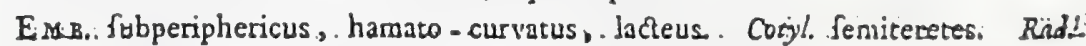
centripeta..

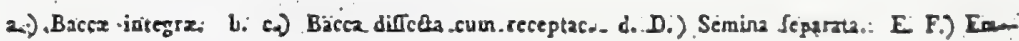
bryonis figura \& fitus in albuwine.." 
Tab. CXXXI

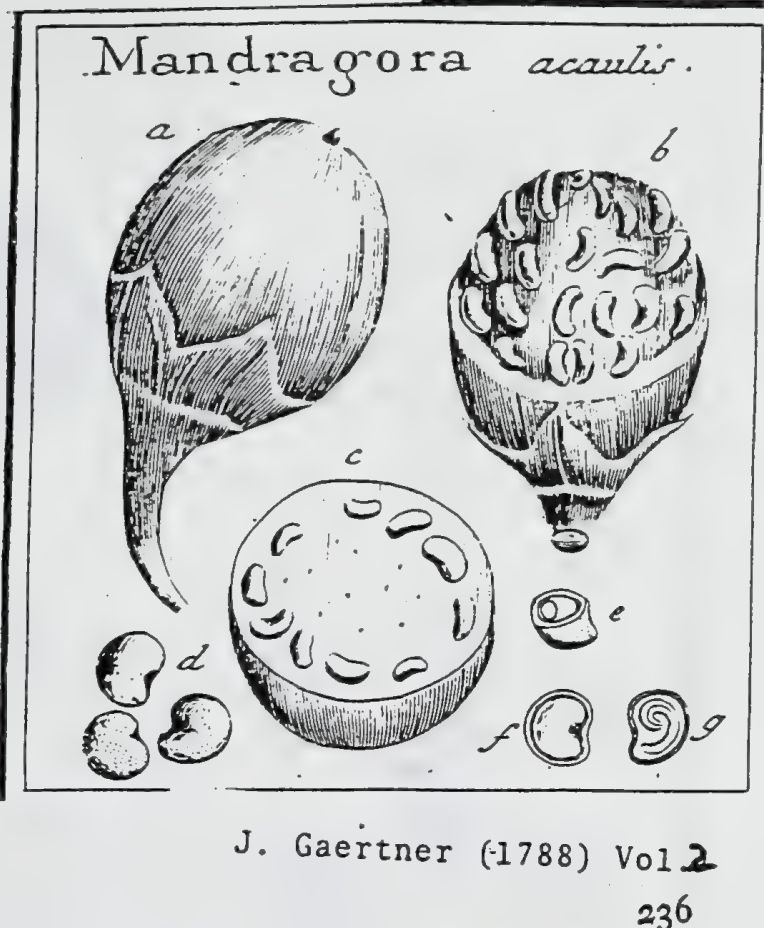

DCCLXVIII. MANDRAGORA. TOURN. t. I 2 .

Calyx monophyllus, femiquinquefidus. Cor. campanulata, quinquefida. Stam. quinque. Ovar. fuperum. Styl. unicus, Atigmate capitato. Bacca. folida unilucularis. Sem. plura, prope peripberiam nidulantia.

Mandoragora acaulis. Tab. I31. fig. I.

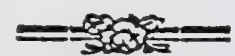

Mandragorn. Dod. pentpt. 457. BesL. Eyf. vem. IX. t. 1. f. 1. BLaKw. berb. t. 364. MiLl. diq. ic. t. I73. HaLl. bijf. 12. 578.

Atropu acaulis, fapis aniforis. LINN. $\sqrt{y} f$. veg. $22 x$.

PER. Bacca grandiufcula, rotunde - aut ovato-globofa, ftria depreffa obfoleta longitudinali in utroque latere infcripea, fpongiofo - carnofa, folida, unilocularis, absque ullo cavitatis internx veltigio.

REC. nullum, prxter ipfam bacex fubfantiam fpongiofam, cui femina in omuem fenfun prope peripherian immerfa.

SEM. plura, fupra triginta, reniformia, verfus umbilicum compreffufcula, in dorfo auten craffiora, e fpadiceo lutefcentia, fuperficie quafi arrofa, nec tamen afpera.

I N T. duplex: exterius cruftaceum, crafum, durum; interius membranaceum, album. A L B. fenini conforme, carnofun, album, embryonem involvens.

EMB. fubperiphericus, fpiralis, lacteus. Cotyl. femiteretes, verfus apicem attenuatx. Rad. craffa, centripeta.

2.) Bacen integra. b.) Eadem decorticata, cum fitu feminum, c.) Ejusdem fectio transverlalis. d.) Seminz integrz. e.) Semen transverfe diffeaum. f.) Albumea decorticatum. \&) Embrynnis in albumine fitus.

Defectu loculamenti confpicui atque receptaculi feminum a cortice difcreti, non tantum ab Atropa fed \& a reliquis Solanaceis abunde differre mihi videtur. Tribuit equidem Cl. Jussiev Mandragorx fure receptacula intus: prominula; fed ifta ego non reperio. Anne \& Melongena huc trahi deber, cujus baccam perinde folidam omnes icanes exhibent? 


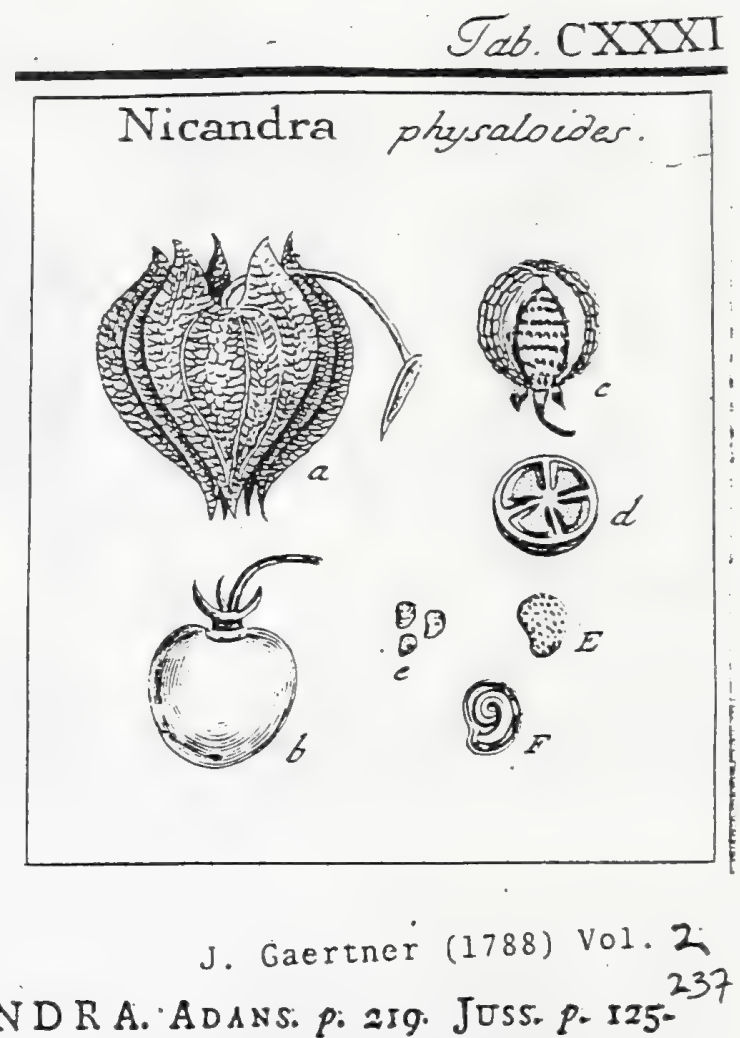

DCCLXIX. NICANDRA. ADANS. p: 219 . JUSS. p. $125^{-2}$

Calyx monophyllus, pentagonus, profundiffme quinquefidus, fegmentic haftato - cordatis conniventibus fructum obtegentibus. Cor. campanulato ampliata, obiter quinquefida. Stam. quinque. Ovar. fuperum. Styl. fimplex. Bacca exfucca, tri - quinquelocularis. Recept. difcreta. Sem. numerola.

Nicasdra phyfaloides. Tab. 13 I. fig. 2.

Alliekengi fore amplo violaceo. FEuv. persu. 724 . t. 16.

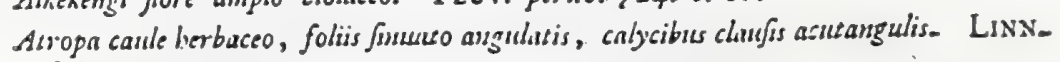
$\int y / l$. veg. $2=x$.

Icon. Jace. obf. IV. t. 98 .

PER. Bacea intra calycem ablcondita, fphacrica, exfucca, fordide lieanines aut fpadicea, uri-quadri-1. quinquelocularis. Curicula chartacea, glabro,

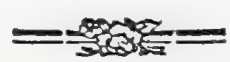

tenuis. Caro nulla, preter fublanciam cellulofan tenuem, in fuperficie cuticulic interna.

REc. numero loculamentorum refpondentia, extrorfum craftiora, introrfum cuneifornit compreffa, axi longitudinaliter affixa, cetera undique liben, fungofa, fcrobiculata.

SEM. numerofiflima, reniformia, comprefluffula, pundis excavatis denfe con: fperfa, e fpadiceo rufefcentia.

IN T. duplex: exterius fungofo-coriaceum; interius membranaceum.

AL B. femini conforme, carnofum., aqueo-pallidum, embryonem involvens.

EM 8. Subperiphericus, fpiralis., lacteus. Caryl. feniteretes. Kad. centripeta;

2.) Calsx maturus. b.) Bacea denudata integra. c:) Eadem decorticata, eum receptaculo locu. lamenti anterioris denudato. d.) Bace transverfim feda. e. E.) Semina (cparata. F.) Seren apertum cum litu \& figura albuminis atque embryonis. 


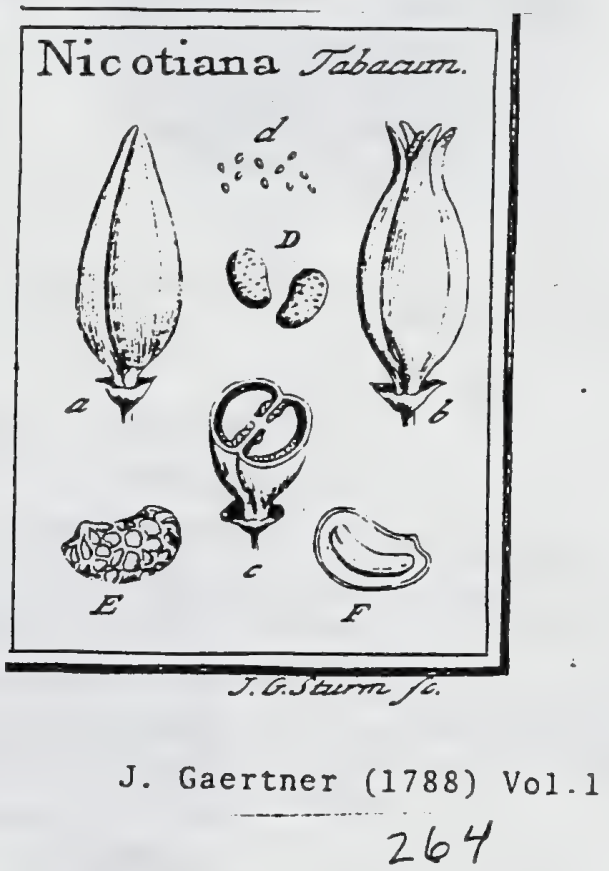

CCCXXXI. NICOTIANA. TouRN, t. 4I. LINN. gen. 248.

Calyx quinquedentatus. Cor. infundibulitormis. Stans. quinque. Styl. unicus,: Capfula bilocularis. Recept, maximuin plano-convexum, Semina parva, fubreniformia.

Nicotiana Tabacum. Tab. 55. fig. II.

Petum Tabacum. BLA KE. herb. t. 146.

Nicotiana foliis lanceolato ovatis fefflibus decurrentibus, floribus acutis. LiNs. f4ß. veg. 221 .

PER. Capfula ovato-conica, calyce veftita, glabra, quatuor friis depreffis notata, $\hat{b}_{i-2}$ locularis, apice quadrifariam dehilcens. Septum cumplex, valvis contrarium.

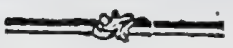

REC. maximum, fungolum, ovato acuminaturn, hinc convexum, inde planum, aut reniforni-concavum, ope laminz intergerinz, fepto utrinque affixum.

SEM. numerofifima, exigua, ovata, fubreniformia, lineis I. nervis elevatis (fi recentia aut in aqua emollita fuerint) egregie reticulata, (padiceo-lutefcentia.

IN T. duplex, coriaccum \& meinbranaceum, urrumque tenue.

$\Lambda\llcorner$ в. feınini conforıne, carnofum, aqueo-pallidum.

Eм.8. teretiusculus, leviter curvatus, niveus. Coty/. femicylindricx. Rad. longa, cra $\int_{a}$, centripeta.

2. B.) Capfula denudata, integra-\& dehifcens. c) Eadem difreeta, cum figura \& infertione recepeculi. d. D.) Semina exfiecata, rugola. E.) Seminis recentis fuperficies reticulata. F.) Embryo intra albumen, 


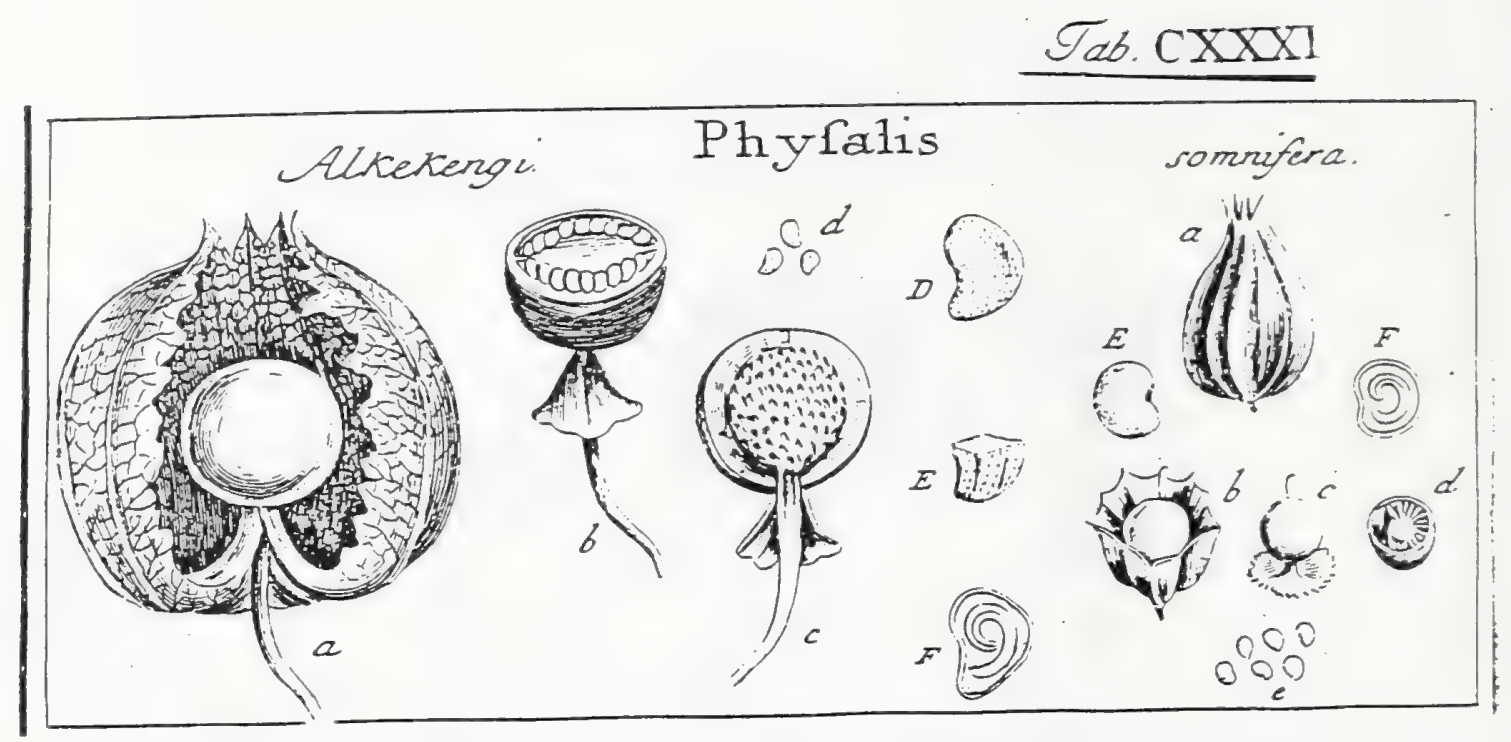

J. Gaertner (1788) Vol2

DCCLXX. P H Y S I I S. LINN. gen. 250. Alkekengi.

TOURN. inft. t. 64.

Calyx monophyllus, quinquedentatus, per maturitatem inflatus, fructum occultans. Cor. monopetala, rotata. Stam. quinque, antheris conniventibus. Ovar. fuperum. Styl. fimplex, ftigmate óbtufo. Bacca fucculenta bilocularis. Recept. adinata, non difcreta. Sem. plurima.

PHySALIS Alkekengi. Tab. 1; I. fig. z.

Alkelengi f. Halicacabum. BLAKw. berb. t. 16x.

Plyyalis folits conjugatis cordutis fmuatis, caule ranzofo. HaLL. hifs. 17.577 .

Thyjalis folies gemrinis integris acutis, eaule herbaceo inferne fubramofo. LNN 万y. veg. $=22$.

PER. Bacea intra calycem infarum miniatum abcondita, globofa, fucculenta, glaberrima, nitida, coccinea aut miniaca, bilocularis. Cuticula menibranacea, renuifrims Caro mollis, pulpora, rubra. Diffepimentum anguftifirimum, membranaceum.

RRc. centrale, folidum, globofum, carnofum, fcrobiculatum, cum pariose interno baccx ope diffepimentí cohxrens.

SEM. numerofifima, reniformia, compreffa, elevato-puncticulata, flavefcencia aut rufefcentiz.

INT. duplex: coriaceum atque membranaceum.

$A \perp B$. carnofum, durum, album, embryonem involvens.

En B. fubperiphericus, fpiralis, lactelus. Cotyl. Semiteretes, Ead. icntripetz

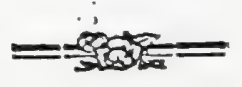

x.) CaTyx apertus cum bacea integra. b.) Bacea diffecta. c.) Beceptac. denudatum. i. D.) Se mine feparata. E. F.) Semen difiectum cum embryone.

PHYSALIS fomnifera. ibid:

Solanum fonviferums. CLus. bifl. $=. p .85$.

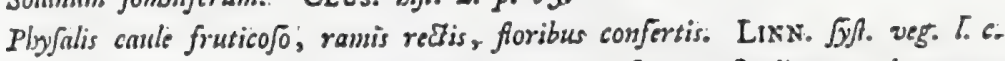

Calyx maturus (a.) ovato - pyramidatus, pubefcens, fpadiceus, decagonus = angulis alternis (b.) minus extantibus. Bacca (b. c.) fphacrica. coccinea, nitidiafima, bilocularis (d.), pulpofa. Semina (e. E.) grandiufcula, rotundato reniformia, compreffa, puncticulara, pallide lutefcentia. Embryo (F.) hemicyclicus aut fubannularis, intra albumen locatus. 


\section{J. Gaertner (1788) Vol3}

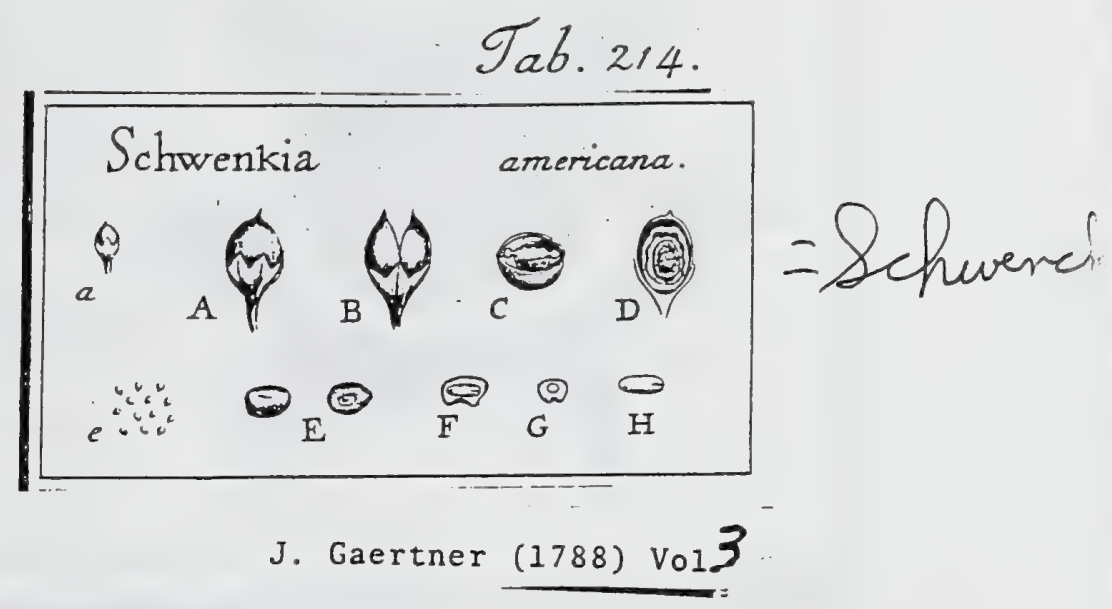

183

\section{C}

\section{3. $S$ C H W E N $\Lambda^{\mathrm{K}}$ I A.}

LINN. gen. 1233. ed. Schreb. 38. Juss. gen. p. 123:

Cal. monopliyllus, tubulofus, quinquedentatus, ftriatus, inferus, perfiftens: Cor. monopetala, tubulofa; fauce inflata, plicis quinque glandulolis itellatim dilpofitis claula; glandulac dux fuperiores longiores. Stam. 5.: duo fertilia fuperiora, longiurs: tria caftrats, fetacea. Ovar. fuperun; itylo fimplici. ftignate obtulo. Capl: ovata, parva, bilocularis; didep. valvis parallelum. Rec. difepimento marginato adnatum. Sem. numerola, angulata, umbilicata, Alb. cannufum, Emb. transverfus; Iad. centrifuga,

184

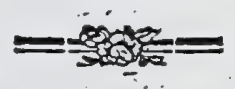

Schromril americana, Tab. 214 . fig. 3.

Scbrenkia. LIN gen pl. p. 567. Syst. veg. ed. 14. po.64. AIT. Lort. kew. 1. p. 29. WILLD. Spec. pl. T. I. P. 1. p. 106.

Ex dono amicilimi $D^{\text {al }}$ Decandolle.

PER. Capfula parva, ovata, turgide lenticularis, verfus apicem mucronula: tum nagis compreffa, calyci infiltens, coriacea, glabra, pallide fpadicea, longitudinaliter dehifcens, bilocularis, bivalvis. Diffepimentum fublibe. rum, cralliufculum, margine incraflato undulato inftructum, valvis parallelum.

REc. ovatum, diffepimento medio utrinque adnatum, convéxum, fcrobicüla. to-punctatum, quibus eminentiis femina arcte fibi approximata umbilicis adharent.

Sem. numerofa, hinc convexa, inde angulata 1, cuneato-truncata, obtula, ad baGı umbilico minino immerfo inftucta, fubtilifime verfus umbilicum lineata, fufca.

IN T. Gimplex, craffiufculum, cruftaceo-coriaceum, adnátum.

A L B. Semini conforme, carnofum, aqueo-palliduns.

EM B. transverfe in albumine locatuc, centralis, ovato-oblongus, fere medul. laris, lacteus. Cotyl: breviftme, obtufa. Rad. craflufcula, ovata, obtu. $\mathrm{fa}, \mathrm{ab}$ umbilico externo remota, centrifuga!

\section{EXPLICATIO FIGURA,}

A. A.) Caprula integra. B.) Eadem dehifcens. C.) Ejucitem (edio transverialic D.) Valvula altera ablata, eum forma \& fitu dilfepimenti" atque receptaculi, c. E.) Serriaz feparata. F. G.) Embryonis fiaus iutra albumen. H.) Idear folutue, 


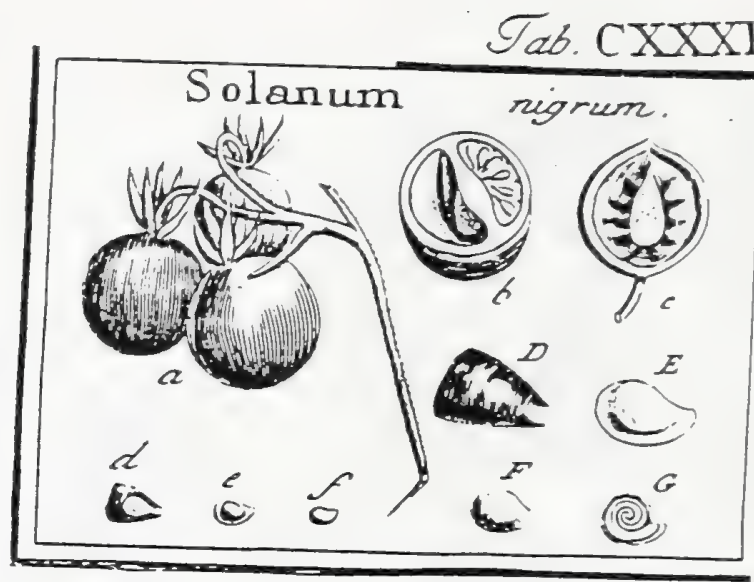

\section{J. Gaertner (-1788) Vol 2}

\section{SOLAN U M. TOURN. t. 62. LINN. ger. $25 \mathrm{I}$.}

Calyx quisıuefidus. Cor. rotata, limbo patente quinquefido. Stam. quinque, antheris conniventibus gemino poro apice dehifcentibus. Ovar. fuperum. Styl. Gimplex, ftigmate obtufo. Bacca fucculenta bilocularis. Recept. adnatum. Sem. plura.

SOlanum nigrum. Tab. 13.1. fig. 4 -

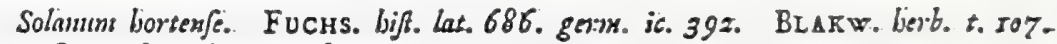
OED. for dain. to 460 .

Solunum coule inermi berbaceo, folits ouatis dextato augruatis, racemis dificlise mutantibus. LiNs. Jy\%t. veg. 224

Varietas baceis luteis, foliis laciniatis.

PER. Bacca globofa, fubvillofa, flavefcens, fubdiaphana, pulpora, bilocularis. Diffepinentum membranaceum, cum' receptaculo connatum.

REc. carnofum, folidum, a diffepimento non diforetum, fed ejus medio arcte. adnatum.

SEM. plura, circiter vigimi quinque in fingulo loculo, ovato-acuminata; rofellata, compreffa, margine membranaceo ciucta, pulpa molli bavefcerme \& diaphana obvoluta.

Ix T. triplex: extimum pulpofum, fenfim exarefcens; medisus chartaceum, glabrum, albicans aut ftramineum, in narginesn membranaceum ampliatum; intimstn itidem menibranaceum, allum, tenue.

A L B: obovato-roftellatum, carnofum, aqueo-pallidum, tenuifimum ut fetc nullum.

EM в. filiformis, fpiralis, Iacteus. Cosyl. Semiteretes, unum cum dimidio-Spira gyrum abfulventes. Rad, brevis, centripeta.

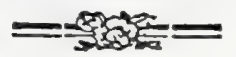

2.) Baccz integra. b.) Loculamenta cum infertione feminum. c.) Receptac. denudatum. d. D.) Semen intra pulpam. c. E.) Idem, exeufiz pulpa, membranaceo marginatum. f. E.) Al. bumen integrum. G.) Idem difTedum cum embryone.

Solanum indictom. Liss. ex fide Martim.

Bacca paulo major quam Afparagi, coloris ex aurantio in rubrum vergentis. Cuticula characea, duriufcula. P'ulpa aquofa. Recept. oblongum, pla. niufculum, fepto undique adnatum. Semina circiter viginti, comprefia, ovato - reniformia, pallida.

Solanum tomentofum. LiNN. ex fide Martini.

Bacca magnitudine Groffularix, cerx flavx coloris, fetis albis ftellatis prafertim verfus apicem confperfa, unde ad tactum afpera. Cuticula chartacea, tenax. Pulpa mucilaginofa, feminibus undique circumnata. Recept ovatum, craffiufculum, a fepto non difcretum. Semina fupra triginta, lenticularia, pallida 


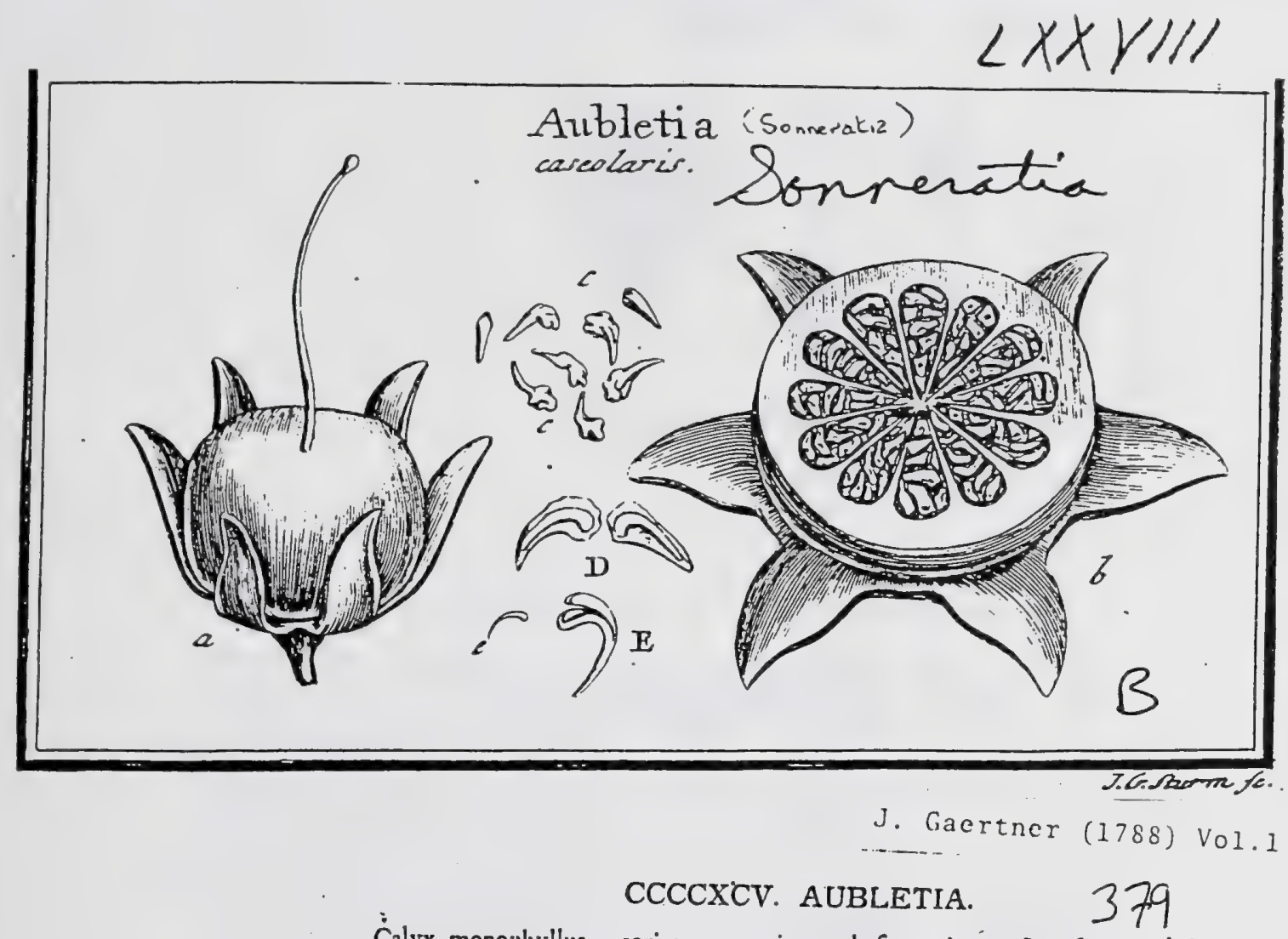

Ċalyx monophyllus, coriaceus, quinque-1. Rexpartitus. Cor. hexapetala? Stam, numerofa. Styl. unicus, filiformis, perfiftens. Pacca fupera, multilocularis. Loculamenta farcta. Semina numerola, polymorpha, nidulantia.

A U в. Eт I A cafcolaris. Tab. 78. fig. 2.

Mangium cafeolare album. Rustrн. ainb. 3. p. zrr. t. 73.

Rhizophora foliis ovatis obtufis, floribus folitariis, fructibus orbiculatis deprefis mucronatis. LIN $\mathrm{N}$. Jyfl. veg. 442.

E cullectione Bankfiana.

PER. Bacca fupera, globofa, depreffiuscula, nylo filiformi terminata, glaberrima, glauca, multilocularis. Cortex tenuifrmus, membranaceus, carri arcte adnatus. Caro duriuscula, granulofa, albicans, Loculamenta duodecim aut plura, feminibus \& carne inter fe mixtis farcta. Diflepimenta tenuia, a carne non difcreta.

REc. nullum; fcmina in omnem fenfum directa, atque interpofita pauca carne, infar lapidum pavimenti fibi mutuo juncta.

SEs. numerofillima, mulifurmia \& fractorum dentium fruftulis omnino xinula, plerumque tamen irreguiariter clavata, curiata, eburnea.

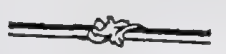

IN T. duplex: exterius cruflaceum, crafum, fragiliflimum; interius meubranaceum.
tenuiffunum. A в в. nullum.

-EM в. clavato-curvatus inftar pedi, lacteus. Cotyl. foliacex, tenuifinne, canaliculato
convolutx; exterinre involvente interiorem, paulo minorem convolutx; exteriore involvcnte interiorem, paulo minorem. Rad. tereti ecuini-
nata, longa, vaga.

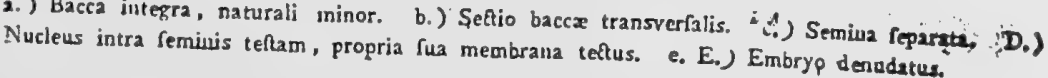




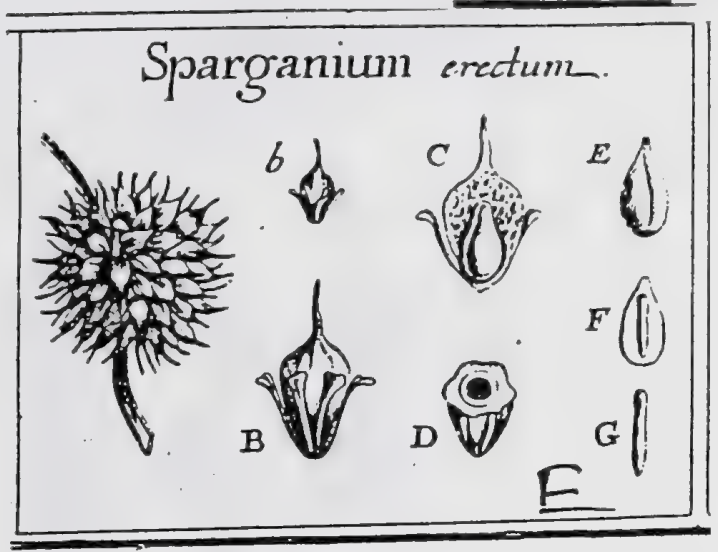

J. Gaertner (1788) Vol.1

\section{SPARGANIUM. TOURN. t. 302. LINN. Gem. I04T.}

Flores conglobati, lexu diftincti mafculis fupra femineos in eodem caule. Mas. Cal. triphyllus. Cor. nulla. Stam. tria. FEM. Cal. hexaphyllus. Cor, nullz. Drupa ficca, furpera, unilocularis. Enbryo longitudine albuminis.

Sparganium erectum. Tab. 19. fig. 4 .

Sparganium. CA ss. epit. 732. Best. If Eyff. vern. VII. t. 2. f. 3.

Sparganium caule foliisque ereftis. HALı. hifl. 2. n. 1303.

Sparganinm foliis ereatis triquetris. LINN. Jyft. veg. 841.

PER. Drupa fupera, exfucca, turbinata, fubulato rofirata, inferne a vicinarum prelfione varic angulata. Cortex fpongiofus, ad apicem craflifimus, ad bafin extenuatus. Putamen fubofieum, ovato conicum, unilocularc: parte fuperiore angufliore, cum parvo formaine in apice.

REc. commune globofun, carnofum, fcrobiculatum; proprium, funiculus umbilicalis filiformis, fomini adnatus, per foramen putaminis, ad bafin feminis defeendens.

SEM. u!̣icum, ovato acuninatum, pallidum, aut viridefcens, ad bafin chalaza fufca notatuin.

IN T. fumplex, membranaccum, diaphanum, a nucleo facile fecedens.

A св. femini couforme, farinofum, candidifinum, molle, ut in aqua facile in pultern convertatur.

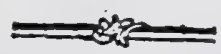

Eмв. monocotyledoneus, teretiusculus, rectus, lacteo albicans, longitudine fere at.
buninis.

a.) Amentum fensineum. b. B.) Drupa (eparata. C.) Ejus cortex longitudinaliter finus \& pati. men dcuudatun. D.) Drupx fétio transverfalis. E.) Semed cum funiculo umbilicali. F.) Af bumen Jongitudinalitic fetum, cum embryoue. G.) Embryo feparatus.

Nec milhi unquan contigit duo videre fernina aut drupam bilocularem, uti Tournes fortii icon habet, neque id etian Adanfono. famil. 2. p. 467. 


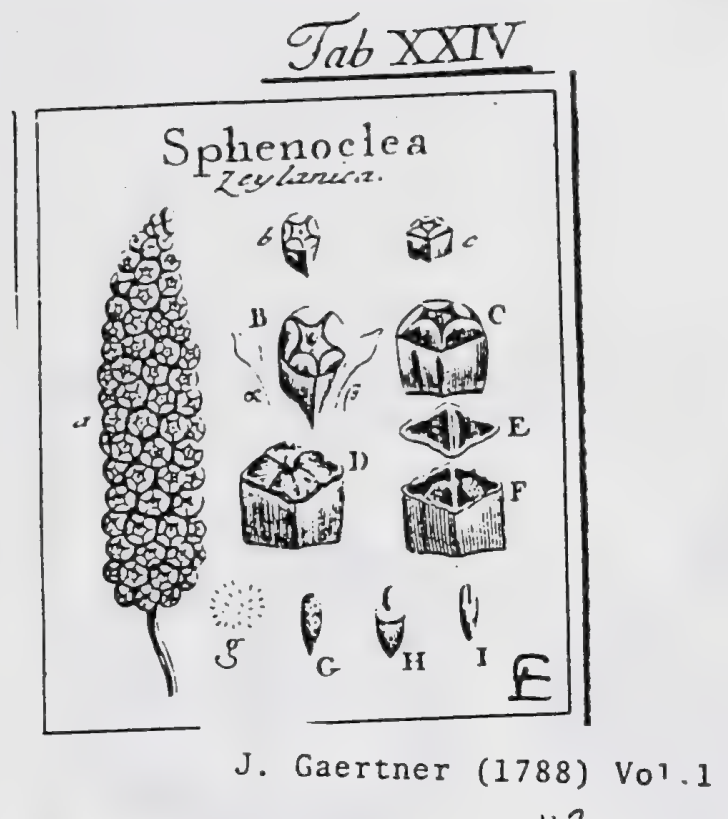

113

\section{SPHENOCLEA.}

Calyx pentaphyllus, fuperus: foliolis rotundatis, concavis, conniventibus, perfifientibus. Cor. .... Stam. .... Styl. . . . Capfula infera, cuneiformi-comprefta, bilocularis, circumscilTa. Receptacula libera, deorfuen pendula! Semina numeroflliuna, minutifima.

SPHENOCLEA reylanica. Tab. 24. fig. 5 .

Tembul-wanna. zcylonens. E collect. fem. hort. lugdb.

PER. Capfula infera: calyce aut corolla perfiftente, connivente, coronata; fupra amplior, rhombeo-ovalis; infra cuneiformi compreffa, atque bafi fua in aciem rećtam, verticaliter pofitam defunens; cetera membranacea, tenuiffina, diaphana, bilocularis, circumfcifta. Operculum rhomboideum, rigidiusculum, extus friis quatuor, cruciatis infriptum.

REC. tereti acuminatum, in fingulo loculamento fingulum, diffepimenti parti fupre$m x$, fua crafiore extremitate affixum, altera autem tenuiore deorfum propendens, undique liberum, puncticulatum, fungofum.

SE s. numerofifima, minutifima, apparenter lineari-fcobiformia, fed armato oculo fpectata, terctiuscula, verfus umbilicum attenuata, puncticulata, pallide fpadicea.

IN T. fumplicifimum, tenuifimum.

A z в. femini conforme, crafliusculum, carnofun, aqueo-pallidum.

Es в. dicotyledoneus, tcretiusculus, longitudine fere albuminis, lacteo albus. Cotyl. breviliinx, vix rite diflinctx. Rad. longa, receptaculo obverfa.

2.) Spica frugiferz. b. B.) Capfula in fitu naturali fpetata, calycis foljolis coneavis contefa \& ad utrumque latus fipula florali (a. $\beta$. ) lanceolato-unguiculata, fipata. c. C.) Eadem a latere fpeRata. D.) Eaderu, excuris foliolis calycinis, folo (uo operculo thomboideo tcata. E. F.) Operculum remotum, \& receptacula libera in fingulo loculamento fupremx parti difiepimenti affix 2. c. G.) Semina (cparata, H.) Embryonis fitus intra albumen, 1.) Embryo feparatus.

II4

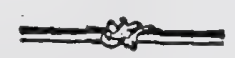

Non plane certus lum, utrum enbryo fit dicotyledoneus? rimam tamen, duarum cotyledonum indicem, aliquoties vidiffe mihi videor. 

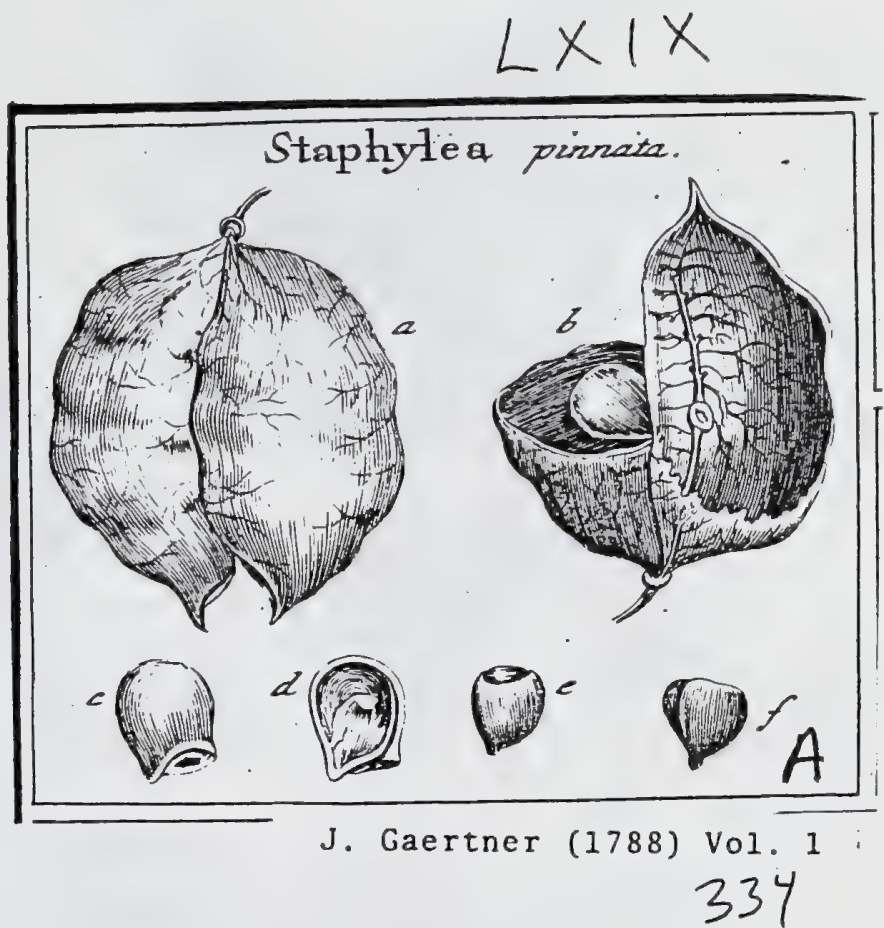

CCCCXXXI. STAPHYLEA. Tour N. $t$. 386. Linn. ger. 374 .

Calyx quinquepartitus. Cor. pentapetala. Stam. quinque. Styl. duo 1. tres. Caplulae duael. tres, coluratac, iullatae. Semina nucamentacta, bafi truncata.

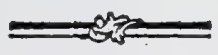

Si A т н т e a pinnata. Tab. 69. fig. I.

Staphilodendrum. CAM. epit. 17I. B EsL. h. Eyff. vern. frut. t. 8. f. I.

Staphlylea foliis pinnatis. Ha L L. hifl. 1. n. 831. LIN N. 44 f. veg. 296.

PER. Capfula, ex duabus inter fe connatis, compofita, orata, didyma, menbranacté, inllata, venofa, bilocularis, apicibus acuminatis introrfum dehifcens.

REC. ncrius craffus, inedio fepto innatus, utrinque funiculos umbilicales brevifiumos, fuboppofitos emittens, qui per maturitatem in latas areas umbilicales fungolas mutantur.

SEM. Fex ad decem in fingulo loctlamento, quorum unum aut duo duntaxat adolefcunt, fubglobofa, offea, glaberrima, nitida, e luteo rufefcentia, verfus bafin ccarctata \& in obliquum acumen definentia, juxta illud vero quafi truncata, atque lata arca unbilicali exfculpta.

IN. T. triplex: extimum nucamentaceum, cultro bipartibile, foramine in bafi \& canali pronrio, pro embryonis vafis nutritiis, exfculptum: medium membranaccum, tenuilïmum, albidum, nucis parietem internum obveftiens; intimuna fubcoriaceum, lata chalaza ferruginea notatum.

A $\llcorner$ B. nullum.

E. в. magnitudine cavitatis feminis, fuberectus, albus. Cotyl. obovatae, carnolae, plano-convexae. Rad. brevis, compreffiuscula, infera aut relative centripeta.

a.) Capiula intogra. b.) Eadem aperta, cum receptaculo \& feminum fita. c.) Semen feparatom. d.) Nucis valvula cum membrana fua propria \& eanali nutritio, e.) Nucleus decorticatus. f.) Embryo denadatus. 

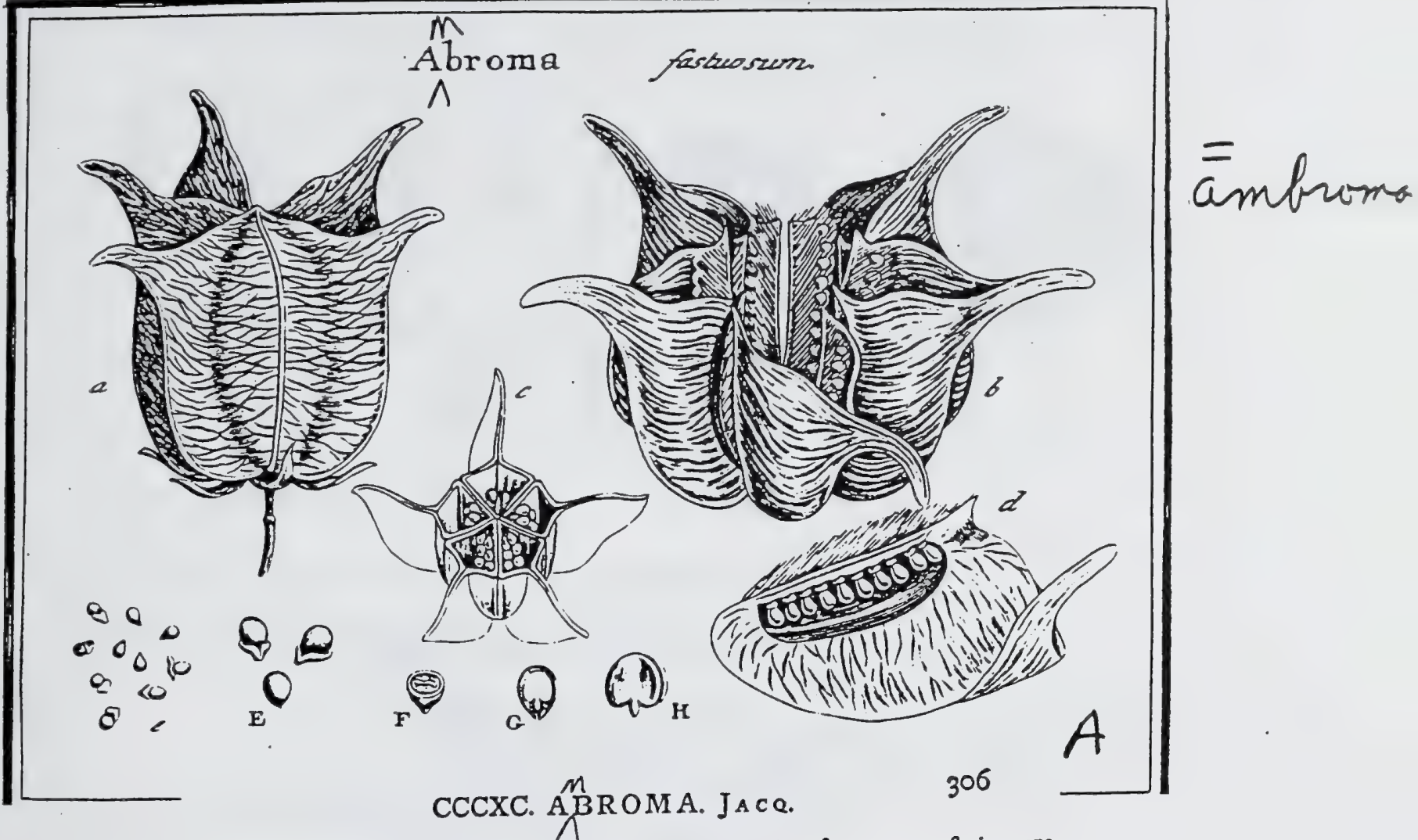

Caly $\times$ pentaphyllus. Cor. pentapetala unguiculata: unguibus fuperne anguftatis, canzliculatis; inferne dilatatis, quadrato-ovatis, extus \& apice pilofis, fornicatis, in urcei fpeciem conniventibus. Nectar. campanulatum, quinquefidum, laciniis oblongis obtufis apice recurvis. Filament. nulla. Antherx quindecim: ternis ad fingulain nectarii divifuram extus pofitis. Styl. quinque. Capfula quinquealata, quinqueroftrata, quinquelocularis. Scmina plurima, incomplete arillata.

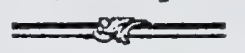

Aв Rом A faluofum. Tab. 64. fig. I.

Icon. J A c C. hort. 3. p. 3.t. I.

Ainbroma angufa. Li n N. Juppl. 54. 44 f. veg. 606.

Ex herbario Bankfiano.

PER. Capfula grandiuscuia, membranacea, venis reticulata, fpadiceo fufca, ovata, pentagona, alis quinque furfum latefcentibus $\&$ in totidem cornua compreffa, divaricata, definentibus, fipata, quinquelocularis, fuperne inter cornua quinquefariam dehifcens. Diffepinenta duplicata, ex intlexis valvularum marginibus formata.

R Ec. nullum; femina margini diffepitnentorum centrali incraftato \& canis crinibus barbato, duplici ferie affixa.

SEM. numerofa, ovato-globofa, verfus umbilicum acuminata, nigro fufca, aut atra, inferne arillo contecta.

Arillus membranaccus, incompletus, tenuis, albus, hinc breviffunus, rima incilus, inde integerrimus, oblique rotundatus, dimidio lemine brevior, per maturitatem deciduus.

IN T. duplex : exterius coriaceum, craffusculum, durum; interius membranaceum, rufefcens, chalaza fufca notatum.

A Ł . femini conforme, craffum, carnofum, aqueo-pallidum.

E м B. longitudine fere albuminis, niveus. Cotyl. cordato orbiculatx, foliacex, tenuiffi$m x$, transverfun figınoideo-flexuofx. Rad. teretiuscula, brevis, centripeta.

a.) Capfula claufa. b.) Eadem, fupra naturaiem dehifecntiam, parlulam magis didueta. c.) Ejus fetio transverfalis. d.) Diffepinenti margo, ab uno latere a pilis repurgatus, ut Seminum infertio appareat. e. E.) Semina foluta, cuin, \& absque Arillo. F.) Seminis \& albuminis feflio transverfalis. G.) Embryo intra albumen. H.) Idem feparatus,

Dilatatos petalorum ungues, vulgo Nectarium exterius appellare folent; ob fabricam autem atque confifentiam fuain aptius pro ipfius coroll $x$ parte haberi poffe videntur. Reniformia fernina, neque in hac, neque in altera fpecie, qux Abroma 

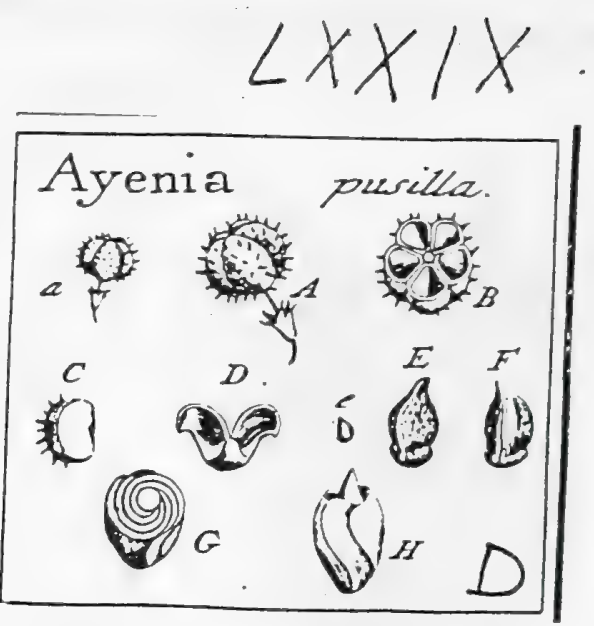

J. Gaertner (1788) Vol.1

CCCCXCIX. AYENLA. Lin s. gen. 1020. 382

Calyx pentaphylllus. Cor. pentapetala, unguibus longis. Stam. quinque, thalamo in. ferta Styl. unicus. Capfula compofita, pedicellata, pentacocca. Semina folitaria,
inverfa,

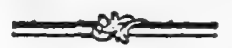

AYENIA pufilla, Tab. 79. fig. 4 .

Dayenia inernis, foliis oblongo cordatis marginibus dentatis, floribus axillaribus. MILL. diat. ic.t. IIS.

Alyenia foliis cordatis glabris. L IN N. fyft. veg. 821. aqu. holm. 1756. tab. 2.

PER. Capfula compofita, pedunculo fetaceo fupra calycem elevata, rotundato pentagona, pentacocca. Cocculi ovati, hinc convexi, aculeolis mollibus muricati, inde angulati, sniloculares, bivalves, elaftice dehifcentes.

REc. commune filiforme, in axi fructus pofitum; proprium, circatricula in angulo cocculorum interno, cui femina affixa.

$S E$ ss. folitaria, gigartoidea, apice mucronata, bafí retufa, hine gibba, inde fubangu. lata atyue linea depreffa longitudinali inferipta, undique panctis elevatis fcabra, nigro fufica.

Ist. duplex: exterius crufaceum, craffum, fragile; interius membranacenm, paliidum.

A L B. nullum.

E 3 в. fominis cavitati conformis, inverfus, Iuteus. Cotyl. rotondatz, bilobx, foliacex, circa radiculam fpiraliter convolutx. Radic. fufiformis, recta, fupera.

2. A.) Fructus integer. B.) Idem transverfe fectus. C.) Cocculus (epanatos, claufus, D.) Idem eiaftice disruptus. e. E.) Seminis dorfum. F.) Ejus pars ventralis, G.) Cotyledones \& radicuIa transverfim fectz. H.) Embryo denudatus integer. 


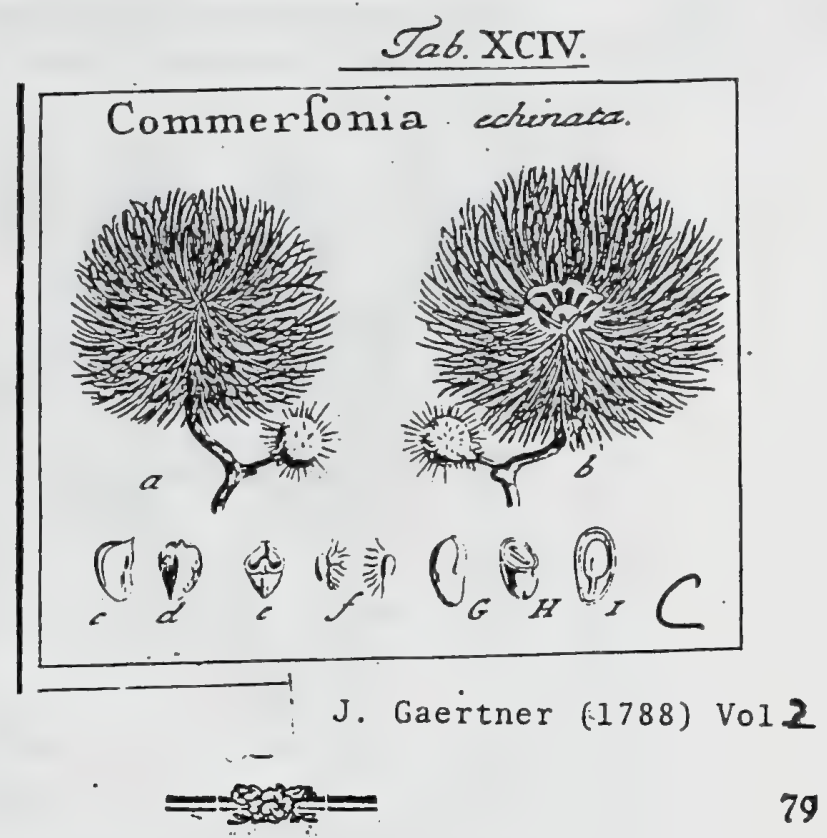

\section{C O M M ER S O N I A. LINN. gen. 1380.}

Calyx monophyllus quinquepartitus. Cor. pentapetala, calyci inferta: petalis bali dilatatis. Nectarium decempartitum: laciniis alternis lanceolatis: alternis filiformibus villofis. Stam. quinque. Ovar. fuperum, globofum. Styl. quinque, ftignatibus globofis. Capfula fetis mollibus echinata, quinquelocularis.

Commersonis echinata. Tab. 24. fig. 3:

Dafjpogon. SOrand. m/s.

Commerfonia. Lins. fiyt. veg. 304.

Ex herbario Bankfiano.

PER. Capfula fupera, fubglobofa, corticata, pentacocca, quinquevalvis. Cortex coriaceus, undique fetis mollibus villofis echinatus, apice quinquefariam dehifcens. Cocculi quinque, abovati, deorfum anguftati, oflei, hinc gibbi, jnde angulati, ex dorfo femibiloculares, bivalves: valvulis cocculorum contiguorum inter fe conferruminatis \& diffepimenta capfula propria formantibus.

REC. nullum, prater angulum loculamentorum centralem.

SEM. in fingulo loculamento gemina . ovato - oblonga, fupra paulo craftiora, levifime compreffa, rubro ferruginea, in vertice autem nigricancia, incomplete arillata.

Arills membranaceus, tenuifimus, albicans, lacerus, umbilico feminis affixus, ejusque totam partem ventralem, inon autem dorfalem, obtegens.

IN T. duplex: exterius coriaceum, craffum, duriufculum; ixterius membrana. ceum, tenue.

AL в. femini conforme, carnofum, pallidum.

Eis в. longitudine fere feminis, erectus, lutefcens. Cotyl. ovatx, fubfoliz. cex, planse. Rad. teretiufcula, cotyledonibus brevior, infera.

a. b.) Capfula integra \& dehifcens. es d.) Cocculus feparatus ciaufus a latere \& a parte trali (perfatus. e.) Idem transverfe fedus, a dorfo (pecatus. f.) Seminz cum arillo. G.) Semen naturali majus, excufio arillo. H.) Ejusdem fetio transvertalis, 1.) Embrguaic, is fcmine verticaliter fedo, figurs a:yue fitus. 

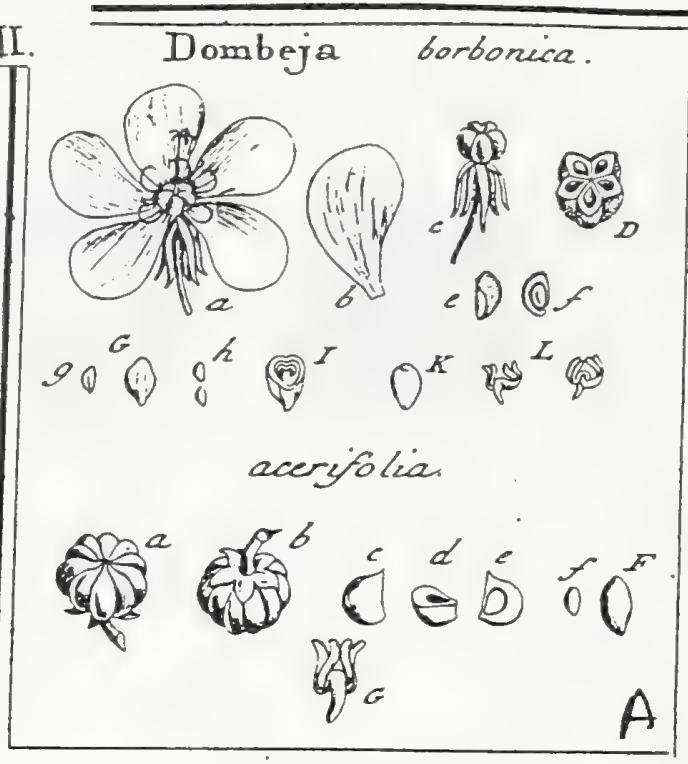

\section{Sterculiaceae}

\section{D O M B E Y A. CAVAN. JUSS. p. 277 .}

Calyx duplex: exterior triphyllus, caducus; interior monophyllus, quinquefidus. Cor. quinquepartita, petalis obovatis fulfalcatis. Seam. viginti: quinis longioribus fterilibus; reliquis dimidio brevioribus fertilibus; omnibus bafi in urceolum brevem connatis. Ovar. quinque. Styl. filifornis, Itigmatibus quinque recurvis. Capfulx quinque, in unam conniventes, uniluculares. Semina folitaria aut geroinata.

DOMBEYd borbonica, Tab. 137. fig. I.

260

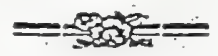

Arbre a fern's en bouquets, de lisle de France. A Cl. Hermann.

PER. Caplulx quinque, ad axem cohxrentes atque fructum pentagonum fuperne umbilicatum formantes, ovatx, verfus axem cuneiformi-compreffx, uni: loculares, rima longitudinali ad angulum centralem dehifcentes \& ab axi fecedentes. Loculamentum propria lamina cartilaginea veftitun; dorfum autem fuberofum, compreffum, latum, undique villis fordide cinereis rigidiufculis \& longis tectum, ut fructus fubglobofus, obiter infpicientr, appareat.

REC. connsune nullum; proprinn mullum, proter angulum centralem, cui feminat affixa.

SEM. duo, altero tamen frepius abortiente, ovats, fubangulata, inferne acu minata \& quafi roftellati, fufco - ferruginea.

IN T. triplex: extimun ab epidermide, tenuiffinum; medinm cori:ceum durum; iminntm membranaçeum, rufefens, chalaza atra in vertice notatum.

ALB. tenue, carnofum, duriufculum, niveum, intra cotyledones denerfum.

Eм в. curvatus, pallide lutefcens. Cot $y l^{\circ}$ foliacex, bipartitx: Inciniis linearibus undulato - aut chryfaloideo-convolutis. RaL. teretiufcula, inferat:

a.) Flos magnitudine naturali. b.) Petalum feparatum. c.) Fruetus maturus integer. D.) Ider transicerse (cetus. c.) Capruia (eparata intc:ra. f.) Eadem longitudinaliter aperta, cum fita feminis. 5. G.) Semen folitarium (ubtrizonum. h.) Scuirs geninata. I.) Semen transverfe. fietum. k.) Albumen denniatum. Lo) Embrya folatus, ab anteriori \& pofteriori parte fpetatus, cum corylcdonibus explicatis.

Ommes foris partes, proter cxterni calycis foliola, perfiftunt, atque corolla rigefcens \& crecta fructum occultat ac tuetur. Specien forfan deternimare poterunt, qui Cavanillei opus pofrident.

\section{DONBEYA acerifolia. ibid.}

Fruit d'un grand arbre, a fenilles d'enable, blandies, de Pisle de Bourbon.

A Cl. Hermaxis. Prof, argentor.

Fructus orbiculatus (a), depreffiufculus, torulofus, gilvus f. mucularum ftaphylodendri culore, glaberrimus, nitidus, calyce quinquefido (b.), albo-tomentofo exceptus. Caplulac denx aut pauciores, 9. 8. 7. quinis tament femper plures, fencirculares (c.), verfus axem cumciformi - comprelic (d), in durfo autem rotundatx, fuberofx, uniloculares (e.), non dehifcentes. Loculamenti membrana cartilaginea, nitida. Dorfum latum (c), cratum, ex fubltancsa fungofa alba. Semina (f. F.) folitaria, e caltanco rufefcentia. Integuncuta, chalaza \& albumen prorfus ut in priccolcinti. Embryo (G.) lutelcens. Cotyled. bipartitx, replicatx, undulatic. Kad. infera.

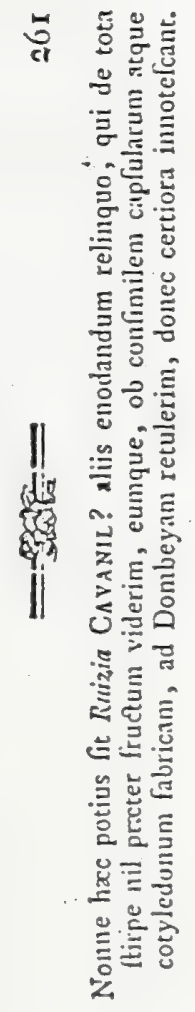




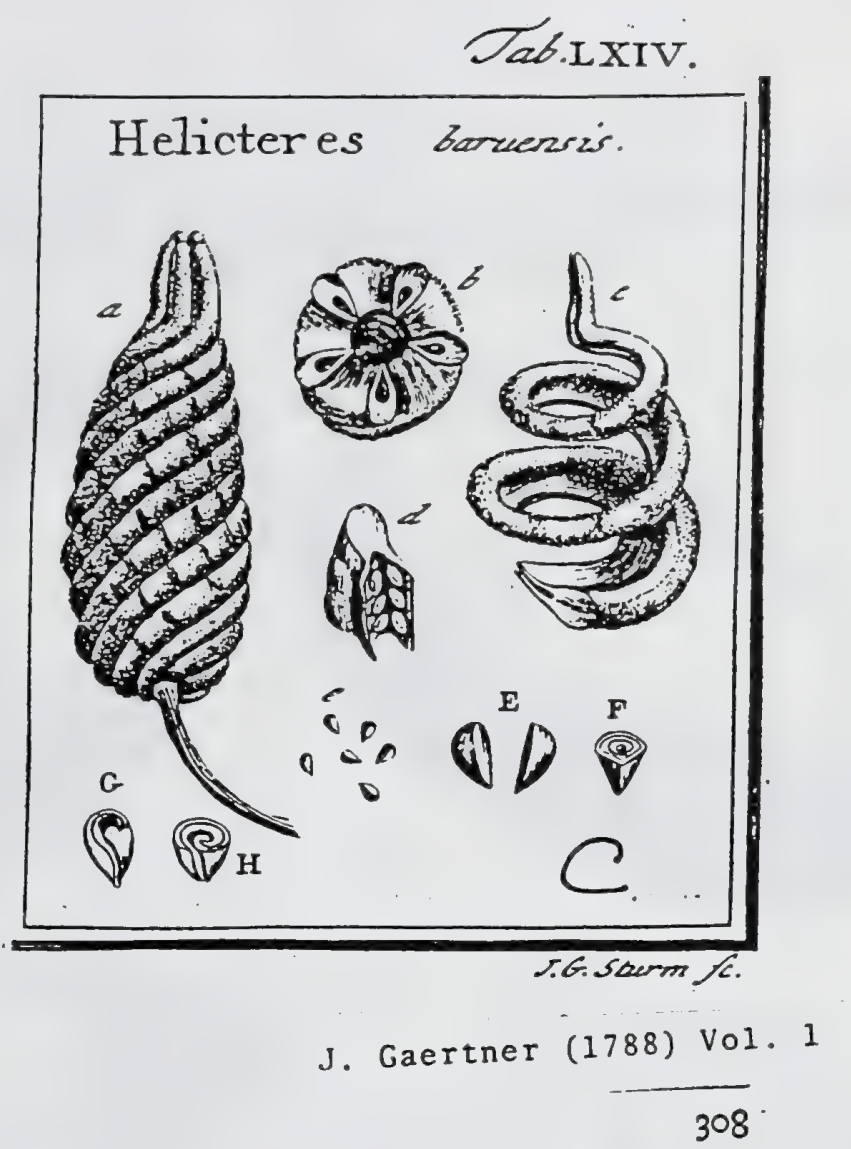

CCCXCII. HELICTERES. Li N N. gen. 1025.

Calyx monophyllus, obliquus, quinquefidus. Cor. pentapetala. Stam. decem 1. plura. Styl. quinque. Capfulz quinque longiffimo pedunculo communi infiftentes, fxpe fpiraliter intortx, uniloculares, margine interno dechifcentes. Semina futurz dehifenti affixa.

HELICTERES baruenfis. Tab. 64. fig. 3.

Helifieres folits cordatis ferratis, foribus decandris, fructu compofito contorto: apicibus reftis. JA C C. hifl. aneer. 1. p. 236. t. 149.

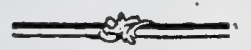

Helitteres decandra, foliis cordatis ferratis, fructu contorto, apicibus rettis. LIN N. Jifl. veg. 825 .

PER. Capfulx quinque, receptaculo communi, filiformi, longiftimo innatx, fuberofo coriacex, fpirales, in apicen rectum porrect $x$, hinc rotundatz, varicof $x$, pubefcentes, inde glabrx, in aciem compreflx. uniloculares, univalves, futura interna dehilicentes.

REC. nullum, prxter inarginem futurx dehilcentis, cui femina ntrinque alternatim affixa.

SEM. numerofa, quinquaginta circiter in fingula capfula, obovata, angulata, glabra, fufco - caflanea.

IN T. duplex : exterius coriaceum, durum, craffusculum; interius tenuifimum, fuperficie interion fubcarnofa.

$\Lambda\llcorner$ B. nullum, proter laminam carnofam integumenti interni.

Eм в. magnitudine ferninis, albus. Cotyl. foliacex, tenuifimx, fpiraliter convolutx. Rad. brevilfinza, acuminata, rclative centripeta.

2.) Frufus integes, b.) Idem fupra bafin transverfe feêtus, nnmerum apfularum \& contorfionis modum ofendens. c.) Capfala reparata integra. d.) Ejusdem portio refeta, cum infertione fer parata. F.) Seminis \& embryonis fertio transverfalis. G.) Embryo denudatos. H.) Cotyledo num convolutio. 


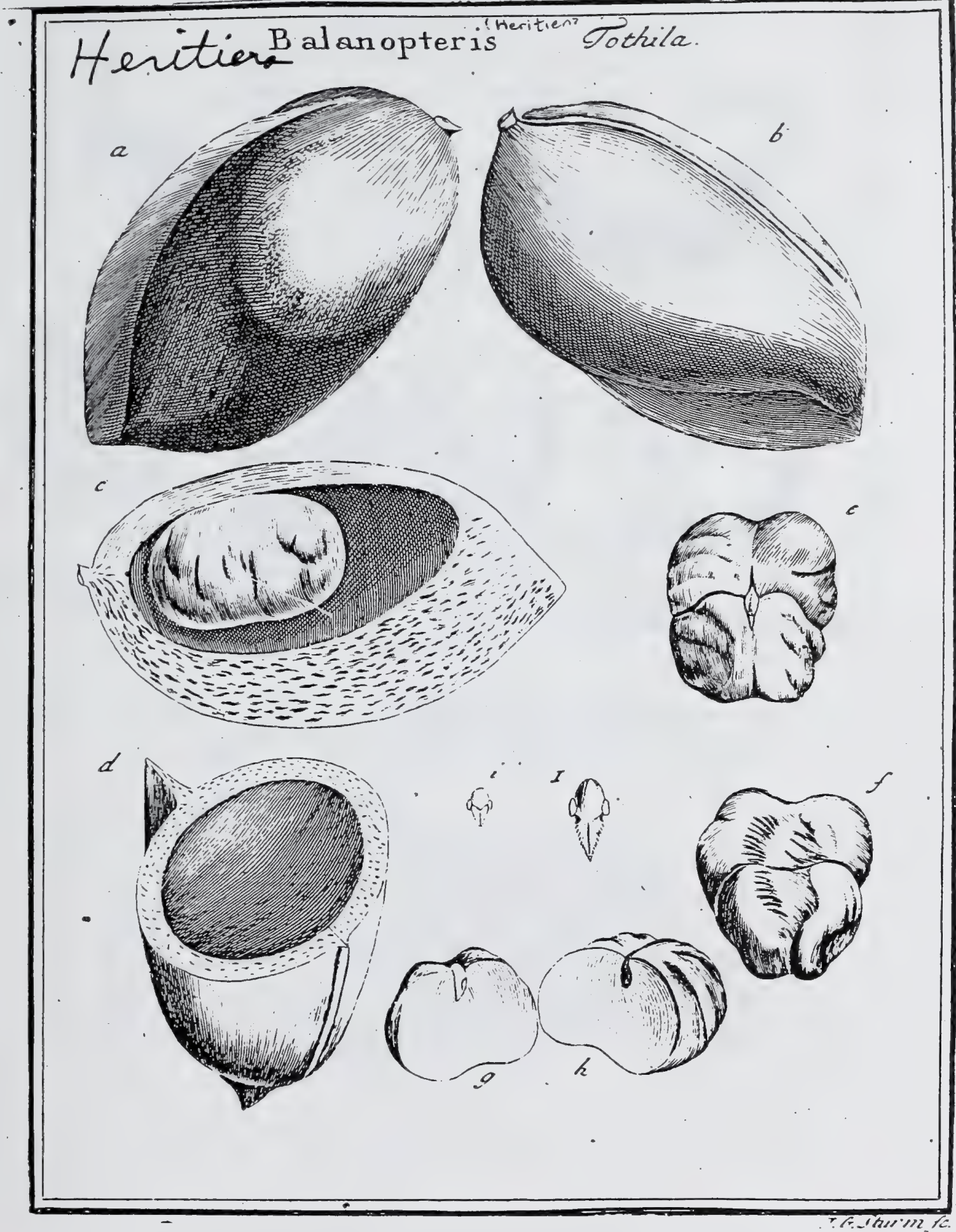




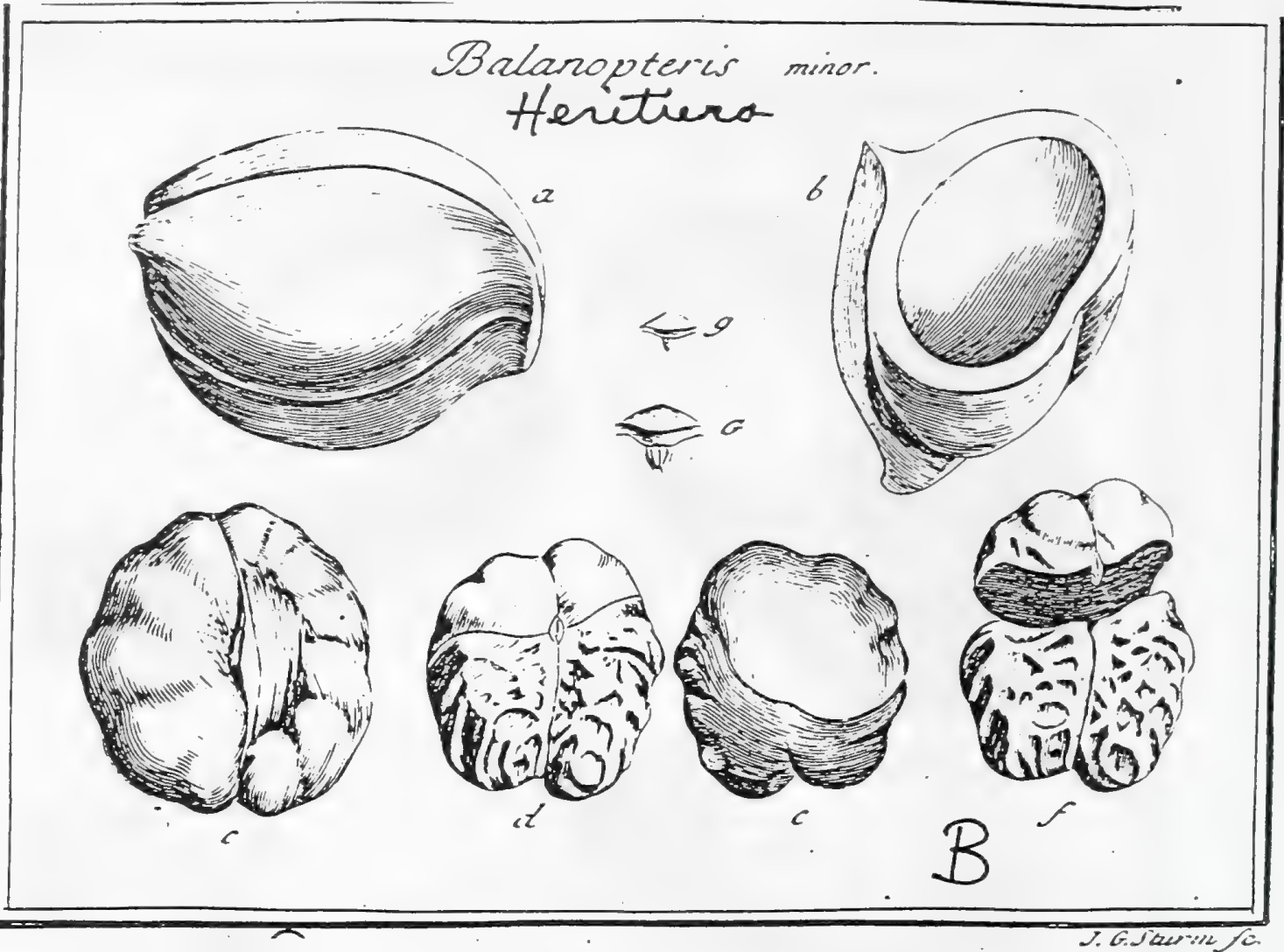




\section{J. Gaertner (1788) Vol 2}

DCIÍ. B A L A N OPTERIS.

Flos.... Nuces una plures lignof evalves, earina dorfi in criftam rigidam ampliata.

BALANOPTERIS Tothila. Tab. 99.

Tothya \& Fothila. Herm. muf. 48. Burm. Zeyl. 226. LinN. Zeyl. p. 237. E collect. hort. lugdb. \& Bankfiana.

PER. Nuces geminæ, aut plures? grandes, ovatx, inferne transverfim ventricofe, fuperne acuminato recurva, hinc futura longitudinali inforiptx, inde carina in criftan rigidam ampliata notate, uniloculares, evalves. Putamen nudum, fibrofo - lignofum, ad futuram ventralem cultro filfile, ad carinam vero dorfalem integerrimum, glabrum, fubfplendens, gilvum 1. coloris nucularum Staplylodendri. Loculamentum depreffum; feu, in fitu nucis horizontali, transverim latius quan altum.

REC. nullum; femen futurx ventrali adnatum.

SEM. unicum, grande, ovato-globofum, tuberculis \& rugis irregularibus, ficuti Caftanez femen, infcriptum, cetera glabrum, rufefcens.

Is r. fimplicifimum, papyraceum, facile a nucleo fecedens, nec intra ejus rimas demiffum.

$\Lambda$ L B. nullum.

.EMB. femini conformis, lutefcens, hine valde gibbus atque crucisto fulco infcriptus, inde depreffiufculus, fimplicique rima transverfali incifus. Cotyl. carnofx, craffifimx, irregulares, inxquales: inferiore paulo majore. Plsin. diphylla, compreffa, foliolis acuminatis, hirfutis. Rad. ovato-acuminata, comprefla, in propria cotyledonum rima hxarens, futurx nucis obverfa.

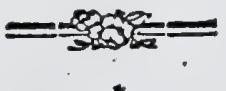

2. b.) Nux integrz, a parte derfali atque ventrali fpectatz. c.) Ejus feQtio longitudinalis, cum fitu \& figura.feminis. d.) Eadem transverfe feat. e.) Embţonis pars ventralis. f.) Ejusdem latus dorfo olserfum. 8.) Cotyledon fuperior minor. b.) Cotjl. altera inferior. i. L) Radicula \&. plumula feparata.

BaLANOPTERIS minor. Tab. 98. fig. 2:

Fruitus Infula Mazritii. A Cl. Hermanno Prof. Argentor.

Nux (a) procedenti fimillima, fed dimidio fere minor, fecundum futuram ventralem depreffo fulco exarata, \& verfus utrumqque latus (b) admodum pulvinata f. transverfim infigniter lata, cetera autem ficuti procedens formata atque colorata, minus tamen vivide lutea, minusque fplendens. Semen (c) magnitudine loculanenti, lenticulari comprefun, in medio cicatrice umbilicali longitudinali notatum, ad latera fulcatum, glabrum, rufefcenti ferrugineum. Embryo a parte ventrali (d.) reticulato rugofus, a dorfali autem (e.) leviter convexus, glabriufculus. Cotyledones $\left(f_{0}\right)$ carnof $x$, crafie, inæquales. Radicula (g. G.) fubimmerfa, brevifima Plum. tetraphylla, foliolis oppofitis; acuminatis, carinatis, glabris. 


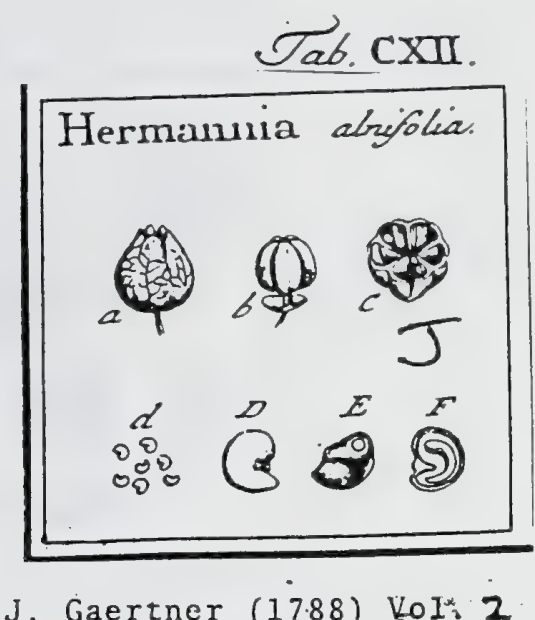

140

DCLV. HERMANNIA. TOURN. inf. t. 432. LIN . ger. $82 \%$.

Calyx quinquefidus. Cor. pentapetala, petalorum unguibus fenitubulatis. Stam. quinque, inferne fubcoalita. Ovar. fuperunı. Styl. quinque. Capf. pentagona, quinquelocularis. Sem. plura, renifornia.

Hermannia alnifolia. Tab. 112. fig. 10.

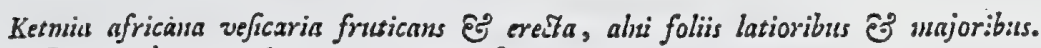
Cons. bort. ainff. 2. p. 155. t. 78.

Hermannia foliis cuneifurmibus lineatis plicatis crenato emarginatis. LINN. fyft. veg. 610 .

PER. Capfula intra calycem ventricofum leviter infatum hacens, fubpedunculata, pentagona, tenuis, fpadicea, quinquelocularis, quinquevalvis. Diffepimenta medio valvulatun dorfo adnata.

REC. nullum; fenina margini diffepinentorun centrali utrinque affisa.

SE M. plura, octo l. duodecim in fingulo loculo, parva, reniformi - angulata, glabra, fordide cinnanomea: umbilico ruberculato in medio ventris.

IN T. duplex: exterius coriaceum, durum, irafiufculum; interius membranaceum, rufe fcests.

A ¿ в. carnofum, criffum, album.

E м в. femicirculari-curvatus, lutefcens, erectus. Cotyl. ellipticx, planx, fubfoliacex. Rad. seretiufcula, arcuata, infera \& fimul centripeta.

2. b.) Capfula calyce obteta, atque denudata. C.) Ejus fectio transverialis. d. D.) Semima Icparata. E.) Scuinis \&-albuminis fedtio transverfalis. F.) Semen loggitudinaliter difrceum cum fitu \& figurz Embryonis intra albumen. 


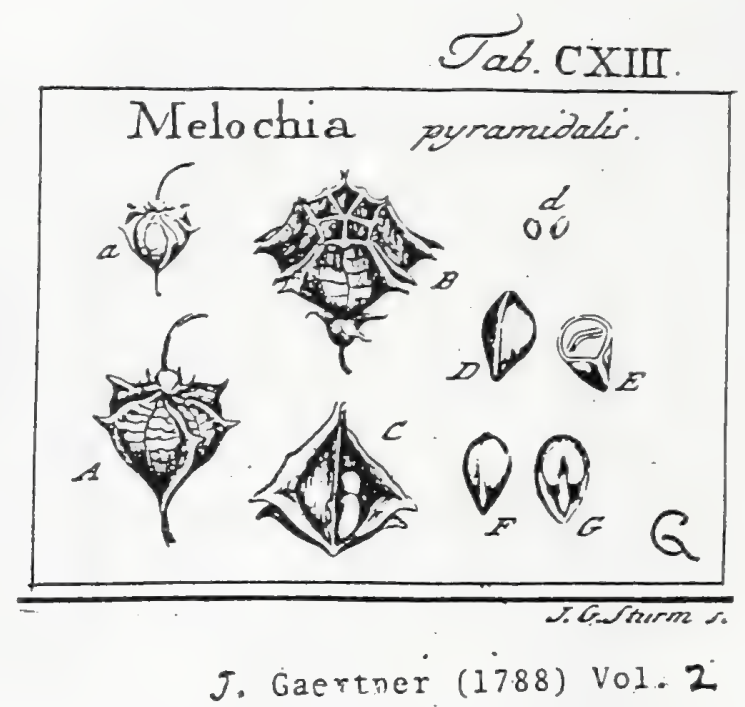

\section{I53}

DCLXIV. MEI O CHIA. LINN. gen. 829.

Caly.x femiquinquefidus. Cor. pentapetala. Stam. quinque in tubum connata. Ovar. fuperum. Styl quinque. Capfula quinquelocularis. Sem. geminata.

Melochia pyramidalis. Tab. II 3 . fig. 7 .

Alther brofstiana frutefcens, incarnato fore, fagopyri semine. PLuk plbyt. t. $I_{3}$ t. $f .3$.

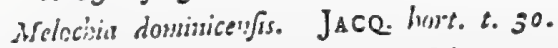

Meluchia foribus umbellatis, cayjullis pyramidatis pentagonis: angulis mucronatis, foliis mudis. LiNs. byfe veg. 625 .

PER. Capfula membranacea, vafculofo - reticulata, e ventricofa bafi in brevem pyramidem faltigiata, alis quinque angultis \& prope bafin in mucronem horizontalem productis angulata, quinquelocularis, quinquevalvis. Valvulx fecundum alas dehifentes, intus lepto medio ftipate.

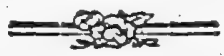

REc. nullum, proter marginem centralem difepimentorum, cui ferrina ope brevilfimi funiculi umbilicalis affixa.

SEx̀. duo, rarius unicum, ovata, deorfum acuminata, hinc convexa, inde angulata atque linea longitudinadi albicante notata; cetera glabra, ferrugineo - fulca.

IN T. duplex: exterizs coriaceum, crafiufculum; interins membranaceum, album, chalaza nigra in vertice notatum.

A L в. carnofum, craffum, album.

E M B. longitudine albunsinis, erectus, luteus. Cotyl. fuborbiculatx, folsicex, trassverfim curvatæ. Rad. teretiufcula, recta, infera.

2. A.) Capfula integra. B.) Eadem dehifcens \& transverfin diffeas. C.) Seminum in loculamentis fitns. d. D.) Semina integra. E.) Semen transverfe feetum. F.) Albumen decorticaturn integrum. G.) Sdem longitudiualiter apertum cum fitu \& Gigura Embrgonis. 


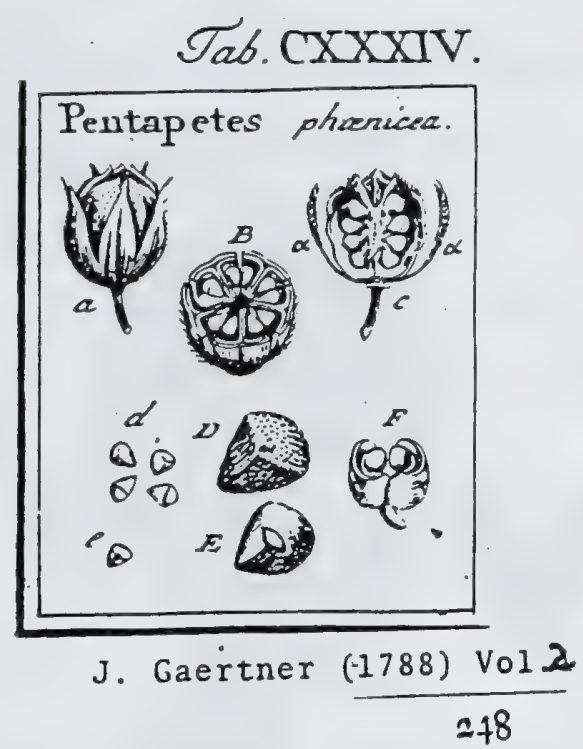

DCCLXXXII. PENTAPETES. LINN. gcn. $834^{\circ}$

Calyx monophyllus, profunde quinquefidus. Cor. quinquepartita, cum ftaminum bafi coalita. Stam. uumerofa : filamentis quinqque linearibus, planis, intus coloratis, extus albo-pulverulentis, fterilibus; reliquis filifurnibus, triplo brevioribus, fertilibus: omnibus bafi in urceolum connatis. Ovar. unicum, fuperuin. Styl. filiformis', Ptaminibus fterilibus paulo longior, apice quinquefidus. Capf. corcicata, fimplex, quinquelocularis, quinquevalvis. Sem. plura, angulata.

Pentapetes phocnica, Tab. 1:34 fig. 4 .

Sjamin. RHEED. mal. 10. p. 1. t. 1. vir noftra, propter folia cordata. Alcea indica husido baftato folio, flore blattarie phoeniceo. PLUK. plyyt. t. $255 . f .3$ Blattaria Zeylanica, fore anto cocciseo. Сомм. hort. x. p. II. t. 6. bene.

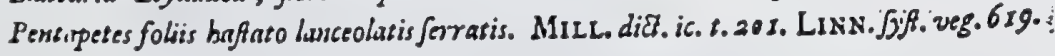

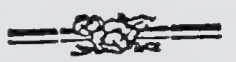

PER. Capfula ovato-globofa, fetis apprellis hirfuta, quinquelucularis, quinquevalvis, corticata. Curtex herbaceo - coriaceus, tenuis, a valvulis non fponte fecedeus. Valvulx cruftacex 1. offex, intus laxigatiffimx, ex duabus fegmentis navicularibus ita coadunatx, ut diffepinenta evadant bipartibiliz. Seta quinque, apice fubplumofx 1 . antenniformes, futuris valvularum interjectux.

REc. nullum; femina margini centrali \& incraffato diffepimentorun, duplici ferie in quovis loculo, affixa.

SEM. plura, circiter odo in fmgulo loculamento, trigono-pyramidata, punctis elevatis ninutifimis confperfa, obfcure cinerea.

IN T. triplex: extimun tenue, arete adharens, nec nif radendo folubile; medium cartilagineum, glabrum, nigro-fufcum; intimuu niembranaceum, lutefcens, lata chalaza fufca in verrice notatum.

A L B. membranaceo-carnofum, tenuilimum, album, intra cotyledonum plicas defcendens.

Eмв. magnitudine feminis, curvatus, lactus. Cotyl. foliacex, bipartite, chryfaloideo - contortuplicatx. Kad. teretiufcula, centripeta. 2.) Fruchus integer. B.) Capfula difreda, cum diffepimentis bilamellatis. c.) Semiaum infer-
tio, atque fetre antenaiformec $(\alpha, \alpha)$ futuris interjecta d. D.) Semina (eparata. c. E.) Integrum. nuclei cum tuberculo chalazino. F.) Embryo folutus \& explicatus.

Nequaquan hxe Pentapetis fpecies ad Dombejam referri poteft, ut vult Cl. Cavanilles. Eufi enim famina \& piftillum id non impedirent; calyx tamen, capfula fimplex, atque numerus \& infertio fcminum, combiuationem iltam pruhtbere videntur. Proxima ceteroquin affuitas inter hæc duo genera negari nequit, quum proter conformitatem faminum, piftlli \& corollx, ecian cotyledonibus ad bafin ufque bifidis \& limeari - oblongis confpirent. 


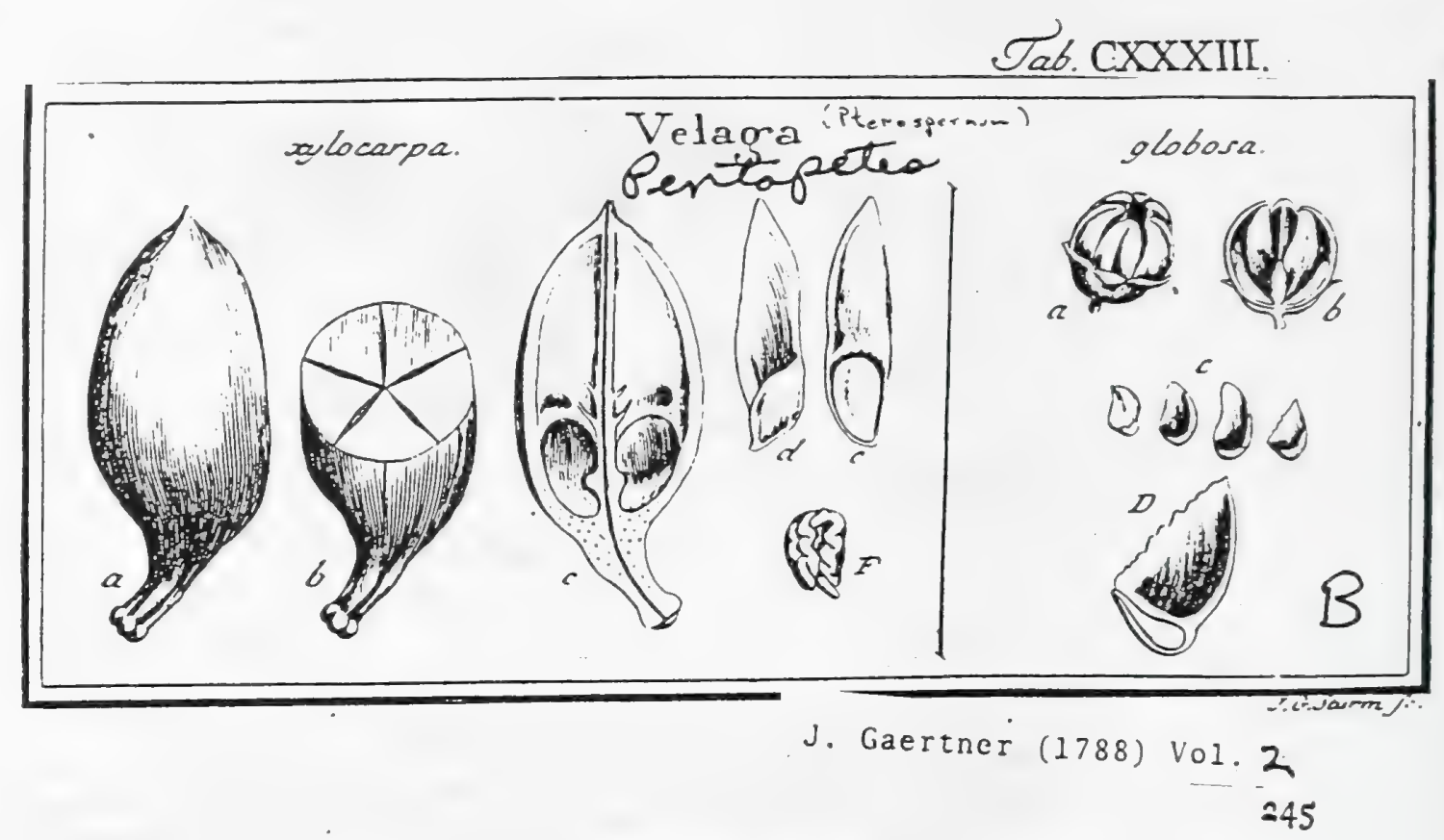

DCCLXXVIII. V E L A G A. ADANS. p. 389:

Calyx fimplex, oblongus, quinquefidus. Cor. pentapeala. Stam. quinque fterilia, longion, interjecta pluribus brevioribus fertilibus: omnibus bafi in tubum connatis. Ovar. unicum. Styl. fimplex capitatus. Capro lignofa, quinquelocularis, quinquevalvis. Sem. pauca, alata.

VELAGA xylocarpa. Tab. 133. fig. 2.

Pterofpermadendrum folio aceris, fouse fruduque majore. AMM. Ad. petrop. VIII. p. 216. t. 17 .

Pentapetes foliis cordatis repandis. LINN. Cyf. veg. $6 \mathrm{Ig}$.

E collect. fem. hort. lugdb.

PER. Capfula lignofa, clavato - ovata, albo tomento pubefcens, quinquelocularis, quinquevalvis. Loculamenta compreffa, angultifima. Difepimenta crafiffima, a valvulis introrfum cuneiformi angulatis non difcreti.

RE'c. nullum, prater funiculos umbilicales lineares, comprefíos, e margine centrali diffepimentorum oriundos.

Sem. pauca, circiter fex in quovis loculo, e quibus autem vix duo adolefeunt, ovata, plano - convera, fuperne in alam membranaceam definentia, rufefcentia.

INr. duplex: exterins membranaceum, in alam ampliatum; interius nucleo conforme, tenue, ferrugineum, intus lamina farinofa duplicatum.

A L B. nullum; proter laminam integumenti interni farinofam, intra cotyledonum plicas demerfam.

EM в. obovatus, compreffus, curvatus, Jacteus. Cotyl. foliacex, chryfaluideacontortuphicarx. Rad. teretiufcula, infera \& fimul centripeta.

a) Capfula integra, b.) Ejus fedio trasverfalis c.) Eadem longitulinaliter partia, eum locuiamentorum \& funic. ambilical. forma. d) Semen feparatum integrum. e.) Ejusdew ancleus Lenudasus. F.) Ėmbryo folutus \& auturs.

2.46

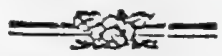

VRLAGA g.oborat. ibid.

E collect. Bankfiana; fruetus a Konigio niffus.

Capfula globofa (a), glabra, charmacea, tenuis, fexlocularis, fexvalvis, fpadiceo fufca, bafi calyce monophyllo, campanulato, quinquefido? excepta. Valvula extus linea depreffa longitudinali infcriptx, intus diffepimento medio. (b.) ftipatx. Receptac. columnare (b.), longitudine dimidix capfulx. Semina (c. D.) in fingulo boulo circiter octona, alata, deorfum incumbentia rufefcentia, excepta bafi nigro-fufca, fplendente \& transverfim, pro recipiendo nucleo (D.), cavitate clavata infructa.

V-chementer dubito, ut hrec fit genuina Velagx fpecies, \& fufpicor potius LA. gevfroendie effe fructum: cujus quippe femina.perinde funt alata, \& ufitarior -quoque fenarius partium numerus. Nucleum maturum non vidi. 


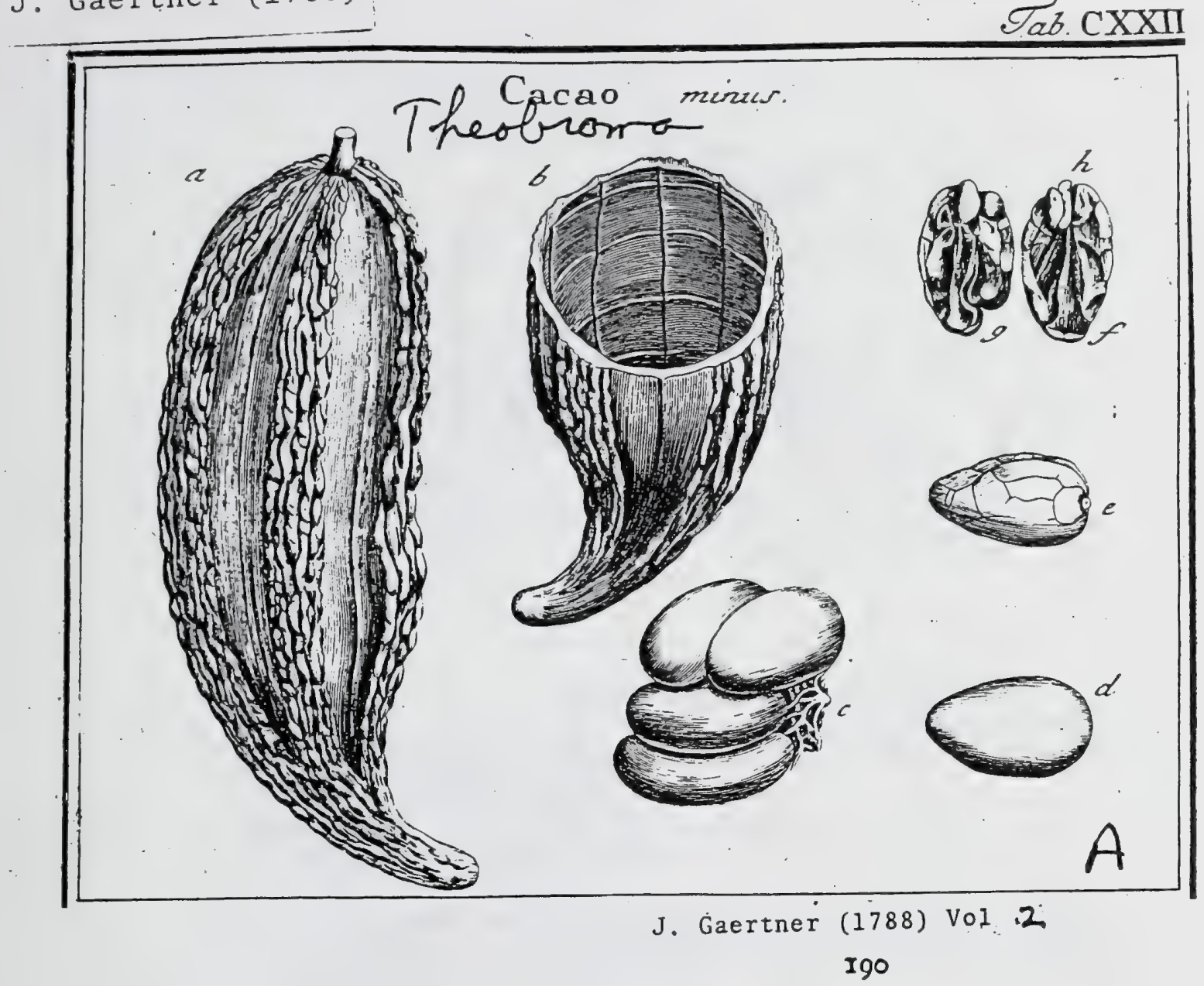

DCCVI. CACA O. Tour. t. 444. Theobroma. LinN. ger. 900.

Calyx pentaphyllus. Cor. pentapetala. Stam. decem, filamentis 5 longioribus fterilibus, \& s brevioribus fertilibus: omnibus bafi in urceolum connatis. Ovar. fuperum. Styl. fimplex. Bacca corticata, roltrata. Semina numerofa. Embryonis cotyledones multilobæ.

CACAO minus. Tab. 122. fig. I.

Cacao. SLoAN. biff. jam. 2. p. 75. t. 160. BLAKW. berb. t. 373. TRACT. anonym. du Cacro EF du Sucre. p. 3. t. I. bene.

Theobroma folits integerrimis. Lisi. fyft. veg. 696 .

PER. Bacca corticata, ovato-oblonga, roftrata, glabra aut fafeiis verrucofis longitudinalibus infignita, unilocularis? per xtatem .nigro-fufca. Cortex fublignofus, modice craffus, mtus ftriis longitudinalibus atque transverfalibus in areolas oblongo-quadrangulas difcretus. Pulpa per maturitatem a cortice fponte fecedens, butyracea; in vetufto autem fructu, vafculofofpongiofa, undique femina involvens, omnique diffepimentorum veftigio carens.

REC. nullum manifeftum; femina nidulantur intra pulpam.

SEM. numerofa, viginti \& ultra, grandiufcula, ovata, levicer compreffa aut a mutuo contactu obfolete angulata, glabra, in recenti fructu pallidé rubeo$\mathrm{la}$, in vetufto, fordide cinerea aut fufca.

IN T. duplex: exterius cruftaceum, tenue, fragile; interius membranaceo-pulpofuni, intra cotyledonum rimas fe fe demittens.

A L. B. nullum.

Емв. femini conformis, rimofus, oleofus, in vetufto fructu fufcus. Cotyl. dux, in plures lobulos irregulares inter fe tamen cohxrentes; profunde fectx. Rad. teretiufcula, capitellata, intra obtufiorem cotyledonum extremitatem latens, vaga aut centrifuga?

2.) Bacea integra. b.) Corticis evifeerati fettio transverfalis. c.) Semina per vafeulofam pulpama conglutinata. d.) Semen feparatum. c.) Embryo denadatus. f. g.) Cotyledonum facies interna anfrátuofa. h.) Radicula denudata.

Varietas major, baccas largitur 9. 1. I2. pollices longas, \& 3. 1. 4. "craftas, cetera autem priori conformes. Utrasque, omnes fere auctores, dicunt 


\section{Stylidiaceae}

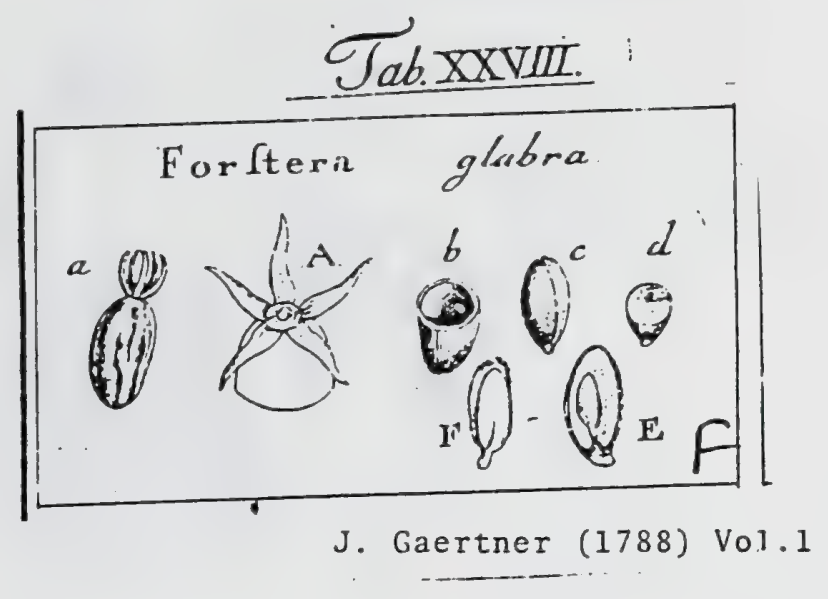

CLXIX. ATHECIA. = Fonstero

Calyx quinquepartitus fuperus: foliolis lineari lanceolatis perfiftentibus. Cor. $\ldots$ Sian..... Styl. ... Hacca infera, unilocularis, monofperma. Semen roftellatuin. Einbryo excentricus.

АтнесіА glabra.

Forflera glabra. Tab. 28. fig. 6.

Ex dono $\mathrm{Cl}$. Forsteri.

PER. Bacca infera, ovata, carnola, demum coricea \& ragola, calycis foliolis quinque ac intra ea, artola plana cum parva papilla in medio coronata, unilocularis.

REC. nuilum; femen fundo baccx alnatum.

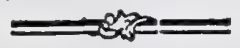

SE «. unicum, grande, elliptico fphxroideum, linea depreffa longitudinali, quafi fu: tura fpuria infcriptum, ad bafin in roltellum conicum, aduncum productum, ruf. fo fpadiceum, glabrum, duriflinum.

IN T. funplex, cruftaceum ac ferc nucamentaceum, nucleo aretifime adiatum, infra albumen in proceflum coracoideum umbilicalem elongatum.

A в . Semine brevius \& ad umbilici Sedein perforatum, cartilagineum, duriflunum; candidum.

EMB. dicotyledoneus, erectus, dimidin albumine longior, extra lujus axcm \& dorfo feminis propior pofitus, lacteo albus. Cotyl. obuvato oblongx, foliacex, tenuiffunx, planx. Rad. brevis, teretiuscula, infera.

2. A.) Fruetus integericum (uo calyce. b.) Bacea difrecta. c.) Semen (eparatum. d.) Idem transverfe fectum. E.) Ejus fectio longitudinalis, cum fitu embryonis intra albumen, F.) Embryo Separatus.

Singularis \& valde inufitatus eft embryonis fitus in hoc femine; non folum quia extra axem pofitus, fed quia alter cotyledonum margo dorfum \& alter ventrem fcminis refpicit: id quod in fubglobofo \& funul albumunofo femine fere absque exemplo eft. 


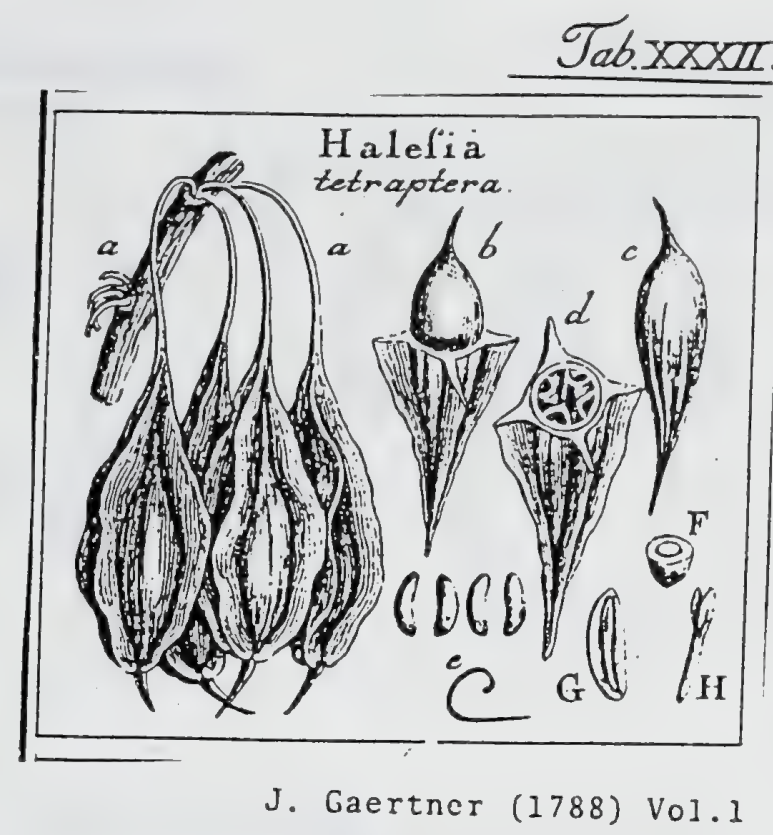

160

CXCV. HALESIA. Lin N. gen. 596 .

Calyx quadridentatus fuperus. Cor. monopetala qnadrifida. Stam. duodecin ad fedecim. Styl, unicus. Drupa exfucca infera. Putanen inflatum: loculamentis fe-: miniferis parietalibus.

Italfsia tetraptera. Tab. 32. fig. 2.

Frutex padi foiiis ferratis, floribus monopetalis albis campaniformibus, frutu craffo tetragono. Catesb. carol. I. t. 64. Sf.ligar. au. 11. tab. 28.

Halefia fructibus menbranaceo quadrangulatis. ELL1s. transati. LI. t. 22. f. $A$.

Halcfia foliis lanceulato ovatis, petiolis glandulo/is. LIN N. Jiff. veg. 473 .

PER. Drupa ceficca infera, obovato oblonga, quadrilatera, fupra fiylo, infra pedunculn longifmun tcrminata. Cortex tenuis, fungofo inembranaccus, in quatuor alas laterales rigidas extchuatus. Putamen offeum, obovatum, utrinque acumina-

tuin,

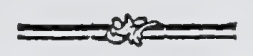

161

tum, intus in medio inane, aut fubnantia furfuraceo fungofa repletum, ad peripheriam vero quatuor loculamentis feminiferis, undique claufis, flipatum.

REC. nullum; femina fundo loculamentorum afixa.

SEM. in fingulo loculamento unicum, oblongun, curvulum, palliduin.

IN T. finplex, membranaceum, tenuillimum.

A в. femini conforme, carnofum, crafliusculum, album.

EM B. dicoryledoneus, erectus, longitudine albuminis, lacteus. Cotyl. lincari oblongx, fubfoliacex. Rad. longa, linearis, comprefta, infera.

2. 2.) Fruktus integer. b.) Putamen fuperne, \& c.) totum denudatum. d.) Drupa transverfim Sêta. e.) Senika foluts. F. G.) Albuminis fectiones cum fitu \& figura embryonis. H.) Embryo Separatus. 

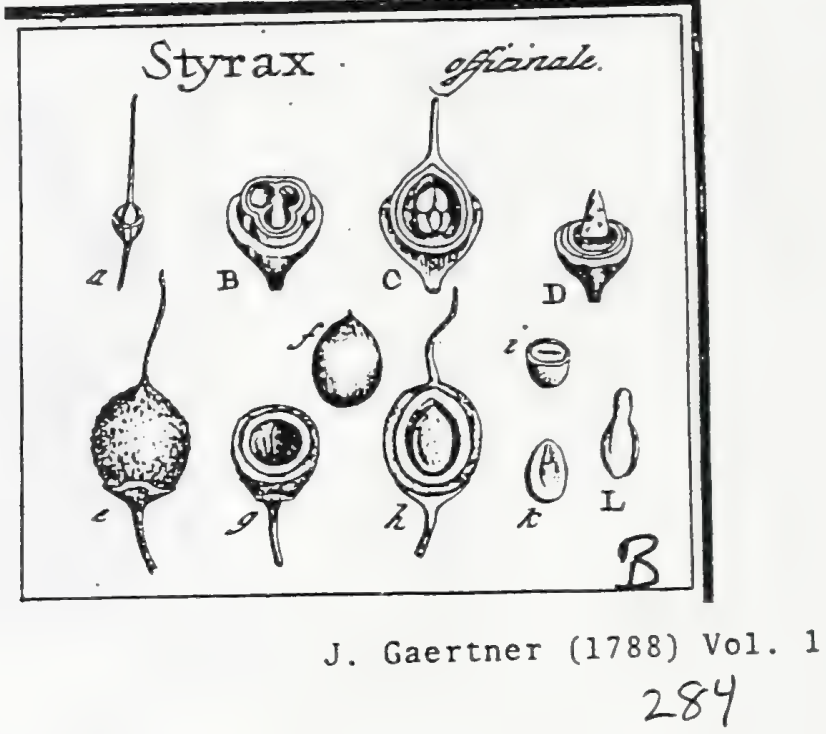

\section{STYRAX. Tourn. t. 366 . LINn. gen. 595.}

Calyx monophyllus quinquedentatus. Cor. infundibuliformis quinquefida. Stan. fubduodena. Styl. unicus. Ovarium triloculare poly'permum. Drupa matura unilocularis, mono-l. difperma.

Strrax officinalc. Tab. 59. fig. 5.

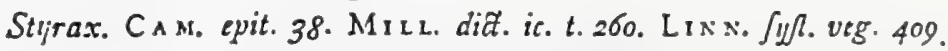

PER. Drupa exfucca, ovato globofa, Aylo perfifinte terminata, cano tomento pubescens. Cortex tenuis, coriaceus. Putamen ofieum, fragile, buxei coloris, ante maturitatem confanter triloculare, poftca uniloculare, evalvc.

$R$ Ec. columnare, fungofum, longitudine dimidii putaminis, orulis quattror aut quinque in fingulo loculamento fiparum, per maturitatem plerunque penitus obliteratum.

SE 3r. matura tria, duo, aut fxpiffme unicum: illa vatie angulata; hoc ovato globofum, amygdaloideun, pallidum, aut rufefcens.

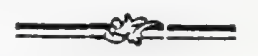

IN T. duplex: exterius fublpongiofum, crafiusculum; interius arachnoideun.

$\Lambda$ ८в. femini conforme, carnofum, craftum, album. Em r. compreflus, inverfus, niveus. Cotyl. ellipticx, fubfoliacex. Rad. crafla,
fupera.

a.) Ovarium immaturum. B.) Ejus fetio transverfalis, C.) Idem longitudinaliter apertum, cum ovulis recptaculo columnari affixis. D.) Receptac. denudatum. e.) Dropa matura lategra. f.) Putamen denudatum. g. h.) Drupa fêtio longitudinalis \& transverfalis, cum femide (h.) foli-

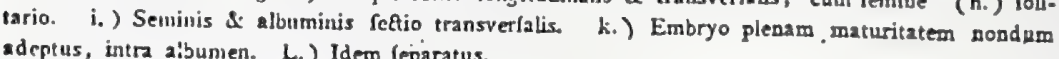

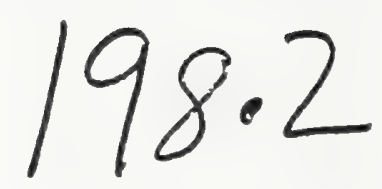




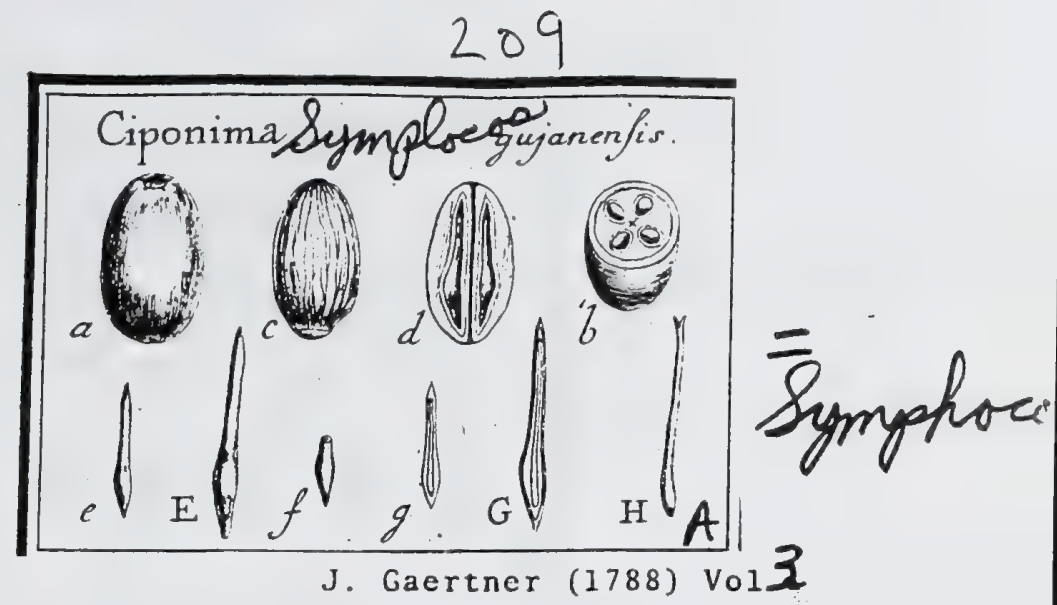

106. C I P $0 \mathrm{~N}$ I M A.

A ив в. guian. t. 226. Juss. gen. p. $15 \%$.

Cal. quinquefidus, villolus, femi-fuperus, bafi bracteis nunitus. Cor. monopetalil, tubulofa: tubo fub divifuris limbi paulum coarctato; limbo quinquepartito, patente. Stam. plurima; filamentis fupra faucem corolla duplici ferie infertis, bafi coalitis; antheris bilocularibus, fubrotundis. Ovar, femiinferum; ftylo fubulato, villofo; ftigmate capitato. Drupa femi-infera, putanine quadriloculari. Sem. quatuor, fubulata, fupra bafin trumofa. if Alb. carnofum. Emb. erectus, filiformis; rad. longifima, obtufa, infeta. CI 11

ONıma guianenfis. Tab. 209. fig. 1.

Symplocos pedunculis muleiforis, foliis integris fubtus villofis. L'HERIT. AET. SOc. Lim. Loud. 1. p. 175. Willd. Spec. pl. T. 3. P. 1. p. 1435. PERSoon fons. 2. p. 74 .

Ciponima grianesfis. А ОвL. guian. x. p. 567. CavaN. diJ. 7.p. 37 r. t. $2 \pi 7$. Ex dono amicifimi $D^{\text {ai }}$ Dupuis.

PER. Drupa ovato - oblonga, furfum paulo attenuata, femi-infera, 1. calyce per maturitatem inxquali \& cum carne continuo infra verticem cincta, glabra, atropurpurea, Caro tenuis, pulpofa. Puramen ovatum, ad bafin paululuin cuarctatum, derafun, a vaforum impretlionibus longitudinaliter ftriatum, durum, offeum, quadriloculare. Loculamenta ex fubftantia magis colorata \& duriore formata, fed cum putamine ip fo intime conferruminata, oblonga, ex fundo acuminato anpliata \& dein rurfus anguกded, lavigara.

REC. nullum; femina loculamentorum fundo affixa.

SE ג. folit:ria, ex acuminata bafi incraffata, 1. ftrumofa, furfum vero fubulata, erecta, fufca.

Is r. fimplex, membranaceum, tenue. 170

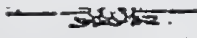

A L в. fenini conforme, carnofum, album.

Емв. teretiufculus, ereetis, albus. Cotyl. brevilimx, acutx, divergentes. Rad. Ionga, teretiufcula, curvula, verfus bafin incrafaca, 1. fubclavata, obtufa, infera.

\section{EXPLICATIO FIGUR胥.}

1.) Drapa integra. b.) Eadem transrerfe feeta. c.) Putamen (eparatum. d.) Idem longitadinaliter diffedum, cun fitu \& figura loculamentorum. e. E.) Semen folutum. f.) Ejusilem feaio transverfalis. g. G.) Albumen longitudinaliter diffeduon, cum fatu embryonis. H.) Embryo feparatus.

In nullo exemplorum noltrorum putamen obfervavimus quinqueloculare, nec obliterati loculamenti quinti in ullo aderat veftigiuin; an itaque noftra ftirps ab illa Cll. virorum, Jussizu \& L'Heritier, generc diverfa?

Ob feminum fabricam diverfam \& embryonis fitum contrarium, Ciponimam cum Hopea combinari non poffe luculenter apparet. 


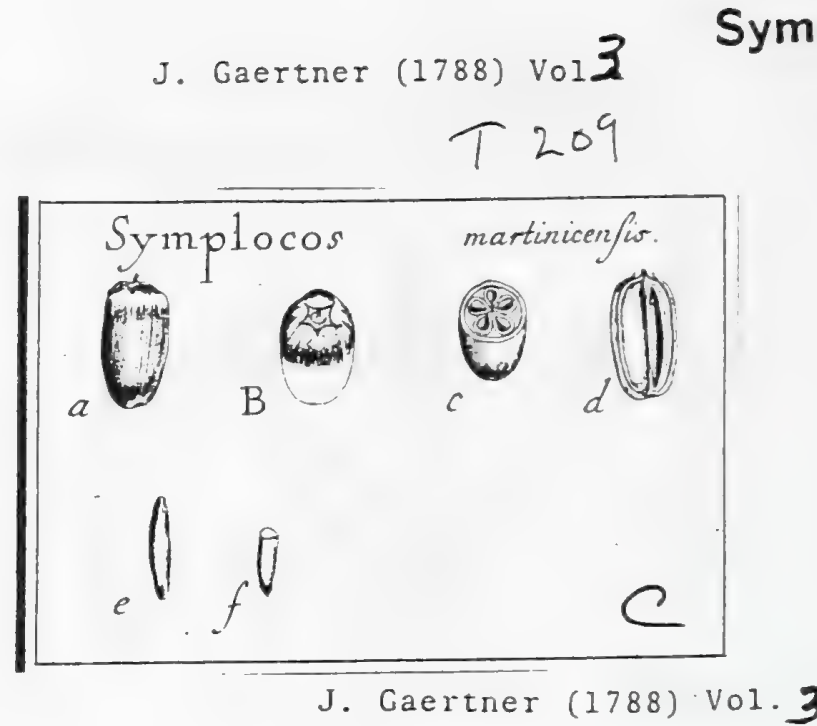

108. S Y M P L O C O S. . 141

Linfoi gen. 677: ed. Schreb. 1223. Juss, gen. p. 157.

SW ARZ obf. $t$. 7 .

Cal. monophyllus, fuperus, quinquefidus, ad bafin bracteis foliaceis inftructus. Cor. monopetala; tubo brevi; limbo 5-1.8 - fido: lacinlis xqualibus, patentibus, reflexis. Stam. plurima; filamentis fubulatis, erectis, exfertis, corollx fupra bafin quadruplici ferie infertis; antheris erectis, quadrilocularibus. Ovar. inferum; ftylo fimplici, Jongitudine ftaminun; ftigmate quinquelobo. Drupa femiinfera, exfucca. Putamen quinqueloculare. Sem. folitaria, Alb. ... Emb. ...

SYMPLOCOS martinicenfis. Tab. 209. fig. 3i

Simplocos. JACe. amer. p. 166 . Linn, Spec. pl. p. 747. Syff. veg. ed. 14. p. 699.

Symplocos pedunculis fubracemofis, follis glaberrimis cteinlatis. L'HeRIT. AD. Soc. Limr. Lond. I. p. 175. WILLD. Jpec. pl. T. 3. P. 2. p. 1435. Persoo: Jyn, 2. P. 74.

142

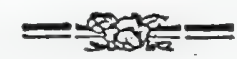

Icon. JACQ. anser. pit. t. 26 r. f. 4T: SWARz 1. c.

. Ex collectione Bankfiana.

PRR. Drupa obovato-oblonga, furfum incraffata, obtufiffima, ftyli reliquiis faftigiata, femiinfera, e calycis dentibus obtufis cilintis vertice tantun prominula, obfoletiflime rotundato-pentagona, rufefcens. Caro tenuis, firma, per maturitatem coriacea, exfucca. Putamen figura drupæ, in vertice mucronulatum, offeum, quinqueloculare; locillamenta oblonga, ex fubftantia duriore quam putamen ipfum compaginata, \& inter fe conferruminata, relicto canali angulato in putaninis axi pro a fcenfu valurum nutrientium.

R e c. nullium.

SEM. folitaria, oblonga, in dorfo convexa, ad latera planiufcula, \& verfus ventreni cuneata, rufefcentia, l. férruginea.

IN T. finplex, membranaceum, tenue,

$\Lambda \mathrm{LB}, \ldots$. .

EMB. . .

\section{EXPLICATIO FIGURE.}

2.) Drmpa integra. B.) Eadem a vertice vila. c.) SeAio ejusdem transverfalis, cum fitu loculamentorum. d.) Eadern longitudinaliter difieta. e.) Semen folutum. f.) Idem transverfe featum.

Icon fructus a Cel. SwaRz 1. c. tradita. a noftra recedit Ob embryonic defeaum nondum plane liquet, (nifi diverfum loculamentorum numerum refpiciamus,) an Symplocos cum Ciponima genere fit jungenda. 
J. Gaertner (1788) Vol $\mathbf{2}$

Tab. 209 .

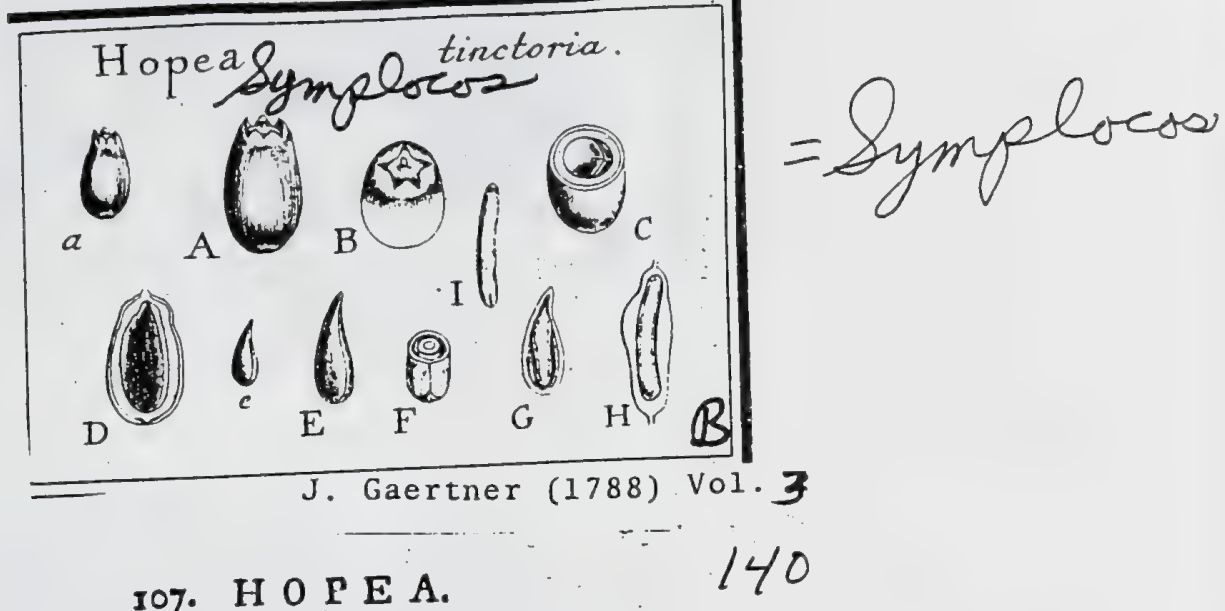

LiNn. mant. 1270. gen. ed. Schreb. 1222. Juss. gen. p. 157.

Cal. monophyllus, quinquefidus, fuperus, perfiftens. Cor. pentapetala, bafi ftaminum fafciculis connexa. Stam. plurima; filamenta in quinque fafciculos bafi connata, corolla longiora; antherx quadrangulares. Ovar. femiinferum; Atylo fenfin incraffato, perfiftente; ftigmate fimplici, oblique depreffo. Drupa feni - infera, a calyce perlifterite obvolucrata, putamine triluculari. Senina folitaria, nucleo diffimili. Alb. carnofum. Emb. inverfus.

HopEA tinctoria. Tab. 209. fig. 2.

Arbor latri folio, foribus ex foliorum alis. CATESB. carol. t. p. 54. t. 54. Symplocos floribus confertis fefliburs, foliis glaucinis. L'Herit. Ait. Soc. Limm. Loud. x. p. 176. WILLD. Jpec. pl. T. 3. P. 2. p. 1436 .

Hopea. Lins. mant. p. 105. Syft. veg. ed. 14. p. 6gg. Persoon fyn. 2. p. 72 .

\section{E collect. Cl. Desfontaines.}

PER. Drupa parva, ovata l. elliptica, femiinfera, 1. immerfa, vertice tantum e calycis dentibus obtufis prominula, e viridi lutefcens, 1. glauca. Caro tenuis, putamini adnata. Putamen ellipticum, craffufculum, offeum, triloculare. Loculamenta femielliptica, furfum acuminata, duo plerumque abortientia, relictis rimis inanibus. Diffepimenta membranacea.

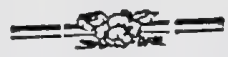

Rec. sullum.

$S \mathrm{EM}$. in fingulo loculamento fingulum, (dunbus vero ut plurinum ahortar作 \& acuminatum, in dorfo convexum, ad latera planiufculum \& obtufe cuneatum, fufcuni.

IN T. duplex: exterius (arillus) nucleum laxe involvens, faccatum, craffum, carnofo - coriaceun1; interius membranaceum, tenuifinium, albumini arcte adnatum, ad ambas extremitates in anfas filiformes fundo \& apici integumenti externi infertas protractum.

$\Lambda_{\perp}$ B. femine multo anguftius, \& illi forms plane difimile, oblongum, fub vertice acuto gibbo incraffatum, carnofum, album.

E м в. tereti-oblangus, curvulus, vertice albuminis paulo propior, quam ipfius bafi, levifime declinis, inverfus, albus. Cotyl. brevilimx, obtu$f x$, accumbentes. Rad. longa, teres, obtufa, fupera.

\section{EXPLICATIO FIGURE.}

1. A.) Drupa integra, naturali \& aucte magnitudine. B.) Eadem a vertíce vifa, curt calycis (a) Eadem enm patamine longitudidentibus perfiftentibus. C.) Ejusiem fectio transverlais. D.) Eade fecum. G.) Ejusdem fedio naliter diffeda. e. E.) Semen feparatum. F.) ldem trali modo diffectum, \& embryonis futus longitudinalis, eum aucleo in Gitu. H.) Albumten retticalls.] 
1) $\mathrm{A}$ 


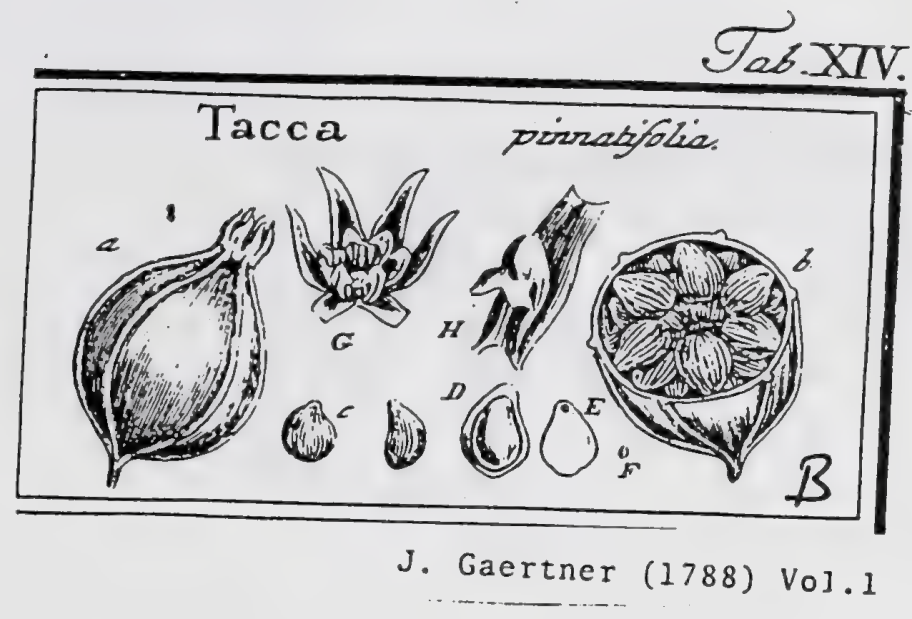

\section{TACCA. LINN. gen. I394.}

Calyx monophyllus, fexfidus : laciniis oblongis conniventibus. Petala fex, bafi laci- niarum calycis inferta, galeato fornicata: Jabio galex emarginato, bilobo. Anthe$r x$ oblongx, fornici petalorum intus affixx, apice fuo deorfum fpectantes. Styl. unicus, brevis, rectus, craflus. Stigma orbiculatum, fellatum: radiis fex obtufiusculis, fupra convexis. Bacca infera, unilocularis. Semina parietalia. Ex fchedis b. Solandri.

T A c c a pinnatifolia. Tab. 14. fig. a.

Katu-Schena. R н Е Е D, mal. IT. p. 4I.t. 2 .

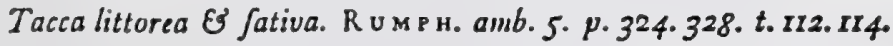

Leontopetaloides. А м м А N. Comm. petrop. 1736 . Vol. VIII. p. 217. t. 13.

Tacea pinnatifida. Fors T. gen. n. 35. Lx N. Jy/. veg. 455.

- Ex herbario Kankfiano.

PER. Bacca inembranacea, toto flore perfifente coronata, fubglobofe, nervis fex elevatis cofata, unilocalaris, aqueo pulpola.

REC. nullum : femins parictibus baccx undique affixa.

SEм. plura, grandiuscula, fubovata, mutua preffione varie angulata, longitudinaliter frizta, pallide rufesccutia.

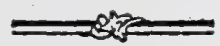

INT. duplex: exterius coriaceum, craffusculum; interius menbranaceum, tenuifimum, pallidum.

Al B. femini conforme, carnofun, aqueo-pallidum.

E\& 8: minutulus, ovato globofus, lacteo-albicans, in bafi albuminis prope unbilicum pofitus.

a.) Baces integra, b.) Eadem trassverfe fecta, cum fitu feminum naturall. c.) Semina foluta. D.) Semen longitudiualiter apertum, cum albumine integro. E.) Albumen verticaliter fectum, cum fitu embryonis naturali. F.) Einbryo folutus \& auctus. G.) Floris explicati figura naturali major. H.) Folioluin calycinum infigniter austum, cum petalo bafi ejus inferto.

De antherarum numero haud latis certus fum, cum in ineo fpecimine deficiant omnes; at fex tantum numerafte videtur SOLANDER, qui etiam petala pro filamentis cucullatis habuit. De numero fyylorum dubium plane nullum eft, unicum duntaxat, \& figma, quale fupra defcriptum, coram video. 


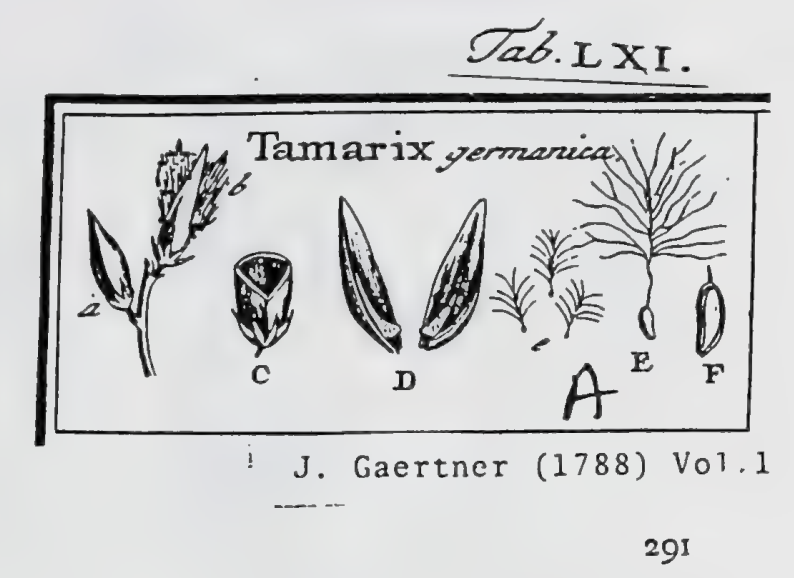

CCCLXVII. TAMARIX. LIN . gen. 375.

Calyx quinquepartitus perfiftens. Cor. pentapetala. Stam. quinque 1. decem. Sty. tres. Cappfula unilocularis. Receptacula parietalia. Semina criaita.

TAMARIX gerınanica. Tab. 6r. fig. x.

Tamarifcus. BLA $\mathrm{K}$ w. hetb. t. 33T. OEDER. for. dan. t. 234.

Tamarifcus fpicis foliofis. HALL. hifl. I. n. 948 .

Tamarix floribus decandris. L IN N. fy/f. veg. 296.

PER. Capfula pyramidata, triquetra, unilocularis, trivalvis.

REc. linca elevata, medio ralvularum parieti interno inferipta, verfus bafin definens in laminam fpongiofam, cui femina undique affixa.

SEM. numerofa, cxigua, ollonga aut ovata, leviter comprefla pallide rufefcentia, terminata capillis ramofis albis flipitatis.

IN T. fumplicinimum, membranaccum, tenue.

A t. B. n!llum.

Eм в. Femini conformis, lutefiens. Cotyl. oblongx, plano convexx. Rad. parva conica, infera, \&, ob receptaculi fitum, centrifuza.

a. b.) Capfula integra \& dehifiens. C.) Eaden transirrfin feta. D.) Valrula cum receptaculi infercionc. c. E.) Semina feparata. F.) Enbjrjo foin feninis tefta contealus. 


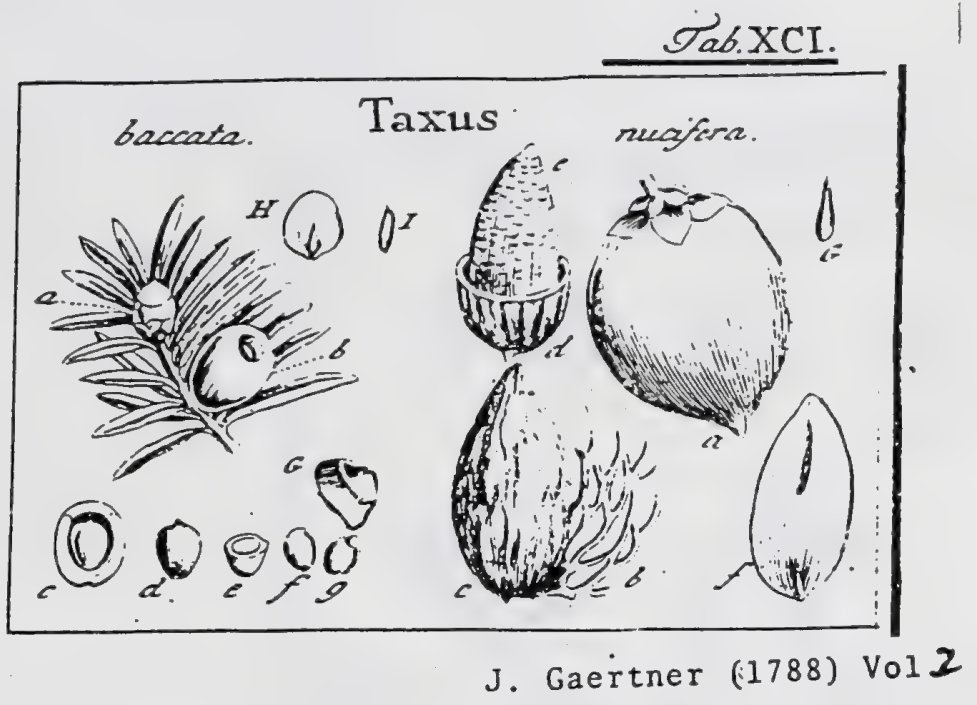

65

DLXX. T AXUS. TOURN. inft. t. 362. LINN. gers. II35.

Flores fexu diftincti in feparatis ftirpibus. MAS. Calyx imbricatus fquamis rotundatis, concavis, quaternis aut feptenis. Cor. nulla. Receptac. in columnam elongatum, cui affixx Anthers fubdenx, poft dehifcentiam lobato peltatr. FEM. Cal. ut in mare. Cor. nulla. Receptac primo orbiculazun, anguftum, fungofum; deinde fubharnifphacricum, membranaceum; denique carnofum, baccatum, coccineum. Ovar. unicum, ovato - acuminatum. Stigma fimplex, feffile. Nux a receptaculo baccato involucrata, ovata, unilocularis, evalvis.

TAXUS baccata. Tab. 91. fig. 6.

Taxus. Dod. pempt. 859. CaMr. epit. 840. BLaKw. berb. t. 572. opt Taxeus baccifera. HacL. biff. 3i. $166_{3}$.

Taxas foliis approxinuttis. Lins. Jjyt. veg. 895.

PER. Nux offea, obovata, apice nucronata, turgide lenticularis, glabra, atra, unilocularis, evalvis, involucrata receptaculo foris grandefaeto; ovatoglobofo, apice pervio, carnofo, coccineo.

REC. nullum proter fundum involucri.

SEM. unicum, cavitati nucis conforme, ad balin tamen proceffu mamillari infignitun, pallidum.

IN T. fimplicifinum, membranaceum.

A L в. magnitudine \& figura feminis, carnofum, crafteflemum, album. 65.

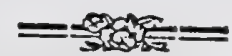
E M s. monocotyledoneus, tereti-acuminatus, feu fufformis, erectus, lacteus.
Rad. leviter attenuata infera.

2.) Nux immatura, proputio membranaceo albo ad medium ufque veffita. b.) Involuçnom nucis maturum, apice faltem perviun. c.) Ilem longitudinaliter diffetum, cum nucula in fitu. d.) Nux feparata. e.) Ejus fectio transverfalis. f. g. G.) Semen denudatum eretum (f.), \& inverfum ( 8 . $\mathrm{cum}$ fua mamilla umbilicali. H.) Embryo intra albumen verticaliter diffectum.
1.) Idem folutus.

Taxus nucifera. ibid.

Taxus nucifera. KF.MPF. anoen. p. 814. t. 815.

Taxus foliis diftmutibus. LIN fyjt. veg. 895.

$$
\text { A Cl. Houtuyn. }
$$

Nux corticata: Cortice baccato, ovato acuminato (a), glaberrimo, nitidifimo, viridi, pallidis ftriis variegato, molli, aromatico. Arillus reticulatus (b) membranaceus, tenuifimus, carni \& putamini interjectus, atque hujus bafi (c.) affixus. Putamen ovato-oblongum (c), rugofulum, furfum attenuatum, tenue, uniloculare (d.), fragile. Semen (e) putamini conforme, integumento fimplici furfuraceo tectum. Albumen (f.) figura feminis, oleofum, pallidum, fragile. Embryo (f. G.) in bafi albuminis, monocotyledoneus, tereti-acuminatus, lacteus.

Corticis baccati figuram \& defcriptionem e KeMPFERo mutuatus fum; videant itaque alii, num omnino claufus, anne faltem per maturitatem apice obturatus fit? Arillus, quem ad nateram delineavi, nihil aliud efre mihi videtur. nusm invalurri earnofi mamhmun intarm? 


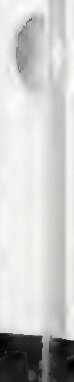




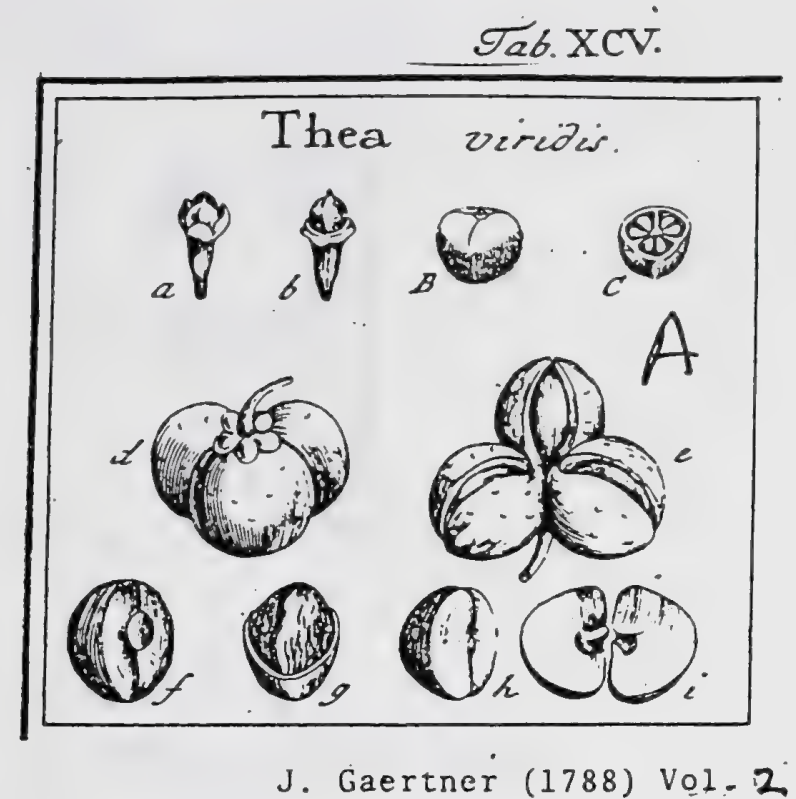

83

\section{T H E A. LINN. ger. 668 .}

Calyx penta -1 . hexaphyllus. Cor. penta -1 . euneapetala. Stam. numerofa: Ovar. fuperum triloculare: ovulis in fingulo loculo quaternis aut fenis. Styl. unicus. Capf. trilocularis trifperma.

Thea viridis. Tab. 95. fig. I.

Thea, frutex folio cerafs, flore rofe filvefiris, frudu zoni, bi- E? ut plucimsus tricocco: KenPP. amoen. p. 505. t. 506 .

Thee finenfrum. BREYN. ic. p. 17. t. 3. BLAKW. berb. t. 35 t. 35 2.

Thea floribus enneapetalis. Liss. Jyft. veg. 496.

PER. Capfula fupera coriacea, nunc Gmpliciter globofa, nunc ex duobus, \& frequentifime, ex tribus globis quaf contata, trilocularis, trivalvis; extus fumofa \& punctis callofis difficis consperfa.

REc. nullum; femina angulo loculamentorum centrali affixa.

SEM. in maturó fructü folitaria, grandia, globofe angulata, nucamentacea, Spadicea, Umbilico rotundato, amplo, claufo in latere interno notita.

IN T. duplex: exteriits: cruftaceum, craffufculum; durum; fragile; iriterius membranaceo - coriaceum, vafis ramolis impreflis reticulatun, fere inftar Nucis mofchatex, fufco-ferrugineum.

A L B. nullum.

EMB. Senini conformis, in adulto fructu gilvus. Cotyl. craffx, plano-convexx, gibbx, extus ab impreflionibus vaforum rugatz, - amygdalino carnofx, oleofr, fragiles. - Rad. brevis, craffa, fubcylindrica, intra cotyledones latens, centripcta.

2. b. B.) Ovarium immaturum integrum. C.) Idem difreaum exm ovalorum infertione. d. e.) Capfula matura integra \& dehifeens. f.) Semen feparatum integrum, 8.) Ejusdem sas. cus ad dimidium refectus \& deundata feminis membrana reticulato - sugofa bo) Embrgo deandatus. i) Cotyledones fepasatz, enm Radicula media.

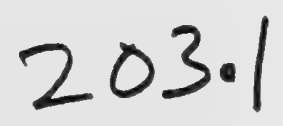




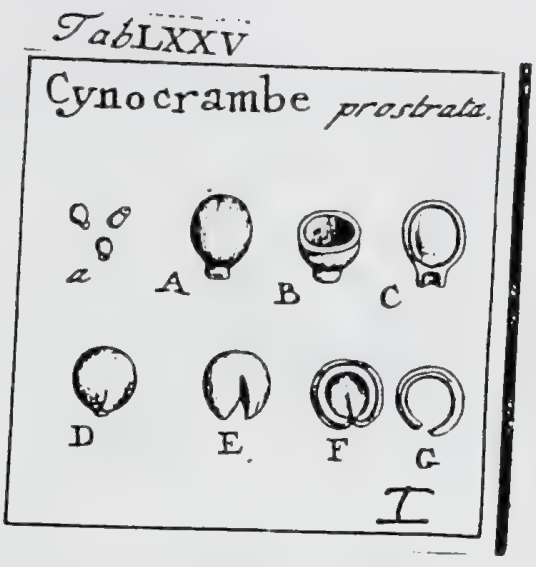

J. Gaertner (1788) Vol. 1

362

CCCCLXXI. CYNOCRAMBE. Tou R N. $t .485$.

Flores fexu diflineti in cadem ftrpe. MA s. Cal. bivalvis. Cor. nulla. Stam, fubduodena. Fem. Cal. bivalvis. Cor. nulla. Styl. unicus. N'ux parva, proceffu umbilicali cavo appendiculata.

CrNocramae proftrata. Tab. 75. fig. 9.

Cynocrambe diofcoridis. В А U н. prodr. 59.

Cynocrambe al/ines foliis. B A R R. ic. 335 .

Theligonum. Lis s. Syf. veg. 857 .

PER. Nux parva, fupera, ovato globofa, coriacea, nigro fufca, bafi in proceflum breven cavtm elongata, unilocularis, evalvis.

REc. nullum; fenen fundo nucis, mediante tuberculo umbiiicaii aftixum.

SEs. unicum, globofum, pallidum, parro tubcrculo umbilicali ad bafin notatum.

IN $r$. fimplex, membranaceum, tenuiffunum.

A L 8. globolum, carnofum, aqquco-pallidun, a bafi ad mediun usque bificum.

EMB. filiformis, fubperiphericus, intra albuninis fubftautian locatus, annularis, lacteus. Cotyl. Semiteretcs. Rad. longa, infera.

a.A.) Nucula integra. B.) F.adem transverfe-\&. C.) longitudinaliter fecta. D) Stmen Ieparatum cum tuberculo fuo unibilicall. E.) Albumen denudatum femibilobum, losis paulifper diducis. F.) Embryouis fitus intre aloumen. G.) Idemi feparztus. 
- 1 


\section{J. Gaertner (1788) Vol 3}

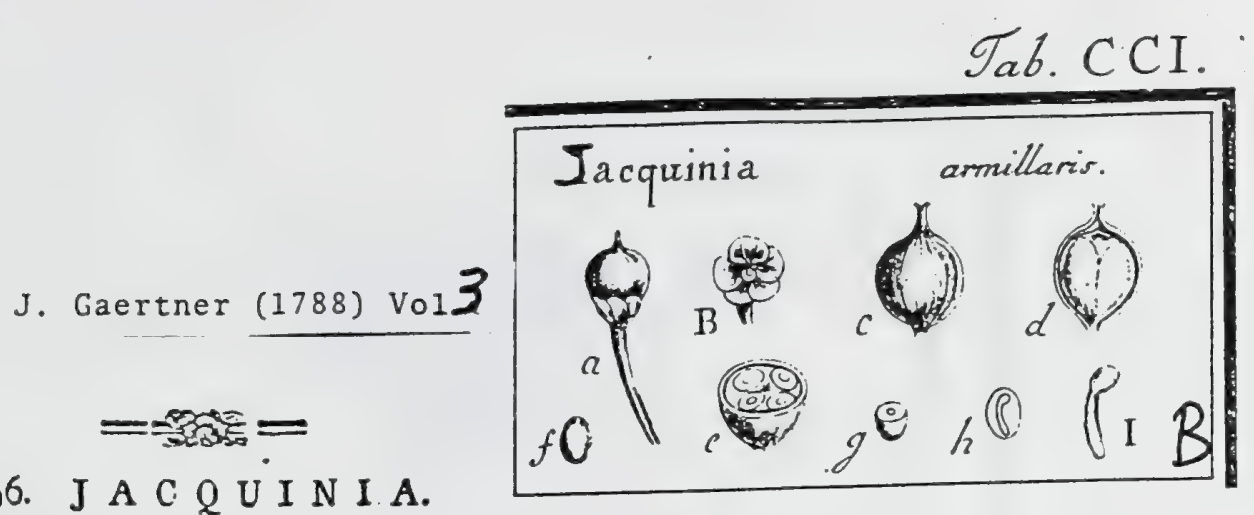

\section{J A C Q U I N I A.}

JACQ. amer. po. 53. LIN gen. 254. ed. Schreb. 346.

JU'Ss. gen. p. I5x. LA MAвCK ill. gen. $t$. $12 \mathrm{r}$.

Cal. quiuquepartitus, inferus; foliolis rotundatis, concavis, ad bafin breviffime unguiculatis, adpreffis, perfiftentibus. Cor. monopetala, campanulato - tubulofa; limbo duplici decemfido: laciniarum ferie externa patente, interna minore cum externa alternante erecta. Stam. quinque; filamentis fubulatis, infmo tubo infertis; antheris ovatis, non exfertis. Ovar. fuperum; ftylo fimplici longitudine fere ftaminum; ftigmate capitato, quinquecrenulato. Bacca parva, corticata, unilocularis, tetralperma. Rec. nullum. Sem. ovata, glabra. Alb. carnofum. Emb. erectus, longus, curvatus.

JAcQuisia armillaris. Tab. 201. fig. 2.

Arbor baccijera lauvifolia, fruifu corallino ribum infiar racemofo calyculato venenato. Sloan. bijt. 2. p. 89. t. 190. f. 2.

Xylocyfe fruticofum; foliis elliptico - ovatis, fubtus cinereis; pedunculis ramofis, aluribus. BROWN. jam. 372.

Cbryyoplyyllum Barbafco. LOEFL. it. 204. 267. ed. germs.

Jacquinia foliis obtufis cum acumine. JAce. amer. p. 53. 8. 39. LINN. Jyft. veg. ed. 14. p. 229 .

Jacguinia foliis obtufss corinceis, floribus racomsofis, baccis fubtetrafpermis. SWARTZ obf. p. 85 .

Jacquinia foliis cuneiformibus, ramis ad ramificationes nodofis verticillatis. VAHC ecl. 1. p. 26. WILLD. Spec. pl. T. 1. P. 2. p. 1064 . PERsoon fyn. pl. x. p. 234 .

Ex infula Hifpaniola a $D^{\text {no }}$ Porteau.

PER. Bacca parva, pifo paulo major, ovato-globola, infera, hine calyci perfiftenti infiftens, inde in mucronem producta, corticata, glabra, fulva, unilocularis, tetrafperna. Cortex coriaceo - fungofus, ficcizate fragilis. Pulpa carnofa, feminibus undique adhxrens, ante maturitatem faturate viridis, polt maturitatem vero havelcens.

REC. nullum; fenina a carne undique circundata, \& funiculis umbilicalibus brevilinis columnula, e centro calycis affurgenti, adharentia.

SEN. quatuor, (quorum vero unum, vel duo plerumque abortant,) pulpa interpofita remotiufcula, ovata, l. ovato-oblunga, utrinque obtufa, glabra, turbinata, l. ab adjıcentibus ad latera planiufcula, dilute caltanea, 1. rufefcentia, chalaza paulo cbfcuriore ad bafin lateris interui notita.

I* T. finplex, nembranaceum, firnum, 1. fubcrultacẹm, ab albumine vix ficedens.

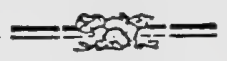

AI B. femini conforme, carnofum, album.

E M 8 . longitudine fere albuminis, fed bafi ejus paulo propior, erectus, incurvus, niveus. Cotyl. brevilimx, ovatx, fubfoliacex, 1 . Ienticulari - convexz, obtuix, vix difcretx, accumbentes. Rad. longiffima, filiformitereciufcula, incurva, umbilico externo obverfa, infera.

\section{EXPLICATIO EIGURE.}

a.) Bacca immatura, calyci infiftens. B.) Calyx feparatus cum difeo \& colnmnula centrali, quibus bacea \& femina affixa funt. c.) Bacca matur, a calyce feparata, integra. d.) Cortex baces longitudinaliter apertus, ut pulpa \& feminum fitus appareat. c.) Settio bacez transterGalis cum feminibus. f.) Semen folutum. 5.) Albumen trasverfe feQtum. h.) Situs embryonis intrz albomeo. I.) Embryo feparatos, valde auetus.

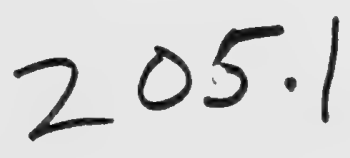




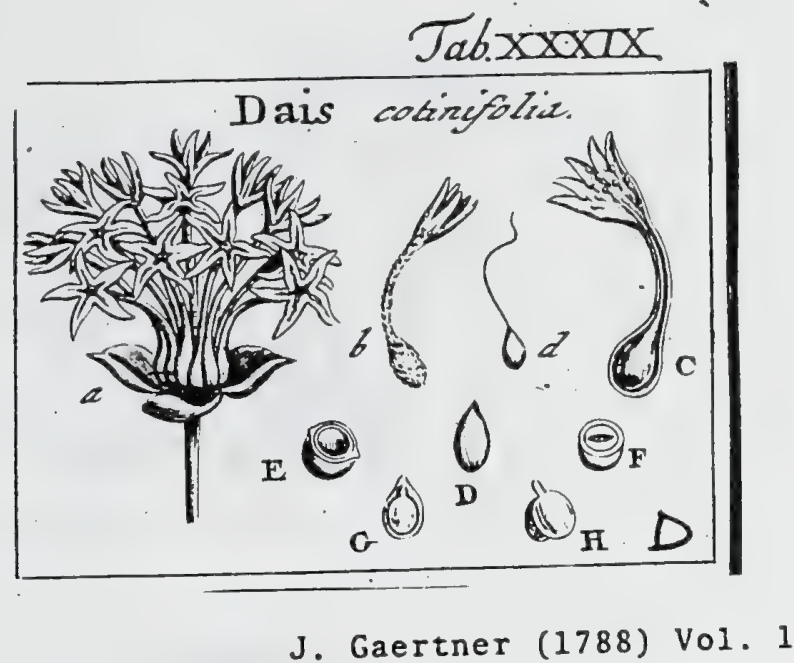

CCXXVI. DAIS. LINN. gen. 540 .

Involucrum forale tetraphyllum: Cal. nullus. Cor. infundibuliformis, quadri-1. quinquefida. Stam. octo l. decem. Styl. unicus. Nux fupera, corticata, unilocularis.

DaIs cotinifolia. Tab. 39. fig. 3.

Dais foribus quinquefdis decandris. LI N N. fy/2. veg. 403 .

PER. Nux fupera, parva, ovato acuninata, tenui-corticata, corolla perfinente vefita. Epidermis inembranacea, pallida, diaphana, ad utrumque latus in marginem prominulum albicantem incraltata, facile fecedens. Putamen offeum, tenue, fragile, extus livido albidum, intus atruin, uniloculare, evalve.

REc. nulluin, prexter funduin corollx.

SEN. Unicum, nucis cavitati conforme, pallidum.

IN T. fimplex, inembranaceum, tenuifimum.

A L B. femini conforme, modice craflum, carnofum, a ßbum.

Е м в. magnitudine fore albuminis, inverfus, lacteo-albus. Cotyl. ovato-rotundatx, fubfoliacex. Rad. teretiuscula, brevis, fupera.

8.) Umbella floralis integra, b. C.) Corolla puculam veftiens. d. D.) Nucula deaudata. E) Ea. dem transverfe feta, ahsque nucleo. F.) Ejusden \& albuminis fexio transver(alis, G.) Alburaen verticaliter fetumi cum firu embryonis, H.) Embryo feparatus. 
Thymelaeaceae

J. Gaertner (1788) vol 3

$T 215$

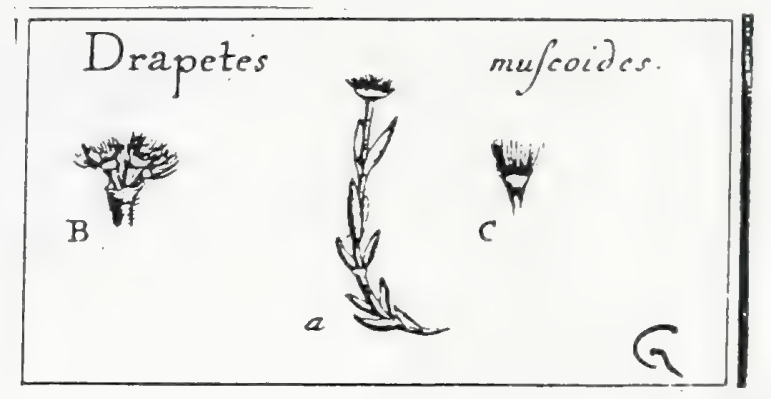

J. Gaertner (1788) Vol 3

199

D R A P E T E S.

Flores terminales, aggregati, involucro univerfali monophyllo brevifimo col. lecti.

Cal. commusis, diphyllus, mulkiforus; proprius pilis barbatus. Cor. monopetala, rgualis. Sem. villofiufcula, Rec. parvum, nudum. Buxks $M \iint_{s}$.

200

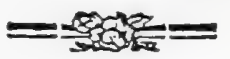

Drapetes mufcoides. Tab. $21 \%$. fig. 8 .

Drapetes. LAMARCK Journ, dHif. naf, n. 5. p. 186. t. 10. PERSOON fy. x. t. 148 .

A Cl. Lambert.

(De fructu nil addere pofium,)

EXPLICATIO FIGURE.

2.) Plantula integra, foliis oppoftis oblongis felilibus concaris apice hirfutis. B.) Flores th capitulum bas involucro diphyllo deciduo munitum congefti, fafciculato-agregati, brevifume pedicellati, C.) Receptaculum feparatum, fuuglobufura, fetulis albidis feriçeis crinitum,

206.2 


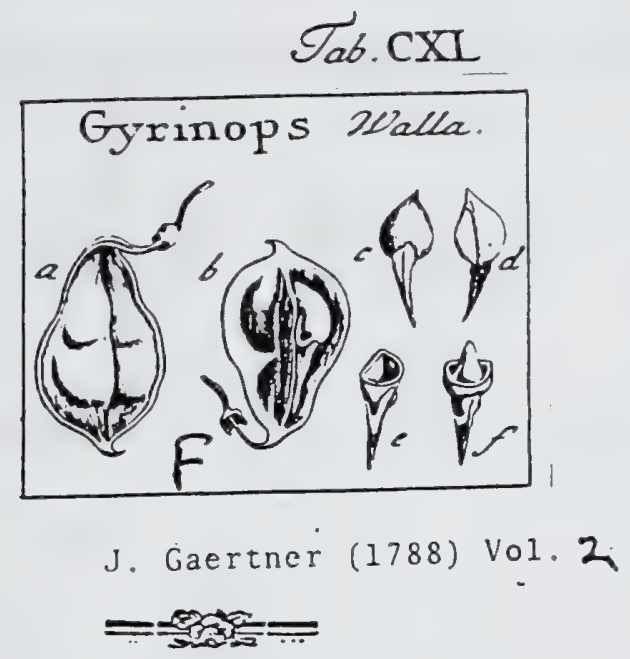

\section{G Y R I N O P. S.}

Calyx inferus, monophyllus, cylindricus, brevis, edentulus. Cor. Stam. . Capf. compreffa, pedicellata, bilocularis. Semina folitaria, deorfum fubulato - caudata.

GYRINops Walla. Tab. 140. fig. 6.

Walla. Zeylonenf. E collect. fem. hort. lugdb.

PER. Capfula coriacea, obovata, compreffa, ad feminum fedem gibbora, linea depreffa longitudinali in medio utrinque inferipta, ad ambitum masgine anguftilimo tumidulo circumdata, fuperne in brevem mucronem acuminatum producta, inferne autem in longum \& gracilem pedunculum attenuata, bilocularis, bivalvis. Diffepinentum anguftum, valvis con. trurium.

REC. nullun, proter cicatriculam mininam utrinque in fuperiore diffepimenti parte, e qua femen pendet.

SEM. folitaria, grandiufcula, ovato acuminata, hinc valde convexa, inde plana, e fpadiceo ferruginea, caudata. Cauda fungofo-fuberofa, alba, femine fesqui longior, triquetro fubulata, e bafi feminis lanceolato \& furrecto principio oriunda, mox autem gracilefcens, atque rectà verfus capfulz fundum defcendens.

INT. duplex: exterins coriaceun, duriufculun; interius membranaceum.

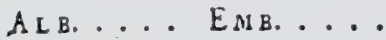

2.) Capfula integra. b.) Valvula altera, a parte füa interna fpectata, cum infertione feminis. c. d.) Seminis fuluti lasus dorfale atque ventrale. c.) Tefta ferminis transverfun feeta, eum sanda a latere fpectata, ejusdem priscipium lanccolatum oftendens. f.) Eadcon cum rudimeuto nuclei. 


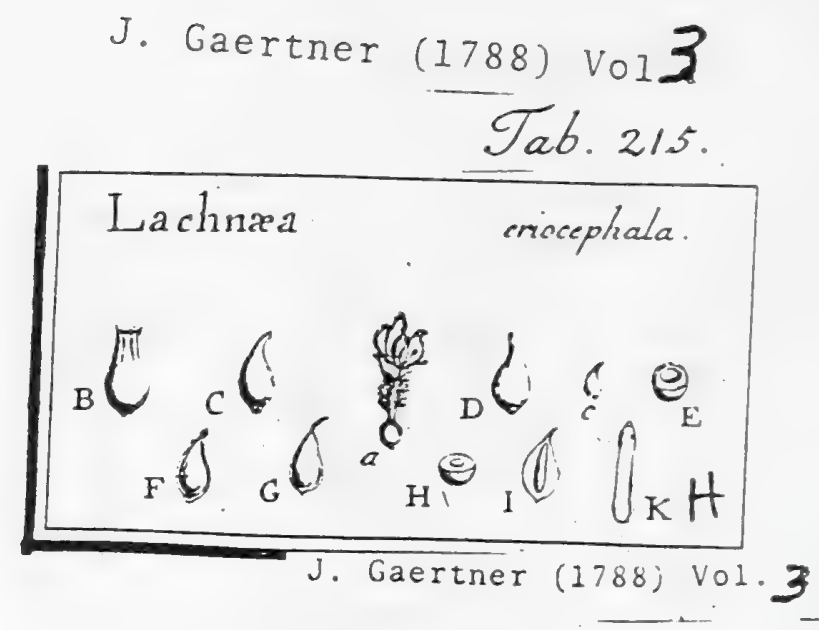

154. L A C H N A E A. Roy. 195
LINA. gen. 490. ed. Schreb: 66g. Joss. gen. p. $77^{\circ} 19$

LAMABCK ill. gen. $t .292$.

Cal, nullus; nifi corollam velis. Cor. monopetala, tubulofa; tubo longo, vlllofo ad faucem dilatato; limbo quadripartito, inxquali. Stam. osto, exferta; filamentis fetaceis, fummo tubo infertis; antheris ovatis, erectis. Ovar. fuperum; Atylo fimplici, fublaterali; ftigmate capitato, hifpido. Nucula corticata, unilocularis, evalvis. Sem. unicum. Alb. craffum, caruofum. Emb. linearis, inverfus.

Lachnaea eriocephala, Tab, 215. fig. 4.

Palferina (erioceplala,) foliis linearibus convexis imbricatis, capitulis lanatis.

THUNB. prodo p. 75 .

Lacluaea capitulis folitariis lanatis, foliis quadrifariam imbricatis. LINN. Spee. pl. p. 514. Slijt. veg ed. 14. P. 374. W 1LLD. Spec. PL T, 2. P. 1. p. 4340 PERSOUN Jy 1 . $p .438$.

Ex collectione Cl Desfostaines.

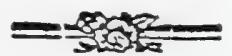

funiculus umbilicalis, filiformis. Sem. unicum, erectum. Alb. tenue, carnofum. Emb inverfus, rad. difcreta.

Passerina nivalis. Tab. 219 , fig. 6 .

Pafferina ramis proftratis, foliis linearibus obtufinfculis carrofis fubciliatis, floribus axillaribus dioicis. RANOND Bullet. de la Soc. pbiloms. 16. 4I. p. 13I. f. 4 . Iil alpibus pyrenaicis legit amicifimus D'Stromeyer, Prof. Gotting.

PER. Nux minuta, fupera, a corolla perfiftente viridiufcula emarcida tunicata, elliptico - acuminata, ftyli reliquiis faftigiata, fetulis minimis adpreffis confperfa, pallide fpadicea, corticata. Cortex membranaceus, temuis, a putamine lubenter fecedens. Putamen nuci conforme, apice vero curvulum, lineis profundis fongitudinalibus ftriatum, ad ventrem fulco infcrip. tum, bafi cicatrice umbilicali tuberculari orbiculari rufa, cui vara umbilicalia inferta, infignitum, olieum, fragile, modice crafum, atro-fufcum, uniloculare, evalve, monofpermum.

- REC. nux fundo corolls adnata; putamen ope funiculi umbilicalis filiformis a corticis apice per ventren putaminis ad ipfius bafin defcendentis cortici affixum; femen ipfum fundo putaminis adhæret.

SEM. unicum, cavitaten teftx exacte replens, elliptico-ácuminstum, erectum, dilute ferrugineum.

IN T. Gimplex, membranaceum, tenuifimum, àdnatum, bafi cbalaza fufca no. tatum.

Es в. femine paulo brevior, inverfus, lackeus, Cotyl, etlipticx, obtifx, craffiufculx, carnofx, plano-connvexx, accumbenteś. Rad. rhomboideo- L ovato-acuninata, compreffulcula, dimidias' cotyledones-longitudine zquans, difcreta, umbilico contraria, fuperera. cula - curnlla tunicante denudata. d. D.) Putamen a cortice folutum; cum vafis umbiliealibus,

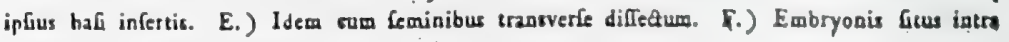
slbumer. G.; Idem Lulutus. 


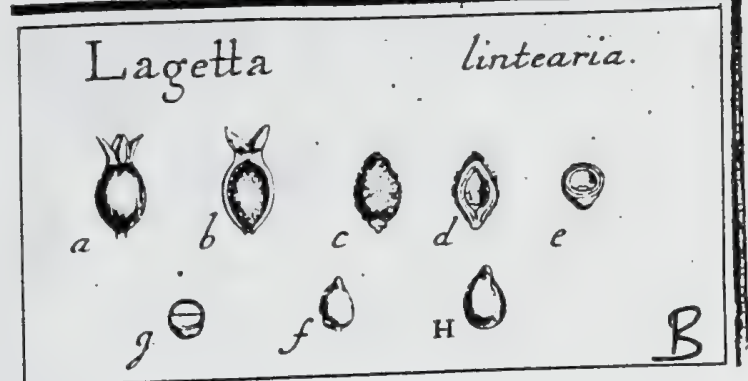

J. Gaertner (1788) Vol.3

\section{L A G E T T A.}

Juss. gen. p. 77. LAMARCK ill. gen. $t, 289$ :

Cal. nullus; nifi corollam velis. Cor. monopetala, ovato-oblonga, modio ventricofa, fauce coarctata, ftylo tantum pervia, fubcoriacea, tomentofa, glandulis quatuor inftructa, quadrifida, perfiftens. Stam. octos filamentis breviffinis, fauci corolly fupra tomentum infertis 3 antheris oblongic, erectis. Ovar, fuperum ; ftylo fimplici, brevi; Itigmate truncato. Nux a corolla perGftente tunicata, hirta, corticata, fupera. Rec. nullum. Sem. unicum, erectum. Alb. exiguum, carnofum. Emb. inverfus.

LagetTA lintearia: Tab. 215 . fig. S.

Lnurifolia arbor folio longo mucronato levi fplendente, cortice interiore int telas plurimas lineariun aemulas extenfilio. SLOAN jam. 337. bif. 2. \%. 22. t. 168. f. .. 2. 3. t. 169. f. $x$.

Doplune (Lagetto, ) Ficis paniculatis terminalibus, foliis ovatis acutis. SWARZ prod. p. 63. Fl. ind. occid. 2. p. 680. WILLD. Jpec. pl. T. 2. P. т. p. 419.

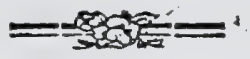

Lagettr. Lamarck dif. 3. p. 376 . Persoon fyn. I. p. 434.

Bois dentelle. Gall. Nicous. doning. 272. t. x. f. $x-5$.

Ex dono $\mathrm{Cl}$. Duruis.

PER. Nux fupera, a corolla coriacea fufca perfiftente laxiufcule tunicata, 1. intra ipfan plane abfcondita, ovata l. elliptica, utrinque paululum attenuata, coroll $x$ fundo adnata, fetulis fericeis lutefentutibus eredis hirta, corticara. Cortex tenuis, coriaceo-membránaceus, putamini adnatus. Putamen ovatum, utrinque attentuatum, ad bafin a vafis umbilicalibus perterebratum, tenue, fuboffeun 1. teftaceum, fragile, uniloculare, evalve.

REc. nullun; nux fundo calycis affixa, \& femen bafi putaninis adhicrens.

SE M. unicum, ovato-acuminatum, ad bafin umbilico protuberante inftructum, erectum, pallidum.

IN T. fimplex, membranaceum, tenuifimum.

$A$ L B. Senini conforme, exiguum, carnofum, album.

EM в. albumine paulo brevior, ellipticus, inverfus, a!bus. Cotyl. ovatx, carnofx, plano-convex $x$, accumbentes. Rad. brevifima, obtufiufcula $\downarrow$ tubercularis, umbilico contraria, fupera.

\section{EXPLICATIO FIGURE.}

a.) Nux a corolla athuc tunicata. b.) Nux denudata; c.) Eadem feparata. d. e.) Corticis \& putaminis fedtio longitudinalis \& transvetfalis. f.) Semen feparatum. 8:) Ejusdem fectio transver[alis. H.) Embryo folutus.

De Embryonis figura non fatis fum certus.

Albumen in hac ftirpe valde exiguum, uti in nonnullis aliis generibus ex Thymelcarum ordine, in quibus quidem femper adeft albumen, at in 12 minam carnofam integumenti nonunquam attenuatum. 


\section{J. Gaertner (1788) Vol 3}

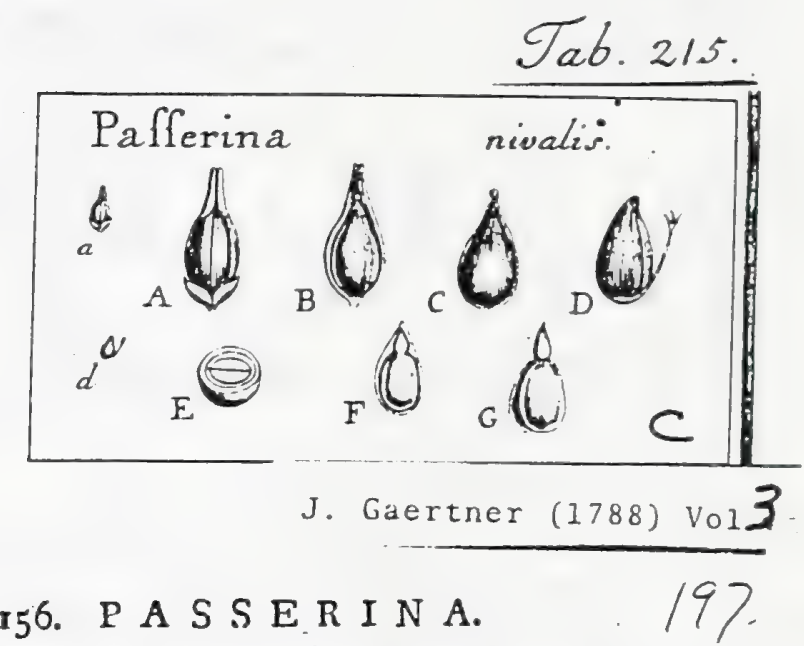

Linn. gen. 489. ed. Schreb. 668. Juss. gen. p. 77.

Flores bafi ftipulis duabus muniti, interdum dioici.

Cal. nullus, preter corollam. Cor. monopetala, marcelcens, perfiftens 3 tubo medio ventricofo; limbo guadrifido, patente, in fructu vero recto, laciniis conniventibus. Stam. octo, exferta; filamenta fetacea, fummo tubo inferta; antherx erectx. Ovar. fuperum; Itylo. fimplici, fliformi, fublaterali; ftigmate capitato, hifpidulo. Nux parva, corticata, unilocularis, evalvis. Rec

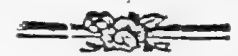

funiculus umbilicalis, filiformis. Sem. unicum, erectum. Alb. tenue, carnofum. Emb inverfus, rad. difcretz.

Passerina nivalis. Tab. 215 , fig. 6.

Paferina ramis proftratis, foliis linearibus obtufulfulis carnofis fubcilintis, floribus axillaribus dioicis. Ramond Bulles. de la Soc. pbilom. 13. 4r. p. 13r. f. 4. In alpibus pyrenaicís legit amiciámus $D^{\prime}$ Stromeyer, Prof. Gotting.

P ER. Nux minuta, fupera, a corolla perfiftente viridiufcula emarcida tunicata, elliptiço-acuminata, ftyli reliquiis faftigiata, fetulis minimis adpreflis confperfa, pallide fpadicea, corticata. Cortex membranaçeus, tonuis, a putamine lubenter fecedens. Putanen nuci conforme, apice vero curvulum, lineis profundis Jongitudinalibus ftriatum, ad ventrem fulco infcrip. tum, bafi cicatrice umbilicali tuberculari orbiculari rufa, cui vafa umbilicalia inferta, infignitum, offeum, fragile, modice crafum, atro-fufcum, univ loculare, evalve, monofpermum.

REC. nux fundo corollx adnata; putamen ope funiculi umbilicalis filiformis a corticis apice per ventrem putaminis ad ipfius bafin defcendentis cortici affixum; femen ipfum fundo putaminis adharet.

SEM. unicum; cavitaten teftæ exacte replens, ellipticQ-ácuminatum, ereçum, dilute ferrugineum.

IN T. fimplex, membranaceum; tenuifimum, àdnatum, bafi cibalaza fufca no. tatum.

EM B. femine paulo brevior, inverfus, lacteus, Cotyl. elliptica, obrifa, crafo fiufculx, carnofx, plano-convexx, accumbentés. Rad. rhomboideo-1. ovato-acuniinata, compreffufcula, dimidias cotyledones longitudine rquans, difcreta. umbilico contraria, fupeera.

\section{EXPLICATIO FIGURE}

a. A.) Frieas integer. B, ) Corofla longitudinaliter dimidlata, czim nucula in fita. C.) Nus; cula a curnlia tunicante denudata. d. D.) Putamen a cortice folutum; cum vafis umbilicalibus, ipfius hafi infertic. E.) Idem cum feminibus transverfe dilfeaum. I.) Embryonif fitus iatra albumen. G.) Idem fulutus.

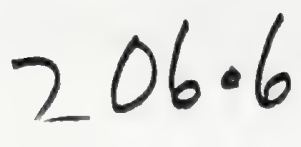


Tab.XXXTX

Thymelaeaceae

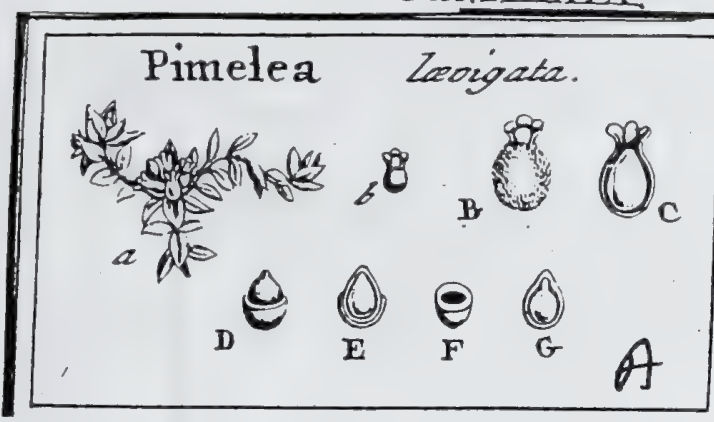

J. Gaertner (1788) Vol.1

CCXXIV. PIMELEA. B A N S. $\quad 186$

Calyx nullus, nifi corollam velis. Cor. monopetala, ventricofa, fauce anguitata infundibuliformi, limbo quadrifido, laciniis ovato oblongis. Stain. duo, in fauce corollix. Styl. unicus. (Ex fchedis Soland.). Nux corticata, fupera, umilo cularis.

Pimelea levigata, Tab. 39. fig. $I$.

Bankfia proftrata. Forst. gen. n. 4.

Pafferina diandra, pito $\int a$, foliis ovatis. $\mathrm{L} \mathrm{INN}$. $4 \mathrm{ff.}$ veg. 374

Ex herbario Bankfiano.

PEr. Nux fupera, parva, corolla perfiftente fericeo alba veflita, ovato acuminata, core ticata. Cortex tenuis, coriaceus. Putamen fuboliteun, fragile, fufcum, hine tria modice clevata lougitudinali notatum, cetera glabrum, uniloculare, evalve.

REc. nullum, prxter fundum corollx.

SEM. unicum, magnitudine \& figura cavitatis putaminis, pallidum.

IN T. fimplex, merubranaceum, tenuifimum, in bafi chalaza fufica notatum.

$\Lambda$ ¿в. femini conforme, tenue, carnolum, album.

Е м 8. albumine paulo brevior, inverfus, lutefcens. Cotyl. rotundato ovatz, carnolz, renues, plano-convexiusculx. Rad. fubcylindrica, fupera.

2.) Frutus in ramaloram axillis \& extremitatibus aggregati, feftiles. b. B.) Corolia frutur vefiens. C.) Nucula desudata. D.) Cortex ad diuidium a putamine refefus. E-) Putamen Longitudiualiter apertum.

E.) Albumen trausverfe fedium.

G.) Ejus feflio longitudiualls, eum fiqura \& fitu embryouis.

206.7 


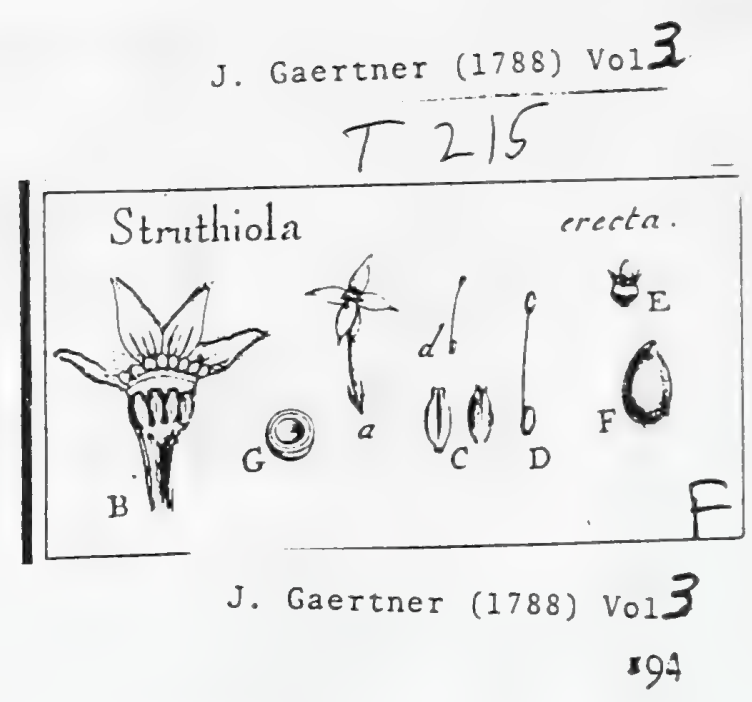

\section{S T R U TH I O L A.}

LINN, mant. 1244. gen. ed. Schreb. 216. Juss. gen. p. .7\%"

LAMABCK ill. gen. $t .78$.

Cal nullus, proter corollam. Cor. monopetala, tubulofa, perfiltens, marcefcens; tubus longus, filiformis, fub fauce parum anipliatus; limbus guadatodus: laciniis lanceolacis, acuminatis, patentibus. Ge Stam. quatuor, five oblongz, ad faucem corollx locatx \& bafi cilis cinela brevifima anthere premz tubi parti ampliatz inferta, fubrefflia; frate, compreflulcula, longiovatx, ad apjcem angultati, emarginato-truncalo complici, laterali, fetaceo, tudinaliter plicatx, erecta. Ovar. fuperum, ftylo tmis. Nux corticata, unjftamina non attingente; ftigmate capitato, pubescente. carnofum. Emb,... locularis, evalvis. Rec. nullum. Sem. unicum. Alb. carnorum. Emb,

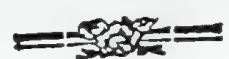

Strethloca erecta: Tab. 215. fig. 3.

Nellandra (tetrandra,) foliis linearibus imbricatis glabris, fioribus Lateralibus; nefraris ollonis. BERG. 'f. cap. p. 133.

Strutbiola glabra. Lins. mast. p. 41. Syf. veg. ed. 54 . p. 1640

Strutbiola foliis linearibus glabris, ramis glabris tetragonis. THunB. prod. p. 76 .

WILLD. Spec. pl. T. I. P. 1. p. 69z. PEBSOON fyn 1. p. $14^{8}$.

Icon. WENDL. obf. t. 2. f. I0,

P ER. Nux parva, intra corollam inclufa, ovata, apice curvula acuminata, corcicata. Cortex tenuis. Putamen tenue, uniloculare, evalve

REC. nullum; preter funiculum umbilicalem, fliformem, e corticis apice ad putaminis bafin defcendentem \& ibi affixum.

SEM. unicum, cnvitatem putaminis replens, ovato-achmiaatum, pallidum.

IN T. Gimplex, membranaceum, tenuifimum,

A B. Femini conforme, craffun, carnofum,

EMB....

\section{EXPLICATIO FIGURE.}

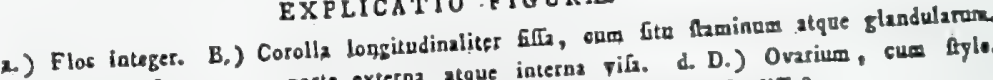

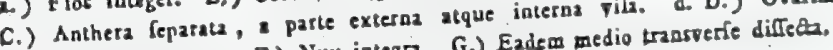

E.) Gianduiz feparata, F.

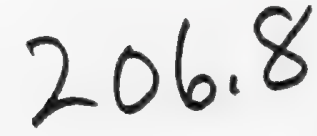




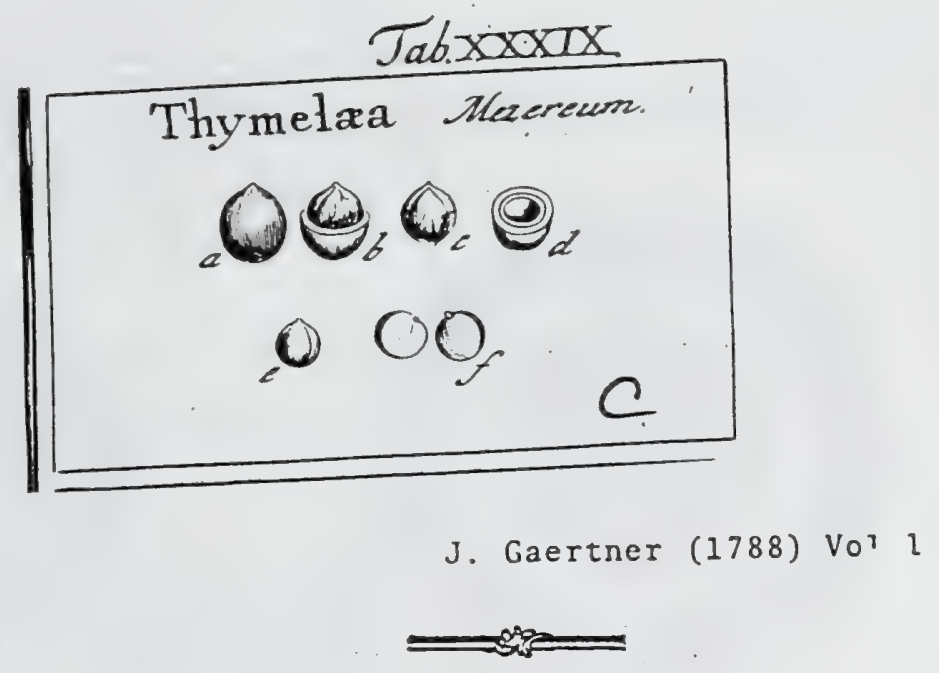

CCXXVII. THYMELEA. Tourn. $t .366$. Daphne. L I N gen. 485 .

Calyx nullus. Cor. monopetala quadrifida. Stams, octo. Styl. unicus. Drupa bace cata, Cupera, unilocularis.

Thymel.ea Mezereum. Tab. 39. fig. 4.

Thymelcea f. Lnureola. B I A K w. herb. t. 582. OE DER. flor. dan. t. 268.

Thymelac spica cylindrica, fuperne foliofa. H A L L. hifl. I. n. 1024.

Daphine floribus feffilibus ternis caulinis, foliis lanceolatis deciduis. LIN S. Syfit veg. 37 .

PER. Drupa baccata, fupera, ovato globola, pulpola, rubra, unilocularis, Caro te; nuis, fucculenta. Putamen cruftaceum, tenue, fragile, nigruin, nitidurn.

REc. nullum; fernen apici affixum.

SEM. unicum, cavitati putaminis conforme, fpadiceum, aut rufe feens.

IN T. fimplex, membranaceum, tenuiffunum.

A L B. nuilum.

Eмв. Iphxricus, inverfus, Jacteo albus. Cotyl. carnofx heunifpharicx. Rad. fub. globola, minutula, fupera.

a.) Drupa integra. b. c.) Putamen denudatum. a.) Drupa transverfim fetra, e.) Semen decorticatum. f.) Cotyledones (eparatz.

Poffet quoque pericarpium, Bacca, dici, quia putamen coloratum \& glabrum eft.

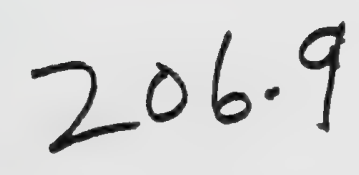


Thymelaeaceae

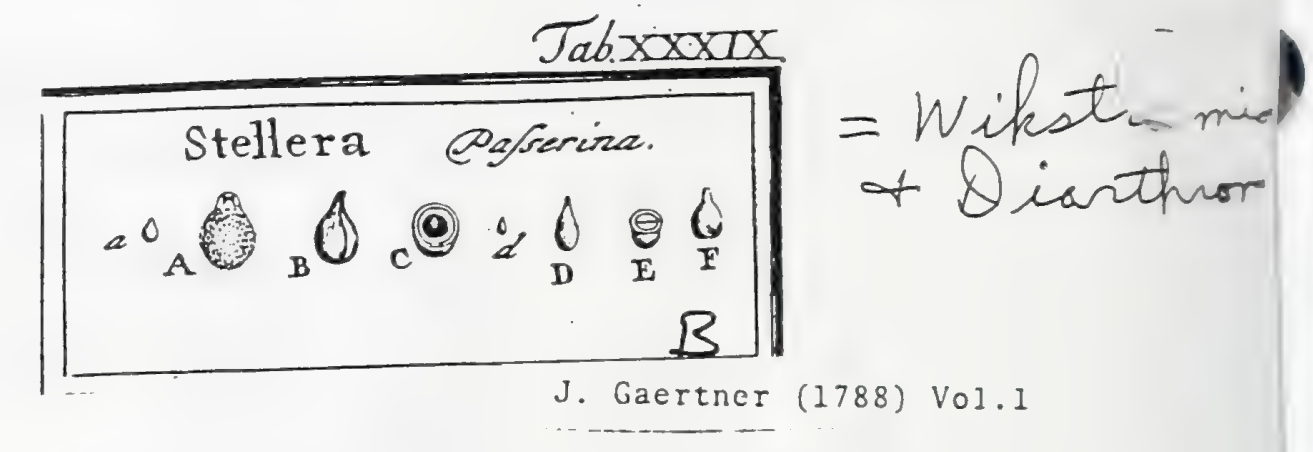

186

CCXXV. STELLERA. LIM.N. gen. 499:

Calyx nullus. Cor. monopetala, quadrifida. Stam. octo. Styl. unicuof Nux fu. pera, corticata, unilocularis.

Stellera Pafferina. Tab. 39. fig. 2.

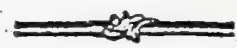

187

Linaria altera botryoides montana. CoL. ecphr. x. p. 82. t. 80.

Stellera foliis linearibus, floribus quadrifidis. HALL. hif. I. n. 1028. LINN. Silf?. veg. 373 .

Icon. J A c Q rar. t. 80.

P E . Nux fupera, parvula, ovato roftrata, imembranaceo corticata, perfiffente corolla veflita. Cortex א. epidermis tenuilfuna, pallida, facile fecedens. Putanen tenue, fragile, atrum, glabrum, lucidum, in roftrum leviter incurvum definews, \& ad alteruin latus linea elevata notatuin, unilüculare, evalve.

REC. nullum, przter funduin corollx.

SES. unicum, cavitati nucis conforme, albicaus.

IN T. funplex, fubmembranaceuin, fuperficie interna fubcarnola.

A в. nullum, nifi integumenti laminam internam carnofam vclis.

Eмв. femini conformis, inverfus, lacteus. Cotyl. ovatx, carnofx, plano-convexz. Rad. teretiuscula, fuperz.

a. A.) Nucula vefita. B.) Eadem denudata. C.) Ejus fealo transver(alis, d. D.) Semen de corvicatum, E, ) idern traosverfe fetum. F.) Embryo denudatus.

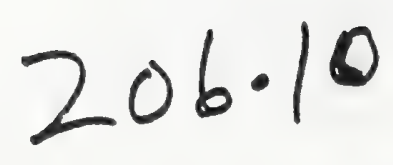


Tiliaceae

$T_{a b}$. CXXI.

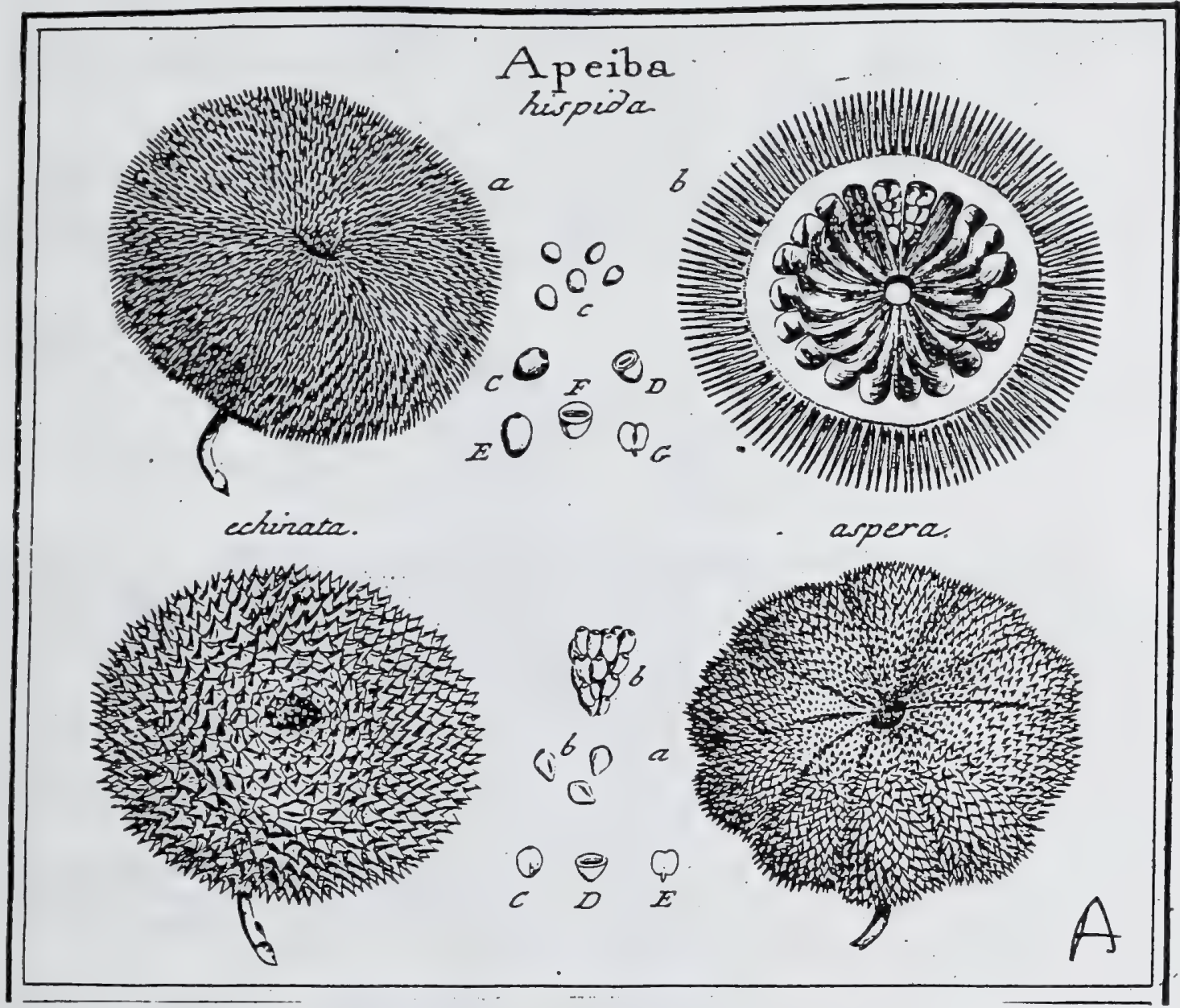




\section{J. Gaertner (1788) Vol. 2}

DCCIV. A PEIB.A. Aubr. Aubletia, ScHr. ger. 889.

Calyx quinquepartitus. Cor. pentapetala, unguiculata, fimbriata. Sam. numerofa. Ovar, fuperum. Styl. fimplex, ftigmate perforato, denticu-

\section{88}

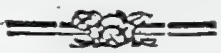

lato. Bacca corticata, plurilocularis, foramine in bafs dehifcens. Sem. numerofa, nidulantia.

Apeiba hifpida. Tab. 125. fig. I.

Apeiba folits ovatis. Jubtus incmis, foribus racemofis luteis. AuBd. gusian. 543. t. 215 .

Ex dono Dn. Aiton.

PER. Bacca corticata, dura, orbiculata, depreffa, fuperne umbilicata, inferne foramine rotundo a lapfu pedunculi pertufa, undique fpinis mollibus \& villofis hifpidata, 18-20 locularis, e fpadiceo-fufca. Cortex corjaceus, craffus. Pulpa mollis, fugax. Diffepinenta membranacea, tenuifina, prope peripheriam integerrima, verfus centrum autem deliquefcentia \& quafi in fibras foluta.

Rec. nullum; femina ita nidulantur intra pulpam, ut fuis umbilicis periphe: riam refpiciant.

Ses. numerofa, irregulariter ovata aut rotundata, compreffiufcula, fub $p$ padicea, tuberculo umbilicali fufco \& foramine exilifimo pertulo in extrenitate fua obtufiori notata.

IN T. triplex : extimum tenuifimum, forfan e pulpa exficcata ; medium cruftaceum, durum, glabrum, caftaneum, fublucidum; intimum ftramineo p.llidum, lata chalaza fufca, prope ipfun umbilicum, notatum.

A LB. carnofum, crafiufculum, candidinimum.

EM B. nagnitudine albuminis, niveus. Cotyl. obovato-aut rotundato-cordatx, foliacex, planx. Rad. teretiufcula, in contrariam ab umbilico plagam diects.

a) Bacca integra b.) Ejusdem fedio transverfalis. c. C.) Semina feparata. D.) Semen trans verfe featum. E.) Albumen denudatum integrum. "F.) Ejusdem atque embryonis fectio trane verfalis. G.) Embryo folutus.

Anbigit hac fpecies inter A. Tibuurbou \& Petoumo AUBL. cum priori enim longitudine fpinarum, \& cum pofteriori numero loculamentorum congruit.

APEIBA alperá. ibid.

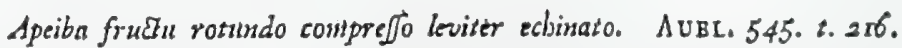

Bacca (a) orbiculata, depreffa, toris obfoletis octonis J. denis infignita, acu. leolis conicis brevibus pubefcentibus undique muricata, fordide nigricans aut cinerafcenti-fufca. Cortex coriaceus, craffus, durus. Loculamenta 8. I. 10. diffepimentis tenuiffimis, per maturitatem luceris. Senina (b. b.) paulo grandiora quam in precedenti \& magis ovato-acuminata, cetera vero refpectu umbilici, albuminis (C.) \& embryonis (D. E.) prioribus fimillima.

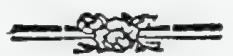

APEIBA echinata. ibid.

EX dono anicif. Dr. BerkHEY.

Bacca (a) rutundata, umbilicata, deprefia, tota atra, absque ullo villorum veftigio. Aculei angulato - pyramidati, ex lata \& deprefis lineis reticulatis circumferipta bafi, in pungentem cufpidem attenuati. Cortex tenuis, durus, fublignofus. Loculamenta 8. L 10. Semina magnitudine atque forma ut in prima fpecie. 


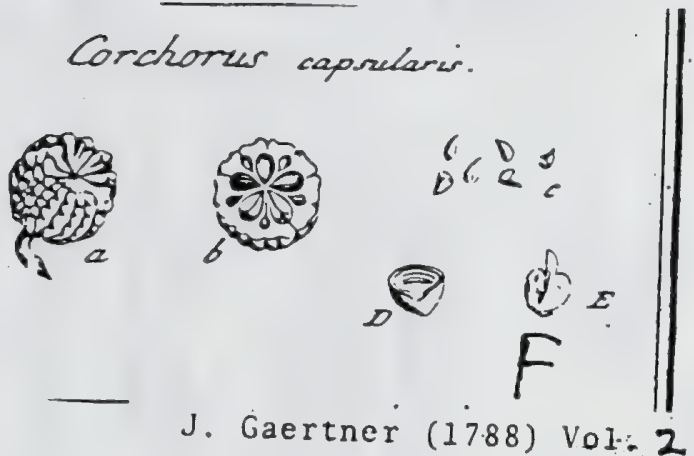

Tiliaceae

482

CORCHORUS. vid. Vol. I. p. $30 \%$.

Corchorus capfularis. Tab. 179. fig. 6.

Alcea olitoria, f. Corcborus americanus, prelongis foliis, caffula friata fubruturida brevi. PLuK. pbyt. t. $=55 . f$. 4 .

Corchorus capfulis fubrotzudis depreffis rugofis, foliorum ferraturis infimis fetrceis. LiNN. Syft. veg. 501.

Capfula (a. b.) fuberofa, globofu, depreffufc:ula, decemfulcata \& in fulcorum dorfo irregulariter tubercularo rugofa, pfoudolecemlocularis, decemvalvis. Loculamenta quinque majora (b.) fertilia, gemino Seminum ordme ltipata; minora totidem, ad intertticia priorun juxta peripheriam pofita, fterilia, vacua. Semina (c.) numerofa, angulata, ferrugineo-fufca. Integumenta, chalaza, albumen (D.) \& einbryo (E), prorfus ut in fupra defcriptis. 
Tab. CXII.

Antichoxus deprefsus.

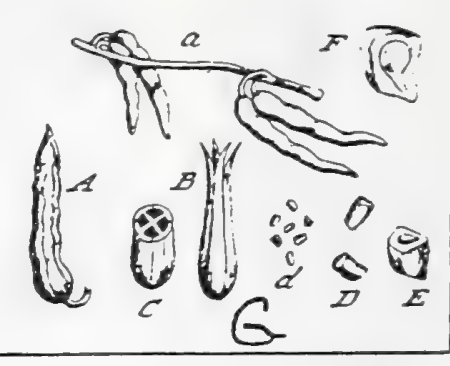

J. Gaertner (1788) Vol 2

144

Tiliaceae

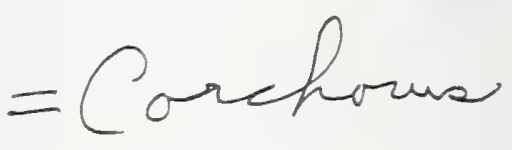

DCLII. AN TI CHOR U S. IINN. gen. I257.

Calyx quadriphyllus. Cor. tetrapetala. Stan. octo. Ovar. fuperum. Styl. fimplex. Capfula fubulata, quadrilocularis, quadrivalvis. Sem. plura.

Antichorus depreffus. Tab. II 2 . fig. 7..

Anticborus. Lins. mant. 64. Jÿr. veg. 359 .

- Ex horto Amftelod.

PER. Capfula parva, tereu - fubulati, - friata, obfulete nodulofa, quadrilocularis, quadrivalvis. Valvulx coriacex. Difepimenta membranacen mediis vilvulis longitudinaliter inferta.

REC. nullun; fensina margini centrali diffepimentorun, duplici in quolibet loculamento ferie affixa.

SEM. plura, duodecim ad fedecin in Gngulo loculo, parva, varie angulata, fubcompreisa, ferrugineo - fufca.

IN T. duplex: coriaccum \& membranaceum, utrumque tonue.

A L B. fenini conforme, carnofum, pallidum.

EM B. albumine paujo ninor, erectus, lutefcens. Cotyl. fubrotundx, lenticulari comprefic, tenues. Rad. tereti - acuninata, infera \& fimul centripeti.

a. A.) Capfulx plerumque gemiuatz, pediccllatx, fubter eaulem reflexx. B.) Capfula dehifccns. C.) Ejus fettio trausverfalis. d. D.) Scuina feparatz E. F.) Albuminis fcetio transierfalis atque longitudinalis, cum fim \& figura Embryonis.

Vix' meretur a Corchoro feparari, cui quippe ultro varius contigit partium fructificationis numerus; vit ex C. affitanti atque copfulari fatis patet.

207.3 


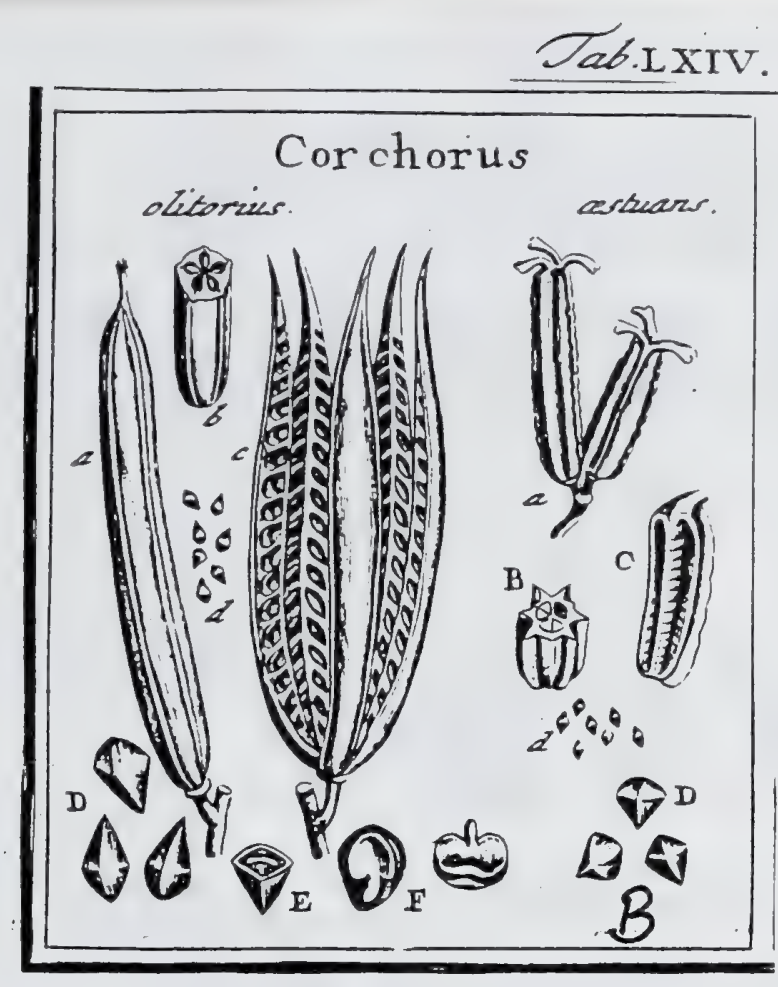

J. Gaertner (1788) Vol. I

CCCXCI. CORCHORVS. TourN. t. 135. LinN. gen. 675 .

Calyx pentaphyllus. Cor. pentapetala. Stam. plurima. Styl. unicus. Capfula tri-l. plurilocularis, Loculamenta fubdivifa feptulis transverfalibus incompletis. Semina plurima angulata.

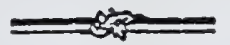

СОRС ноR Us olitorius. Tab. 64. fig. 2.

Corchorus. С а $\mathrm{M}$. hort. $47 . t .12$.

Corchorus capfulis oblongis ventricofis, foliorum ferraturis infimis fetaceis. IIN N. fuf. veg. 501 .

PER. Capfula oblonga, fubcylindrica aut fufiformis, obfoletiffme pentagona, apice in roftellum attenuata, quinquelocularis, quing̨uevalvis. Valvulx coriacex, intus fpongiofx \& per feptula transverfalia, in partiales cellulas pro feminibus divifx.

REc. nullum, prxter marginem centralem diffepimentoram, cui fenina duplici ferie Jongitudinali affixa.

SE 3. numerola; angulata, fubpyramidata, nigro fufca. Umbilicus in parte fenuinis. acuminata, lineola alba longitudinali notatus.

IN $\mathrm{x}$. duplex : exterius coriaceum, craffusculum; interius, fpadiceo ferrugineum?, chalaza fufca parva notatum.

A т.в. Semini conforme, craftum, carnofum, album.

Eм в. compreffus, leviter curvatus, luteus. Cotyl. cordato-rotundatx, foliacex, cochleari-concavx. Rad. teretiuscula, brevis, centripeta.

2.) Capfula integra. b.) Eadem diferza. c.) Vaivula dehifientes d. D.) Seminz feparata. E. F.) Embryo intra albumea. G.) Idem (eparatus,

CORCHORUS xfluans. ibid.

Icon J A c Q. hort. I. t. 85 .

Corchorus capfulis oblongis trilocularibus, trivalvibus fexfulcatis fexsufpidatis, foliis cordatis: ferraturis infimis fetaceis. LIN N. Syfl. veg. 501 .

Capfula (a.) oblonga, tribus roftris patentiflimis apice bifidis, teriminata, trilocu- laris (B.), trivalvis. Valvule intus (C.) rugis transverfalibus obloletis, loco feptulorum, notatz; extus genina ala dorfali crenulata \& lubundulata, Nipatx. Semina (d.D.) parva, varie angulata, duplici feric (B.) pofita, nigricantia Reliqua omnia ut in pracedenti. 


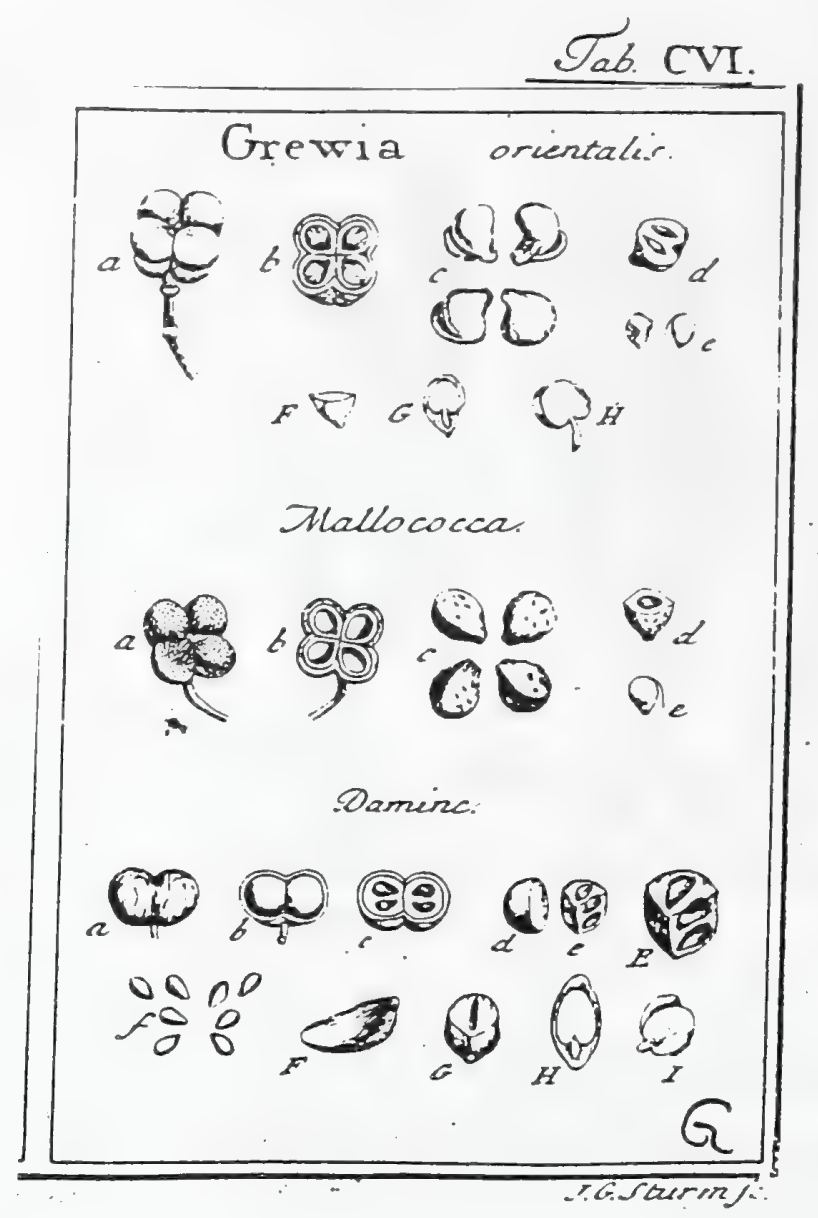

Tiliaceae

207.5 
DCXVIII. GREW I A. LINN. ger. I026.

Calyx pelaphyllus. Petala quinque: bafi fquama nectarifera. Stan. numerofa. Ovar. fuperum. Styl. finiplex. Bacca di-1. tetrapyrena: officulis uni - bi - quadrilocularibus.

Grewia orientalis. Tab. 106. fig. 7 .

Pai-paroea f. Couradi. RHezD. nsal. 5. p. 91. 2. 46.

Grewia foliis fublanceolatis, fioribus folieariis. LINN. fy/f. veg. 826 .

$E$ collect. fem. hort. lugdb.

PER. Bacca iubglobofa, depreffa, per exficcationem rotunde tetragonn: fucculenta, tetrapyrena. Cuticula in recenti fructu crocea, villofa. Caro

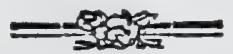

pulpofa, fugax. Officula lapidea, gigartoidea, fulco profundo in dor 50 infcripta, bilocularia.

R E c. commuse in fundo baccx, cui fcil. pyrenx acuminata fua bafi affixx; proprium, futriculus umbilicalis capillaris, e bafi loculamentorum, ad ob. tufun feninum verticen libere adfcendens.

SEM. in fingulo loculamento unicum, adeoque in tota bacca odfo, obovata, lenticulari - compreffa, fublivida aut fpadicea.

IN T. duplex: exierius tenuifimun, aridum, arilli adinftar facile de femine fecedeus; interius, membranaceum rufelcens, chalaza fufca, in vertice notatum.

A L B. femini conforme, carnofun, tenue, album.

Ear B. magnitudine fere albuminis, luteus. Cotyl. ovato-orbiculatx, follacex, planix. Rad. teretiufcula, oblique verfus bafin fructus directa, $f$. infera \& fimul aliquantifper centripeta.

2.) Baerz exficentz integra b.) Eadem trassetfe fedz, cam officulis in fitu. c.) Pyrenz feraratz, integrz. d.) Pyrces transvertam fedta. e.) Semina cum fuis funiculis opillaribze F.) Semen transverfe feetum. G.) Albuminis feetio longitudinalis. H.) Enbryo folntus.

Grewia Mallococca. ibid.

Mallococen cresiatis. FoRst. clsar. 12. 39. ad. ups. 3. p. I7.9.

Grevia folis cordatis ovato oblongis crematis fcabris, pedicellis axillaribus trifio. ris, frulu tetracocco. LiNs. Jyft. veg. 827.

E collectione Bankfiana.

Bacca (a) rotundato - tetragona, depreffa, fetulis minutis undique fabrata, tetropyrena (b). Officula (c) ovato acuminata, turgide lenticularia, rugis E tubcrculis minimis exafperata, unilocularia (d.), cratfa, dura. Semina (e) foliurit, adeoque in totp bacca quaterna, obovata, deorfum infigniter attesuar fublivida, funiculo umbilicali filiforni rigido inftucta. Integum. triplex: exsimum, prorfus ut in prxcedenti; medizus, coriaceum, craffufcuJum, rufefcens, ingenti tuberculo clialazino atro notatum; intimum, tenuifr. num, pallidun. Albumen \& Embryo plane ut in procedenti.

Grewia Damine. ibid.

an Grenis falvifolia. Liss?

Danise. Zeylunenf. E collect. fem. hort. lugdb.

- Bacca globofa (a), didyma, dipyrena (b.), per vetulatem rugofa, cinerafcens. Ofricula duo (c.d.c.E.), femiglobofa, lapidea, quadrilocularia: lock lamentis in fingula pyrena gemino ordine pofitis (c), duobus fil. fuperio-

114 -

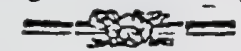

ribus (e. E), totidenque inferioribus, onnibus transverfalibus. Semina (f. F.) folitaria, adeoque in tora bicca octona, oblonga, angulata, niver. Integum. finplex, chartaceum, aridum, candidillinum. Albumen (G. I!.) carnofum, lutefcens. Embryo (H. 1.) luteus, cotydedomibus fulditcess, planis; radicula brevi, centripeta.

Hre fpecies adhucdum dubia eft, quin nihil de ea mihi notun, praterquam folus fructus, quem ad aliud genus non apte referre potui. 


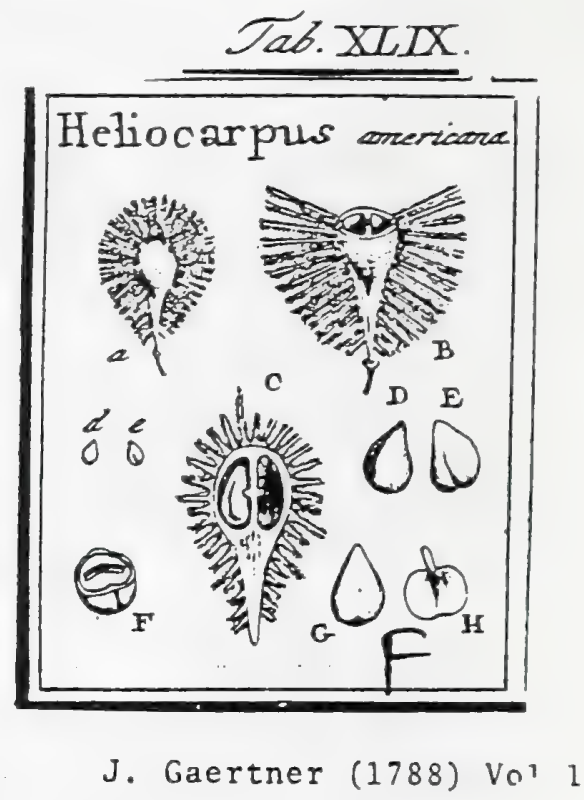

\section{5}

CCLXXIV. HELIOCARPUS. LIN gen. 606 .

Calyx quadriphyllus. Cor. tetrapetala. Stam. duodecin. Styl. duo. Caplula fu. pera clavata, radiis filiformibus plumolis cincta.

Heliocarpus americana. Tab. 49. fig. 6.

Heliocarpus. Linn. h. Cliff. tab. 16. En RET, decad. t. 45 . Lins, filfo veg. 447 .

PER. Capfula fubclavata, lenticulari comprefta, pubefcens, radiis filiformibus, plumofis, bifidis, ad utrumque margincm cincta, bilocularis, bivalvis. Dillepineutum valvis contrarium.

'REc. tuberculum parvum utrinque in medio diffepimenti, cui femen affixum.

SEM, in fingulo loculamento unicum, ovato acuminatum, hine angulo carinatum, inde planiusculum \& inferne fulco levi exfculptum, fpadiceo fufcum.

IN T. duplex: exterius crufaceo coriaceum; interius membranaceum, chalaza atra in bafi notatum.

A в в. Cunisi conforme, carnofum, album.

Eм в. longitudine albuıninis, inverfus, niveus. Cotyl. orbiculatx, utrinque leviter emarginatx, foliacex, tenuifiumx, fubconcavz. Rad. cylindrica, recta, fupera.

a.) Caprula Interra. B.) Eadem difrata. C.) Ejasdem valvula alterz, cum fita (eminum. d. D.) Semiois dorlum angulatum. c. E.) Ejusdeni pars ventralis. F.) Sersen transverie fedtum, cum

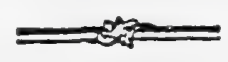

curvatura cotyledosum intra albumen. G.) Nucleus denudatus, cam chalaza gigra IL) Eur bryo feparates. 


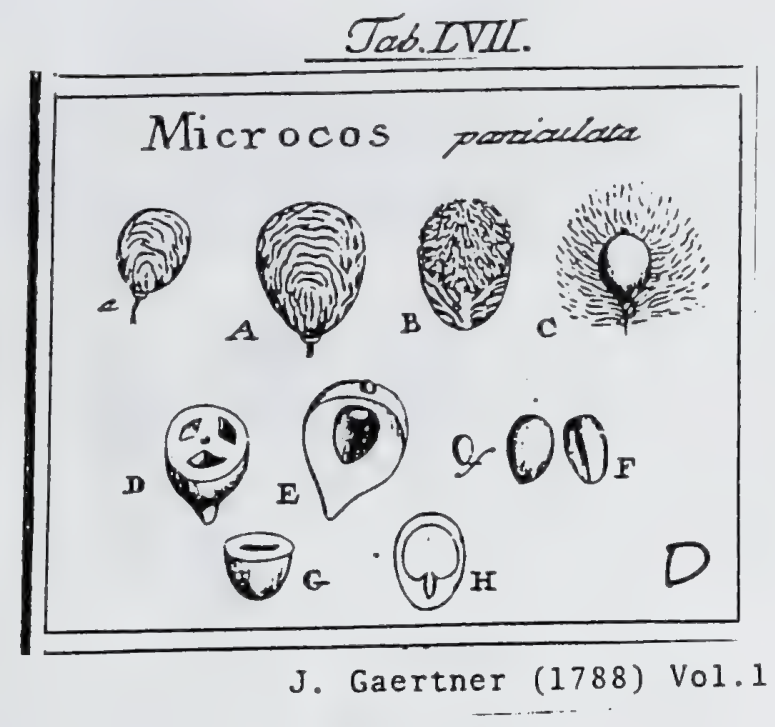

CCCXLIII. MICROCOS. B U R M.

Calyx pentaphyllus, inferus. Cor. pentapetala, paria. Stam. numerofa. Styl. unicus. Drupa baccata.' Putamen fibris crinitum triloculare. Semina apice affixa.

Microcos paniculata. Tab. 57. fig. 4.

Schageri-cottam. R н E E D. mal. I. p. 105. t. 56 . bene.

Microcos foliis alternis oblongis acuminiatis. B U R M. zeyl. 159.t. 74.

Grexia foliis ovato oblongis, floribus paniculatis. LIN N. fy/. veg. 827 .

E collect. fem. hort. lugdb.

PER. Drupa fupera obovata, obfolete trigona, rugis arcuatis pulchre vermiculata, ce. terum glaberrima, nigro fufca. Cuticula tenuiffuna, cum fibris putaminis cohxrens. Caro per xtatein exarefcens. Putamen ofleum, craffifimum, obovatum, deorfum in mucronem attenuatum, undique fibris ofieis capillaribus, arcuatim in. llexis, denfe crinitum, triloculare, ad axem perforatum.

REc. cicatricula callola in fuprema parte anguli interni locularnentorum.

$\dot{S}_{\text {E M. }}$ in fingulo loculamento unicüm, obovatum, hinc convexiufculum, inde angula. tum \& in parte fuperiore umbilico notatum, rufefcens.

IN $T_{\Delta}$ fimplex, membranaceum, tenue.

A L в. fumini conforme, carnofum, pallidum.

E M в. magnitudine fere alburminis, compreffus, erectus, luteus. Cotyl.cordato-rotundatx, foliacex. Radic. teretiufcula, infera.

2. A) Drapa integra. B.j Cuticula fuperne detracta. C.) Pntamen integram. a parte intälöt

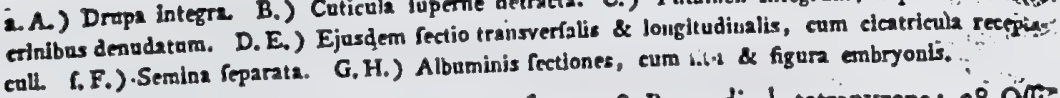

Cum Grewia fociari nequit. Nam Grewix funt : $1^{\circ}$ Bacca di-1. tetrapyrena; $2^{\circ}$ O cula bi -1 . quadrilocularia. $3^{\circ}$ Semina exalbuminola, horizontalia. $4^{\circ}$ Embryonis: radicula centripeta. 


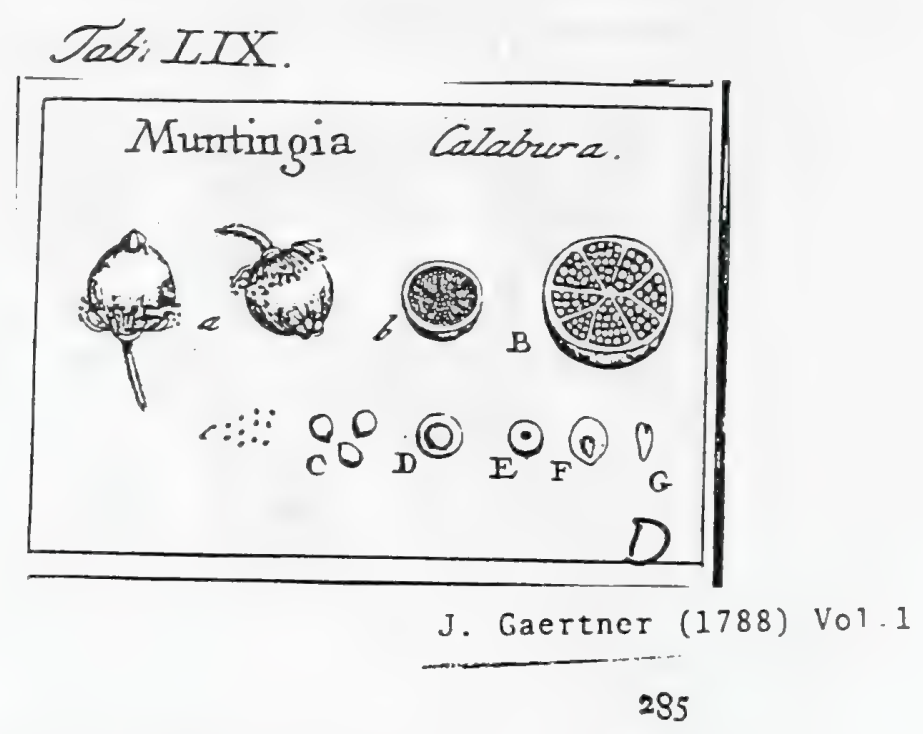

CCCliX. MUNTingia. Plum. gell. t. 6. Lina. gen. 651.

Calyx quiuquepartitus. Cor. pentapetala. Stanl. plurima. Stigma pyramidatum

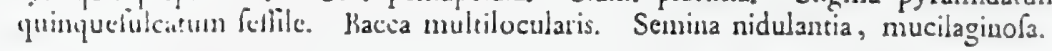

Muxingia Calabura. Tab. 59. fig. 6.

Loti arboris folio angufiore, rubi fore, fructu polyfpermo umbilicato. SLOAx. hif. jam. 2. p. 80.t. 194.f. I.

Muntingia. LIN s. Ju/. veg. 490.

Ex herbario Bankfiano.

$P E$ R. Pacca fpharica, nigmate quadri-1. fexfulcato feffili umbonata, fucculenta, multilocılaris. Diffepimenta membranacea, tenuiffuna, verfus peripherian fubdivifa, onde loculamenta inxqualia, irregularia.

$R E C$. nulluin; fernina in pulpa nidulantia.

SEM. nuncrofifima, ininutula, fphxrica, glaberrima, nitida, pallide albicantia aut Araminea.

INT. fimplex, membranaceum, tenue ; fuperficie exteriori, ab aqua, in mucilaginem pellucidillimam refolubili.

A LB. Semini conforme, carnofun, fubfriabile, album.

Eмr. Inngitudine dimidii circiter albumins, teretiusculus, rectus, niveus. Cotyl.jbrevillinx. Rad. craffa, ad unbilicum converla, raga.

2.) Bacca integra. b. B.) Eadem difęta, c. C.) Senina (eparata. D.) Seninis in sqna emollitl fuperficies, in (p'ixram mucilaginolan pellucidau converfa. E. E.) Albumiuis foftiones, cuin fitu embrjonis. G.) Enibryo feparatus.

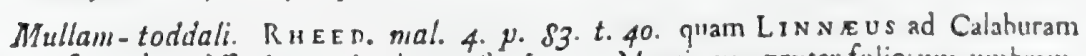
refert, diverlilinni gencris planta ell, \& cum Munsingla, proter folioi um umbram, niluil commune habet. 


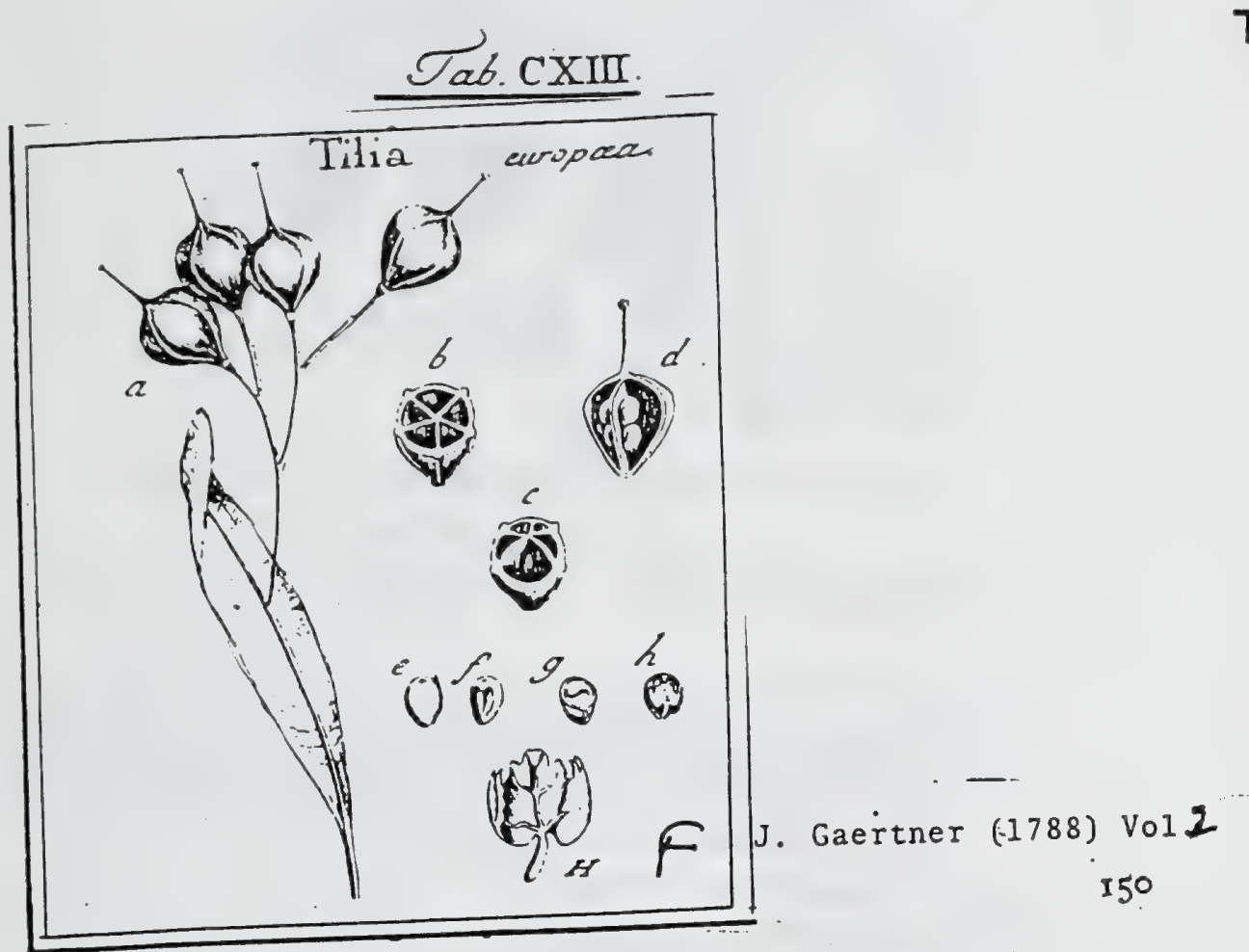

DCLX. T I I I A. TOURN. inft. t. 38r. LINN. gen. 660.

Calyx quinquepartitus. Cor. pentapetala. Stam. numerofa. Ovar. fuperum: Scyl. Gmplex. Capfula coriacea quinoueloculuris evalvis. Ovula geminata; Senina auten folitaria. Fructus pedunculus communis ligula membranscex aridx adnattus.

Tilia europxa. Tab. 113. fig. 3.

Tilin. BLAKw. herb. t. 469. OED. flor. dan. t. 553. OELHAv. t. I4. 15. bene. Tilia folits cordato lanceolatis, fpongiolis ad nervorum folii angulos fefjilibus. HaLl. bift. n. 1030 .

Tilia foribus nectario deflitutis. LiNx. $\int 3 \%$. veg. 493.

PER. Cipfula coriacea, fubturbinata nut ovato globofa, itylo perfiftente longo cerninata, coftis quinque filiformibus obfolete angulata, fufca aut fumofa, pubefcens, quinquelocularis, evalvis. Diffepimenta nembranacea, tenuilfiona, alba, cultis fructus obverfa.

REC. nullum; ovula duo, unum fupra alterum, angulo centrali loculamcntorum alfixa.

SEn. folitaria, rariffime in uno loculo gemina, quin ficpe in tota capfula matura vix uno plura, ovato-acuminara, hinc convexa, inde obfolete angulata \& in medio ventre cicatrice oblonga umbilicali notata, fcrobiculo pirvo in vertice exar.ıta, glabra, p.Ulide rufefcentia.

INT. fimplex, crafiufculum, fubeartilagineum.

A L B. carnofum, craffuni, pallide lutefcens, chalaza fubrotunda in vertice notatum.

E M. longitudine albuninis, erectus, in recenti femine gramineo viridis. Cotyl. foliacex, transverGm flexuof $x$, cordatx, fubtrilobx, dentatx. Kad. tcretiufcula, leviter curvata, infera. d.) Eadem lorgitudinaliter aperta, cum fitu \& infertione ovulorum. c. f.) Semina ab utraque grimam fguoideam, quam embryo parte (pectata. 5.) Seminis \& ands in albuanine fitus. H.) Embrgo folutus \& auctus.

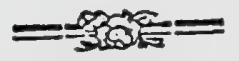

Dehifcentes a bafi capfulas, - ut vult Linizeus, hadtenus mihi non contigit videre, ncc futuris, valvularum indices, deprehendere potui ullas; quare rumpi potius fub germilatione; quam dehifcere capfulam fufpicor.

Cotyledones intra feminis tunicas jam jam dentatx, nonnifi Tilix, quod ego quidem firin, conceffx funt. 


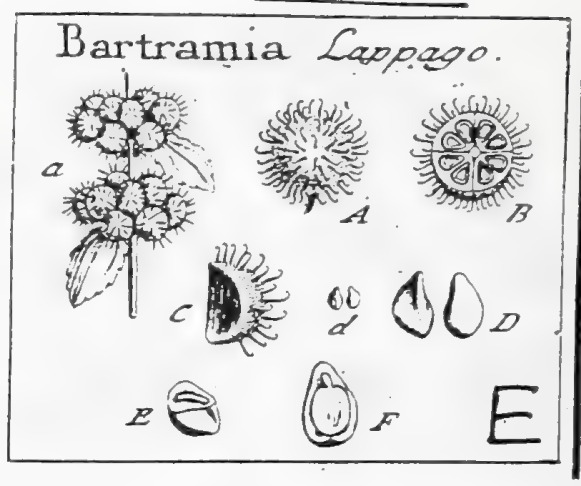

J. Gaertner (1788) Vol.

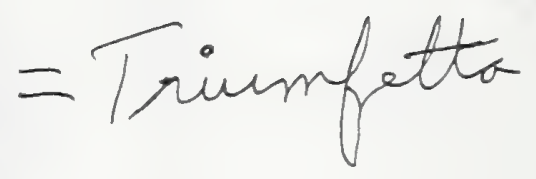

\section{I37}

DCXLIV. B A'R T R A MIA. Linn. gen. edit. ${ }^{-V}{ }^{*} n_{0} 480$.

Calyx pentaphyllus, infra apicem ariftatus. Cor. pentapetula Nectar. quinque glandulofa, globofa, ad bafin petalorum. Stam. quindecim. Ovvar. fuperum. Styl. fimplex. Capfula fetis uncinulatis hifpida, quadripartibilis in cocculos biloculares evalves. Semina folitaria, adnata.

Bartramia Lappago. Tab. 111. fig. 5.

Lappago ansboinica. RUNPH. amb. 6. p. 59. t. 25. f. 2.

I39

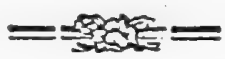

Lappola benglialenfis tetrofpermos, ribefii folio, eclsinis orbiculutis ad fulionnen ortums plurimis Sefilibus. PLuK. phyt. t. 4r. f. 5."

Trizmfetta fioribus calyculatis, foliis rhombeo-ovatis. Jace. biff. 547. t. 90 .

Trinunfetta foliis bars integris indizifis. L.INN. Jy/. veg. 444.

Ex herbario Bankfiano.

PER. Capfula fpharica, altio tomentora, aculeolis fetaceis, uncinulatis, glabris echinata, tetracocca, quadripartibilis. Cocculi coriacei, hinc convexi, inde angulati, biloculares, evalves, feminibus adnati.

REC. nullum; femina apice \& parietibus cocculorum affixa.

SEir. Solitaria, adeoque in fungulo cocculo gemina \& in tota capfulit nctona, ex ovatn ventre furfum attenuata, hinc convexa, inde angulara, rufefcentia, loculamentorum parietibus adhærentia.

INT. duplex: exterizs crultuceo-coriaceum; interius membranaceum, pallidum, lata chaliza fufca in bafi notatum.

A L B. carnofum, craflum, album.

Eм в." magnitudine albuminis, inverfus, lutefcens. Cotyl. foliacex, tenues, margine, non autem lateribus fuis, ut in Triumfetta, axi obverfx. Rad. teretiufcula, brevis, fupera.

2. A.) Capfula integra. B.) Easlem transverfim fcat. C.) Cocculus (eppratus. d. D.) Scmina

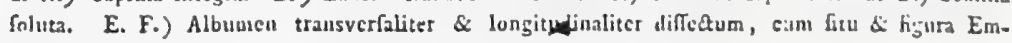
brọuis.

Nonnunquan capfulx tantun tricoccx \& tripartibiles funt; in aliis vero poffunt facili negotio in fex l. octo partes dividi, ut fingulum femen proprio fuo loculamento corticatum fit, ficuti in nomullis Mabraceis. A Triumfetta igitur, non tantum calyce \& nectariis, fed \& fructu polycucco, aperte differt. 


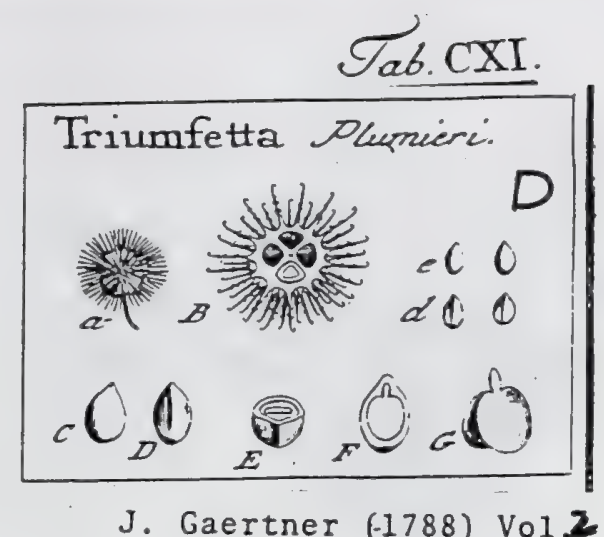

DCXLIII. TRIUMFET TA. PLUM. gen. t. 8. 137 LIN N. ger. 600.

Calyx nullus. Cor. pentapetala. Stam. fedecim. Ovar. fuperum. Styl. fimplex. Capfula uncinulato echinata, integerrima, quadrilocularis, evalvis. Semina folitaria, libera.

Triunfetta Plumieri. Tab. 111. fig. 4.

Triulinfetta frubu ecbinato racemofo. PLUM. gen. 40.

Lappula bermudenfis altbeoides Jpicuta, fruhin orbiculari majore. PLuk. plbyt. t. $245 . f .7$.

Trinmetta floribus calyce defitutis. JAce. bifl. anser. 146 .

Triumfetta foliis bafi emsarginatis, floribus ecalyculatis. LiNs. fyft. veg. 444. Ex herbario Bankfiano.

PER. Capfula globofa, coriacea, aculeis uncinulatis \& retrorfum hifpidis.echinata, integerrima, tri- $L_{0}$ frequentius quadrilocularis, evalvis, nec in cocculos feparabilis.

REC. nullum; femina interno loculamentorum angulo prope verticem affixa:

SEN. folitaria, ovata, hinc convexa, inde angulata, glabra, dura, cinerea.

IN T. duplex: cruftaceum, craflum, \& membranaceun, teinue, rufefcens, bafi clialaza magna fufca nocatum.

A I B. carnofum, craffum, album.

E s в. magnitudine fere albuminis, inverfus, lutefcens. Cotyl. ovato-cordate, foliacere, planiufculx. Rad. teretiufcula, brevis, fupera.

a.) Capfula integra. B.) Eadem diffect \& aueta. c. C. d. D.) Semina ab atraque parte (peCata. E.) Seminis \& nuclei fectio transver[alis. F.) Albumeu longitudinaliter difretum cum fitu embryonis. G.) Embryo folutuc. 
r

- 1 


\section{Trapaceae}

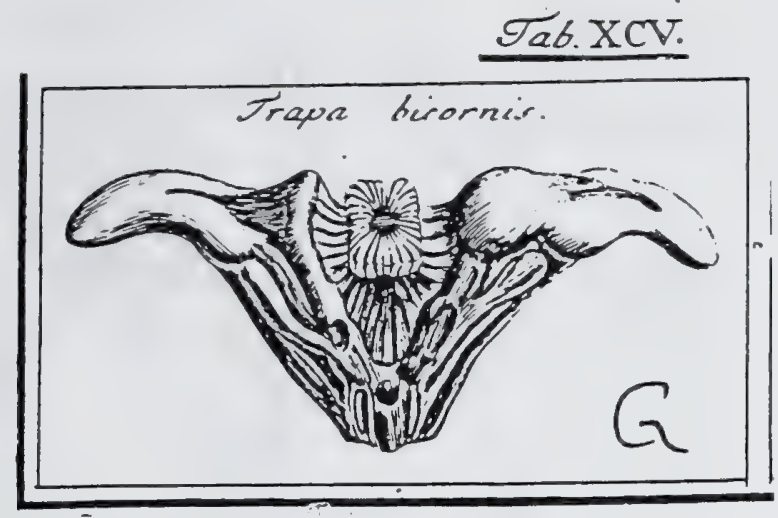

J. Gaertner (1788) Vol. 2

84

$T R A P A$. Conf. Vol. I. p. 127 .

TAPA bicomis. Tab. 95. Eg. 3.

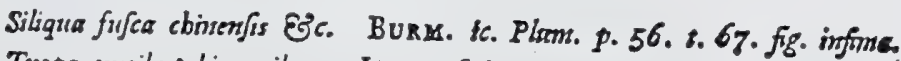

Trapa mucibus bicornibus. LINN. Cylf. veg. 262.

E muleo jorriuno.

Nux coriaceo-lignofa, nigro fufca, inverfe pyramidata, rhombeo-tetragona, inferne coftis atque fulcis elevatis, ramofis, ocellatis atque varie inter fe cunfuentibus pulchre areolata; fuperne capitulo tetragono, radiatim ftriato atque rotundo foramine pertufo terminata; ad utrumque vero latus craffilitino cornu, horizontaliter patente atque modice recurvo armats. Loculamentum unicum, nucis corpori, fua forma refpondens. Nucleus defuit. 


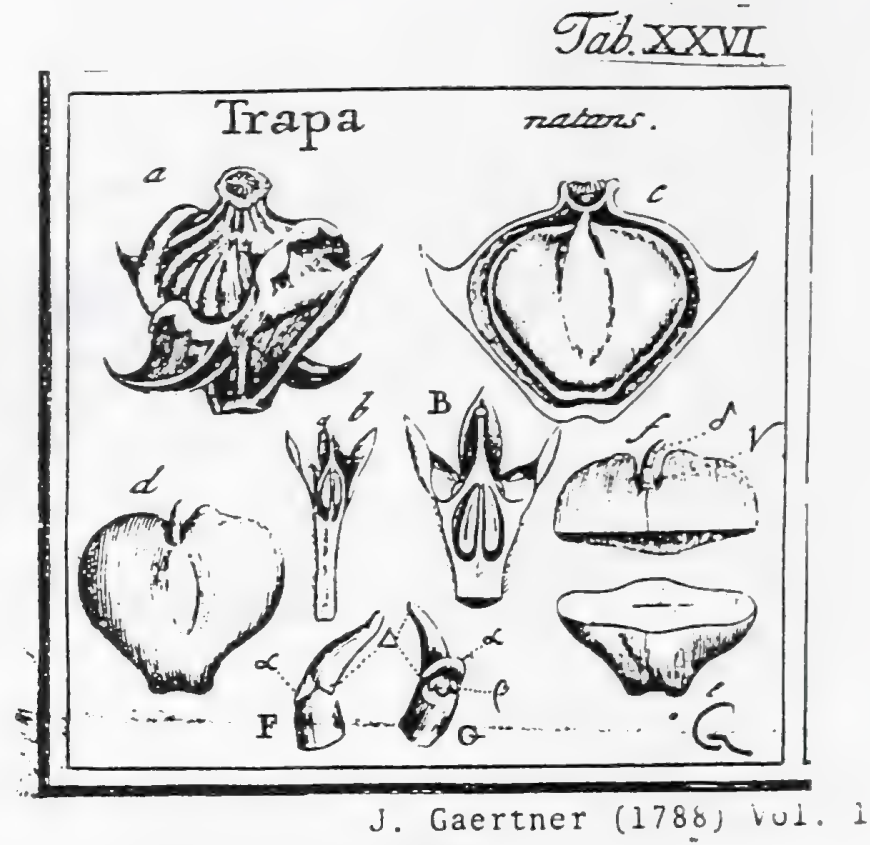

\section{TRAPA. LINN. "gen. 157. Tribuloides. TOURN. t. 437.}

Calyx fuperus quadripartitus, foliolis in fpinas fructus adolescentibus. Cor. tetrapetala. Stam. quatuor. Styl. unicus. Ovarium biloculare? ovulis binis pendalis. Nux matura cornuta uinilocularis monolperma.

T. A \& A natans. Tab. 26. fig. 5

Tribulus aquaticus. D O D. cereal. 245. CA s. epit. 715:

Trapa petiolis foliorum natantium ventrico/is. HA L L. hill. 1. n. $52 \%$.

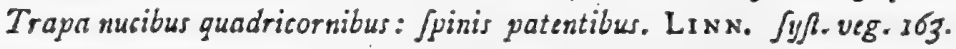

$P E R$. Nux infera, coriacea, dura, fubturbinata", rhombeo tetragona, fpinis quatuor validiflinis furfum incurvis in medio armata, obfolete fulcata, unilocularis, non dehifcens, fed per foranen verticis, tcuui pellicula \& convergentibus fecis claufum, germinass.

REC. feminis maturi nu!lum; orulorum vero: funiculus brevifimus umbilicalis e fupiema diffepimenti parte ad ovula descendens, eque pendula fuftinens.

SEN. uuicum, carnolum, grande, magnitudine \& figura cavitatis internx nucis.

IN T. funplex, membranaceum, in fuperiore feminis parte fpongiofum; craflum, cetera tenue, arcte adnatum, rubro ferrugineum.

A 1 в. nullum.

Es в. dicoryledoneus, inver[us, Ceınini conformis, anygdalino carnofus, albus. Cotyl. inxquales, alicra maxima, crallilima, totam fere molem \& figuram uuclei tiliciens; altera minuta, fquamulx fubrotundx forma bafi radiculix adjacens. Kad. tereti acuminata, Jeviter incurva, fupera. Plumula minutifima, iotra coryledonew uninorem latens.

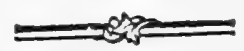

a.) Nux integra. b. B.) Ovarium immaturum, biloculare, cum fuis ovulis. c.) Nux unllocularis, longitudinaliter aperta. d.) Semen decorticatum. e.) Cotyledonis majoris pars inferior refeat. f) Ejusdem portio fuperior verticaliter fita, ut radicula in confpentum veniat. F. G. $\left.y_{0}\right)$ Kadicala f.) Ejusdem portio fuperior verticaliter hus, cum annexa fibi cotyledone minore $\left(\alpha, \alpha_{0}\right), q u x$ in G. $\left.\alpha_{*}\right)$ furfum reflexa, ut Plumala ( $\beta_{\text {) }}$ ) appareat. ( $\delta$. $\Delta$.) Radicula apex.

Anbigit \& hxe, ficuti Nelumbo, inter plantas mono-et dicotyledones, quandoquidem fub germinatione feminis nonnif unica coryledon in lucem prodeat. Hine quoque fecundum rigorem monocotyledonibus poterit affociari, uti jam olinn fufpicatus ef ADANSONUS, fam. 2. p. 83. 


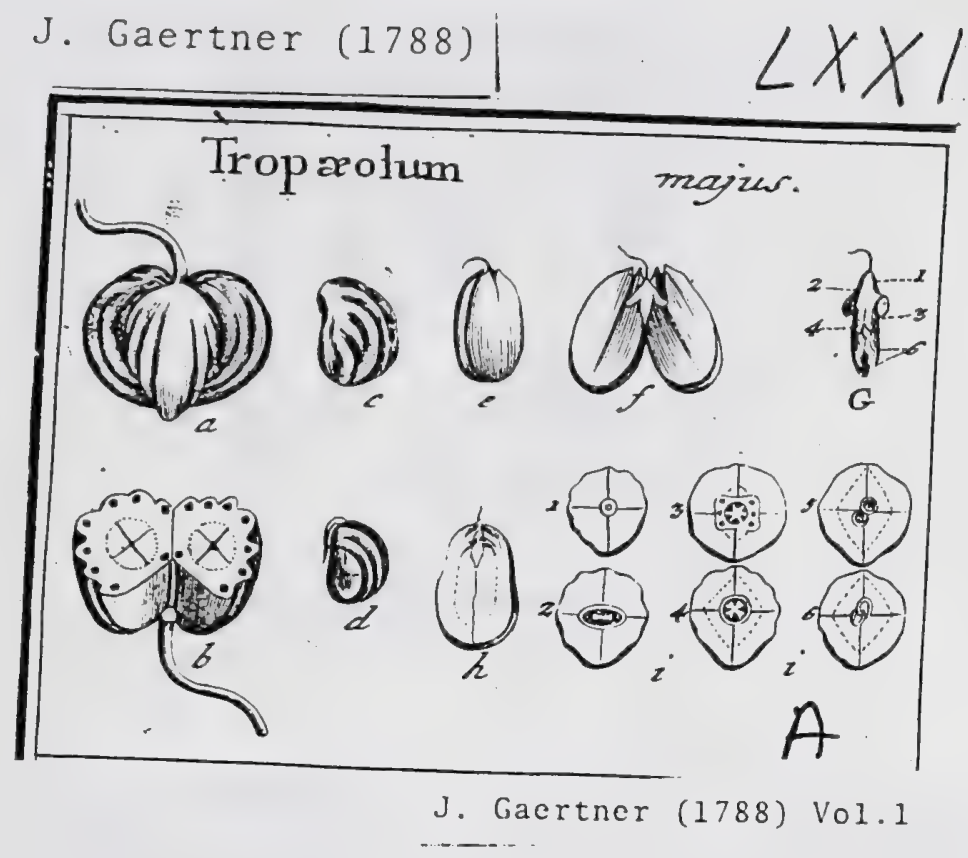

CCCCXCVI. TROPÆELUM. L IN N. gen. 466.

Calyx monophyllus, calcaratus, coloratus. Cor. pentapetala, inaqualis. Stam. octo. Sijl. unicus, Jaccie tres, funcolix, rugofx, monolperıx.

I'ROT.EOL M majus. Tab. 79. fig. I.

Viola inodora feandens, nafurtii fapore, maxima odorata. Herm. lugdb. 628. ii. 629 .

Cardamindum majus. R I v. pent. t. 97.

Tropreolum foliis peltatis fubquinquelobis, petalis obtufis. Lins. $\sqrt{1 / f} / \mathrm{v}$ veg. $35 \%$

PER. Baccx tres, per maturitatem exfuccx, fungofx, profunde fulcata \& rugate" hine gibbx, inde angulatx, furfum angufat $x$, fordide albicantes.

REC. filiforme in axi fructus pofitum.

SEM. Colitaria, elliptico. Sphxroidea, per xtatem vero rugata, externx figurz bacex conformia, rufefcentia, apice funiculo umbilicali terminata.

I N.T. fimplex, membranaceum, tenue, nucleo maturo arcte adharens.

A \& в. nullum.

EM в. magnitudine \& figura feminis, inverfus, albus. Cotyl. ante maturitatem squdripartitx, poftea bilubx, dimidiato ovat $x, \operatorname{craf} x$, apice bidentatx, tandem ita inter fe conferruminatx, ut feparari amplius nequeant. Plum. grandiuscula, conica, comprefta, diphylla, foliolis venofis, convolutis. Rad. conica, brevis, fupera, funicuio unbilicali terminata, intra cotyledonum dentes latens

a. b.) Fructus immaturus integer, \& diffectus. c.) Bacea matura (eparata: d.) Semen decorticatum. e.) Enibrjo in aque emollitus. f.) Cotyledones divaricatz, cum plumula in fita naturali, G. , Plumulv (eparata h.) Cotyledones conferruminatz longitudinaliter diffecte. L L). Sectiones coryledonum transverfales, radicula \& plumula fabricam (I - 6.) oftendeotes.

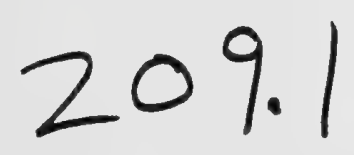


Turneraceae

Tat.I Xxv1

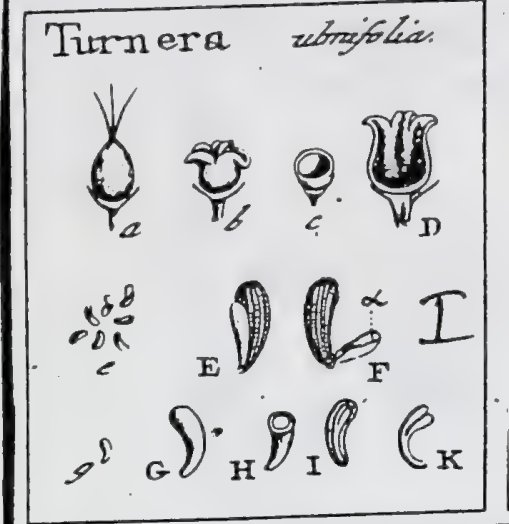

J. Gaertner (1788) Vol.1

366

CCCCLXXVI. TURNERA. PLUM. gen. t. I2. LIN N. ger. 37 g.

Calyx monophyllus infundibuliformis. Cor. pentapetala. Stam. quingtest Sify

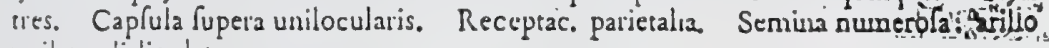
unilaterali ligulato.

TURNERA ulinifolia. Tab. 76. fig. 3 .

Titrurn frattefreils ulmifolia. MART. cent. 49.t. 49.

Tu"nera floribus fefflibus peliolaribus, foliis bafi biglandulojis. L1ws. hort. Cliff: tal. 10. Jijl. vicg. 296.

PER. Cap̧fula fupera, ovata, obfolete trigona, pubefcens, unilocularis, ab apice ad me: dinin trifarian dehifcens.

REC. lince tres elevatae, parieti caplulae interno longitudinaliter inferiptae, funiculis umbilicalibus numerofitmis, brevilfmis nipatae.

SEs. plurima, modice ineurva, oblonga, verfus umbilicum attenuata, teretiuscüla? fcrobiculis minutiffmis [eriatis cxarata, e caftanco fufca. Arillus dimidiatus sy gularus, meinbranaceus, tenuis, albicans, feminis parti concavx accumbens ivondique liber, unbilico infertus.

1 Х̇т. dupiex: exterius crufaceun, tenue, fragile; interius membranaceum, pallidumo:A. B. Semini conforme, tenuc, carnofum, album.

E. в. Cubclaratus, arcuatus, lutcicens. Cotyl. ovato oblongx, plano convexx: Rod. tereti acuminata, curvata, centrifuga.

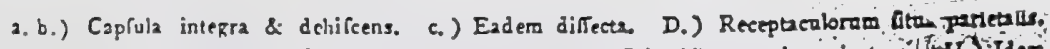

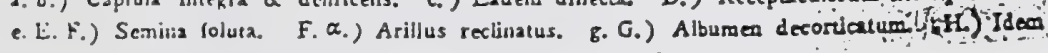
diffectum. 1.) Embryouis fitus in albunise. K.) Embryo feparatus.

$2 / 0.1$ 


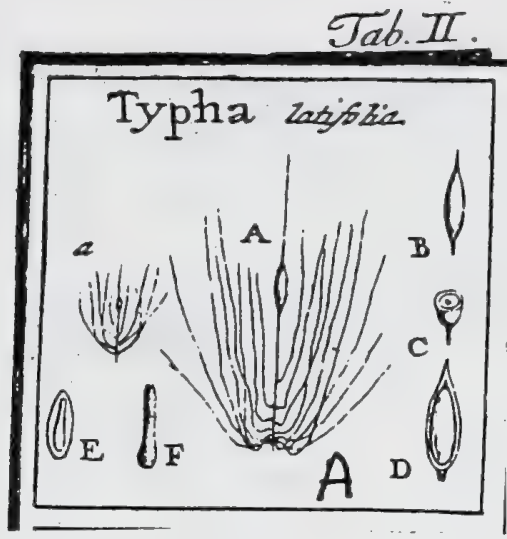

J. Gaertner (1788) Vo].1

XII. TYPHA. TOURN. t. joI. LIN N. ger. 1040.

Flores mafculi fupra femineos, in f́pica tereti denfifima, tripetali, trillenones. Flores feminci, in finnili fpica, apetali. Semenuudum, pedicello capillari, pilofo.

ТҮвн a latifulia. Tab. 2. fig. I.

Typha. CaM. epit. 607. Oeder. flor. dan. t. 645 .

Typha clava unica. Hall. hif. 2. n. 1305 .

Typha foliis fubenfiformibus, fpica mafcula femineaque approximatis. Liss. fyfoveg. 84 I.

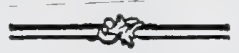

Icon. Sem. GREw. anat. t. 72 .

PER. nulluin.

REc. consmune: fcapus fpicx feminex, undique feminibus tectus; proprium: pedunculus capillaris, fernine triplo longior, a bafi ad medium pilis longiflunis albis diflitis fipatus, apice definens in cotylain minutilimam, femini fubjectam.

SEM. unicum, parvum, nylo perfiltente terminatum, terctiusculum, glabrum, pallidum, aut Spadiceum.

IN T. fumplex, inembranzceum, tenuifiunum, facile fecedens.

A t. в. femui conforme, carnofum, folidiusculum, lutescens.

E м в. monocotyledoneus, longitudine fere feminis, rectus, albicans. Plum. teretiacumiliata, longa. Rad. incrallata, infera.

a. A. B.) Semen integrum. C.) Idem trassverfe feflum, D.) Ejusdem feltio longitudinalis.

E.) Albuncu longitudinaliter apertum, cum fitu embryouis. F.) Embryo feparatus.

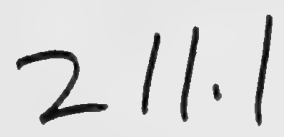


$-$ 
Ulmaceae

Tab. L XXVII.

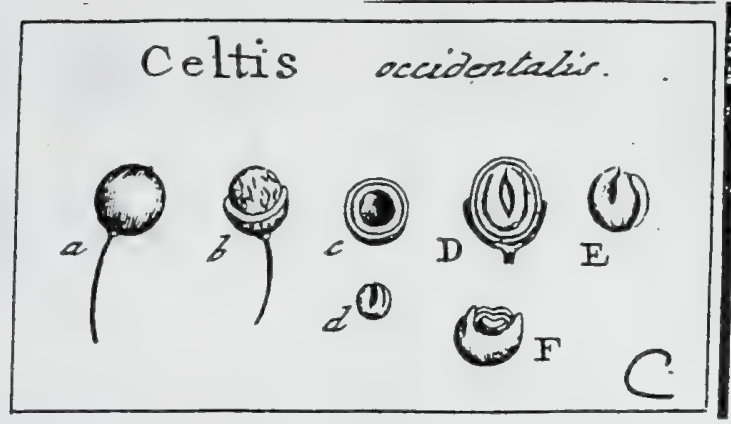

1. batetner (17ss) Vol.1

374

CCCCLXXXVII. CELTIS. T O u R N. t. 283. L.I N. gen. II 43.

Fioncs hermaphroditi \& masenli in eodem trunco. Cal, quimpe-1. fexpartirus. Cor. mul!3. Sta:n, quingue 1. fex. Styl. duo 1. quatuor. Drupa baciata unilocularis. Semen unicum, invertum.

CE.t. is occidemealis. Tab. ?: lig. 3 .

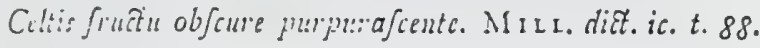

Cilits fuliis oblinue ovatis ac:sminatis. Lax: fy/f. veg. 912.

PÉ. Drupa baciara, fupcra, orato globola, nigro-purpurea. Caro tenuis. iPuta. men globulum, ollium, durum, cburnco candidum, cxtus fubrugolum, unilo. culare, evalue.

REc. nu'lum; femen apice affixum.

Si: unicum, globofum, rufefcens.

Ixт. fumplex, membranaccum, tenue.

A.li. mcmbranacco-carnofum, tcuuc, intra plicas cotyledonum demerfum, vabaga fere in gelatinam convertibile, ficut in malraceis.

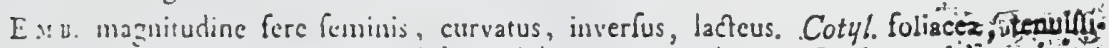

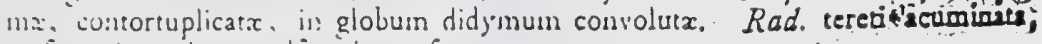
verlus apicem baccax adiecridens, fupera.

212.1 


\section{Ulmaceae}

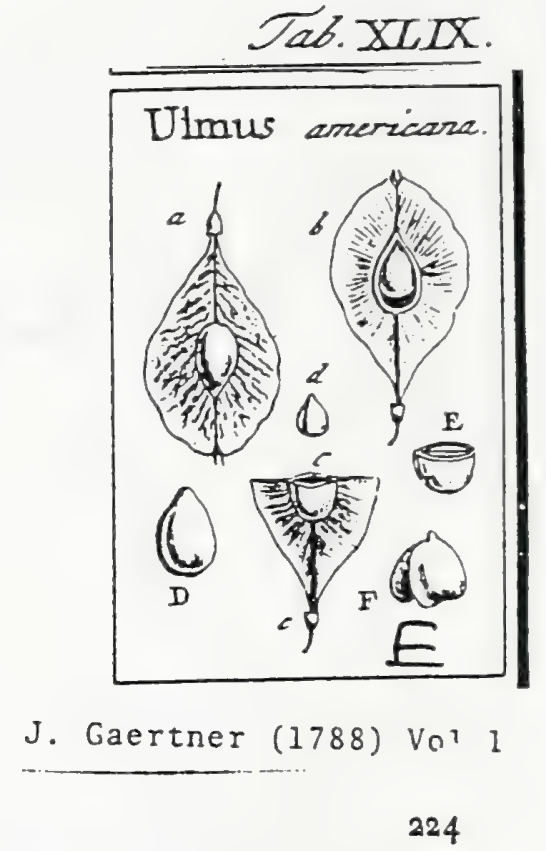

C'́LXXIII. ULMUUS. TOURN. t. 372. Linn. ger. 316.

Calyx monophyilus, quinquefidus, interne coloratus. Cor. nulla. Stann. quinque. Styl. duo. Caplula fupera, unilocularis, fuliaceo compreffa. Semen folitarium:

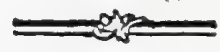

ULisus americana. Tab. 49. fig. 5.

Ulmus foliis aqualiter ferratis: bafi inccqualibus. Lrs s. fyßo. veg. 265.

PER. Capfula fupera, foliaceo comprefia, obovata, in pedunculum calyce perfinente munitum attcnuata, unilocularis, evalvis. Loculanentum in centro capfulz, extus fpongiofum, intus glaberrimum, lenticulari compreffum.

REC. funiculus umbilicalis filiformis, ex apice loculamenti oriundus, atque altcri feminis margini usque ad bafin adnatus.

SEM. unicum, ovatum, fupra mucronatum, lenticulari compreffum, e viridi fpadiceurn.

IN T. fimplex, coriaceum, tenue. ',

A Łв. nullum.

EMs. Semini conformis, inverfus, albus. Cotyl. obovatx, carnofx, plano.convexiusculx. Rad. brevis, fupera.

a.) Capfula integra. b.) Loculamentum apertum, c) Samara transverfion fetal d. D.) Semeo cum funiculo umbilicali aduato. E.) Idern diffetum, F.) Embryo. 
UNKNOWNS

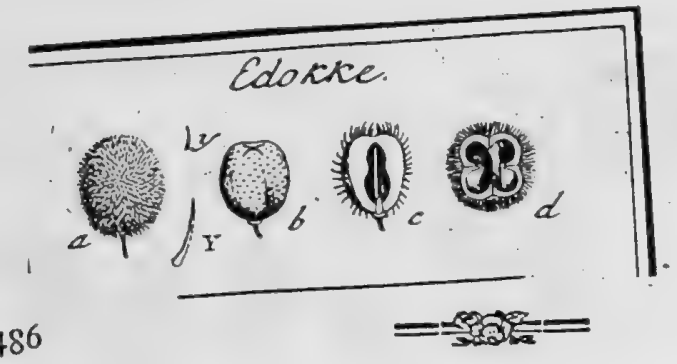

Tab.CLXXX.

J. Gaertner (1788) Vo1: 2

EDOKKE zeyloners. Tab. 180. fig. 7.

E collect. feni. hort. lugdb.

Capfula coriacea, ovata l. obovata (a. b.), Spinis acicularibus (y. Y.), retror: fum feabris \& caducis undique obtecta, obfolete teuragona, unilocularis (c. d.), quadrivalvis (d): Valvularum futuris introrfum porrectis (c. d.), ut interna cavitas evadat quadriloba, aut quadrilocularis. Recept. nullum. Semina .... in pulpa capfulan replente nidulantia?

Gies.
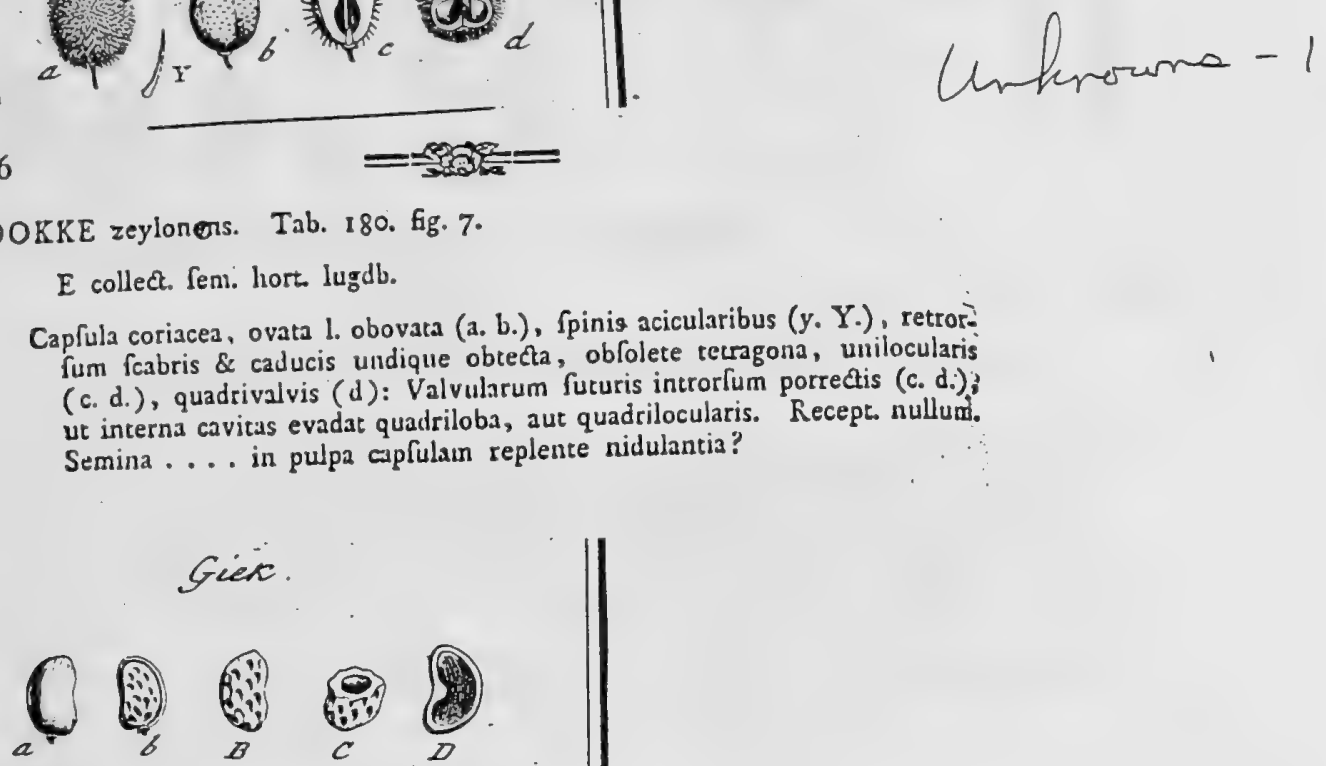

GIEK zeylonens. Tab. 180. fig. 8 .

- E collect fem. hort. lugdb.

Drupa carnufa, parva (a. b.), ovato-reniformis, turgide lenticularis, deoifum gibba, rubrs. Caro pulpofa, per xtatem exarefce:as, ut fola cuticula rugofa putamini fuperinducta fit. Putamen (b. B. C. D.) offeum, crafiufculum, fcrobiculatum, uniloculare (C.), evalve. Semen unicum, cavitati putaminis (D) conforme. Nucleus defuit.

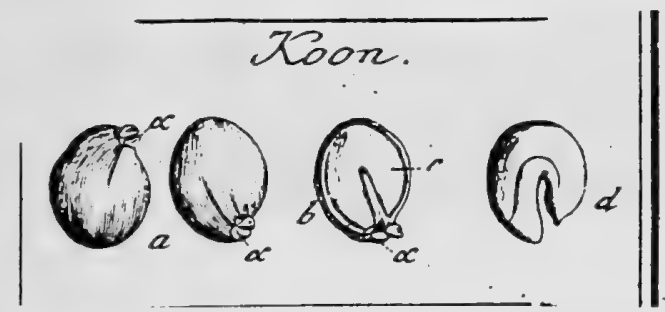

KOON zeylonens. Tab. 180. fig. II.

E collect. fem. hort lugdb.

Nuces una plures receptnculo communi affixx. Putamen (a. b.) obovatum, a Jateribus compreffiufculum, cruftaceum , durum, tenuc, evalve, glabrum, : ferrugineum aut caftaneum, ad bafin derufum \& in duo tubercula alba-

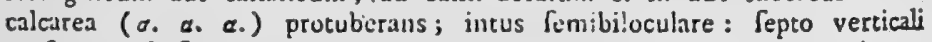
cruft:ceo a bafi ad median nucis cavitatem (b.) porrecto. Sepnen unicum, (c.), nucis cavicati conforme, r. hamato - conduplicatum. Integum. pro. prium duplex: exterius membranaceum, aridun, fpadiceo nigrum, venis! niveis, quafi calcareis, pidum ; interins fubfpongiofun; ferrugineum, chalaza tuberculata fufca in feminis crure craffiore \& longiore terninatum. Albumen prorfus nullum. Enibr. (d.) femini conformis, anygdalinocarnofus, albus. Cotyl. craffx, incumbentes, per maturitatem pertinaciffine inter fe coalitx, ut faltem linea depreffa, divifionis index, in utroque latere fuperfic. Rad. conica, brevis, in crure embryouis tenuiore \& breviure.

Nullum plane dubium eft, quin hx nuces fint genuinus fructus Ochnx $=9$. dasice Schreb. gen. "1. 89I. Receptaculum commune mithi vilderc non contigit, quia omnes nuces erant folutr.

213.1 


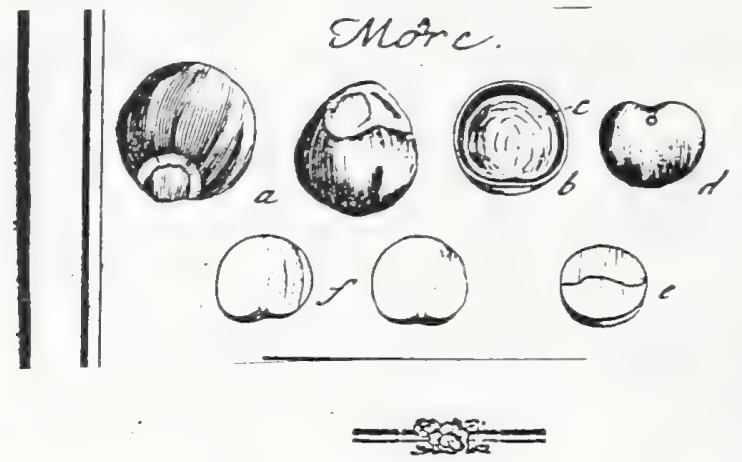

J. Gaertner (17.88) Vol. 2

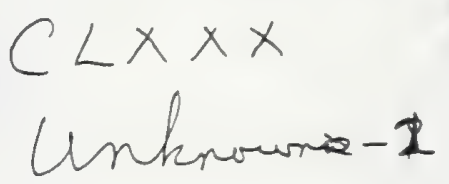

MORE zeylonens. Tab. 180. fig. 5.

E collect. fem. hort. Jugdb.; ex feminar. Chelfeano; \& ex inf. Mauritii per $\mathrm{Cl}$. Herisann. Profo argent.

Senina fubglobofa (a. b.), coriaceo-nucamentacea, anthracina aut e ferruginte-nigra, fplendentia : baf derafa albicante. Integ. duplex: exterius corinceum, tenue, per xtatem fragile; interins membranaceum, valis \& rugis obfoletis arcuatis (b.) infcriptum, cinerafcens. Albumen nullum. Embryo (c. d. e. f.) femini conformis, fubglubofus, bafi levirer deprefius (d.) f. aliquantum concavus, furdide albicans. Cotyl. (e.f.) hemifpharica. Rad. minutula (f.) bafin feminis refpiciens.

Similitudinem habent cum feminibus Pavie. Cunf. Ehret. dec. t.75.

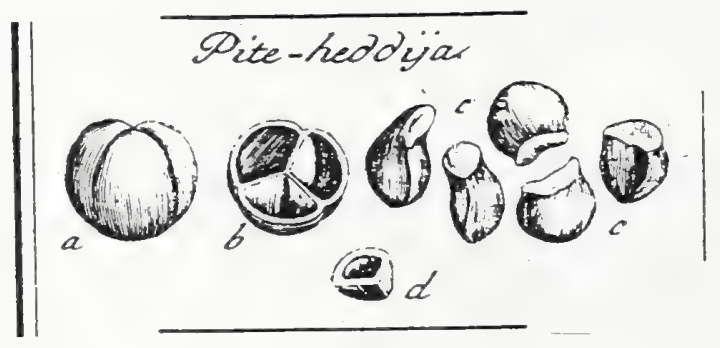

PITE - HEDDIJA javan. Tab. 180. fig. 2.

E collect. fem. hort. lugdb.

Bacca fubglobofa, per xtatem coriacea, trifulca (a.), trilocularis (b.). Diffepinen fexternis refpondentra. Recept. nullum, fed femina pinerita tenuia, fulcis externis refondicis fuis derafis late affixa. Sefupremis loculamentorum formicibus loculo, grandiufcula, nucamentacea, nina (c. c.) unum aut due in fingulo loculo, grandiufcula, ad umbilicum varie \& irregularicer angulata, faturate caltanea, fublucida, indeg. exterius (d.) crafiun, ofleo-cru-

ampla area derala pallidia 1 .
ftaceun. Nucleus defuit.

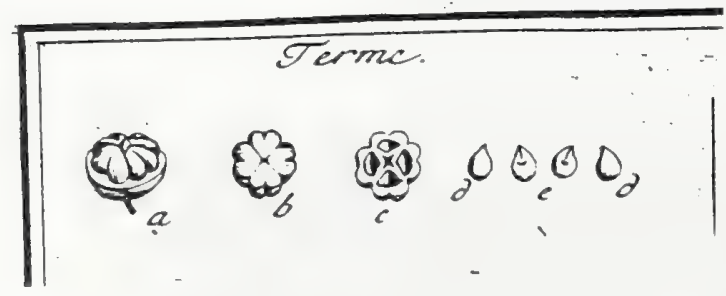

TERME javan. Tab. 180. fig. 1.

E collect. fem. hort. Jugdb.

Drupa parva carnofa. Putamen lapideum, depreftiufculum, fuperne (a) nucrone brevi tetragono - pyramidara, \& ex eo, fulco cruciato infignitum, inferne (b.) torulis octo, per paria junčtis, exaratum \& in media bafi, catali tetragono (b. c.) perforatum, yuadriloculare (c.), evalve. Recepe. funiculi umbilicales, ex curali axcos, per propria in mediis loculamentis forming (d. e.) folitaria, ovata, furfum acuminata, hinc convexa (d. d.), inde angulati (e.) \& in medio angulo acuminata, hisilicali notata, rufiefcentia. Nucleus defuit 
UNKNOWNS

J. Gaertner (17.88) Vol. 2 $C<x x$

Unhroune-3
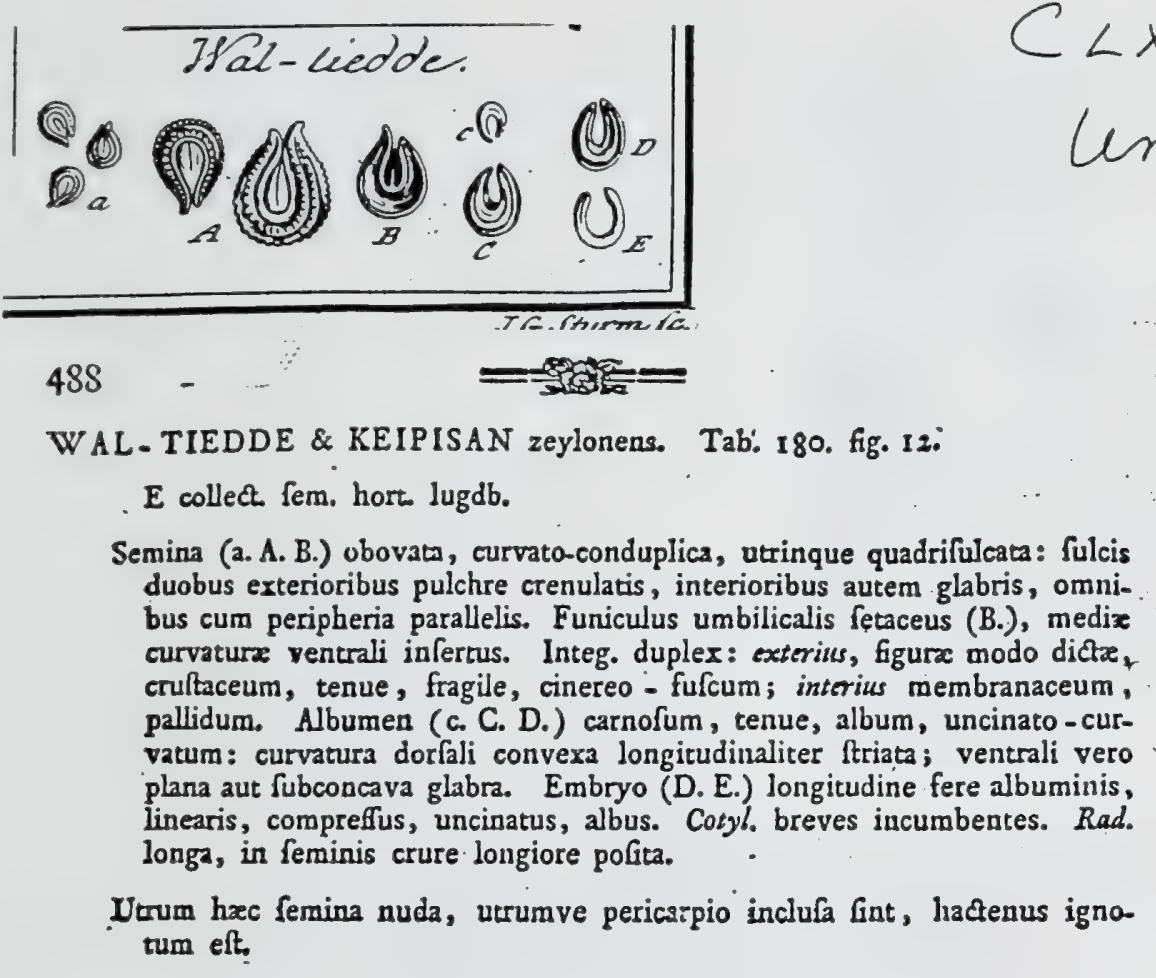

Based on the draunings Wal-tiedde is a membug the MerigermacearN 1/20/94

213.3 


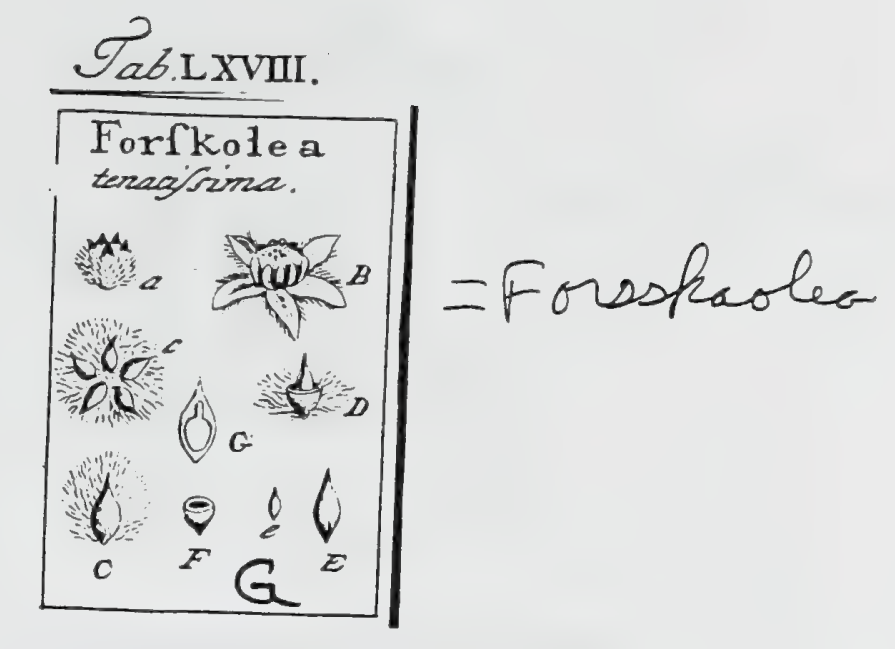

\section{J. Gaertner (1788) Vol. I}

CCCCXXVIII. FORS SIK A LEA. LINN. gen. 1262.

Calyx pentaphyllus. Cor. ofto-1. decapetala, petalis fpatulatis. Staın. ofto l. decem. Styl. quinque. Capfulae quinque lanatae. Semina folitaria.

FORSKOHLEA tenaciflima. Tab. 68. fig. 7 .

Forskollea foliis ovatis Jerratis. Lins. faft. 1. t. 1. fill veg. 437.

PER. Capfulac quinque, parvae, ovatac, utrinque acuminatae, compreffae, membrinaceac, tenuiffimae, lanatae, uniloculares, fernen laxe ambientes, non dehifcerites.

REC. nullum; femen apici capfulac affixum.

SEM. folitarium, ovatum, utrinque acuminatum, lenticulari compreffum, glabrum, ferrugineun.

IN T. finplex, fubcoriaccum, tenue.

A L. . femini conforme, carnofum, tenue, album.

EN B. inagnitudine fere ferninis, inverfus, lactcus. Cotyl.ovatae, foliaceae, planae: Rad. teretiuscula, recta, fupera.

2.) Capfulz lana connexz. B.) Floris fịura. c. C.) Capfulx (eparatz. D.) Seminis fitus intra opfulam. e. E.) Serwen feparatuns. F.) Idem transverfe feftum, G.) Embryonis figura \& fitus intra albumen.

Numerus capfularum variat, a ternario ad quinariunn.

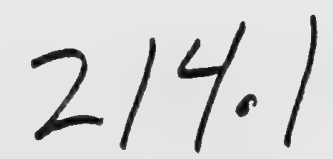




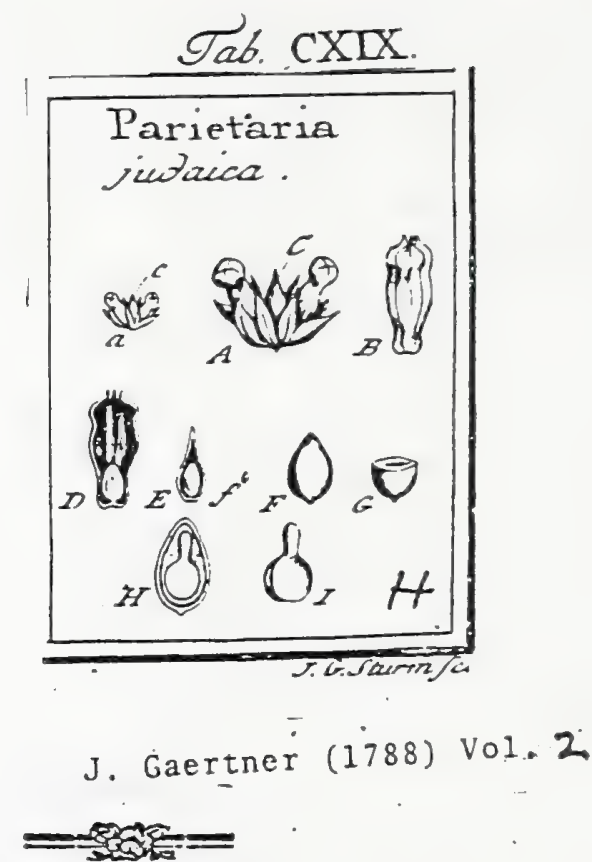

DCC. P A IET A RIA. TOURN. inft. t. 289.

LIN N. gen. II5:.

Flores duo hermaphroditi atque unicus femineus intra involuctum coramune hexaphyllum. HERM. Cal. quadrifidus perfiftens. Cor. nulla. Stan. quatuor. Ovar. fuperun. . Stigma penicillitorme. FE.M. Cal. Cor. \& Ovar. ut in hermaph. Semen utrinque unicum, calyce maturo claufum, . Subpedicellatum, nitidum.

Parietaria judaica. Tab. IIg. fig. 8.

Parietarin folits ovato lanceolatis fubbirfuris. HaLc. biff. 11. $16{ }_{3}$.

Parietaria foliis ovatis, 'caulibus erefilis, calycibus trifloris, corollis neafculis elongato gylinidricis. LINN. fyft. veg. 908.

PẸR. nullum; calyx maturus, claufus, femen laxe complectitur \& occultat.

REC. nullum, nifi tuberculum velis minutulum in bafi feminis, cujus, tanquam pedicelli ope, cum fundo calycis connectitur.

SEM. unicum, ovatum, furfum anguftatum, lenticulari-compreffum, glabrum, nitidum, atrum, bafi papillula umbilicali alba inggnitum.

IN $T$. duplex: exterius cruftaceum, tenue, fragile; iriterius membranaceum, tenuifimum.

A L B. carnofum, aqueo-pallidum.

E. B. albumine paulo minor, inverfus, lacteus. Cotyl. orbiculatx, foliacex. Rad. cylindrica, recka, fupera.

2. A:) Flores hermaphroditi laterales \& femineus foltarius (C. C. ) comanni involuero 6 - L. 8 phỵllo comprehenG. B. D.) Calyx maturus foris hermaphroditi, claufus \& apertus. E.) CaIvx floris feminci apertus. f. F.) Semen feparztum integrum. G.) Ijem transperie diffetrom. H.) Ejusdem fectio longitudinalis, cum Gitu \& tigura embryonis intra asbumen: L) Embrye feparatus.

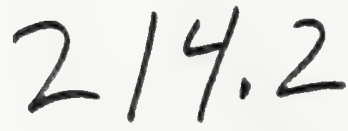


Urticaceae

Tab. CXIX.
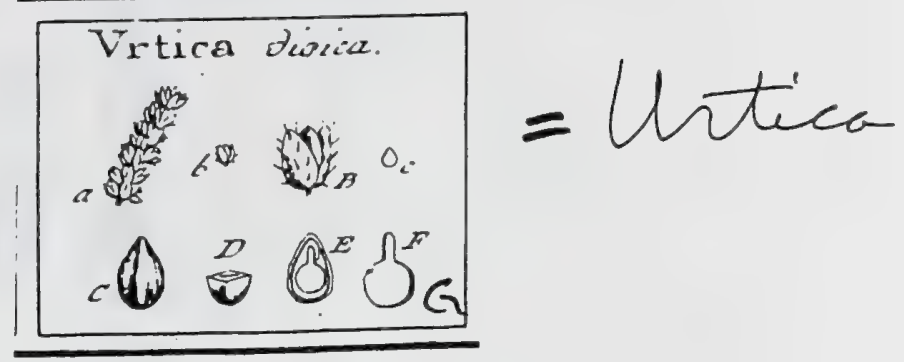

J. Gaertner $(1788)=$ oil. 2

183

DCXCIX. UR T I C A. TOURN. inft. t. 30S. LINN. ger. I054.

Flores fexu diftincti, in eadem vel in feparata ftippe. MAS. Cal. tetraphylllus. Cor." nulla. Nectar. centrale, cyathiformi. .Stam. quatuor. FEM. Cal. bivalvis. Cor. nulla. Ovar. fuperum. Stigma Tefrile. Sem. unicum, liberum, nitidum.

Urtica divica. Tab. 119. fig. 7 .

Urtica urens altera. DoD. penipt. 151. BLAKIw, berb. t. 12. mas. OED. flo:dar. $t .746$.

Uriica folits oppofitis cordatis; racemis geminis. LINN. Jyl. veg. $5490^{-}$

PER. nullum; calycis valvulx femien complectuntur.

KEC. nullum.

SEM. unicum, parvum, ovato attenuatum, lenticulari comprefím, nitidurn, pallide albicans.

'Ix T. duplex: chartaceum, bafi foramine umbilicali pertufum; \& membranaccum, tenuiffimum, pallidum.

At B. carnofum, modice craffum, albicans.

Eм. longitudine albuminis, inverfus, nivous. Cotyl. orbiculate, foliacex. Rad. cylisdrica, recta, fupera.

a.) Racemulus frugifer. b. B.) Semen calyce conclufum c. C.) Idem denudatum. D.) Idcur trasterfe rectum. E.) Ejasdem fidio longitudinalis cum lita \& fgura embronis intra altuEca. F.) Embryo Colutus. 


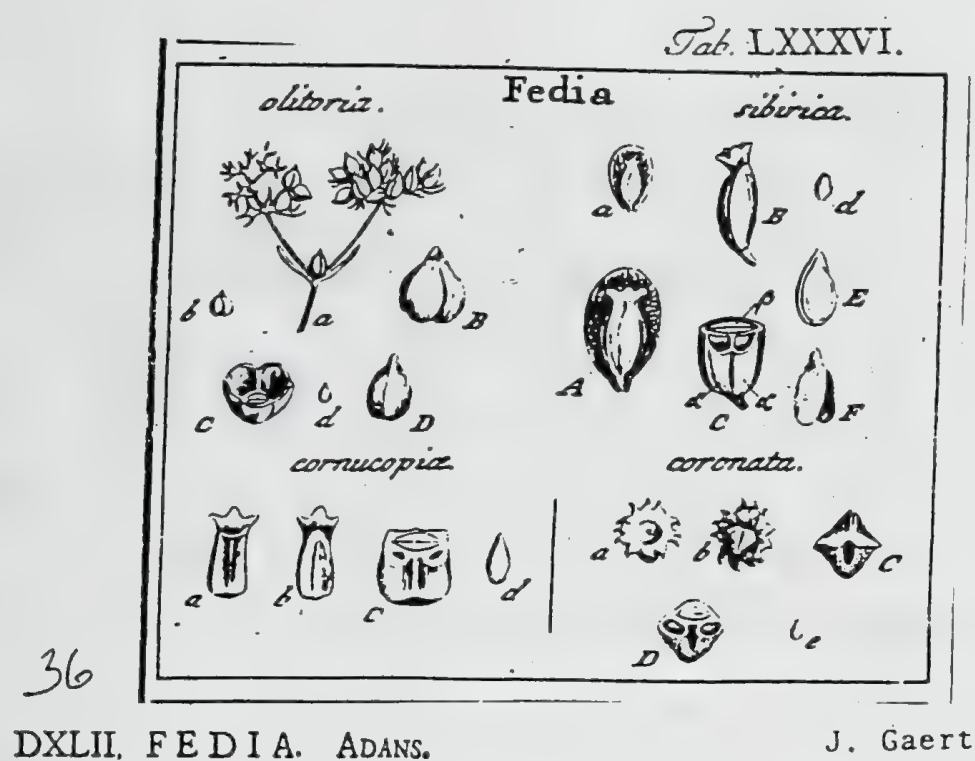

Valerianaceae

DXLII. FE D I A. ADANS.

Calyx Superus monophyllus tri -1 . pluridentatus. Cor. monopetala, limbo quinquefido, regulari \& irregulari. Sam. duo ad quinque. Ovar. inferum. Styl. fimplex. Capfula coronata, trilocularis: loculamento unico fertili.

FEDIA olitoria. Tab. 86. fig. 3.

Locuffa mino:" Ruv. monop. t. 6. f. 2. OED. flor. dan. t. $73^{8}$.

Valerianslla folis oblongis rariter incifis, corous feininis funzplici acsuninata. HALL. bif. n. 214.

Valeriana foribus triandris, caule dicbotomo, foliis linearibus, fruthu fonplici. LiNs. Jyft. veg. 80.

PER. Capfula infera, fubglobofa; calyce oblique truncato \& inxqualiter tridentato corolnata, hinc ex medio fulco didyma, inde tribus ftriis filiformibus notrta, trilocularis, evalvis. Loculamenta duo fterilia infata; unum fertile, lenticulari compreffum.

REc. nullum.

SEM. unicum, ovato acumisatum, compreffum, pallide lutefcens.

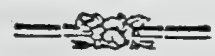

I.v. fimplicifinuu, membranaceum.

A L B. nulluns.

Es B. Fenini conformis, inverfus, albus. Cotyl. planiufeule, tenues. Rat. brevis, fupera.

2) Fnetus in cotymbo terminati. b. B.) Capfula feparata, a parte ventrali fpecata C.) Eadem transverfe feta, a dorfo fpectata, cum loculanentis duobus vacuis atque unico dorfali fertili. d. D.) Semen \& embryo in fitu naturali.

Fedia cornucopix. ibid.

Valerinnella cormucopioides. Riv. monop. t. 5.

Valeriana foribus diandris ringentibus, foliis. ovatis feflilibus. LINN. $f y f t$. veg. 79 .

Capfula $(a-C$.) fubparallelipipedea, comprelfiufcula, fungofa, calyce dimidiato \& tridentato coronata, hinc (a. C.) leviter concava, inde (b.) planiufcula, utrinque autem linea longitudinali elevata in medio notata. Lochlamenta fpuria (C.) anguftifinia, \& fere oblitterata. Semen (d.) ovato acuminatum, compreffum. Albumen nullum. Embryo inverfus, Juteus.

Fedia fibirica, ibid.

Valerima lusen brunilis. AмM. rutb. n. 25. t. 3.

Valeriana zetrafenon, fenine foliolo imsato. HaLl. Comss. Goett. 7751. p. 207. t. 9.

Valerious fioribus setrandris aqualibus, folis pimnatifidis, feminibus palece ovali adsatis. LINN. byf. veg. 81.

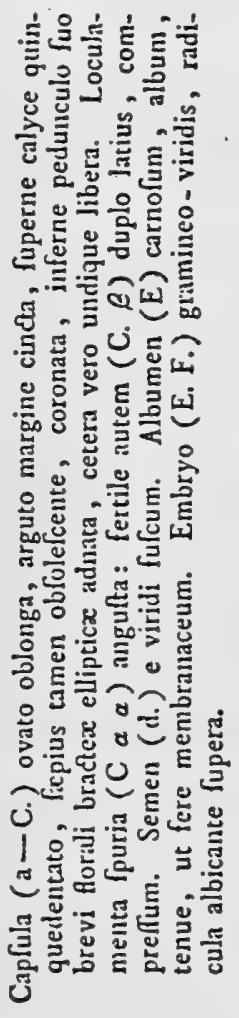

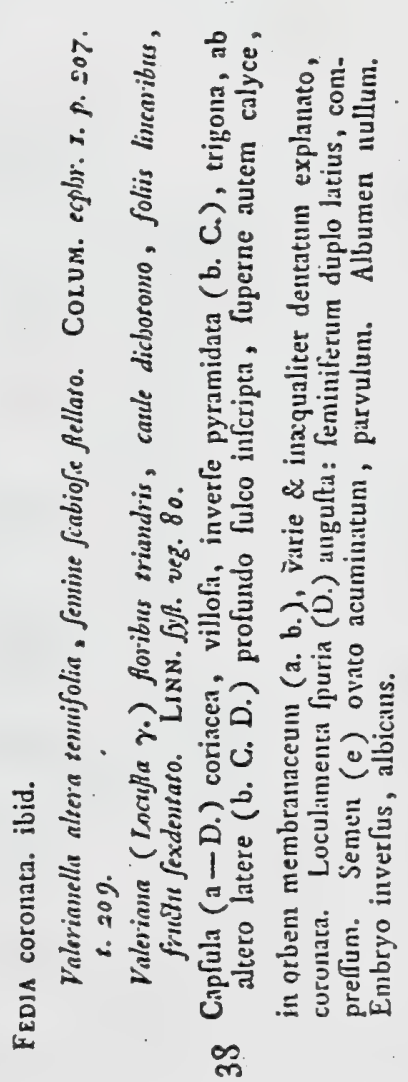

I (1788) Vol. 2 
Tat. IXXXVI.

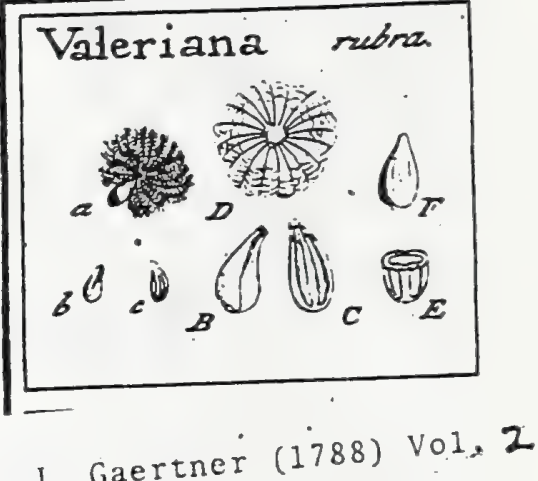

\section{VALERIANA. TOURN. inft. t. 52. LINN. gen. 44}

Calyx fuperus, per maturitatem in pappum feffiem plumofum refolubilis. Cor. fupera, monopetals, fxpe calcarata; linbo varie divifo. Sam. unum ad tria. Ovarium inferua uniloculare. Styl. finplex. Semen calyce corticutum.

VALERIANi rubra. Tab. 86. fig. I.

Visleriana rubra. Riv. monop. t. 3. f. 2.

Valeriana foliis gluberrimis, floribus calcaratis. Hiale. bift. 1t. 213 .

Valeriana fioribus monandris casulatis, foliis lauscolatis issegerrimis. LiNN. fyt. veg. 29.

PER. nullum, proter feminis cruftam, e calyce euatam.

REC. nullum.

SEM. unicum, inferum, ovatum, furfum anguftatum, compreffiufculum, hine ftrin unica deprefla, inde fulcis tribus elevatis notatum, rufefcens, pappolum. Pappus feffilis, femine longior, radiis circiter vigint, incurvis, plumofis, bafi in cupulam membranaceam, inverfe conicam, connatis.

IN T. duplex: exterius cruftaceum, a calyce; iuserius membranaceum, album . diaphanum.

A L B. nullum.

Fм R. femini conformis, inverfus, lutefcens. Cosyl. ad normam crulta exterioris obfolete fulcate, carnofa. had. conica, fupera.

a.: Semen marurum cum fuo pappo. b. B.) Ejusdem, excufro pappo, facies fimpliciter frizts. a. C.) Ejusdem latus elevato fulcatum. D.) Pappus a parte inferiore in cupulam coniam deswiste fyetatus. E.) Senuinis feaio transverfalis. F.) Embrgo denudatus in litu naturali.

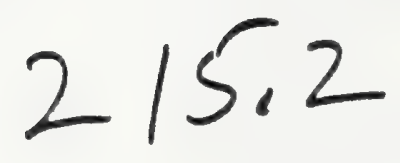




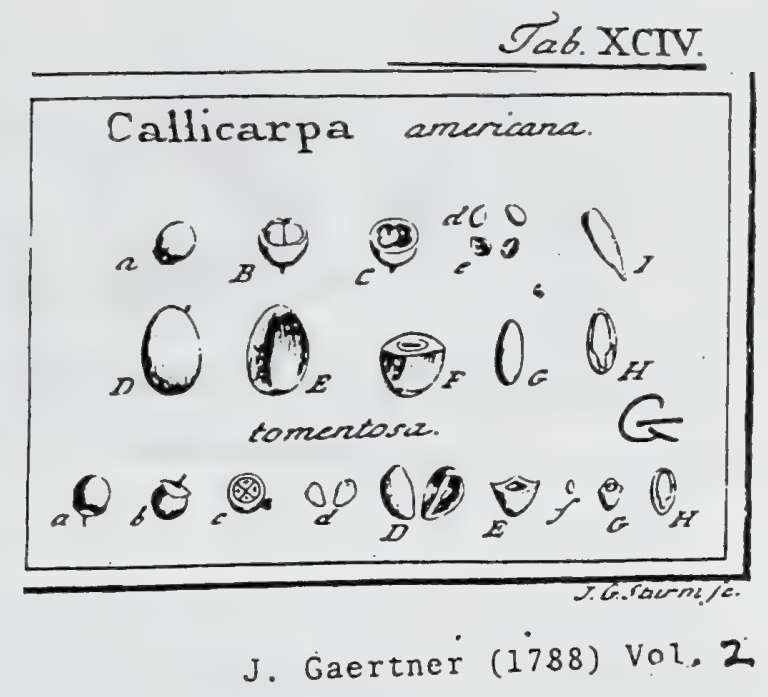

DLXXXVIII. C A L L I C A R P.A.' LINN. ger، 135 .

Calyx monophyllus quadridentatus. Cor. monopetala quadrifida. Stam. qua: tuor. Ovar. fuperum. Styl fimplez Bacca unilocularis tetrafperma.

Callicarpa americana. Tab. 94 fig. 5 .

- . Anorymos baccifera verticillata, folio molli छ̇ incano. PLUK. pbyt. t. x36.f. 3.

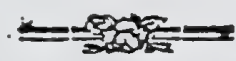

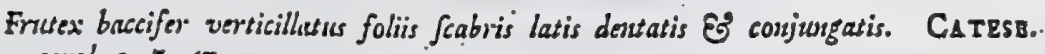
carrol. 2. 7.47.

Calliurrpa folitis ferratis fubtus tomentofis. Lins. Gyf. veg. 153.

PER. Bacca fupera, magnitudine piri minoris, globola, pulpofa, primum rubra, denique atro-purpurea, unilocularis.

REC. nullum; fermina fundo bacce affixa.

Sex. quattuor, offea, elliptica, hinc convera, inde leviter concava, pallida.

IN T. duplex: exterius cruiticeum, durum, nucleo latius; interius membranaceum, tenue, lutefcens.

ALB. ovato - oblongum, compreffum, femine anguftius, tenue, carnofurs, aqueo-pallidum.

E 11 B. Jongitudine fere albuminis, erectus, lacteus. Cotyl oblongx, carnof $x$, planiufculx. Ral. fubulaca, cotyledonibus brevior, infera

2) Bacez integra. B.) Seminz fuperne deuudatz. C:) Bacez vailocularis featio transwerle. d. D.) Seminis latus dofale convexum. e. E.) Ejusdem pars veatralis fubconcara. F.) Idea transverfe fectum. G.) Albumen integrum. H. I.) Embryo intra albumen \& folutus.

Baceas tantum mutilas obtinui, quare de vero embryonis fin in hac fpecie mon certus fun.

Callicarpa tomentofa. ibid.

- Callicarpa foliis integerrimis lanatis. LINN. Lif. veg. 153. Illa. Zeylonens. E collect. fem. hort. Jugdb.

Bacca pirva, magnitudine grani piperis, atra, ftigmate pallido terminatx, calyce albo - tomentofo, orbiculato, fubedentulo aut obfoletifime quadridentato, patentifimo excepta, unilocularis (c.), tetrafperma. Semina (d. D. E.) ofica, ovata, hinc convera, inde cum fulco elevato obloleto concava. Albumen (f. G.) femine multo minus, triquetrum, fubpellucidun. Eqabryo (H.) certiftme eirectus, albus. 
Verbenaceae

LVI

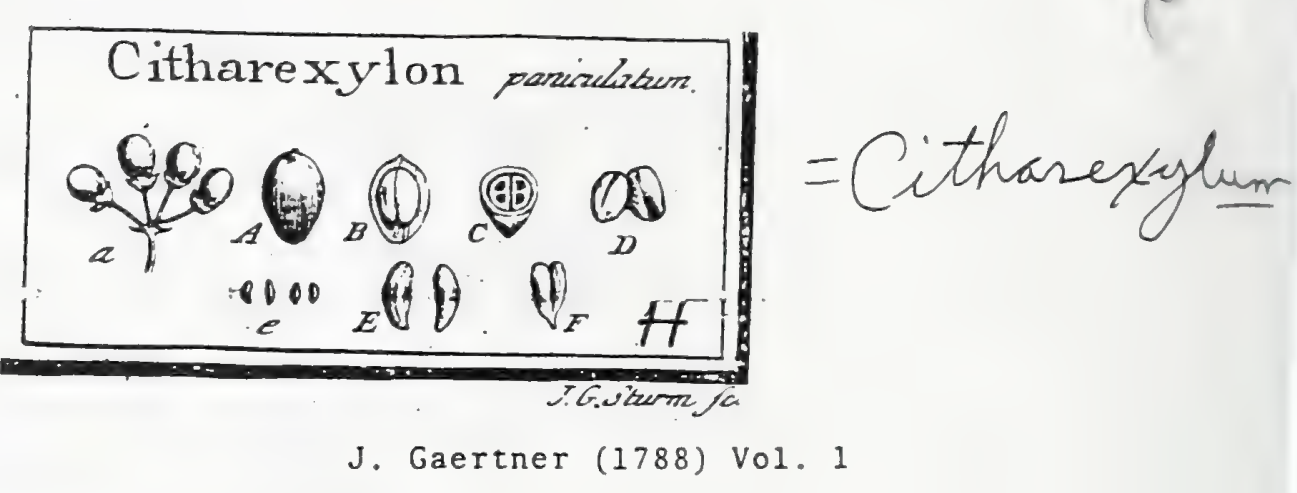

CCCXXXIX. CITHAREXYLON. LinN. gen. 760.269

Calyx quinquedentatus. Cor. infundibuliformi rotata: laciniis aqualibus. Stam. qua $0^{-}$ tuor inzqualia. Styl. fimplex. Bacca dipyrena: officulis bilocularibus,

Citharexylon paniculatum. Tab. 56. fig. 8.

Ex herbario Bankfiano. Habitat in Jainaica.

PER. Bacca calyce brevi campanulato excepta, ovata, atra, glabra, unilocularis ' di: pyrena. Officula ovata, dura, plano convexa, fulco oblolete in dorfo inforipta; bilocularia.

REc. nullum ; fernina bafi affixa.

$S$ E M. in fingulo loculo unicum, oblongum, fubtrigonum, rufefcens.

IN T. finplex, membranaceum, tenue.

A ᄂ. B. nullum.

Ëм в. fernini conformis, crectus, albus. Cotyl. oblongx, carnofx. Rad, acuminata; infera.

a.) Baces interra. B.) Onicula denudat2, C.) Bace transverfim (nt2, D.) Oficula ceparati: e. E.) Senina foluta. F.) Enibrjo denudatus.

Sola corallx forma a Valkameria differt.

216.2 


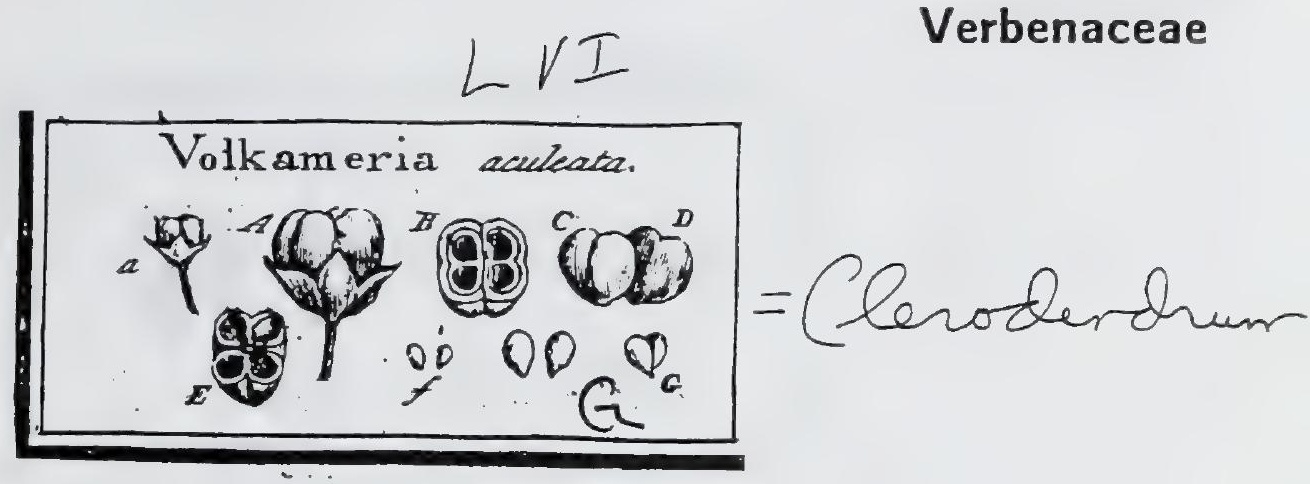

\section{J. Gaertner (1788) Vo1. 1}

\section{7}

CCCXXXIV. VOLKAMERTA. LA N N.gen. 788.

Calyx quinquefidus. Cor, ringens quinquepartita. Stam. quatuor inzqualia. Stig. bifidum. Bacca dipyrena: olliculis bilooularibus.

VOLKAMERIA aculcata. Tab. s6. fig. 3.

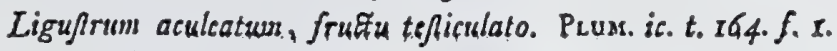

Clerodendrum fruticofun fpinofum, foliis inferioribus confertis; fuperioribus op. pofitis, pedunculis tripartitis alaribus. Brown. hifl. jam. 262, t. $30 . f .2$.

Volkameria Spinis petiolorum rudinentis. JAcC. hif. amer. $185 . t$. 117 . LIN. Syf. veg. 577.

Ex herbario Bankfiano.

PER. Bacca fubrotunda, exfucca, tetracollis, quadrifulca, nitida, dipyrena, bifariam fecedens. Officula duo cartilaginea, obcordata, hinc convexa, fulc o medio infcripta, inde plana, glabriuscula, bilocularia.

REC. nullum; fenina bafi loculamentorun affixa.

SEM. folitaria, ovato oblonga, hinc convexa, inde fubangulata, rufefeentia. V

I $\mathrm{N}$. duplex, utrumque membranaceum, tenue.

A \& в. nullum.

E M B. femini conformis, erectus, albus. Cotyl. carnolx, plano convexz. Rad. minima, conica, infera.

2. A.) Baca integra, calyce excepta. B.) Exdem transverfe feta C. D.) Orieuta deaudata. E.) Oficula coadunata, transverfion fetie f. F.) Secaina feparata. G.) Embryo denudatus. 


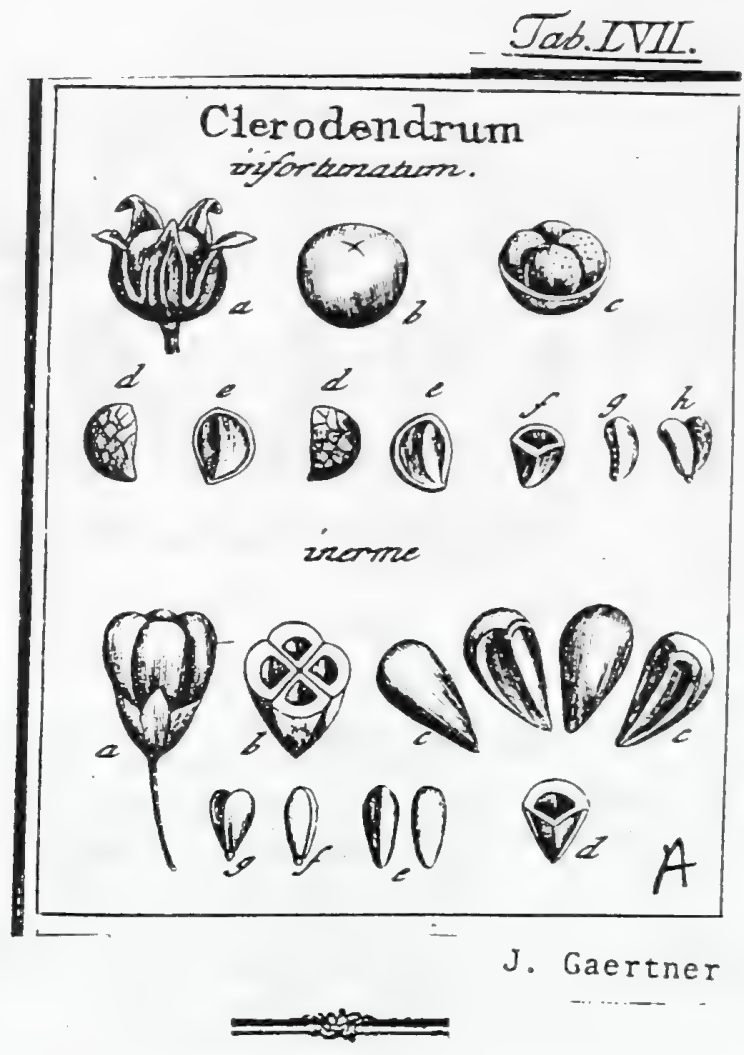

CCCXL. CLERODENDRVM, LIN $\mathrm{x}$. gtগ. 789.

Calyx quinquefidus campanulatus. Cor. infundibuliformis, quinquefida. Starm quatuor. Styl. unicus. Bacea unilocularis tetrapgrena, per maturitatem fape quadripartibilis. Oficula unilocularia.

CleROdENDRUM infortunatum, Tab. 57. fg. I.

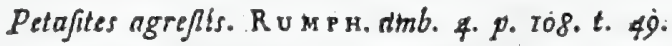

Clerodendron folio lato E' acuminato. B U R M. zeyl. 66. t. 29.

Clerodendrum folits cordatis tomento/is. Lin N. fill. veg. 578 .

Pinnakola. zeylonens. E collect. fem. hort. lugdb.

PÉ. Bacca fucculenta, cajycis laciniis triangularibus trinerviis contecta, fubglobofa, depreffiuscula, fulco cruciato in vertice infcripta, unilocularis, tetrapyrena. Cuticula tenuis, glaberrims, fplendens, non debifcens. Pulpa mollis, per ztatem evanescens. Ollicula luboftea, hinc convexa rugofa, inde angulata glabra, unilocularia.

Rec. nullum; femiria bafi tffixi:

$S E M$. in fingulo officulo unicum, eidemque conforme; rufefteris.

IN T. duplex, utrunque membranaceun, tenue.

ACB. nullum.

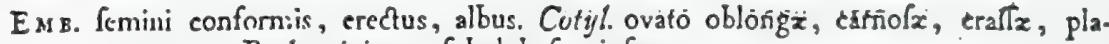
no convexx. Rad. minima, fubglobofa, infera.

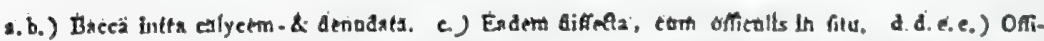

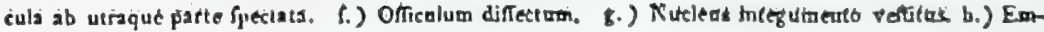
bryo deaudatis.

CLENODENDKUM inerIne. ibid.

Nir.notsjil. R n E E. D. mal. s. p. 97.t. 49 . bene.

Volkamerin ranis inct nuibus. Lx $\mathrm{x}$. Sy/. $2 \mathrm{eg} .577^{\circ}$

Burende. zeylonens. E collect. fem. hort. lugdlz:

Hacca turbinata (a), tetracollis, tetrapyrena (li), per msturitaten quadripartibilis (c.c.). Carn craltiuscula, fuberofa, dorfo pyrenarum adnata. Pyienx coriaceocrufacex, albicantes, deorfum infigniter acuminat, fuperne meuridrio gibbx,

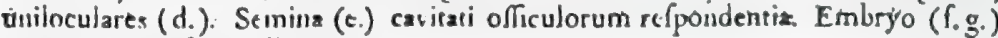
erectus, carnofus, albus.

Unicum ruidem femen, fun Clerodendro, tribuit Burksaneus, \& hane manifeftum errorein fuum queque fecit LINNE US: in oinnibus enim Pinnakolz baccil conconflanter reperio fimina quatuor, \& totidem quoque Pesafita luo adfcribit Rus ousus. 


\section{Tab.LVII.}

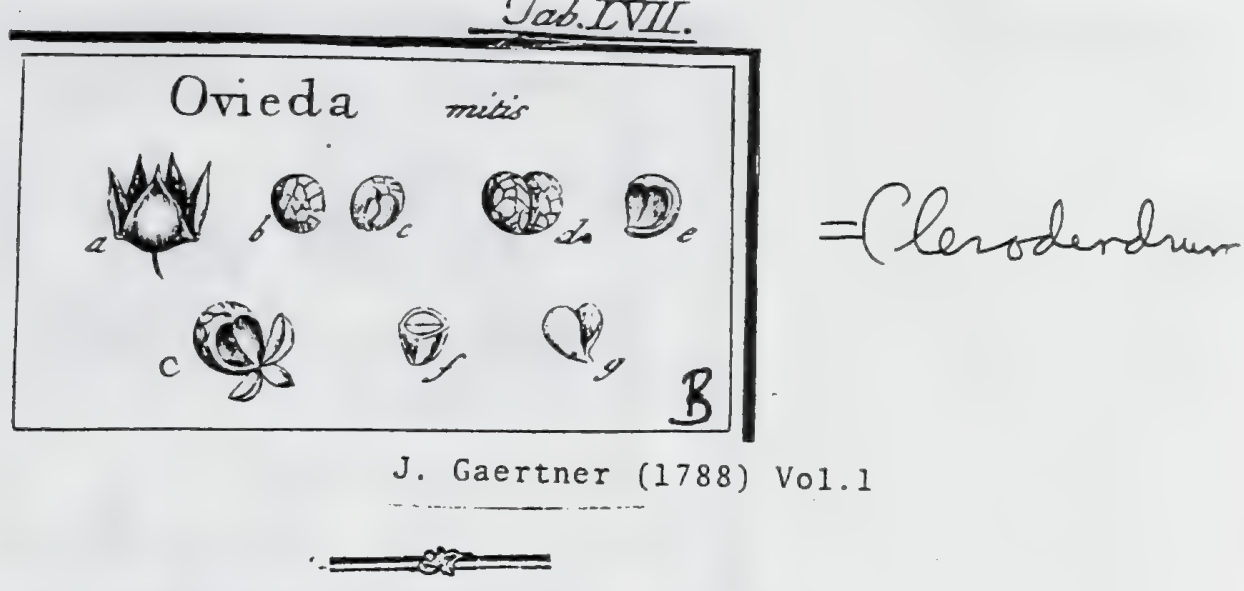

CCCXLI. OVIEDA. LINN. gen. 787.

Calyex quinquefidus. Cor. monnpetala infundibuliformis trifida. Stam. quatuor inxqua: lia. Styl. unicus. Bacca unilocularis tetrapyrena, per maturitatem quadripartibilis? Officuls unilocularia.

OVIEDA mitis. Tab. 57. fig. 2.

Ovieda foliis, lanceolatis jubrepandis. B U R M. flor. ind. 136. t. 43. f. 1. 2. LINx. S4/. veg. 577 .

Ex herbario Bankfiano.

PE R. Bacea fucculenta, calycis laciniis acute triangulis contects, fubglolofa, unilocularis, tetrapyrena, per maturitatem exarefcens, quadripartibilis. Cuticula matura fubfpongiola, rugola, dorfo pyrenarum adnata. Pyrenx regulariter quatuor, fed pleruinque dux tantum adolefcentes, coriaceo-cruflacex, hinc gibbx, rugofx; inde concavx aut angulatx, uniloculares.

REc. nullum; ferina bafi affixa.

$S E M$. in fingulo loculo unicuin, eidemque conforme, rufefcens.

IN T. fimplex, membranaceum, tenue.

A Ł B. nullum.

EM в. Cemini conformis, erectus, albus. Cotyl. obovatz, carnofx, craflx, planoi convexi. Rad. conica, brevis; infera.

a.) Calyx maturus amplas, froctum obtegens. b.) OTiculi maturi dorlum. c.) Ejusdem pars veas tralis. C.) Bacca monopyrena, cum tribus ovulis abortivis ad bafin. d.) Bacea dipyrena. e.) Oftculan decorticatum a parte veutrali fpectatum. r.) Ejusdem \& embryonis fectio transverfalis. 6.) Embryo denudatus.

Orulorum numerus quaternarius, uti naturalis, ita quoque conflantifimus eft.

Valdia Plunieri, diverfifimi generis planta ef, fi reete fe habet genericus character, quem ei tribuit Adansonus. fam. 2. p. $157^{\circ}$ 


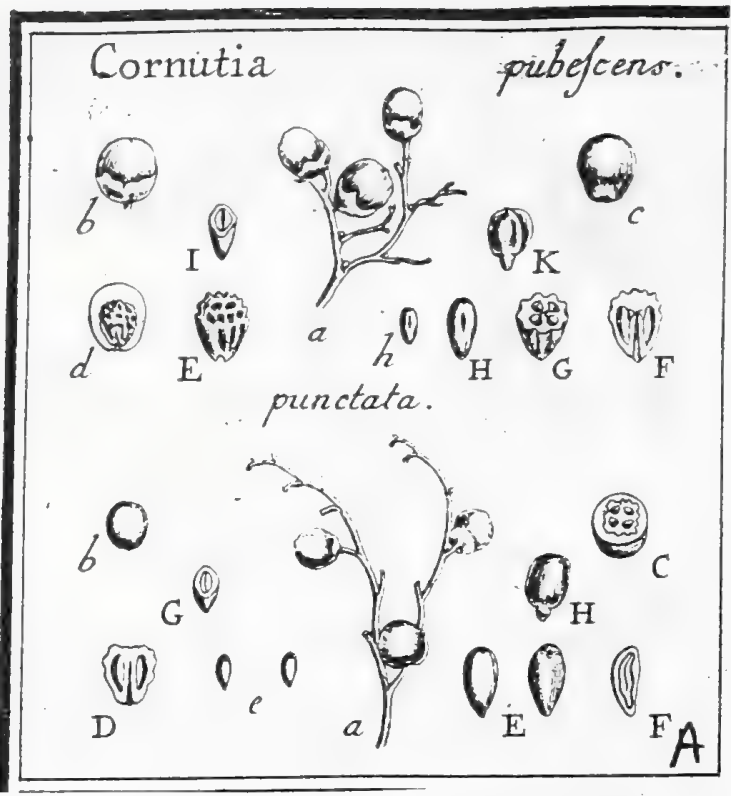

133. C O R N T I A.

Piom. gen. t. I7. Linn. gen. 766. ed. Schreb. ro28. Juss. gen. p. 107. LAMIARCK ill. ger.it. $54 \mathrm{r}$. Agnanthus. VAILL。 act. gall. 1722.

Cal. monophyllus, parvus quinquedentatus, per maturitatem inæqualis, inferus, perfiftens. Cor. monopetala, inxqualis, tubulofa : tubo longo; limbo quadrifido, inxquali. Stam. 4, inzqualia, nonnulla exferta; filamentis fubulatis; antheris inclinatis. Ovar. fuperum; Itylo bifido; Itigmatibus craffuufculis. Drupa parva, baccata, putamine quadriluculari. Rec. nullum. Sem. Solitaria: Alb. fubnullum. Emb, erectus.

Cornutra pubefcens. Tab. 213. fig. 1.

Habitat in Infula Cayenna, ab-amicifimo $D^{\text {ae }}$ Decandolle.

PER. Drupa magnitudine pifi, baccata, obovata, a calyce amplo laxe amplexata. Caro crafiufcula, fucculerita, putamini arcte adnata. Putamen obovatum, bafs bidentatum, ad verticem punctis excavatis reticulato. fcrobiculatum, deorfum vero fulcis longitudinalibus exfculptum, a baf fere ad verticem ufque per axem canali fubulato perforatum, offeum, quadriloculare. Loculamenta ubovato-oblonga, cuneiformia, uno 1. duobus fxpius obliterantibus.

KE c. nullum: vafa umbilicalia, in axi putaminis adfcendentia, feminum umbilicos adeunt, \& ipfa in fitu erecto fuftinent.

SEM. folitaria, obovato - oblonga, rotundato - angulata, 1. verfus ventrém cuneata, ad ventrem rima levi umbilicali infigrita, pallida, 1. albicantia.

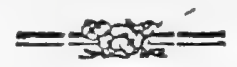

-IxT. fimplex, membranaceum, ad verticem chalaza minima ferruginea inGgnitum, caterum pallide fpadıceum, intus carnofum.

$\Lambda$ L B. nullum: prxter laminam carnofam, crafiufculam, cum integunento firmiore intime conferruninatam.

EM B. obovarus, femini conformis, fed paulo brevior, erectus, albus. Cotyl. ovati, amygdalino-carnofx, plano-convexx, bafi emarginatx, levifime curvatx, incumbentes. Kad. parva, difcreta, ovata, obtufa, ab umbilico externo averfa, infera.

\section{EXPLICATIO FIGURE}

2.) Pars cyma frugiferx. b.) Drupa integra, colyce veftita. c) Eadem a calyce feparata. d.) Ejusdem fectio retricalis, cuar-Getu putaminis. E.) Putaren feparatum. F. G.) Idem verticaliter \& transrerfe featum, cum fitu feminum \& forma loculamentorum. h. H.) Semina fepirata, a ventre fpectata, cum rima umbilicali atque chalaza. 1.) Ejusdem fedio transverfa. lis. K.) Embryo folutus.

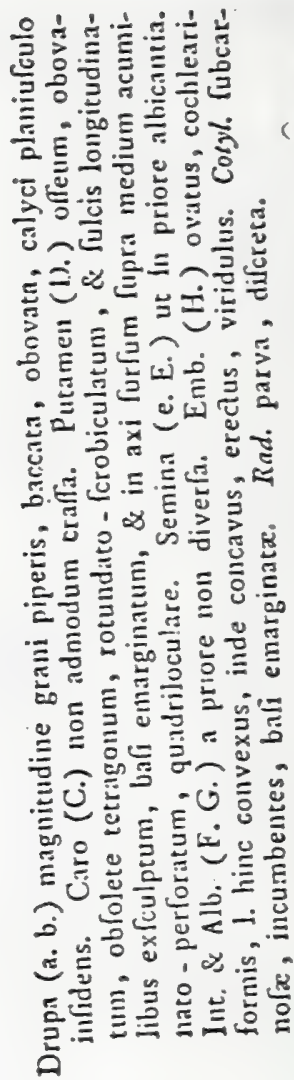

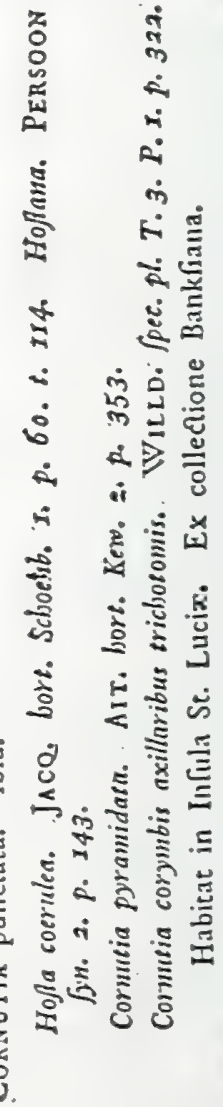




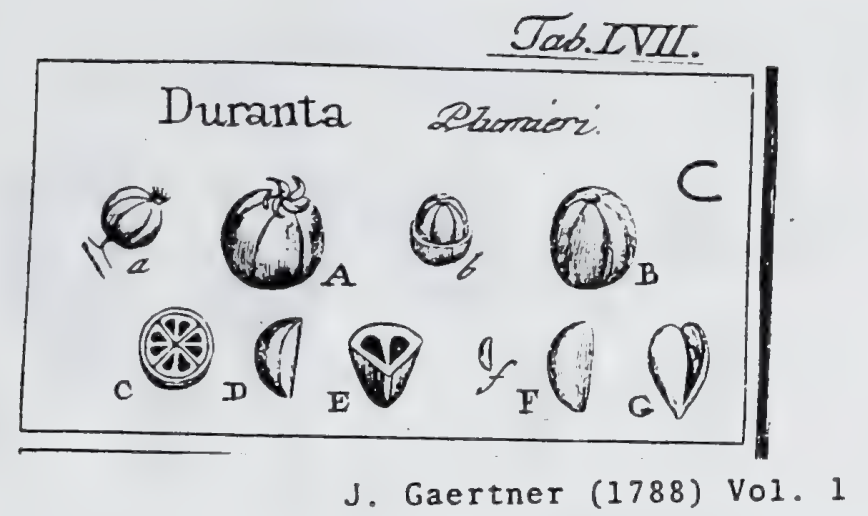

\section{DVRANTA. LIN . gen. 786. 272}

Calyx quinquedentatus. Cor. monopetala infundibuliformis quinquefida. Stam. quatuor inxqualia. Styl. unicus. Bacca unilocularis tetrapyrena: officulis biloca-j

D U R A $x$ × Plumieri. Tab. 57. fig. 3.

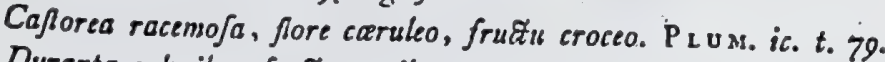

Duranta calycibus fruatescentibus contortis. LIN . Sy $/$ veg. 577 .

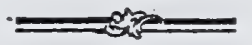

PER. Bacca fucculenta, calyce involuta, ovato globofa, rubra 1. crocea, unilocularis, tetrapyrena. Calyx maturus ventricofus, vittis quatuor faturatius coloratis, totidemque aliis pallidis, diaphanis infignitus, fuperne coarctatus, quinquedentatus: dentibus fubulatis dextrorlum contortis. Caro tenuis, pulpofa. Officula quatuor dura, triquetrs, in dorfo arcuata, blocularia.

REc. nullum ; femina bafi affixa.

$S E M$. in fingulo loculo unicum, eidemque conforme, rufef́cens.

IN T. fimplex, membranaceum, tenue.

A \& B. nullum.

. Em B. oblongus, cuneiformi compreffus, erectus, lacteus. Cotyl. ovatz, carnofz, pla. niufculz. Rad. acuminata, brevis, infera.

a. A.) Bacca calyce contecta, b.B.) Eadem denudata. C.) Ejas fectio transverfalis. D.) O(ficulum Separatum. E.) Jdem diffetum. f.F.) Semen folutum, G.) Embrjo denudatus. 


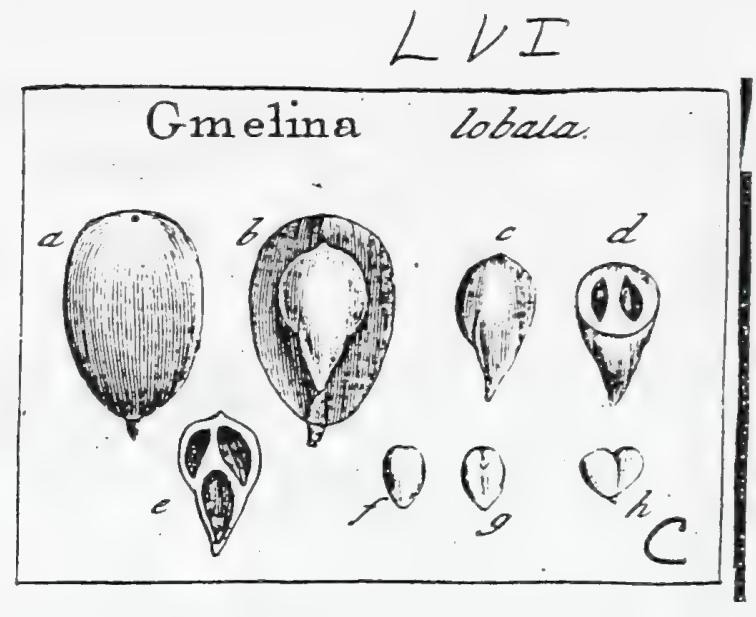

J. Gaertner (1788) Vol.1

CCCXXXVI. GMELINA. LIN gen. $7 \sigma_{3} .268$

Calyx obfolete quadridentatus. Cor. quadrifida campanulata. Stam. quatuor inxqu: lia. Anthers dux bipartitx \& dux fimplices. Styl. unicus. Drupa baccata, pr:-? tamine triloculari : loculamento inferiore nerili.

G MELTN A lobata. Tab. 56. fig. 5.

Jambofa fyluefris parvifolic. Ruspr. amb. 1. p. I2g. t. 40 .

Gmelina afiatica. Li N. N. Jifl. veg. 565 .

E colleêt. fem. hort. lugd.

PEx. Drupa baccata, ovata, magnitudine zizyphi domefticz, atra, glabra. Caro in verufo fructu fpongiofa. Puiamen offeum, obovatum, fuperne craftum, cum lobulis duobus lateralibus; inferne infigniter acuminatum; intus triloculare: loculamentis duobus fuperioribus fertilibus; tertio inferiori conftanter flerili.

REc. hullum; femina fupreme parti loculamentorum affixa.

SEM. in fugulo loculamento fuperiori unicun, ovatum, obefulum, hinc magis convexum, inde planiusculum, albicans aut pallide framineum, caruucula parví umbilicali fub vertice notatum.

IN T. fimplex, membranaceum, tenue.

A L B. nullum.

Eм в. Remini conformis, albus. Cotyl. ellipticx, carnofx, crafiuscula. Rad. conica, minima, infera.

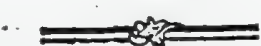

a.) Drupa integra. b.c.) Putamen dentüatum. d.c.) Ejasdem fectio transverfalis \& longitudinalis, cum firu loculamentorum. f.) Serninis dorfum. g.) Ejus pars veatralis, cum caruocula umbilicall, h.) Embryo desudatus.

Cumbulu. Hort. Mal. r. p. 75. t. 4t. nequaquam Bignonia Catalpa, fed genuina Graclinz fpecies eft, ut ex fructu abunde patet. 


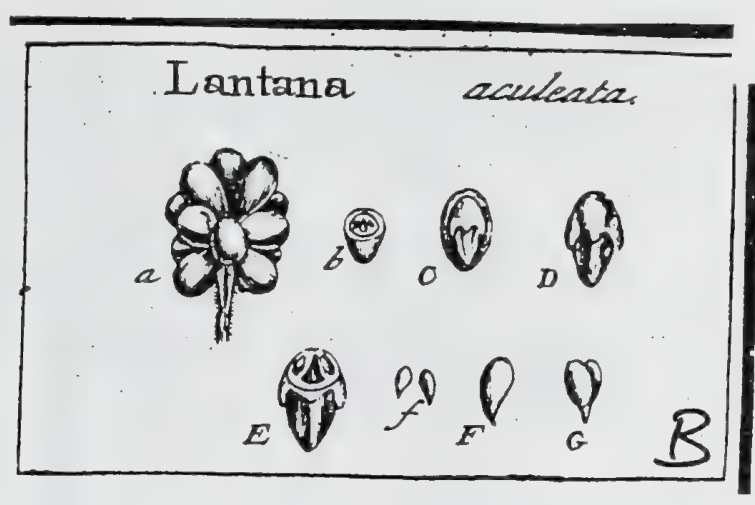

J. Gaertner (1788) Vol. 1

\section{LANTANA. LIN gen. 765. 267}

Calyx obfolete quadridentatus. Cor. monopetala, limbo quadrifido inxquali. Stam. quatuor fubinxqualia. Styl. unicus; figma uncinato refractum. Drupa baccata: putamine triloculari: loculamento inferiore ferili.

Lantana acuíeata. Tab. 56. fig. 4.

Viburnum americanum odoratum. urtica foliis latioribus, fpinofum, $\therefore$ floribis miniatis. PLux. phyt. t. 233 . f. 5 .

Lantana folits oppofitis, cauls aculeato ramofo, Jpicis hemifpharicis. Lins. Jy/. veg. 566 .

Per. Drupa baccata, mollis, ovata, atra, glaberrina, nitida Cara pulpofa, tenuis. Putamen offeum, gigartoides; fupra craftum, obtufum, cum duobus lobulis latera.

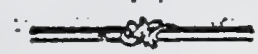

libus, deorfum vergentibus; infra in roftrum conicum compreffum elonganim: niloculare, loculamentis duobus fuperioribus fertilibus; inferiori $\mathcal{L}$ intermedio vacuo, Jlerili.

REc. nullun; femiua parti fupremx loculamentorum affixa.

SEM. in fingulo loculamento fuperiori unicum, obovatum, deorfum infigniter acumis. natum, compreffiusculum, album, in vertice areola fulca notatum.

Ix т. fimplex, membranaceum, aridum, candidum, friabile.

A 1. B. nullum, preter tenuifimam laminam carnofam integunenti.

Ex в. Cemini confornis, ereetus, albus. Cotyl. ellipticx, carnof $x$, tenues. Rad. tes, reti acuminata ${ }_{2}$ infera.

2.) Spica matmra integra. h.) Drapa transverfim feets. C. D.) Putamen denudatum. E.) Ejus: dem loculamenta aperta, f. F.) Semen feparatum. G.) Eubryo denudatus. 


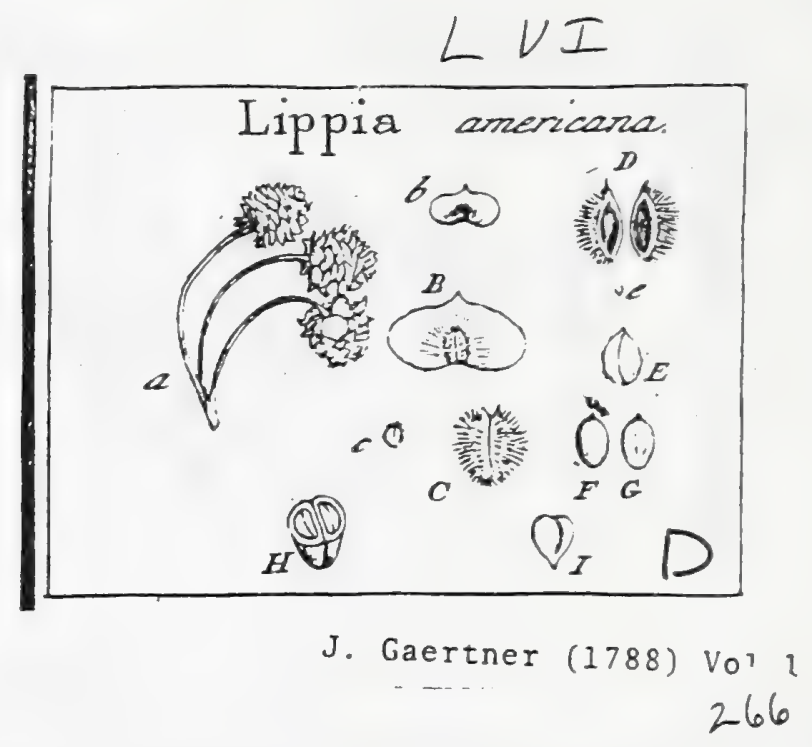

CCCXXXIIL LIPPIA. Houst. Lins. gen. 781.

Calyx quadridentatus, per maturitatem bivalvis. Cor. infundibuliformis quadrifida. Stam. quatuor. Styl. unicus. Semiua duo offea, calyce corticata Embryo erectus.

La p P I A americana. Tab. 56. fig. 2.

Lippia capitulis pyramidatis. Lins. fi/f. veg. 574.

FR U CT. longe pedunculati, capitati, Capitula ovato globofa, magnitudine pifi mejoris, imbricata fquarnis numerofifimis, latiflimis, bafi emarginatis, apice mucronatis, calyces occultantibus.

PER. nullum. Calyx maturus bivalvis, valvulis membranaceis, carinatis, hifpidis, Semina externe obregentibus.

RE.c. nullum, prater fundum calycis, cui fernina aftixa.

бЕм. duo, coadunata, ovata, fuboflea, hine convexa, glabriuscula, inde plana, aut fabconcara, albicaritia.

IN T. duplex: exterius crufaceo cartilagincum, craftiusculum; interius membranaceum, tenuiftmum; pallidum.

A L. nuilum.

Eм в. figurá cavitatis feininis, erectus, albus. Cotyl obovatx, camolx; altera pla. no-convexa; altera utrinque plana. Rad. acuminata, minima, infera.

a.) Fratus pedunculati. b. B.) Brafter norales. c.C.) Calyx maturus, femina obiezens. D.) Idem biparieus. e. E.) Semins coadunata. F.) Ś(olinis dorfum. G.) Ejusdem veuter. H.) Semisa uransverlim letia. I.) Embrjo denudatus.

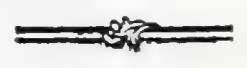

Expungendum \& cum Blairia fociandum ofle hoc genus, - fua dponte liquet; calyx cuin certilfime fuperus non $c h$.

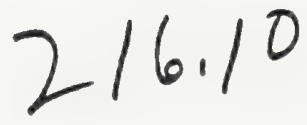


Tab. CVI:

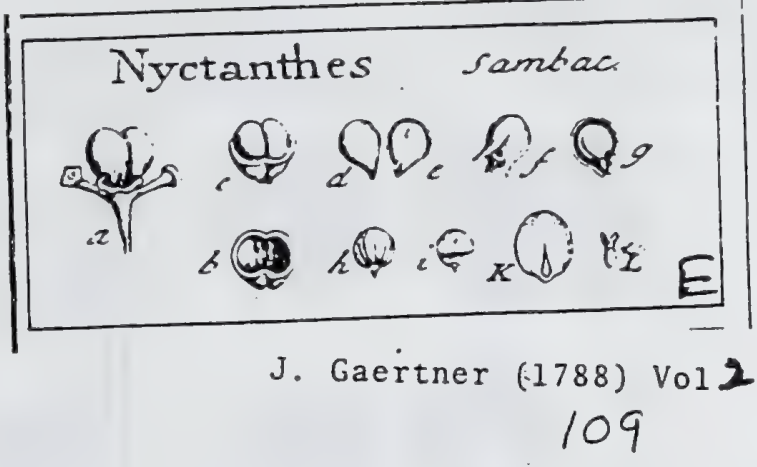

\section{D'́XIV. NYCTANTHES. LINN. ger. I6.}

Calyx fex -1 . uctifidus. Cor. fex -1 . octifida infundibuliformis. Stam. duo. Ovar. fuperum. Styl. finplex. Eacea unilocularis. Semina duo arillata.

Nyctanthes Sambac? Tab. 106. fig. 3.

Flos manore. RUмpн. amb. 5. p. 52. t. 30.

Jufuimum limonii folio conjugato. BURM. Zeyl. t. 58. f. 2.

Nyctanthes foliis inferioribus cordatis obtufis, fuprerioribus ovatis acutis. LINN. Jist: veg. 56 .

Esbakirindi altera Zeylasica. E callect. fem. hort. lugdb.

Per. Bacen fubglobora, didyma, unilocularis, nigra. Caro mollis, per vetuftatem coriacea.

REC. nullum, proxter funiculum unbilicalem brevifimum, e feminis bufi, fundo bacce infertum.

SEM. duo, hemifpharica, fpadicea, arillasa.

Arillus chartaceus, tenuis, clafticus, obovatus, plano-convexus, fensen laxe ambiens, a bafi trifatian dehifcens.

INT. finplex, membranaceun, venis inferiptum, non arcte adnatum, bafi in funculum umbilicalem l. pedunculum feninjs fubulatum defnens.

A I B. femini conforme, vaforum impreffionibus infcriptum, cartilagineum, aqueo - pallidum, verfus peripheriam auten fufcum.

EMB.・dimidio albumine brevior, ereftus, fubulatus. Cotyl. minutullx, acuminatx. Rad. craffa, ovato - oblonga, infera.

1.) Baces integrz. b.) Eadem transverím diriecta. c.) Arilli in fitu naturali inura hacesm. d. c) Jidem exempti, ab utraque parte fpectati \& adhucdum chaifi. f.) Arillus a bafi duinifcens. 8.) Ssminis Gtus intra arillum. h.) Idcm f(paratumi. i.) Ejurdem \& albudinis feftio transvcr[alis. K.) Albumen longitudinaliter difcetuı, cum fitu embrģonis. L.) Embryo folutus.

Duplex habetur Ethakiriesti in collectione feminum horti lugduno batavi.

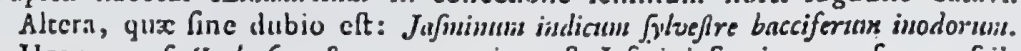
Her.s. muf. Zeyl. 60. \& qux genuina elt Jafmini fpecies, proferens fcil. baccas fphxricas, ex luteo fpadiceas, juniperinis paululum majores \& femen unicum, manifefte baccatum continentes. Altera vero, fupra defcripta, tota fua fabrica ad Nyctanthem accedit, \& ejus genuina fpecies ctt. Sed anne hice ad Simbac, :mne vero ad aliam fpeciem referenda fir? id alis cnudandum relinquo. 


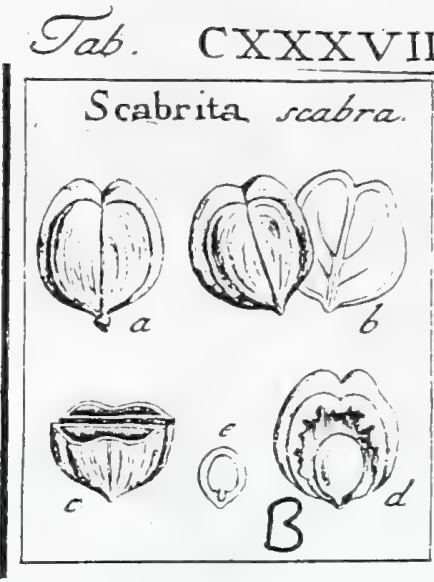

J. Gaertner (1788) Vol.2

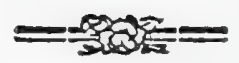

265

DCCXCVIII. S C A B R I T A. LINN. ger. I 24 .

Caly'x truncatus, cdentulus. Cor. mouopetala, hypocrateriformis: limbo quadripartito, laciniis bilobis. Stan. quatuor. Ovar. Superum. Styl. flifornis, apice bifidus. Capf. chartacea, ovata, fupra emarginata, bilocularis, bipartibilis, cvalvis. Sem. folitaria, bafi affixa, dimidia caprula breviora

Sćabrita fcabra Tab. 138. fig. 2.

Scabrita. Linn: mant. $37 \cdot$ Jyf. veg. 447 .

A Cl. Thunberg.

Capfula, femen, albumen, embryo, quin ip ${ }_{a}$ omnium partiun confiftentia atque color, adeo ad am:1/Fn cum illis Parilii Vol. l. p. 234 defcripti congruuut, ut iltius characktr te verbo ad verbum tranfcribendus eflet, fi plenam fructus Scabritx defcriptisnem dare vellemus. Sufficiat igitur amoratro, quod totum difcrimell ad foian: recieat maguitudinem, qua frustus Scabritz ab illo Parilii fupcratur. Ionnen tumen \& alsatomen fructus non fuperfluam dusisaus, ut \& alii hac de re judicare queant.

2.) Frutus intenet. b.) C-nfula feparatz. c) Earundem fedio trasverfalis. d.) Seminis fryu$r$, magnitudo \& G:us in fundo capfulz apertz. c.) Embryo intra albumen difietum. 


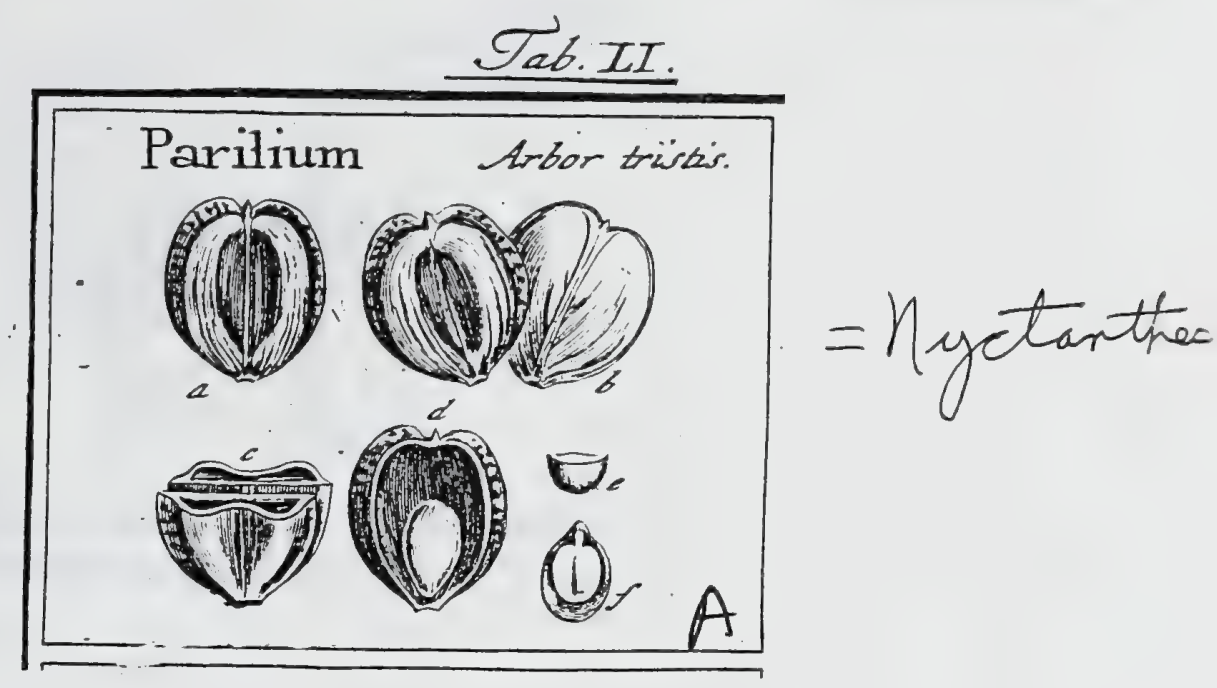

J. Gaertner (1788) Vol.1

\section{CCLXXXVIII. PARILIVM.}

Calyx monophyllus edentulus. Cor. infundibulifonnis: limbo fex-l. oftifido. Stam duo. Styl. unicus. Capfula coriacea, bilocularis bipartibilis. Senvina folitaria.

PARILIUM arbor trillis. Tab. 51. fig. I.

Manja-pumeram. R и EЕD. mal. 1.p. 35.t. 27 .

Nyctanthes caule tetragono, foliis ovatis acuminatis, pericarpiis membranactis compreffis. L I s s. Jigl. veg. 56 .

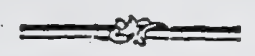

PER. Capfula coriacea, fupera, obcordata, aut obosata, turgide lenticularis, in medio didymo ventricola atque firia clevata longitudinali uotata, ad latera in marginem anguftum \& acutum comprefla, caterum chartacea, fragilis, bilocularis, bipartibilis: fegmentis plano convexis, extus e callaneo fufcis, intus pallidis, integerrimis, evalvibus.

REC. nullum; femen fundo loculamenti affixum.

SEs. unicuin in fingulo loculancento, obovatum, deorfun modice acunninatum, hinc convexuin, inde planum, fufcum.

IN T. fimplex, membranaceum, tenue.

A ८в. Semini cogforme, carnofum, modice craflum.

Езв. maguitudine fere albuminis, erectus, compreftus, albus. Cotyl. foliacez, tenuifiunx, ellipticx. Rad. teretiufcula, brevis, infera.

a.) Capfula integra. b.) Fadem bipartita. c.) Ejusdena felio transverfalis. d.) Semen intra lockJamentum, eoque (in meis exemplaribus) multo angunius. e.) 1deas transveríe featum. f.J Embryo denudatus \& in fitu iuverfo repratentatus.

De vero radicula fitu haud certus furn, quia in ineis fpeciminibus omnia fernina foluta \& in varias plagas directa erant: igitur ex Hort. Mal. fitum ei inferum affignavi, donec certiora innotefcant. Nyctanthes habet baccann carnofan \& fenina arillo claltico conclufa, ficuti Coffea ; hinc a Parilio, fi non anthologice, certe carpologice, mirum quantum differt. 


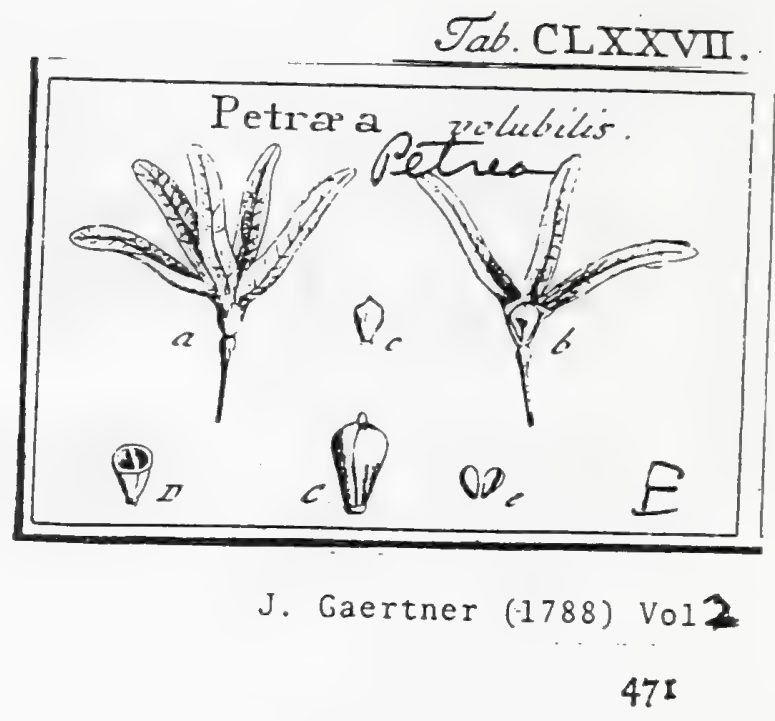

\section{P E T R Æ A. LINN. gen. 764 .}

Calyx turbinatus, fauce fquamulis quinque ftipata, limbo quinquefido longifimo feariofo. Cor. rotata. Stam. quatuor, didynama. Ovar. unicum intra calycis ventrem. Styl. fimplex. Capf bilocularis, calyci immerfa.

Petrea volubilis. Tab.'177. fig. 5 .

Petiea. JAce. biff. 180. t. 114. LinN. byf. veg. 565.

Ex herbario Bankfiano.

PER. Capfula intra calycis ventrem; parva, turbinata, bilocularis, evalvis.

REc. nullum; feriina bafi loculamentorum affixa.

SEM. folitaria, obovata, deorfum anguftata, plano-convesa.

IN T. fimplex, nembranaceum.

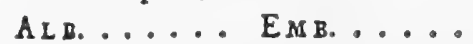

a.) Calsx maturus integes. b.) Idem difiectus, eam Caphula, magaitudine naturali. C.) Caprala - aucar D.) Eadem difreaza. c.) Semina.

Rarifine fructum maturat, ex obfervatione JAce. 1. c.

216.14 


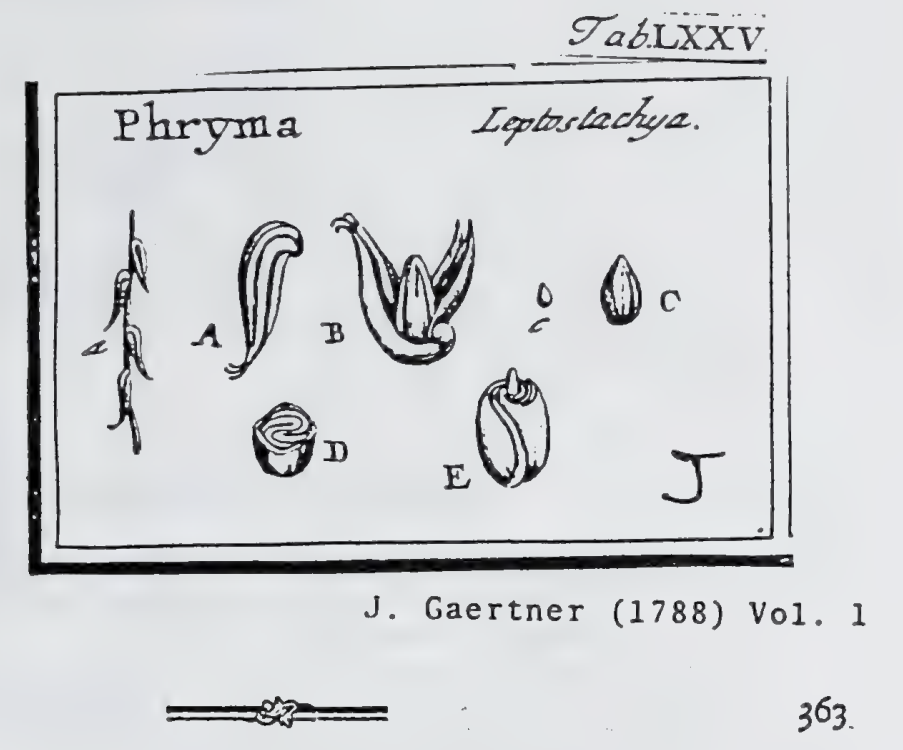

\section{CCCCLXXII. PHRYMA. Lim N. gen. 738 .}

Calyx monophyllus, bilabiatus, quinquedentatts perfiftens. Cor. monopetala, rin gens. Stam. quatuor inxqualia. Styl. unicus. Semen unicuin, calyce te乞tura. Eın. bryo inverlus convolutus.

PнRYMA Leptofachia. Tab. 75. fig. 10.

Amaranthi ficuli fpica, floribus parvis purpureis propendentibus herba floridana. Y L U K. plint. t. 380. f. 5 .

Phryma foliis ovatis Serratis petiolatis, calyce monophyllo quinquefido. LINN. Sigf. veg. 548 .

PER. nullum, prater calycem claufum, defexum, pyramidato fubulatum, quinquefulcatum, bilabiatum, inxqualiter quinquedentatum: dentibus tribus fetaceis recurvis \& duobus inembranaceis rectis, faucem claudentibus.

REC. nullum.

SEM. unicum, ovatum, fupra attenuatum, obfolete pentagonum, fpadiceo-fufcum.

IN T. finflex, fubcoriaceum, tenue.

A L E. nultum.

E м в. Cemini conformis, inverfus, albus. Cotyl. figmoideo-flexưf $x$, circa radiculan ccu axem, Spiraliter convolutx. Rad. tereti acuminata, recta fupe:a.

a. A.) Calyx claufus. B.) Ejus labia f(parata, cum feminis fitu. c. C.) Semen folutum. D.) Idem transycrfe fectum, cum flexura cotyledonum. E.) Embryo denudatus, in fitu naturali. 


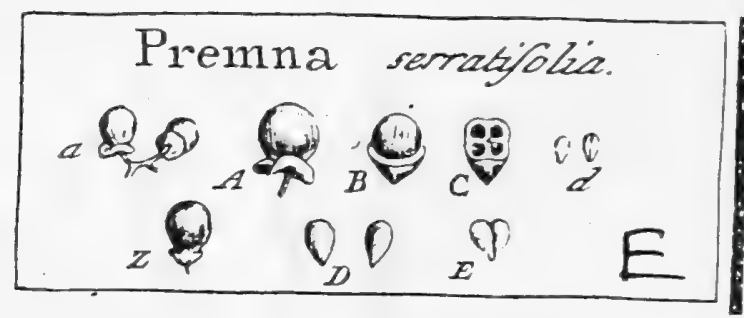

CCCXXXVII. PREMNA. LIN IN. gen. I3I6.

Calyx orbieulatus integerriunus, aut obfolete bilobus, etiam obiter quadridentatus. Cor. quadrifida. Stam. quatuor inxqualia. Styl. fimplex. Drupa baccata: putanine quadrilocolari. Semina folitaria.

PREMNA fertatifulia. Tab. 56. fig. 6.

Sambucus zeylanica odorata aromatica. HERM. nus. zeyl. I4. B О R M. zeyl. 209.

Premna foliis. Jerratis. LIN.N. Jufl. veg. 565.

Mindi. zeylonens. E collect. fern. hort. lugdb.

PER. Drupa baccata, parva, fphzrica, rufefcens, aut fufca. Caro tenuis, fubcoriacea. Putamen offeum, fubglobolum $\mathcal{C}$. cotunde tetragonum, quadriloculare, ad axem perfozatum.

REC. nullum; femina bali affixa.

SEM. in fingulo loculamento unicum, ovatum, deorfurn acuminatum, híc convexum, inde obrolete angulatum, pallidum.

IN т. fimplex , membranaccuin, teuve.

ALBa nullum.

$\therefore$ EM B. femini conformis, crectus, albus. Cotyt obovatx, compreflx. Rad acuminatai, infera.

2. A.) Drapx integra, cam calyce integertimo, Z.) Alia cam calyce obfolete quadridentato. B:) Pun tainen fuperne deaudatum. C.) Idem trausverfe fertum. d. D.) Semina ab utroque Latere petata! E.) Ensbryo denudatus. 


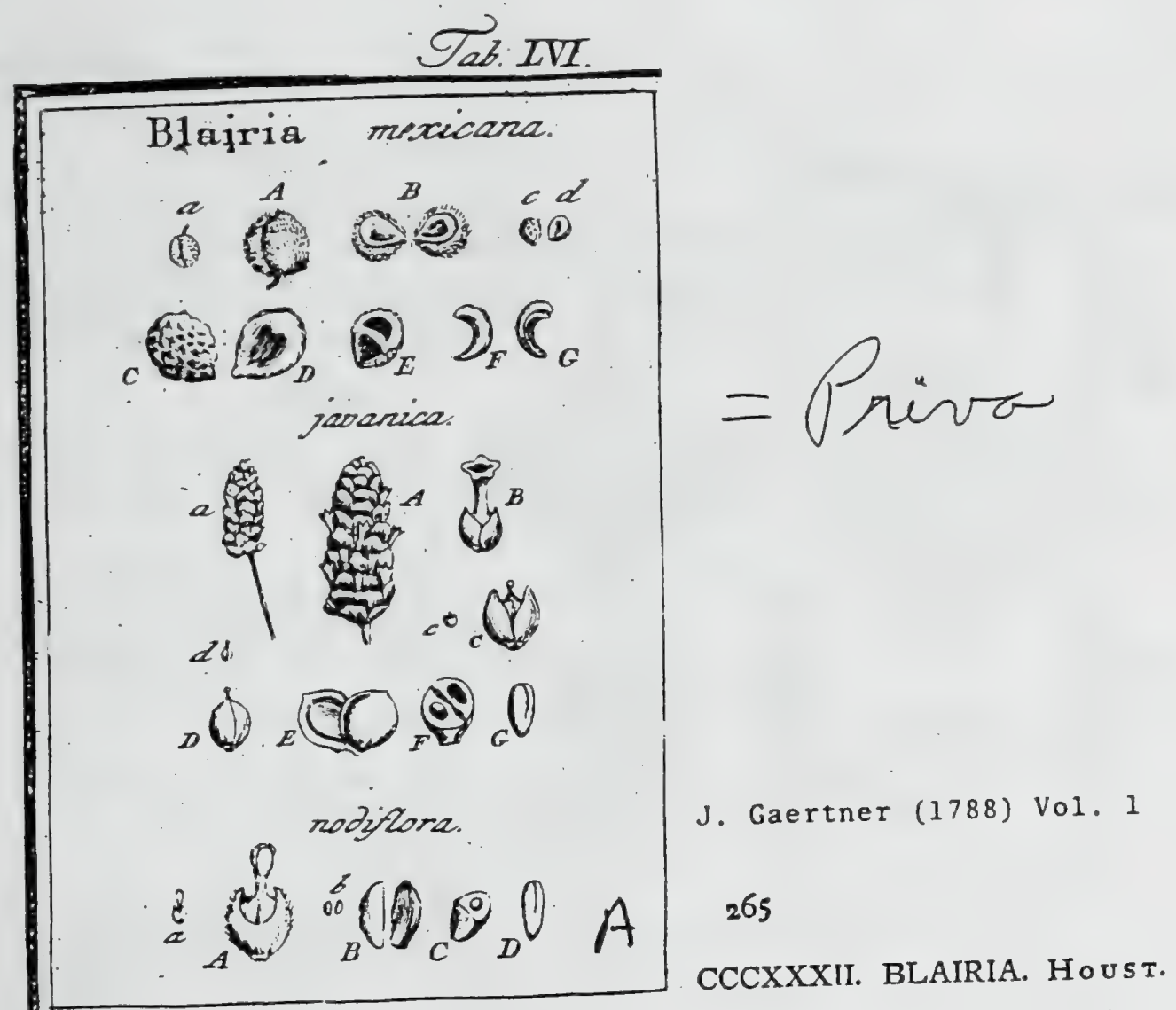

Verbenaceae

Calyx quadri-1. quinquedentatus, per maturitatem bivalvis. Cor. infundibuliformis quinquefida. Sta!n. quatuor: duobus fxpe ferilibus. Styl. unicus. Semina duo, ofiea, nuda.

Bi A IRI A inexicana. Tab. 56. fig. I.

Verbena mexicana, trachelii folio, fructu aparines. DIL e. elth. $40 \%$ t. 302. f. 389 .

Verbona diandra, Spicis laxis, calycibus fructus refiexis rotundato didymis hifpidis. LiNs. filf. veg. 66 .

PER. nullum, prxter calycem perfiftentem, feinina obtegentem, fetis fabratum.

REC. nullum. Sernina fundo calycis affixa.

SEx. duo, oftea, in globulum ovatum coadunata; hine convexa, tubereulata, inde glabra, planiuscula, aut leviter concava; pallida.

IN $T$. duplex: exterius offeum, craffum, durum; interius papyraceum, friabile, candidiflinum.

$\Lambda$ LB. nullum.

Eм в. arcuatus, fubenmpreflus, erectus, a!bus. Cotyl. oblongx, plano-convexx, longitudine Jimidii embryonis. Rad. conica, compreIIa, infera.

a. A.) Semina coadunata, enlyce feabro veftita. B.) Eadem (eparata. c. C.) Seminis pars dor(alis. d. D.) E.jusdem latus ventrale, E.) Integ. offeum uransverim (etam. F.) Embrye membrana Interna vetitus. G.) Idem denudatus,

BLAIRIA javanica. ibid.

266

Detbena fplcis mamerofis oblongo conicis, foliis ovato oblongis fubrerulatis, caule etefto. RuRM. fl. Ind. p. 22. t. 6. f. 2.

Spicz fubeylindricx (a. A.), bafi crafiores. Corolla (B.) quinquefids, Calyx maturus (B. c. C.) bivalvis. Semina in globum coadunata (D.), plano con: vexa (F. F.), glabra, albicantia. Integ. cartilagineo coriaceum. Enbryo (G.) teretiusculus, rectus, lacteus. Rad. infera.

BLAIRIA nodillor. ibid.

Verbena nodiflore. ВАuн. prodr. 125. Lic. BuRM. J. ind. t. б.f. т.

Verbena tetrandra fpicis capitato conicis, foliis ferratis, caule repente. I IN $x_{0}$ i fy $\ell . v c g .66$.

Calyx maturus (a. $\Lambda$.) bifidus. Semina (b. B.) oblonga, plano-convexa (C.), rufefcentia aut luteola, glabra. Integ. coriaceum. Embryo (D.) fuboylindricus, rectus, erectus, lacteus. 
Cal. monophyllus, tubulofus, quinquedentatus, perfiftens. Cnr. monopetala, tubulofa; limbo inxquali, bilabiato: labio fuperiore majore adfcendente, inferiore triparkito. Stam. \& didyuama, intra corollam recondita, quorum

174

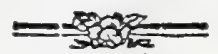

duo minora fterilia; filamentis bafi corollx infertis, medio fquamulofis. Ovar. fuperum; ftylo fimplici; ftigmate quadrifido. Drupa ficca, putamine quadriloculari. Sem. folitaria, erecta. Alb, Q. Emb, erę̧us; rad. acuminata.

Tamonea fpinola, Tab. 213 , fig. 2;

Violae furredae latiore folio species peregrina. PLUKN, plyytog. to 234.6 . 40 Kaempfera. BANks Reliqu, Houft. p. 3. t, 2,

Verbena (curaffavica) diandra, fpicis longis, calycibuis ariftatis, folits ovatis argute ferratis, LINN, Spec. pl. p. 28. SWARZ obf. p. 17.

Ghinia fructibus quadrijpinofss, foliis glabris. WILLD. Spec, pl, T. 7. P, I. p. 114.

Gbiria verbenacea. SWARz for, ind. occid. 2. p. $108 \mathrm{~g}$.

Tumonea curafacuica. PERsoON fyn. 2. p, 139.

Tainonea Spinofa. SWARz prodr. p. 94.

Ex collectione Bankfiana.

PER. Drupa parva, calycis laxe, amplexantis bafi affixa, ficca, obovata, li inverfe pyramidata, ad verticem obtufiftime umbonata, rutundato-tetragona; anguli prope verticem in fuinas quatuor, acutas, drupam coronantes producti. Caro tenuis per maturitatem in membranam, cum putamine arcte conferruminatam, immutatur. Putamen drupx confimile, canali compreffo per axem adfcendente perforatum, offeum, quadriloculare. Loculamenta rotundato-aingulata, paulo latiora quan, craffa, ovato-oblon, ga," deorfum acuminata, monofperma.

REC. nullum : femina ventre angulo loculamentorum interno leviter ad. harent.

SEM. Folitaria, loculamenta exactc replentia, ad bafin in mucronem attenuata, rotundàto-triquecra, albicantia,

IN T. fmplex, membranaceutr, crafiufculum, pallide fpadiceum, ad verticem cbalaza minima ferruginea rotarum, intus carnofum.

A I B. nullum: nifa laminam integumenti internam carnofam, ab ipfo non fepar rabilem, fumas.

EMB. obovatus, erectus, magnitudine fere feminis, slbus, Cotyl. ovatz, fubcarnofic; altera externa plano + convexa, altera interna in fulcum eleva. tum incraffata; incumbentes. Rad. breviflima, difcreta, conico-acums nata, infera.

\section{EXPLICATIO FIGURR}

A.) Pars fice fruziferz. B.) Drupa integra, a calyce denudza. C. D.) Putanea transacifie * longitudinaliter diffetura, cum Gitu \& forma loculamentorum a. E, ) Semen Cparatan F.) Idem uassverfe fectum G,) Embryo folukus, a dorto sifus.

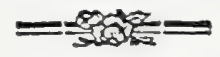

TAMONEA mutica, ibid.

Glinia mustica. WILLD. Spec. pl. T. I. P. 1. p. Ir4. SWARZ f. ind. occid. 2. p. 1090.

Tamonea Spicata. AUBL. Guimt. 2. p. 660.

Tumousa frutibus musicis, foliis tomentofis. Sivarz prod.p. 94. Persoon fyn. 2. p. 139 .

Ex collectione Cl. Desfontaines.

Drupa (a. B.) intra calycem tenuem inclufa, \& vertice tantum ex ipfo prominula, (c. C.) parva, baccata, obovata, in vertice ftylo filiformi brevi faftigiata, glabra. Caro (D.) tenuis, aduata. Putamen (D.E.) ovatum, in vertice fubcilifime mucronulatum, angulis 1 . Sulcis quatuor anguftis longitu dinalibus.infcriptum, fcabriufculum, quadriloculare.

Ii, qui Sebeftenarum ordini albumen tribuere malunt, non valde errant; lamina enim integumenti carnofa omnibus characteribus albuminis carnofi utitur, excepta cralticie minore \& nexu intimo cum integumento. 


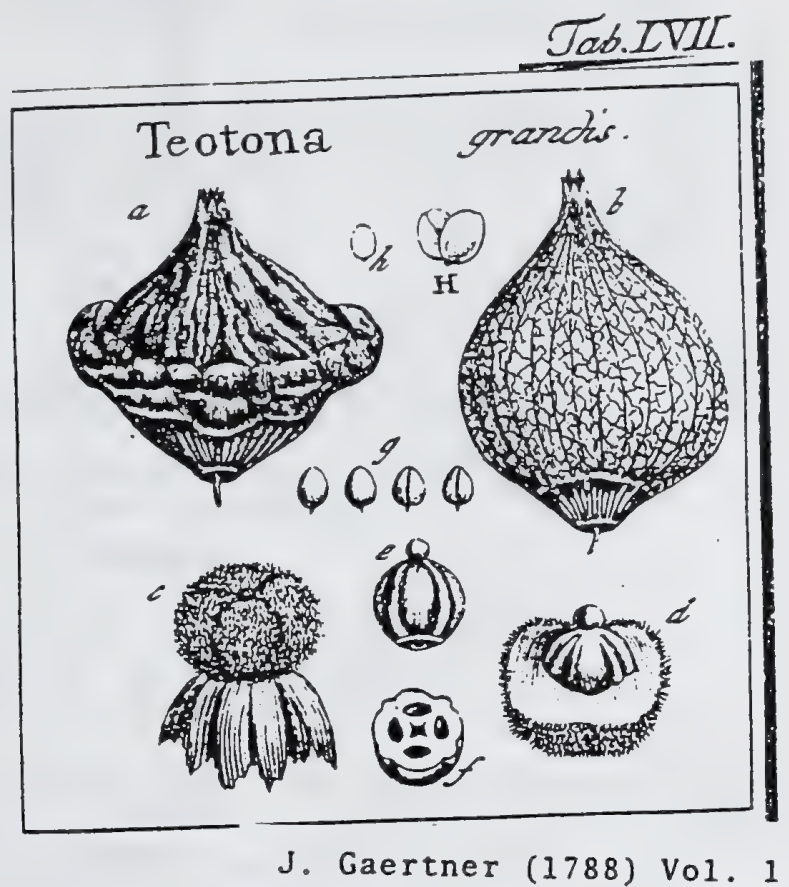

CCCXLV. TECTONA. LIN Nं. ger. 1371.

Calyx maturus inflatus: ore contracto quinquedentato. Cor. infundibuliformis quin: quefida. Stann. quinque. Styl. uuicus, Drupa ficca hirta Putamen quadriloeulare. Semina folitaria

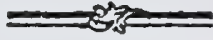

TEC T ON A grandis. Tab. 57. fig. 6.

Tekka. R нев D. mal. 4. p. 57.t. 27 .

Fatus. RU M P H. amb. 3.p. 34.t. 18 .

Tetrona. Li N N. Syft. veg. 199. -

Theki. zeylonens. E collect. fem. hort. lug Jt.

PER. Drupa exfueca, intra calycem inflatum latens, fubglobofa, deprefiiuscula, ro. tundato tetragona, undique villis rudiusculis crifpis \& cinerafcentibus hirfuta. Cortex fuberofo fpongiofus, friabilis. Putamen ofleun, fubglobofum, tuberculo totundo terıninatum, quatuor fulcis elevatis anguftioribus totidemque toris rotundatis craffioribus exaratum, quadriloculare, ad axem perforatum.

REC. nullun; femen vertici loculamentorum affixum.

SEM. in fingulo. loculamento unicuın, lenticulari turgidulum, e cinereo-albicans \& a latere interno, rufefcente funiculo umbilicali, a vertice ad bafin defcendente, notatum.

IN T. fimplex, membranaceum, aridum, tenue, puncto fufco chalazino in vertice infignitum.

A цв. nullum.

EMB. femini conformis, erectus; candidiffimus. Cotyl. ellipticx, carnofx, plano convexx. Rad. globulofa, minima, infera..

a.) Calyx corrugatus. b.) Idem in aqua emolitus, c) Dropa integra. d.) Palamen in cortice craito hxerens, e.) Idem denudatum. (.) Ejusdern fectio transverfalis. 8.) Semint ab atroque latere (pectata, H. H.) Embryo deuudatus 


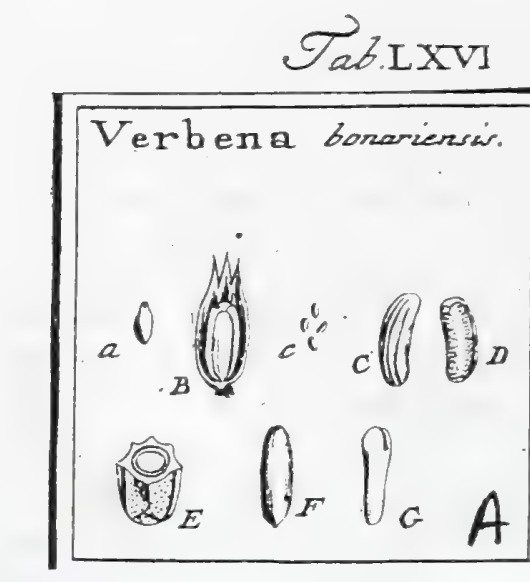

J. Gaertner (1788) Vol. 1

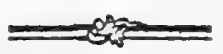

\section{CENTURIA QUINTA.}

\section{CCCCI. VERBENA. TourN. t. 94. LIN N. ger. 32.}

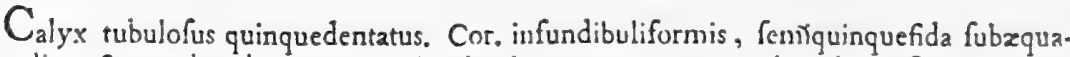
lis. Stam. duo 1. quatuor. Semnina immatura, comnuni tunica veflita; matura quaterna, cortice dorfi craffiore.

VERB EN A bonarienfis. Tab. 66. fig. I.

Verbena bonarienfis altiffima, lavendula canarienfis folio, fpica lavendula. Ditr. cltit. $4.06 . t .300 .5 .3 .97$.

Verbena tetrantra, fuicis fafciculatis, foliis lanccolatis amplexicaulibus. LIN N. fin. vig. 66.

PER. nullum; femina intra calycem immutatum.

REC, nullum.

SEN. quatuor, oblonga; hinc convexiuscula, Ariata, ferruginea; inde fubangulata, albicantia, pusctis minutis callolis fcabrata; ad latera margine prominulo circumfcripta.

IN T. duplex: exterius in dorfo crufaceun, craftum, in marginem definens, in ventre extenuatum \& fubmembranaccuin; interius totum membranaceum.

A L B. nullum.

Exв. fubcylindricus, erectus, lacteus. Cotyl. brevifimx. Rar. longa, crafta, infera.

a.) Calyx maturus integer. B.) Idem longitudinaliter apertus. c. C.) Seminis dorfumo D. E.) Ejusdem pars ventralis. E.) Idear transverfe fettum, F.) Nucleus decorticatus. G.) Embryo denudatus.

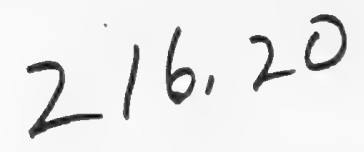




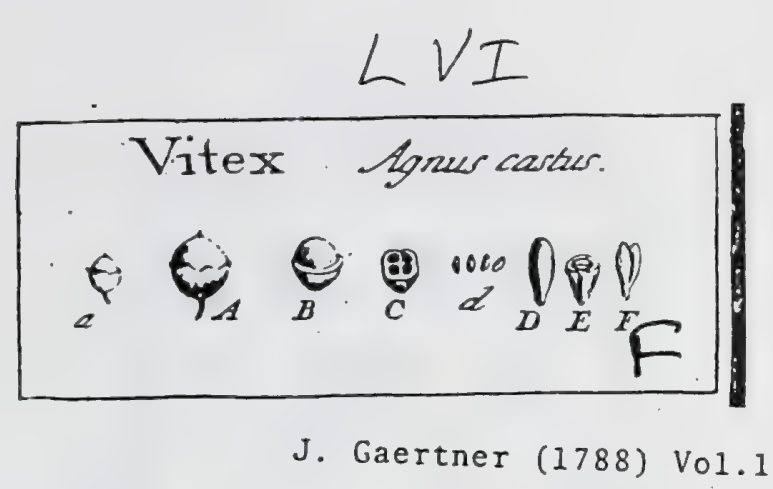

CCCXXXVIII. VITEX. Tо бRN. t. 373. LrN gen: 790: 269

Calyx quinquedentatus. Cor. ringens bilabiata. Stam. quatuor, inxqualia. Styl. unicus; figmatibus duobus. Drupa baccata, putamıne quadriloculari. Sem. folitaria.

V 1 т E A Agnus caftus. Tab. 56 .. fig. 7 .

Vitex. R Iv. monop. $t$. 118 .

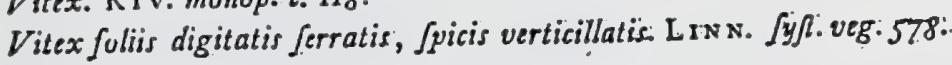

P ع R. Drupa baccata, caljce excepta, globofa, apiculata, rufefcens, magnitudine grañi piperis majoris. Caro tenuis fubaromatica. Yutamen ofleum, ovato globolum, dẹor fum acuminatum, quadriloculare.

REC. nullum; femina bafi aftixa.

$S E N$. in fingulo loculamento unicum, oblongum, inferne acuminatum, angulatum rufefcens.

IN T. fimplex, membranaceum, tenue.

$\Lambda$ L8. nullum.

Es в. femini conformis, ereetus, lutelcens. Cbtyl. oblongre, carnolx, compreflz: Rad. acuminata, brevis, jnfera.

2A.) Drnpa integra. B.) Patamen fuperne denudatum. C.) Idern difreaum, d. D.) Seming f parata. E.) Semen (masverfe fettum. F.) Embryo denudatus,

Veram baccam tetrafpermam, ut vulgo volunt, fruftra in Vitice quxres; nec corol: lain fexfidam mihi unquam videre contigit, nifi in figuris I. R. H. unde genecie characterein haufit LinNeUs. 



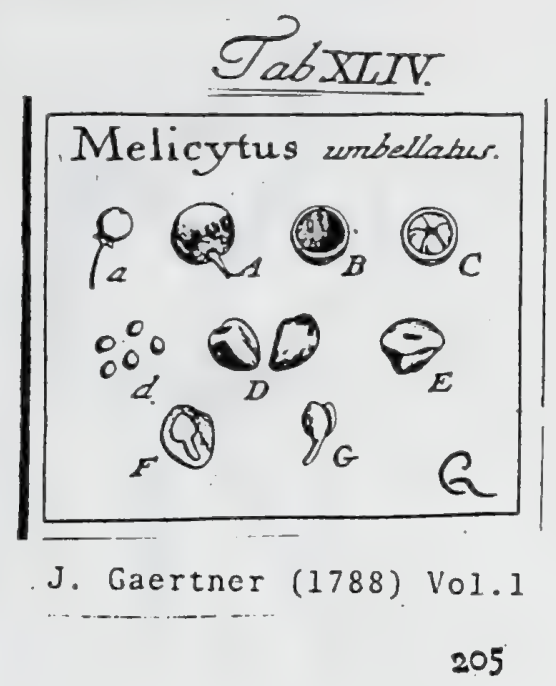

CCXLIV. NIELICYTUS. Forst.

Flores fexu difinat in fẹaratis truncis. MAs. Calo monophyllus, quinquedentatus.

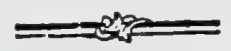

Cor. pentapetala, calyce triplo longior. Stam. quinque. Fess. Cal. \& Cor. uf in mare. Nectar. Squama quinque ovatx, calyce paulo breviores, inter petala infertx, ovario incumbentes. Styl. brevifímus. Stigm. explanatuin, quadri, L quinquelobum: lobulis rotundatis parvis. (Ex fcliedis b. SolandrI). Capfula) baccata unilocularis. Semina nidulantia.

Mexicytus umbellatus. Tab. 44. fig. 3 .

Tachites umbellata. SolAnd. $m / s$.

Ex herbario Bankfiano.

PE r. Capfula baccata, globofa, glabra, corjacea, farcta medulla tenui per maturita. tem exarefcente, unilocularis, quadri-1. quinquevalvis.

REC. nullum; femina in pulpa nidulantia, absque confanti fitu.

SEM. pauca, circiter quinque grandiuscula, himc convexa, inde angulata, fulca.

IN T. triplex: extimum, pellicula tenuis e pulpa exficcata; nedium coriaceum, craf. fiusculum; intimum membranaceum, chalaza fufca notatum.

A L 8. femini conforme, carnofum, oleaginolum, pallidum, cito rancefcens.

Eм в. longitudine albuminis, compreffus, luteus. Cotyl. foliacex, ovatx; planx. Rad. teretiuscula, longa, infera aut centrifuga.

a. A.) Capfula integra. B.) Eadem diffecta, C.) Situs feminum, heic vero jufto nimis regalaris: reprafentatus. d. D.) Semina (cparata, E.) Albuinen transverfe fectum, I.) Enabryonis fitus in albuniue. G.) Enbryo (eparatus.

Proxima affuitate jungitur fequenti.

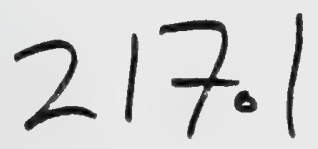




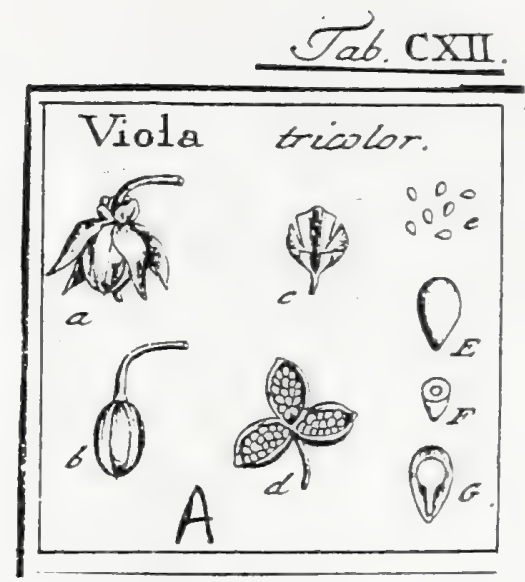

J. Gaertner (1788) Vol 2

DCXIVI. VI O L A. TOURN. inft. t. 236. IINN. gen. I007.

Calyx pentaphyllus. Cor. pentapetala, irregularis, calcarata. Stam. quinque, antheris in tubum coalitis. Ovar. fuperum. Styl. fimplex. Capfula unilocularis, trivalvis. Semina valvulis affixa.

Viola tricolor. Tab. 112. fig. I.

Herba Trinitatis. Fuchs. biff. lat. p. 813 . germ. ic. 461. OED. flor. darn. t.623. Viola tricolor. 'DOD. pempt. 158. Riv. pent. t. I 22. f: 1.2. BLAKW. herb. t. 44. Viola coule angulofo diffufo, foliis ovatis dentatis, fore calyce duplo longiori. HaLL. biff. it. 568 .

Vioh caule triquetro diffufo, foliis oblongis incijis, fipulis pinnatifidis. LIN. 6.7\%. veg. 803.

PER. Capfula elliptice globofa, fex fafciis longitudinalibus, diverfi colotibus, albicintibus fcil. \& rufefcentibus, aut viridibus, in Ggnita, unilocularis, trivalvis: V'alvulis primo concavis, deinde naviculari conniventibus atque femina excutientibus.

REC. dorfi valvularum fuperficies interna, cujus medio femina ope funiculorum brevium per feries longitudinales affixa.

SEM. numerofa, fupra triginta, ovato acuminata, lacvia, fplendentia, pallide ftraminea 1. albicantia.

INT. fimples, chartaceum, tenue.

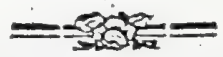

A L B. carnofum, craflum, album.

EM в. longitudine fere albuminis, gramineo viridis. Cotyl. orbiculatx, planiufculic. Rat. cotyledonibus paulo longior, recta, teretiufcula, centrifugh.

a. b.) Capfula integra. c.) Endem transverlin Ican, cum rcceptaculis \& funiculis tombilicalibus. d.) Vabvuls dehifecntes cum feminibus. e. E.) Scunina feparata. F. G.) Albuminis featio trausrerfalis \& lonzitudinalis cum fotn atque forara Embryonis.

Viola odorata. LINN.

Capfula fubglobofa, rotunde trigona, unicolor. Senina ad fingulam valvulam circiter quina, ovato - globofa, fordide albicantia, prioribus duplo majora. Unibilicus grandis, glandulofus, in pedunculum craffun deorSun elongatus \& furfum in apophyfin fubulatam, femini accumbcntem productus. Integunı. cruftaceun, fragile. Embryo ut in procedenti; fiepe tamen radicula fola viridis, cotyledones autem lutefcentes. 


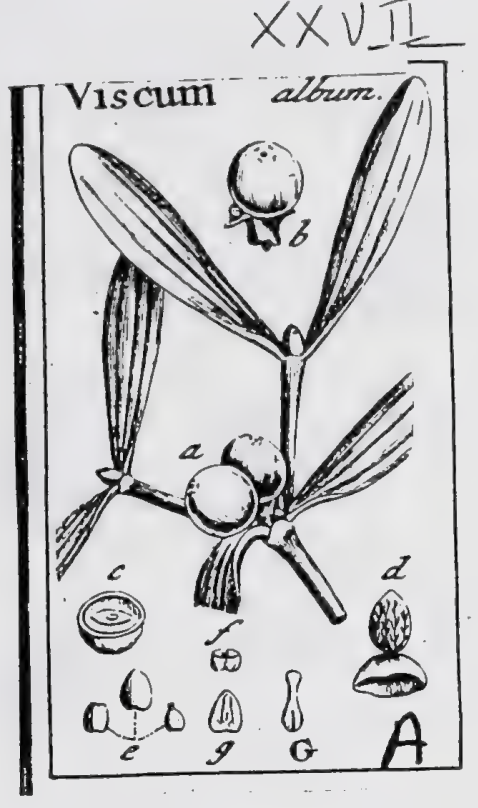

J. Gaertner (1788) Vo?, l

CLVII. VISCVM. TOURN. t. 380. LINN. gen. 1105 .

Flores fexu diftincti, nunc in eadem, nune in feparatis plantis. MAs. Cal. quadripartitus. Stain. quatuor. F E Mr. Cal. tetraphyllus, fuperus. Bacca pulpofa unilocularis. Semen unicum. Cotyledones collaterales!

V iscum album. Tab. 27. fig. :.

Vifcum. BLAK w. herb. t. 184 .

Vifcum foliis lanceolatis obtu/is, caule dichotomo, Spicis glomeratis axillaribus. HaLL. hifl. 2. n.160g. LI N N. Jyf. veg. 883 .

$P E R$. Bacca infera, cicatriculis quatuor fufcis a calycis lapfu in vertice notata, fphxrica alba, diaphana, unilocularis. Pulpa vifcida, pellucida, femini circumfura.

REc. nulluin, preter funduin bacex, cui femen affixum.

SEM. unicum, ellipticum, quafi emarginatum, \& inde cordatum aut fpharice triangulum, lenticulari compreftum, carnofum, vafis dendriticis albis (fi recens) fuper fundo graminco viridi pictum. Umbilicus in bafi feminis, leviter emarginatus.

IN T. Simplex, tenue, membranaceum, diaplaanuin, facile fecedens.

A L B. femini conforme, carnofum, mollitisculum, gramineo viride.

EM B. dicotyledoneus, inverfus, longitudine fere albuminis, albicans. Cotyl. compreßx, feni ovatx, in eodem plauo verticali ita juxta $f_{e}$ pofitx, ut folo foliolorun fuo rum margine interno le mutuo contingant. Rad. longa, teretiuscula, apice incrallata, fupera.

2.b.) Bacca integra, c) Ejus atque feminis fectio transverfalis. d.) Semen recens membrana fua, vafeulis picta, veftitum. e.) Albumell deaudatum, varix figurse. f.) Idem trausverfe fectum, g.) Ejusdem foctio longitudiualis, cun fitu embryonis, G.) Embryo feparatas.

Semina-Vifei, pluribos, quam unica, radiculis germinantia vide apud Malptcü Op. omis. p. m. 140. fig. 105. Z. Z. Tourn. inf. t. 380. M. Duн A Frut. edit. germ. 2. p. 166. \& EJusd. Phllf. arb. edit. germ. p. 174. t. x. f. Conf. etian Hamb. Mag. XXI. P. 273. In univerfun Dusamelius numeruia radiciriarum, illi angulorum feminis xqualem ftatuir, ita, ut unico angulo predit tum femen, unicam; duobus, duas; \& tribus, tres radiculas fub germinationé promat; at non dicit, utrum ante id tempus iftx radiculx jam jam in fernine for: matx lint, nec ne? mihi hactenus illam pluralitatem radicularum, in feninibus Vifci videre non contigit. 


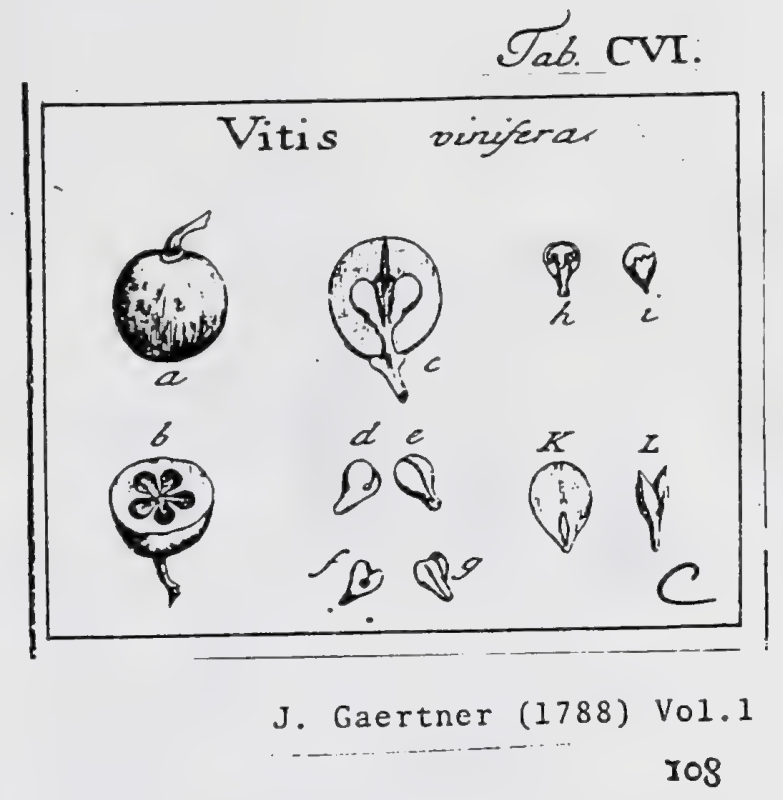

\section{VIT IS. TOURN. inf. t. 384. LINN. gen. 284.}

Calyx quinquepartitus, minimus. Cor. pentaperala: petalis apice cohrerentibus \& calyptrx in modum genitalia obtegentibus. Stam. quinque. Ovar. fuperum. Styl. fimplex. Bacca immatura quinquelocularis, at niatura unilocularis pentafperma.

VITIs vinifera. Tab. 106. fig. 2.

Vitis. Blakw. berb. t. 153. Schmid. aralys. t. 7. optime.

Vitis foliis feinitrilobatis birfustis dentatis. HaLl. biff. 13.825 .

Vitis foliis lobatis finuatis nudis. L1s.s. Jjy. veg. 244.

PEK. Bacca globofa, pulpofa, ante maturitatem regulariter in quinque boculamenta partita, poltea vero unilocularis, fubpellucida, colorata, aut excolor.

REC. columma centralis, brevis, ex pedunculi baccx fibris lignofis orta, cujus apici femina ope funiculi umbilicalis proprii affiguntur. Funiculus filiformis, fecundum interi:um feminis latus ufque ad ejus apicem decurrens, deinle in dorfum reflexus, foramen umbilicale denum ingredicns.

SEM. quinque, ut plurimum vero pauciora, ofiea, gigartoiden.

Is: T. triplex: extinutm membranaceum, ante plenam maturitatem fubcarnofum, funiculo umbilicali quoque fuperinductum; medium offeum, fragile, ex profundis fulcis ventralibus quafi femibiloculare, in medio dorfo foramine umbilicali perforatum; intimtm membranaceum, tenue, rufefcens aut ferrugineum.

AL B. cavitati teftx feminis conforme, carnofum, durum, album.

E м в. dimidio albumine paulo brevior, erectus, Jacteus. Cotyl. lanceolatx, hisc obtufiflime carinata, inde planxe. Rad. teretiufcula, infera.

2.) Bacea matura integra. b.) Eacea immatura diffeas loctlanentof́. c.) Receptaculum fominum, d. e.) Scmina ab utroque latere (petata \& tuuica fus extima adhuc vefita. f.) Tefta - Ifex latus dorfalc. 5.) Ejusiem pars ventralis. h.) Ezdem transterfe fects, i.) dibumen a

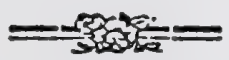

I09

dorfo fpceintnm, atque tunica fai propriz ex parte exntum. $K$.) Idem longitudiualiter dirtettum, cur Gitu cubryouis. L.) Embryo folutus. • 


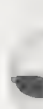

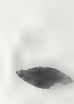

c. 


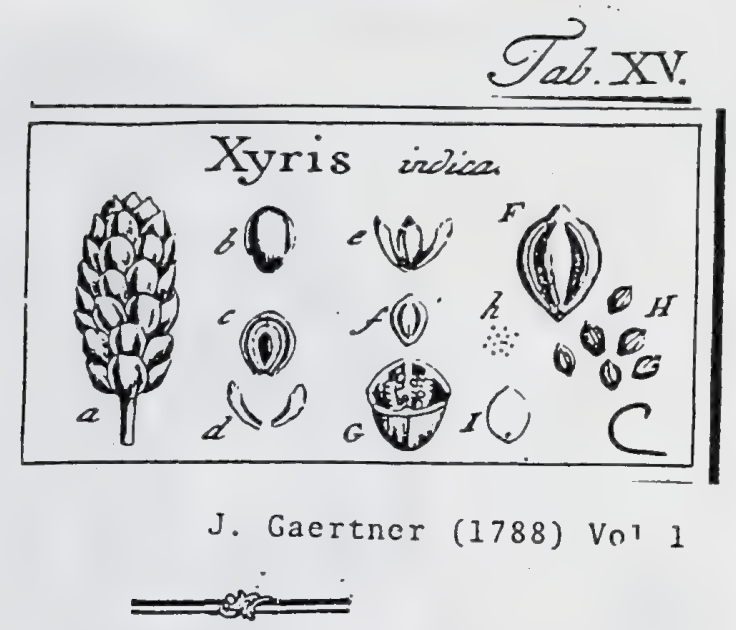

LVIII. XYRIS. LINN. gen. $\sigma_{4}$.

Calyx. Glume tres cartilaginex, nitidx, inxquales: una exteriore maxima, ovatorotundata, concava; duabus interioribus arcuatis, naviculari-compreffis, apice denticulatis. Cor. tripetala. Stam. tria. Styl. unicus. Capfula fupera, unilo. cularis ad angulos rimâ dehifcens. Semina parietalia.

XYRYS indica. Tab. 15. fig. 3.

Kotsjiletti-pulli. R нев D. mal. g.p. 13.t.7.

Gladiolo palufri accedens malabarica, e capitulo botryoideo florifera. P $\mathbf{U}$ R: pliyt. t. $416 . f .4$.

Xyris. Lin s. $\int y$ ft. थeg. 95 .

E collect. fem. hort. lugdb.

PER. Capfula fupera, obovata, trigona, unilocularis, ad angulos rima tantum dehifcens, apice autem \& bafi cohxrens nec in valvulas fecedens.

REC. fulcus elevatus lateribus internis caplulx adnatus, numerofifinis funiculis capil: baribus, breviffunis ftipatus.

SEM. numerofiffima, minutifima, ovato-globofa, longitudinaliter friata, apice \& bafi leviter inucronata, ibique nigro fufca, cetera vero rufelcentia, aut pallida, fuiis tantum rufefcentibus.

IN T. fimplicilimum, membranaceum, arefe-aduatum.

A z в. femini conforme, carnofum, duriusculum, pallidum.

Емв. minutifimus, punduli nivei fpecic, in albuminis parte, parietes caplulx refpiciente, locatus.

a.) Spica matura integra, b. ) Gluma calycina major, a dorfo fpctata. c.) Ejusdem latus internuni, cum glumis duabus minoribus in fitu naturali. d.) Glumse ninores feparatx. e.) Cap̧lulx, glumis minoribus fipata. f. F.) Eadem rinis de'lifcens, G. ) Ejusdem foftio trausverfalis, .cum recrptaculis feniusm. h. H.) Semioa feparata. I.) Albumen longitudiualier featum, cum fito mbrjouis.

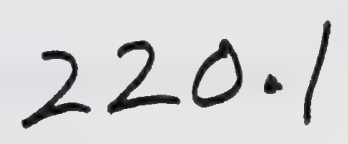



Tab. III.

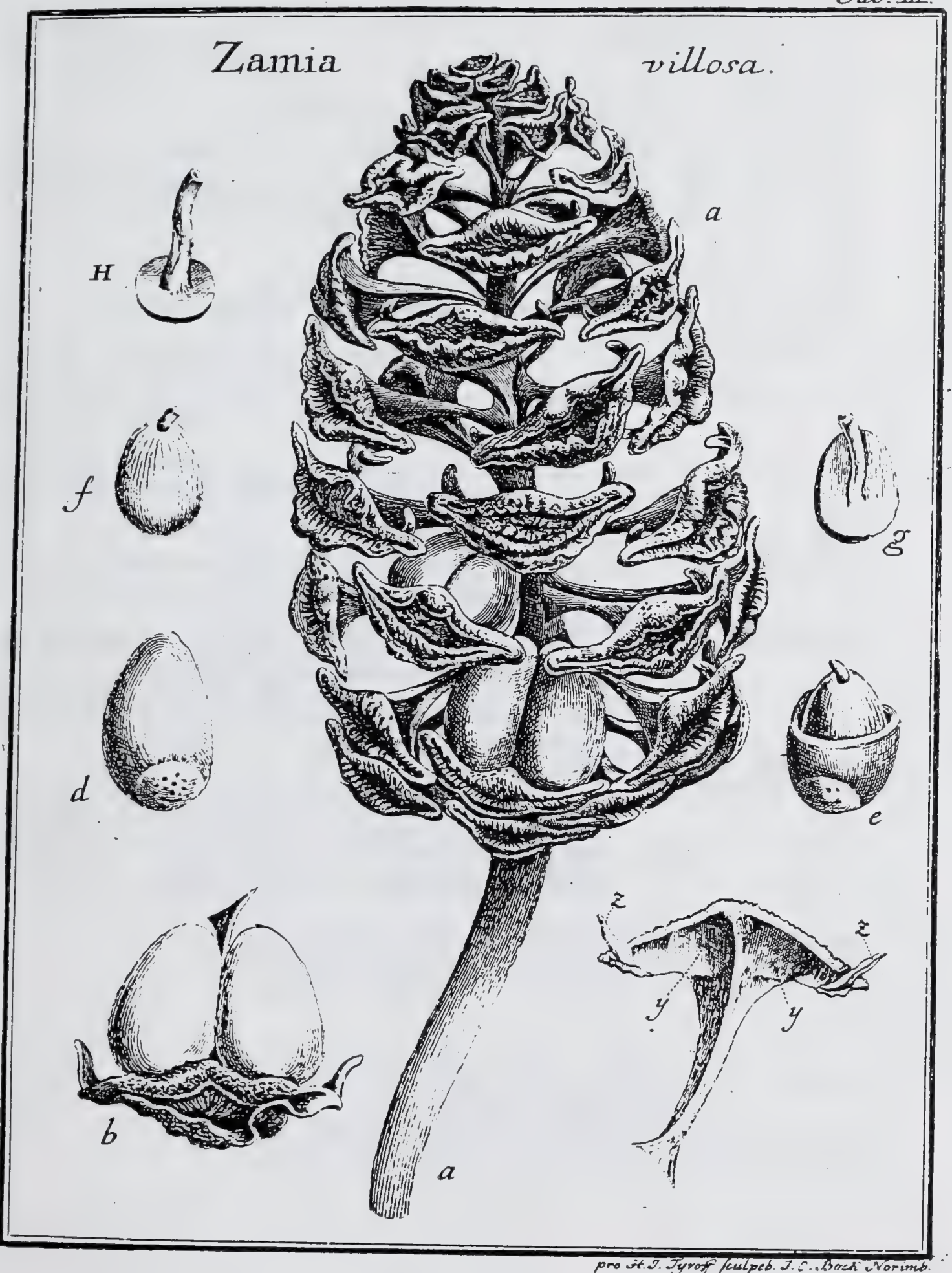

$$
221.1
$$


Zamiaceare

J. Gaertner (1788) Vol.1

15

XX. ZAMIA. LiNN. gen. 1227 .

Flores Sexu diningi in feparatis caudicibus. MAs. Amentum ftrobiliforme, fquamarum fuperficie interiori Autheris globolis tecta. Fess. Amentuin ut in mare, fyuamis intus Bacca gemina, felliti.

Zs M i caffra (villofa) Tab. 3 .

Cycas caffra. Thunв. alt. ups. 2. p. 284.t. 5 .

Zamia frondibus pinnatis: foliolis lanceolatis acuto fpinofis. Lins. fuppl. 433. Jyj. veg. y26.

FrUct. Atrobilaceus, ovato oblongus, fubpedalis, pedunculatus. Squanx peltata, longe pritiolatx: petiolo exirorfum latescente, triquetro: peltis rhomboideis, urrinque acuminatis, fuberofo coriaceis; extus fcrupolis, rugofis, fuscis; intus juxra petiolum, arca rotunda pallida utrinque notatis, ac prope extremitates, lamella introrfum verfo auchis.

PER. Bacca, ad fingulam peltam gemina, ovata, obfoletifime trigona, bafi derafa, carmofa, glabra, unilocularis. Cuticula tenuis, in vetufto fructu pallide framinea. Caro molis, fungola, modice cralla.

REC. nullum: femen bafi adnatum.

SEM. unicum, grande, ovato globofum, inverfum, apice umbonatum, pallidum.

Isт. funplex, tenuifimum, cum interno baccx pariete conferruminatum.

A L в. nullum, nifi vitellum velis.

VI T. femini conformis, anygdalino-carnofus, albus, fecundum axem, canali, pro recipiendo cmbryone, perforatus, cetera integerrimus.

EMв. monocotyledoneus, incompletus: fenpo teretiusculo, fubflexuolo, inferne in vitelli fubflantia radicato, fuperne extra ejus aperturam prominente, libero. Rad. fubretufa, fupera.

a.) Strobilus delaiscens. b.) Squama feparata, cum baccis in fitu naturali. c.) Ejusdem facies intenua . cum duabus areolis $(y . y$.$) , ab infertione baccaruin enacis, \& iamellis duabus (z.z.), Introrfum$ veris, proxima haccarum paria ab iuvicem discrininantibus. d.) Bacca feparasa. e.) Ejusdeni fertio transverfalis, cum fitu fruinis. f.) Semen denudatum. g.) V'itcli intio longitudinalis, infercionem embrjonis oftendens. H.) Embryonis lcapus denudatus, in bafi vitelli radicatus.

221.2 


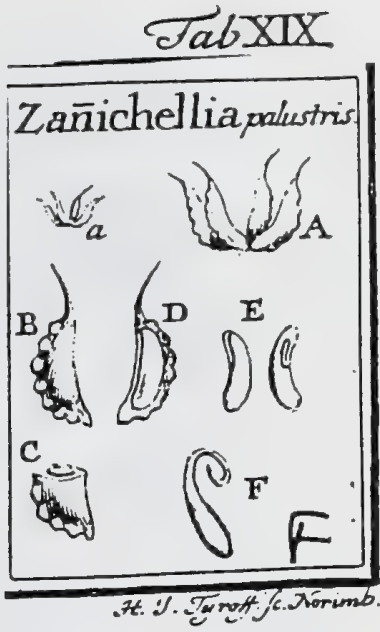

J. Gaertner (1788) $V r^{*} 1$

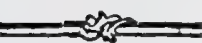

LXXXIX. ZANICHELLIA. M ICH. gen. t. 34. LINN. gen. 1034.

Flores fexu diflincti in cadem planta, MAs. Cal. nullus. Cor. nulla. Stam. unicum. FEM. Cal. campanulatus. Ovatia quatuor aut plura. Enbryomis radicula Spiralis.

ZaNiCHELLia palufris. Tab. ig. fig. 6.

Potamogetoni fimilis graminifolia ramofa E ad genicula polyceratos.' PLux: phyt. t. 102. f. 7 .

Zanichellia palufris major, foliis granineis. Mrсн. gen. t. 34. f. 1.2.

Zanichellia. Ha LL. hif. 2. n. 1604. L I N. Jy/. veg. 838.

- ICON. OEDER. flor. dan. t. 67 .

PER. Capfulx quatuor ad octo, fubfalcatx, erecto patentes, Aylo reclinato rofiratx, in dorfo tuberculato crenulatx, cetera glabrz, cruflaceo-coriacex, lenticulari compreffx, uniloculares, evalves.

REC. nullum.

SEM. unicum, forma \& magnitudine cavitatis capfulx, pallidum.

IN T. Gimpliciffmum, araclmoideum, ut fere nullum.

A 28. nulluin.

Ем в. monocotyledoneus, inverfus, albus, magnitudine ipfus feminis: extremitate inferiori cralliore, fubclavata, compreffiuscula; fuperiori autem fenfim attenuata, atque in Radiculam filiformenn, duplici gyro fpirali convolutam \& ad alterum feminis latus detortam, definente,

2. A. B.) Capfula integra. C.) Capfula transverfe feta. D.) Semen denudatum. E) Embrgo ab utroque latere Speciatus. F.) Idem, explicato radicula gyro.

Poftent cum Lis N F. fcmina nuda dici; attamen tectis videntur magis vicina, propter ny lum perf:nentem \& figuram filiqux xmulam, quare etiam VA ILLANTIO, Michello \& HaLlero fructus hic dicitur capfularis. 
- 1

e

2 


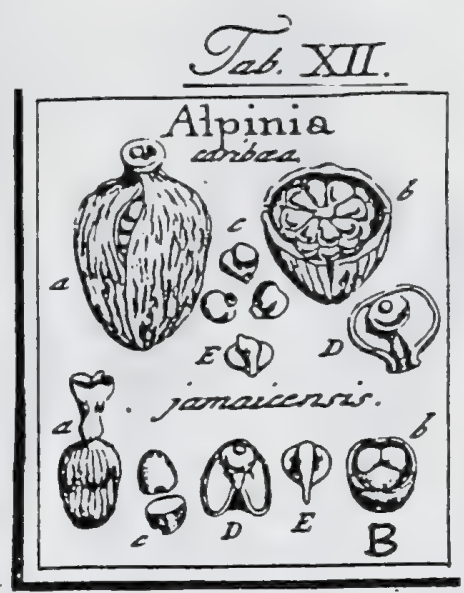

\section{J. Gaertner (1788) Vol.1}

XL. ALPINIA. Plum. gen.t.3. Linn. gen. 4.36

Corolla monopetala, irregularis: limbo duplici. Stam. unicum. Styl. fimplex. Cap. fula baccata, infera, unilocularis, evalvis. Sernisa receptaculo centrali affixa. Embryo vagina vitellina velitus.

A z PINIA racemofa (caribza in ic.) Tab. r2. fig. 2.

Alpinia racemosa alba, cannacori foliis. PLuM. ic. t. 20.

Alpinia. LI N N. Syf. veg. 5 I.

PER. Capfola baccata, ovato globora, corollze bafi perfiftente umbonata, firiata, obfolete trigona, coriacea, fordide nigricans, unilocularis, preflione trifarian dehifcens. Valvulx intus furfuraceo fcrupofx, absque veftigio diffepinenti. Pulpa in inaturo fructu nulla, nec fernina ullo modo involuta.

REc. fubftantia cellulofa, axem fructus efficiens, cui fensina affixa.

SEM_plura, ad triginta, gigartoideo-globofa, angulata, in-umbilicum amplum turgidulum definentia, lavigata, lucida, helvola l. lutefcenti- Spadicea.

IN T. duplex: exterius coriaceum, tenue; interius unembranaceum, tenuiftunum, ferrugineo fufcum, a nucleo non folubile.

A ц в. candidifinum, farinofum, umbilici profundo canali exfculptum, remife arosnaticum.

Vı globolus, carnofus, luteolus, foramine in vertice pertufus, ex quo embryo aliquantulum prominet.

E м в. fubclavatus, figmoideo-curvatus, albicans. Cotyledon crafla, fublanceolata, apice denudata Radic. teretiuscula, vitello immer反a, centripeta

2) Capfula integra. b.) Exdem transverfe feta, cum (eminibus axi affixis. c.) Semina foluta.

D.) Seminic feflio longitudioalis, cum fitu \& Ggura albuminis atgue vitelli. E.) Vitellus verticalites Seatus, cum embryose denudato.

AIPINIA jamaicenfis. ibid.

Ex herbario Bankfiano.

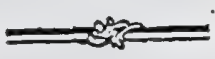

Capfula ovata (a), longo corolla infundibulo coronata, obfoletifine trigona, parce \& elevato thriata, cliartacea, atra, unilocularis (b), evalvis, vix phafeolo inediocri major. Pulpa per maturitatem exarefcens in membranulas tenuifimas, feninibus, absque diffepimenti vefigio, interpofitas. Semina (c) panca, quinque 1. fex, pro capfula inodulo, grandiufcula, ovata, anguiata, amplo umbilico perforata, rufféenti-fpadicea, non nitida. Albunen (D) farinofum, candidifinnum, inodoruin. Vitellus (D. E.) caudato globolus, carnolus, luteolus. Embryo ( $E$. in vitello longitudinaliter aperto.) rectus; teretiusculus, verfus umbilicum attenuatus. 

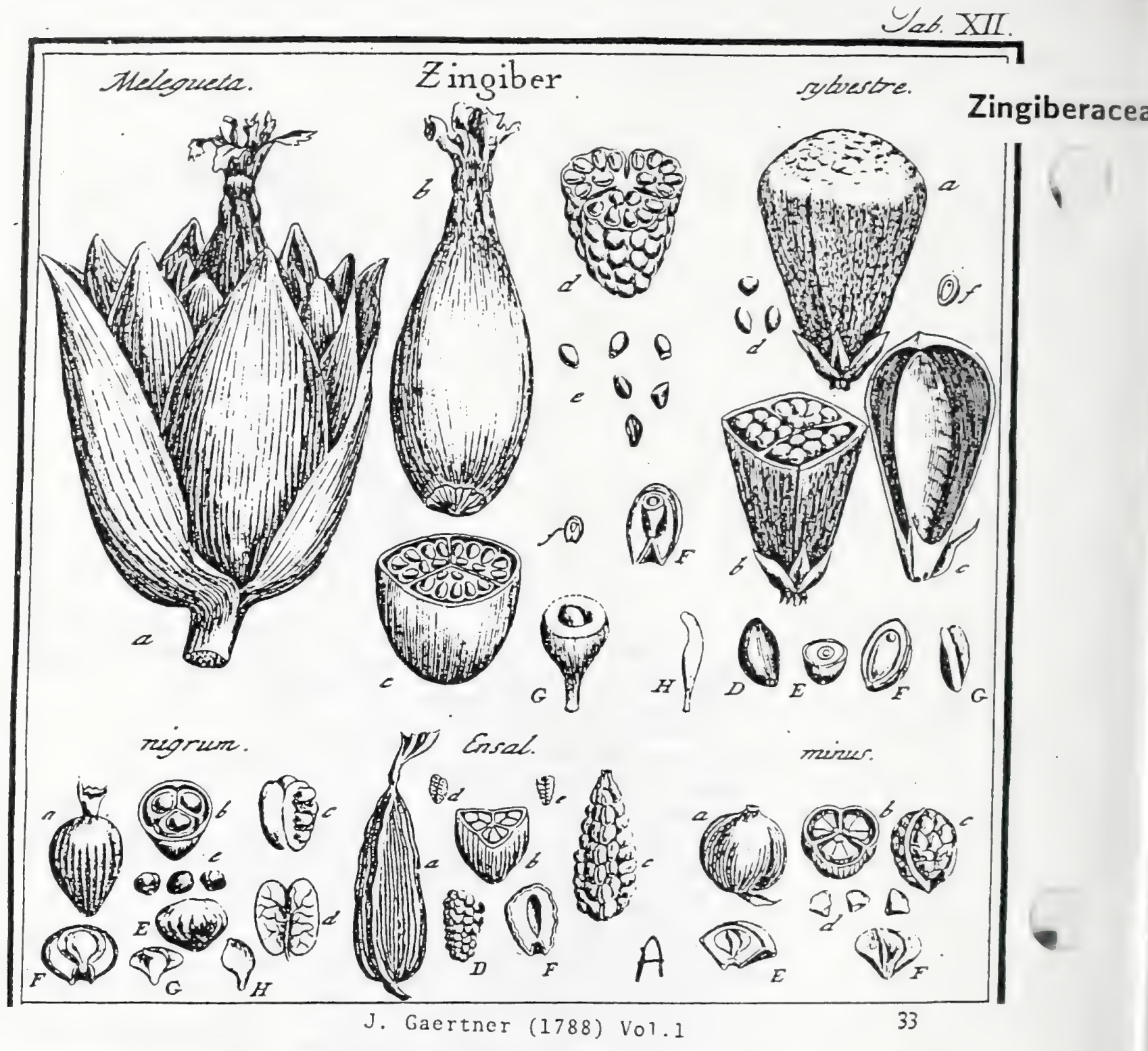

XXXIX. ZINGIBER. Offic. Amomun. Lin n. gen. 2.

Corolla monopetala, irregularis: limbo duplici. Stam. unicum. Styl. fimplex. Capfula baccats, infera, vilocularis. Semina in pulpa nidulantia. Enbryo vitelli vagima inclufus.

34

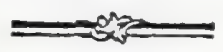

Zingiber Meleguetta. Tab. I2. fig. I.

Melegetta. Lов. advers. p. 445. ВА и. hif. 2. p. 204.

Cardanomins majus. Bes L. mus. p. 14. t. 4. f. prima.

Frufus cajeputi. TREw. Commerc. lit. nor. 1737. p. 132. t. 1. f. 9. 10. 11.' E pag. 164. t. 2. f. 6.7.8.

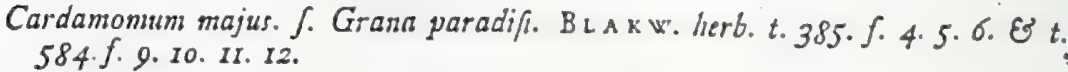

Amomum angufifolium. Grand Cardamome de Madagafcar. Sonмe R^ т. voyag. ind. orient. Vol. 2. p. 242. t. 137.

Ex dono Dn. La gir Pharmacop. Stuttgardienfis.

PER. Capfula fquamis fioralibus maximis in frobilum convergentibus excepta, ovato oblonga, collo nodulofo roftrata atque perfiftente corolla serminata, obfolcte trigona, fubfriata, fordide rufefcens, trilocularis, evalvis. Diffcpimenta membra. nacea. Loculamenta farcta fubftantia fpongiofa in cellulas pro femmibus divifit.

REC. nullum, prater pulpan exaridam, in qua femina vario fitu nidulantur.

SEM. nunserofa, ovato-globofa, varie angulata, Ixvigata, nitida, plumbea, livida, aut glauca, ad bafin profundo umbilico exfculpta, \& albicante inargine fubtumid IN T. duplex: exterius coriaceum, tenue; interius tenuifrmum, ferrugineo-nigricans,
arctiflune nucleo adnatum.

A цв. femini conforme, candidifunun, farinofum, aromaticum.

VI T. carnolus, infundibuliformis, lutcfcens, grate aromaticus, in medio albuminis locatus eneum embrvonems. folo cius anice cxcento, vaoinass. 
Esiв. oblongus, Jacteo albicans. Cotyledon lineari-oblonga, modice curvata, carnola, obefula. Rad. attenuata, teretiuscula, verfus umbilicum directa.

2.) Serobiles ex fquamis floralibes, ovatis, parallele friatis, capfulam cingcotibus, maguitudine na. turali. b) Capfula deaudaca. c) Ejus fetio iransverfalis. d.) Pulpz fangofa pars, cum feminibus in fitu naturnit. e) Semina foluta. f. F.) Seminis feftio longitudinalis, cum fitu Vitelli intra albumen. G.) Vitellus folutus \& infigniter autus, cum eabryone fibi inclufo. 11.) Embryo desudaius, valde aufius.

ZING IBER fylveftre. ibid.

Cardamomun zeylanicum fylvefre, aquaticum, acte, fapore calami aromatici. HERM. mus. zeyl. g6. K URM. 月. zeyl. 54 ?

$E$ collect fein. hort. lugdb. cum nomine Lanquas.

Capfula pyramidata (a. fed male fitus in icone inverfus), comprefte trigona, floris reliquiis lawceolatis reliexis corouata, fordide cinerea, \& fibris abruptis longitudinali-

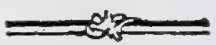

bus friata, coriacea, trilocularis, trivalvis (b). Diflepimenta membranacea, me. dio valvularum (c) adnata. Caro per maturitatem fere evanefcens \& quafi in glu. ten induratumn converfa, femnima obvolvens. Semina (d. D.) numerofa, ovata ac angulata, ferrugineo-fulca, fuperficie inæquabili, vix tamen puncticulata. Integumentum fimplex, arctifime adnatum. Albumen (E. f. F.) candidifimum, farinofum. Vitellus (E. F.) in medio albuminis locatus, ovato oblongus, carnofus, luteolus, ficutialbumen vix, aut parum aromaticus. Embryo (G. in vitello longitudinaliter (eqto) teretiusculus, rectus, albicans.

Non poteft effe fructus Lanquas, cui fecundum Ruмpнium bacca L. capfula fit gíobola \& femipollicaris.

ZINGIBER nigruIn. ibid.

Cardamomum zeylanicum, fruffu rotundo nigro, in caulium fummitate. HE R M. parad. bat. 320 . B v R M. fl. zey!. 54 .

Allow \& Alughas. zeylonens. E collect. fem. Iort. lugdb.

Bacca ovato globofa (a) coroll $x$ bafi infundibulifurmi coronata, nitida, glabra, aut obfolete friata, atra, fubunilocularis. Cortex pergameus, tenuis, intus tribus fu!cis prominulis (b.), loco diffepitnentorum, inferiptus. Caro fungofa (b. c. d.) albicans, in tres lobos, vafis $\left(d_{0}\right)$ inter fe connexos, divifibilis. Semina in fingulo lobo fex ad decem, nidulantia (c), fubglobofa, 1 . angulata, rugofula, fufca aut nigricantı. Albumen (F.) candidilimun, fragrantifimum, farinofum. Vitcllus (F. G.) carnolus, gratilfune aromaticus, verticilliformis. Embryonis cotyledon (F. G. H.) ovato-lanceolata, crafta, carnola, fuperne inflexa. Rad. teretiuscula umbilico obverfa.

Obf. Cum huic vera bacca fit \& nulla feptis diftiricta loculamenta, Alpiniz \& Glubbx videtur proxima.

ZıNG в E R Enfal. ibid.

Cardansomum cums filiquis $\int$. thecis longis. Ba ur. hif. 2. p. 205.

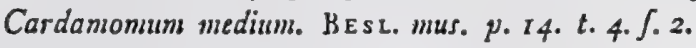

Cardamomum majus. B L A K w. herb. t. 584. $.17-2 \pi$.

Cardamomum Enfal diäum. He R м. mus. zcyl, 66. B ч в м. fl. zeyl. 54 .

E collect. fem. hort. lugdb.'

Capfula oblonga (a), pyramidata, triquetra, longitudinaliter fulcata, coriacea, trilocularis (b). trivalvis. Pulpa (c) fpongiofa, tenuis. Semina (d. D.) irregtlariter angulata, rugofo-tuberculata, f padicea, hinc (d. J)) gibba, inde (c) fulco longitudinali exarata, \& infurne (F) profundo umbilico exlculpta. Albunen (F) farınolum, candidiffunum, aromaticum. Vitellus..... Embryo......

ZING I B F, minus. ibid.

Cardamomum cum filiquis $f$. thecis brevibus. В А Ч н. hifl. 2. p. 205.

36 Cardamonum minus. EES L. mus. 14. l. 4. f. 3 .

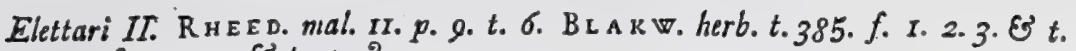
$584 . f .2-7 \cdot E^{2}$ t. 371 ?

Capfula fubglobofa (a), trifulca, obtufe mucronata, friata, coriacea, rufefcentiftraminea, trilocularis (b), evalvis. Diflepimenta membranacea (c) cum pulpa fpongiofa femina obtegente, cohxrentia. Semina deprelinuscula (d), pyramidato angulata, inflar lapidum pavimenti fibi mutuo junda (c), fordide rufefcentia, fu. perficie inxquabili, vix tamen rugola. Albumen (E) candidiflunum, farinofum, aromaticum. Vitellus (E. F) turbinatus, carnofus, lutefcens. Embryo (F.) lanceolatus, craffus, figmoideo curvatus. 
$-$

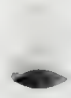



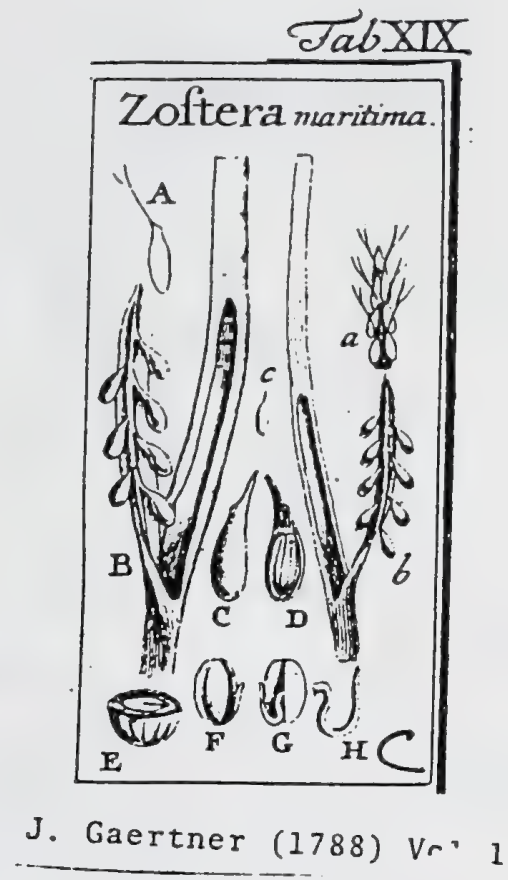

76

LXXXVIII. ZOSTERA. LIN g. gen. 1032.

Cavitas intra folium grainineum ablonga, fructificationis partes occultans. Receptay culum conmune lineare, a parte fua interiori frugiferum. Cal. nullus. Cor. nulla: Stam, alterna. Capfulx alternx. Semina folitaria. Embr. uncuformis.

ZOST ER A maritima. Tab. ig. fig. 5.

Alga ad mare. OE D. flor. dan. t. 15 .

Zoflera pericarpiis Sefflibus. LIN N. Jyft. veg. 829. it. wefgoth. t. 4. rudis.

P E R. Capfula ovato roftrata, ftylo capillari femibifido terininata, compreffiusculas; umcmbranacea, diaphana, unilocularis, eval vis.

REc. commune lineare, intra cavitatem folii pofitum, hinc planum, inde nervo met dio prominulo fipatum, e quo capfulz vario nuinero, ofto ad duodecim, alters natim pofitx, pendent; proprium, nullum : femina capfulis ipfis mox fub rofelifo aftixa.

SEm. unicum, parvum, ellipticum, lenticulari compreffun, ftriatum, pallide șish fescens.

IN T. fimplex, fubcoriaceum, modice craffum.

A I B. nullum.

VIT. cotyledoniformis, farinolo carnofus, albus, femini conformis; hinc integerrimus: folidus, inde rima verticali ad axem usque incifus ac femibilobus.

Eм в. inonocotyledoneus, filiformis, in uncum curvatus, lutefcens: bafi fua in me dio axe vitelli radicatus, inde rccta defcendens, poltea vero furfum intlexus, rimi curvaturatn legens ac libero fuo crure, circa medium vitelli latus, acuminato fine! defimens.

2. A.) Capfula immaturx, fylo capillari femibisdo inftrutex in fitu naturali, b. B.) Receptach lum e cavitate folii extraftum \& a latere fuo intenio fpetlatuin. c. C., Capfula maturs ispantat D.) Eadem longitudinalites aperta, cum femine friato ad bafin rofri capfule alixo. E) Sented tunnsverfe fetum. F.) Vitellus integer, cum embryonis crure libero. G.) Virelli lobulas ilid refeQtus, ut embryonis infertio pateat. H, ) Embryo a vicelio lolutus \& infiguiter auflus. \%o 
$-$

$-$

- 


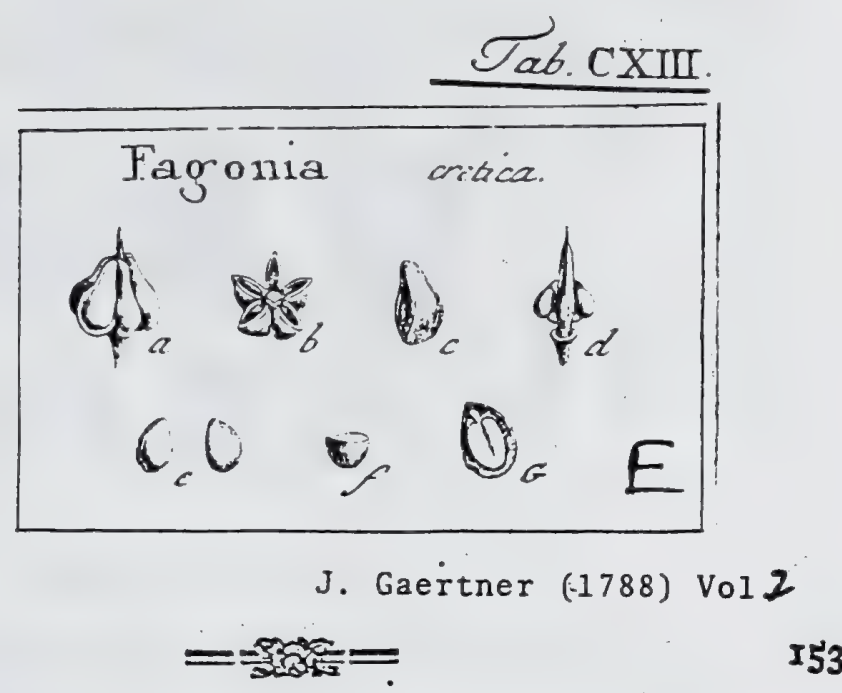

DC̣LIII. FAGONIA. TOURN. inft. t. I4r. LINN. gers. 53 I.

Calyx pentaphyllus. Cor. pentapetala. Stam. decem. Ovar. fuperum. Styl. implex. Capfula pentagona, decenvalvis. Scmina folitaria.

FAgonıa cretica. Táb. 113. fig. 6.

Trifolium Spinofum creticum. Clus. biff. 2. p. 242.

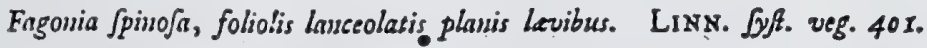

PER. Capfula ovato pyramidata, quinqueloba $f$. ftellato-pentagona, quinquelocularis, decemval vis: loculamentis naviculari-compreffis, carina dehifcentibus.

REc. columuare, pentagono - fubulatum, in axi fructus pofitum, cui \& valvulx \& funiculi umbilicales fetacei, mox fupra bafin, inferti.

SEM. folitaria, ovata, fuperne anguftata, inferne ad funiculi umbilicalis infertionem leviGime emarginata, lenticulari \& fere foliaceo compreita, ferrugineo fufca, minutifinse excavato - punctata.

Is T. duples: extcrins tenuifiraum, $a b$ aqua in mucilaginem flavefcentęm, pellucidam \& modice cralan intumefcens; interius curiaceum, tenue, albumini arctifine adnatum, ferrugincum.

A L B. curtilagineum, tenue, album.

$E_{M B}$ B. longitudine albuminis, inverfus, luteus. Cotyl. ellipticx, foliacex, te. nues. Rad. compreffa, linearis, fupera.

a. b.) Canfula integra \& difeta. c) Loculamentum nariculare, feparatum. d.) Receptac. columnare, cum infertione feminum. e.) Semina integra. f.) Semen diffectum, G.) Albumeu longitudinaliter apertum, can fitu \& Gigura Embryonis. 


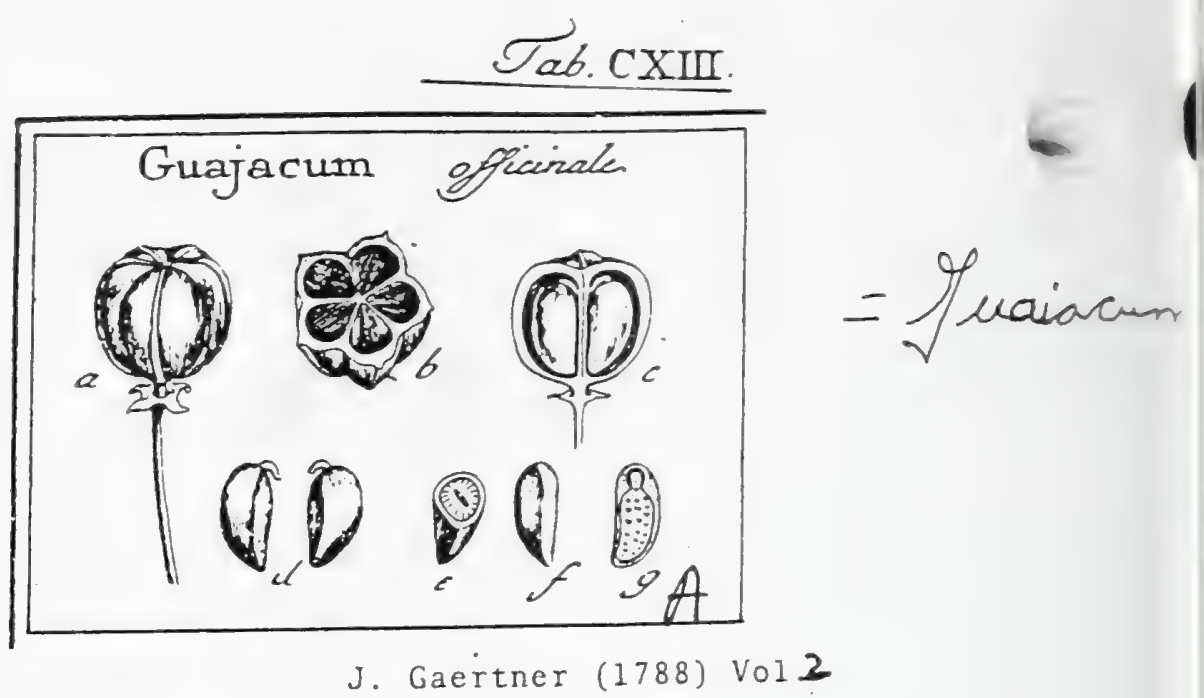

148

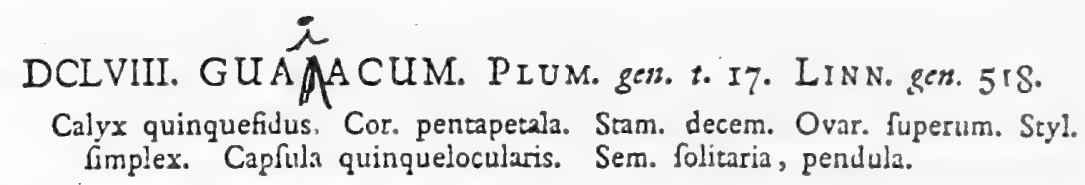

Guajacum officinale. Tab. 113. fig. I.

Pruno vel Evonynno affinis arbor, folio alato buxeo fubroturdo. SLOAN, bifo. jain. 2. p. J33. t. 222. f. $3-6$.

Grujacum jamaicenfe, foliis velut muria conditis Jpilfius virentibus, flore fubcar ruleo. PLUk. plyyt. t. 35. f. 4 .

Lignum vita ex jamaicn, $f$. Guajactm. BLakw. berb. t. 530. f. 1. 2. .

Gurijactuit foliolis bijugis obtufis. LINN. Jyft. veg. 396.

E collect. Bankfiana.

PER. Capfula fubturbinata, brevifime pedicellata, pentagona, coltis alatis anguftifimis in rotundo angulorum dorfo notata, pulpufo - corticata, glabra, pallide ferruginea, quinquelocularis. Diffepimenta fimplicifina, membranacea, mediis parietibus affixa.

Rec. nullum, proter funiculum umbilicalem crafum, brevem, fubulatum, e feminis vertice ad internum angulum loculamentorum procedentem.

SEM. folitaria, grandiufcula, fuperne crafiora obtufa, inferne attenuata, hine convexa, inde angulata, rufefcentia.

IN T. duplex: exterins craffum, coriaceum, (an in recenti femine carnofum?) facile folubile; interius membranaceum, ferrugineum, albuniui pertinaciffine adnatum, \& intra ejus rimas defcendens.'

ALB. femini conforme, albicans, cartilagineum, duriffmum, undique rimis tenuillinis, fere ad embryonis cavitatem penetruntibus, incifund.

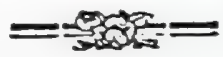

EMB. longitudine albuminis, inverfus; luteus. Cotyl. foliacex, craftiufculx, plance, in fuperficie externa ab imprelfionibus rimarum albuminis obfolete ferobiculatx. Rad. cylindrica, craffa, fupera.

2. b.) Capfula integra \& trensverfim diffecta. c.) Seminum in axam fractus infertio. d.) Seauiua integra e.) Seminis \& albuminis rimofi fectio transveralis. f.) Albumen deaudatum. 5.) Ejusitem fedio longitudinalis cum fitu \& figura Embrgonis.

Sxpifime duo 1. tria loculamenta abortant, remanentibus tamen earum veftigiis: atque tunc fructus a defcripta figura regulari vario modo recedit, $u$ ti id videre eft in icone Plumieri $L \mathrm{c}$.

Capfula inmatura, utique cortice pulpofo tecta \& quafi carnofa eft, fed cortex ille, omni tempore, continuus, atque diffepimenta fimplicilfima ac indivifibilia deprehenduntur; ut vix cum Cl. SCHREDER() confentire queam, qui fructum hunc ex duabus aut pluribus capfulis diftinctis vult compofitum.

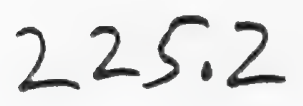




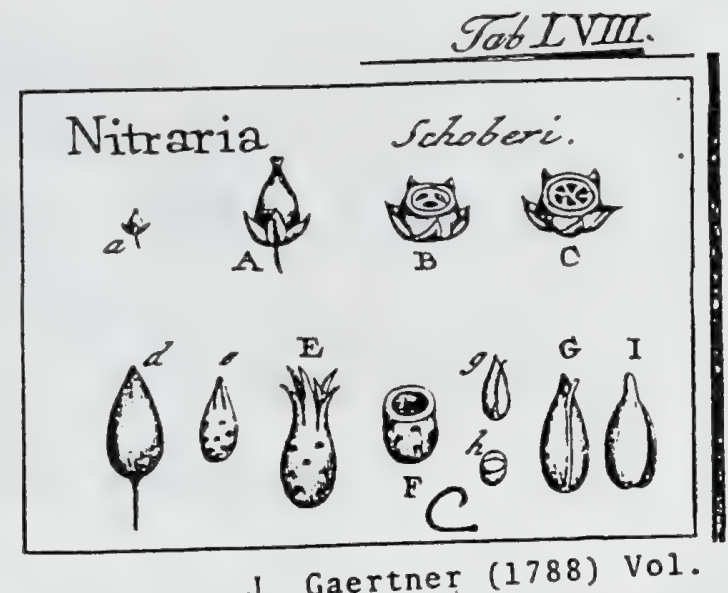

CCCLI. NITRARIA. L IN N. gen. 602.

279

Calyx quinquefidus. Cor. pentapetala. Stam. quindecien aut plura. Styl. brevifimus trifidus. Ovariun triloculare. Drupa matura unilocularis: putamine ferobiculato, apice valvato.

NI T R A R I A Schoberi. Tab. 58. fig. 5.

Ofyris foliis obtufis. GMEL. fibir. 2. p. 237.t. 98 .

Nitraria. LIN AE. Petrop. nou. VII. p.315. t. Io. Mu a R. hort. goett.t. 2. fyfl. veg. 445 .

280

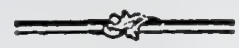

PER. Drupa baceata, ovato acuminata, nigra. Cortex carnolus, tenuis, fallus. Putangti offeum, ovato acuminatum, foveolis circiter duodenis fparfis fcrobiculatum, apu in fex lacinias fubulatas, longitudine alternantes, divifuin, per maturitatem cog ftanter uniloculare.

REć. nullum, preter funiculum umbilicalem filiformem, a fumno putaminis apicice ad bafin feminis defcendentern.

SE s.. unicum, (ovulis feil. duobus femper abortientibus,) ovato acuminatum, fpadiceuniz

IN r. duplex: exterius aridum, friabile, facile fecedens; interius membranaceumy tenue, luteolum.

Ar. nullum.

Es в. Cemini conformis, inverfus luteus. Cotyl. ellipticx, crafrx, plano-convexi Rad. teretiuscula, brevis, fupera.

a. A.) Ovarium immatarum, cum tribus figmatibus, fere feffilibus, B.C.) Idem diffetum triloç Iace \& rarifime fexloculare. d.) Drupa matura, e.E ) Putamen denudatum, apice fexfidam F.) Idem difactum, g.G.) ( Semen cum furiculo umbilicall, h.) Idem difetum. I,) Embrjo denudatus. 


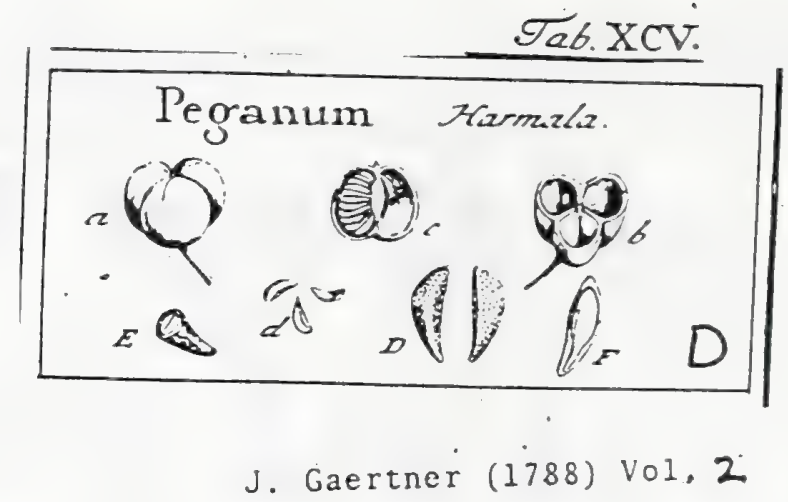

87

\section{PEGANUM. LINN. zer. 6oI. Harmala. TOURN. inft. t. 133 .}

Calyx pentaphyllus, aut nullus. Cor. pentapetala. Stam. quindecim. Ovar. fuperum. Styl. fimplex, ftigmate triquetro. Capf. trilocularis, urivalvis poiyfpermz

Peganuas Harmala Tab. 95. fig. 6.

Harmala. DoD. pempt. 121. BLAkw. berb. t. 310.

Pegmuns foliis mulatifidis. LiNn. Jyft. veg. 445.

PEa. Capfula trigono globofa, apice leviter umbilicata, trifula, trilocularis, trivalvis. Difepimenta medio valvularum adnata, fulcis externis depretfis refpondencia.

REC. nullum, prater marginem difepimentorum centralem incraffatum, cui femins in fitu horizontali alfixa.

SEM. plurima, oblonga, fubulata 1. angulaca, verfus umbilicum attenuat: ipadiceo - fufca, minutiarine frobiculato reticulata.

IN T. dup!ex: exterius fubfongiofum, tenue; intesius membranaceum, fuperfic:e fus urterma carnolum, album.

A L. B. nullum, nifi carnofam integumenti interni laminam vclis.

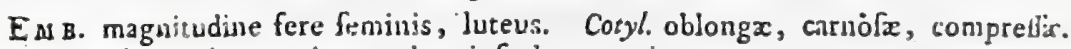
Rad. tereti-acuminata, longiufcula, centripeta.

a.) Capfula integra. b.) Eadera ditreta.. c) Vaivula cum feminum infertione. a. D.) Semina scparata. E) Semen transverfe, \& F.) Idem longitudinaliter diffetum, cum forma \& titu Enbryodis.

\section{4}




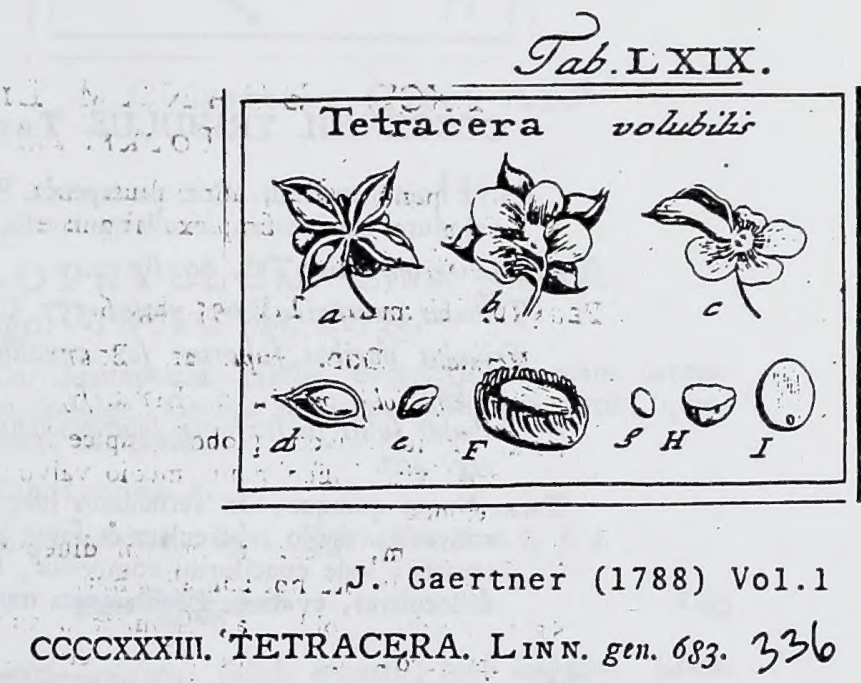

Calyx monophyllus, quadrifidus, lobis rơtundatis, fobinxqualibus. Cor. nulla. Stam. plurima perfiftentia. Capfula quatuur: uniloculares, monofpermx. Semina arillata.

Tetracera volubilis. Tab. 69. fig. 3. . ":j!

Arbor americana convolvulacea platyphyllos, foliis ferratis. P L u c. phyt. $t$. I46. $f$. $I$.

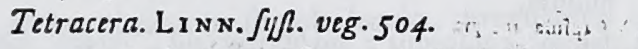

Ex herbario Bankfiano.

PER. Caplulx quatuor, ovatx, utrinque acuminatx, horizontali patentes, coriacex, glabrx, nigro caftanex, uniloculares, margine fuperiori dehilcentes.

REC. nullum; femen fundo capfulx affixum.

SЕM. unicum, ovatum, fubrugofum, fubangulatum, atrum, lucidun, minutifimé puncticulatum, arillatum

Arillus carnofo membranaceus, albus, inferne integerrimus, umbilico adnatus, fuperne longitudinaliter rima divifus, \& ex ea, verfus utrumque latus, in laciniary lineares parallelas profunde fiflus.

INт. duplex : exterius chartaceum, aridum, arctiffme interiori adhxrens; interius: membranaceum, rufefcens, albumini adnatum.

A z в. femini conforme, fabulofo carnofum, durum, aqueo-pallidum.

Ess. minutillunus, fubovatus, lacteus, in bafi albuminis pofitns. Cotyl. brevifimz. Rad. rotundata, infera.

a.b.) Fruatus integer, ab atraque parte (peitatus. c.) Capfula dehifcens. d. e.) Semen arillo teftam.

F.) Arillus in aqua tepida explicatus. g.) Semen denudatum, H,) Nibumen transverfe feanm.

I.) Embryonis figura \& fitus in bafi albuminis. 


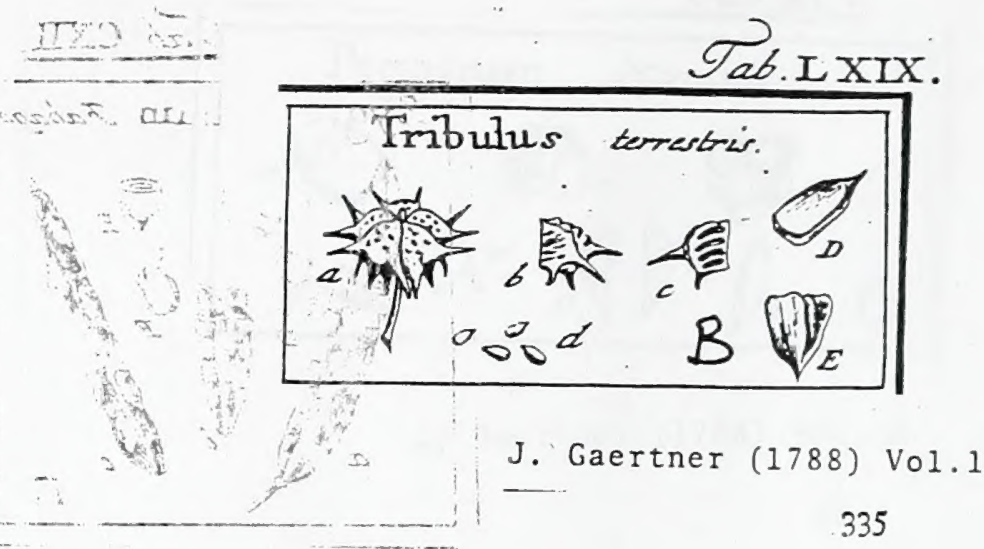

CCCCXXXII. TRIBULUS. TOURN. t. 14t. LINN. gen. $53^{2}$.

Calyx quinquepartitus. Cor. pentapetala. Stan. decem. Styl. unicus. Nuces quinque vel plures coadunatx, loculis transverfis.

Tz в и Lus terrentris. Tatb. 69. fig. 2. .

Tribulus terrefris. D० D pepipt $557 . \mathrm{CA}$ s. epit. 714 .

Tribulus paribus foliorum fex aqualibus, fruatu. quadricorni. HAII. hif. I. n. 947 .

Tribulus folits fub exjugis fubaqualibus, fominibus quadricornibus. L is s. Syf. veg. 402.

PER. Nuces quinque, in verticillứm fubglobolum coadunatz, offeo-crufacex, hinc I convexa rugolo tubcrculatx \& fupra bafin a:uleis quatuor rigidis, rectis, defexis armatx; inde cunciformi coinprefix, fimpliciter rugofx; pallide framinex, qua-
driloculares, evalves.-Loculamenta transverfa, longitudinali ferie difpofita.

yin: atis di

REc. nulfürn; ferina angulo ccutrali loculamentorum aflixa. SEM folitaria, parallelipipedea, comprefliuscula, antice infigniter acuminata, poltioas
truncata, areolaque fufca clialaziua-nutata, pallide firaninea.

IN T. fimplicinfum, hembranaceum, fubdiaphanum.

- 10tinascis ALB, Bulum. Ensa. femini conformis. fubloorizontalis, Jutcus. Cotyl oblongx, utrinque planx.
at poftice emarginato-truncata. Rad. conico acumurat, centripeta.

a.) Fruetus integer. b.) Nux (eparata, a latere (pectata, c.) Endern longitudinaliter aperti a.) Fruetus integer. b.) Nux (eparata, a latere
d. D. Semiza fepanta E.) Embryo denudatus. 


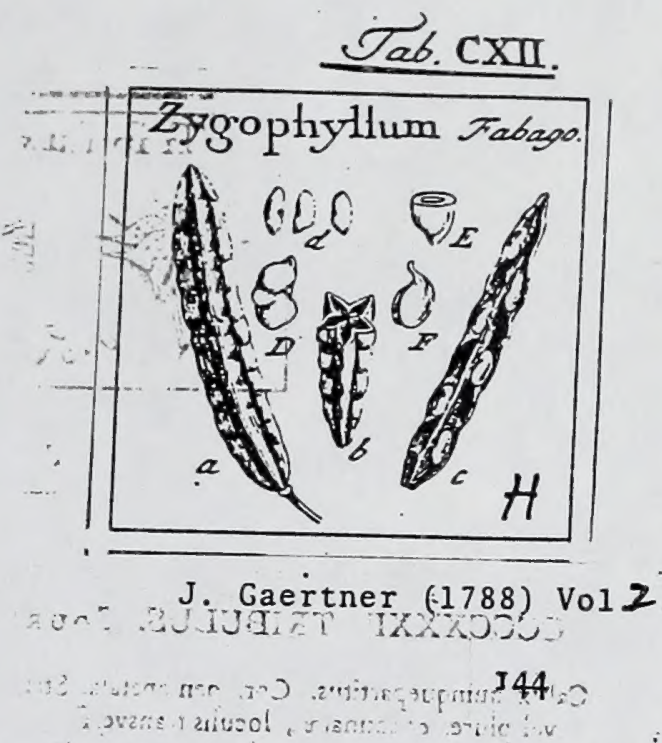

DCLIII. ZYGOPHYLLUM. LYNN gen. 530 .

Fabago. Touk N. inft. $t$. 335 .

Calyx pentaphyllus. Cor. pentapetala. Nectar. decaphyllum. Stam. decem. Ovar. fuperum. Styl. fimplex. Capfula oblonga, quînquantgularis, quinquevalvis. Sem. plura, compreffá.

Zygophyllum Fabago. Tab, I thjifig. 8.

- C.: $\cdots$

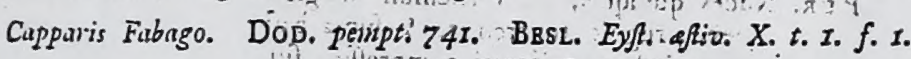

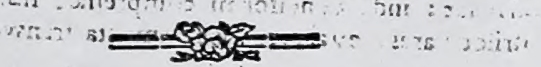

zjgophyllhun foliis conjugatic pestiolatis: foliolis obovatis, caule berbaceo. LINN. Syjt. veg. 400.

PE R. Capfula ânte plenam maturitatem teretiufcuła, glabra, pulpa molli farcta, deinceps columuari-oblonga, exfucca, argute pentagona, ad feminum fedem repando - nodulofá, quinquelocularis, quinquevalvis.

REC. nullum; femina margini, difepimentorum centrali, duplici in quovis loculo ferie affixa.

SEM. plura, decem circiter in fingulo loculo, irregulartitet ovata, fubrenifor: min, fublexuofa, comperfa, viridula, aut fordide rufelterntia.

IN T. duplex: exterius herbaceo-carnofum, tenue, lubricum, in recenti fructu fubbaccatum; interius cruftaceum, albicans, fragile.

A L B. nullum.

E м в. feminis cavitati conformis, inverfus, lutefcens ant viridis. Cotyl. foliacex, tenues, fubflexuofx, fubovatz. Rad. teretiufcula, curva, fupera.

2) Capfula integra b.) Eadem diffetan c.) Valvula feparata, cam infertione feminum. d. D.) Seminz diver[z formz, E.) Semen transverfe feţum. F.) Emabryo denudatus.

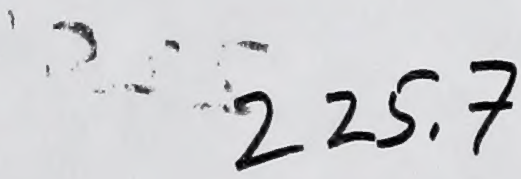




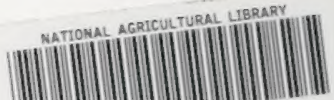

1022228850
0 